!.

\section{سالنامهاحصائيوى افغانسمةان}

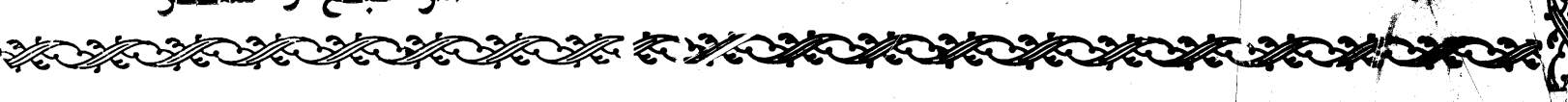

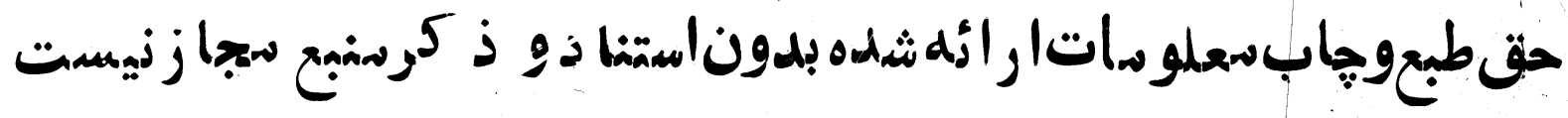




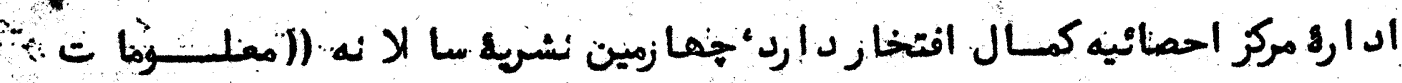

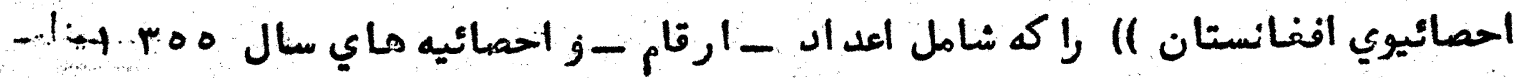

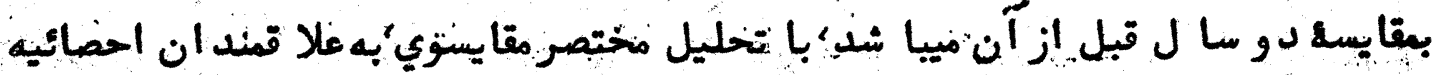

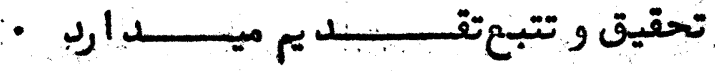

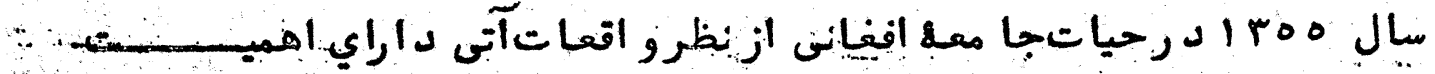

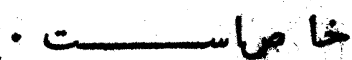

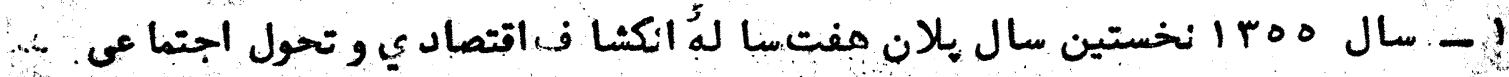

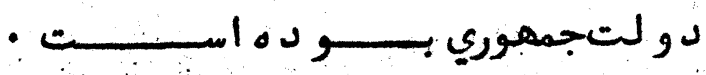

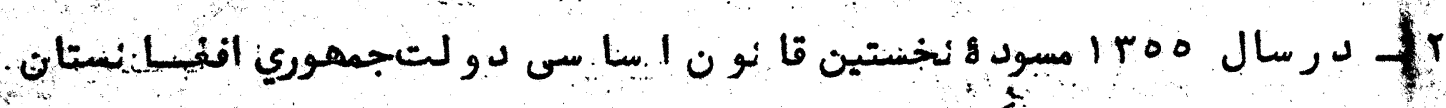

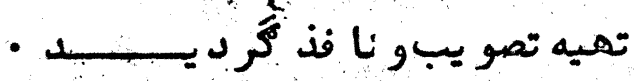

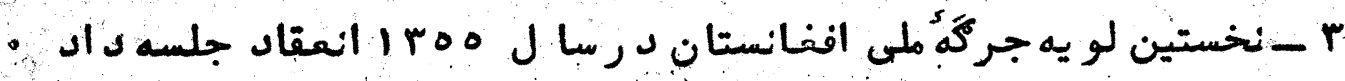

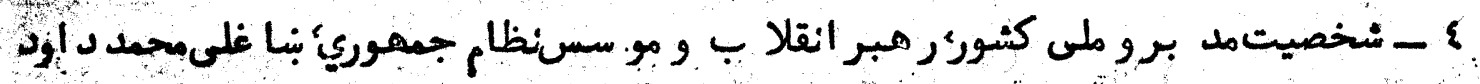

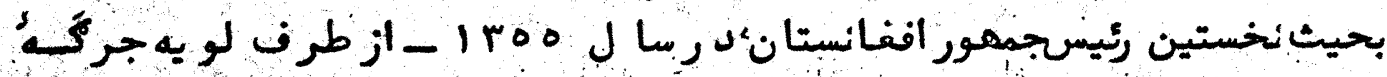

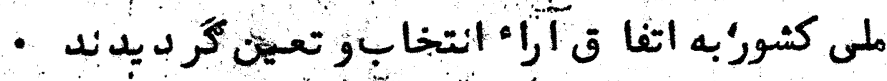

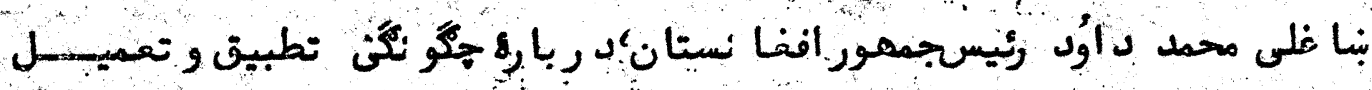

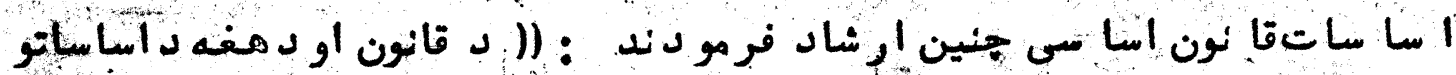

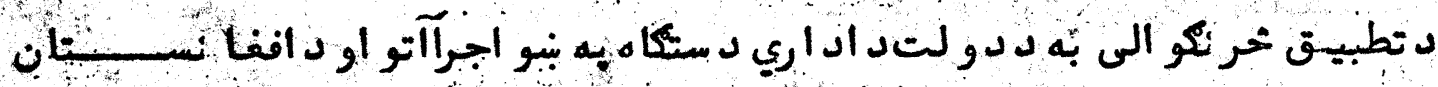

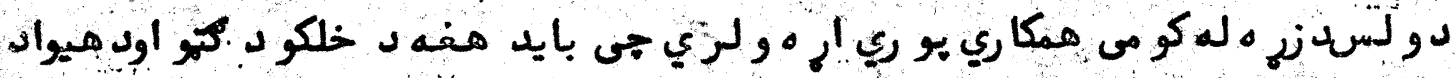

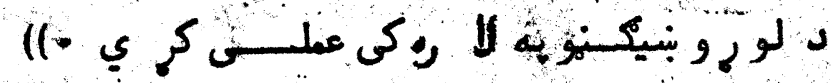

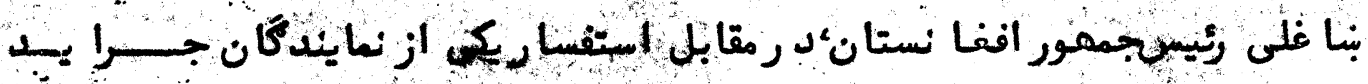

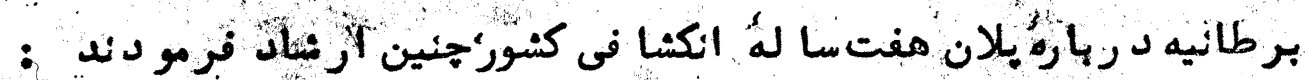

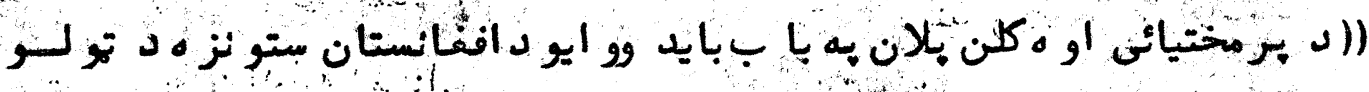

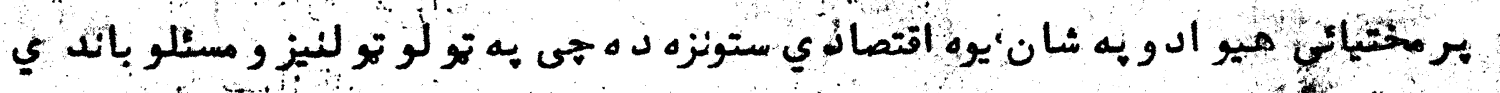

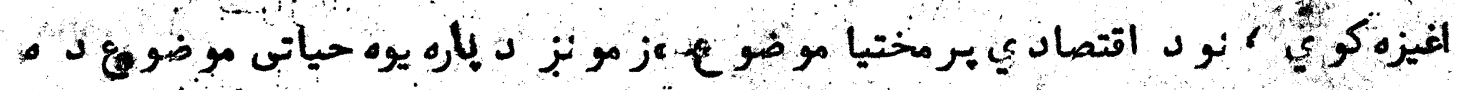

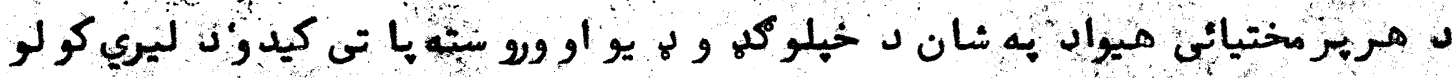

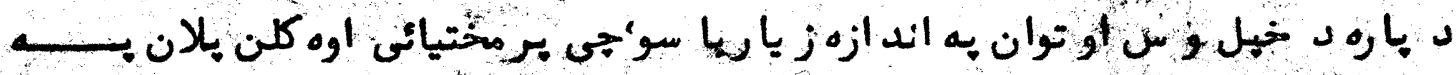

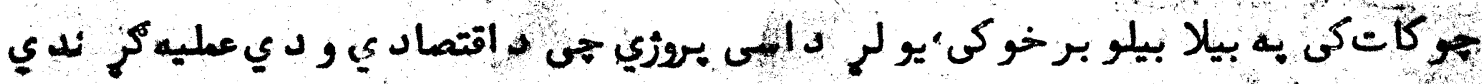

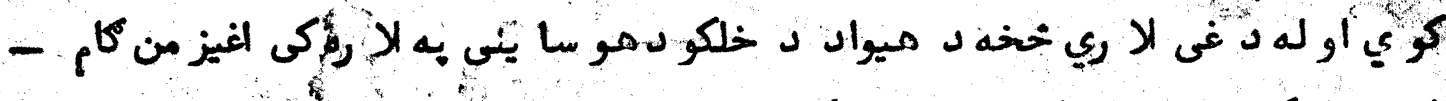

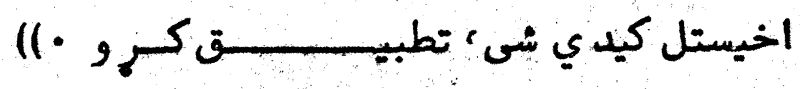




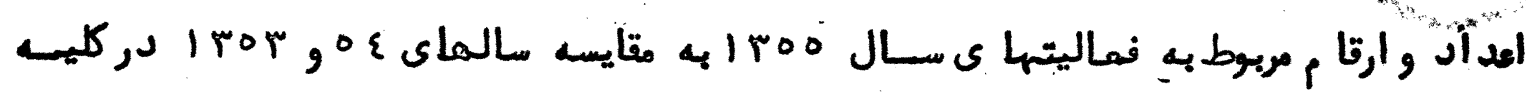

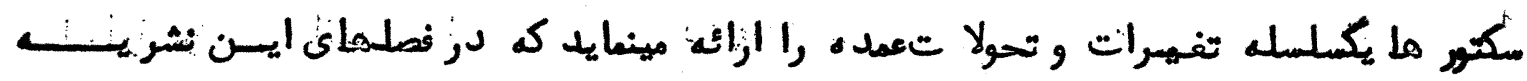

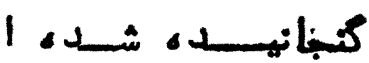

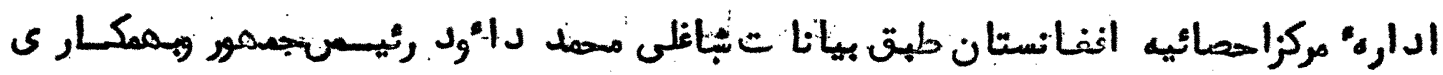

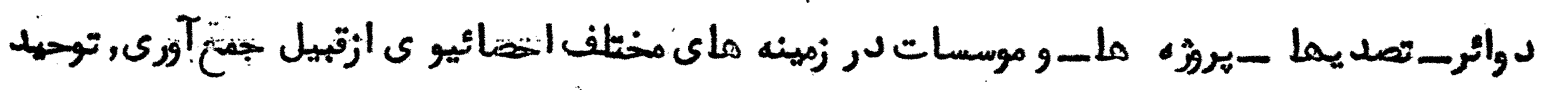

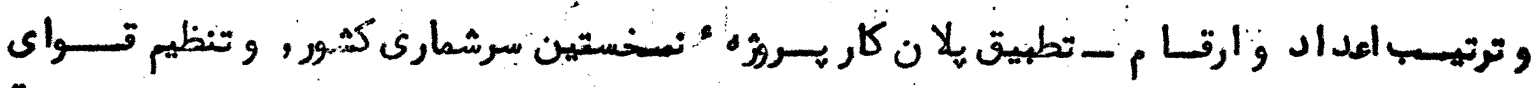

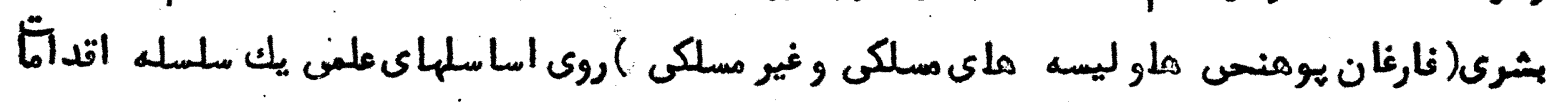

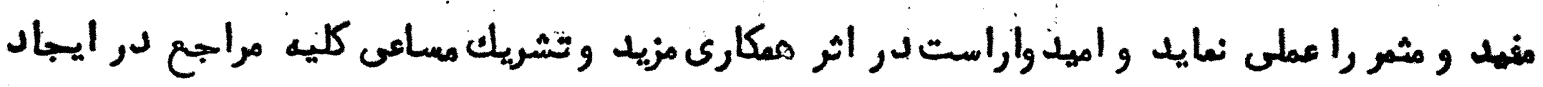

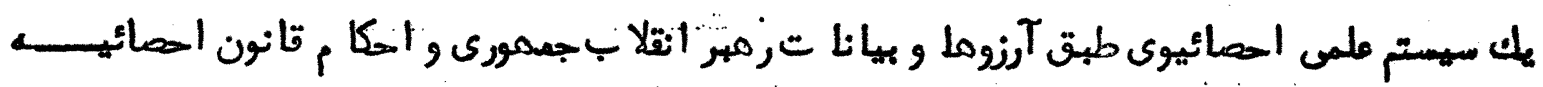

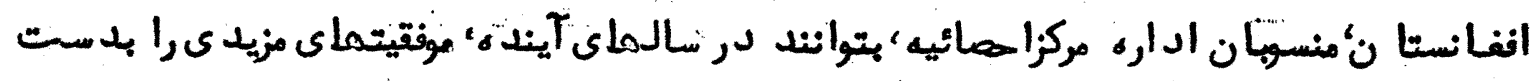

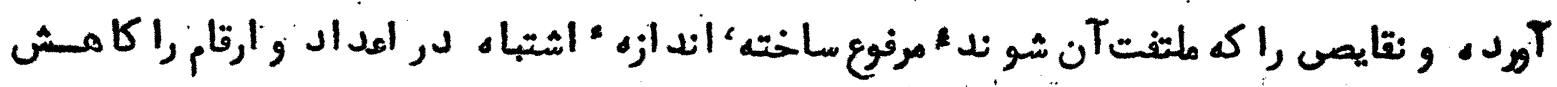

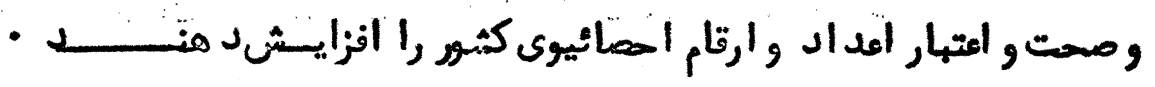

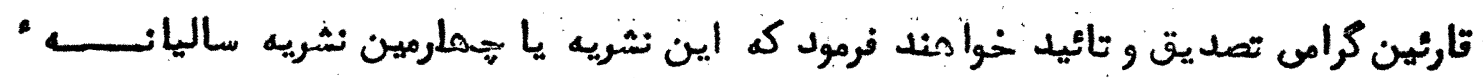

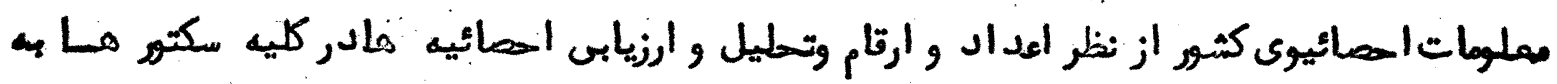

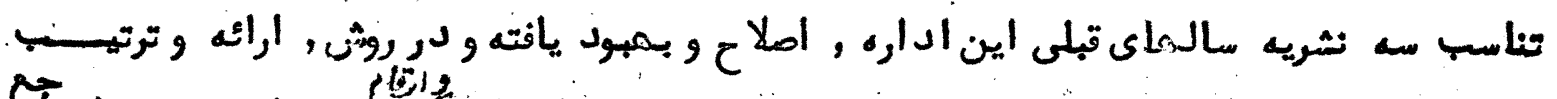

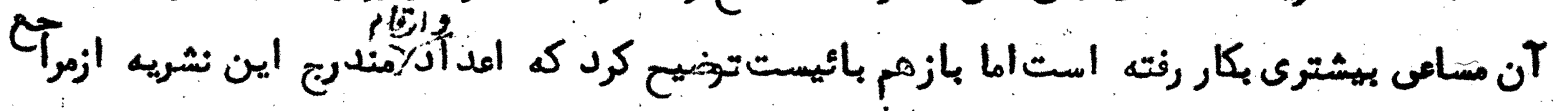

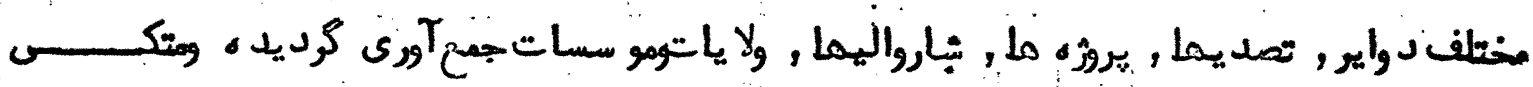

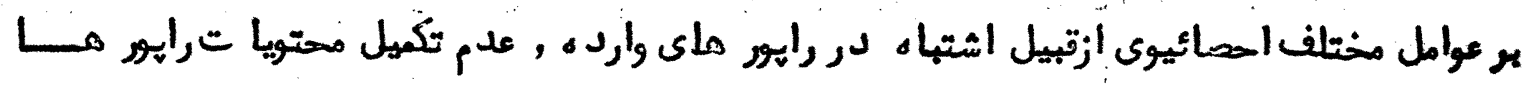

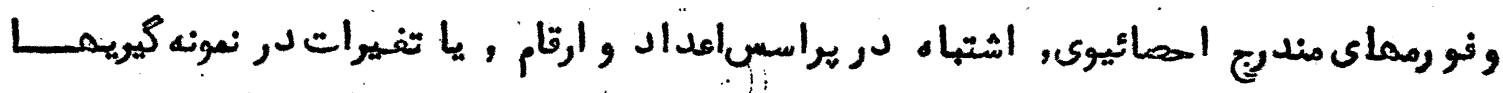

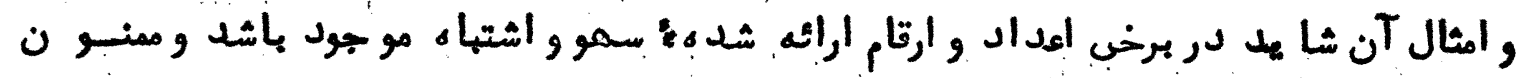

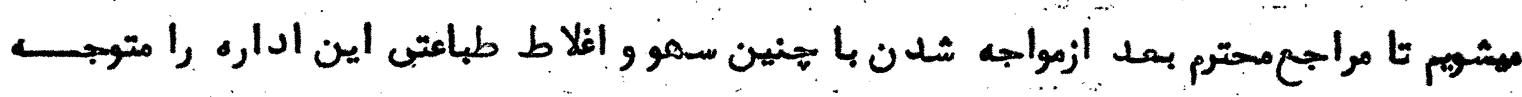

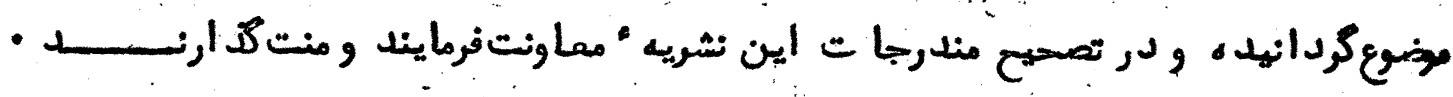

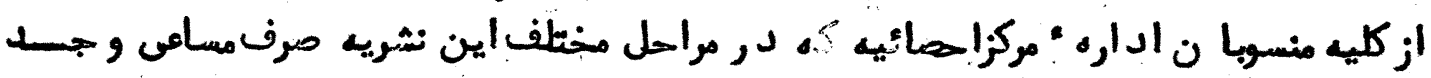

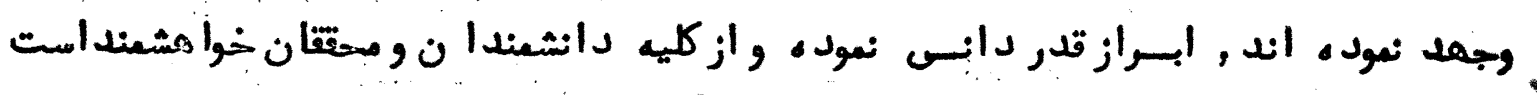

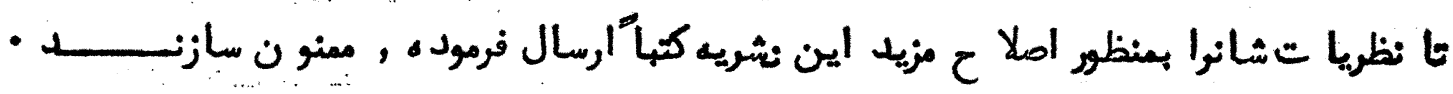
عهدالكريم حكيمسنـن

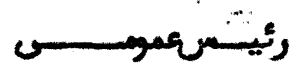



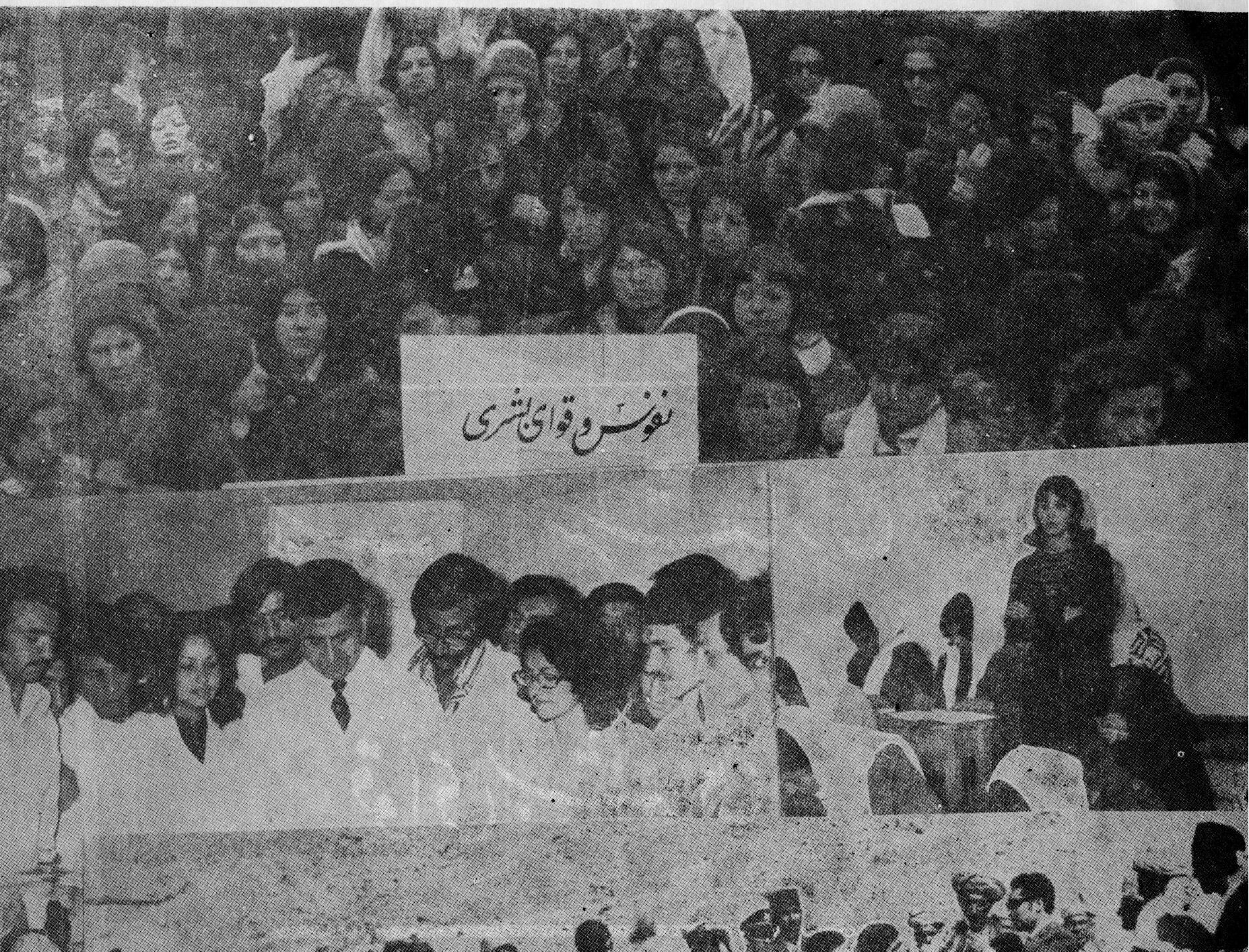

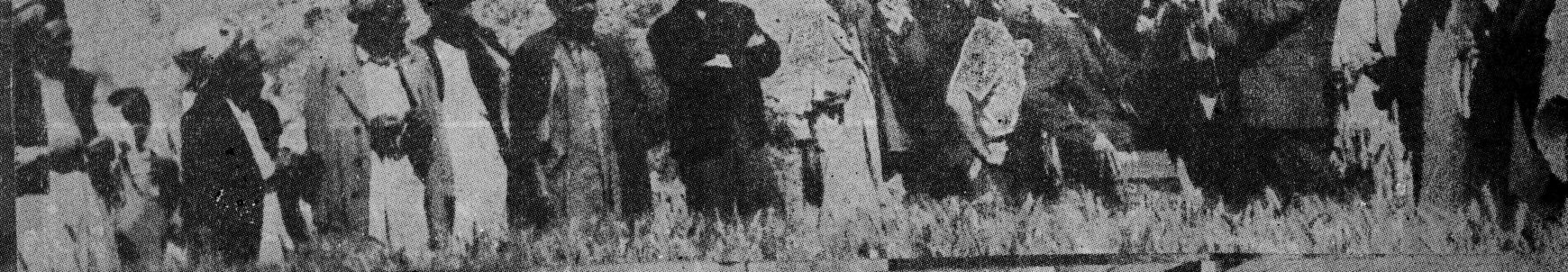

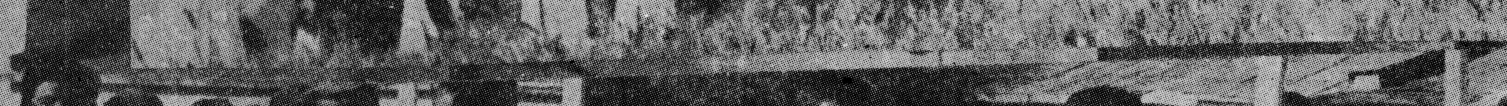

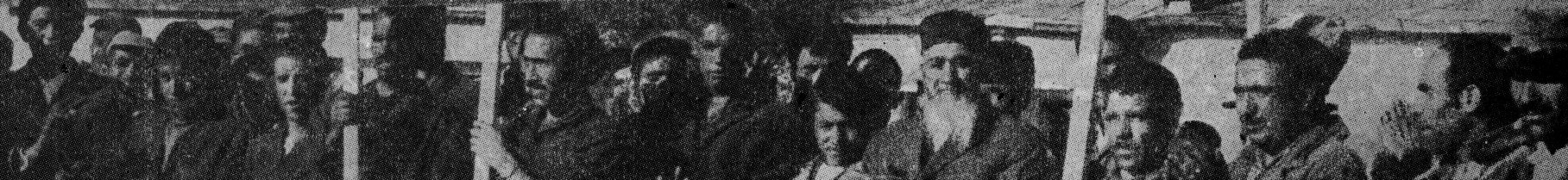

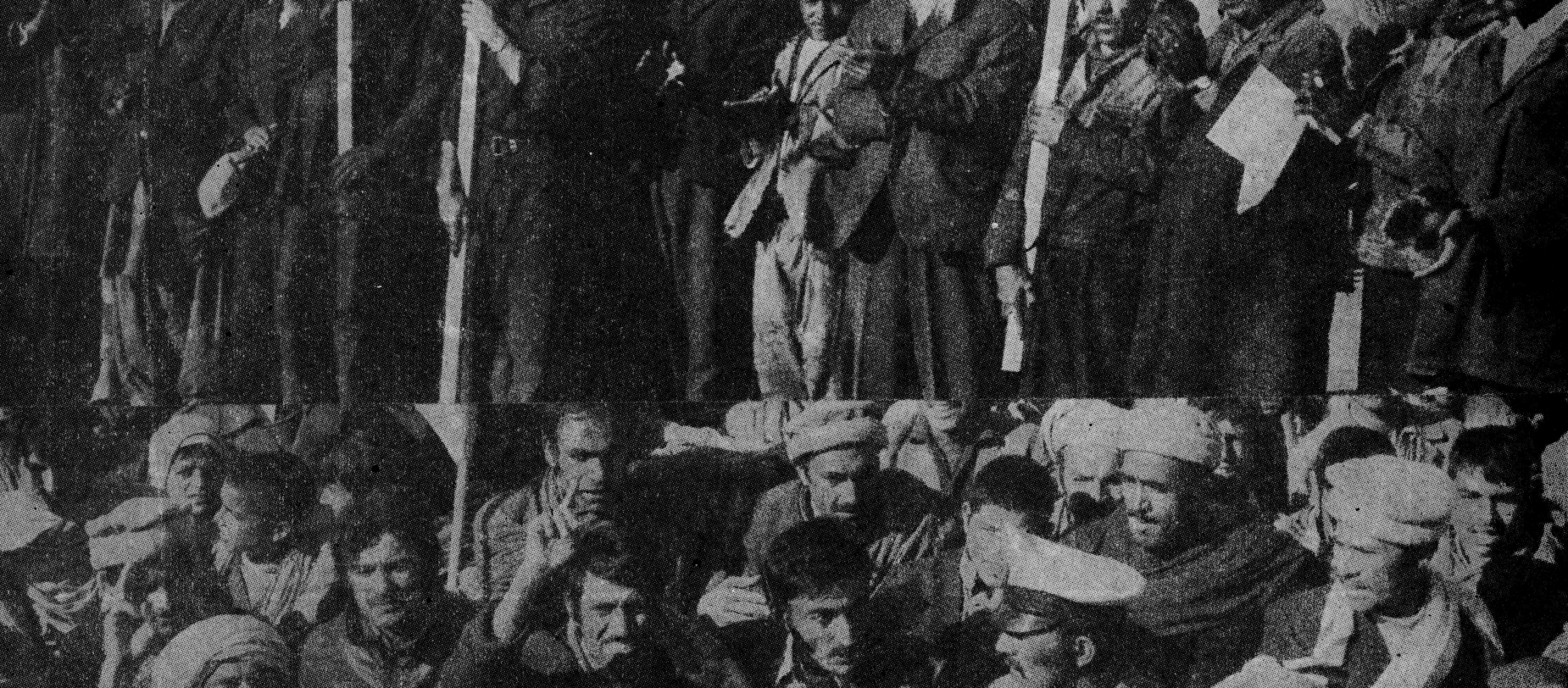
ma $)=3$ (x) 


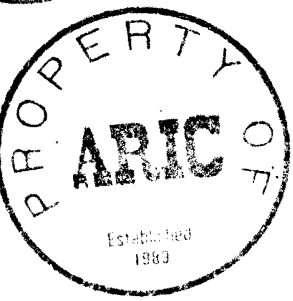

فs

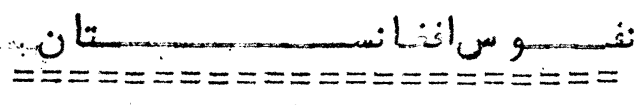

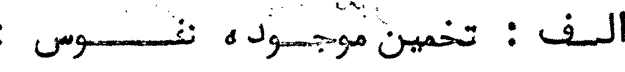

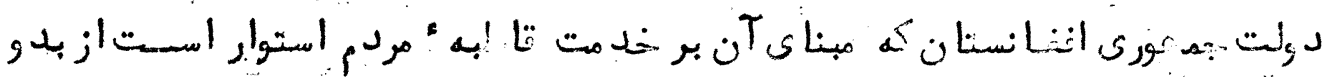

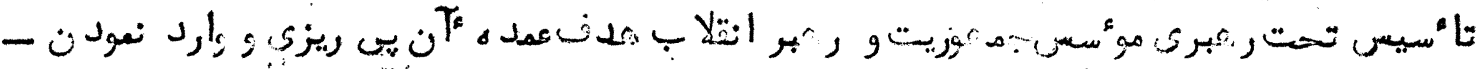

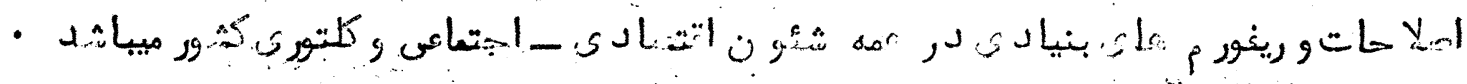

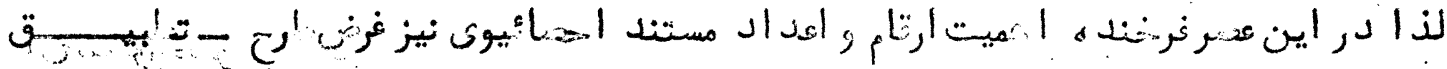

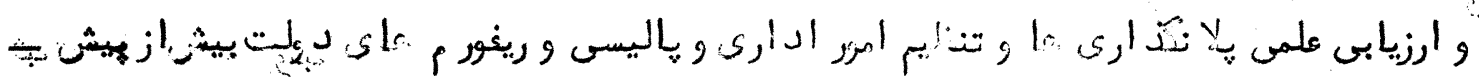

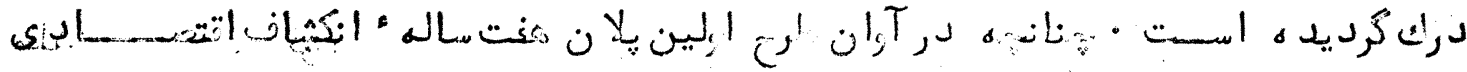

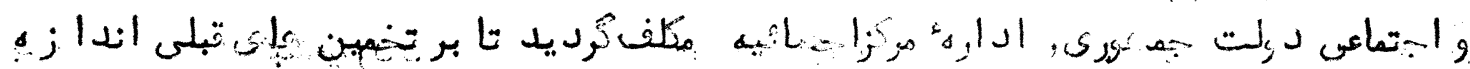

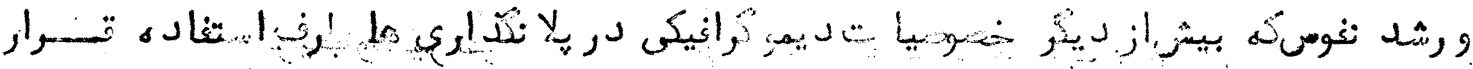

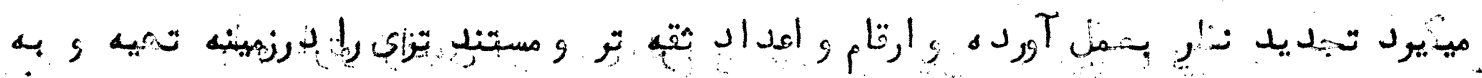

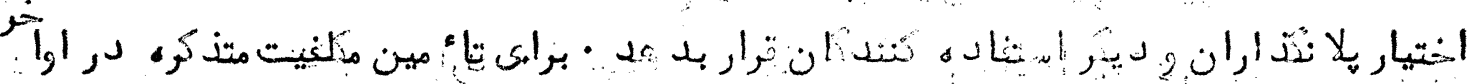

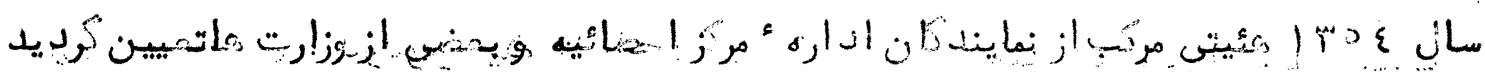

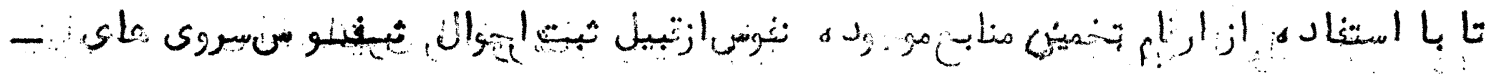

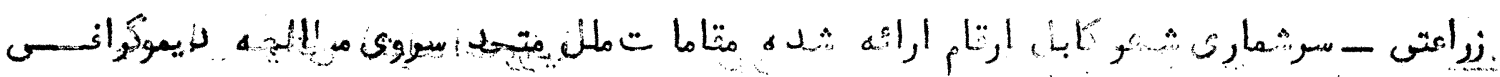

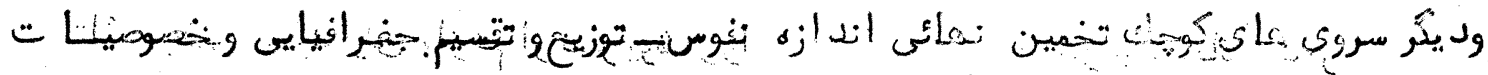

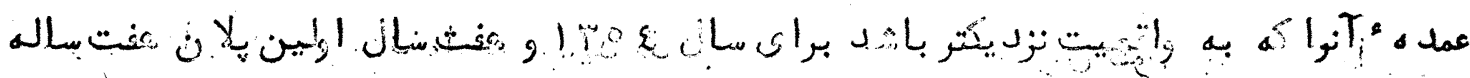

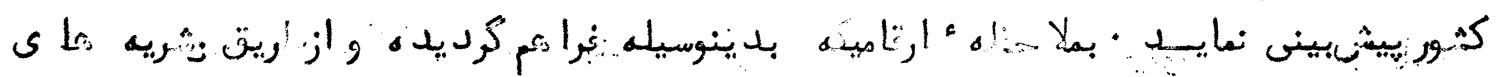

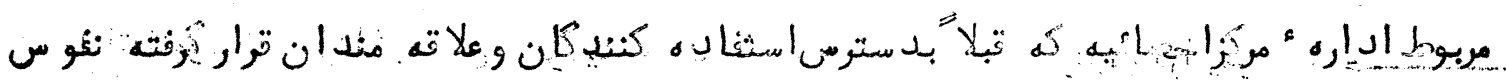

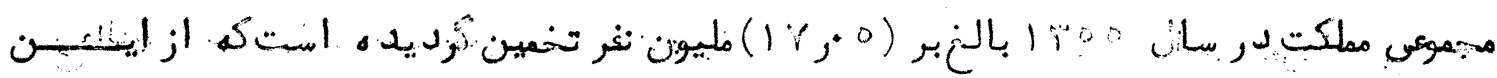

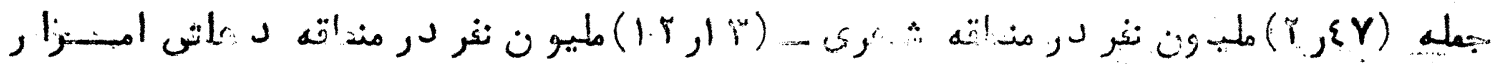

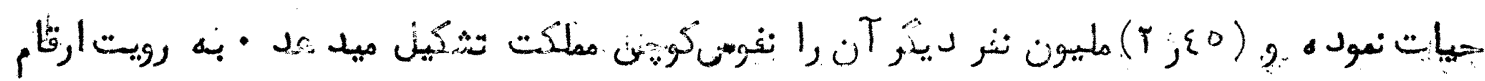

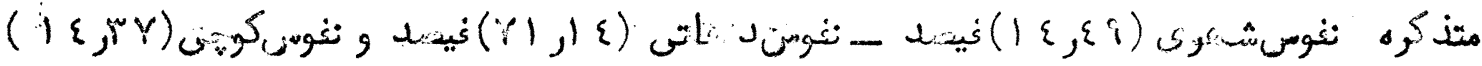

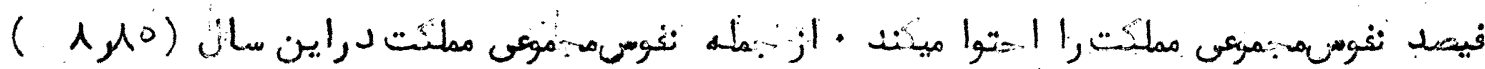

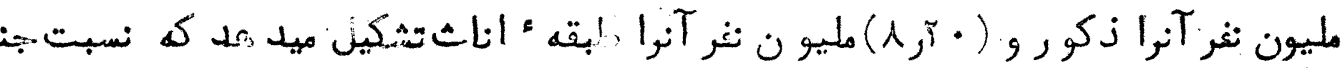

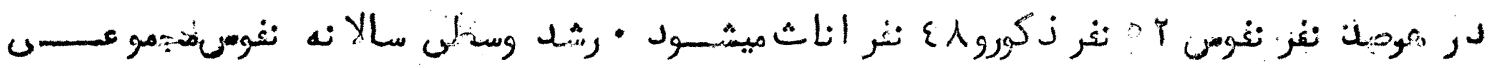

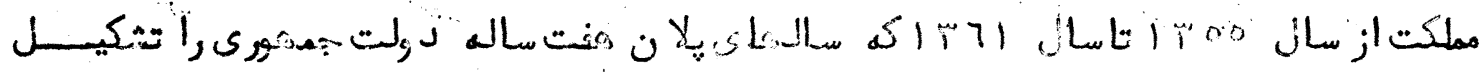

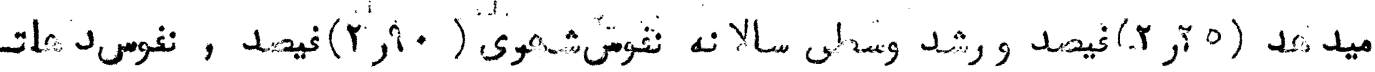

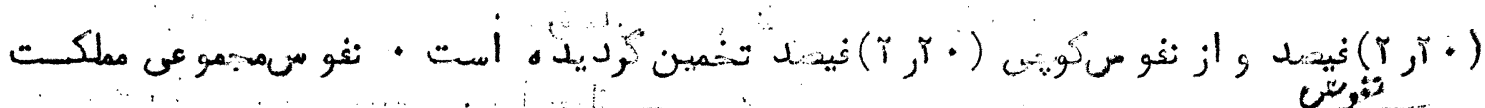

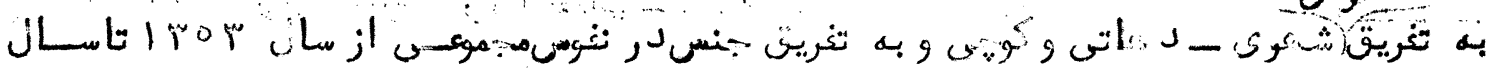




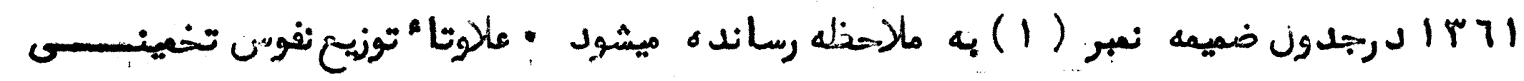

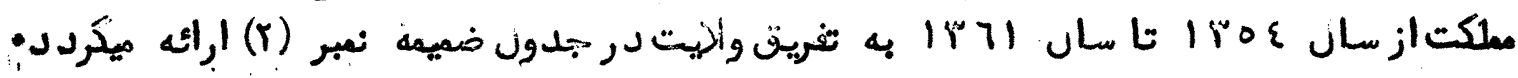

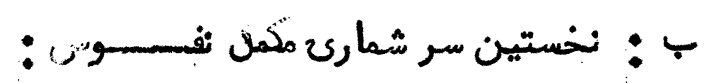

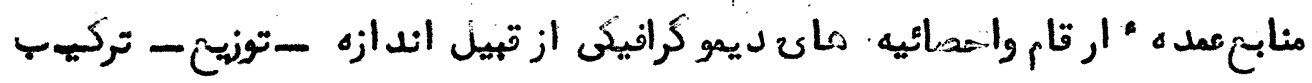

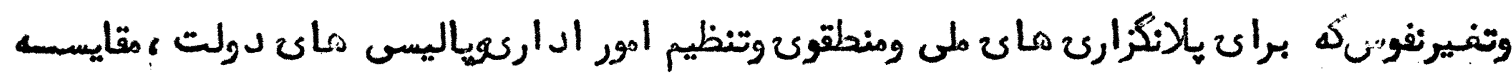

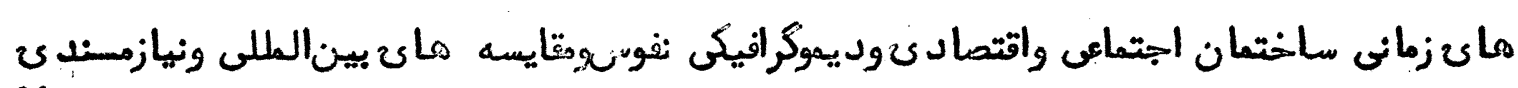

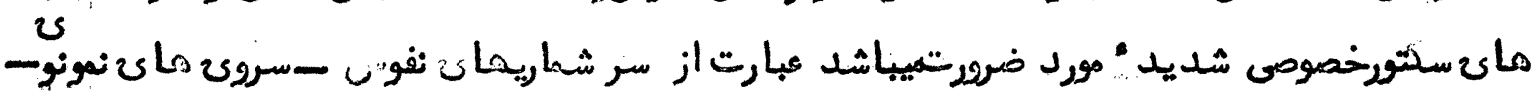

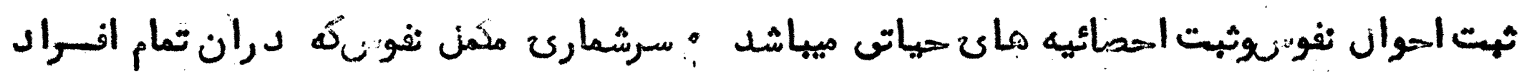

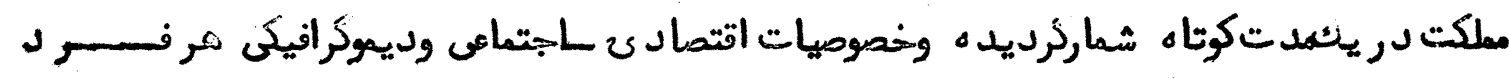

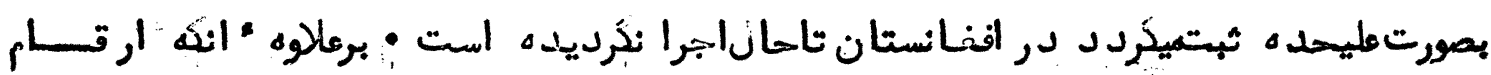

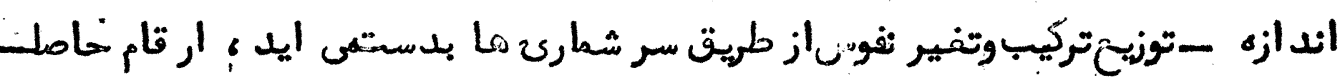

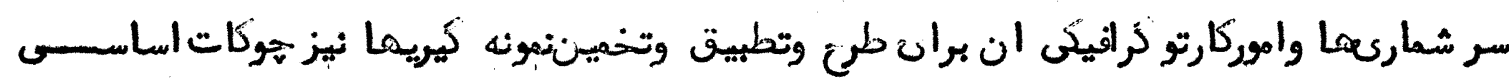

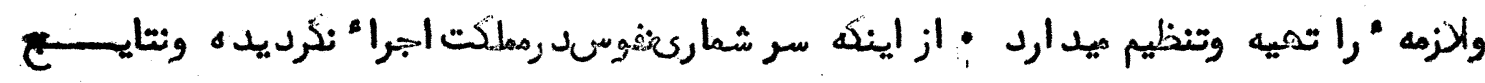

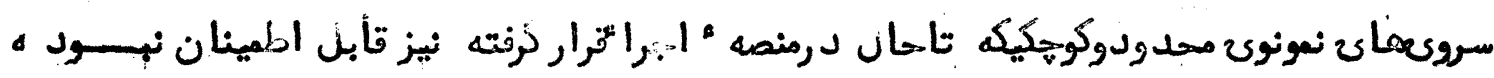

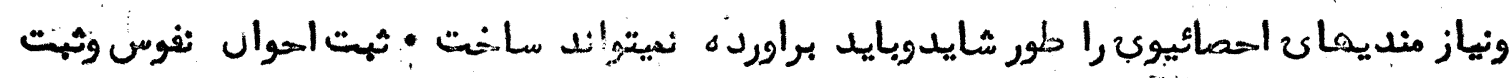

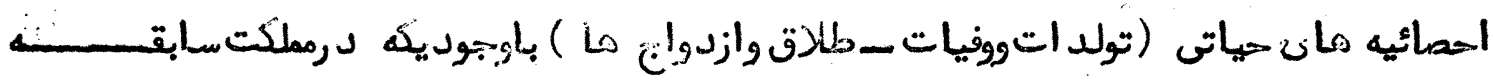

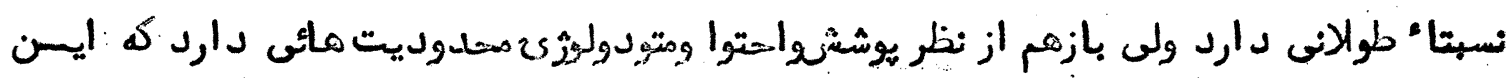

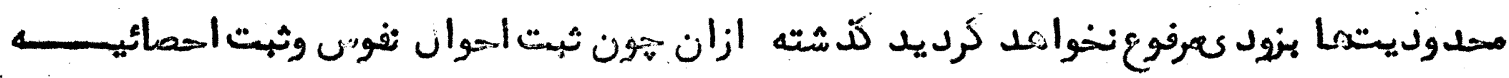

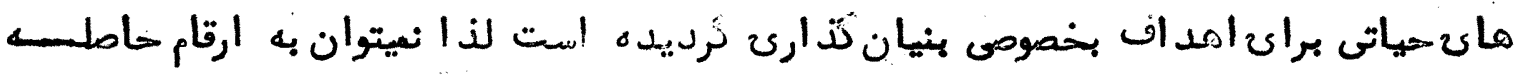

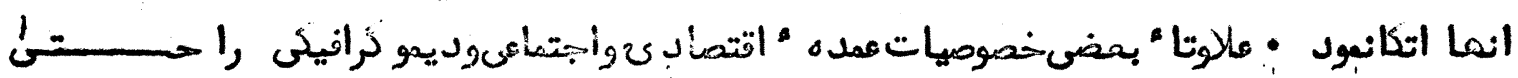

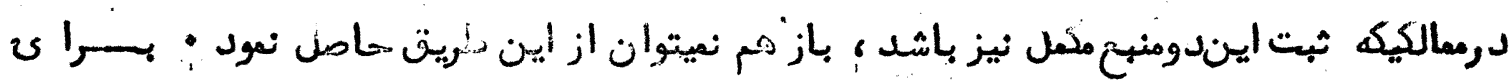

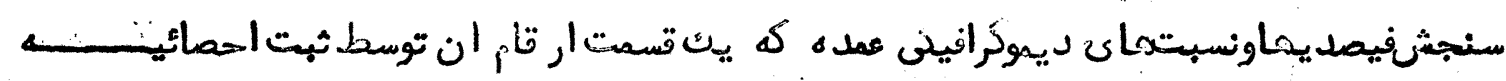

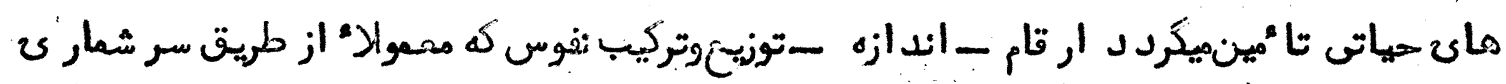

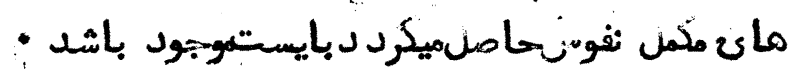

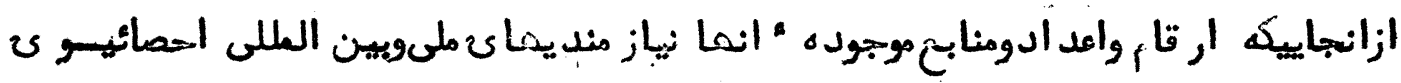

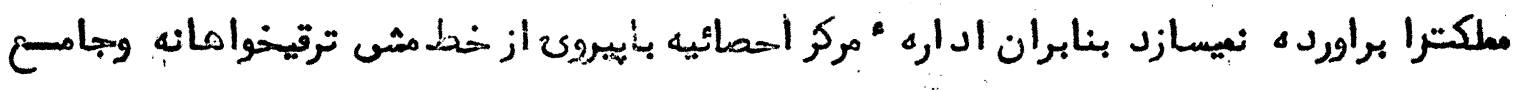

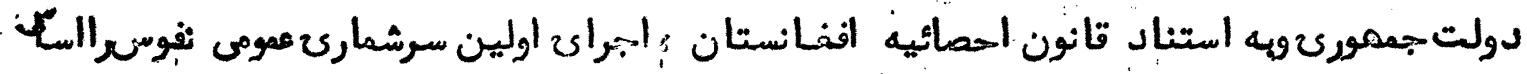

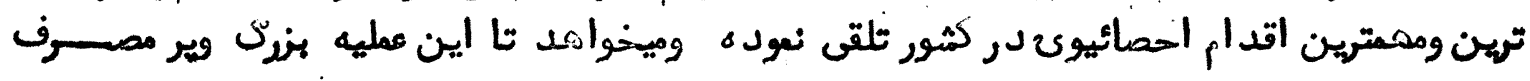

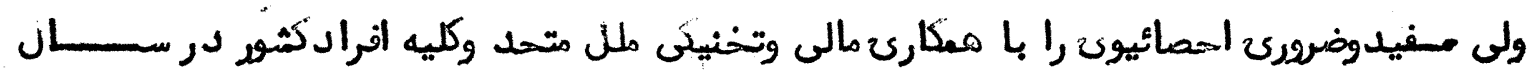

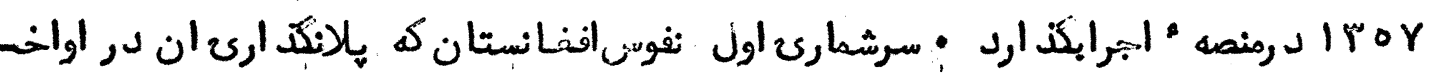

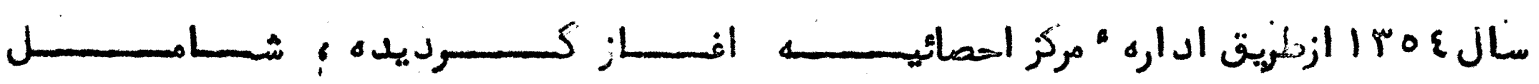




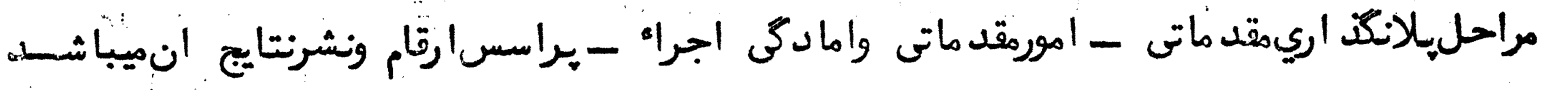

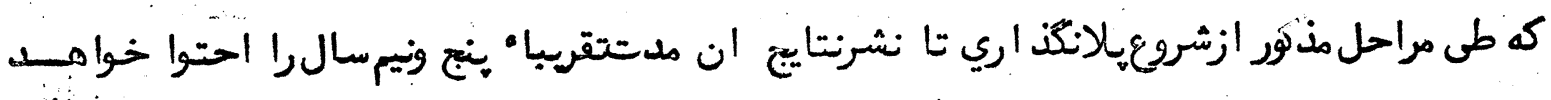

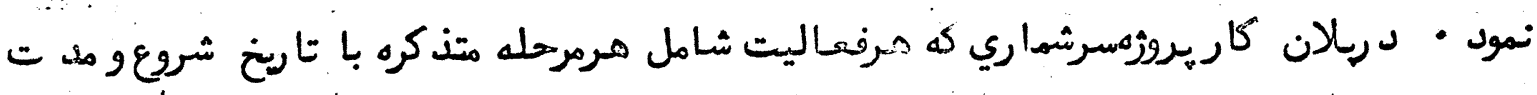

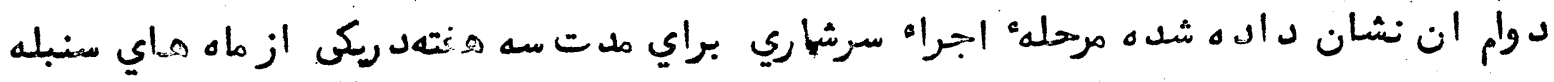

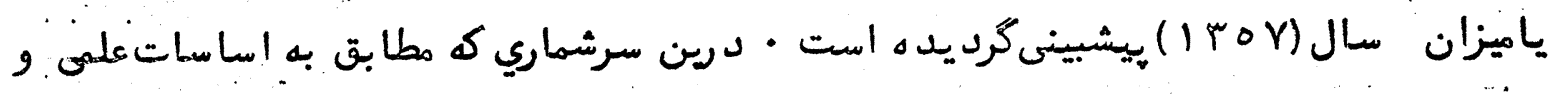

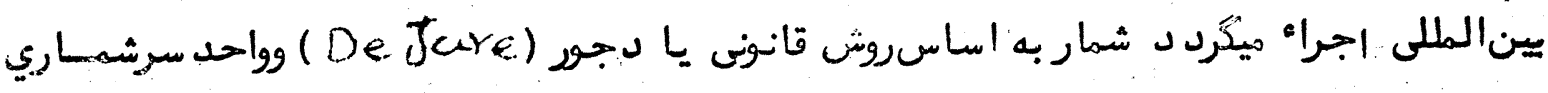
خانواريود ه وسرشماريتوسط مصاحبه" مستقيم سرشماران تطبيق ميكرد د •

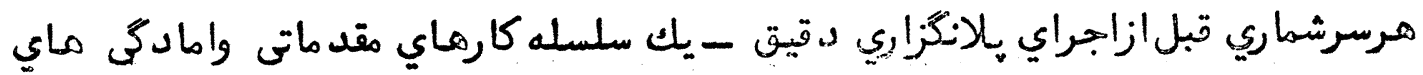

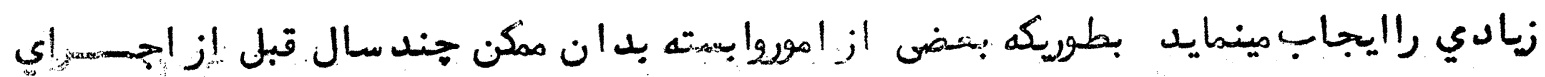

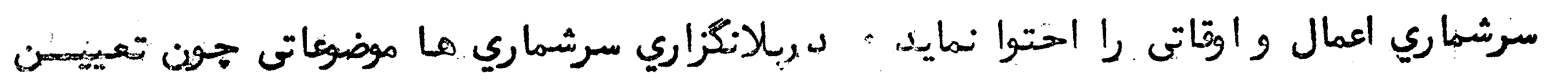

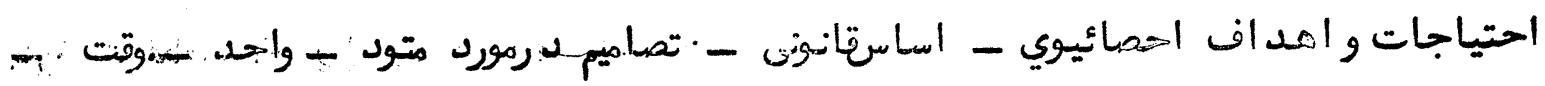

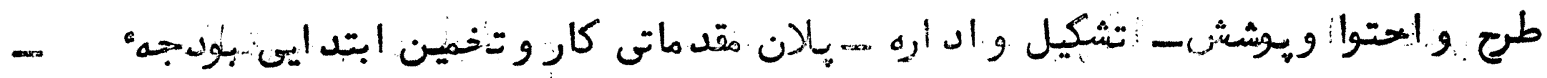

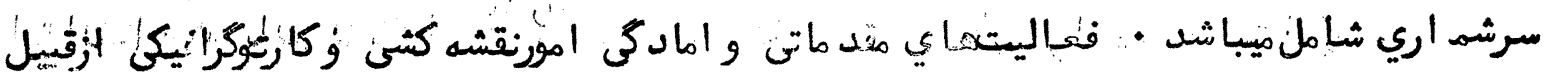

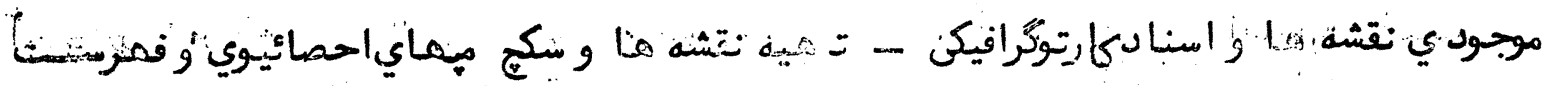

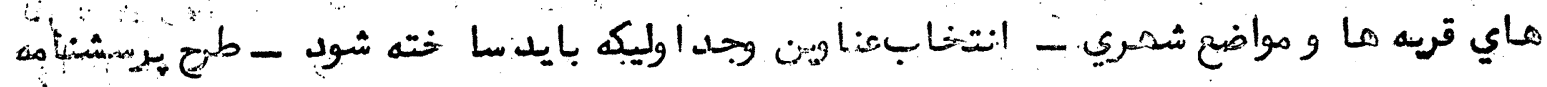

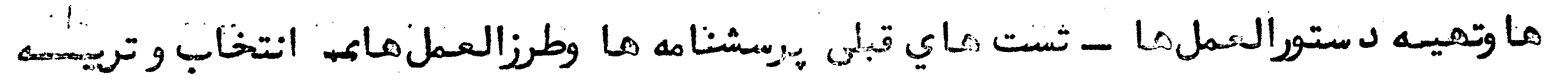

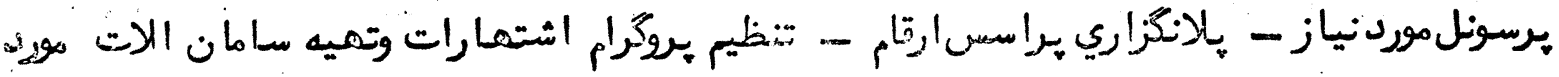

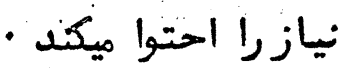

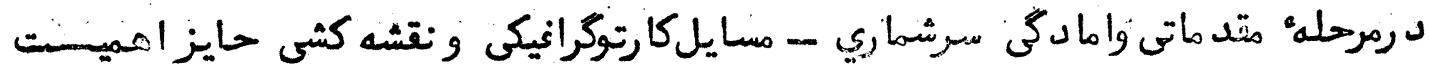

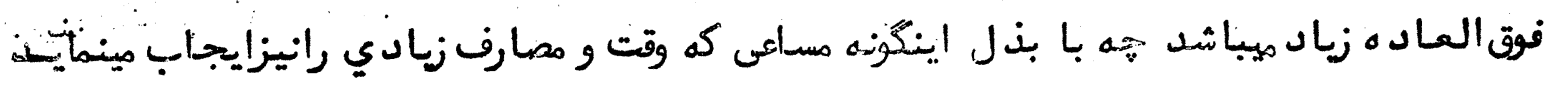

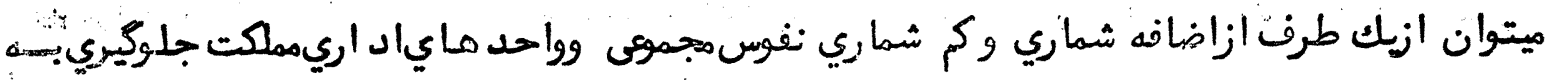
علا ورد وازجانب ديكُرتعيين و ترسيم سلحات شمارونظارتى راكه براي بلانكراريمرحله اجراي

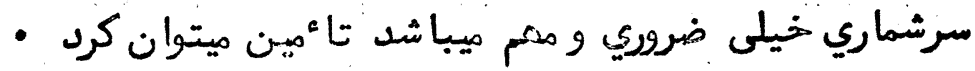

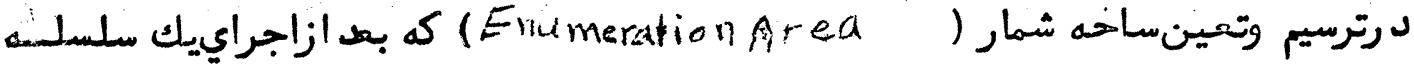
كارماينقشه كشى زياد ساحوي صورتميكيرد - د وخصوصيت عمده " مد نظركرفته ميشود :

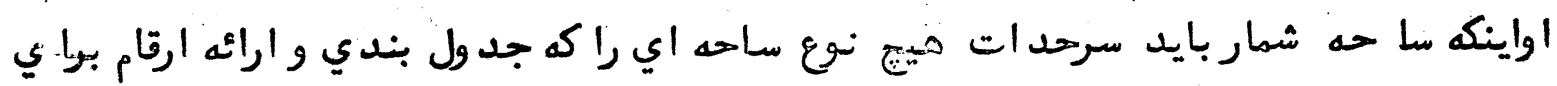

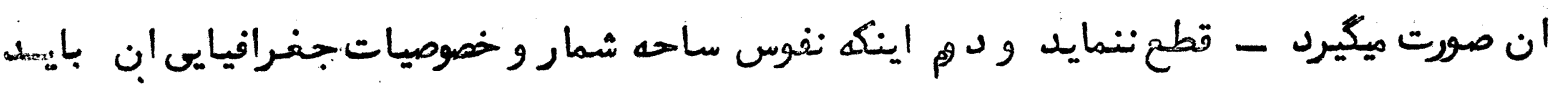

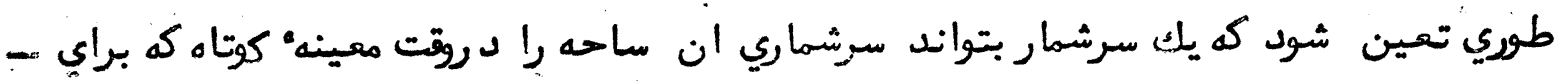

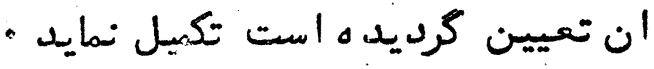




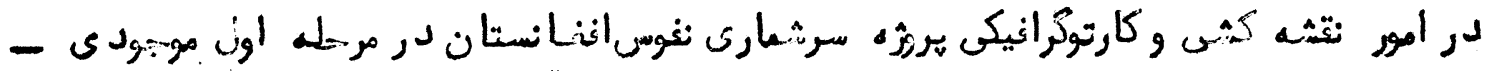

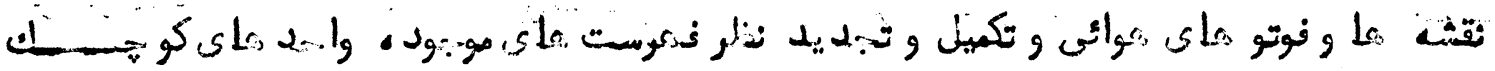

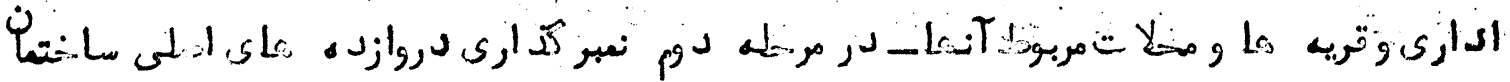

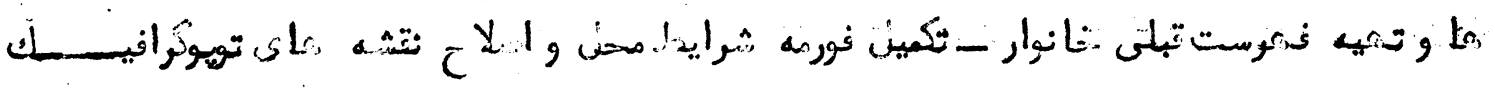

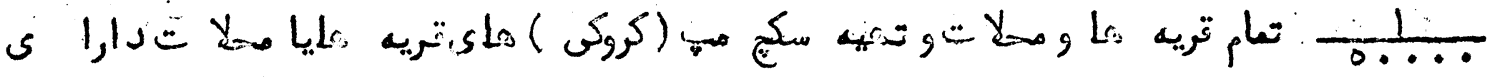

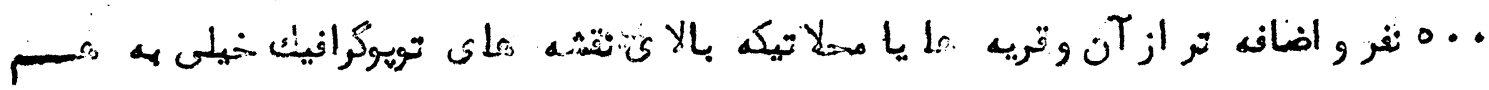

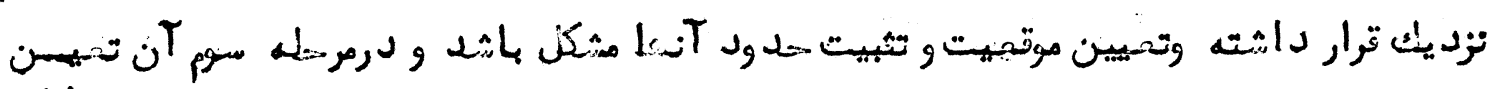

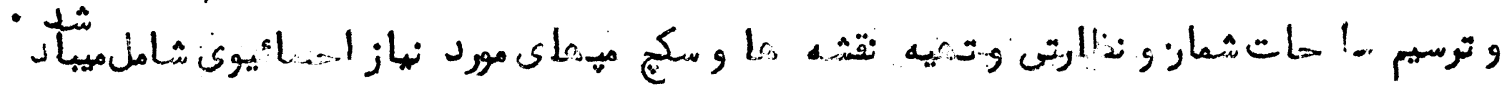

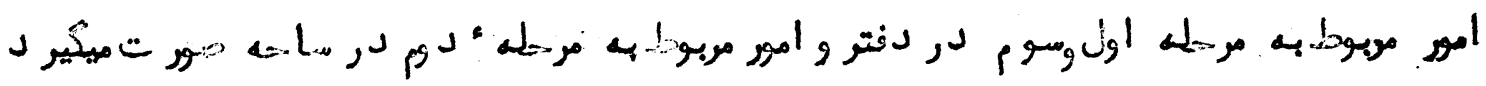

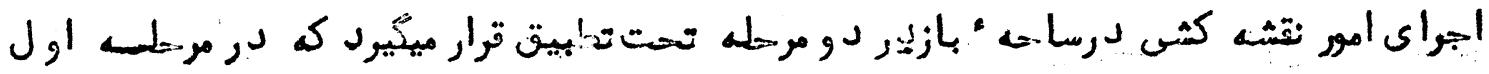

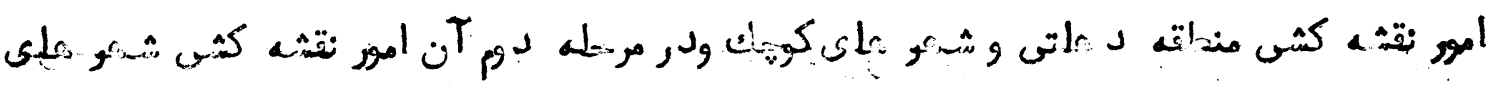

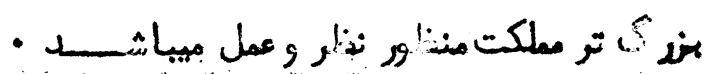

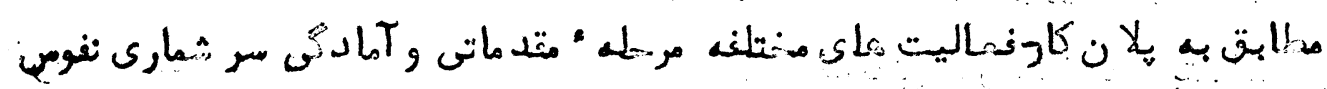

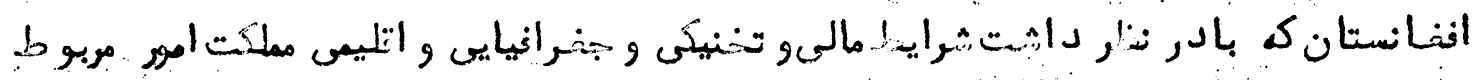

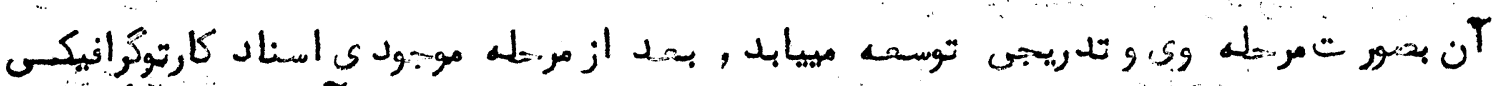

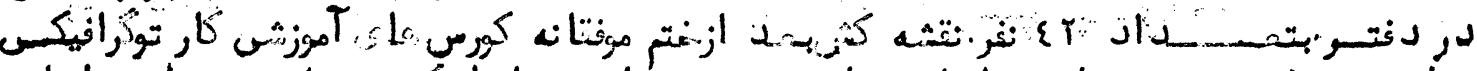

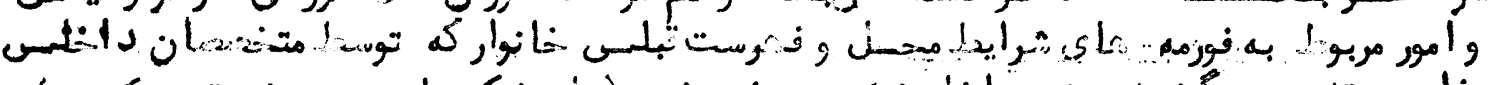

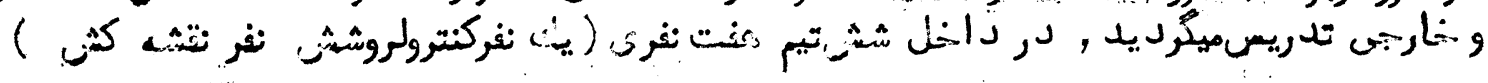

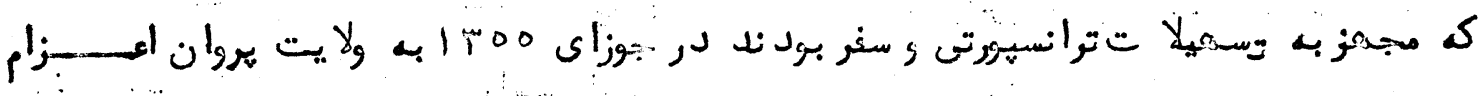

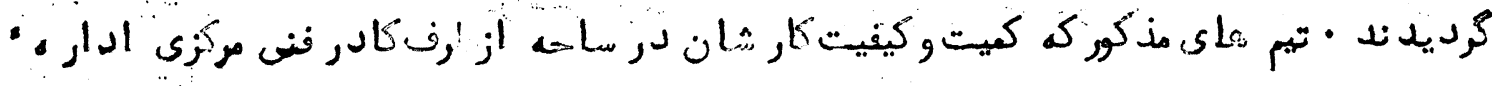

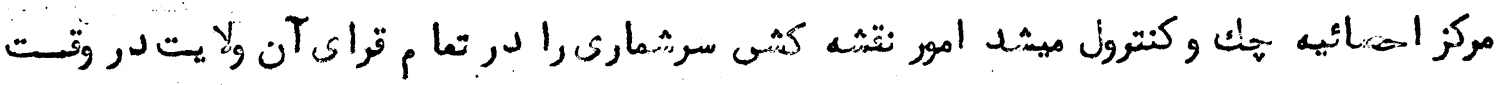

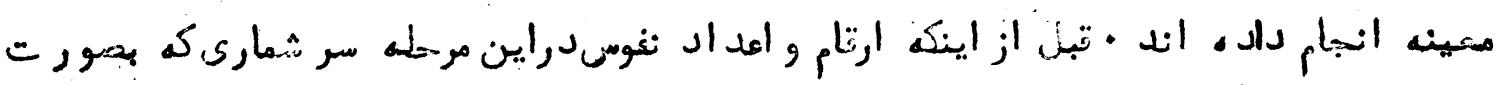

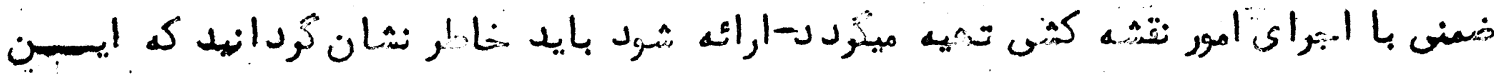

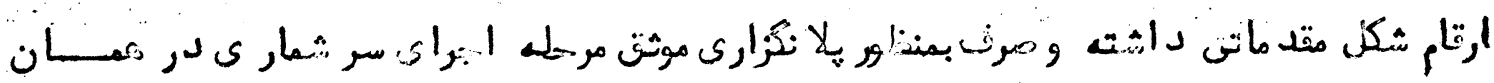

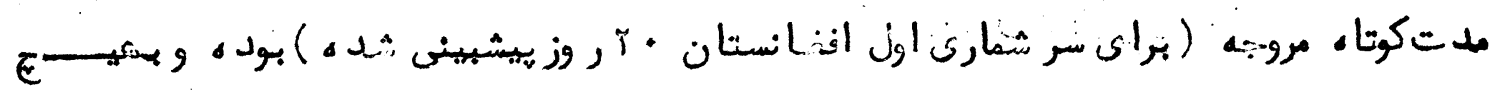

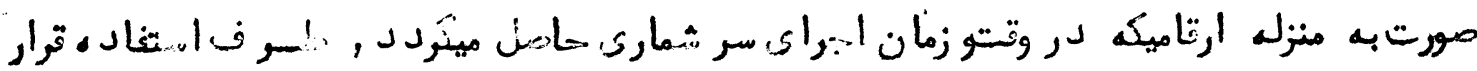

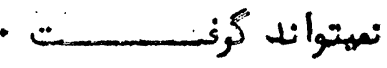

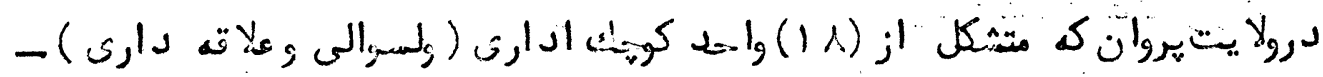

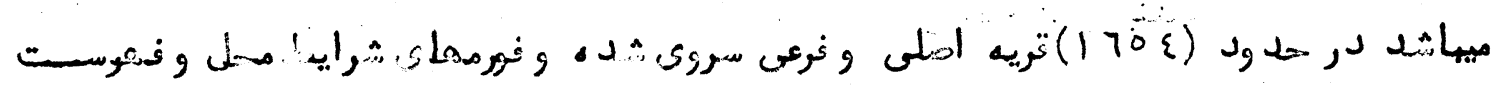

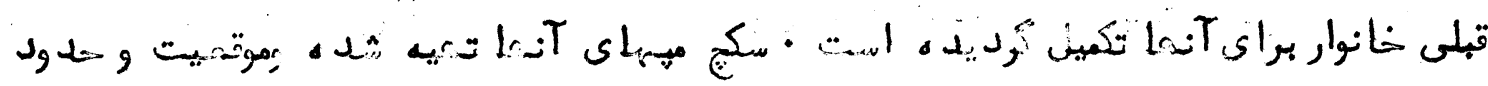

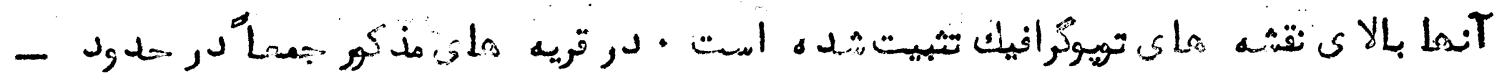

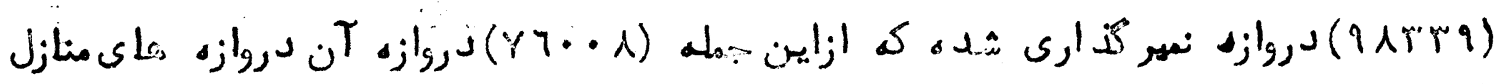




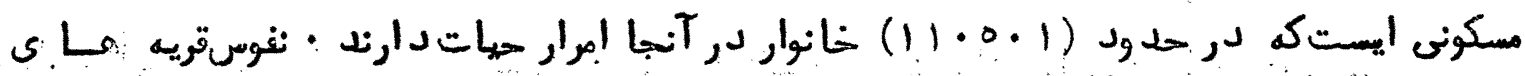

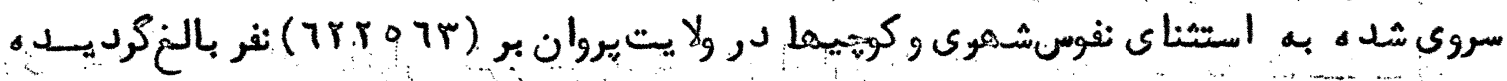

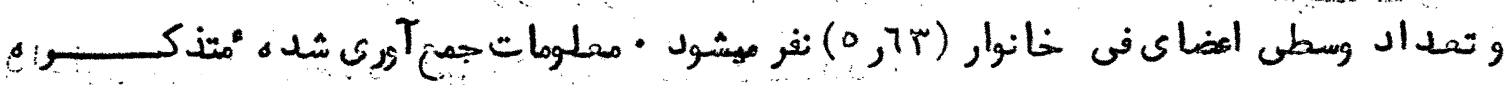

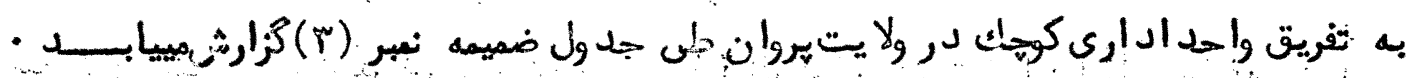

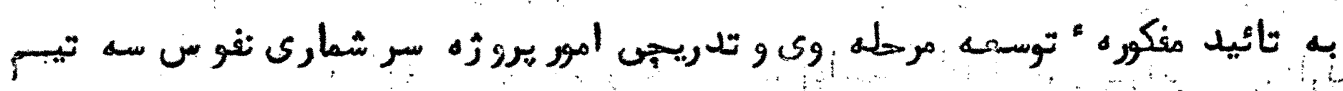

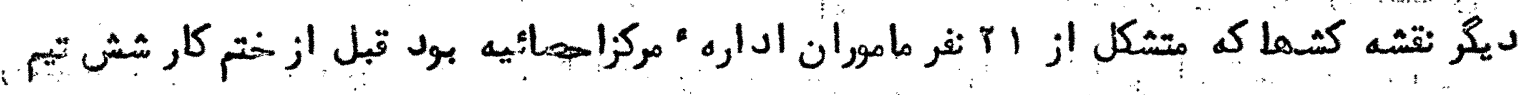

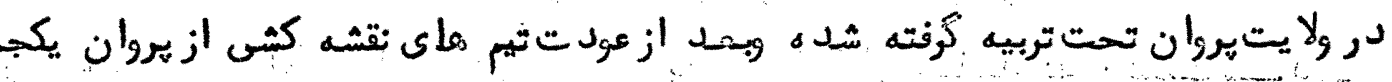

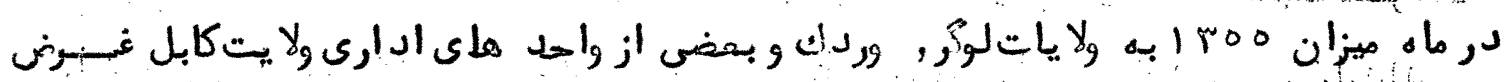

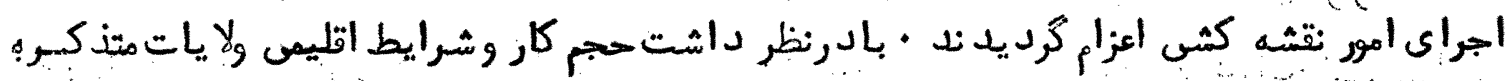

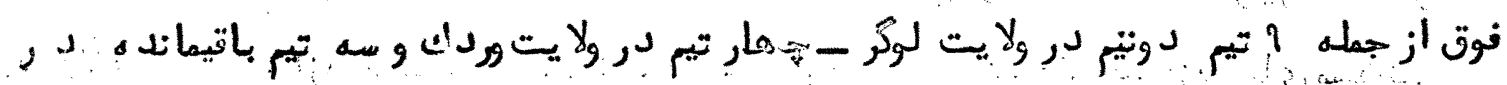

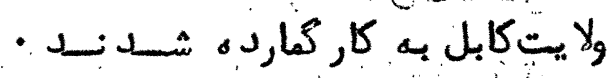

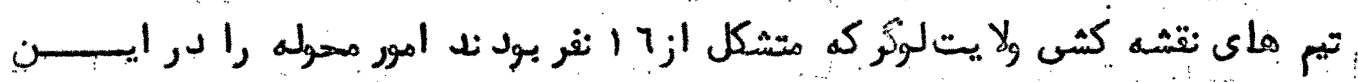

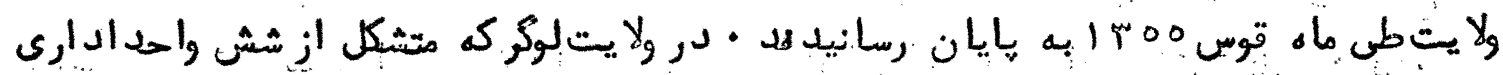

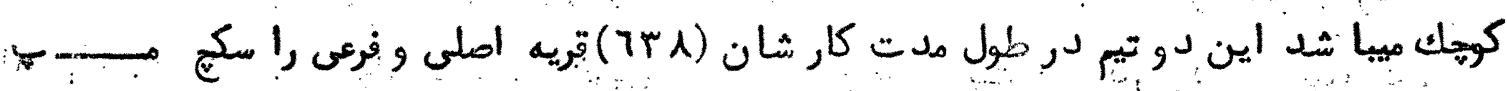
نموده وغورهه شرايط مهل ولستقبلى خانوار را برايشان خانه برى كرده اند • درقريه هاي.

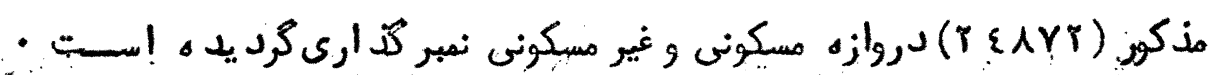

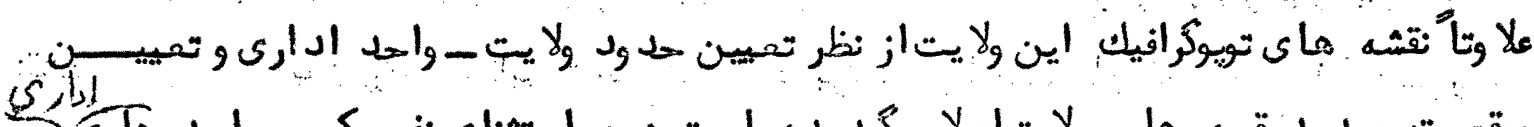

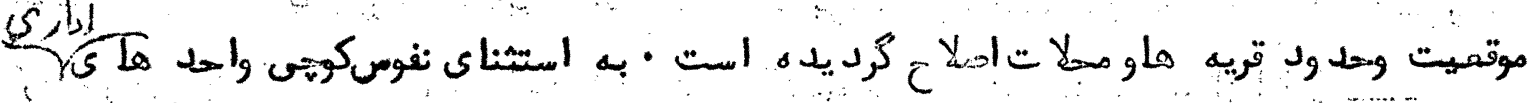

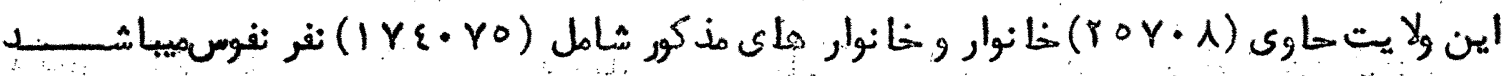

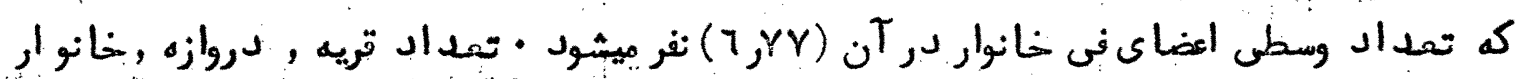

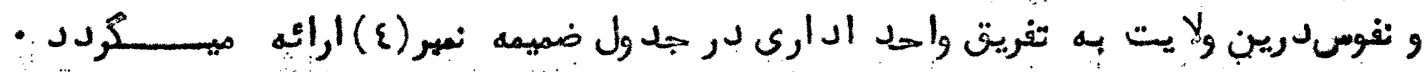

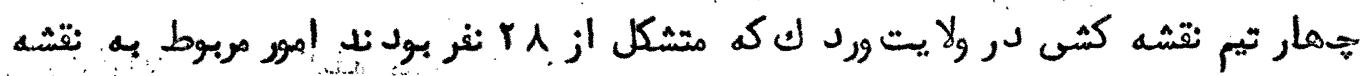

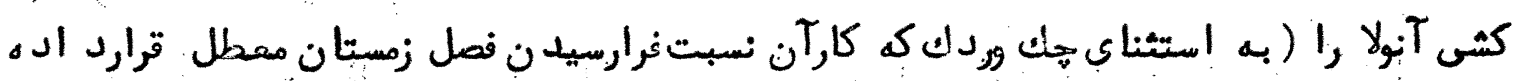

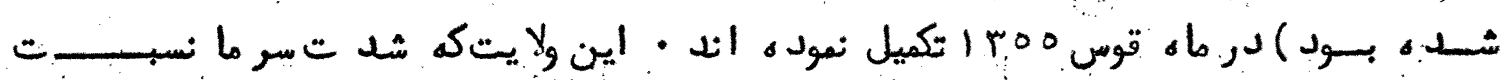

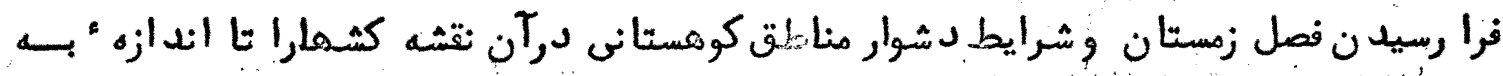

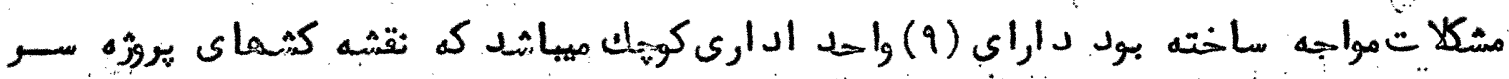

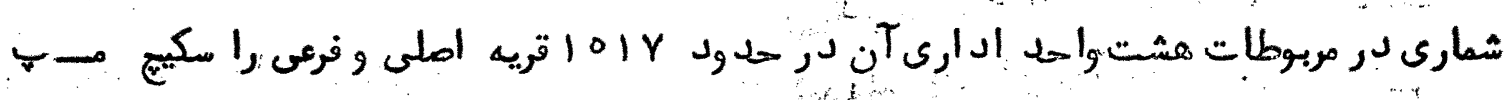

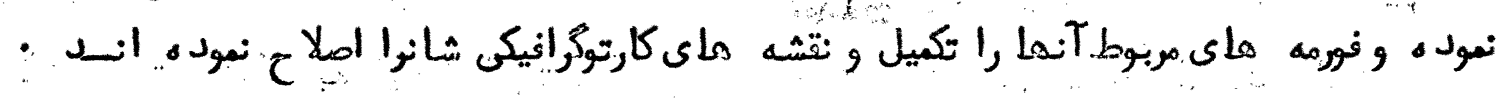

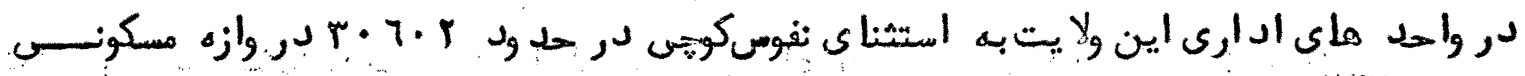

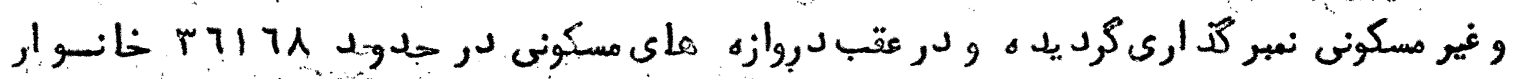

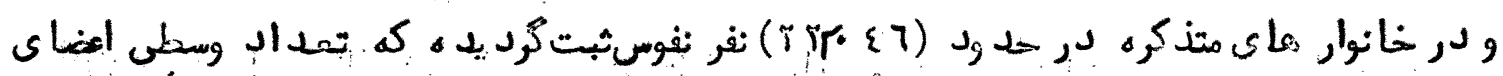




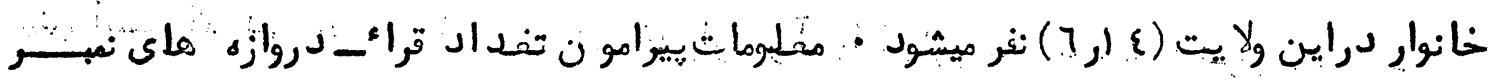

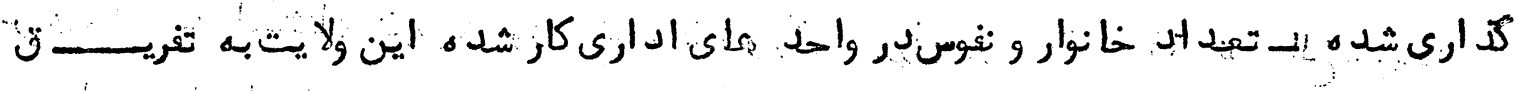

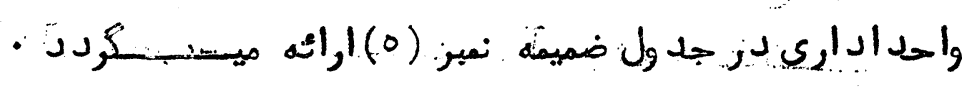

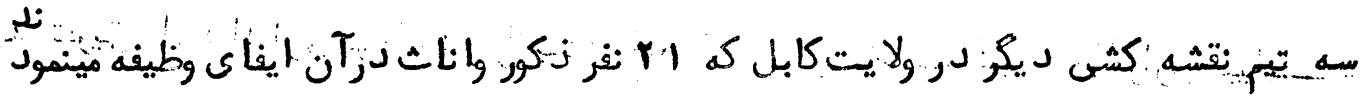

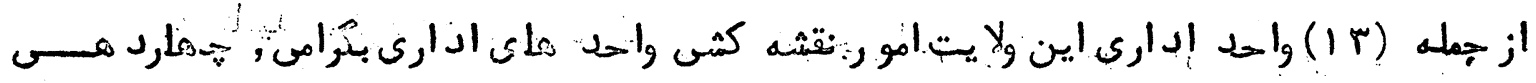

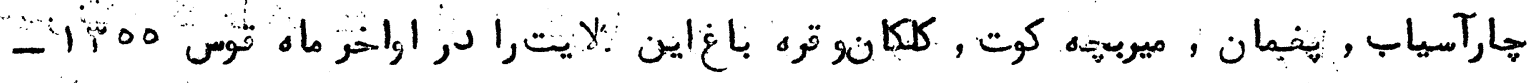

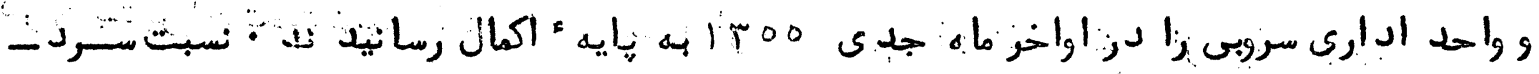

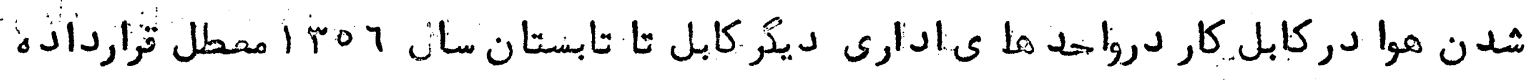

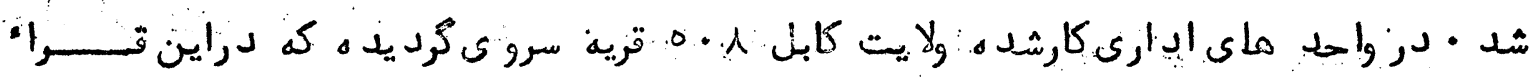

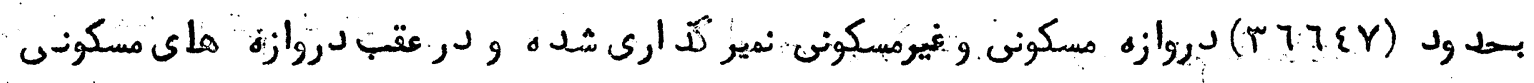

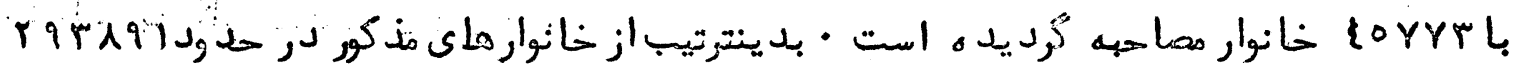

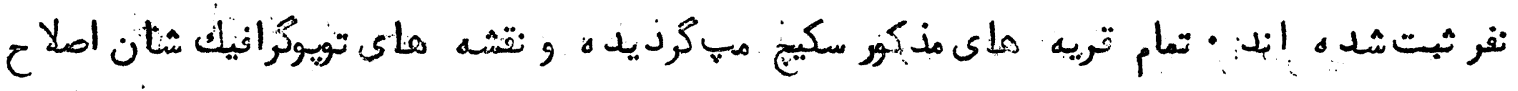

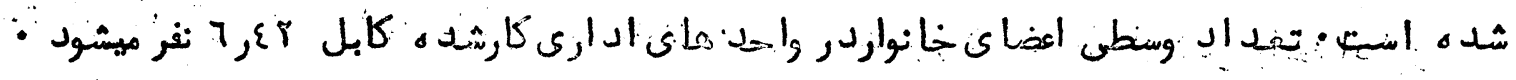

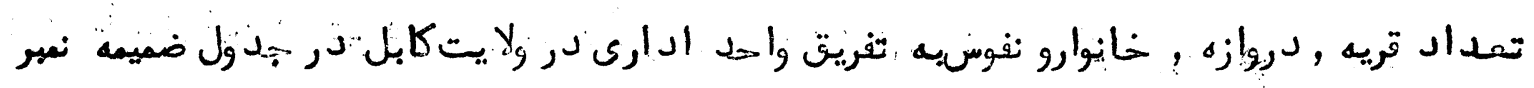

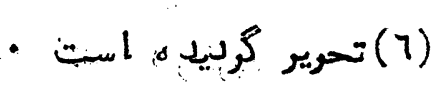

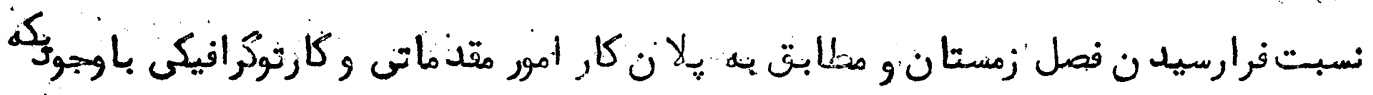

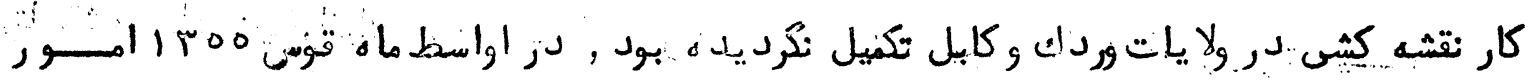

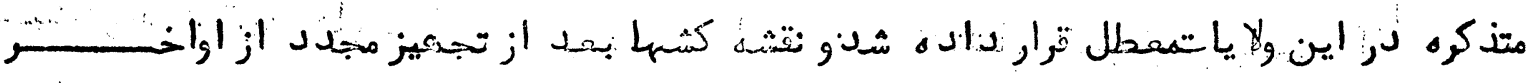

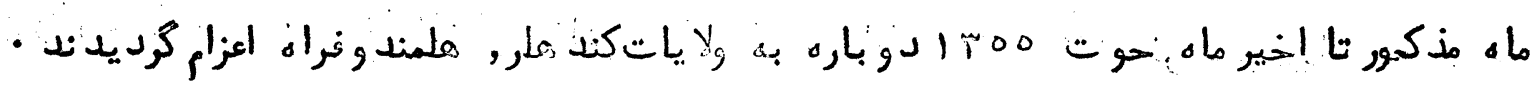

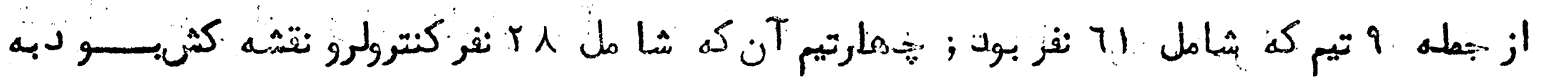

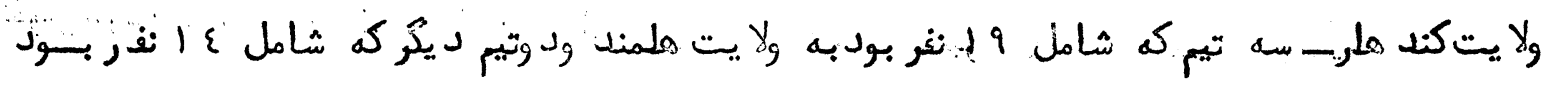

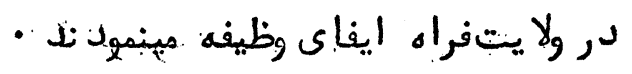

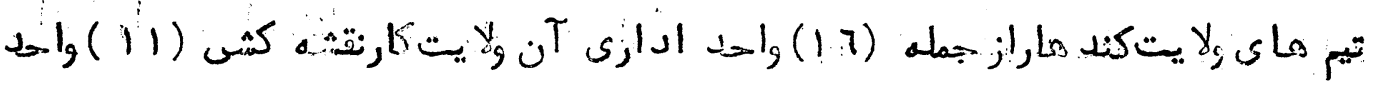

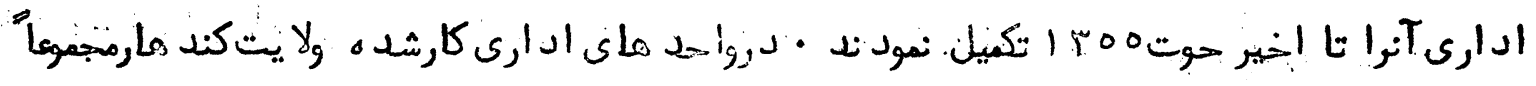

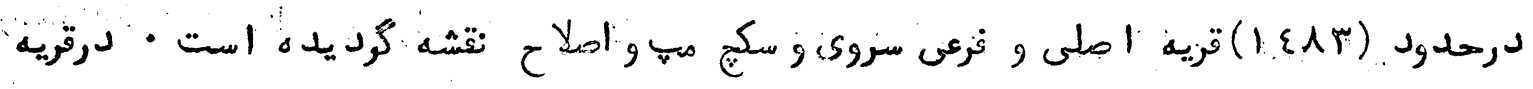

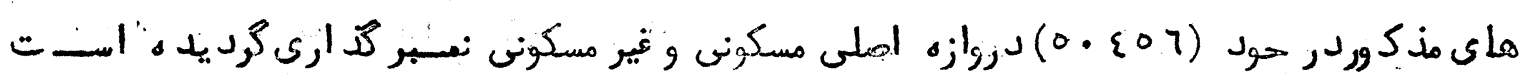

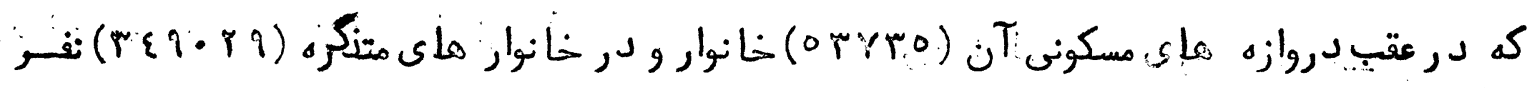

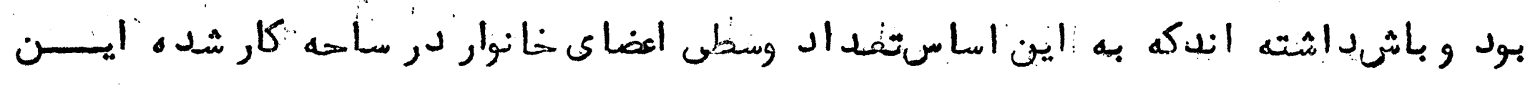

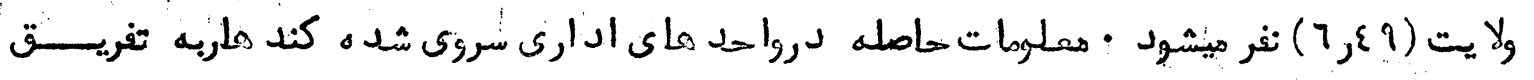

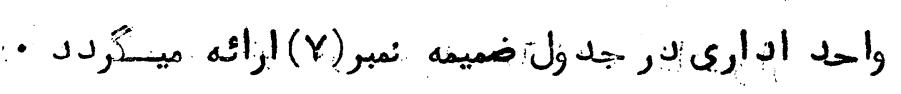

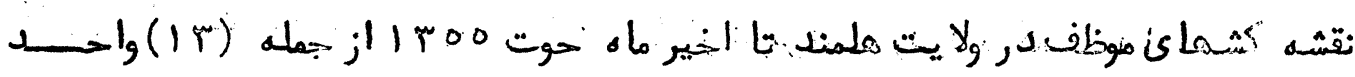


ادارى كوهك آن ولايتكار نقشه كشى (• () واحد ادارى Tنرا تكميل نموده اند • در واحد هـاى

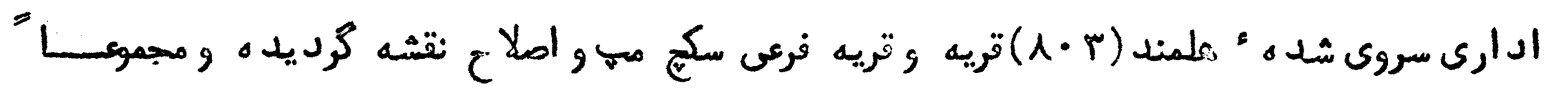

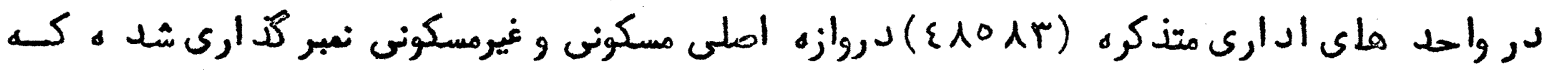

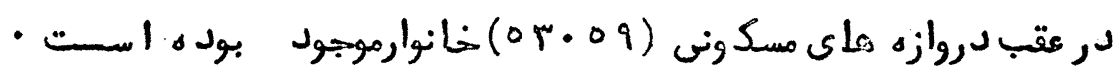

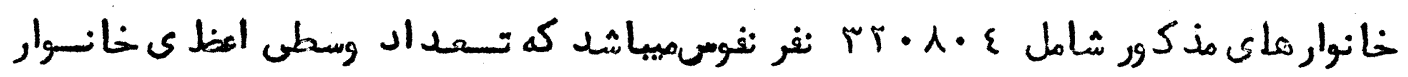

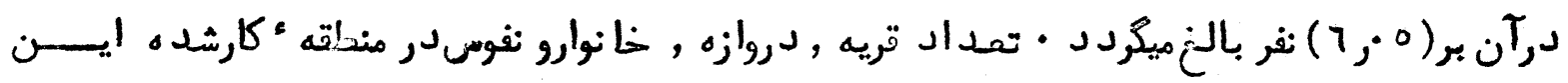

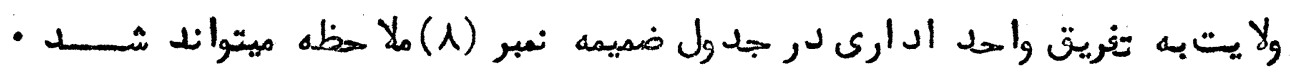

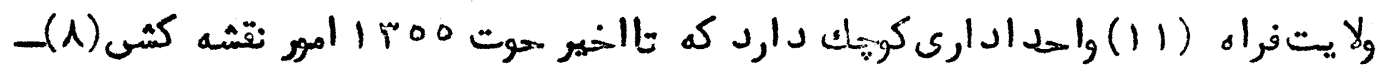

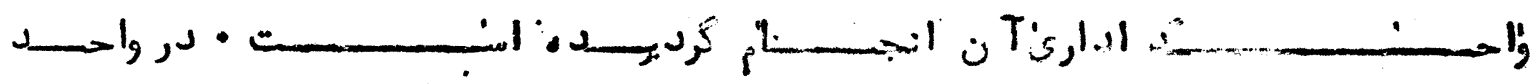

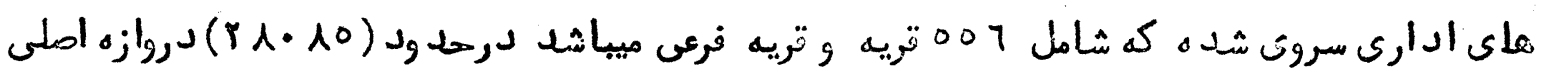

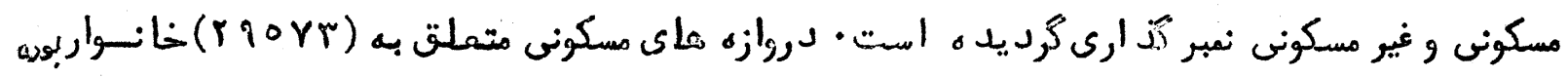

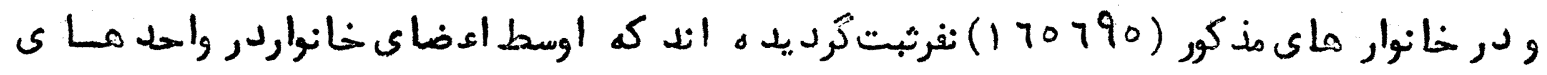

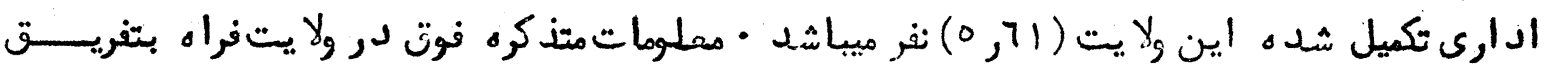

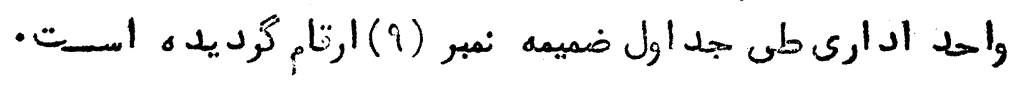

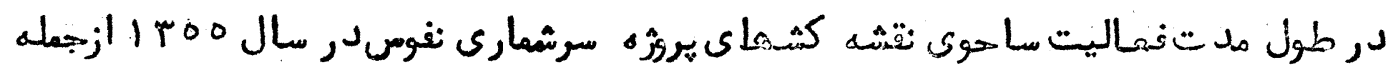

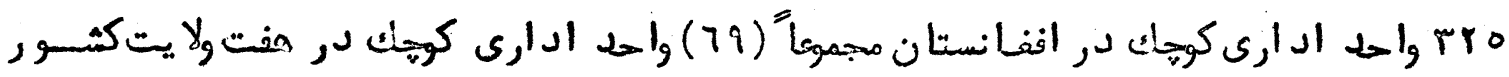

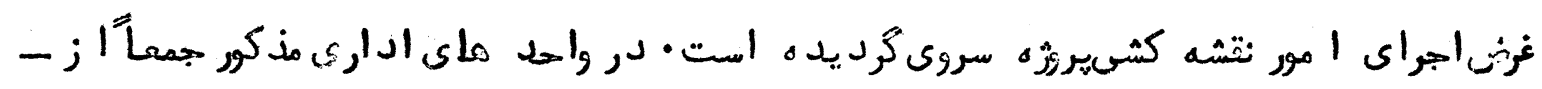

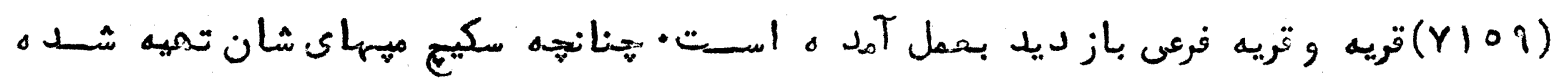

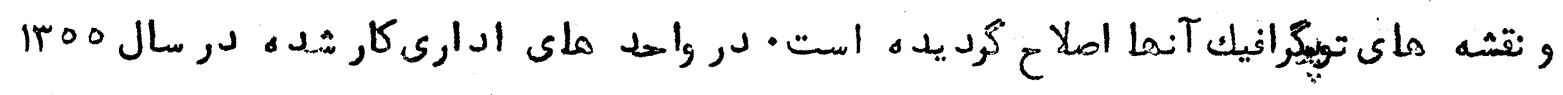

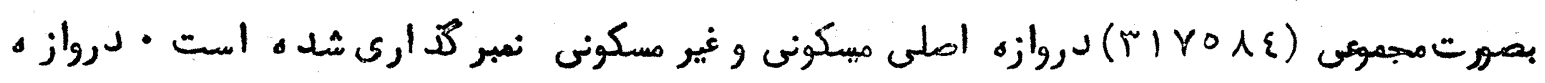

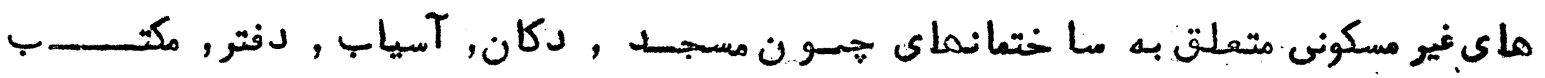

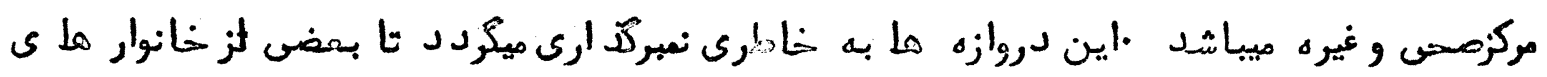

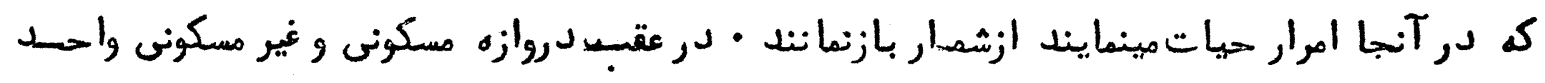

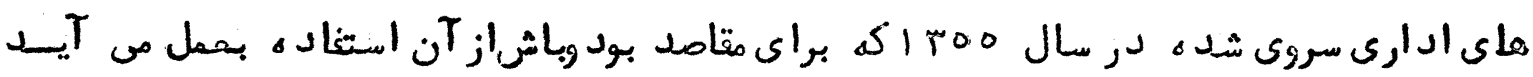

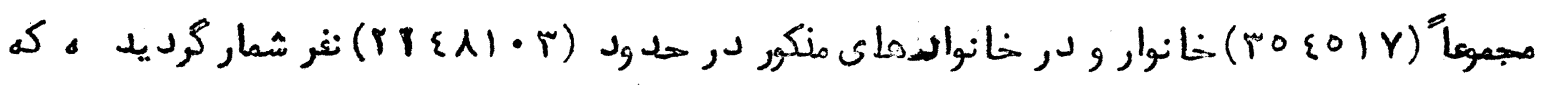

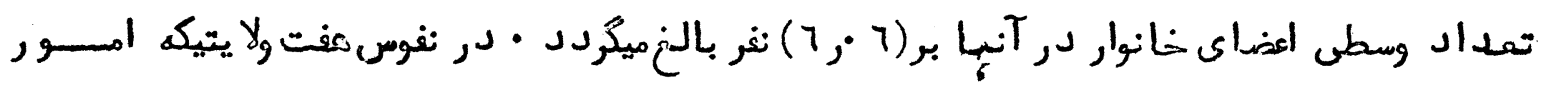

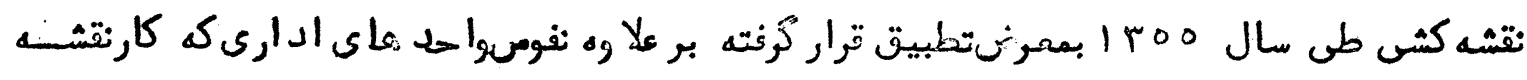

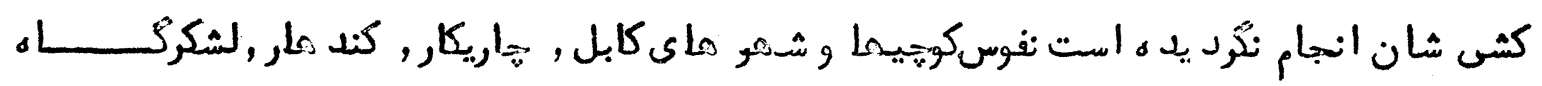

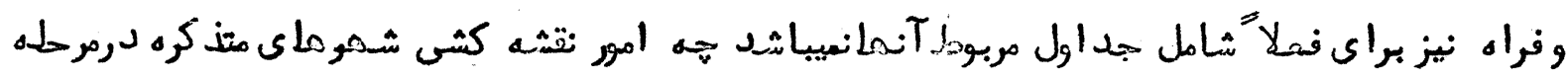

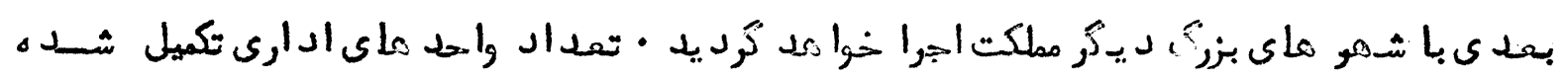

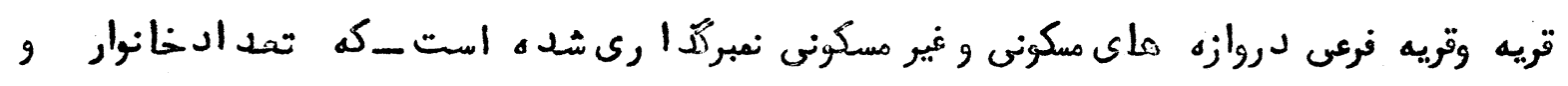




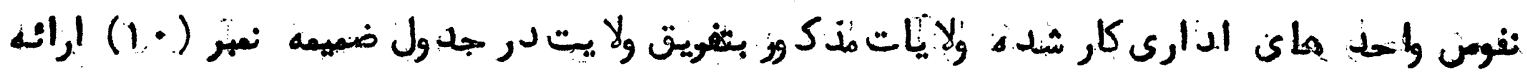
كرديلة. انبست

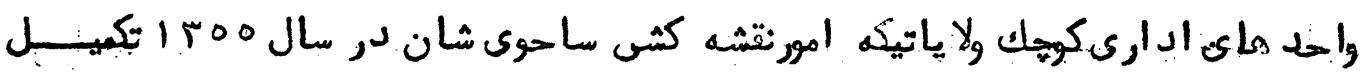

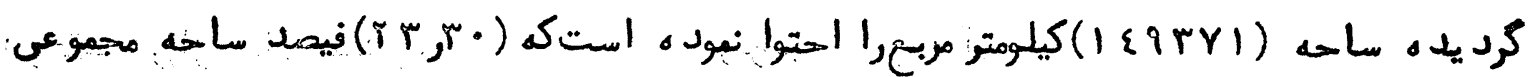

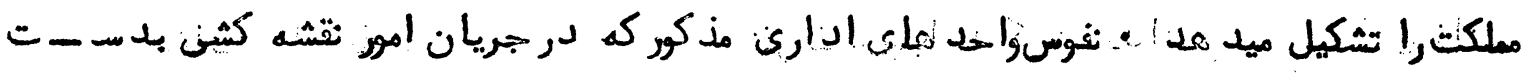

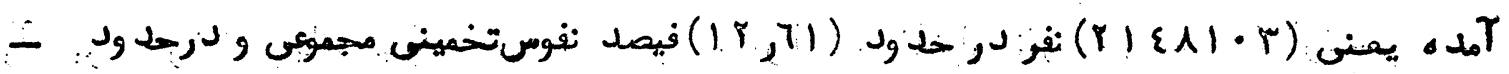
(IY,YY)

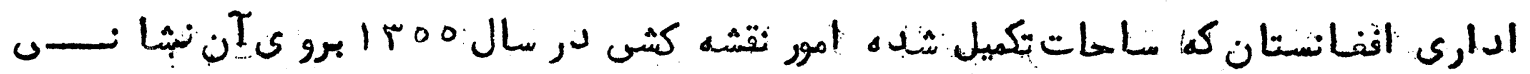

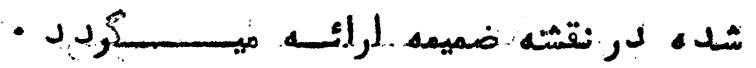

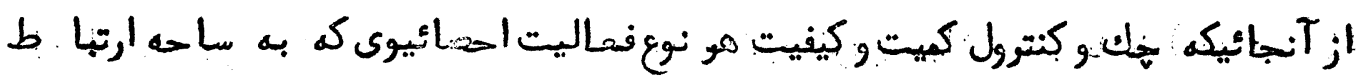

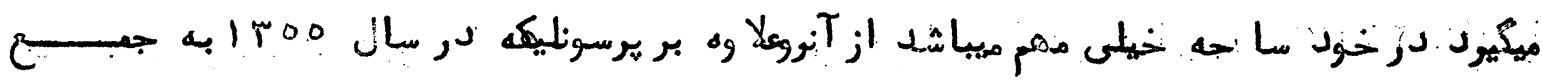

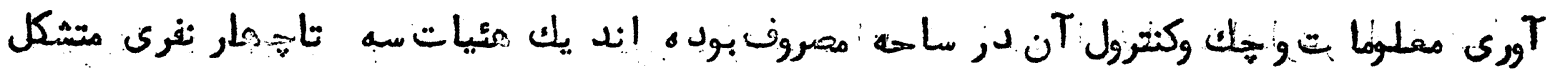

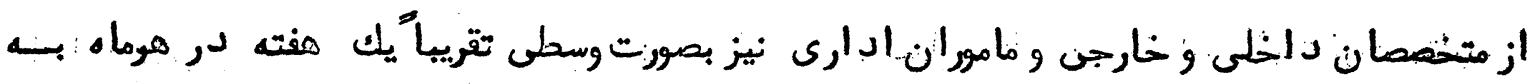

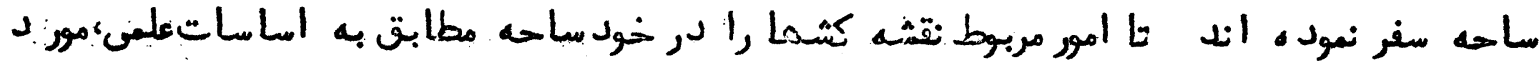

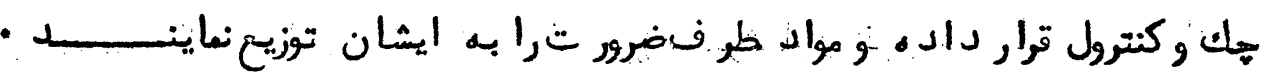

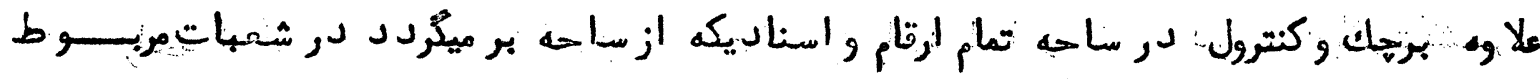

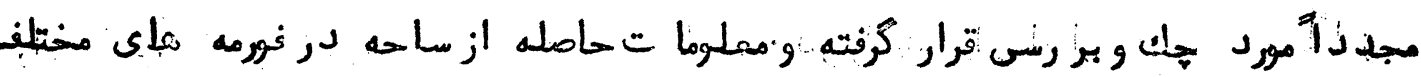

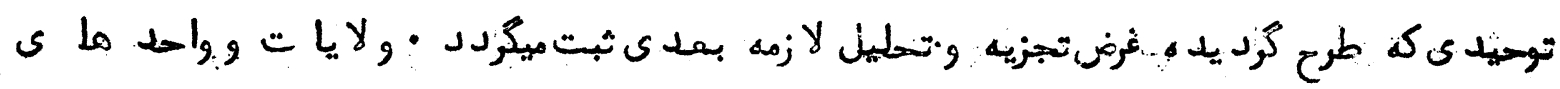

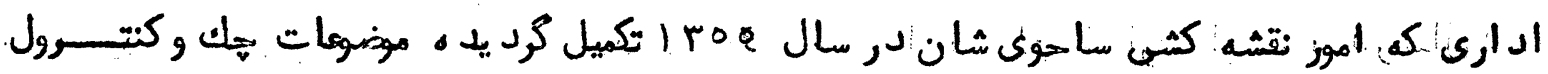

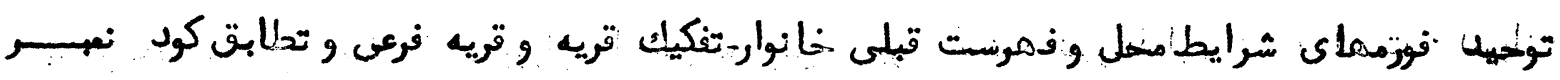

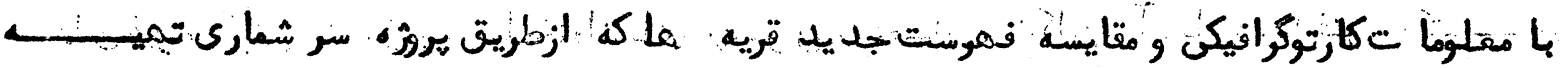

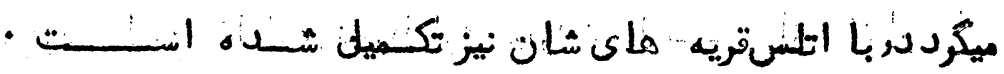

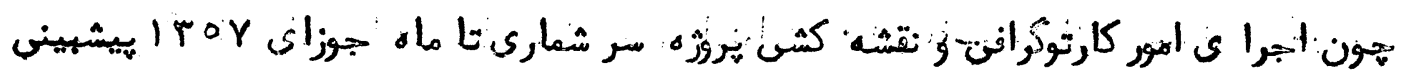

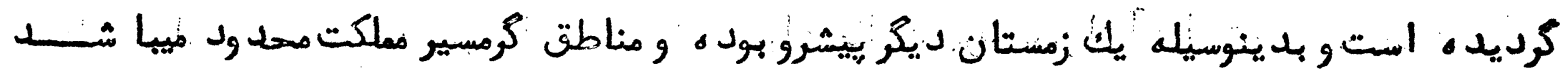

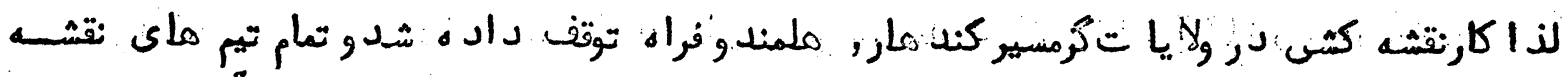

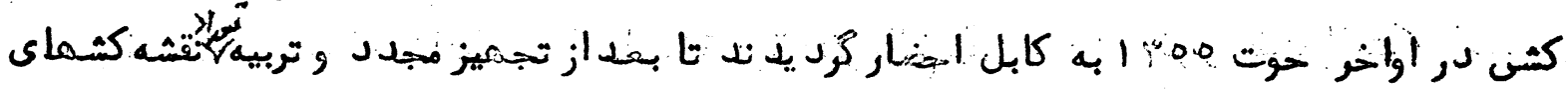

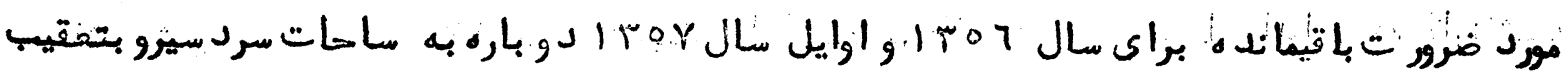

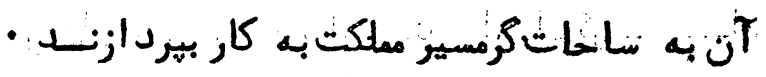

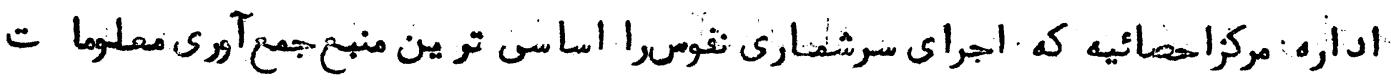

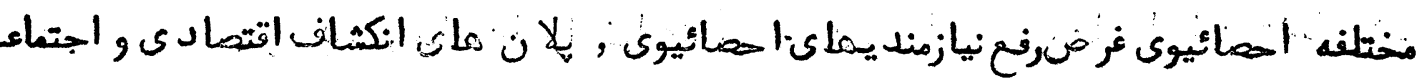

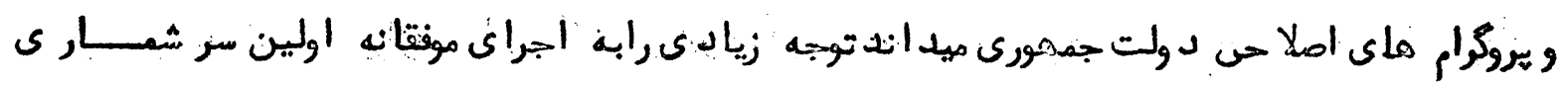




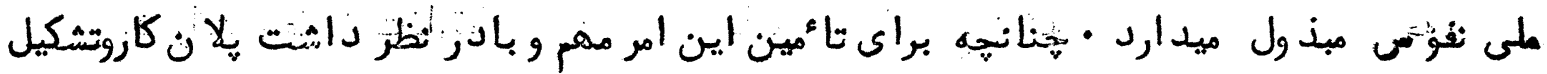

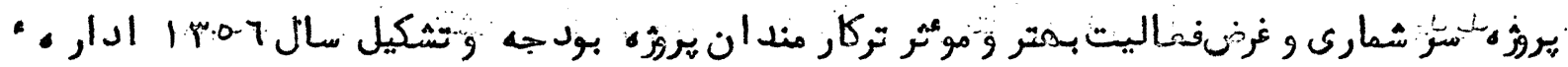

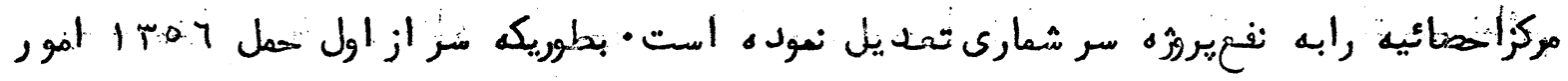

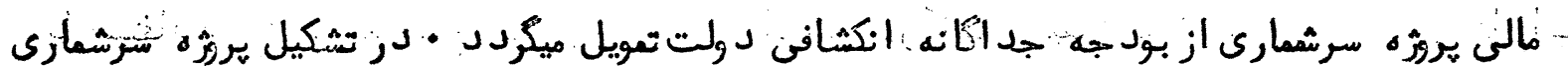

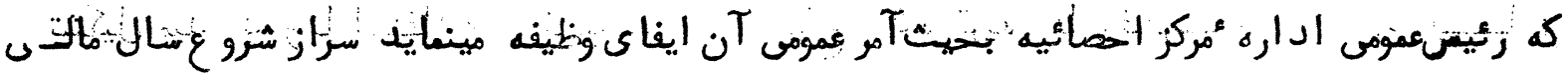

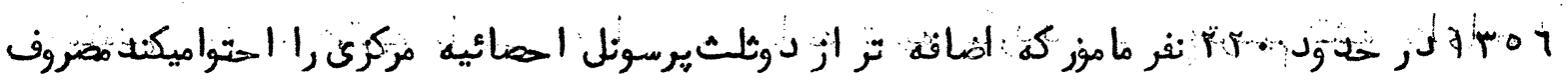

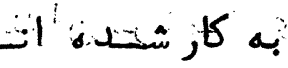

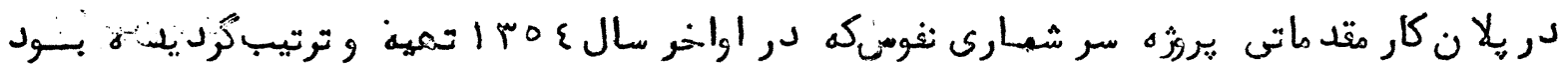

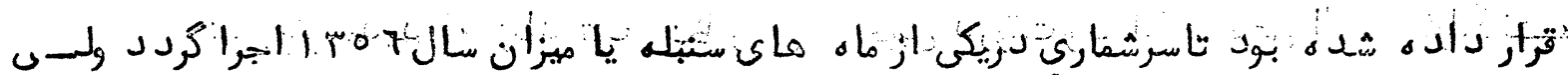

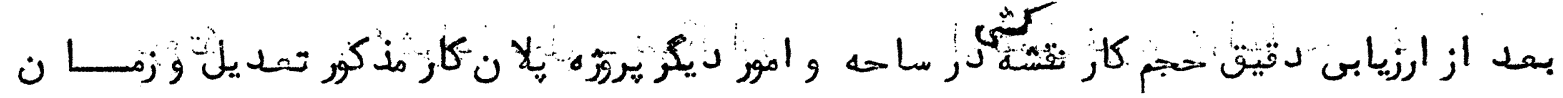

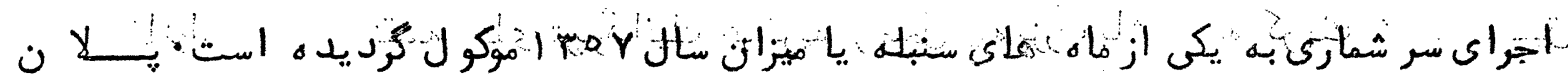

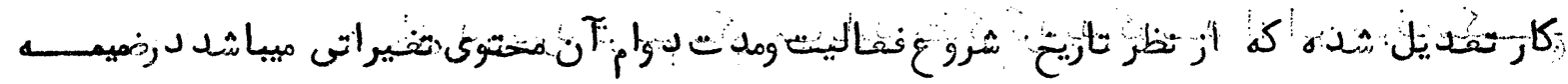

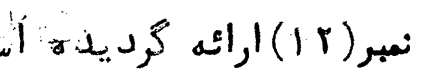

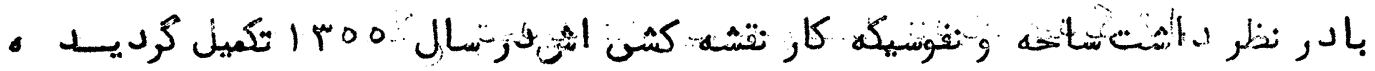

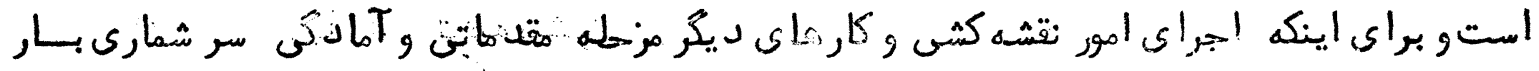

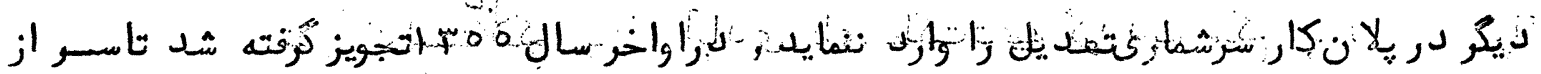

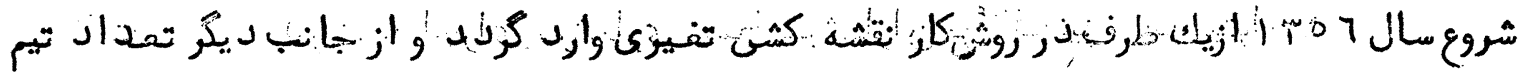

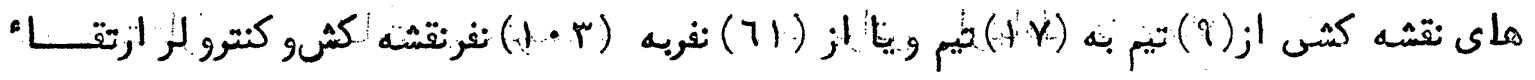

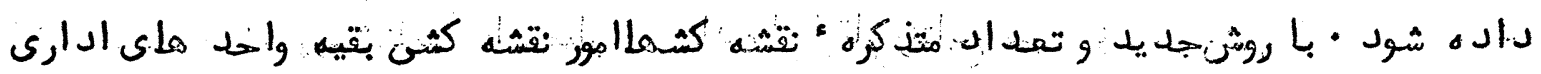

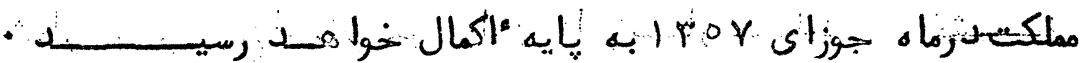

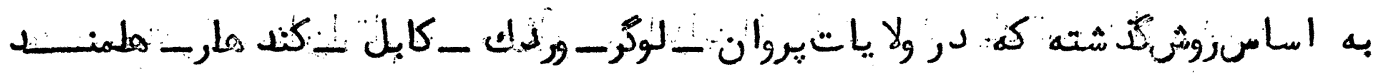

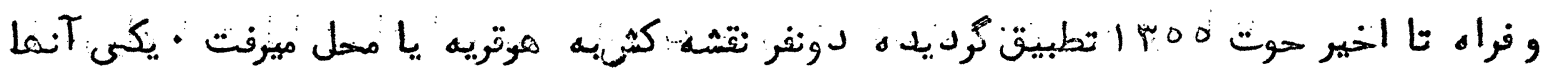

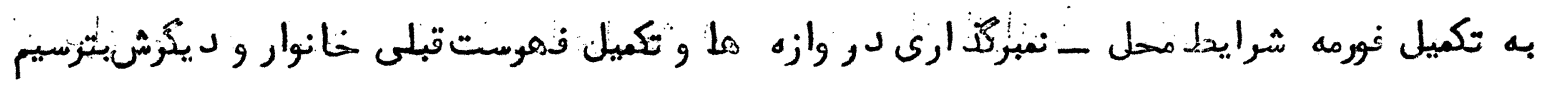

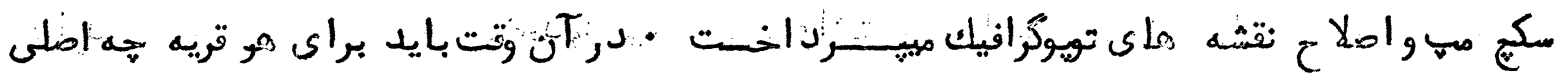

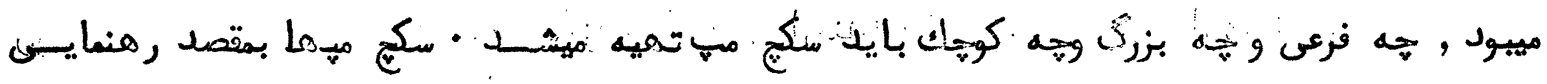

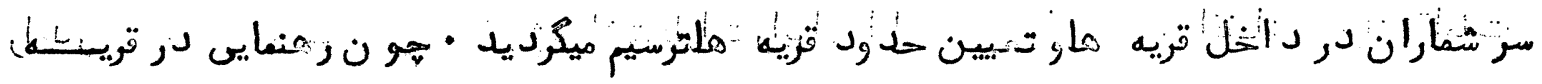

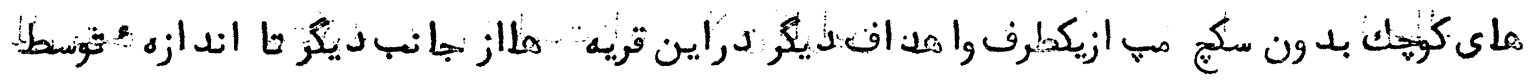

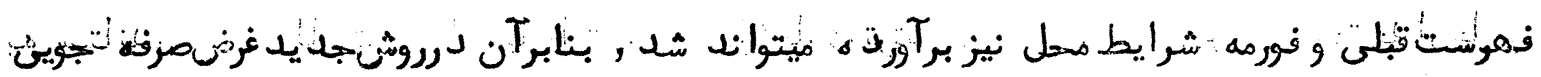

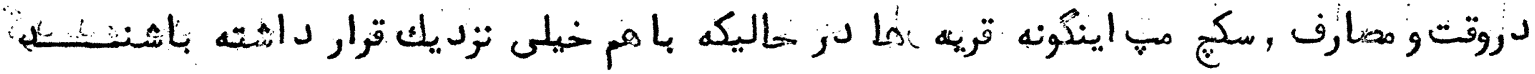

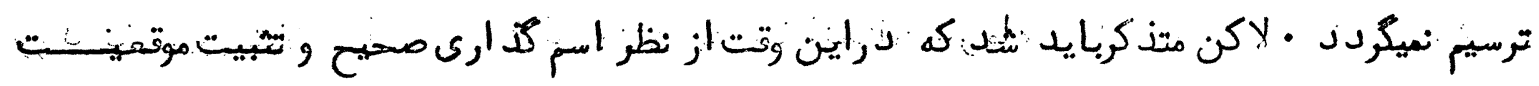

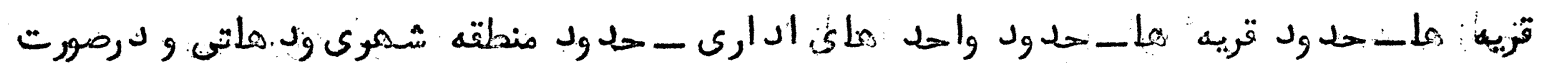




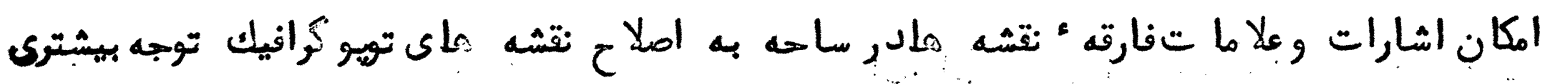

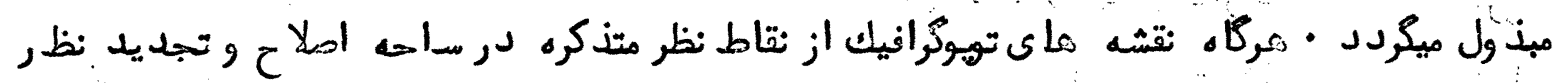

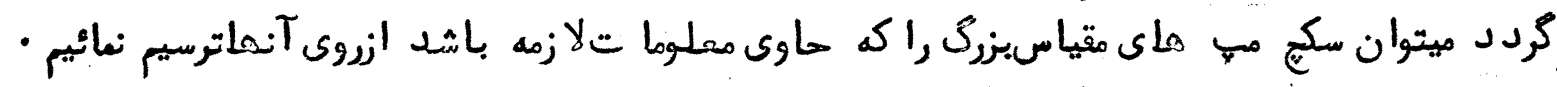

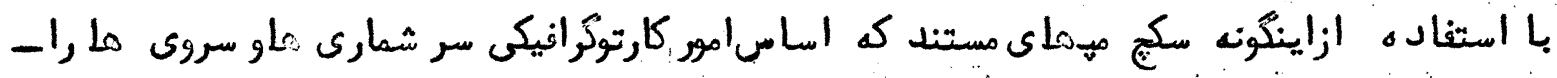

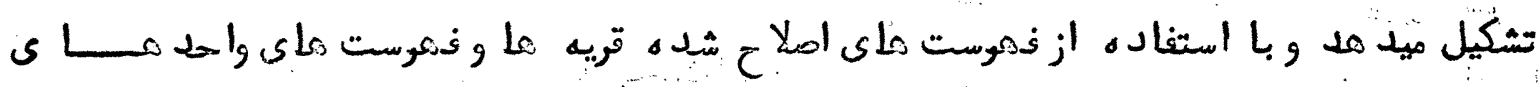

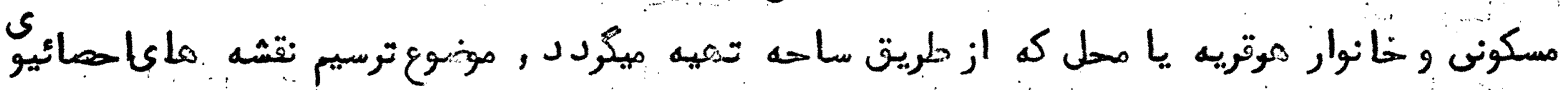

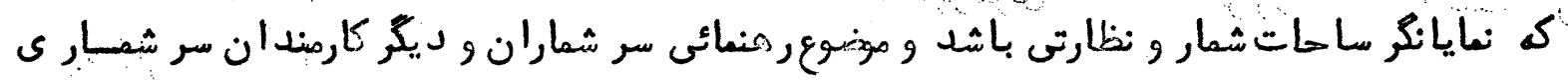
•اء مين ميتواند شد

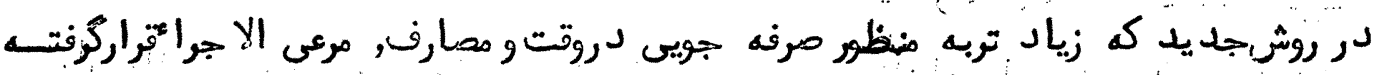

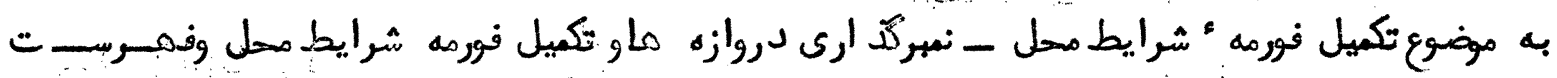

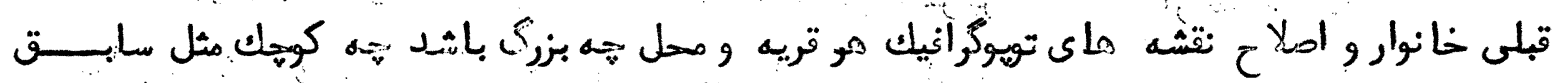

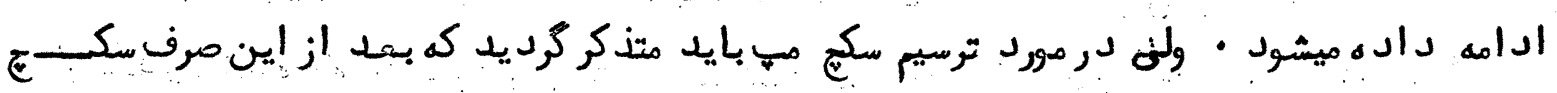

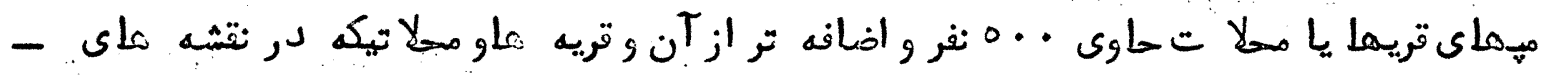

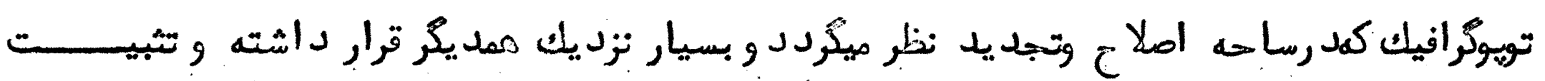

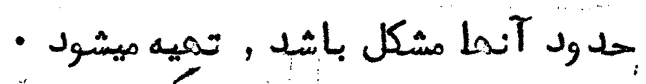

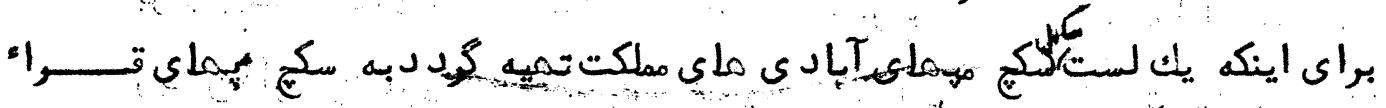

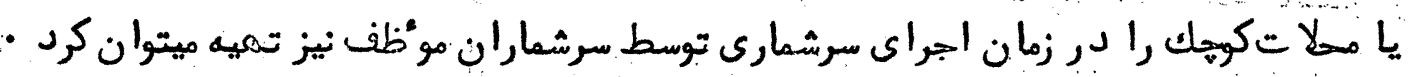

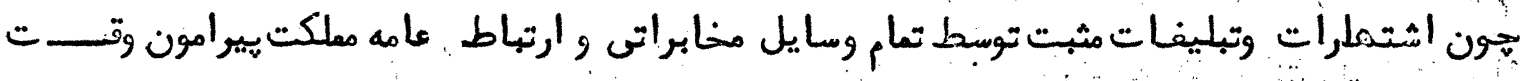

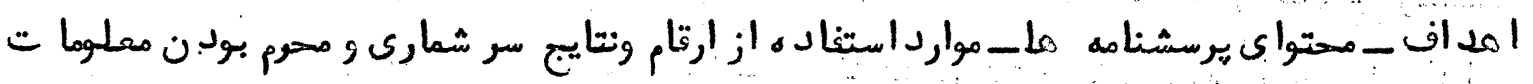

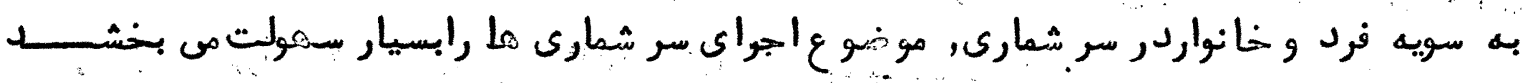

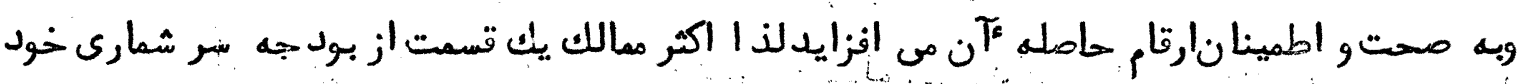

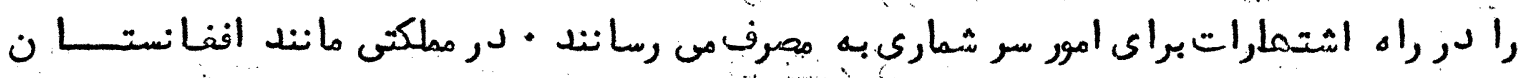

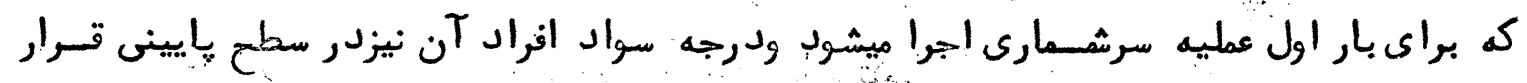

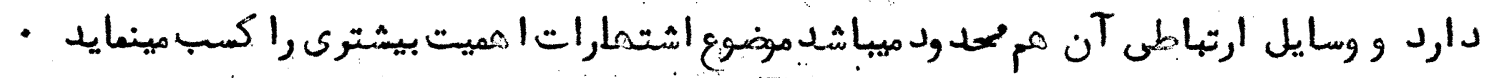

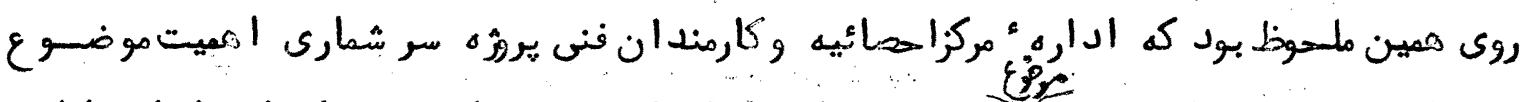

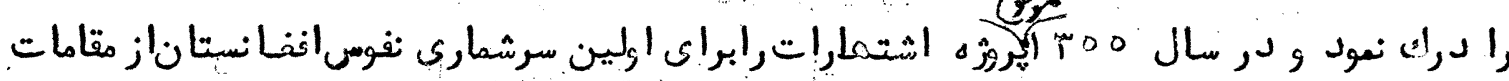

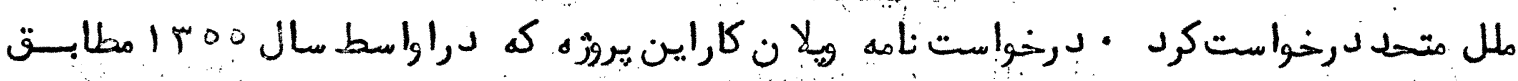

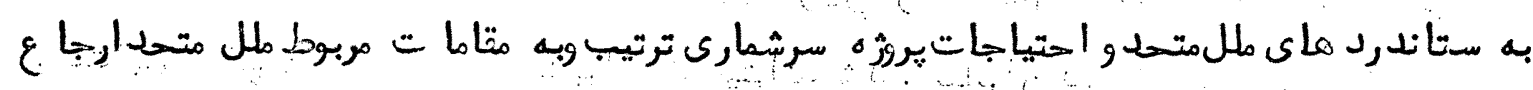

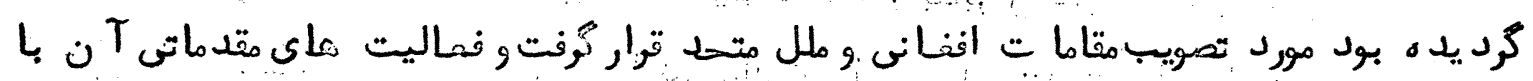

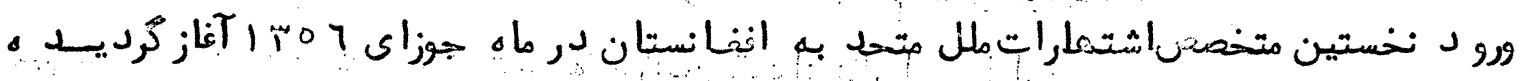

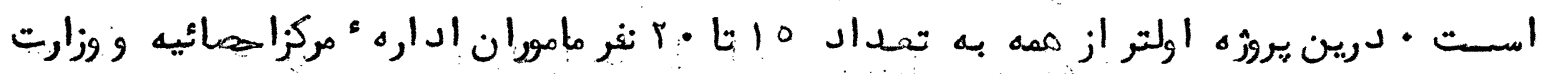




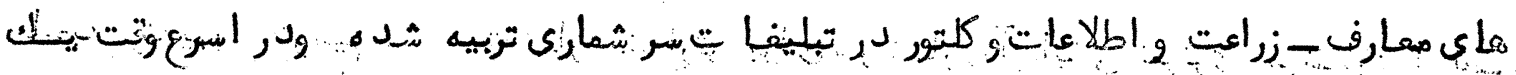

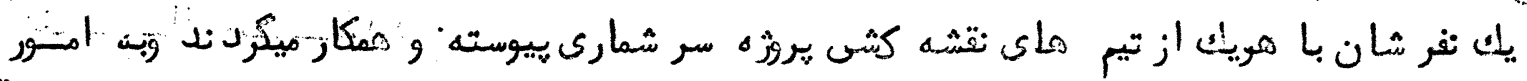

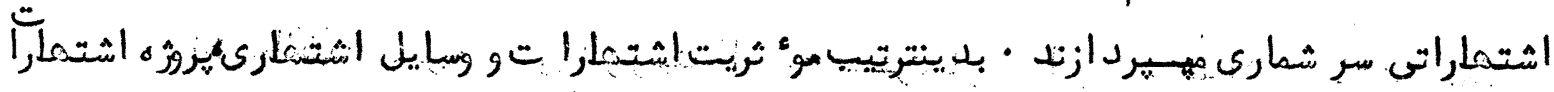

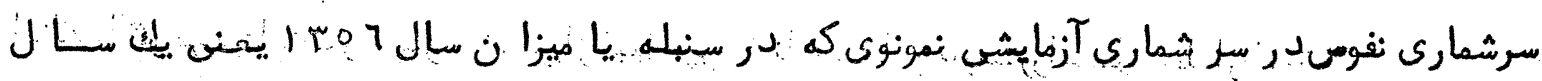

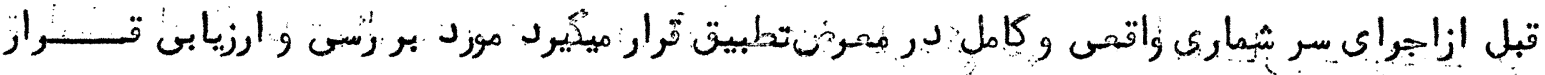
12

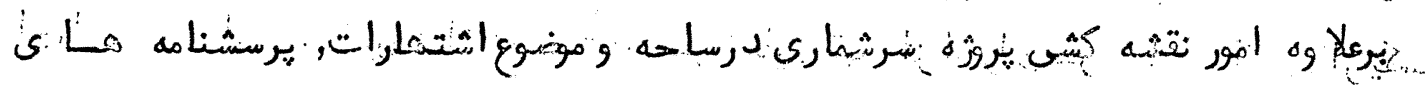

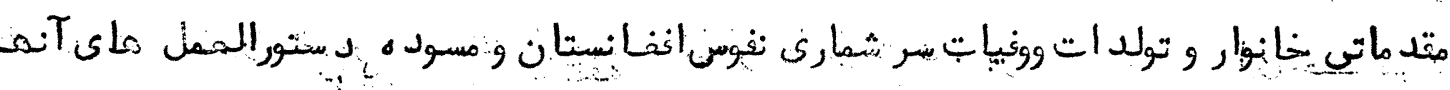

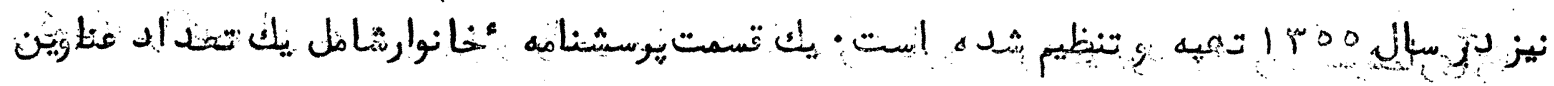

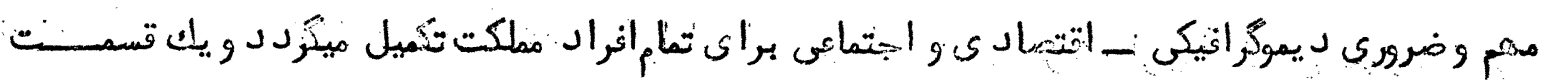

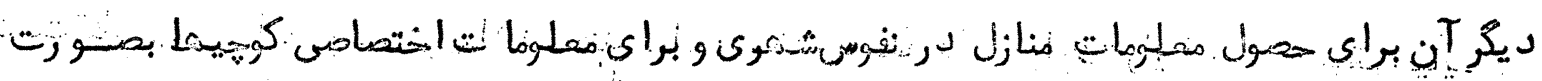

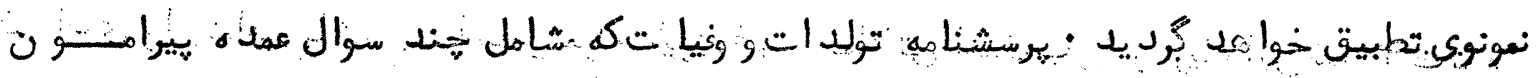

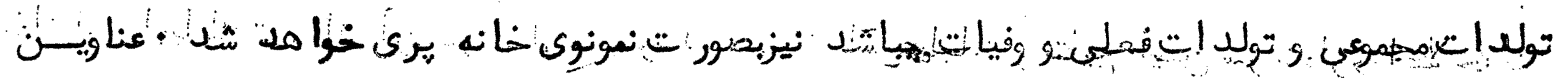

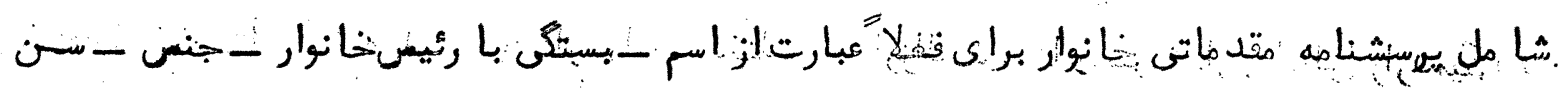

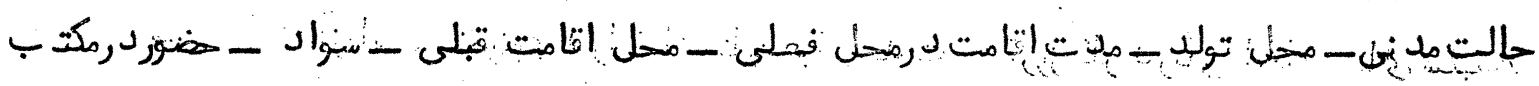

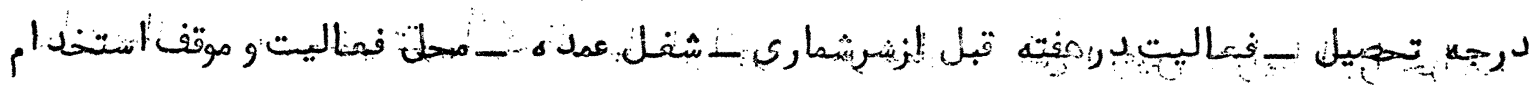

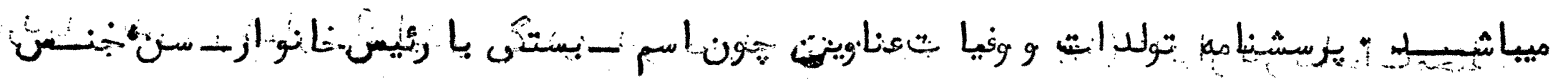

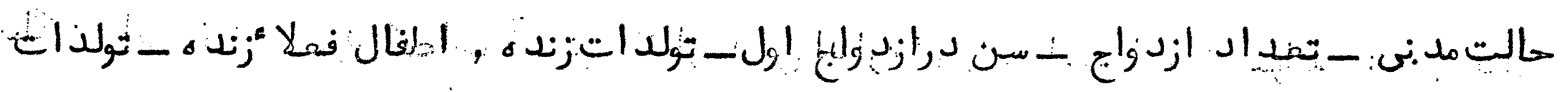

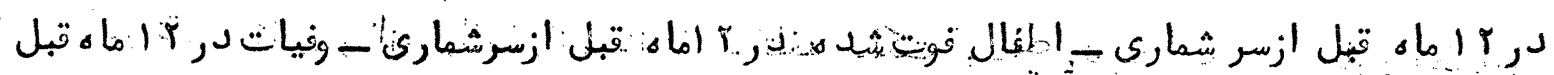

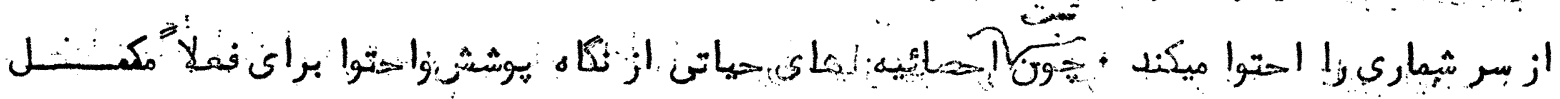

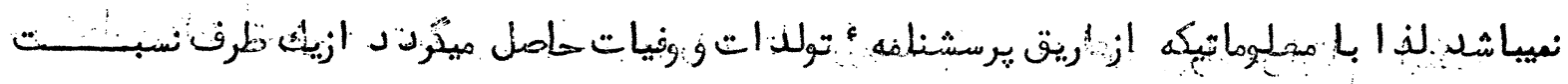

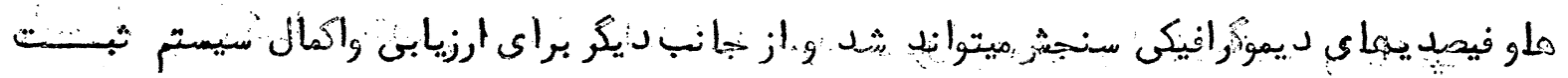

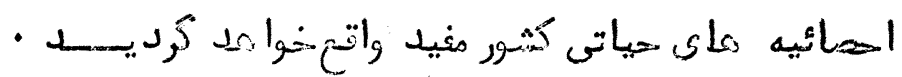

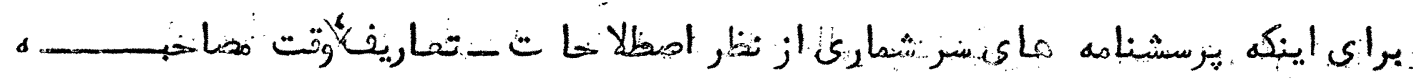

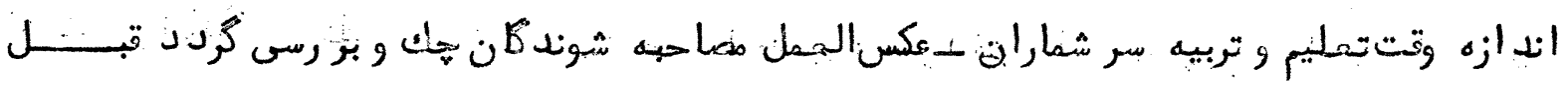

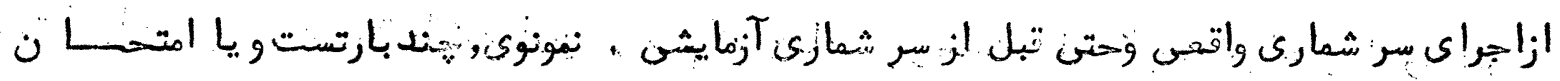

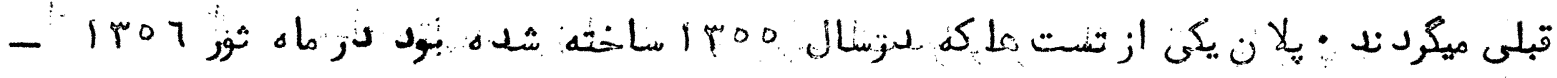

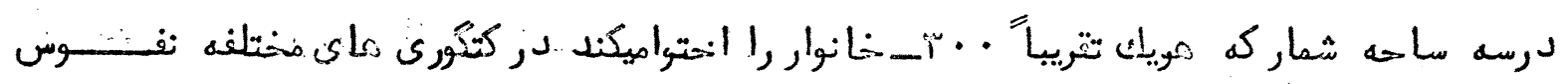

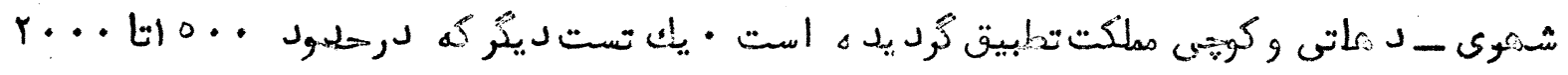

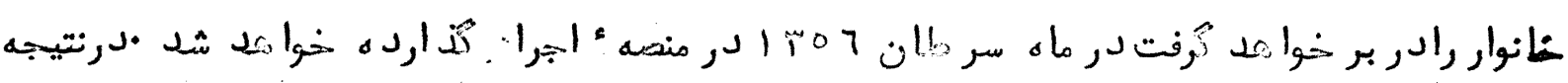

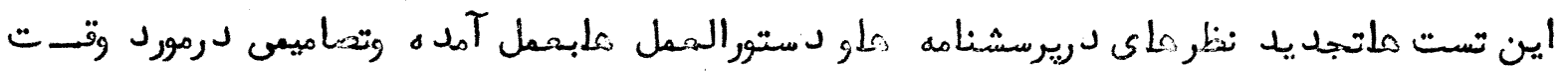


مداحهه وتميين و ترسيم ساحا تشار و نثارتى براى سر شمارى آزمايشى نمونوى وسرثمارى الملسى

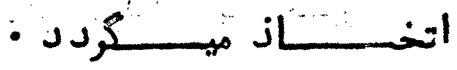

در ممالكيكك تجزبه تبلى در زمينه اجراى سـرشمارى ها و جود ندارثته باشد و بسرائ

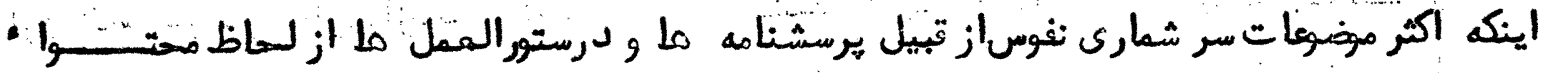

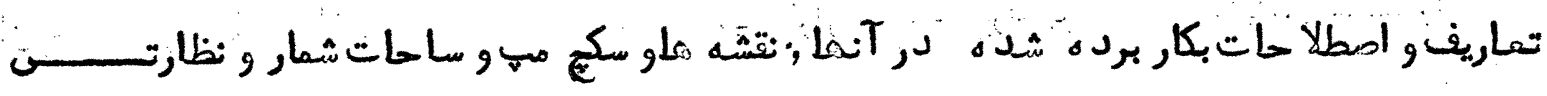

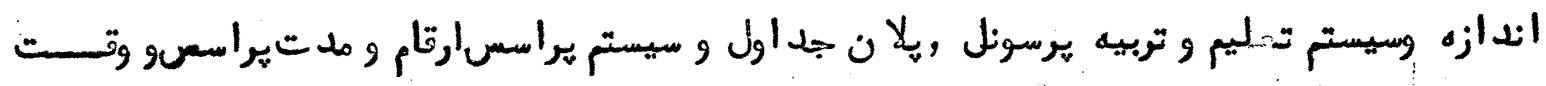

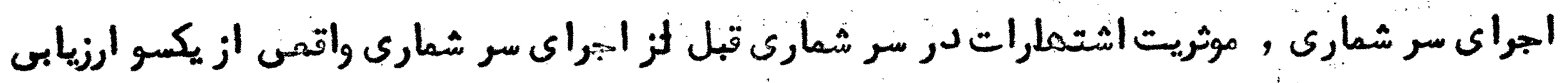

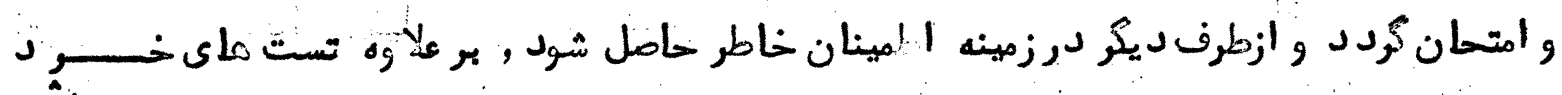

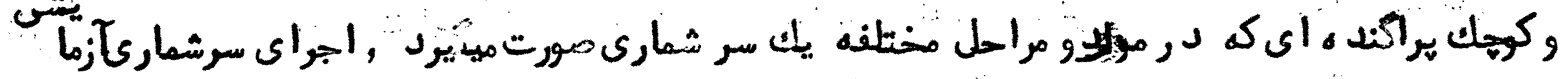

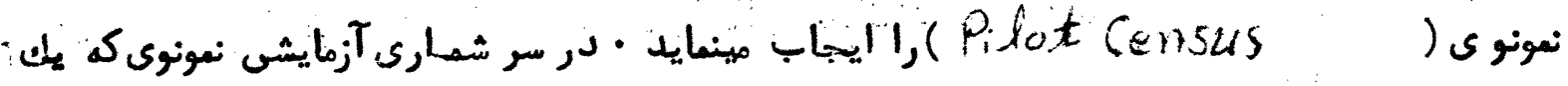

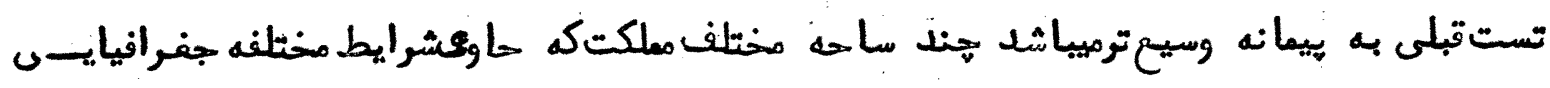

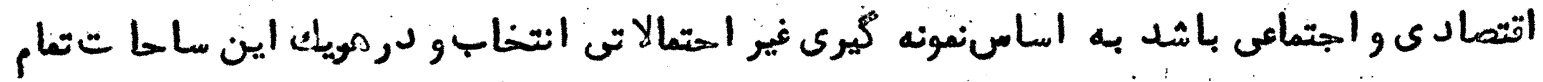

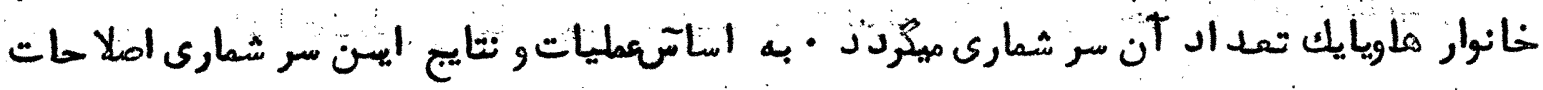

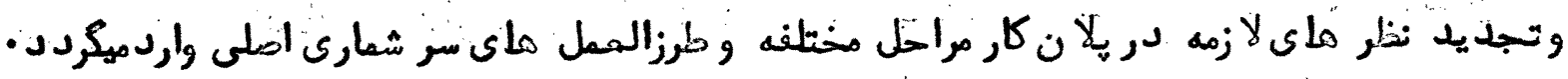

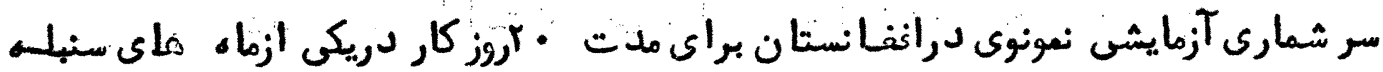

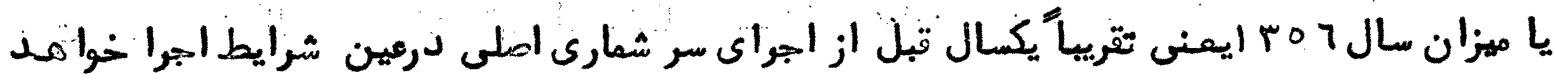

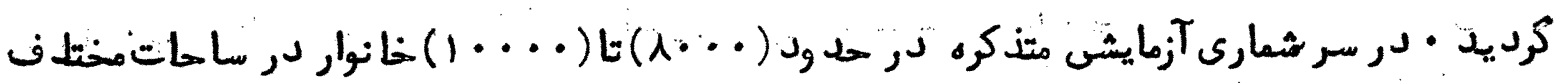

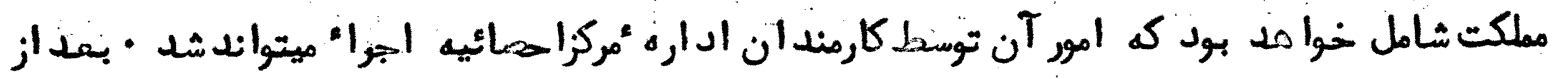
تكميل امور نقشه كشى وكارتوكرافيكي در مناملق مختلفه مملكت أرمواضع نمونه اين سر شمارى انتخاب

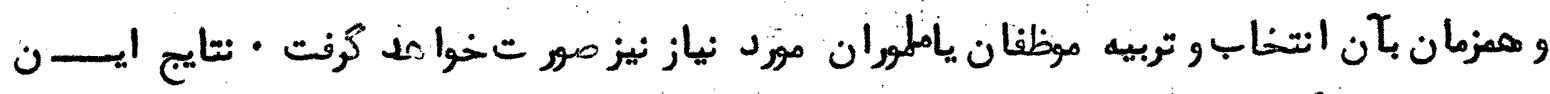

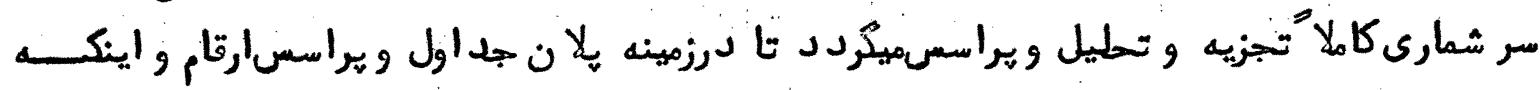

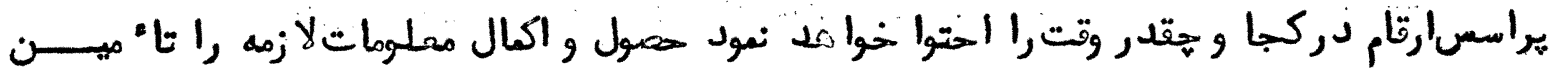

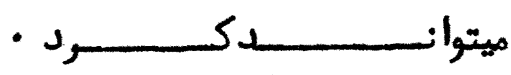

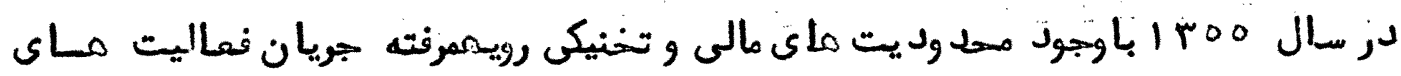

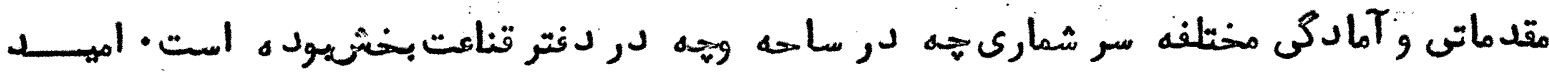

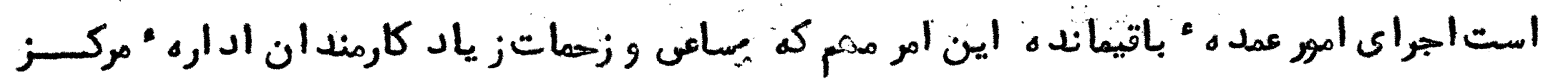

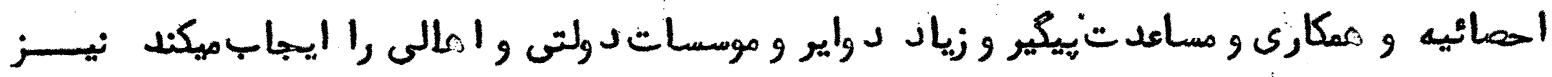

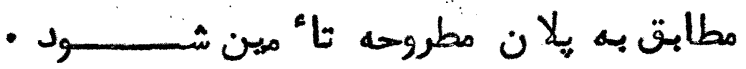




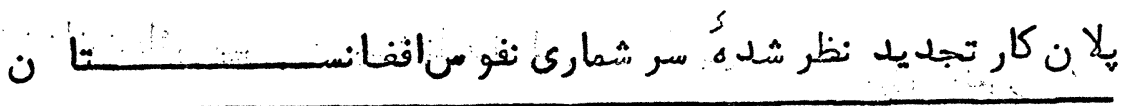

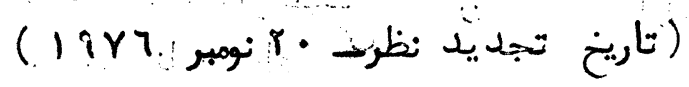

$$
\text { مخل }
$$

فعاليت ماي يوزوزه

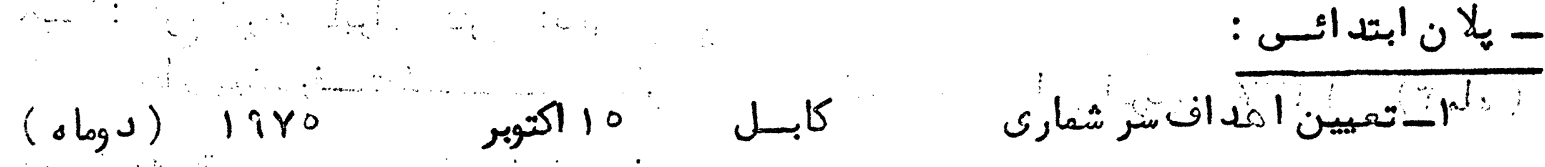

$$
\begin{aligned}
& \text { r إساسرانونى سر شمارى }
\end{aligned}
$$

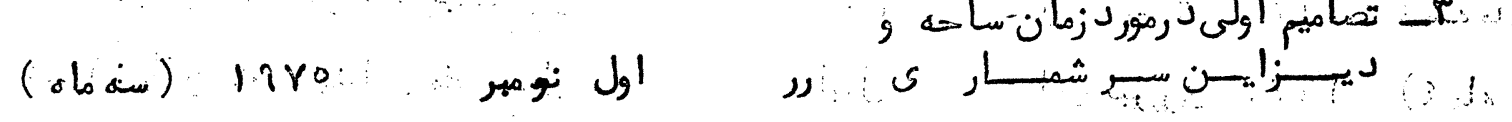

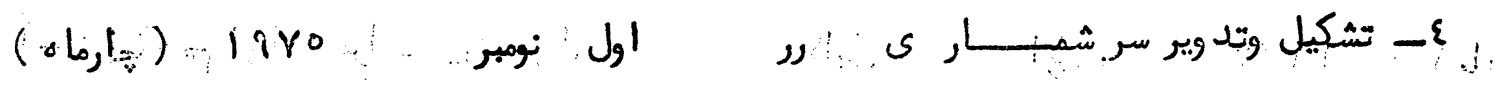

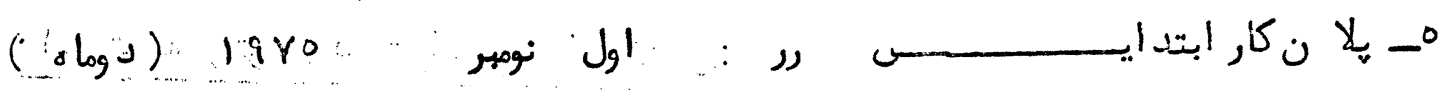

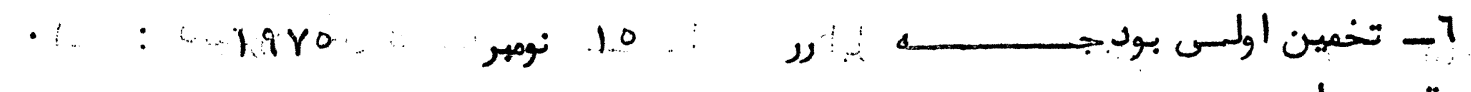

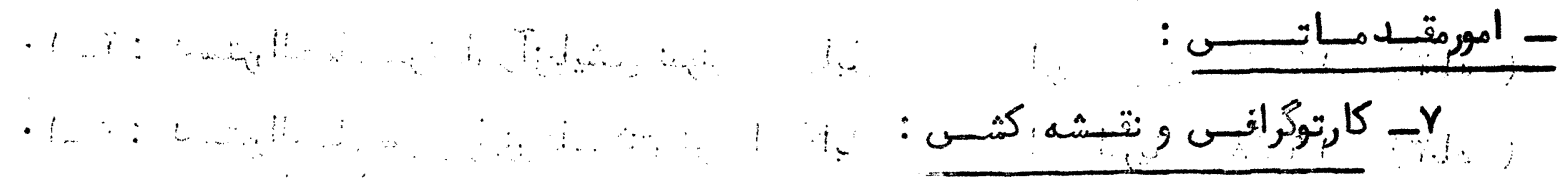

$$
\begin{aligned}
& \text { r_ا:نقشه مائموبهـود }
\end{aligned}
$$

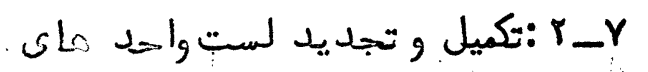

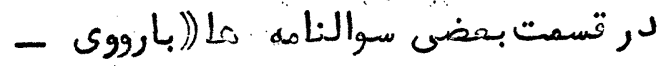

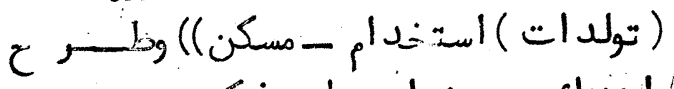

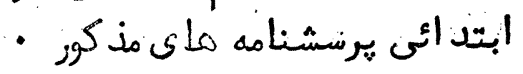




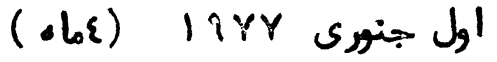

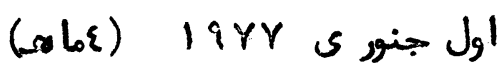

لــ : ييشنهاد نمائى بيرامون يرسشنامه املى كابل

נ

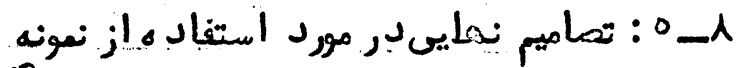

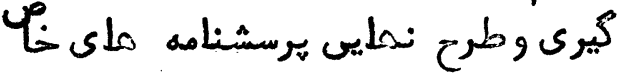

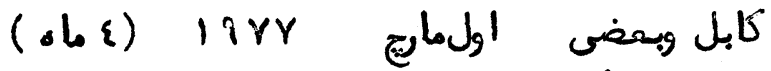
جا ماي ديكّر

كابل اول إيريل

גـ Y : طرح فورمه مابراى كنترول ادارى رايور

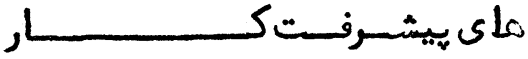

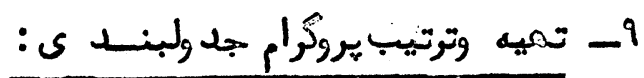

كابل 9-1 : يلا ن ابتد ائى جد ولبنسـد ى

أول اكتن كابـ

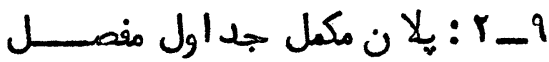
كابل 9-r : تقسي اوتا تمراحل مراسسارتام

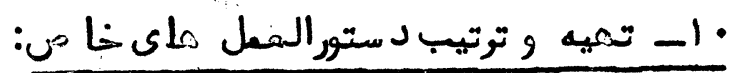

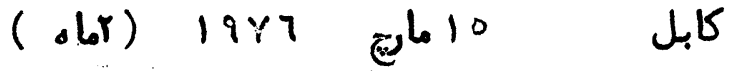

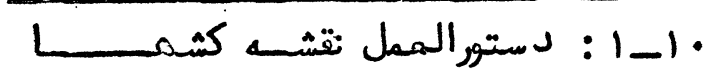

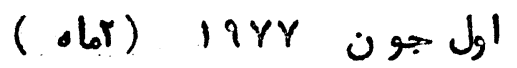
• ا_Y : دستورالمعل سرشماركآزمايشى نمونوى كابل اول ايريل الهو

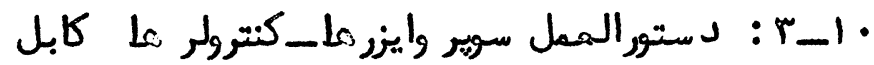
وسر شماران (براى سرشمارى كامل ) ا

اول مى الك ماه ) ا

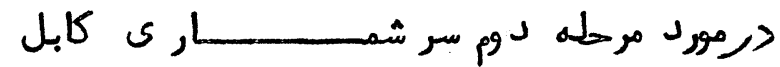

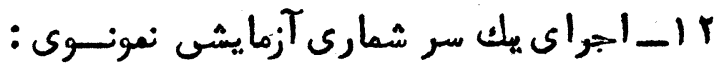

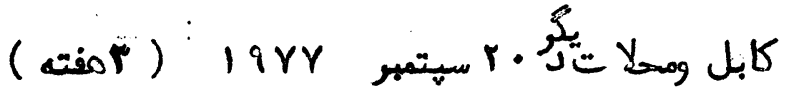

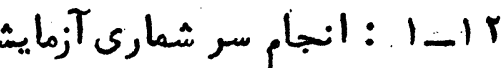

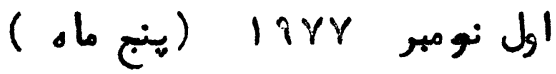
كابل

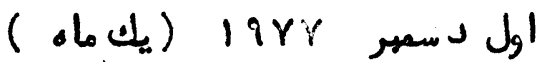
كابل

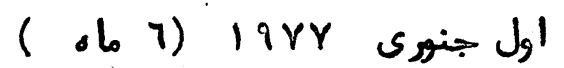
كابل سراسر مدت تهر5 تمام كثور

اول جنورى اليك ماه )

$$
\text { ســراسر مدت تهري }
$$

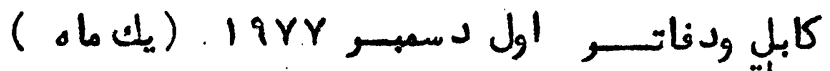

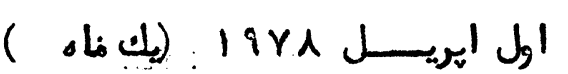

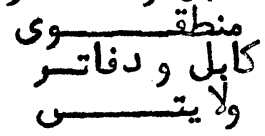

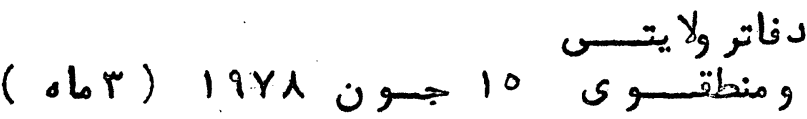

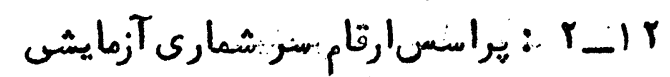

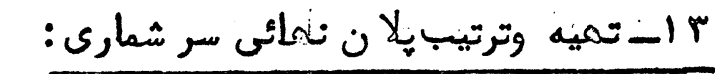
ع ا- خيالخورمه ماو برسشنامه ماي نمايى

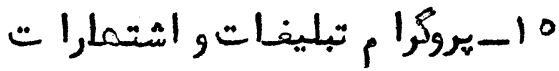
: 7 إ- تاسيسدفاتر منطقــــــو ى Y ا- اسيسدفاتر ولايت

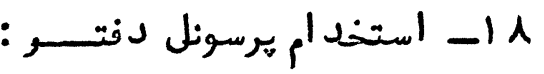

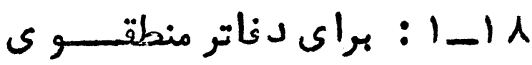

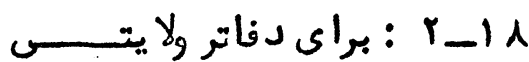

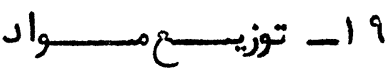




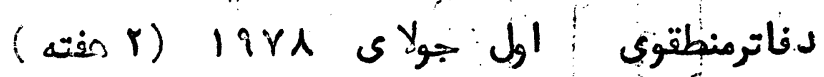

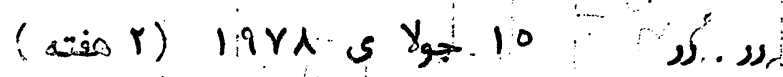

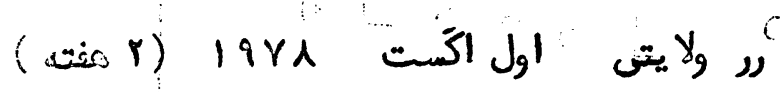
נر

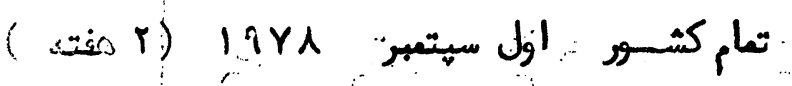

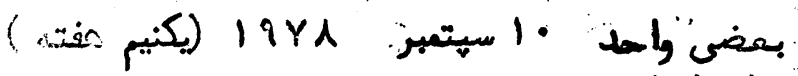

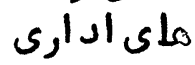

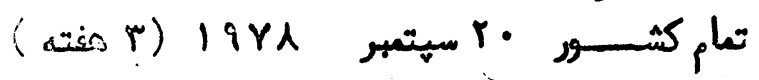

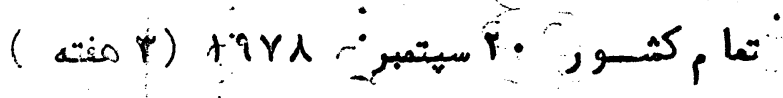
10

كابل ودفاتر " 10 اكتوبر كابسـل

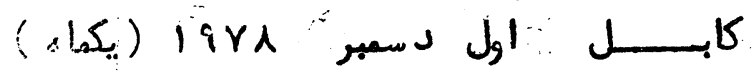

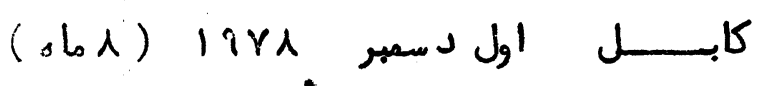

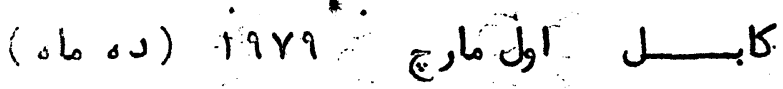

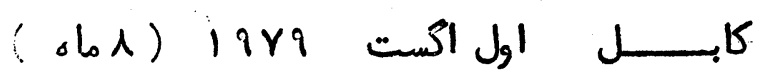

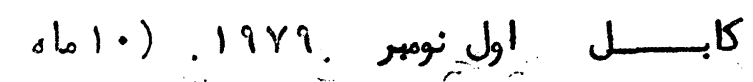

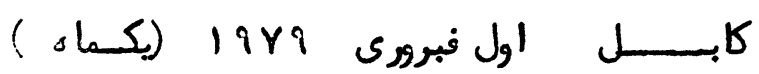

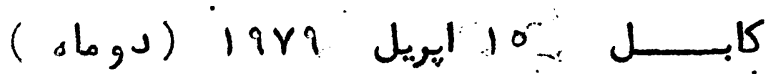

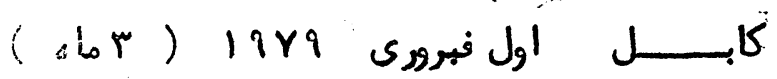

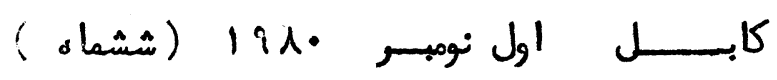

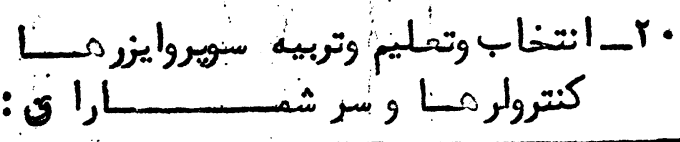

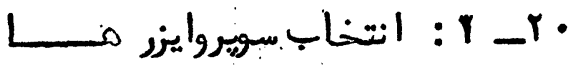

•

•r_r

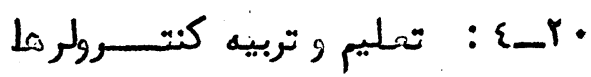

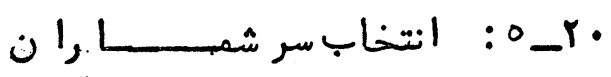

•r_r : تعليم وتربيه سر شمــارا ن

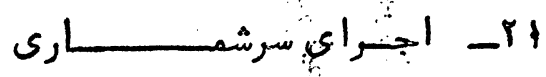

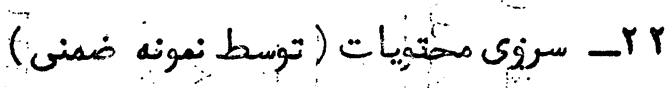

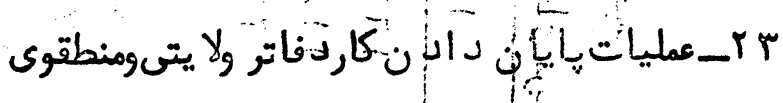

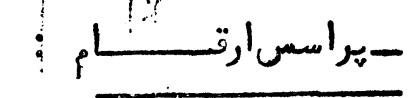

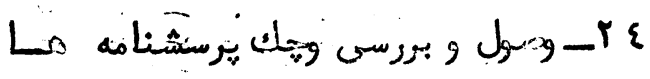
مب_احتائيه ماى الولى درمورد نفوس Tr_انتخاب نمونه براى جذاول مفصـل

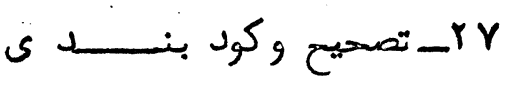
ג 9r-_جسدولبنــد

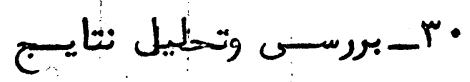

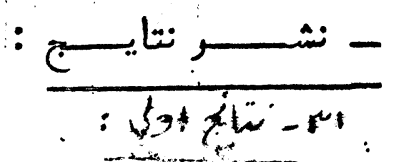
ا

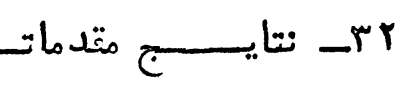

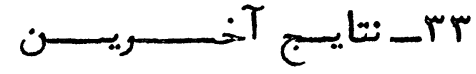




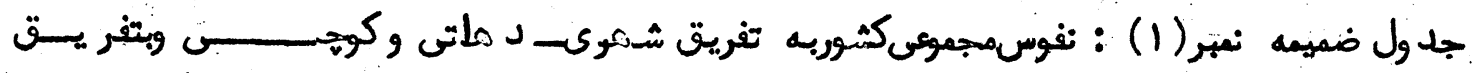

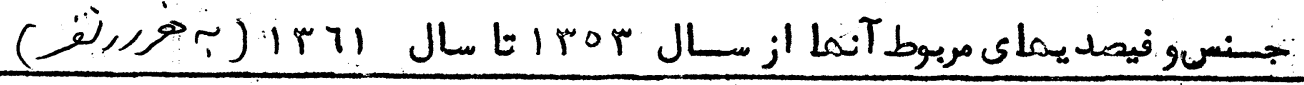

\begin{tabular}{|c|c|c|c|c|c|c|c|c|c|}
\hline 1971 & 157 & 1709 & irod & iroy & 1907 & $1 r 00$ & 1 1To\& & iror & مثخدمــــا ت نفــــــوس \\
\hline 1971. & $191 \varepsilon 9$ & $1 \mathrm{AY} \cdot \mathrm{T}$ & IArYo & $1 Y 1000$ & $I Y \varepsilon \varepsilon \gamma$ & $18 \cdot 0$. & 17970 & 1789. & مجموع نفوسكثــــــــور \\
\hline IrA\&r & $\mid$ |ro\&| & IrrEY & 17909 & $1878 \lambda$ & $I r \varepsilon \cdot r$ & ITIT\& & $11 \lambda \gamma$. & $1171 \varepsilon$ & منجملَ : نفوسد ماتى \\
\hline rq८६ & r人ir & $r \wedge \cdot r$ & rYlo & rTr. & roßג & $r \varepsilon 7 \wedge$ & rrq. & Trtr & ل..... رر شنىوى \\
\hline$\curlyvee \curlyvee \wedge \varepsilon$ & rYiT & r por & $r q .1$ & Yo.qY & r\{q & $r \varepsilon \varepsilon \lambda$ & $r \varepsilon=0$ & rror & נر كوخس \\
\hline $1 \cdots 1$ & $9 \lambda \cdot \varepsilon$ & 9710 & १ะ.r. & MrrI & $q \cdot r \wedge$ & 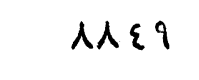 & 1777 & 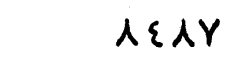 & مجموع نفوس : تحسد اد ذكور \\
\hline $97 \cdot 9$ & $9 r \varepsilon 0$ & $9 \cdot 91$ & $\wedge \curlywedge \varepsilon 0$ & ᄉTr & $\wedge \varepsilon \cdot q$ & $1 Y \cdot 1$ & 89.99 & $Y \lambda \cdot r$ & 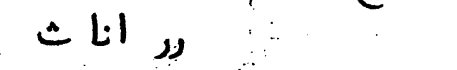 \\
\hline ITAYT & $17 \varepsilon T r$ & $17 \cdot \varepsilon q$ & $107 \gamma \varepsilon$ & $10 r \cdot 1$ & $\mid \varepsilon .901$ & $1 \varepsilon 7 \cdot r$ & $1 \varepsilon 87$. & arorr & \\
\hline Ar & $\Lambda r, \varepsilon$ & Ar, 0 & $\Delta r, Y$ & $-\lambda r \mu$ & טr. & ار lr l l l l l & (r) & r & 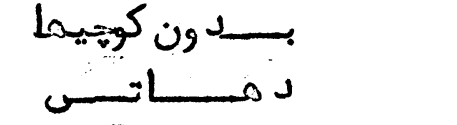 \\
\hline $\mid Y, Y$ & $1 Y, T$ & ivo & $\mid r, r$ & irgt & $\mid r$ & 17,9 & $17 x$ & $17, \gamma$ & 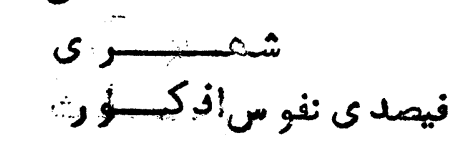 \\
\hline $01, \cdots$ & $01, \Gamma \cdot$ & $01, \varepsilon \cdot$ & 01,7 & $01, y \cdot$ & $01,1$. & 01,10 & or... & or & 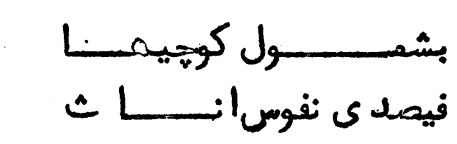 \\
\hline$\varepsilon q, \cdot$ & $\varepsilon \wedge, \curlywedge \cdot$ & $\{\Lambda, \uparrow$. & $\varepsilon \wedge, \varepsilon \cdot$ & $\varepsilon \wedge, r \cdot$ & $\{\Lambda, \gamma \cdot \cdots$ & $\{\wedge, 1$. & $\varepsilon \wedge, \cdot \cdot$ & $\{Y, q \cdot$ & 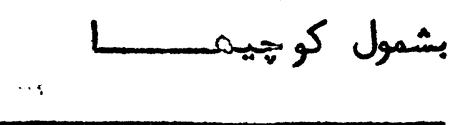 \\
\hline
\end{tabular}




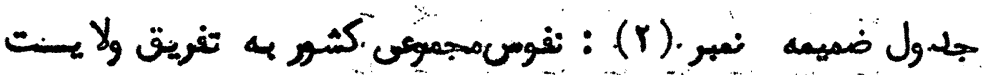

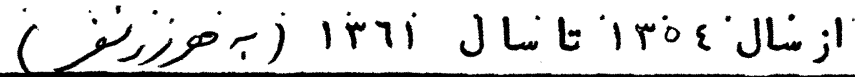

\begin{tabular}{|c|c|c|c|c|c|c|c|c|c|}
\hline II & tri. & 1009 & Irol & Iroy & & 1907 & 1500 & 1roq & \\
\hline IYAY & Irry & $17 \lambda \Lambda$ & $17 \varepsilon$. & $109 \varepsilon$ & & $10 \varepsilon 9$ & $10 \cdot 0$ & $1 \varepsilon 7 \%$ & \\
\hline iror & |rr| & |rr| & 187 & IrEY & & $I r \cdot \varepsilon$ & IIVY & $110 \%$ & \\
\hline$\varepsilon r \gamma$ & $\varepsilon Y \gamma$ & $\{.1 \lambda$ & $\xi \cdot \hat{\Lambda}$ & 99 & & $r$ & r人l & rYr & \\
\hline r & ryl & ror & $r \varepsilon \varepsilon$ & rrr & & rrq & rr & rlq & \\
\hline 1110 & 1108 & $|1 M|$ & $11 \cdot 0$ & $1 \cdot \lambda \cdot$ & & 1.07 & I.rr & $1 \cdot 1 \cdot 1$ & \\
\hline $1 \cdot 7 r$ & I. \& & $1 \cdot 11$ & 990 & QYr & & ror & ir? & $\eta \cdot \lambda$ & \\
\hline iror & |rr| & 1891 & Iryr & IYYT & & $1 r=0$ & $11 Y Y$ & $\therefore 101$ & \\
\hline$r r \cdot$ & rip & $r \cdot i$ & $\quad r 98$ & rir & & Y.AT: & YYq & YYY & \\
\hline$\{१ \wedge$ & $\{\lambda\}$ & $8 Y 7$ & $\{70$ & $\therefore \varepsilon \circ \varepsilon$ & & $\therefore \varepsilon \varepsilon \varepsilon$ & $\varepsilon r \varepsilon$ & $\varepsilon r \varepsilon$ & \\
\hline 00. & ord & oro & $01 r$ & $0 \cdot 1$ & & 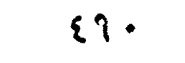 & ६Y१ & $\varepsilon \gamma \lambda$ & \\
\hline 77r & $7 \varepsilon \lambda$ & Trr & Tr. & 7.0 & & 011 & oYA & 070 & \\
\hline - : & ord & oro & $01 r$ & $0 \cdot 1$ & & $\varepsilon \vartheta$. & $\varepsilon \curlyvee q$ & $\{7 \lambda$ & \\
\hline ros & $r \varepsilon Y$ & rr? & rri & rrr & & $r \cdot \varepsilon$ & $r \cdot \lambda$ & $r$ & \\
\hline$o \cdot r$ & $\varepsilon q\}$ & $\varepsilon \wedge$. & $\{7\}$ & $\{\circ \uparrow$ & & $\varepsilon \varepsilon \lambda$ & $\varepsilon r \wedge$ & $\varepsilon r$ & \\
\hline$\varepsilon \wedge$ ! & $\{7\}$ & $\{0 \wedge$ & $\varepsilon \varepsilon \gamma$ & $\varepsilon r \lambda$ & & $\varepsilon r \wedge$ & $\{\mid \curlywedge$ & $\varepsilon \cdot \lambda$ & \\
\hline ori & 077 & $00 \varepsilon$ & $O\{1$ & or & & 017 & 0.0 & \&ir & \\
\hline$\varepsilon \cdot q$ & $\varepsilon \cdot \bullet$ & ril & $r \wedge 1$ & TY & & r7o & rot & $r \leqslant$ & باد \\
\hline $17 !$ & $\lambda \varepsilon r$ & Arr & $\lambda \cdot \varepsilon$ & YAT & & 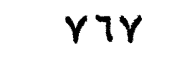 & Yol & YMiti & \\
\hline$\varepsilon r \lambda$ & \&l入 & $\varepsilon \cdot \lambda$ & rqq & $r q$. & & $r \wedge l=$ & rrr & riq & غراه \\
\hline $1 \mathrm{Tl}$ & $11 \cdot \gamma$ & 1.17 & $11 \%$ & 11. & & $1 \cdot 1$ & 1.0 & $1 \cdot 1$ & نهيروز \\
\hline rrq & rrr & $r r \varepsilon$ & rir & $r \cdot q$ & & $r \cdot r$ & Y9० & 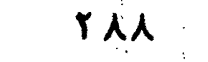 & ملمند \\
\hline q\& & qrr & $9 \cdot 1$ & $1 \lambda 1$ & $\lambda T$. & & $\lambda \varepsilon 1$ & Arr & $\lambda \cdot r$ & \\
\hline$r \varepsilon 7$ & rry & $r r \cdot$ & rrr & r ro & & $r \cdot \lambda$ & $r \cdot l$ & $r q \varepsilon$ & زابل " \\
\hline O\&Y & or. & $01 Y$ & 0.7 & $\varepsilon \uparrow \varepsilon$ & & $\varepsilon \wedge r$ & $\varepsilon Y\}$ & $\{7\}$ & ا \\
\hline ral & $r q$. & ral. & ryr & $r 7 \varepsilon$ & & rot & $r \varepsilon \wedge$ & rrq & \\
\hline ?q & ris & rrr & $=r 00$ & ror & $\because$ & $r\{\Lambda$ & $r \varepsilon \cdot$ & rrr & \\
\hline TAYT & $17 \varepsilon r r$ & $17 \cdot\{9$ & $107 Y \varepsilon 1$ & $o r \cdot \lambda$ & & $1 \varepsilon 901$ & $1 \varepsilon 7 \cdot r$ & 1817 & \\
\hline TYA & YYIT & $r 70 r$ & $r 7 \cdot 1$ & ro\&Y & & 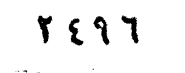 & $r \varepsilon \varepsilon \wedge$ & $r \varepsilon \cdot 0$ & كويهما \\
\hline 971. & $\mid 91$ ही & $\mid \lambda Y \cdot T$ & I ArYo 1 & $\begin{array}{c}\text { IY } 100 \\
\therefore \quad: \\
\end{array}$ & & IY \&\&Y & 18.0 & 17770 & \\
\hline
\end{tabular}




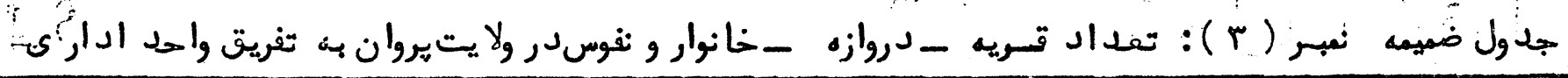

\begin{tabular}{|c|c|c|c|c|c|c|c|}
\hline \multirow{2}{*}{ متسـر مربسهـ به كيلو } & \multirow{2}{*}{ 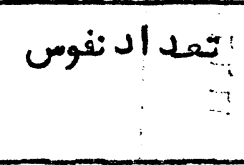 } & \multirow{2}{*}{ تعداد خانوار } & \multirow{2}{*}{ تعـداد دروازه مسكونى } & \multirow{2}{*}{ 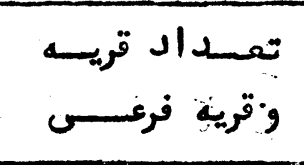 } & \multicolumn{2}{|c|}{, } & \multirow{2}{*}{ 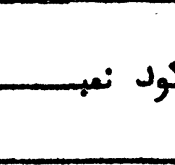 } \\
\hline & & & & & اسم واحداد ارى كوتجكي & نوعواحد ادارى & \\
\hline rYr & rrisi & $\because$ oylt & $\varepsilon \varepsilon r \varepsilon$ & 77 & كايسيسـا & ولسوالى & $\cdot r \cdot 1$ \\
\hline$\varepsilon 10$ & $r>\varepsilon \varepsilon 7$ & $\therefore 7911$ & o9r. & $\therefore g r$ & ت & נ & $\cdot t \cdot r$ \\
\hline rrq & 1777. & -.... rrar & rivi & ir & اله ساى & علاقدارى & $\cdot r \cdot r$ \\
\hline$|Y|$ & 01910 & $\therefore 1 \cdot \varepsilon \varepsilon \gamma$ & 19.98 & $\mathrm{dA}$ & كومستان. & ولسوالى & $\cdot r \cdot \varepsilon$ \\
\hline 191 & IrETג & rinr & $r \cdot 0.0$ & $\cdots \varepsilon r$ & كوه بنسـد & كلاقدارى & $\cdot Y \cdot 0$ \\
\hline 010 & 0771 & $1 \cdot r y o$ & $\wedge \vee \wedge \cdot$ & lor & نجسرا' - & ولسوالى & $\cdot r \cdot T$ \\
\hline$\gamma \cdot 7$ & $\varepsilon+97$. & $\because \% 9 \cdot$ & $\therefore \quad 19.90$ & Irr & رخه هنجشير & & $\cdot r \cdot Y$ \\
\hline rilr & $r \cdot 7 r r r$ & \&४६० & $\therefore \quad-0.071$ & 11 & نيار قريه : & علاقدارى & $\cdot r \cdot \lambda$ \\
\hline$r \cdot r$ & $17 \cdot 78$ & rrin & $\therefore \quad r \xi \varepsilon \Lambda$ & ir & دره مزاره & & $\cdot r \cdot \lambda$ \\
\hline 119 & Thro & Irate & Y & $\quad r 9$ & $\therefore$ & مركز ولايت & $\cdot r \cdot 1$ \\
\hline $10 \cdot \varepsilon$ & $0.1 \cdot \varepsilon 1$ & 1700 & AYo & ir & غورينــد ' & ولسوالــ & $\cdot r \cdot r$ \\
\hline roq & $|Y| i r$ & ritr. & $=\ldots r \xi \cdot q$ & 79 & شنــوارى & علاقدارى & $\cdot r \cdot r$ \\
\hline$\varepsilon Y$. & $\alpha \varepsilon>\wedge q$ & 979 & $\therefore \quad \therefore \quad 77 . r$ & $2 x$ & بs, & ولسوالى & $\cdot r \cdot \varepsilon$ \\
\hline$r \cdot 1$ & irer & $117 r$ & $r r \varepsilon \varepsilon$ & 7. & كوه صاقن & علاقدارى & $\cdot r \cdot o$ \\
\hline $19 \varepsilon$ & O 10 Yrr & 1.r & $\therefore \quad 8777$ & $\therefore=$ & جبل السراب & ولسوالـس & $\cdot \pi \cdot 1$ \\
\hline 认从 & 1701. & $r \cdot r r$ & $r \cdot Y \tau$ & $\because \quad \because \quad \therefore \quad$ & سالنـــــ & علاقدارى & $\cdot r \cdot Y$ \\
\hline १ะ१ & rYYY & $\varepsilon 1 \varepsilon$ & orrr & $1 \varepsilon \varepsilon$ & سرخ vارسا & ولسوالى & $\cdot r \cdot \lambda$ \\
\hline $9 \cdot 1$ & I7Ire & $r 7 \varepsilon 0$ & $\operatorname{rrqd}_{-}$ & $\therefore \quad 1 \because$. & 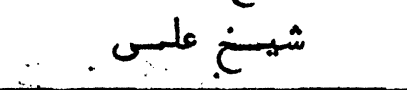 & علاقدارى & $\cdot \pi \cdot 9$ \\
\hline 11019 & Trrotr & $11.0 \cdot 1$ & ixrrq & $170 \varepsilon$ & & & \\
\hline
\end{tabular}




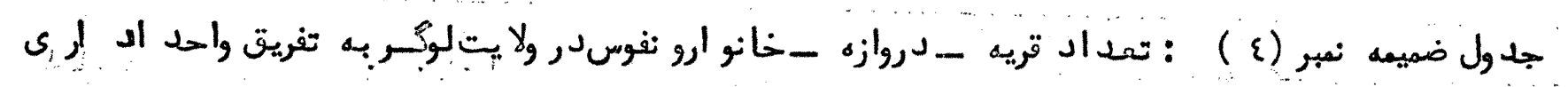

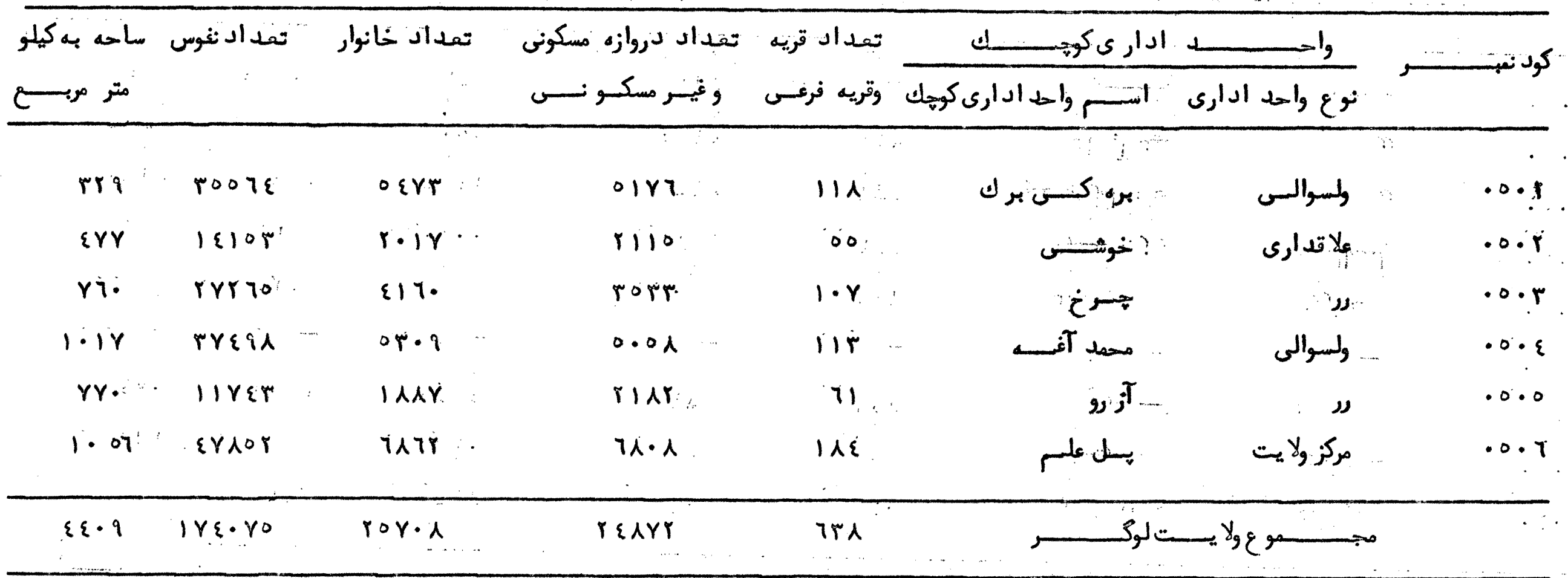


$(r \cdot)$

جدول ضميمه نعر( ) ) : تعداد قريه ـ دروازه - خانوار و نغوسوالح ملاى ادارى تكميل شده درولايتميد ان به تفريق واحه ادارى

\begin{tabular}{|c|c|c|c|c|c|c|c|}
\hline ساحه به كيلو & تملاد نغوس & تعـداد خانوار & تعد اد دروازه مسكونى & تعـداد قريسـه & ىكـو & واحســــ & \\
\hline 1149 & $r 0100$ & $r \wedge \varepsilon \cdot$ & $Y \wedge 77$ & $1 Y \varepsilon$ & جلـــــــز & علا تدارى & $\cdot \varepsilon \cdot r$ \\
\hline$\varepsilon \Lambda^{\circ}$ & $r Y \cdot 10$ & r\&凡 & rire & Irr & & נر & $\cdot \varepsilon \cdot r$ \\
\hline Iror & IrA\&? & : Y10₹ & $r \cdot r q$ & 118 & داى مير داد & علا تدارى & - $\varepsilon \cdot 0$ \\
\hline TIS & oq7Ar & $1 \cdot \gamma \cdot \cdot$ & qar & $77 r$ & مركو بتمستسود & ولسوالى & $\cdot \varepsilon \cdot 7$ \\
\hline Irry & rirol & rolr & rigr & rrr & حمه اول بمسود & ננ & $\cdot \varepsilon \cdot \gamma$ \\
\hline $10 \cdot Y$ & $Y Y Y \cdot\{\tau$ & גוד & $\cdot r \cdot T \cdot r$ & 1018 & - & سمو ع ولد. & \\
\hline
\end{tabular}




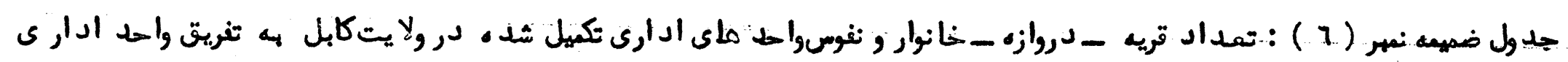

\begin{tabular}{|c|c|c|c|c|c|c|c|}
\hline \multirow{2}{*}{ 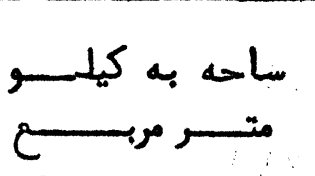 } & \multirow{2}{*}{ تمداد نفو س } & \multirow{2}{*}{ ت تمداد خانوار } & \multirow{2}{*}{ 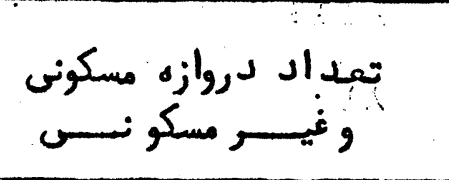 } & \multirow{2}{*}{ تريه فراد قريسهو. } & \multicolumn{2}{|c|}{ al } & \multirow{2}{*}{ كود نهــر } \\
\hline & & & & & اسم واحهادادركويكل & نوع واحه ادارى & \\
\hline $1 \varepsilon r$ & r) १६r & ฉ११४ & \&lor & rq & بكرامستى & ولسبرالسى & $\cdot 1 \cdot r$ \\
\hline - & - & - & - & - & - & با له جهار & $\cdot r \cdot r$ \\
\hline$r x s$ & rqYir & $7 \cdot 17$ & oror & r & تجمارد مى & ولسرالس & $\cdot l \cdot \varepsilon$ \\
\hline$i \cdot 1$ & rijoi. & $\varepsilon \|$ & rrre & rr & : جاراسيا ب. & علاقدارى & .100 \\
\hline- & - & - & - & - & - & - & $\cdot i \cdot r$ \\
\hline 1109 & rquro & \&ใช & $01 r 1$ & 101 & سرويسى & ولسوالى & $\cdot 1 \cdot r$ \\
\hline $1 \varepsilon 9$ & $710 r \varepsilon$ & 9071 & $Y \cdot 7 \cdot$ & $1 \cdot r$ & يخمـان & 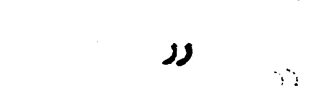 & $\cdot 1 \cdot \lambda$ \\
\hline- & - & - & - & - & - & - & $\cdot 1 \cdot 9$ \\
\hline$=7 r$ & $\{Y \mid Y\}$ & 7091 & $\{\varepsilon \circ\}$ & $\varepsilon r$ & ميربجه كوت & 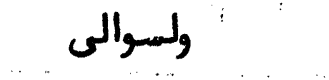 & -110 \\
\hline$\varepsilon \varepsilon \varepsilon$ & אודותו & $r 190$ & $\operatorname{rrq}$ & ry & : & 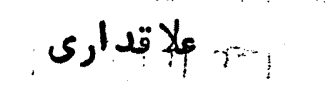 & .111 \\
\hline 111 & $\{r \cdot \circ \wedge$ & $\operatorname{rar} 1$ & $\varepsilon \gamma \cdot \gamma$ & or & 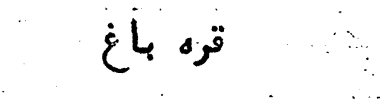 & ........ ولسبوالي : & . II \\
\hline - & - & $3-$ & $40769 \%$ & $\cdots$ & - & - & dir \\
\hline$r\{7\}$ & rir人? & qorrr & rา7๕r & $0 \cdot 1$ & $\mathcal{L}$ & ســـوع ولايسـتكا & \\
\hline
\end{tabular}




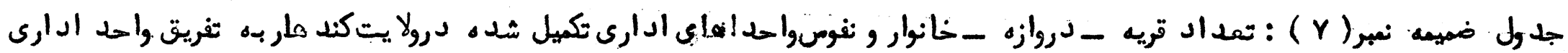

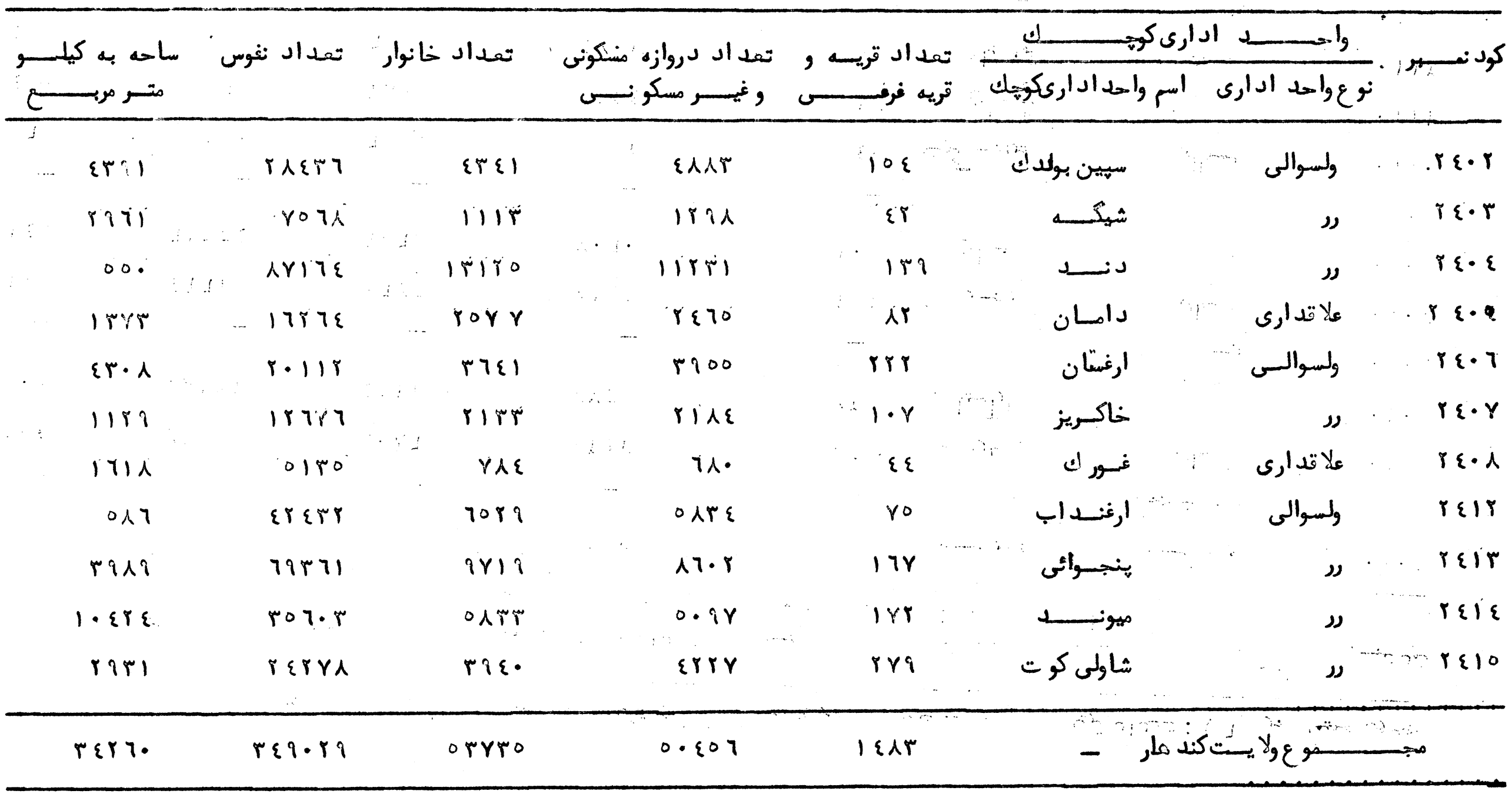




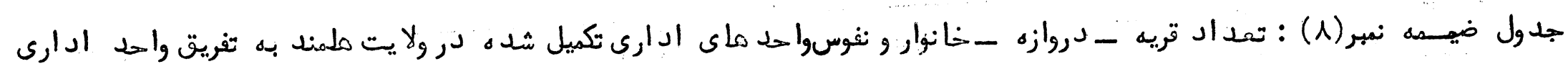

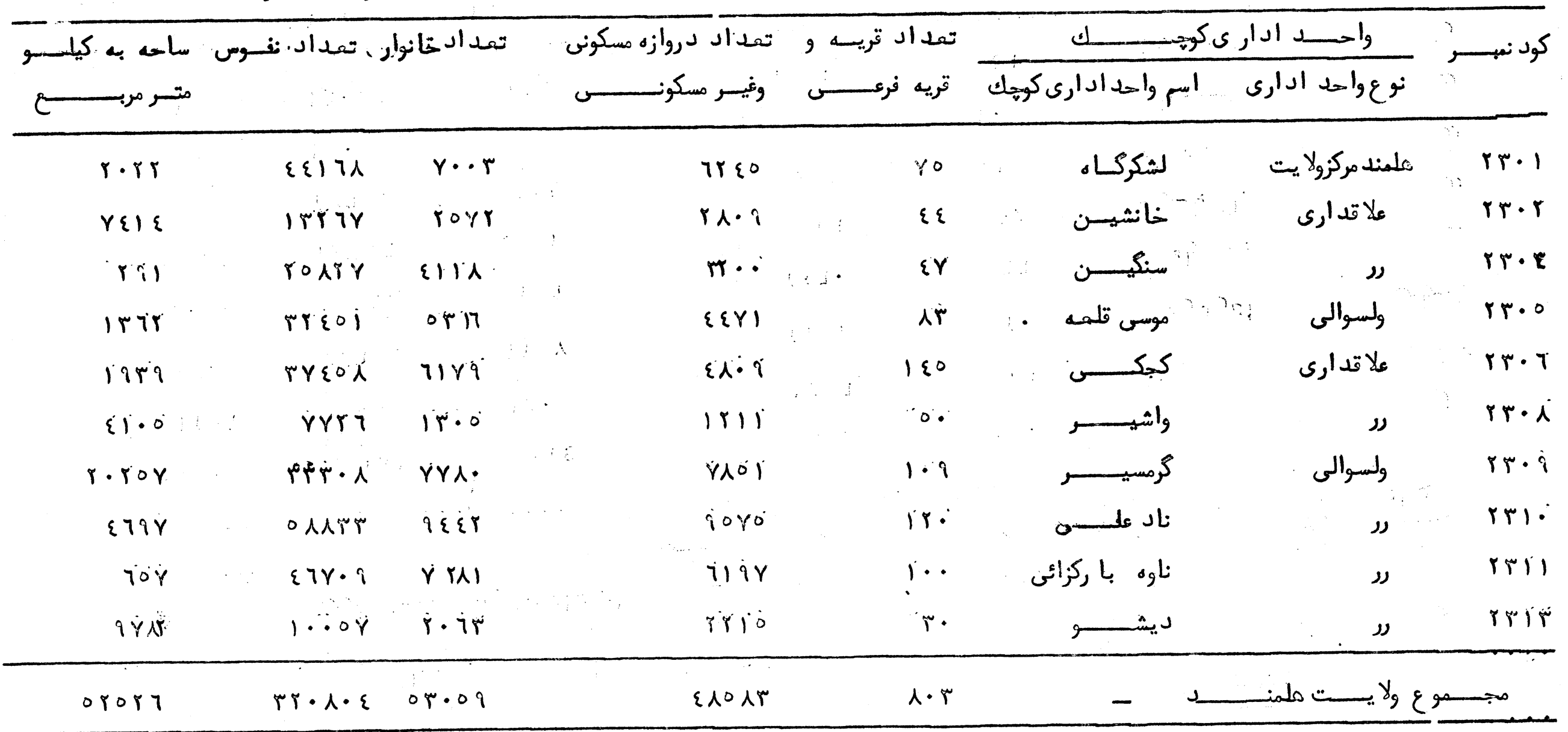




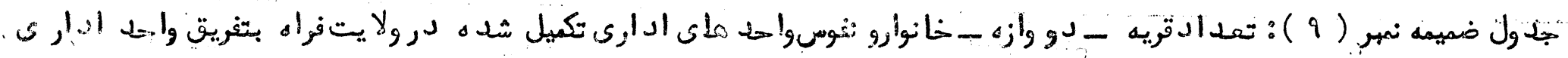

\begin{tabular}{|c|c|c|c|c|c|c|c|}
\hline \multirow{2}{*}{ 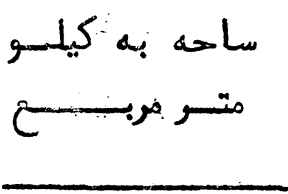 } & \multirow{2}{*}{ تحداد نفون } & \multirow[t]{2}{*}{ تمد اد خانو ار } & \multirow{2}{*}{ 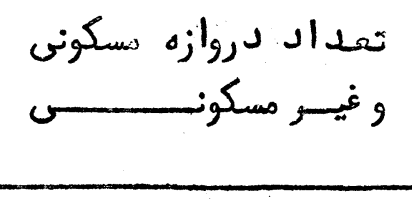 } & \multirow{2}{*}{ قريسه فرعسيسـ و } & \multicolumn{2}{|c|}{ وا } & \multirow{2}{*}{ كود نهيســـــ } \\
\hline & & & & & اسم واحس ادارككولمن . & نوعواحذا ادارى & \\
\hline roro & $\{711\}$ & $Y \quad Y 9 \&$ & $\because 0901$ & 11. & فــــراه : : : & مركز ولا يت & $Y 1 \cdot 1$ \\
\hline 1909 & $1 \cdot 1 \varepsilon r$ & $11 \cdot 9$ & 1807 & rT & خائ سفيد & علاقد ارى & $r \cdot r$ \\
\hline or.o & $1478 \varepsilon$ & ris & risir & $r \cdot$ & أثار دزه & ولسوالى & ri.o \\
\hline$r \cdot \lambda l$ & IrTtr & rYiq & $x \varepsilon 7$. & A 77 & هكـــواه & נر & ri. \\
\hline Orrs & r1017 & ฉ११ห & ogr & 11 & بالا بلـــوان & נر & $H r \cdot r$ \\
\hline 7807. & YYTOY & $\varepsilon \varepsilon \circ \curlywedge$ & rilq & 115 & قلمــــــاه & رנ & $\therefore r \cdot \lambda$ \\
\hline $77 \cdot r$ & $10 \cdot r$. & rYoq & $r r \cdot r$ & $1 \cdot 1$ & كسدــان & נر & $-r i \cdot q$ \\
\hline orra & 17.97 & $r \cdot 19$ & ror. & $\{\tau$ & لا لن & נر & ril \\
\hline ro719 & 170790 & rqorr. & $31 \cdot 10$ & 007 & ـراه & ـــــوع و ولايسـت & مجس \\
\hline
\end{tabular}




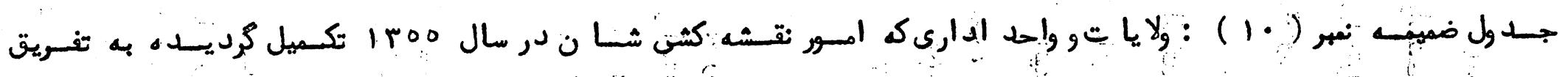

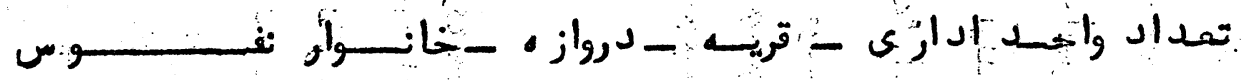

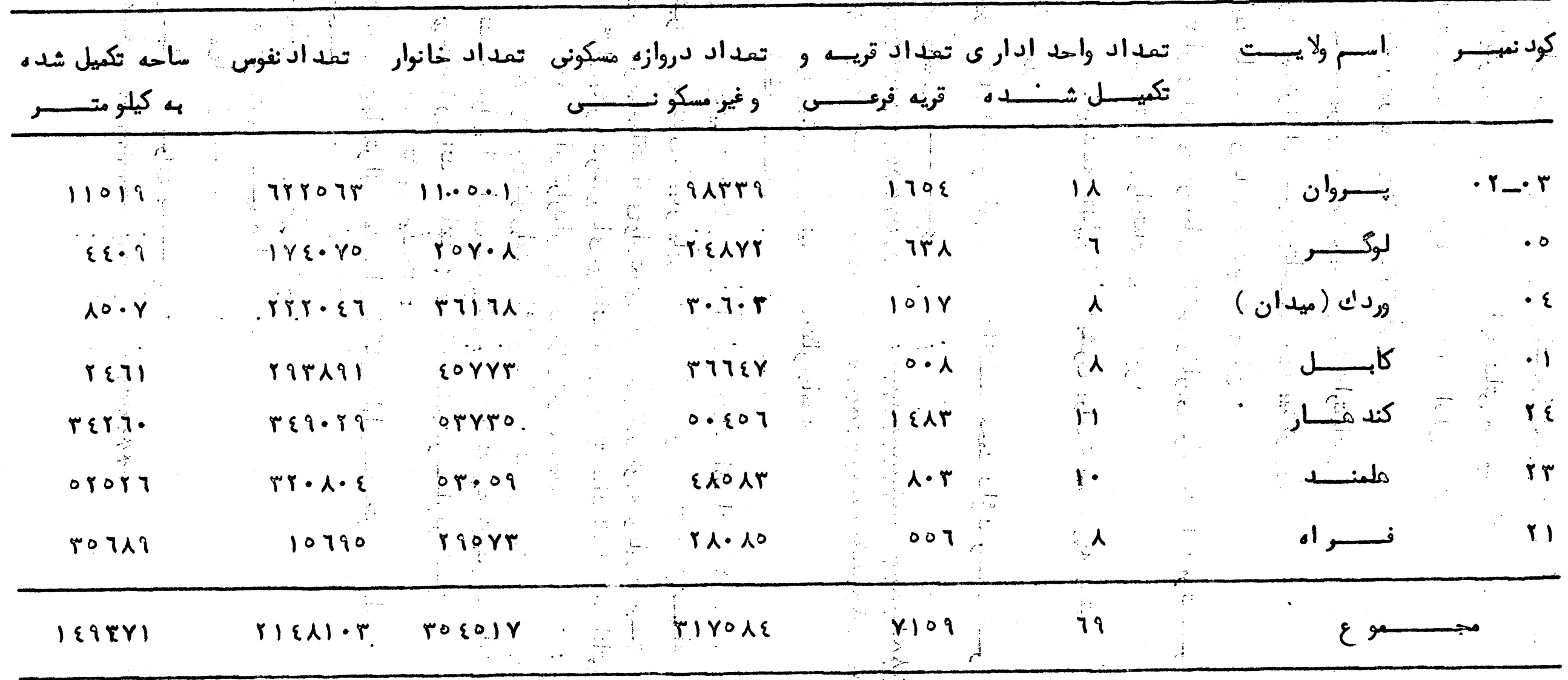




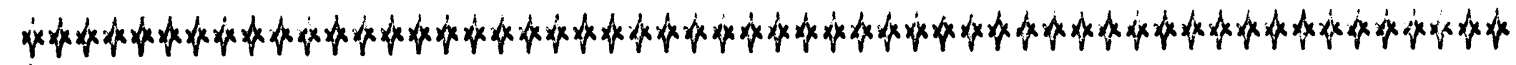

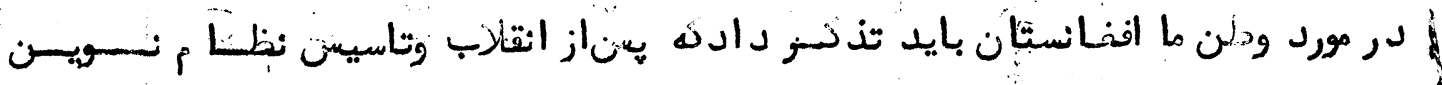

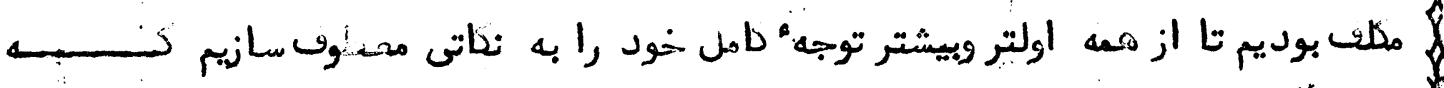

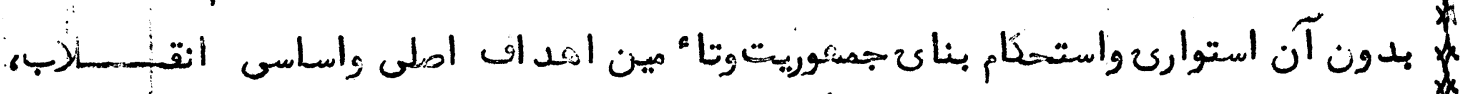

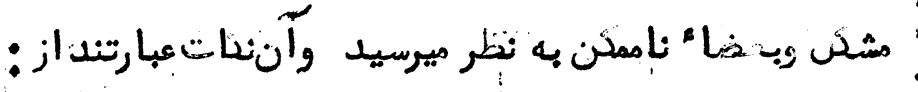

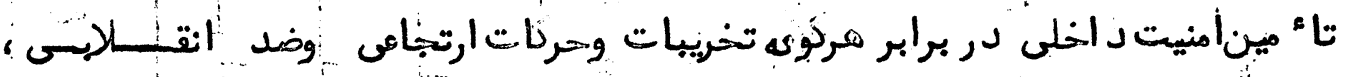

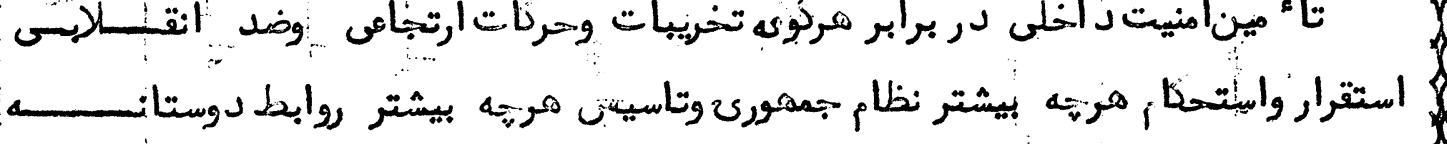

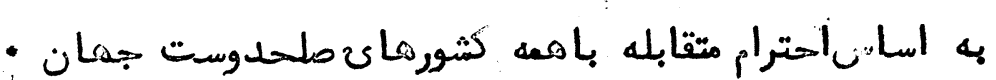

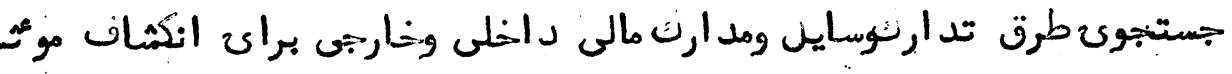

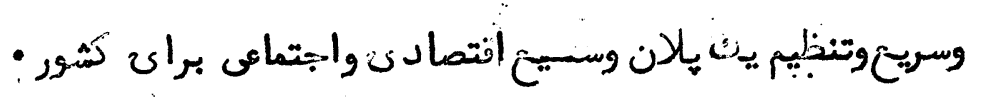

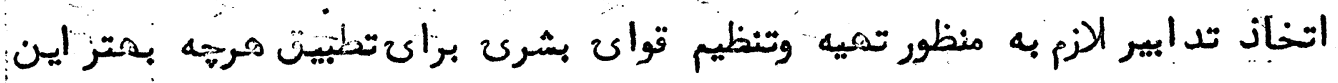

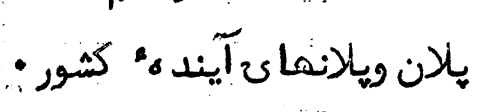

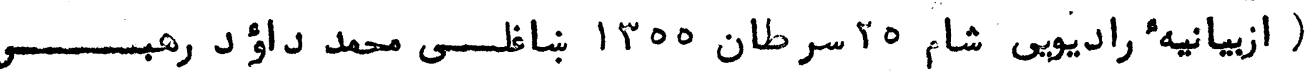

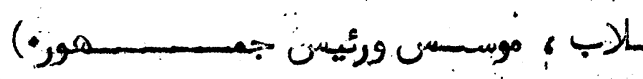

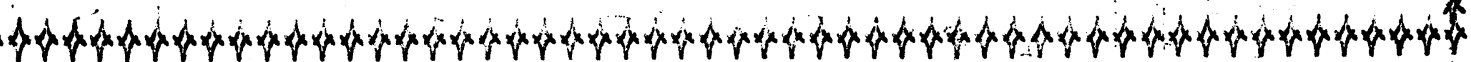

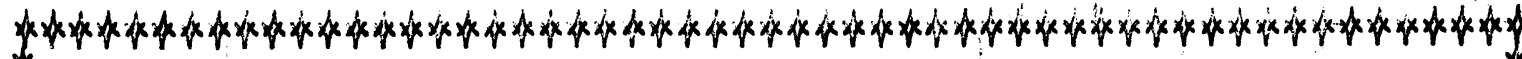

$$
\text { قواى بشرك بحيث نيرون خد متكار جامعه }
$$

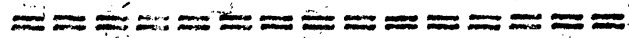

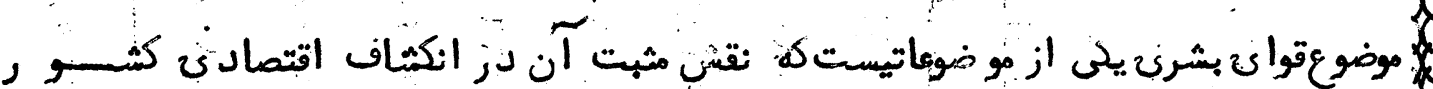

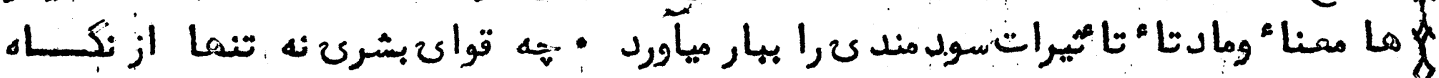

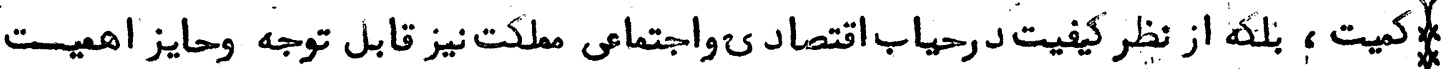

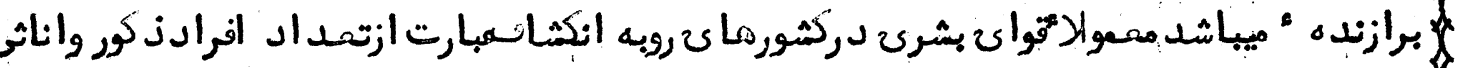
:

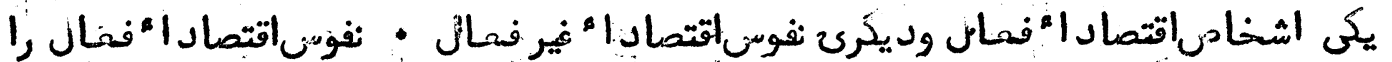

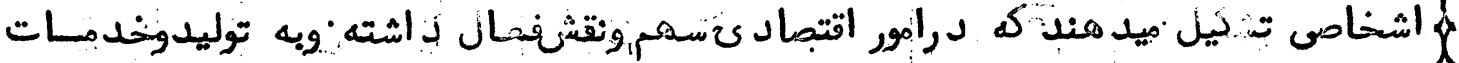

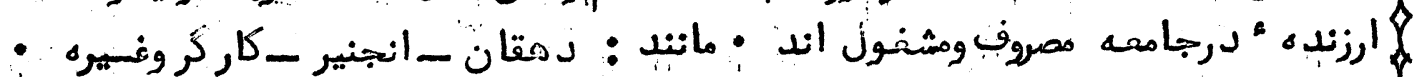

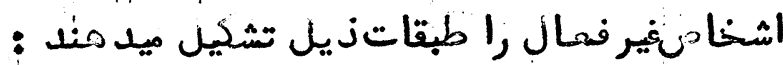

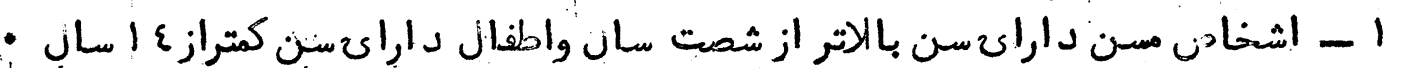

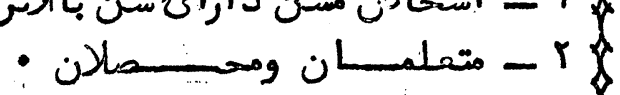
:

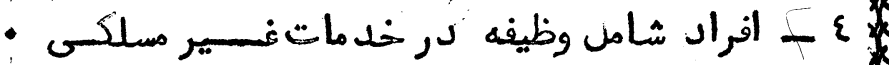

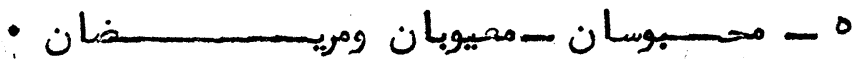

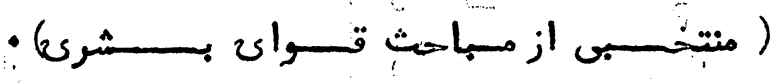

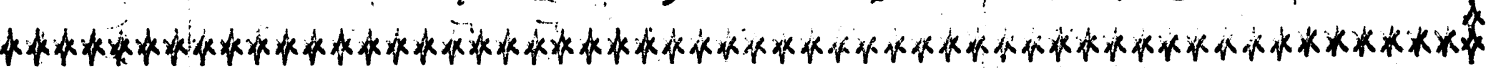


- 395 an

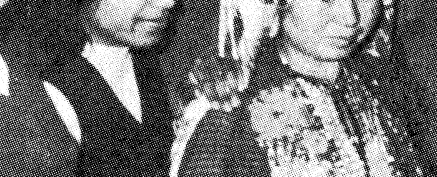
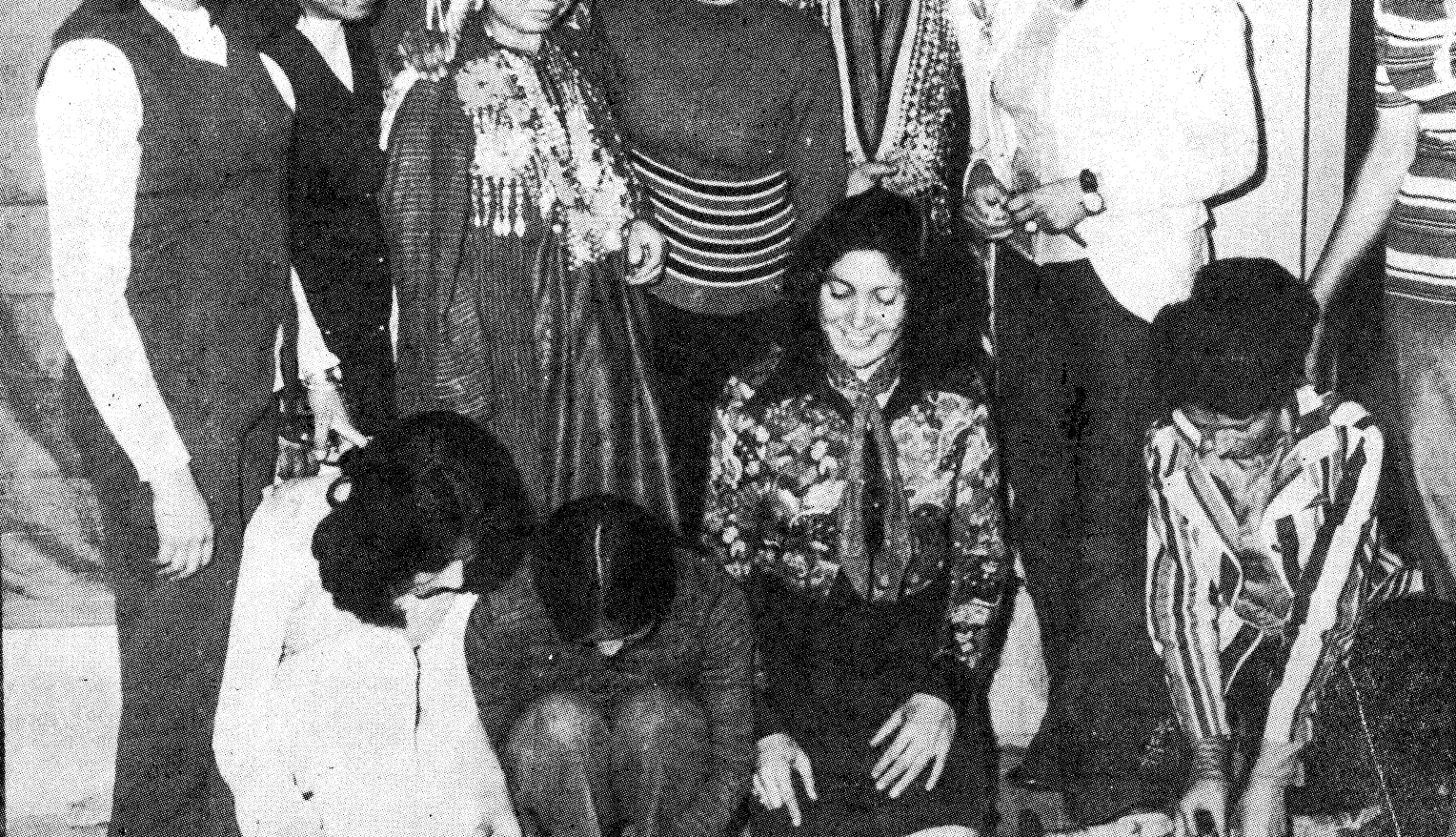

$-1.2 \pi$

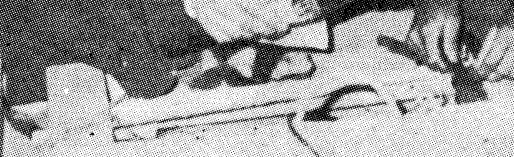

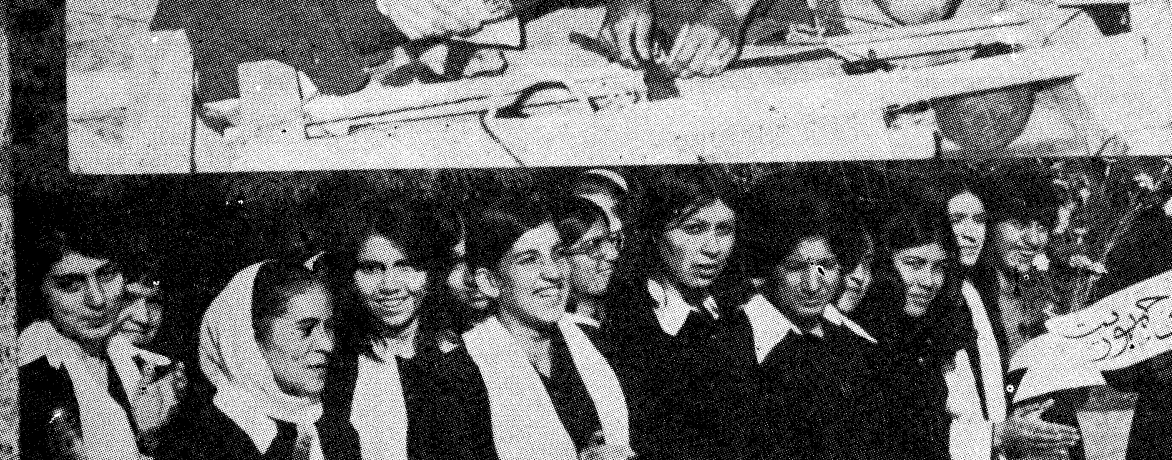

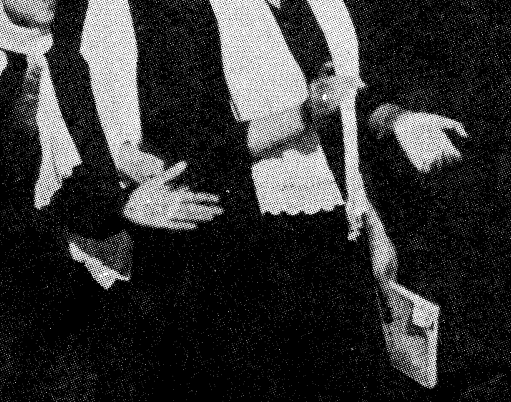

II

Dip?

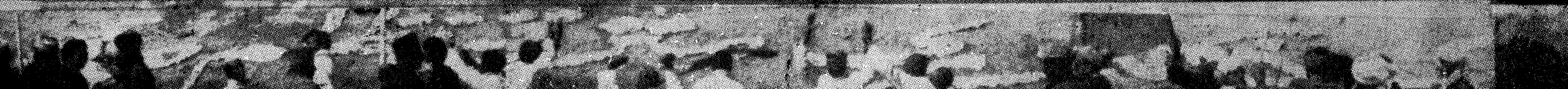

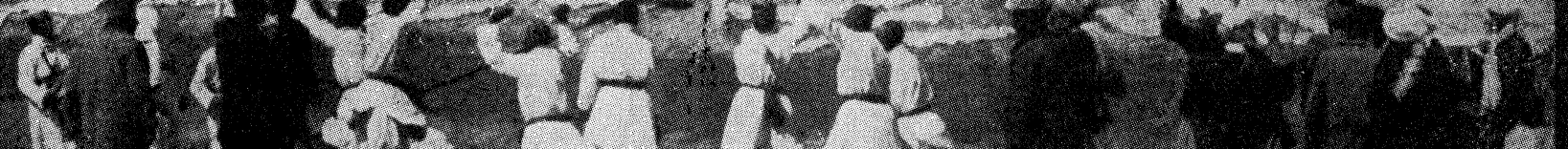

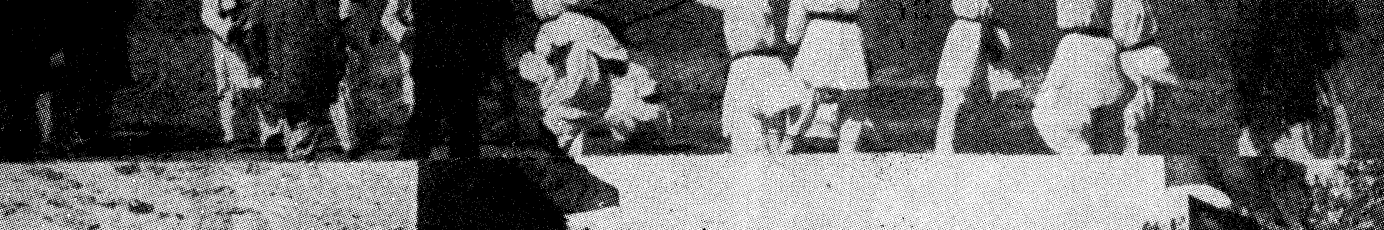

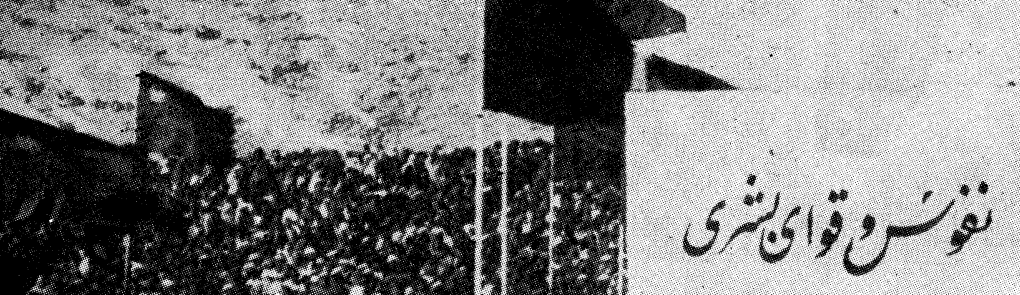

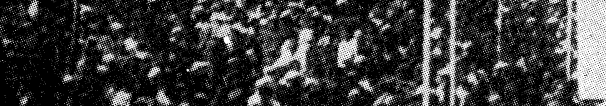
B.t. 8

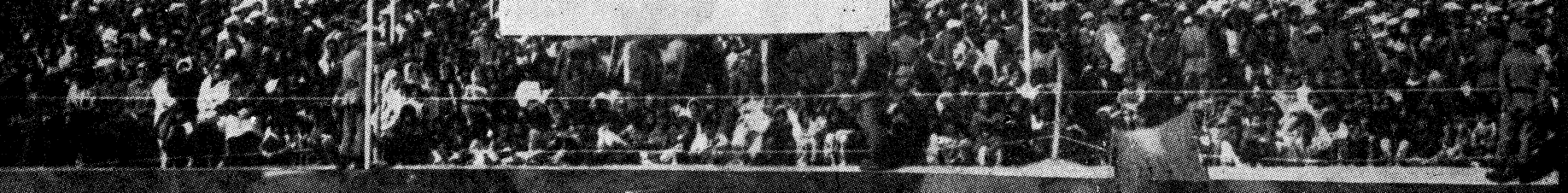




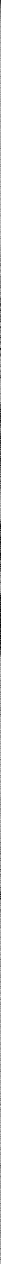




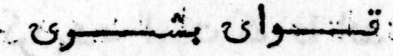

\section{IニニニニニニI}

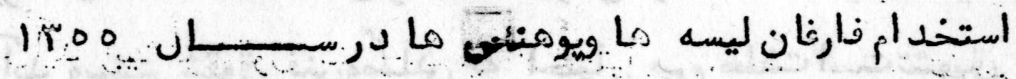

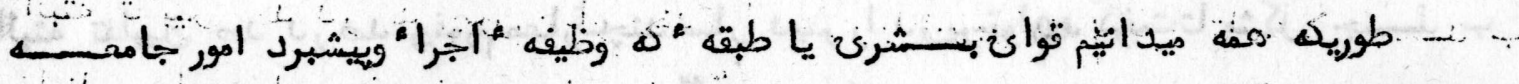

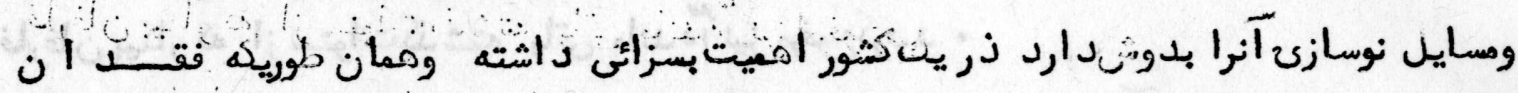

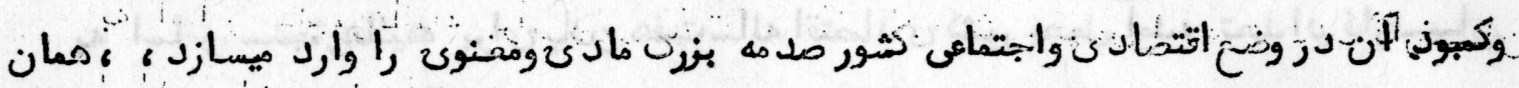

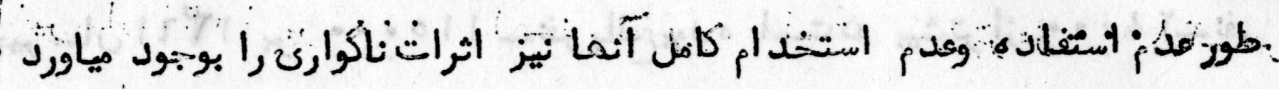

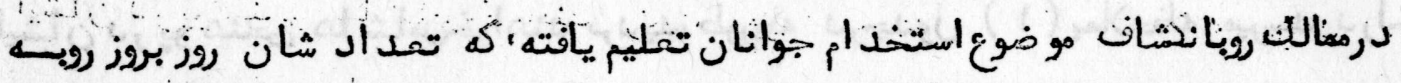

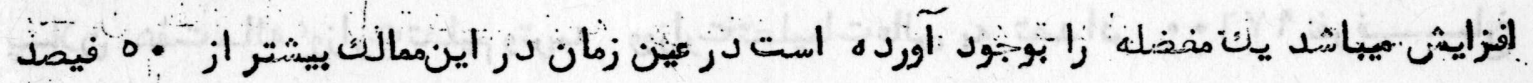

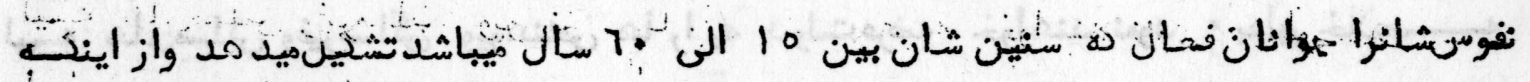

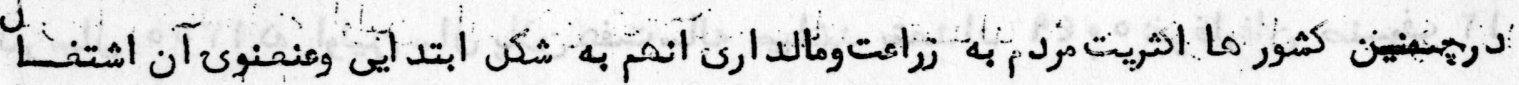

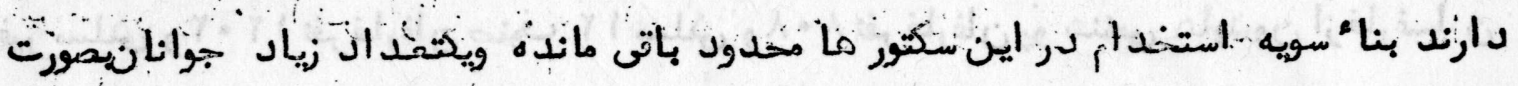

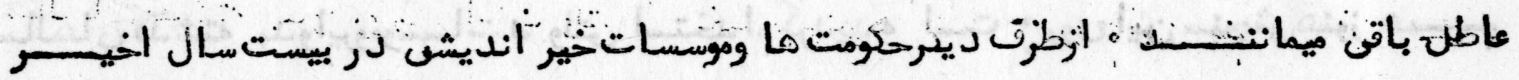

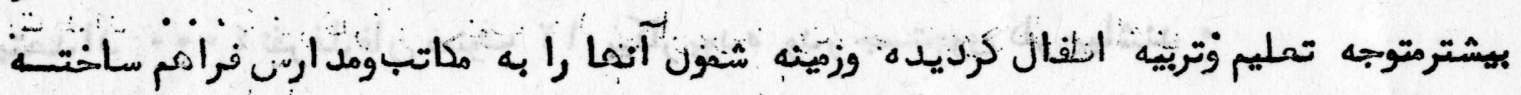

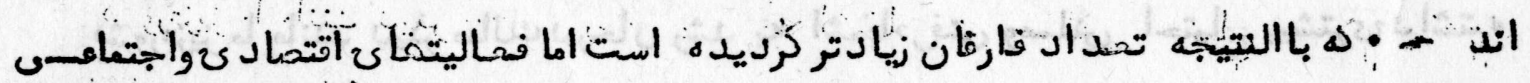

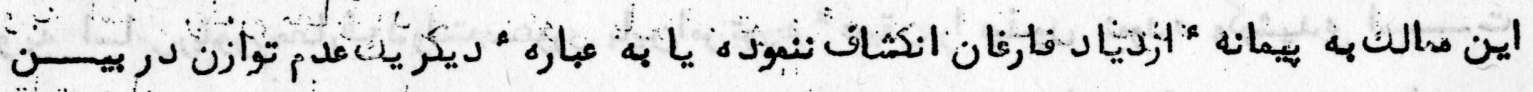

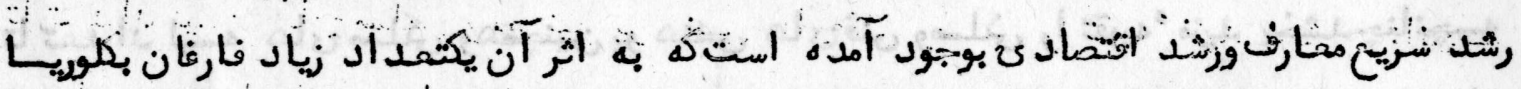

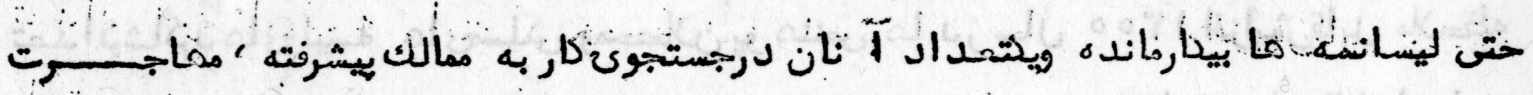

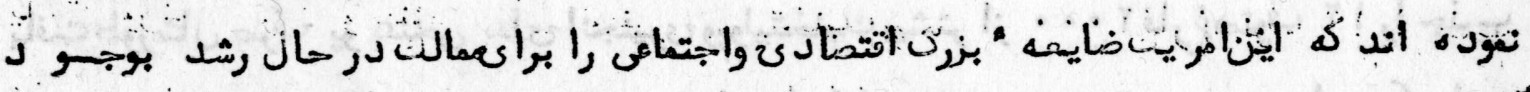

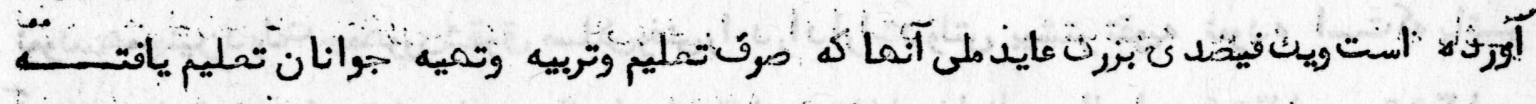

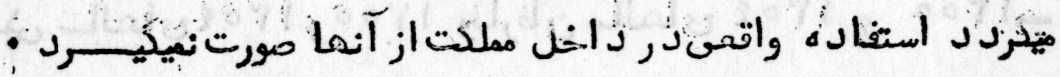

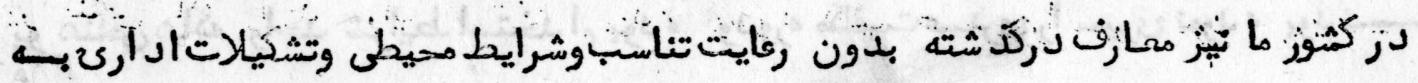

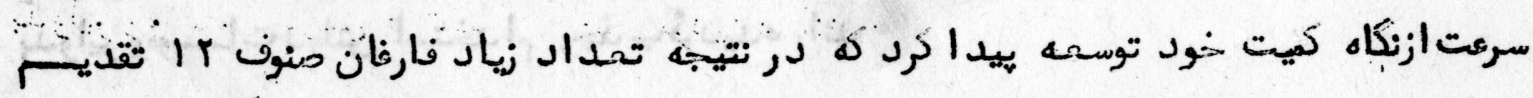

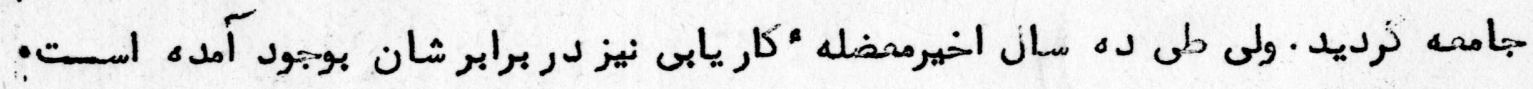

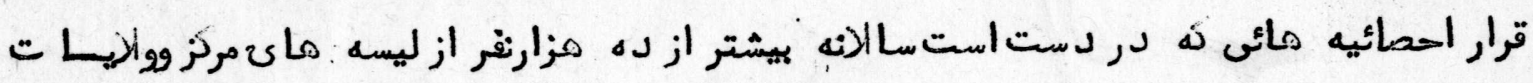

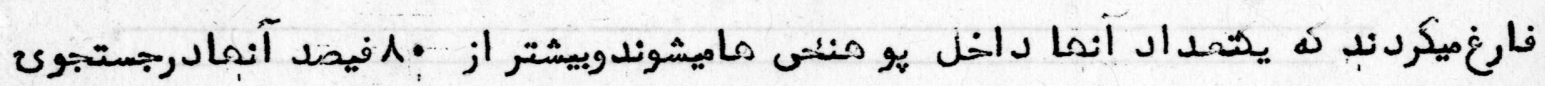
كار ميباشند :

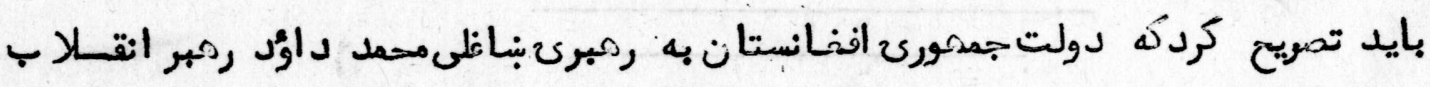

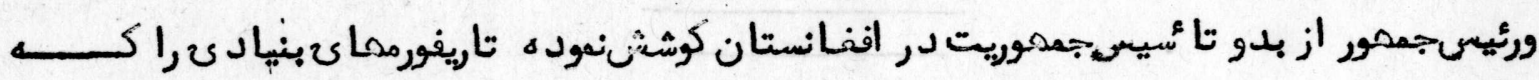

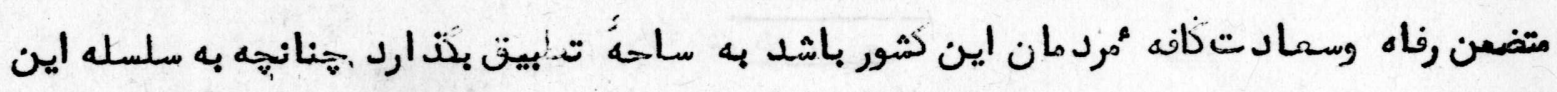

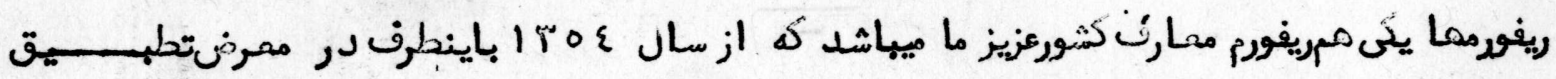




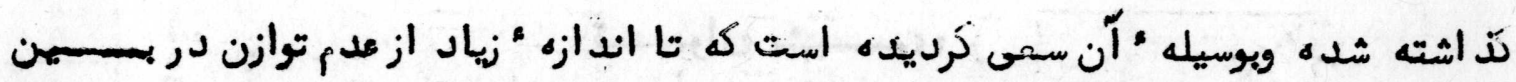

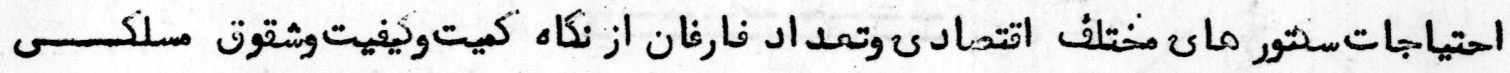

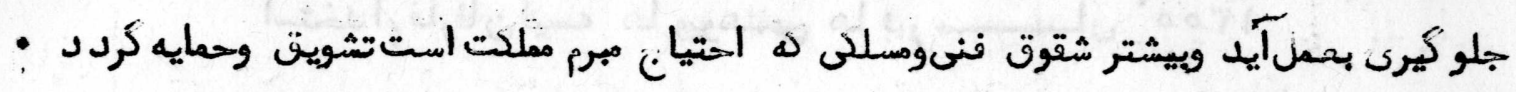

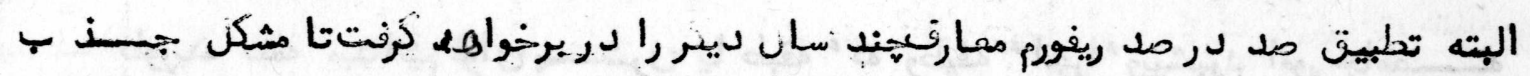

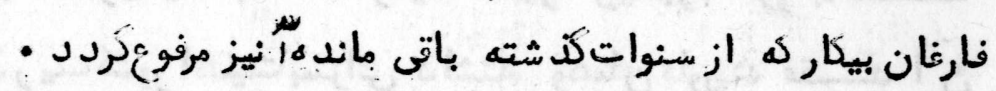

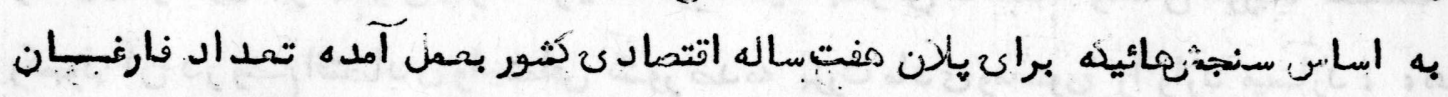

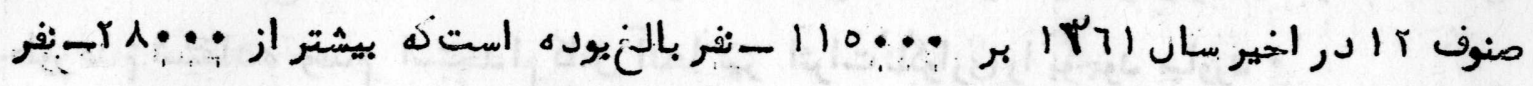

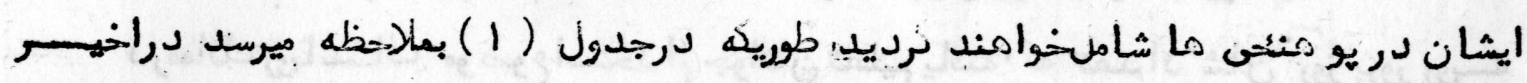

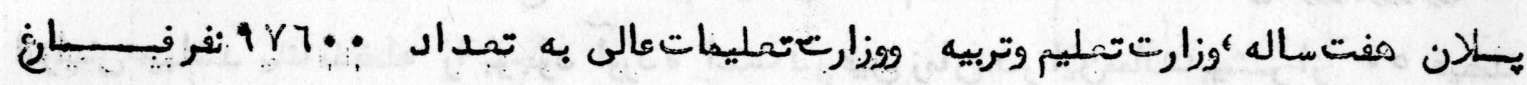

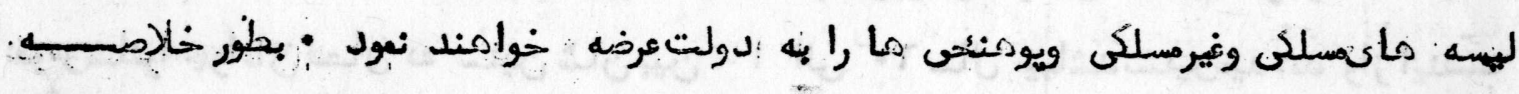

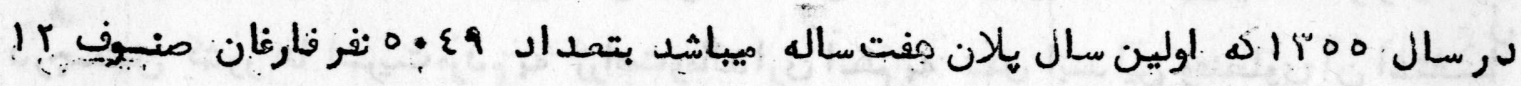

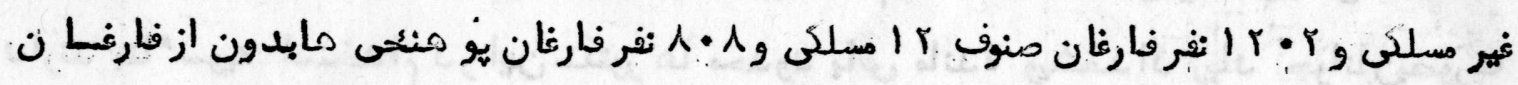

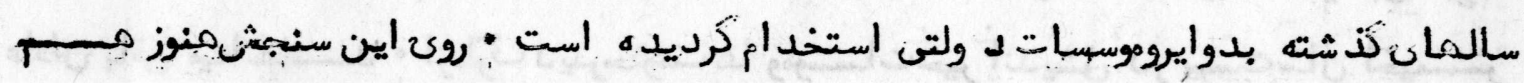

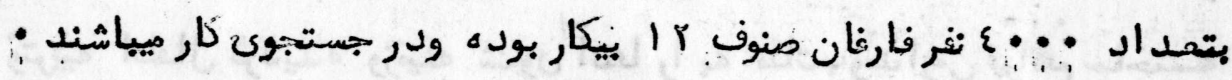

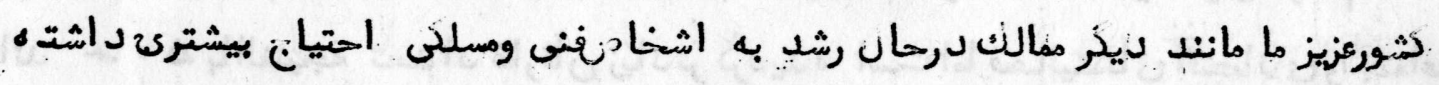

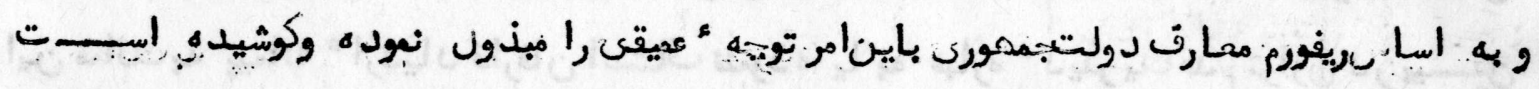

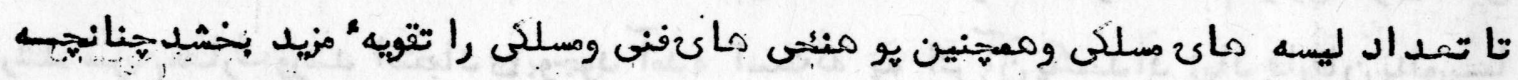

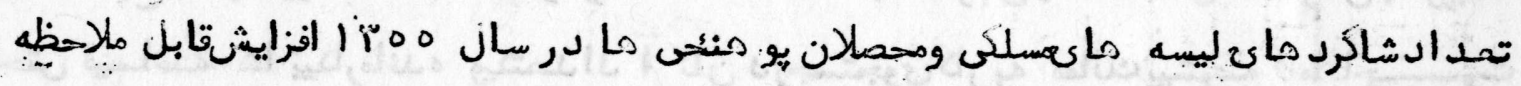

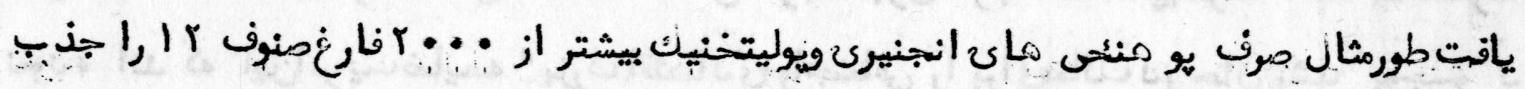

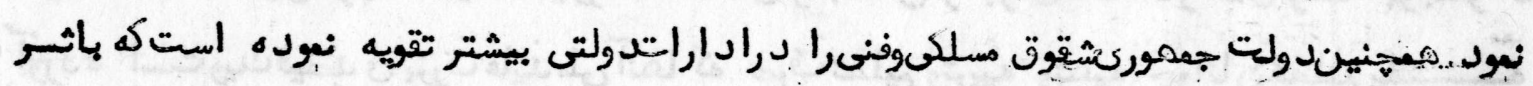

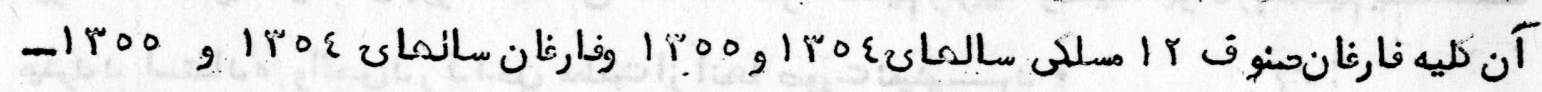

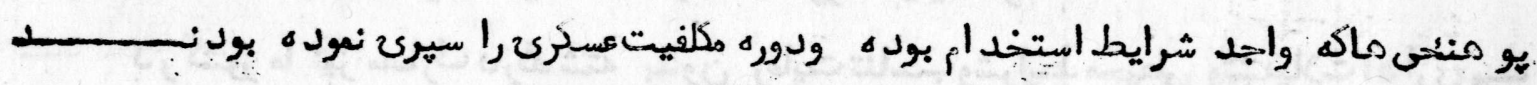

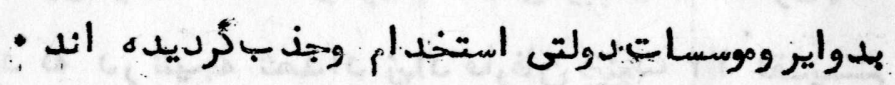




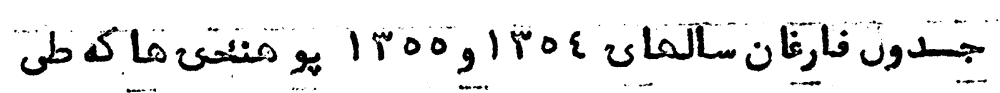

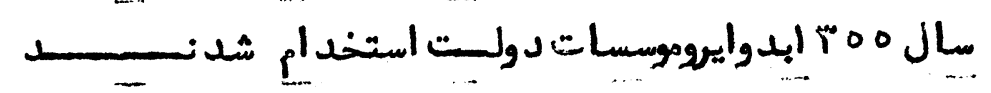

\begin{tabular}{|c|c|c|c|c|c|c|c|c|c|c|c|c|c|c|}
\hline 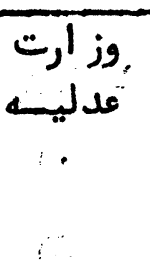 & 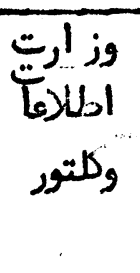 & عامست & وز الخله & مخابرات & 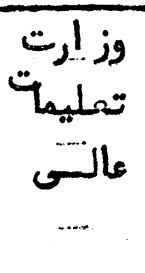 & وز دفــاع & تجارت & وماليـهو & 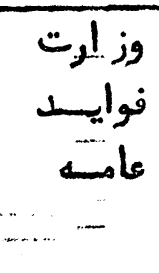 & نراتوت & وتمليف & 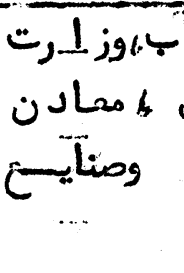 & وزبــ & \\
\hline- & - & 1 & - & 1 & -1 & - & $r$ & $\gamma \varepsilon$ & - & - & 1 & 1 & is & اقتصبياد \\
\hline - & 1 & $r$ & $\varepsilon$ & $\varepsilon$ & - & - & - & $r$ & $r$ & $\tau$ & $r$ & ir & ro & 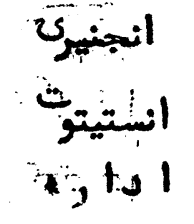 \\
\hline - & - & - & - & $\ldots r$ & - & 10 & $-r$ & r & $T$ & $\ldots$ & 7 & $r$ & - & صنبيجي:8 \\
\hline- & - & - & IT & - & 1 & $\ldots$ & - & - & $r^{\prime}$ & $\ldots$ & 11 & 97 & 9 & يولِيتخنياِك \\
\hline- & - & - & - & - & $r$ & $\ldots=$ & - & - & - & $m 5$ & $P I$ & -1 & $i$ & نراعـــــــــــ \\
\hline - & \&o & - & - & - & - & - & - & $r$ & $r$ & - & $r$ & 7 & - & انبياتِ \\
\hline$r \gamma$ & & & & - & & - & - & & - & - & 9 & - & - & شرعيات \\
\hline$=$ & - & - & - & - & - & $=$ & - & $\cdots-$ & - & - & $\therefore-$ & $r a$ & $\gamma$ & عسلوميم \\
\hline rT & 1 & 1 & 1 & 1 & -1 & - & $\therefore-$ & 278 & $\therefore: \quad \pi$ & - & $r$ & r & $i$ & حقــوق \\
\hline $0:$ & $\varepsilon \gamma$ & $\varepsilon$ & 19 & $\curlywedge$ & 7 & 10 & $\varepsilon$ & $170^{\circ}$ & $\varepsilon 7$ & ra & 78 & 17 & $7 \%$ & مجمسوع \\
\hline
\end{tabular}




\section{جدون فارئان سالدأع}

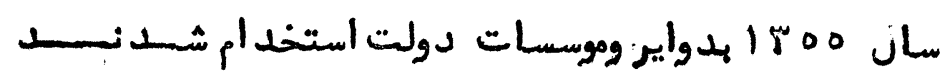

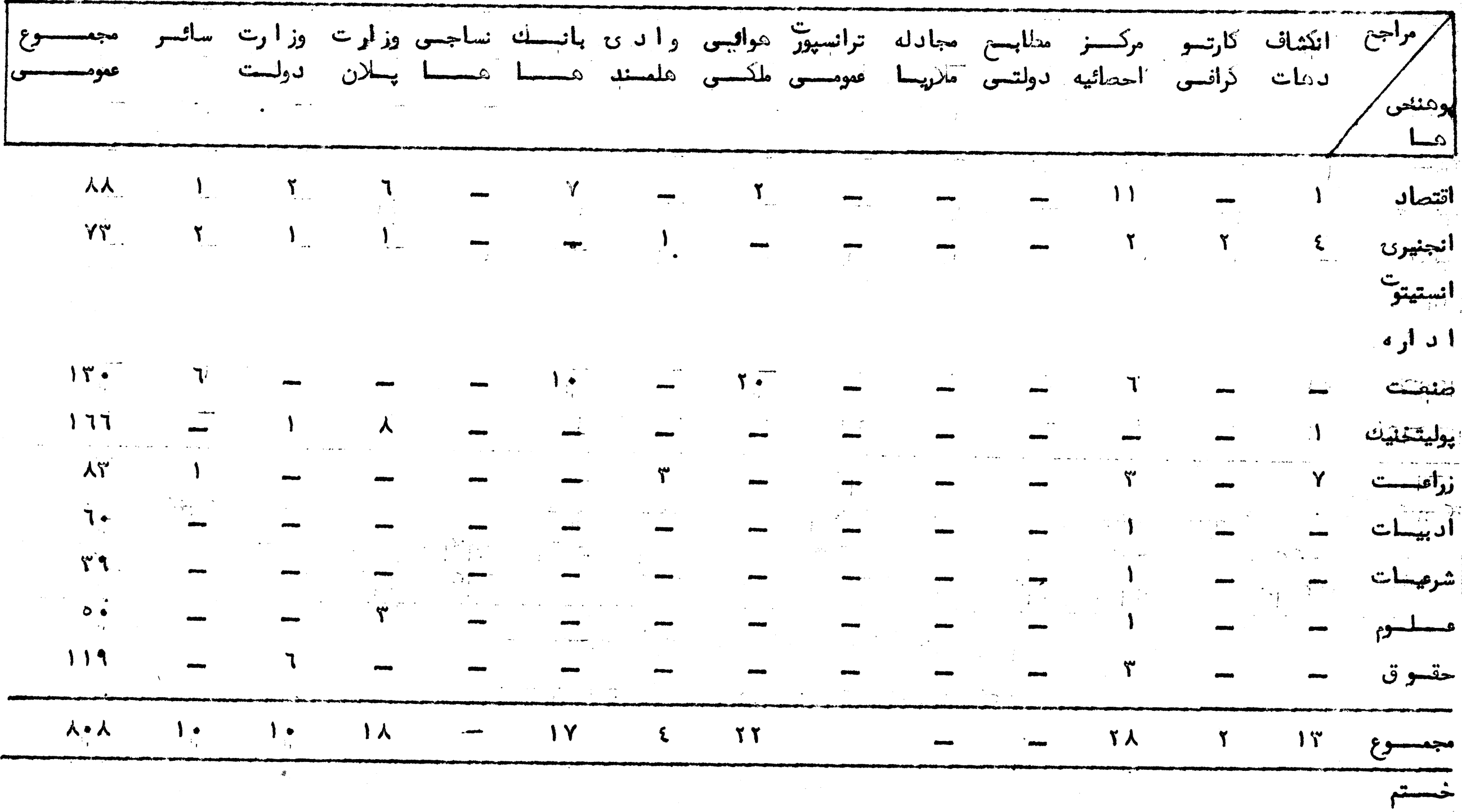




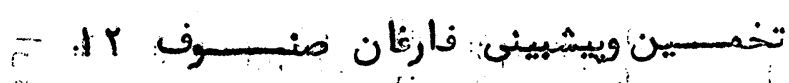

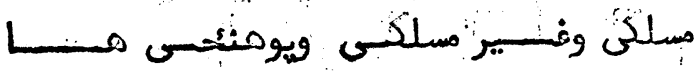

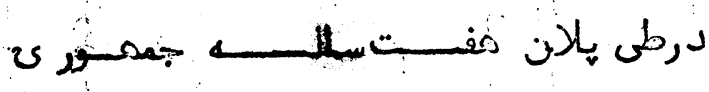

$(1571-1900)$

جسـدول (1)

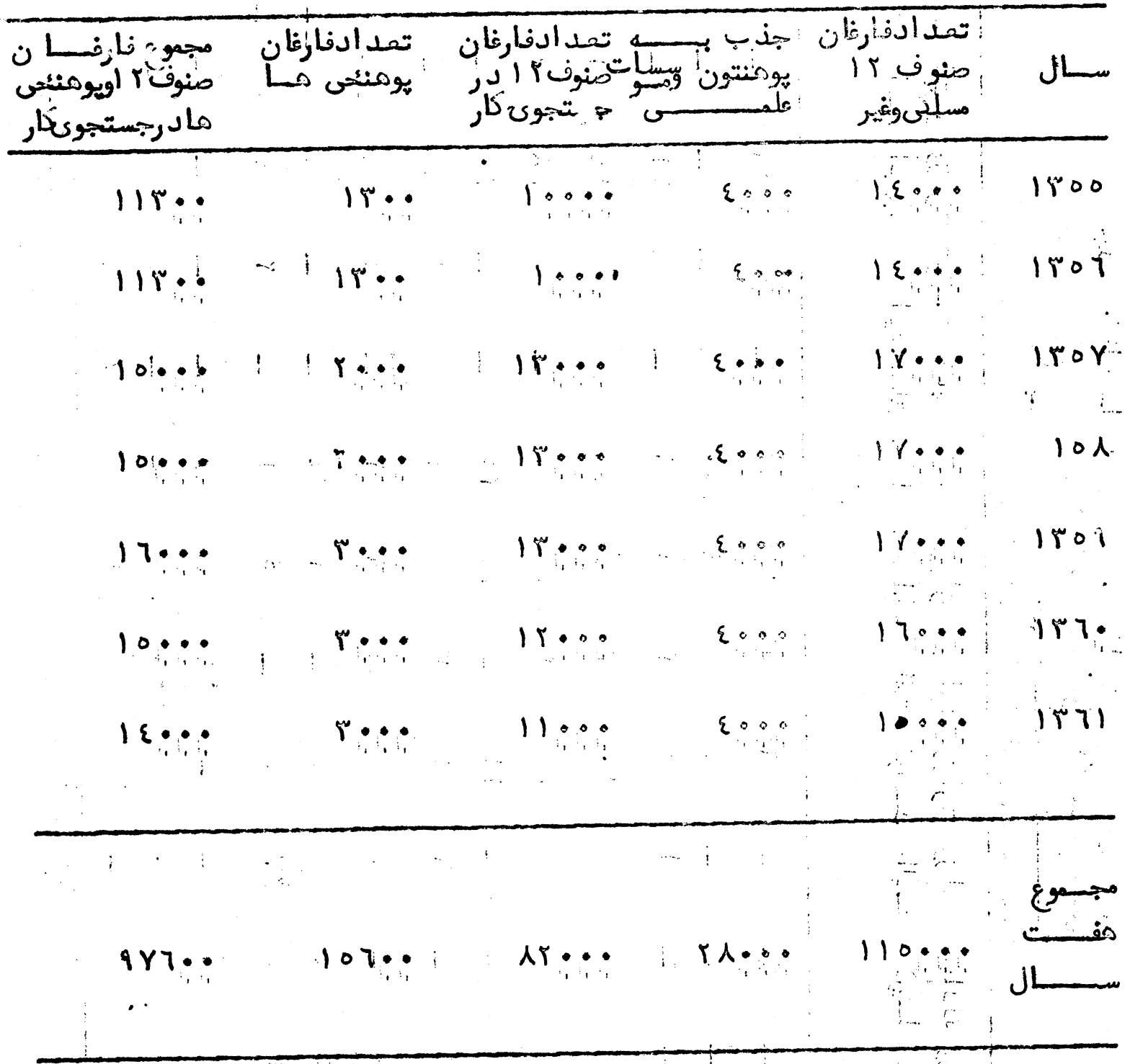

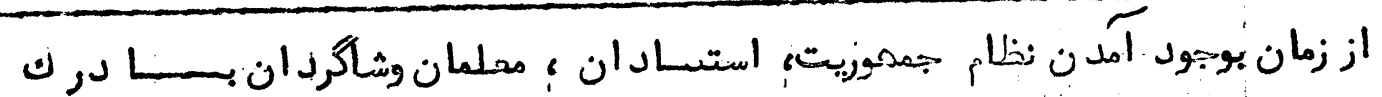

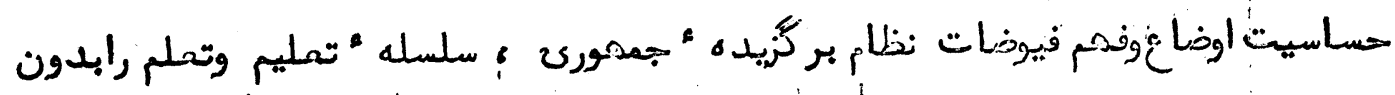

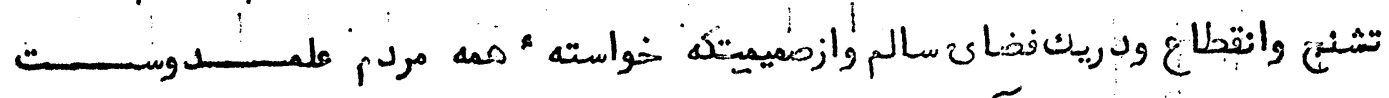

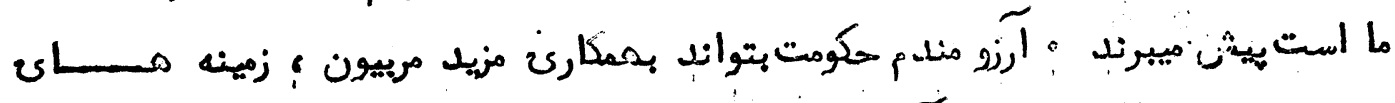

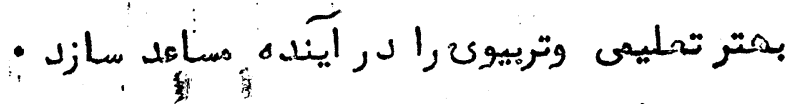

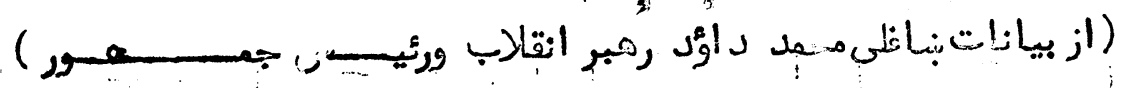




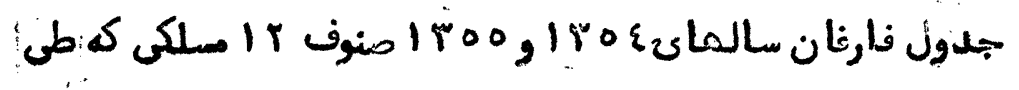

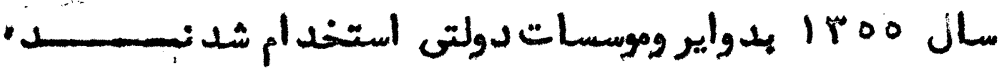

\begin{tabular}{|c|c|c|c|c|c|c|c|c|c|c|c|c|c|c|c|c|c|c|}
\hline 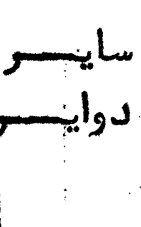 & نجازارت & & تعومد & كلتو رولارت & مَ & לे & هلا & ماليــ & فوز ارتـا & نراهت & ممارف & ومناد ارت & & & آبـو إ & كرا & & \\
\hline- & & - & - & - & & - & - & - & 1 & 0 & ir & $r$ & - & - & 7 & - & - & ميخانبكى صنج ع 1 \\
\hline- & & - & - & - & & - & - & - & - & - & $\varepsilon$ & 10. & - & - & - & - & - & تخنيكــــميم بلـن \\
\hline - & & - & - & - & & - & - & 1 & 。 & $r$ & 9 & 1 & - & - & $r$ & - & 1 & ميخانيكى كنبنمار \\
\hline- & & - & - & 1 & & 0 & $=$ & - & 1: & $r$ & $\dot{r}$ & 17 & - & - & i $\varepsilon$ & 1 & - & مينانيك كابسل \\
\hline- & & - & - & 1 & 1 & 9 & - & $r$ & ro & $r$ & 11 & $\gamma$ & - & 。 & ro & $r$ & $1:$ & تخنبن ثانسو ى \\
\hline 1 & & ○ & - & - & & - & - & - & 11 & - & 11 & ro & - & - & $r:$ & - & 1 & ميخانيكىخوست \\
\hline 1 & & - & 1 & r & & $r$ & $\div$ & 8 & 1 & 1 & 0 . & $r$ & - & 1 & - & - & - & ليسه جمدوريت \\
\hline - & & - & - & r & & $\circ$ & - & $\dot{\gamma}$ & $\varepsilon$ & - & 7 & $r$ & - & 1 & - & - & $r$ & ليسه ميزرمنوتولنه \\
\hline$\varepsilon \wedge$ & & - & - & - & & 1 & $\varepsilon$ & זיז & r & - & $r$ & $\varepsilon$ & - & - & rT & - & - & ليسه تجـار ت \\
\hline or & - & - & - & 1 & & 1 & $r$ & $r y$ & 。 & - & 。 & 1 & - & $r$ & $\varepsilon$ & - & - & اد اره " عامــــــ \\
\hline- & - & - & - & - & & - & - & - & - & 10 & - & - & - & - & - & - & - & زراعت بنــــلا ن \\
\hline- & & - & - & - & & - & $=$ & - & - & $1 \cdot 1$ & - & - & - & - & - & - & - & نرامت هلمســـد \\
\hline 15 & - & - & - & - & & - & - & - & 11 & - & 1 & $r$ & r & $\varepsilon$ & $r$ & 0 & $v$ & منايتمابــــــ \\
\hline 117 & & $\circ$ & $T$ & $T$ & & IT & $Y$ & 9. & $\pi$ & TY. & 180 & TYO & $\bar{T}$ & $T \Gamma$ & TYY & $\pi$ & $\overline{Y T}$ & 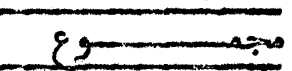 \\
\hline
\end{tabular}




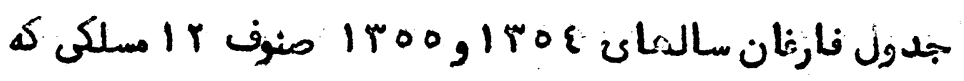

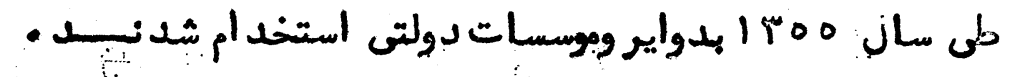

\begin{tabular}{|c|c|c|c|c|c|c|c|c|c|c|c|c|c|c|c|c|}
\hline ك & جنكا & بانكما & لفنسا & نهلهندى & كند مئمَّ & א & ملمند & افنـا: راديـ & وزانله & منحابرّار & كابســـ بندا & & ملكوئى & تمالرّتً & 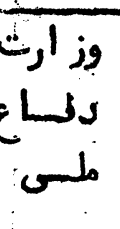 & \\
\hline rr & - & - & - & - & - & - & - & 7 & - & - & - & - & - & - & - & ميخانيكى منف ع 1 \\
\hline $10 \xi$ & - & - & - & - & - & - & - & - & - & - & - & - & - & - & - & خنيكير بلــــن \\
\hline $7 r$ & : & $:$ & : & $\varepsilon$ & 1 & 1 & 7 & - & - & $r$ & - & - & - & - & - & يخانيكى كنب مار \\
\hline$r \gamma$ & & & $\varepsilon$ & & & $r$ & : & $1 \%$ & $\therefore$ & 1 & r & & & r & ." & ميخانيكى كابـــله \\
\hline 110 & - & - & - & & - & - & - & r & $1 \varepsilon$ & $r$ & ir & - & $r$ & D. & - & تخنيكن ثانبـــو ك \\
\hline ir & $r$ & - & - & - & - & 1 & r & - & - & 11 & 1 & 1 & - & - & - & مينانبكى خوست \\
\hline ry & - & 1 & - & - & - & - & - & - & - & - & - & - & - & - & 7 & ليسه جمدوريسـت \\
\hline rq & & - & - & - & - & - & - & - & - & 1 & - & - & $r$ & r & $r$ & ليسه مهرمنوتولنبــــ \\
\hline Iri & 1 & $1:$ & - & - & - & - & - & - & - & - & - & - & - & - & - & ليسه تجـــار ت \\
\hline 118 & - & 1 & - & - & - & 1 & - & - & - & - & 1 & - & - & $r$ & - & اد اره "عامســـــــ \\
\hline 90 & - & - & - & - & $=-$ & - & - & - & - & - & - & - & - & - & - & زراعت بفــــلا ن \\
\hline 118 & - & - & - & - & - & - & 9 & - & - & - & - & - & - & - & - & زراعت كلمنـــــد \\
\hline 09 & - & - & ० & - & - & - & - & - & - & - & 1 & - & - & - & - & منايت كابــــــل \\
\hline $1 r \cdot 0$ & $r$ & iv & 1 & $\varepsilon$ & 1 & 0 & 11 & 19 & $1 \varepsilon$ & 19 & ir & 1 & 7 & Ir & $\alpha$ & $\varepsilon$ \\
\hline
\end{tabular}




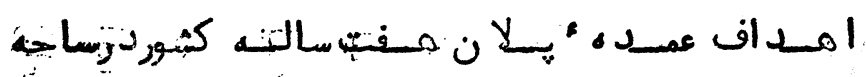

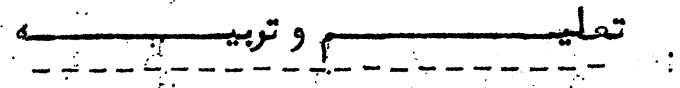

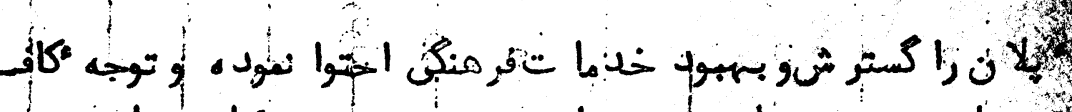

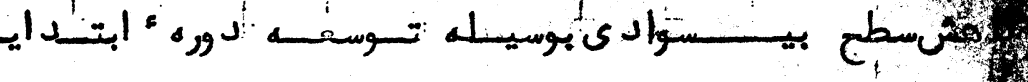
ها

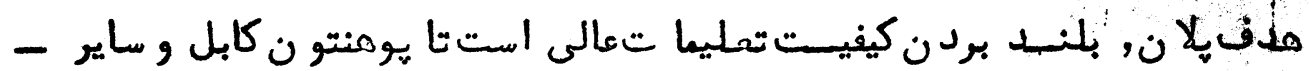

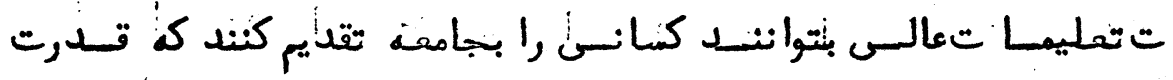

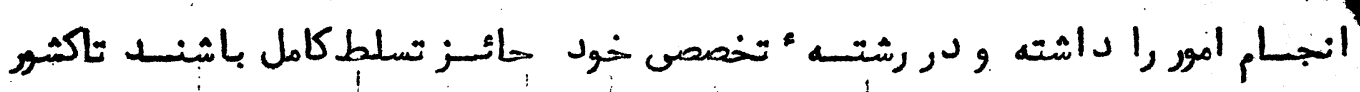

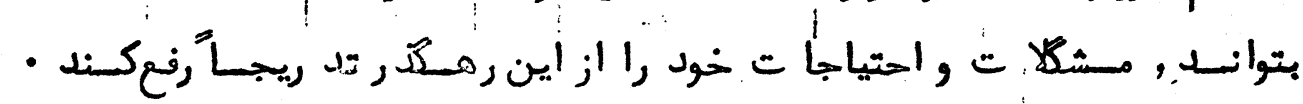

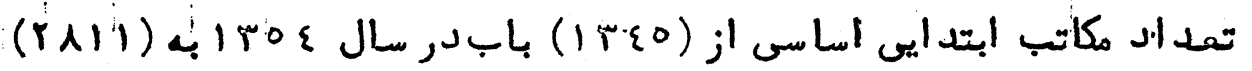

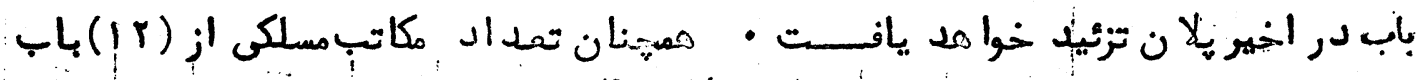

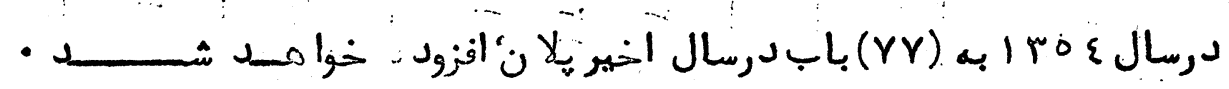

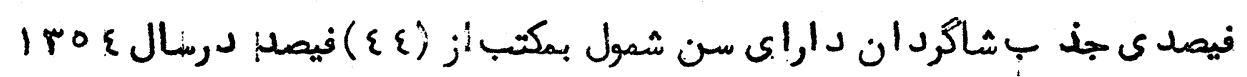

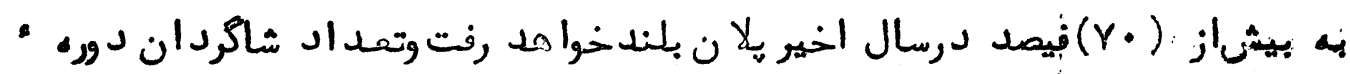

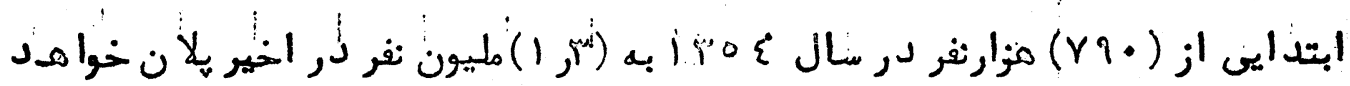

\section{米米米米米米米米米米米米米米米米米米米米}

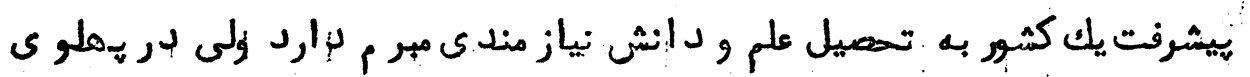

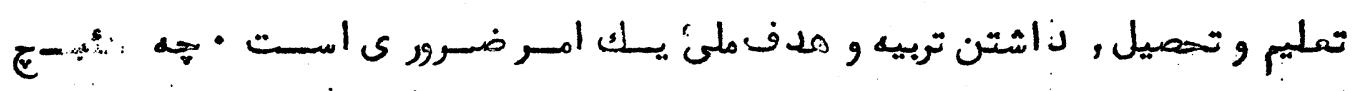

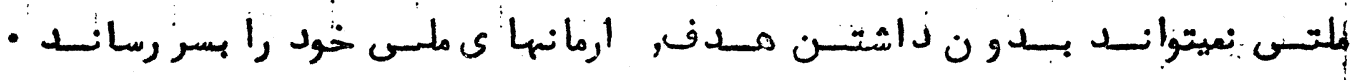

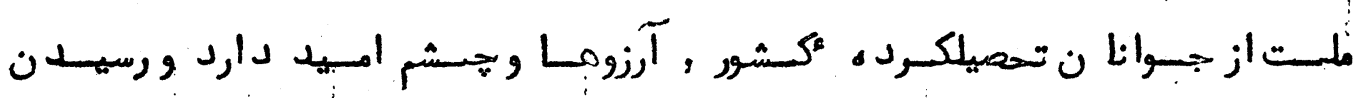

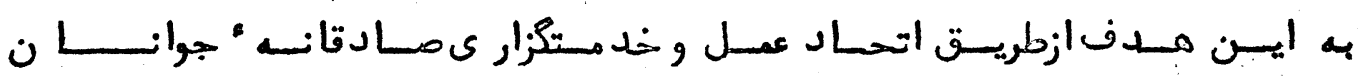

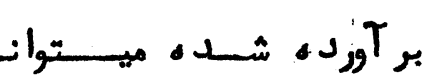

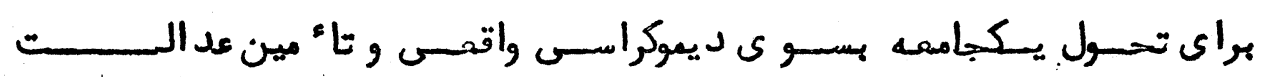

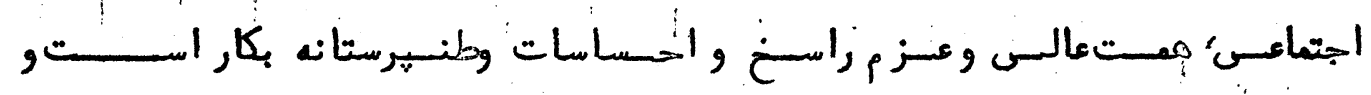

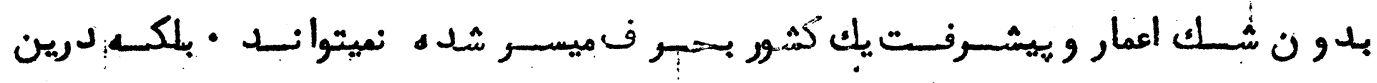

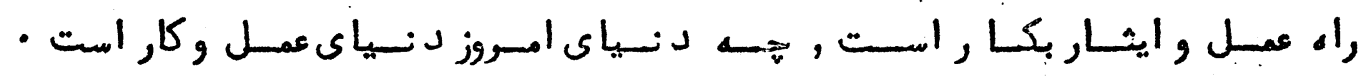

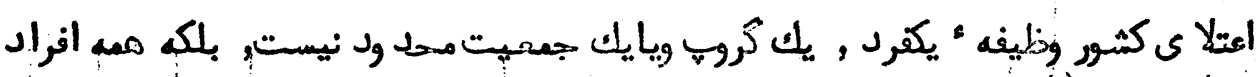

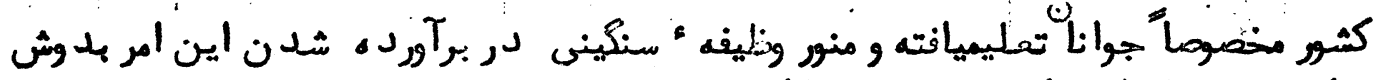

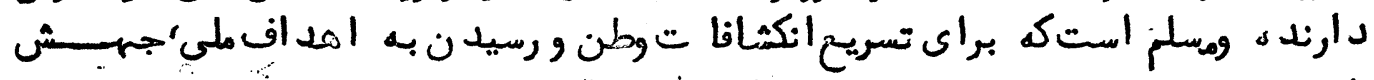

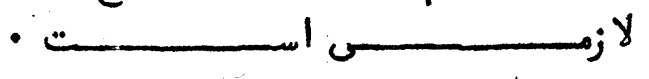

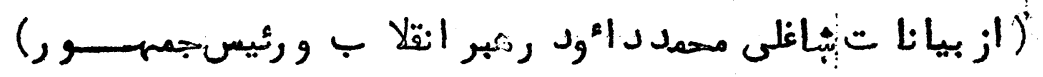


فصلحوم

الحصائية -

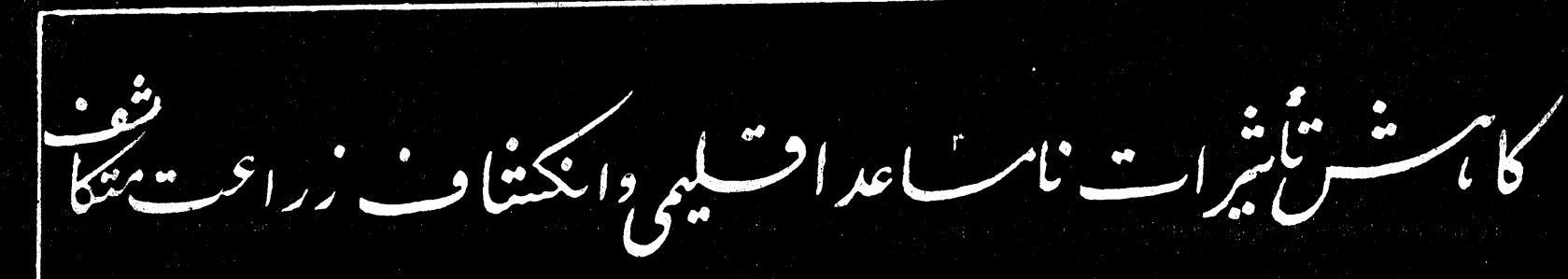

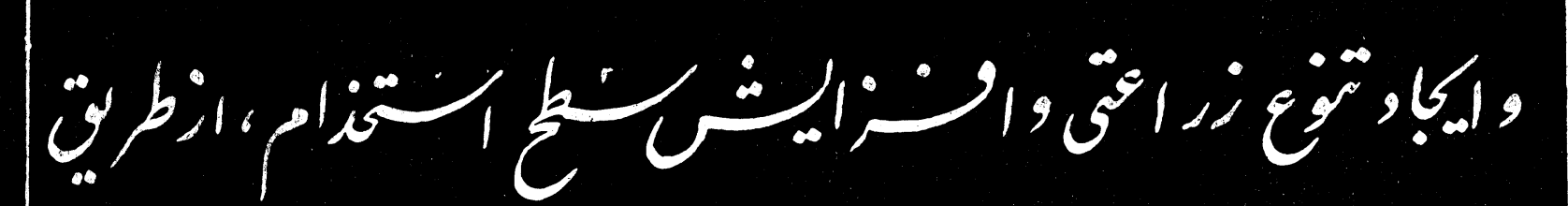

,

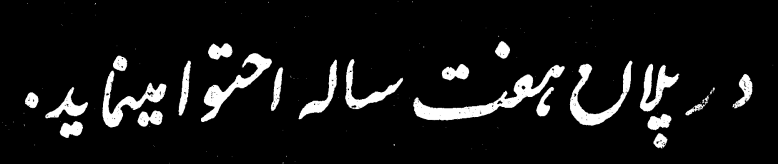

(1)

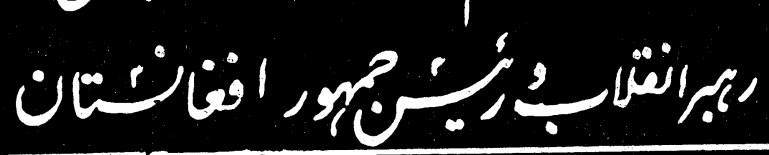


3

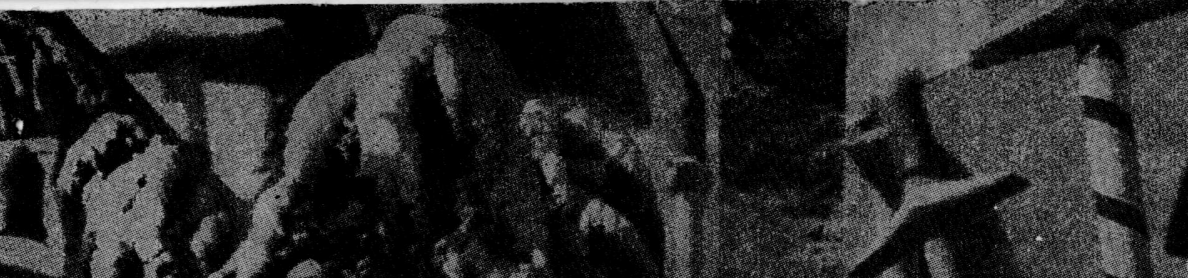
Wh $x^{m}$ is at. (fi. ex. a)

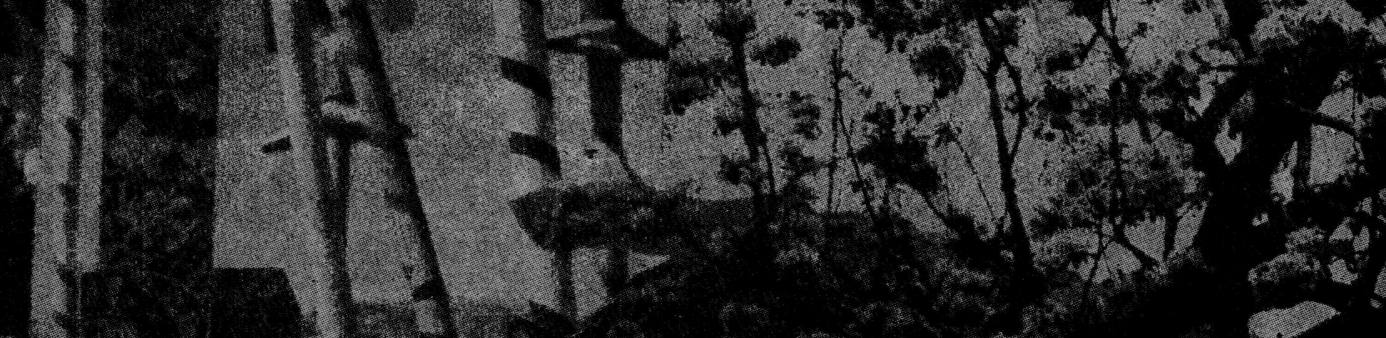

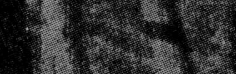

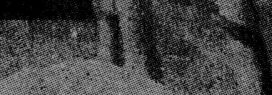<smiles>[13CH3][13CH3]</smiles>

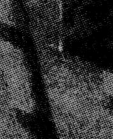

$\rightarrow 13$ vir

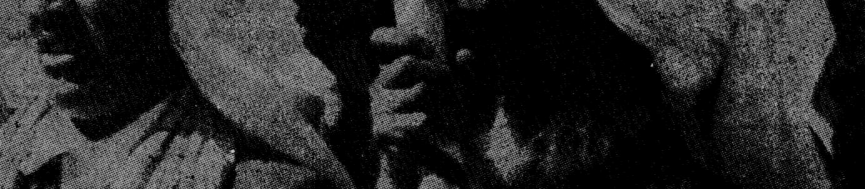
$y-3$ 1.

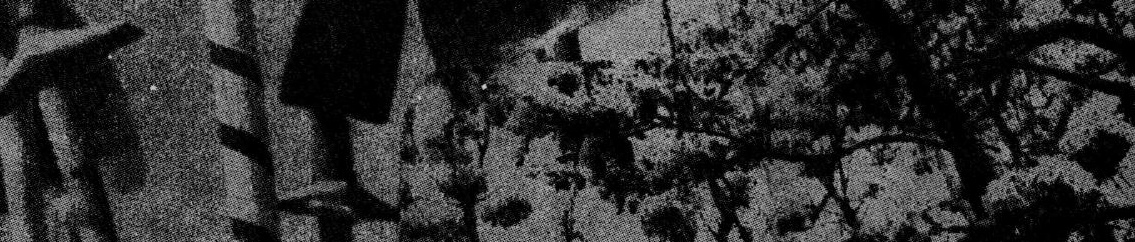

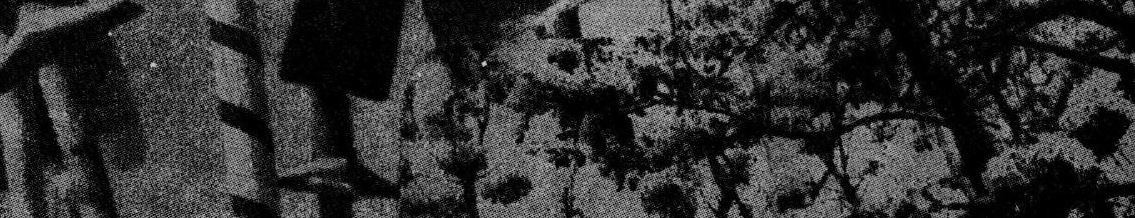
10 (1) 


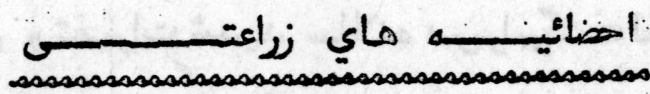

ممانطوريك زراعت در تاءمين و بمبود وضع اقتمادي ممالك جمان سم نقشارزنده: - مونمان

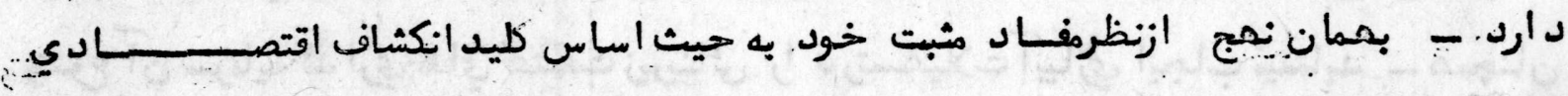

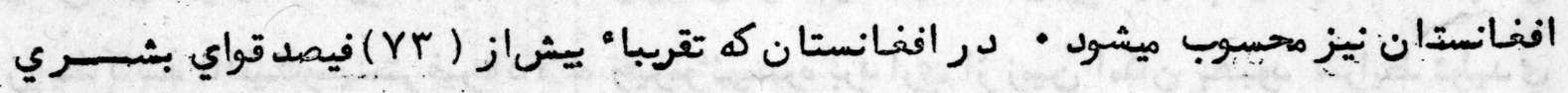

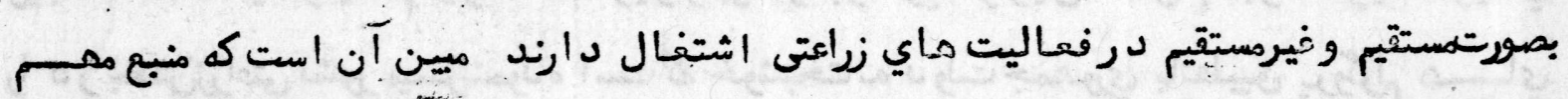

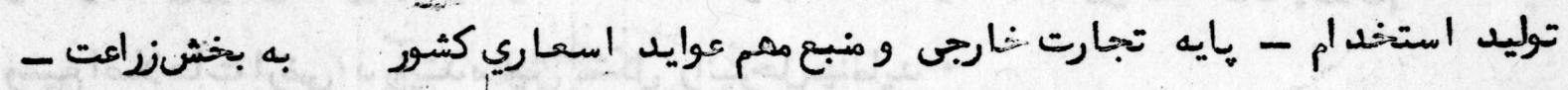

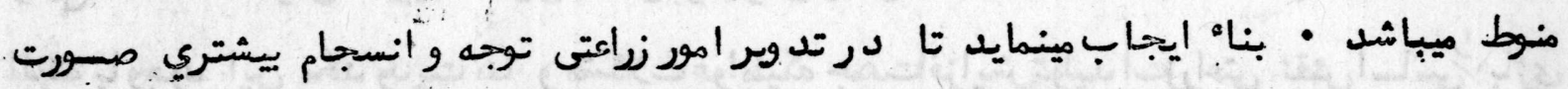

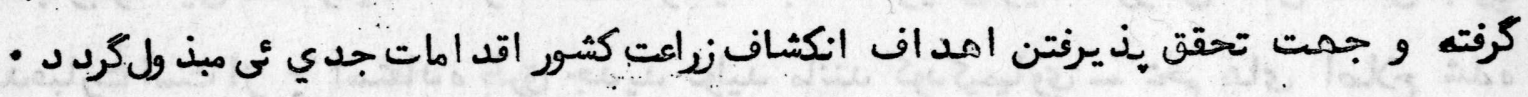

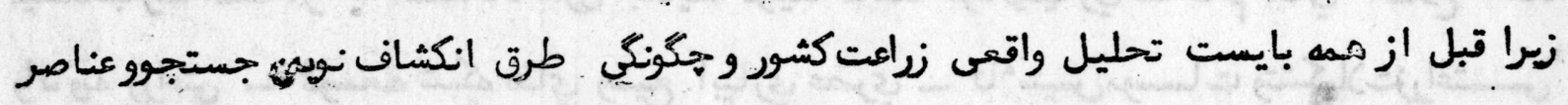

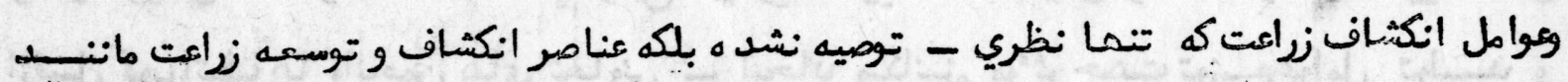

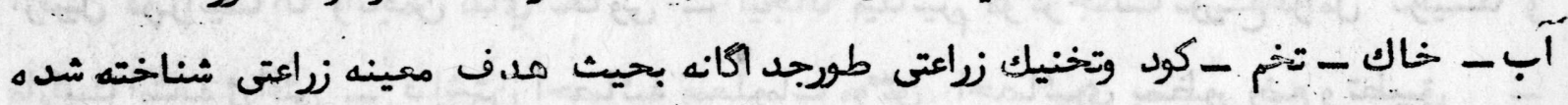

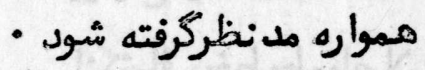
مكذ اء تكيل امد اف زراعتى دربروكرام ماي مطروحه بانظرد اشت انطبات آن به شرا يط

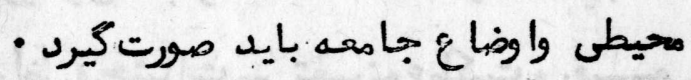

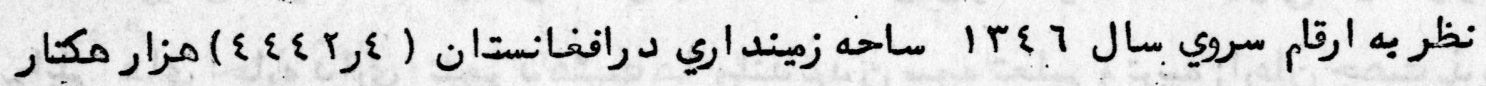

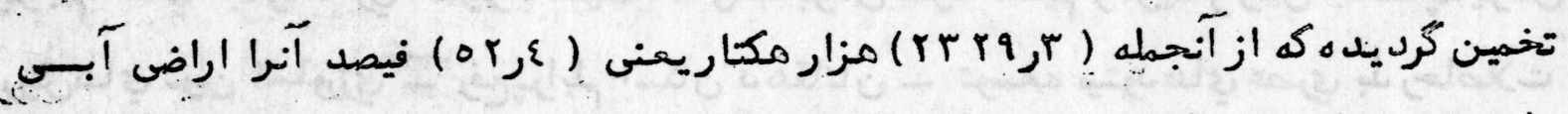

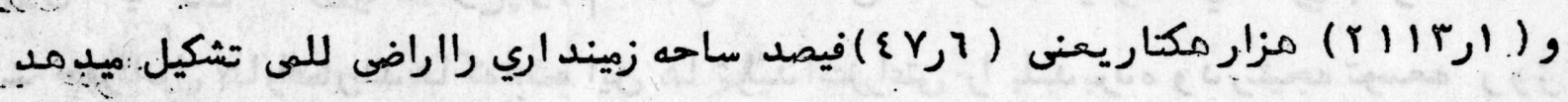

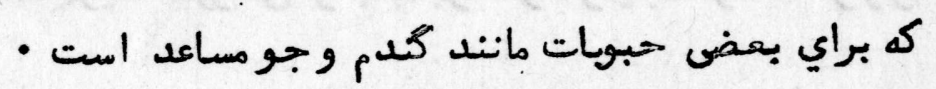

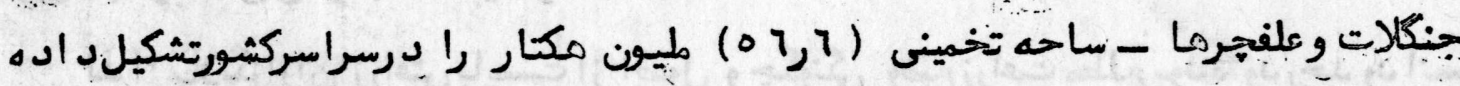
كه ازجمه (

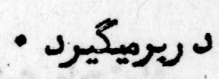

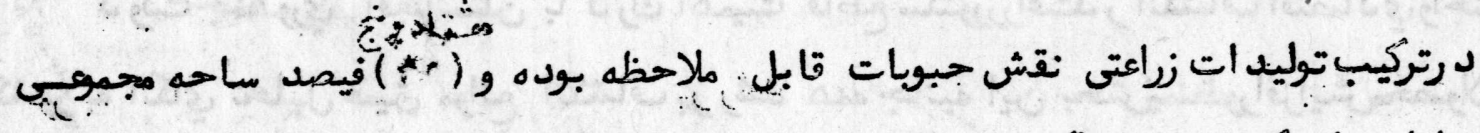

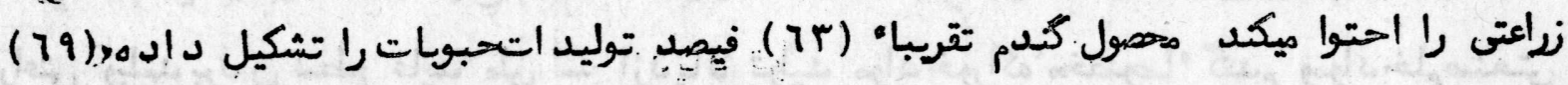

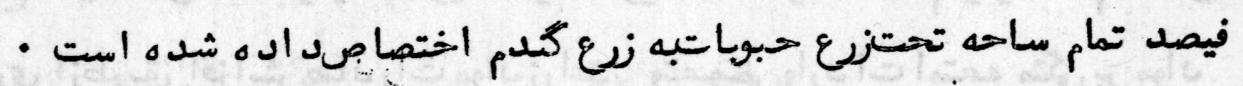

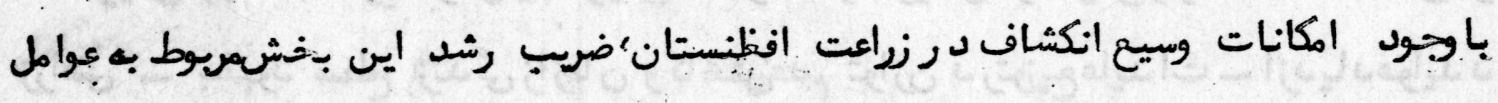

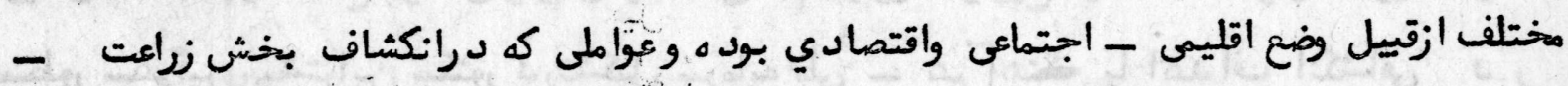

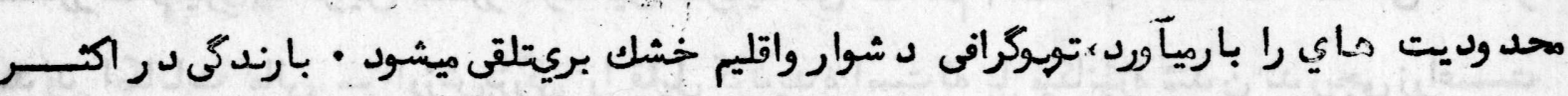


نواحى زراعتى به تناسب مطلوب نبوده ود راثريائين بود ن رطويت نسبتى مقد ارتبخيرزياد شده

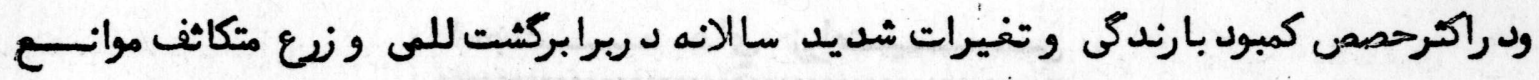

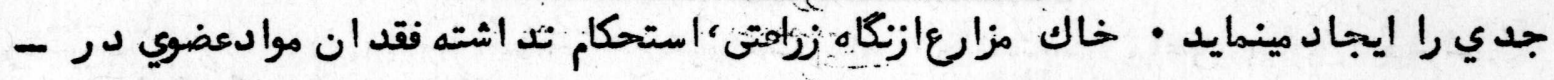

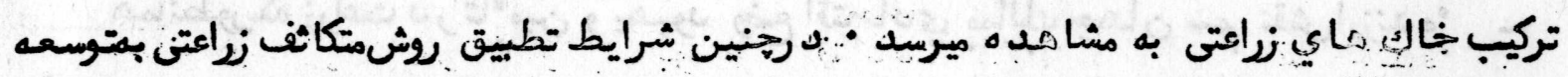

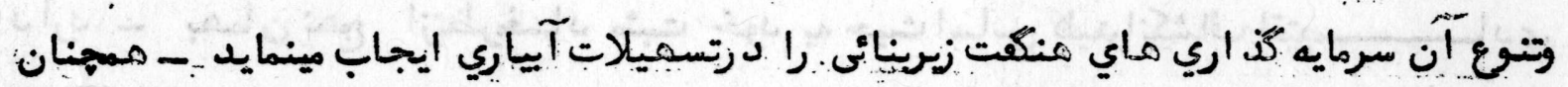

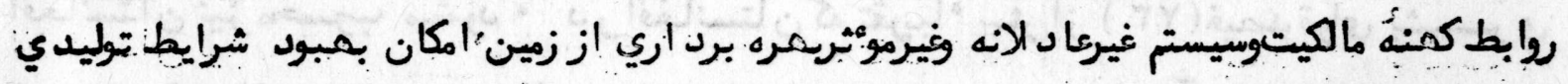

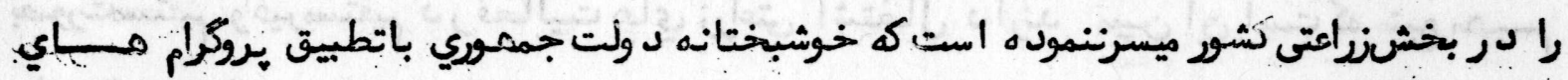

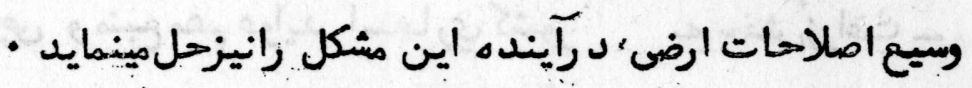

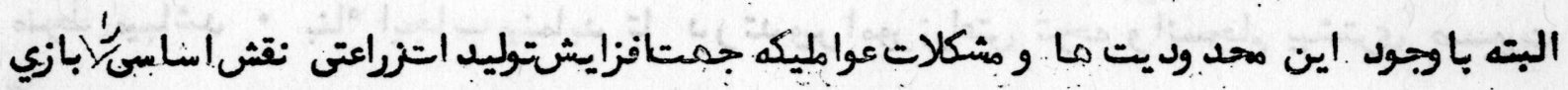

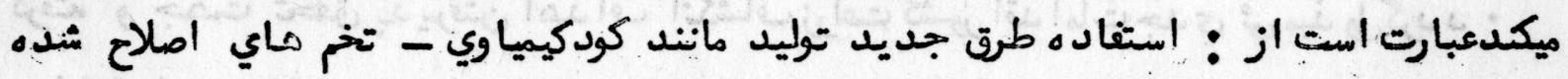

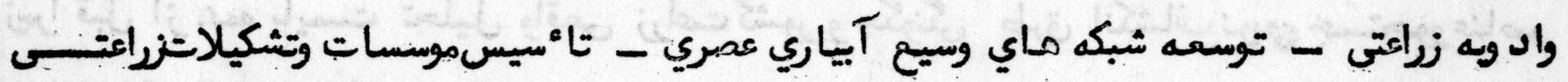

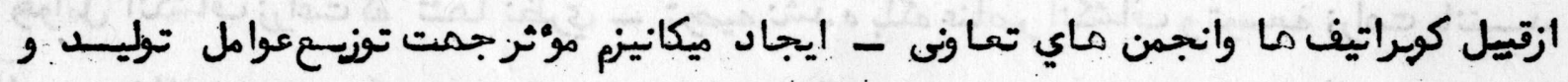

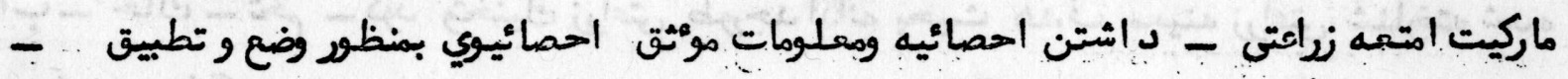

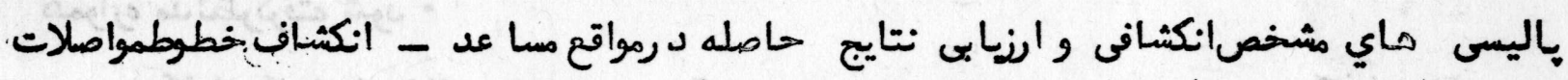

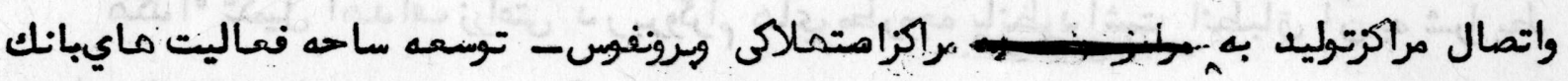

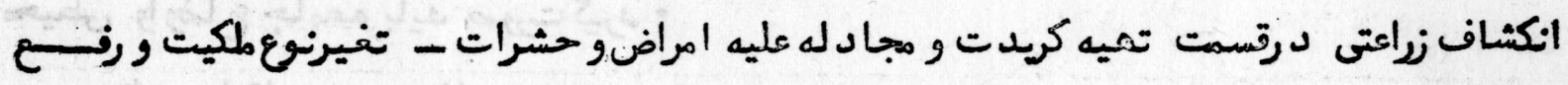

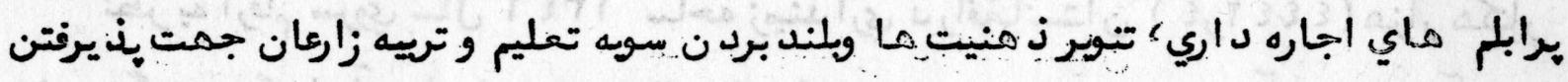
روثماي نوين كشاوزي - رفعبرابلم إسكان دمقانان - توسبعه ميتود ماي عصري بذ رحاصلات

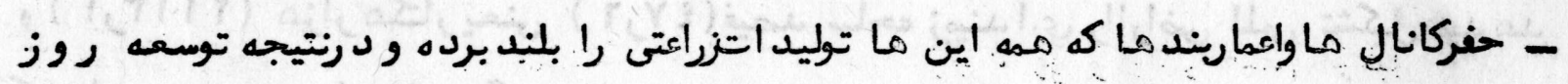
افزون تجارتخارجى را باعث ميشود

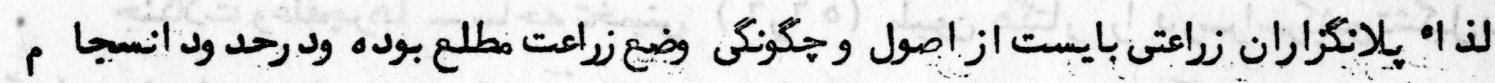

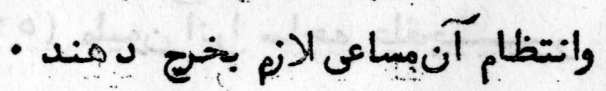

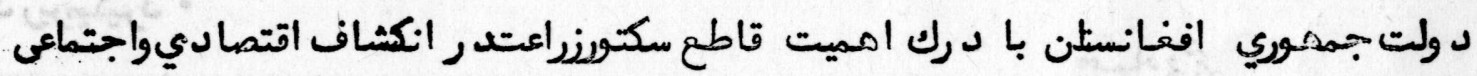

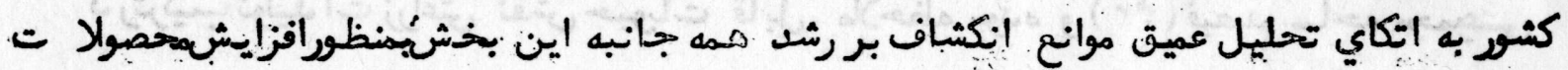

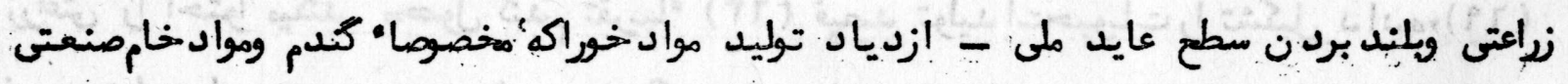

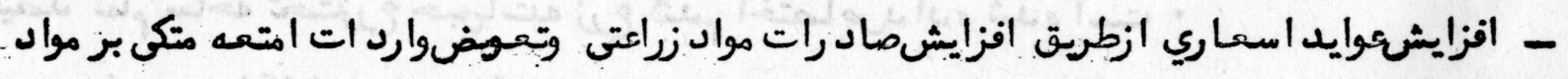

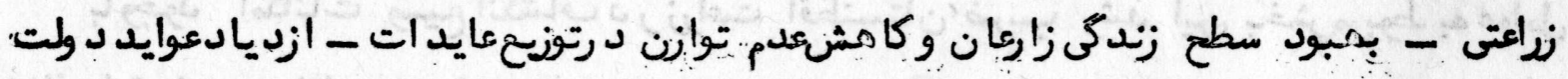

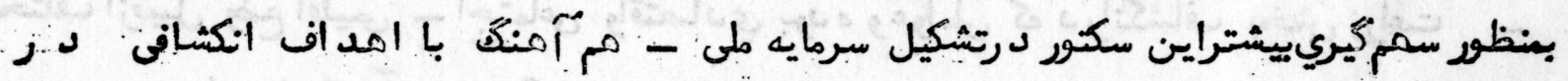

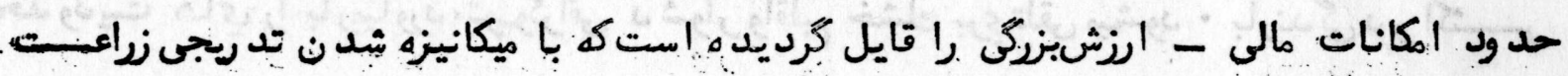




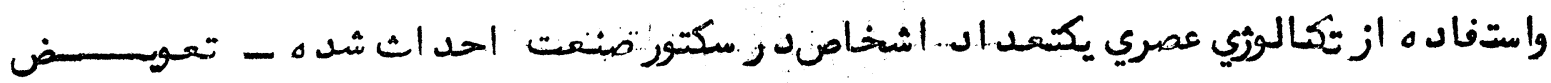

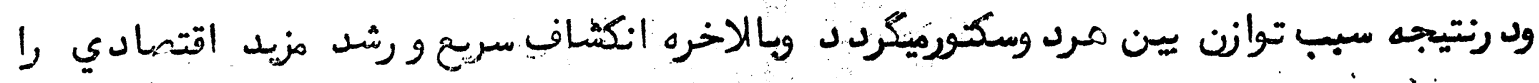

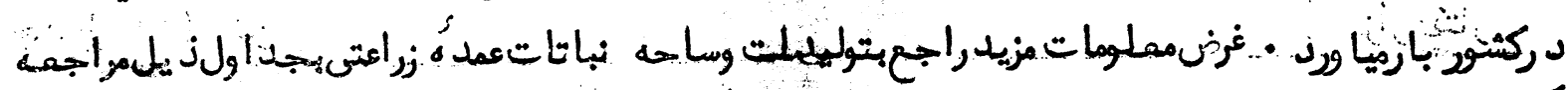

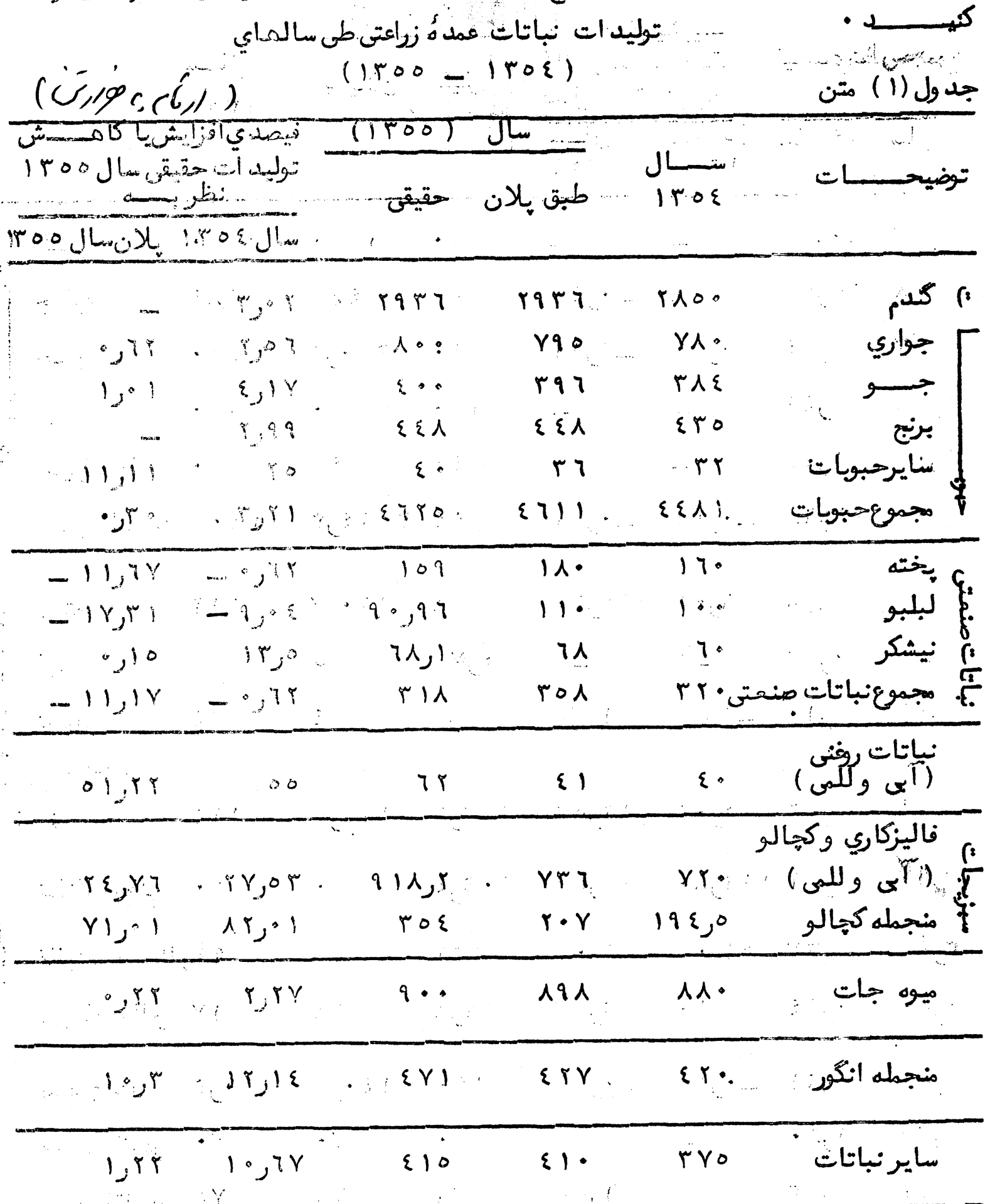


ساحه نباتات عمده زراعت

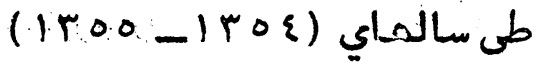

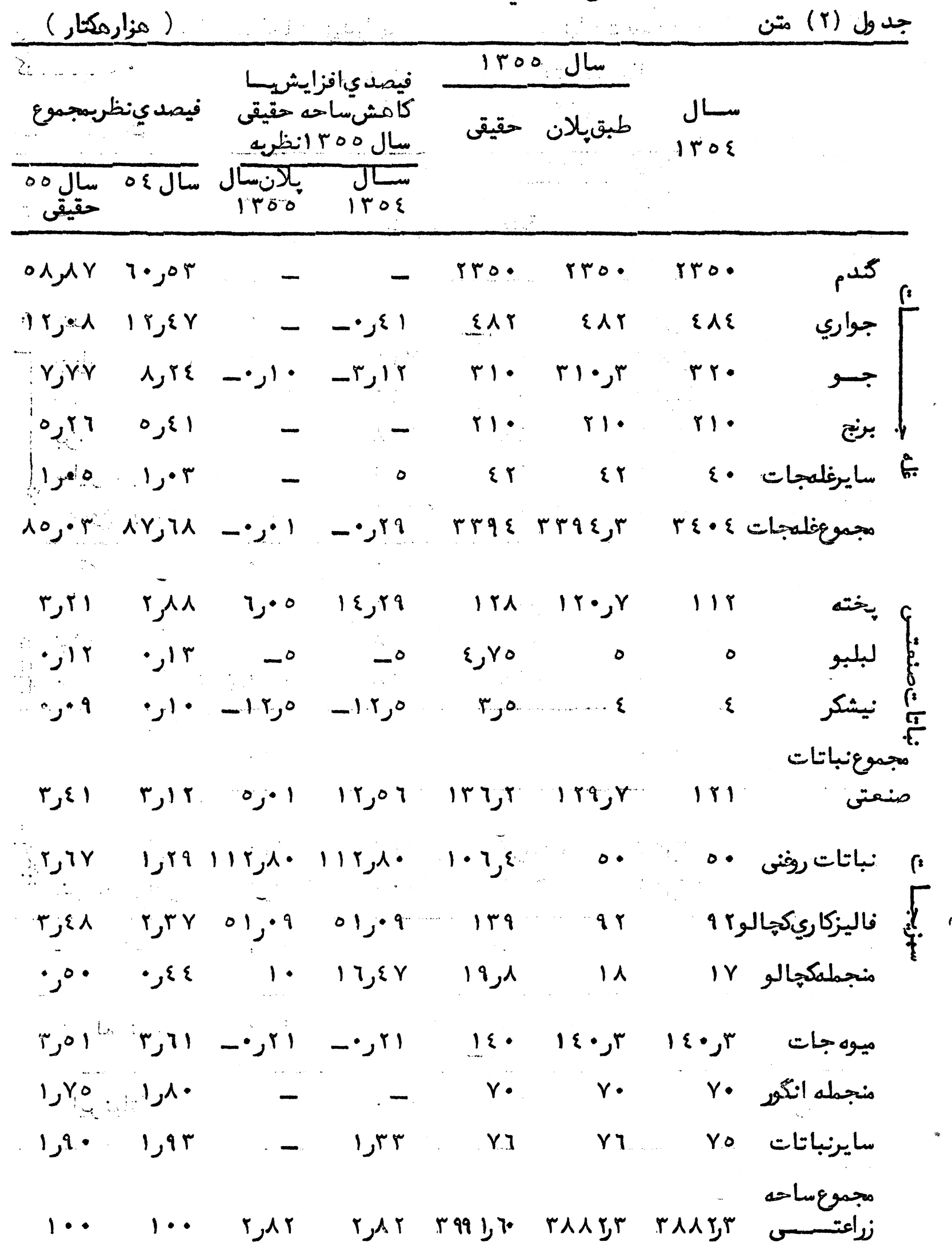


اوسط حاصلات نباتاتعمده زراعت

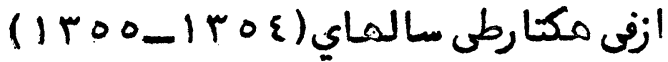

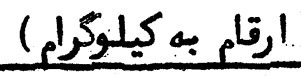

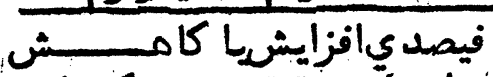

توليد آتحقيقى في مكــا

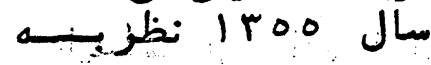
سال

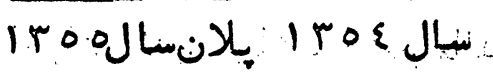

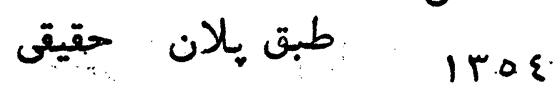

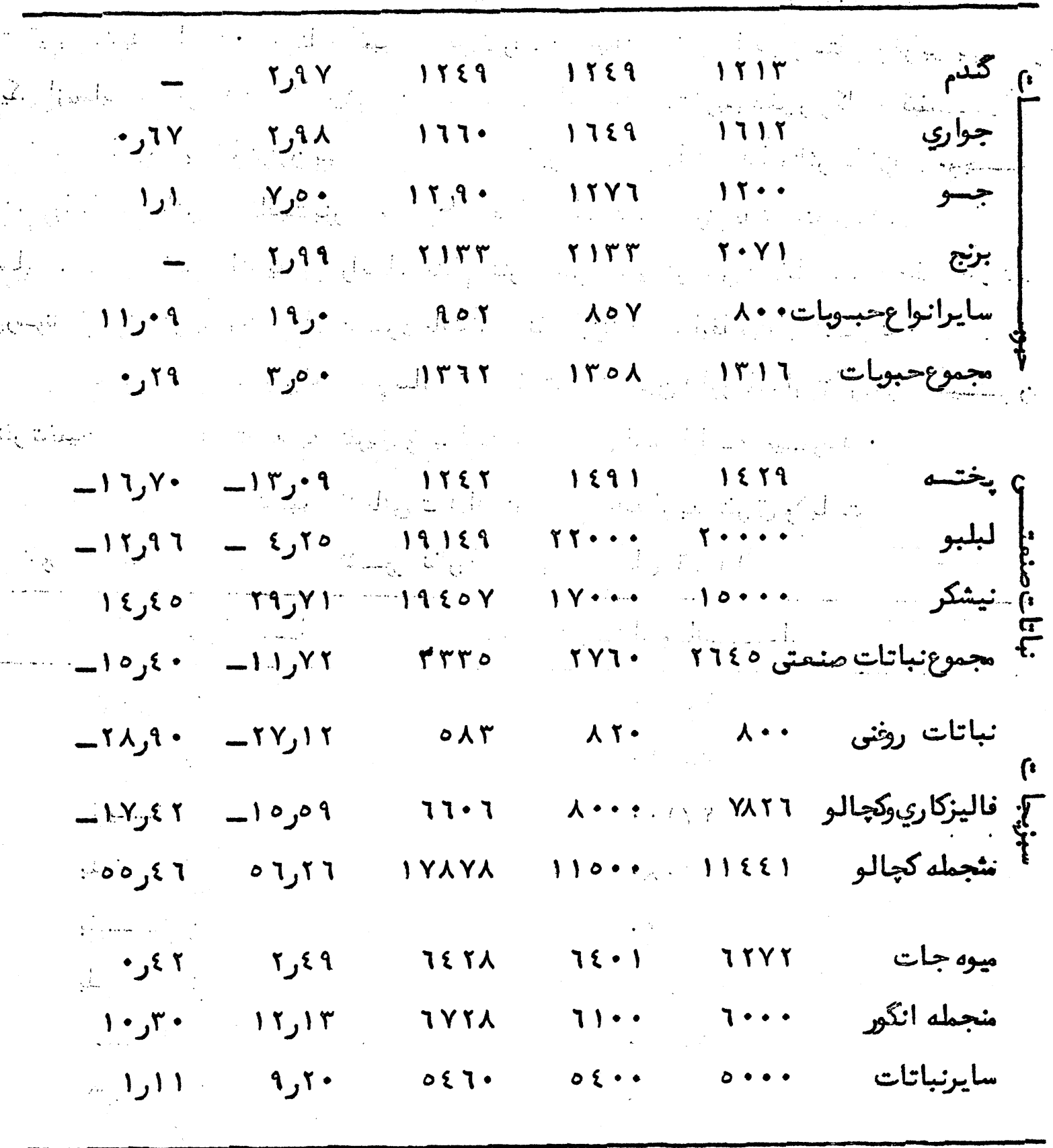




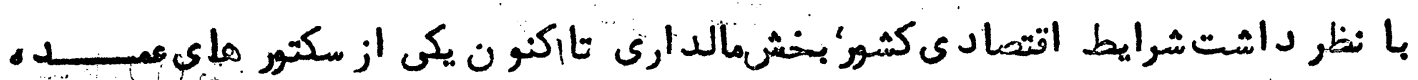

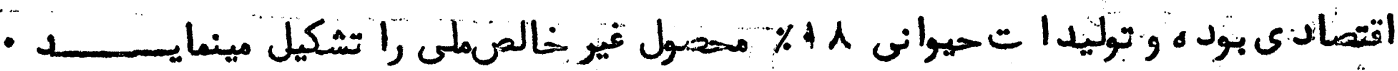

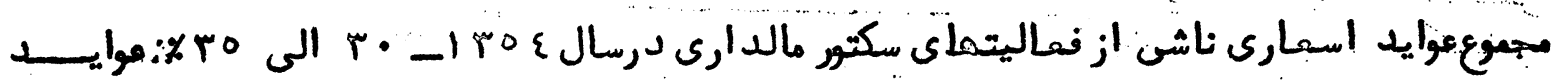

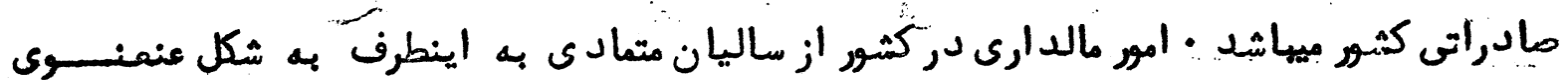

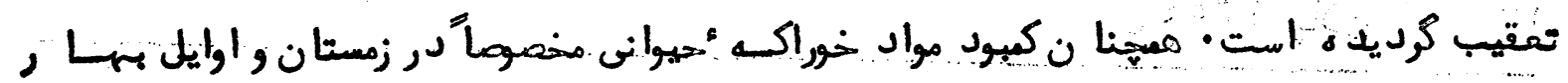

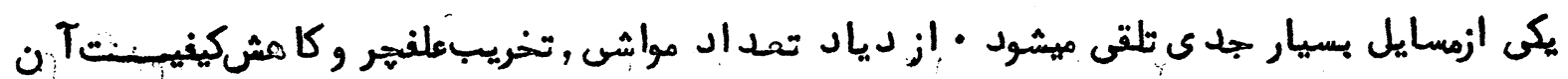

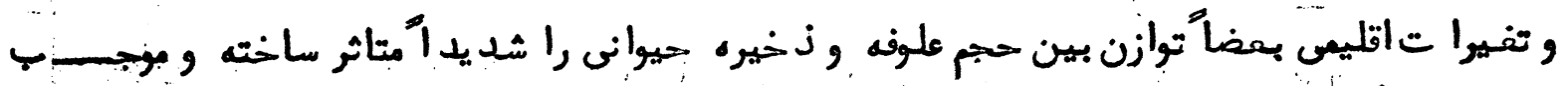

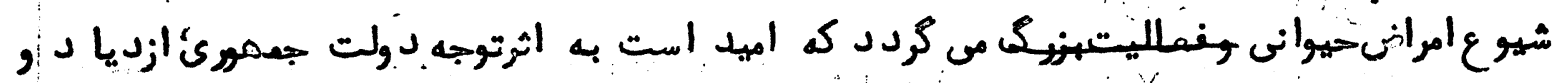

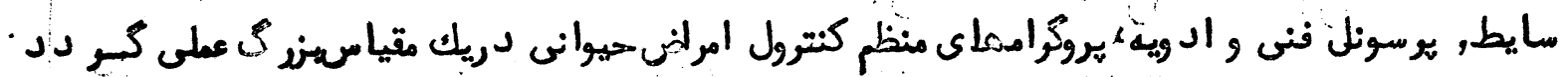

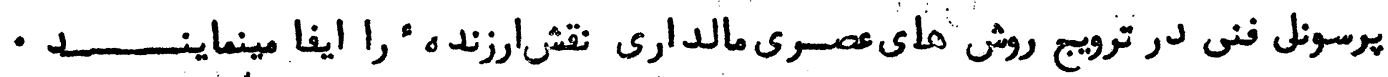

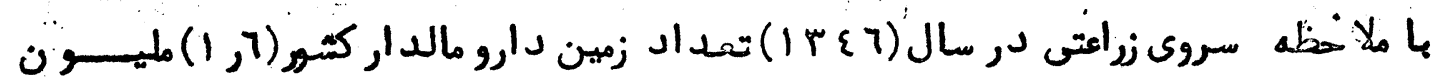

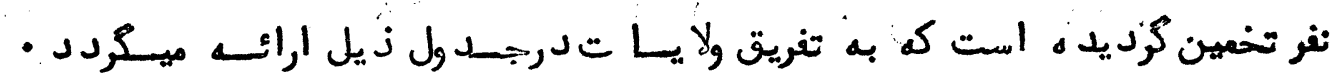

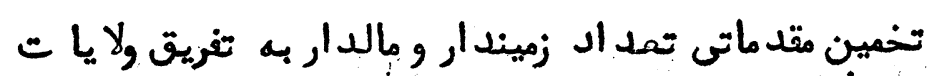

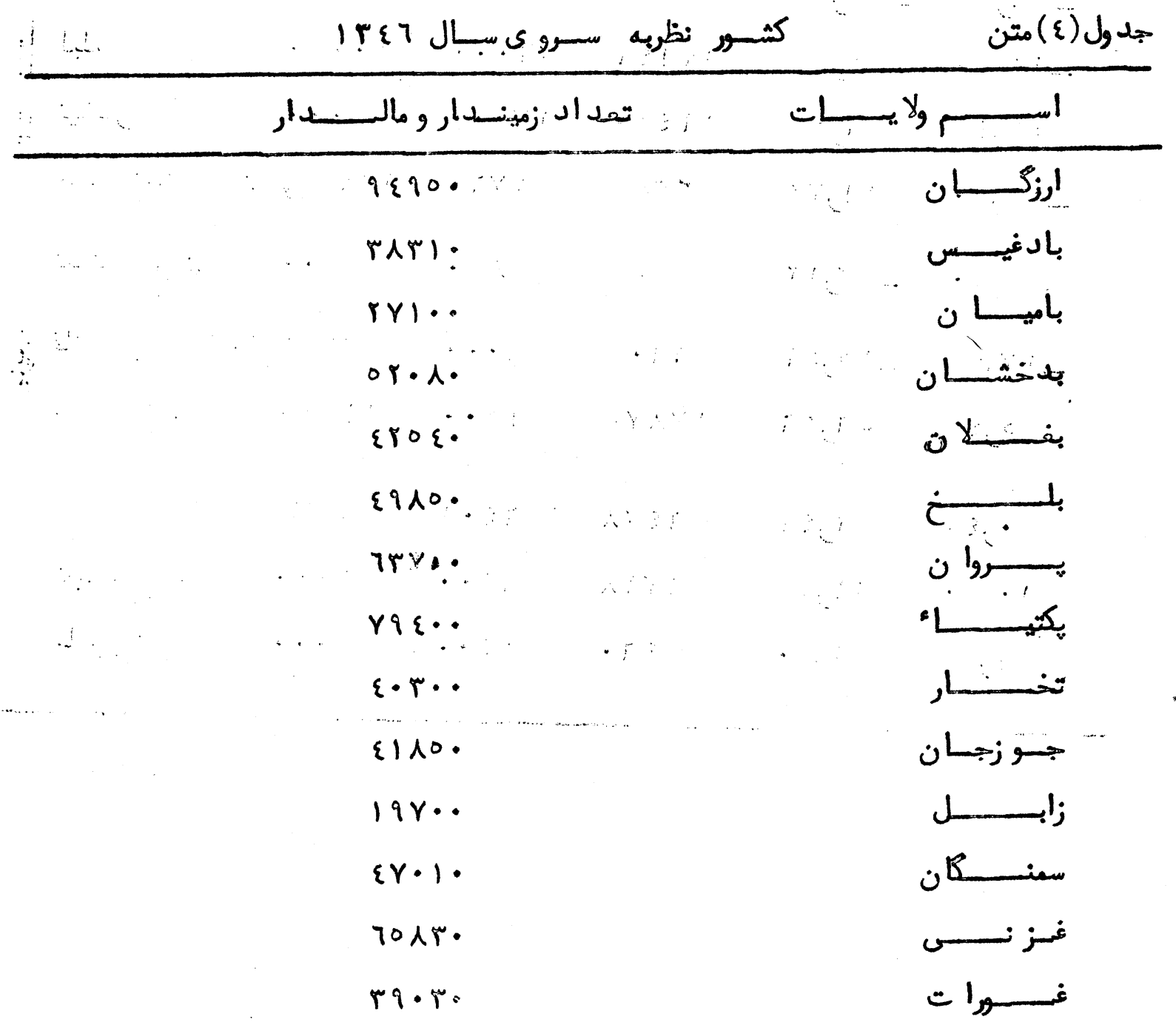




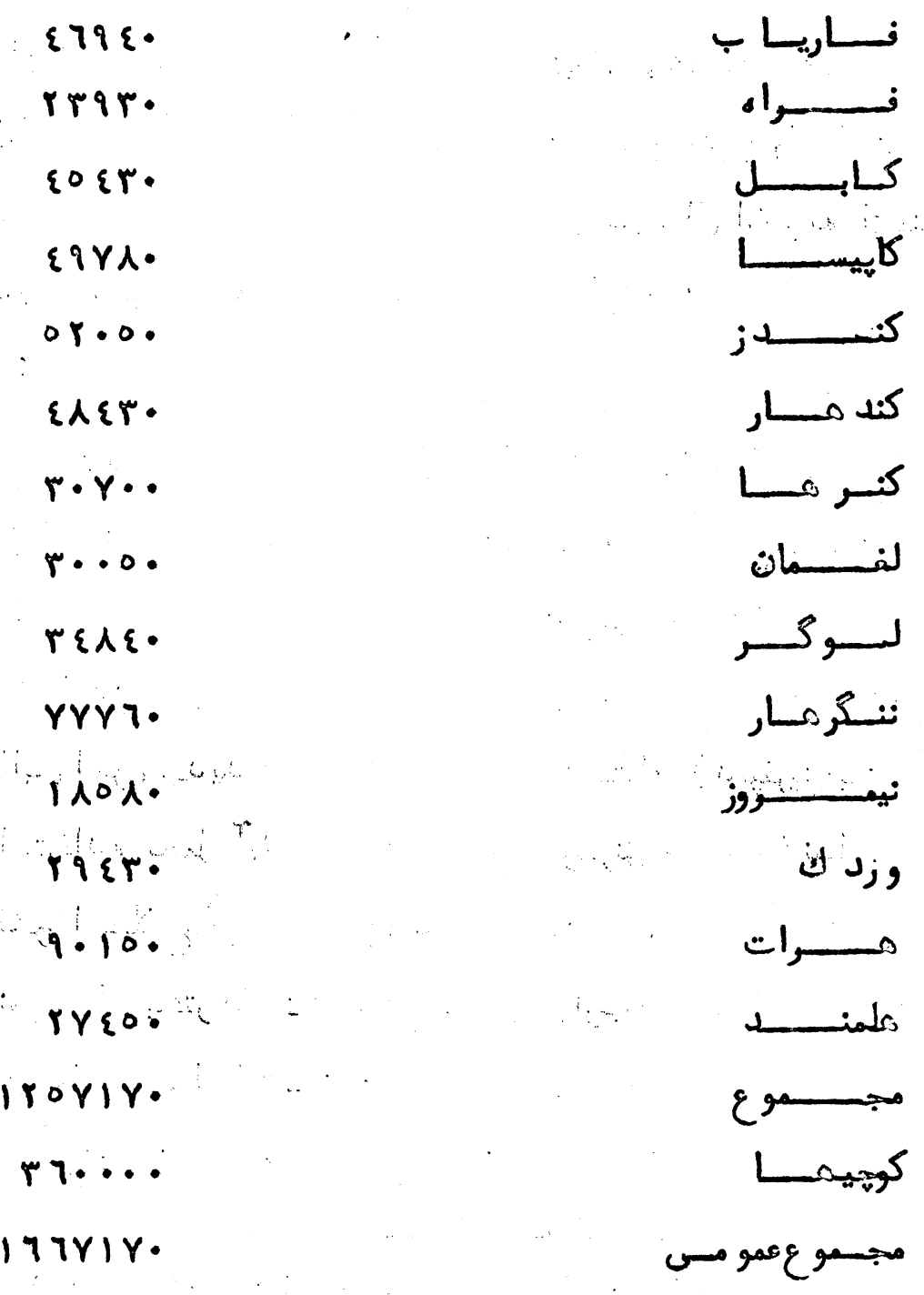

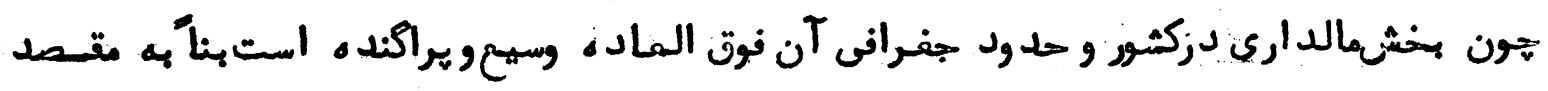

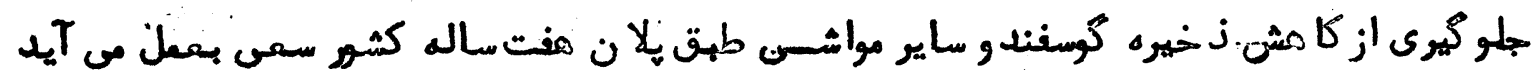

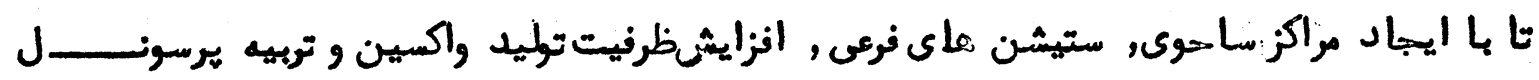

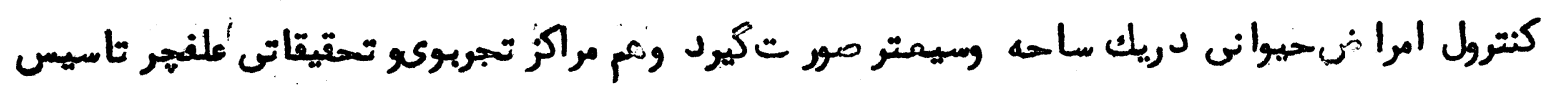

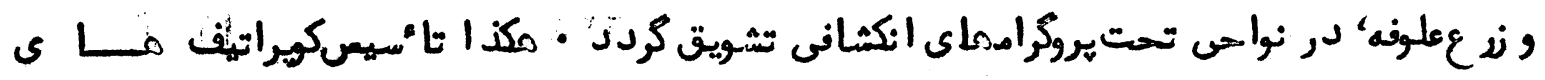

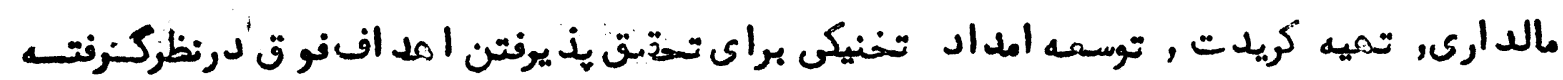
شـده است

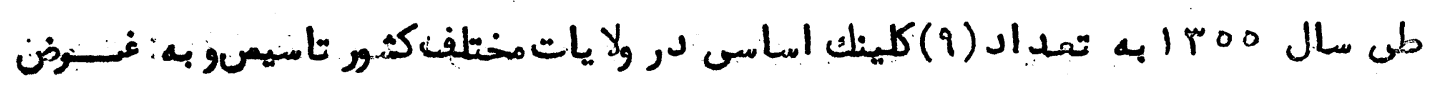

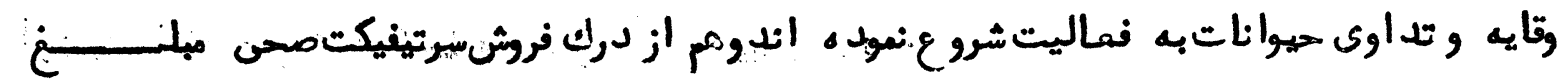

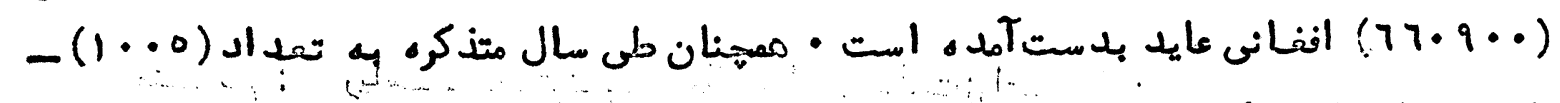

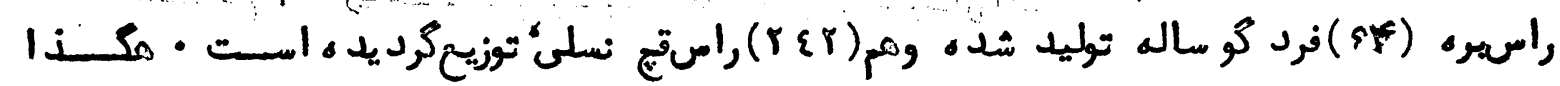

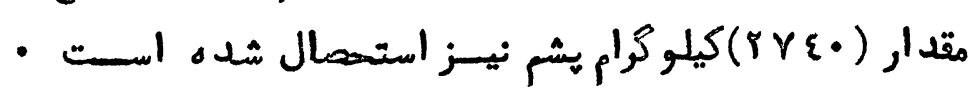

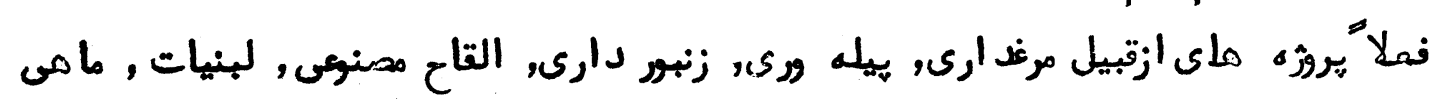

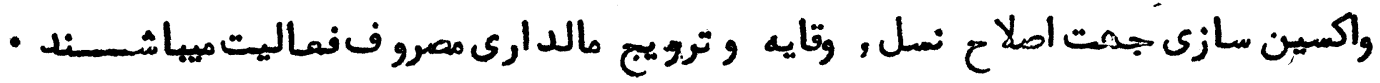




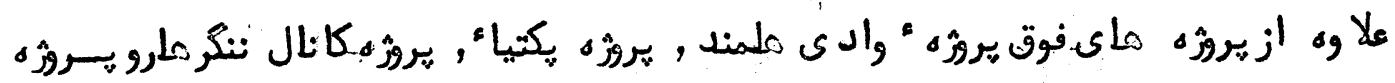

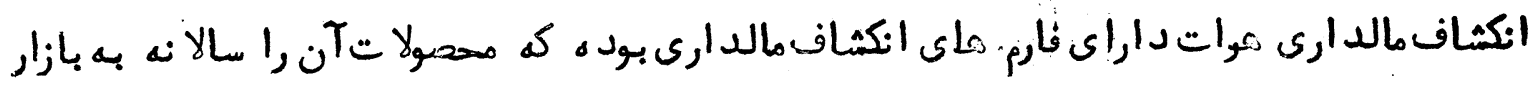

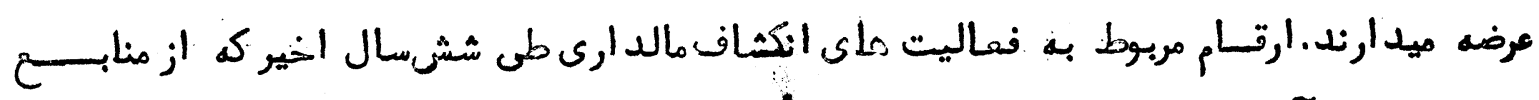

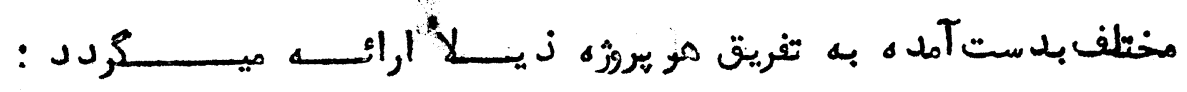
:

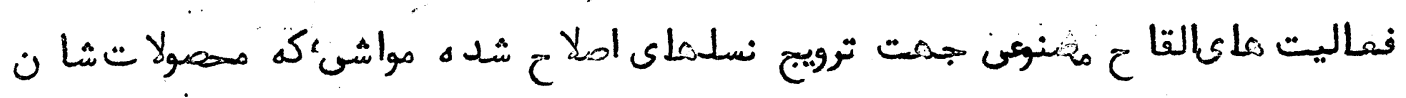

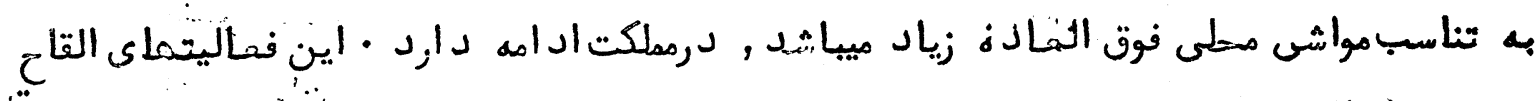

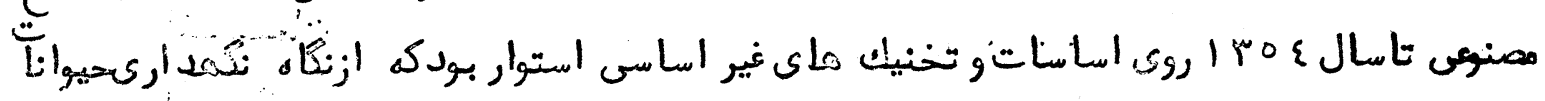

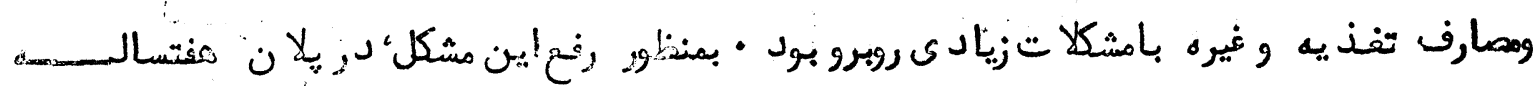

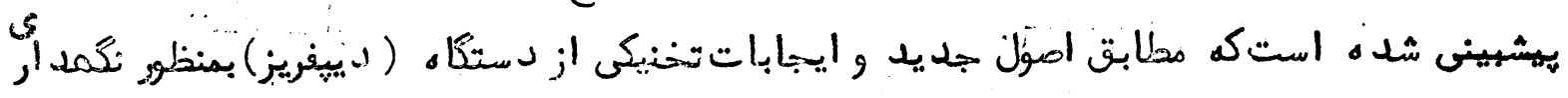

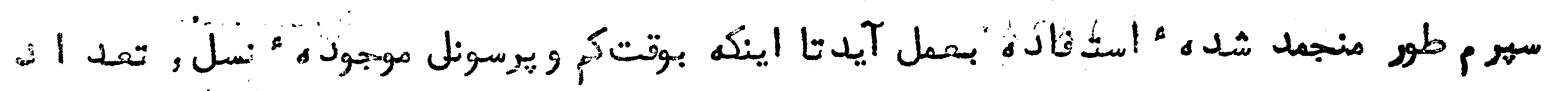

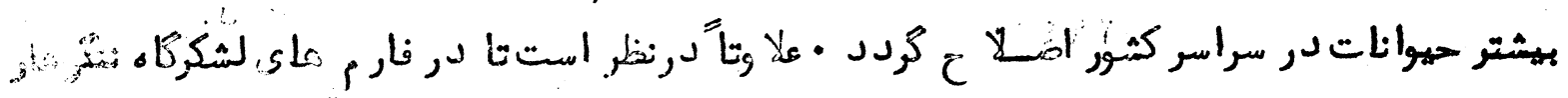

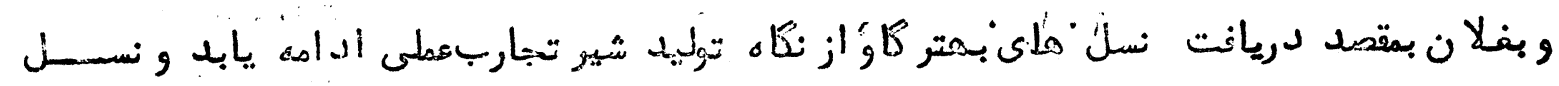

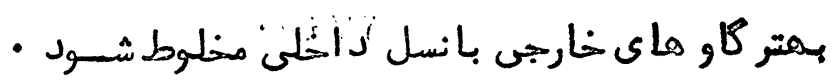

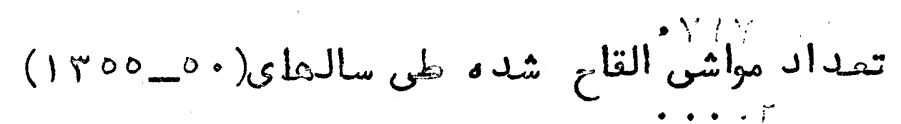

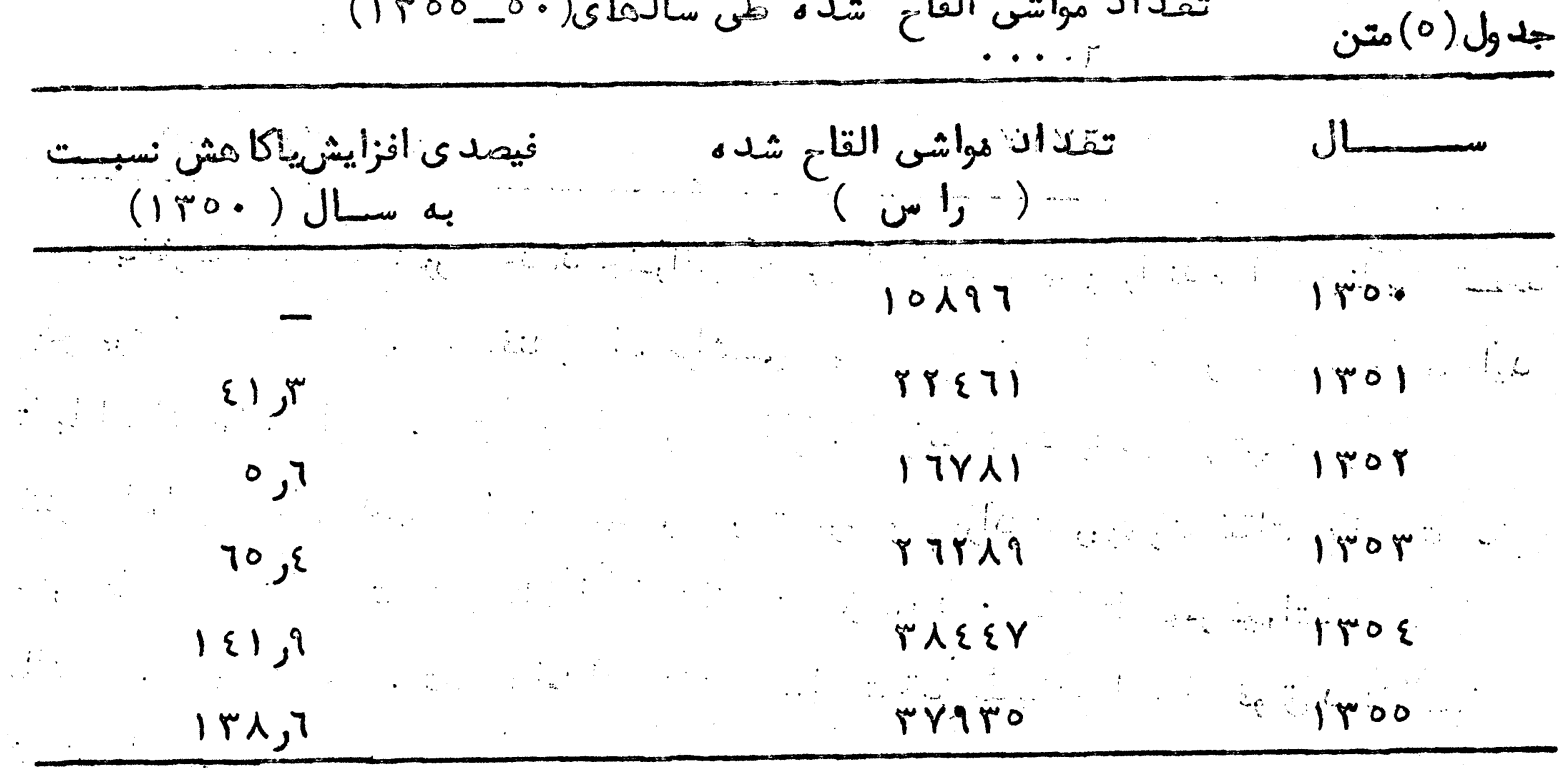

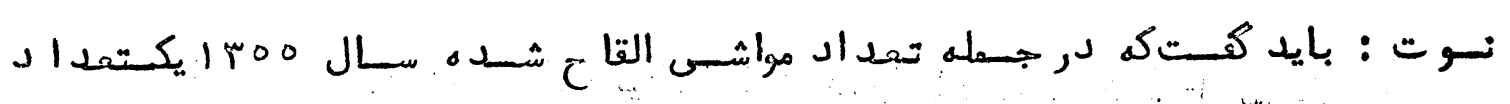

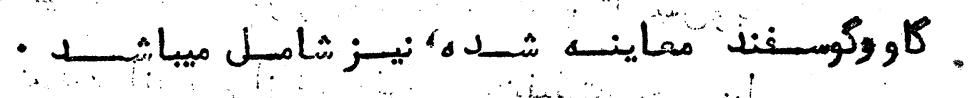

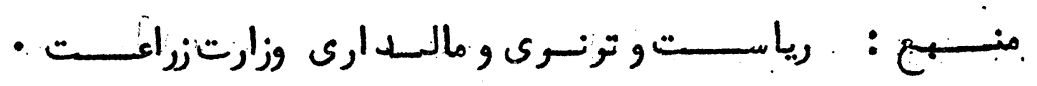




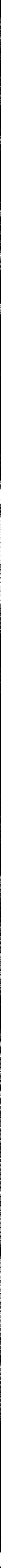




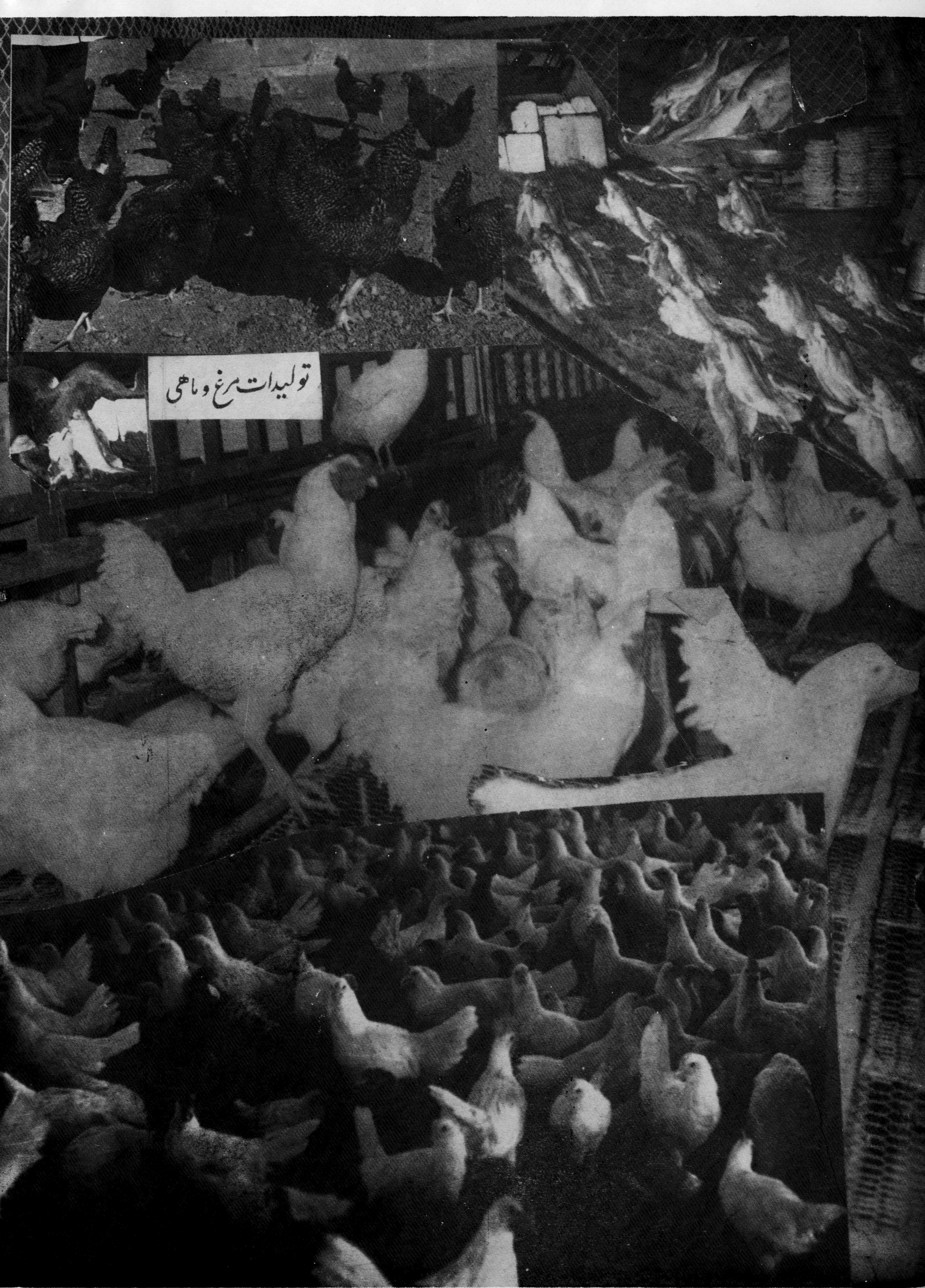




\section{:}

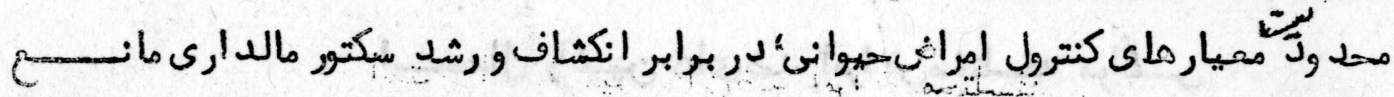

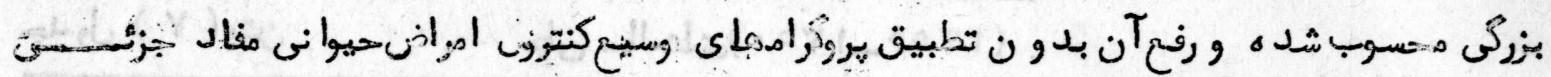

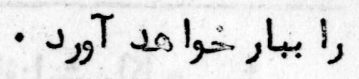

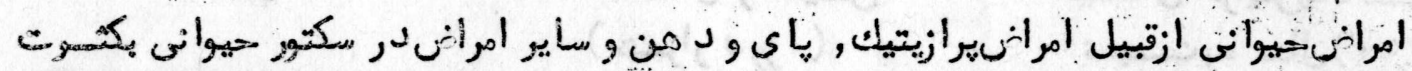

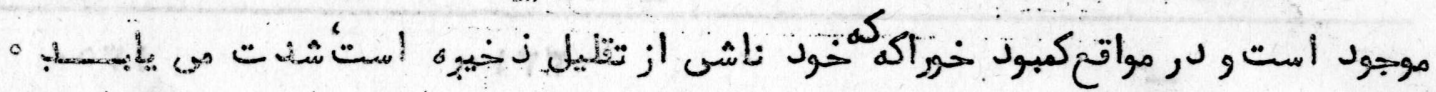

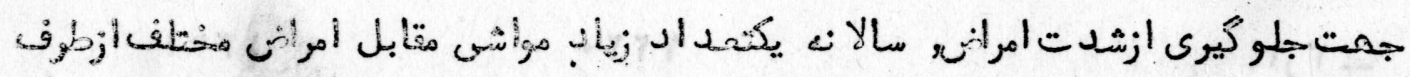

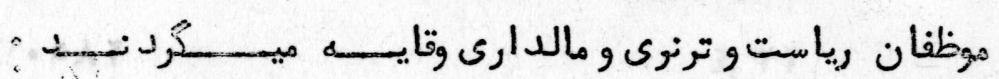

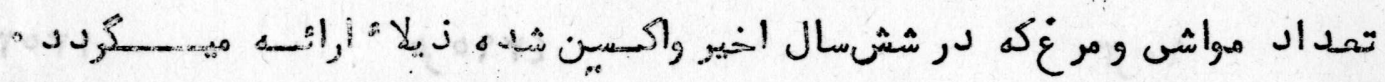

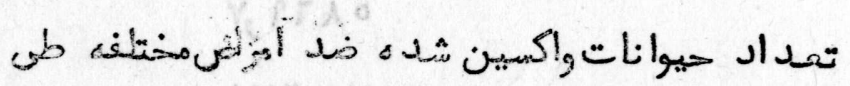

$$
\text { (1.roo_1100) }
$$

جـ

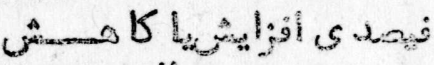

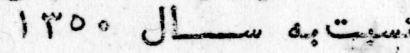

ه ش ش

$(0,1,1,0)$

\begin{tabular}{|c|c|c|}
\hline $60 \cdot \cdots-$ & $\cos =16018, \varepsilon$ & 150. \\
\hline $\begin{array}{l}-r r y \\
-r \varepsilon, 2\end{array}$ & 1001, & $\begin{array}{l}\text { 1rol } \\
\text { Iror }\end{array}$ \\
\hline IVTj & r人民。 & Irop \\
\hline$-\forall \gamma_{3} \mid$ & عر אדז' & 1rog \\
\hline$\varepsilon \cdot r, r^{\prime}$ & $r 100, \ldots r$ & 1500 \\
\hline
\end{tabular}

Ji

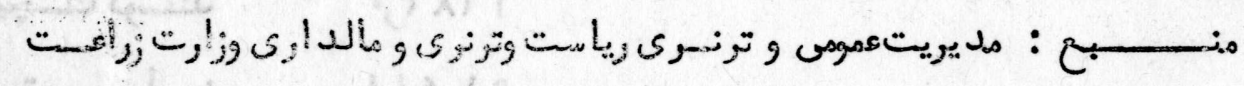

$$
\text { r- واكسين سـازى : }
$$

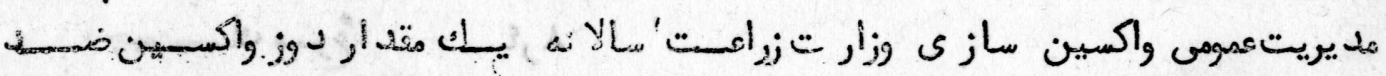

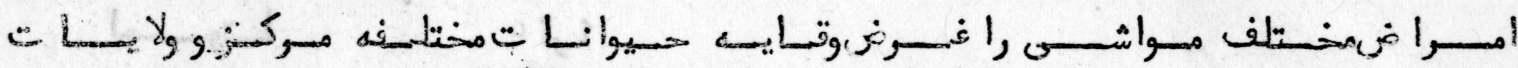

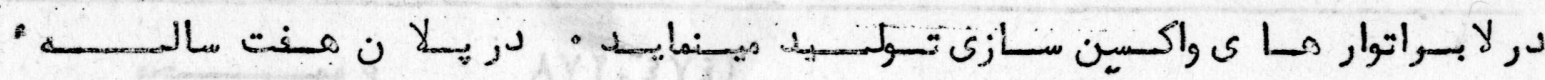

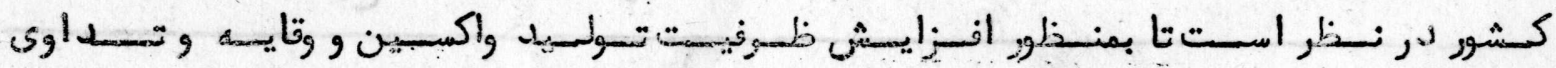

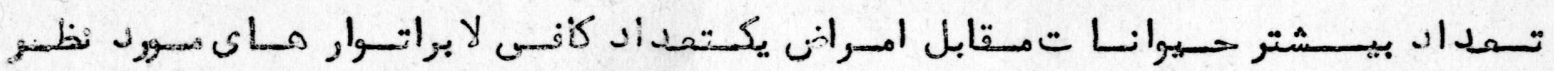




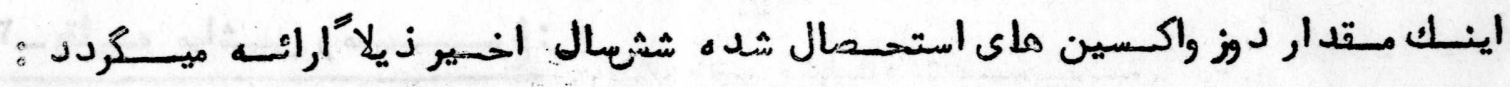

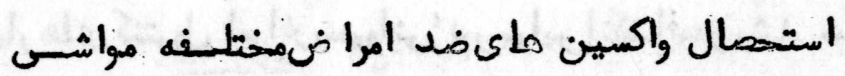

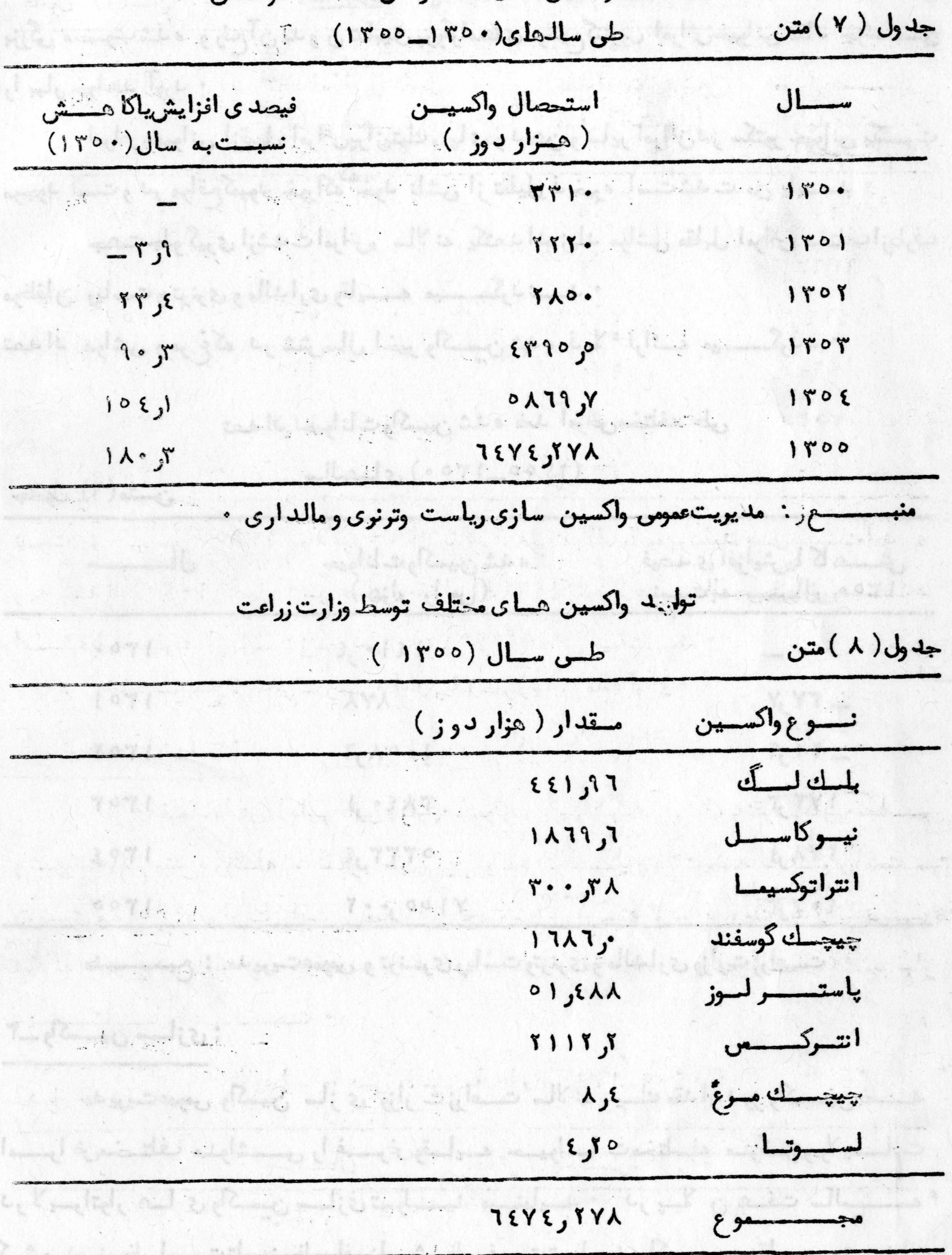




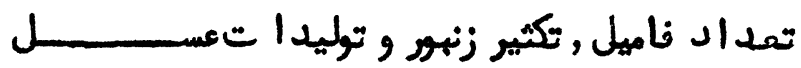

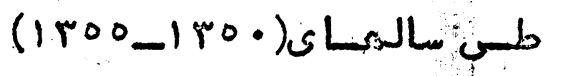

جدول (9) متن

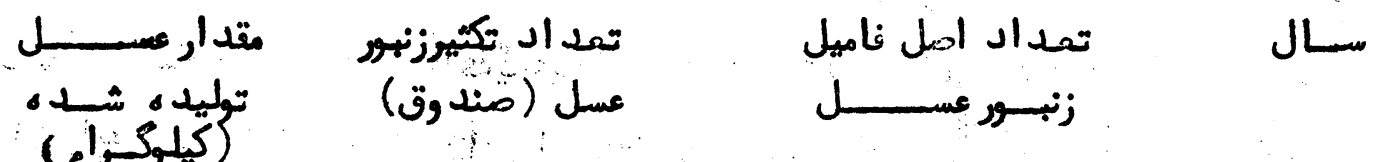

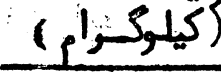

หจ7.

00

Iยห

1ro.

Tritrit

$1 \varepsilon$

irq

1001

ใะY

riv

Y TY

roor

I TrV

or.

791

iror

roro

1)

ri

1T०\&

Y $7 \cdots$

YYA

- 1 1roo

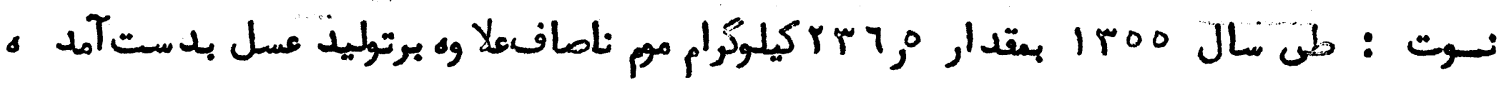

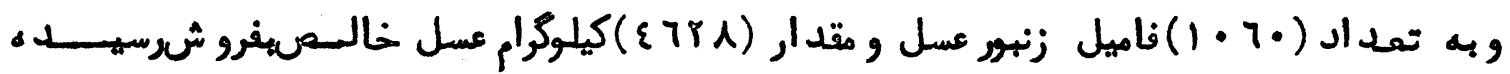

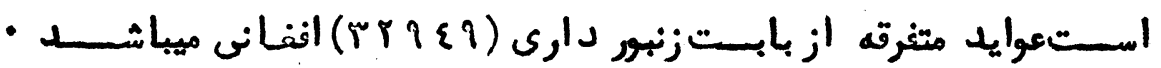

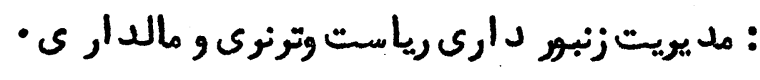

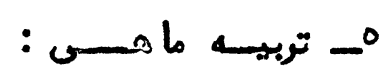

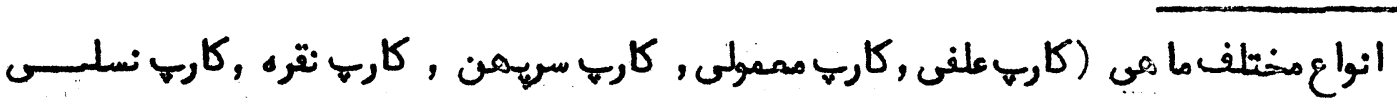

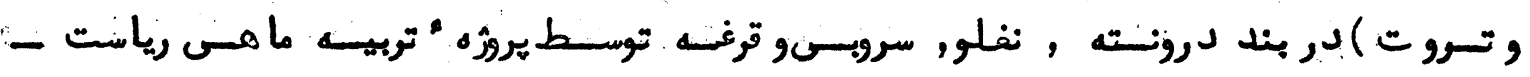

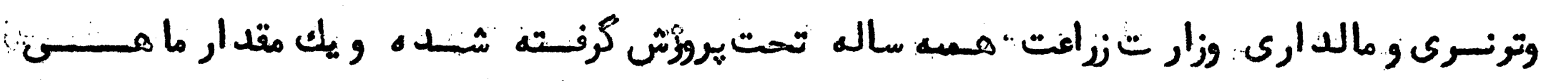

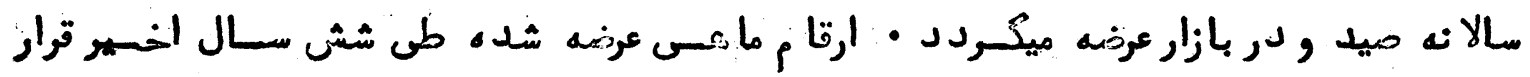

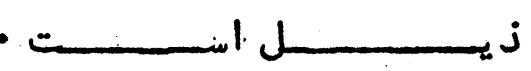

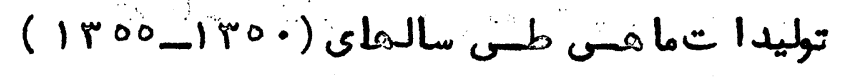
جادول (• (1) متن

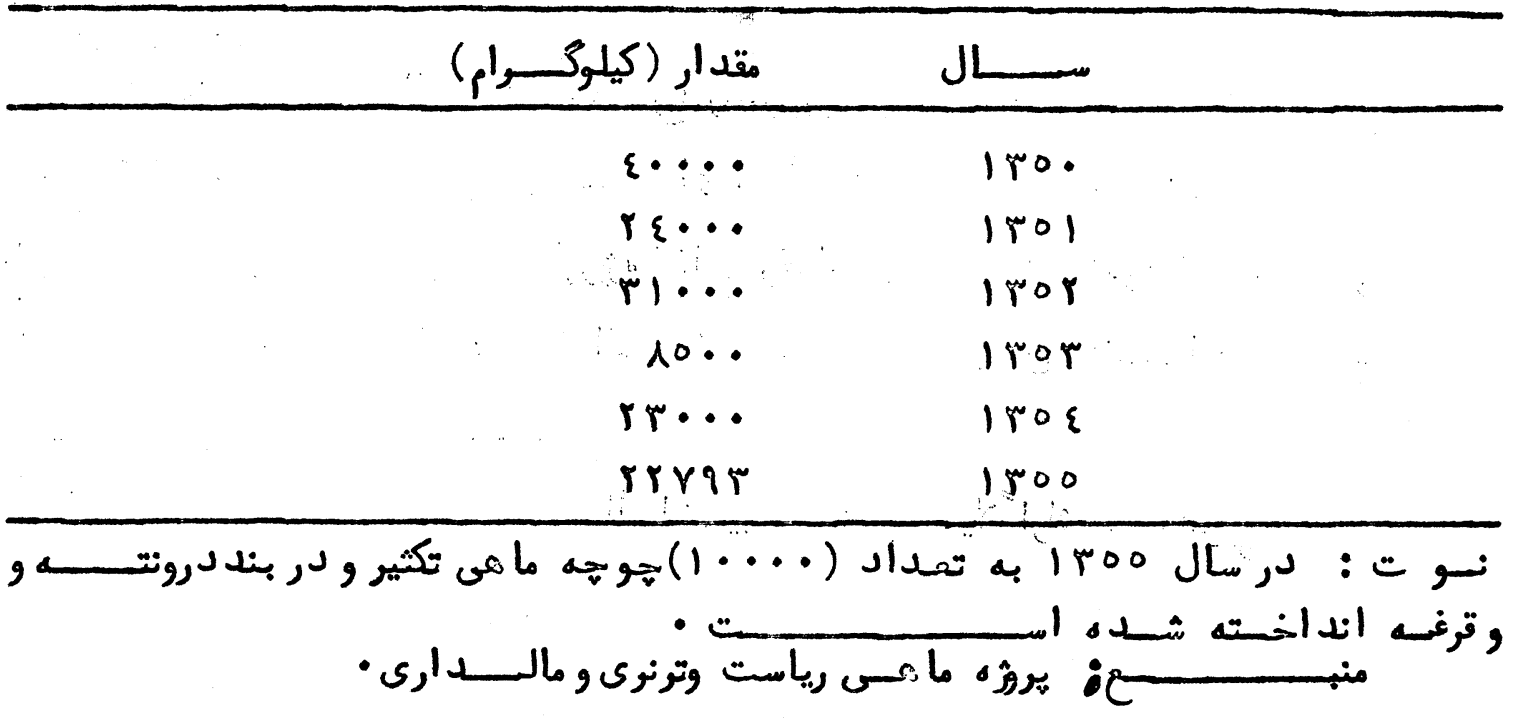




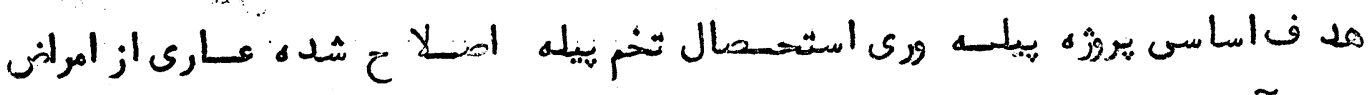

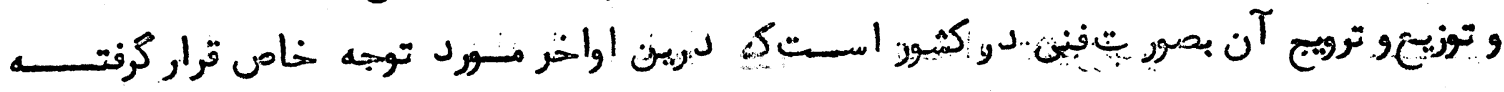

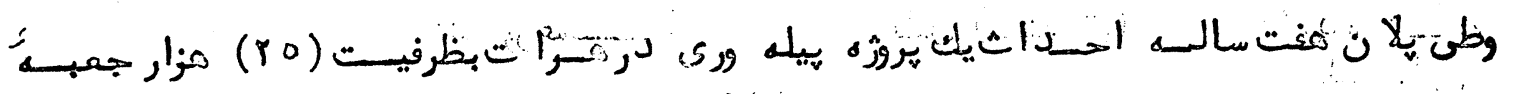

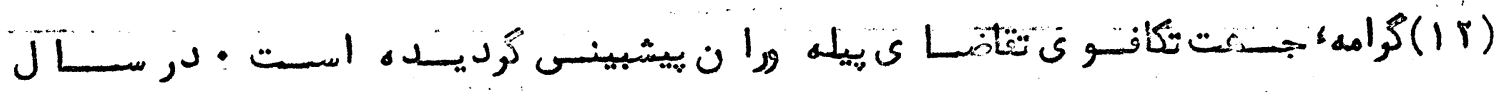

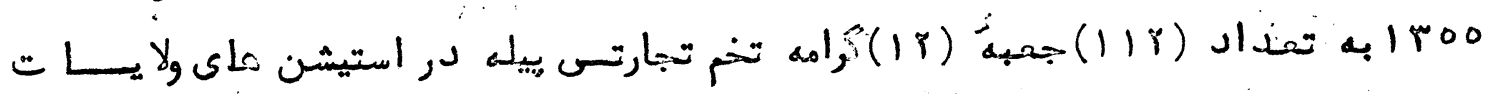

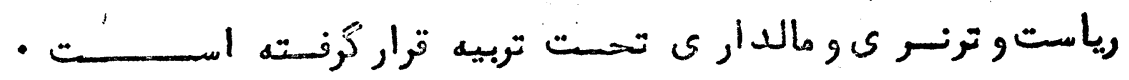

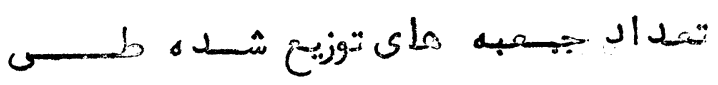

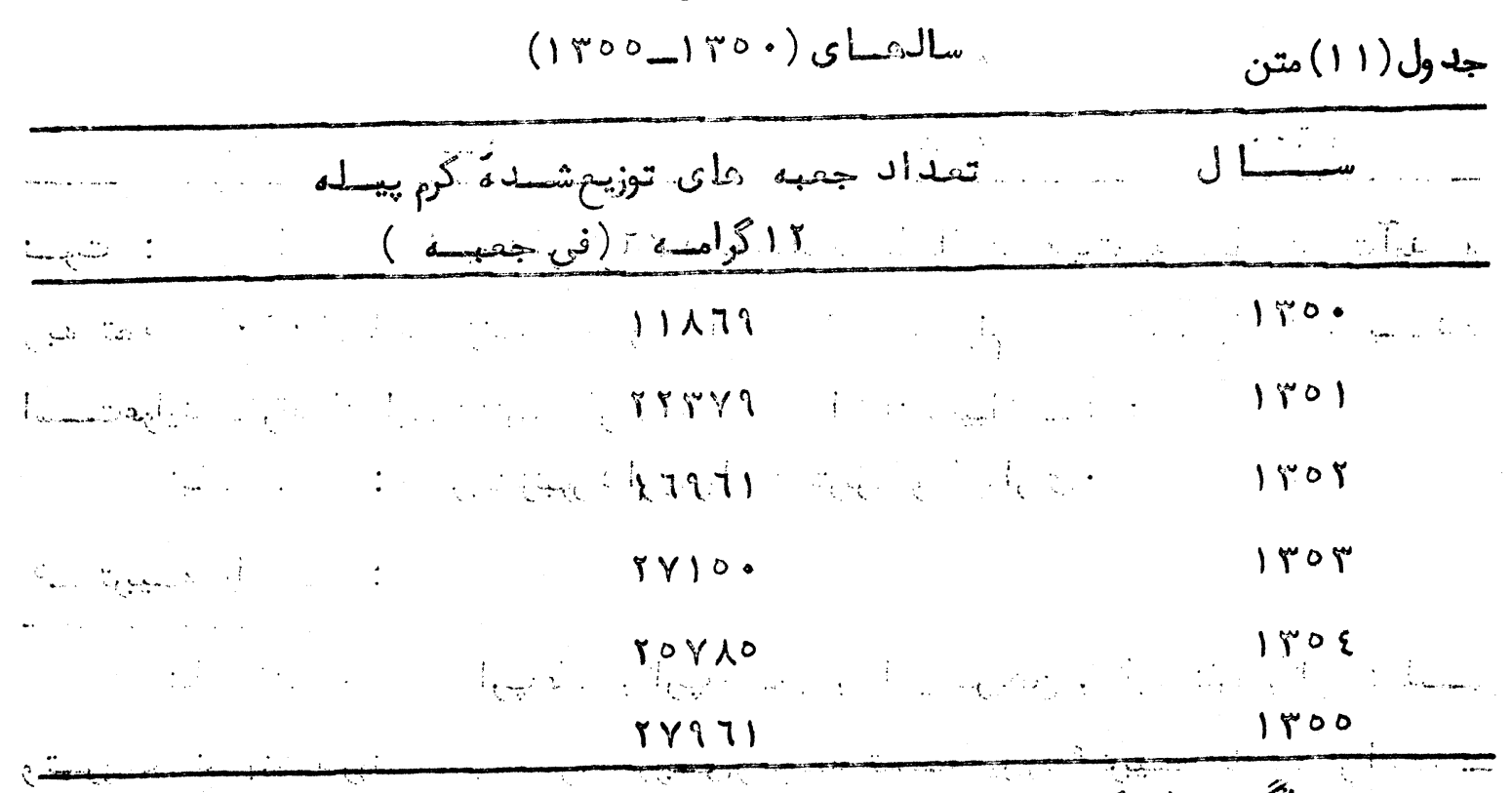

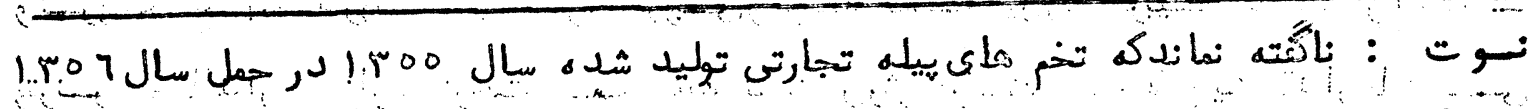

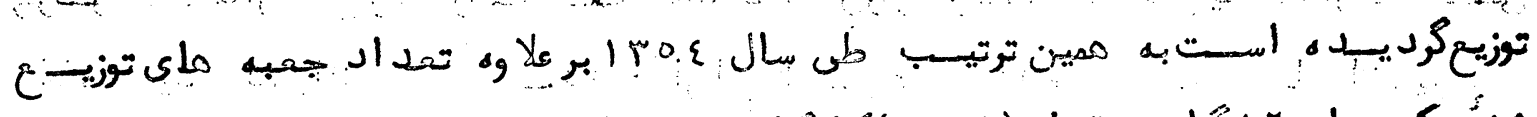

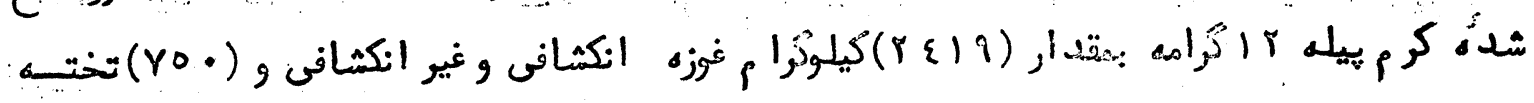

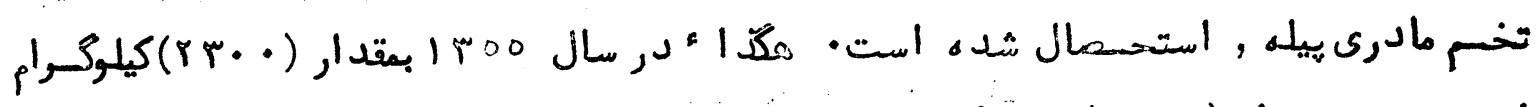

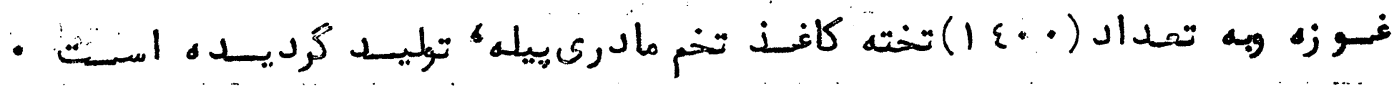

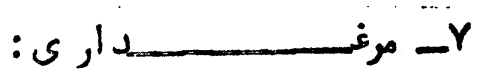

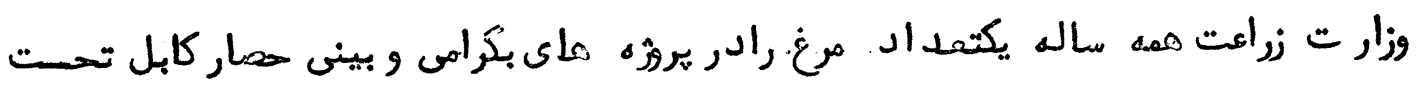

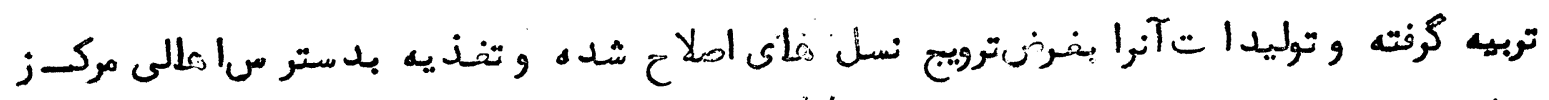

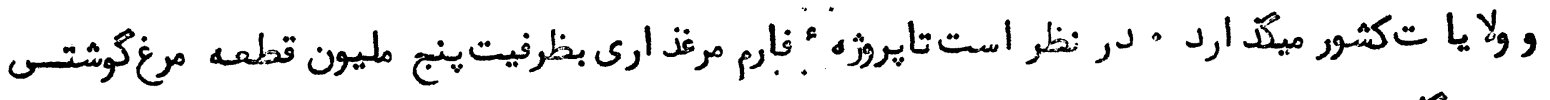

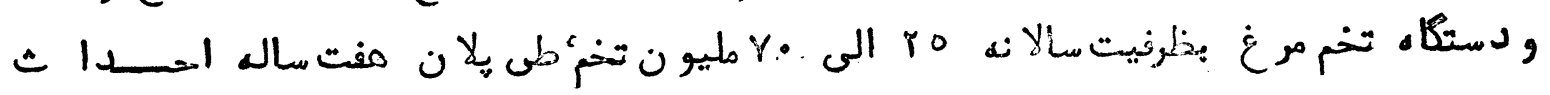

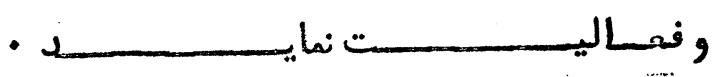

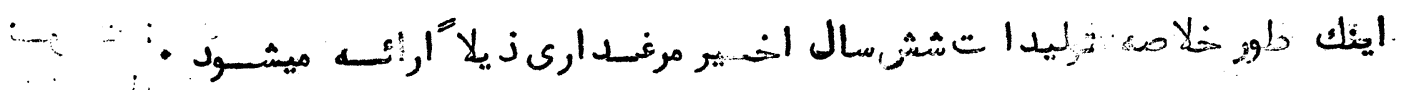


توليد

$(1900-1100)$

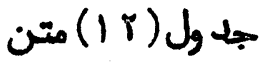

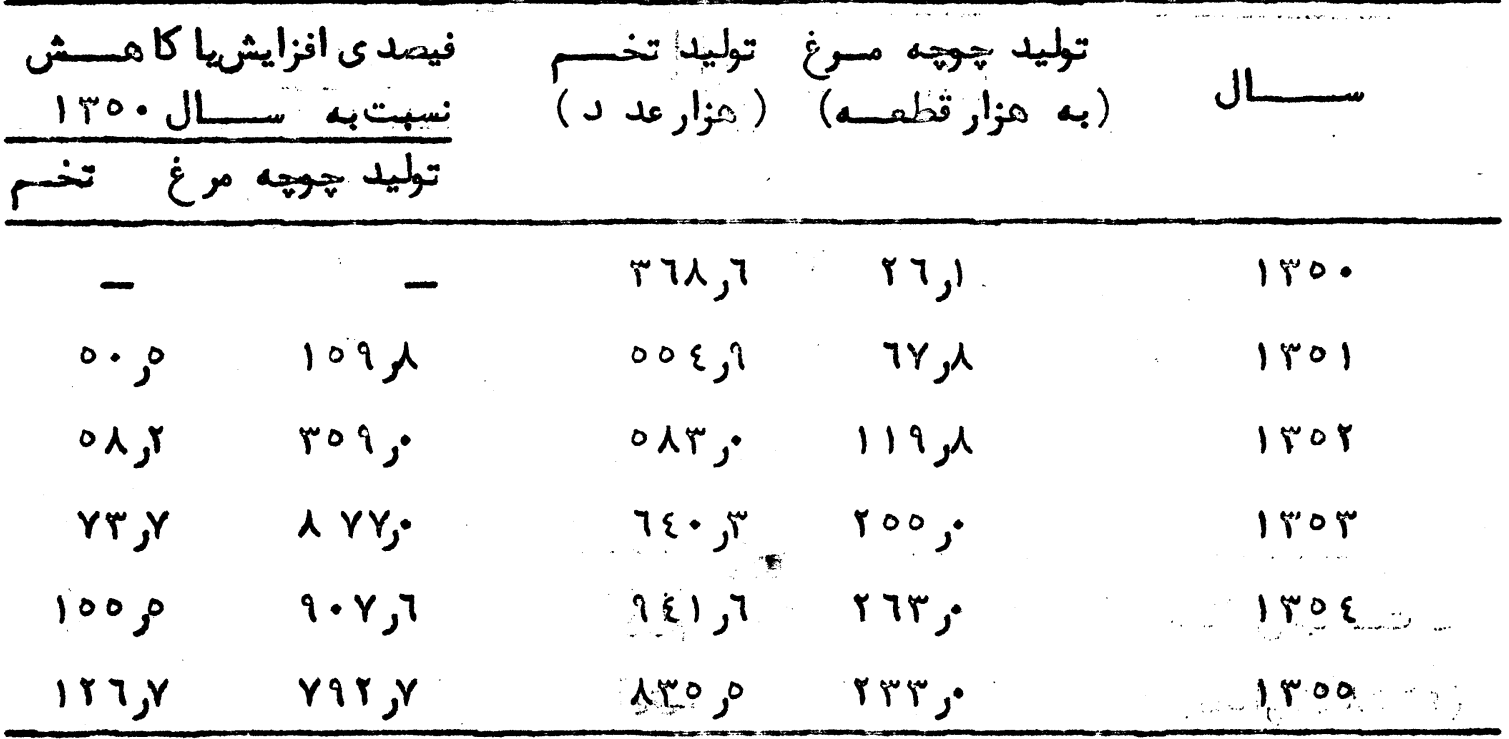

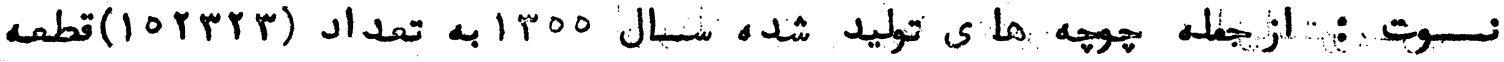

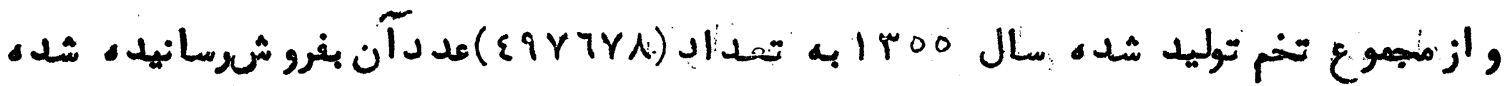

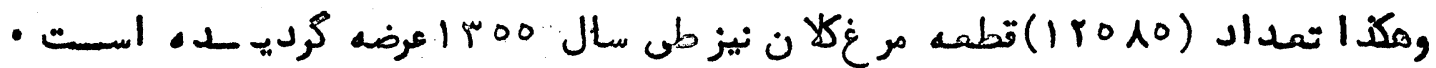

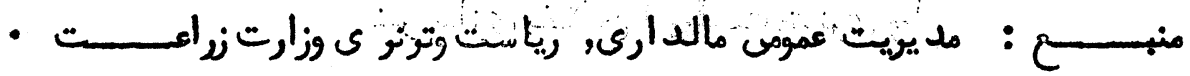

استحسمال مسـواد غذايى حسيوانى طسى

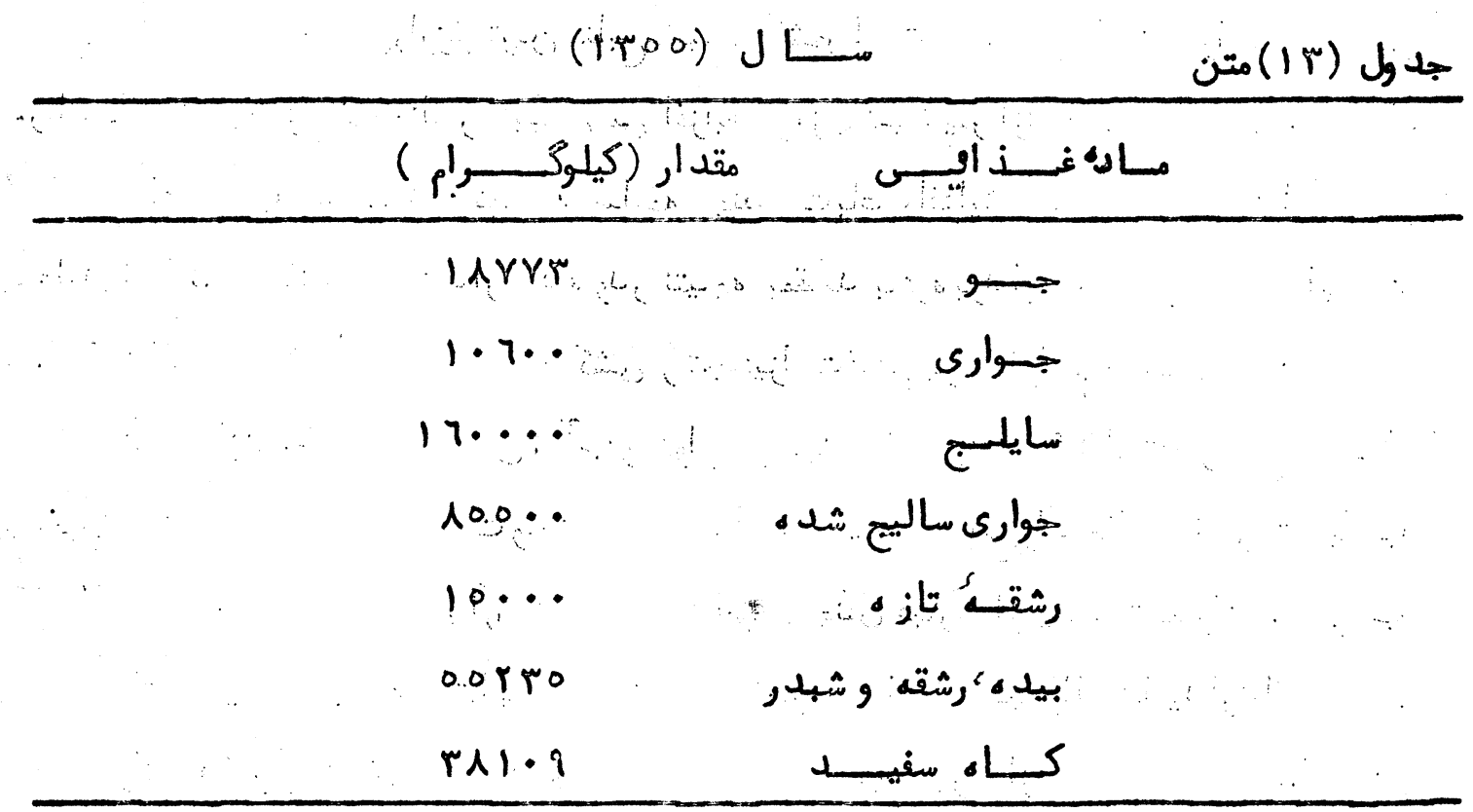

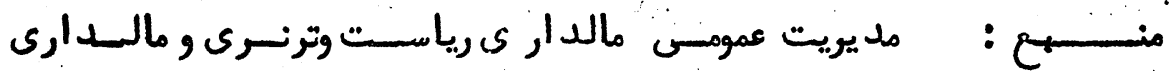

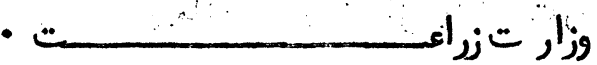




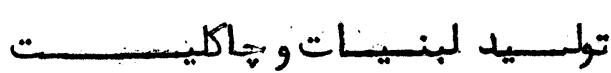

(1) جلول (ع 1) متن

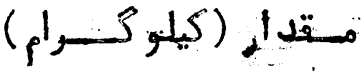

ماد

$\varepsilon r \cdot \cdot r$

$700 \%$

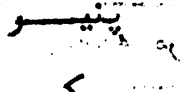

$I \leqslant \mid Y$

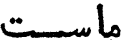

I. Tr

TYY

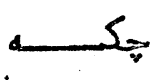

\%

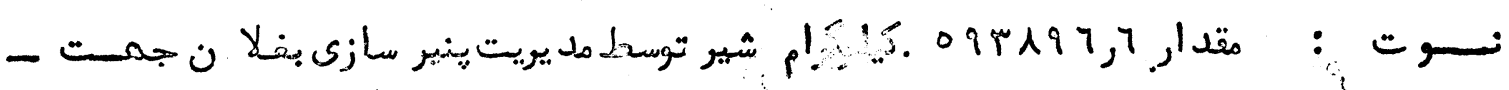

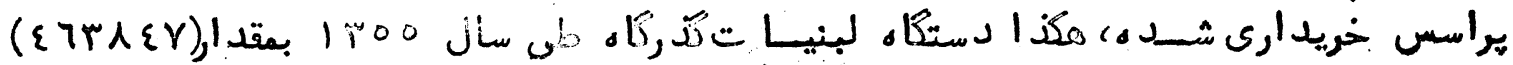

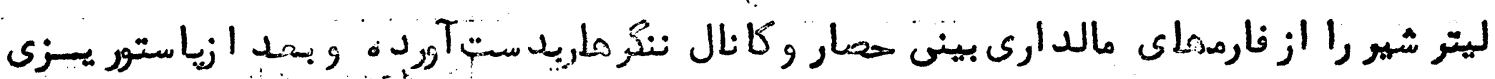

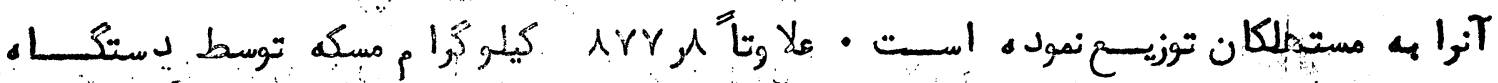

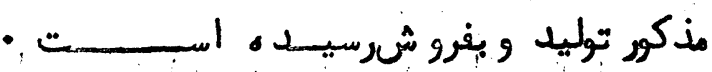

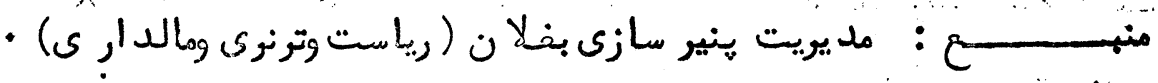

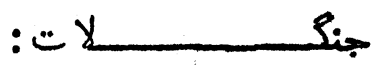

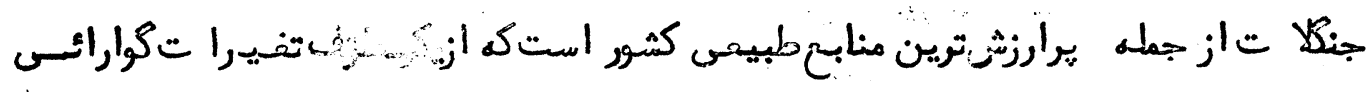

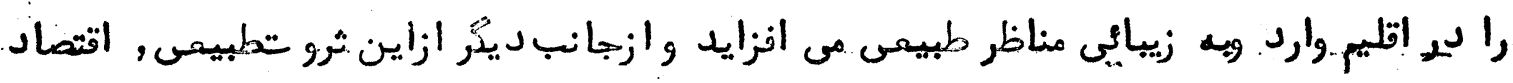

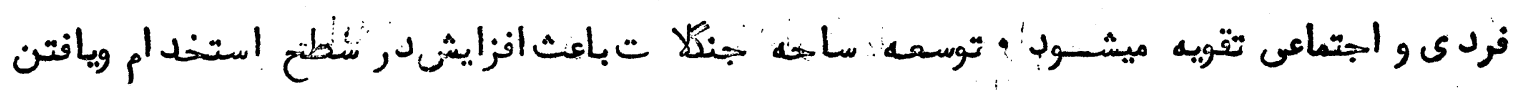

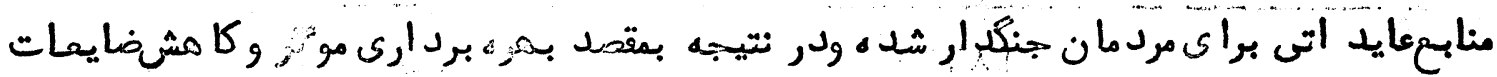

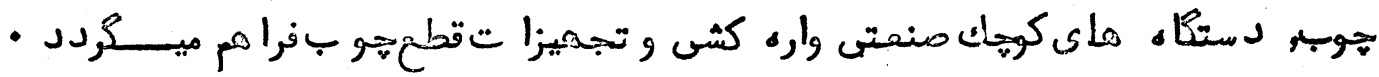

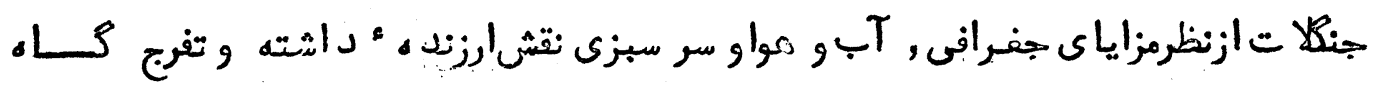

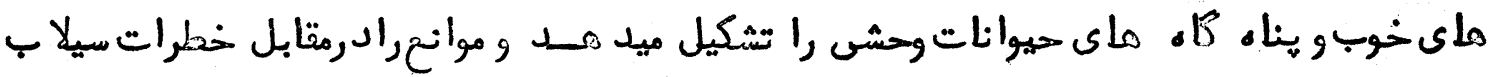

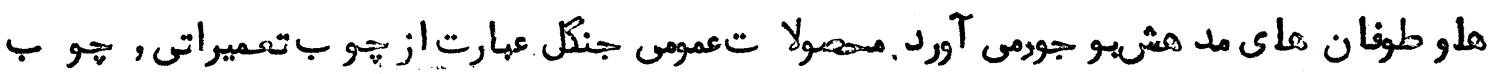

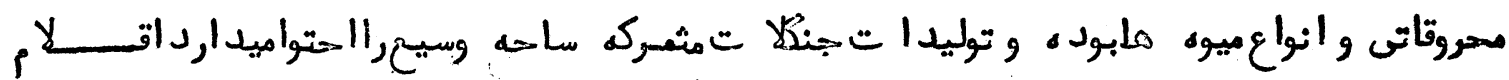

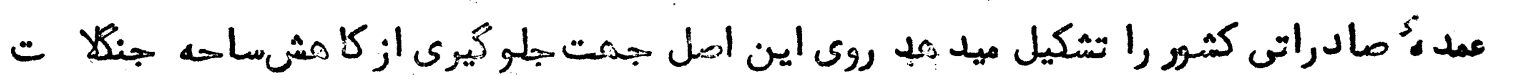

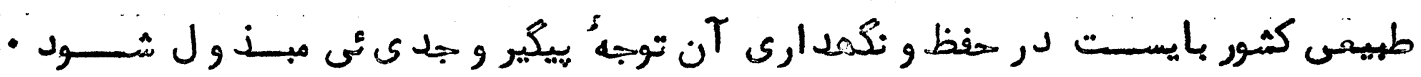

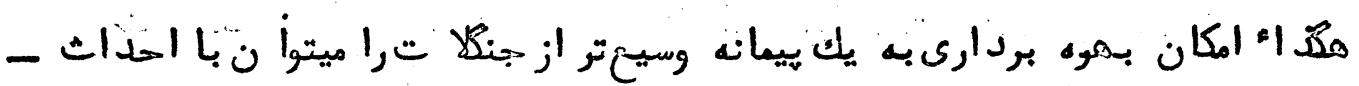

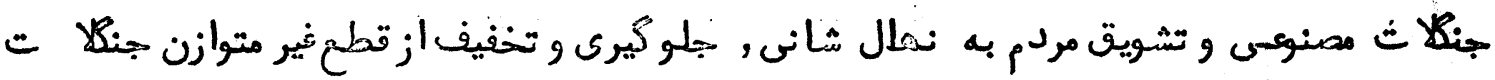

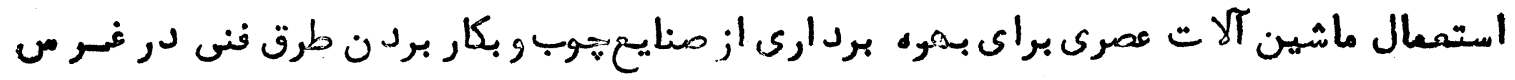

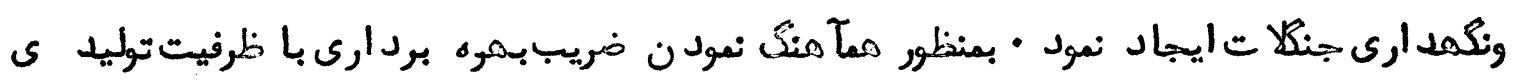




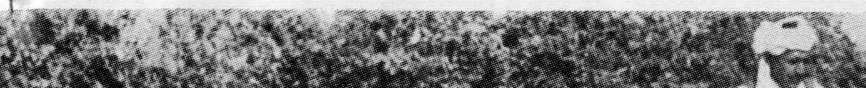

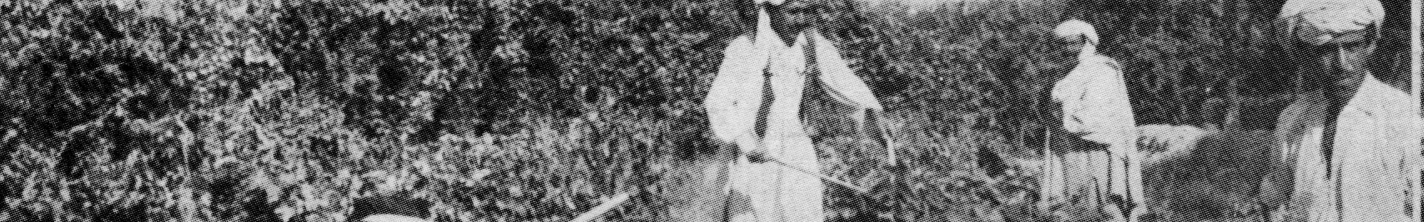

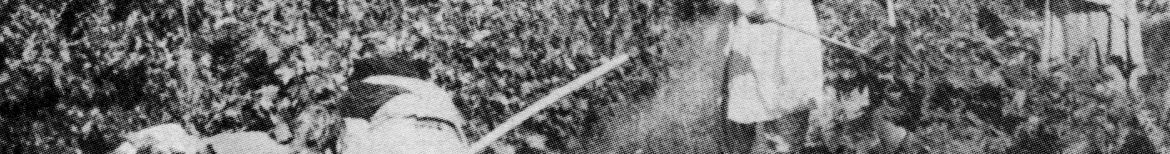
conting

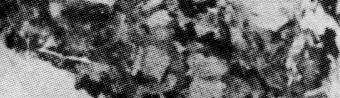

$\therefore$ is

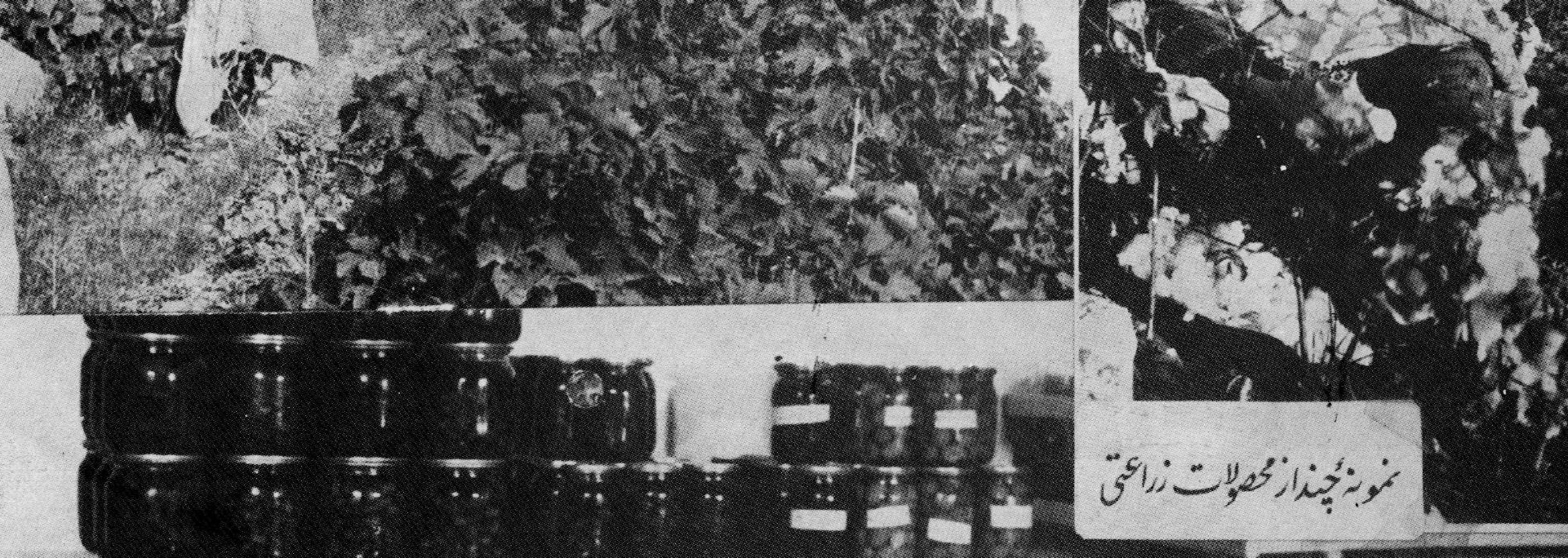

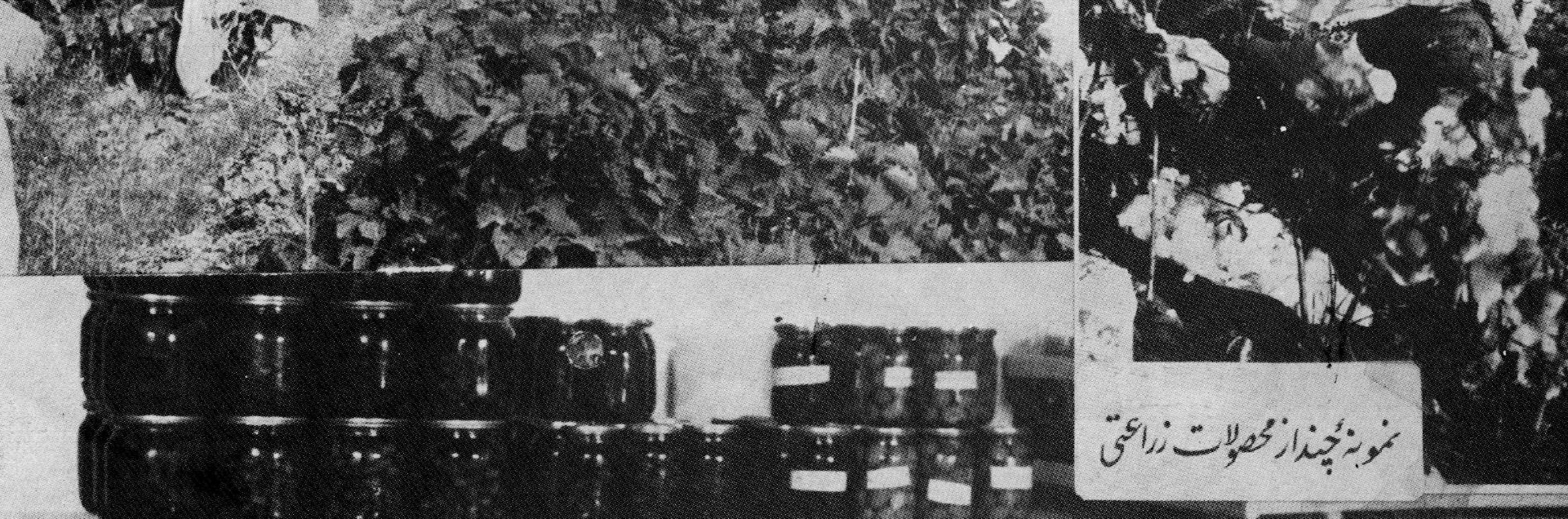

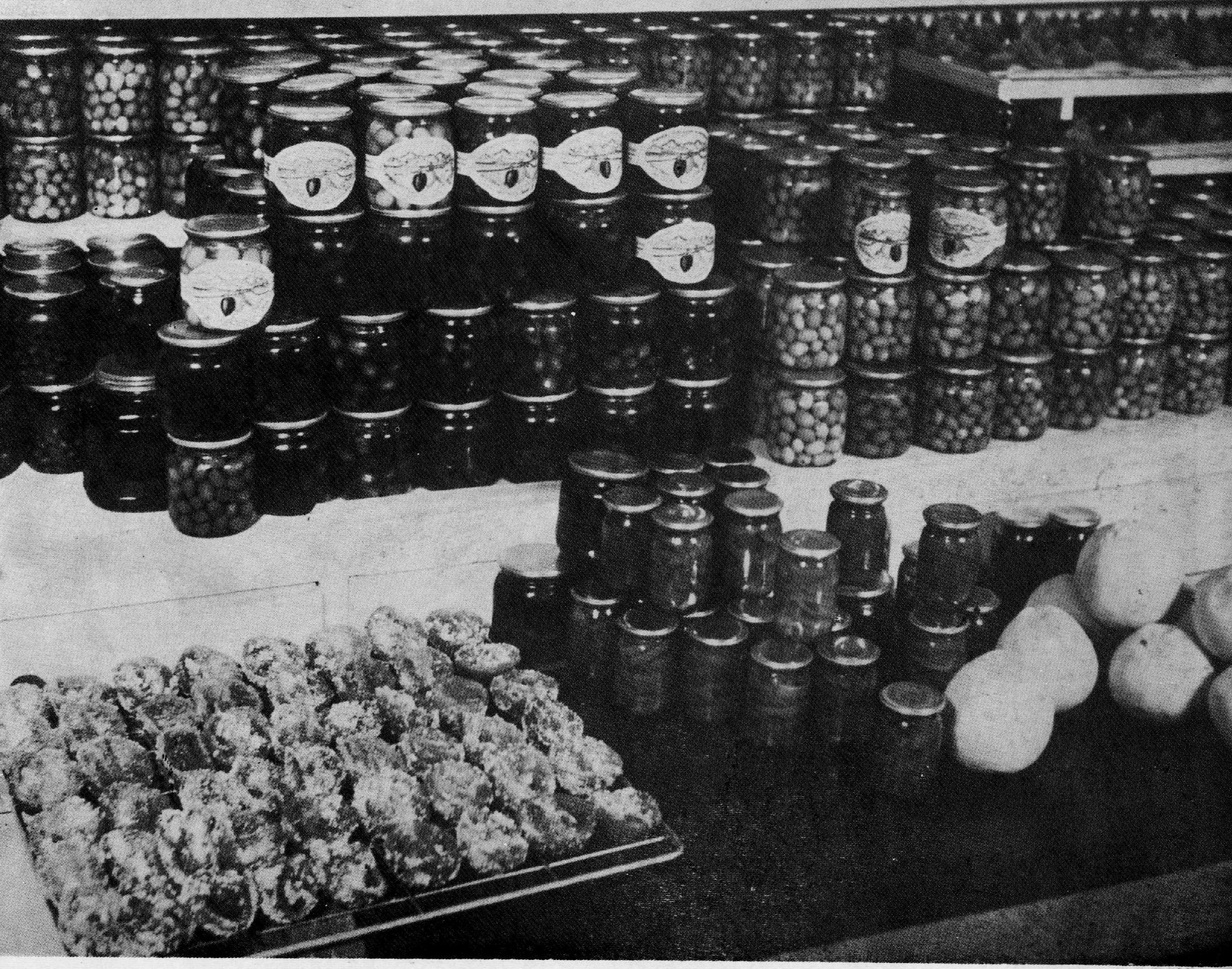




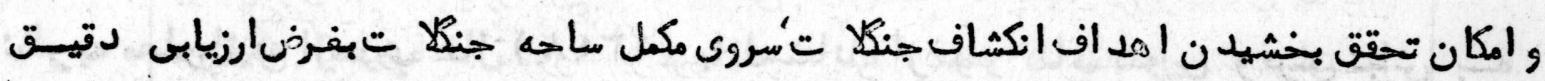

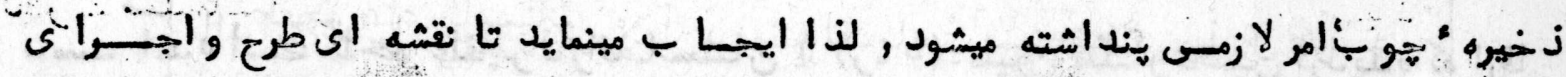

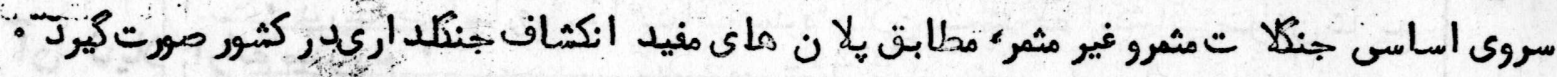

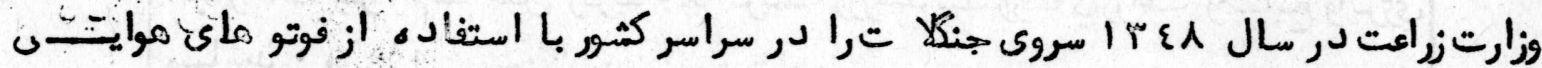

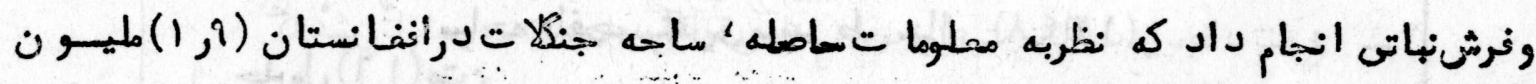

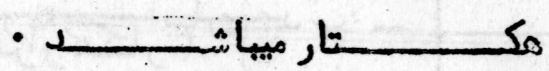

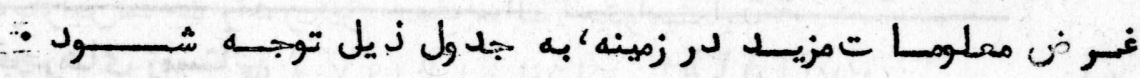

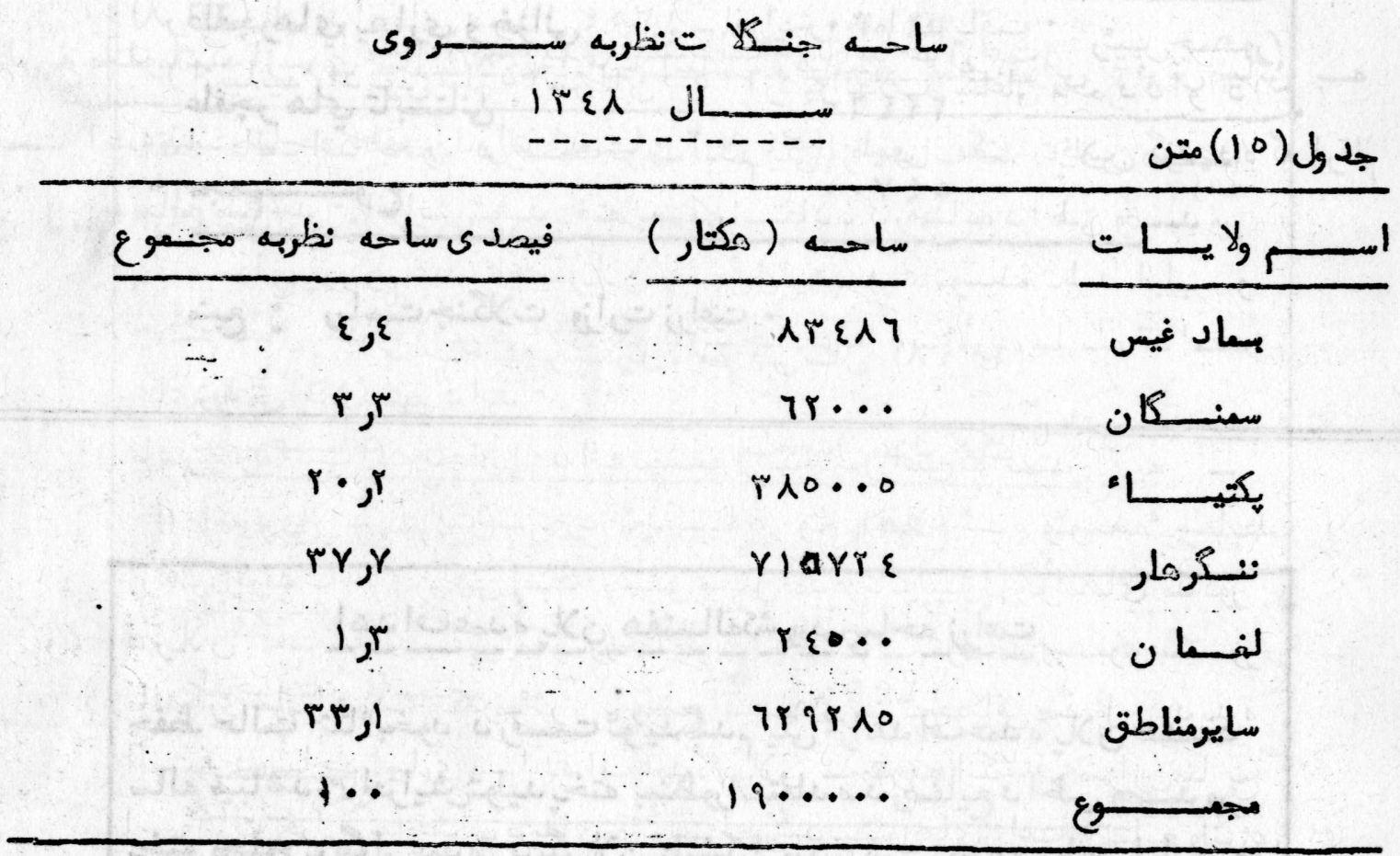

منهع : رياست جنكلا ت وزارت زراعت • مأح علفتجه:

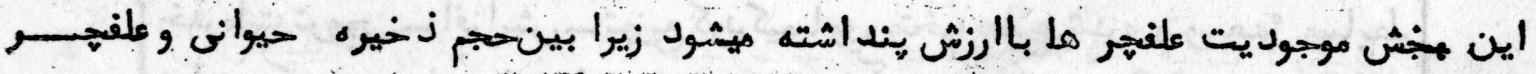

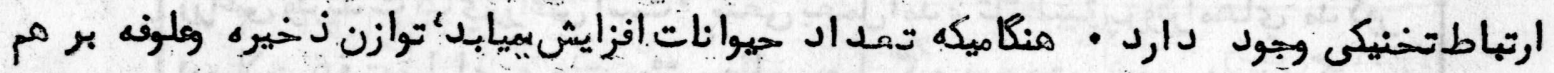

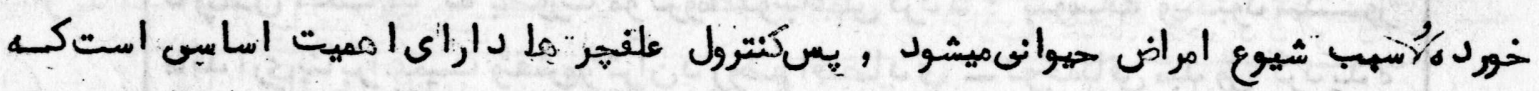

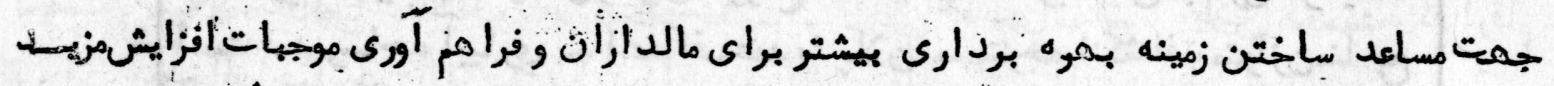

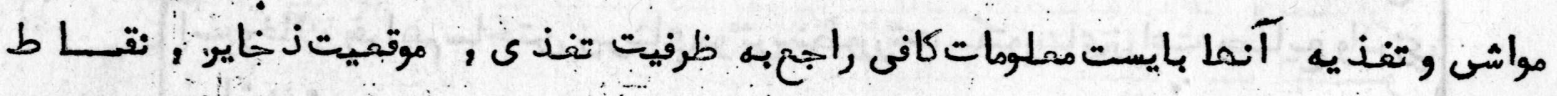

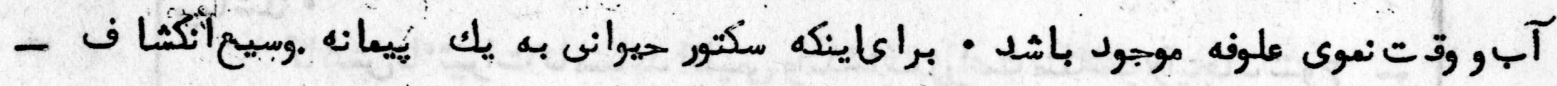

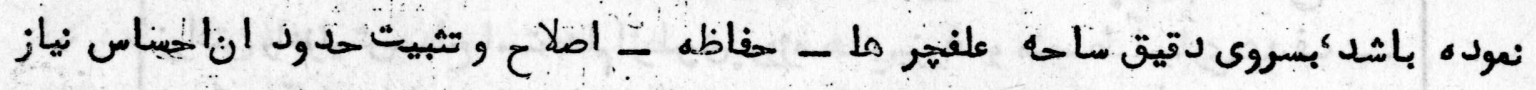

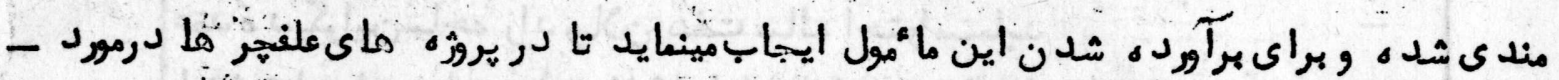

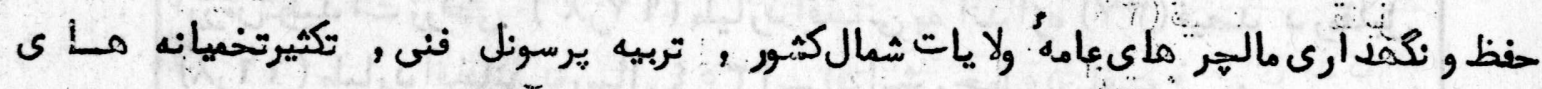

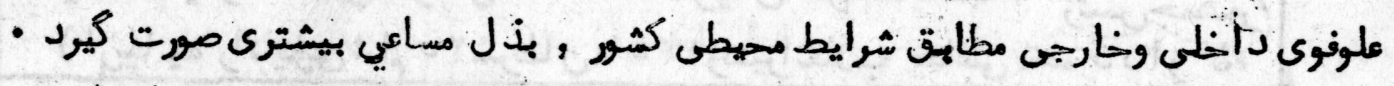




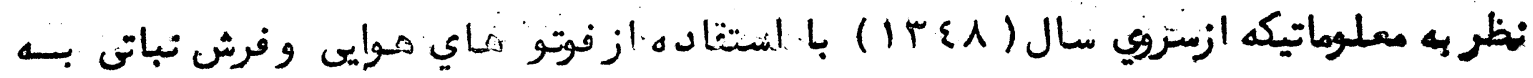

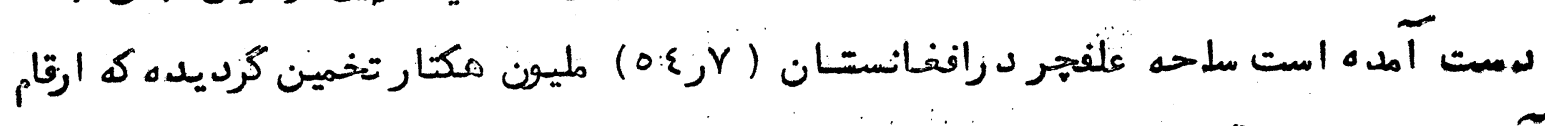

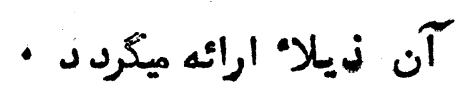

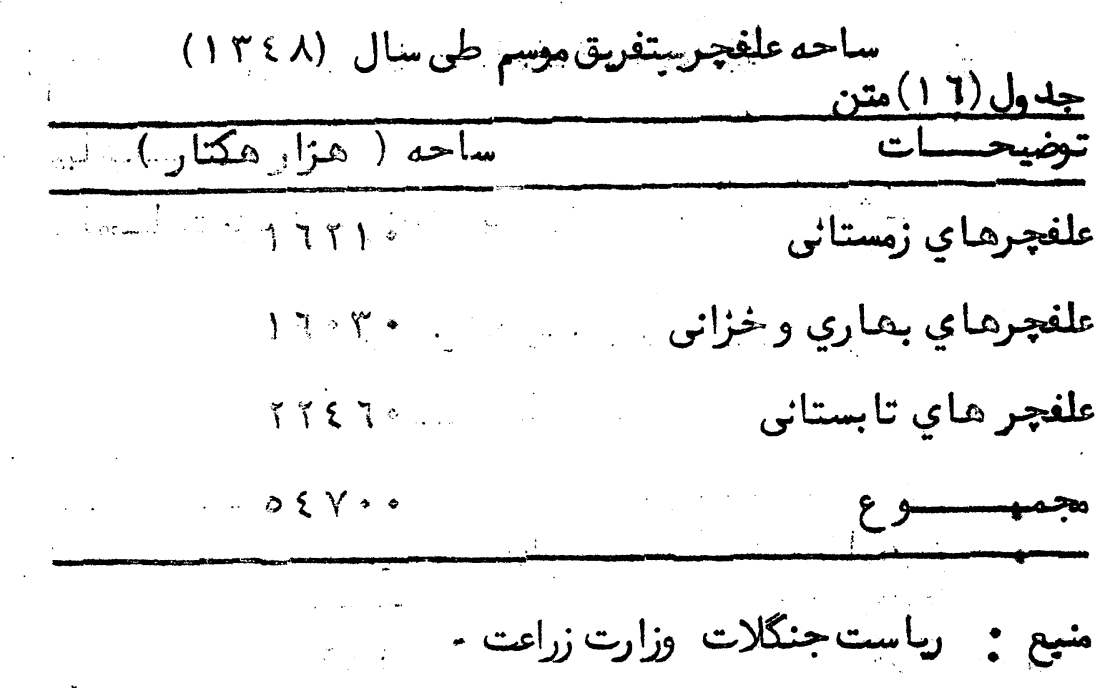

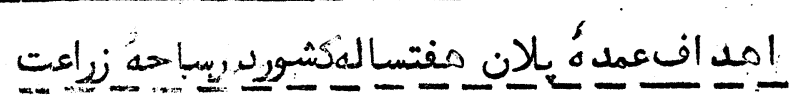

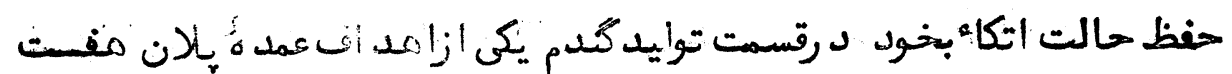

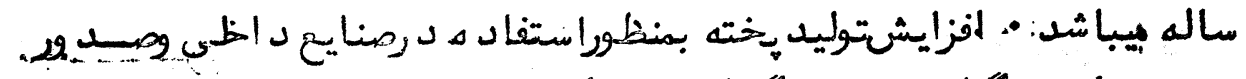

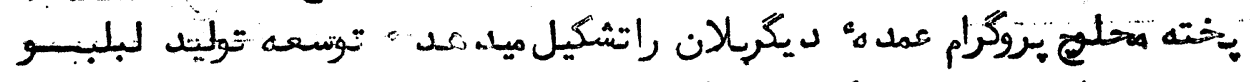

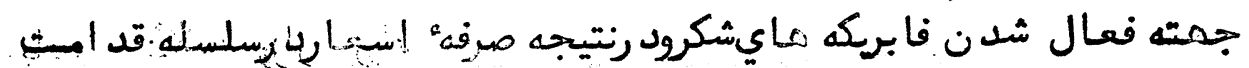

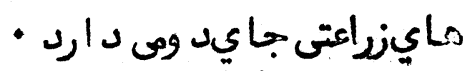

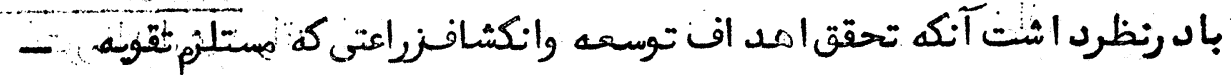

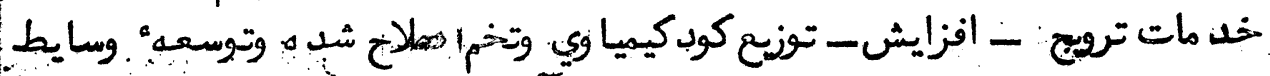

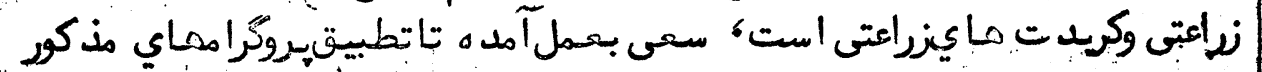

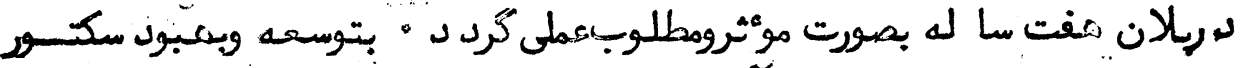

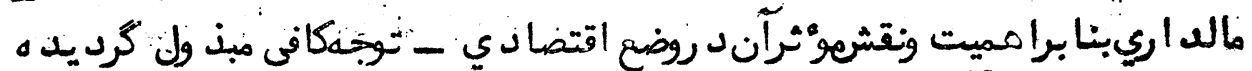

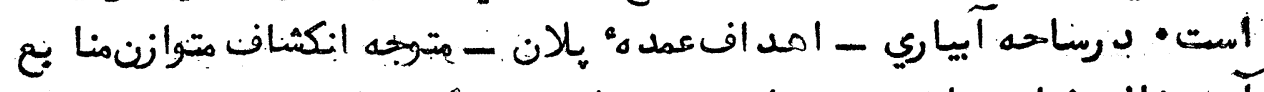

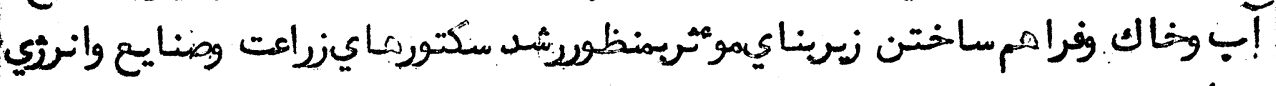

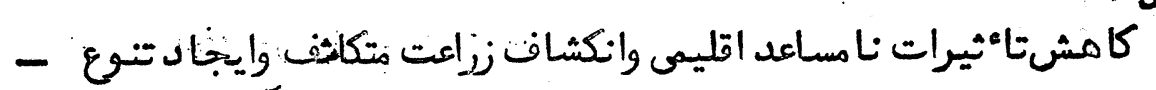

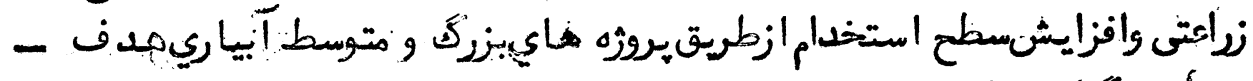

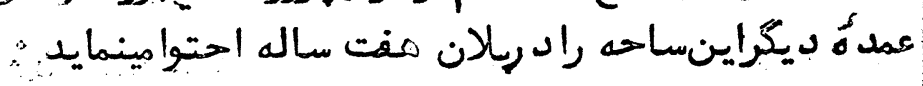
ارزشتوليد ات زراعتى ( )

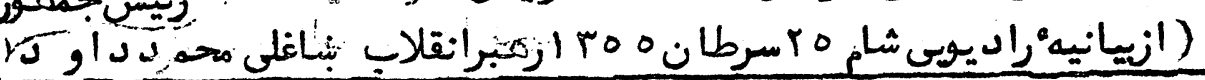




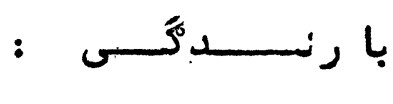

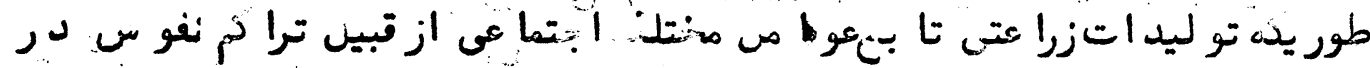

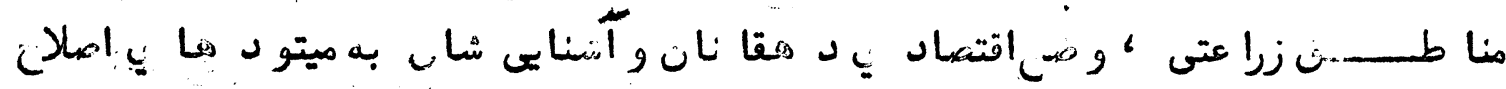

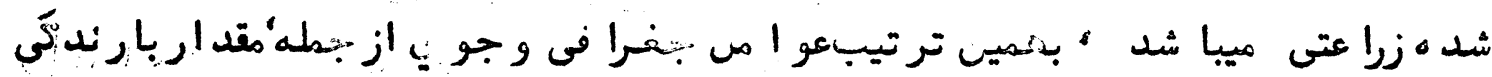

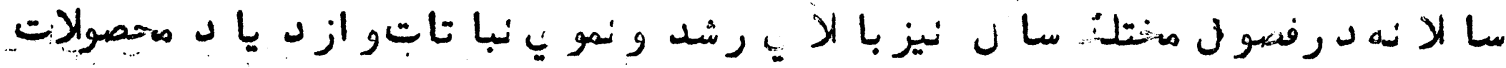

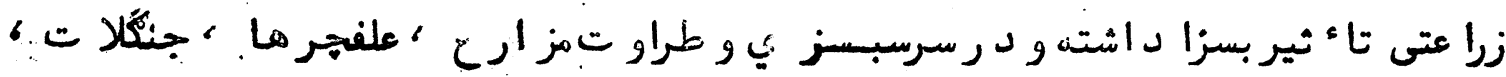

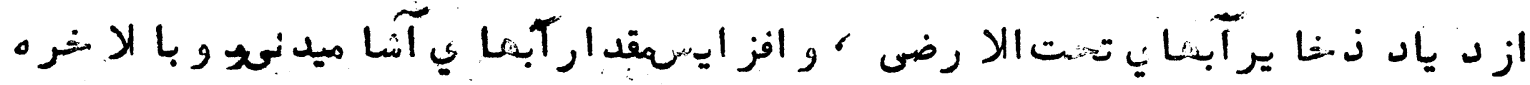

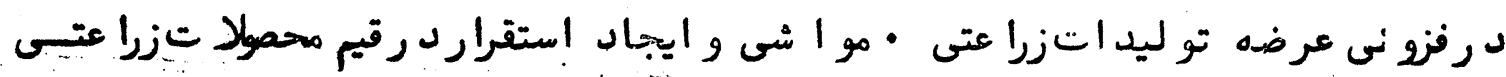

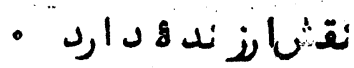

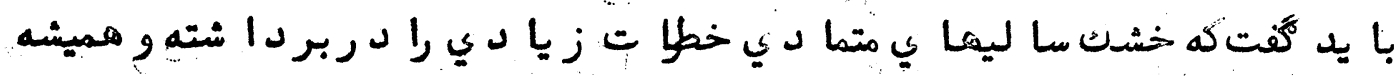

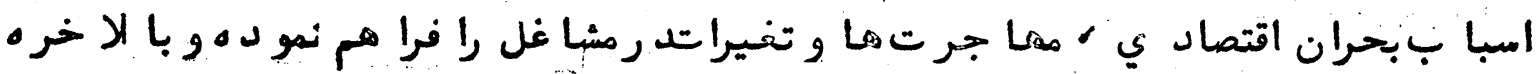

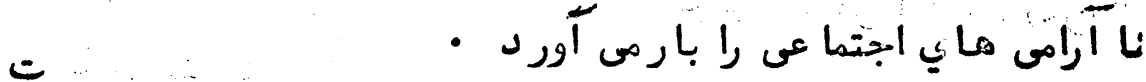

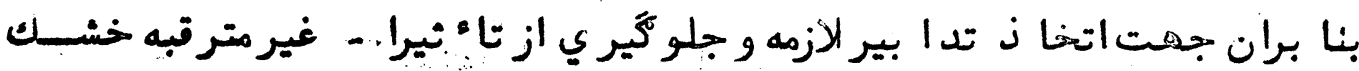

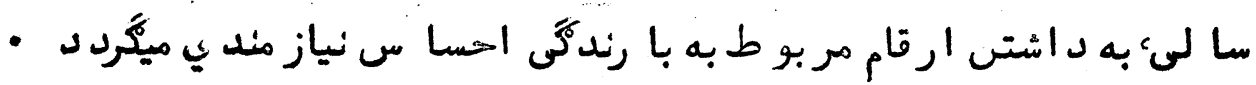

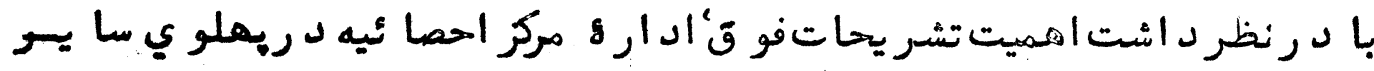

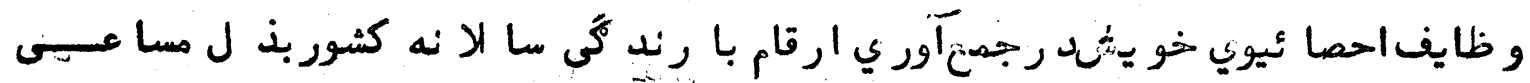

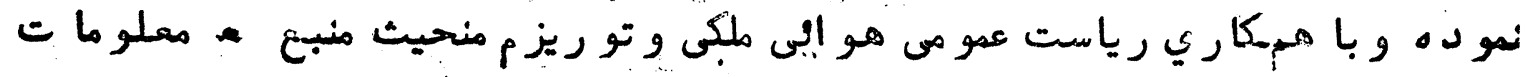

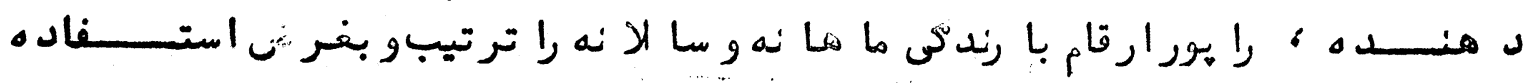

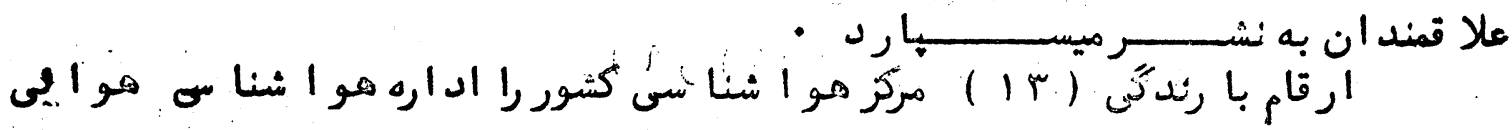

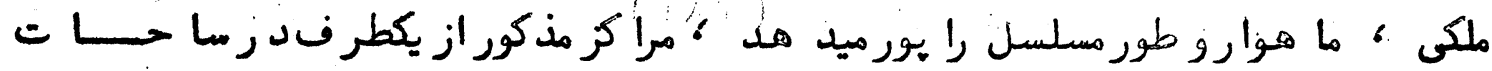

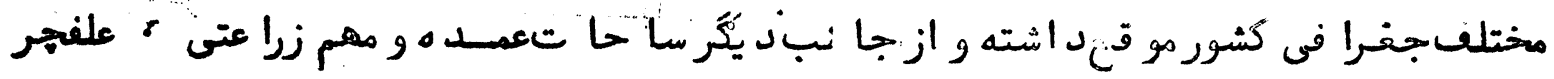

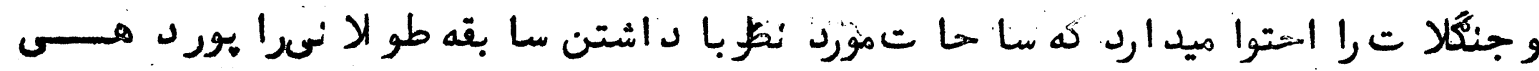

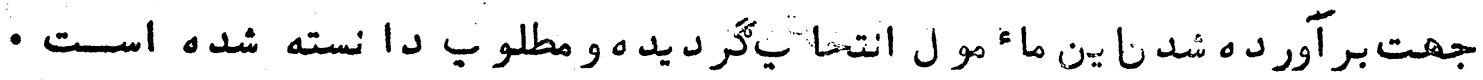

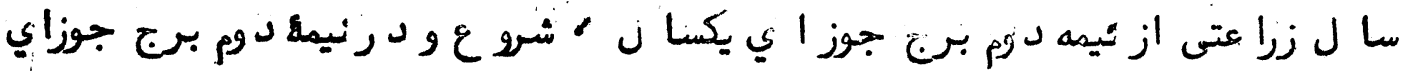

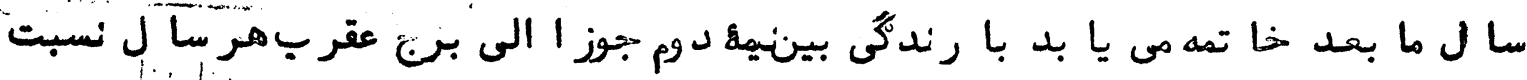

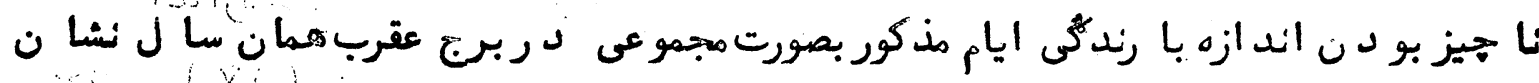

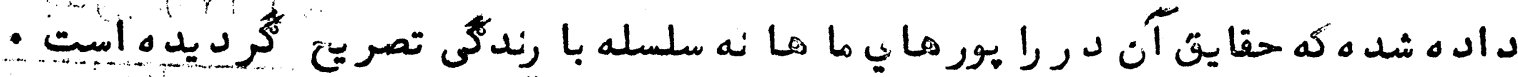

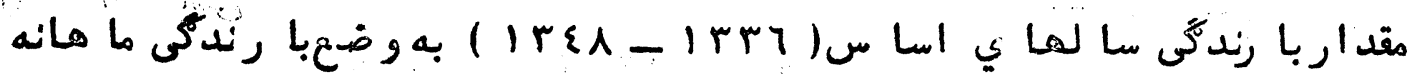

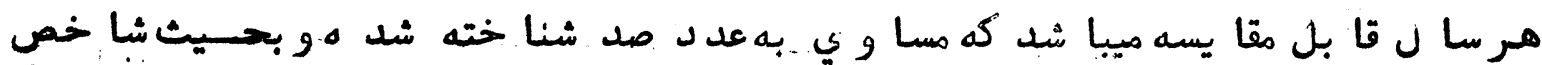
فته 
مقداربا رندكى سا لناي زراعتى (

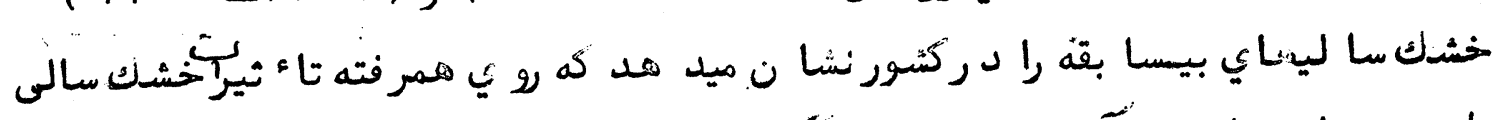

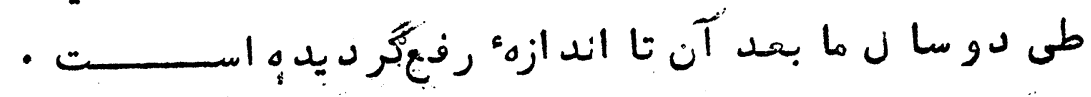

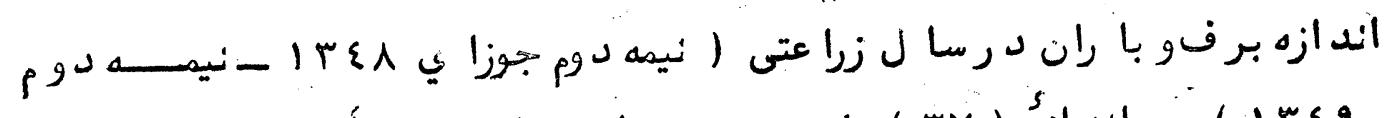

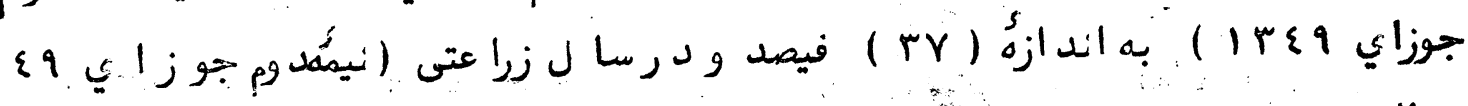

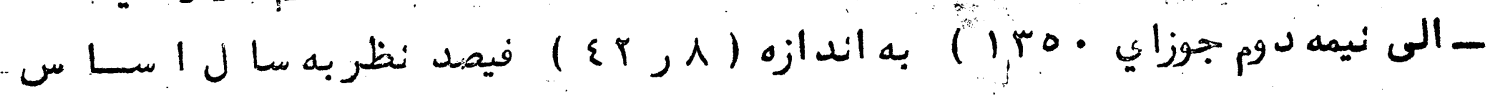

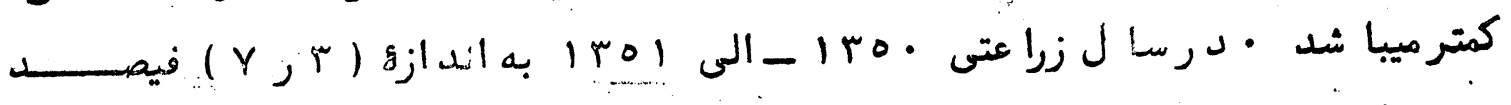

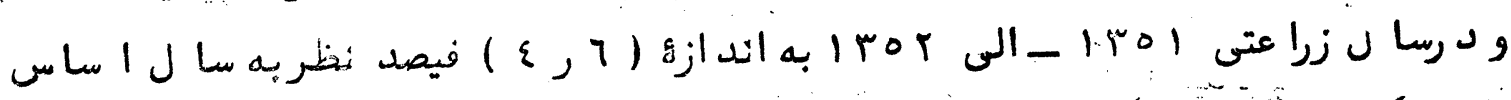

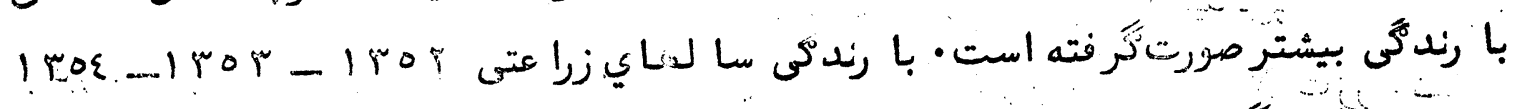

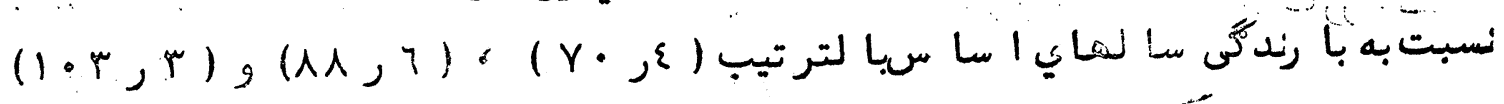

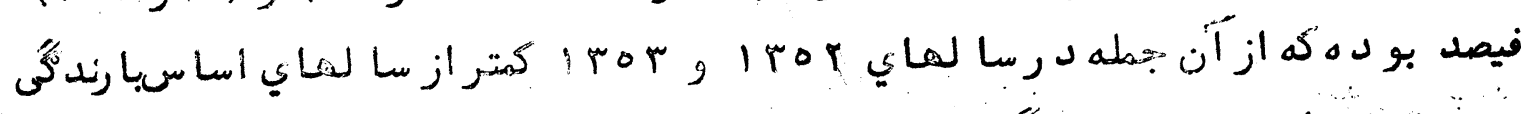

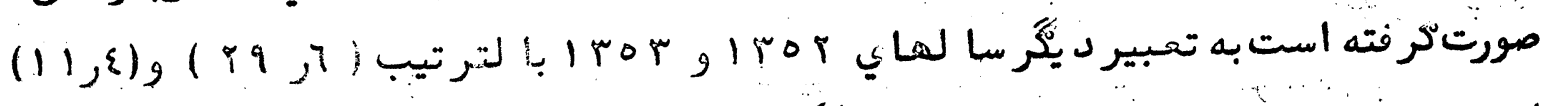

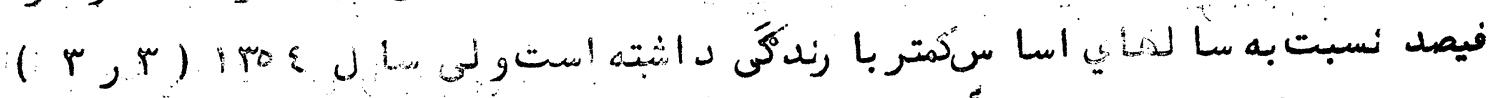

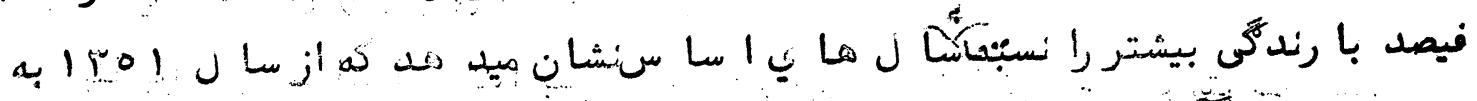

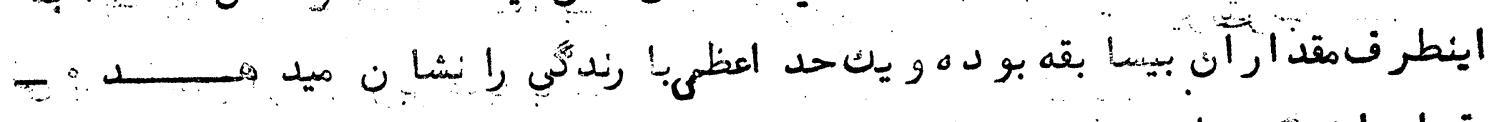

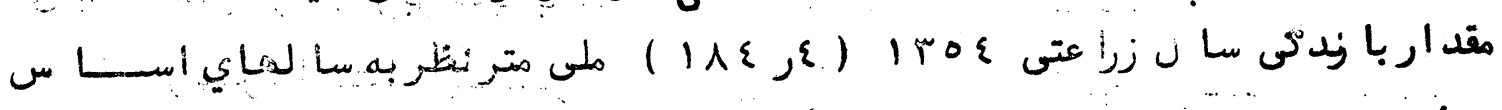

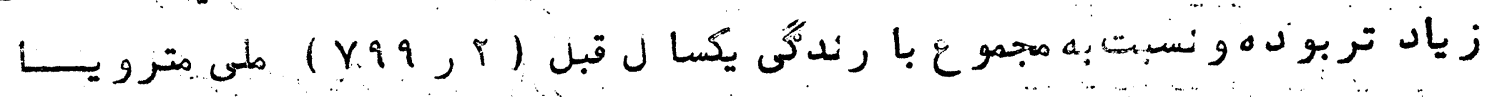

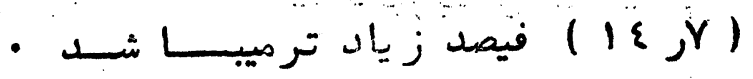

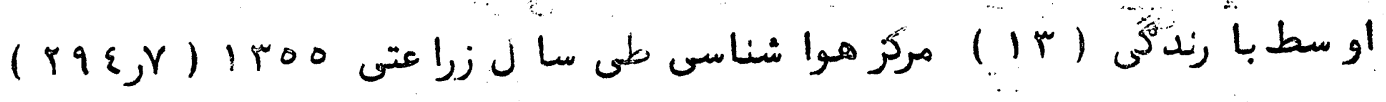

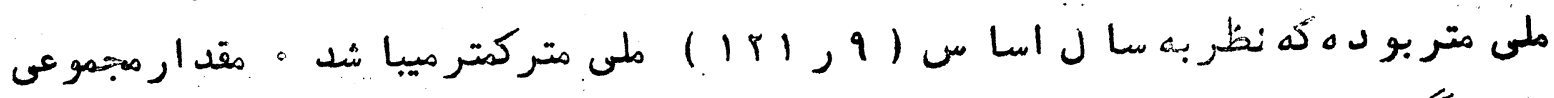

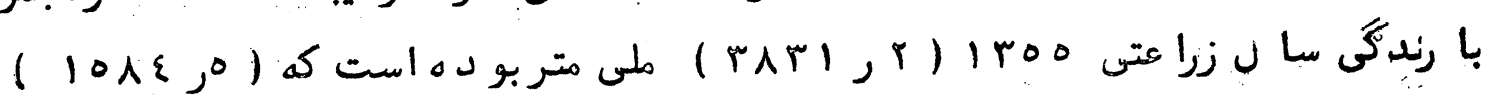

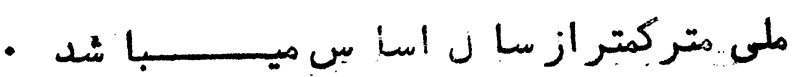

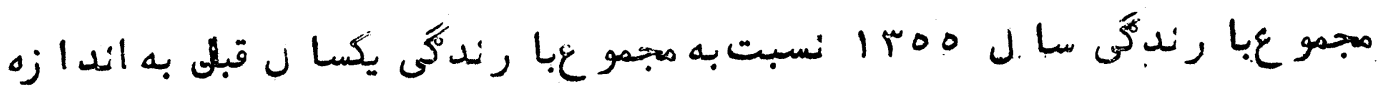

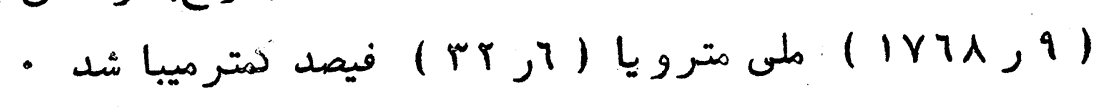

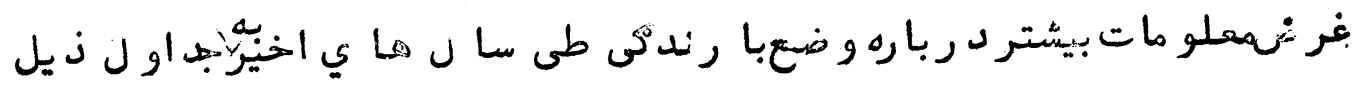

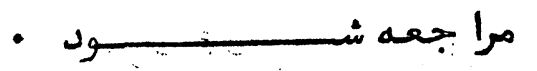

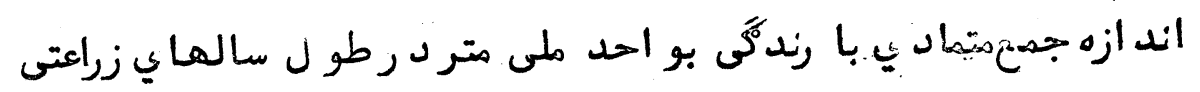

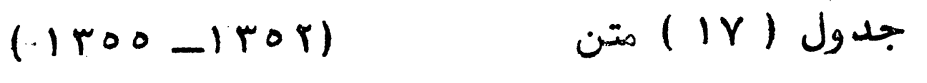

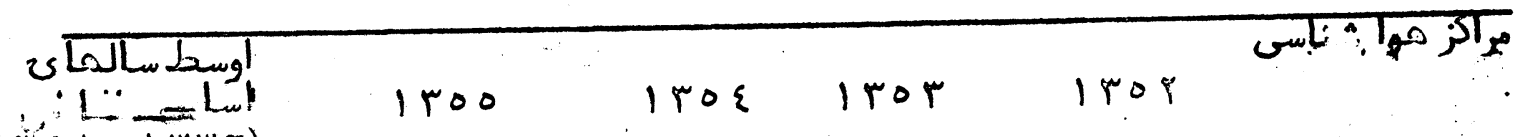
(198)-1y)

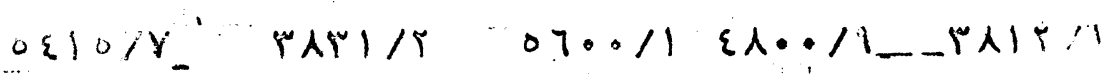




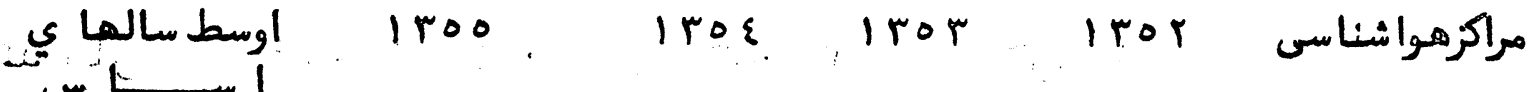

$(\operatorname{Ir}(\lambda-r)$

\begin{tabular}{|c|c|c|c|c|c|}
\hline$--\{17,7$ & $r q \leqslant, r$ & $\varepsilon r \cdot, \gamma$ & $r q q$ & rq & \\
\hline
\end{tabular}

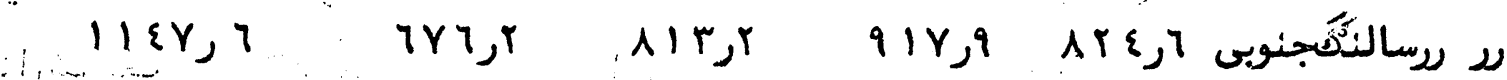

لע لע لע أسمالى

لر

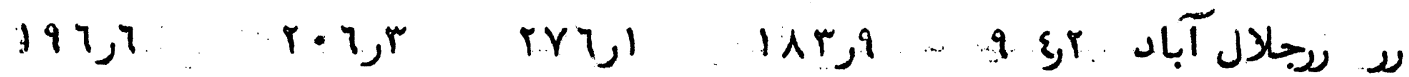

لا لـ

\&०ا,

עل لركنيند

لرع

رد

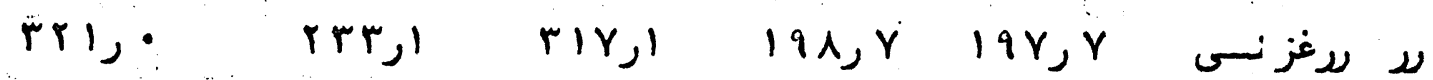

لע

لע رومزارشريف :

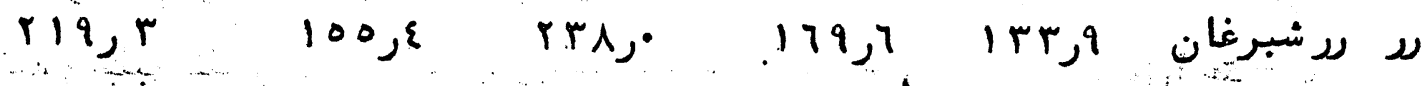

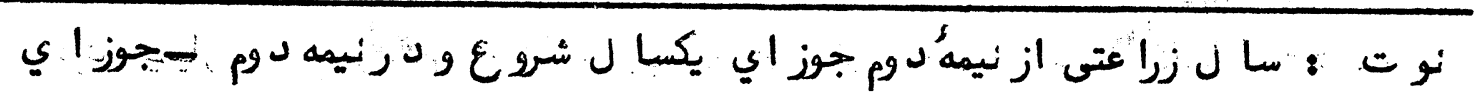

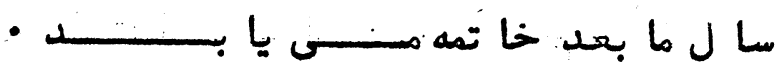

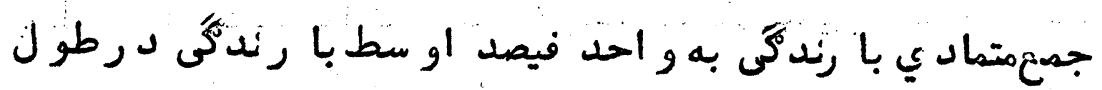

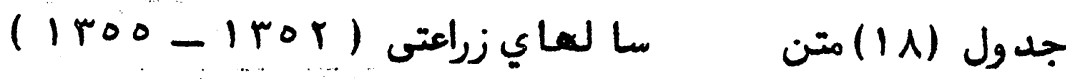

\begin{tabular}{|c|c|c|c|c|}
\hline 1 roo & lrog & iror & Iror & مراكر هوا شنـا سى \\
\hline$Y \cdot, r$ & r r & $\Lambda \wedge, \lambda$ & $Y \cdot, \varepsilon$ & \\
\hline$\cdots \circ 1, q$ & $Y \cdot \lambda$ & $\lambda \cdot \mu^{\circ}$ & VI & سا لنكّ جنوبى \\
\hline VA & $\Lambda \Lambda, r$ & مr. & $7 v, 1$ & لرشيطا لى . \\
\hline$\{9,7$ & $\lambda \cdot r$ & $\wedge \varepsilon, 0$ & $0 r, 1$ & كا بل . كا. \\
\hline $1 \cdot \varepsilon, 9$ & $1 \varepsilon \cdot \varepsilon$ & $9 r, o$ & $\varepsilon r, q$ & جلال J آباد \\
\hline TY, r & $1 \varepsilon \varepsilon, \gamma$ & 97, & $0 \cdot 0$ & نيسلا ن \\
\hline$q r, r$ & $9 \lambda, \lambda$ & $1 \cdot 1$ & $q \varepsilon, p$ & خو ســت \\
\hline$T r, r$ & $1 \varepsilon \varepsilon ر^{\circ}$ & $97, r$ & $r \varepsilon, r$ & كـندز \\
\hline
\end{tabular}




هن

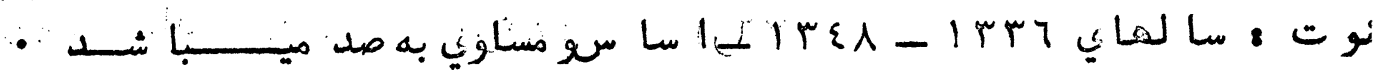

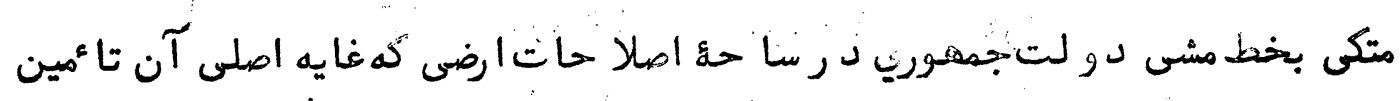

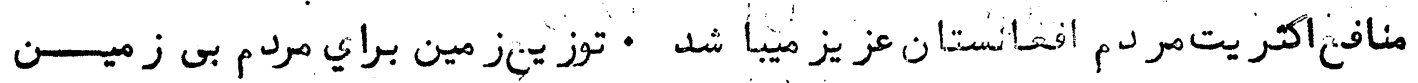

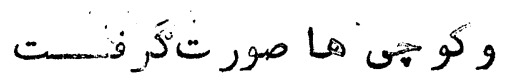

$$
\frac{1}{i}+\frac{1}{+}
$$

بمنظور حمايه و تشو ين بيستسرزا رعين به اند ازؤ (نز لده ) فيصد د رقيمت خــر يد

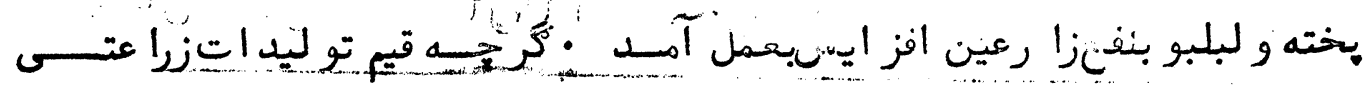

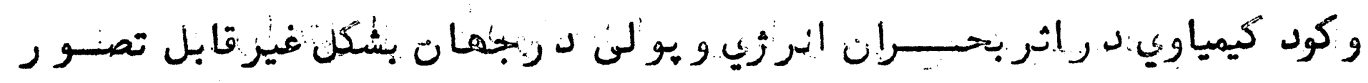

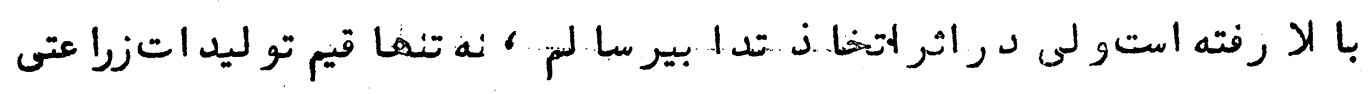

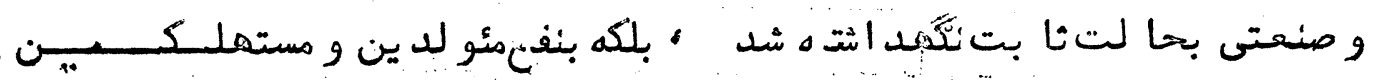

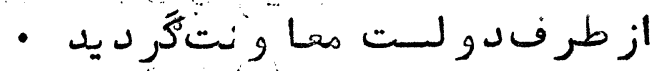

$$
\begin{aligned}
& +\frac{1}{1}+\frac{1}{1}
\end{aligned}
$$

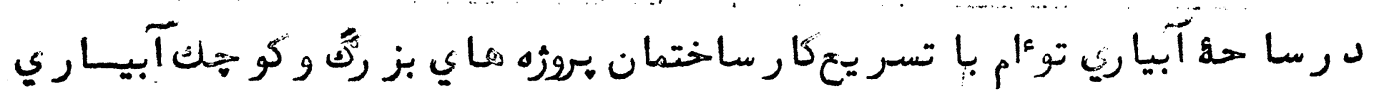

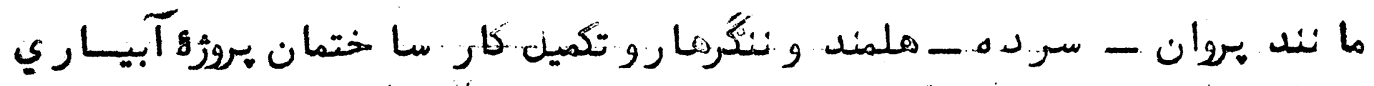

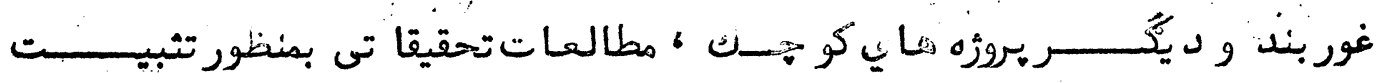

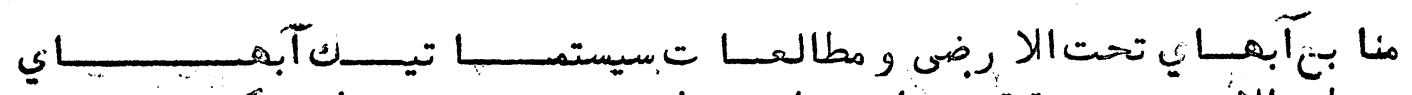

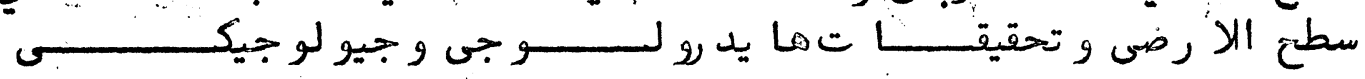

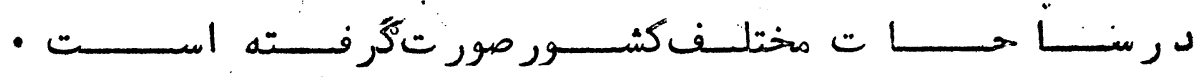

( منتخبى از بيا نات بنا غلى محدد د اؤد ز زهبــر انقلا بور رئيسجمهور )

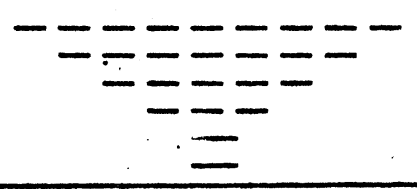




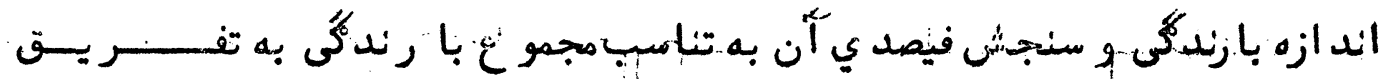

مقد اربارندئى (ملى مثر)

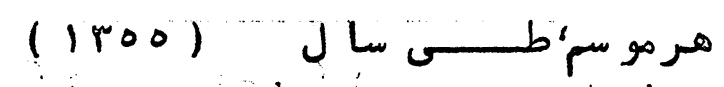

جدول (19) )

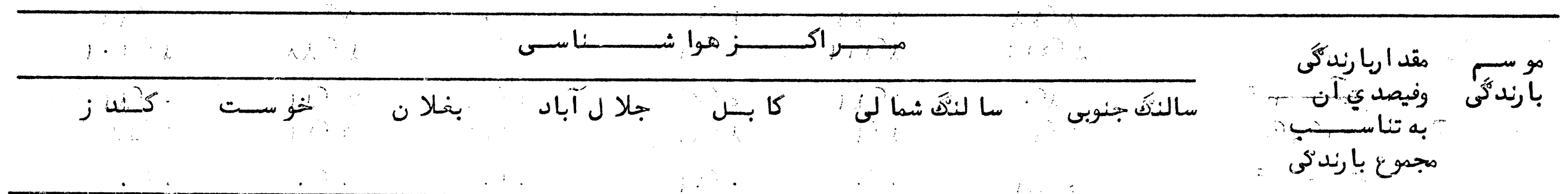

\begin{tabular}{|c|c|c|c|c|c|c|c|c|}
\hline$y$ & $i$ & 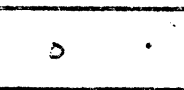 & $\varepsilon$ & $r$ & $\cdots$ & 1 & 3 & 1 \\
\hline$\Lambda \varepsilon j$ & $1 \cdot \wedge$, & $1 \varepsilon 9,7$ & 09 & r & $r \vee \tau, T$ & $11 \%, 9$ & مقد اربارندقّى & ار. \\
\hline$r 1 j 7$ & $Y Y, \varepsilon$ & $\{\Lambda, \gamma$ & rro & $r 7$ & rro & $r \wedge, 0$ & فيصــــــــي & \\
\hline ر & rr & •ر & $\begin{array}{l}T Y, r \\
r 7, ?\end{array}$ & $\begin{array}{l}\dot{ر} \cdot \\
\dot{:}\end{array}$ & $\begin{aligned} & 0 \\
& \cdot 1 \lambda\end{aligned}$ & •ر. & فيصد اريا رندئى & تابستان \\
\hline$r 0,1$ & 0 & $r 7, r$ & • & $1 \varepsilon 0$ & 170, & $9 \varepsilon$ & مقد ار بارندنى & خز ا ن \\
\hline $9, y$ & • & A.,$\gamma$ & 71 & 9,7 & $r$. & $\mid \varepsilon, \gamma$ & فيصــــــــــي & \\
\hline $107, r$ & $\lambda \varepsilon$ & $\mid r i, \lambda$ & $00, \gamma$ & $11, r$ & $r \wedge r, r$ & $r$ & فقل ار با رندىى & زمستان \\
\hline $0 \wedge, Y$ & 17,0 & $\{r, \lambda$ & $r \cdot, \varepsilon$ & $\Delta r$ & $\{7, \varepsilon$ & 07,9 & فيمســـــــــي & \\
\hline$r r 7, r$ & rqr,o & $r \cdot \wedge, 1$ & $1 \wedge r, \xi$ & 101,1 & ArT, & $7 \varepsilon 7$ & مقدا ريار رندكى & مجموع \\
\hline
\end{tabular}




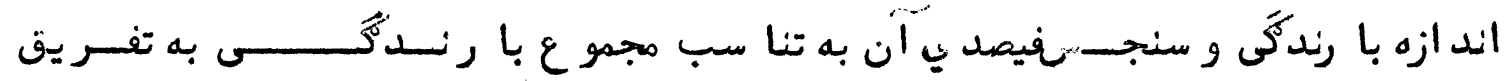

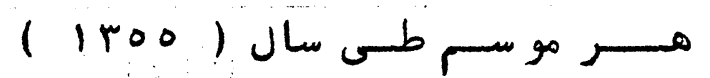

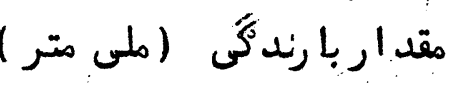

اد اهه جبـدو ل (a) ) متسـن

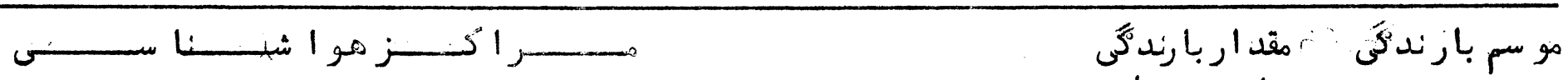

\begin{tabular}{|c|c|c|c|c|c|c|c|}
\hline ئبَرغا ن & مزار شر يف & ميمــــــه & غـز نسى & عرا ت & قذــدمار . & 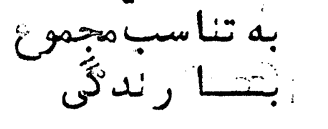 & $\cdots$ \\
\hline ir & ir & 11 & $1 \cdot$ & 9 & $\wedge$ & & $\cdots$ \\
\hline$r \cdot r$ & $\varepsilon \varepsilon, r$ & $1 \times 1, \varepsilon$ & $\varepsilon \varepsilon, \gamma$ & $9 r, r$ & 10,1 & مقدار بارندنَى & بهار \\
\hline$r \cdot j q$ & $r$ & $\Delta \varepsilon \wedge$ & $r 1,0$ & $r \wedge, \lambda$ & $r, r$ & فيصـــــــــي & \\
\hline •ر. & 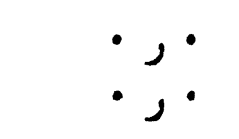 & $\begin{array}{l}\dot{\rho} \cdot \\
\dot{\mu}\end{array}$ & $\begin{array}{l}r q, r \\
r \varepsilon, .\end{array}$ & $\begin{array}{l}\dot{\rho} \\
\dot{\rho}\end{array}$ & $\begin{array}{l}r \wedge, r \\
i v, \varepsilon\end{array}$ & 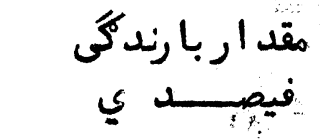 & تابستان \\
\hline $\begin{array}{l}r r, 1 \\
\mid r, .\end{array}$ & $\begin{array}{l}19, \varepsilon \\
19,1\end{array}$ & $\begin{array}{l}\{7,0 \\
1 \varepsilon, \xi\end{array}$ & $\begin{array}{l}i r, r \\
i, 0\end{array}$ & $\begin{array}{l}\{1, r \\
17, \xi\end{array}$ & $\begin{array}{l}1,7 \\
\cdot, \gamma r\end{array}$ & فيصــار بارنديدي ئي & خــزان \\
\hline $\begin{array}{l}1.1, r \\
0 r, 0\end{array}$ & $\begin{array}{l}r r, r \\
0 \leqslant ر\end{array}$ & $\begin{array}{l}q 9,0 \\
r \cdot, r\end{array}$ & $\begin{array}{l}110,9 \\
00,9\end{array}$ & $\begin{array}{l}l 1 r, r \\
\{\varepsilon, 1\end{array}$ & $\begin{array}{l}17 \varepsilon, r \\
Y \varepsilon, \gamma\end{array}$ & فيصدار بارندئدي & ز زمتان \\
\hline $19 \varepsilon, 1$ & $1 \varepsilon \theta, 1$ & rri, $q$ & $r \cdot r, \xi$ & ro. & rY. & مقد ار با رندكى & مجمو ع \\
\hline
\end{tabular}

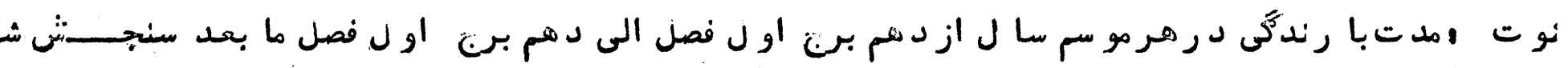

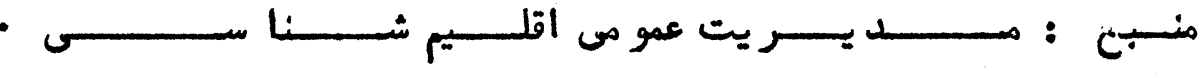


او سط با رند"ى و فيصد يَّآن به تفزيف فصول سال

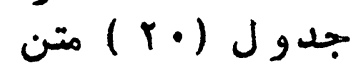

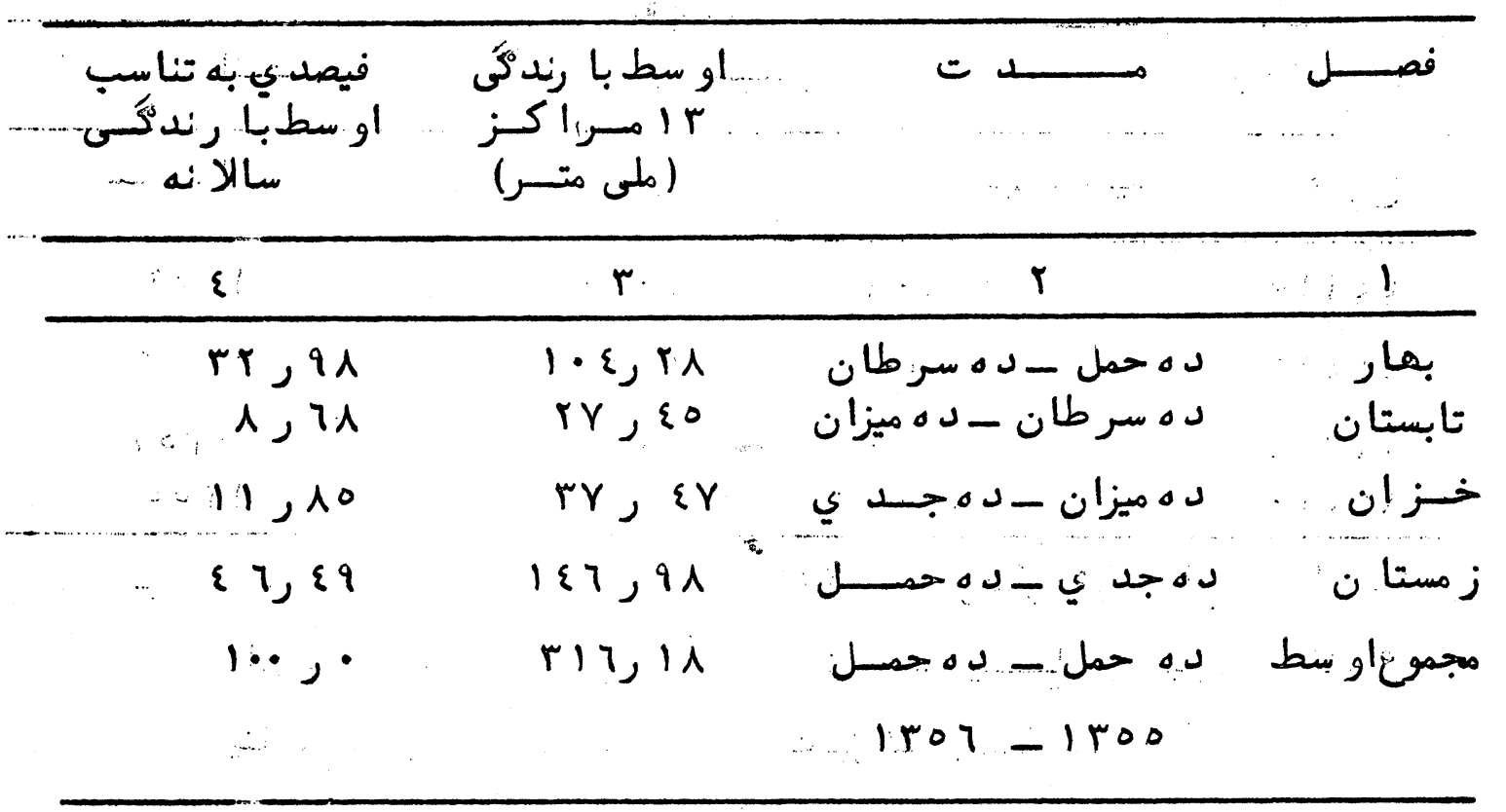

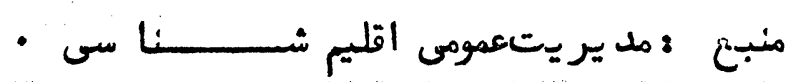

جهت معلو ماتمز يد به جدا و ل (

كو د كيمياوي

يكى از اهد ا فعمذه بلان انكشا في كئور مو ضو ع بلند برد ن حا صـسلا ت

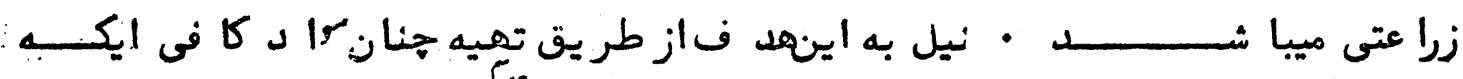

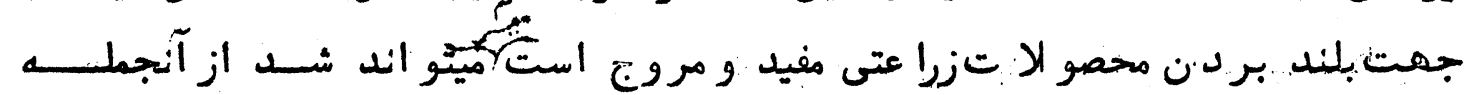

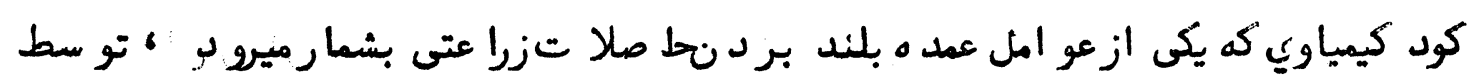

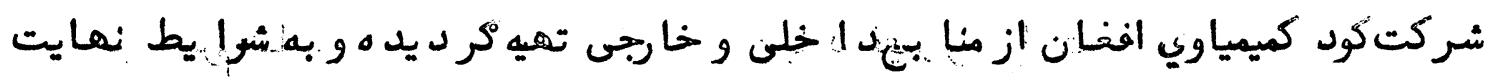

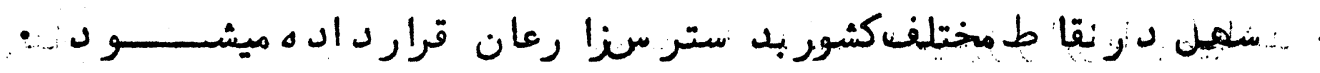
ارقام مر بو ط فرو شات شركتكود كيمياوي افنان د ر مو رد توز يعكو د كيمياوي.

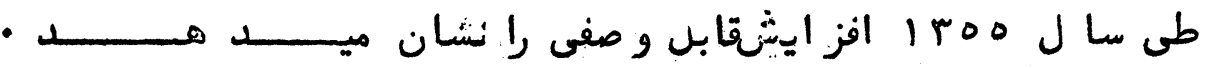

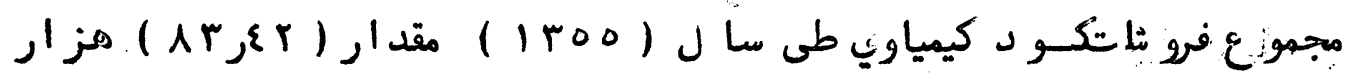

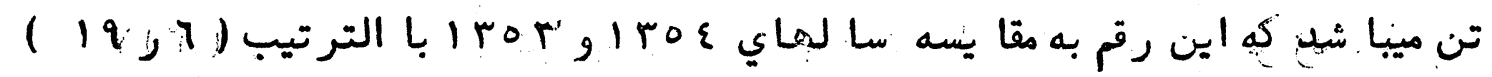

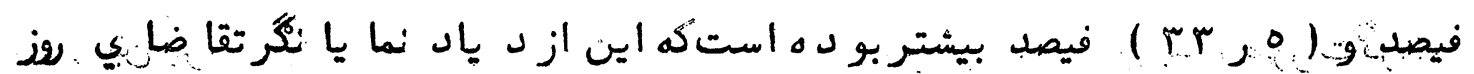

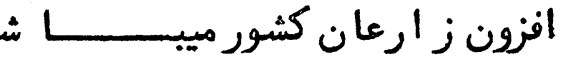

علا و تا بايد متذكر شد كه د رتوز ينكو د د اي امو نيم فا سفيتو يوريا بمقايسه.

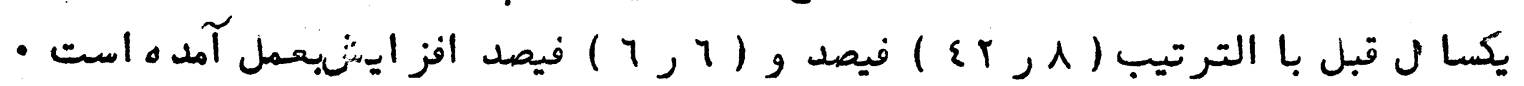




$$
-07 .
$$

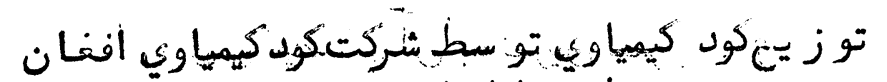

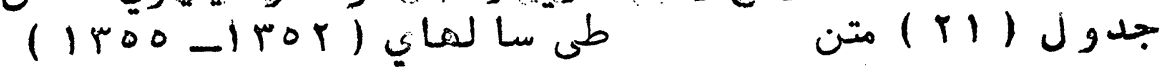

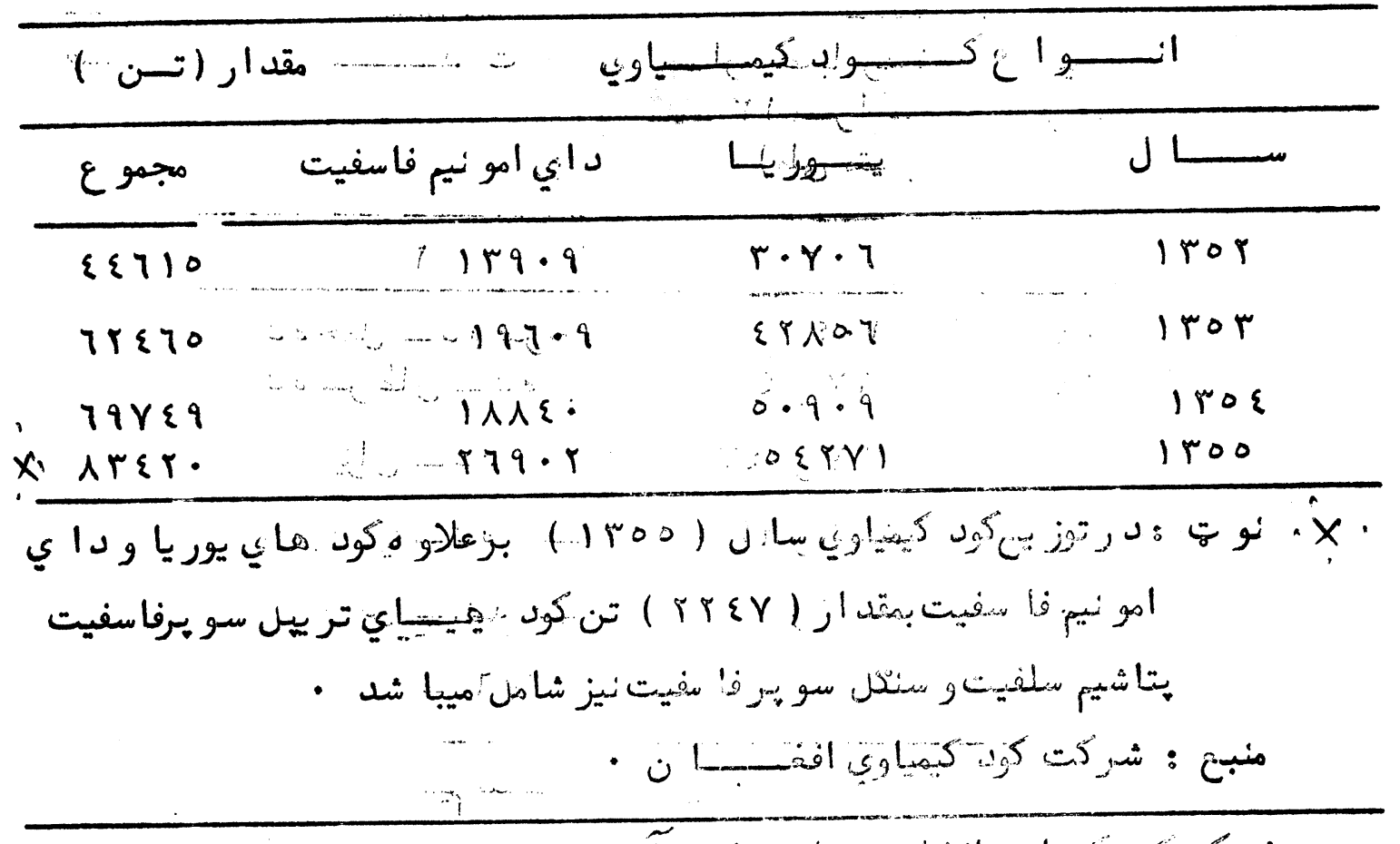

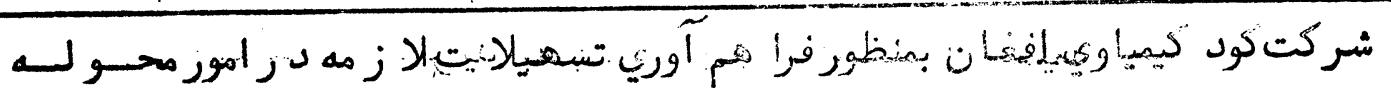

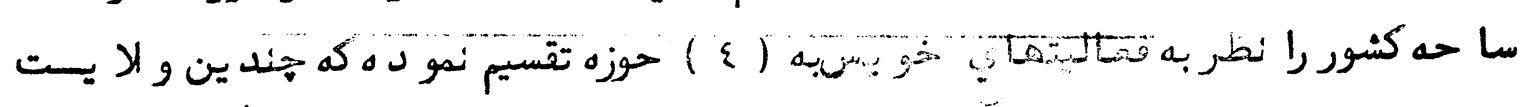

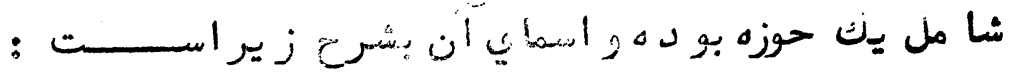

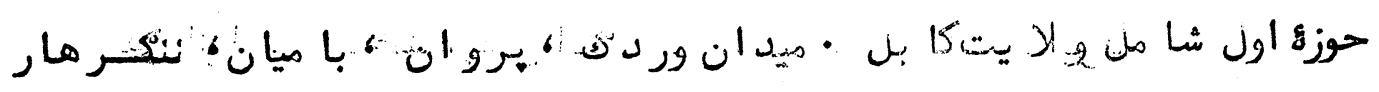

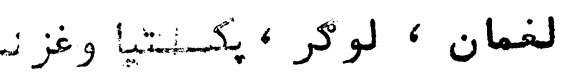

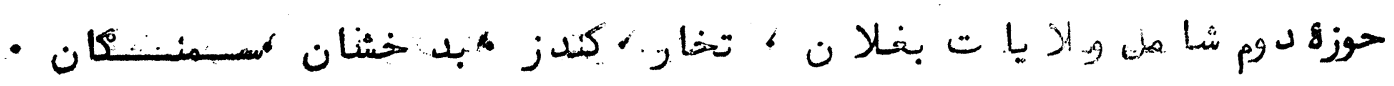

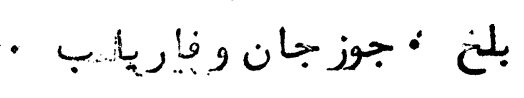

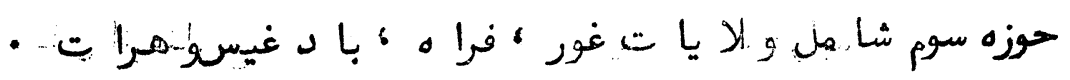

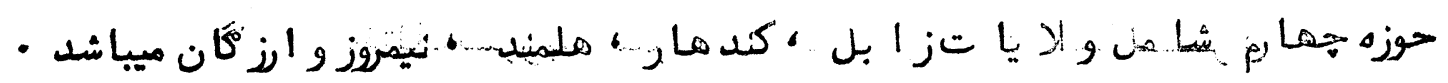

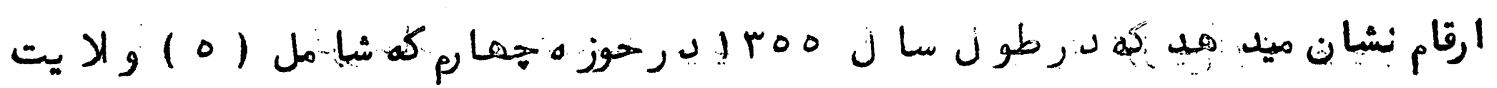

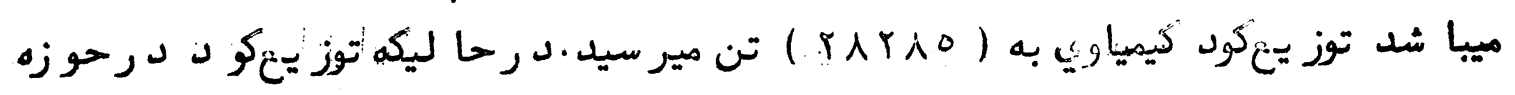

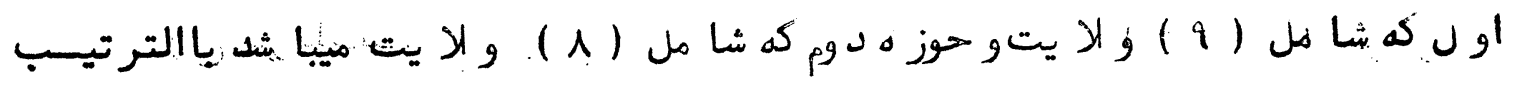

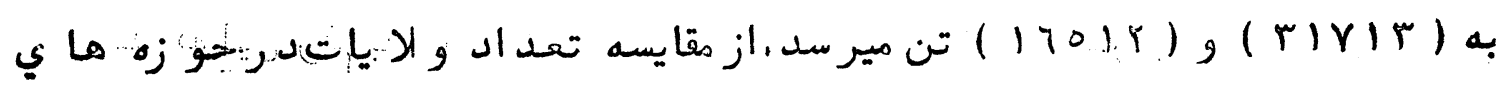

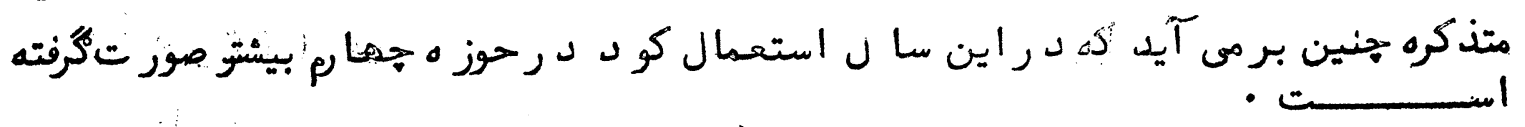




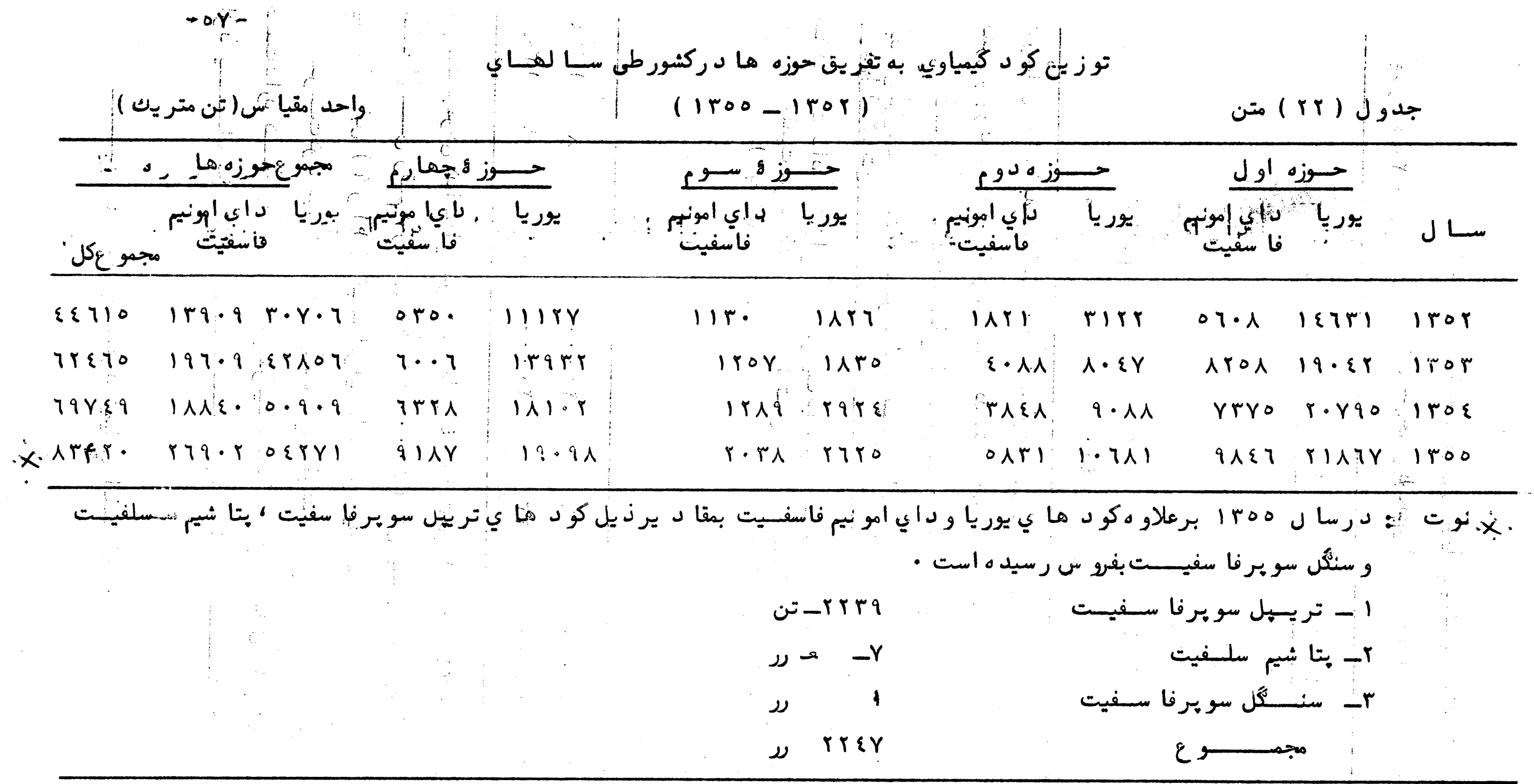

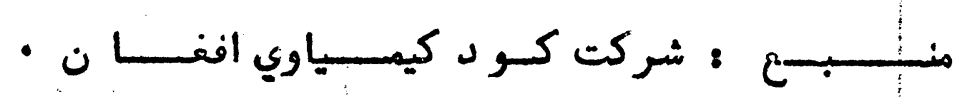


تعيـل اد منازه ماي فروسكود كيمياوي به تفريق حوزه هـا

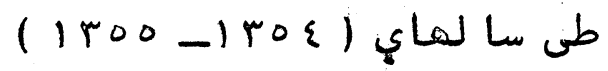

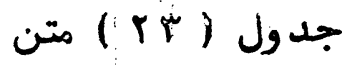

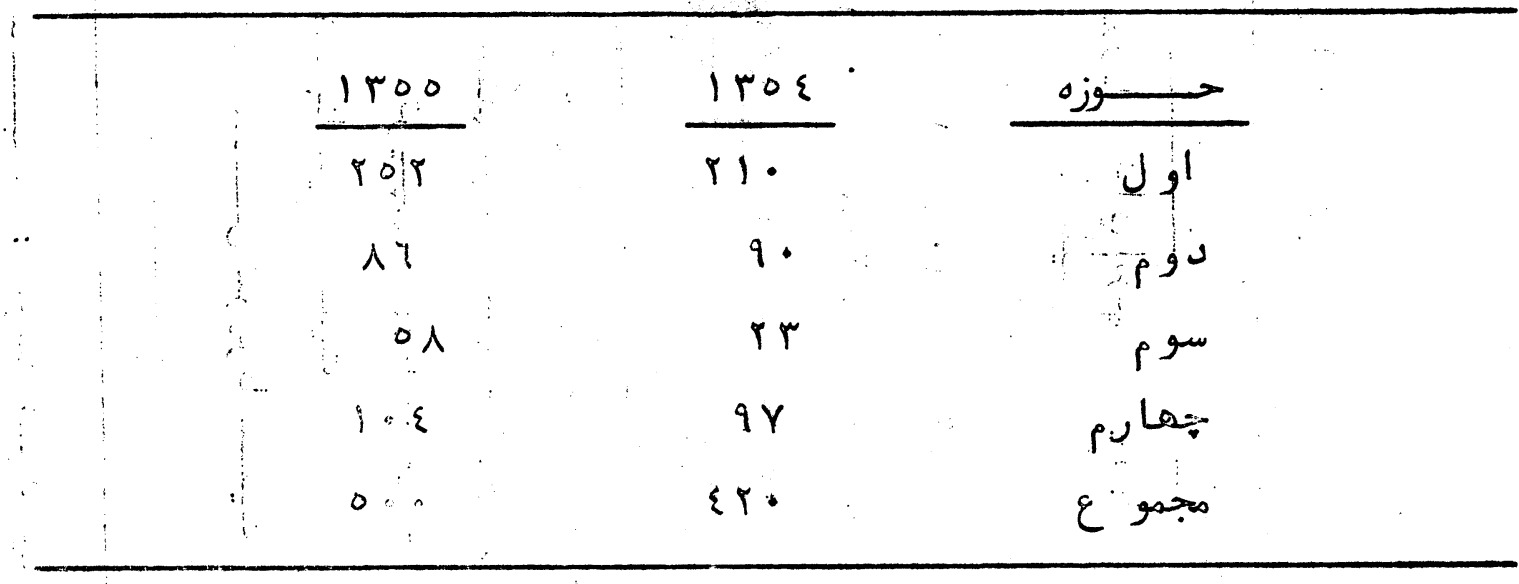

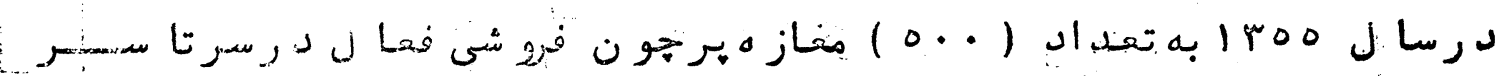

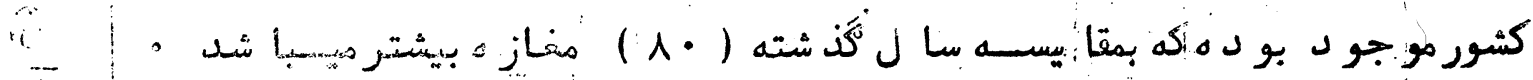

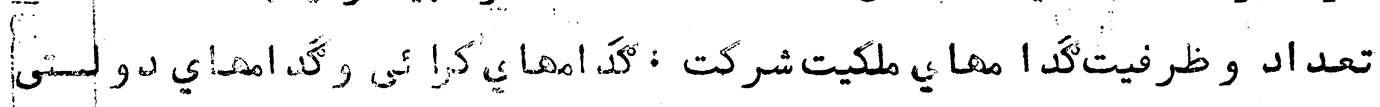

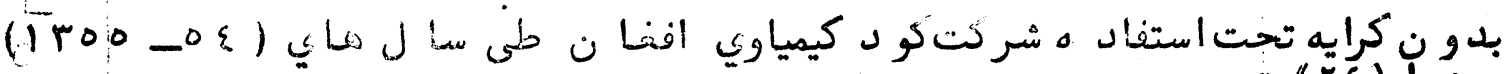

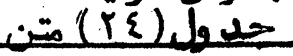

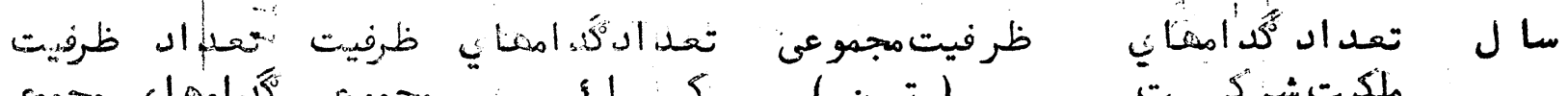

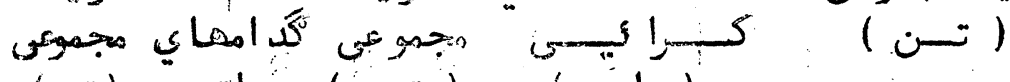

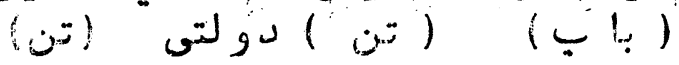

كبا

كرا يـ

$(\div)$

\begin{tabular}{|c|c|c|c|c|c|c|}
\hline 10.. & 1. & $\xi \ldots$. & 07 & $r r \ldots$ & $\Lambda$ & Iros \\
\hline $10 \ldots$ & 1. & $\{10 \ldots$ & r & $r r \ldots$ & $\Lambda$ & 1 roo \\
\hline
\end{tabular}

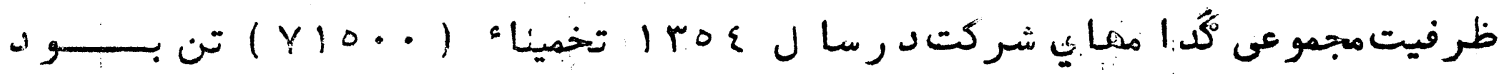

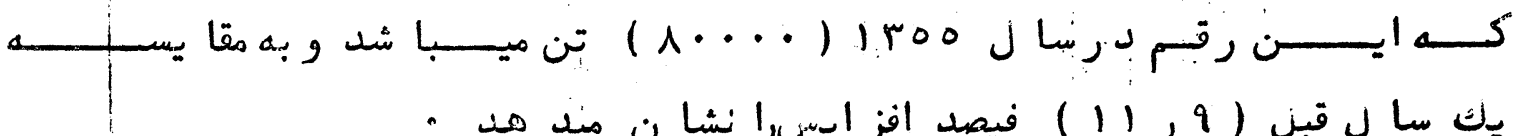

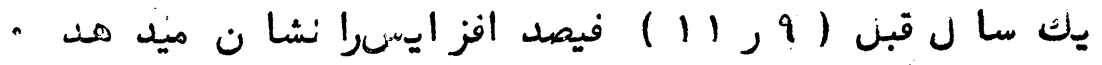

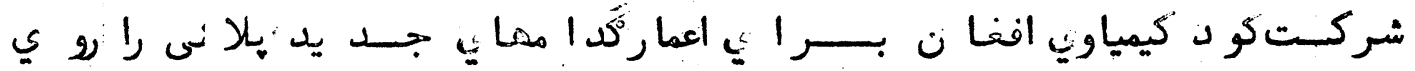

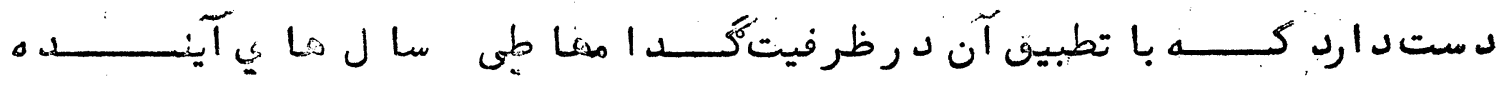

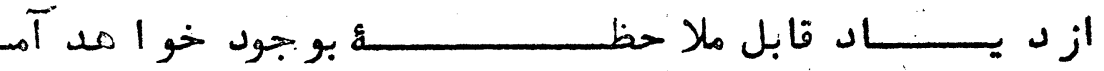

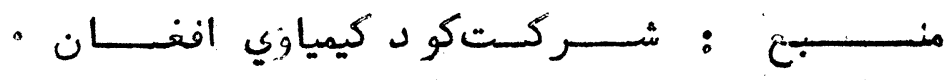




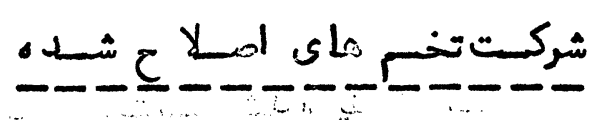

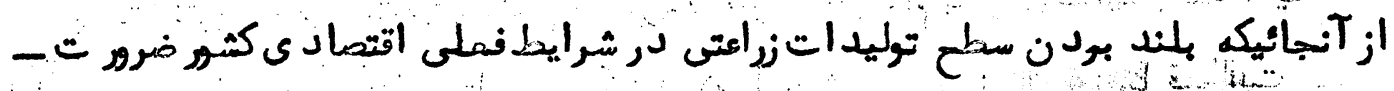

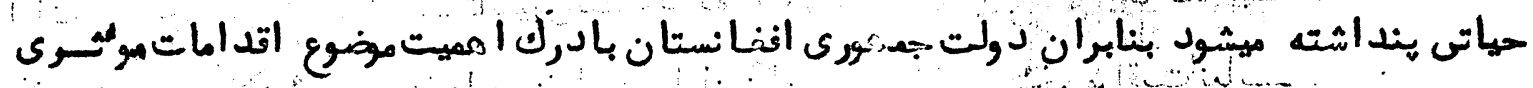

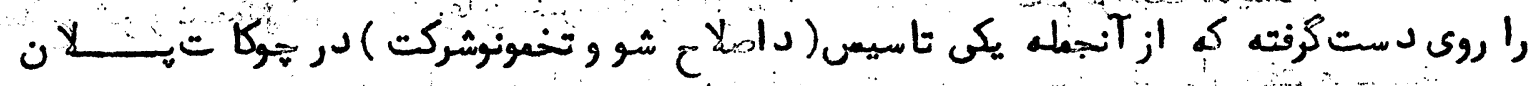

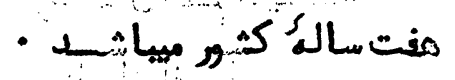

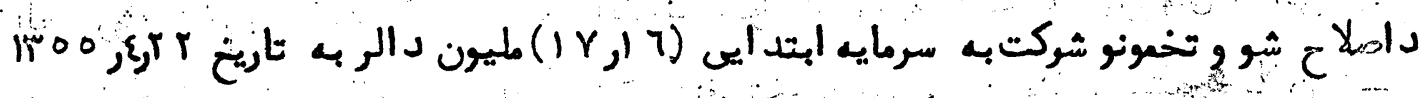

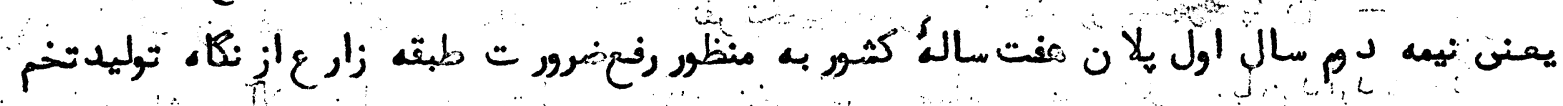

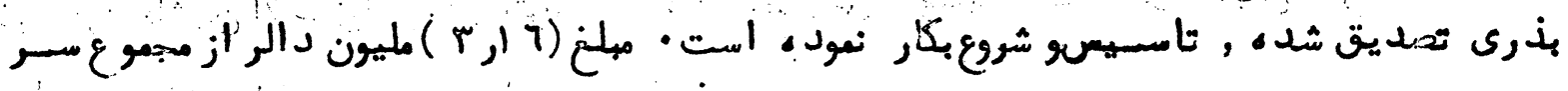

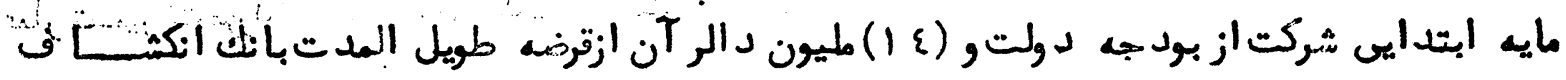

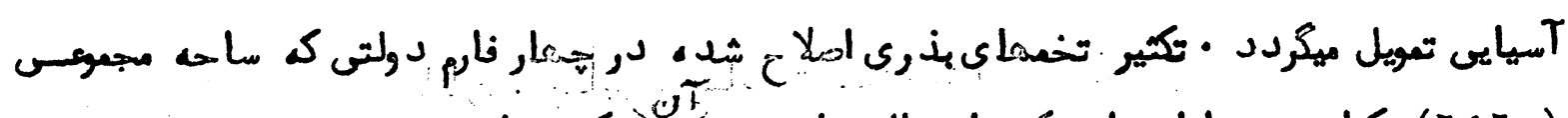

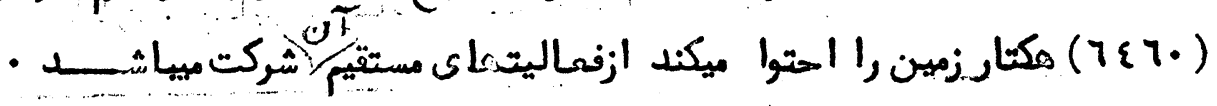

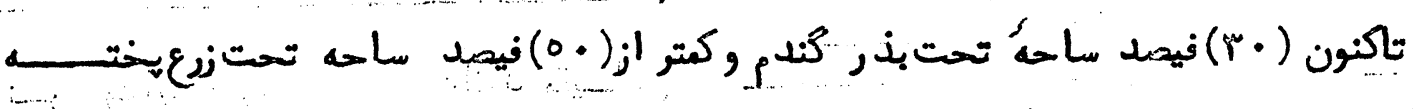

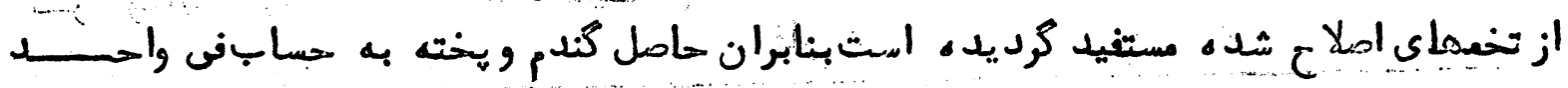

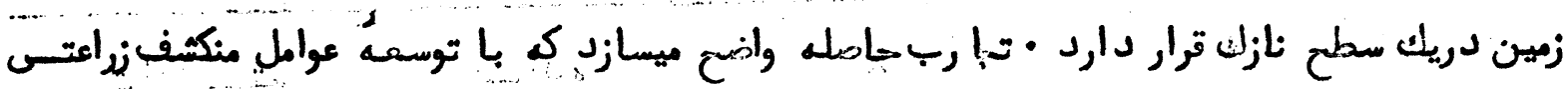

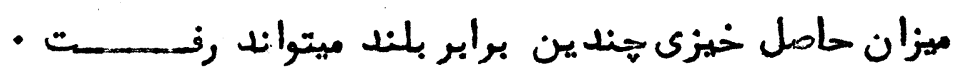

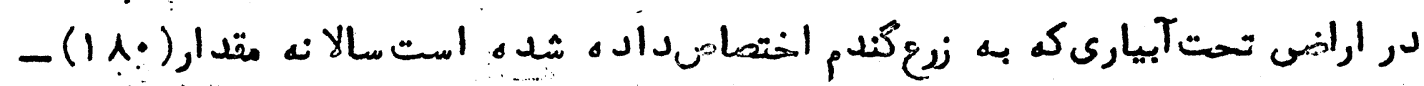

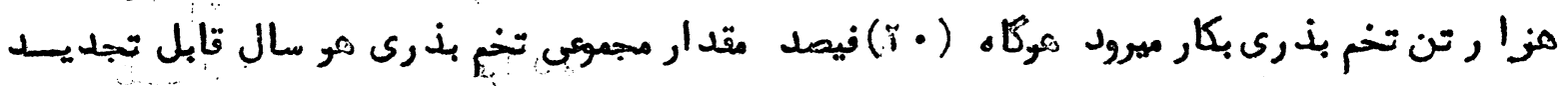

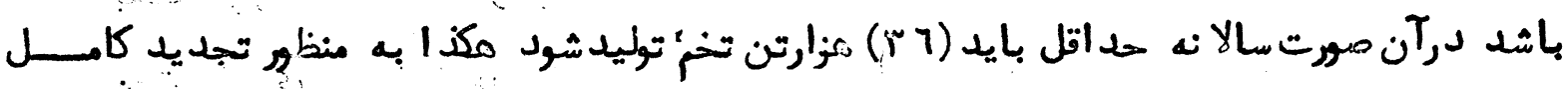

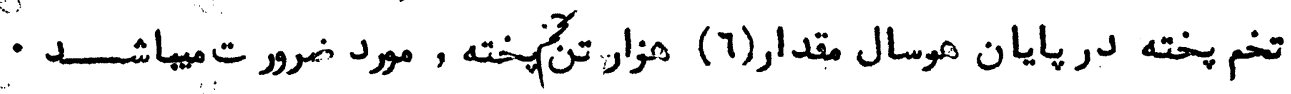

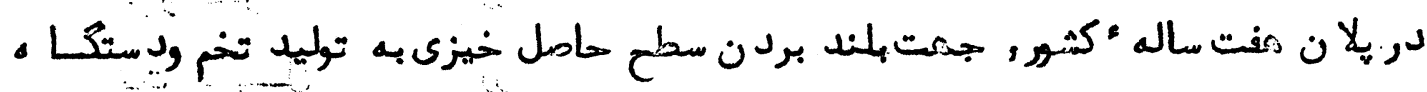

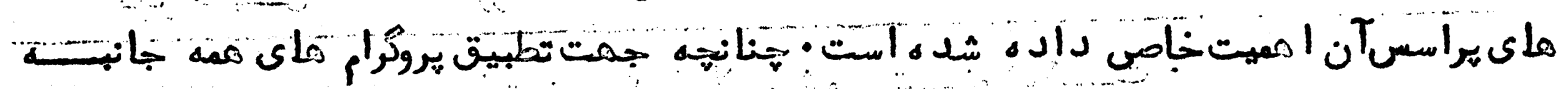

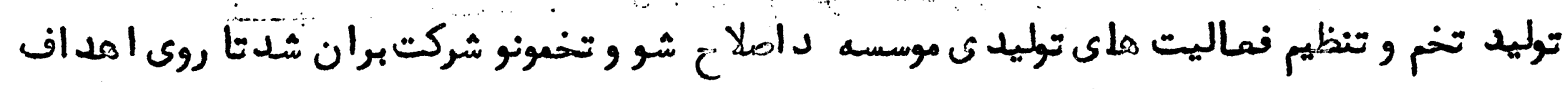

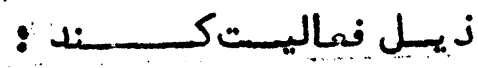

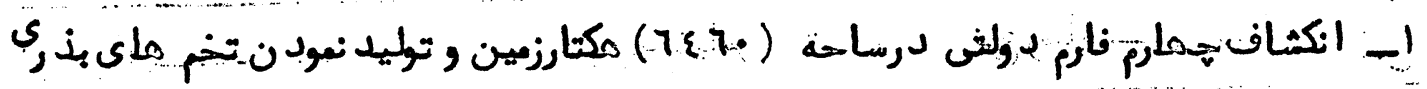

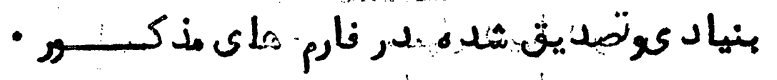

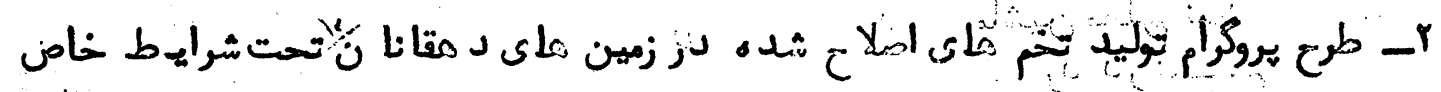

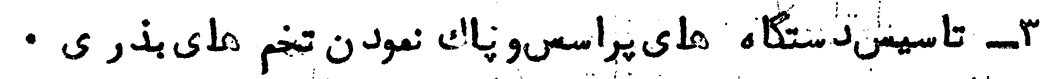

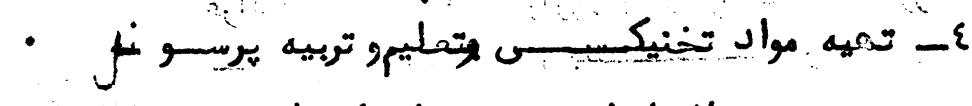

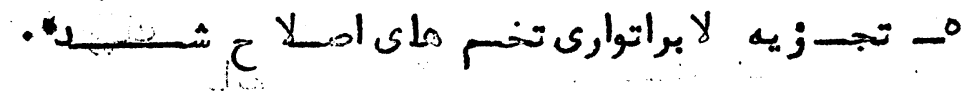

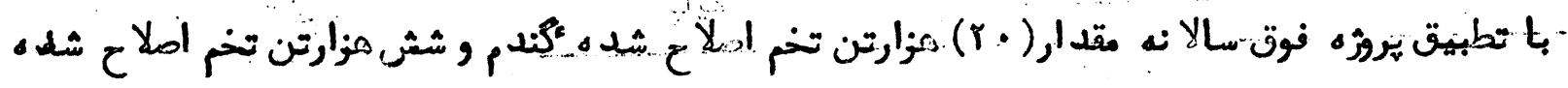




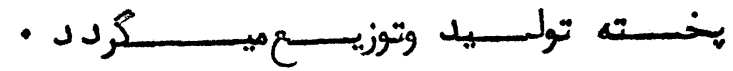

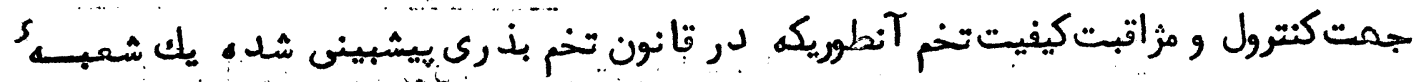

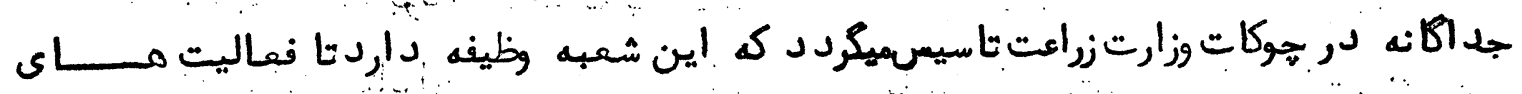

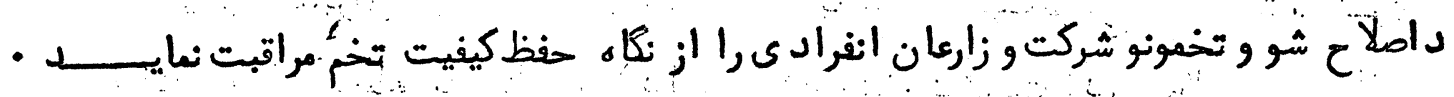

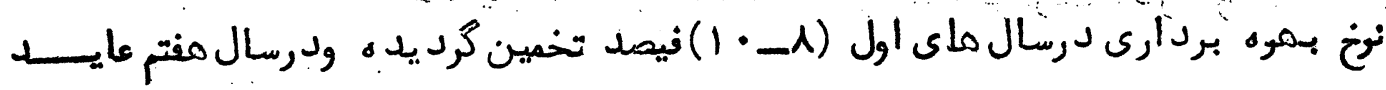

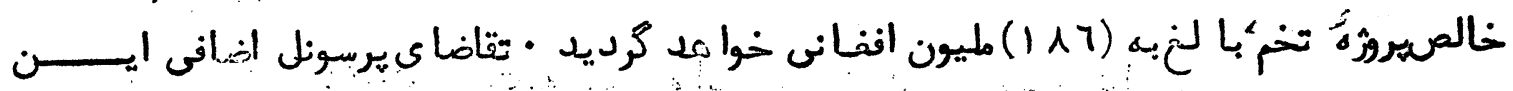

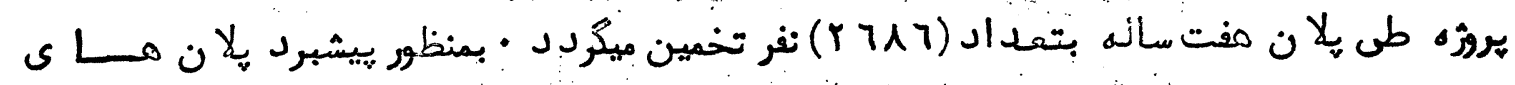

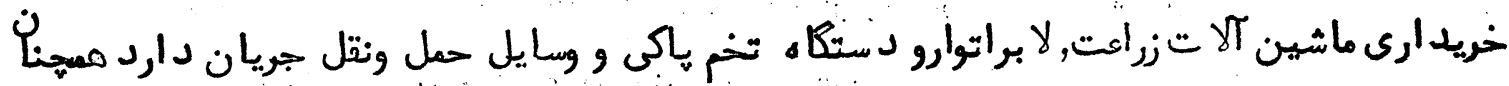
اعمار تمعيرات مورد ضروز تروى دست است سأمان , ونايل و وسايط تحسل أستفاد ه فحلىشركت

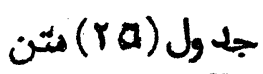

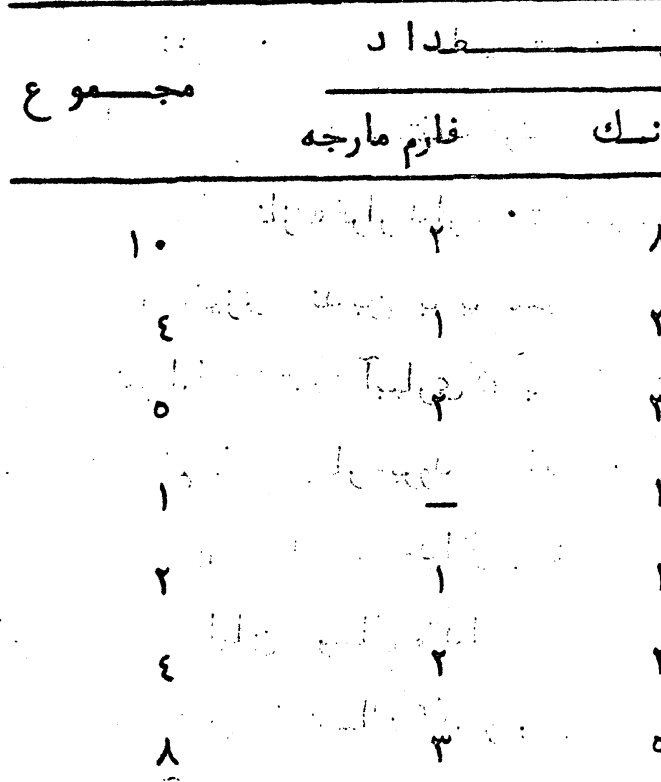

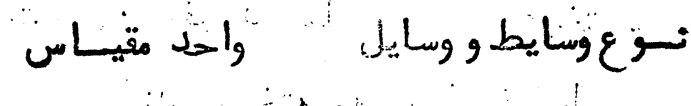

$\lambda$

r

$r$

1

1

$r$

0

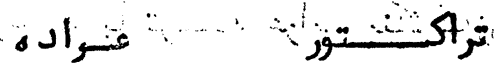

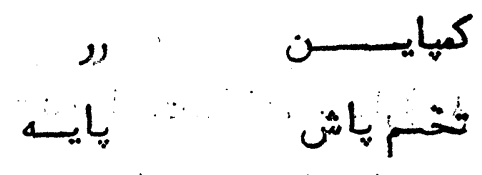

عرا

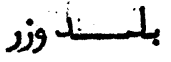

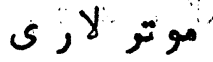

موتر خـــر د

"موتر نمايكـل

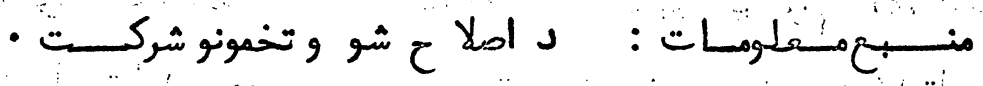

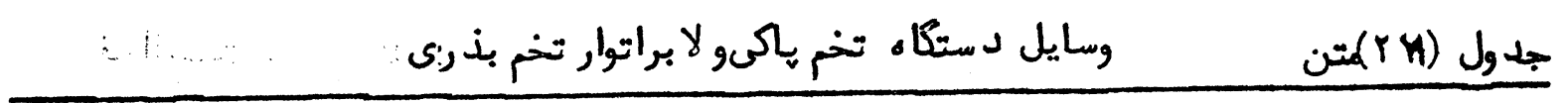

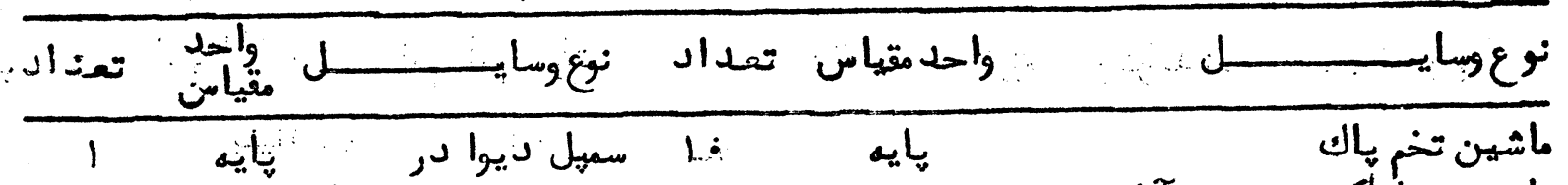

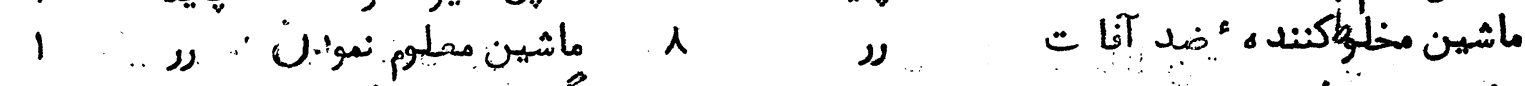

\begin{tabular}{|c|c|c|c|c|c|}
\hline 1 & נת & ترازوى حساس & 1 & נת & إرشقه و شبدر \\
\hline 1 & 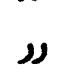 & ترازوى علاند ىلا براتوار & r• & & \\
\hline 1 & ננ & ترازوى بشل .ويـــت & $r \bullet$ & عراده & \\
\hline$\gamma$ & 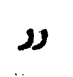 & جرمينتس - & - & - & d \\
\hline & ננ. & 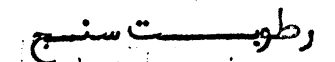 & $r$ & ليايه & تجزيه نمود ن تخم بذرى \\
\hline
\end{tabular}





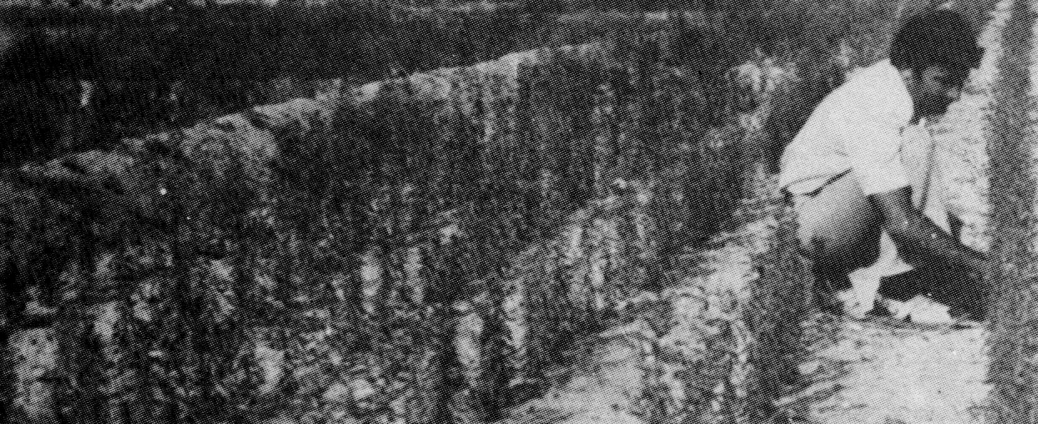

\section{ax $170=$}

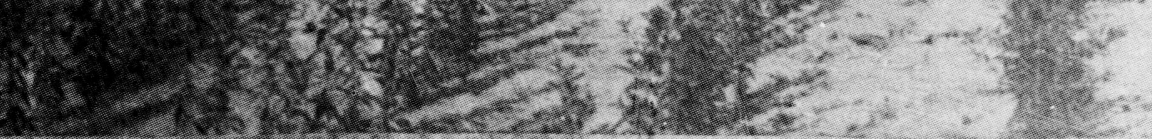

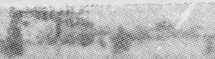




$$
\text { جدول (rv.) مستن }
$$

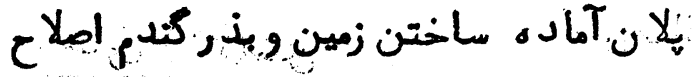

\begin{tabular}{|c|c|}
\hline ساحه ( مكتار) & اسـ مـار \\
\hline
\end{tabular}

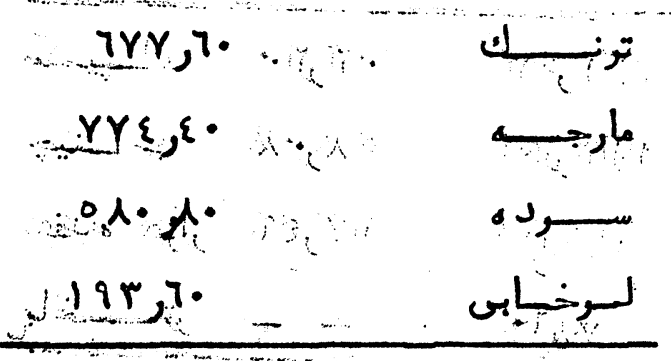

$\operatorname{TrT} \varepsilon \theta$ \%

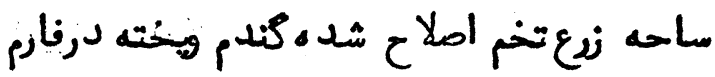

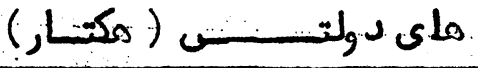

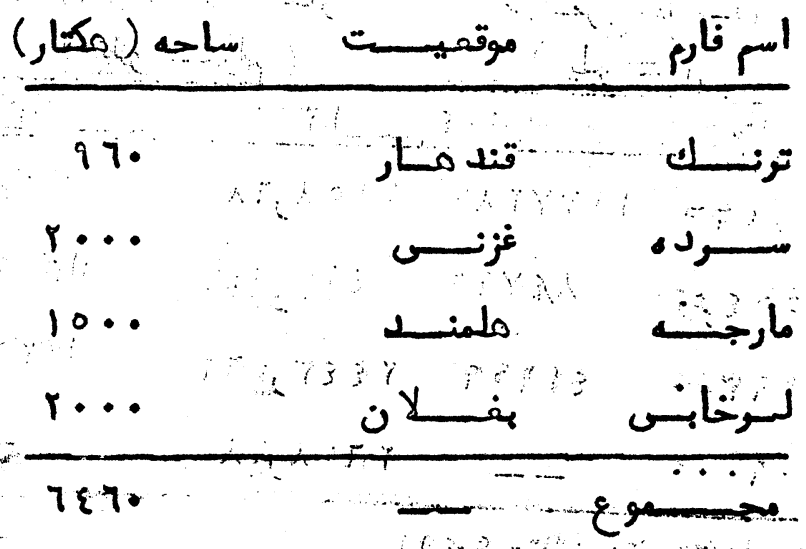

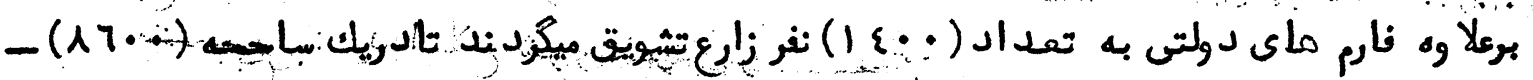

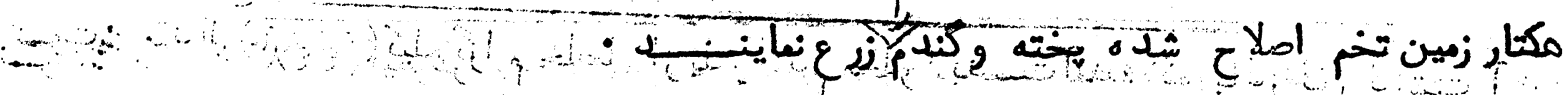

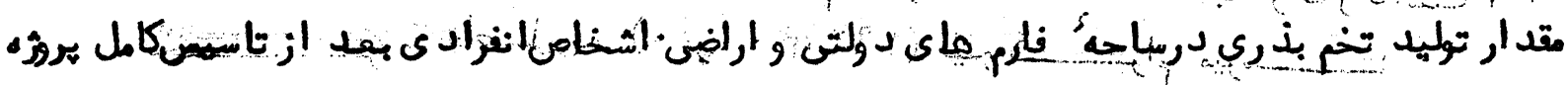

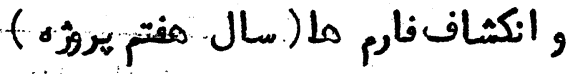

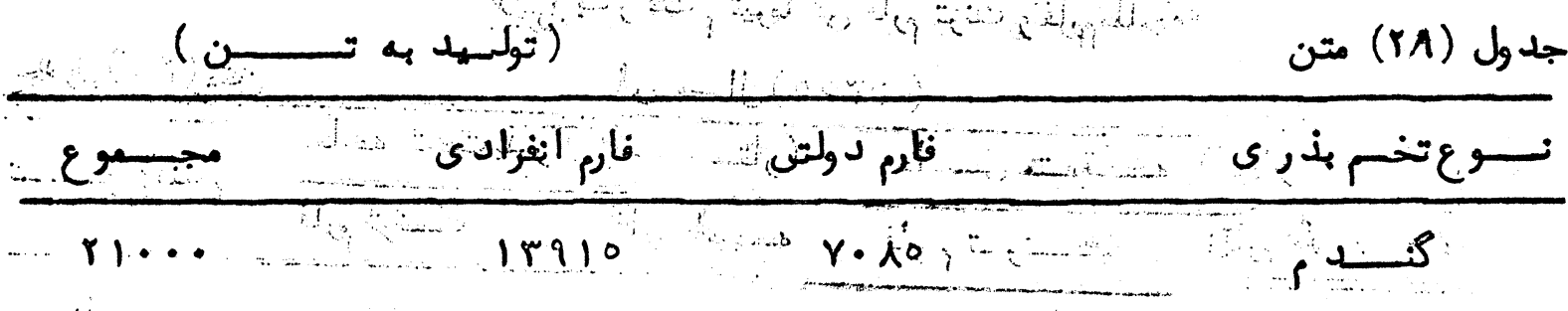

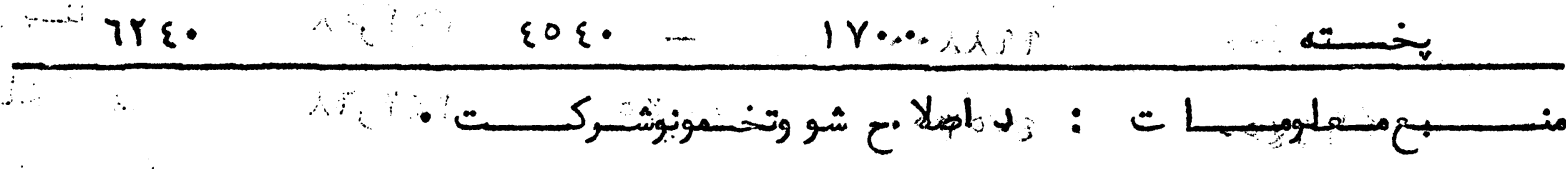

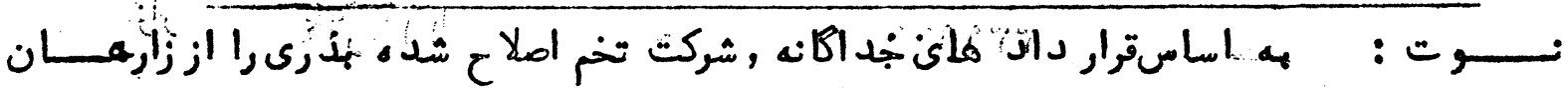

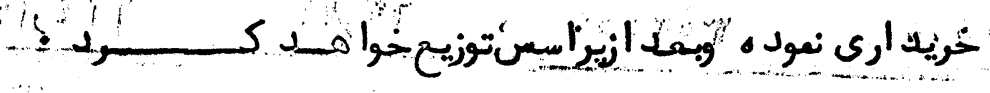

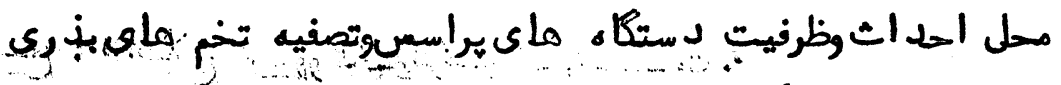

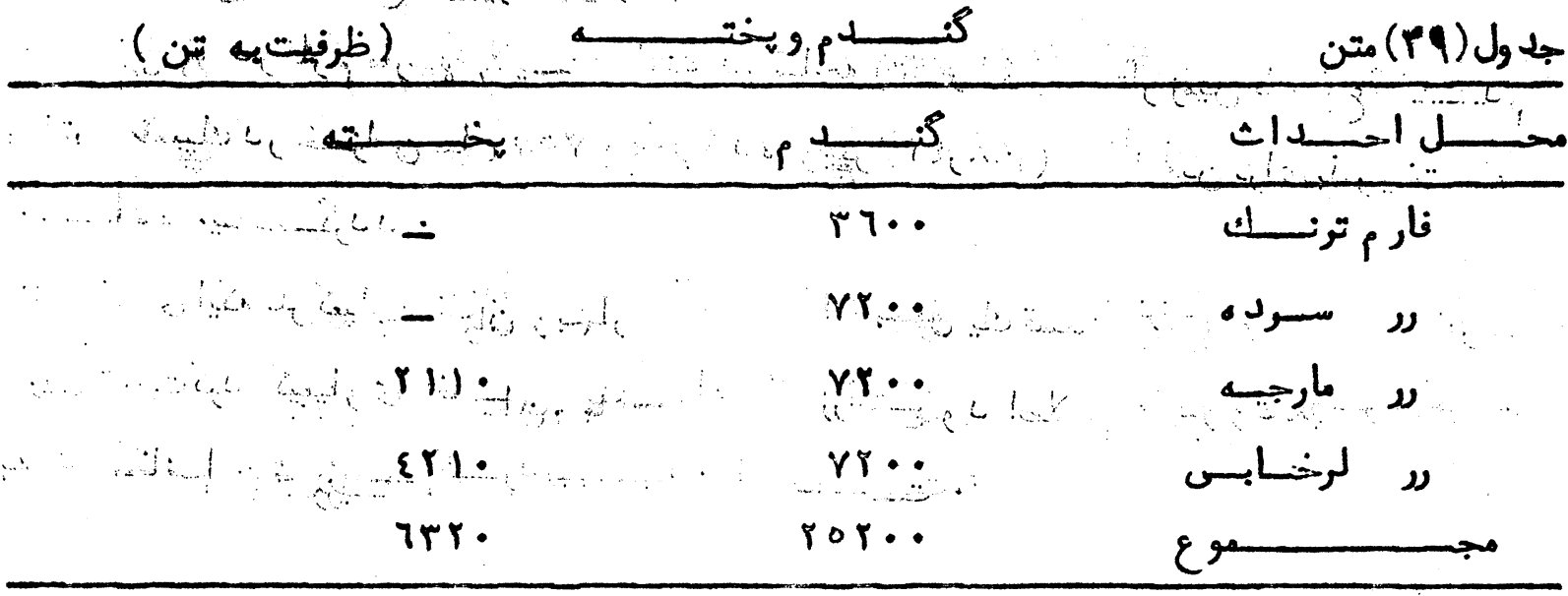

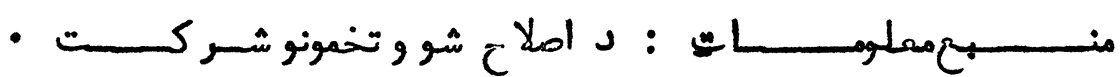




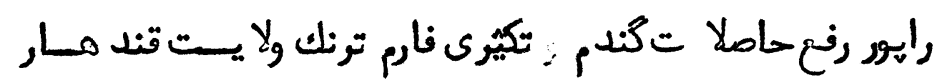

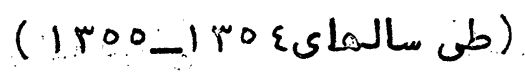

جدول (r) (r) مثن

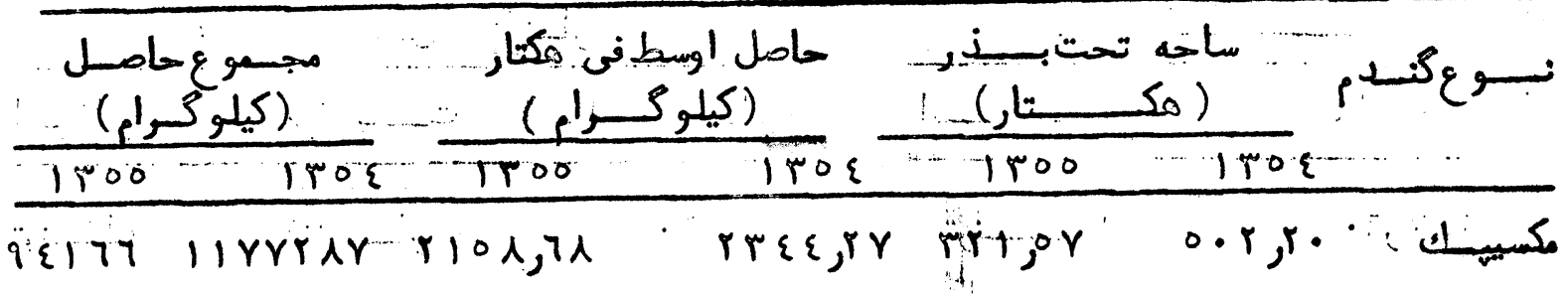

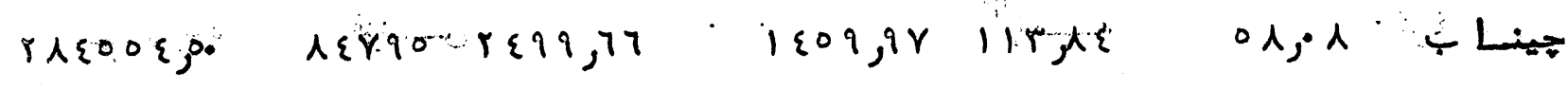

هrqr..

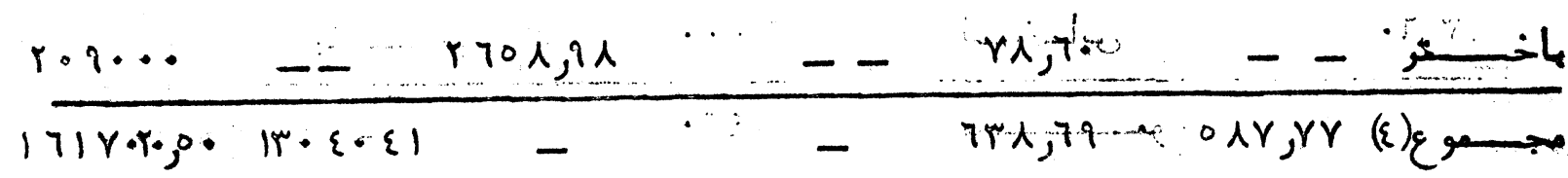

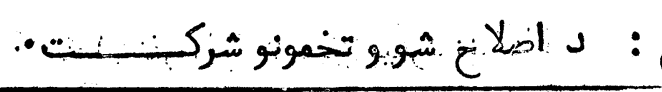

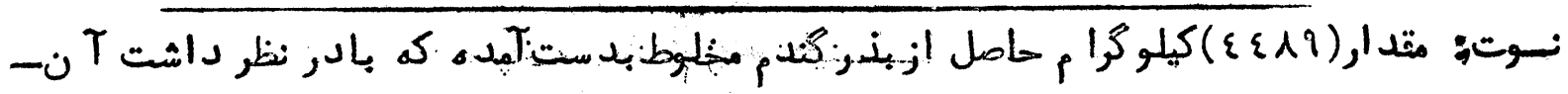

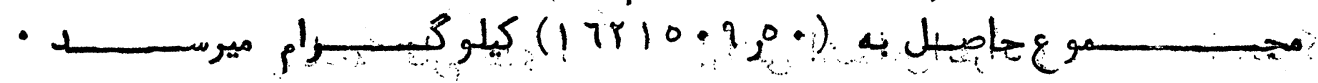

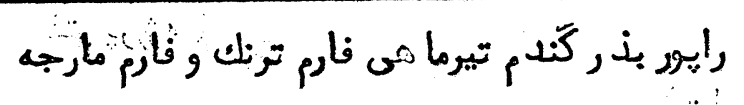

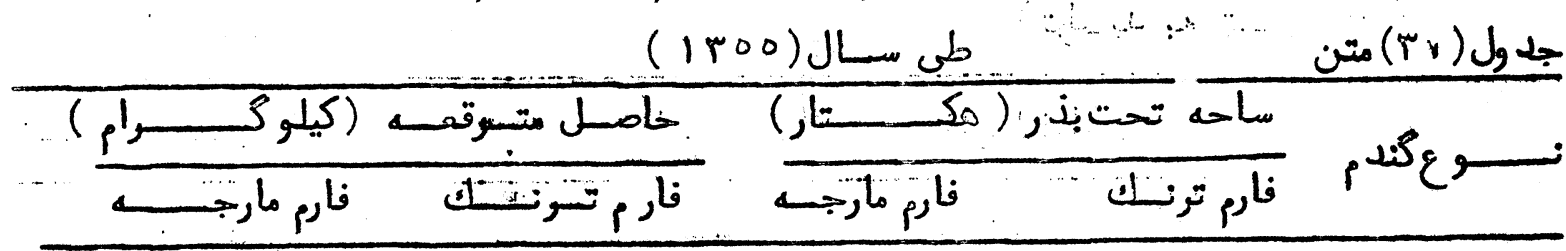

\begin{tabular}{|c|c|c|c|c|}
\hline$\therefore-$ & १я人А : & - & ro1,01 & جيسنا ب \\
\hline r $9 \varepsilon 0$. & : \&०oro. & ry, ro & $1 \leqslant r, \lambda$ & باخــــر \\
\hline & rrq? & - & $119,7 \varepsilon$ & هنده هزار \\
\hline $1110 \ldots$ & roroo. & Tr, & $|r \varepsilon,| \cdot$ & مكسي \\
\hline$\varepsilon \cdots 90$. & $r .977 \ldots$ & $|\varepsilon| ر \mid \varepsilon$ & YrA & \\
\hline
\end{tabular}

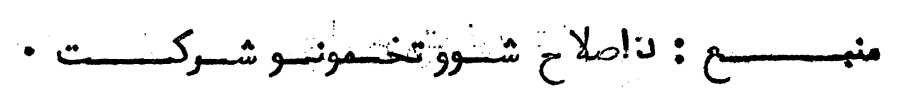

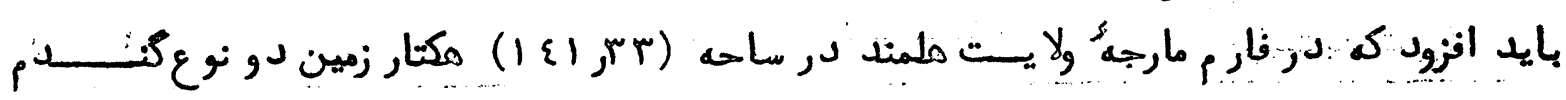

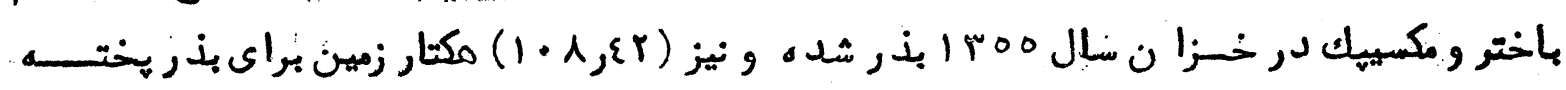

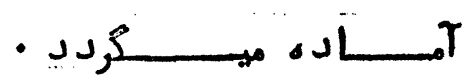

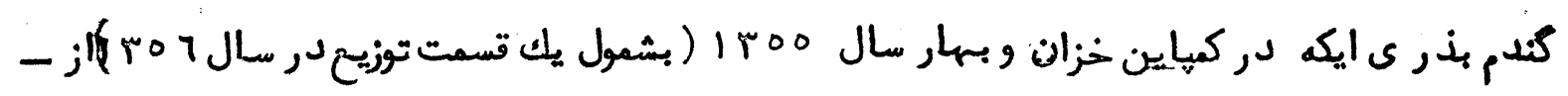

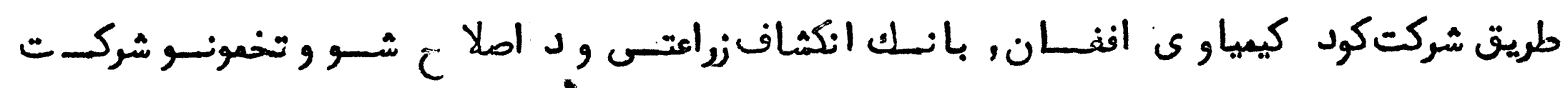

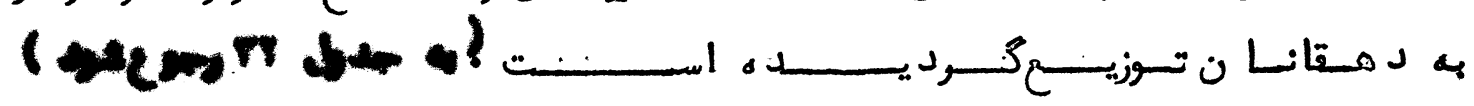




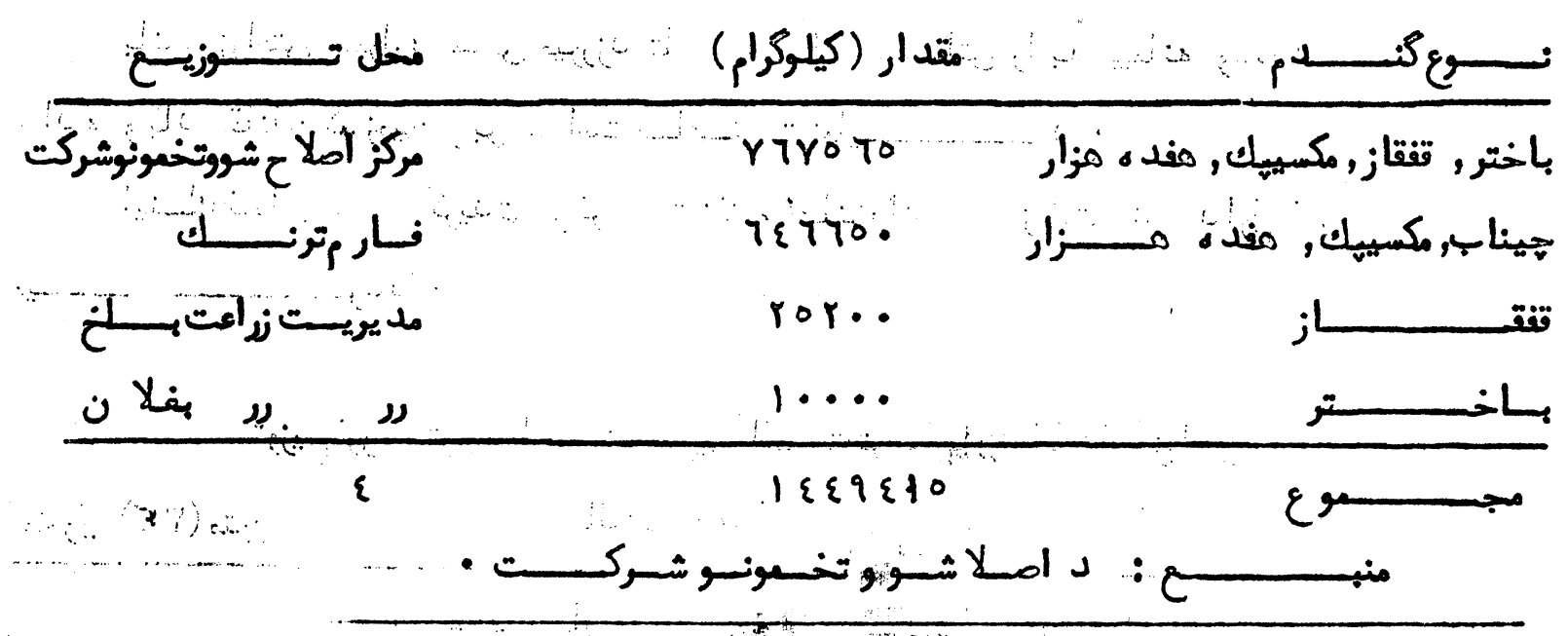

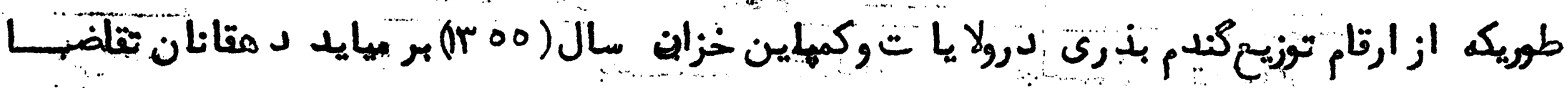

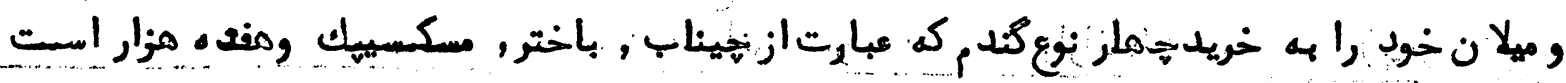

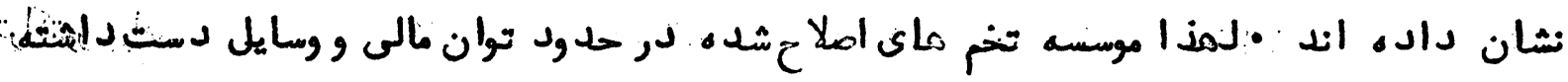

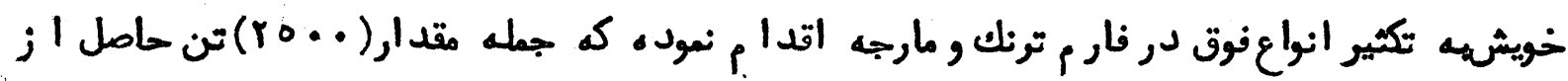

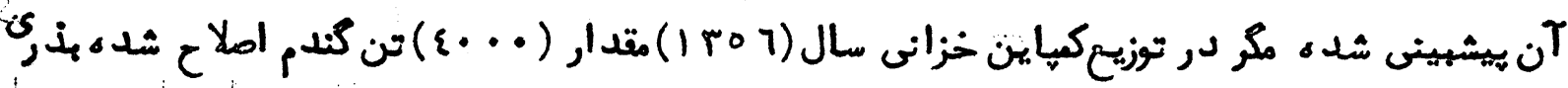

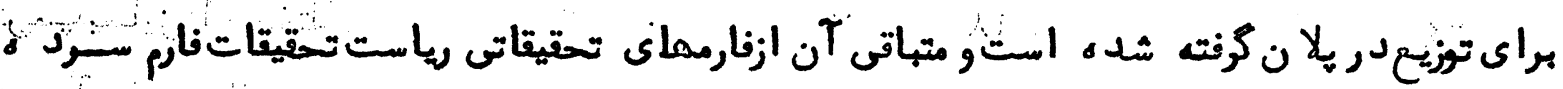

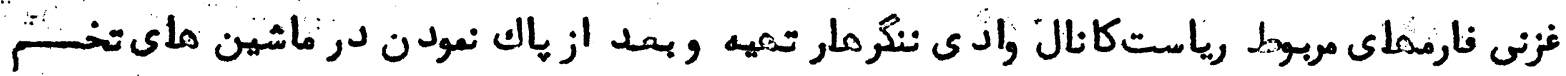

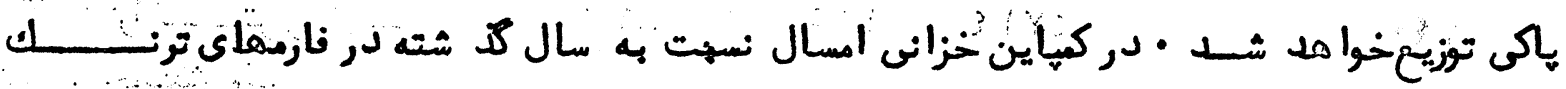

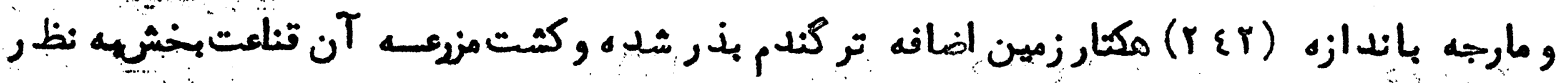

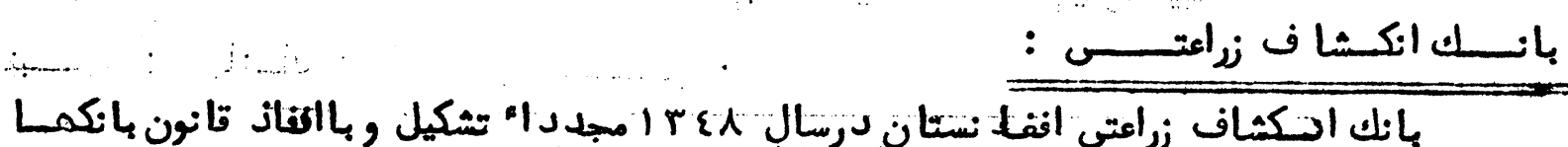

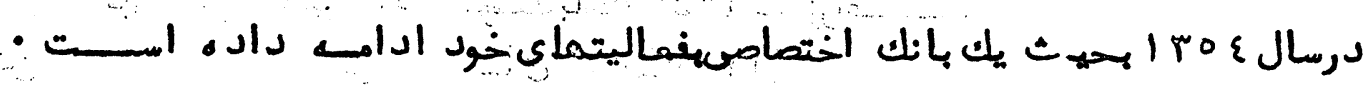

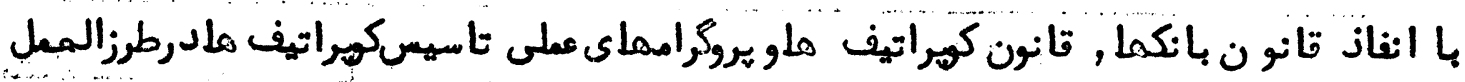

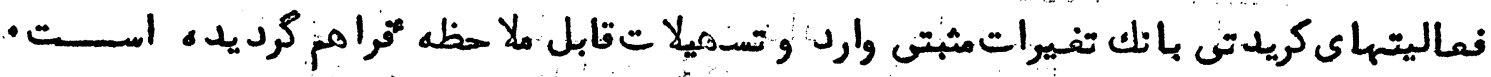

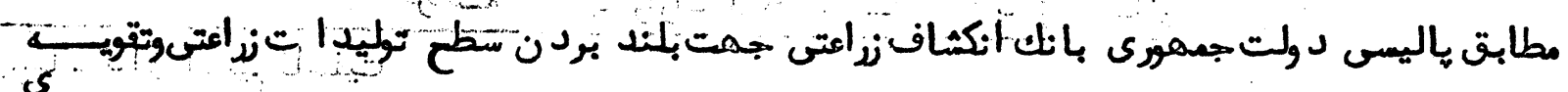

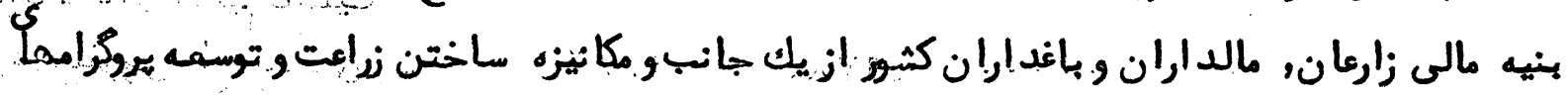

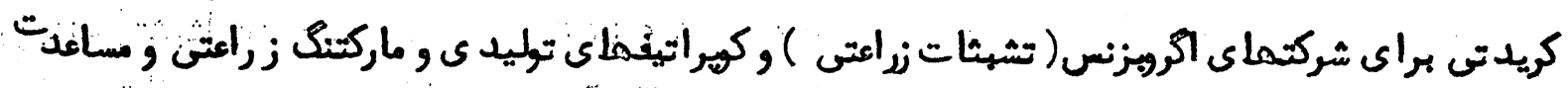

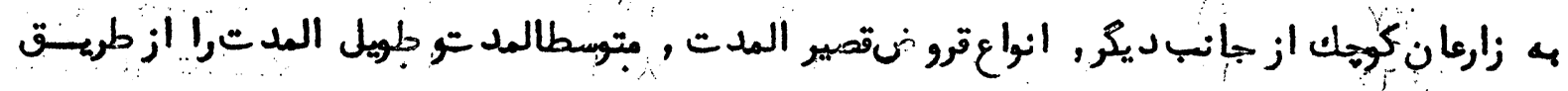

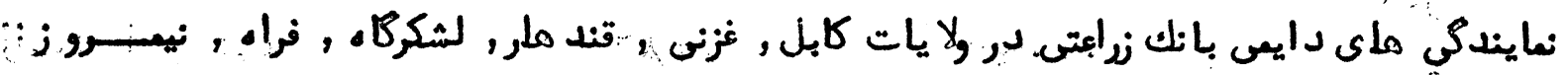

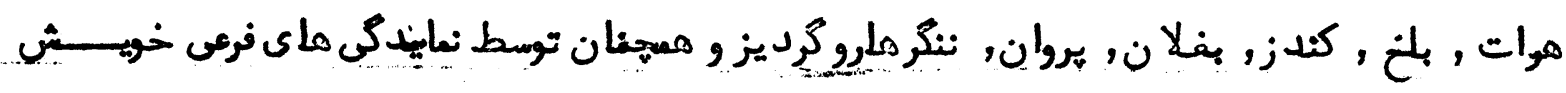

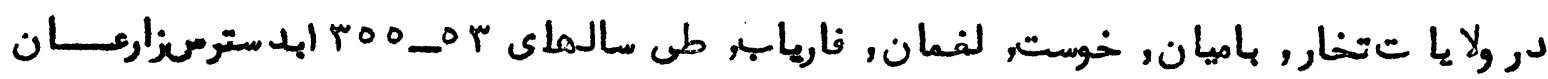




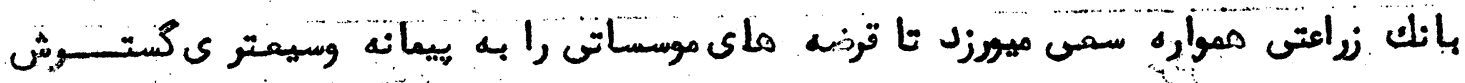

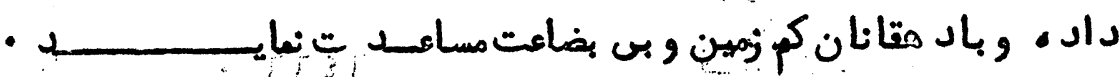

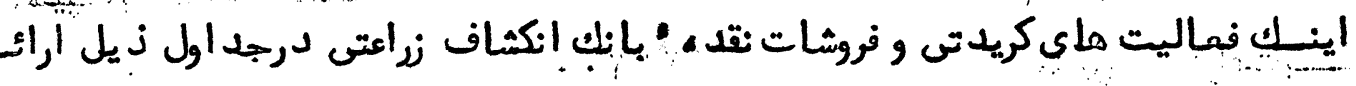

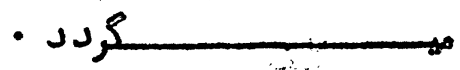
توزيح تروختوسط المدت و طويل المدث توسط بانك انكثاف زراعتى

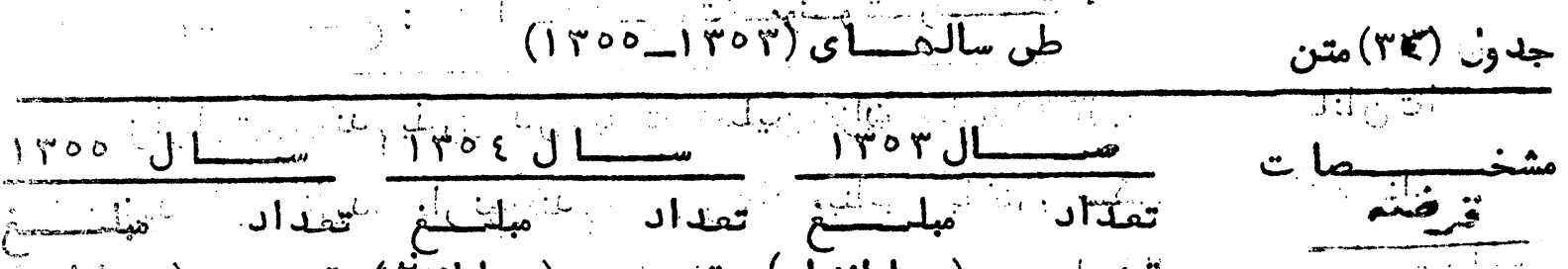

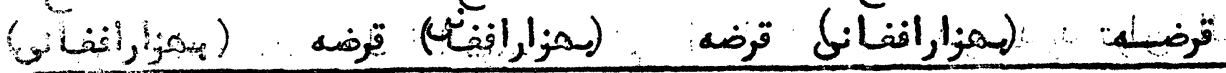

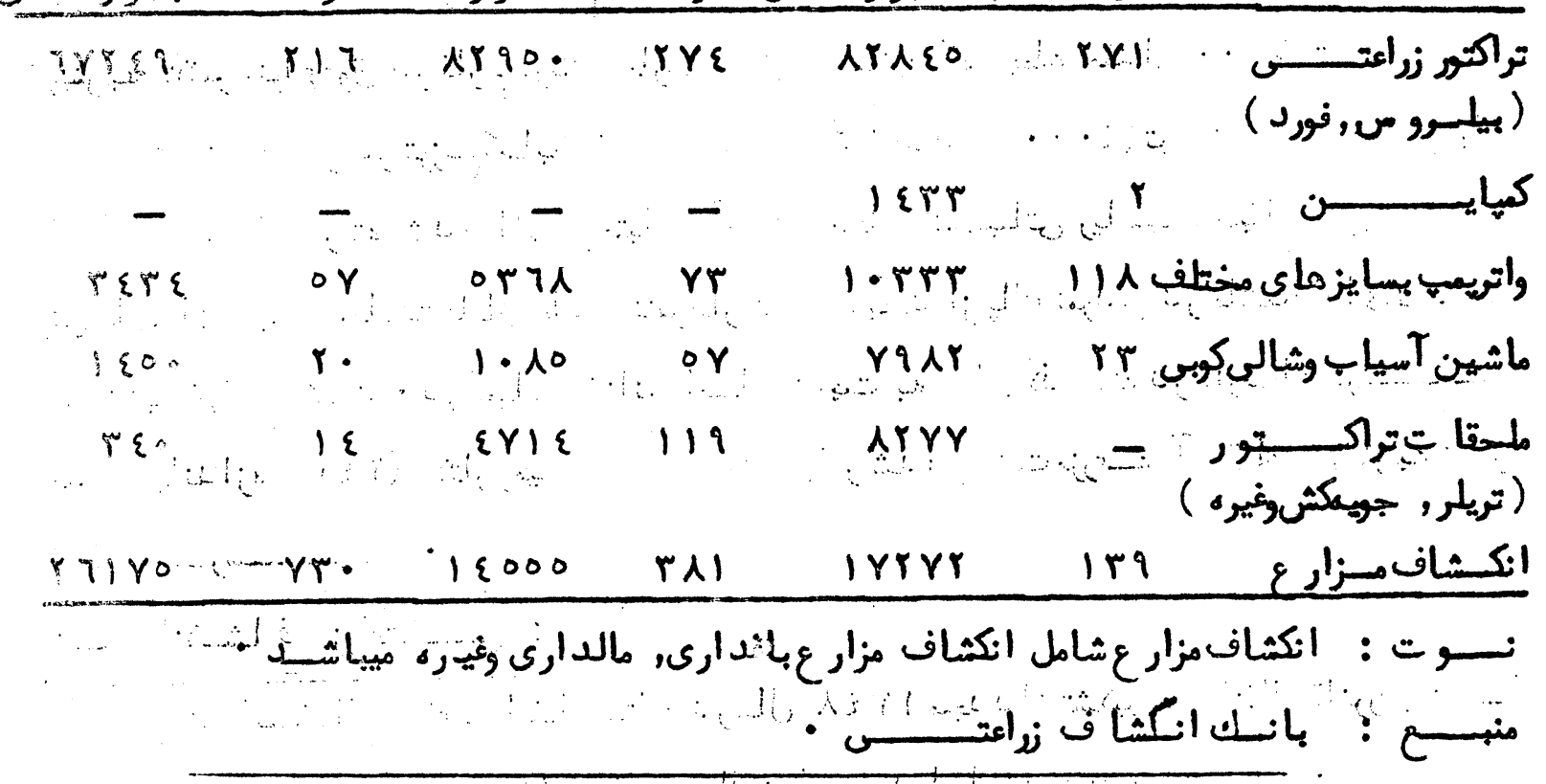

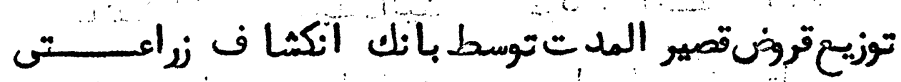

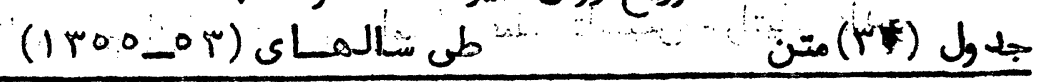

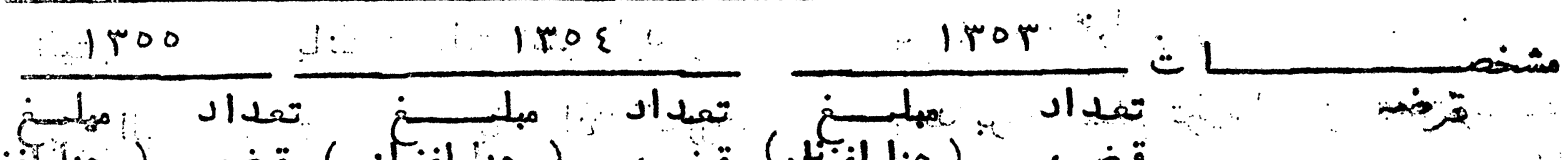

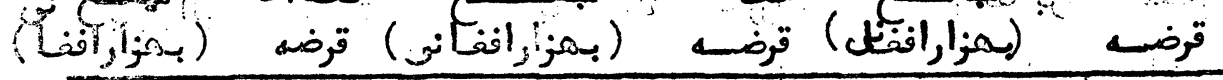

\begin{tabular}{|c|c|c|c|c|c|}
\hline$=010 M \beta \wedge \varepsilon$ & OY\&YO & $\varepsilon \cdots \cdots$ & $\varepsilon>\curlyvee \wedge \varepsilon$ & 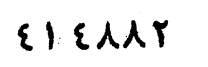 & 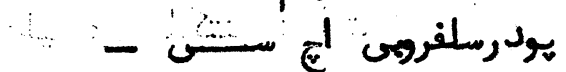 \\
\hline $17 \varepsilon 70$ & $\gamma$ & $\curlywedge \varepsilon \wedge \curlywedge Y$ & $r r$ & $r \varepsilon 7 r r$ & \\
\hline YrYIY,Y & $\varepsilon r$ & oqur & $r 7$ & rotr & 19 \\
\hline $\mathcal{M} M \varepsilon, \varepsilon 70$ & 19. & ligy & $1 \varepsilon$ & $\lambda \cdot 1 \varepsilon$ & $1 \cdot$ \\
\hline & - & $1 \cdot \varepsilon \cdot \varepsilon \gamma$ & - & rrATrA & 0 \\
\hline
\end{tabular}




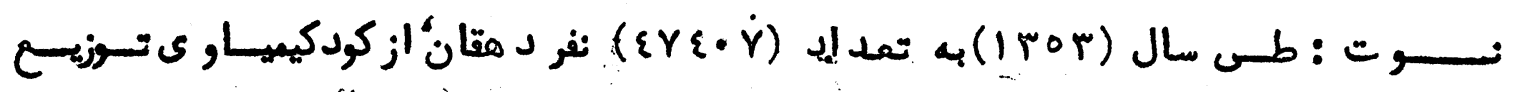

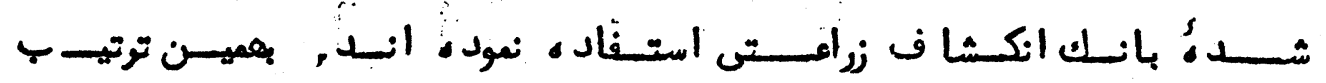

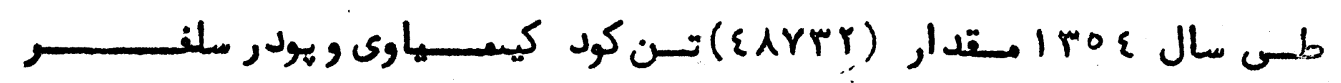

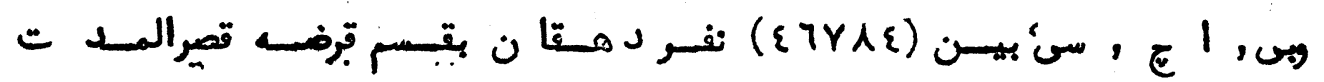

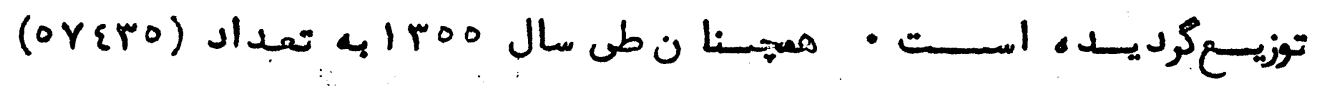

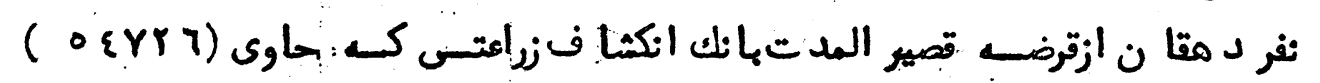

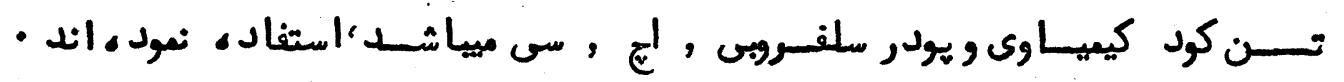

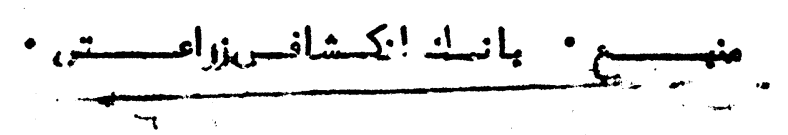

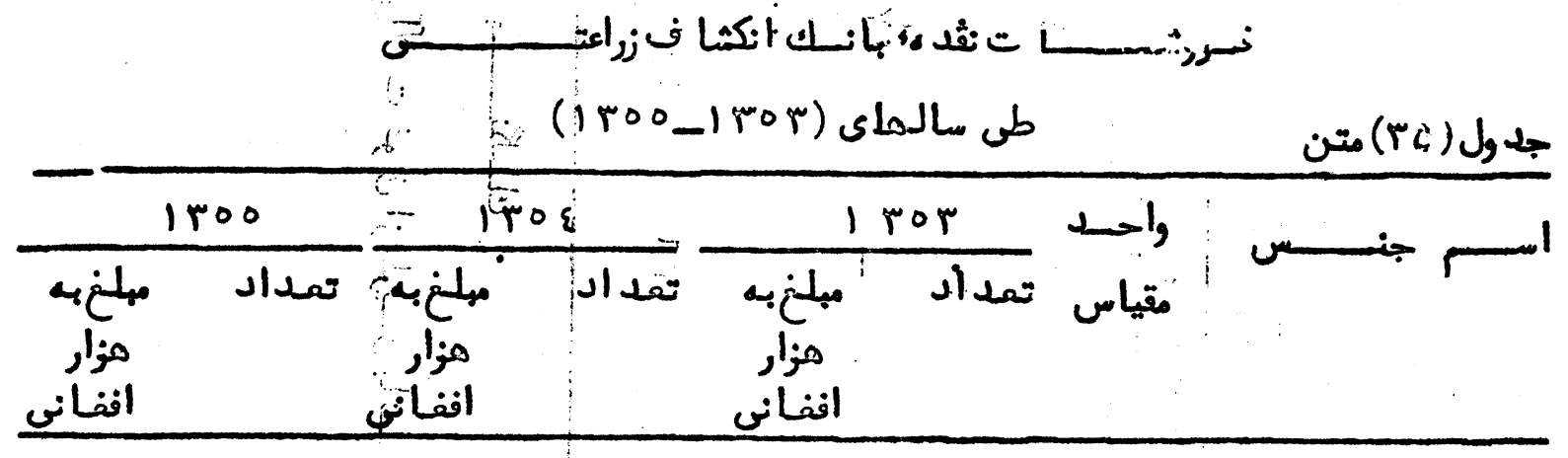

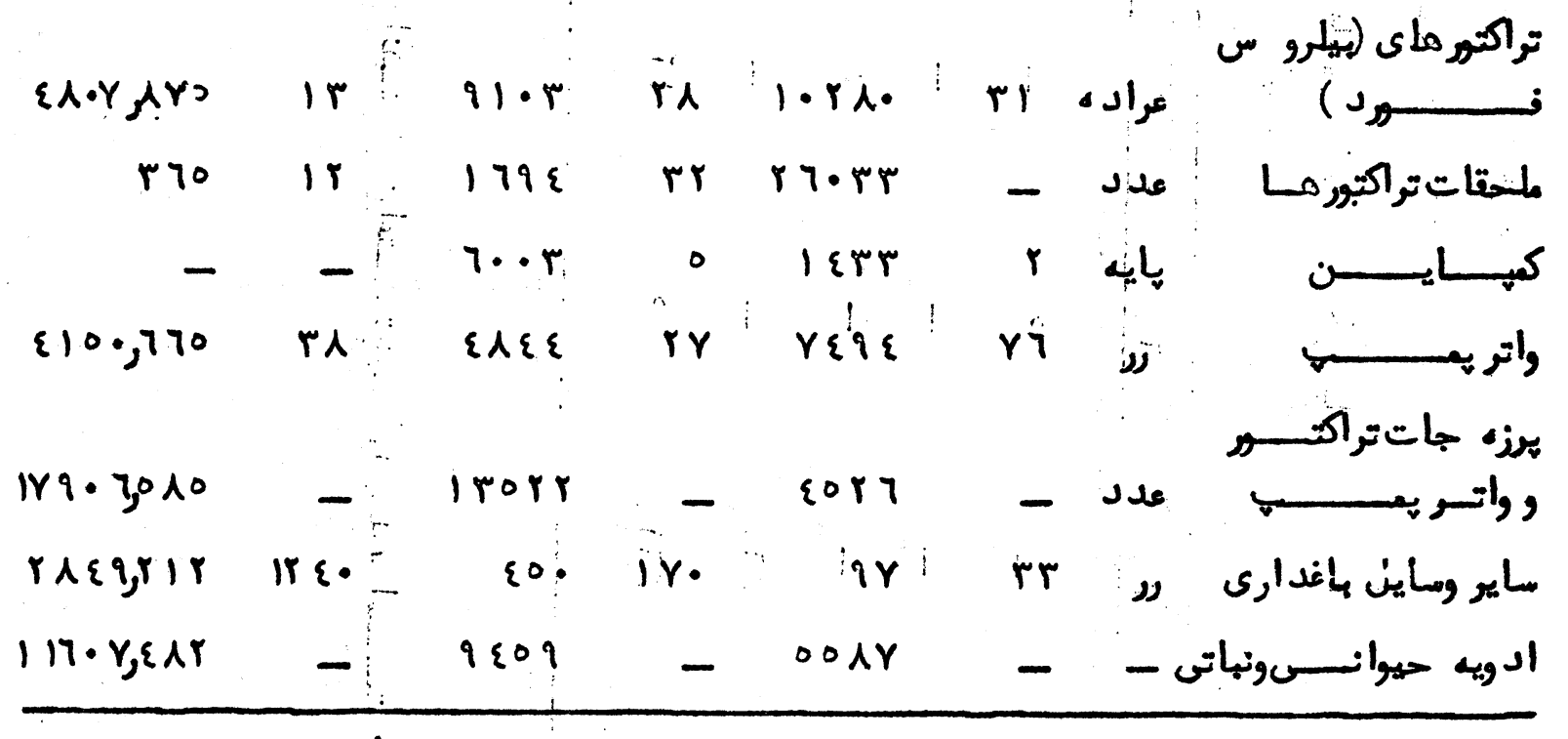

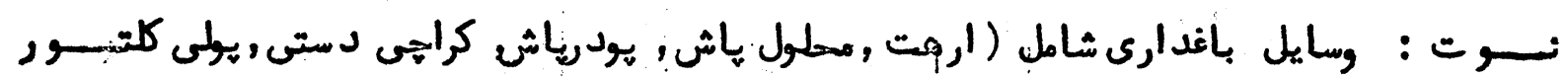

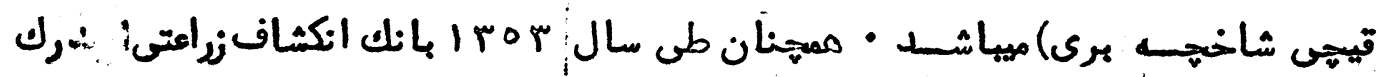

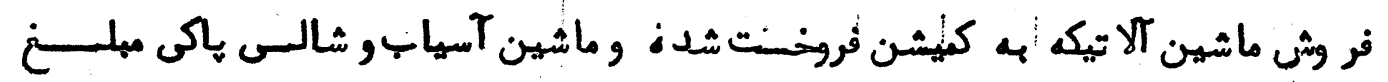

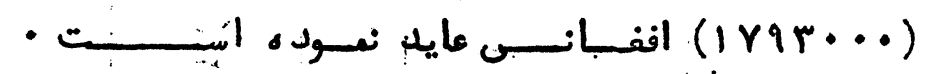




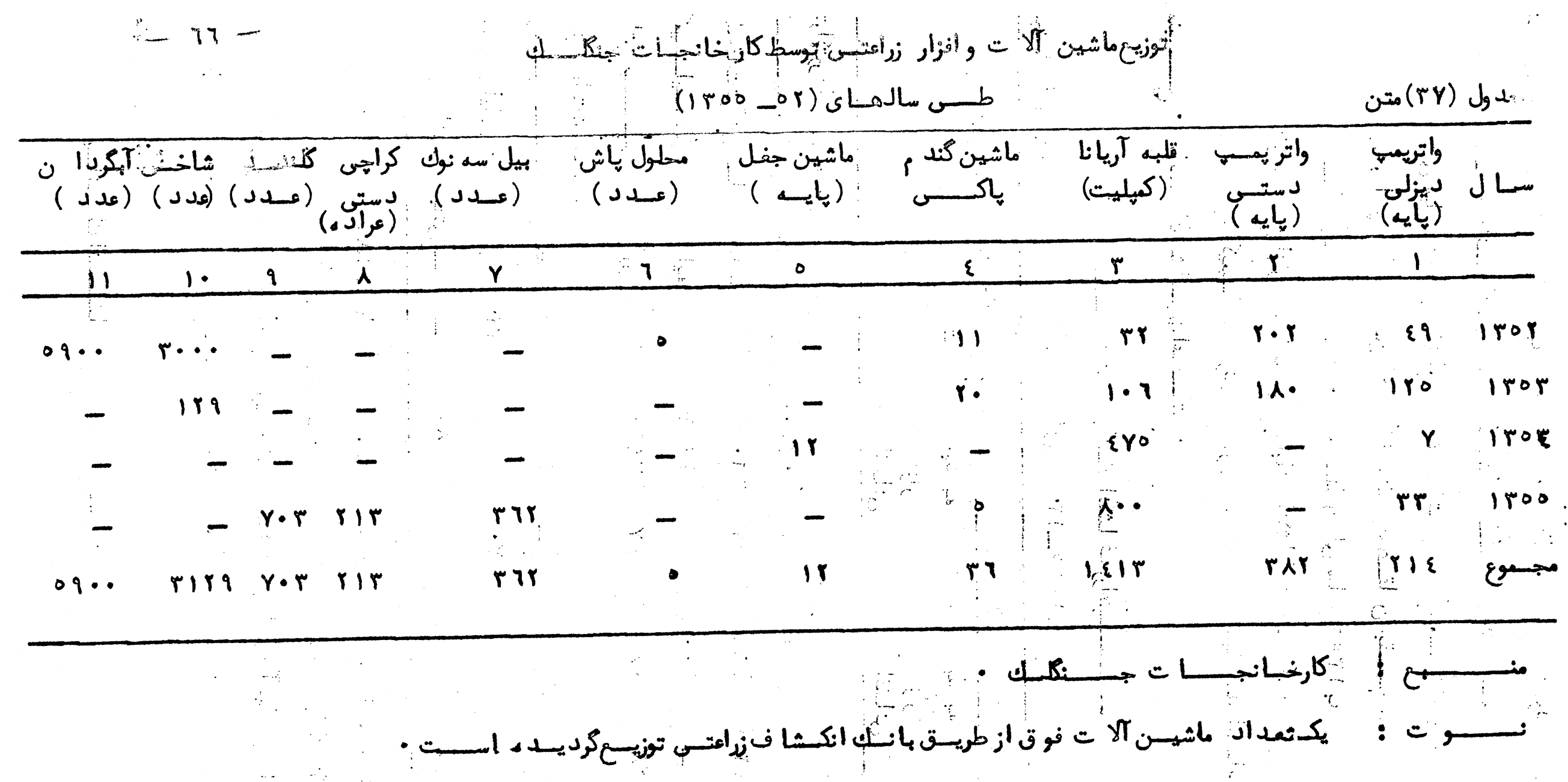




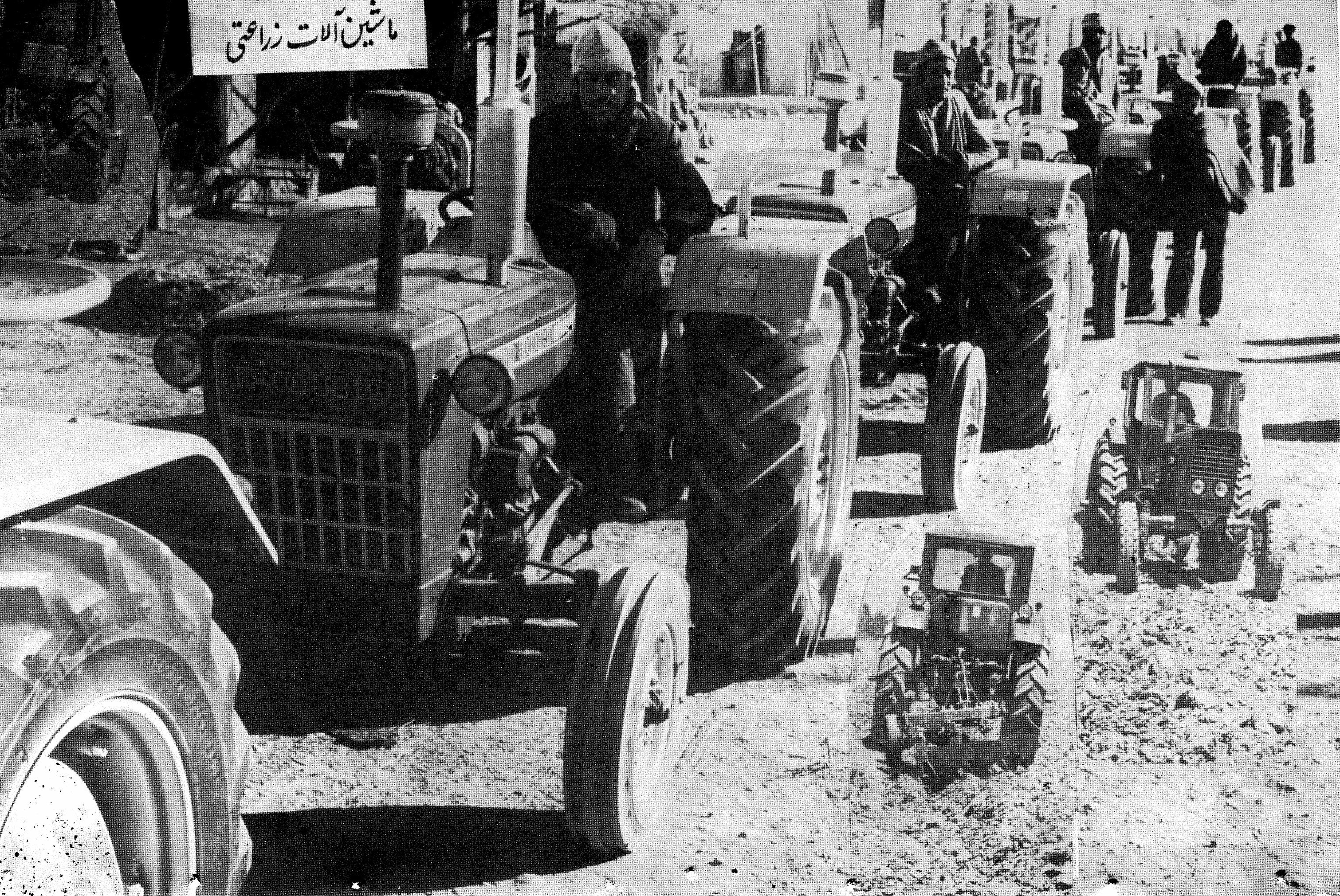


دولت جمهودى الغنا نستـانعلى الرغم مشعلات موجوده، ازنكاه

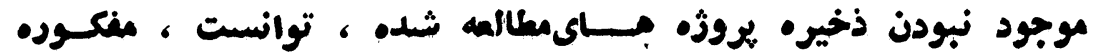

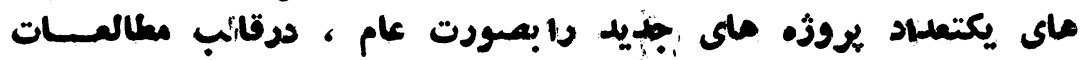

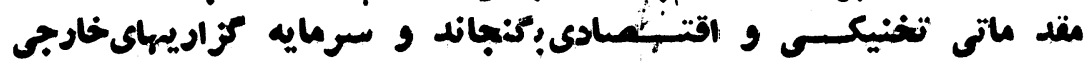

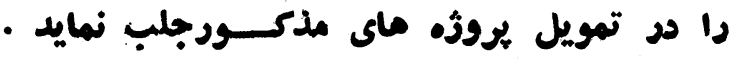

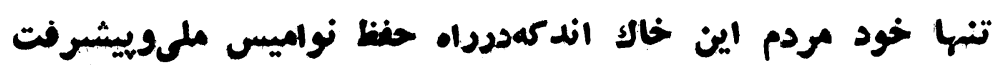

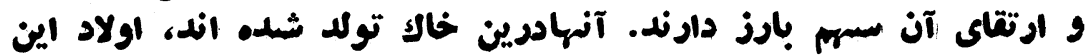

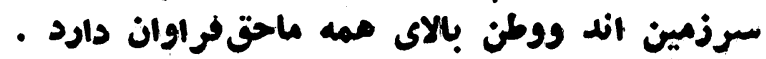

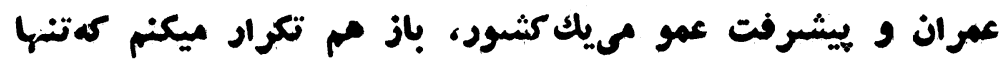

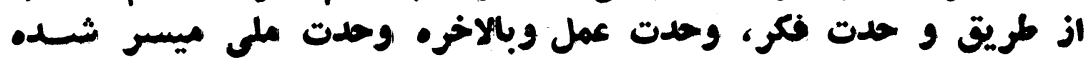

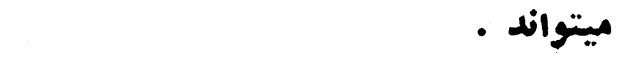

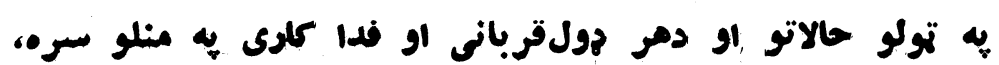

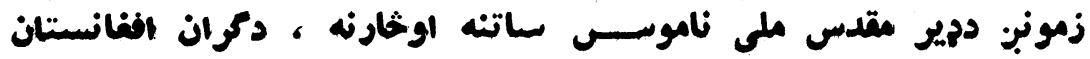

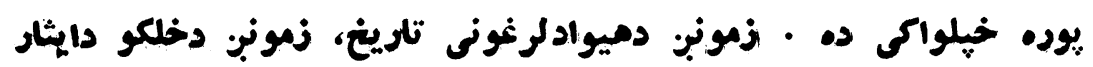

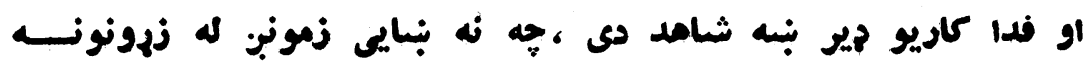

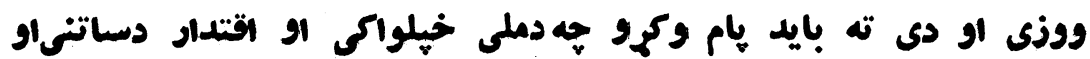

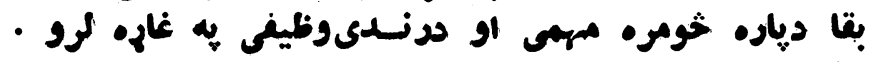

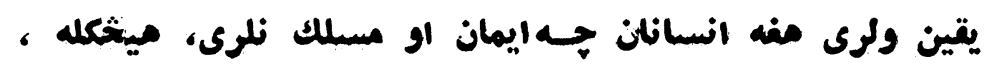

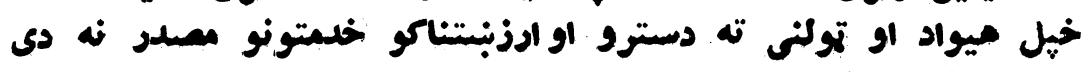

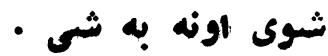

شنصى كه به بيشرفت وطنوبهبود حال مردم خود علاقه دارد،

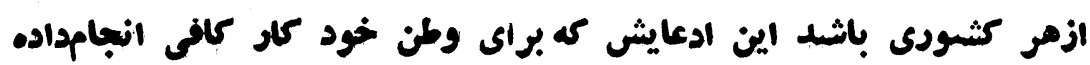

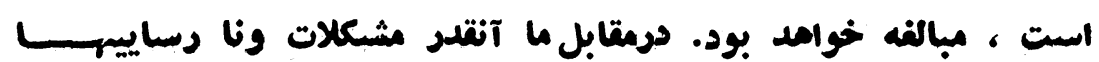

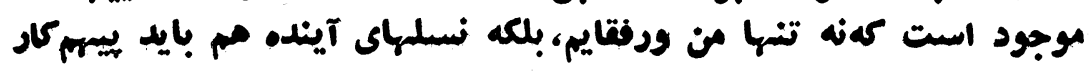

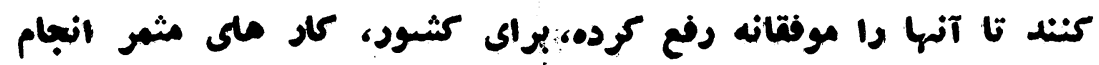
(منتخبى از بيانات رمبر انتلاب

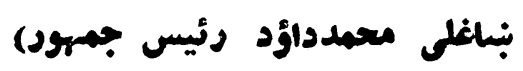




\begin{tabular}{|c|c|c|c|c|c|c|c|}
\hline \multicolumn{2}{|c|}{ مجس } & \multicolumn{2}{|c|}{ اشخـا منانفرادى } & \multicolumn{2}{|c|}{ 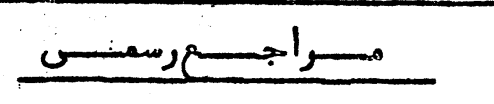 } & \multirow{2}{*}{ واحه مقيا س } & \multirow{2}{*}{ نوع مابشن آل ت وافزار } \\
\hline 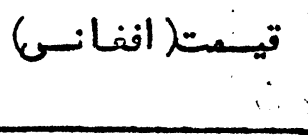 & تسمعاد & تيمتفى واجيدا & تسمداد & قيمتفى واحسـا & تمداد & & \\
\hline$\frac{\hat{A}}{\operatorname{rig00}}$ & $\frac{v}{r r}$ & $\frac{4}{r \cdots}$ & $\frac{0}{7}$ & $\frac{k}{710}$ & $\frac{r}{r y}$ & $\frac{r}{L}$ & 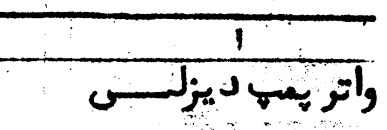 \\
\hline$\varepsilon 7 \ldots \ldots$ & $\lambda \cdot$ & - & - & oro. & $1 \therefore$ & كهيليت & تلبــ T \\
\hline rryo.. & $\therefore$ & yor.? & $r$ & yor.. & $r$ & يايسـ & ماشهن كندم هاكسى \\
\hline $7 \cdot\{0 \varepsilon$ & rir & - & - & 178 & $r i r$ & عندد & يذـل سه نسـوك ك \\
\hline 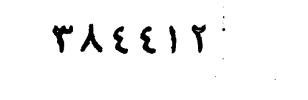 & rir & $1 \lambda \cdot \varepsilon, Y_{0}$ & $\xi$ & $11 \cdot \varepsilon, \gamma_{0}$ & $r \cdot q$ & 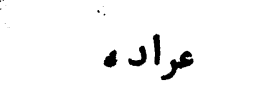 & كراجسى دستسـ \\
\hline $1 \varepsilon \cdot 7 \cdot$ & $r \cdots$ & - & - & $r$ & $Y \cdot r$ & عـداد. & كنسـد دو سـ:ــره \\
\hline
\end{tabular}

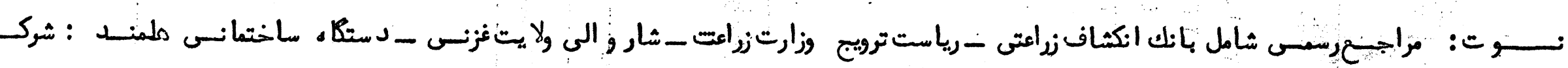

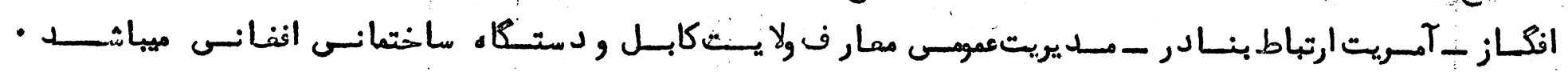

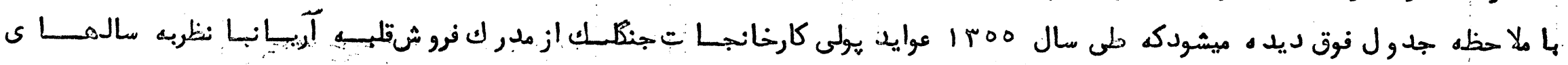

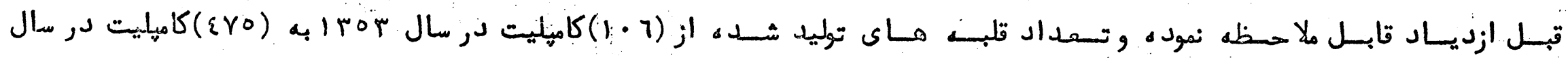

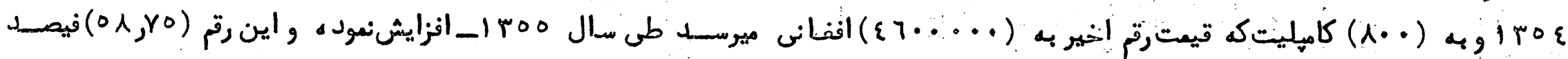

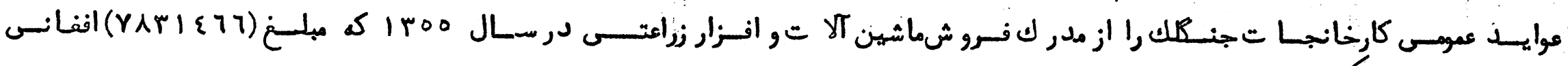

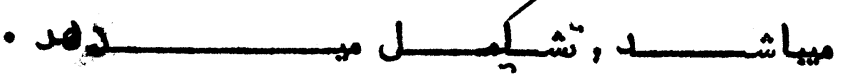




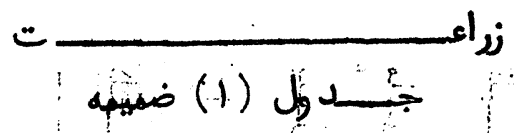

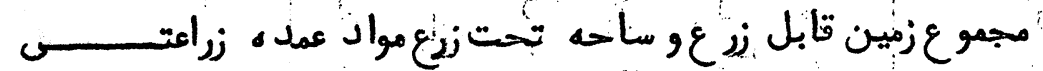

(ارقام به هزار هكtار)

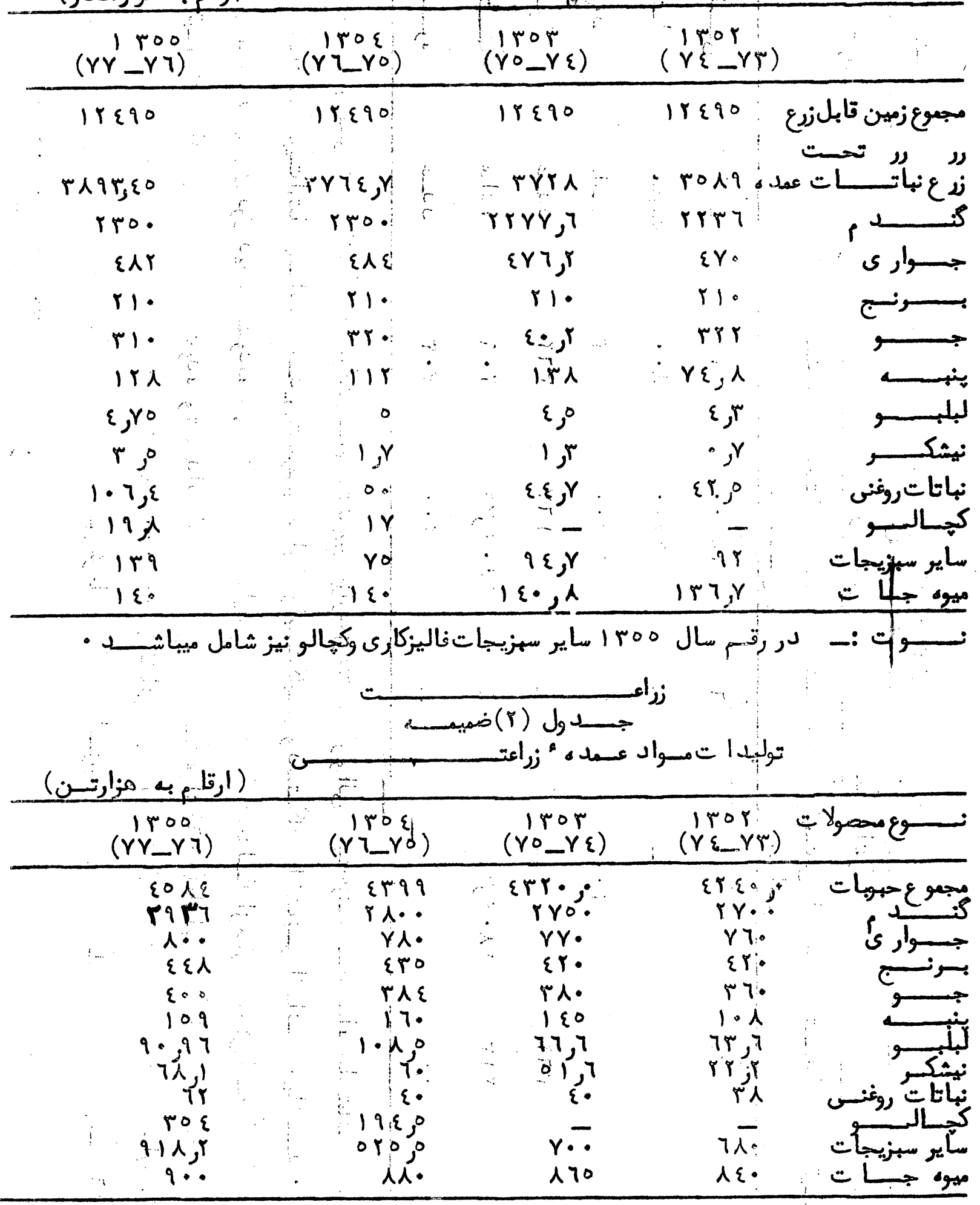




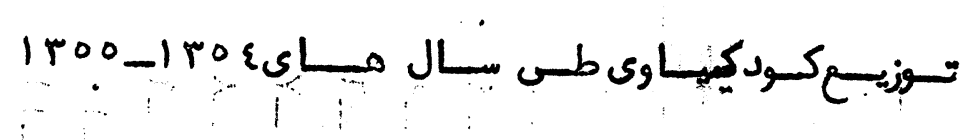

(مزإِتهـن

جل ول ضعيمه (r)

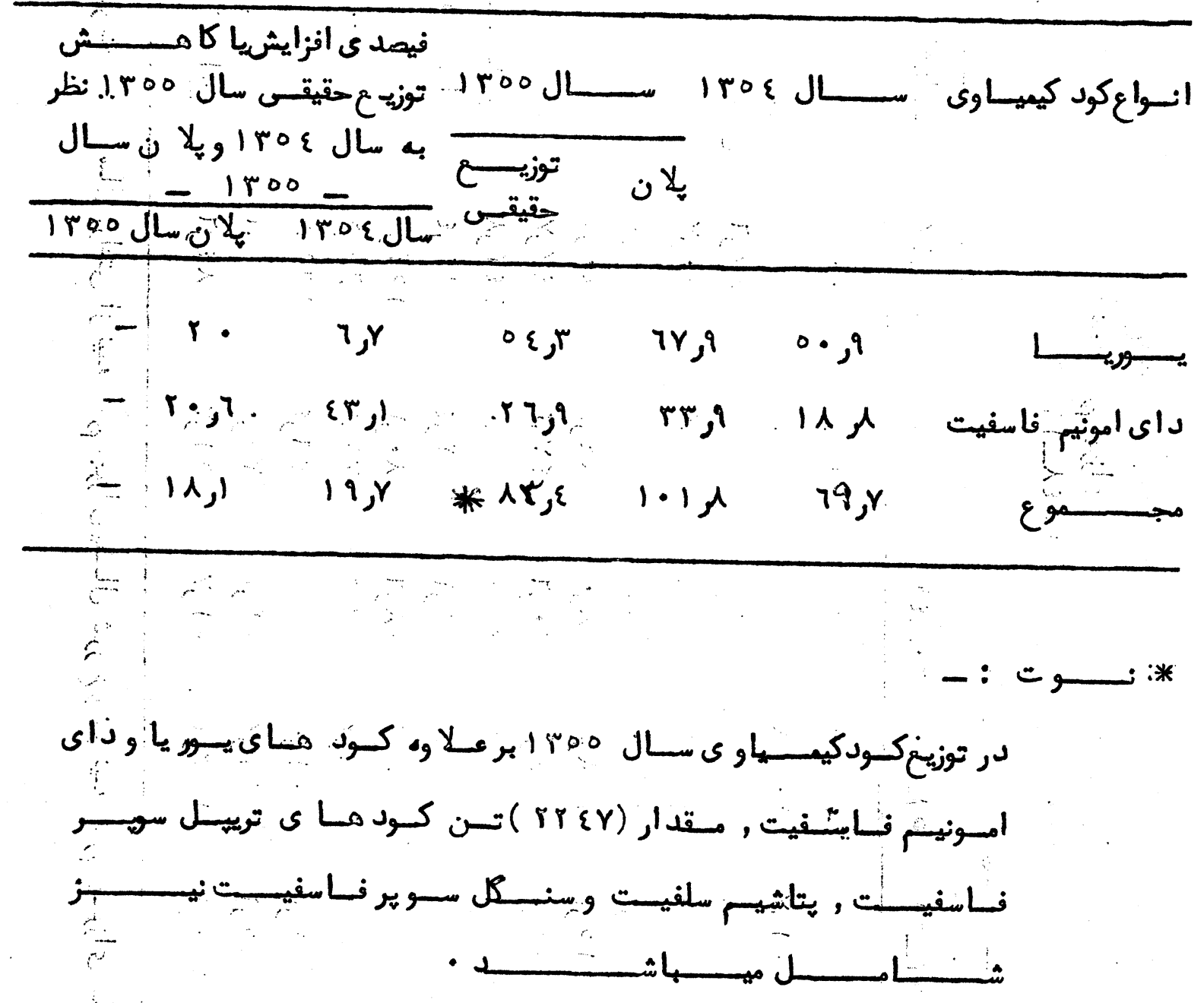

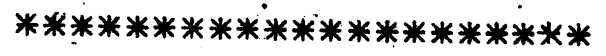

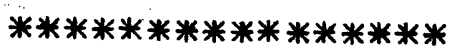

米米米米米

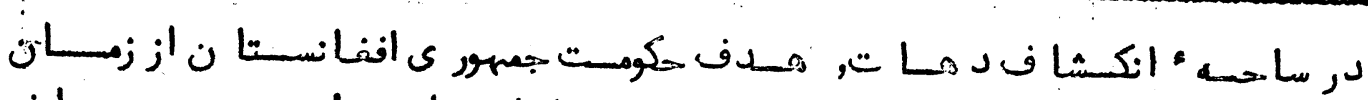

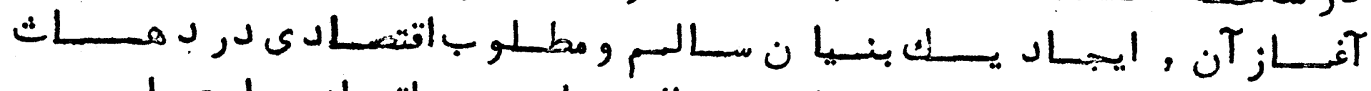

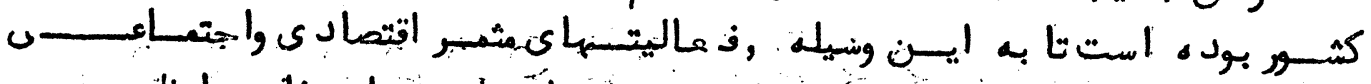

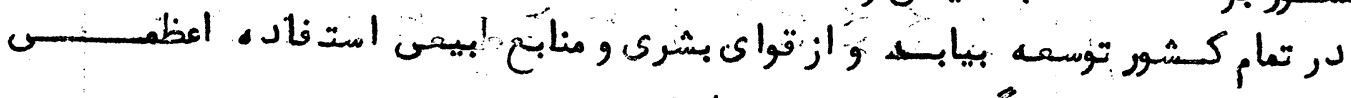

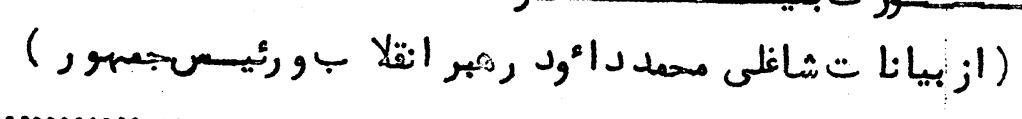




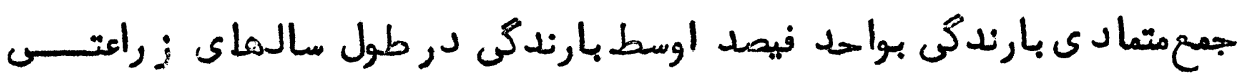

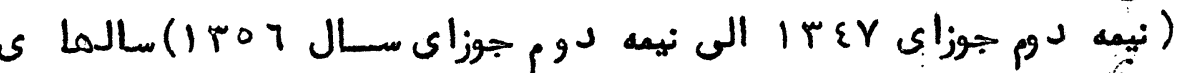

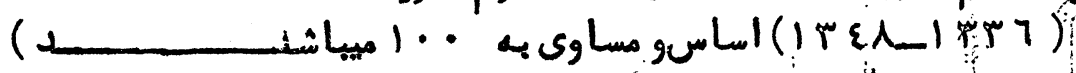

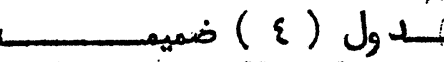

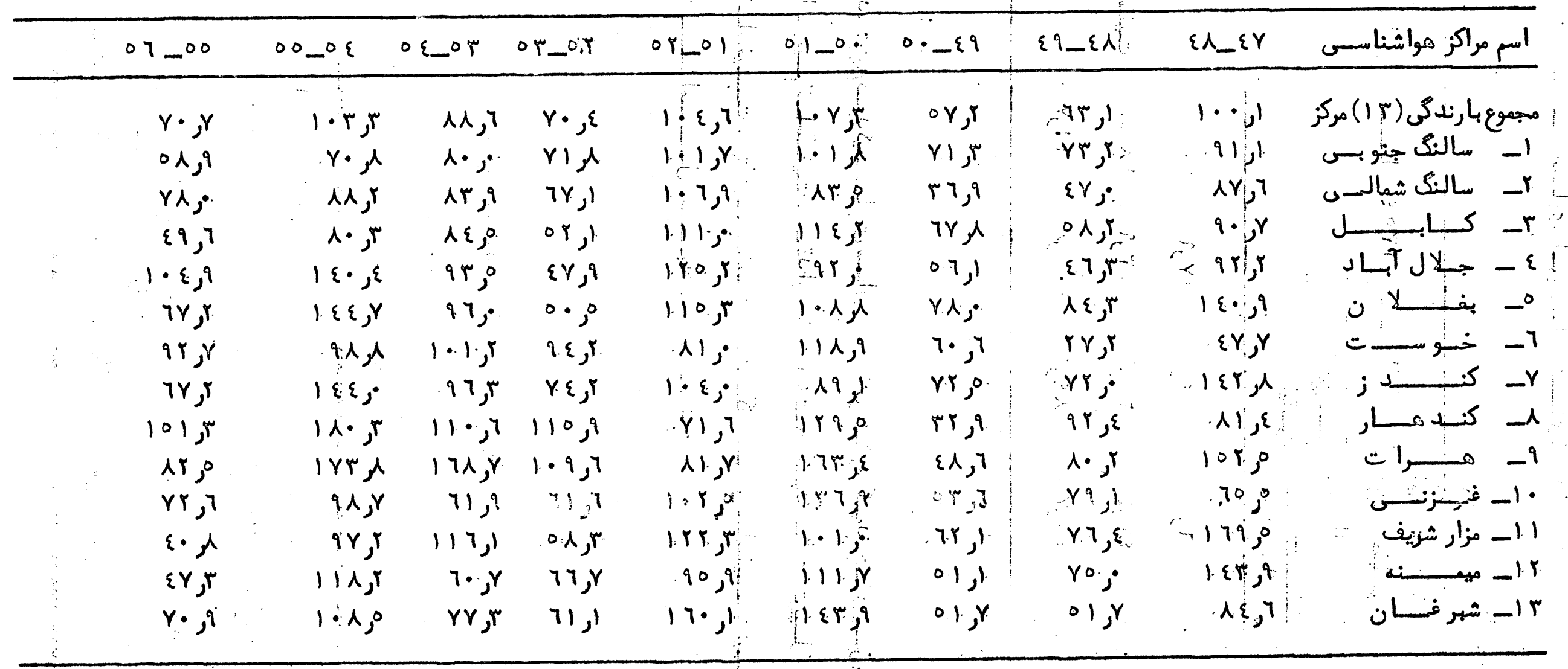

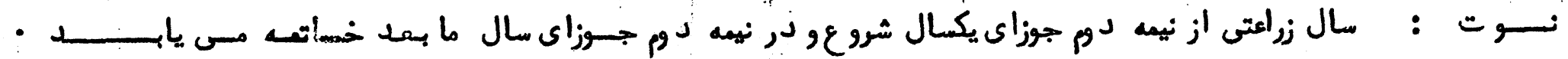




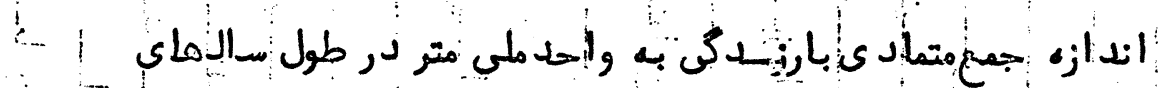

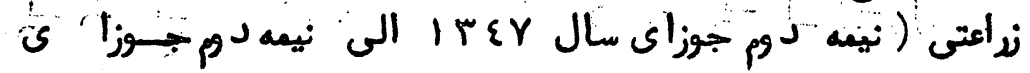

( ) ror

\begin{tabular}{|c|c|c|c|c|c|c|c|c|c|c|}
\hline 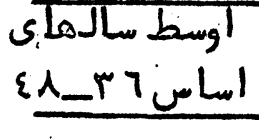 & 07 1_0 & $00-0 \varepsilon$ & $\{\circ\{\circ \%$ & ortor & or - 01 & $01-0$. & $0 \cdot-\varepsilon q$ & 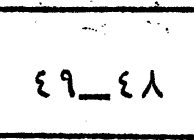 & $\varepsilon \mathcal{L}\{Y$ & اسم مراكز مواشناسي \\
\hline $0\{10, Y$ & r r r r & $0.7 \because 1$ & $\{\wedge \cdots, ?$ & rẹpr & ب. & 0 & $r ! \cdots, 0$ & ؟ $210,0$. & $0\{r:\{\}$ & هوع بارندكى (r 1 ) مركز \\
\hline$\{1.7, \tau$ & $T q \varepsilon ; Y$ & $\varepsilon r:, Y$ & $r 79, r$ & $r q r, r$ & $\{r o\}$, & $\varepsilon\{r\}$, & $r r i, 0$ & $r i r$ & $\varepsilon \mid \gamma$, & اوسط بارند3 \\
\hline $11 \varepsilon \gamma, \tau$ & r & $11 \%, r$ & 918,9 & AT $\varepsilon$ & $117 Y, 0$ & $11.71,0$ & 入少 & $\lambda \varepsilon \cdot r$ & $1 \cdot \varepsilon 0,9$ & 1- سالنك جنوبــى \\
\hline $11 r 1, y$ & ANT, & 999,1 & $9 \varepsilon q, q$ & $Y \circ 9,9$ & $17 \cdot 9,0$ & $9 \varepsilon 0 ;$ & हार, & Ors, & 991,1 & سُالنك شمالـــــ \\
\hline$r \varepsilon \cdot \varepsilon, 1$. & $L Y \cdot, T$ & Yrr, & $r q \cdot s ?$ & $111 \% 0$ & $\cdot r+1, \lambda$ & rar.ג & r. & · $r \cdots$, & 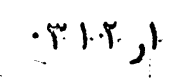 & r r \\
\hline 197,7 & $r \cdot 7, r$ & rY & 9 & $i \varepsilon \cdot r$ & $r \varepsilon\}, r$ & $r \lambda \cdot j$ & r & $91 ;$ & 111,5 & ع- بلهال آبــــــاد \\
\hline$r \cdot \lambda, l$ & $r \cdot v_{j}$ & $\{\varepsilon\}$, & $r 90, Y$ & $100, y$ & roo, & Troj r & $r \xi \cdot r$ & rog & $\varepsilon r \varepsilon, !$ & ن \\
\hline$\varepsilon 0 \mid \lambda$ & $\{1 \wedge, q$ & $\{\varepsilon\rceil, \gamma$ & $\varepsilon \circ \gamma, r$ & $\{Y 0,0$ & rrr, & orrs & TYr,Y & Irr. & $r 10, r$ & $=-1$ \\
\hline$r 19,8$ & Y) & . & $r \cdot Y, Y$ & $r r 7,9$ & بر بrrr & $r \wedge \varepsilon, 0$ & $r r 1.0$ & ? & $\{0.7$, & كيــ \\
\hline $1 \varepsilon \dot{y} y$ & $r \cdot Y, \varepsilon$ & $r 09,5$ & 101,9 & 177,7 & $10.5,9$ & $|\wedge 7|$, & $\varepsilon r, r$ & 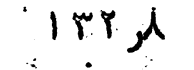 & 118, & كند هــــــار \\
\hline$r r \cdot \theta$ & $119, y$ & $r 99,9$ & rik, & ror, & I $1 \mathrm{kr}$ & ryojq & A & $\mid i \varepsilon s$ & ro: & -9 - هـــــــــــ \\
\hline rris & rrr, & $r \mid Y, 1$ & $191, y$ & 198,7 & $r r q, 1$ & $\varepsilon r q\rceil$, & ivrs & q & $r \cdot j$ & • إ_ غبيزت \\
\hline ra. & 109.1 & \&Tr & TrY, & r(7l. & $r y o, q$ & $\{r Y, \xi$ & $r \cdot \because r$ & צو & . & -11 \\
\hline 9 & $99, \gamma$ & - $T \cdot 0, T$ & $r \xi \varepsilon, \hat{C}$ & Irrs & T०Y & rirs. & $1+19$ & إر & $r \circ Y, \varepsilon$ & 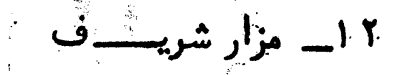 \\
\hline$r$ & $100, \varepsilon$ & rrij, & 179,7 & هورrris & T. & r10,0 & 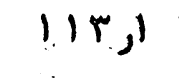 & r & $-110,7$ & 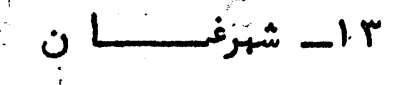 \\
\hline
\end{tabular}

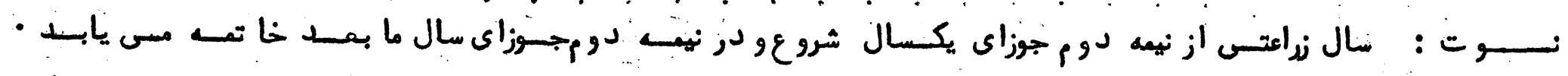




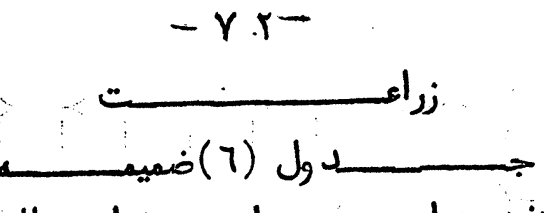

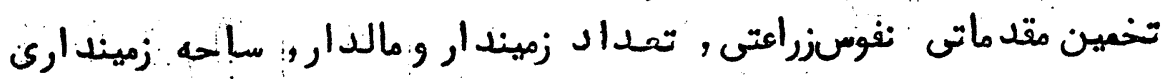

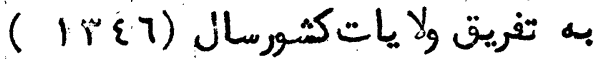

\begin{tabular}{|c|c|c|c|c|c|c|}
\hline نويب ) & بـــد ارك & ساحسـُ & تـعـداد زه & & قـــراء & \\
\hline مجن..ــموع & للمســـ & Tبسى & & & & \\
\hline$Y$ & 7 & 0 & $\varepsilon$ & $r$ & r & 1 \\
\hline T० \&? \&. & riar. & 7rYq & १ะ१०. & Pフ11\%. & $\varepsilon 00$ & 3j, \\
\hline$Y Y \cdot 0 .$. & $7 \cdot r q \wedge \cdot$ & $1770 \%$ & r人rl. & Y90Y7. & ro. 7 & \\
\hline $1 \leqslant 90 \varepsilon$ & rryo. & 11089. & $r r_{1} \ldots$ & $r \wedge 0 \cdot \varepsilon \cdot$ & r 10 & \\
\hline $9=97 \%$ & $7 \cdots 1 \cdot \cdots$ & $r \cdot \lambda \Lambda \cdot \cdot$ & OY.人• & rqArr. & $7 \cdot Y$ & \\
\hline II $\{1 \varepsilon$. & $Y \varepsilon \wedge Y O^{\circ}$ & $\varepsilon \cdots \wedge \uparrow$. & \&Y०\&०: & 27791. & rᄉr & \\
\hline $10709 \%$ & $\varepsilon \varepsilon r \varepsilon r$. & M Rro.. & \&१人०. & $r \gamma \ldots$ & $r 7 \varepsilon$ & \\
\hline Y\{พไ\}. & 7897. & IVOY & Trr.. & \& PrYr. & $r \xi 0$ & \\
\hline$\varepsilon \Uparrow \wedge \circ \varepsilon$. & $107 \lambda .2$ & rA|V*. & $Y q \varepsilon \cdots$ & $\gamma \cdot \varepsilon 77^{\circ}$ & $1 \cdot r y$ & \\
\hline$M=v o$. & $|\varepsilon q| \varepsilon \wedge . \cdots$ & $r \cdot q r \gamma$. & $\varepsilon \cdot r \cdot \ldots$ & rrtrre & 719 & \\
\hline I\&IIYY. & : ₹१人Yץ. & $q r r \ldots$ & $\{110$. & $r q .07$. & $\varepsilon \varepsilon \curlywedge$ & \\
\hline$\varepsilon \circ \varepsilon \varepsilon 7$. & १|Yᄉ. & rride & 198.6 & iryro. & $70 r$ & \\
\hline $901 \div 1$. & vri7l. & TrIV.. & $\varepsilon \gamma \cdot 1 \cdot$ & STr|o. & r 71 & سمنك \\
\hline ᄉ\&i人o. & ro१ะ०. & 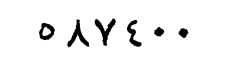 & $70 \lambda r$. & $Y \varepsilon \cdot r l \cdot$ & $r \cdot r q$ & غزنس \\
\hline 107.9. & $\varepsilon, 9 \mid 10$ & $r\rceil \varepsilon r \varepsilon \cdot$ & $r q \cdot r \cdot$ & rIYrA. & 19r & \\
\hline lo Yrr:. & $97 \varepsilon Y \%$ & $7 \cdot \lambda \cdot r \cdot$ & $\varepsilon \neg 9 \varepsilon$. & $\{10\{0$. & $\{07$ & ناريـ \\
\hline$r\{17 r$. & $\|$ ) & $7 r<70$. & rหr. & rq. ro. & $\{Y\urcorner$ & \\
\hline rr人rq. & $0 \cdot r ! \cdot$ & rᄉYqA. & $\varepsilon \circ \varepsilon r$. & $\operatorname{Trq1}$ & rᄉ\& & كابـ \\
\hline$r \cdot r 1 . q$ & $r \varepsilon \dot{\imath}$ & 19981. & 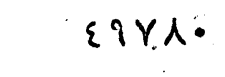 & $\{7 \cdot 1\}$. & rᄉl. & $(1) \cdot L$ \\
\hline $1 \varepsilon \vee 70^{\circ}$. & \&r人०Y. & 1. EYqr. & OY.O. & ro\&々r. & rqr & \\
\hline YNYro. & I Яชช६• & ०ค971. & 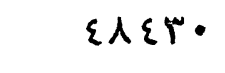 & $\circ \wedge \cdots$. & ror & \\
\hline $\mid$ Tr|₹• & $100 \%$ & $1170 \%$ & $r \cdot v \cdot \cdot$ & $r 717 r$. & 170 & كنر \\
\hline IrO\& & $\gamma 0 \ldots$ & $|189|$ & r.o. & $17191:$ & rYR & لفــــ \\
\hline ห१人ร. & ה ה & irrti. & $r \varepsilon \wedge \varepsilon$. & rrYrt. & r 70 & \\
\hline r.rr人. & 9.070. & rו rre. & YYYT. & $7 \varepsilon \cdot 9 \cdots$ & orl & \\
\hline Mrq. r. & qrYOT. & $r \cdot 10^{\prime}$ & 1101 & $119.1 \circ$ & $7 \cdot r$ & نيمســ \\
\hline Irr.h. & $q \cdot \gamma \cdot$ & $|r \hat{r} \cdot| \cdot$ & ห१६r. & r人YV\&. & INr & | \\
\hline r०. r \&ᄉ. & 1710.1. & $\wedge / \wedge \varepsilon \curlyvee$. & 9.10 & $710 \ldots$ & $1 \cdot 19$ & هــــرات \\
\hline ᄉl $\varepsilon Y i$. & $11 \ldots$ & A|ry|. & YY\&O. & roo9i. & $7 \cdot 7$ & هلمنــــــــد \\
\hline YYY६O & 1.人19rY. & $119 r 71 r \cdot$ & Irovir. & 1. ᄉrqAY. & lorre & \\
\hline-- & -- & $\quad--$ & & ro..... & - & كويتهـا \\
\hline$\Pi Y Y \varepsilon \circ \varepsilon \cdots$ & $10112 r \%$ & $119471 \%$ & $17781 \%$ & mrrq人y. & lorr. & مجموع عمومى \\
\hline
\end{tabular}

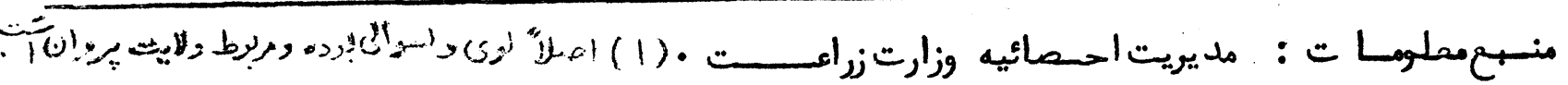




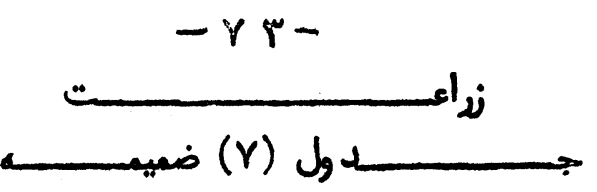

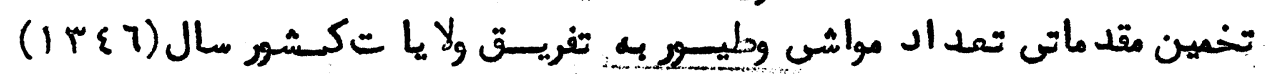

\begin{tabular}{|c|c|c|c|c|c|}
\hline \multicolumn{2}{|c|}{ 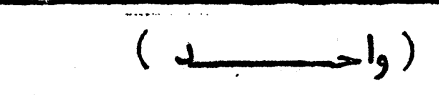 } & و طيســـ & 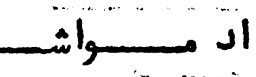 & تمهـــــ & اســ ولايكاّات \\
\hline B وميسش & 9 & ; & كوسفندقره قل & كوسفند.عات ى & \\
\hline 7 & 0 & $\varepsilon$ & $r$ & $r$ & \\
\hline & logr $\varepsilon$. & rYIEr. & - & OYATY. & \\
\hline r re. & 1.ro.. & r人T7\%. & \&YYYO. & 1 199477. & \\
\hline & $1 \varepsilon \varepsilon 07$. & $\varepsilon q \cdot \varepsilon \cdot$ & - & roorde & \\
\hline $1 \cdot 9 \cdot$ & irreo. & rorrle & riq. & ryary. & \\
\hline- & 11717. & 1人77દ. & $\therefore r \lambda \ldots$ & Tr10.. & \\
\hline & irrq. & lor \&\&. & 1r9r77. & 1. Yoo. & \\
\hline$\therefore \quad-$ & 7.91. & $r u \cdot r \cdot$ & sa - & ryile & \\
\hline 791. & $19 \cdot \varepsilon r \cdot$ & rry. & - & IEr|r. & \\
\hline - & $109 \cdot r$. & $17 \varepsilon \wedge 9$. & $1 \cdot r \lambda 1$. & \&l०Y६. & \\
\hline - & rr\&Y\&. & iroir. & หาqนะร. & rqOYr. & \\
\hline - & r101. & oqrT. & - & rrrrq. & \\
\hline - & l11r.. & $1 \cdot\{\cdot r \cdot$ & 011001 & 9rג\&r. & سمتكان \\
\hline - & $r \cdot r>q$. & \&ro.. & $\ldots \ldots-$ & 14r7.. & غزنســـس \\
\hline - & ।૮ะqY. & irrre. & $1.9 \cdots$ & $\{\varepsilon \circ \varepsilon$. & \\
\hline - & $197 \cdot 1 \cdot$ & $\wedge \varepsilon r 1$. & qrarie. & $r l \cdot \lambda .$. & \\
\hline - & Errr. & $7 \cdot 10$. & 71. & $\varepsilon \wedge \gamma \cdot \varepsilon \cdot$ & \\
\hline - & $\{\wedge\{\ldots$ & 917. & - & $7 \varepsilon \cdot 1 \cdot$ & كسابسل . \\
\hline $.7 .$. & $077 r$. & o ₹rג. & $\ldots-$ & ᄉาr人. & كائيســـاء') \\
\hline 187. & IYqY.. & vrite & reYri. & rIArE. & كنـــــ \\
\hline- & 17\&ro. & oor.. & - & $\varepsilon \cdot \mid r \lambda$. & كند هنار \\
\hline rیle & $7 \cdot\{0$. & irrq. & - & $70 \mathrm{AY}$. & كنــــره \\
\hline $0 . r$. & royr. & $001 \%$. & - & $\varepsilon \wedge \varepsilon$. & لفــــــان \\
\hline- & rirג. & ror. & - & rrrq. & لوكـــــــ \\
\hline ior. & l\&Ar^. & $\{r \mid 1$. & - & מדים & نتكر هـــار \\
\hline - & $r \cdot r 7$. & Arג.. & $1 \cdots$ & rrryr. & نيمـــــــروز \\
\hline - & 0.99. & r97. & - & r.rro. & ور د ك \\
\hline - & r.Yor. & riprt. & $11 \% 7$. & 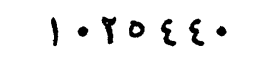 & هـــا \\
\hline$r r \cdot$ & $7 / r \varepsilon$ & YAAY. & $\cdots-$ & $r q q \cdot \curlywedge \cdot$ & هلمنــــــ \\
\hline (Pril. & rrq.or. & आ! & 7รุ1หง. & $\|r 7\| \cdot 1$. & مجســموع \\
\hline- & $r \cdot q \cdot \cdot \cdot$ & $Y Y:$ & - & $r 7 \cdot r \cdot \ldots$ & كويهما \\
\hline rrri. & roqqor. & rIATYr. & 7ร9/人я. & $1 \varepsilon q 7 r \cdot 1 \cdot$ & مجموع عمومى \\
\hline
\end{tabular}

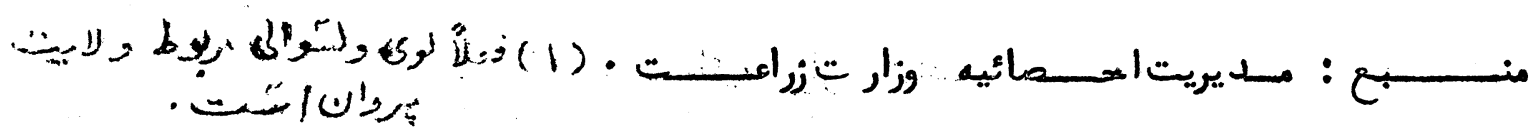




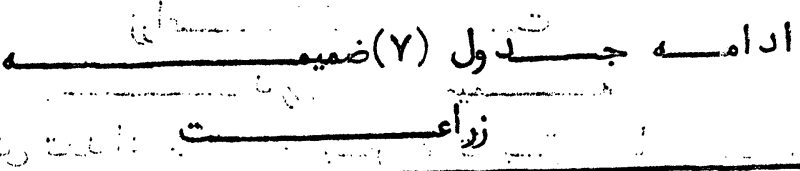

\begin{tabular}{|c|c|c|c|c|c|}
\hline 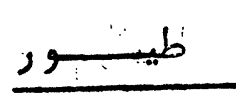 & قاطن. & : مركيـسب & اسبــــاب & 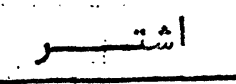 & \\
\hline 11 & 10 & 9.7, & $\lambda$ & $Y$ & \\
\hline$r r \cdot i r \cdot$ & : - & qrik. & YYY & $91 \ldots$ & ارز \\
\hline $1197 \%$. & $|r| \cdot$ & IYqo. & - $43,0, y$ & $.1 \% 0 \mid$ & \\
\hline rro.7... & - & r.人o, & $\therefore r+71 \%$ & Yo: & \\
\hline YY:YO. & - & orrl. & $=\left(r_{0}, 1,7\right.$. & . $\quad 87$. & \\
\hline Ir $\{\varepsilon 0$. & $\therefore \quad-$ & $\{0,1 \ldots$ & rop?. & . YYI. & بفـــالVا \\
\hline rlorr. & $1.1 \cdot r \cdot$ & $. \varepsilon 1 . Y Y=$ & .0097. & $\lambda: \leqslant 0$ & \\
\hline IArAr. & $\cdots-$ &.$+7 \cdot 1 \cdot$ & $\because \varepsilon q$. & $\varepsilon \gamma \cdot$ & \\
\hline พ9019. & $q r \wedge \cdot$ & E\ๆ & $\therefore 1,1$ & 11\%9. & بكتي- \\
\hline$|Y \wedge 0|$ & $\therefore 177$ & $\varepsilon 119$. & $\because Y T 1 \leqslant 0$ & $\{\zeta$ & تخ \\
\hline$\{\varepsilon १ ० \wedge$. & $\because \quad-$ & $Y Y \cdot 1 \cdot$ & $7 r \varepsilon r_{0}$ & . & \\
\hline I\&YY.. & 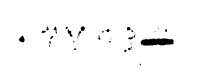 & . &. .175 & $.1 \% Y Y ?$ & ; بــ \\
\hline $1 \varepsilon 0 \cdot \gamma \cdot$ & . $\cdots$ & ᄉᄉro。 & 0.17 & $7 \cdot 1$ & سمنـــــان \\
\hline$x 71,8 \cdots$ & - $\because \therefore<-$ & . $\wedge \varepsilon \Omega \Gamma \cdot$ & $. Y Y: \circ$ & IA: & \\
\hline -11roy. & $\cdots+\cdots-$ & $\varepsilon \cdot 7 r \cdot$ & AO.. & $\therefore$ & \\
\hline Lrryre & $\cdots \quad:-$ & $.7 \cdot 91 \cdot$ & rorro & .975 & - is \\
\hline lollgr. & $\cdots-$ & $.71 \varepsilon \uparrow$. & YYI. & . $9 \leqslant \AA$. & فــــــ \\
\hline 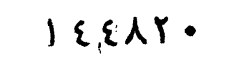 & . $\quad-$ & . ryok. & Ir\&. & $.10:$ & \\
\hline I.7R. & $\cdots \quad-$ & ... & . IYr. & $\cdots Y$ & كايبيدســـا \\
\hline rYq\&० & $\cdot \quad-$ & $\varepsilon \cdot 0 \ldots$ & $-\wedge) \wedge \varepsilon 1$. & Itro. & كنـــــــــ \\
\hline$Y I \cdot A Y \cdot$ & $\quad-$ & $7 \cdot \lambda$. & - : YrY. & $\div ! \cdot 9 \cdot$ & \\
\hline 0771 . & $\cdot-$ & $179 \%$ & $\ldots 119$. & . 1. & كيز مـ \\
\hline 10 Yo... & $1\{0$. & $r r \cdot \varepsilon \cdot$ & IVr. & .... & \\
\hline Irqra. & $\cdots 7 \bullet$ & rurq. & $11 \varepsilon$ & . Tr & لو3. \\
\hline I qrre. & $17 \cdot r$ & r\&Yᄉ. & $Y Y=$ & $11 \%$ & :ند, مــا \\
\hline $1109 \ldots$ & $\cdots \quad-$ & r & $17 \varepsilon$ & I TOY. & نيمســـووز \\
\hline rquro. & - & EYOT. & - & $\therefore \varepsilon 0_{i}$ & و د ك \\
\hline rIו. & $\cdot-$ & 0970. & $|\lambda| \vartheta$. & $17 \times 7$. & هـســرا ت \\
\hline rEYr . & $\because ; \quad-$ & $r r \cdot r \cdot$ & $\quad \quad \vee q 0$ & IrrY. & ملمــــــند \\
\hline O97.rY. & . E. r. & Irp & rqrqr. & 1.7911. & $\rightarrow \infty$ \\
\hline r..... & $\cdots-$ & qr... & . ro... & $1 \% \cdot \because \cdot$ & 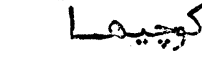 \\
\hline Trq. rr. & c \&lro. & 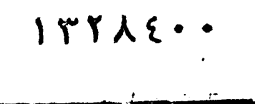 & . $\{\cdot \xi q\} \cdot$ & ร911!。 & 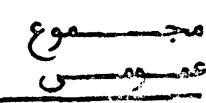 \\
\hline
\end{tabular}

مسد يويت احسمائيه وزار تزاء 


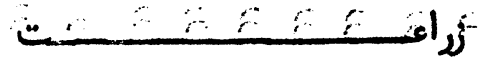

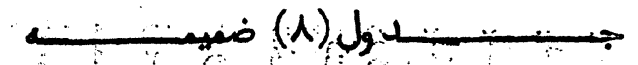

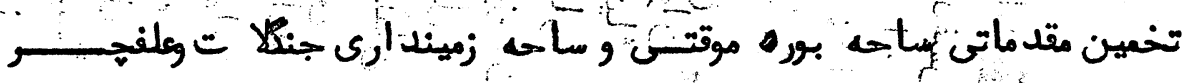

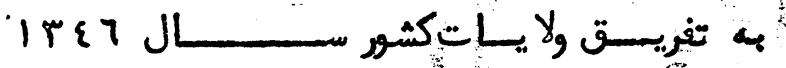

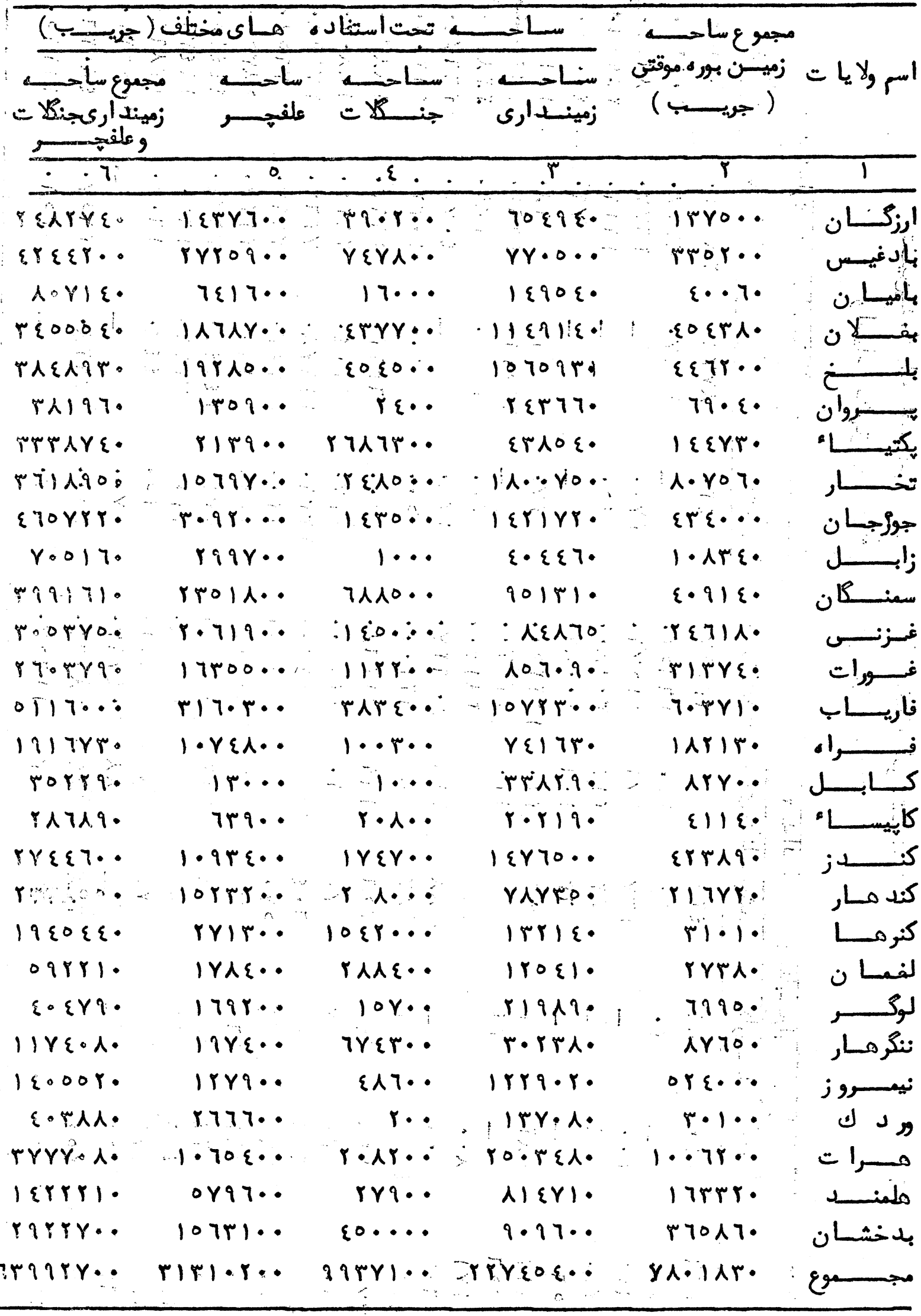

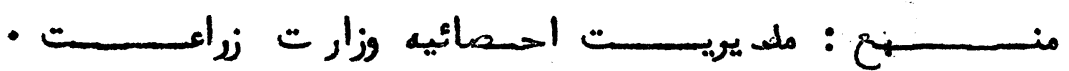




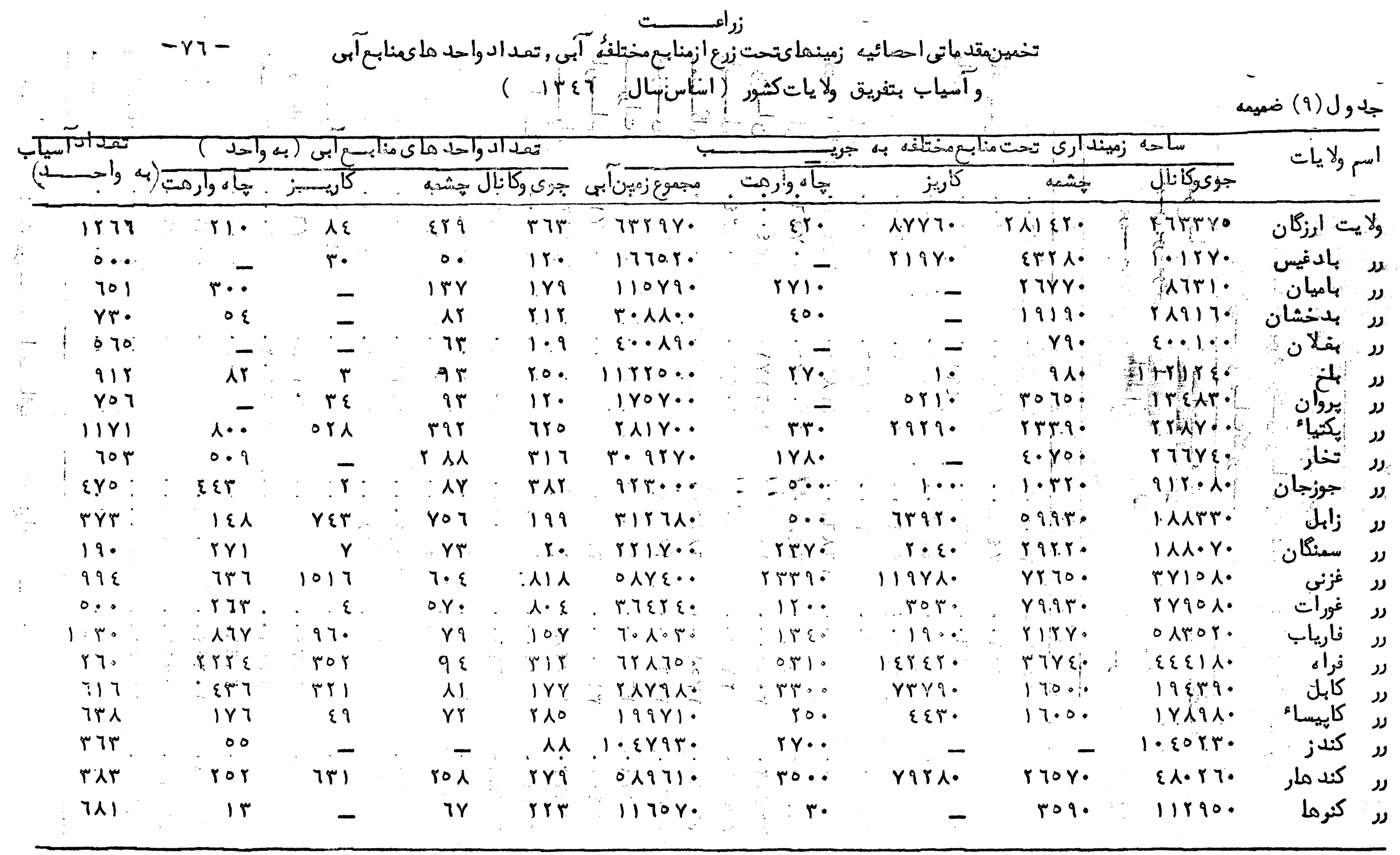




$$
-r r
$$

is

$12 \ldots$

ㄷ…

(9) ادمس جبسدول

\begin{tabular}{|c|c|c|c|c|c|c|c|c|c|c|}
\hline \multicolumn{4}{|c|}{ 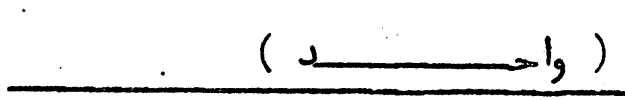 } & \multicolumn{6}{|c|}{ 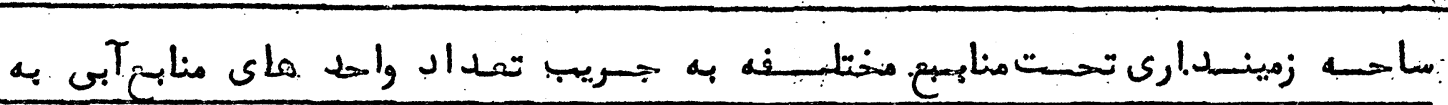 } & \multirow[t]{2}{*}{ اســـات ولايســات } \\
\hline 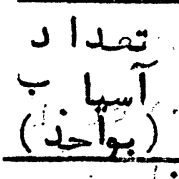 & وآر متاه & كاريز & (n) & جوكوكانال & مجموع زمين آبى & تاه وارمت & كاريز : & 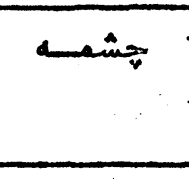 & جوى وكانال & \\
\hline 071. & - & - & $r$ & ६० & 119१. & - & - & r.. & 11871. & ولايت 'لفمـان \\
\hline 纟ัT & 91 & ir & $179^{\circ}$ & $10 \xi$ & irmpio. & $19 \cdots$ & r 9. & $\curlywedge \varepsilon \cdot$ & i.9rr. & ولايت لوكــــر \\
\hline $1 \cdots 1$ & 10 & Y90 & ri. & $r Y \varepsilon$ & r)Yr. & 7. & ६rro. & Y|人|• & $\mid \varepsilon Y\} \mid$ & ولايت ننكرمـار \\
\hline $1 \%$ & $1 \varepsilon$. & 11 & $r$ & $19 r$ & $r .10 \ldots$ & $\cdot \operatorname{lr} \cdot$ & 171. & - & rqAiq. & ولايت نيمــــروز \\
\hline Arr & - & דיז & 019 & 019 & $|r \lambda \cdot| \cdot$ & - & $99 \ldots$ & $\varepsilon r \varepsilon \gamma$. & Vรา & ولايت ورد ك \\
\hline $1 r \cdot r$ & qo. & re & 104 & $r \cdot r$ & 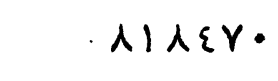 & 710 & Ar $\varepsilon$. & $\varepsilon \mid r$. & YqqYo. & ولايت هـرات \\
\hline 017 & 7. & rri & iro & rry & A|rया. & 77. & $11 \varepsilon 10$ & rir. & Trisile. & ولايت ـ هلمنــــد \\
\hline $1 \wedge \varepsilon Y 0$. & 1 $\{90$ & $T Y \varepsilon 1$ & 0009 & YATY & 119r71r. & ${ }_{i}^{T \cdot r r}$ & ㅅㅅㅅ. & irrit. & $1 \cdots 9 \cdot 1 \gamma$ & ع \\
\hline
\end{tabular}




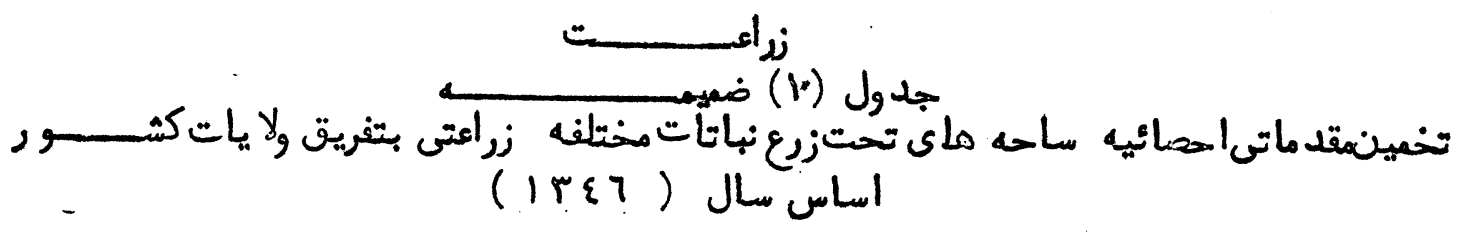

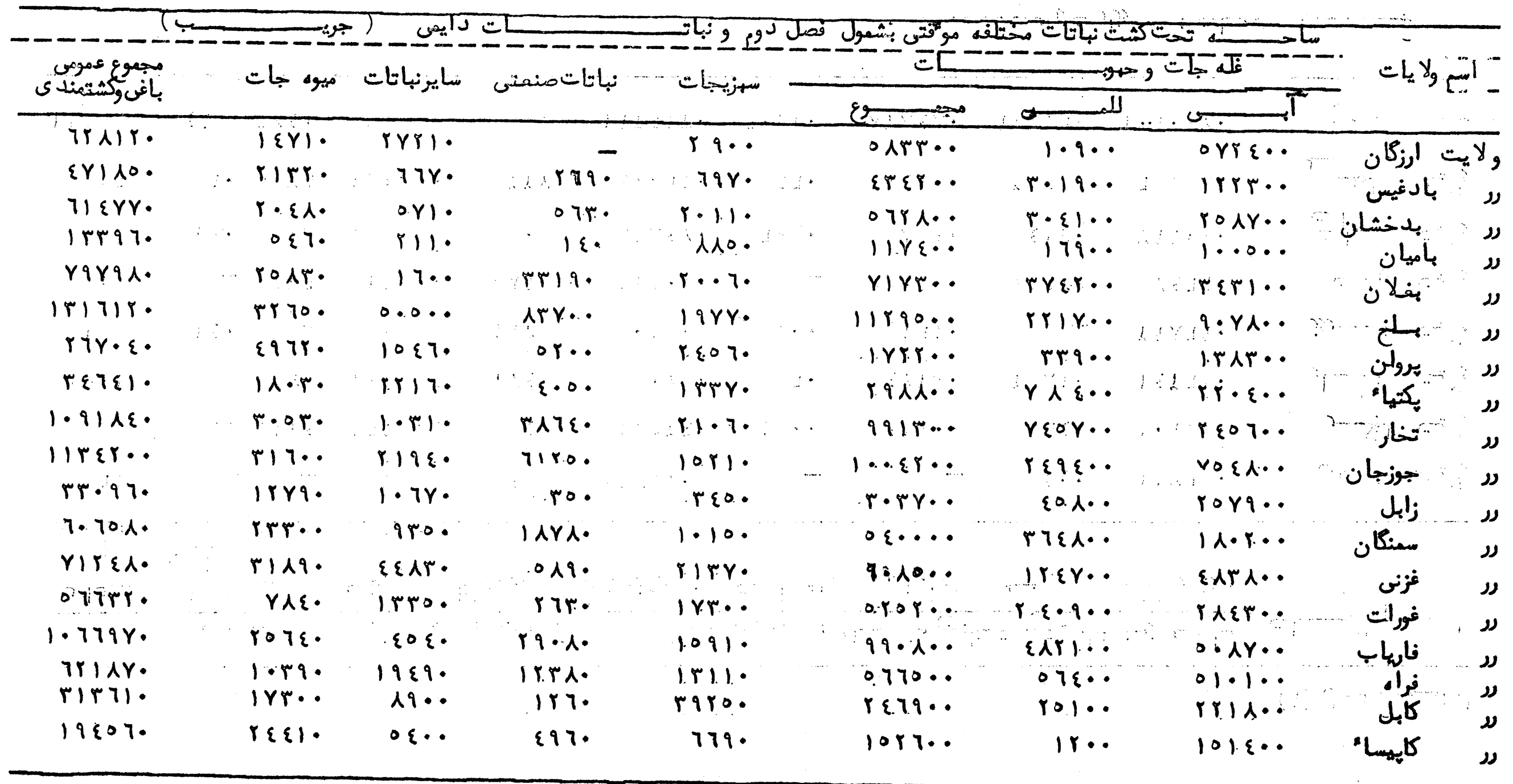




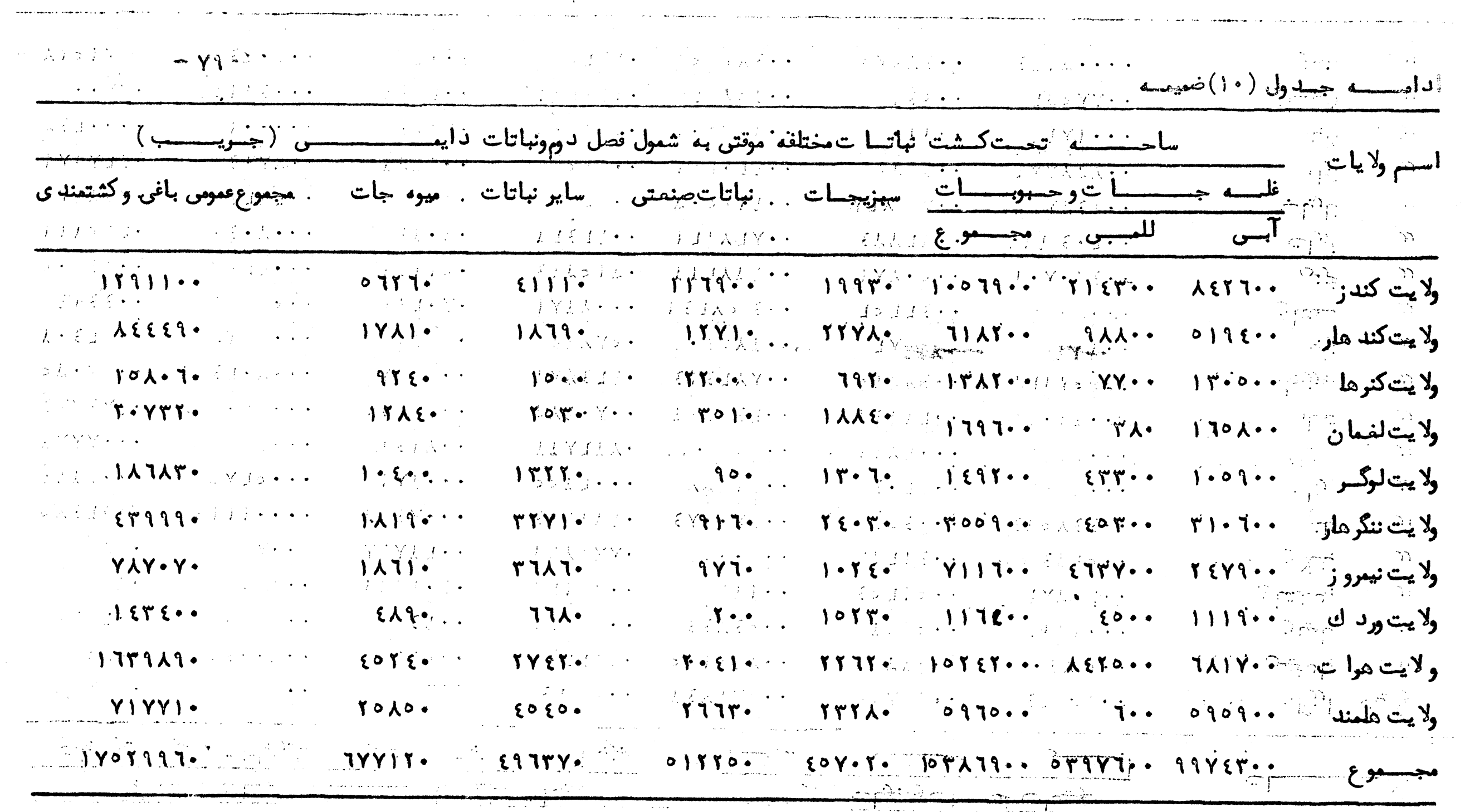

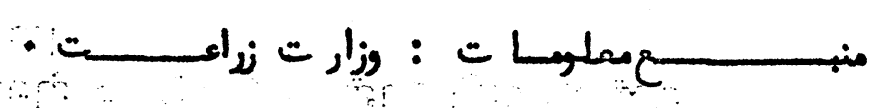




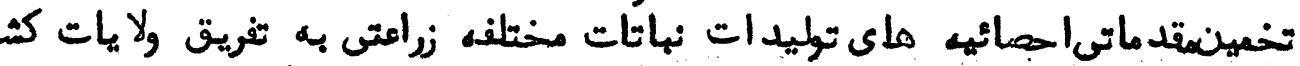

أناس سال (

\begin{tabular}{|c|c|c|c|c|c|c|c|c|}
\hline \multicolumn{2}{|c|}{ (سيركابل } & \multicolumn{2}{|c|}{ توليدات سايو نهات } & \multicolumn{3}{|c|}{ توليدات علد جآ وحهوبات (سير كبل) } & \multirow{2}{*}{$\leftarrow$} & \multirow{2}{*}{ اسم :-ولايـ } \\
\hline مهوه جات & سايونباتات موقتى & نباتات ص نمتى & سزيجبات & مجعــــوع & للمســن & & & \\
\hline r०ᄉᄉ97. & ร११าร.. & - & $\varepsilon 7 q \wedge \cdots$ & rerq10.. & lior... & r\{7וrr. & & ولايت \\
\hline $1707 . \%$ & $\varepsilon r r \ldots$ & $\therefore \varepsilon \cdot q_{\cdots}$ & 1.srrye. & $\varepsilon \varepsilon \curlyvee . \varepsilon .$. & $\therefore$ rorom & 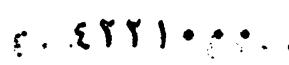 & & נט \\
\hline rYフגזr. & IrIrr.. & $\operatorname{rirq\cdot \varepsilon \cdot }$ & $r / 91 \cdots$ & |ะหจุ!.. & $\{0710 \ldots$ & $9 \lambda \pi \div 7 \cdots$ & & עN \\
\hline 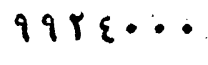 & r rᄉ70... & | $1.7 \ldots$ & 00 . . . . & $\operatorname{rrrla} \cdot \cdot$ & $\therefore \cdot \varepsilon_{0} \cdot 7 \lambda \cdot \bullet$ & $\because 7910 \cdots$ & & ננ \\
\hline 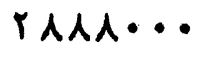 & r\&rr... & $|\varepsilon| \gamma \ldots$ & rYATrY. & $11.9 \varepsilon \cdots$ & $1187 \ldots$ & $9.91 .1 \cdots$ & & נג \\
\hline$\varepsilon \wedge \wedge \varepsilon \wedge \cdot \therefore$ & $r \cdot T r \ldots$ & 18007. & $r \gamma q \cdot 1 \cdot \cdots$ & 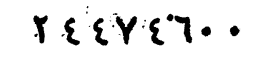 & " |िधтr 7. & $11.0 \% \ldots$ & تخخ & נر \\
\hline 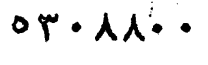 & $\varepsilon \gamma \cdot Y \varepsilon \cdots$ & inrro.. & YAY\&79. & : \{ोรTYA.. & OTYYE.० & rurreq.. & $\cdot \cdots$ & נرנ \\
\hline rogrri. & ATr7.. & $100 \cdot r \cdot$ & reTra... & r.0019.. & ATYY A & $r|\wedge r \varepsilon| \cdots$ & فارياب & ע \\
\hline IArAT\&. & \&rAY.. & rrrr.. & rro.q1.. & $197.79 \ldots$ & r.rur.. & lecrry... & فراه & ננ \\
\hline$r \varepsilon 7 \ldots$ & $r 1 \ldots$. & \&०น & goryro. & 1.r.Ar.r.. & $r \cdot i r .$. & $99 \wedge 1 \ldots$ & كابل & נر \\
\hline$\{1 \cdot \wedge \lambda$. & IIr\&... & I & $|r 7 \varepsilon \varepsilon|$. & irrry.. & I\&\&.. & Tro人ᄉ.. & كايهيسا. & נג \\
\hline YIOIA\&. & 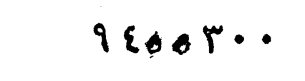 & rart... & r人o ๆะq. & \&OЯイY\&.. & roore.. & $\varepsilon r \mid r \ldots$. & كندز & ענ \\
\hline
\end{tabular}




\begin{tabular}{|c|c|c|c|c|c|c|c|}
\hline \multicolumn{4}{|c|}{ 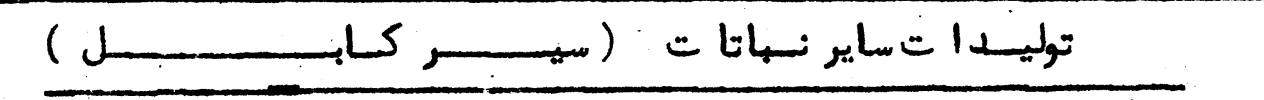 } & \multicolumn{3}{|c|}{ 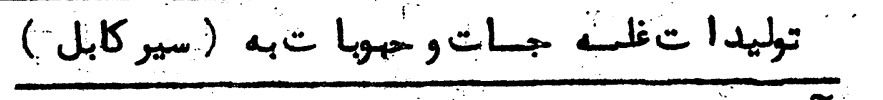 } & \multirow{2}{*}{ استحم ولاي-Lات } \\
\hline "ميوه جات رخشته باب & سايرنباتات موقتي & نباثاتصنمتي & ت سمزئهن . & 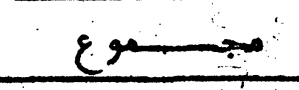 & للبــــــ & T & \\
\hline $1 \varepsilon r 7 r \ldots$ & $\varepsilon \curlyvee \varepsilon \curlyvee 0 .$. & \&oY० & $\{0 / \cdot \varepsilon \varepsilon$. & $r \varepsilon \wedge, 00 .$. & I\&Ar... & rutru... & ولا يت كند مار \\
\hline D Tritre & $r r \cdot \because \cdot$ & 1trieg. & $100 \mathrm{Yo.}$ & oritr. & qF६.. & - & ولايت كنرهـا \\
\hline rrosks. & 0017. & $i \wedge 0: \varepsilon \gamma \cdot$ & Errq. & $97 \varepsilon 7$. & \{० 7.. & $9119 \ldots$ & ولايت لفعان \\
\hline $19971 .$. & rivrie.. & r६r. & rYirig. & $\{Y 00\}$. & 0197. & EYrY... & 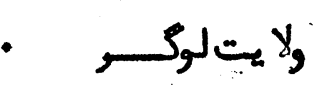 \\
\hline 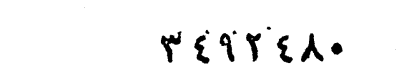 & $r 1^{0} \cdot q \cdot \cdot$ & orgorr. & oarr.r. & 17:YrT.. & o\&ri.. & $100 \% \ldots$ & رلا يـت ننكر هار \\
\hline rqurq. & grivi... & Pहाi.. & $170 \wedge \wedge \lambda$. & 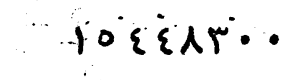 & $7 \cdot r \wedge l \cdots$ & $q \varepsilon r \cdot r \cdot \cdot$ & ولا يت نبمسروز \\
\hline iigri. & jorre.. & $r \therefore$ & $r \cdot 100 \xi$. & \&०५ $\{0 .$. & $010 .$. & $\{\{\gamma\} \ldots$ & ولايتي ورد ان \\
\hline YITYYE. & Y.rT\&.. & 77001. & ErrTir. & $\varepsilon \tau \tau^{\prime} \mid \tau_{0}$ & $\operatorname{Ir} \varepsilon A_{\ldots} .$. & rrvili. & ولايت مر ا ت \\
\hline$\varepsilon r \varepsilon r \wedge$. & $90 \varepsilon \varepsilon 0 .$. & Aliq. & zragir. & rirre. & $\wedge \varepsilon$. & PYYI97. & ولايت ملمنـــد \\
\hline $1171019 r$. & 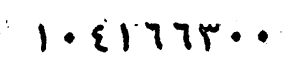 & $r 17.90^{\circ}$. & q.risir. & orr $\varepsilon \wedge \cdot \lambda .$. & $q \cdot\{r r \mid \cdots$ & $\varepsilon \varepsilon \gamma \ldots \gamma \gamma \ldots$ & موع \\
\hline
\end{tabular}




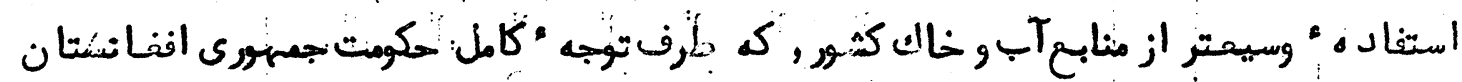

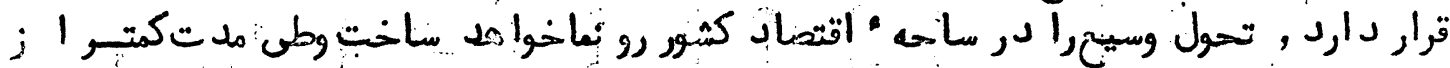

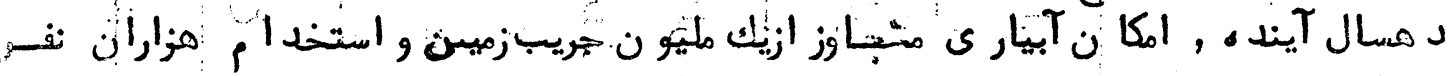

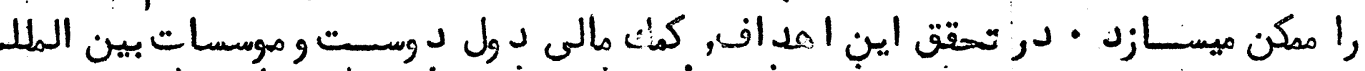

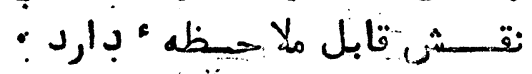

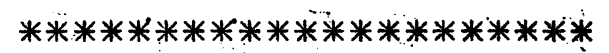

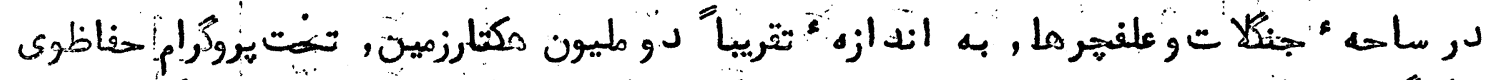

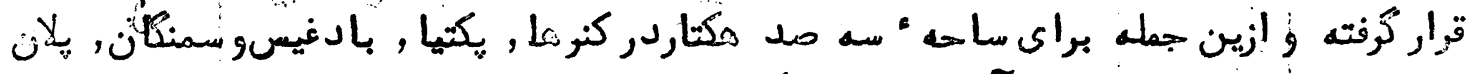

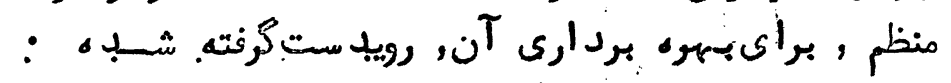
**************************:

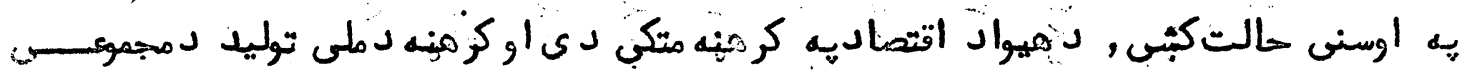

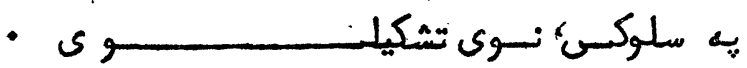

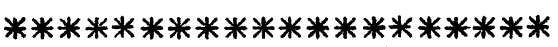

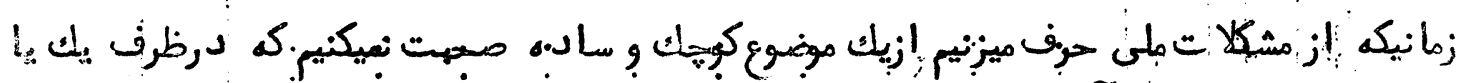

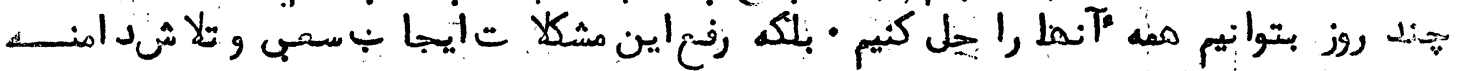

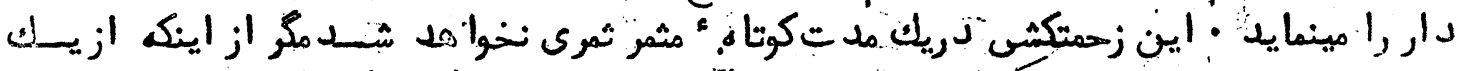

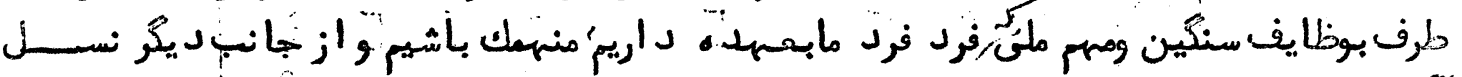

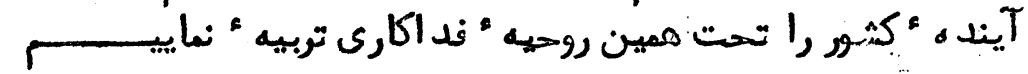 *************************1.}

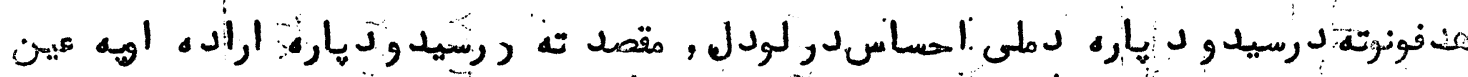

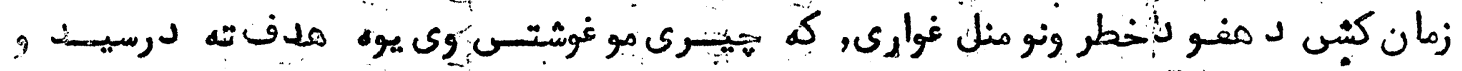

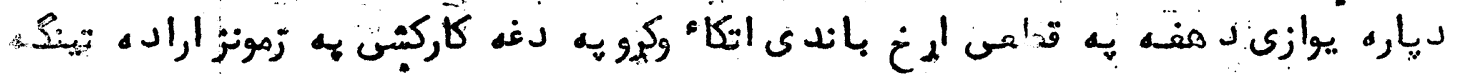

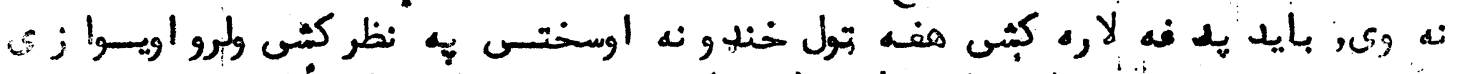

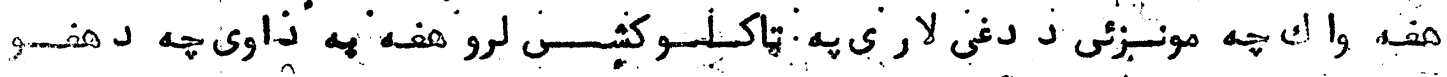

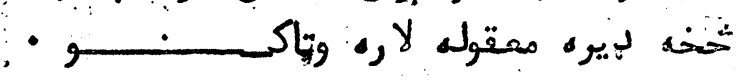

\section{*************************}

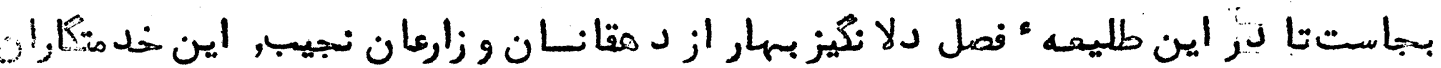

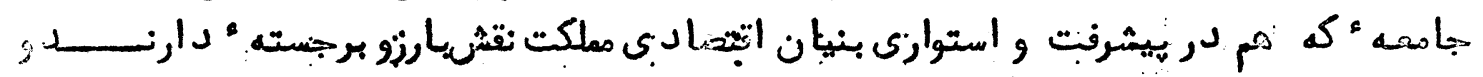

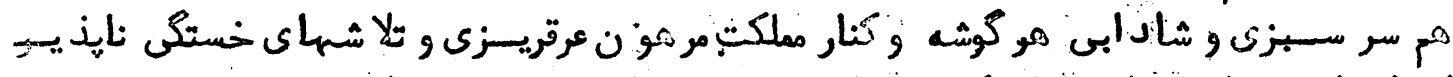

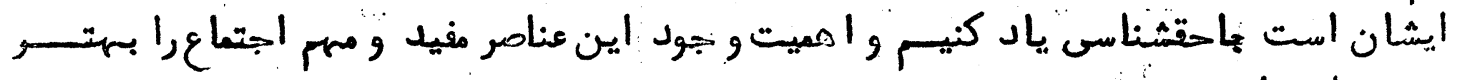

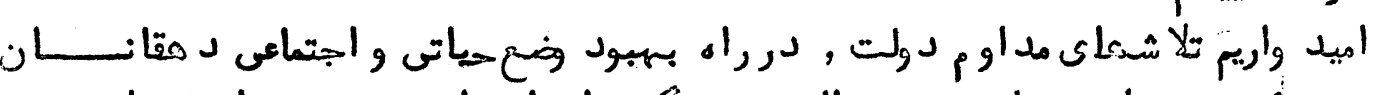

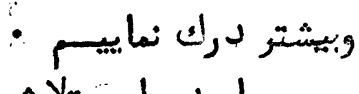

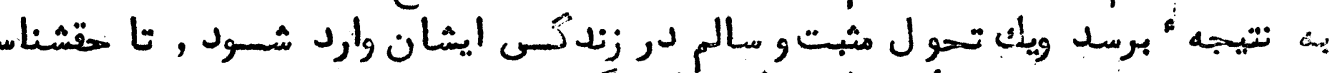

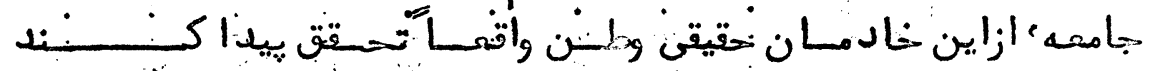

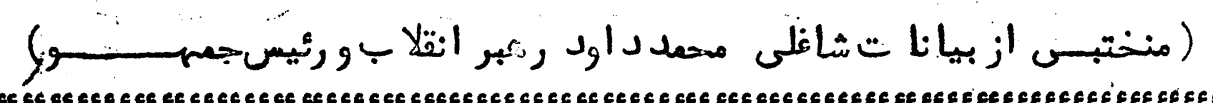


فصاسنو

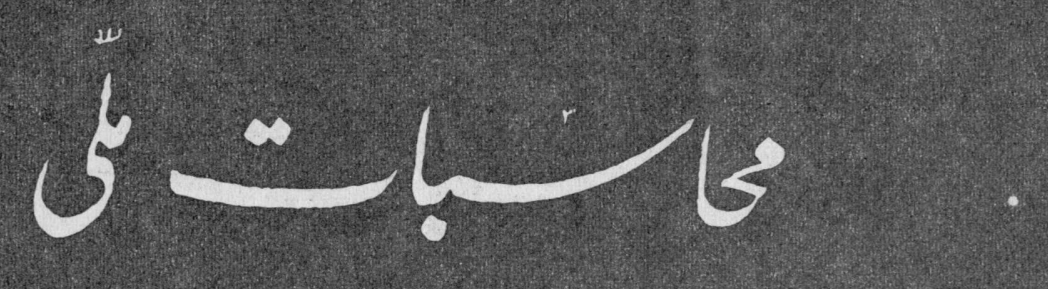

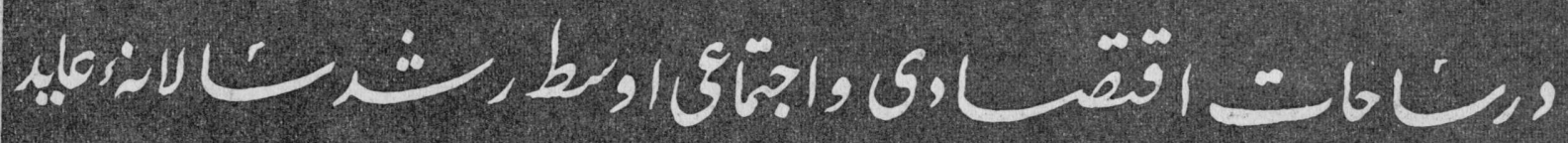

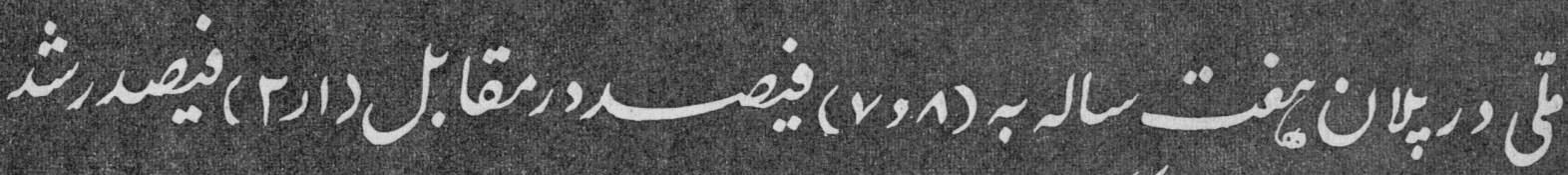

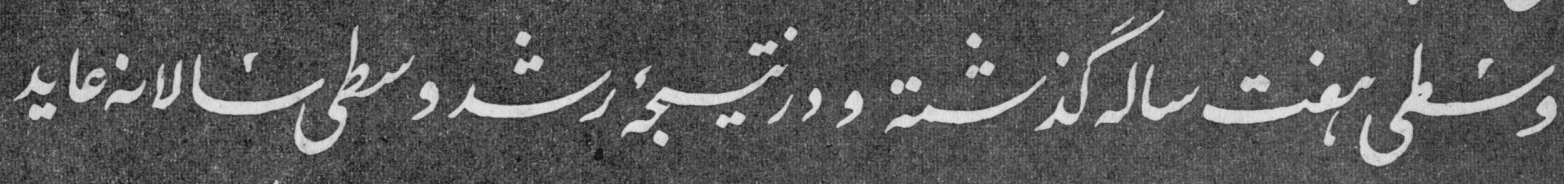

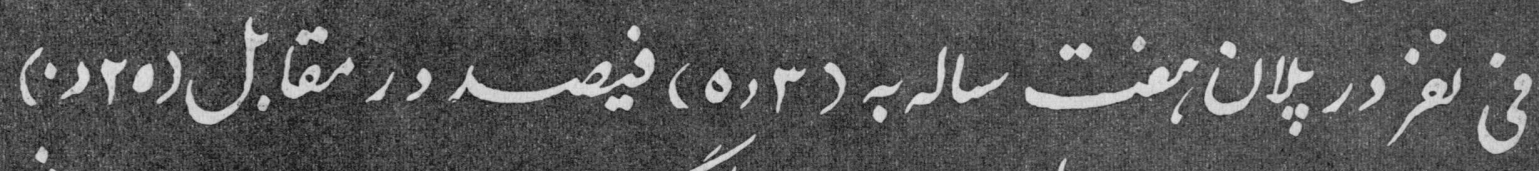
i

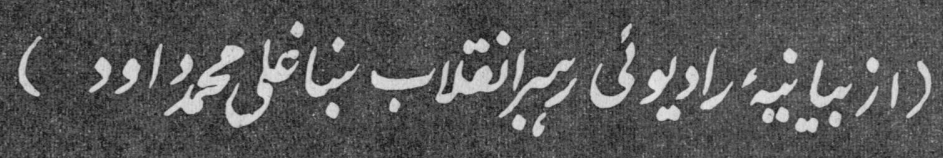




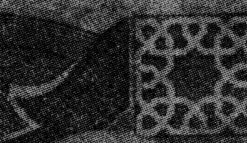

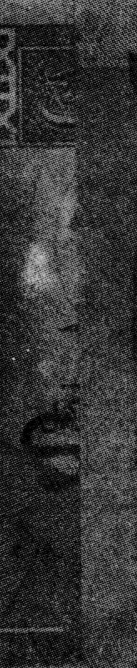

ân

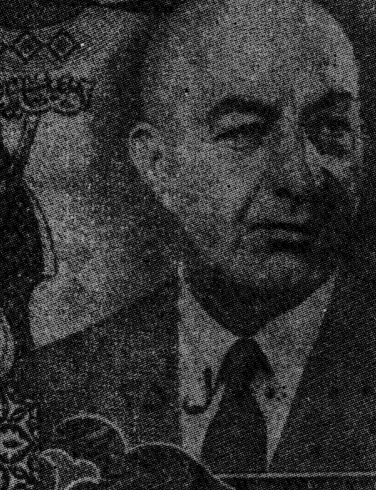

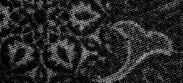
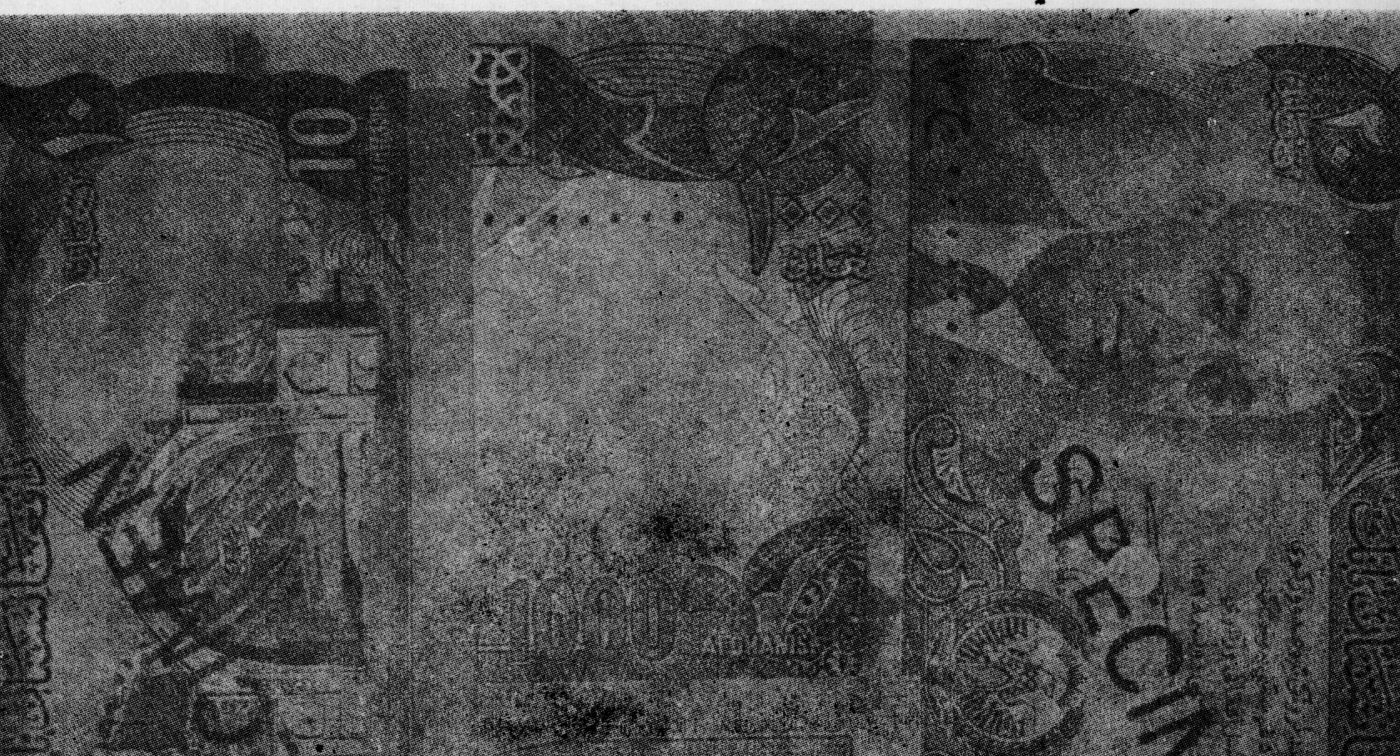

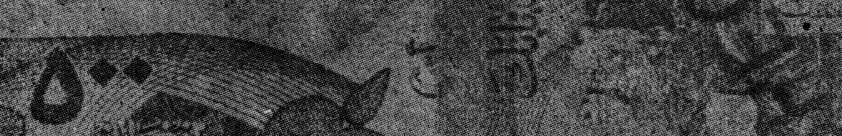
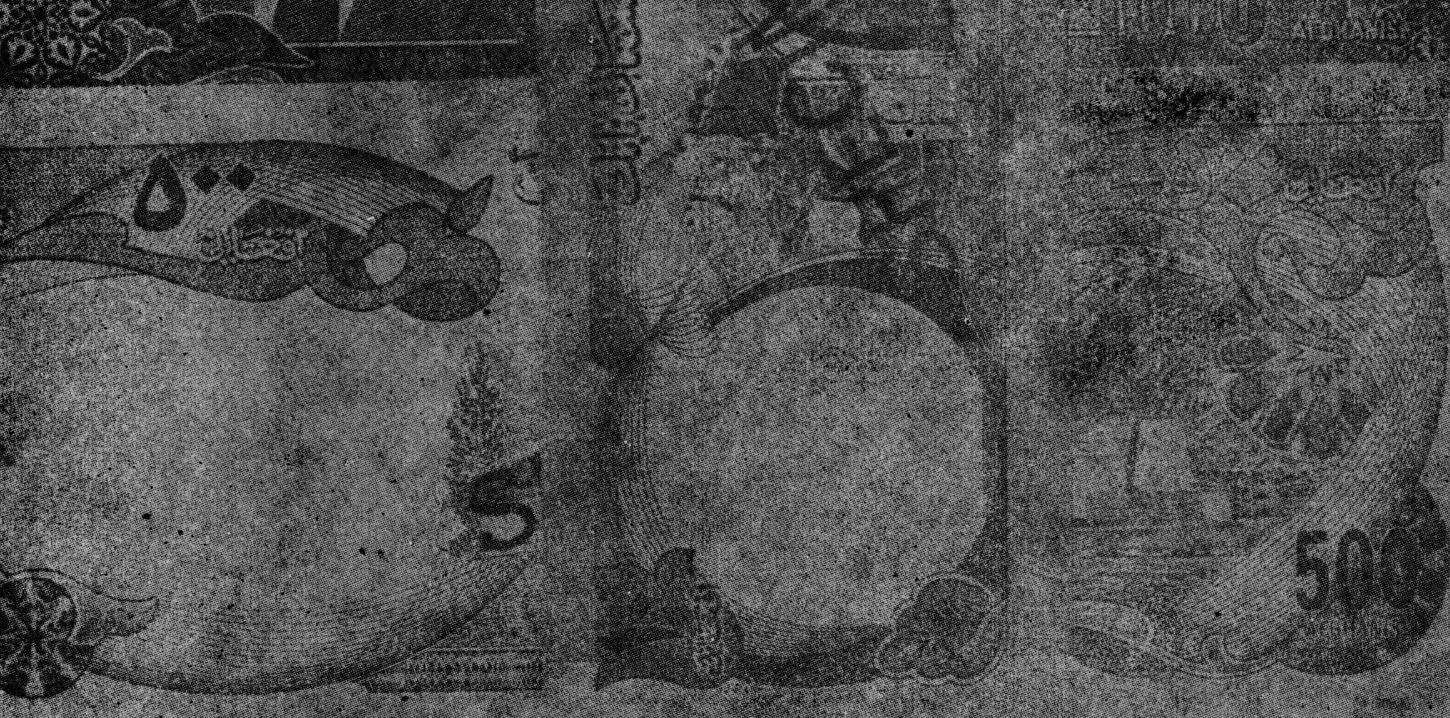

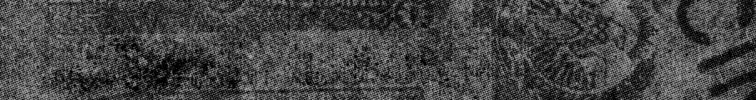
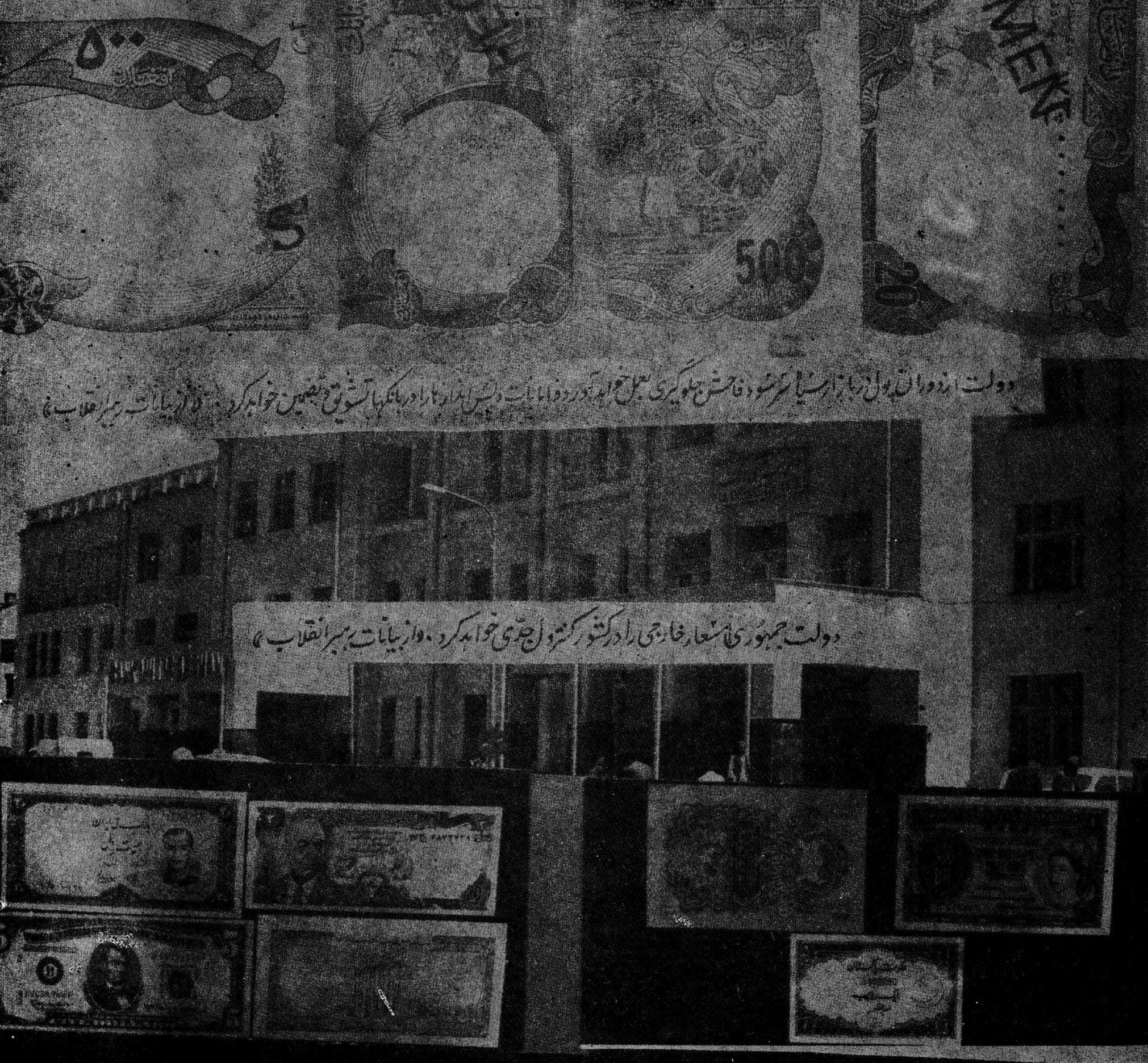

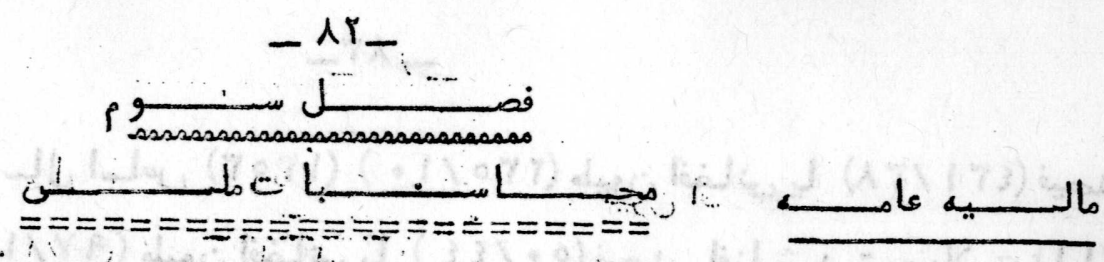

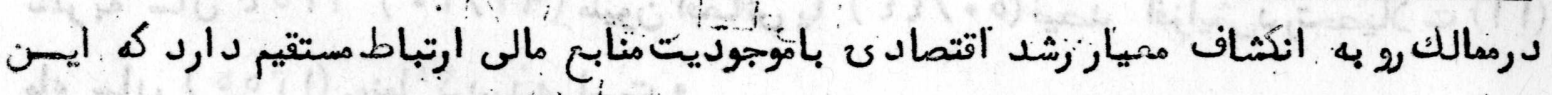

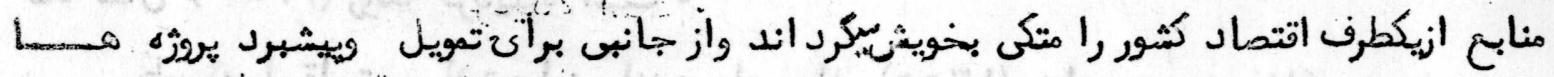

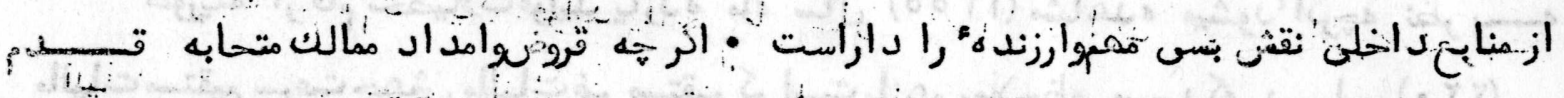

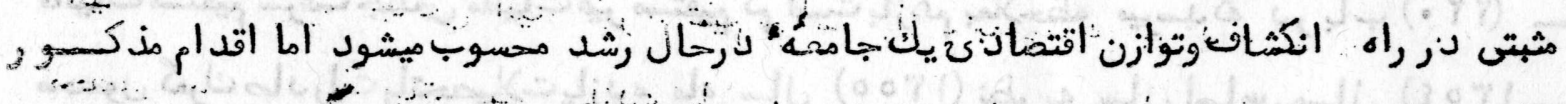

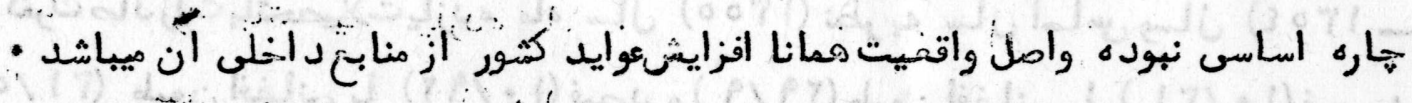

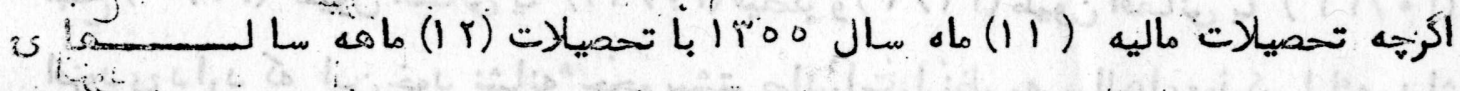

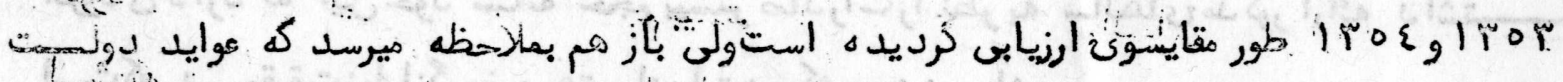

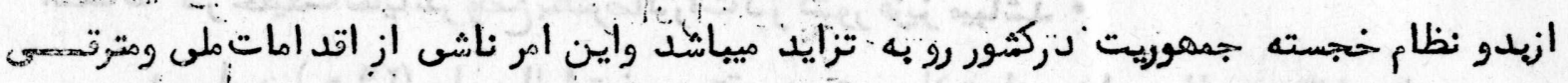

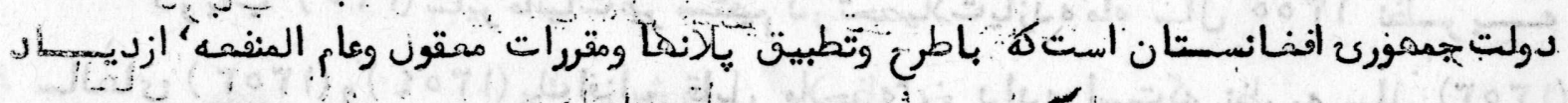

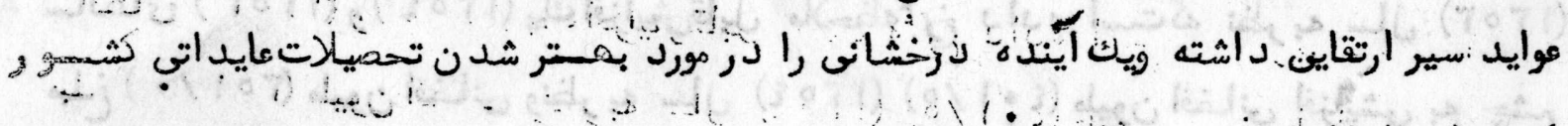

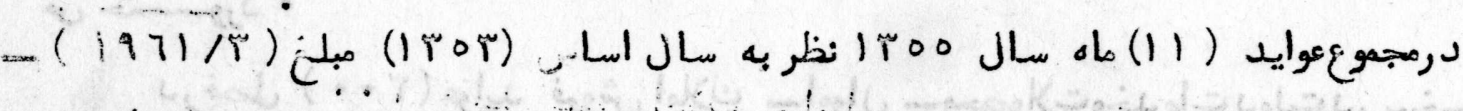

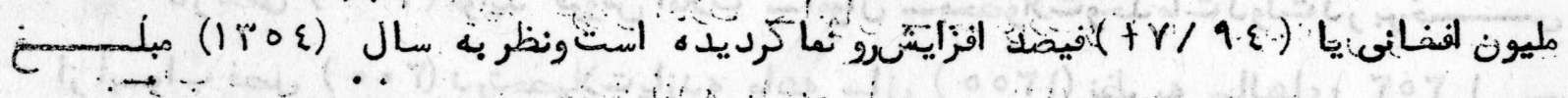

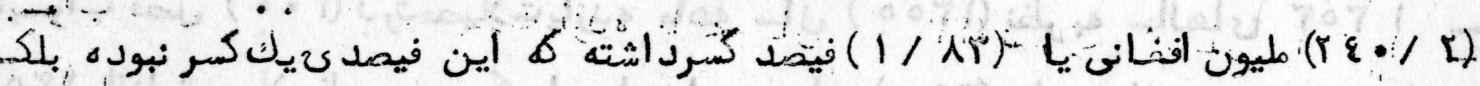

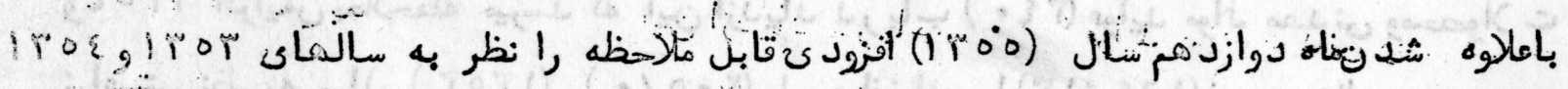

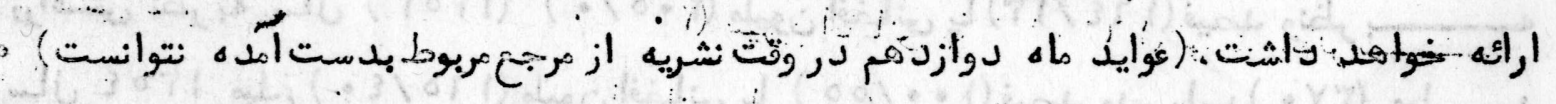

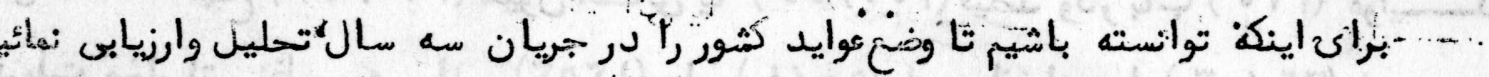

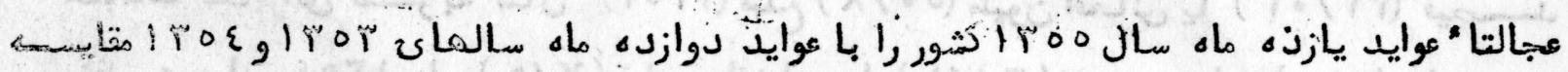

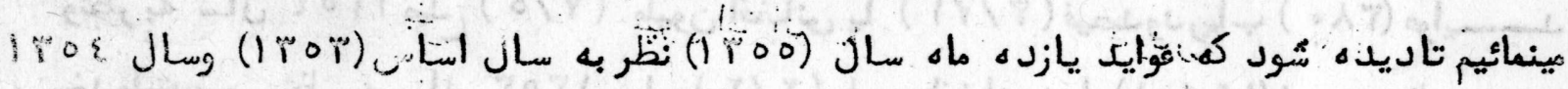

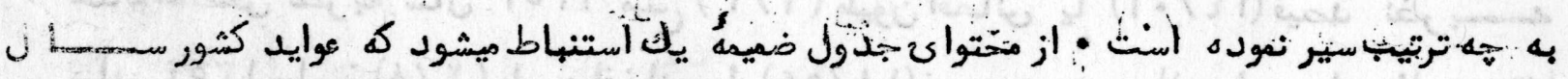

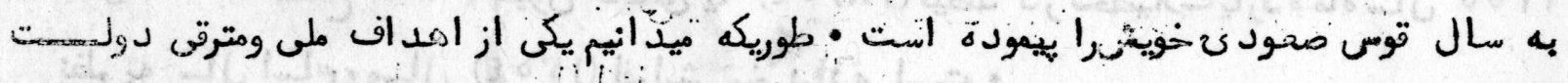

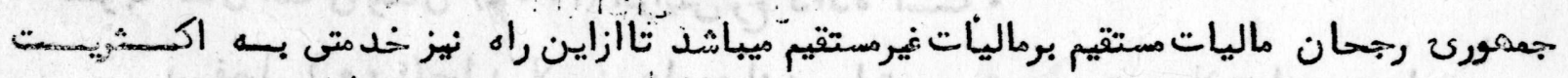

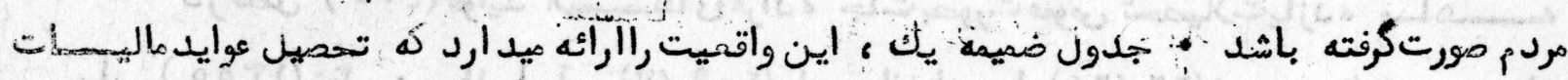

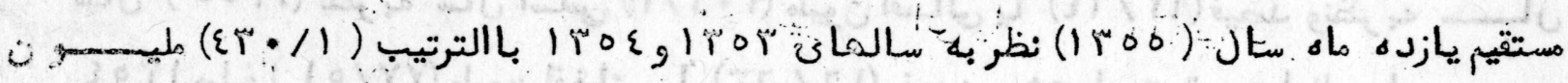

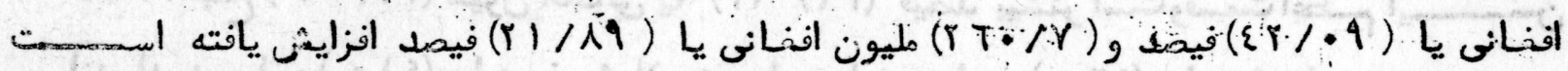

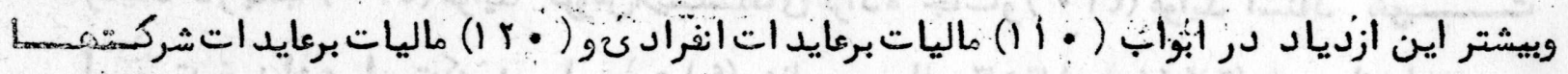

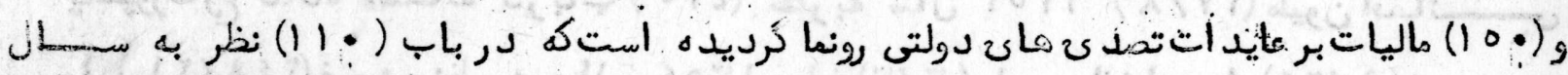

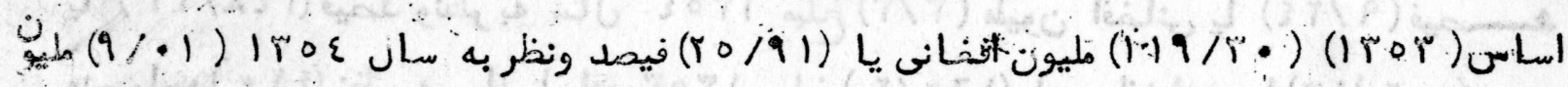

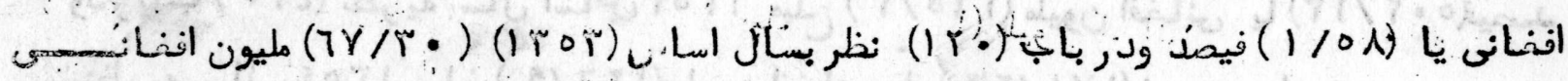

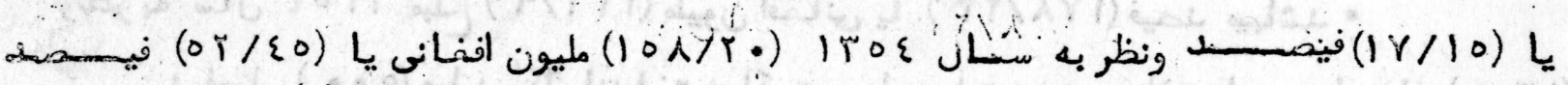




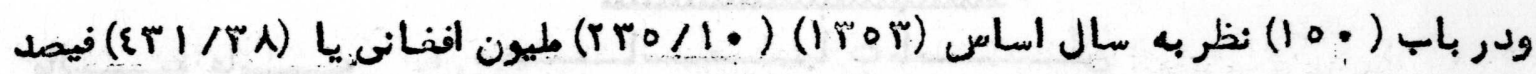

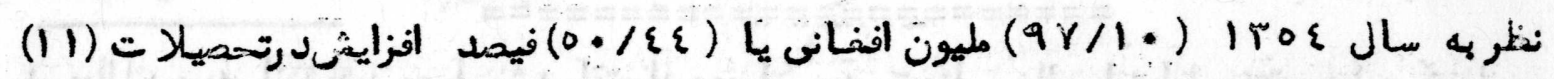

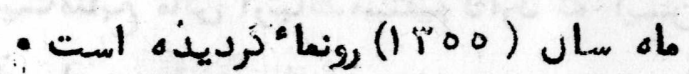

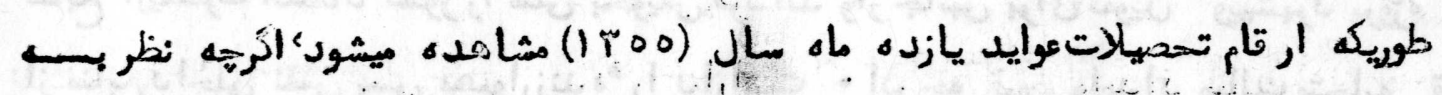

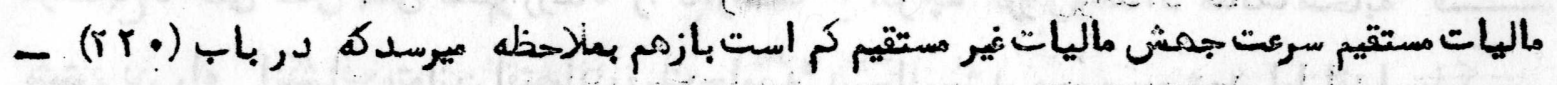

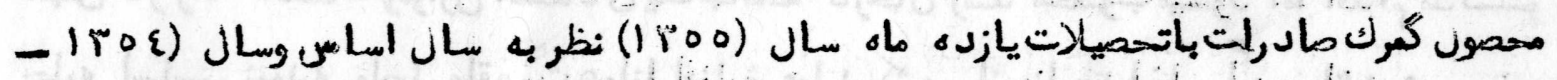

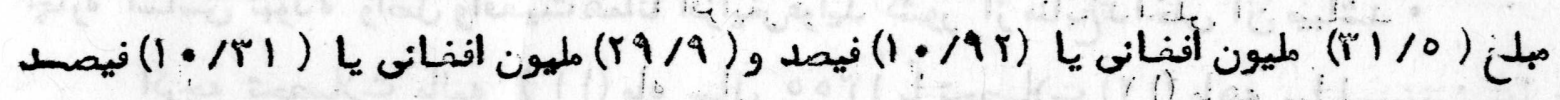

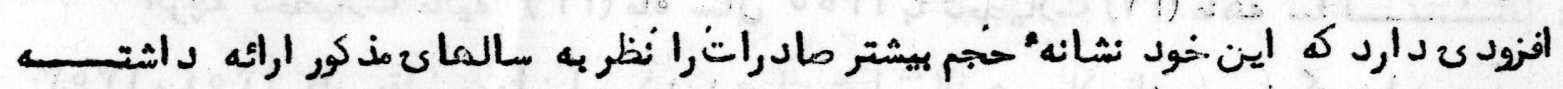

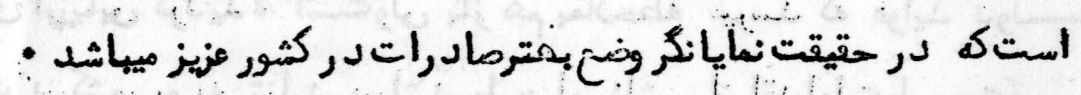

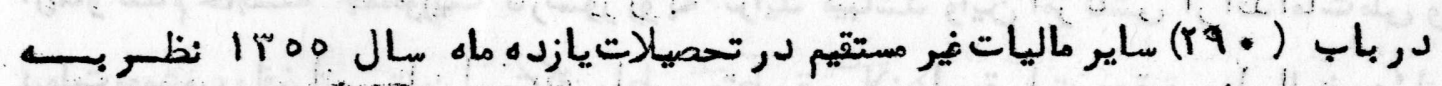

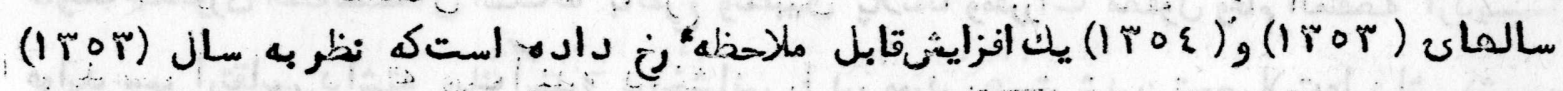

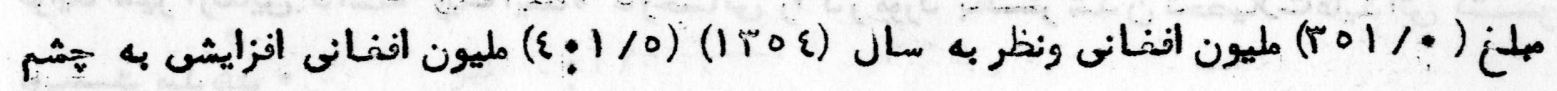

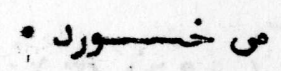

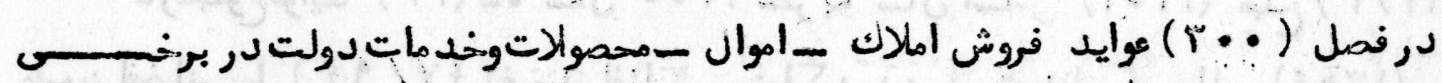

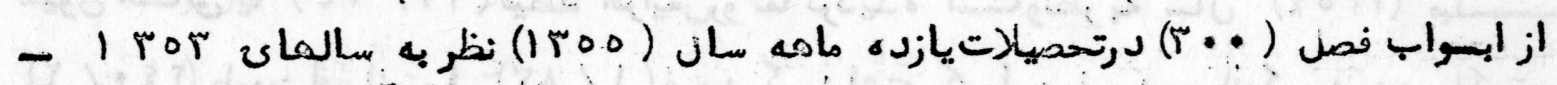

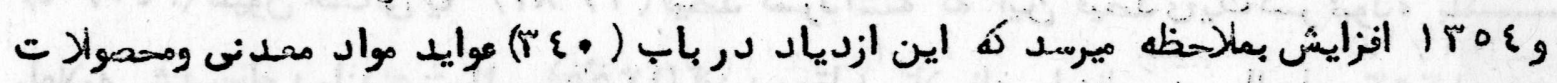

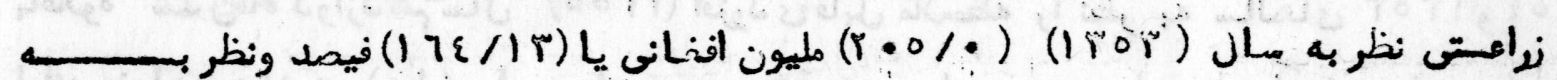

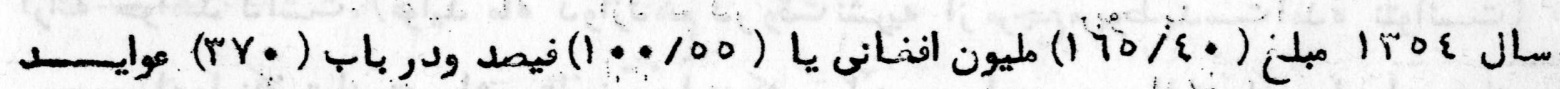

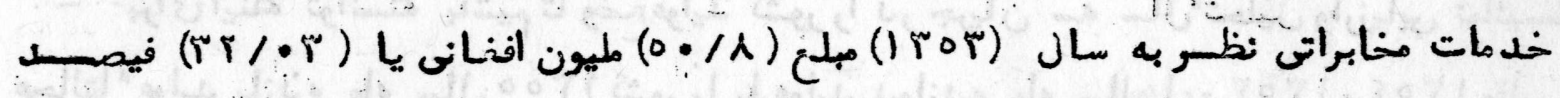

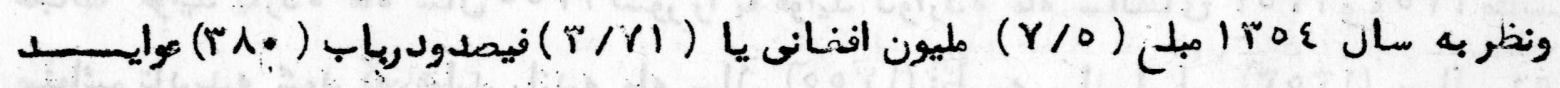

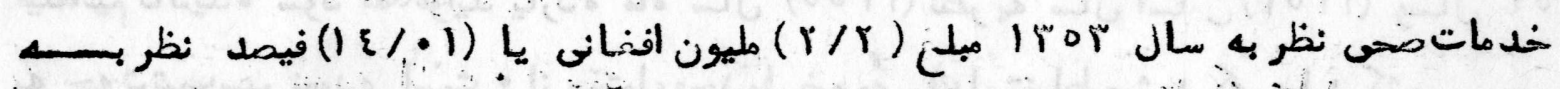

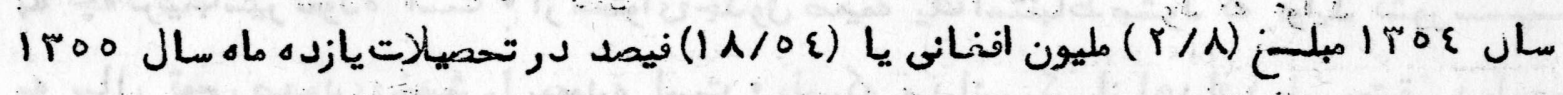

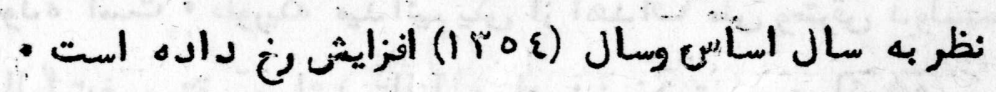

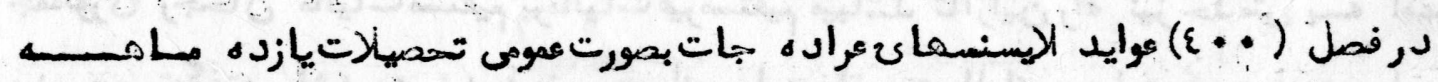

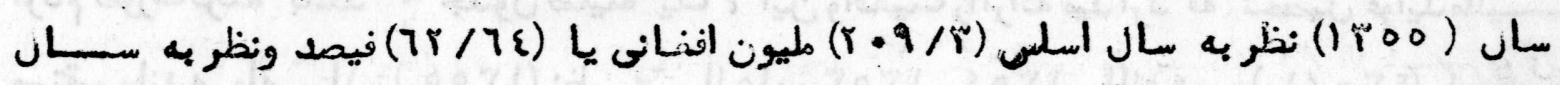

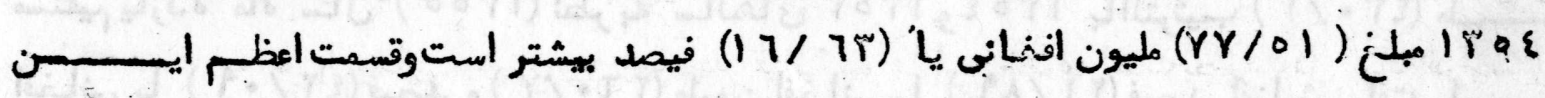

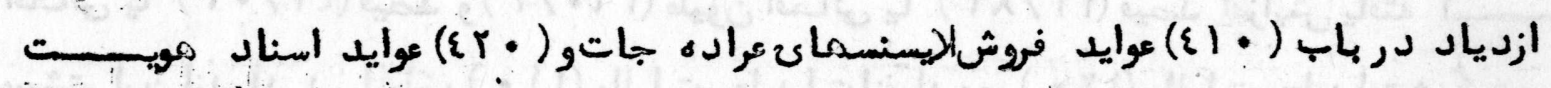

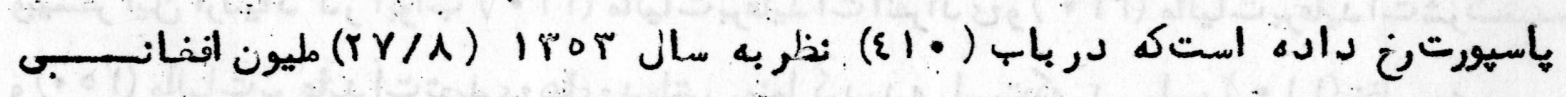

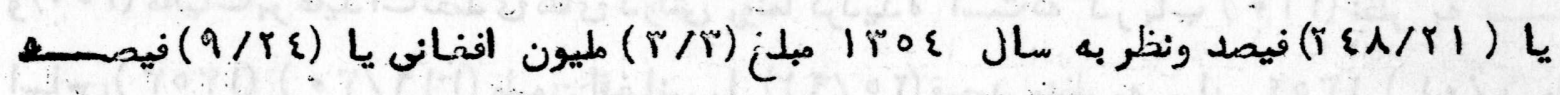

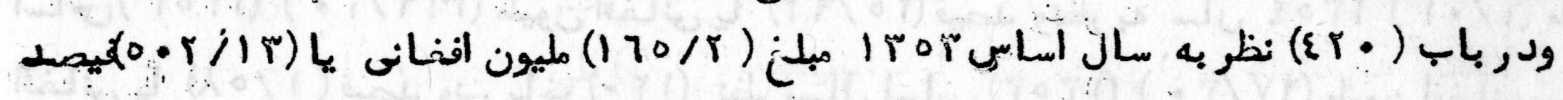

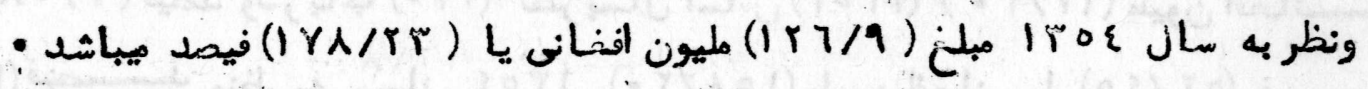

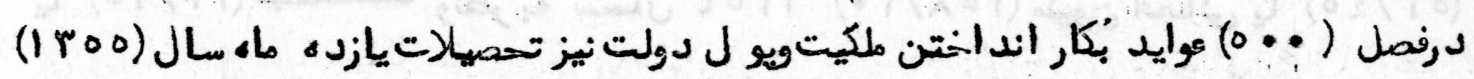




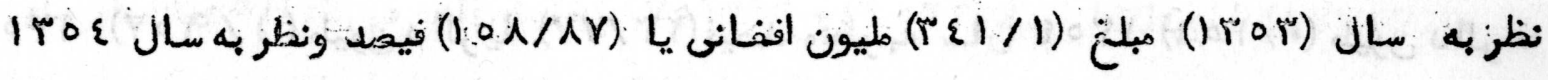

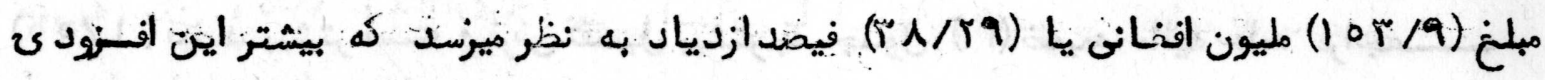

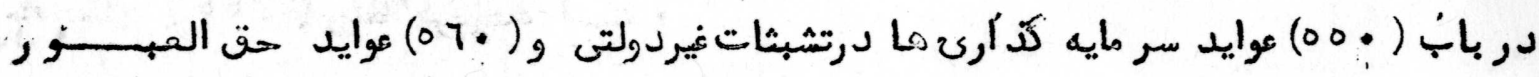

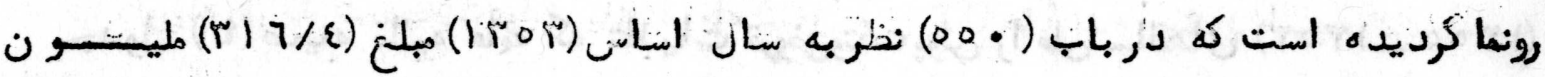

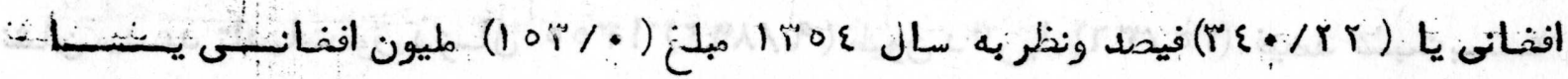

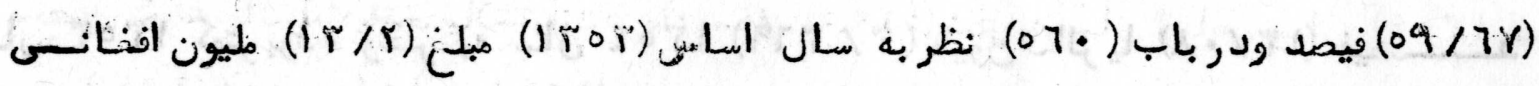

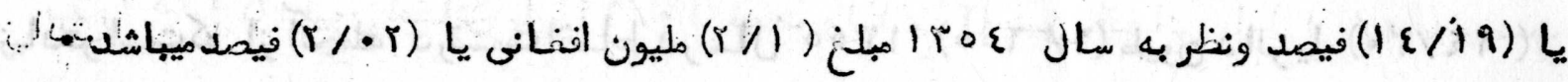

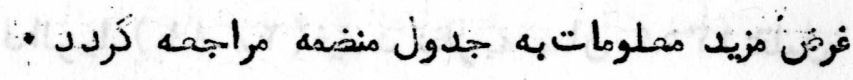

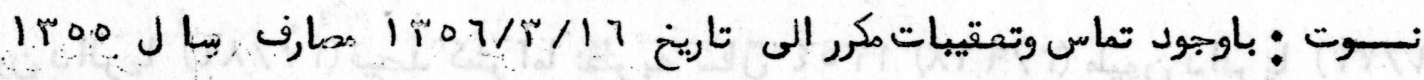

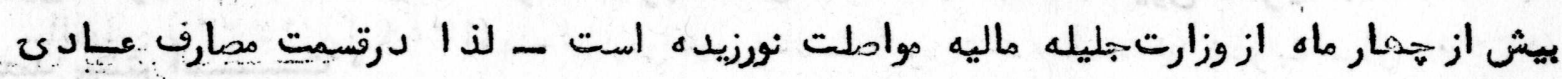

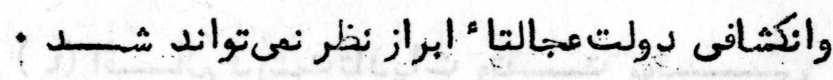

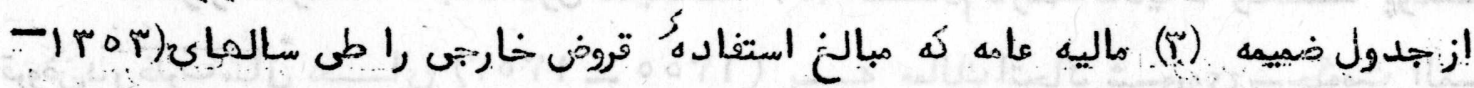

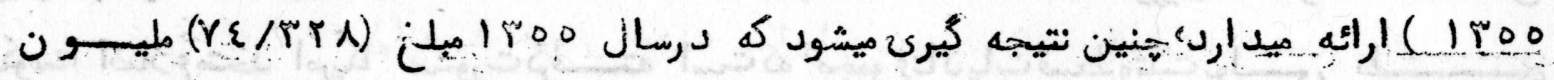

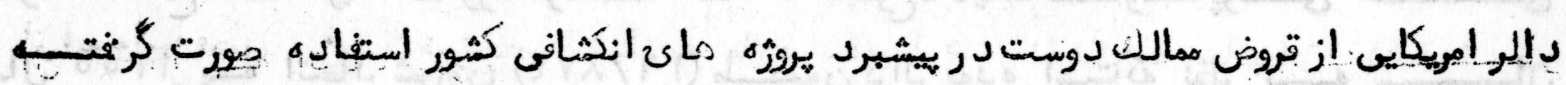

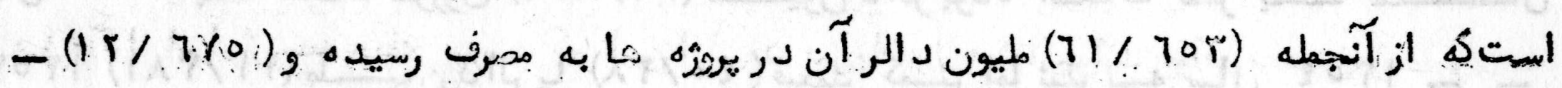

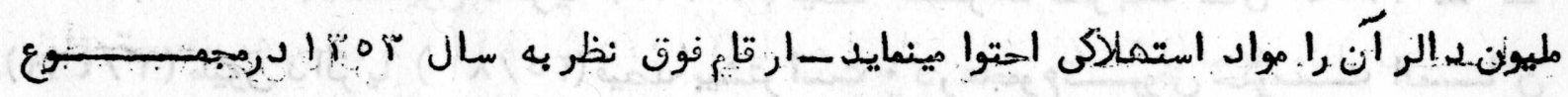

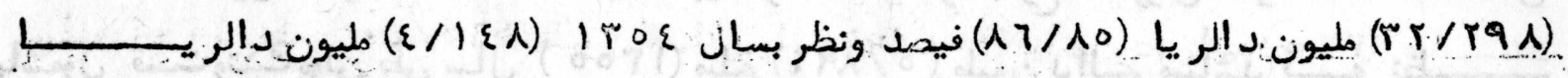

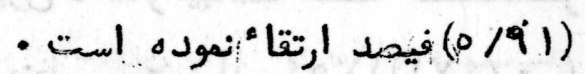

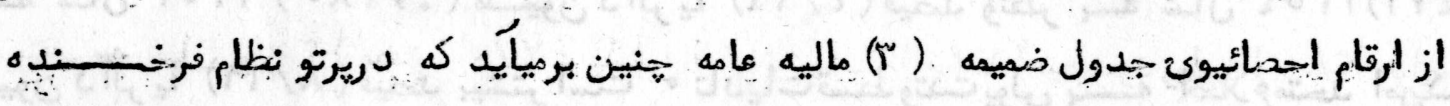

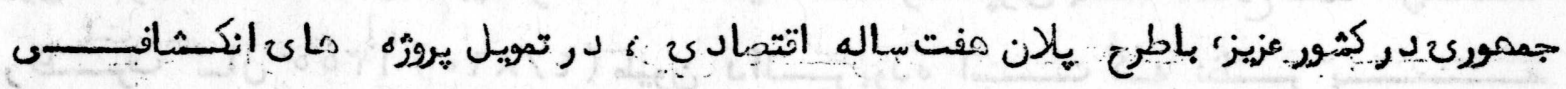

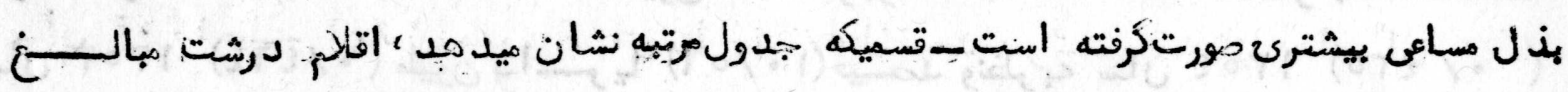

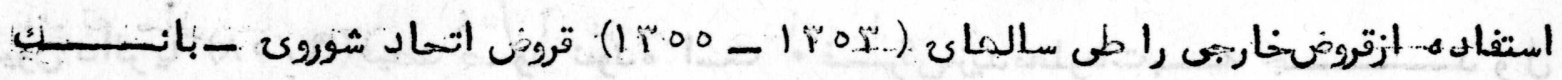

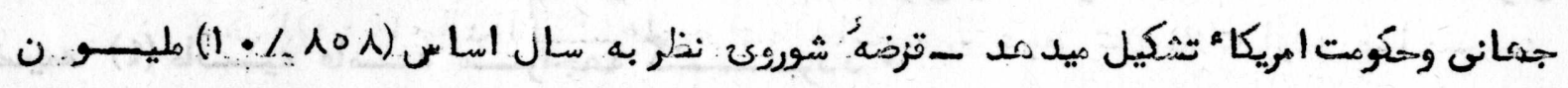

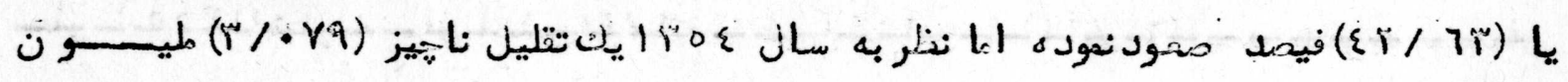

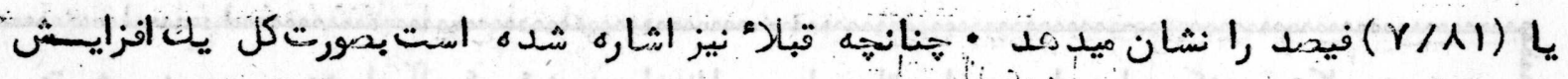

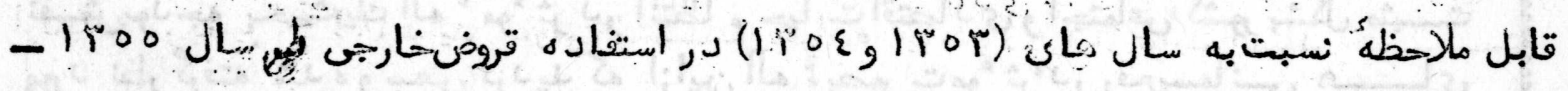

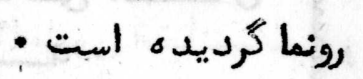

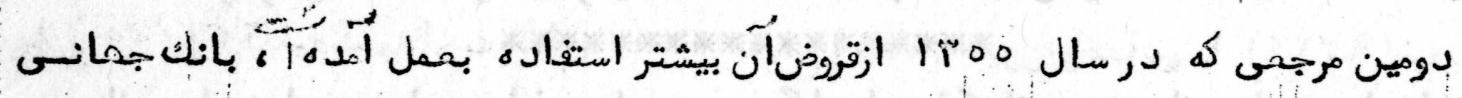

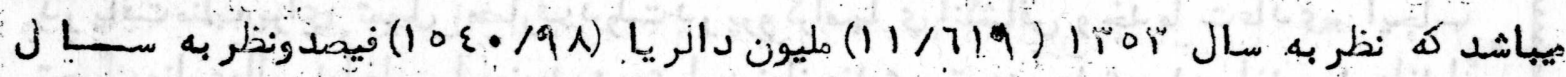

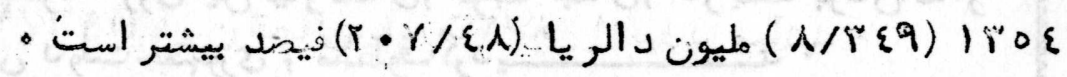

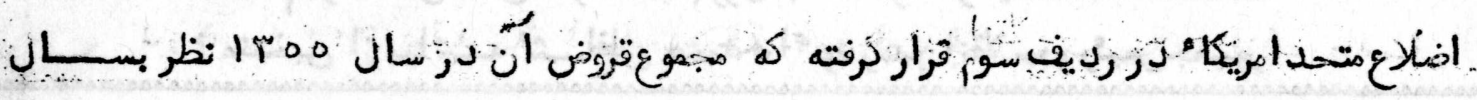




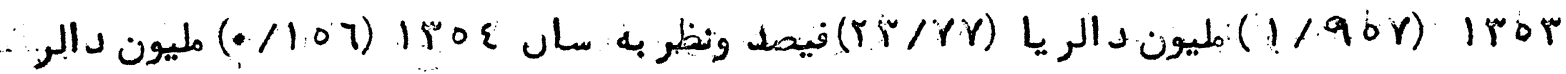

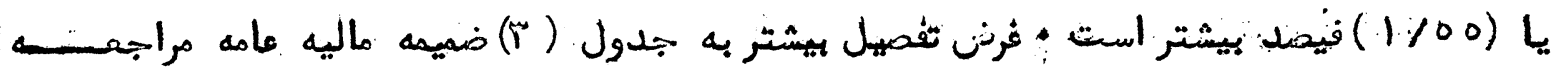

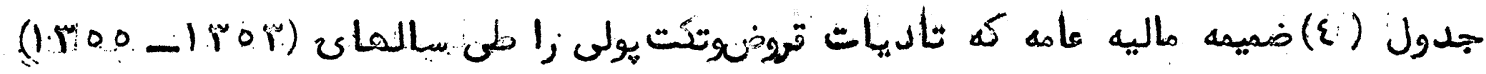

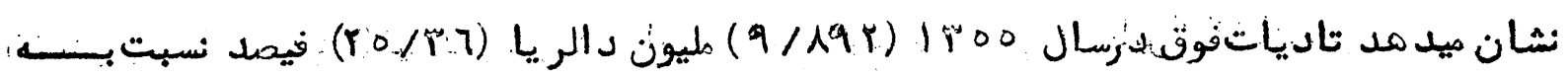

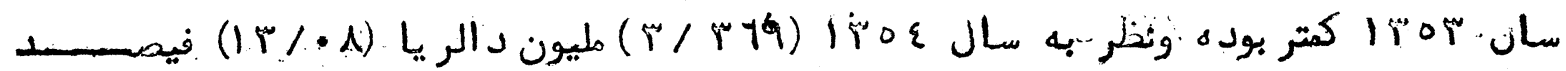

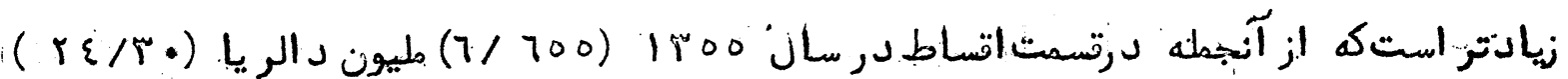

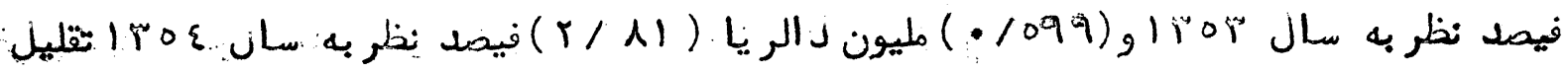

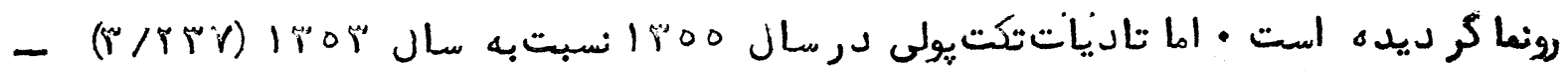

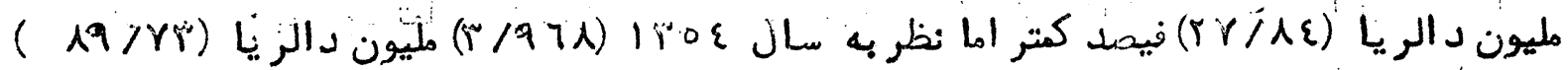
فيضد بيشتر النسون

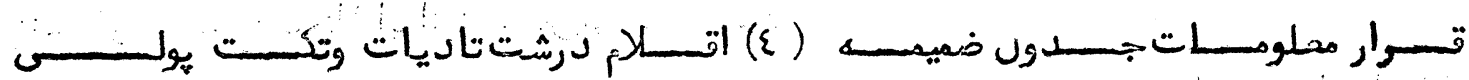

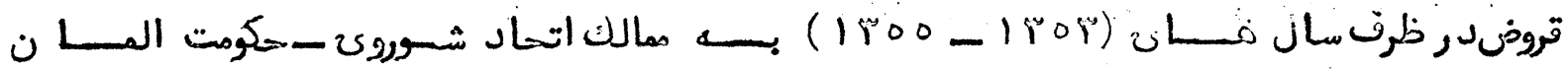

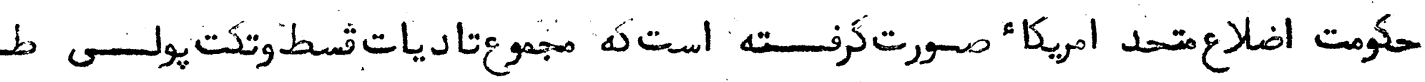

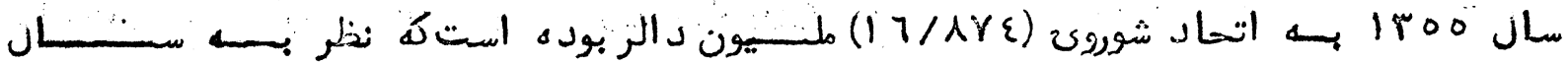

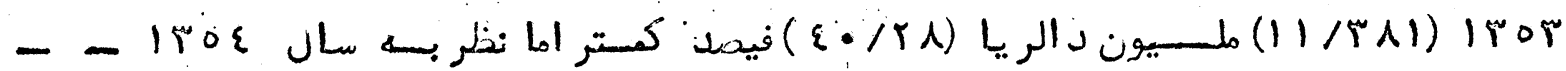

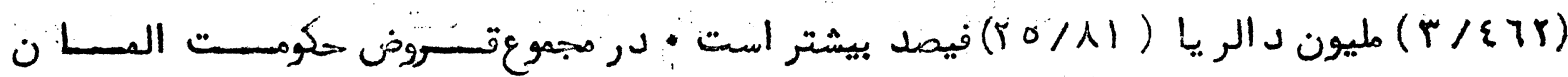

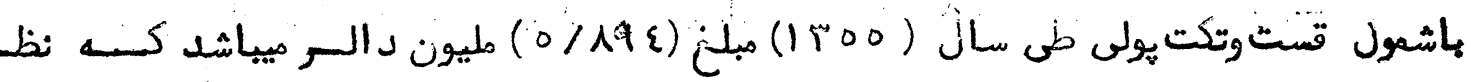

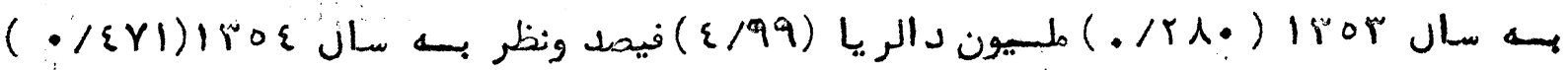

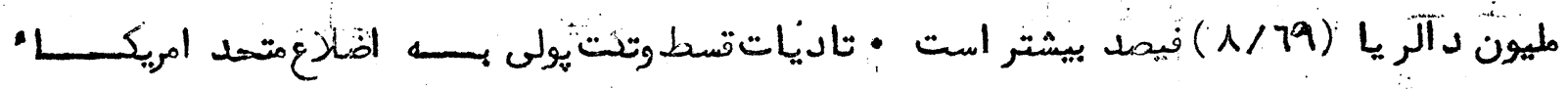

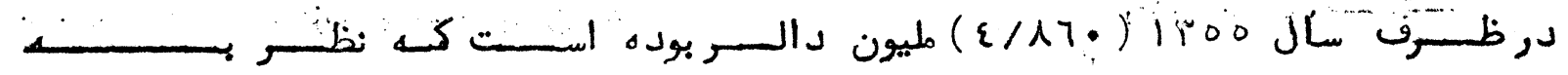

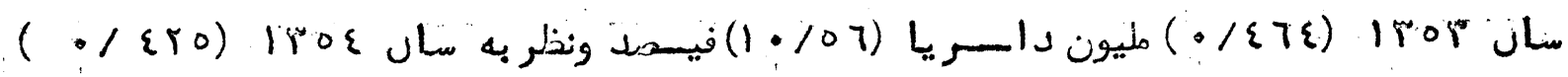

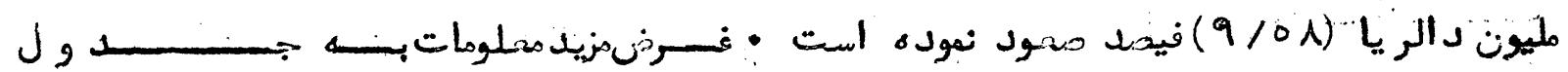

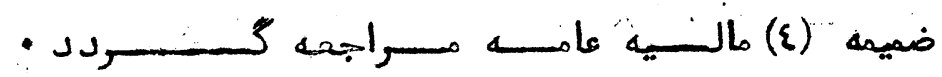

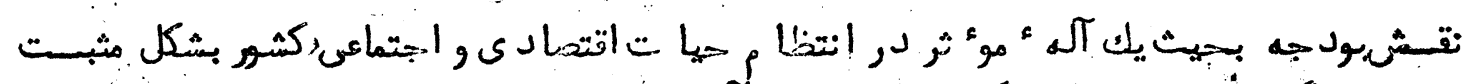

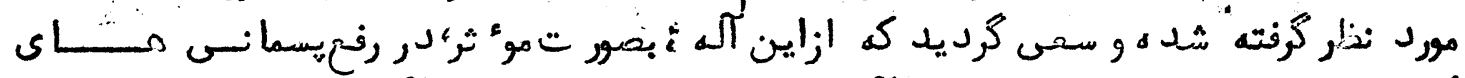

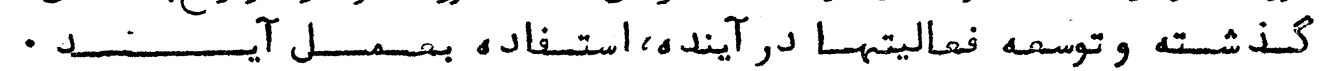

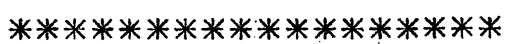

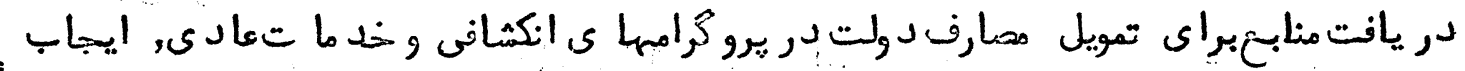

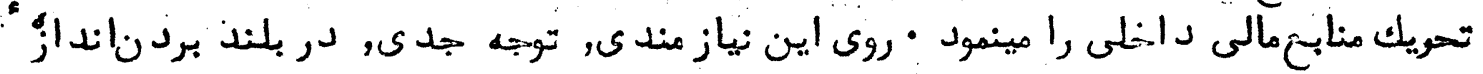

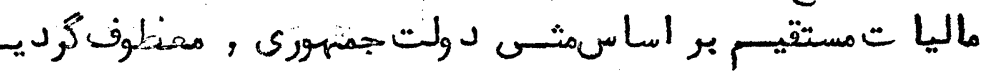

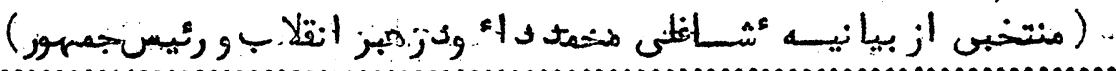


$-\wedge 7-$

مالســـــ عامســ

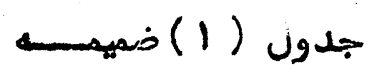

ارقام (بطيون افنانسى )

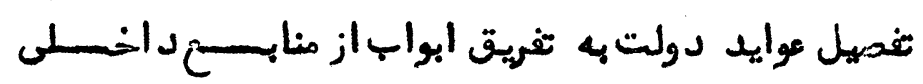

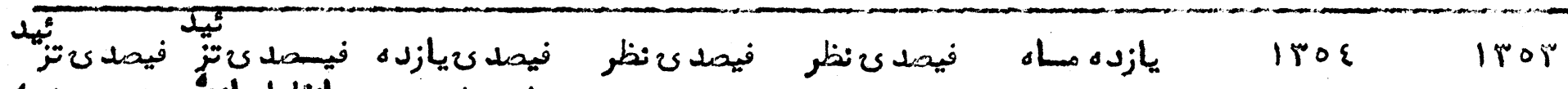

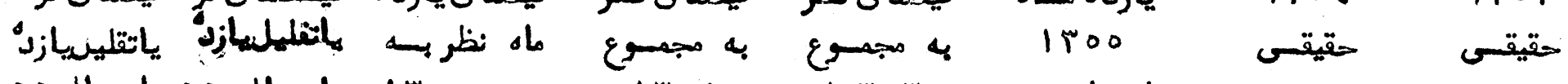

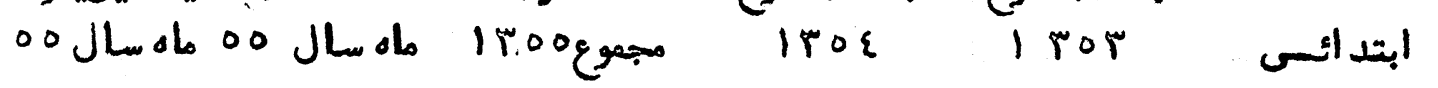

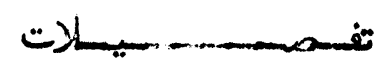

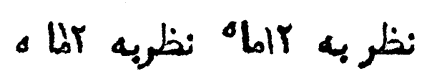

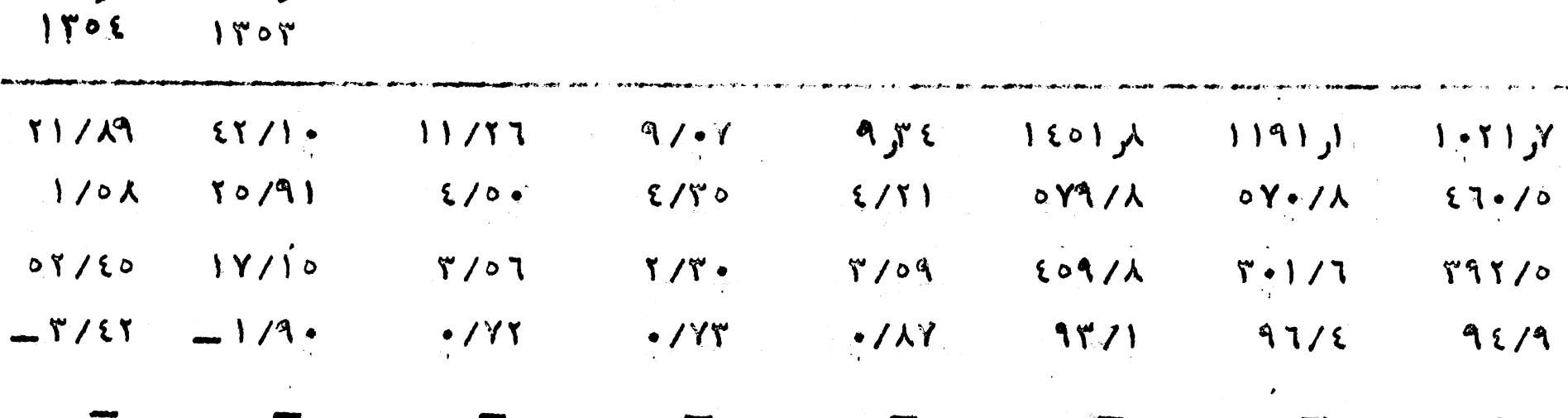

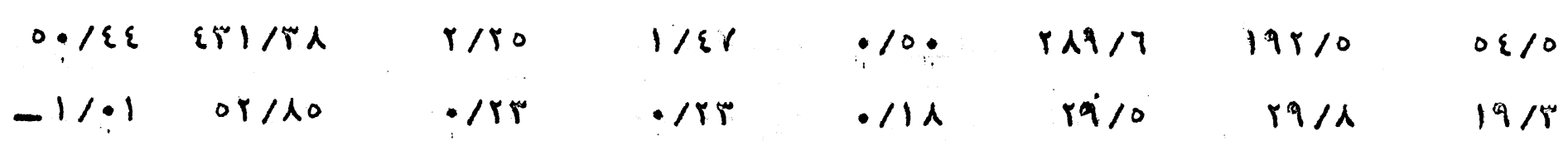

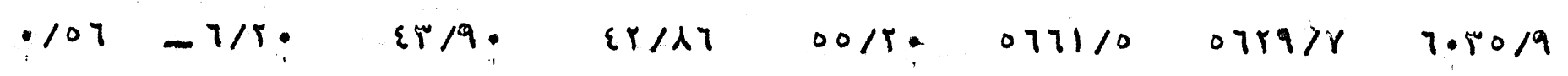

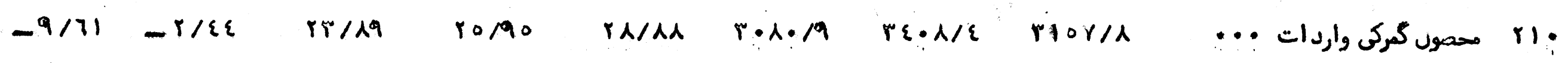




$$
-\lambda r
$$

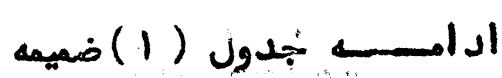

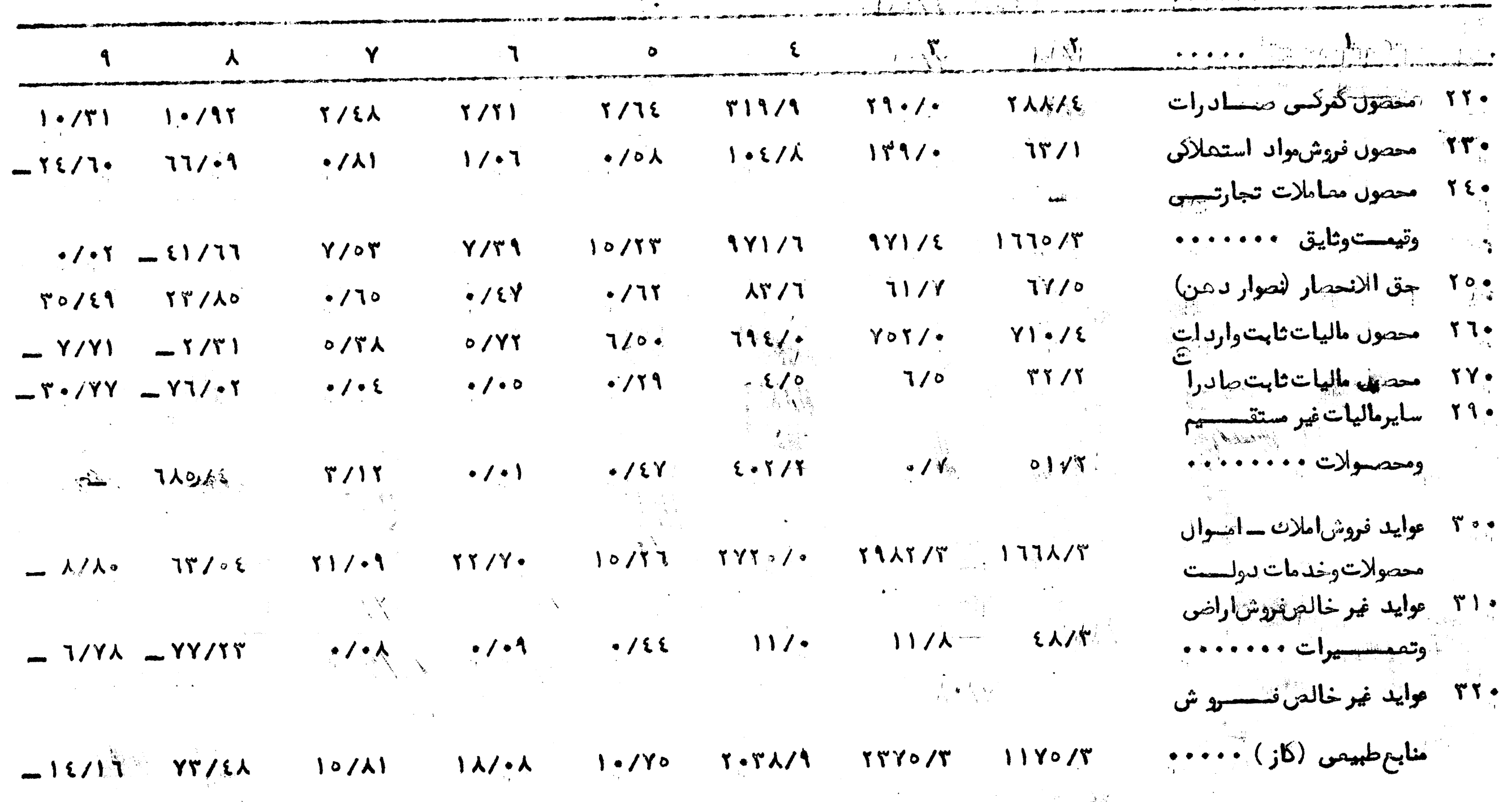




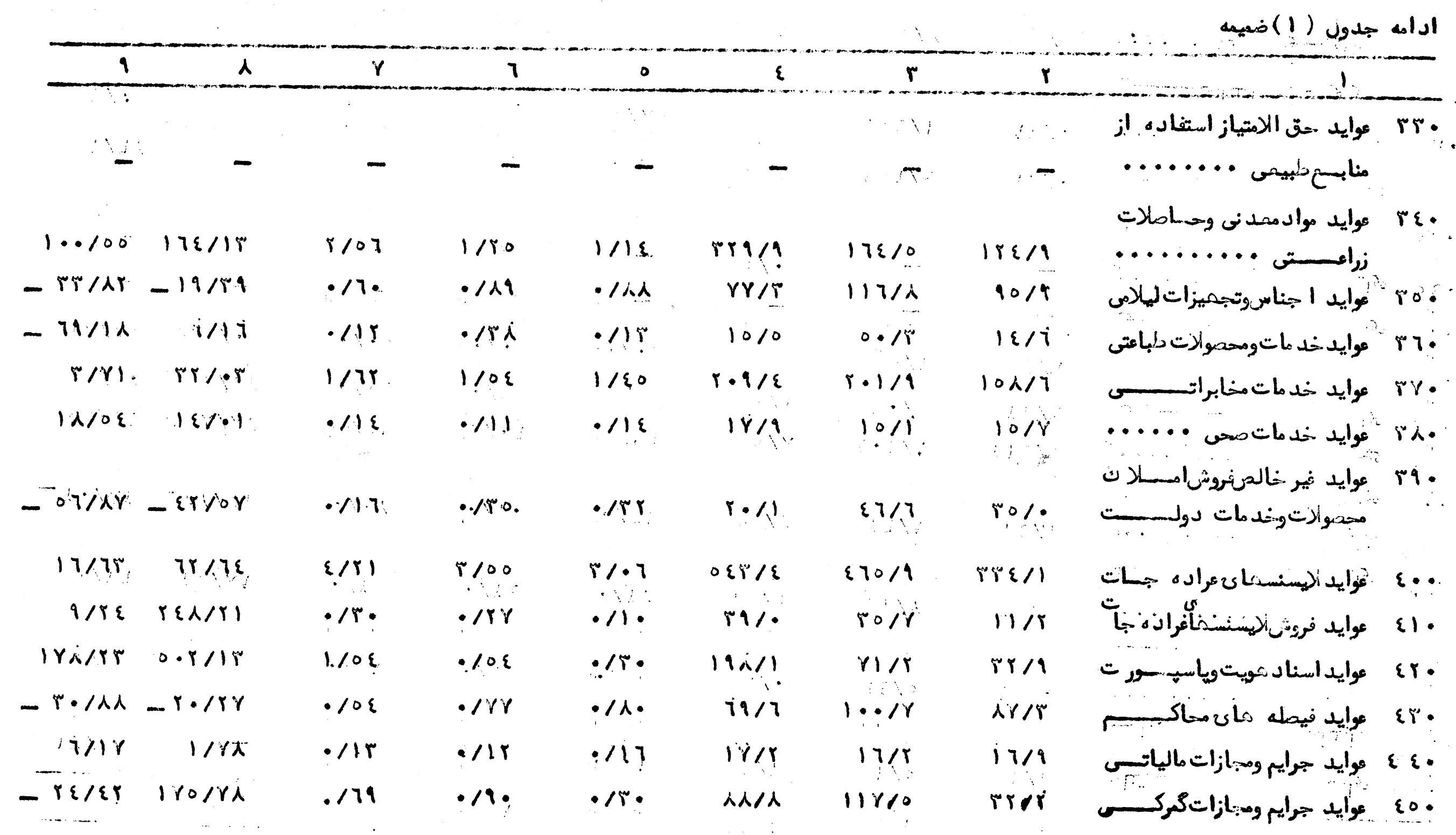




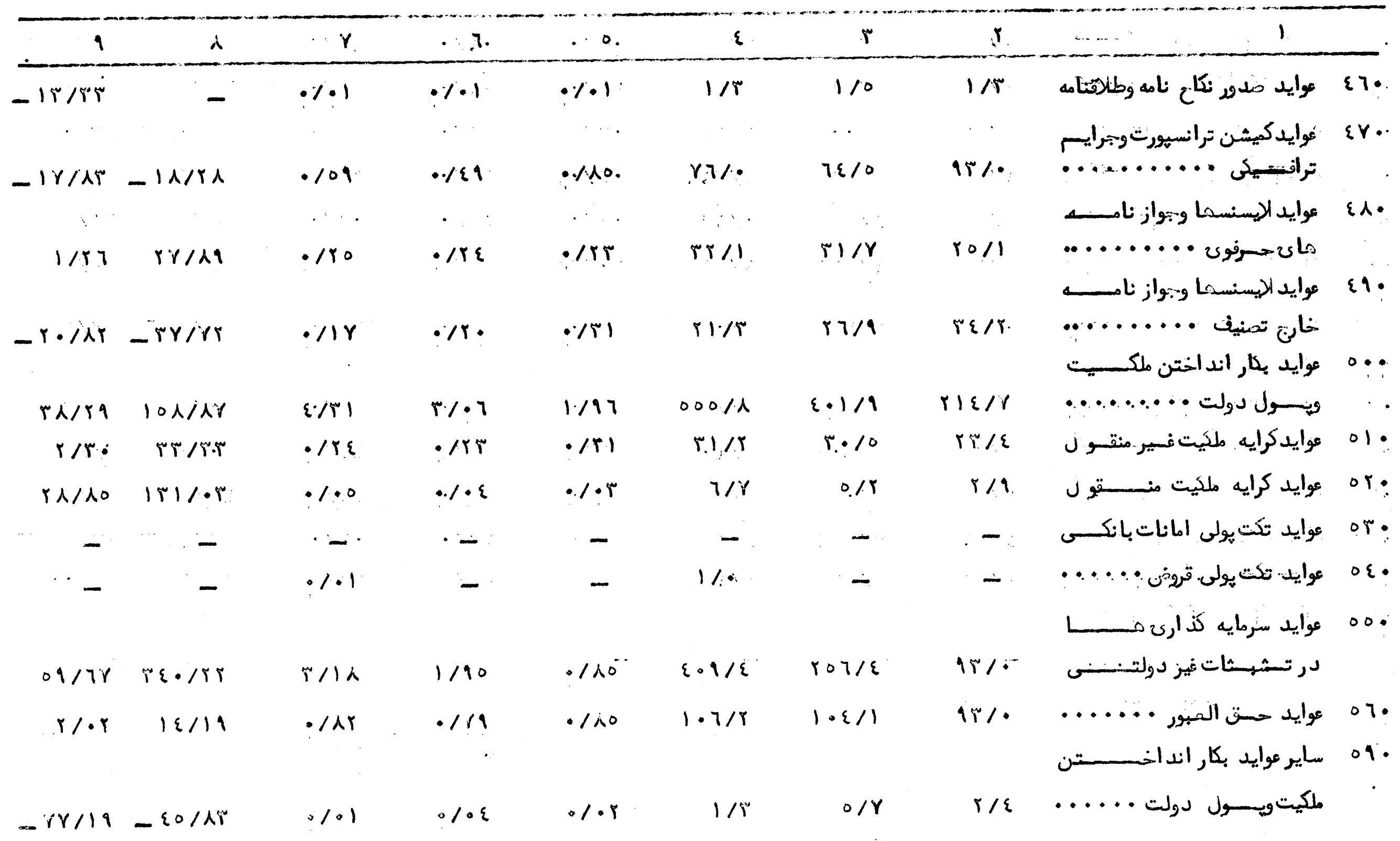


$-9 \cdot-$

ادامه جلول (1) بضميس

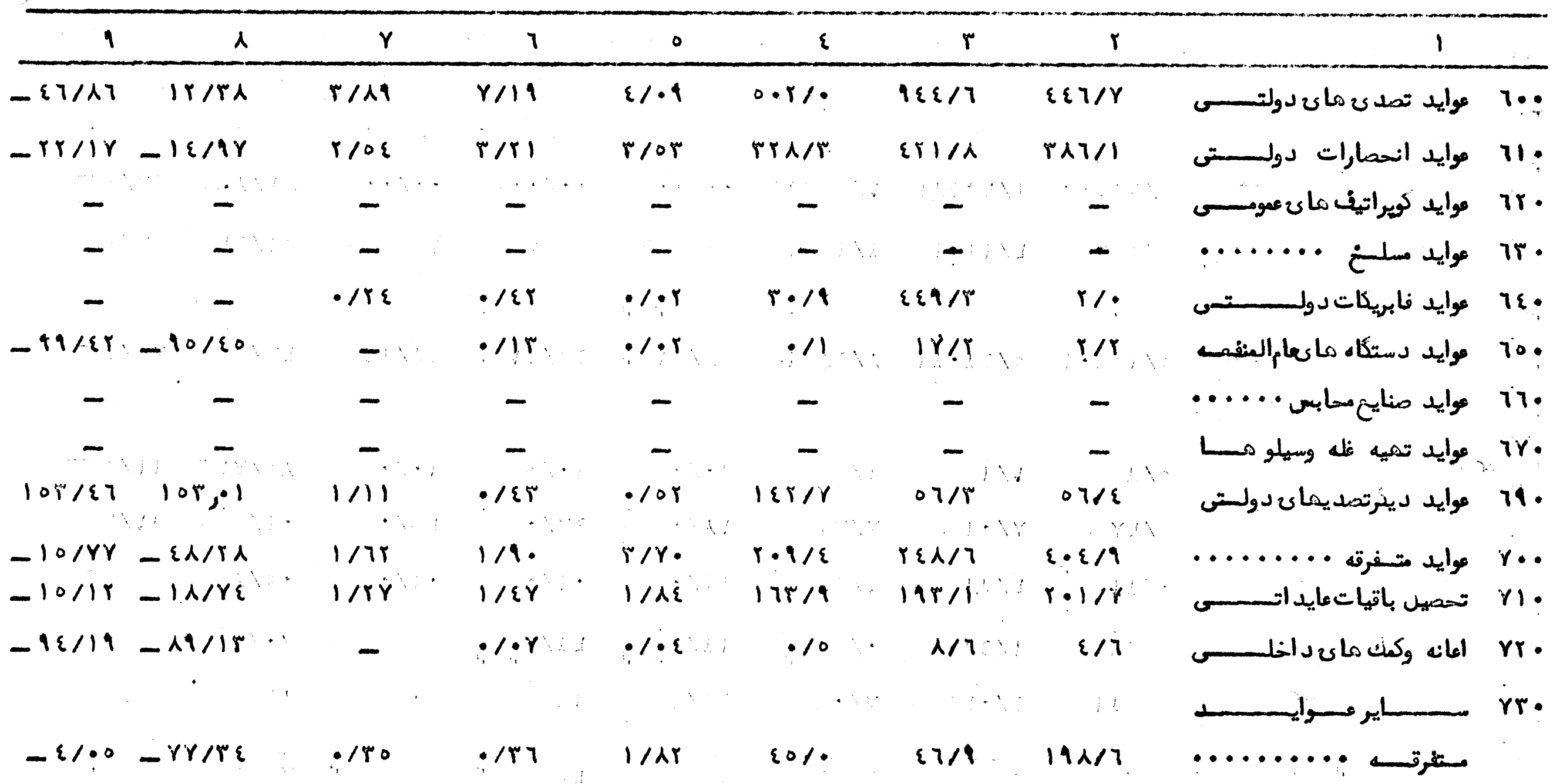




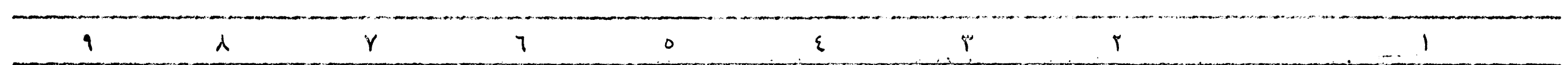

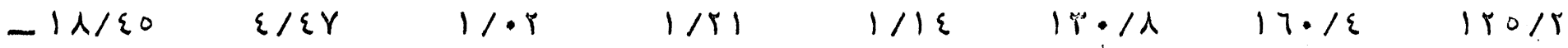

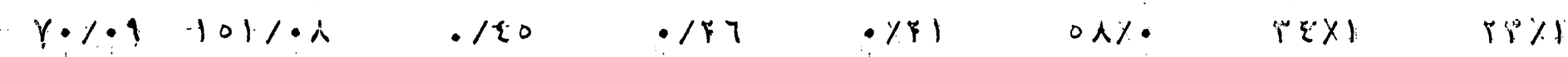

- 0110 r/0.

$\varepsilon 7 / 94$ -

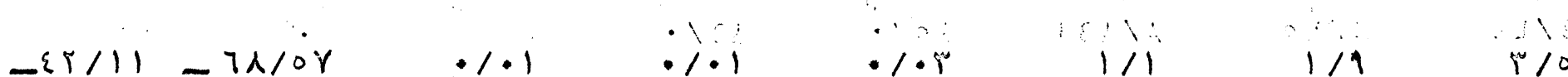

-

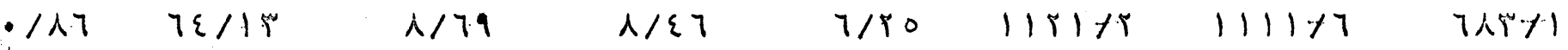

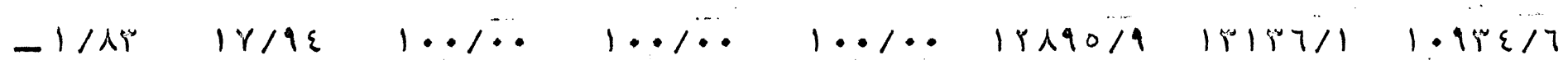

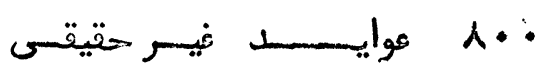

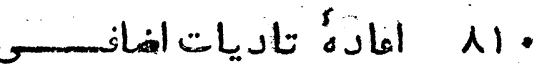

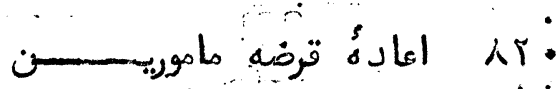
NP.

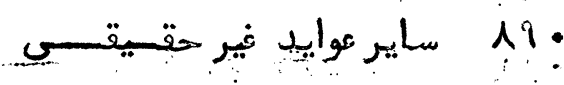

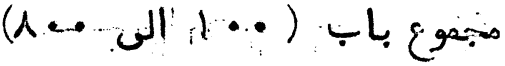

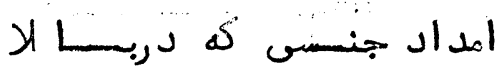

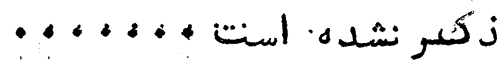

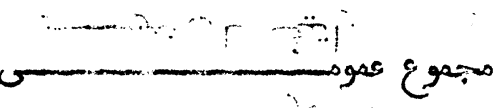




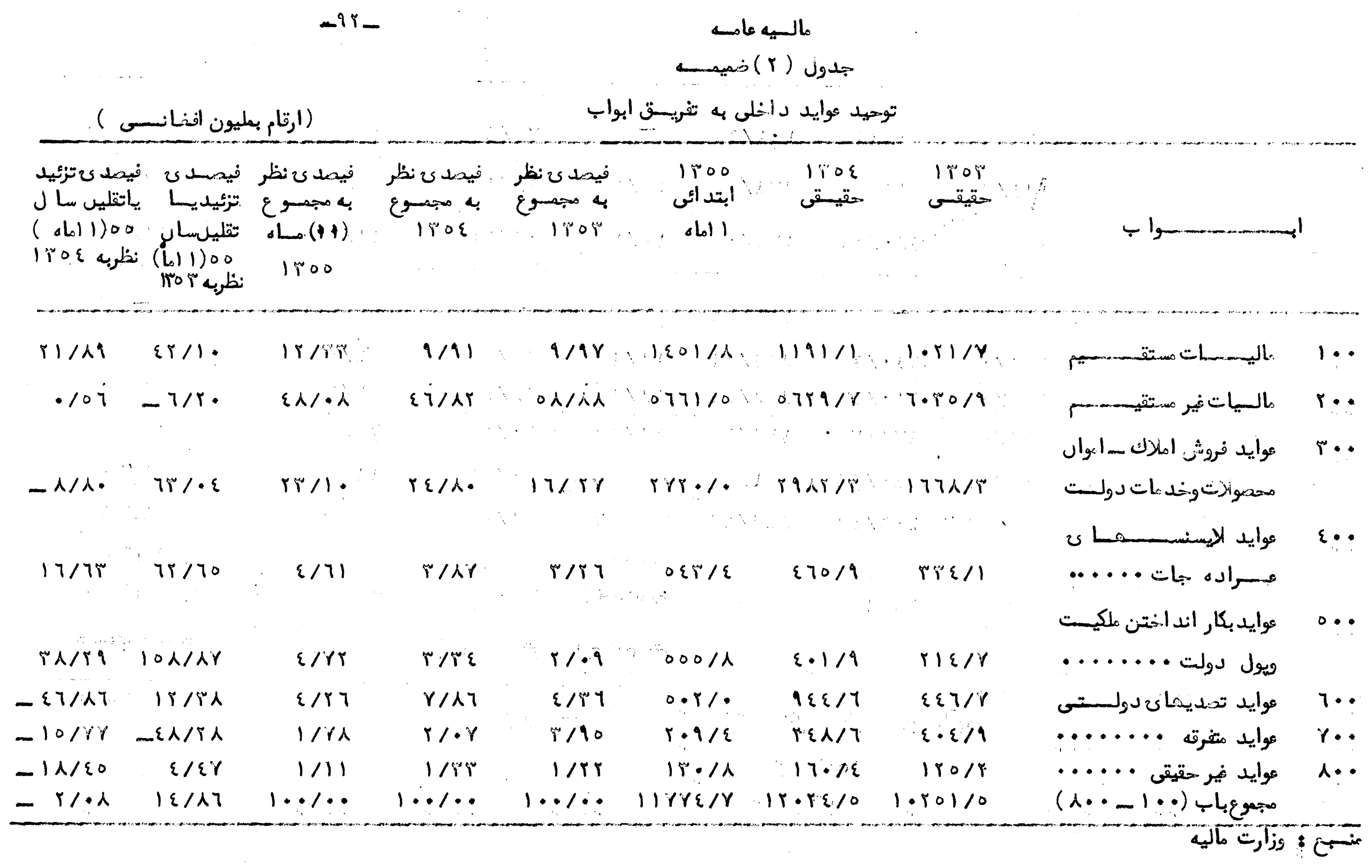


-9r_

ماليســــ

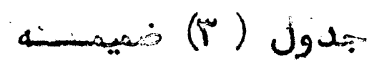

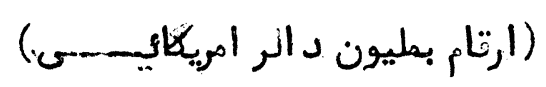

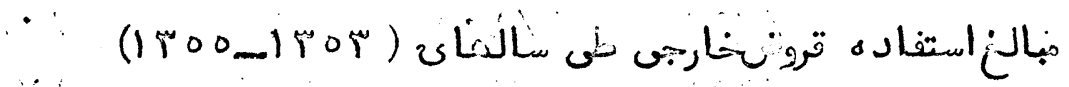

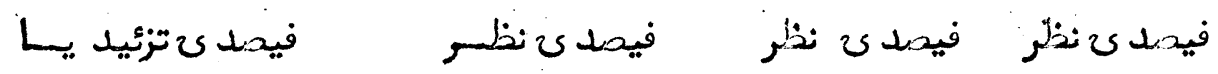

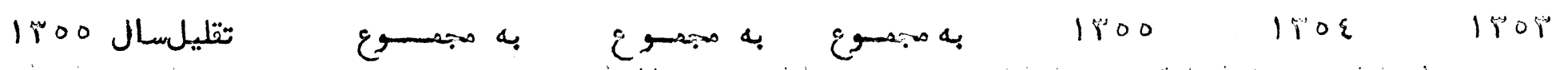

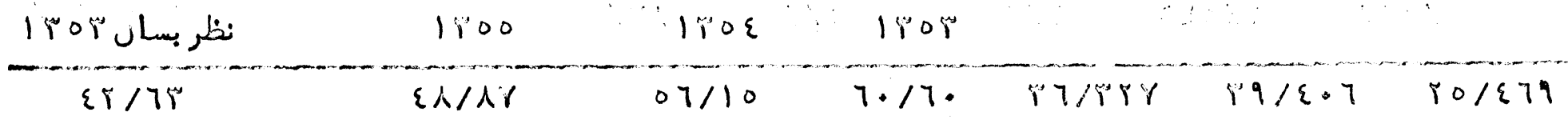

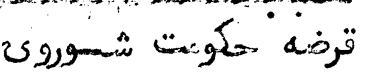

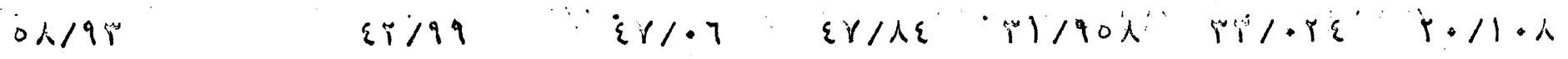

• יח

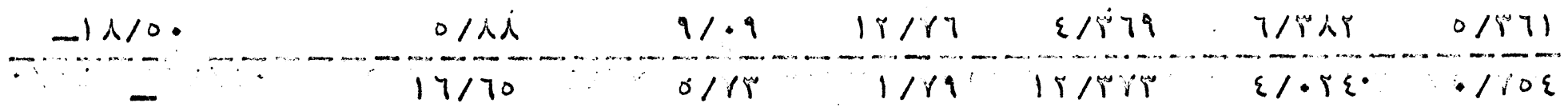

مواد استحملركى

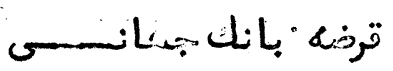

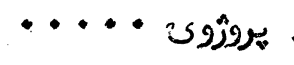

مواد الهتهـلاكسى

rop 18

$\mid \pi / n$

$1 \varepsilon / 4$.

h/rit

- ro/ar

$8 / 11$

$11 / r r$

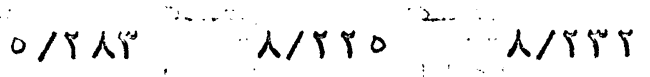

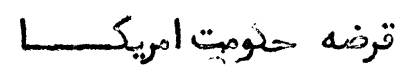

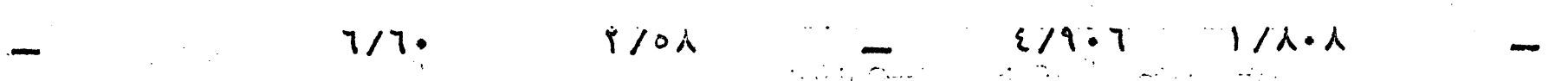

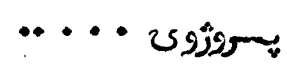

مواد استملاذكسى 


\begin{tabular}{|c|c|c|c|c|c|c|}
\hline 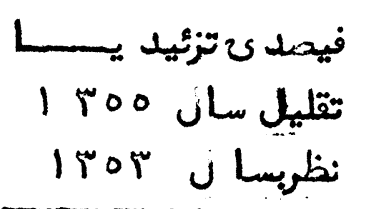 & 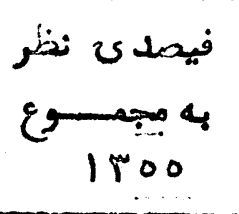 & 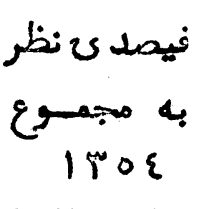 & 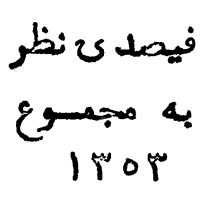 & 1500 & $190 \varepsilon$ & IrOY \\
\hline - & 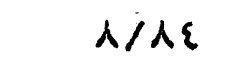 & . & - & $7 / 081$ &.$/ 1007$ & 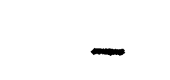 \\
\hline - & $A / A q$ & $\cdot \pi$ & - & YOYI & . Tro. & - \\
\hline - & - & - & - & - & - & - \\
\hline$-r T / 0 \varepsilon$ & r/7 & $\lambda / 91$ & $15 / 10$ & $\varepsilon / A \uparrow$ & $T / Y 07$ & $0 / \varepsilon \ldots$ \\
\hline$-10 / 0$ & $1 / .0$ & •|हl & $15 / 20$ & : r rar & :/rII & $0 / \varepsilon \ldots$ \\
\hline - & \&/Or & N/O. & - & $i / \varepsilon \ldots$ & $0 / 970$ & - \\
\hline - & r/9. & 1100 & - & $\Gamma / 100$ & $1 / .19$ & - \\
\hline - & $r / r$. & 1100 & - & illoo & $1 / . 人 4$ & - \\
\hline - & - & - & - & - & - & - \\
\hline - & 1,00 & $1 / M 1$ & - & $1 / 101$ & ./1r. & - \\
\hline - & 1100 & $\mid / r i$ & - & $1 / 101$ & . /9i: & - \\
\hline- & - & - & - & - & - & - \\
\hline
\end{tabular}

ترضه حلومت هيكوسلوايكا

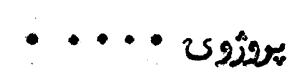

مواد استــلانسى هون

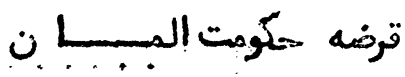

كوبرن

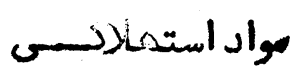

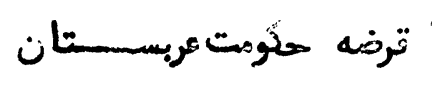

…...

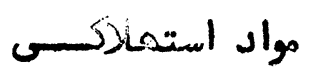

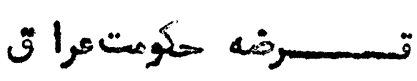

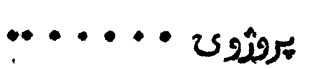

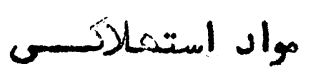




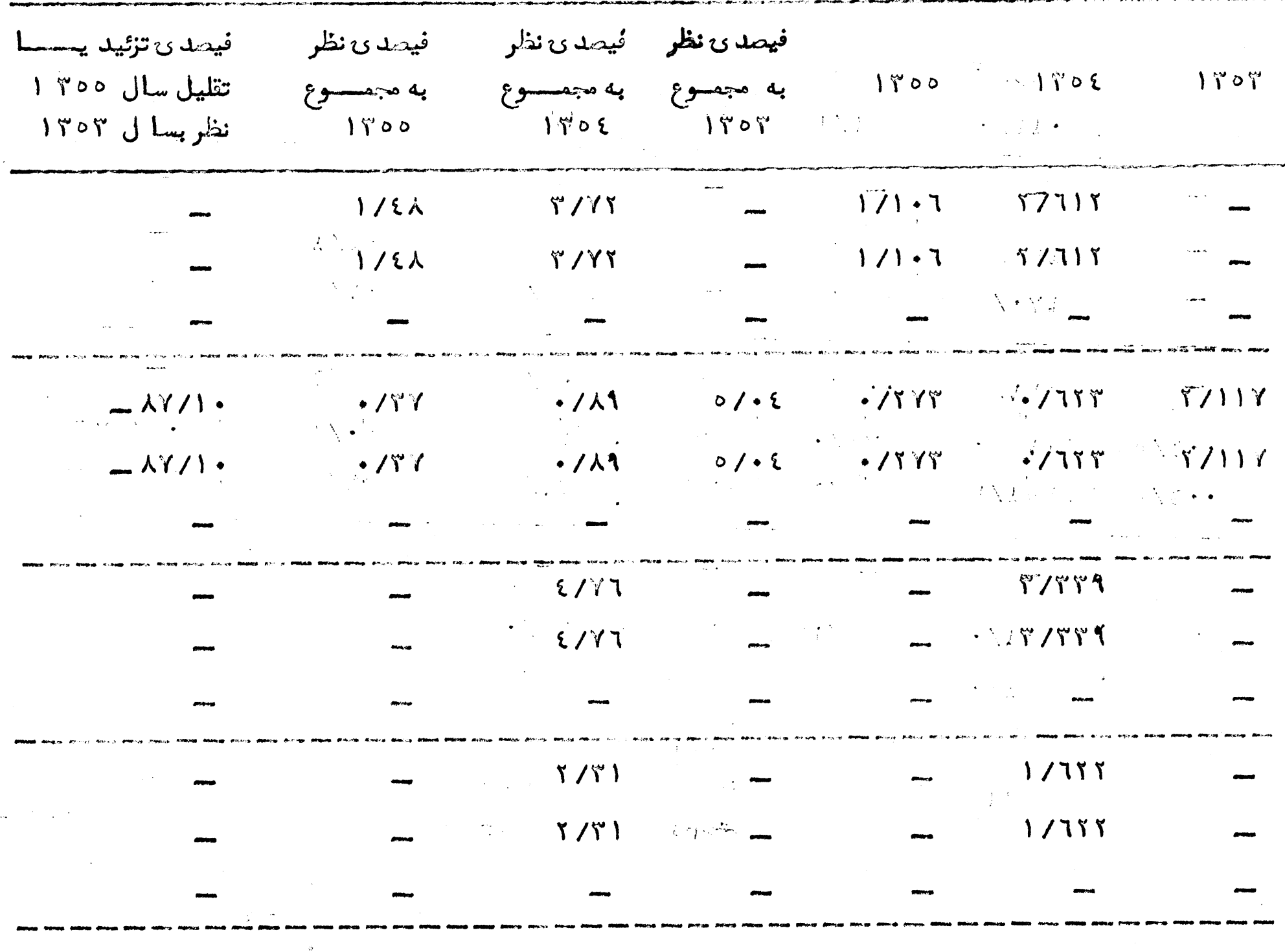

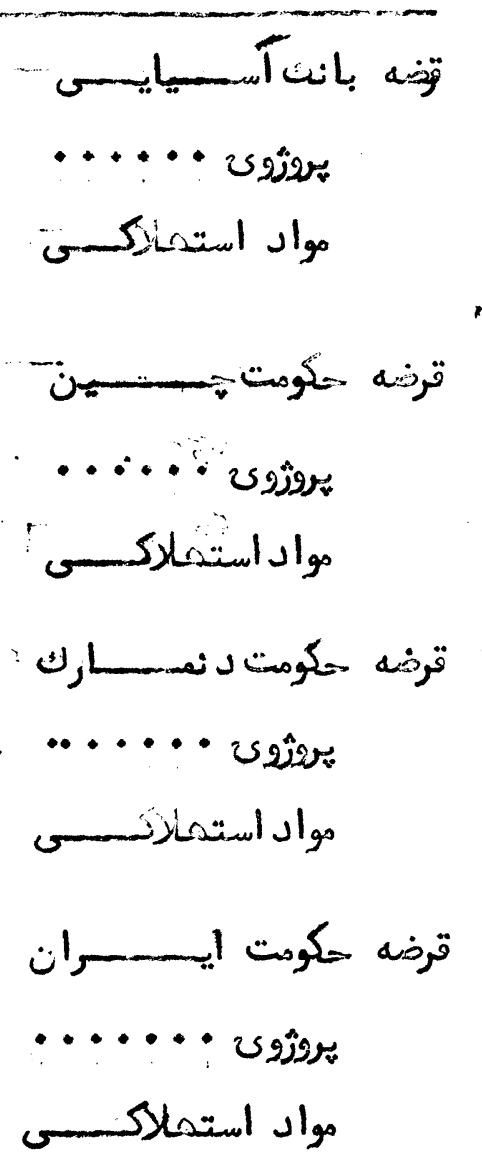


-ir

ادامه جبـدون

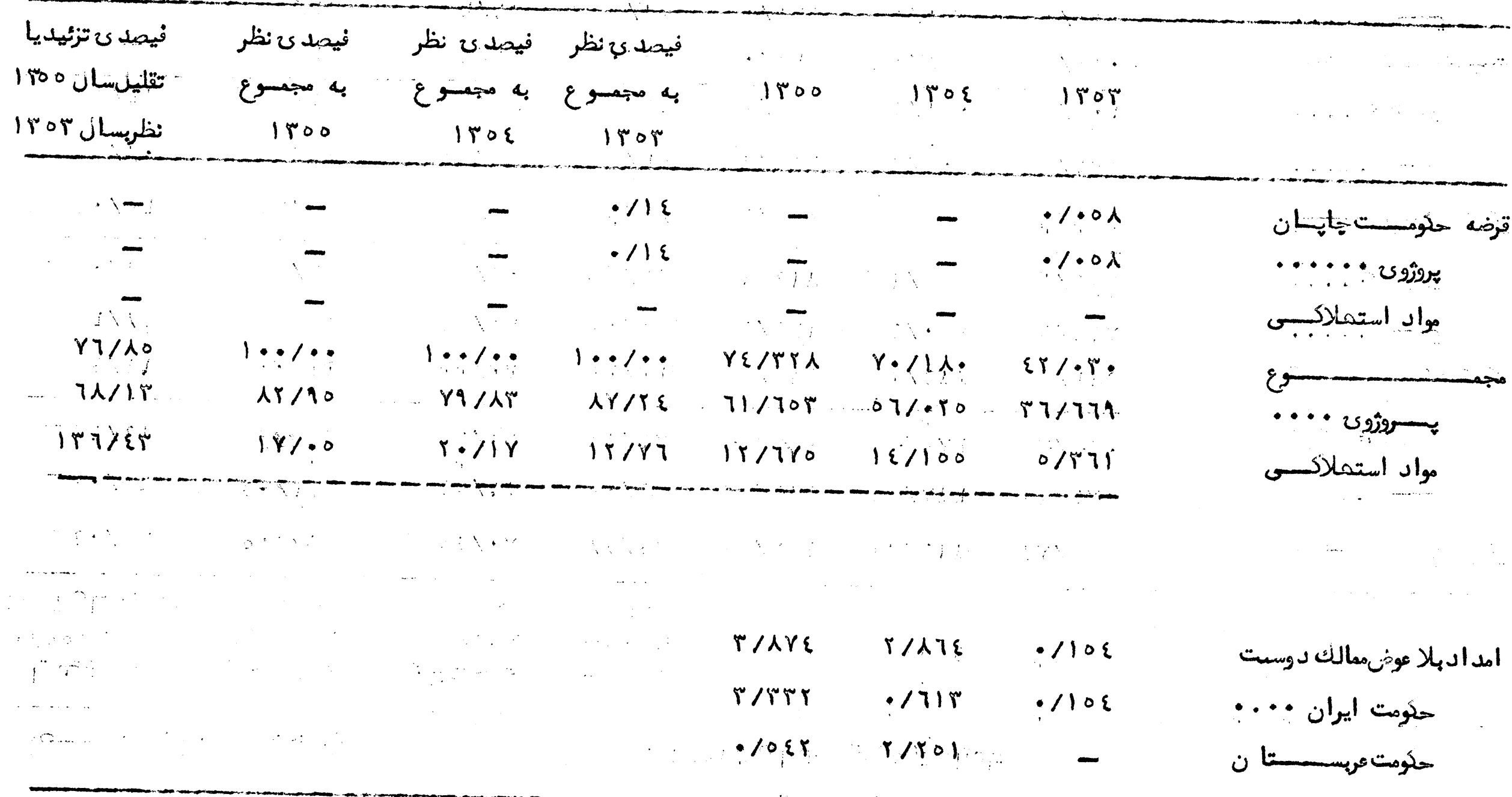




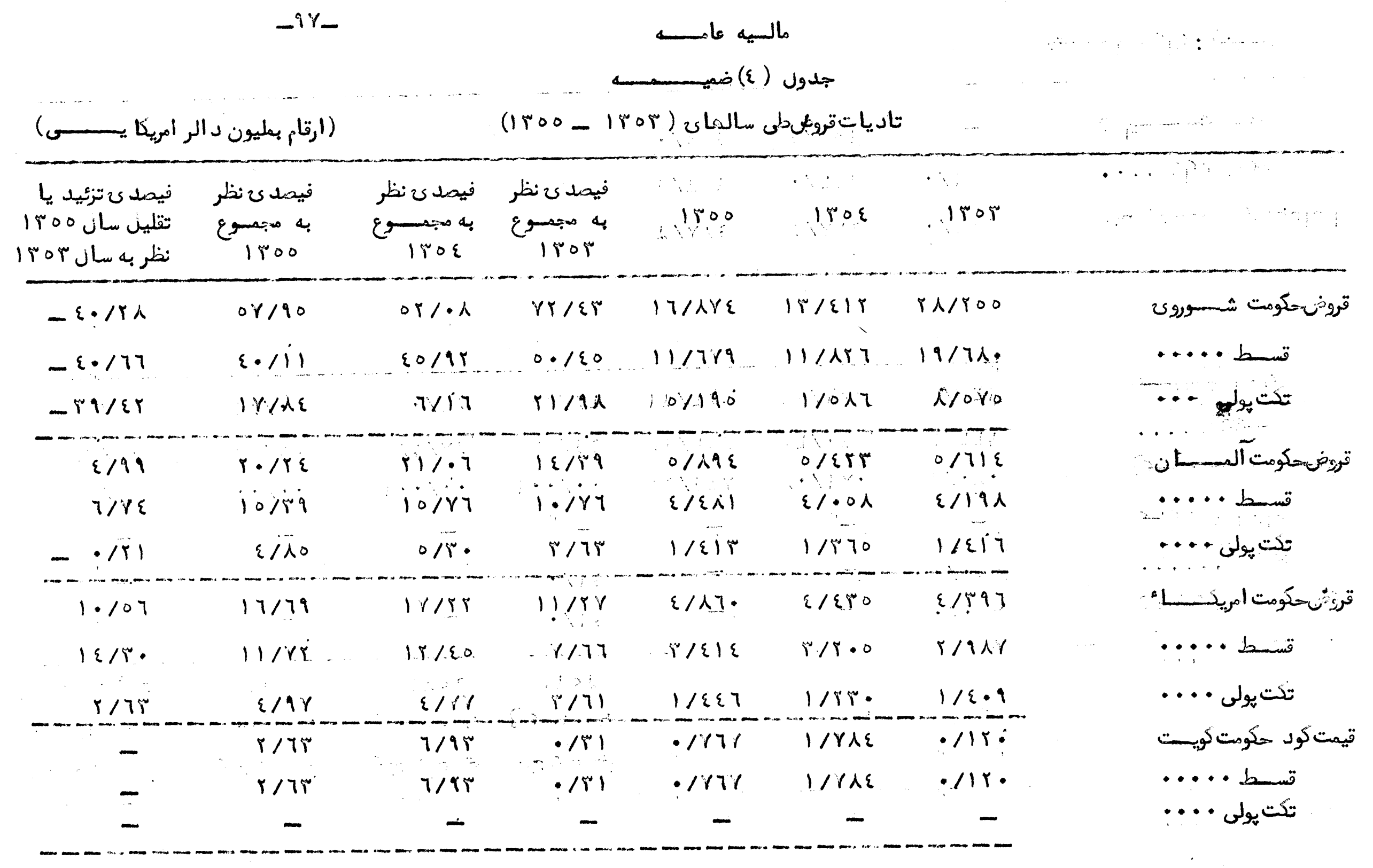


ادامه جــول (\&)

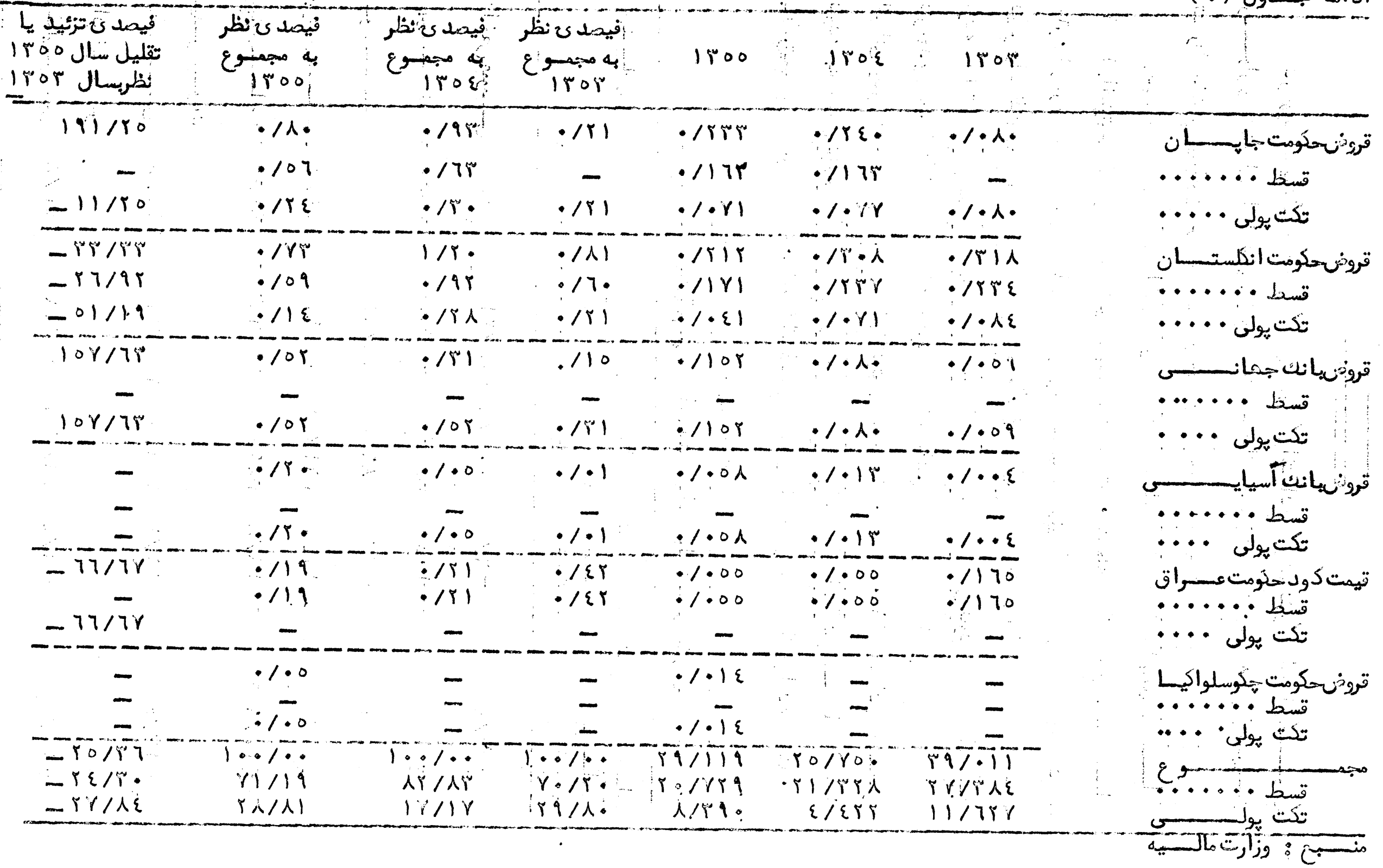




\section{Еニニニニニニ}

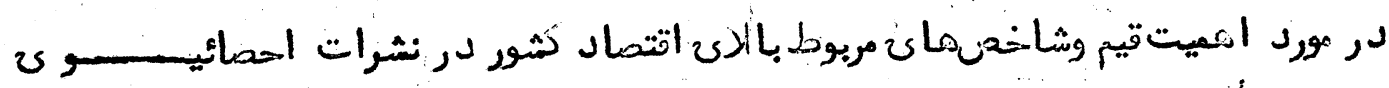

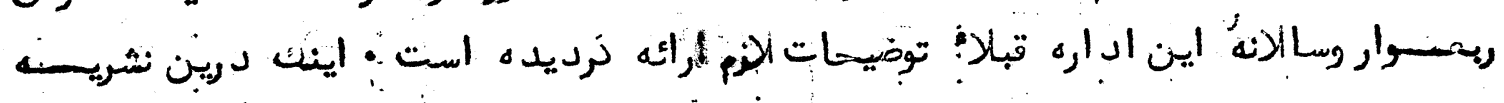

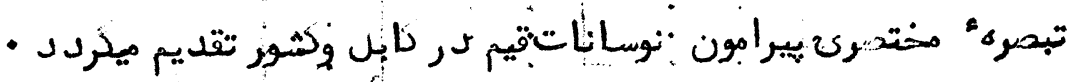

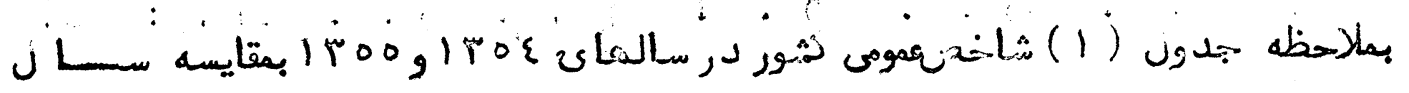

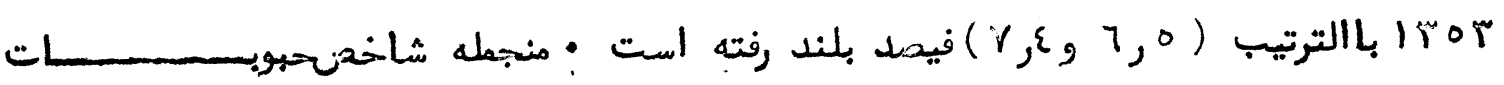

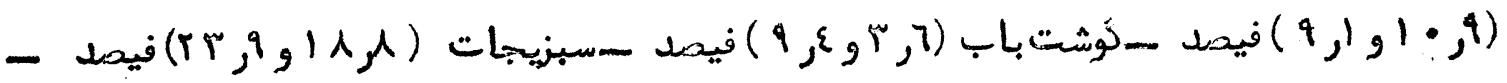

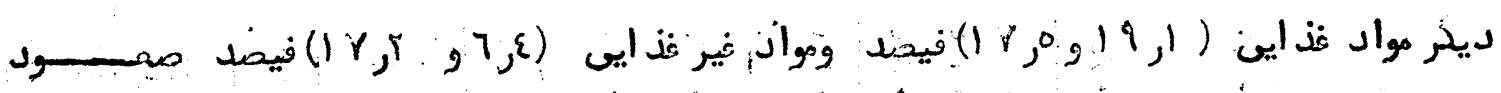

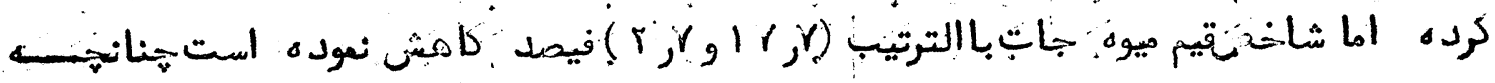

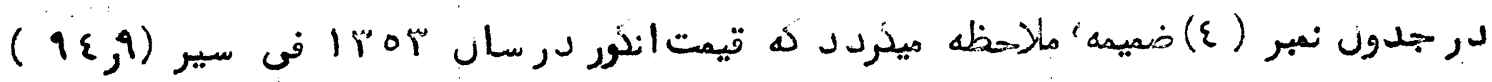

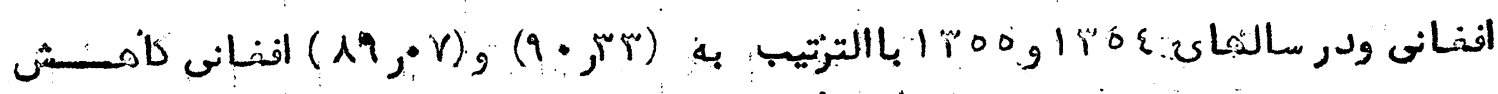

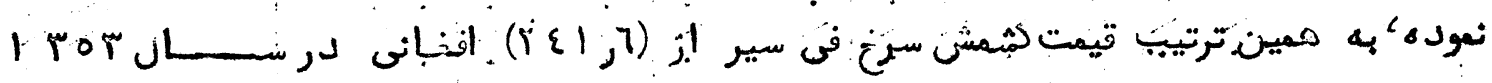

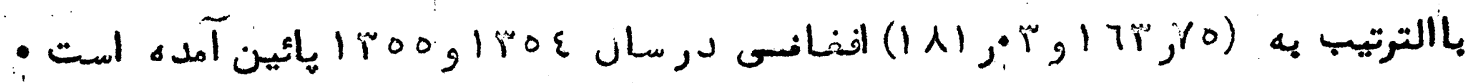

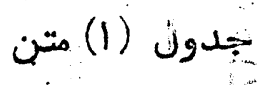

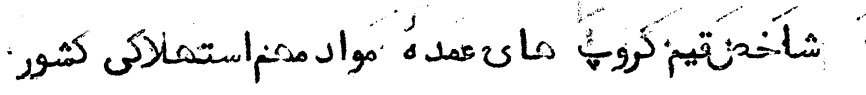

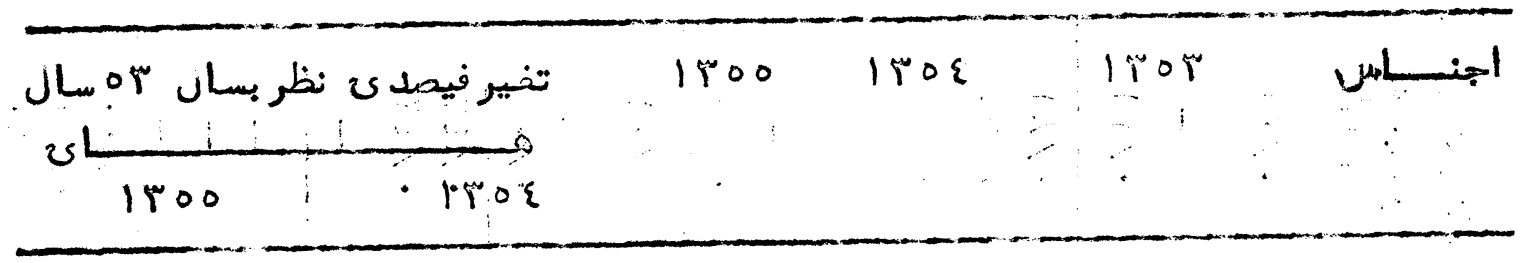

\begin{tabular}{|c|c|c|c|c|c|}
\hline$+V / \varepsilon$ & $+7 / 0$ & $r \cdot / r \wedge$ & rq人/rl & $r A \cdot / l$ & شانح بعومهسـى \\
\hline$+9 / 1$ & $+1 \cdot 11$ & $r \cdot r / 0 r$ & $r \cdot N / T r$ & rマᄉハ & 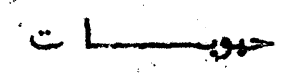 \\
\hline$+q / \varepsilon$ & $+r / 7$ & r人ฯハ & r7A.7II & roo/l & 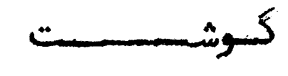 \\
\hline$-r / Y$ & $-18 / r$ & $r 7 / r)$ & $\Gamma \cdot 0 / 9 \Gamma$ & $581 / q$ & ميوه جســــات \\
\hline$r r / 9$ & tikis & $r \varepsilon 9 / 00$ & rro/rV & r $\dot{Y} / \mathrm{r}$ & \\
\hline$+18 / 0$ & $+19 / 1$ & 「₹q/9१ & YOY/ET & YT/A & ايـســـ \\
\hline 18 & $+7 / \varepsilon$ & $17 \curlywedge / \varepsilon \gamma$ & $105 / 91$ & $\mid \varepsilon r / A$ & \\
\hline
\end{tabular}




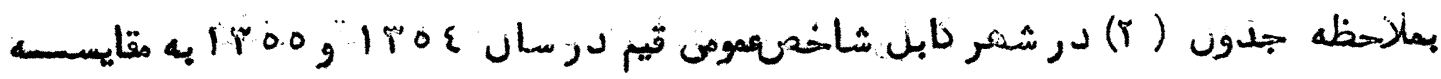

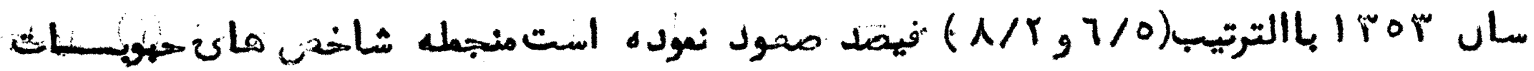

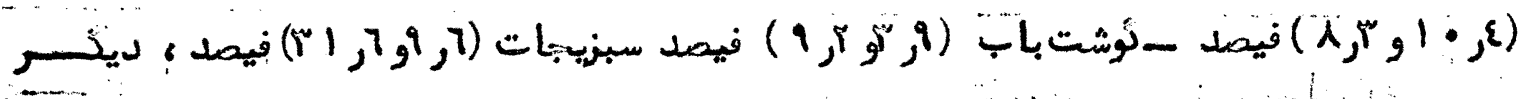

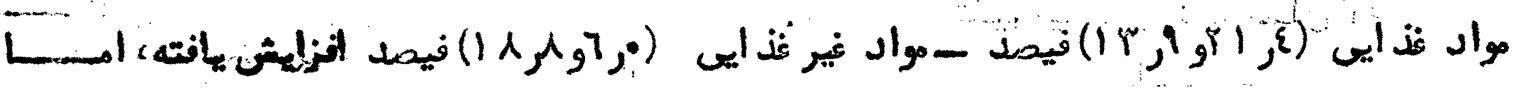

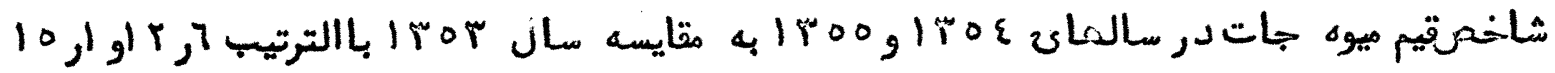

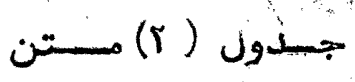

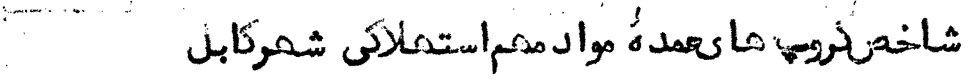
فيمط - امشنيافته 1

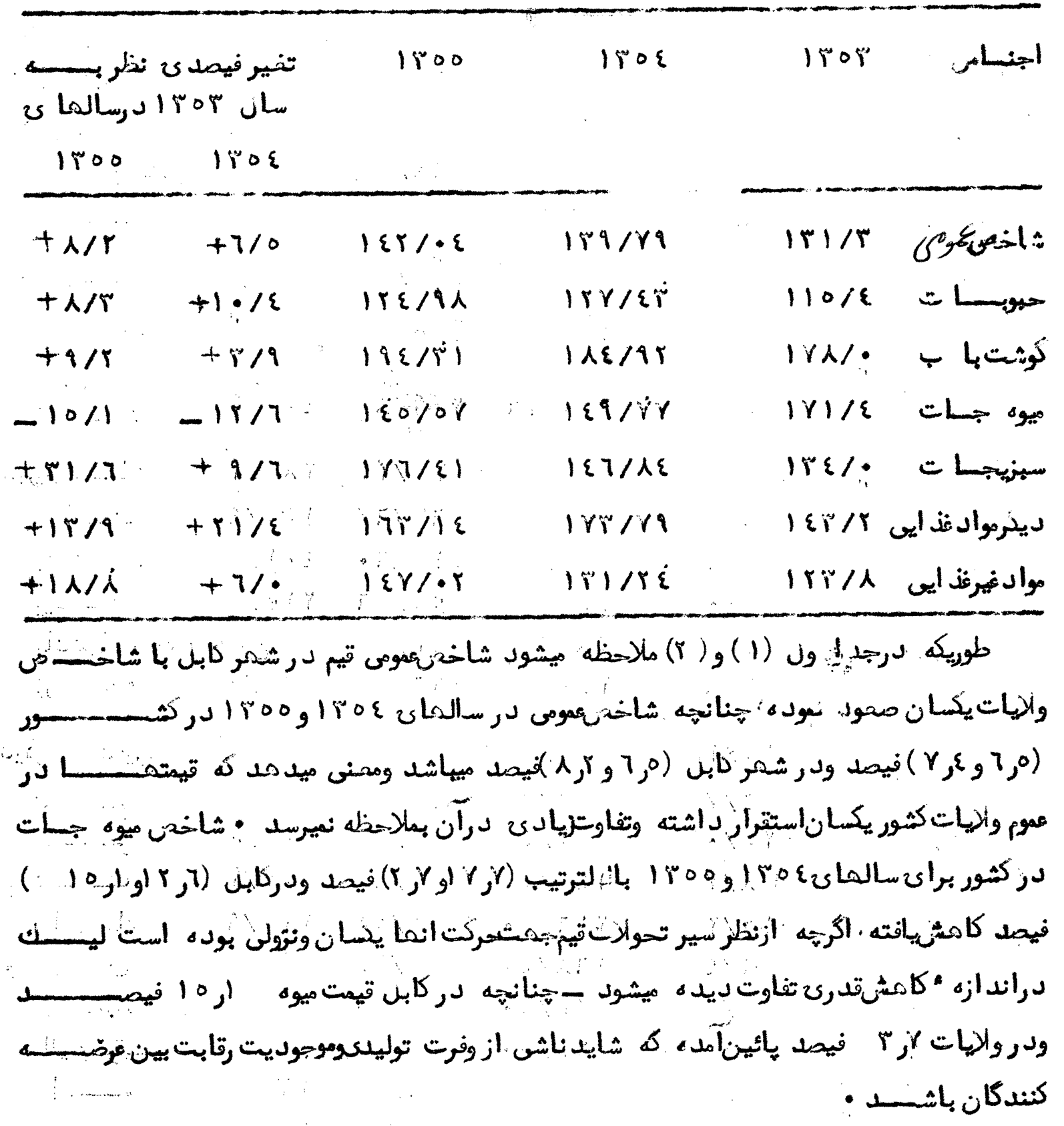




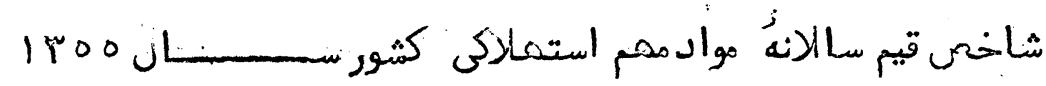

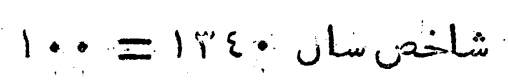

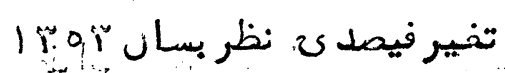

1Tes lrog lror.

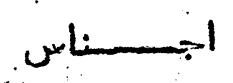

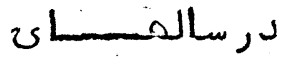

1500 To\&

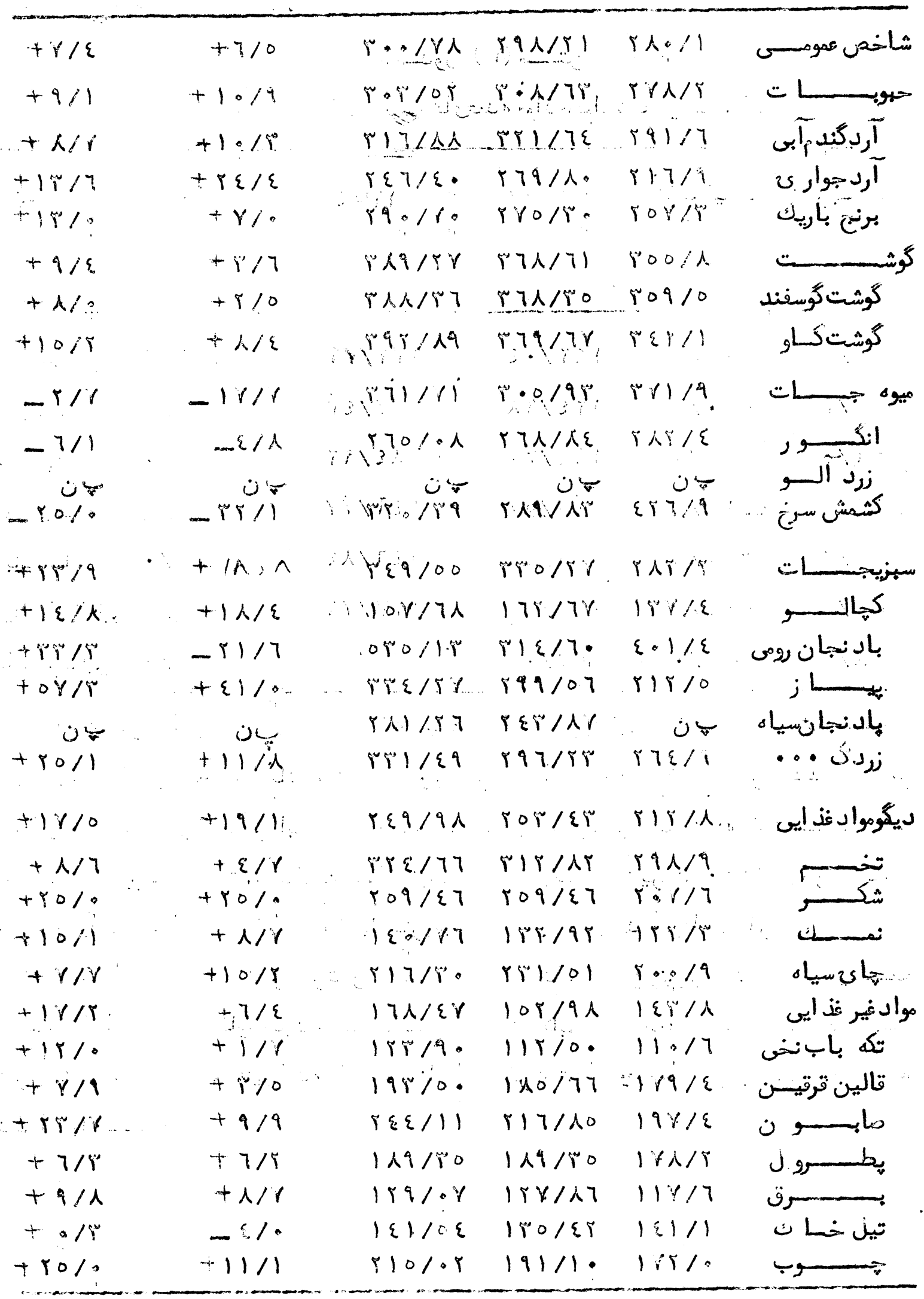




\section{$(1 \cdot r)$}

$$
\begin{aligned}
& \text { اوسط:تيم متوازن مواد استملاكى كثور }
\end{aligned}
$$

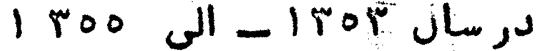

\begin{tabular}{|c|c|c|c|}
\hline 1roo & Irog & I TOY & واحل مقيا \\
\hline $0 \wedge / M 1$ & $09 / 11$ & $0 \% / 7$ & فى سيسر \\
\hline$\{r / 1\}$ & $\varepsilon \wedge / \bullet r$ & $r \lambda / T$ & נג \\
\hline$\varepsilon r / 1\rceil$. & $i \pi \varepsilon / 7 \pi$ & $1 r 0 / 1$ & ננ \\
\hline
\end{tabular}

$\varepsilon \varepsilon / / \lambda$

$\{\mid \lambda / \varepsilon\} \quad \varepsilon \cdot \Lambda / 0$

נע

rVI/A\&

ror/tr rir/a

ננ גנ ננ

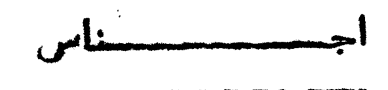

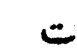

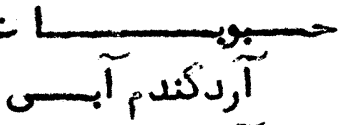

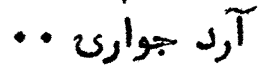

برنغ باريســنـ

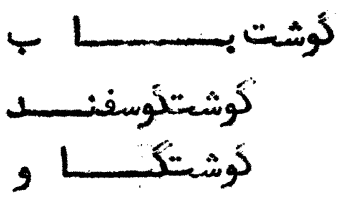

\begin{tabular}{|c|c|c|c|}
\hline $19 /: \gamma$ & $1 \cdot / r i$ & $1 \varepsilon / 9$ & $\mu$ \\
\hline$\dot{ن}$ & كآن & كن & ננ \\
\hline$|\wedge| / \bullet r$ & $171 \%$ & $r\{1 / 7$ & ננ \\
\hline
\end{tabular}

\begin{tabular}{|c|c|c|}
\hline WT/IY & 斗/1人 & 「人/1 \\
\hline $\mid r r / .1$ & YI/Yr & $91 / 0$ \\
\hline$\varepsilon r / R q$ & $\forall \wedge / T^{2} \varepsilon$ & $r r / r$ \\
\hline $09 / 91$ & $01 / 90$ & \\
\hline$r \wedge / r \lambda$ & $r 0 /$ l & TS/O \\
\hline rY/rq & Y人/: \& & $r \cdot \lambda / \varepsilon$ \\
\hline 旧/1人 & $111 / 11$ & $179 / 7$ \\
\hline IV/Ah & IT/ & $1.0 / 0$ \\
\hline - ET/TY & ז1ר/110 & i7h/. \\
\hline
\end{tabular}

$17 / 17$ I $1 \varepsilon / 100$

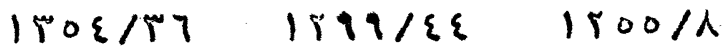

$r \vee / \varepsilon 0: \quad r \varepsilon 1 / 10 \quad$ rI9\%

riso ra/ro ro re

rirt $r / r \cdot r / 1$

$91 / 77$ 9R/R TN/T

ber H/.

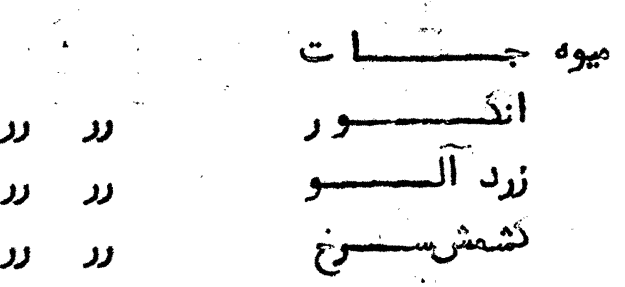

עل עل

נر " נג "

ענ נת

נע

ננ נת

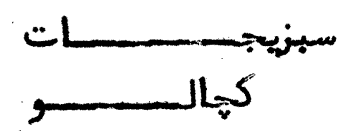

باد نجان رودى باد يونجان

باد نهجان سيا هار

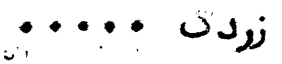

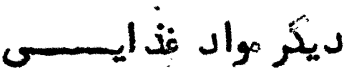
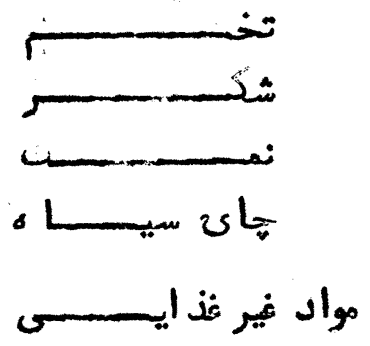

$$
\text { فيقد دانه }
$$

فى متر متر

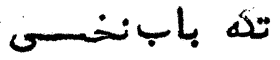

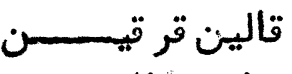

في سير مير مري

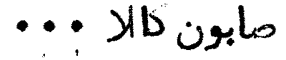
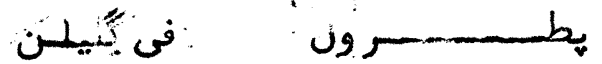

في فيلو وات

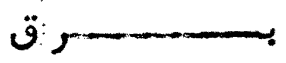

في سير

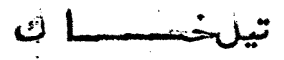

ע

י- 


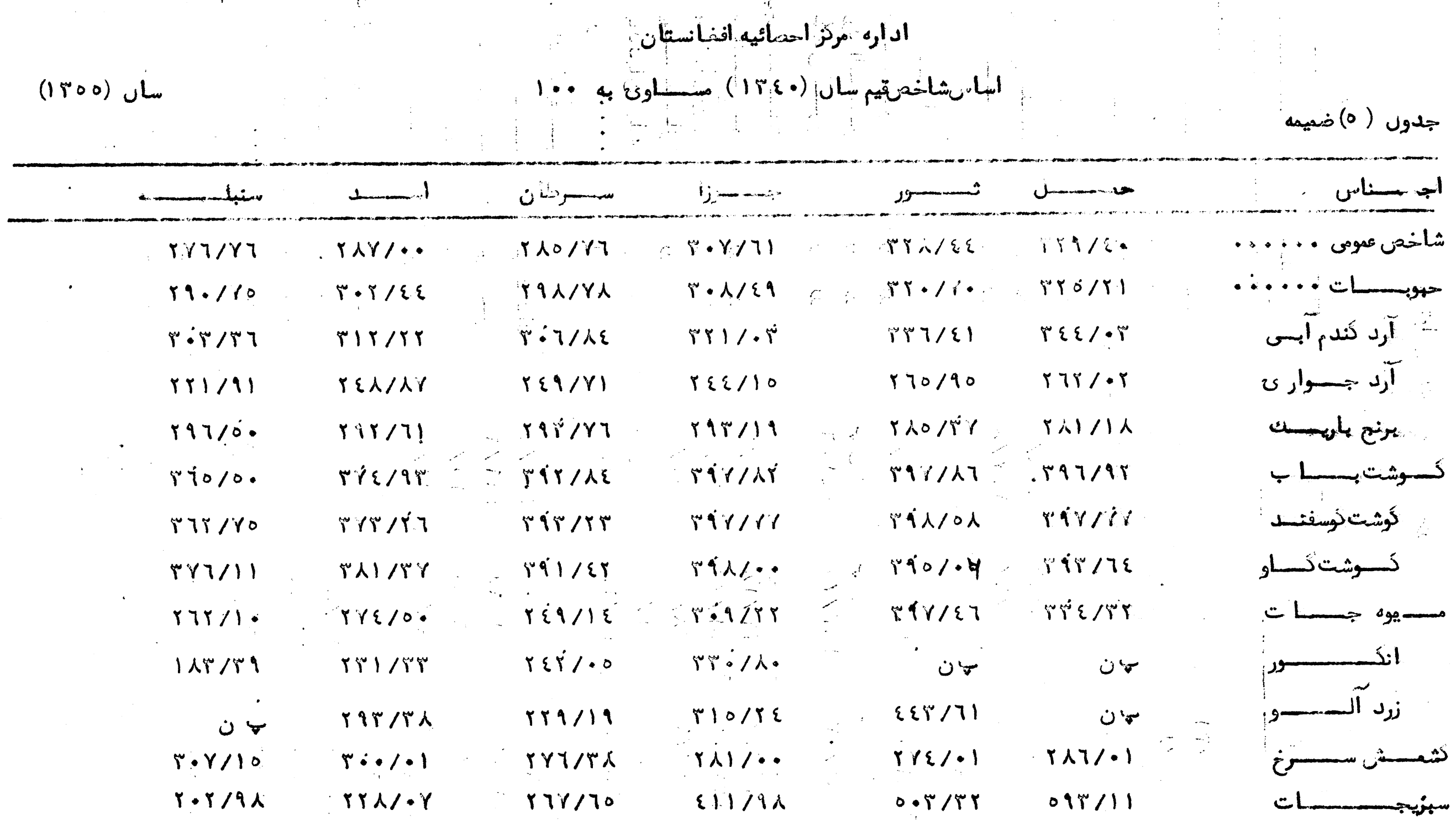




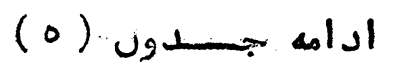

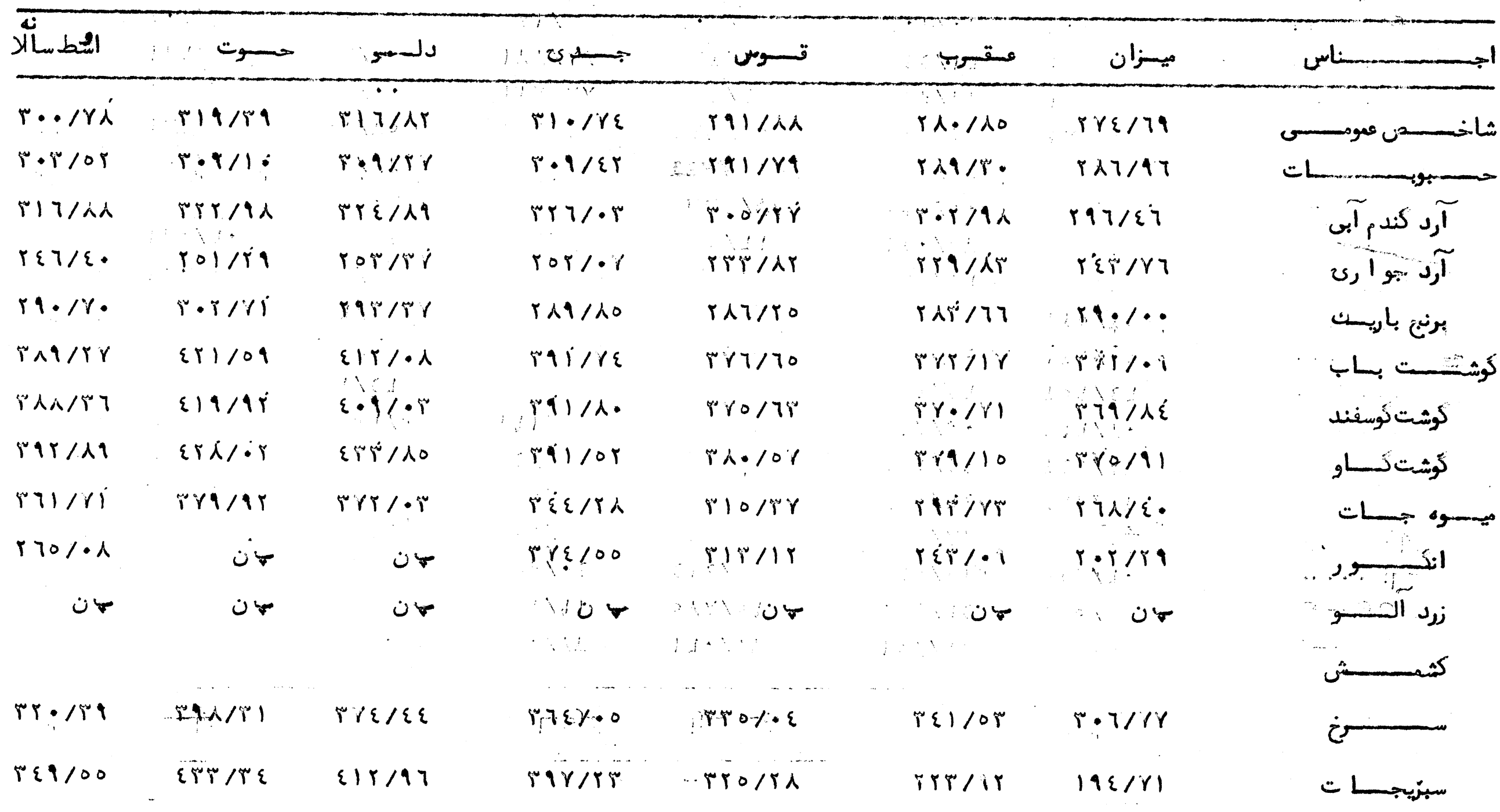


$(1 \cdot 0)$

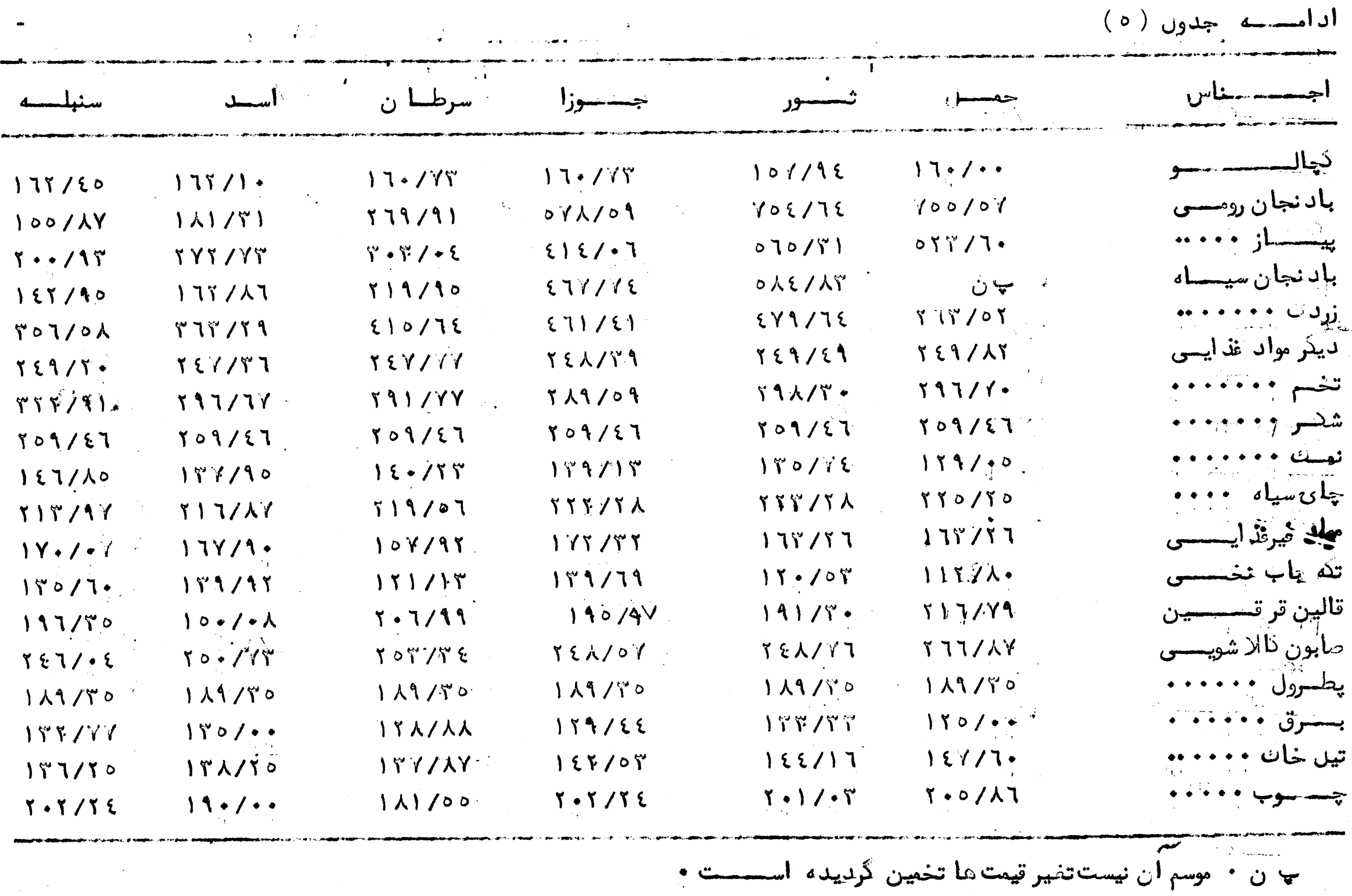


$(1 \cdot 7)$

اد اهه جسـدول (0)

\begin{tabular}{|c|c|c|c|c|c|c|c|}
\hline السُطـسالانه & حسوت & دلـر & جـ & قـوس & مسترب & ميـزان & 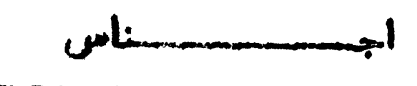 \\
\hline $10 \gamma / 71$ & $100 / 0 \%$ & $178 / 17$ & 1 & $1\{7 / 1\}$ & $\mid \varepsilon 7 / \lambda\}$ & $1 \varepsilon \gamma / 0 \varepsilon$ & كالــــــــــو \\
\hline oro/lr & $9 r r / 1$. & $\Lambda \Lambda \varepsilon / \gamma \lambda$ & $\lambda \varepsilon \checkmark / r \wedge$ & $7 \cdot 9 / 79$ & $r \varepsilon r / 1 \wedge$ & $171 / 09$ & هاد نجان رومس \\
\hline Tัน & $\because \wedge \mid / \varepsilon \wedge$ & roג/rᄉ & rYY/\&r & $r\{F / \Lambda q$ & Y/T/६. & $r: q / v\}$ & ي \\
\hline$r \wedge 1 / r 7$ & ن & ههن & نه & ن & $r \varepsilon \uparrow / 10$ & $|\varepsilon+/ \widetilde{\mid}|$ & باد نجان سيــا \\
\hline TYו/\& & rru/.. & $r r \varepsilon /$ r.o & гт7/.. & $Y \varepsilon \cdot / Y Y$ & rot/he & $r \cdot q / r q$ & زردك · . . . . \\
\hline T\&१/qג & ror/rl & ror $/: \ell$ & ro1/00 & rol/7r & ro.MOo. & Y६९/६. & ديخرمواد غذ ائى \\
\hline TY\&/7T & 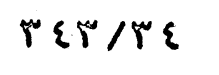 & rol/or & ro\{/77 & To\&/Tr & ror/lr & 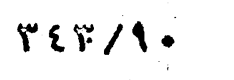 & تخم |...... \\
\hline$r 09 / \varepsilon 7$ & r०q/६ T & $r 09 / \varepsilon 7$ & $r \circ q / \varepsilon 7$ & $r \circ q / \varepsilon\}$ & $r 09 / \varepsilon\}$ & r०q/६T & شكر ....... \\
\hline $1 \varepsilon \cdot / \gamma 7$ & $\mid \varepsilon \lambda / 0 \lambda$ & $\mid \varepsilon x / \varepsilon$ & $1 \varepsilon \lambda / 0 \lambda$ & $\mid \varepsilon \varepsilon / .9$ & $1 T k / 0$ & $1 r F / 99$ & نملك ـ . . . . \\
\hline rIT/r. & $r \mid 1 / 77$ & rI.E/Ir & $. r 11 / \varepsilon r$ & TIR/R & $r \cdot \uparrow / \cdot \varepsilon$ & $r+r / p r$ & جاكسياه : ". \\
\hline $17 \mu / \varepsilon \gamma$ & $|r| / r \mid$ & $1 \gamma 0 / 7 \varepsilon$ &. $\mid \nabla \varepsilon / \Upsilon 1$ & $180 / 91$ & $177 / 0$ & $17 \% / F Y$ & مواد هيرثذ ايـــن \\
\hline Irr/9. & $151 / 77$ & 151.104 & $1.11 / 17$ & $190 / 04$ & $11 \varepsilon / 17$ & $110 / 5$ & تكه باب نخستىن \\
\hline $191 / 0$. & I $1 \mathrm{r} / 09$ & $197 / 5$ & $191 / 7 \varepsilon$ & $|1| / \varepsilon \lambda$ & $r \cdot r / r r \cdot$ & 198/R & تاليلن قر قيســــن \\
\hline 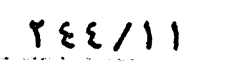 & $r 19 / . r$ & rFY/VE & RF:/TT & rをマハ人 & r\{q/१\}. & $r 0 \cdot / \varepsilon \lambda$ & مابون كالالا شويس \\
\hline $119 / 70$ & 111/100 & $119 / 40$ & $119 / 70$ & 1 1 & $119 / 100$ & $1 \times 9 / 50$ & 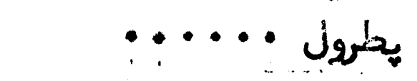 \\
\hline $187 / 4$ & $181 / 77$ & IrYR & $15 \cdot 100$ & $15 \cdot 100$ & $177 / 77$ & IrP/RY & بـرق ! . . . \\
\hline$|\varepsilon| / 0 \varepsilon$ & $1 \varepsilon_{0} / 71$ & $\mid \varepsilon \lambda / T$. & IEN/Ar & ITN/YY & ITO/OT & $1 \% 7 / .0$ & تيل خاك. . . . \\
\hline$r 10 / . r$ & rrer/od & $r \varepsilon \tau / r$ & $r \varepsilon r / r \varepsilon$ & rrysirs & $r r_{Y} / 01$ & $r \cdot q / \varepsilon \lambda$ & "- \\
\hline
\end{tabular}

ه ن : موسم آن نيستأتفير قيمت ما تخهيسن كرديده الست : 
$(1 \cdot 8)$

$$
\text { اداره مزوز الحمائيه افنانستسان }
$$

اوسط قيم متوازن ماهانه وساليانه در كثور طى سمال (

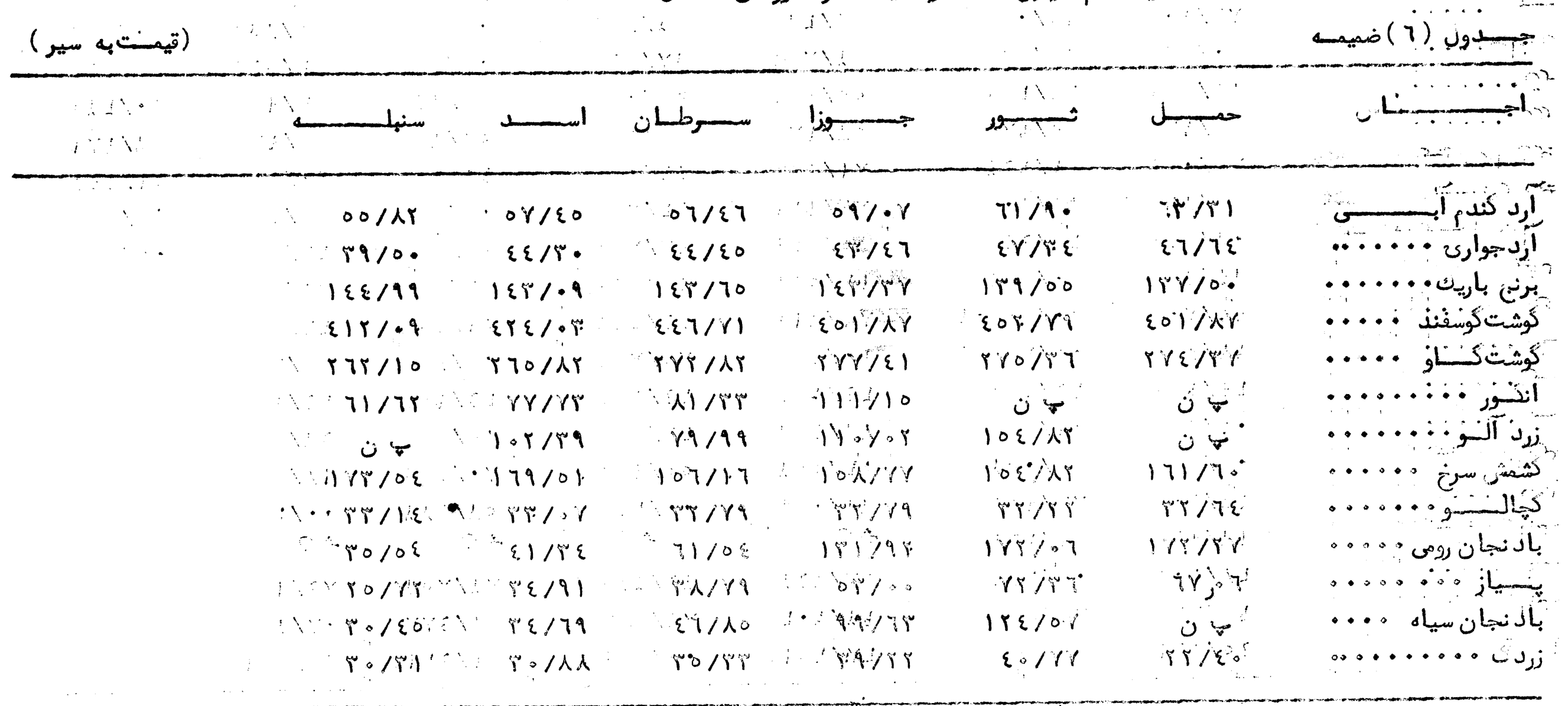

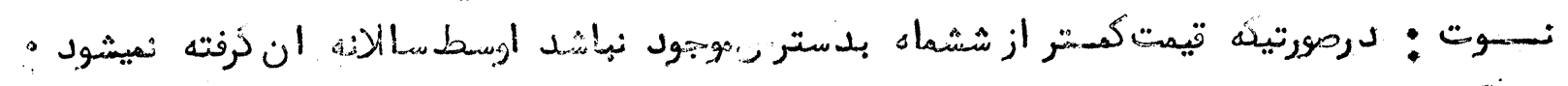

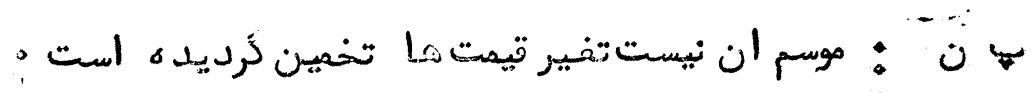




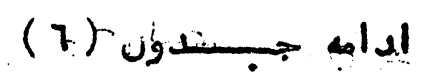

\begin{tabular}{|c|c|c|c|c|c|c|c|}
\hline 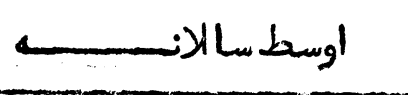 & ـ & دلســـــو & جــــــ & قــــــوس & عسـقرب & مستيزان & اجس \\
\hline OヘハMI & $01 / \varepsilon r$ & $09 / 1 / \lambda$ & $09 / 91$ & $07 / 18$ & $00 / 10$ & $0\{100$ & 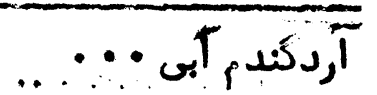 \\
\hline$\{Y / \wedge\}$ & $\varepsilon \varepsilon / \gamma$ & $\{0 \times 1$. & $\varepsilon \varepsilon / i \gamma$ & $\varepsilon 1 / 7 \%$ & $\{. / 91$ & $\varepsilon Y / Y q$ & آردنجوارى ..... \\
\hline I\&ร & $\mid \varepsilon \lambda / \cdot \Gamma$ & $\mid \varepsilon r / \varepsilon\}$ & $|\varepsilon| / \gamma \varepsilon$ & $149 / 91$ & $|r| r|r|$ & $|\varepsilon| / \lambda \mid$ & برنج يار بك. . . \\
\hline$\{\varepsilon 1 / 1$ & $\varepsilon / \gamma / \cdot{ }^{\prime}$ & $\{7 \varepsilon / 77$ & $\varepsilon \varepsilon 0 / . q$ & Eri/RT & $\varepsilon r \mid / T$ & $\varepsilon r \cdot / l \varepsilon$ & كونه \\
\hline$P Y Y / A \varepsilon$ & $r q \wedge / r r$ & $r 90 / \varepsilon r$ & $r r r / 10$ & $870 / 97$ & $r 7 \varepsilon / r r$ & rTr/.! & Sوث- \\
\hline 19/. r & ' & كَ ن & $150 / 10^{\circ}$ & $1.0 / 41$ & $11 / 21$ & $7 r / 9 r$ & انكور . . . . . . \\
\hline نه & : : & $\dot{U}$ & : & - & 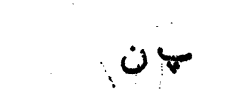 & نه & زدرآلـــو : ? . \\
\hline$|1| / \cdot r$ & Yro,.0 & .111 .10 .7 & $r \cdot 0.799$ & $119 / 9$ & $19 r / 9 y$ & I & كمشى سرخ . . \\
\hline rr/l & $r 1 / r r$ & $\Gamma r / \varepsilon q$ & $r \varepsilon / r$ & $r 9 / 97$ & $r 9 / 97$ & r.!e & 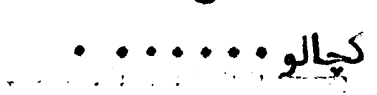 \\
\hline $\mid r r /: 1$ & rrI/A. & $r \cdot 1 / r r$ & $194 / 11$ & $1 r \lambda / 9 r$ & $00 / \varepsilon$ & 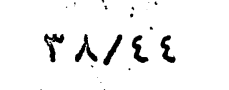 & بادنجان روم ·. \\
\hline$\varepsilon Y / Y \uparrow$ & $\varepsilon \Lambda / . \Delta Y$ & \&Q/AT & (i) $/ T$ & $r 1 /: 9$ & 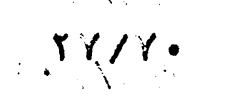 & $r r / 10$ & بسياز • • . . \\
\hline $09 / 91 \ldots$ & צن & ن & نr & $\dot{0}$ & $0 \% / . \gamma$ & $r \cdot 1 !$ & باد نجان سياه . \\
\hline ri/l & एPlद & YYT/TY & rily & $r \cdot 7 \varepsilon r$ & rm/l & r.T/rq & زرد ث • . . . \\
\hline
\end{tabular}


$(1 \cdot 1)$

آذأمه جـــــ (7)

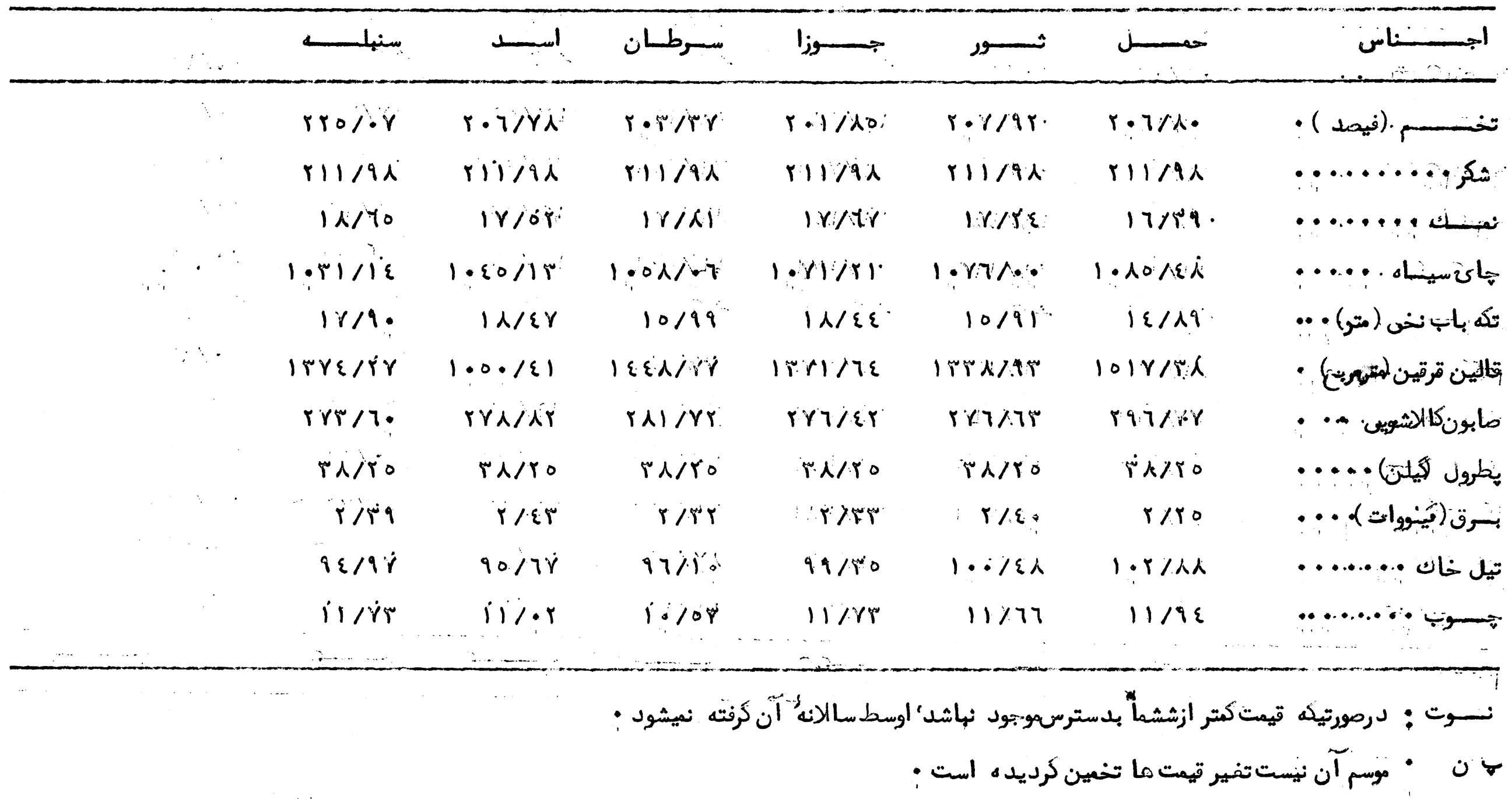


(11)

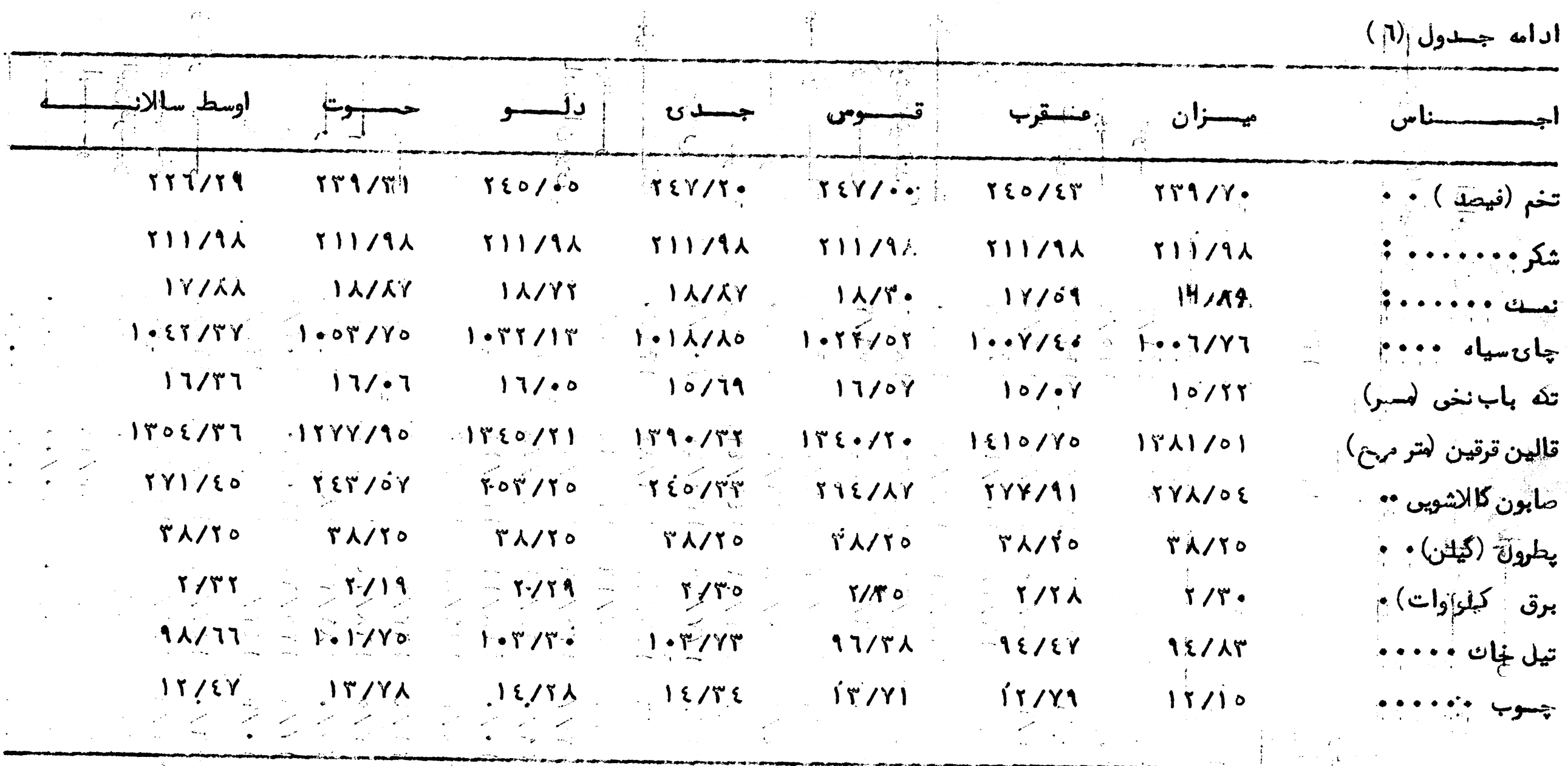

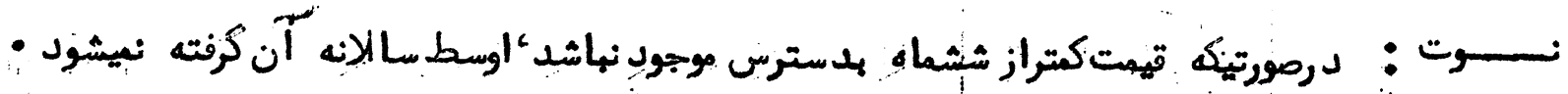

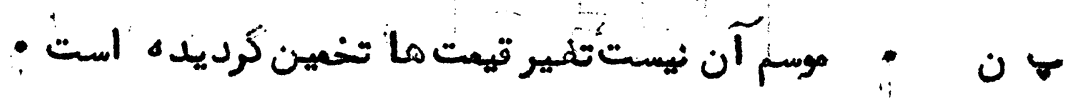




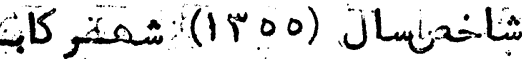
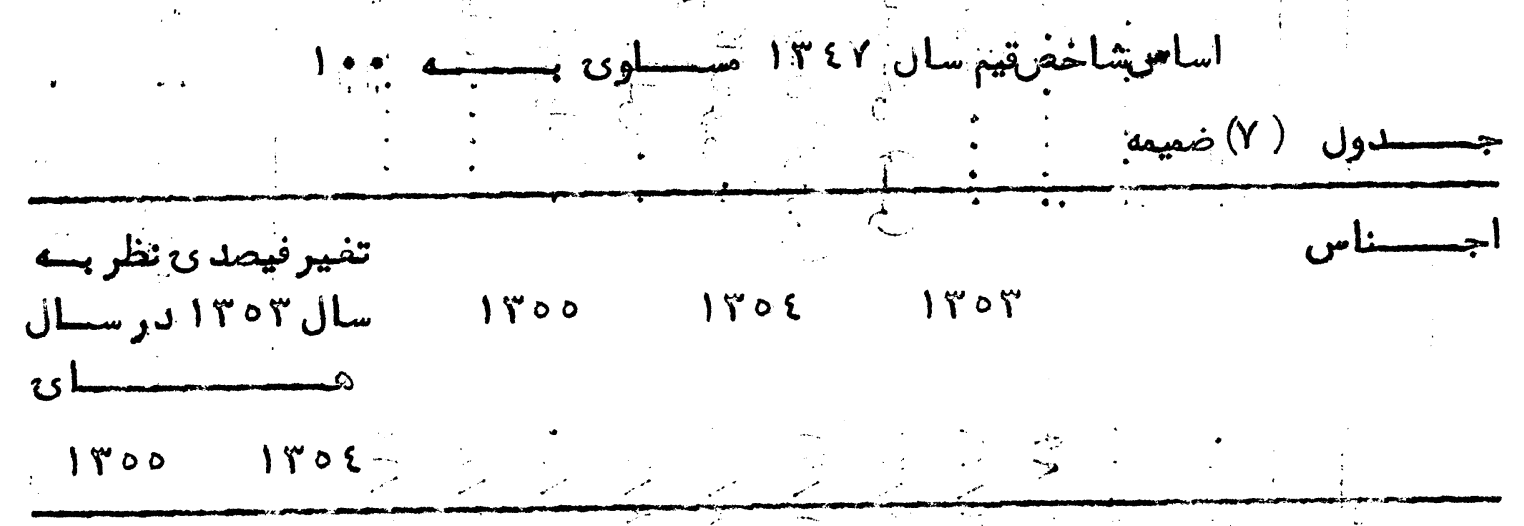

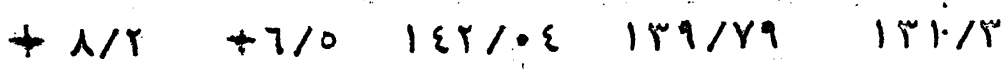

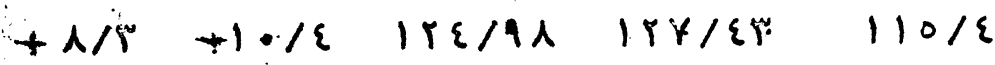

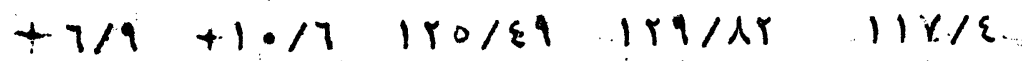

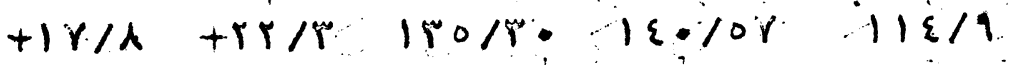

$+1 / \lambda-0 / 7$ 117/r $1.0 / 9 r \quad 1 \cdot] / 9$

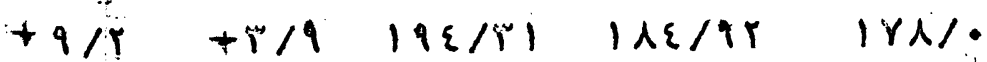

$+7 / 0+0 / A$. IqI/AY I IE/HA IAY/A.

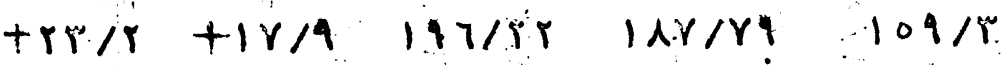

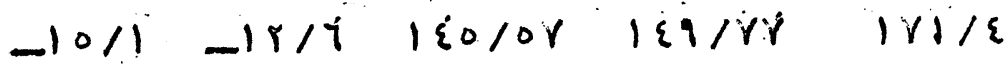

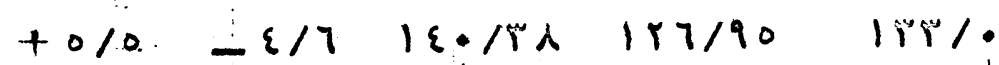

ن $\quad$ ن $111 / 99 \quad 1 \varepsilon 9 / \varepsilon Y_{6} \quad \dot{0}$

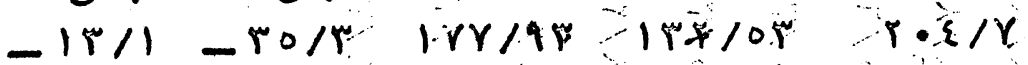

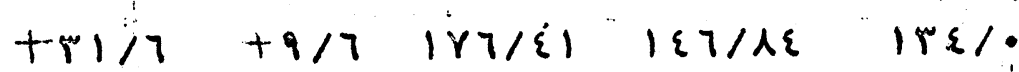

$+1 r / s+1 r / \varepsilon$ Irr/17 $180 / 7 \varepsilon \quad$ lor/r

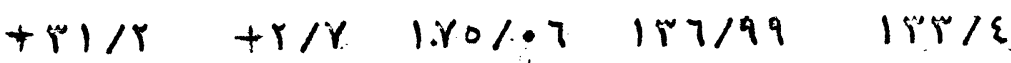

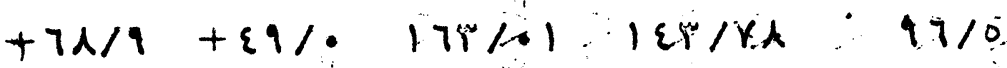

$+r \cdot r / 0-1 \cdot 1 \cdot 191 / 11 \quad|r \cdot / 11 \quad| \varepsilon \varepsilon / 7$

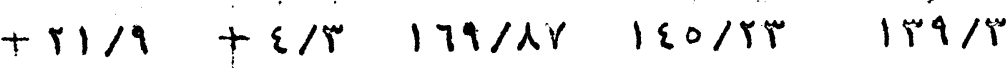

$+1 r / q+r \mid / \varepsilon \quad 17 \% / 1 \varepsilon$ ।rr/rq $\mid \varepsilon r / r$

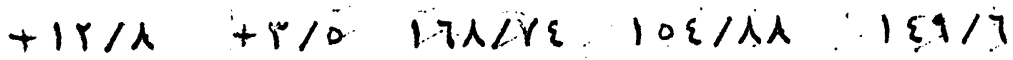

$+r 0 /+r 0 / \%+19 / r r$ l $19 / 5 r \quad 101 / \varepsilon$

$+r r / r+1 r / 9$ iro/7r Ir./re $\quad: i / \varepsilon$

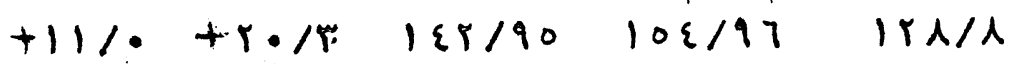

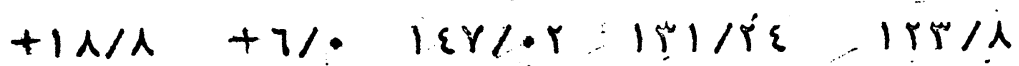

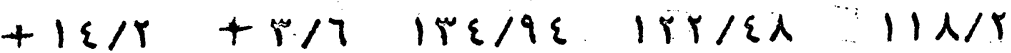

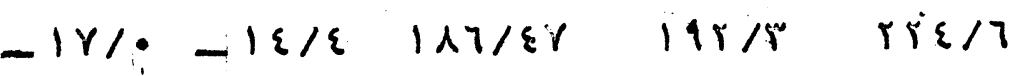

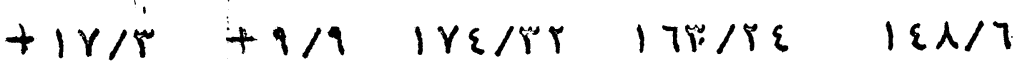

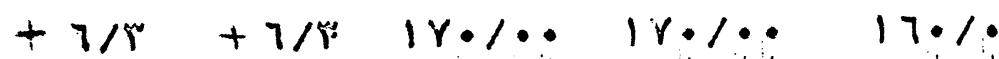

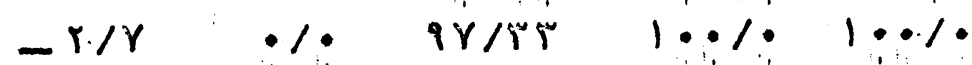

$+.11-r / 1 \quad$ in/71 lir/ar irlo

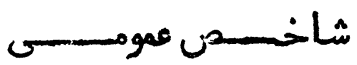

$ت$

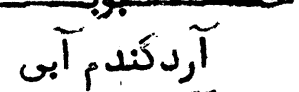

آردجيوا ر اردينم

برنب باريسك

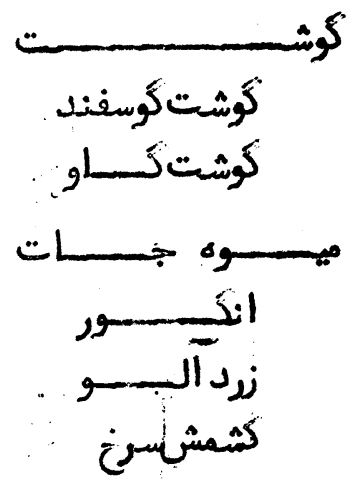

$ت$

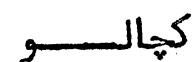

باد نجان رومى

ي باد

باد نجان سياه

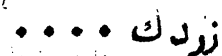

ديكر مواد غذ ايــــى لرد

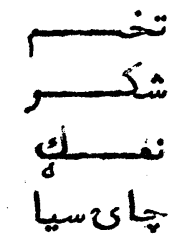

مواد غير غذ ايــــــــ

تكه باب نتخ

قالين قزقسيين

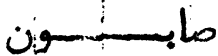

يط

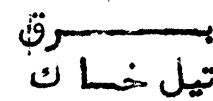




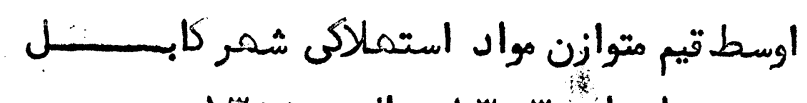

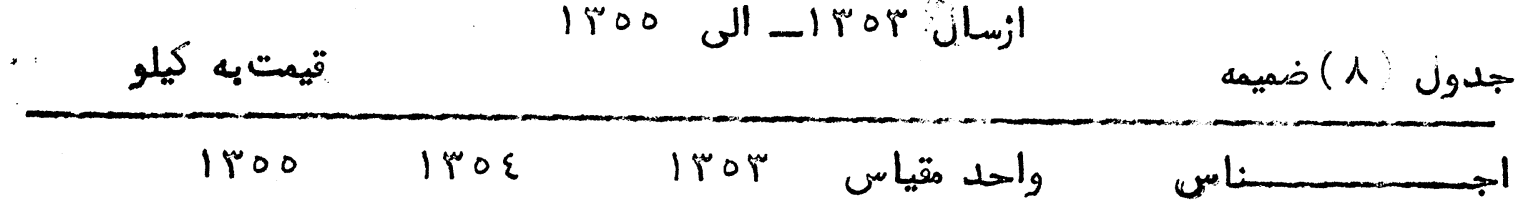

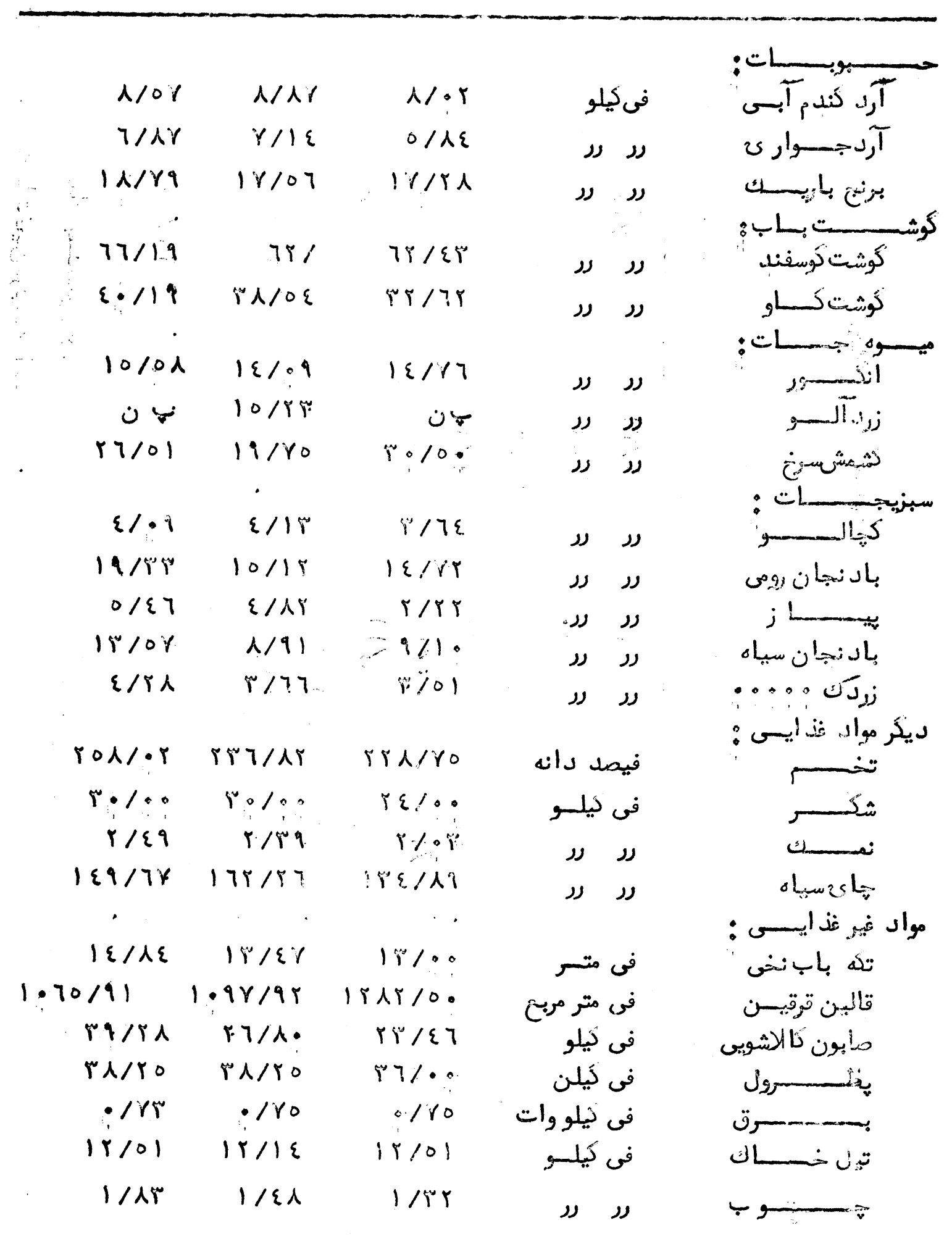


(11

\begin{tabular}{cccccc}
0 & \\
\hline
\end{tabular}

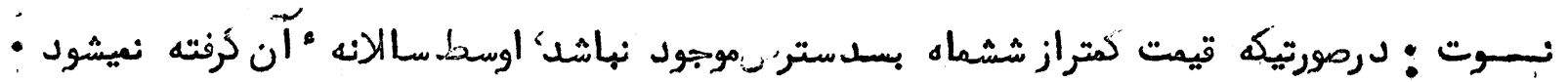

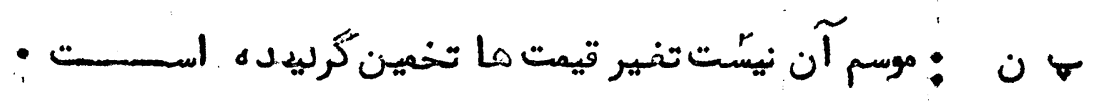


(1) $\varepsilon)$

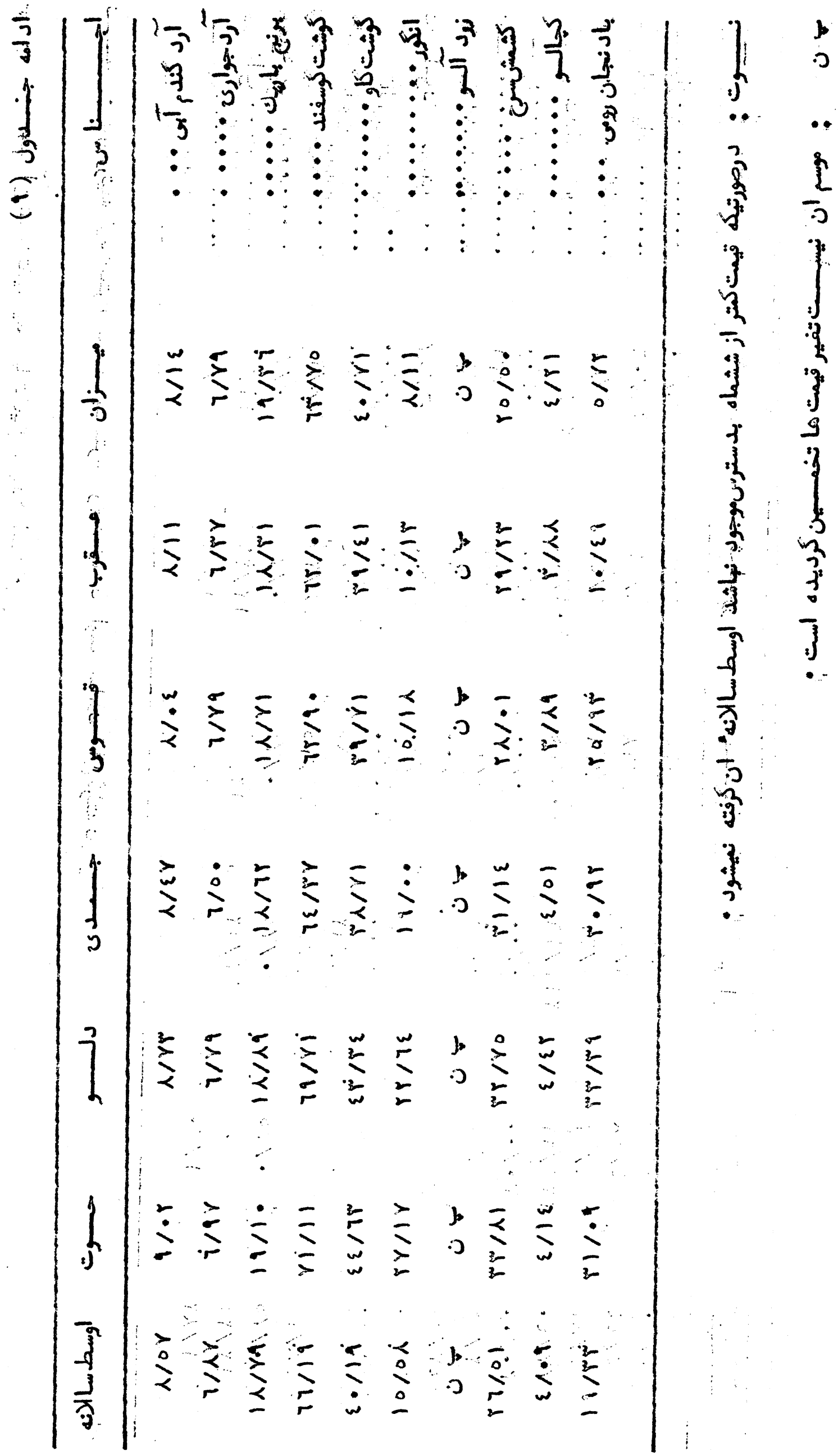


(110)

(9) (j)

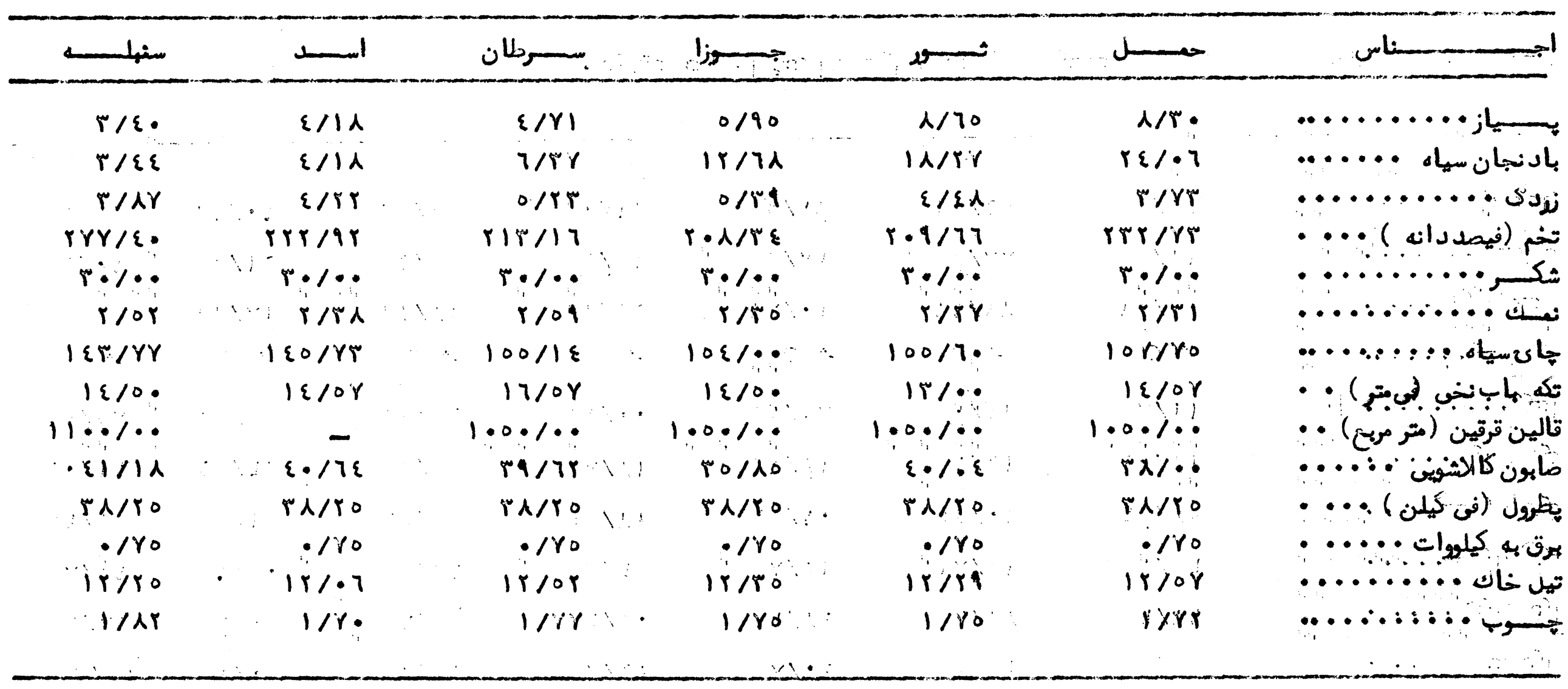

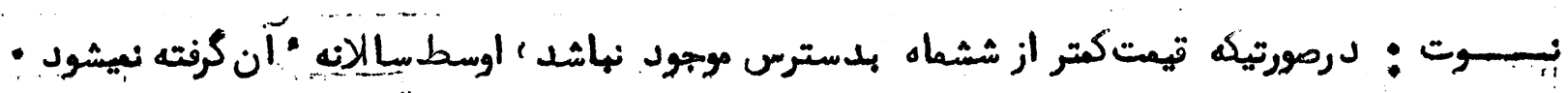

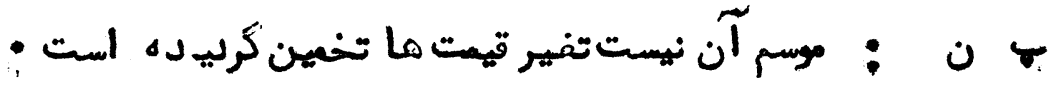


(117)

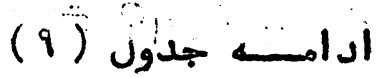

\begin{tabular}{|c|c|c|c|c|c|c|c|}
\hline اوسطس الانه & حسـوت & دلـــــو & بـــــــ & تســــوس & عســترب & مستــــان & : \\
\hline $0 / \varepsilon 7$ & $r / 10$ & $7 / 7 \pi$ & $\varepsilon / 40$ & $\varepsilon / . r$ & r/1ג & $r / n$ & 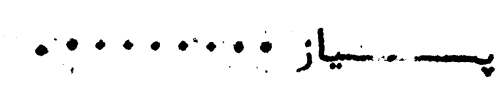 \\
\hline 15108 & $r \varepsilon / Y \xi$ & $r r /$. & $19 / \ldots$ & $1 \varepsilon / 9 \varepsilon$ & $9 / .7$ & $r / 71$ & باد نجان سيساه . . . . \\
\hline$\varepsilon / r \gamma$ & $\varepsilon / r \gamma$ & $\varepsilon / 0$ & $\varepsilon / \varepsilon_{0}$ & $\varepsilon / .9$ & $r / 7$. & r/ & زردك ه \\
\hline rO人/:r & rro/.. & $r \wedge 0 / \ldots$ & $r \cdot ? / \cdot$ & rro/.. & rit/ir & $r \cdot \cdot / \cdot n$ & 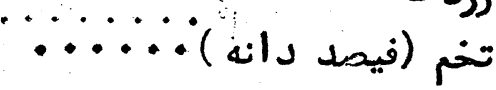 \\
\hline$r \cdot / \cdot$ & $r \cdot / \cdot r$ & $r_{i} / \cdot$ & $\sim \cdot / \cdot$ & 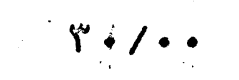 & $r: 10$ & $r \cdot /$. & ו \\
\hline$T / \varepsilon \uparrow$ & $r / 7 \xi$ & $: \quad r / i r$ & $r / T r$ & $r / \varepsilon r$ & $r / \varepsilon$ & $r / 0 r$ & نمستك............... \\
\hline 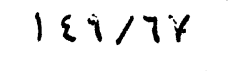 & $107 / 5 \mathrm{i}$ & $\mid \varepsilon \wedge / 01$ & |\{人/a) & $\mid \varepsilon 7 / 1 i$ & $\mid \varepsilon \cdot / T r$ & $1 \varepsilon r / 70$ & 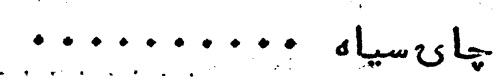 \\
\hline $1 \varepsilon / 人 \varepsilon$ & $10 / 8$ & $10 / 70$ & $10 / T_{0}$ & $10 / 74$ & $1 \varepsilon / 07$ & $1 \% / 7 \pi$ & تكه باب نخى (فى متر ) ) \\
\hline $1.70 / 91$ & $1 \cdot 10 /$. & $1.0 \cdot 1 \cdot$. & $1.0 \cdot 1 \ldots$ & $11 \cdots 1 \ldots$ & $11 \ldots 1 \ldots$ & $1 \cdot 0 \cdot 1 .$. & قالين قرتين (متر مربن) . . \\
\hline rus & $r q / 7$ & $49 / 70$ & "ristru & Tr/Ar & $r i / 2 i$ & $5 q / 7 q$ & مابونبا الاشويى : . . . \\
\hline rג/ro & re/ro & r人/ro & r人/ro & rN/TO & ケ人/ro & T人/TO & يطرول (فى كيلن ) • . . . \\
\hline . Irr &.$/ 7 r$ & . & . rro &.$/ 10$ & $\cdot / Y 0$ & $\cdot / 80$ & برق به كيلووات ...... \\
\hline$|r / 0|$ & $1 T / R$ & $15 / 10$ & 1T/ & Ir/ra & Ir/ro & litrer & تيلنخان .......... \\
\hline I/Ar & $r /: 0$ & $r /: 0$ & $1 / 9 r$ & $1 / 47$ & $1 / 07$ & I/Ar & 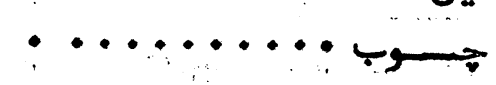 \\
\hline
\end{tabular}

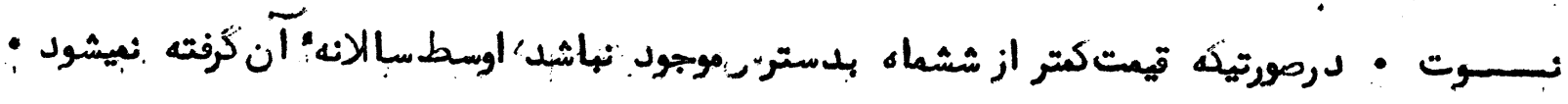

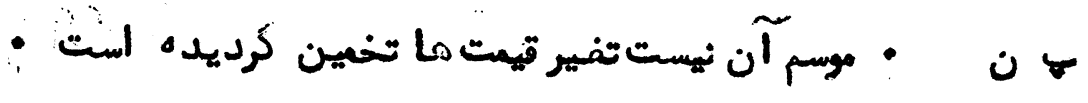


(IIY)

اداره مركراحمائيه افنانستان

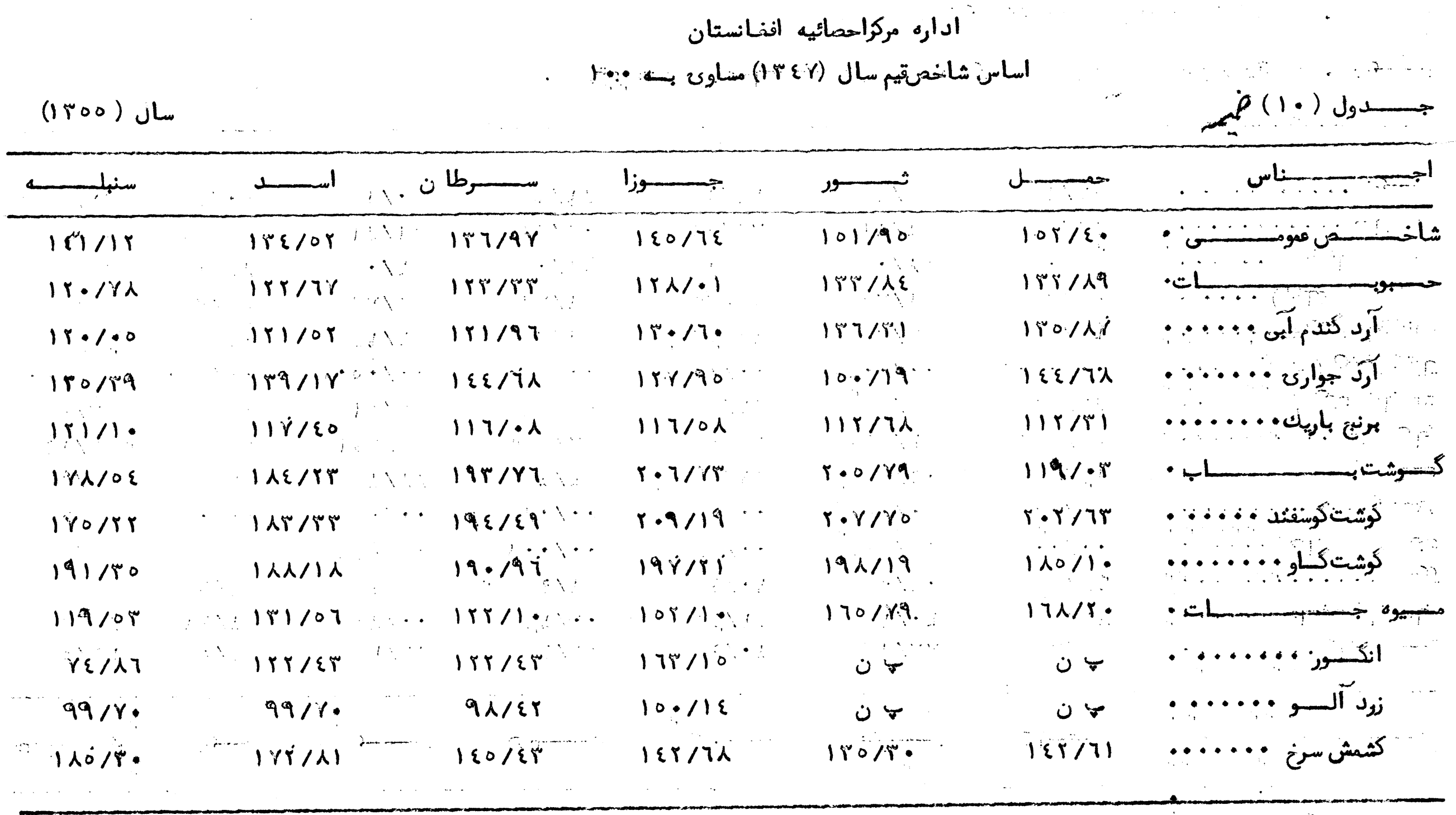

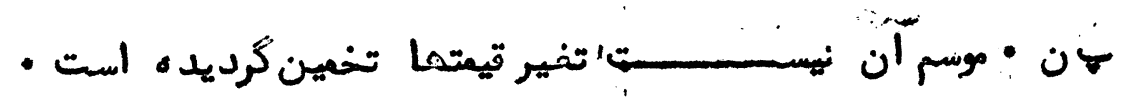


(1)1)

ادامه جـدون (.๑. (1.). .

\begin{tabular}{|c|c|c|c|c|c|c|c|}
\hline $\begin{array}{c}\text { اوسطط سالانه } \\
\text { • • }\end{array}$ & حسـسـوت & دلــــو . & جــ & قـــــوسن & 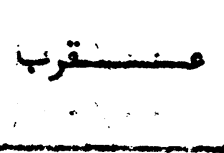 & منستهيزان & من . \\
\hline $\mid \varepsilon r / \bullet \varepsilon$ & $100 / 18$ & $101 / 89$ & $\mid \varepsilon \varepsilon / 1 r$ & Irr/rt & $|5| / 08$ & $|r| / \mid r$ & $\because$ \\
\hline Ir\&/9R & $1 r: 1 n^{*}$ & $\mid 57 / 71$ & $18 r / 97$ & $119 / \cdot \varepsilon$ & $111 / 0 \%$ & $1 r \cdot \operatorname{lrd}$ & :L \\
\hline $150 / \varepsilon q$ & $\mid r r / .7$ & $|r \gamma / \lambda|$ & $|r \varepsilon / \cdot|$ & $|1 \mathrm{~V} / \mathrm{P}|$ & "人/1 & $119 / 18$ & آردكند \\
\hline ハroハু & ITr/r. & $194 / 77$ & IrY/90 & 1\%ץ/77 & Iro/ra & 194177 & آرد جوارين ؛ : \\
\hline $117 / x$ & $111 / 19$ & $117 / 19$ & $110 / 4 r$ & $110 / 8 \gamma$ & $11 \% / 1$ & $119 / 1$. & برنغ باريك : : : : \\
\hline $19 \varepsilon / 51$ & $r i \cdot M i$ & $r \cdot 0 / 77$ & $11 \lambda / 7$ & $117 / 11$ & $\mid$ | $1 \% / A \mid$ & $119 / 17$ & • \\
\hline $19 T / N T$ & $r \cdot \lambda / r r$ & $r \cdot \varepsilon / r$ & $\mid i \lambda / \varepsilon q$ & $\mid \Lambda \varepsilon / 1$ & $|\alpha| 10 \lambda$ & ixiky & كوشت كوسفند : \\
\hline $19 i / r r$ & $1 \mid 8 / 91$ & $r 11 / 7 r$ & $189 / .1$ & $19 \% / 19$ & $19 r / \varepsilon$ & $191 / 88$ & 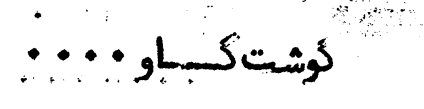 \\
\hline $18010 Y$ & INY/R & $|\gamma| / \ldots$ & $107 / 1$. & IrV/7ن & Ir\&/Mr & $11 \cdot / \varepsilon \lambda$ & - مات \\
\hline Iร。' & $r \varepsilon \varepsilon / / r$ & $r . r / 97$ & IVI/Y & IrT/Yo & $91 / 47$ & $Y \Gamma /: T$ & انكس : : : : : : : \\
\hline ن & $\dot{v}$ & $\dot{v}$ & ن & ن & ' & هי ن ن & نرد آلو • • • . \\
\hline $18 r / 9 r$ & Yr $7 / 91$ & $119 / 89$ & $r \cdot \lambda / 99$ & $101 / 91$ & $197 / 18$ & $|\gamma| / \mid \varepsilon$ & 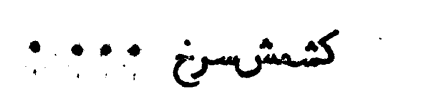 \\
\hline
\end{tabular}

ها ن - موسم آن نيستثنيز قيتما تخهين كرديده است . 
(111)

ادامســــ جـــدول (:1)

\begin{tabular}{|c|c|c|c|c|c|c|}
\hline سنبلـــــــ & اســــــ & ســـــــان & جــــــــــــ & شــــــــور & حمســـل & 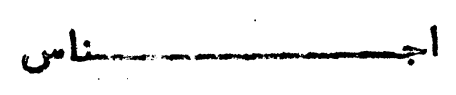 \\
\hline $1 \cdot V / \varepsilon 0$ & $|r T / Y|$ & $119 / 10$ & $1 \wedge T / \varepsilon=$ & 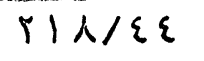 & TIT/Tr & - تL \\
\hline $117 / 01$ & $1 / 9 / 71$ & $17 \% / 9 \cdot$ & ITYMT & 1 & $187 / 19$ & كيالو ....... . . \\
\hline ro/rt & $7 \& / . Y$ & qr/ri & $11 \cdot 104$ & r「マハT & $Y \varepsilon \uparrow /\}$. & باد نجان روه . . \\
\hline $1 \cdot 1 / \varepsilon 9$ & IrE/Pr & $1 \varepsilon_{0} \cdot 109$ & $|r| / 7 \mid$ & rON/T: & T\&R/r & هياز ;........... \\
\hline $0 . / 4 R$ & $71 / . r$ & $9 r / 19$ & 110011 & Y7T/rI & rol/rq & باد نجان سياه . \\
\hline $10 \% / 0 \mathrm{~V}$ & $17 \gamma / \varepsilon 7$ & $r \cdot r / O r$ & $T 19 / \lambda \alpha$ & lerers & $\mid \varepsilon \wedge / \cdot 1$ & زردك . . . . . . \\
\hline $18 \cdot / 91$ & $178 / 9 \varepsilon$ & $\mid r \cdot / r \varepsilon$ & $179 / \varepsilon 0$ & $177 / 7 \varepsilon$ & lor i. & ديكر مواد ثذ ايــــــــ · \\
\hline$|\wedge| / \varepsilon Y$ & $1 \varepsilon 0 / 79$ & $|r q / \varepsilon|$ & $197 / 90$ & her/t & $|0 r / r|$ & ت \\
\hline $\mid A q / Y \gamma$ & $\mid 19 / T \gamma$ & $104 / T \gamma$ & $119 / T Y$ & $1 \times 9 / 98$ & |ล⿻コ一 & شك, ,...... \\
\hline ITX/Tr & $M \cdot R$ & $1 r \cdot / 1$. & $111 / 71$ & $11 \varepsilon / 7 \varepsilon$ & $117 / 77$ & نمكك .......... \\
\hline $\mid r r / 41$ & 159/1 & 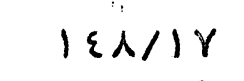 & $\mid \varepsilon \gamma / \bullet$ & $|\varepsilon \wedge / 7|$ & $10 \cdot / 77$ & 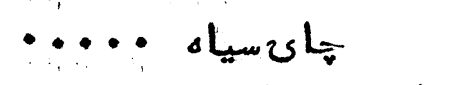 \\
\hline $1 \varepsilon 7 / Y \lambda$ & $\mid \varepsilon r / \eta 1$ & $10 r / 19$ & |हr/i| & lroplor & $1 \varepsilon 5 / 0$. & 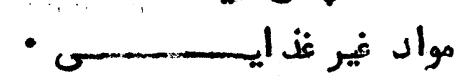 \\
\hline$|r| / \lambda \mid$ & $1 T r / 80$ & $10 \cdot / 74$ & $|T| / 1 \mid$ & 扒人 & ITY/EO & تكه بابنخ : : : \\
\hline $195 / 78$ & $10 r / 9 r$ & 1 Nir/9r & $10 \mathrm{~N} / 9 \mathrm{~T}$ & 1Ni/9Y & INP/AY & قالين ترقين ... \\
\hline IAr/Rl & イ・ハ人 & $180 / 10$ & $107 / 15$ & $\mid r r / 61$ & $170 / 77$ & مابون كالًاّشويسى . \\
\hline $\mid r_{\varphi} / \ldots$ & $1 Y \cdot 1 \ldots$ & $18 \cdot 1 \ldots$ & $18: 1 .$. & $1 r_{0} / \ldots$ & $1 r_{0} / \ldots$ & يحرول • .... \\
\hline $1 \cdots 1 \cdots$ & $1, \cdot 1 \cdot$ & $1 \cdot 1 / \cdots$ & $1 \cdots 1 \cdot$ & $1, \ldots$ & $1 \ldots 1 \cdots$ & 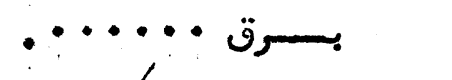 \\
\hline $119 / . \varepsilon$ & HV/r. & $|r| / 7 r$ & $\mid r \cdot / \cdot 1$ & $11 / \varepsilon /$ & ITr/10 & 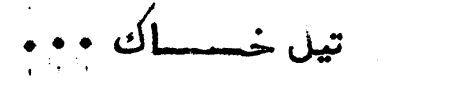 \\
\hline $10 k / 17$ & IEr/Ar & $104 / 71$ & lor/1r & $10 r / 18$ & $1 \varepsilon 9 / 07$ & 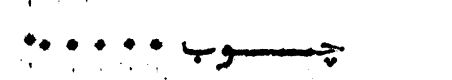 \\
\hline
\end{tabular}


$\left(1 r_{0}\right)$

ادأمســ جدول (. (1)

\begin{tabular}{lllllllll}
\hline & & & \\
\hline
\end{tabular}




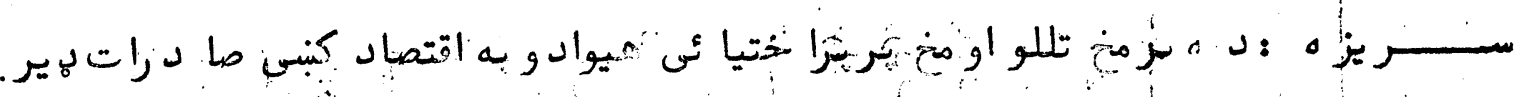

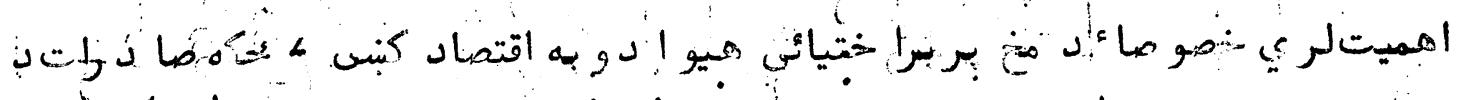

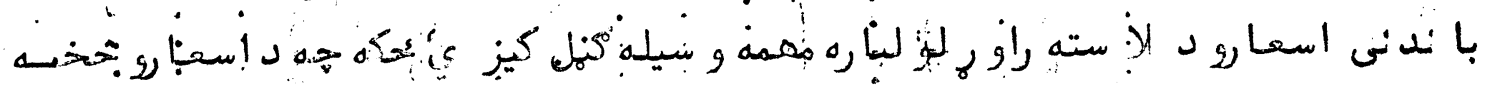

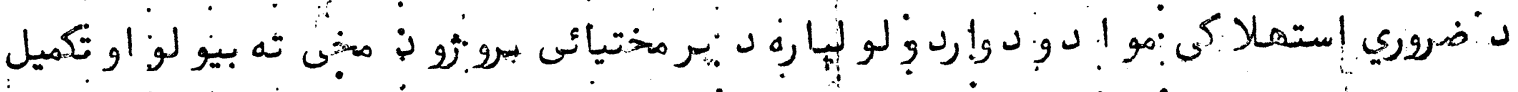

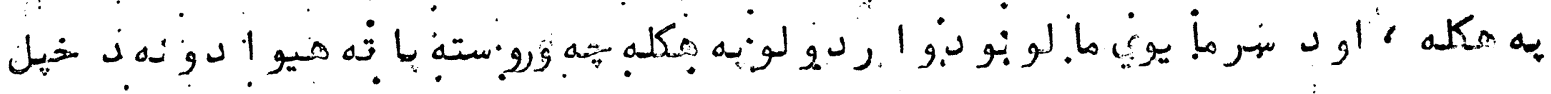

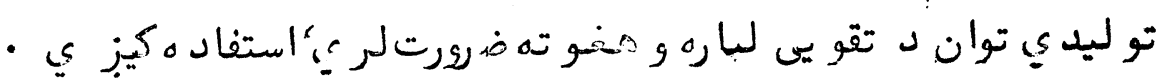

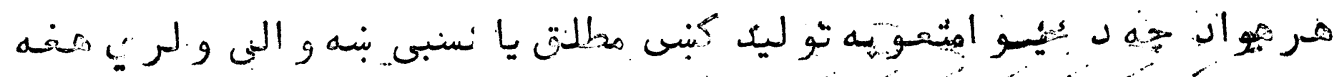

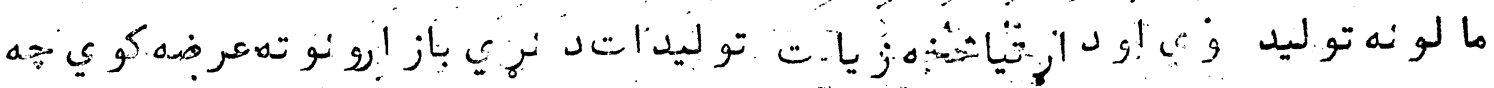

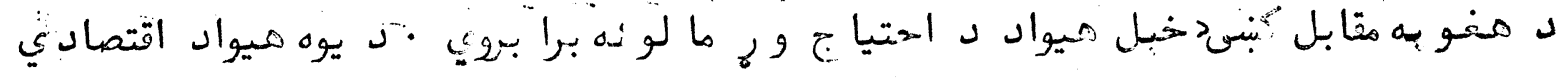

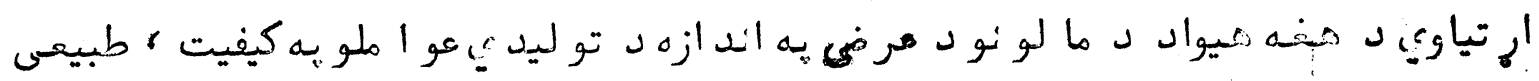

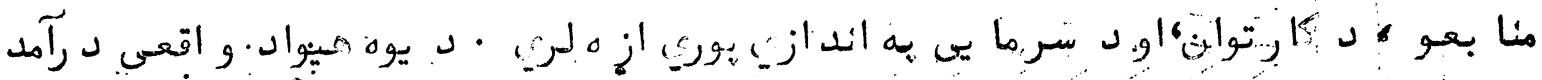

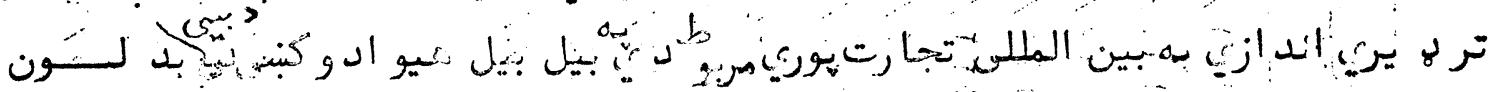

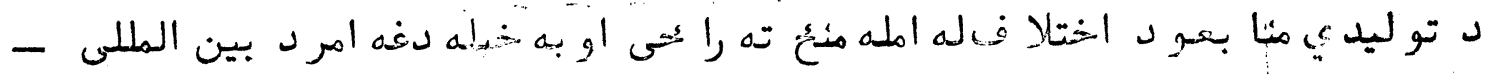

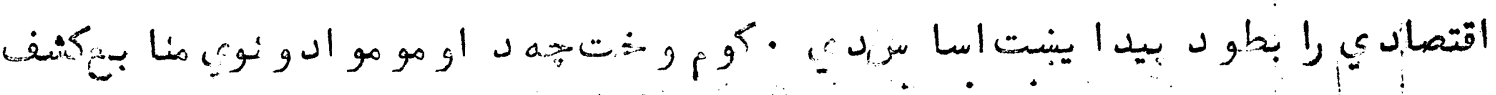

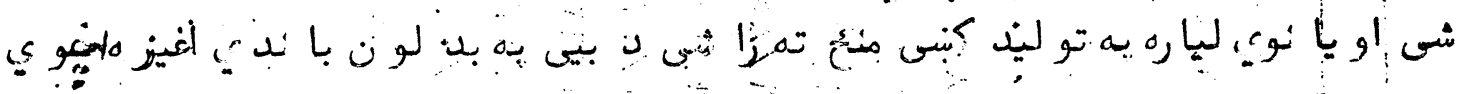

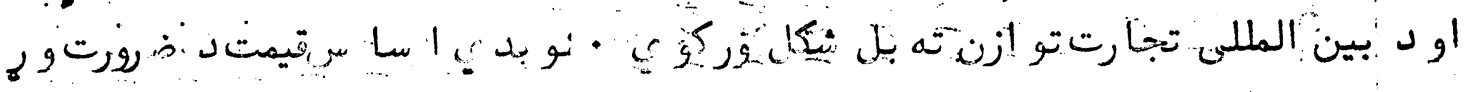

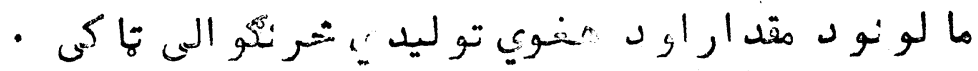

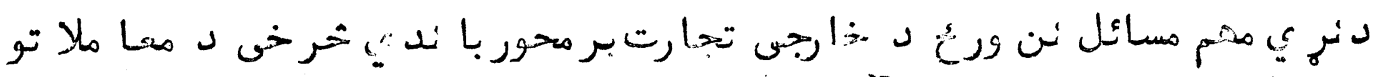

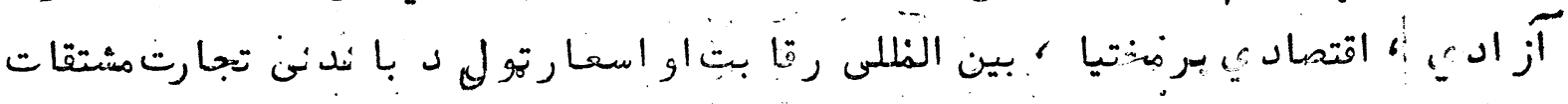

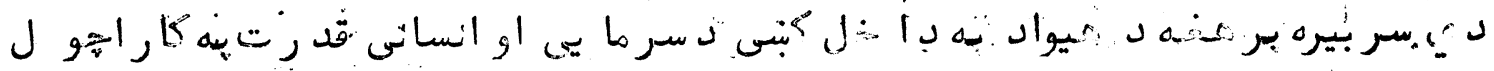

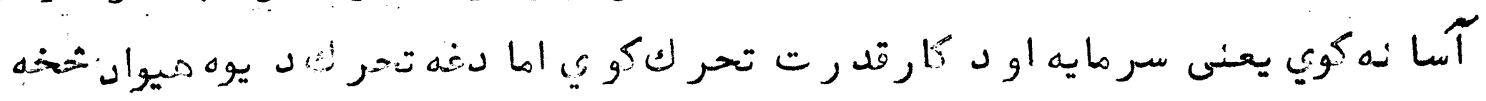

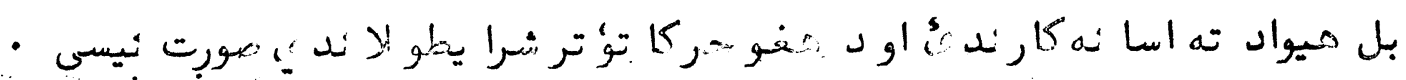

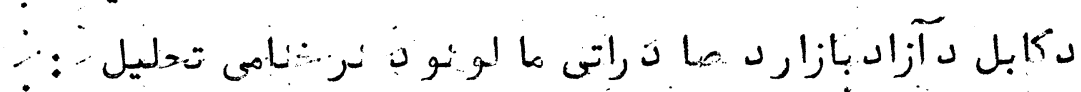

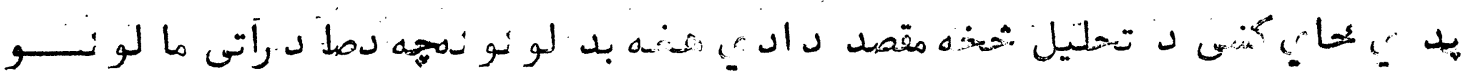

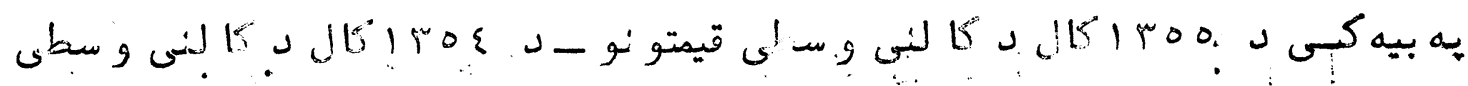

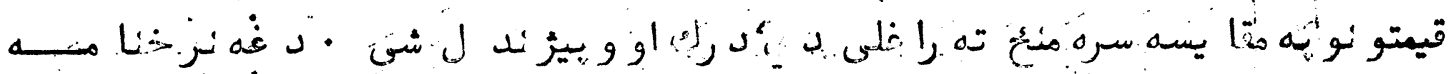

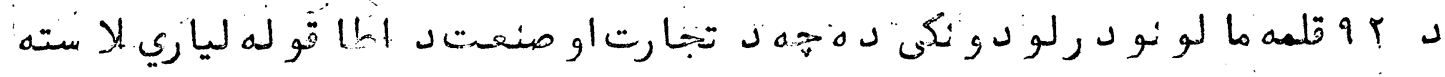

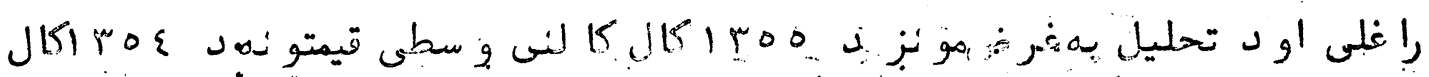

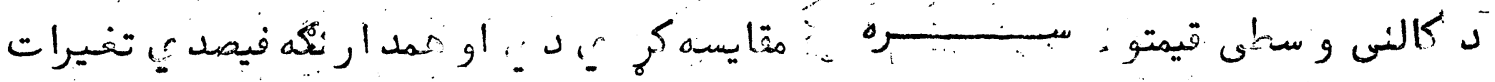

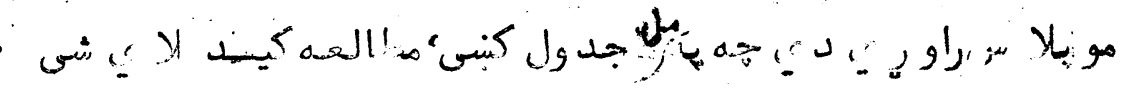




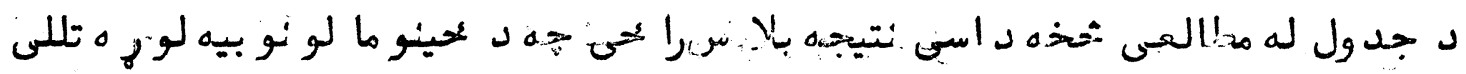

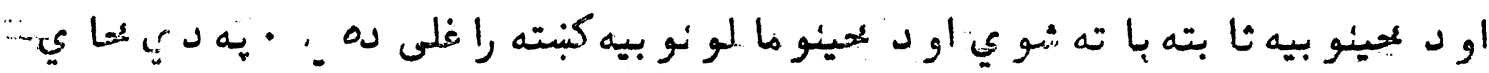

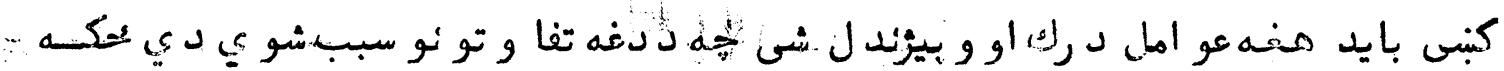

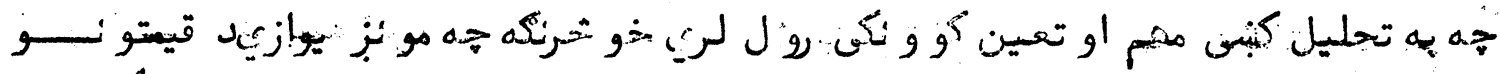

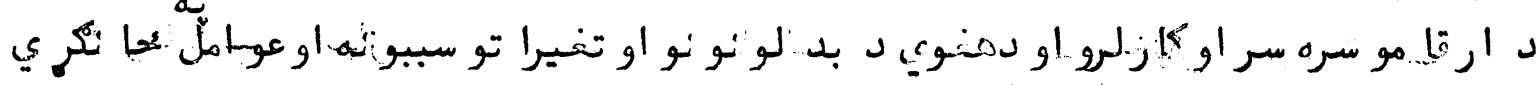

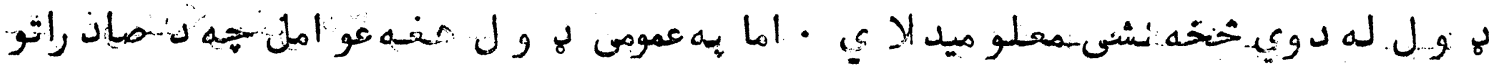

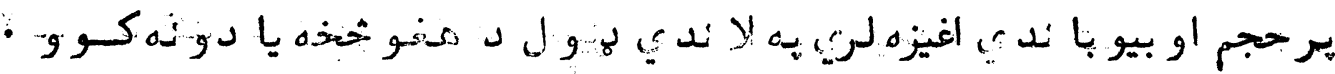

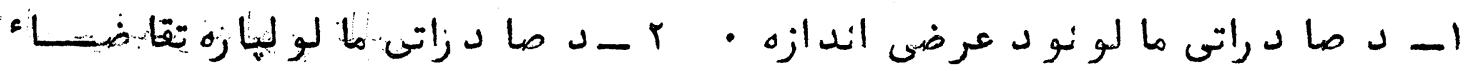

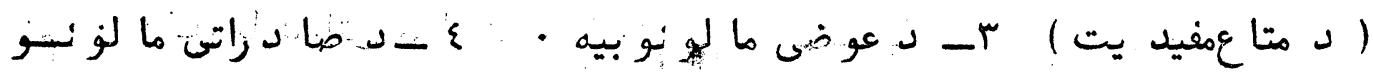

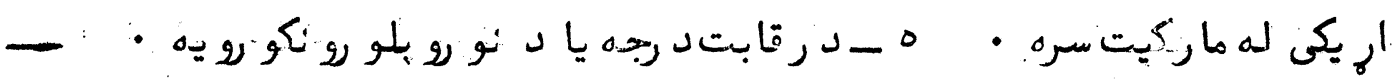

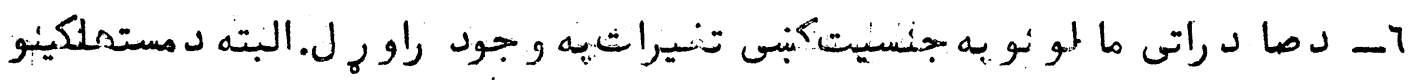

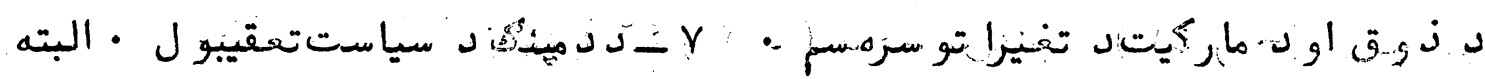

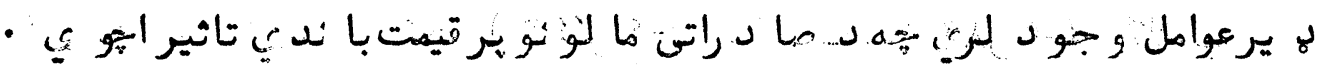

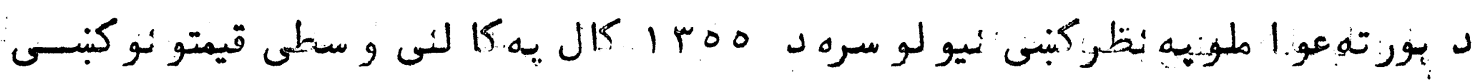

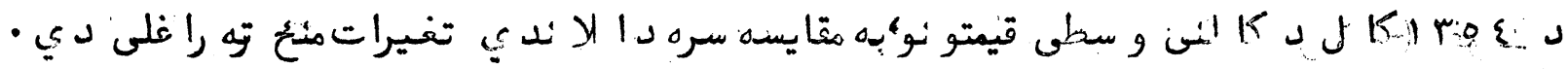

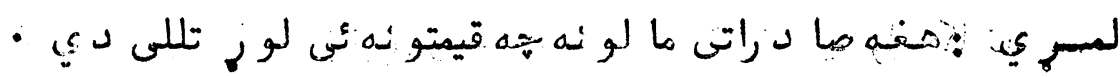

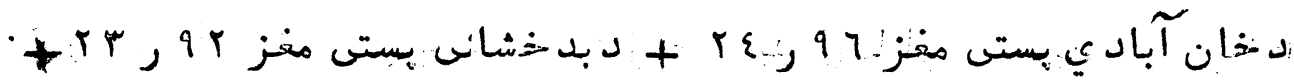

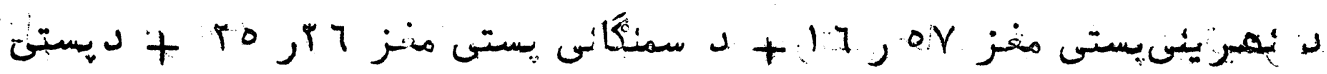

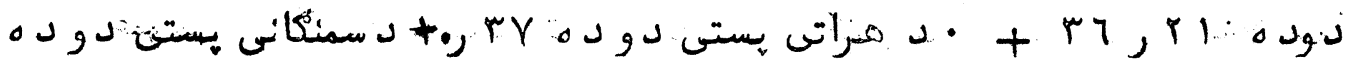

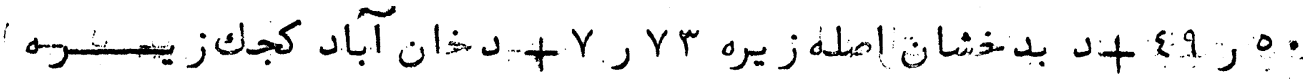

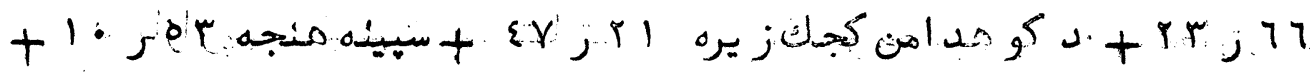

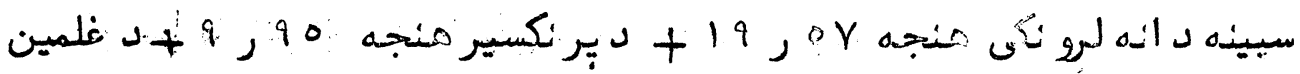

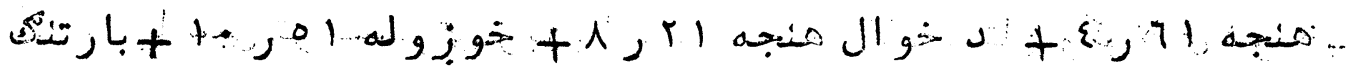
كا

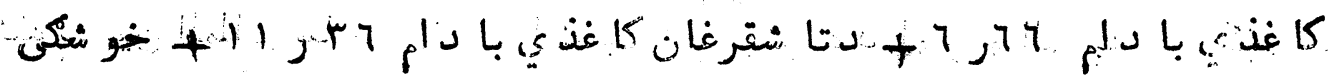

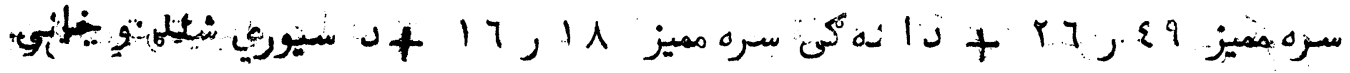
حابرر

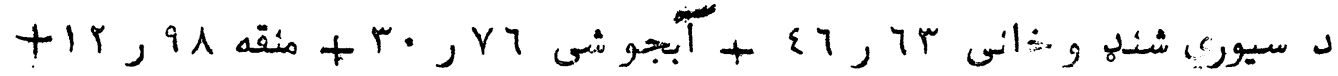

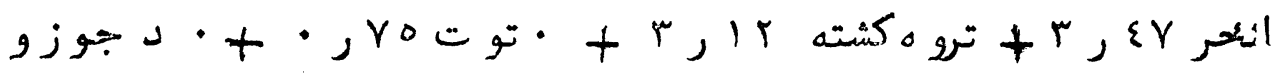

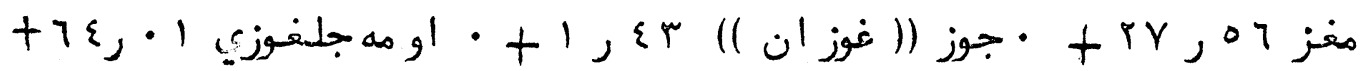
اورته جلغوزي

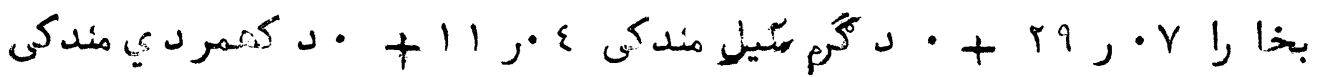




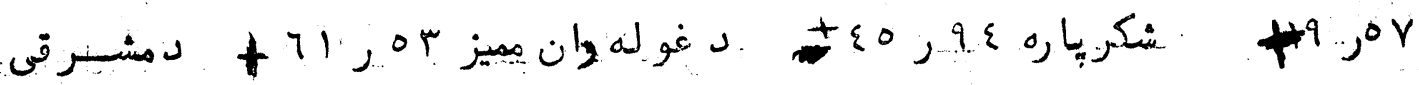

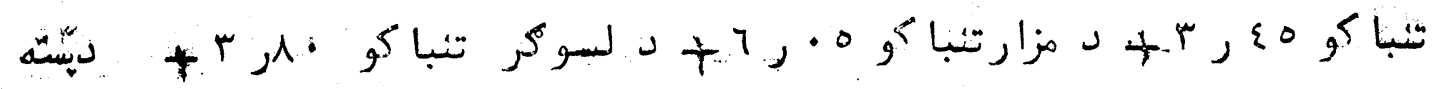

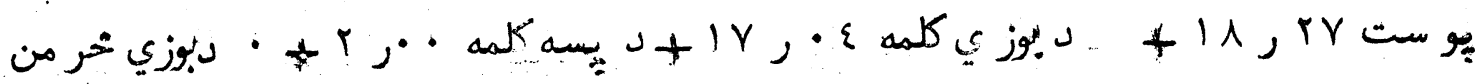

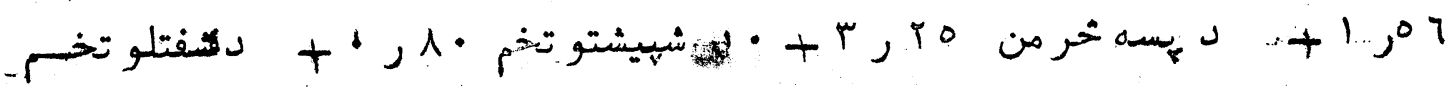

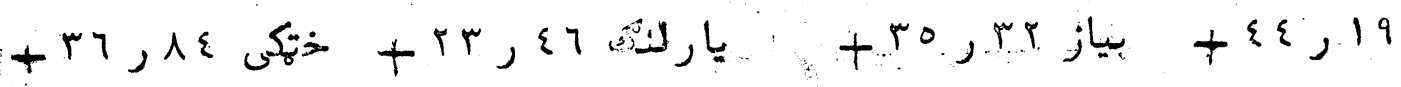

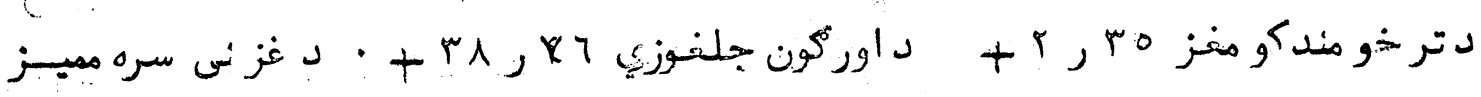

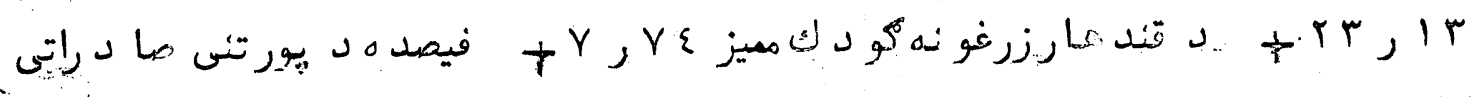

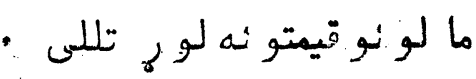

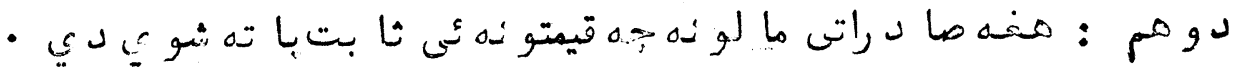

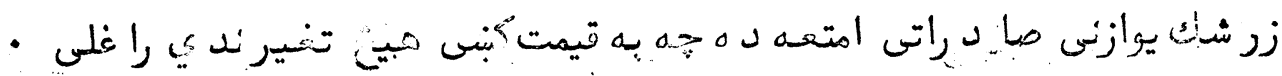

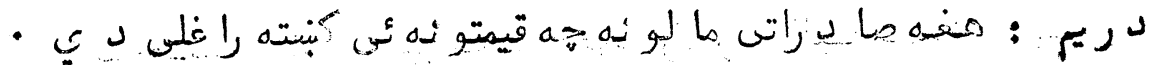

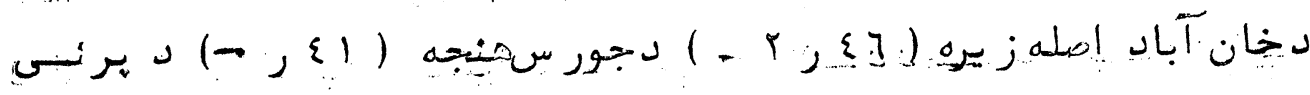

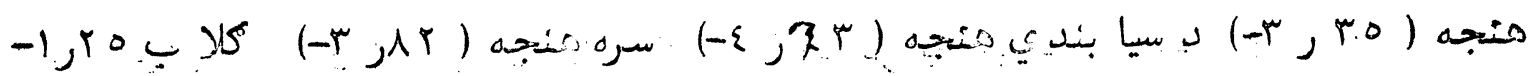

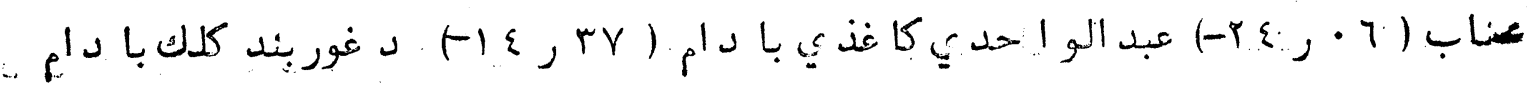

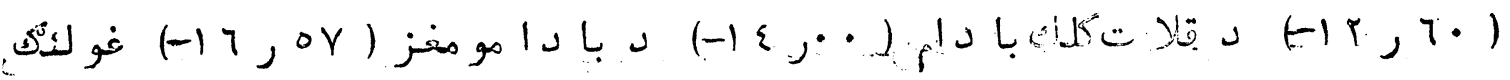

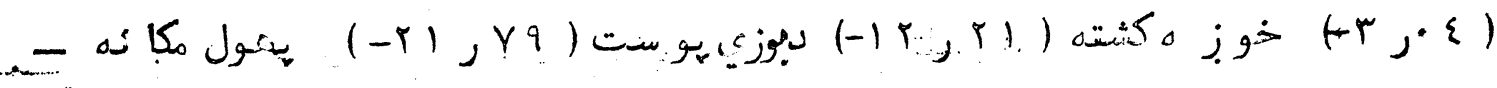

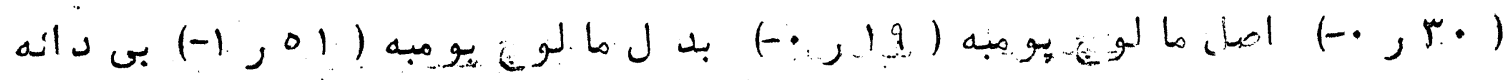

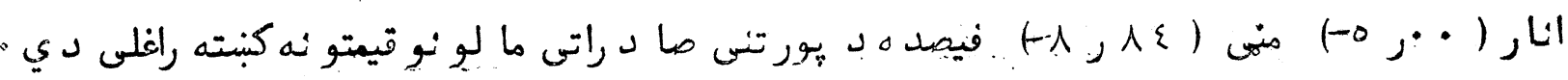

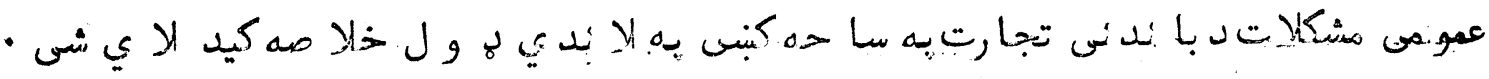

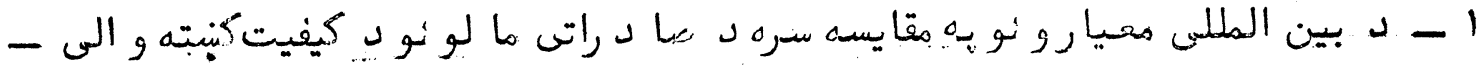

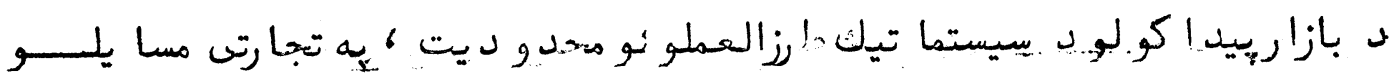

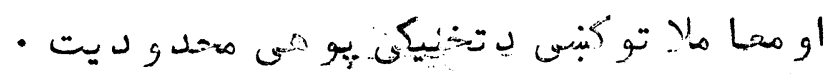

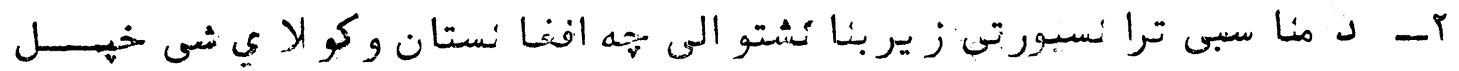

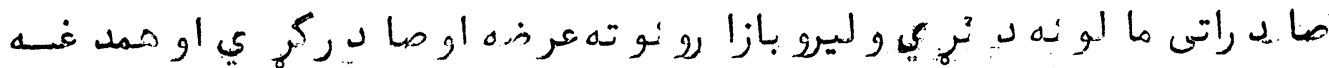

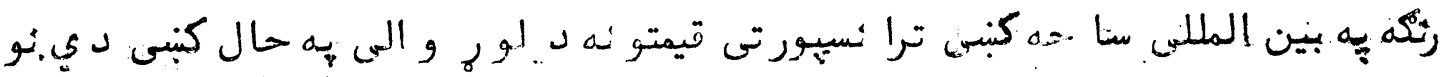

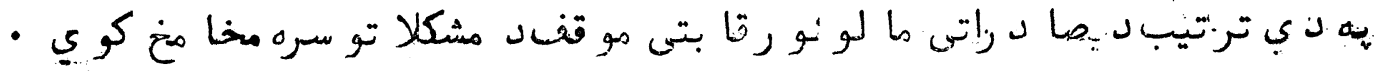




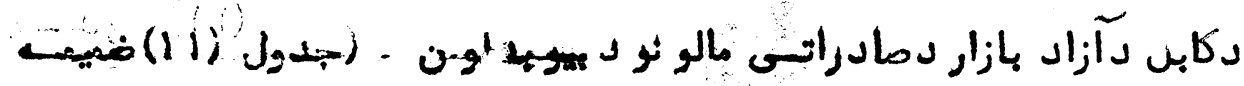
ニニニニニニニーー:ニニニニニニニニニニニニニニニニニニニニニ

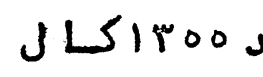

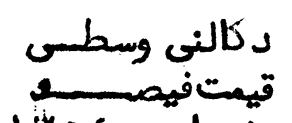

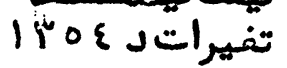

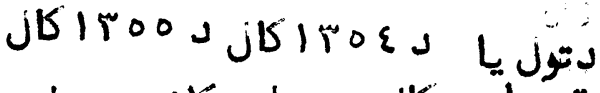

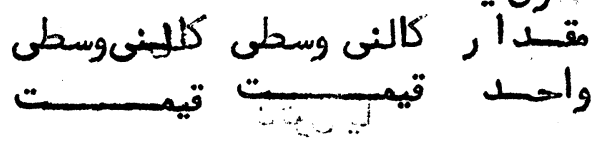

دشيانو نســوم

45

كال دكالنىوسطى

قيمت يه مقايسينـيه

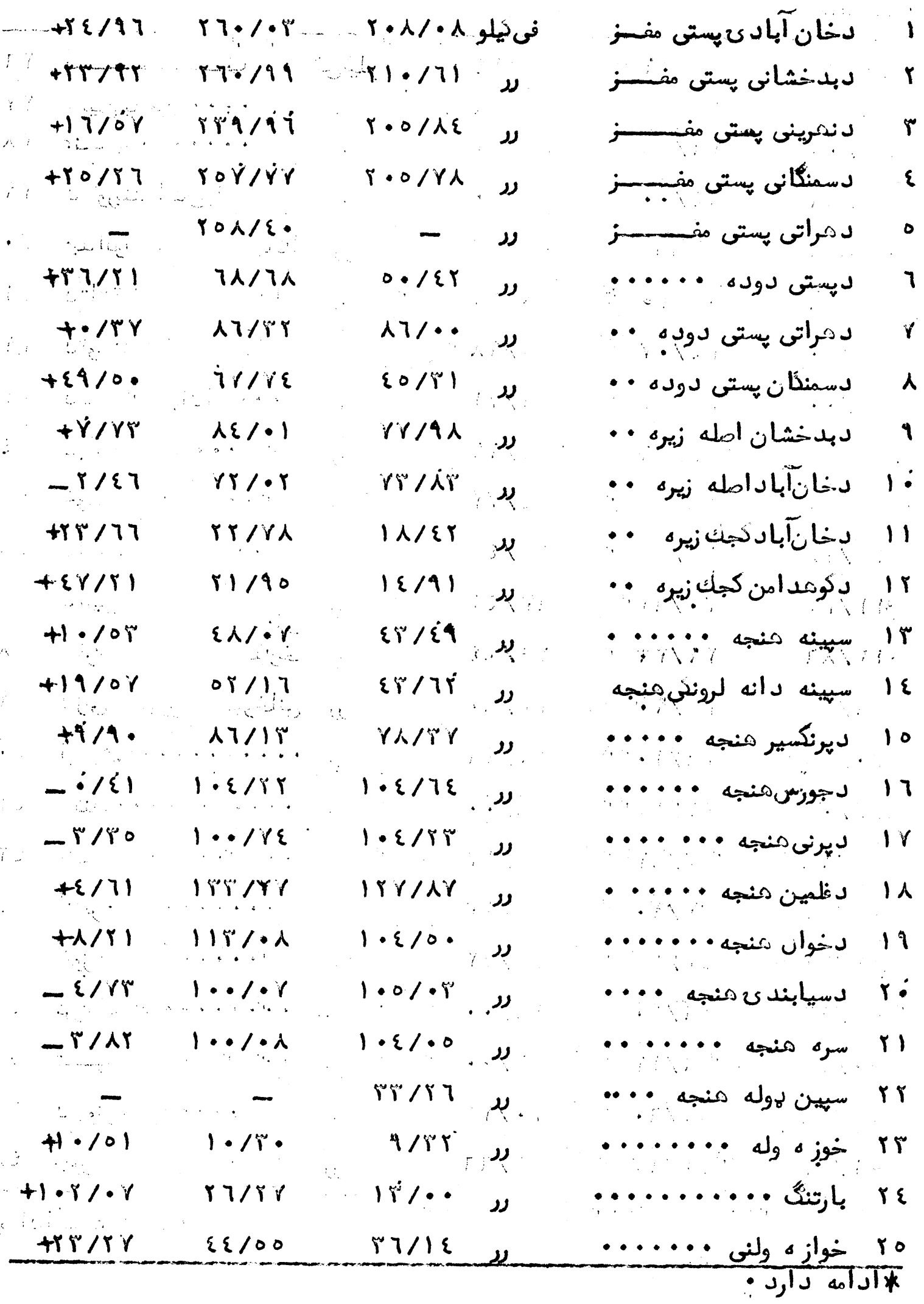




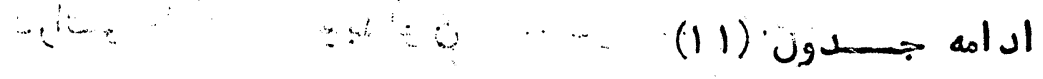

ناز

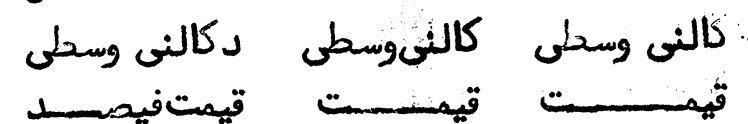

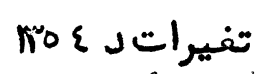

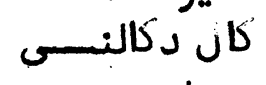

دتون يا

مقـــالر

كنه دشيانســو نســـــوم

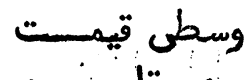

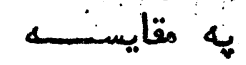

$-1 / 10$ ro/79 rille

$\begin{array}{lll}-1 / r 0 & 10 / 79 & 1 / 1 / 2 \pi\end{array}$

-rster = ry/97 ro/0\%

$+7 / 77 \quad 78 / 0 \quad 7.100$

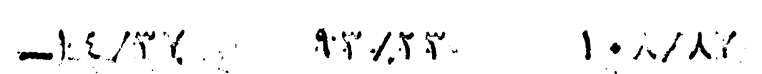

$+11 / 17 \quad 90 / 18 \quad 01 / 0.1$

$-1 r / 7 . \quad r \varepsilon / 8 r$ r人

$-1 \varepsilon / \cdots \quad r 1 / 0 \varepsilon \quad \pi 7 / \dot{r}$

- 17/0r lir/sa $109 / 19$

$+r T / \varepsilon 9 \quad$ lN/Tr $\quad \varepsilon / R$

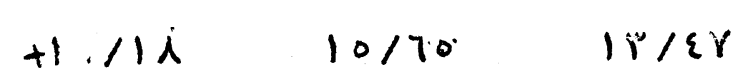

Hirr $r \cdot / 7 r \quad 7 r / \varepsilon 1$

+Ir/A7 ST/R rT/AE

$+\varepsilon 7 / 7 \%$ P

$+r \cdot 187 \therefore \quad 19 / 97$

$-r / 0 \varepsilon \quad r i / 10 \quad r i=$

$+1 r / 4 \alpha \cdots \quad 1 \% / 7 r \quad 11 / 1 \%$

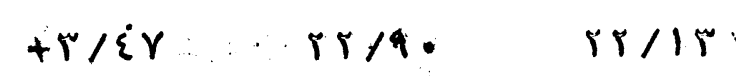

-IT/YI rr/ET rT/Rr

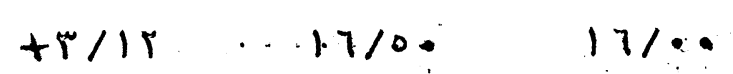

$+. / 70 \quad 17 / 01 \%$

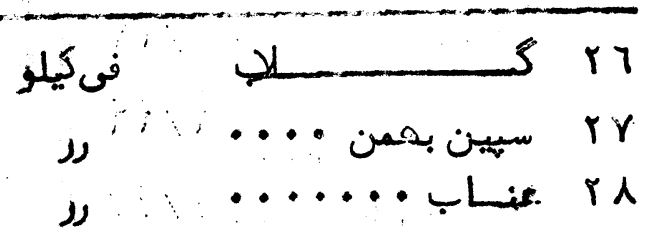

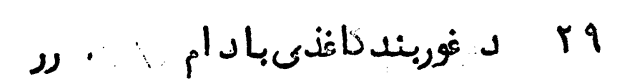

:

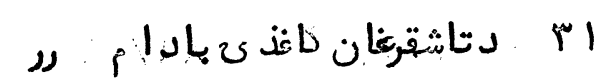

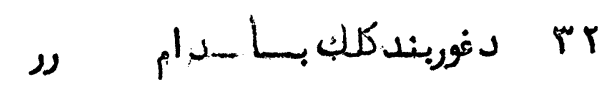

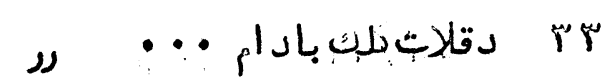

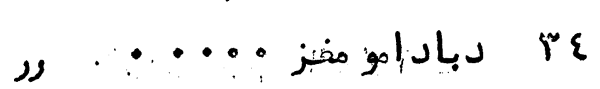

ro

ر

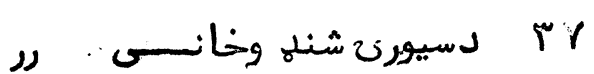

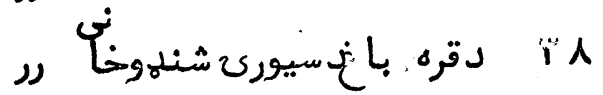

q

ع

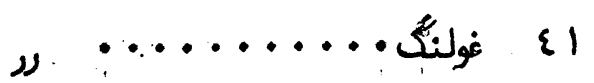

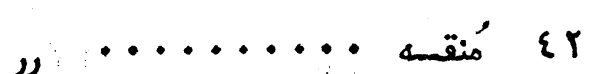

ر

ع

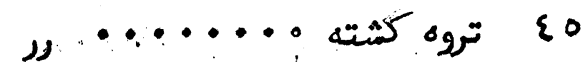

ו

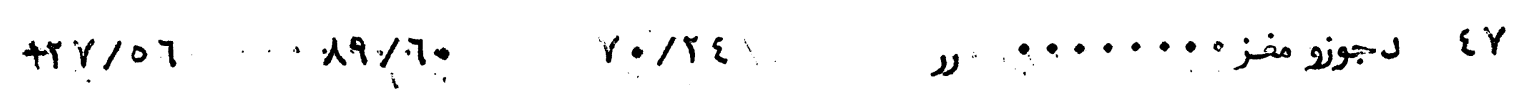

$+1 / \varepsilon+\ldots$ Fi/9R

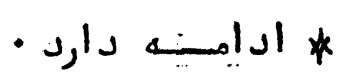


اد امســــ جدول (1)

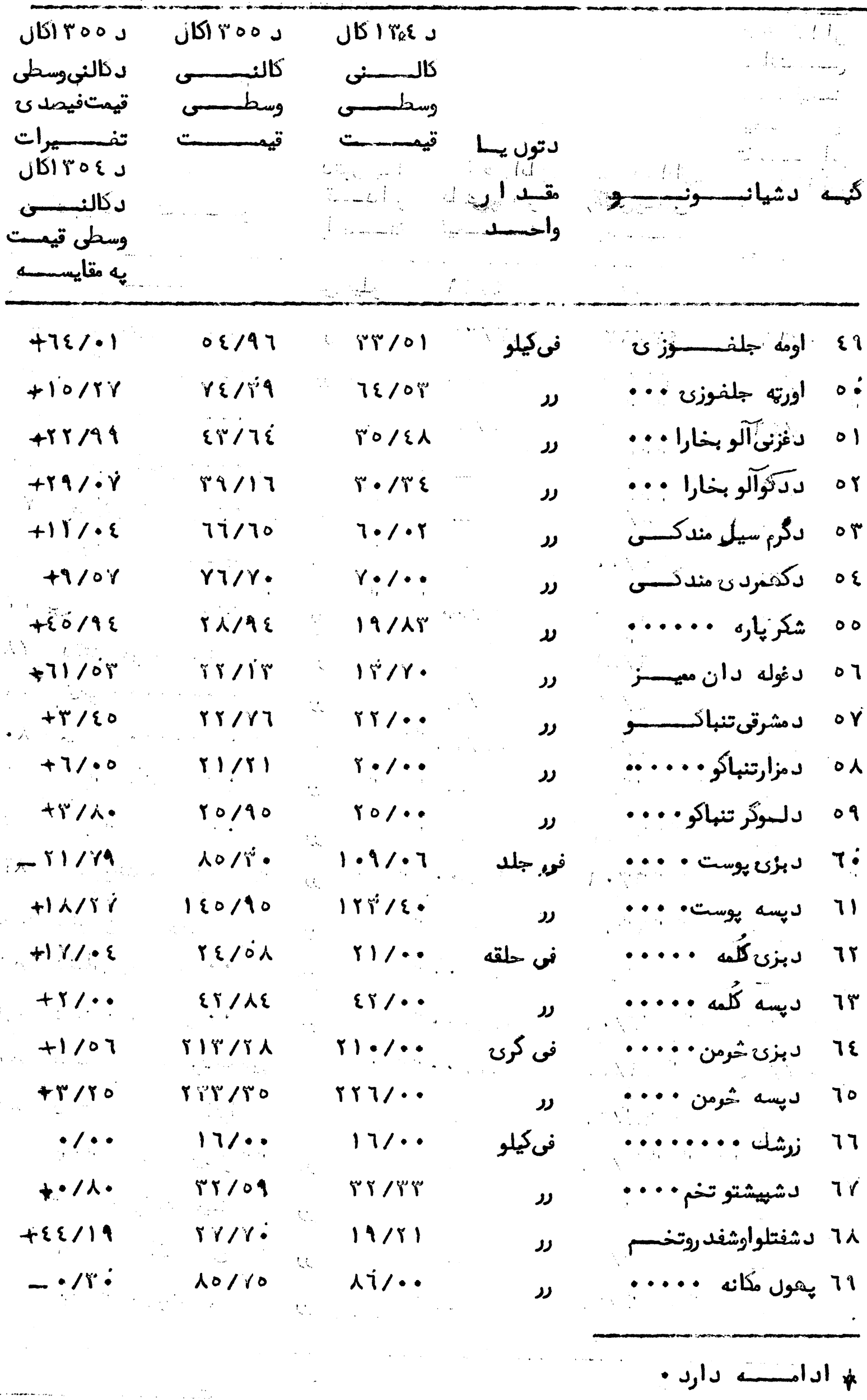


اداهه جسدول (II)

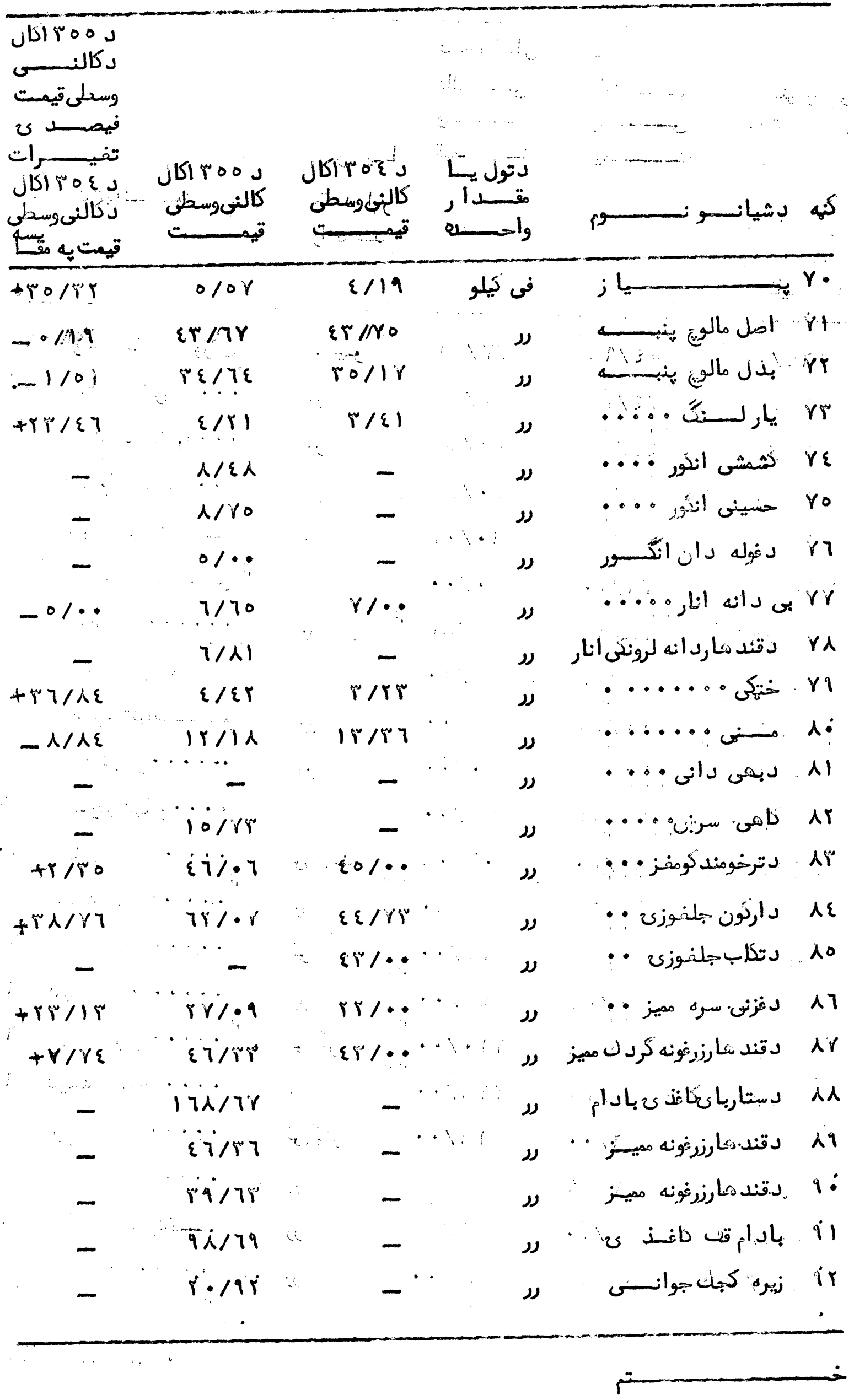




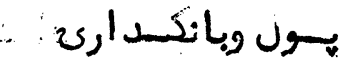

\section{ニニニニニニニ}

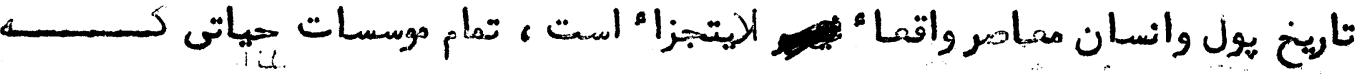

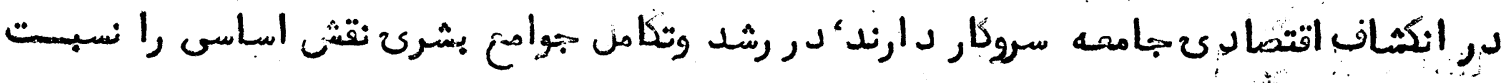

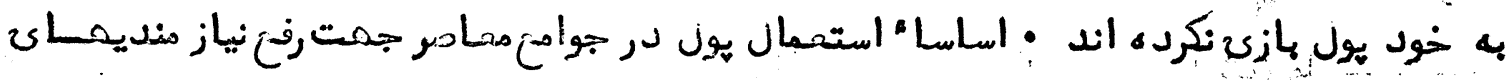

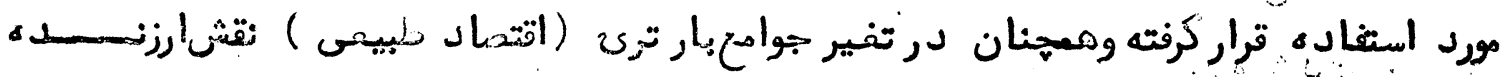

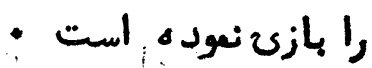

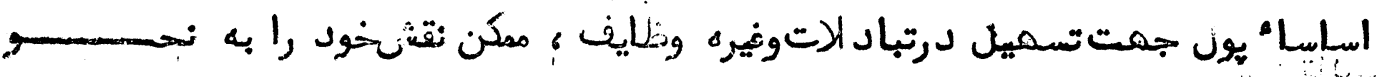

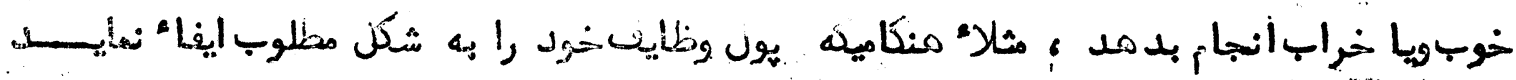

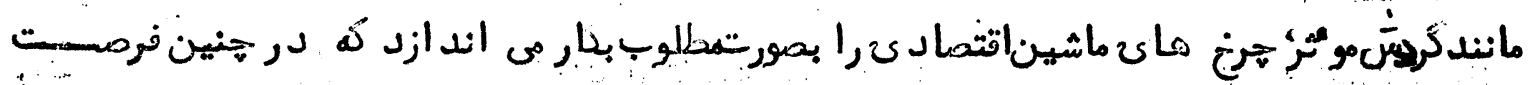

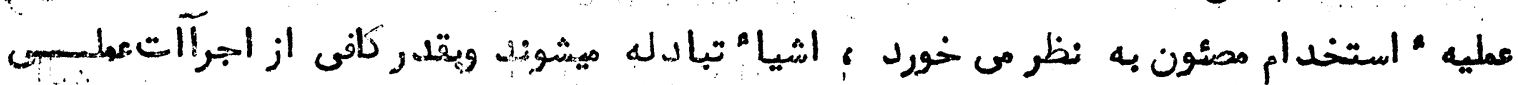

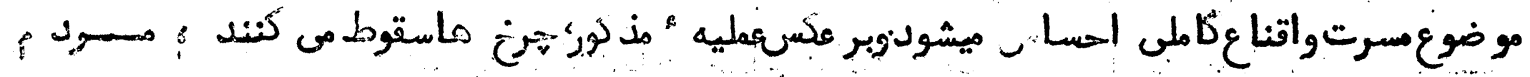

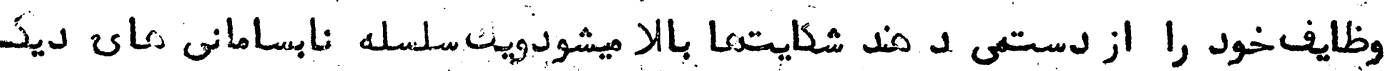

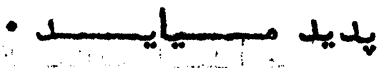

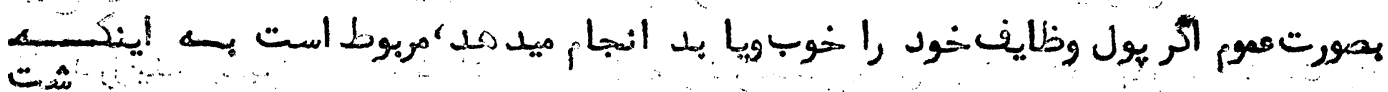

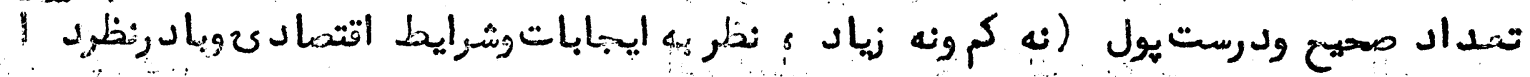

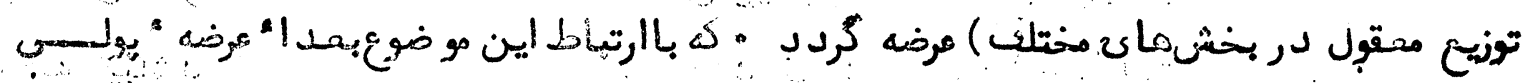

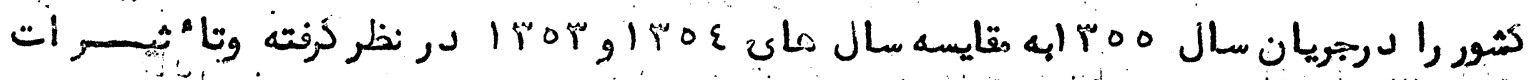

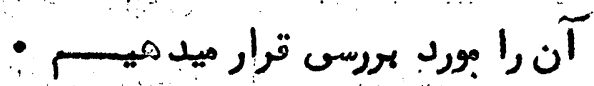

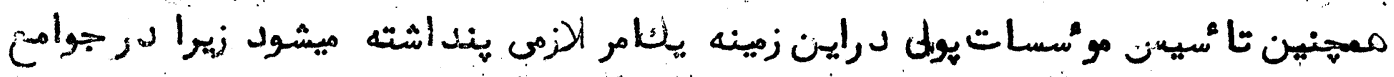

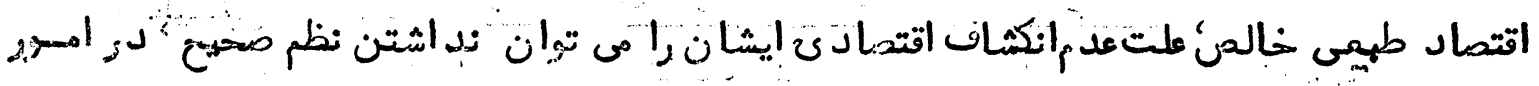

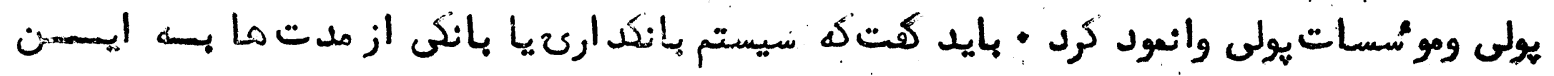

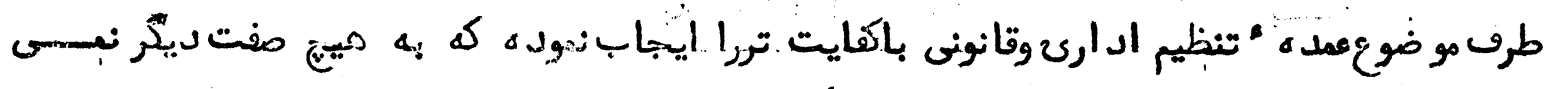

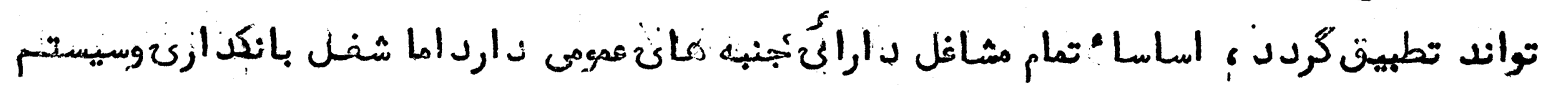

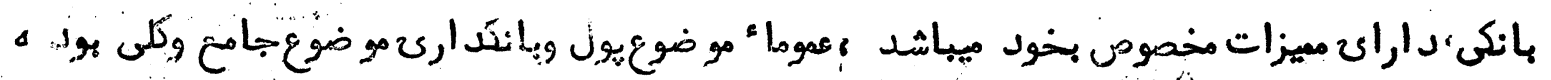

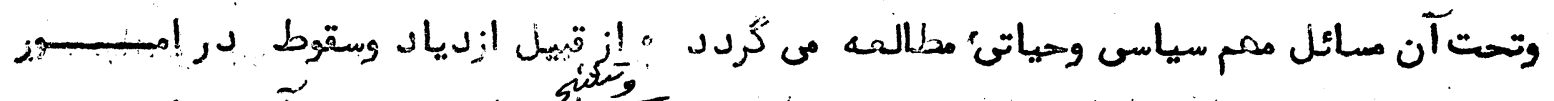

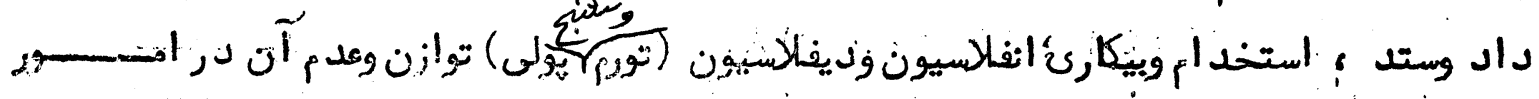

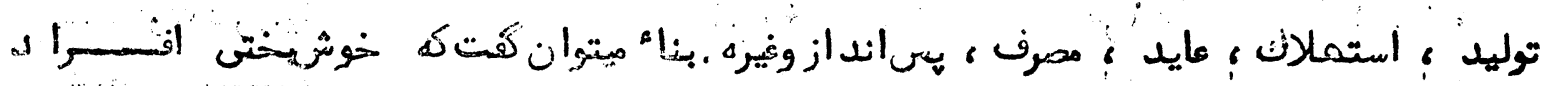

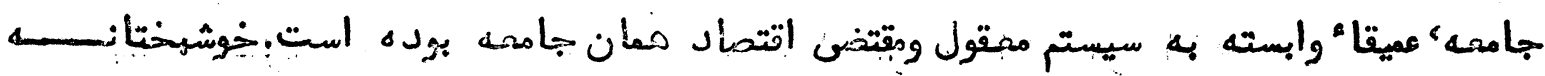

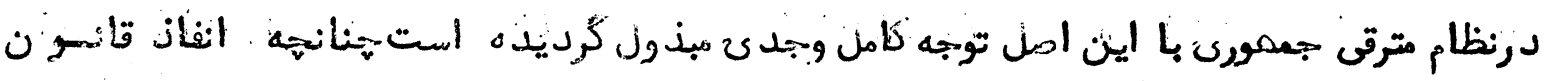

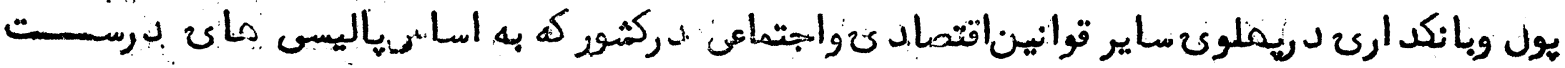




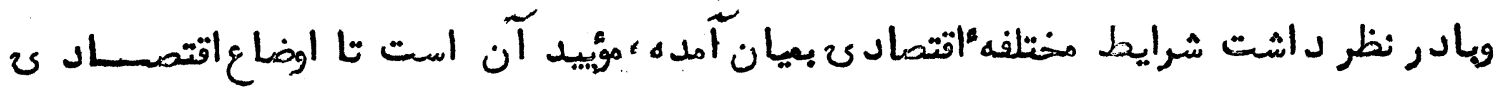

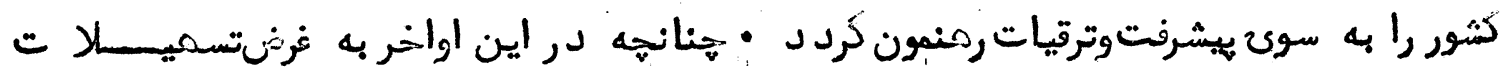

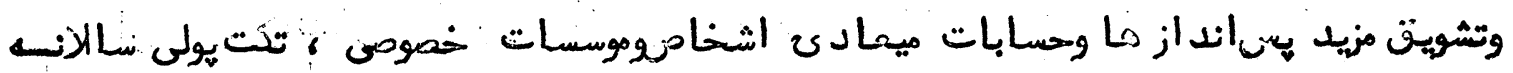

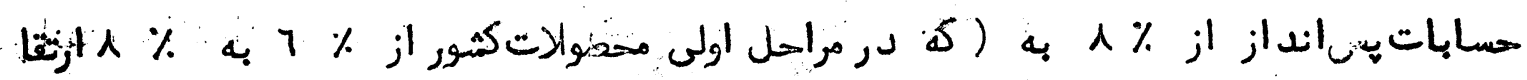

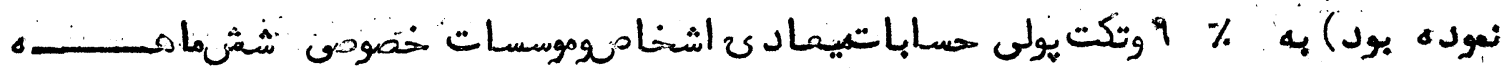

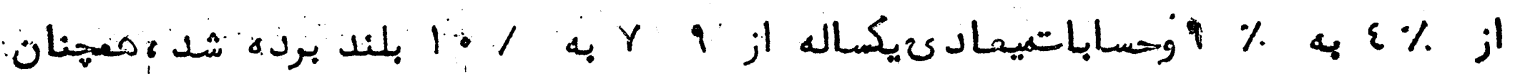

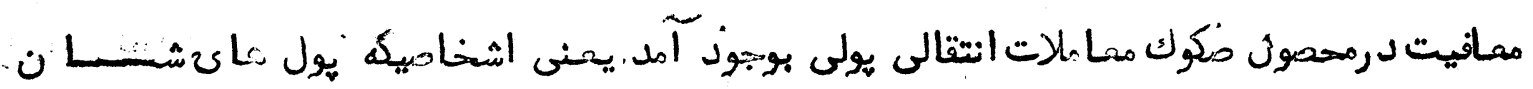

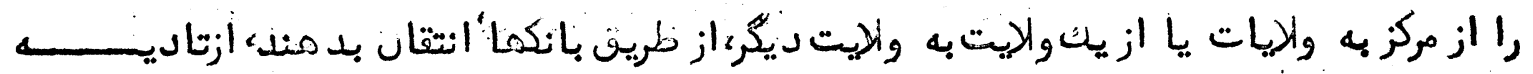

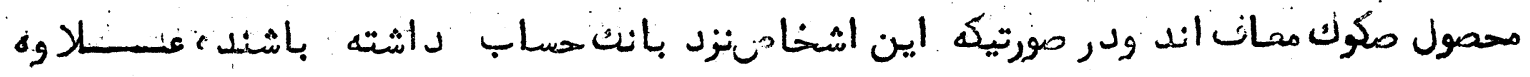

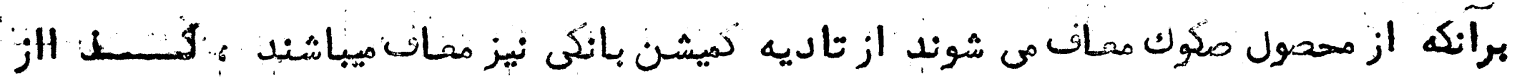

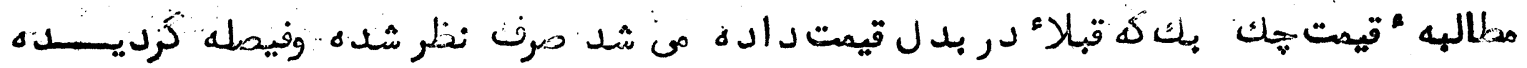

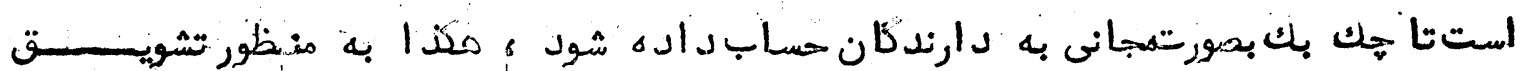

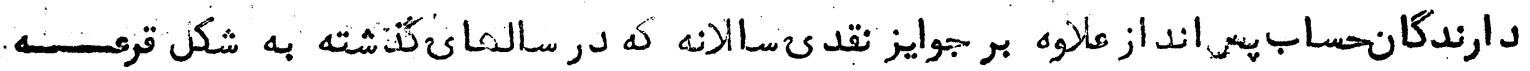

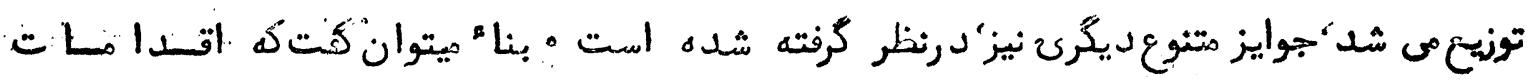

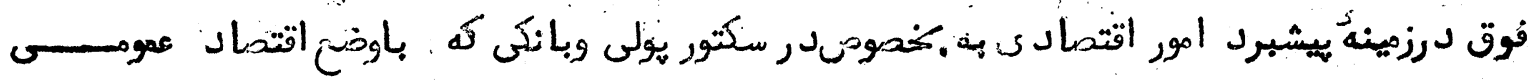

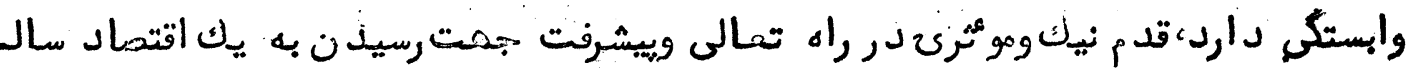

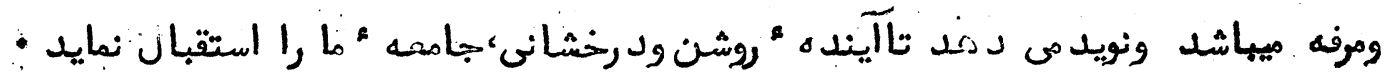

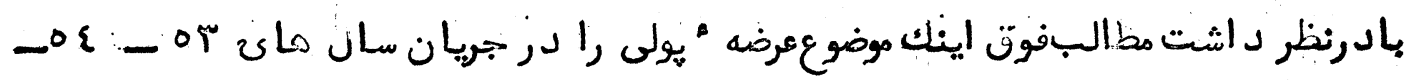

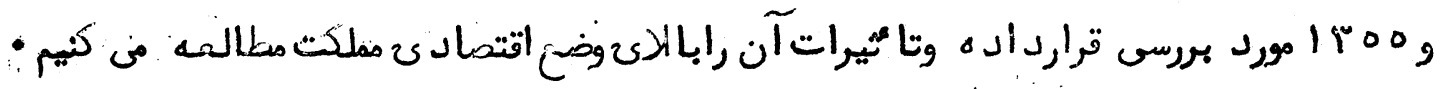

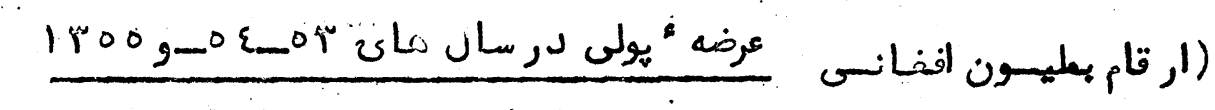

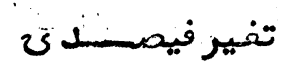

بمان

1ró

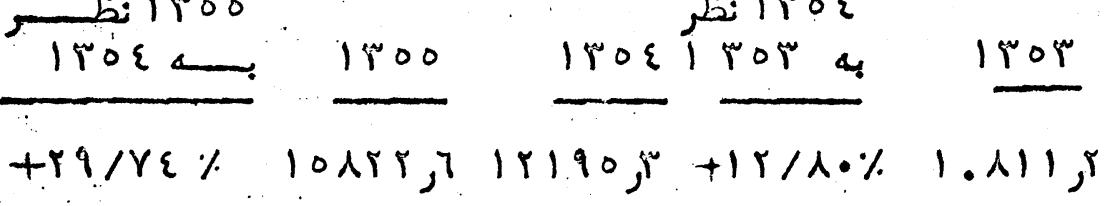

$+r, \gamma \varepsilon \% \quad \lambda r 1,0$

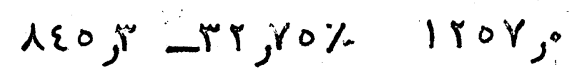

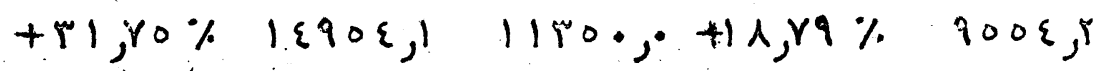

$-19,46 \% \quad 1.09,0 \quad 180, \%+r, 7 \% \% \quad 179$

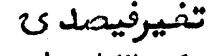

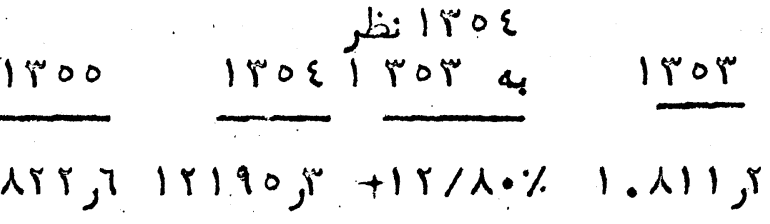

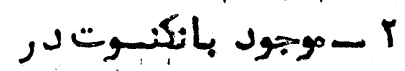

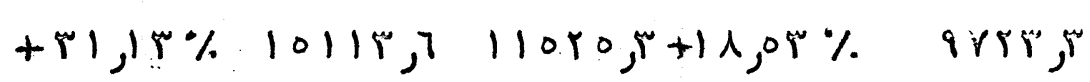

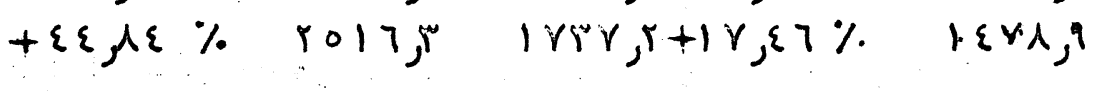

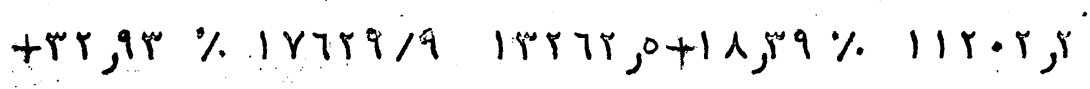

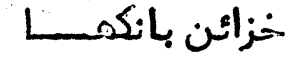

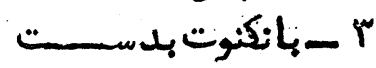
ع-مسكوك درجريان

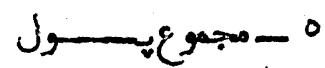

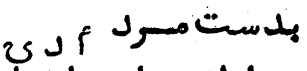
1

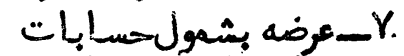

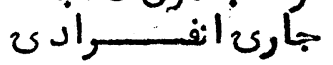

م 


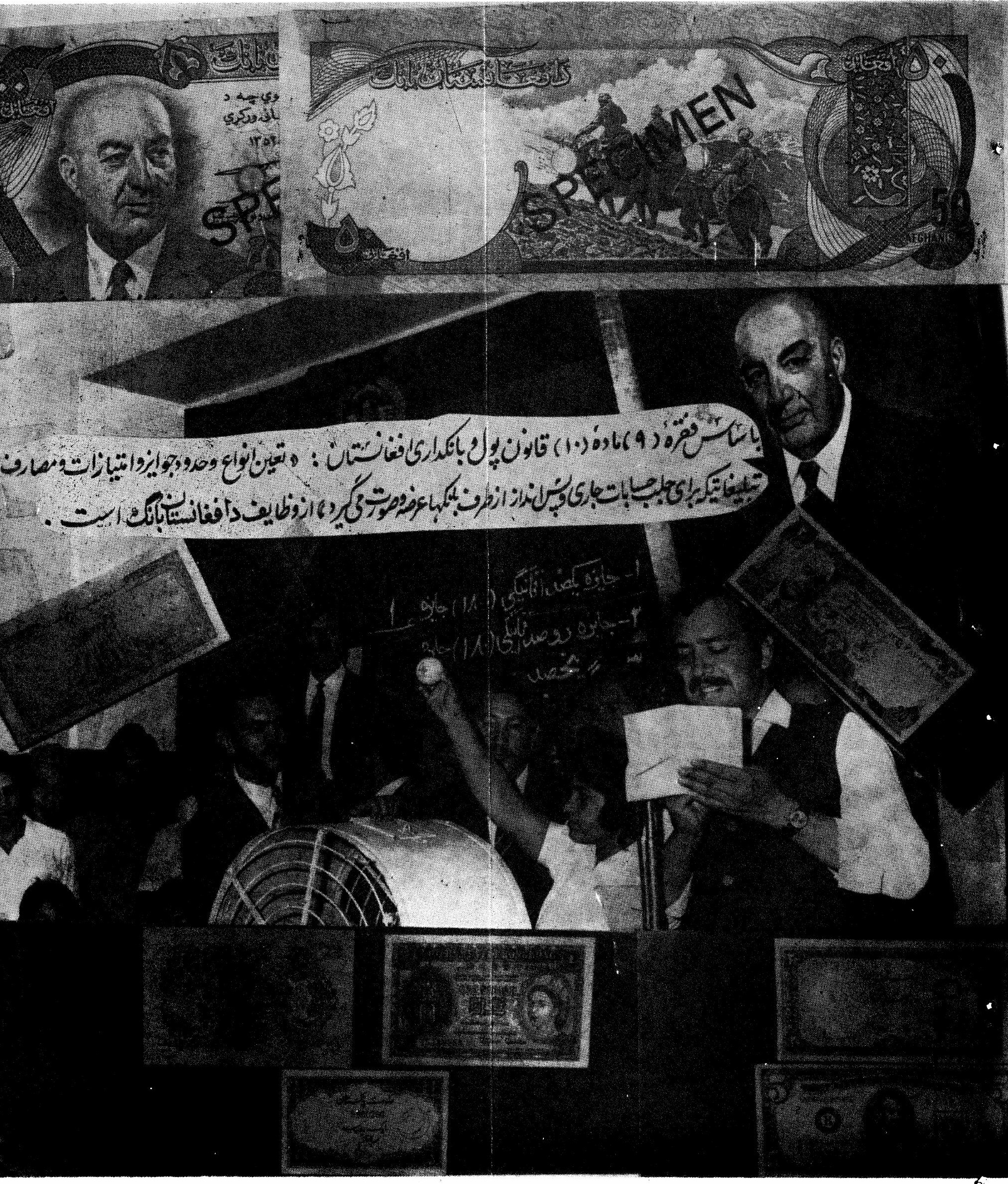




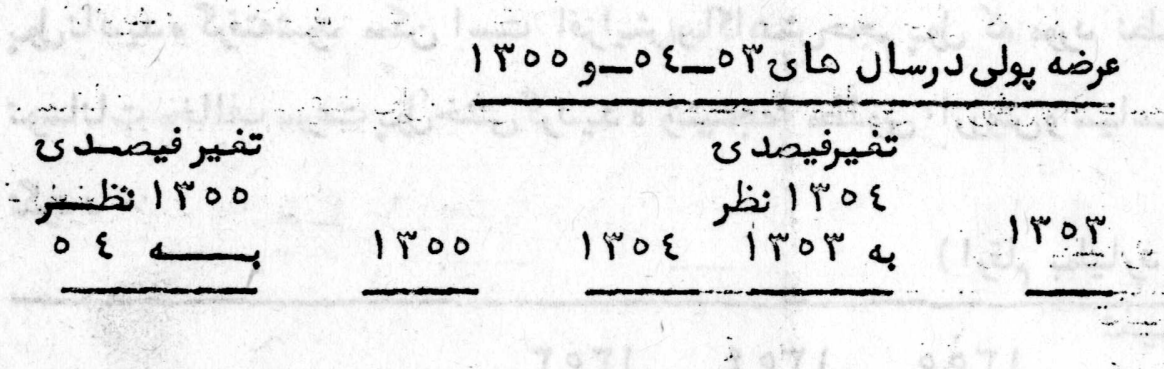

* r,or $\%+r 7 \cdot \beta \quad 17 r r, r+1 ; \% \%+7 \cdot r, r$

(ارقام بمليون افنانى)

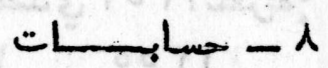
أهاثات انفرا دن

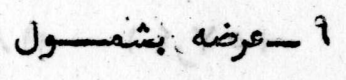
حسابات امانا تهن

انفـ

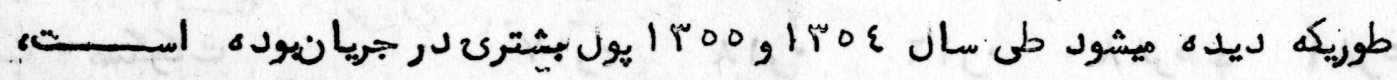

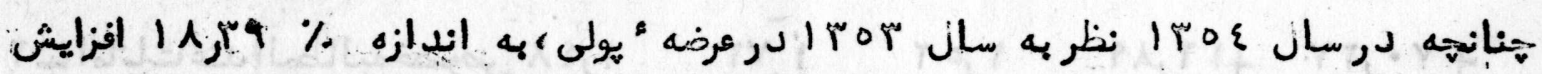

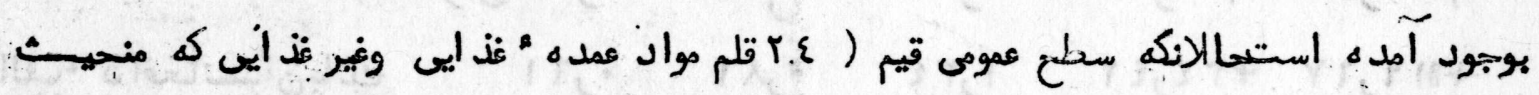

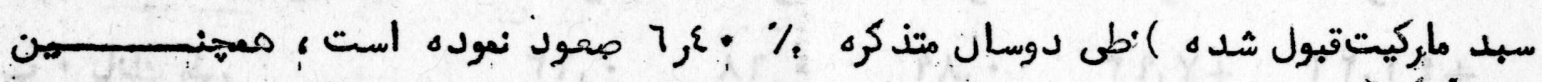

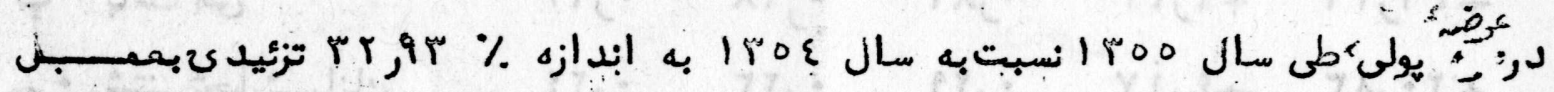

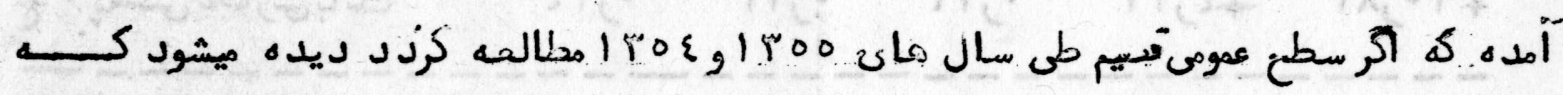

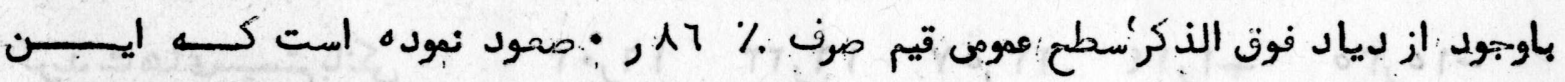

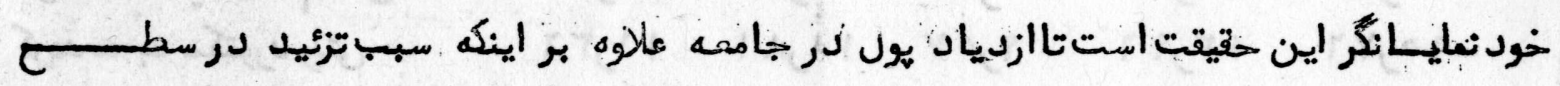

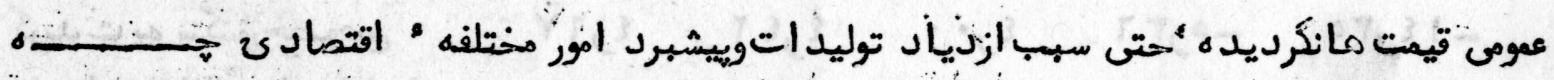

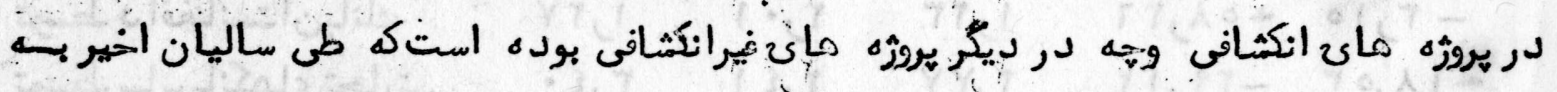

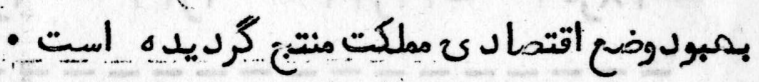

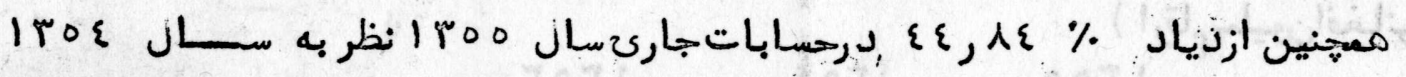

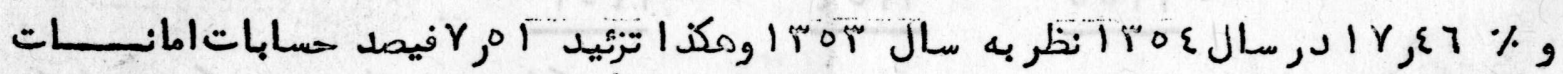

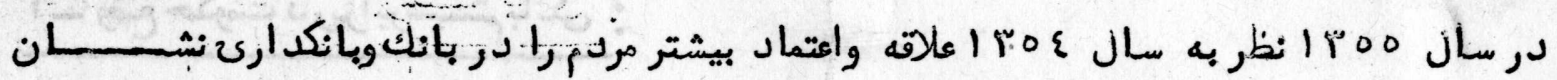

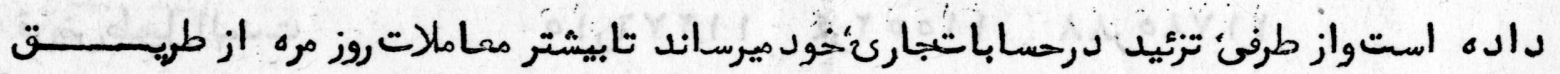

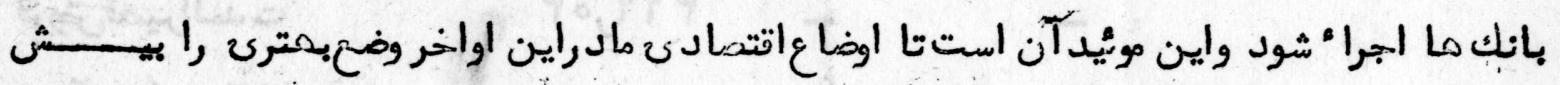

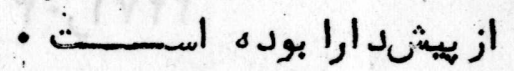

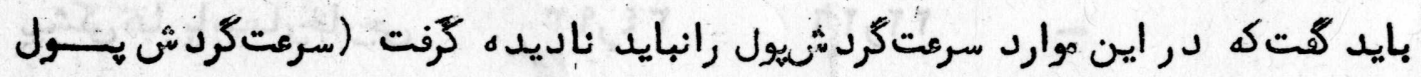

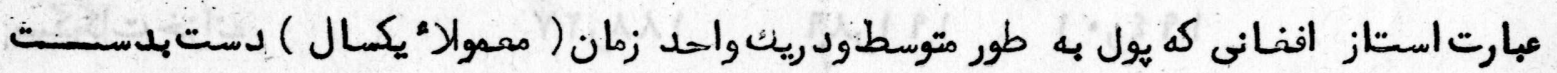

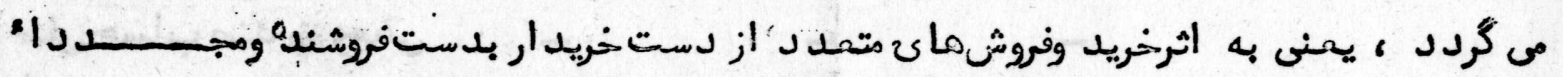

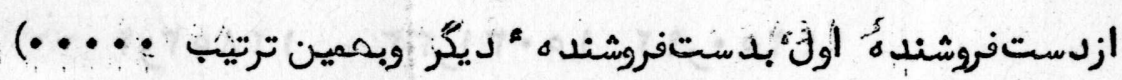

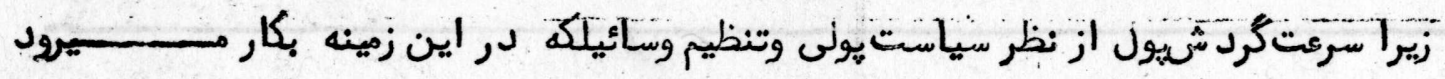

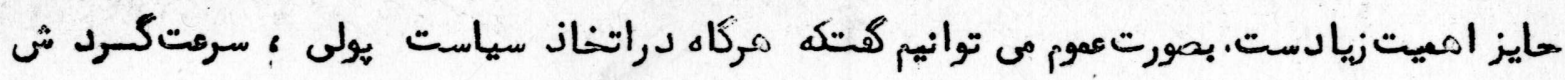




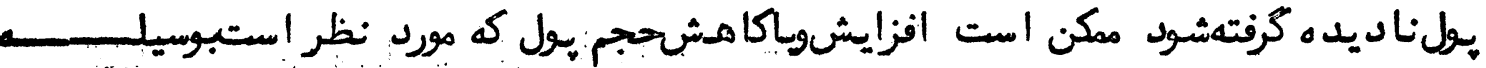

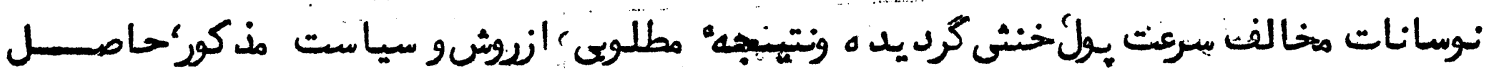
(ارقام بمليارد افغانى )

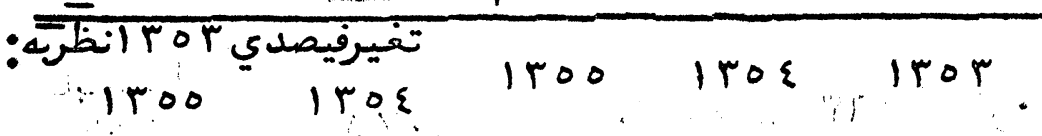

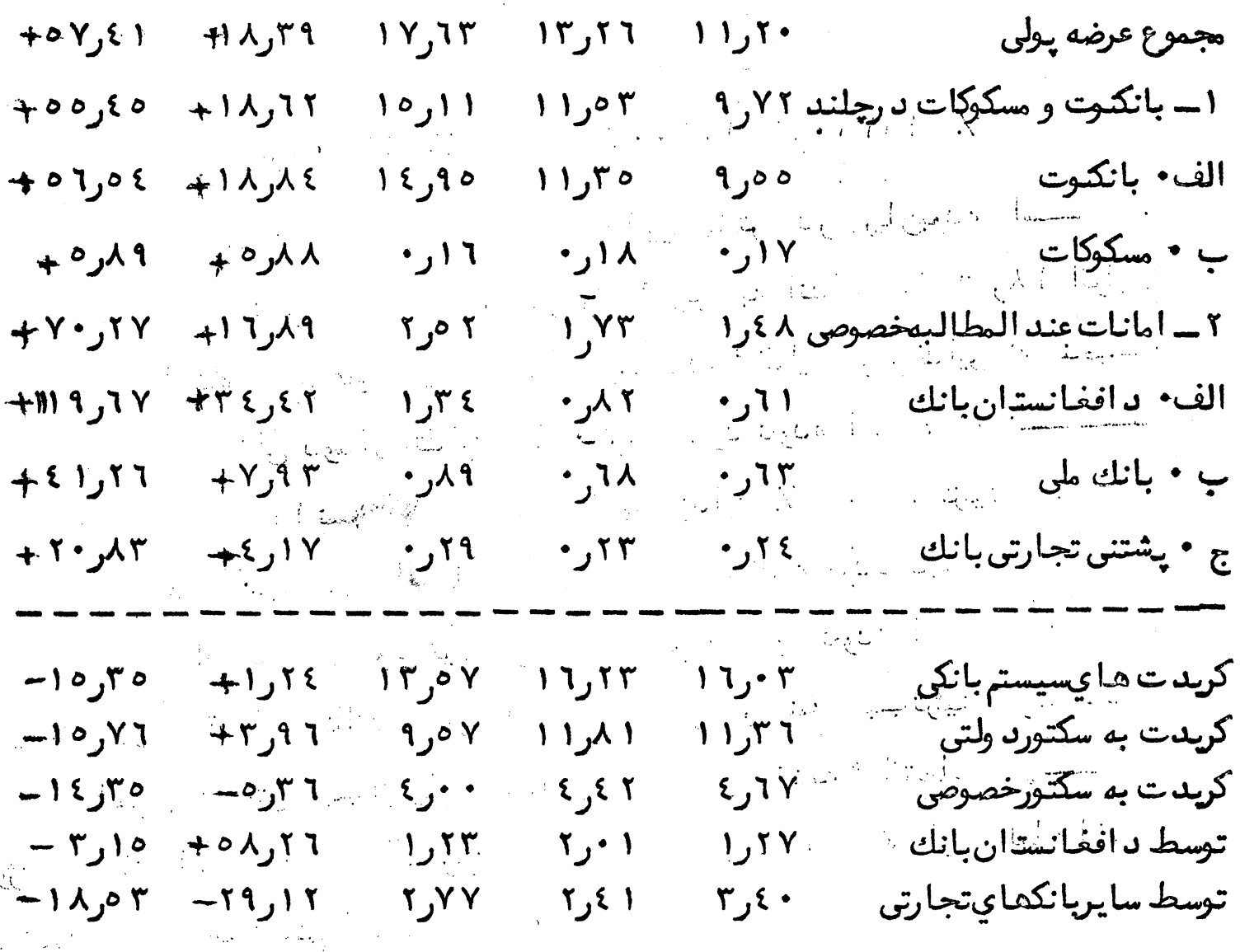

(ارقام بمليونافنَانى

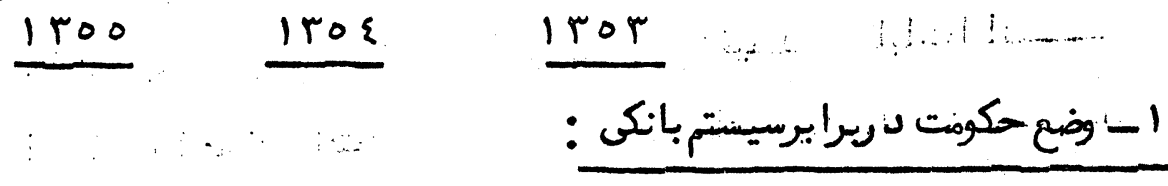

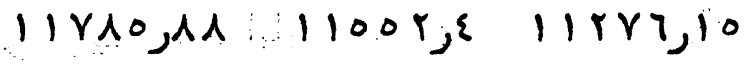

\begin{tabular}{|c|c|c|c|}
\hline- & - & r77,or & قروضقضتير.المدت . \\
\hline$r \vee,: r$ & rrז\& & $q \wedge \vee, r$ & ه افنـانى \\
\hline & $r r, r T$ & $r \varepsilon, q r$. & ارخارجى \\
\hline & 191,19 & $\mid \wedge \lambda, r V$ & \\
\hline
\end{tabular}

IEroegr 100rigr irkorj
منفى حساب صند وق وجنى

مجنمس 


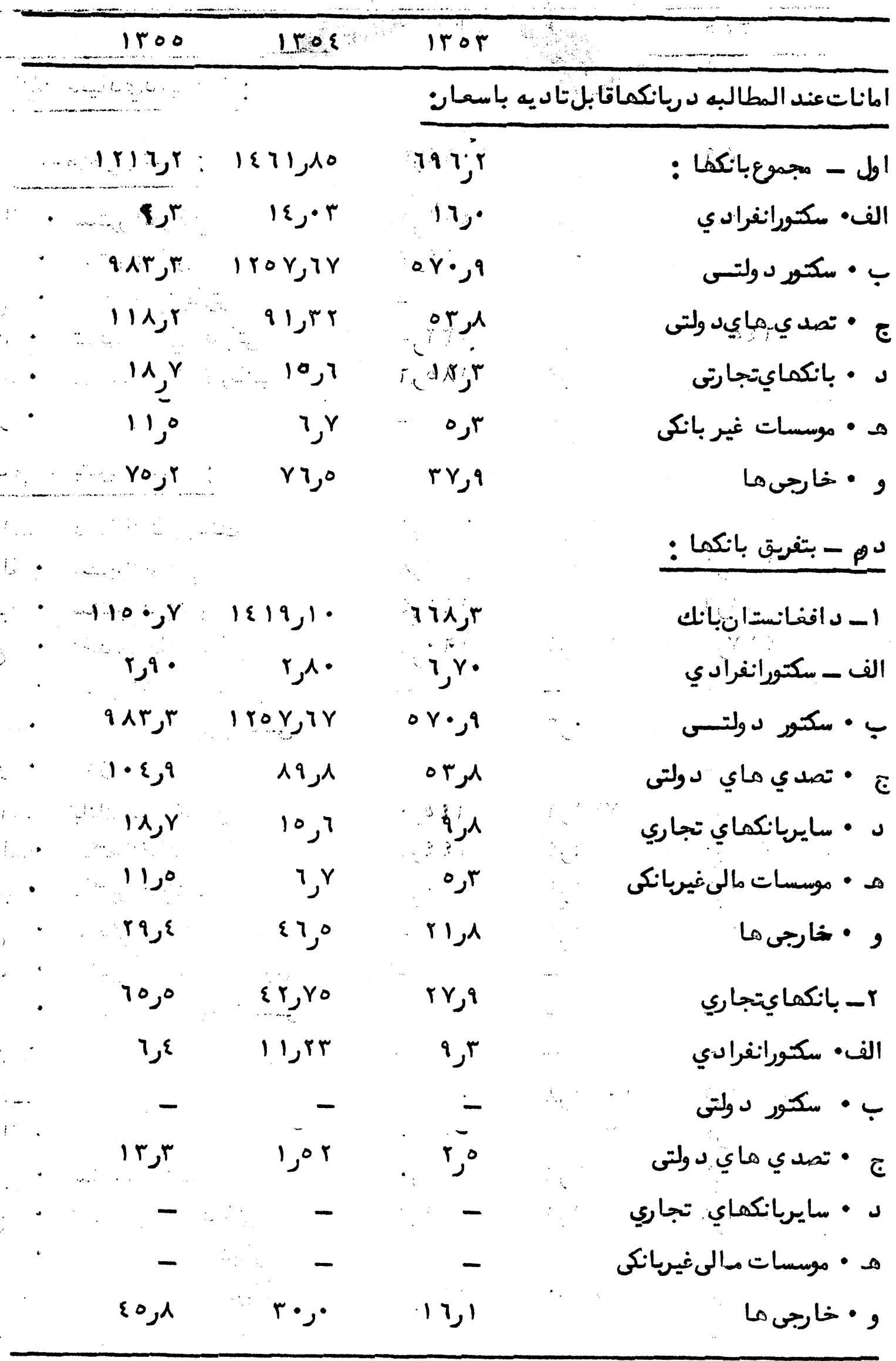




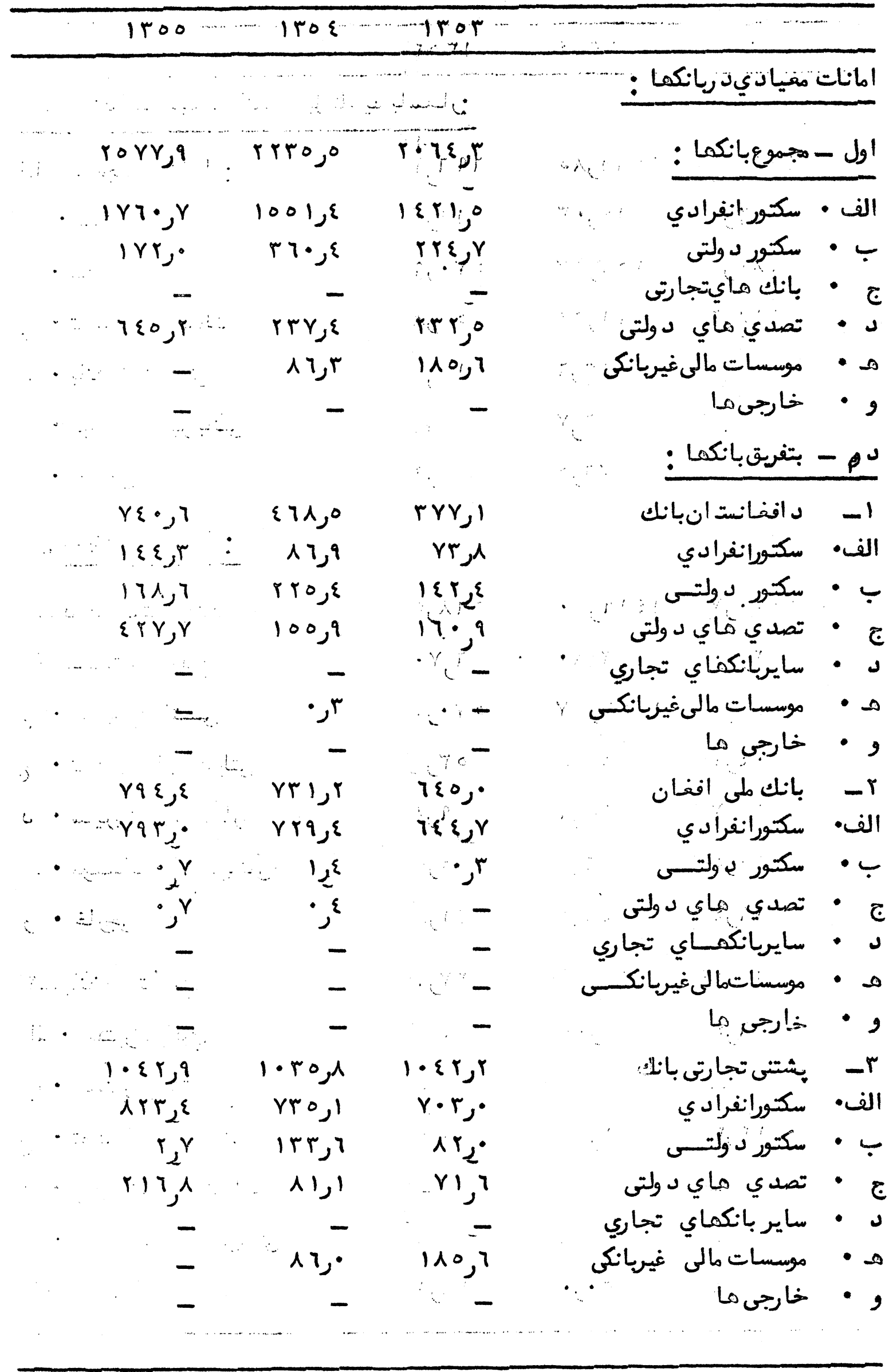




\begin{tabular}{|c|c|c|}
\hline & & بافغانى : \\
\hline - & $\varepsilon 11 \cdot, \cdot$ & اول - مجموع : \\
\hline$\cdot 1,7$ & $1 r \cdot 0,0$ & سكتور انفرادي \\
\hline $9 \mid v, 1$ & r & $Y \wedge 1, \varepsilon$ \\
\hline$r \cdot v r, r$ & $10 r \cdot 9$ & تصدي ينايد والت \\
\hline$\varepsilon \varepsilon r, \gamma$ & $109, r$ & ديكريانكمايتجار: \\
\hline $7 \vee 9, \varepsilon$ & $r q r, r$ & موسسات مالى غيرانكى \\
\hline$r r \wedge, r$ & $1 \varepsilon r, 0$ & ا- - ارجى مـا \\
\hline & & لد - بتفريق بانكما : \\
\hline$\{0 \wedge 7,0$ & $r 11+1$ & ا ـ د افغـانستانبانك \\
\hline Vir, & inr,o & الف: سكتورانغرادي : \\
\hline 110,0 & $r \cdot 1, r$ & ب سكتورد ولتــى \\
\hline 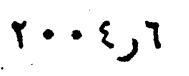 & $1 \varepsilon r \wedge, 7$ & تصدي هاي دولتى \\
\hline$\{r q, \varepsilon$ & 10r & سنايريانكماي تجاري \\
\hline$r \mid r, r$ & $r \cdot \gamma$ & هـ... موستسات مالى غير بانكن \\
\hline ror & $r o, \varepsilon$ & 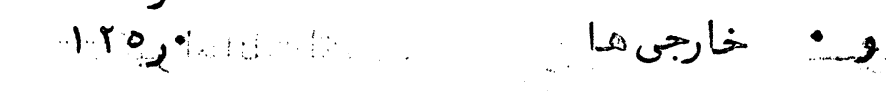 \\
\hline 9000 & $r 19, r$ & r- بانك ملى افغـان \\
\hline$\{q \wedge,\{$ & $\varepsilon r r, \wedge$ & الف • سكتورانفرادي ــ ـ \\
\hline$\lambda, r$ & $r$ & ب سكتور دولتـــى \\
\hline$\{r$ & $r_{0}$ & ج " تصدي ماي دولتى \\
\hline $1 \varepsilon$ & $7 \boldsymbol{J}^{\circ}$ & 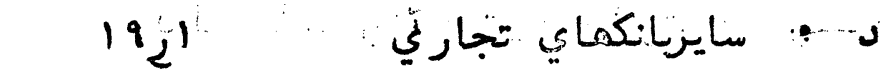 \\
\hline$r 01,9$ & $r 10,9$ & مـ . موسينسات مالى غير بانكى \\
\hline$r 0, r$ & $r$ & و • ارجي ما \\
\hline$\{\mid r, \varepsilon$ & $r 0 \cdot r$ & r-rيتى تجارتى بانك : \\
\hline$V \varepsilon r, q$ & $1 \lambda \varepsilon, r$ & ألف • سكتور انفرادي \\
\hline$q r$ & $\therefore \quad \Delta r, r$ & بَ • سكتور دوانتسلى \\
\hline$r 7, \varepsilon$ & $\therefore r, r$ & ج تصدي مـاي دولتى \\
\hline - & $\ldots \quad-$ & ب • •. بـاير بانكماي تجارتى \\
\hline r & . & مـ موسسات مالى غير بانكى \\
\hline$r q, 0$ & $\varepsilon \cdot{ }^{\bullet}$ & 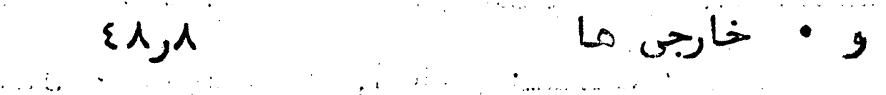 \\
\hline
\end{tabular}




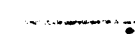

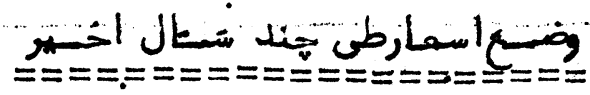

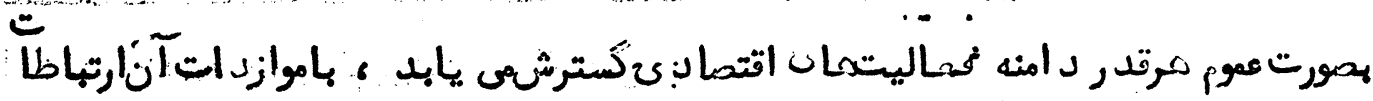

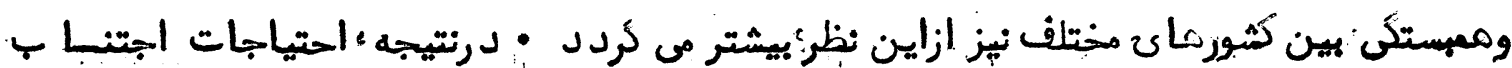

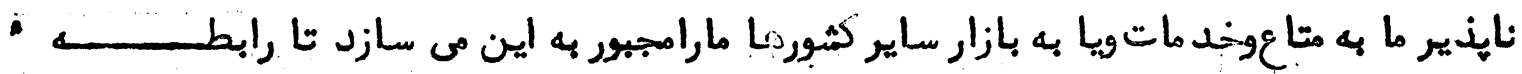

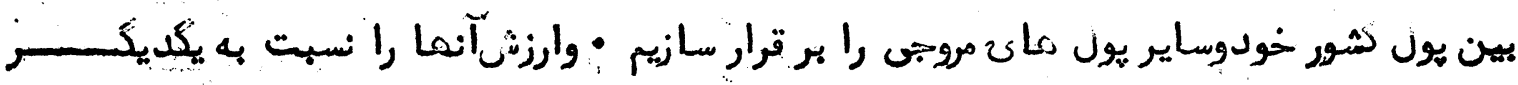

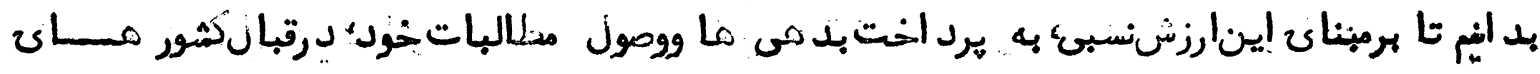

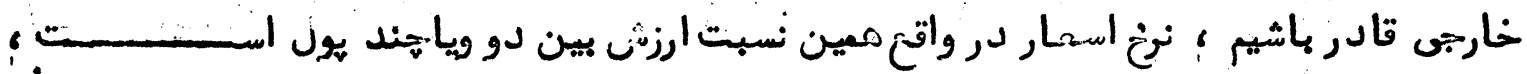

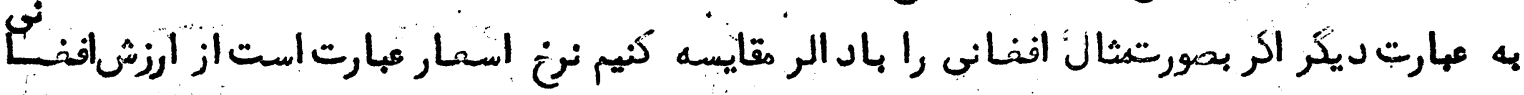

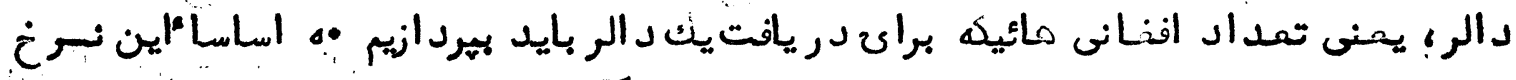

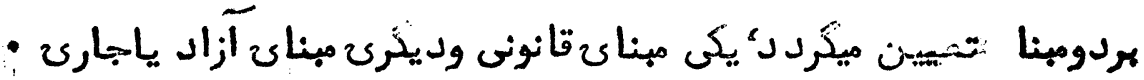

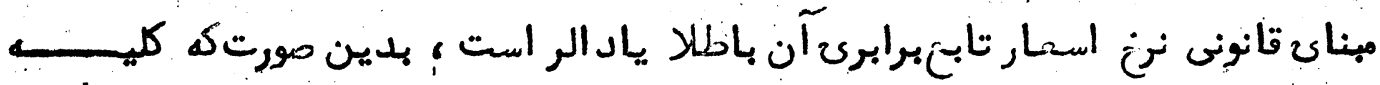

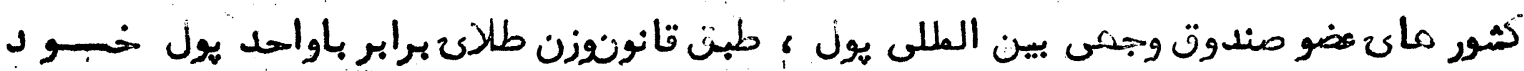

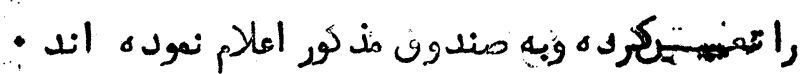

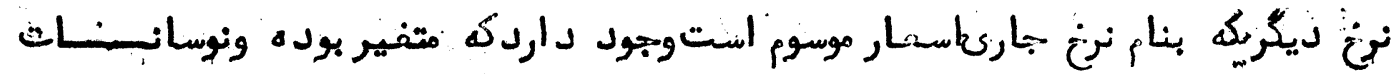

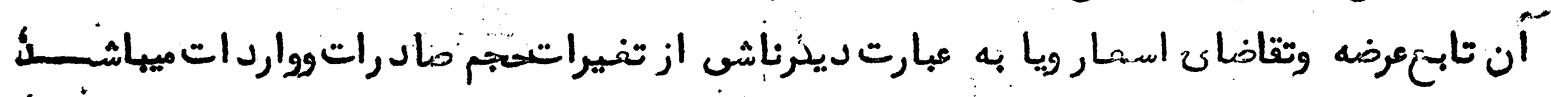

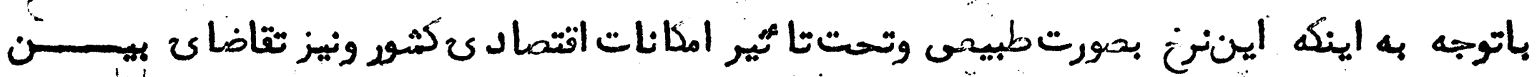

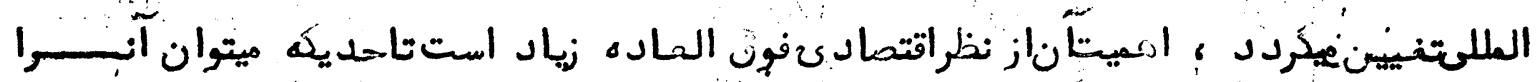

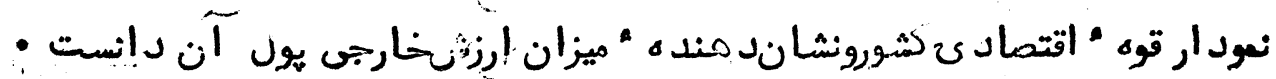

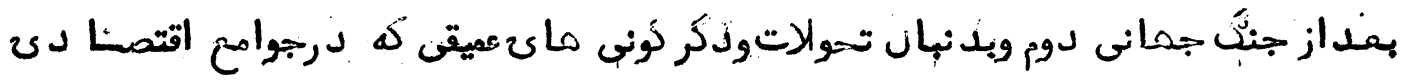

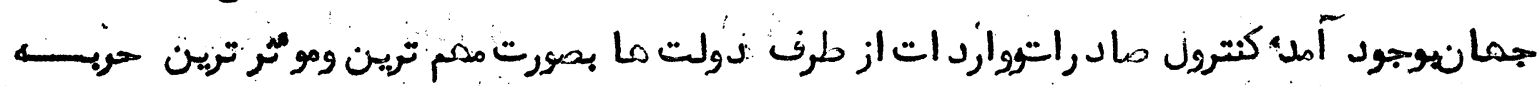

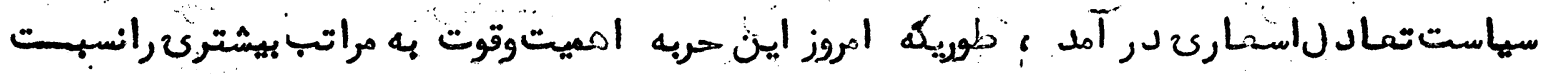

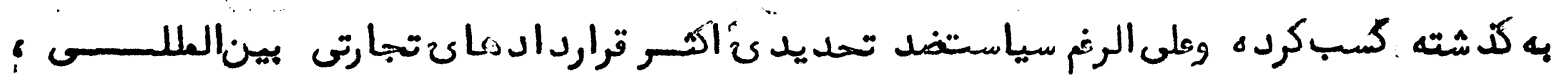

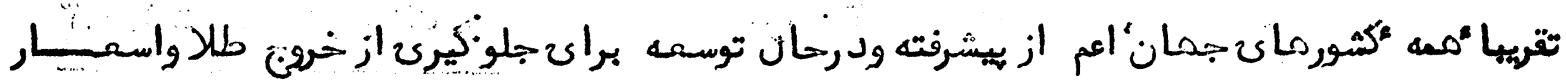

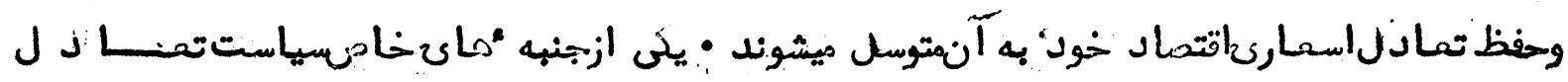

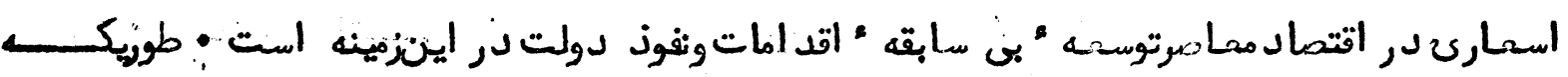

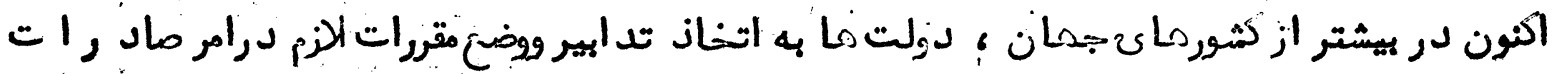

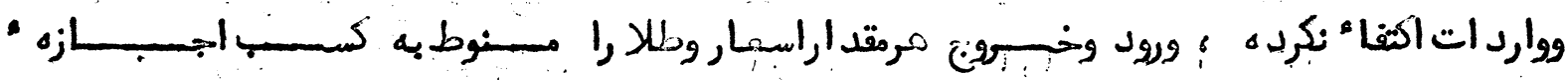

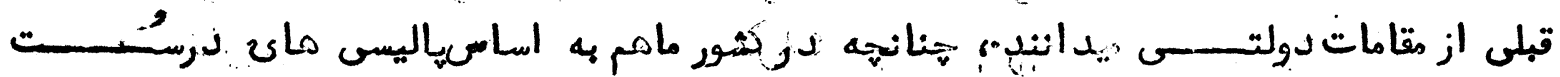

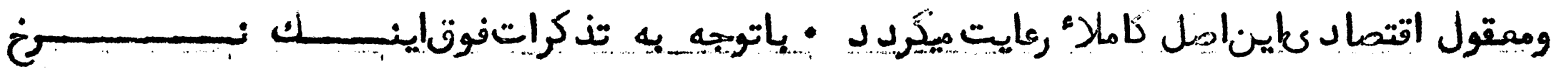




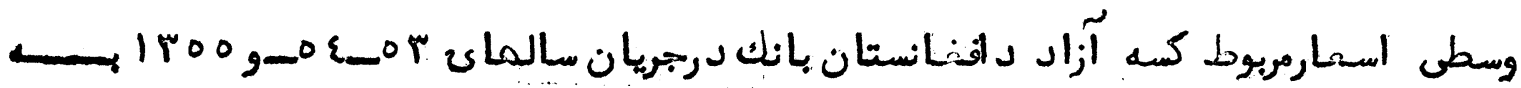

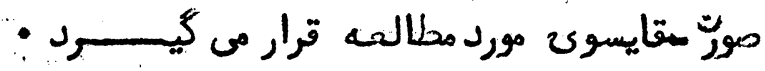

\begin{tabular}{|c|c|c|c|c|c|c|}
\hline \multicolumn{2}{|c|}{1100} & \multicolumn{2}{|c|}{ 1ros } & \multicolumn{3}{|c|}{$190 \%$} \\
\hline فسـومثر & خهيد & فرو ثن. . & خسريل . & فسروش & خريســ & \\
\hline $9 r, \varepsilon \varepsilon$ & $\pi 9,9 \%$ & Irr,o\&, & 117,19 & $1 \varepsilon$ & $|r|$ & اسهوندنترلينبّ \\
\hline ritir & مار & $r r$ รO & $r i$ & $r \cdot \lambda$ & $17, \varepsilon$ & r - -فرانَّك سويسى \\
\hline o & or so & $01,09$. & r & 09 , r. & 00,7 & r ـــ بالر امريكائ \\
\hline 81,89 & $r i, i$ & rir & $Y I, i \varepsilon$ & rr, & $r I$ Ar & ع - مارث آلمانسى \\
\hline ع 11 & $1 \cdot, j \varepsilon$ & קצr & $\mid Y, 01$ & Ir, $\lambda\rangle$ & 11,57 & 0ـفرانَّك فرانسونح \\
\hline 0,77 & 0,07 & $7 \cdot r$ & o jir & $0, \varepsilon \varepsilon$ & $0 \varepsilon$ & ج_كلد إرياكتانى \\
\hline & & i, ro & $7, \hat{r r}$ & 7 & $7: Y$ & كلد ار مندى \\
\hline
\end{tabular}

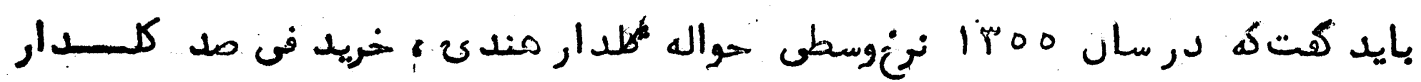

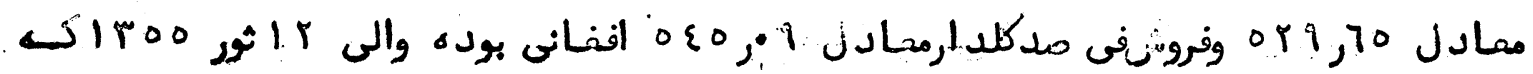

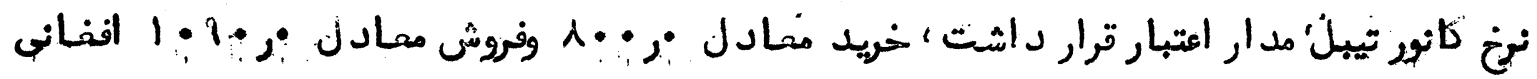

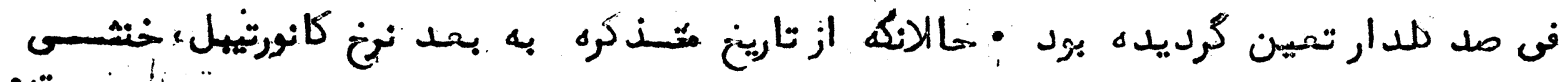
ونون بارتر مدار اعتبار بوده است كه بحورت وسنطى الى ختم سان

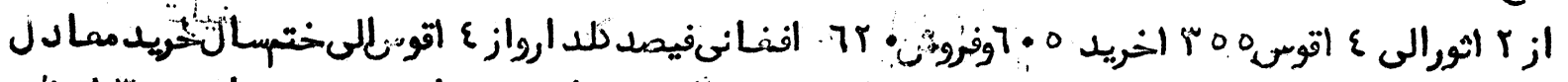

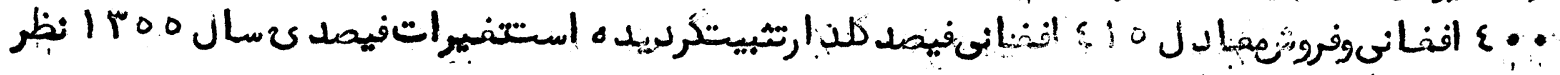

$$
\begin{array}{r}
\text { ف2 } 1 \% \\
-7,91 \% \\
+7,0 \% \\
-8,77 \% \\
-18,7 \% \\
+\varepsilon \% \%
\end{array}
$$

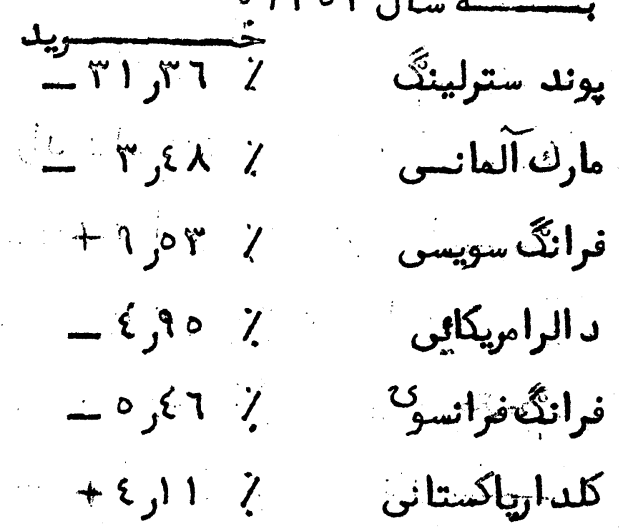

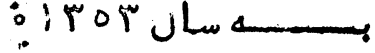

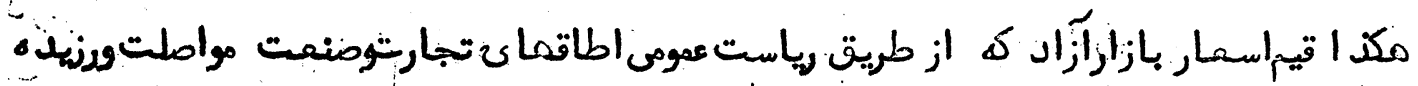

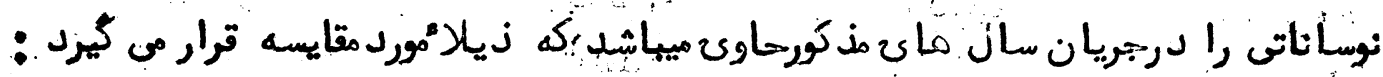

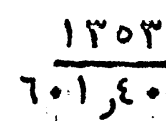

$0)^{1,19}$

$1 \% \varepsilon, \gamma \varepsilon$

$07,0 \varepsilon$

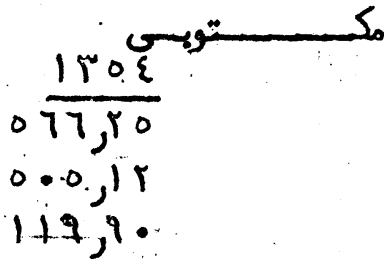

$00, \varepsilon$

r), $7 \mathrm{r}$ $\frac{1500}{10,77}$

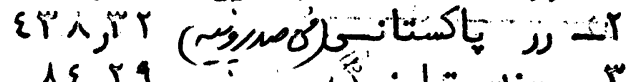
ᄉ $\varepsilon$, 4 $\varepsilon \gamma, 0$ ? $19,0 \varepsilon$
ع - د الر امريكائسى هـ مارك آلمانسي 


\section{نق}

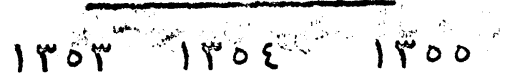

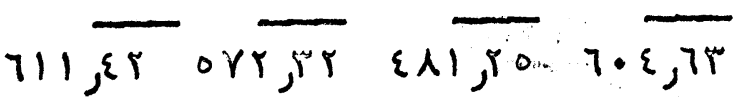

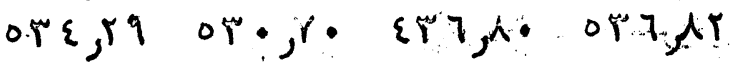

$\mid r q, 1 \%+1\}$

ligrirogo

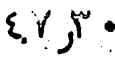

$0\urcorner, Y \varepsilon$

$07, \mid \leq: 0\}$

दा.

$11,9 R^{2}, 41,74 \quad 19,0$

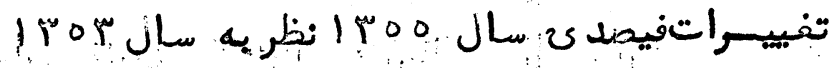

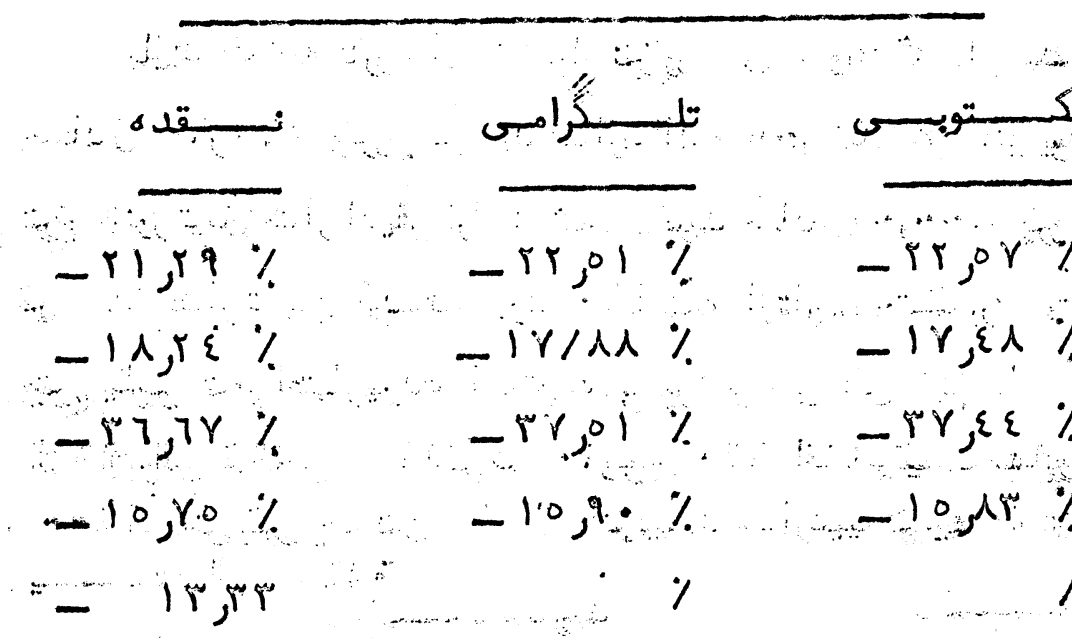

119,80

00,0

1 roo

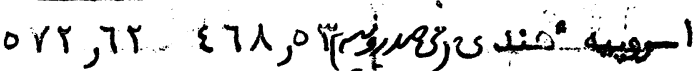

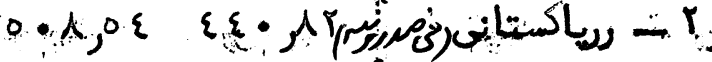

- $-r$

$A \varepsilon, 0 Y$

ستر لينتئ الع الع

$\{r, r\}$

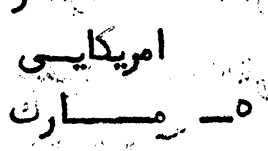
آلمانســــ

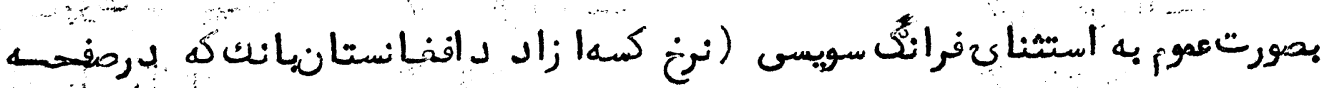

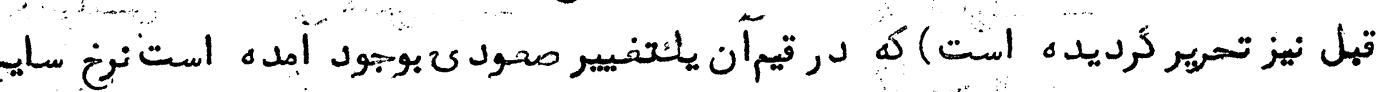

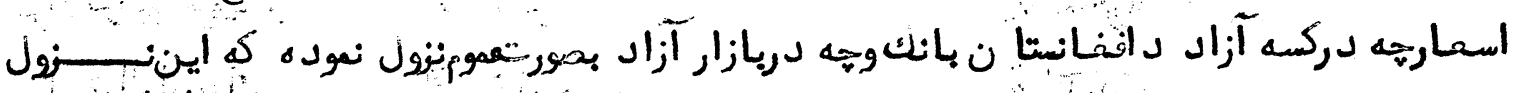

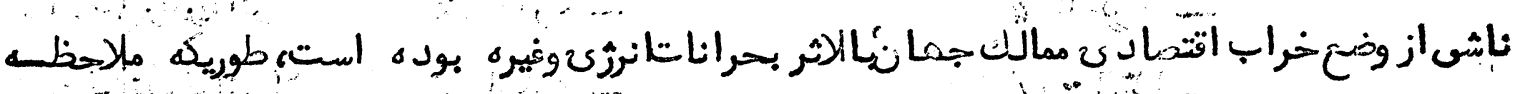

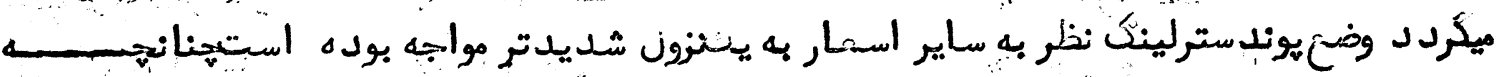

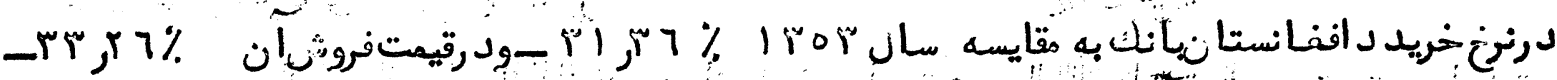

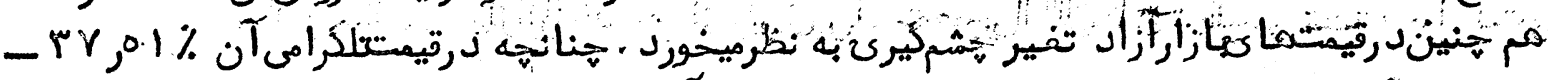

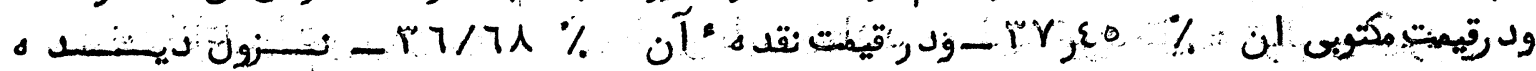

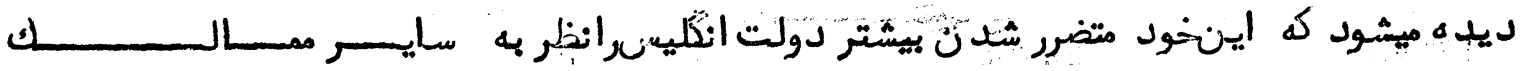

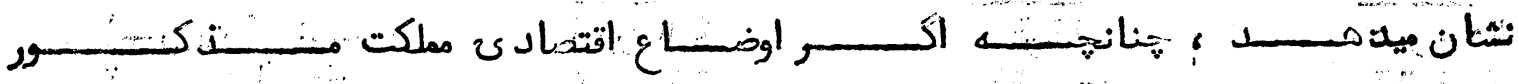

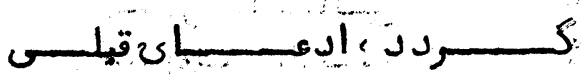
a

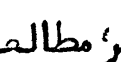

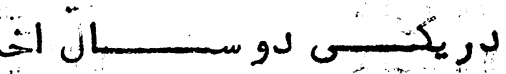

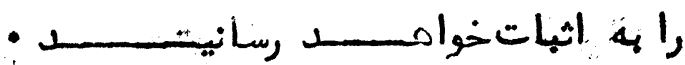



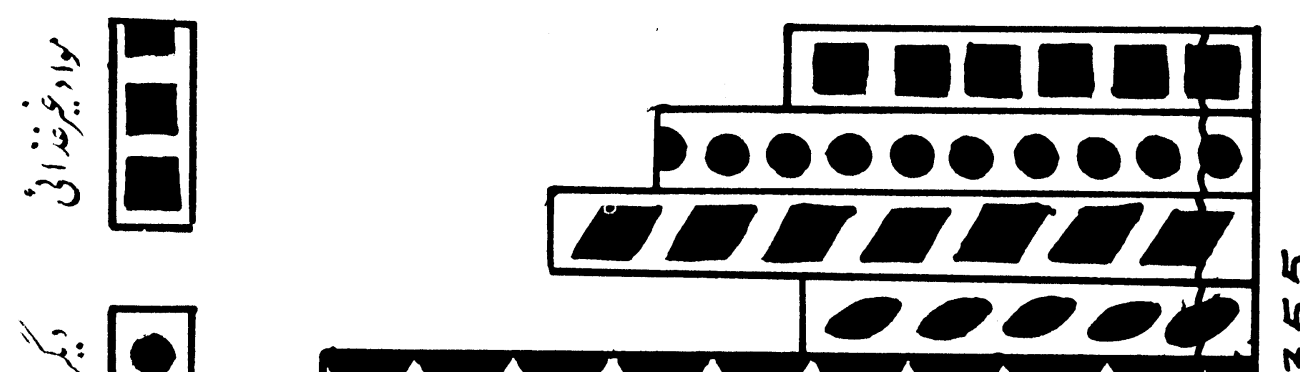

?

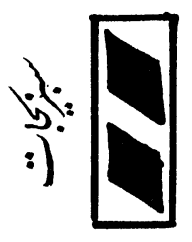

गे

8

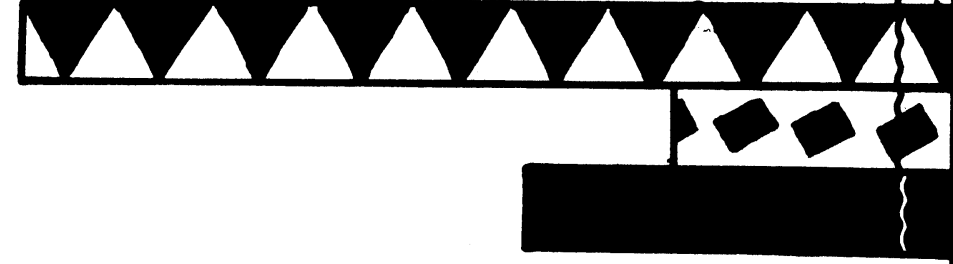

$n$
$n$
$m$

M

:

ذं

$\underset{1}{3}>$

3.
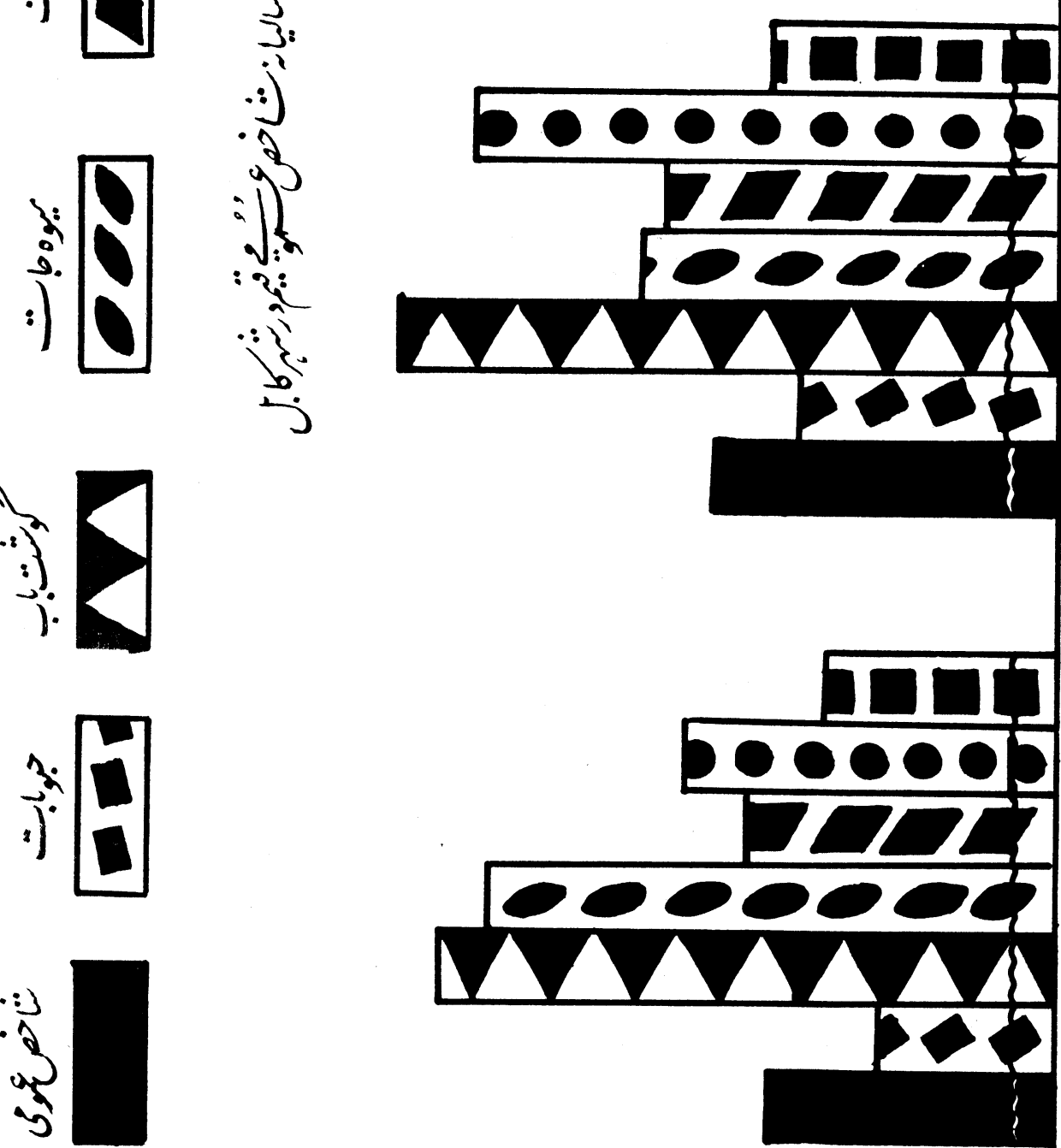

$m$
$n$

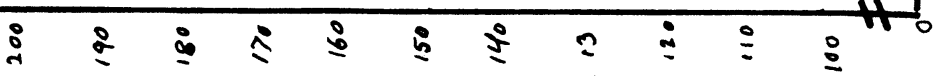




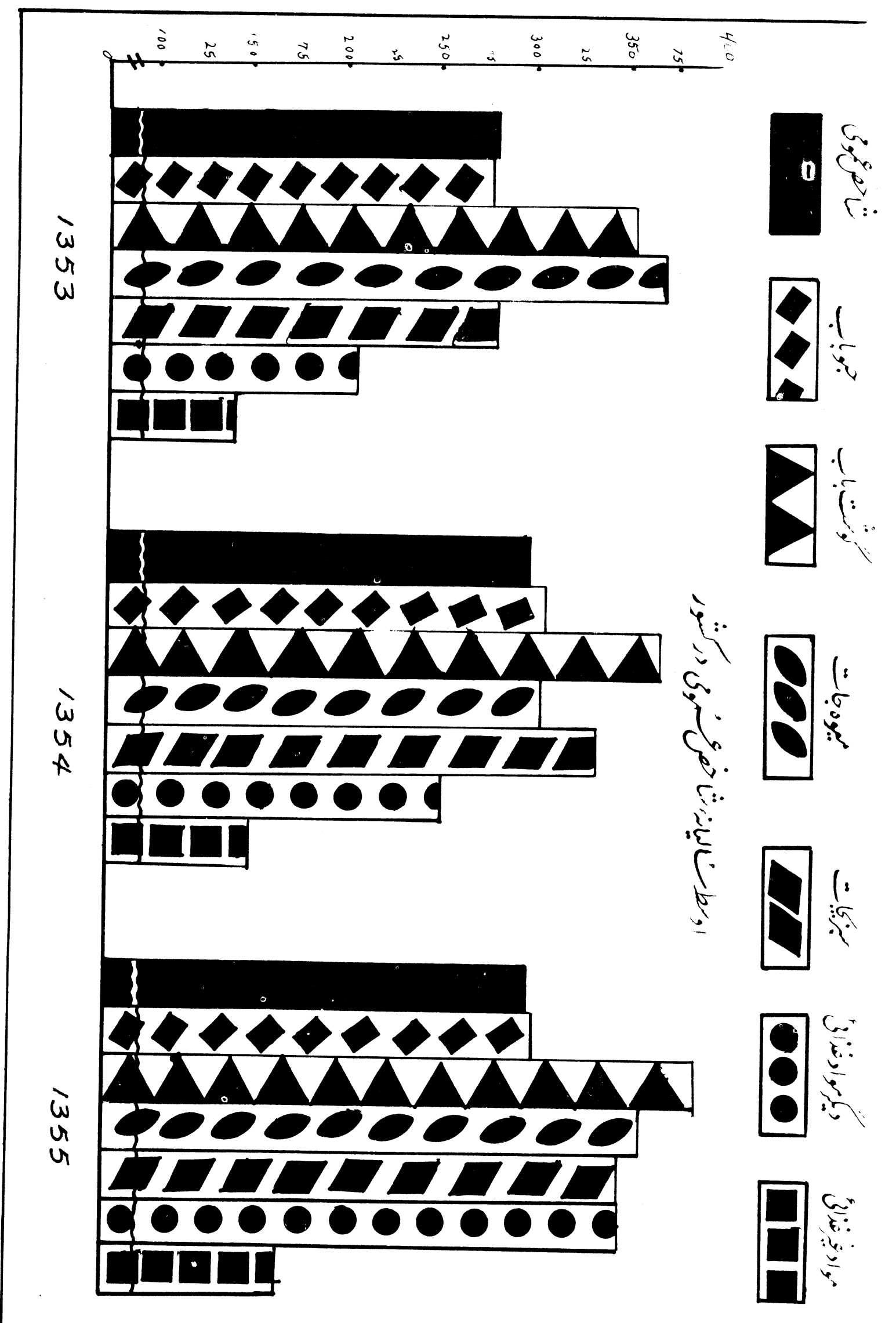


1000:10

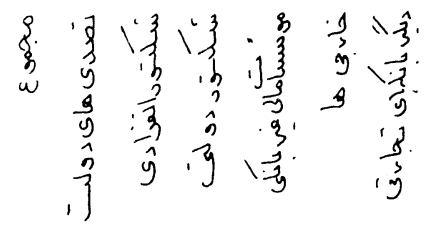

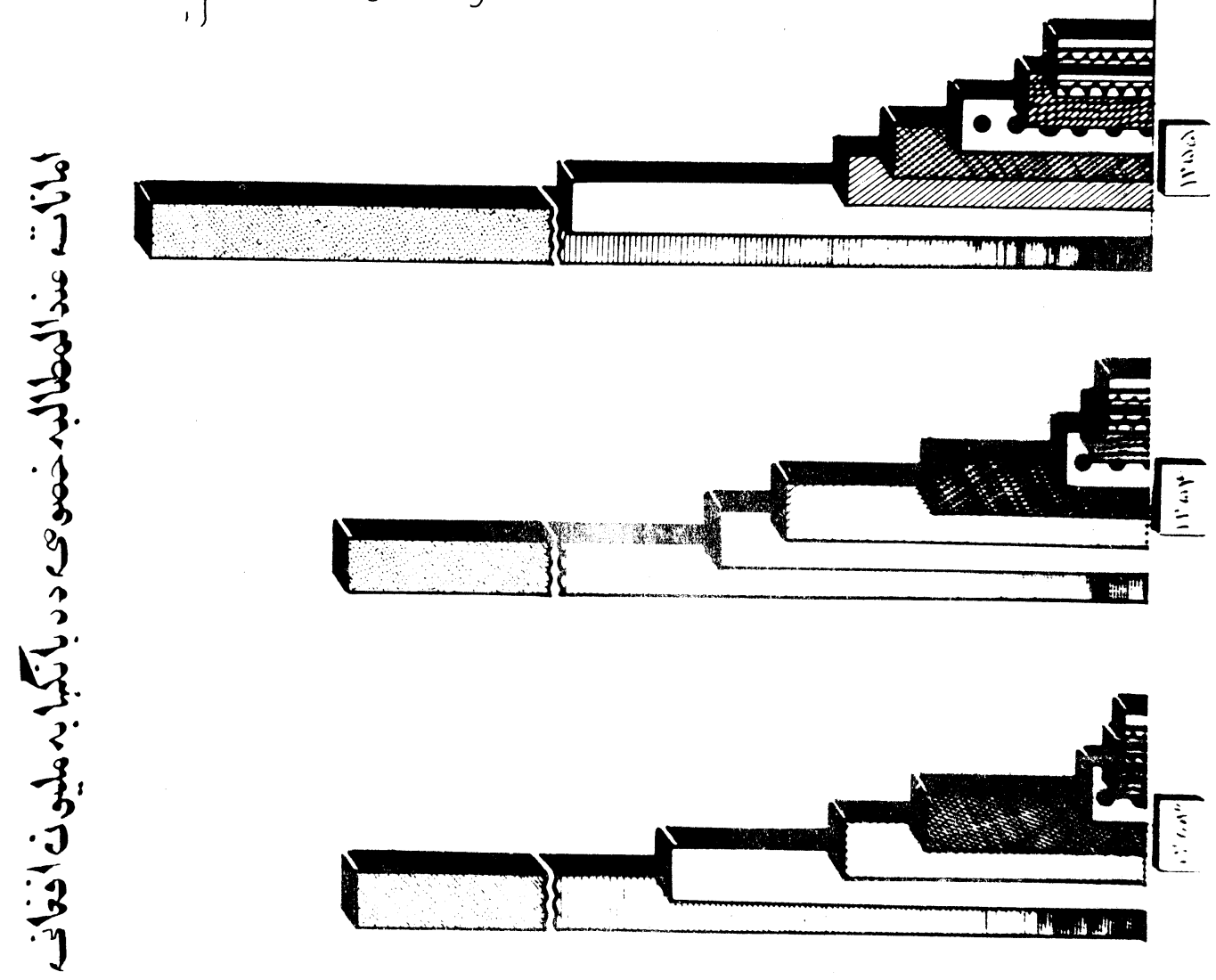

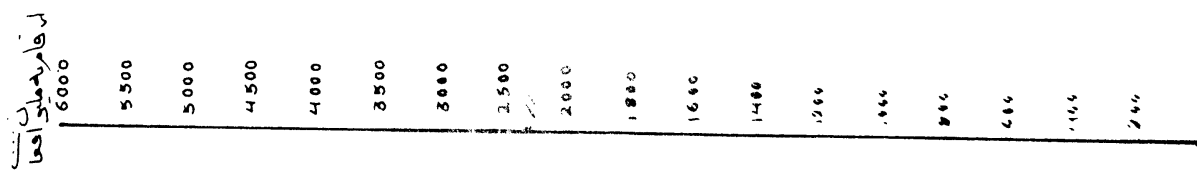




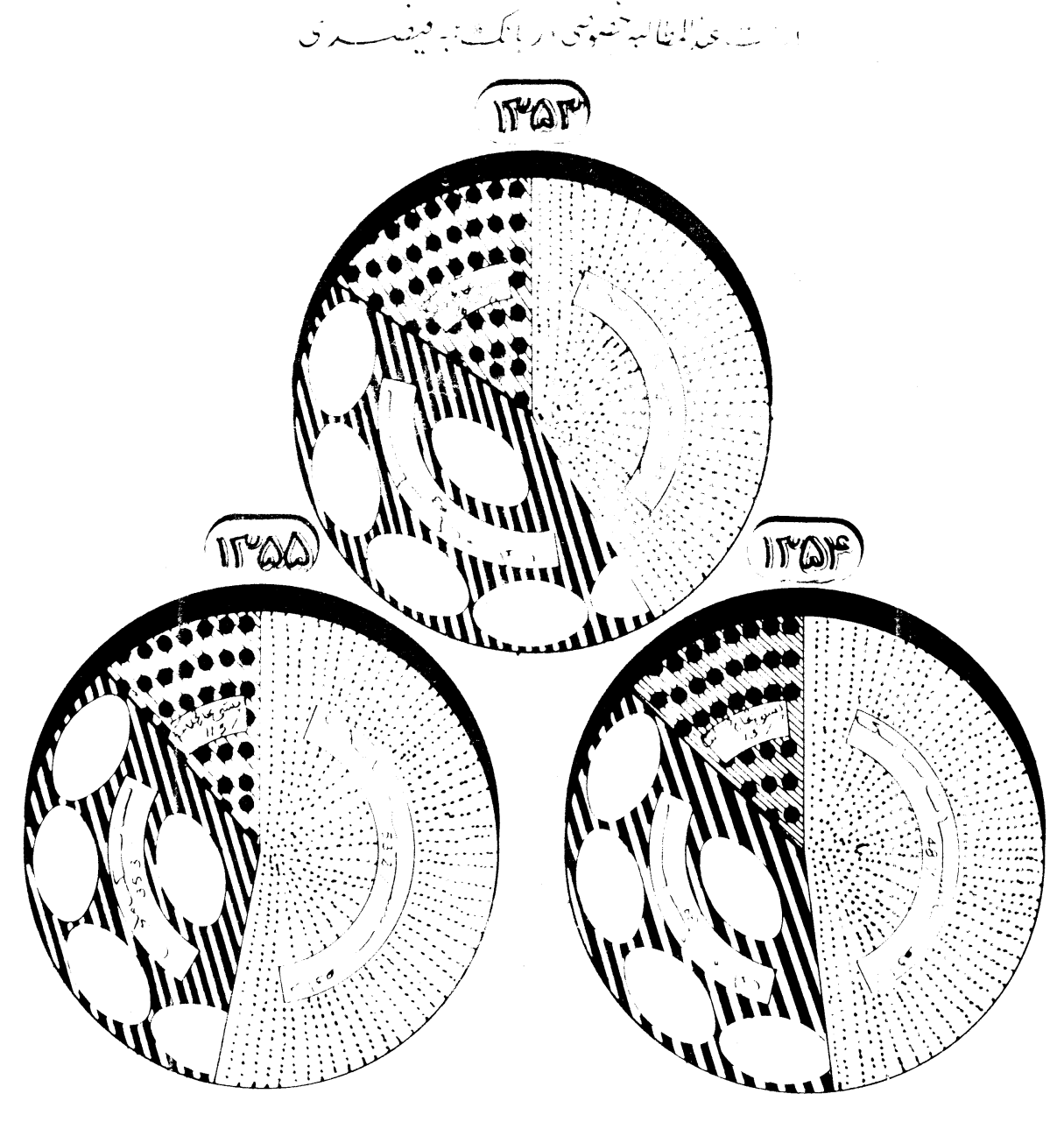




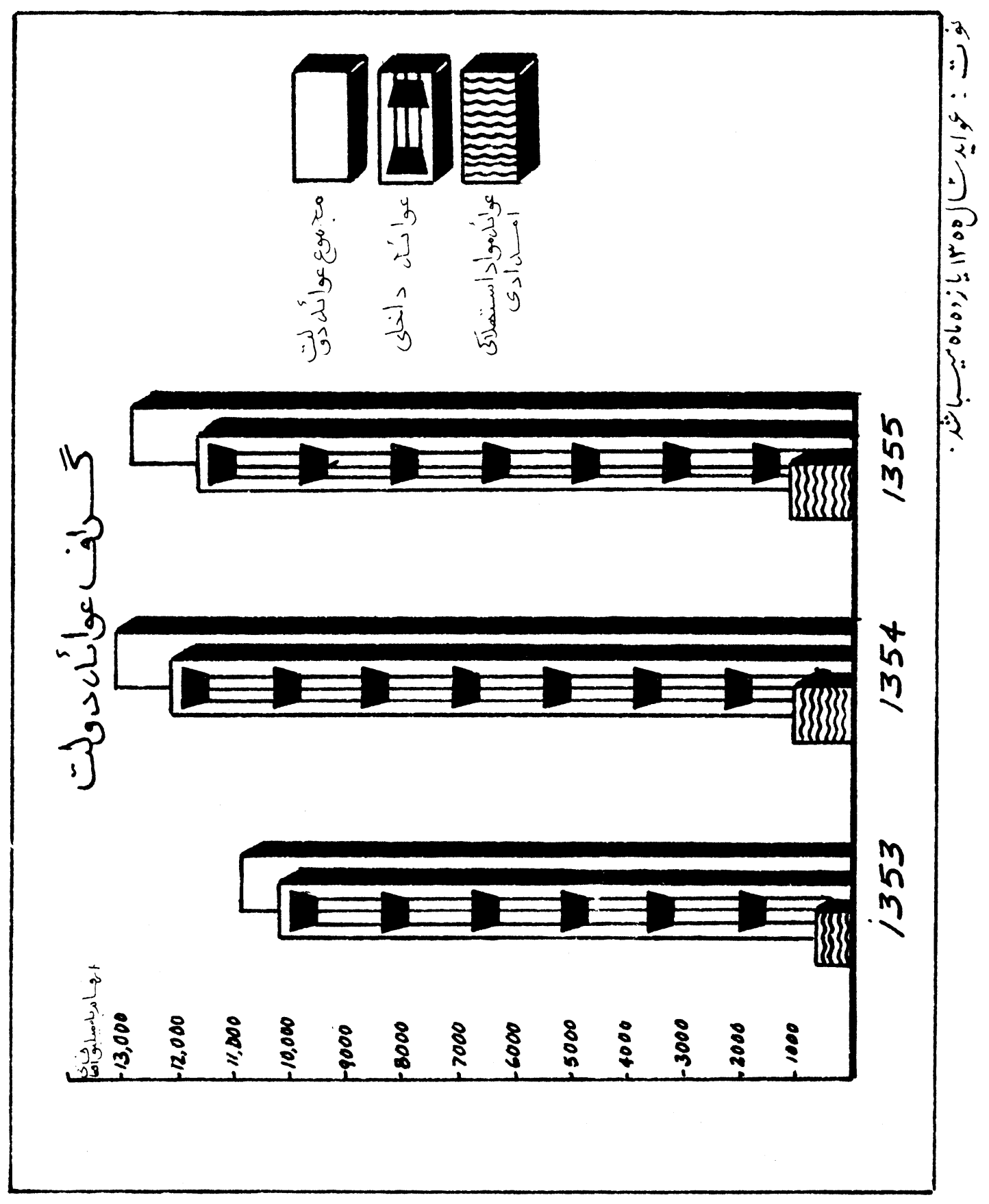




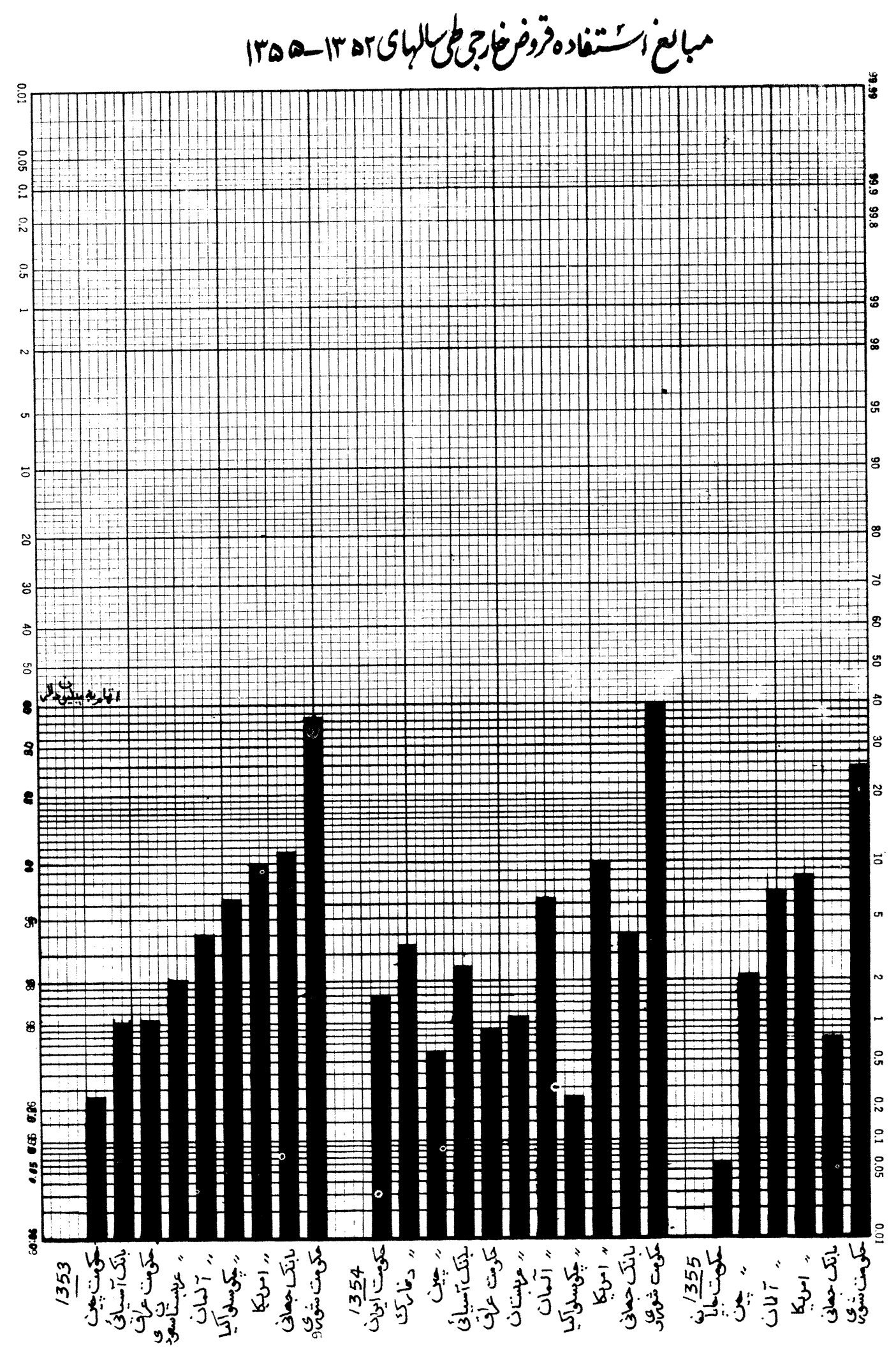




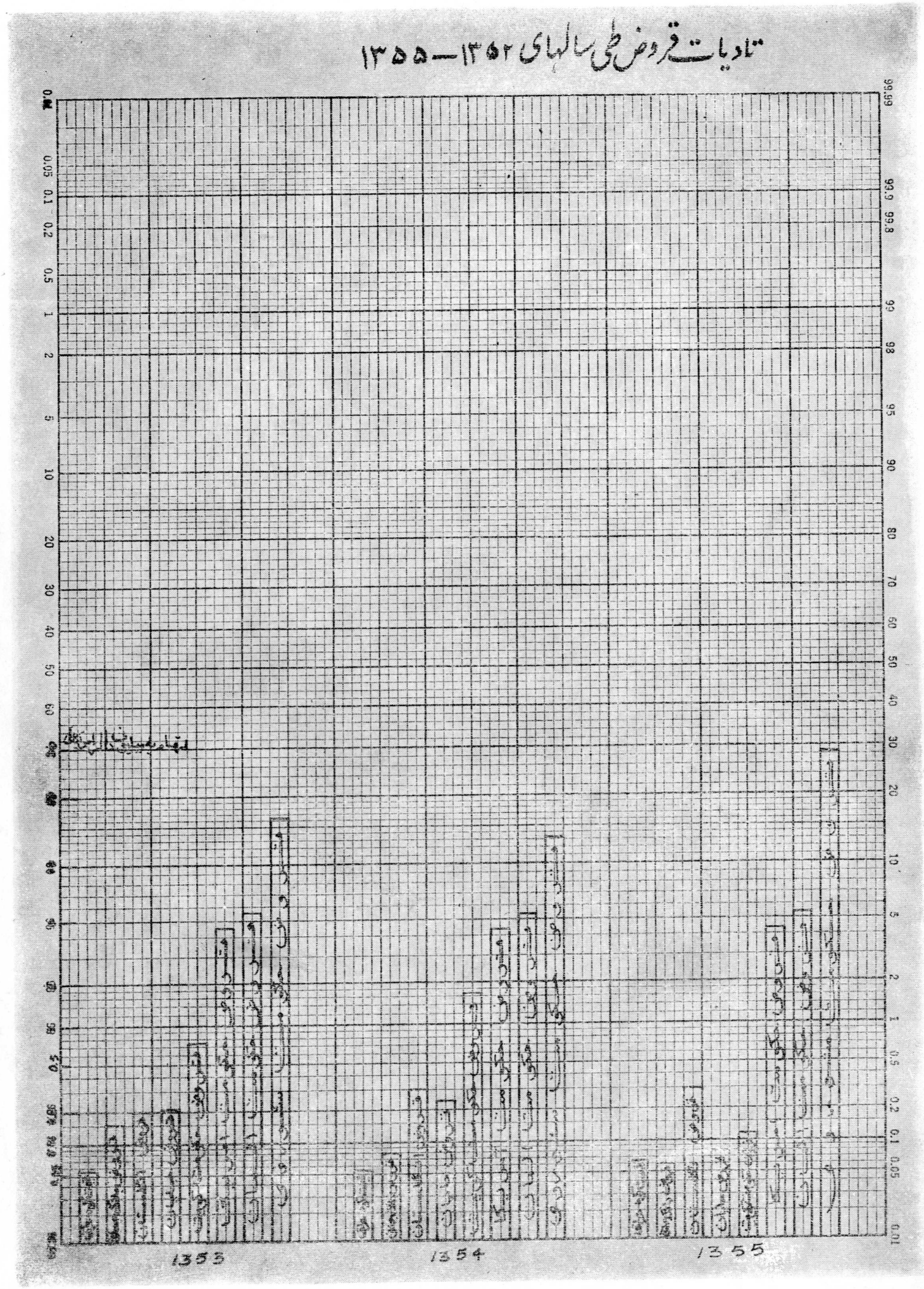




\section{فصلومبام}

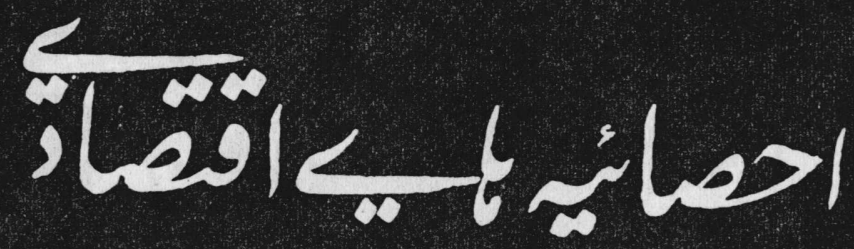

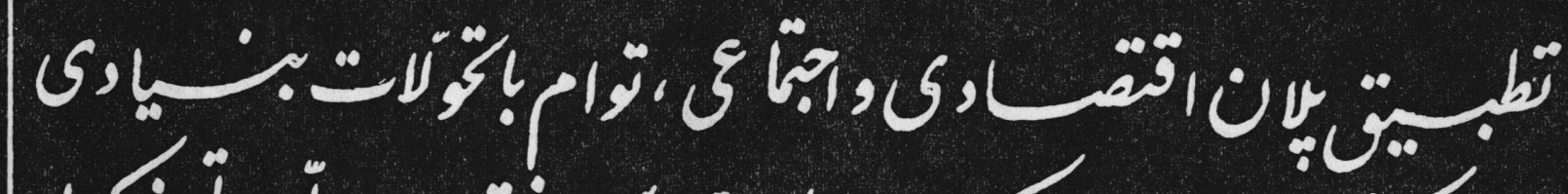

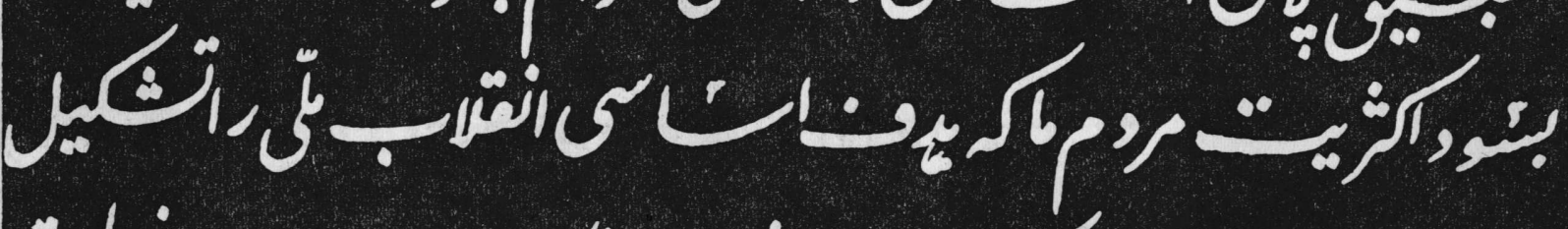

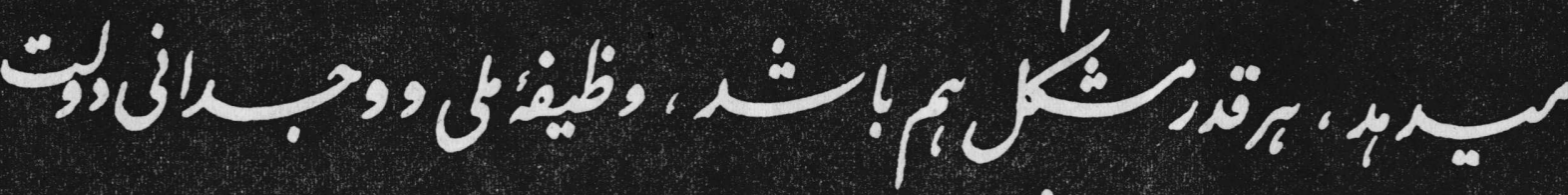

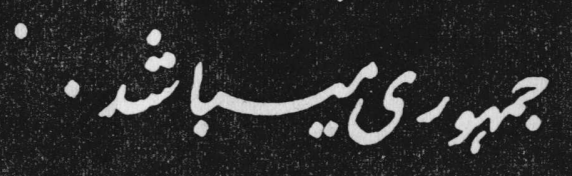

(1) 

$\therefore \quad$ i. $\quad$ o

ي ائية

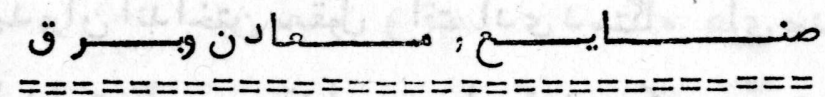

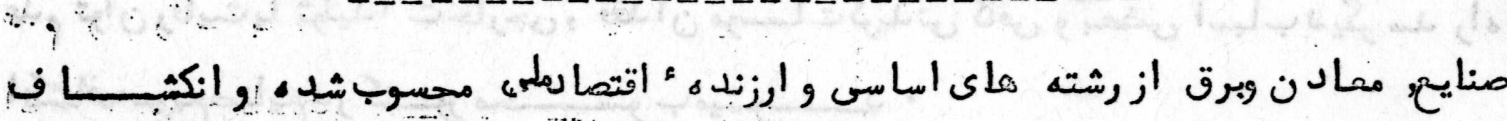

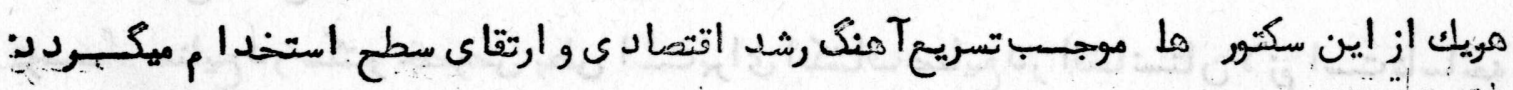

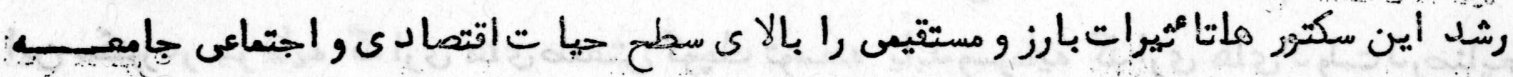

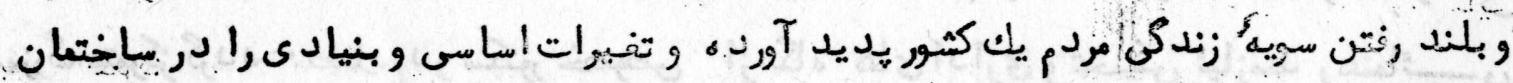

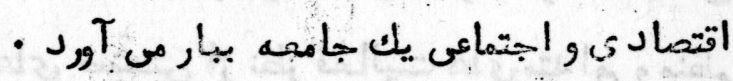

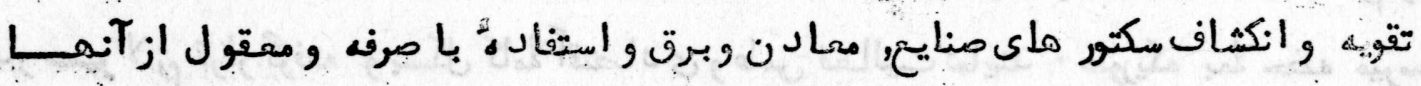

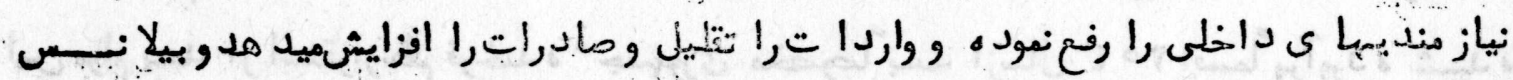

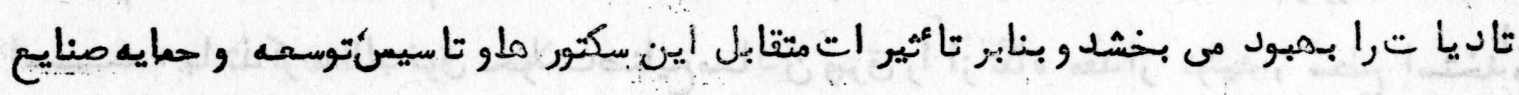

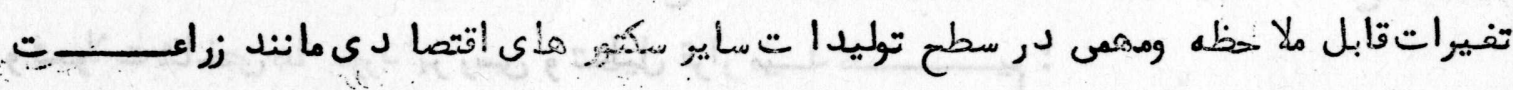

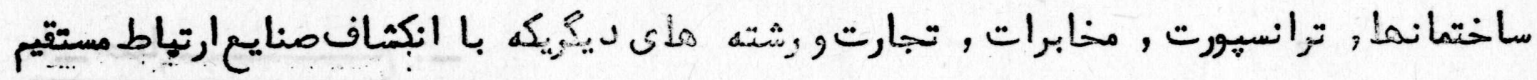

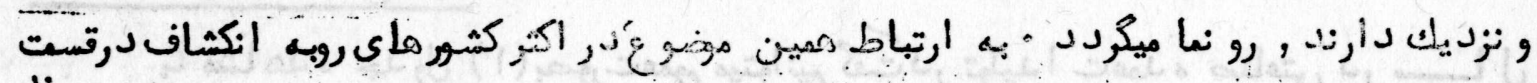

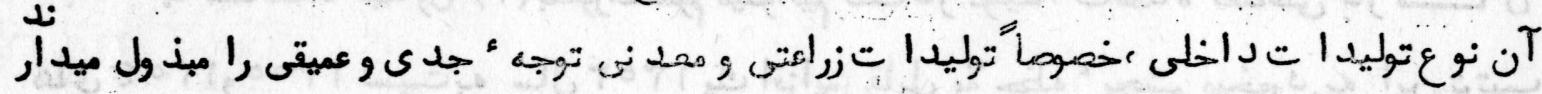

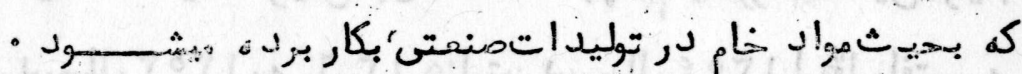

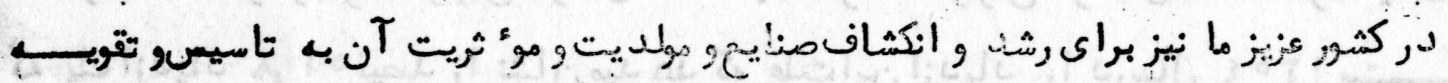

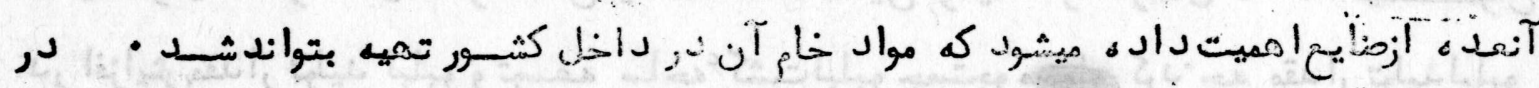

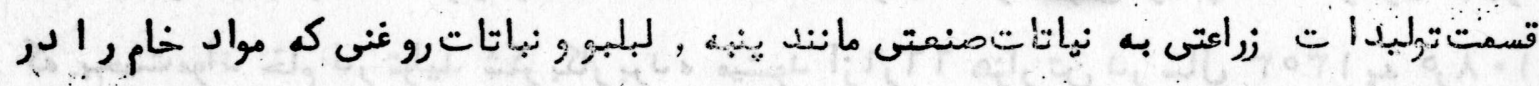

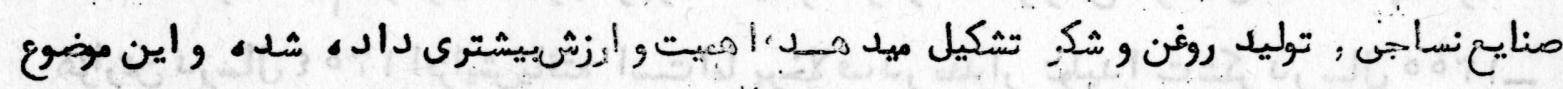

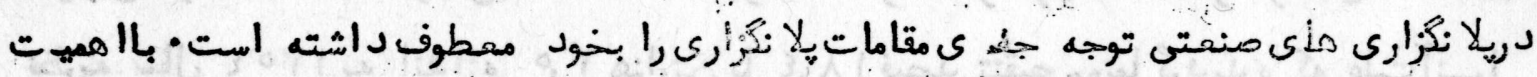

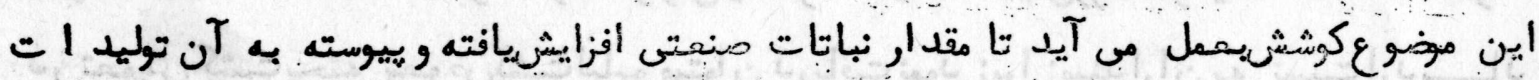

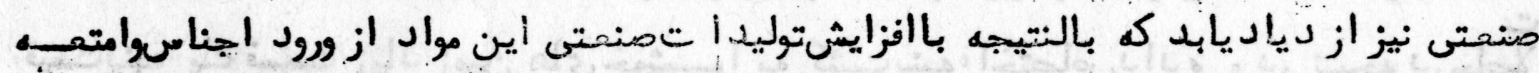

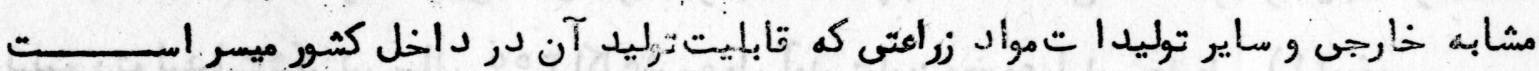

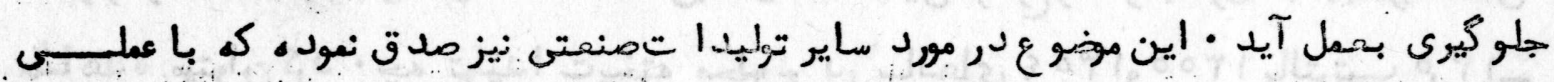

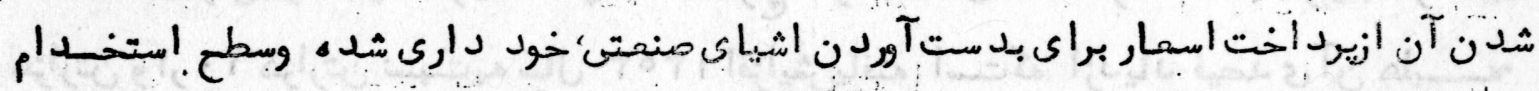

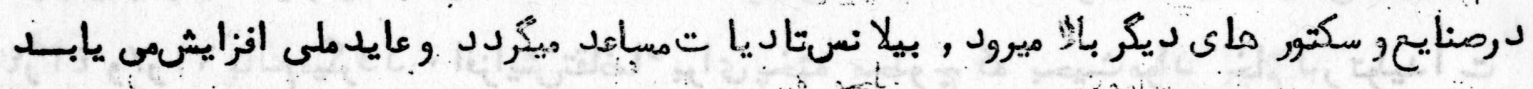

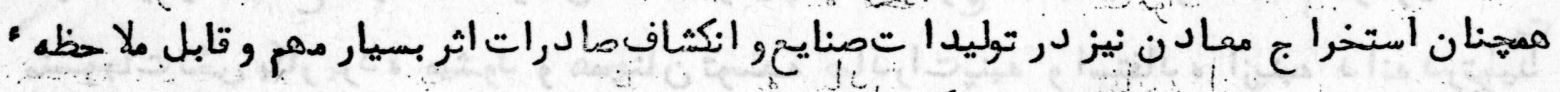

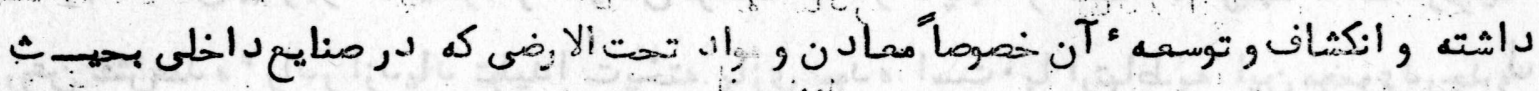

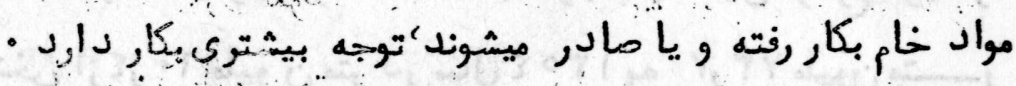




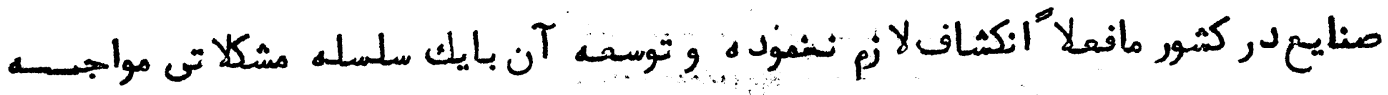

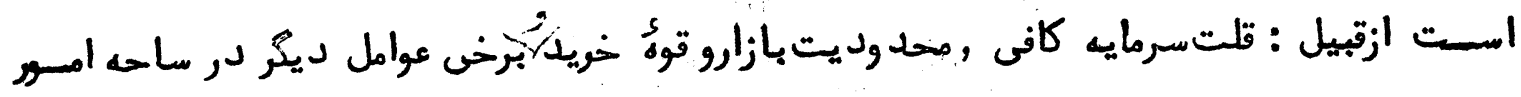

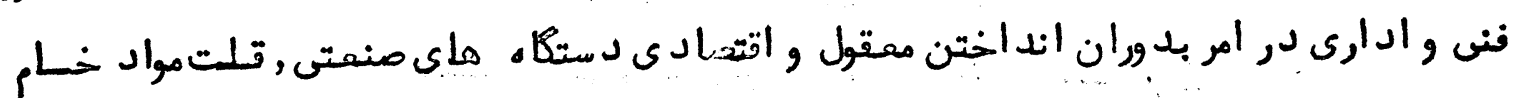

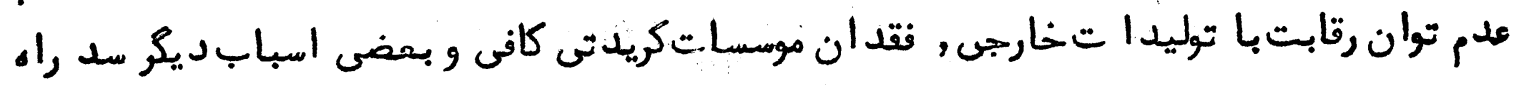

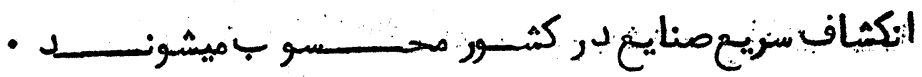

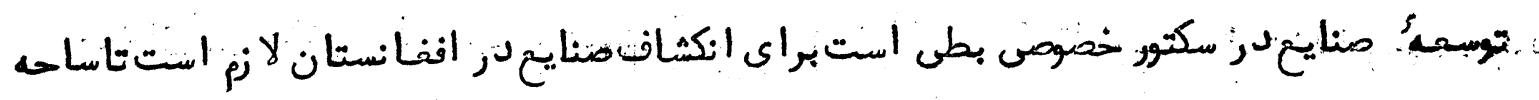

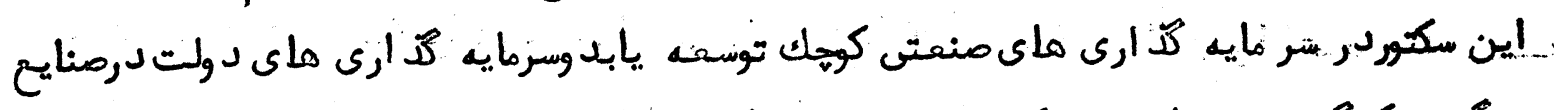

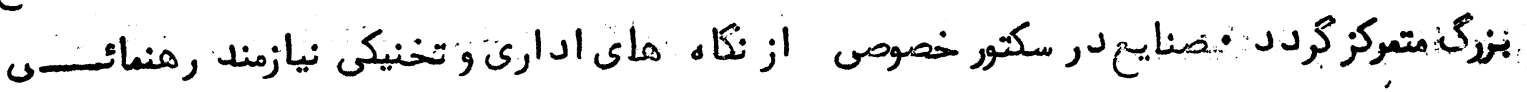

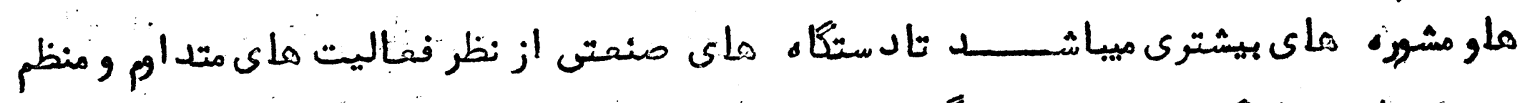

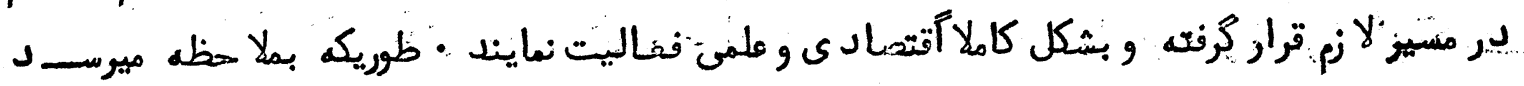

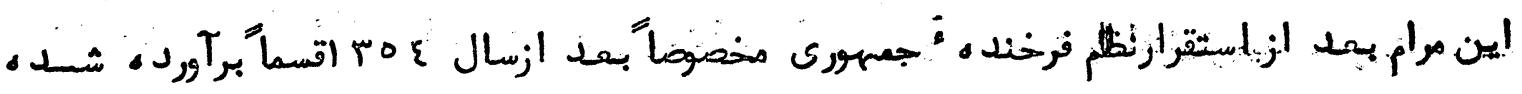

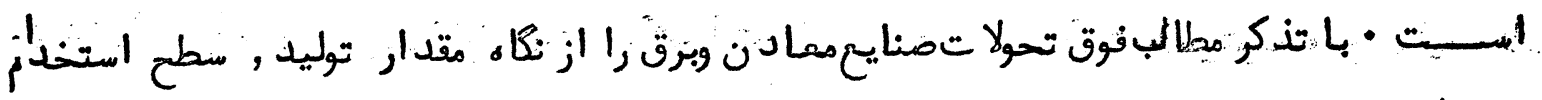

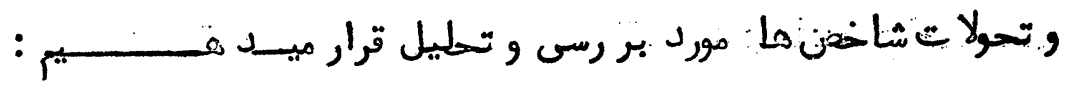
- :

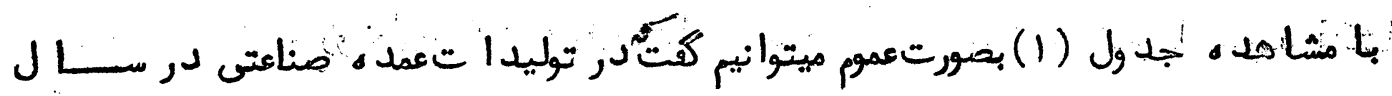

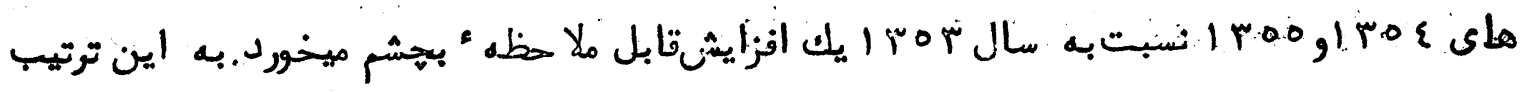

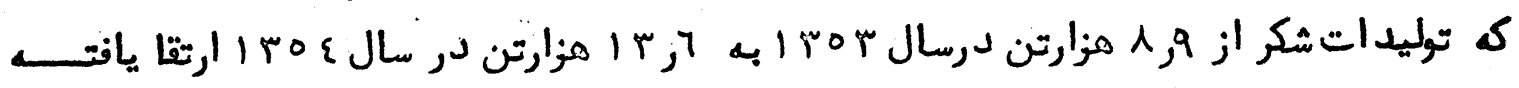

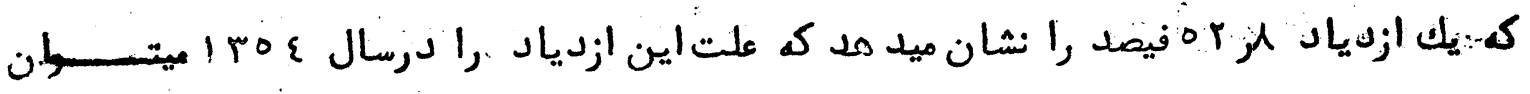

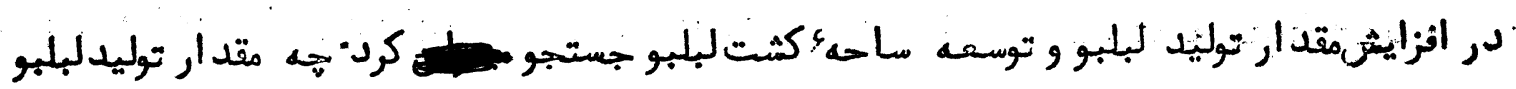

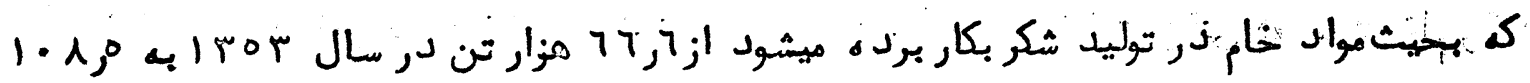

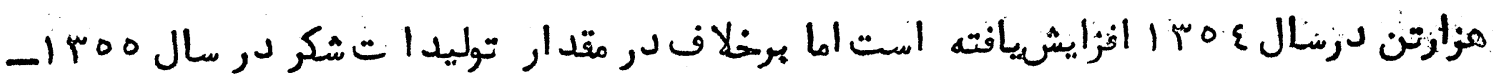

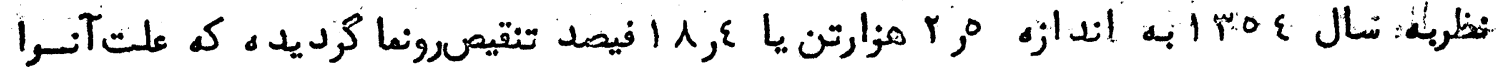

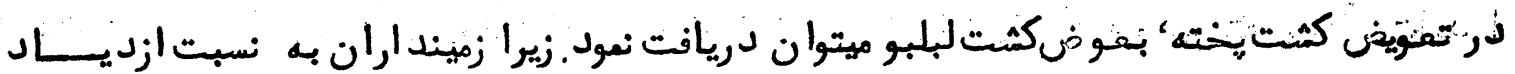

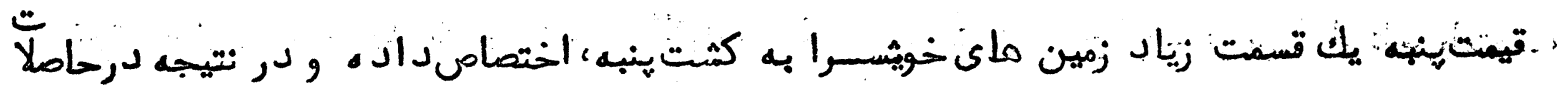

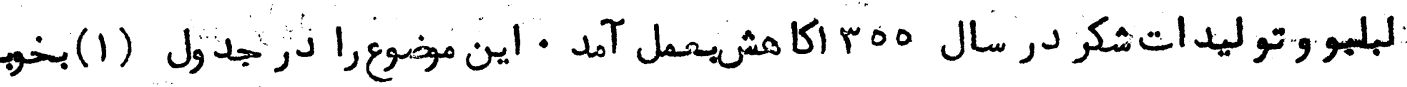

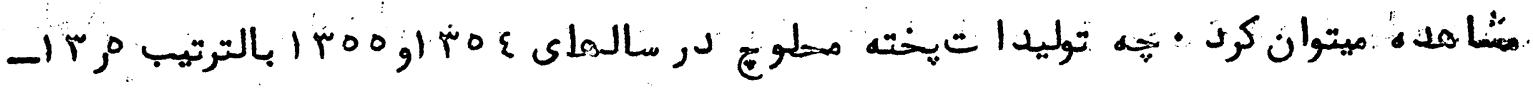

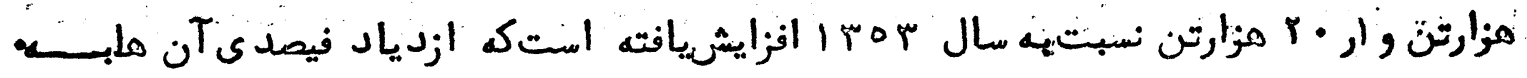

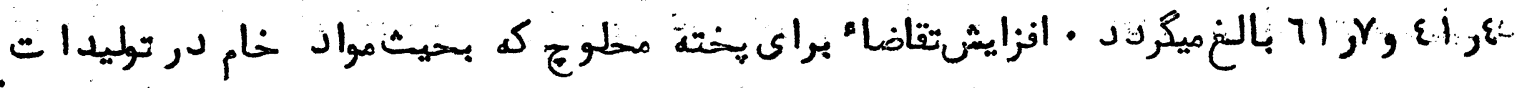

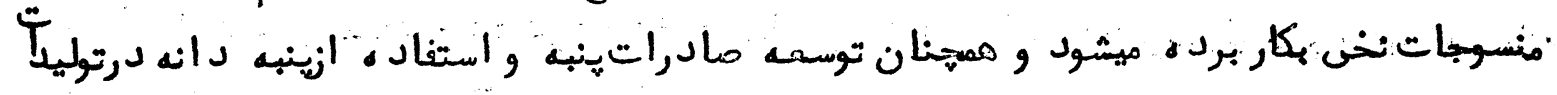

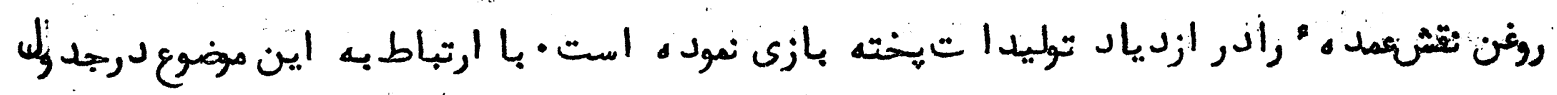

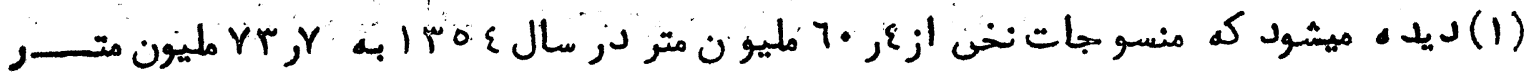




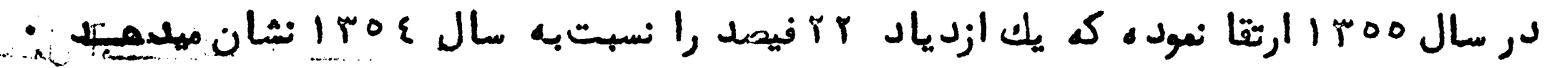

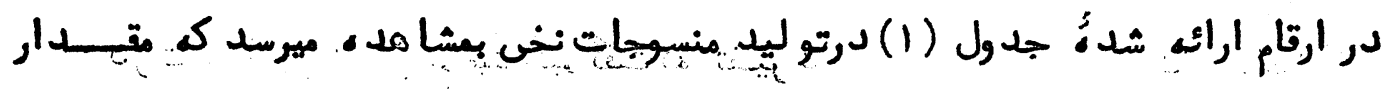

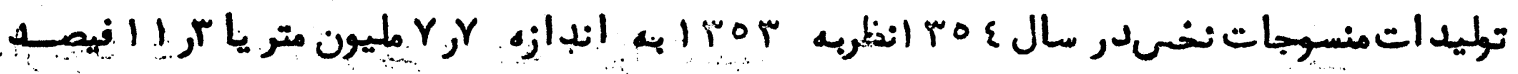

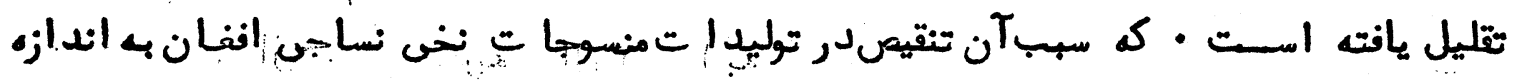

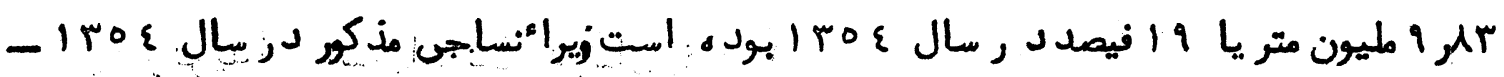

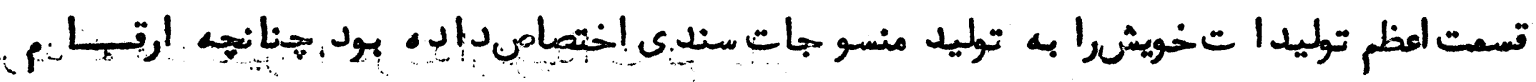

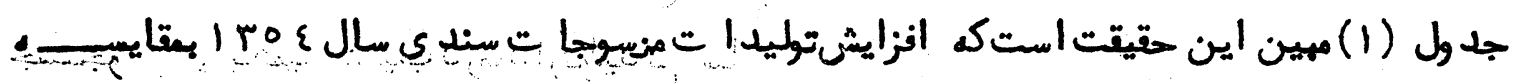

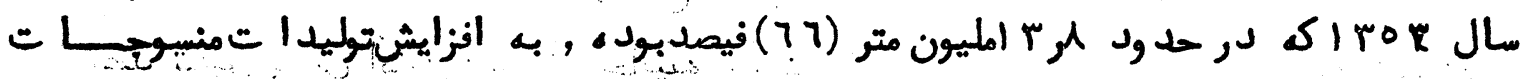

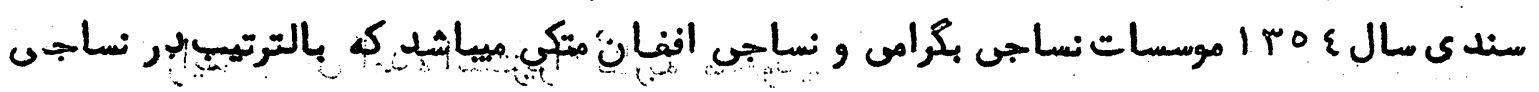

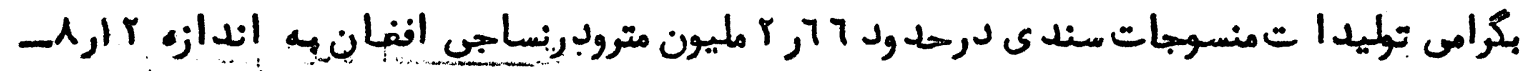

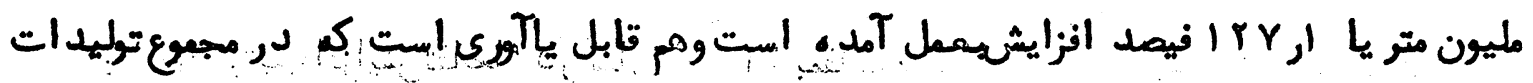

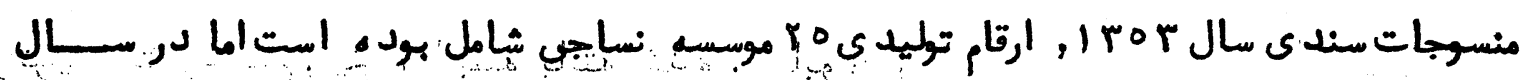

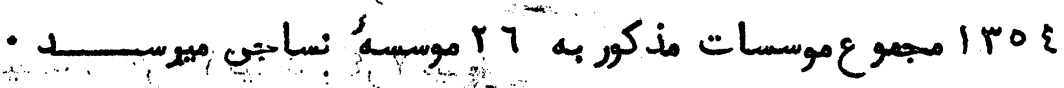

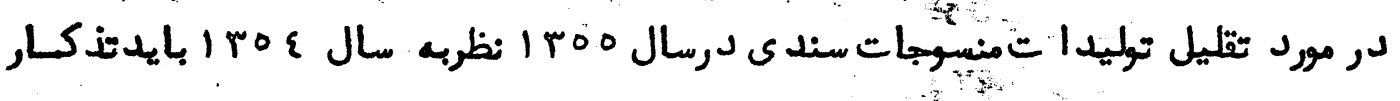

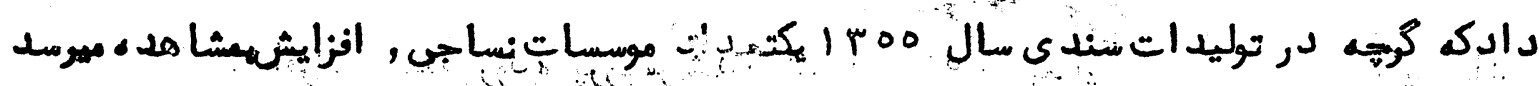

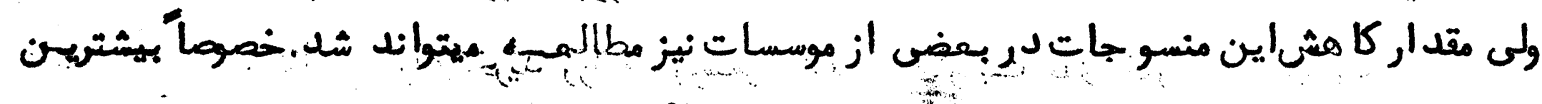

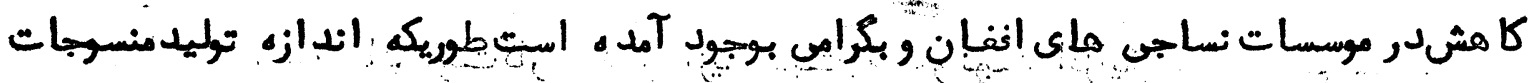

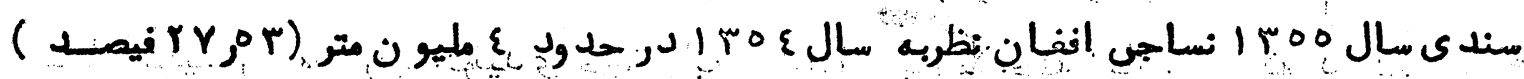

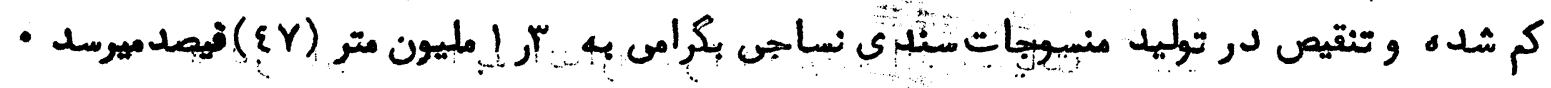

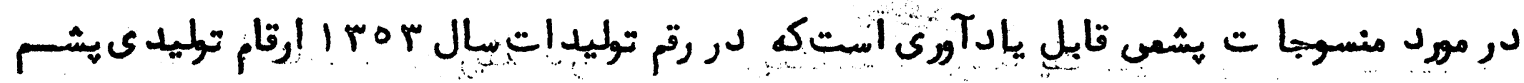

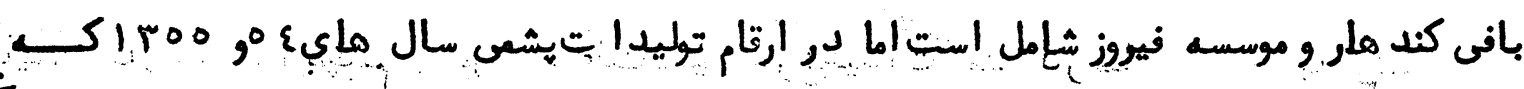

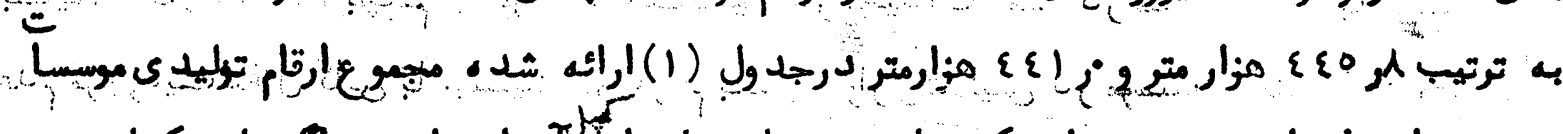

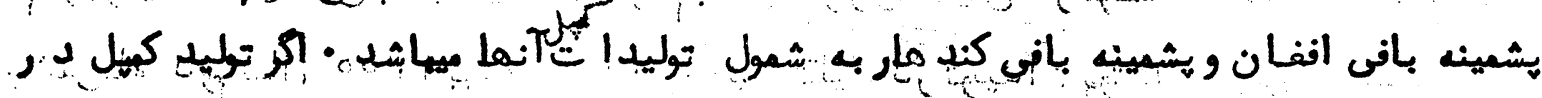

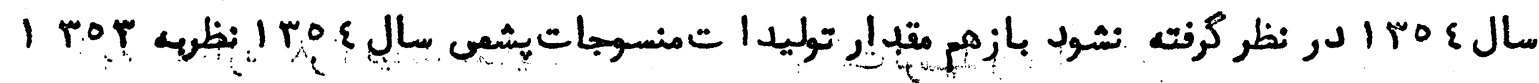

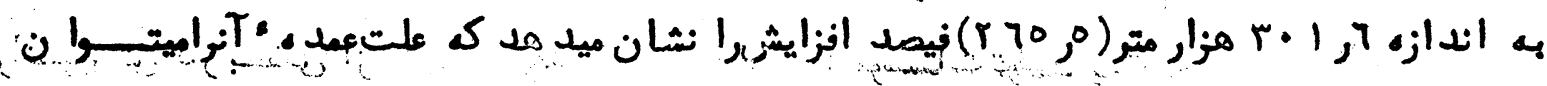

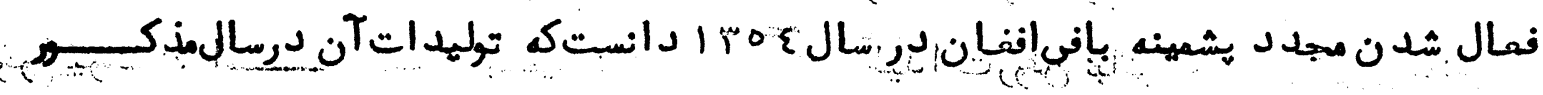

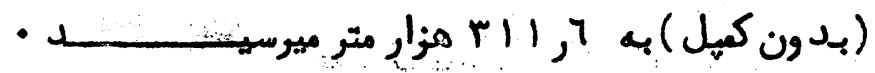

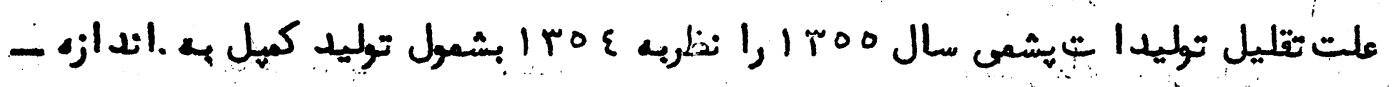

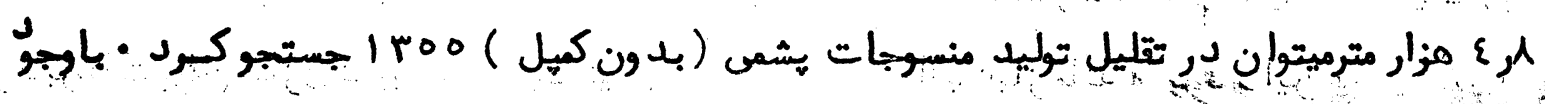

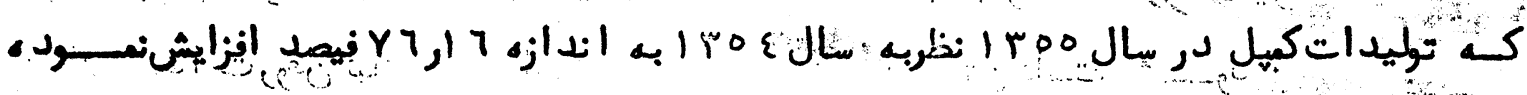

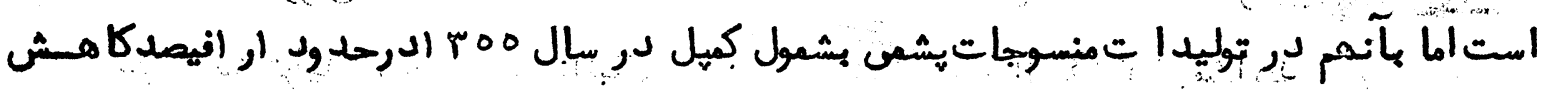




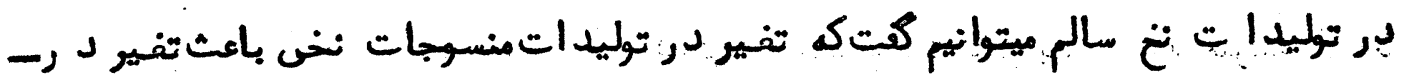

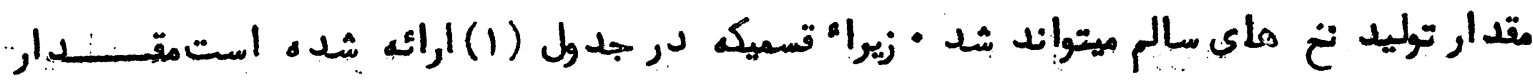

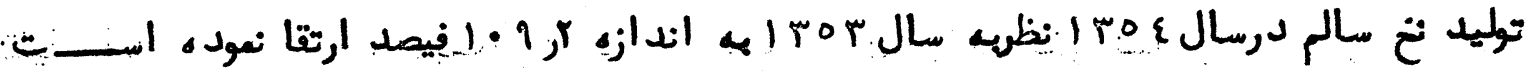

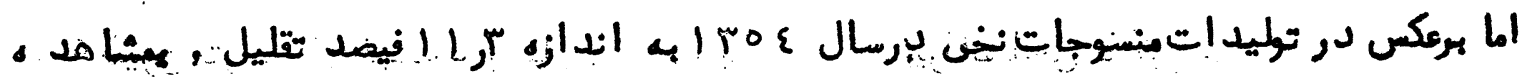

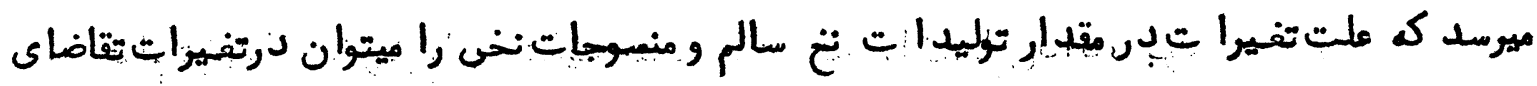

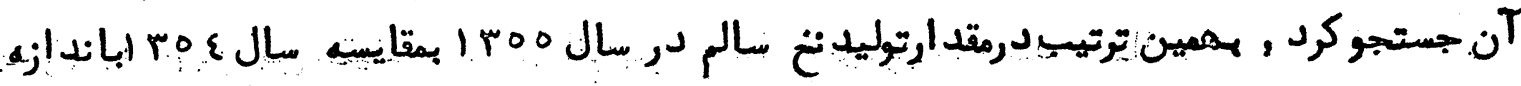

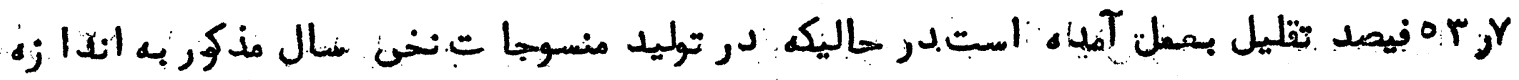

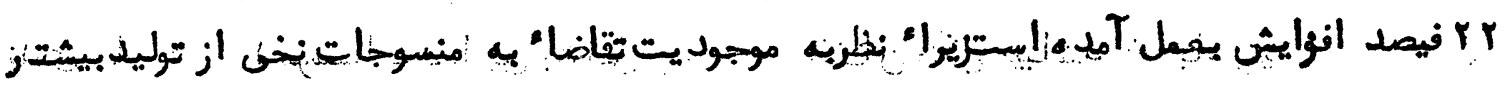

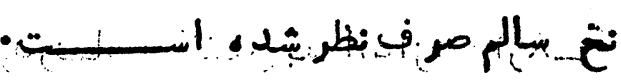

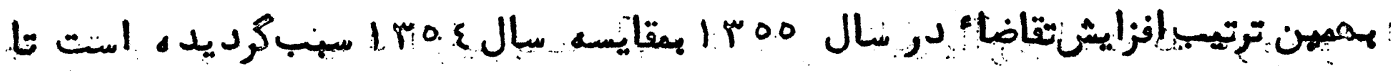

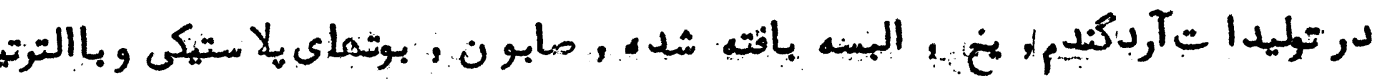

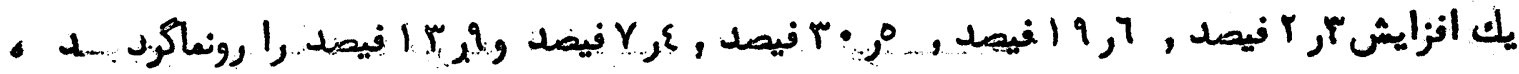

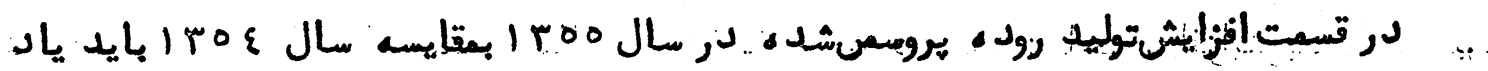

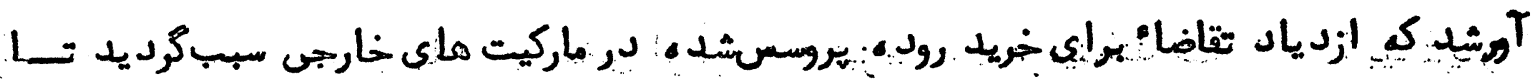

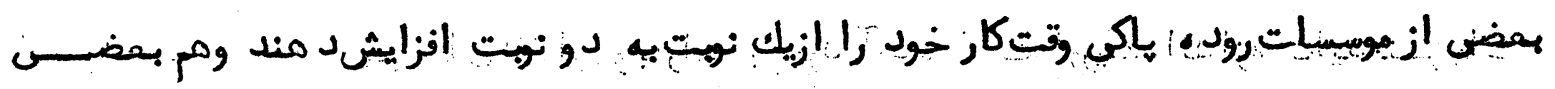

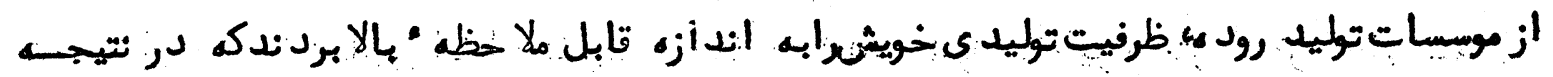

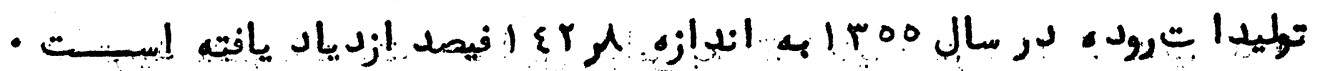

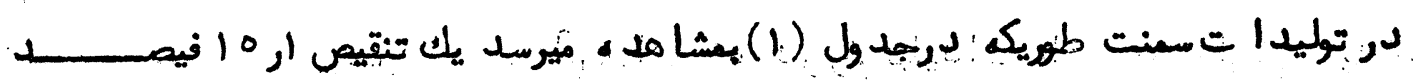

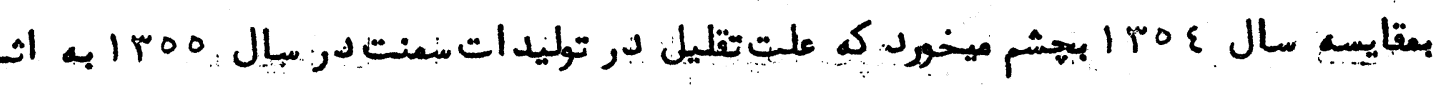

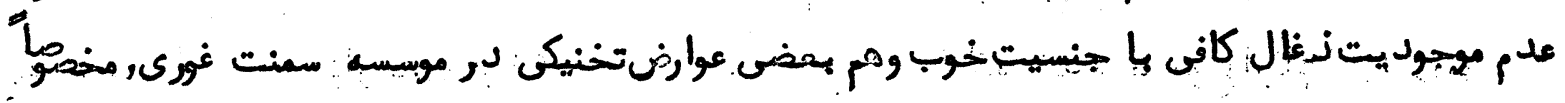

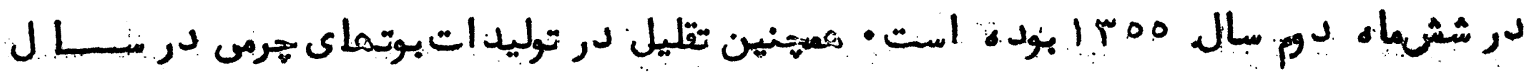

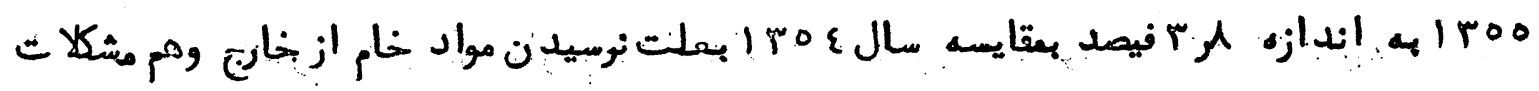

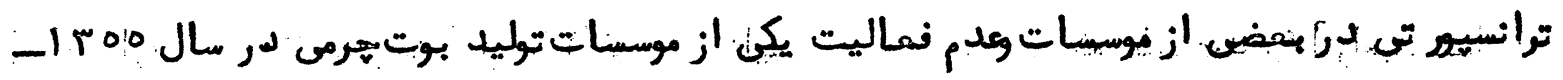

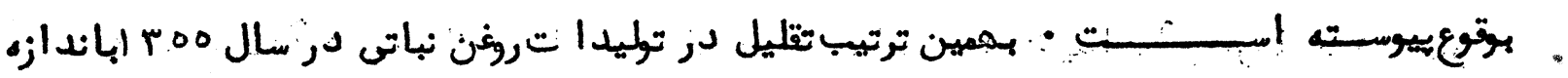

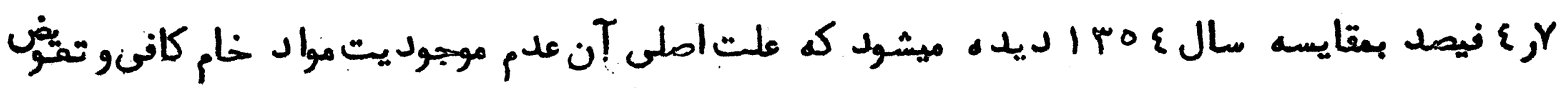

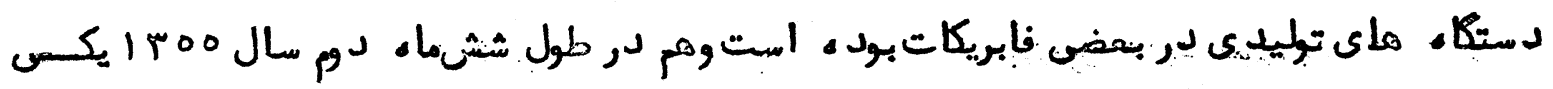

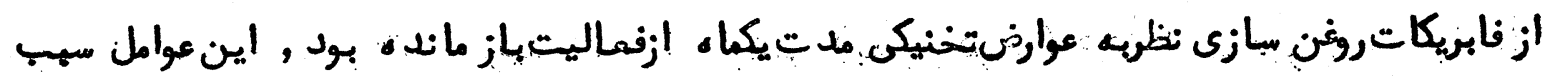

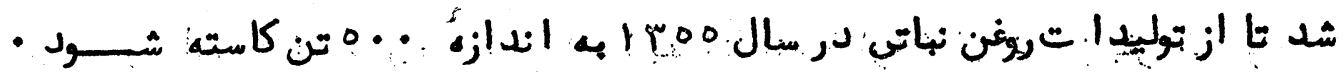

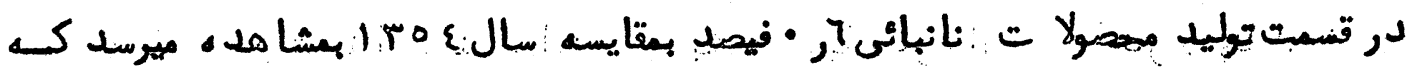




\section{(fo}

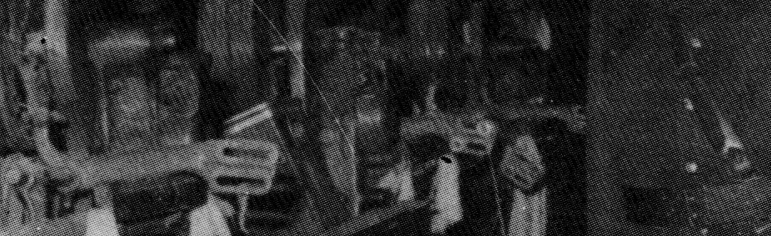

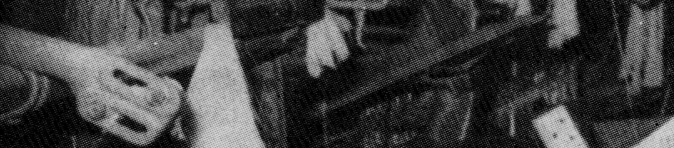

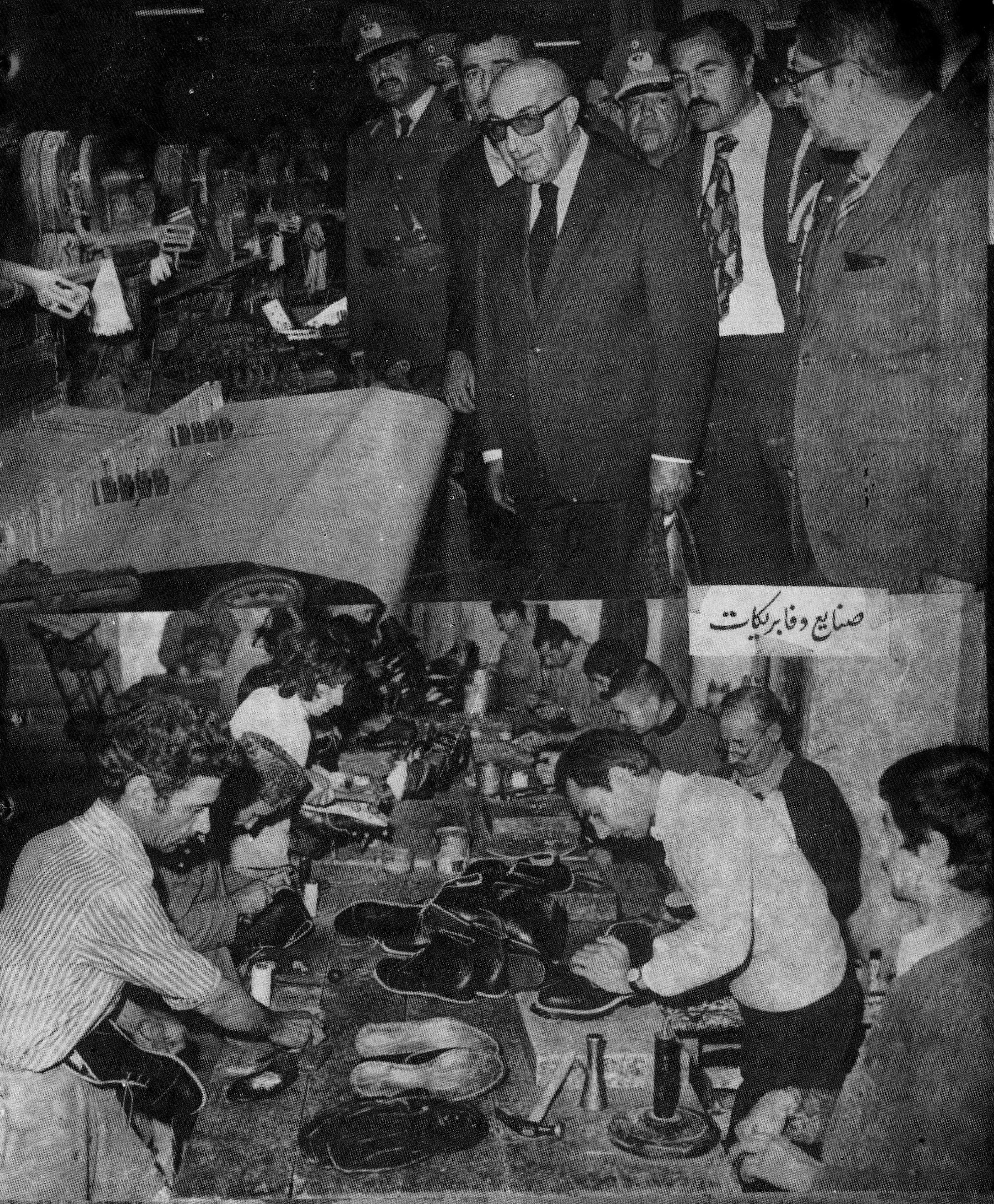

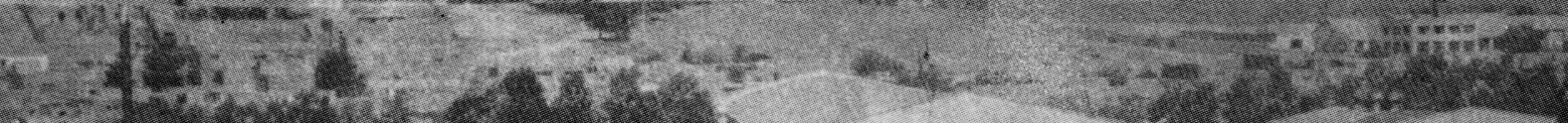
$\operatorname{lox}_{x \rightarrow 2}=1$ $=5+13$

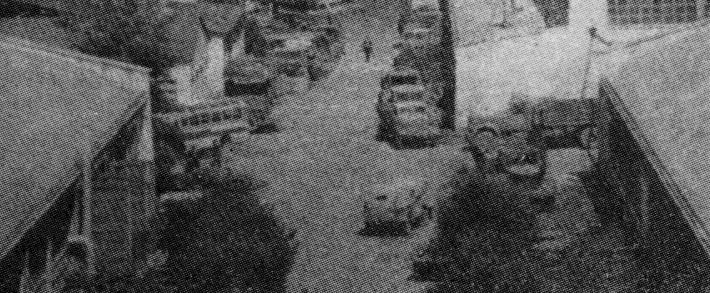

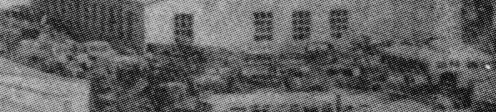




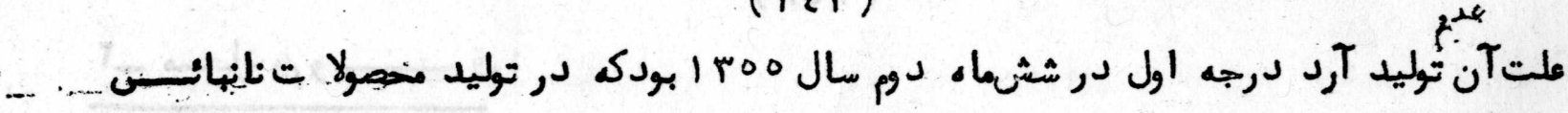

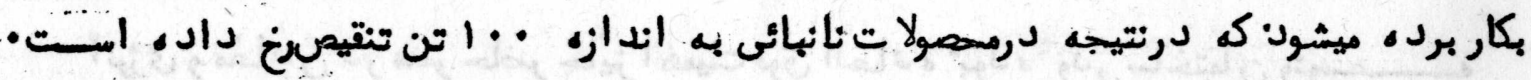

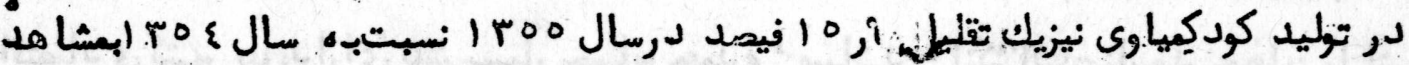

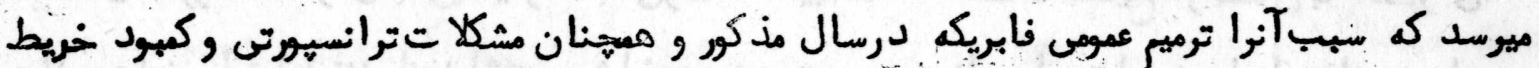

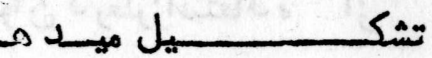

تولسيد اتعمده " مناعتي سالمهـ

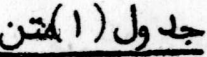

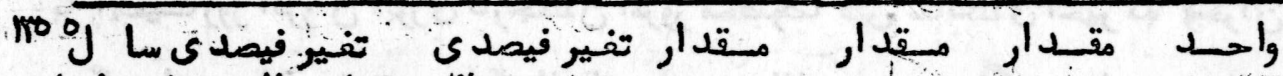

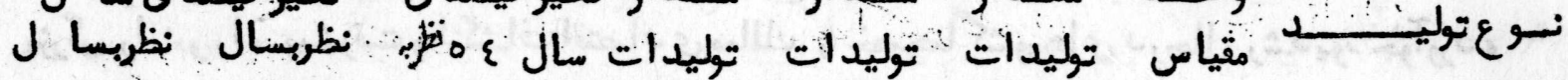

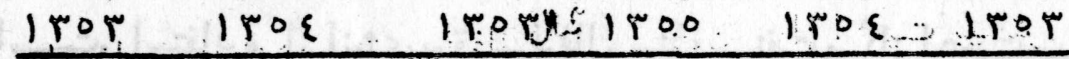

$+1,\{+r, r+7,0 Y, q \quad 0 T, 7 \quad$ or + $\because+17, \varepsilon+19,7+00,911,9,5 \quad 0,9$ ر $+r \xi, \gamma-1 \lambda, \varepsilon+o r, 111, \quad 1 r, 1 \quad 1,9 \quad$,

روغن نباتسنى

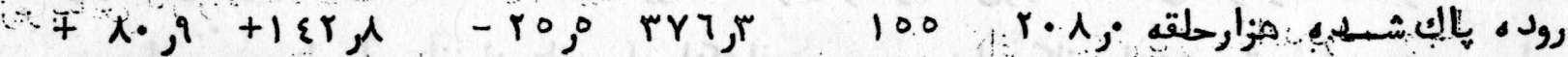
+ -r, -

+ منسوباثنه

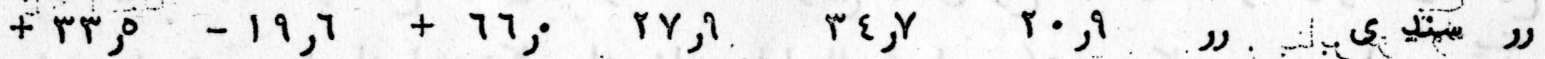
رנ ريشص * * البسه بافته شدّه ر رداد r كودكيمياوى $+r \cdot \beta+\gamma, \varepsilon+1 r, 0 \quad r, q \quad r, \gamma \quad r, \varepsilon$ ر + بريكــ

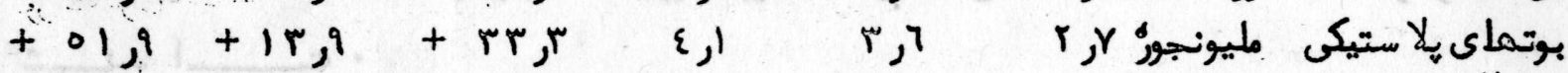
سعن

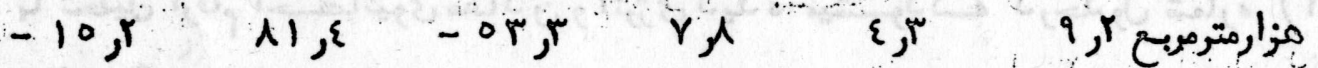
ت

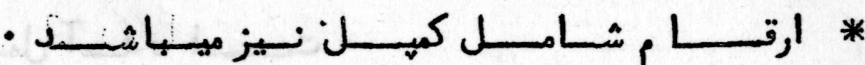

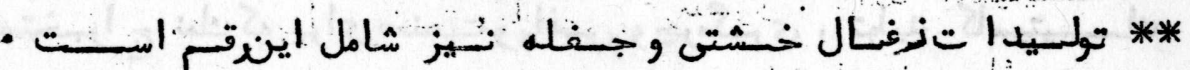




\section{(I£ז)}

y.

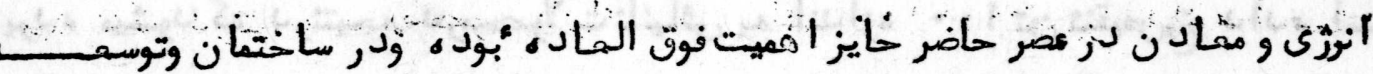

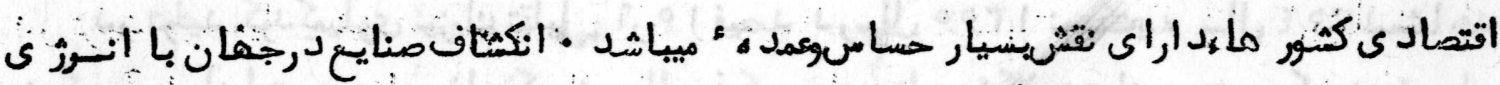

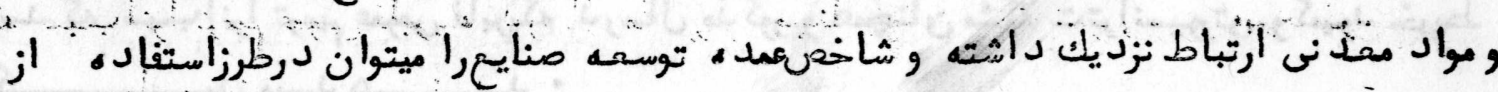

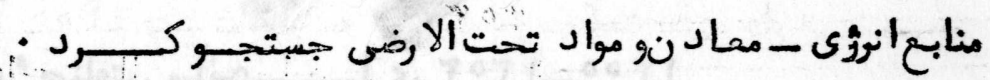

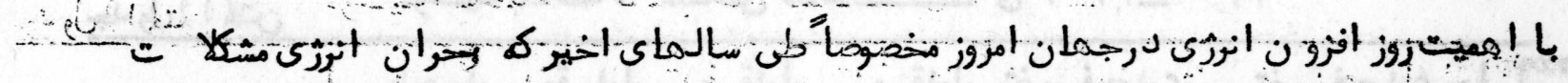

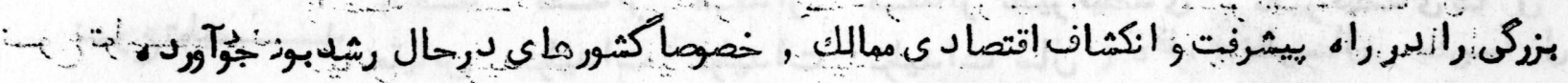

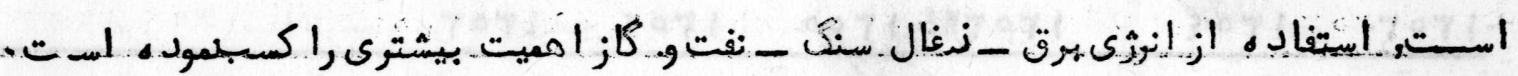

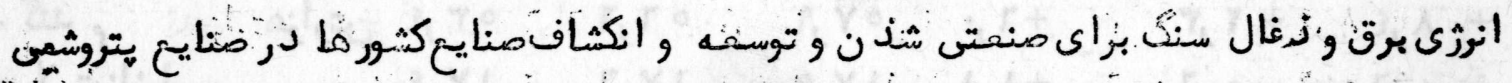

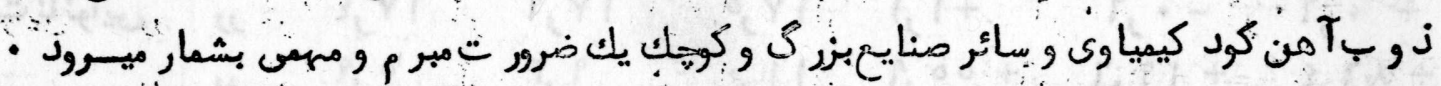

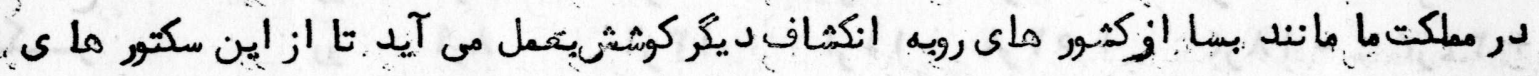

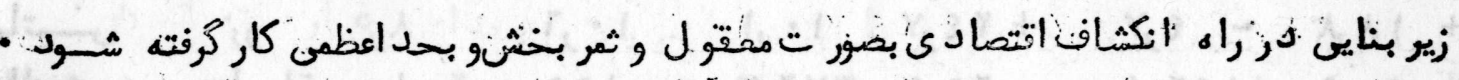

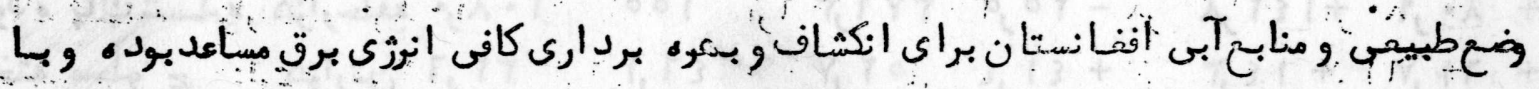

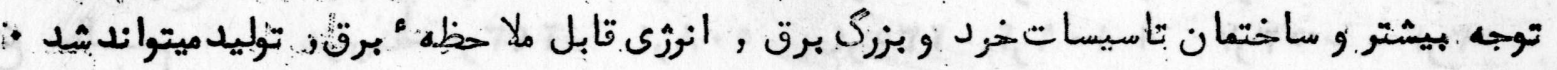

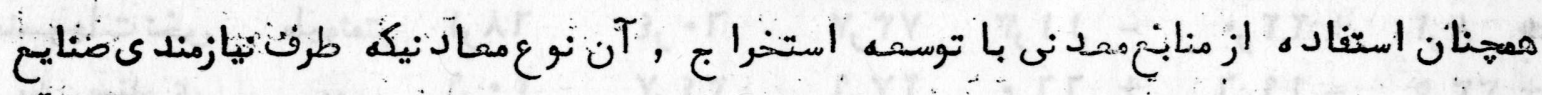

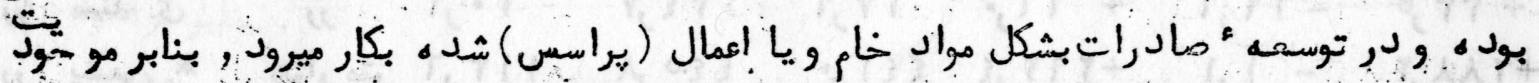

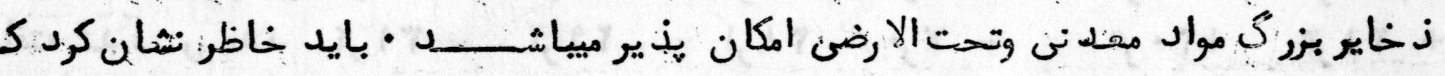

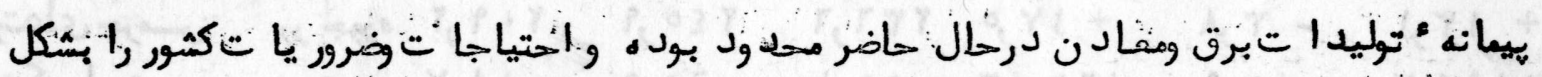

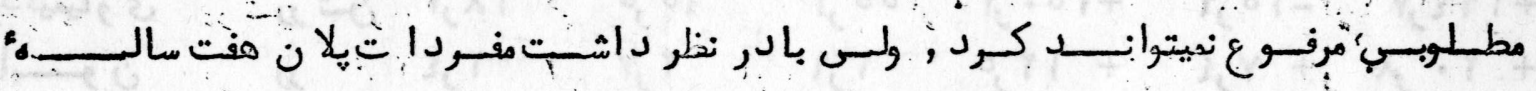

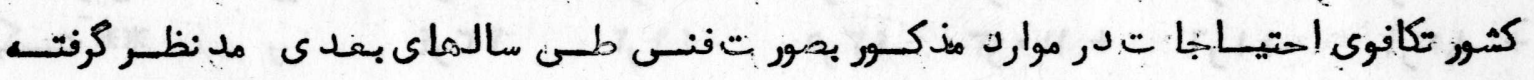

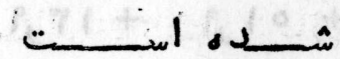

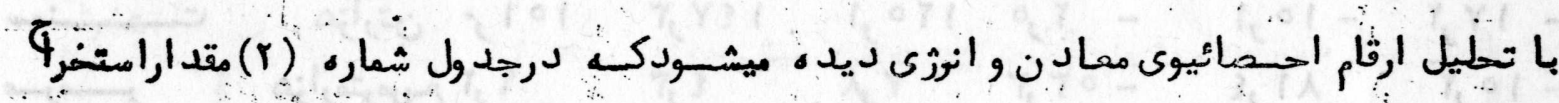

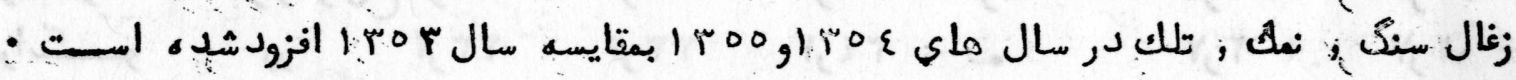

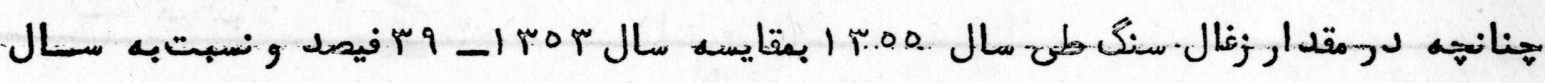

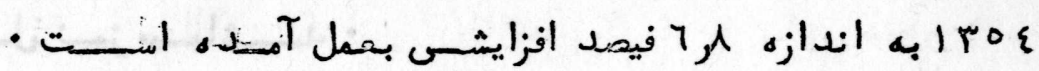

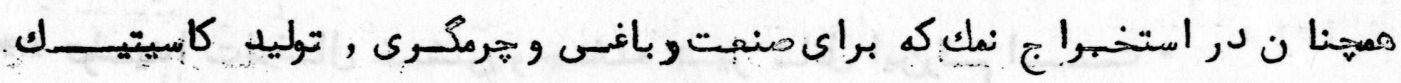

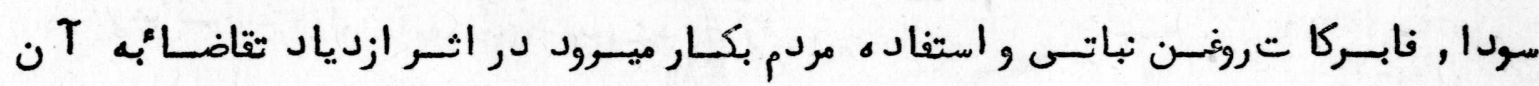

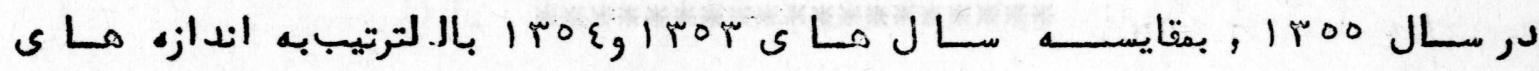

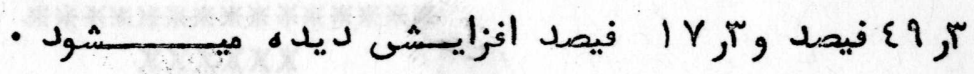

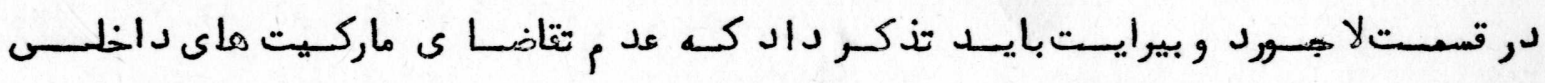




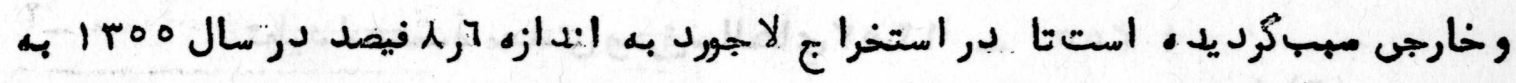

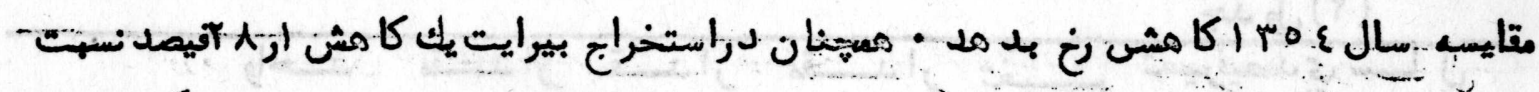

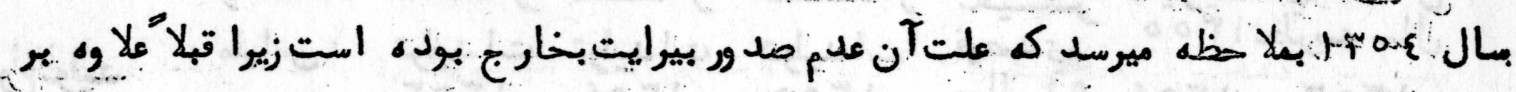

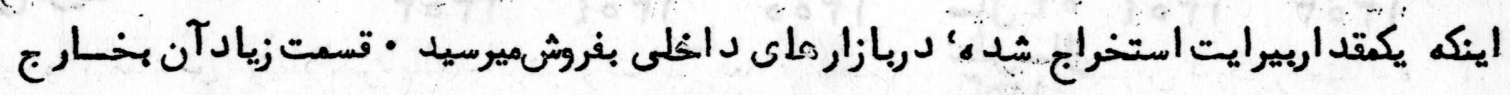

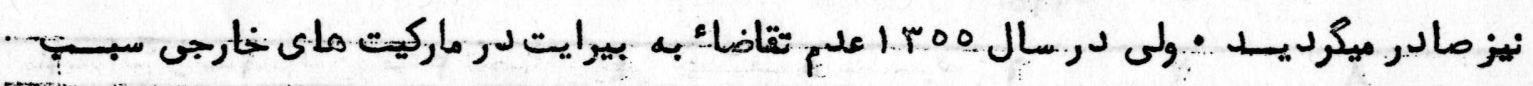

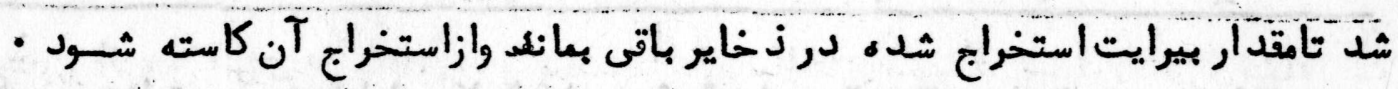

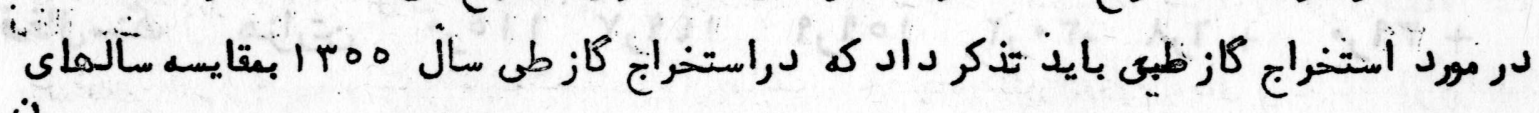

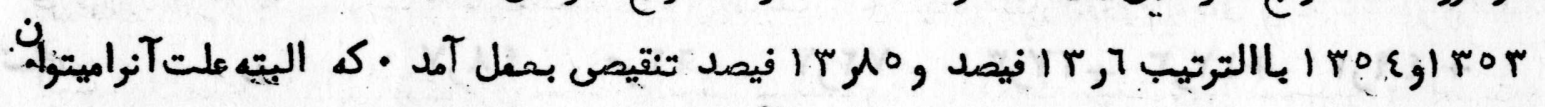

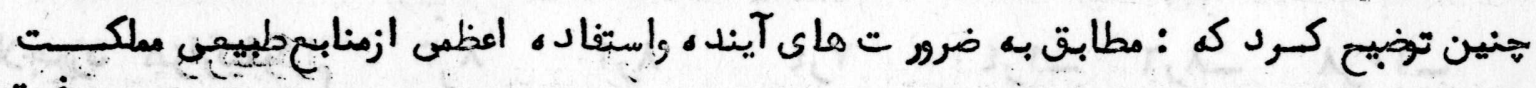

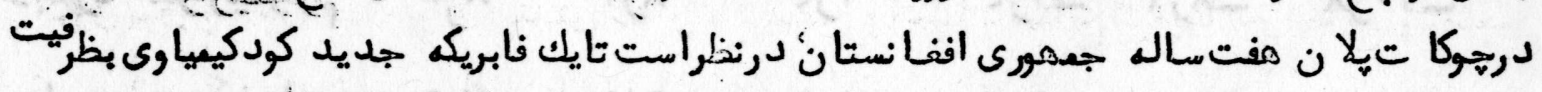

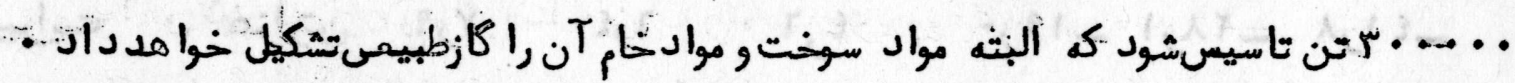

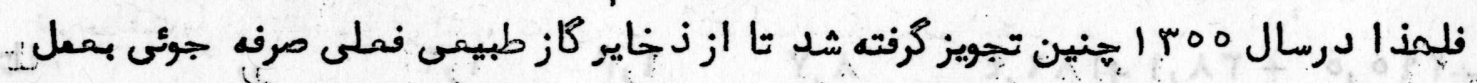

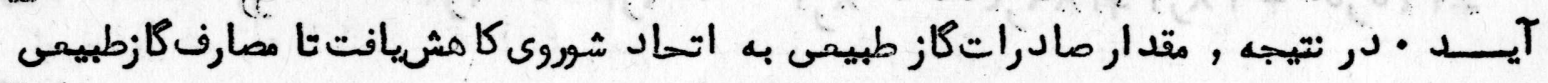

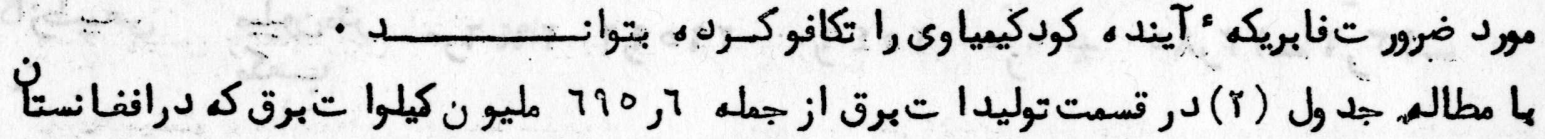

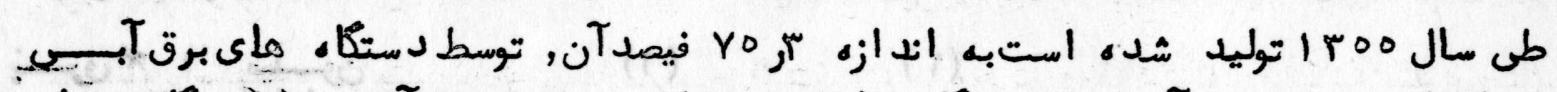

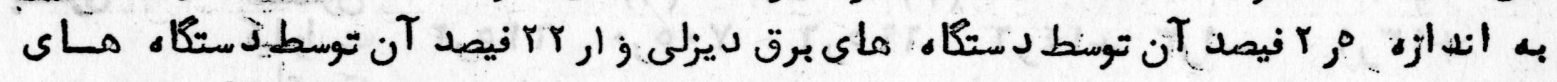

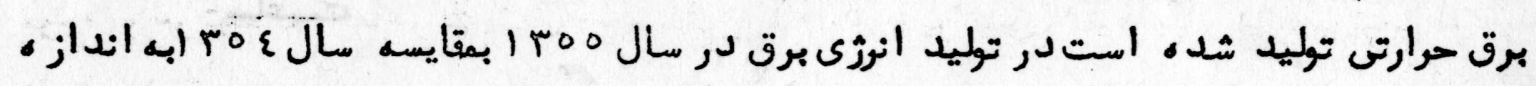

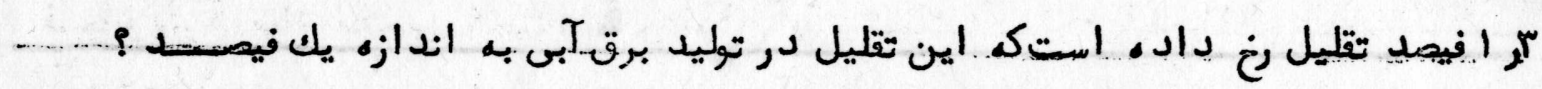

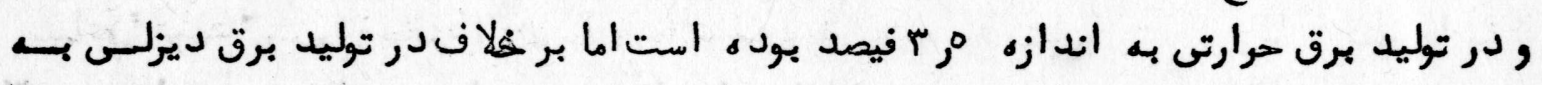

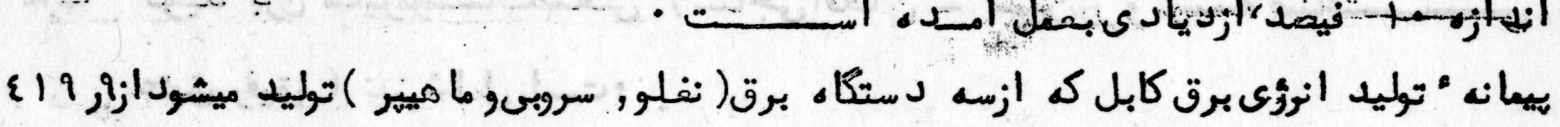

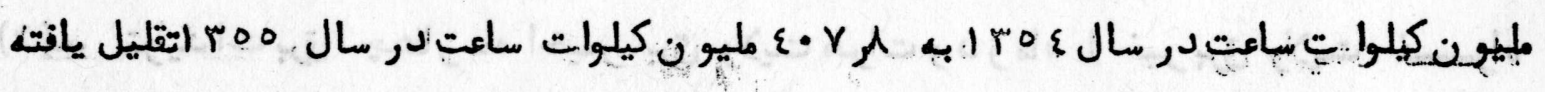

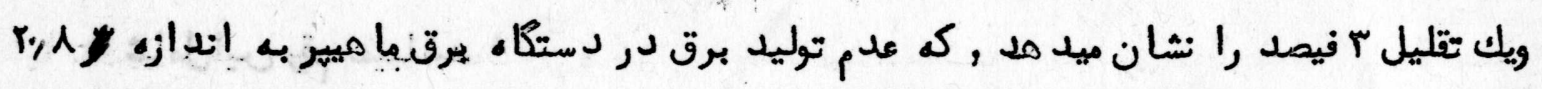

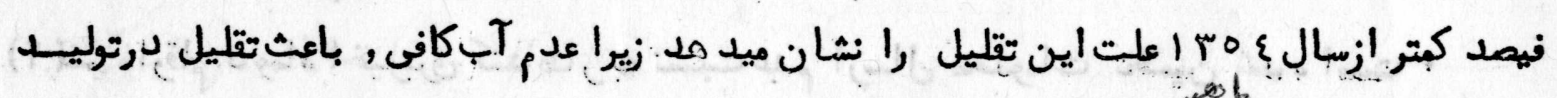

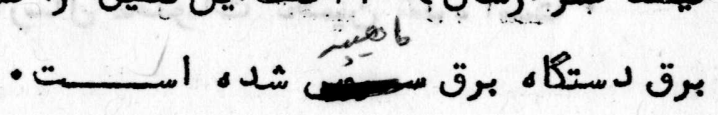

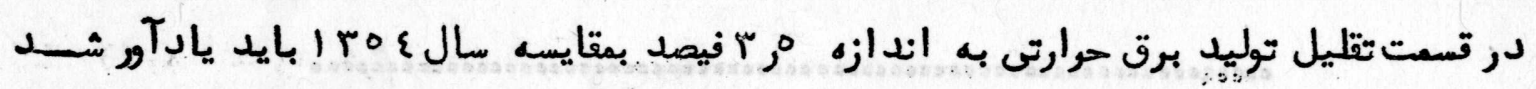

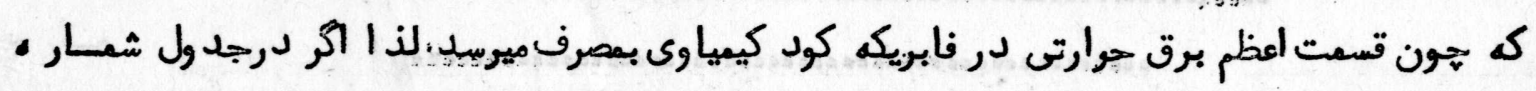

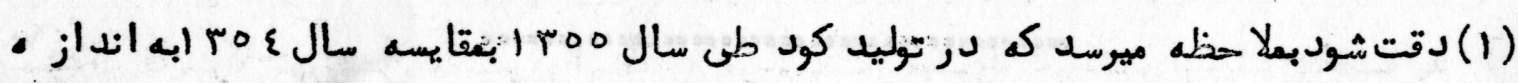

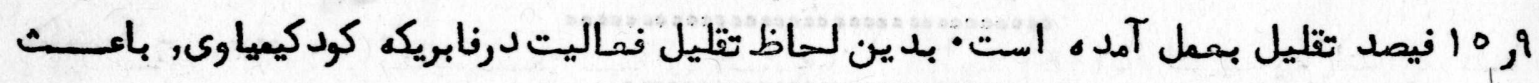

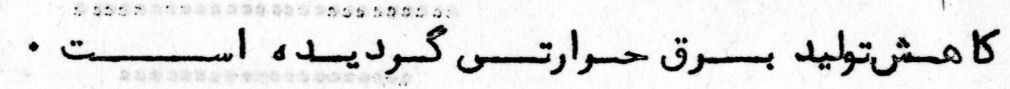




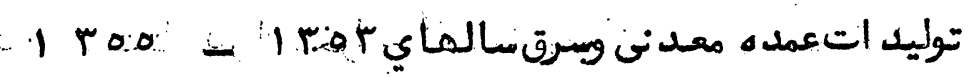

(r) جد:

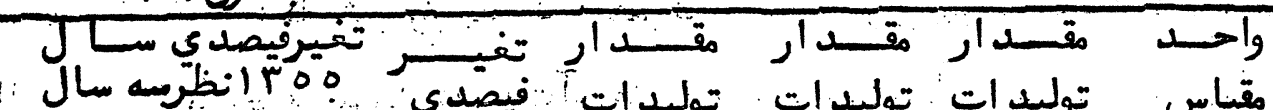

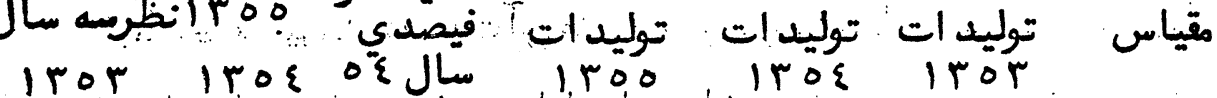

l. Iror iros of

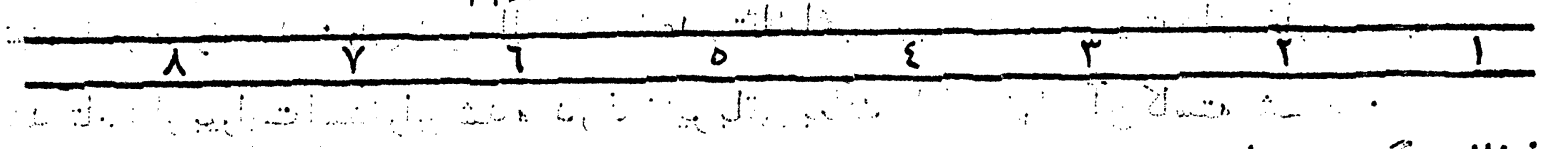

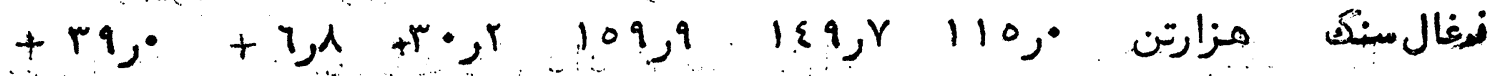

+\&q,r

لاجورد مزاريلنوكرام

يترايت : مزارتن

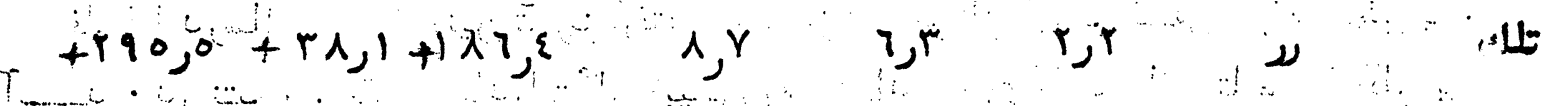

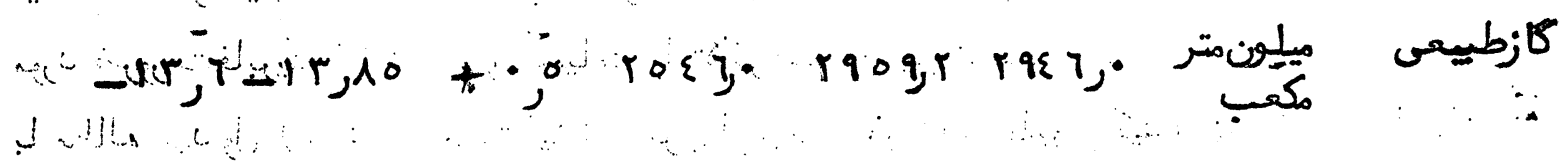

نهرق *

(4)

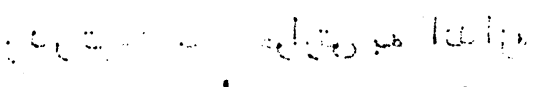

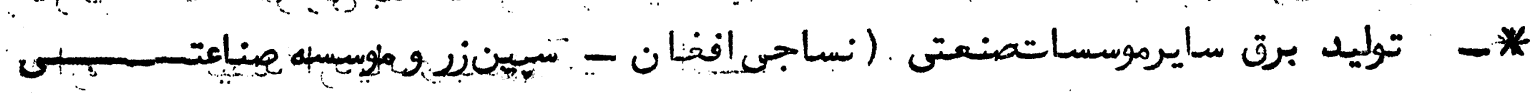

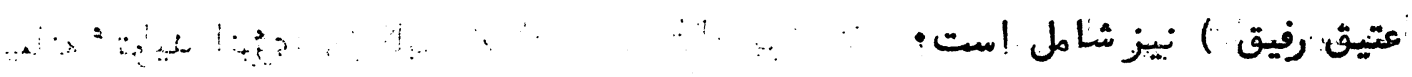

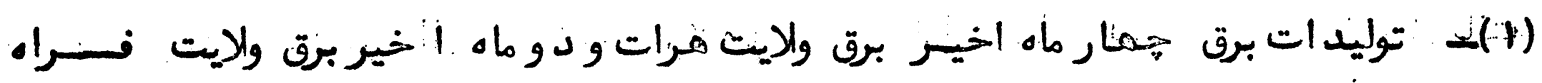

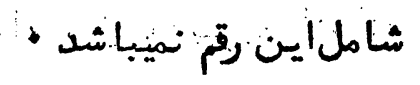

(r)

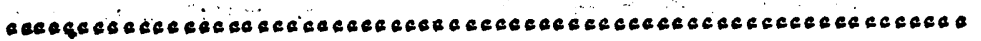

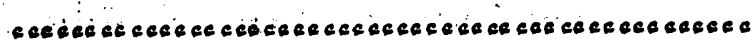

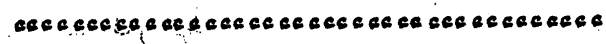

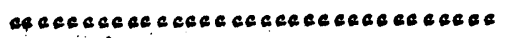

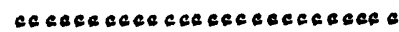

acectecescentecte

$\operatorname{ceccscsccsec}$ 


\begin{tabular}{|c|c|c|c|c|c|c|c|c|c|}
\hline سبال & ن & منسال, or & or مبنال & سـال & ع سـال & نبـال هـ & نهبا ل rع & انوا عشاجِـــص هــــا & شعـاره \\
\hline $1\{\lambda\}$ & $1: \varepsilon 8, j^{*}$ & Ir $\varepsilon$ زY & $\mid \| r$ & 91,7 & $1 \cdot 1,9$ & $10, r$ & $Y r, O$ & شاخصعموتس & \\
\hline $17 r, 7$ & 1098 & $1 \times 7,9$ & $\mid 1.0 \mathrm{~s}$ & $.9 \varepsilon, r$ & $1.0,6$ & $\lambda \mu, 0$. & Yo, r & شباخختيتوليدانتفنتى & \\
\hline I.r & $1 \cdot \varepsilon$, & 199 & Y. &.$\wedge \cdot \lambda$ & $r \cdot \rho$ & orf & $\lambda \mu, \gamma$ & 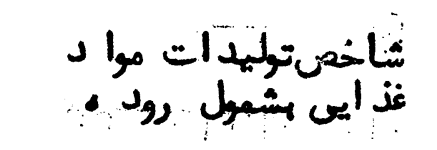 & الف: \\
\hline $7 r_{j}$ & T15 & $\circ \gamma, g$ & : & r & $00,0$. & $\varepsilon r \beta$. & ع & آرد كنـــــ & 1 \\
\hline غ غرع $1 \cdot 1$ & $1.0, \varepsilon$ & $1 \cdot \varepsilon, r$ & $1 \cdot 1 \lambda$ & $9 \gamma, 1$ & $9 r \mu$ & 91,5 & $19, \varepsilon$ & محصولا ت نانباتسى & $r$ \\
\hline 210 & $r \xi o$ & rr & $r q \circ$. & $110 ;$ & $i \cdot j$ & 90, & $190^{\circ}$ & & $r$ \\
\hline $1 r \cdot j$ & 109,9 & $1 \cdot \varepsilon, y$ & $i r$, & iro & $1.1,1$ & $i q,\{$ & إكر باת & شيك & $\varepsilon$ \\
\hline ror,o & 870 & i & $1 \varepsilon r, T$ & $\eta 1, Y$ & $1 \cdot r 0^{\circ}$ & $r \circ$ & ro, & روغن نهاتـــي & - \\
\hline$r\{\varepsilon, r$ & $1\{x ; 1$ & $19 \cdot 1$ & $\mid(\lambda)$, & r. & $\cdot 2$ & $\therefore-$ & - & روده، باك شده & ? \\
\hline$r \cdot 1, \varepsilon$ & $19 r, 1$ & I & : & $1 \cdots$ & Irrs? & $1.0, y$ & Y & 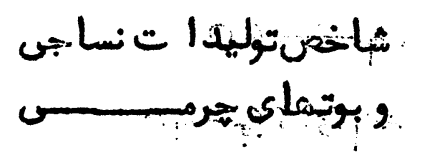 & 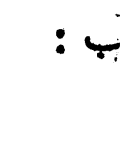 \\
\hline$r l \cdot r$ & $r Y \varepsilon, \varepsilon$ & $19 \varepsilon$ & $1 \varepsilon \wedge ر$ & $9 \cdot 0$ & 111,0 & $i 7 \cdot y$ & $i r, r$ & 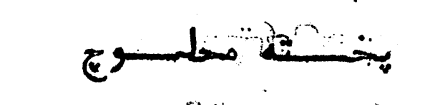 & 1 \\
\hline IYY;o & rrs; & $\mid Y \cdot \lambda, \bar{\gamma}$ & $|r| j^{\circ}$ & $119 j$ & $118 \pi$ & ז'ו & $0 q, 5$ & 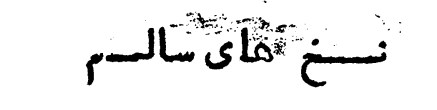 & r \\
\hline $119, \pi$ & $\eta r y$ & r إ· & 99,1 & $q \dot{\gamma}, r$ & $9 r$ \& & $Y q, i$ & $r i s$ & منسوبات نتـــن & r \\
\hline$r>\varepsilon, 7$ & rrq, & 1981 & $r \wedge r, \varepsilon$ & $1 \varepsilon \cdot r$ & $Y \wedge, Y$ & $r r, r$ & $r 70$ & منسو جات سنــدى & $\varepsilon$ \\
\hline 100,8 & $10 \%$ & $\varepsilon \cdot ;$ & $\{\gamma$; & $97, r$ & 109 & rrrg & lor, & منسو جات يشمسى & 。 \\
\hline
\end{tabular}


(! \&Y)

ادامس جسد ول (r)

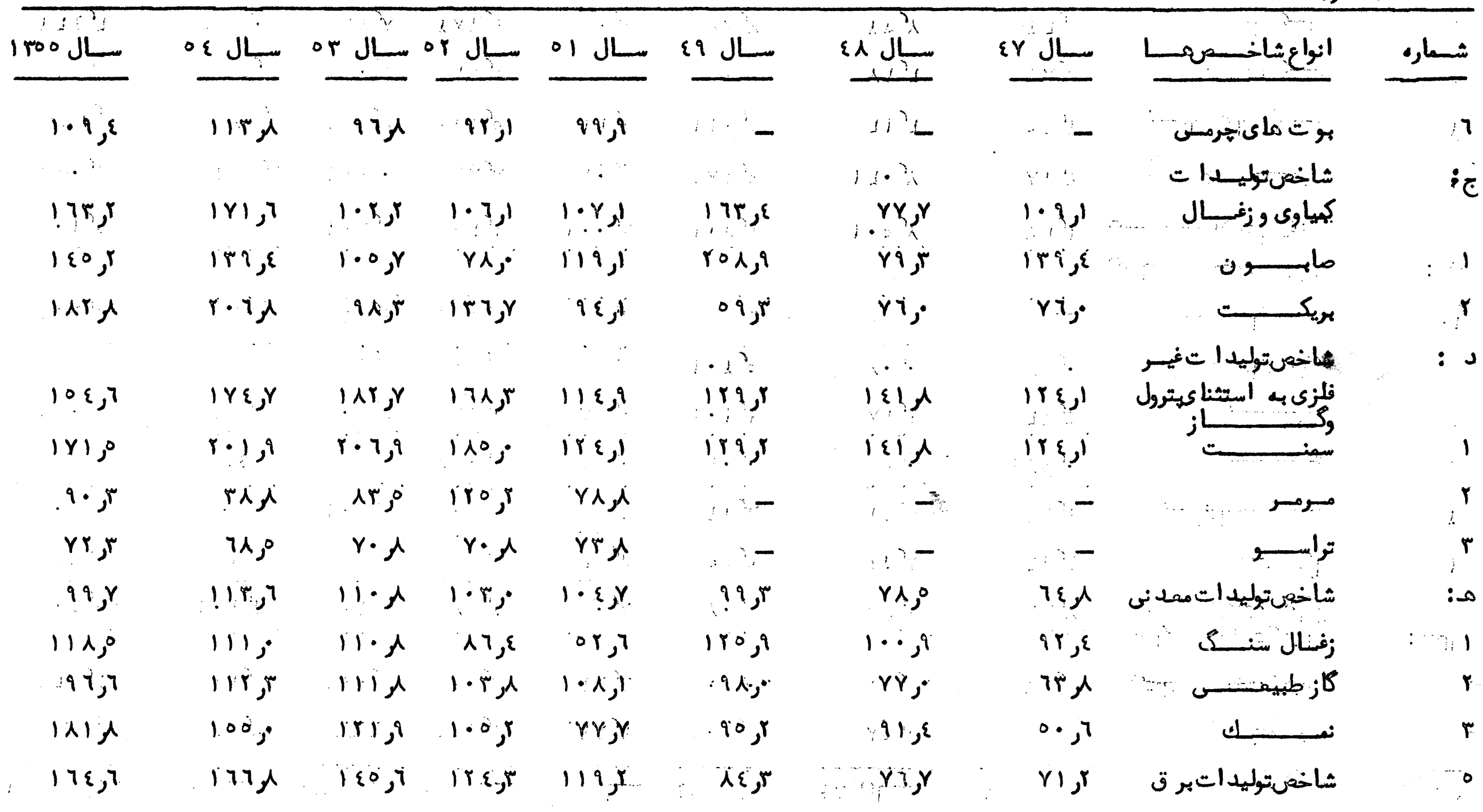


: نسطع استخد ام درصنايع - معادن و برق

درجد ول ذينا ملاحظه ميشود كه تعد اد مجموعى كاركان منايع - معادن ويق درسال

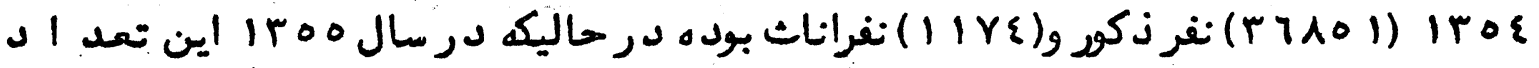

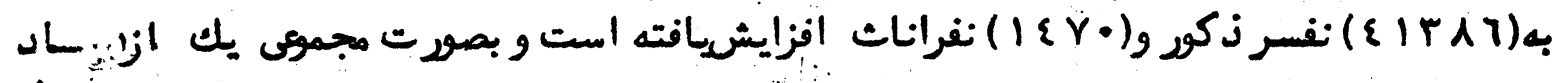

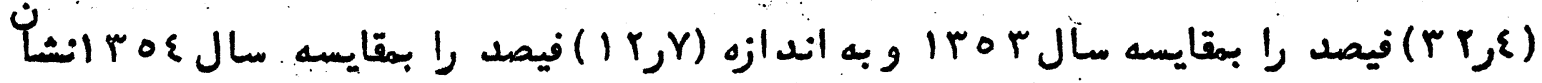

ميد مد كه درين مورد ياء: افزايشقابل ملاحظه در سطح استخد ام ديده ميشود :

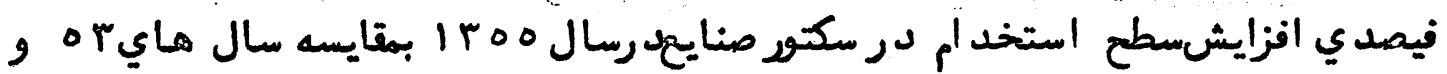

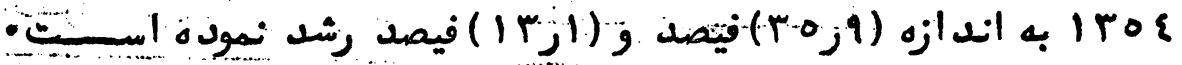

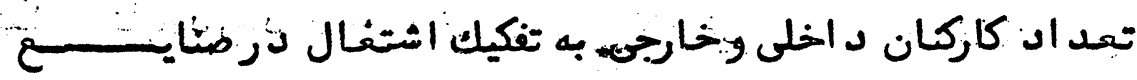

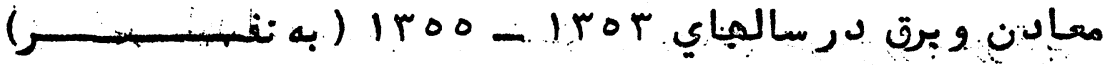
(६) ( )

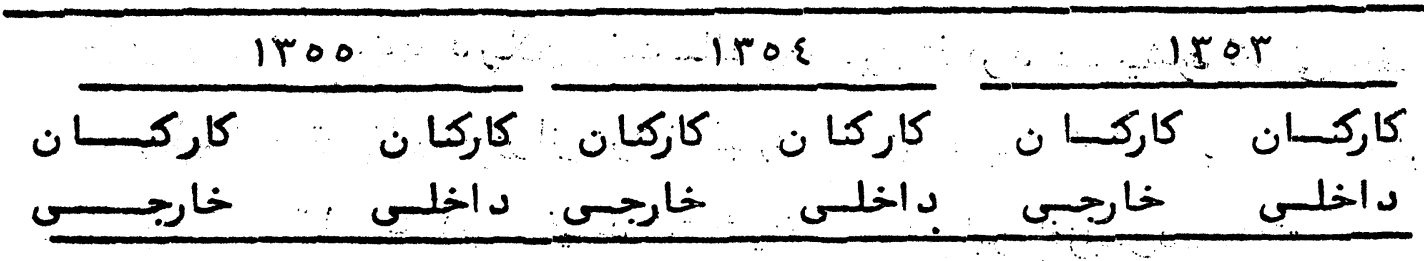

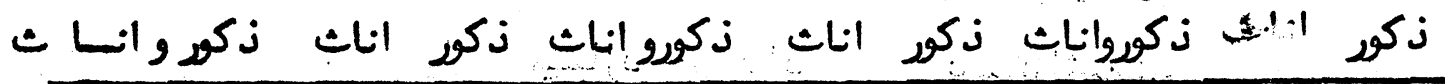

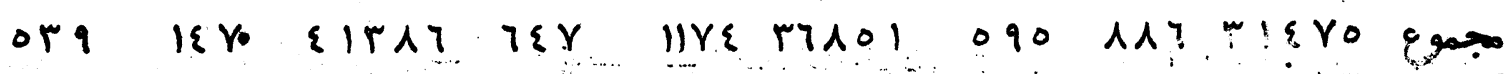

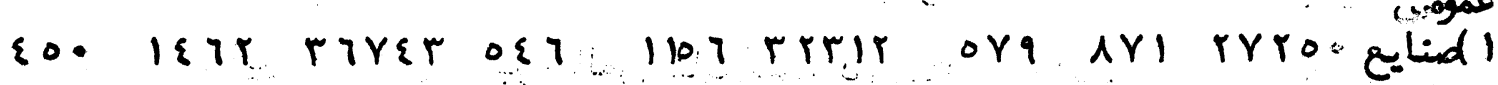

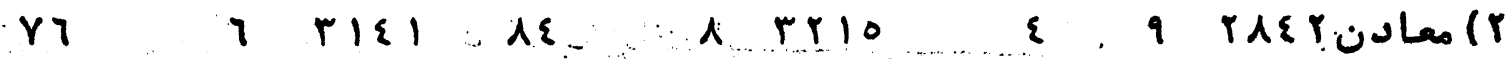

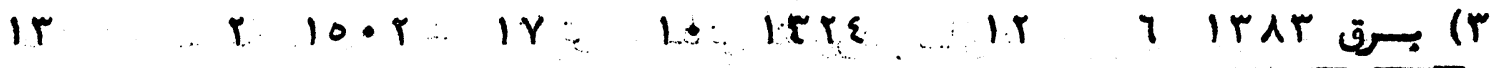

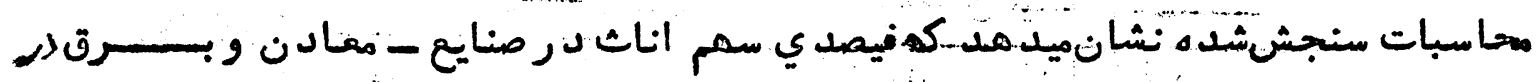

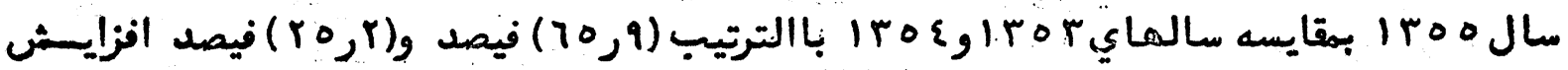

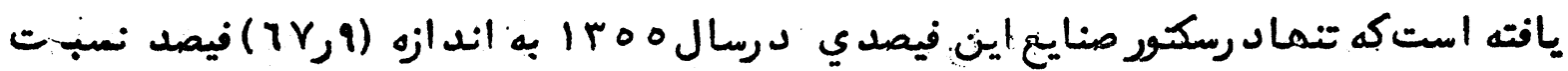

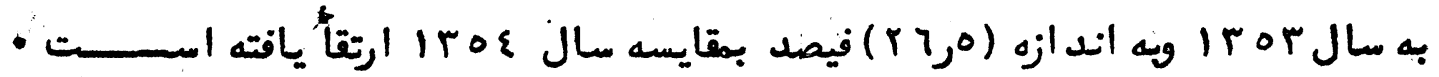

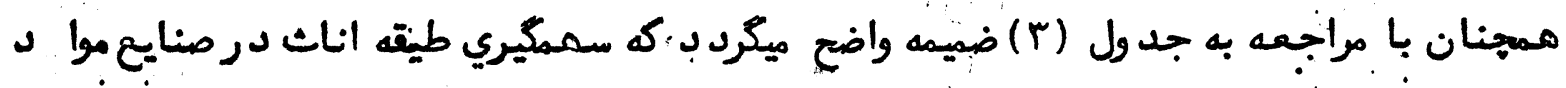

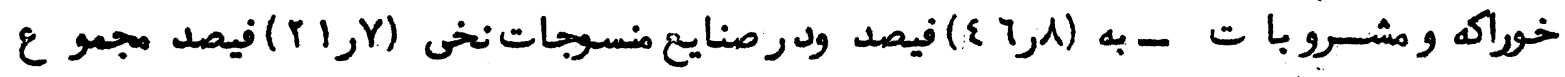

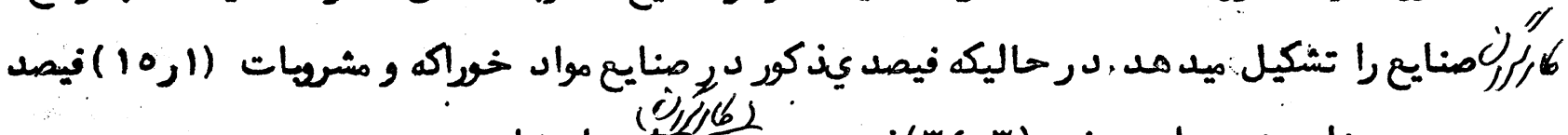

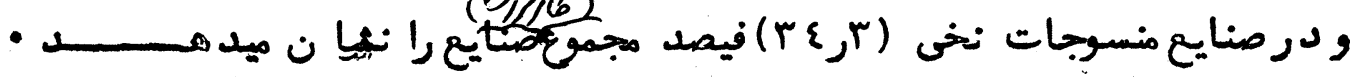

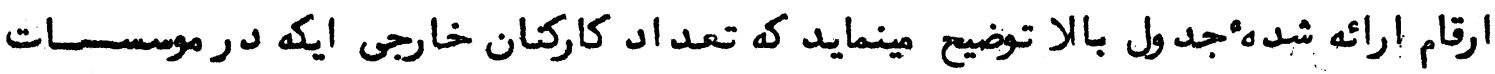

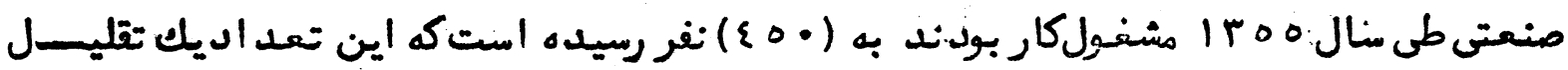

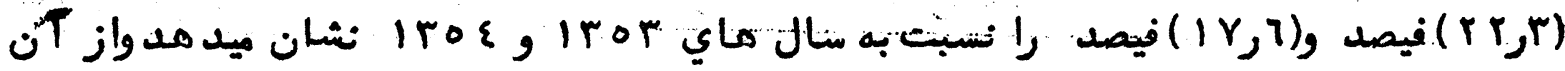




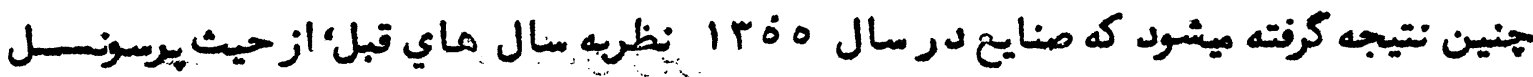

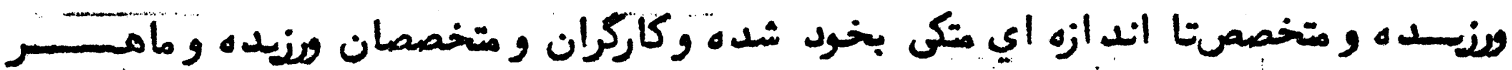

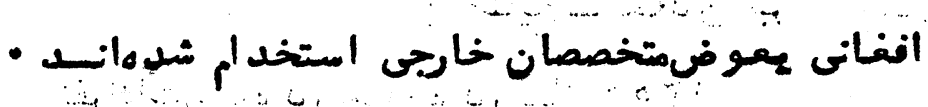

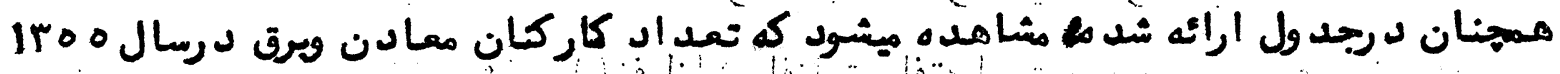

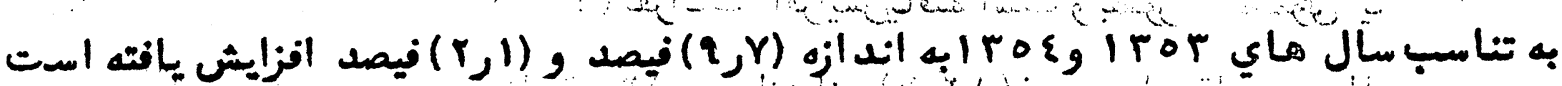

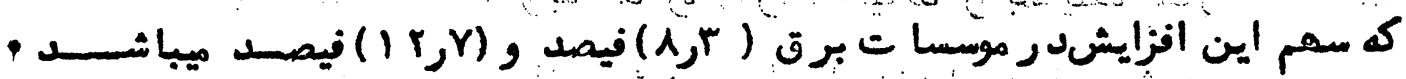

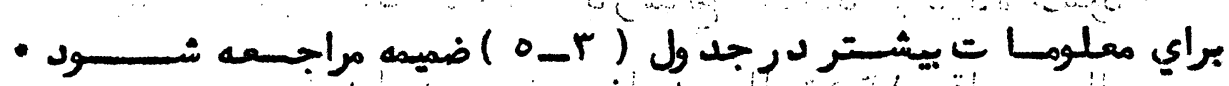

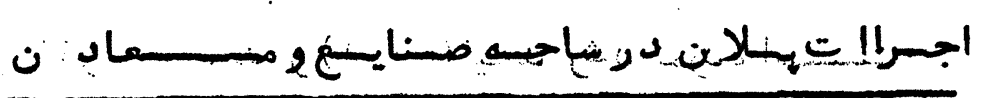

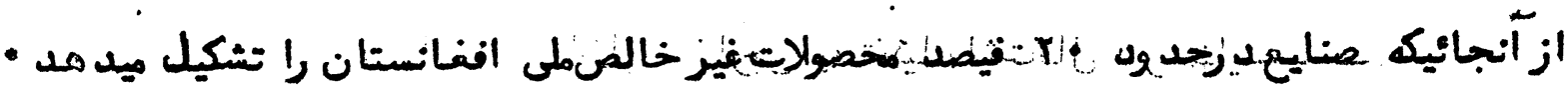

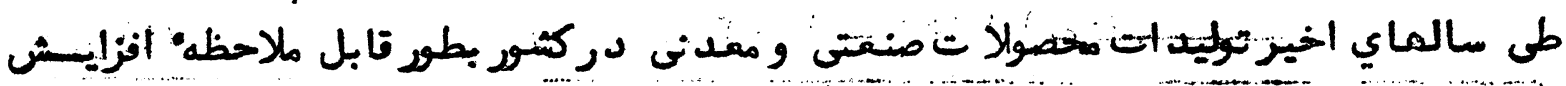

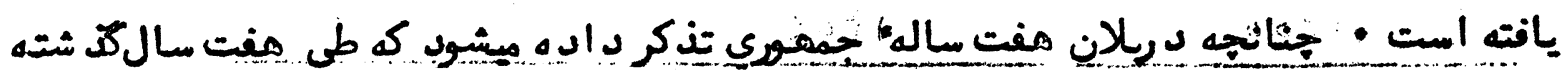

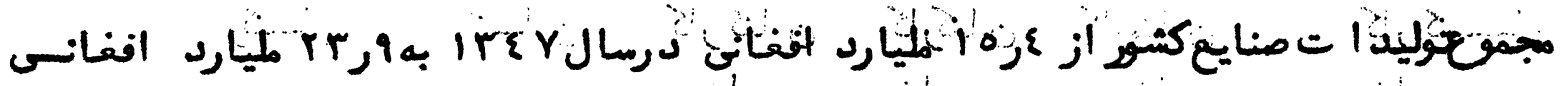

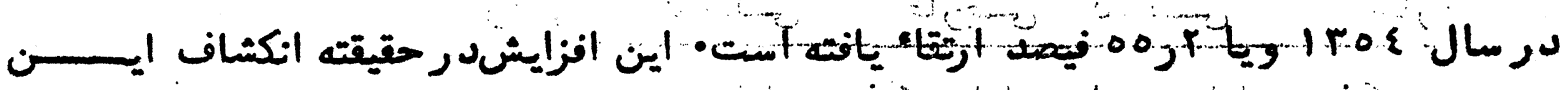

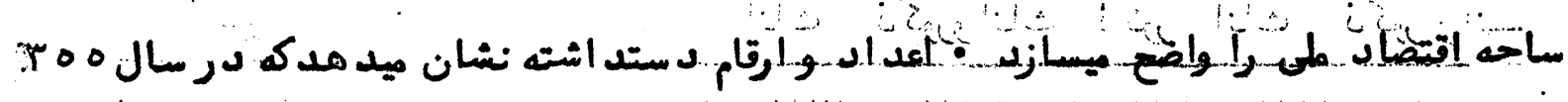

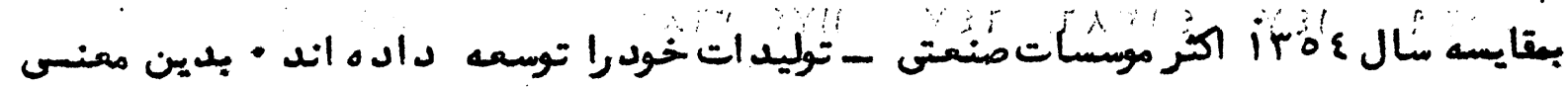

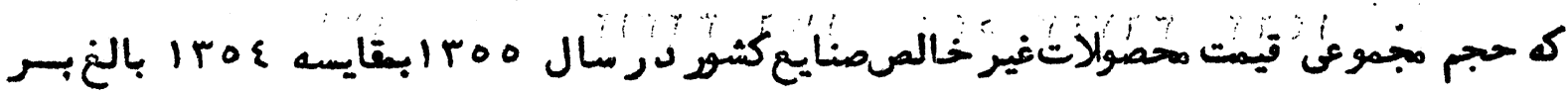

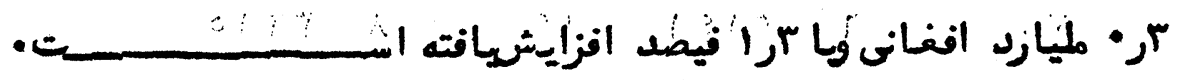

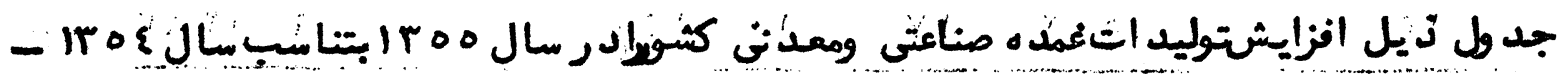

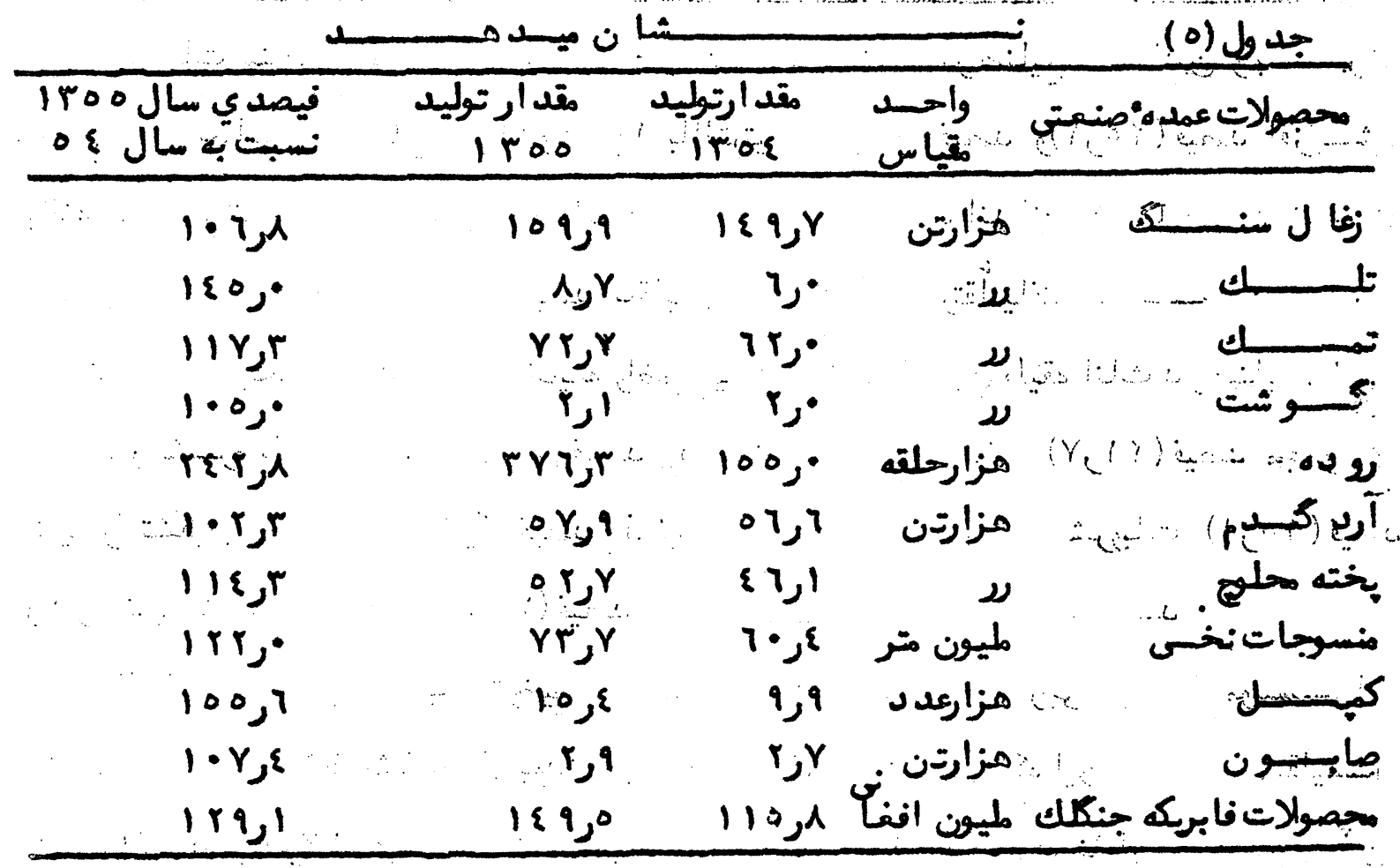




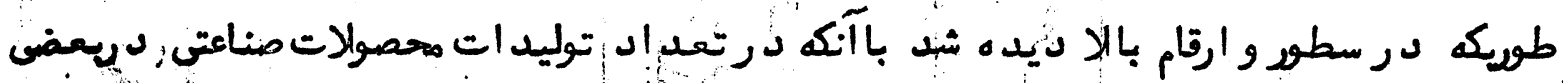

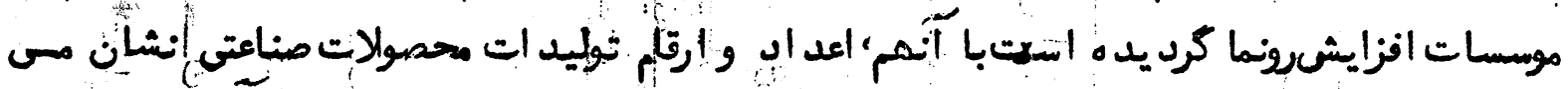

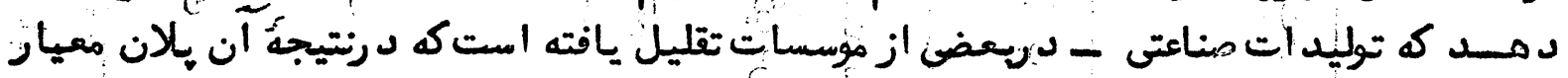

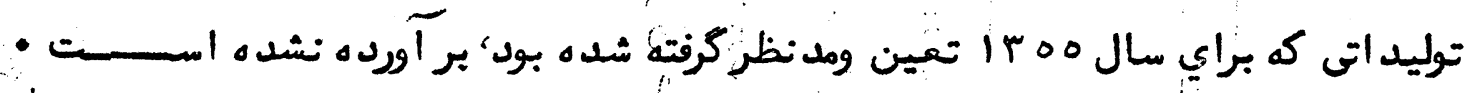

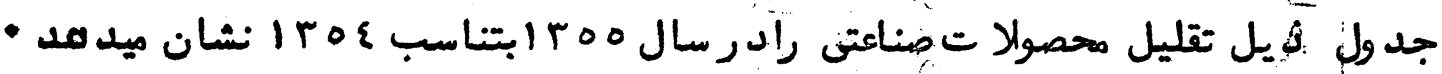

جدول (1)

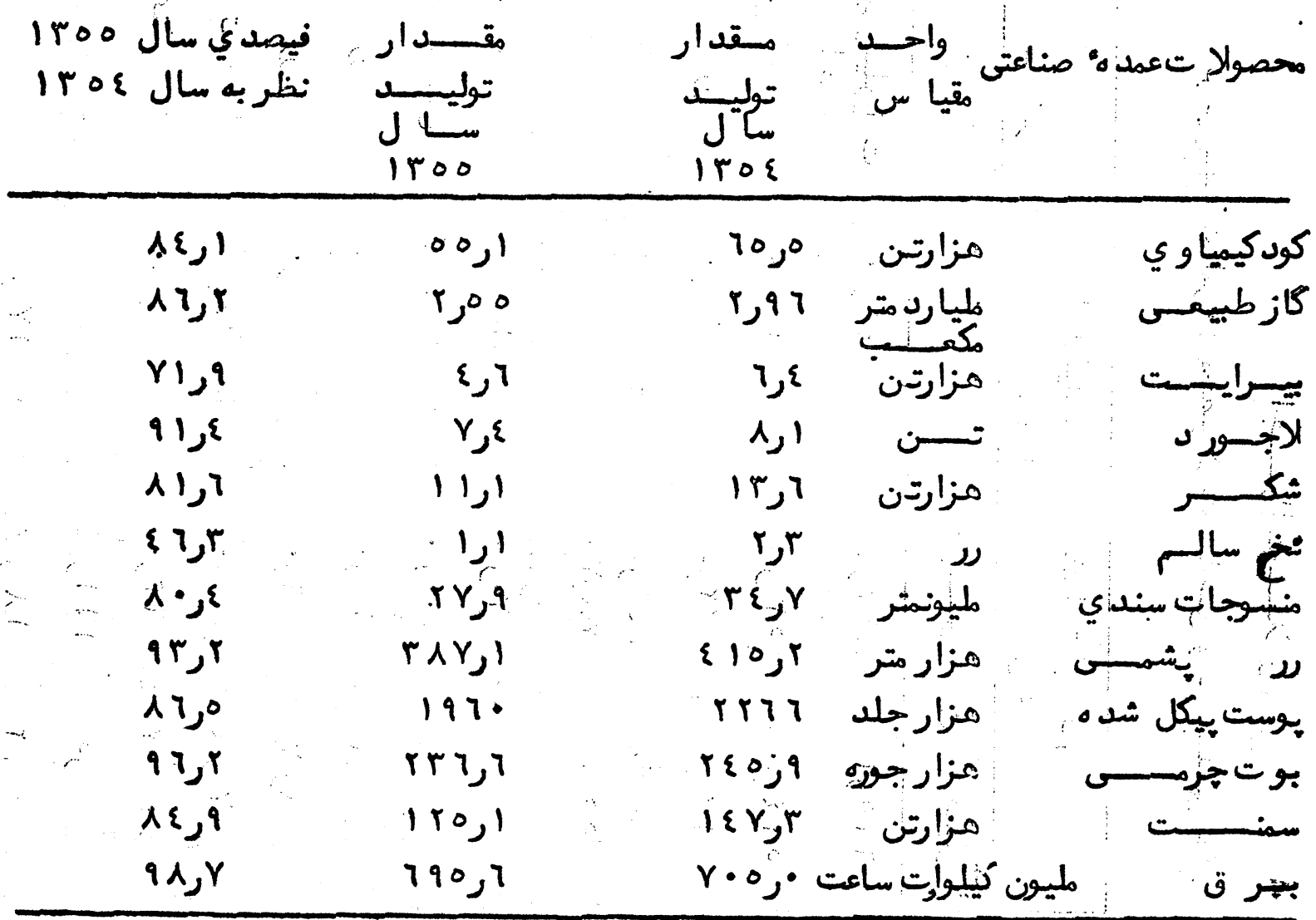

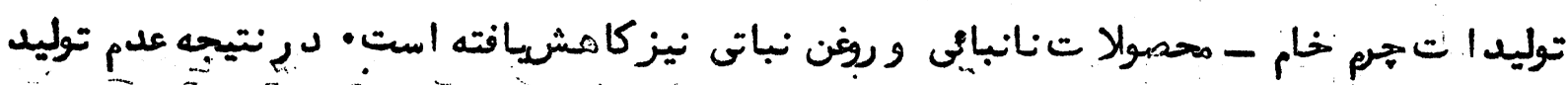

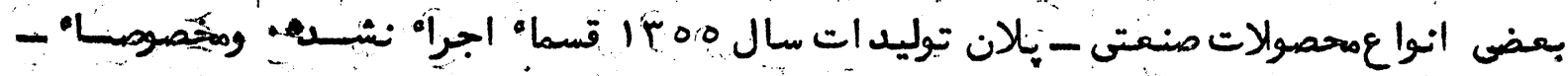

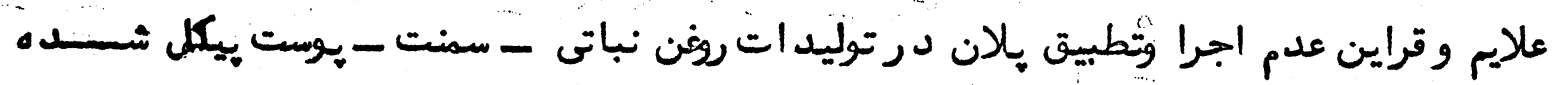

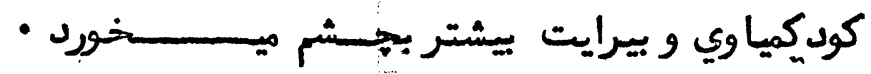

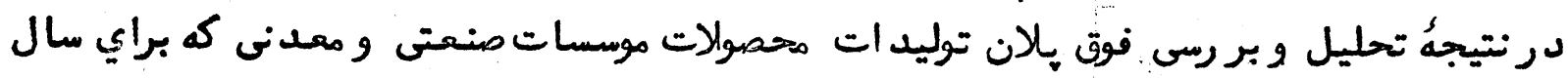

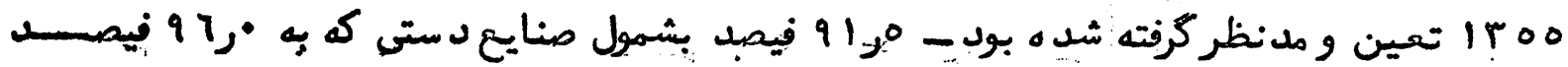

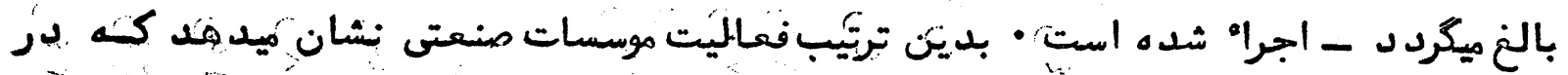

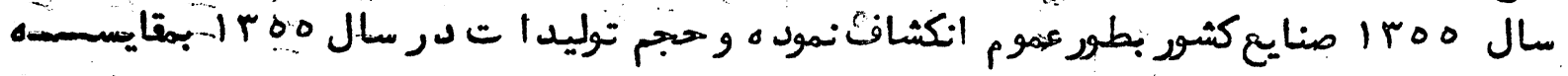

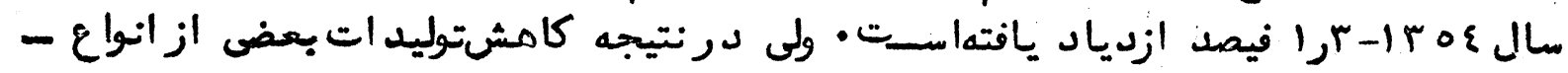

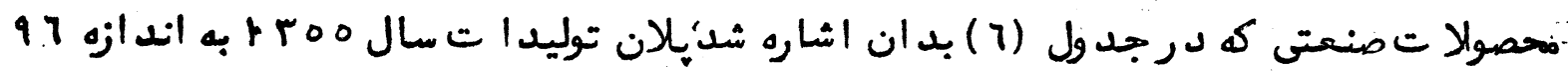

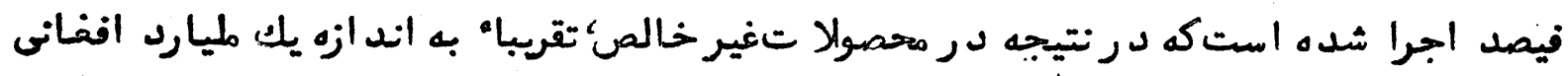

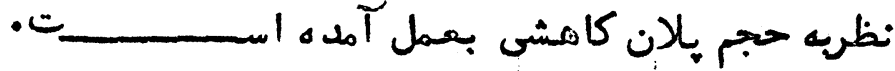

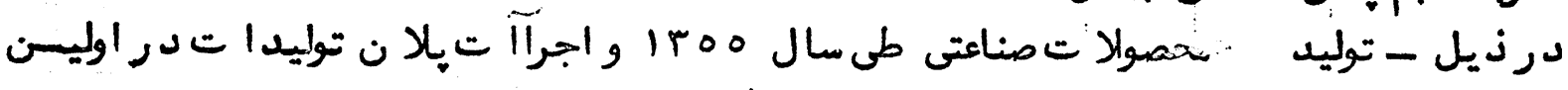

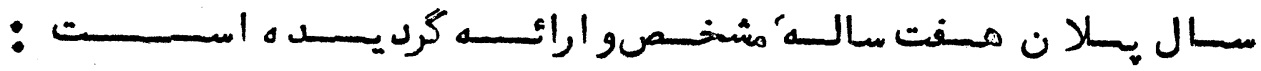


$(101)$

(v) جدو (v)

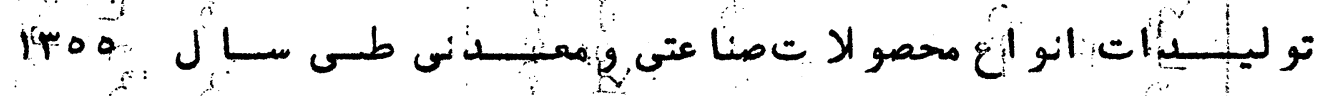

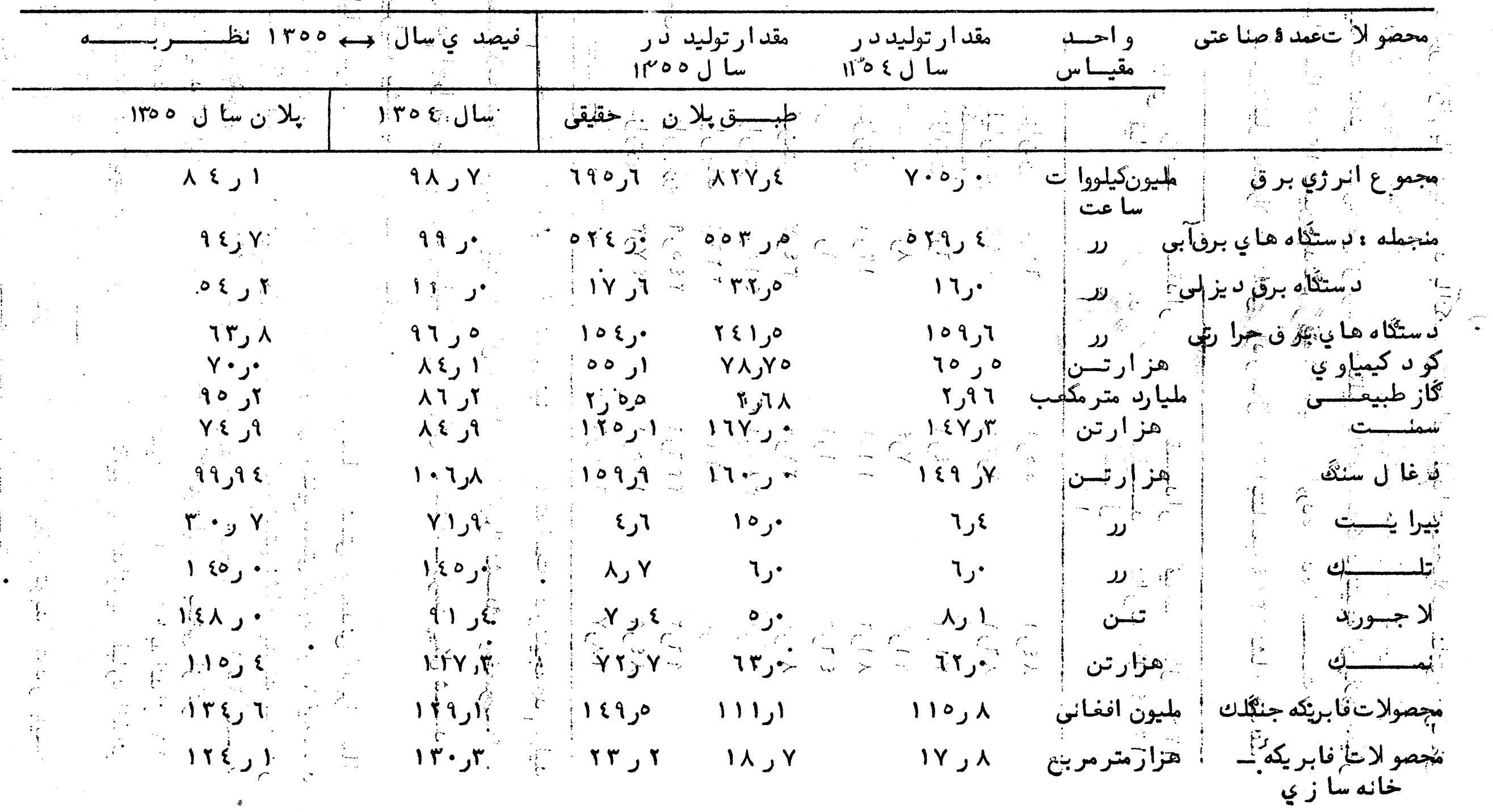




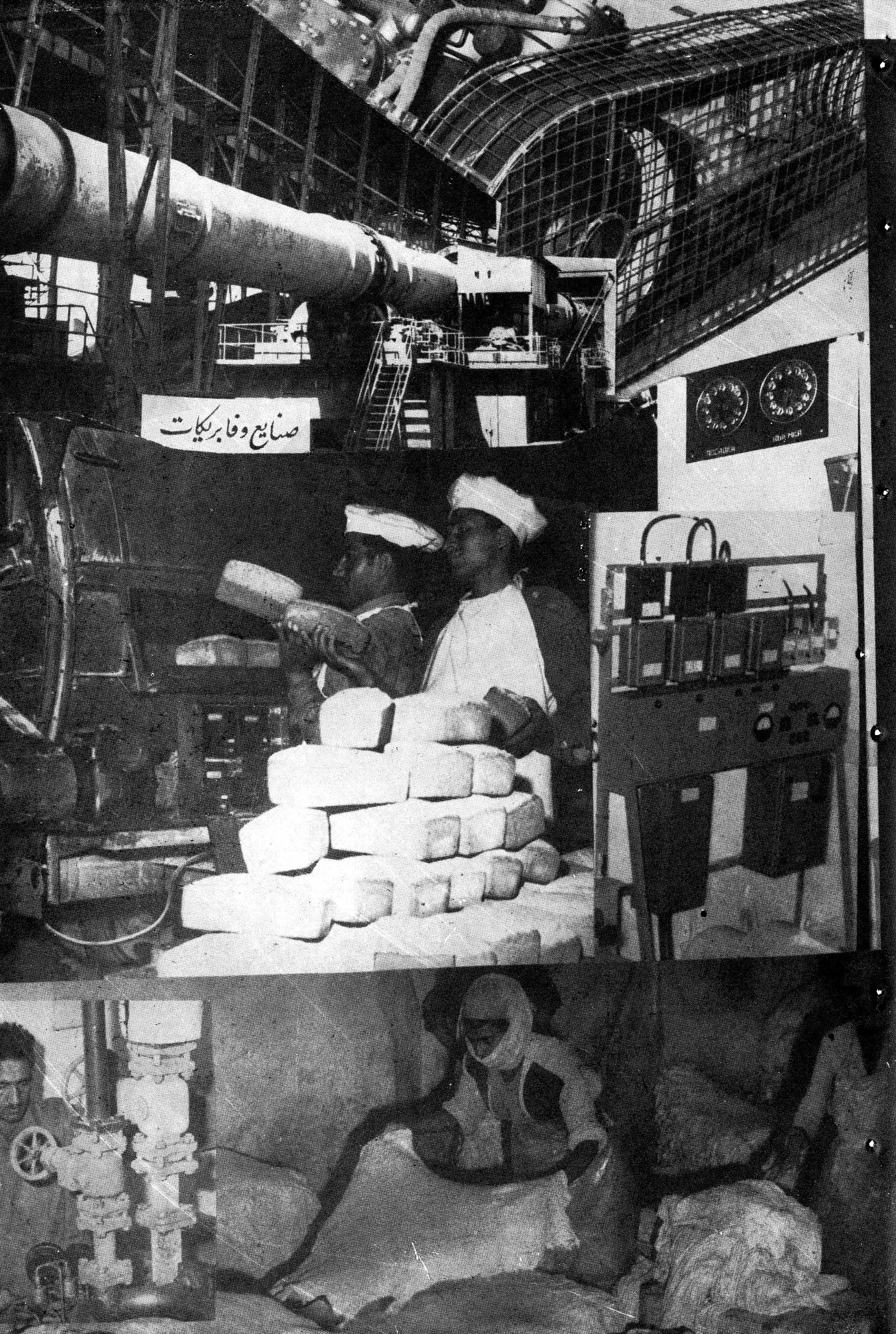




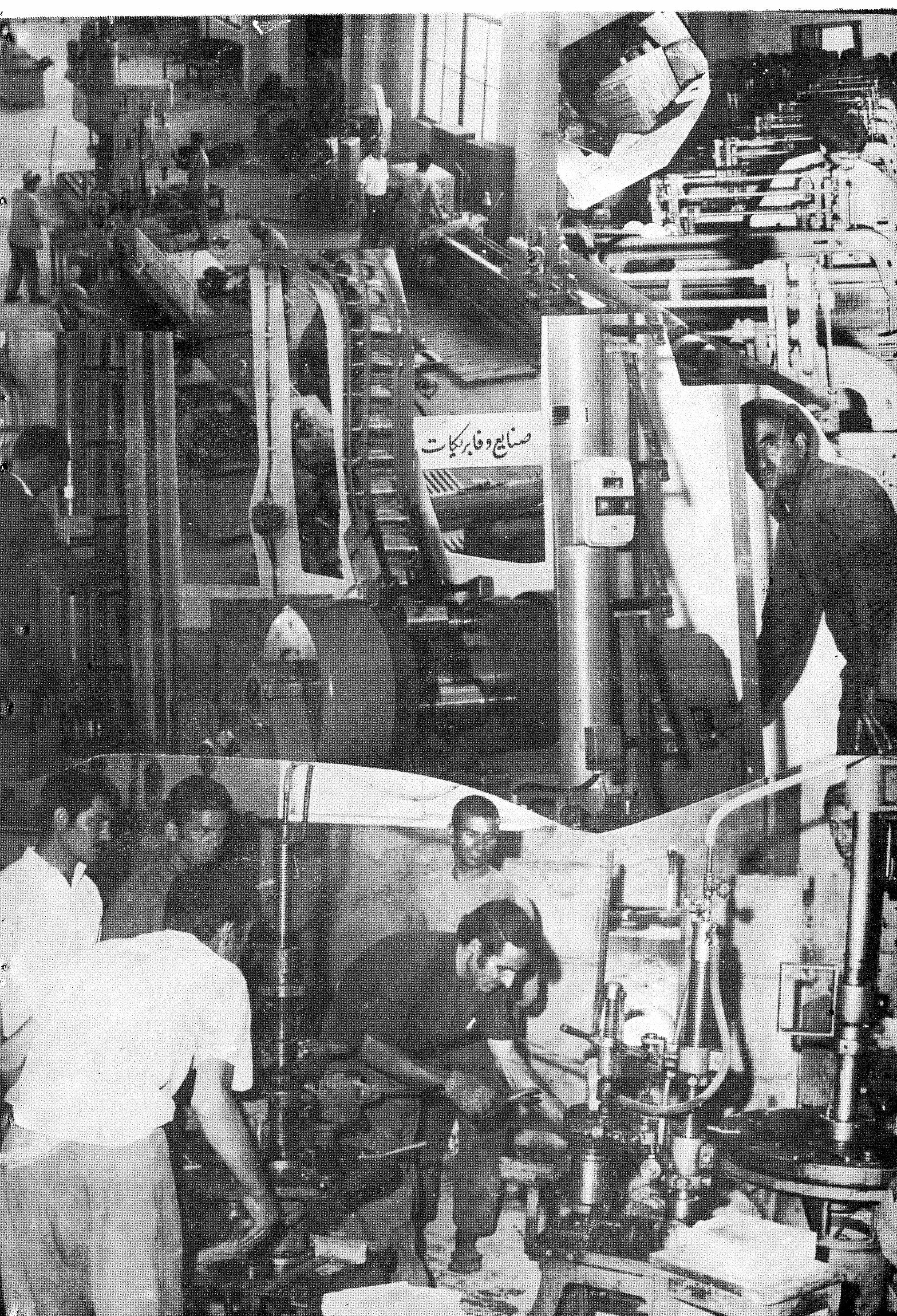




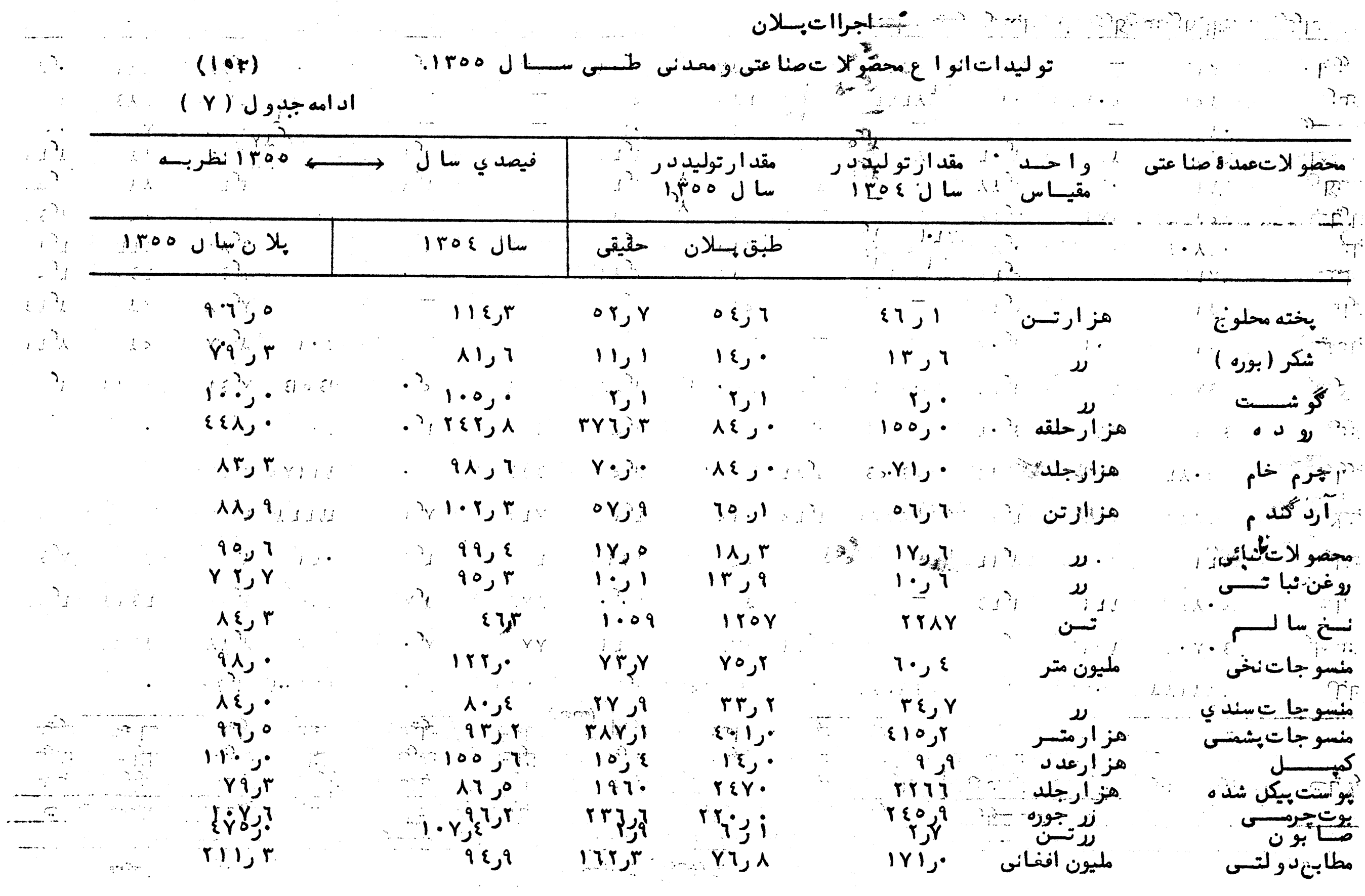




\begin{tabular}{|c|c|c|c|c|c|c|c|c|c|c|c|c|c|}
\hline \multirow{2}{*}{\multicolumn{2}{|c|}{ 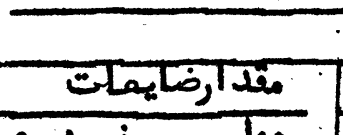 }} & \multirow{2}{*}{\multicolumn{2}{|c|}{ 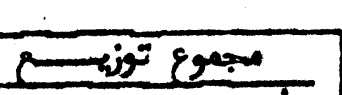 }} & \multirow{2}{*}{\multicolumn{2}{|c|}{ مزار }} & \multirow{2}{*}{\multicolumn{2}{|c|}{ 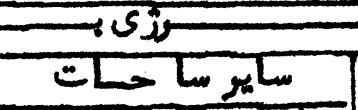 }} & \multirow{2}{*}{\multicolumn{2}{|c|}{ 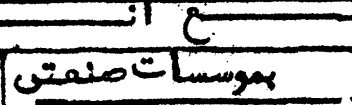 }} & \multicolumn{2}{|c|}{1} & \multirow{3}{*}{ 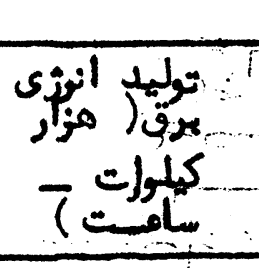 } & \multirow[b]{3}{*}{ ولايات } \\
\hline & & & & & & & & & & בــبوار & Th & & \\
\hline نظيحد 5 فيليد & 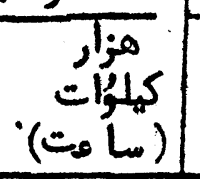 & تظيه & 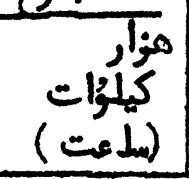 & نظيهد 5 نظيل & 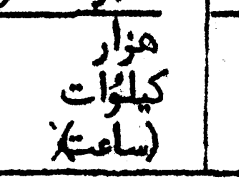 & فظهدي & 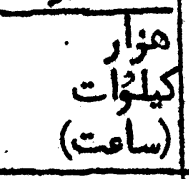 & نظيكدى & كيلرًأَ) & 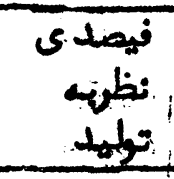 & هزئرات & & \\
\hline$\{0,9$ & $\operatorname{Ir}=\{\lambda \cdot$ & $0 \varepsilon$ & Yorq1 & $\cdot \gamma$ & rY7o & $1 \varepsilon, 0$ & orA9o & $r, q$ & 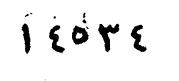 & $r \varepsilon, q$ & $1897 \cdot r$ & rYITYI & $\because$ \\
\hline$r r, r$ & 8995 & $r r, r$ & vili & - & 11 & 17,0 & irir & $17,0^{\circ}$ & |ra| & $r i,{ }^{\circ}$ & $\{109$ & $1 \cdot \lambda \cdot \xi$ & ــ مار - مار \\
\hline$\{0,7$ & $r i \varepsilon\}$ & $\dot{D} \varepsilon, \varepsilon$ & rooq & $1, x$ & riy & $\therefore \mathrm{T}$ & $r$ & - & - & ا ו & riti & $\xi Y \cdot 0$ & \\
\hline$\varepsilon$ & $i$ & 90,5 & $170^{\circ}$ & $r, r$ & $T_{A}=$ & $1 \varepsilon 9$ & ro & 10,0 & T & 11,5 & $1 \cdot r$ & in & \\
\hline $\mid Y, \varepsilon$ & 0719 & ir, t & יצדו & 1.10 & 071 & $i, i$ & 010 & $07,9$. & larrr & $r$ & Yr£o & ritio & \\
\hline r r & 19\% & $\lambda \eta, \gamma$ & $0 \wedge 119$ & $\therefore$ & $\varepsilon r \varepsilon$. & 0 & rory & $T r, r_{\lambda}$ & 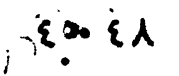 & 198 & $9 \cdot 7$. & $7 Y \circ \circ$ & \\
\hline$r r$ & $\circ \cdot$ & or & $1 \cdot \varepsilon$ & i & 112 & $r, r$ & : & rار & 。 & 7. & qr & $10 \varepsilon$ & غزنى . \\
\hline 0,5 & rY9 & $9 \varepsilon$ & $\varepsilon) \circ \varepsilon$ & 0 & rir & rrer & $r q \cdot \varepsilon 1$ & r r r r r & Ir & 11,5 & Y907 & $\varepsilon r \lambda \varepsilon \varepsilon$ & \\
\hline 19,8 & ro & A. $r$ & $1 \cdot r$ & - & - & - & - & - & - & $\lambda \cdot r$ & 1.8 & Irr & \\
\hline$r q, r$ & ra & $r \cdot \mu$ & $9 r$ & - & - & 19,5 & ro & - & - & $01 \%$ & TY & tro & فرا \\
\hline 0,1 & o \{\} & $9 \varepsilon, \varepsilon$ & $91 \% 4$ & $\cdot r$ & $r 7$ & $1 V_{j} \lambda$ & Irrr & 19,9 & $199 r$ & 07,0 & $0 \& 77$ & $974 r$ & \\
\hline$r, \pi$ & rTI & $9 \gamma, \varepsilon$ & iryimg & 11,1 & pIr. & $r, \varepsilon$ & $\therefore \operatorname{lol} 1 \lambda$ & $Y 0,9$ & 1.7109 & $r$ & \&rY & $1 \varepsilon \cdot Y 9$. & \\
\hline $1 \varepsilon ; \gamma$ & or & $10 \mathrm{~g}$ & $r \cdot 1$ & - & - & re,g & 119 & - & - & 01,7 & IAr & ror & \\
\hline $1 r, 9$ & $r Y$ & liر & 178 & זرץ & - & $7, r$ & . I. & o & $\ldots 1$ & $\cdots Y r_{g} r$ & $1 \varepsilon$. & $19 \varepsilon$ & . \\
\hline 17,5 & rr & Ar & $11 \varepsilon$ & $r, r$ & $r$ & זر 17 & $r y$ & r & $r$ & $7 \cdot r$ & Af & atrat & \\
\hline 0 & $\varepsilon V^{\lambda}$ & 90 & $q \cdot \varepsilon \wedge$ & - & - & 0 & \&Y & $r \cdot \overline{-}$ & TI & $r$ & 19.0 & 9०५ & كندز \\
\hline r. & 190 & $r r ;$ & $\varepsilon \cdot 7 \cdot$ & s. & $\lambda \varepsilon$ & $x \cdot s$ & Arr & ro; & rirq & - & $\cdots-$ & ह1ג & جوزجان \\
\hline
\end{tabular}




\begin{tabular}{|c|c|c|c|c|c|c|c|c|c|}
\hline 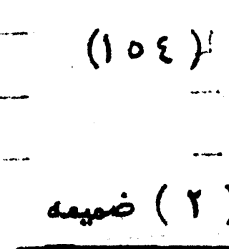 & جـ & $\therefore$ & $(1$ roo $)$ & سـ & افنـا نستاه م. & انزوزى برقد د, & توليد وت & & ( بليون كيلورإت ساعت ) \\
\hline 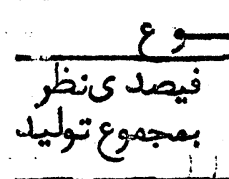 & 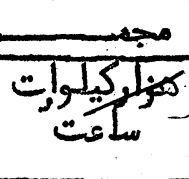 & 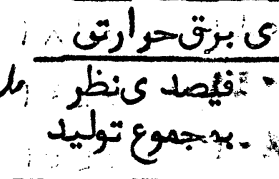 & 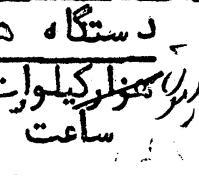 & 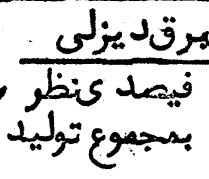 & 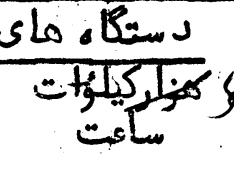 & 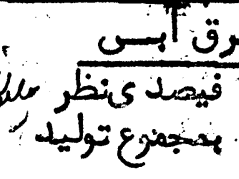 & 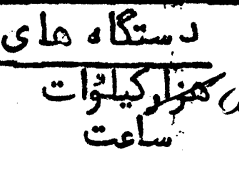 & jens & توليد ويتوزيــــــــ \\
\hline 9 & 1 & $y$ & 9 & 0 & $\varepsilon$ & $r$ & $I$ & & 12 \\
\hline $1 \cdots$ & 790,7 & $1 \cdots$ & $10 \varepsilon$ & $1 \ldots$ & $\because r, 7$ & 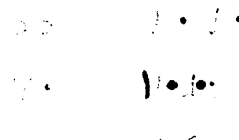 & OY $\varepsilon$ & & مجموع توليدا انزوى برق \\
\hline$r i, r$ & $\varepsilon q \wedge, \gamma$ & $i \gamma, \varepsilon$ & 10. & $V \varepsilon y^{\varepsilon}$ & ار & $T \varepsilon$ & rro, & & مجسوع توزيحا انوزىهر ق \\
\hline & & & s. & & $\ldots$ & $\therefore \therefore$ & $\therefore$ & & 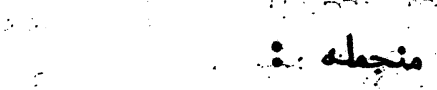 \\
\hline$r \varepsilon, T$ & $1 Y \cdot \rho$ & $r, 7$ & $0, j$ & R & 7,5 & $r \cdot r$ & 109 & 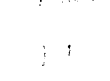 & كه خانوار \\
\hline$r q, r$ & $r \cdot r$ & $Y 7$, & $\| 18$ & $r 7$, & $\varepsilon, \tau$ & ع & $\lambda \cdot, y$ & & بوسيسات ضنمتى \\
\hline كِ 10 & $100, \pi$ & $\because \gamma, \tau$ & $1 i, y$ & $1 \cdot 5$ & 1 & $i v, i$ & $9 r$ & & هُ شتايو ساحات \\
\hline$r$ & 19,9 & $1 \cdot r$ & $10, y$ & $r$ & $\therefore \varepsilon$ & $\cdot, y$ & $r$ & (4) & عرائخود دمتكاه \\
\hline$r \wedge, r$ & 197,9 & r & ; ز & ro, & $\varepsilon, 0$ & ; & $\mid \wedge i, \varepsilon$ & & مقدار مايمات \\
\hline
\end{tabular}


$(100)$

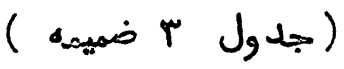

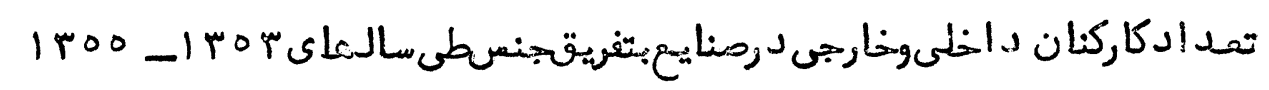

\begin{tabular}{|c|c|c|c|c|c|c|c|c|c|c|c|c|}
\hline \multirow{2}{*}{\multicolumn{2}{|c|}{ كاركنان خارجســى }} & \multirow{2}{*}{\multicolumn{2}{|c|}{ ساير مستخدمان }} & \multirow{2}{*}{\multicolumn{2}{|c|}{ كاركران توليـد }} & \multicolumn{4}{|c|}{ 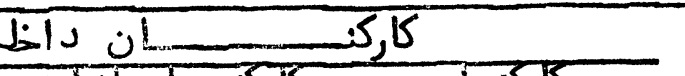 } & \multirow{3}{*}{ دستطان ه } & \multirow{3}{*}{ سال } & \multirow{3}{*}{ 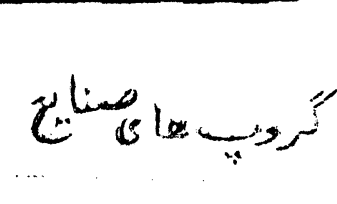 } \\
\hline & & & & & & 5,101 & $-3,5$ & نL & (3) & & & \\
\hline ث ا & زكور & 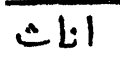 & زكور & ثا & زكور & 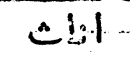 & ذكور & ثا. & ذكور & & & \\
\hline IT & IT & 11 & 1. & 9 & $\Lambda$ & $\bar{Y}$ & 7. & 0 & $\xi$ & $r$ & I & $I$ \\
\hline - & 7 & 1 & Y19 & 879 & 99. & 10 & \&r: & rג. & rirq & ro & iror & منايح منـــواد \\
\hline - & ir & $r$ & $\circ .$. & rre & 1497 & rq & 011 & rYr & $r \varepsilon \cdot \gamma$ & YY & $150 \varepsilon$ & 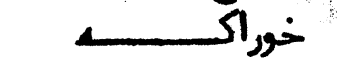 \\
\hline - & ० & 1 & ri & iri & 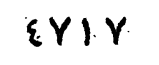 & ir & 0.1 & $\nmid \wedge \varepsilon$. & $D 0 \varepsilon \varepsilon$ & rl & 1room & 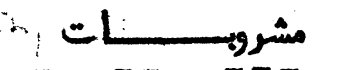 \\
\hline - & $r$ & 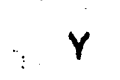 & $9 \gamma \cdot:$ & ir & qrr & 7 & $0 . Y$ & Y T & 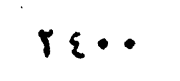 & ir & irop". & منايح تهلكثى \\
\hline - & 1 & $Y$ & ^•. & 10 & xrr & 11 & 0.11 & re & rrqI & 11 & 1.00 & هروغنكثن:هـ \\
\hline - & 1 & Y T & $1 \cdot r r$ & - & Arr & 1.7 & Y17 & $\varepsilon r$ & rori & Y & 1900 & م شمولسيهن ند \\
\hline 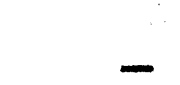 & o & o & r 10 & Ar & $19 \varepsilon 0$ & $r$ & $|\gamma|$ & 9.: & $r \varepsilon \cdot 1$ & $r \varepsilon$ & iror & منايس \\
\hline - & 7 & $r$ & ro. & Yo & r.1.r &.$r$ & r.q. & $\wedge \cdot$ & $r 7 . ?$ & rT & Iros & منسوجــــــات \\
\hline - & ० & - & 189 & Or & $178 \%$ & $r$ & $r \varepsilon r$ & Do & $r \cdot 9$. & $\Upsilon \varepsilon$ & 1.500 & سنــــــــــــ \\
\hline - & 11 & YT & $10 \pi$ & $1 \cdot r$ & (1) TY & $\varepsilon Y$ & $Y \varepsilon 1$ & 110 & $1 \cdot\{Y \mid$ & $r$ & iror & منايــــ \\
\hline - & $\Lambda$ & $F_{7}$ & $1 \varepsilon 7 \varepsilon$ & $r r \cdot$ & qrrq & $\varepsilon r$ & vir & $\mathrm{r} \wedge$ & Her. & $r$ & lros. & منسوجـ \\
\hline - & 10 & ry & Irre & rro: & 1. rro & - & Trq & rir & $1 r 7 \cdot r$ & $r$ & 1,500 & نخــ \\
\hline - & - & - & r人e & - & $r \cdot q$ & 1 & $1 \gamma \varepsilon$ & 1 & צודר & $r$ & iror & بخته محلـــــه \\
\hline - & - & - & $\varepsilon \cdot 7$ & - & ᄉ\&r & $r$ & riq & $r$ & 1011 & $r$ & Irog & به استثنـــاى \\
\hline - & 7 & - & $\varepsilon \mu$ & - & ror & 1. & $0 . \varepsilon$ & 1. & $\mid Y \varepsilon 0$ & $r$ & 1900 & سيهــــــــن ند \\
\hline
\end{tabular}




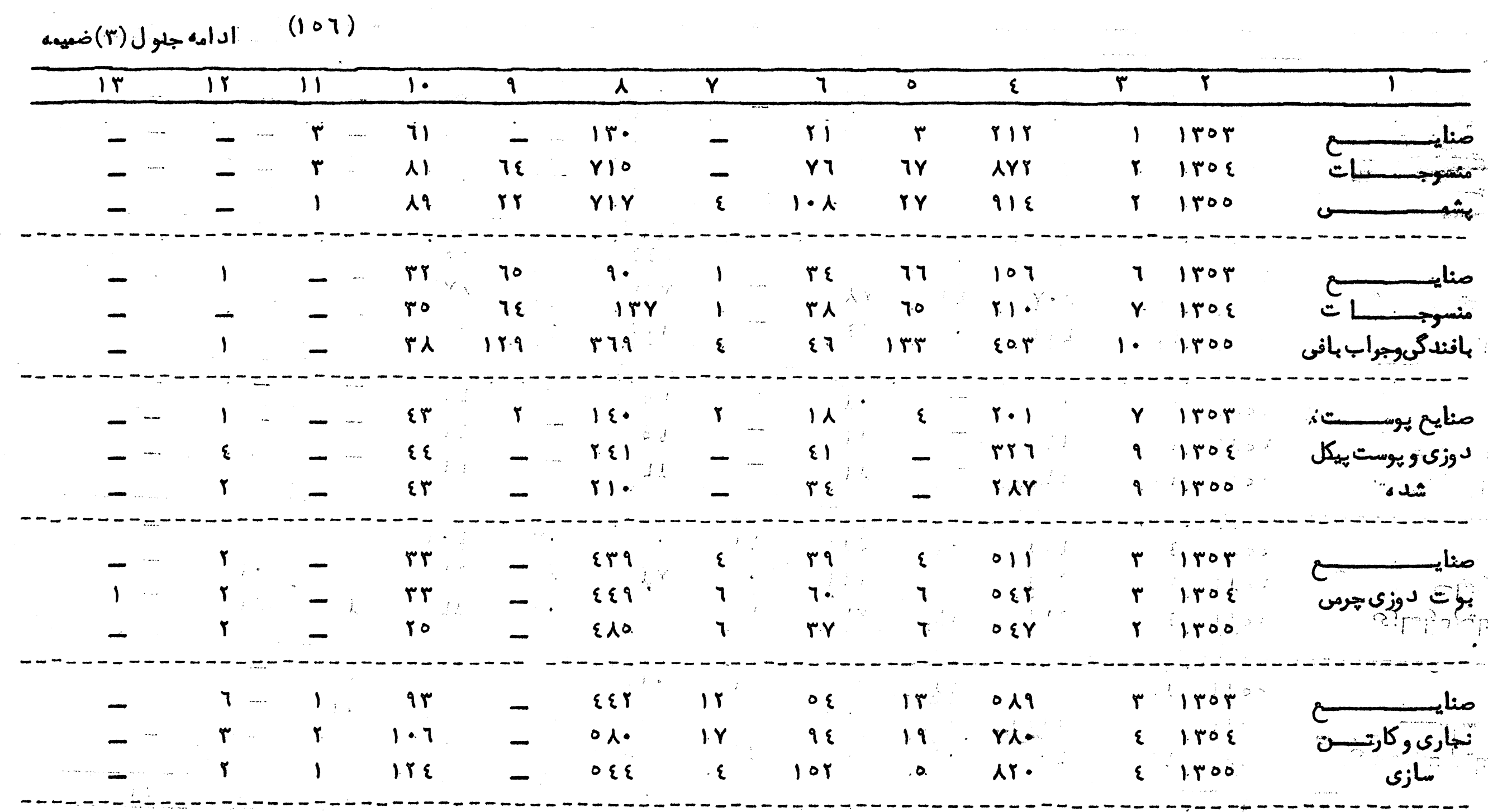




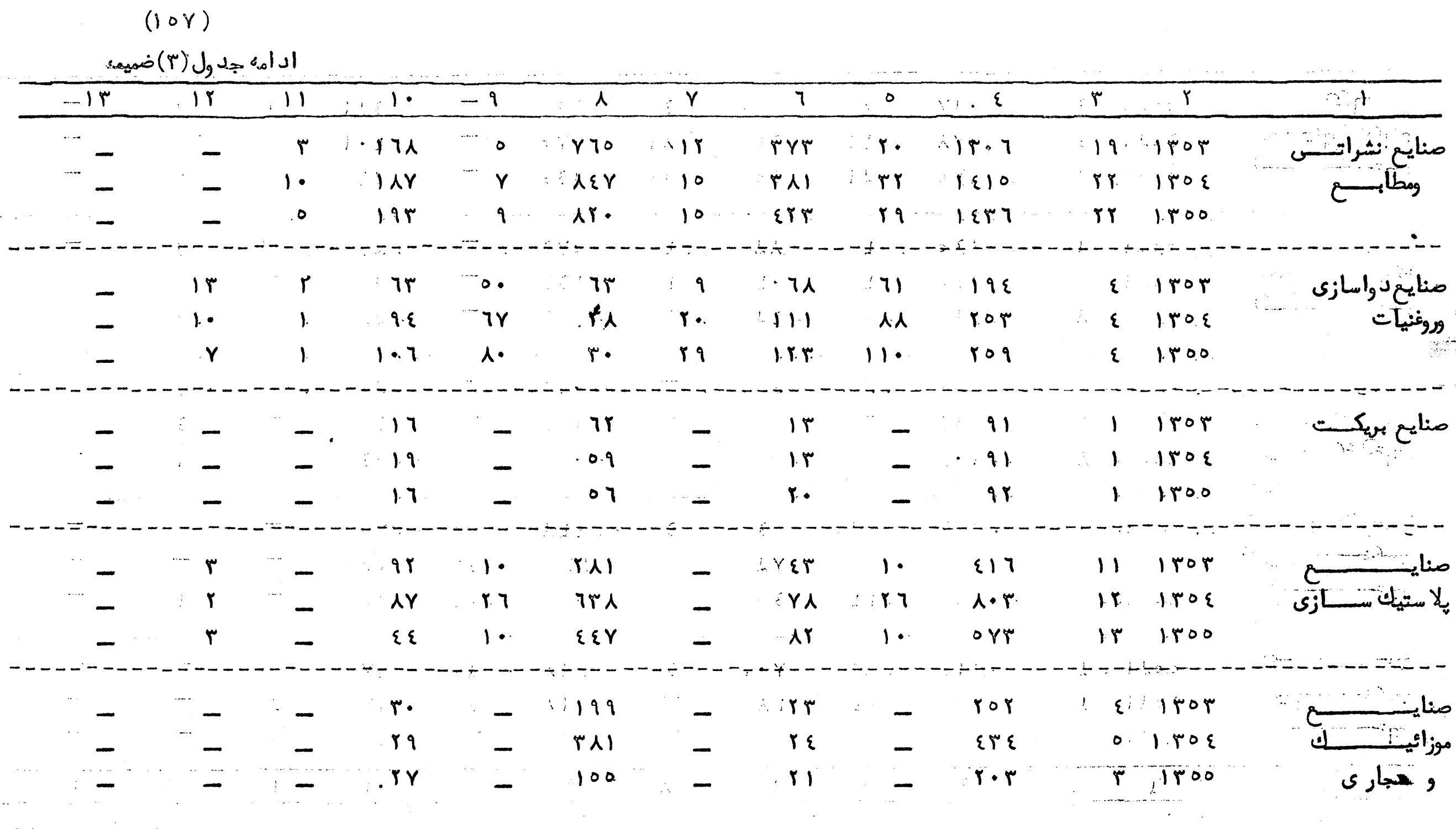


$(1 \circ 1)$

اد امه جدطل (r) לهنيس (1)

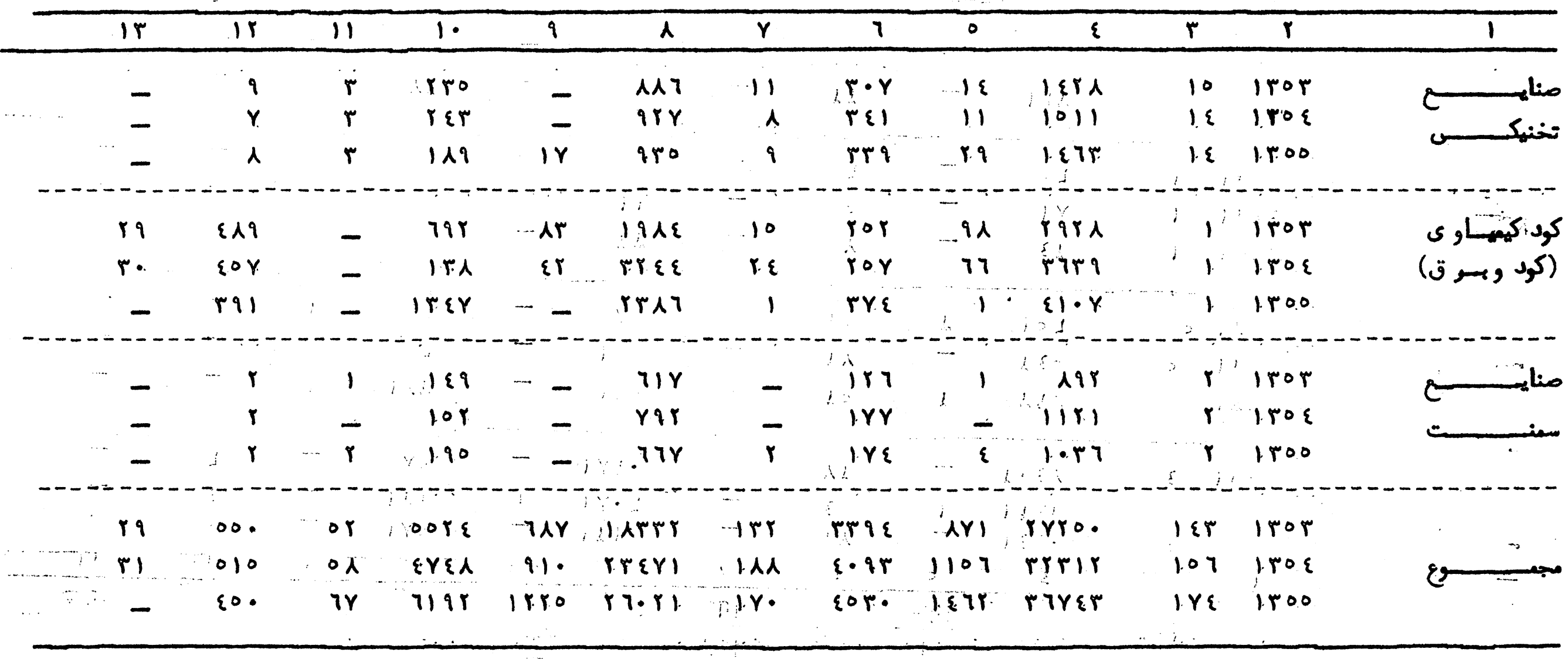




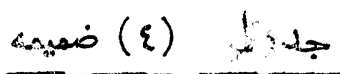

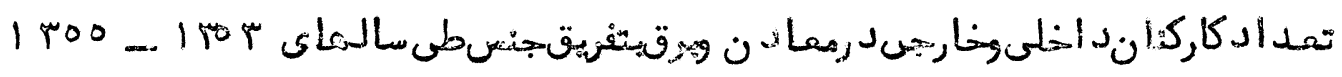

\begin{tabular}{|c|c|c|c|c|c|c|c|c|c|c|c|c|}
\hline \multicolumn{2}{|c|}{ كارك!ن خارجهـ ني } & \multicolumn{2}{|c|}{ سايرومستخلهمان } & \multicolumn{6}{|c|}{ 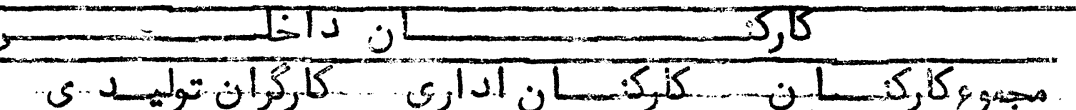 } & \multirow{2}{*}{ 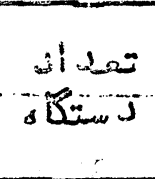 } & \multirow{2}{*}{\multicolumn{2}{|c|}{ 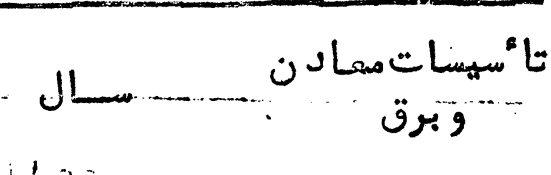 }} \\
\hline 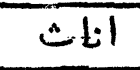 & ذكور & $=-1$ & ذكور & 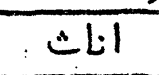 & .95 & 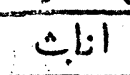 & .95 & 4 & زكور & & & \\
\hline 15 & II & $I I$ & 1. & 9 & 1 & $r$ & 7 & 0 & 9 & $r$ & $I$ & 1 \\
\hline - & $\varepsilon$ & - & 110 & - & $1 Y 11$ & - & $r r$ & - & $1 \varepsilon \xi$. & $\varepsilon$ & iror & مماد ن زغغـــال \\
\hline - & $\xi$ & - & irr & 1 & $11 \cdot 7$ & - & \&o & 1 & $19 \mathrm{ir}$ & $\varepsilon$ & irog & \\
\hline - & 7 & - & 10 & - & 119 & - & rr. & - & $r \cdot \varepsilon r$ & $\varepsilon$ & 1.500 & سنـف \\
\hline - & - & 1 & irr & - & 190 & 1 & ro & $r$ & rqr & 。 & iror & \\
\hline - & - & - & \{\rceil & - & ivr & - & $r Y$ & - & $r \varepsilon 0$ & ○ & 1rog & مماكَن ن نعــــك \\
\hline - & - & $r$ & $\varepsilon \gamma$ & - & $\lambda \varepsilon$ & 1 & ro & $r$ & 107 & $\circ$ & 1000 & \\
\hline - & - & - & 18 & - & r & - & $r$ & - & ६ & 1 & irot & \\
\hline - & - & - & $r$ & - & 11 & - & - & - & 11 & 1 & 1rog & لاجس \\
\hline - & - & - & $r$ & - & 1 & - & 7 & - & 1.7 & 1 & 1500 & \\
\hline- & - & - & $r r$ & - & 99 & - & tr & - & 194 & 1 & iror & \\
\hline - & - & - & $r \mu$ & - & 19 & - & 17 & - & 1Tru & 1 & 1 To\& & 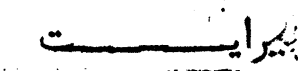 \\
\hline & $=$ & $=$ & 11 & $=$ & 11 & $=$ & 1.8 & - & 1.9 & $=-1$ & $\begin{array}{l}1,500 \\
==-1\end{array}$ & 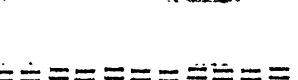 \\
\hline - & - & - & 0. & - & $10 \%$ & - & $1 \varepsilon$ & - & rir & 1 & iror & \\
\hline - & - & - & Ir & - & 101 & - & $1 \varepsilon$ & - & $1 \wedge \varepsilon$ & $r$ & $1, r 0 \varepsilon$ & 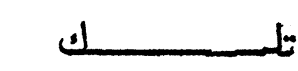 \\
\hline - & - & - & 11 & - & $1 Y \wedge$ & - & 11 & - & r) & $r$ & 1,500 & \\
\hline
\end{tabular}


$-17$.

اد أمه جل ول (ع) ) ضميده

\begin{tabular}{|c|c|c|c|c|c|c|c|c|c|c|c|c|c|}
\hline 15 & Ir & 11 & 1. & $\overline{9}$ & $\bar{\lambda}$ & $\gamma$ & 7 & 0 & & $\varepsilon$ & $r$ & $r$ & 1 \\
\hline- & - & $\varepsilon$ & 917. & $\dot{-}$ & Yᄉr & $r$ & 09 & & 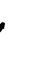 & $0.0 Y$ & & is ror & . \\
\hline- & 10 & $\rightarrow$ & $A 1$ & $r$ & ry & $\varepsilon$ & rro. & $\gamma$ & 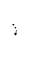 & $70 r$ & 1 & 1ros & \\
\hline- & $Y \cdot$ & - & $r \gamma$ & - & r77 & $r$ & 107 & $r$ & & 099 & 1 & 1.100 & \\
\hline
\end{tabular}

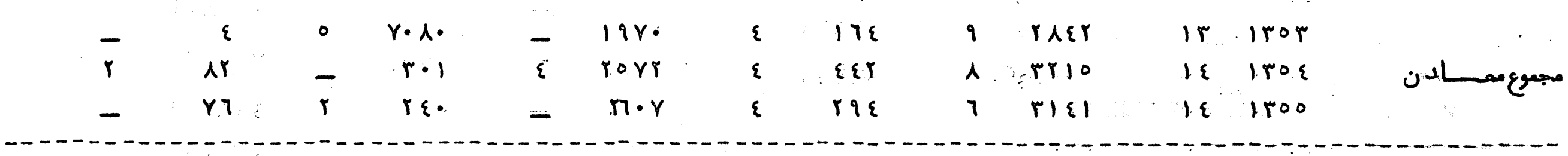

\begin{tabular}{|c|c|c|c|c|c|c|c|c|c|}
\hline - & ir & $r$ & $\varepsilon \cdot \lambda$ & - & $Y_{1} \cdot$ & $\varepsilon$ & $Y 70$ & $7 \cdot$ IrAr & 17 iror \\
\hline r & 10 & $\varepsilon$ & - rrq & Y & $r \cdot 1$ & $\varepsilon$ & $Y \varepsilon \varepsilon$ & $1 . . \operatorname{lrr} \varepsilon$ & $11 \quad 1.0 \varepsilon$ \\
\hline & Ir & - & 10. & 1 & $9 \gamma \lambda$ & 1 & $\varepsilon r q$ & $1.0 \cdot r$ & r. troo \\
\hline
\end{tabular}

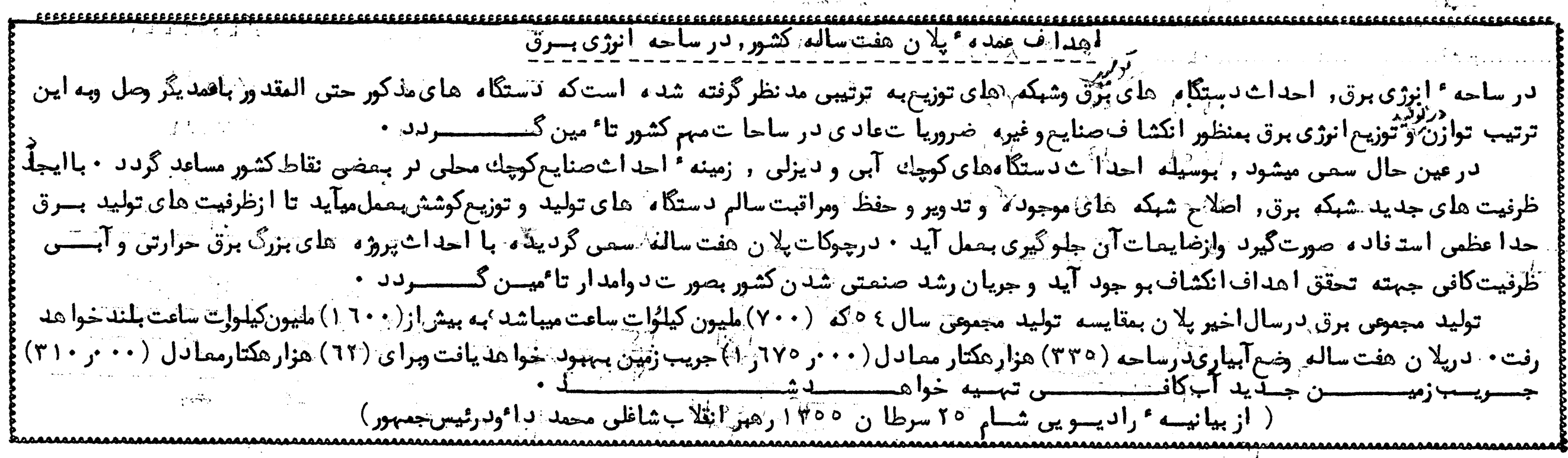


(1 71)

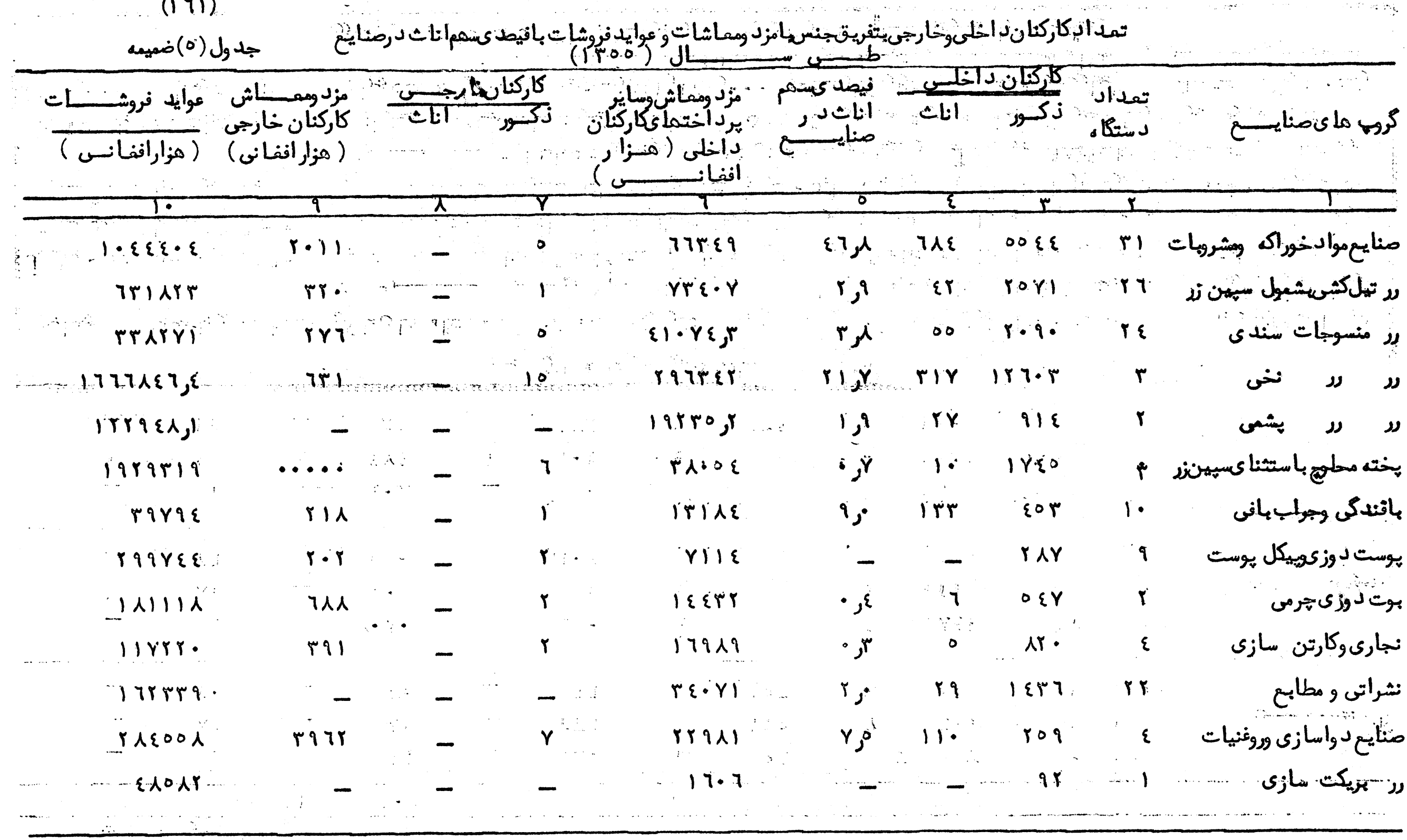


$-17 r$

اد امه جدول (0) ضميعه

\begin{tabular}{|c|c|c|c|c|c|c|c|c|c|}
\hline 1. & 9 & $\lambda$ & $Y$ & 7 & 0 & $\varepsilon$ & $r i$ & $r$ & 1 \\
\hline rrq⿻YA & \&rT & - & $r$ & $\| R$ & • & T. & orr & $1 r$ & منايح هلا ستهك سازى \\
\hline 17 1 7 & $1 \varepsilon$ & - & 1 & olir & - & - & $r \cdot r$ & $r$ & لد مززائك و حجارى \\
\hline rolror & $r \cdot r r$ & - & $\lambda$ & rirgo & $r$ & 19 & $1 \varepsilon 7 \%$ & $1 \varepsilon$ & ر رتخنيكــس \\
\hline Tr人i\&o & $\cdots$ & - & rql & דוד & ار • & 1 & $\{1 \cdot \gamma$ & 1 & נر كودكيهاوى(كود وهرق) \\
\hline IAY. Tr & 1117 & - & 4 & riqur & نr & $\varepsilon$ & $1 \cdot r 7$ & $r$ & 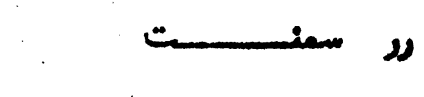 \\
\hline$\wedge)\{\varepsilon q \varepsilon \cdot 0$ & Irrgis & - & $\{0\}$ & VA\&०१४, & $1 \cdots$ & $1 \varepsilon \pi$ & r & $\int \gamma \varepsilon$ & \\
\hline
\end{tabular}

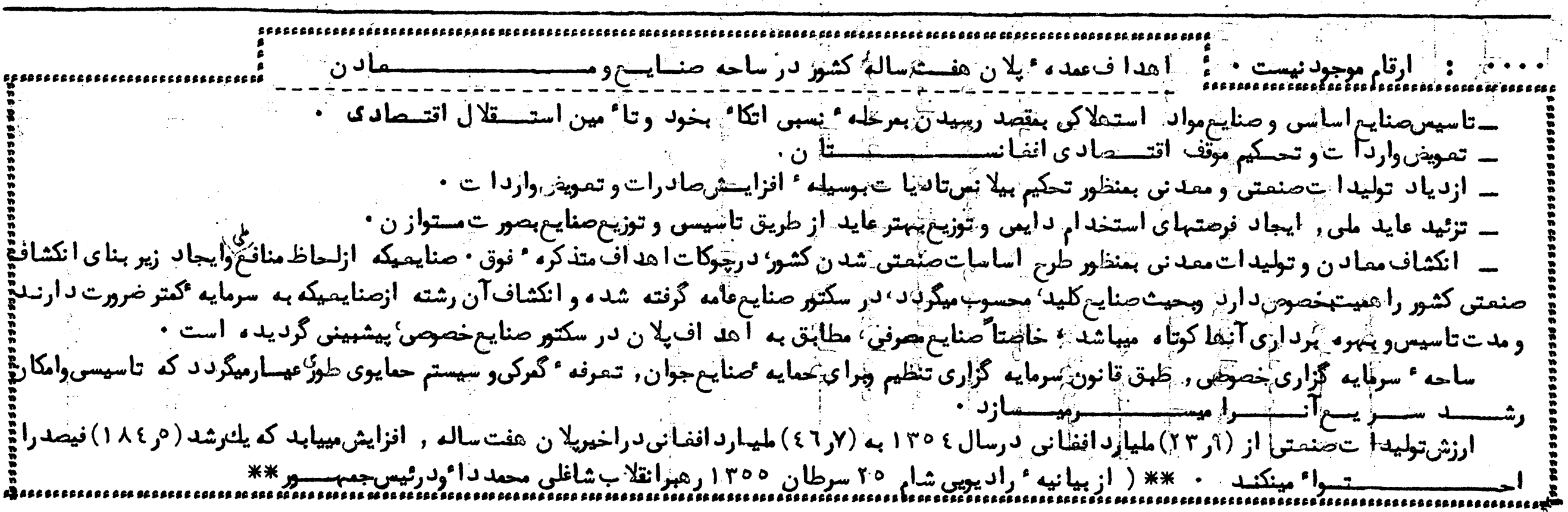




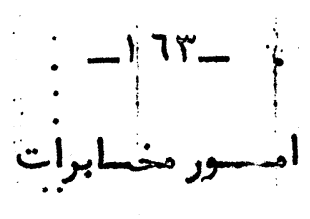

\section{ニニニニニニニ}

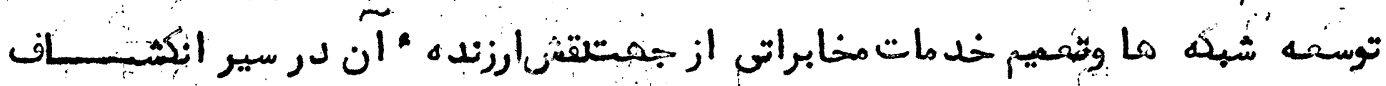

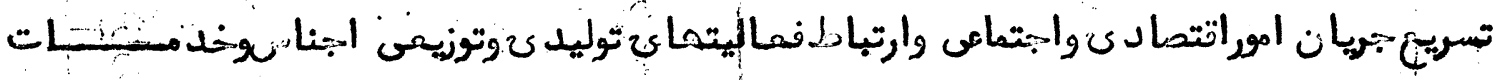

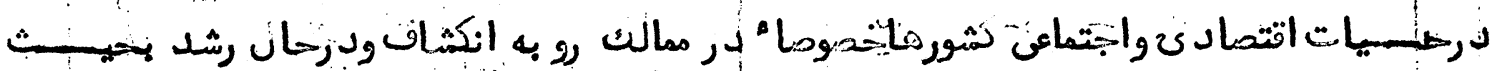

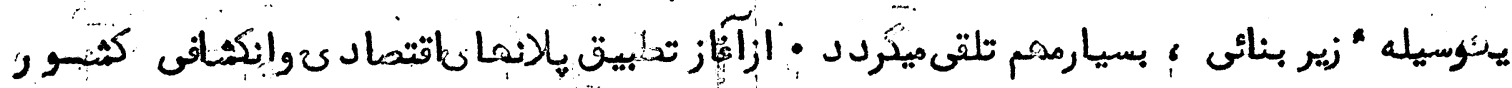

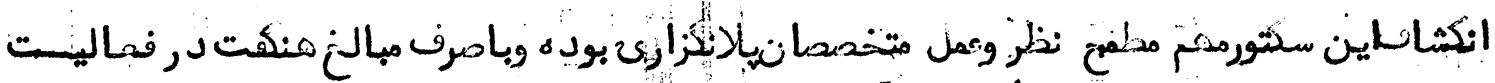

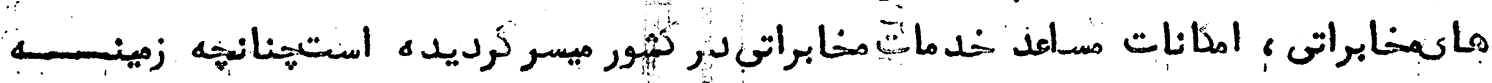

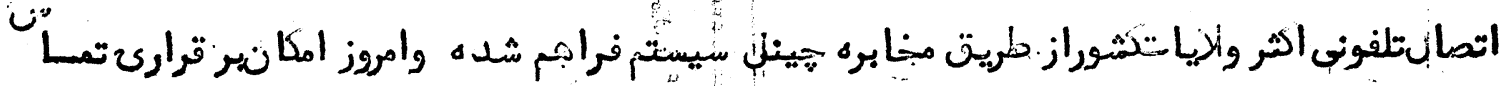

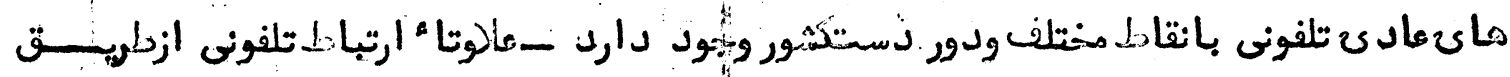

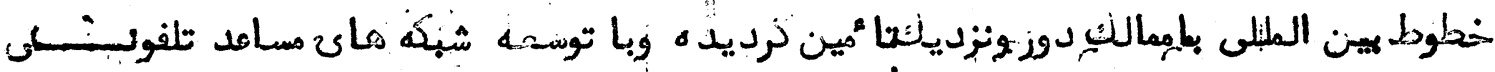

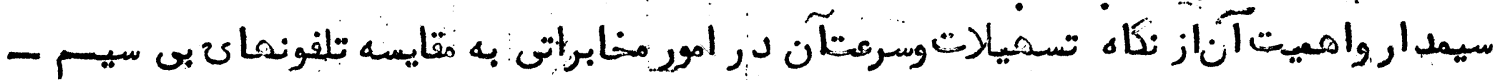

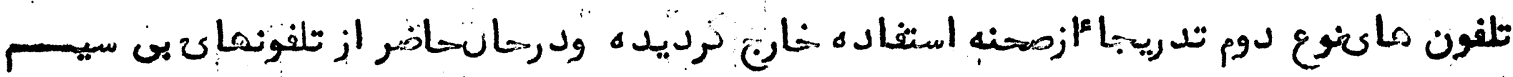

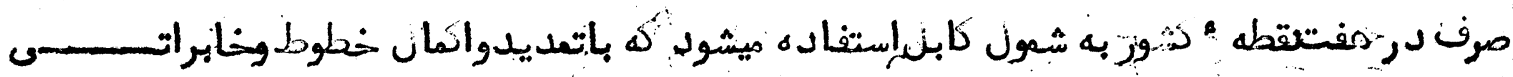

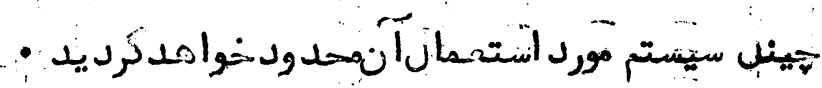

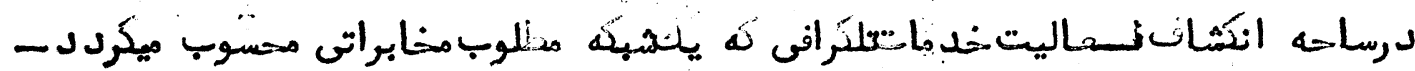

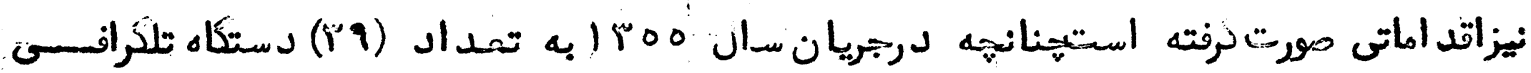

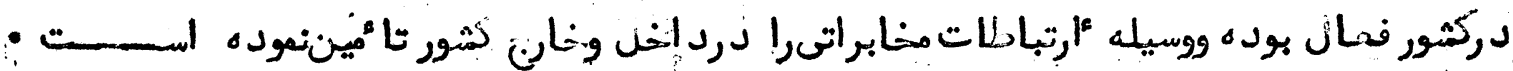

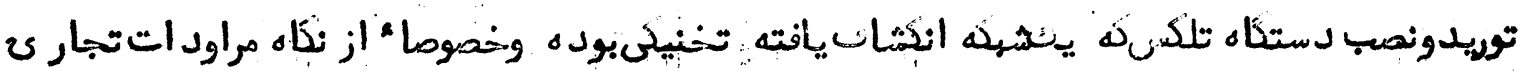

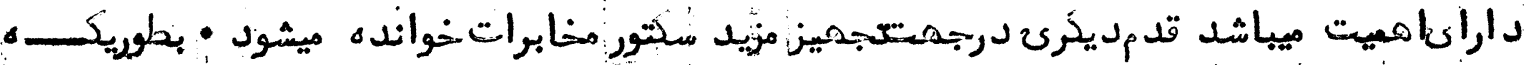

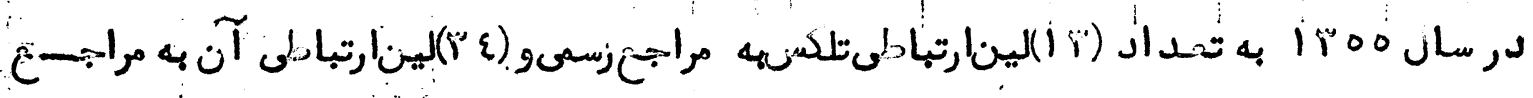
خصوصى توزيخ خديده است

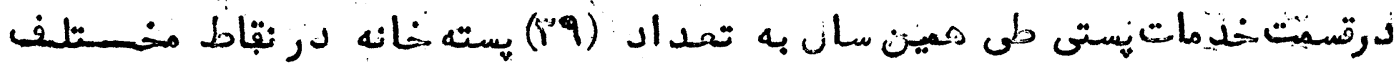

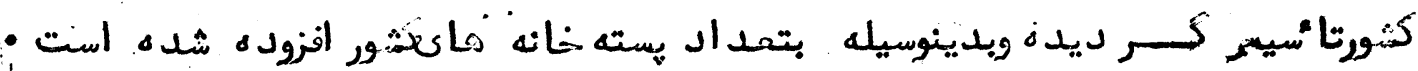

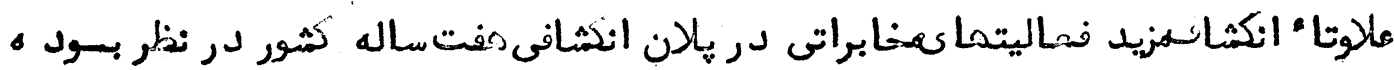

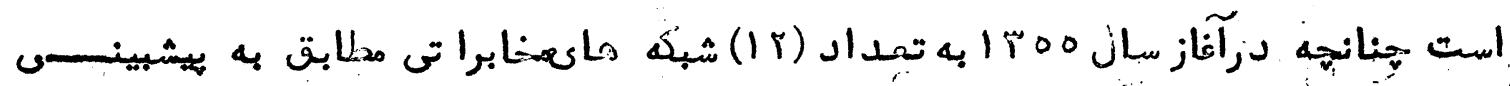

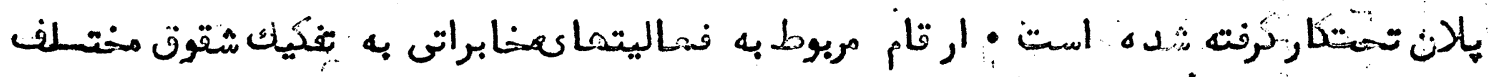
زيلاء ارائه ميكردد :

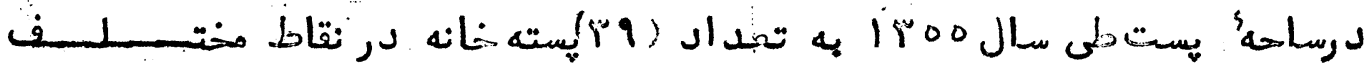

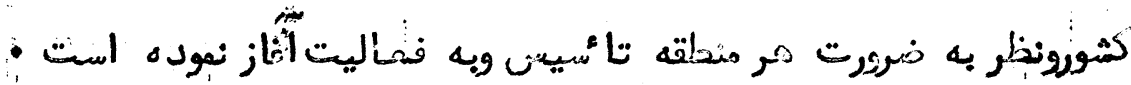




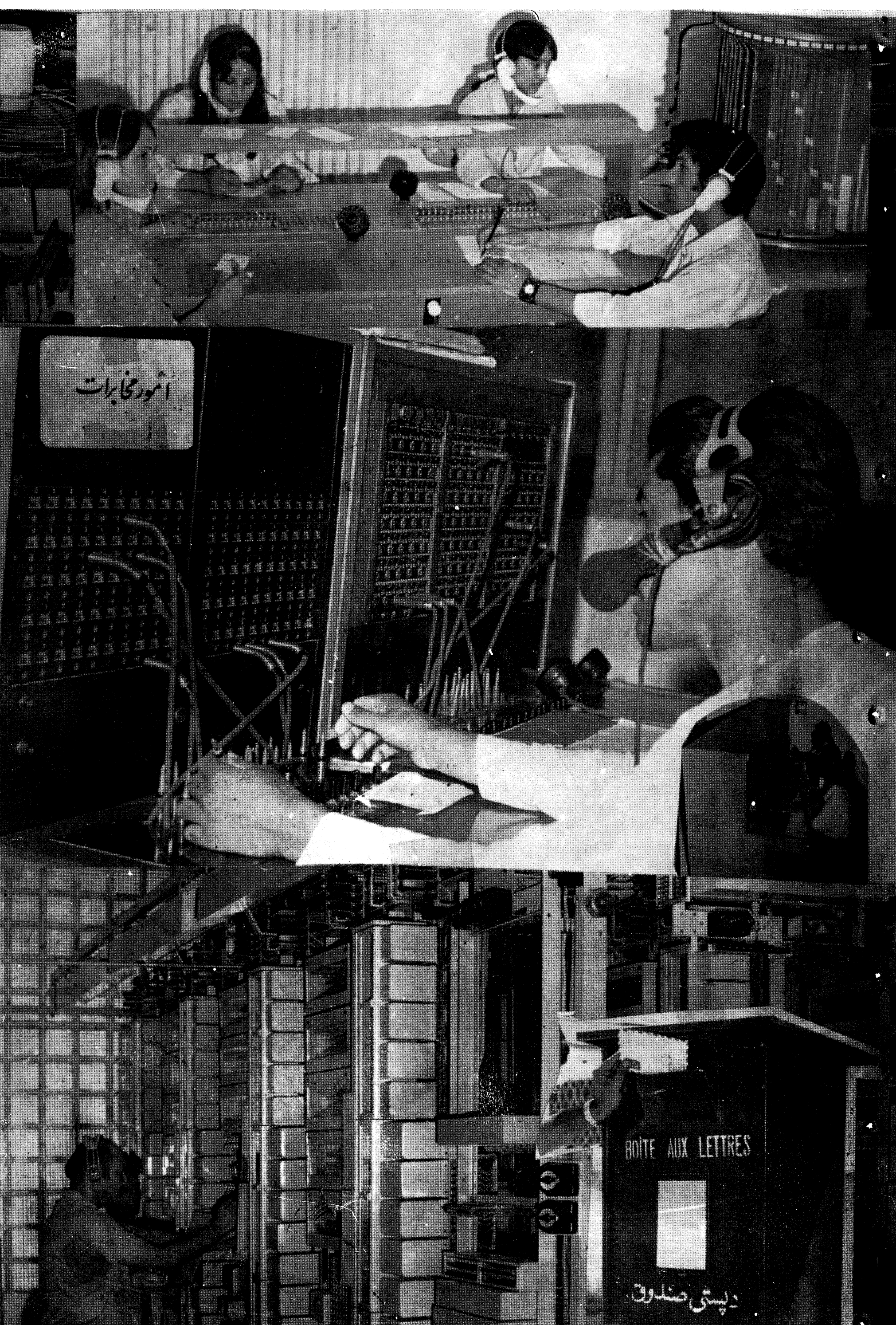




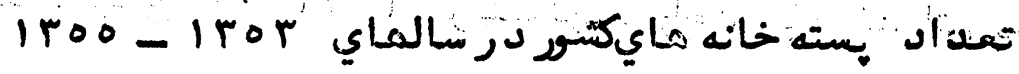

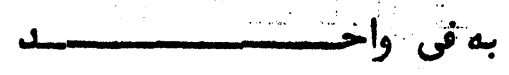

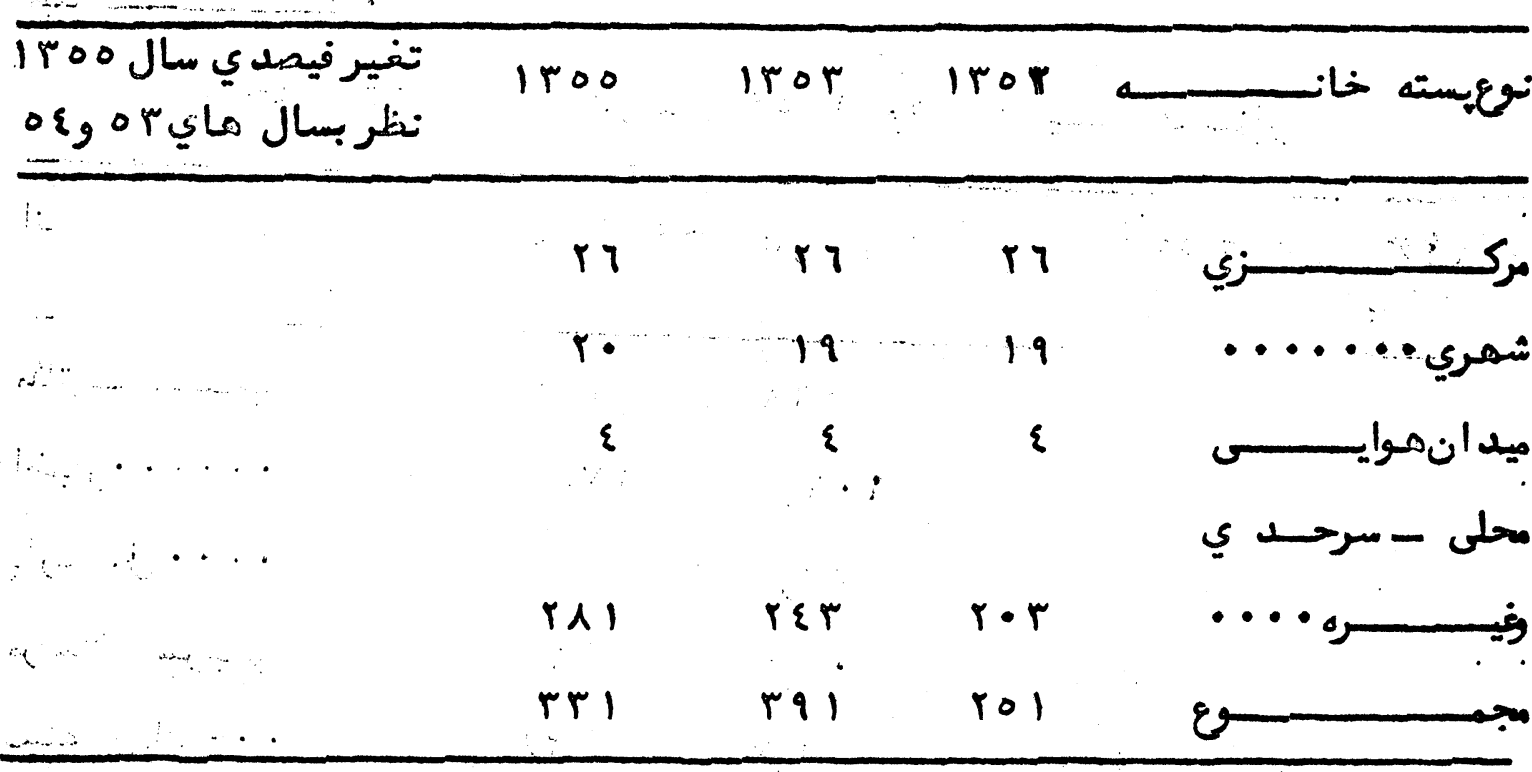

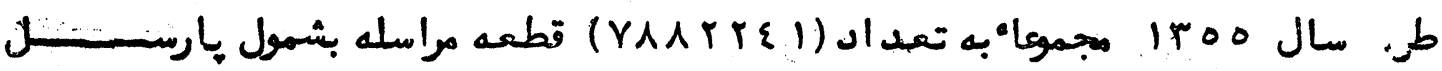

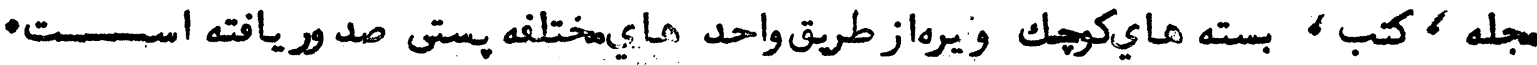
اين رقمدر مقايسه باسال قبل ياءتزائد رجو فيصد رانشان مى لدمد -

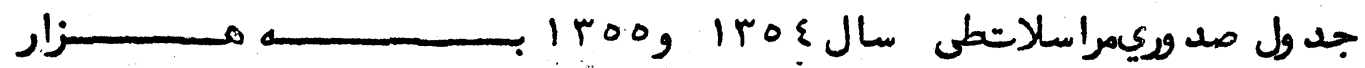

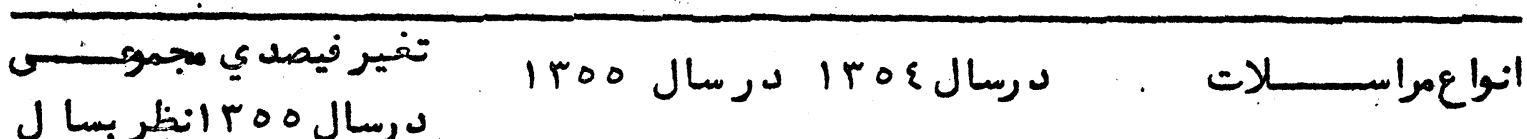

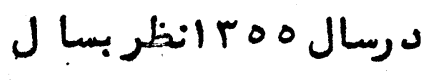

I ros

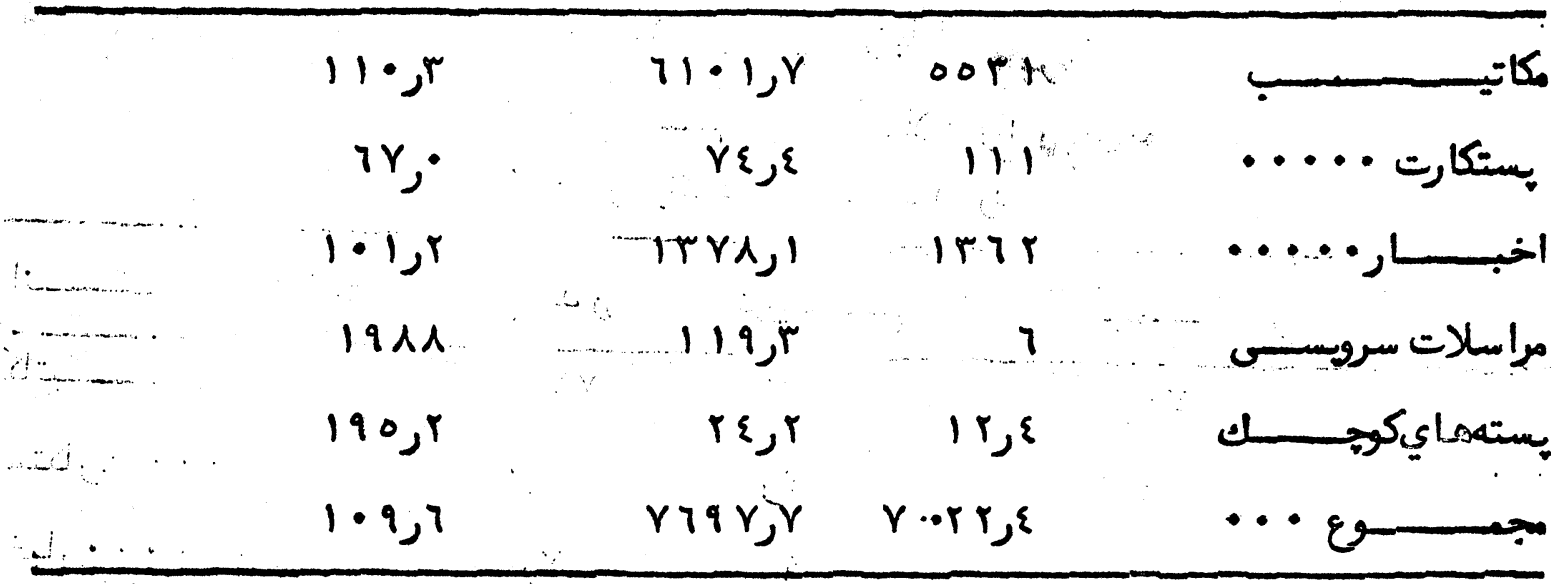

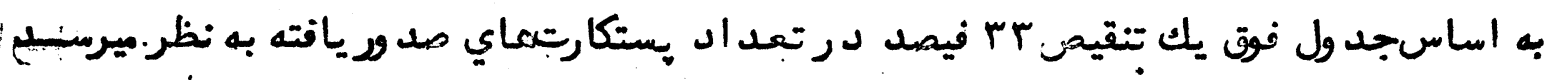

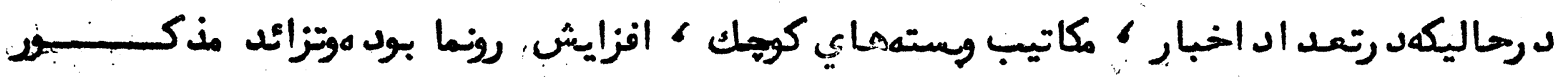
درتعد اد مرابلاتسرويسى قابل ملاحثلميباشد -

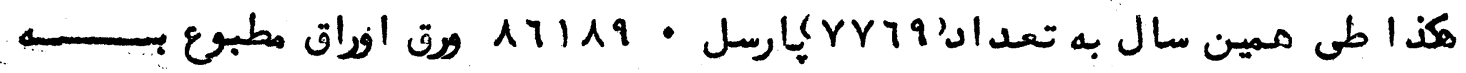

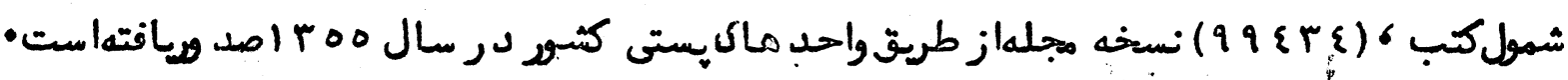




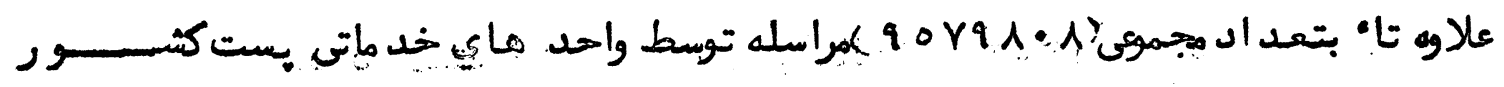

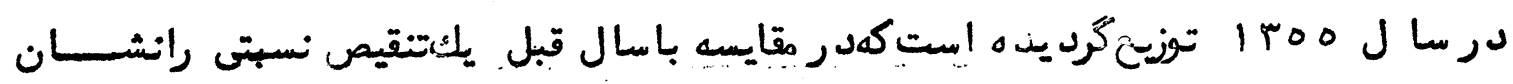

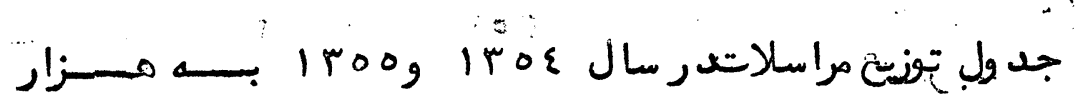

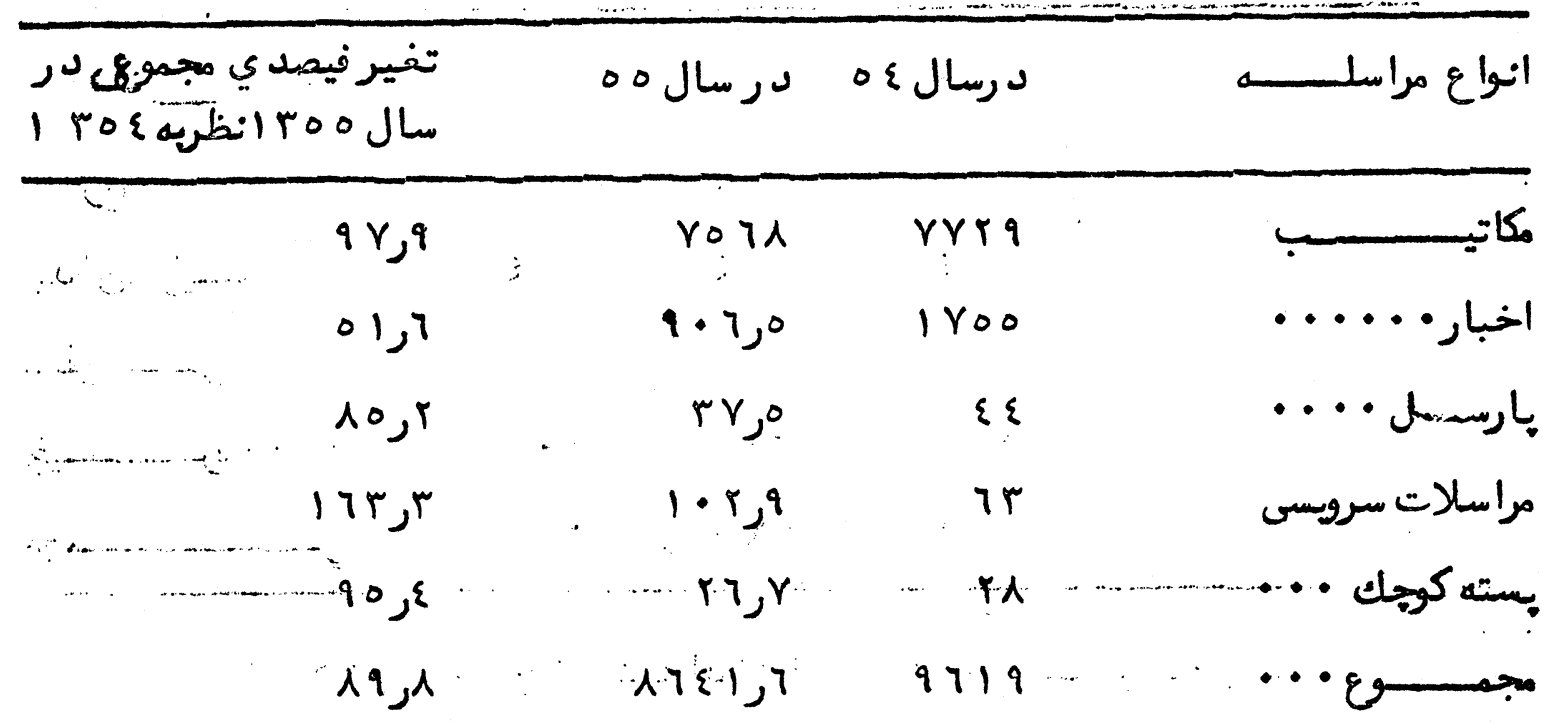

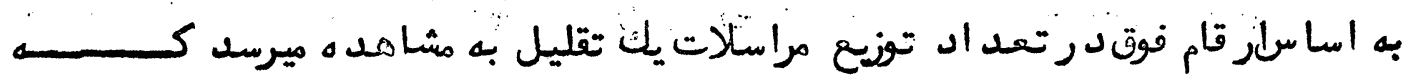

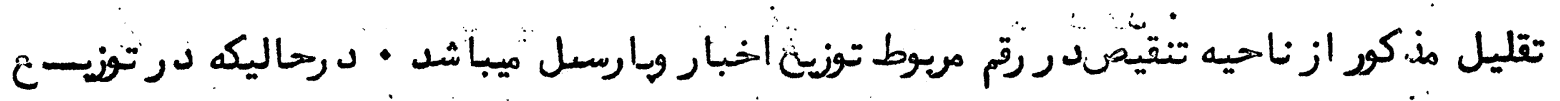

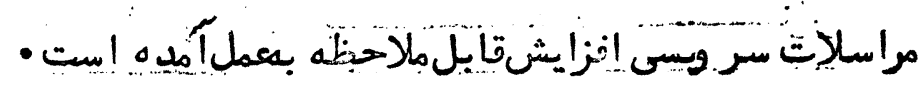

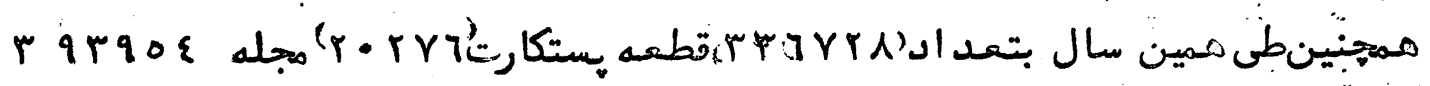

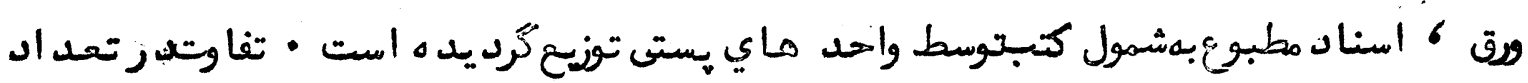

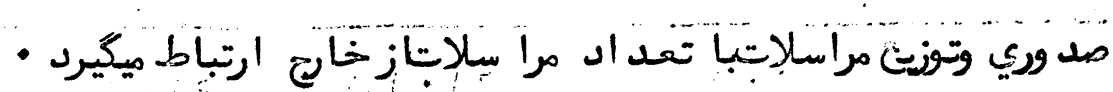
جد ول . ذيل فيمدي إسبهم انواعمراسلات را در مجموع توزبح . .

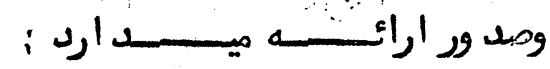

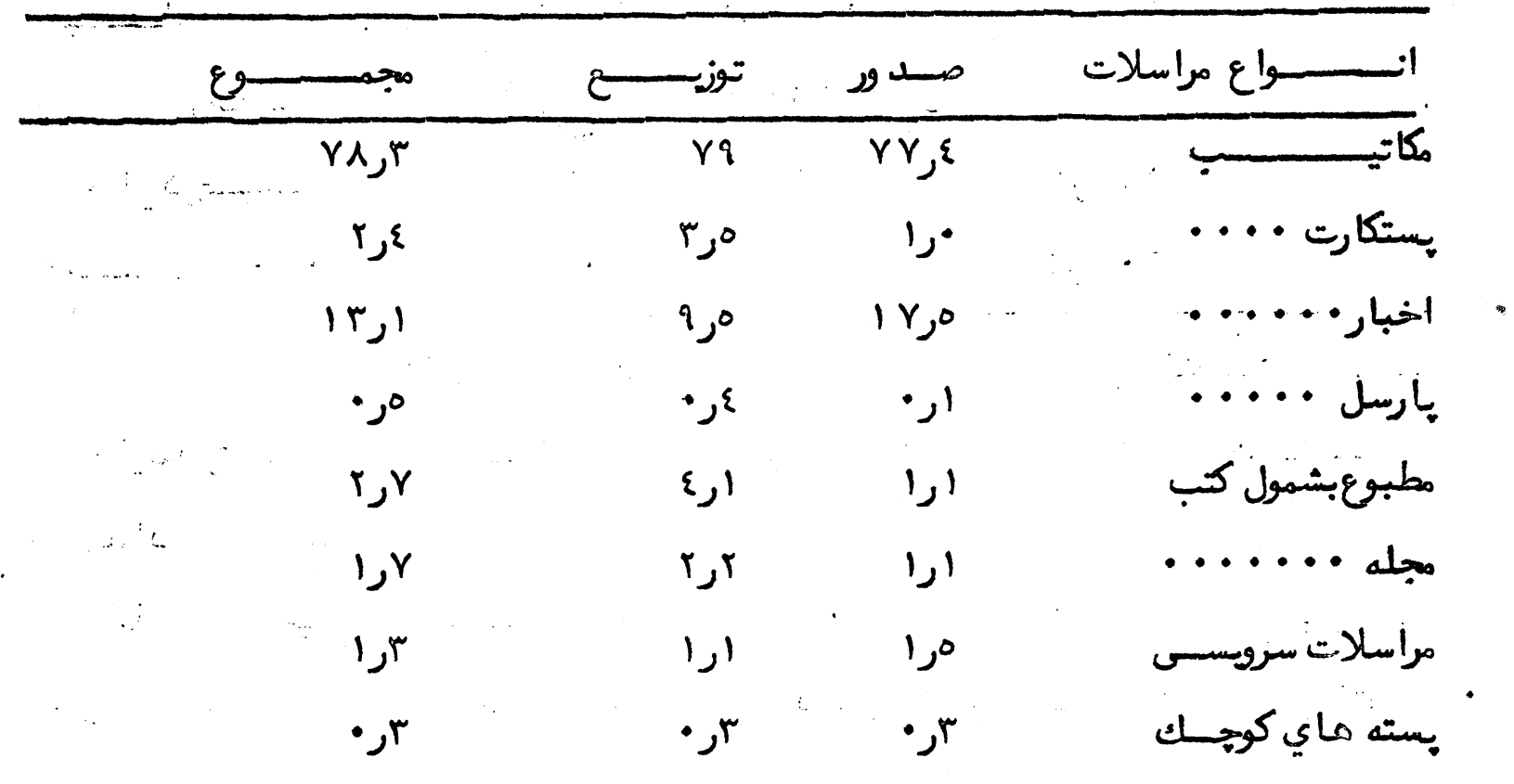




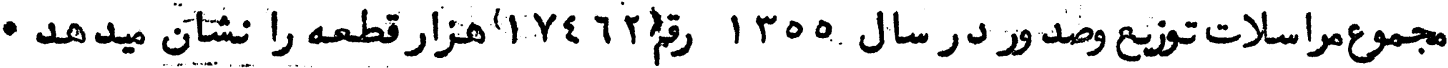

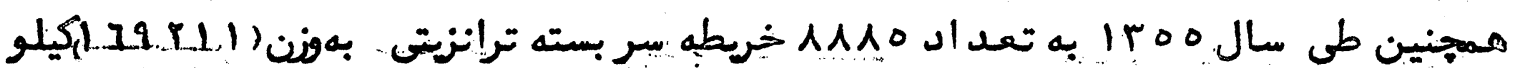

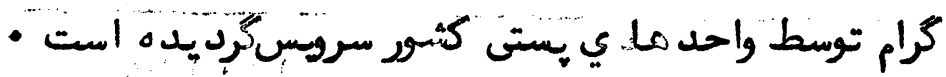

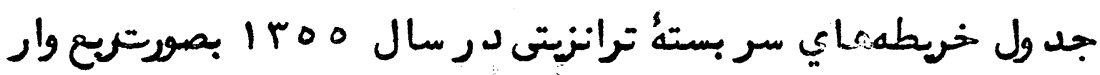

\begin{tabular}{|c|c|c|c|c|c|c|}
\hline \multirow{2}{*}{ كيلوكرا م- } & \multirow{2}{*}{ تخديطة } & \multicolumn{2}{|c|}{ ازباكستـــان به مسكـــــو } & به هاكستان & ازمسكــو & \\
\hline & & فن فيكيوكرام & تعد ادخريطه & وزنبسكيلوكرام & تعد اد خريطه & \\
\hline$\varepsilon \cdot 10 q$ & $r \cdot 01$ & ro^ & $1 \% 7$ & rrovo & 1910 & ريع اول \\
\hline$\{0 \cdot 0 \gamma$ & $r\{\mid r$ & $r q \cdot r$ & $10 \%$ & \& $\{100$ & TrY. & ريع دم \\
\hline$\varepsilon \% \cdot 0 \cdot$ & TrTt & $\{\xi \wedge\}$ & TrT & r1017 & $r \cdot r \cdot$ & إس سم \\
\hline$\varepsilon \bullet 9 \leqslant 0$ & $\$ 100$ & 1070 & iro & rore. & $r \cdot r \cdot$ & \\
\hline 19911 & & Iros. & 77. & 10.7781 & Arro & \\
\hline
\end{tabular}

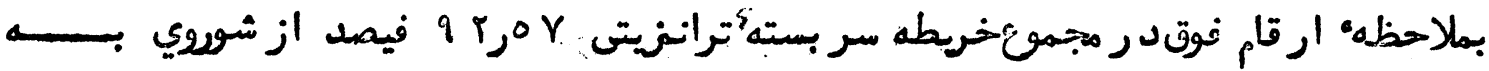

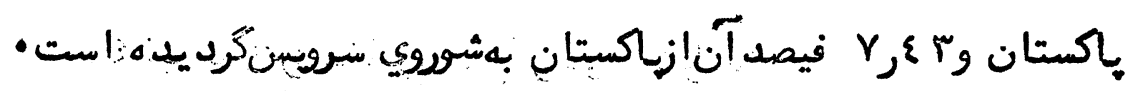

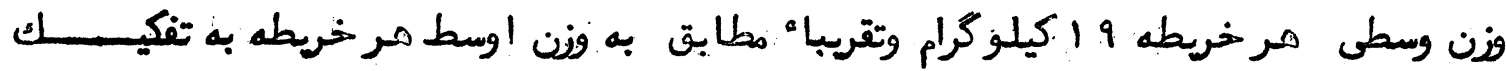
- مملكتميباشد من

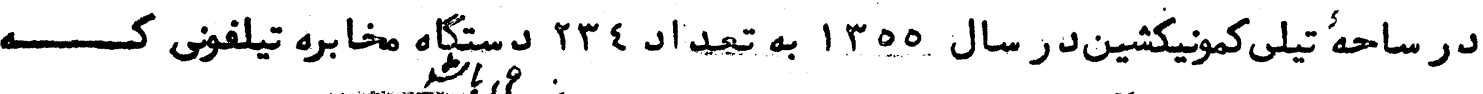

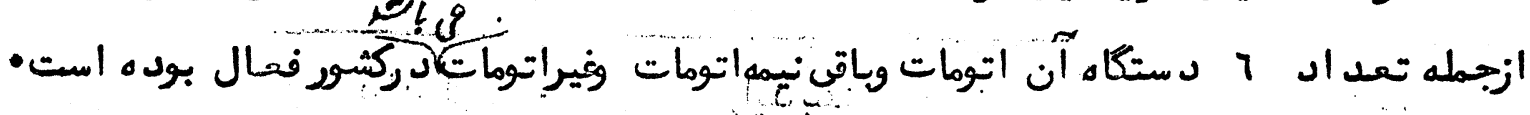

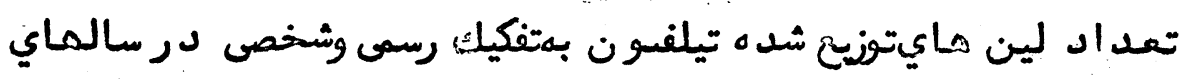
ميبا

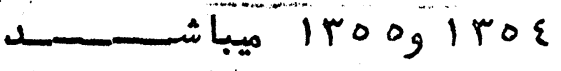

مشتركسينتيلفون

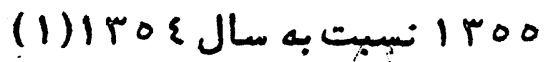

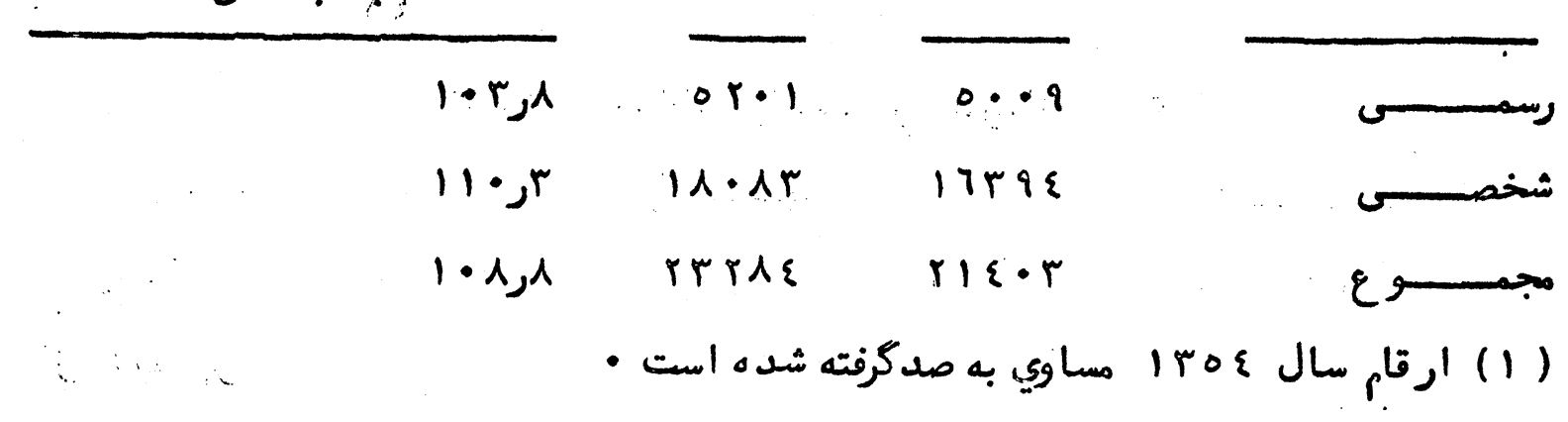

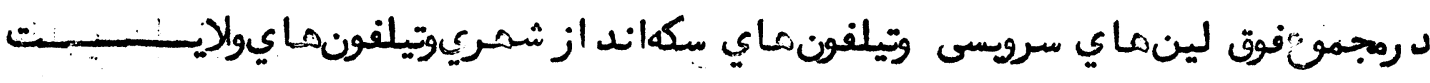

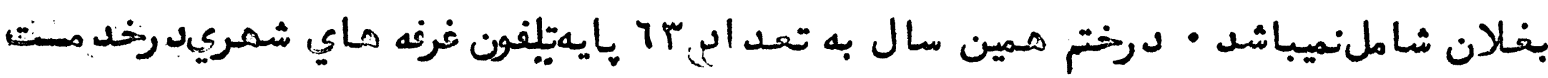

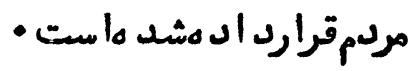




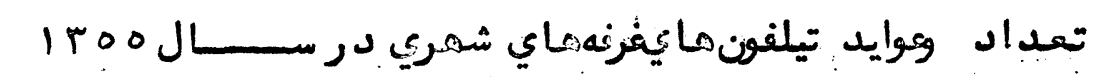

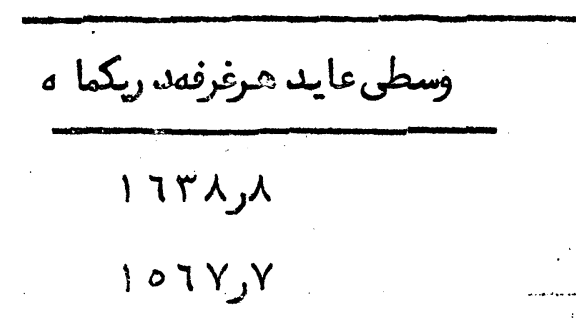

$Y>\varepsilon, 0$

$17 \cdot 7,5$
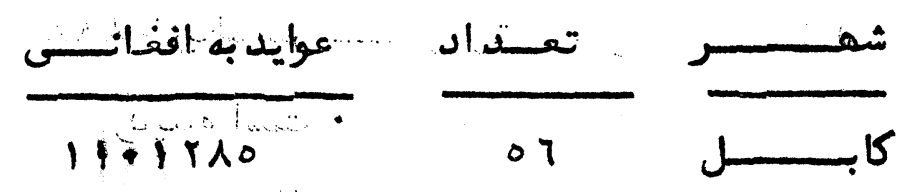

$0 T \varepsilon r+\quad r$

مســر ات

lirs?

(t) $\quad$ in...in

r

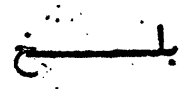

$-$

$|1 \times 7 \cdot 8|$

it

بر.

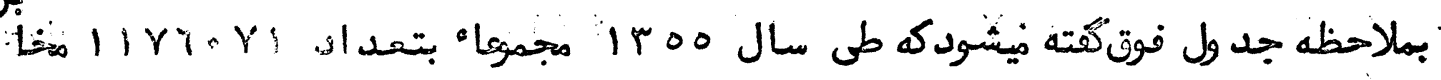

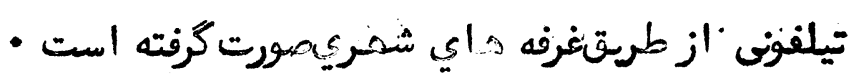

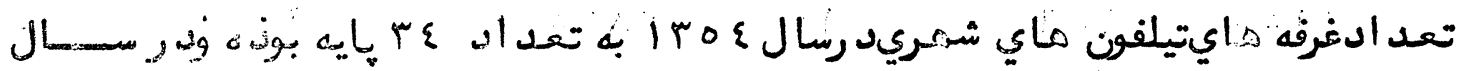
Iroo

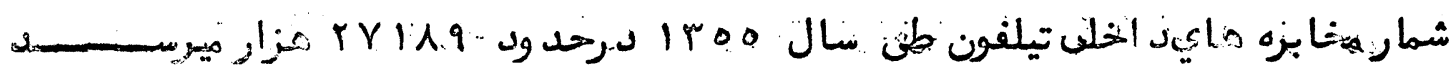

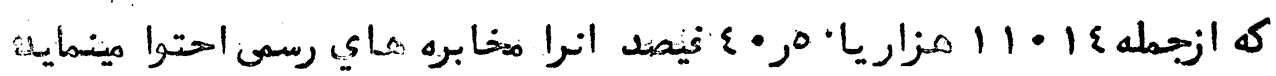

تمصيل

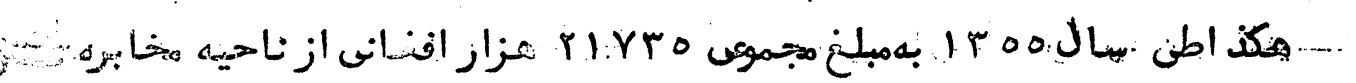

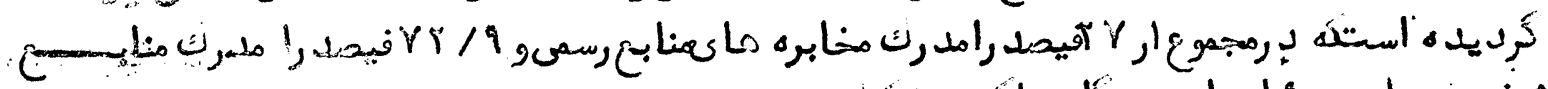

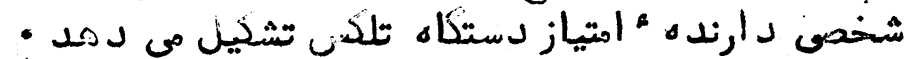

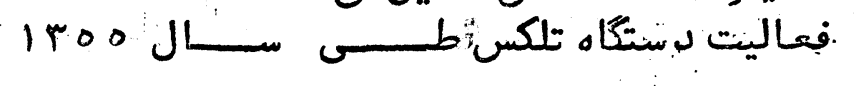

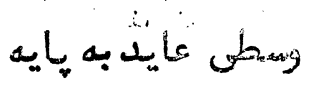

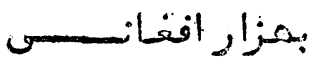

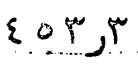

\&10,9

$\{? \tau, \varepsilon$
rIVTO

$019 r$

10入 $r_{0}$

تعد اد لين بنايه

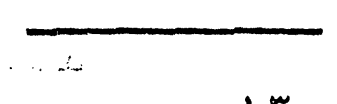

منابع رسمى . ........

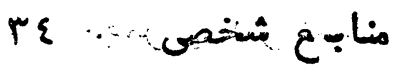
$\varepsilon \curlyvee$

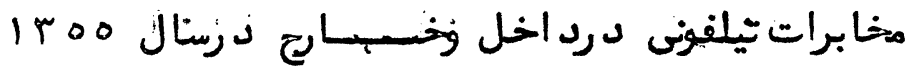

S1

rYil?

$1101 \varepsilon$

17180

\{०

พ人ᄉ1

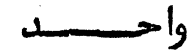

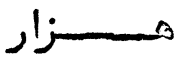

ענ

لע

עل

$\mu$
نسيسو ع هخابسره

مخابردتيلفونى درد اخل

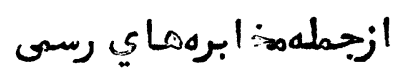

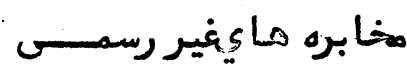

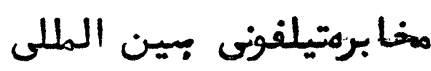

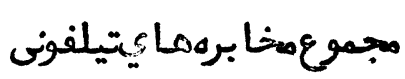




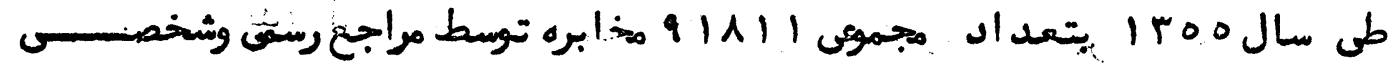

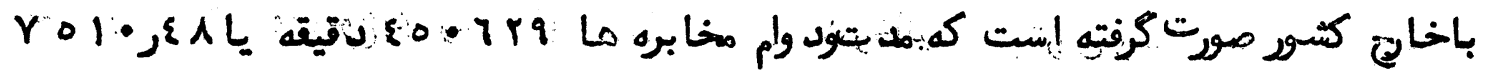

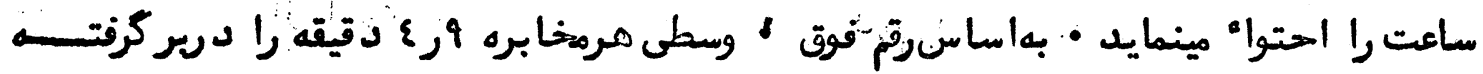

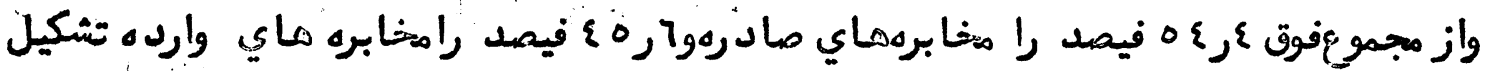

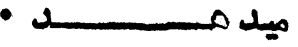

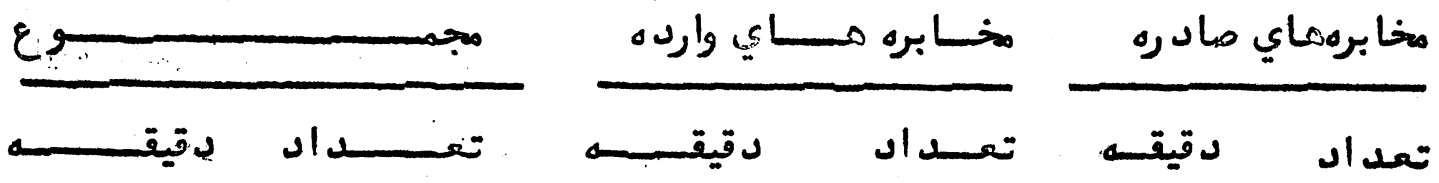

$$
\begin{aligned}
& \text { \&0.7rq q|111 r.人q| }
\end{aligned}
$$

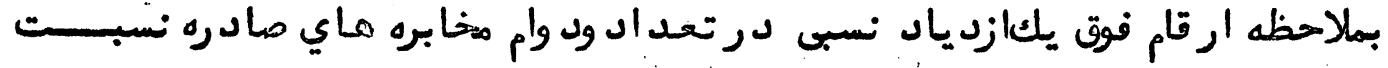

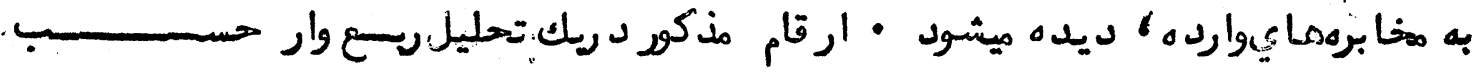

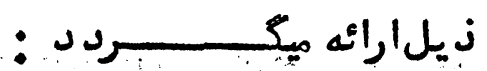

$$
\begin{aligned}
& \text { تعد اد منابرات تيلفونى ودوام ان بــــ } \\
& \text { تفكيك مر ريس }
\end{aligned}
$$

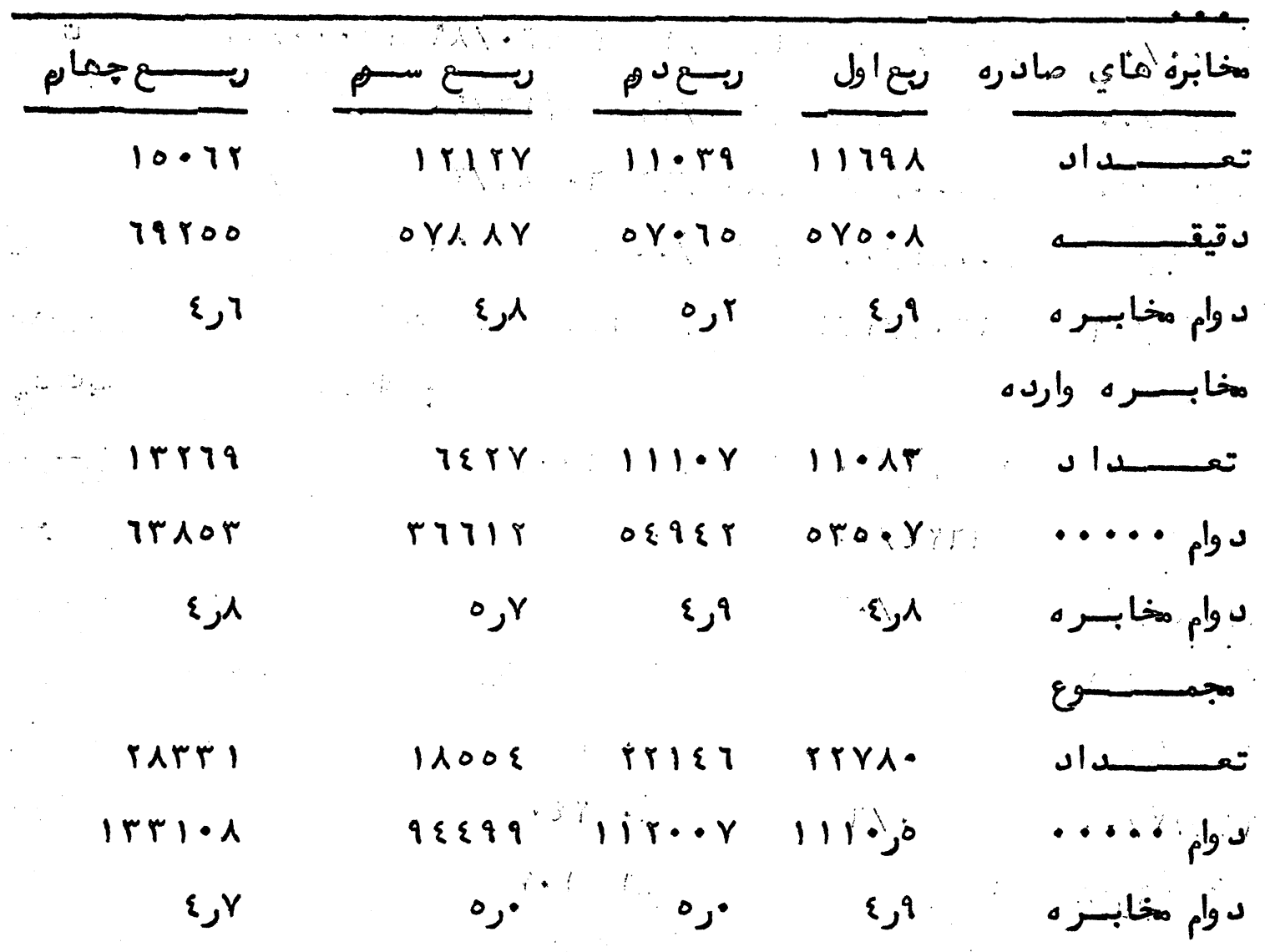




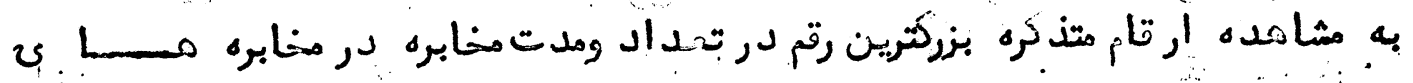

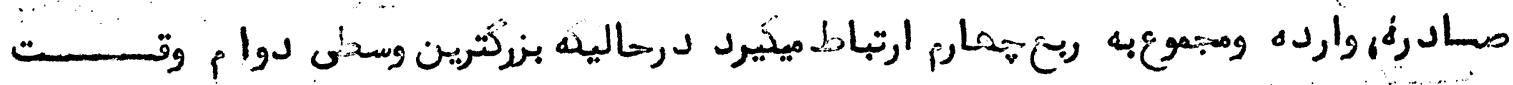

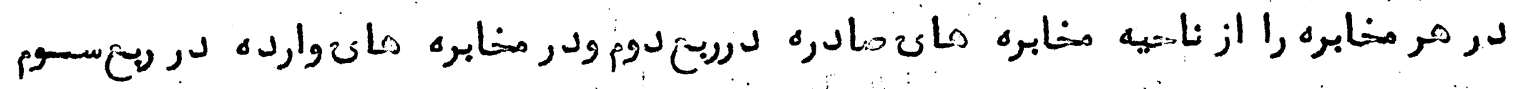

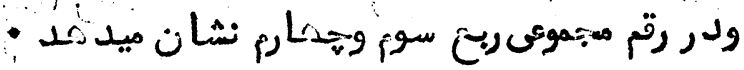

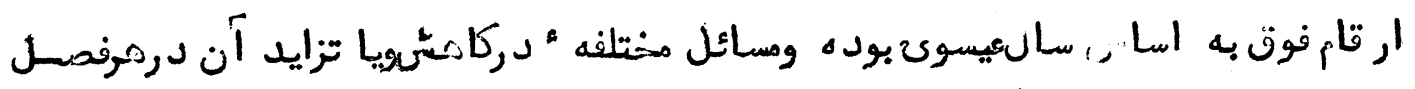

$$
\text { : بلان }
$$
تاثي

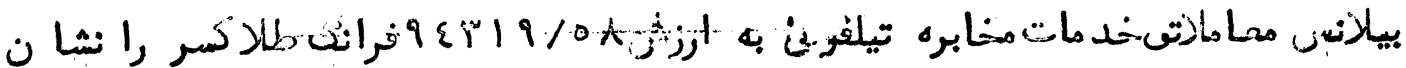

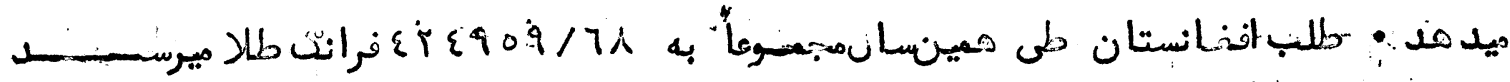

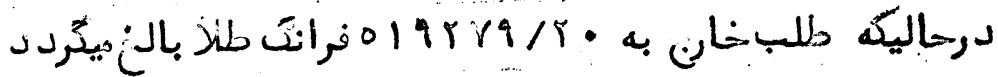

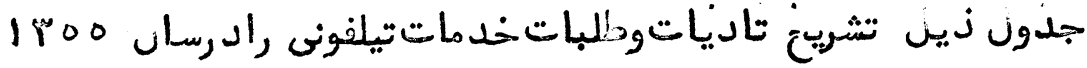

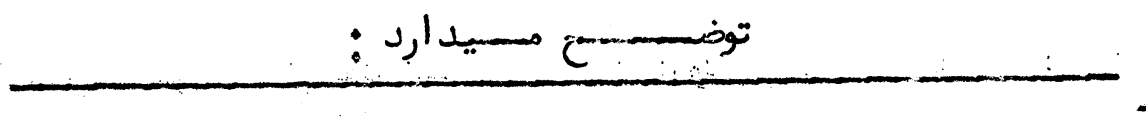

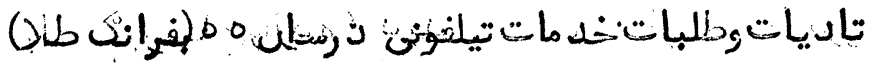

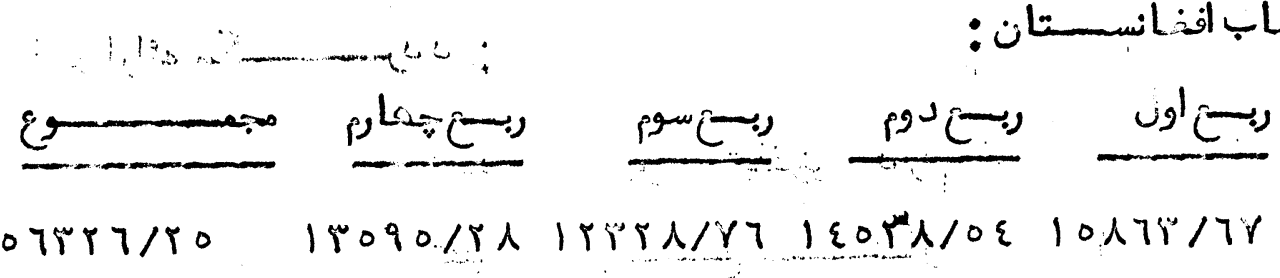

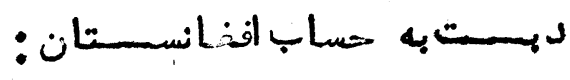

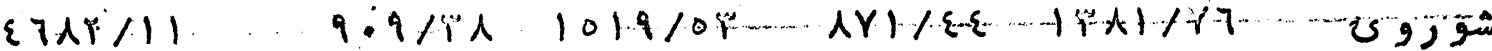

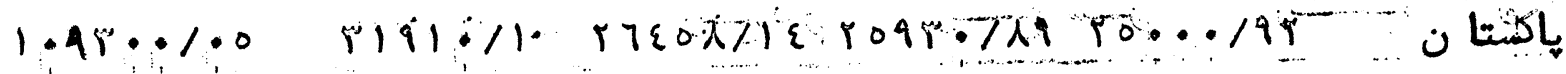

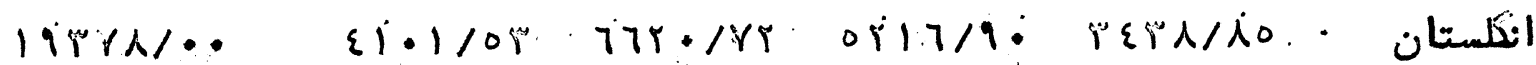

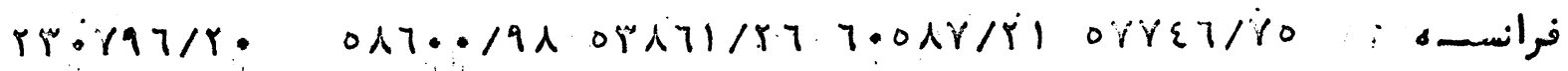

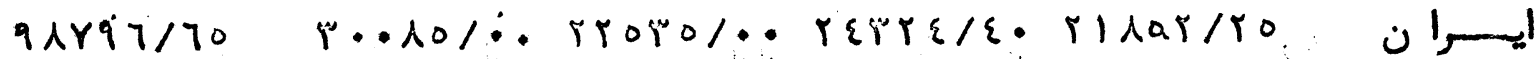

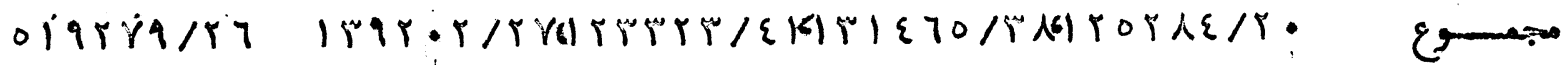

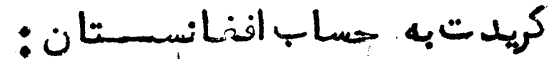

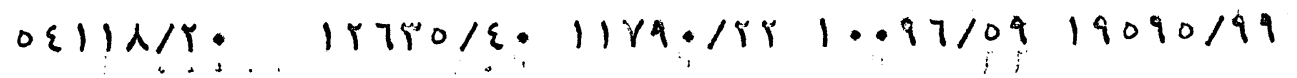

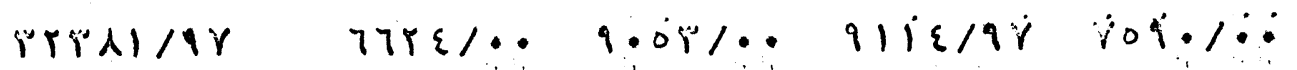

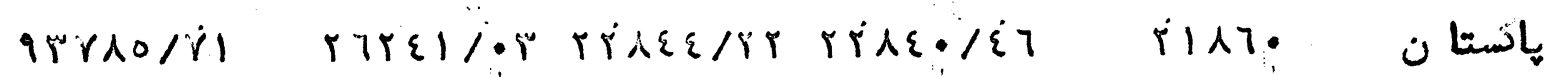
ا人70广/01 P101/11

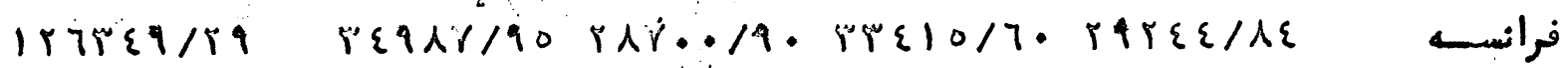

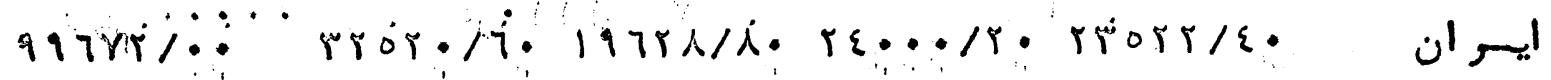

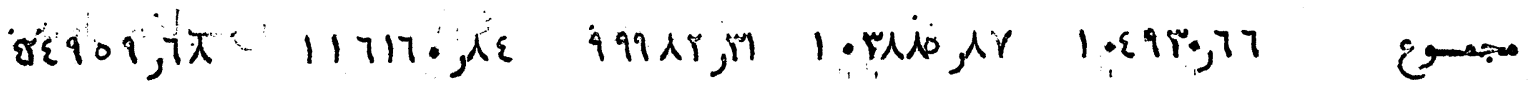

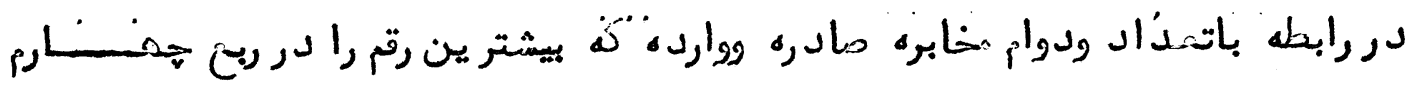




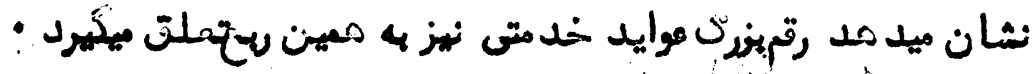

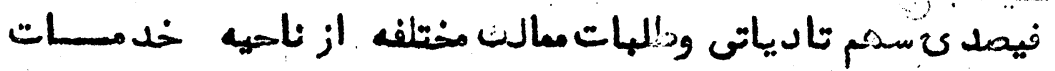

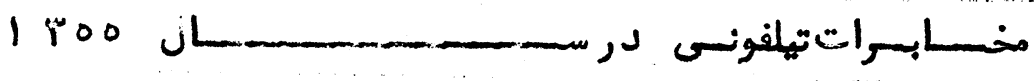

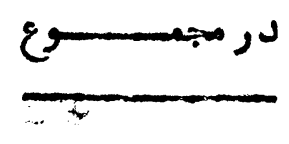

$11 / r$

$r / 9$

$Y 1 / 0^{\circ}$

$\varepsilon / 1$

rr/A

$Y 1 /$

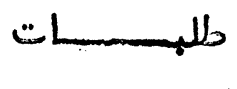

$18 / 8$

$8 / 7$

$Y Y / I$

$\varepsilon / \varepsilon$

$59 / 8$

$r i / r$
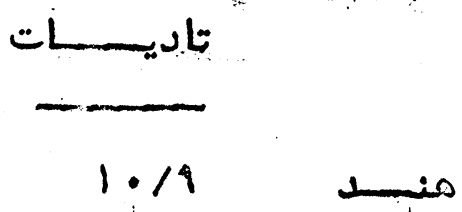

شور و كن

YI

باكستان

ill انsis

$\varepsilon \varepsilon / \varepsilon$

$11 /$
فرانســ

ايسمسران

به اساسار قأرفوق بيشترين رقم مماملاتى از ناحيه مخابره تيلفونى بانثورفرانسه درحاليكه

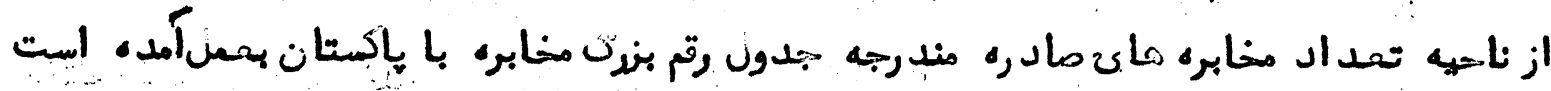

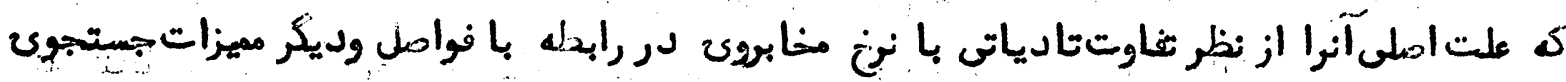

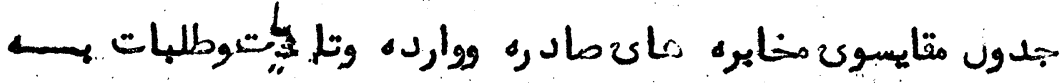
ميتوان كرد :

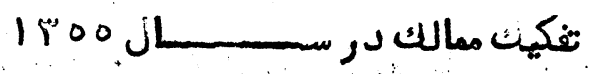

مخابرهادره: هنبوع

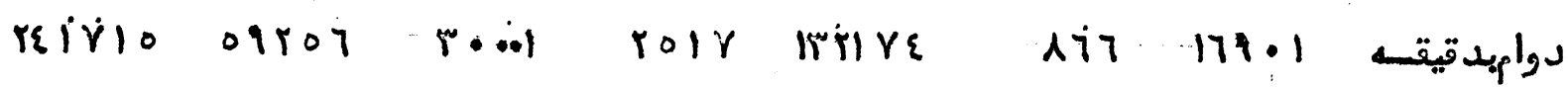

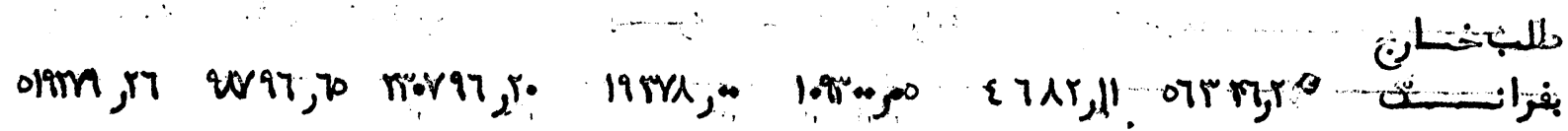
ElA10 IIrTY TrYO

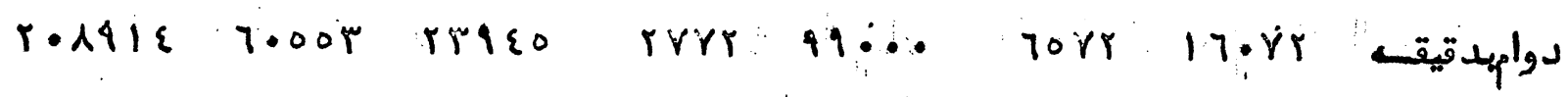
طلب بـالائ

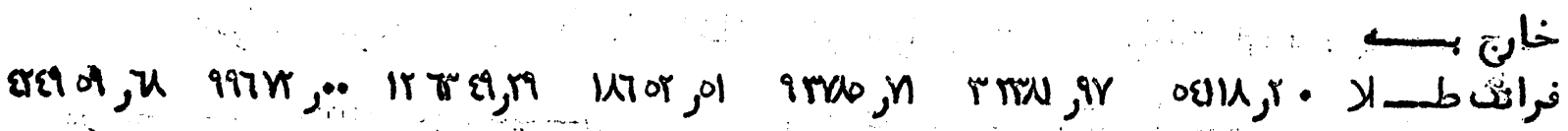




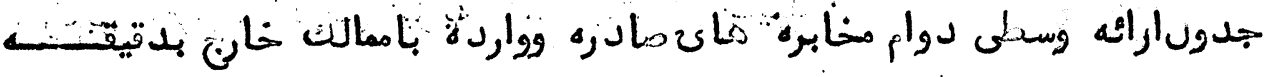

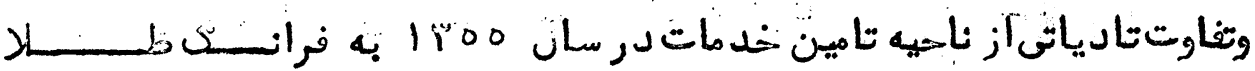

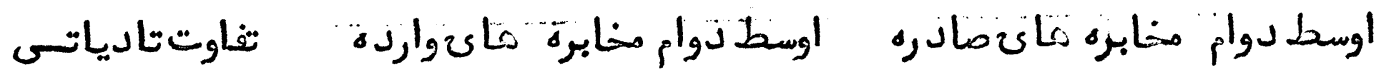

\begin{tabular}{|c|c|c|c|}
\hline$-r r \cdot \lambda / \cdot 0$ & $T / r$ & $0 / \varepsilon$ & $\cdots \cdots$ \\
\hline r8799/א7 & $0 / \varepsilon$ & $\varepsilon / 0$ & \\
\hline$\therefore-100 i \varepsilon / R \varepsilon$ & $\varepsilon / 0$ & $\varepsilon / \varepsilon$ & 18 \\
\hline - $r Y O / \varepsilon q$ & $7 / 5^{\circ}$ & $7 / r$ & \\
\hline$-1 \cdot \varepsilon \varepsilon \varepsilon 7 / 9 i$ & $r / r$ & $0 / 1$ & \\
\hline Pro/ro & $0 / 1$ & $0 ハ ゚$ & \\
\hline - $9 \varepsilon \% i \mid 101$ & $\varepsilon / 99$ & $\varepsilon / 1$ & \\
\hline
\end{tabular}

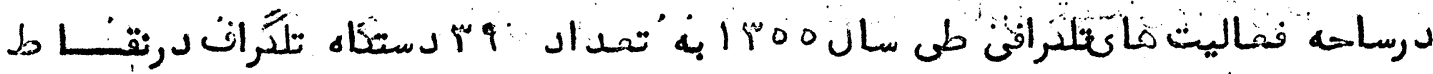

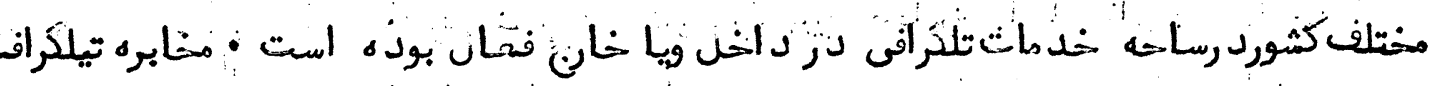

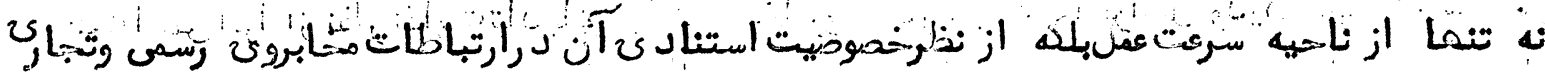

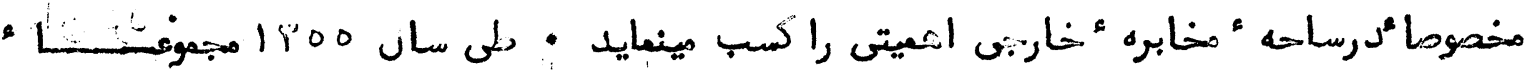

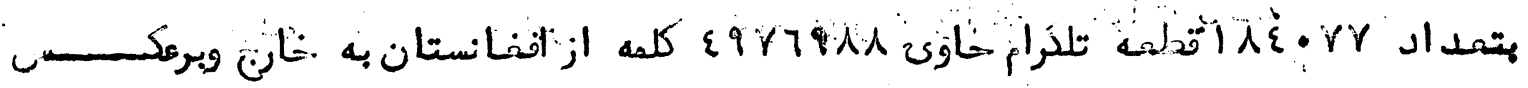

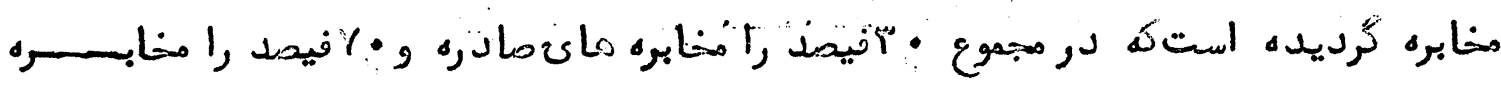

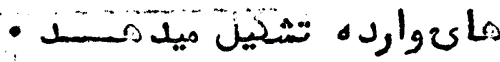
تحدات ميخابره ماين مادره ووارده تلكراف به تخريق

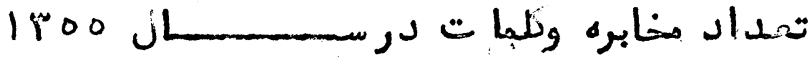

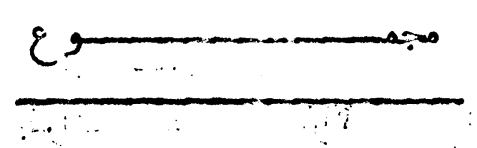

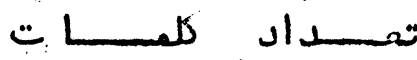

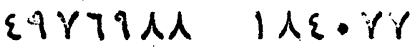

منابسـره كLاك وا رده

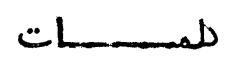

proolrt
تمبـداد

irkq.8 $14 \cdot 1170$
مغابسره فسان مسادره تعســــاد $001 \mathrm{r}$

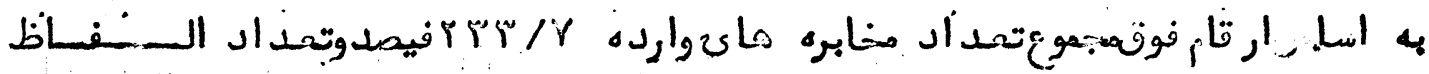

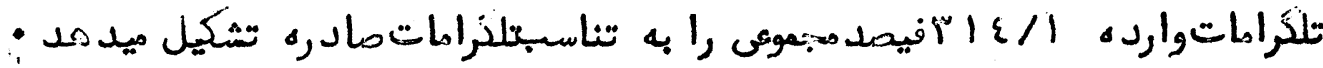

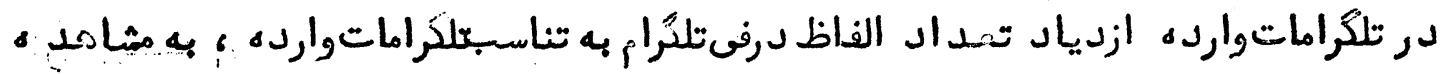

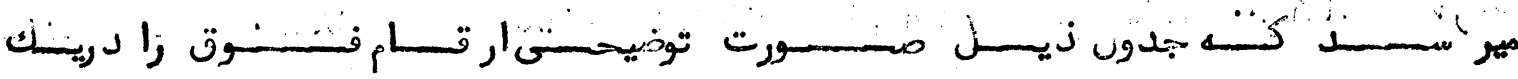




$$
\begin{aligned}
& -i r r
\end{aligned}
$$

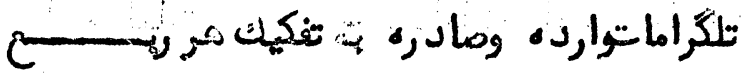

$$
\begin{aligned}
& \text { درزســان } 1900
\end{aligned}
$$

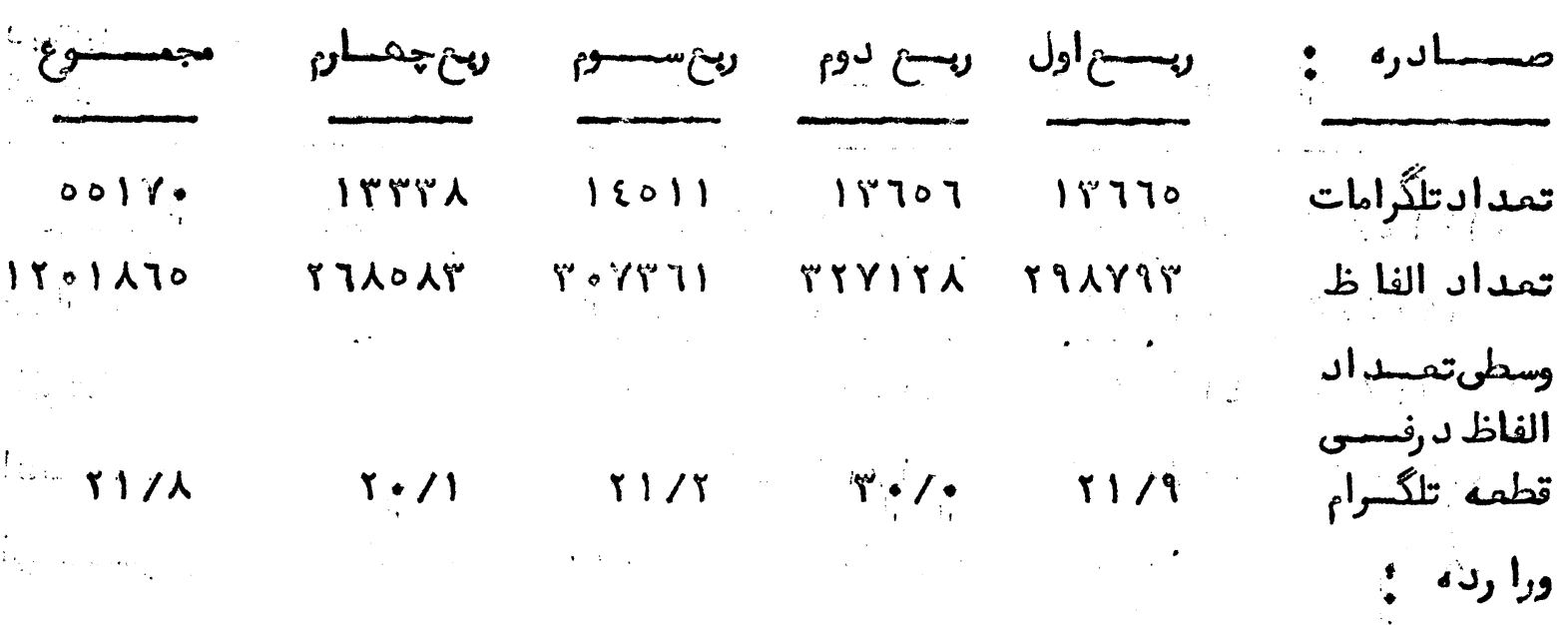

\begin{tabular}{|c|c|c|c|c|c|}
\hline iraq:8 & rip & Pitio: & ए। & r.rol & تحد ادتلكرامات \\
\hline "rroitr & gortro & 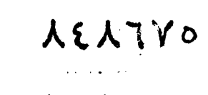 & १19ร91 & qviping & داد النسـاظ لـ \\
\hline & & $\therefore$ & & & على تحسـدا \\
\hline$r q / r$ & 「人ハ & YO/ & rY & $1 / 7$ & طمه تلكّرام \\
\hline 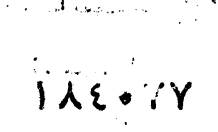 & $\{7997$ & $\{r \lambda\} 1$ & 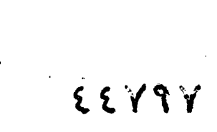 & $\varepsilon \varepsilon \varepsilon r r$ & تمدـاد تلكرام \\
\hline $\begin{array}{l}69879 \text { 人 } \\
.\end{array}$ & Irrritit & 1107077 & ITr7EIT & irrrier & تمدلداد الفاظ تمداد \\
\hline$r / / 1$ & Y $7 /:$ & $r \varepsilon / r$ & $r q / 8$ & $Y \Lambda / T$ & ه تلكر ام \\
\hline
\end{tabular}

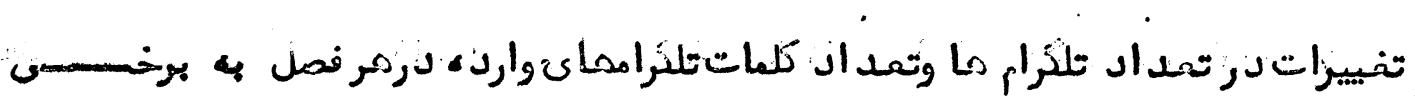

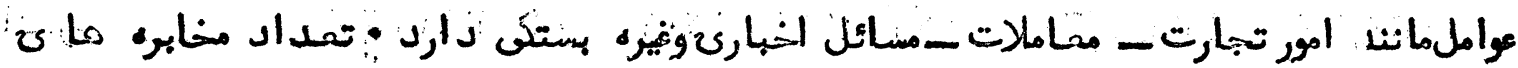

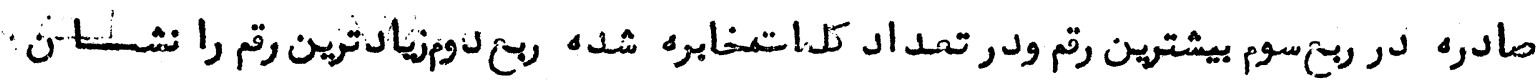

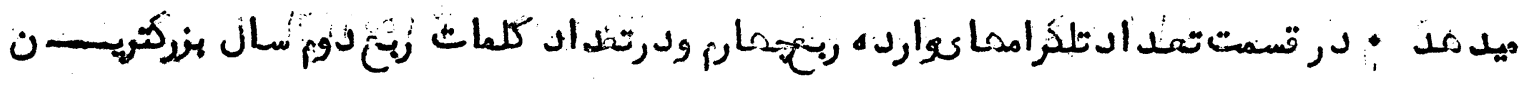

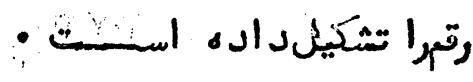

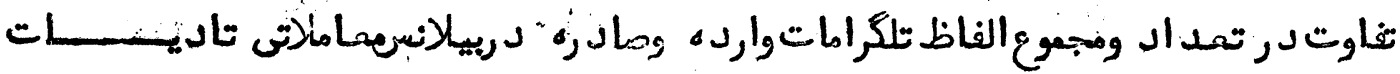

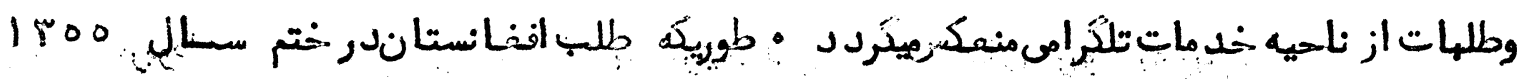

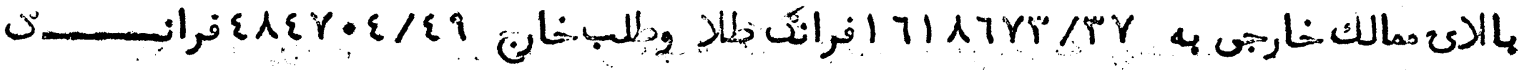

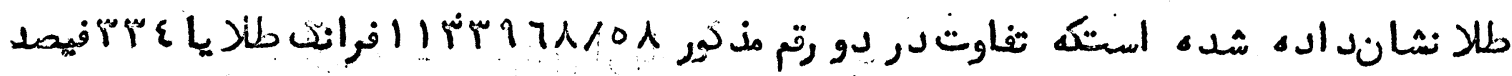




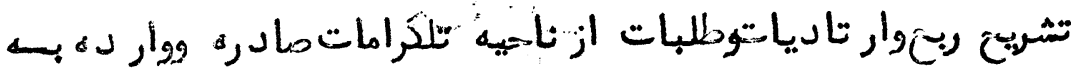

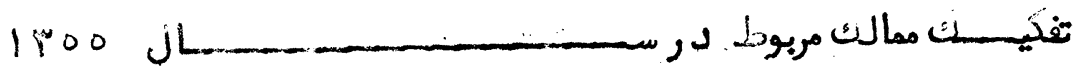

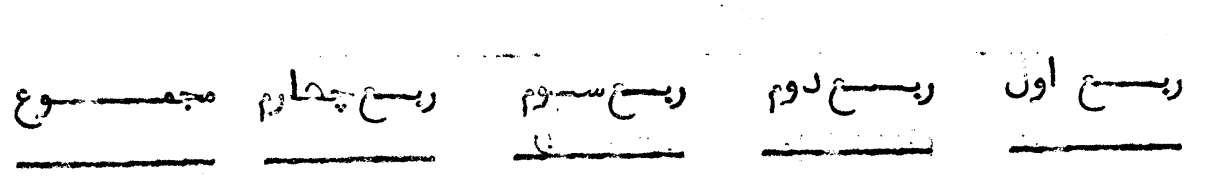

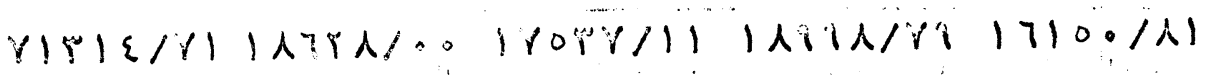

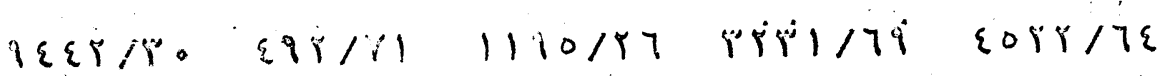

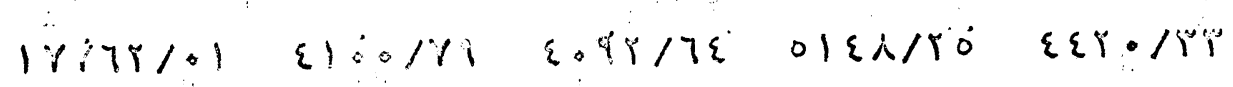

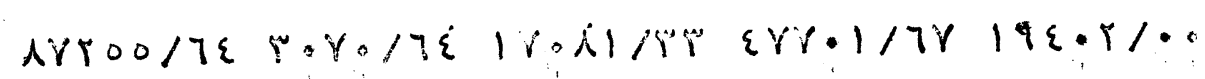

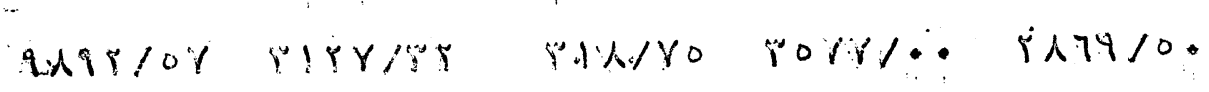

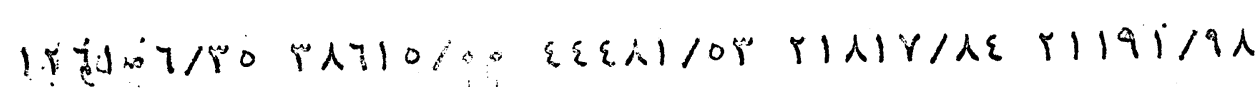

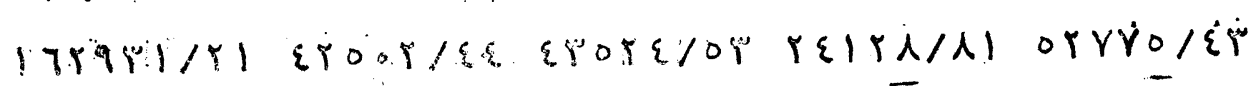

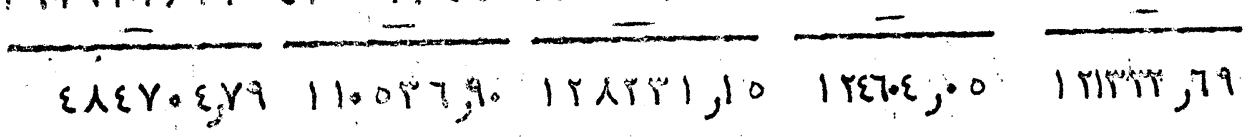

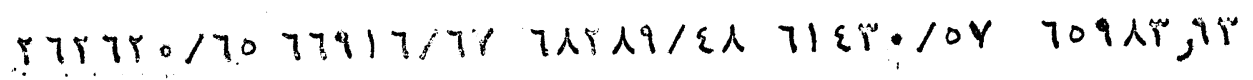

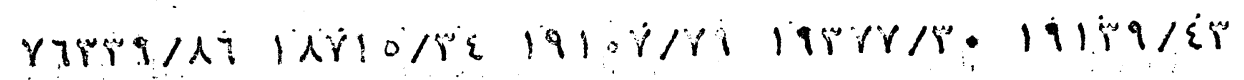

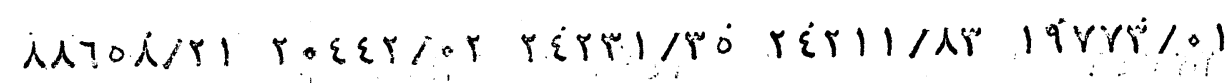

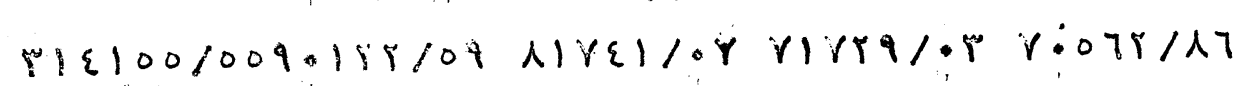
$Y ! 01.101$ Vi\%

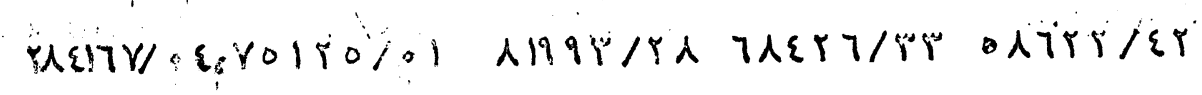

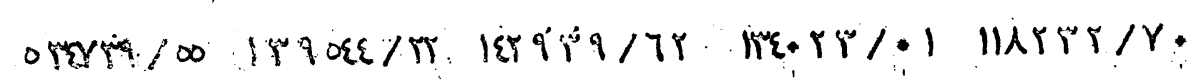

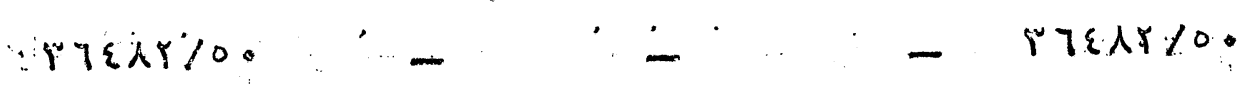

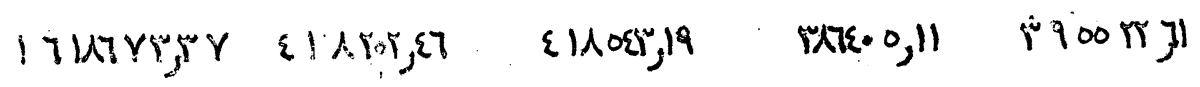

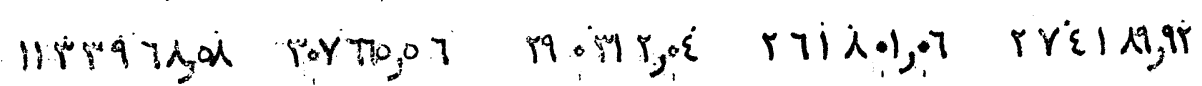

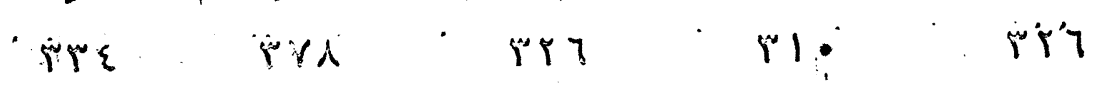

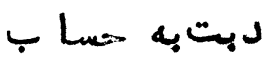

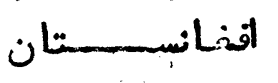

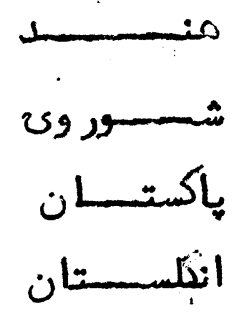

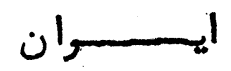

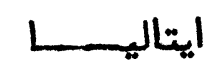

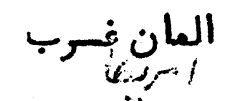

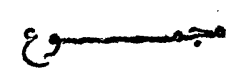

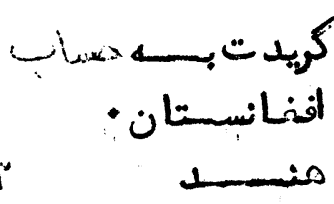

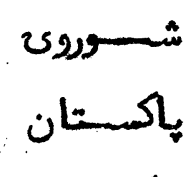
انكسمتان ايســـا ن ن ايتاليسـا المانفربرب
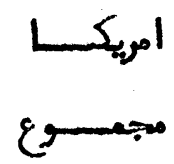
ثغاوت مث:جموعى نغاوتفيدل ناون

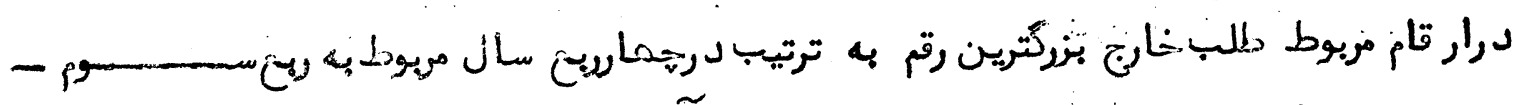

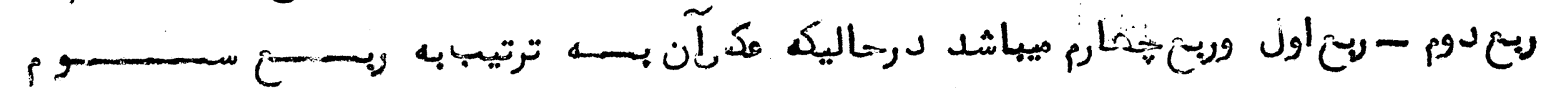

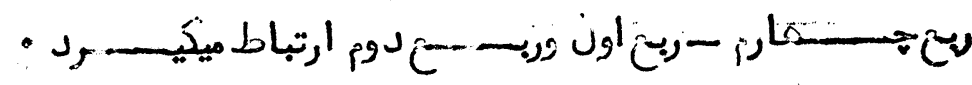




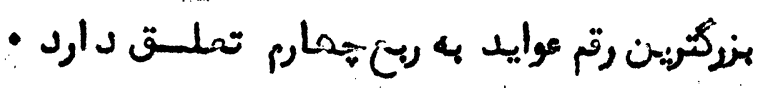

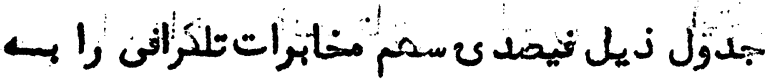

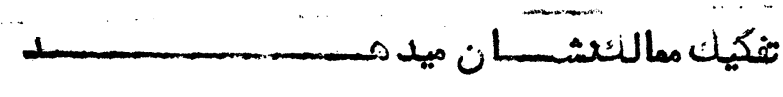

( ( ) ( ) ( )

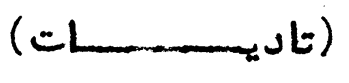

درم:مستسوع

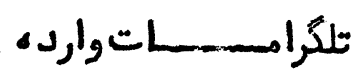

تلكرامات صسـادر،

$10 / 9$

$17 / 5$

$1 \varepsilon / \gamma$

مســن

$\varepsilon / i$

$\varepsilon / \gamma$

$0 / 1$

010

$1 / 4$

شسو رون

$19 / 1$

$19>\varepsilon$

$\varphi / \dot{\gamma}$

باكتا ن

i/o

$i / 2$

INi.

انبكستان

ז

ايســــان

$19 / 0$

$18 / 7$

rT.

ايتاليـا

rris

pro

iris

المانفز

$1 / 2$

$Y M$

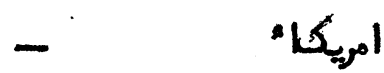

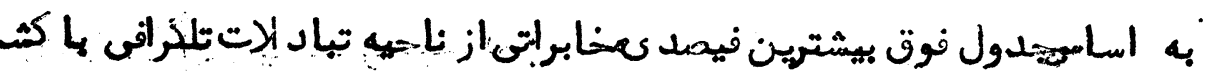

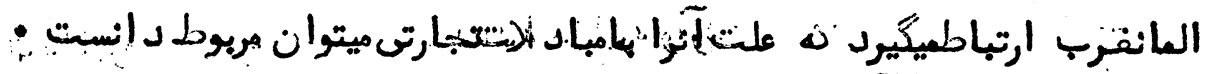

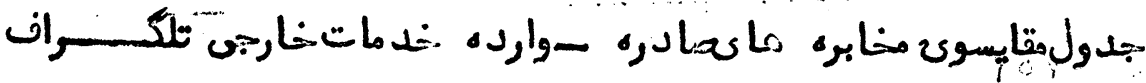

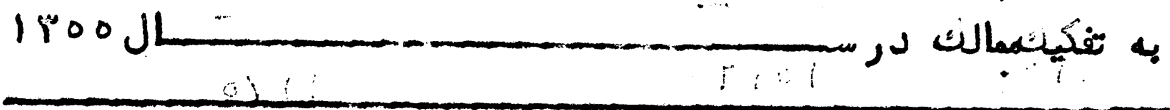

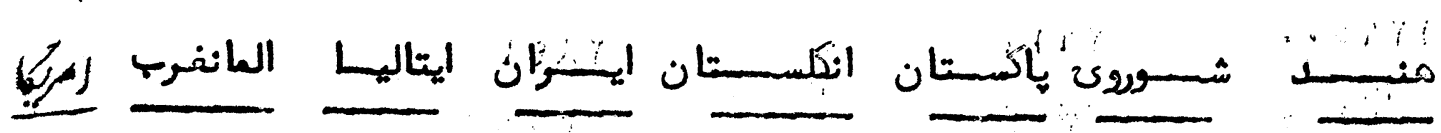

$$
\text { تلكرامسات }
$$$$
\text { مسادره : }
$$

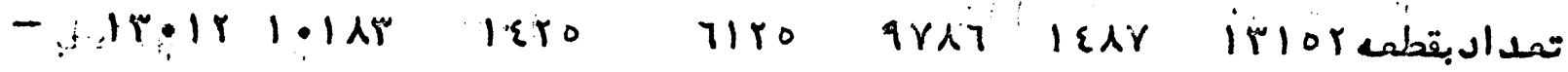

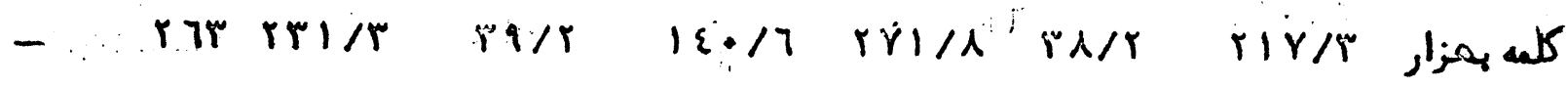
وسطسكمات

-

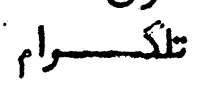

- تادئس bـ طران لان 


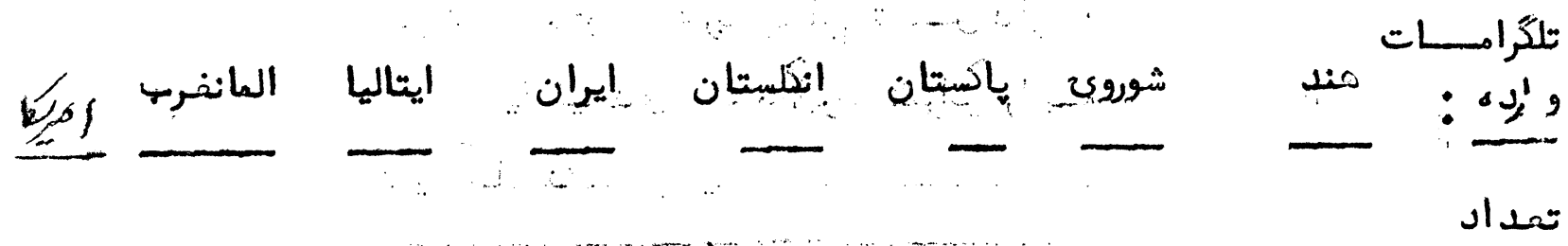

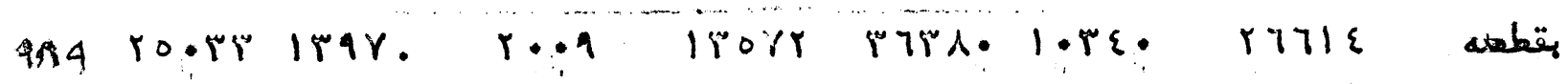
الفاظل

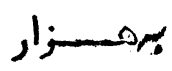

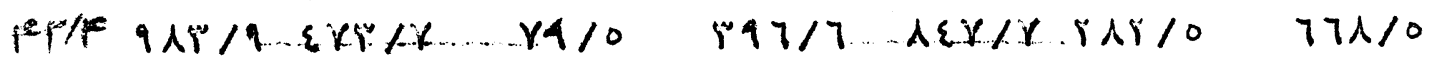
كلهــ जrang الفــاظ

$\therefore . .$.

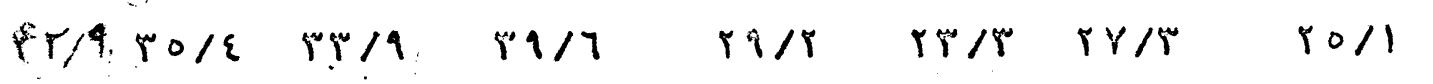
J رفنس ملبـات بفرانت

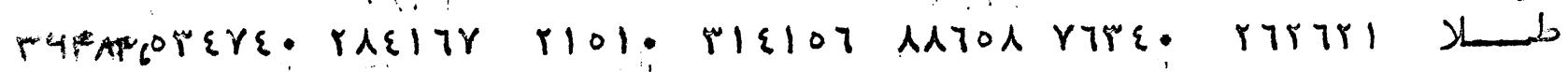

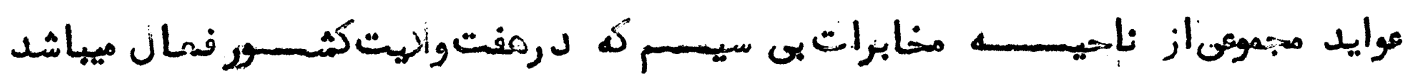

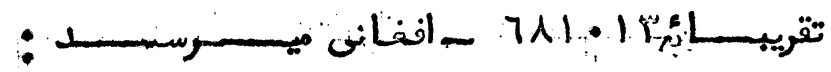

\begin{tabular}{|c|c|c|c|}
\hline 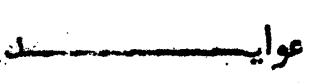 & تحدلاده مذابره وارده & تمد ادمنابره مادره & والايســــــات \\
\hline \&\&|ror & - & - & 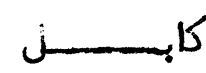 \\
\hline o\&ro. & 1047 & 1180 & بدخشسا ن \\
\hline 1910. & $r 918$ & $Y \wedge\{\lambda . . ;$ & فاريســـا ب \\
\hline 1900 & ripri & ivi & نيبـــــــروز \\
\hline$\varepsilon \because 17$ & IVTA & YIT & غـــــــورات \\
\hline o\& $i^{\circ}$ & 111 & $1 \cdot 1$ & باد نهــــا \\
\hline$\lambda 1 \cdot \mid r$ & $7710^{\circ}$ & $0.1 \varepsilon$ & q \\
\hline
\end{tabular}

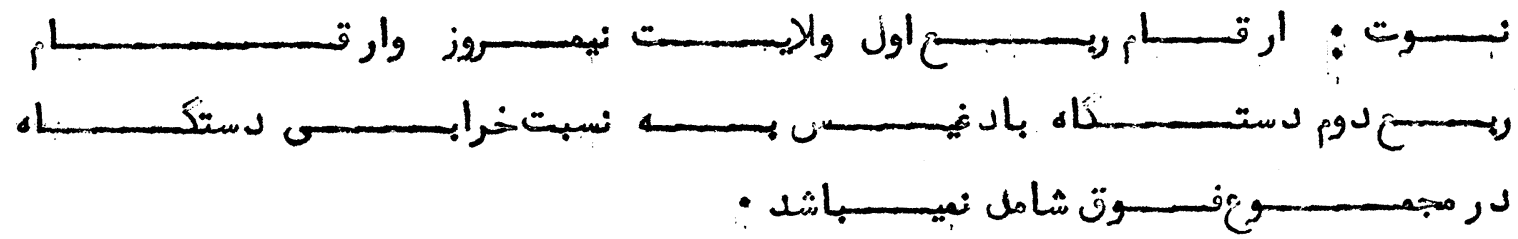




$$
-1 \times 7
$$

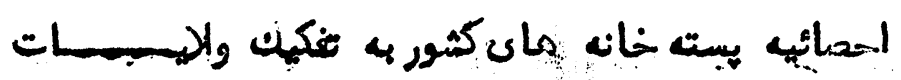

(1) dxas

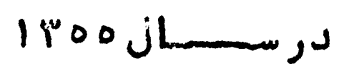

2.7
$\frac{17}{17}$

$1 \lambda$

11

$\lambda$

1.

I.

7

10

9

14

i

r

$i$

r

9

$1 \lambda$

14

ir

1

。

I1

$r$

1

7

r.

ru|

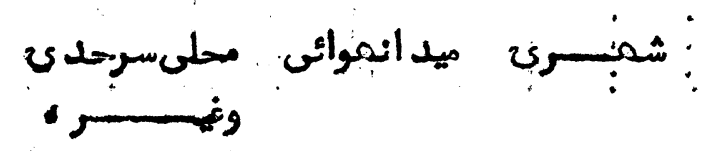

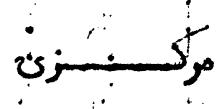

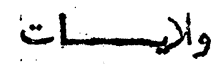
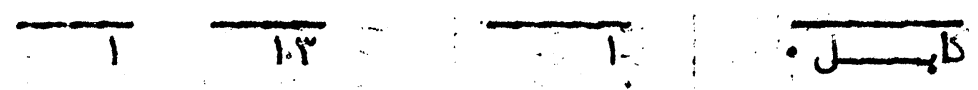

1.

-..."

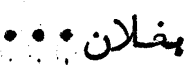

كندز • -

تغار •...

- بدخشان

سمنكًان :-

بلة :

:

فاريسـا ب...

باميان . . -

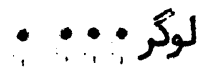

ككيا ...

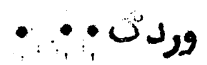

غزنق

زابل . ...

- كند ماري

$\therefore \underbrace{}_{j}$

ملمنــــ

فراه . . . .

نه

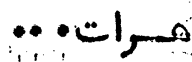

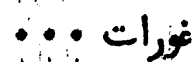

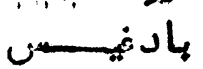

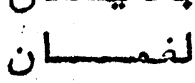

ننكرمهــــا ر

rT

مجمعــــ 


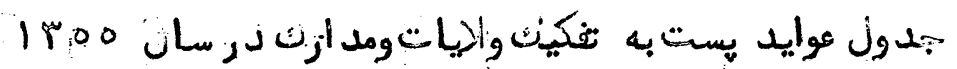

(i) جـ

\begin{tabular}{|c|c|c|c|c|c|c|c|}
\hline 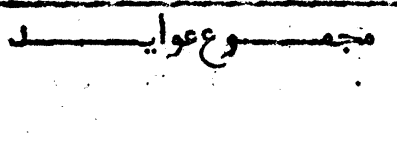 & 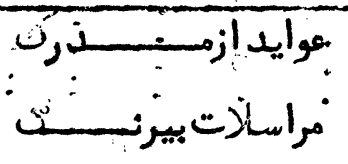 & 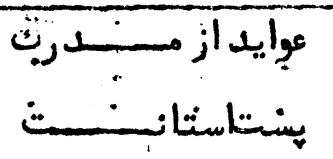 & 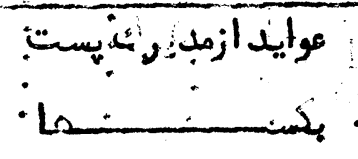 & :رسمس شوشن & 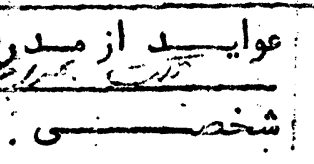 & 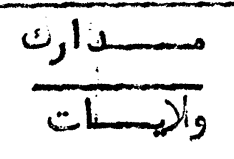 & شعاره \\
\hline$\varepsilon \cdot \% \curlyvee 0 \varepsilon \cdot \varepsilon$ & AFr & 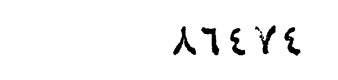 & ITrTOA & 1.00997 & $\Gamma), r \cdot v \varepsilon$ & كابـــــــ - & 1 \\
\hline 1YบT\&।T & IrTri & oqra & rritir & $010 \hat{\gamma} \cdot \varepsilon$ & rovaqa & كنب ماريه.... & $r$ \\
\hline $100 \varepsilon 7 \varepsilon 0$ & $\gamma \varepsilon$ & $1 \varepsilon \varepsilon 9$ & 01. & O.OVT\& & I. EYrKA & مرات•• & $r$ \\
\hline 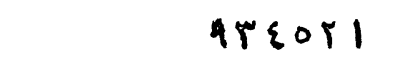 & Tr & YITI & ir.. & OrEY人T & $\varepsilon .7491$ & 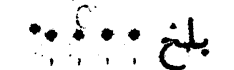 & $\varepsilon$ \\
\hline$\cdots$ rorte & 9811 & - & - & FVYTYY & $\varepsilon Y Y Y: 1$ & بكتياء • •• & 。 \\
\hline Irkt1or & $\varepsilon$ & - & - & qrilrg & \&O人.P $\}$ & نتكرطار م- & $T$ \\
\hline .00\&TYT & Nr & 19 & 791: & Tะช & 199700 & ملعند :- . & $\gamma$ \\
\hline rrilr & 1810 & - & 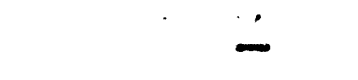 & rarrit & iriro: & غزنســــــي. & $i$ \\
\hline$r r_{\bullet} \varepsilon r q$ & - & - & - & צדיצדי & $\lambda i \cdot 9 \gamma$ & بنــــلن ن & 9 \\
\hline 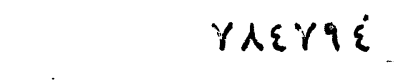 & - & - & - & $\varepsilon 1: \ldots 1$. & 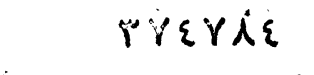 & كنبز + ? & $1:$ \\
\hline r.qqir & - & - & - & $10 \div 111$ & $\therefore$ rarAl & بدخشا ن ن & 11 \\
\hline rqiojo & - & - & - & STYOYA & $09.0 \%$ & 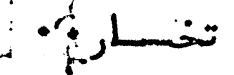 & 15 \\
\hline - r:r人it & - & - & - & $17 r 071$ & Eirry & سمنكـلـان" & $1 \pi$ \\
\hline
\end{tabular}


$-I Y N$

اد ارم (r)

\begin{tabular}{|c|c|c|c|c|c|c|c|}
\hline 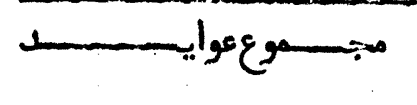 & 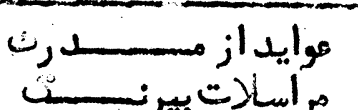 & 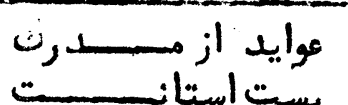 & عوائي از مدرني يست & $\because 2$ & 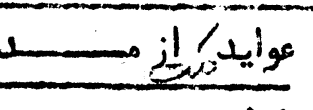 & مستـــــ & شعارج \\
\hline $01010 \xi$ & - & - & - & 499014 & $1107 \varepsilon 1$ & فاريتـاب & $1 . \varepsilon$ \\
\hline O\&YOYO & - & - & - & $\{1.011\}$ & IrTErr & تجوزجهــان & 10 \\
\hline r.0r人9 & - & - & - & 19人7us & $77 . r$ & وردن . . . & 17 \\
\hline 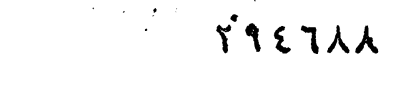 & - & - & - & $17 r o \varepsilon 1$ & $11 n 1 \varepsilon \gamma$ & باميان.' •. & 18 \\
\hline 1ard..: & - & - & $\because$ & $1714 \lambda$ & 1095 & لوخر .... & 11 \\
\hline r.07人⿺7 & $79 \ldots$ & - & - & rtorOO & 99791 & لفان - . & 1.9 \\
\hline or9odr & $\cdot-$ & - & - & sos?h & $\vee \varepsilon<7 \%$ & يووان .. & $r$. \\
\hline$r \cdot r .001$ & 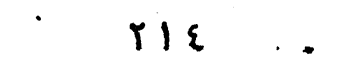 & - & - & I Irrit & r r.\%. & زابل •.. & ri \\
\hline ro..r. & - & - & - & rerlare: & retos & 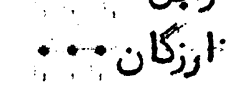 & rr \\
\hline MITIYE & $r$ & - & - & rotiro & 00997 & فــراه ه & rr \\
\hline rาะท & - & - & - & ripe & $9 \% \cdot 1$ & نيمويز > - & $r \varepsilon$ \\
\hline $11 r 7 \cdot r$ & - & - & - & 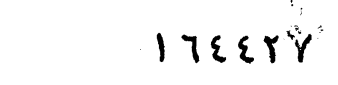 & rkli. & غورات & ro \\
\hline $\begin{array}{r}\mid \text { |lerqu } \\
\text { orvriroe. }\end{array}$ & r Tru & 90999 & 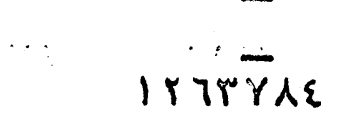 & 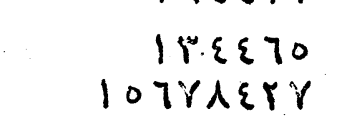 & $\begin{array}{r}\text { EolY } 7 \\
\text { ror:l Tr }\end{array}$ & 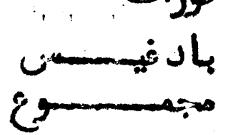 & rT \\
\hline
\end{tabular}

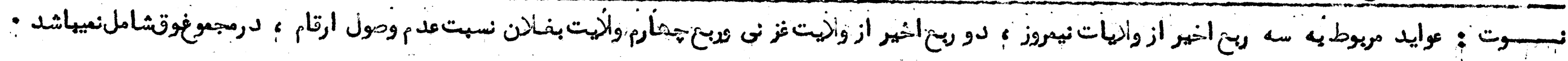




\begin{tabular}{|c|c|c|c|c|c|c|c|c|c|}
\hline oي- & بيتة هان & 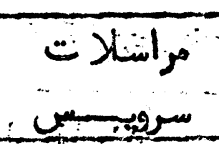 & هلــــــ & 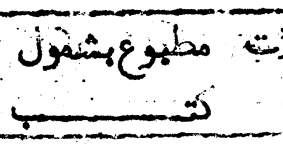 & : بارسست & 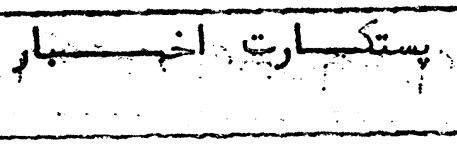 & مذاتسي & ب & شماره \\
\hline$r \varepsilon \mid r \cdot \varepsilon r^{\circ}$ & r10:Y & $\varepsilon \cdot \varepsilon 1 q$ & $\varepsilon .07 r$ & $\therefore$ 人.7人1 & $77 \varepsilon \lambda$ & $\left\{\alpha N^{\prime} \mid \mathcal{O}\right.$ & $r(\lambda) \cdot \lambda i$ & كابـــل & 1 \\
\hline rogr.r & ६० & $\therefore$ & 790 & rig & rio & orlo1 $\varepsilon q \gamma$ & 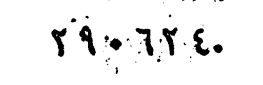 & مــــــــات. . & r \\
\hline rr人r:\&: & 17 & - & - & riv & 77 & 178ג, •ris & $r+40 \lambda 0.1$ & 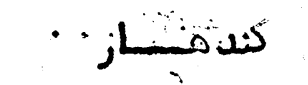 & $r$ \\
\hline$\varepsilon$ :oqrr & $\varepsilon$ & PIrrq & - & $\cdots$ & 101 & १人\&१४ & rresty & هل- & $\varepsilon$ \\
\hline rrrist. & ᄉ. & $i j$ & - & - & 19 & Prollo & $198 \times 9 \%$ & كنبـــــــــــ & 0 \\
\hline miretz & $\varepsilon q$ & . & ro & \&o & ث:1:1 & $\gamma_{\lambda}$ & miroos & نبكرفـــــار ' · & 7 \\
\hline ETo|Aג & 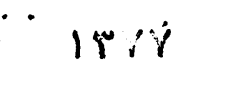 & - & $17 \varepsilon$ & $r$ & $\varepsilon 7$ & $\|\varepsilon V\| r$ & II 10 & 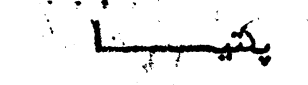 & $\gamma$ \\
\hline rigro. & - & - & - & $\cdots$ & 15 & $170 \varepsilon \varepsilon 8$ & lorest & فارينـــــابـا & $\dot{\lambda}$ \\
\hline$r \cdot r \cdot r l$ & - & 79 & - & - & - & $1+1 \cdot 1$ & lasts: & غزنــــــن & $\dot{8}$ \\
\hline rriror & - & $\operatorname{lr} \lambda \varepsilon$ & - & - & 11 & $098 \cdot r$ & $109 \mathrm{YgY}$ & $\therefore$ & 1: \\
\hline rrdirl & 911 & rTh & $\varepsilon \%$. & 。 & 118 & IE9TY & rrort & بدخشسا ن & 11 \\
\hline IEvi.. & T. & 110.1 & & A & 71 & \& 7 O & $|\varepsilon| \sim \varepsilon q$ & ملدنــــــ & 15 \\
\hline $\mid r 9741$ & 1 & - & - & - & in & 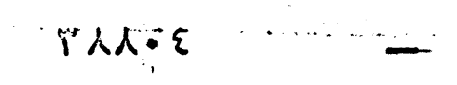 & $q \cdot i \cdot i$ & فــــــــــ ه & $1 T$ \\
\hline ryorto & 1 & rt & ErYP1 & - & ir & I.r\&AT & NYO\&70 & جَوزتجــــان & $1 \varepsilon$ \\
\hline
\end{tabular}




\begin{tabular}{|c|c|c|c|c|c|c|c|c|c|c|}
\hline 11 & $1 \%$ & 9 & $\lambda$ & $\gamma$ & $\pi$ & D & $\varepsilon$ & $r$ & $r$ & 1 \\
\hline OrTIl & - & - & - & - & ir & - & 1 & OYY.० & غـــــار & 10 \\
\hline VIo\&A & - & $7 \varepsilon$ & - & rqo & - & - & - & $8.07 \%$ & ارزخكــــــان & 17 \\
\hline T\&|r| & Irr & irq & \&o & $\varepsilon \varepsilon \varepsilon$ & 17 & 940 & IYTI & opari & باميســــان & ir \\
\hline$\wedge \uparrow \cdot \varepsilon \lambda$ & - & $=$ & $\cdots$ & - & - & - & $\because$ & 19. $\{$ 人 & تـــــــار & 12 \\
\hline r.rTqY & - & $0 \varepsilon$ & 11 & piql & $17 \varepsilon$ & oqi9 & $r y$ & 191078 & بفـــــــلان & 17 \\
\hline oरqui & - & $r \cdot 19$ & - & $\therefore-$ & $\varepsilon$ & $\div$ & - & o711: & سنيكـــا ن & $r:$ \\
\hline Wiह9 & - & - & - & $\because$ & i & - & - & Wrid & لفمــــان ن & ri \\
\hline THYO & - & $\therefore$ & - & - & $r$ & $\div$ & - & TMYT & لوخ & $r r$ \\
\hline 71070 & - & or & - & $\because$ & - & - & $r$ & inol: & ميـــــــان & ri \\
\hline lirgrg & - & - & - & - & 。 & \&/Pr & - & $77 \gamma_{0}$ & نيمـــــوز & $r \varepsilon$ \\
\hline $711^{\circ}$ & - & - & - & - & - & - & $r$ & $718 \cdot r$ & زابســــــل & ro \\
\hline $0010 \varepsilon$ & - & $r$ & - & - & $\ldots 1$ & - & - & .00100 & باد نيجسـس & $r$ \\
\hline 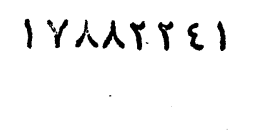 & rETIT & 11951. & 4. $\varepsilon \pi \varepsilon$ & 17119 & $8 \times 79$ & WUAl| & $r \varepsilon \varepsilon \varepsilon 1$ & $71 / 1 V \varepsilon r$ & مجمنـــوع & \\
\hline
\end{tabular}

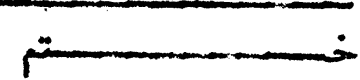




\begin{tabular}{|c|c|c|c|c|c|c|c|c|c|c|}
\hline مجمســـــــوع & بونهاك & سرويســـلات & مشعبـ كتبك & مجلـــــــ & يارســـلات & اختـــــبار & يستكـارت & مكاتيــــبـب & و والايستــــات & شماره \\
\hline$\{\uparrow\{0 \uparrow . \varepsilon$ & $r \varepsilon \|\}$ & oorl & 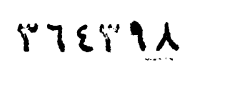 & $1 \varepsilon \cdot \varepsilon \varepsilon r$ & YY700 & $9971<9$ & YY:AT\& & 47009r! & كابيسبــــــل & 1 \\
\hline revot: & 00 & 1 & 1914 & TRTI & roq & Mrit & 187 & ropis & o & $r$ \\
\hline 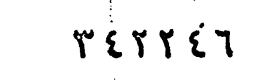 & 117 & $1 \ldots$ & 1.0 & $M$ & 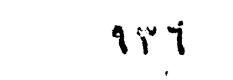 & $r \cdot y \cdot r$ & $\varepsilon \tau \cdot \psi$ & roodrs & كند مبــــار & $r$ \\
\hline Pry.oq & $\varepsilon 0^{\circ}$ & vorga & rits & ii 70 & $\dot{D} \varepsilon \varepsilon$ & llie: & pq & rrTl & $\dot{c}$ & $\varepsilon$ \\
\hline TRYEY: & $r$ & \&ir & $\varepsilon r$ & $1: \not\{\uparrow\}$ & $0<1$ & $9 \ldots$ & $7 \times r^{\circ}$ & YI119! & كنـــــــــ & 0 \\
\hline or人al. & $1 \%$ & !: & $|r| \varepsilon T$ & $1010^{\circ}$ & 0.9 & $\{\xi \xi \uparrow\}$ & re & qทq।ó & نبكر مــــارد & 7 \\
\hline rori.y & $r r l$ & - & 741 & $097 r$ & 195 & 7Pleq & - & rrvigq & يكتيـــا & $\dot{\gamma}$ \\
\hline rro\&ll & - & - & - & - & ril & IVAso: & - & litiv: & فاريـــا ب & $\lambda$ \\
\hline rוזוז & - & 000 & $\varepsilon \vee 9$ & $r ! \cdot \Lambda$ & 198 & rigr & $0\}$ & $r \cdot r i \cdot \hat{i}$ & فزبنســــ & $\vdots$ \\
\hline ונידודיו & 9 & $r \cdot v \varepsilon$ & Iहry & $r \cdot r l$ & $\varepsilon q 9$. & rroti & $\varepsilon \varepsilon$ & rITIS: & 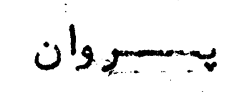 & $1:$ \\
\hline |TMTOI & 701 & r) & rq & IYrY & $\forall i \varepsilon$ & $1 \varepsilon \varepsilon \dot{\varepsilon}$ & ro & $1.0 \varepsilon i \varepsilon$ & بدنششا ن & 11 \\
\hline $171 \varepsilon 87$ & ir & $\varepsilon r \varepsilon$ & $\varepsilon \varepsilon$. & $7 r \varepsilon$ & is? & ro10 & rI & 101190 & ملجنـــــــد & ir \\
\hline
\end{tabular}




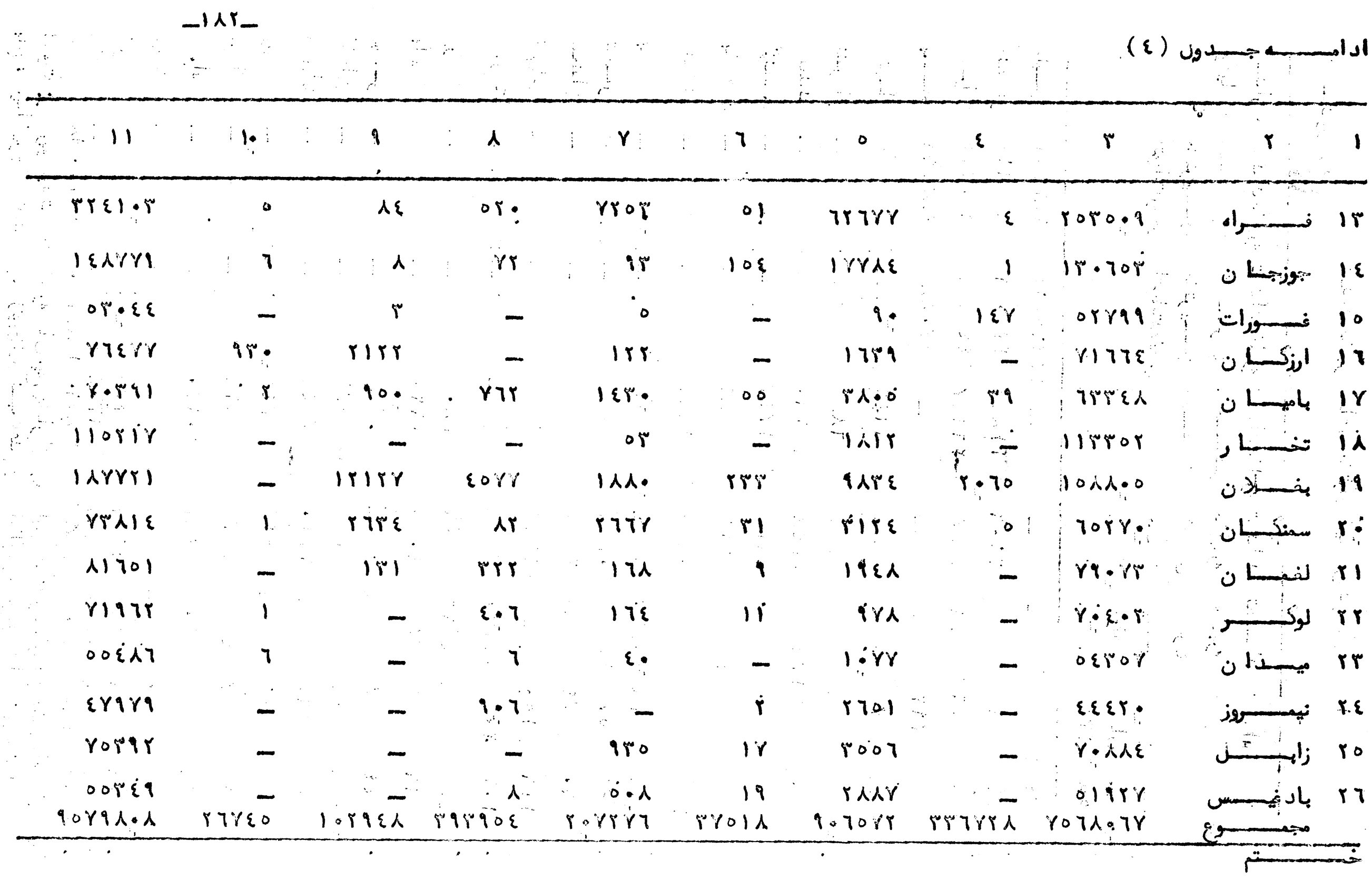




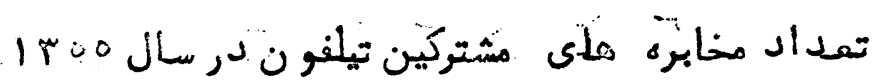

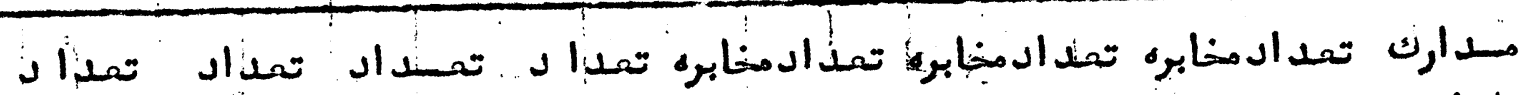

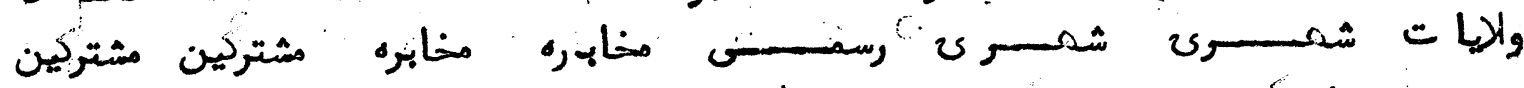

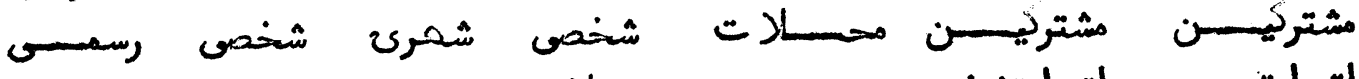

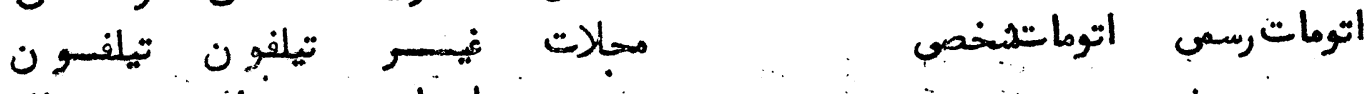
. العزمات دربنان درسـال

$1800: 1500$

\begin{tabular}{|c|c|c|c|c|c|c|c|c|}
\hline rrrq & ITPY & - & - & & 1r710Y9 & & NANYlor & u \\
\hline rNr & 1179 & - & $r \cdot 9=7$ & $\because$ I & $11 r \varepsilon \cdot \gamma$ & & kroTrr & لدمار \\
\hline 18 & Irrt & $0 \cos 29$ & ONTSY & หา7\& & $\mid$ | $|\varepsilon \varepsilon r| 0$ & & Trildo & سرات \\
\hline$r * 1$ & IYTS & $\because$ & - & - & $08: 11$ & & ए人\&\&19 & \\
\hline - & $r y$ & $17 \varepsilon 09$ & $00 / 1$ & 7าะด & & - & $\because$ & يكتيـا \\
\hline r $\varepsilon$ & $10 \lambda$ & $\div$ & IPI9 & $7110^{\circ}$ & & - & - & ننكرمار \\
\hline$r:$ & $r r$ & IYNA: 7 & 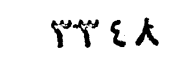 & Po.r & & - & - & نــ \\
\hline 190 & 7. & - & $\rightarrow 7 r 8$ & $: \mid \gamma \varepsilon \gamma$ & & - & $=$ & \\
\hline - & - & $1 \varepsilon q \varepsilon 0$ & $r \cdot 1$ & $\wedge \xi$ & & - & - & \\
\hline 1.0 & YTq & - & 11007 & IEqY & & - & - & \\
\hline 99 & $r i$ & 159 & $\vdots \quad-$ & $:$ & & - & $\because$ & تشان \\
\hline$Y \varepsilon$ & or & 10.00 & 1.507 & $91 \mathrm{rr}$ & & - & - & مار. \\
\hline $7:$ & $r \varepsilon$ & - & ro9 & TrY & & - & - & كان \\
\hline 197 & 100 & - & $r \varepsilon 770^{\circ}$ & mior & $r$ & - & - & \\
\hline $1 \cdot r$ & $r \cdot Y$ & l1ro: & - & - & - & - & - & جوزجبـ \\
\hline$\varepsilon i q$ & - & $\{\wedge \uparrow\}$ & or 7 & $r \wedge \cdot r$ & & - & - & \\
\hline 77 & 7 & rror & $\varepsilon \cdot 1]$ & 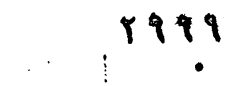 & & - & - & \\
\hline$\varepsilon \varepsilon$ & $\curlywedge$ & - & $\therefore \quad-$ & $\because$ & $\therefore$ & - & - & \\
\hline 101 & $r \varepsilon$ & rood & ror & or 1 & & - & - & \\
\hline$|r|$ & 178 & - & mil: & $r i \varepsilon \varepsilon$ & & - & - & يكر'ن \\
\hline \{o & $1 \varepsilon$ & - & $01 \varepsilon$ & $r \varepsilon 0$ & & - & $\div$ & $j$ \\
\hline 71 & $r$ & \&)० & 1087 & $q T \varepsilon$ & & - & - & ارزكان \\
\hline$\lambda \varepsilon$ & Do & or: $\varepsilon$ & rOdY & $1 \cdot T r$ & & - & - & نسـراه \\
\hline$\varepsilon \varepsilon$ & $r$ & - & - & $\cdot-$ & - & - & - & تهمر \\
\hline $\begin{array}{l}r \varepsilon \\
\text { or }\end{array}$ & 9 & $0 \varepsilon$ & $19 \varepsilon r$ & 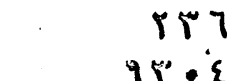 & 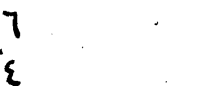 & Z & - & غورا- \\
\hline or & $100 \%$ & $\begin{array}{l}\text { 7Nis' } \\
\text { YYopir }\end{array}$ & $\begin{array}{l}\text { oryr } \\
\text { leqvir }\end{array}$ & $1010 \%$ & loNTro & $: \overline{0}$ & $1 . Y r=0$ & \\
\hline
\end{tabular}


جد ول كاركنا ن فنى وادارى يست درسال

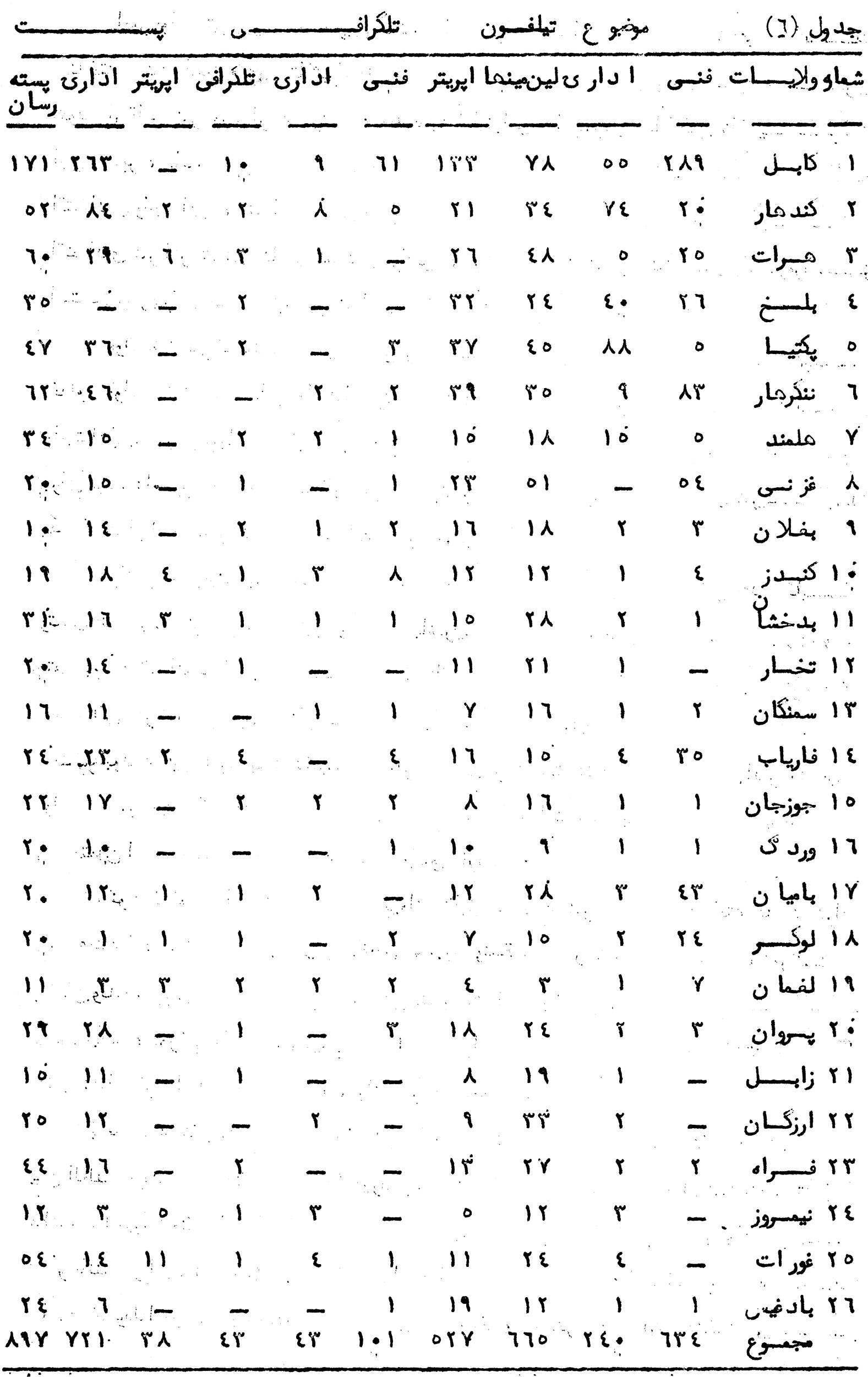




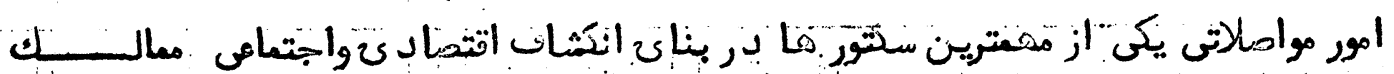

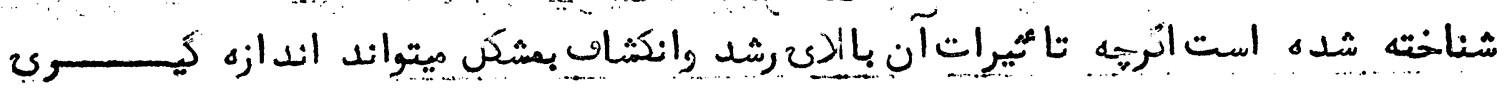

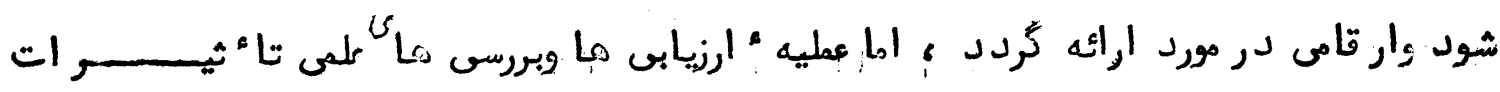

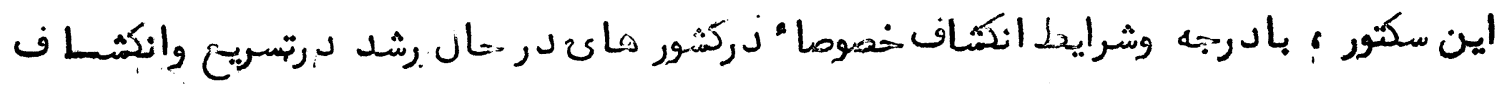

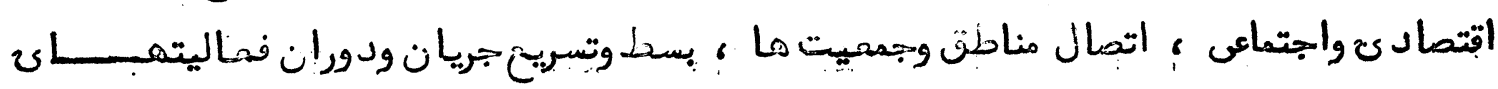

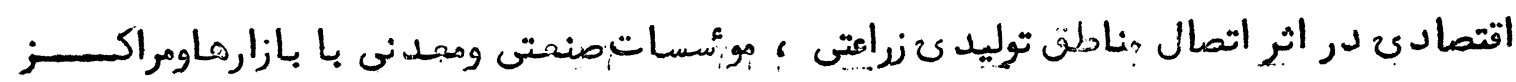

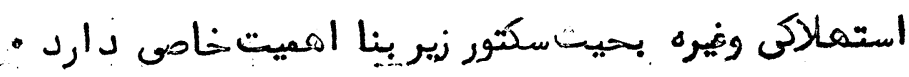

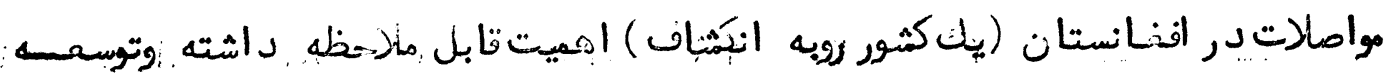

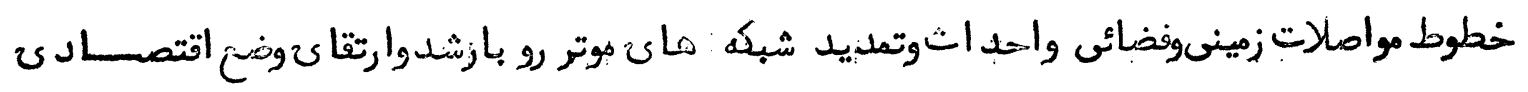

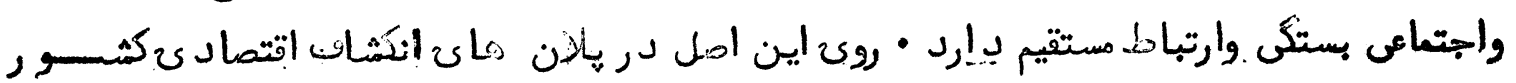

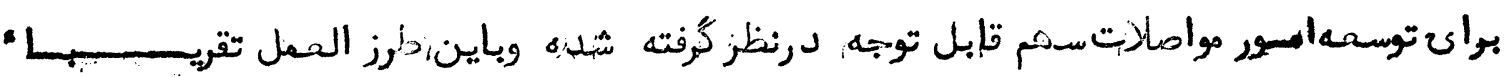

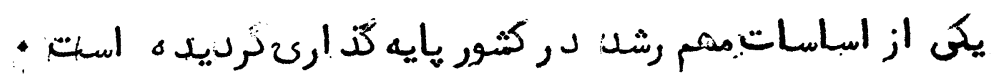

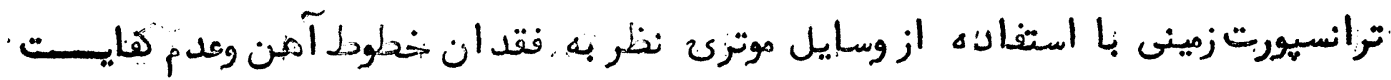

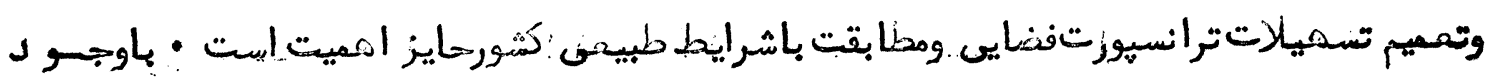

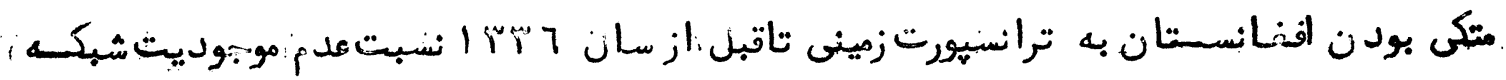

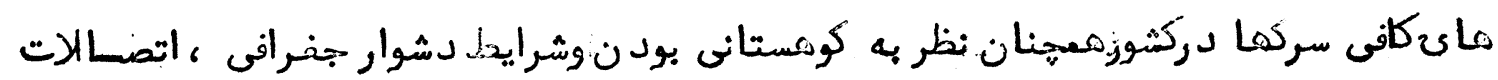

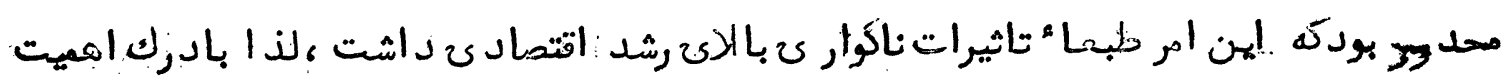

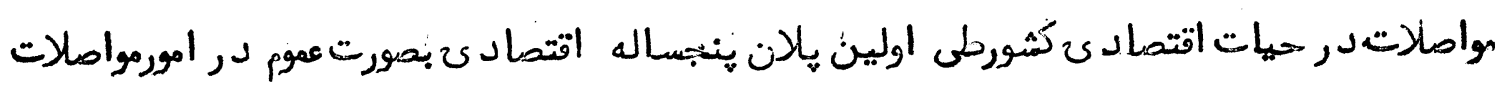

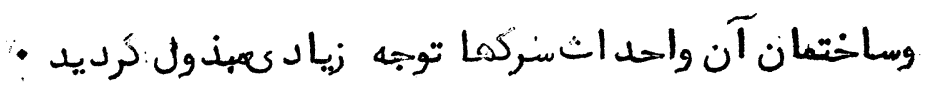

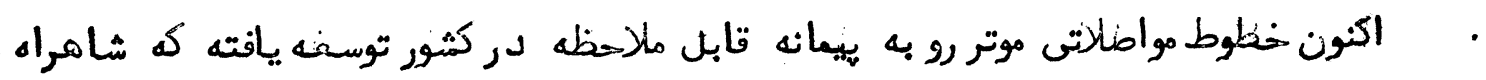

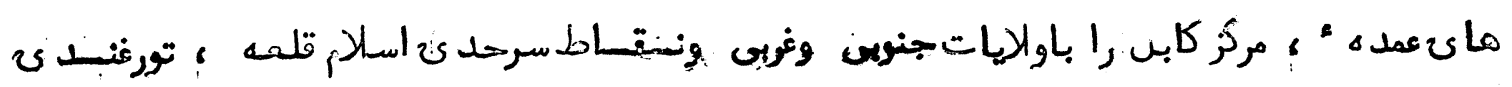

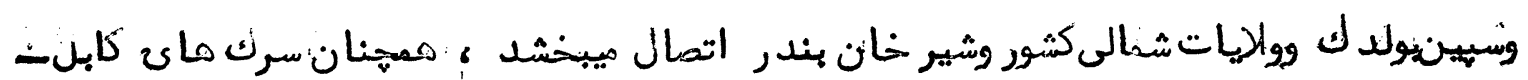

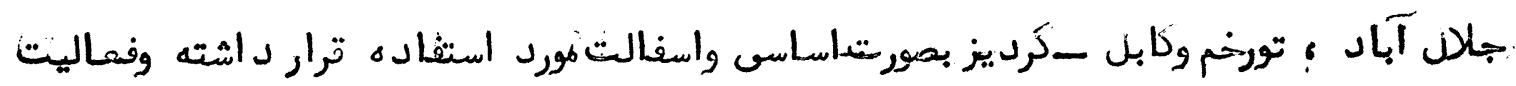

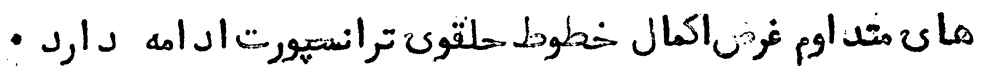

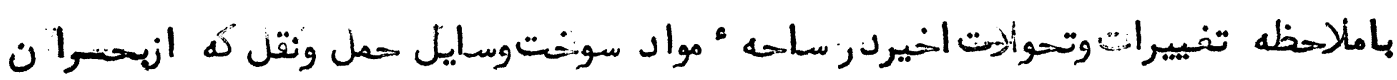

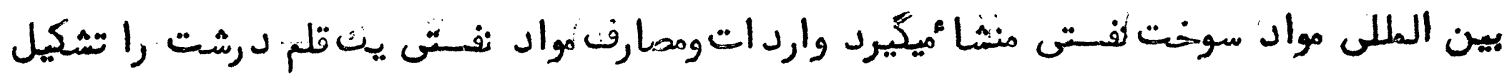

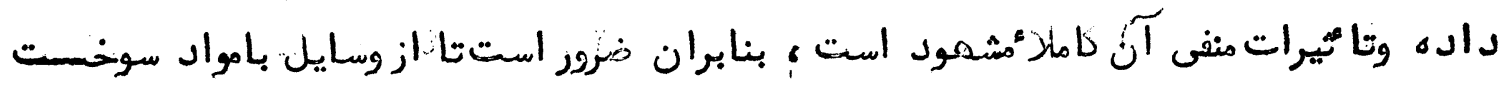

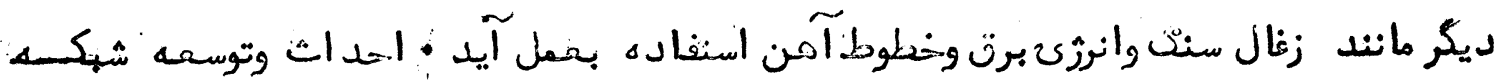

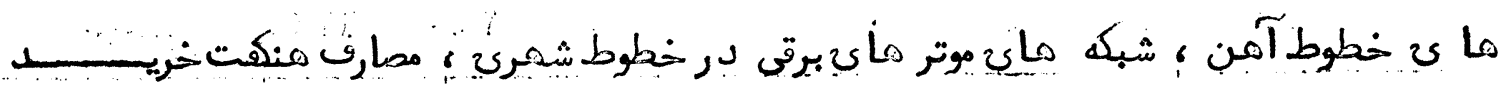




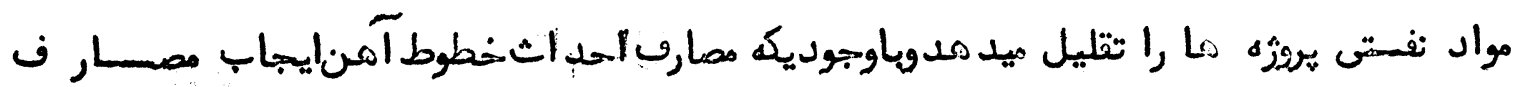

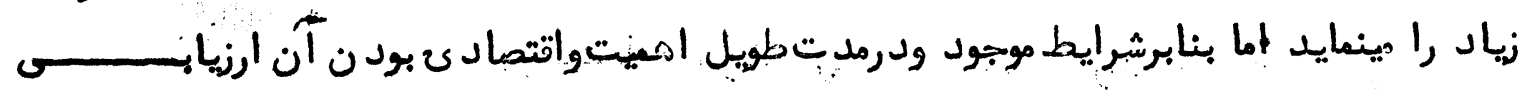

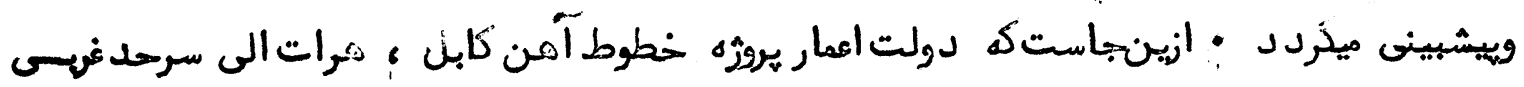

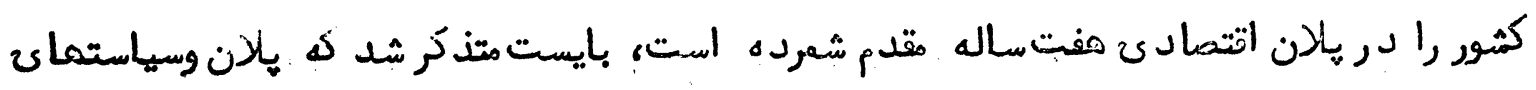

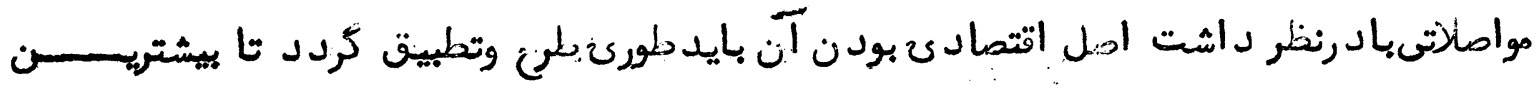

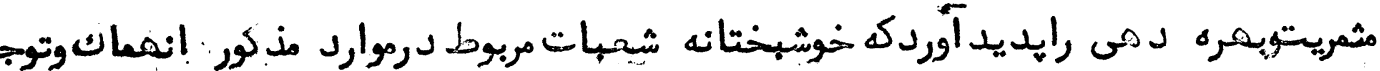
عميقى دارند :

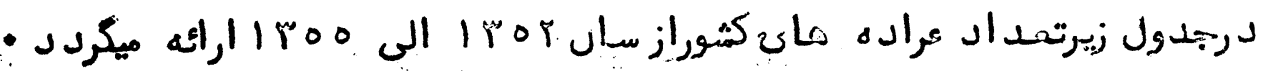

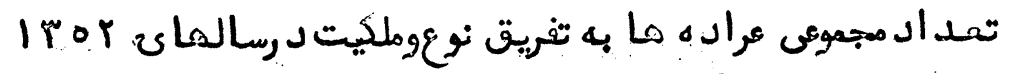

1900 الـ

جدون (اول )

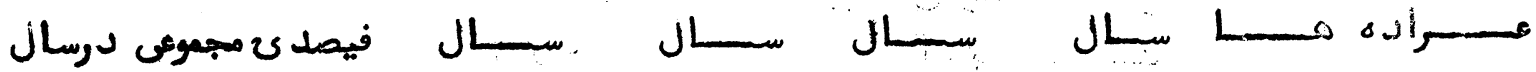

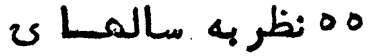

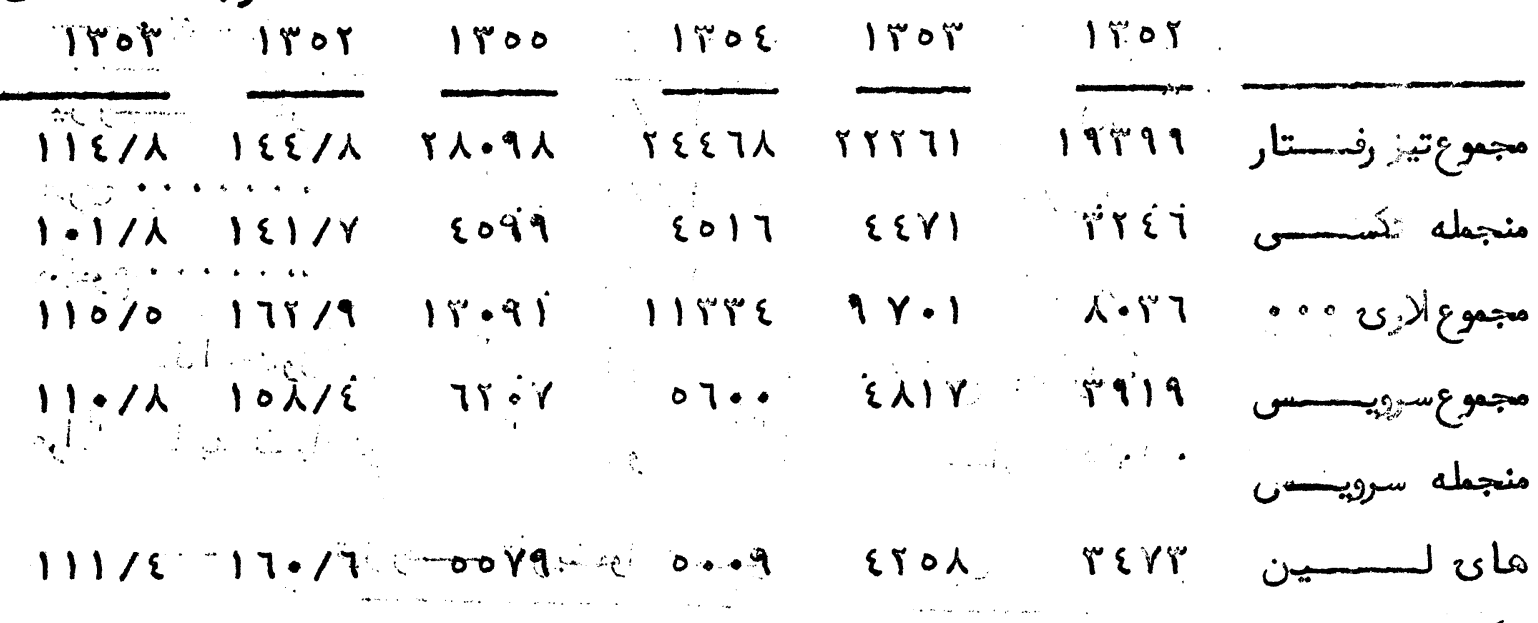
Ir:/ $r$ r ري موتر سايكســ

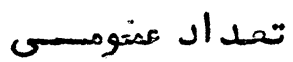
عراده هابسـد ون منون

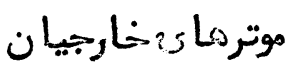

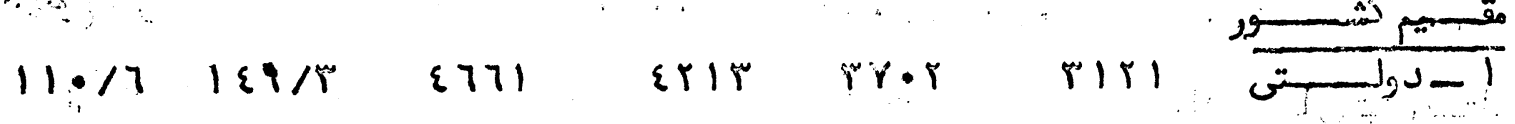

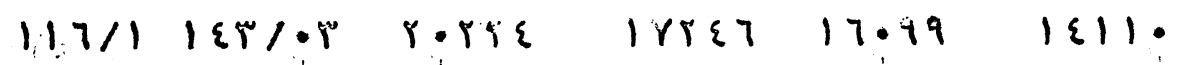

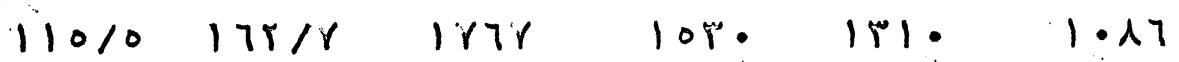

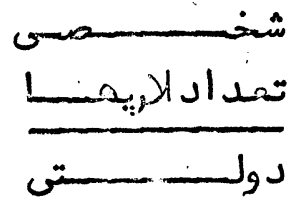

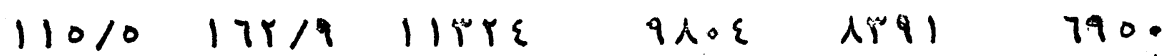
عراده هان مريوط

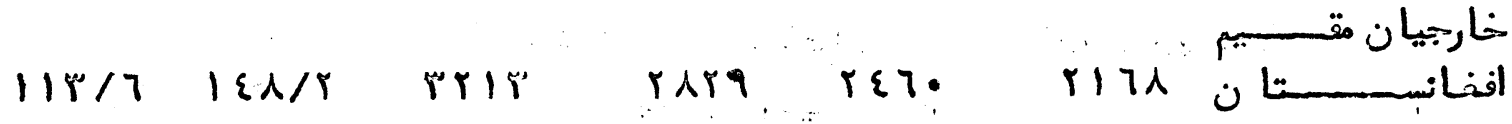




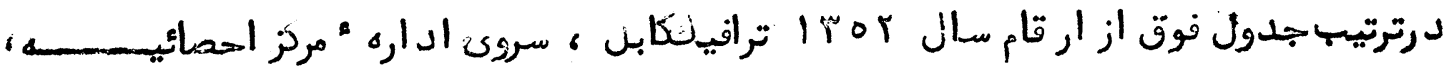

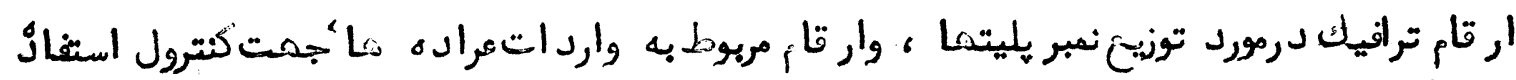

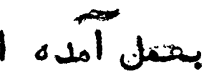

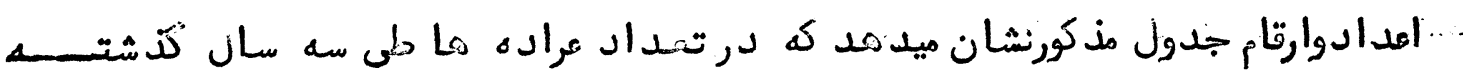

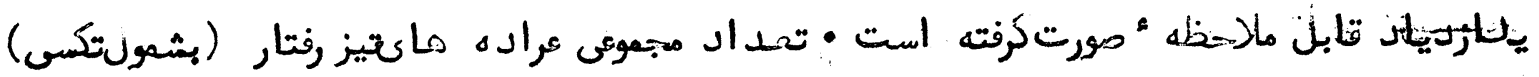

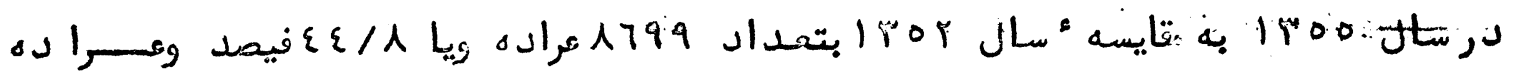

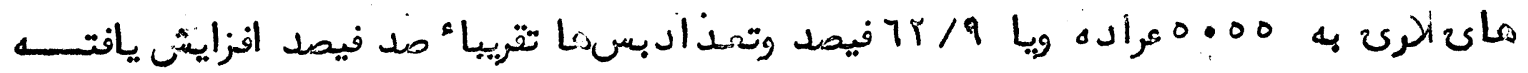

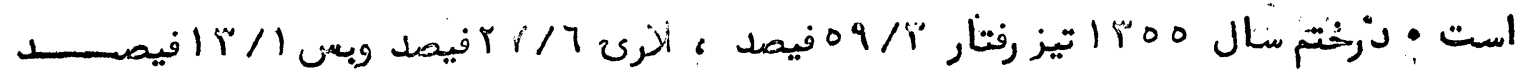

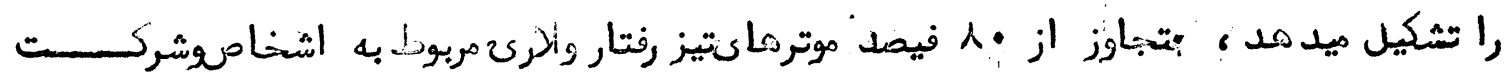

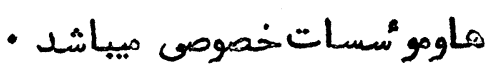

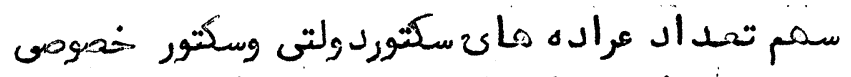

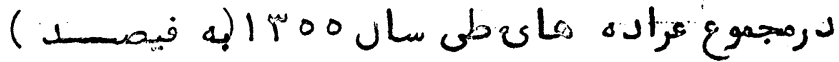

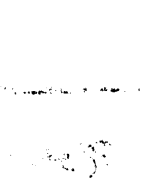

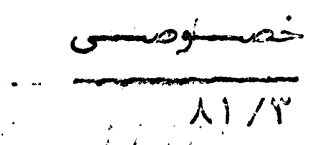

$17 / 0$

$人 \% / 1$

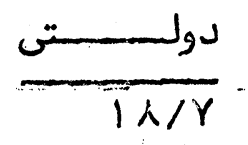

$1 \% / 0$

$17 / 9$
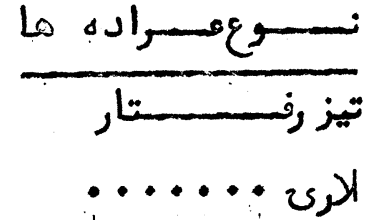

$\because \cdots \cdots \bullet$ \&

هكذا جدول ذيل عراده ما رأ به تفكيك والخيات توذيح ميد ارد :

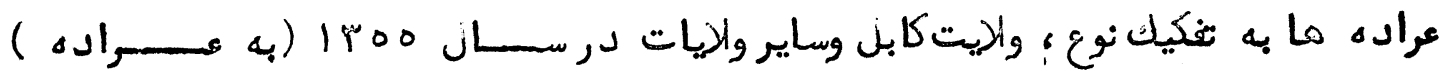

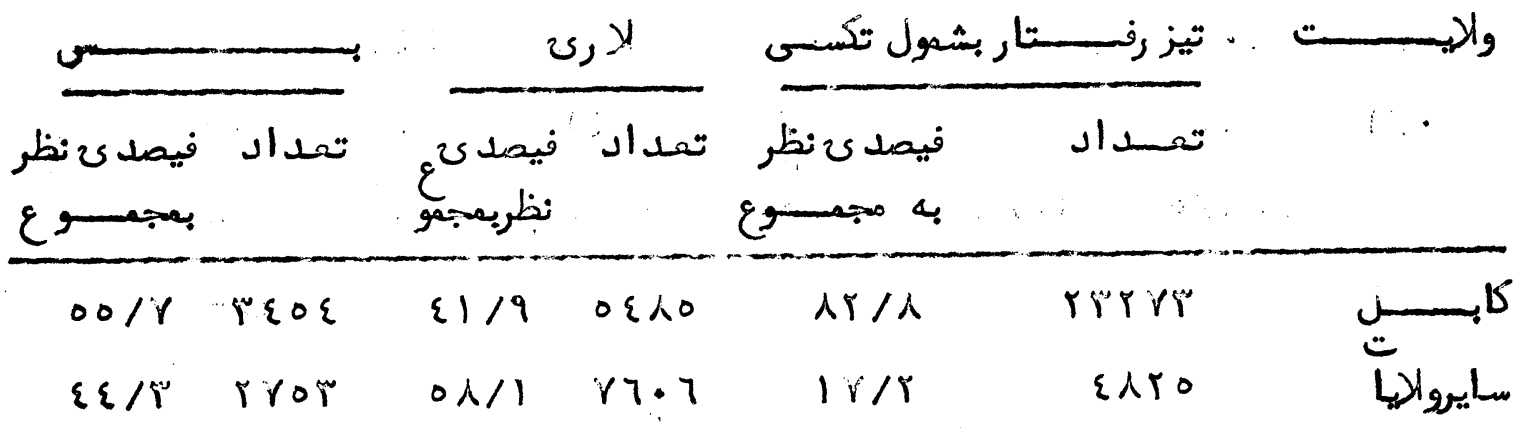
$1 \cdot 1 \cdot \pi \cdot r \quad 1,01 \cdot 11 \cdot 91 \quad 1 \cdots / \cdot \quad r 1 \cdot 91$ مجموعكثور

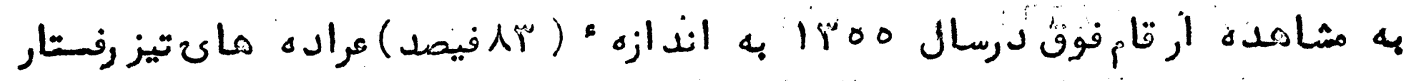

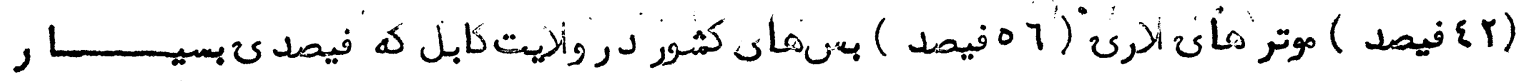

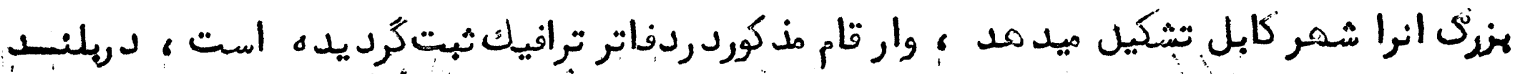

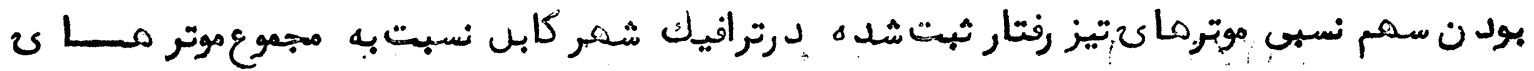

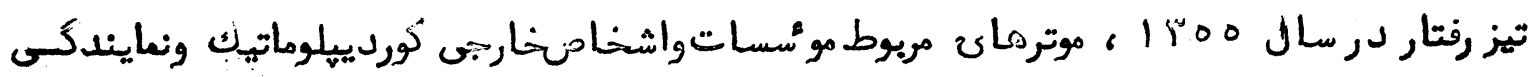

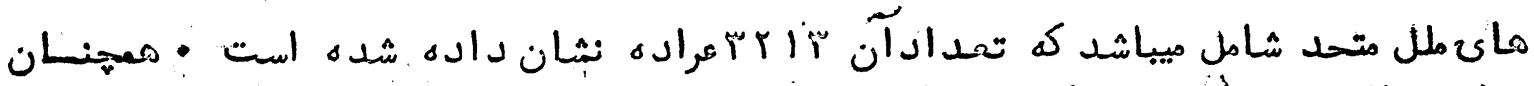

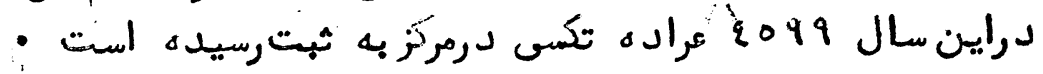




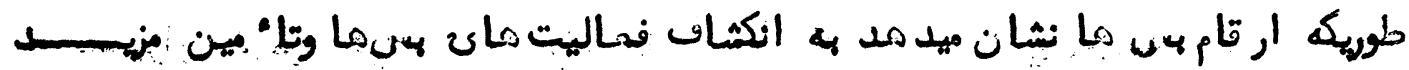

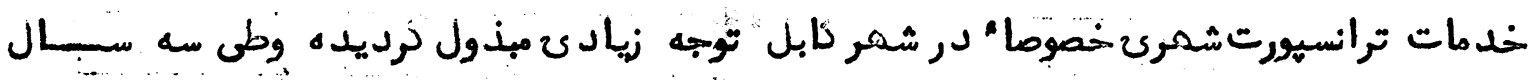

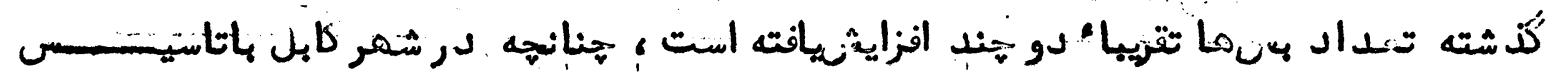

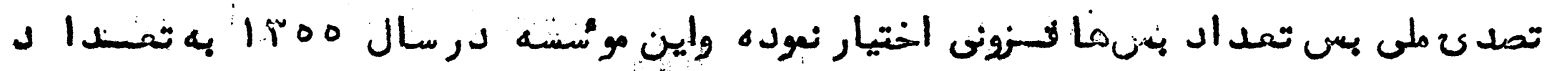

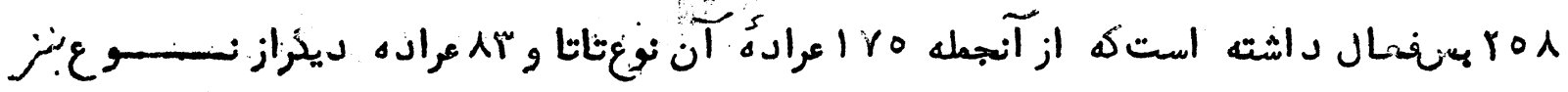

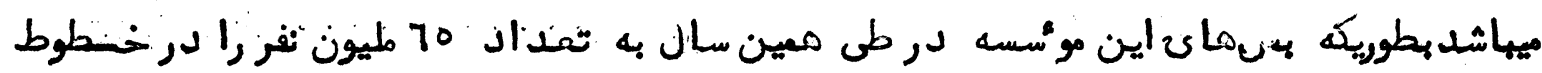

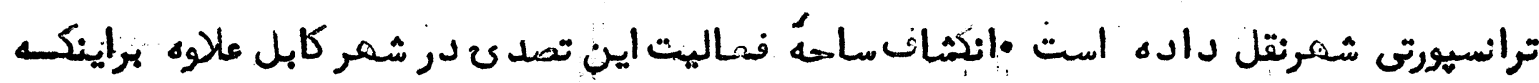

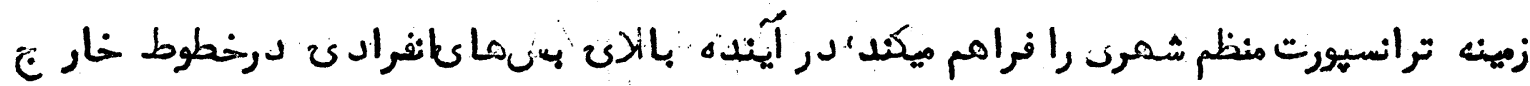

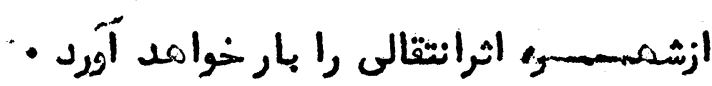

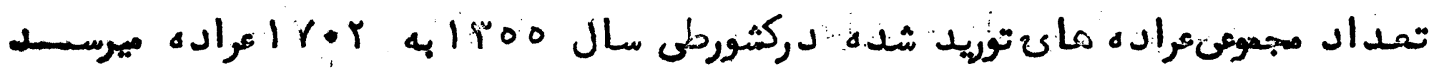

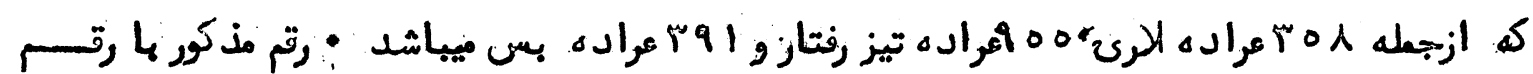

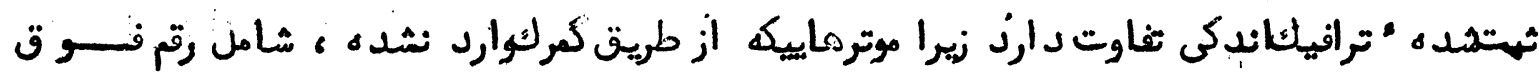

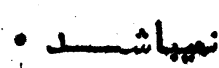

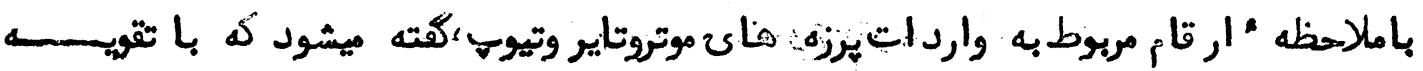

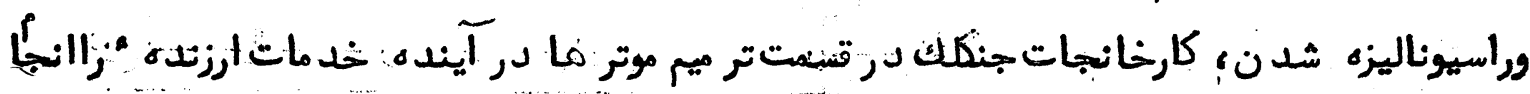

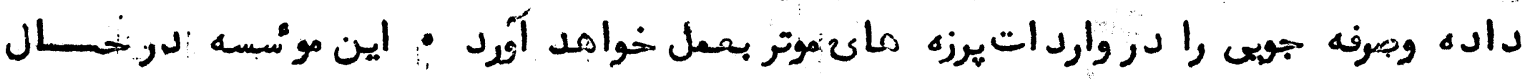

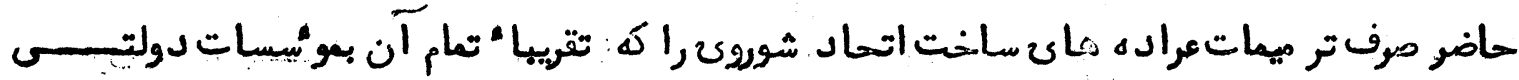

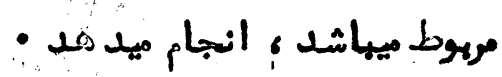

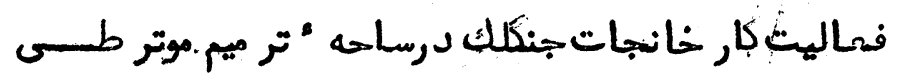
بالمبان

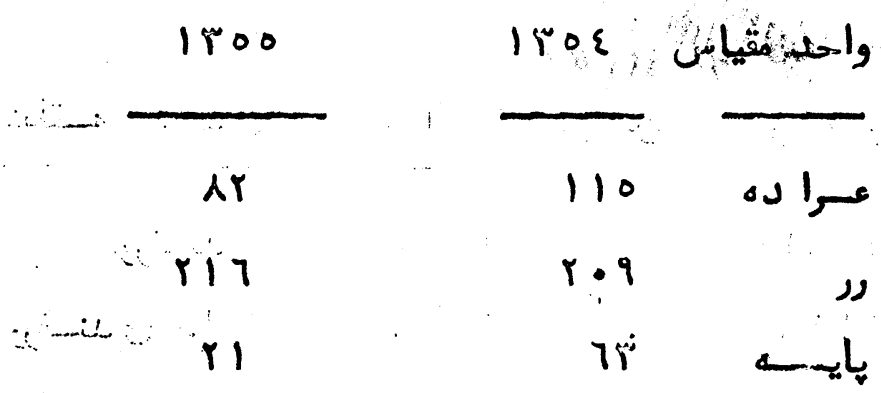

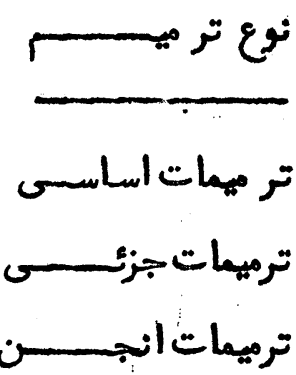

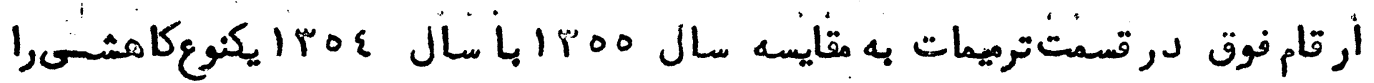

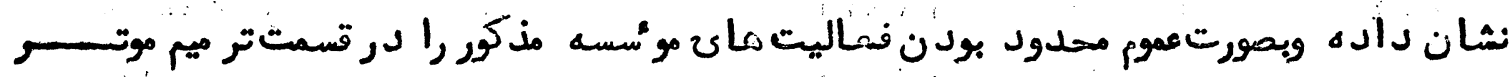

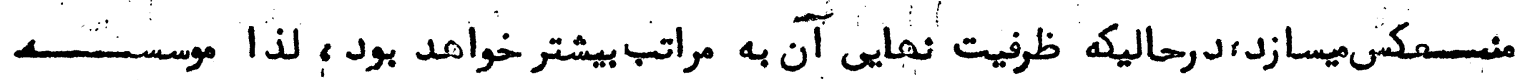

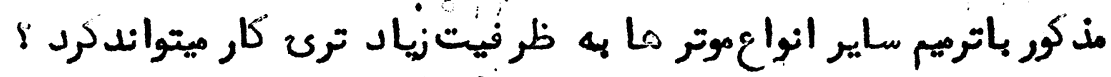




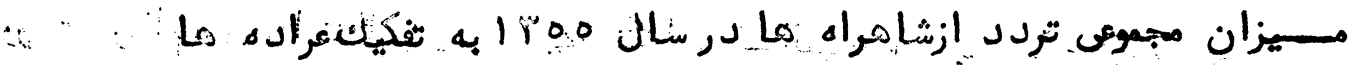

\begin{tabular}{|c|c|c|}
\hline 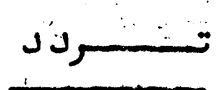 & واحســــــــــ & 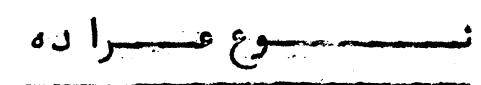 \\
\hline$\vartheta \cdot r \cdot \wedge$ & دنيمنســـــ & عرآده ماك اذافه "از مشت ت \\
\hline lopreys & & 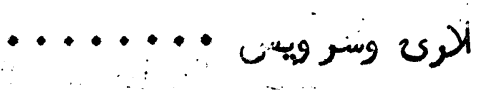 \\
\hline $741 \cdot 19$ & & 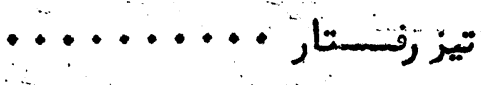 \\
\hline . \&YY & נת & \\
\hline
\end{tabular}

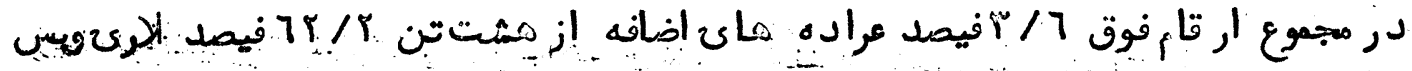

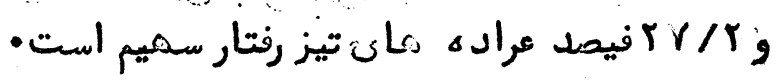

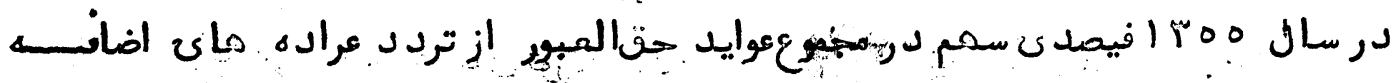

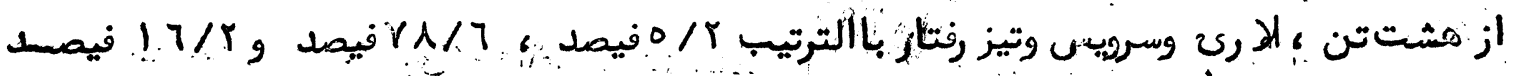

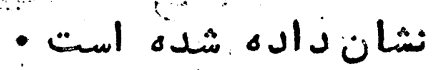

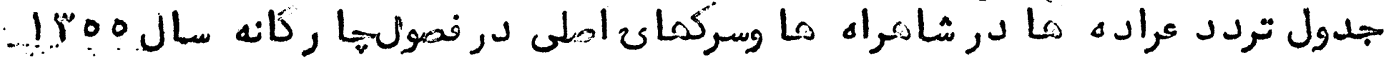

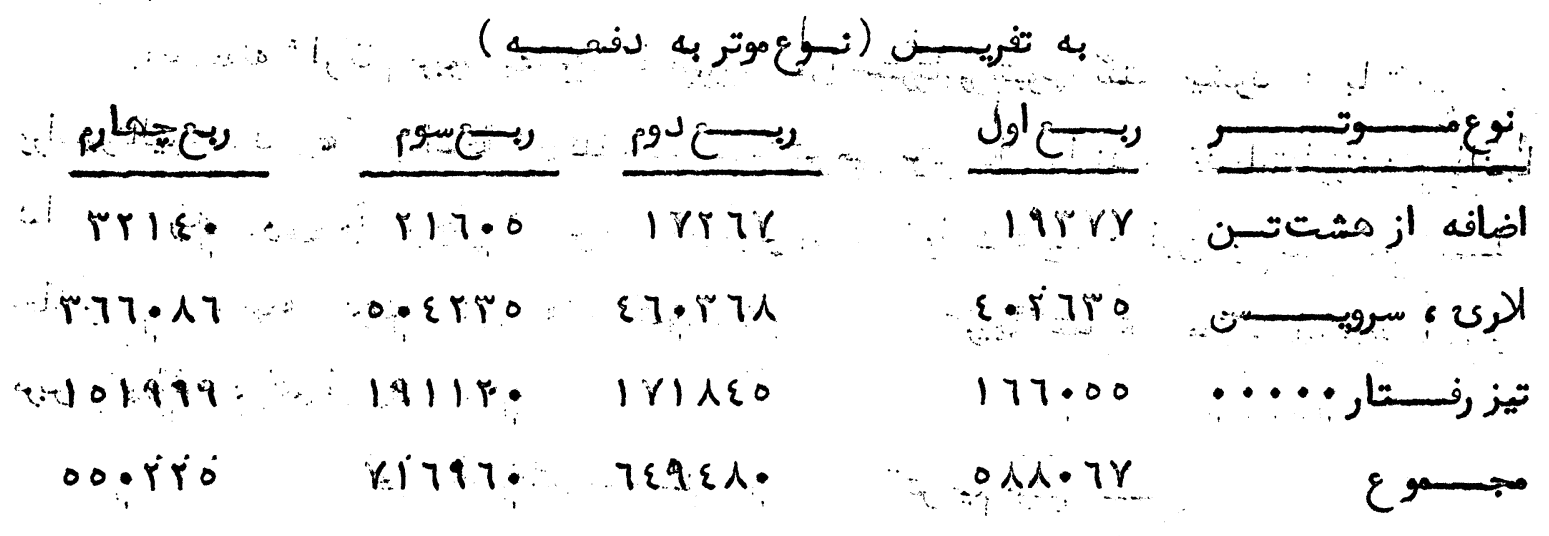

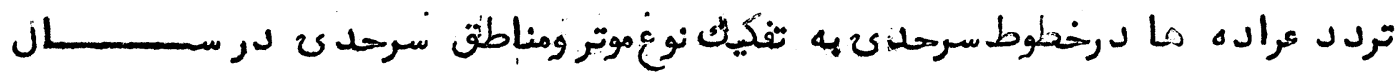

$$
\text { :e? }
$$

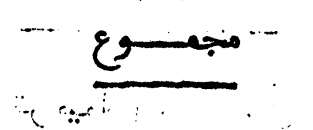

lrotr

10178

₹ฤเ

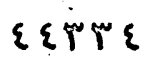

- $1 \varepsilon 01 \varepsilon$

iror 7

7o1rA
(

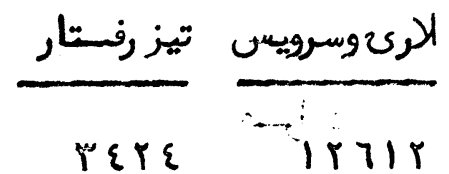

$r \varepsilon\urcorner \wedge$

$1117 \%$

9r.. $r \cdot 1 \cdot$.

litir riarl

lok $110 \mathrm{q}$

rutrit

$1 \varepsilon \wedge 19$

$9 \% 0:$

६८१६ร

(به (1900)

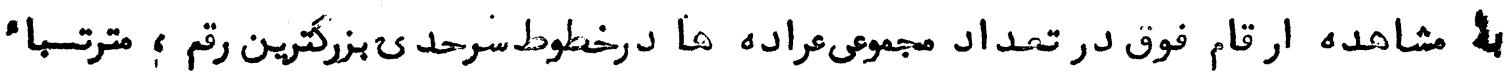




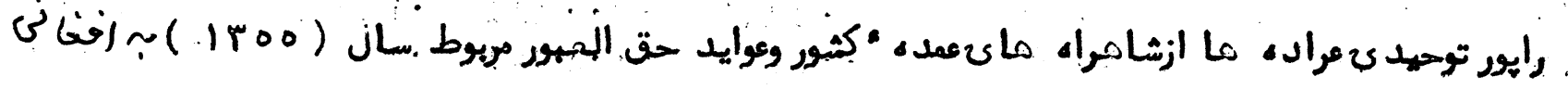

جدول (r)

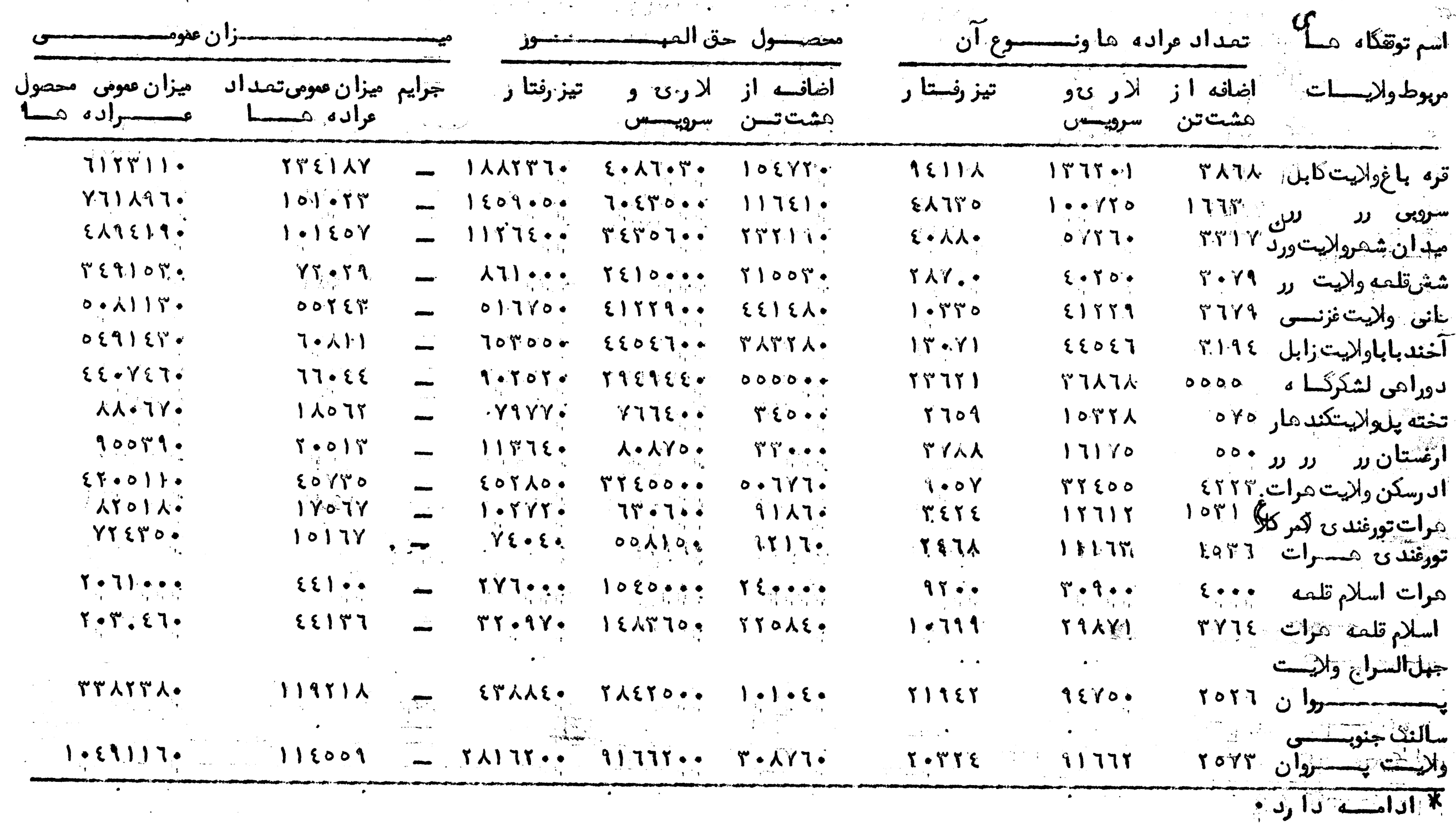




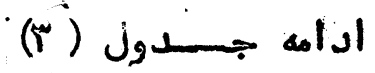

\begin{tabular}{|c|c|c|c|c|c|c|c|c|}
\hline \multicolumn{3}{|c|}{ ميس_ان } & \multicolumn{3}{|c|}{ محضفا } & \multicolumn{2}{|c|}{ تمس } & \multirow{2}{*}{ اسمب توقفكاه هاين الايـــات } \\
\hline ميزان عقومي محصول & تميزان عمومادهـئ & جرايم & تيز رفتار & س & 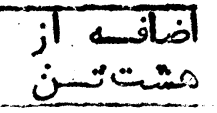 & تيزرفستار & 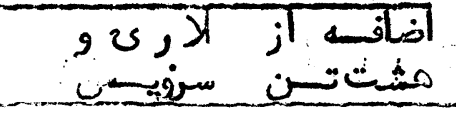 & \\
\hline IEYYYY. & 114r? & - & 9ar.... & $9 \cdot 7 \cdot \cdots$ & TTERE. & $1.9 \cdot 7$ & $9 \cdot 7 \cdot 3$ & \\
\hline $1.94798 \cdot$ & $7175 \%$ & - & กตร & 10.8.10.:- & Arsss: & 1.01 .80 & 0.170. & \\
\hline Y01001: & EqTน & $r \xi \bullet$ & \{07r : & $1987 \cdot \varepsilon \cdot$ & $\Lambda r_{\varphi} ? \cdot$ & $10 Y \cdot r$ & rtque & \\
\hline IVATrV. & ir $q \varepsilon$ & $r \cdot \bullet$ & $r \lambda \cdot \varepsilon \cdot \cdot$ & IEY०YH. & Nore. & $\mid \varepsilon \cdot r \cdot$ & $\left\{Y x_{\varepsilon}\right.$ & \\
\hline$\curlywedge \wedge \circ \varepsilon \wedge \cdot$ & $0.1 \times 7 \%$ & - & $|\gamma \varepsilon|$ IT. & 70711. & $011 \varepsilon$ & $1 \vee \varepsilon 17$ & rro:l & \\
\hline reiro. & $1 \varepsilon 0 \wedge \varepsilon$ & - & $10 \xi \varepsilon$. & $r r\{\gamma \dot{\lambda}$. & ri䧃. & $10 \varepsilon \varepsilon$ & lirra & \\
\hline rMo $77 \%$ & \&7AYT & - & $\varepsilon 758 \%$ & $|\varepsilon| 01 \therefore$ & $\gamma 7+\mu^{\prime}$ & $10 \varepsilon 01$ & r.r7o. & \\
\hline 17180.8 & $095 \cdot \varepsilon$ & - & นE:9r. & 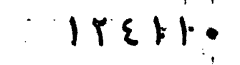 & (17... & $r \Leftrightarrow r a$ & \%०71: & \\
\hline & & & & & & $\cdot$ & $\ldots$ & \\
\hline r & $150 \% .7$ & - & $\{77 \varepsilon$ & r. $?: A \cdot \bullet$ & rorte & TYYT & .910. & \\
\hline rEYo\&r. & ovreo & - & r.rir. & 17XTro. & 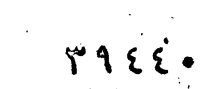 & r|qर। & prito & \\
\hline rldiso: & VIYAᄉ & - & $\varepsilon \varepsilon 0^{\circ} q \varepsilon$ & ) & 7815. & EYYT & . oolitr & \\
\hline I NerTt. & $\{\varepsilon \Upsilon \Upsilon \xi$ & $\cdots$ & $\{i \lambda \cdot \gamma$. & $|\gamma \varepsilon \in| \therefore$ & \&१: & $177 \cdot r$ & riRdr & \\
\hline o. IRTH. & $\ldots|1 \cdot \cdot \varepsilon|$ & $1 \ldots$ & VAETr. & EYITIV. & I.T\&. & rir) & $1<000^{10}$ & سفي \\
\hline $\begin{array}{l}\text { r.o人 } \\
\text { ris } 919 .\end{array}$ & $\begin{array}{l}Y 5|\varepsilon| \\
\mid \varepsilon 7094\end{array}$ & - & $\begin{array}{l}\text { YYRE. } \\
1 Y 7.70 .\end{array}$ & $\begin{array}{l}\text { Ir人7:0. } \\
\text { o人रहा?: }\end{array}$ & $\begin{array}{l}1 \varepsilon \varepsilon \cdot \\
17 T r \varepsilon\end{array}$ & 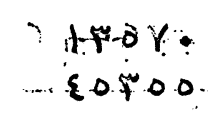 & 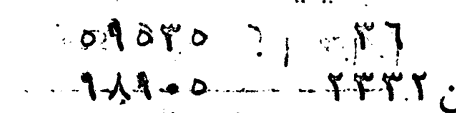 & \\
\hline TYJo0 & IrITr. & 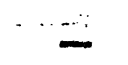 & $\gamma q \cdot \varepsilon \cdot$ & THYO: & xร71: & T9OY & Trro: it: irs, & \\
\hline IAEIYT: & 70 Nid & - & rq7ir: & I\&7人ร7. & ᄉะวน: & $|\varepsilon \lambda| i$ & 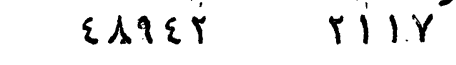 & \\
\hline ro777. & ro. 7 & - & rT:o... & roOA. : & orr $7 .:$ & $\varepsilon \gamma_{2}+\theta_{1}$ & rod & \\
\hline 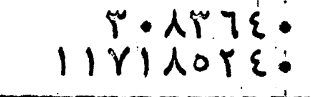 & $\begin{aligned} \varepsilon \mid Y \gamma \xi \\
\text { ro:\{YYY }\end{aligned}$ & $10 \bar{\varepsilon}$ & 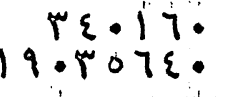 & 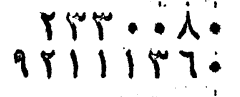 & 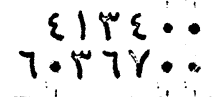 & $71 \hat{1}^{10} \cdot \hat{1}^{\varepsilon}$ & 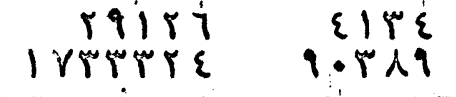 & مجد \\
\hline
\end{tabular}




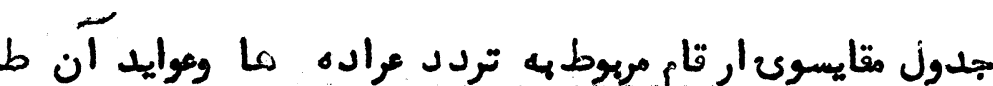

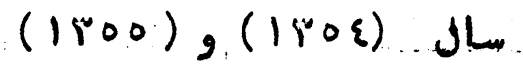

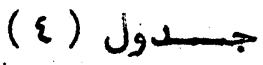

1800 J

$150 \&$ j

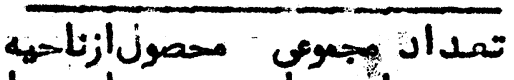

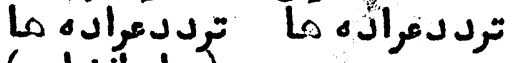
(مزار أفْنـانى)

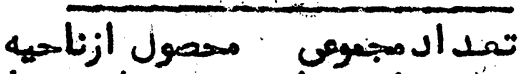

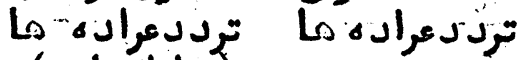

اسستم مخجسلات

كزمزارافناني)

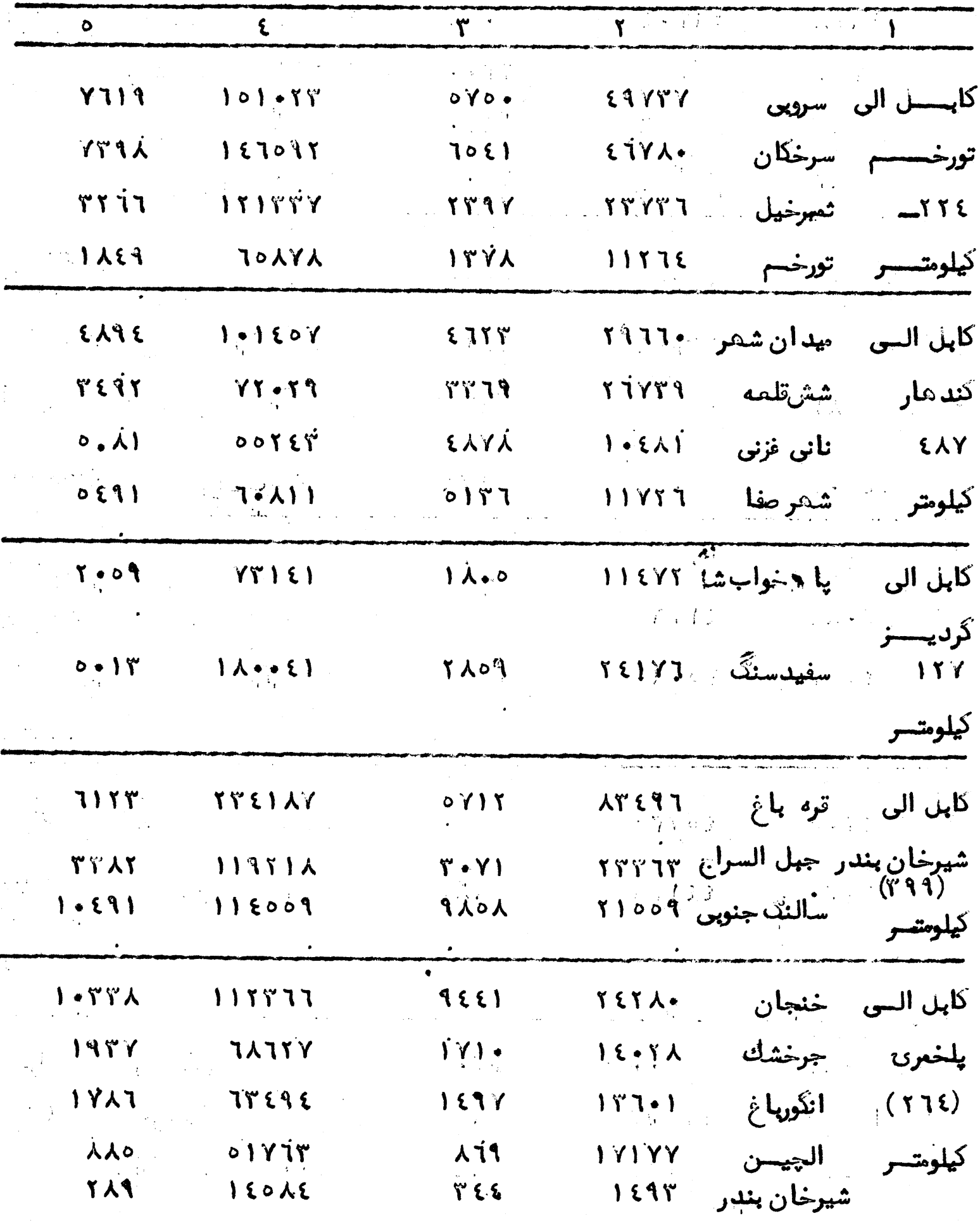


اد امســـه بجنسون (ع)...

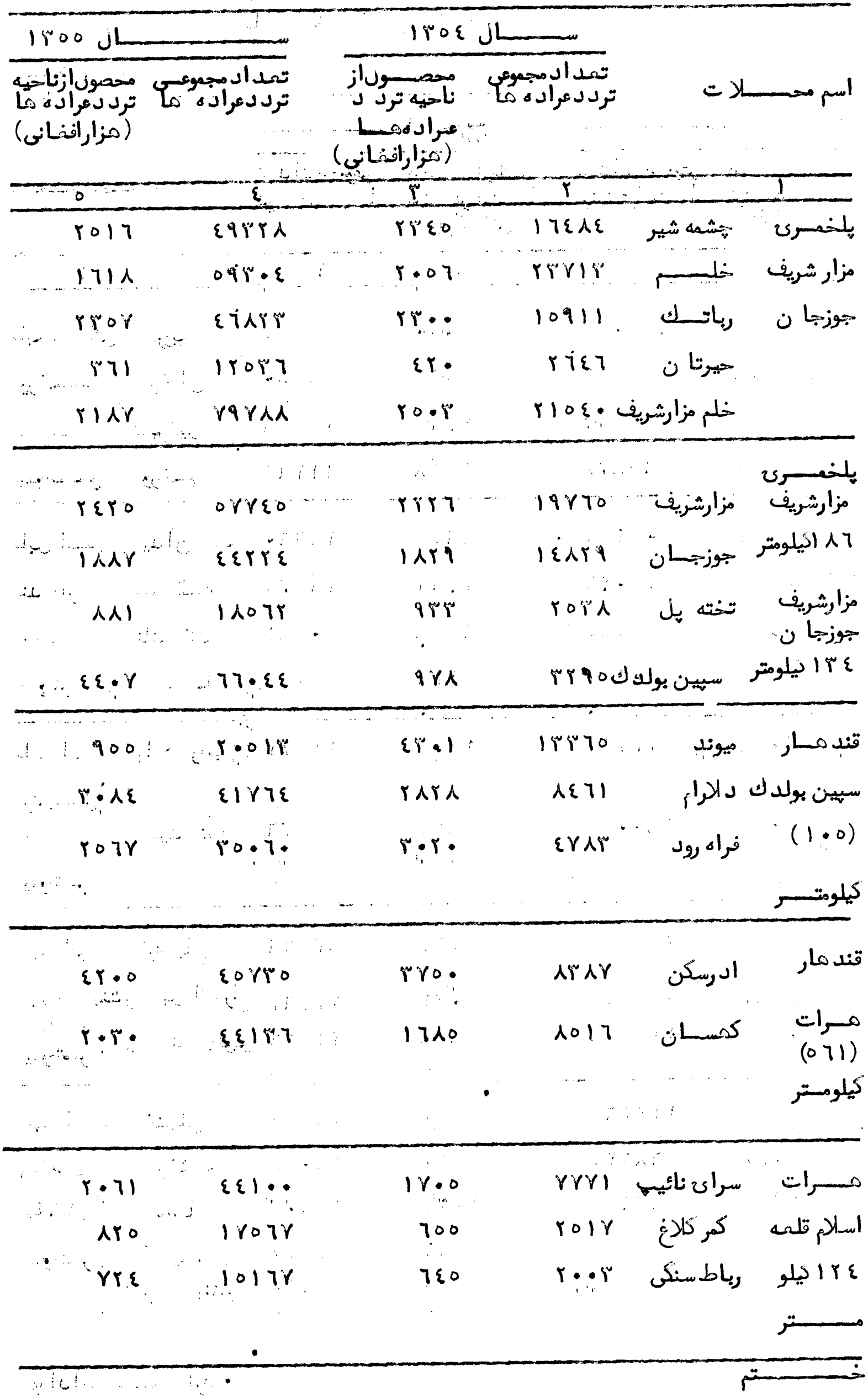




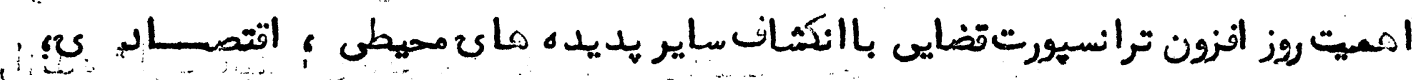

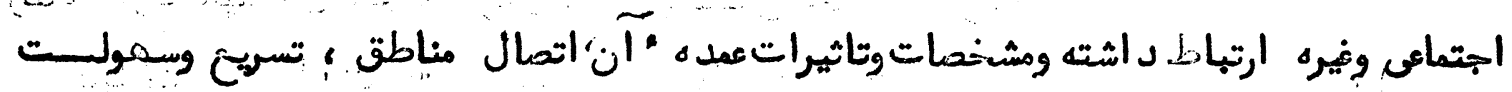

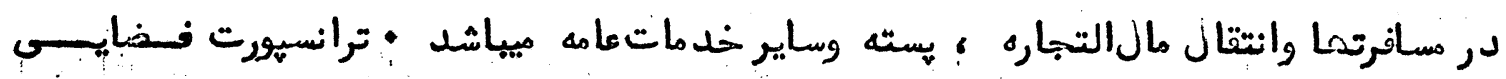

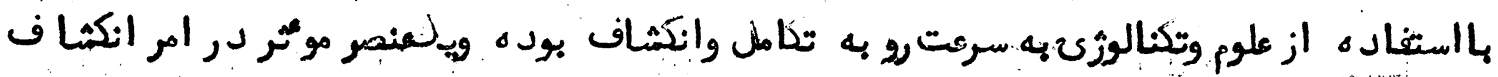

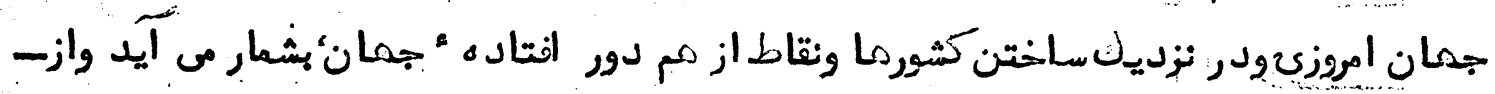

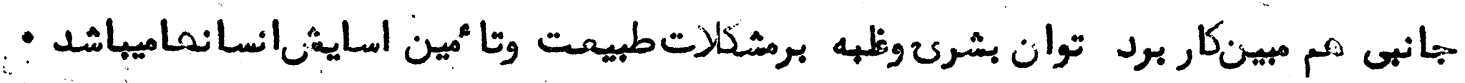

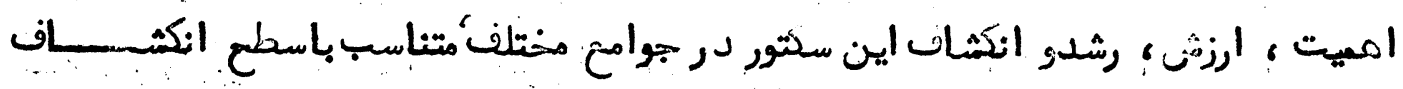

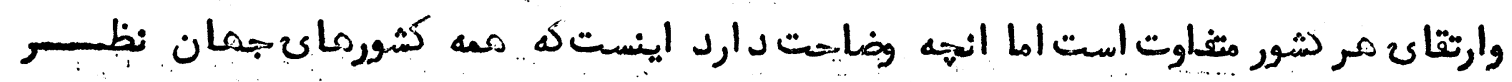

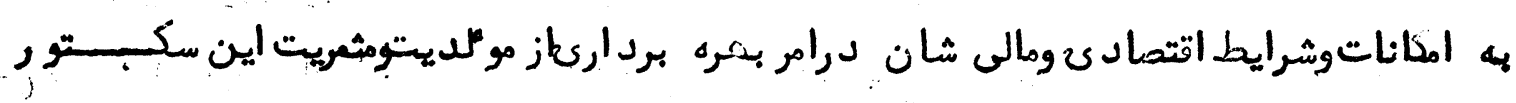
توبه خاص اله دارند

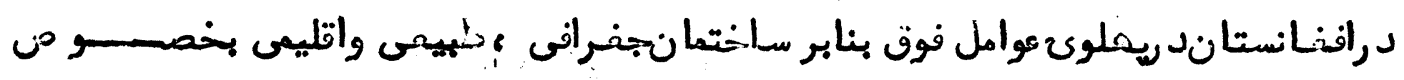

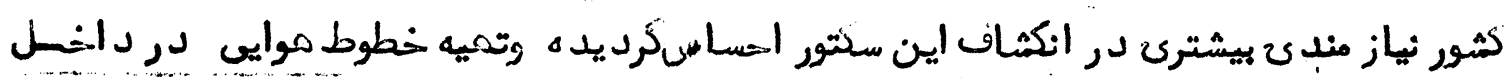

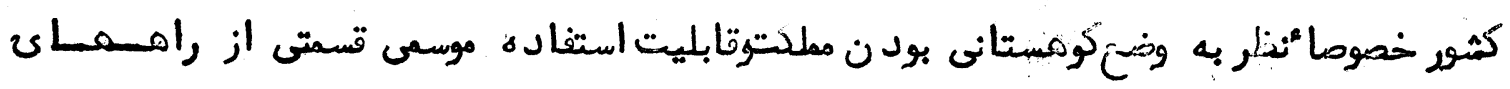

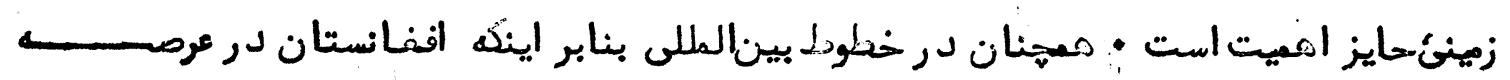

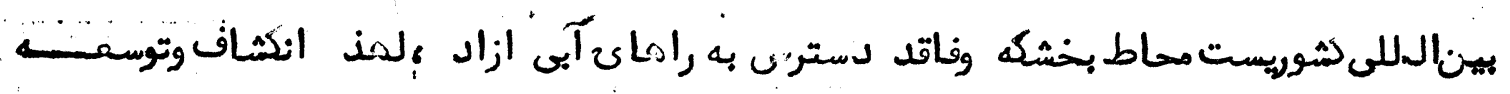

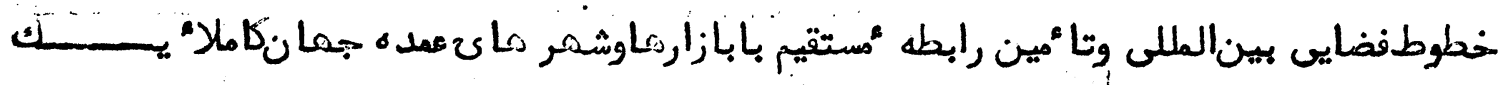

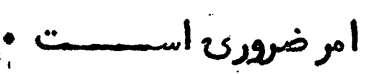

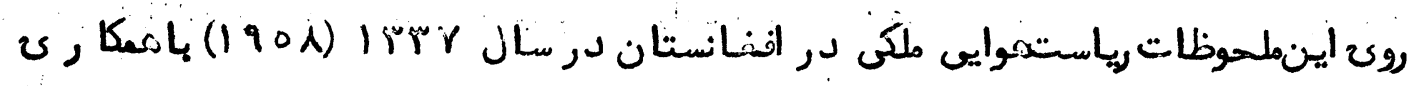

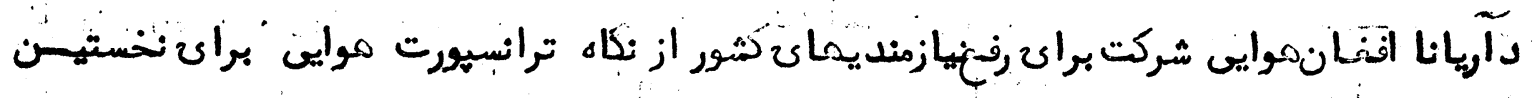

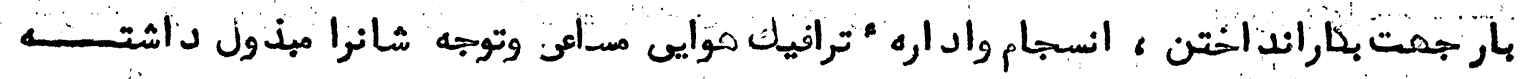

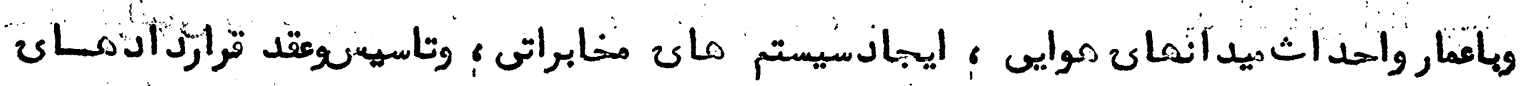

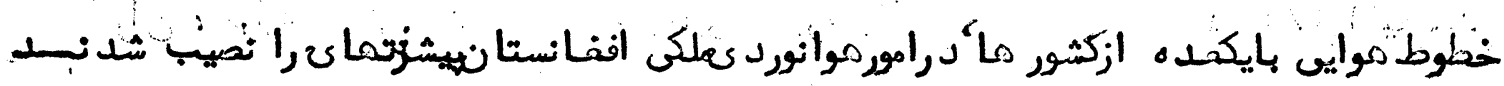

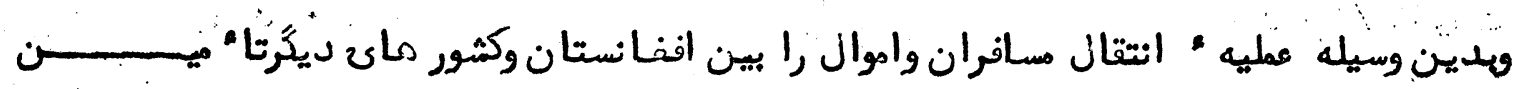

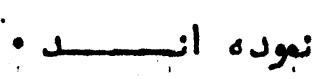

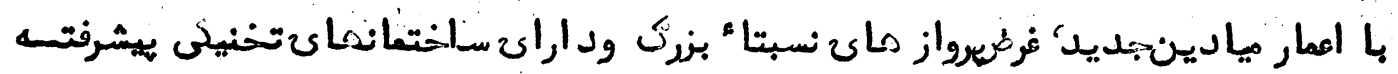

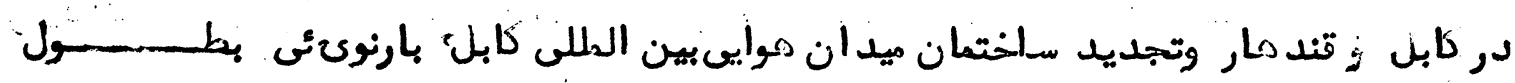

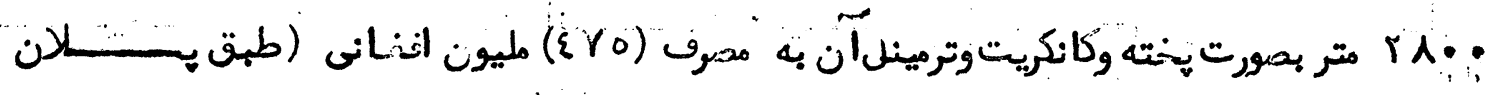

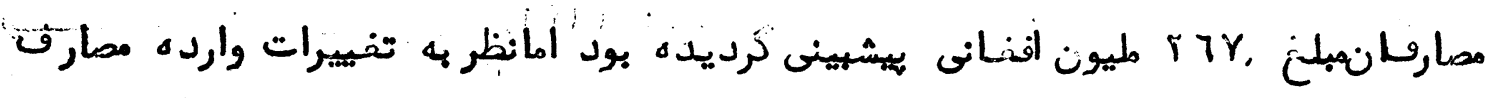

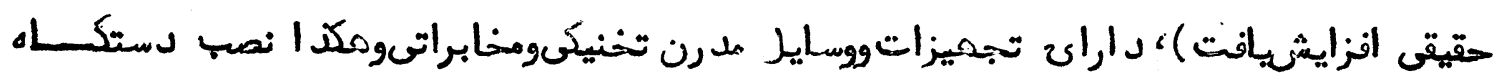

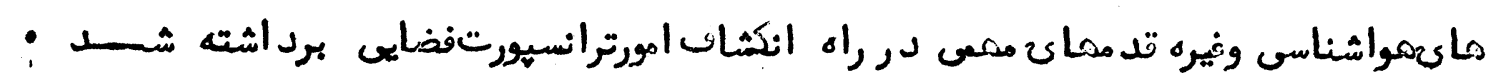




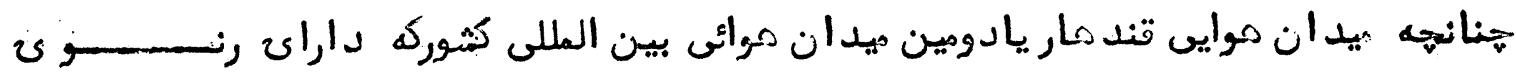

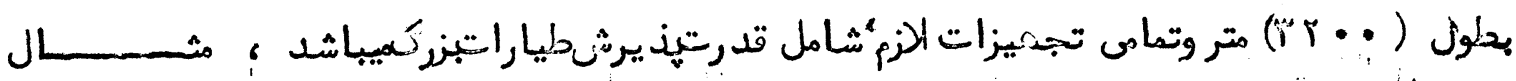

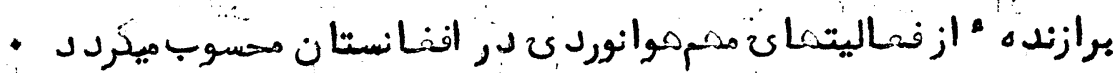

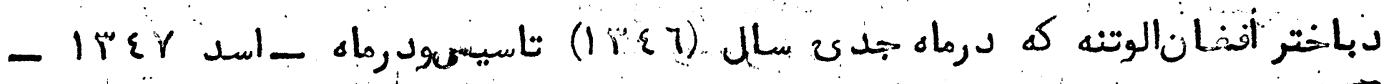

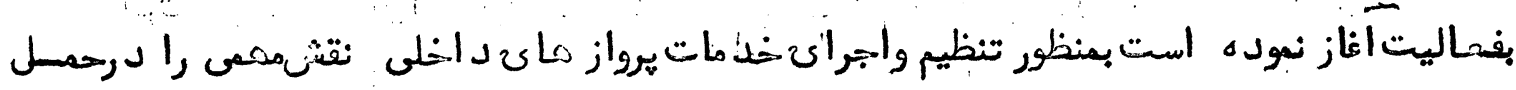

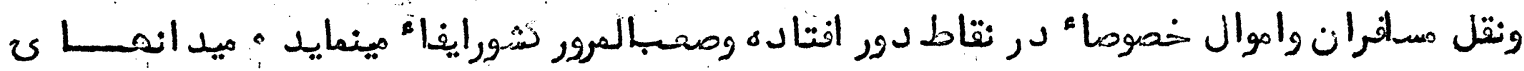

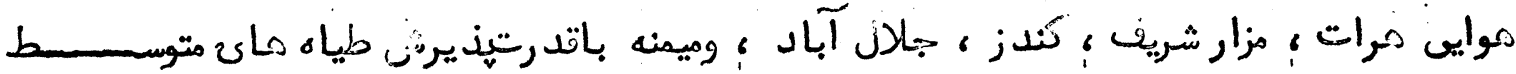

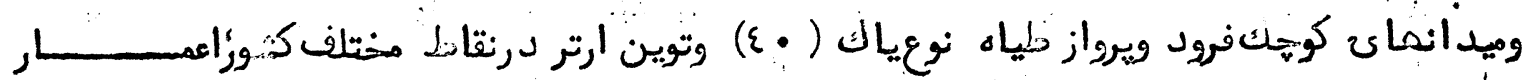

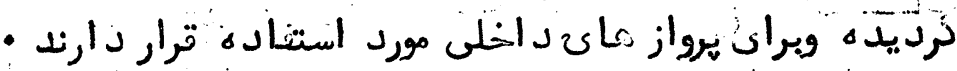

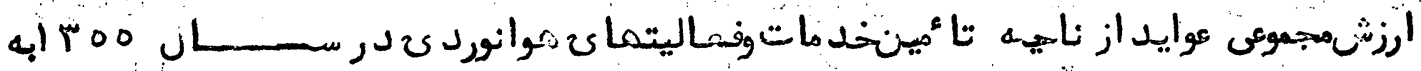

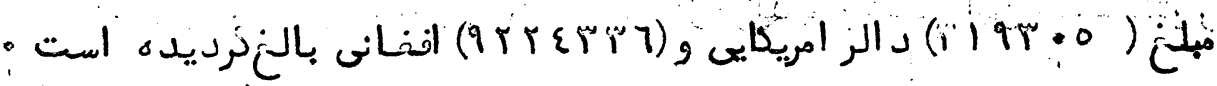

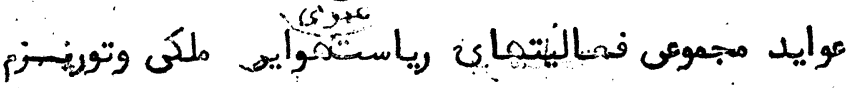

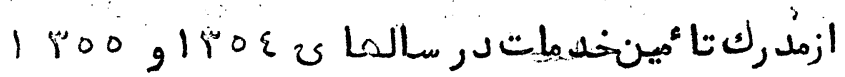

\begin{tabular}{|c|c|c|c|}
\hline 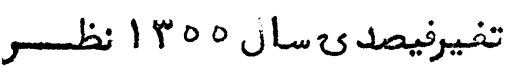 & 1500 & ITo & $\ddots$ \\
\hline 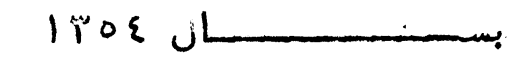 & & & $\therefore \therefore \because \quad \cdots$ \\
\hline $0 / 1$ & r19r:o & $r \cdot 179 r$ & 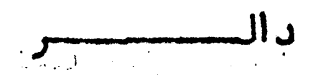 \\
\hline$-1 \varepsilon / 0$ & PYTEYT & $1.89181 \varepsilon$ & 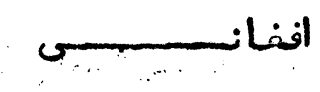 \\
\hline
\end{tabular}

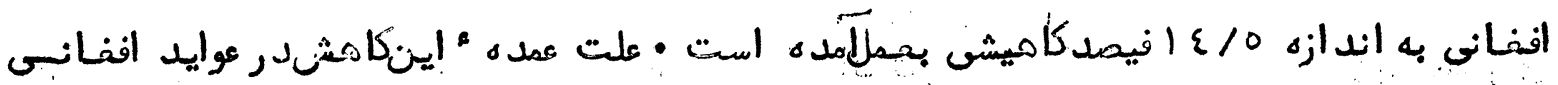

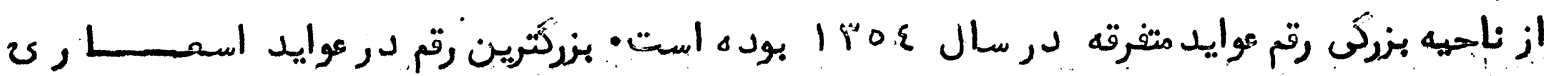

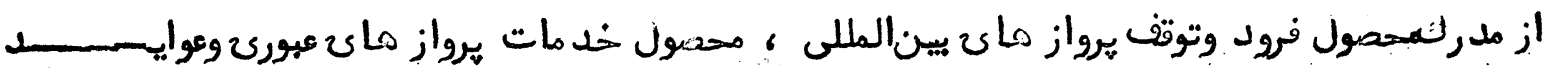

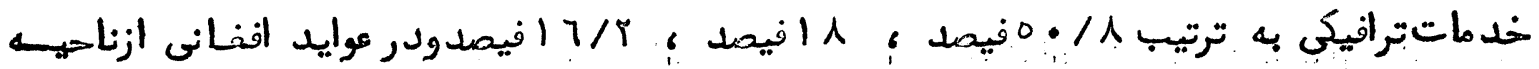

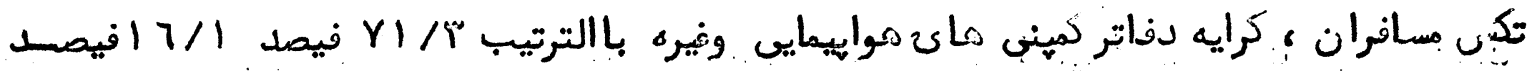

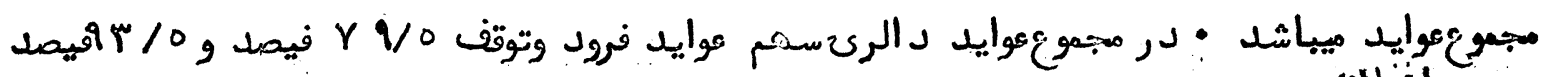

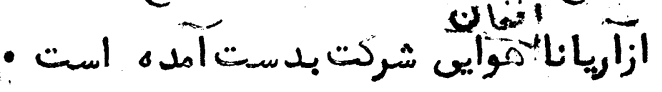

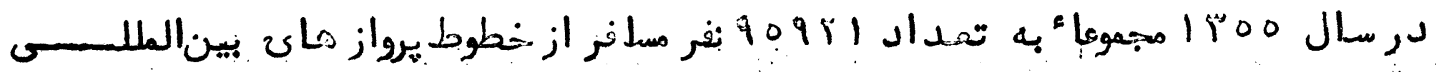

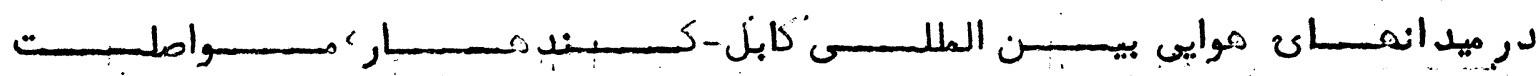

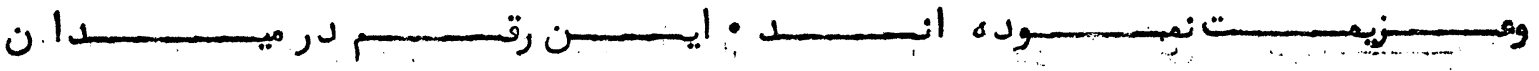

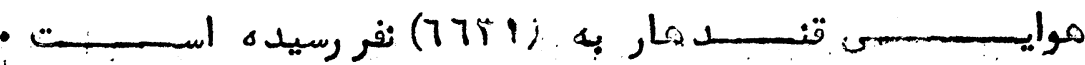




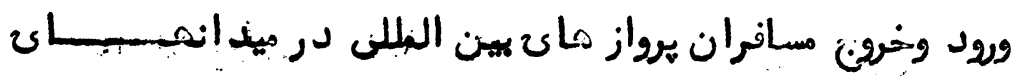

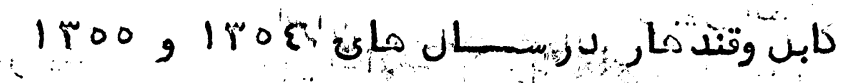

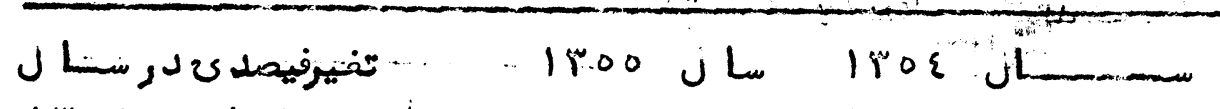

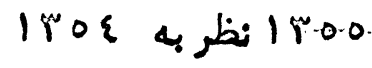

مستســــ

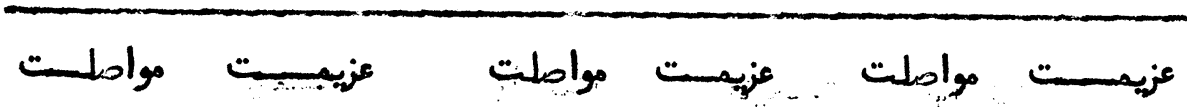

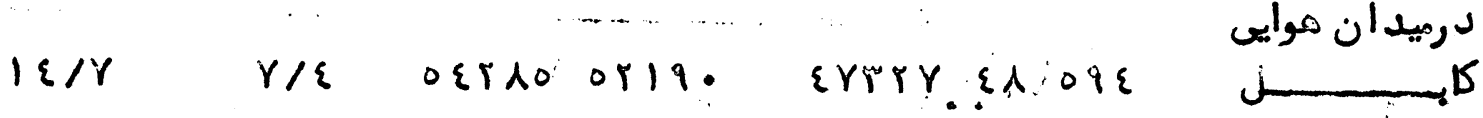

كندميدان موايس

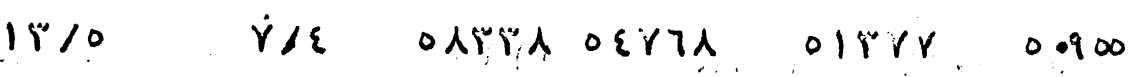

سمم فيصد ك ورود وخرون مسافران در ديد ان ماكن بين الطلى كابل

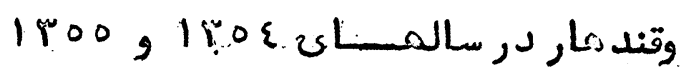

1100

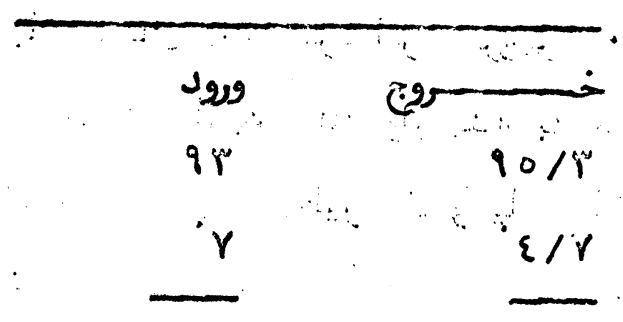

ميدان هوايس : مئ

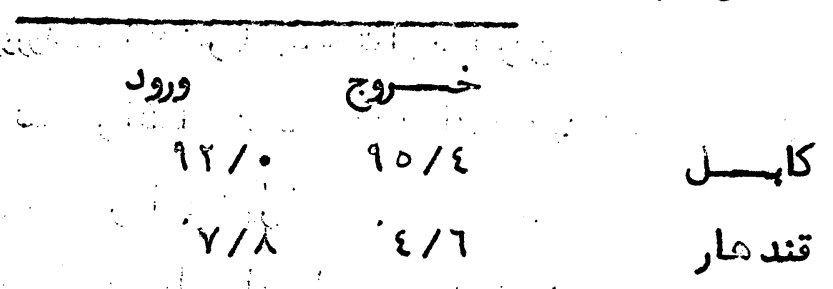

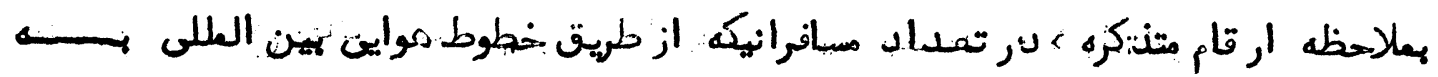

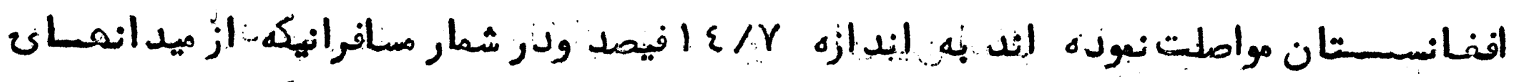

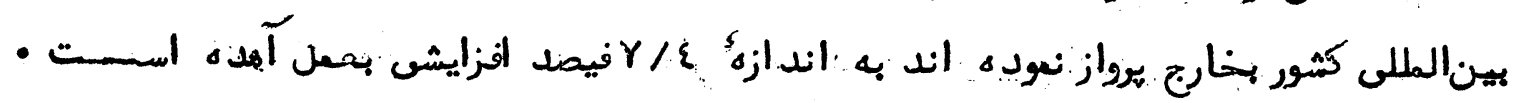

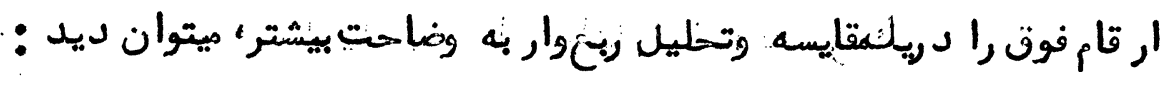

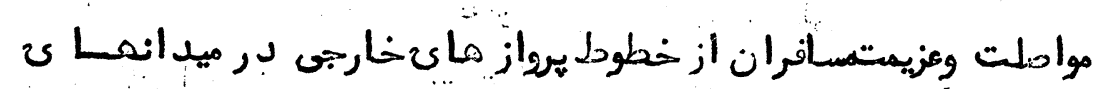

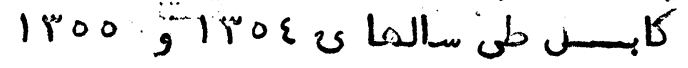

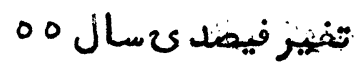

1900 س س

سمبـ

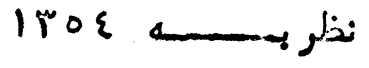

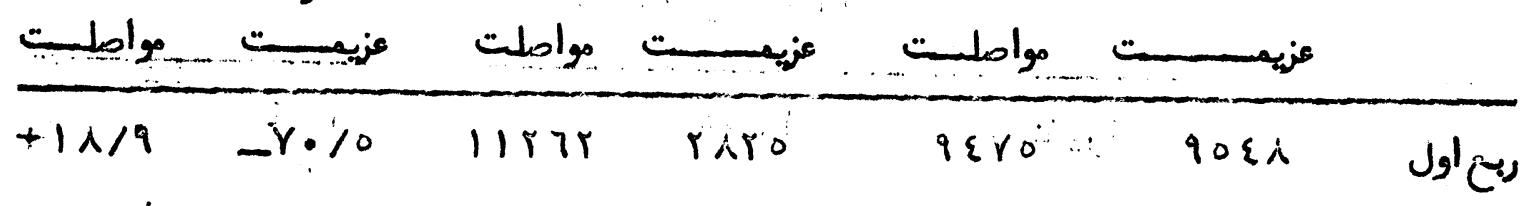

נيعدو

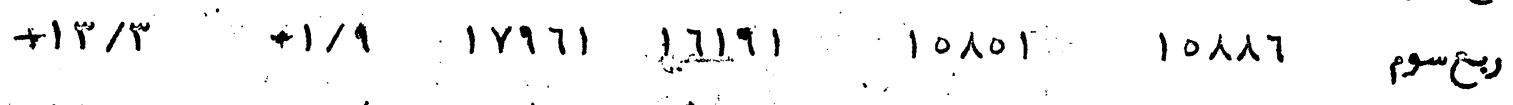

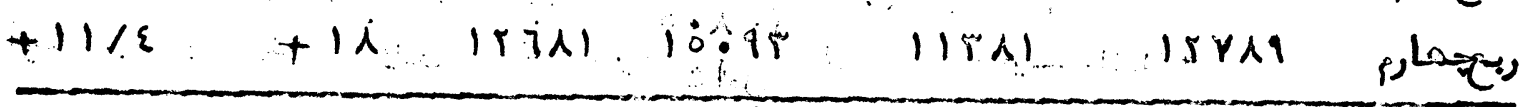




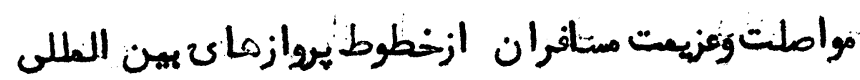

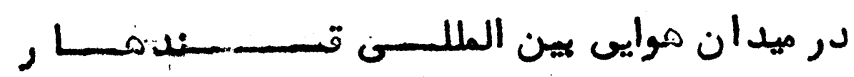

\begin{tabular}{|c|c|c|c|c|c|c|}
\hline 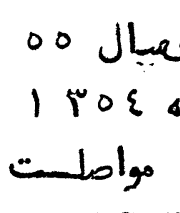 & 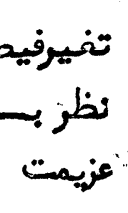 & مواملت & غزيمست & 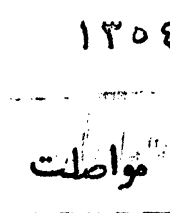 & كزيتـــت & \\
\hline-70 & - & 100 & - & r1000 & 1 & زيغ الول \\
\hline- & - & - & - & - & - & ريت دوم \\
\hline $2=$ & - & r": & - & - & - & ريخ سوم \\
\hline 100 & 9 & $\cdot q \bullet \varepsilon \uparrow$ & roYA & 1190 & rit. & ريخ تجمارم \\
\hline
\end{tabular}

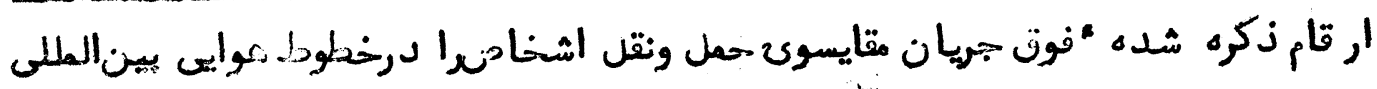

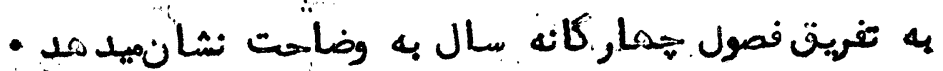

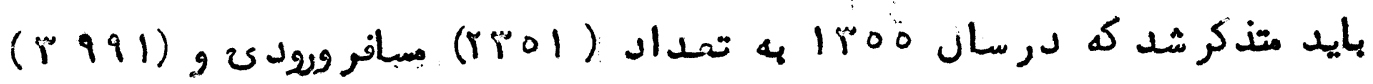

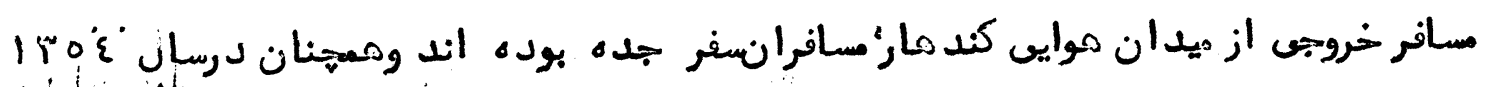

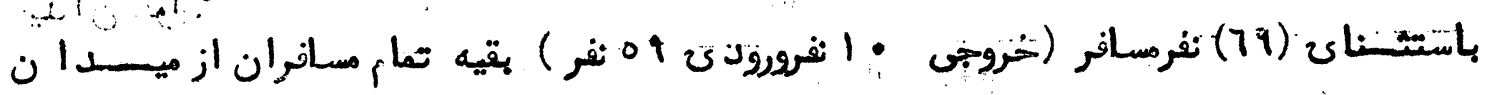

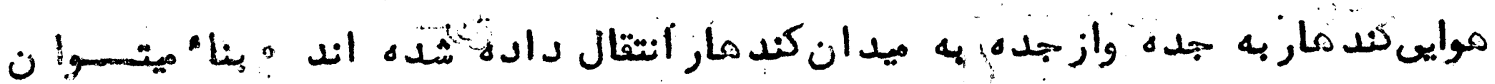

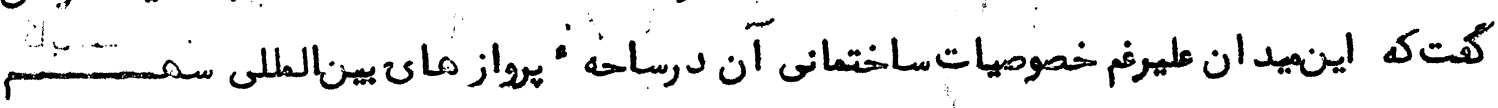

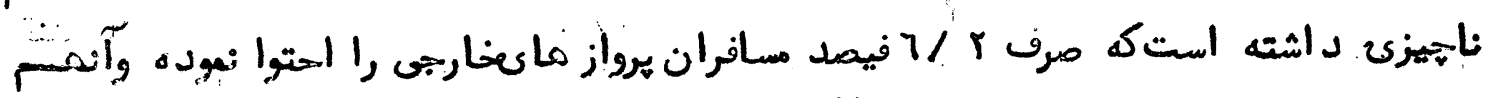

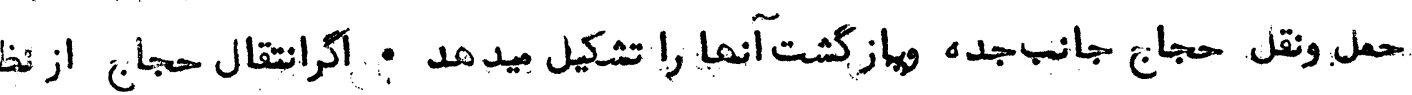

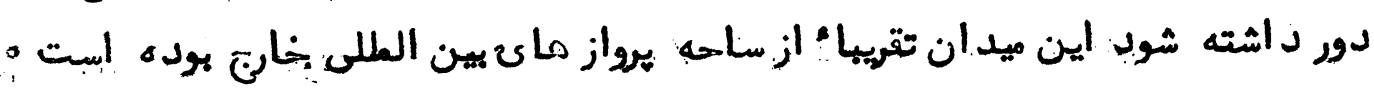

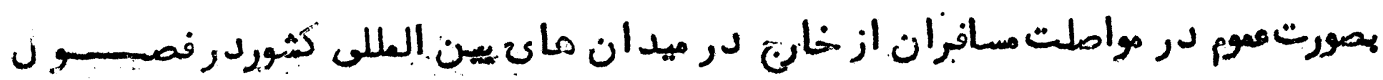

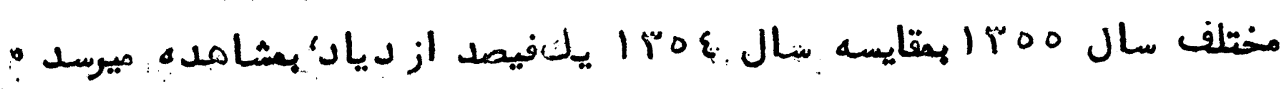

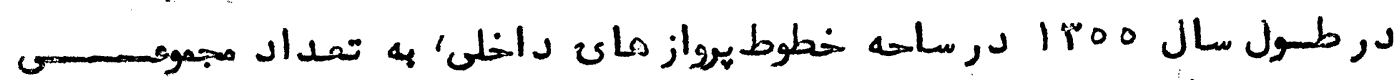

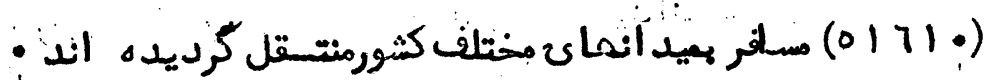

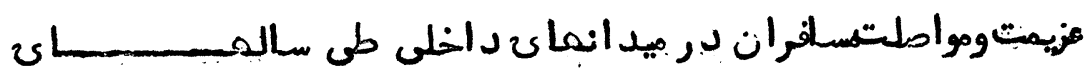
$1500,150 \varepsilon$

\begin{tabular}{|c|c|c|c|}
\hline تظرير فيمد ك درسال & 1700 & & rrog \\
\hline عزيمهـ & عزيمست & مواملت |人ا|| & غزيمست \\
\hline
\end{tabular}




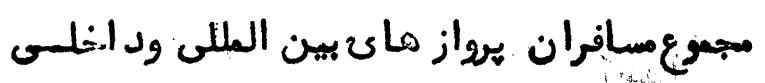

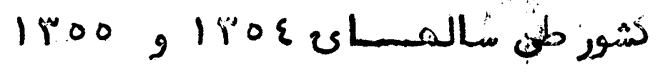

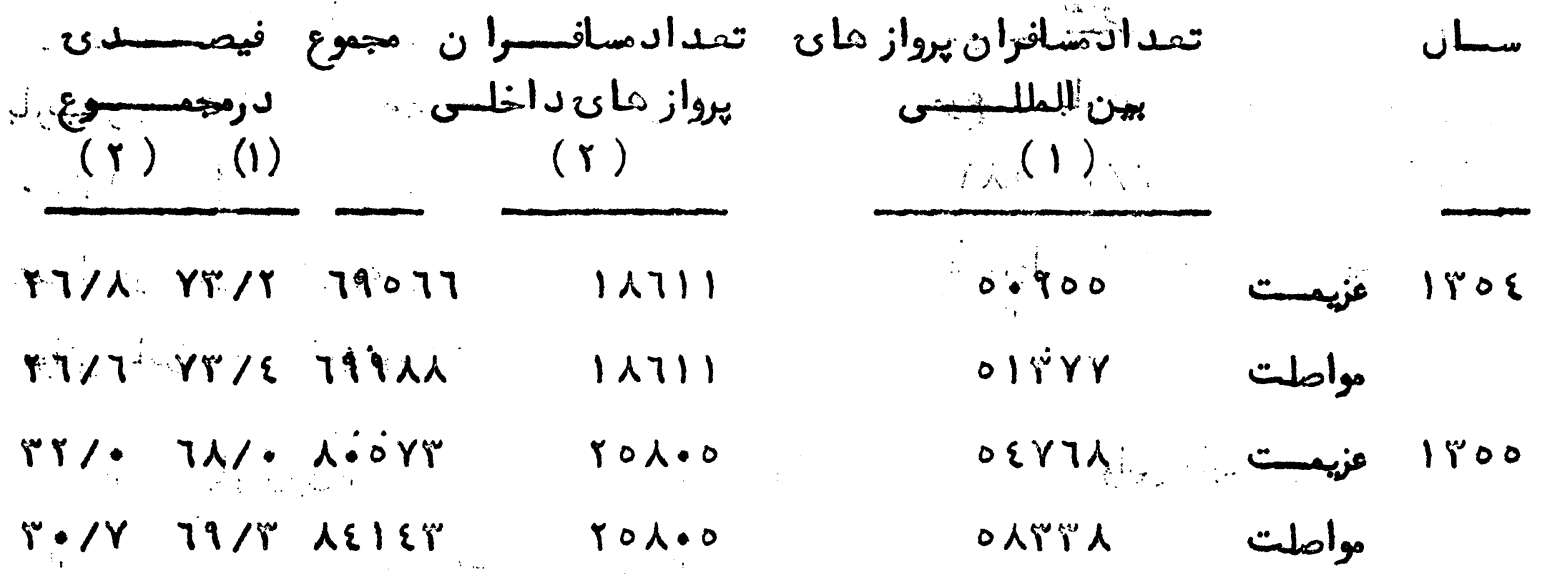

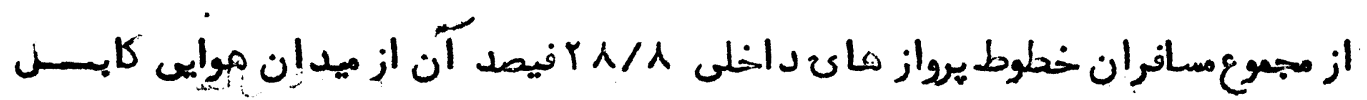

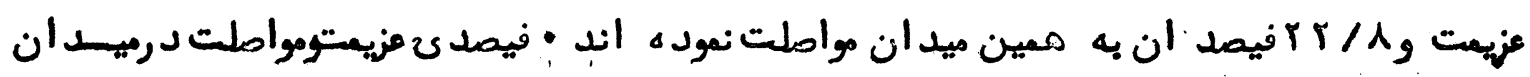

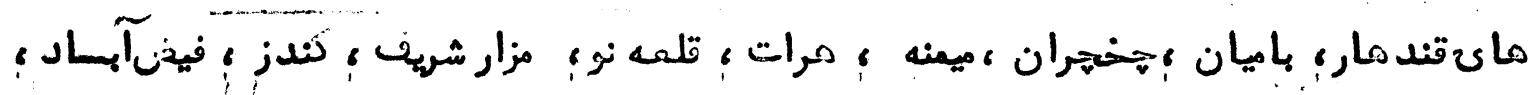

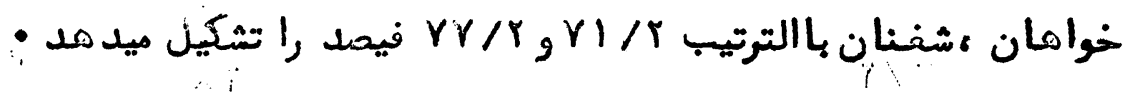

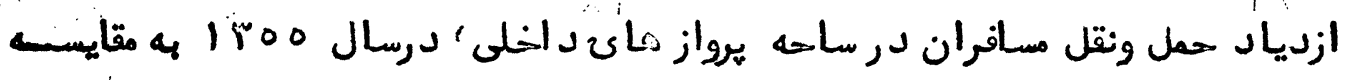

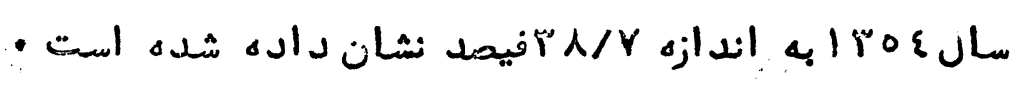
درسامه حمل ونقلاموال طل سان

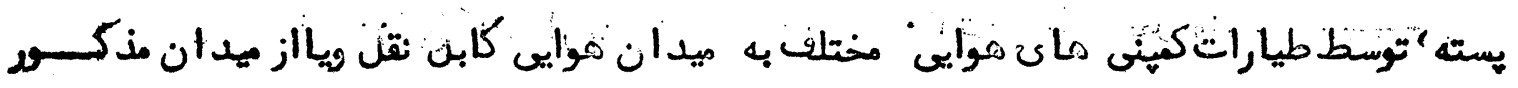

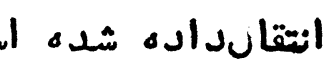

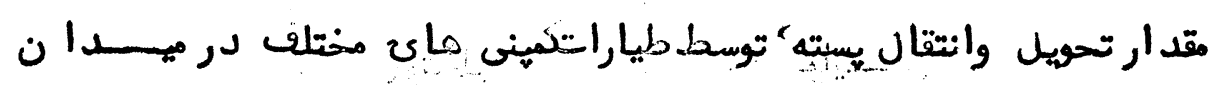

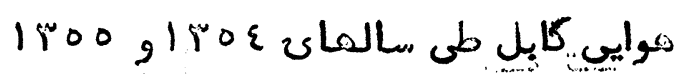

\begin{tabular}{|c|c|c|c|c|}
\hline تفهيرفيصد ى درساسل & سال 1 1roo & سال Ro\& & واحدمقياس & مقدار بـتــ \\
\hline$-Y$ & r.r人 & 11011 & كيلو كرام & 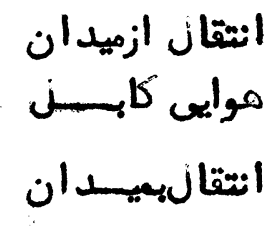 \\
\hline a $r \gamma / 1$ & $0 \wedge \cdot \varepsilon i$ & \&077r & ננ & 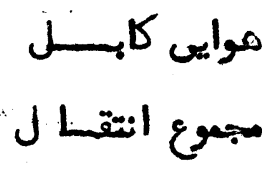 \\
\hline $17 / 5$ & $r \wedge \cdot r 1$ & 7 Tro: & ננ & وتحويــــــل \\
\hline
\end{tabular}




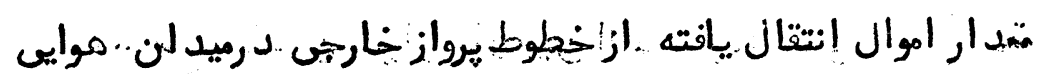

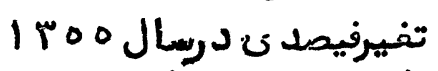

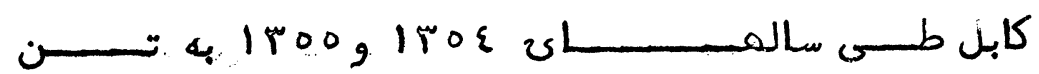

نظر

1roo

1ros

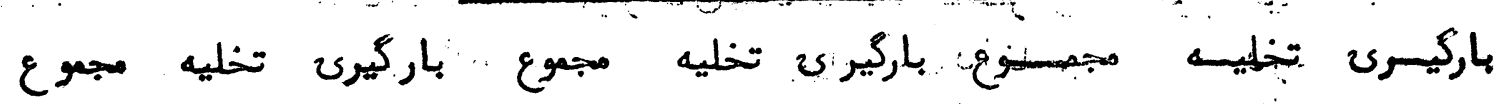

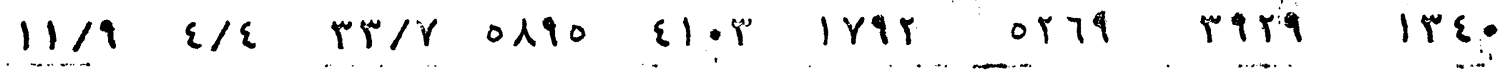

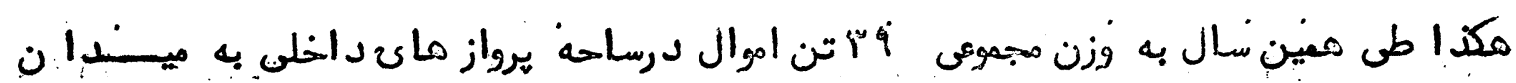

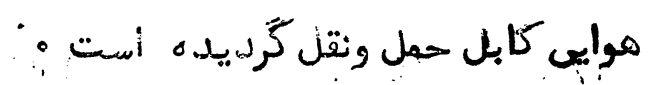

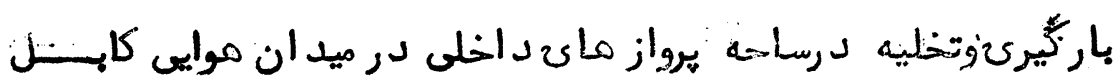

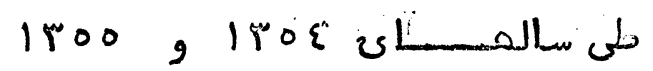
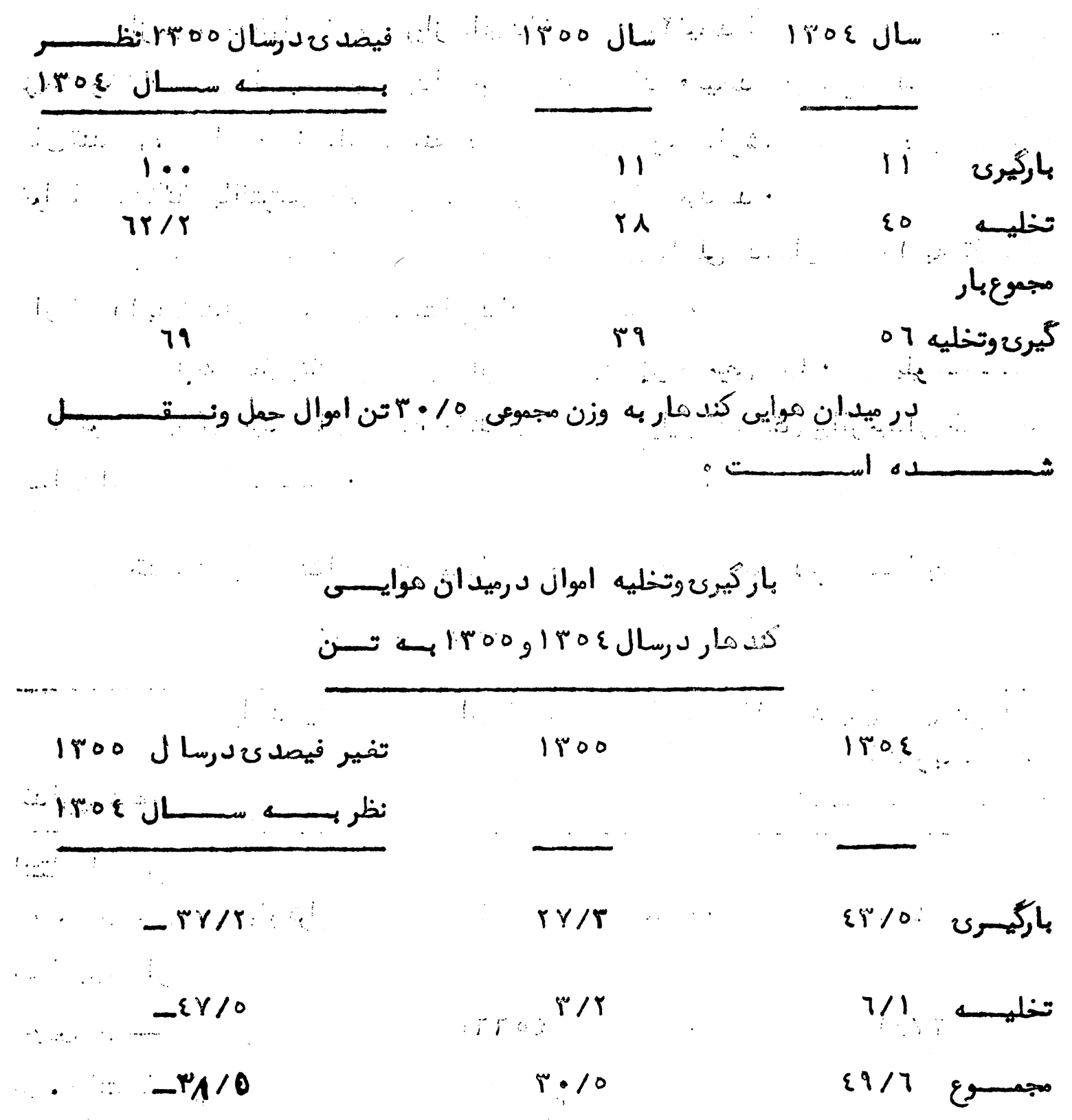


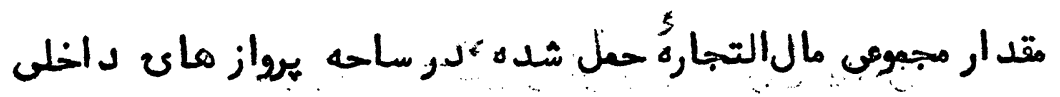

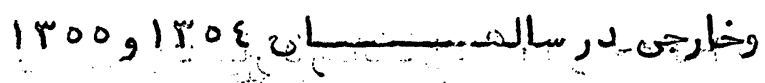

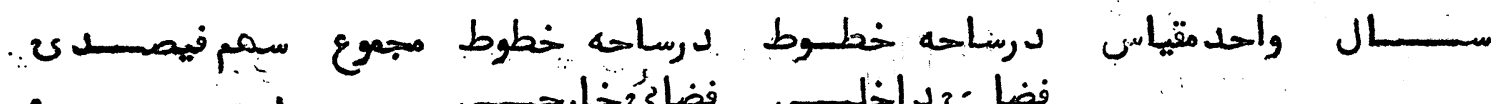

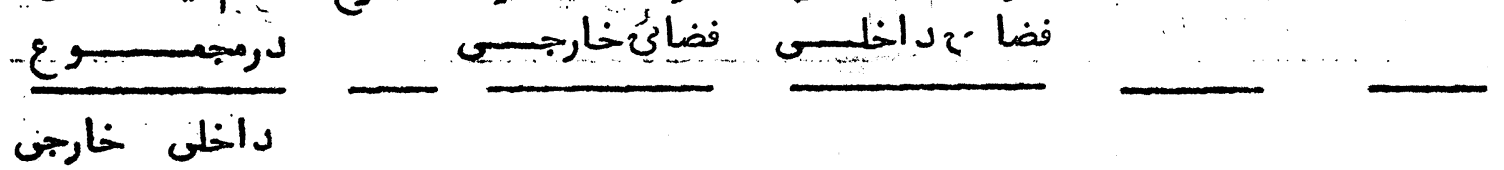

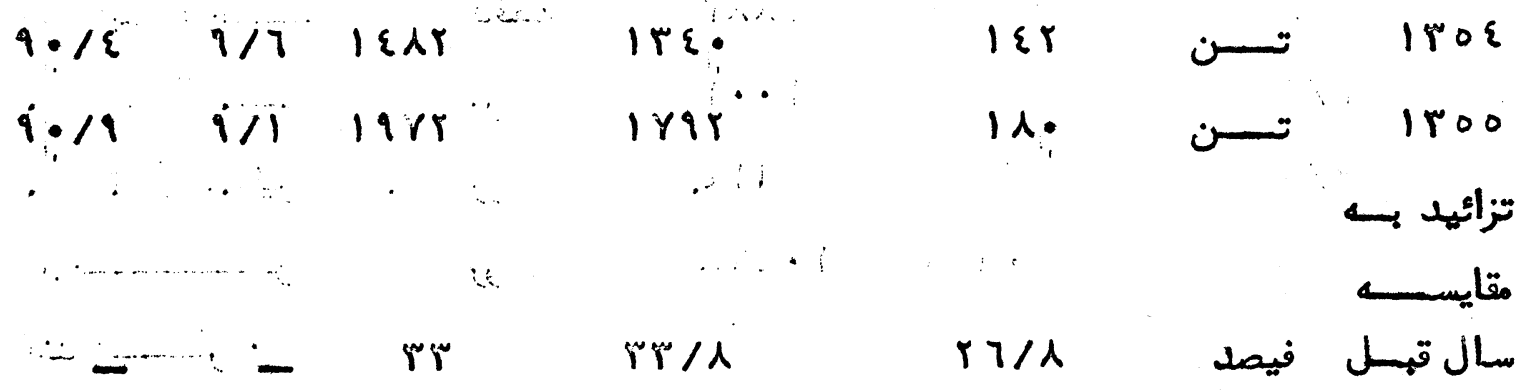

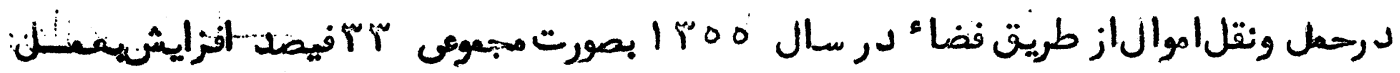

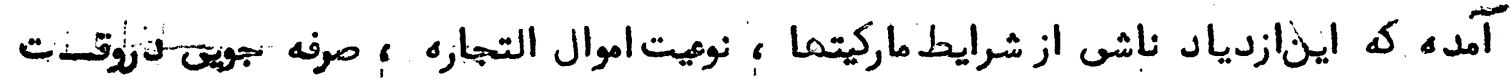

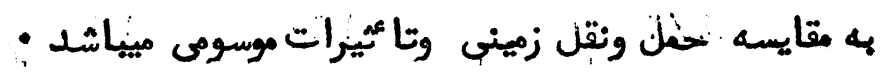

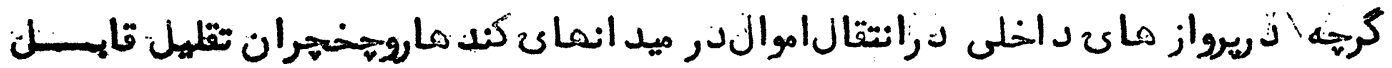

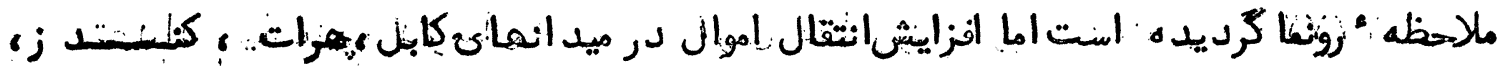

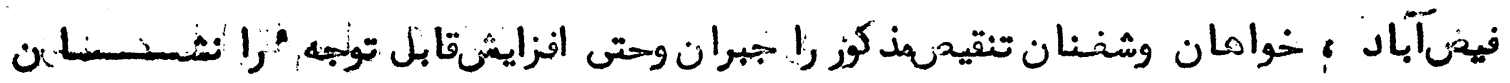

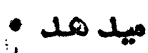

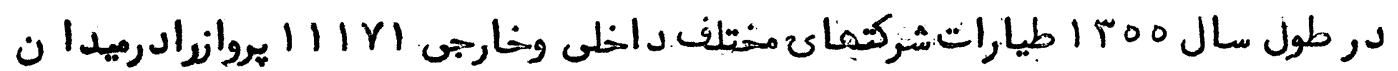

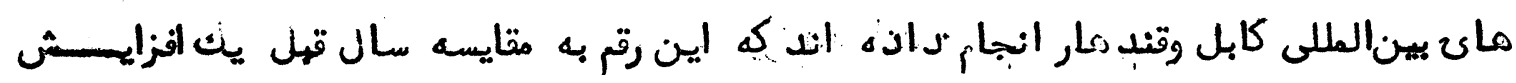

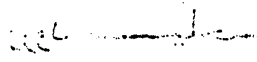

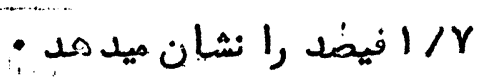

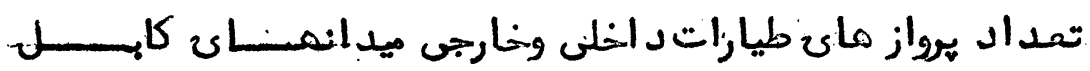

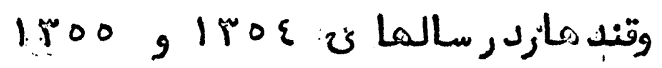

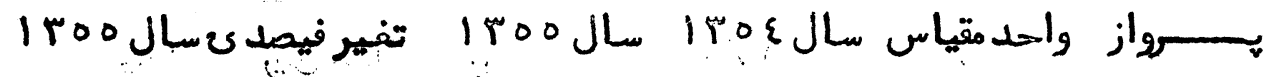

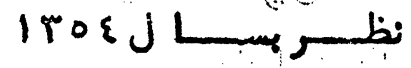

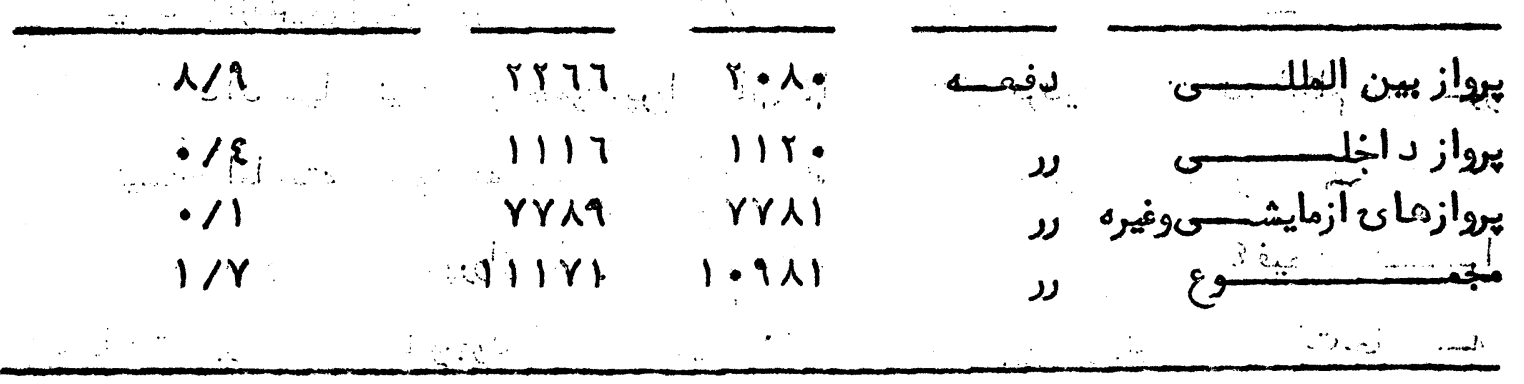




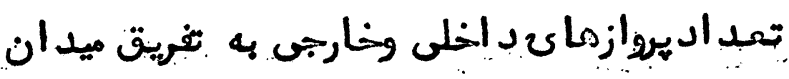

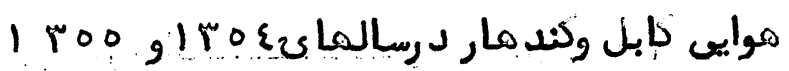

\begin{tabular}{|c|c|c|c|c|c|}
\hline $\begin{array}{l}\text { Troo } \\
\text { Iros }\end{array}$ & تظيرفيصد كسال & 11500 & Irog & واحدمقياس & ميدان هِموايع وِنوع برواز ـ. \\
\hline & & & …… & . & كايســــ \\
\hline & ᄉ & $r \cdot Y r$ & INAr & دفصه & 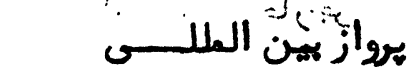 \\
\hline & $r / \varepsilon$ & i 78 & $1 \cdot 1^{7}$ & נر & برواز زاخلــــــــ \\
\hline & $+\because / r$ & virg & VTí & נע - ענ & يهواز أزمايشىوغيز ه \\
\hline & $1 / r$ & $1 \cdot \pi$ & $1 . \varepsilon q 1$ & נע & q \\
\hline & & & - & & كندمهــــــار • \\
\hline & 「ルハ & מיו & $11 \varepsilon$ & נر & توداز يين اللللــى \\
\hline & ro/r & $1 \leqslant 1$ & 119 & עy & هواز د اخلــــى \\
\hline H. & $-\varepsilon / r$ & $17:$ & 178 & נע & يوواز ازمايشى وغيره \\
\hline & Iז/ & $0 \xi \xi$ & \&ᄉ & u & \\
\hline
\end{tabular}

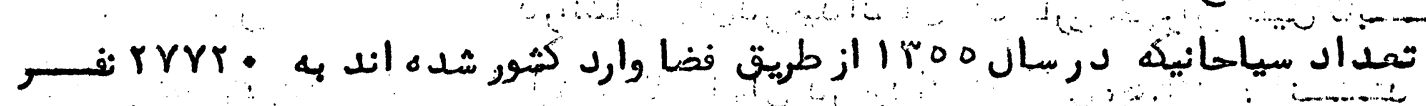

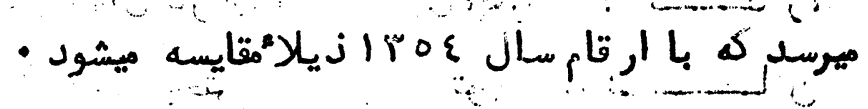

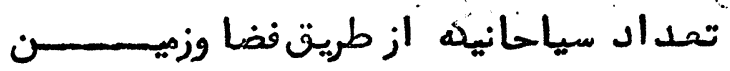

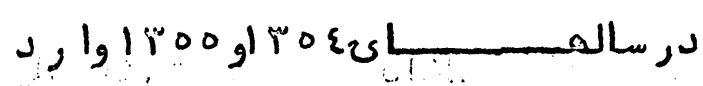

$$
\begin{aligned}
& \text { كثيـــــورشده اند : }
\end{aligned}
$$

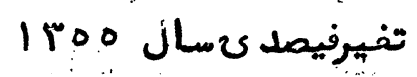

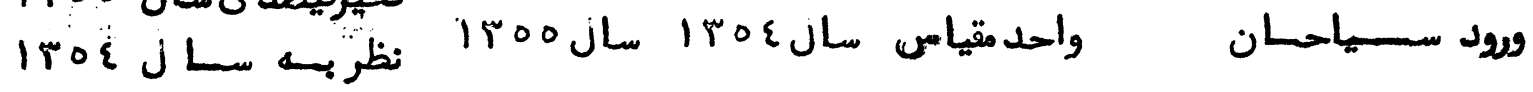

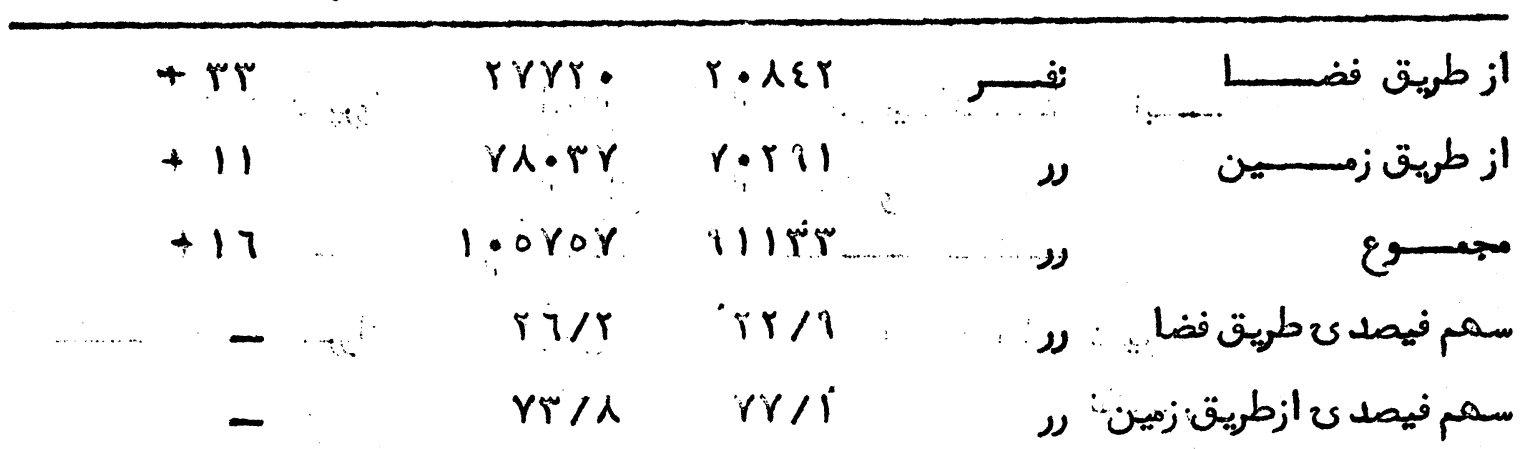

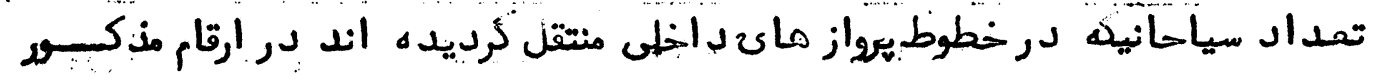

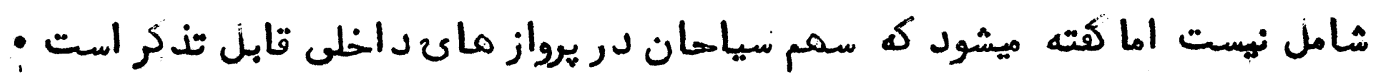

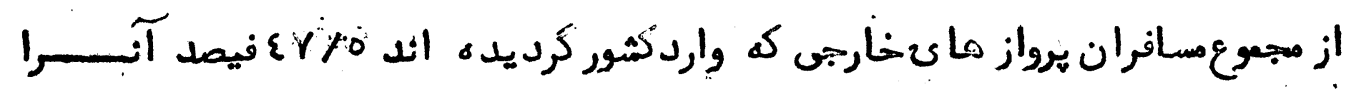

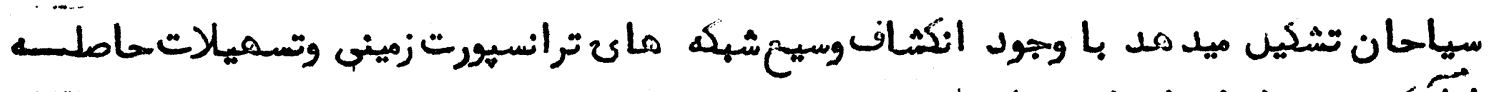

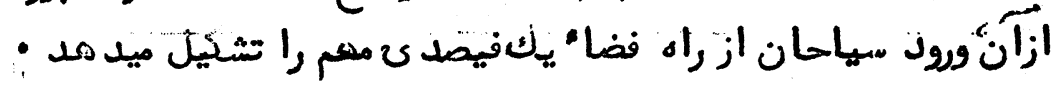


تمسلداد مسافران وسياحان منتقل شده كر كشسو

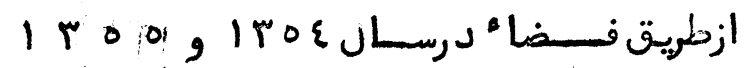

تغير فيصدى سال Iroo

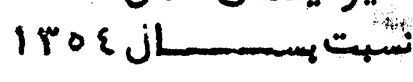

1400

$110 \varepsilon$

احس

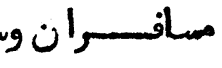

$+11 r 10$

ONFTA OTHE

مجموع مسافران انتقان يافتسـه

$+142 /$

rRY r. TEY

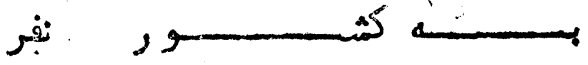

$\varepsilon \gamma / 0 \quad \xi 0 / 7$

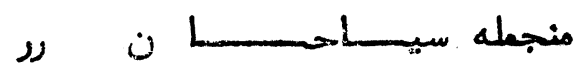

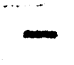

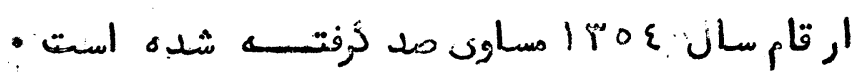

و:ود سياحان از طريت فضا وزنين به تفريق (خاره ما )

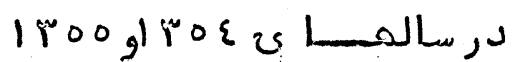

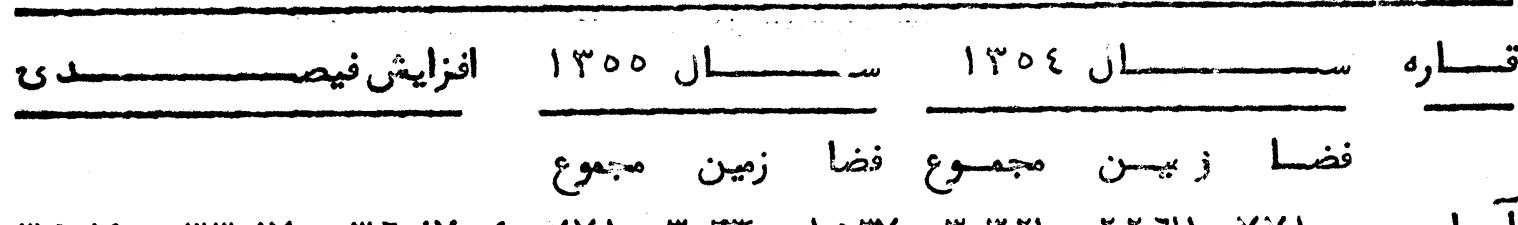

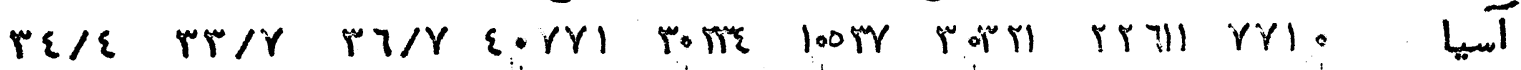

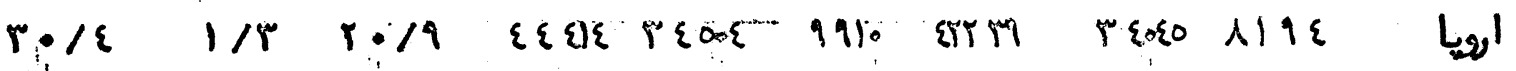

rill

افريقا

$18 / 7$ | آستراليا

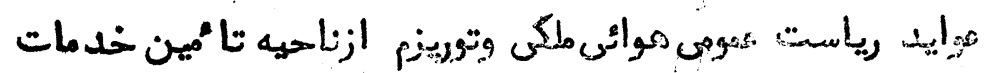

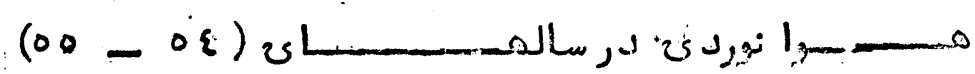

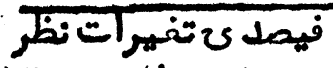

iro\& ل a

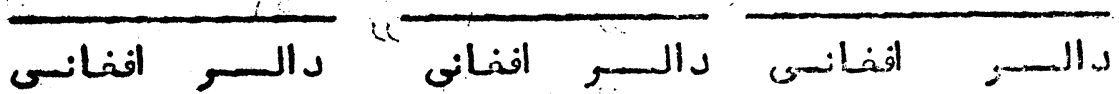

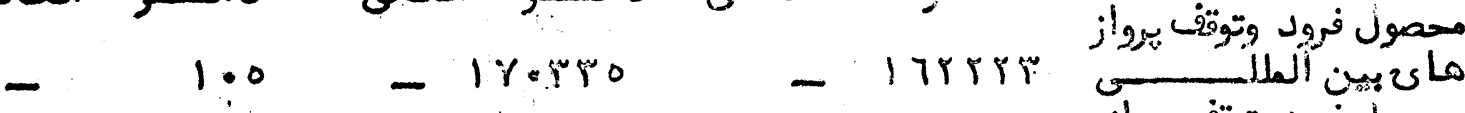

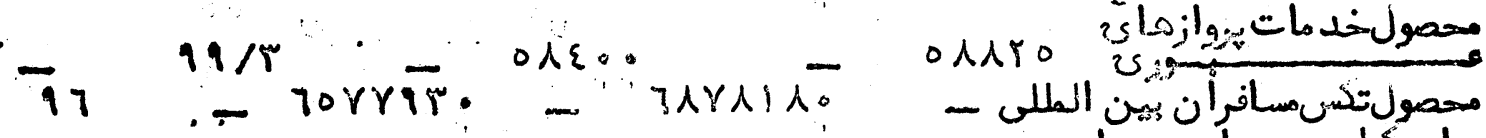

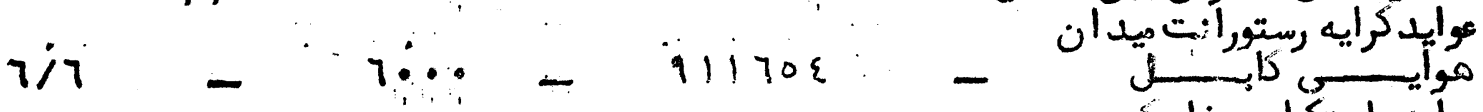

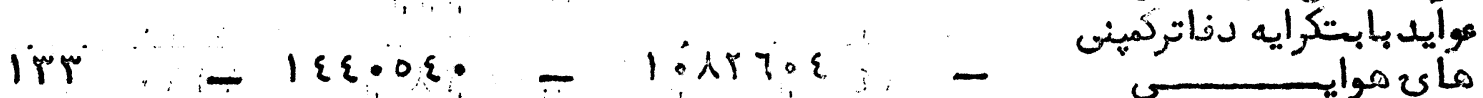

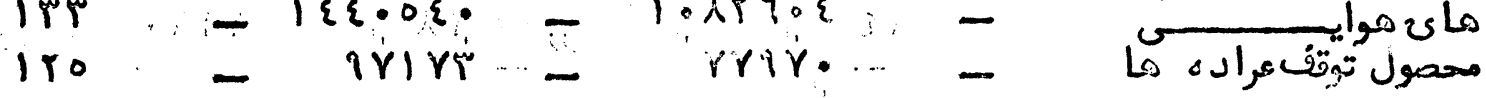




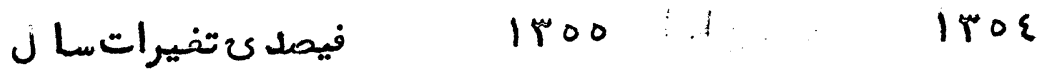

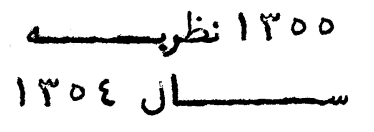

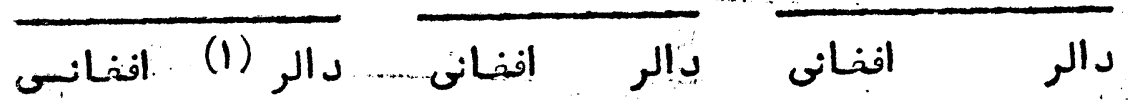

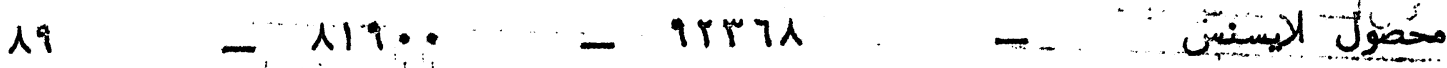

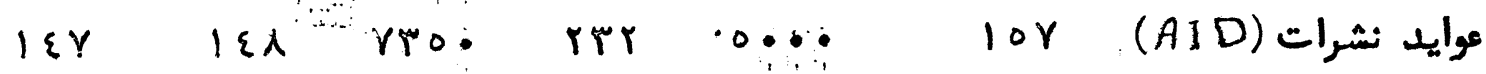

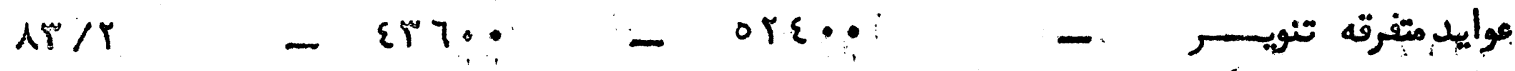

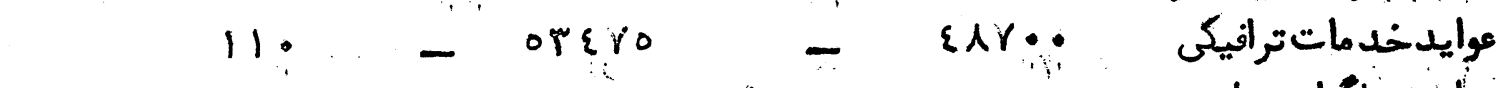

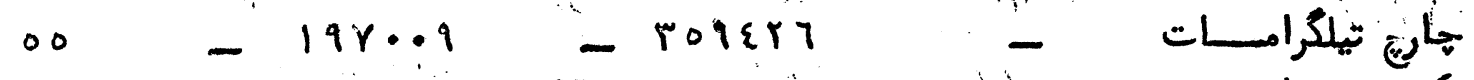

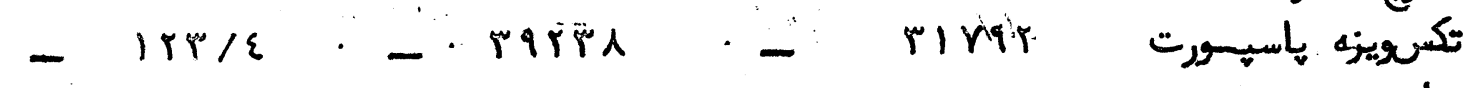
ع $11 / 19.90-1979 \%$

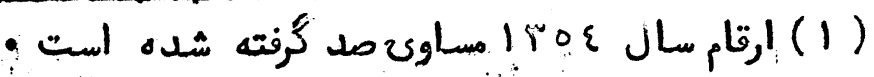

تمـل اد مساقران منتقل شده ازميدان موايى كابل به ميدان هـى

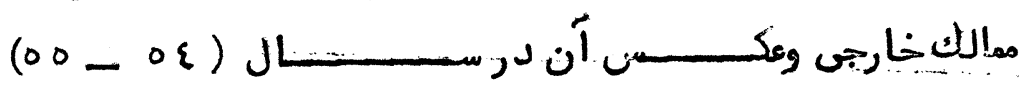

(0)

1908

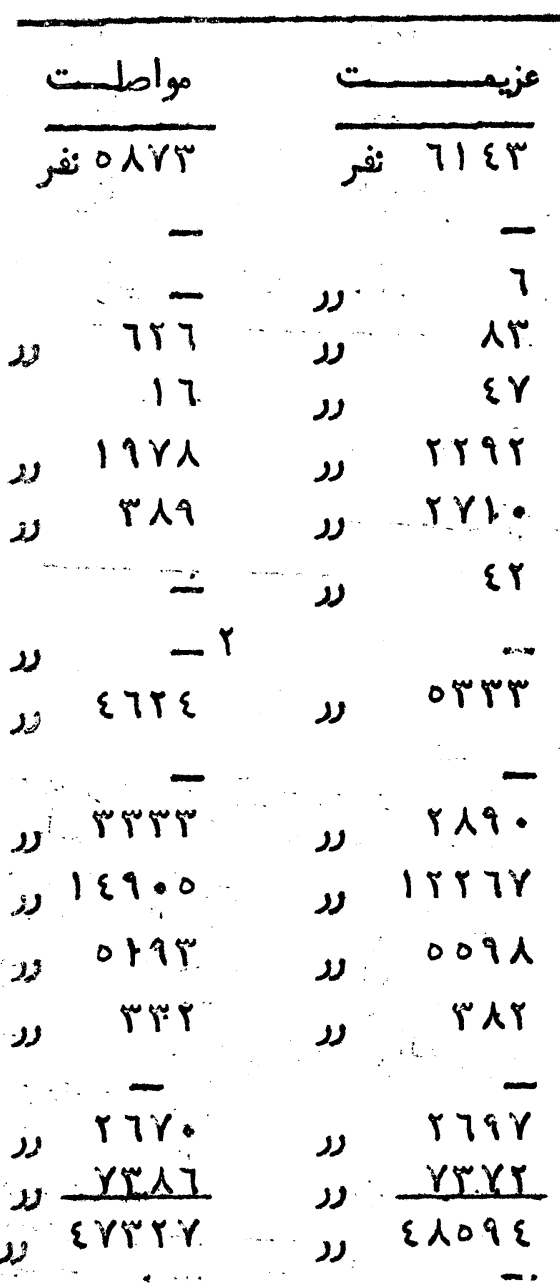

1roo

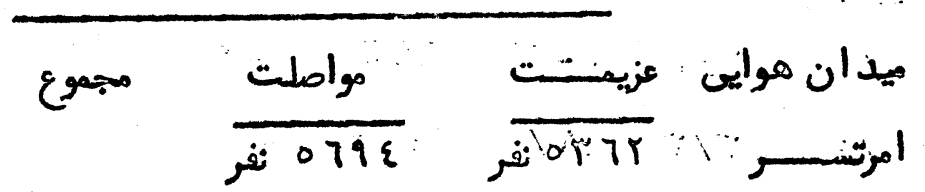

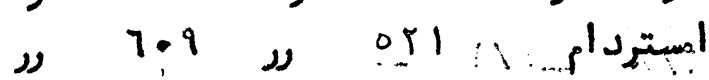

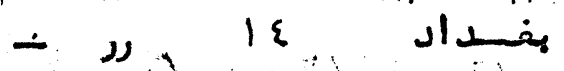

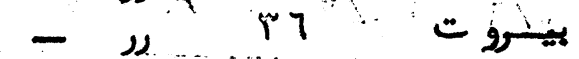

لشهـران

فرانكعورت

استانهول

דسـ

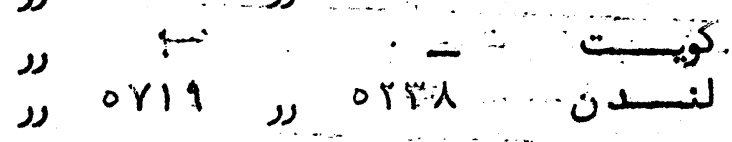

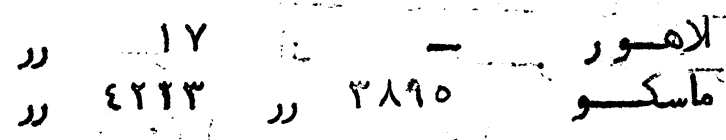

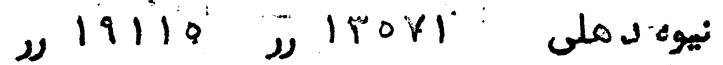

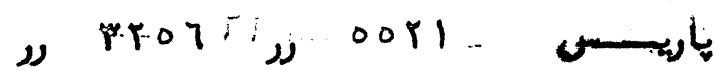

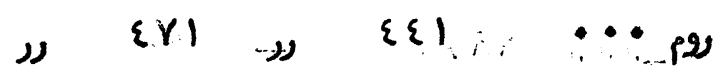

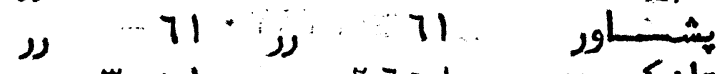

تاشكــــ

تهن

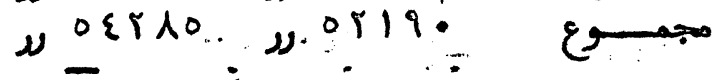


مقدار مهموع اموال منتقل شتده ازميدكأن موايع

جســ (7)

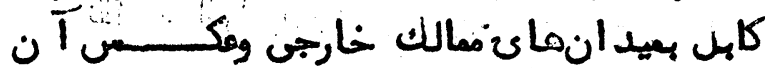

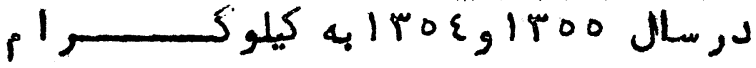

tedenter.

انتقال به ميد ان.هوايع كايل ديرسال

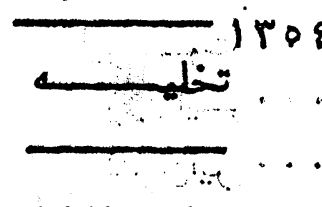

IIrjorsi $\ldots$

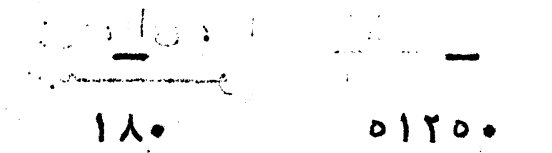

Oภะा|

\{०YY. 1

Irr

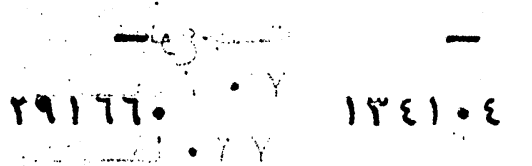

$\circ r \cdot 1$

$\therefore 1 \cdots$

$r \varepsilon r<0$

misk.

TAEF!

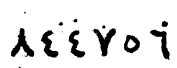

rrikor

rryir:

I $197 \%$.

|xor|

$1147 \cdot 4$

$17 \varepsilon 0$

ir

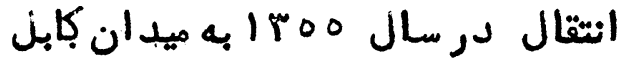
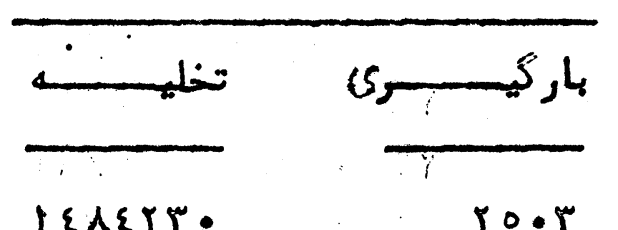

TรA\&YT.

IIr4

$\operatorname{Mr} 90$

اميد ان موايسيى

87197

1 $\{\vee 70$

امسترد أم :

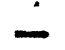

بفداد •?

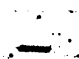

-

$\varepsilon \wedge 9 \cdot \lambda \varepsilon$

7iv

1 ᄀ人从.

irror

เะราศช

าราย

$110 \varepsilon$ ए

IIVE

117.0

rorer

تمران : 10....

$1 Y \cdot 7 r$

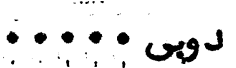

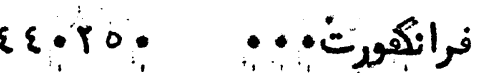

استثانهول

|

17.19

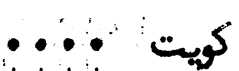

$17780 \%$

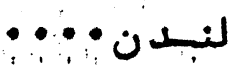

viol

ماسكو •.....

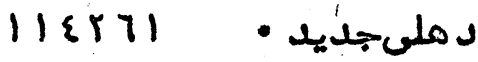

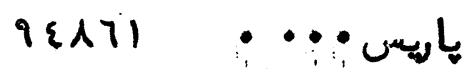

orres

روم : ........

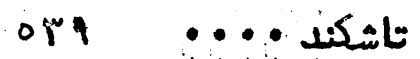

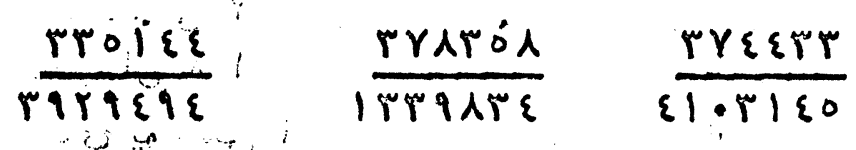

715079

تهران : :

(V)

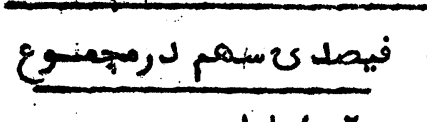

$\lambda \Lambda / \cdot r$

$\varepsilon / r i$

از ميل النمو

: $\varepsilon / 17$

$1 / 97$

$\frac{6}{r \pi r}$

IVE

موايس' د رحمل ونقل اموال ال

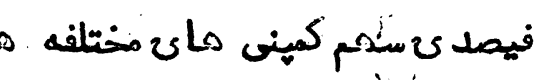

$1 / 00$

IVT

A)

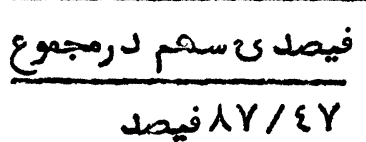

$0 / 9 \%$

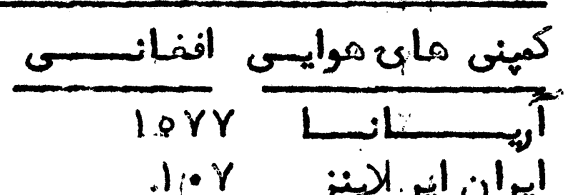

$1 / \cdot 1$.

eiri

T\&

- /T

: / \&

$.1 \cdot 7$

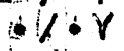

1..

EIrT

$1 \cdot \because 1: \cdots$

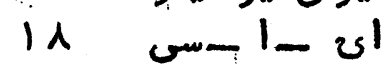

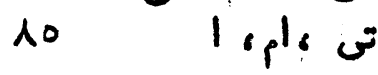

اير فلـ

i

$\because \cdots$

$11 \cdot r$

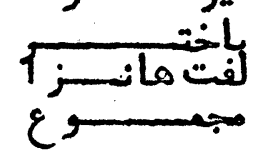




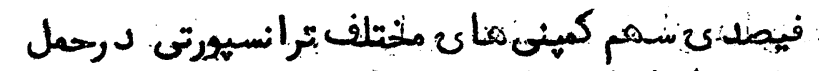

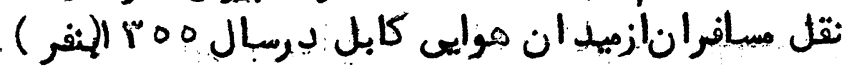

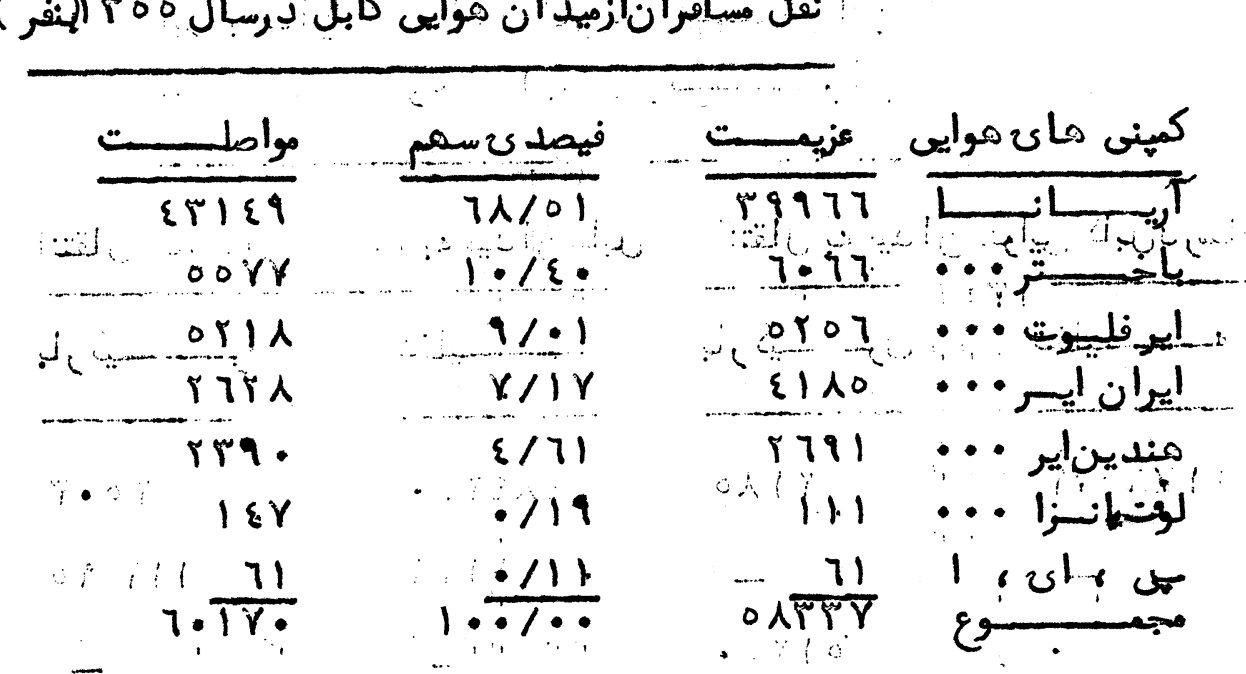

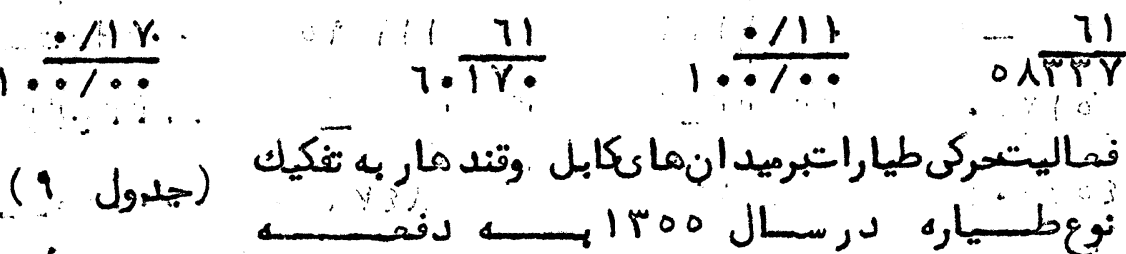

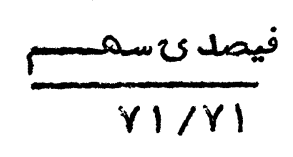

isr

$1 / 7 r$

$7 / 4+4=$

$r / 9 r$

- 7To

$\frac{.111 \%}{1 \cdot 1 \cdot 0}$

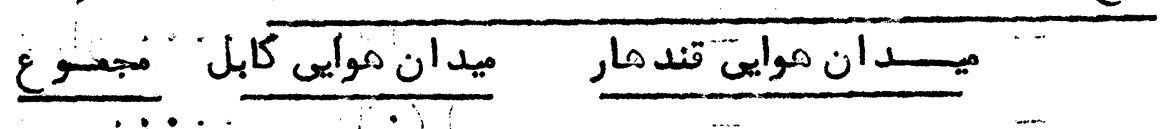

$\{\cdot, \ldots$.

\&). . rर.

löह

$119 \cdots$ iा

I\&5... l\&

rro re ro

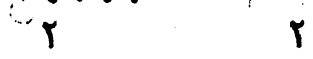

$\because r \cdots \quad r$

$r \quad r$

$r \quad r$

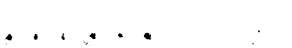

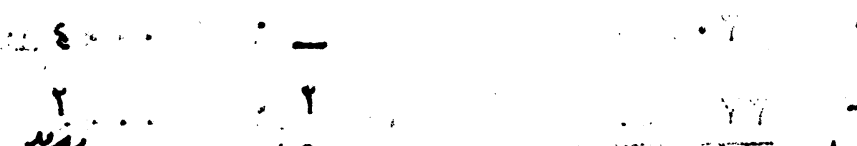

rip iq

$77 \% .77 \%$

$\begin{array}{cc}7 & 7 \\ \text { Ir } & 1 r \\ r & r \\ r & r \\ 1 . & r \\ r & r\end{array}$

$1 \varepsilon$

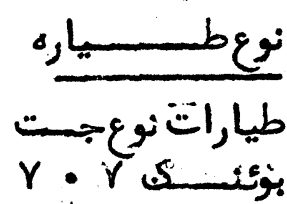

$r$.

rNT

$r$

-

$-$

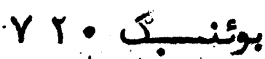

Y Y Y

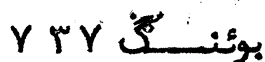

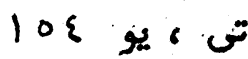

ئ

بيذك ون (1)

- a r roijij

$r \cdot$ troj

تسى كيون

س سـس

طيارات نوعتور بايروت

$\varepsilon$

توين الرتـــــــ

لب سيسي

$1 \wedge \mathrm{\alpha} \Omega$

- 7.

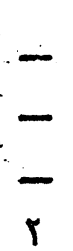

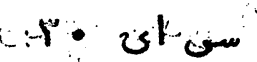

r

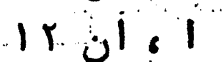

ا 1

$r$ \&

$r:$ : 1

بـ

r人 
$-r \cdot \lambda-$

(1) اد اهه جدول

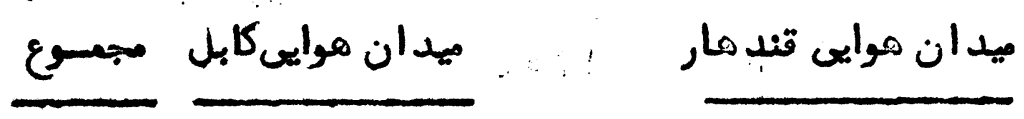

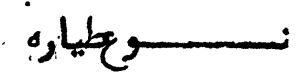

كارات نوعيتن دار

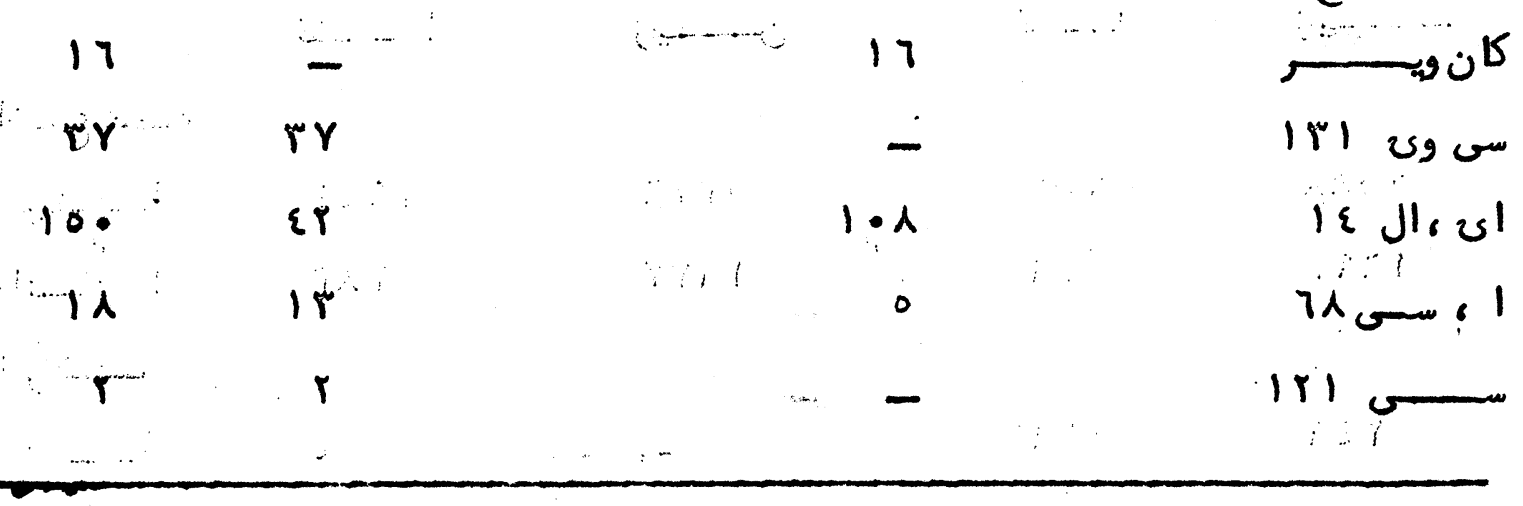

جدول ورود سياحان دركثبور به تخريق مالكتوطيق

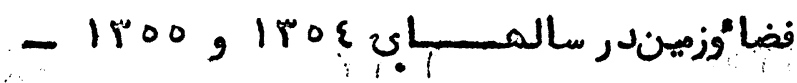

(جدول (: (1) (ج)

1800

1Yos

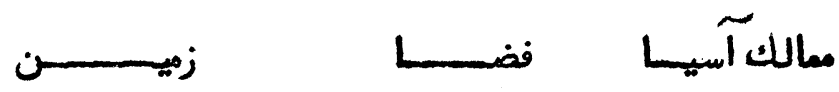

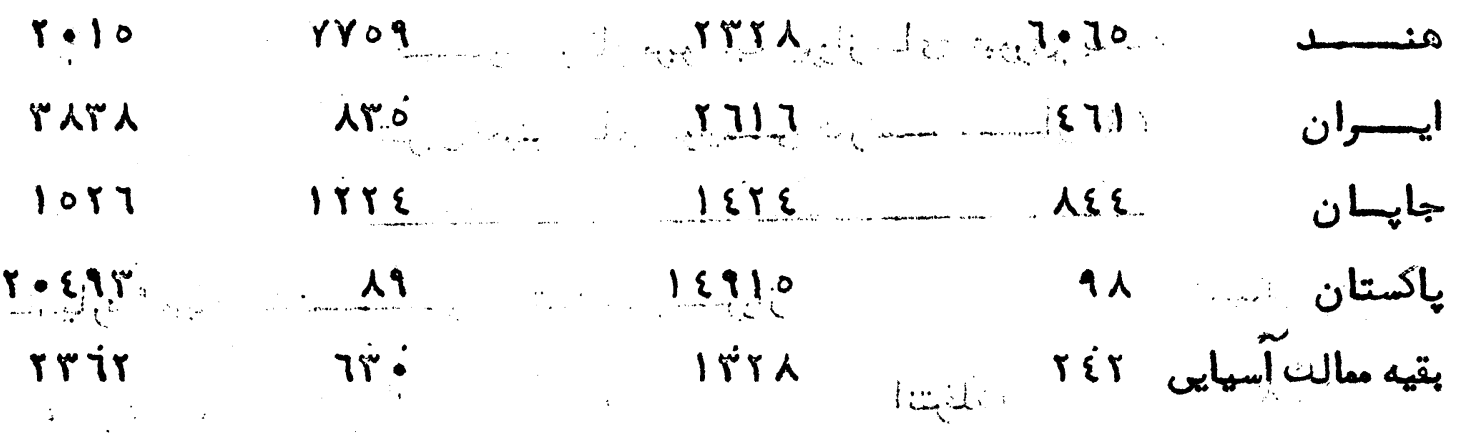

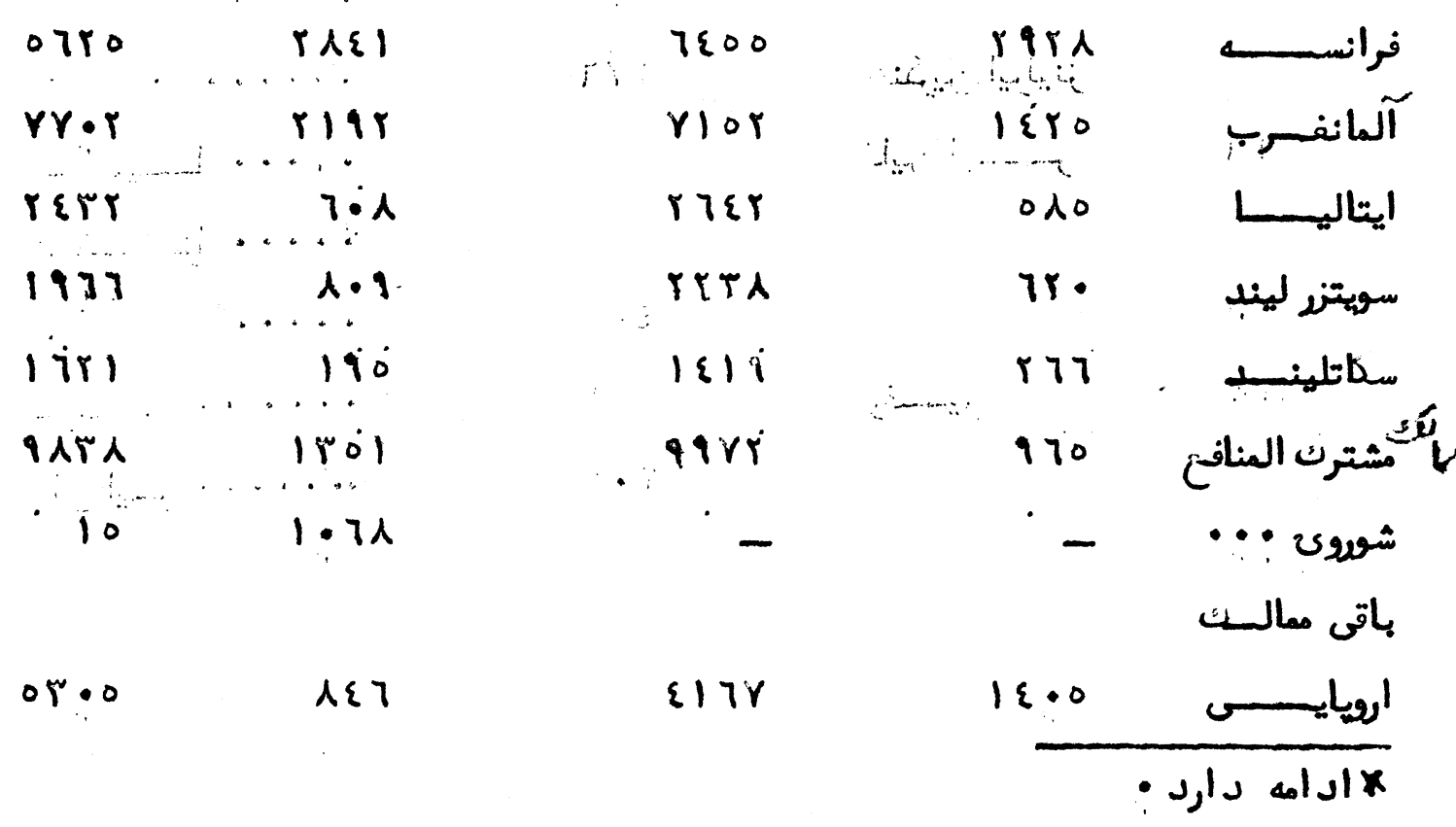


اد امسـه جسدول (1.)

1roo

i.. Iros
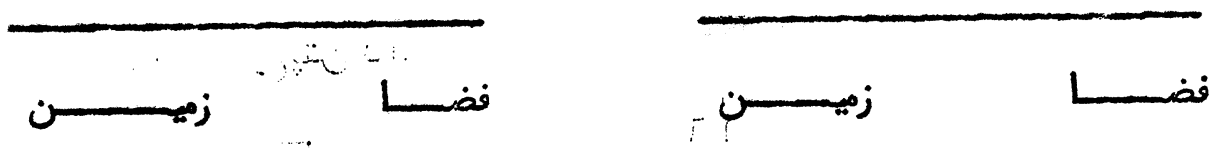

اضلاع متحده

or AN

O9Yo

OYYT

พฯะ।

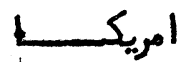

179

ort

I TrY

iN

كانســا دانس

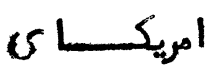

$r\{7$

117

$-$

$Y \varepsilon$

الاتيــــــن

$\{7 \Gamma$

\&१ช

rito

YYQ:

اوقيانوسيه

1108

iro

p.r.

$i j$

(استر اليا)

rrr

$7 \varepsilon$

YqA

71

نيوزيلانــ

ممســالك

افريقاיبـى

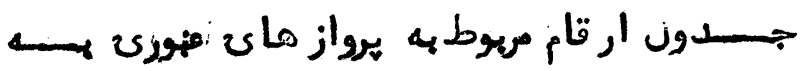

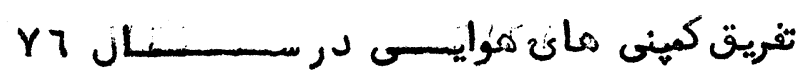

تمدانديواز

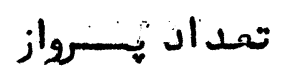

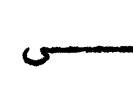

انترفلّ

$i \varepsilon$.

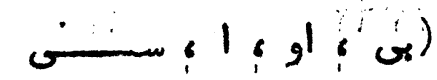

$-$

I.YY

اير فلوت .............

مائكرين اليرلينز

iv

سكاندنياوى . . . . . . . . .

19

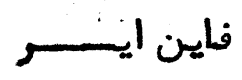
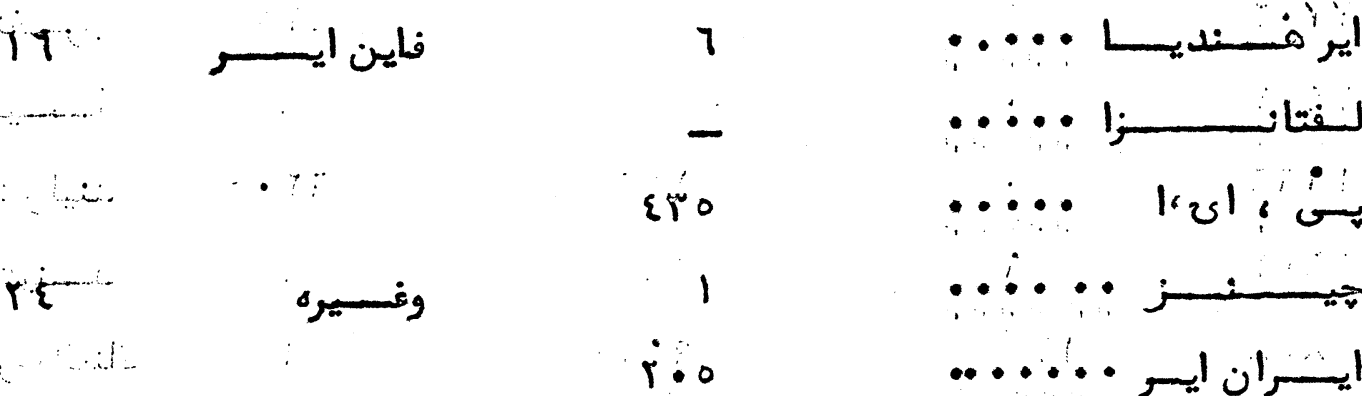

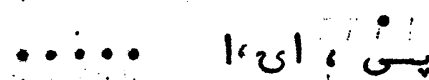

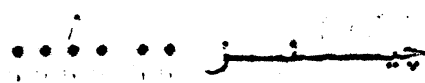

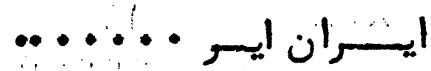




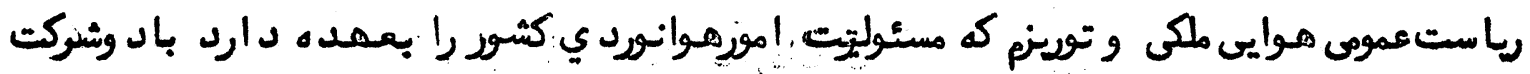

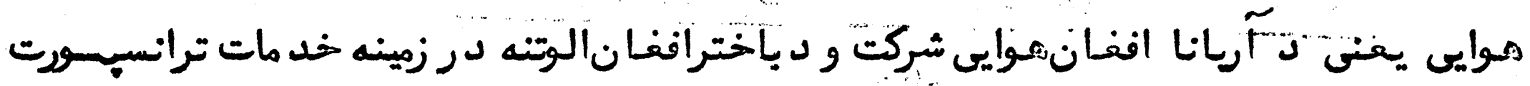

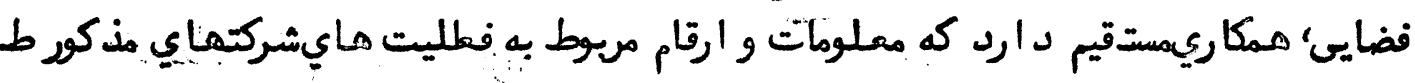

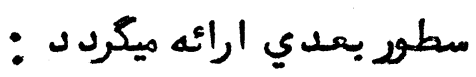

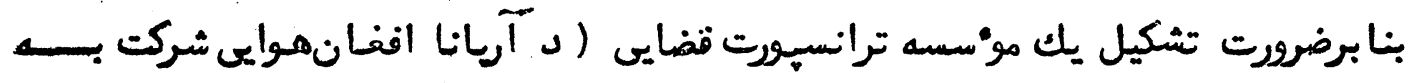
سرمايه مختلط ابتد ايى يك مليون د الر با (10 0) فيصد سهم موسساتدولتى وبانكها و (9 ع)

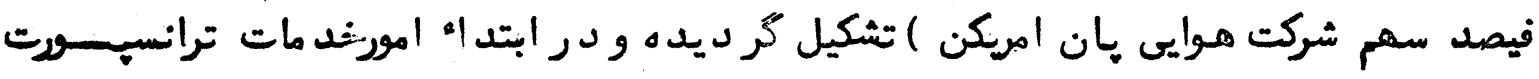

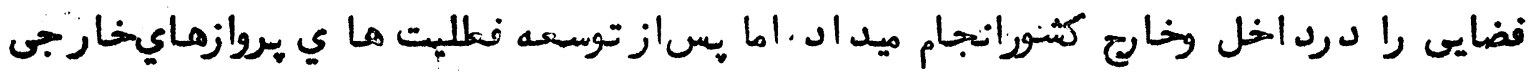

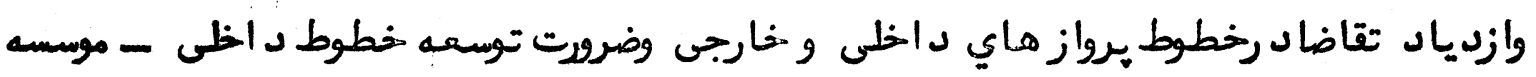
د باختر افغان الوتنه تاسيسو به فعاليت اغاز نموده است •

د آريانا افغان هوايى شركت قطع نظر ازتاءمين خدمات ترانسبورتى منحيث يك موسسه انتفاعى خصوصاء ازناحيه تاءمين اسعارخارجى جلوگيري ازمرف اسعار خارجى - استخدام

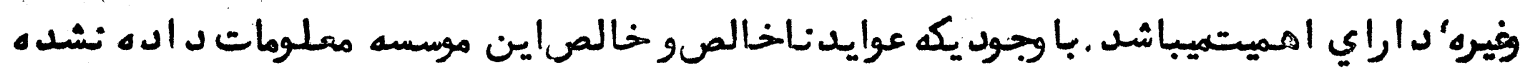

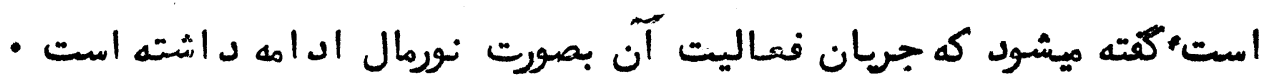

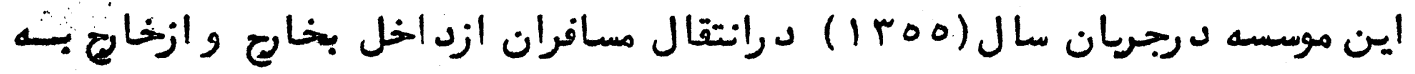

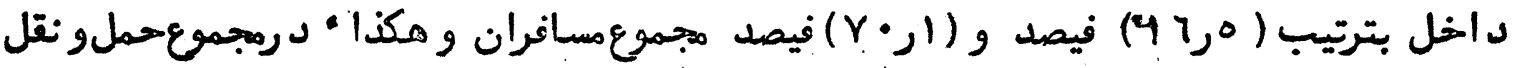

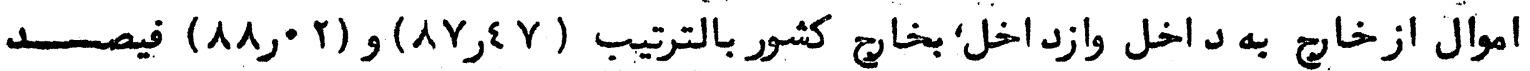

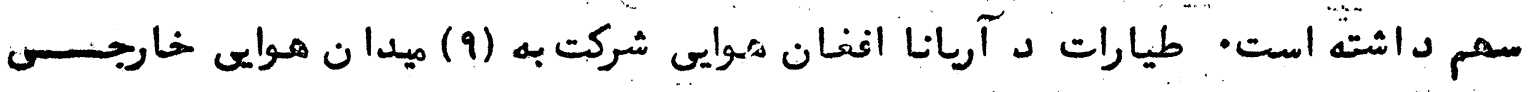

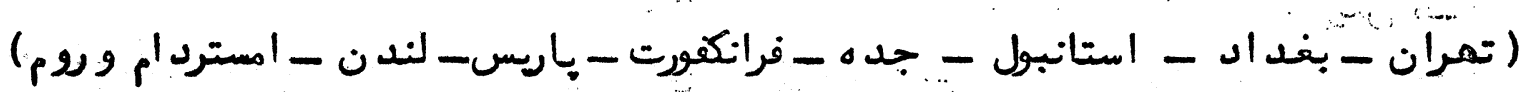

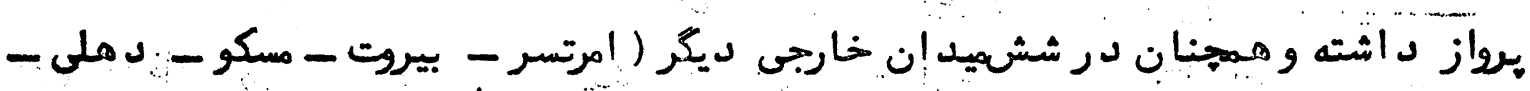

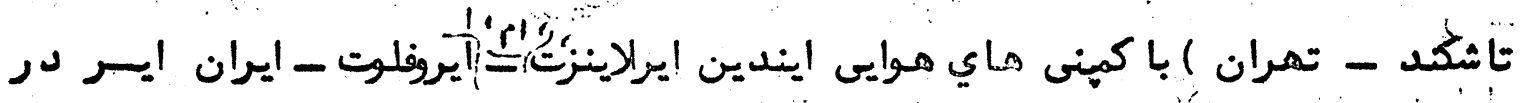

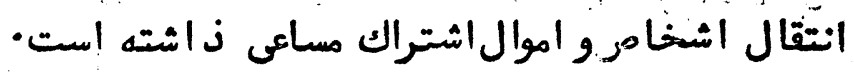

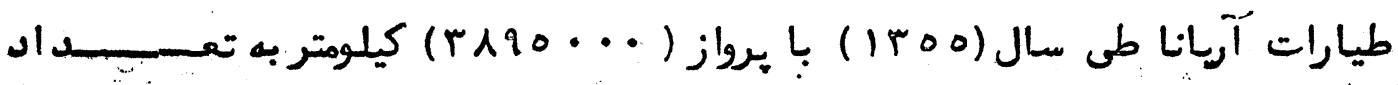

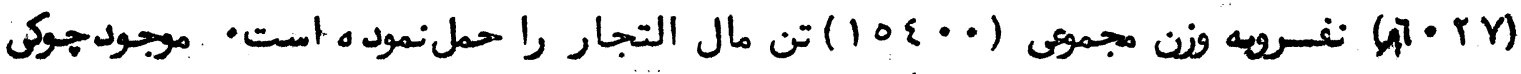

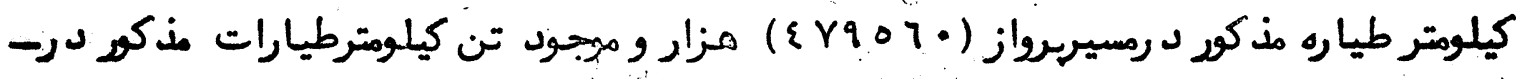

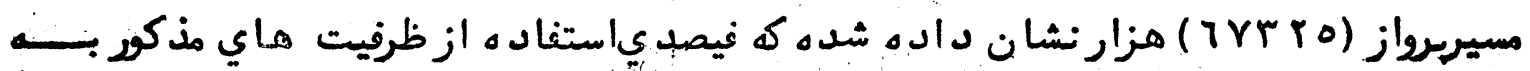

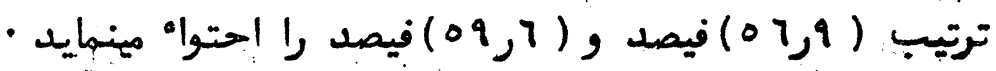




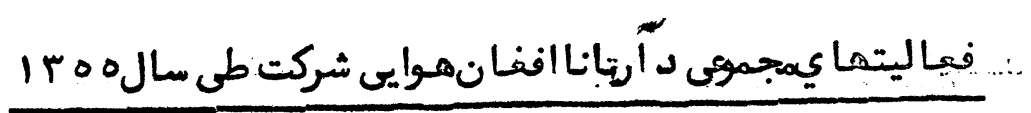

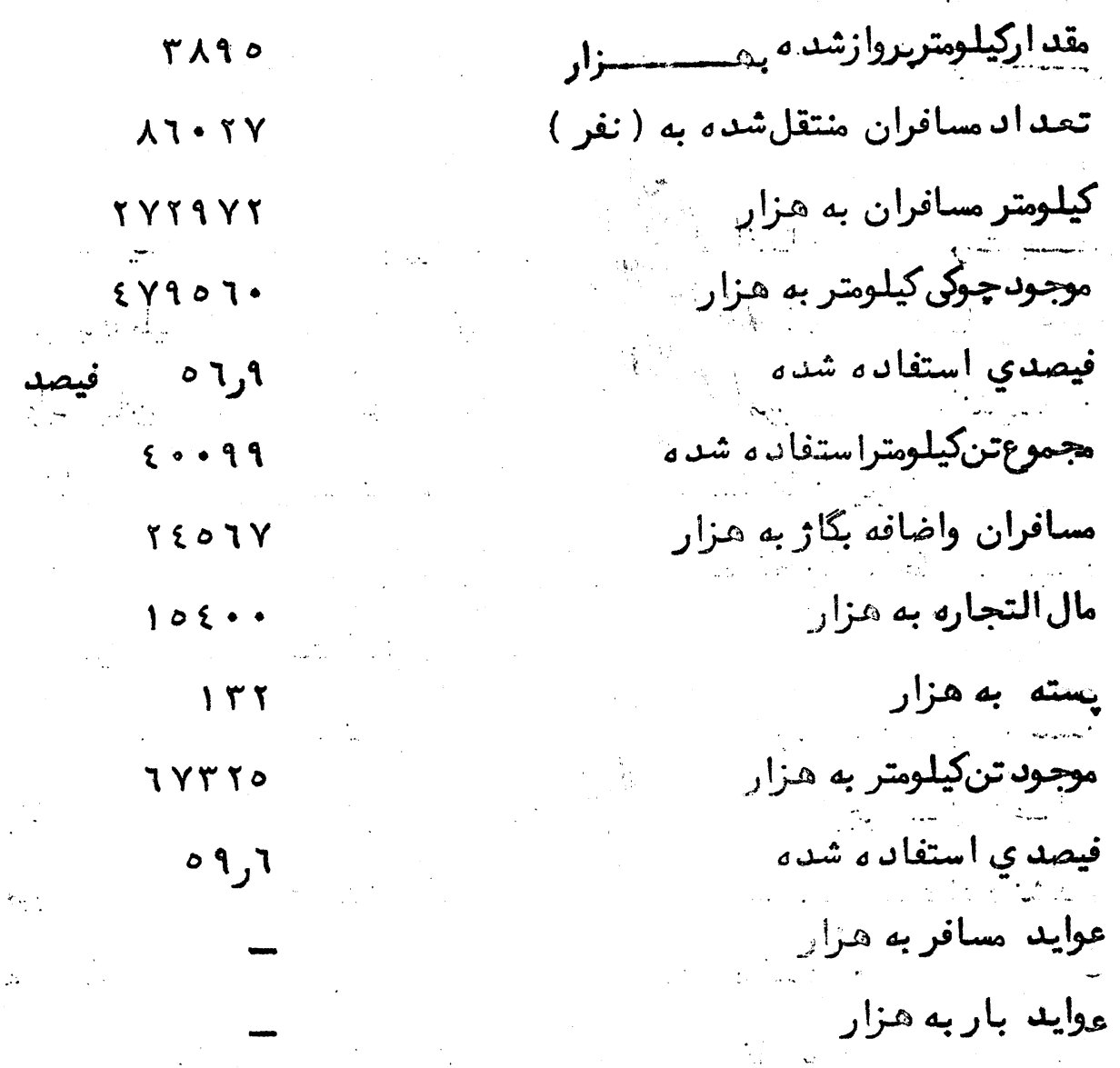

موسسه د. بإخترافنان الوتنه كه نظر به ساختمان طبيعى واقتصادي كثور ومحد وديت

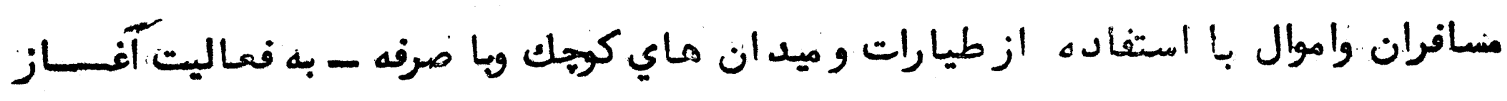

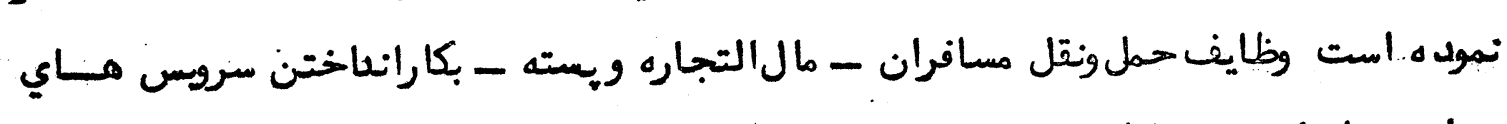

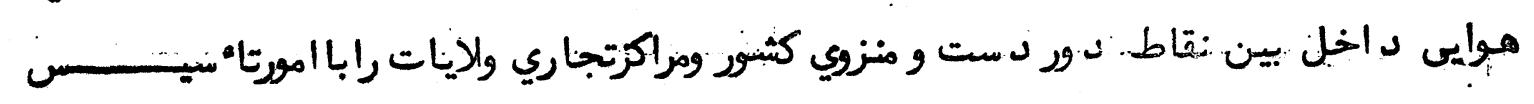

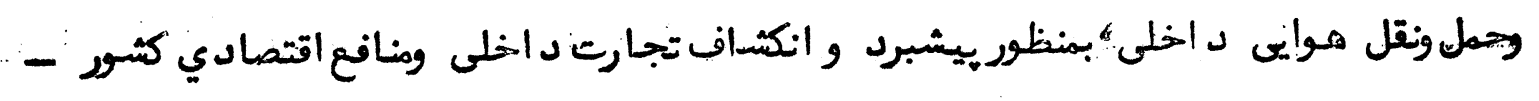

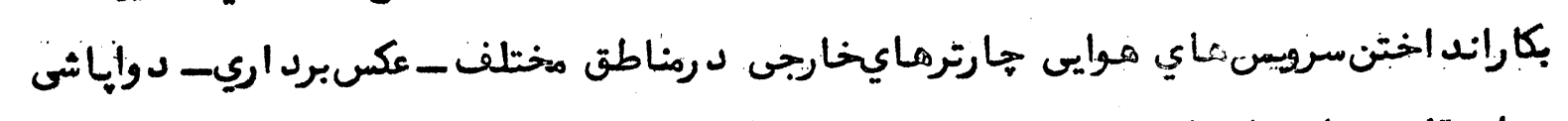

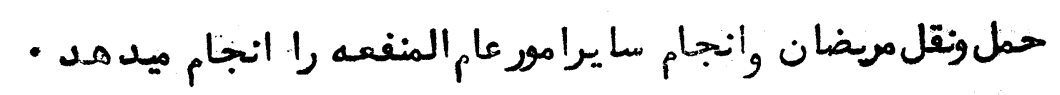

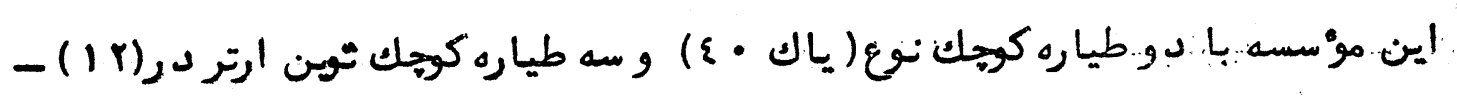

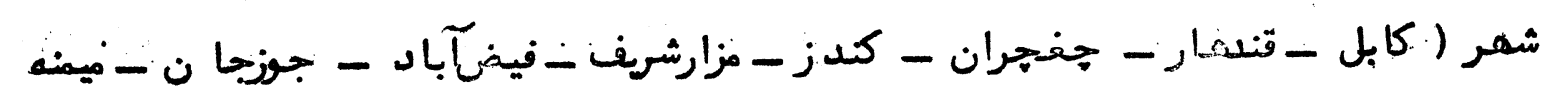

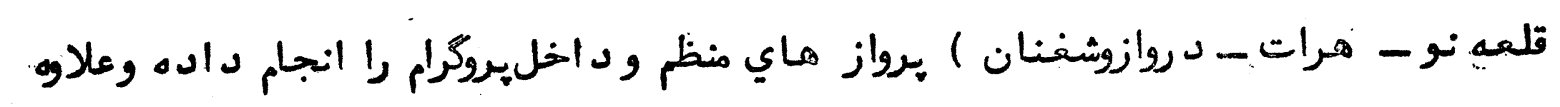

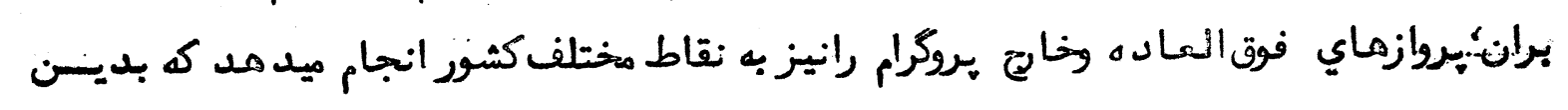

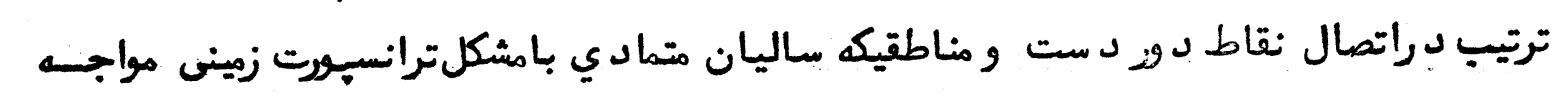

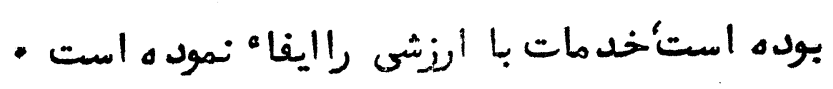




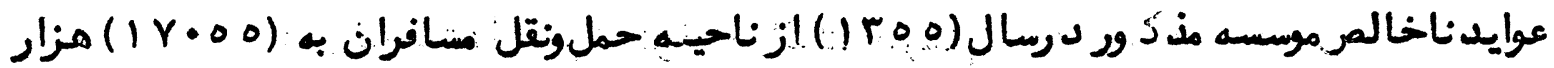

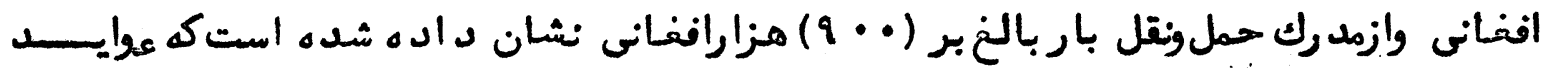

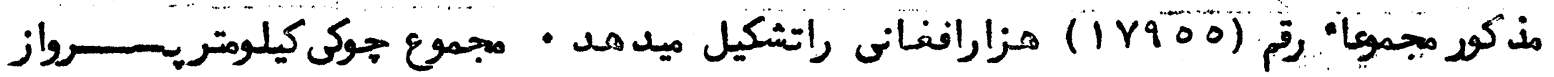

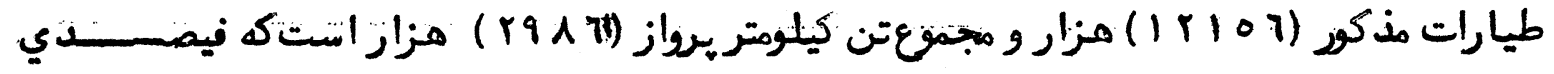

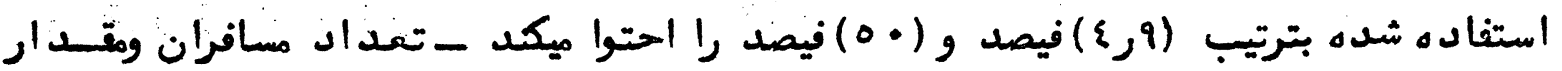

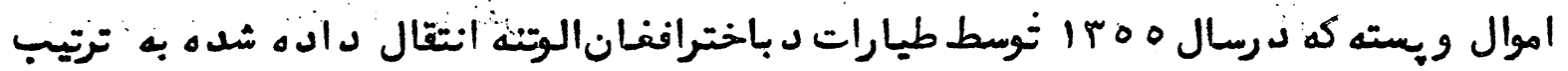

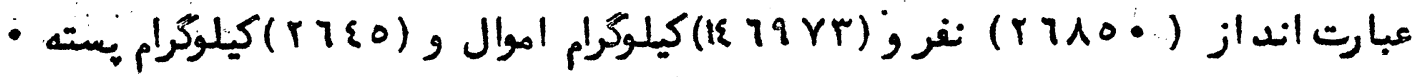

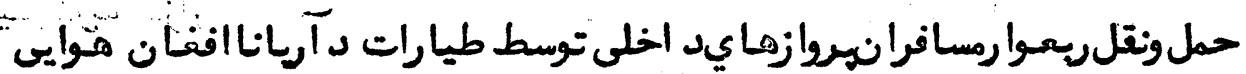

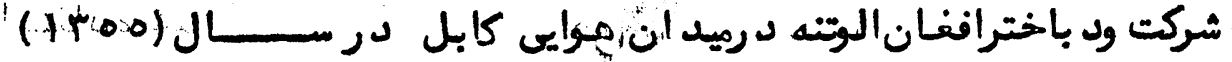

\begin{tabular}{|c|c|c|c|c|c|c|}
\hline مجموع & ريع -مارم & ريع سوم & נرغ دم & رئط & واحد & انتقال مسافران \\
\hline$\Lambda \cdot$ & 01 & 7 & 1 & rr & نفر & عزيمت \\
\hline$r \cdot \lambda$ & $11 \varepsilon$ & - & - & $19 \varepsilon$ & ע & مواصلت \\
\hline $7 \cdot 77$ & 189. & IVO\& & IVE? & YYT & ע. & \\
\hline OOVY & IYAY & 1817 & irro & rrq & $\nu$ & مواصلت \\
\hline $71 \leqslant 7$ & $\mid \wedge\{1$ & YYT. & $I Y \& Y$ & YqA & $\nu$ & 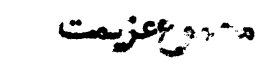 \\
\hline 0110 & $19 \cdot 1$ & 1817 & irro & $9 r r$ & $\because y$ & مواصلت \\
\hline
\end{tabular}

انتقال وتحولكيرياموالطيارات د باخترافظلنالوتنه به ميدان هوايى كابســــل

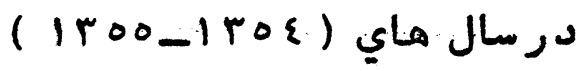

\begin{tabular}{|c|c|c|c|c|}
\hline 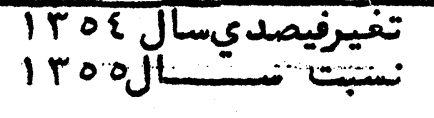 & 1000 & lrog & واحد & انتقال وتحويلد هى \\
\hline rit & $Y \wedge\{1$ & $\{\wedge\}\}$ & كيلوكرام & انتقال ازميد ان \\
\hline$-r_{1}$ & or 9 & $117 \varepsilon$ & كيلوكرام & تحولكيري \\
\hline & ᄉrk. & TYYA & كيلوكرام & مجموع \\
\hline
\end{tabular}




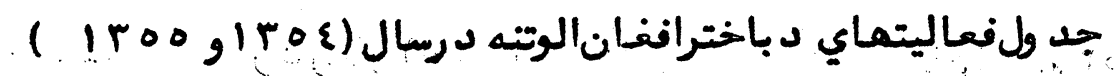

جد, (1)

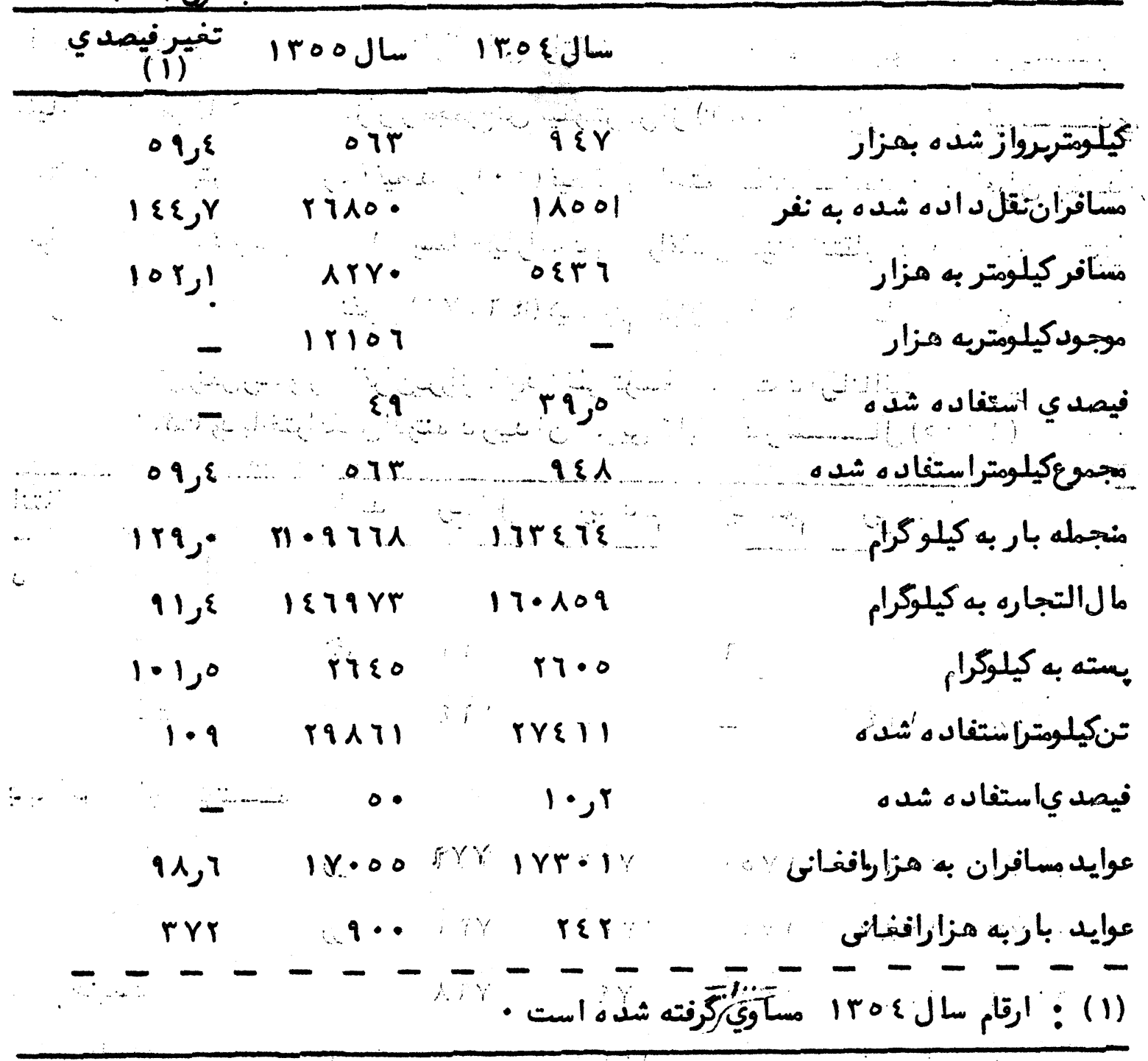

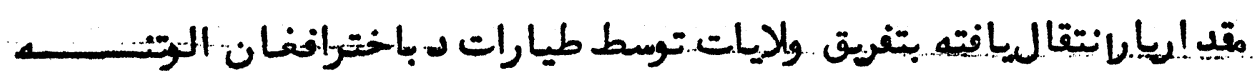

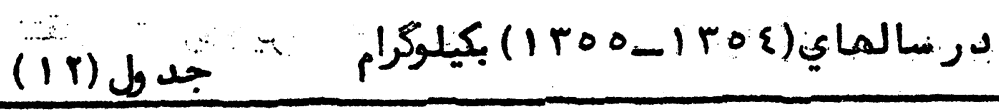

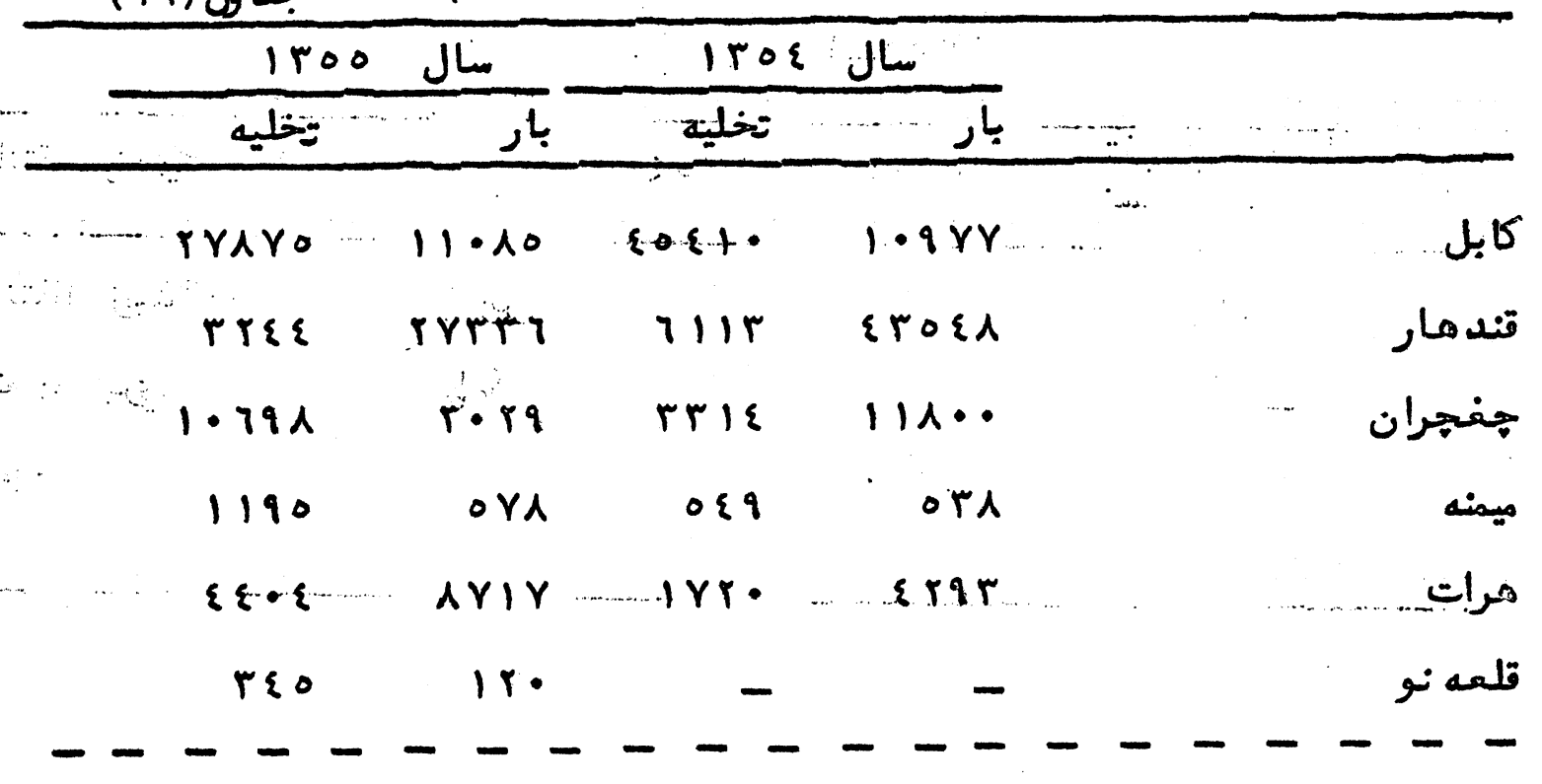


اد اهه جدول(r) (I ) إ)

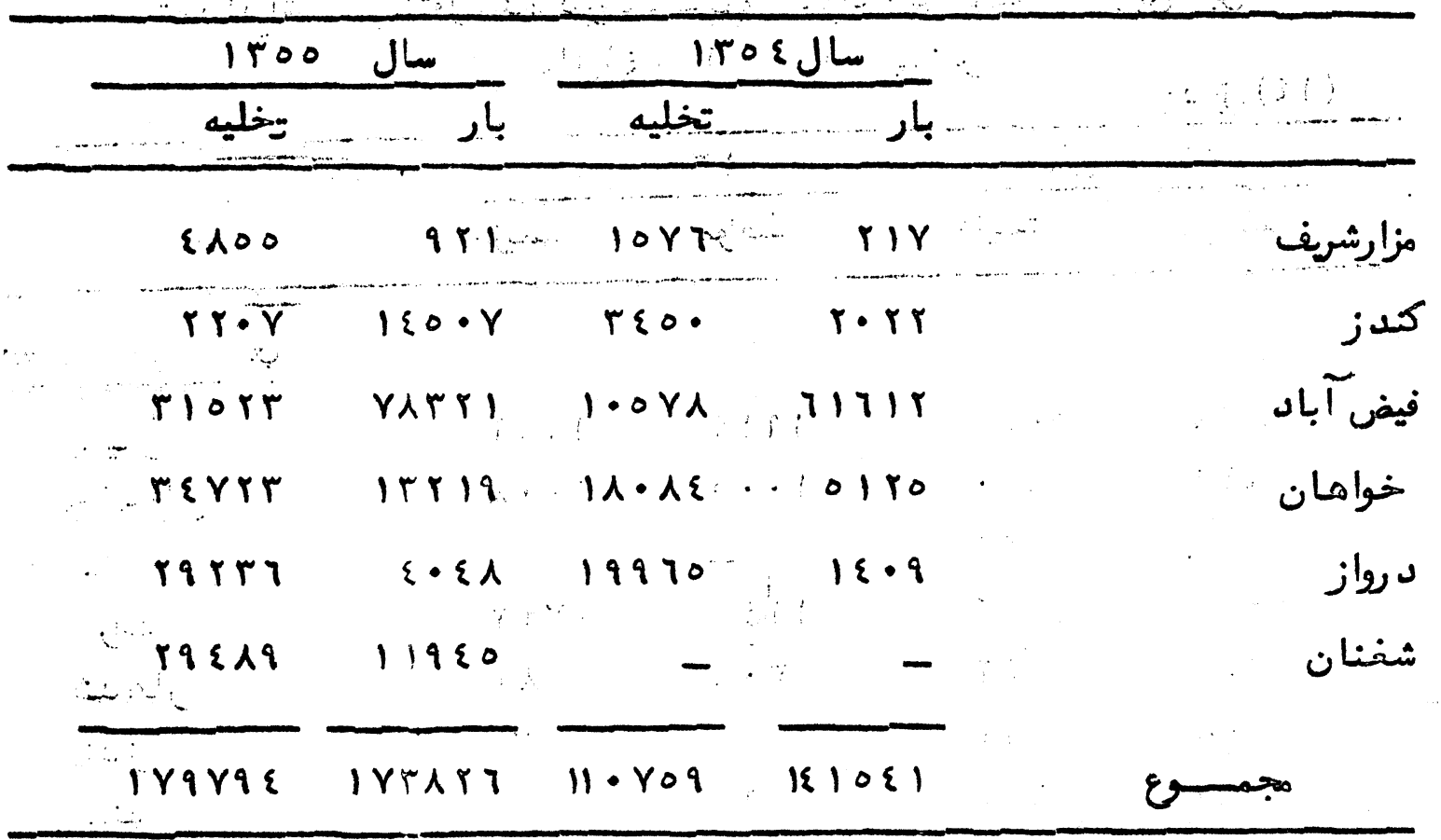

حمل ونقل اشخاصبه تغريق ولايات توسط د باخترافنان الوتنــ

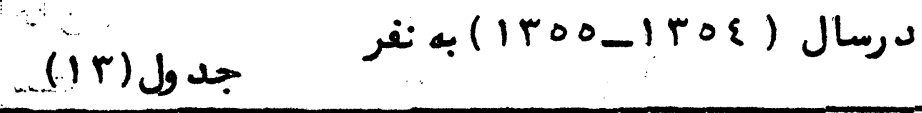

\begin{tabular}{|c|c|c|c|c|c|c|}
\hline \multicolumn{2}{|c|}{ 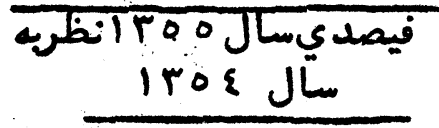 } & \multicolumn{2}{|c|}{ سال 1roo } & \multicolumn{2}{|c|}{ سال \&ُه } & \multirow{2}{*}{$\cdots \ldots \ldots \ldots$} \\
\hline مواملت & عزيمت & مواصلت & عزيمت & مواصلت & عزيمت & \\
\hline Irr. & $-1+1,1$ & $0 \wedge 10$ & 7191 & $\{7 \varepsilon \gamma$ & $00 \mathrm{Vr}$ & كابـــل \\
\hline $19 \cdot$ & $1 \cdot 0, A$ & 1.: & $r \cdot \lambda$ & $\&$ & $=12$ & قند هـار \\
\hline $11, r$ & 117,8 & 1917 & 1101 & FIVY & $19 \cdot 8$ & باميان \\
\hline ........ & $1 r 0, \gamma$ & 19人r & $810 \gamma$ & 1010 & 109. & جغهران \\
\hline$\ldots r \gamma, r$ & $\mid \wedge v, 7$ & $\varepsilon \cdot \varepsilon$ & rve & orr & $\{87$ & ميمنه - - \\
\hline $11 \varepsilon$ & 173 & \&or $\ldots$ & rq.8r & $T\{100$ & $r \xi \gamma \gamma$ & فر厂ت \\
\hline$\therefore-$ & - & $0.1 r$ & 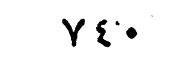 & $r 1$ & 7 & قلعـه نو \\
\hline $1 \leqslant 9$ & 11 & TrAT & $190^{\circ}$ & lorr & j. $\varepsilon$. & مزارشريف \\
\hline$. \mid r \lambda, r$ & 149 & r\&qq & TMFY & $19 \xi 1$ & 1787 & قند \\
\hline .101 & Irr, & rrre. & $r \cdot 9 \Lambda^{\prime}$ & $r r \cdot \lambda$ & rrik & فيذآ \\
\hline$\therefore 10$ & $|\varepsilon|$ & Yrit & $9 r r$ & $\wedge \varepsilon \varepsilon$ & ع & خواهان \\
\hline$\therefore I V A$ & 187 & 1.01 & $1 \cdot \cdot 9$ & $09 r$ & 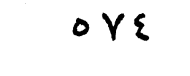 & درواز \\
\hline$\therefore-$ & - & 078 & $7 r_{0}$ & - & - & شخناني. \\
\hline $\mid r \wedge, r$ & $\mid r \wedge, \gamma$ & $1 \cdot 0$ & rod.'s\% & 1ו & |kil| & مجمســــوع \\
\hline
\end{tabular}

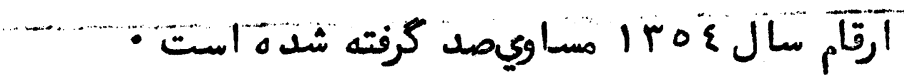




$$
=\quad r 10-
$$

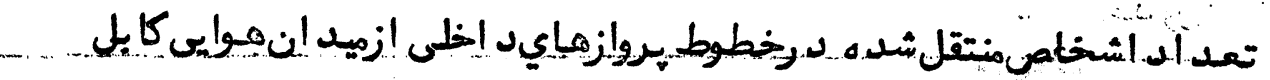

جد

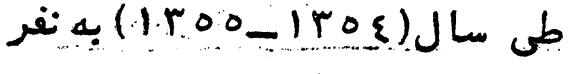

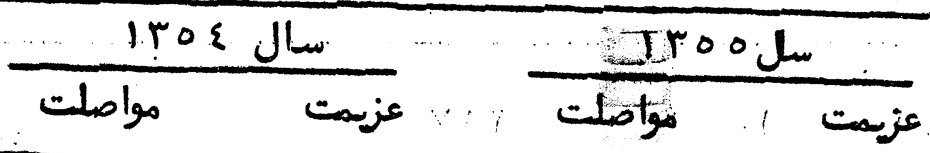

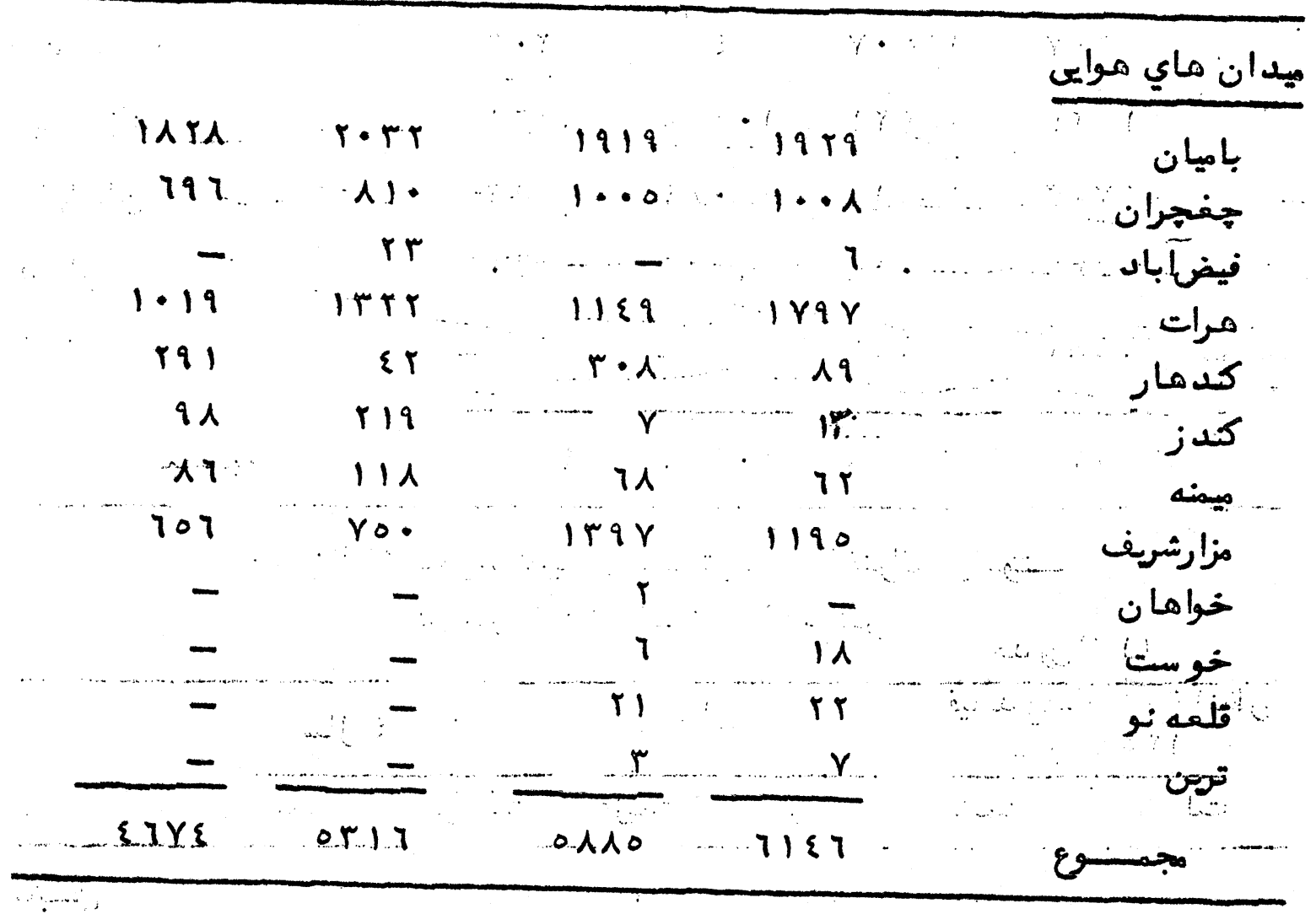

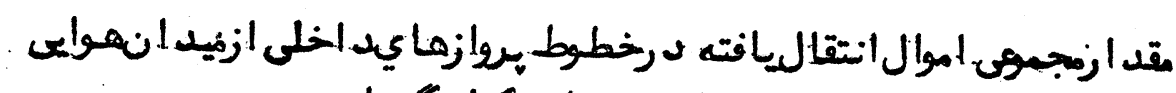

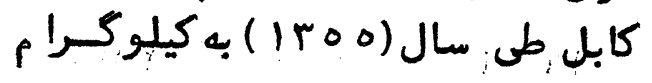

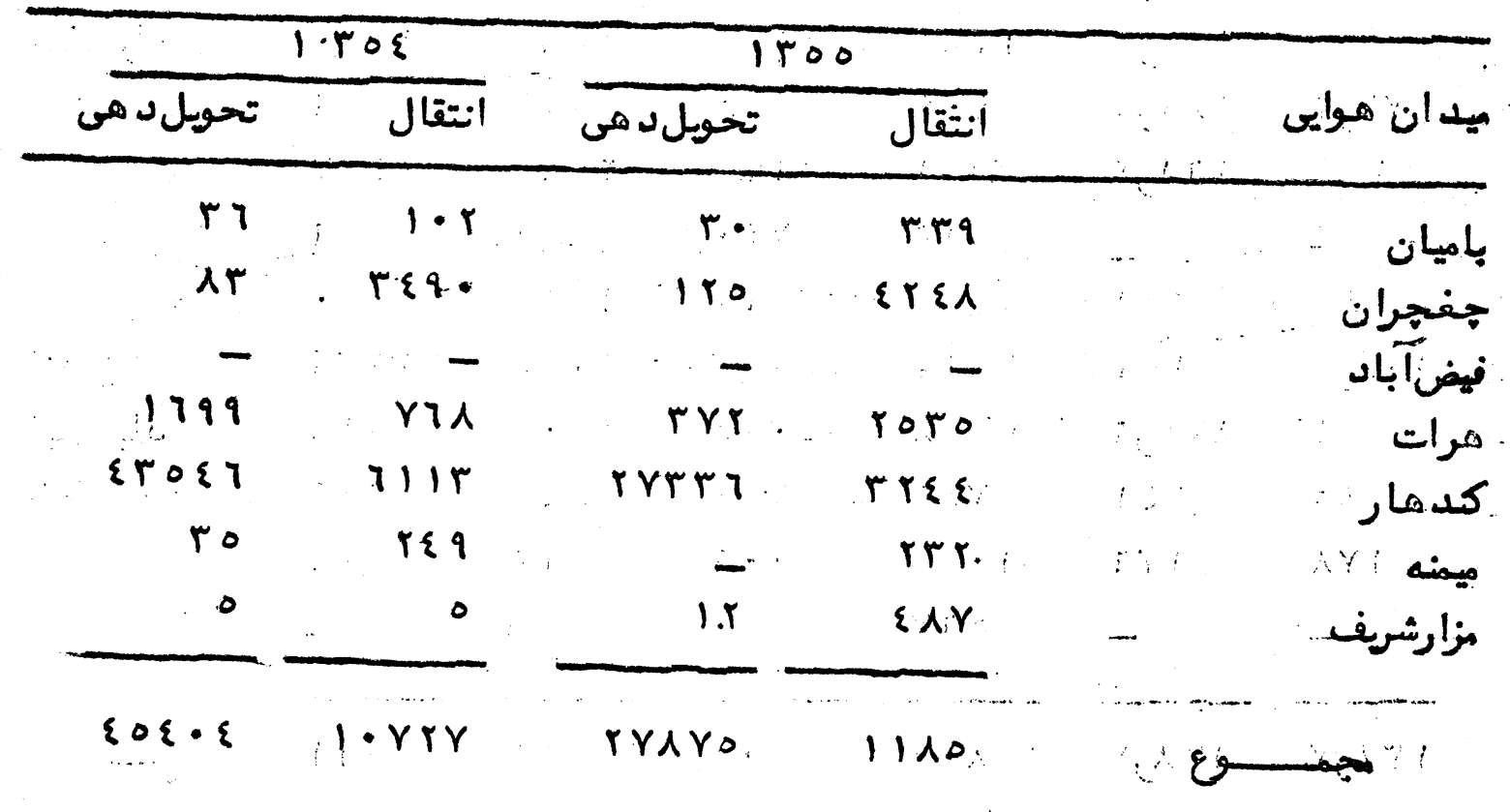




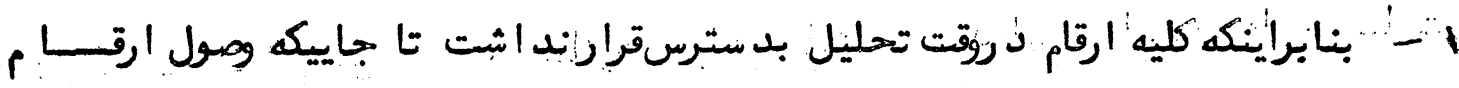

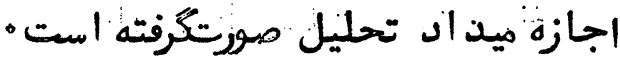

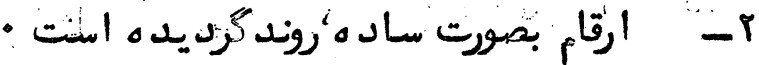

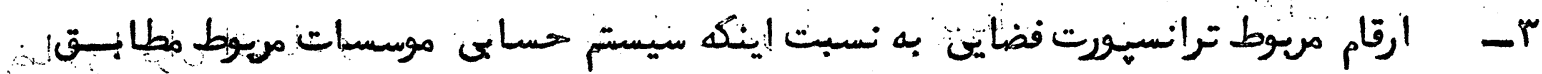

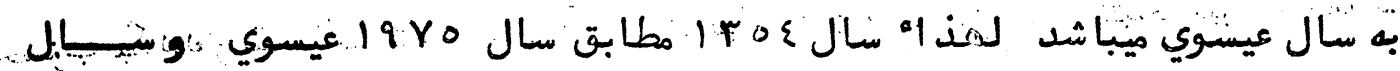

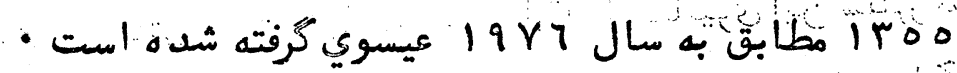

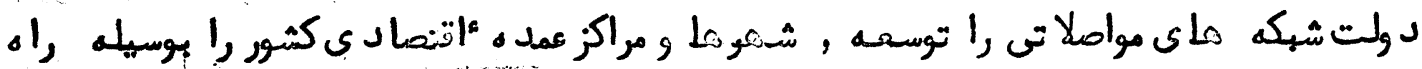

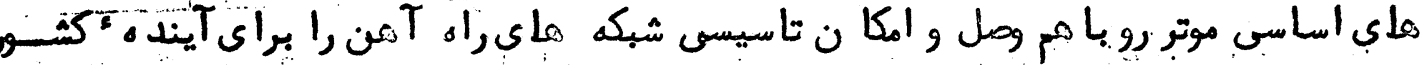

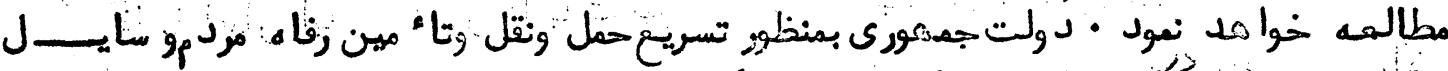

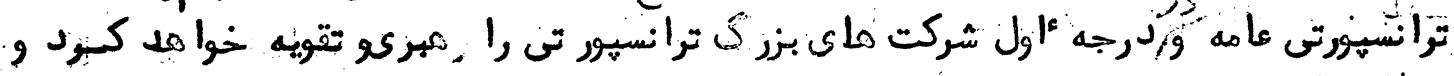

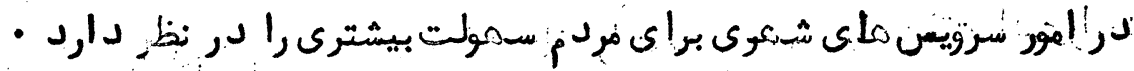
**************************************1\%

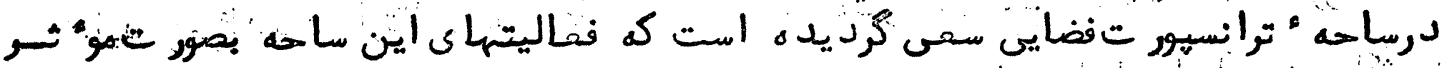

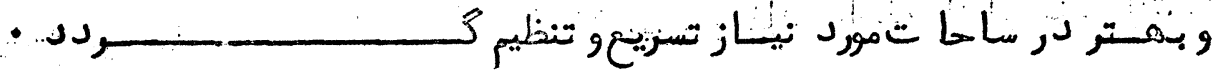

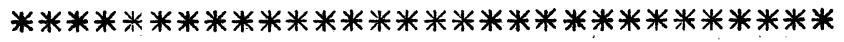

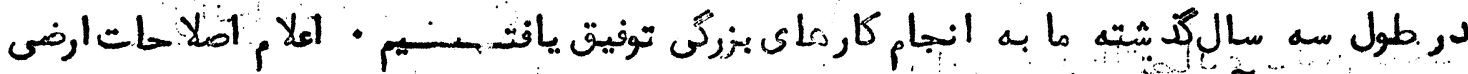

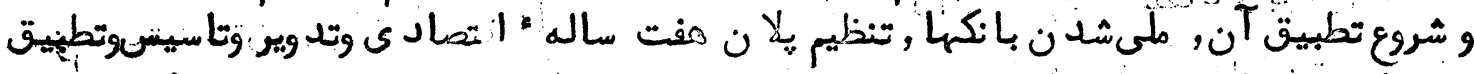

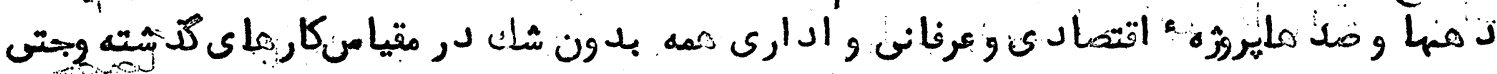

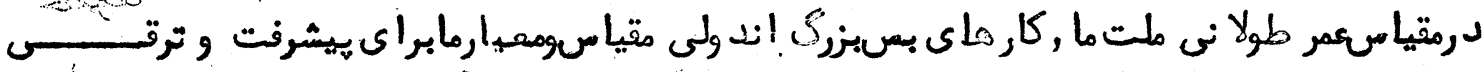

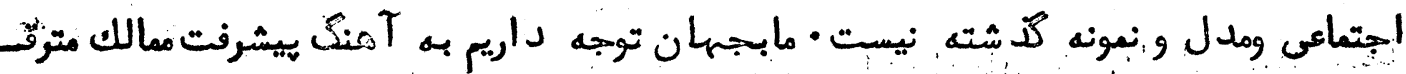

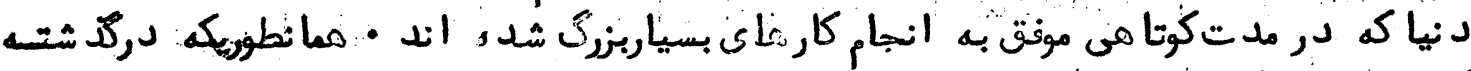

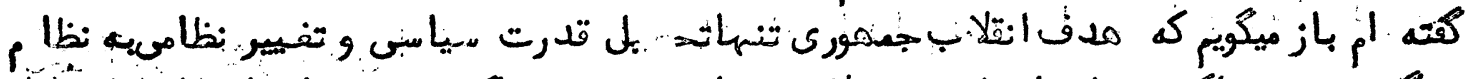

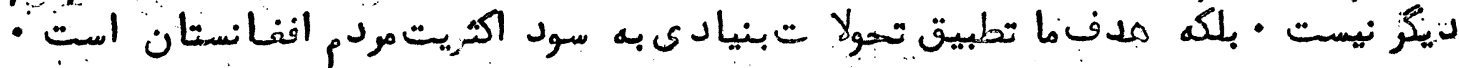

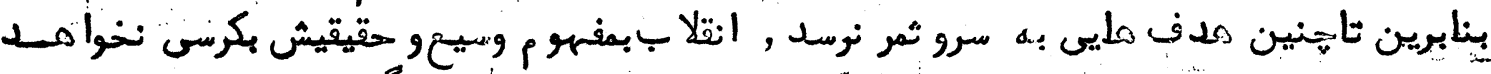

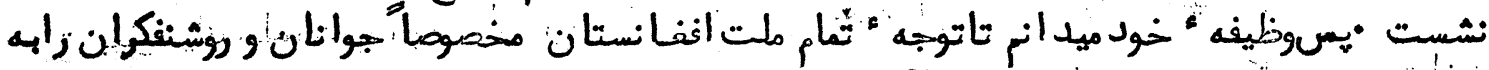

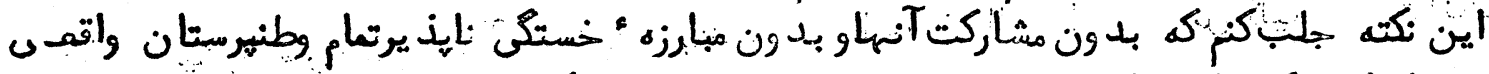

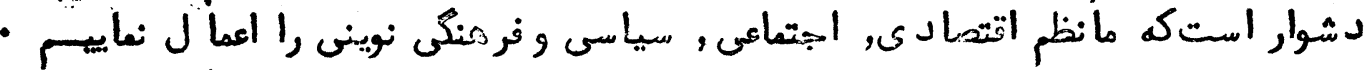
*************************************

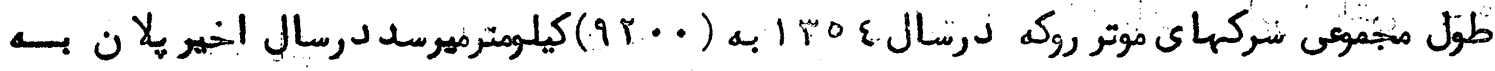

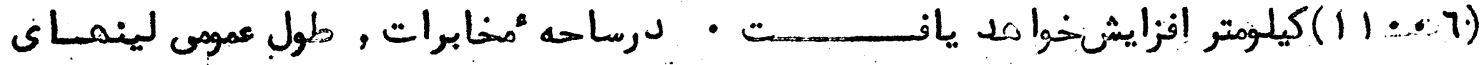

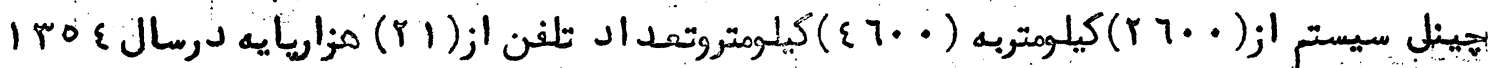

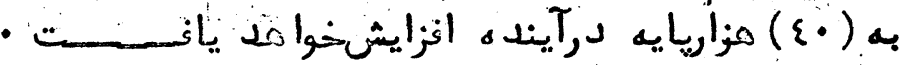

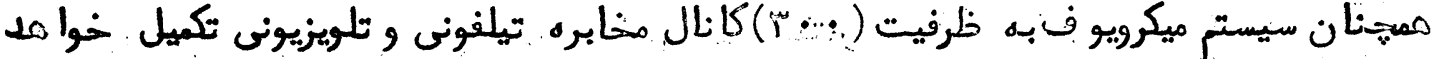

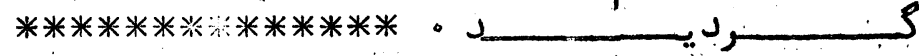
(منتخب ازتهند بيانيه " رهبر انقلاب شاغلى ميحد داودرئيسجمهر افنانستان در موازدواوقات) 


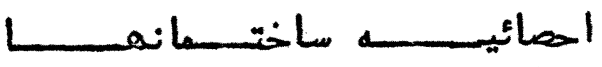

ニニニニニニニニニニニニニニニニニニニニニ

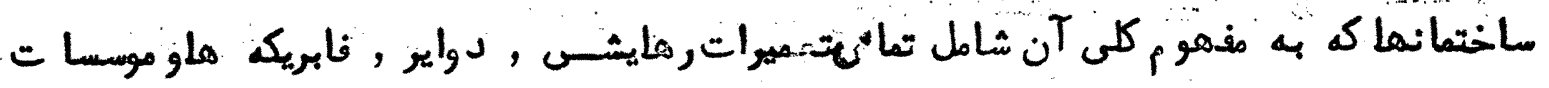

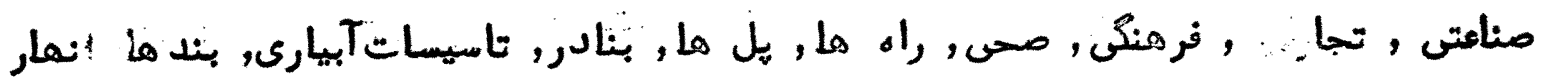

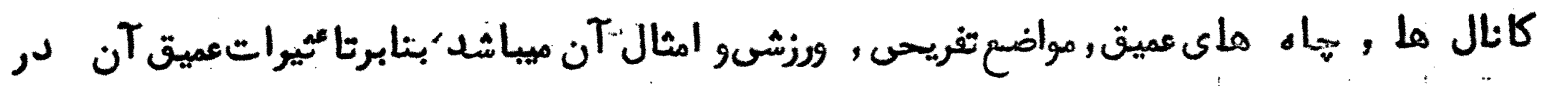

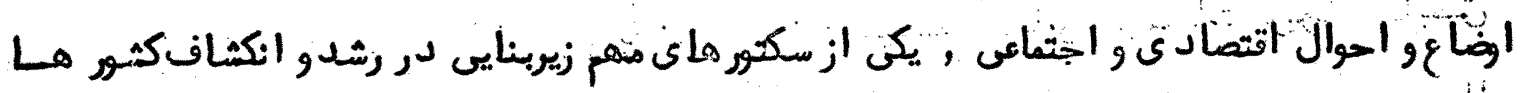

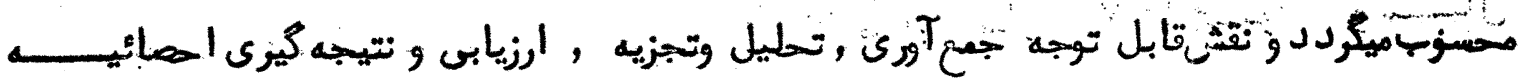

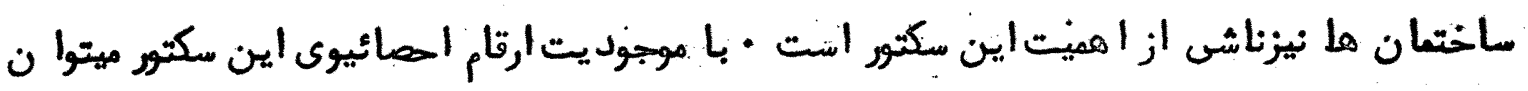

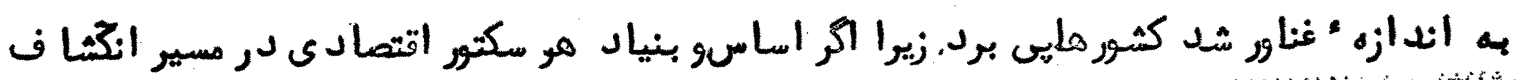

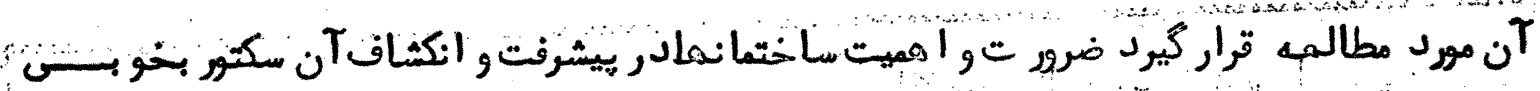

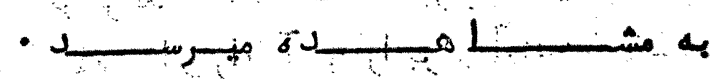

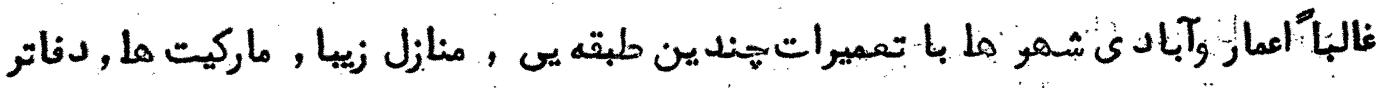

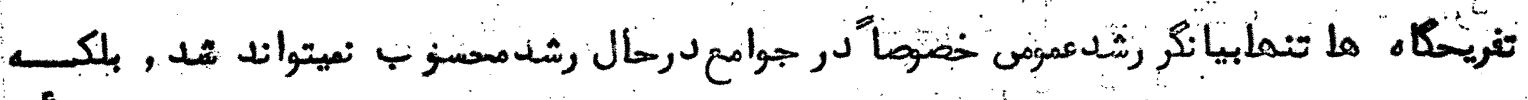

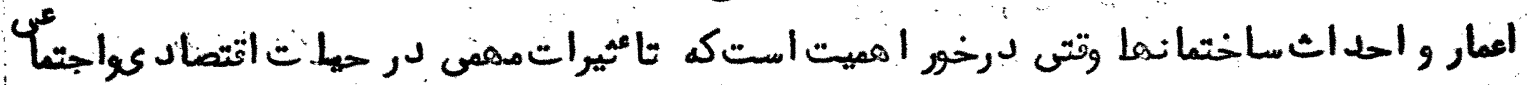

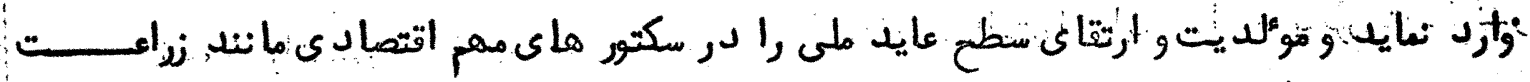

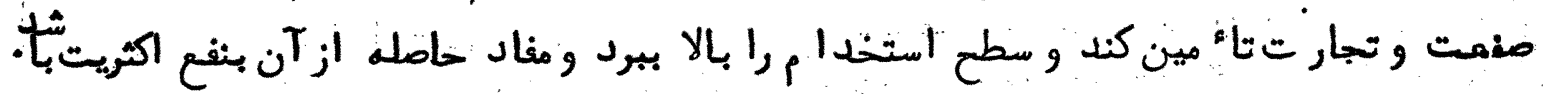

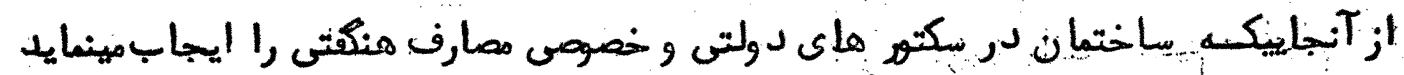

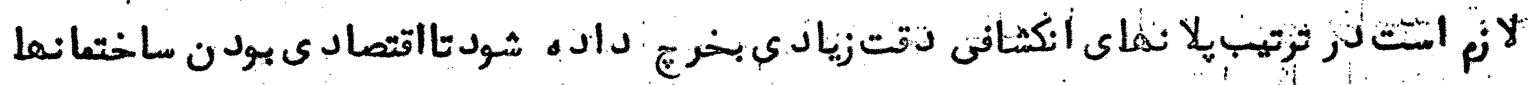

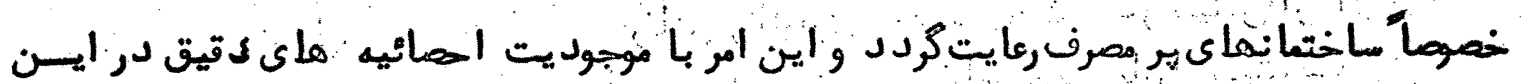

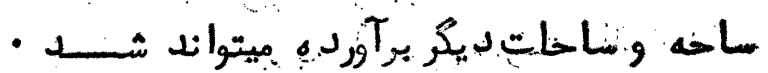

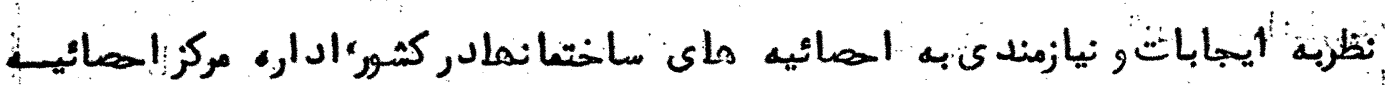

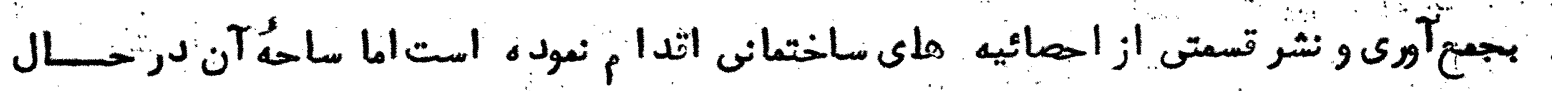

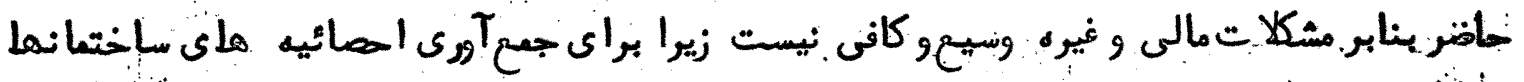

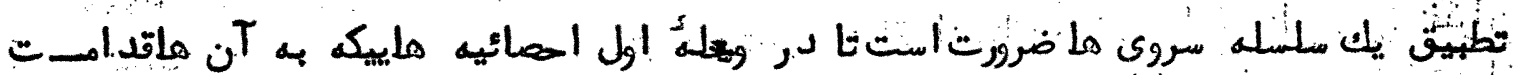

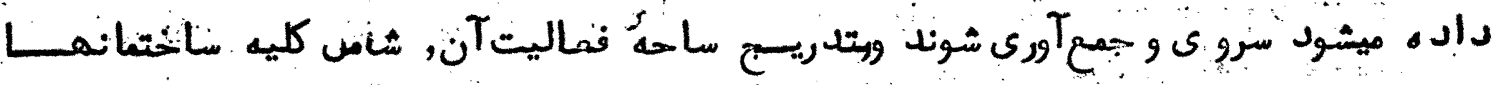

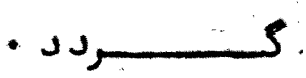

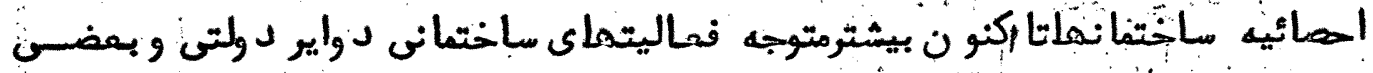

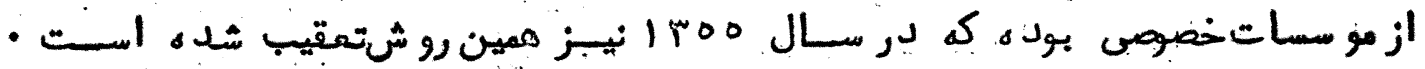

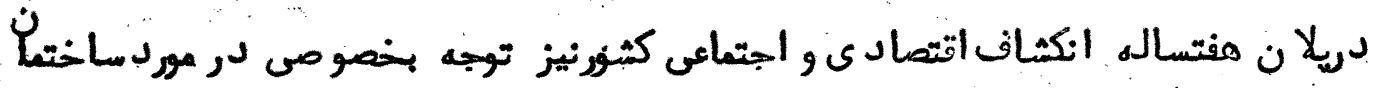

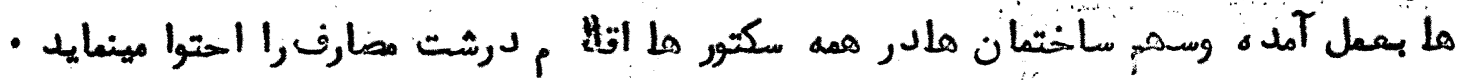

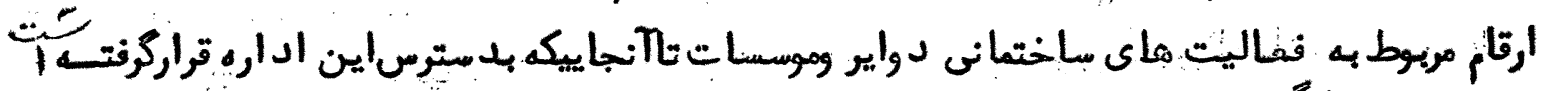




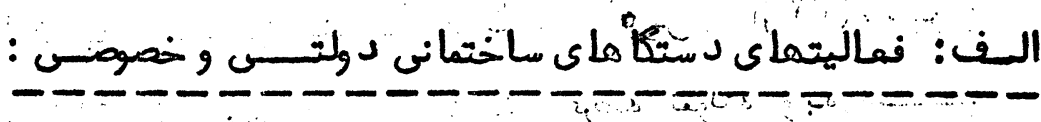

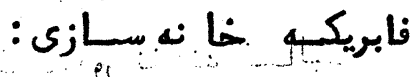

اين فابريكه تا كنو ن يكانه دستكاه ساختمانى بى رثيبدر قسمت مو نتازو ساختيسان

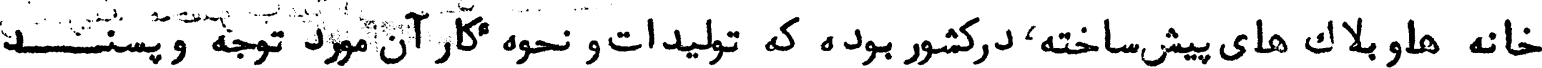

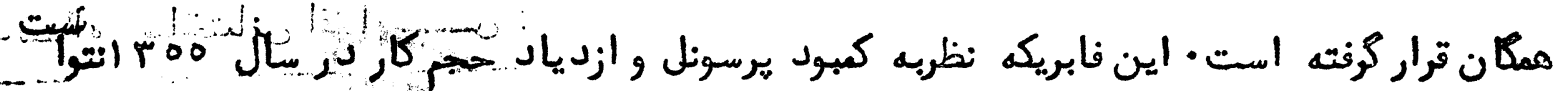

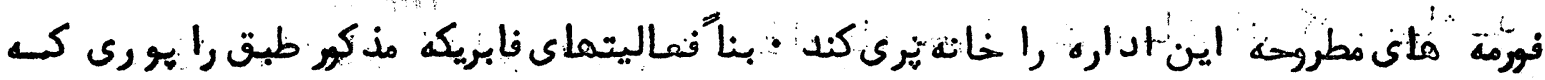

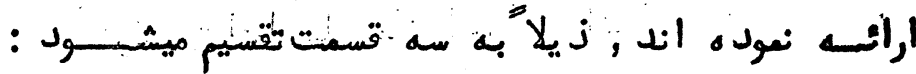

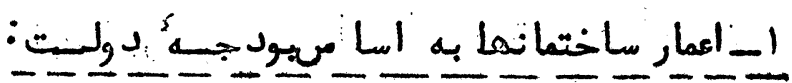

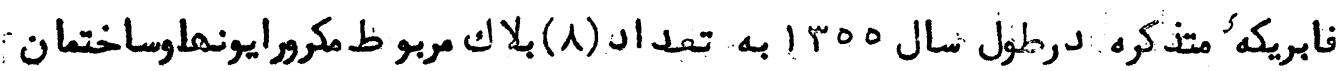

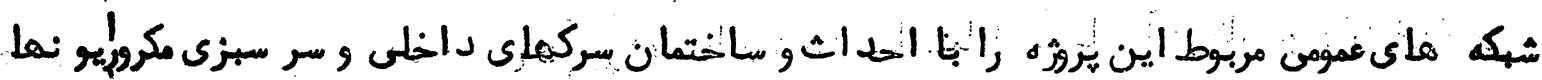

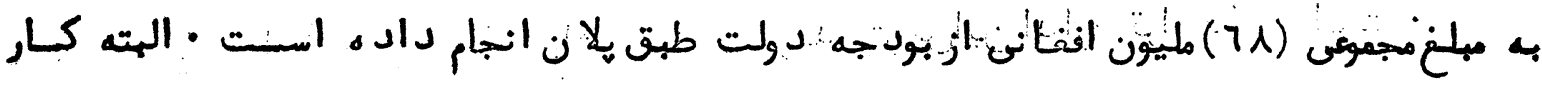

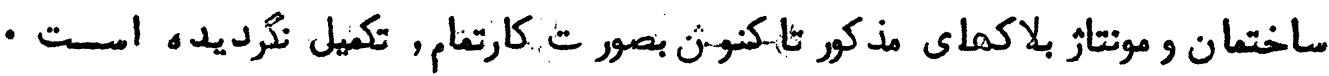

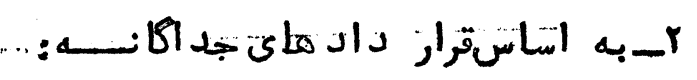

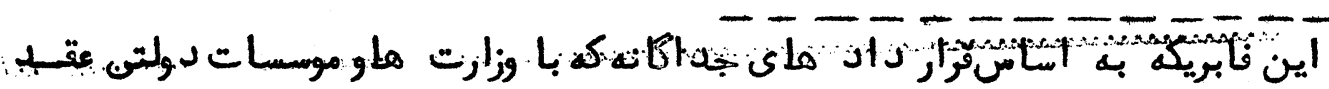

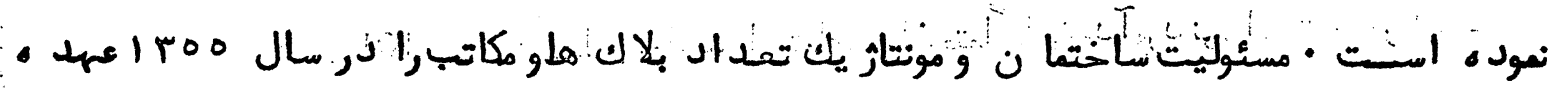

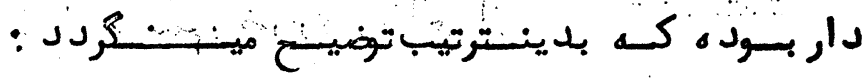

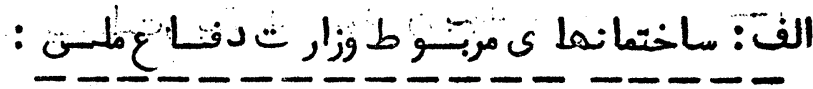

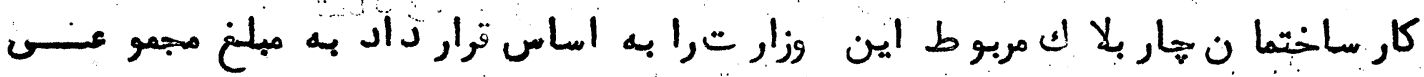

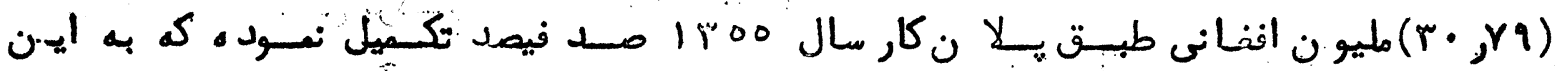

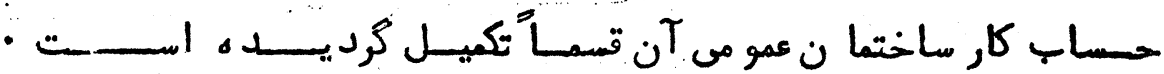

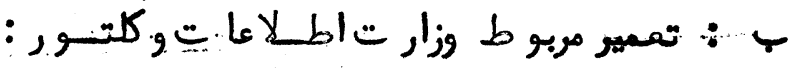

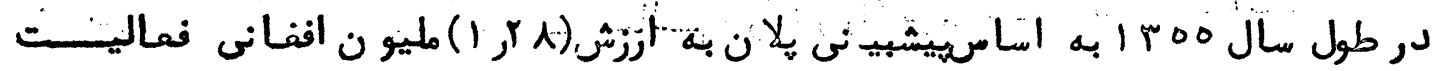

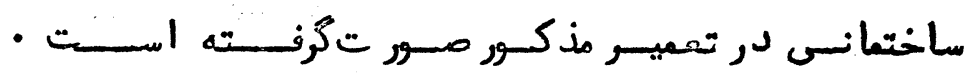

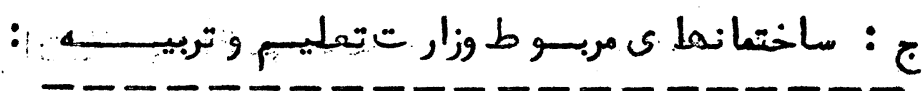

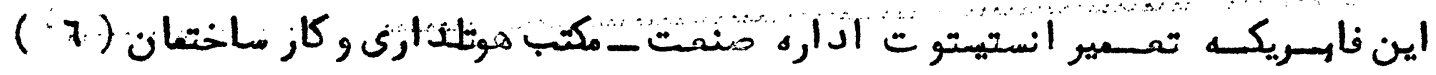

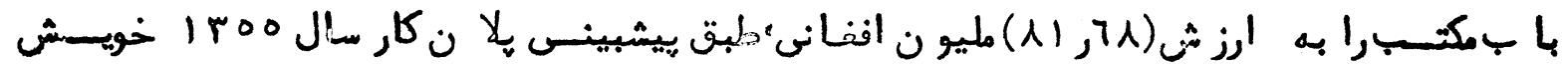

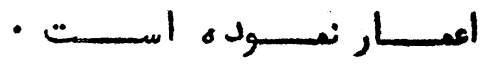

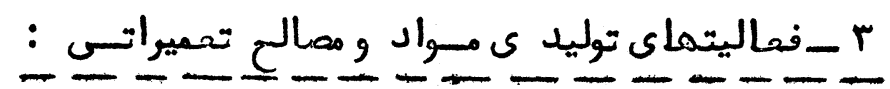

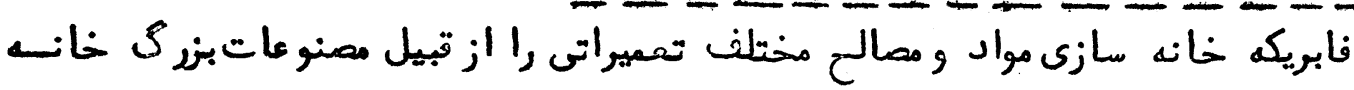

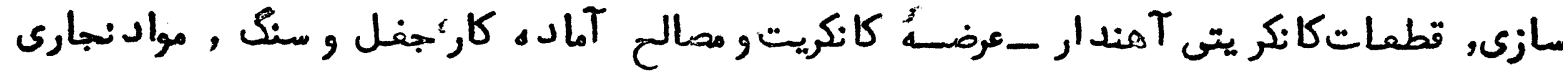




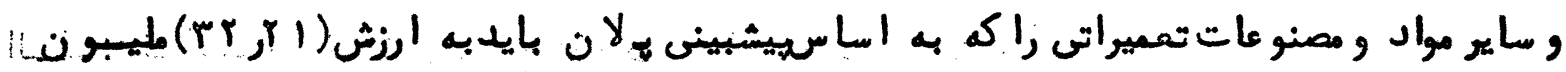

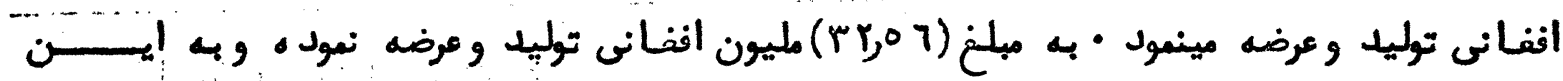

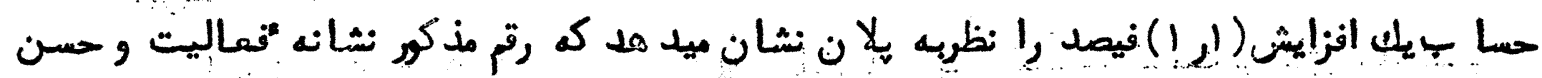

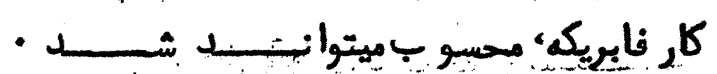

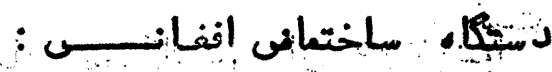
- - - - - - - - -

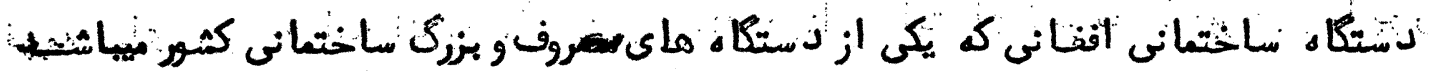

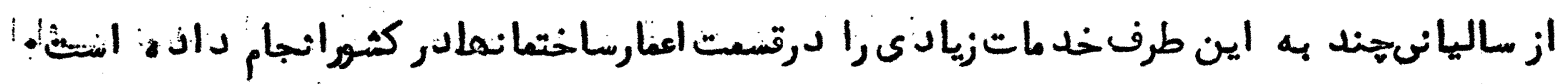

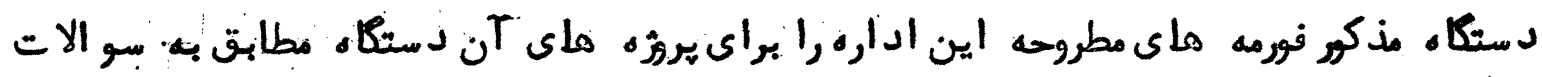

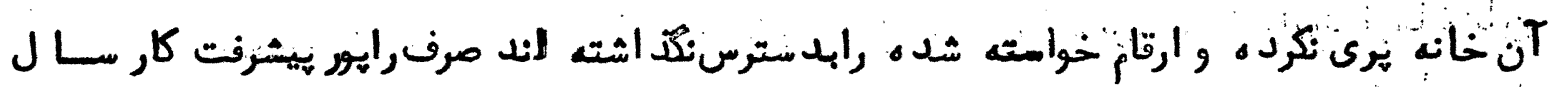

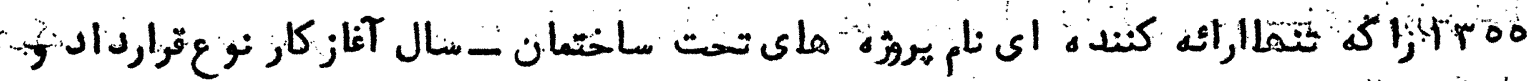

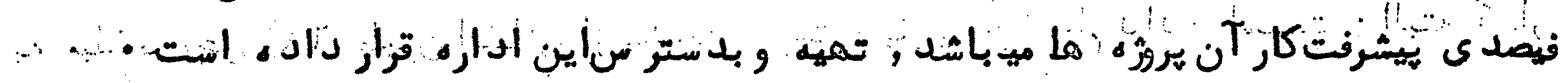

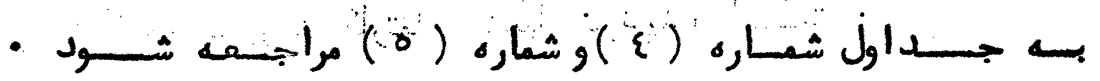

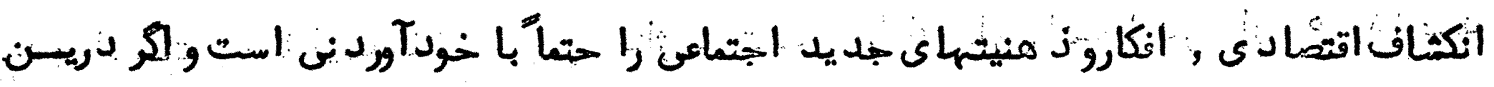

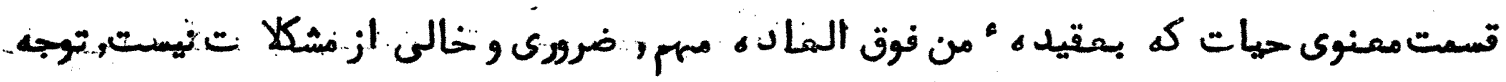

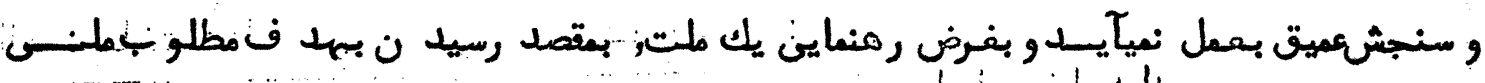

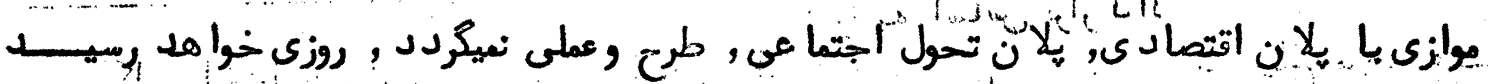

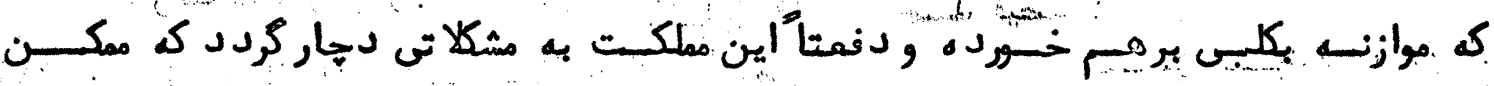

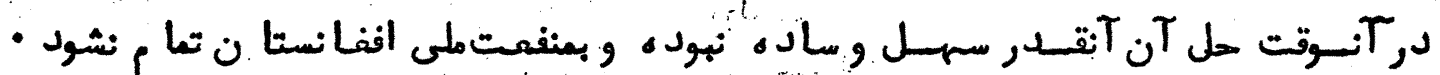

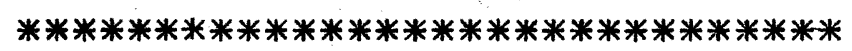

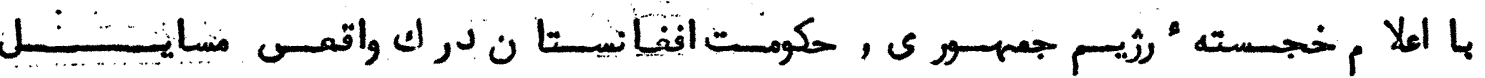

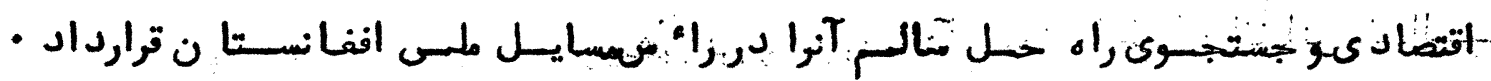
***************

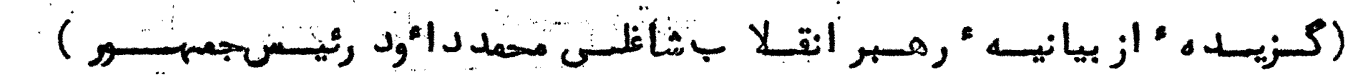


$-\pi \cdot-$

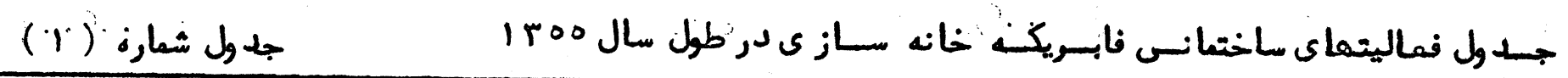

\begin{tabular}{|c|c|c|c|c|c|c|c|c|}
\hline 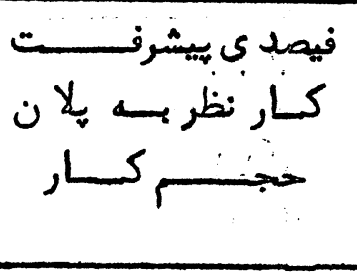 & 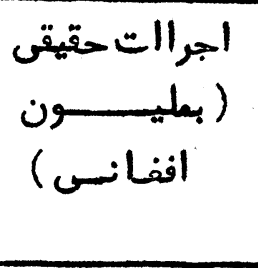 & 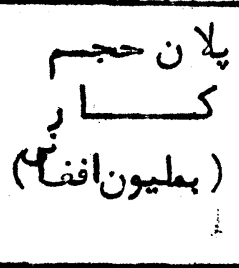 & 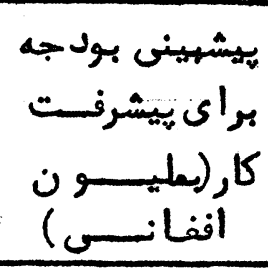 & 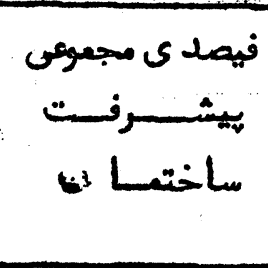 & 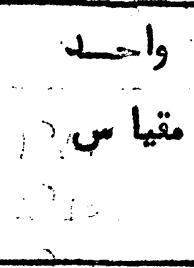 & تعدا & & \\
\hline$V \varepsilon, 70$ & 1,7 & $1, \varepsilon Y$ & $1, \varepsilon r$ & 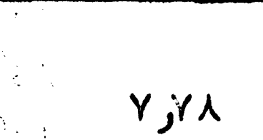 & هلاداث & 1 & 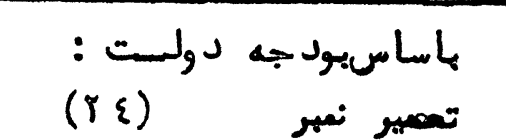 & 1 \\
\hline $10, r \varepsilon$ & 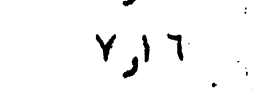 & $\lambda, \varepsilon$. & $\Lambda, \varepsilon$. & $r 7,01$ & . رנر. & 1 & تعمير نمهر & $r$ \\
\hline $1 \cdots$, & $r, \lambda r$ & $r, \wedge r$ & $r, \lambda r$ & $r \cdot, \pi r$ & 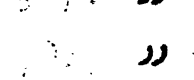 & 1 & تمعير نعبر & $r$ \\
\hline $1 \cdots$, & $r, \lambda r$ & $r, \lambda \gamma$ & $r, \lambda r$ & rogr & 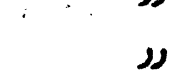 & 1 & تيمير نعبر & $\varepsilon$ \\
\hline$\lambda \varepsilon, \gamma \lambda$ & 7,01 & $r j, r$ & $r, r r$ & | & 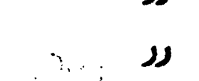 & 1 & تعمير نمر & 。 \\
\hline $1 \cdots, \ldots$ & $r, r \cdot$ & $r, 5$. & $Y, r$. & $r Y \wedge \varepsilon$ & 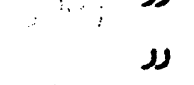 & 1 & تعمير نهر & 7 \\
\hline $0 \varepsilon \varepsilon, Y \cdot$ & $r, r$ & 1,59 & 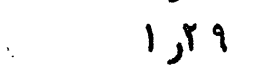 & $\varepsilon \varepsilon, 1$. & נر & 1 & تعمير نمبر & $Y$ \\
\hline$q \cdot, \cdot ;$ & I & $11, \varepsilon \cdot$ & $11, \varepsilon$. & $r q, \lambda q$ & 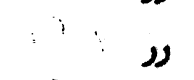 & 1 & تمعير نعير $\quad$ (110) & 1 \\
\hline$\Lambda \cdot, \mu_{0} \ldots$ & $r, \gamma \cdot$ & $q, \varepsilon \cdot$ & $q, \varepsilon \cdot$ & ו & - & - & 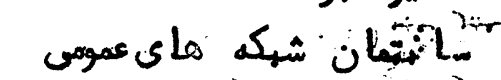 & 9 \\
\hline $1 \ldots, \ldots$ & (. & $\varepsilon, \tau$. & $\varepsilon, r$. & 17,9 & - & - & 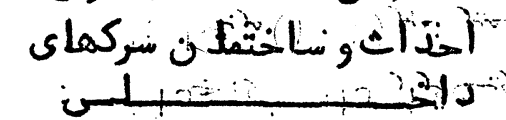 & 1. \\
\hline $1 \cdots, \cdots$ & 1,1 & 1 & 1,11 & $1 \cdots$ & - & - & سر ســزى مكـوروايونفـــــ & 11 \\
\hline $1 \ldots, \ldots$ & 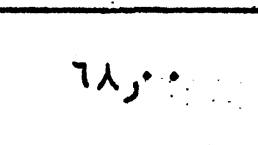 & $7 \mu, \cdot$ & $\lambda \lambda_{1}, \cdots$ & . & & . & مجر,- & \\
\hline
\end{tabular}


جدول شماره (r)

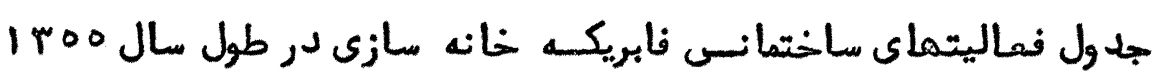

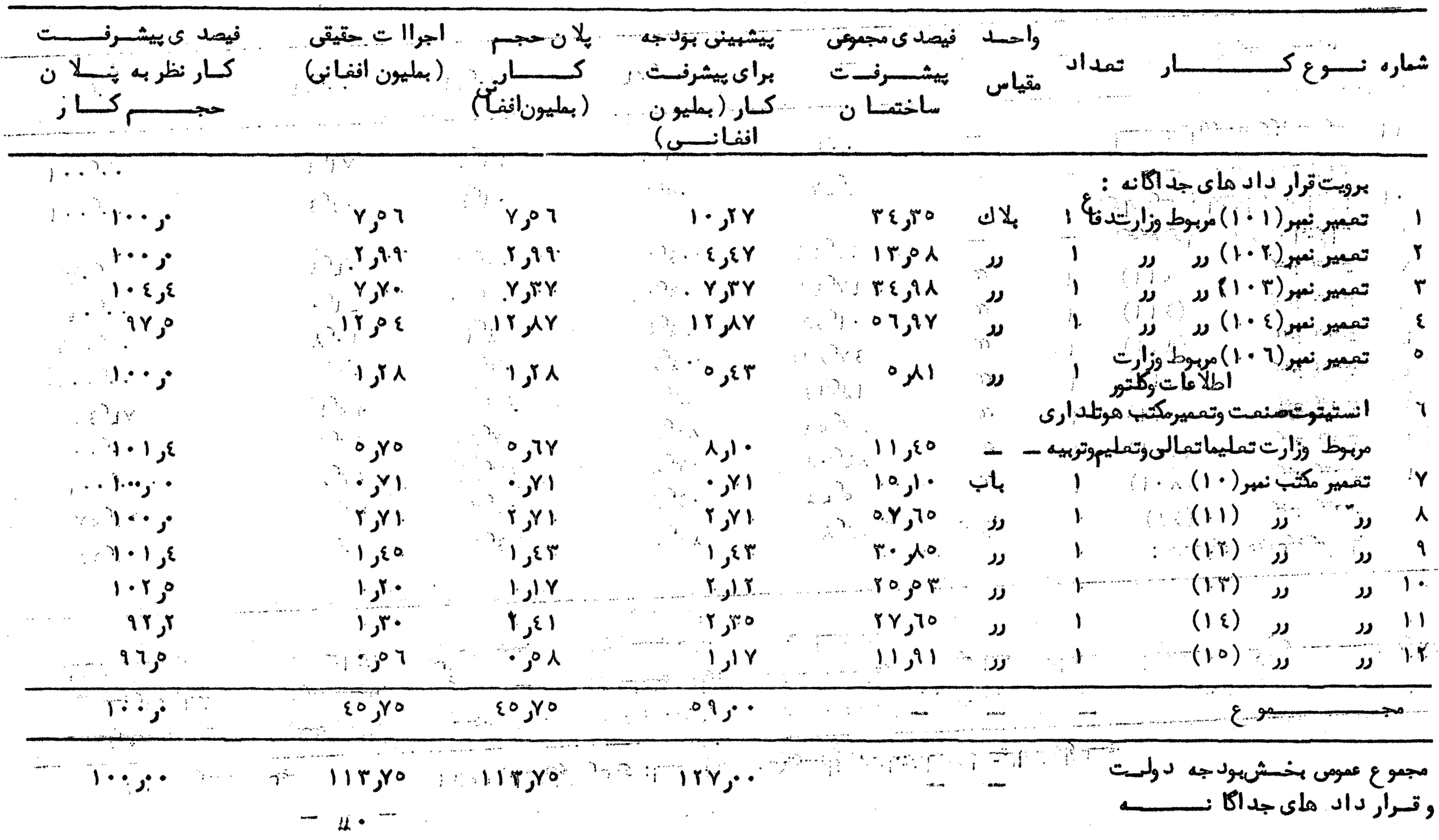




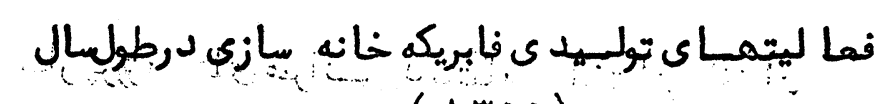

جدول شماره (r) (1)00)

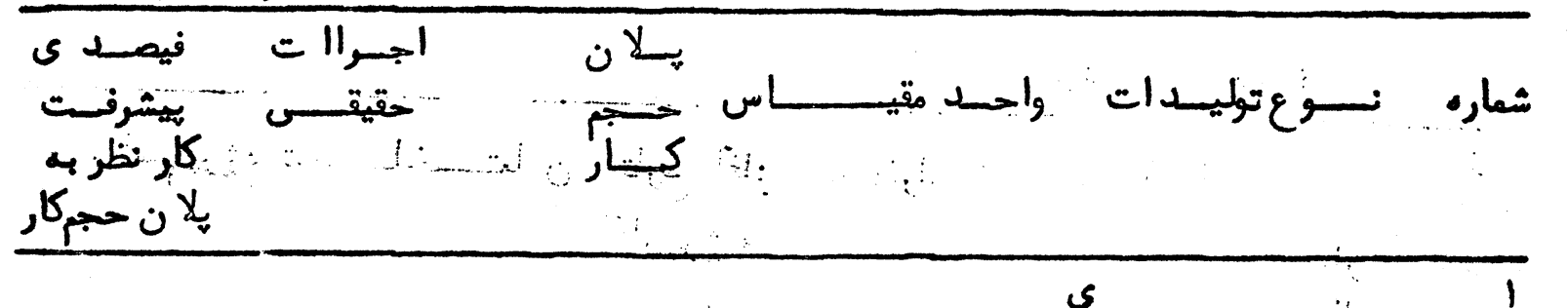

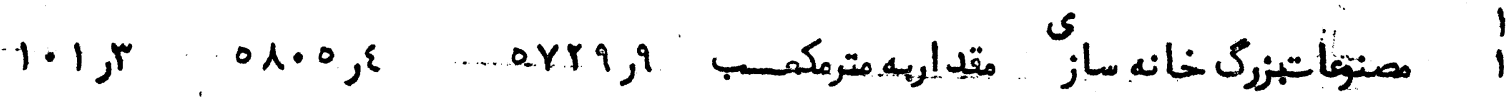

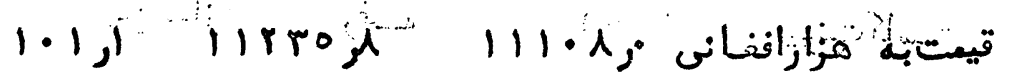

r

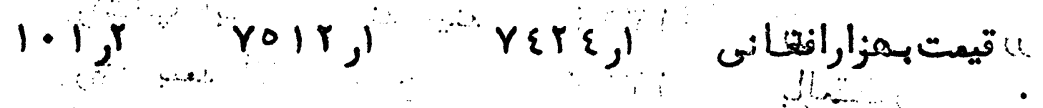

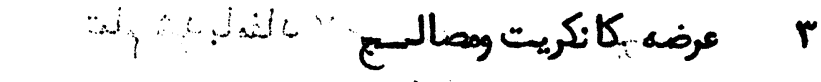

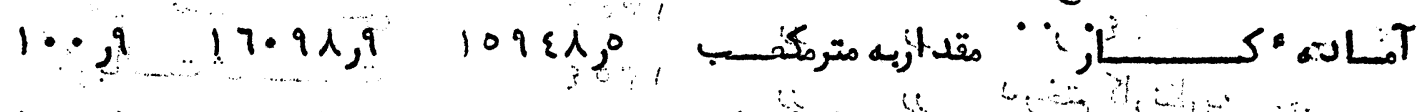

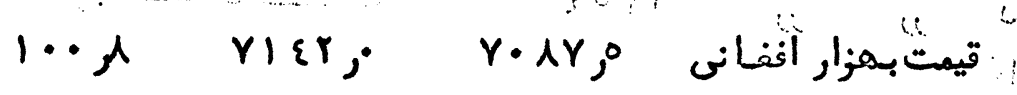

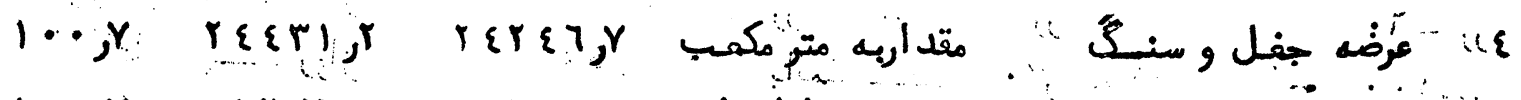

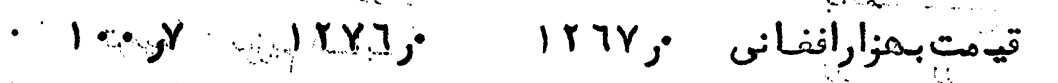

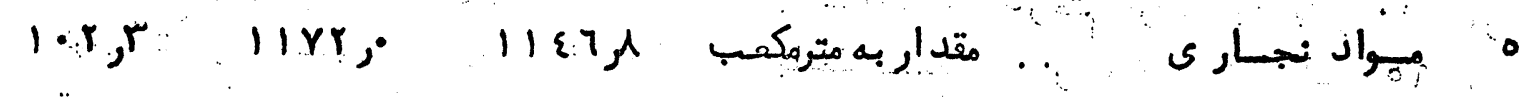

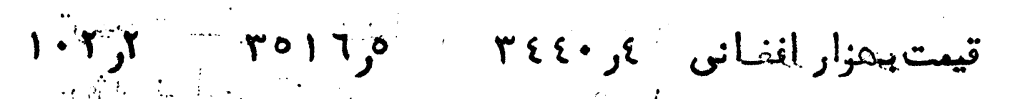

- $\quad$ - $\quad$ -

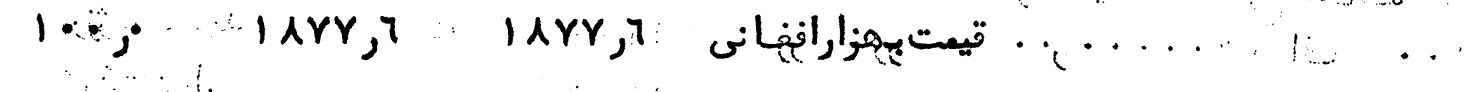

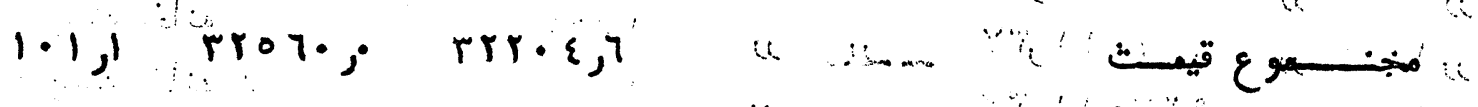

pin

34

il 4 


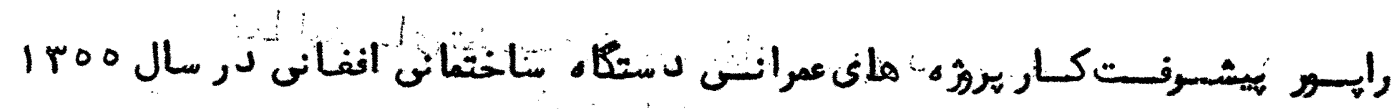
جدول شماره (ع)

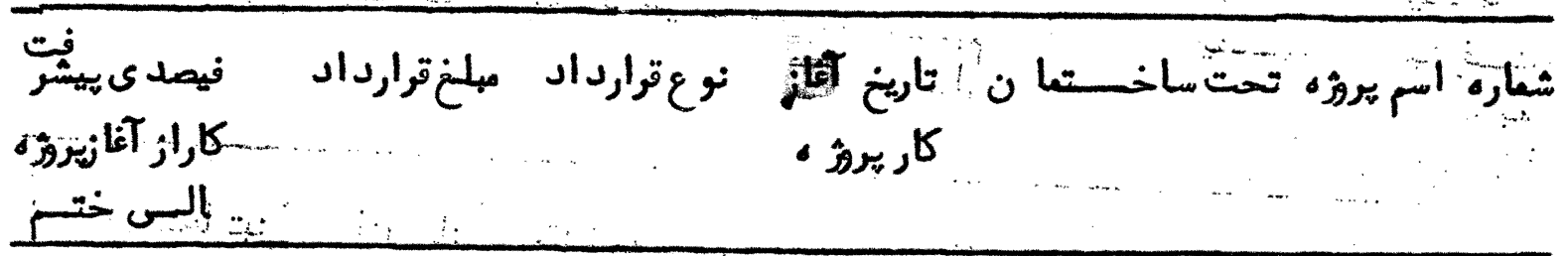

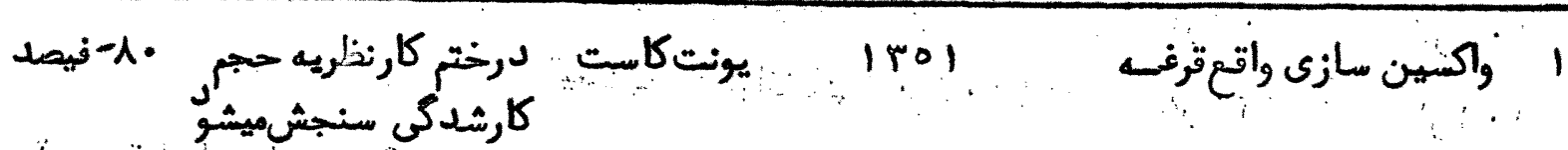

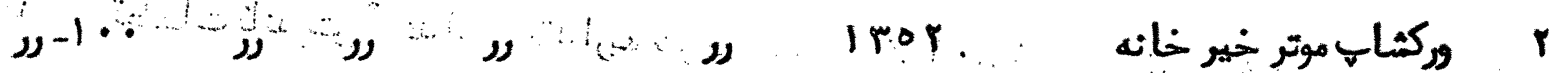

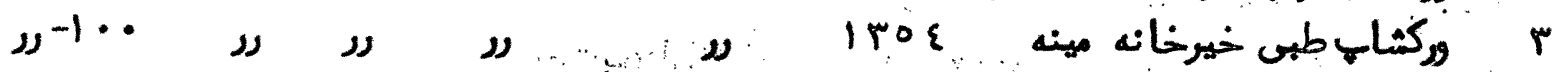

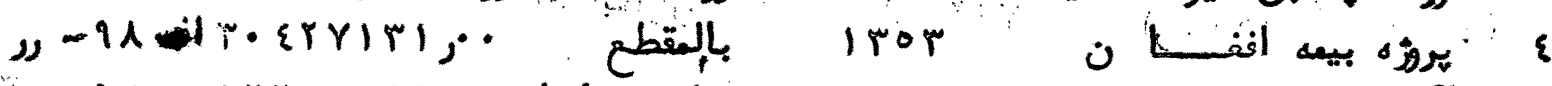

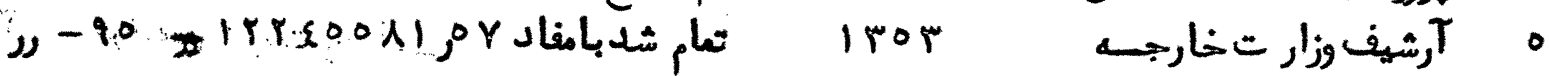

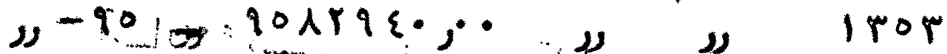

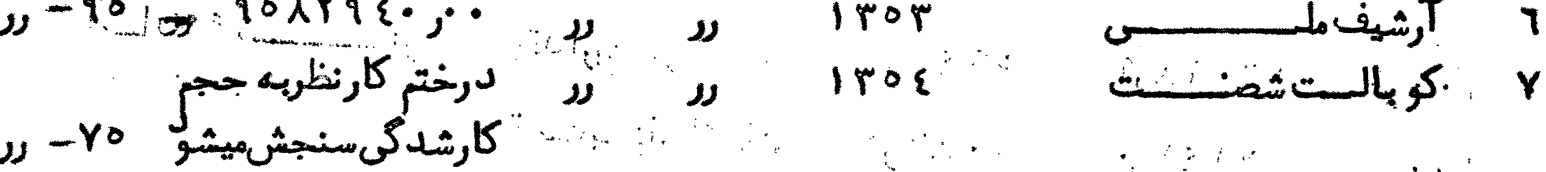

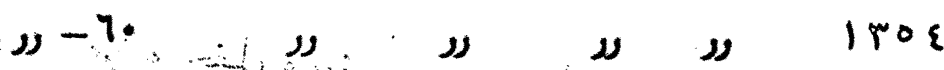

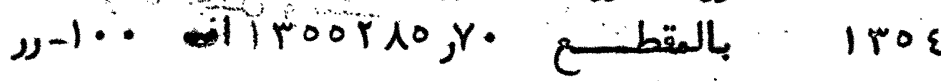

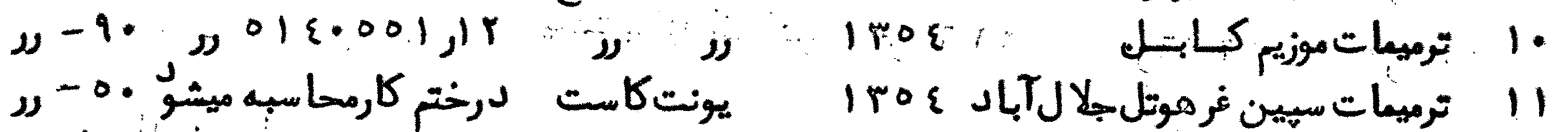

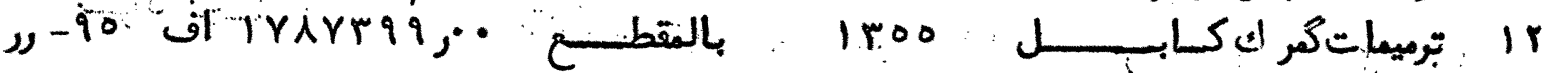

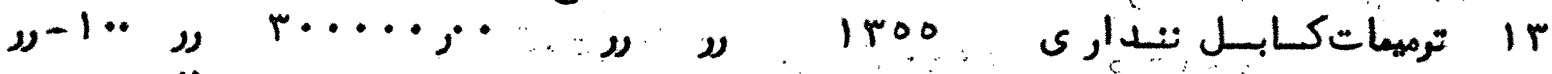

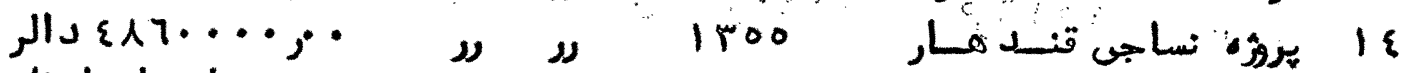

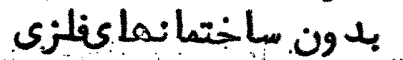

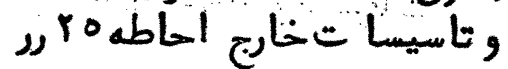

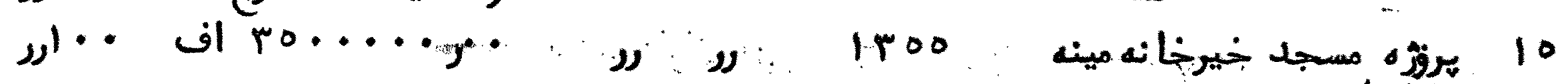

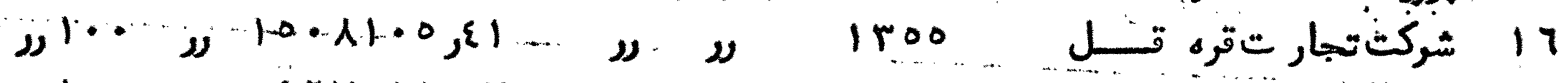

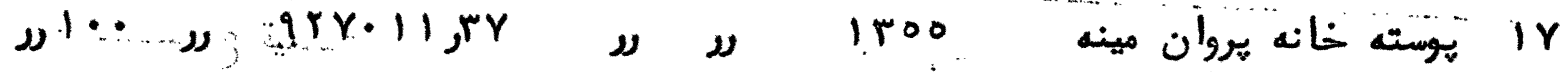

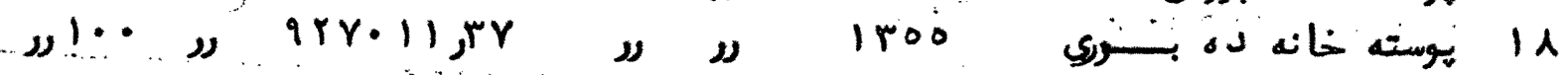

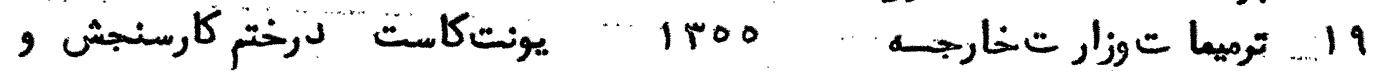

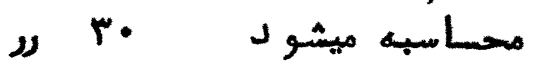

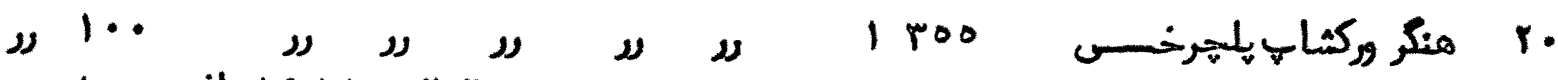
ا r ساختطان وركثلإتحويلنانه

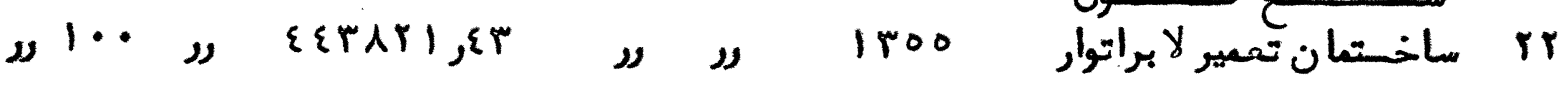

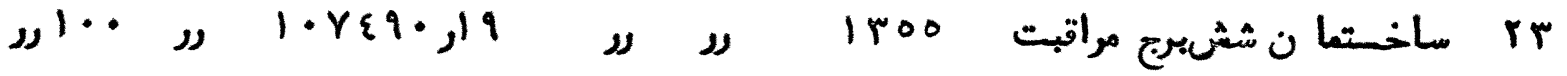

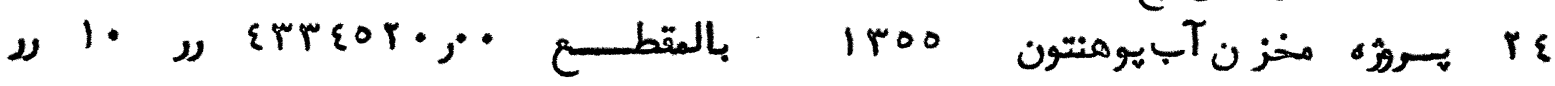




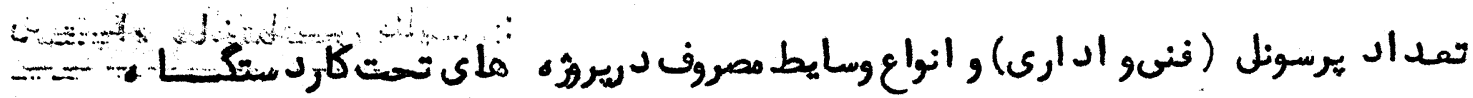

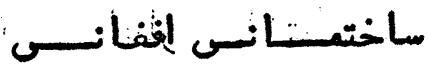

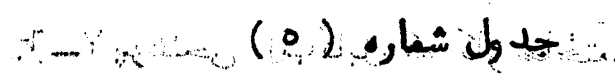

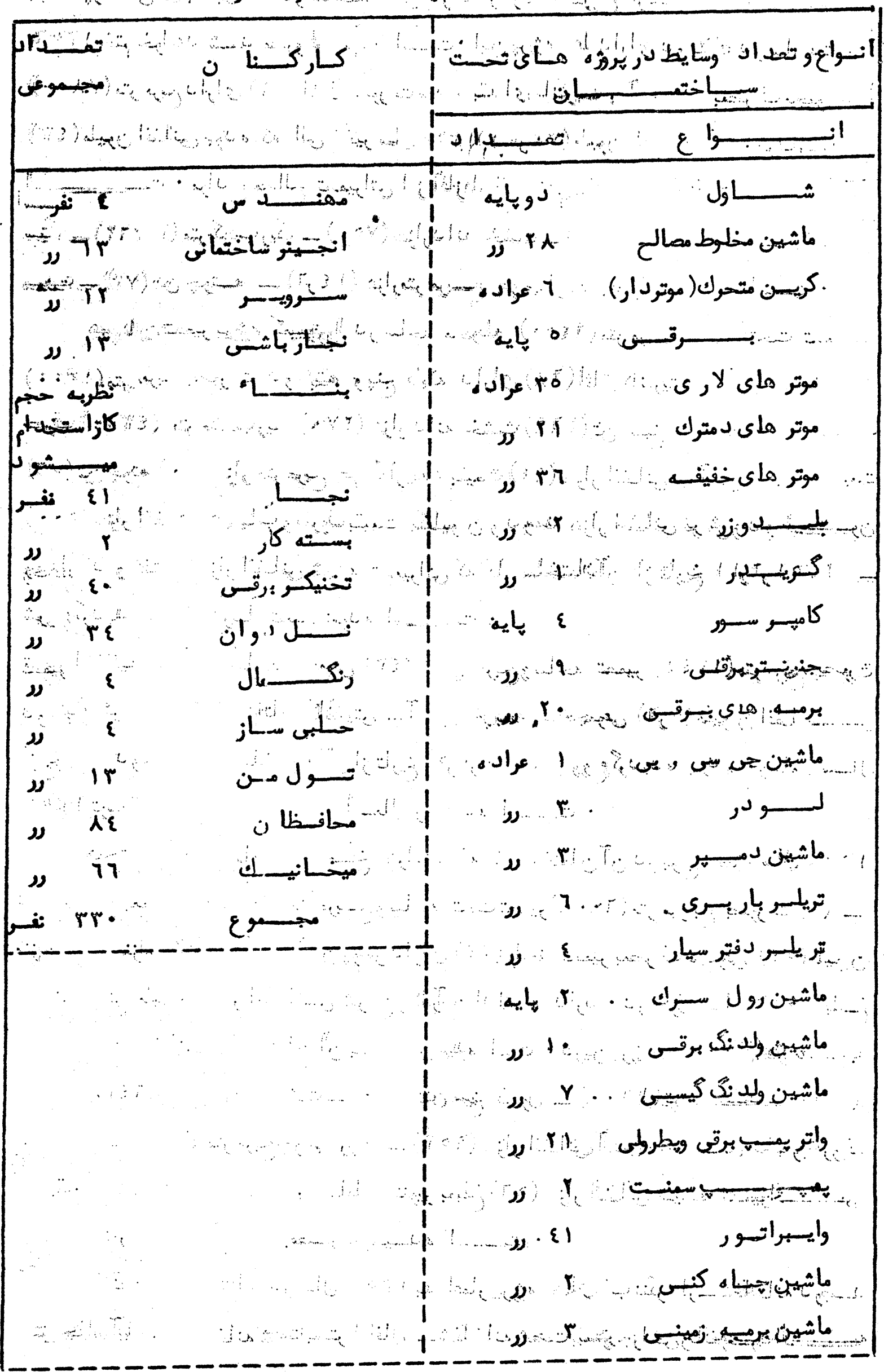




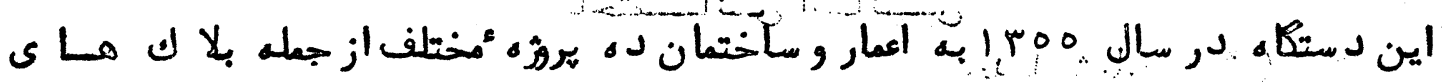

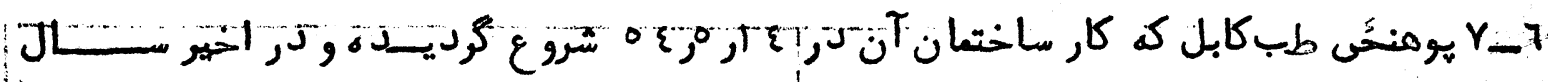

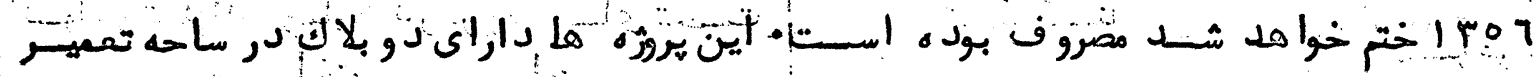

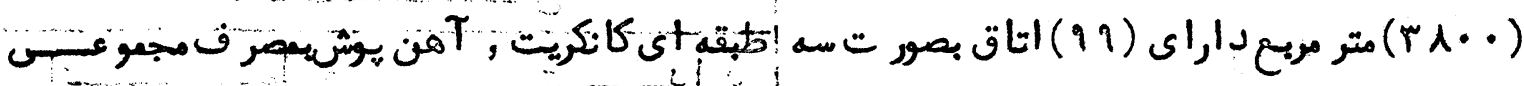

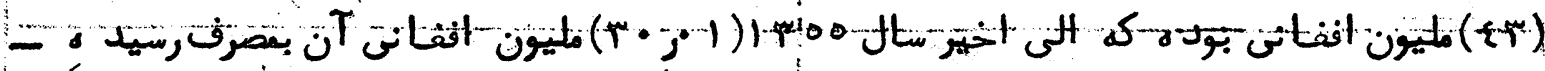

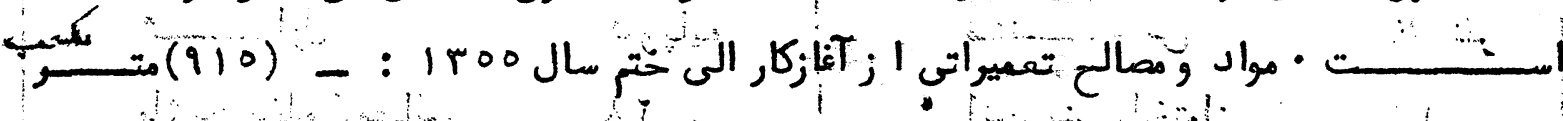

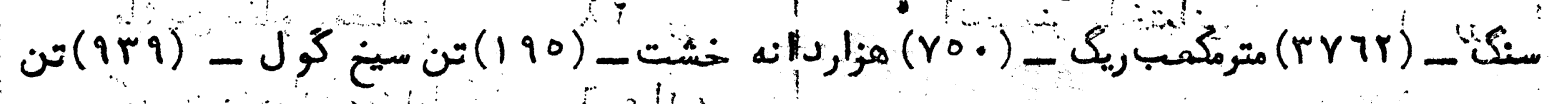

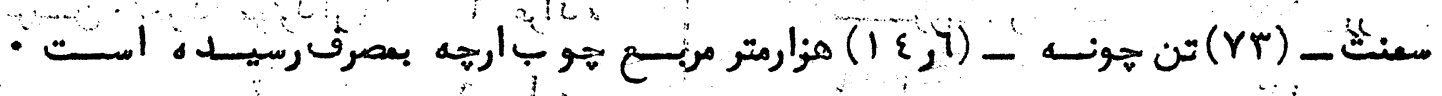

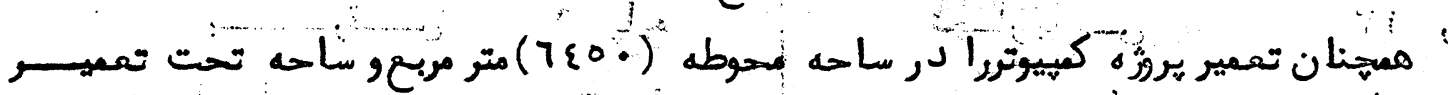

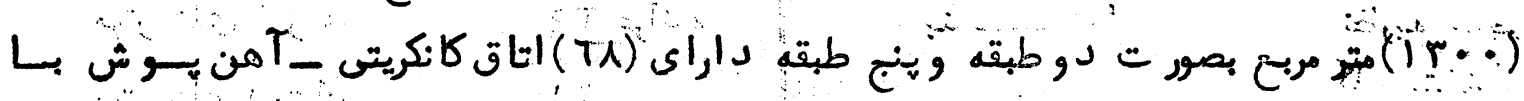

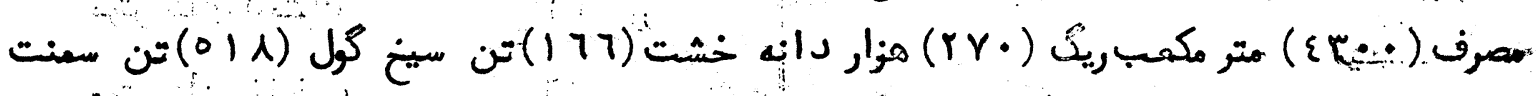

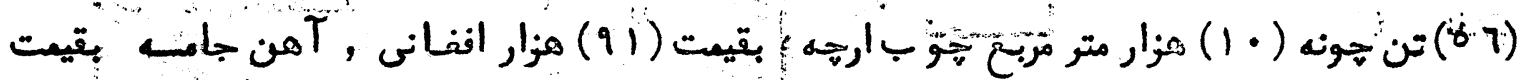

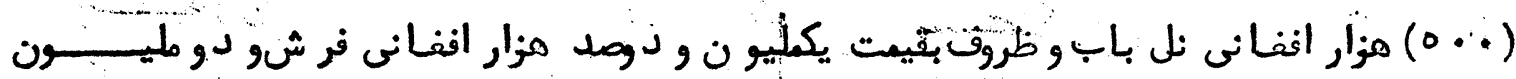

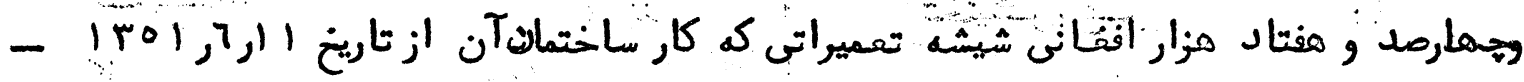

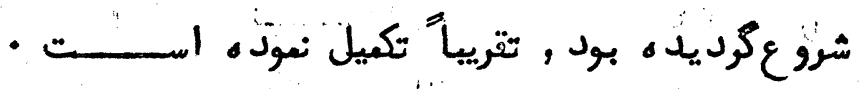

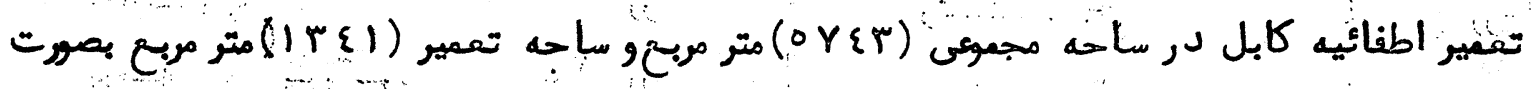

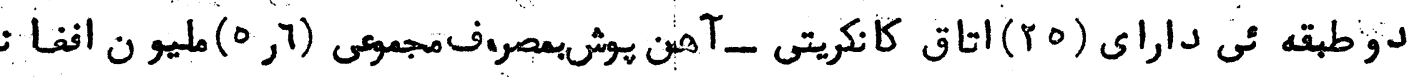

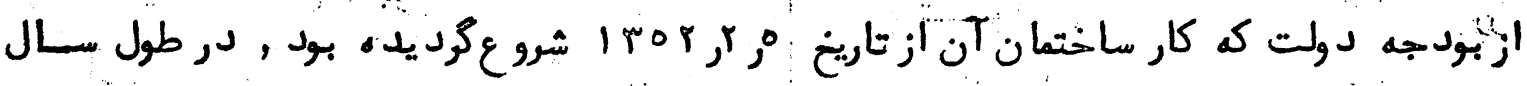

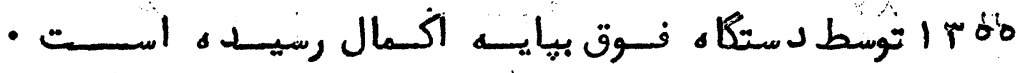

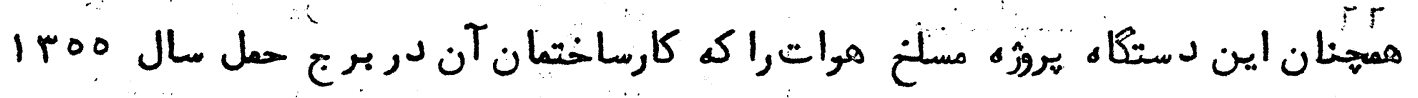

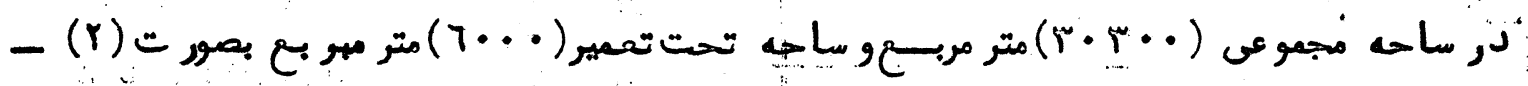

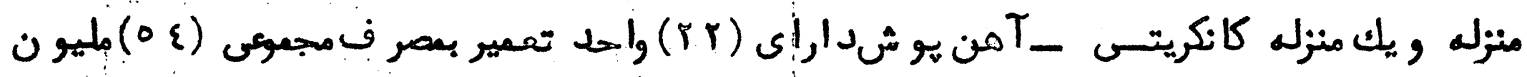

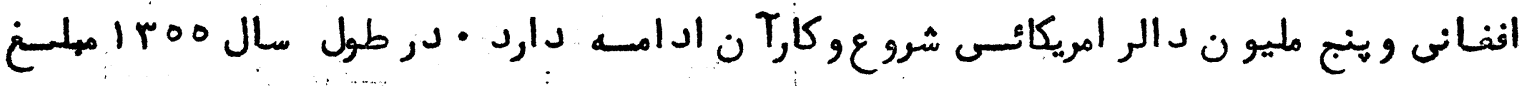

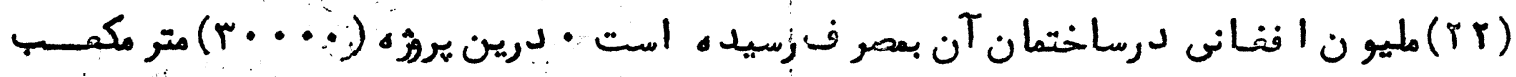

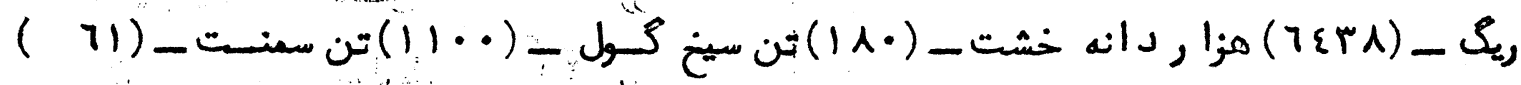

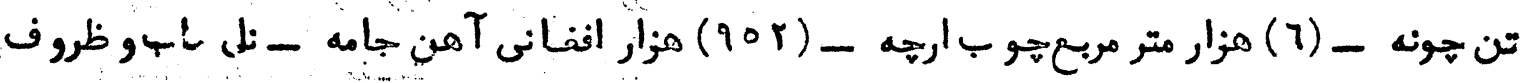

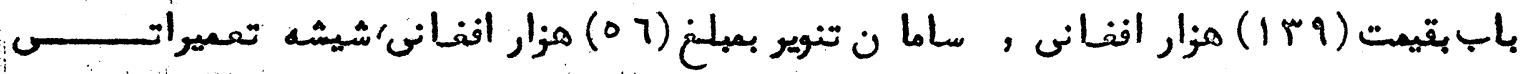

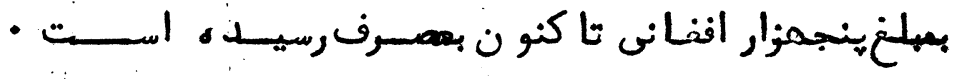

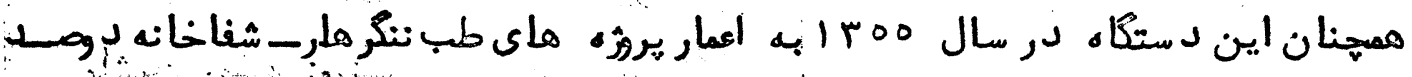

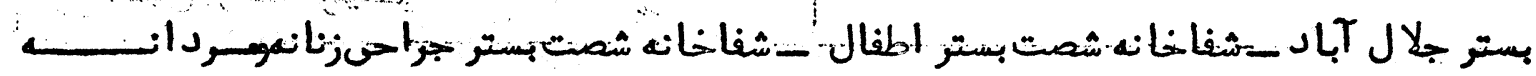




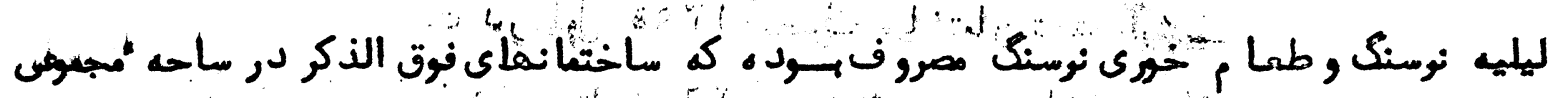

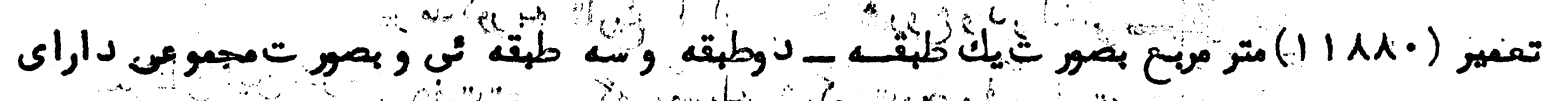

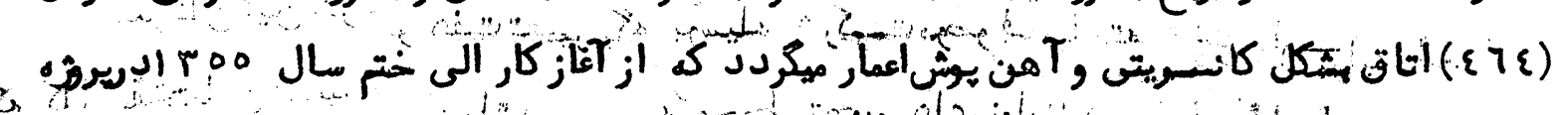

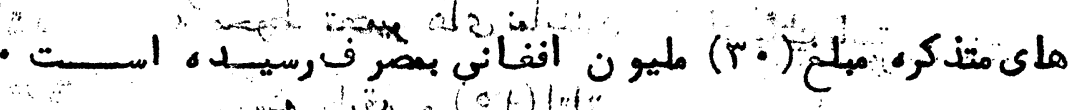

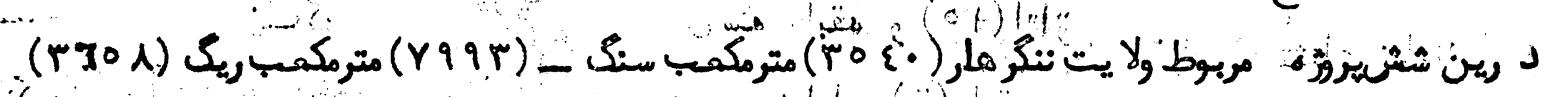

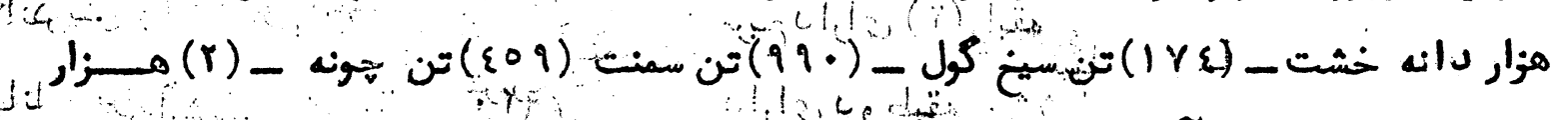

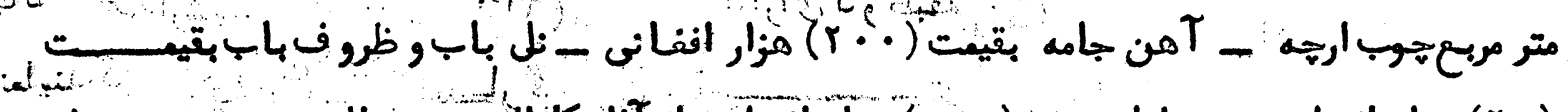

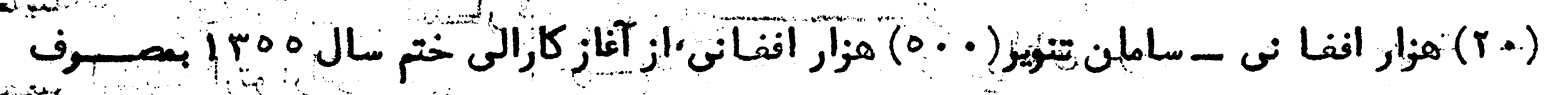

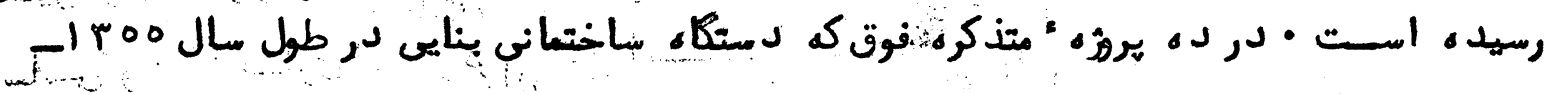

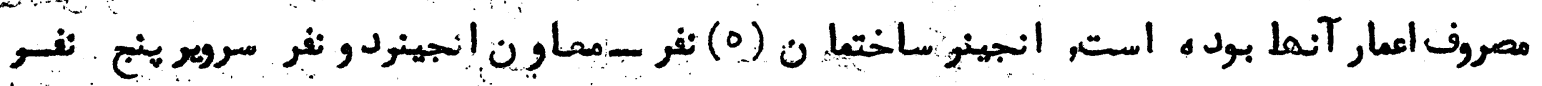

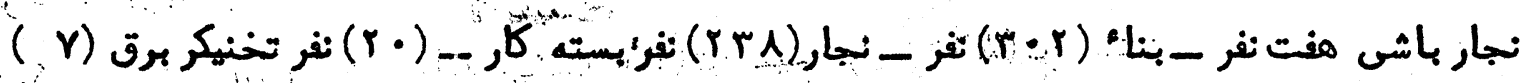

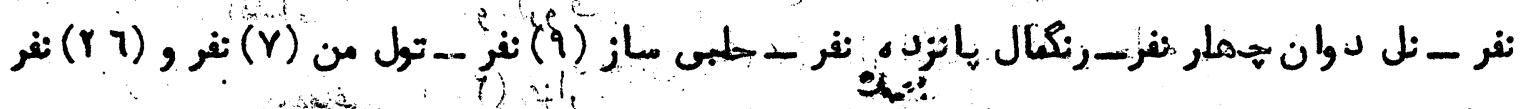

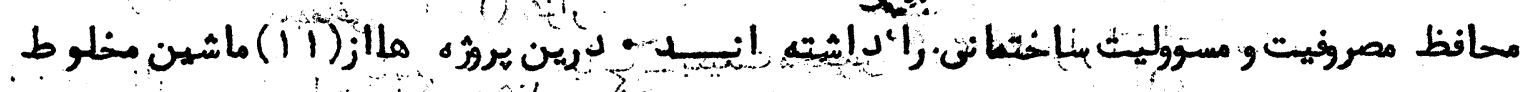

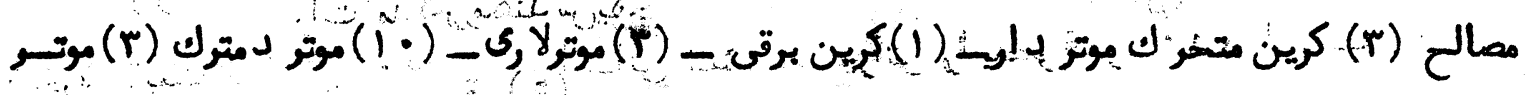

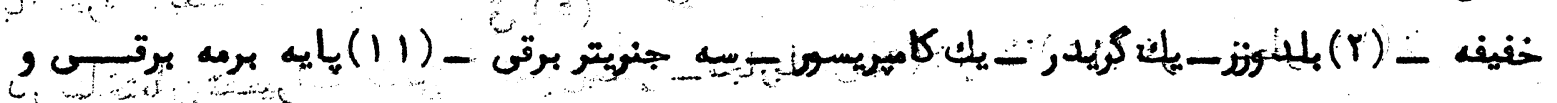

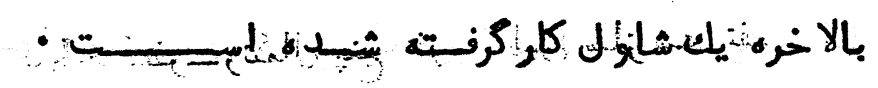

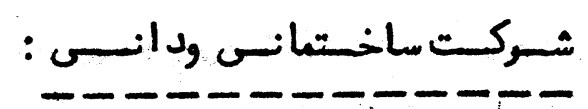

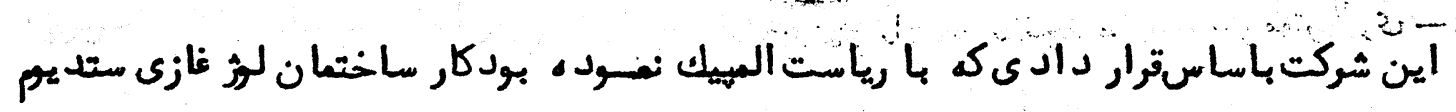

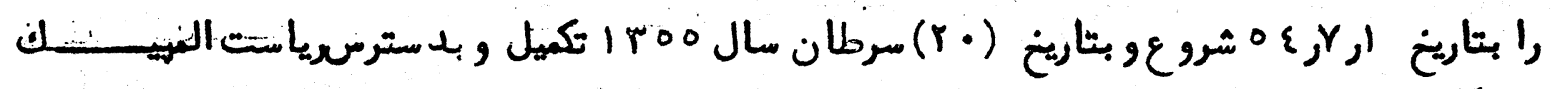

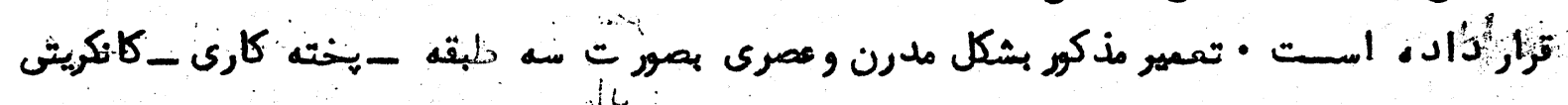

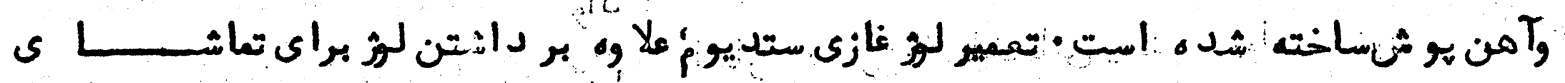

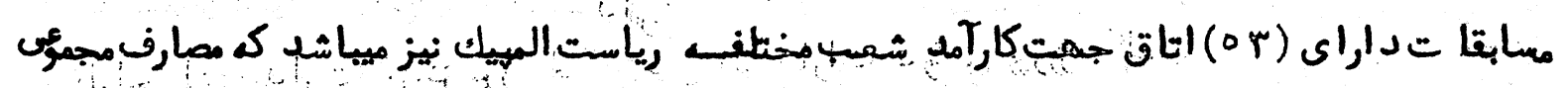

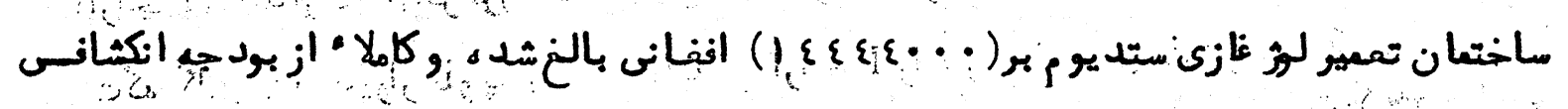

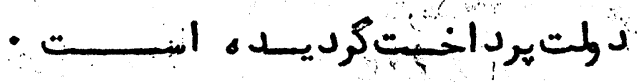

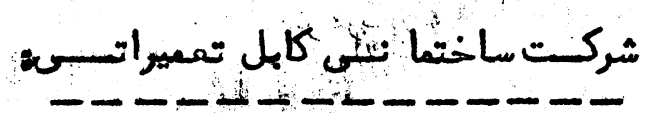

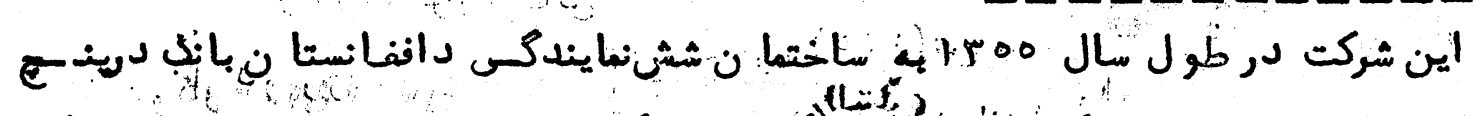

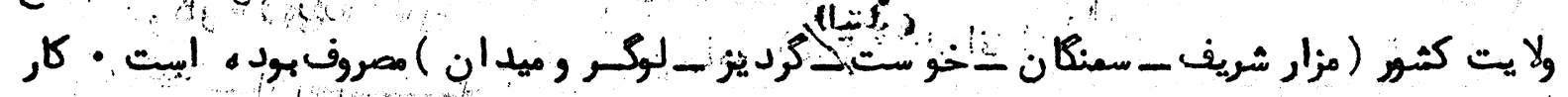

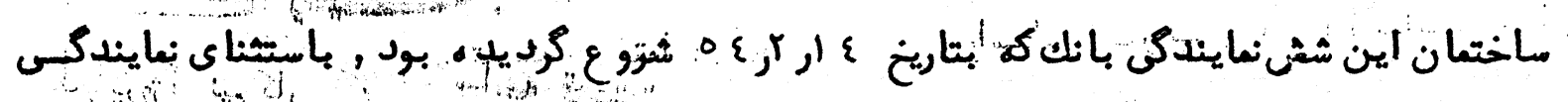

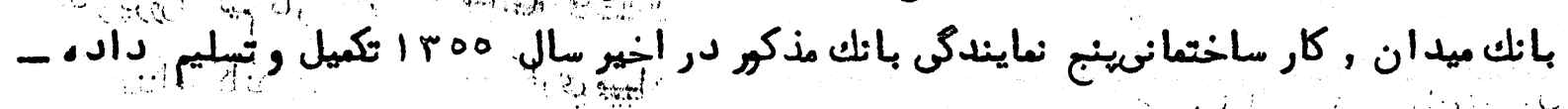




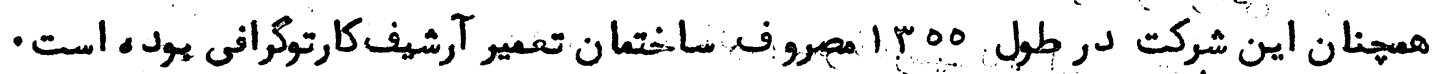

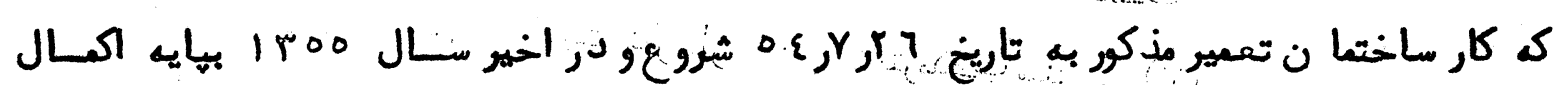

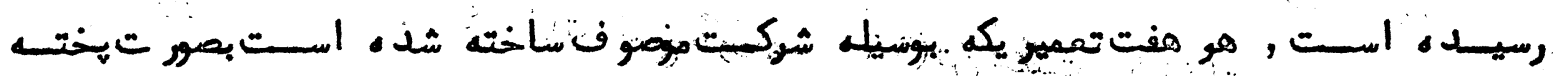

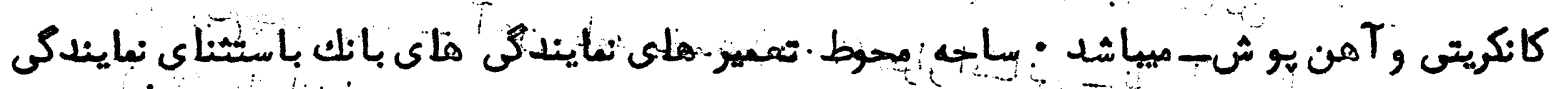

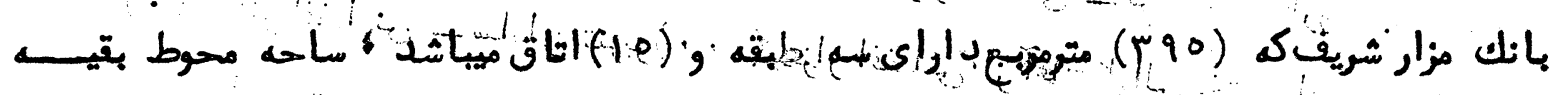

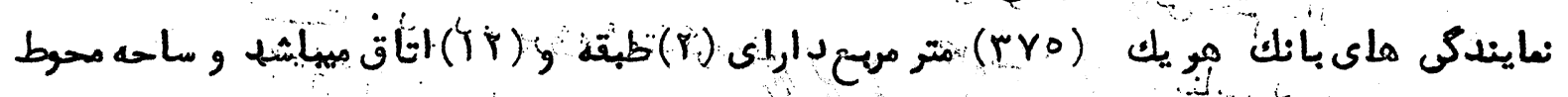

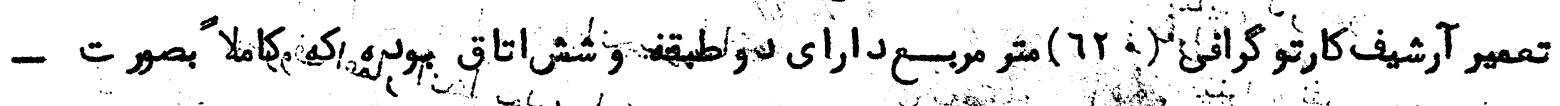

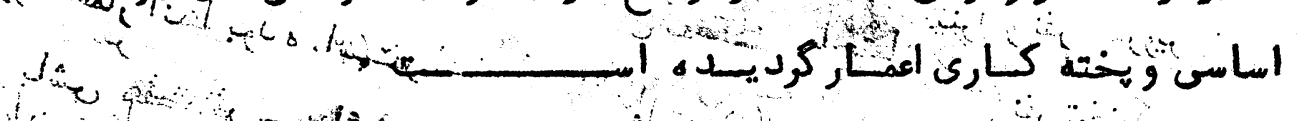

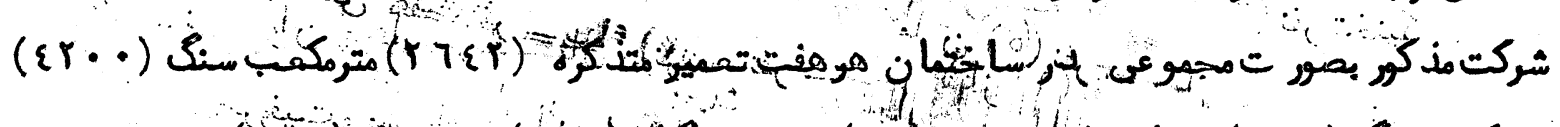

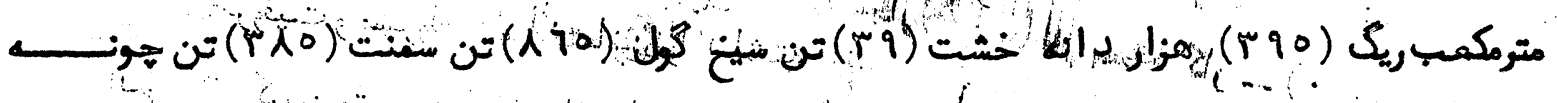

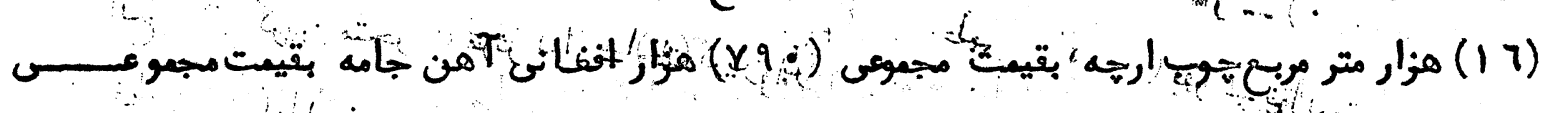

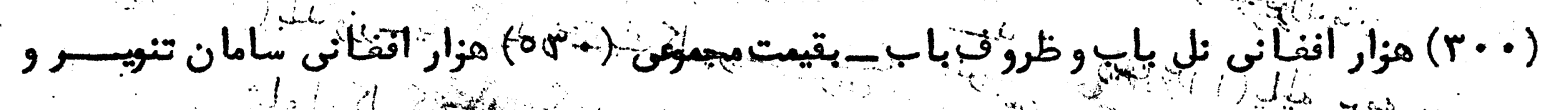

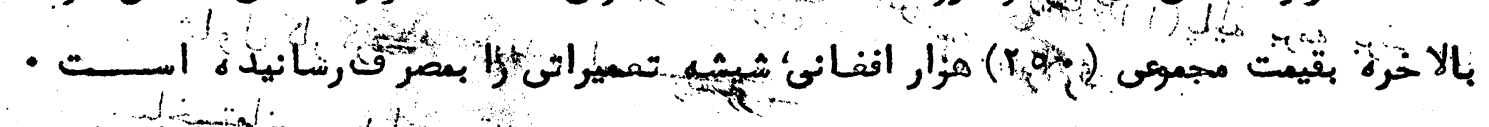

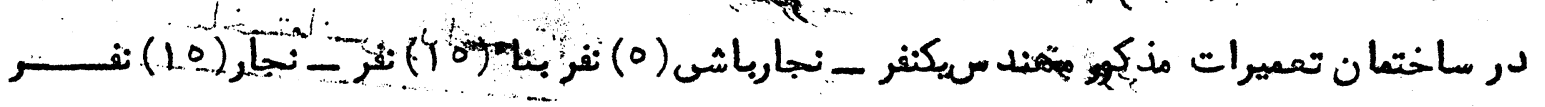

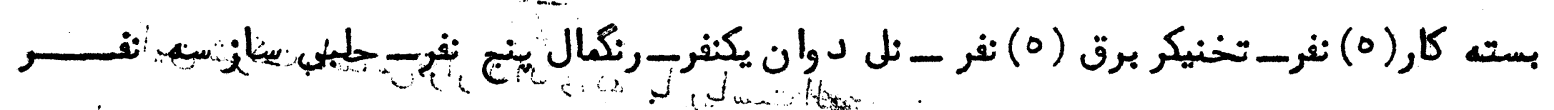

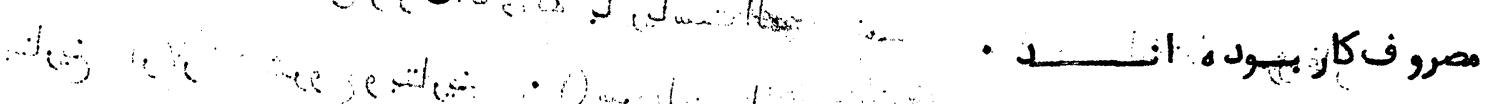

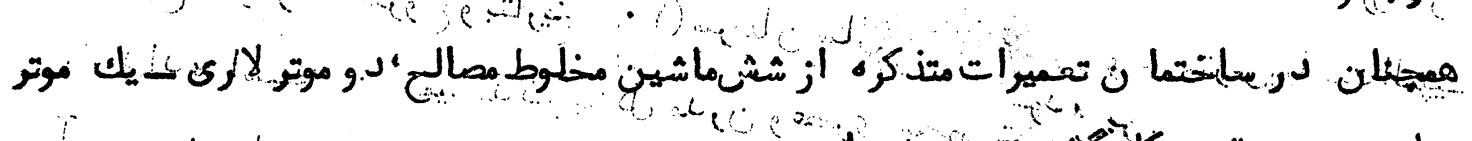

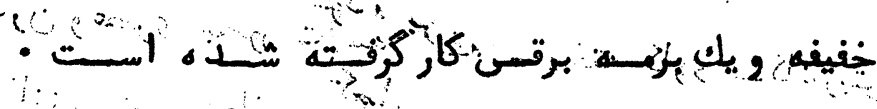

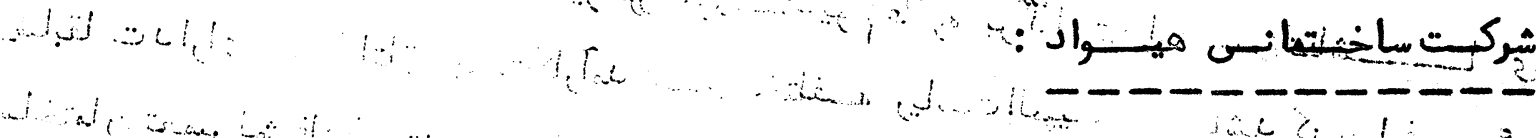

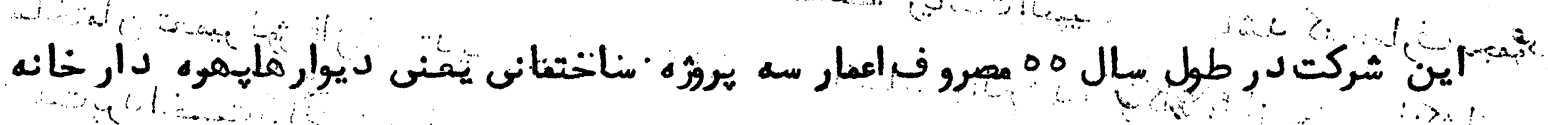

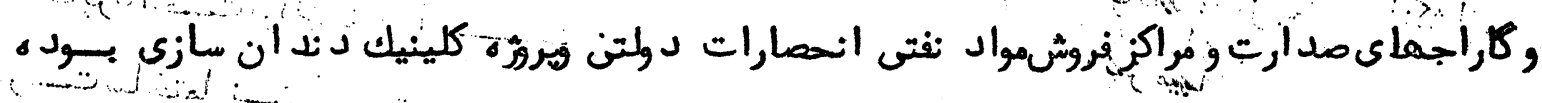

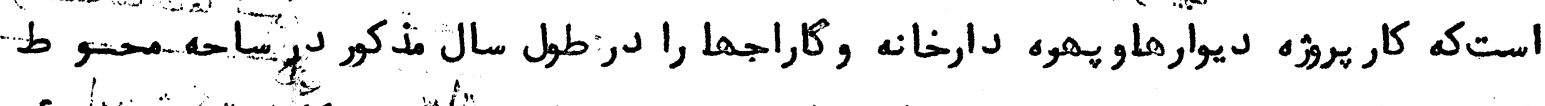
(Yrrr.)

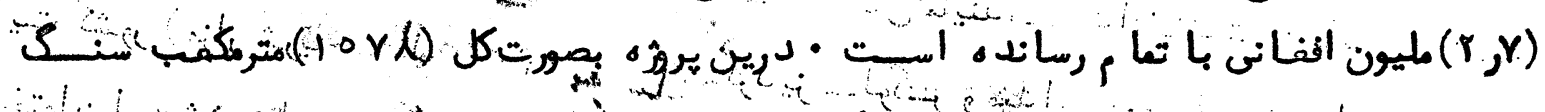

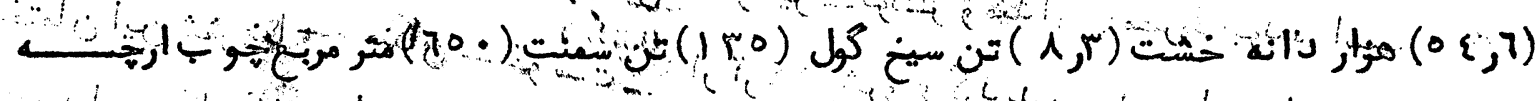

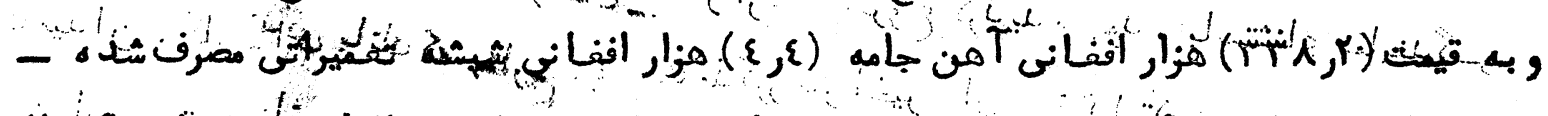

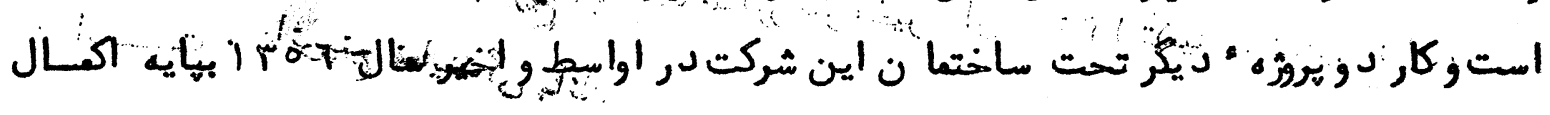

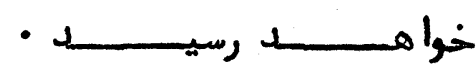

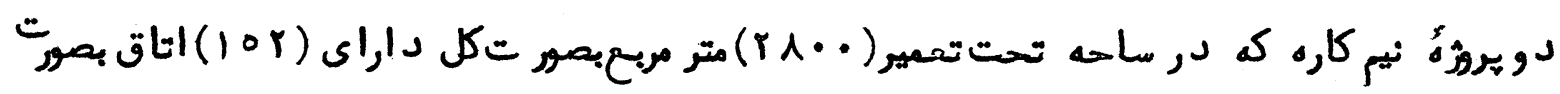

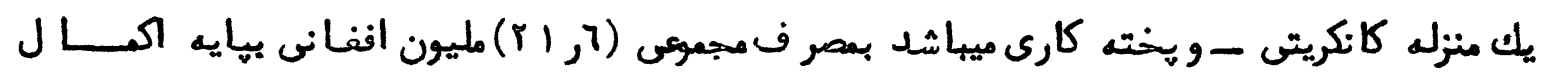




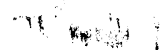

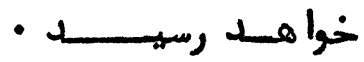

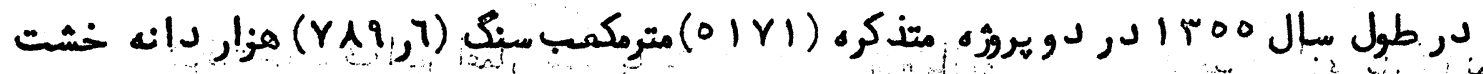

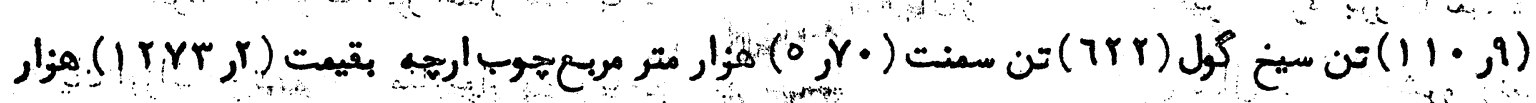

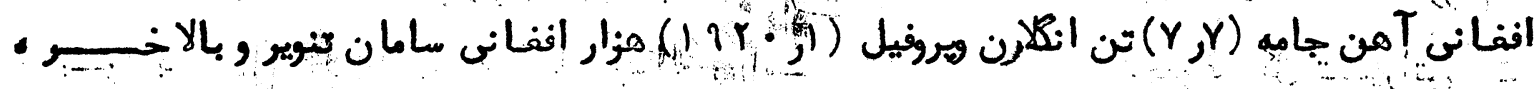

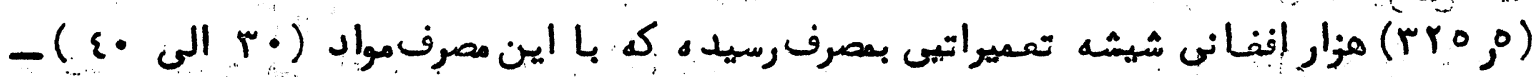

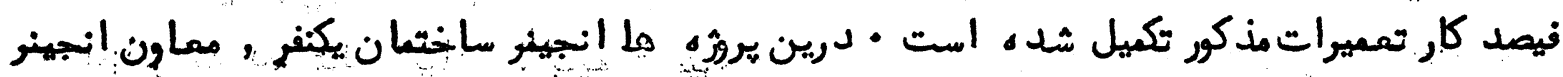

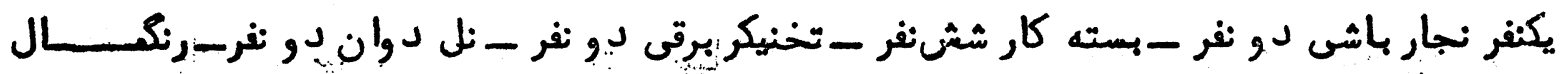

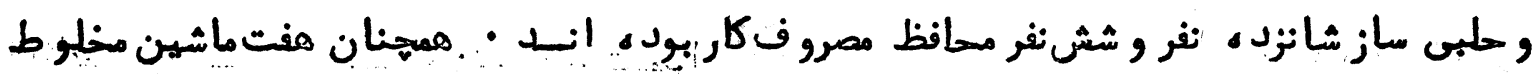

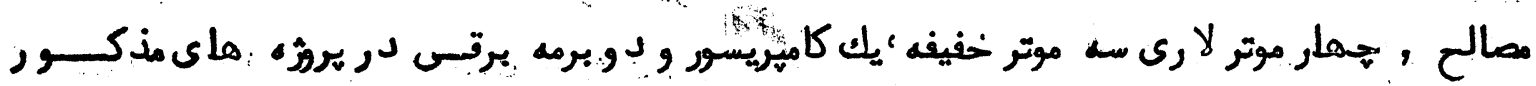
;

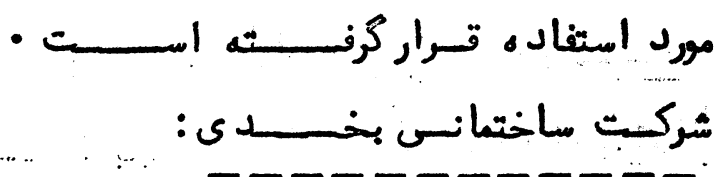

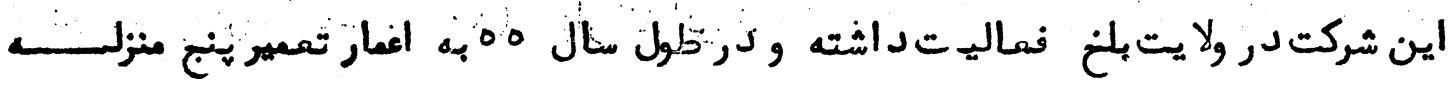

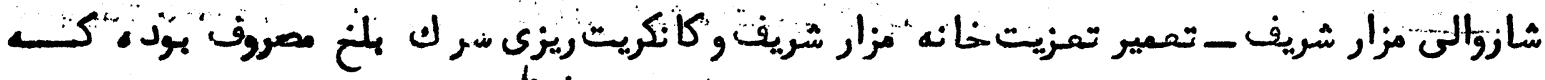

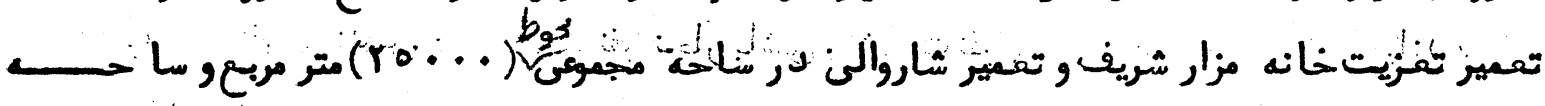

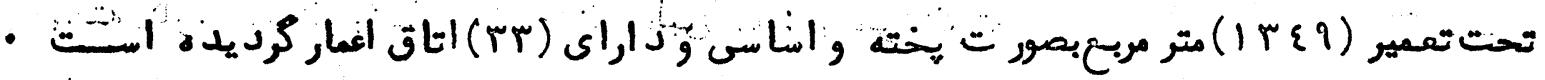

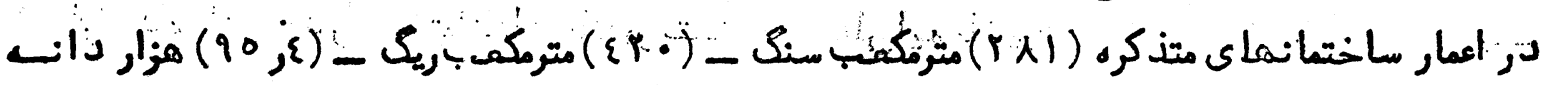

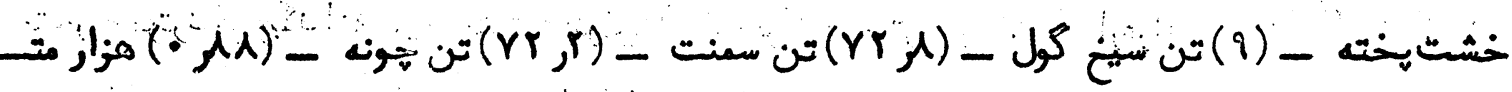

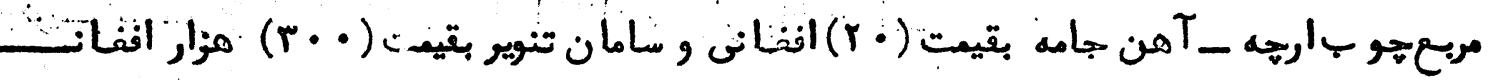

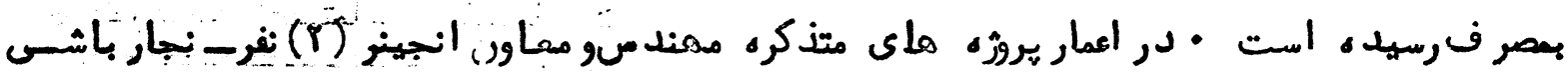

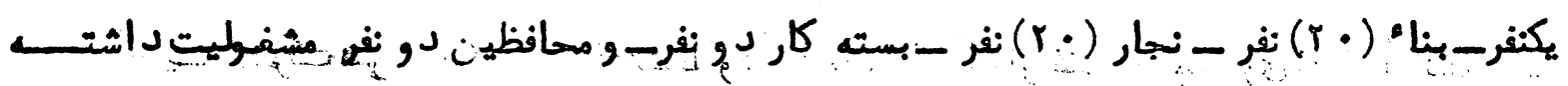

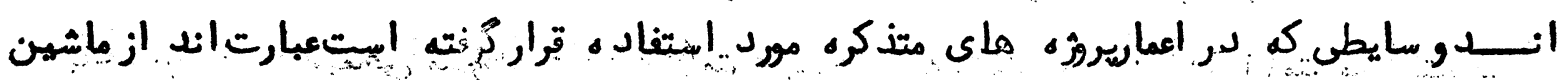

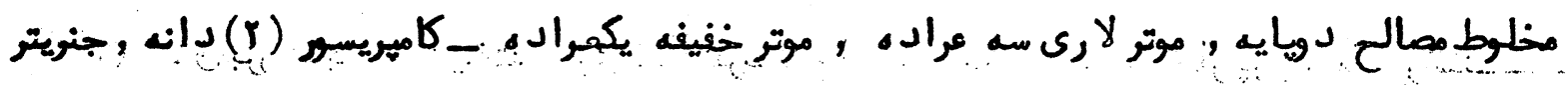

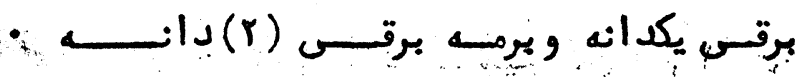

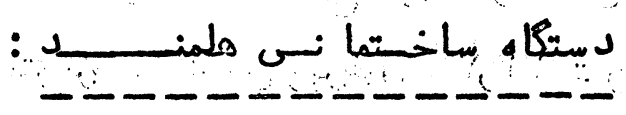

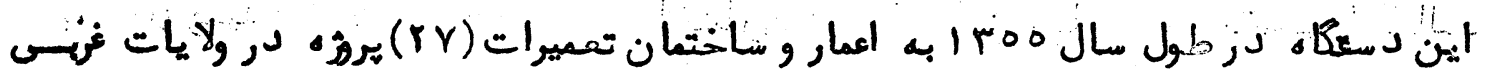

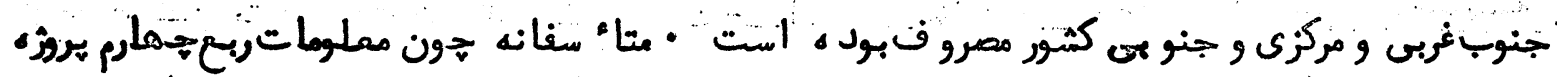

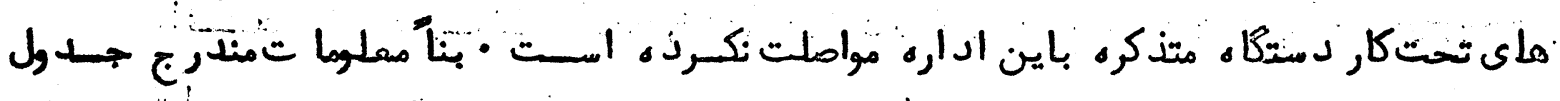

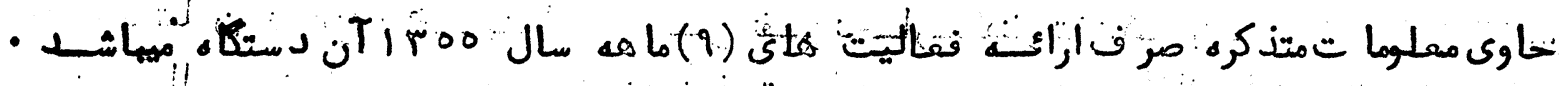

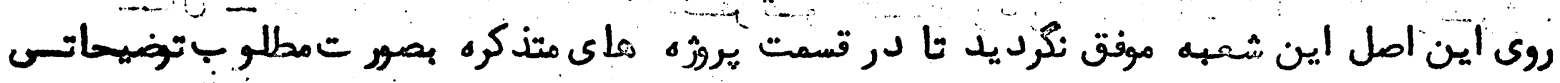




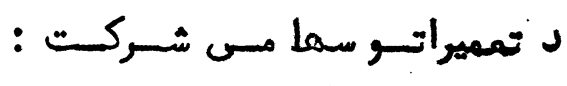

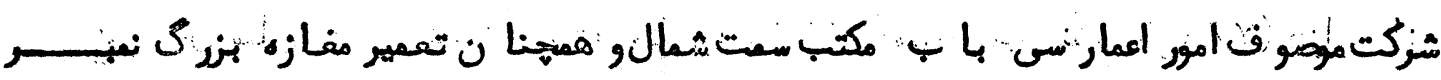

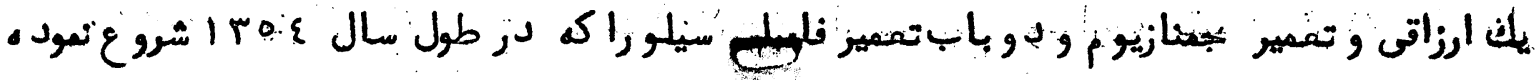

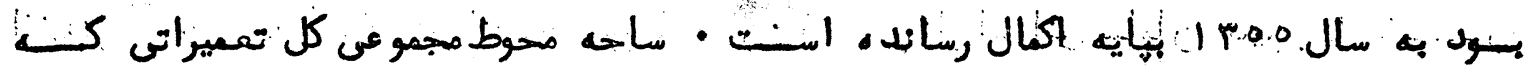

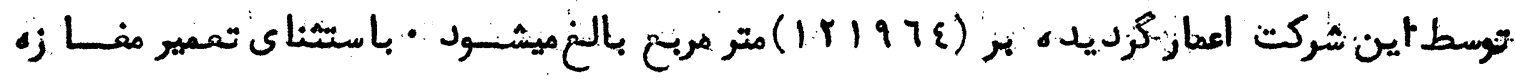

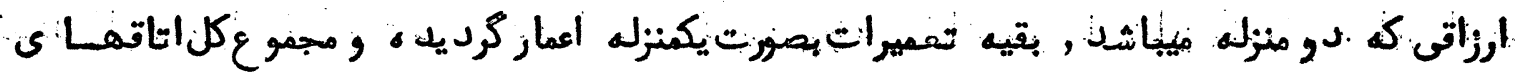

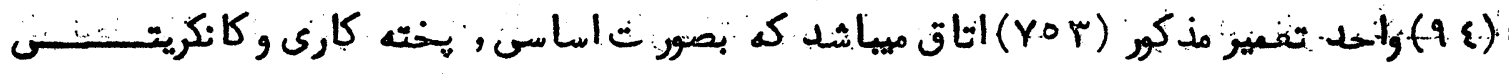

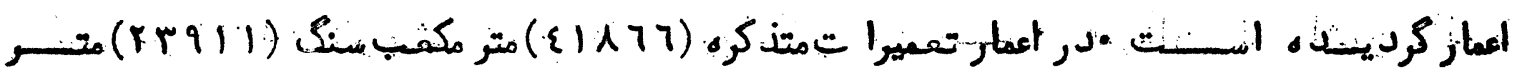

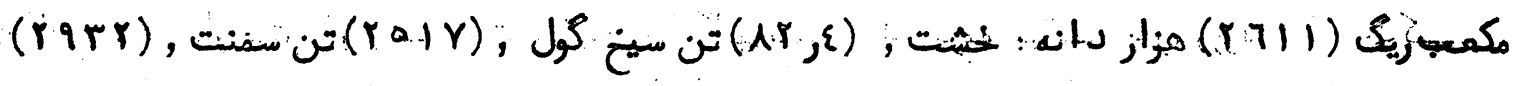

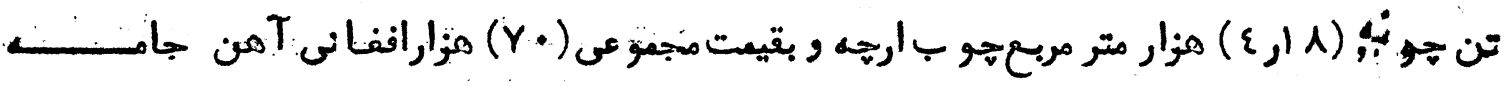

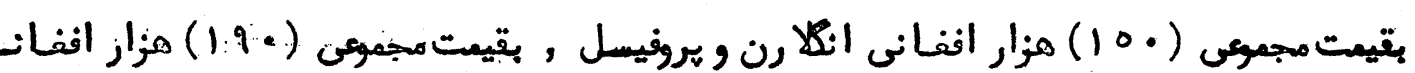

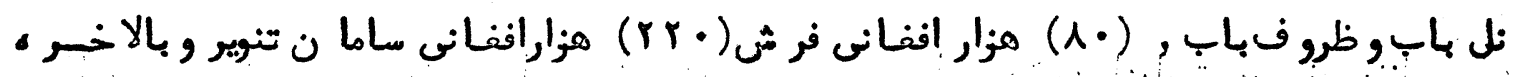

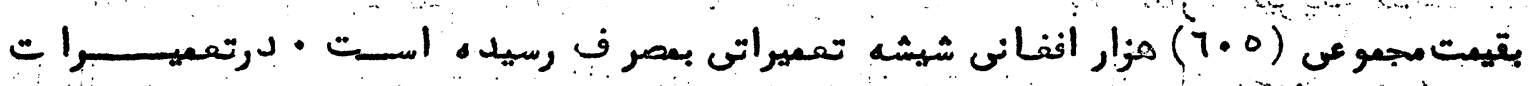

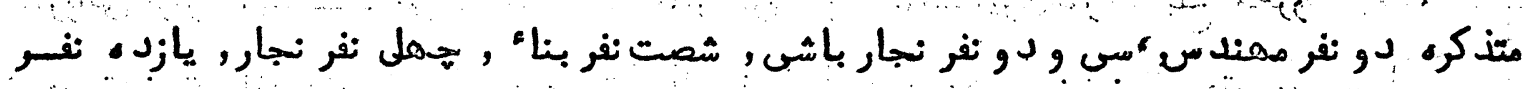

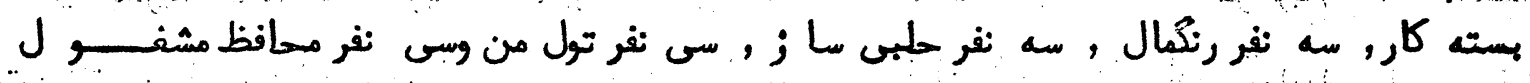

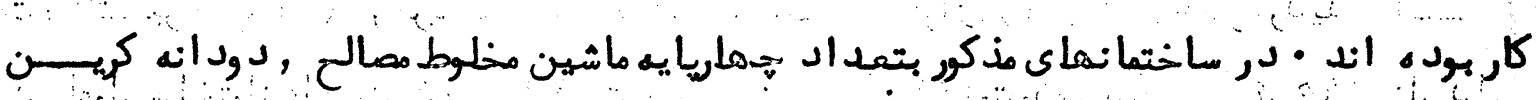

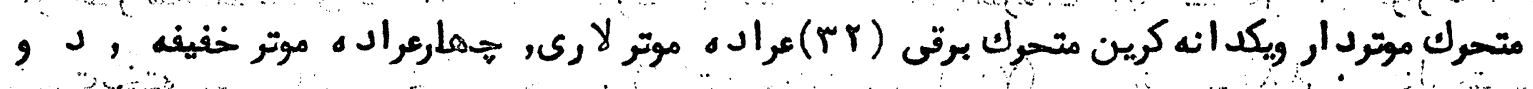

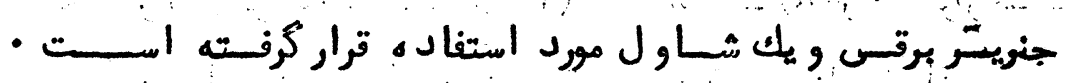

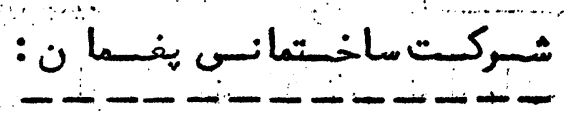

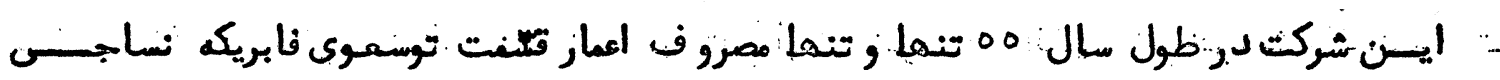

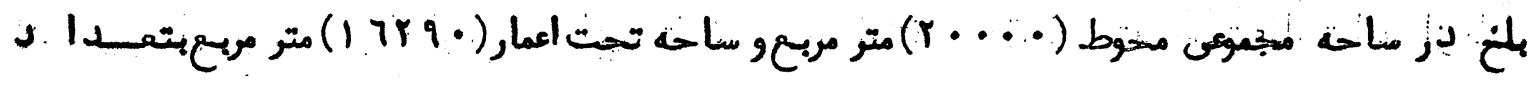

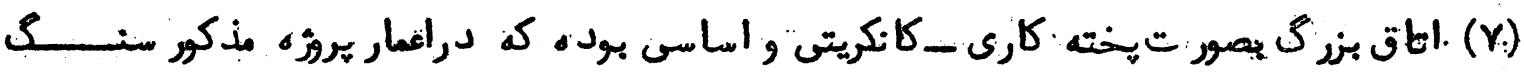

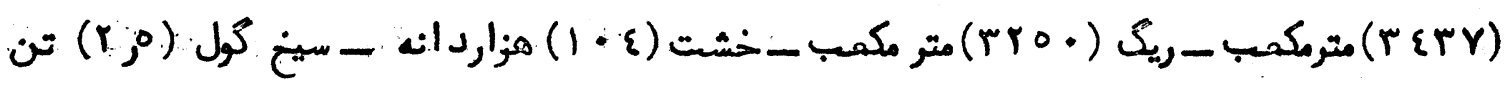

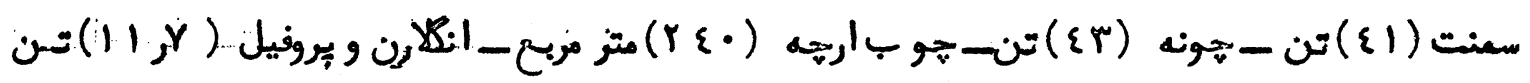

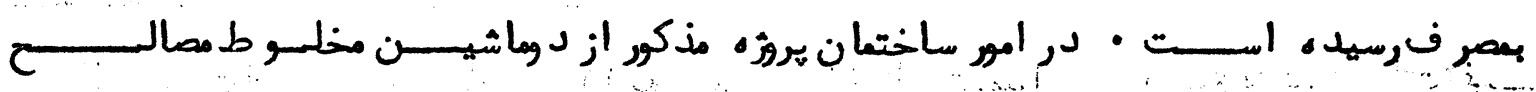

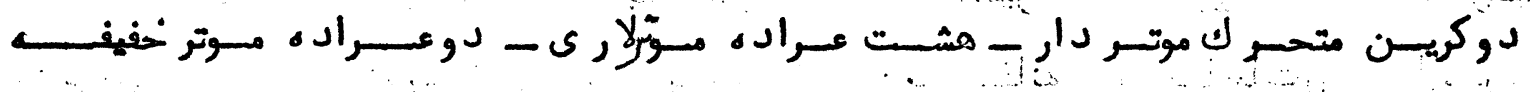

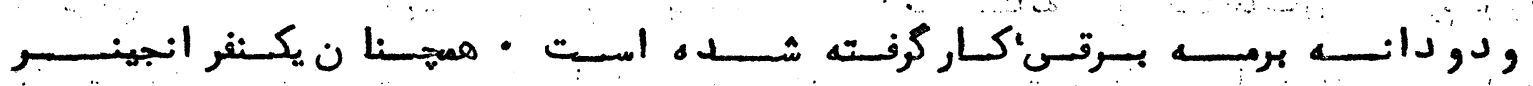

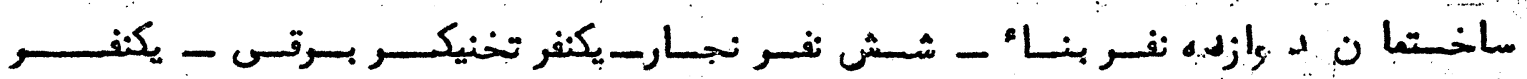

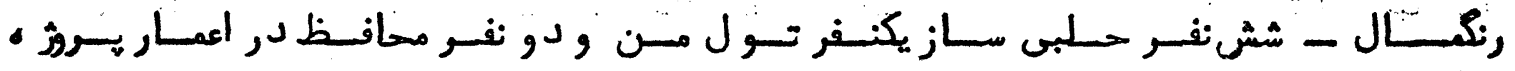

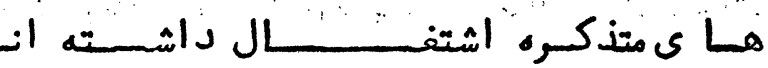




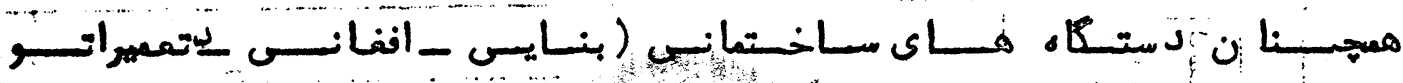

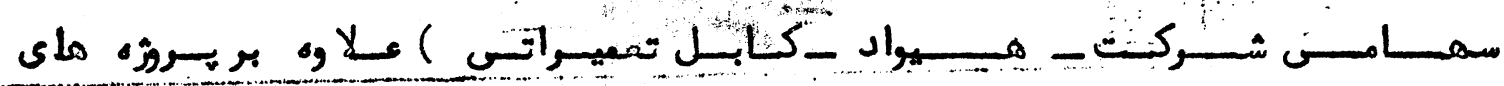

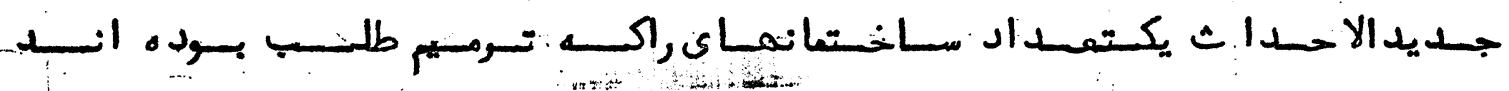

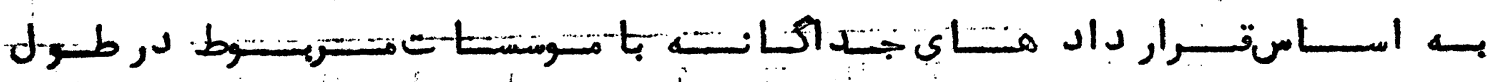

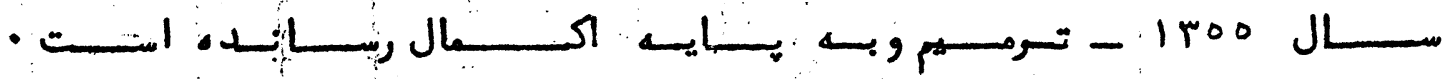

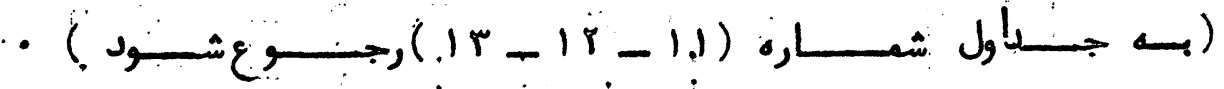

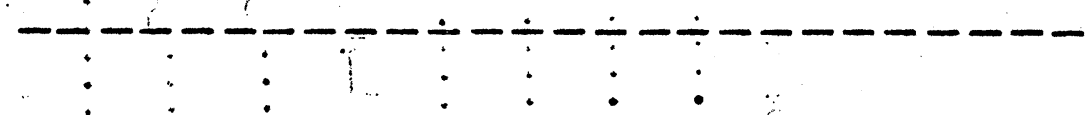

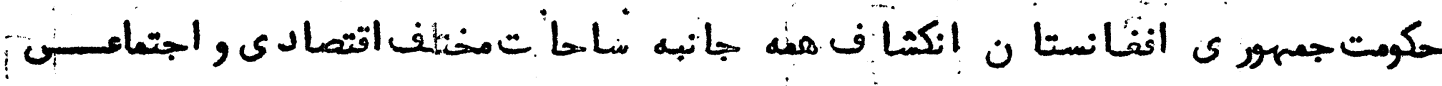

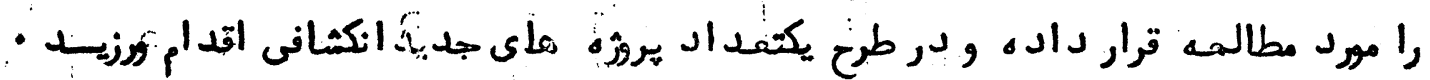

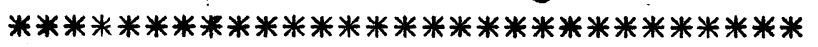

هموطنان عزيز بايد بدانند كه هيج يهيشرفتى, بدو ن كار و زحمت از خود كذرى و ايثارو فدا

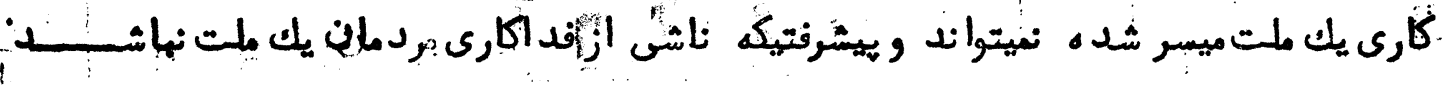

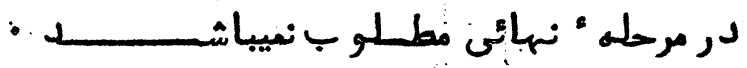

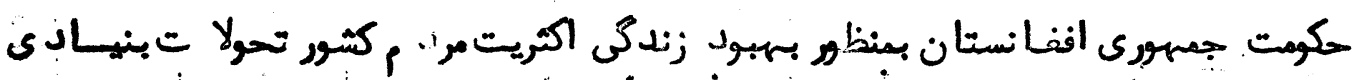

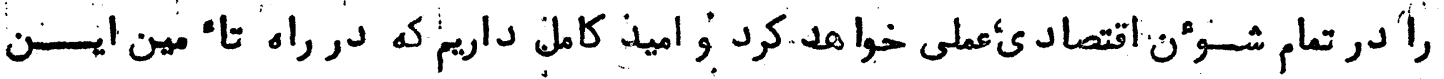

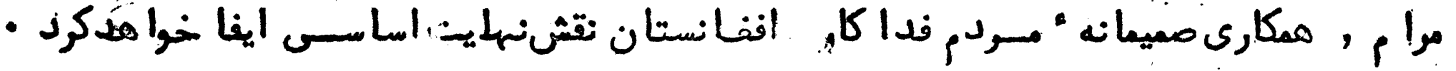

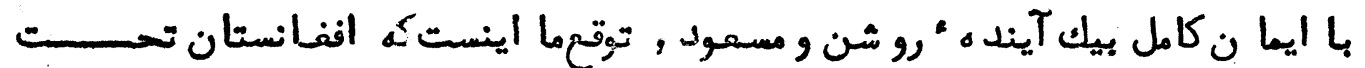

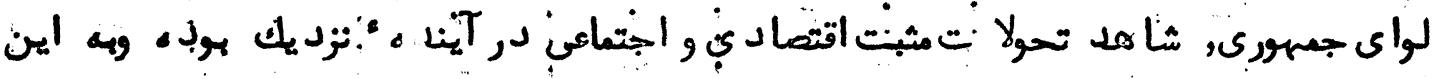

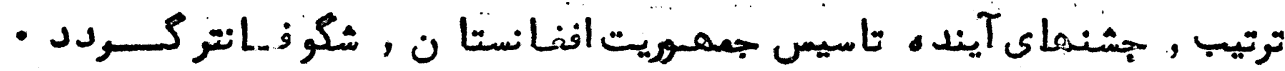
米米米米米米米米

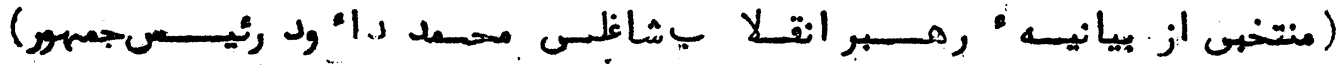

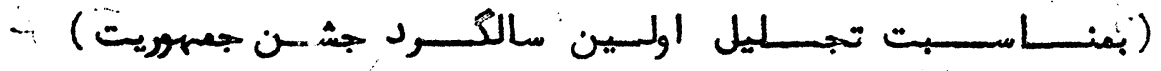




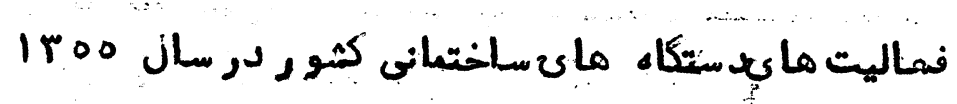

(7)

\begin{tabular}{|c|c|c|c|c|c|c|c|c|c|c|c|c|}
\hline تمعيد & لفت & 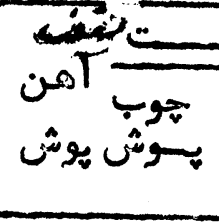 & 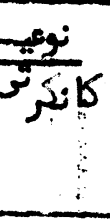 & تمـاد & طبقه & . & 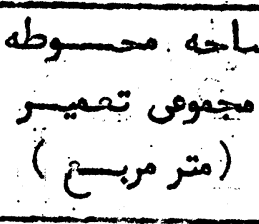 & تاريخ بيشبينيو & 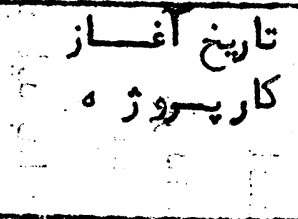 & 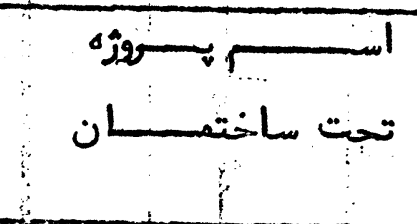 & شمساره & لداختمانكاه \\
\hline$r$ & بلاك Y Y & $=r$ & $\checkmark$ & 99 & $r$ & rג.: & - & اخير Iror & $0 \varepsilon \_0-1 \varepsilon$ & بلاك ماك آَور rطب كابلُ & 1 & \\
\hline r & بلان م & $\nu$ & $\checkmark$ & ${ }^{4}$ & 9 & $1 \% \cdot$ & $7 \varepsilon 0$ & - & $01-7-11$ & 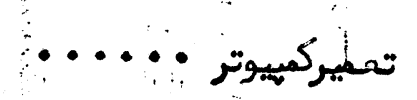 & $r^{\prime}$ & \\
\hline$r$ & - & $v-$ & 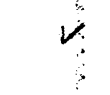 & ro & $r$ & कน & OY\&T & 1 roo & or_r_o & الفائيه كابل : . . & $r$ & \\
\hline rr & - & $v-$ & 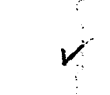 & - & $2 \mathfrak{r}$ & $7 \%:$ & $r \cdot r_{0}$ & نيبه دوم7 7 كا & حمل 1900 & مسلغ هرا ت........ & $\varepsilon$ & \\
\hline$\wedge$ & - & $r-$ & $\checkmark$ & $r \varepsilon=$ & $r$ & rre. & 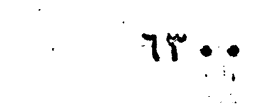 & $00-11-1$ & $o \varepsilon \_r \_r$ & طب ننكرمار ـ ... & 。 & \\
\hline - & - & $\checkmark-$ & $\nu$ & oq & 9 & $0 \cdot: \cdot$ & $0 \ldots \cdots$ & اخيرسال 07 & $0 \cdot-11-r \cdot$ & دومد بستر جلالن آبـاك & 7 & 9 \\
\hline - & - & $\checkmark-$ & 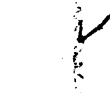 & 07 & $r$ & $11 \cdots$ & $\because-$ & נג & נמ & شميتبستر اطفال • • & $r$ & \\
\hline - & - & $V-$ & & 07 & $r$ & 111. & - & נر & (3) & & $i_{1}$ & i \\
\hline - & - & $\checkmark-$ & $y$ & or & $r$ & 1ᄉ. & - & קנ. & נر & 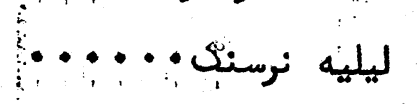 & $i$ & $b$ \\
\hline - & - & $\checkmark-$ & 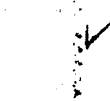 & $1:$ & 1 & 7.6 & - & : ננ : & בנע & طنبا اخوركن نرسنـــــــ & $1:$ & \\
\hline - & - & - & $\stackrel{?}{?}$ & 707 & - & rerrt & $9 \wedge \gamma q$ & $\longrightarrow$ & - & & & \\
\hline 1 & $=$ & $=$ & 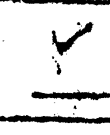 & $\begin{array}{r}0 \% \\
-\quad 0.1 \\
\end{array}$ & $r$ & $\div$ & 1 & $00-\varepsilon=1$ & $0 \varepsilon-2$ & 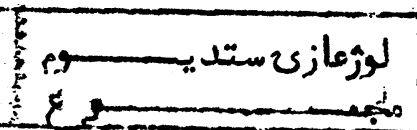 & $!$ & ودانسى \\
\hline
\end{tabular}




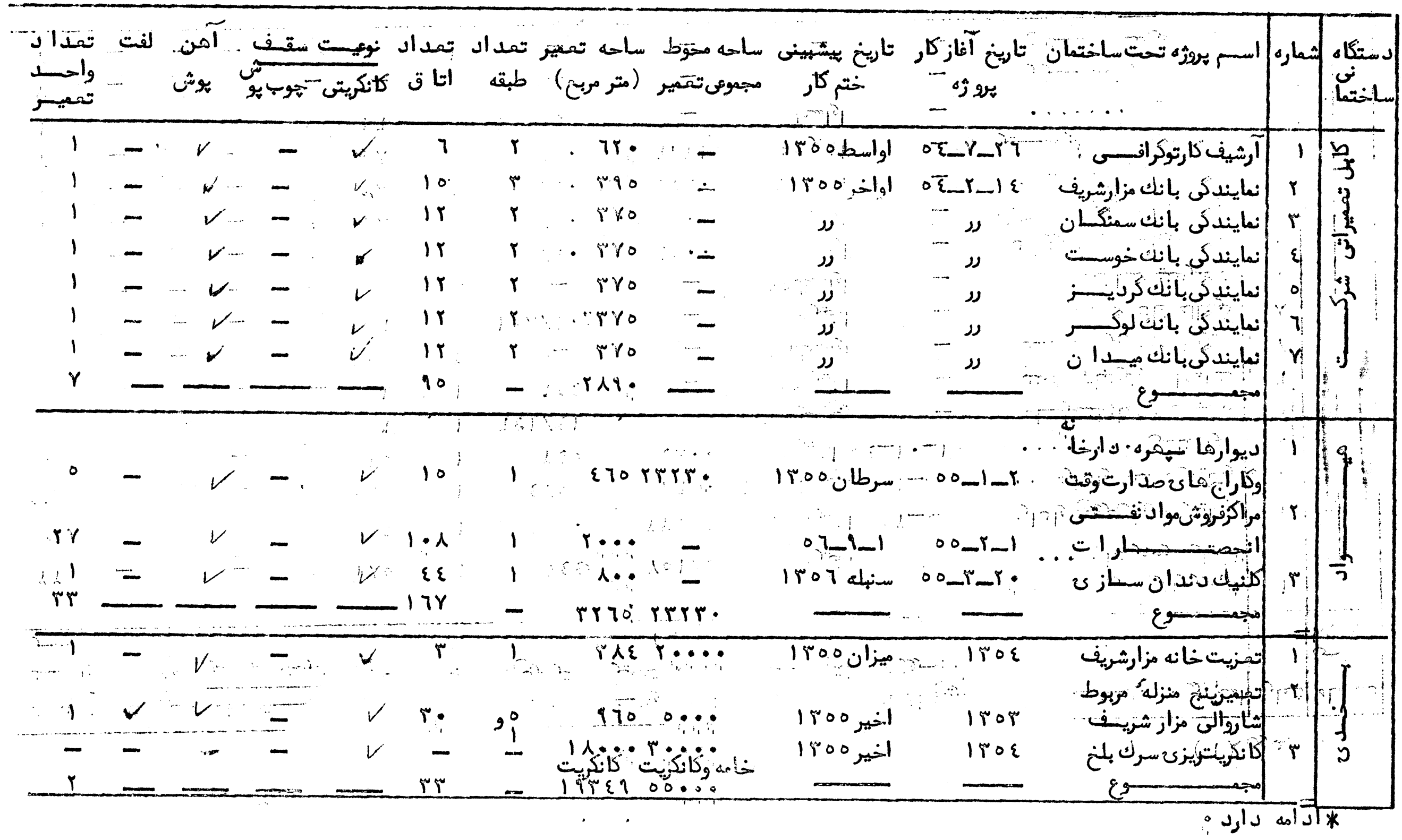


(7) ادمبل

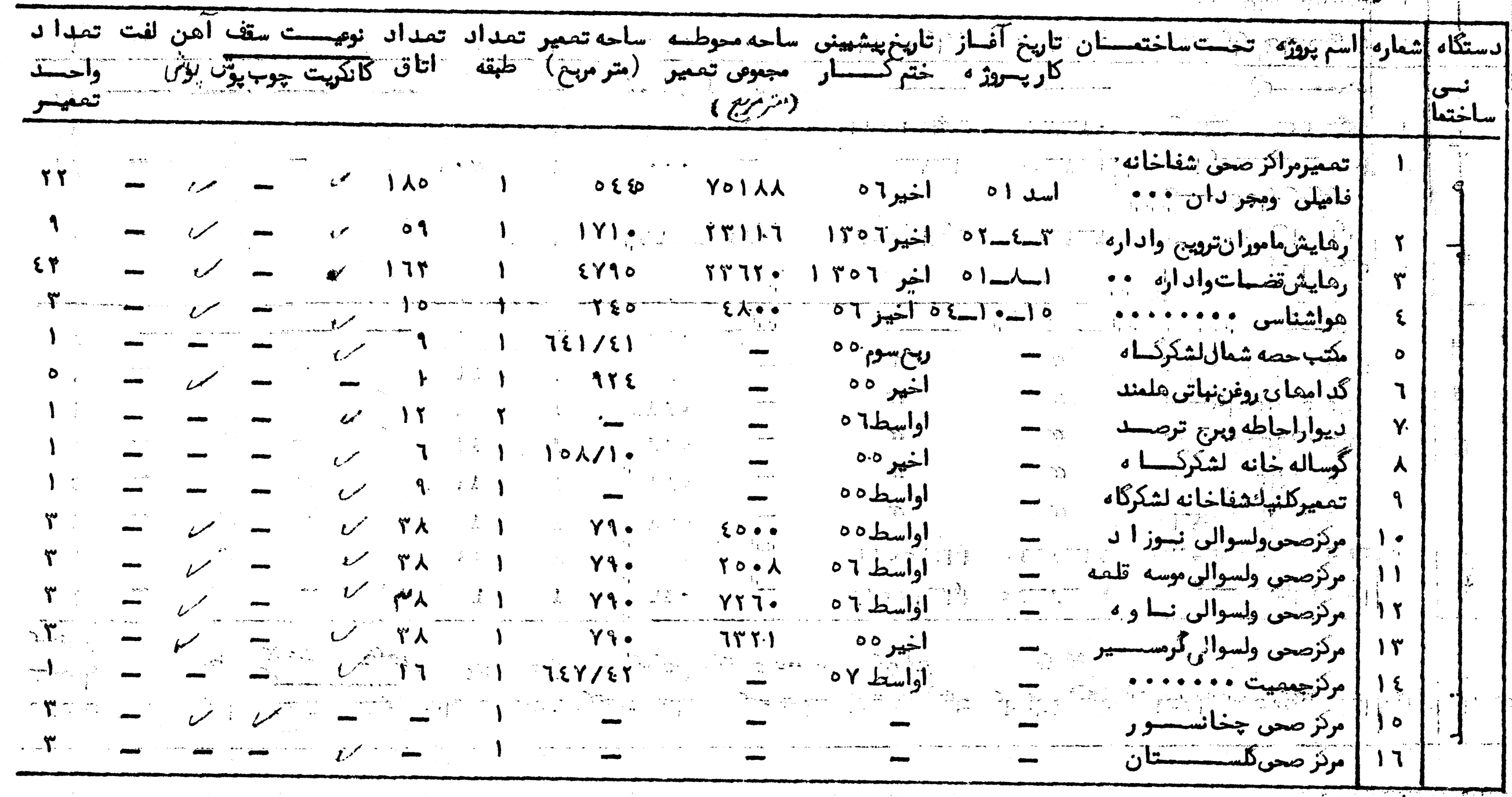

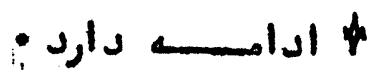




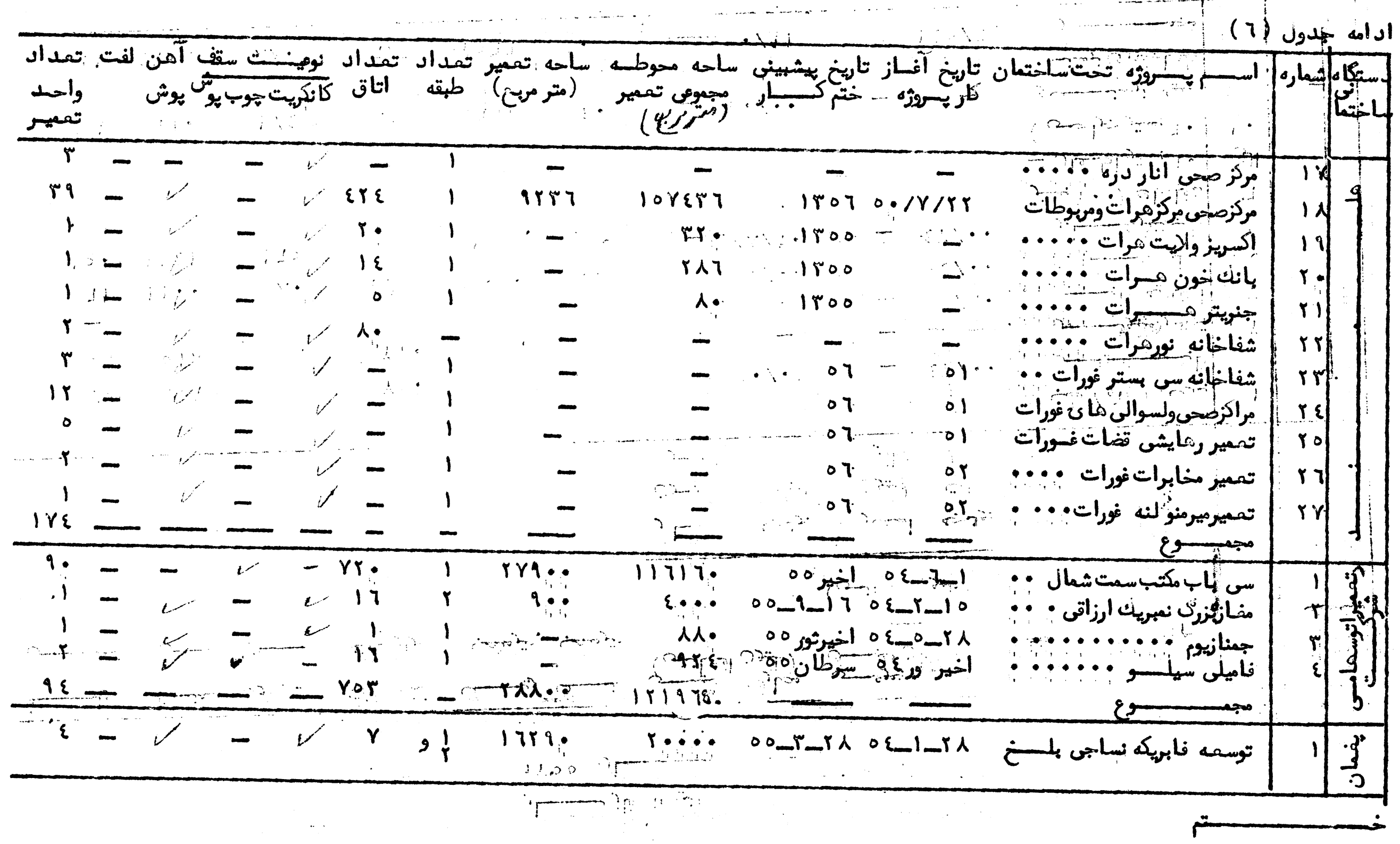




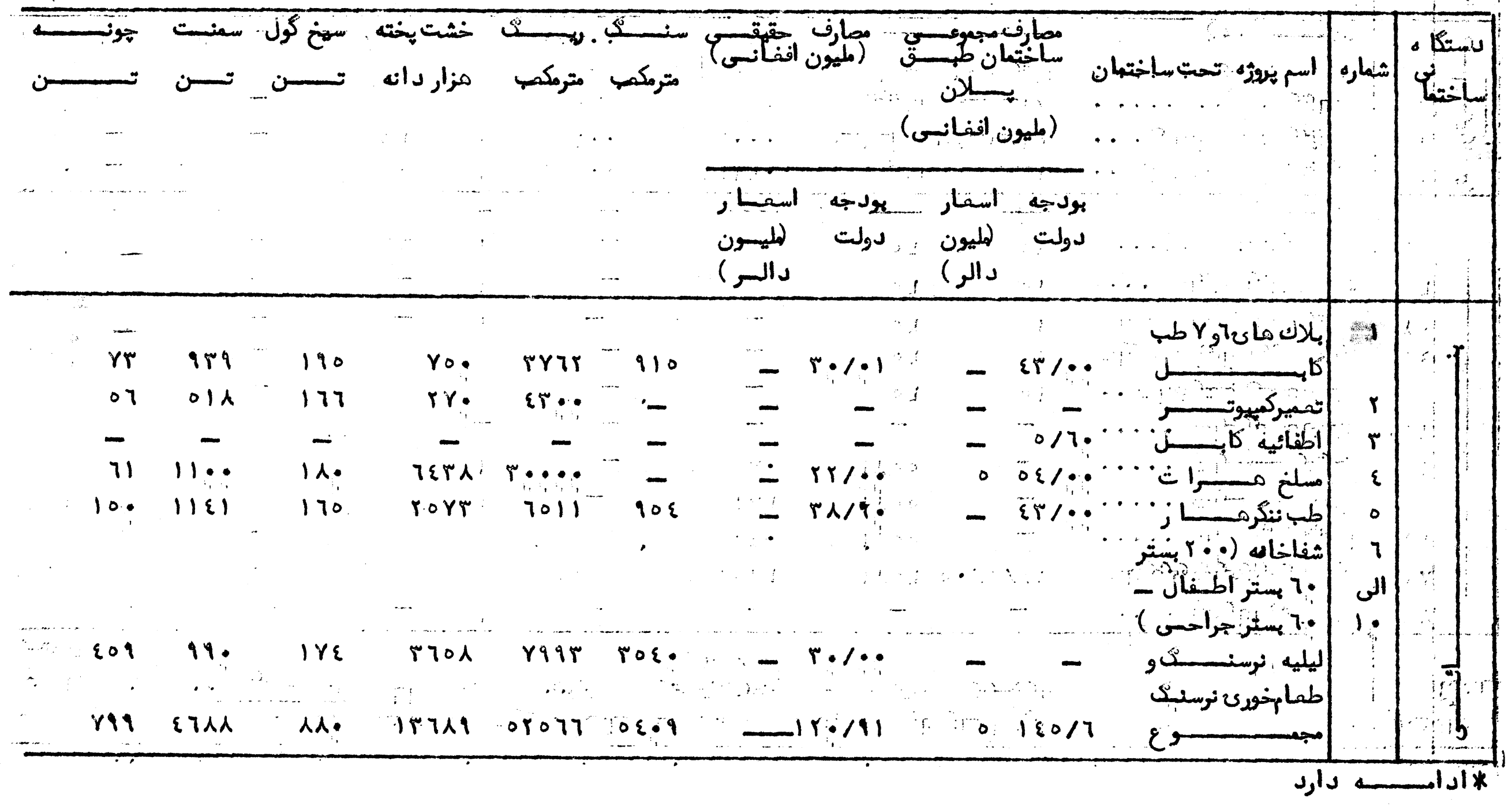


ادامه جسـدون (r)

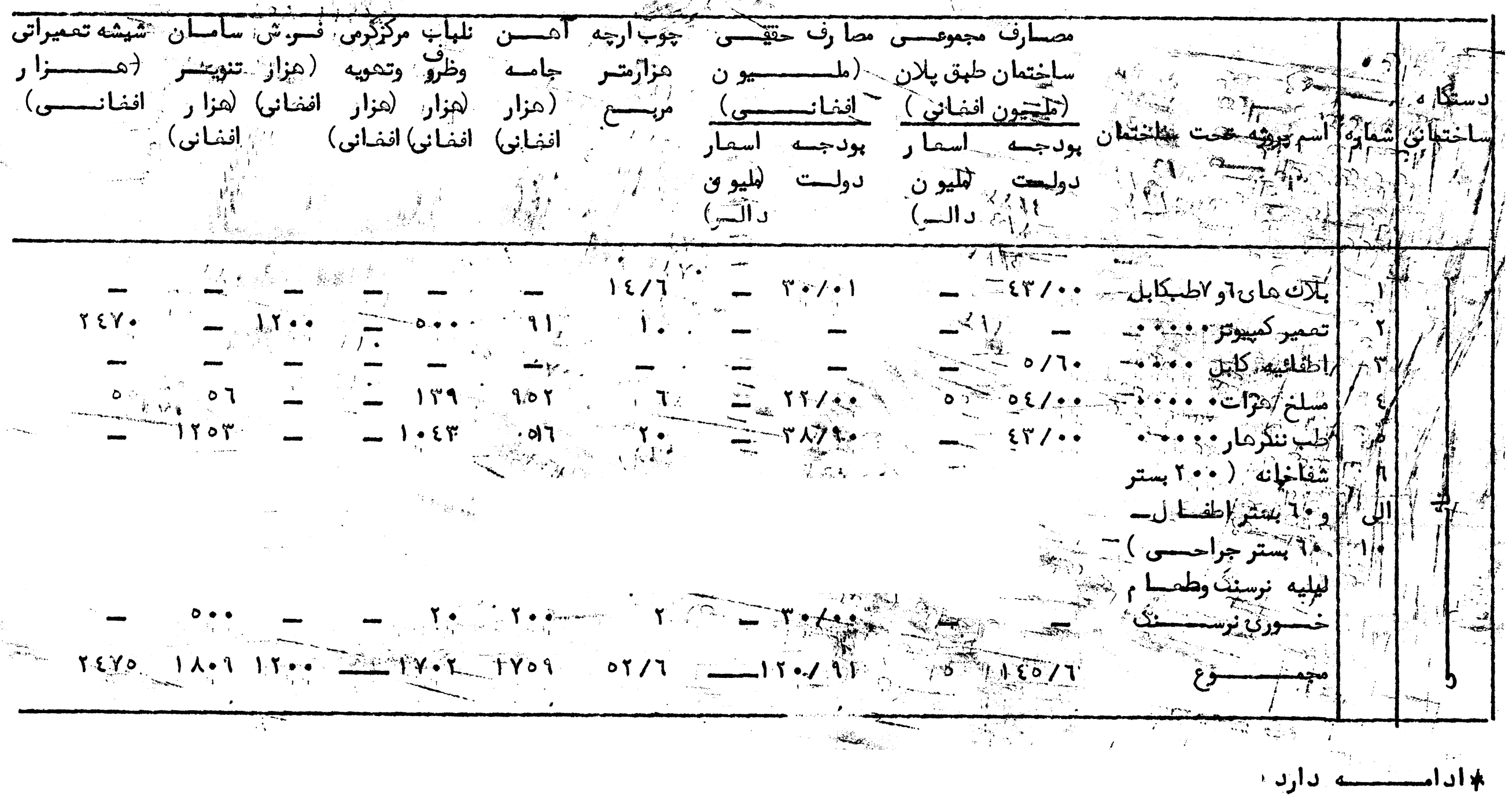


اد امســ جسـدول (r)

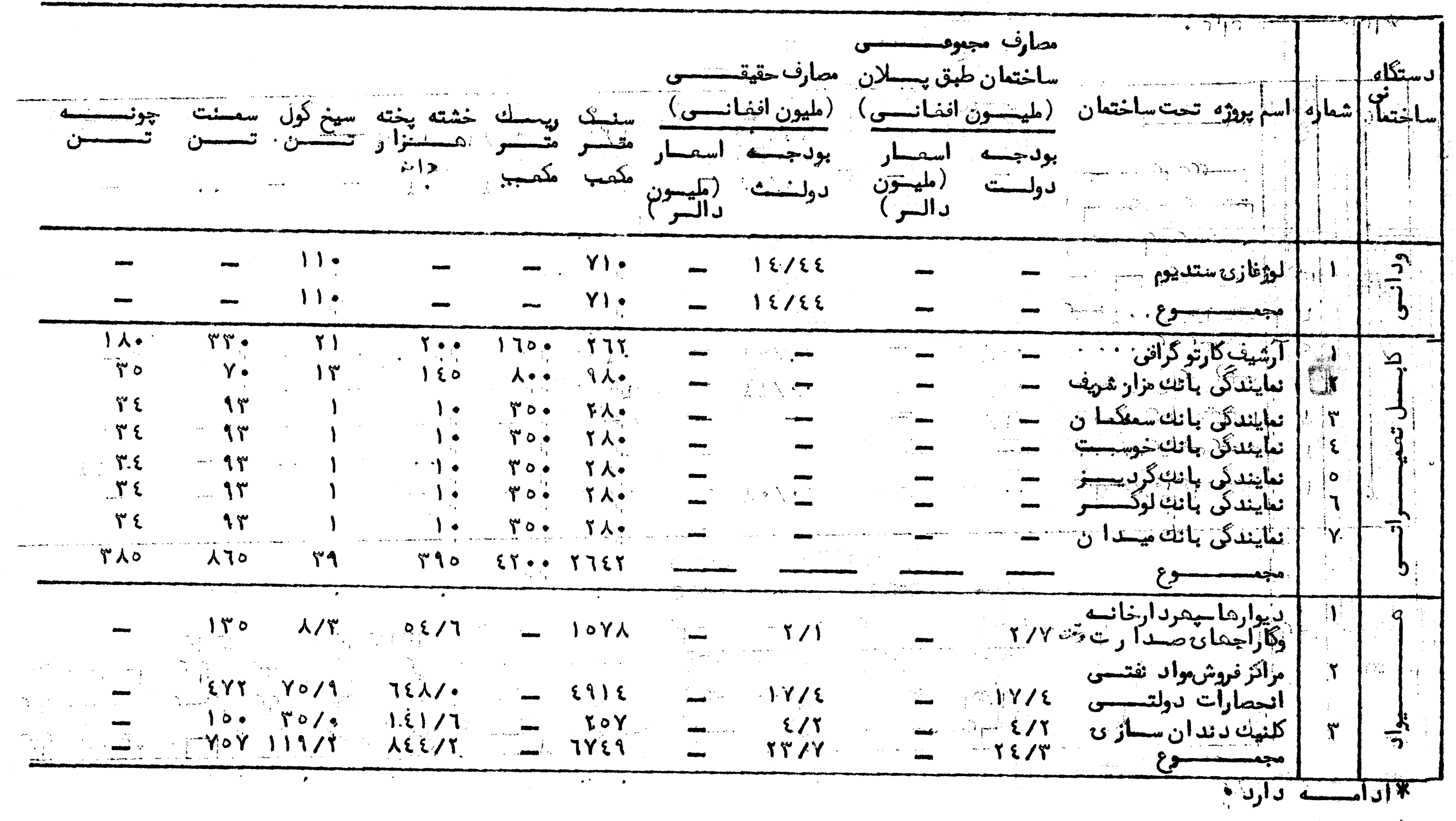




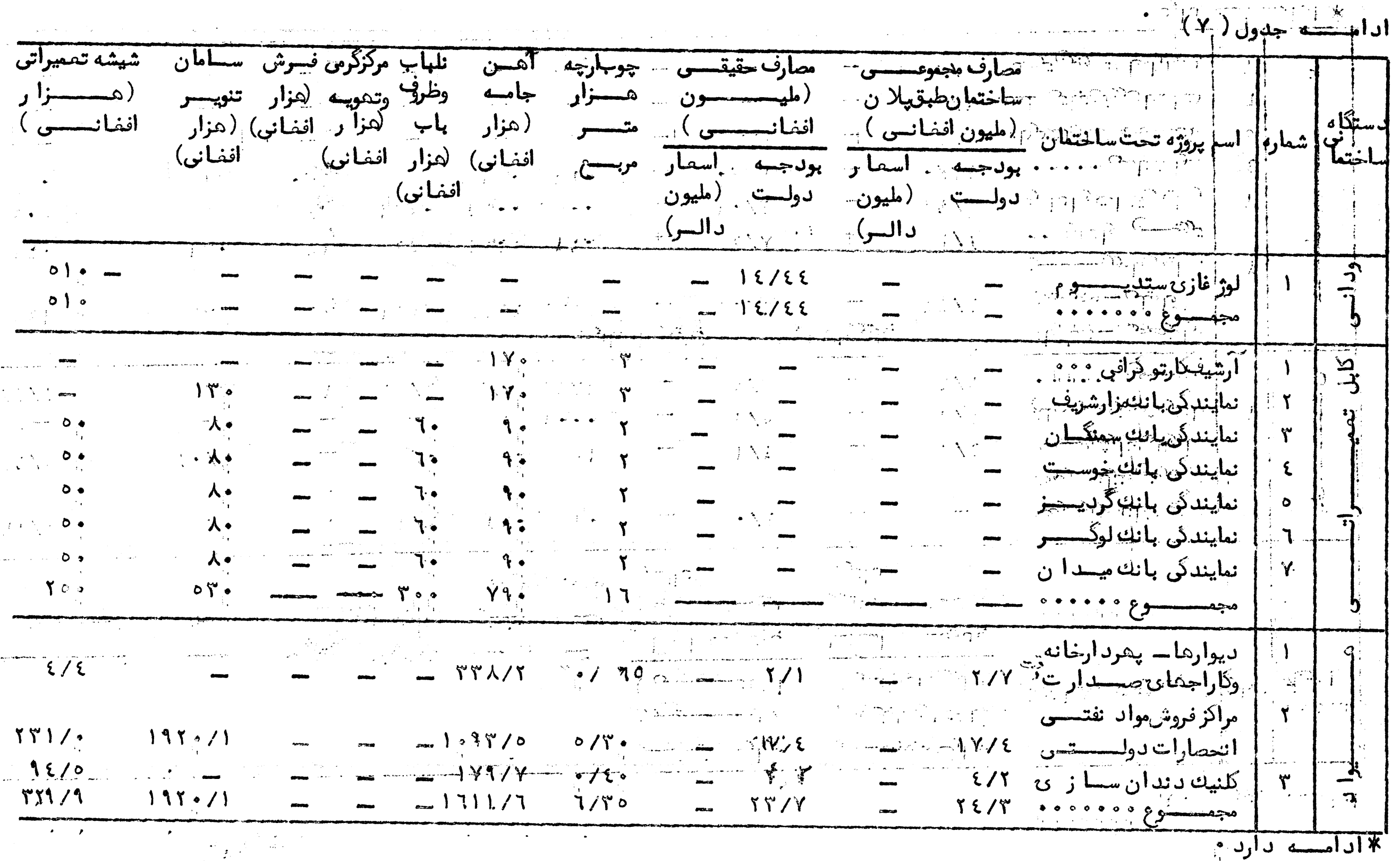


ادامســ جدول (v)

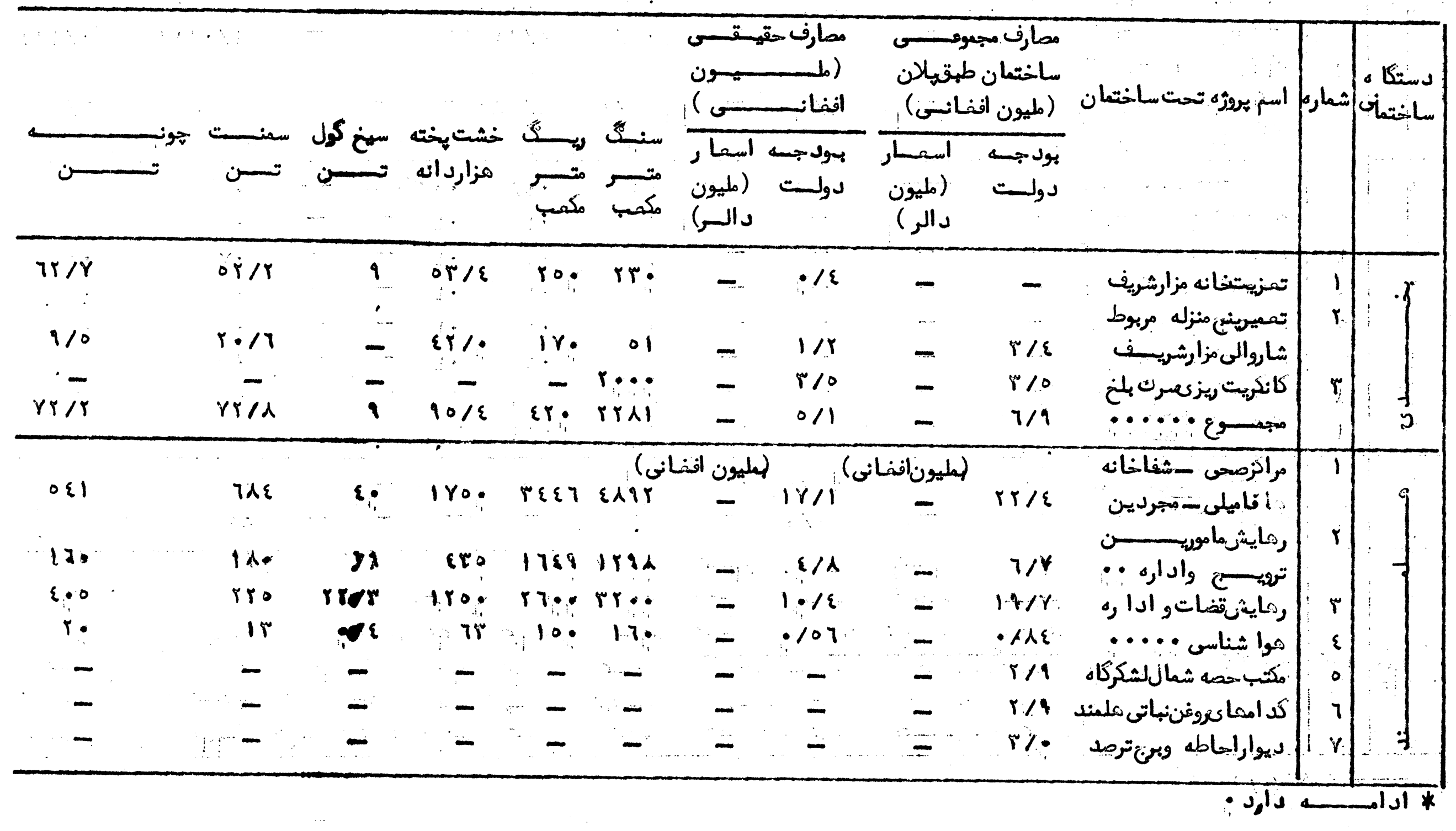


(v) ادامه جس بـدول

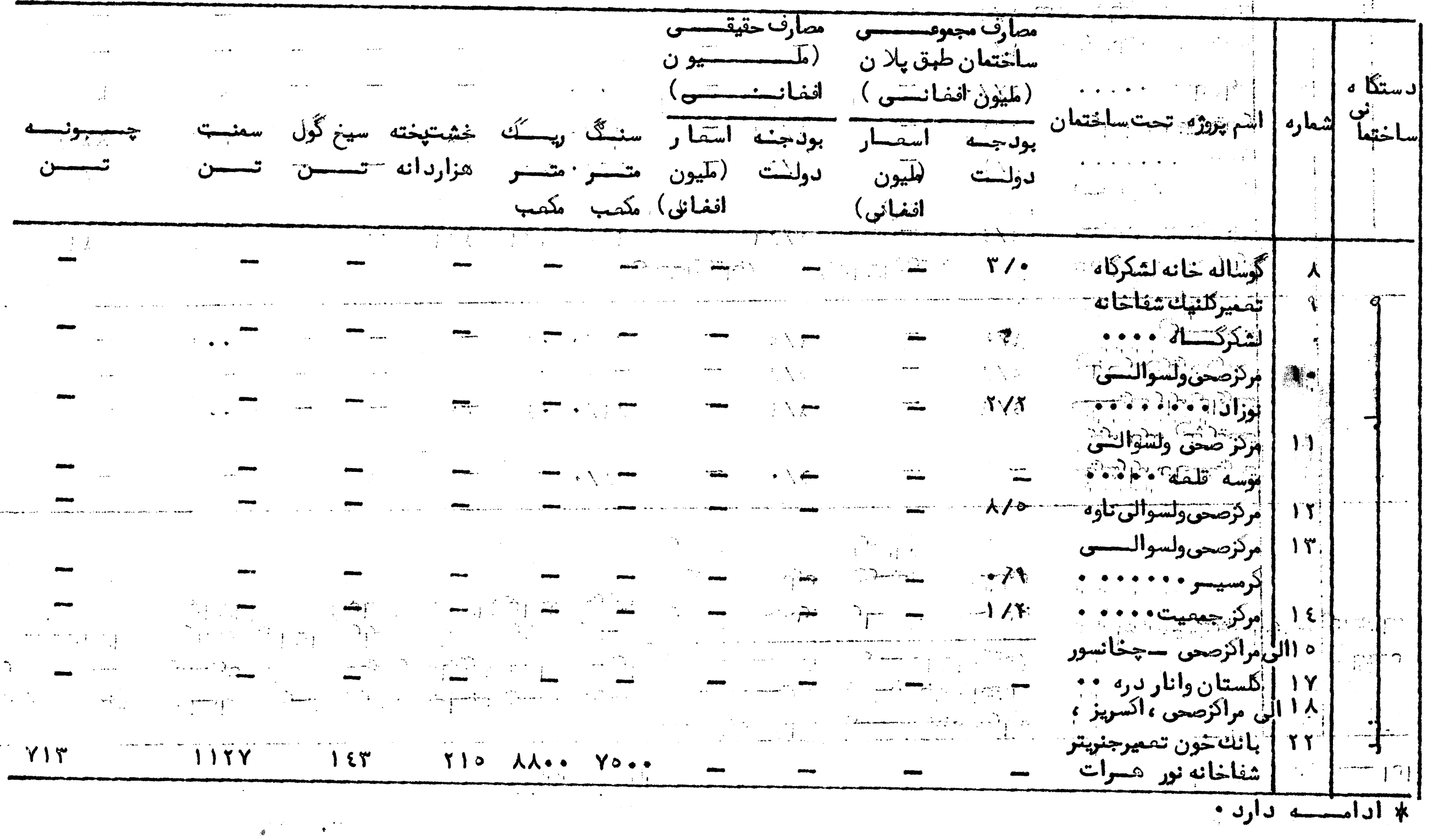




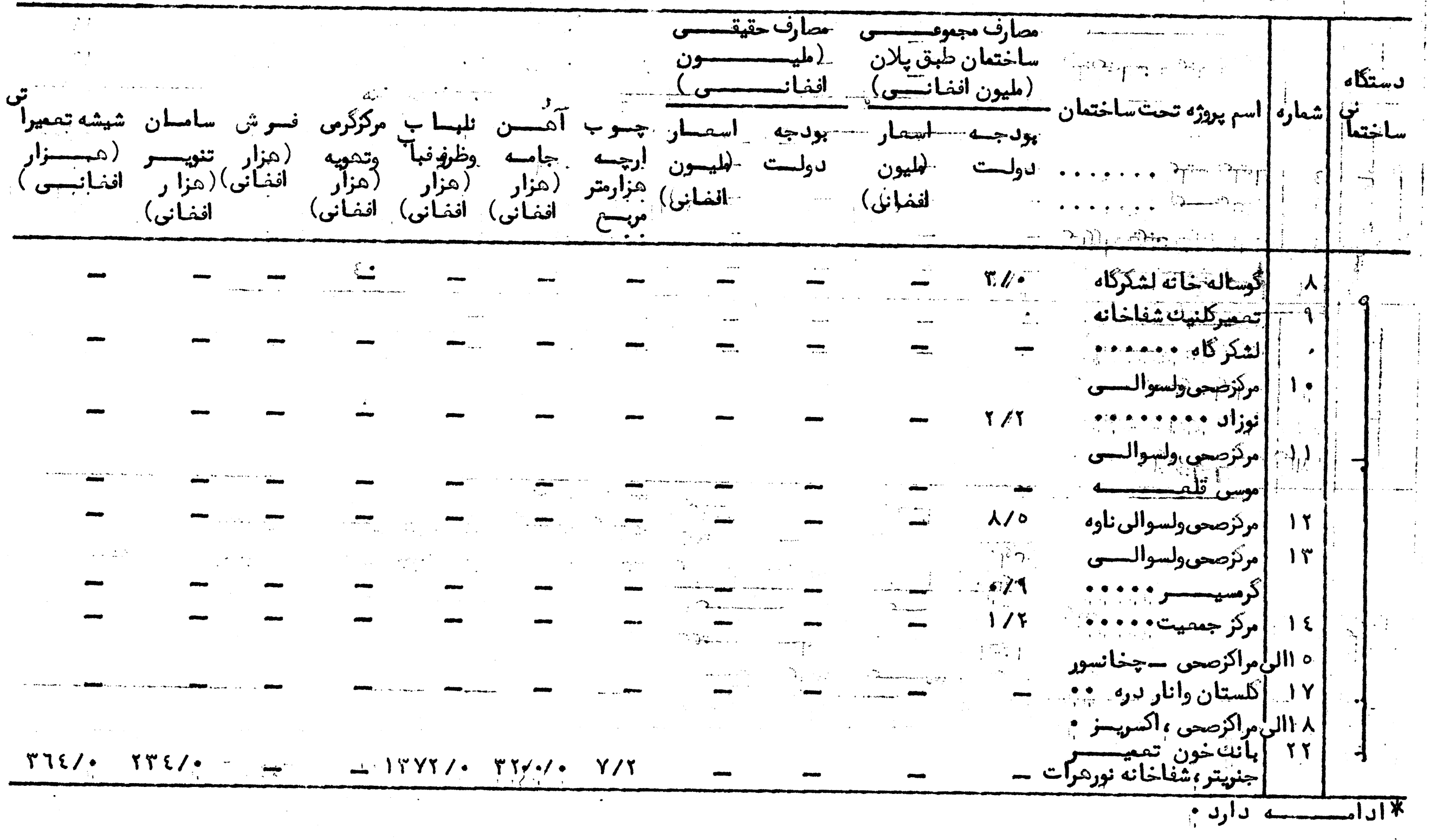




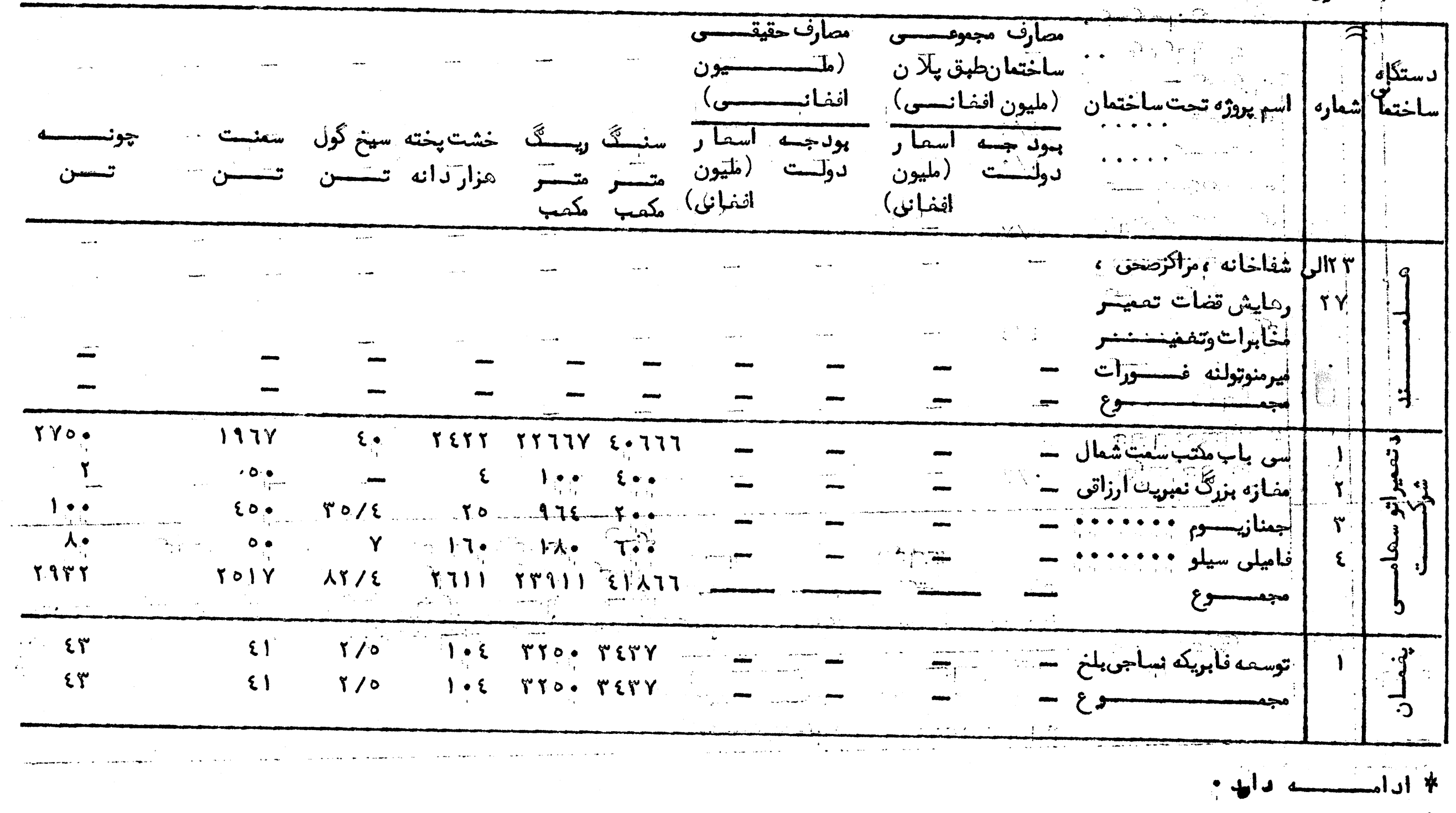


(v) ادامه جــــ

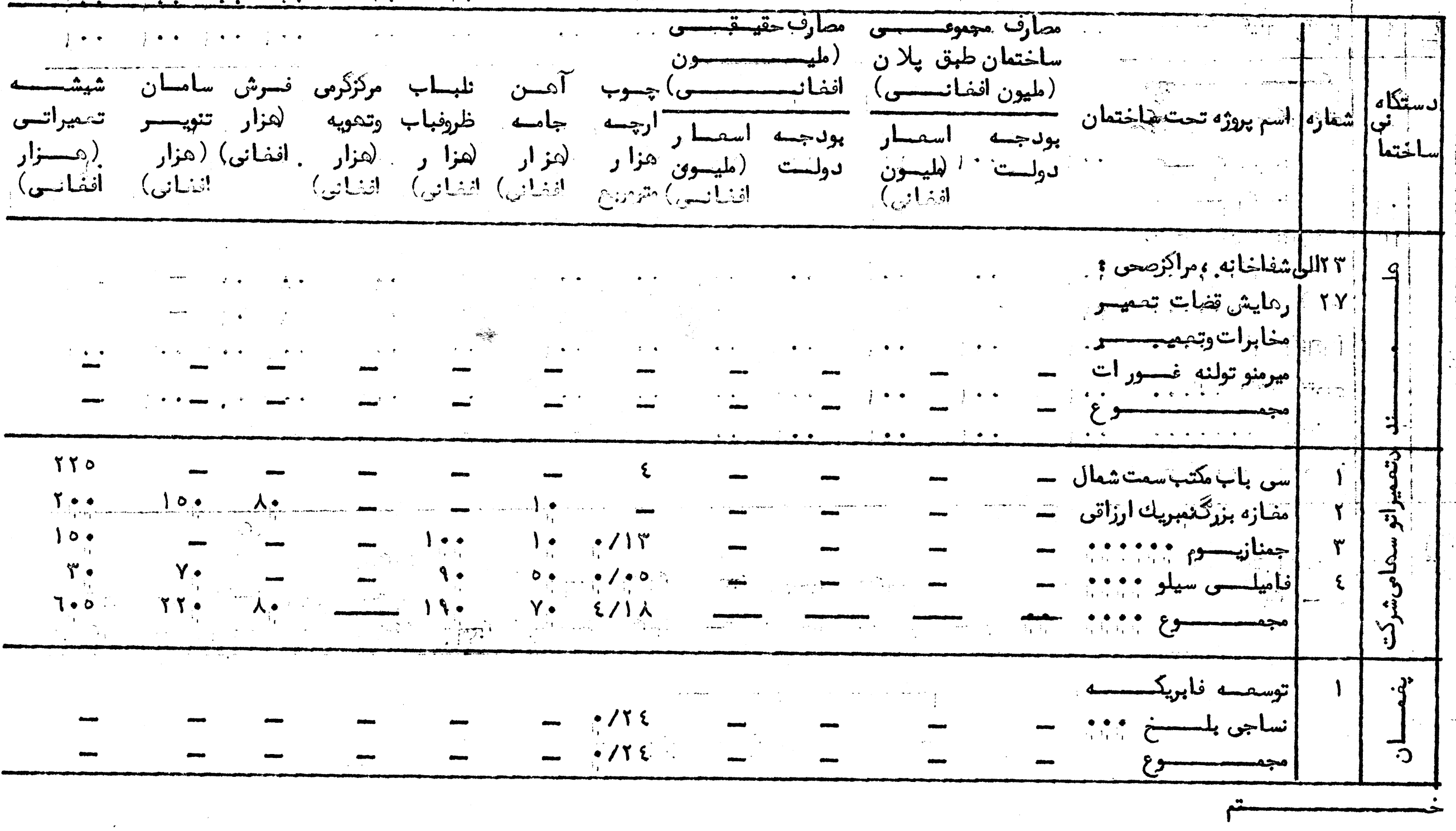




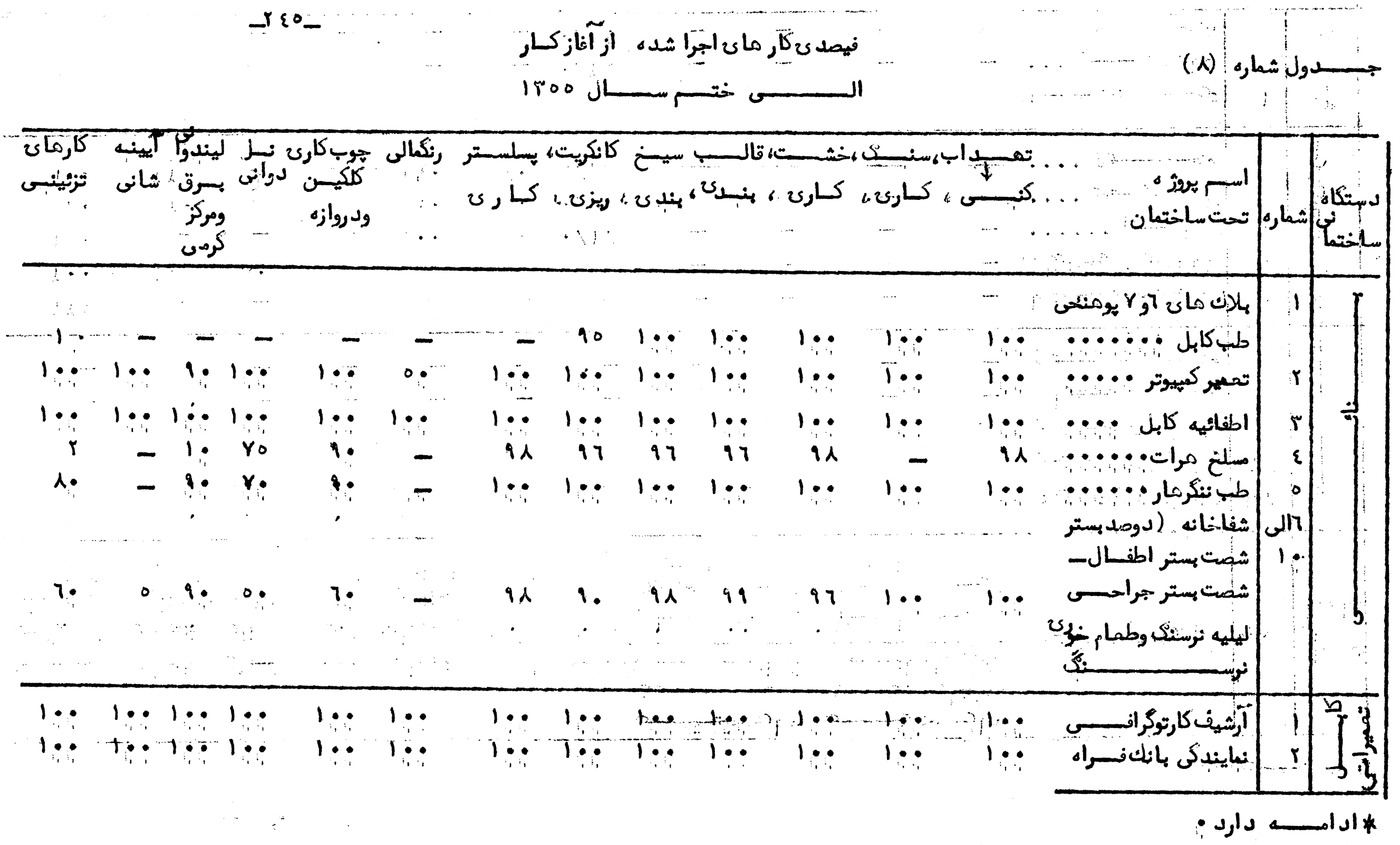


اد امســـ جدوز (i) (1)

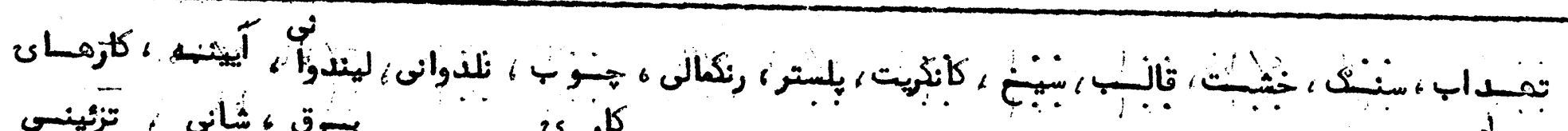

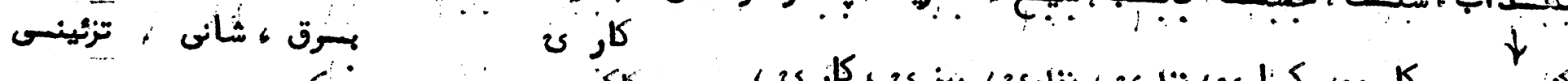

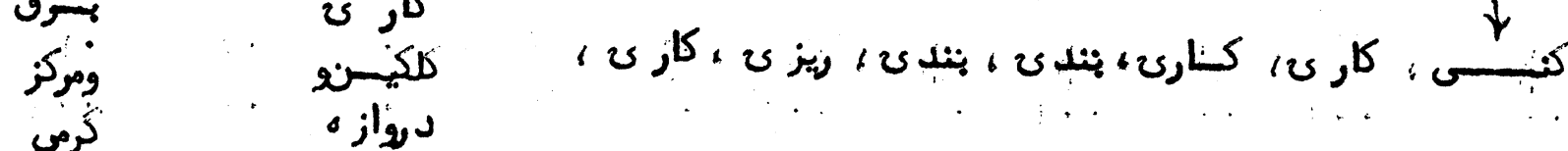

\begin{tabular}{|c|c|c|c|c|c|c|c|c|c|c|c|c|c|c|c|}
\hline ترزين & شأن & 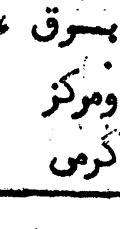 & & لَّاز & & كاز ك ، & ريز ى & 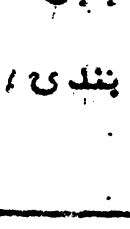 & يند كا & كنارك & كار كا & S & 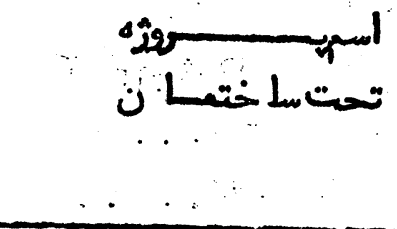 & & \\
\hline $1 \ldots$ & $1 \%$ & $1 \cdots$ & $1 \cdots$ & $1 \cdots$ & $1 \ldots$ & $1 \cdots$ & $1 \ldots$ & $1 \ldots$ & $1 \ldots$ & $1 \ldots$ & $1,:$ & $1 \ldots$ & نعايندكي، نك سمنكان & $r$ & \\
\hline $1 \ldots$ & $1 \ldots$ & $1 \ldots$ & $1 \ldots$ & 10 & $1 \cdots$ & $1 \cdots$ & $1 \ldots$ & $1 \cdots$ & $1 \ldots$ & $1 \cdots$ & $1 \ldots$ & $1 \ldots$ & نايندكى بانك خوست & $\varepsilon$ & \\
\hline $1 \ldots$ & $1 \ldots$ & $1 \ldots$ & $1 \cdots$ & $1 \ldots$ & $1 \cdots$ & $1 \ldots$ & $1 \ldots$ & $1 \ldots$ & $1 \ldots$ & $1 \cdots$ & $1 \cdots$ & $1 \cdots$ & نبايندكن بانك كردينز & ० & \\
\hline 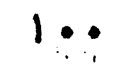 & $1 \cdots$ & $1,:$ & $1 \ldots$ & $1 \ldots$ & $1 \ldots$ & $1 \cdots$ & $1 \cdots$ & $1 \cdots$ & $1 \ldots$ & $1,:$ & $1 \cdots$ & $1 \ldots$ & نمايندىى باند لوكـــ & 7 & \\
\hline- & - & $r$ & $\div$ & $\varepsilon \cdot$ & $\therefore$ & $\because$ & 9. & 1. & $9 \because$ & $4 \cdot$ & $1 \because$ & $1 \%$ & نمايندكى بانك ميدا ن & $\vee$ & \\
\hline & & & & & & & & & & & & & 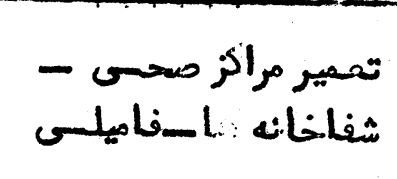 & 1 & \\
\hline ra & \&o & \&o. & \&o & 00. & or & $7 Y$ & 70. & 70 & rr & ro. & r. & $1 \because 9$ & 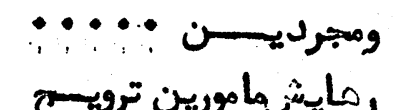 & $r$ & \\
\hline ro & $r:$ & $r:$ & ro & 7. & $0 \cdot$ & 10 & -10 & $1 \%$ & $4 \varepsilon$ & 10 & $i_{i}$ & $1 \cdots$ & 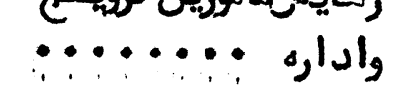 & & \\
\hline$r$ & $\varepsilon:$ & $\varepsilon$ & ro & 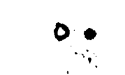 & ro & $\circ:$ & 70 & 70 & 70 & 10 & ᄉ.: & 1,0 & رمايثزتضات وا داره & $r$ & \\
\hline - & 77 & 77 & די & 77 & 77 & 77 & 77 & 7.7 & 7.7 & 77 & 77 & 77 & موا شناسى ؛ ? . . & $\varepsilon$ & \\
\hline $1 \cdot:$ & $1 \%$ & $1 \%$ & $1 \therefore$ & $1 \ldots$ & ne & $1 \ldots$ & $1 \ldots$ & $1 \ldots$ & $1 \cdot 9$ & $1 \%$ & $1 \cdots$ & $1 \ldots$ & مكتب حصه شعال لشكركاه & o. & 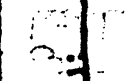 \\
\hline- & $Y:$ & $r_{0}$ & $r$. & $r_{0}$ & - & $\therefore r_{0}$ & $r$ & ro. & 10. & 10 & $1 \ldots$ & $1 \ldots$ & كدامهاكروغن نباتسـي & 7 & \\
\hline
\end{tabular}




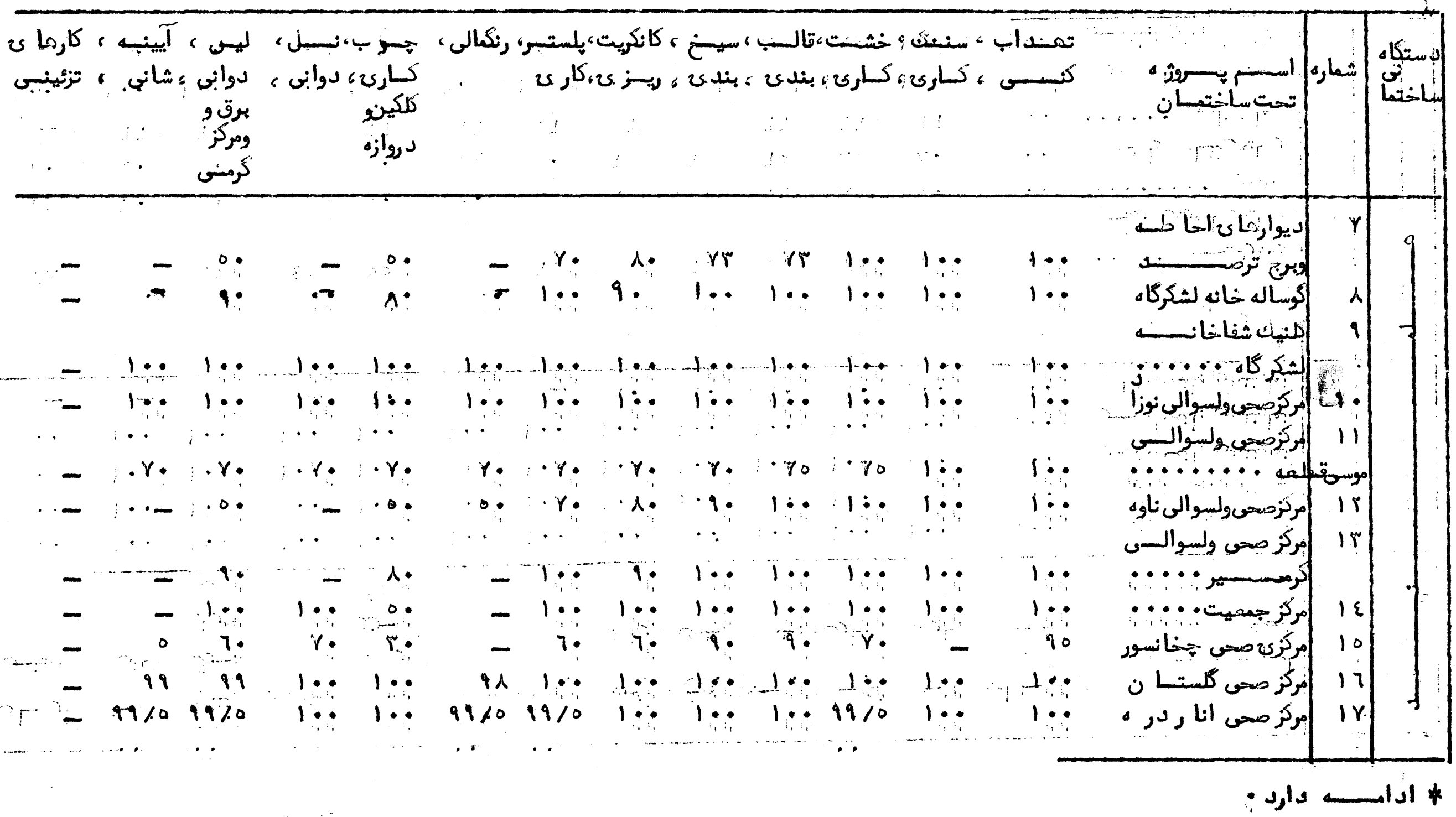




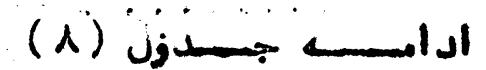

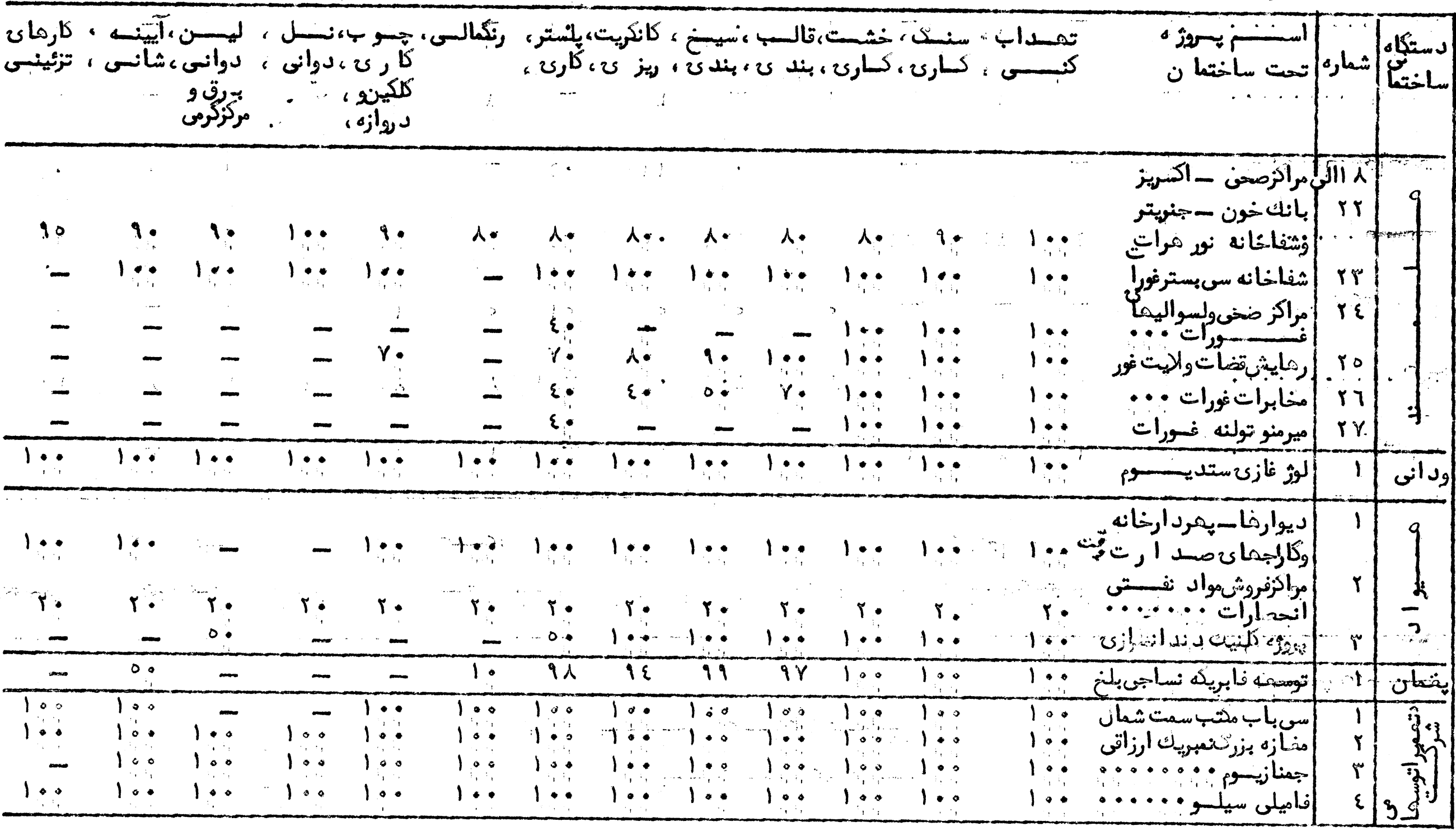




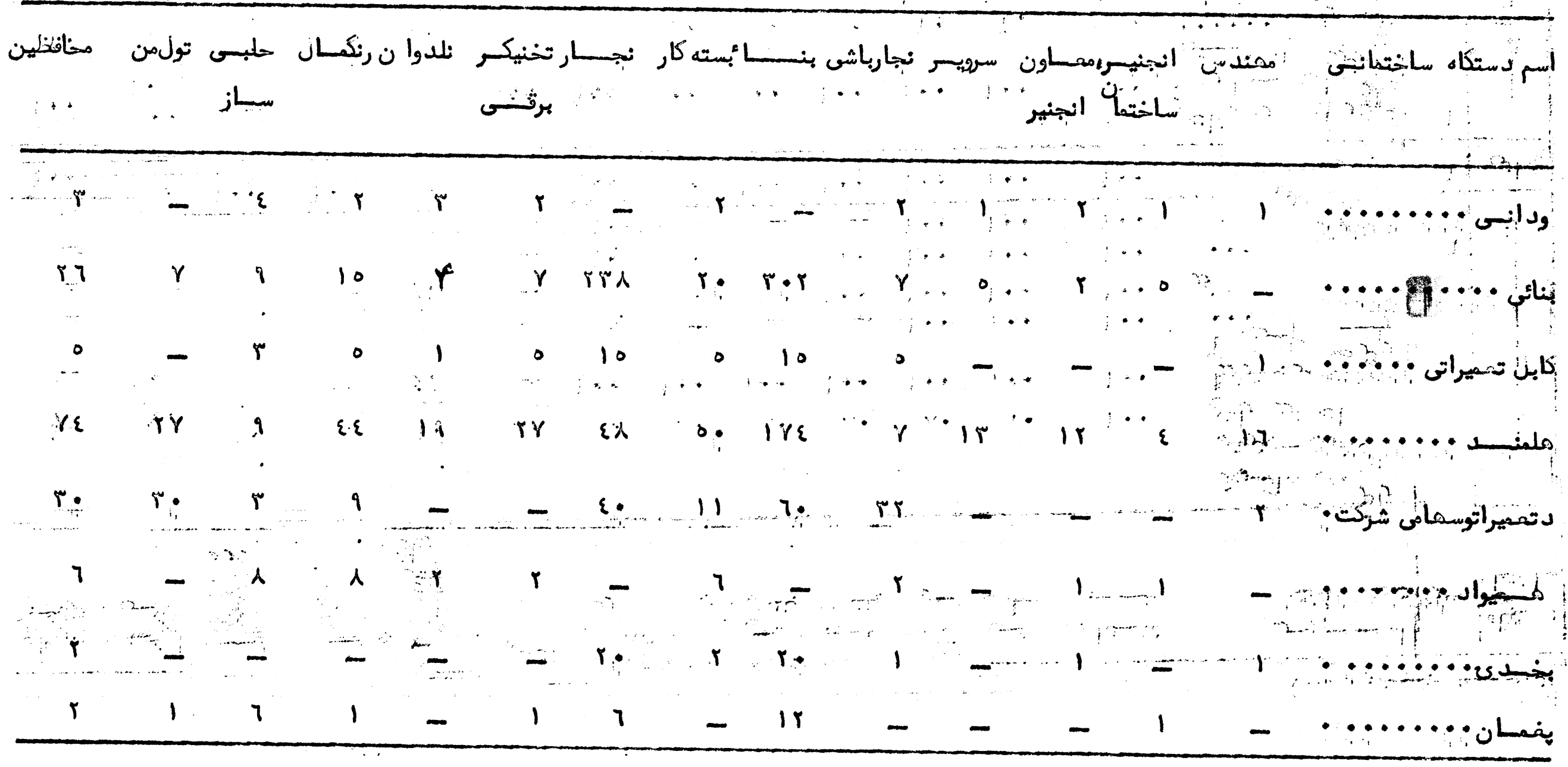




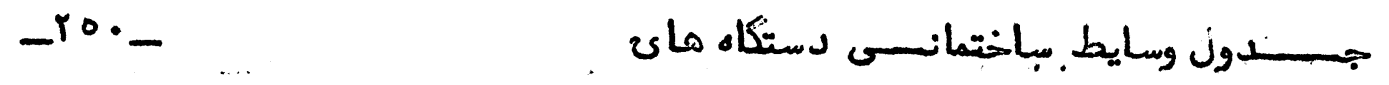

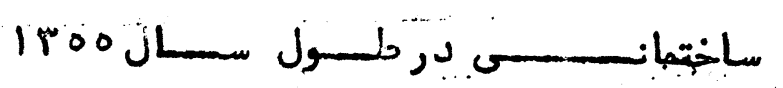

جـون شماره (1)

\begin{tabular}{|c|c|c|c|c|c|c|c|c|c|c|c|c|c|}
\hline شـاول & 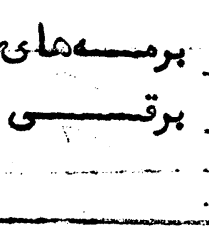 & 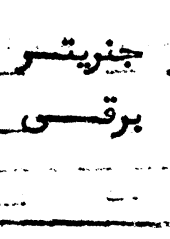 & ر كامتيسو & سكيكه & S & 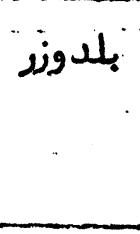 & موتاى & 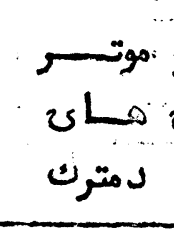 & موتساكن & كرئنسن & مترينس & مخلو ماشيسن & إيسلر دستكاه ساحتماني \\
\hline 1 & - & - & $1 \cdots$ & - & - & - & 1 & $\cdots$ & $\cdots \varepsilon$ & - & 1 & $\therefore$ & $\therefore \cdots$ \\
\hline 1 & 11 & $r$ & 1 & - & 1 & $r$ & $r$ & $\therefore \quad 1$ & ${ }^{\prime} r$ & 1 & $r$ & 11 & $\cdots$ \\
\hline - & 1 & - & - & $=$ & $-\cdots$ & - & $\cdots$ & - & $r$ & - & - & $\begin{array}{l}3 \\
?\end{array}$ & 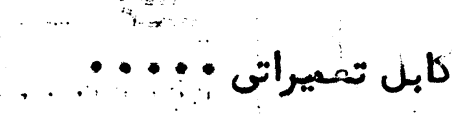 \\
\hline$\varepsilon$ : & 77 & $\cdots$ ir & $r \varepsilon^{-}$ & rr & ro: & $\varepsilon \alpha$ & 9. & $r \cdot$ & ir & - & 今 & ro & $\because \ldots$ \\
\hline 1 & - & $r$ & - & - & $-\infty$ & - & $\varepsilon$ & - & rr & 1 & $r$ & $\varepsilon$ & دت:ميراتوسمامىشركت \\
\hline - & $r$ & - & 1 & - & - & - & $r$ & - & $\varepsilon$ & - & - & $\gamma$ & 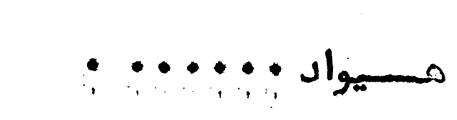 \\
\hline- & $\cdots \cdot r$ & $i$ & $r$ & - & - & - & 1 & - & $r$ & - & - & $r$ & 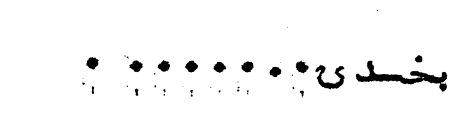 \\
\hline - & $r$ & - & - & - & - & - & $r$ & - & $\curlywedge$ & - & $r$ & $r$ & $\because \cdots \cdots$ \\
\hline
\end{tabular}




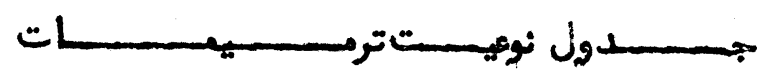

(ii) (ب)

|




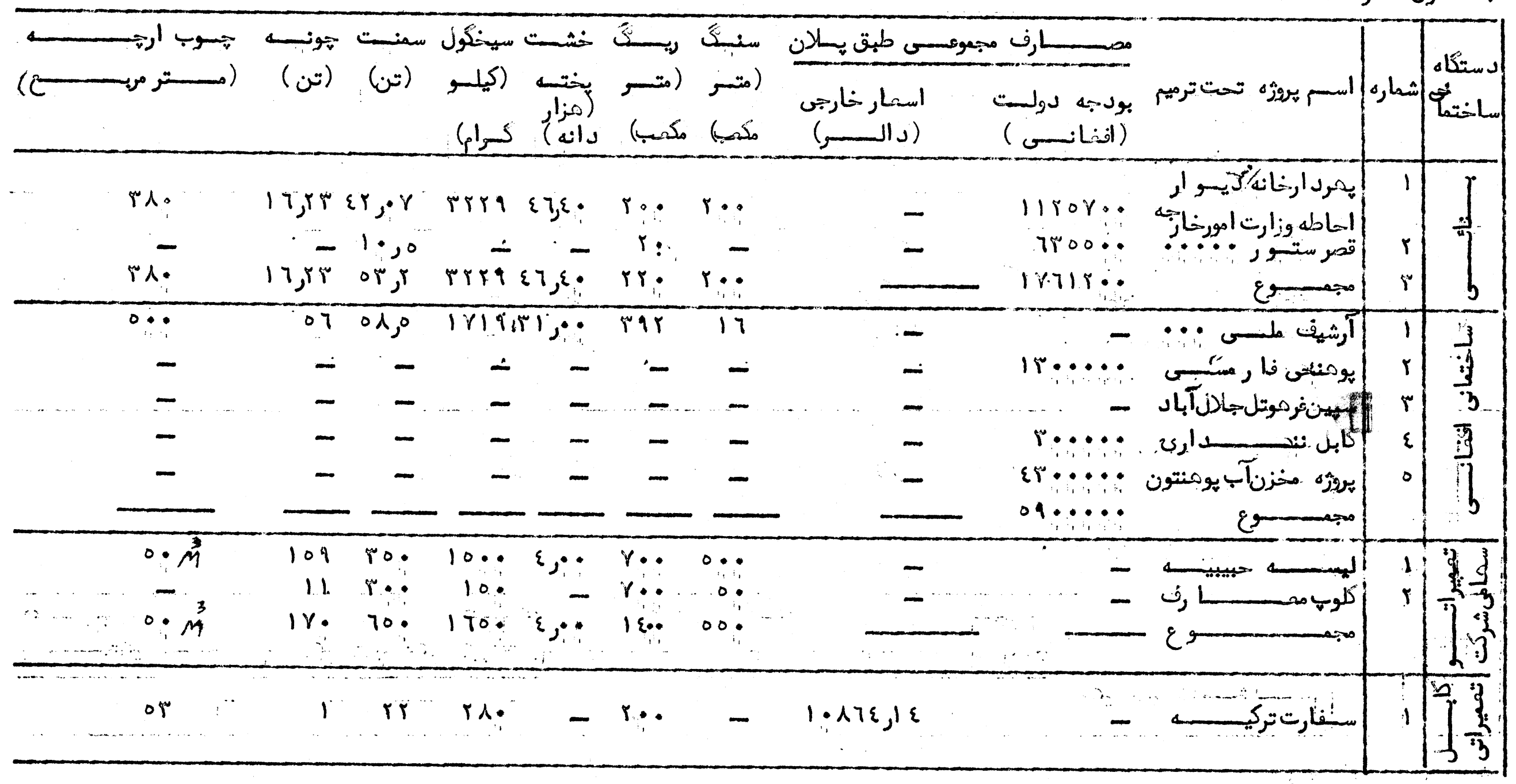




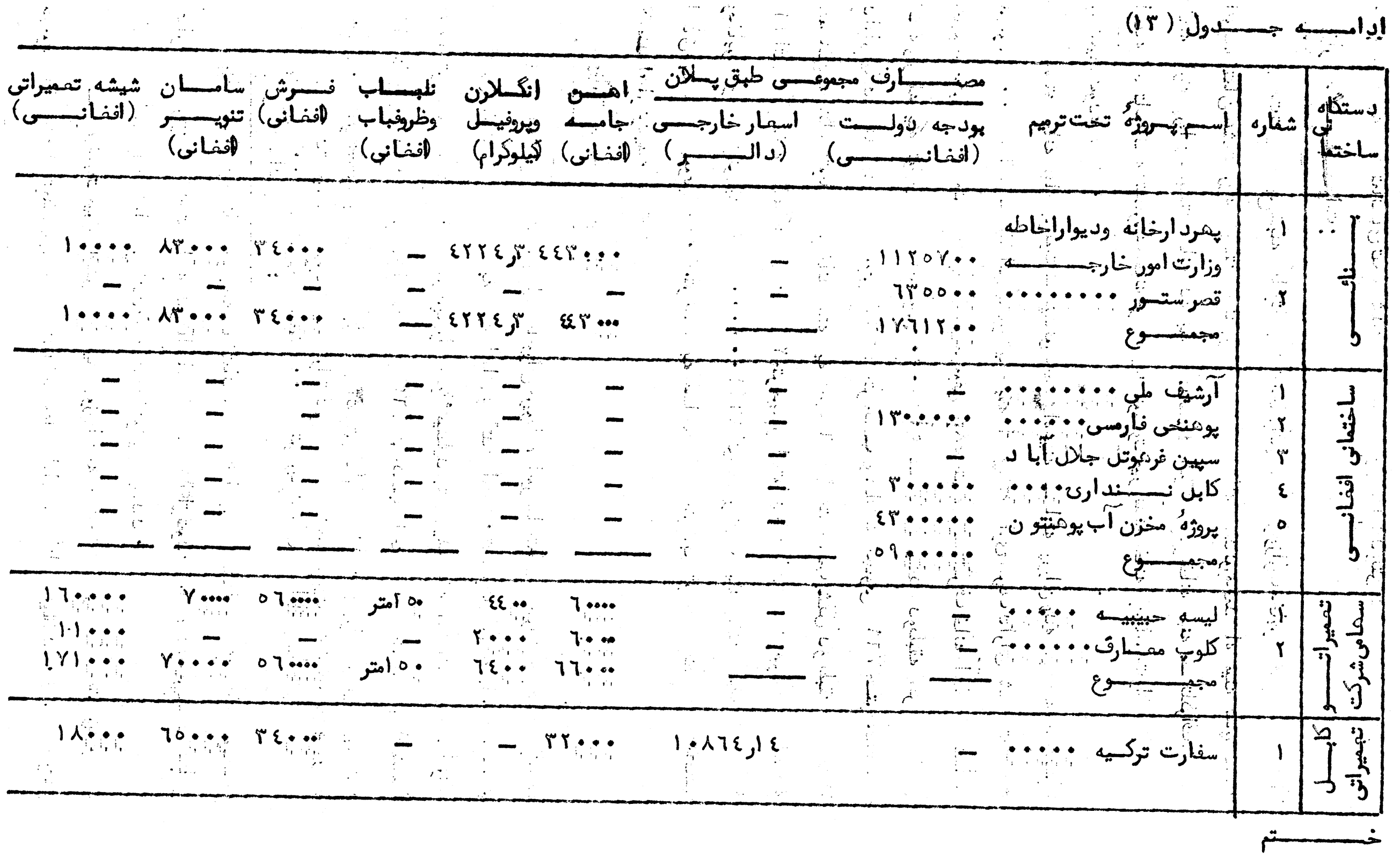




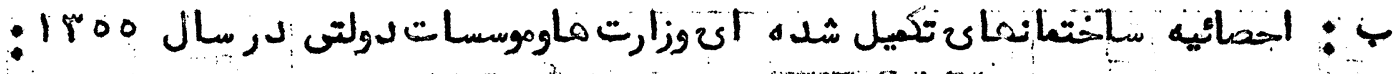

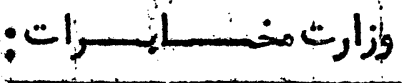

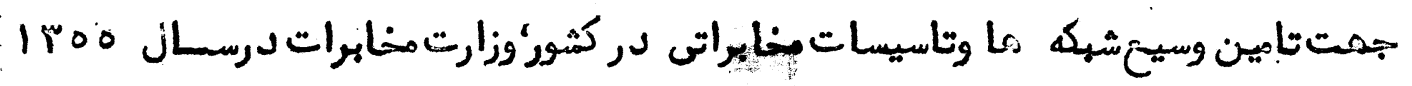

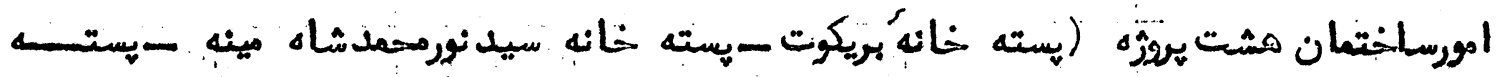

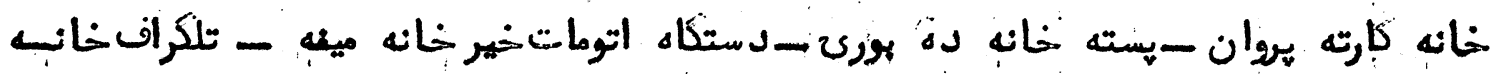

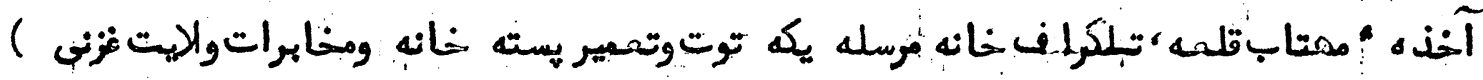

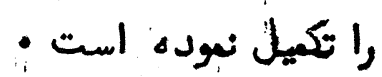

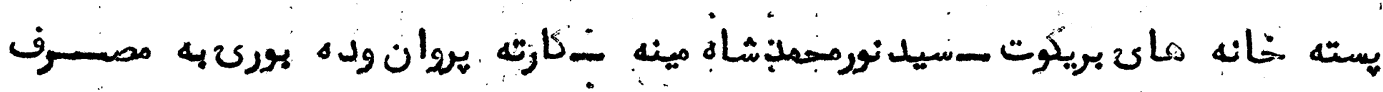

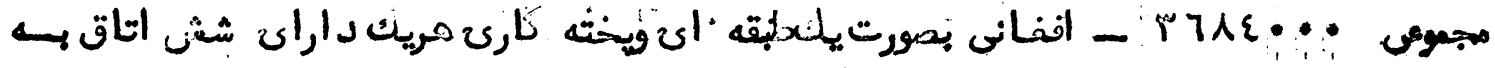

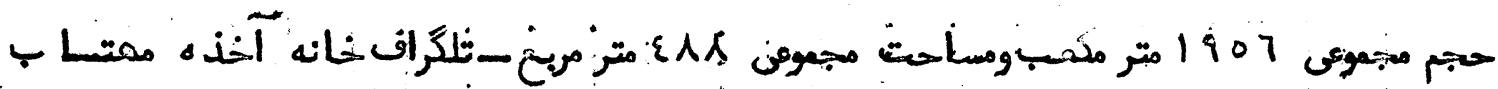

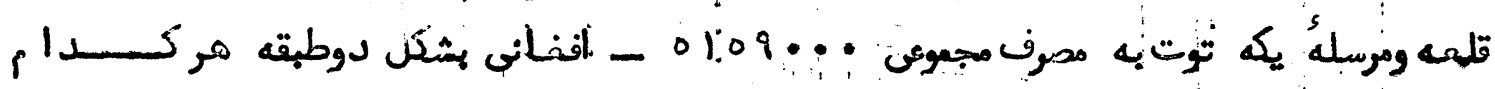

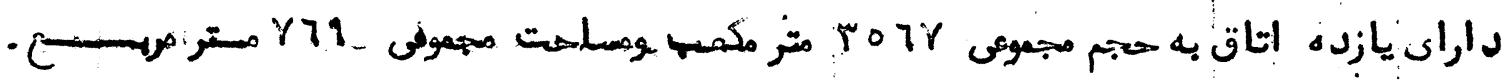

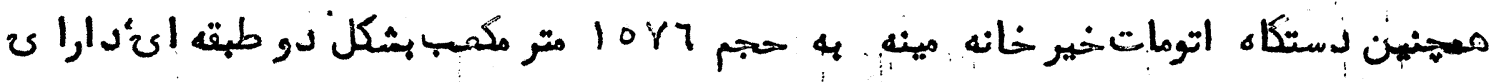

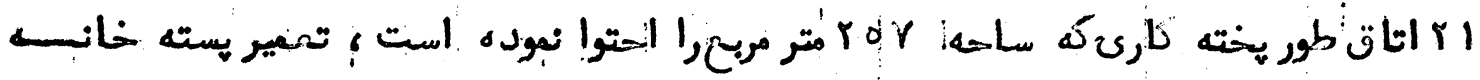

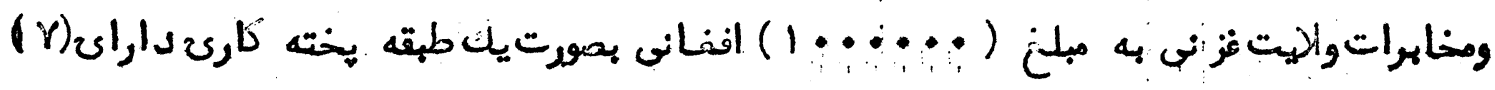

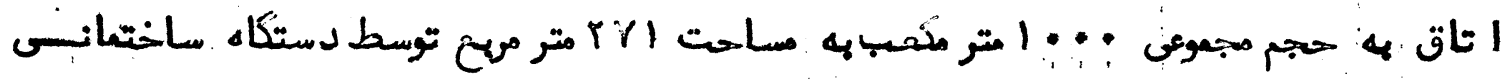

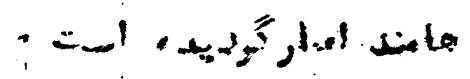

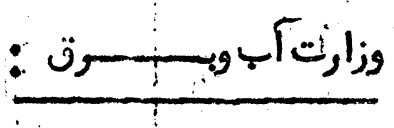

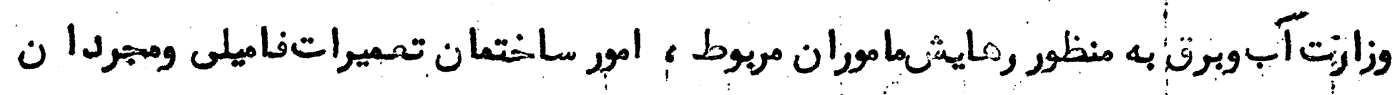

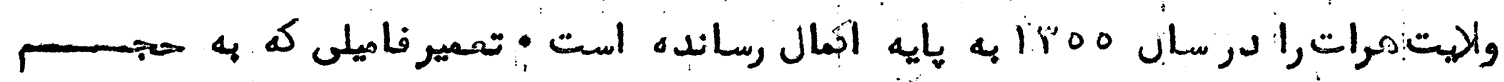

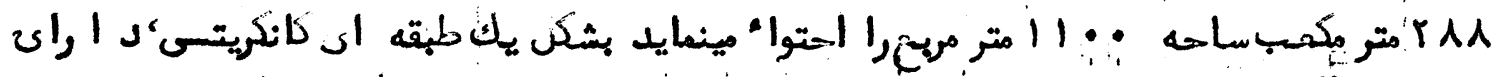

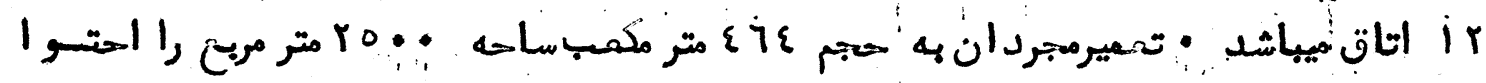

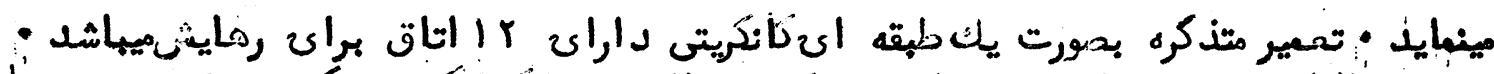

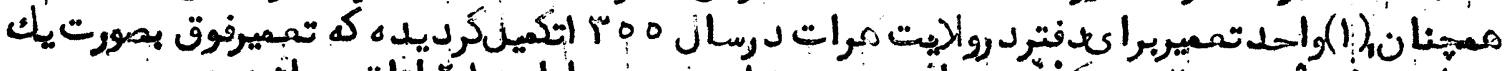

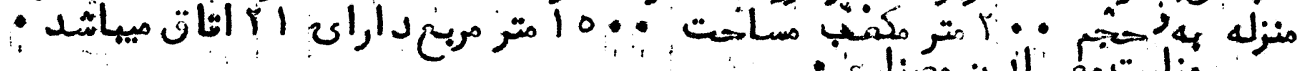
وزان

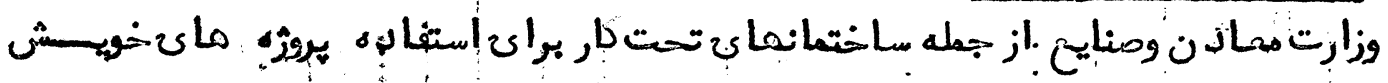

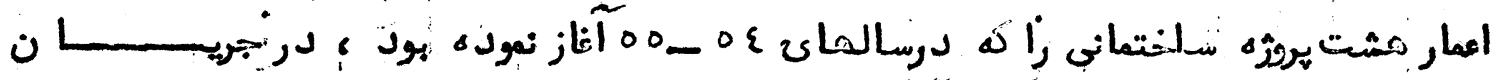

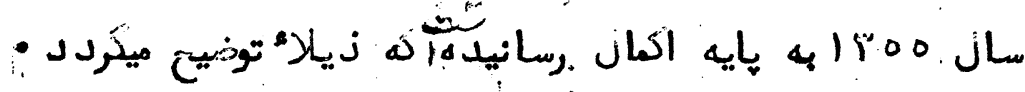

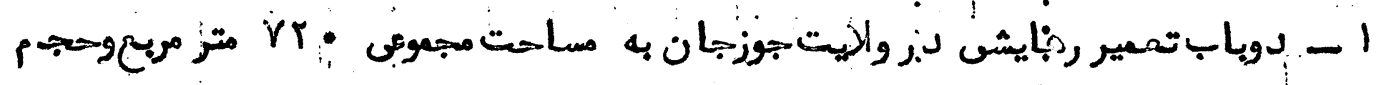

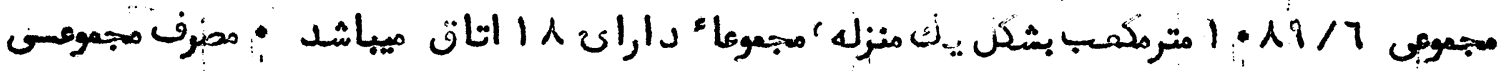




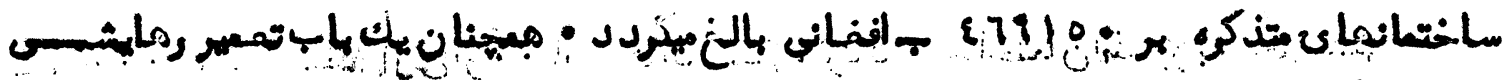

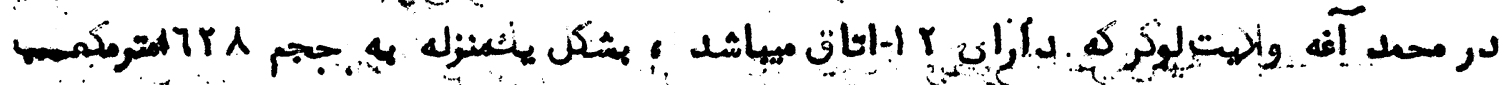

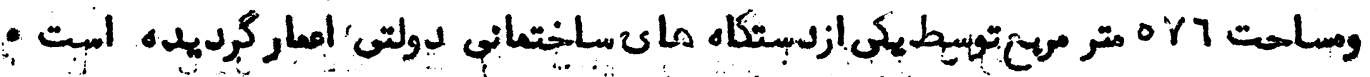

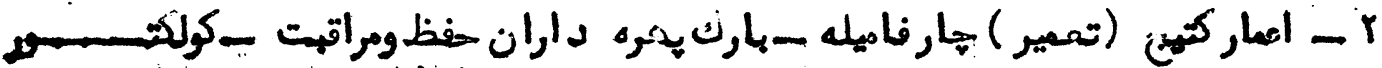

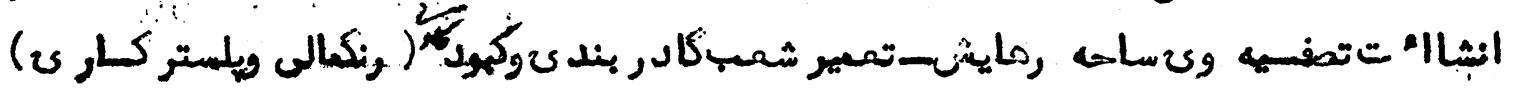

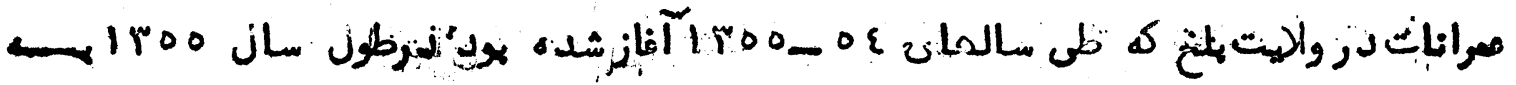

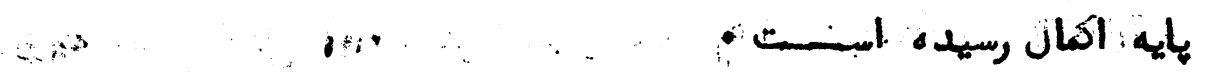

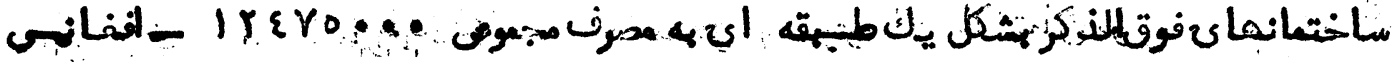

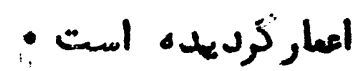

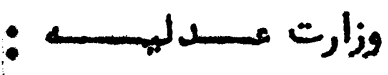

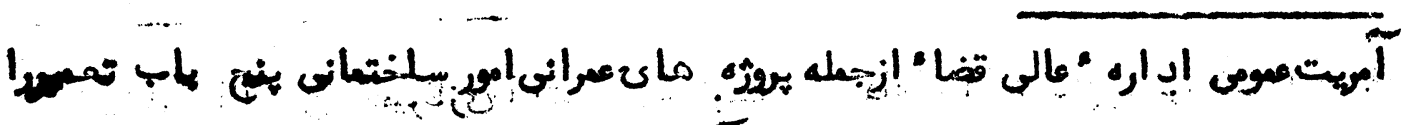

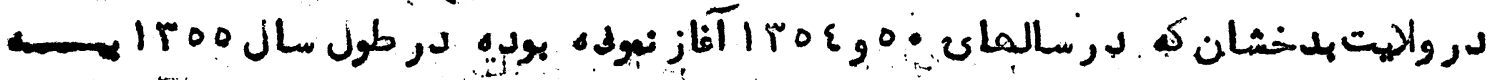

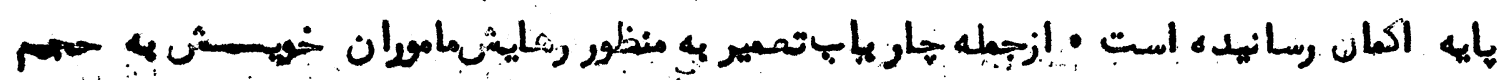

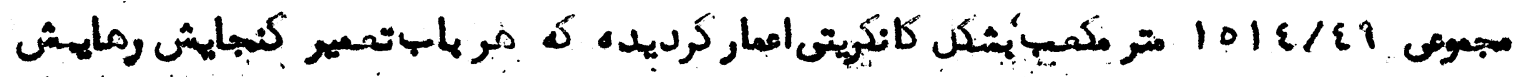

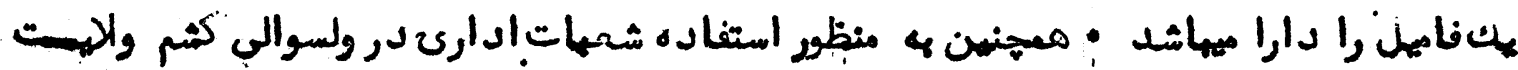

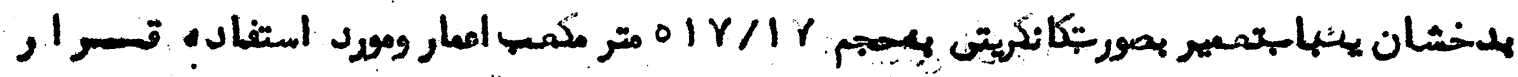

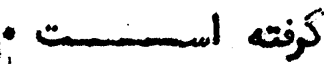
وزارت نراعس

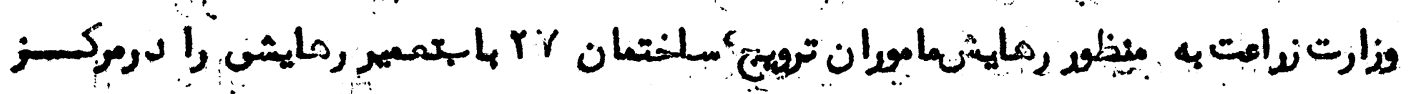

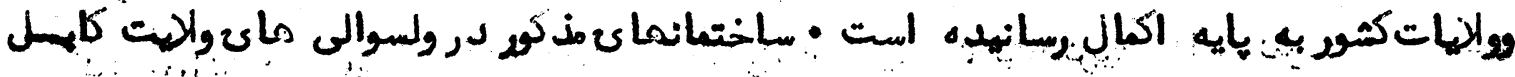

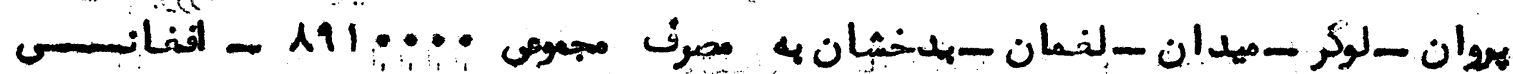

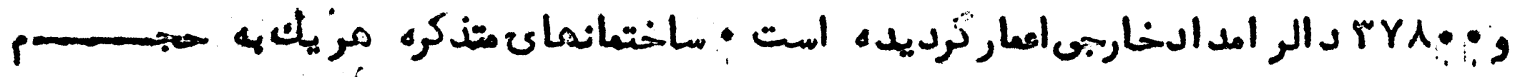

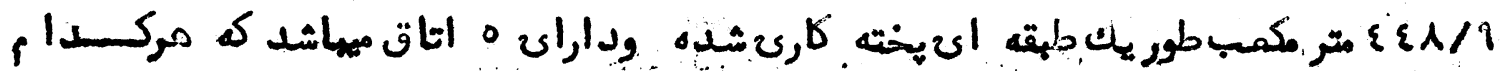

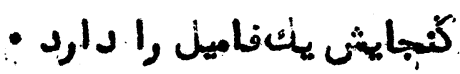

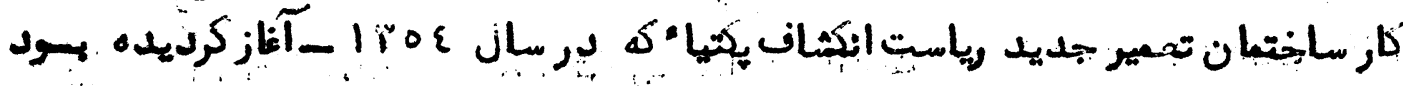

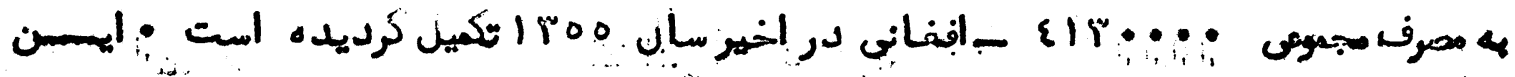

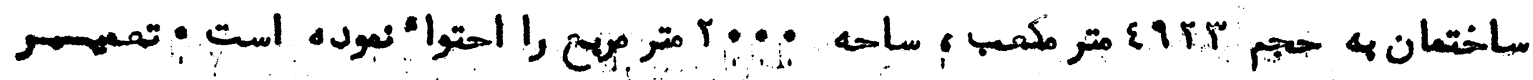

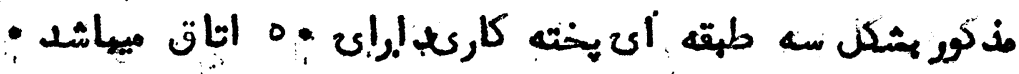

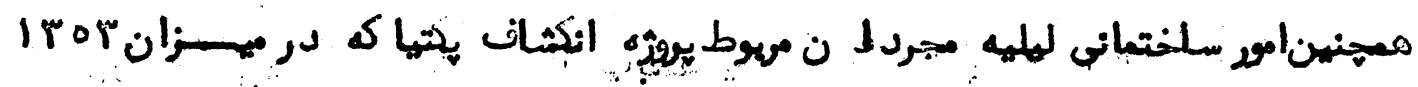

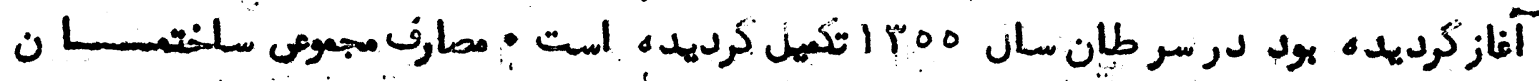




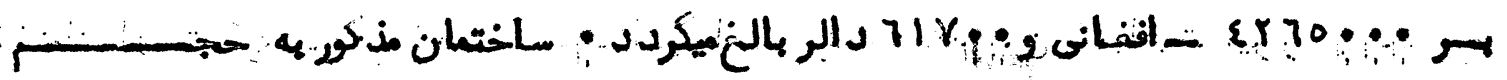

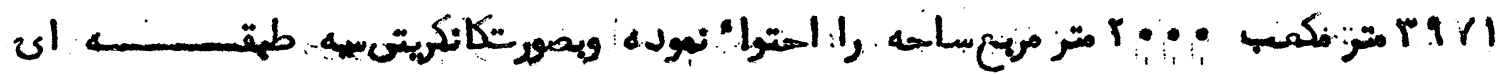

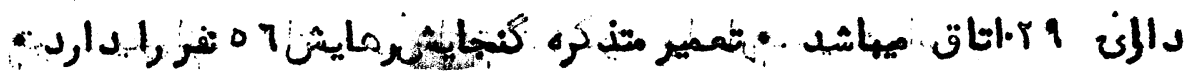

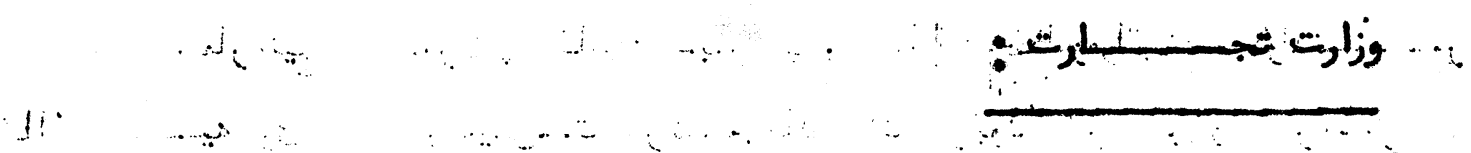

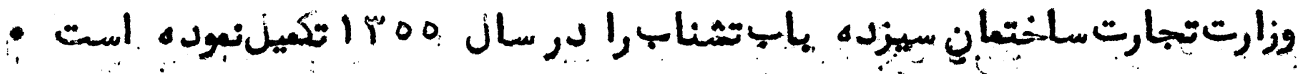

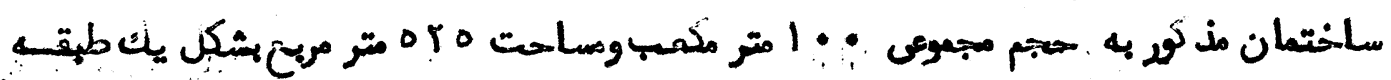

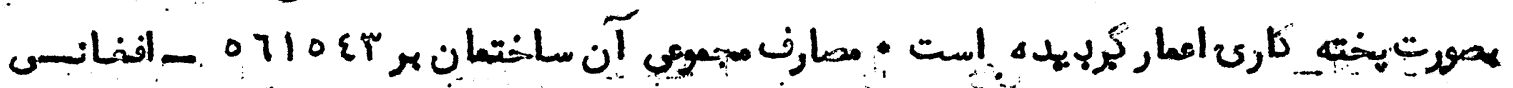

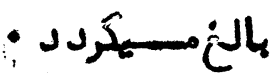

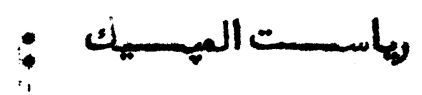

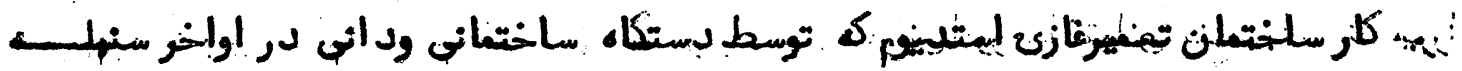

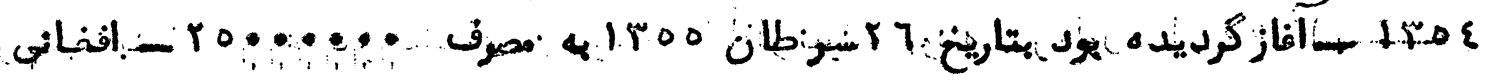

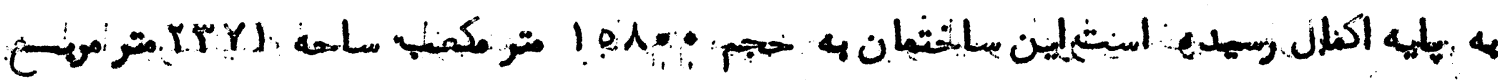

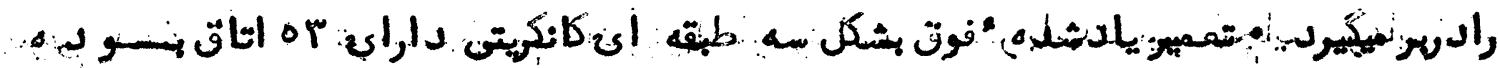

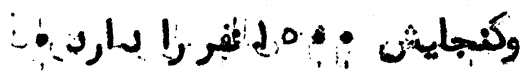
$\dot{H}$

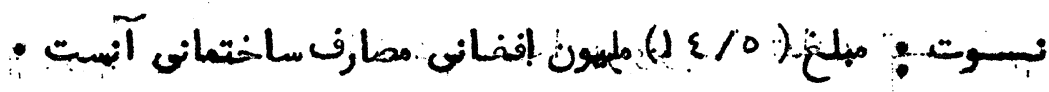

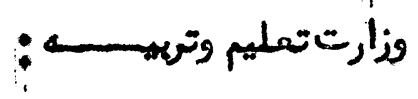

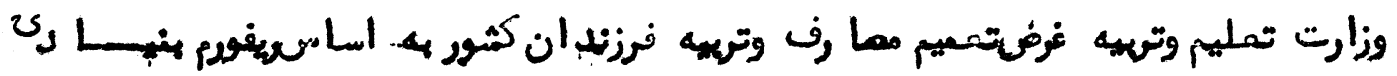

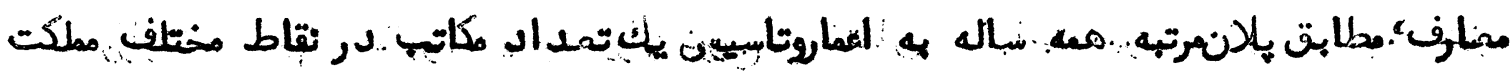

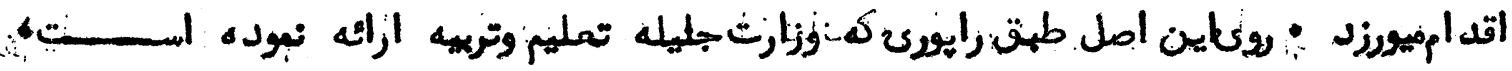

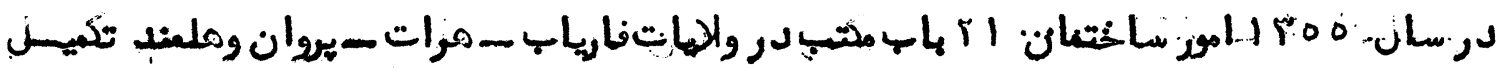

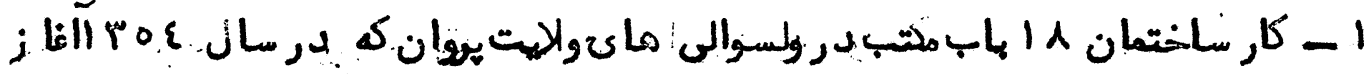

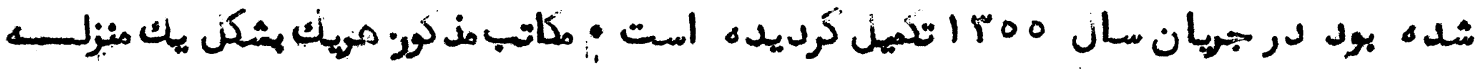

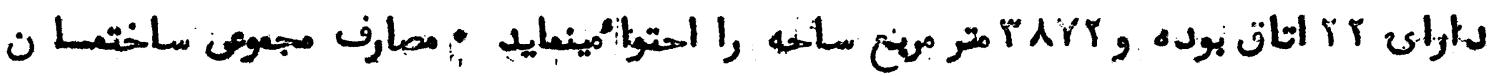

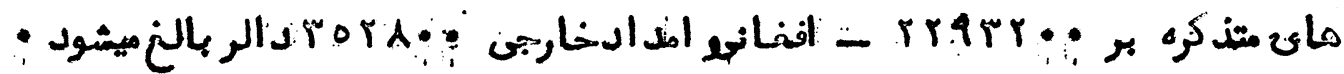

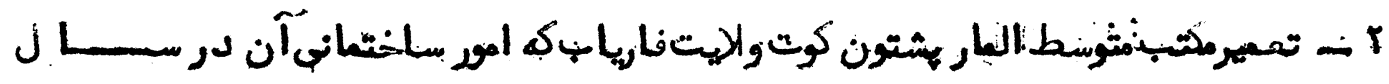

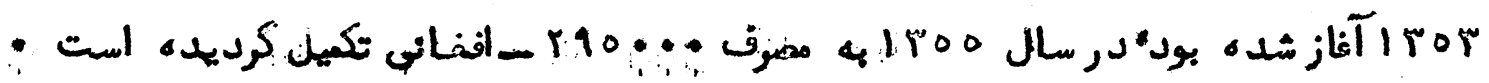

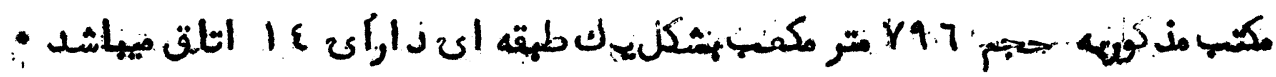

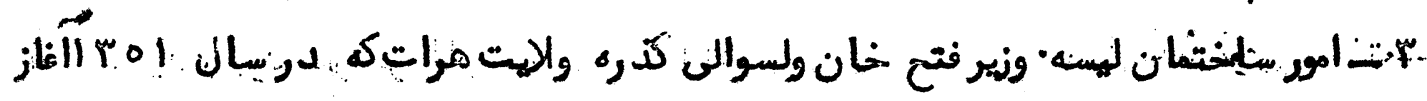




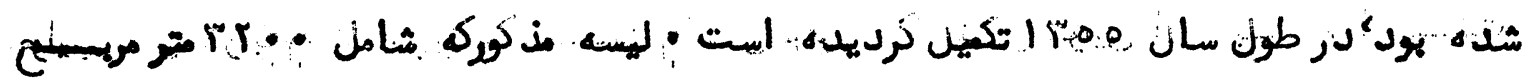

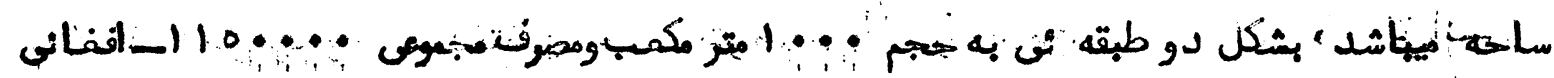
اعماز شنده : استح :

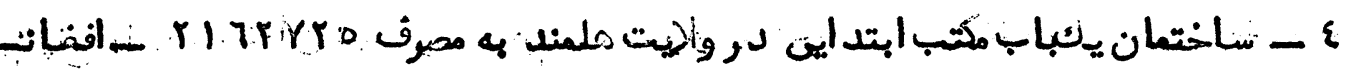

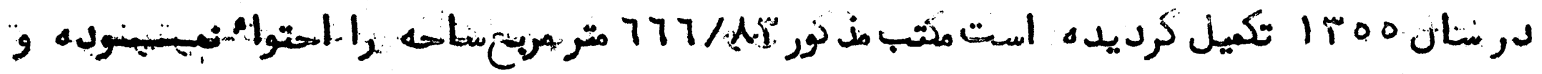

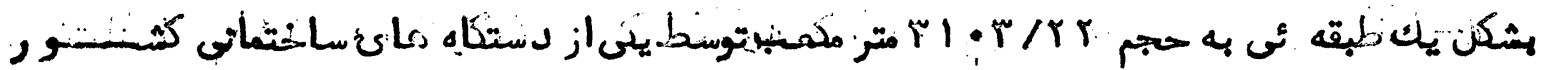
in:

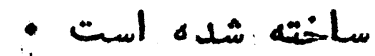

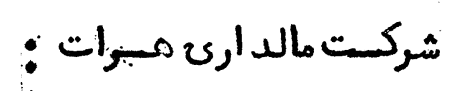

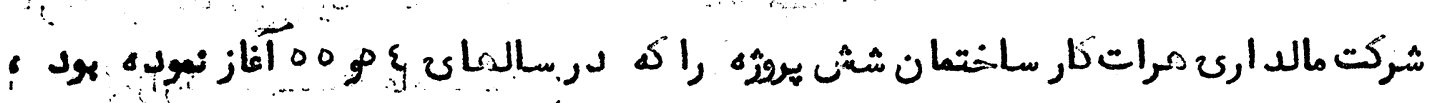

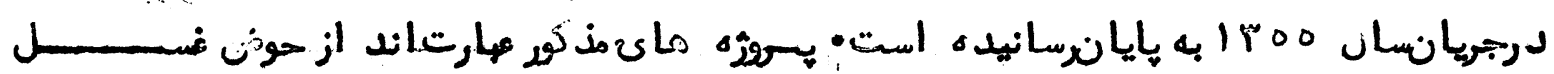

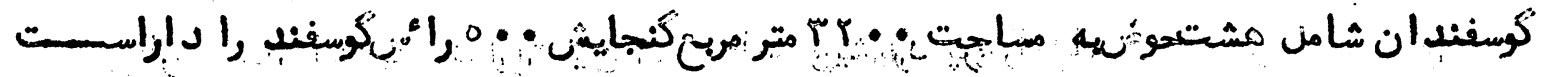

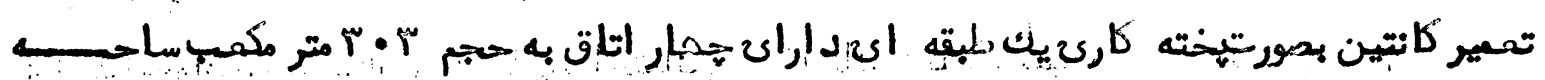

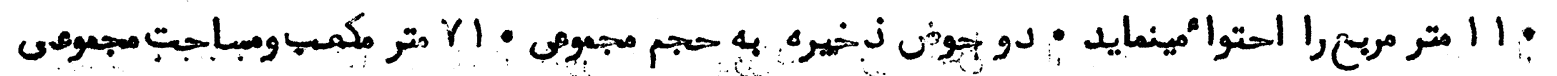

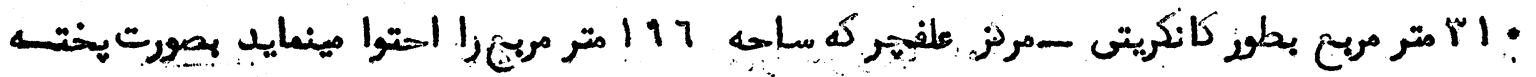

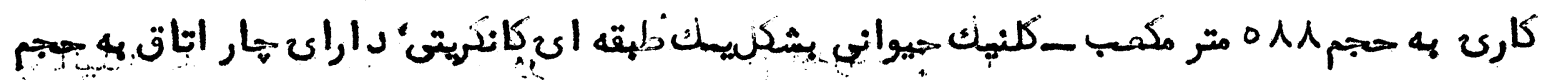

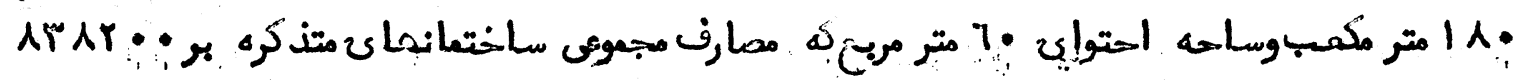

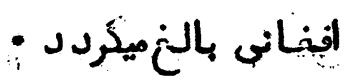
رياست عهوم مواين ملكى وتجونغين :

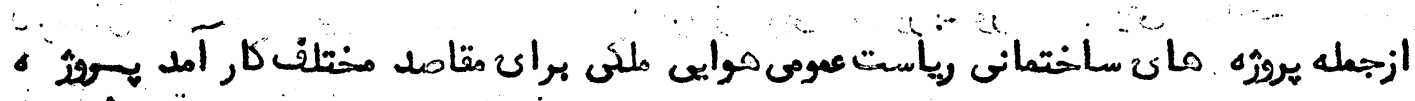

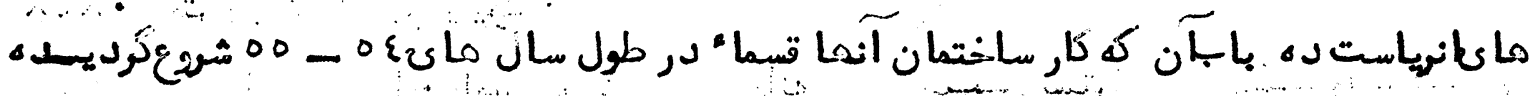

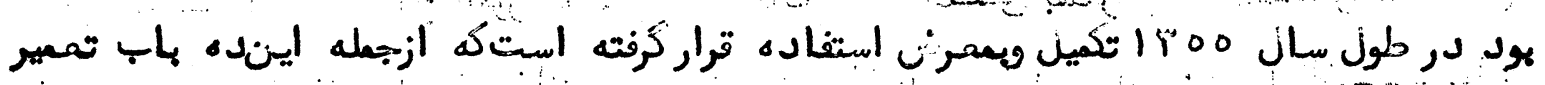

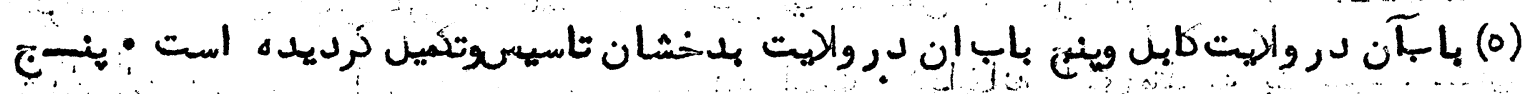

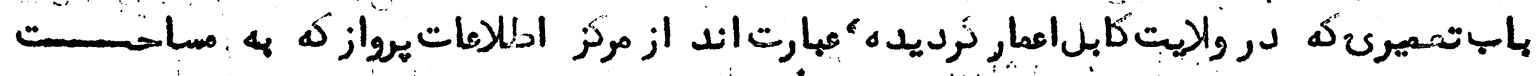
(VA•P)

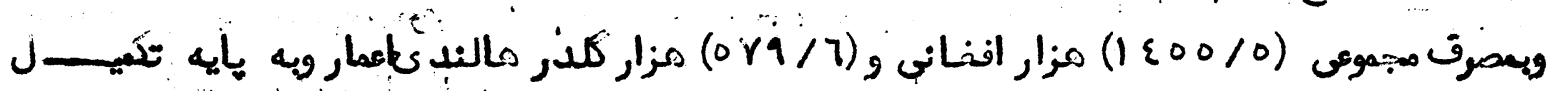

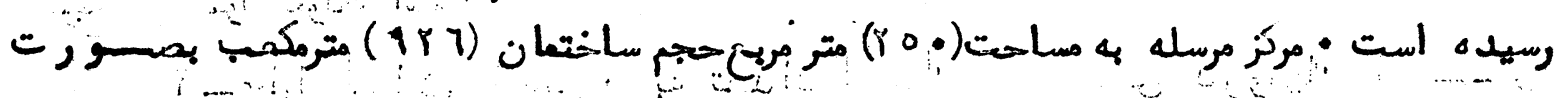

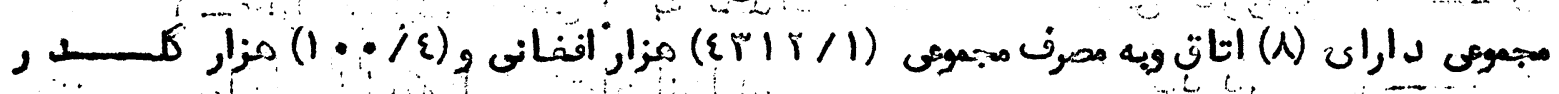

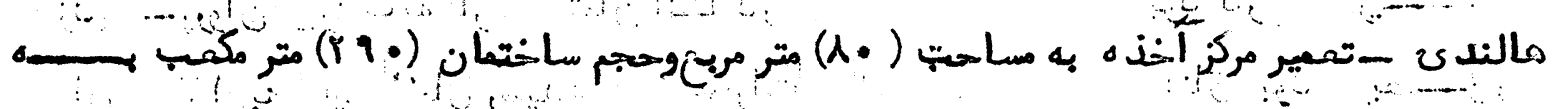

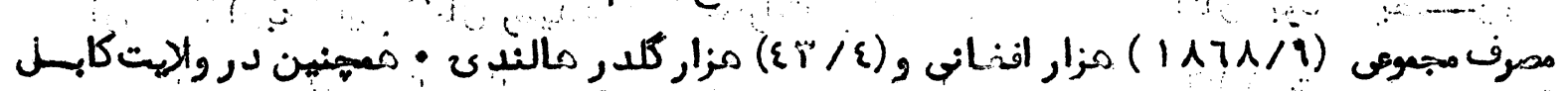




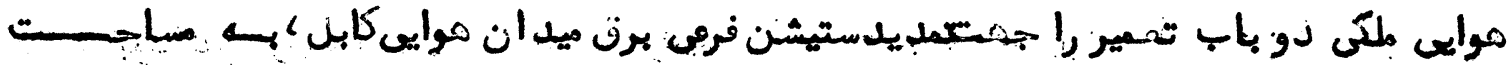

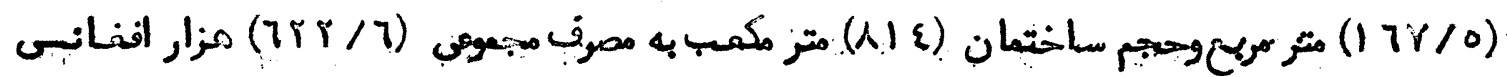

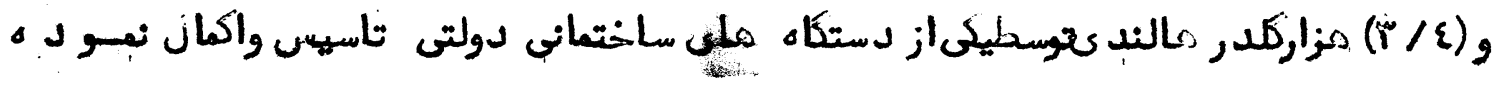

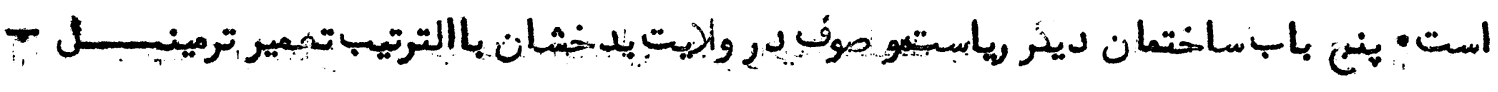

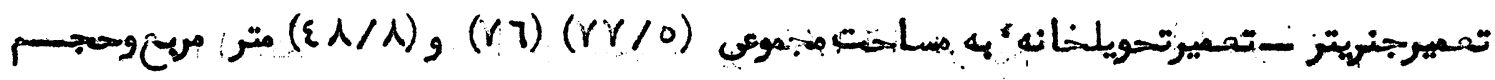

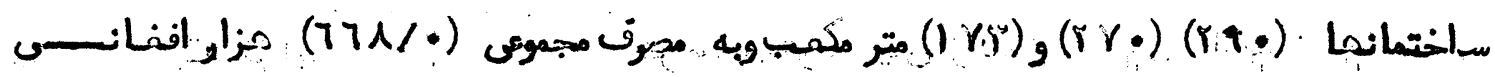

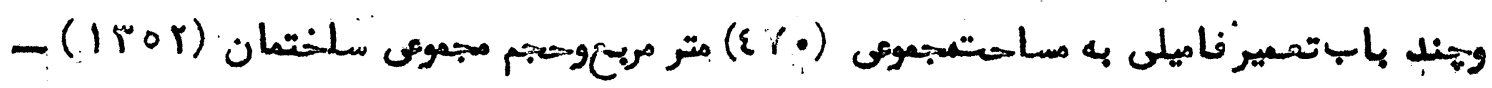

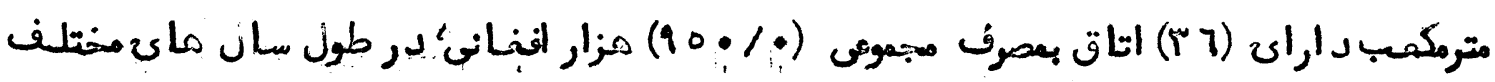

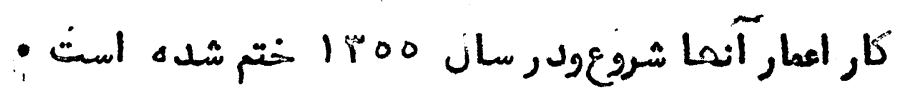

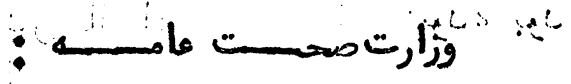

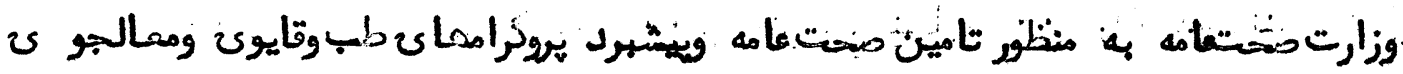

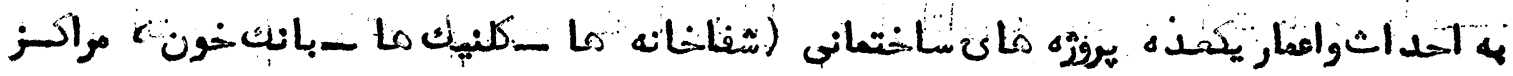

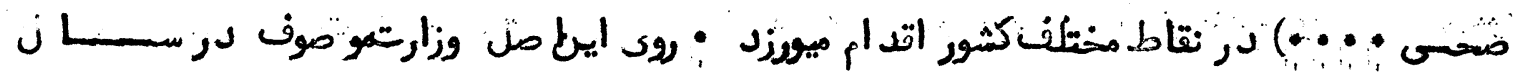

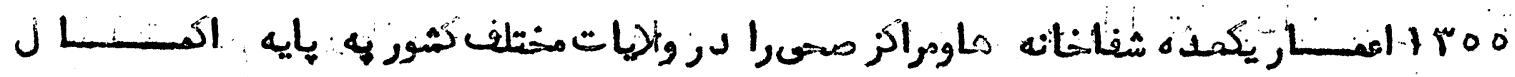

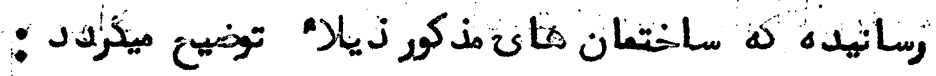

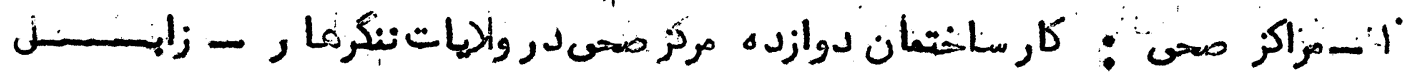

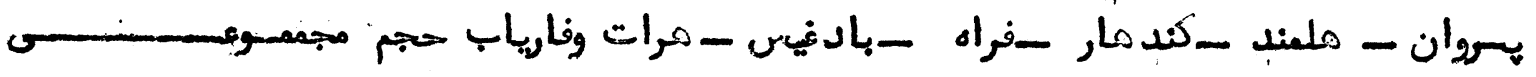

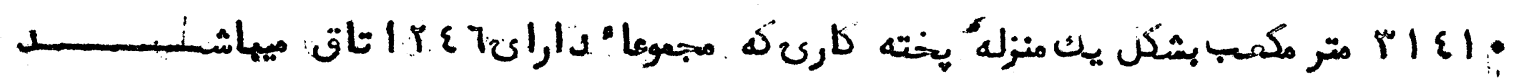

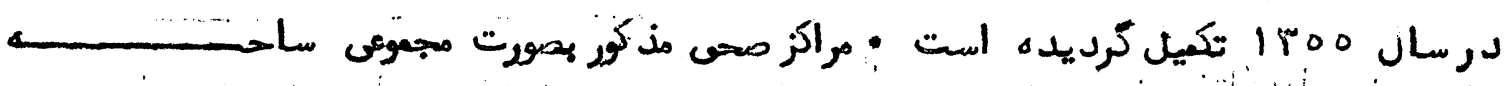
Q A

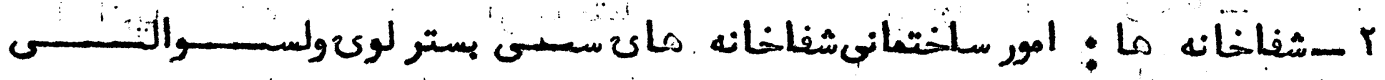

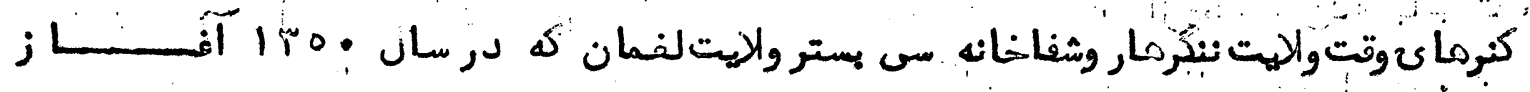

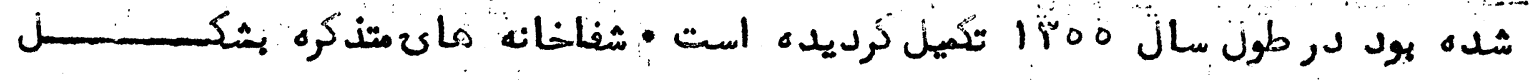

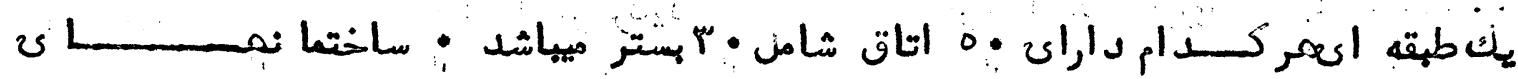

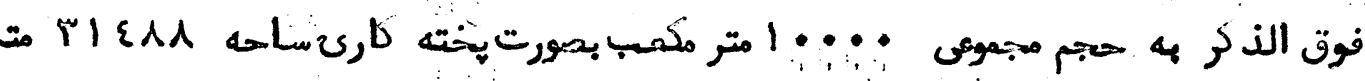

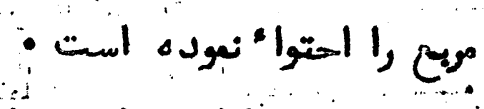

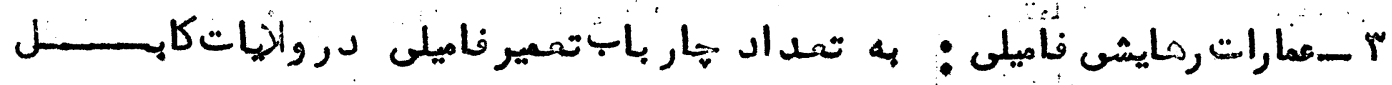

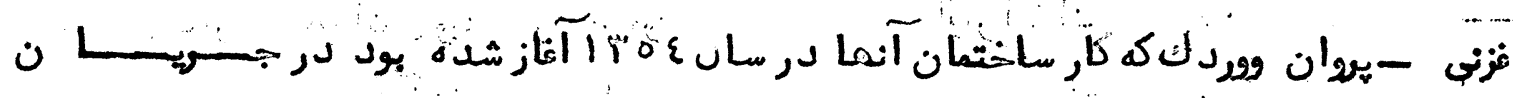

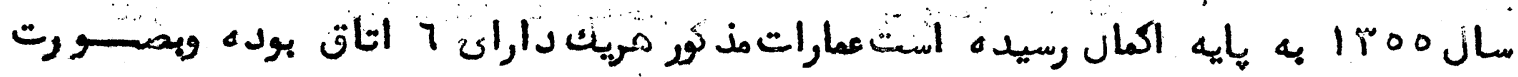

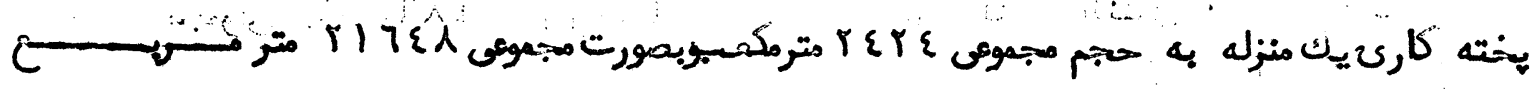




$$
\text { مستسامست دارد : }
$$

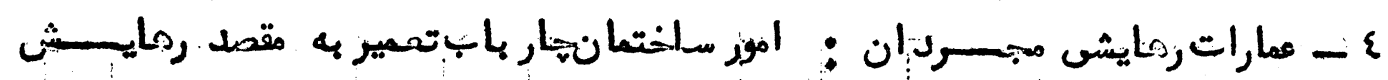

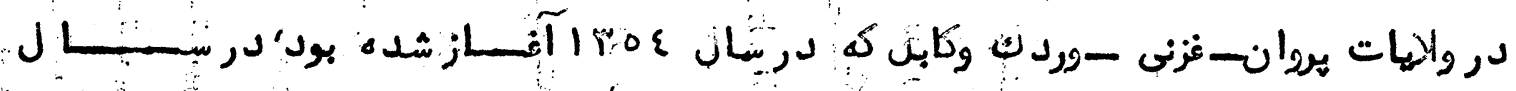
1900

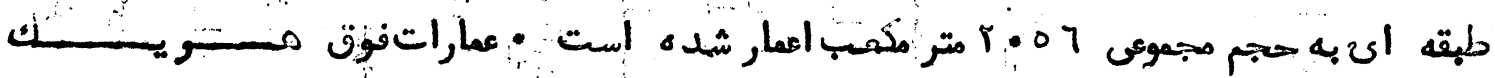

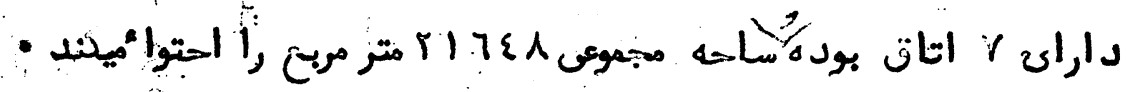

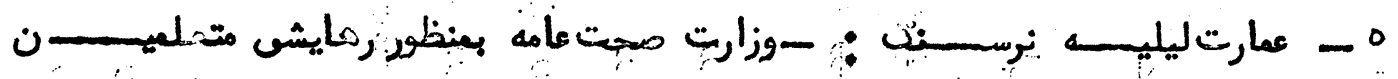

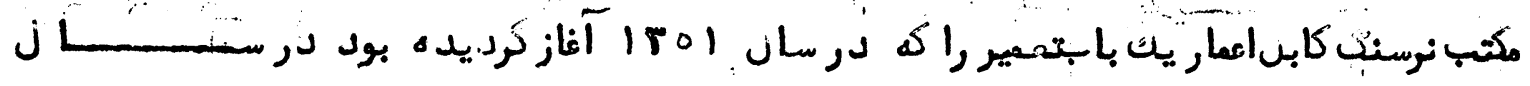

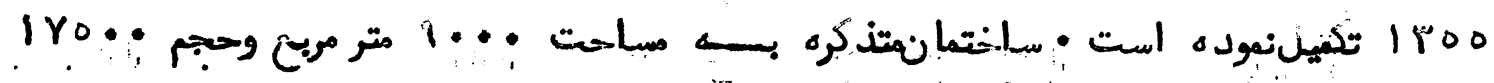

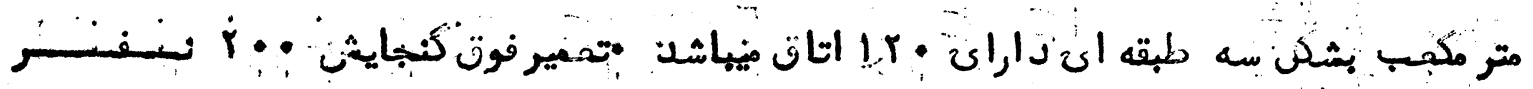

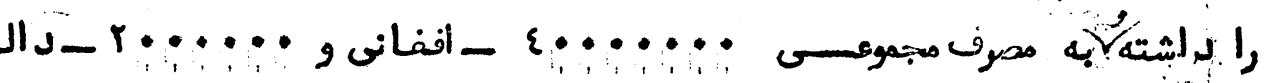

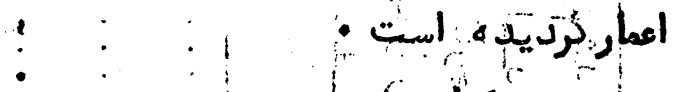

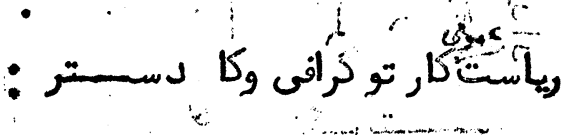

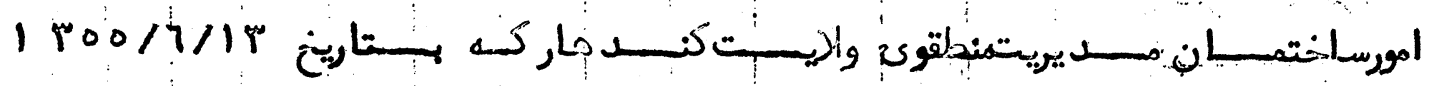

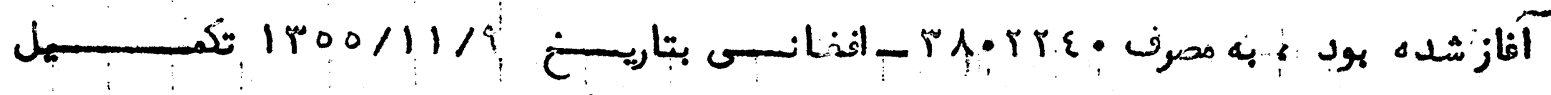

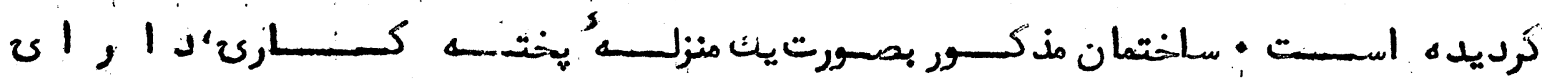

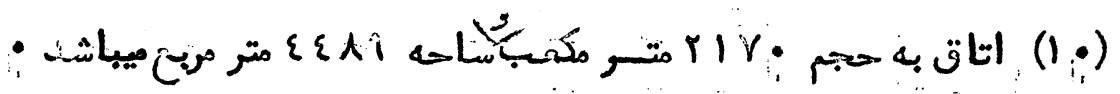

$$
\text { : وزارت ادلــاعـات }
$$

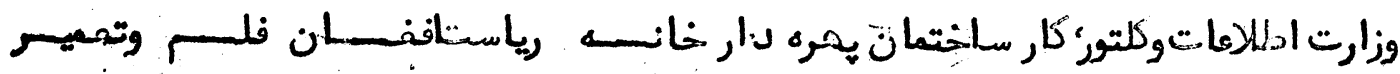

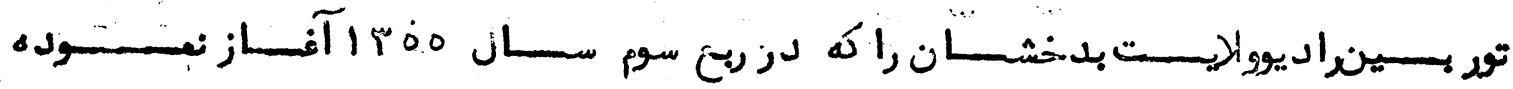

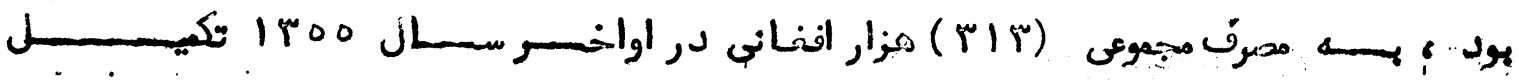

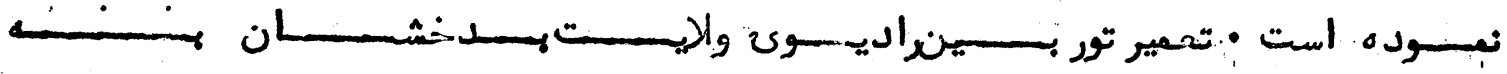

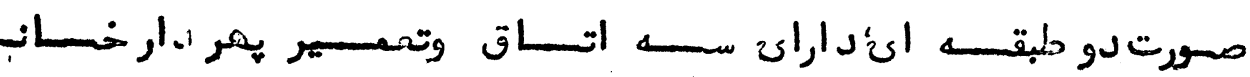

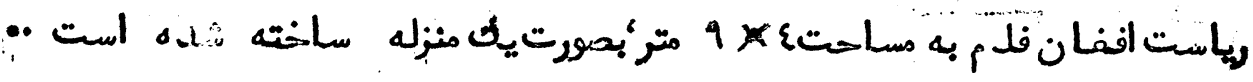
$\left(\left(r_{i}\right)\right)$ 
$-! 7 !-$

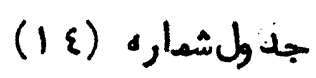

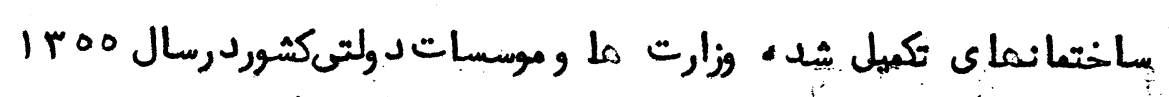

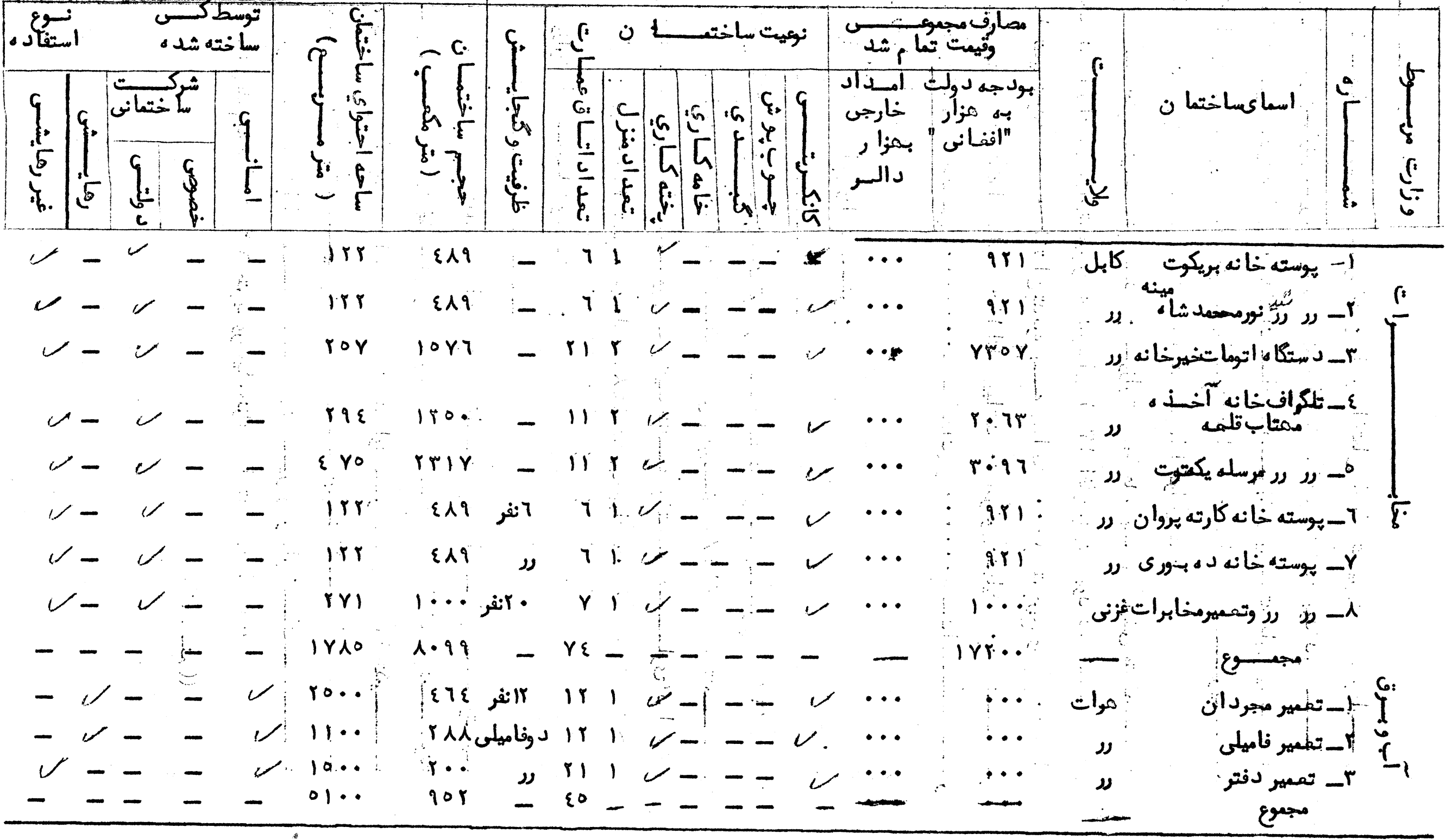


ممادن وصنايس
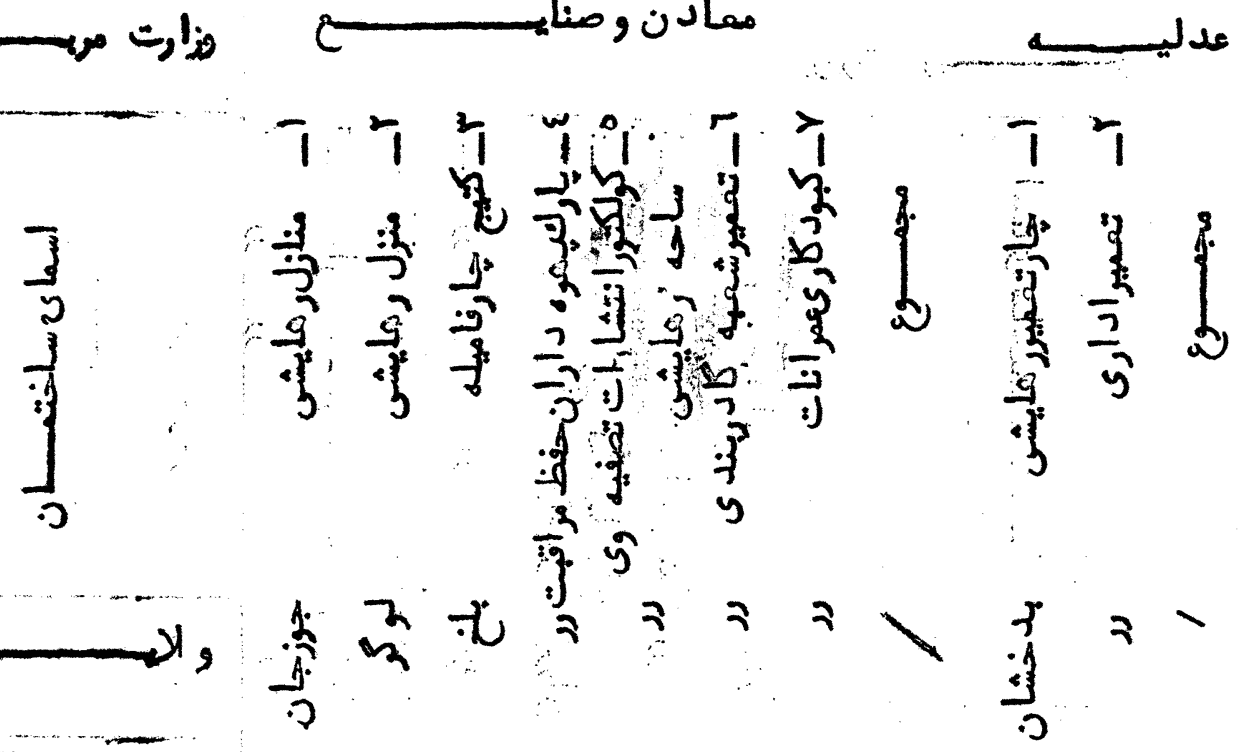

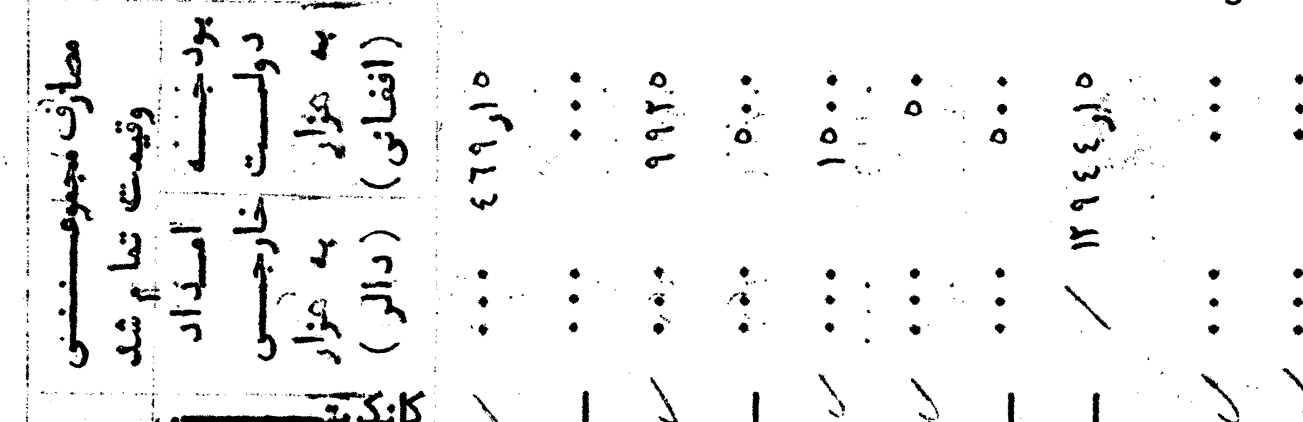

y

年事

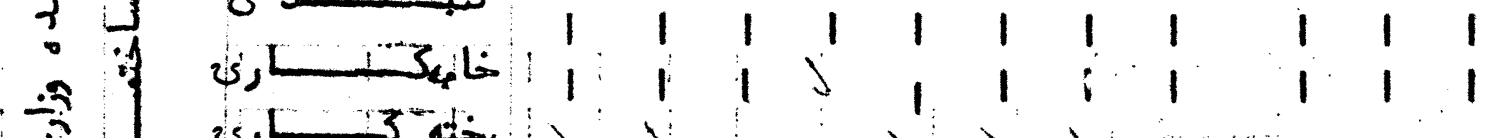

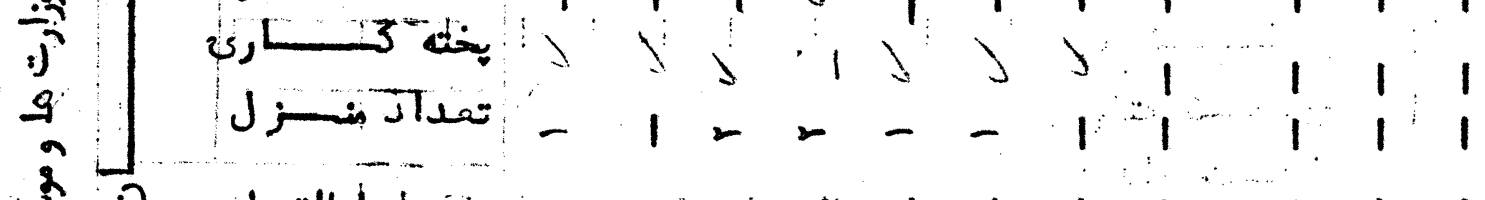

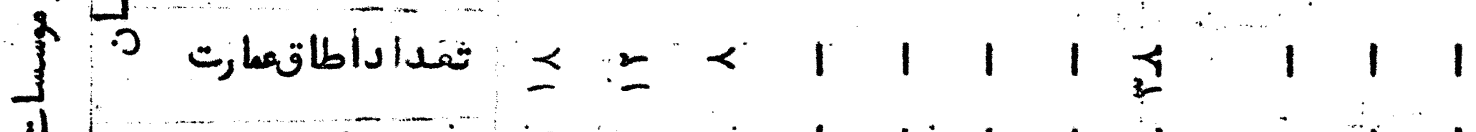

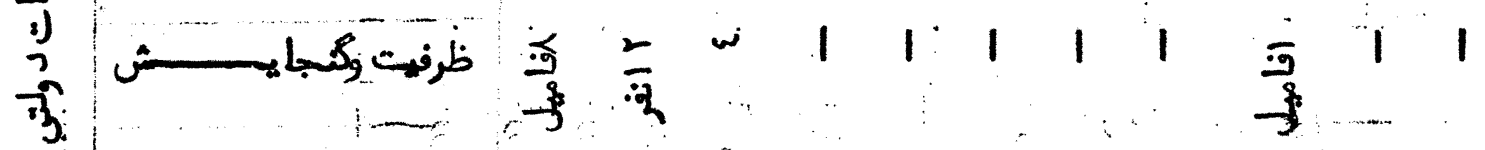

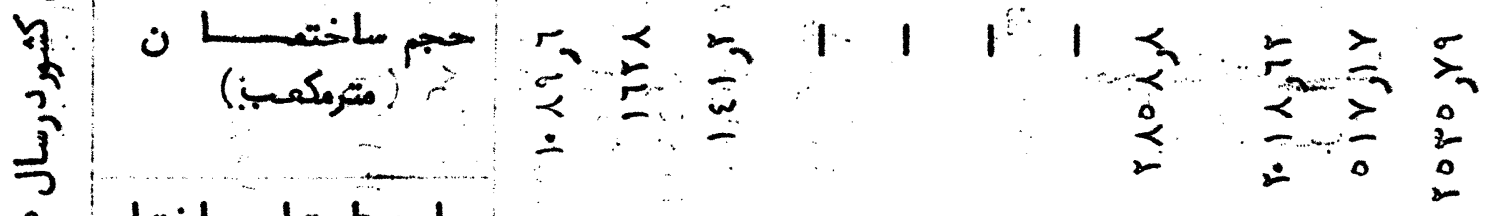

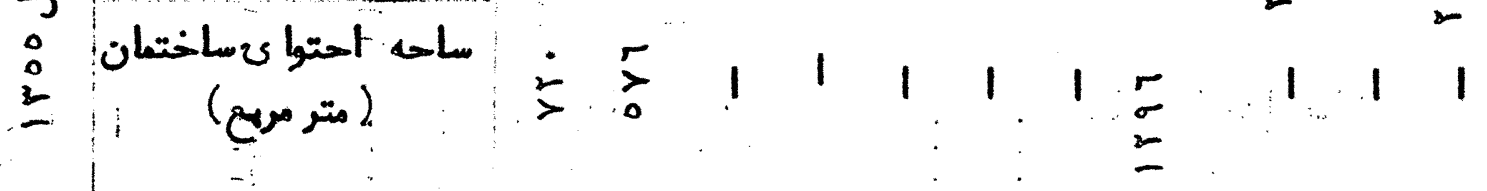

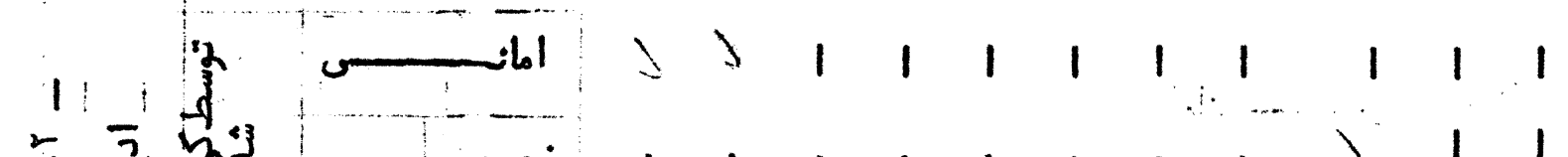

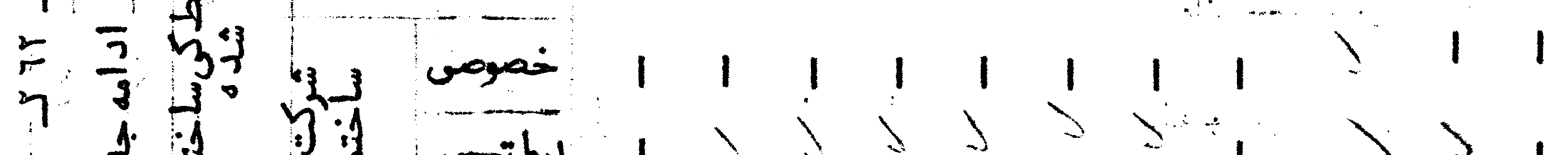

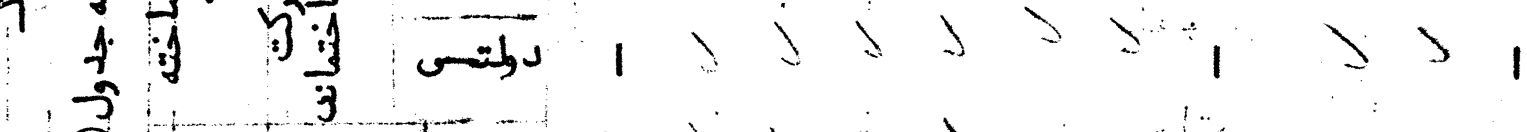

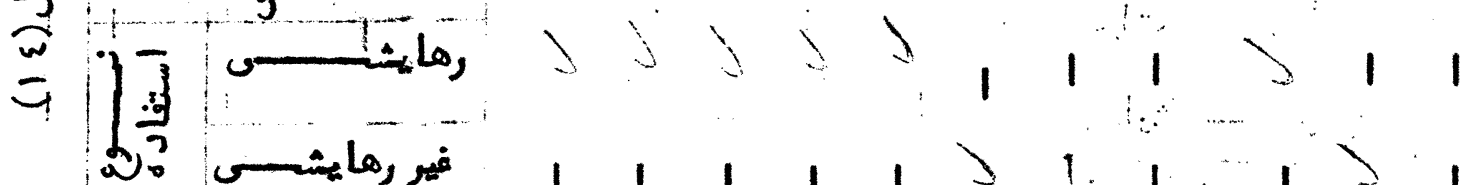




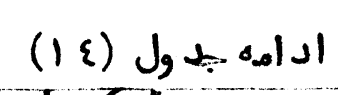

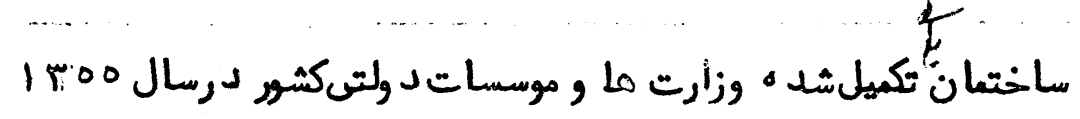

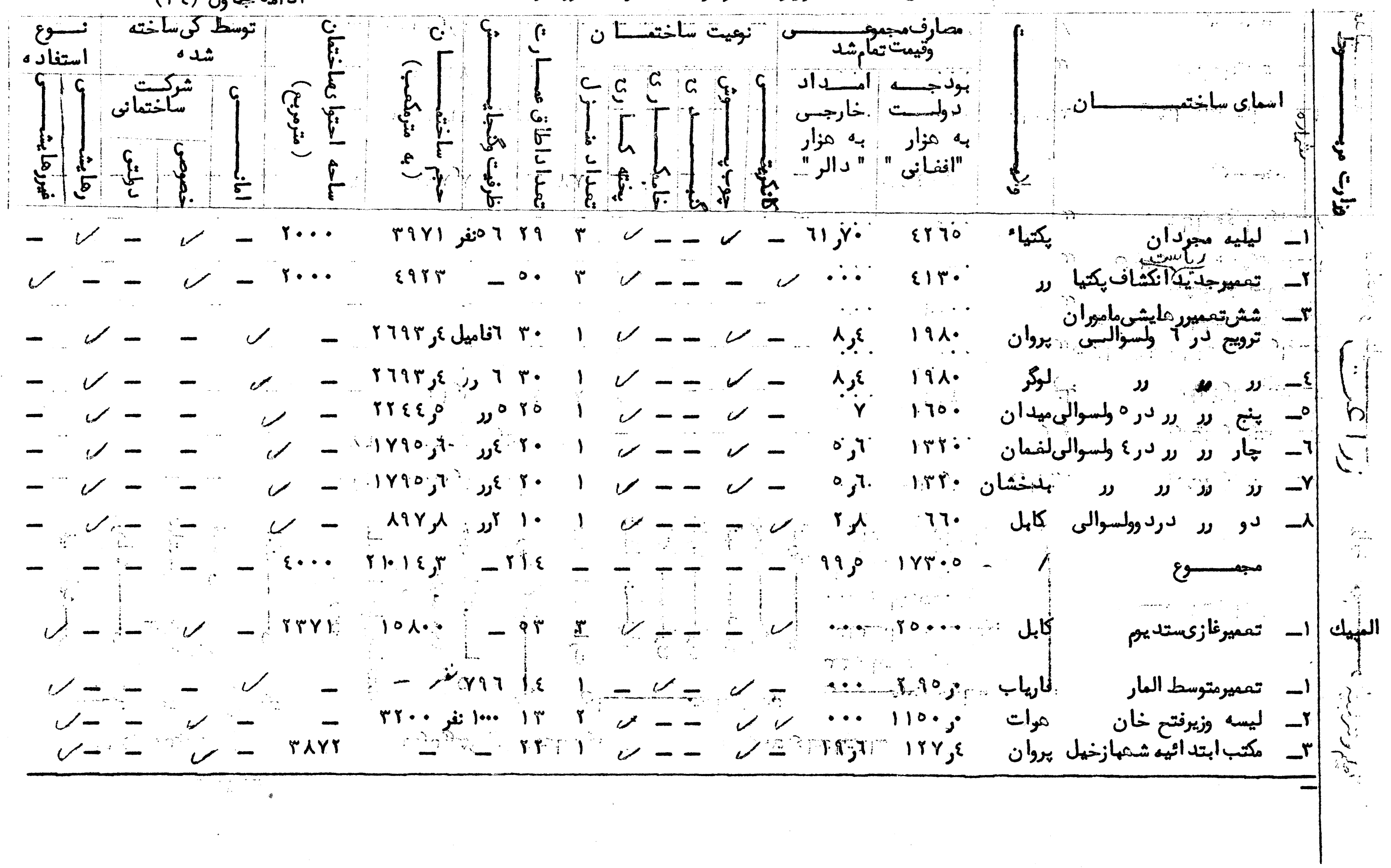




\section{$-r 78$}

ادامه جدول(ع أن (1)

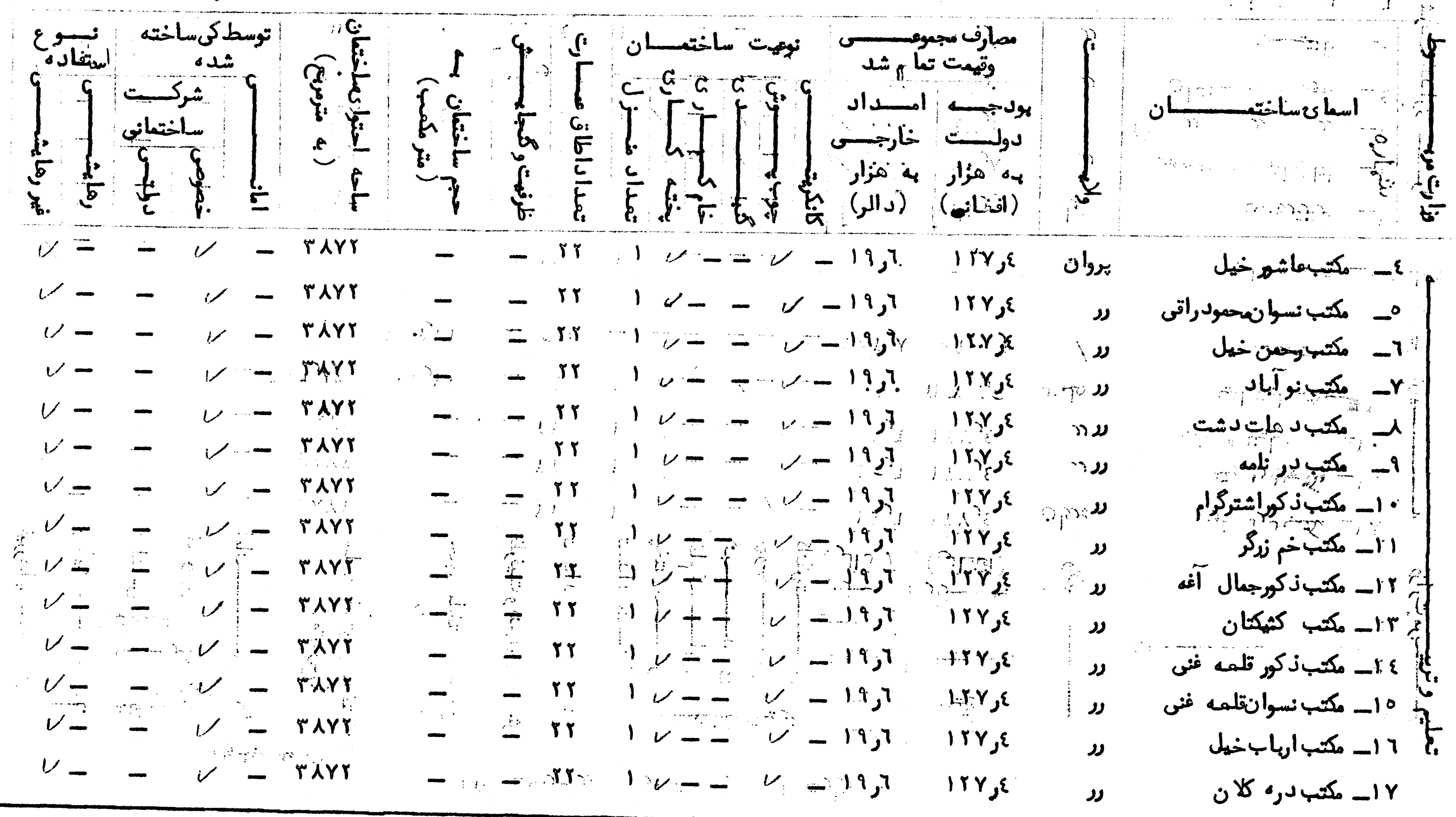

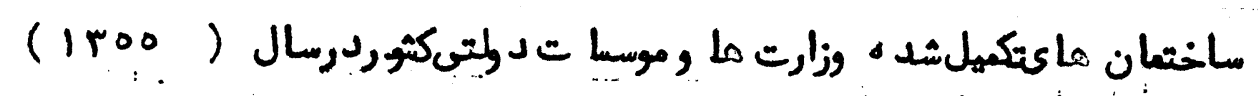

-

$-$

$-$$$
-1 .
$$ 
ادامه جذول (ع) (1) (1)

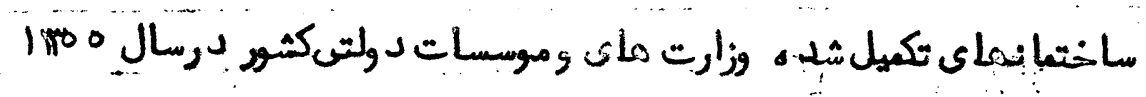
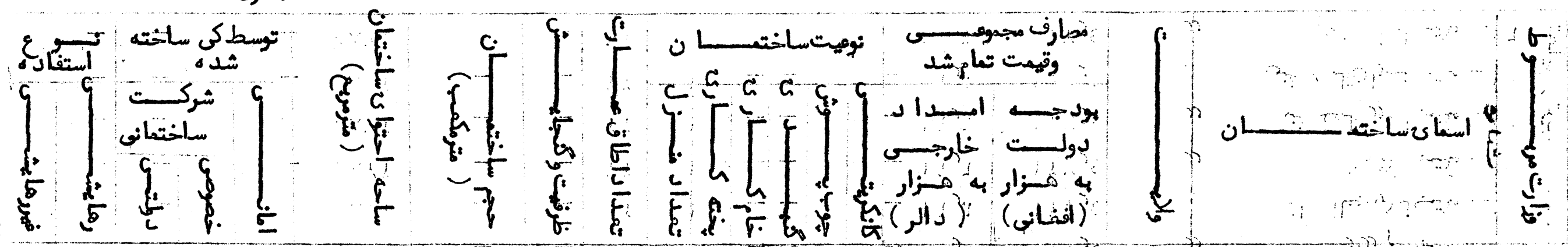

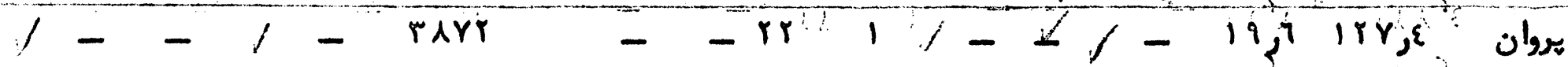

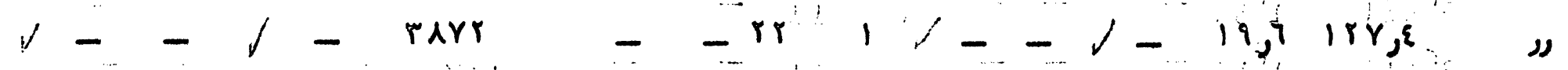

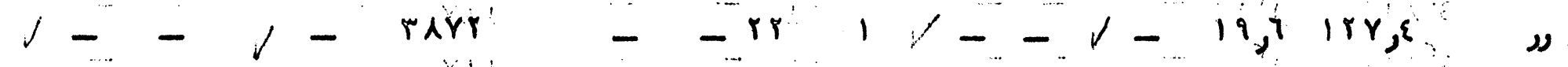

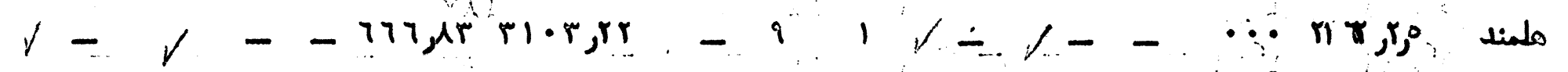

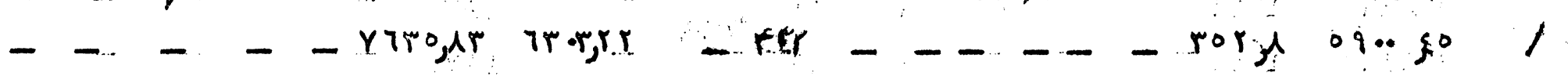

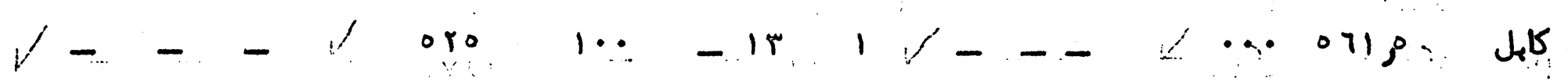

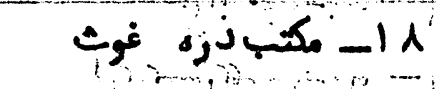
$\frac{1}{2}$

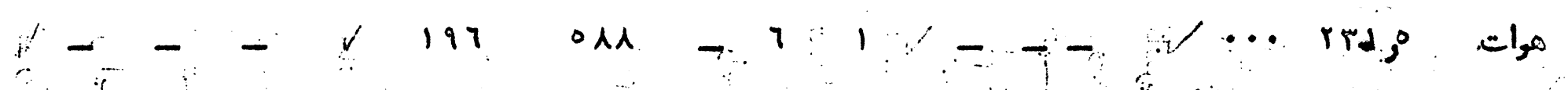

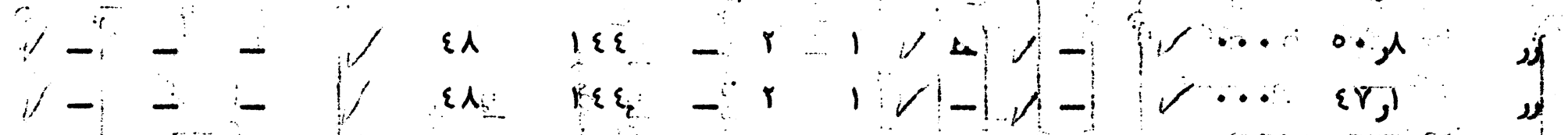

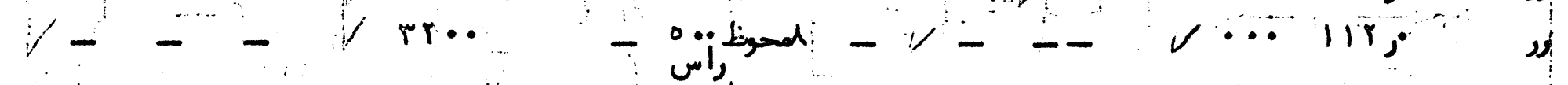

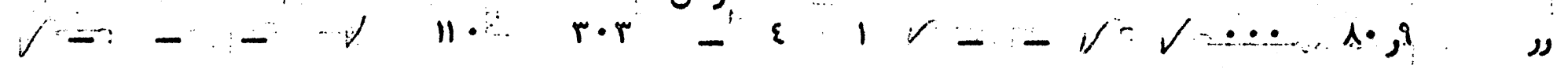

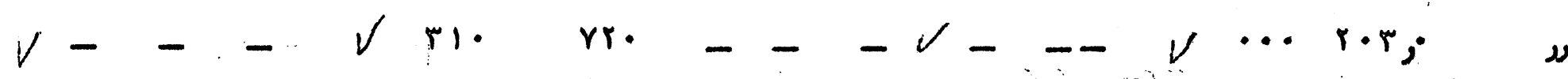

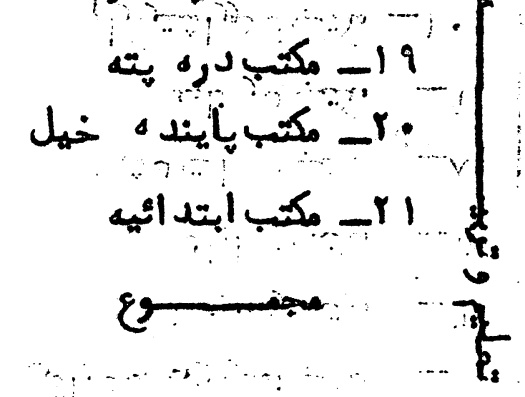

تجارتت ا- تمبيرتشنبابي

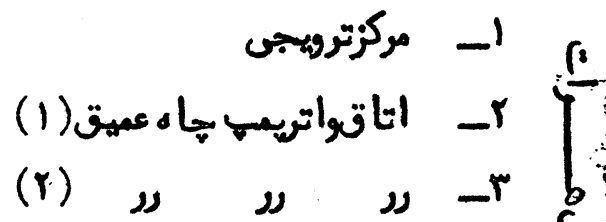
ع - حونغسلكوسفندان

-

ד 
- r7

اد امه جدول (ع آن ()

ساختمانجان ثكيل شتد ه وزارت ما وموتسات دولتى كثودرسال 1100

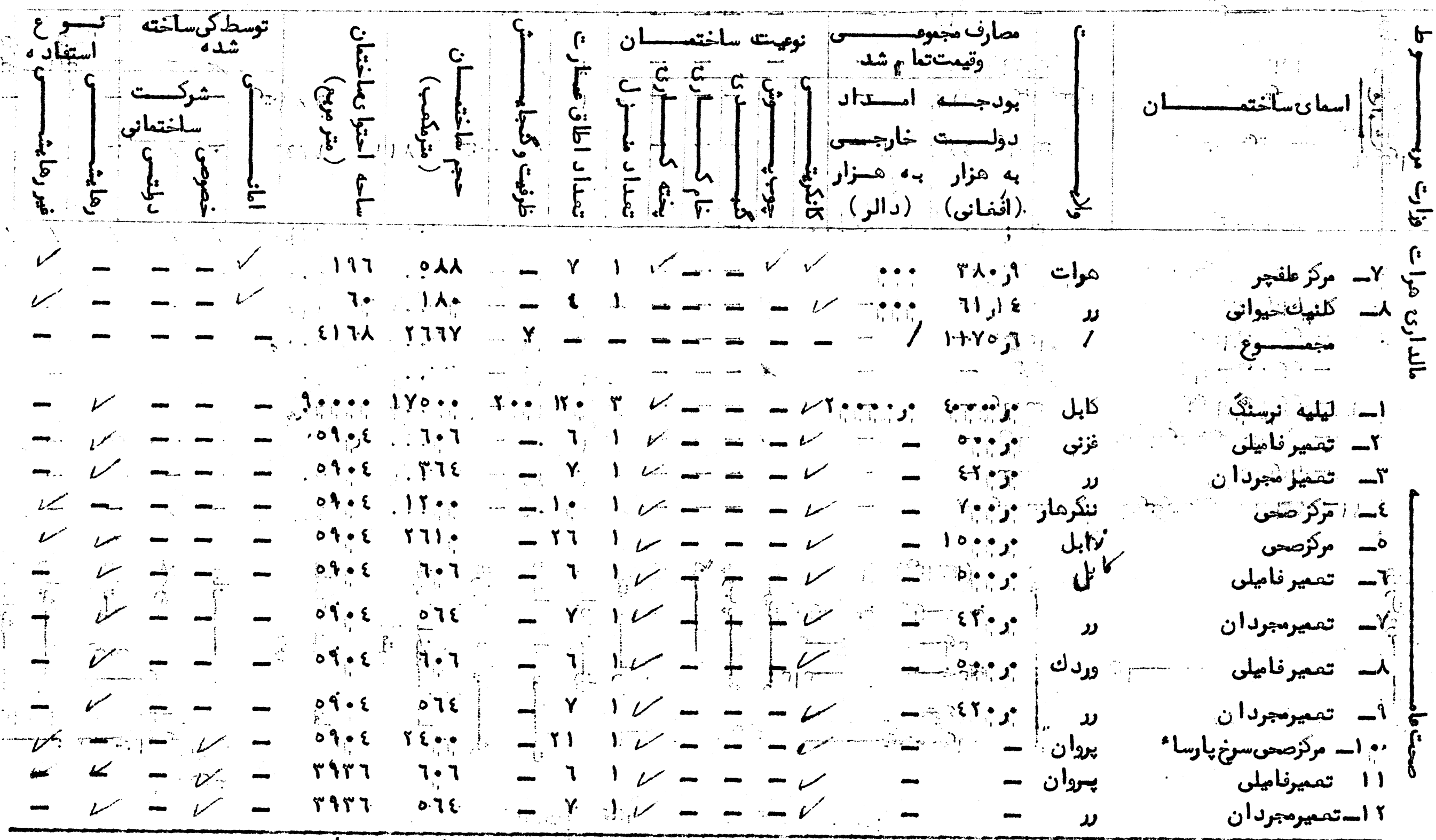



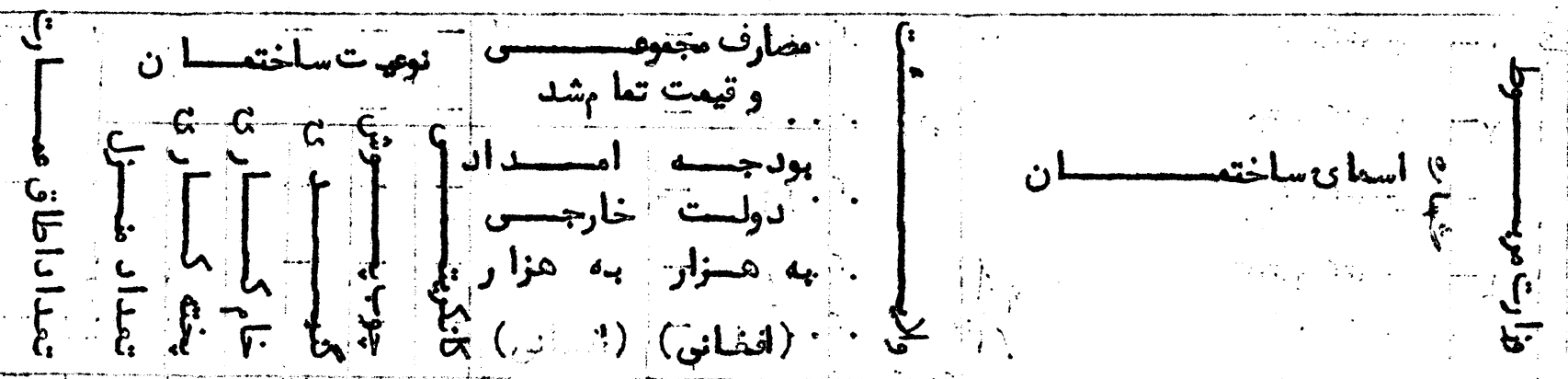

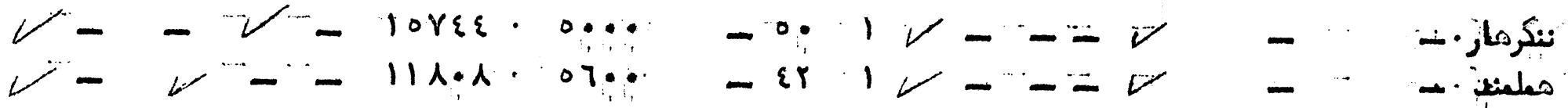

$$
\begin{aligned}
& V-V-\text { - } \\
& \checkmark-V-\text { - } \\
& \text { V- }
\end{aligned}
$$

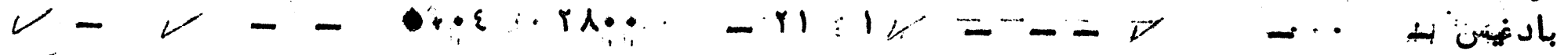

$$
\begin{aligned}
& \text { V- }
\end{aligned}
$$

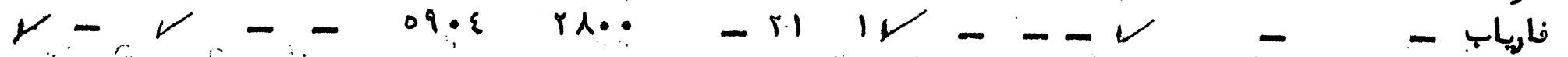

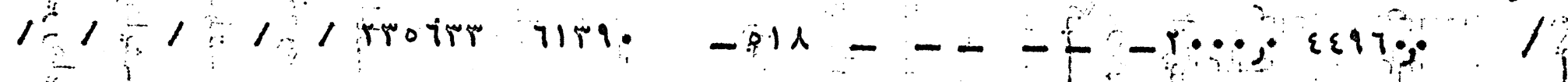

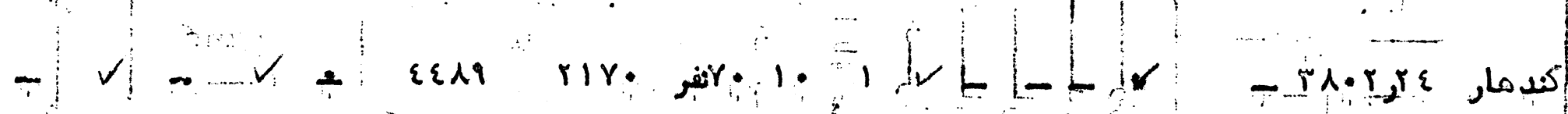

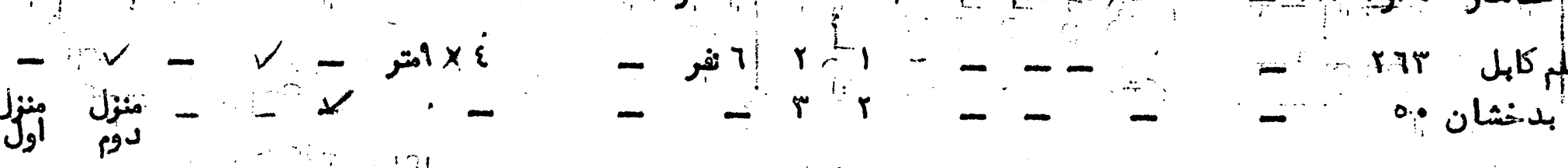

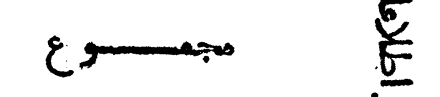




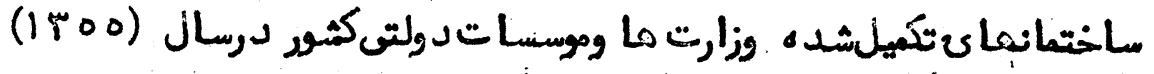

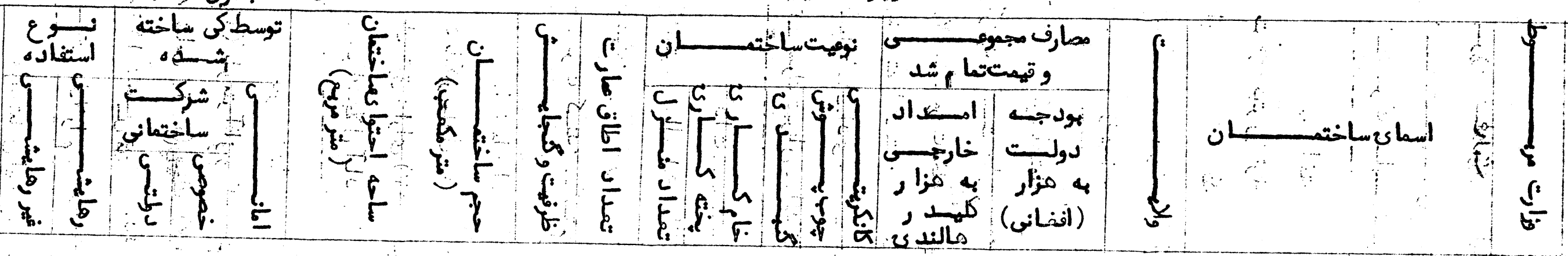

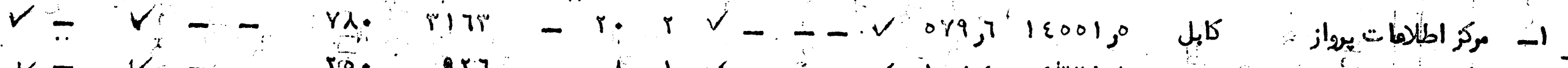

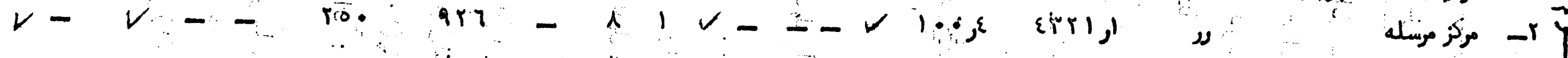

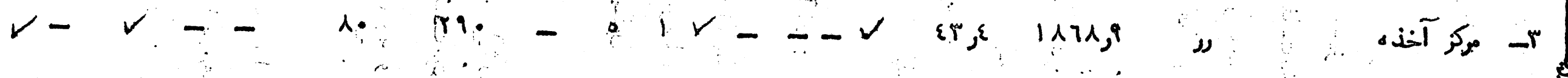

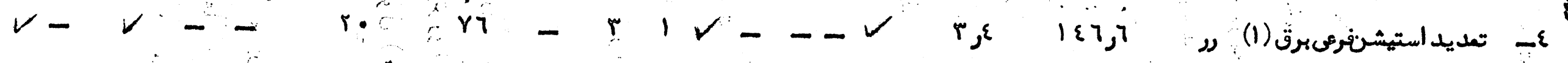

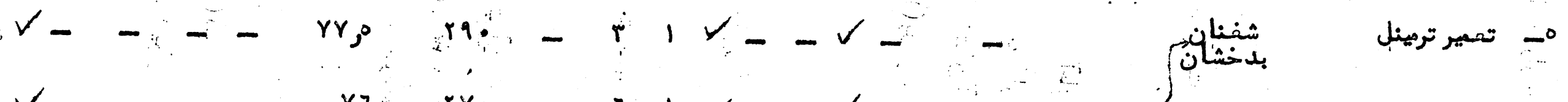

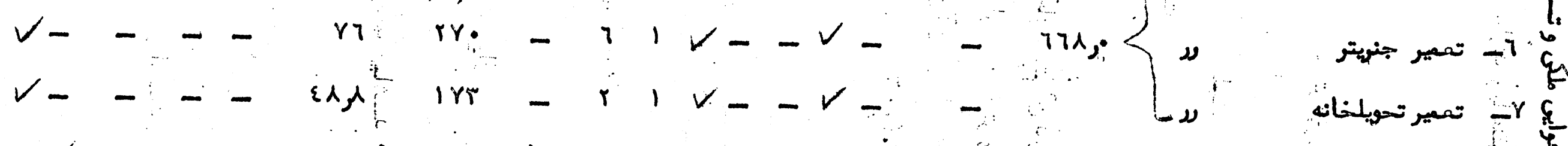

$$
\begin{aligned}
& \text { - } \checkmark-\text { - - ro }
\end{aligned}
$$

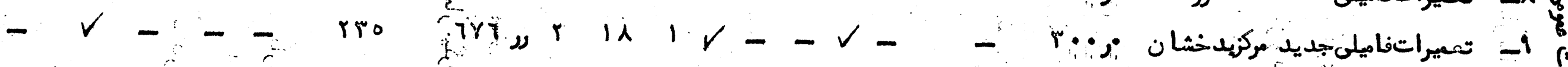

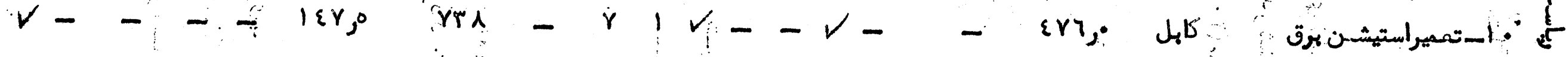

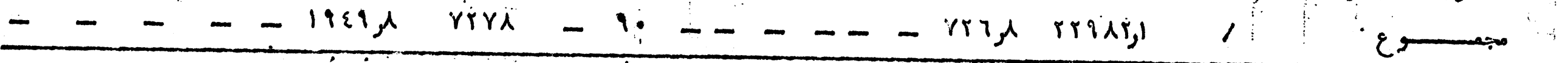




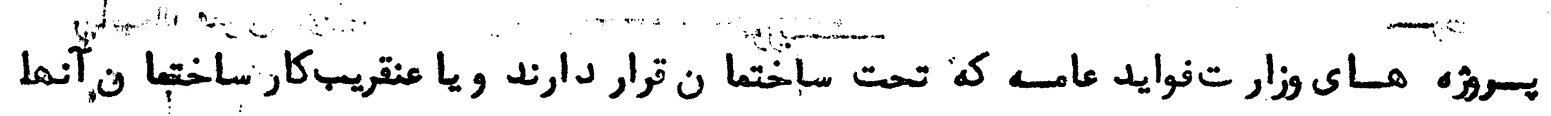

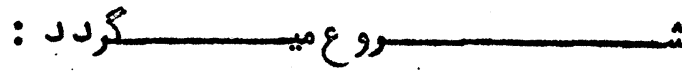

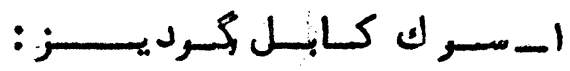

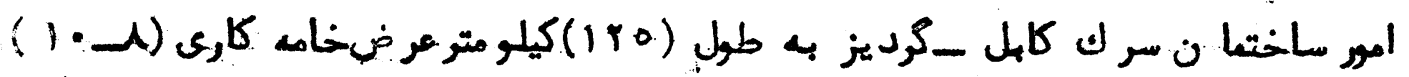

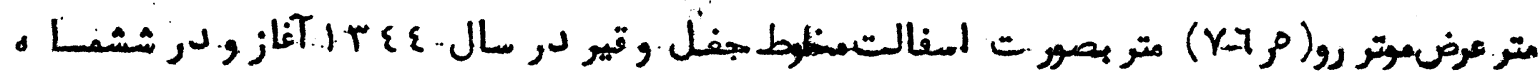

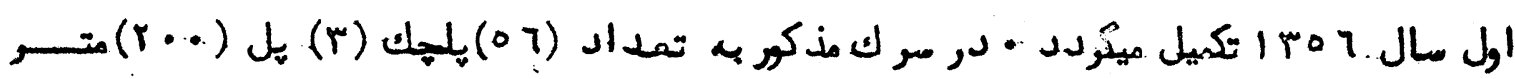

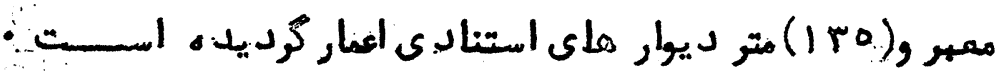
r

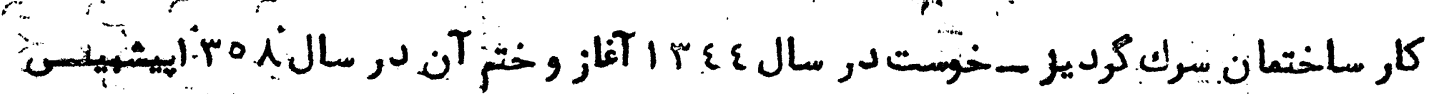

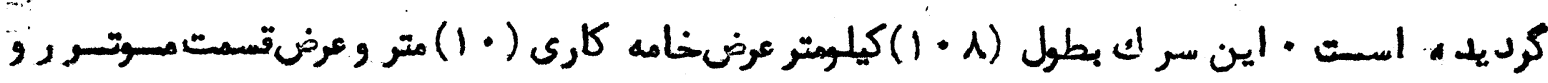

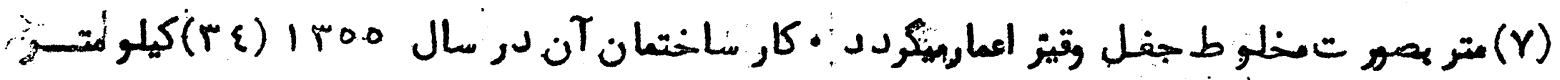

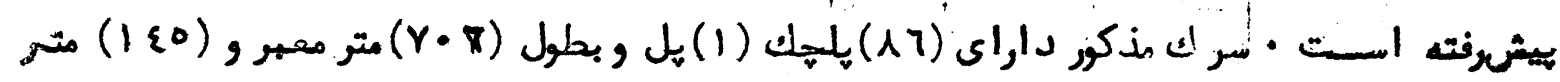

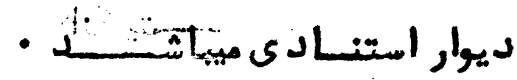

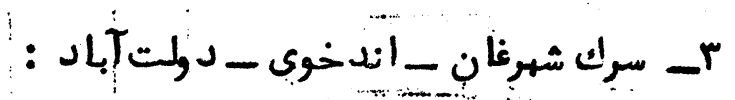

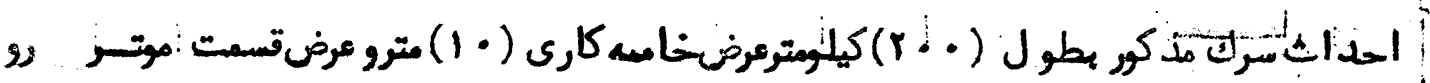

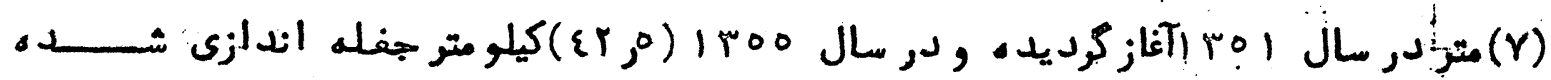

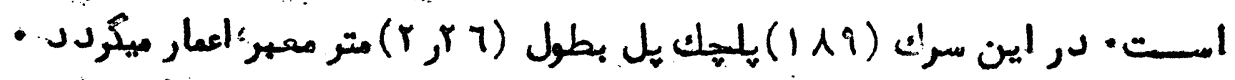

$$
\text { : }
$$

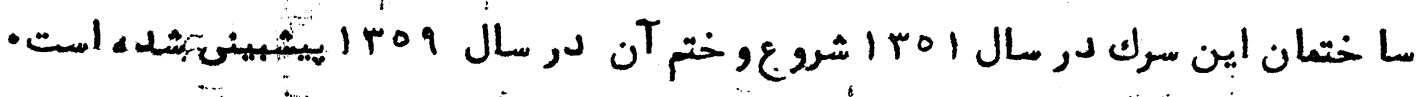

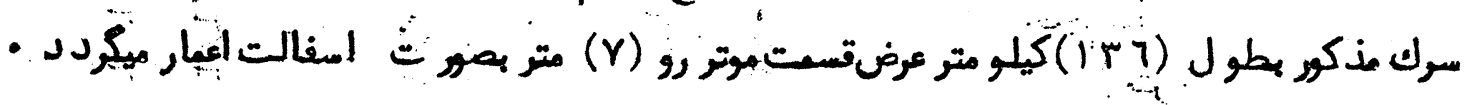

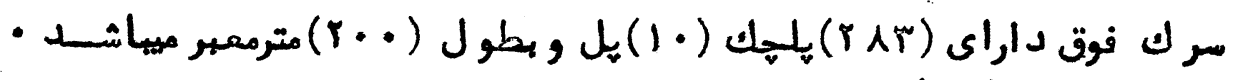

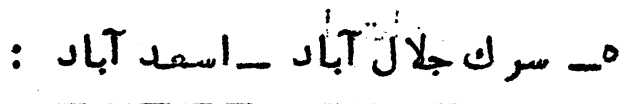

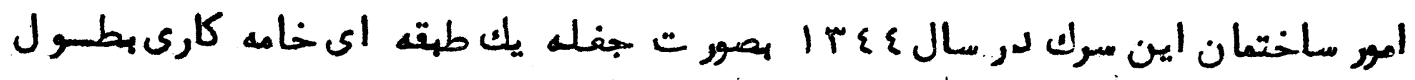

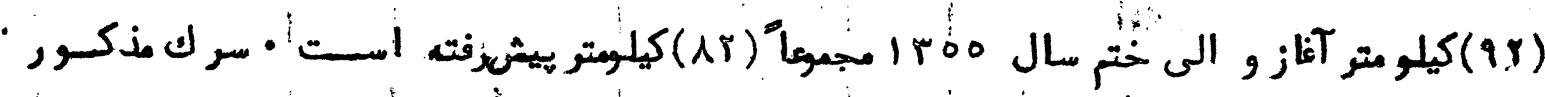

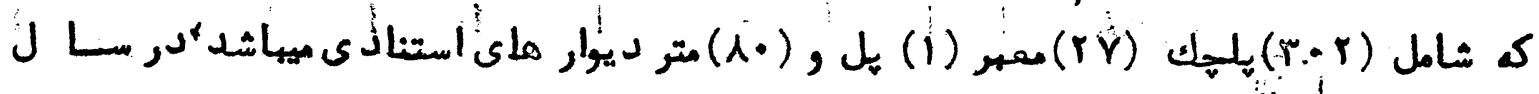
- 1 ا

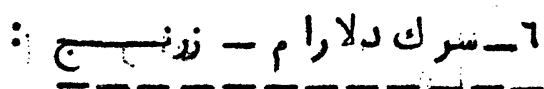

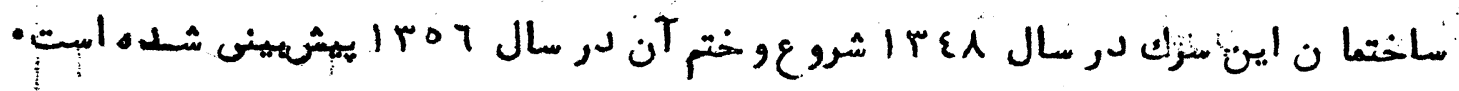




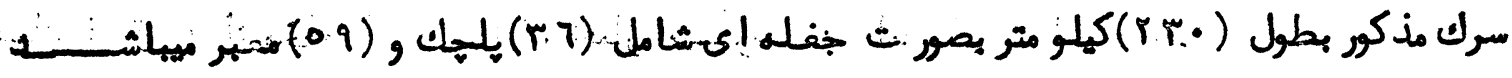

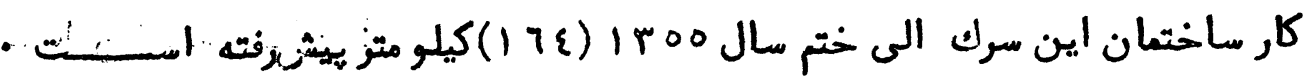

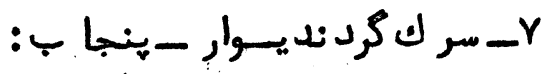

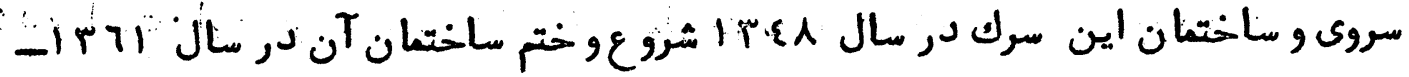

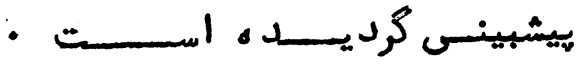

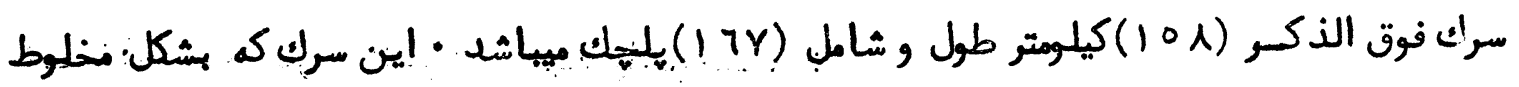

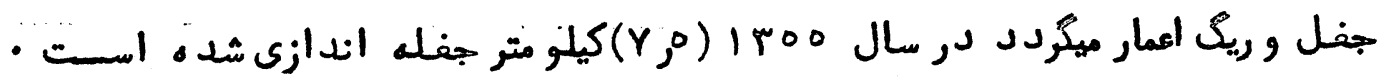

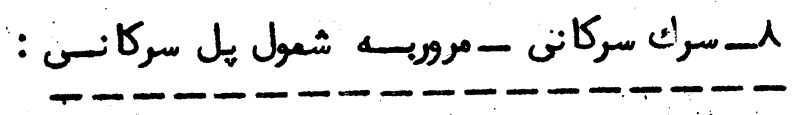

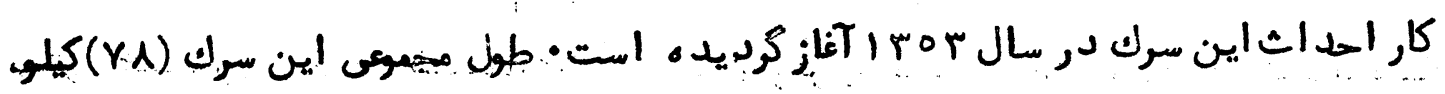

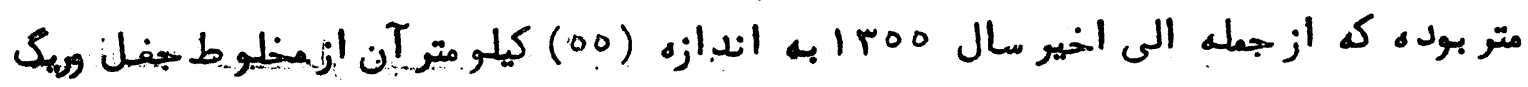

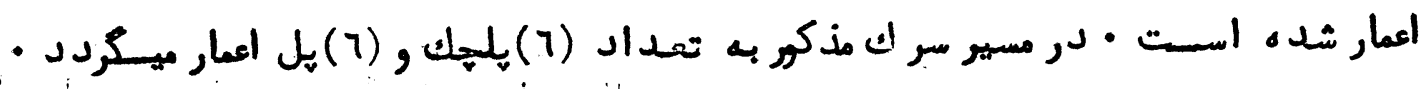

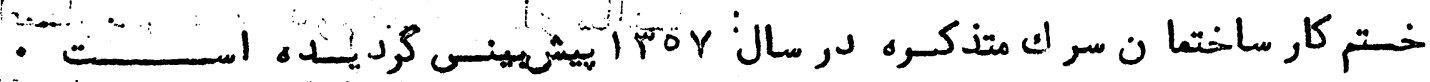

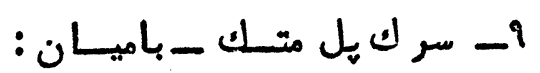

\section{1:}

امور سروى و مدالمـات اتتصادي اين سر الب تكميل وكار سياختمان آن تا كنو ن آغاز نكرد يسـده.

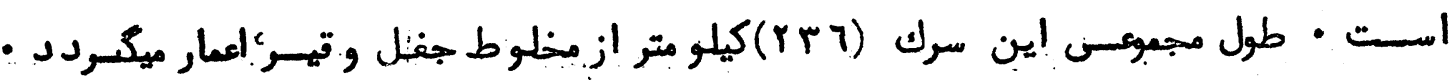

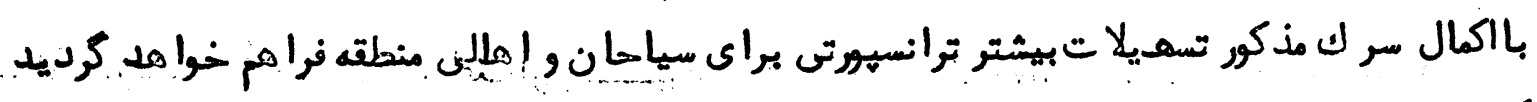

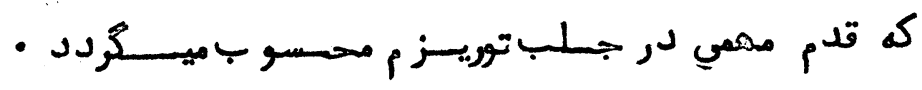
:

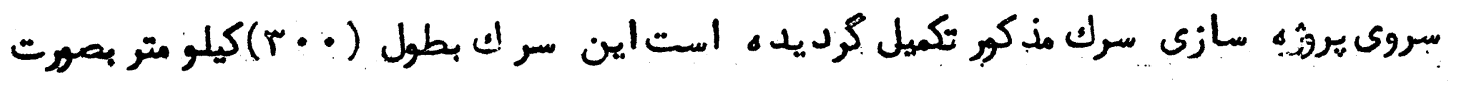

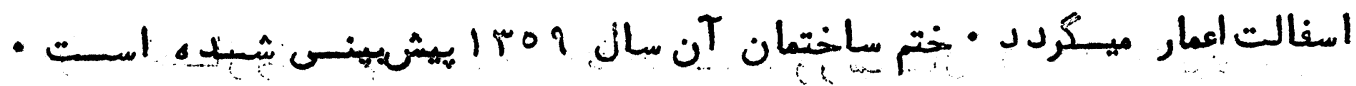

$$
\text { 11 }
$$

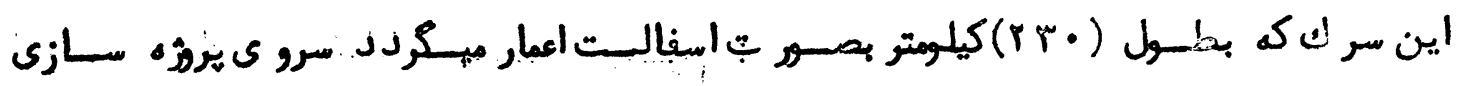

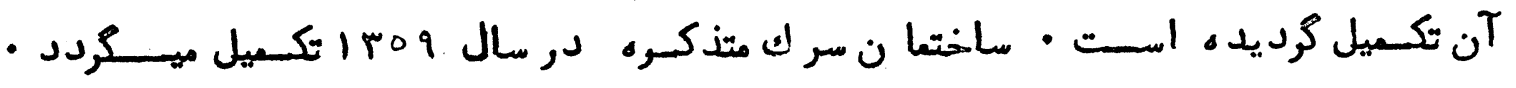

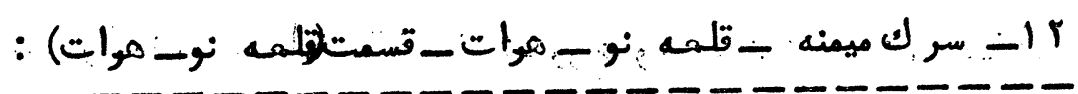

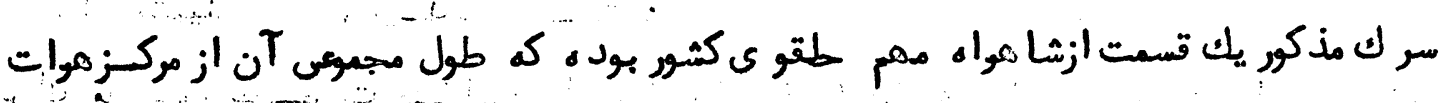

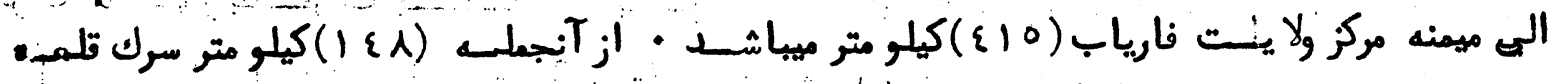

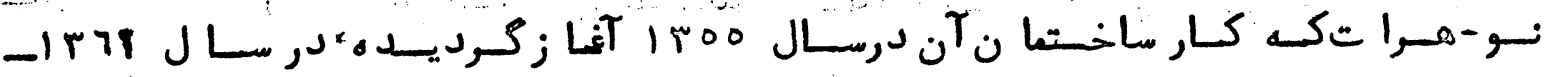

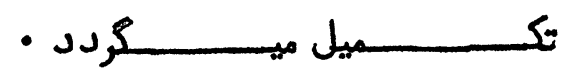




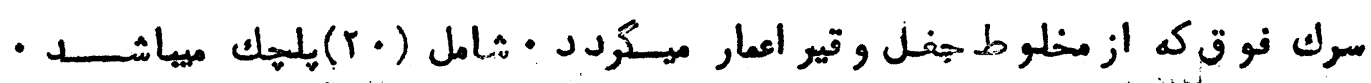

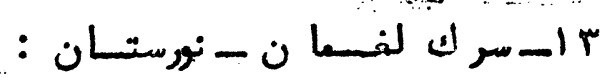

- - - - - - - -

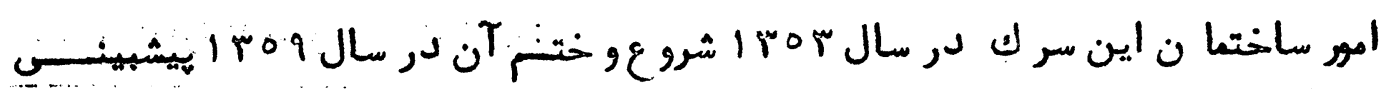

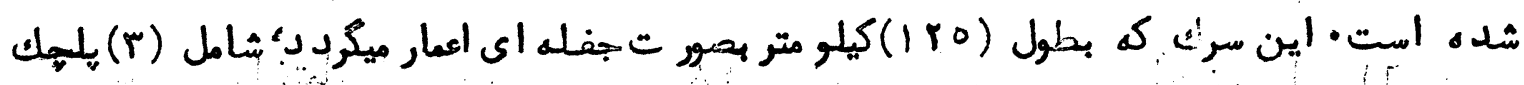

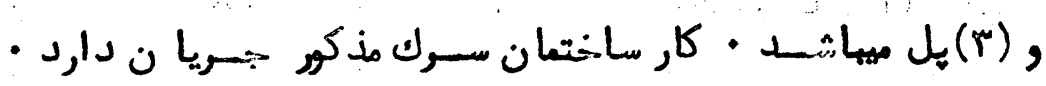

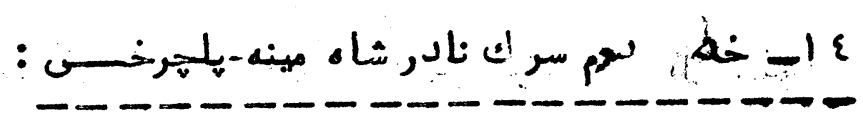

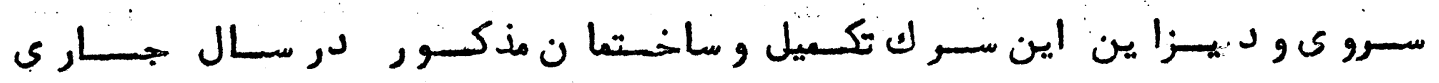

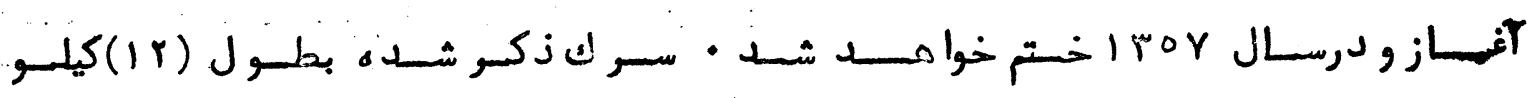

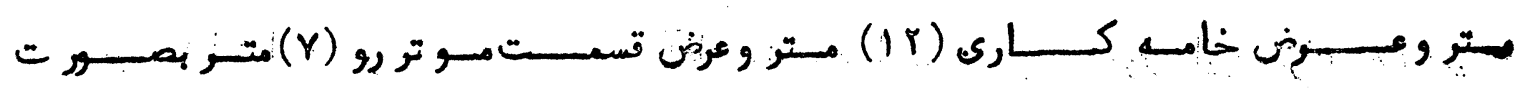

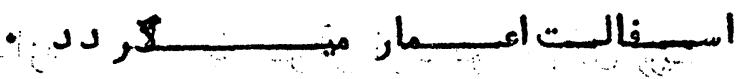

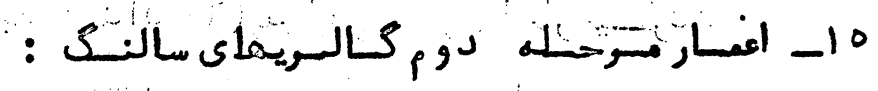

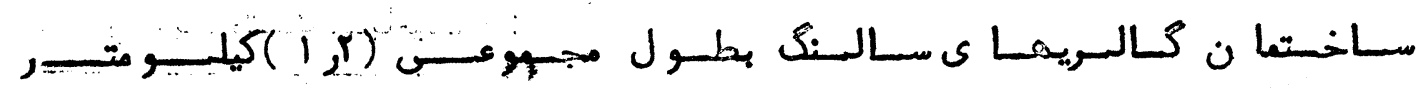

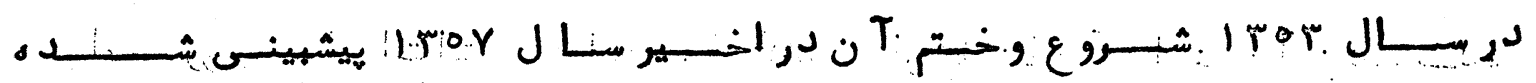

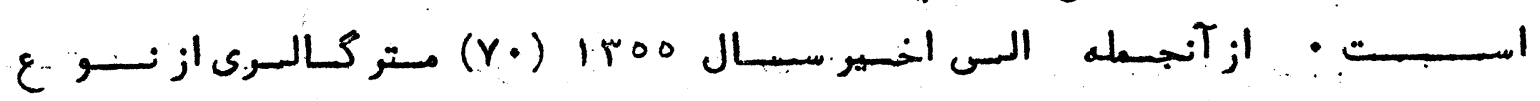

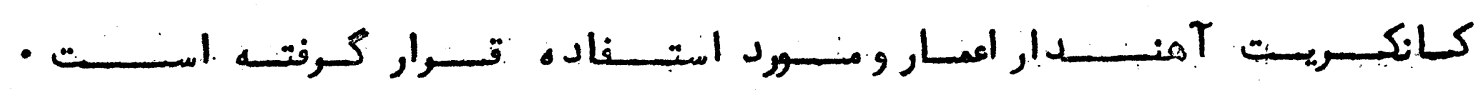
: 17

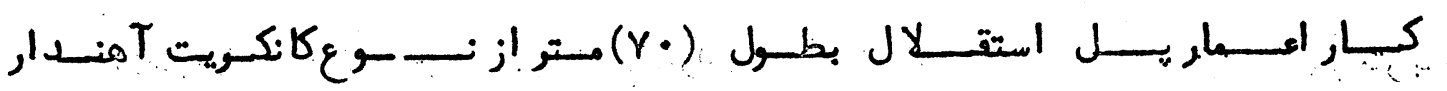

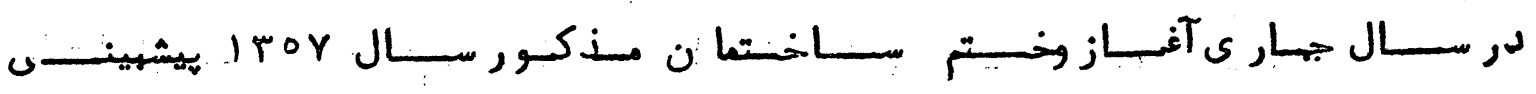

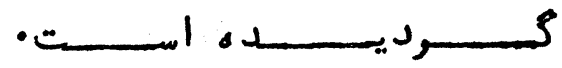

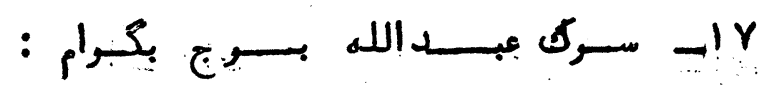

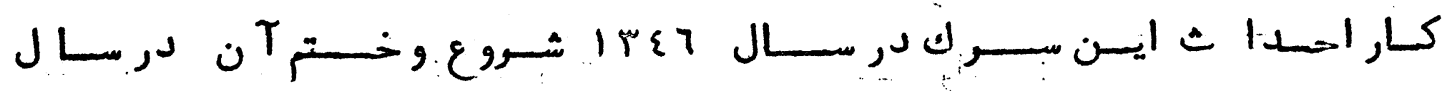

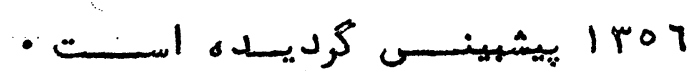

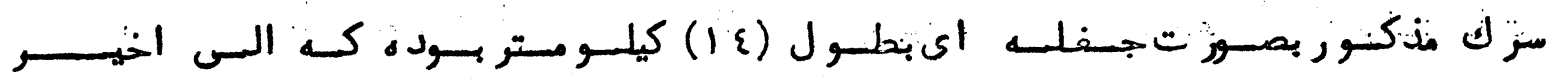

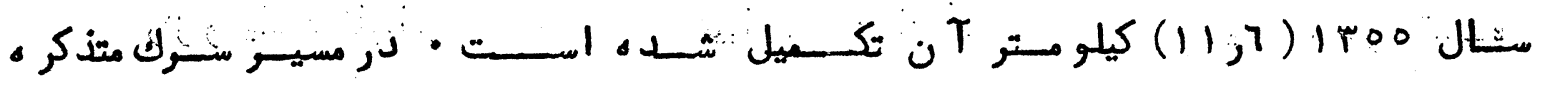

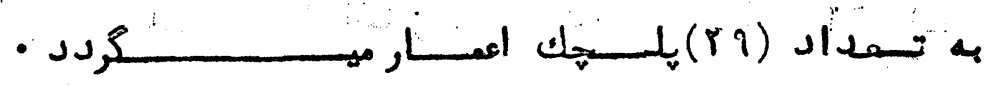




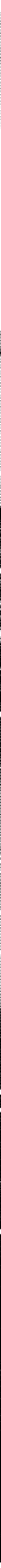




\section{منتخخبى از بيانا ت رمبرانةلابنبها فلمى}

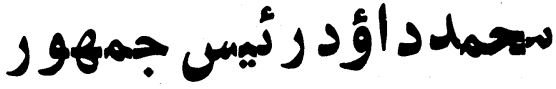

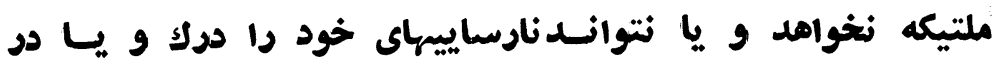

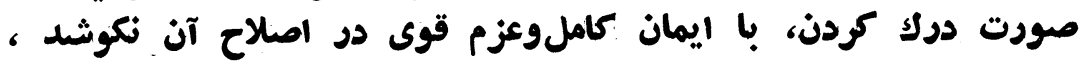

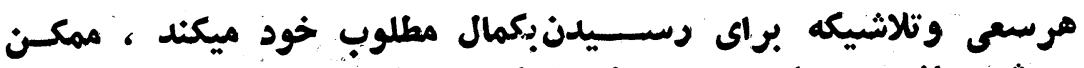

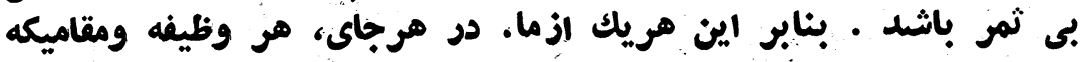

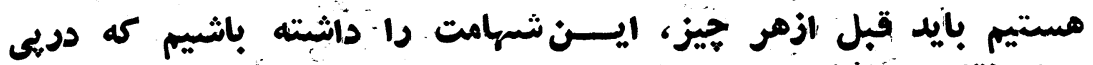

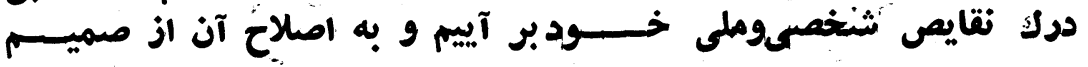

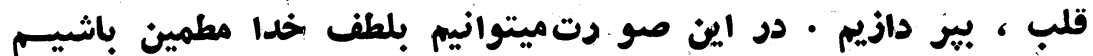

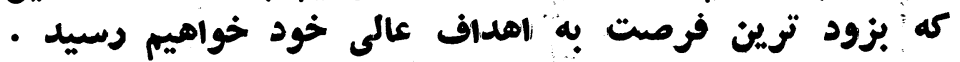

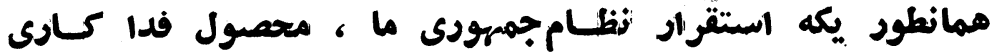

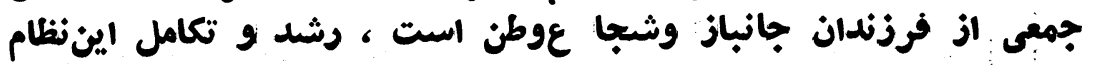

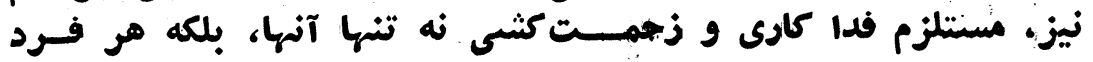

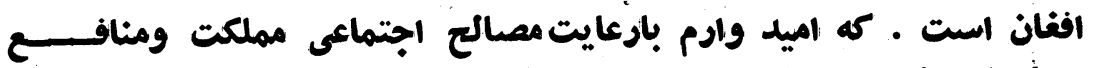

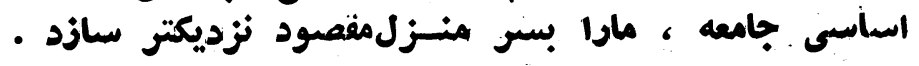

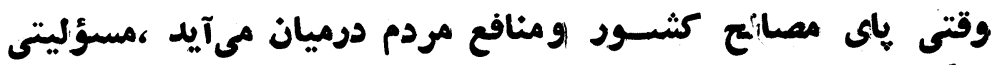

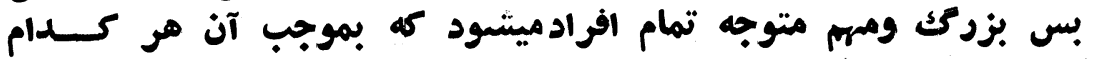

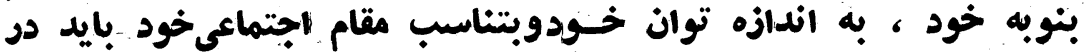

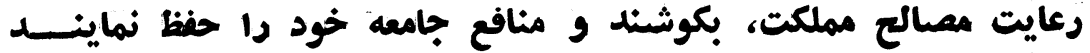

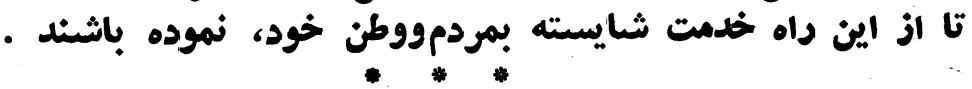

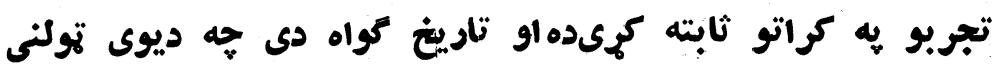

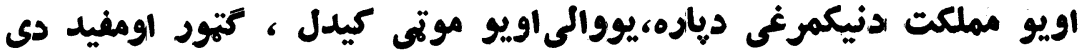

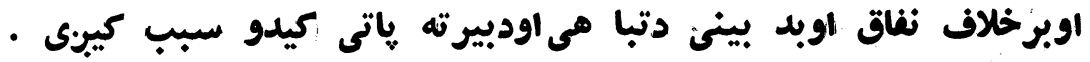

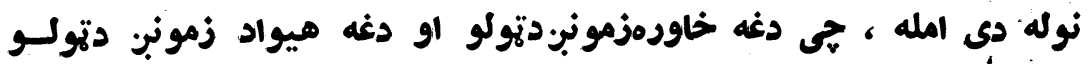

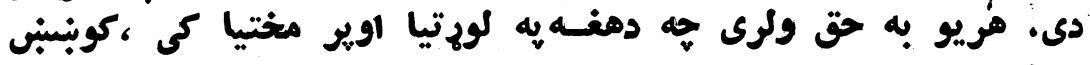

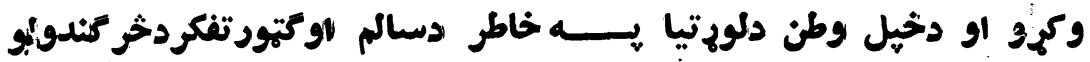


جدول شعاره (10)

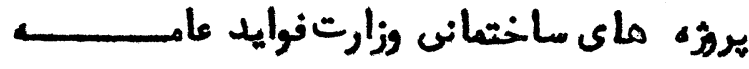

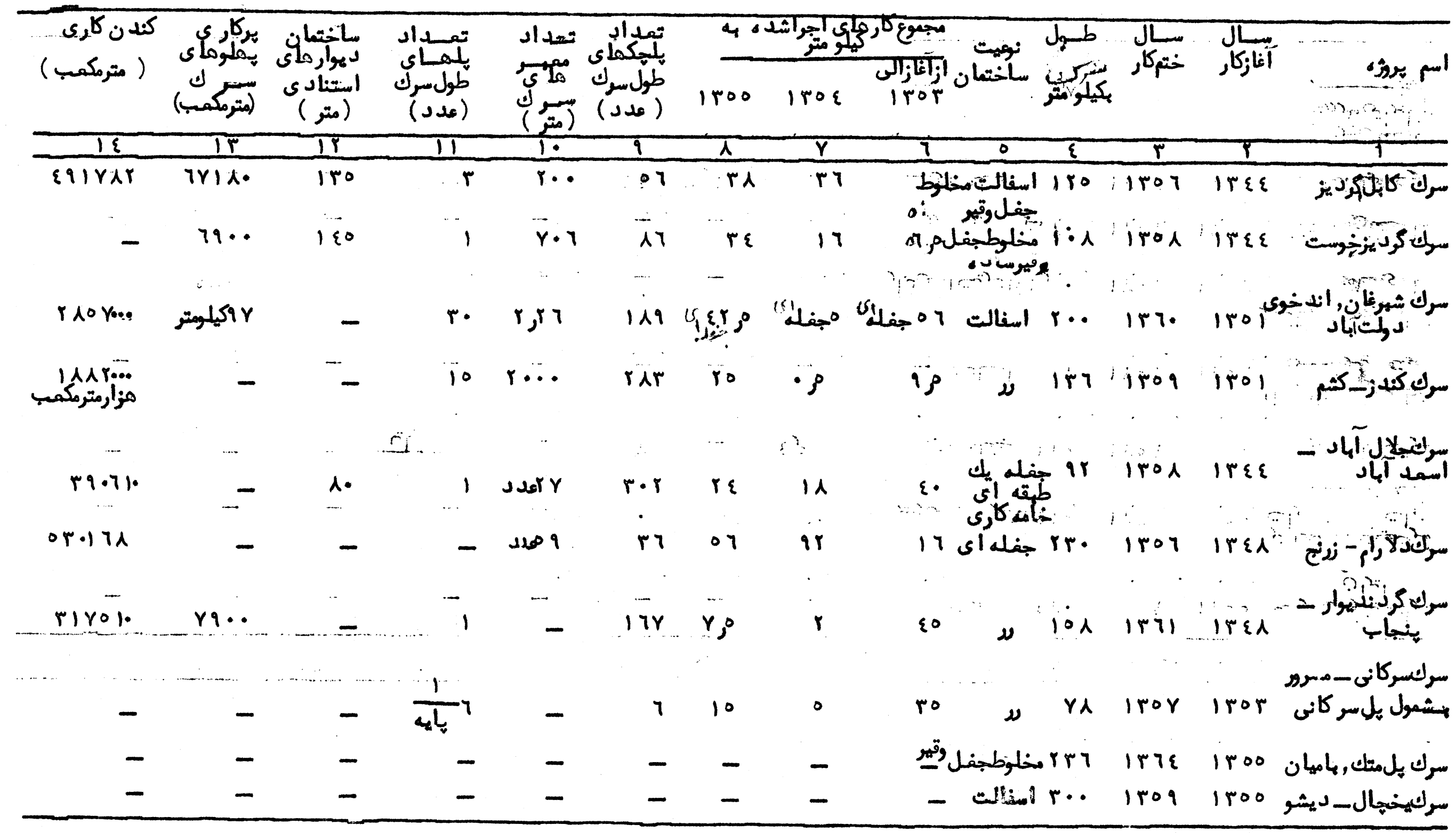




$$
\text { - rvr }
$$

ادـامه يجدول شعاره (10)

\begin{tabular}{|c|c|c|c|c|c|c|c|c|c|c|c|c|}
\hline $1 \varepsilon$ & Tr & $T r$ & 11 & & $1 \cdot$ & 9 & 1 & $Y$ & 7 & $\varepsilon$ & $\bar{r}$ & $\begin{array}{r} \\
\end{array}$ \\
\hline- & $\because$ & - & & - & - & - & - & - & أسفالت - & $r r^{\circ}$ & 1rog: & 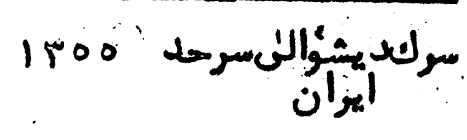 \\
\hline$\therefore$ & - & - & & - & $\because$ & $r \cdot$ & - & - & خلمرط جفل وقير & \& $\left\{10^{\circ}\right.$ & $|r+1|$ & 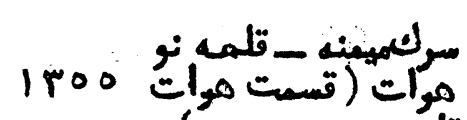 \\
\hline- & - & - & $\frac{1}{4 !}$ & $r$ & - & $r$ & - & $\varepsilon$ & جفله ائ & iro & 1roq & 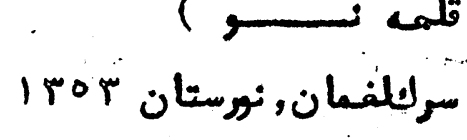 \\
\hline & - & - & & - & - & - & - & - & اسفالت - - & ir & iroy & 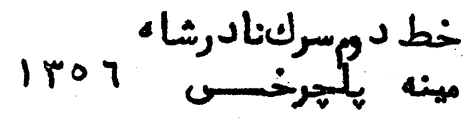 \\
\hline rrsoin & rqur & $\Delta r$. & & - & - & - & - & - & كانكريت آهند ار & $51, \pi$ & iror & 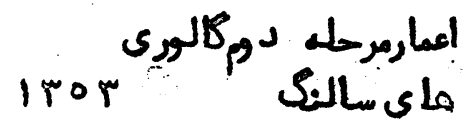 \\
\hline - & - & - & & - & $-\cdot$ & - & - & - & $\nu$ & X. & Inor & 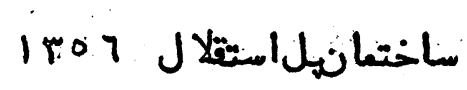 \\
\hline- & n- & - & & - & - & rq & 11,7 & - & جنفه ائ - & $1 \varepsilon$ & irot & 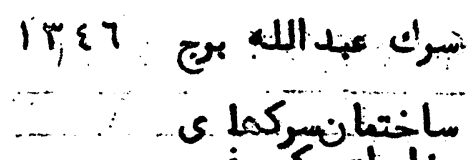 \\
\hline - & $=$ & -21 & i & - & - & - & - & - & - & $18, d$ & $\therefore \quad-$ & 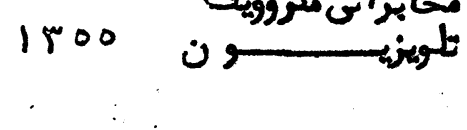 \\
\hline
\end{tabular}


فمـاليتماي ساختما نى رياستب انكثاف دمبات :

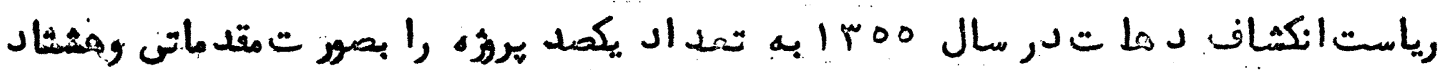

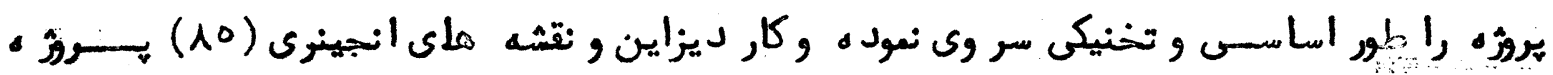

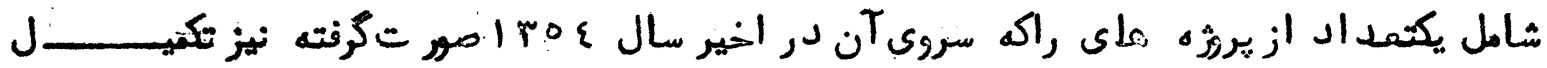

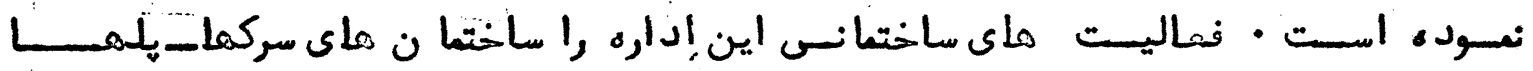

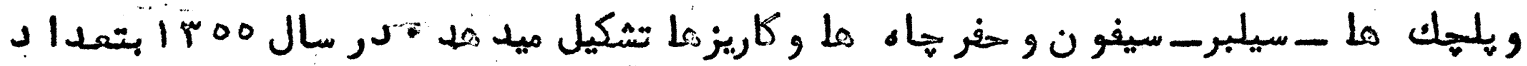

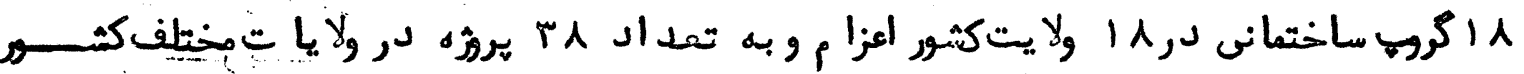

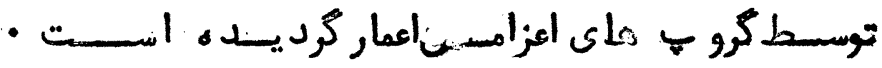

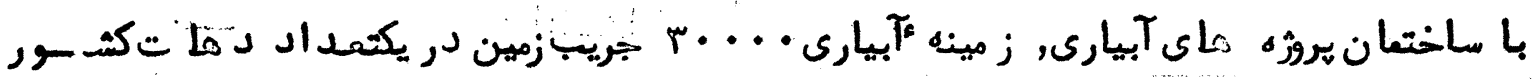

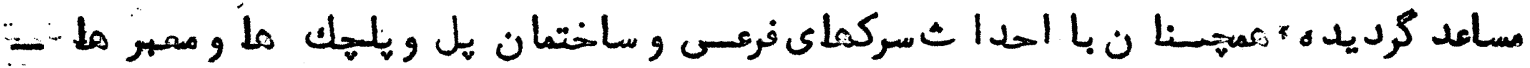

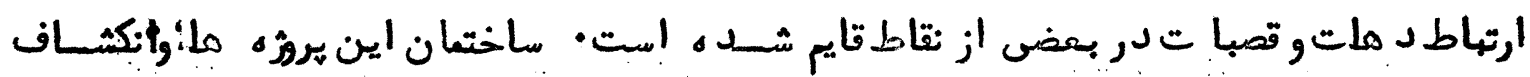

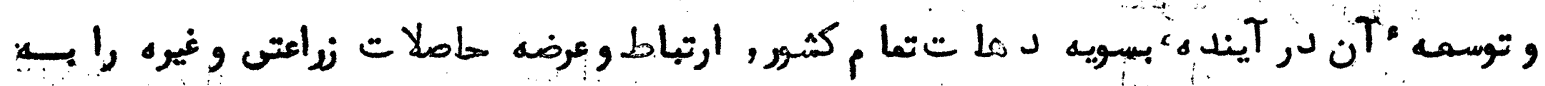

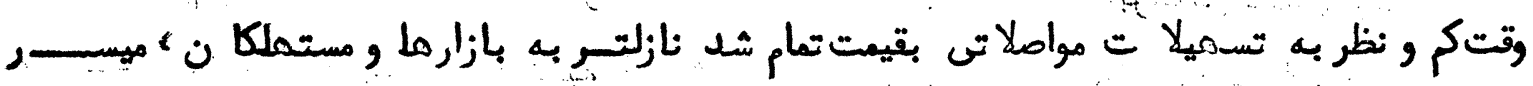

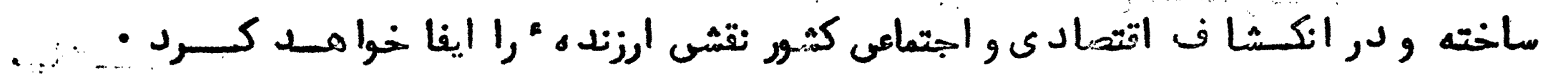

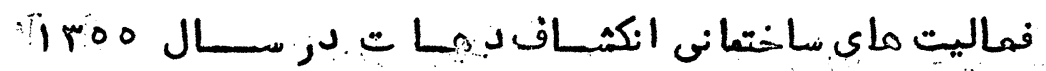

وإبحل مقياس rq.r६r كيلومتر rrtir
irocors

7) 9 หร

Y111

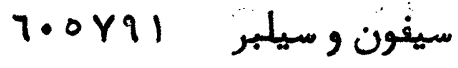

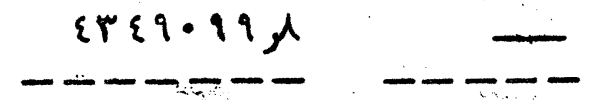

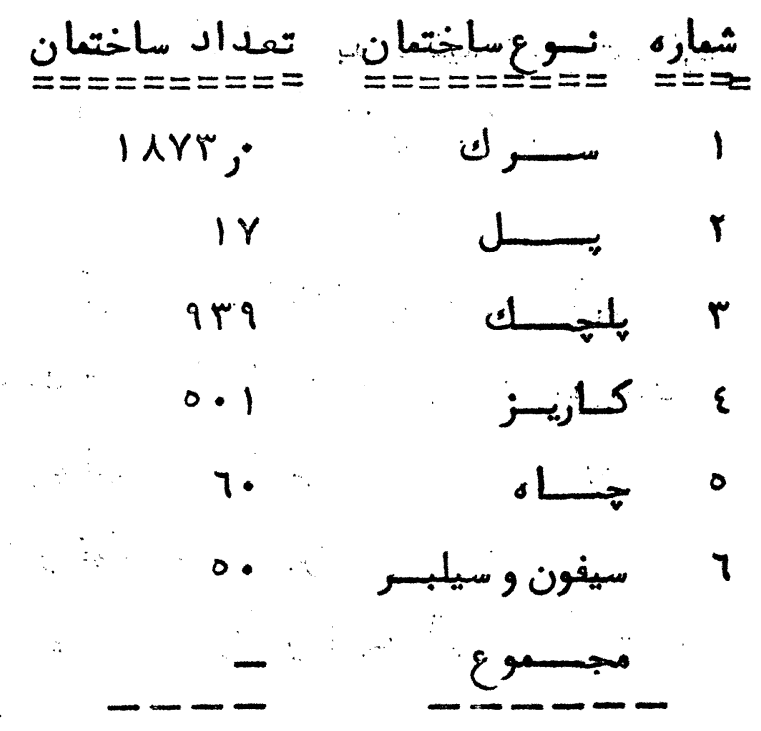

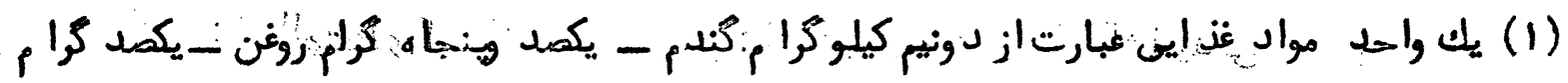

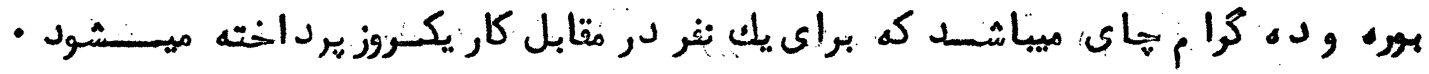




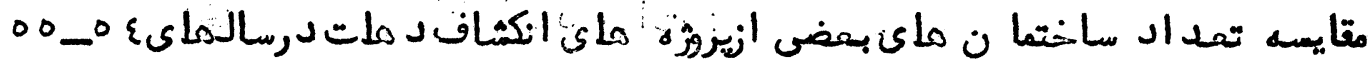

تغير فيصدى سال

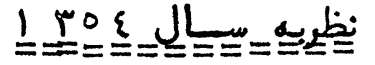

$07 r$

$-0,0$

ن

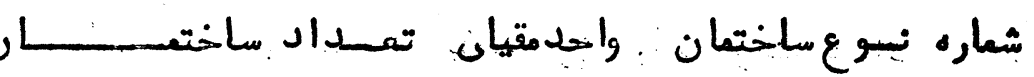

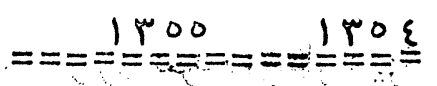

$===:==$

=ニニ=ニ=ニ= = =

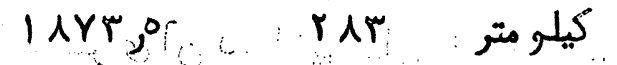

1

r१, 7

$\operatorname{lin}$

11

r

rᄉ, 9

94?

rro

o. $r y$

"إل

هايسه

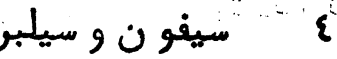

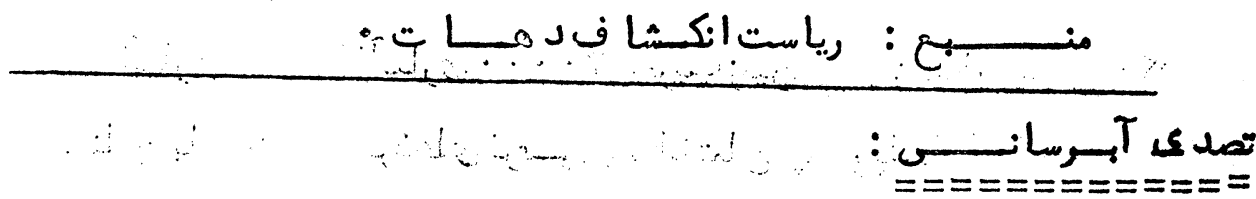

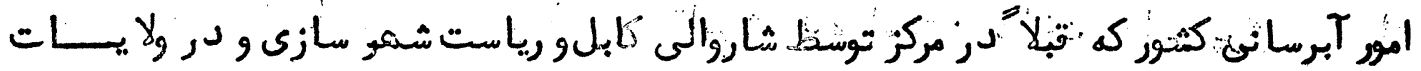

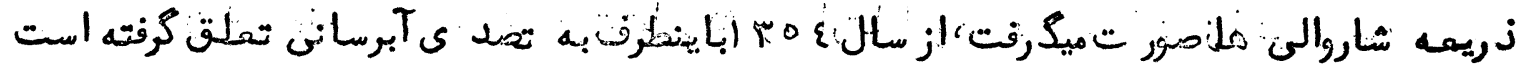

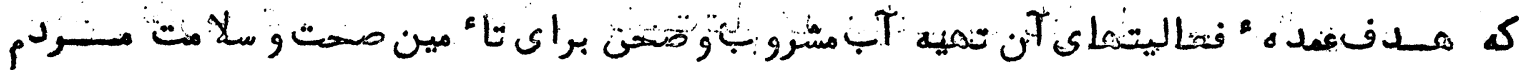

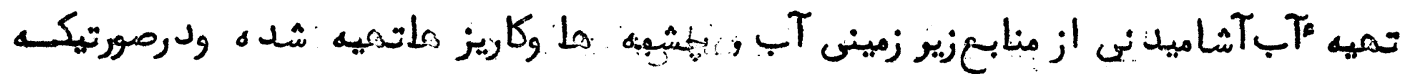

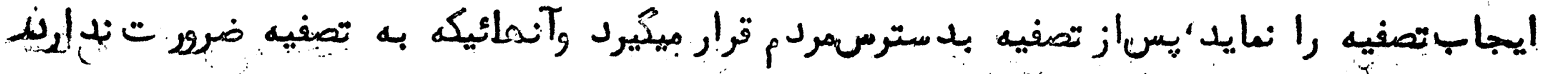

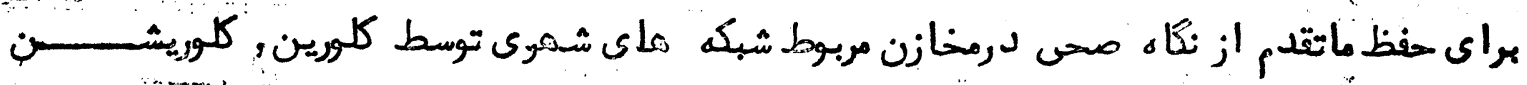

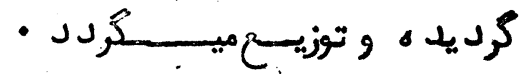

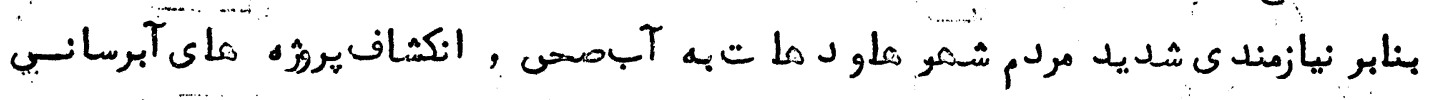

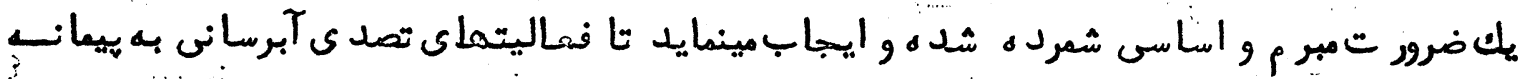

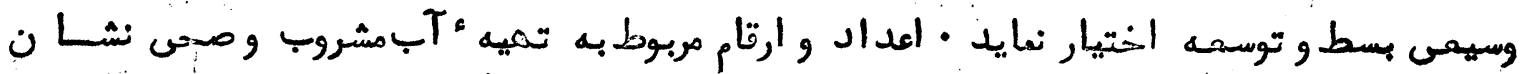

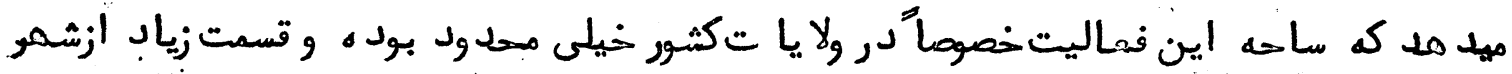

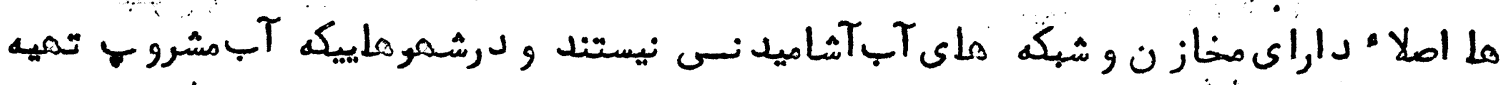

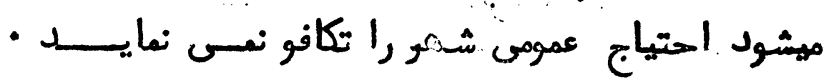

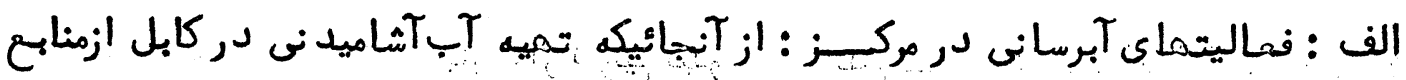

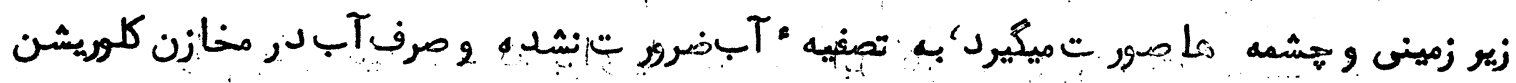

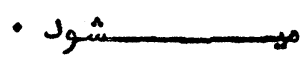

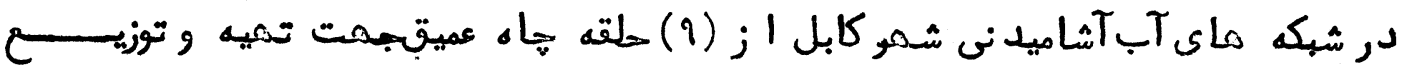

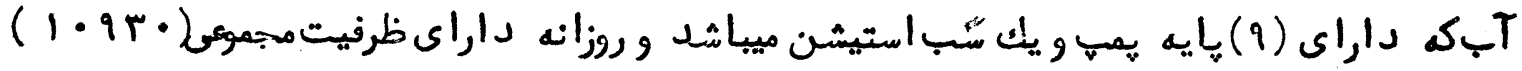

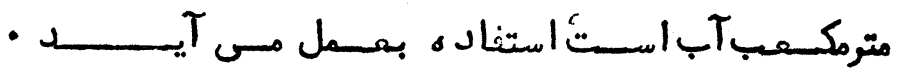


تصدى Tبرسانى براى إنكماف و تمهيه Tباشاميد نى دركابل بروى ماستريلا ن, تقوية شهك

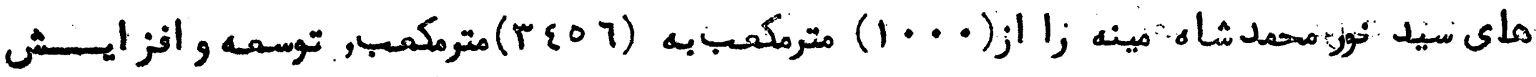

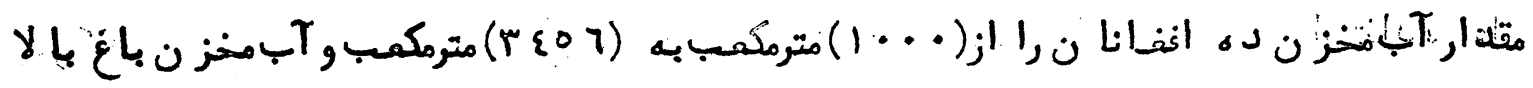

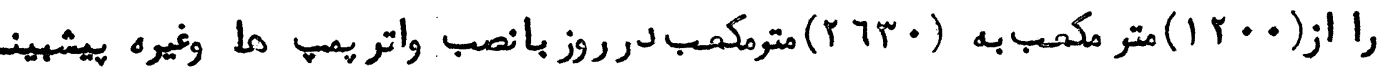
نمسوده المان

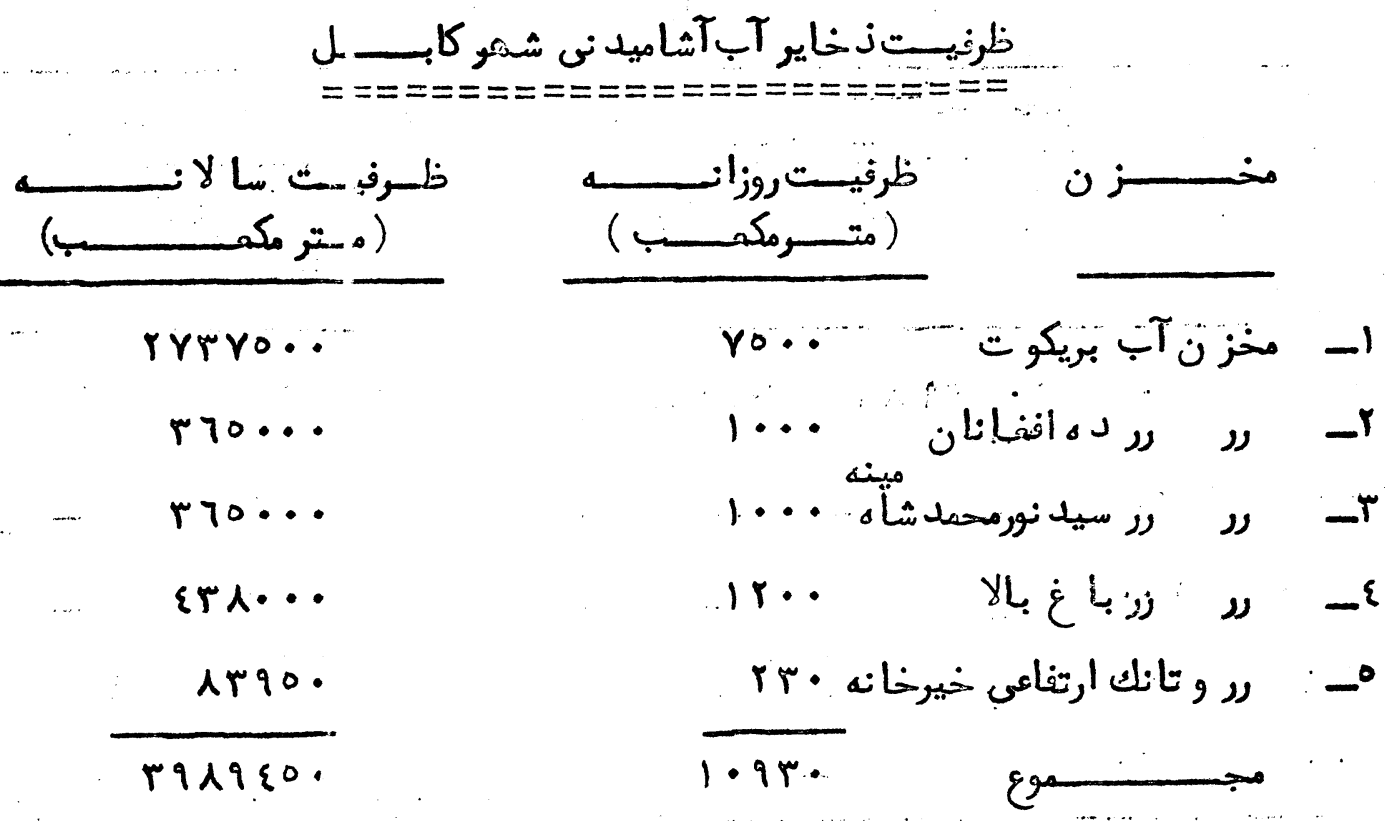

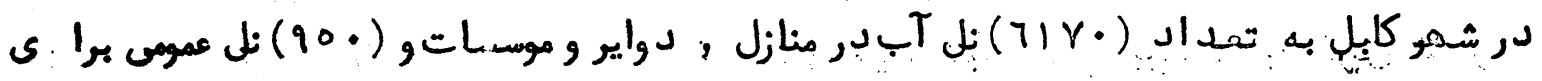

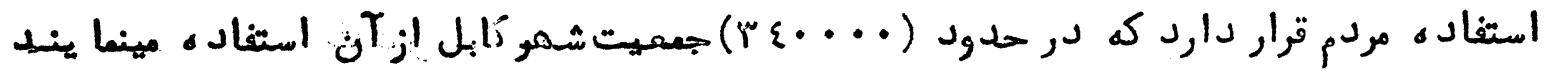

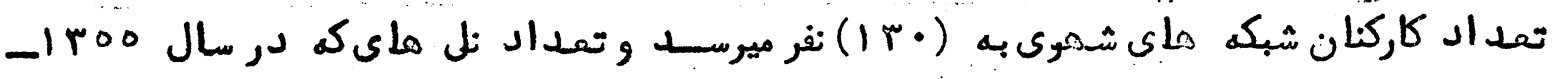

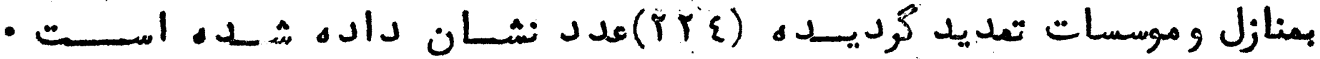
كاركنا ن , محاشات و مزد ها, برد اختماى نقدى و :بهوايد شبكه آبرشانى

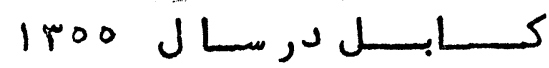

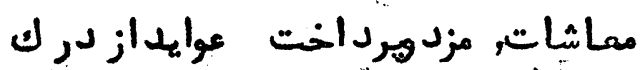

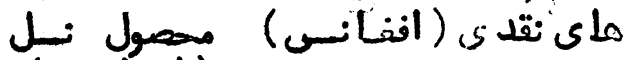

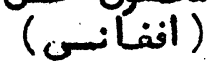

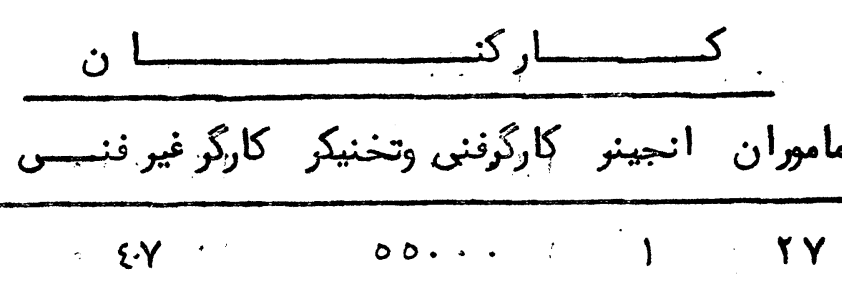

ب:- فعاليتماى آبرساني درولايسات : شبكه هاى آبرسانى در شهوهاي كند هار, مهــرا

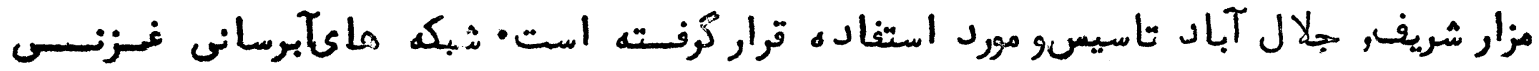

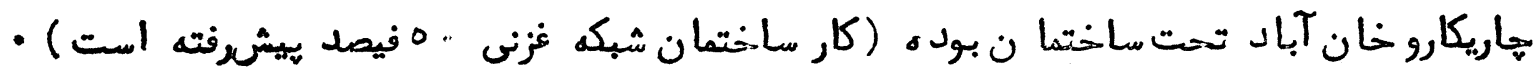

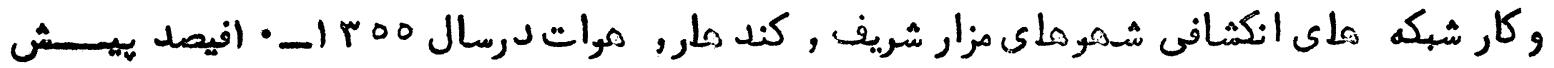

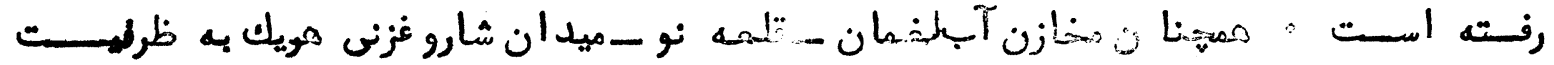




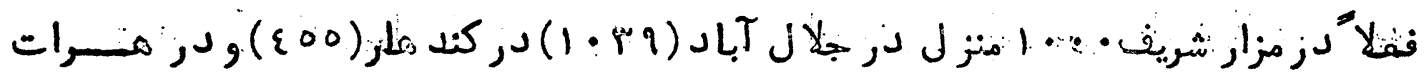

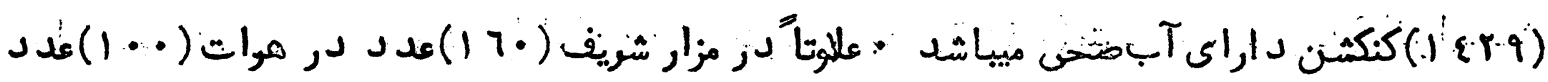

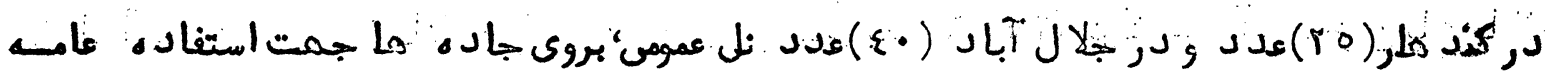

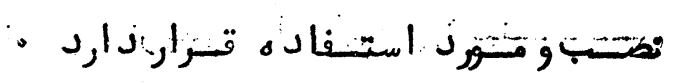
منبح آباشاميدنى - ـظرفيت منبع آبـ ظرفيت مخزله وتعد اد نلها

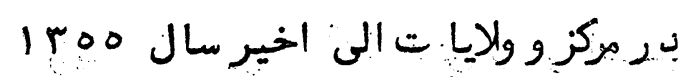

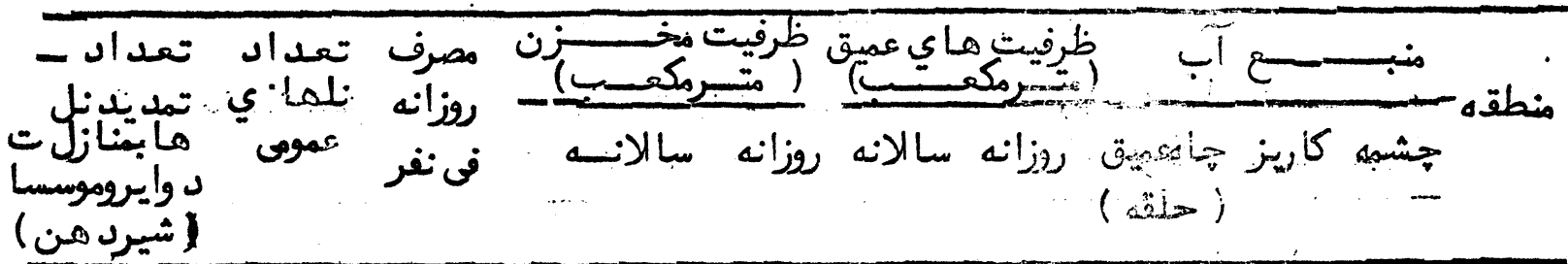

\begin{tabular}{|c|c|c|c|c|c|c|c|c|c|}
\hline $71 . \mathrm{Y}$ & $90 \cdot$ & $\begin{array}{l}7 \cdot 6 \\
1 \cdot 0\end{array}$ & $9 \leqslant 0$ & 9400 & 97 & $77 \%$ & $\therefore . \hat{3}$ & & $r$ \\
\hline$\xi 00$ & ro & ענ & $\therefore$ & - & - & - & $\cdots$ & $r$ & - \\
\hline $1 \& Y q$ & $1 \cdots$ & עد & $\therefore$ & - & $\cdots$ & $-m$ & & $\xi$ & - \\
\hline $1 \cdot \mu_{1}$ & $\varepsilon$ & ע & - & - & - & - & & $r$ & د دrr \\
\hline $1 \cdots$ & 17. & עد & - & - & - & $\ldots$ & ' & $\xi$ & $-c$ \\
\hline
\end{tabular}

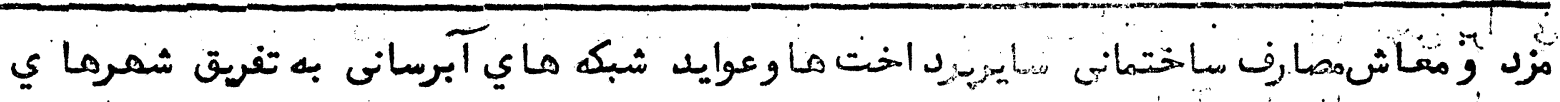
100 J J J e

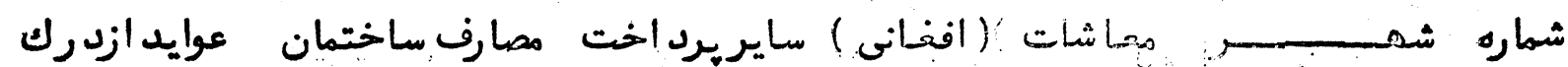

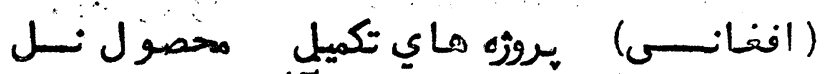

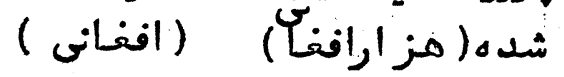

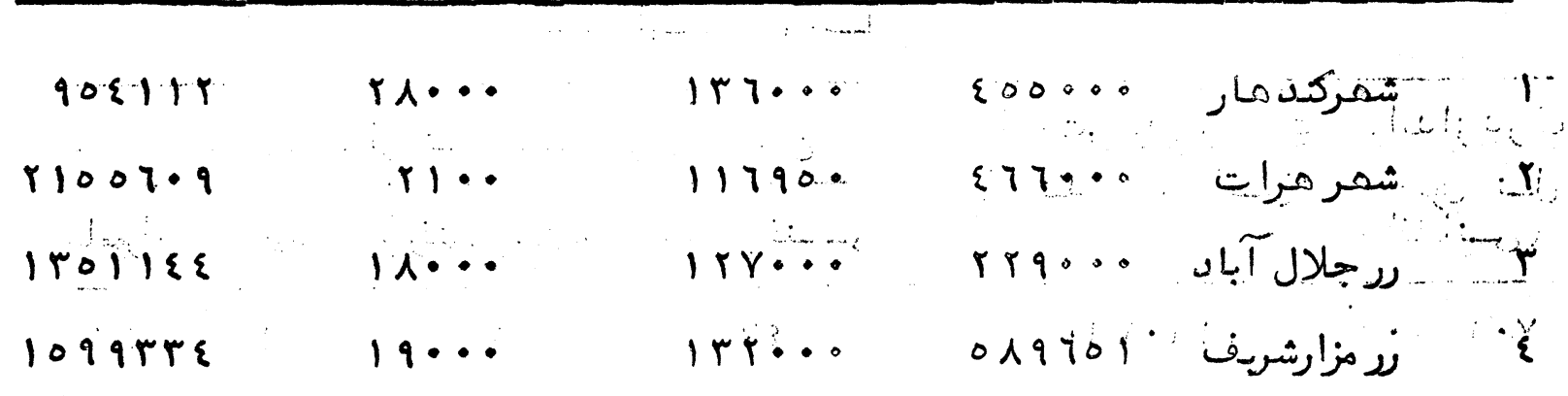




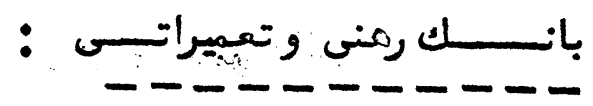

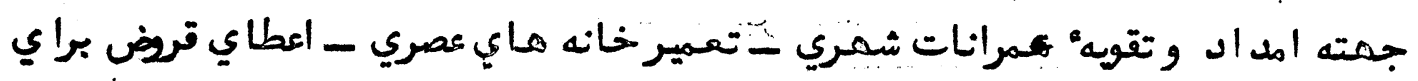

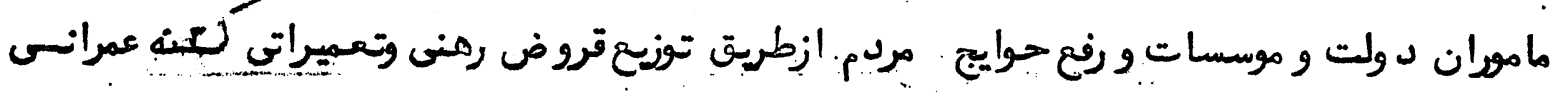

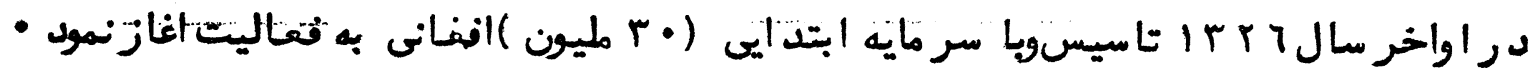

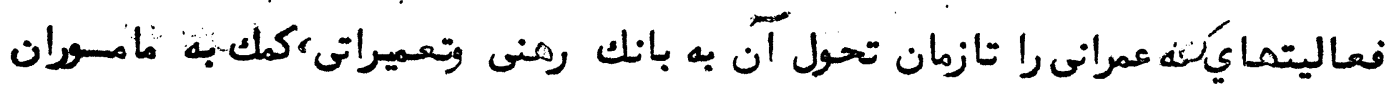
ك بضاعت د وائر د ولتى با توزيح قروضطويل المدت rV ساله با تكانه r فيصد به مامسوان

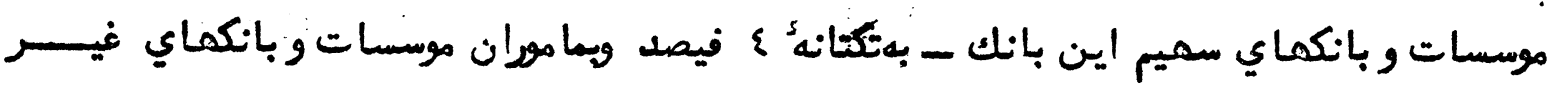

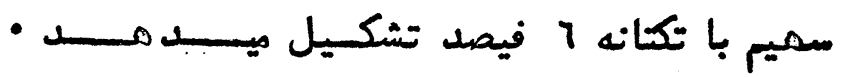
كسه عمرانى در سال rrr I به اثرتجويزد ولت به بانك رمنى وتعميراتى تحول نموده و سر مايه

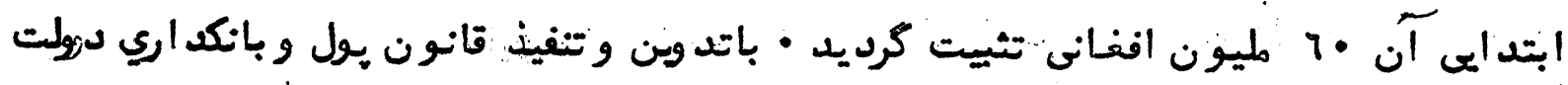

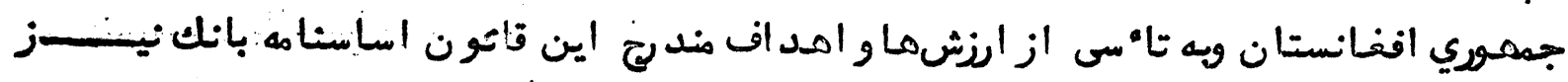
تعديل و منظوركرديد كه دزآن سر مايه مجاز اين بانك • •r مليون افنانى وسرمايه تاديسه

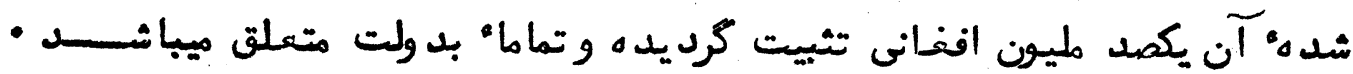

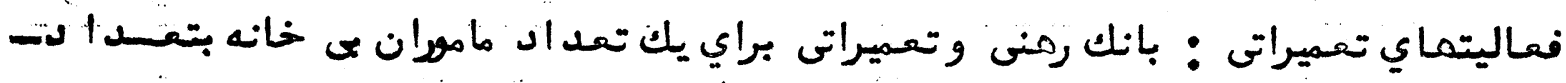
• ب با ب خانه مايكم قيمت لدرحصه بل سوخته اعمار نمود هك به قيمت نمايت نازل مهتوي -

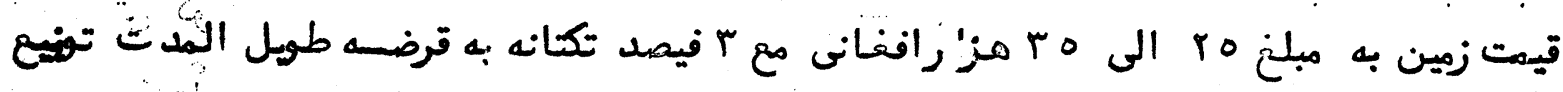

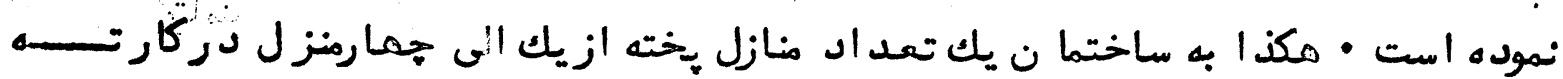

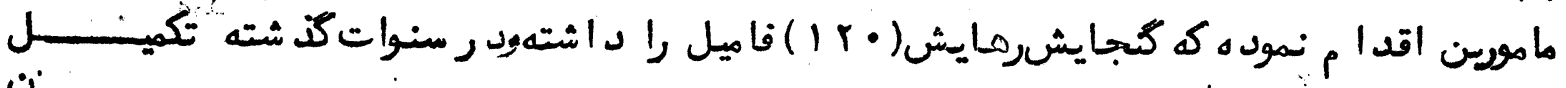

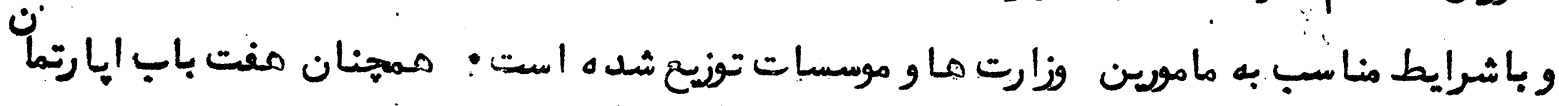

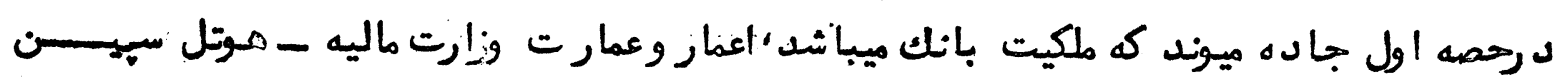

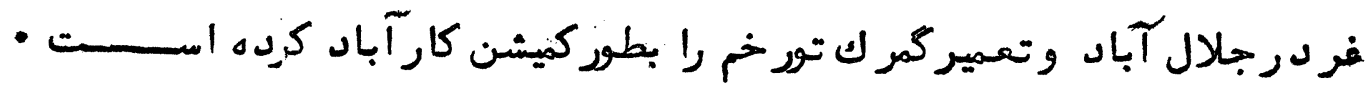
اين بانلك به منظور مساعدت به ماموان كن بضاعت و ه خانه يك اندازه زمين رابه قيمت ناز ل

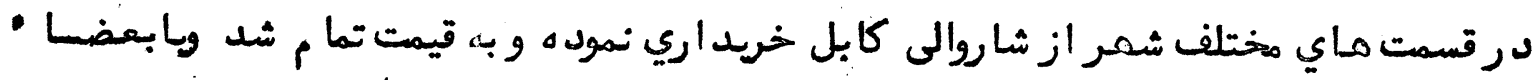
بايك كميشن ناجيز وكز به اند ازه ماي منتلف طور قرضه با نقشه ماي مرتبه، براي مامورا ن -

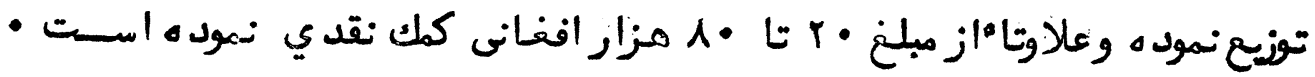


زميسن ماي توزيع شده ازطرف بانك رمنى وتعسميراتى" به مامورانالى

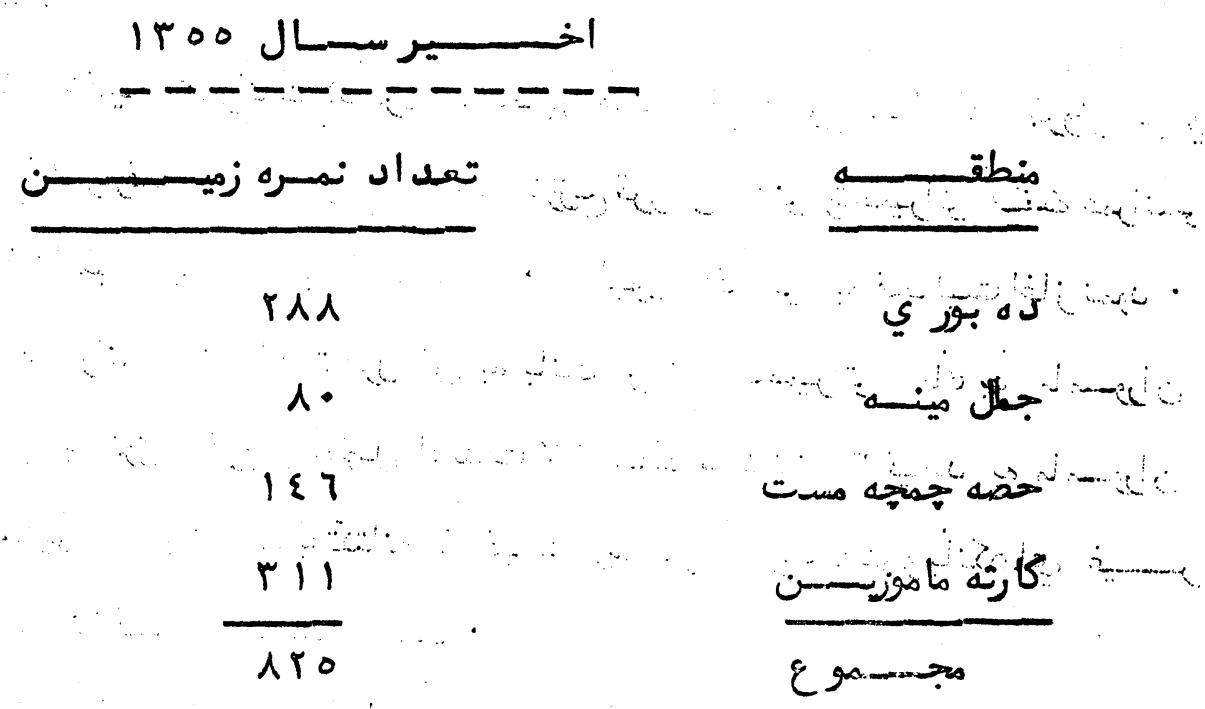

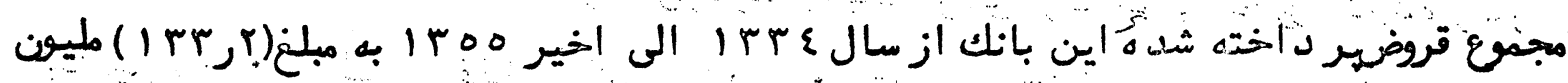

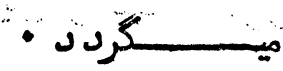

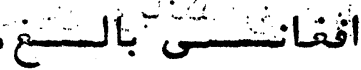

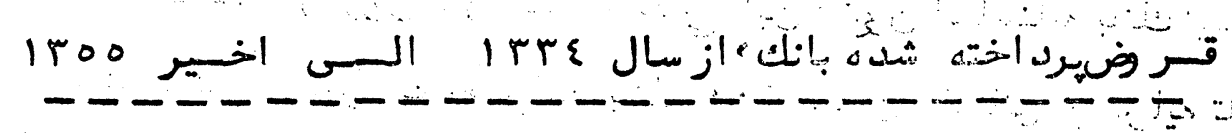

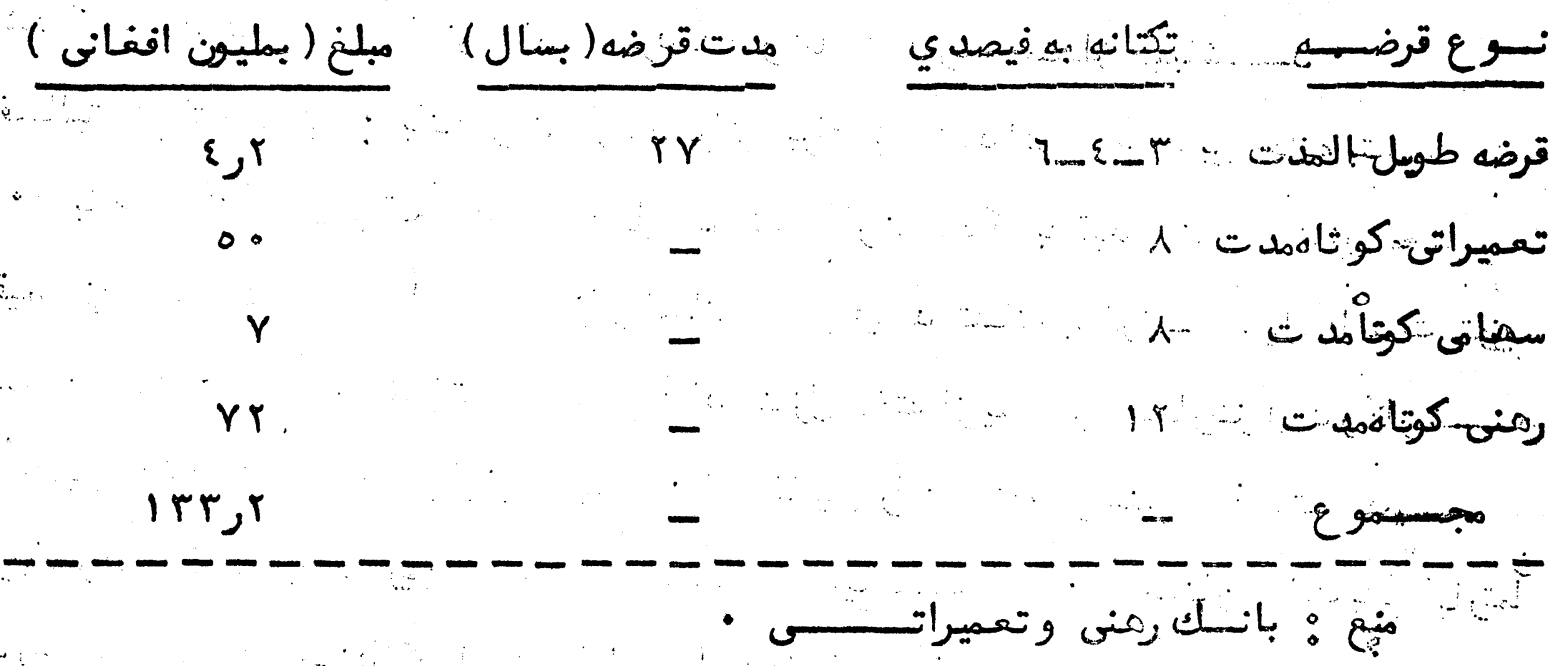

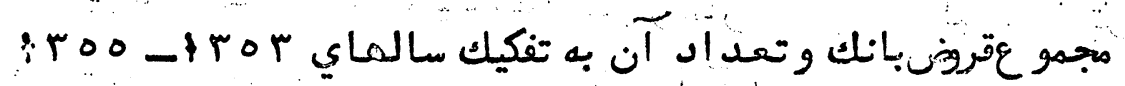

\begin{tabular}{|c|c|c|c|}
\hline مبلغ ( بمليون افغانى ) & تعد اد قرضه & ما مورين وموسنسات & - JL \\
\hline 1,9 & 70 & مامور & jor \\
\hline$T, 90$ & $q Y$ & مامورينــن i i... & 1 1ro: \\
\hline $1 \cdot, \cdots$ & $\therefore \cdots-$ & لد ستكاه ساختمانى بناني & lros \\
\hline $7,9 . \pi$ & rrr & ماموريسن & $\because 1 r 00$ \\
\hline $7, \ldots$ & - & شركت اي - مُ - ا & 1roo \\
\hline$r v, r r$ & - & $------\cdots$ & 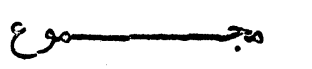 \\
\hline
\end{tabular}

• منبسع : بانك رهنى وتيتميراتسـى

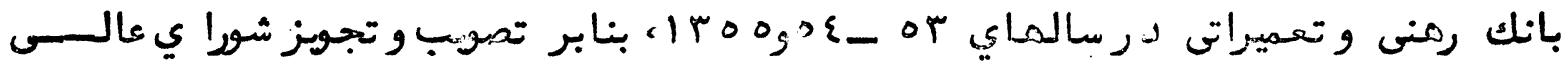

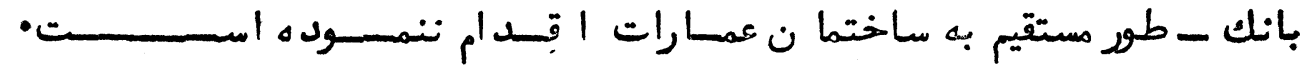




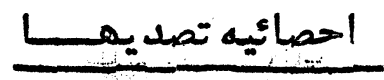

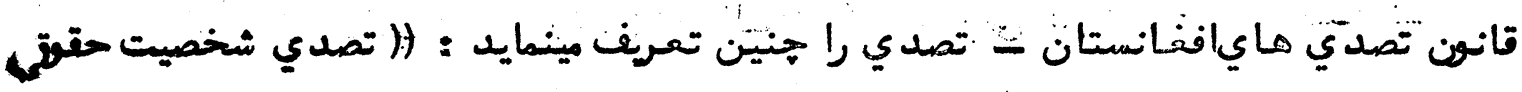

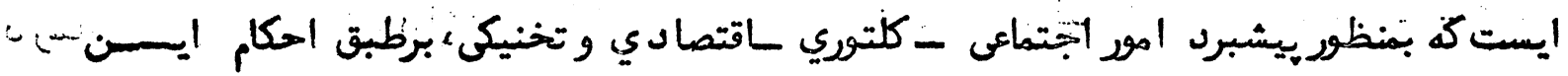

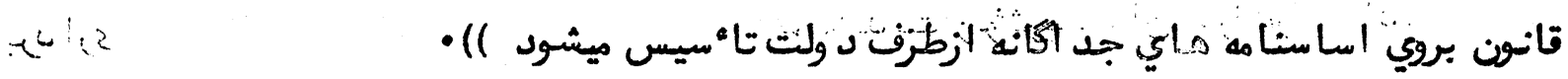

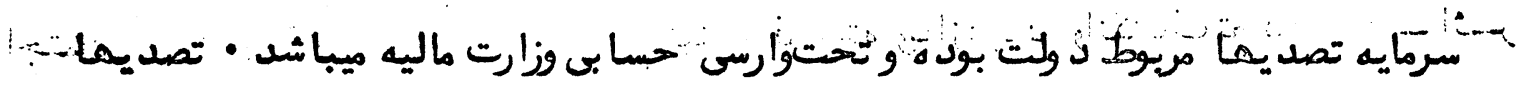

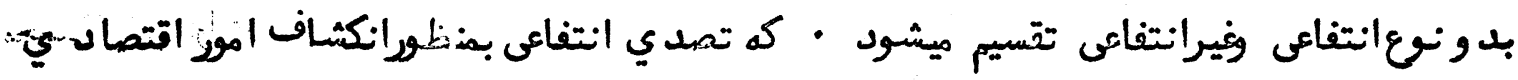

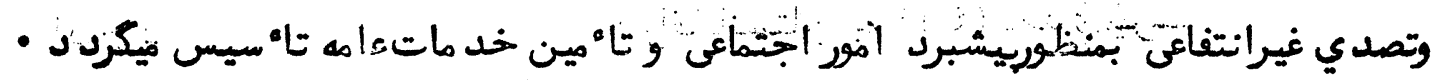

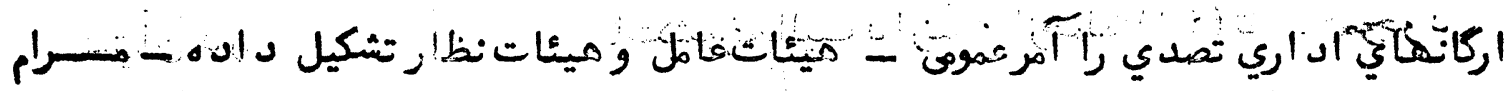

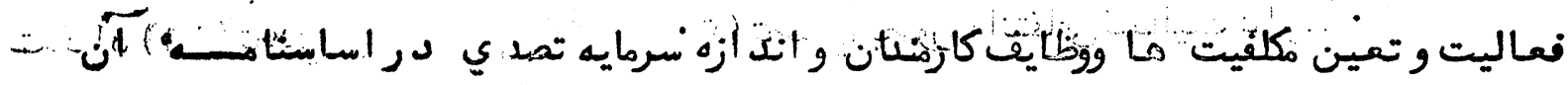

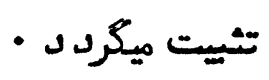

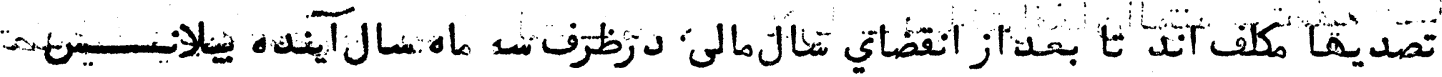

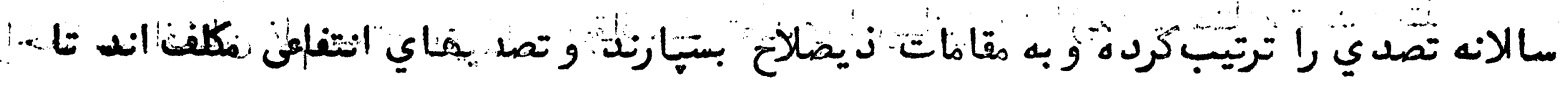

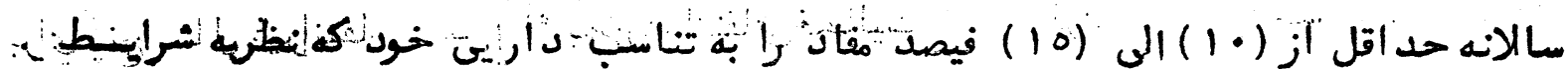

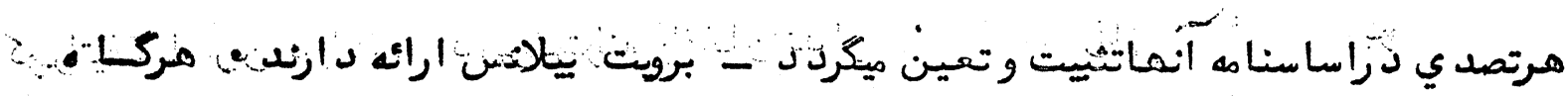

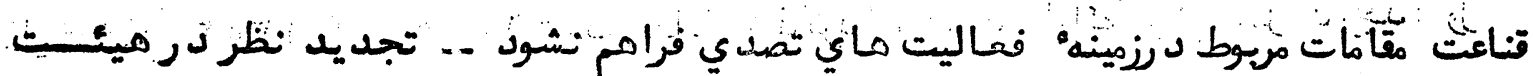

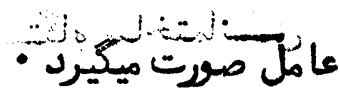

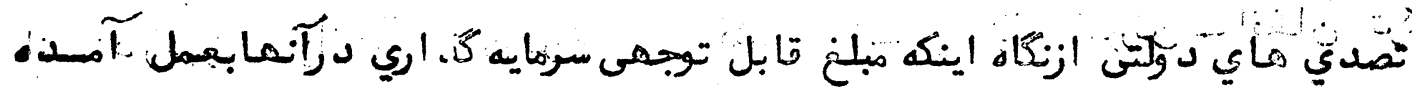

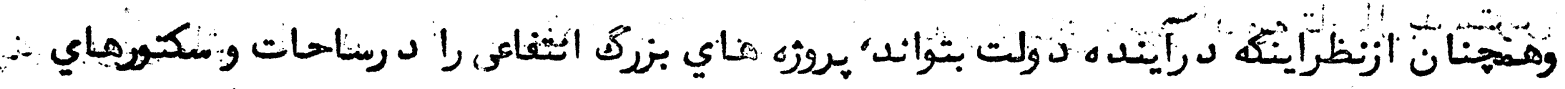

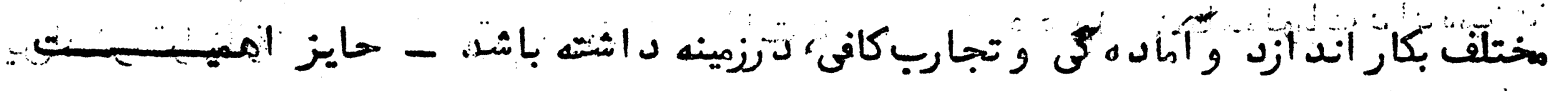
$x+2$ • فراوانَ أمبتى

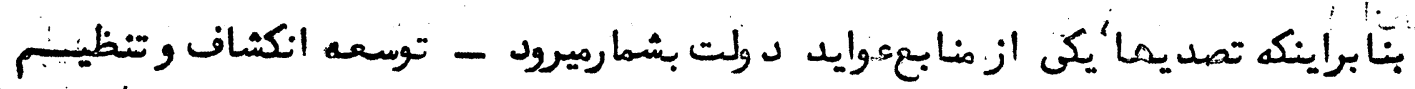

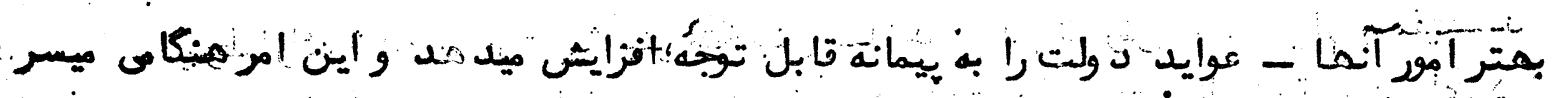

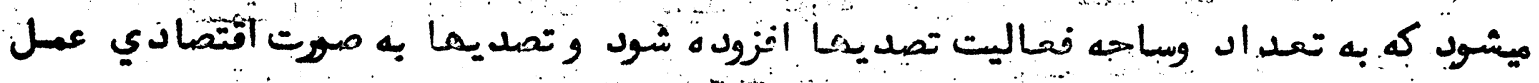

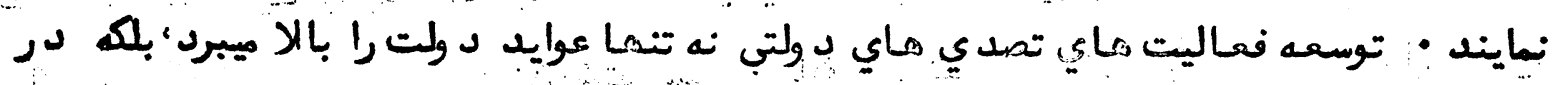

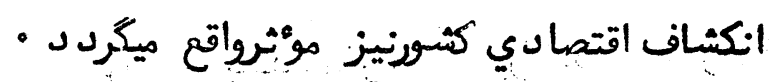

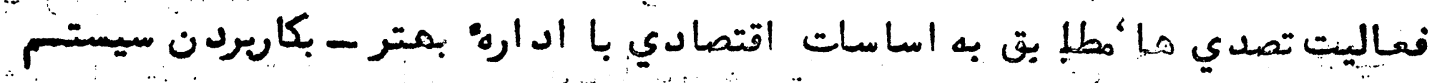

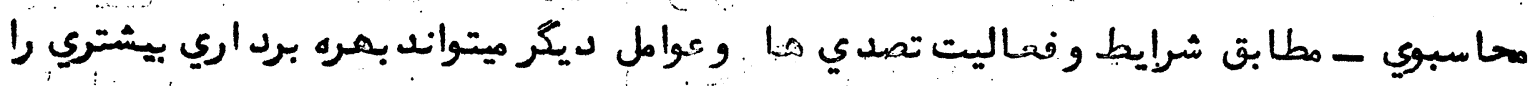

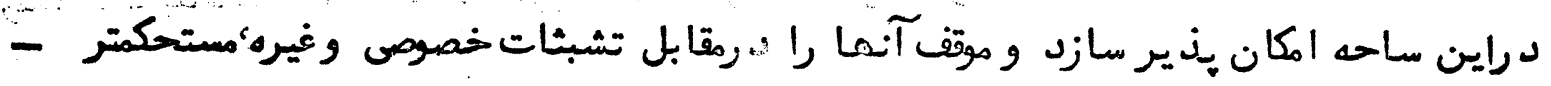

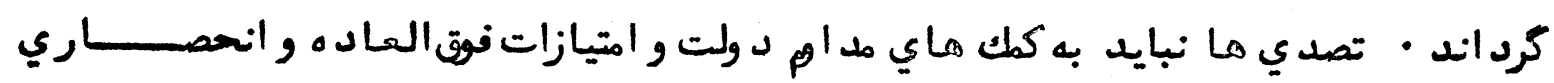




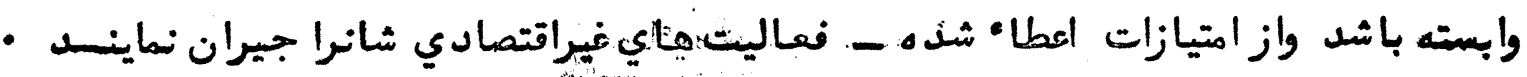

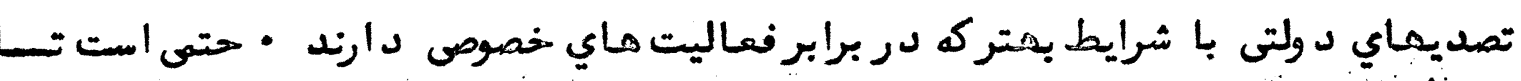

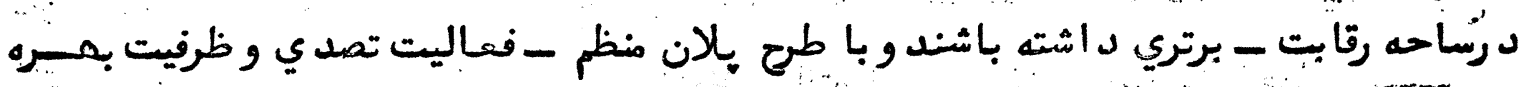

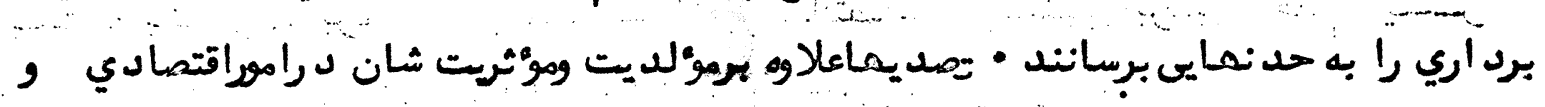

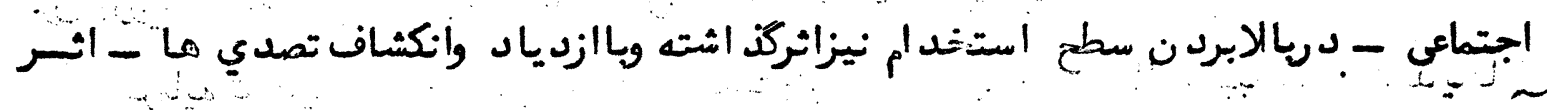

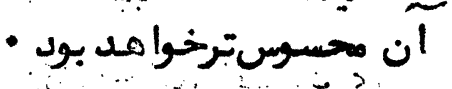

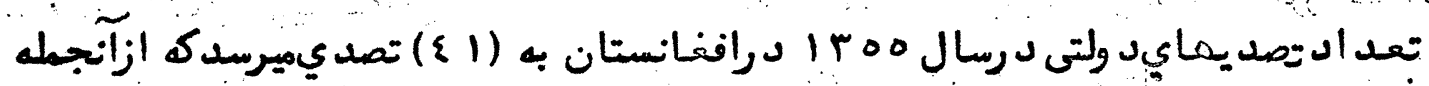

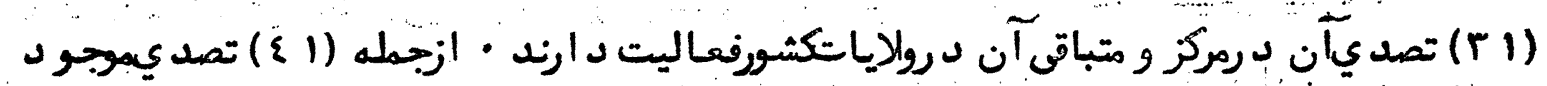

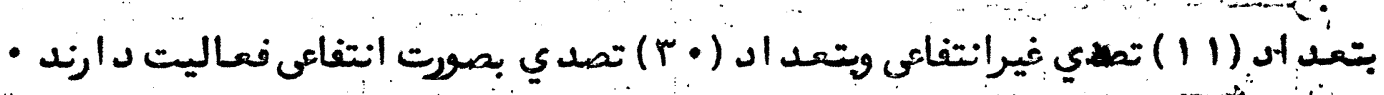

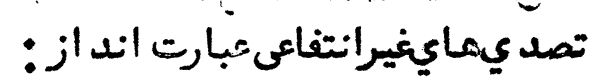

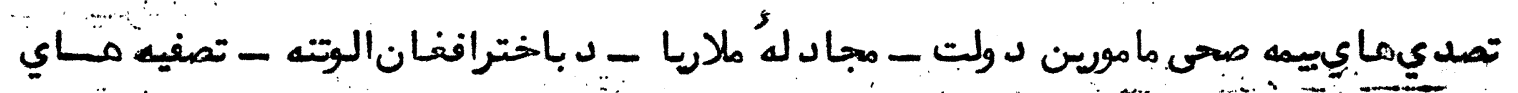

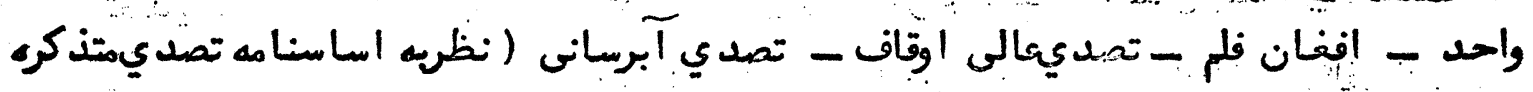

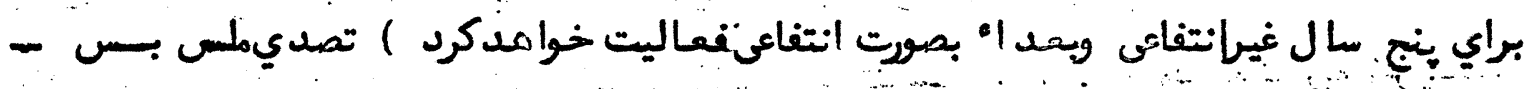

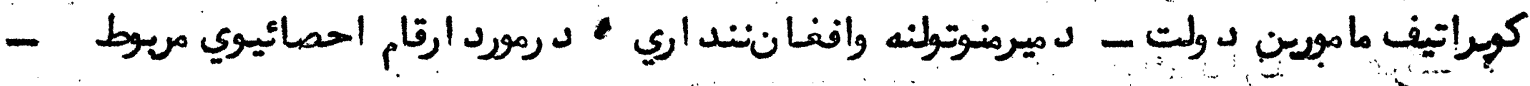

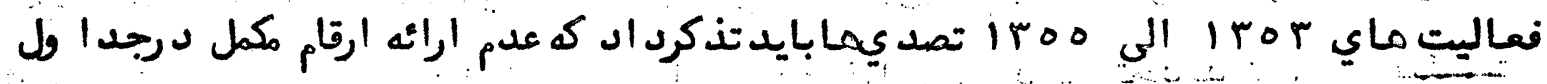

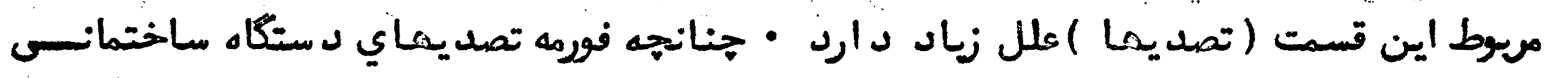

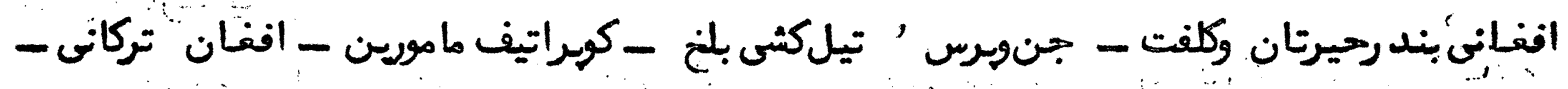

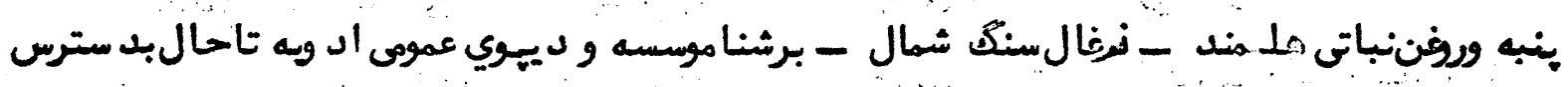

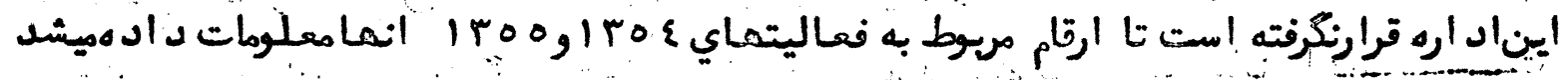

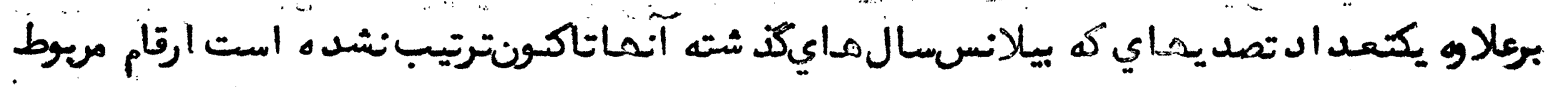

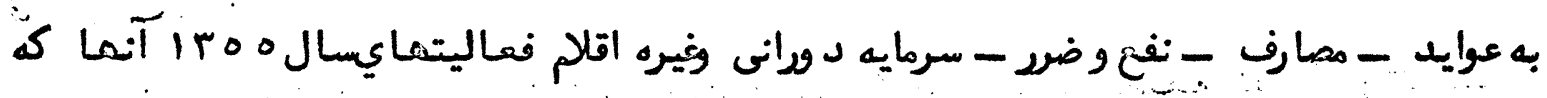

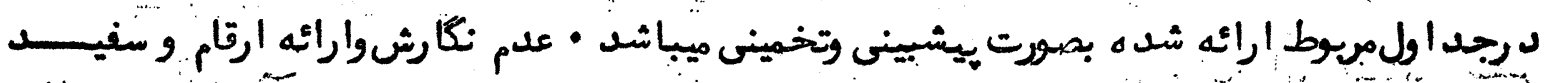

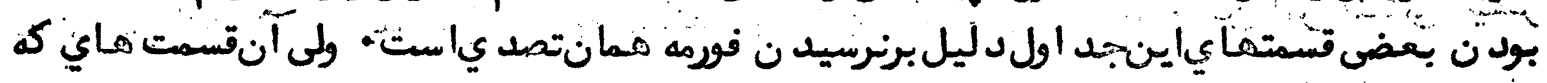

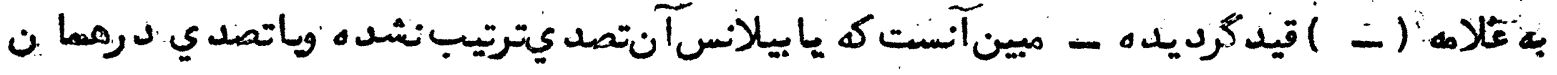

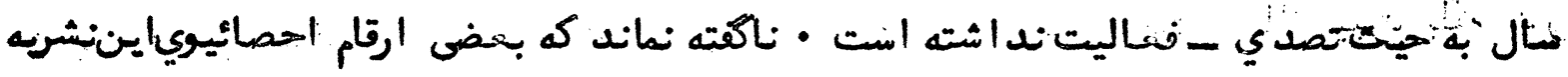

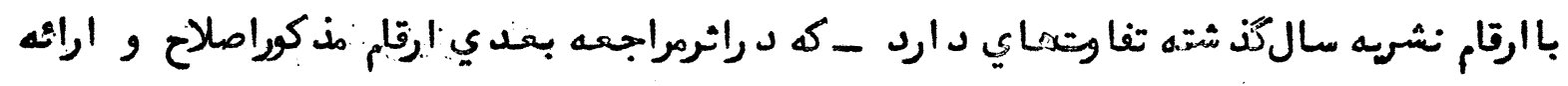

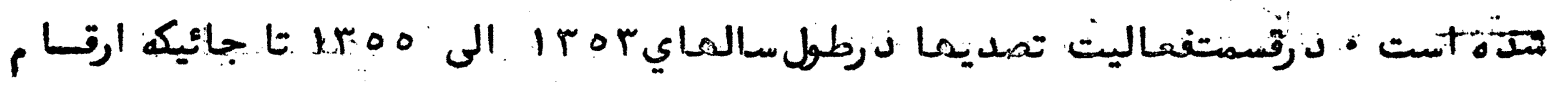

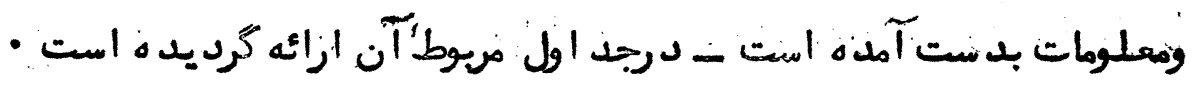




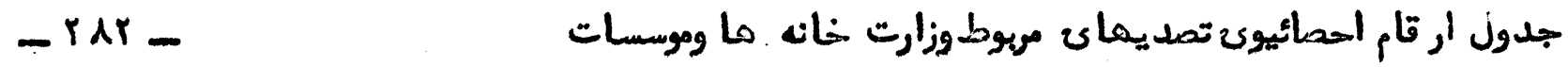

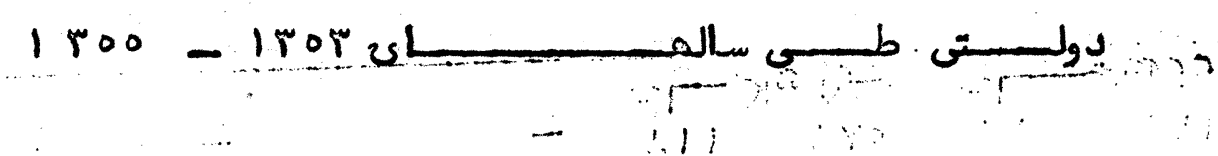

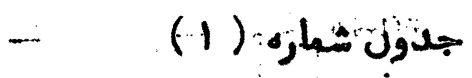

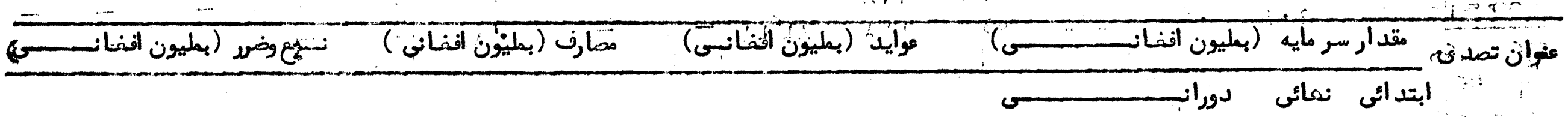

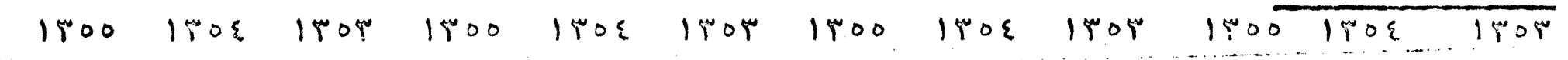

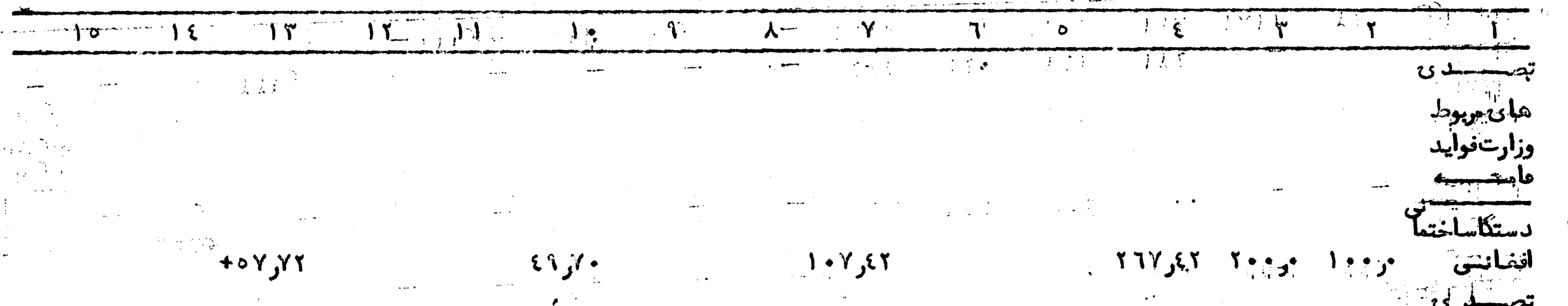

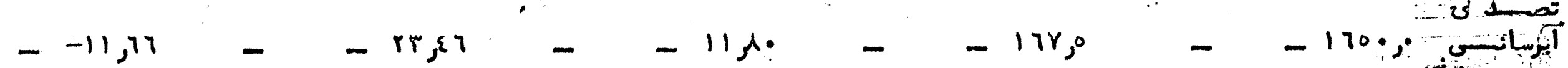

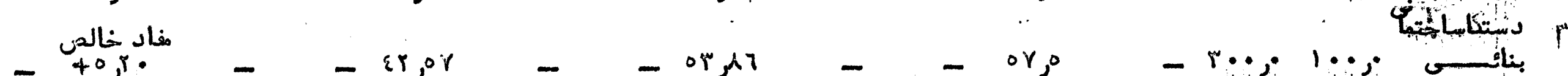

$$
\begin{aligned}
& \text { - +0, - }
\end{aligned}
$$

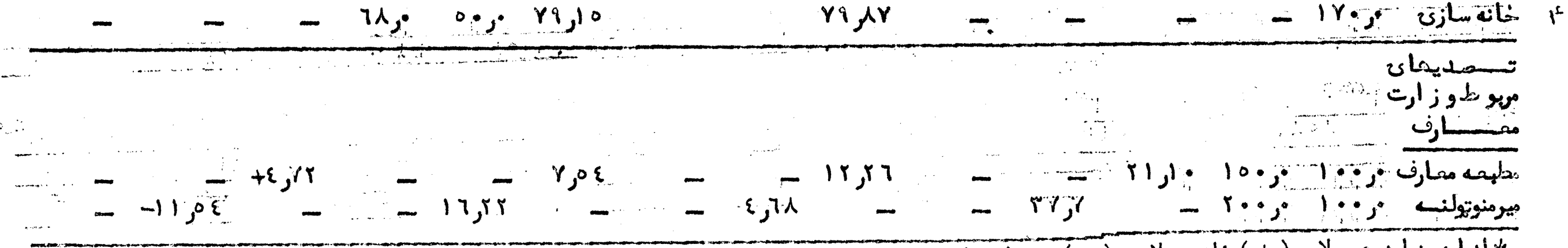

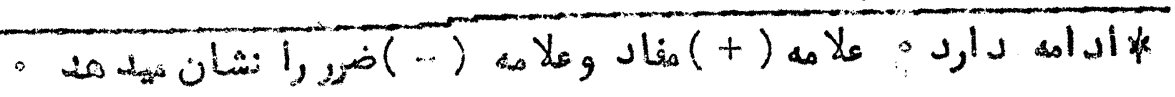




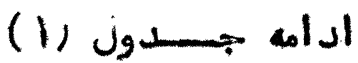

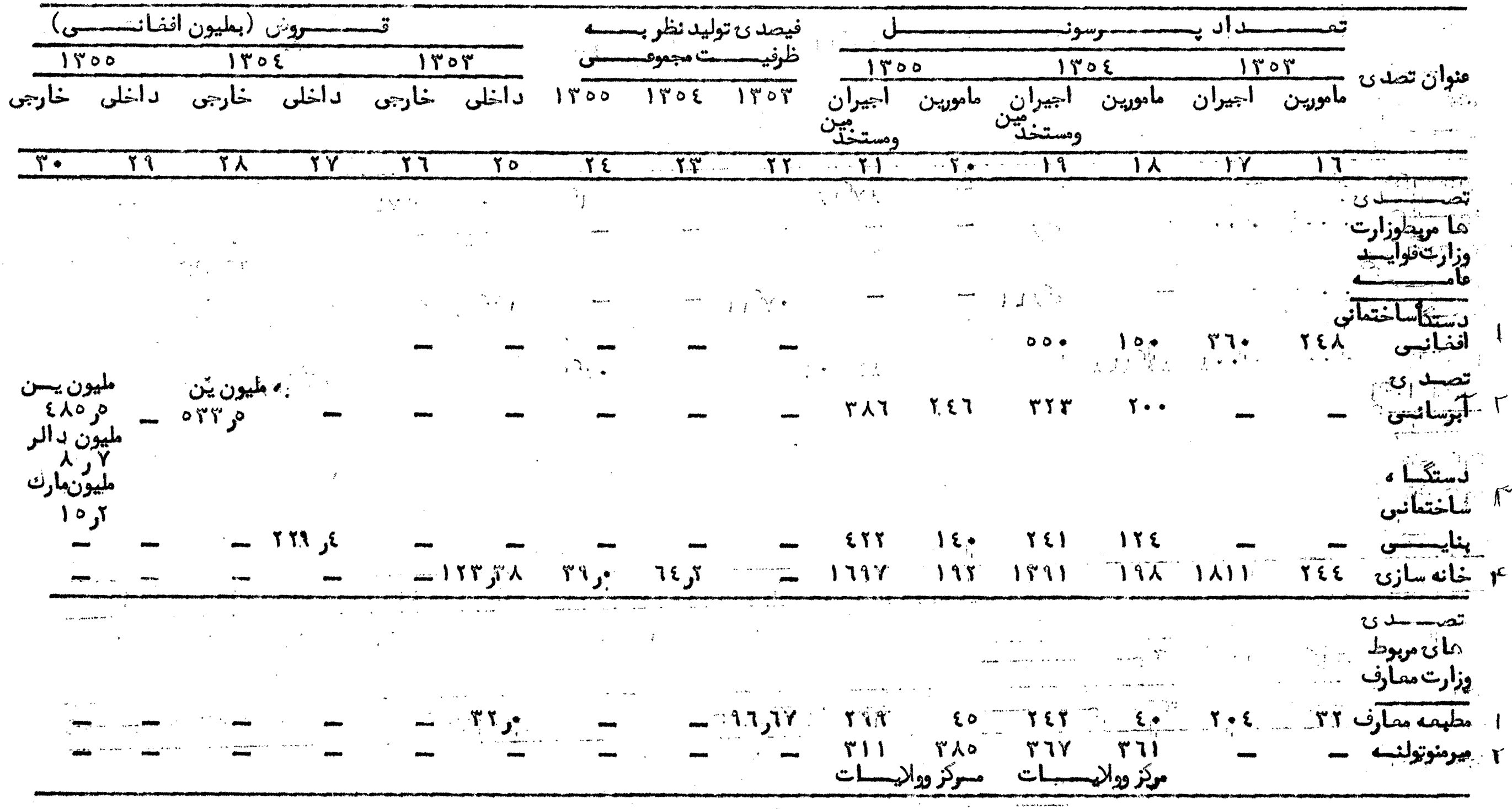




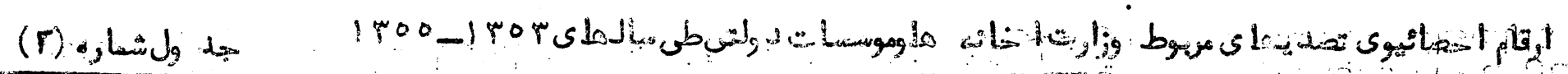

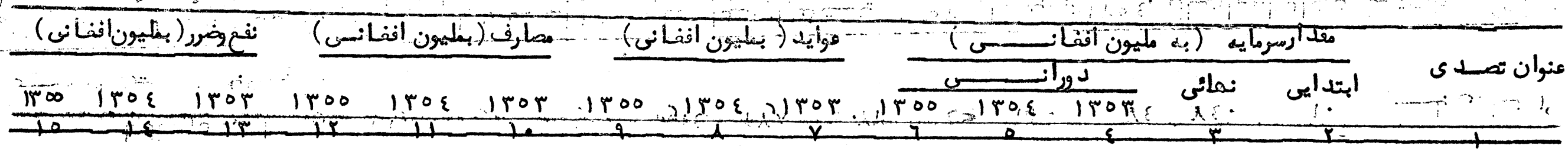

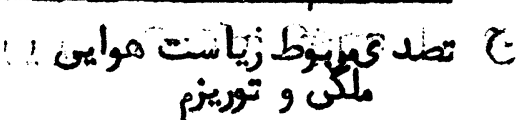

-rارL rY r

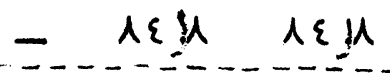
|

-

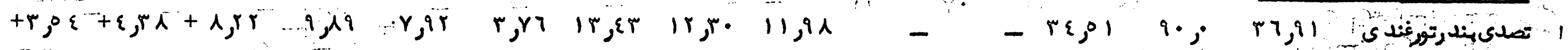

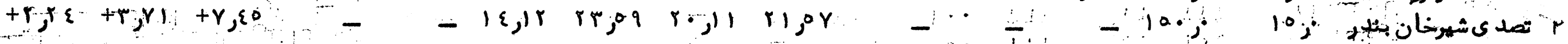

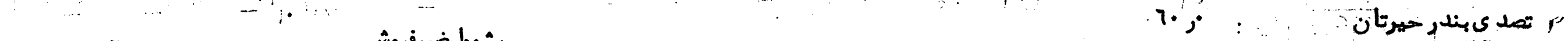

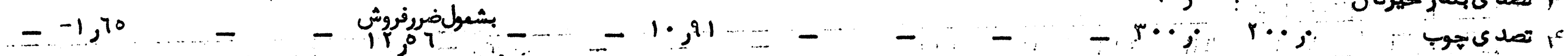

$$
-+r 0,91+r o, 70
$$$$
\text { - } \mid r \cdot \lambda
$$

110,79

I. $\xi y \varepsilon$ $+\{0,2 \varepsilon r+r 0,1 \lambda+70, j$ r r

$+11,\{7-17,9\}+\varepsilon, 7 r \ldots 71,9$ o $9,0, \pi, \varepsilon !$

\section{- pijr pist} ror, $q$ $-\quad-11,7$ $\frac{11,7}{19 r j}$

ध०० 0,8

$\checkmark q, 00$ $r r q, r)$ rog, $\lambda$

$r r, 7 \varepsilon$ $\varepsilon \dot{A}$,

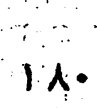

$1 \varepsilon$<smiles>C1CCCCC1</smiles>

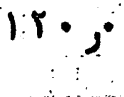
879
-7.0
- $\quad r q \varepsilon, r$ (t),

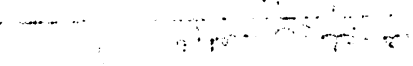




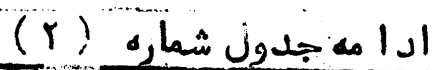

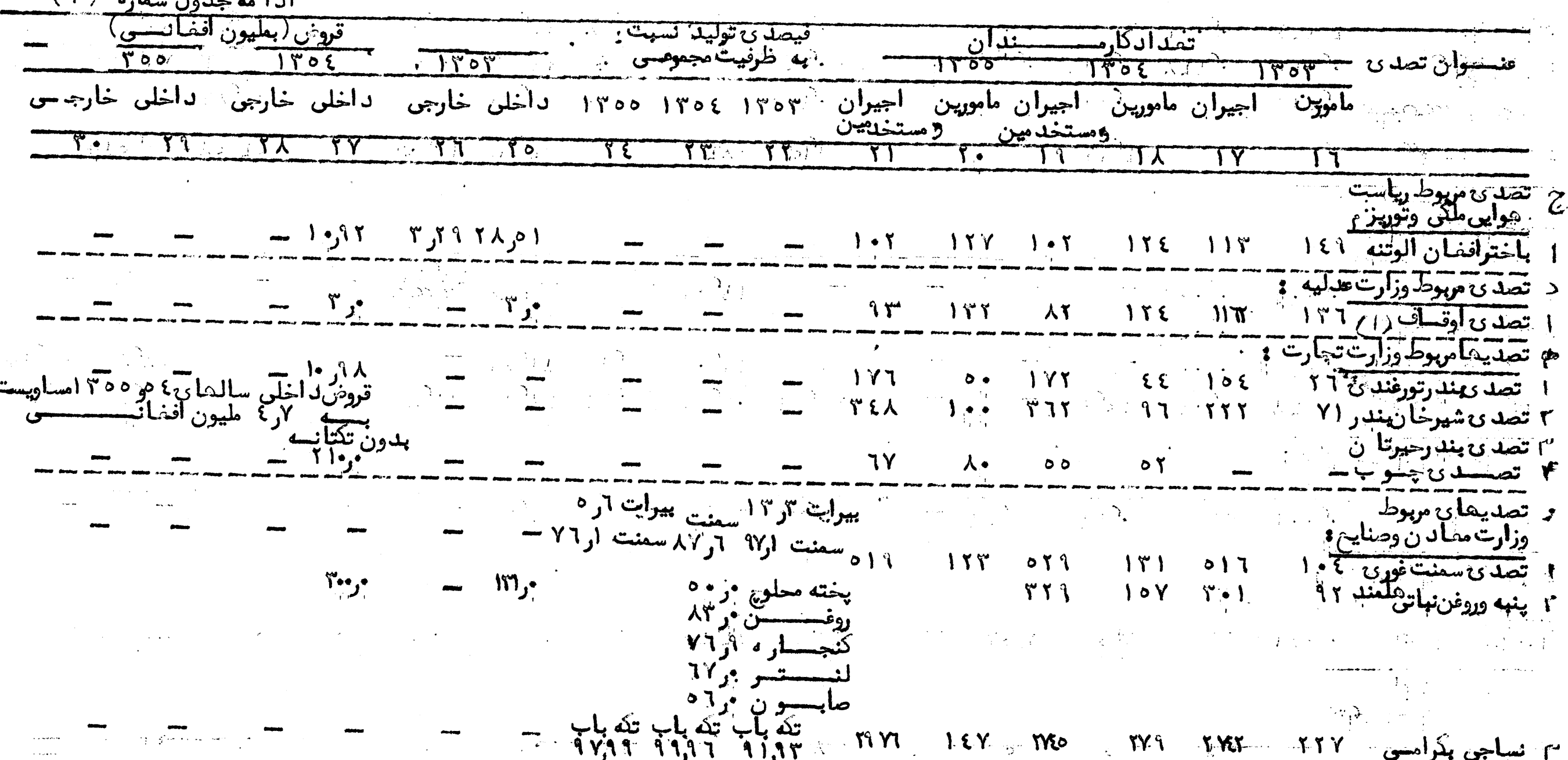

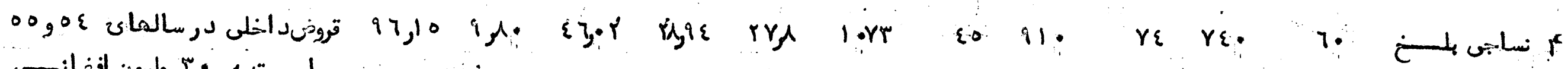

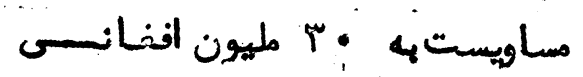

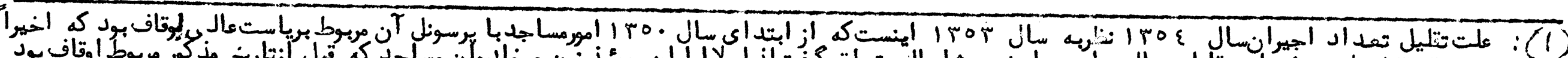

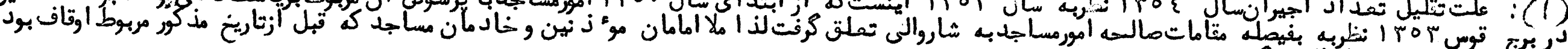

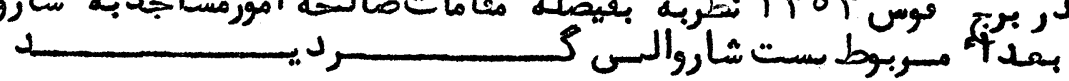


اداهه جدولشماره (r)

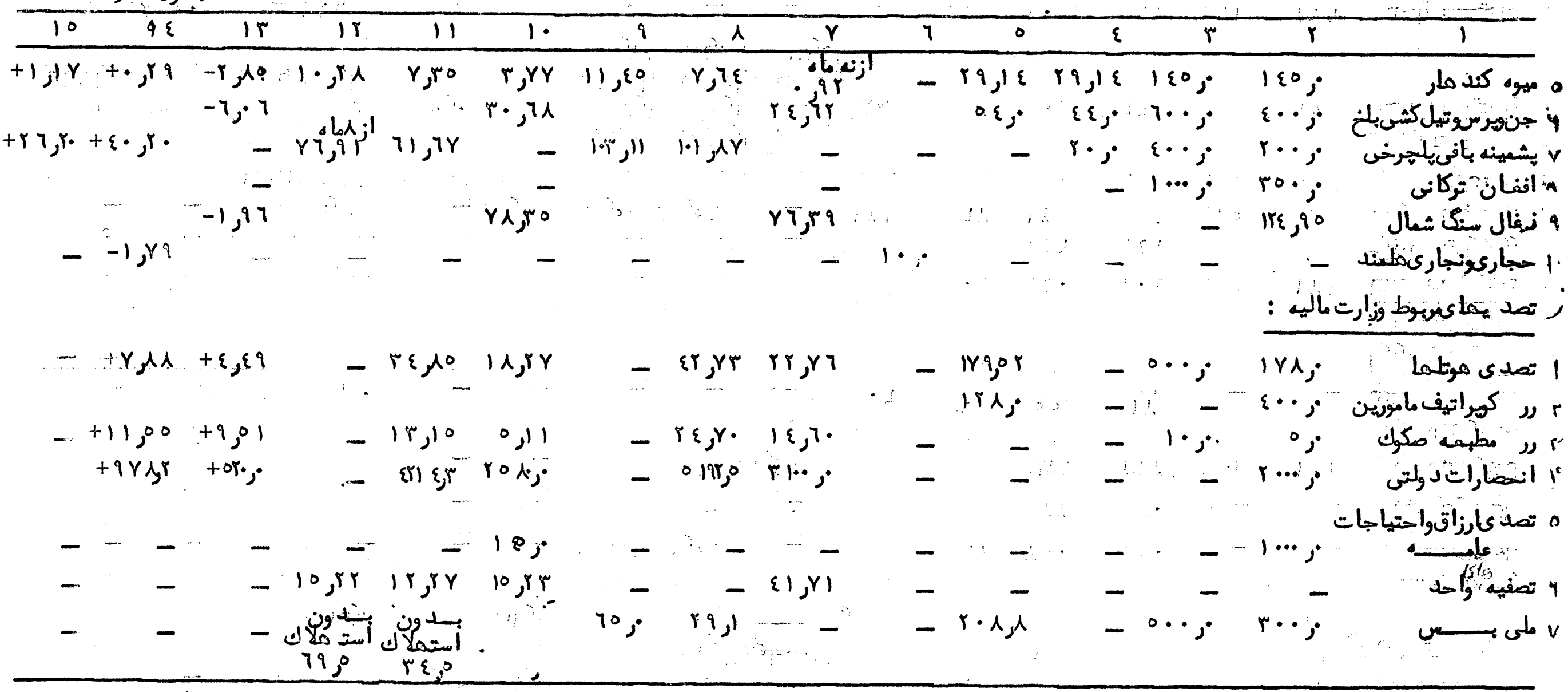




$$
\text { - rᄉr }
$$

الماهه جبدول شعاره (r)

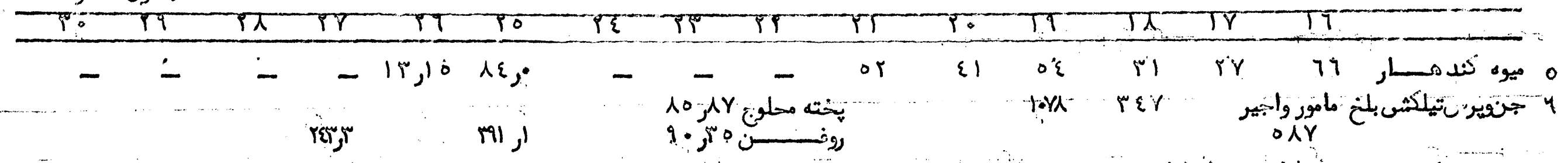

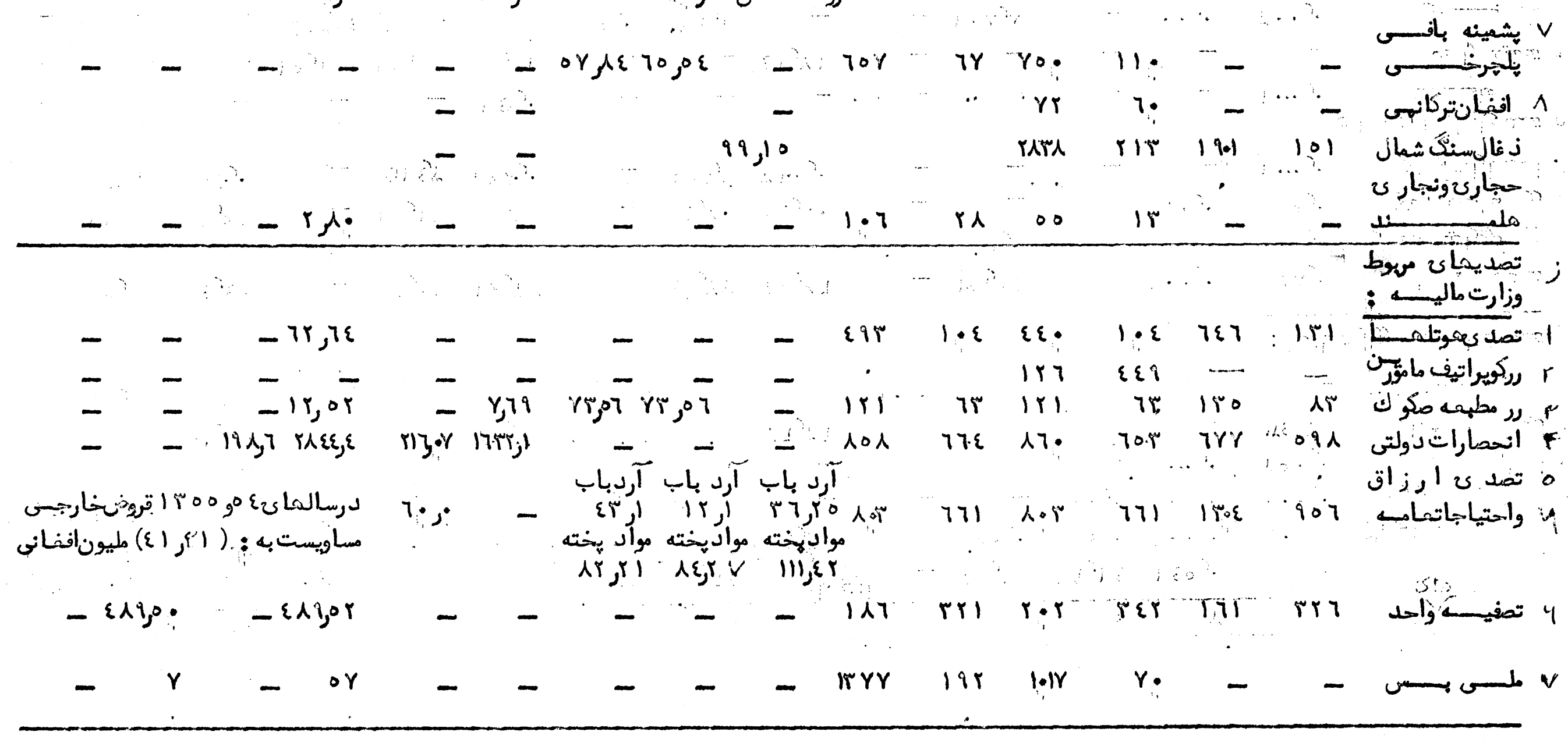




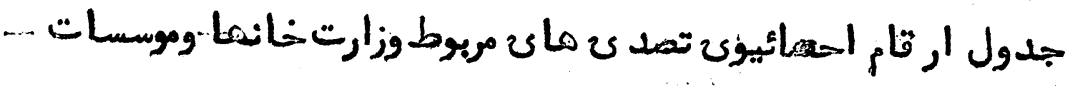

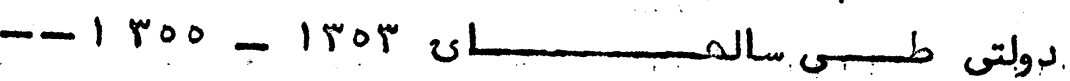

جلجونَ شماره (iv)

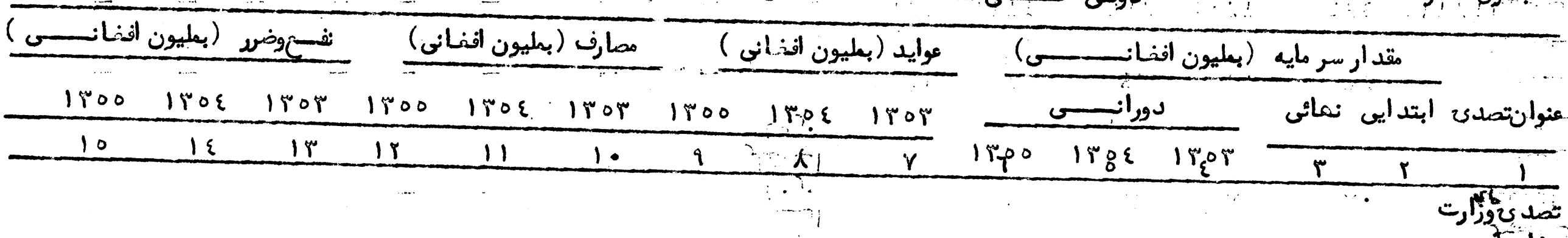

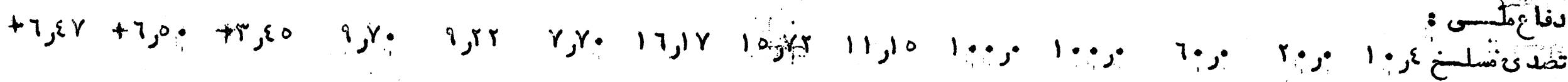
ن تجل -

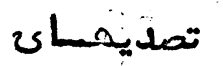
مهود. وزارت

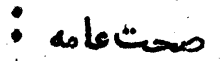

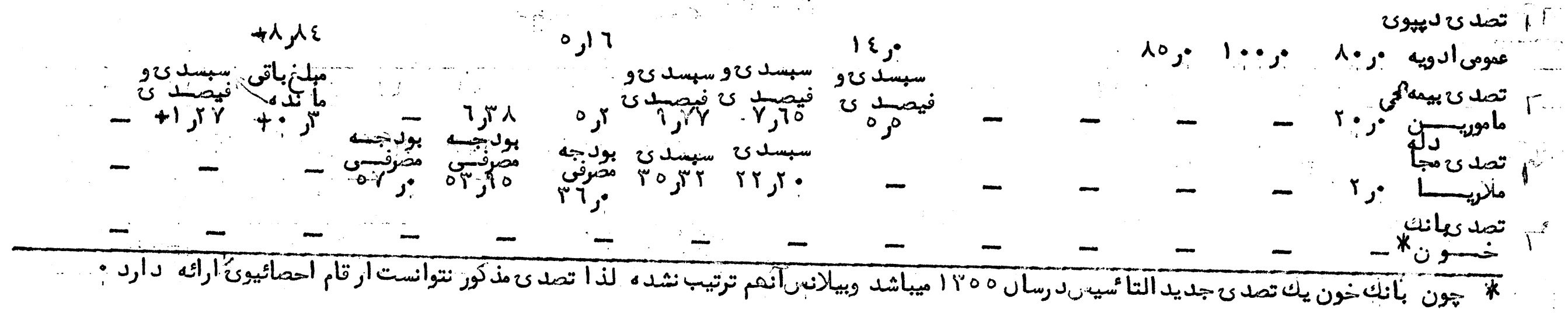


اد امه جدول (1)

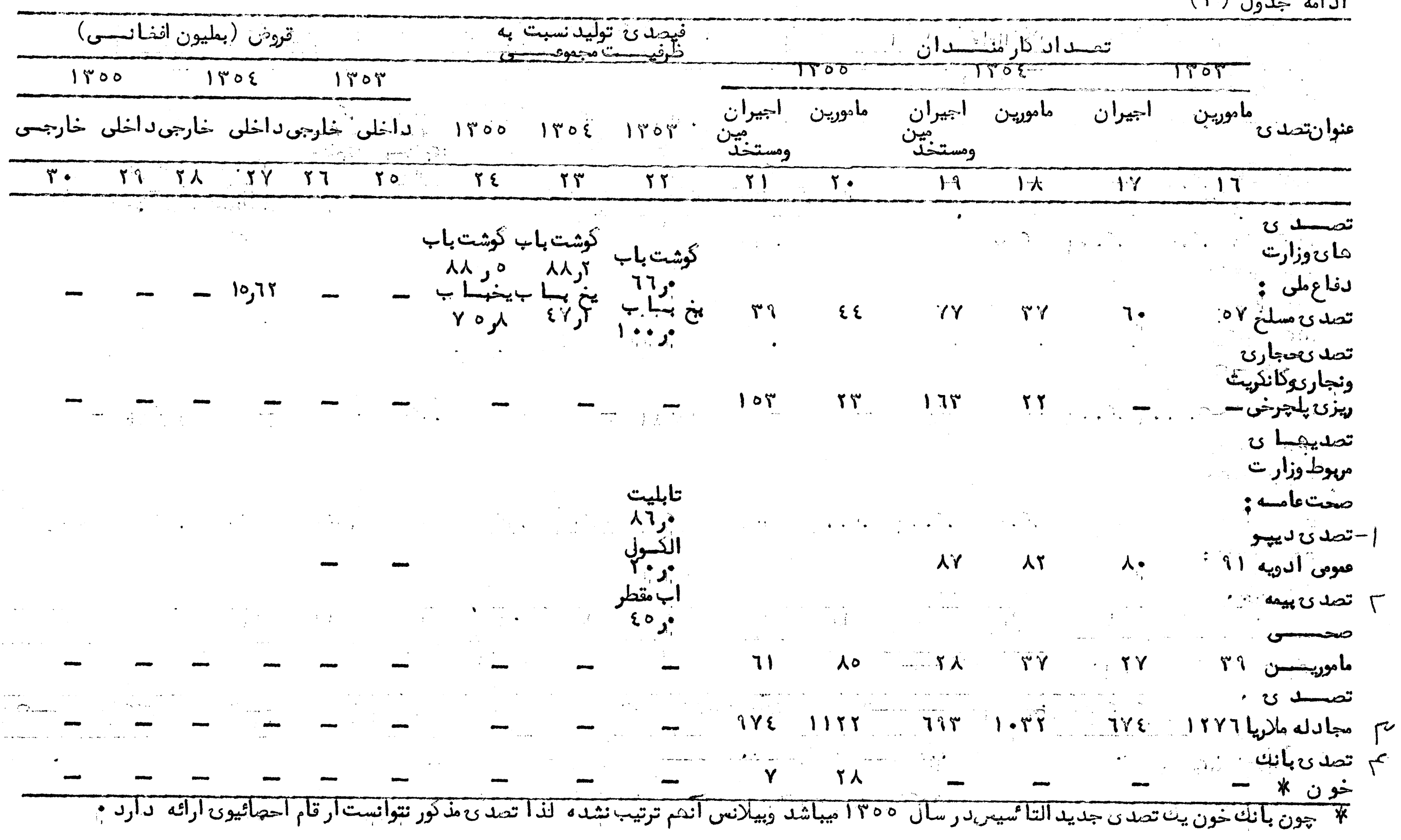


ادامه جدول (r)

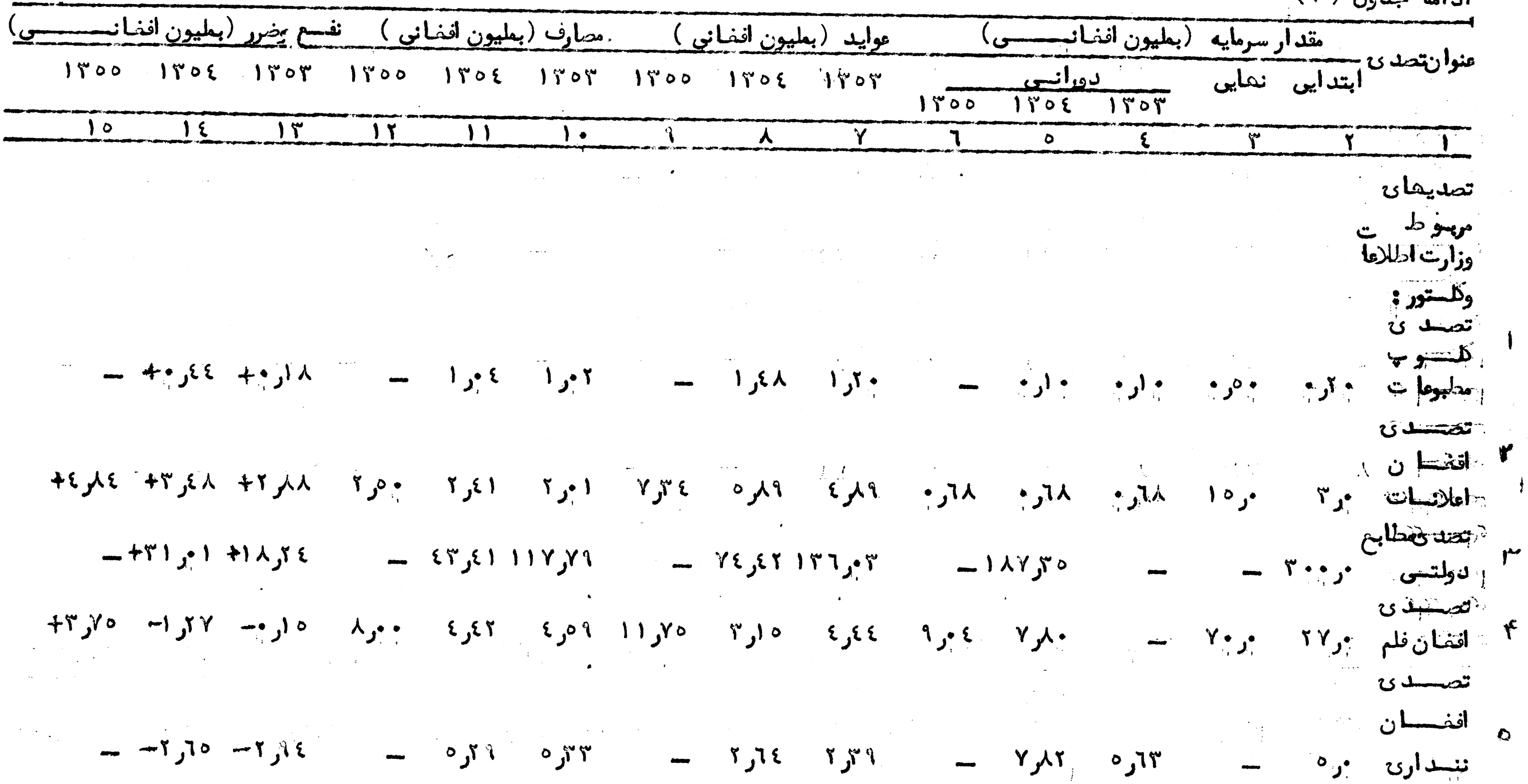


- 991

آدامه ندون (iv)

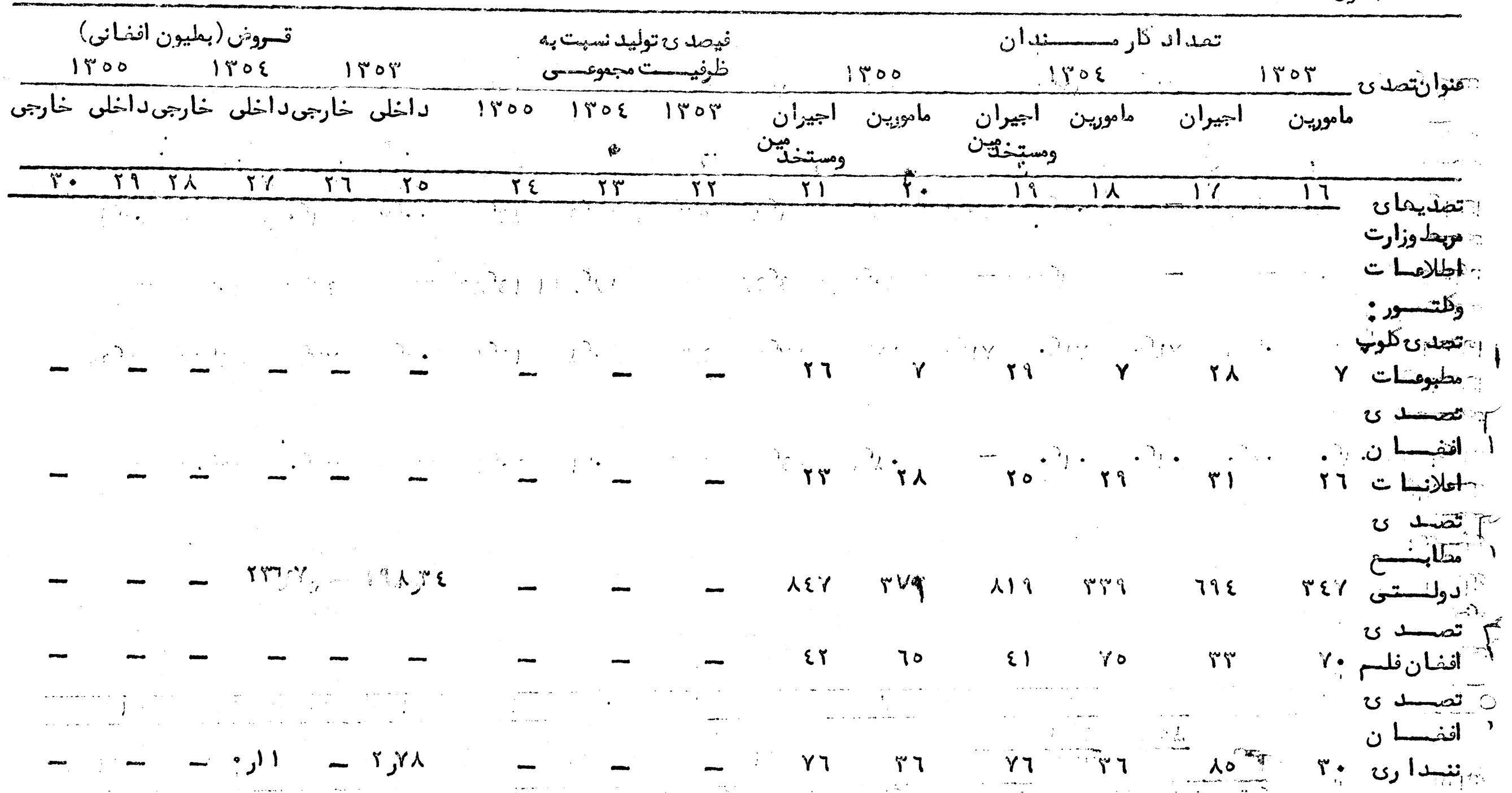



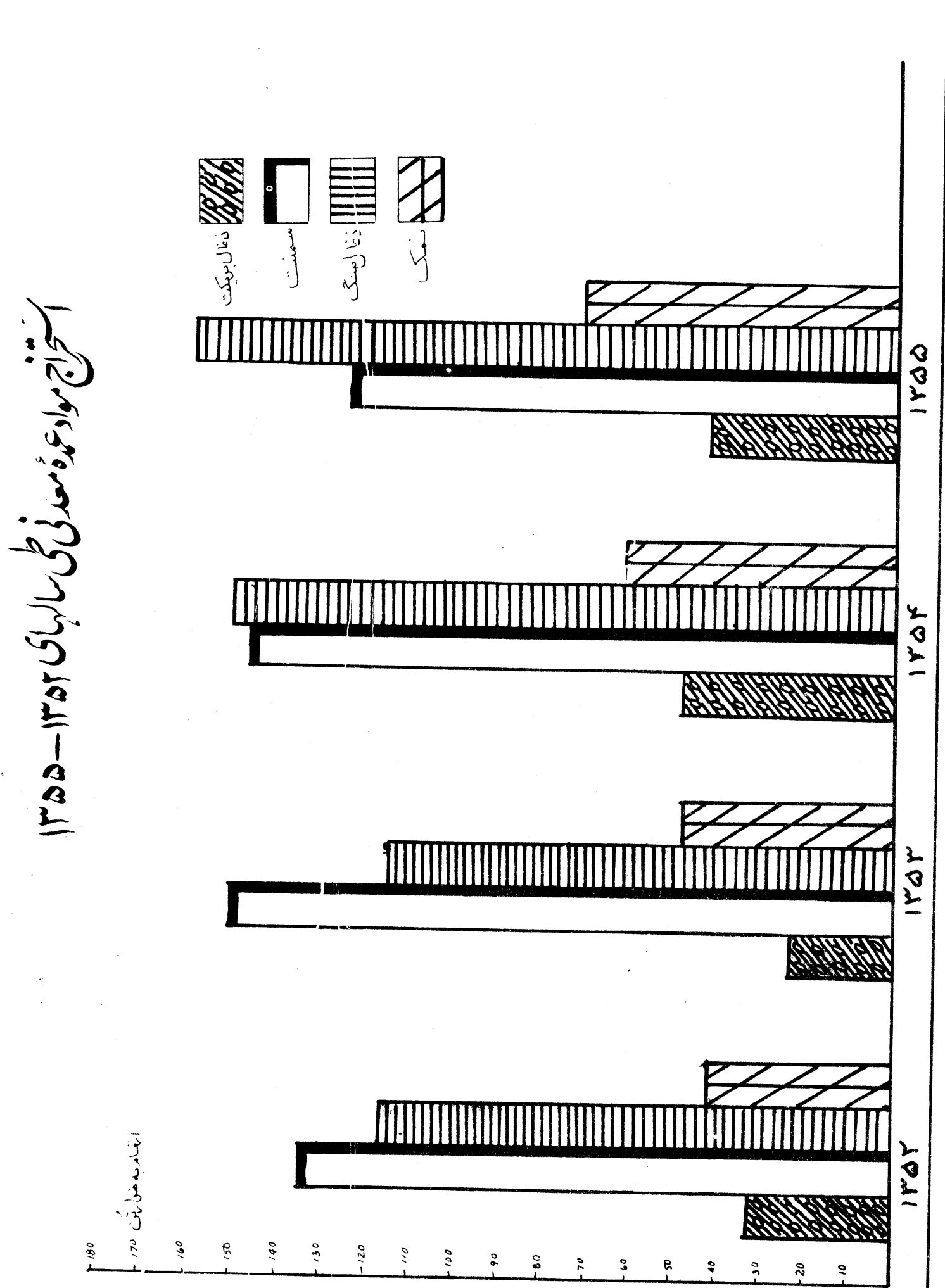

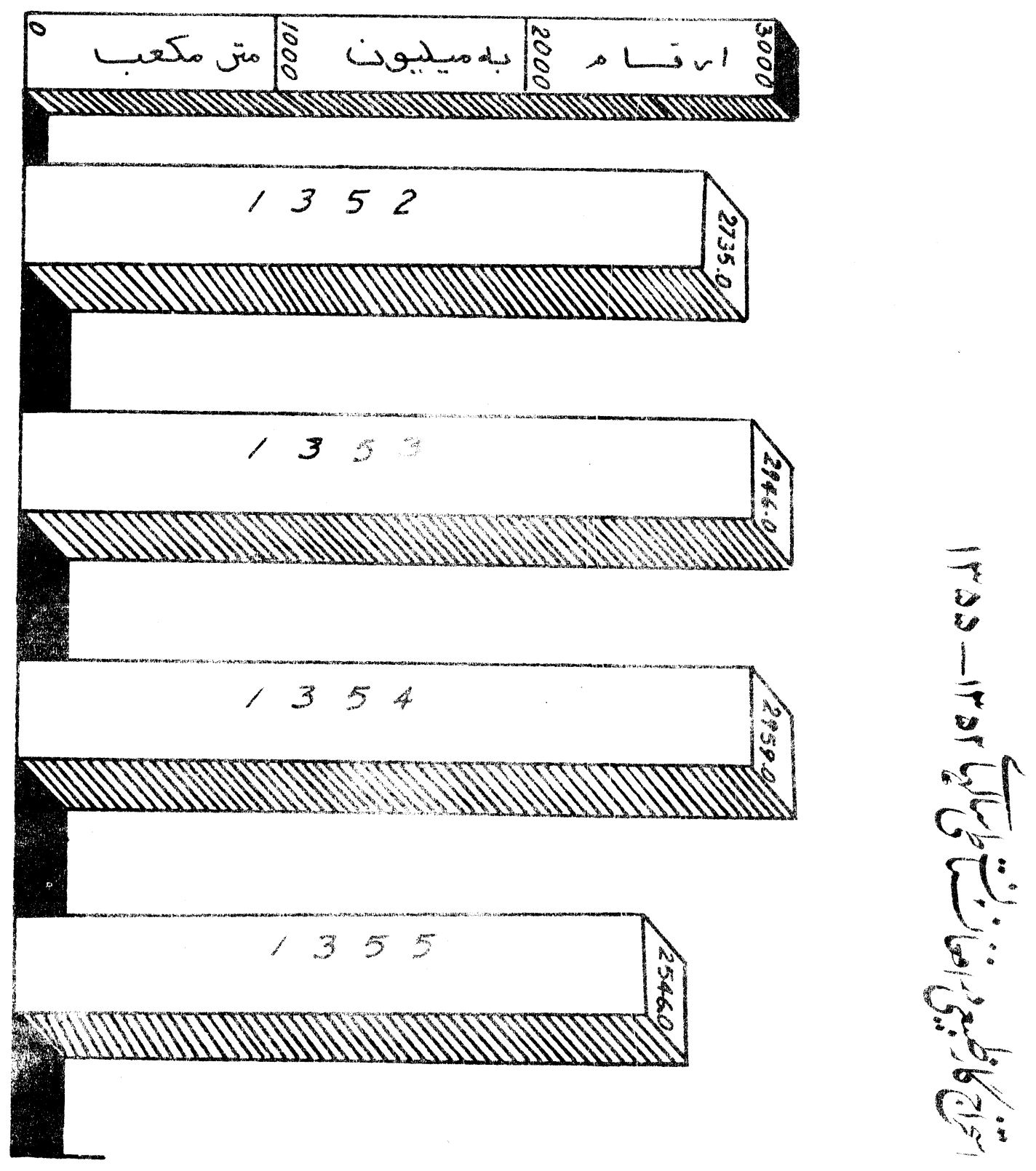


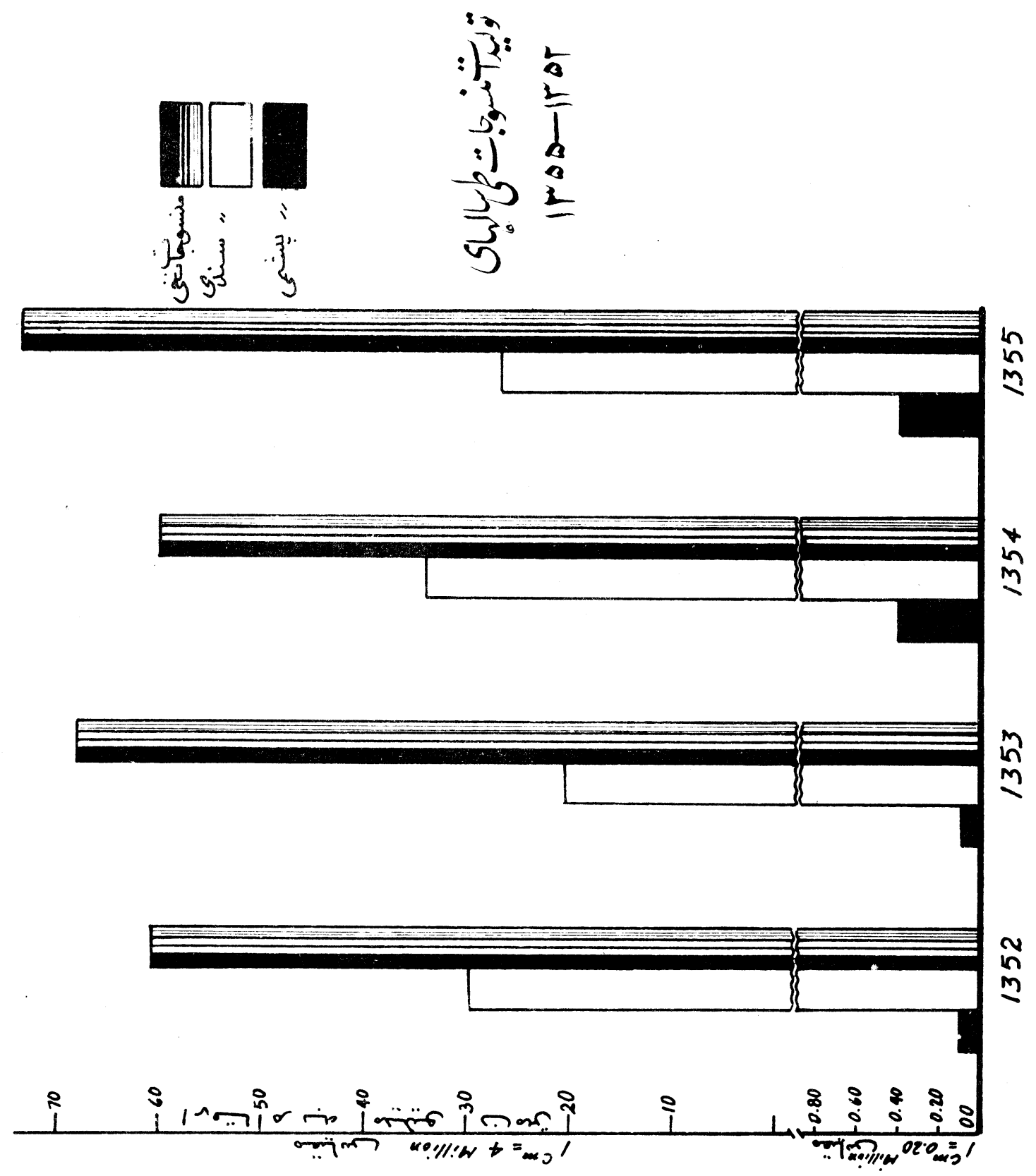




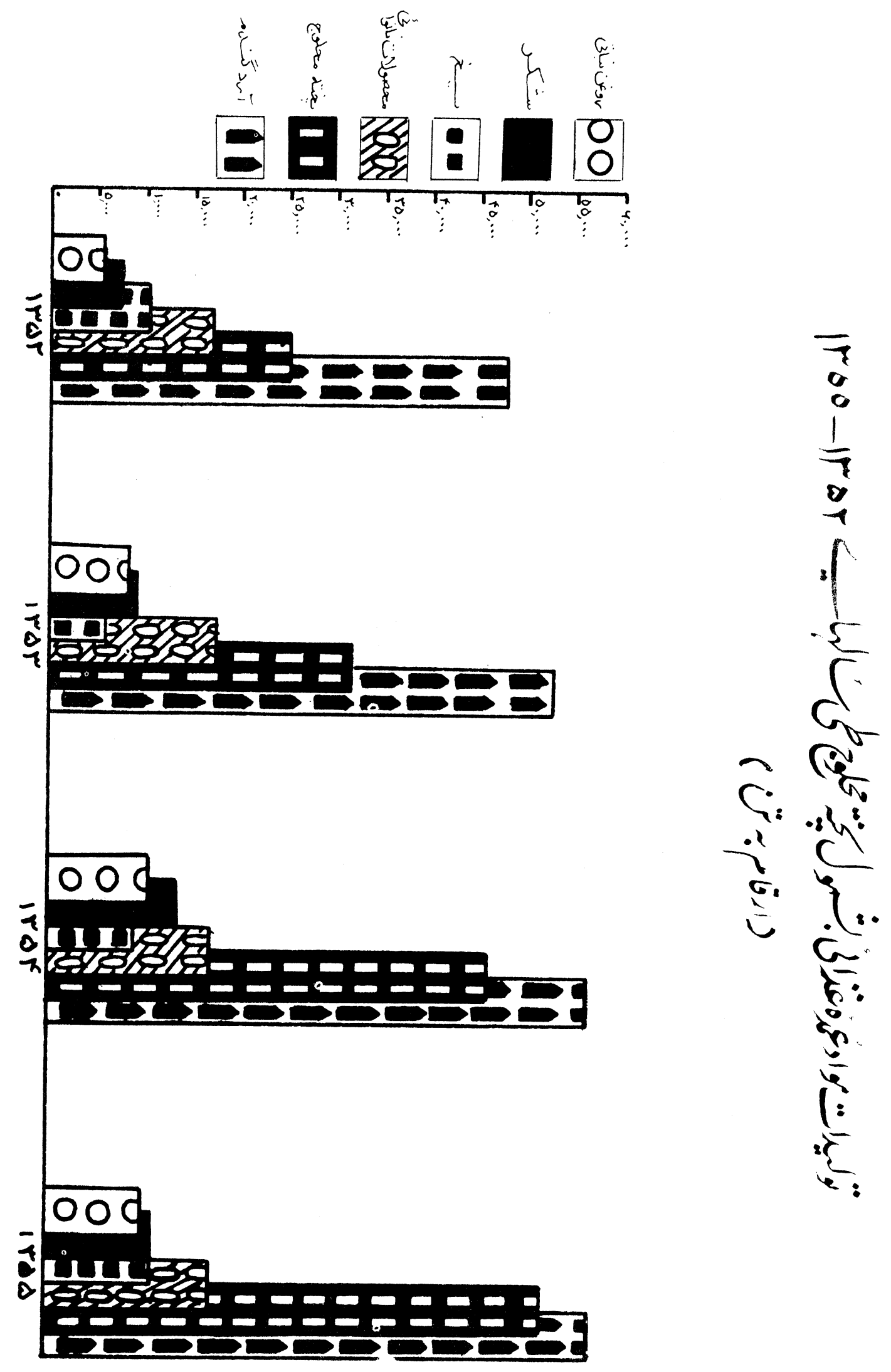




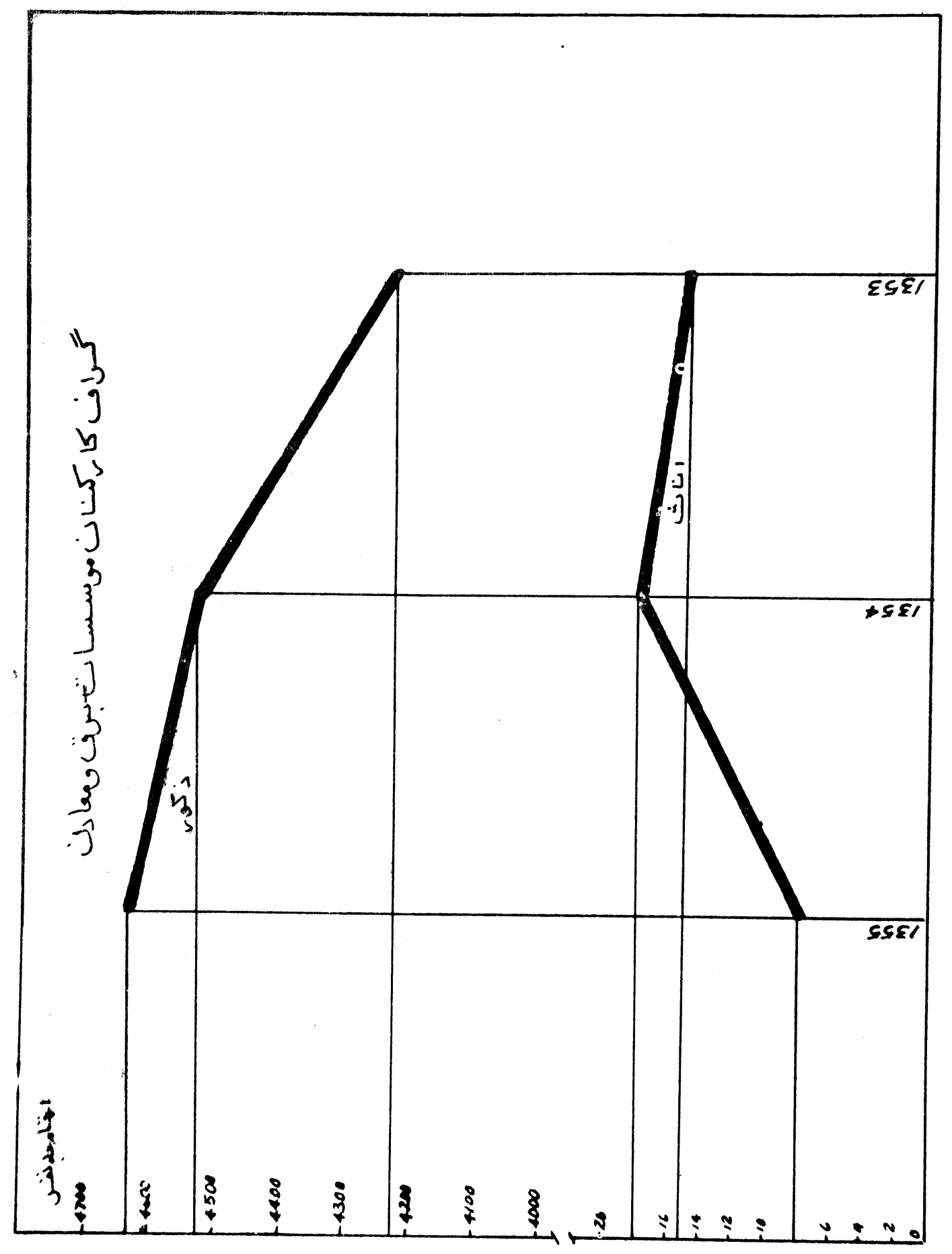




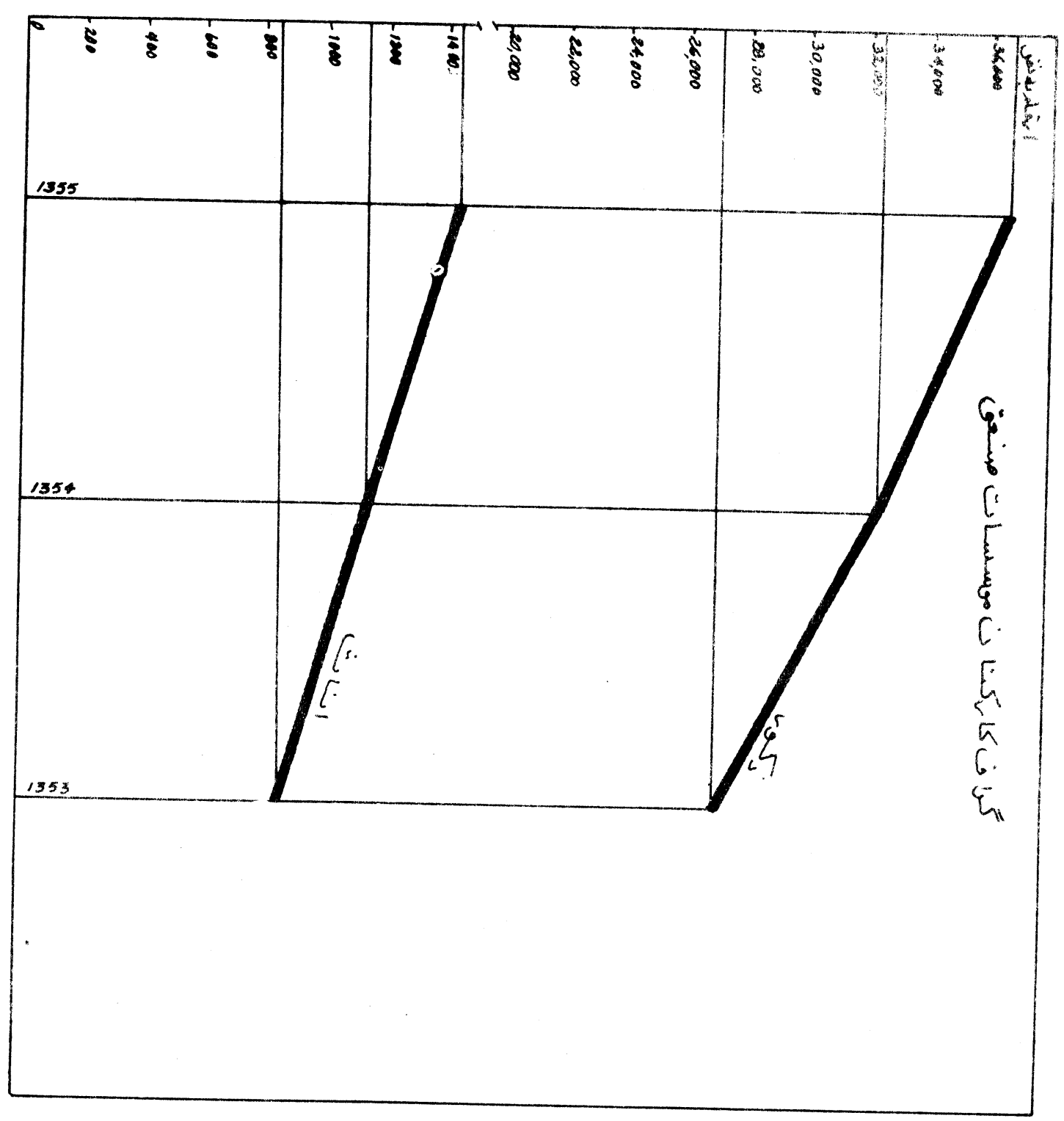



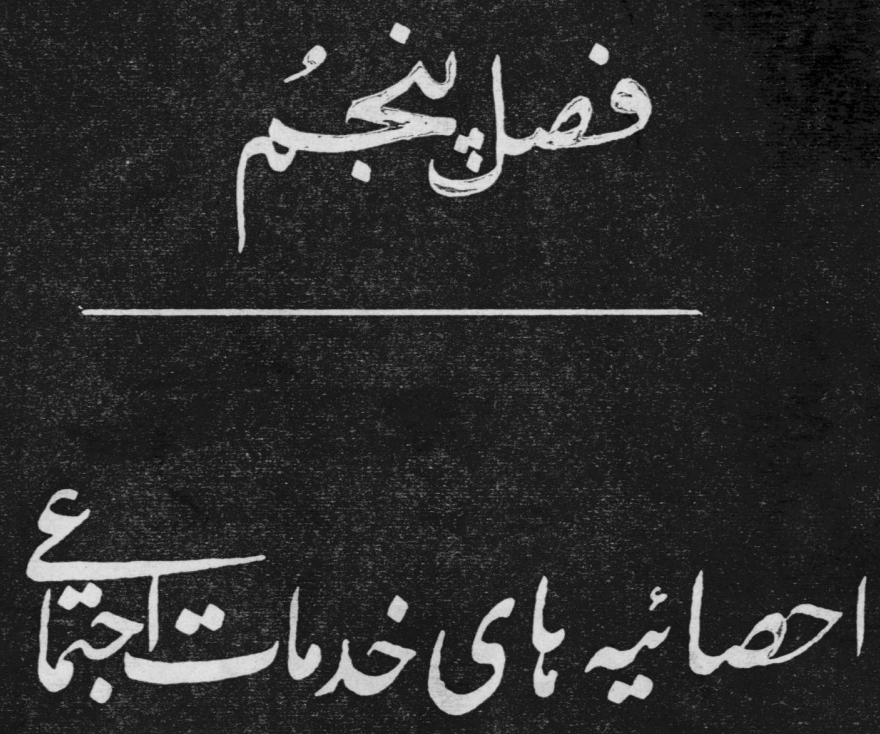

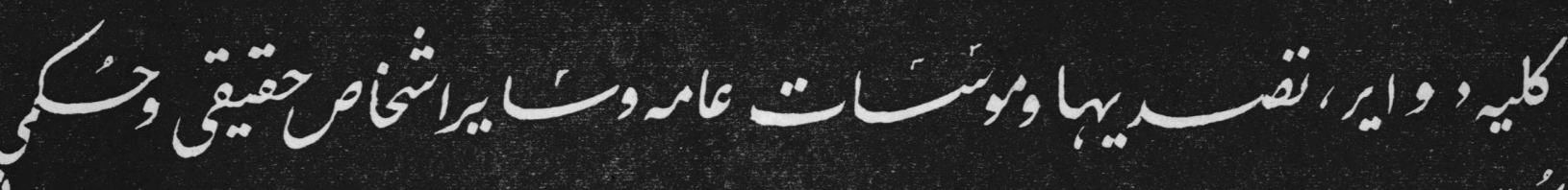

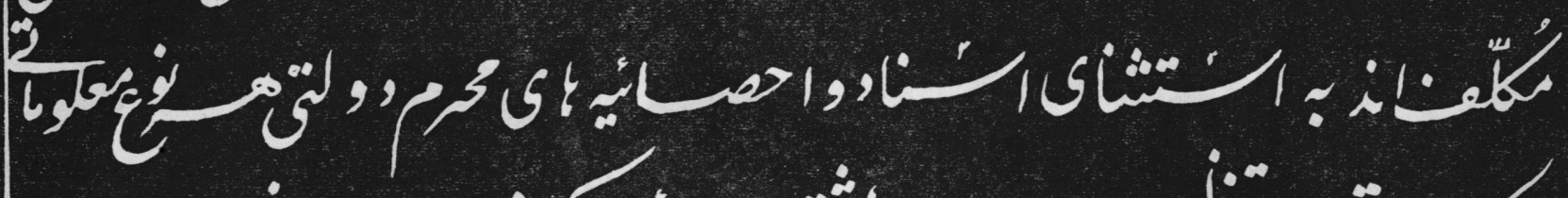

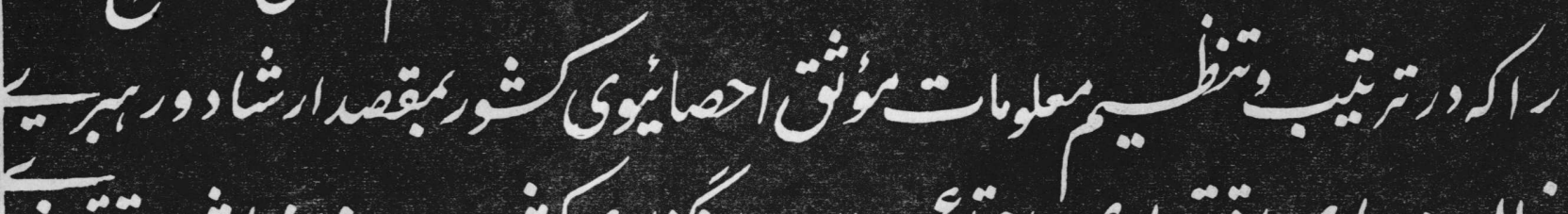

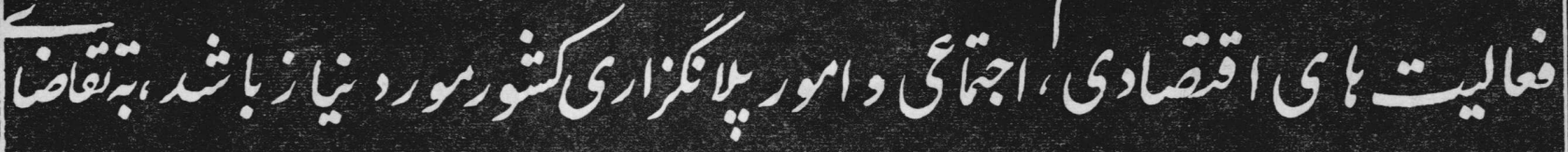

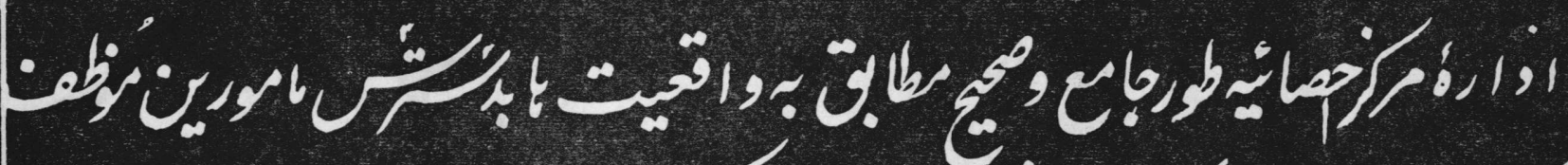

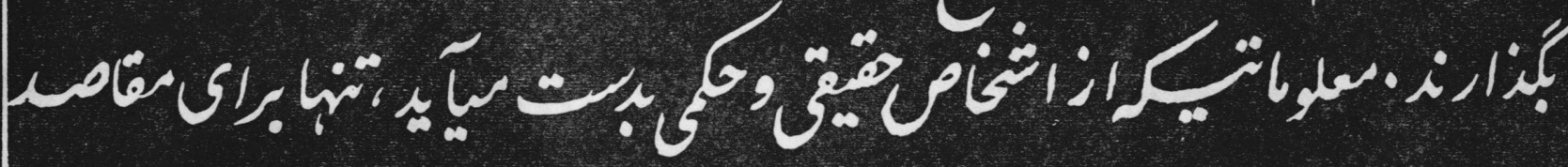

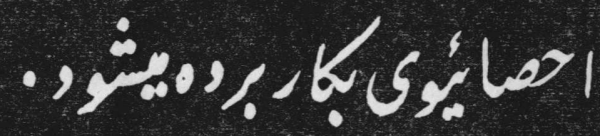

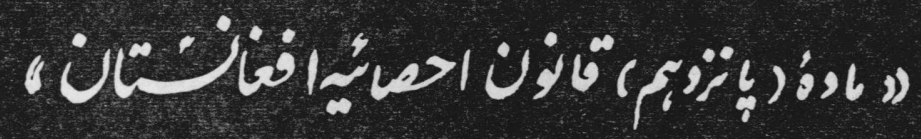


إس

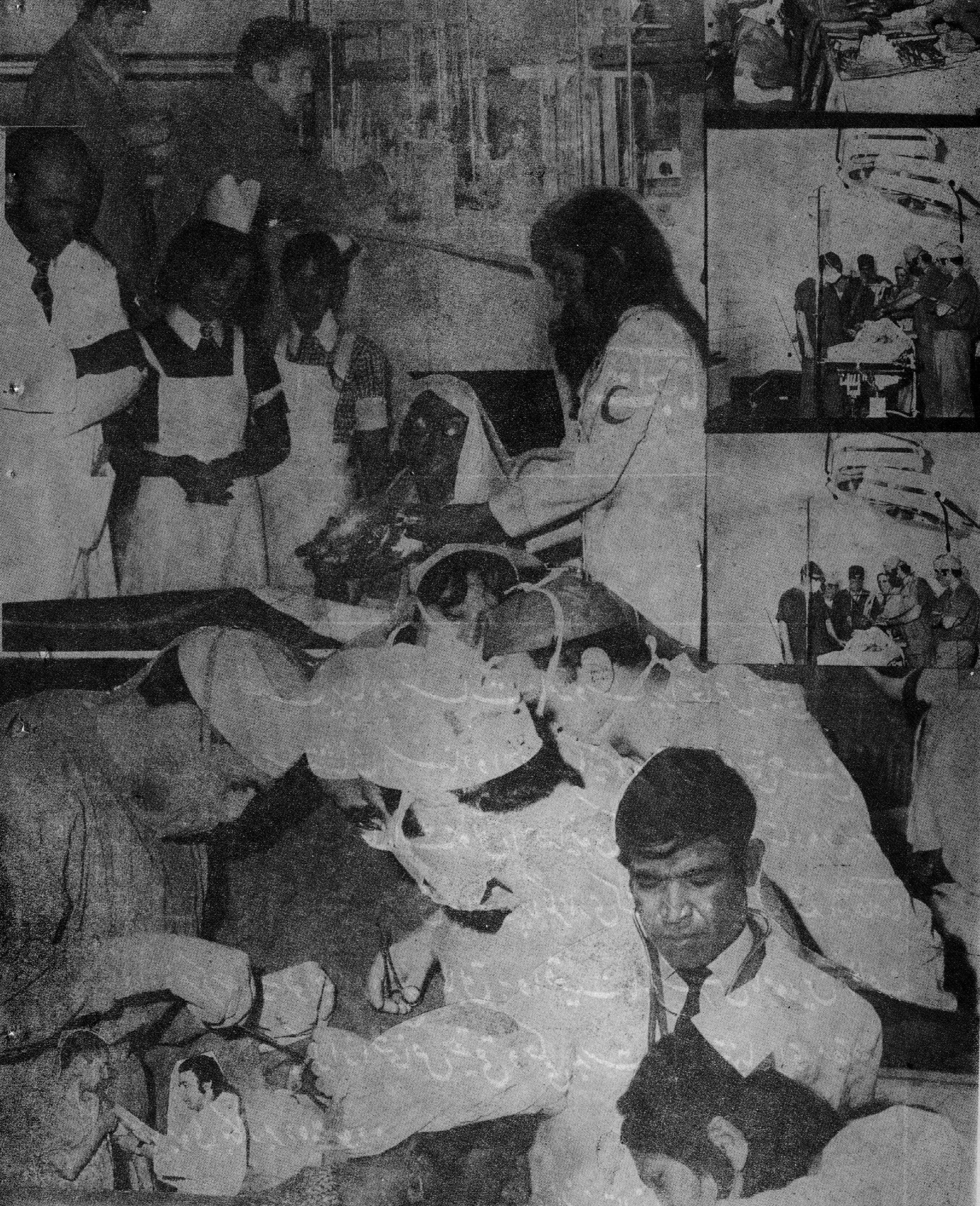

(9

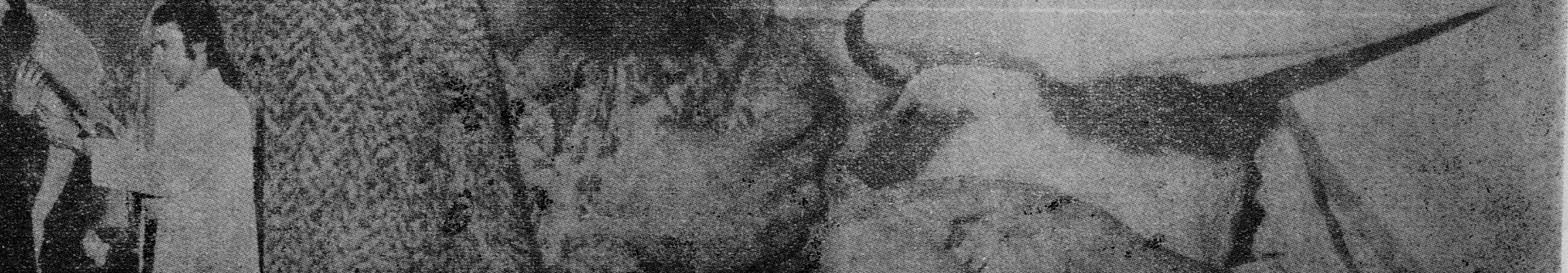




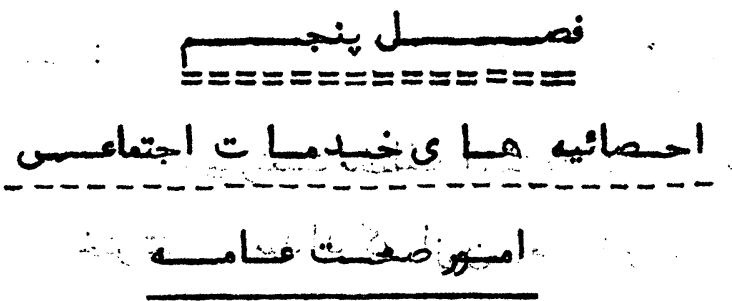

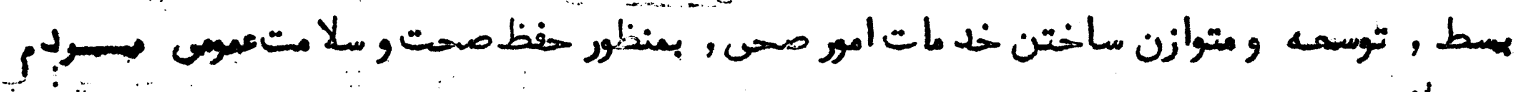

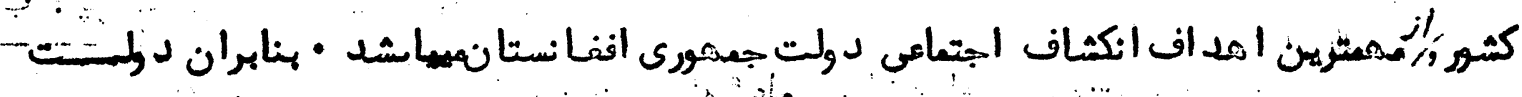

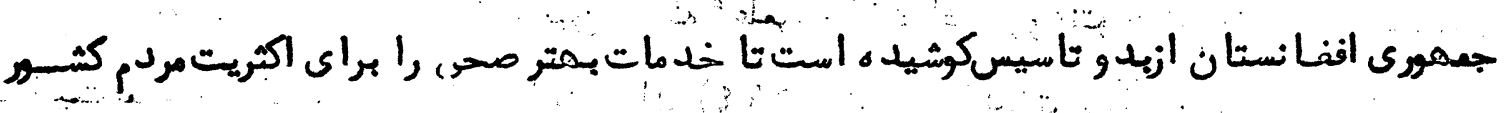

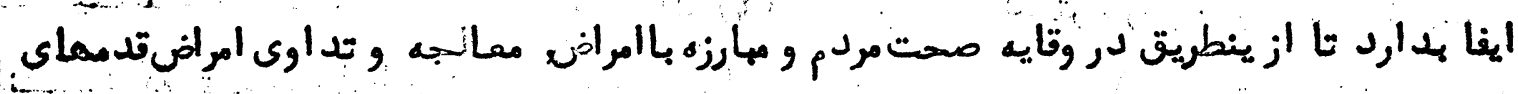

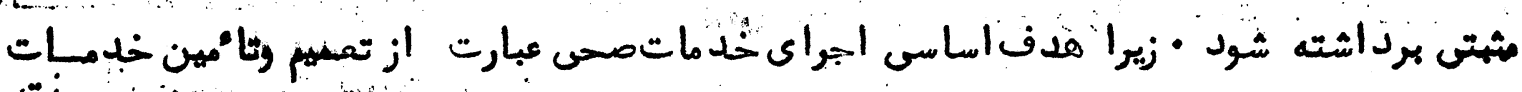

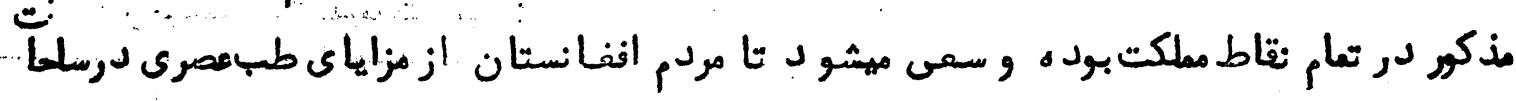

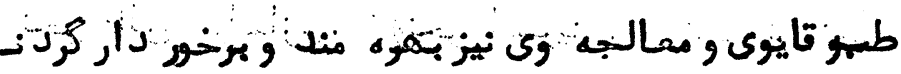

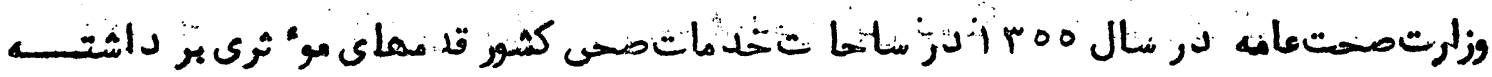

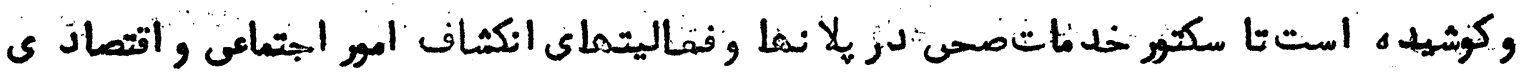

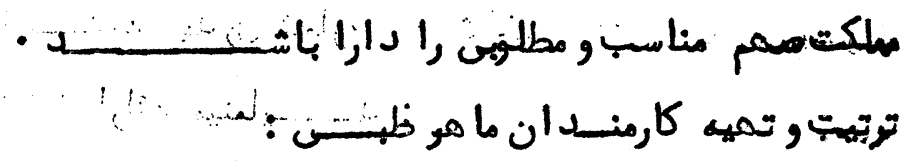

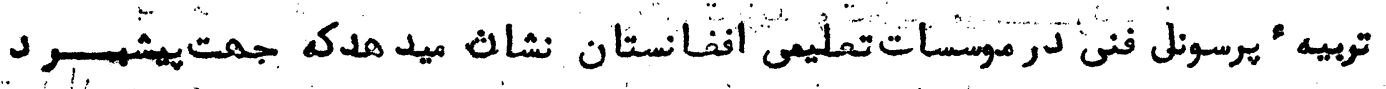

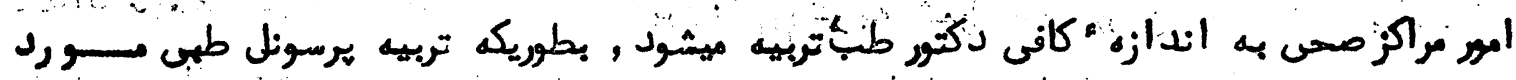

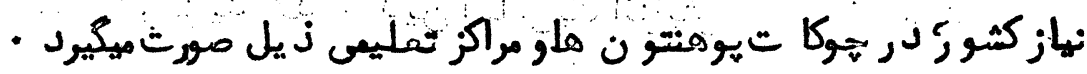

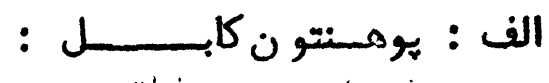

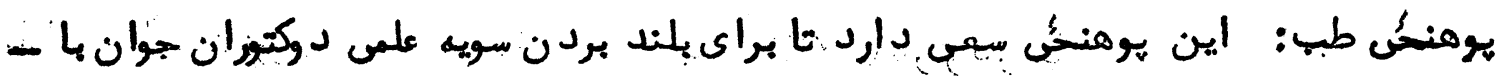

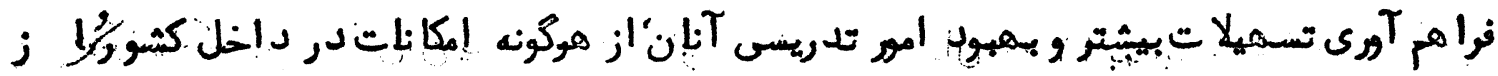

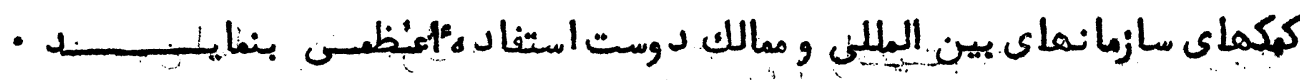

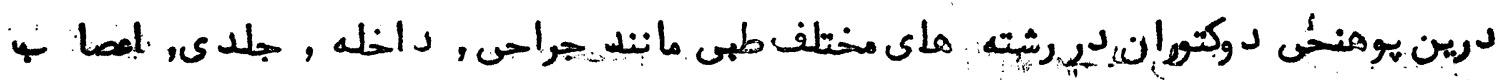

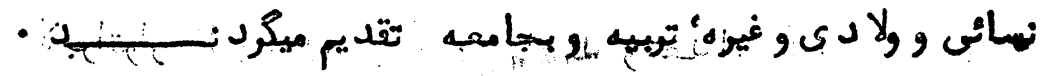

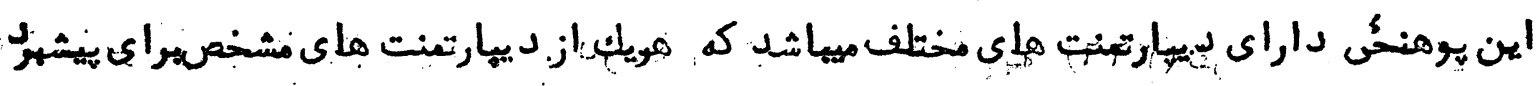

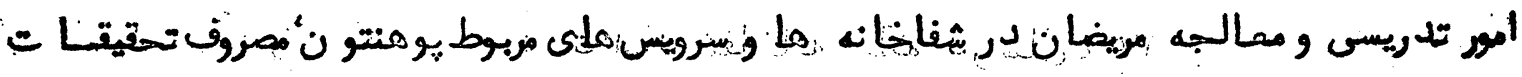

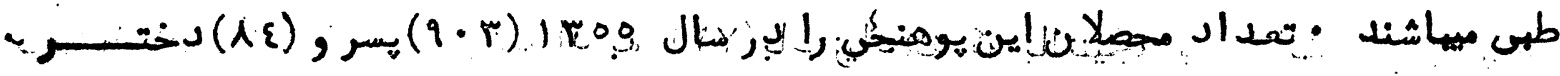

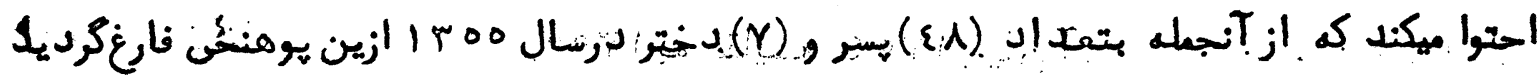




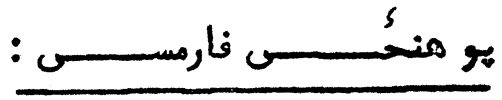

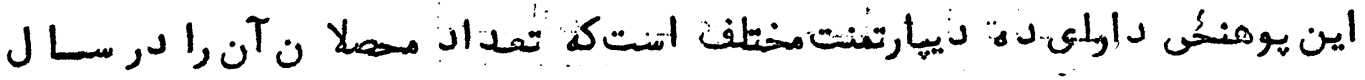

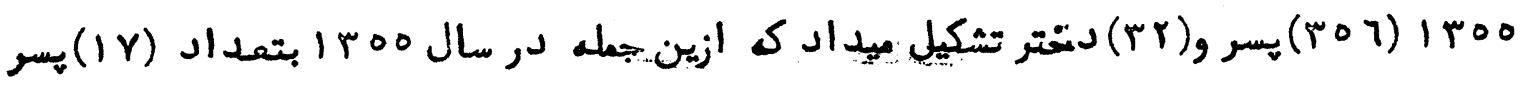

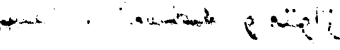

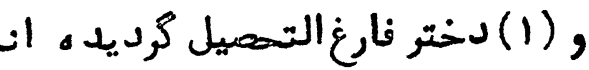

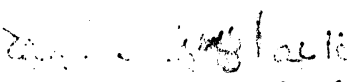

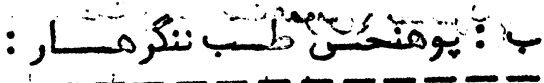

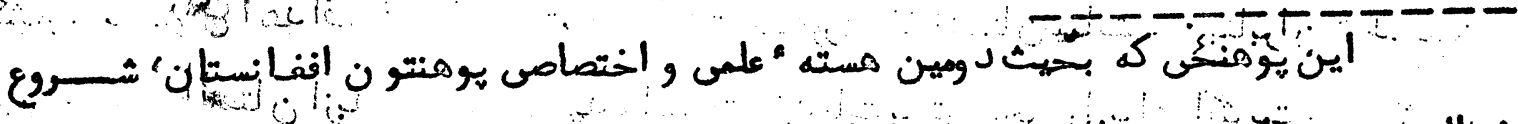

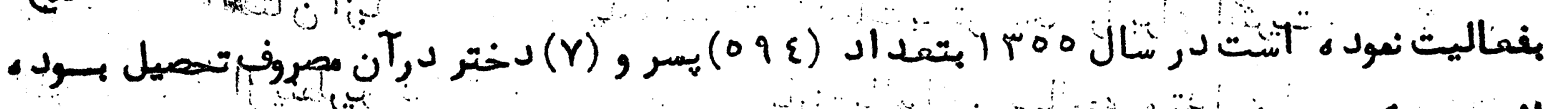

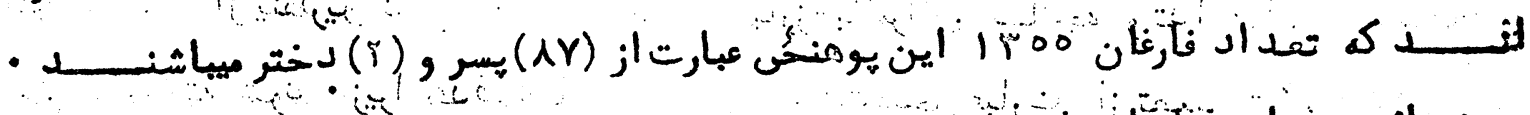
ج : سائر موسنات تقليمات طبن

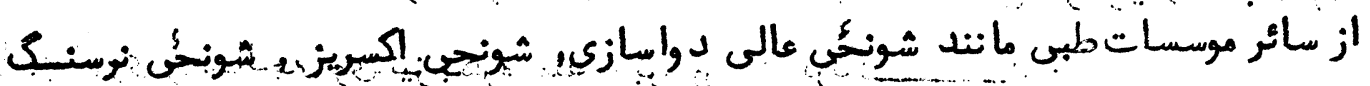

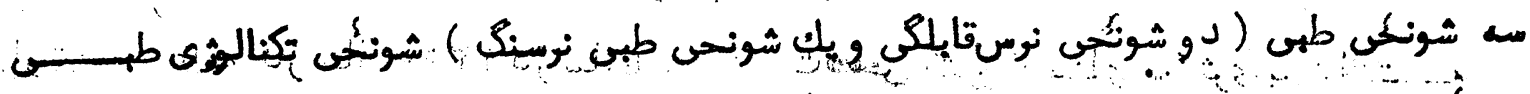

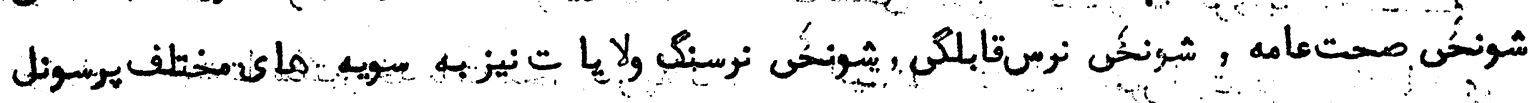

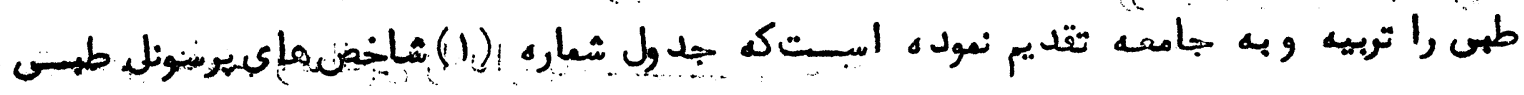

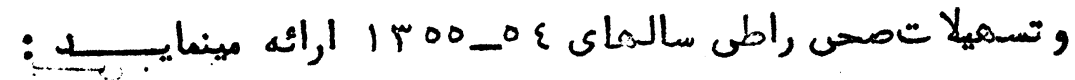

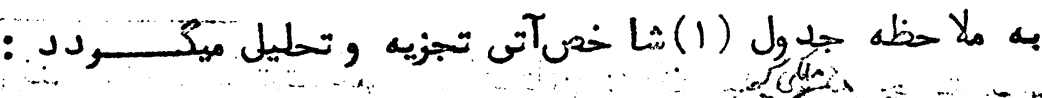

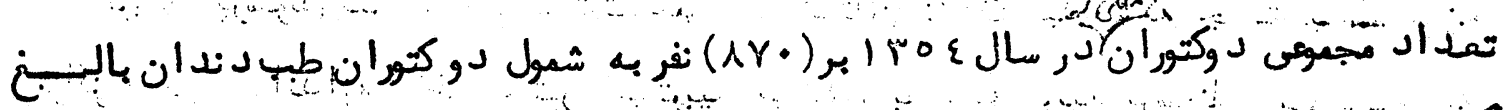

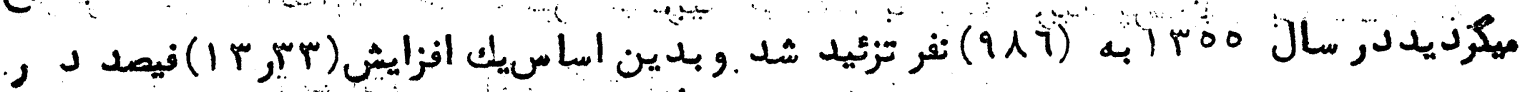

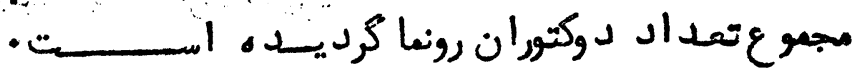

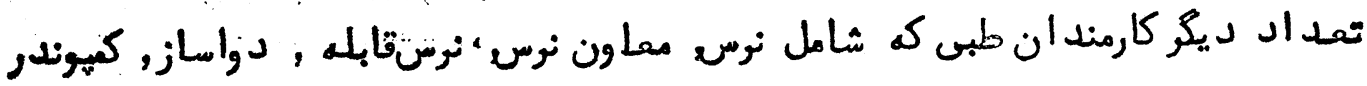

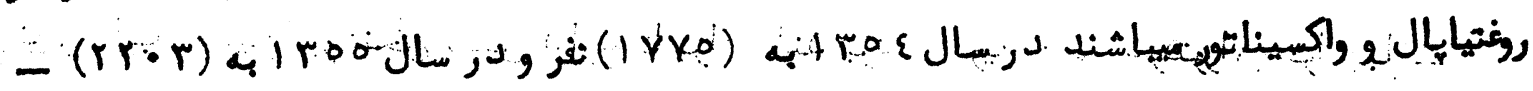

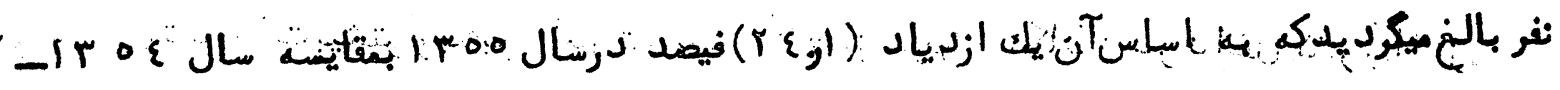

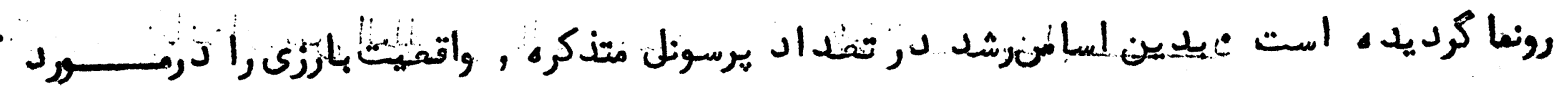

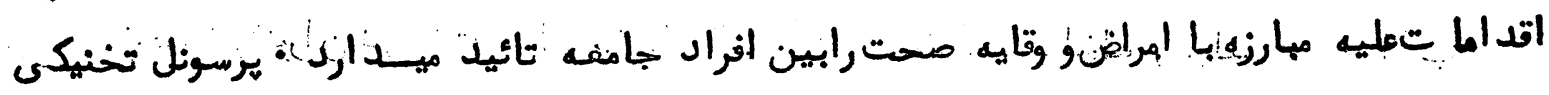

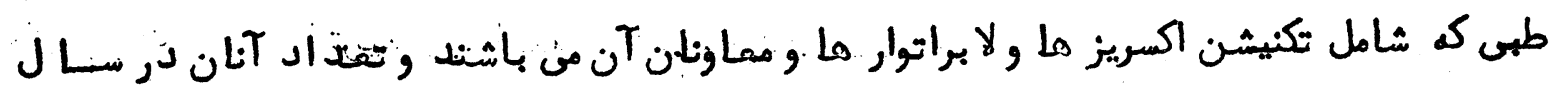

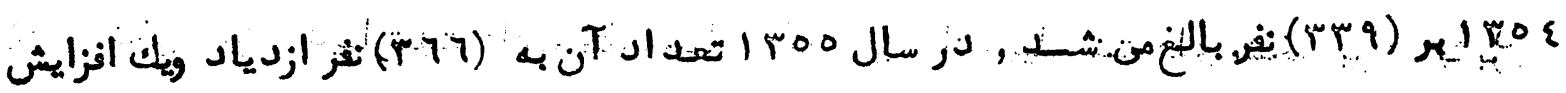

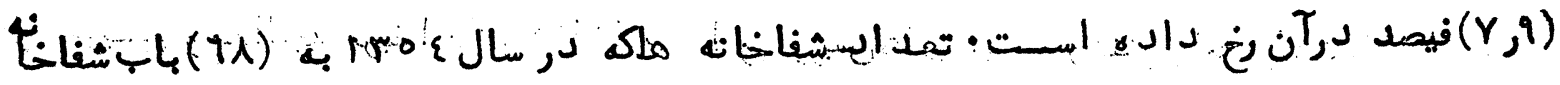

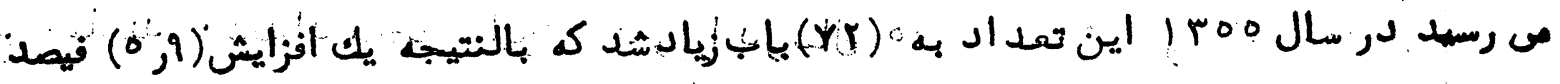

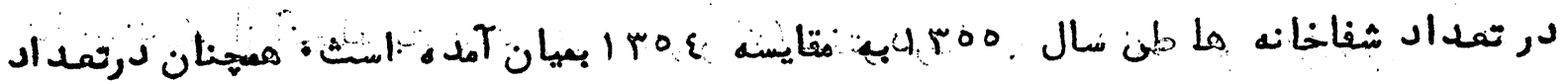

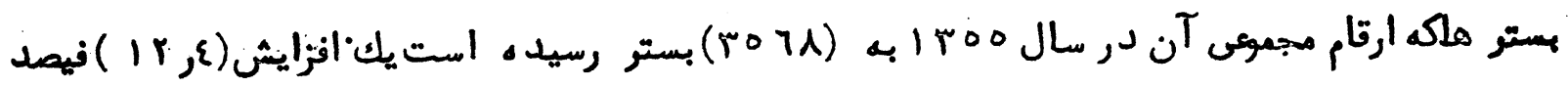

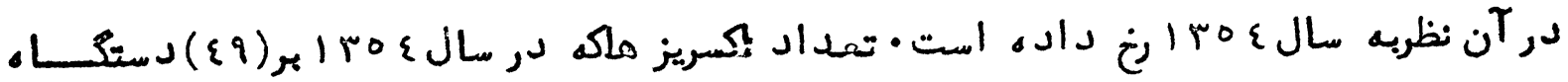




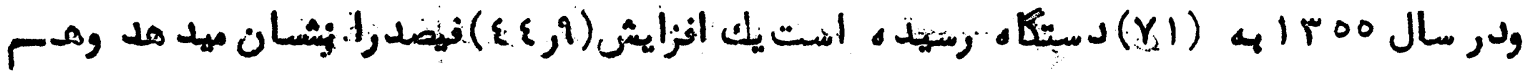

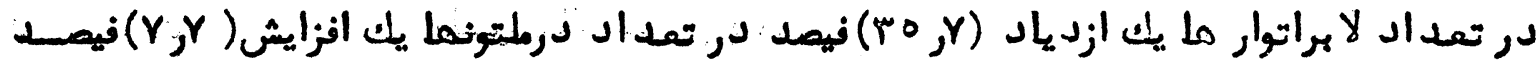

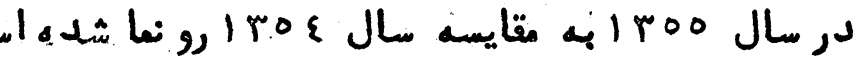
هوكاه ارقام مجموعى دوكتوران با تفداد مجموى نفوسكثوردرسال ع هب ا مقايسه گردد در

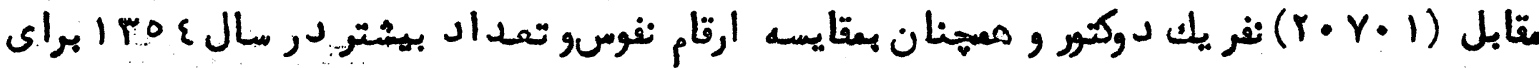

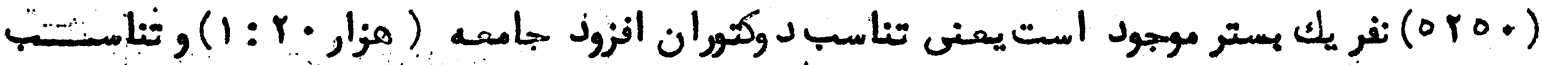

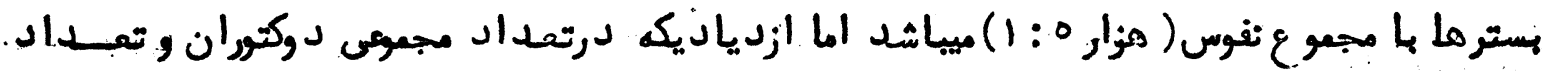

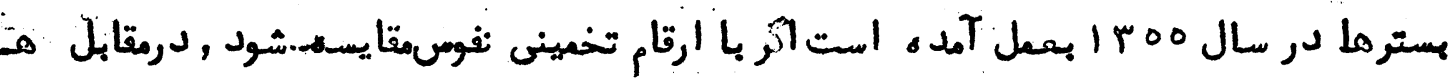

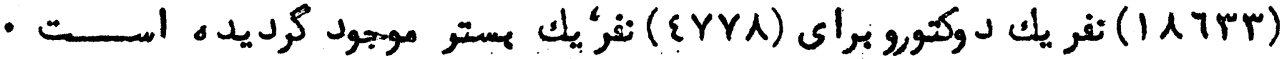

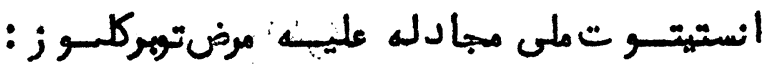

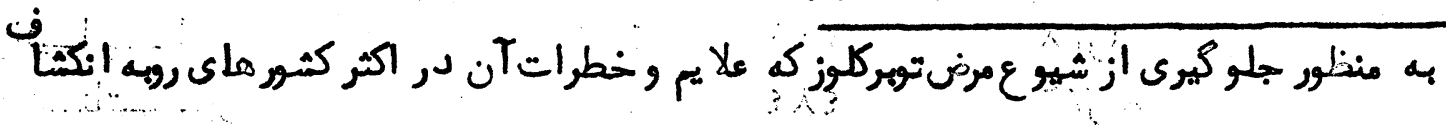

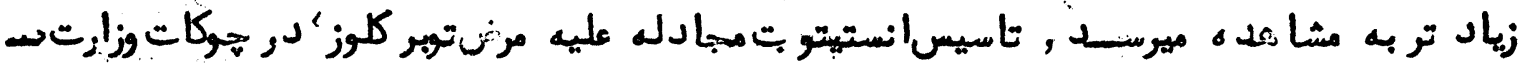

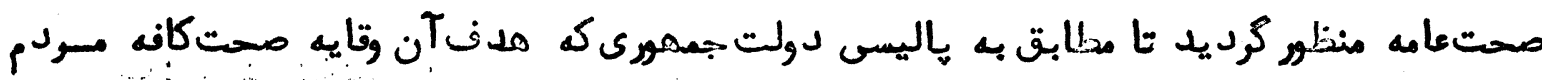

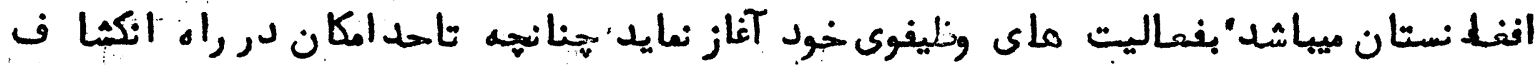

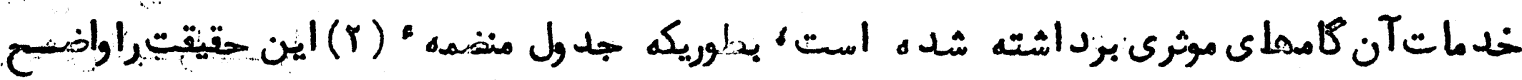

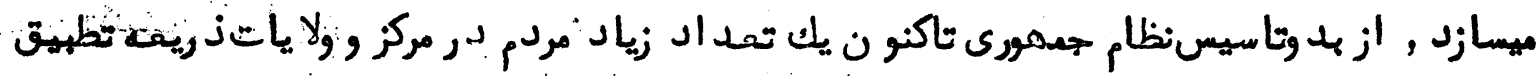

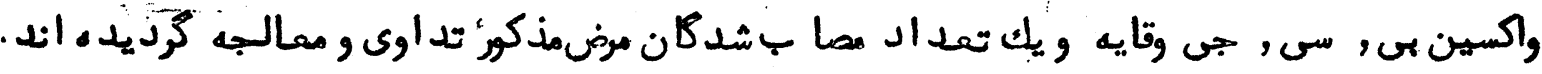

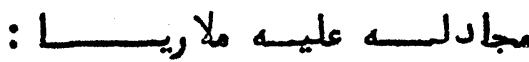

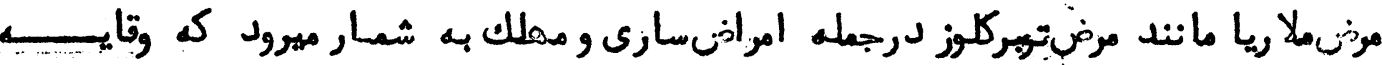

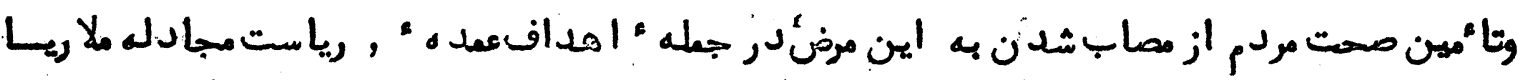

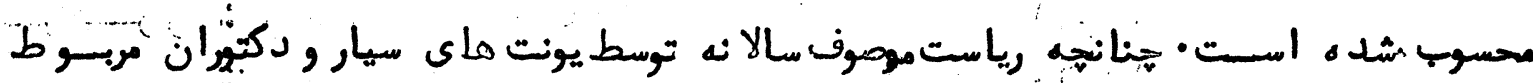

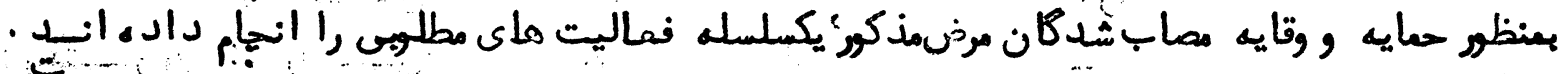

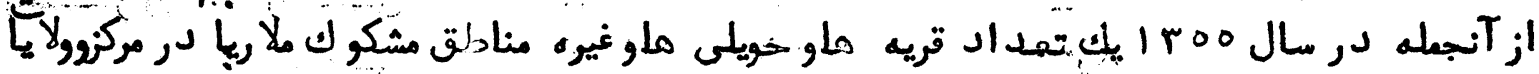

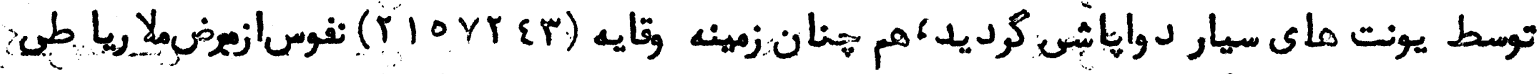

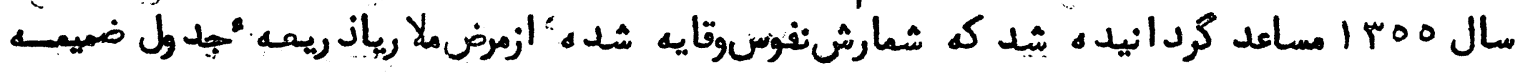

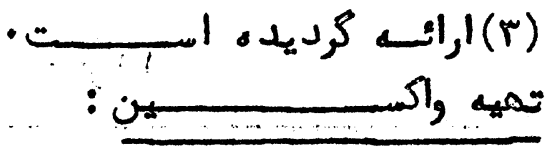

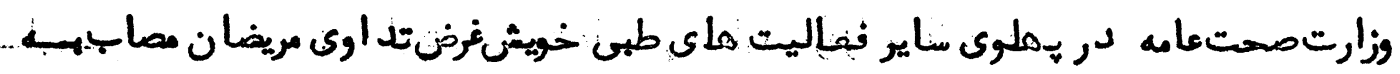

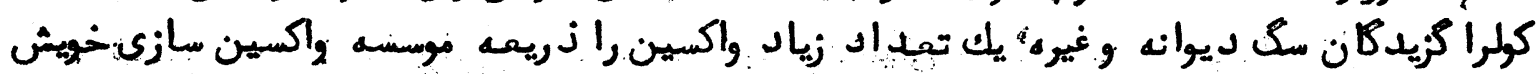

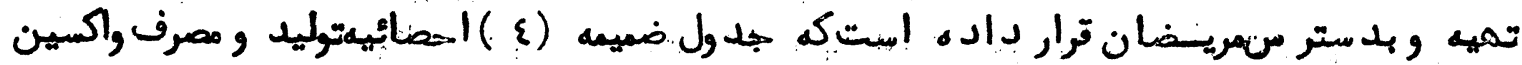

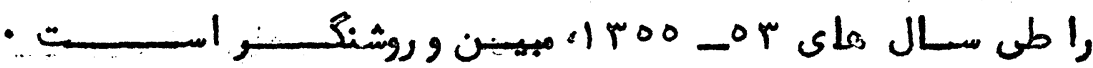




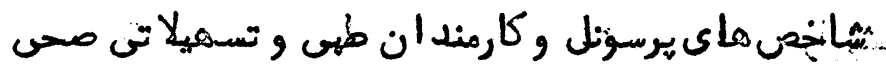

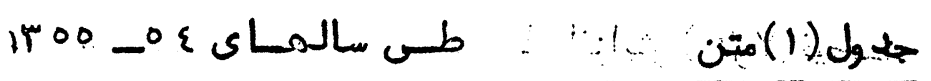

كارمندان, برسنل طبى وتسميلات

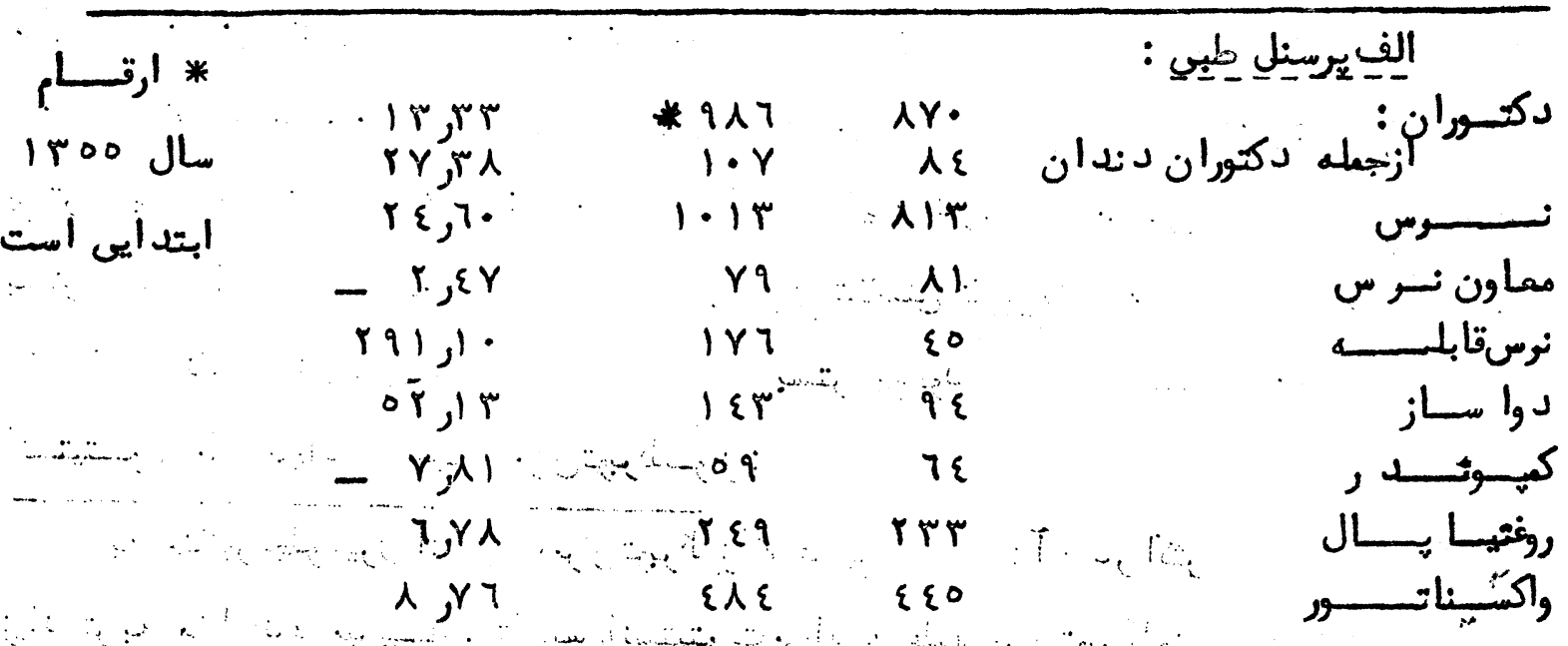

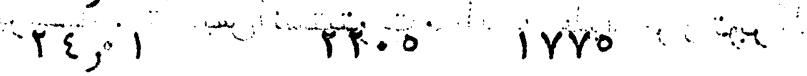

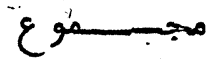

ب: بوسنل تخنيكى :

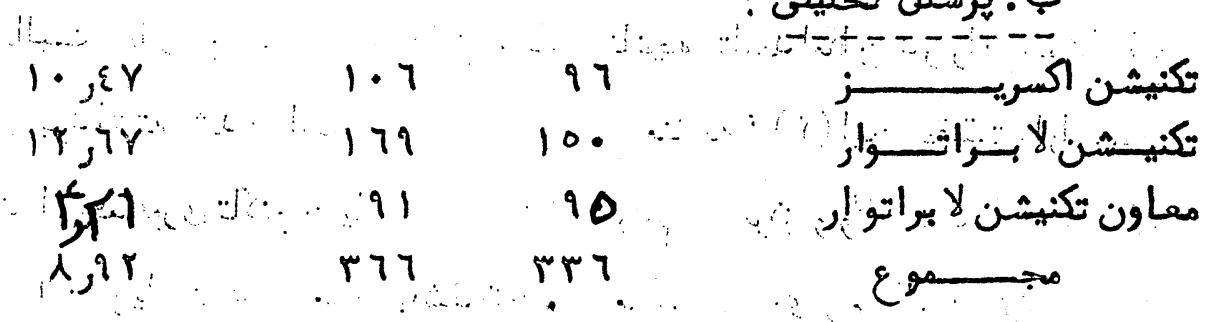

$0 \mu \lambda \quad$ VY $7 \lambda$

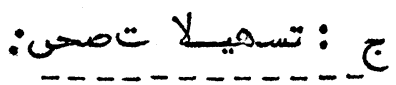

irje roth lrve

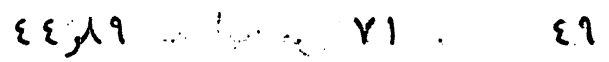

arto lro lef

11,7 O

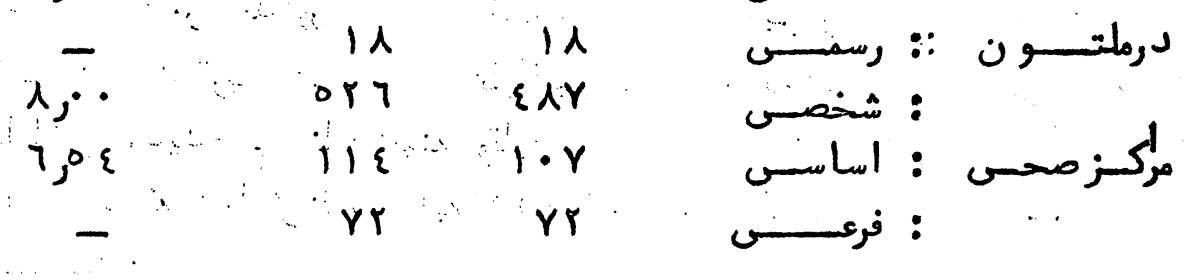

$11.0^{\circ} \quad \varepsilon 7.1 \quad \varepsilon 101$

مجســـموع

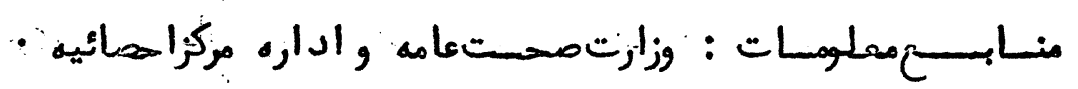

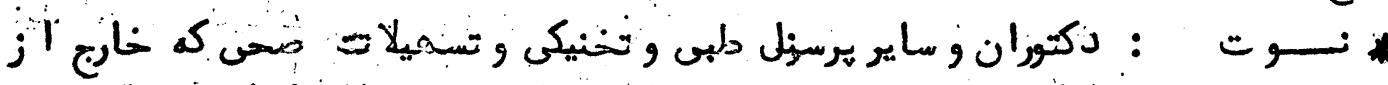

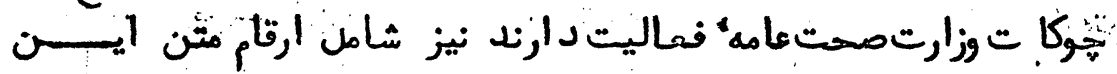




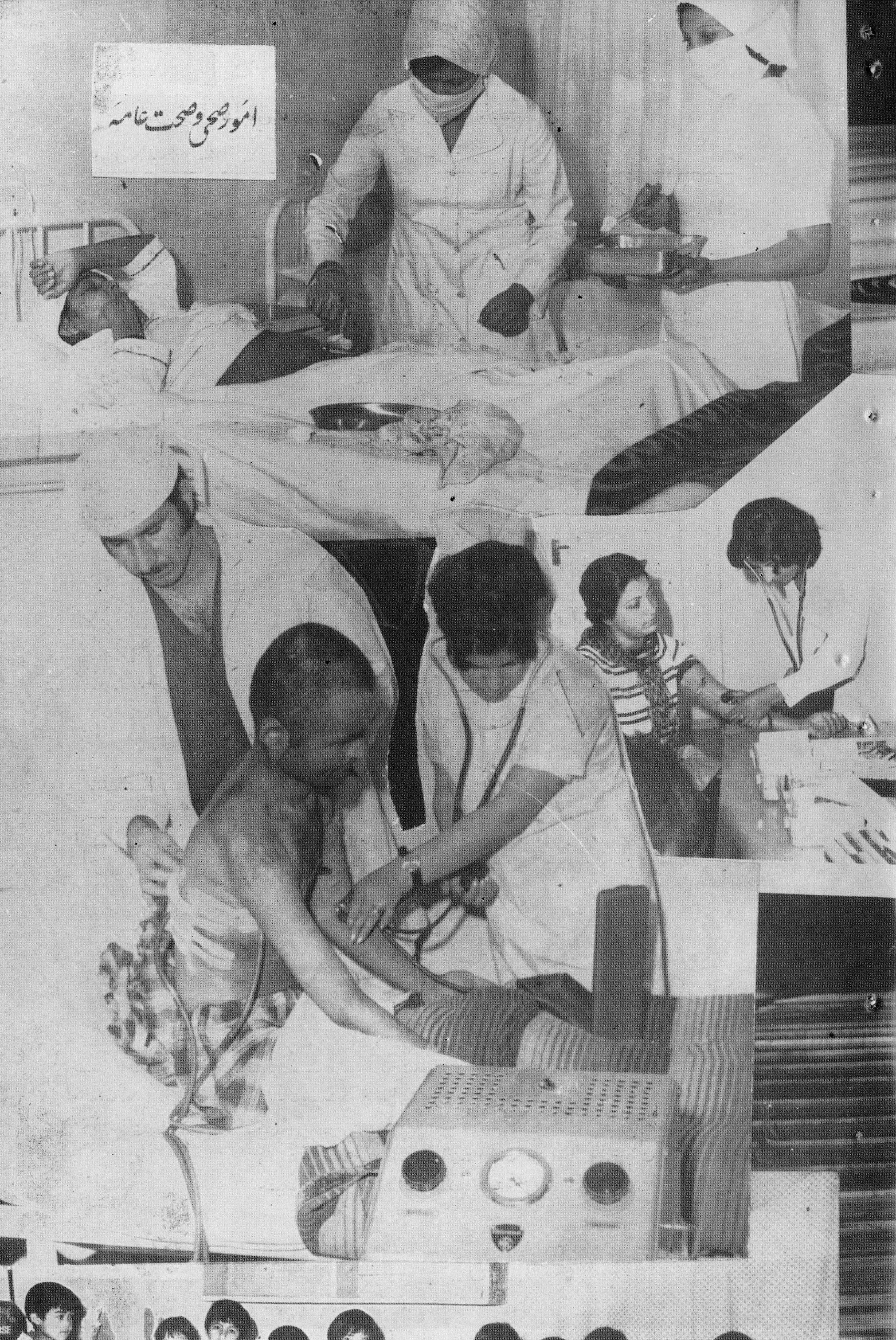




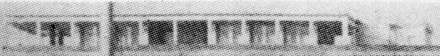

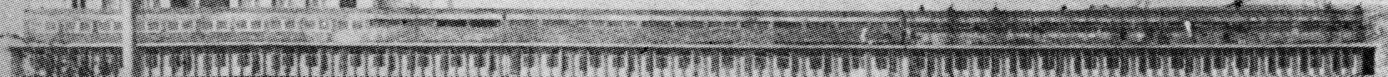

C.

(ht)

(1.0.0.

23.

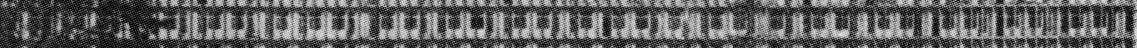

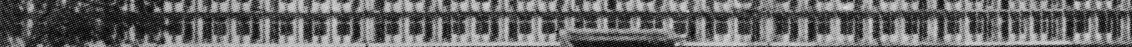
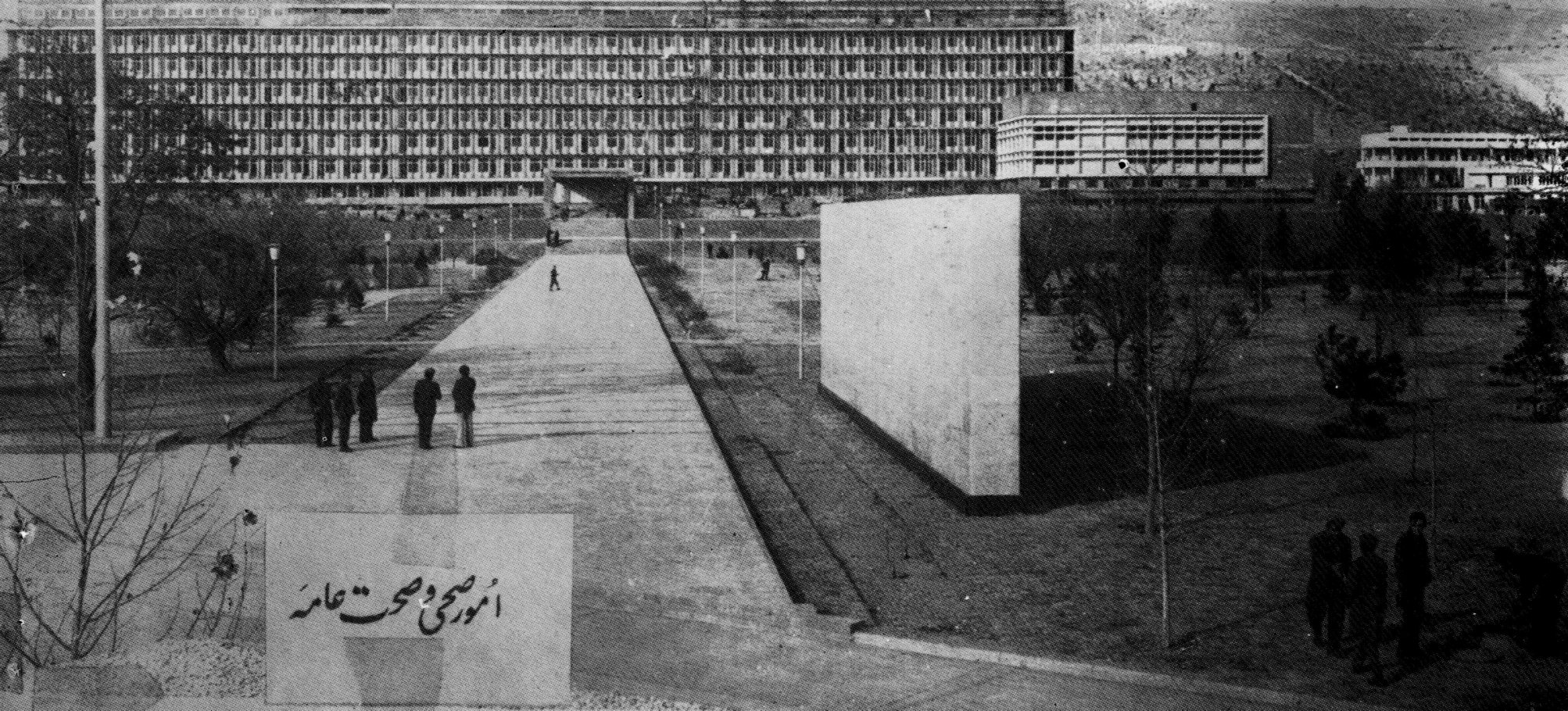

$+4$

जाञाये

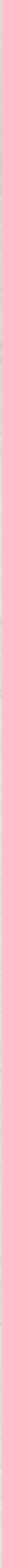




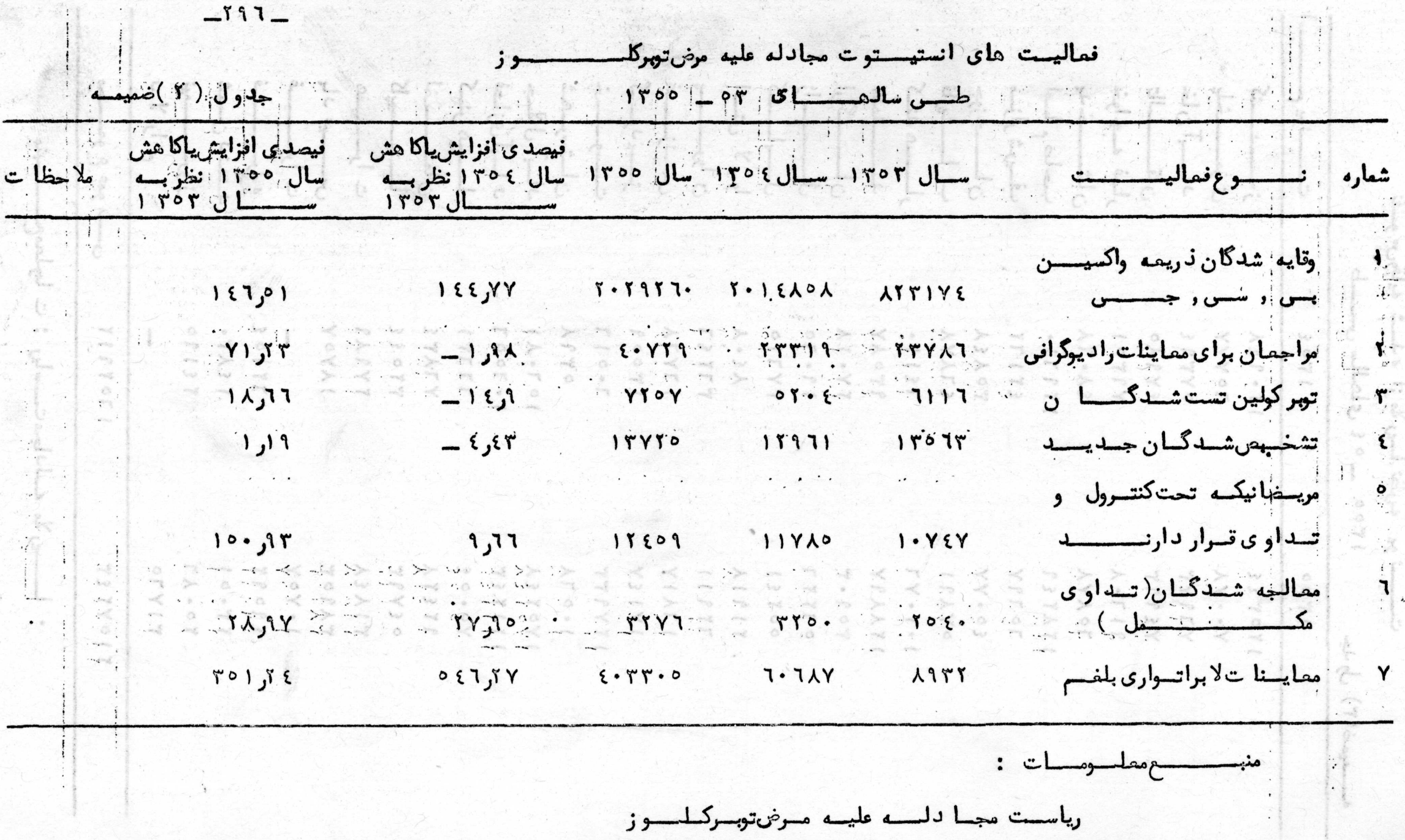




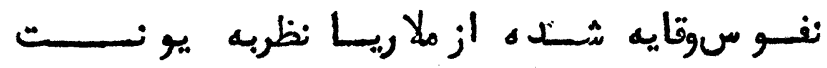

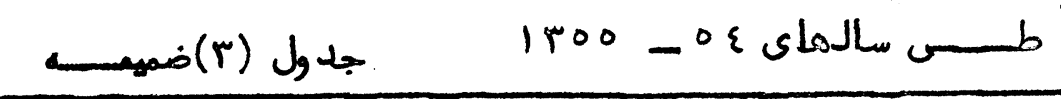

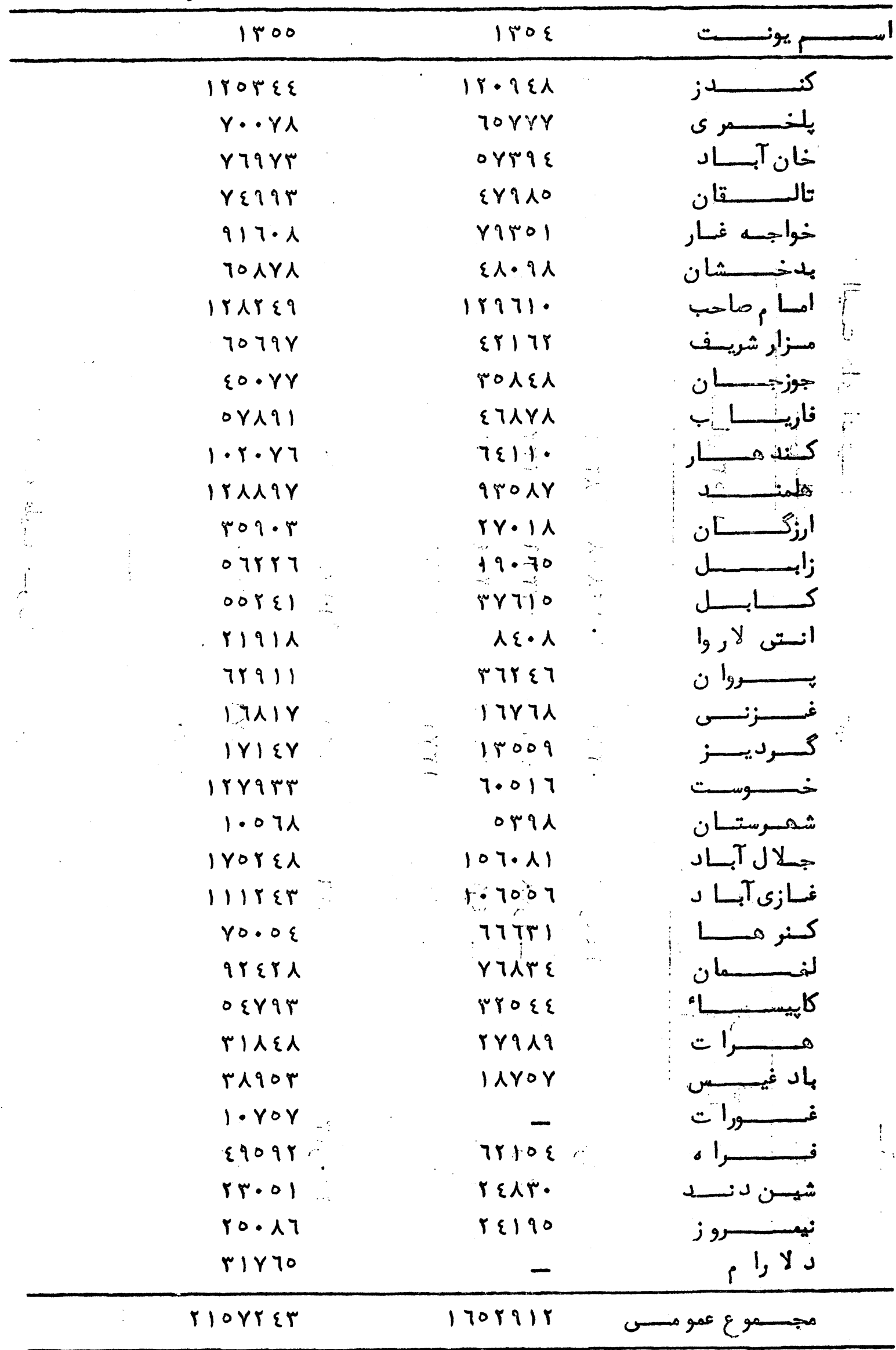

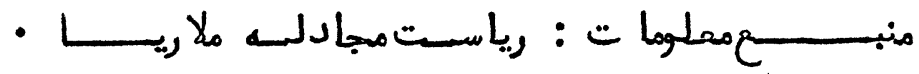




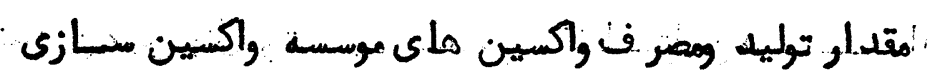

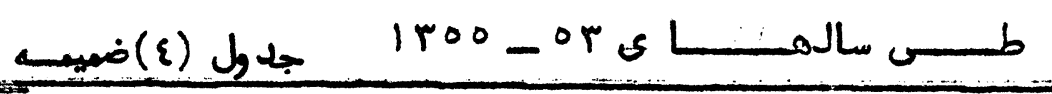

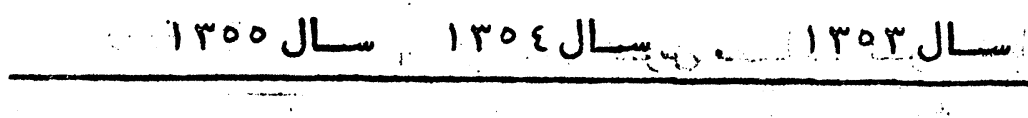

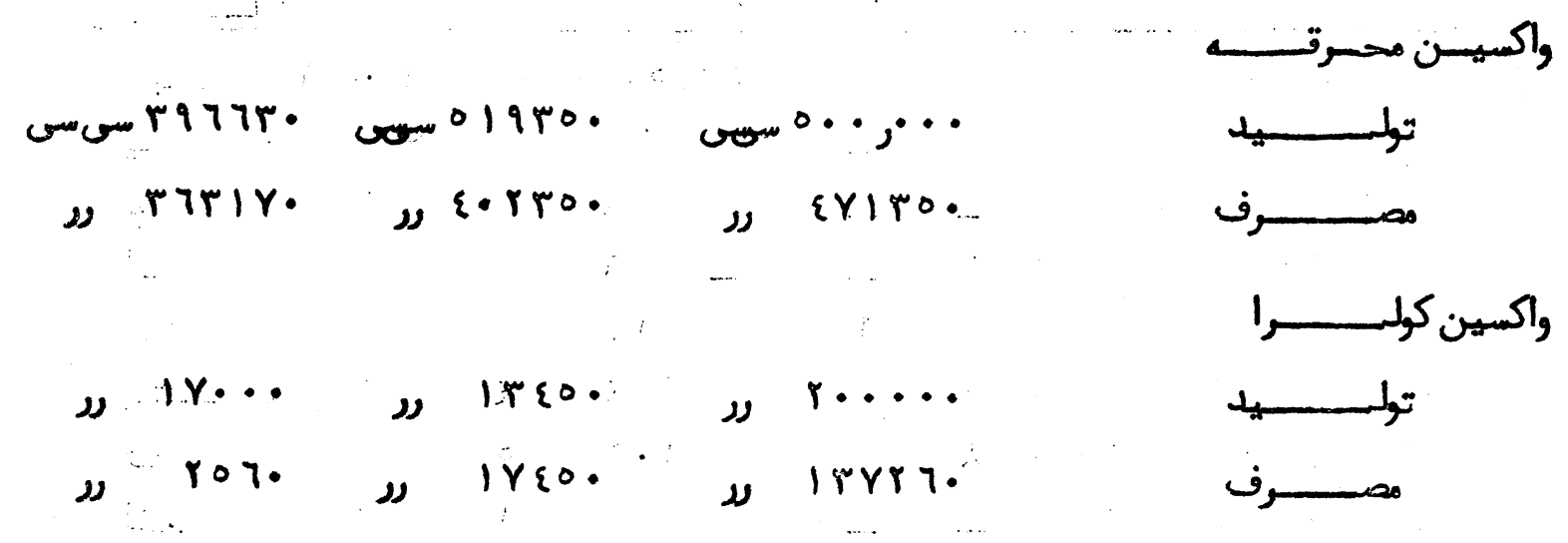

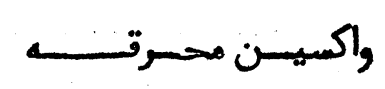

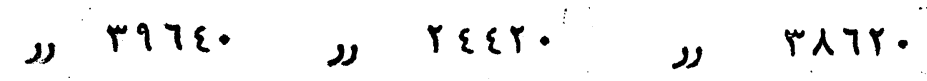

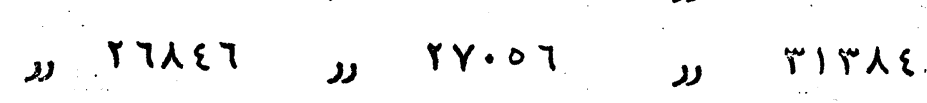

واكسين ضد بـى ديوانه انسانى

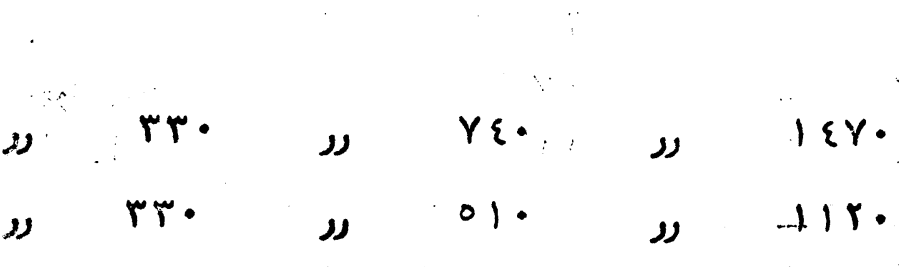

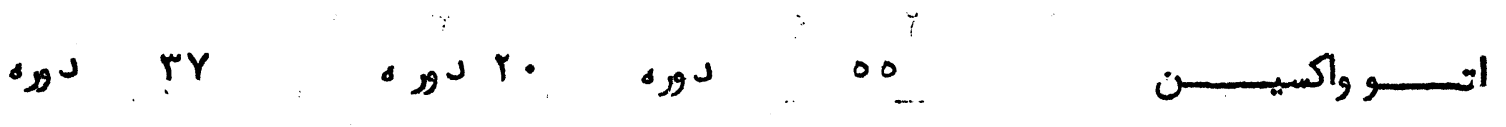

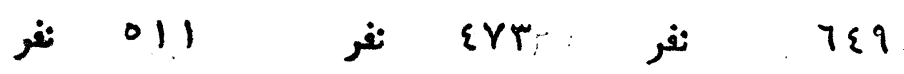

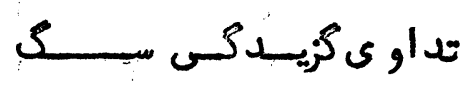

واكسين ضد سكَ ديوانه حهوانى

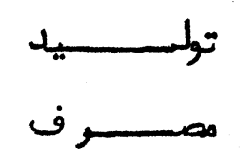

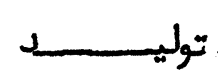

مس مسرف

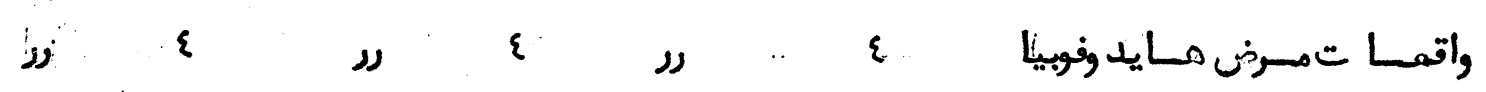

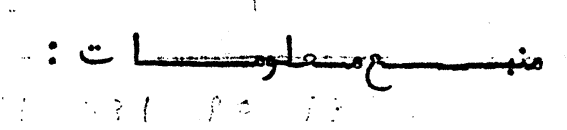

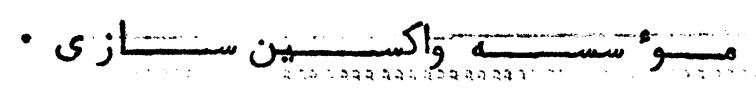

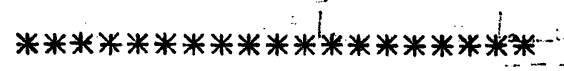

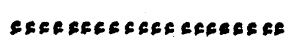

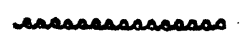

$\dot{v} \dot{v} \dot{v} \dot{\Delta} \dot{x}$ 


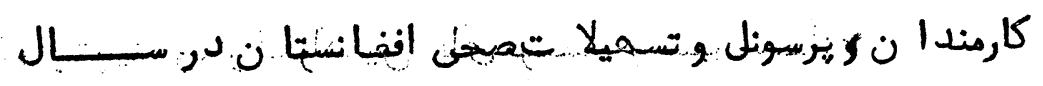

جدول (0) ضمينه

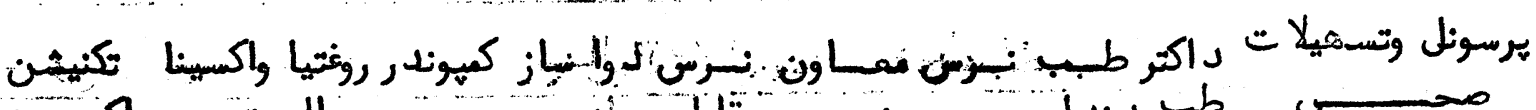

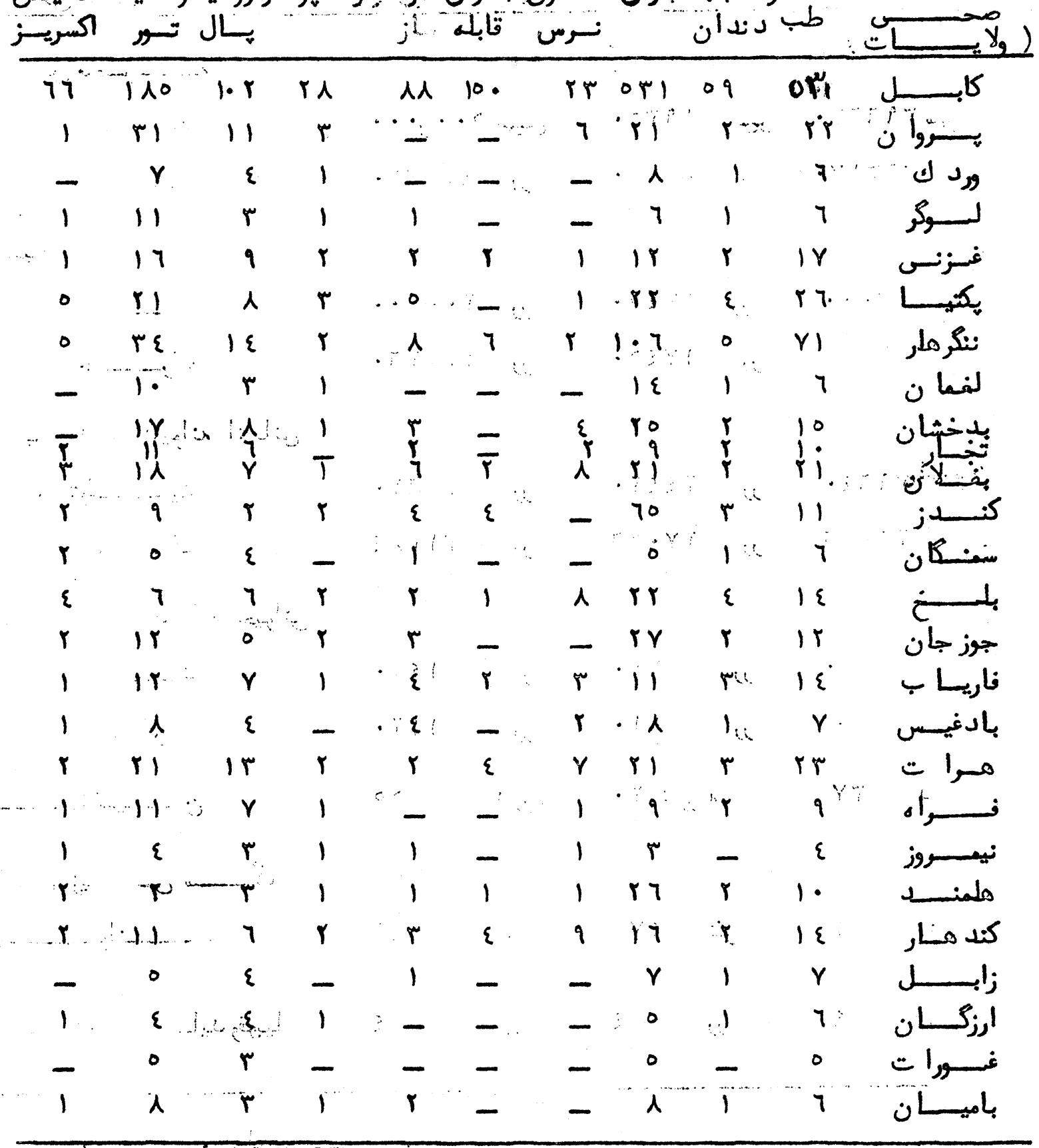

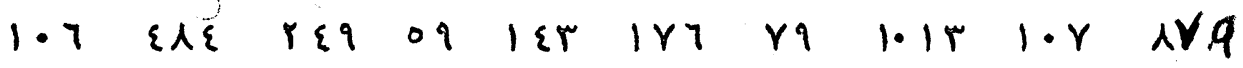

مجسموع 


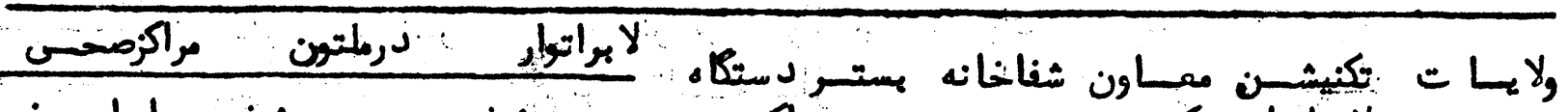
لاهواتوار تكنيشن

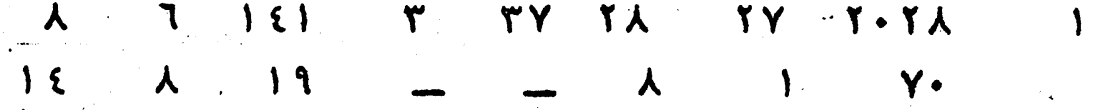

-r r r $r$ - r $r$ r r r r r r r

a $r-r-r-10$

$\& \quad r \quad r-r \quad 1 \quad 1$

$r \quad 1 \quad r r 1-7 r$ \&

$r \circ r \varepsilon 1-9$ \& $10 \varepsilon$,

$r 11$ rr 1 q r. O Trq

$\therefore \varepsilon r+1-\varepsilon-1$ - 1 -

L. \& \& \& $1-r$ r.

$10010-1$ - ro

$11 \circ r \varepsilon .1-1 \quad r 10$.

- r r 1 l \& 11.0

l.r $r-11 r$

$-r \quad r \varepsilon \quad 1 \quad r \quad 0 \quad \varepsilon$ ir

$r r|r| r|r| r$

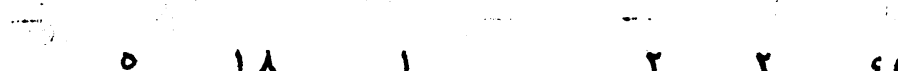

$-011 \quad 1-r r$ \& $\quad r$

$r\{11-1110$

-9 rr $-r$ r r r $\lambda_{0}$ r r

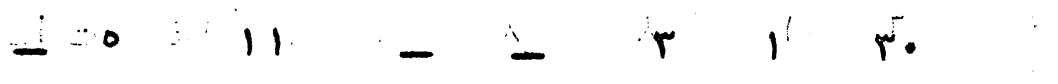

- r o - $=1510$

- r r r $r$ r r

$r,\{$ ro - - o r 1..

- r $r$ - $-r-1$.

- r r 1 - 1 101

- r - 1 - $1-1$ - 1

$r$ r

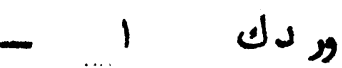

- 1

غزنس

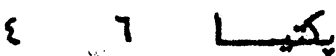

ir ir ir ir

r لفيطا ن 1

بدخشان ع ان

ت

هفلان 1

كنـــ

سمنكان 1

- 1 بـ

جوز جان

فاريـا ب r r

r - بادغيسس

- 0 هـرات

i

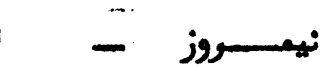

- 1 هلمنــــــ

-

- زابسـل

غ 1 - 1 -

$\begin{array}{lllllllll}r & r & 1 & 1 & 1\end{array}$

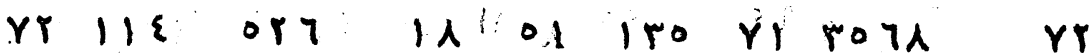




\section{$-r \cdot 1-$}

كار مندان و يرسونل وتسميلا تصحى اففانستا ند رسال ع هم

جدول (7) (1) ذميمه

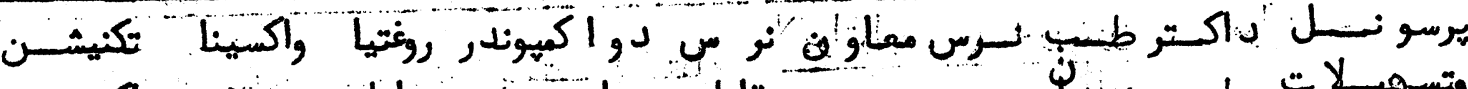

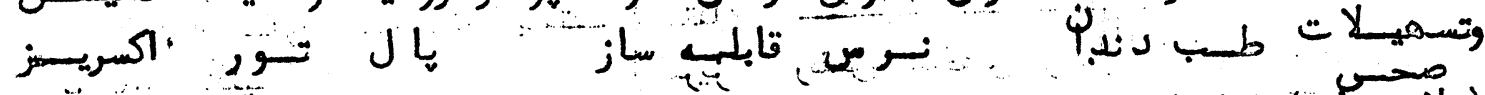

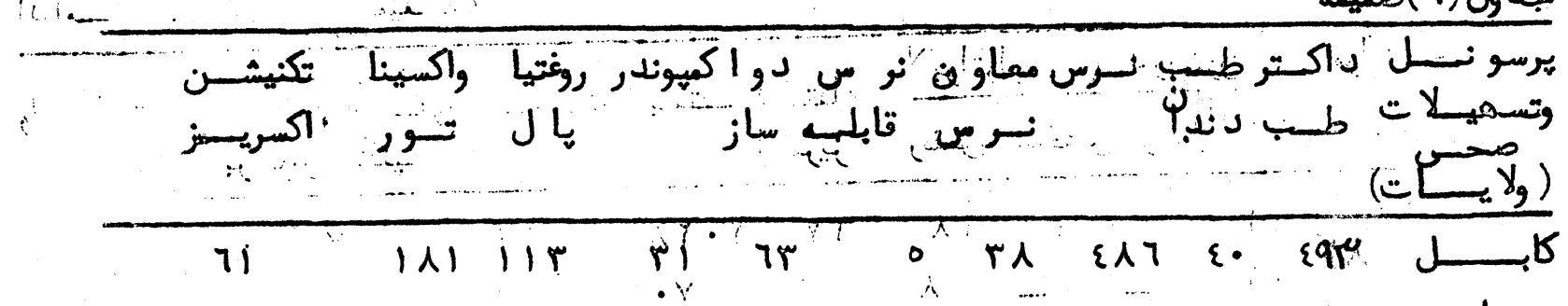

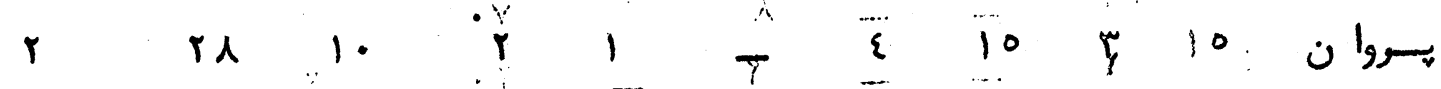

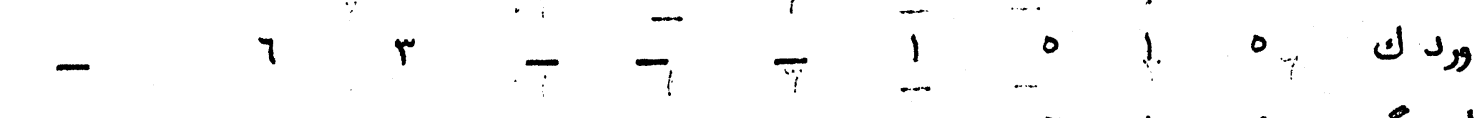

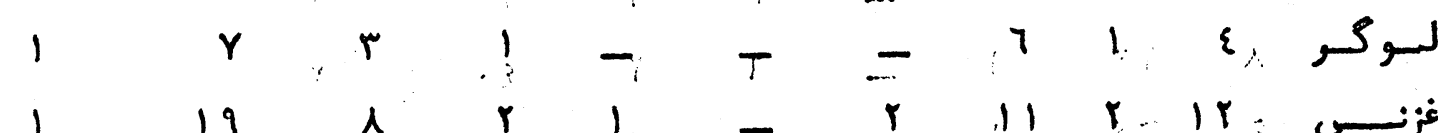

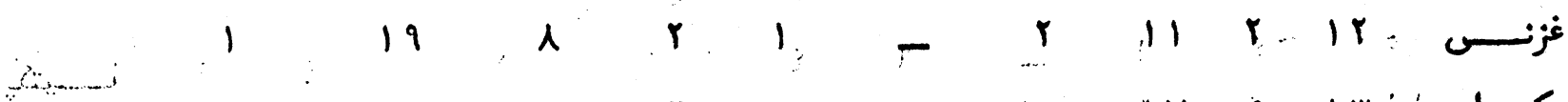

ك Liv 10 r Lir

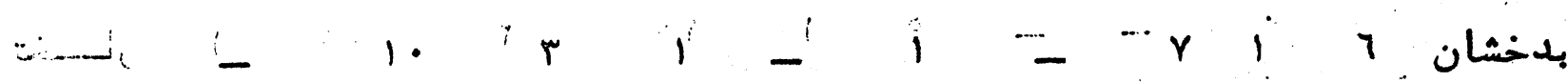

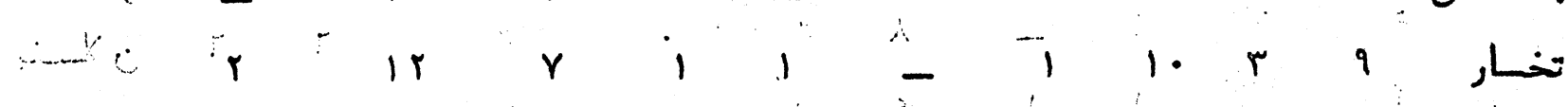

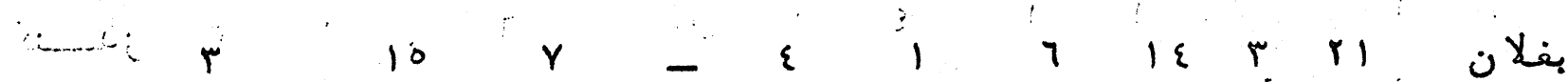

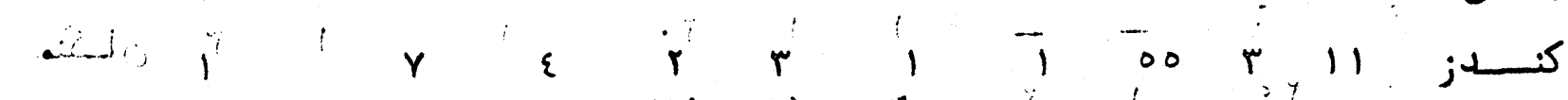

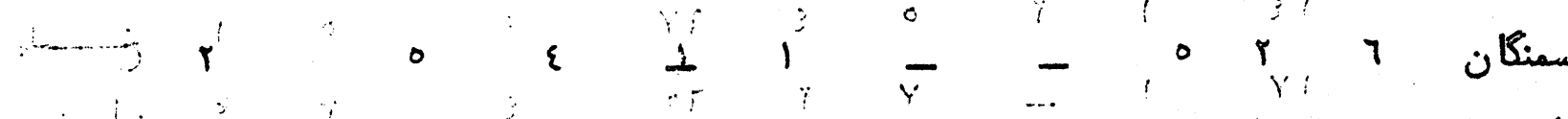

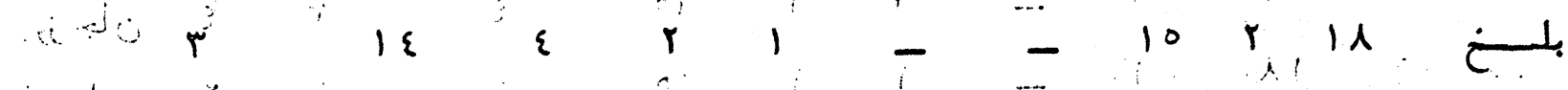
جوز فاريا

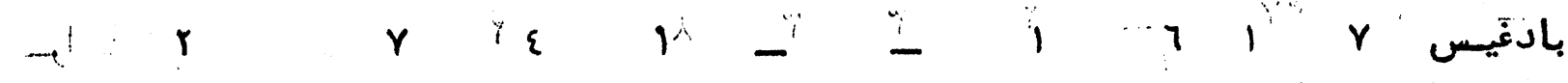

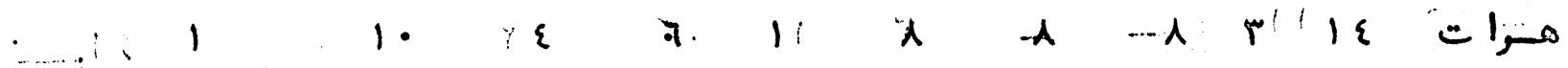
ف $\begin{array}{llllllllll}r & 0 & r & - & r\end{array}$ $\begin{array}{lllllllllll}r & r & r & - & r & 1 & - & r 0 & 1 & 1 & 1\end{array}$

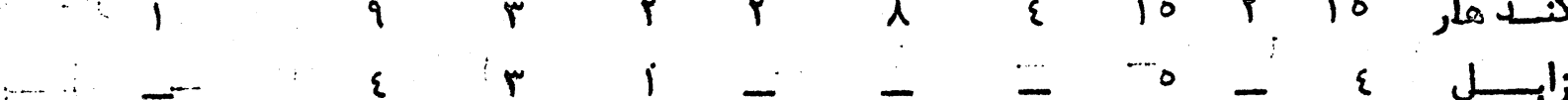

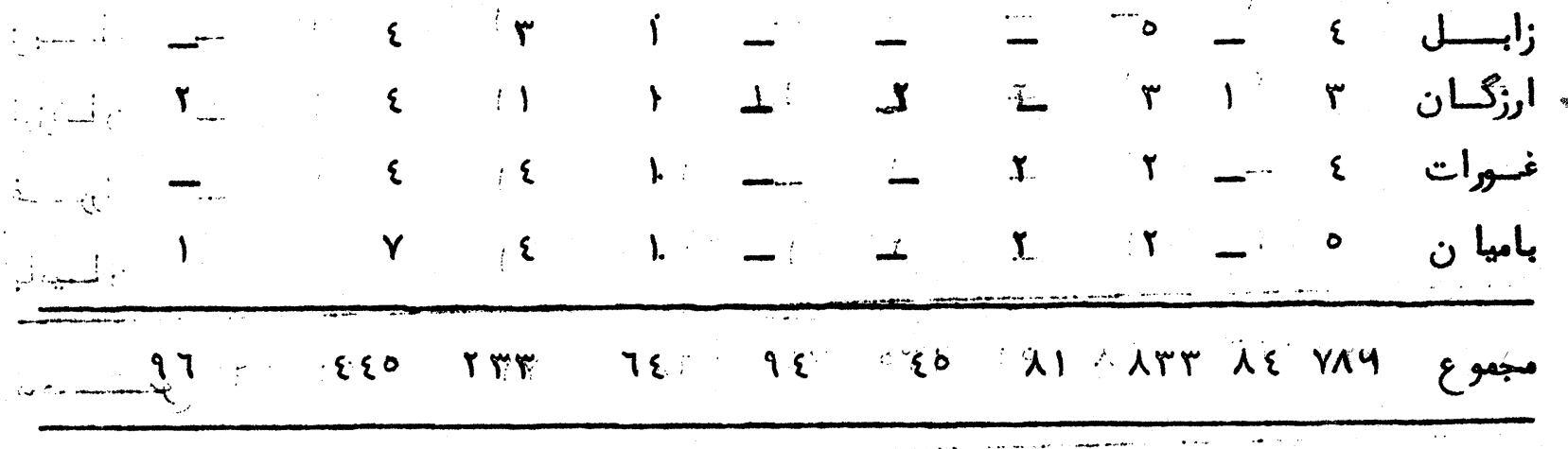



ادامه جدول (7) (7ميمه

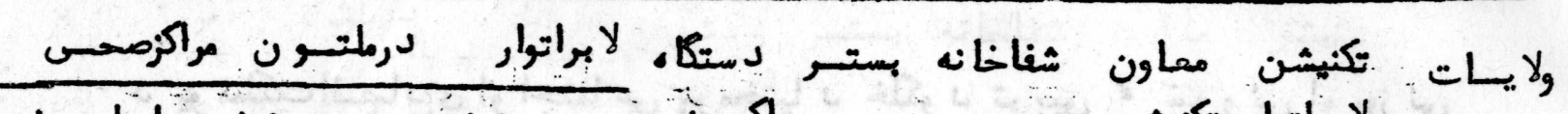

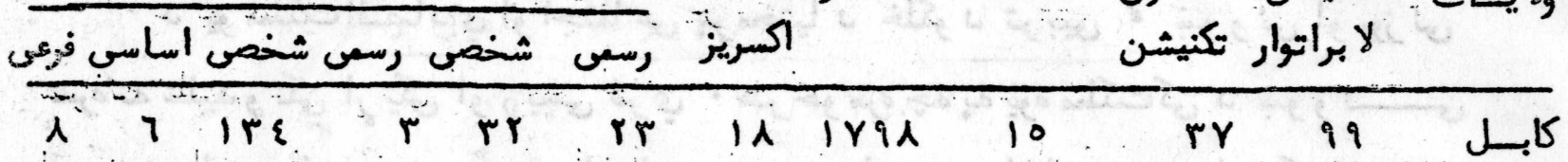

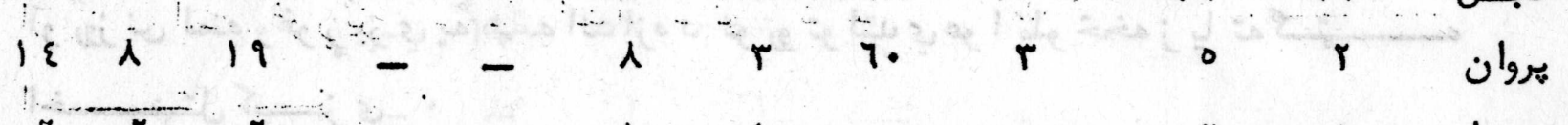
وrr \& $r$ r

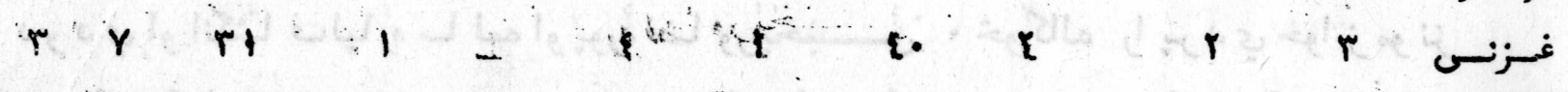
$r 0$ rr $1-a$ r q Pu H لف A $\begin{array}{llllll}r & r\end{array}$ +0.1 .01 ro 1 r 1 r r H.

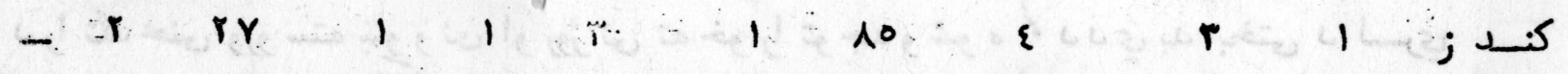

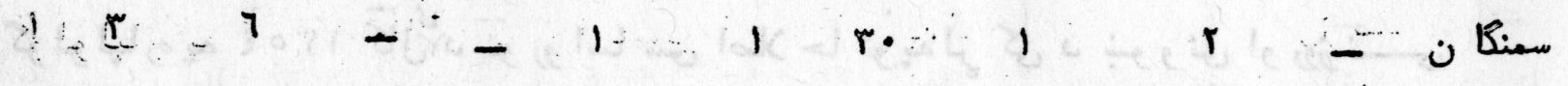
$=r \quad r \varepsilon \quad 1 \quad r \quad r \quad 1$ or $r$ \&

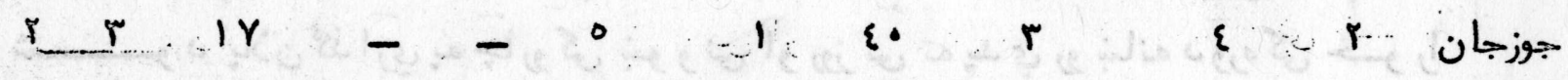
فاريLاب 10 - 10 ro $r\left\{\begin{array}{lllllllllll}r & 1\end{array}\right.$

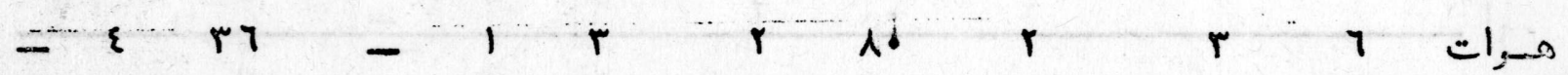
$-0 r r-r \quad r \quad r \cdot r$ r $\begin{array}{llllllll}r & r \\ -r & - & 1\end{array}$

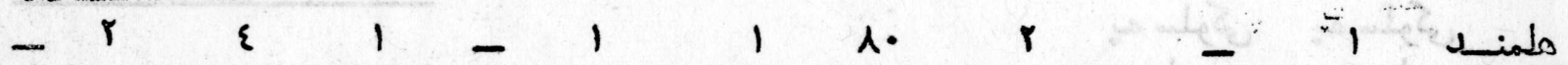
$r \varepsilon r \cdot$ r $\quad$ r - r 1 -

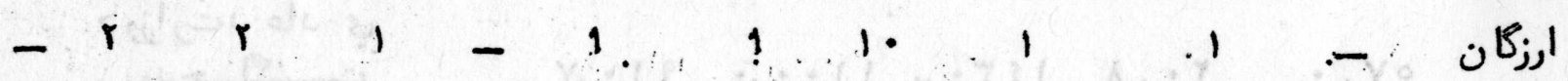
-

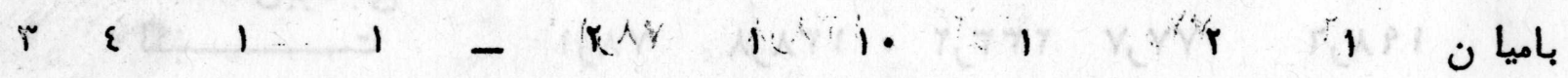




\section{A w id o}

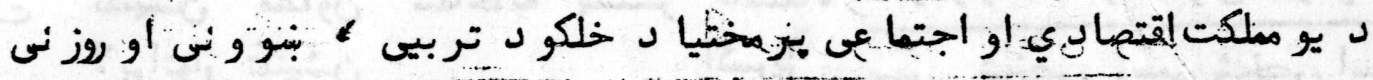

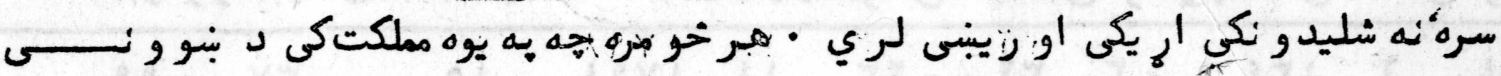

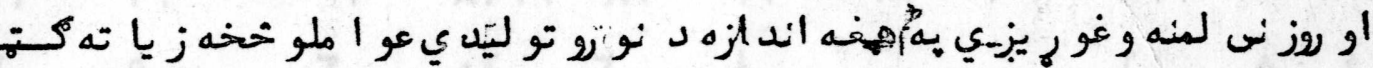

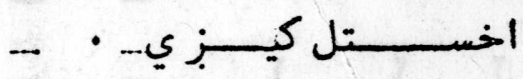

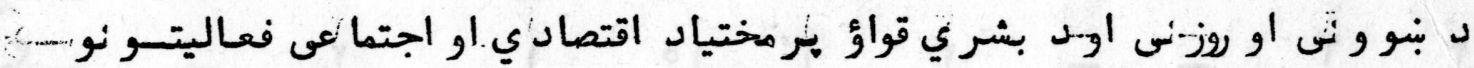

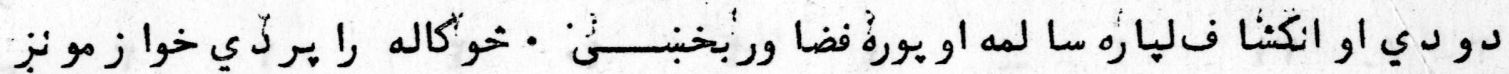

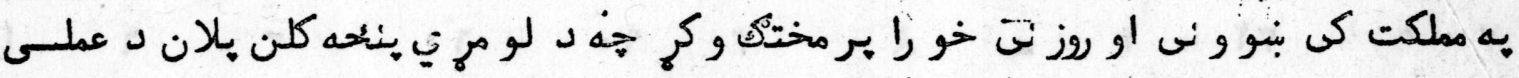

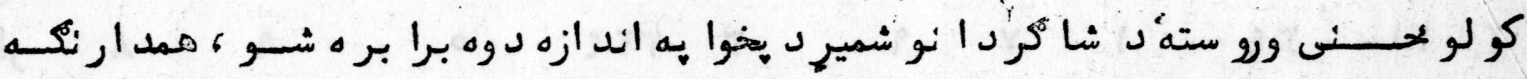

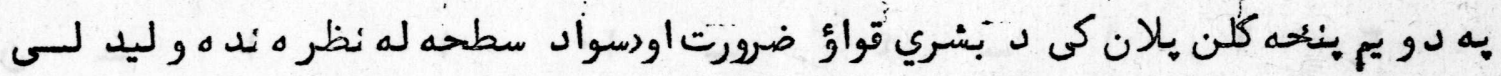

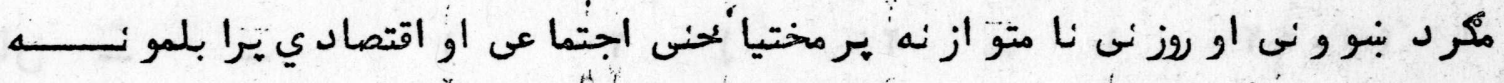

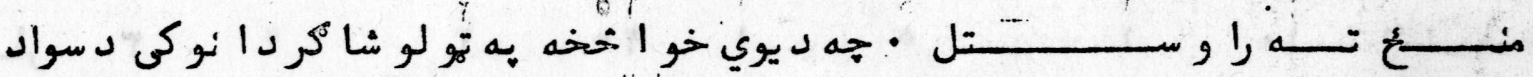

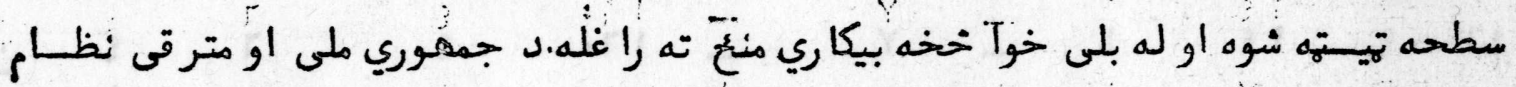

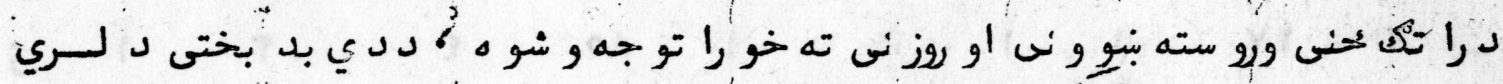

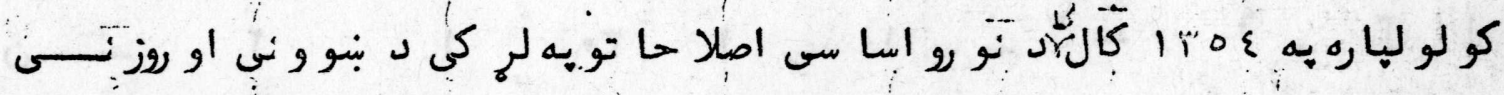

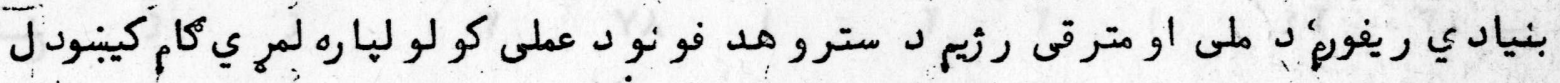

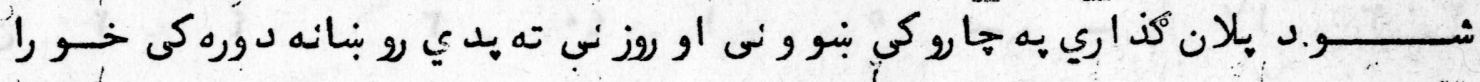

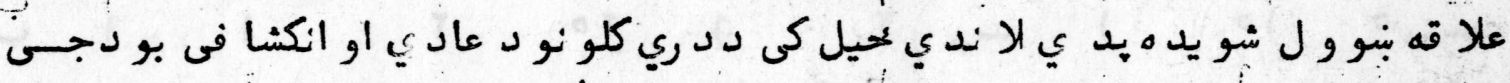

\begin{tabular}{|c|c|c|c|}
\hline 1 roo & $1 r>\varepsilon$ & 1400 & - Iros \\
\hline بد سلوكى به به & به سلوكي لونى & & . \\
\hline
\end{tabular}

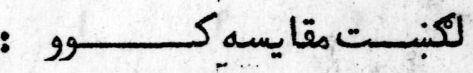

$\circ r_{0} \quad r \cdot, 1 \quad 1 \varepsilon r \cdot,+11 \cdots, 91 \cdot, r$

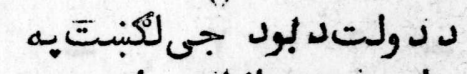

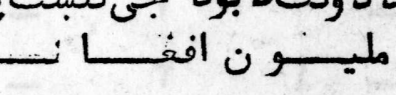

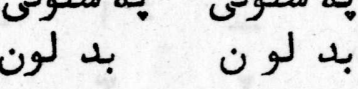

الف : د بنو ونىاوروزين

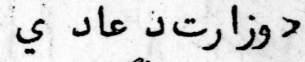

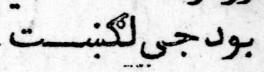
لد انكشافى بودجى بودي

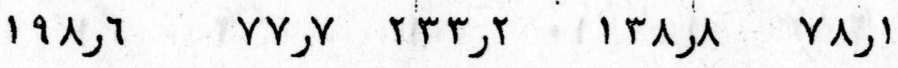

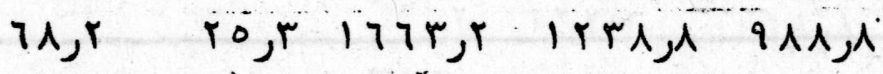

$$
\text { J }
$$

ب : دعالى بعليماتووزارت

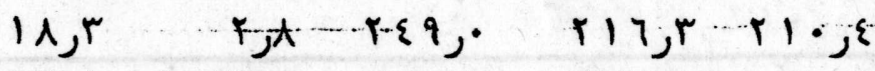

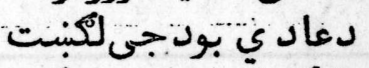
دانكثافى بولجي لكبتبت 


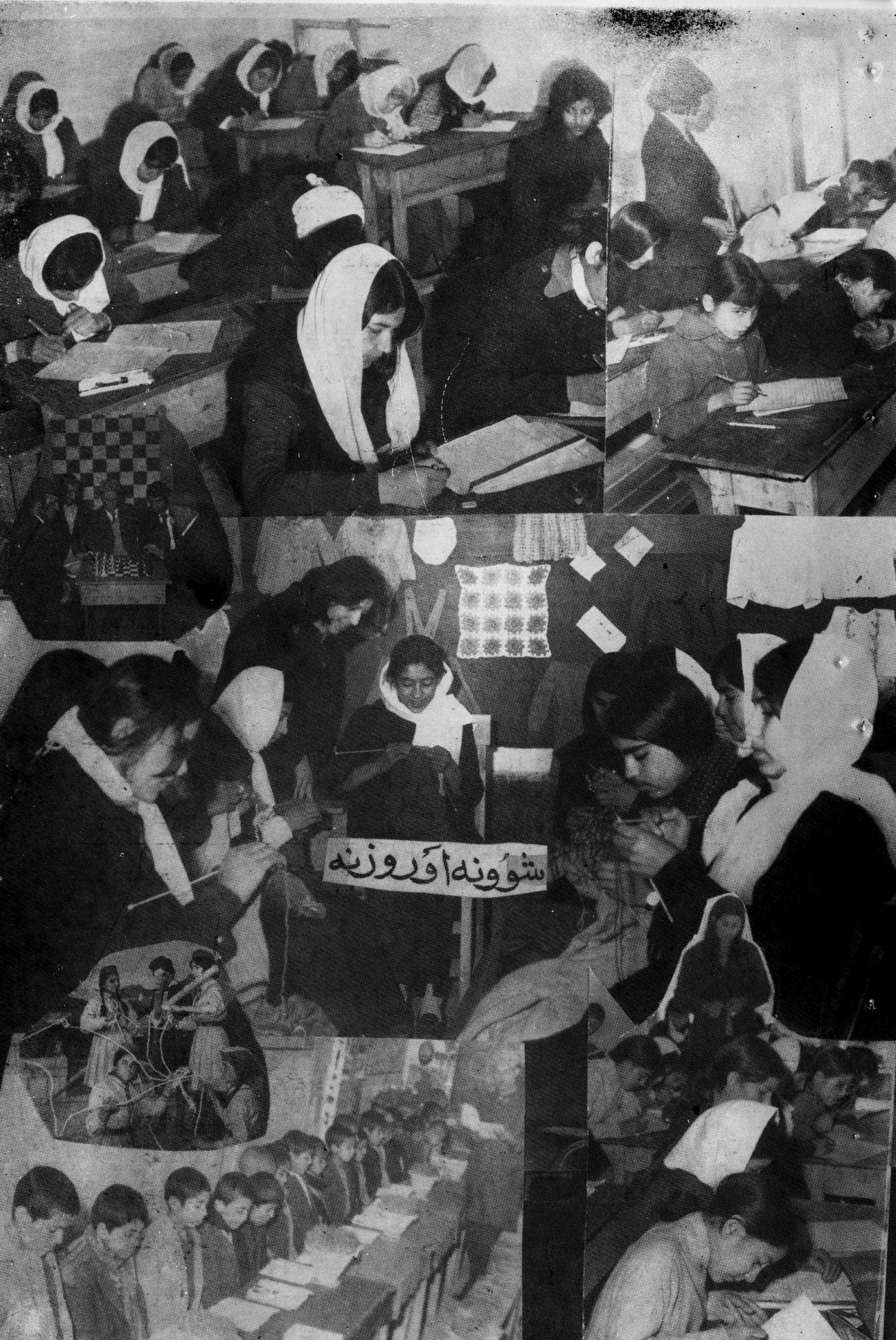




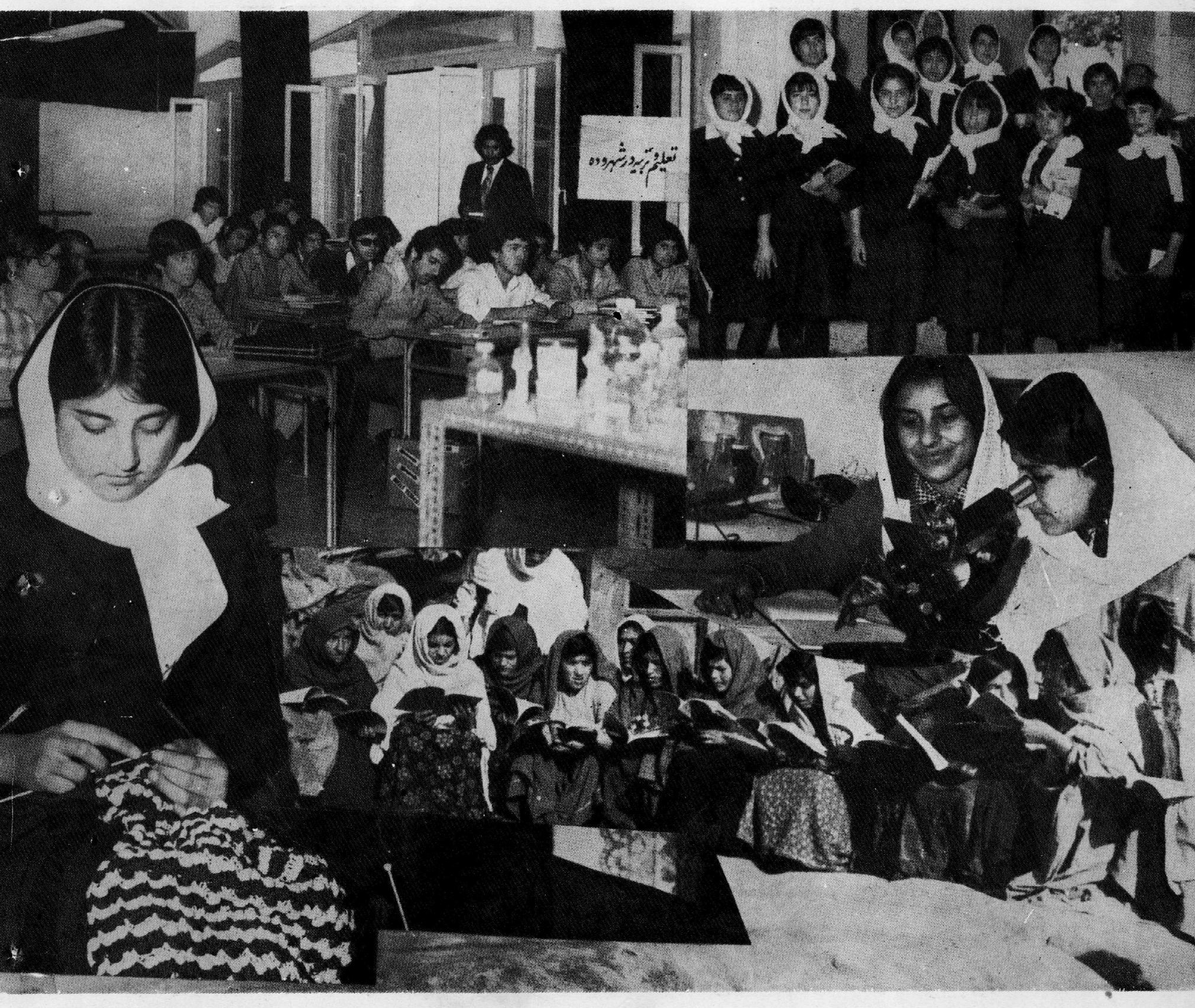




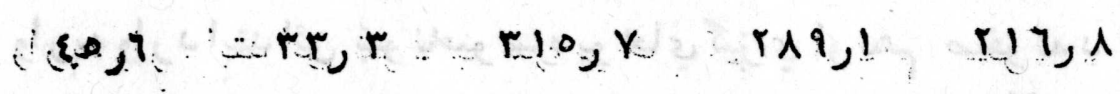
تיب د د دوائر ونول الكنبنيت

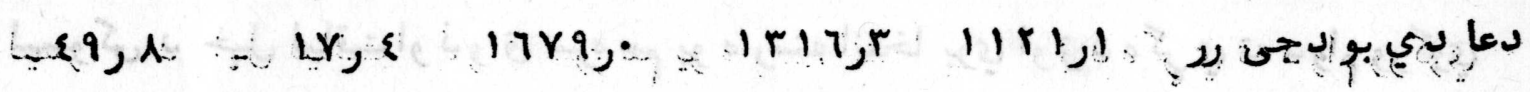
rogl

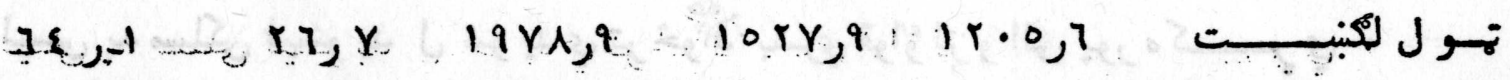

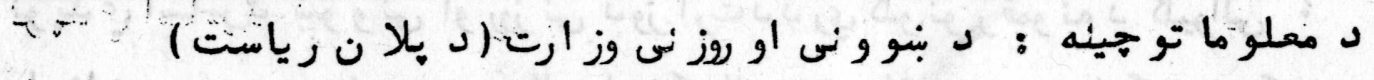
10

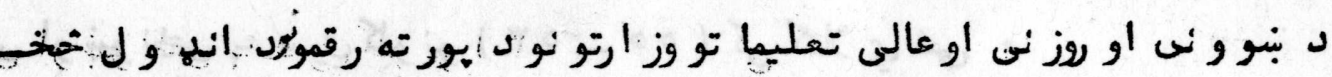

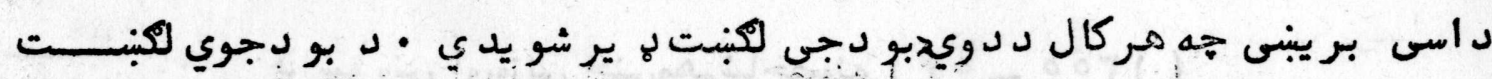

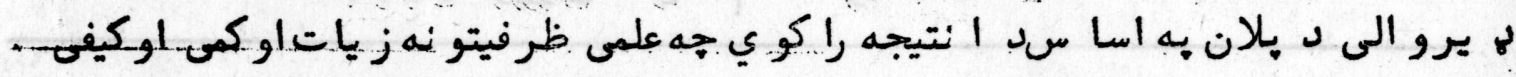

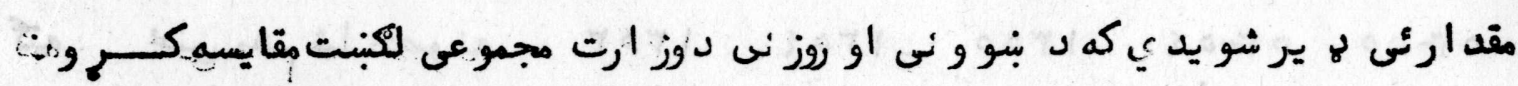

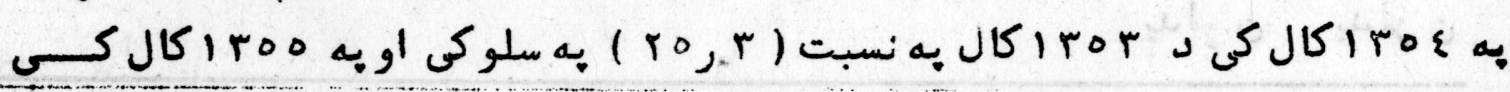

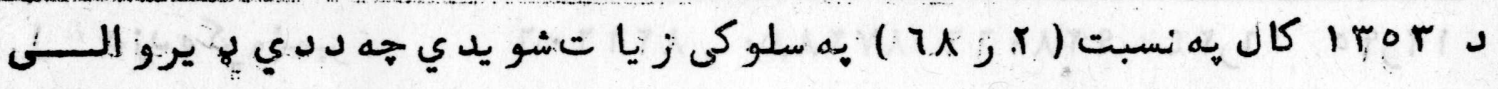

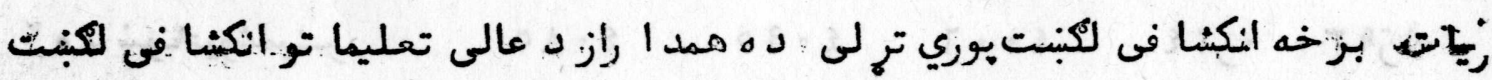

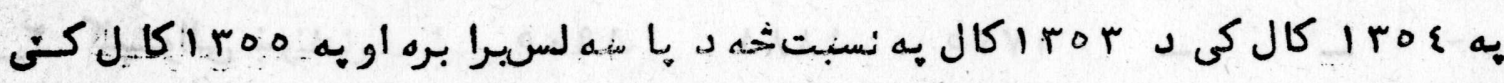

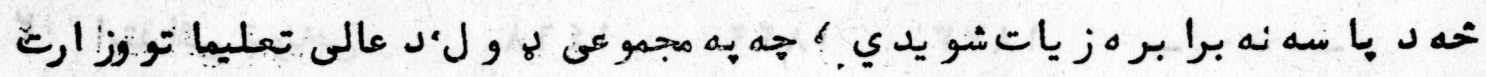

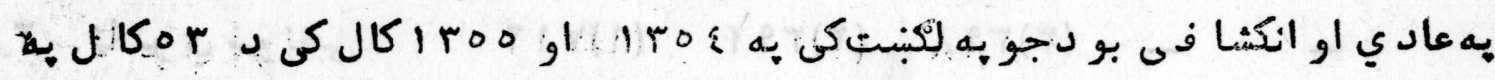

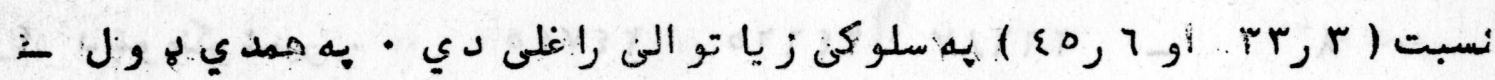

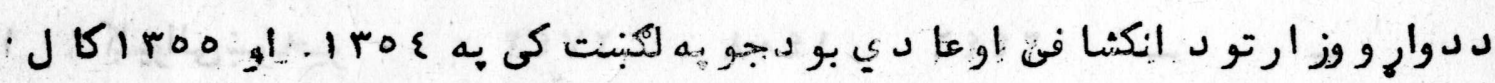

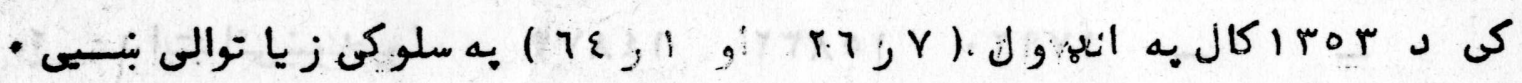

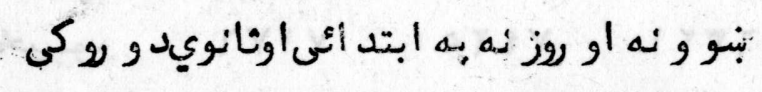

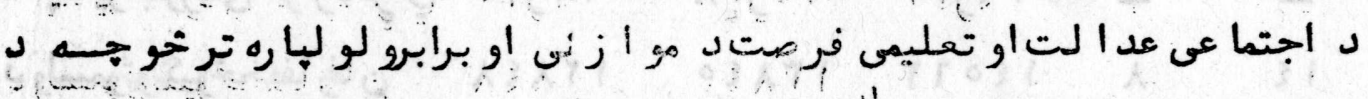

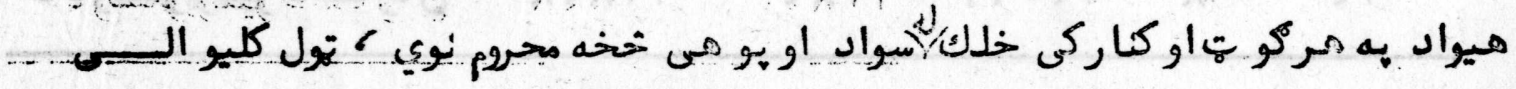

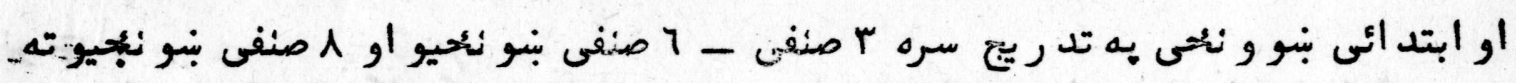

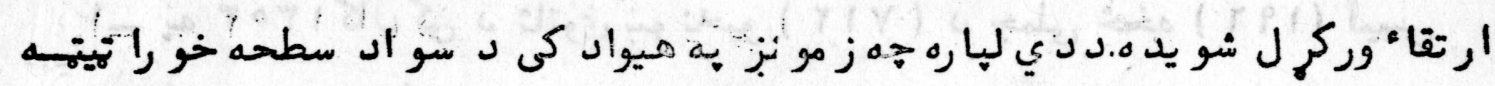

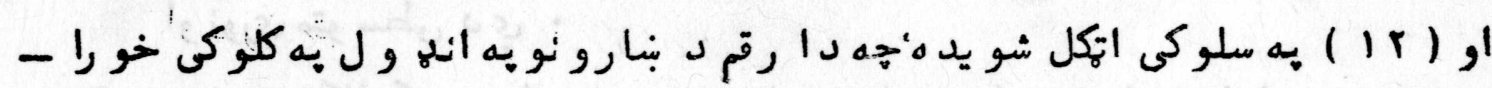

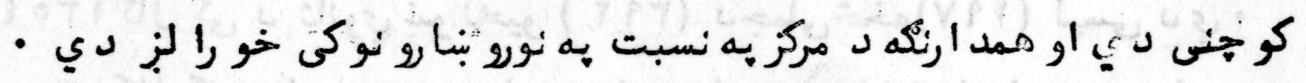

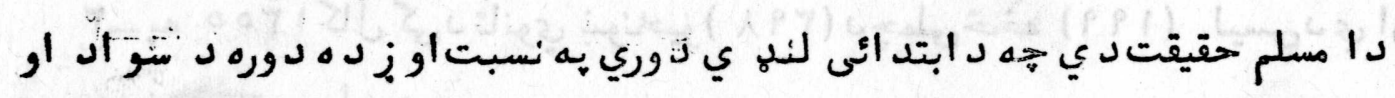

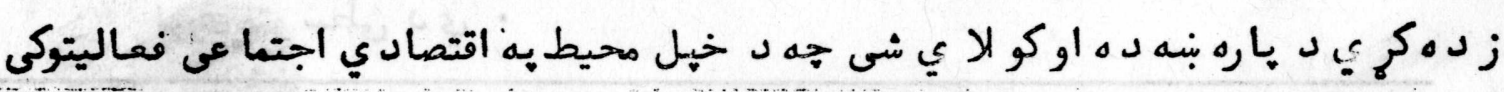

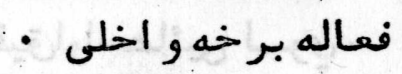

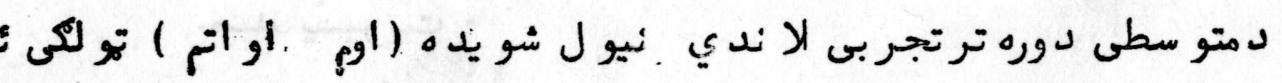




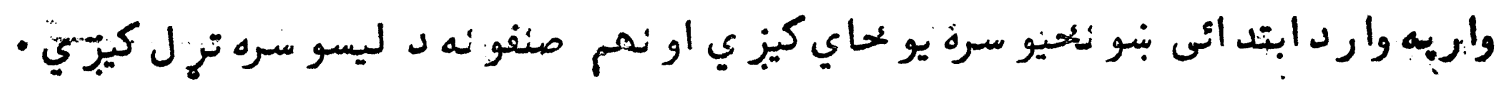

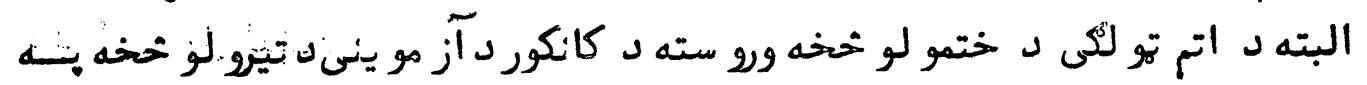

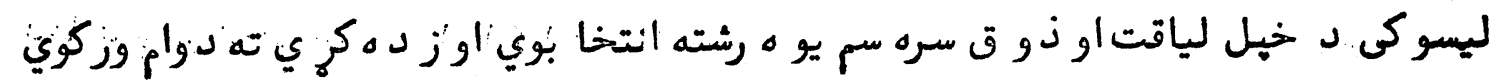

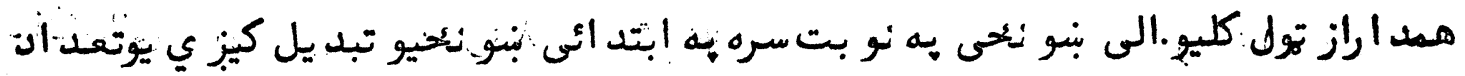

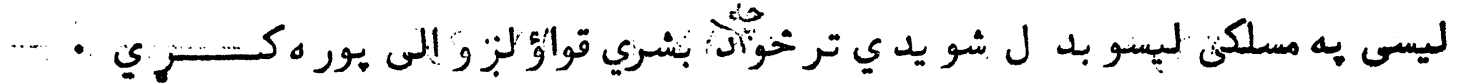

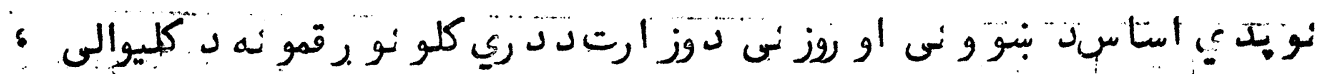

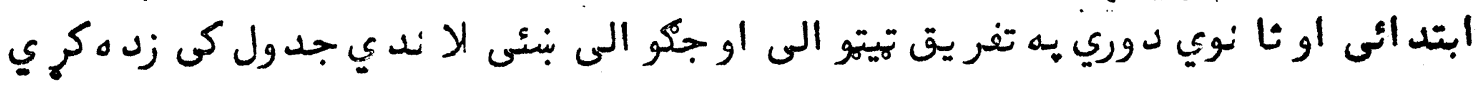

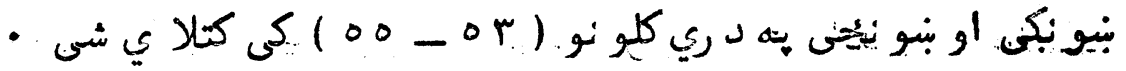

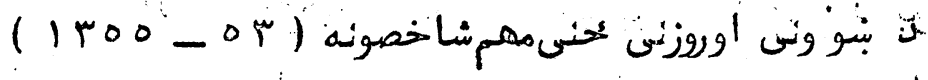

كبه

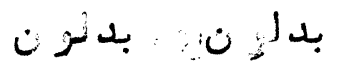

\begin{tabular}{|c|c|c|c|c|}
\hline 15,90 & $7, r \varepsilon$ & $971 \cdot 77$ & $\curlywedge \vee \curlyvee \wedge \wedge$ & 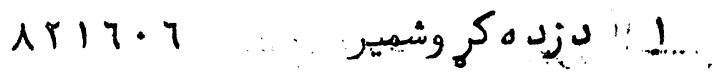 \\
\hline 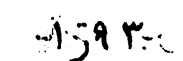 & $\therefore$ & 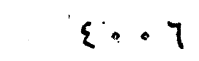 & $\varepsilon=90$ & $\varepsilon \cdot \lambda^{\prime}$ \\
\hline$\ddot{\prime}$ & - & IVTo & $|\wedge \wedge|$ & 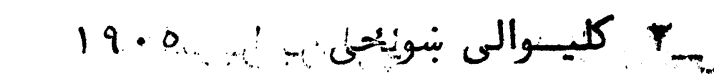 \\
\hline- & $\therefore \therefore$ & INYr & INTT & ابتدائى بنونيكى \\
\hline- & - & $(r) r q 1$ & (r)rqr & (1) Y I \\
\hline$\therefore \Lambda^{7}$ & - & rフフヘY & $r \leqslant 770$ & لد بنو ونكوي شمييز . " \\
\hline- & - & 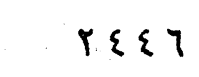 & $1 \xi \cdot 1$ & 1 : ديكيوالى بنونكيويو : \\
\hline - & - & IVqT. & lokrr. & ليج ي. .. د ابتبل ائى بنونيحيو \\
\hline - & 一 & IRTI & Y\&Y० & r ل د انوي بنو نئيسيو \\
\hline- & - & $r \varepsilon, \gamma r$ & rojra & يه يو بنوونكى خُوآزتك ي \\
\hline is & $\Lambda$ & IE० Tr & Irᄉ々 & 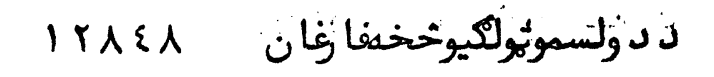 \\
\hline
\end{tabular}

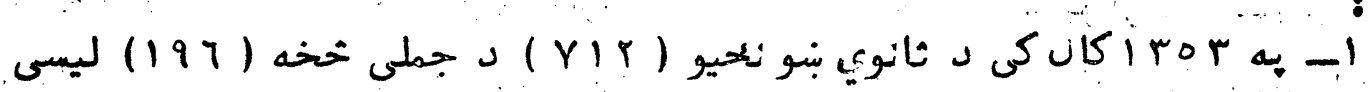

$$
\text { او نوري متو سطى دي }
$$

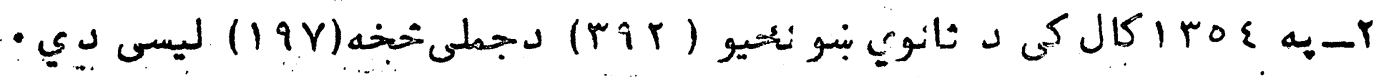

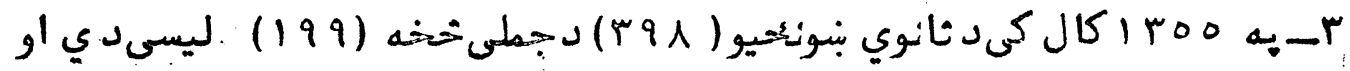
نوري متو سملي دي

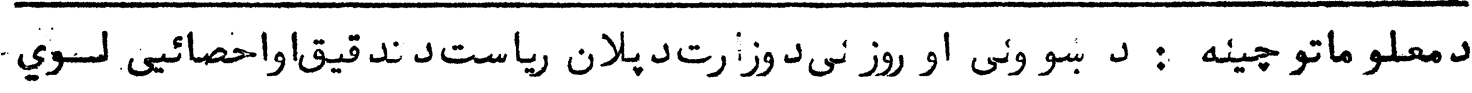




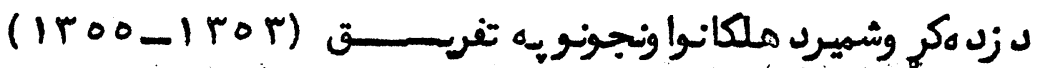

\begin{tabular}{|c|c|c|c|c|c|c|c|}
\hline * & 1500 & 14 & $0 \xi$ & & ror & & o \\
\hline نجونى & ملكان & نجنونى & هلكان & "إنجونى & ماكان & & \\
\hline $1 \cdot r \leqslant 1$ & $\varepsilon Y Y \cap Y$ & $97 \cdot r$ & $\{\varepsilon \Upsilon Y\}$ & $\alpha Y I I$ & \&11VR & كابل & 1 \\
\hline PIT & $r \cdot \cdots \varepsilon r$ & r $\{q\}$ & 11701 & rron & 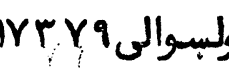 & & $r$ \\
\hline$r \cdot i$ & rᄉo\&r & rrrl & roxkl & rrir & r\&rrt. & & $r$ \\
\hline$r \cdot r$ & $190 \& \varepsilon$ & $19 r$ & IAr|A & 171 & 18770 & & $\varepsilon$ \\
\hline $19 \cdot r$ & $19 \varepsilon 7 \varepsilon$ & IVAT & $|\Lambda T| \Lambda$ & 1819 & Irrr. & & 0 \\
\hline$r Y .$. & rTI & rort & rryog & r|A| & rI\&rr & & 7 \\
\hline$\vee \wedge 9$ & $\{777$ • & YrE & $\varepsilon r r \wedge r$ & $r \cdot r$ & $\{\mid \wedge\{\}$ & & $r$ \\
\hline$r \varepsilon \varepsilon$. & orry & rrIE & 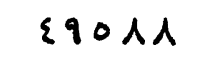 & r人q० & :SOY. & & $\Lambda$ \\
\hline 11.Y7 & rorqr & 1819 & rrq71 & $1 \varepsilon 9$. & rrol. & & 9 \\
\hline$r \cdot 7 r$ & YYY\&O & 1901 & rir & rral & J•Yr & كر. & •اد \\
\hline$\varepsilon \cdot \varepsilon r$ & TY\&. $\varepsilon$ & $r \wedge \cdot \lambda$ & ToV\& & r77q & ro.rr & بدخشان & 11 \\
\hline $19 \cdot 9$ & I9rar & IYA. & INIrY & $17 \cdot \varepsilon$ & $17 \mathrm{Vr}$ & تخار & Ir \\
\hline rror & PrTto & $r \cdot r_{1}$ & YoYYI & rrrr & $r \varepsilon \cdot V \varepsilon$ & بغلان & Ir \\
\hline$\varepsilon \cdot \gamma \varepsilon$ & YYI\&Y & rYq & ror \&q & rroo & r\&vqr & كبدن ز & $1 \varepsilon$ \\
\hline $17 \%$ & $187 \ldots$ & $1 \& \wedge q$ & 11897 & IrAY & $1 \cdot V \varepsilon r$ & سمنكان & 10 \\
\hline Yo.. & rilro & $79 \wedge r$ & $r q \cdot \circ r$ & 7171 & r $70 \leqslant 0$ & بلن & 17 \\
\hline$r \cdot 1 \varepsilon$ & rToqr & rᄉ.. & $r\{\wedge r r$ & rAr. & 11999 & جوزجان & IV \\
\hline 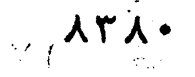 & $r \cdots r$ & VAV\& & YYqYq & YYYo & r7q7. & فارياب & 11 \\
\hline$\therefore 19 r$ & $|1 \cdot \lambda|$ & ᄉ\&. & $1 \cdot r q 7$ & rra & $9 r 7 r$ & بادغيس & 19 \\
\hline 人\{^! & rarrr & VAᄉr & r.707r & $Y r \cdot 1$ & rrgor & & $r \bullet$ \\
\hline $17 \varepsilon 0$ & $190 \mathrm{Yr}$ & $10 r r$ & IAY\& & $1 \varepsilon \cdot \gamma$ & $10 Y Y 7$ & فراه & YI \\
\hline $171 r$ & $79 \cdot 1$ & 1081 & T\&rr & $9 \wedge r$ & $.019 r$ & نيمروز & $r r$ \\
\hline $1 \cdot \hat{1} 1$ & T\{ $\{\varepsilon \varepsilon$ & $1 \cdots 0$ & rr人\&. & $1 \% 1 \cdot$ & rrr\&? & هلمند & rr \\
\hline$\{\Lambda \circ \gamma$ & roorg & ₹६१ & rrrrg & riro & $r \mid\{7 \mid$ & كد هار & $r \varepsilon$ \\
\hline$Y Y \cdot$ & Y०97 & ro. & $Y Y I T$ & rrr & 7910 & زابلب & ro \\
\hline$r \cdot 1$ & r.o Yo & rAr & 19 TVE & 19 & IVY7. & ارزكان & $r T$ \\
\hline$\lambda \cdot q$ & $1 \varepsilon \& 9 \cdot$ & 877 & Irrtr. & $7 \wedge \varepsilon$ & Iรห१人 & غور. & $r V$ \\
\hline 99. & IrTIr & $q \varepsilon$ & I TYR & 117 & |rr\&| & باميان & rᄉ \\
\hline \&人フ\&\& & $19 \cdots 9$ & $\{0 \cdot \varepsilon \cdot$ & AY $\{1\}$ & E r ro. & YYYIY & دكابل؛ & rq \\
\hline Irrgrr & $\lambda \cdot\{A r$ & 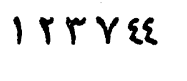 & $V\{q \operatorname{Ir} 7$ & $11 \leqslant r \cdot 7$ & $r \cdot r$ ros & مجمــوع & \\
\hline
\end{tabular}

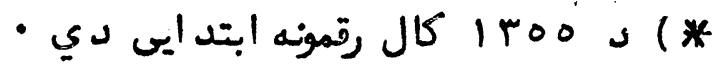

د معلوماتومنبع :د بنوونى اوروزت وزارت د بلان رياست • 


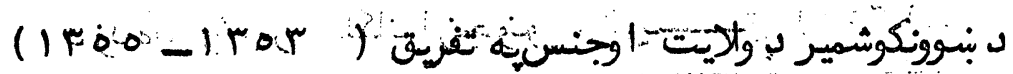

\begin{tabular}{|c|c|c|c|c|c|c|c|c|}
\hline & $* 1$ & roo & & $1+0.8$ & $=1$ & or & & A \\
\hline & ا اناث & ذكور & أl & ز كور & اناث & زكور & & - \\
\hline & $r q r$ & $1 \leqslant 1$. & YY₹ & Iror & TTY & $11 \leqslant r$ & كابل & 1 \\
\hline & $\{y$ & $0 \wedge \cdot$ & $r y$ & $r y 0\} q$ & $1 \wedge r \varepsilon$ & 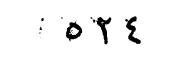 & دكاييس & r \\
\hline & $\Upsilon 1$ & ITro & 71 & IINT & $\therefore !: Y \varepsilon$ & $11 \%$ & يروان & $r$ \\
\hline & - & ort & $r$ & $0 \leqslant r$ & $\therefore$ & o\& Y & ورد كك & $\varepsilon$ \\
\hline & $1 \cdot$ & Trr & Ir & 090 & $: \quad \because 17$ & $0 \vee 1$ & لوكر & o \\
\hline & rr & $1 \cdot 1 \varepsilon$ & $r \varepsilon$ & $q \wedge r$ & $\because \because Y$ & $q \varepsilon \cdot$ & غزنى & 7 \\
\hline & 7 & $I T \cdot r$ & $\checkmark$ & $1 r \cdot 0$ & 7 & 11.8 & يكتياء & $r$ \\
\hline & $Y \cdot$ & $1 \varepsilon 7 r$ & $r v$ & $1 \varepsilon r r$ & $\vee \xi$ & $1 \varepsilon \gamma \cdot$ & ن تنكرقها ر & $\wedge$ \\
\hline & 10 & $\times 17$ & $.1 \varepsilon$ & $7 \vee 9$ & Ir & $7 \pi \varepsilon$ & لنسطان & 9 \\
\hline & Ir & YTr & $\varepsilon$ & Yor & $\lambda$ & rrג & 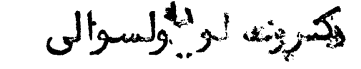 & $1 \cdot$ \\
\hline & 11 & 790. & $r \cdot$ & . YYI & rT & $79 \mathrm{Y}$ & بذخشان & 11 \\
\hline & $Y$ & 017 & $\varepsilon$ & $0 \leqslant 1$ & $1 \cdot$ & $\{$ १६ & تخاز & Ir \\
\hline & $\varepsilon \gamma$ & YIT & $\because \varepsilon 1$ & $Y 19$ & $\because: 40$. & $7 \vee \varepsilon$ & بَمِلان & ir \\
\hline & IV & YYq & $7 \cdot$ & TAr & or & $7 \vee \varepsilon$ & كدذز & $1 \varepsilon$ \\
\hline & YA & $\{\mid \gamma$ & $r \varepsilon$ & risr & ro & riv & سنمنكان & 10 \\
\hline & YYT & $\Lambda \varepsilon \bullet p ;$ & rrq & ATT & 1.91 & Arg & بلن & 17 \\
\hline & rr & $00 \%$ & $r \varepsilon$ & 0.7 & rᄉ & o $\varepsilon$. & جوزجان ' • & IV \\
\hline$\vdots$ & $\Lambda \gamma$ & 179 & $\because 11$ & Arl & kr & $\Lambda \cdot r$ & فارثاب ا' ! & 11 \\
\hline - & $r$ & rqo & $\therefore Y$ & Y1 & $1 \cdot$ & T.YI & 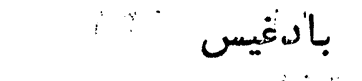 & 19 \\
\hline$i$ & $?: 9$ & $11 \wedge \mathrm{Y}$ & rir & $.11 r v$ & rol & 1110 & هرات & $r \cdot$ \\
\hline : & $r \varepsilon$ & 770 & Tr & 71. & 11 & 077 & فزاه & YI \\
\hline$y$ & $\varepsilon$ & rYo & - & - rVA & $r$ & F०ᄉ & نيمروز & rr \\
\hline$\therefore$ & $r v$ & 097 & $\varepsilon r$ & $7 \cdots$ & $\because \varepsilon \gamma$ & 097 & ملمند . ملد & $r r$ \\
\hline$\because$ & $1 \varepsilon \varepsilon$ & 970 & $1 \varepsilon \lambda$ & , $q \varepsilon r$ & ITY & $\wedge \wedge$. & كـدهار & $r \varepsilon$ \\
\hline & $1 \cdot$ & $r r \cdot$ & $r$ & rrl & $Y$ & 910 & زابل & ro \\
\hline & $1 \cdot$ & $\{70$ & $1 \cdot$ & $\{9 \varepsilon$ & $\varepsilon$ & $\{\succ \varepsilon$ & اززانان & $r T$ \\
\hline & $r$ & $\varepsilon \vee q$ & 1 & $\varepsilon \vee \varepsilon$ & $r$ & $\varepsilon 01$ & غورات & rV \\
\hline & $\therefore 1$ & $\varepsilon \cdot 0$ & $r$ & $\varepsilon \cdot r$ & - & $\cdot r \wedge 7^{\prime}$ & باميان & $r \lambda$ \\
\hline & $r \Lambda: 0$ & INYY. & rAI\& & .1781 & rTVo & 1078 & دكابلنـاز & rq \\
\hline & $\{\{7$. & MTrV & $\varepsilon \varepsilon \cdot \wedge$ & $r \cdot r \circ Y$. & $\{1 \mid r$ & $r \cdot 7 r r$ & مجموع - & \\
\hline
\end{tabular}

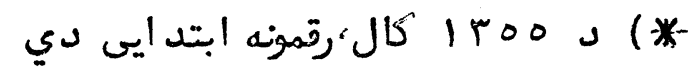

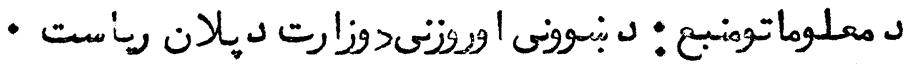




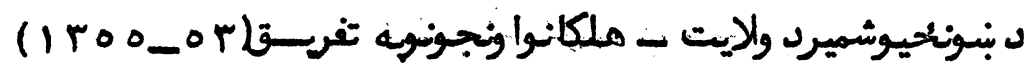

\begin{tabular}{|c|c|c|c|c|c|c|c|}
\hline$*-$ & 00 & & ros & & ror & & \\
\hline نجنونى & ملكان & '- نُجوتى & ملكان & نجونى & ملكان & 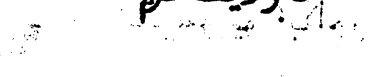 & \\
\hline rr & lis & $r \varepsilon$ & 189 & $T \varepsilon$ & $1 \mathrm{rq}$ & كابل & 1 \\
\hline il & $7 r$ & 19 & $Y r$ & 19 & rr & ولمنسوالى & $r$ \\
\hline$\& Y$ & 101 & rᄉ & 179 & $r q$ & 180 & & $r$ \\
\hline$r$ & 91 & $r$ & 99 & $r$ & 99 & ورد ل & $\varepsilon$ \\
\hline 11 & $\operatorname{ros}$ & IY & $7 Y$ & 18 & $Y 7$ & لوكر & ○ \\
\hline 19 & îr & 19 & $\mid \Lambda T$ & 19 & $|1|$ & غزنى & 7 \\
\hline$\gamma$ & $19 r$ & $r$ & $19 r$ & $r$ & 198 & & $\gamma$ \\
\hline - rr & 17 & rr & $17 r$ & $11:$ & .171 & & 1 \\
\hline$\therefore \ldots$ & $Y \varepsilon$ & ir & $Y \xi$ & $1 r$ & Yo & & $\therefore 9$ \\
\hline$r r$ & Iro & rI & iro & $r r$ & $1 T \varepsilon$ & سوالى & $1 \cdot$ \\
\hline$r \varepsilon$ & 19 & ro & 191 & rr & 198 & بدخشان & 11 \\
\hline 11 & $.11 r$ & $1 \cdot$ & Ir. & $1 \cdot$ & 119 & تخار : & Ir \\
\hline$r r$ & 118 & rr & |ri & $r r$ & $|r|$ & بغلإن & ir \\
\hline Ir & $1 \cdot 7$ & ir & 118 & iv & 118 & كتدز.... & $1 \varepsilon$ \\
\hline 4.11 & 91 & 11 & 99 & $1 \cdot$ & 90 & سمنكان & 10 \\
\hline ro & IVT & $r \varepsilon$ & $|\gamma|$ & ro & 171 & بلخ & 17 \\
\hline $1 \varepsilon$ & $|r|$ & $1 \varepsilon$ & Ir & $\ldots 1 \varepsilon$ & 1 ro & جوزجان & IV \\
\hline$\{1$ & 117 & $\varepsilon \Lambda \ldots$ & $|r|$ & or & 150 & & 11 \\
\hline$\varepsilon$ & $7 r$ & $\xi$ & 71 & $\varepsilon$ & 79 & بادغيس & 19 \\
\hline .r人 & 17 & YY & IV. & $r 7$ & $18 \cdot$ & هرات & $r \cdot$ \\
\hline 11 & 117 & 11 & 117 & 11 & $11 \varepsilon$ & فراه ' & $\cdot r l$ \\
\hline 10 & 01 & 17 & 01 & 17 & $\varepsilon \vartheta$ & نيمروز & ir \\
\hline 0 & $1 \varepsilon \gamma$ & 0 & I\&Y & 0 & $1 \varepsilon 7$ & هلمِد & rr \\
\hline $1 \cdot$ & 171 & $1 \% 3$ & $17 r$ & $1 \cdot$ & $17 r$ & كد مبار & $r \varepsilon$ \\
\hline$r$ & $7 r$ & r. & $7 \varepsilon$ & $r$ & Tr & زابل & ro \\
\hline$r$ & Iro & $\varepsilon$ & IrA & $r$ & $|r|$ & الز & rT \\
\hline$\Lambda$ & $1 \varepsilon \cdot$ & 1 & $|\varepsilon|$ & $\cdot 1$ & $\mid\{1$ & غورات & ir \\
\hline Ir & $1 \cdot \varepsilon$ & 11 & $1 \cdot 7$ & 11 & $1 \cdot \varepsilon$ & باميان & - th \\
\hline 0. & YI & $\varepsilon \gamma$ & Yr & $\{7$ & $Y \varepsilon$ & دكابلبنسار & rq \\
\hline & & $0 \cdot Y$ & rogr & $0 \cdot \varepsilon$ & & $\infty$ & \\
\hline
\end{tabular}

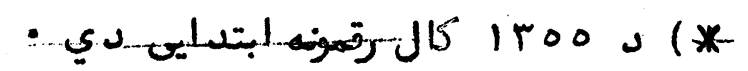

لد معلوماتومنبع: ل بنسونى اوروزتى وزارت د بلان رياست - 


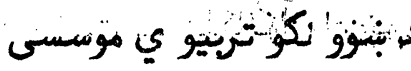

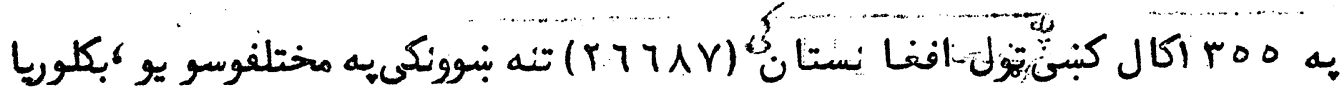

ليسانس : او د بكلور يايحنىيه بنكته سو يه به تد ريسمصور فـ دله -

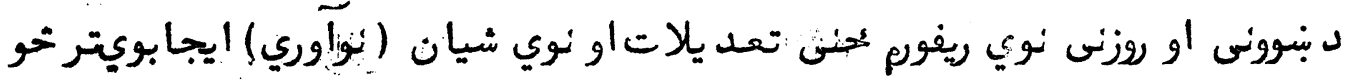

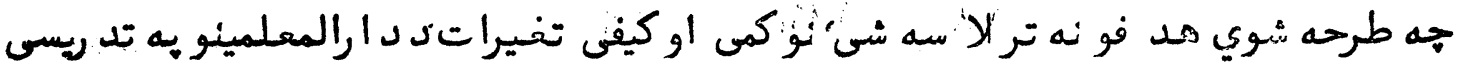

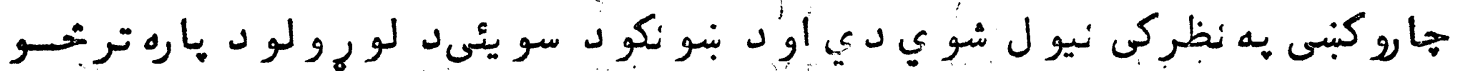

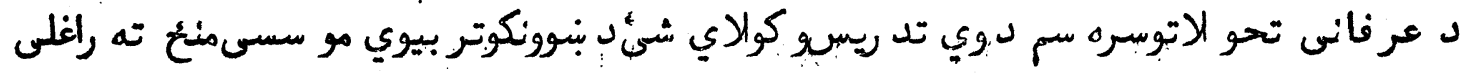

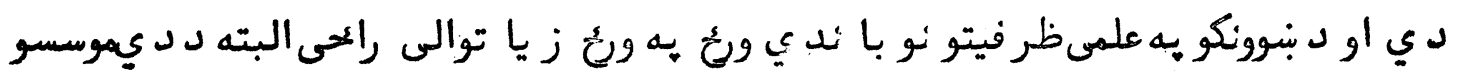

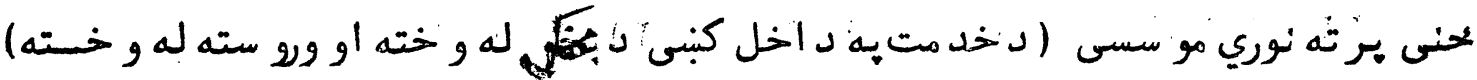

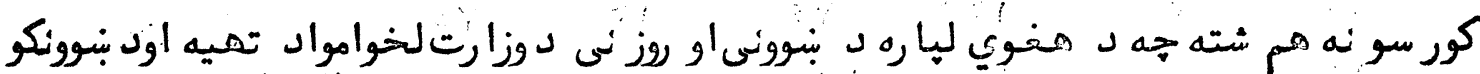

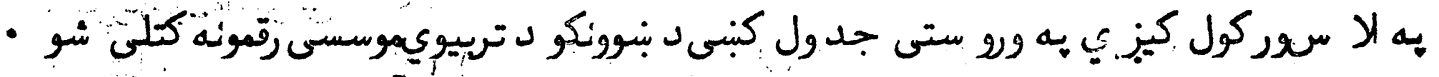

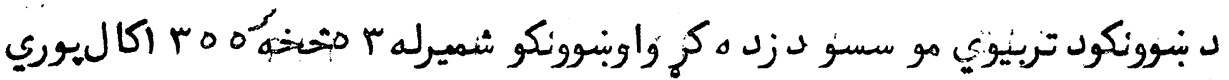

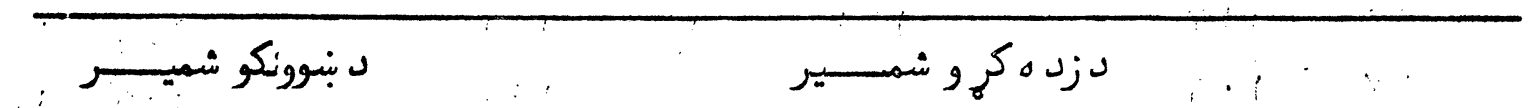

\begin{tabular}{|c|c|c|c|c|}
\hline Troo ...lTos & iror & 00 & 0\{ & or \\
\hline
\end{tabular}

\begin{tabular}{|c|c|c|c|c|c|c|c|c|c|}
\hline$r \varepsilon$ & $r \cdot$ & 11 & rI & o $\}$ & rt & r9q & - & rro & د برواند أرالمعلمين \\
\hline ro & ro & rT & 100 & rq. & ₹1 & $10 \mathrm{Y}$ & 7. & rro. & د بلغ : ر , : \\
\hline$r \varepsilon$ & rq & ry & $r$ & rro & $1 \cdot$ & rrY & $r \cdot$ & $\varepsilon \varepsilon \gamma$ & دكند هار رر : : \\
\hline$r \cdot$ & IV & ir & $r Y$ & $\{\wedge$ १ & $1 \varepsilon$ & $r \varepsilon \wedge$ & r! & TrT & دكندز \\
\hline rr & $r \xi$ & $r r$ & r10 & 011 & $\varepsilon \varepsilon 0$ & TYY & TYT & rAr & دكابل رد \\
\hline$\xi \bullet$ & 41 & $r \cdot$ & $9 V$ & or 1 & Tr & rAl & 117 & Yil & د هرات لر ! \\
\hline ro & $r_{1}$ & 17 & $1 \leqslant 0$. & 700 & $r r$ & Y19 & $r \varepsilon F$ & \&११ & د كا بــل رע \\
\hline rY & $r \cdot$ & 11 & - & r7o & - & $11 \varepsilon$ & $\varepsilon$ & 19. & د كُرد يز رل : \\
\hline rr & To & ru & $1-1$ & rTI & 17 & 01 & 115 & 111 & د بنوونكود تربين : : \\
\hline$r \cdot$ & tr & 10 & iv: & 700 & $r \cdot$ & $8 \cdot 9$ & $r \varepsilon$ & ror. & د نيكرهار ر ل . . \\
\hline $1 \cdot$ & 0 & - & - & $r \cdot \varepsilon$ & - & $1 \varepsilon \hat{\imath}$ & - & & دكرهنبعالى انستيتو \\
\hline - & - & - & - & $r T T$ & - & $9 \mathrm{r}$ & - & - & د بلد نبي روزنى برد \\
\hline$r$ & - & - & - & $\varepsilon q$ & - & - & - & - & لمهاسبى \\
\hline 790 & & TT & $900 \ldots$ & ६१४入 & YYP & T91 & ANr & rq.0 & تول \\
\hline
\end{tabular}

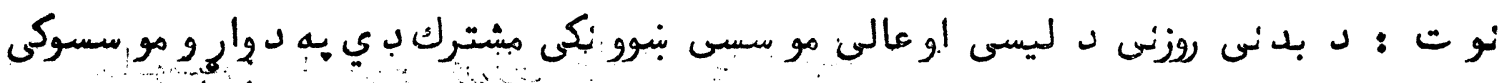

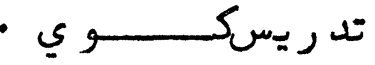




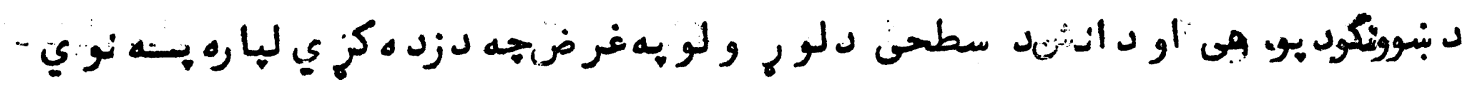

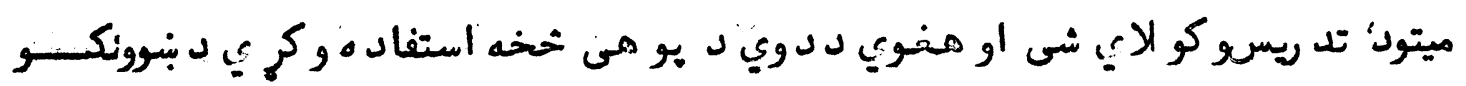

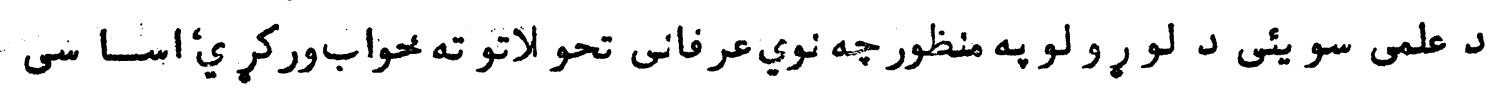

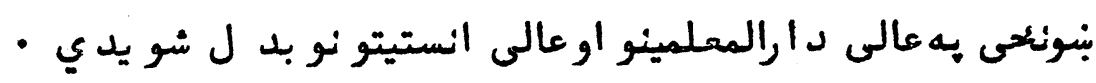

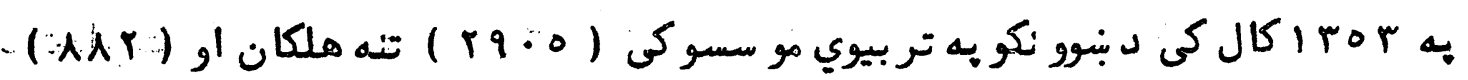

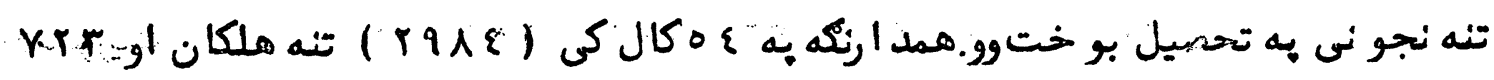

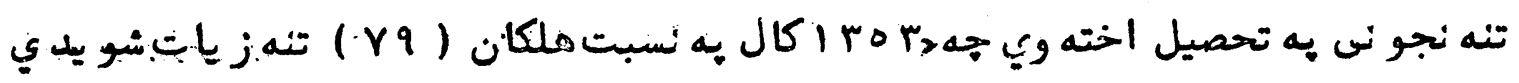

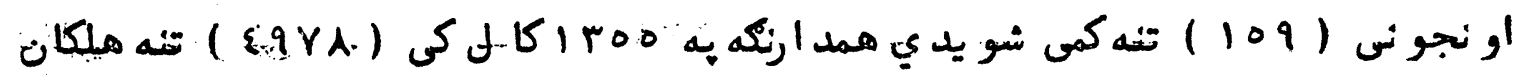

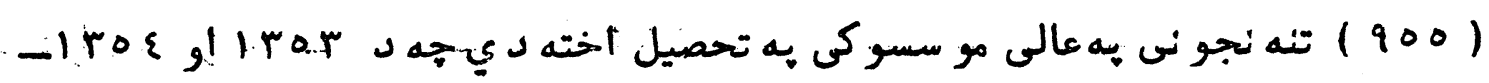

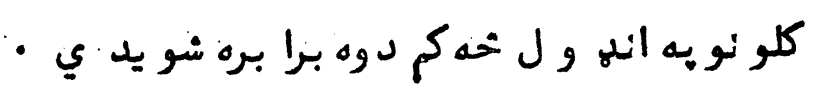

\section{مسلكـى بنوونيحسي}

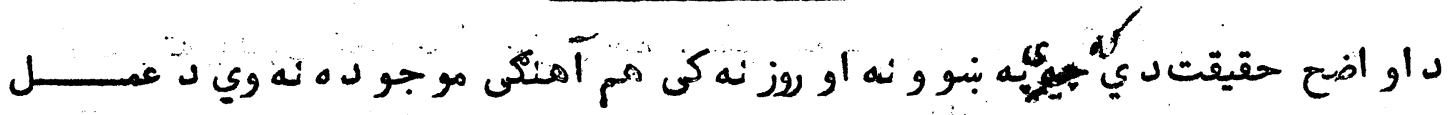

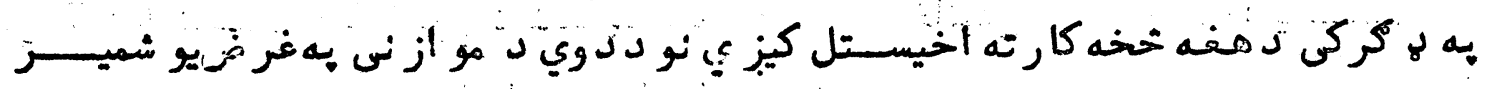

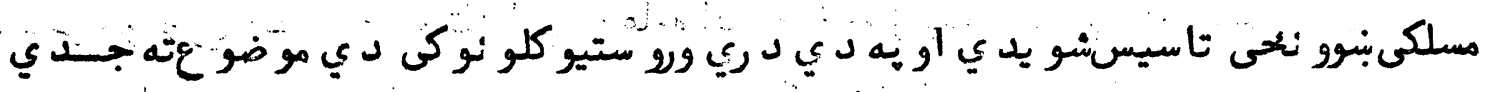

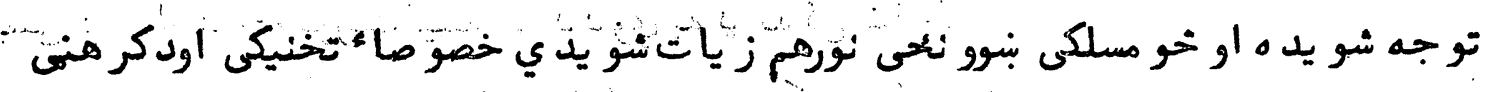

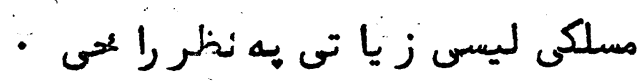

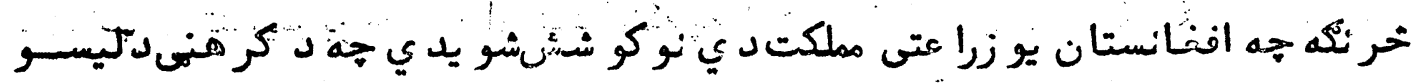

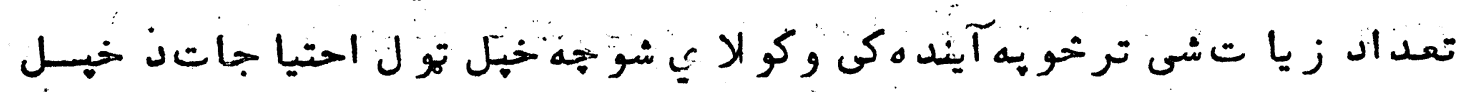

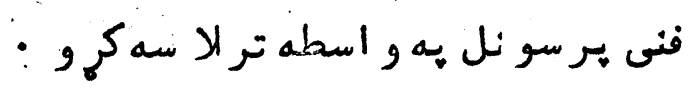

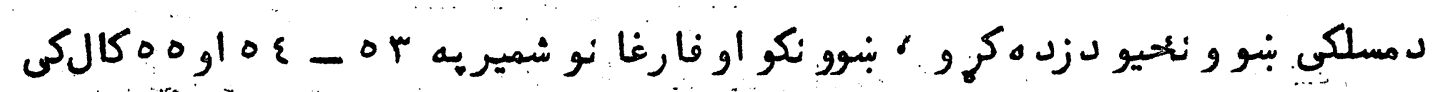

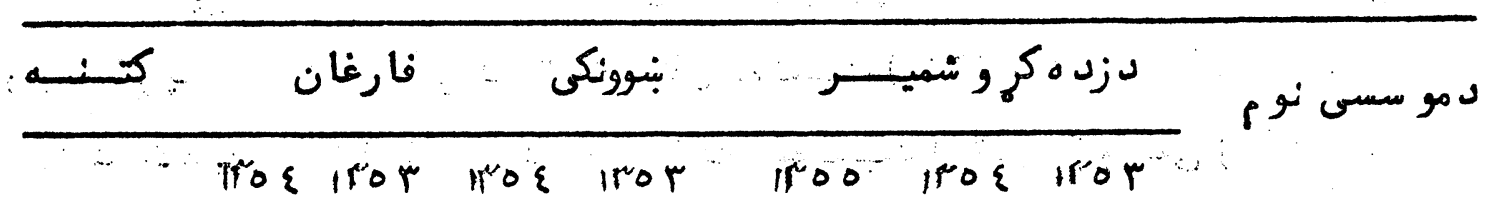

\begin{tabular}{|c|c|c|c|c|c|c|c|c|}
\hline & 111 & १६ & $r r$ & Y T & 001 & $r \cdot q$ & rri & د بغلاند كرهنى \\
\hline : & $r \varepsilon \cdot$ & inr & $r \xi$ & ri & $r \wedge 1$ & rq1 & \&ाץ & د ملمند \\
\hline 1 1roo d & - & - & 1. & - & 199 & 91 & - & كـ فرا ه \\
\hline كالد بنبوونكو & $\Lambda \varepsilon$ & 17 & Yi & $r r$ & ore & $0 .$. & ro. & ـ بحخ \\
\hline اوفارغائسـو & - & - & $r \varepsilon$ & 19 & 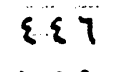 & rro & $1 \cdots$ & كابل \\
\hline شميرد بنوونو & 109 & 187 & $7 r$ & 79 & 7 7 & OrT & $\{9 \wedge$ & ل بـانويت \\
\hline او رزنى - & INT & 171 & Ar & $Y \wedge$ & $\varepsilon\urcorner r$ & \&า & $\varepsilon \cdot \gamma$ & كابلميخانيكى لر \\
\hline وزار رتمونز ته & VI & $Y 7$ & rq & rᄉ & $r \cdot \wedge$ & TAT & rAr & لدخو ســت لر \\
\hline نديراكري • & $\{\wedge$ & 77 & $r q$ & $r \cdot$ & $r \cdot q$ & $r \cdot 1$ & $r \cdot \cdot$ & 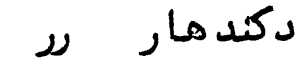 \\
\hline
\end{tabular}


ST. 100 \& \& \& \& د دموتلداري لا ل

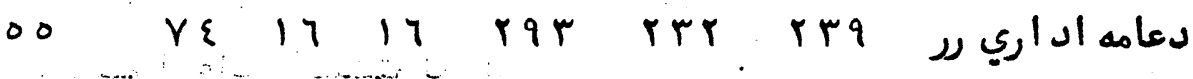
د د تجارت رد

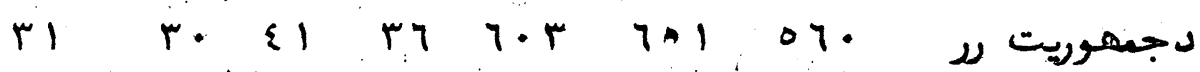
د بدنى وزنى لر • •

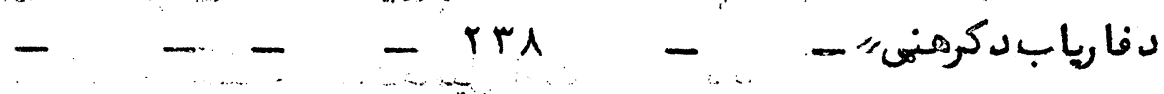

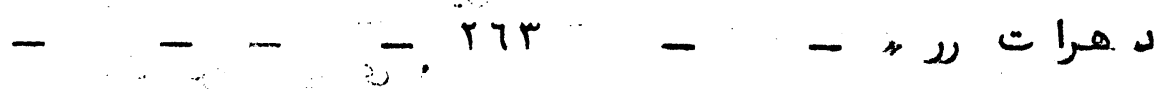
دين ro rq

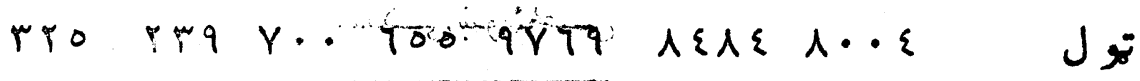

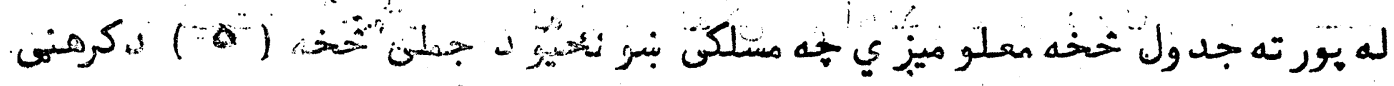

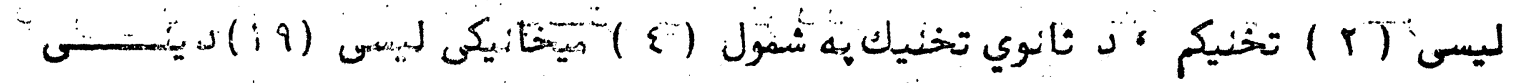

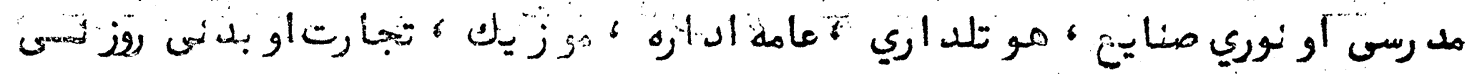

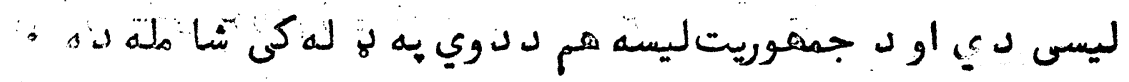

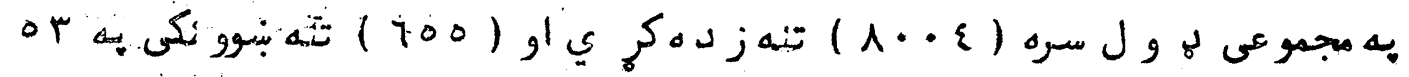

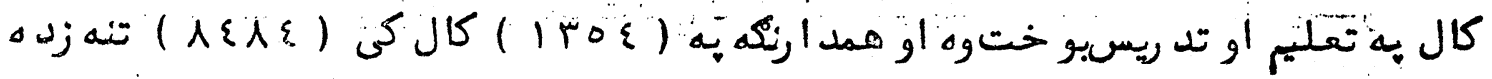

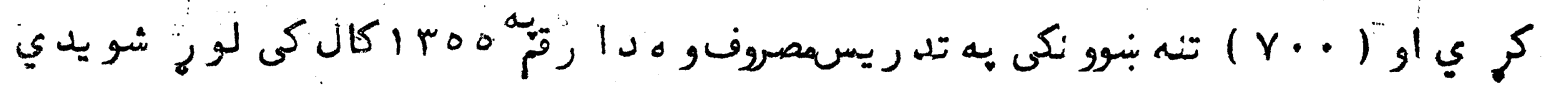

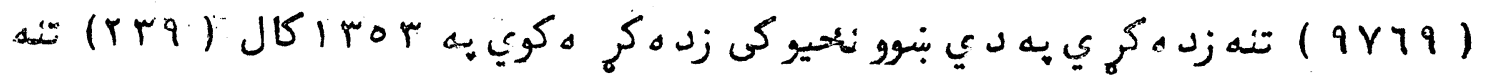

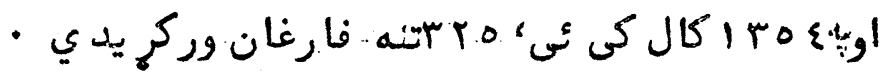

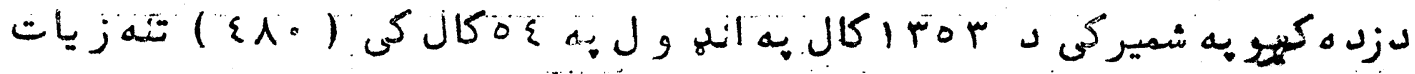

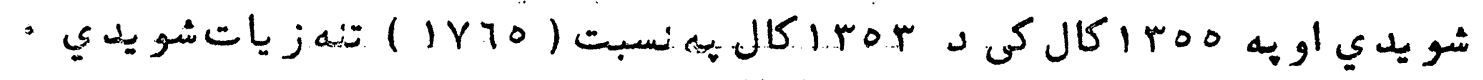

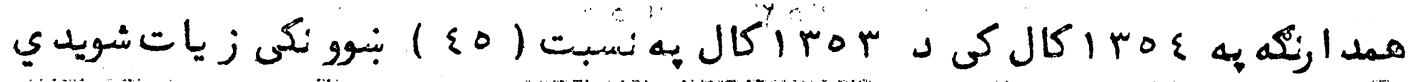

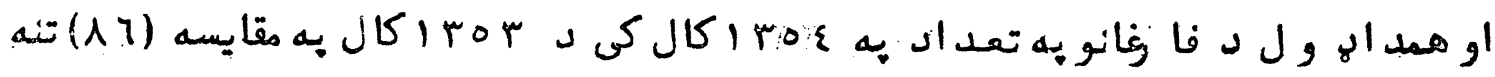

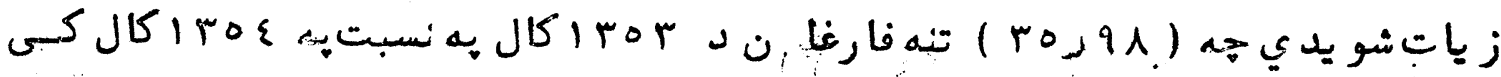

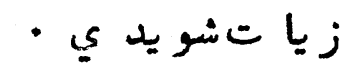

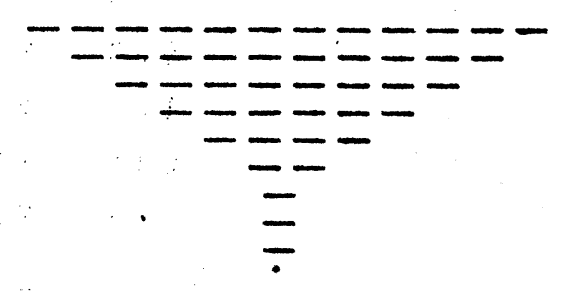


نهارزه ملىهايهبواد

\section{ニニニニニニニニニ}

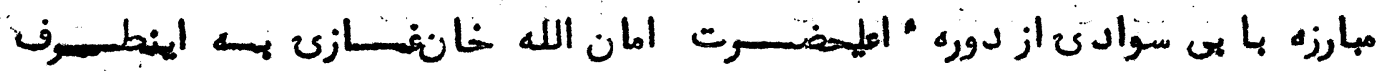

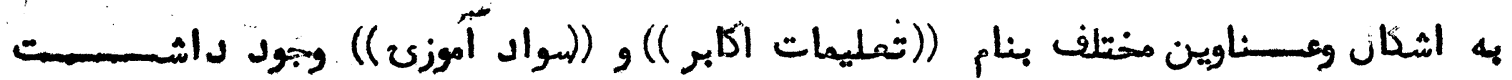

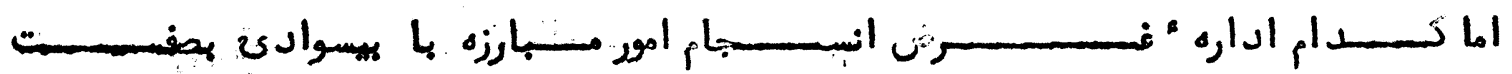

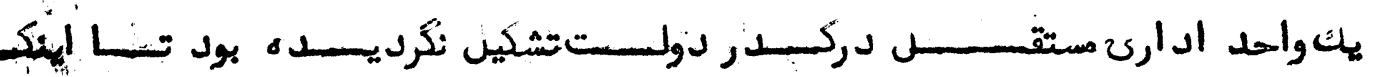

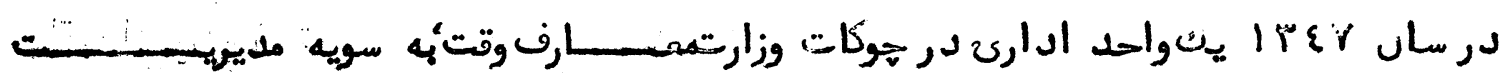

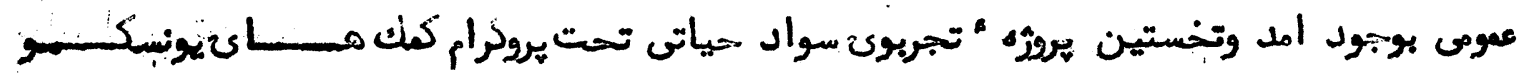

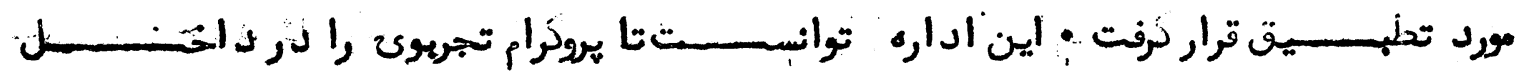

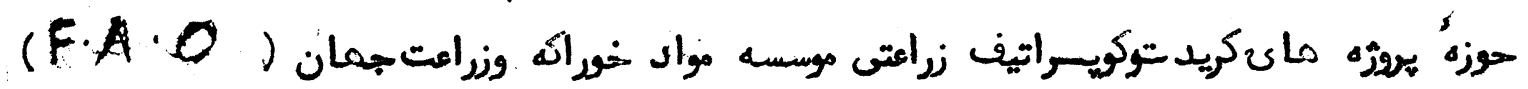

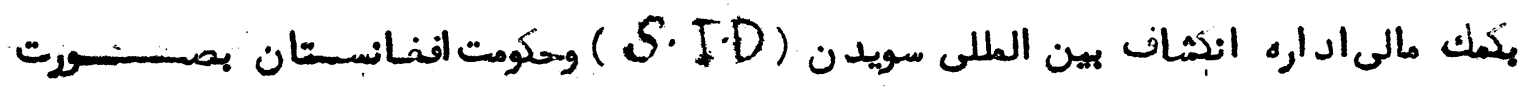

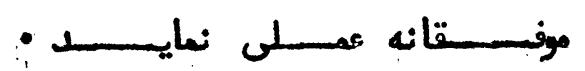

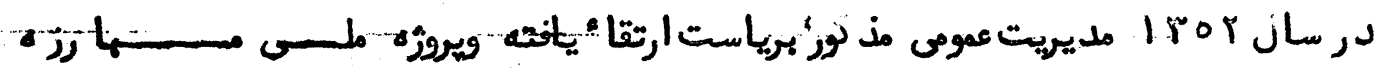

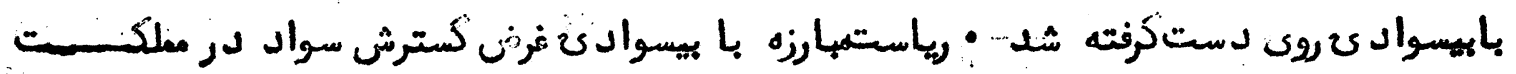

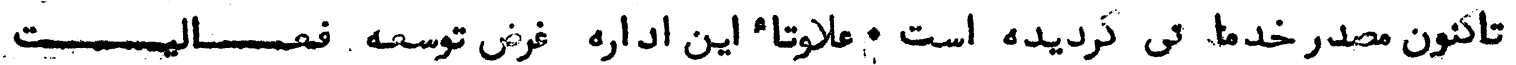

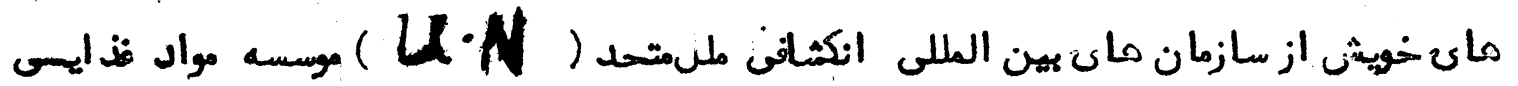

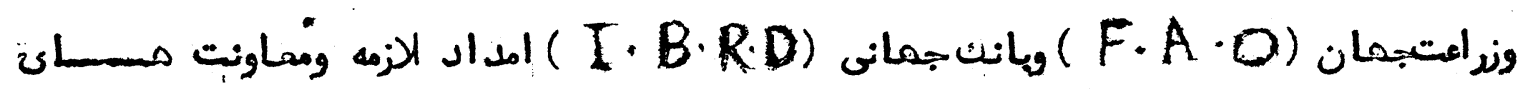

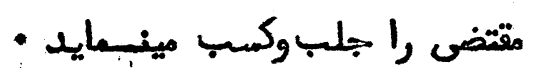

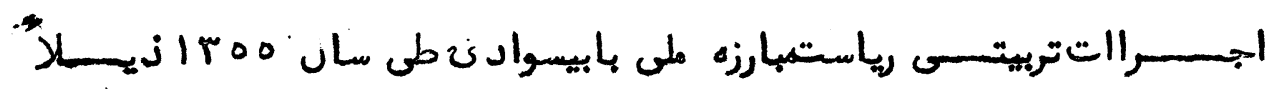

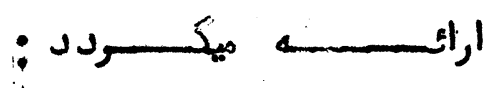

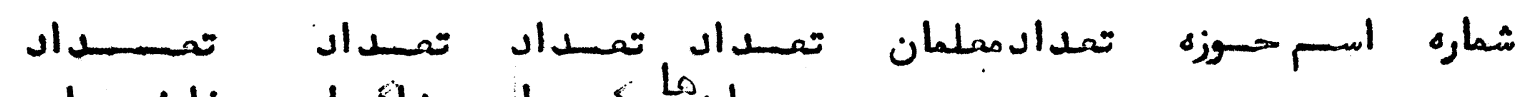

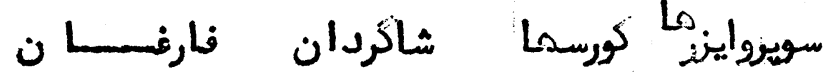

\begin{tabular}{|c|c|c|c|c|c|c|}
\hline$r$ & 7 & 0 & $\varepsilon$ & $r$ & $r:$ & 1 \\
\hline 0.17 & $r r \ldots$ & $r 7:$ & $\varepsilon r$ & 110 & كا بــــ & 1 \\
\hline$\varepsilon$ & $1 \cdot \varepsilon \cdot$ & or & 0 & $r 7$ & بذـــلان & $r$ \\
\hline$r 7$ & $\Lambda \Lambda$ : & $\varepsilon \varepsilon$ & 0 & ri. & يختيــــا & $r$ \\
\hline or & ITE & 77 & $r$ & pr & نتخكرما ر & $\varepsilon$ \\
\hline- & I\& & $r r$ & $r$ & ro & كنروهـــــا & o \\
\hline- & 87 & ז人 & $r$ & $r$ & لوكىــــــ & 7 \\
\hline- & $r \varepsilon$ & Ir & - & 7 & جوزجا ن & $r$ \\
\hline- & Nis & $r \varepsilon$ & $r$ & 17 & هـسرا ت & $\lambda$ \\
\hline- & $1 \ldots$ & 0 & $r$ & Yo & كوهد امن & 9 \\
\hline
\end{tabular}




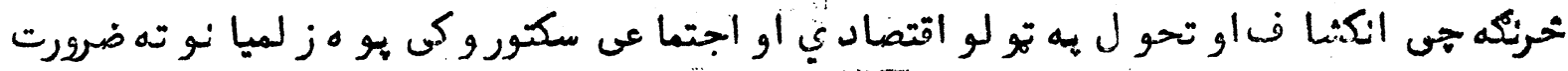

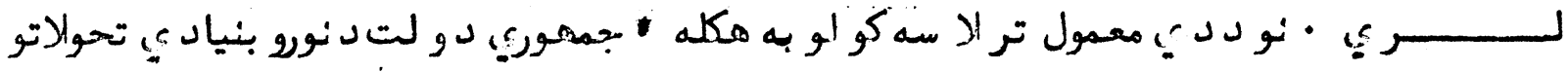

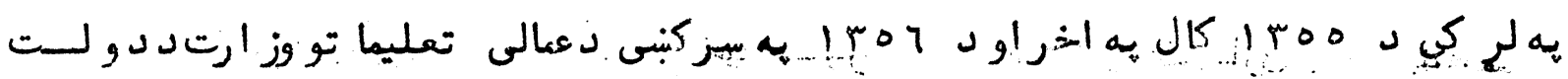

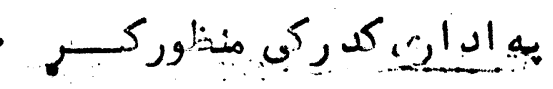

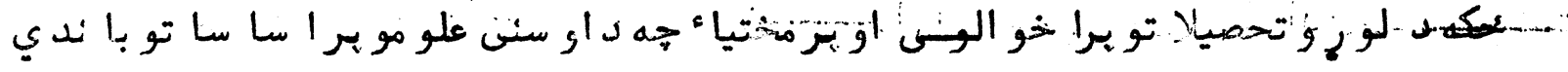

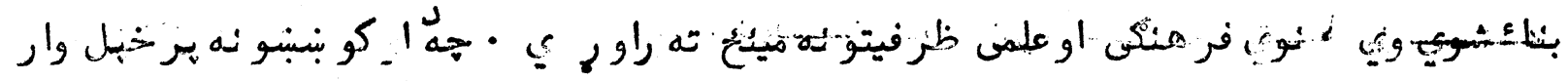

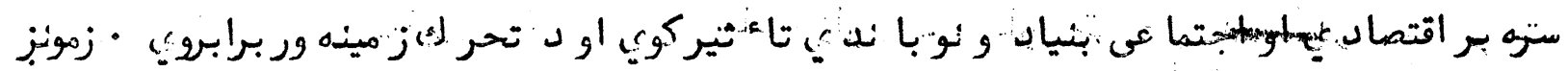

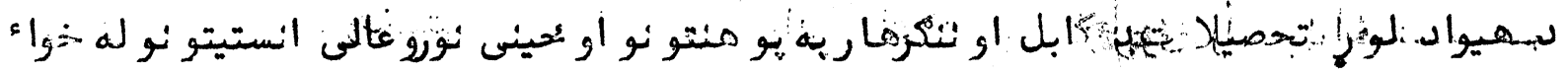

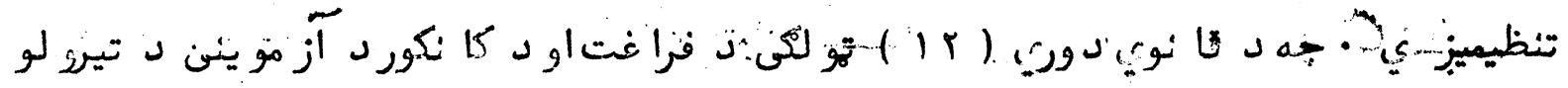

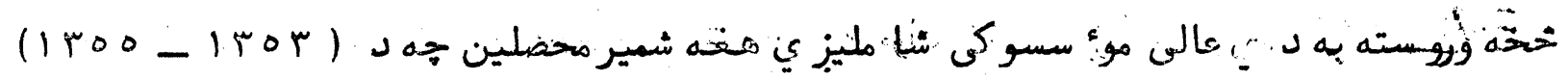

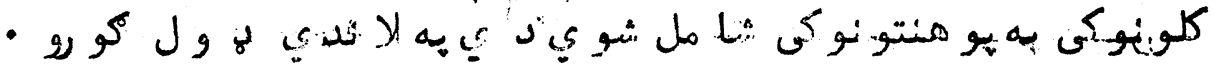

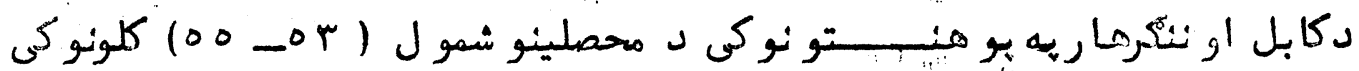

\begin{tabular}{|c|c|c|c|c|c|c|}
\hline$\frac{1400}{1 \mu \sigma r}$ & بـ لو نو نوكى & $\begin{array}{l}\frac{o \varepsilon}{\Delta r} \\
\text { a }{ }^{\circ}\end{array}$ & 1roo: & $\begin{array}{l}\text { i ros } \\
\therefore \quad \therefore\end{array}$ & Iror & 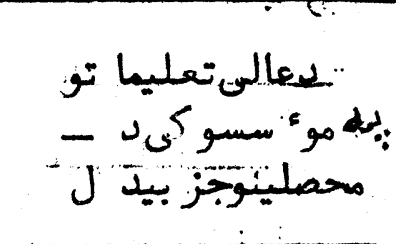 \\
\hline$\varepsilon r,\{\varepsilon$ & & $1 \cdot x^{2}$ & $r \varepsilon 0$ & 19. & IVY & دكإيل طلب يو هنيجيى : \\
\hline$-\{q, \xi\}$ & & $-1 . r, 91$ & $q \varepsilon$ & 17. & 117 & لد حقو قو لر \\
\hline$v, 70$ & & pror & I 11.r. & : : r.le & IV: & 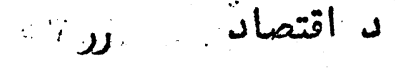 \\
\hline $1, r$ & & $-r \wedge, \varepsilon$. & $\{1\}$ & $r g$ & $\{\cdot 0$ & د اد بياتو لد \\
\hline 11,11 & & $r r, T r$ & ro: : & Tro & IN.Y & 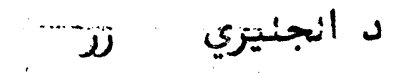 \\
\hline$-19, \varepsilon \varepsilon$ & & $-r 1, r$. & ir & 10 & $1 \cdot 1$ & 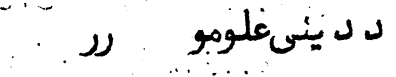 \\
\hline$\varepsilon, i \lambda$ & & $-r \varepsilon, q r$ & $r o F$ & $=r e 0$ & $r \varepsilon 1$ & 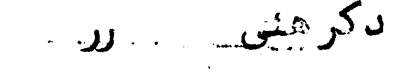 \\
\hline $1 \cdot \mu r$ &.. & $\cdots$ & ril: & $r r$ & $r \cdot$ & 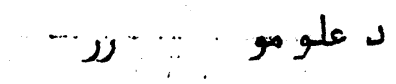 \\
\hline$-77, r$ & & $-\{\wedge, \gamma 1$ & or & $\Lambda \cdot$ & 107 & 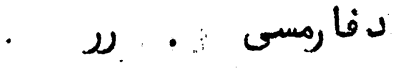 \\
\hline $1 r$ رr & & $-1,97$ & 117 & $1 \cdots$ & $1 \cdot r$ & لدوترني؛ رر \\
\hline 0 & & $r, 01$ & $\varepsilon 1 r$ & $\varepsilon \cdot 0$ & ri & د بو ليتخنيك ر \\
\hline Irr, & & $r \eta r r$ & IVY & $1 \cdot 0$ & $r V$ & 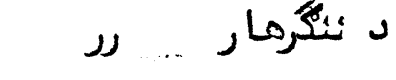 \\
\hline$\xi \gamma \wedge$ & & 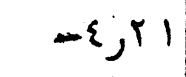 & $r 7 \cdot q$ & rr人o & $r\{q \cdots$ & تهــــو J \\
\hline
\end{tabular}




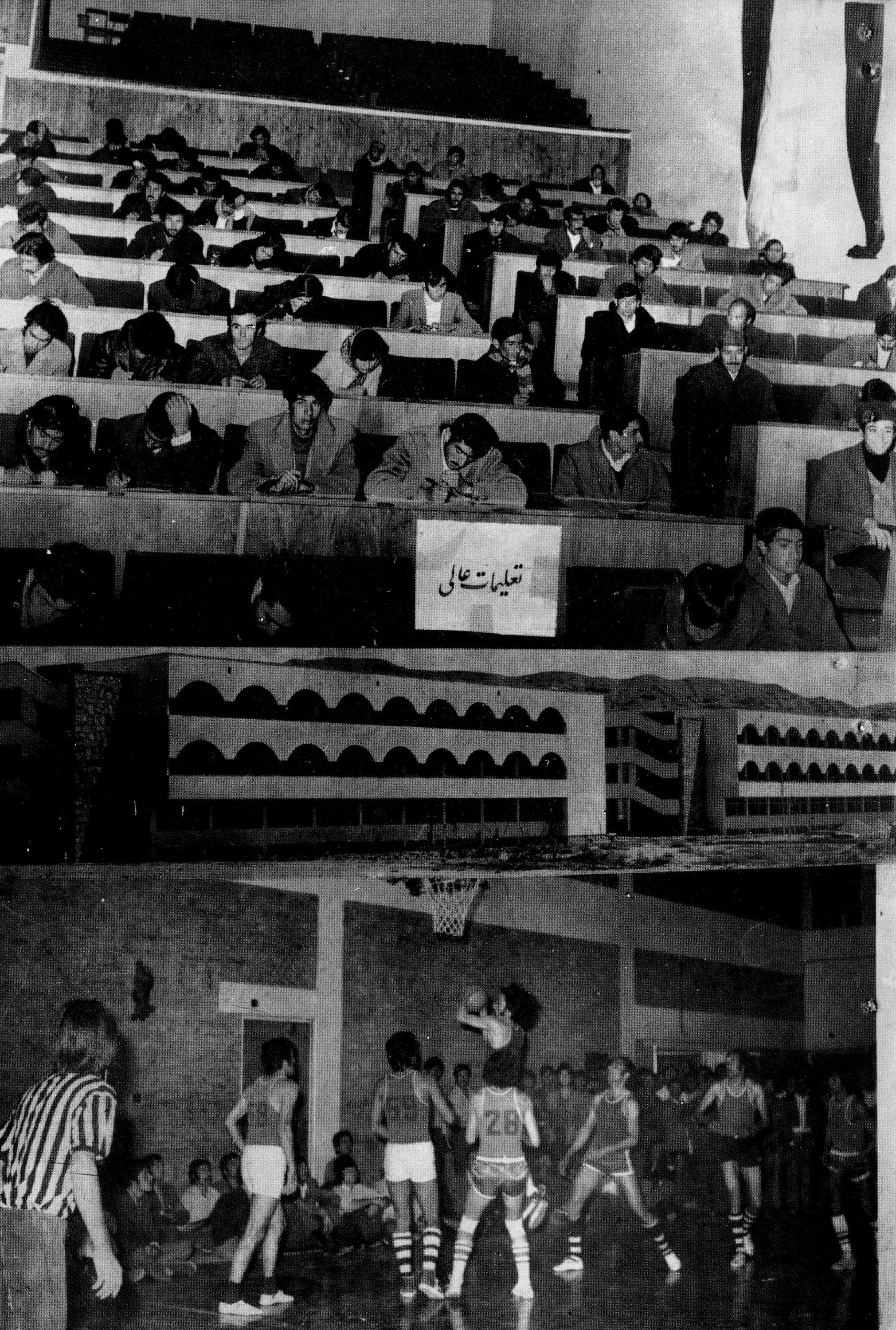




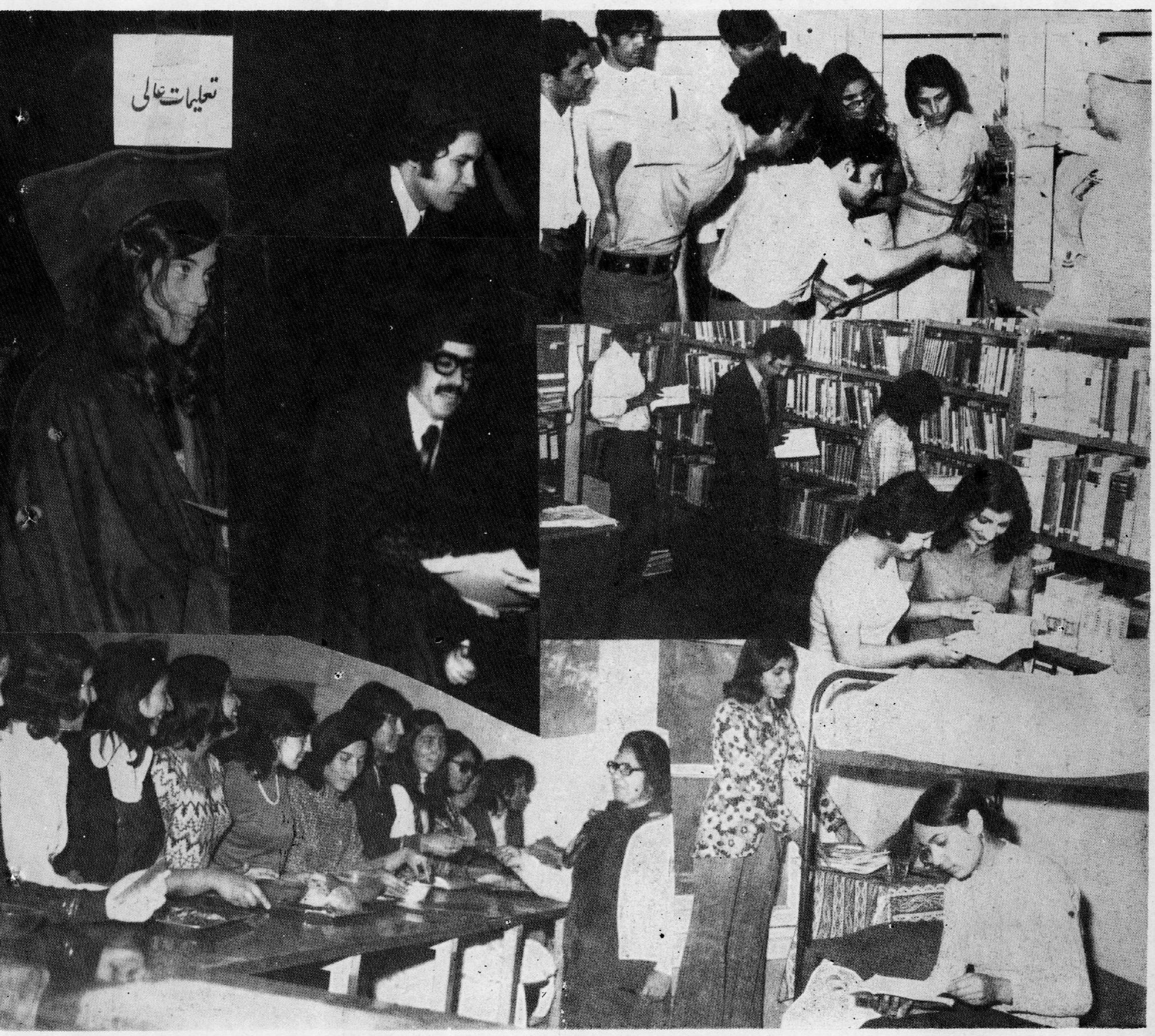




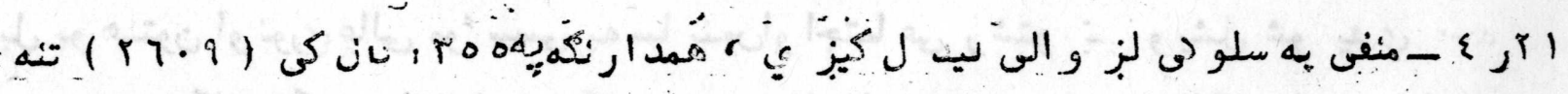

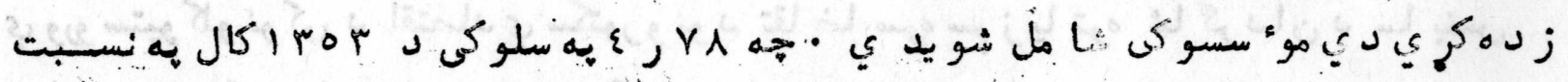

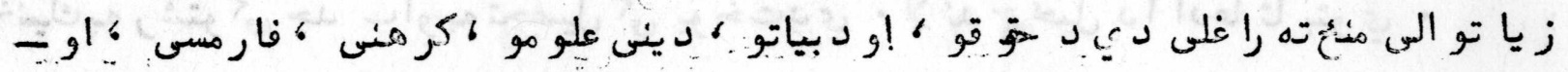

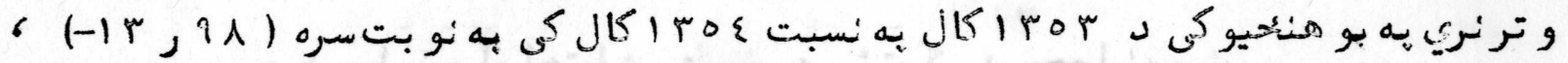

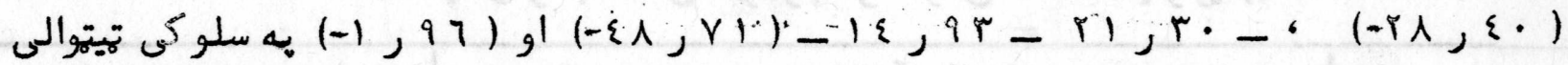

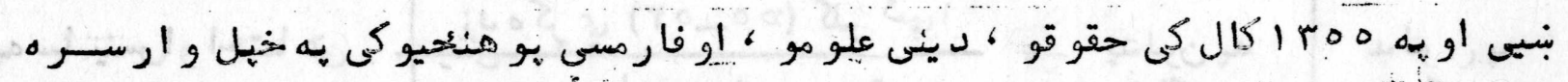
كا

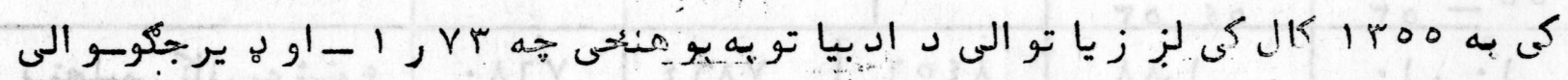

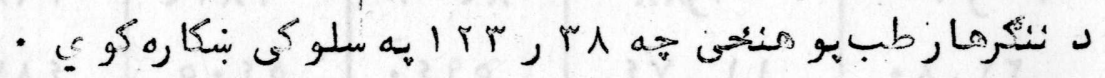

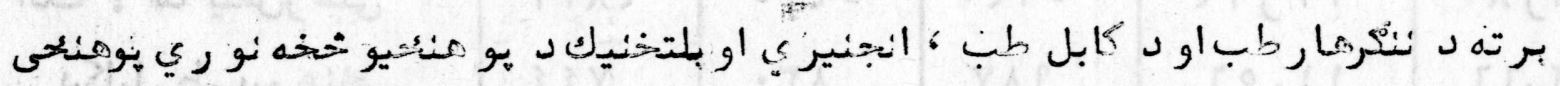

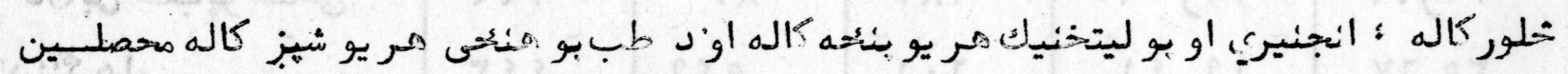

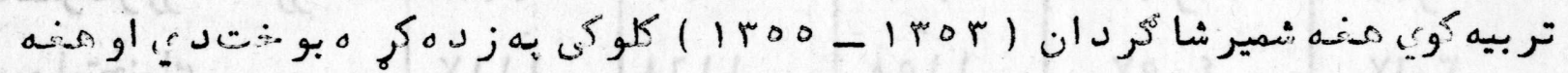

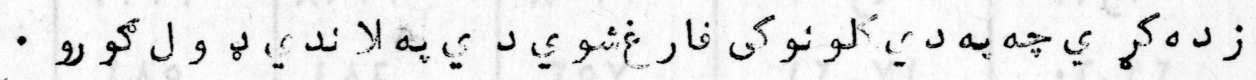

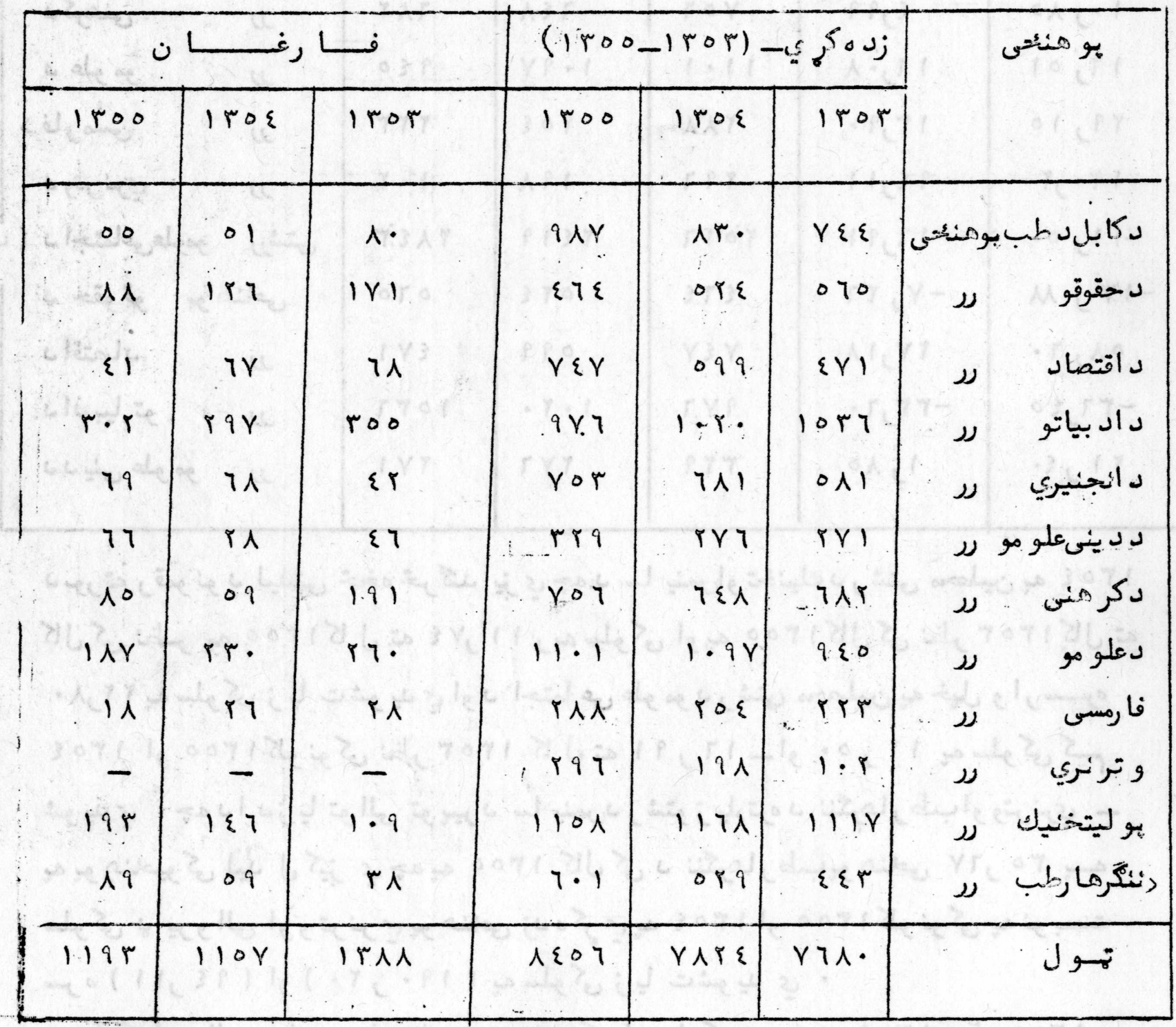

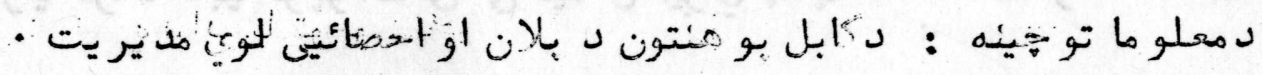




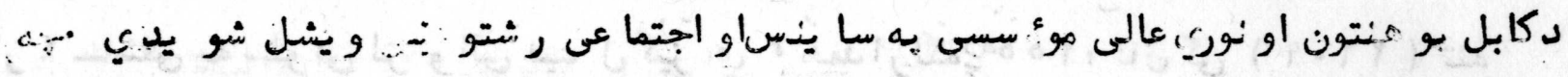

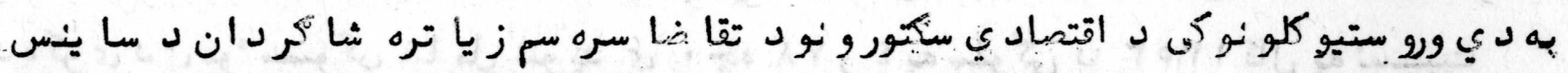

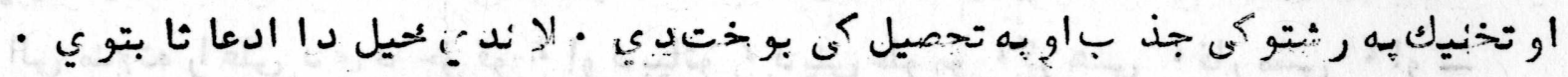

د سا ينسر أو اجتما عى علو بو يه ر شتوكى د محصلينو ويشر

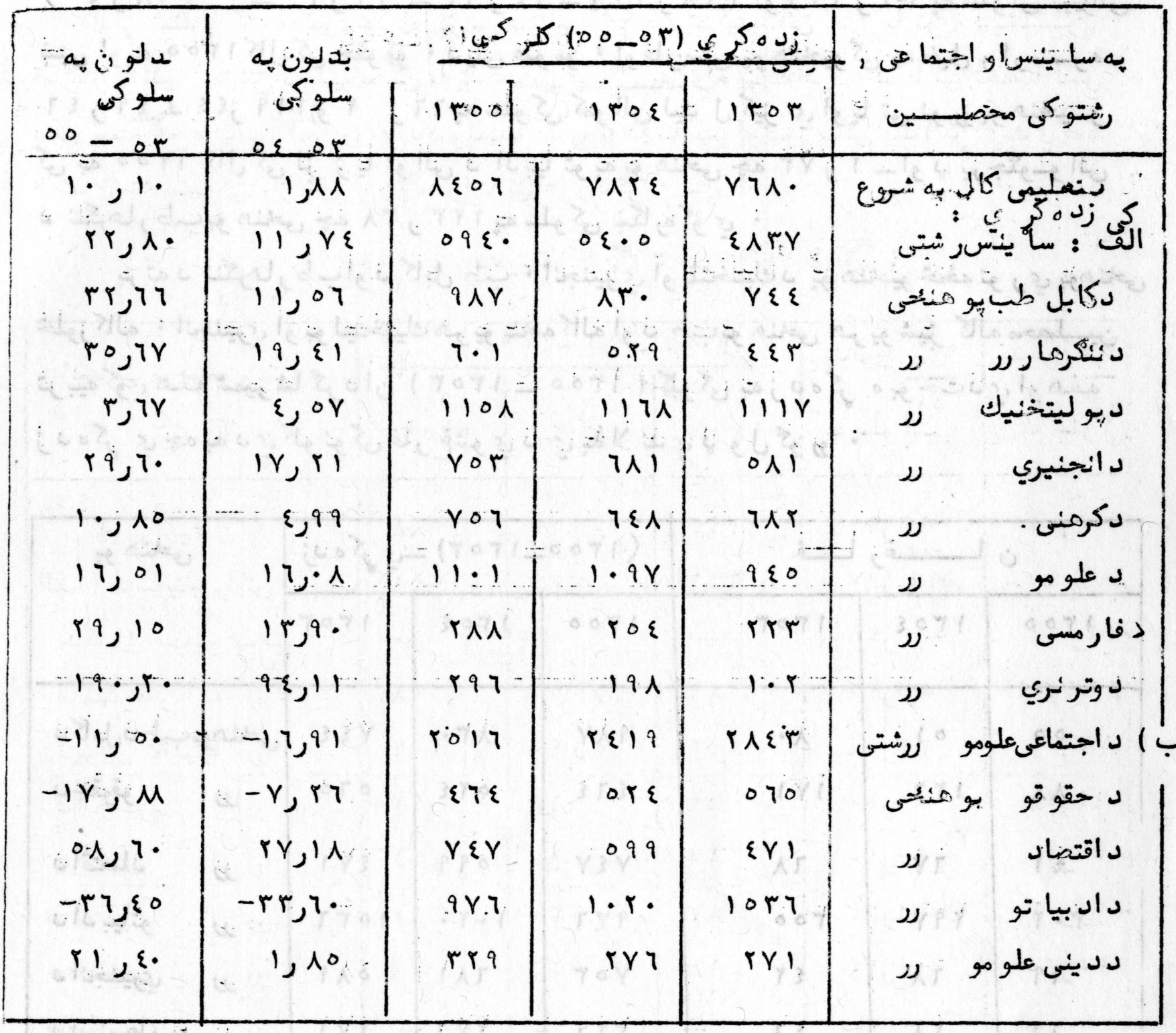

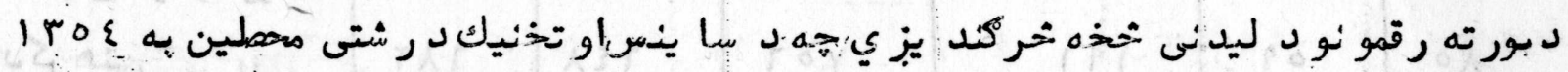

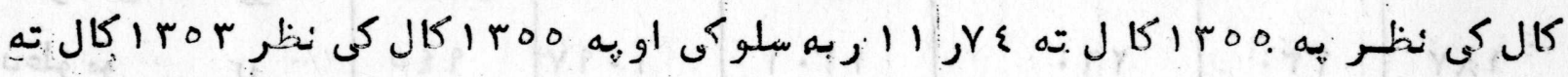

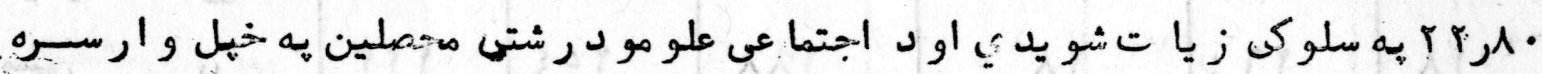

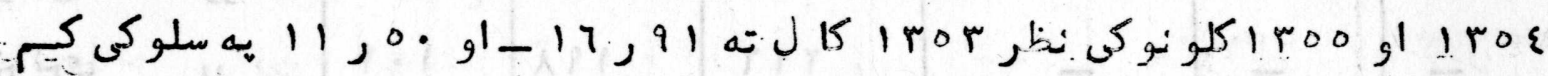

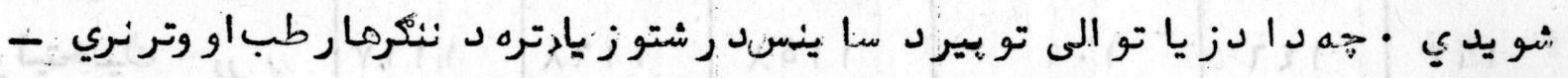

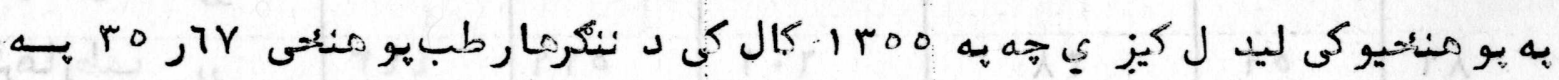

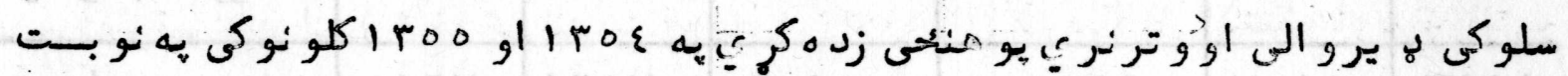

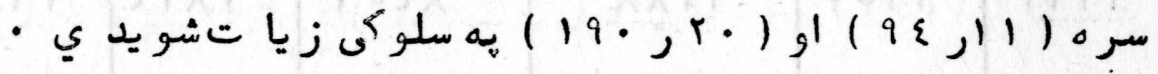

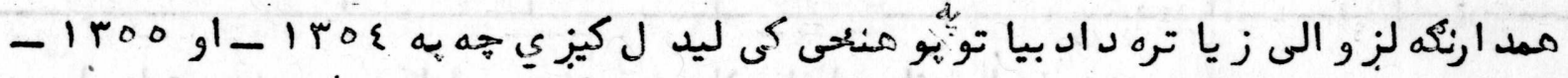




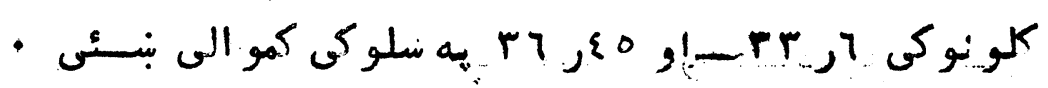

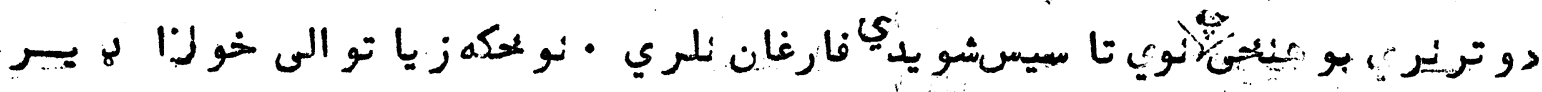

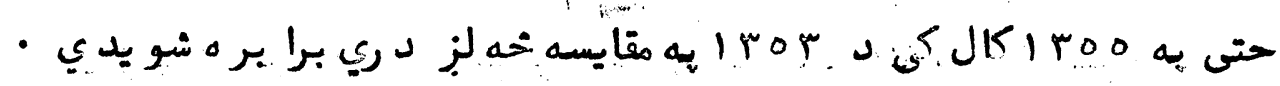
د عالى تجميلا توفاريغا ن :

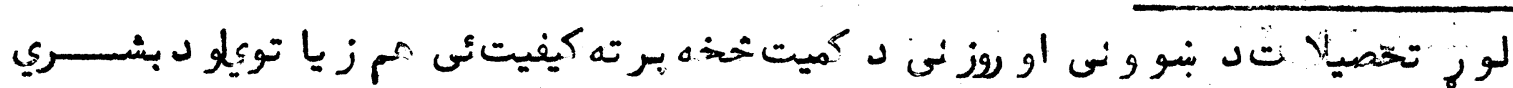

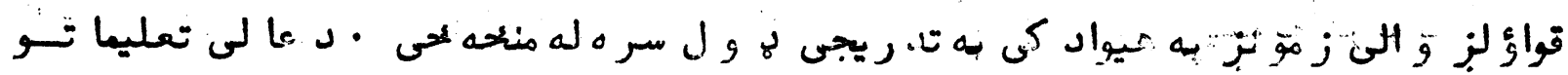

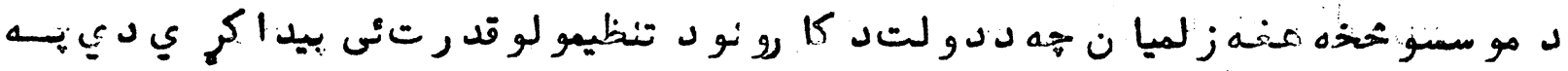

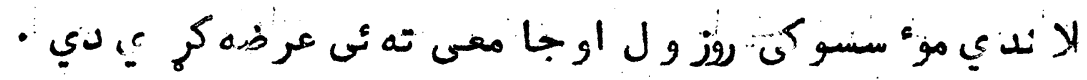

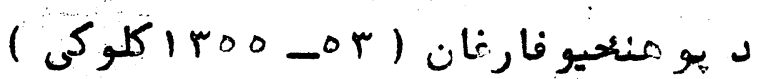

\begin{tabular}{|c|c|c|c|c|c|}
\hline \multirow{2}{*}{ بد لون ئمس } & \multirow{2}{*}{ بـ بـ لون سلوكسي } & \multicolumn{3}{|c|}{$\mathrm{s} S(1$ roo-1ror) } & \multirow{2}{*}{ دعالى مو سسو رشتى } \\
\hline & & $1 . r 00$ & Irog & iror & \\
\hline$i \varepsilon, \cdot \varepsilon$ & $-17,7 \varepsilon$ & 1194 & 1108 & IrAᄉ & تو ل فارِّان \\
\hline$-7,90$ & $-1 \varepsilon, \circ \gamma$ & 797 & $7 r 9$ & $Y \varepsilon \wedge$ & الف ) د ساي \\
\hline$-r i, r o$ & $-r \gamma, r_{0}$ & 00 & 01 & $\Lambda \cdot$ & دكابل طيمب \\
\hline$|r \varepsilon, r|$ & 00,17 & 19 & 09 & $r \lambda$ & د نئكروار \\
\hline$Y Y_{j} \cdot 7$ & $r r, q \varepsilon$ & $19 r$ & $1 \leqslant 7$ & $1 \cdot 9$ & ليولى تخذيك رد \\
\hline & $71,9$. & 79 & 71 & $\varepsilon r$ & د انجنيري \\
\hline$-00,0$ & $-79,1$ & 10 & $\circ \%$ & 191 & دكرهنى ' \\
\hline$-r \wedge ر \cdot r$ & $-11,0 r$ & INY & $r r$ & TY. & دعلو مو \\
\hline : & $-\wedge, 1 \varepsilon$ & 11 & $r 7$ & $r \Lambda$ & دفار مببى \\
\hline- & - & - & - & - & لدوتر نــــي \\
\hline$\rightarrow r, r \varepsilon$ & $-19, \cdot 7$ & ₹? & 011 & $7 \varepsilon$. & \\
\hline$-\varepsilon \wedge, 0 r$ & $-r_{7}, r_{1}$ & 11 & $1 \% 7$ & $|V|$ & يو منيمي \\
\hline $49, V_{1}$ & $-1, \varepsilon \gamma$ & \{1 & 78 & $7 \wedge$ & ل ل اقتهاد \\
\hline$\rightarrow \varepsilon j$ & $-17, r \varepsilon$ & $r \cdot r$ & rqY & roo & د اد بيا تو \\
\hline$+\{r,\{\wedge$ & $-r q, 1 r$ & 77 & $r \Lambda$ & $\{\gamma$ & دل ينى علو مو رر \\
\hline
\end{tabular}

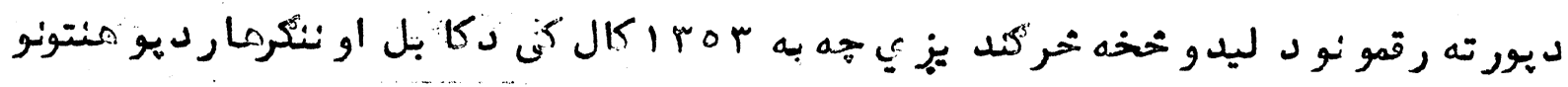

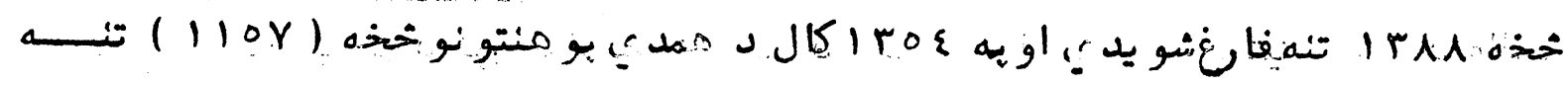

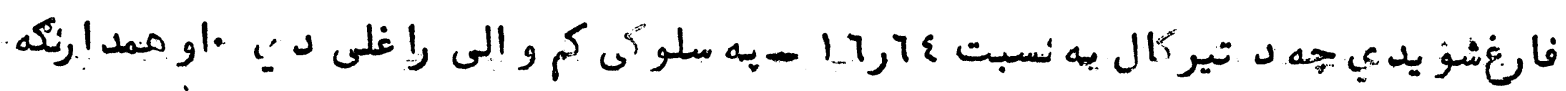




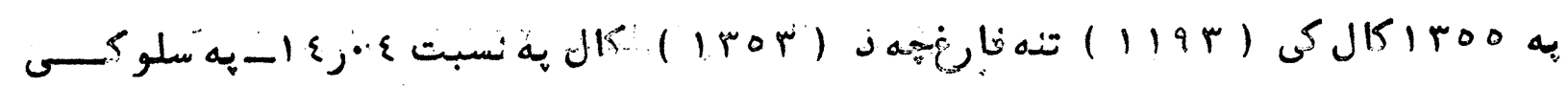

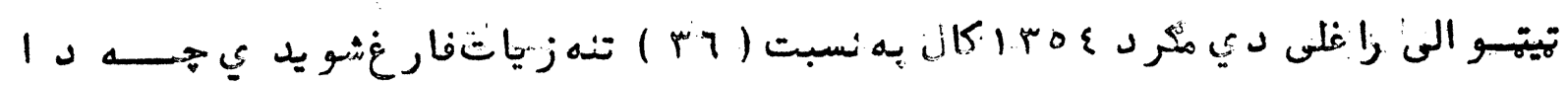

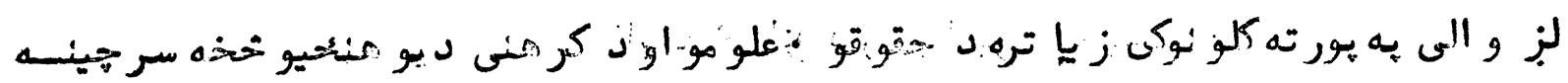

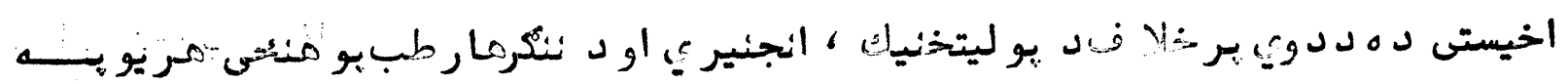
ـ

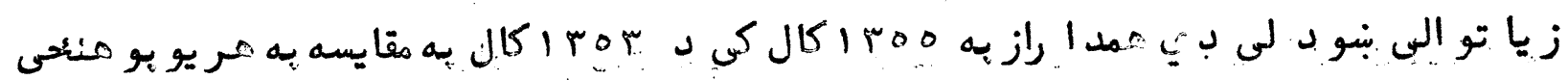

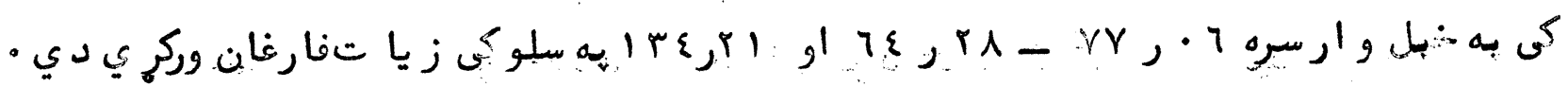

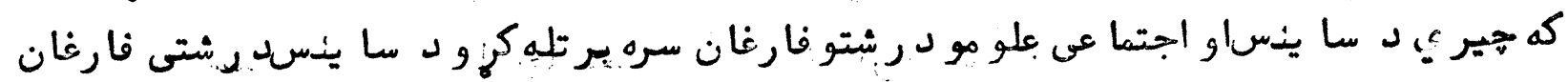

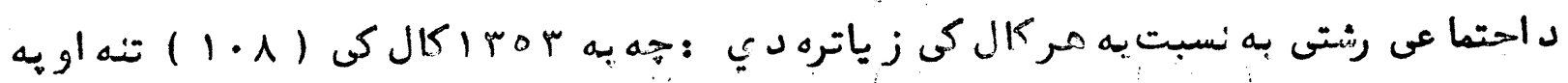

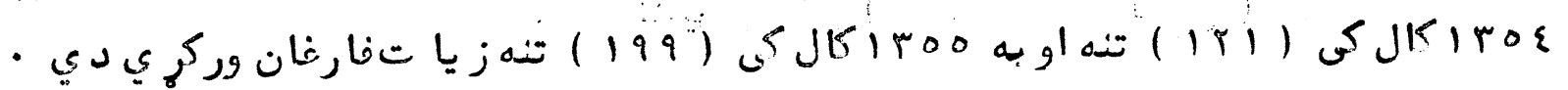
ليليـه اونداري زد ه كوو نكى

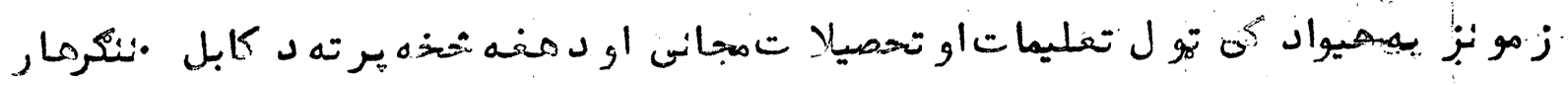

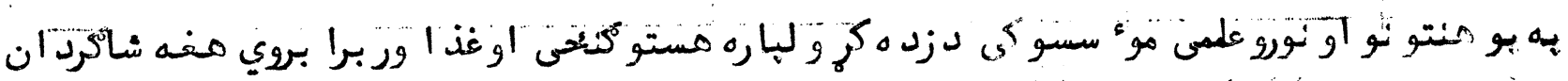

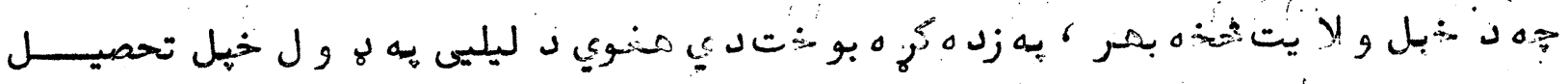

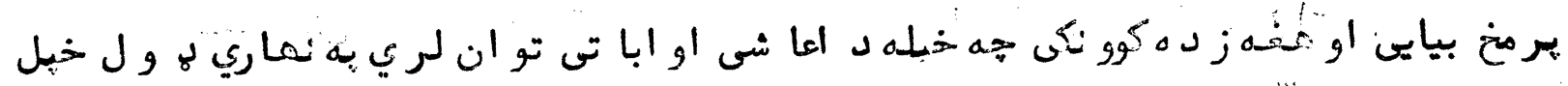

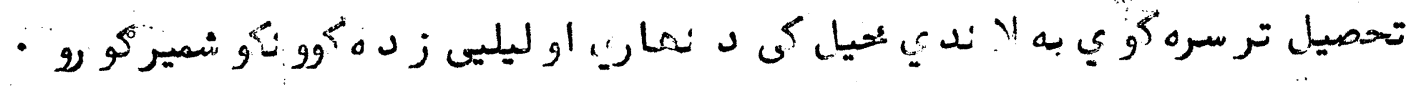
ل ليليى او نماري ز دهوي نكود برتلى محيل

\begin{tabular}{|c|c|c|c|c|}
\hline \multicolumn{2}{|c|}{ د ندماري زد هكو و نكسـى } & \multicolumn{2}{|c|}{ دليليى زد هكوو نكى } & لد موء سسى نــــوم \\
\hline تنــــــ & شميــــــر & تنــــ & شمير & \\
\hline נע & $\begin{array}{r}r q \ldots \\
17\end{array}$ & נע & $\begin{array}{c}\$ 900 \\
010\end{array}$ & 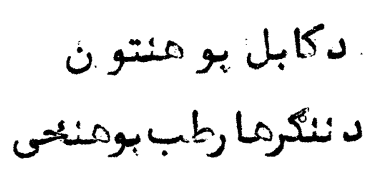 \\
\hline נر & 1917 & עر & $00 \&$. & تهــــول \\
\hline
\end{tabular}

. لدملو ما تو هيئه : د بكابل بو منتون د بلان او احمائيى لوي مد يريت.

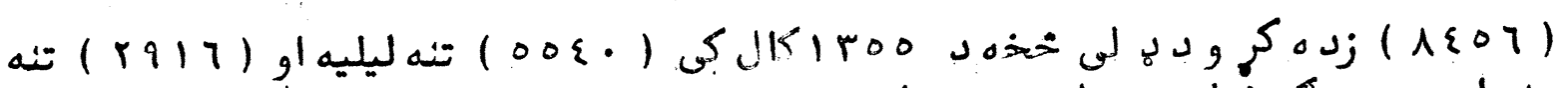

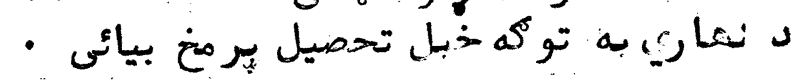

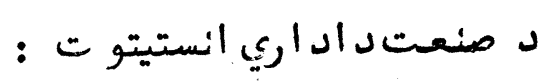

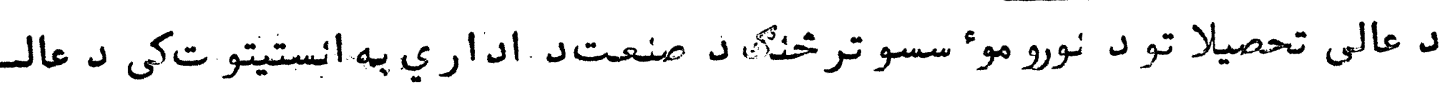

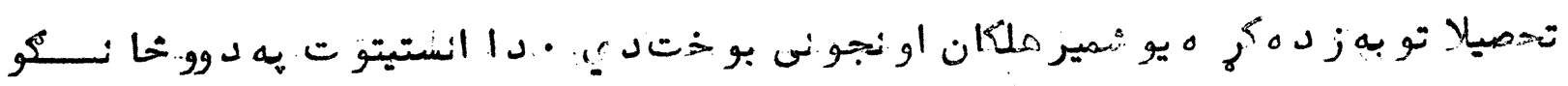




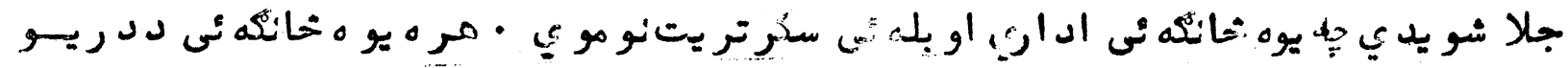

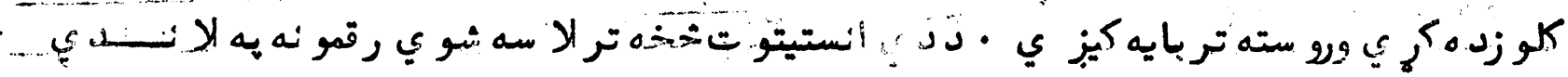

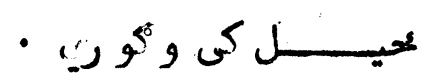

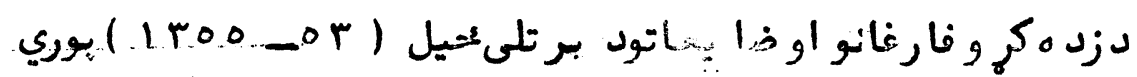

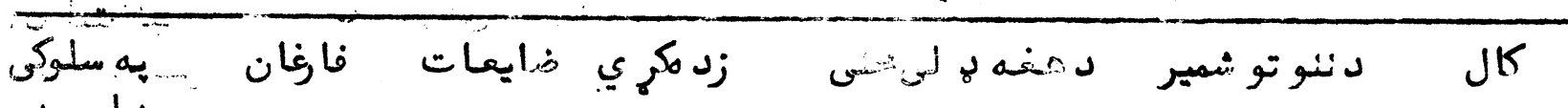

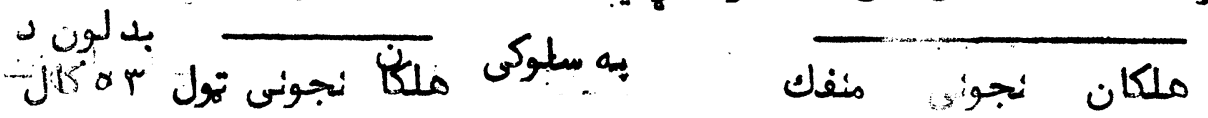
بيه إيسا بيل

\begin{tabular}{|c|c|c|c|c|c|c|c|c|c|c|}
\hline$\ldots$ & -70 & $1 r$ & or & $7, \wedge 1$ & $r 7$. & 19 & $\Sigma Y$ & rYr & PYq & Iror \\
\hline$-\infty, y \vee$ & 01 & $1 r$ & \&० & • & rol & $r$ & 39 & $r \cdot q$ & r & Iroq \\
\hline$r r_{j} ! 9$ & Ar & 17 & 78 & $r, \xi$ & 198 & $\xi$ & $r$ & 174 & 197 & Iroo \\
\hline
\end{tabular}

دمعلوما تو جينه : دصنعتد اداري ألميتو ت ريا ست •

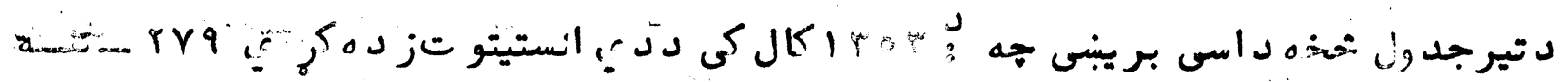

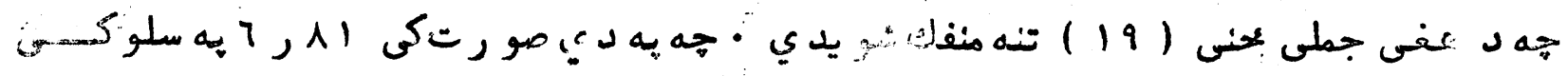

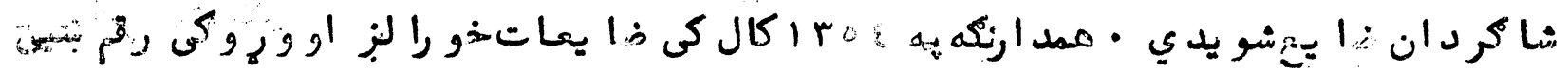

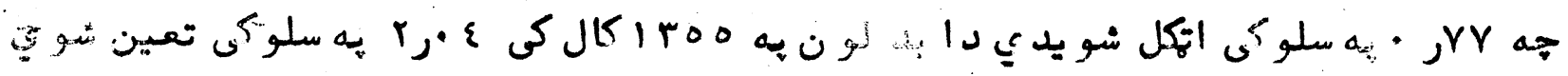

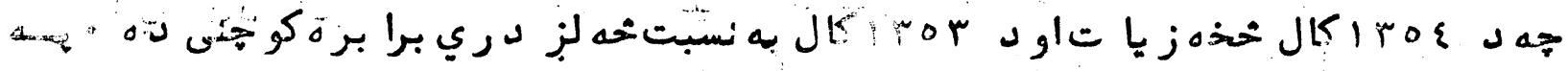

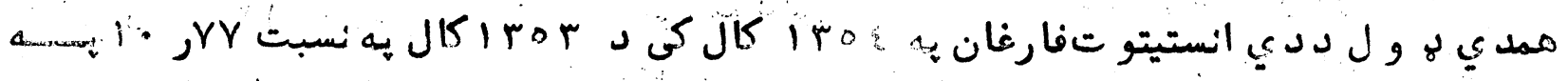

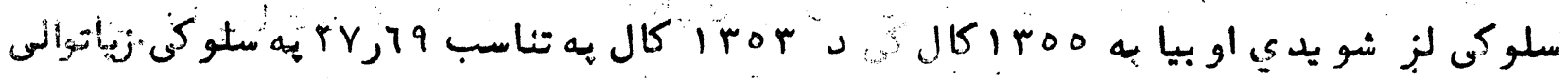

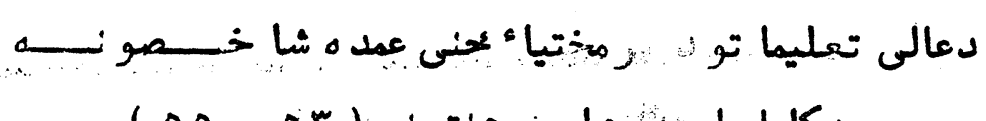

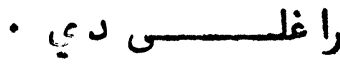

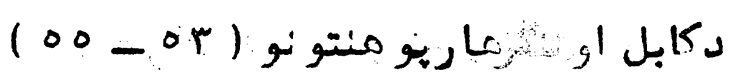

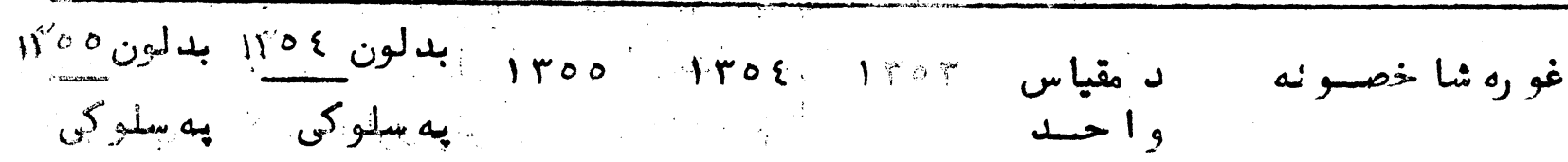

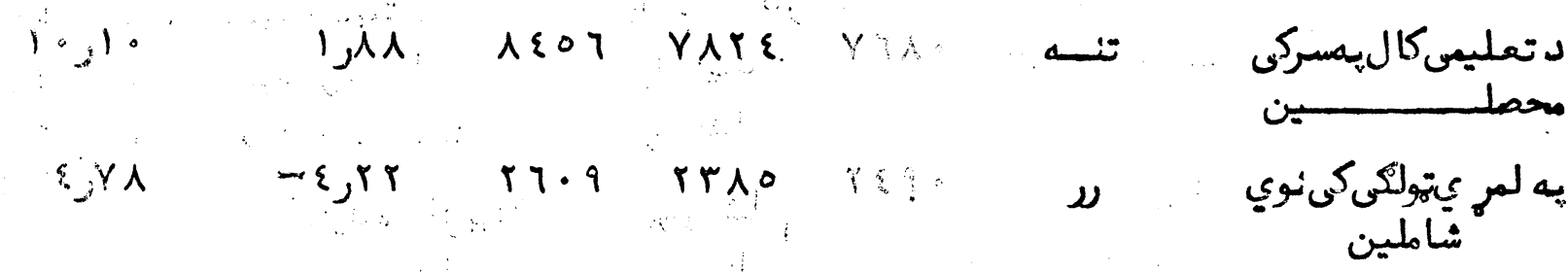

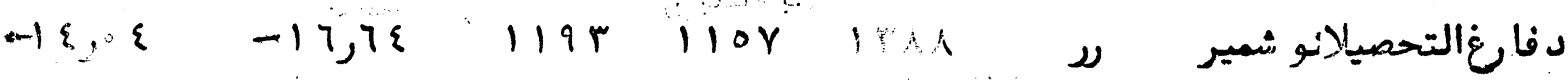

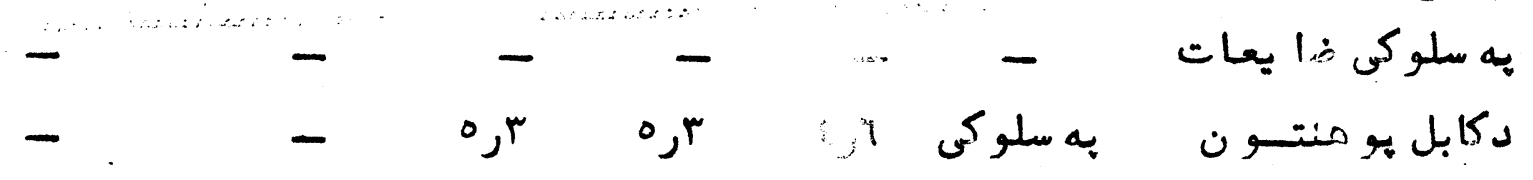




\begin{tabular}{|c|c|c|c|c|c|c|}
\hline به لون به به & بد لون سلوكي ع به & 1 roo & $1 . r 0 \varepsilon$ & Iror & و د مقياس & غــوره شا خــص \\
\hline - & - & FFF & $\mid \lambda, \lambda$ & $\because \cdot 1$ & يَهِ سلو كِى & ليو ليتخختيكى \\
\hline- & & $1 \cdot, \cdot$ & $+\frac{1}{\therefore}$ & $Y$, & 1״: עر & د ننكرمار عب لر \\
\hline 0,19 & $r$ so & 910 & 199 & 179 & تُنـــهـ & 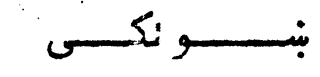 \\
\hline T,re & r & $\vee \wedge \varepsilon$ & Y Tr & VrA & נرנ & كو رنى بنو نكسى \\
\hline- & $\varepsilon, 01$ & $|r|$ & Irr & $|r|$ & زj & با ند ينس بنو نكى \\
\hline
\end{tabular}

د معلو ما تو هينه ؛ د كابل هو منتون د هلا ن لوي مد ير يت .

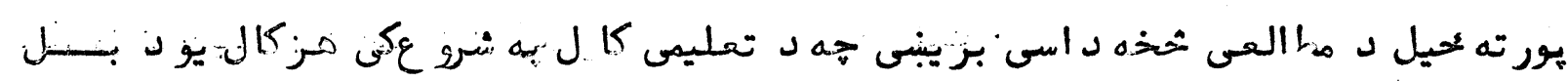

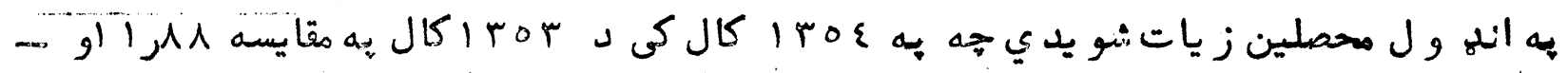

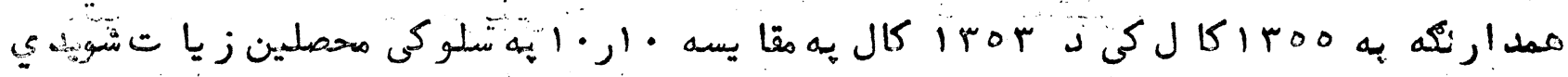

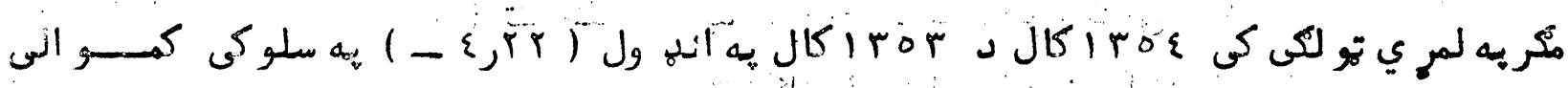

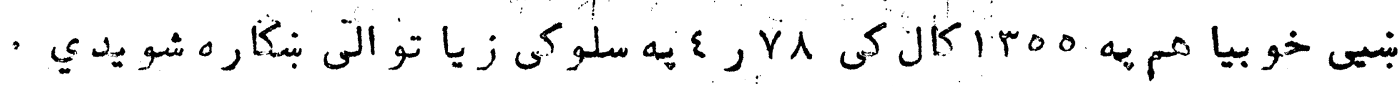

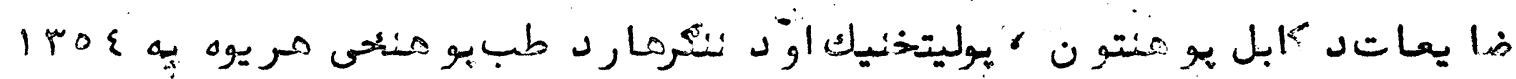

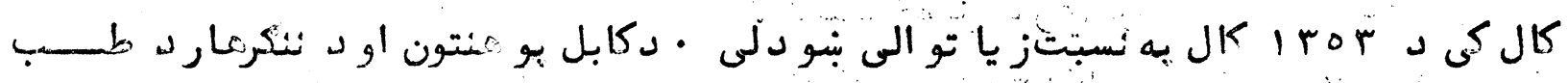

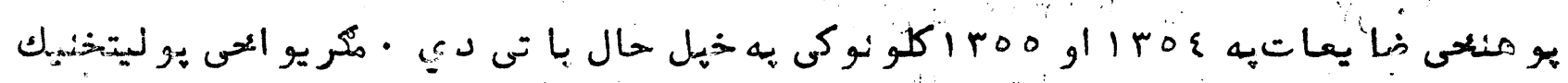

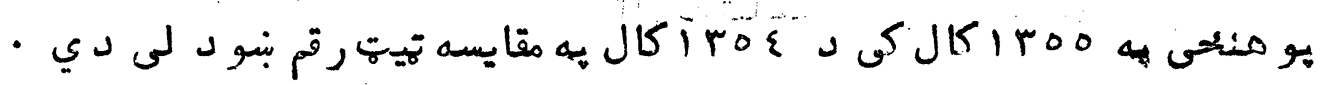

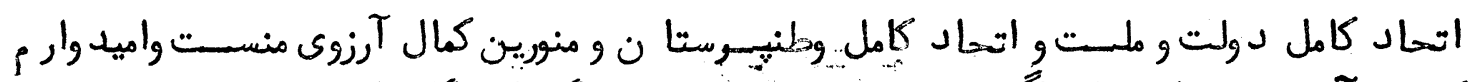

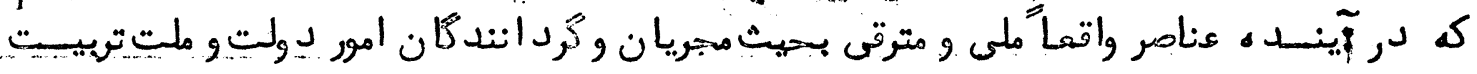

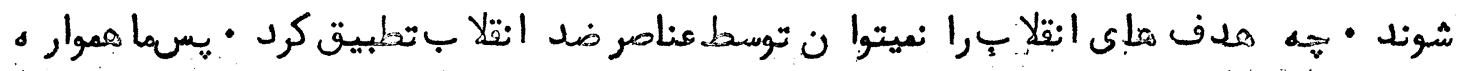

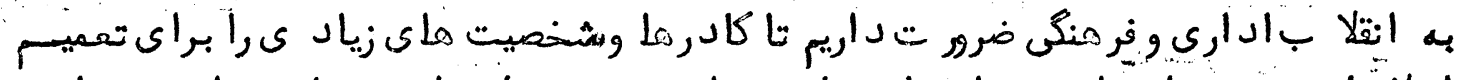

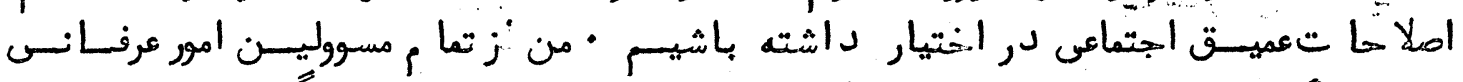

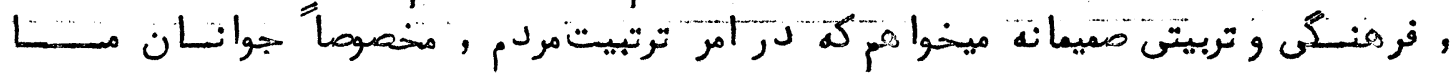

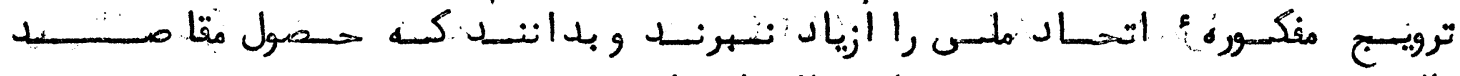

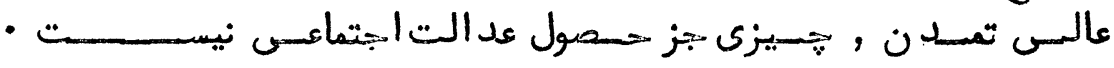

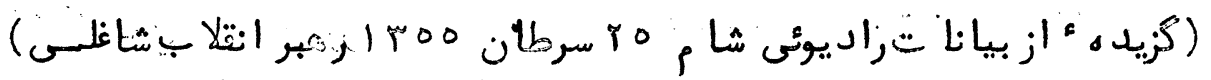

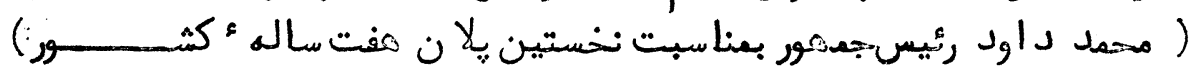




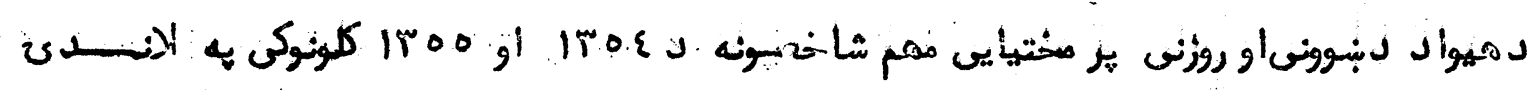

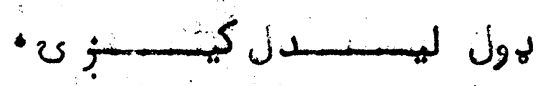

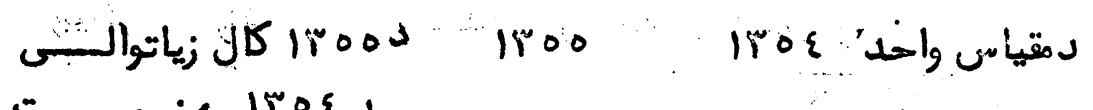

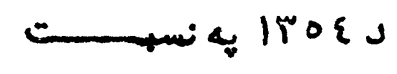

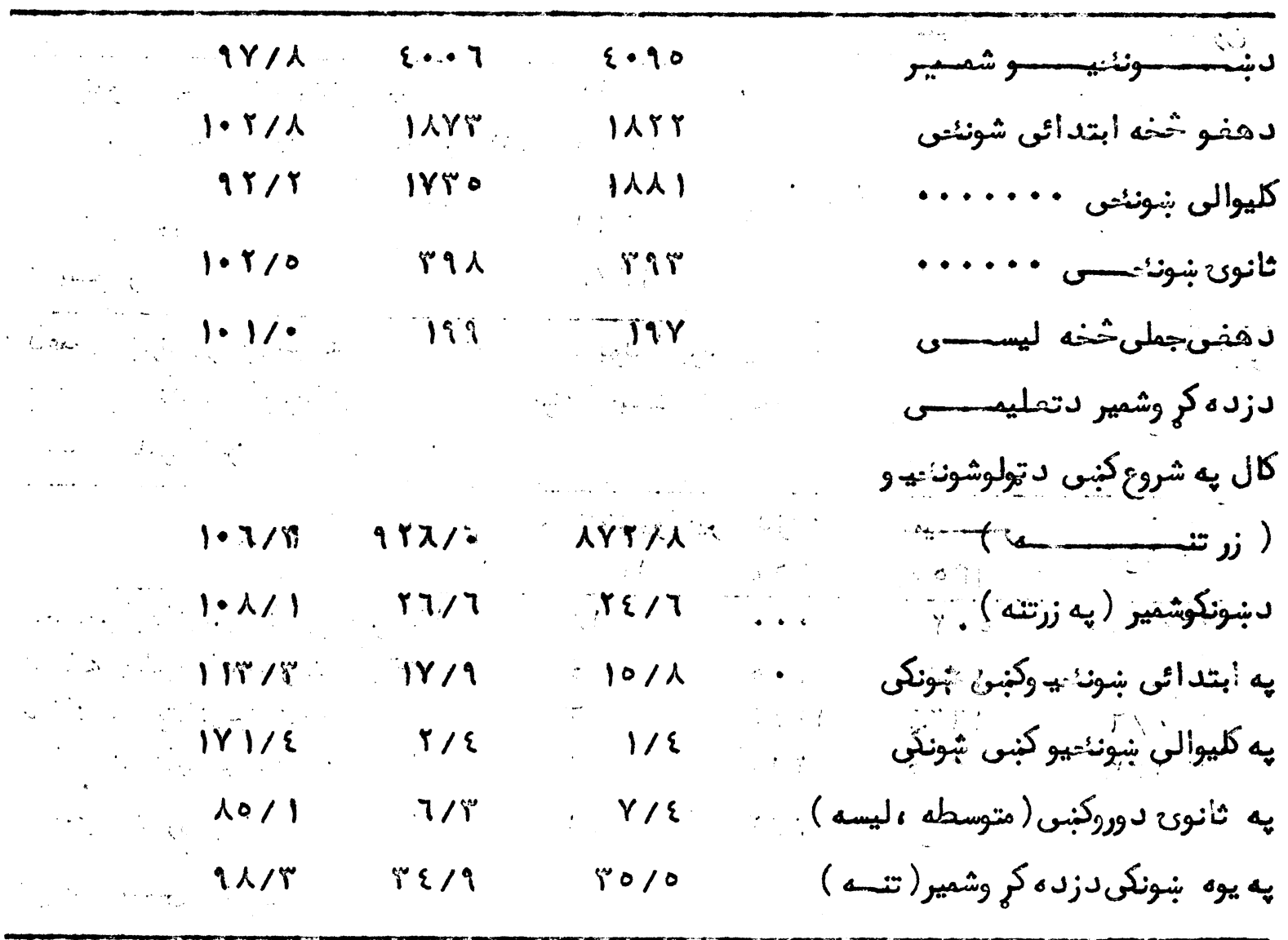

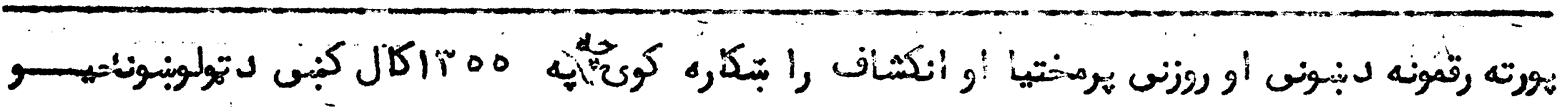

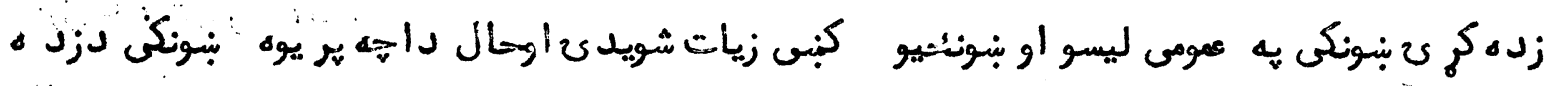

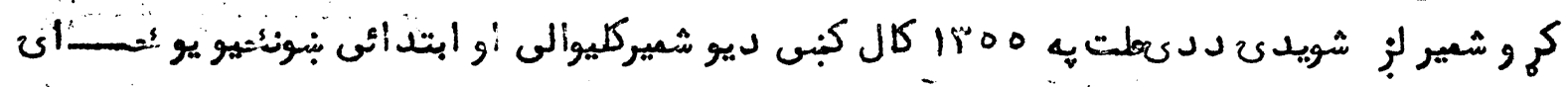

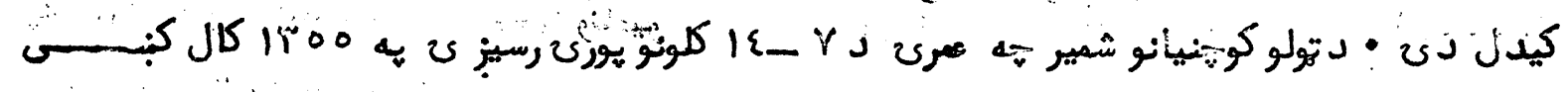

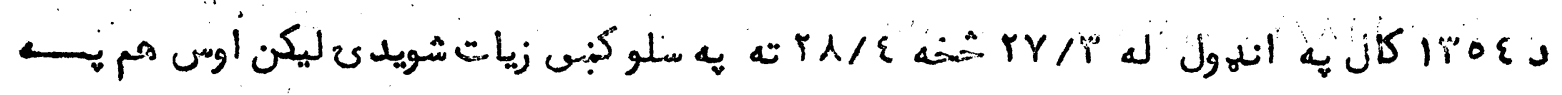

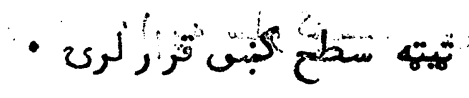

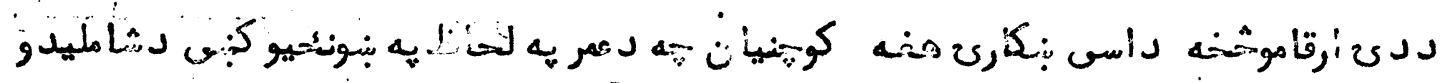

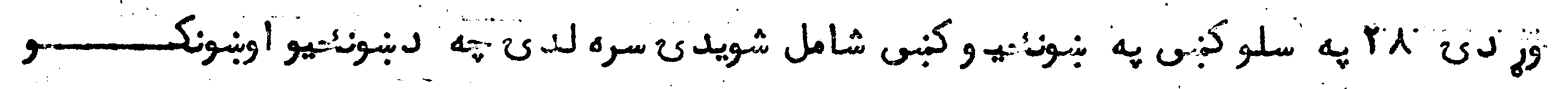

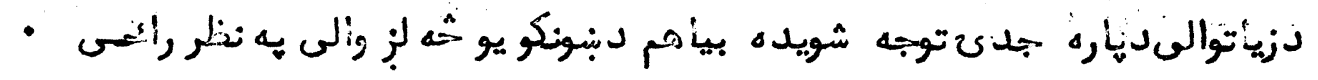




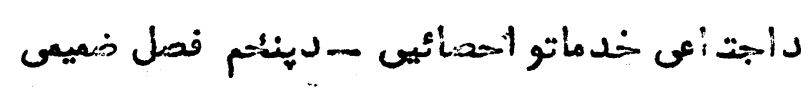

نبوونســا و روزنسـ

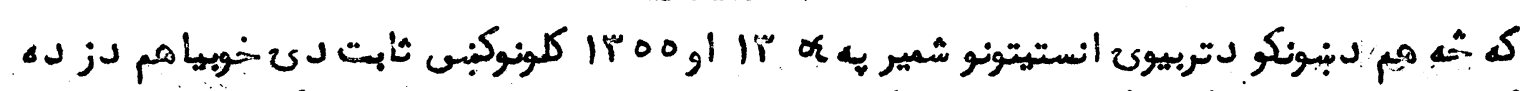

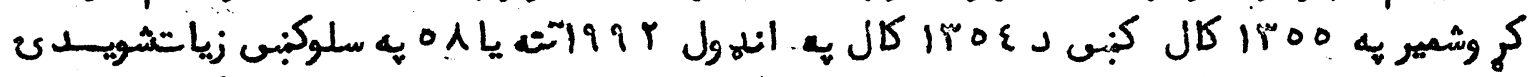

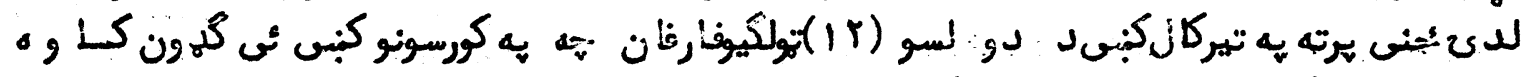

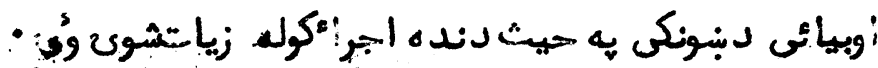

\begin{tabular}{|c|c|c|c|}
\hline 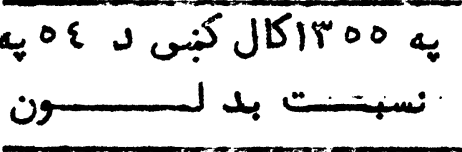 & $\begin{array}{c}\text { JSIY } 00 \\
\ldots\end{array}$ & jLITO\& & . \\
\hline $1 \cdots 1$ & $1 \cdot$ & $1 \cdot$ & دبنونكو دتربيوك انستيتونوشمير \\
\hline $10 \gamma / 0$ & $0 / \varepsilon 0$ & $r / \varepsilon \gamma$ & 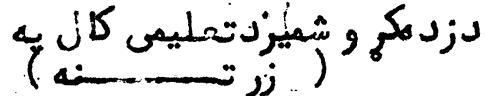 \\
\hline $1 \cdot 9 / 9$ & r10 & YI & دبنونكو بِمير ( .تنـهـ) \\
\hline $100 / 1 \cdots \cdots$ & $1 \varepsilon / 7$ & $17 / 1$ & دليسوفُرغان (زرتنــهـ ) \\
\hline
\end{tabular}

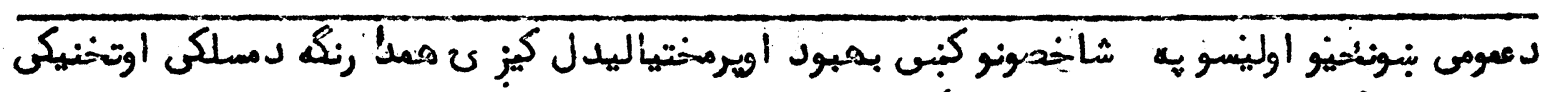

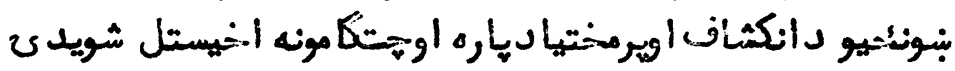

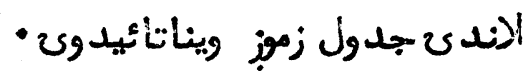

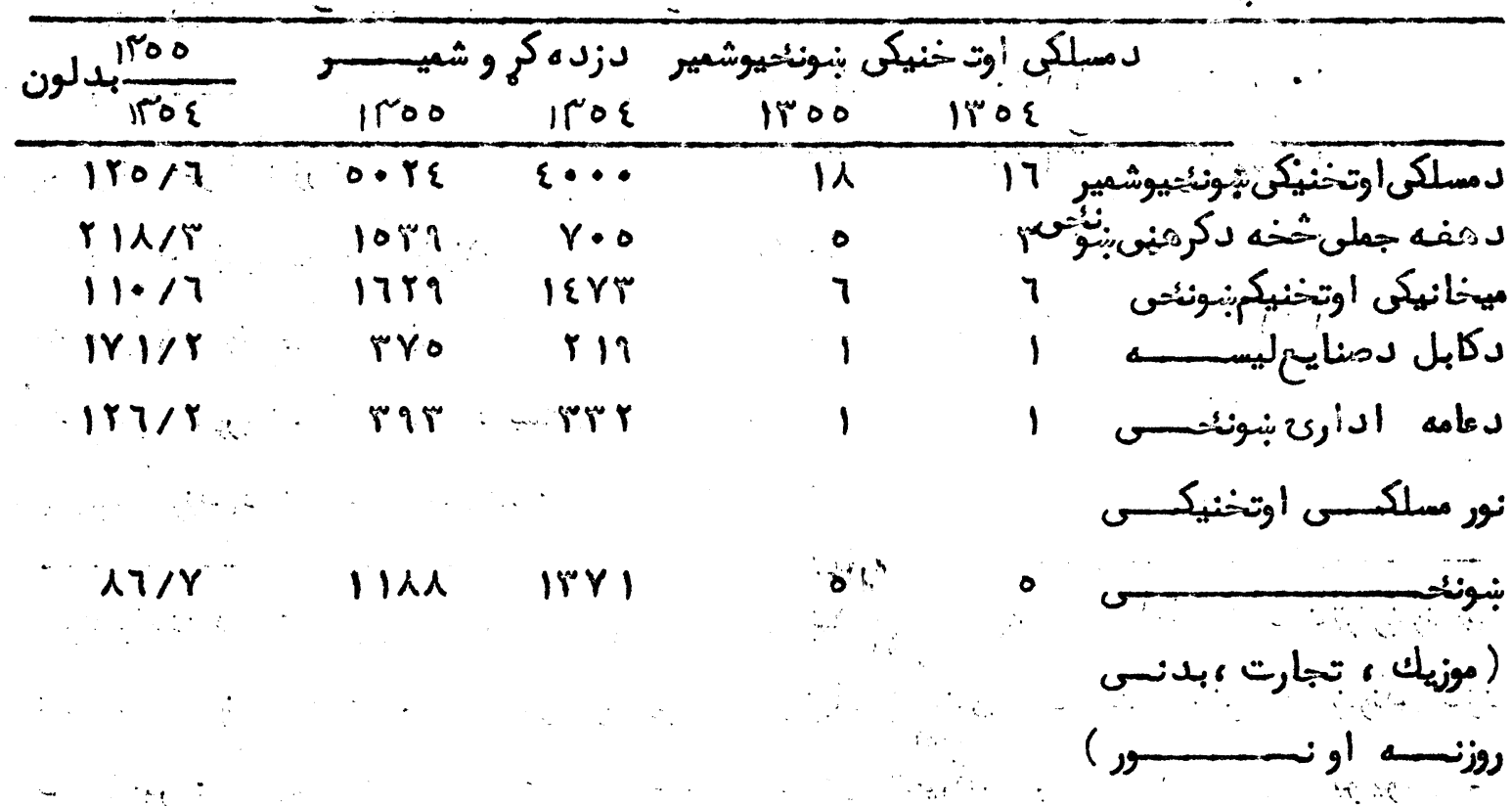

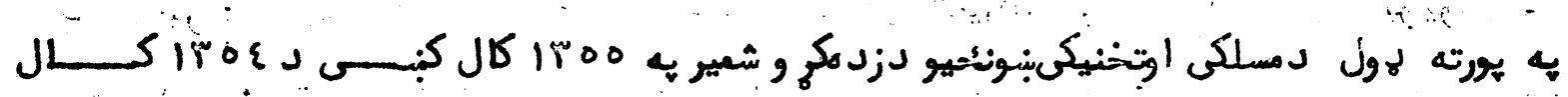

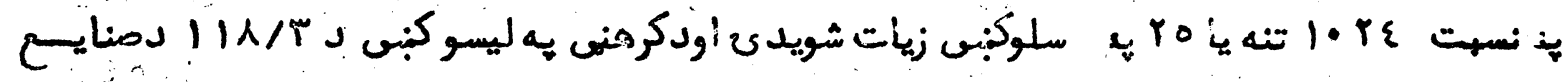

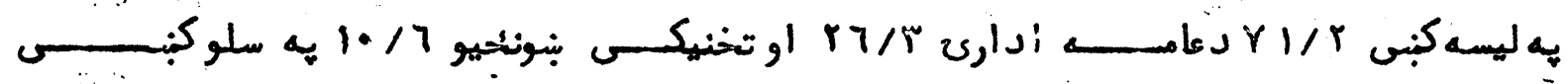

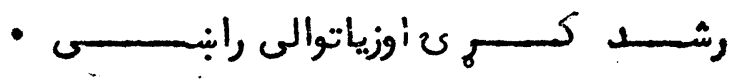

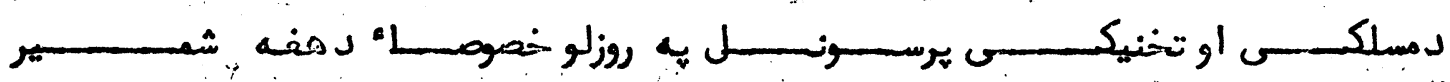

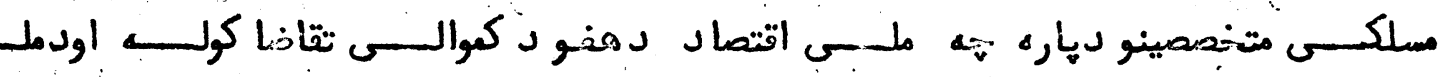




\section{( )}

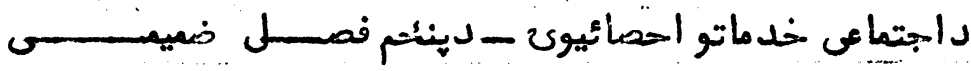

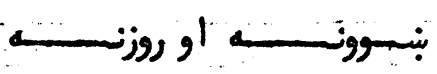

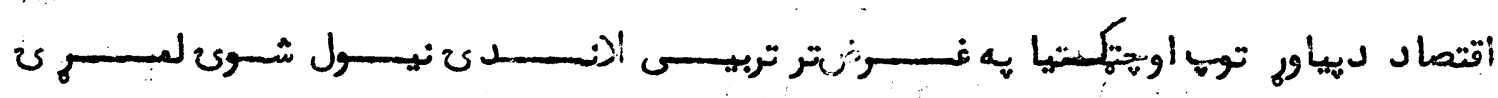

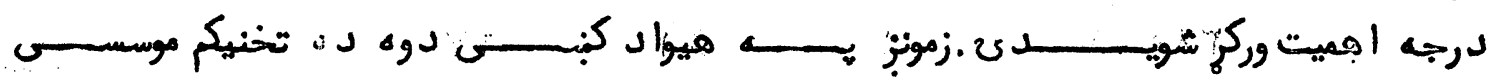

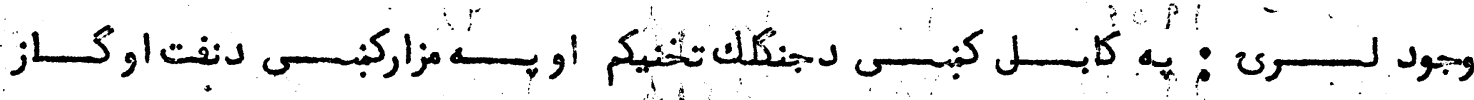

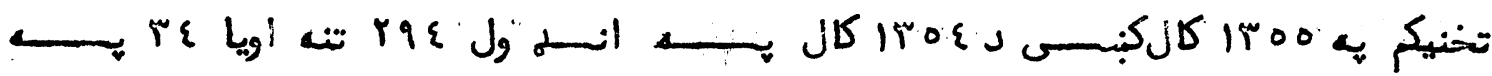

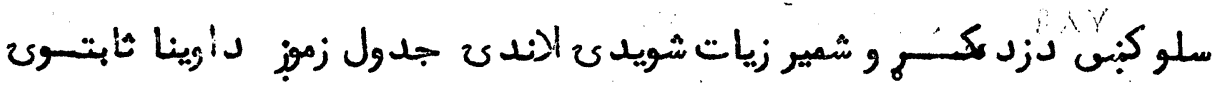

$\therefore$ يه

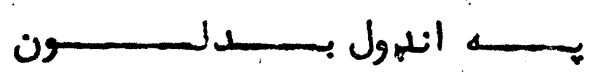

دزي كـــ و شمير دتمليمى

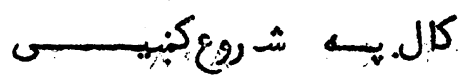

1T.0 $\quad 100 \varepsilon$

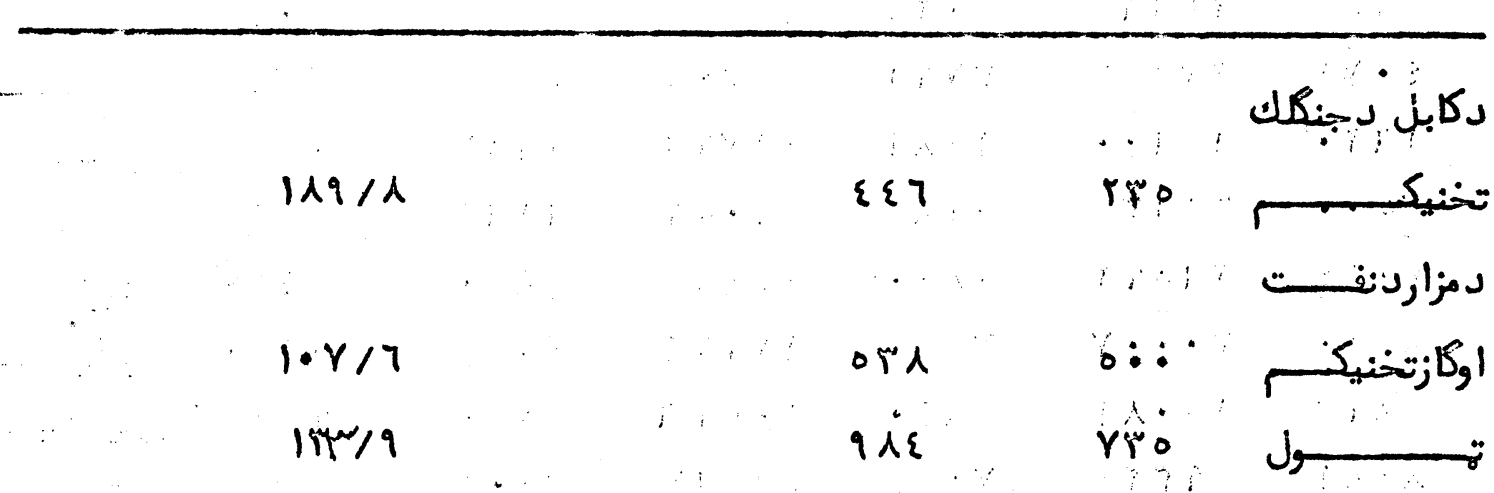

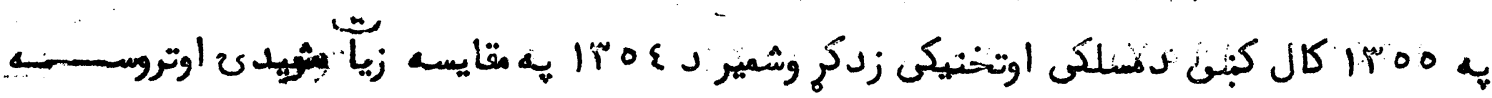

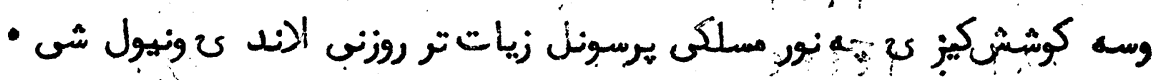

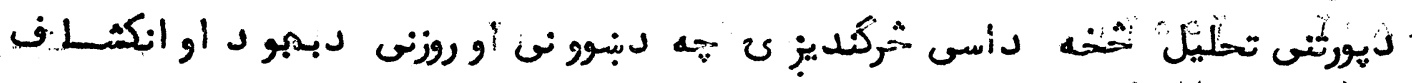

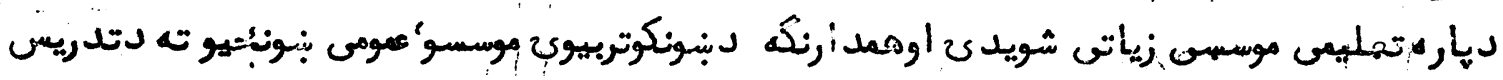

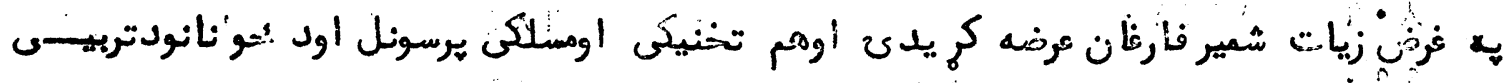

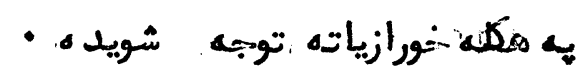

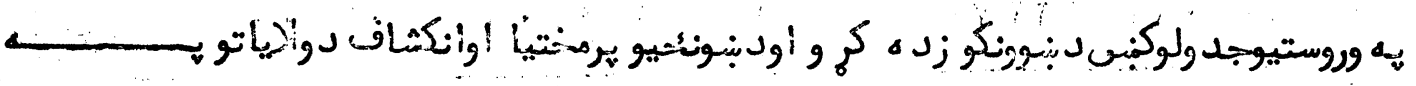

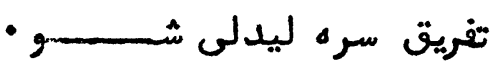


(

د اجتماعى خد ماتواحصائيى د ينججم فمل ضميمسى

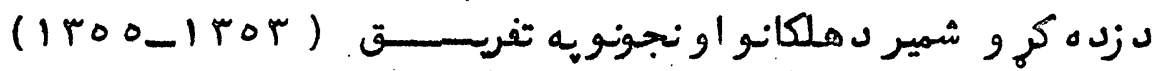

\begin{tabular}{|c|c|c|c|c|c|c|}
\hline & roo & & 1 ros & & jror & \\
\hline نجسـونى & هلكان & نجزتى & هـلكان & نجنـونى & Ala & \\
\hline $1 \cdot r \leqslant 1$ & $\varepsilon \vee \vee \cdot \vee$ & $97 \cdot r$ & $\{\{r Y\}$ & AVIr & $\varepsilon 11 \vee \varepsilon$ & 1 \\
\hline$\therefore \therefore$ & $\because \quad \because \quad \cdots$ & & & $\therefore \ldots$ & & \\
\hline 8771 & $r \cdot \varepsilon r$ & ห\{q & 11701 & rrol & $18 i^{\circ} \times 9$ & \\
\hline$r 7 \cdot \lambda$ & r人̈.६r & rrvi & ro人kl & r.TY & T\&พT & r هروان \\
\hline$r \cdot r$ & $190\{\varepsilon$ & 195 & INTIA & 171 & 18770 & ع وردك \\
\hline $19 \cdot r$ & $19 \varepsilon 7 \varepsilon$ & IVAr & |NTIN & 1819 & IYYS. & ه لوكر \\
\hline$r Y \cdots$ & r7171 & rort & rrrog & $r|\wedge|$ & $r \mid \varepsilon r r$ & 7 غزنى \\
\hline YA9 & $\left\{777^{\circ}\right.$ & rrq & \&rr人r & $7 \cdot r$ & $\varepsilon 11 \leqslant \varepsilon$ & ه يكتياء \\
\hline$r \xi \varepsilon$. & OrTIT & rris & $\{90 \wedge \wedge$ & ห人9० & ₹१० $\mathrm{V}$. & 1 نتكرهار \\
\hline $11 Y 7$ & rorqr & 1819 & rrg7A & 189 & Trol. & 9 لنسمان \\
\hline$r \cdot T r$ & TYY\&O & 1901 & rITIr & rrol & $r \cdot V r \varepsilon$ & \\
\hline$\varepsilon \cdot \varepsilon r$ & $r \vee \varepsilon \cdot \varepsilon$ & $r \wedge \cdot \Lambda^{\prime}$ & 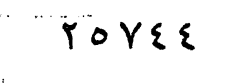 & P77q & po. Yr & 1 |- بدخ \\
\hline $19 \cdot 9$ & IVAr & IYA. & |ᄉ|rV & 1178 & $17 Y r$ & r ا- تخار \\
\hline rTos & IV7 & $r \cdot r .1$ & roYYI. & rerr & $Y \varepsilon \cdot V \varepsilon$ & rا - بفلان \\
\hline$\varepsilon \cdot \vee \xi$ & YYI $\& Y$ & rrqu & ror $\varepsilon q$ & rroo & r\&Yqr & ع إ_كدز \\
\hline $17 \%$ & $1 \% 7 \ldots$ & $1 \varepsilon \wedge ?$ & 11897 & I rAY & $1 \cdot Y \varepsilon Y$ & 10 - سمنكان \\
\hline Yo... & rilro & $791 \%$ & $r q . \circ V$ & 7171 & Y YO \&O & 17 17 \\
\hline$r \cdot 1 \varepsilon$ & r709r & $r \wedge \cdots$ & $r \varepsilon \wedge r r$ & rᄉr. & 91299 & VI - جوزجان \\
\hline$\Delta r \Lambda \cdot \ldots$ & $r \cdot \infty r$ & YAY\& & PYqY\& & YYYO & Prar. & 1ا-_فارياب \\
\hline Aqr & $|1 \cdot 1|$ & $\Lambda \varepsilon \cdot$ & $1 \cdot 497$ & rro & $9 r y r$ & 19 - ـ بادغيس \\
\hline$\Lambda\{\wedge\}$ & rqTr & VAᄉr & riotr & $Y r \cdot 1$ & rrqor & •r- هرات \\
\hline 1750 & $196 \mathrm{rr}$ & lorr & IArET & $1 \varepsilon \cdot \gamma$ & $10 \times V 7$ & ا r- فراه ' \\
\hline 171r & $r q \cdot 1$ & $10 \mathrm{VA}$ & $7 \varepsilon r r$ & $91 r$ & olar & rr- نيمروز \\
\hline $1 \cdot \hat{1} 1$ & $r \xi\{\varepsilon\}$ & $1 \cdots 0$ & rイ人E. & $1 \mathrm{r} \cdot$ & rTr\&q & rr - ملمند \\
\hline$\{\wedge \circ\}$ & roorg. & ₹६१ & rrrvi & riro & 11 871 & ع - كـدهار \\
\hline$r Y \cdot$ & Y०97 & ro. & rrir & rrr & 72 10 & م-ro_ زابل \\
\hline$r \cdot 1$ & $r: \Delta \wedge \circ$ & TAT & IqYYE & Y1P & IVYT. & r \\
\hline $1 \cdot q$ & $1 \leqslant \varepsilon q \cdot$ & 877 & IrTr. & $71 \varepsilon$ & 1ะร91 & r Y r r \\
\hline 99. & Irtir & q $\varepsilon$ & I TYYr & 117 & |Y广\&| & ג r- باميان \\
\hline$\{\wedge T\{\varepsilon$ & $18 . \cdots 9$ & $\varepsilon 0 \cdot \varepsilon$. & 人T\&। & Erro. & VIVIV, & r - ـ دكا بلشد \\
\hline Irrqur & $\Lambda \cdot\{\cdot q r$ & 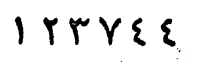 & Y\{१। Y & $11 \varepsilon r \cdot 7$ & $V \cdot V \tilde{V} \cdot \bullet$ & مجموع \\
\hline
\end{tabular}

د م ال كال رقهونه ابتدايى دي

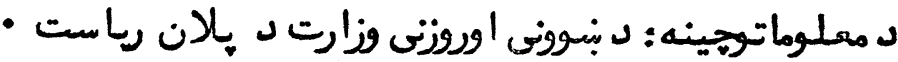


$(\infty)$

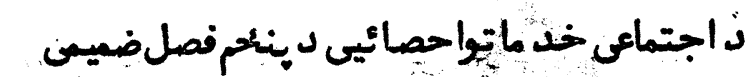

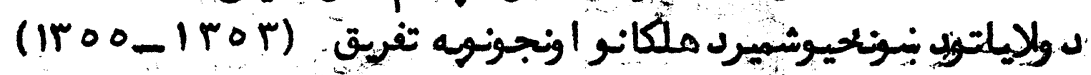

\begin{tabular}{|c|c|c|c|c|c|c|c|}
\hline \multicolumn{2}{|c|}{1500} & \multicolumn{2}{|c|}{ Iroq } & \multicolumn{2}{|c|}{ Iror } & \multirow{2}{*}{\multicolumn{2}{|c|}{ د ولايت نيو.م }} \\
\hline نجونى & هلكان & نجونى & هلكان & نجوتى & هلكان & & \\
\hline$r r$ & 199 & $\Gamma \xi$ & $1 \% 9$ & $T \xi$ & 189 & كابل & 1 \\
\hline 11 & $7 r$ & 19 & Yr & 19 & $r Y$ & كايريسا & $r$ \\
\hline ६Y & 101 & iᄉ & 178 & rq & IVe & بروان & $r$ \\
\hline$r$ & 91 & $r$ & 99 & $r$ & 99 & ورد اك : & \{ \\
\hline 11 & rol & Ir & 78 & ir & Vi & 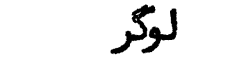 & ० \\
\hline 19 & INT & 19 & INT & 19 & 111 & غزنى | ( غ & 1 \\
\hline$r$ & $19 r$ & $r$ & $19 r$ & $r$ & $19 \varepsilon$ & يكتياء & $r$ \\
\hline$r r$ & r & rr & $17 r$ & YI & 171 & نتكرهار & $\Lambda$ \\
\hline ir & $Y \varepsilon$ & ir & $\checkmark \varepsilon$ & ir & ro & لنشbان & 9 \\
\hline$r r$ & iro & YI & iro & $r r$ & IrE & ا كري ونه & - \\
\hline$r \varepsilon$ & 19. & ro & 191 & rr & 198 & 1 بدخشان & 1 \\
\hline 11 & $11 r$ & $1 \cdot$ & ir. & $1 \cdot$ & 119 & I تخار & $r$ \\
\hline$r r$ & 118 & $r r$ & $1 r 1$ & $r r$ & $1 r \mid$ & 1 1 & $r$ \\
\hline IV & $1 \cdot 7$ & IY & 118 & ir & rir & ا كددز & | \\
\hline 11 & 91 & 11 & 99 & $1 \cdot$ & 90 & 1 سمنكان & 10 \\
\hline ro & Irr & $r \varepsilon$ & $|V|$ & ro & 171 & 1 & 17 \\
\hline $1 \varepsilon$ & $1 r 1$ & $1 \varepsilon$ & $1 r \lambda$ & $1 \varepsilon$ & Iro & I جوزجان & IV \\
\hline ₹ & 117 & $\varepsilon \curlywedge$ & $|r|$ & or & iro & ا فارياب & 11 \\
\hline$\varepsilon$ & ir & $\varepsilon$ & 11 & $\varepsilon$ & 78 & | & 19 \\
\hline rA & 17. & Tr & $18 \cdot$ & דו & Ire & r هرات & $r \cdot$ \\
\hline 11 & 117 & 11 & 117 & 11 & $11 \varepsilon$ & r فراه & Y \\
\hline 10 & 01 & 17 & 01 & 17 & $\varepsilon q$ & 1 نيمرز & rr \\
\hline 0 & $1 \varepsilon r$ & 0 & $1 \varepsilon \gamma$ & 0 & $1 \& 7$ & r هلمند & rr \\
\hline $1 \cdot$ & 171 & $1 \cdot$ & $17 \pi$ & $1 \cdot$ & 178 & r كتدهار & rq \\
\hline$r$ & ז & $r$ & $7 \varepsilon$ & $r$ & $7 r$ & r زابل & ro \\
\hline$r$ & 190 & $\varepsilon$ & 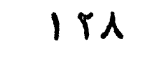 & $r$ & $|r|$ & r ارزكان & די \\
\hline 1 & $1 \varepsilon$. & 1 & $\mid \varepsilon 1$ & $\Lambda$ & $|\varepsilon|$ & r غورات & r \\
\hline ir & $1 \cdot \varepsilon$ & 11 & $1 \cdot 7$ & 11 & $1 \cdot \varepsilon$ & باميان & rᄉ \\
\hline $0 \cdot$ & YI & $\varepsilon \gamma$ & $r r$ & \{\} & $\checkmark \varepsilon$ & شهركابل & rq \\
\hline $0 . r$ & ro.r & $0.1 T$ & roqr & $0 . \bullet \varepsilon$ & rosi & مجمونع & \\
\hline
\end{tabular}


(g)

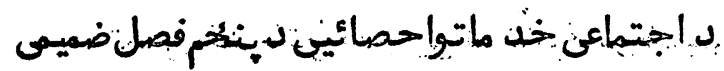

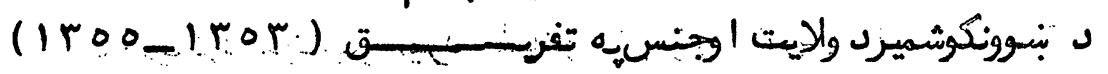

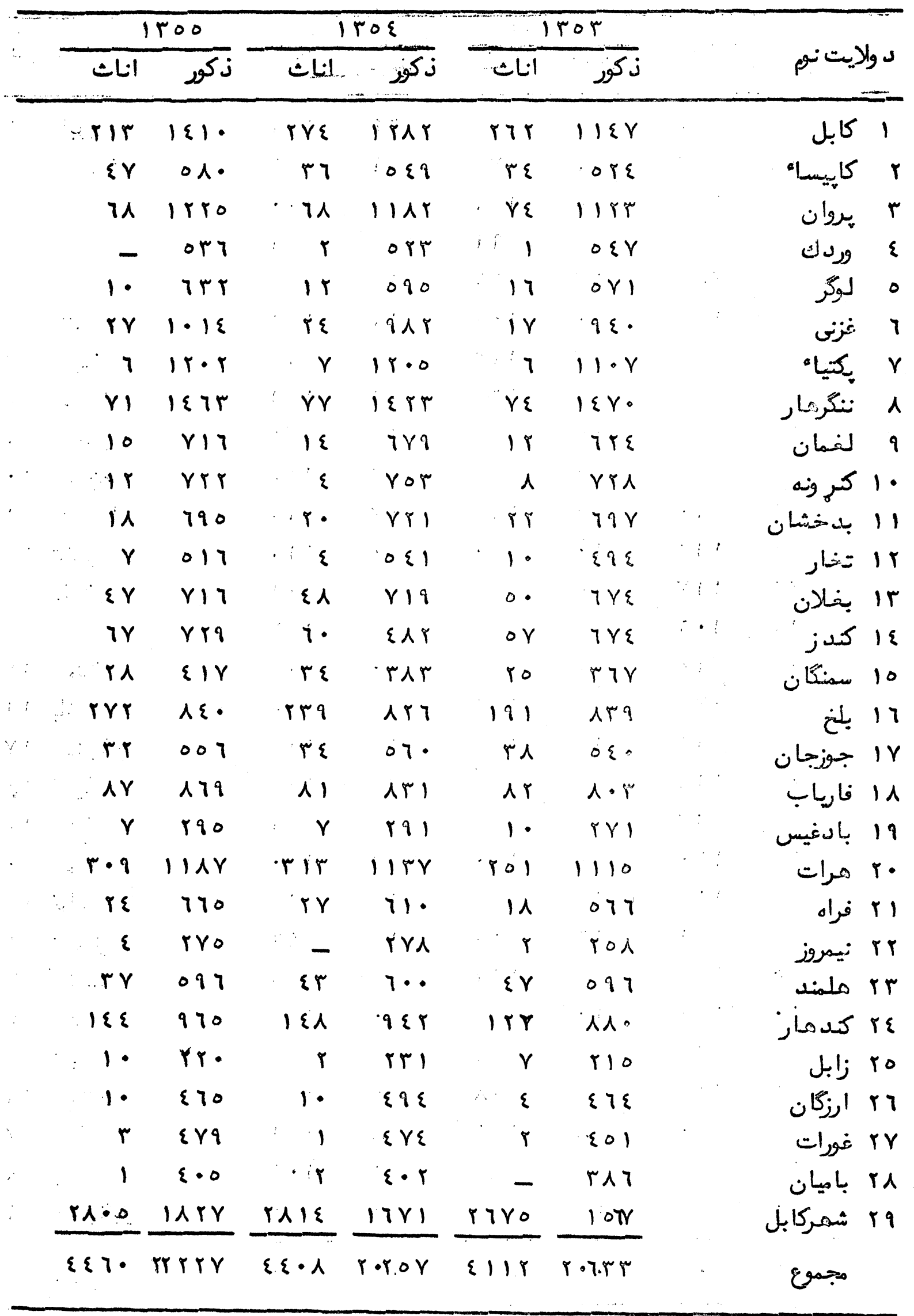

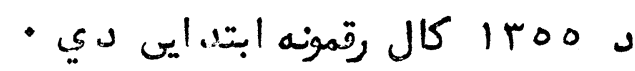

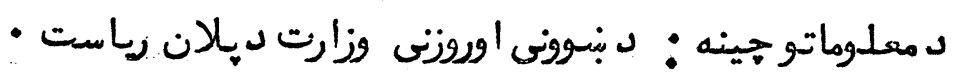


دمتخصصانواو عالى تعليها تو لد بنوونى اوروزنى به بارهكى :

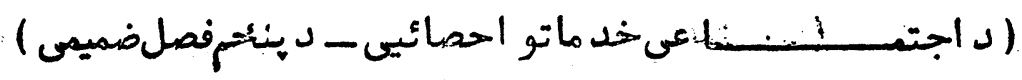

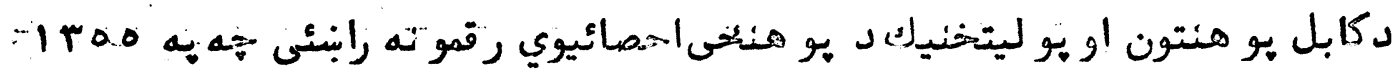

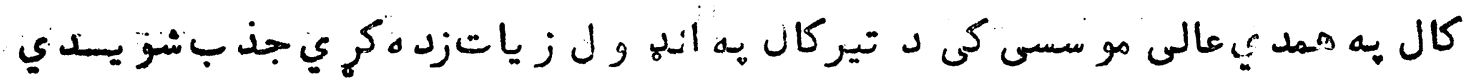

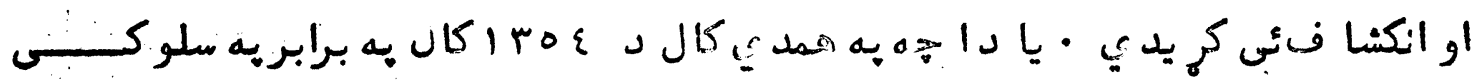

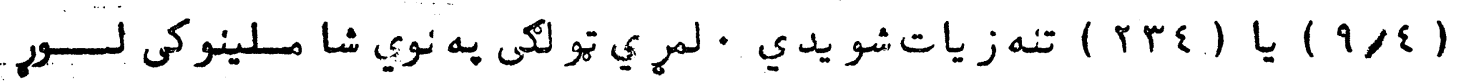

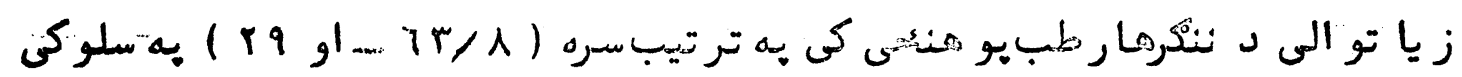

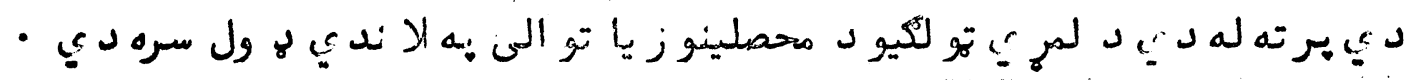

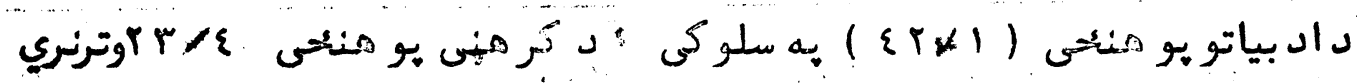

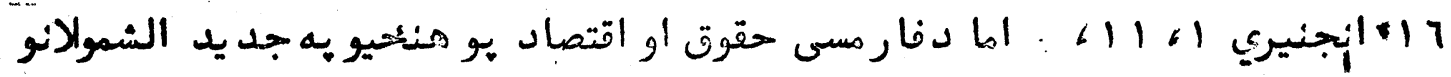

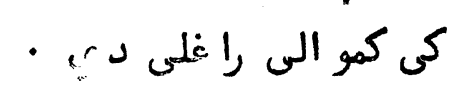

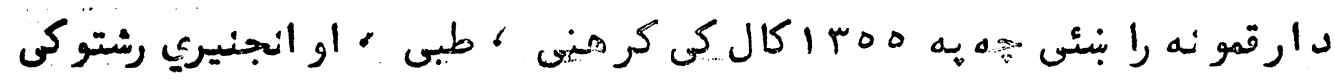

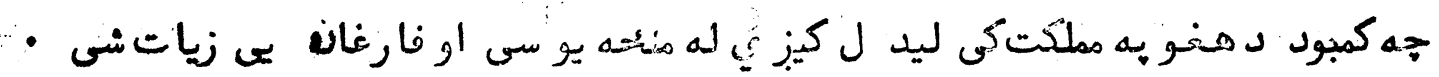

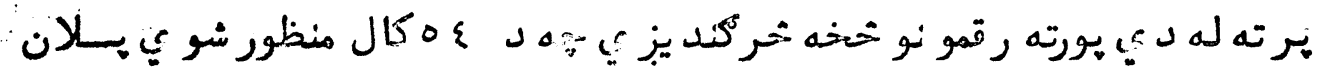

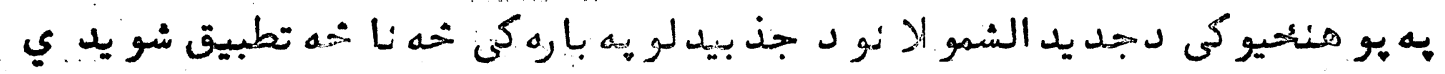

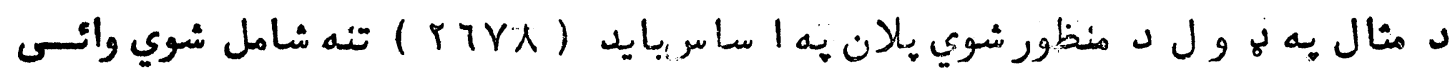

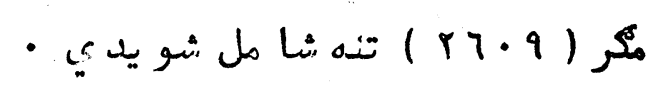

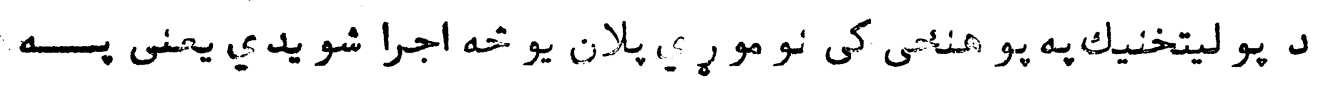

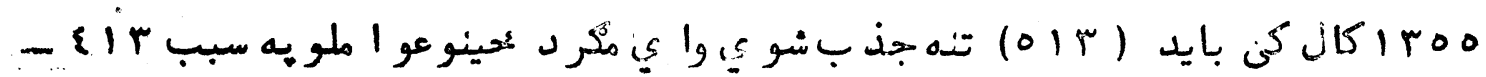

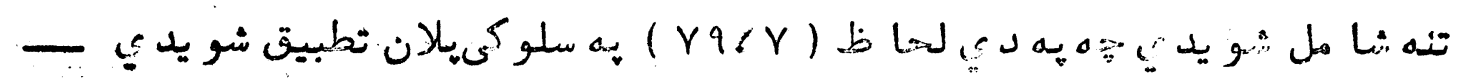

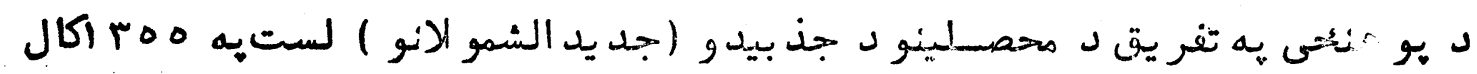

\begin{tabular}{|c|c|c|c|c|}
\hline \multicolumn{3}{|c|}{ 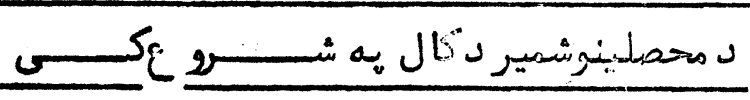 } & \multirow{2}{*}{ 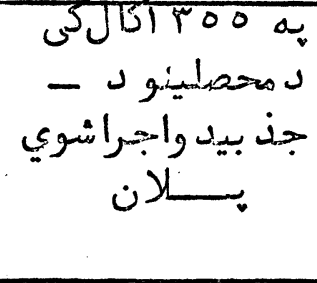 } & \multirow[t]{2}{*}{ يو هنــئى } \\
\hline تطبي سلوكي بهلان & حقيقسى & د سيلان به به & & \\
\hline 1767 & $\{7 \xi$ & Or人 & $016 \mathrm{Y}$ & قويوهنئحي \\
\hline$\Lambda \cdot 6 \varepsilon$ & 987 & 1\%人7 & Irver & \\
\hline $906 \mathrm{Y}$ & YOT & Yq. & $1.16 \mathrm{r}$ & \\
\hline 916. & 1101 & IYYT & $Y q \subset Y$ & \\
\hline $97^{6} \mathrm{Y}$ & $1\{07$ & 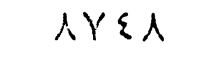 & $9 Y: \varepsilon$ & - \\
\hline$\Lambda \varepsilon \circlearrowleft Y$ & Troq & r9人々 & $906:$ & 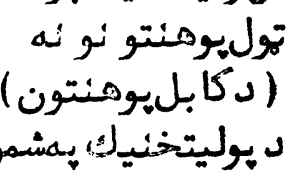 \\
\hline
\end{tabular}

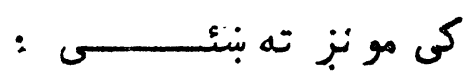


د اجتماعى خد ما تو احصائيي - دينئت فصل ضميمى

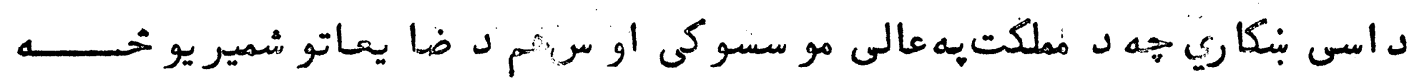

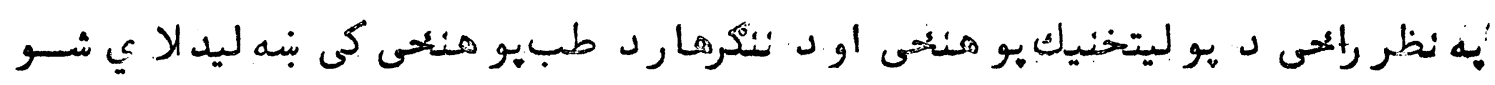

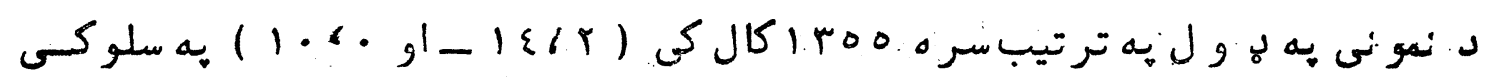

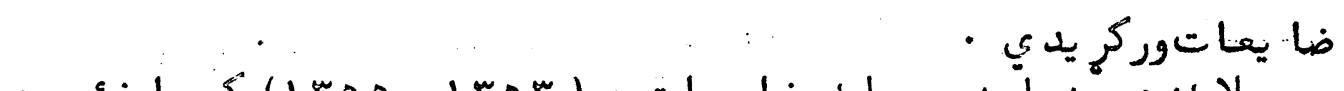

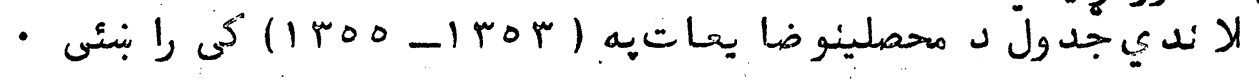

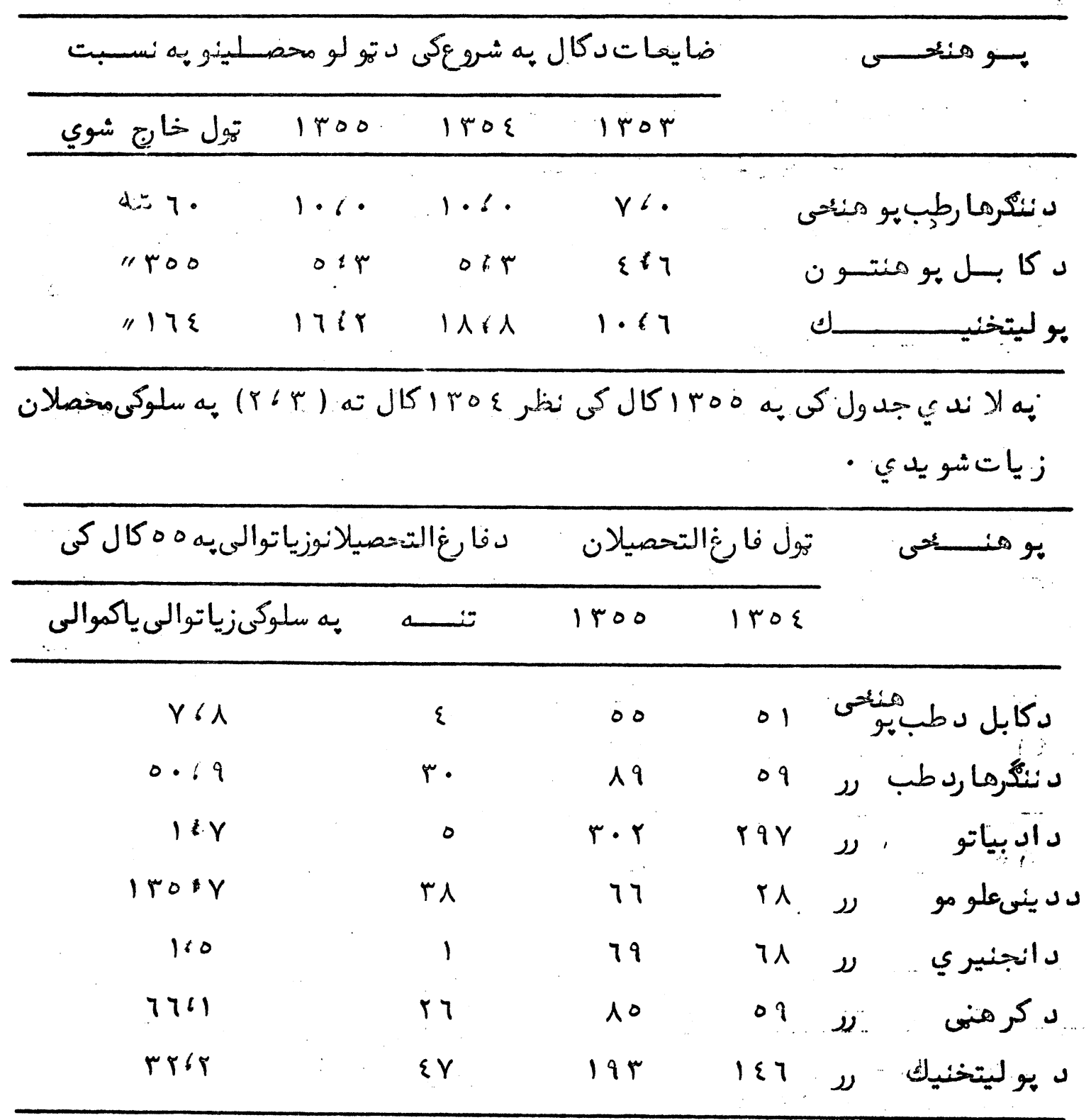

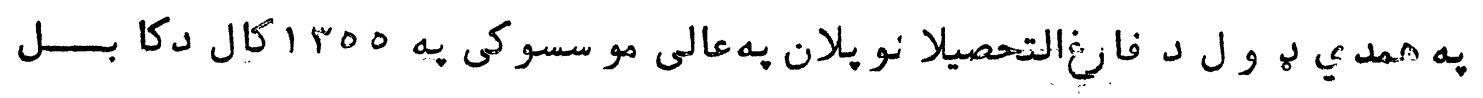

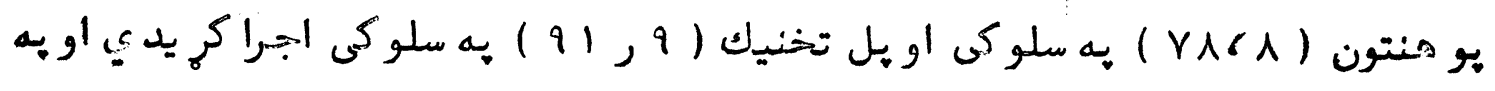

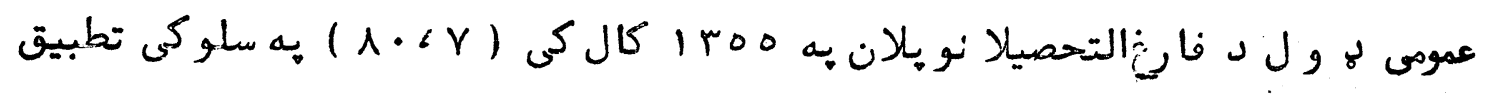

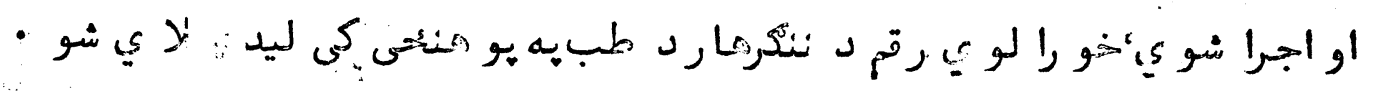




\begin{tabular}{|c|c|c|c|}
\hline 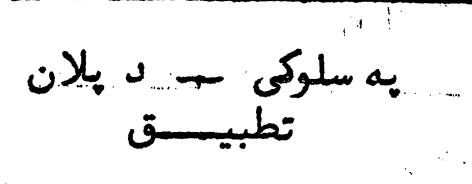 & ي نافئو حقيقى & 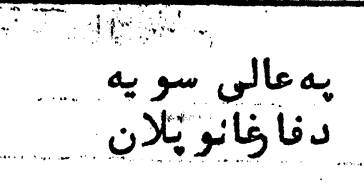 & بو منــــــــقى \\
\hline $91<9$ & 19 & 9. & نيكرها رطب بوهنكي \\
\hline $106 \mathrm{~V}$ & 11 & $r 1$ & دفارمسى رد \\
\hline$r q a q$ & ₹1 & 111 & د اقتصاء : \\
\hline$r r<r$ & $\wedge \wedge$ & ir. & دُ خُقَ'قو \\
\hline A/Gr & $r \cdot r$ & rrr & ذاد بياتو رر \\
\hline Yroq & 79 & $9 \varepsilon$ & د انجنيري لد \\
\hline $00 / 9$ & 10 & $10 r$ & دكرهنـى رد \\
\hline 8169 & $19 r$ & ץ. & بولى تخنيُك ل ل \\
\hline
\end{tabular}

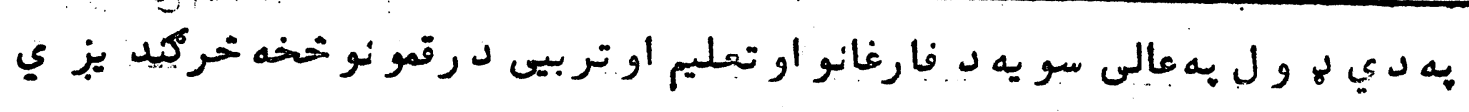

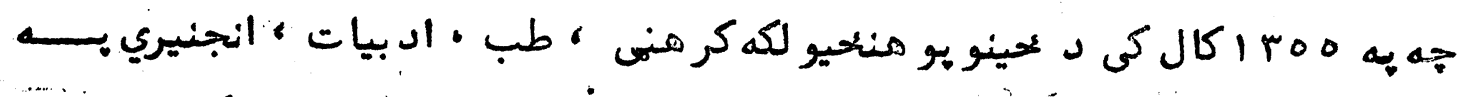

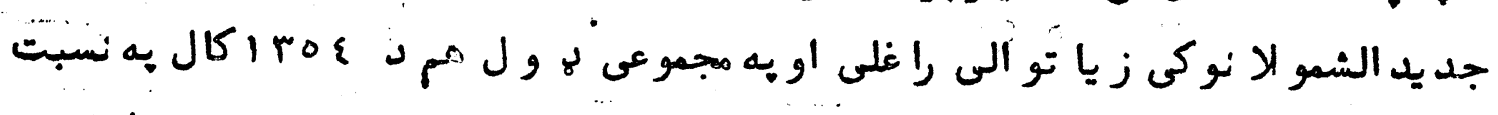

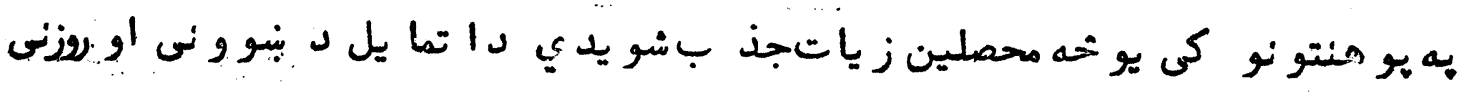

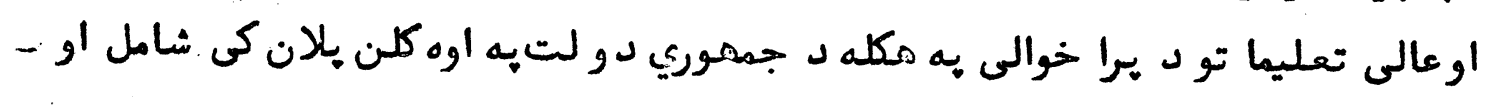

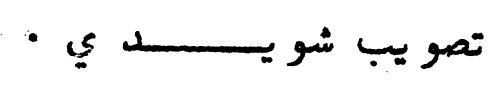

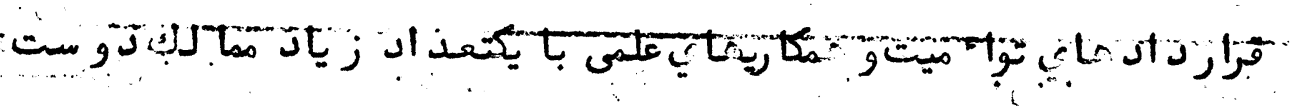

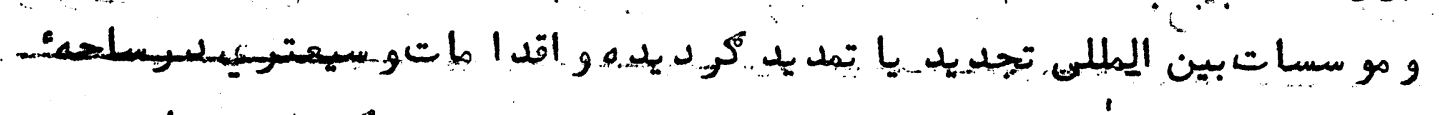

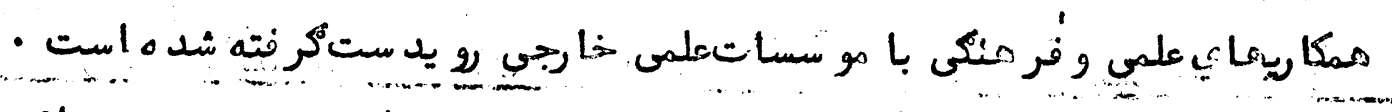

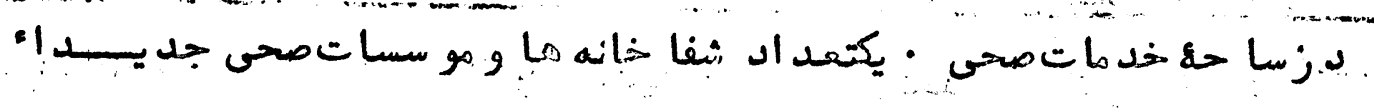

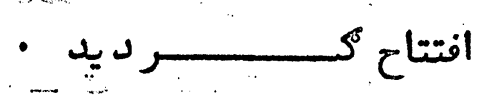

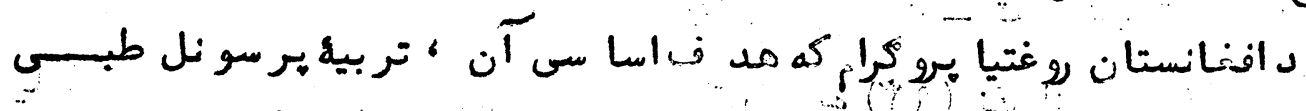

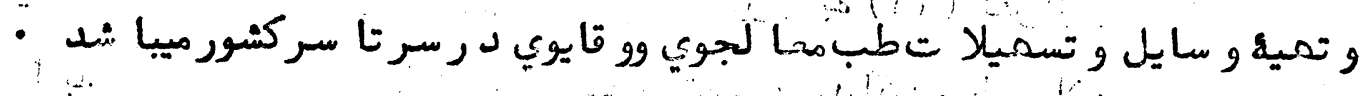

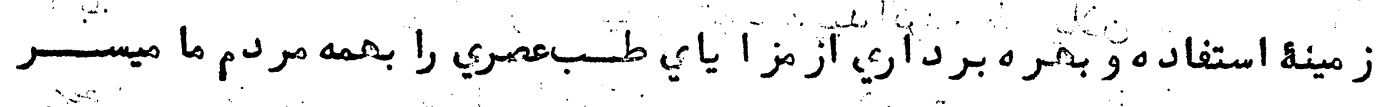

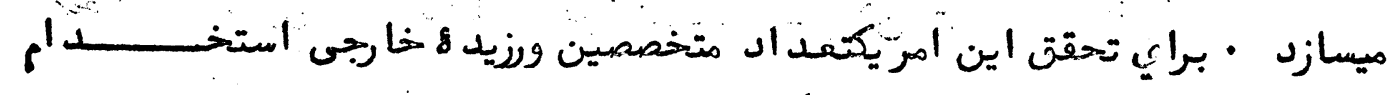

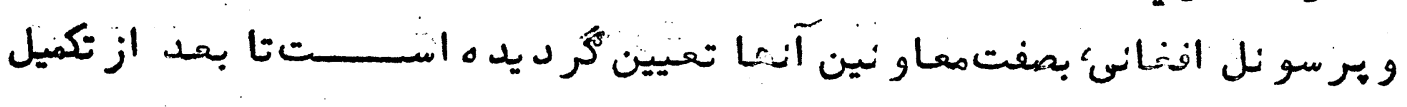

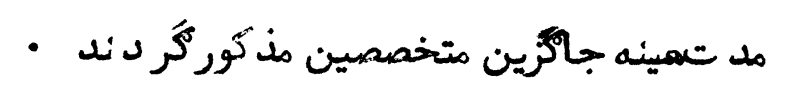

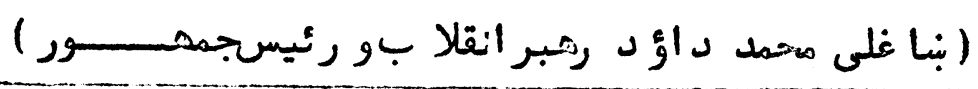




\section{( $v)$}

داجتماعن خد مأتو احصائيى نينتحم فصل ضميفى

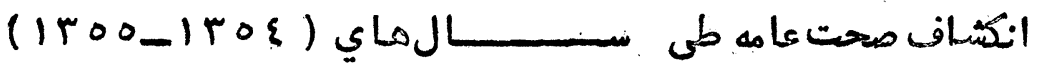

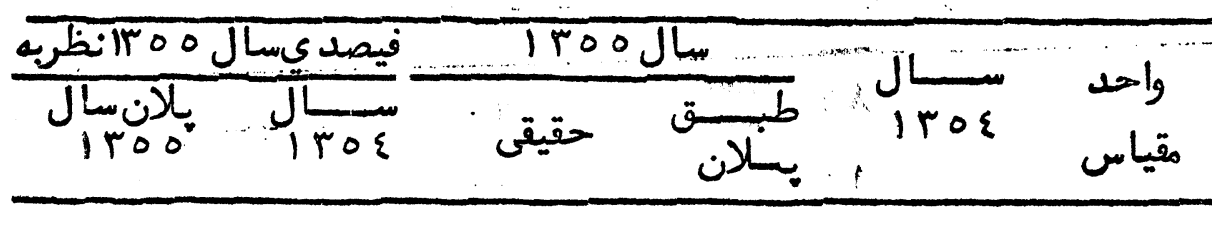

تعد اد شفاخانه هــــــا

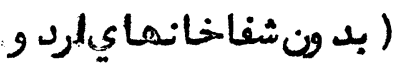

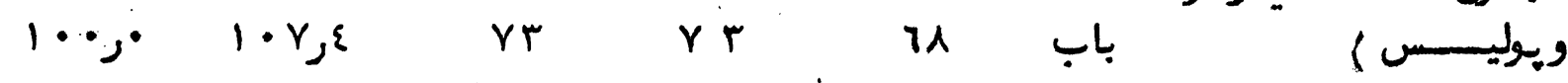

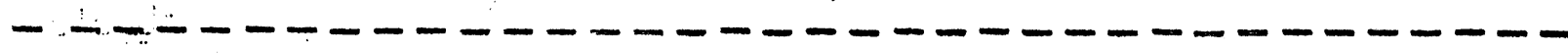

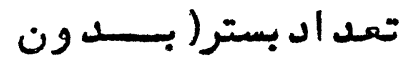
تعد اد بسترشفاخانها ي اد بون

ارد و وبوليس)

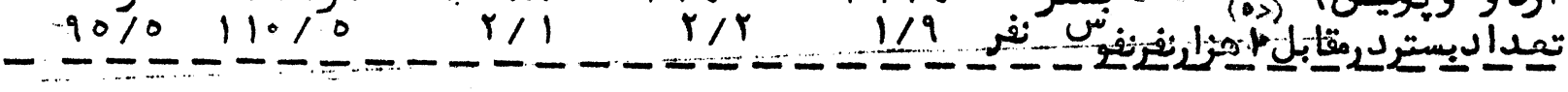
تعد ادمراكرحن اساسى باب

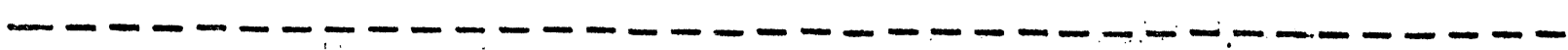
$9 r, r-1 \cdot r, \gamma \quad 0 \varepsilon \varepsilon \quad 01 r \quad 0.0 \quad$ باب تعد ابِي واخانه (رسمى وته

وشخصسى )
- - - - - - - - - - - - - - - - - - - - - - - - - - تعد اد دكتوران( موجود

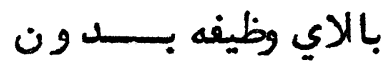

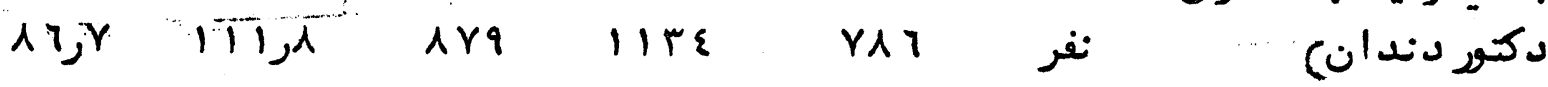
- - - - - دهزارنفر نعنفوراند رمقابل

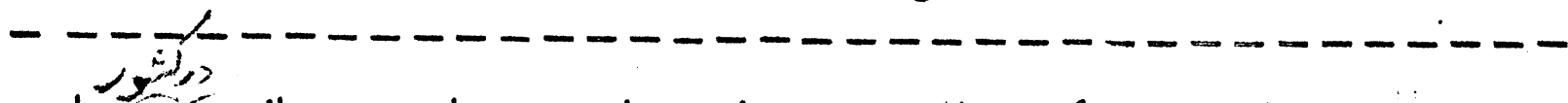

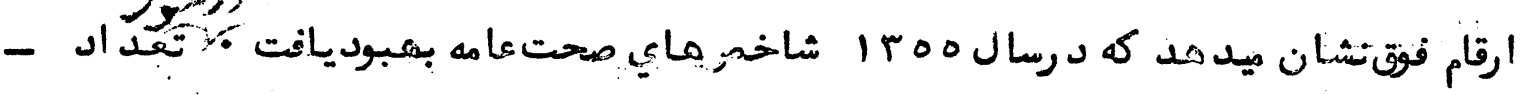

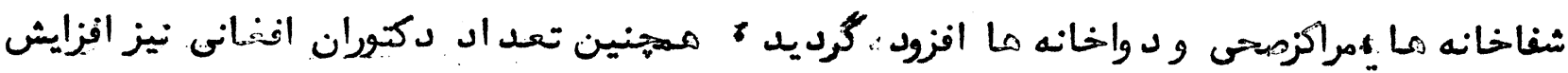

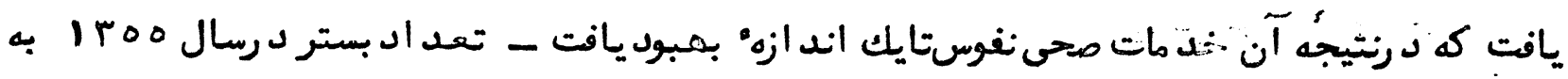

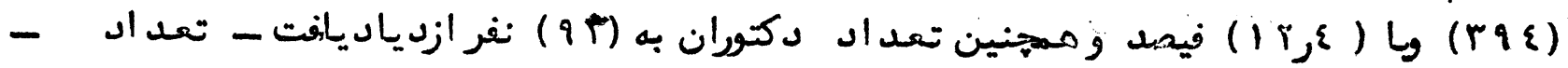

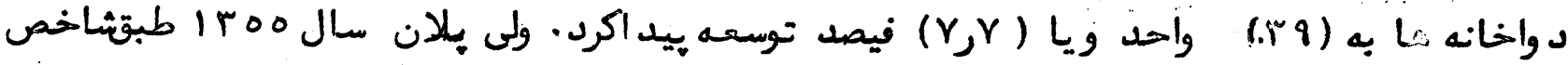

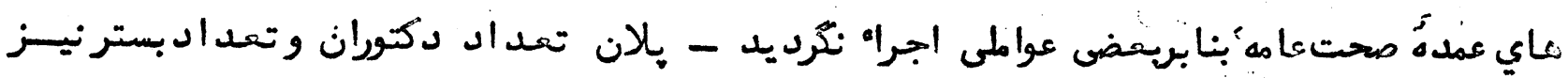

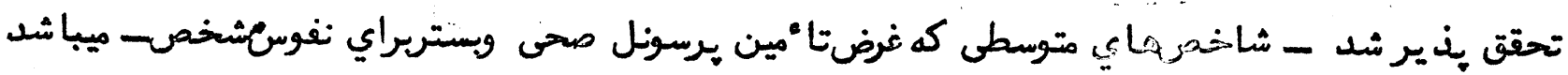


عالى زده كر ى هي باند نهو ميوادوكى

ニニニニニニニニニニニニニ

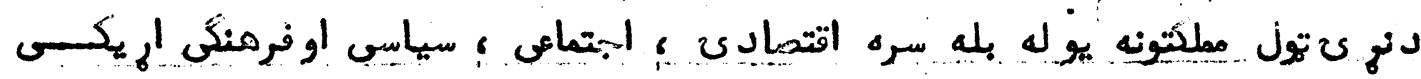

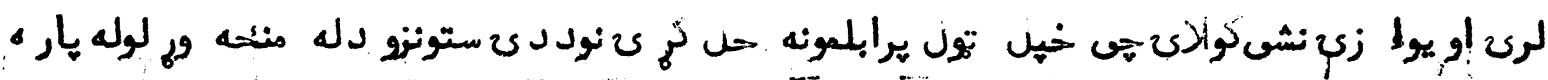

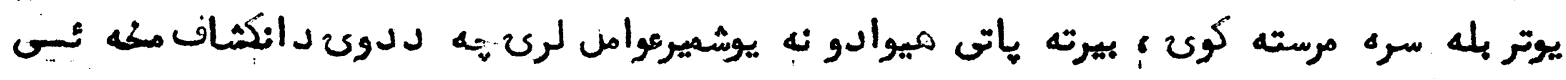

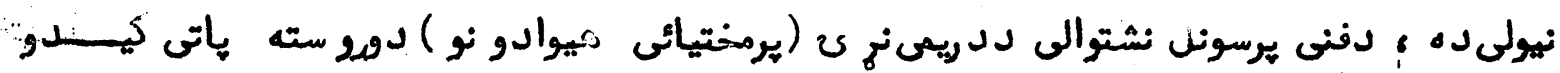

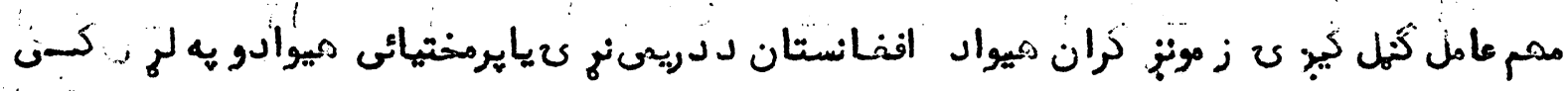

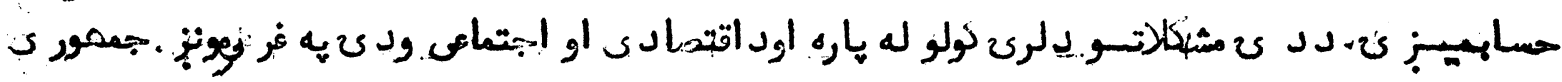

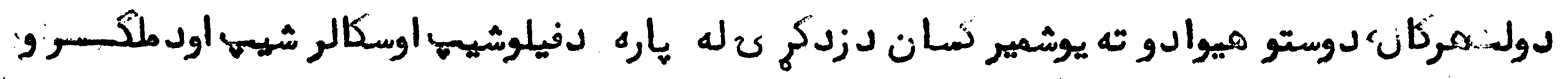

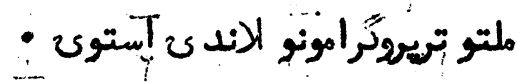
يه

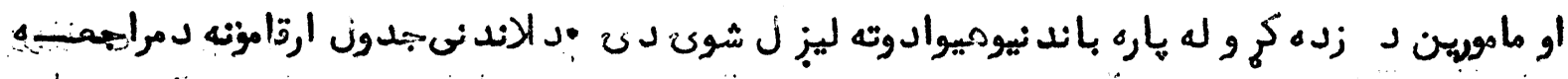
1.

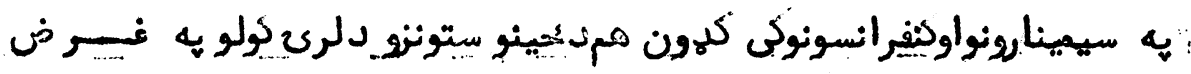

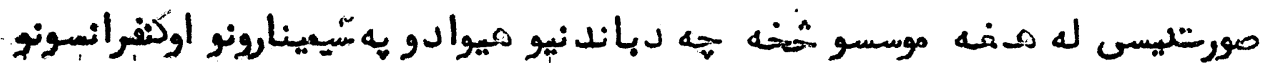

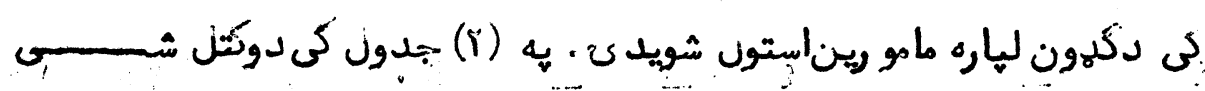

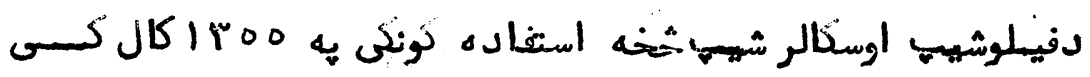

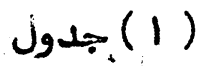

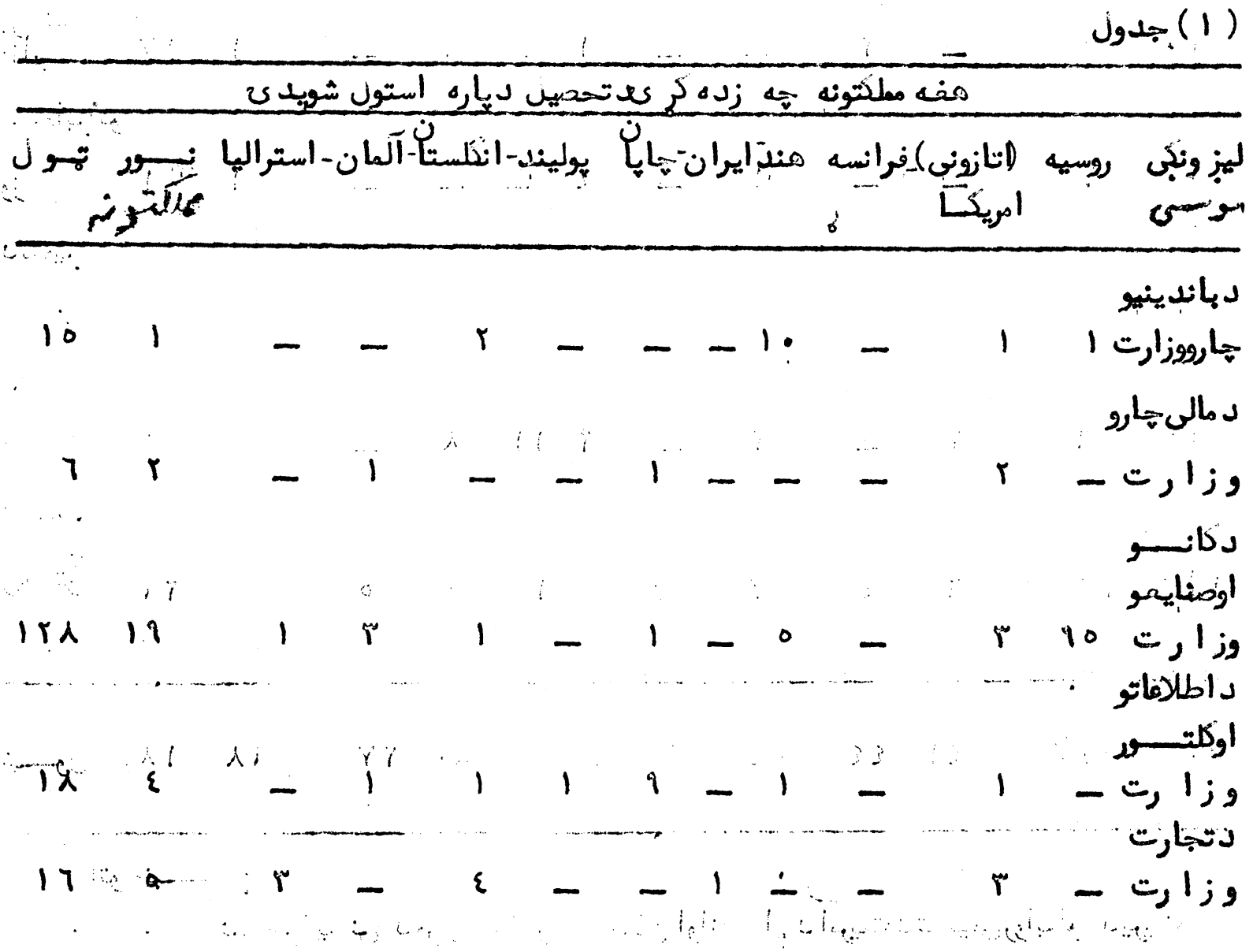




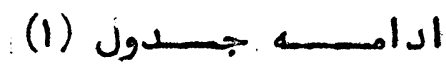

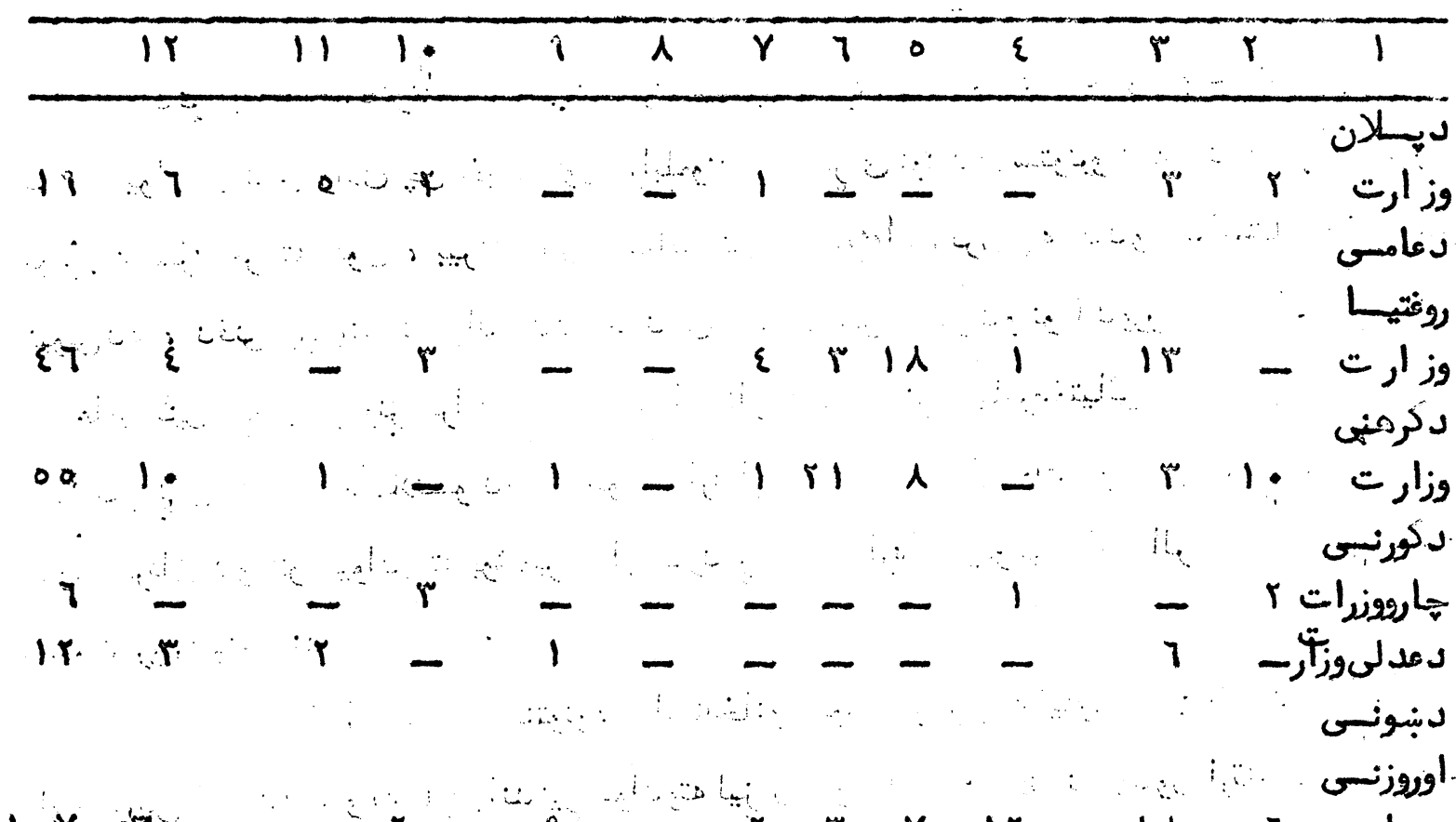

l.r $-r \cdot r$ r $-r$ r

ع 1 ع دواموزايدّ دعالنسن تحليماتو

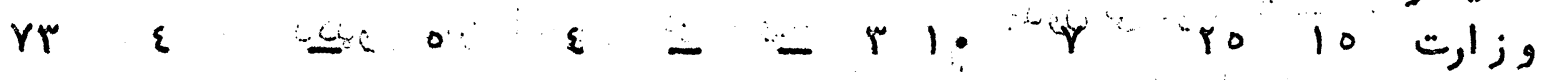
داويواو

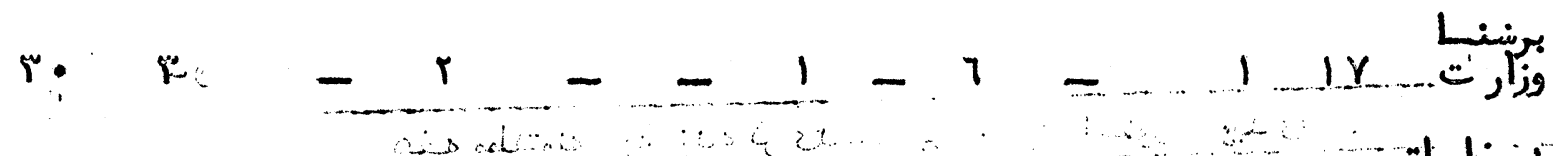
كنمابراتو

1. $r$ وزارتر لدشير تصني مركسزى ro r r $r$ r $\quad r 111-r$ r $11 \gamma r \varepsilon$ ر

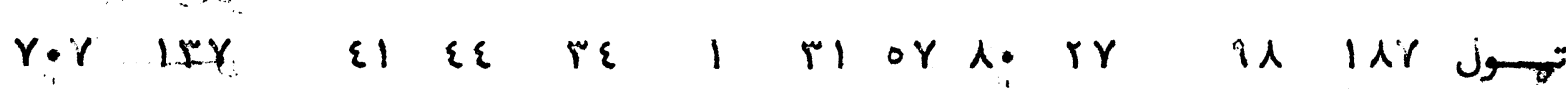
دمملوماتو منبــن

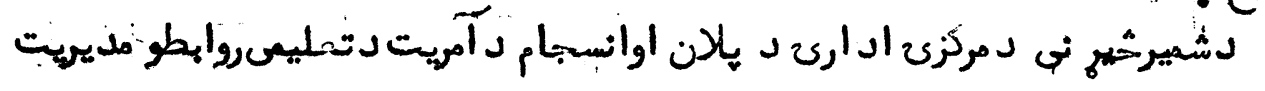




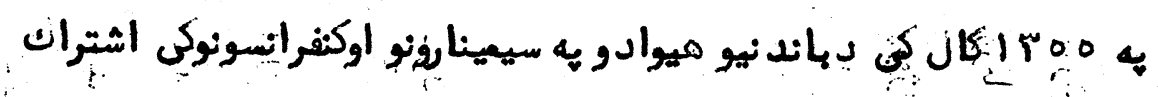

جسـدون (r)

\begin{tabular}{|c|c|c|c|c|c|c|c|c|c|c|c|c|}
\hline تــــول & نورمبالك & it & ا & يوليند & كانادا & جايان & ايرأن & "مند & فرانسه & أانانئنيا & روسيك & لسـيز ونكـــى موسسيسـى \\
\hline 1 & 9 & - & - & - & - & - & - & - & - & - & - & دباند نهو هارو وزارك ·... \\
\hline$F$ & 1 & - & - & - & - & 1 & - & - & - & - & - & 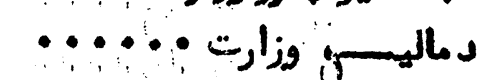 \\
\hline$r_{\bullet}$ & $1:$ & - & - & - & - & - & $r$ & $\curlywedge$ & - & - & - & دكانواوومنائيمو وزارت ! ? ? \\
\hline$\lambda$ & r & 1 & - & - & - & $r$ & - & - & - & 1 & -1 & داطلازعاتو أوكتور وزارت : \\
\hline rr & $r_{\bullet}$ & - & - & 1 & - & 1 & $r$ & - & - & - & $r$ & دتجار توززارت • ...... \\
\hline$\varepsilon$ & $r$ & - & - & - & - & - & - & - & - & t & - & دي لاهن وزارت : .... \\
\hline r & ir & - & $r$ & - & - & 1 & $\varepsilon$ & - & - & 51 & - & 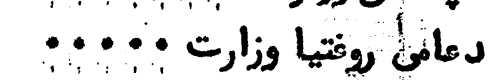 \\
\hline 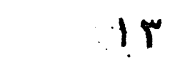 & $\varepsilon$ & - & - & - & - & - & - & $\varepsilon$ & - & $\because$ & 0 & 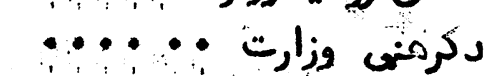 \\
\hline$r$ & 1 & 1 & - & - & - & - & - & - & - & 1 & - & دكونيو حارو وزارته - - . \\
\hline$\varepsilon$ & - & - & - & - & - & $r$ & - & - & - & $r$ & - & دمدليسوزارت • . . . . . \\
\hline 1.1 & rI & 1 & - & - & - & 7 & $r$ & or & $r$ & dr & - & دبنبوني اونوزنى وزارت : : \\
\hline 10 & $r$ & 1 & 1 & - & 1 & $\varepsilon$ & & & a. & & & 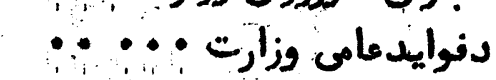 \\
\hline Y & 11 & 1 & - & - & - & $r$ & 。 & $r$ & 1 & 1 & r & ذعالى تمليماتو وزارت : - \\
\hline 7 & - & 1 & 1 & - & - & $r$ & - & - & - & 1 & 1 & دابواويربنا وزارت ?... .. \\
\hline - & - & - & - & - & - & 一 & - & - & - & - & - & دمخابراتو وزارت • . . . \\
\hline 7 & - & - & - & - & - & $r$ & & $r$ & - & - & - & دشعير خهي ثى مركزنا لـ أره \\
\hline ra & 10 & 1 & 1 & & 7 & $r$ & 1 & 7 & 1 & $r$ & $r$ & 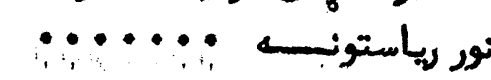 \\
\hline$r \cdot r$ & $11 \varepsilon$ & ir & 。 & 1 & Y & ז & ir & ro & $a$ & rr & 10, & \\
\hline
\end{tabular}




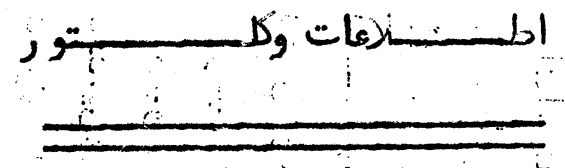

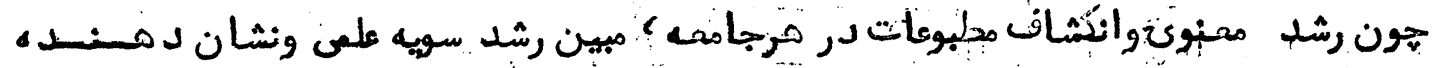

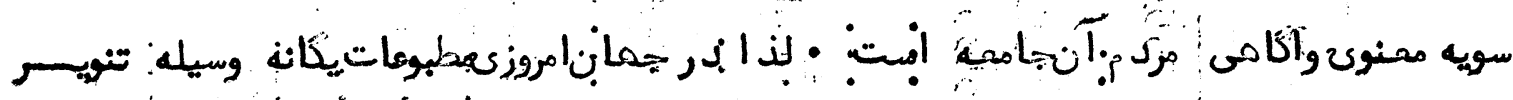

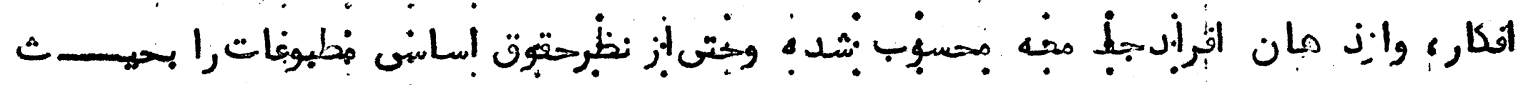

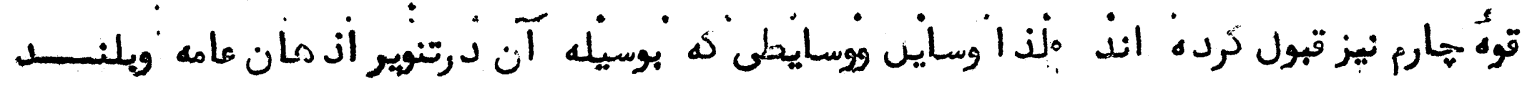

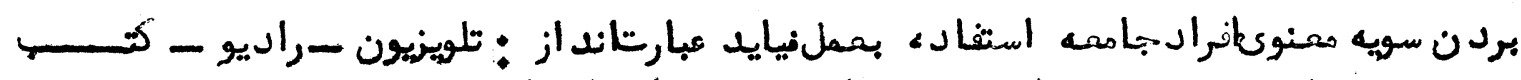

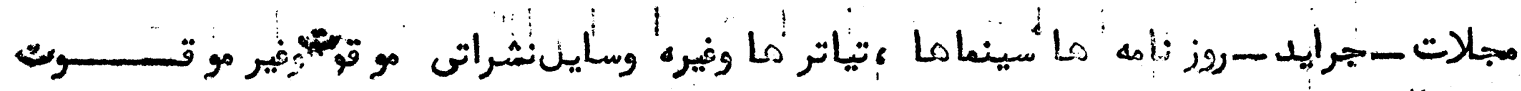

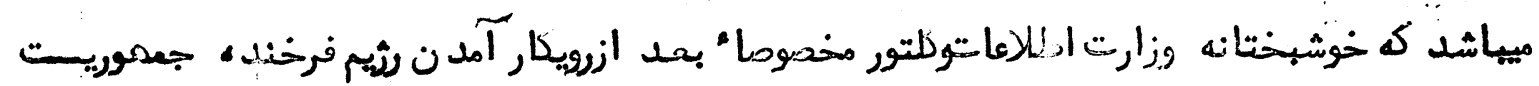

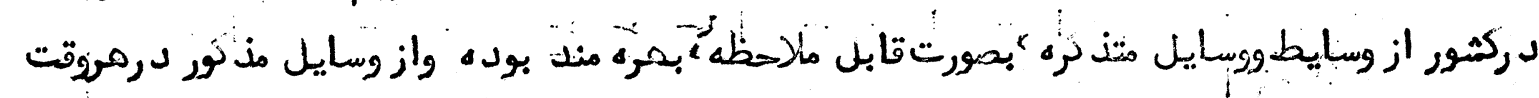

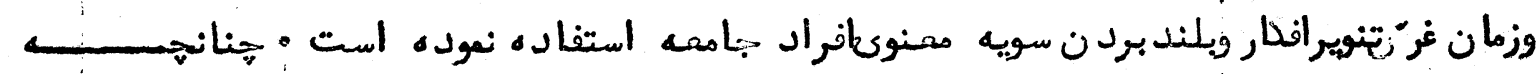

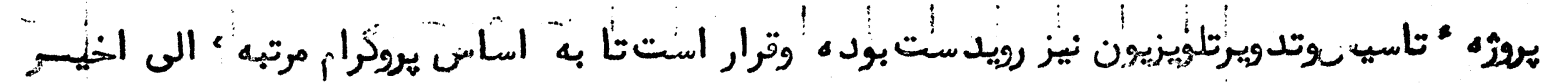

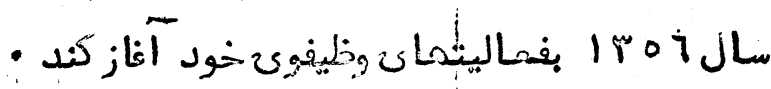

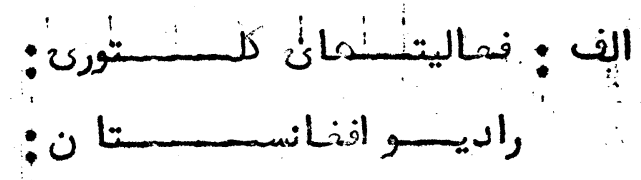

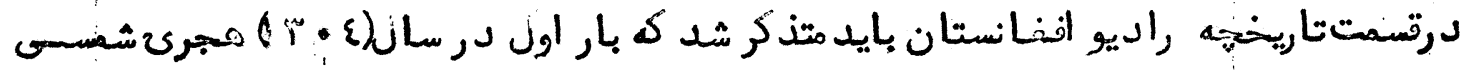

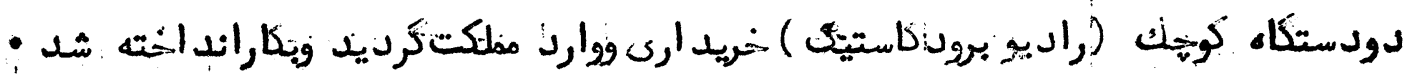

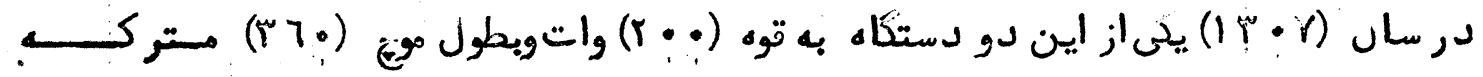

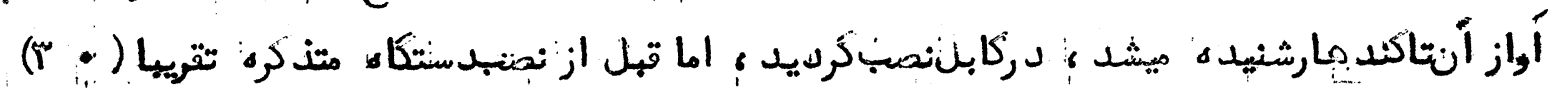

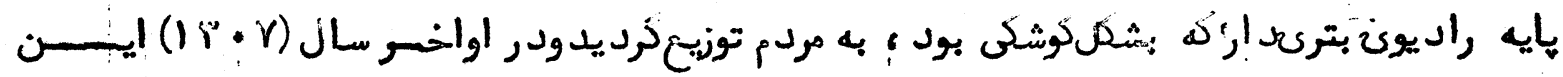

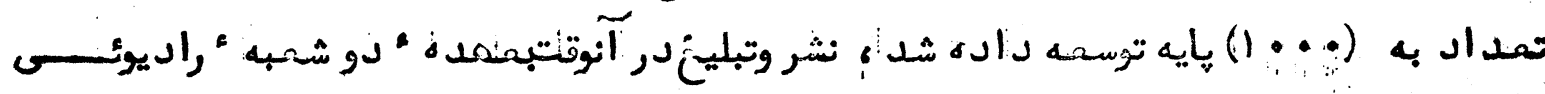

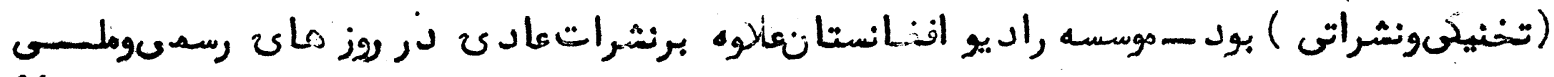

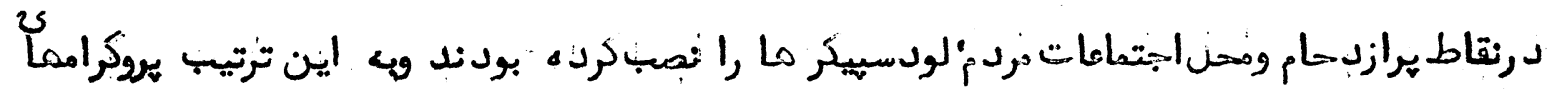

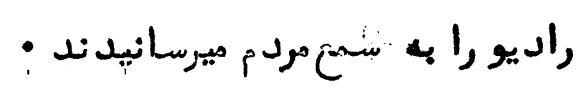

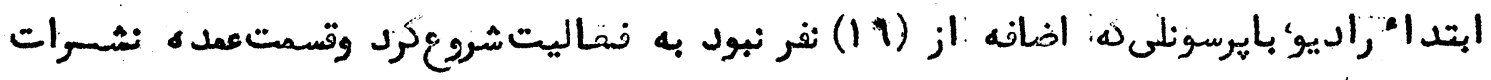

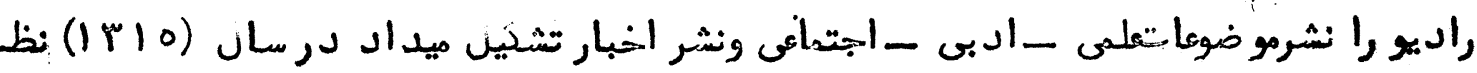

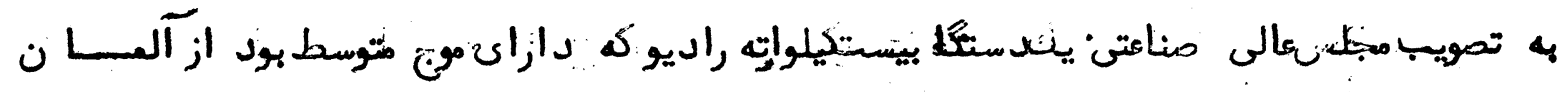

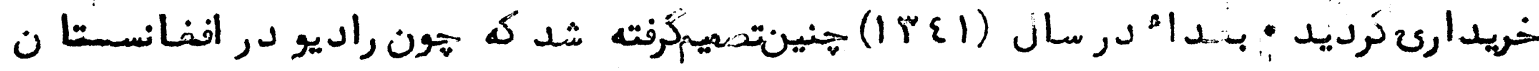

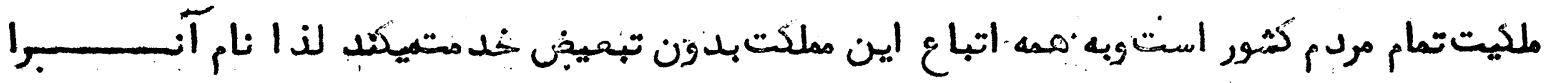

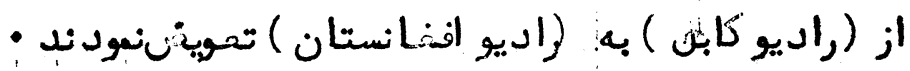


2.

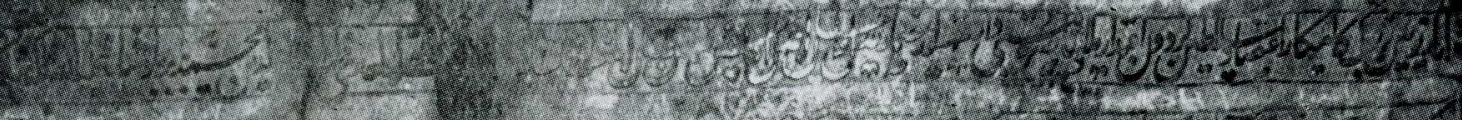

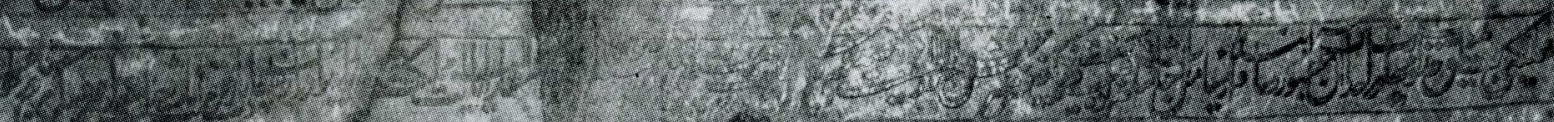
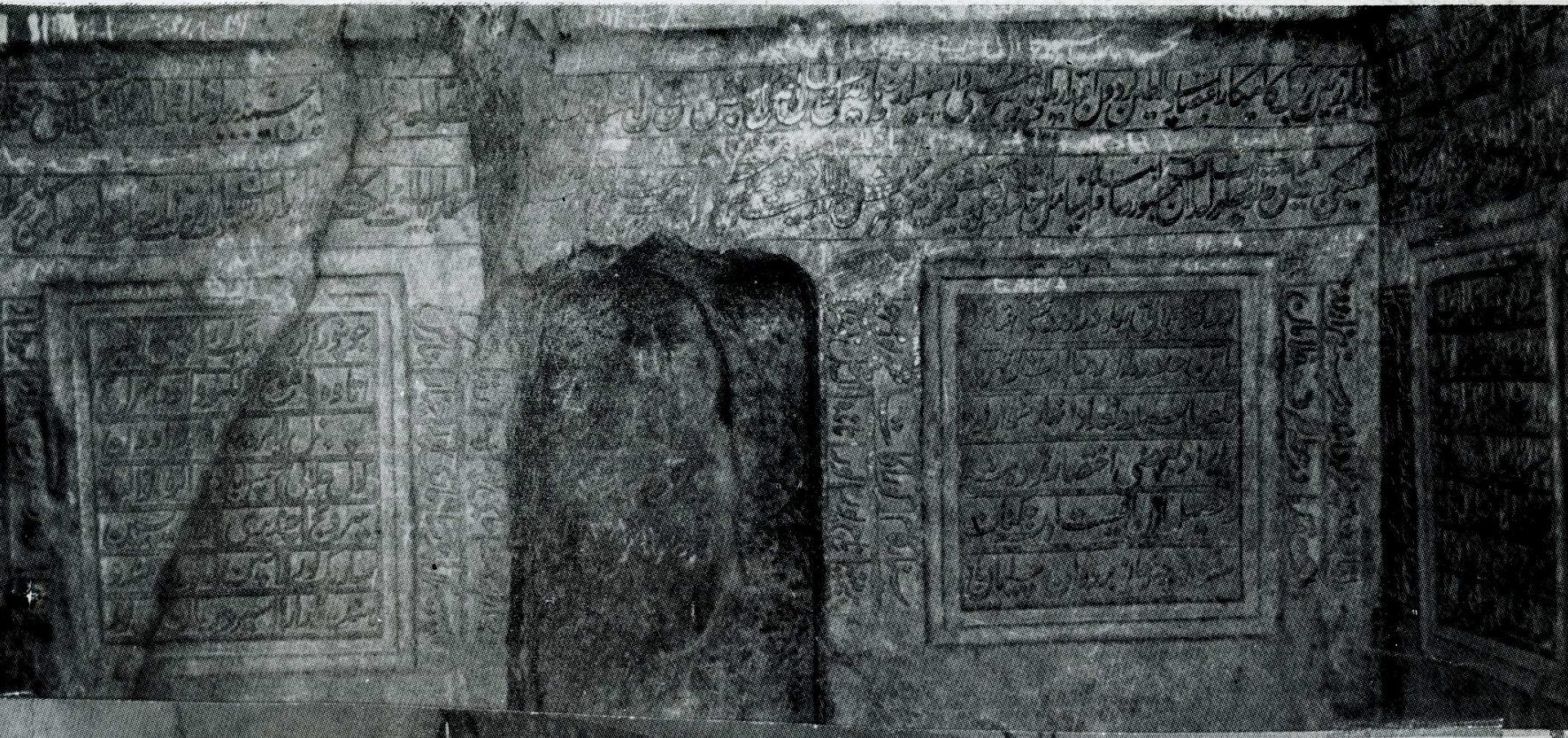

20.1)
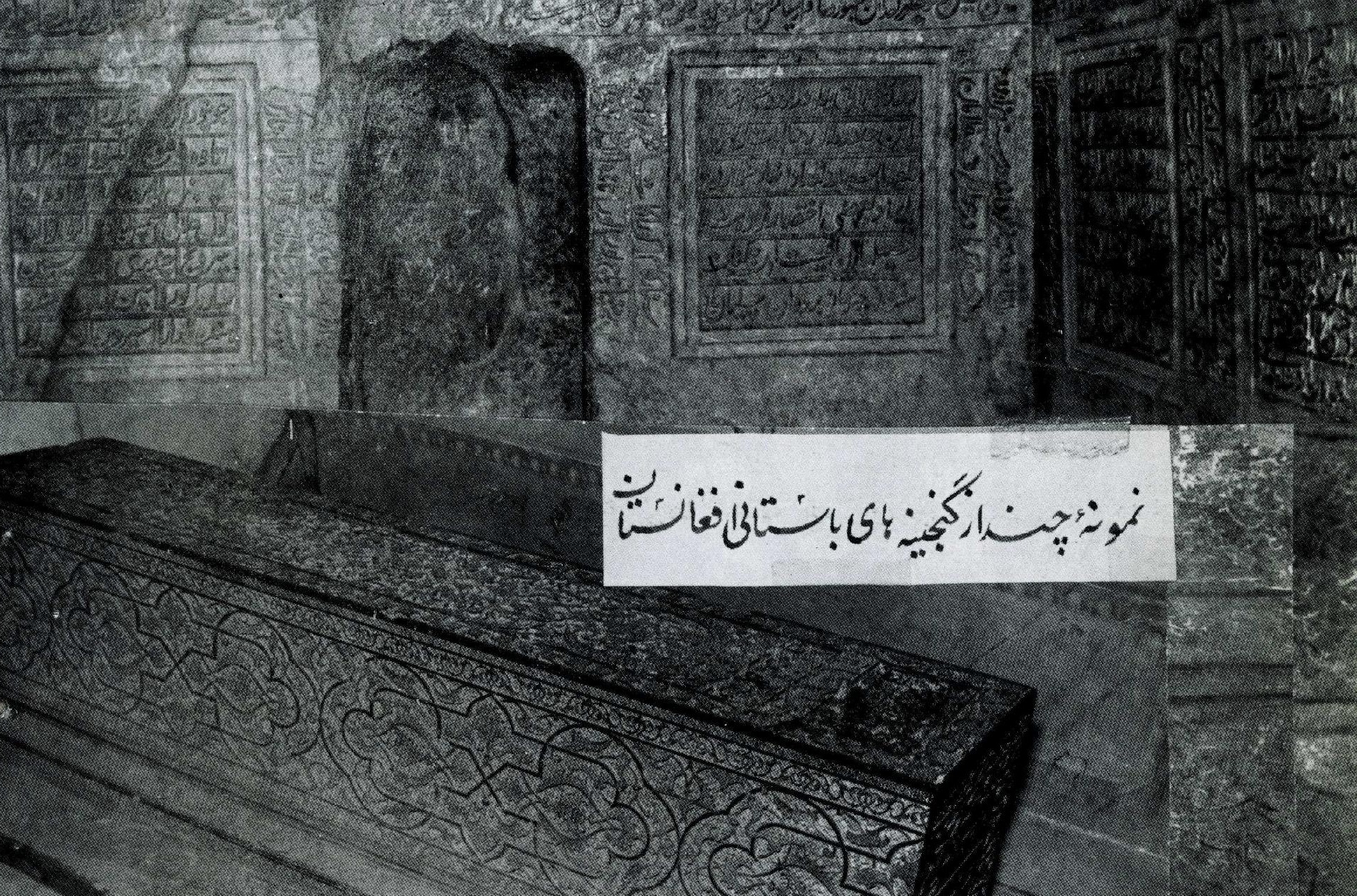

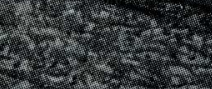

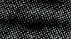

(1)

$\frac{2+2}{\frac{3}{2}}$

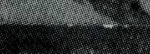

$-2+3 \times 2 x^{2}-25$

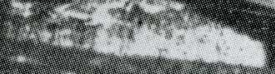

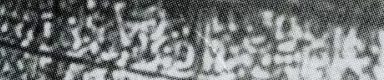

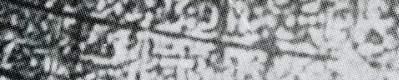

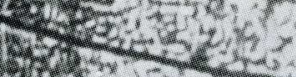
$35 \times 3 x^{2}=3^{2}-3$ Y4 $-2 \leq 53$.

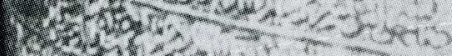

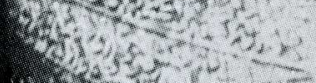
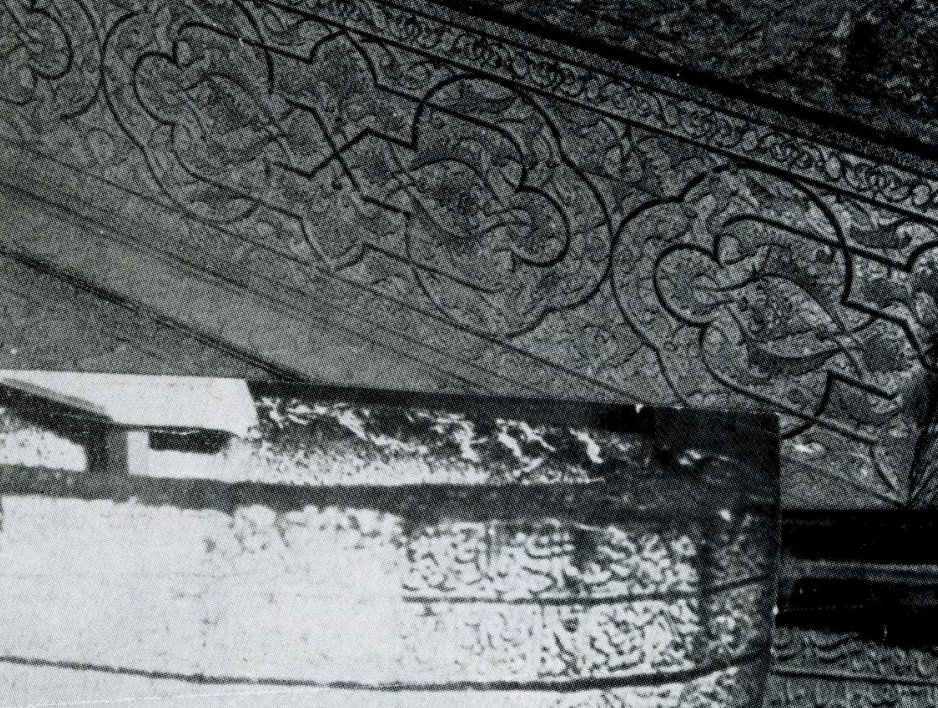

(2) $2-2$

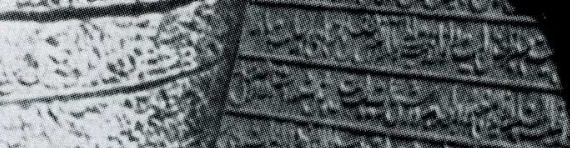

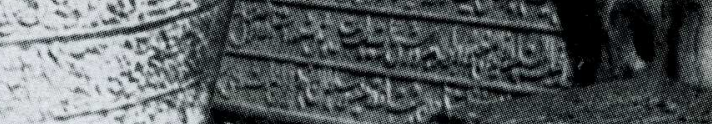

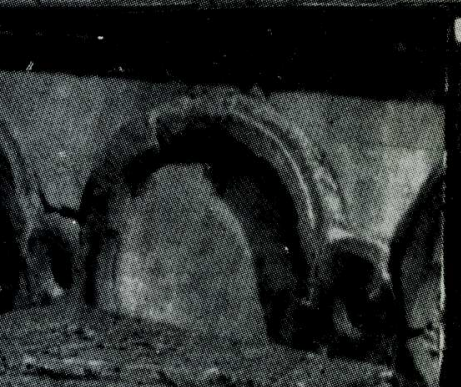
$+3)^{2}$

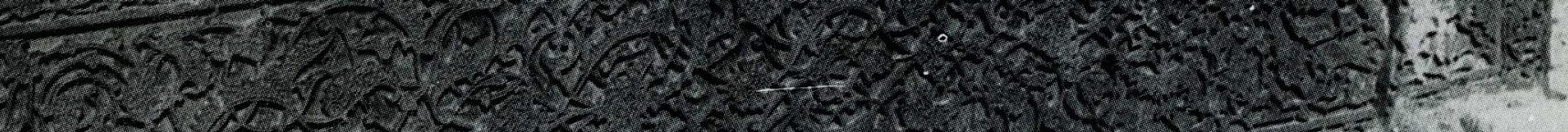

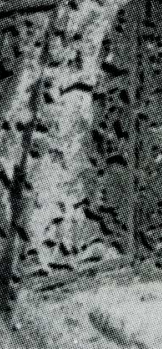
P. 


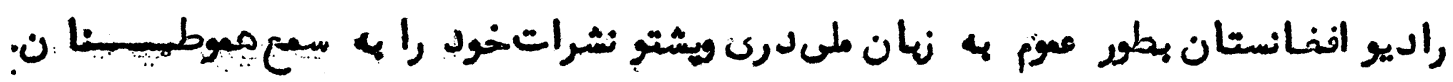

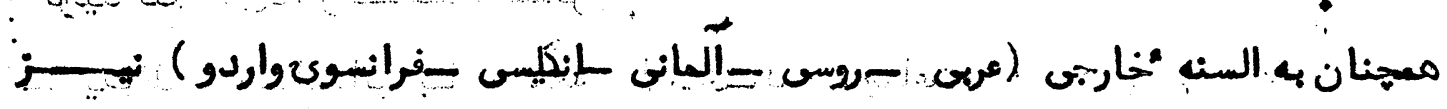
ميرسانســد : مادو

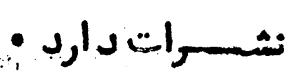

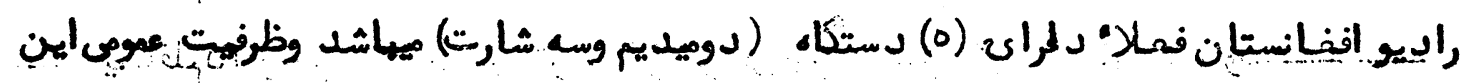
لدستكاه ما (10) كيلو وات است

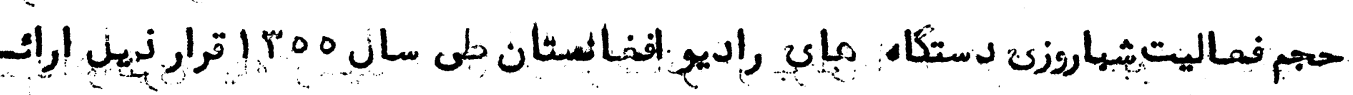

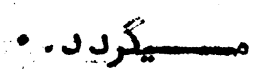
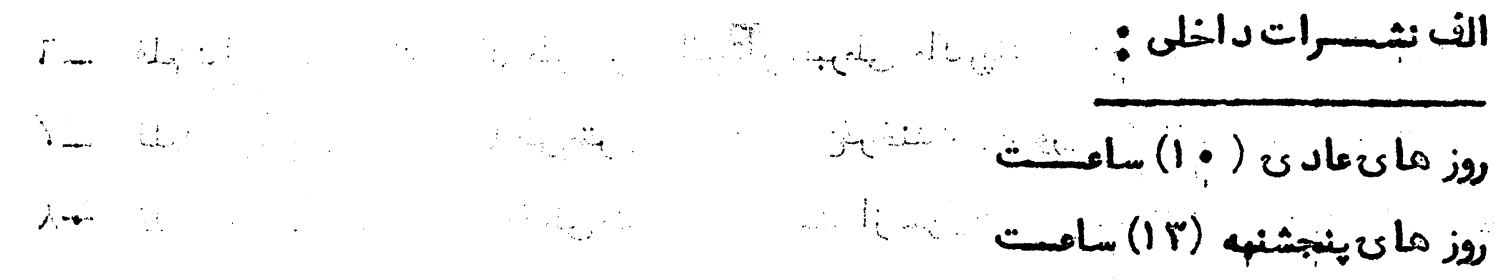

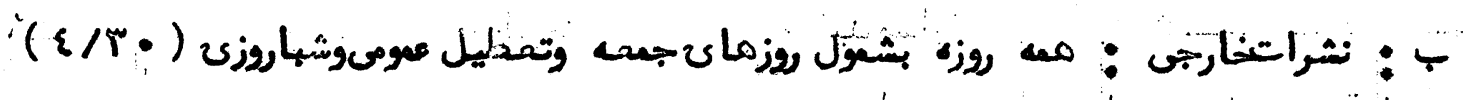

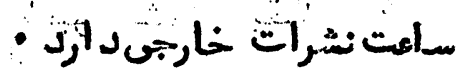

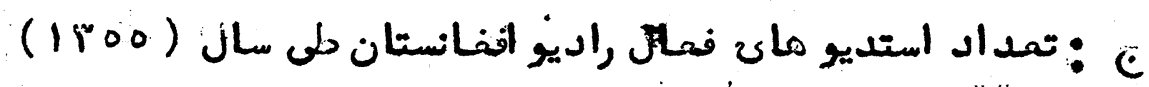

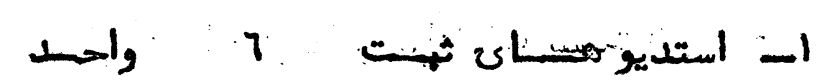

$$
\begin{aligned}
& \text { r r r r r r r r r r }
\end{aligned}
$$

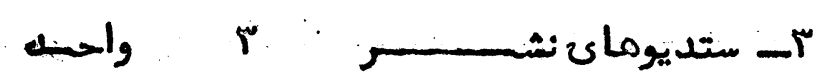

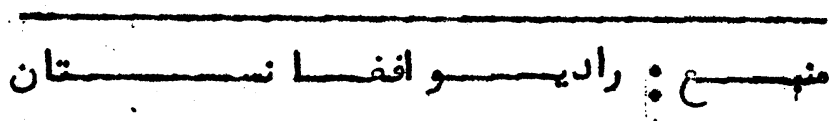

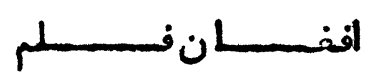

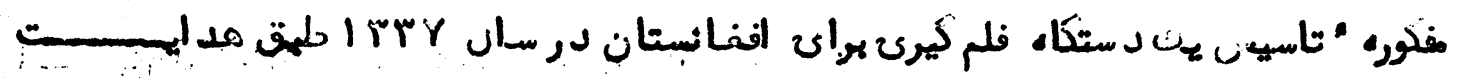

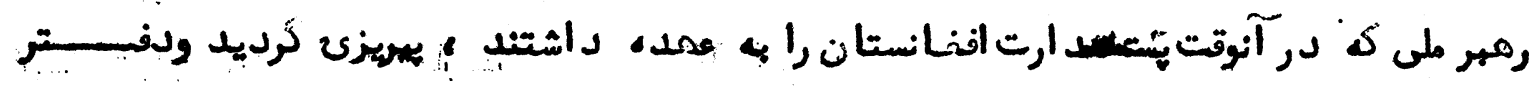

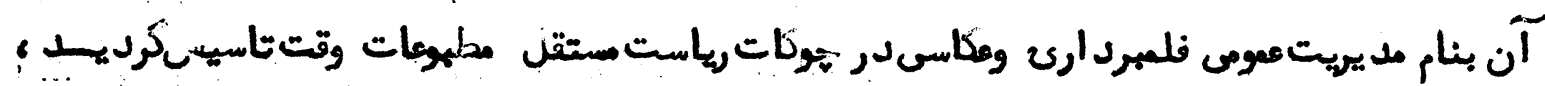

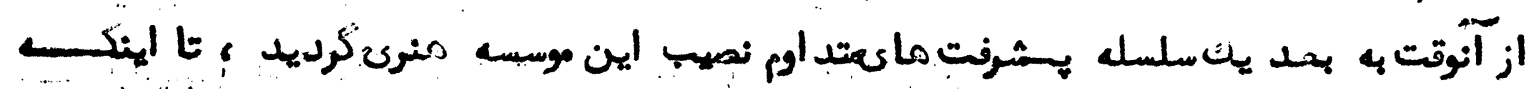

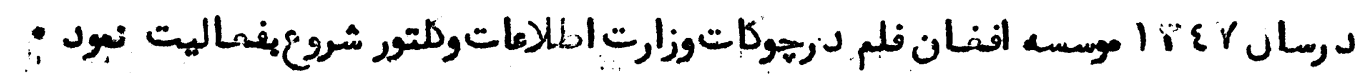

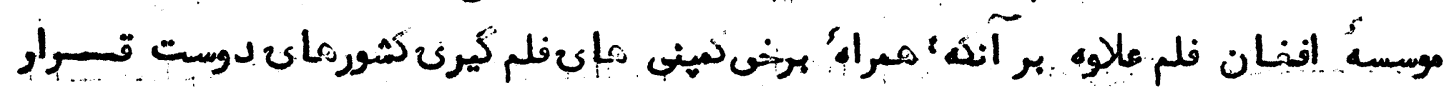

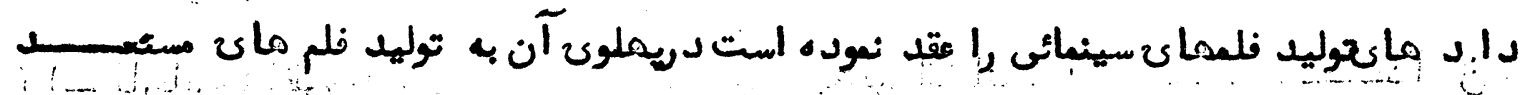

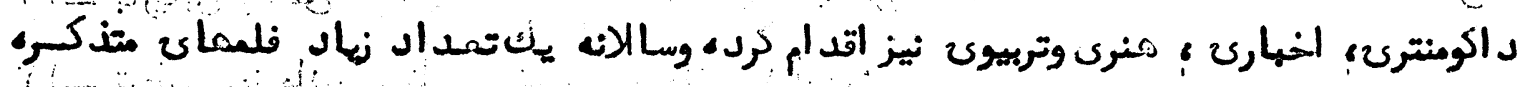




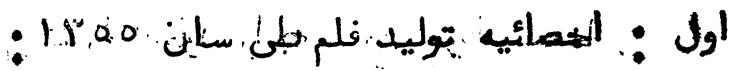

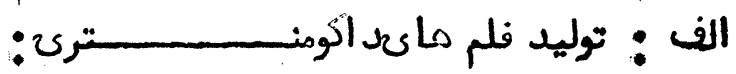

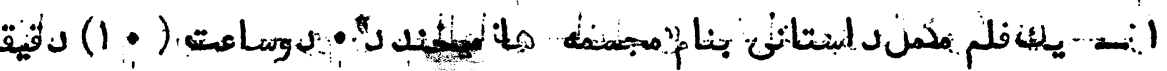

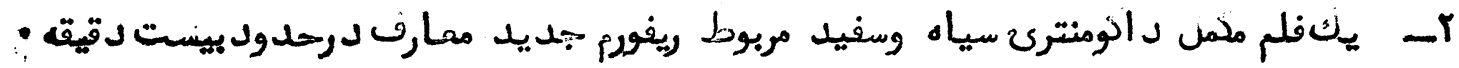

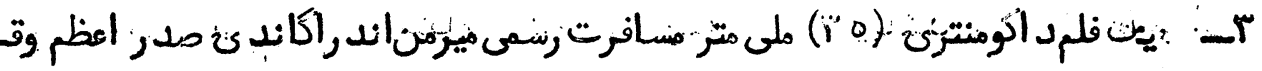

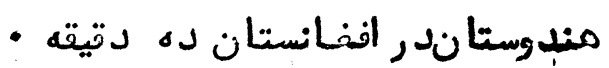

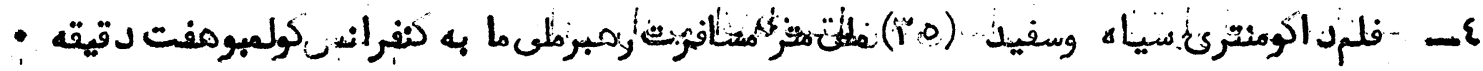

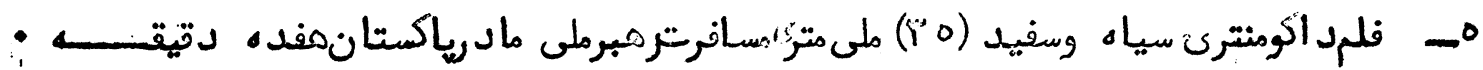

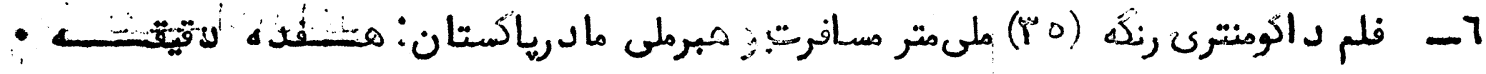

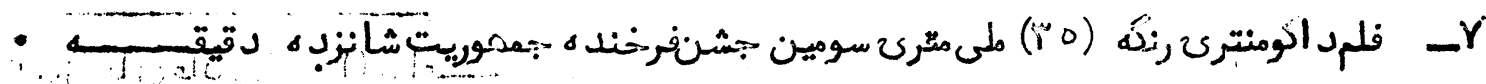

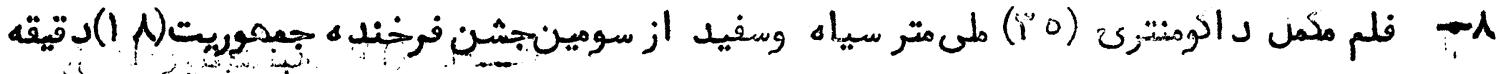

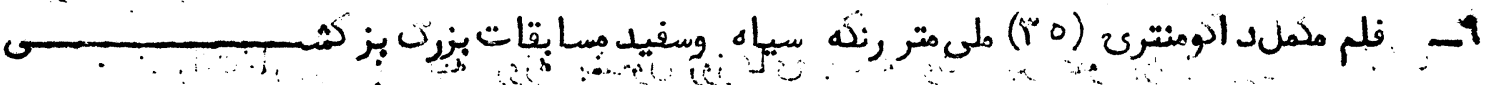

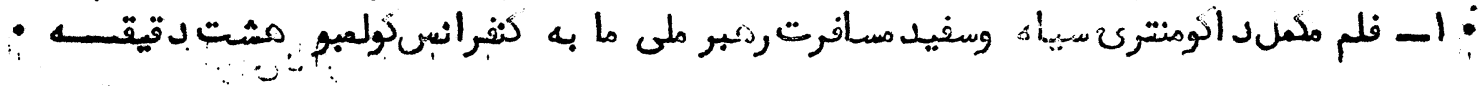

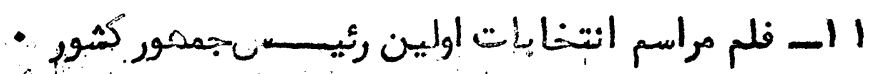

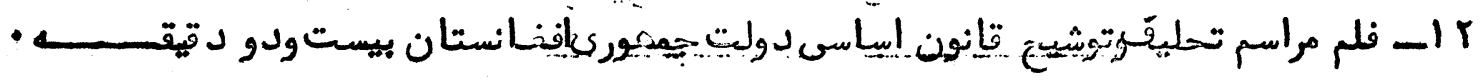

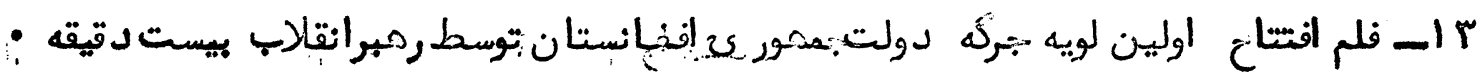

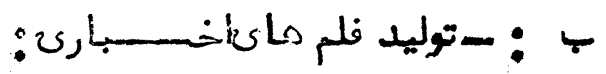

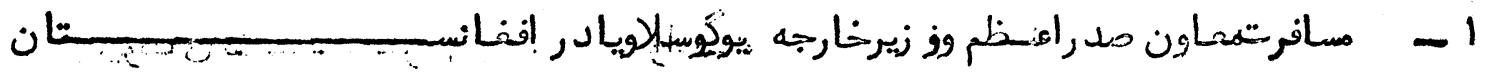

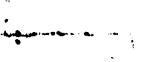

$1 .-1$
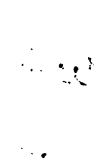

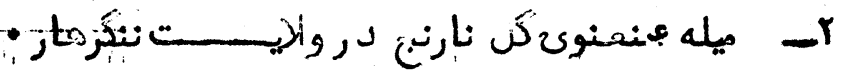

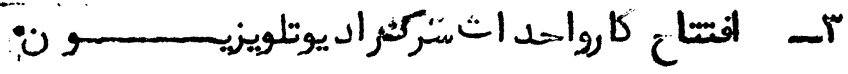

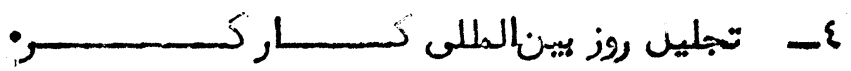

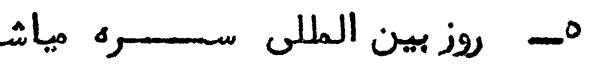

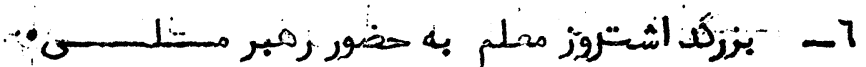

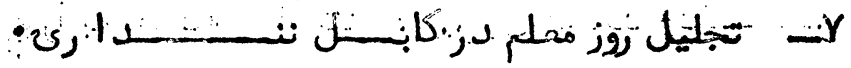

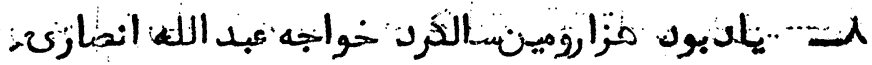

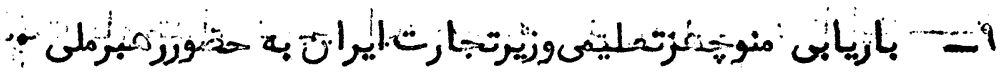

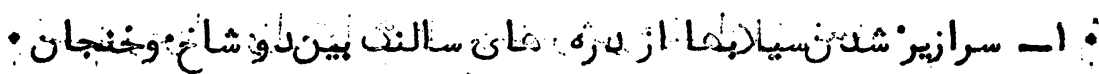

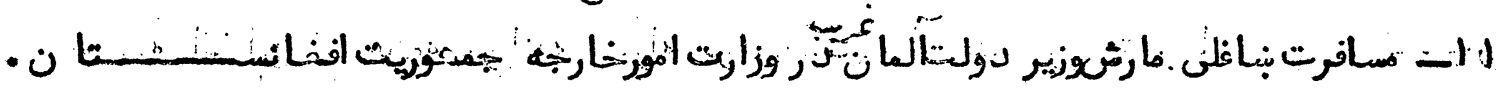
. ن

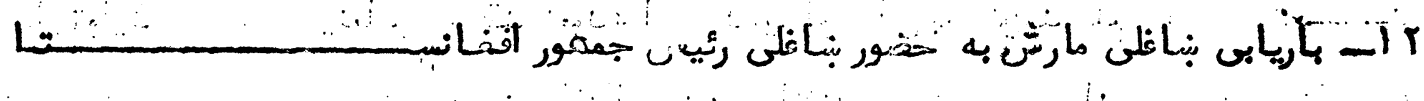

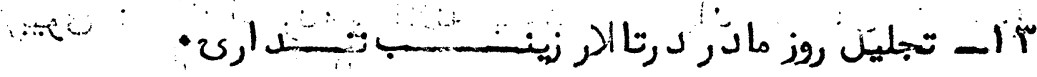

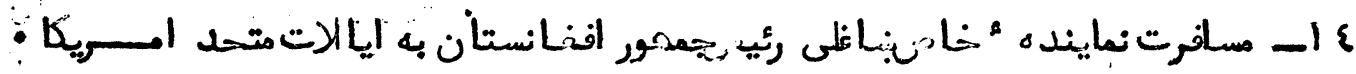




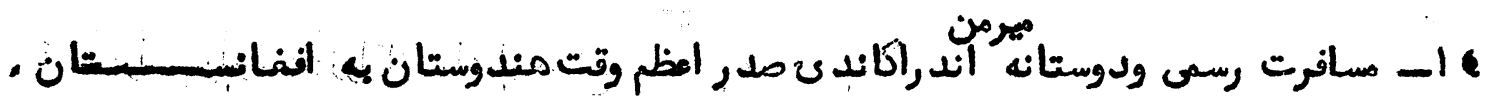

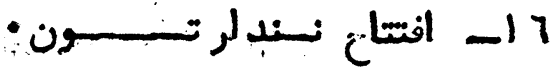

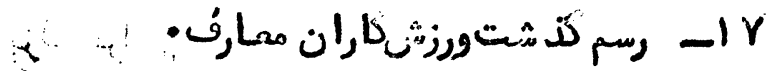

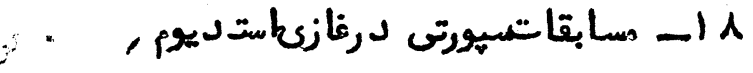

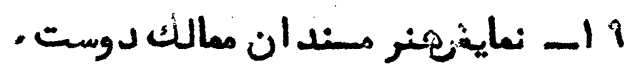

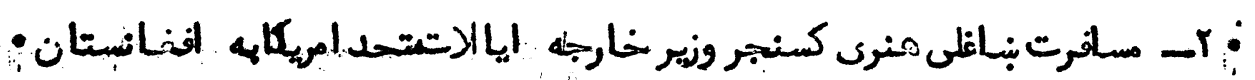

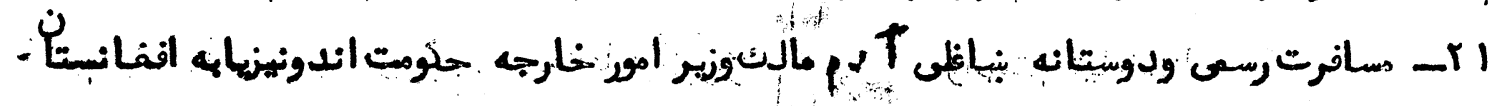

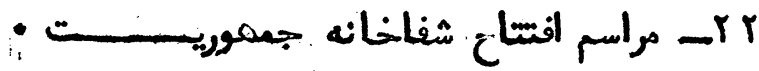

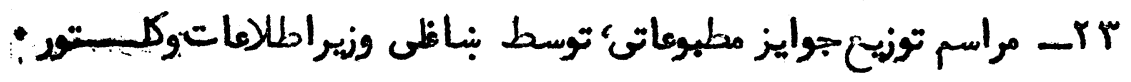

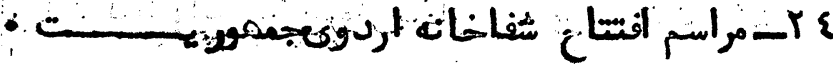
ه

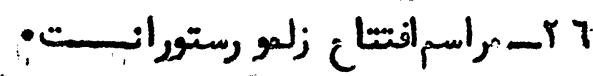

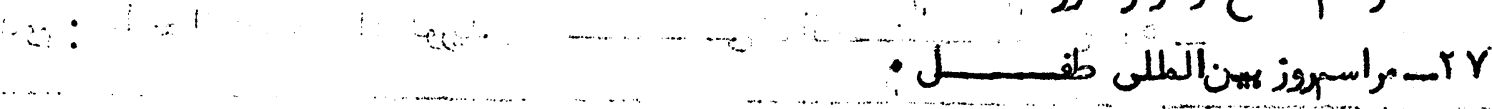

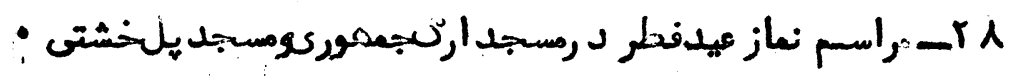

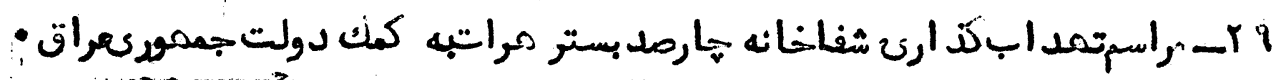

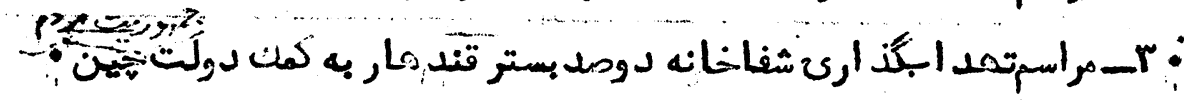

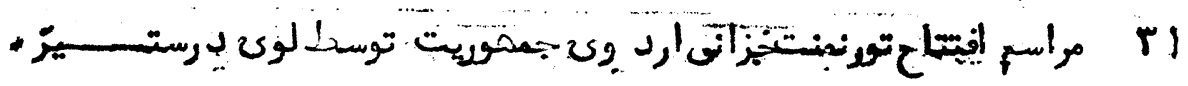

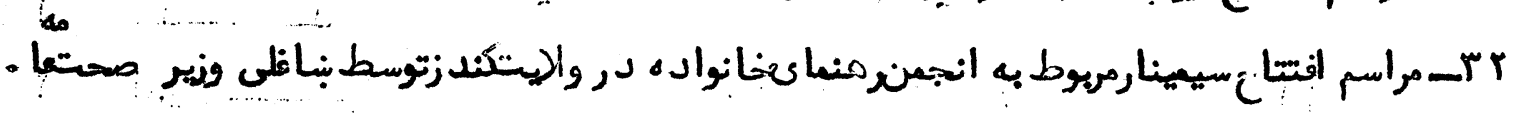

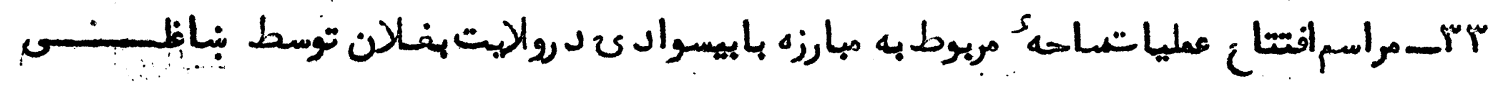
وزيرممارف وقتســـت :

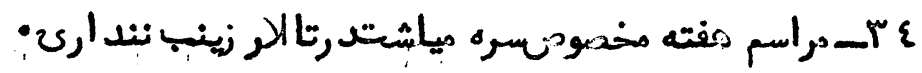

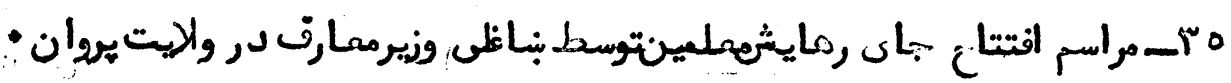

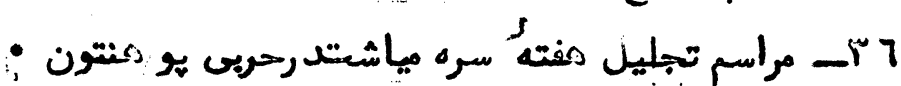

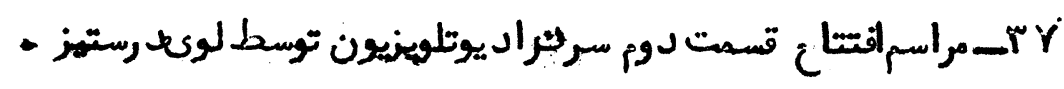

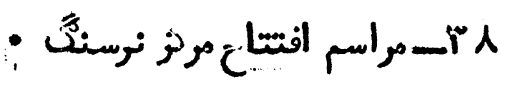

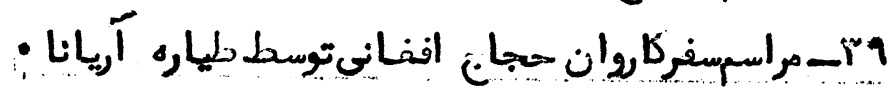
:

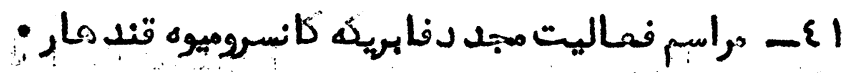

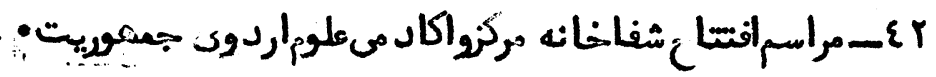

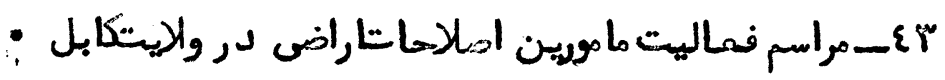

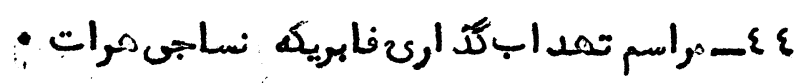




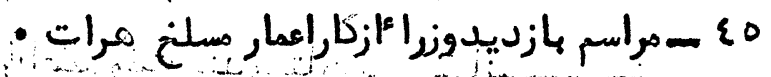

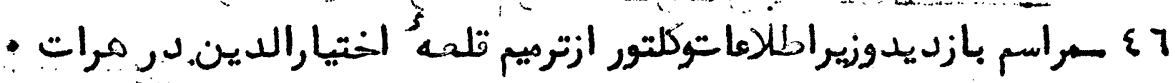

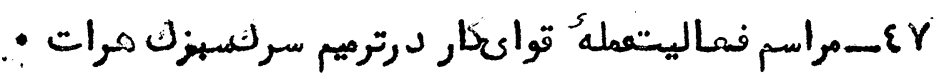

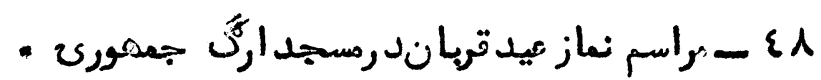

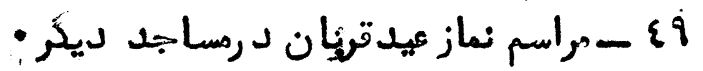
- 0 1

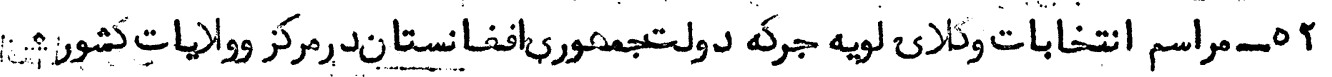

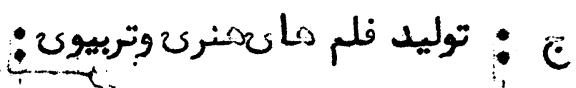

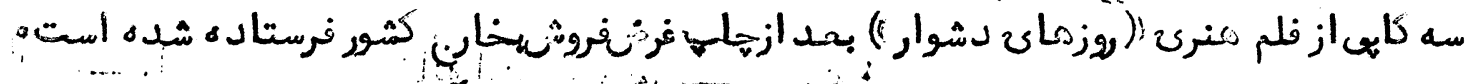

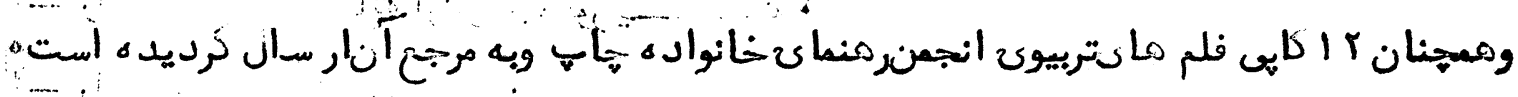

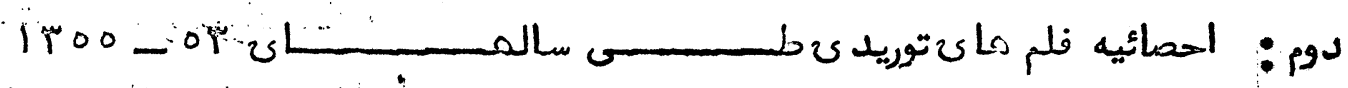

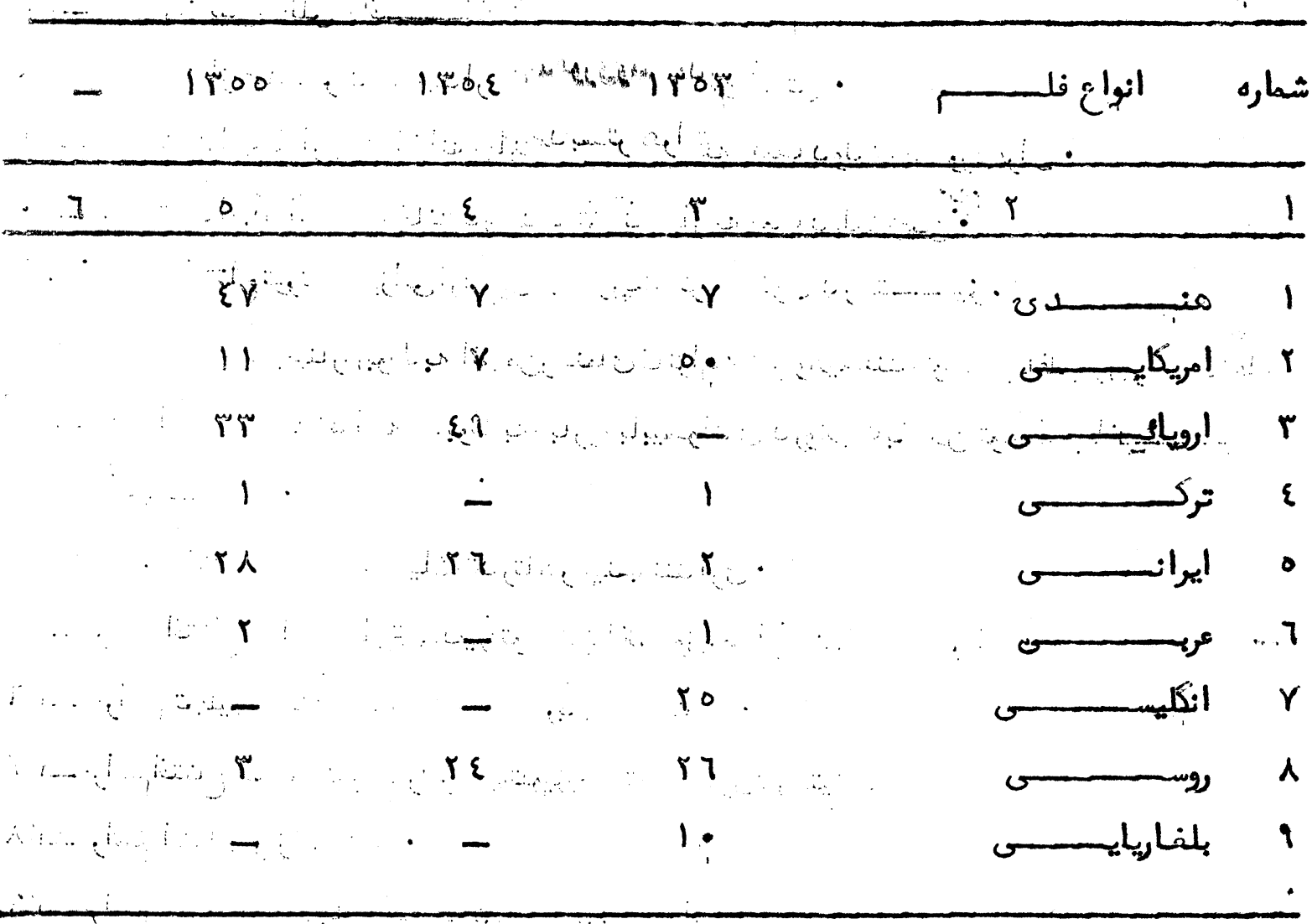

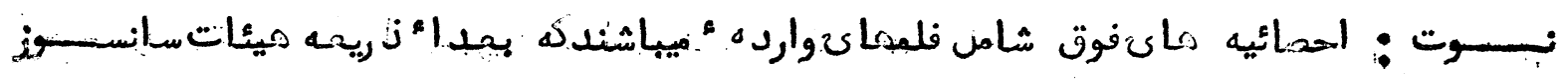

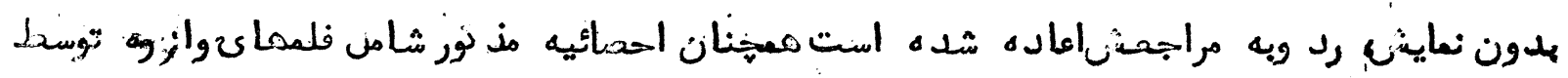

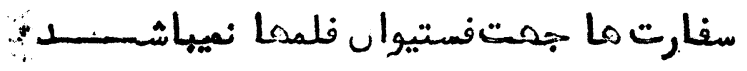

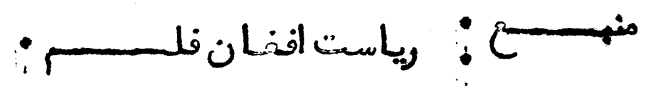




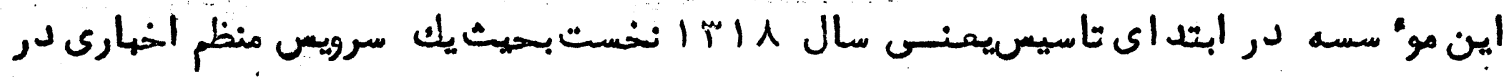

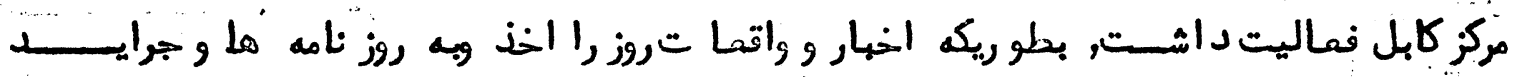

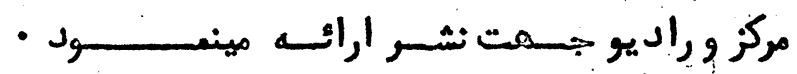

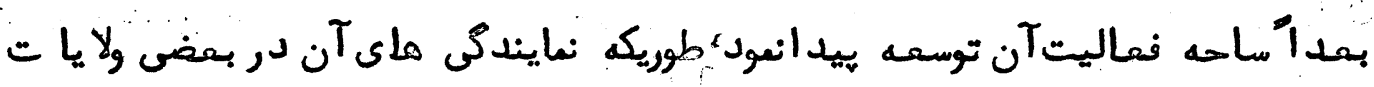

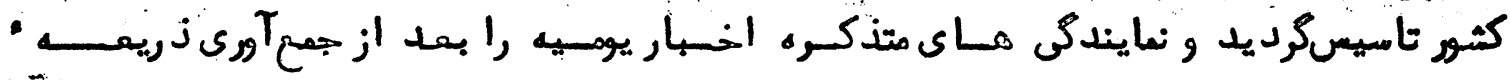

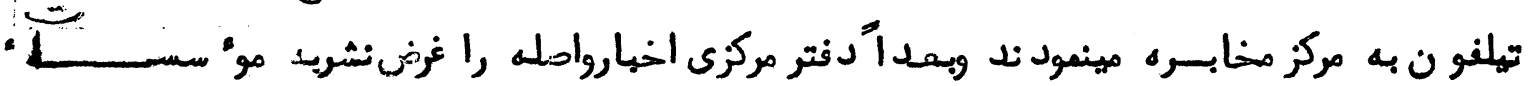

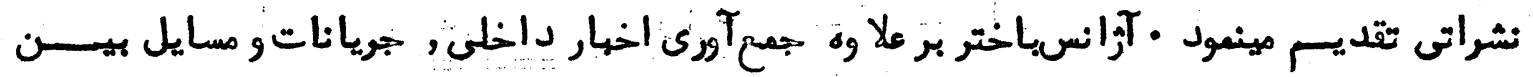

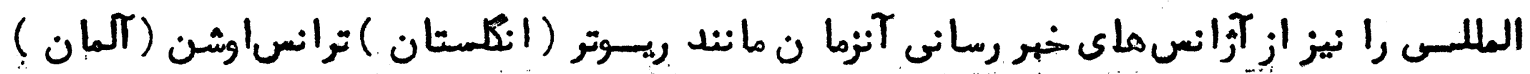

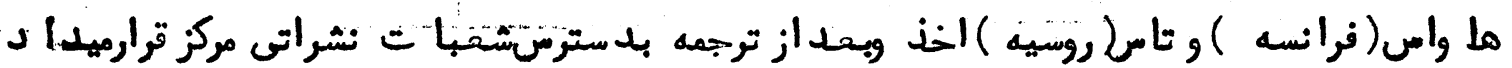

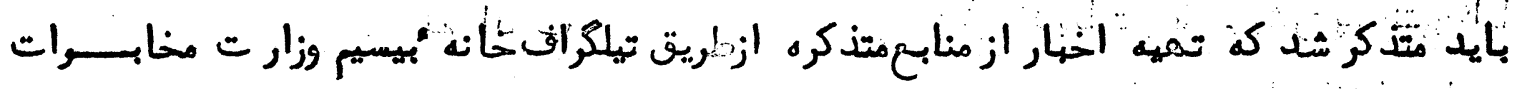

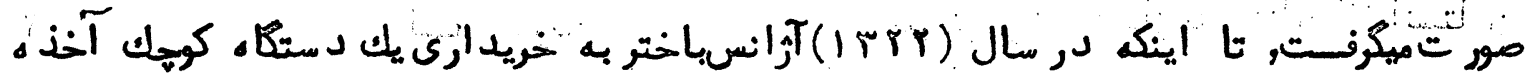

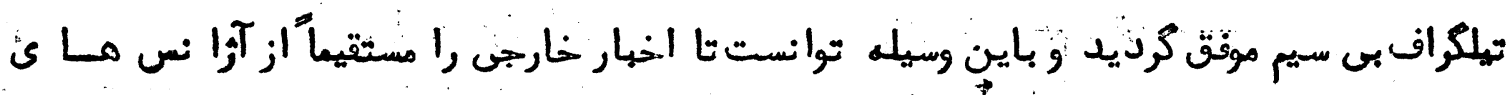

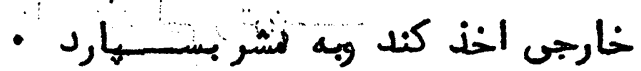

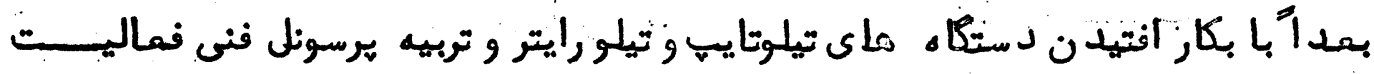

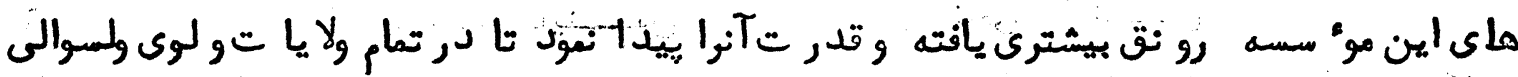

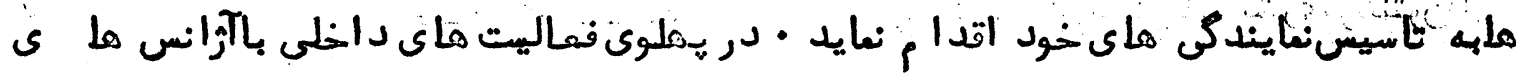

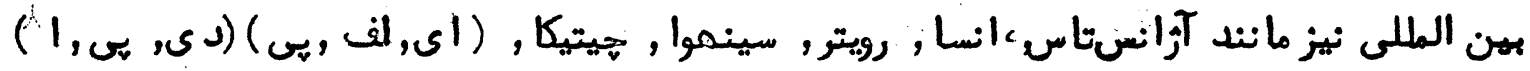

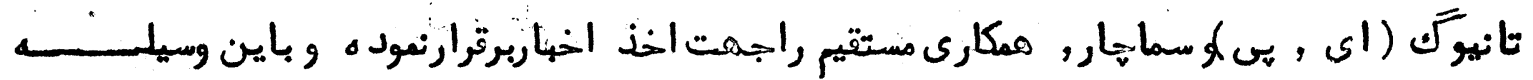

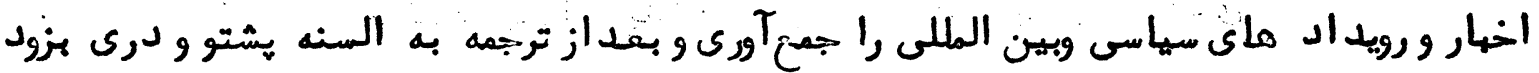

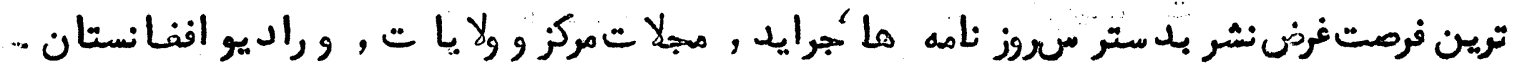

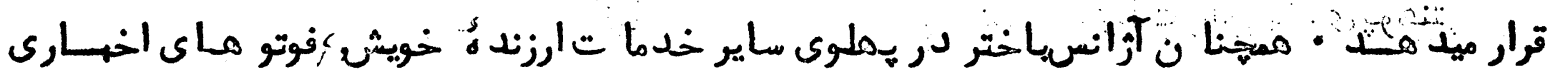

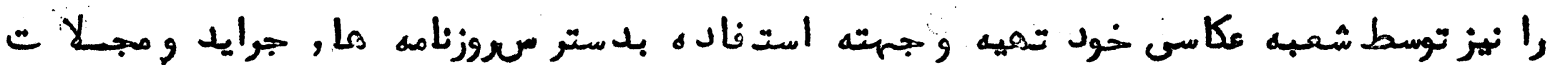

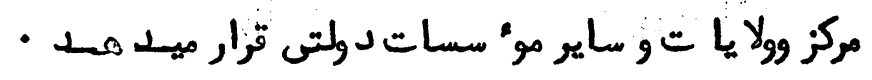

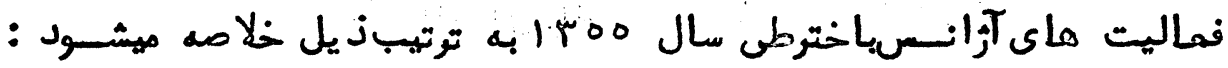

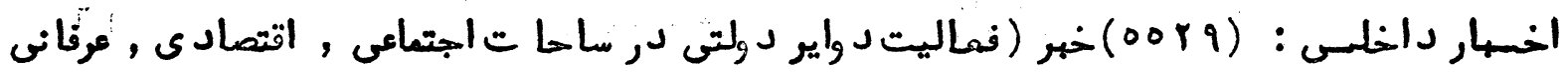

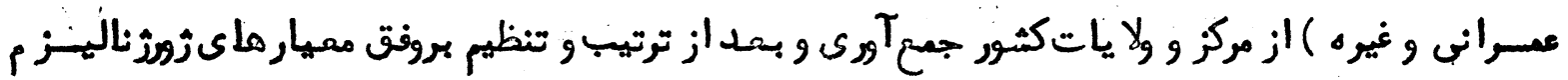

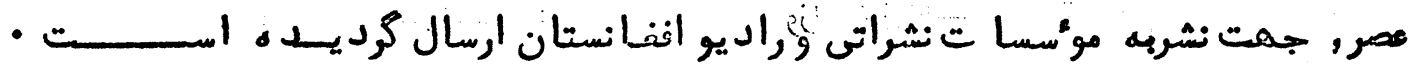

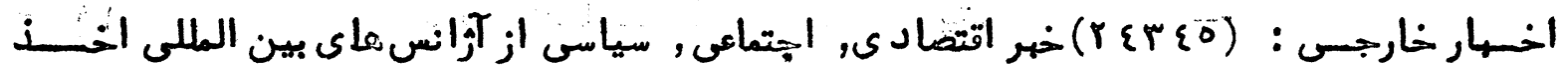

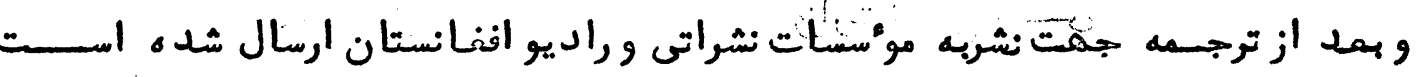




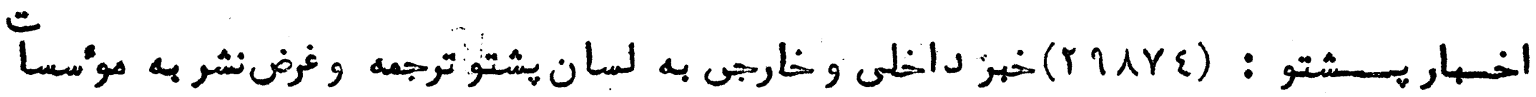

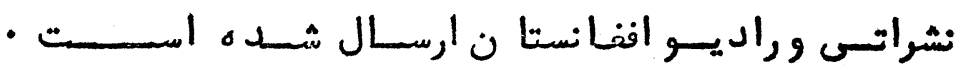

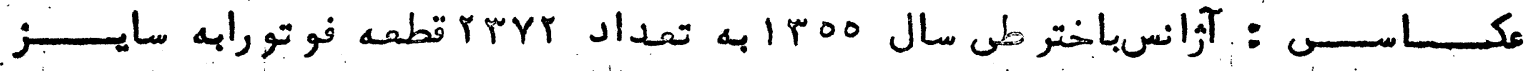
هاى مختلـف تهيه و بدسـتر سمؤ سسـا ت نشراتى و 7070 قطعه رايه سايسز هاى مختف

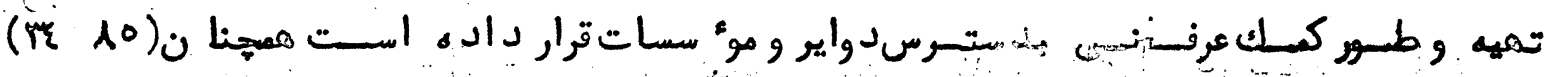

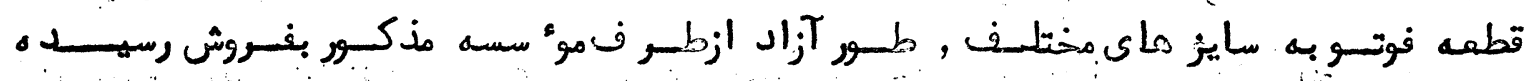

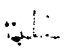

$$
(1+0.0) \mathrm{JL}
$$$$
\text { - }
$$

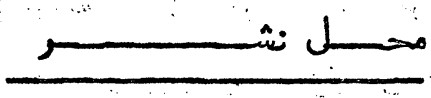

يومنحلن اديبات و علو م.بشركوهنتونكاهل

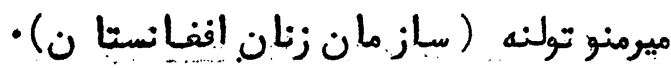

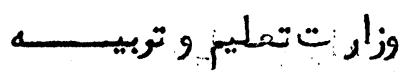

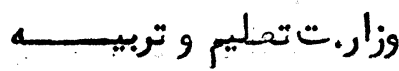

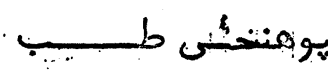
يومنتِن ساينـــــس

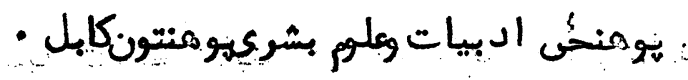

$$
\begin{aligned}
& \text { يوهنبخي حبقو ق } \\
& \text { يوهنحئ زراعســتئ. } \\
& \text { مبارزه با بيسـو الدى لى لئح }
\end{aligned}
$$

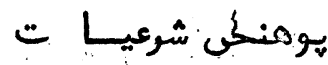

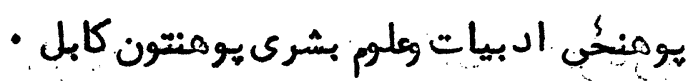

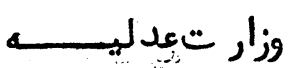
وزازتّعدليه ( إد اره ءعالى قضاء) دافنـانستان بانــ

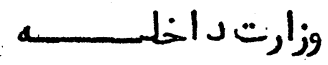
يشتنى تجارتى بانك.

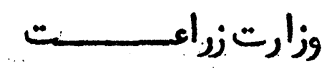

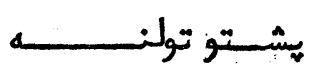

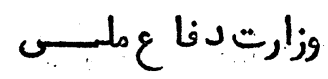
حسو بى يوهنــــتون

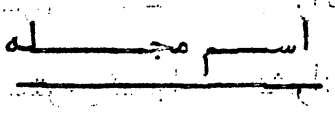
شمسـاره

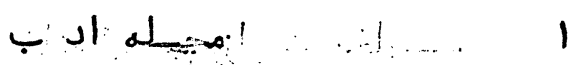

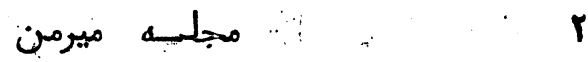

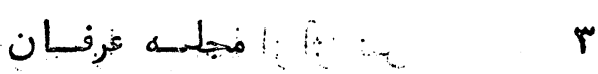

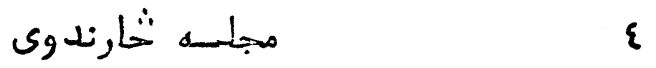

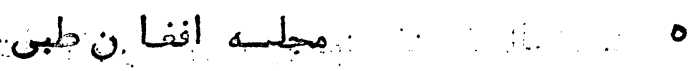

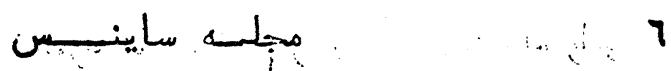

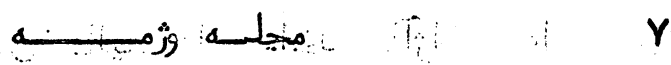
人 9

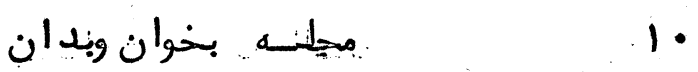
11

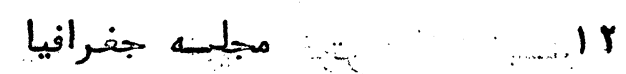
r

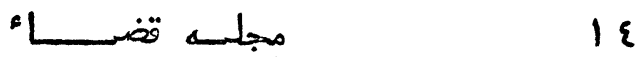
10

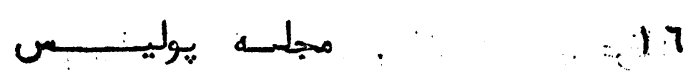
IV

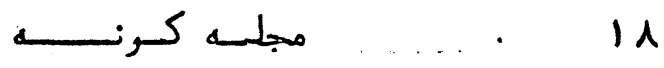
: : : : : 19

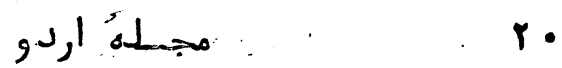

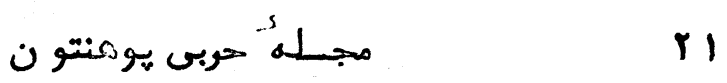




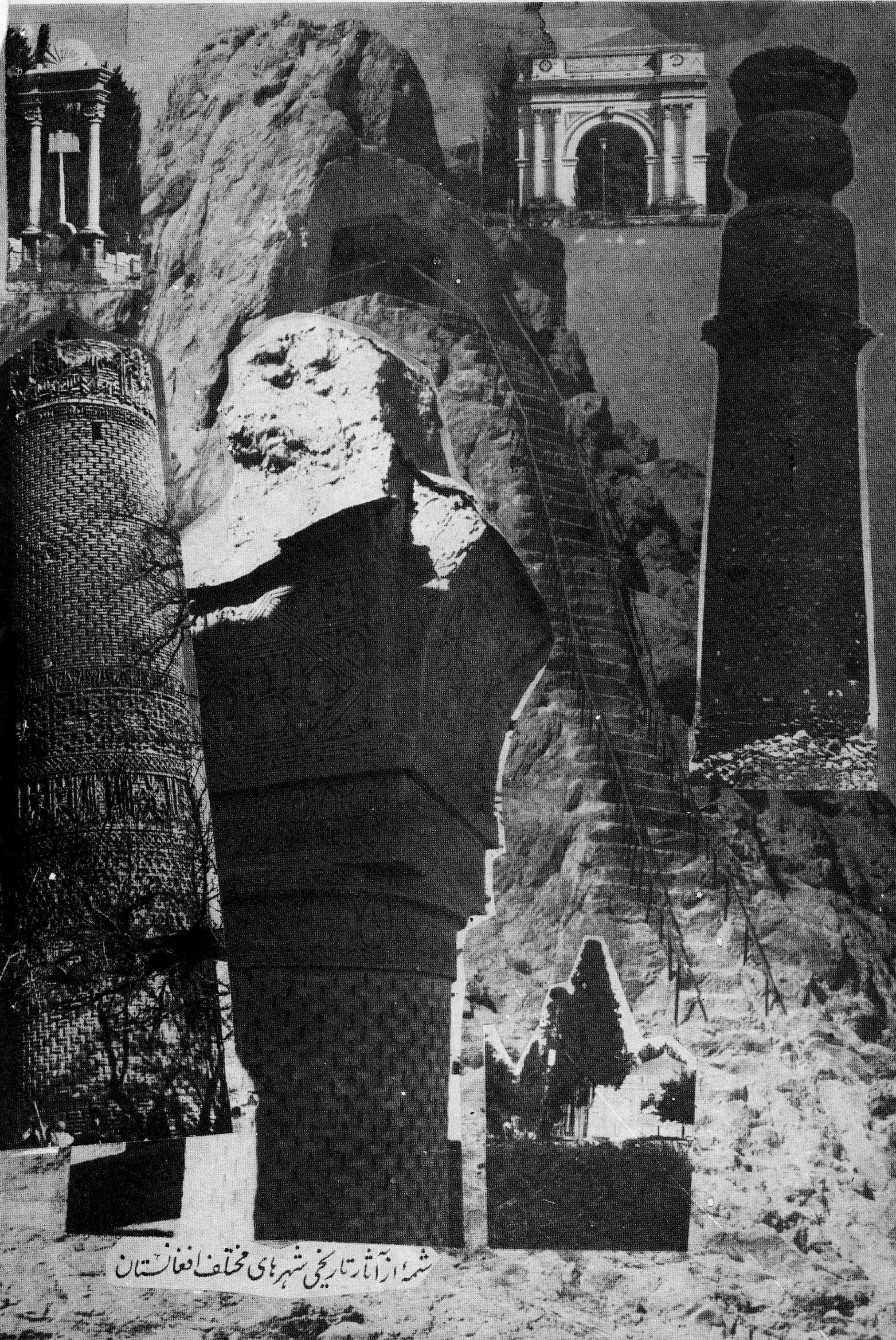




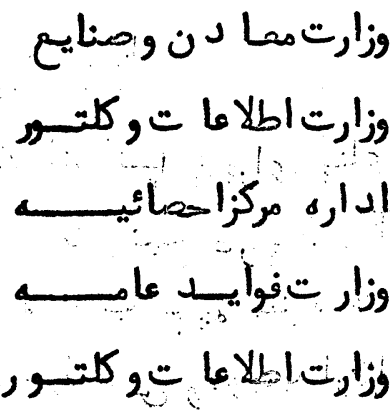

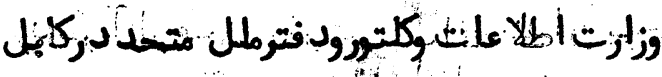
وزارت أللاعات وكلتـور

وزارت الطلاعات وكلتو ر إداره مركزا بمائيسـه

وزار تألاعاتأونكتور

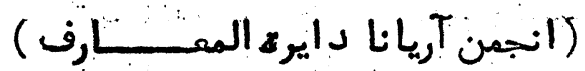

$$
\text { مجسله :كانو اوونايمو }
$$

مجلبه كمــــــــول

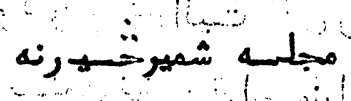

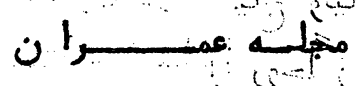

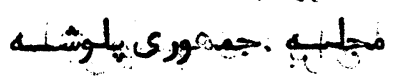
it

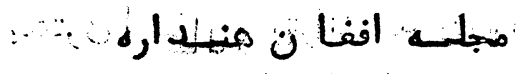
c. Tucost مجندا بـ

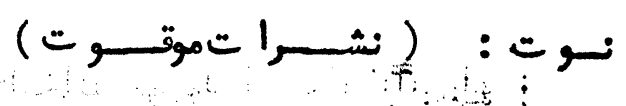
سالنامه اففانستان

$$
\text { معلوما تالحمائيوىانفانستان انفان }
$$
$r$

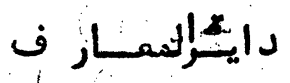
$r$$$
\text { d. }
$$

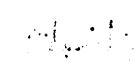

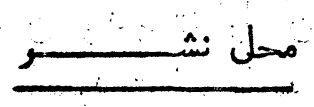

وزار ثغدليه (رياست تقتيسن )

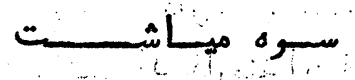

وزار, تمستصعام (موسبه صحتعامه )

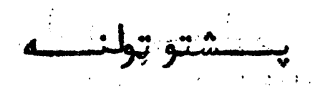

اركاقمـاى تجـارت وصنايسـحن

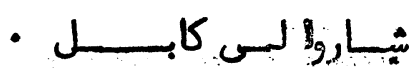

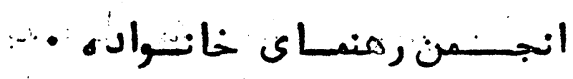

$$
\begin{aligned}
& \text { لســت سائسر جسرايد مركسز در بــال ( }
\end{aligned}
$$

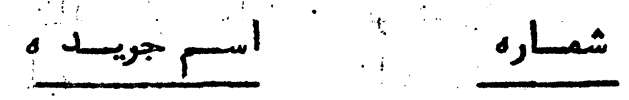

$$
\begin{aligned}
& \text { جـريده "رسمسي } \\
& -1
\end{aligned}
$$

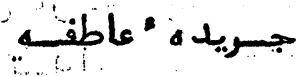

$$
\begin{aligned}
& \text {-r }
\end{aligned}
$$

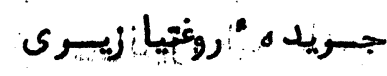

$$
\begin{aligned}
& -r
\end{aligned}
$$

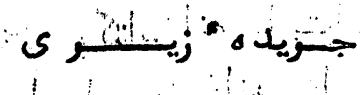

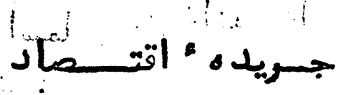

$$
\begin{aligned}
& -\varepsilon
\end{aligned}
$$

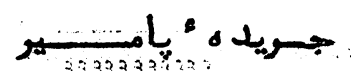

$$
\begin{aligned}
& \text { - } \\
& -7
\end{aligned}
$$

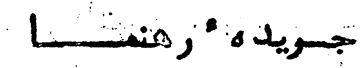

$$
\begin{aligned}
& -Y
\end{aligned}
$$

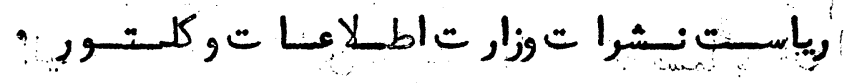




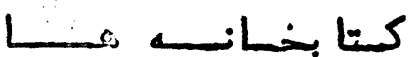 \\ =ニニニニ=ニ=ニ=ニ= =}

همانطوريكه انسانسا ن براى بتاى حسيا ت و دوام فماليت ماى روز مره خويشهه غذا

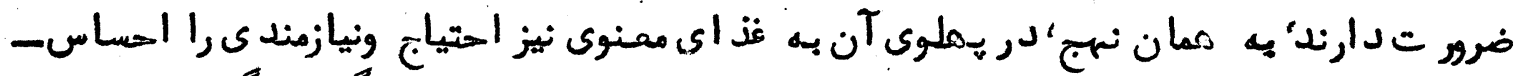

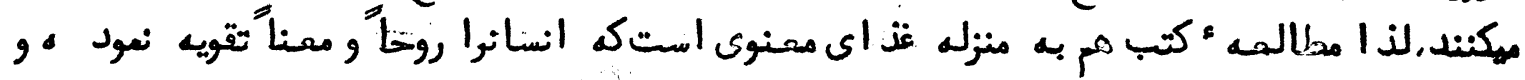

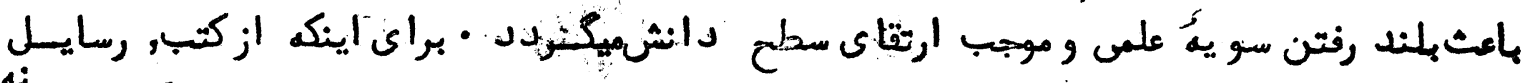

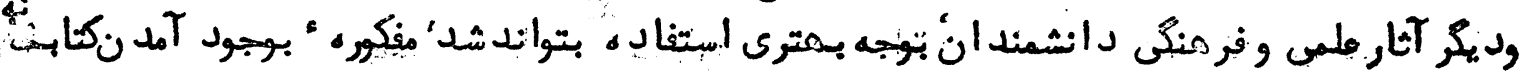

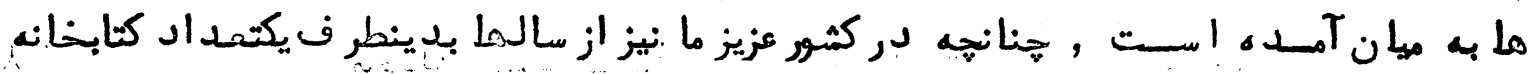

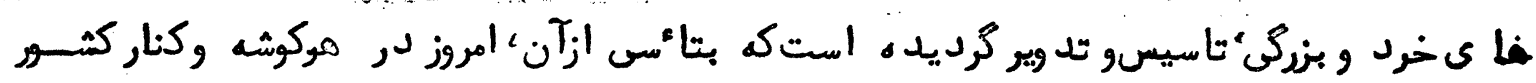

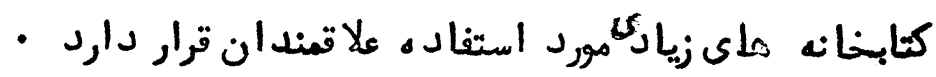

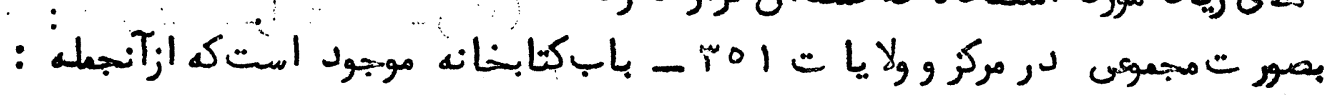

$$
\begin{aligned}
& (\div \mathrm{L})
\end{aligned}
$$

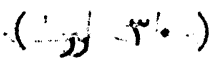

$$
\begin{aligned}
& (3 j(1)
\end{aligned}
$$

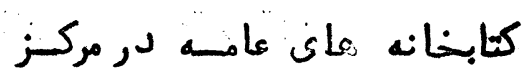

$$
\begin{aligned}
& \text { ( }
\end{aligned}
$$

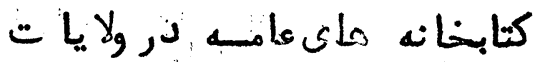

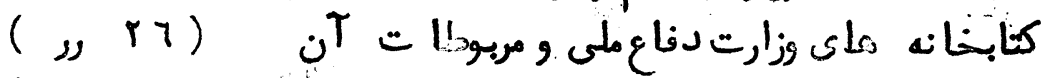

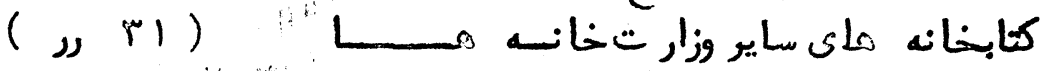

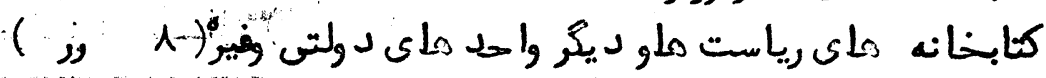

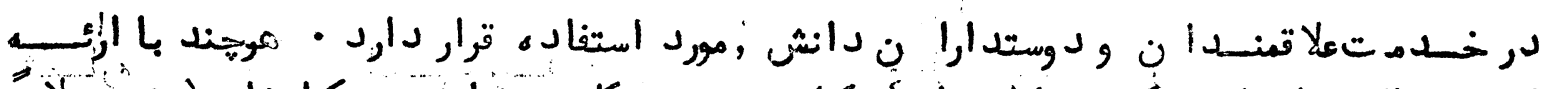

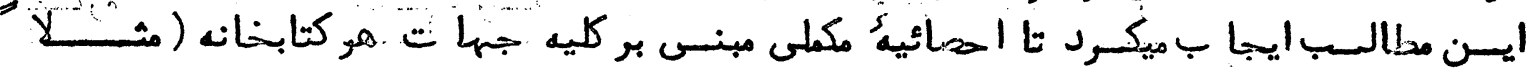

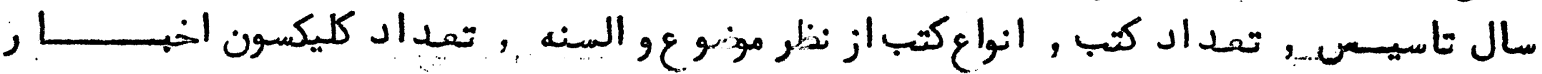

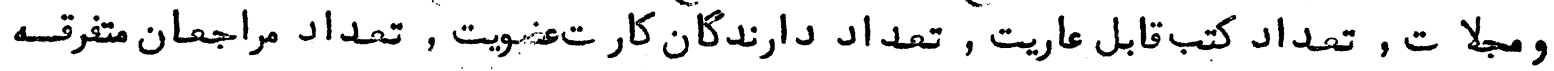

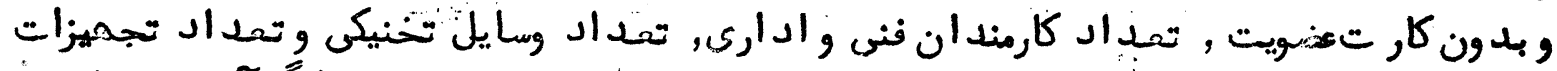

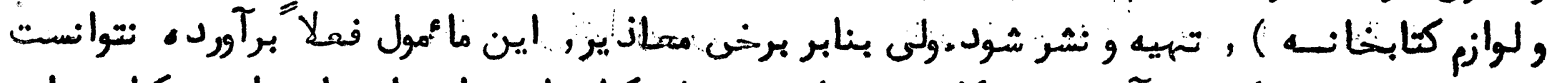

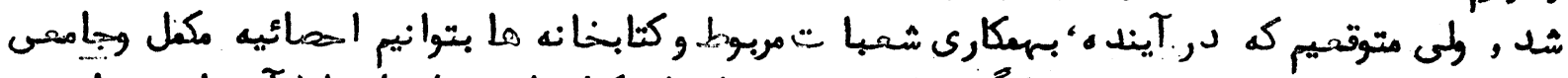

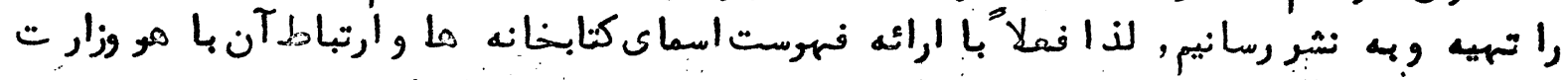

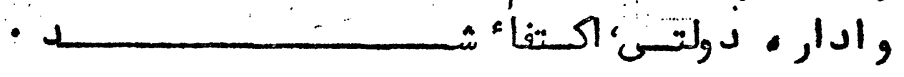




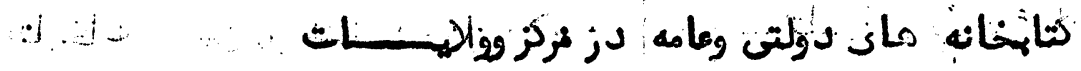

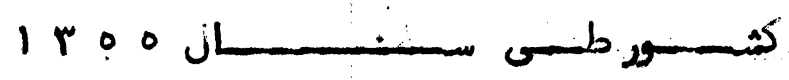

-

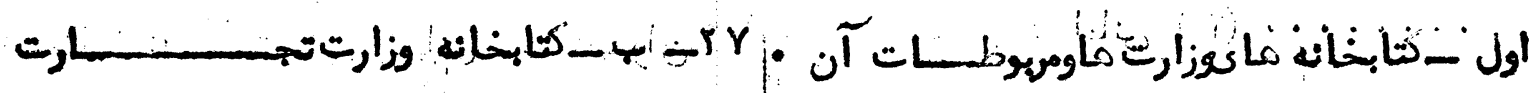

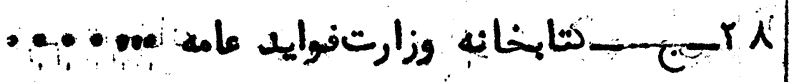

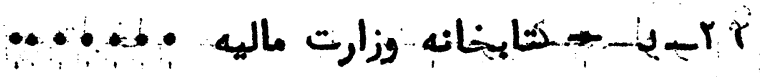

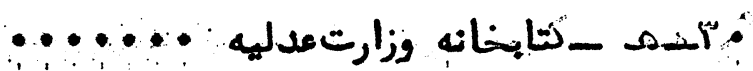

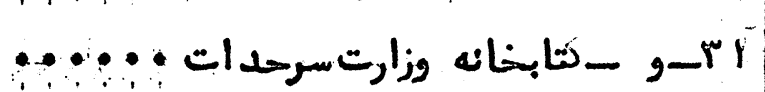

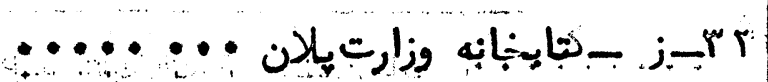

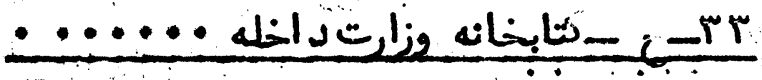

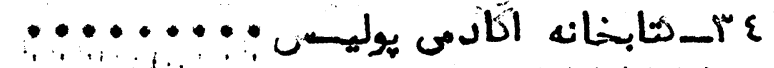

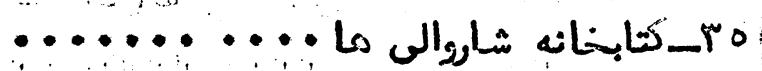

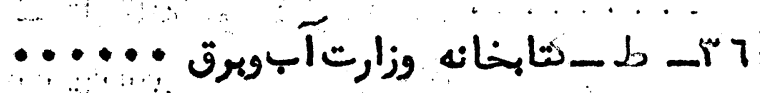

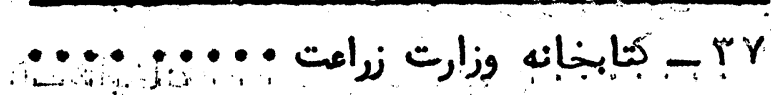

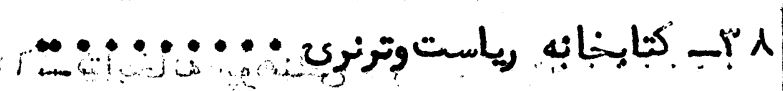

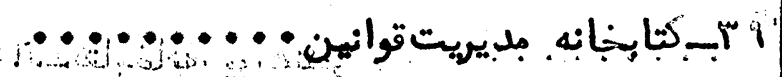
الف - وزارت

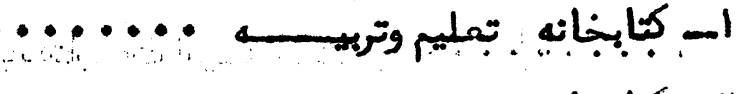

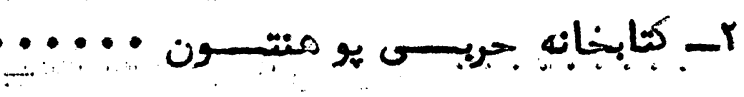

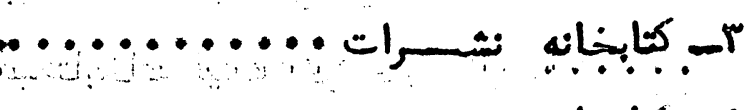

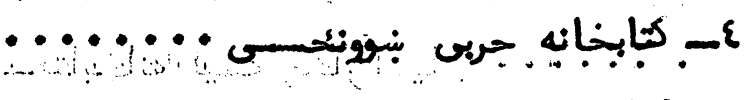

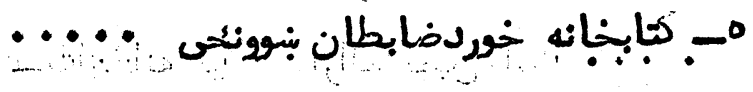

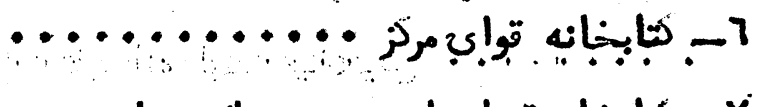

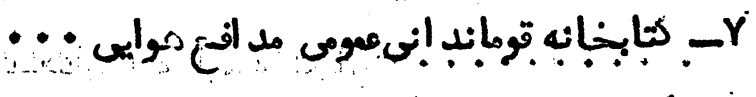

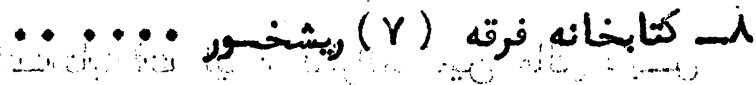

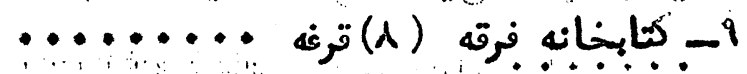

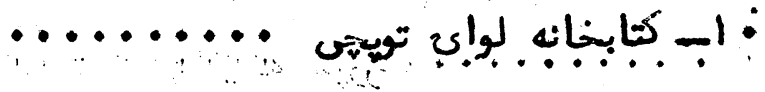
ن

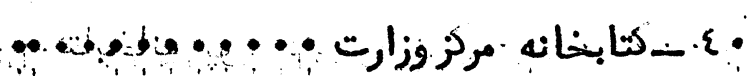

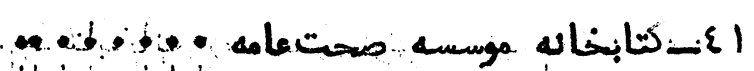

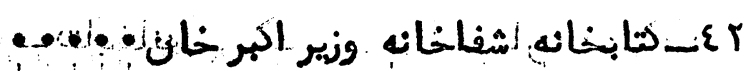

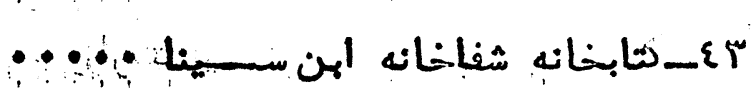

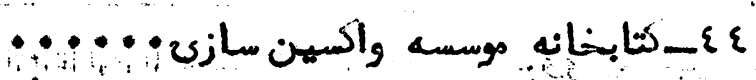

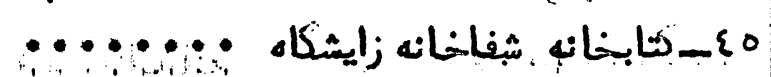

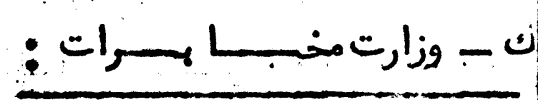

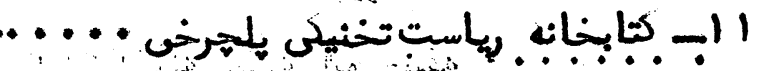
rr

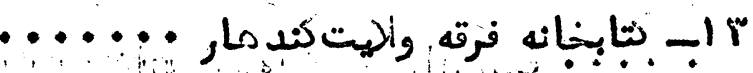

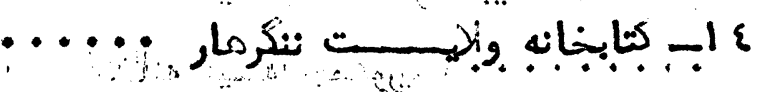

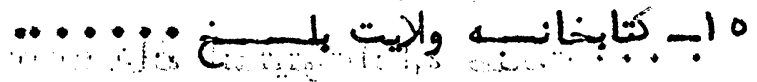

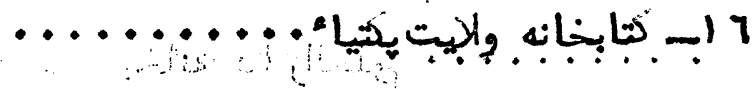

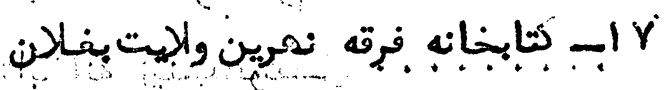
11

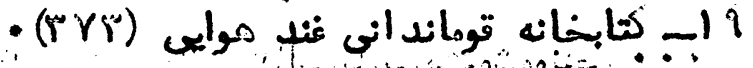

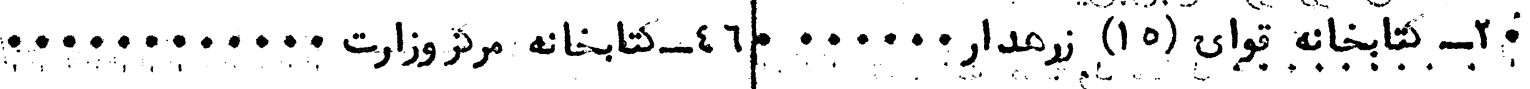

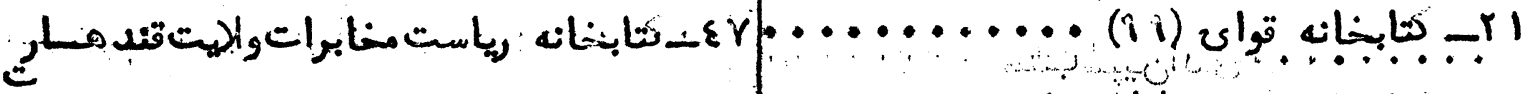

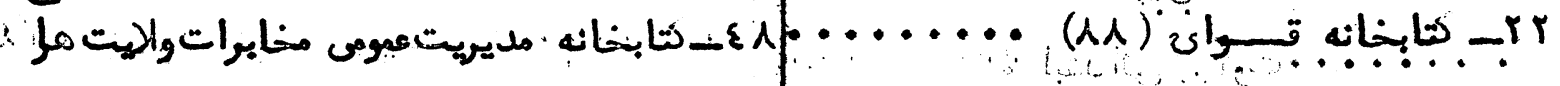

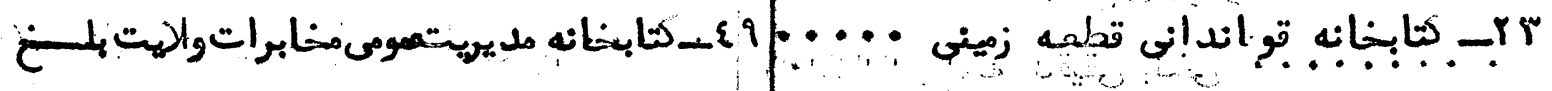

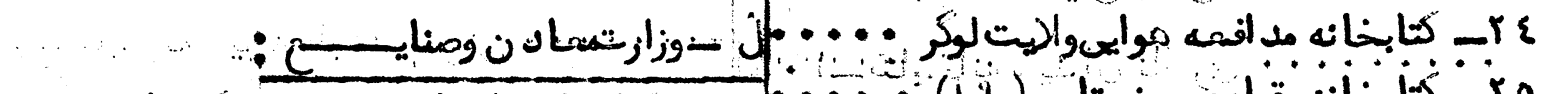

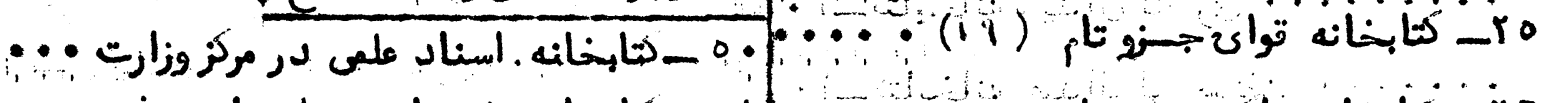

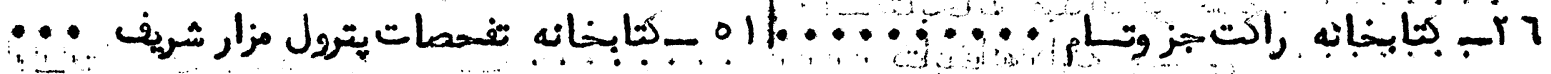


ه

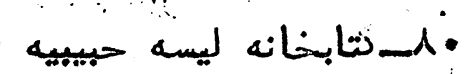

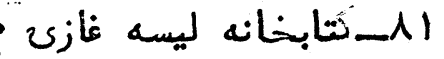

(r)

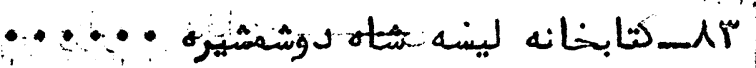

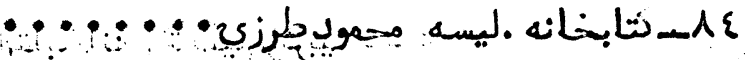

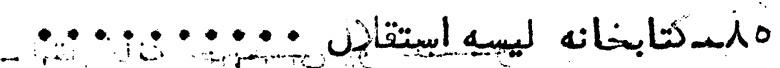

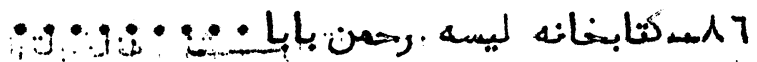

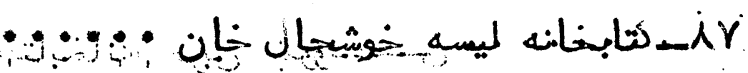

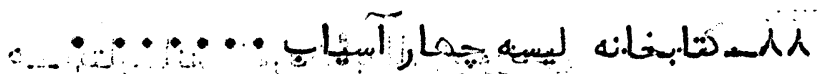

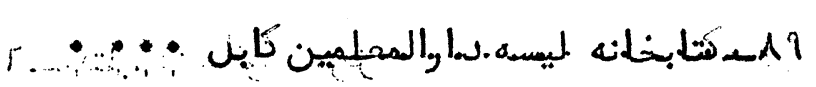

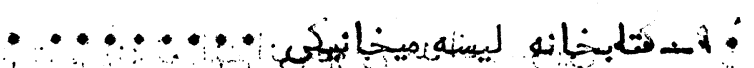

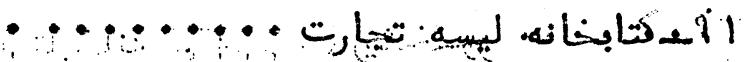
1

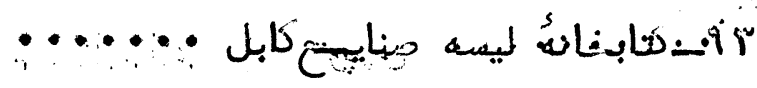
م

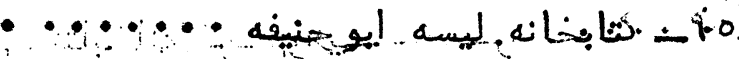

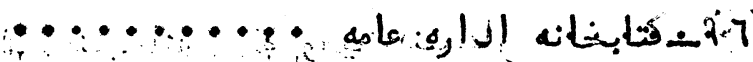

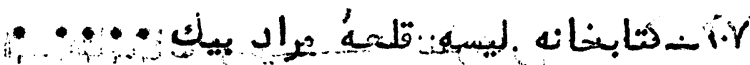
........... •

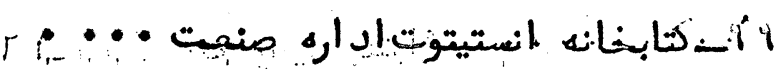

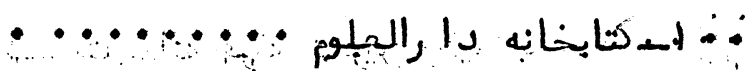

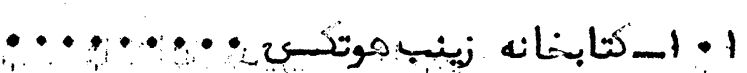

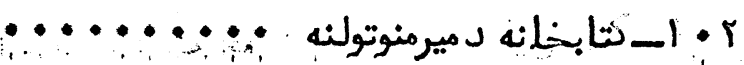

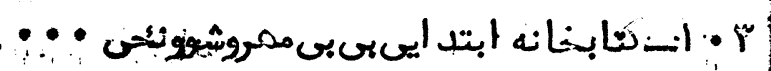

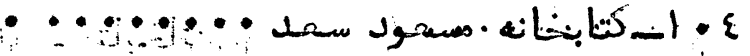

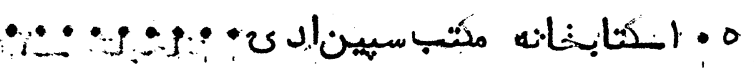

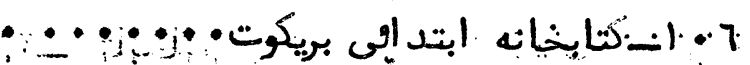

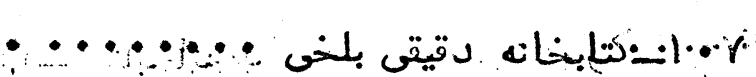

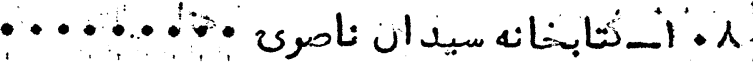

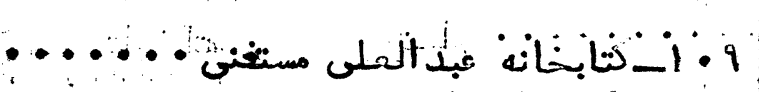

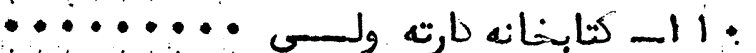

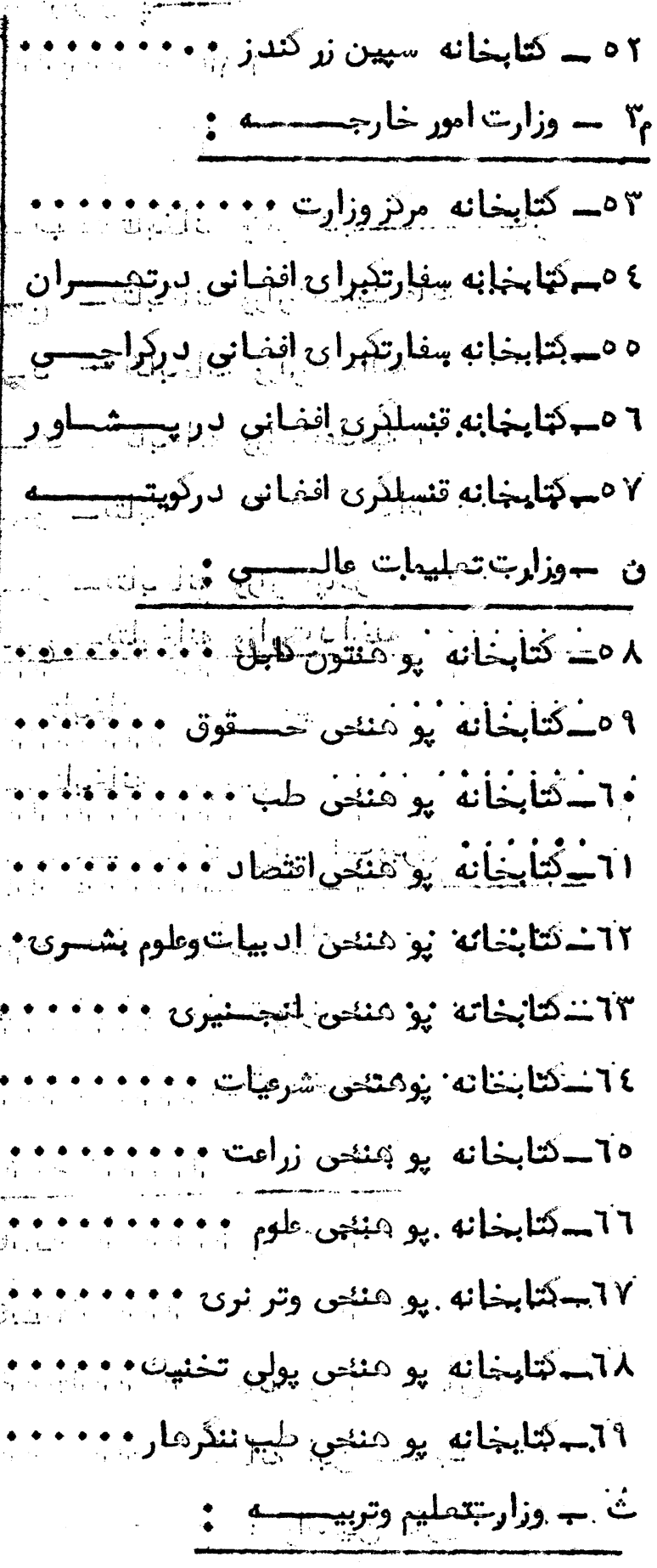

الفت بكاببنمانه ليسنه ها ، مكاتيب شمركوالايتكابل

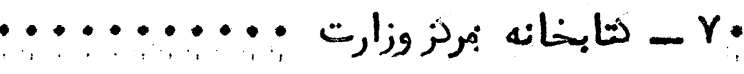

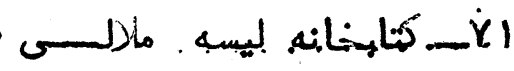

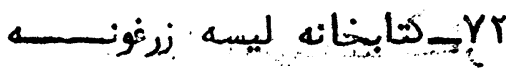
-

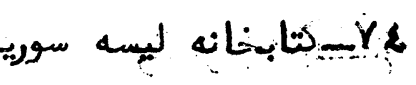

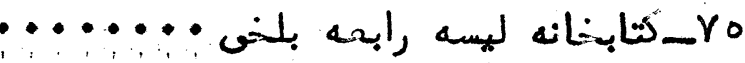

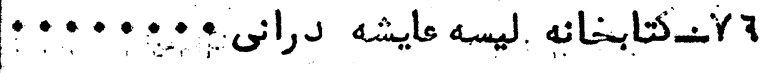

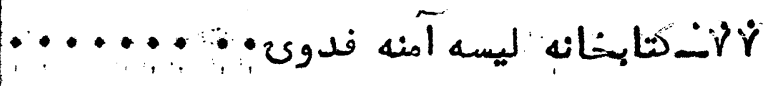




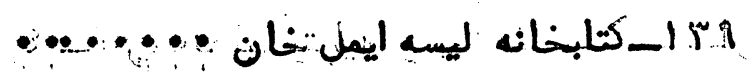

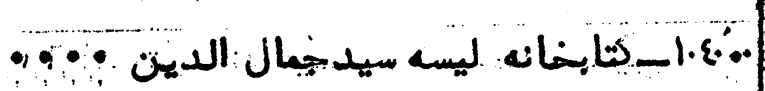

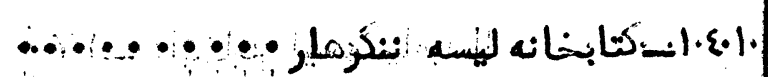

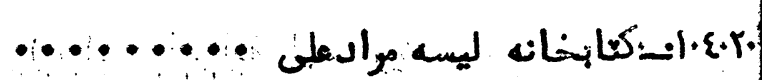

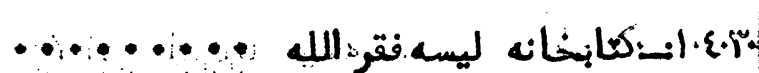

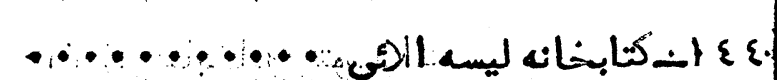

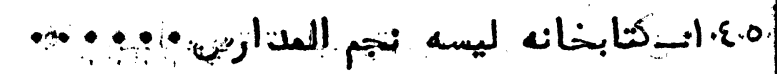

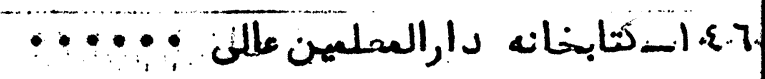

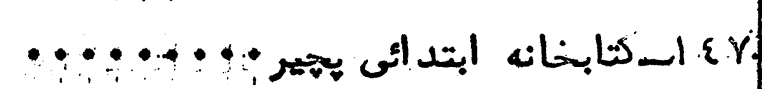

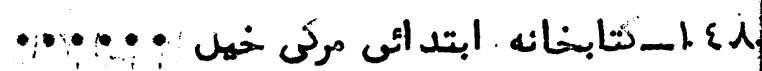

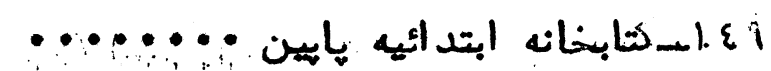

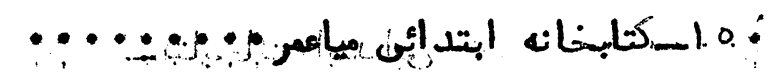

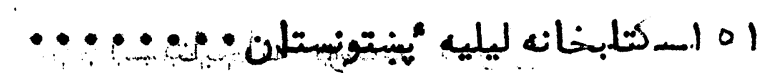

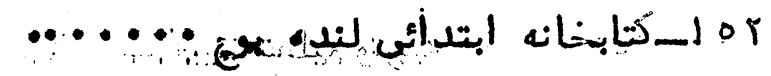

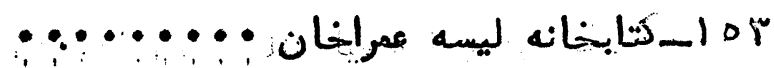

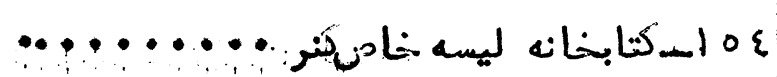

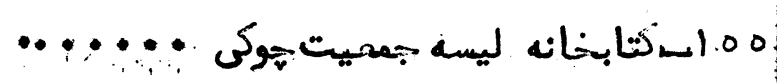

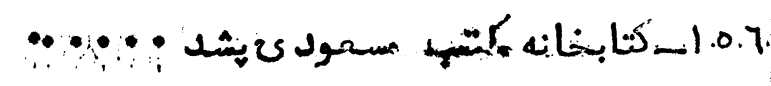

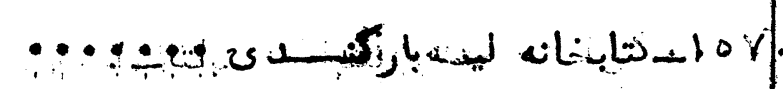

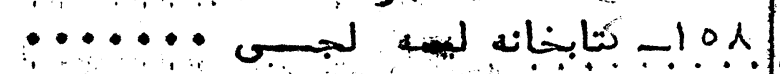

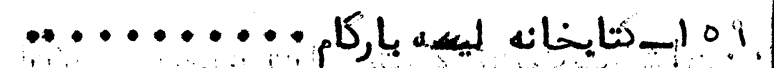

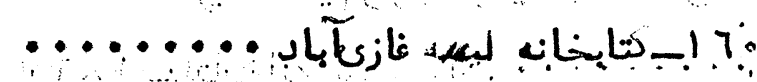

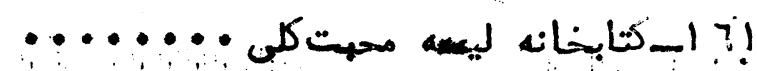

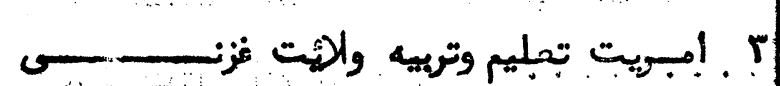

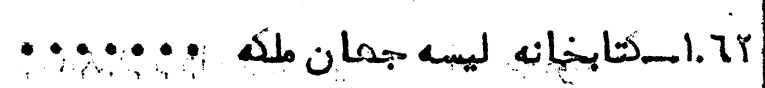

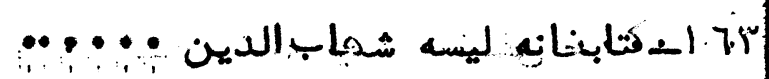

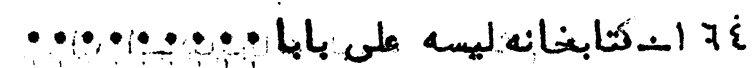

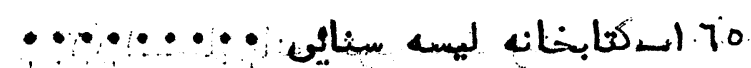

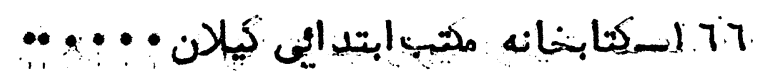

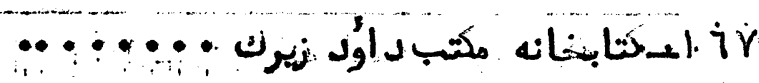
ه

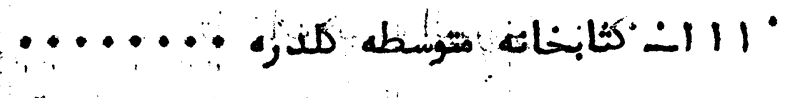

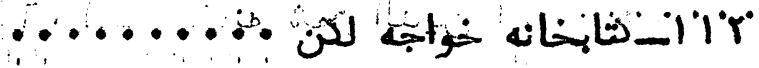

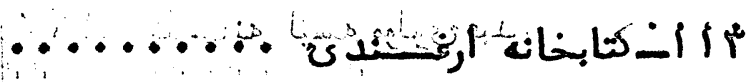

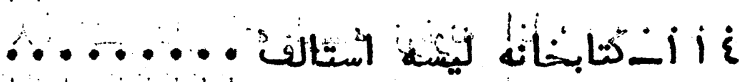
$\therefore \ldots$. .

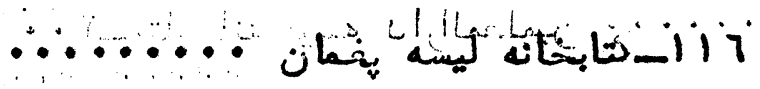

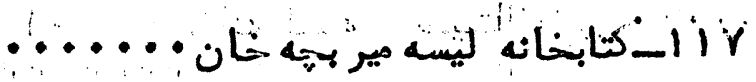

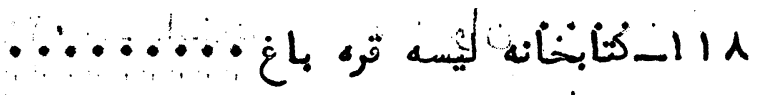

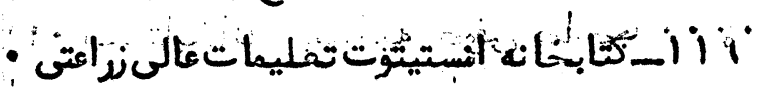

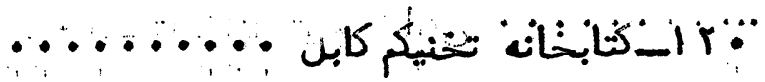

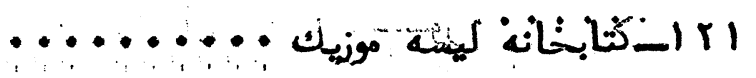

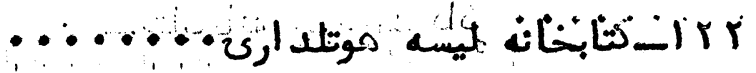

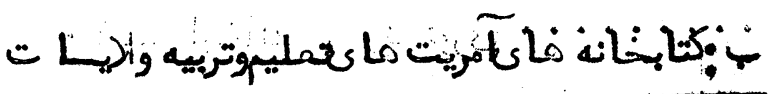

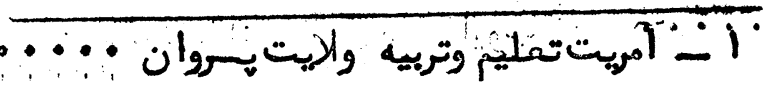

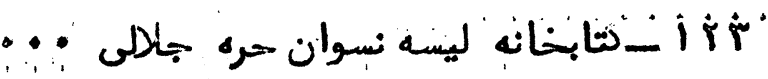

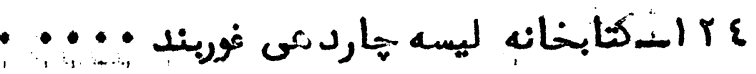

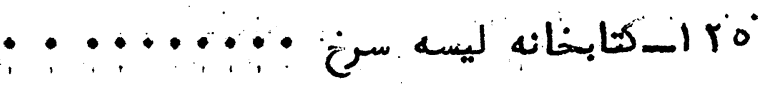

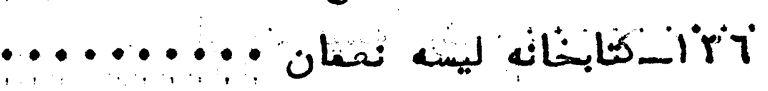

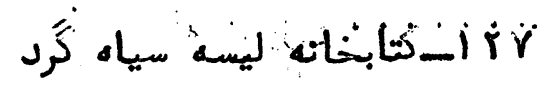

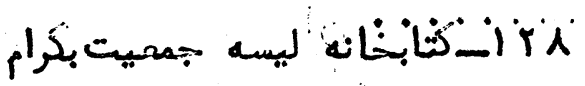

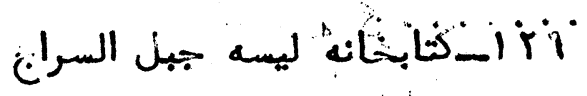

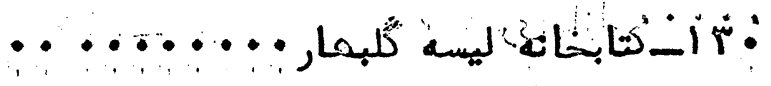

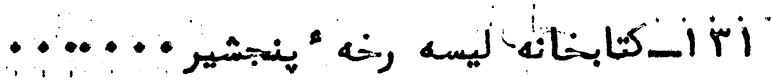

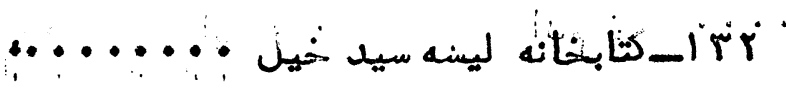

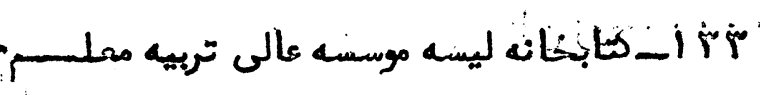

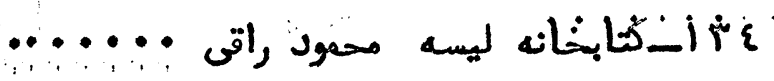

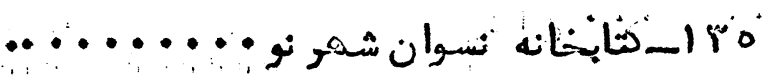

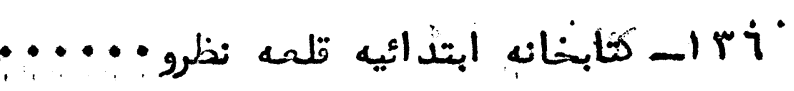
$\because \ldots$

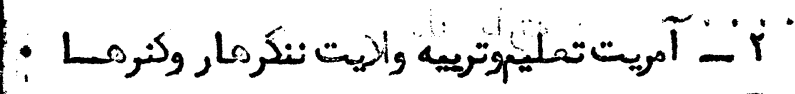


| 110

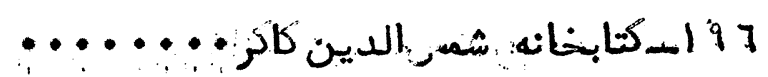

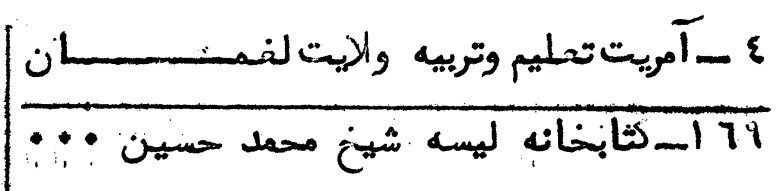

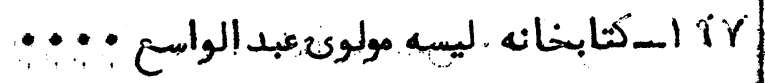

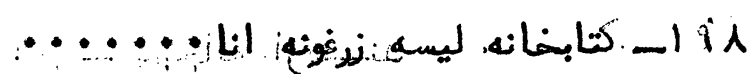

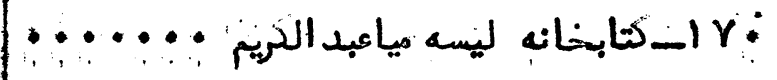

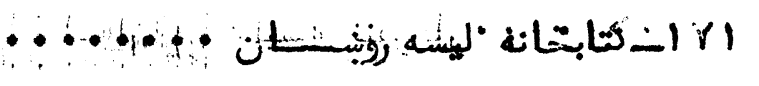

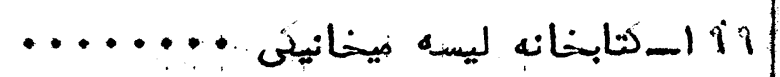

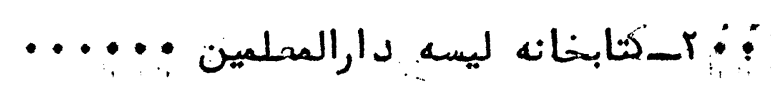
1.

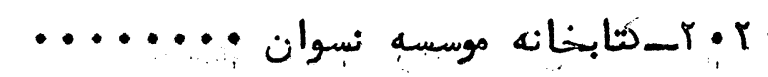

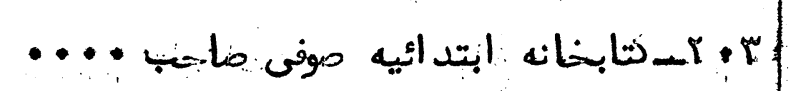

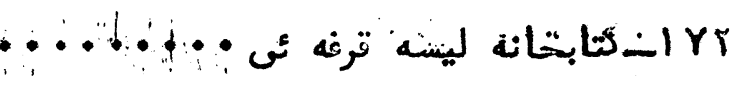

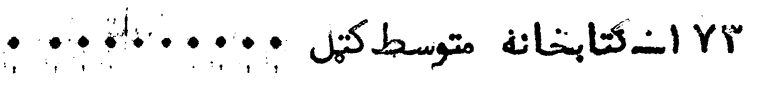

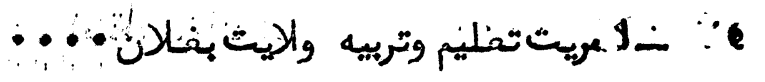

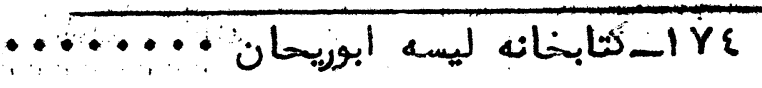
Y Yo

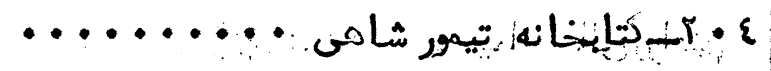

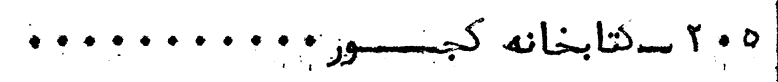

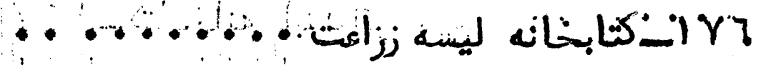

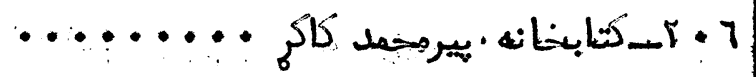

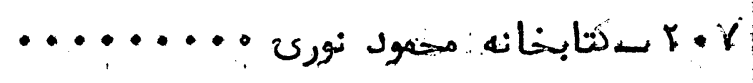

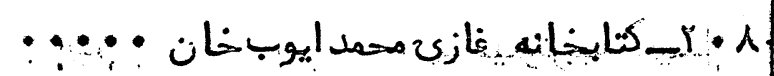

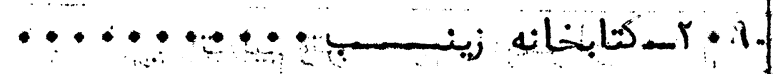

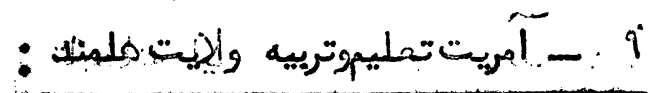

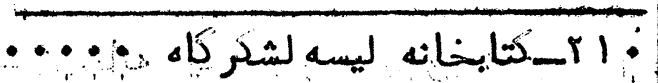

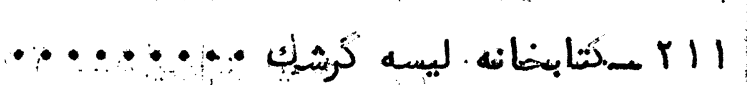

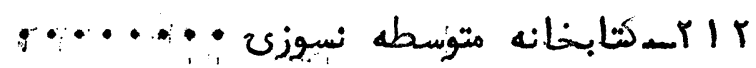

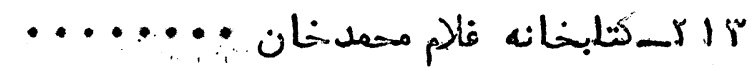

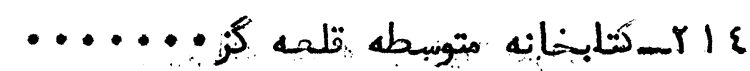
1 1 1

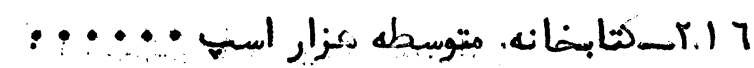

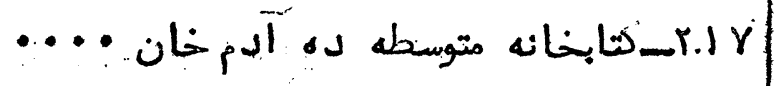
|

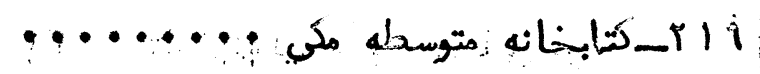

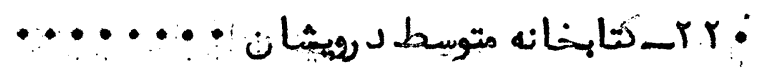
:

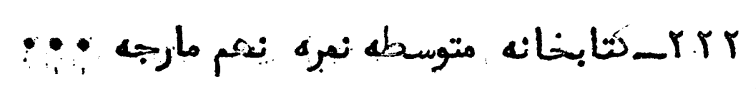

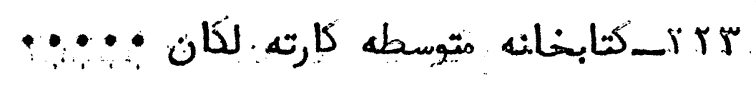

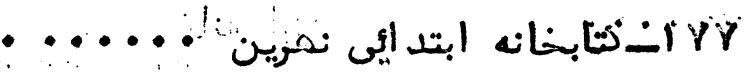

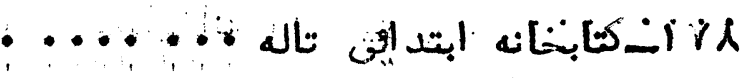

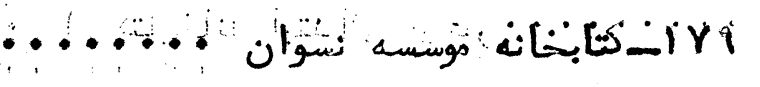

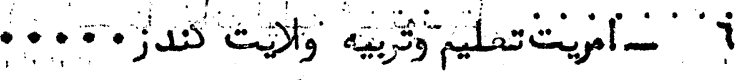

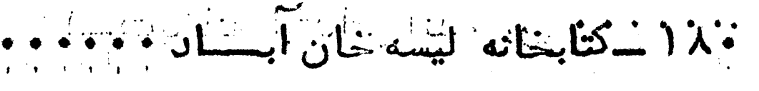

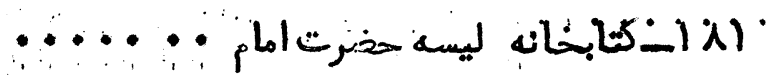

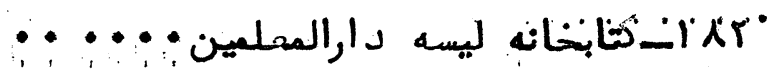

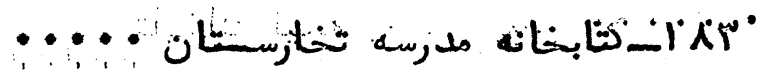

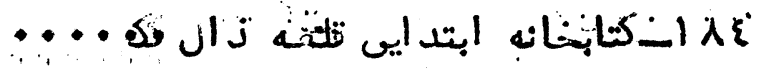

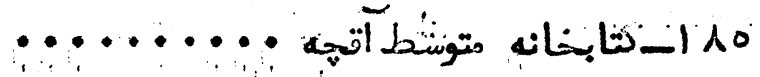

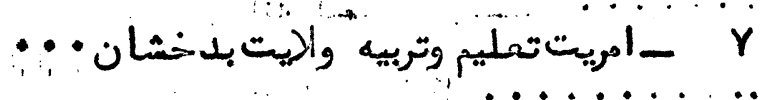

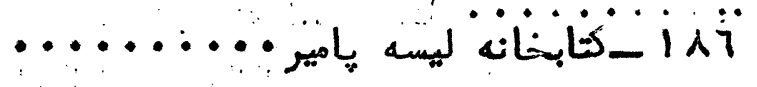
גir

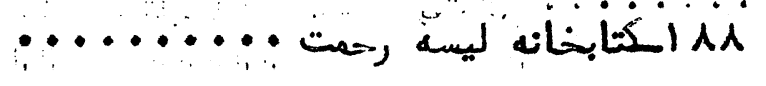

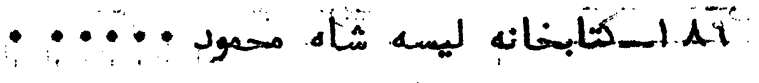

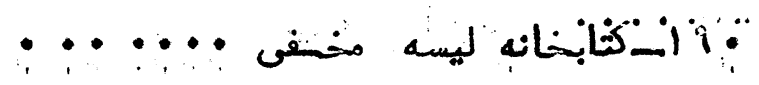

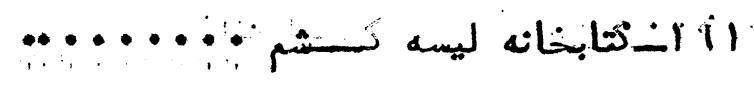
مان

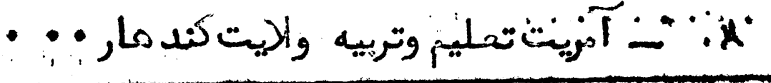

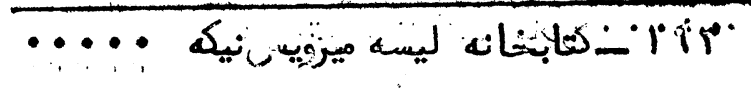

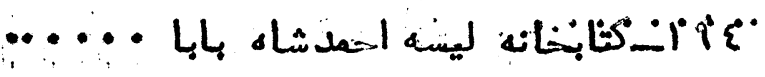


$-\operatorname{rrt}=$

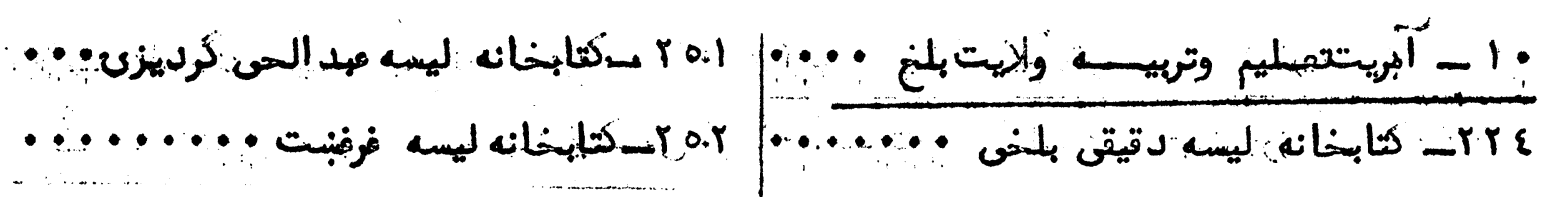

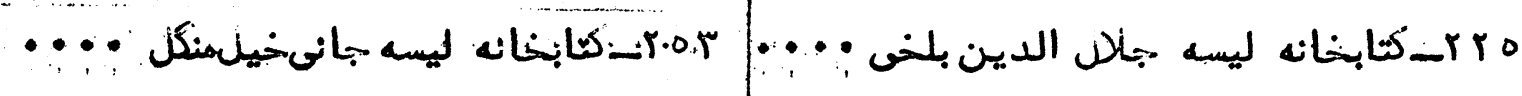

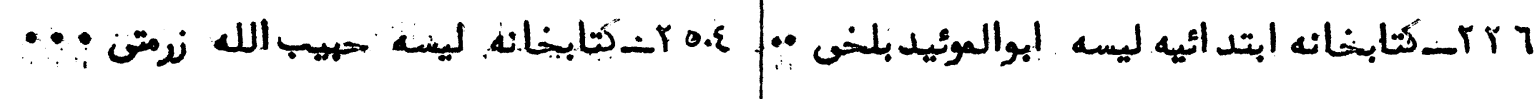

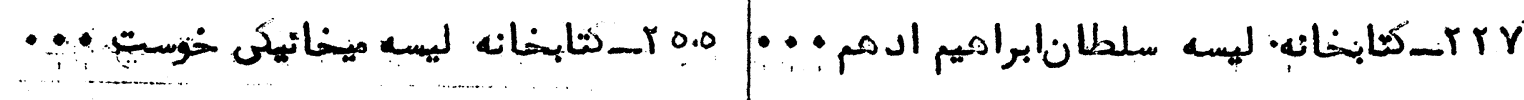

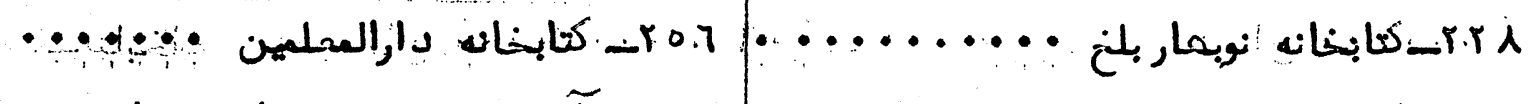

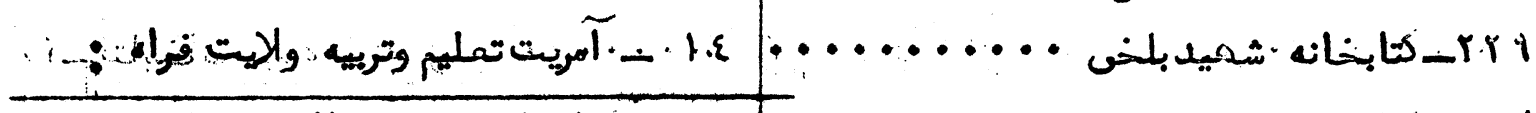

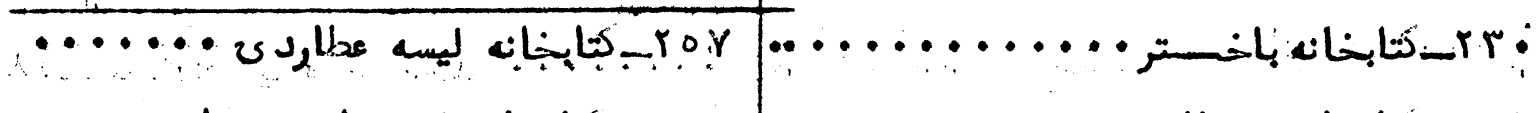

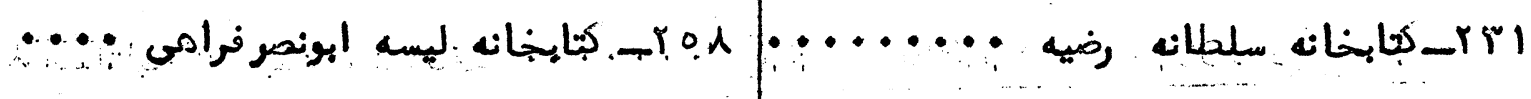

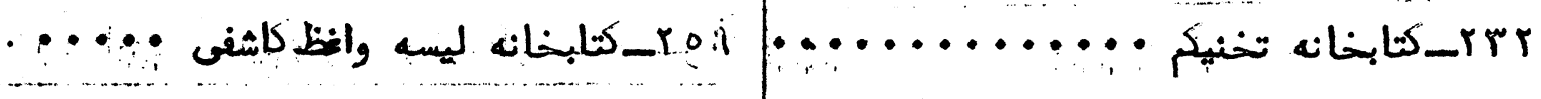

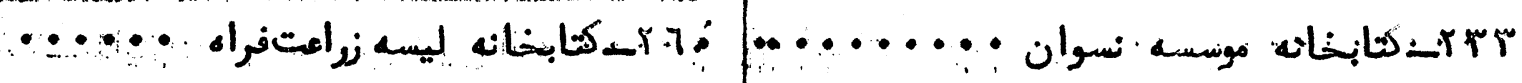

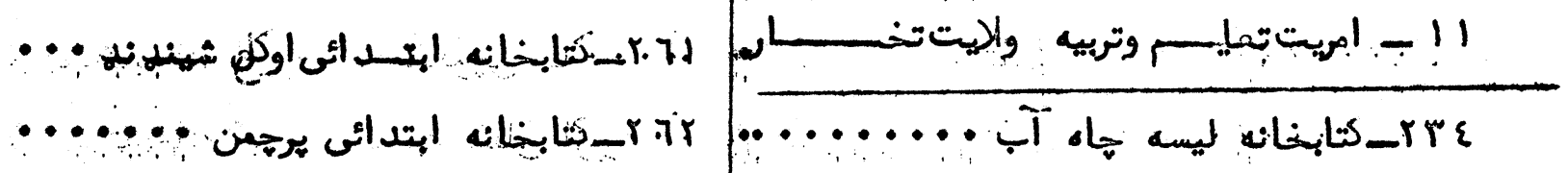

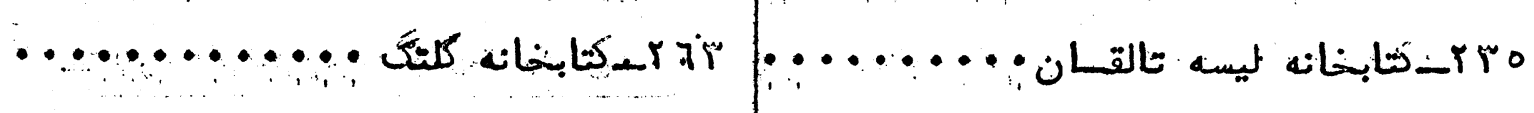

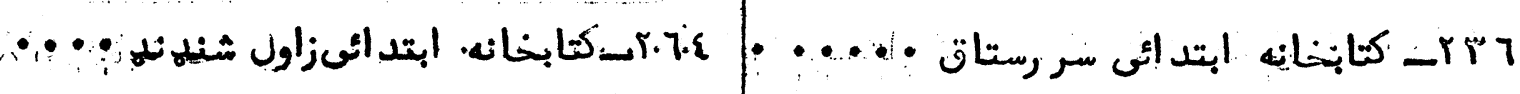

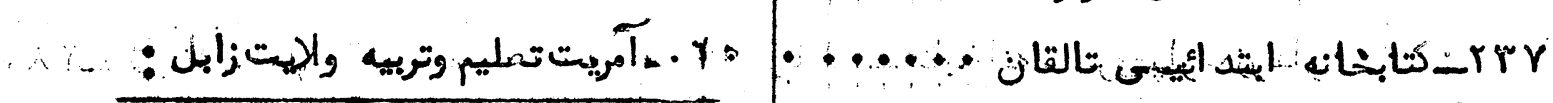

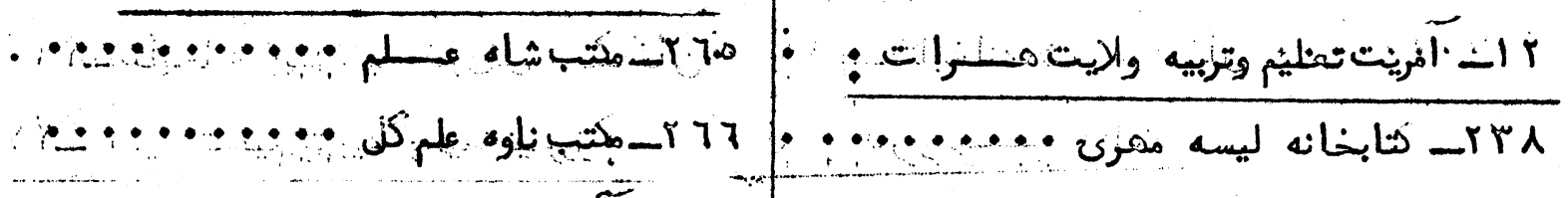

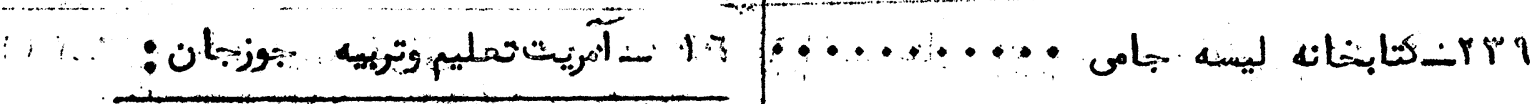

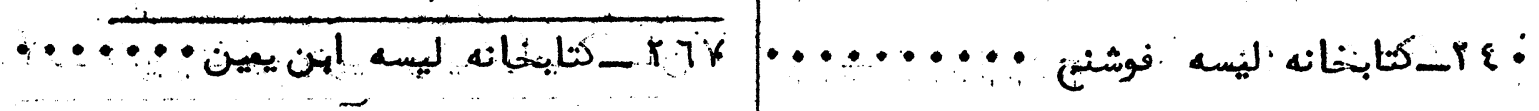

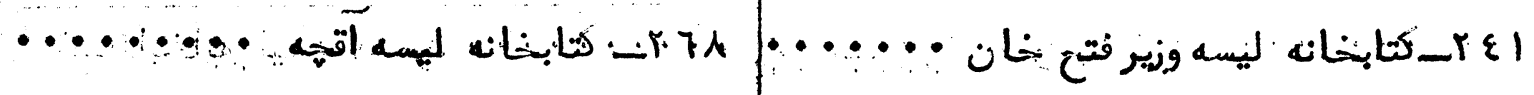

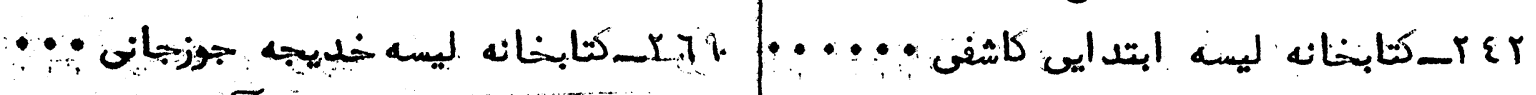

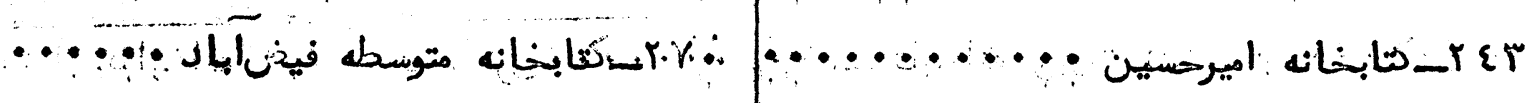

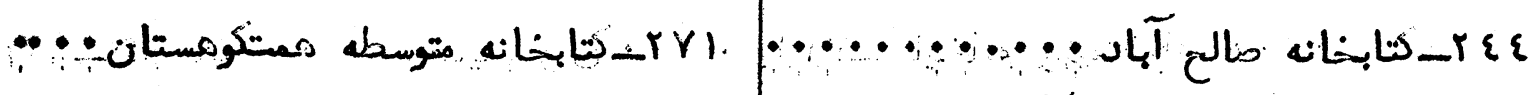

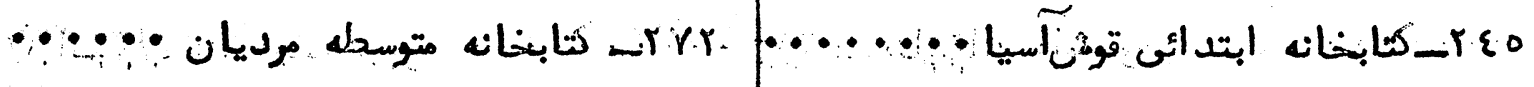

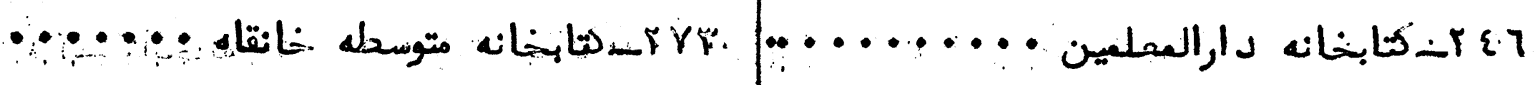

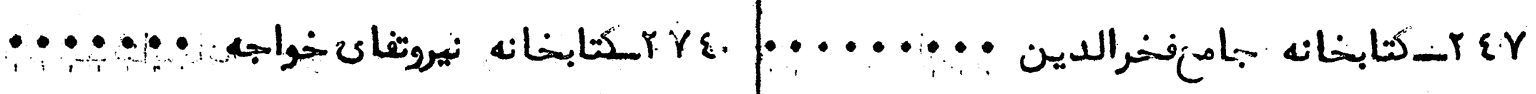

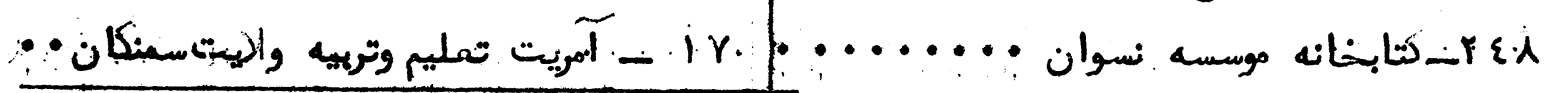

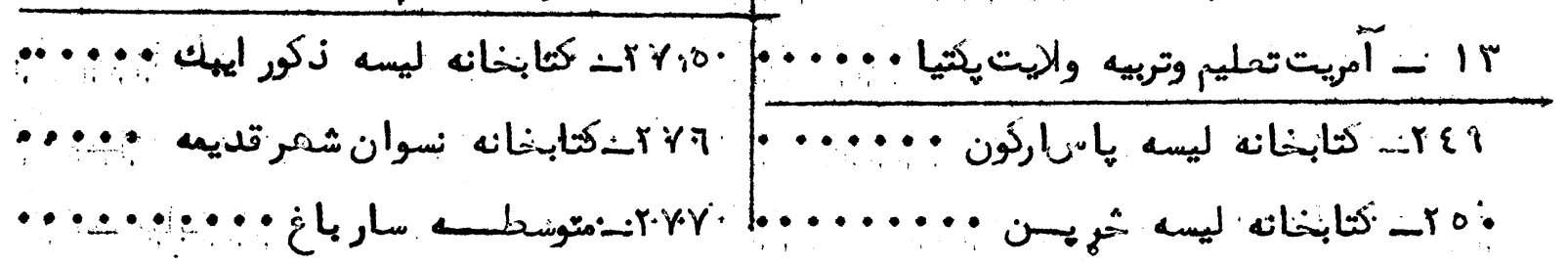




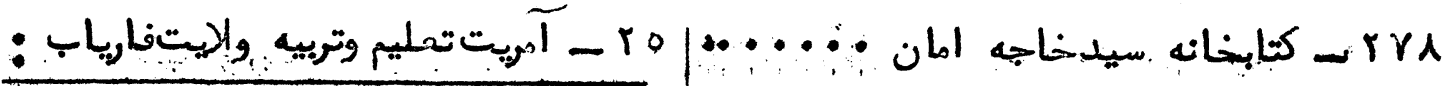

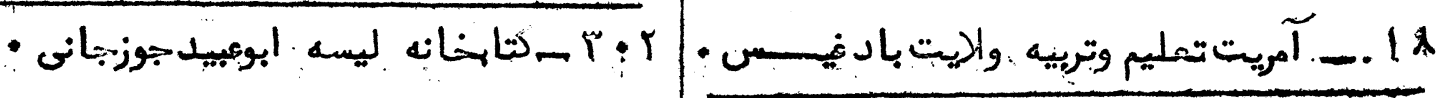

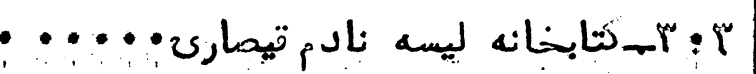

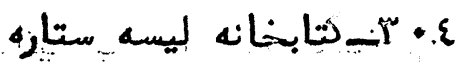

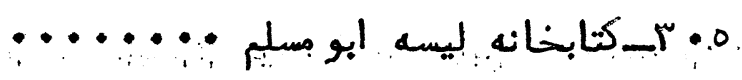

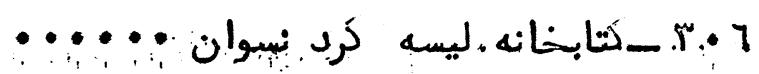

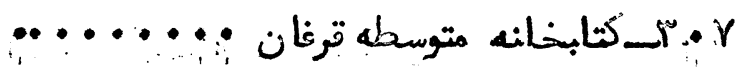

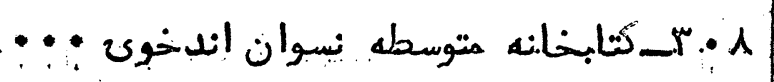

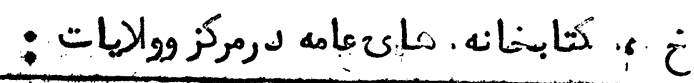

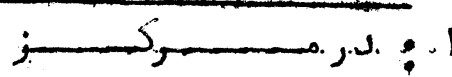

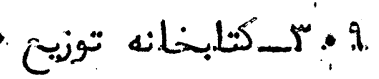

".

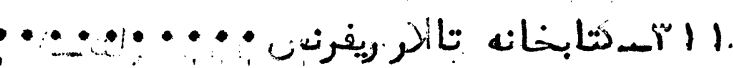

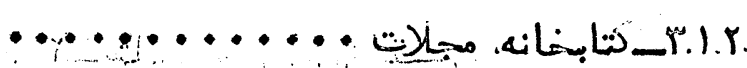

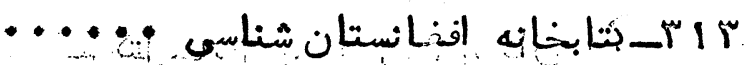

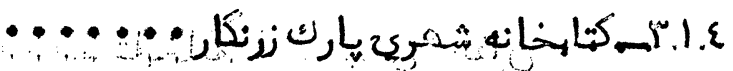

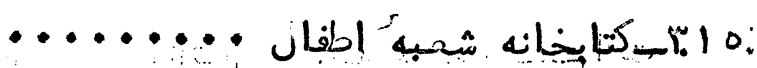

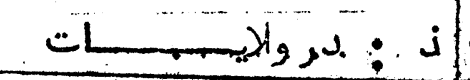

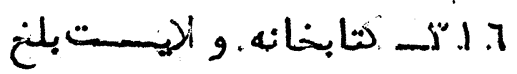

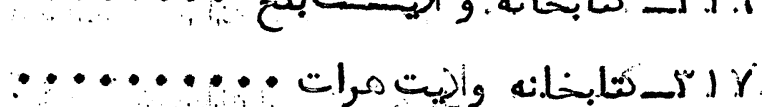

ه

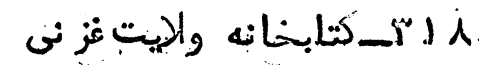

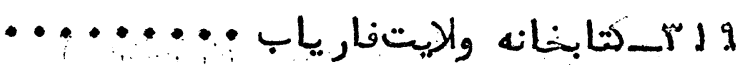

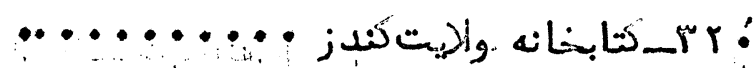

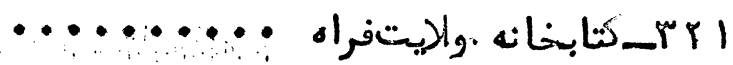

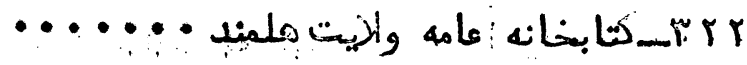

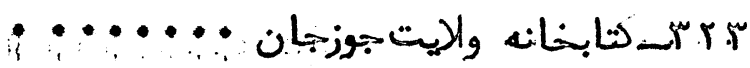

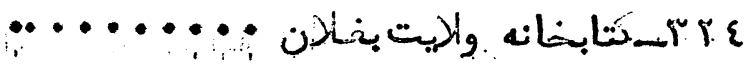

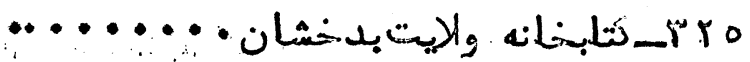

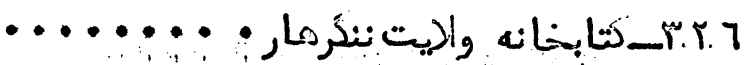

م

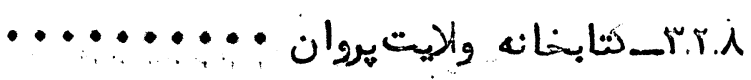

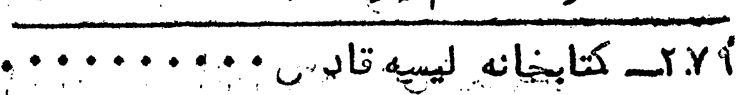

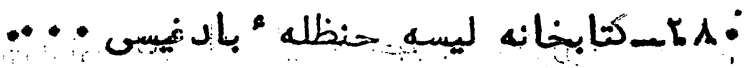

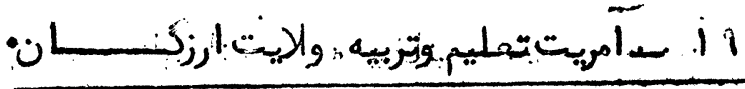

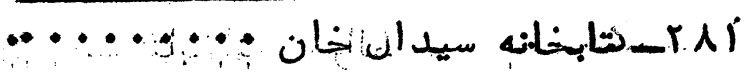

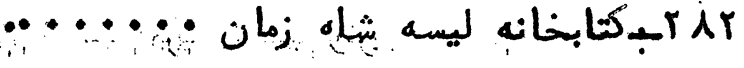

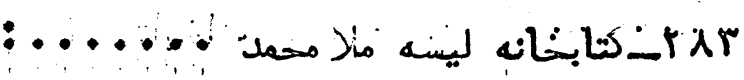

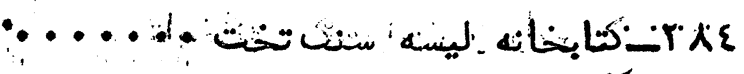

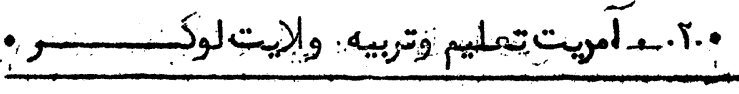

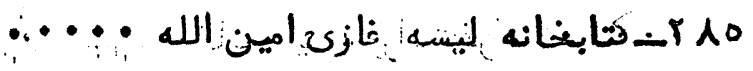

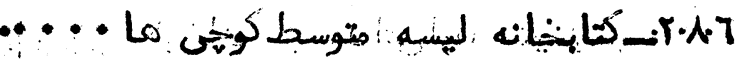

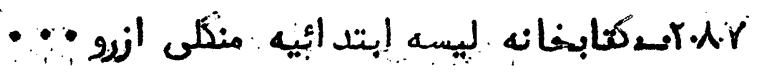

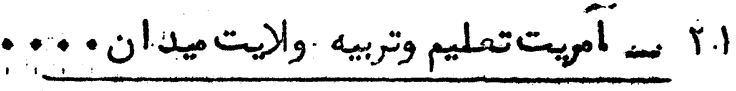

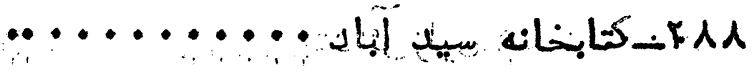

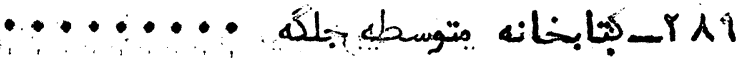
:

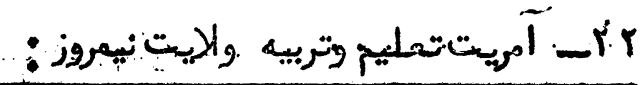

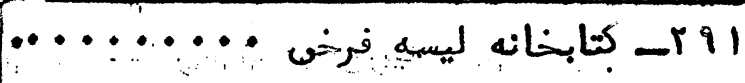

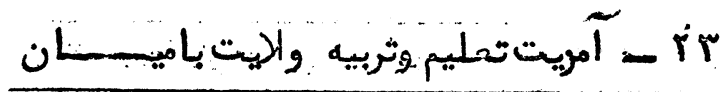

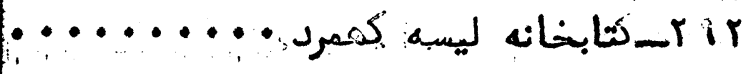
ع نا

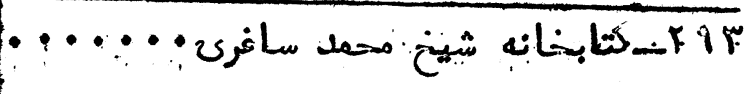

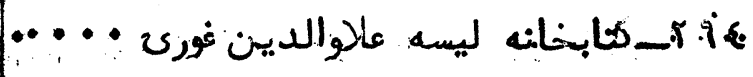

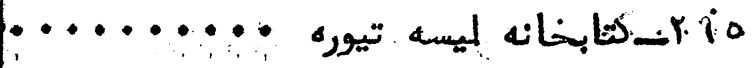

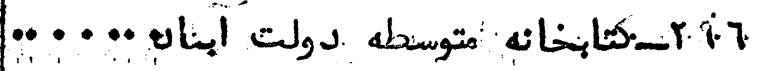

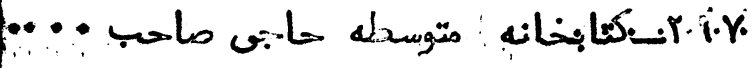

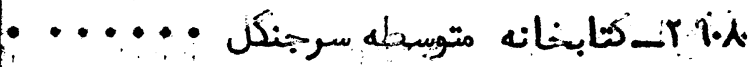

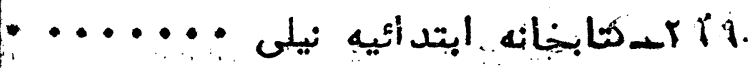

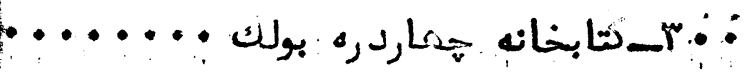

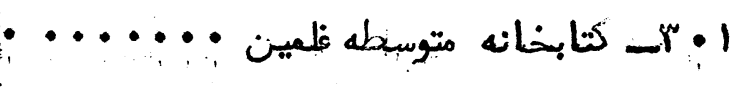


.

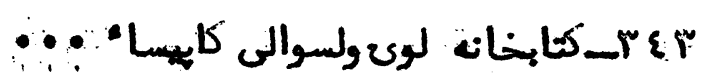

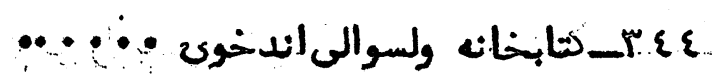

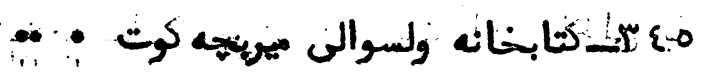

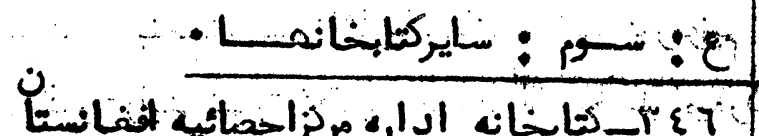

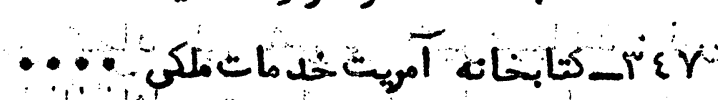

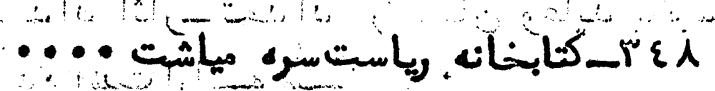

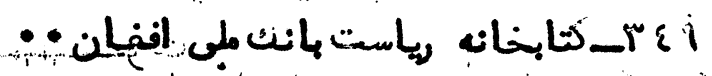

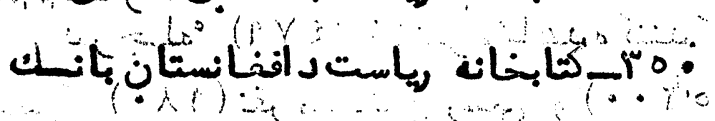

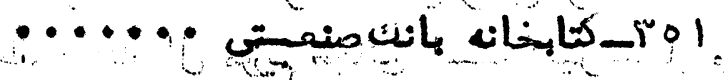

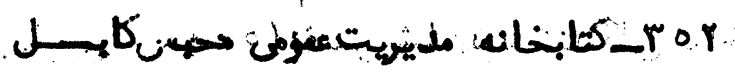

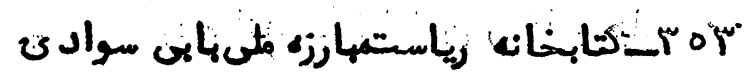

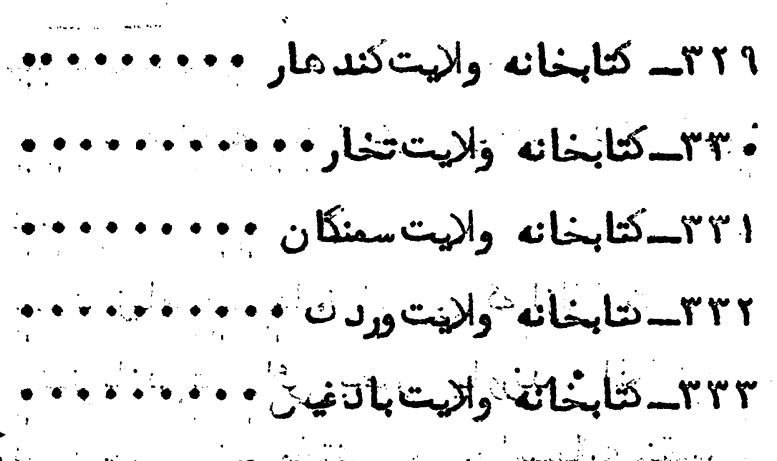

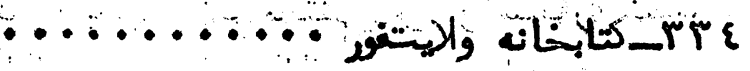

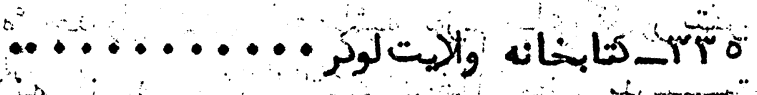

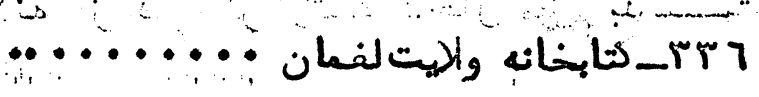

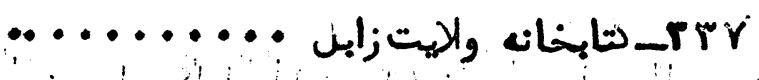

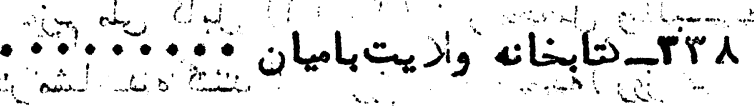

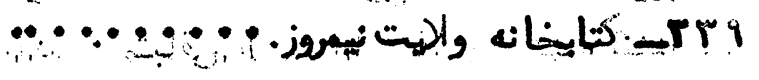

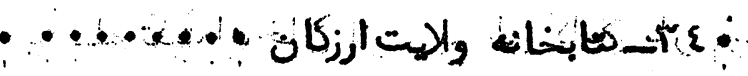

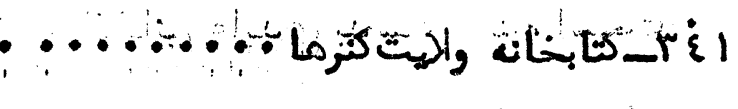

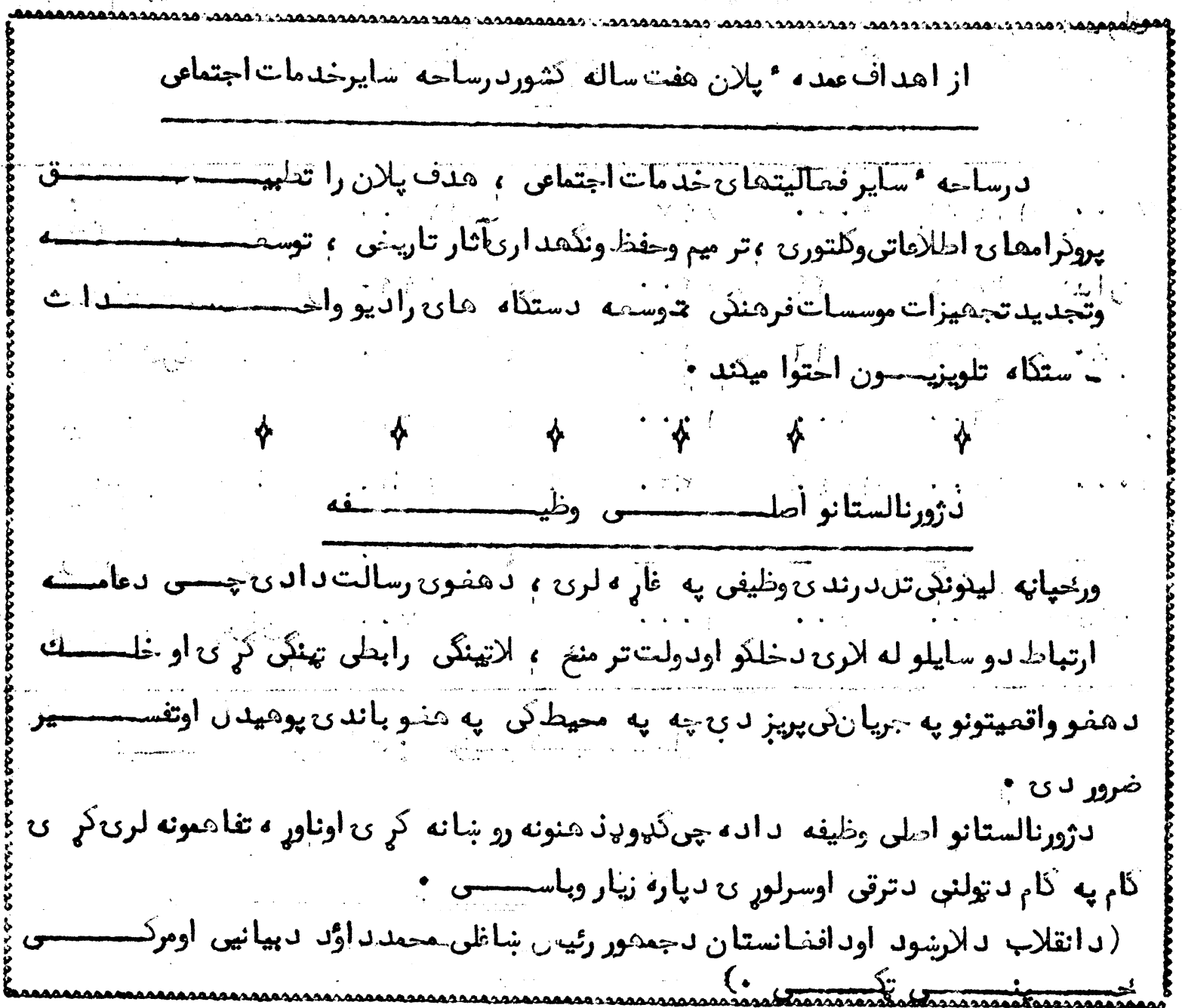




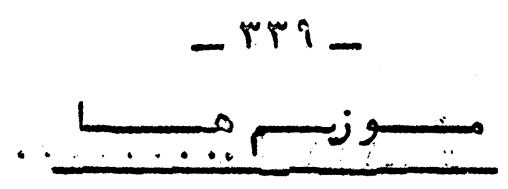

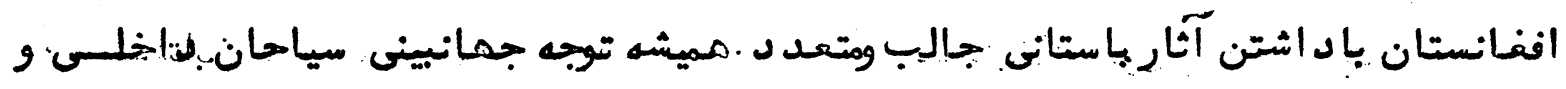

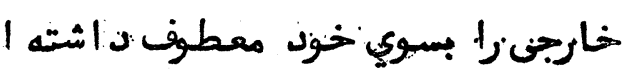

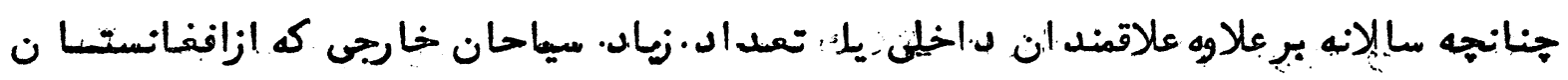

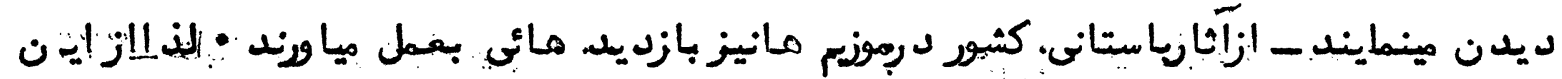

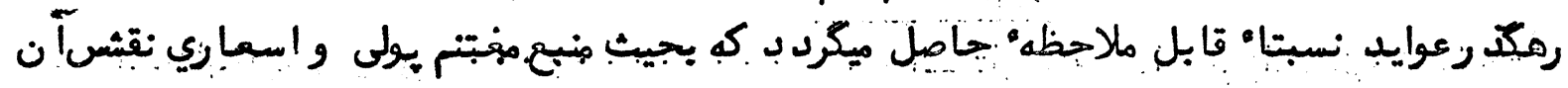

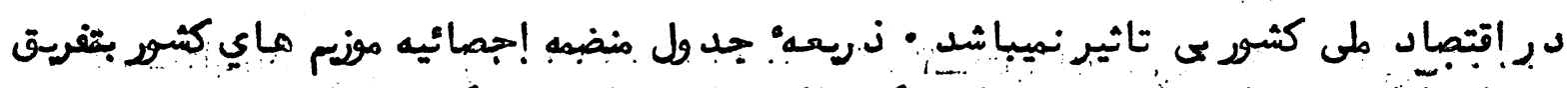

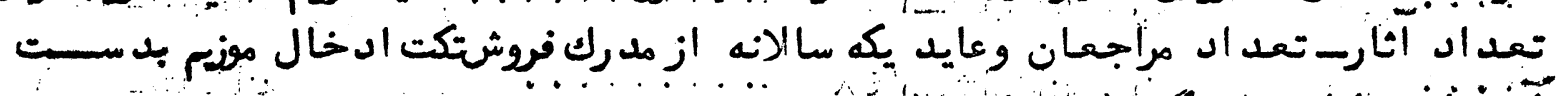

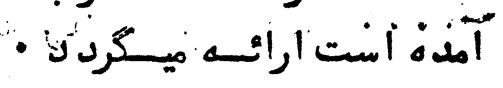

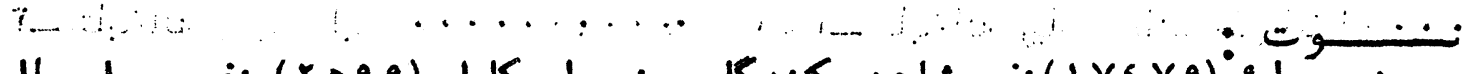

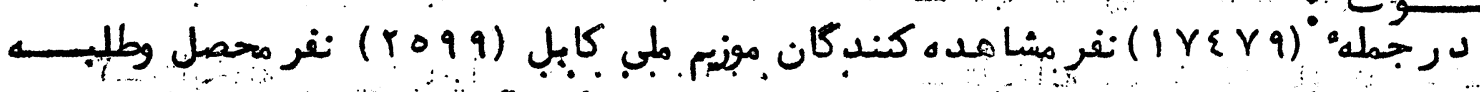

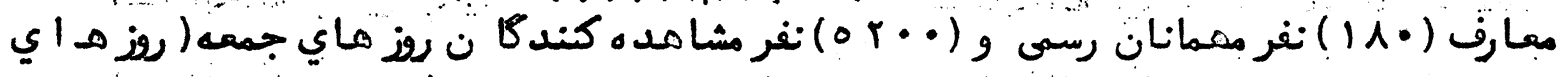

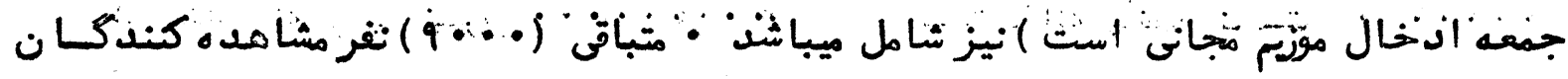

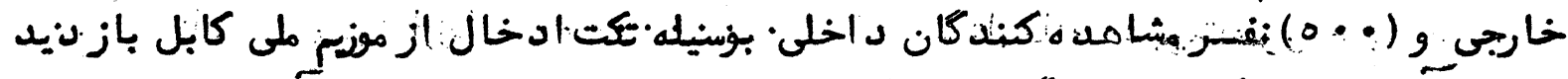

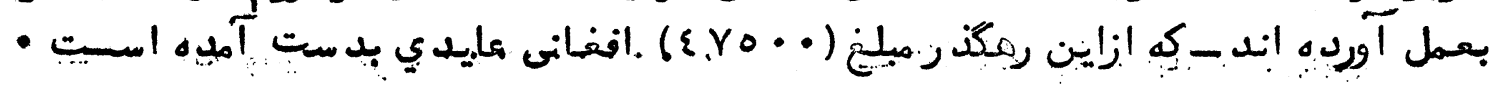

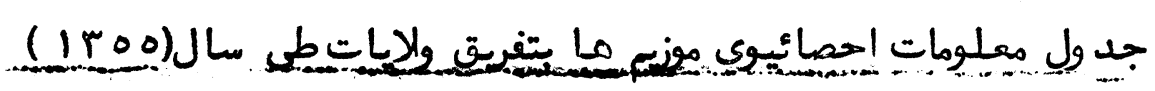

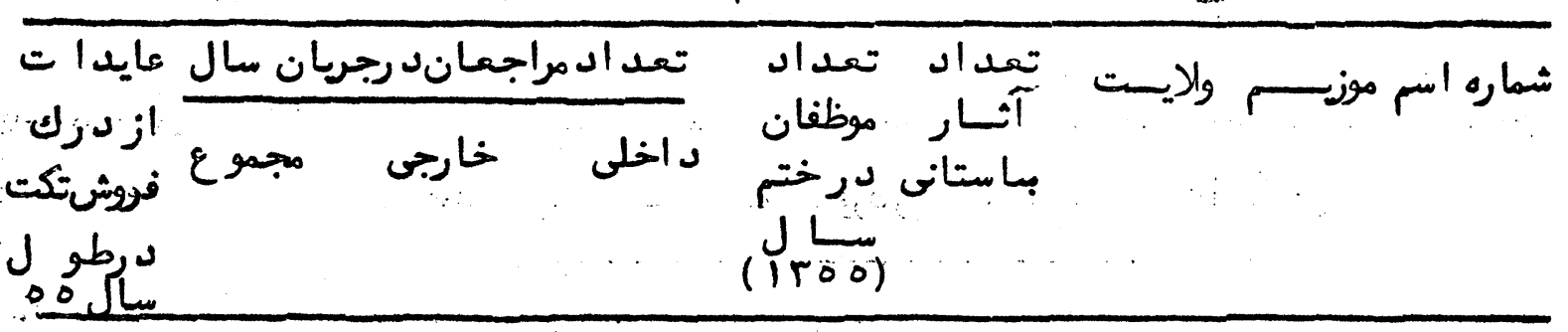

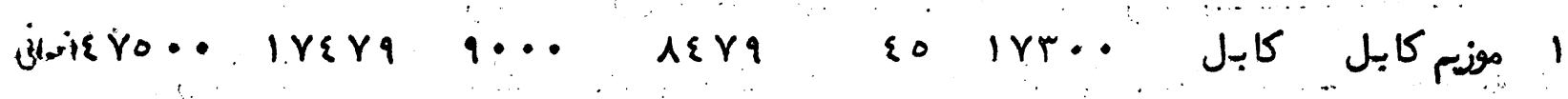

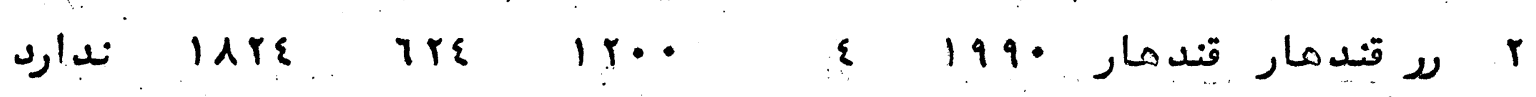

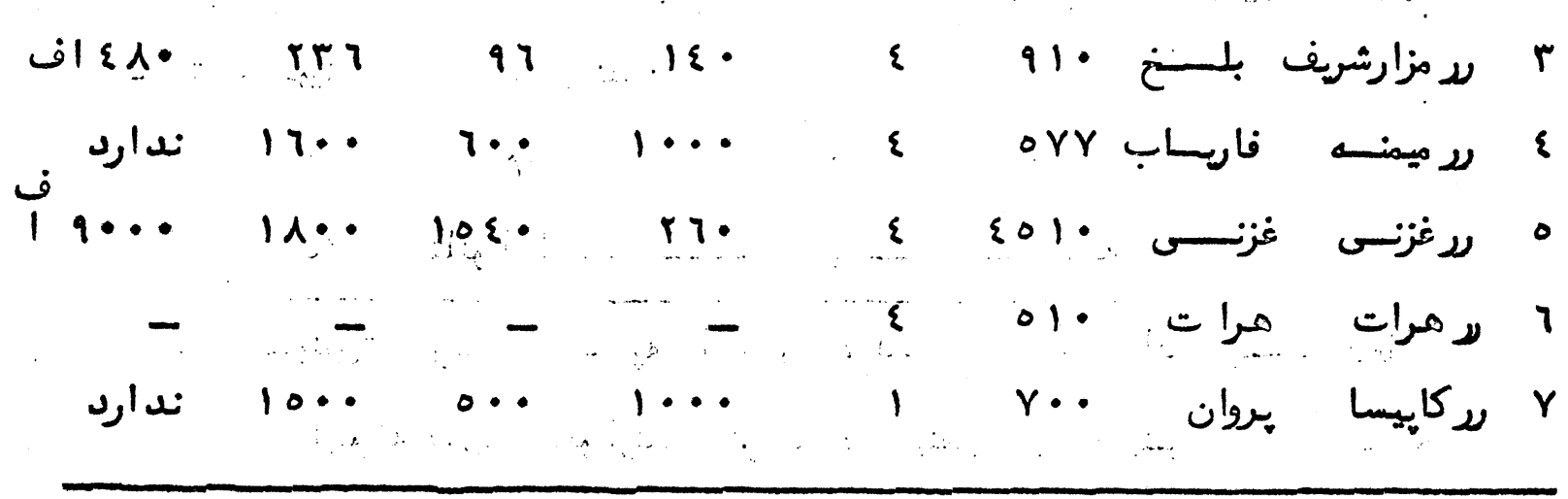

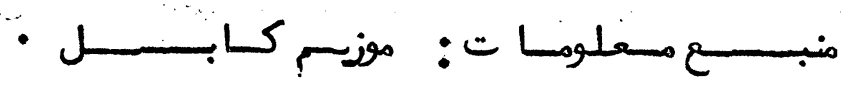

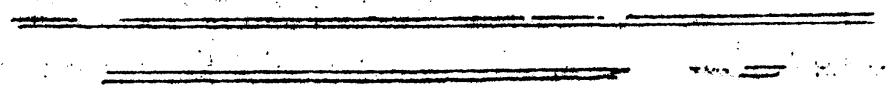




$$
\text { - }
$$

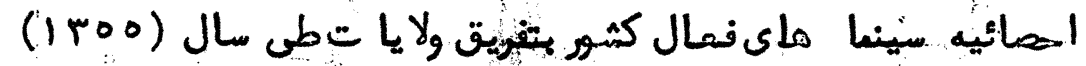

\begin{tabular}{|c|c|c|c|c|}
\hline \multirow{2}{*}{ ظرفزيت بنه هيوكى } & \multicolumn{2}{|c|}{ C } & \multirow{2}{*}{ ما هيــــــقنى } & اســـ ستينمـا \\
\hline & $=y_{9}$ & مسـركــــ & & \\
\hline 014 & & مركسز & دولتس & ا- سينًا \\
\hline irr & & נע & آريانLا & r- נر \\
\hline זיר & & נر & كابل ننداري & r \\
\hline b09 & & נر & زينـــــــب & ع- נر \\
\hline $1 \cdots r$ & & נر & بريكـــو ت & - - נر \\
\hline 101 & & נر & اقبـــــــال & ד- נ; \\
\hline 10. & & עر & فـرخــــــ & - צ- ענ \\
\hline ०ᄉ. & & עر & باخــــــــر & ג- ענ \\
\hline vrr & & $\nu$ & بهارستـان & 9- נر \\
\hline $1 \cdot 7$ & & נر & تيمورشا هـس & 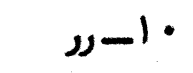 \\
\hline ० ६० & $\therefore$ & נر & ميـرويــــن ن & -11 \\
\hline $9 \cdot 1$ & & رנ & اريســــو ب & 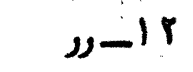 \\
\hline$Y Y \cdot$ & & נy & ميبــــو نـــــد & r \\
\hline ६४१ & لايسـت & & ميمنـــــــــــ & 位 \\
\hline $7 \cdot$ & & נر & 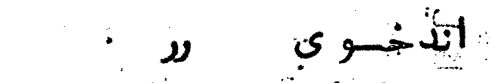 & 10-رנ \\
\hline rot & & נر & 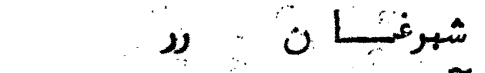 & 17 1- \\
\hline$r r \cdot$ & & ננ & آقيهـــــــ & V \\
\hline ory & & עل & سريســــــل & גו-رנ \\
\hline $07 r$ & & زر & كنـــــــــــ & -19-رנر \\
\hline$r \cdot \cdot$ & , & 'נر & خان آبــا د & r. \\
\hline$\varepsilon \varepsilon \cdot$ & , & קر & يلخمســـ ني & ו ו-צנر \\
\hline$\curlywedge \varepsilon \varepsilon$ & & 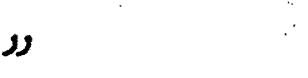 & مزار ننــــارى ر رנ & r \\
\hline$\varepsilon \curlyvee \cdot$ & $\therefore$ & נו & شاروالي نينكر ملار رر & זיז-קנ \\
\hline ory & $\because$ & נִ & "اريك: & ع \\
\hline$\varepsilon r q$ & $\therefore$ & : & هـــــــــــ رر & ro \\
\hline 700 & & 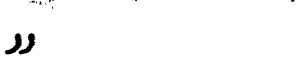 & كنــد مــــار & דיצ-נر \\
\hline$\varepsilon \cdot \gamma$ & $\because$ & נע. & هلمنـــــــــ & $y-r r$ \\
\hline rr. & $\because$ & ננ. & بلــــــــــ & גזי-נر \\
\hline$r \cdot$ & & נر & 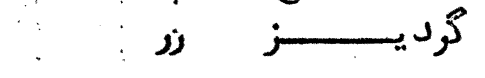 & q \\
\hline$r \cdot$. & & נر & خـــو سنــــت & • יז-رנ \\
\hline TY & & נر & نتــــ هنـار , رر & اוr-נر \\
\hline
\end{tabular}

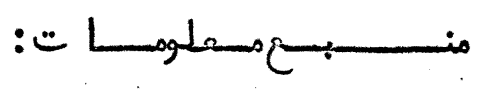

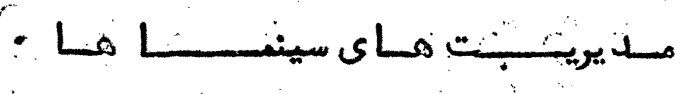




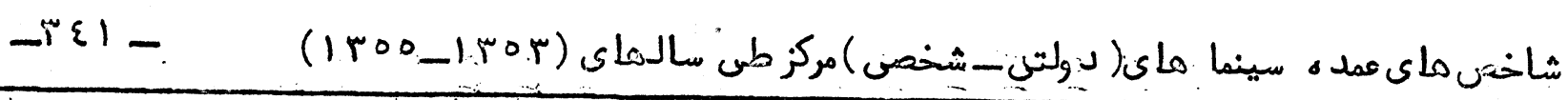

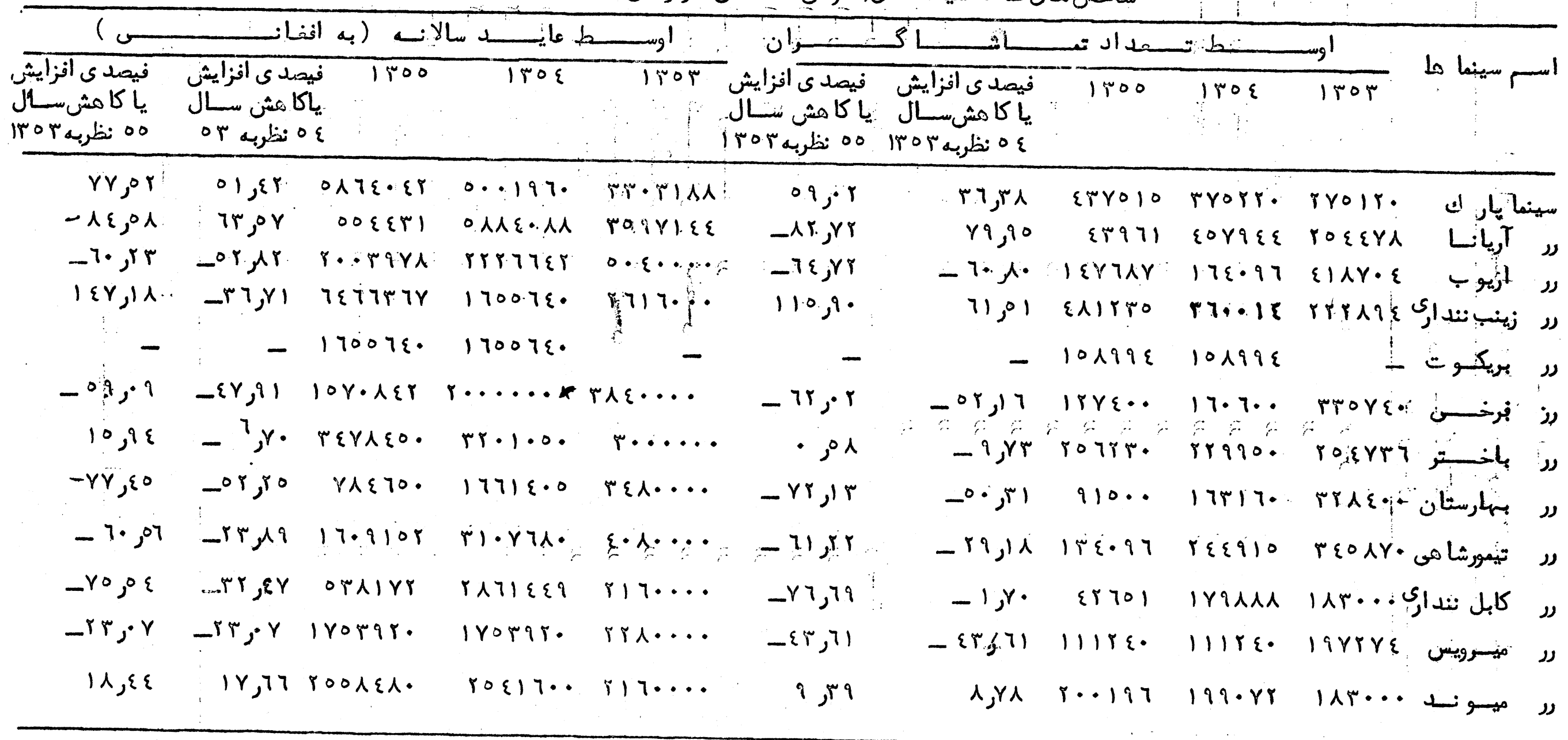

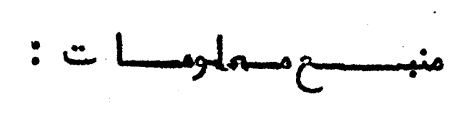

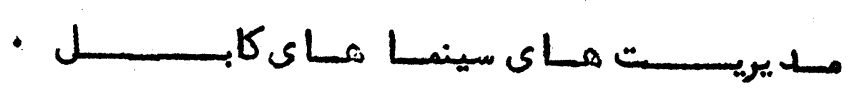




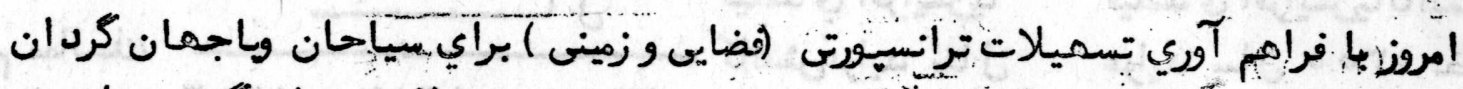

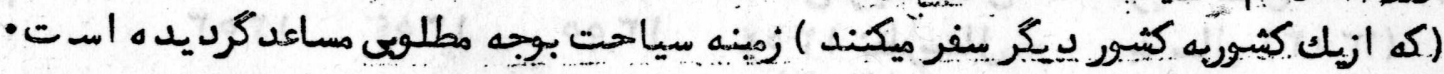

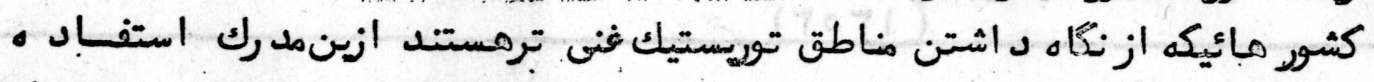

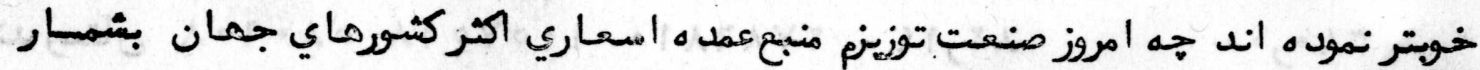

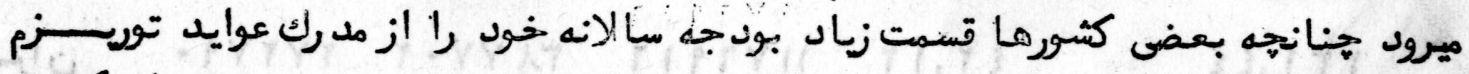

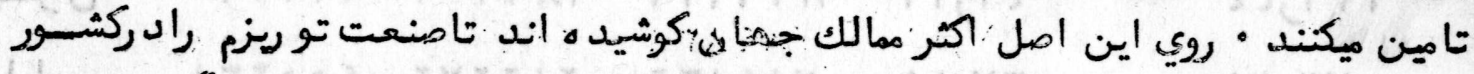

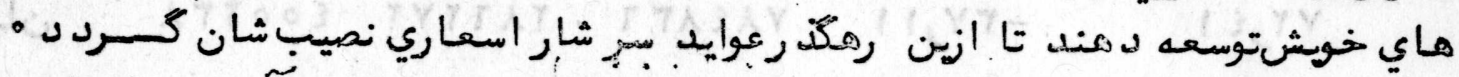

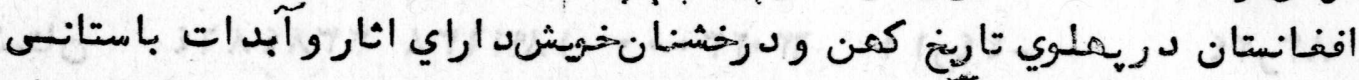

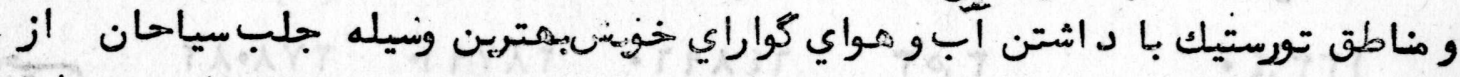

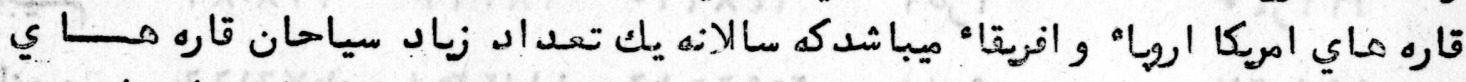

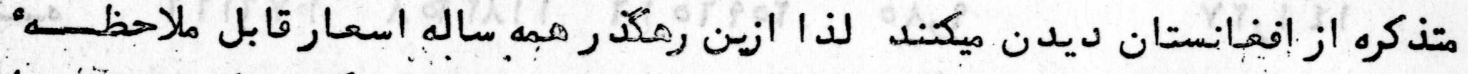

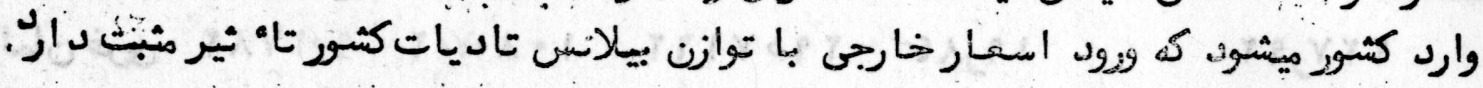

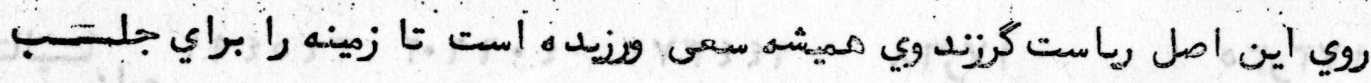

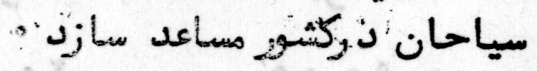

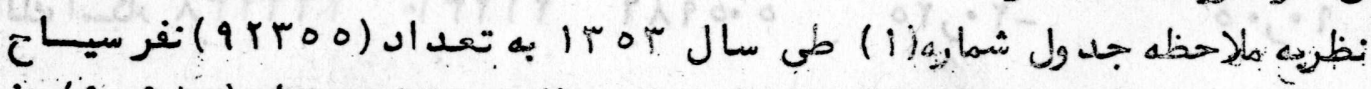

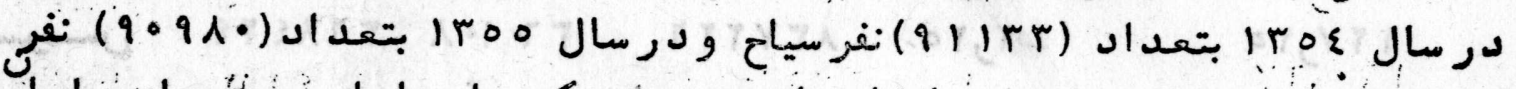

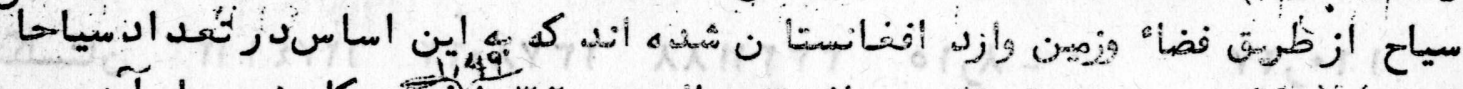

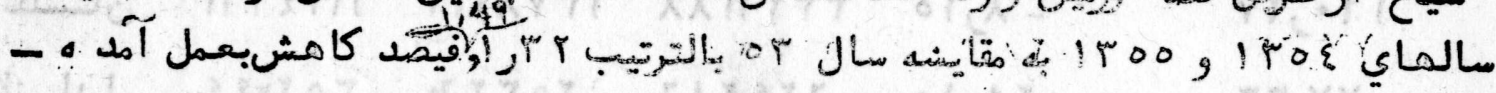

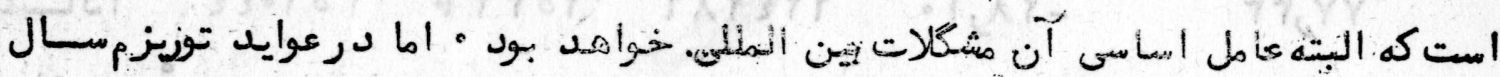

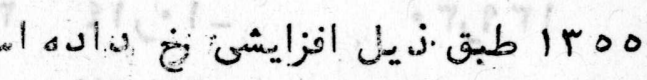

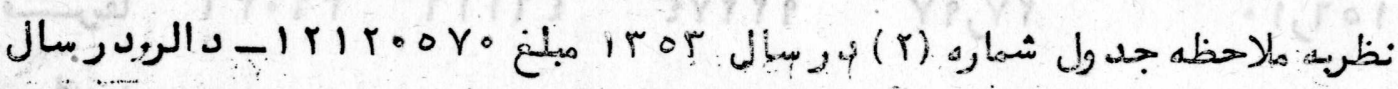

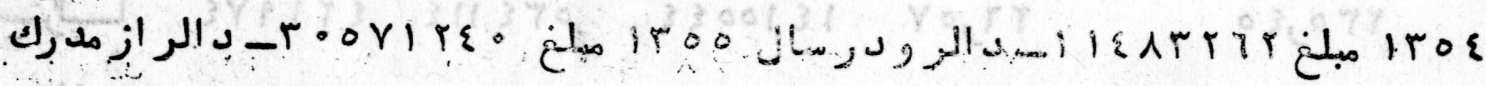

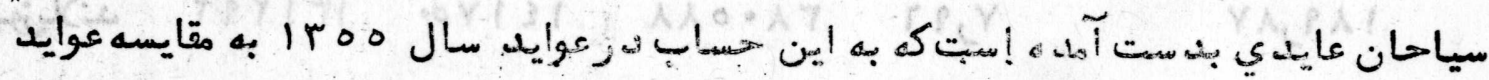
سال

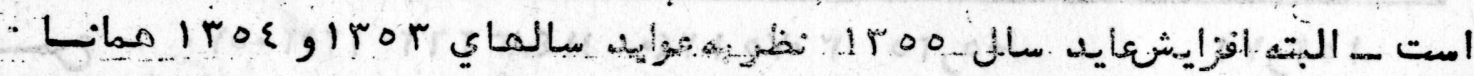

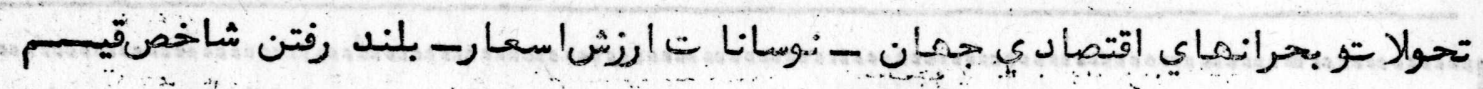

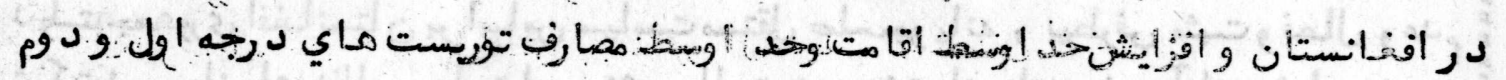

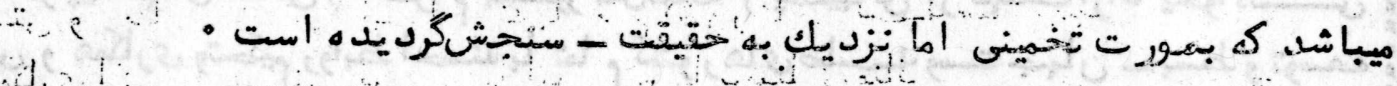




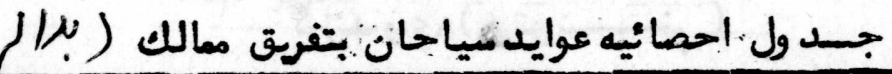

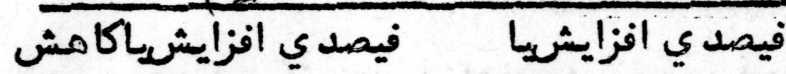

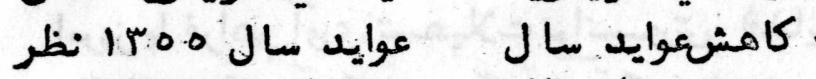

به سال (Iror) J iros
(iror)

س س س

Iroo irog iror the

$r \wedge \cdot, \cdots$

rr

$Y Y,\{1$

Ar, $r \varepsilon$

Irr, •

$1 \varepsilon 1, \mathrm{rV}$

rrvgr

irrgo

$9 \cdot, \cdot 0$

IrY, ro

$17 \cdot, 7 r$

rr,rr

ir

$107,1 \cdot$

$r r o, \varepsilon 0$

$1 \wedge 9, \wedge \mathrm{r}$

rol
AT, I\& TVATAI

$\{r, \boldsymbol{r}$

1187917

$-r v, 11$

YAะATY

$-\varepsilon\{;$

ror

$7 \varepsilon 197$.

9,1

ro9701

19,1

IV,TA

ใะะน

$-r \cdot r_{0}$

0.0917

$-r, r o$

ArYPrT

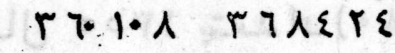

$-1,1$

rrtIN

$-r \wedge, 1 \cdot$

TrEหน

$-1 \cdot 1$

rr,qr

9TrVE

rT, Or

$1 \varepsilon 100\{\varepsilon$

V,97

$r \wedge \cdot 0 \wedge \wedge$

r.,. E rrequrt

HYRer trrYq.

MATYT EOOTHA

يسران

جايان

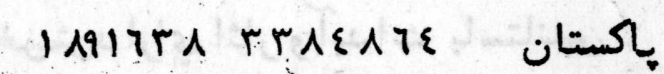




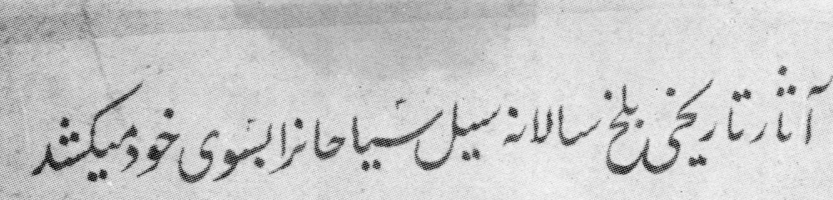

(10.)
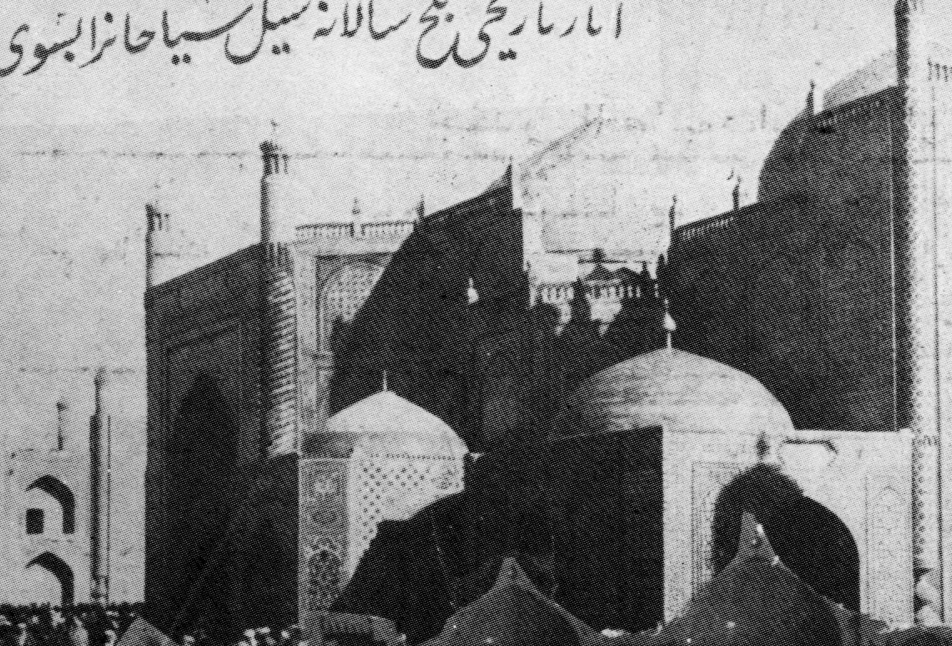

1 .

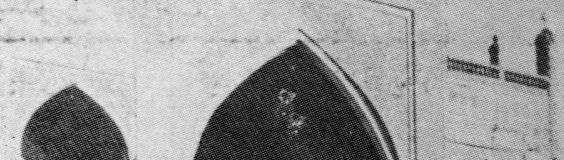

1

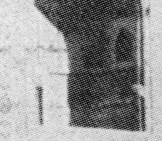

the

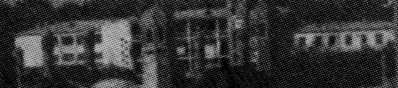

$2 \pi$

3:5:

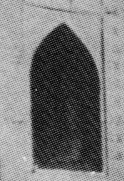

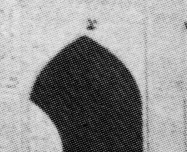

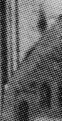

i.

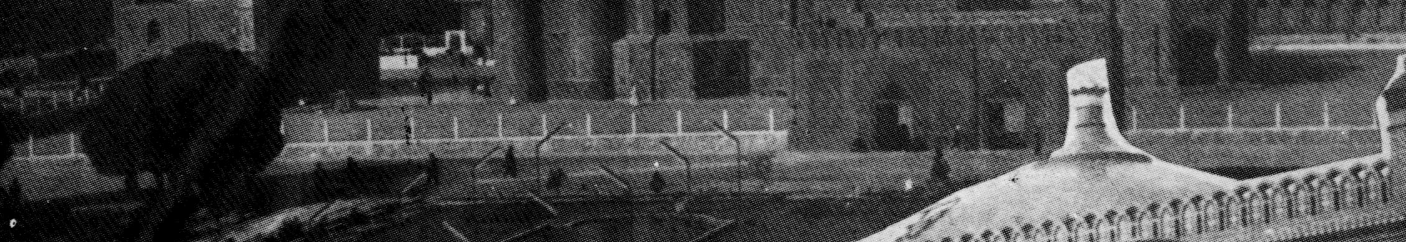

P.

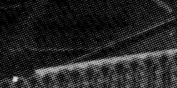

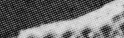

-
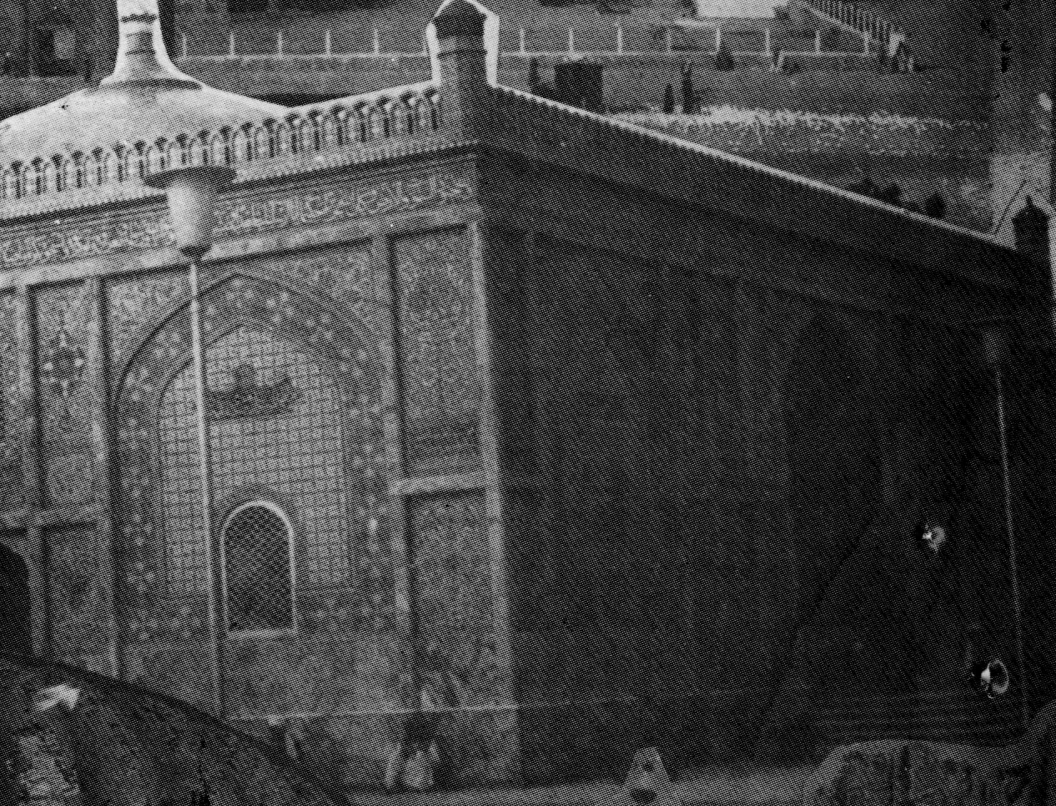

i

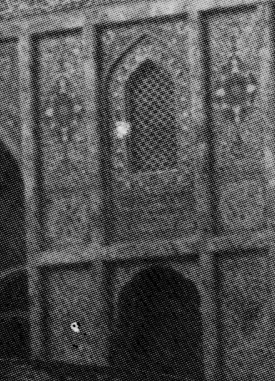

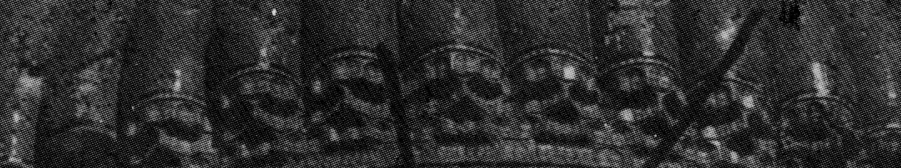

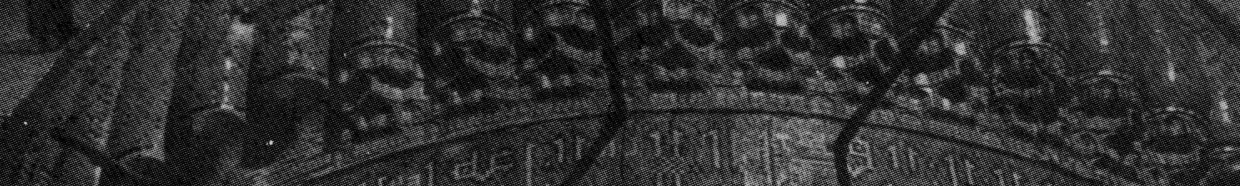

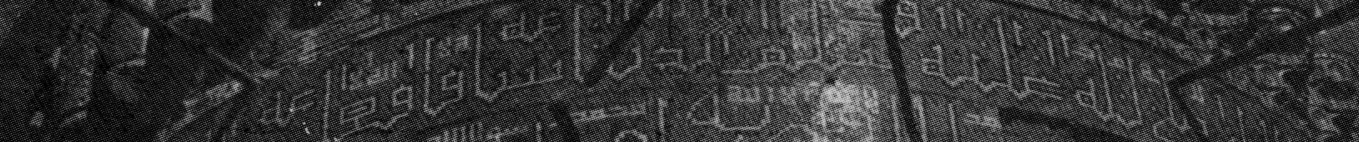

k1

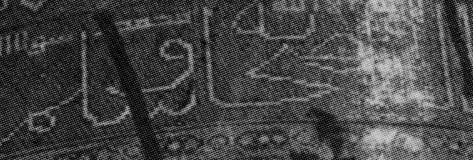

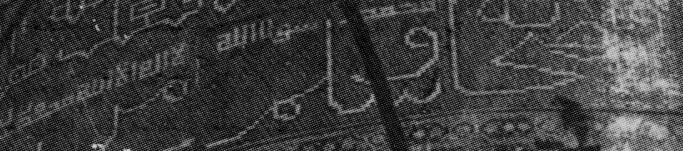

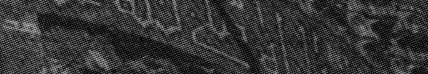

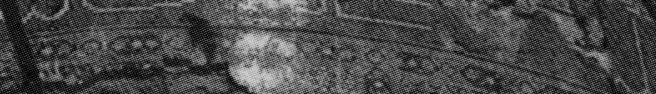

$\sin (0)$

(3)

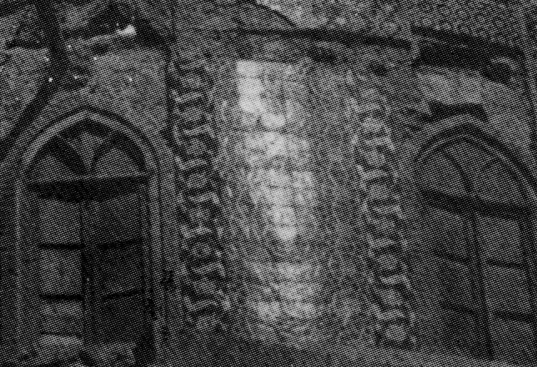


ك

كي ول الحمائيه سيا حان به تفريلق ممال

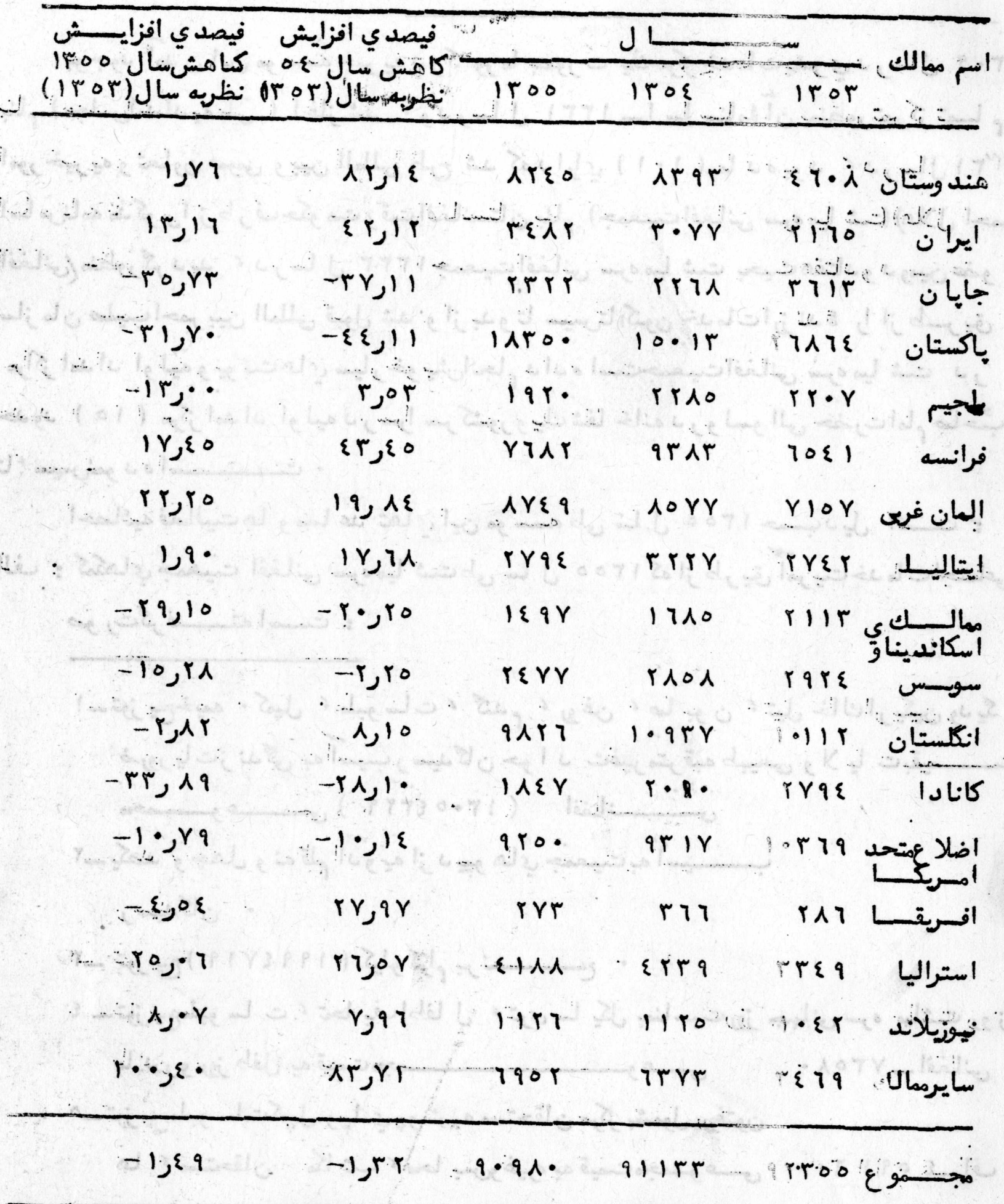




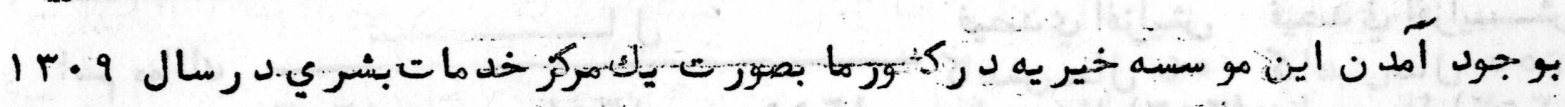

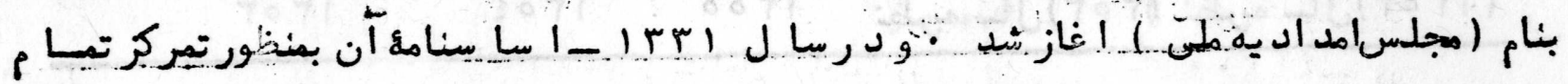

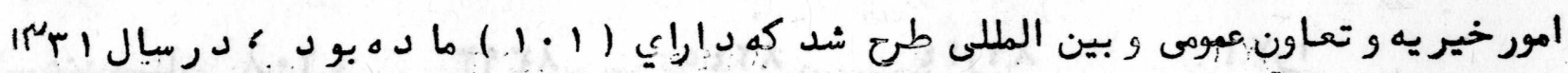

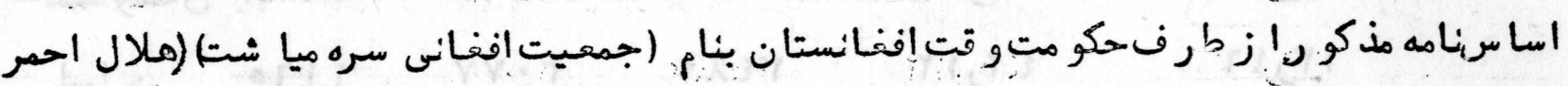

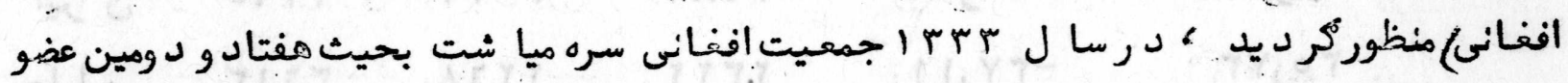

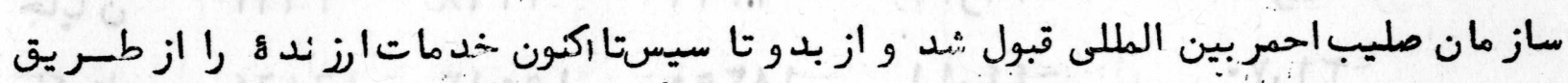

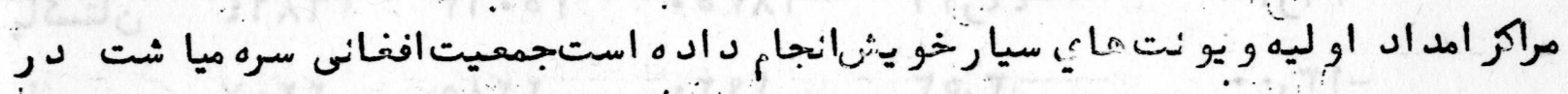

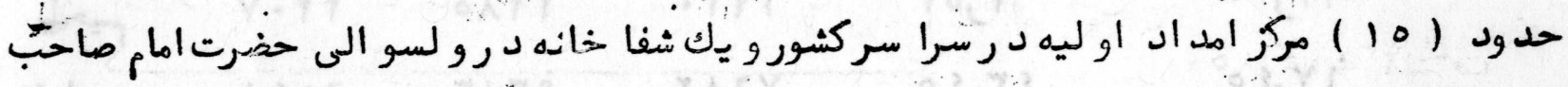

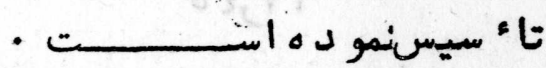

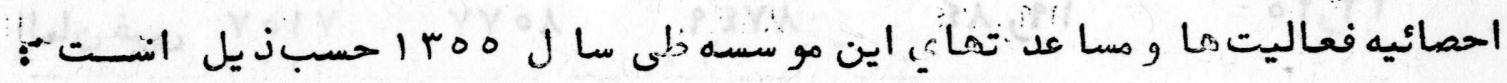

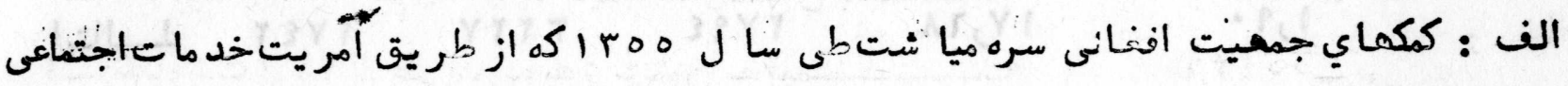
$-6$

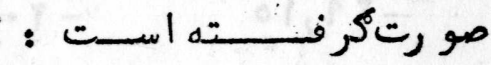

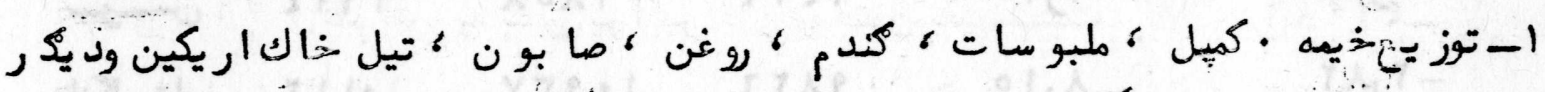

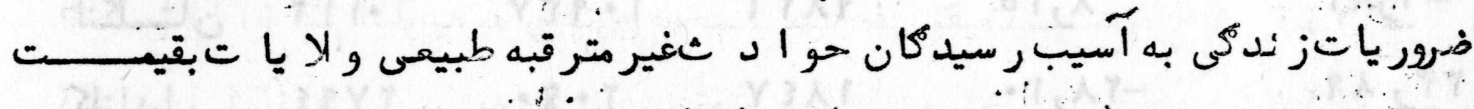

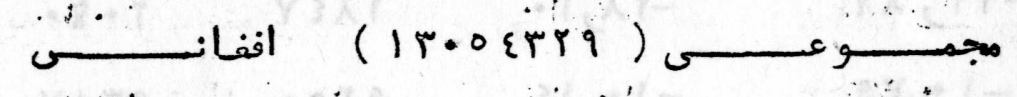

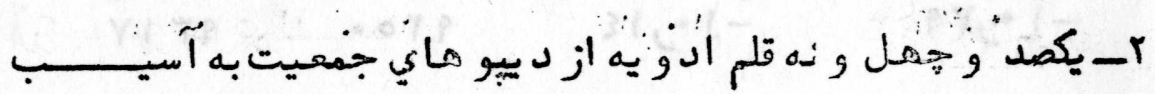
رسيد رئان - r

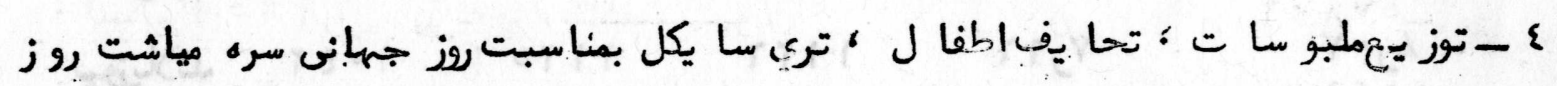

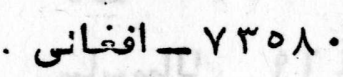

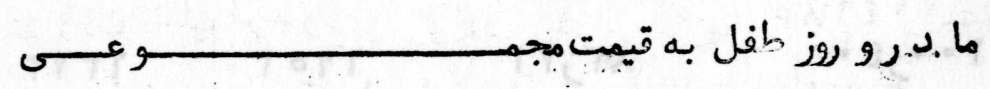

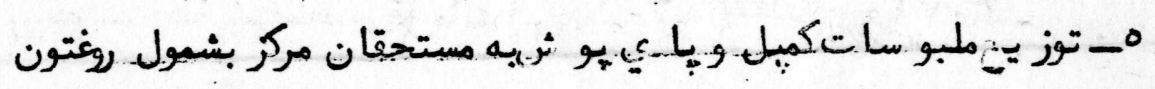

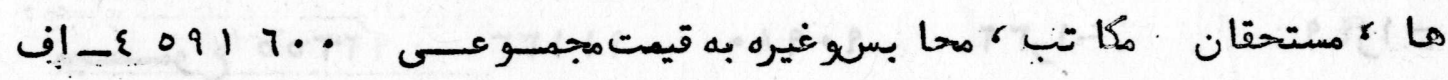
7

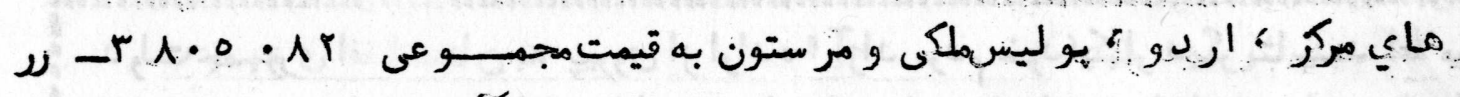

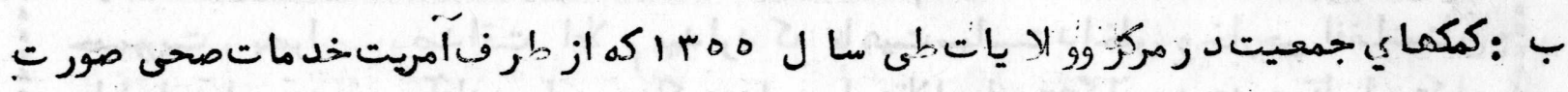

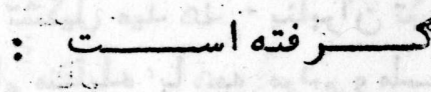

معاو نت هما ئيكه به روغتو ن هاي مركز وو لا يات مهور تكر فته و از آن براي مر يضان بى بضأغت

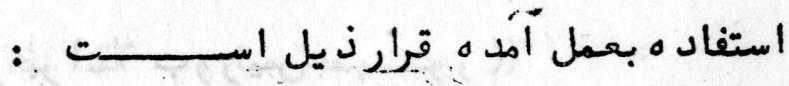

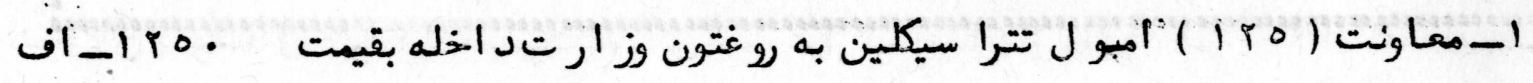
آ- لر ( ع ) قلم ادويه به قطعه منتظره يو ليسبه قيمستست 


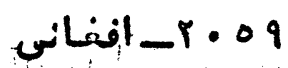

$$
\begin{aligned}
& \nu-1\{r 0 \\
& \nu-119 \ldots \\
& \nu-\{\varepsilon r \ldots \\
& \nu-\varepsilon \ldots \\
& \nu-1 . \ldots \\
& \nu-r \cdot 79
\end{aligned}
$$

r معاونت يك بكسكمكا ر، او ليه بوز ارت د ا خله به قيمست

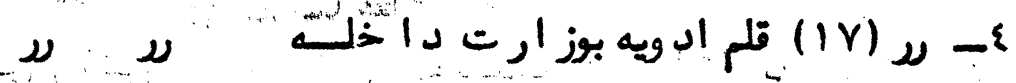

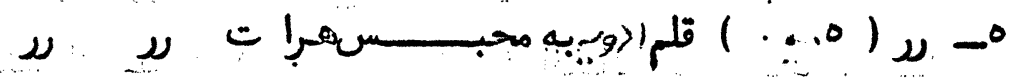

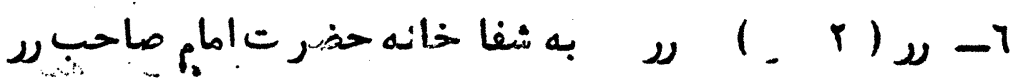

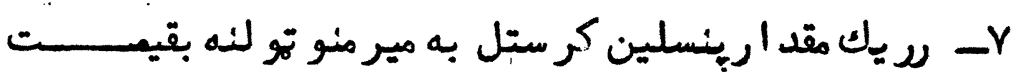

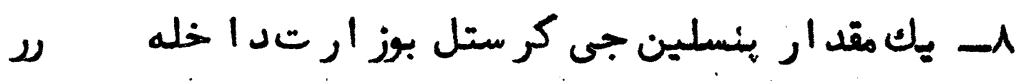

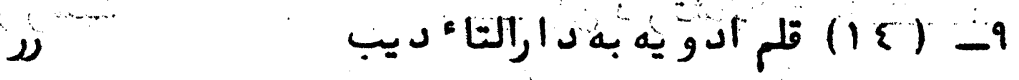

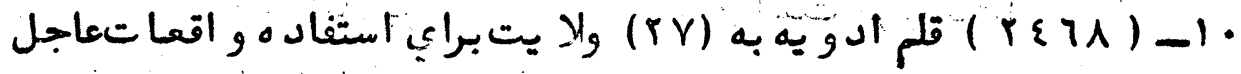

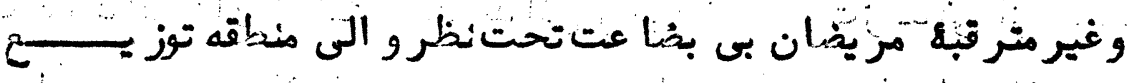

ف군.

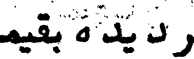

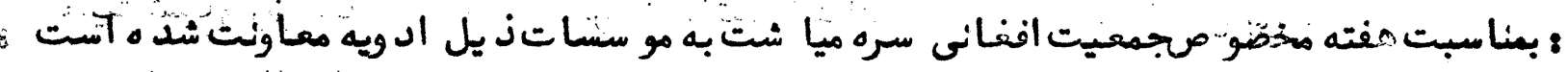

$$
\begin{aligned}
& \text { 1_-19.7V } \\
& \text { j) -0.\&ri } \\
& \text { ע. - } \\
& \text { D. }-\{r \varepsilon \wedge \uparrow \\
& \text { L. - } 7 \mathrm{Yr} \\
& \text { u rrara } \\
& \mu-1 \wedge \varepsilon q r \\
& \nu-0 \wedge \Lambda 1 \varepsilon \\
& \text { j) }- \text { หq } 7 / Y \\
& \text { נ) -orart } \\
& \text { - - I \& T人。 } \\
& \text { s. }
\end{aligned}
$$

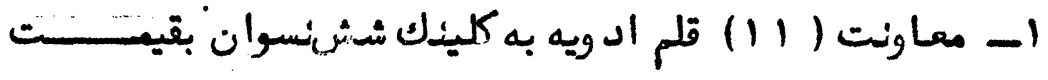

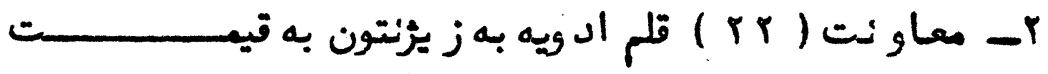

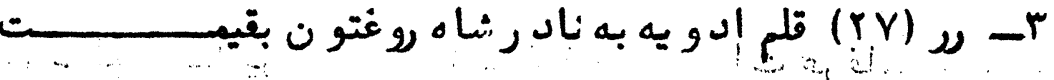

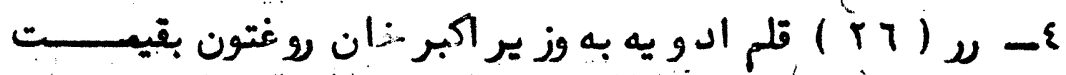

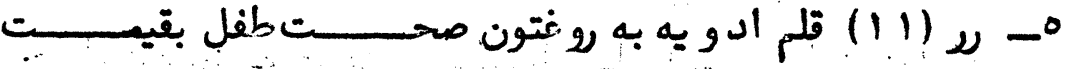

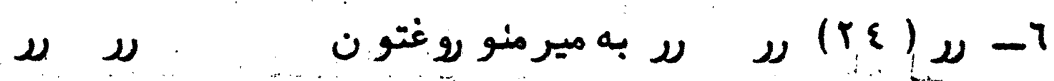

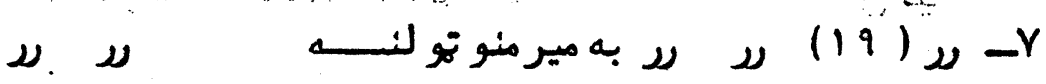

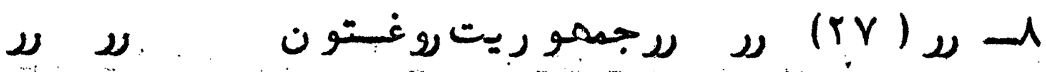

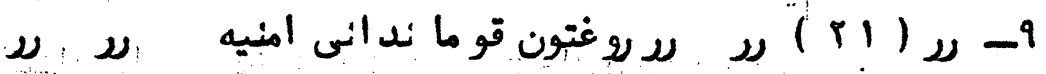

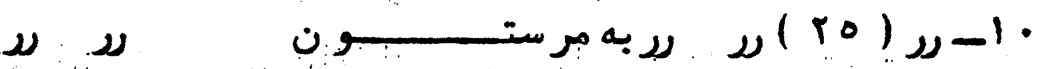

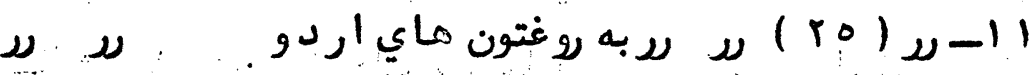

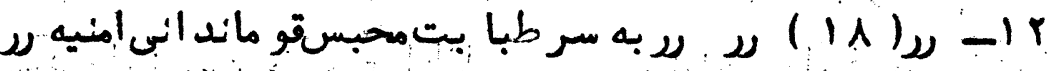

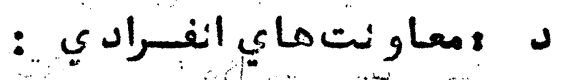

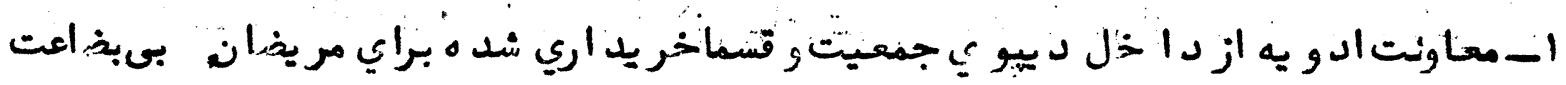

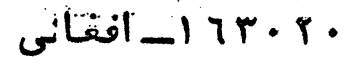

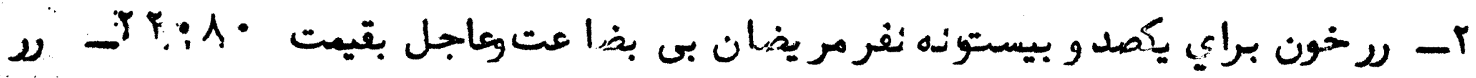

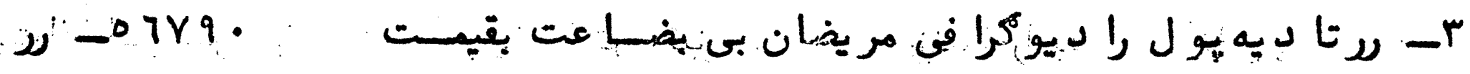

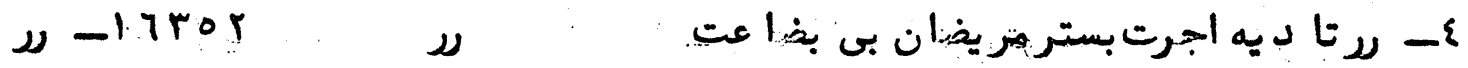

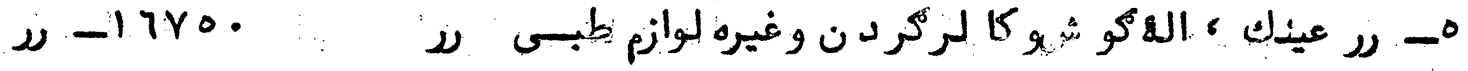

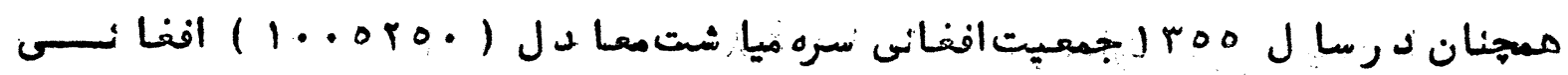




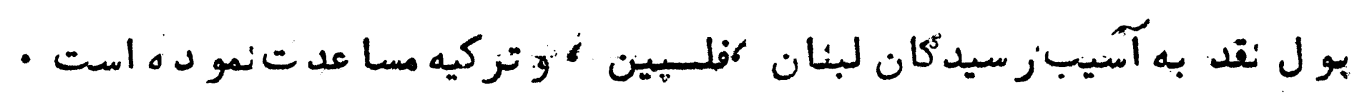

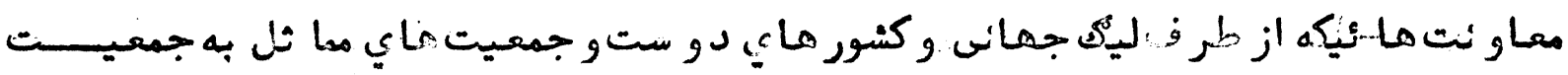

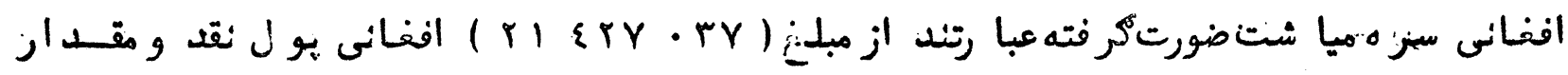
• (Y.11)

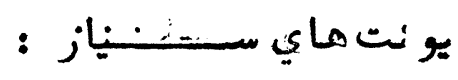

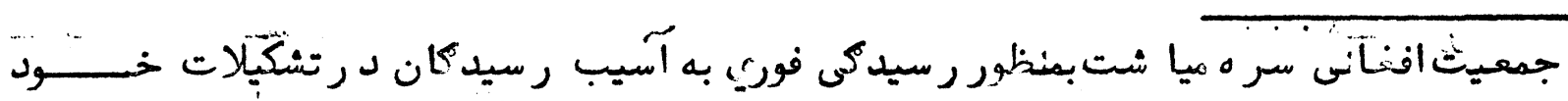

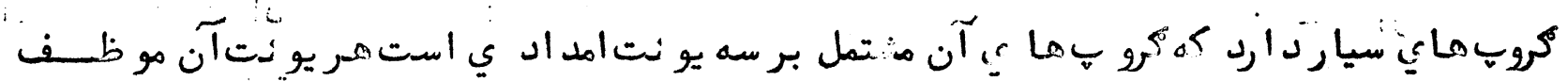

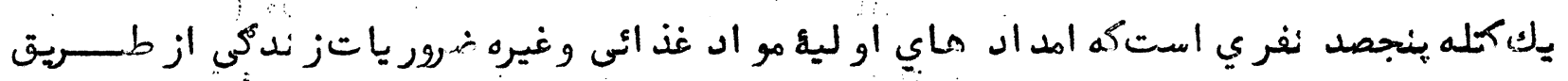

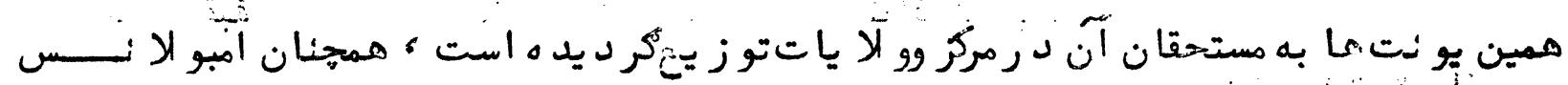

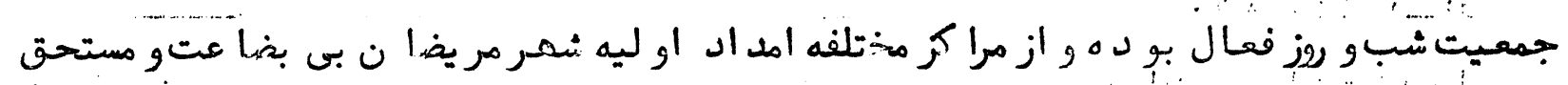

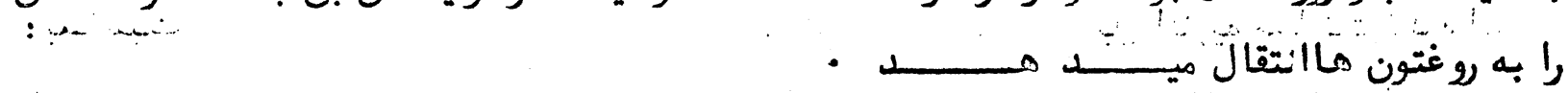

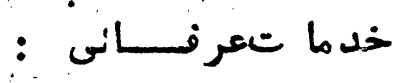

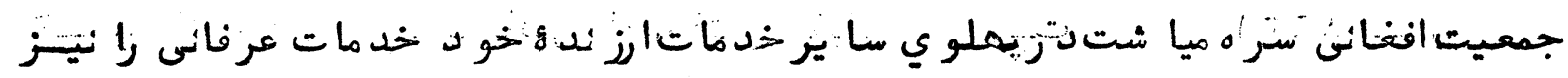

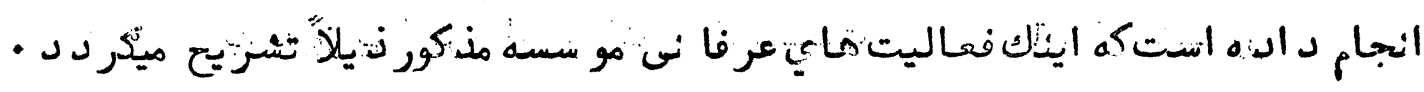

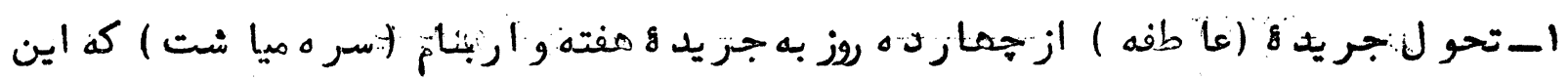

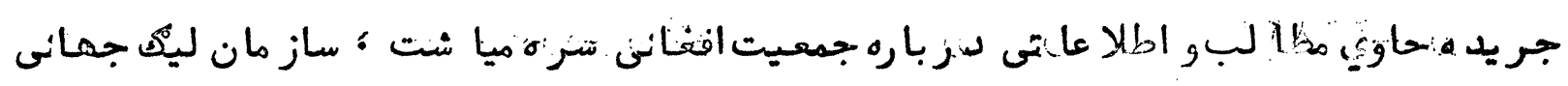

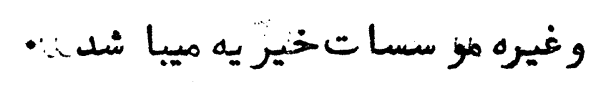

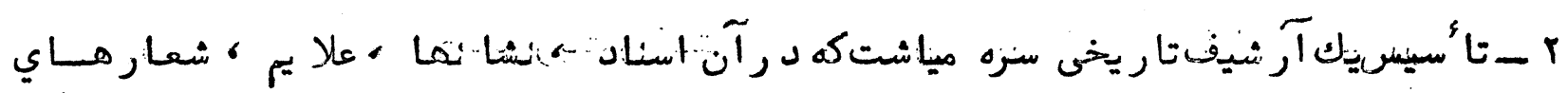

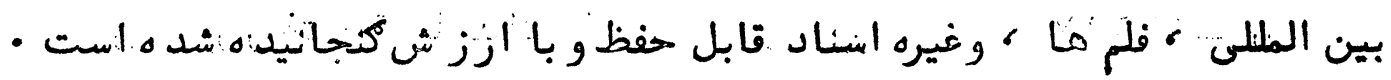

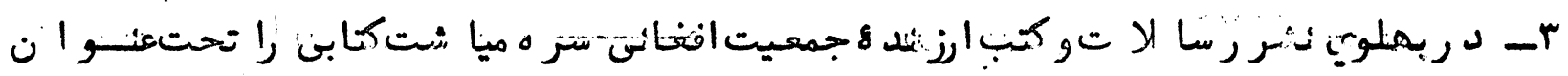

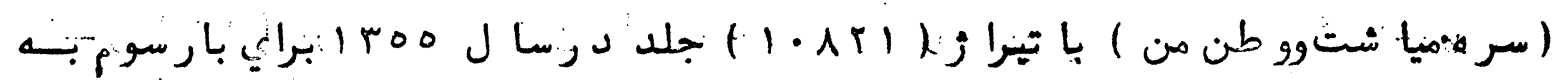

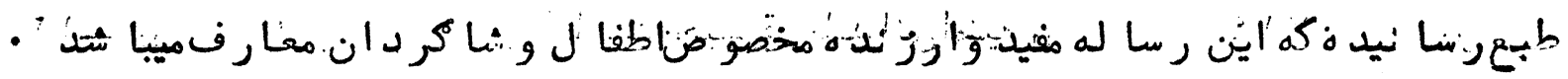

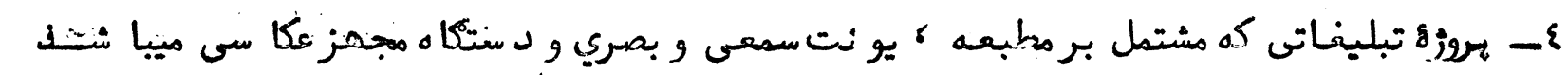

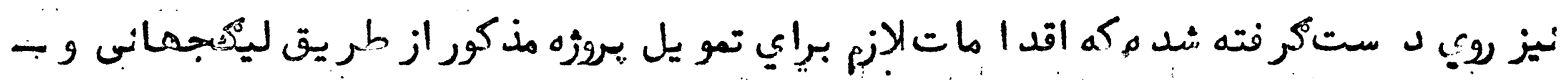

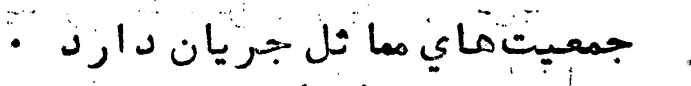
الا تسمبري

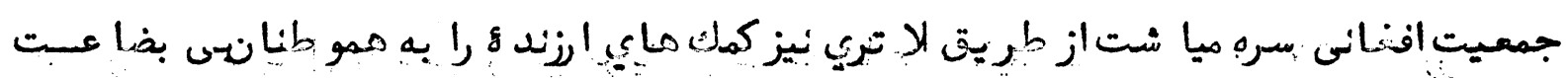

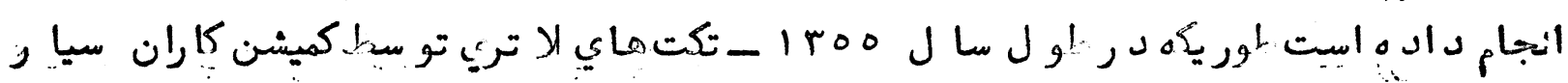

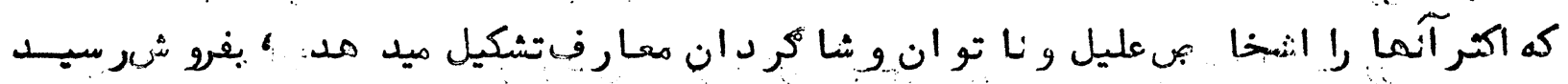

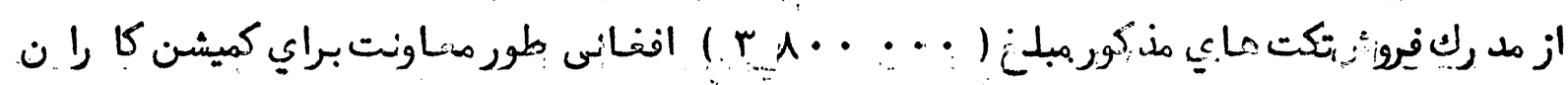

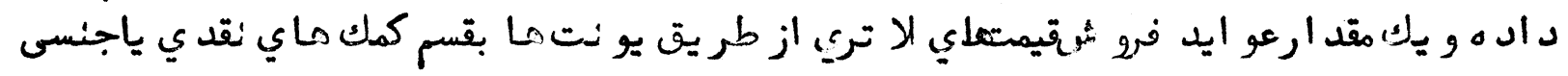




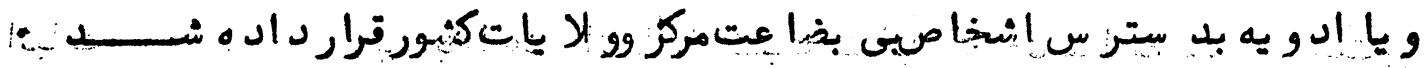

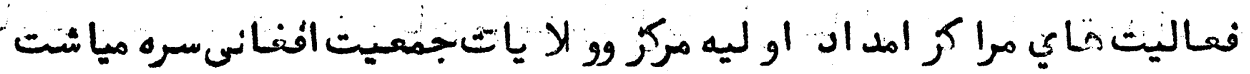
bن سال

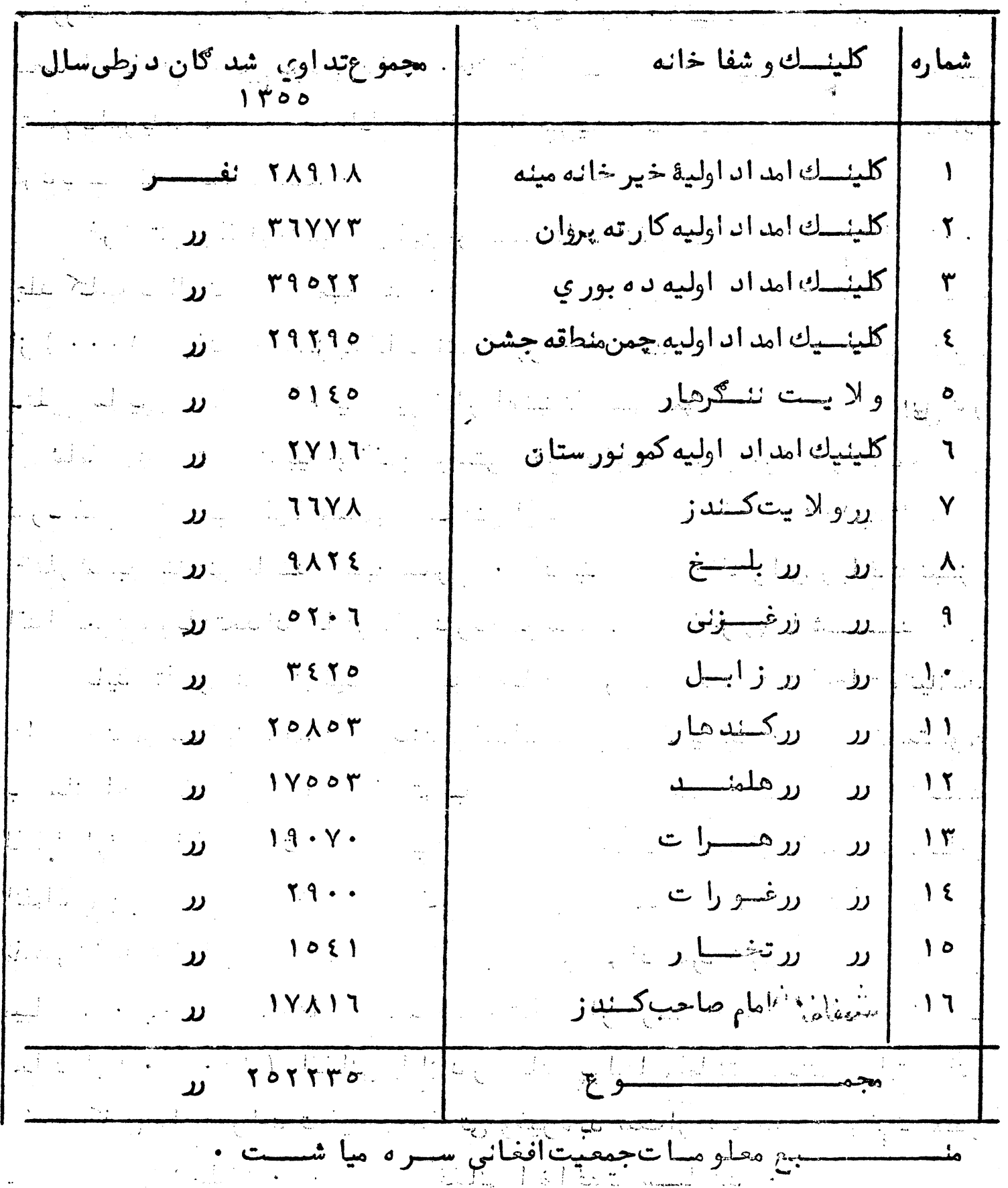

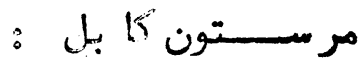

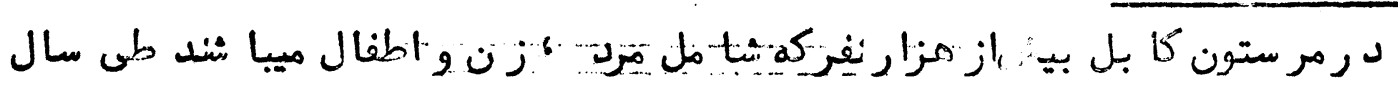

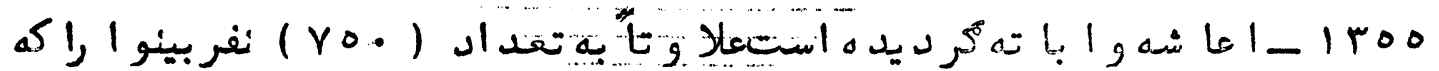

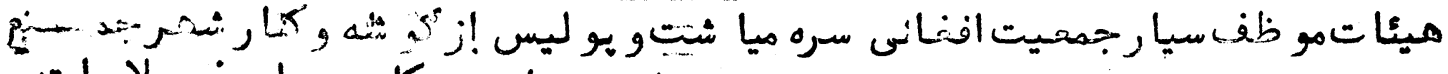

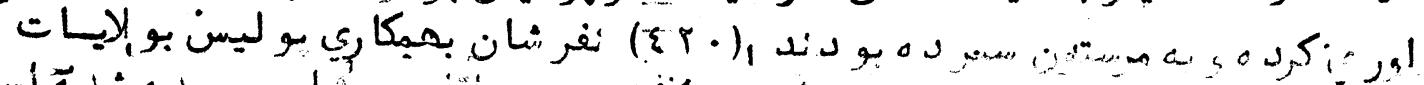

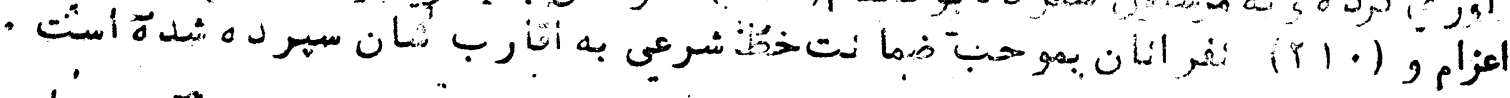

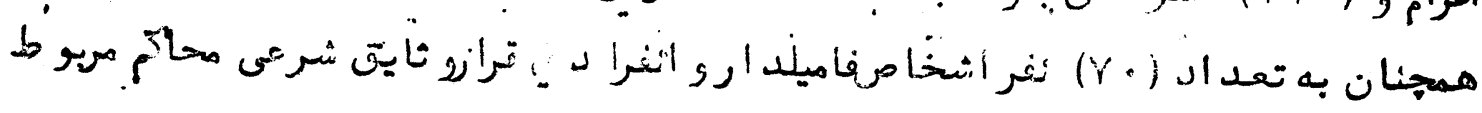




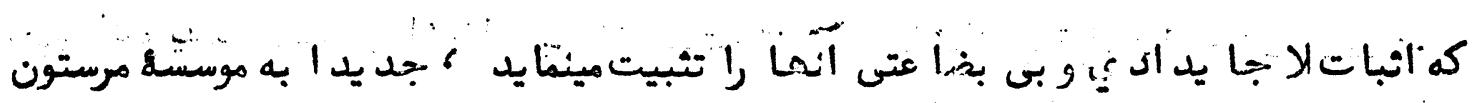

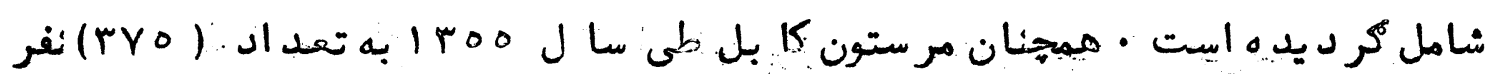

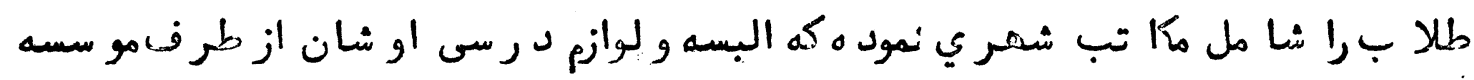

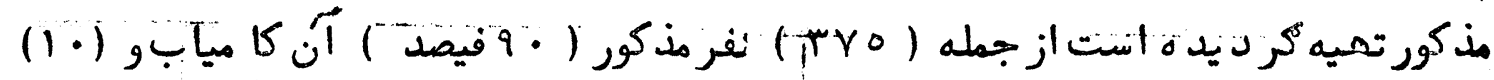

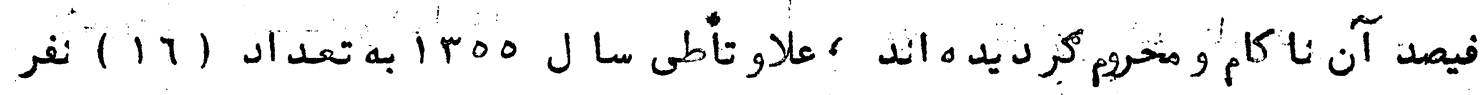

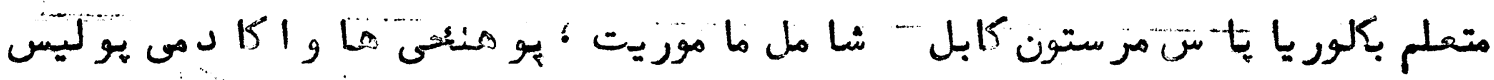

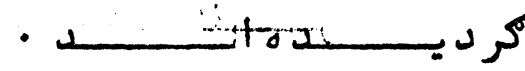

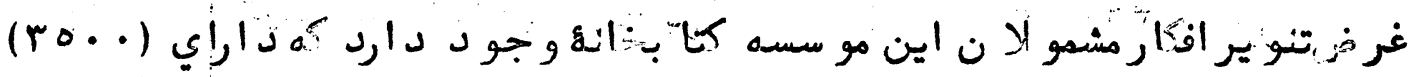

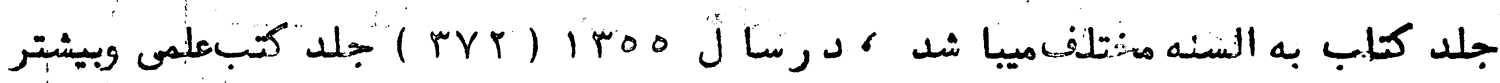

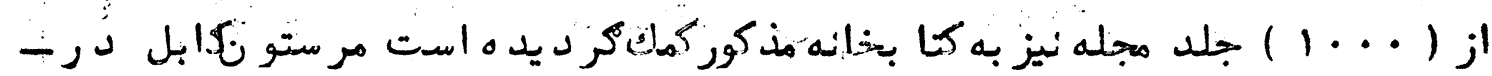

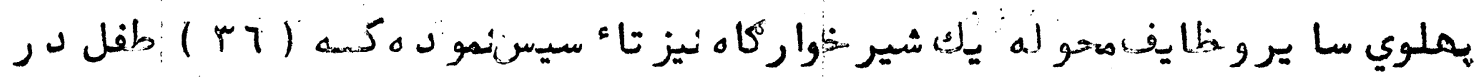

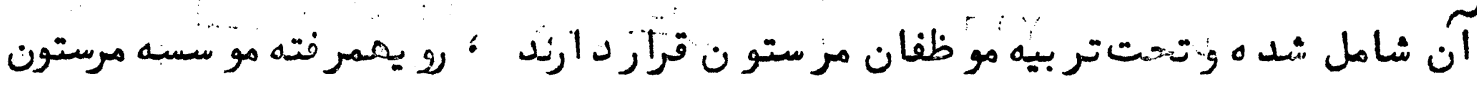

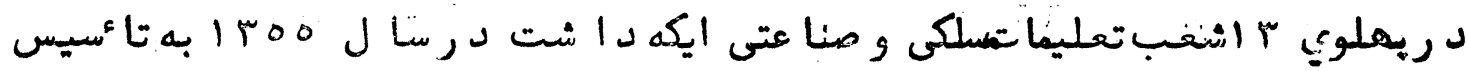

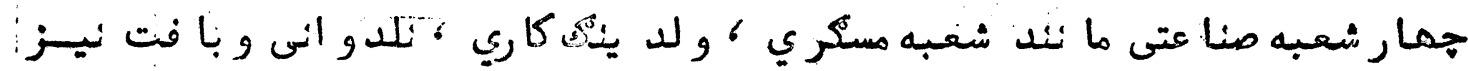

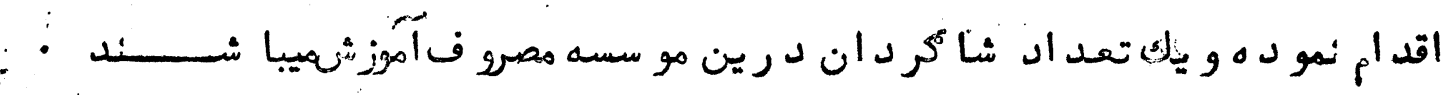

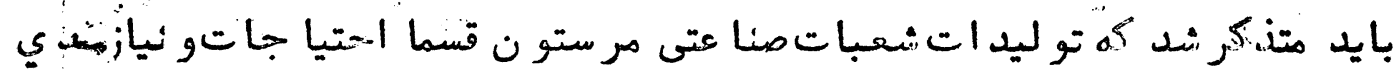

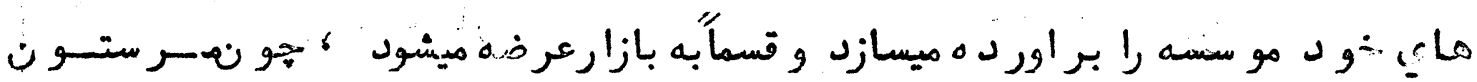

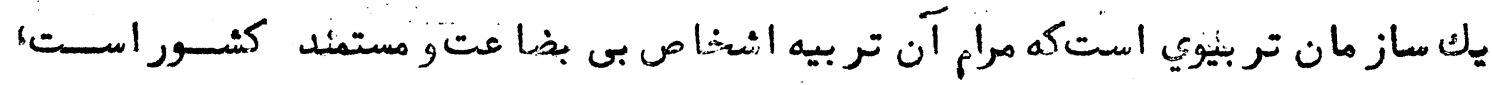

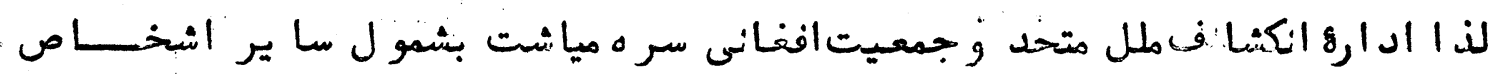

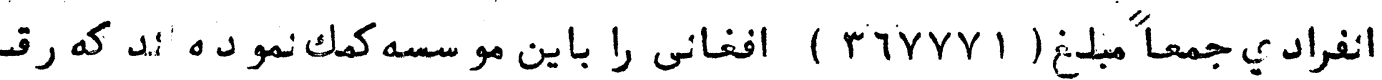

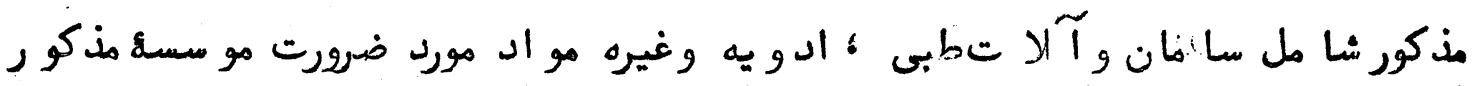

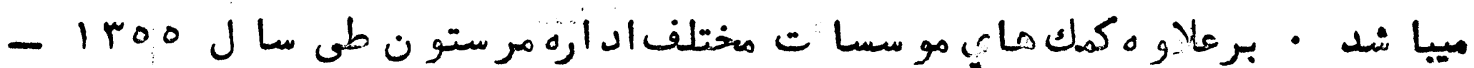

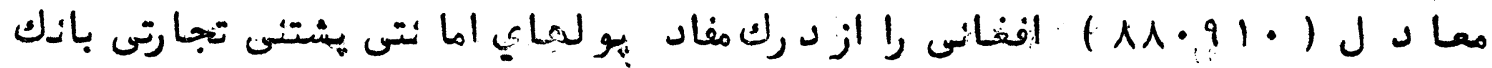

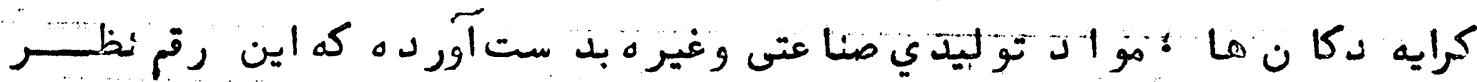

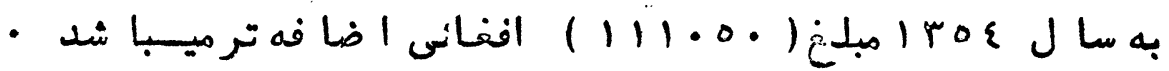

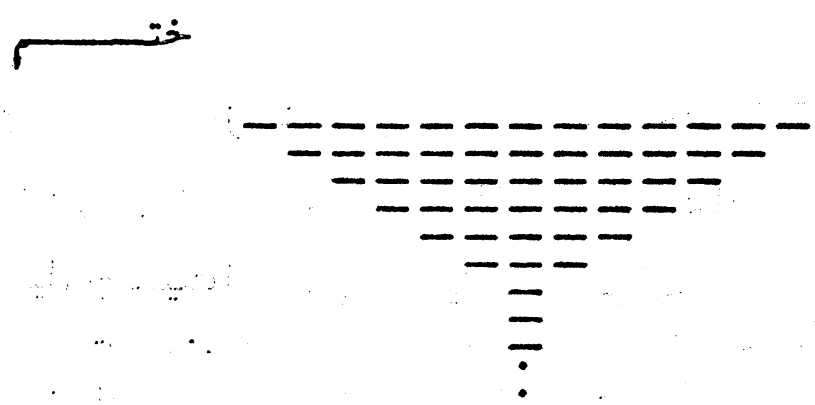




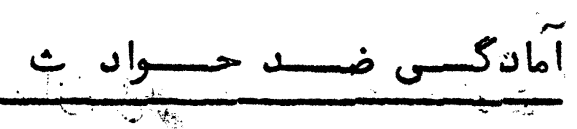

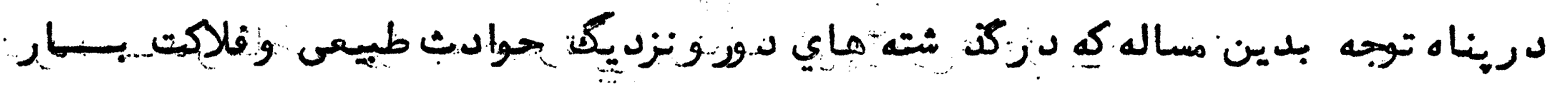

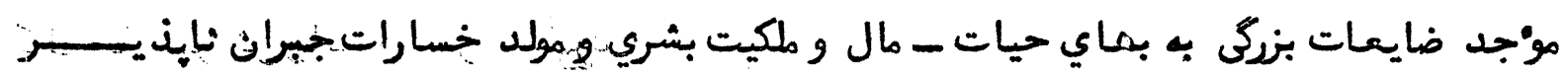

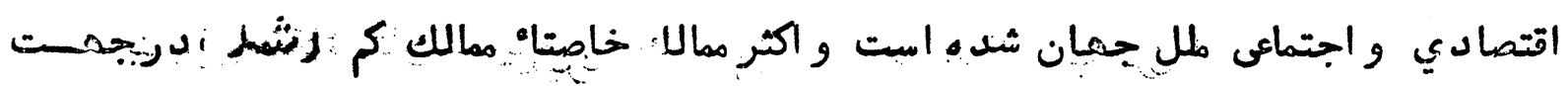

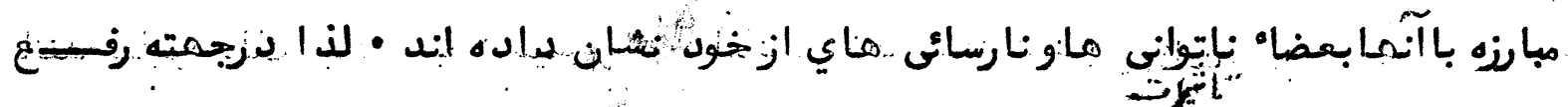

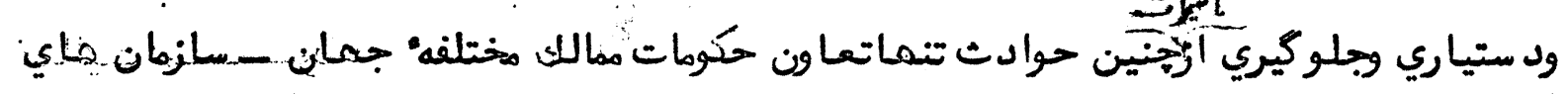

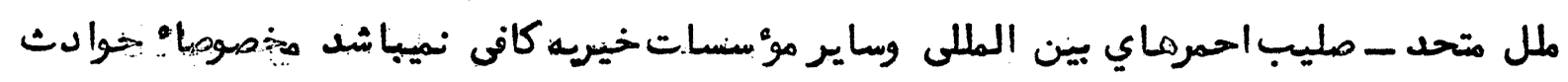

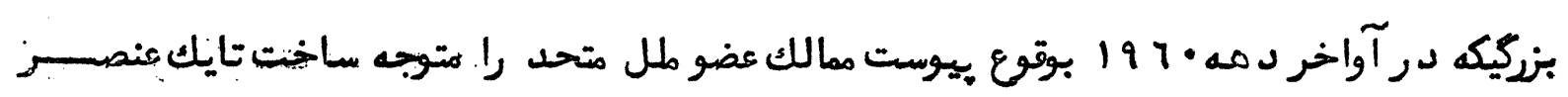

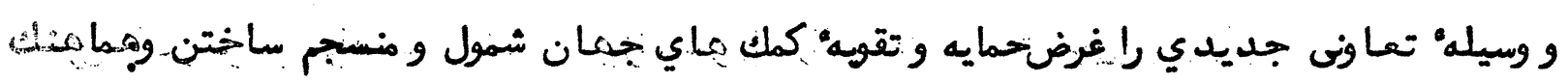

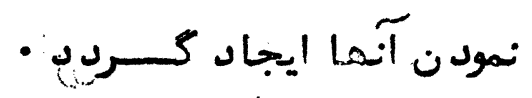

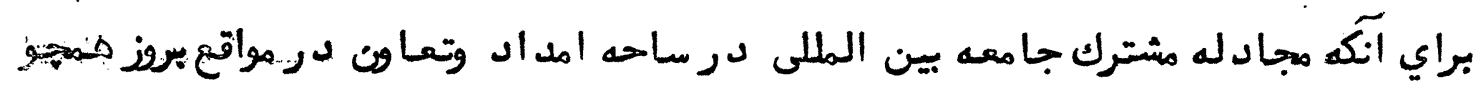

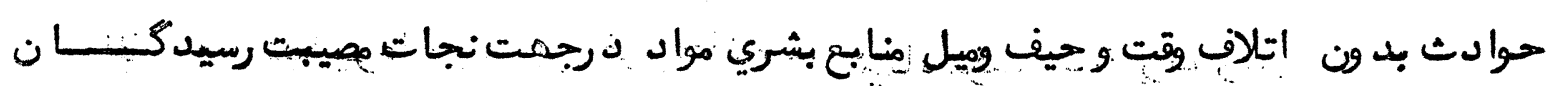

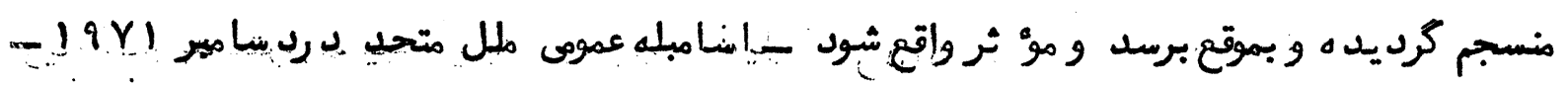

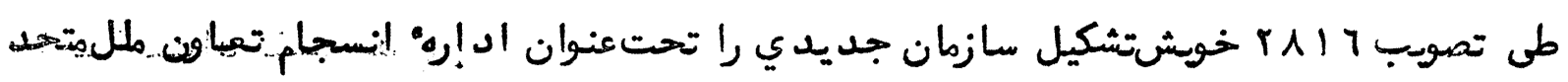

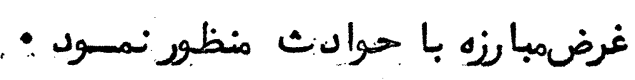

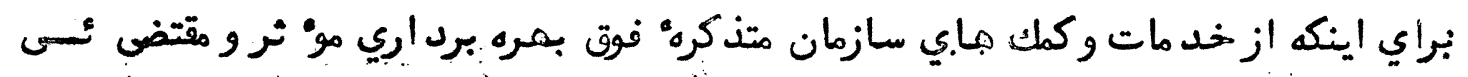

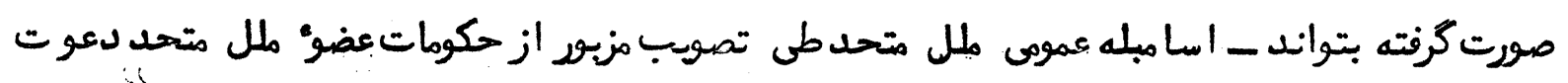

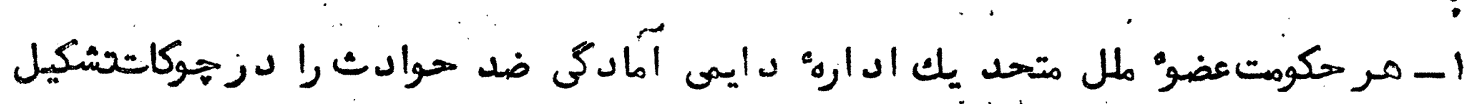
نمود تا :

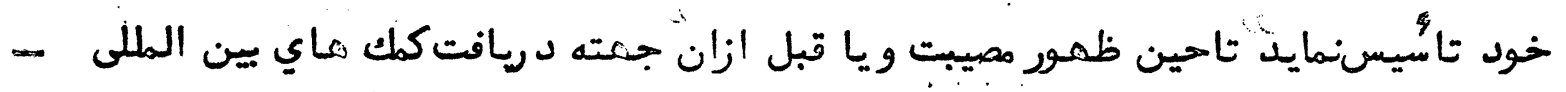

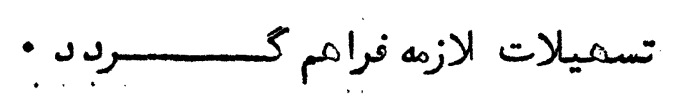

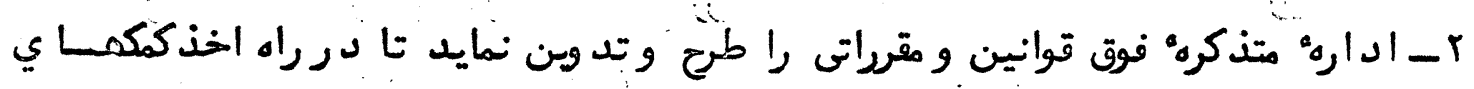

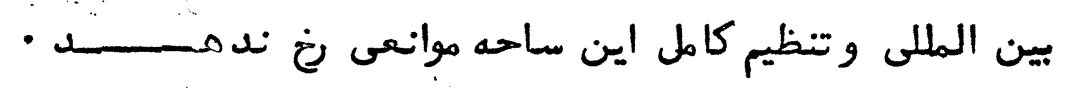

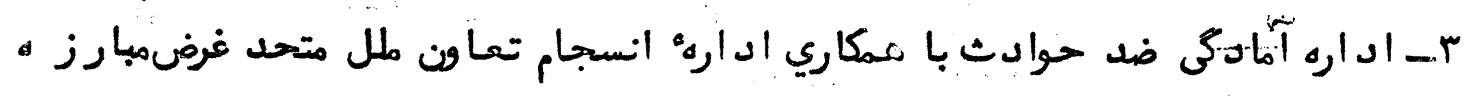

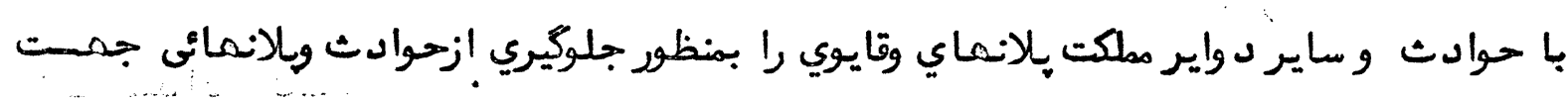

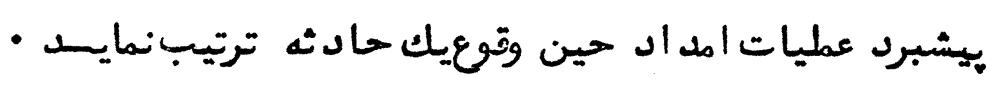

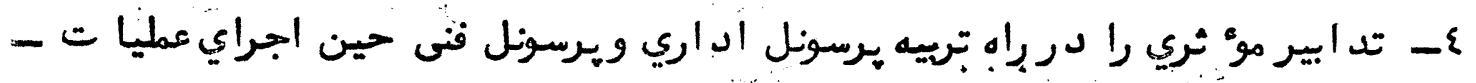

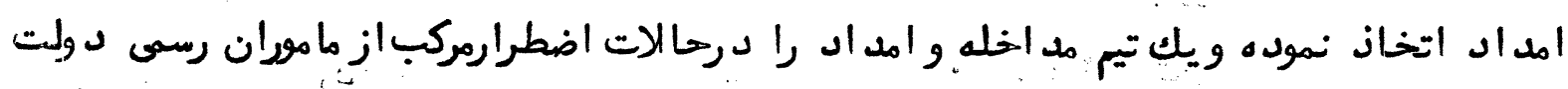

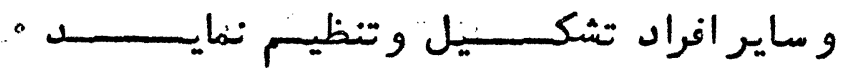


0ـ البسه - لوازم وخوراكه ازتقبيل خيده ـ اد ويه ومواد غذ ائى راكه به زودي خراب-

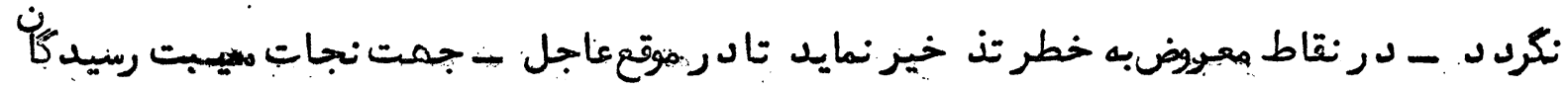

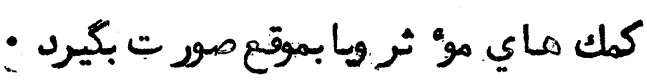

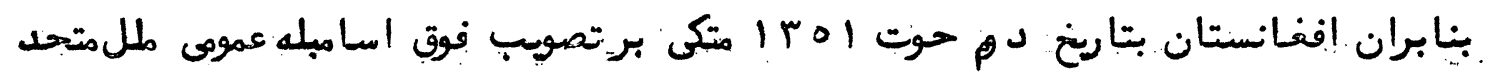

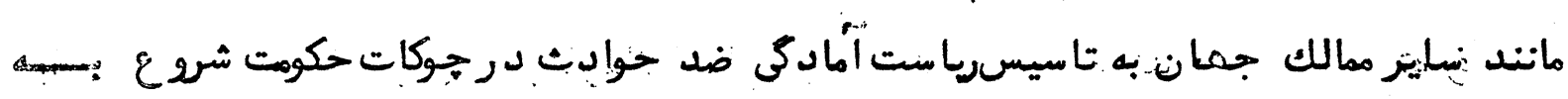

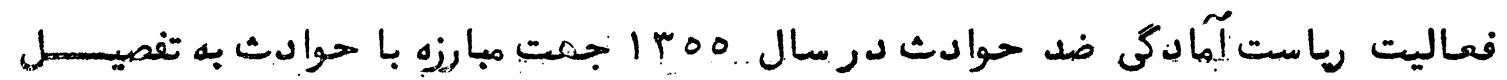

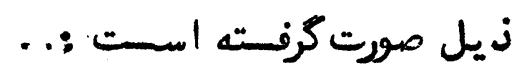

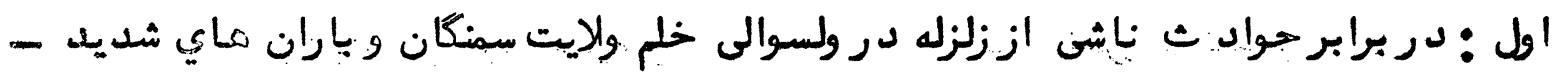

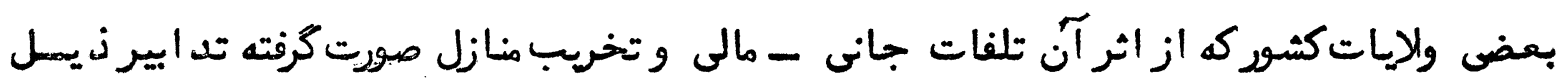

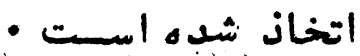

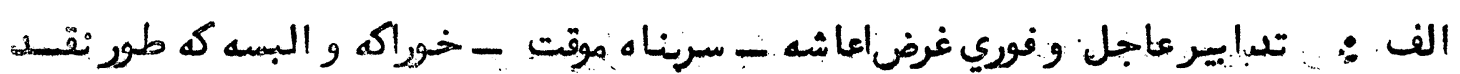

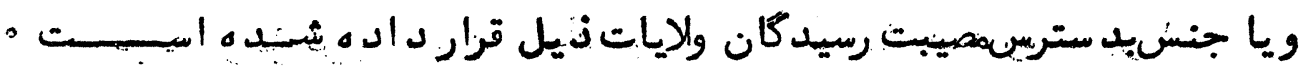

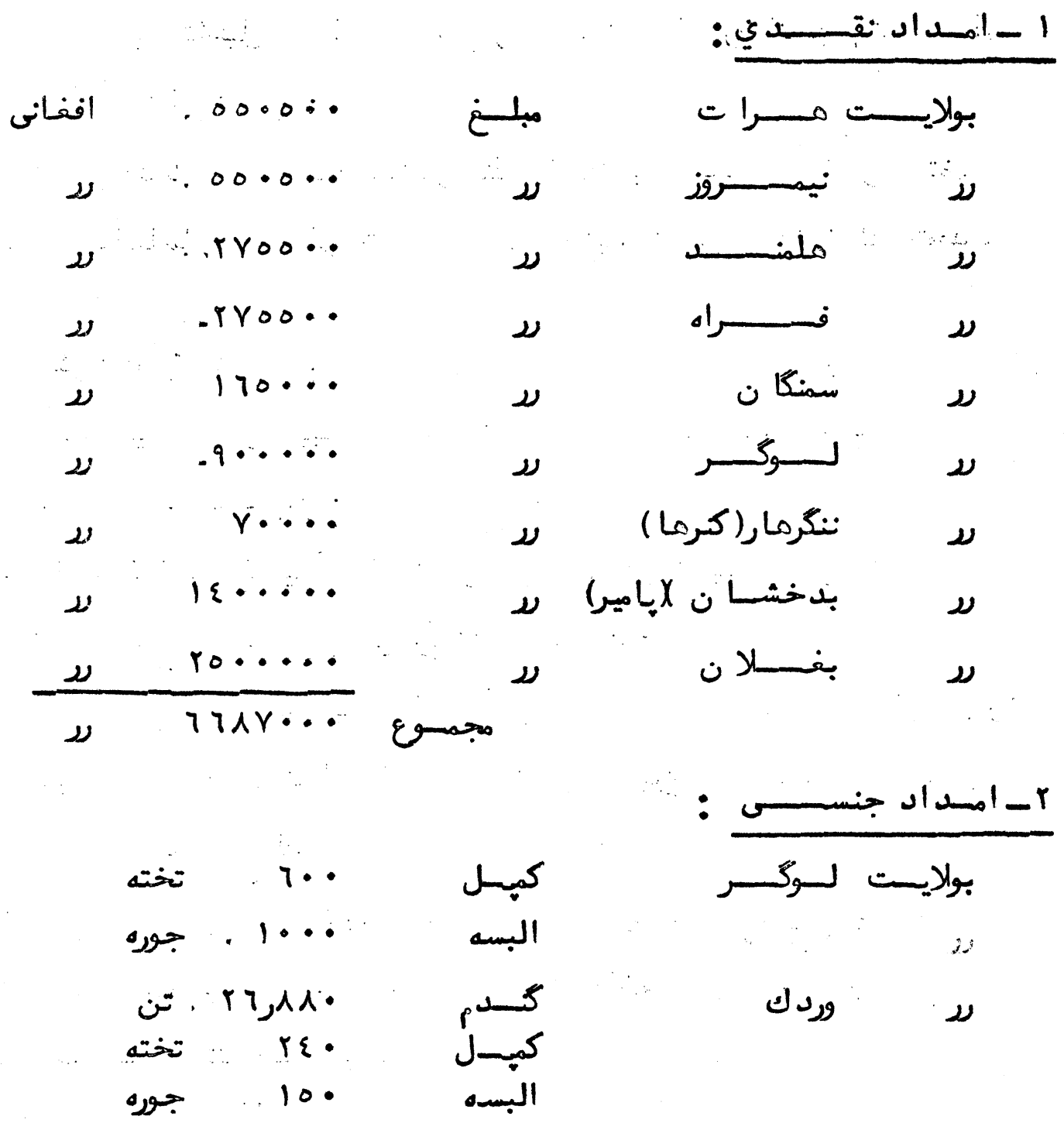




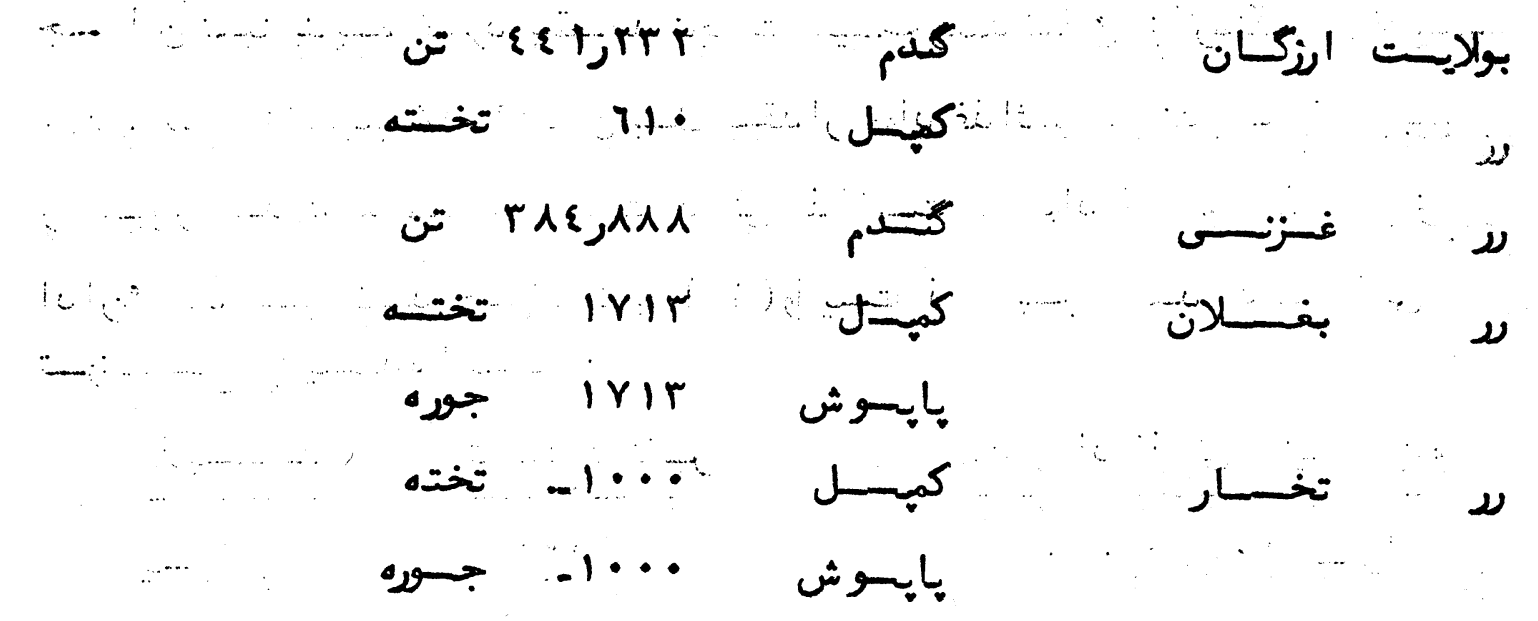

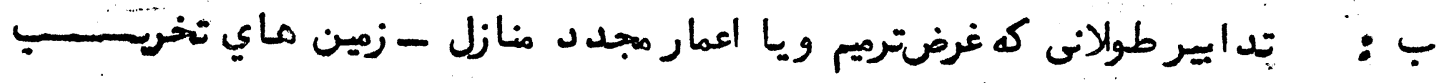
شده امالى ولايات كتور طور امد اد نقدي به ترتيب ذيل انتقال د اده شده اسست

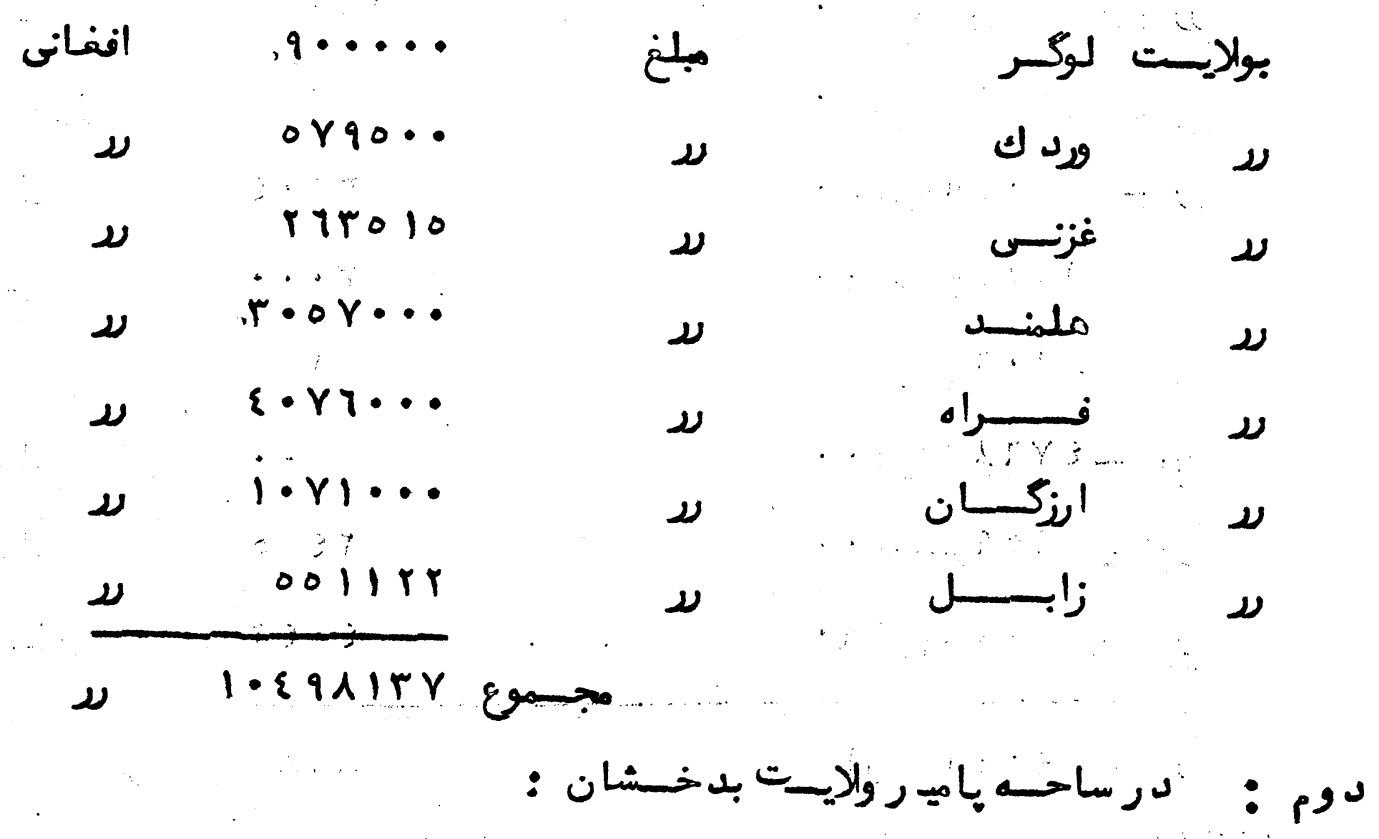

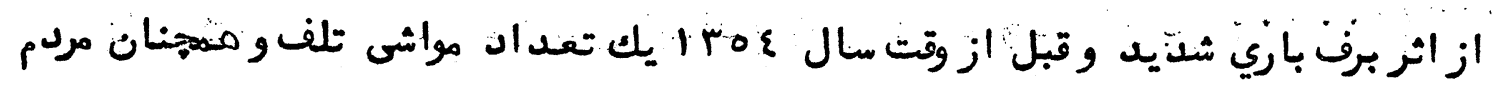

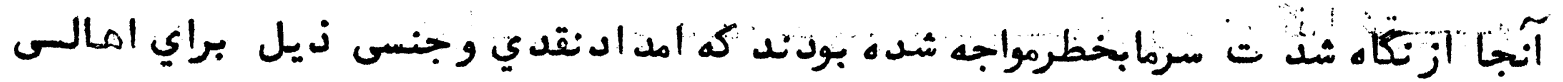

افغانى جمت خريد اريكتجار

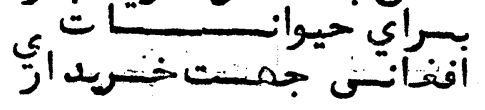

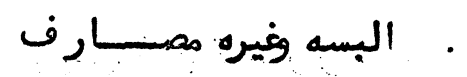

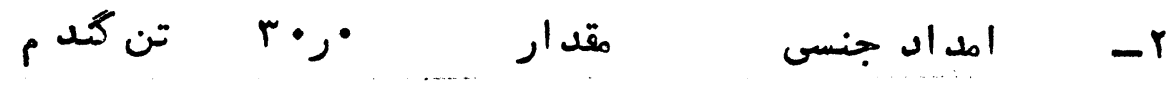

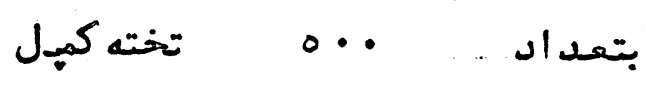

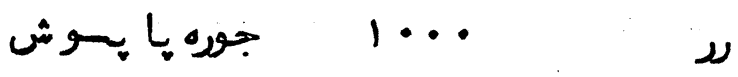

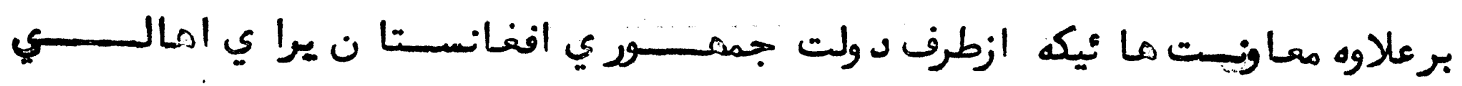

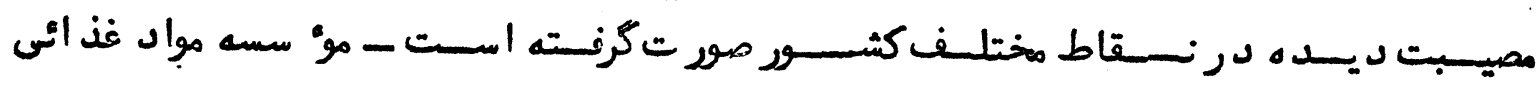




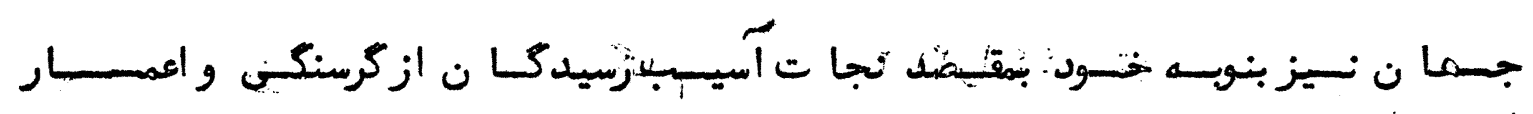

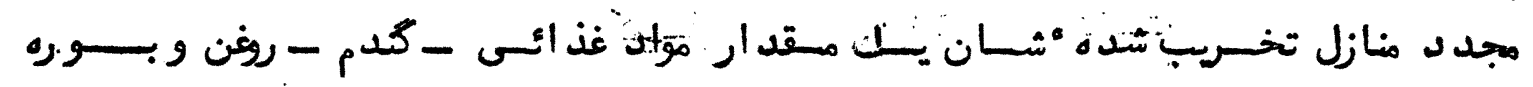

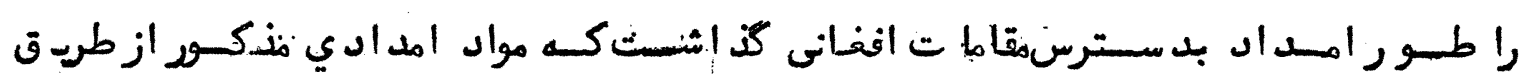

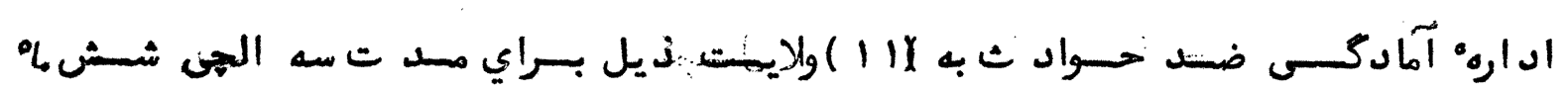

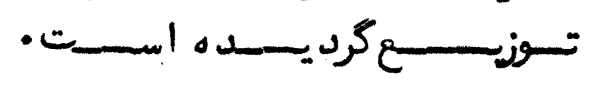

مقد ارمواد غذ ائى توزيع شــده • • • ر

$$
\text { y. - trqikr, }
$$$$
\nu-1 r 10 \text { ro } 2 \text { s. }
$$

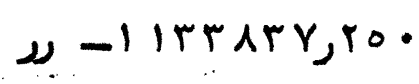

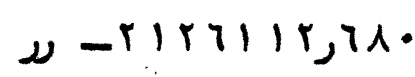$$
\text { - } 2.0 \cdot 170,10
$$$$
\text { ע - • }
$$$$
\text { • }
$$$$
\text { ע }
$$$$
\text { ע }-190911,0 \ldots
$$$$
\text { dirrargit. }
$$
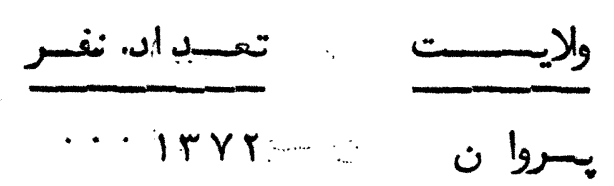

YY人o

$|\gamma| \varepsilon$

. listo

YTY

$$
r d \cdot \varepsilon
$$$$
\text { ...r.: }
$$$$
\text { ......tr? }
$$$$
\text { ...o9.. }
$$

rero

$\{\because \varepsilon\}$

$$
\text { بيمينـكان }
$$$$
\text { بغــــــان }
$$

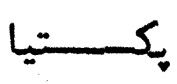

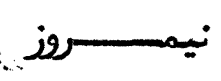

$$
\text { ورد كيمك }
$$

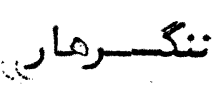

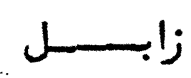$$
\text { بدخشان }
$$

$$
\text { ارنكـــان }
$$

\section{: D.}

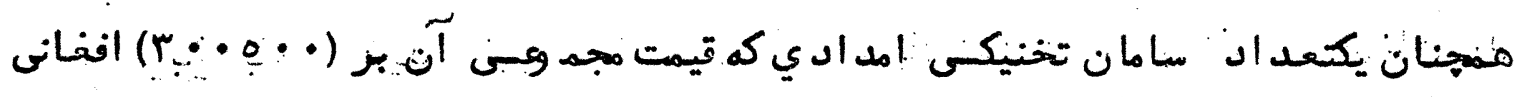

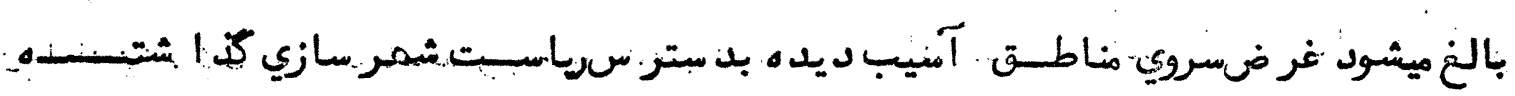

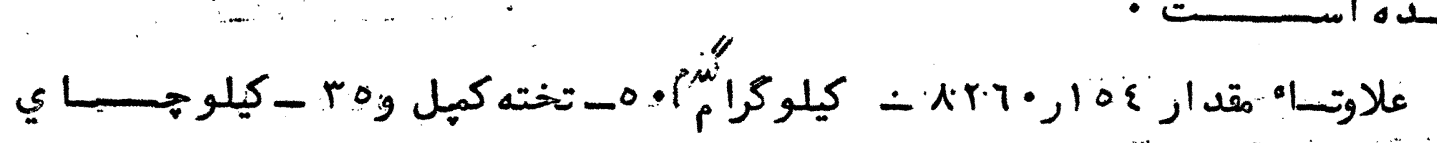

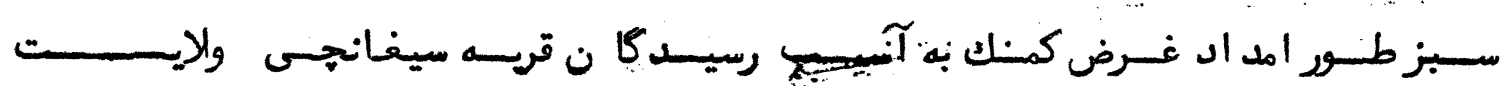

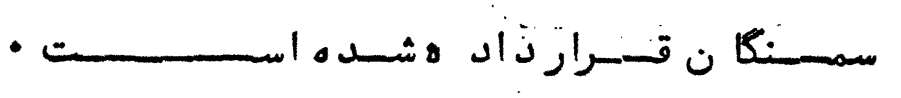




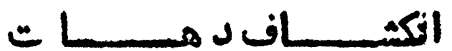

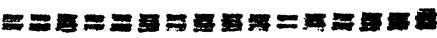

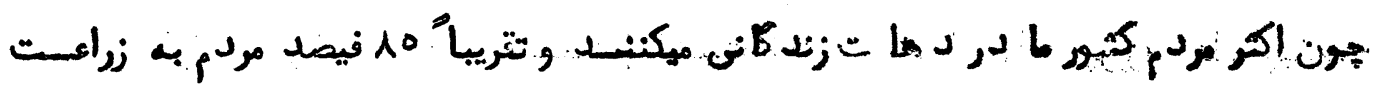

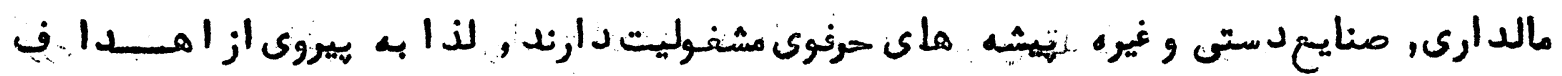

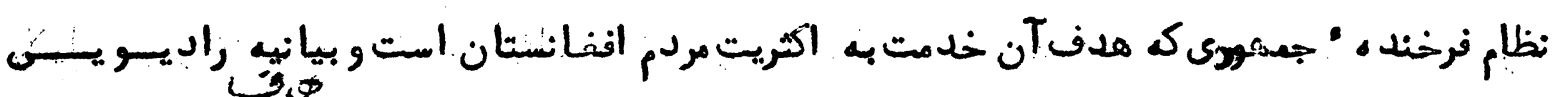

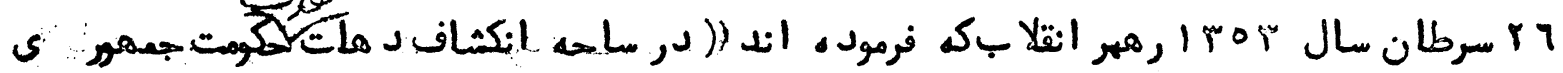

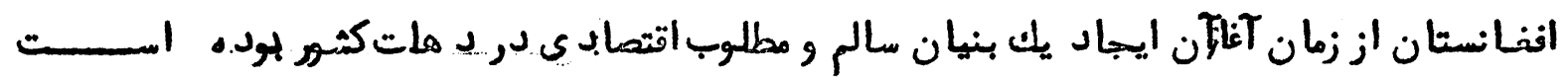

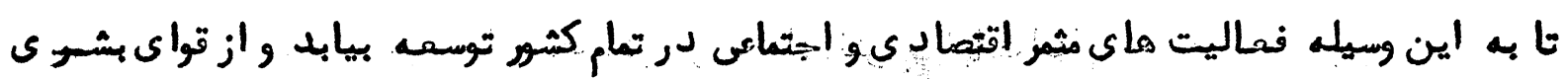

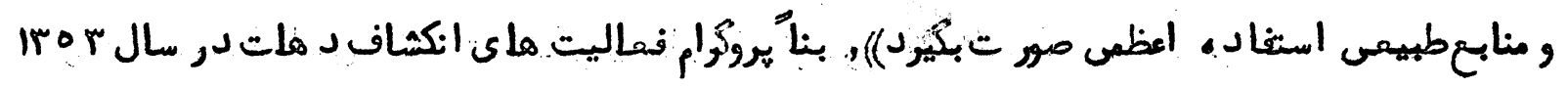

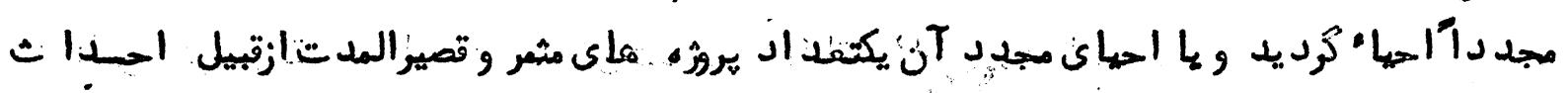

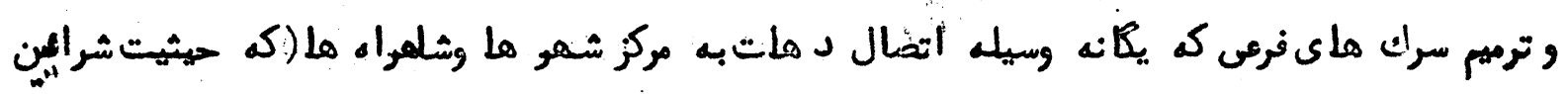

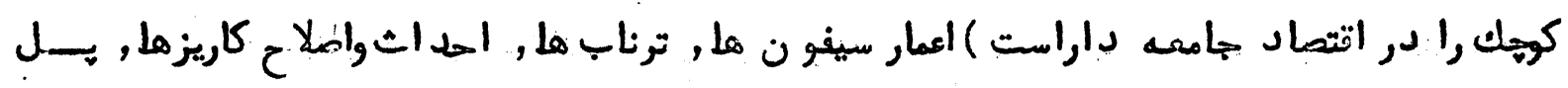

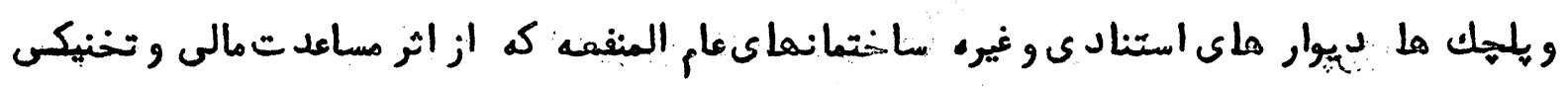

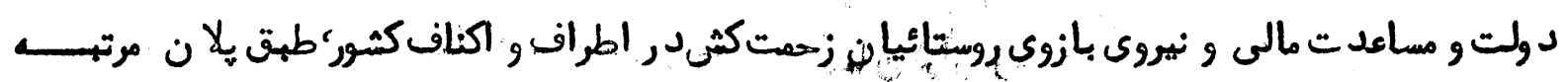

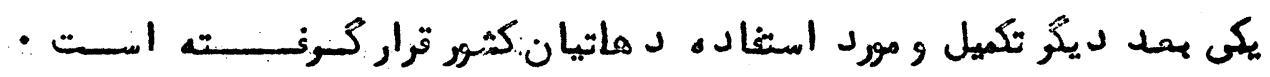

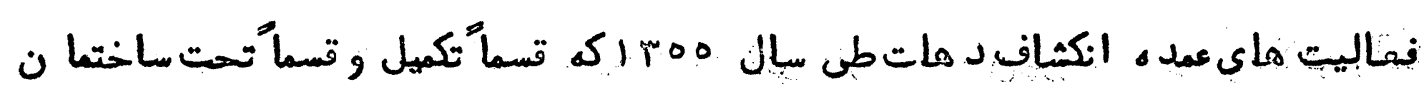

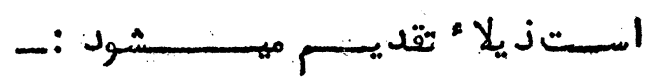

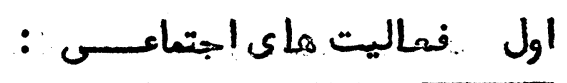

$$
\begin{aligned}
& \text { الـف , امسور محست عامستــهـ : }
\end{aligned}
$$

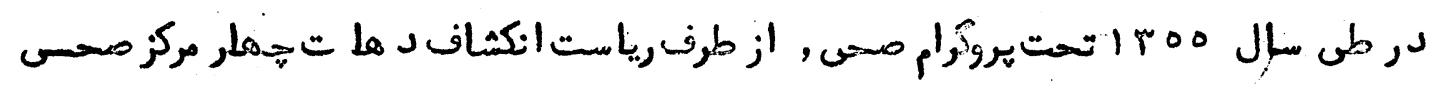

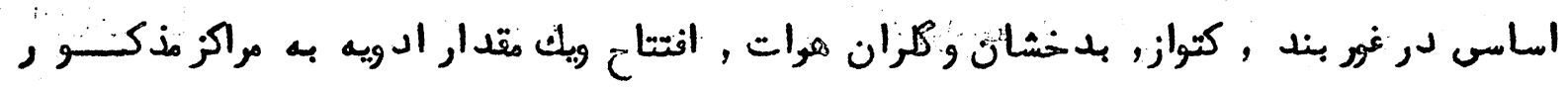

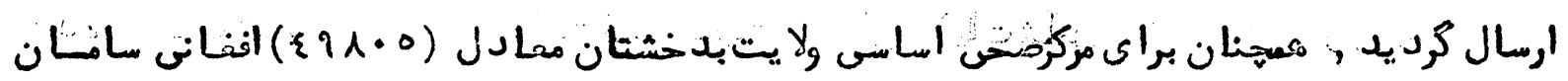

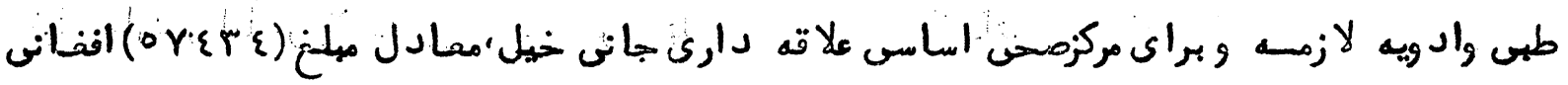

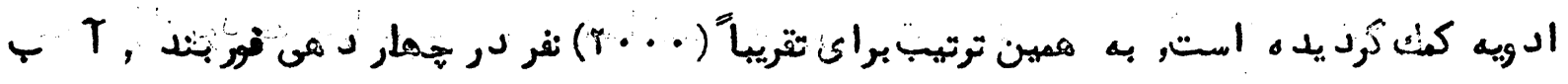

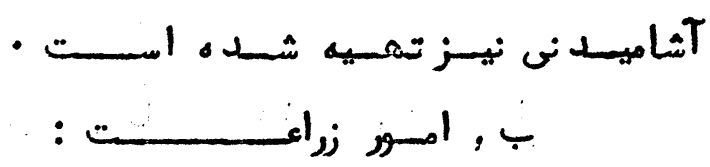

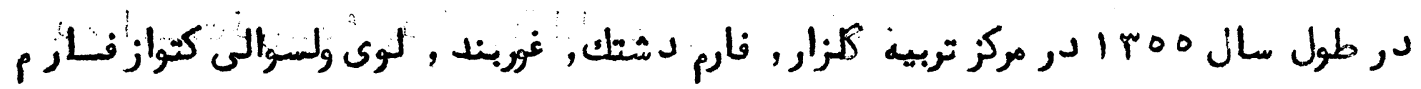

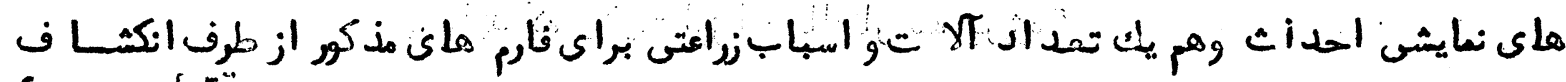

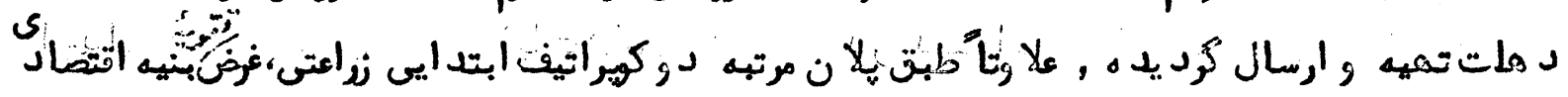

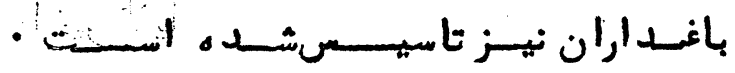




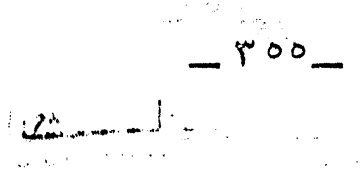

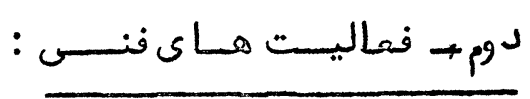

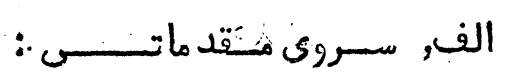

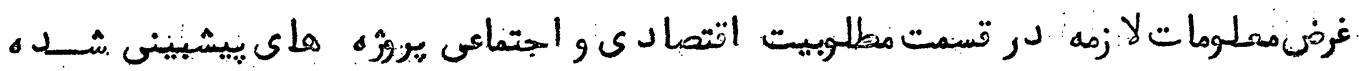

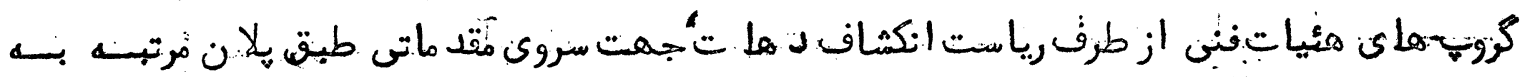

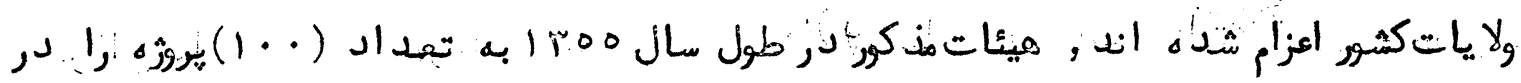

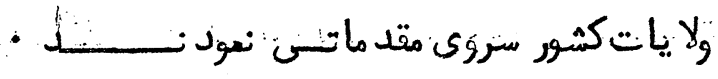

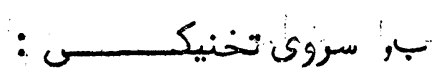

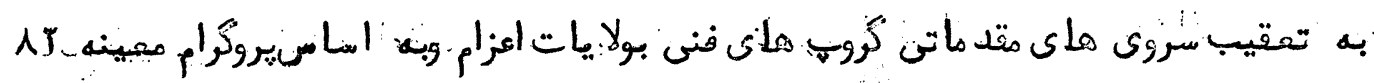

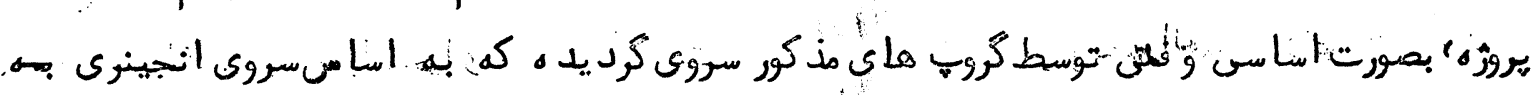

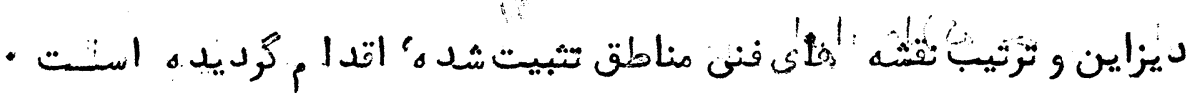

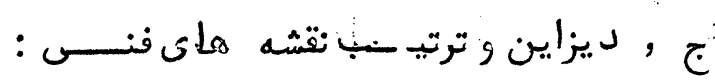

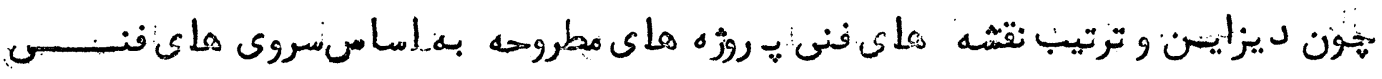

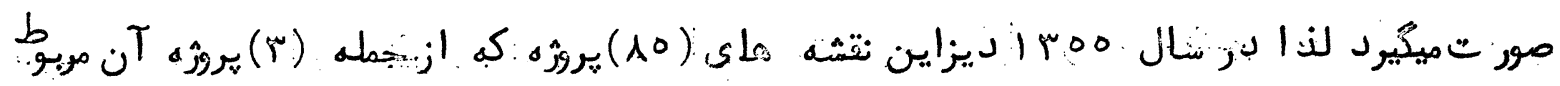

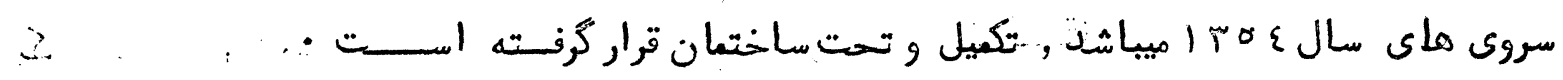

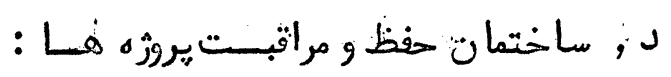

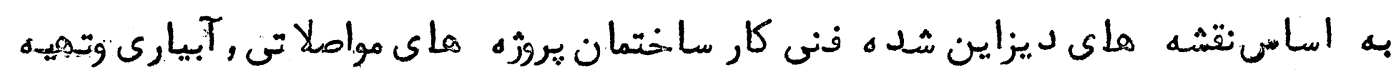

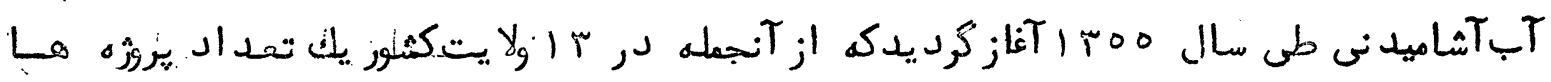

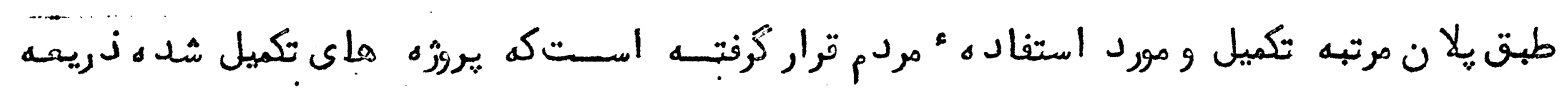

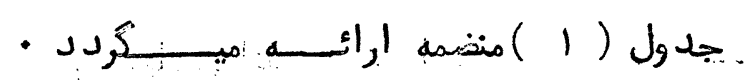

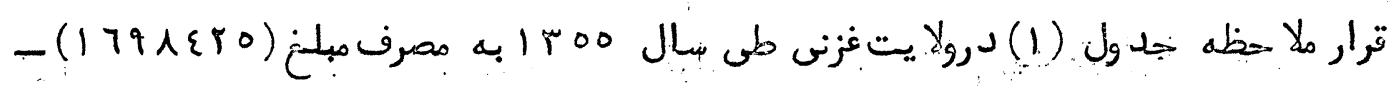

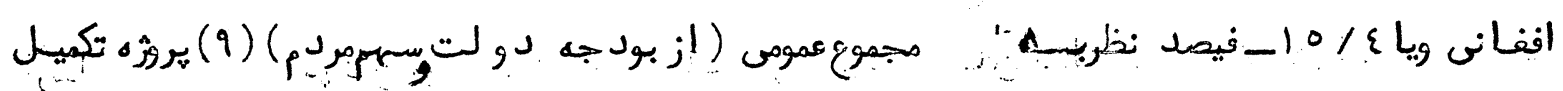

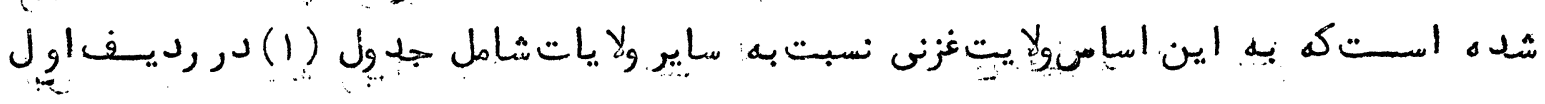

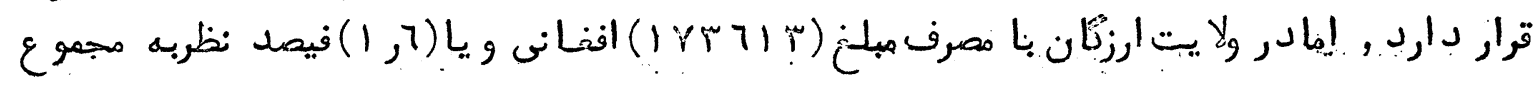

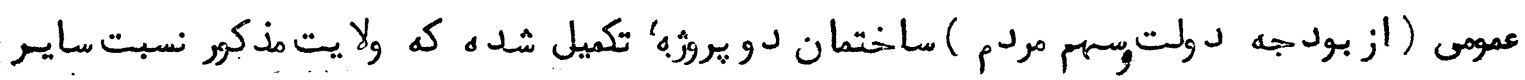

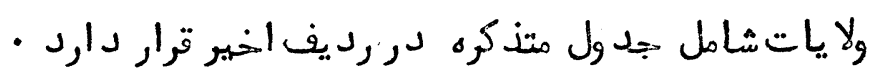

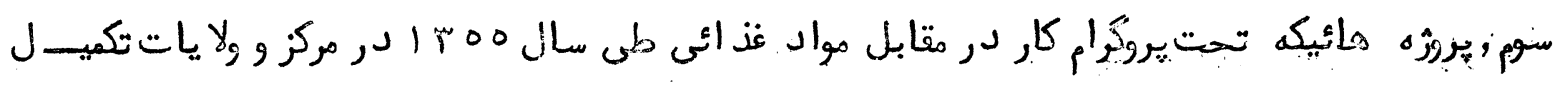

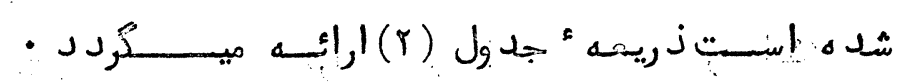

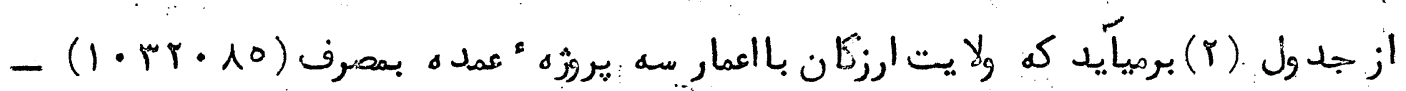

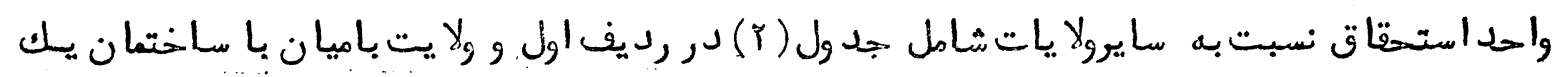

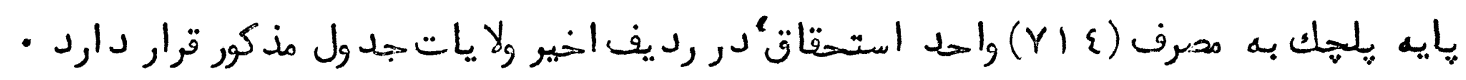

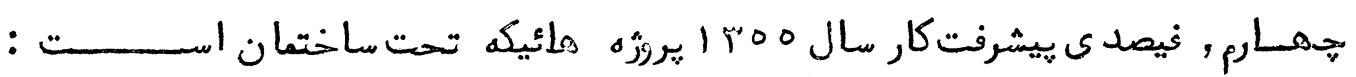




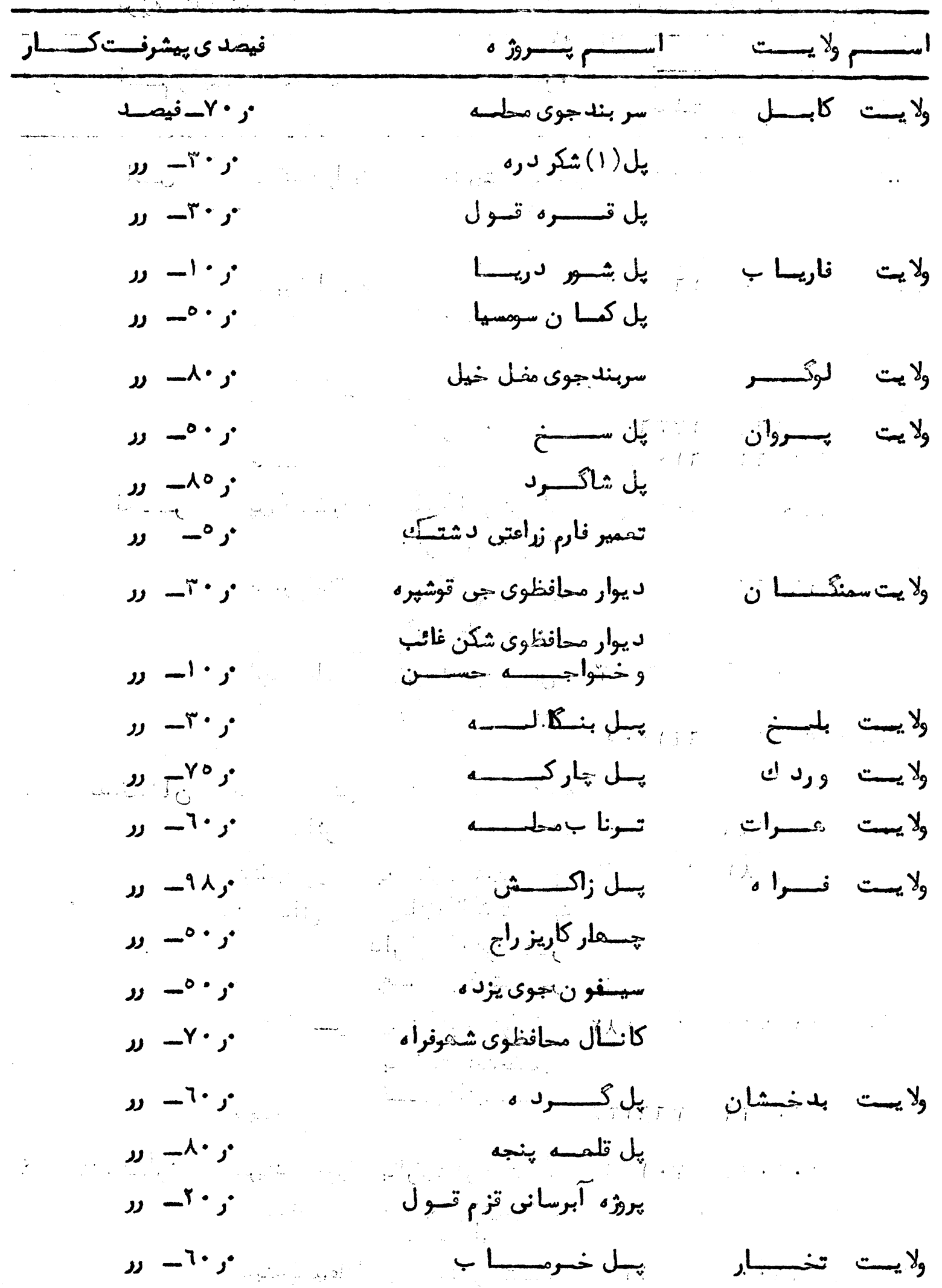




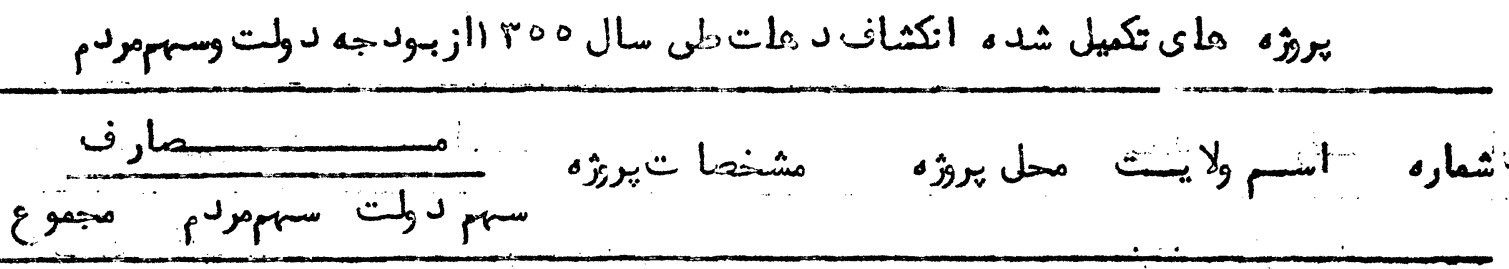

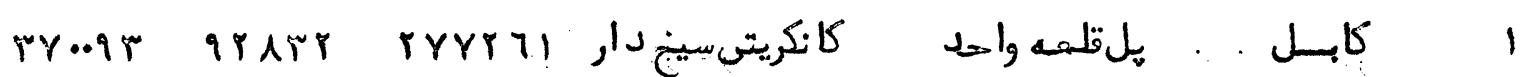

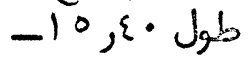

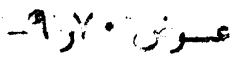

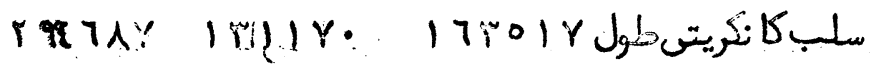

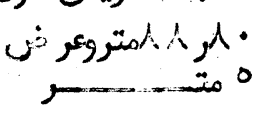

مسمبرخواجسه

مسسانستـور

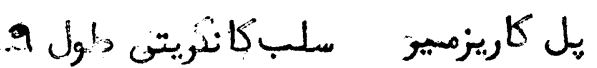

ST\&YY) $9117 \varepsilon$ |YTT.Y,

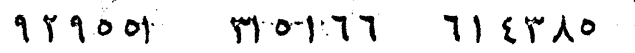

-

ه:-

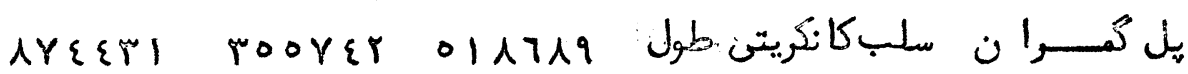

T بلوخـــ

. T.

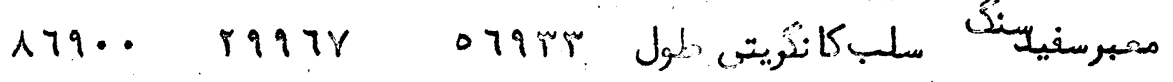

r.

لro\&9 rovar

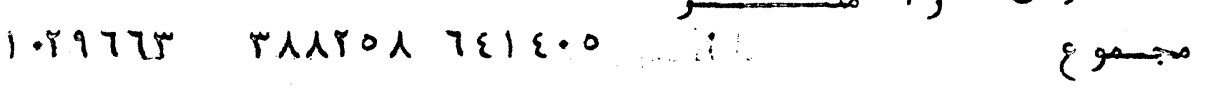

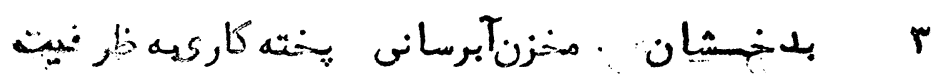

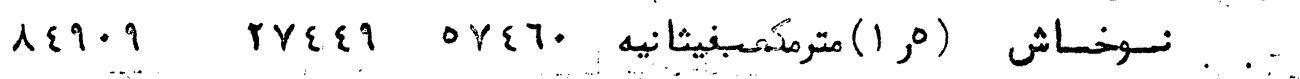

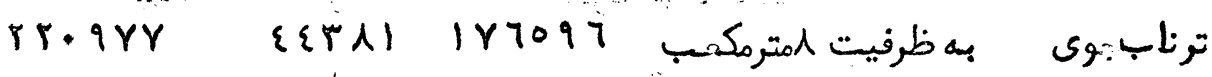

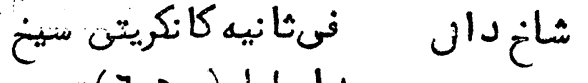

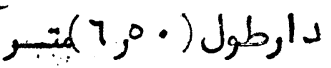

وعسرون

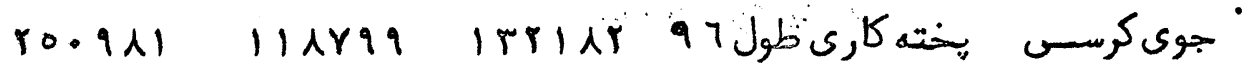

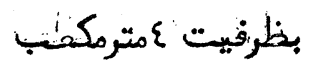

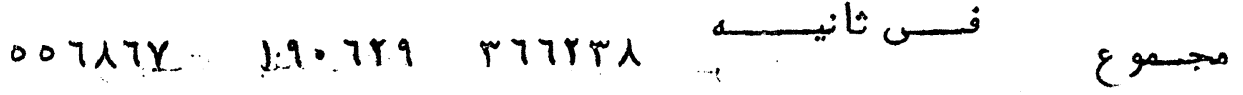

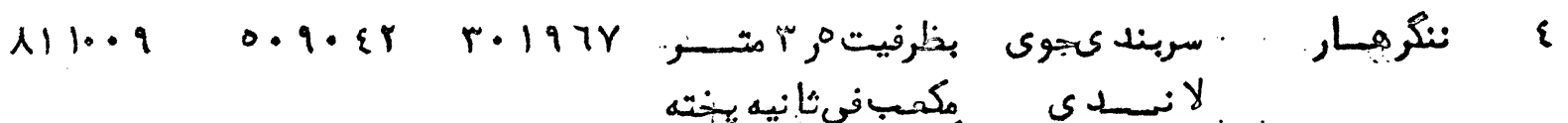

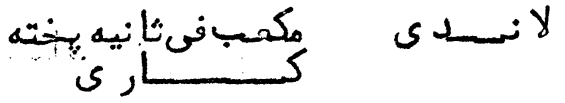

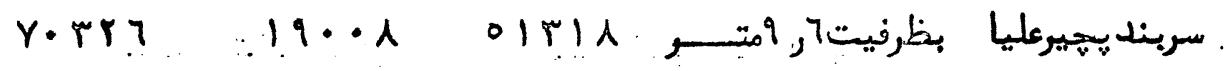

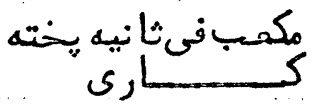

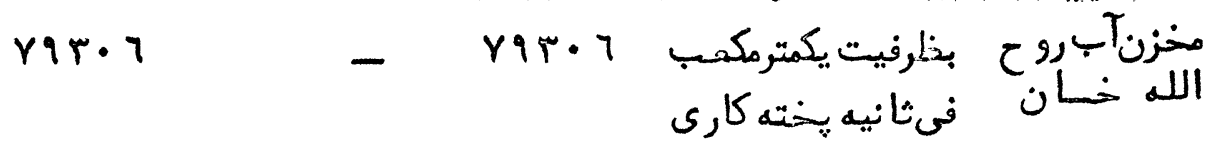

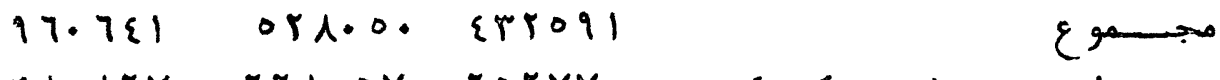

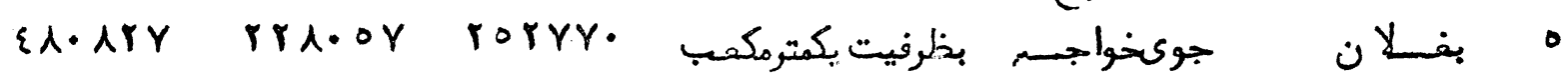

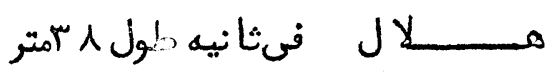

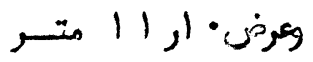


اد امه جــــــــــ (1)

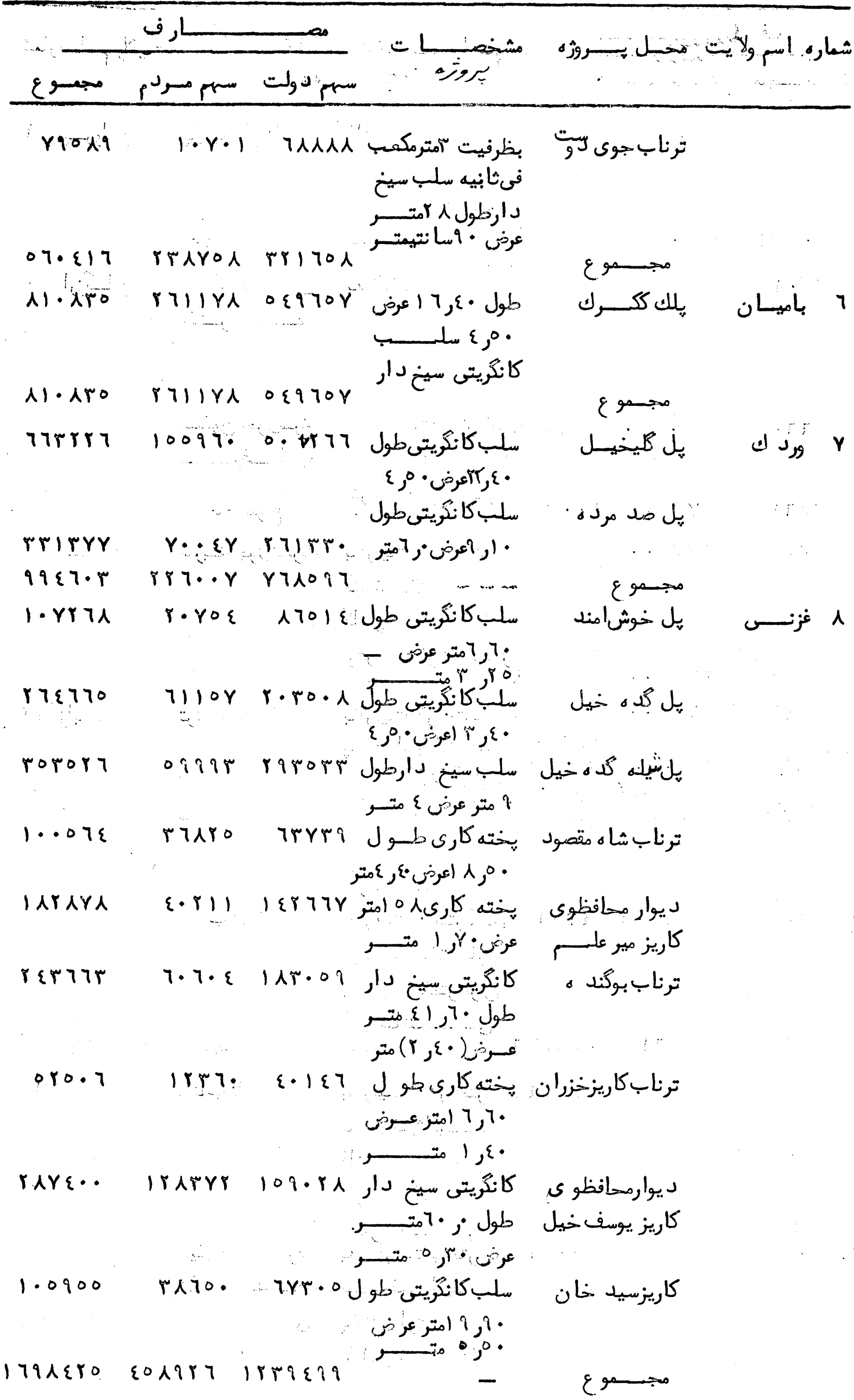


(1) ادامسـ جســد (1)

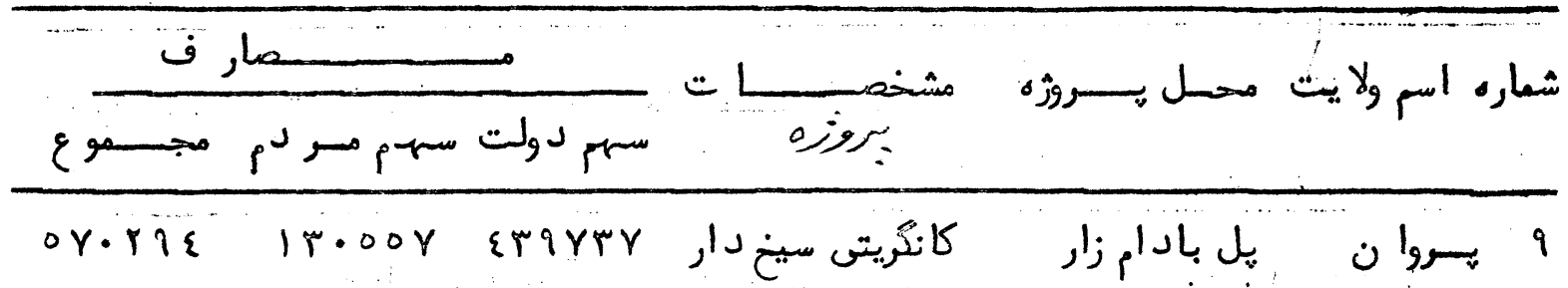

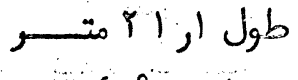

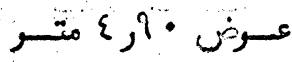

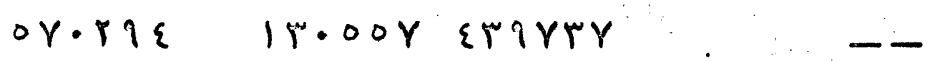

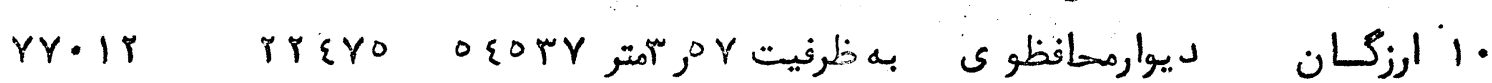

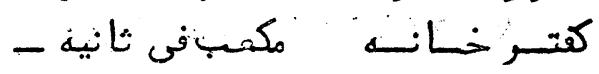

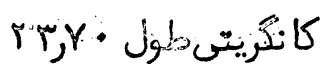

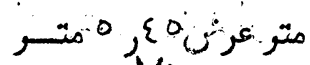

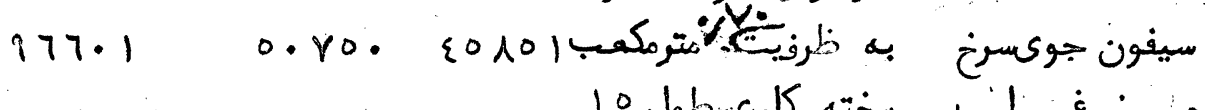

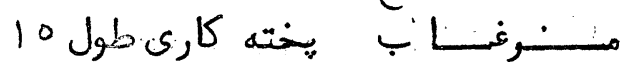

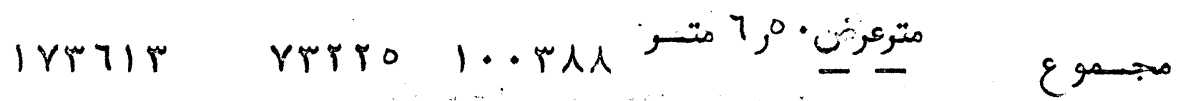

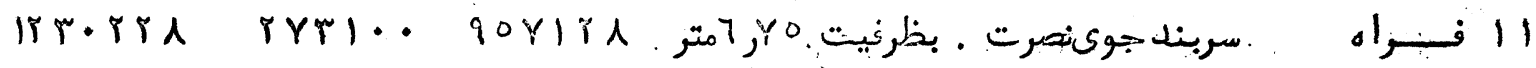

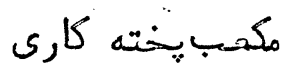

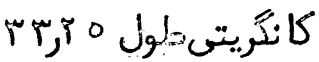

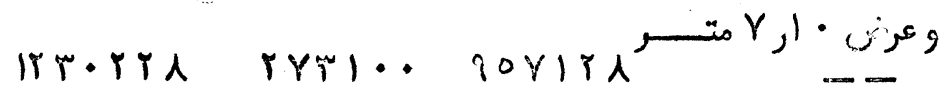

$119 \varepsilon 77$ Vrq..

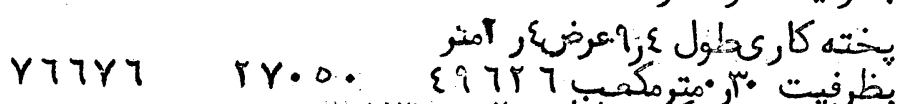

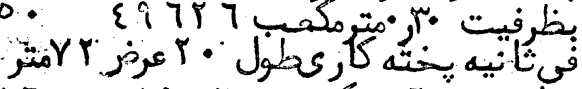

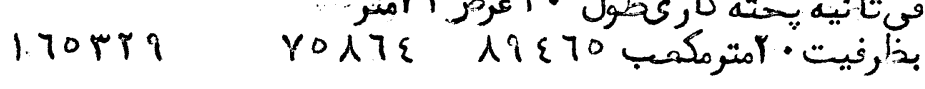

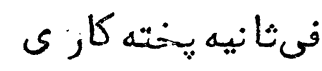

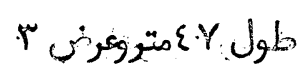

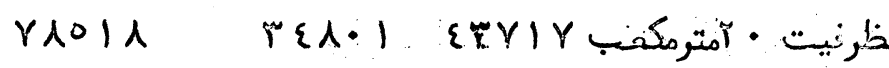

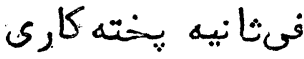

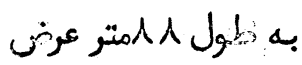

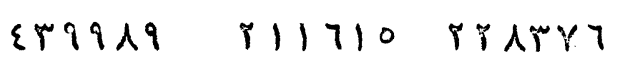
L $Y$ T

YY.0TO YTII

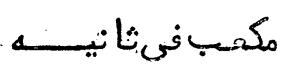

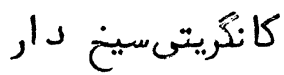

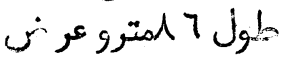

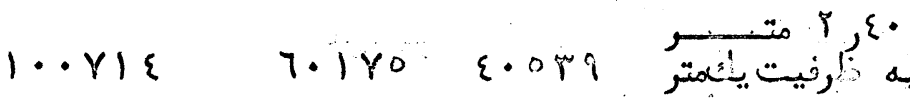

مكسب في ثانيــن

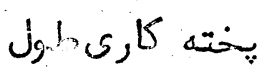

مجنسموع

ترنابَقره قل

Ir

ترناب موكز اك

سيلبر لاجورد

سيلبر لا جورد

ترناب شوخدك

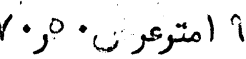

سيفون جوكسره

شاه درشيلــــــ

شينك 
(1) اذامسه جســـ (ادل

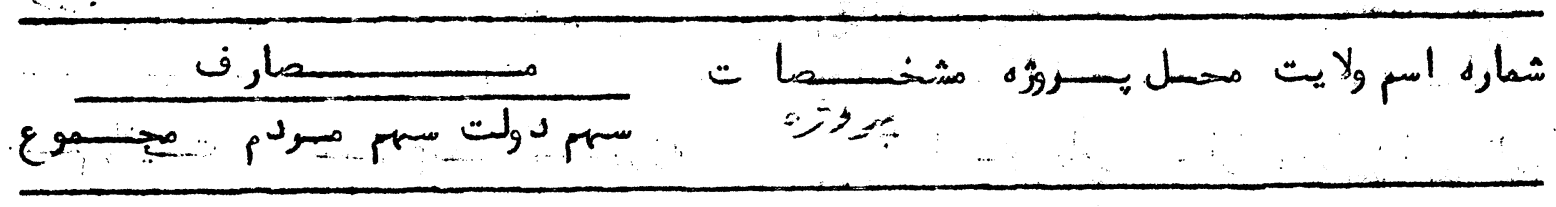

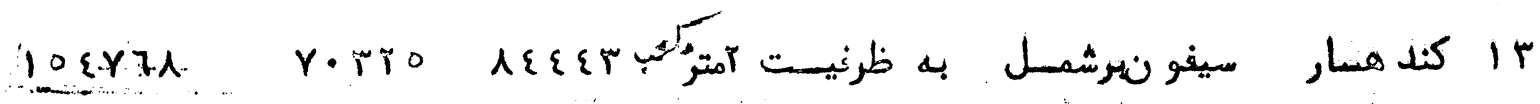

$$
\begin{aligned}
& \text { فى ثانيه يختــه }
\end{aligned}
$$

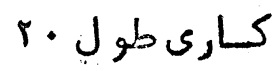

$$
\begin{aligned}
& \text { مستر وعرثن }
\end{aligned}
$$

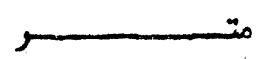

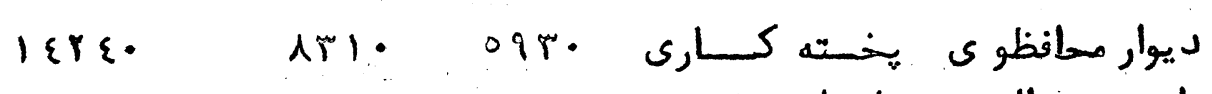

\begin{tabular}{|c|c|c|c|c|}
\hline $1 \cdot \varepsilon \cdot r \circ Y$ & 19991 & $78 \cdot r 09$ & $\therefore---$ & مجسـمو ع \\
\hline - 990RAR & $770 \& 78$ & Yrri?lo & $-\ldots$ & مجسمو ع كل \\
\hline
\end{tabular}

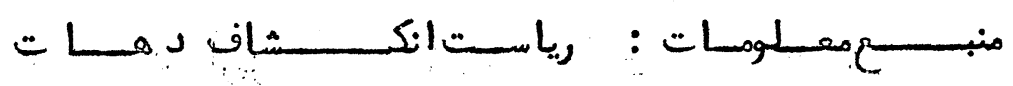

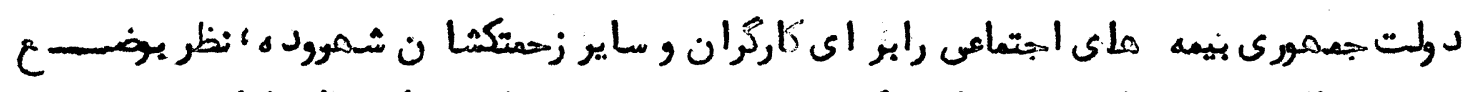

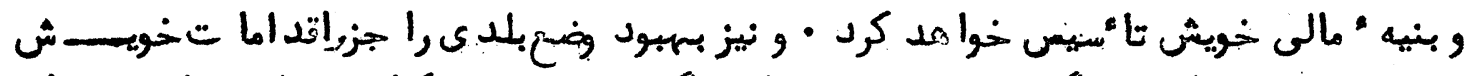

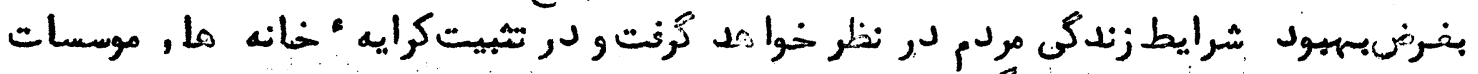

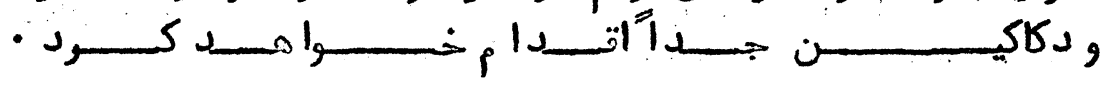

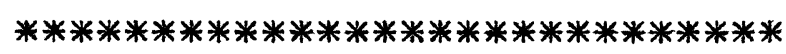

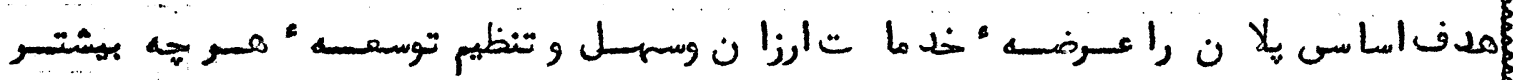

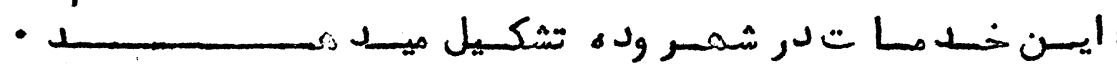

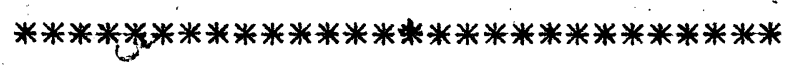

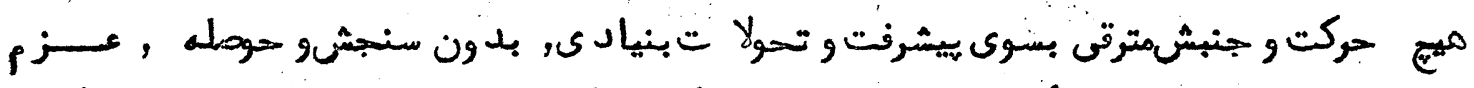

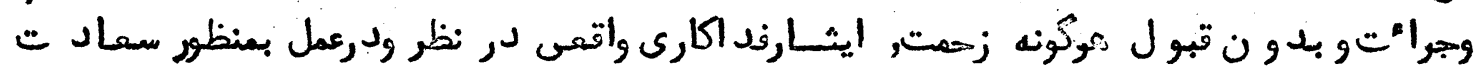

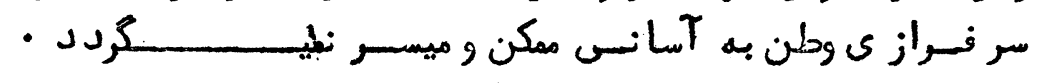

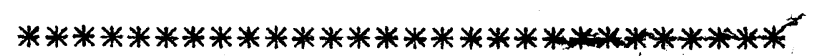

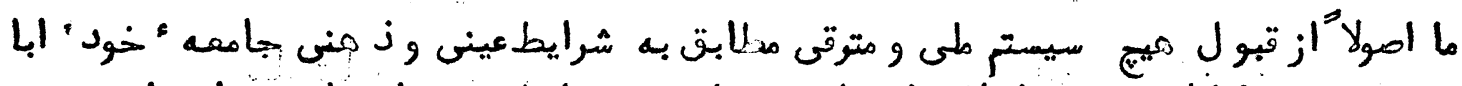

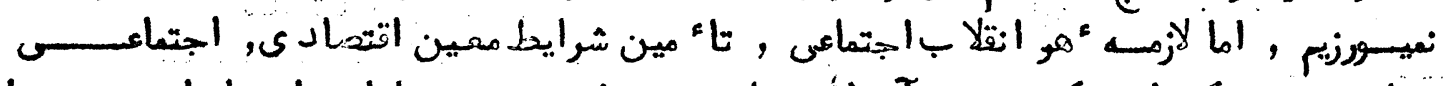

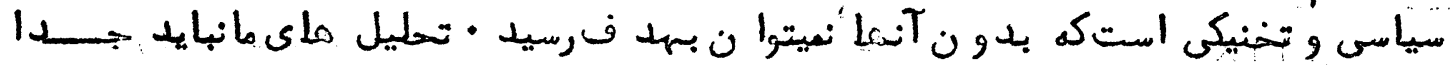

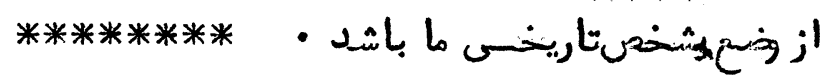

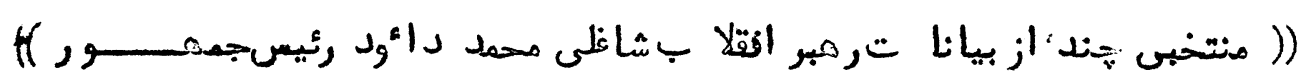

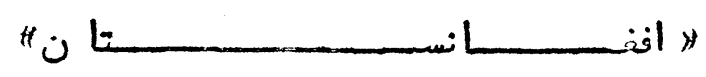


فماليــت هلاى انجام شده رياست انكثاف د هلت تحت بروخرامبواد

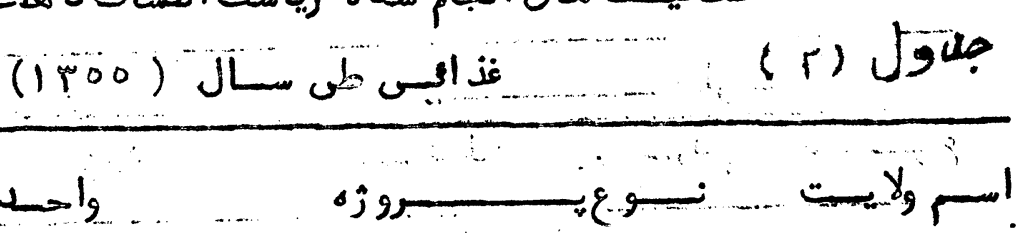

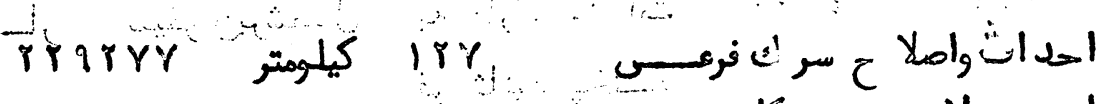

$\underline{L}$

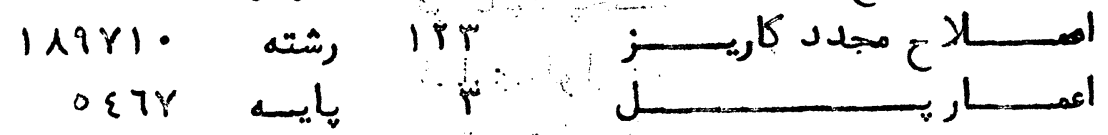

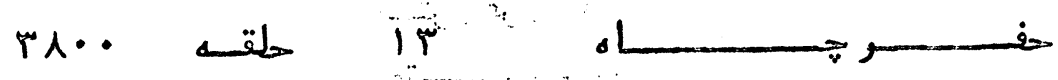

إ عسلـد

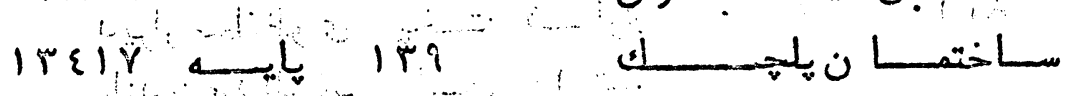

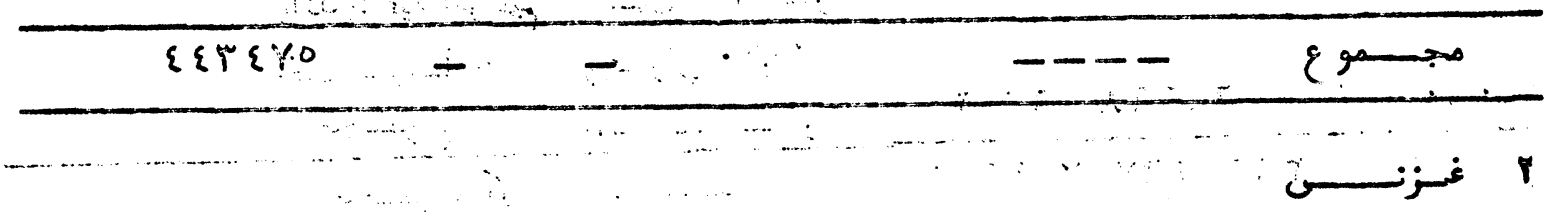

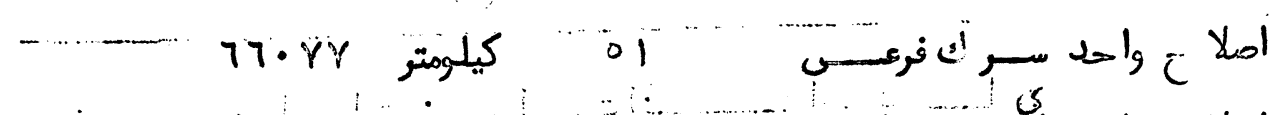

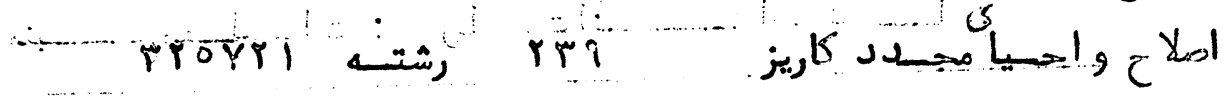

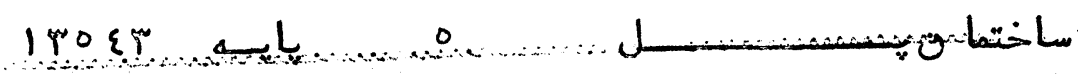

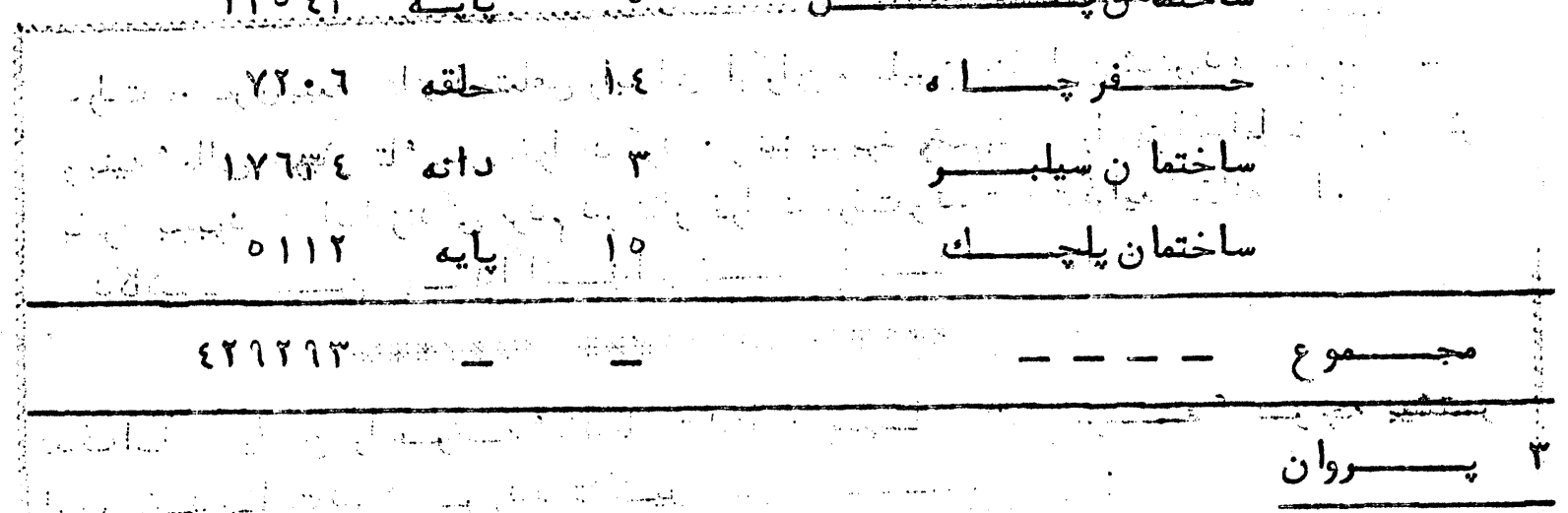

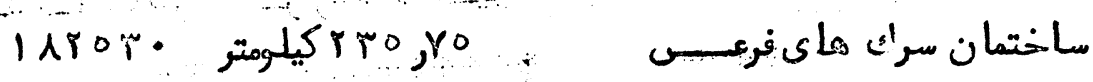

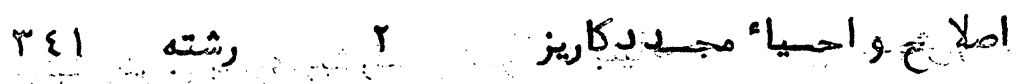

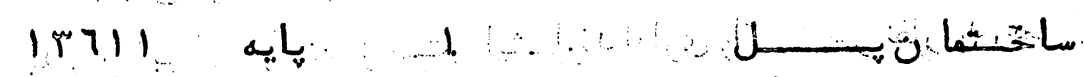

هiा

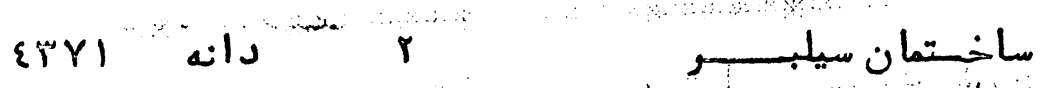

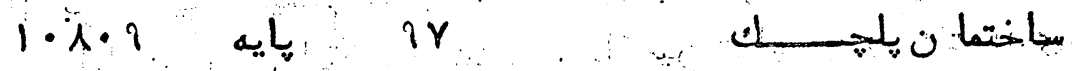

rliko - - مجسموع 
ادامسـه جسـدول (r)

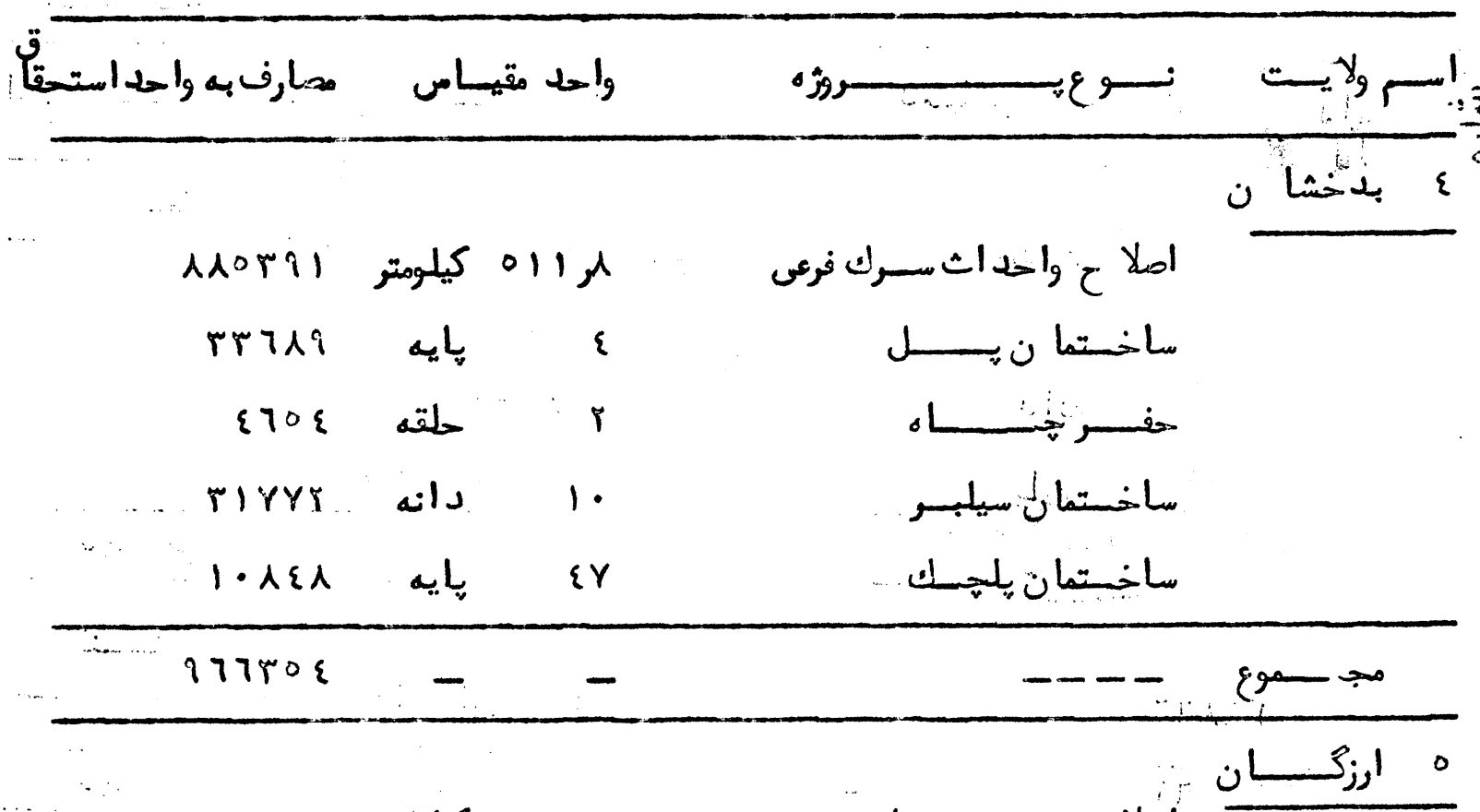

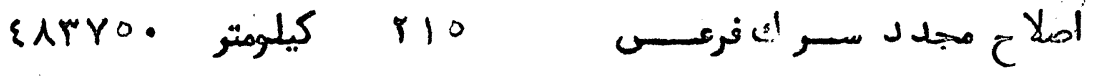

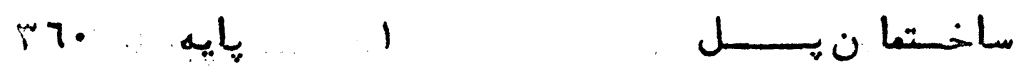

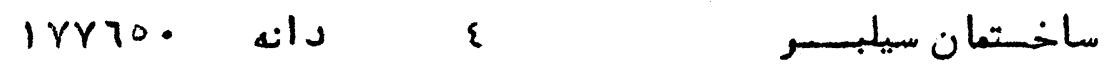

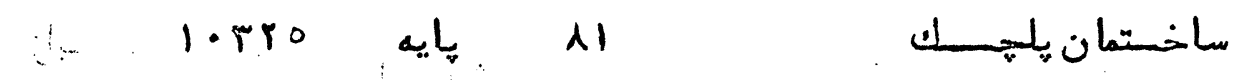

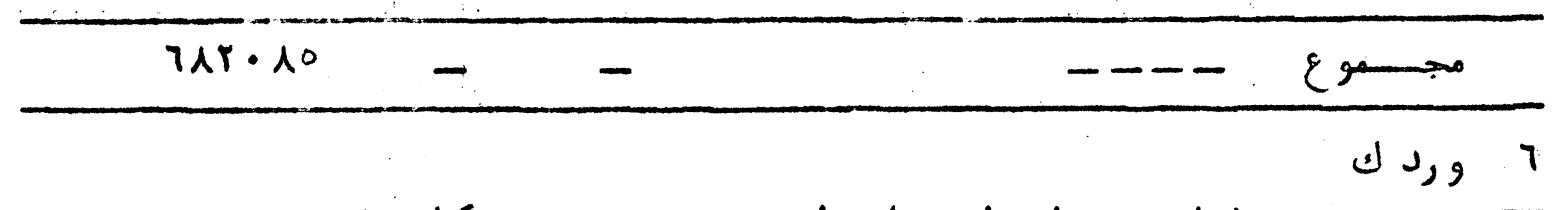

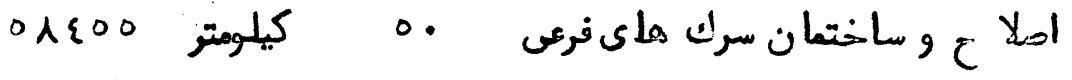

املاح واحنياى مجددكاريسز

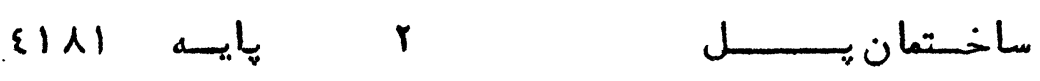

هـ

ساختمان سيلبـــ

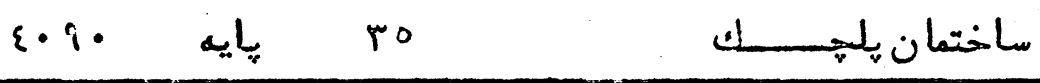

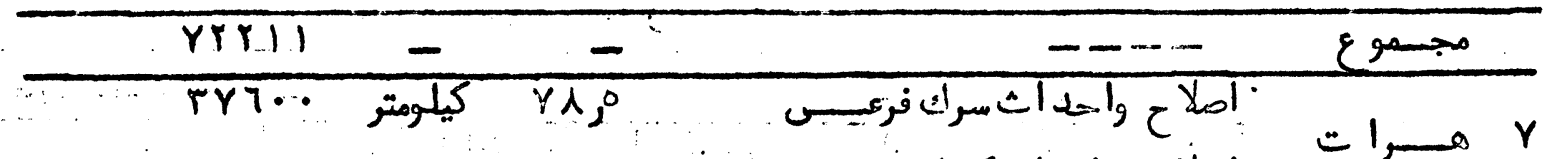

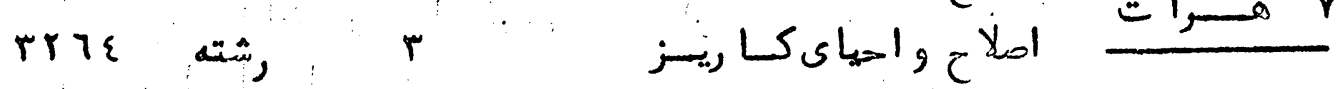

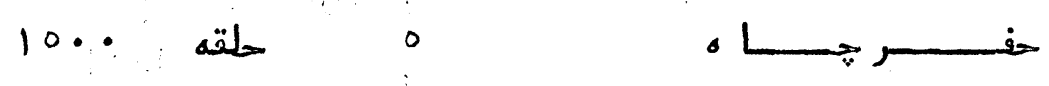

ساختسما ن سيلبسـر

ساختمان يلنهـ

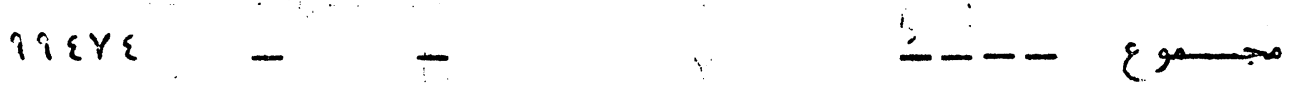


ادامسه جسـ ول (r)

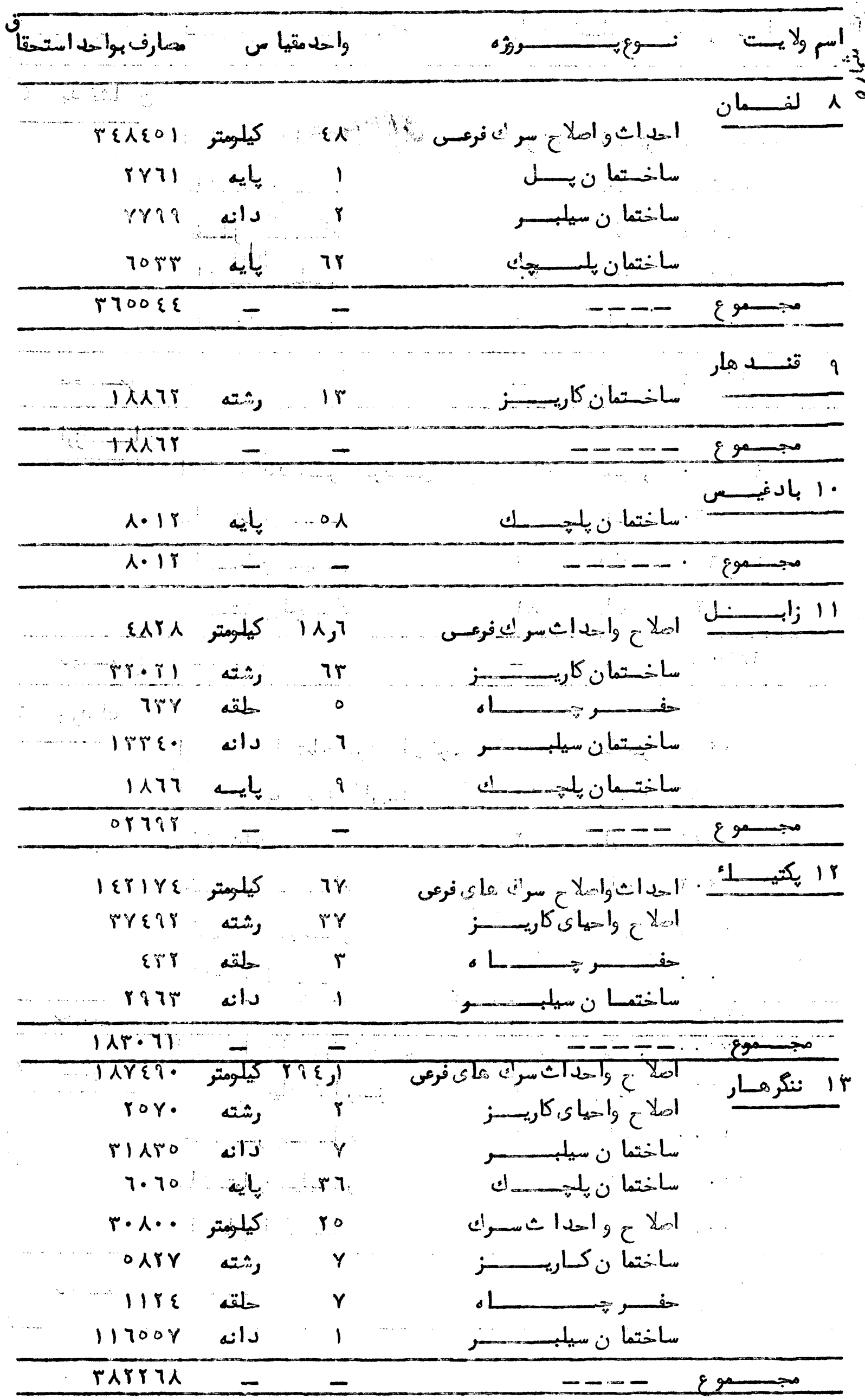


(i) المسه جســـ واحسد مقياس مدارف بواحل استحقا

نسـوع.ع. هـ 每

ROI ST

ساختما ن سيلب

ع 1 ا بنـــان

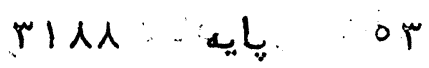

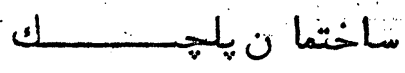

กะนิ

$-\ldots$.

- - -

مجـــــ

10

ساختماف ن يله إيه

$7 \varepsilon 0 \% \varepsilon$

$-$

-

$-\cdots-$

مجسبمو ع

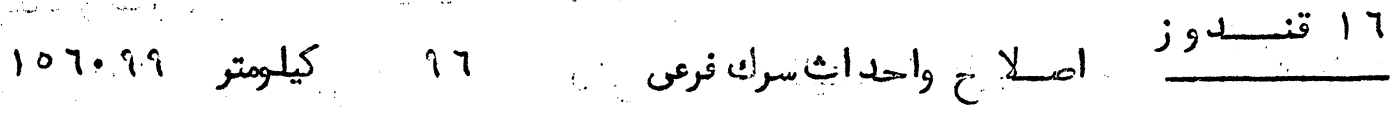

rr 101

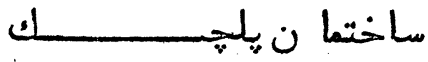

Irirri - -

rr.. r. r.

rit: -

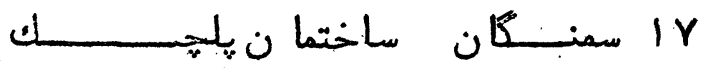

\{71人 il

--D--

$\{7 \mid \lambda$

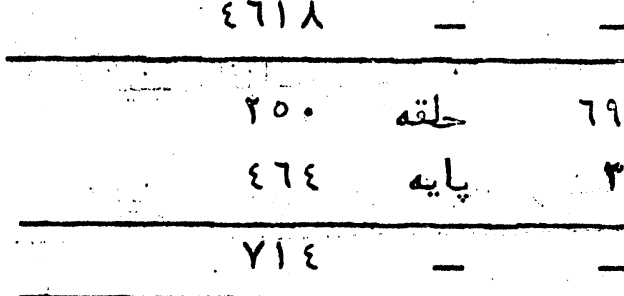

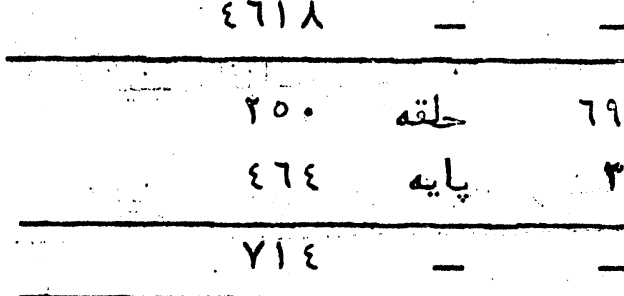

$\{7\}$ يائه

11 غــــورا ت ساختعا ن سيلبـ

- $-\cdots$ مجمو ع

19

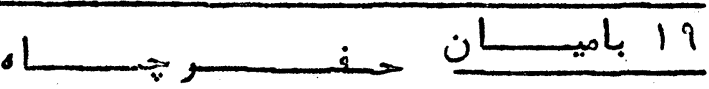

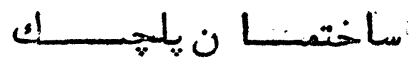

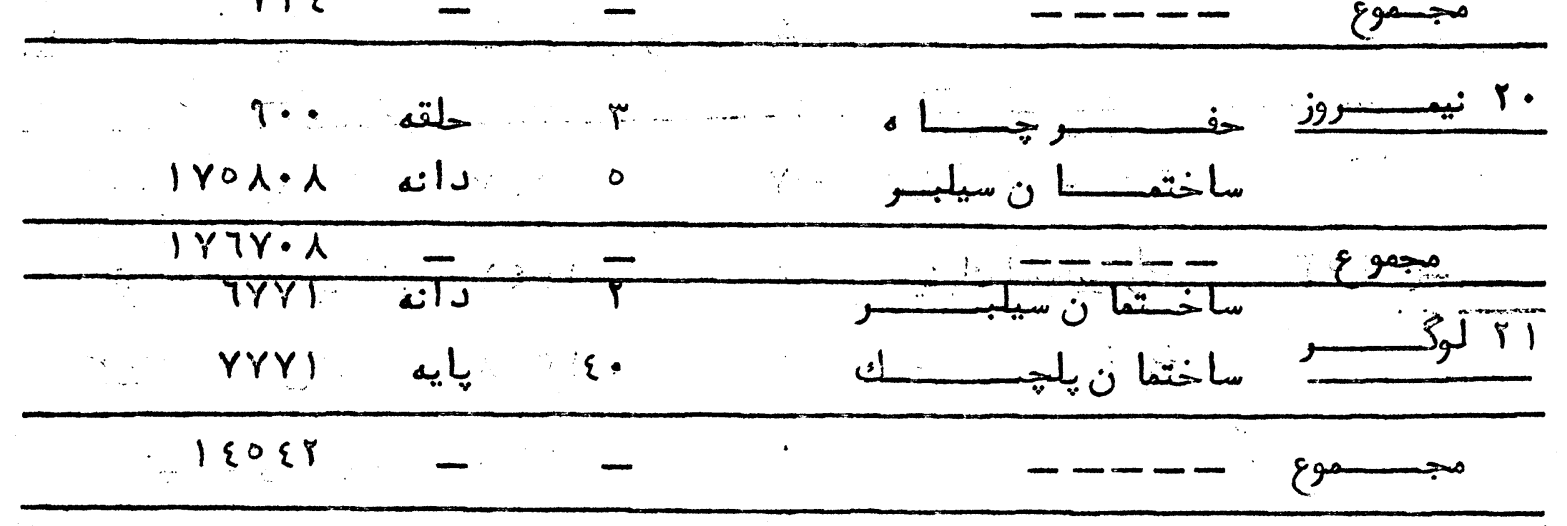

\{rาTrใ?

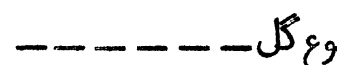

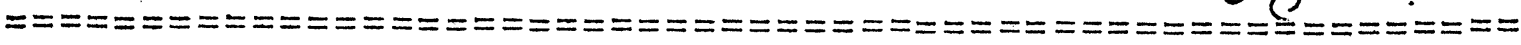

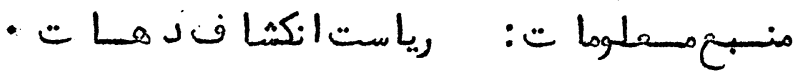

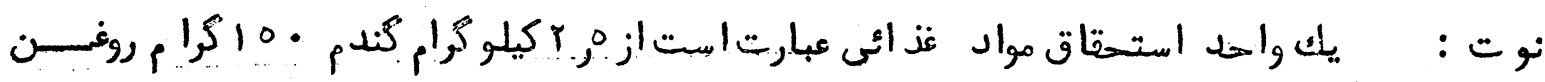

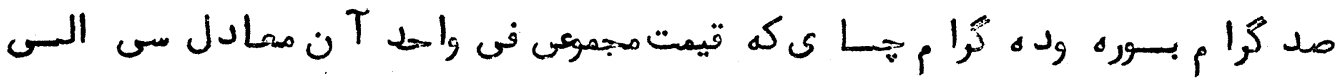

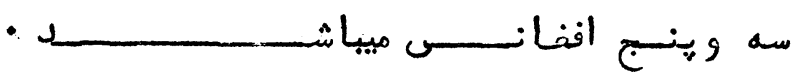




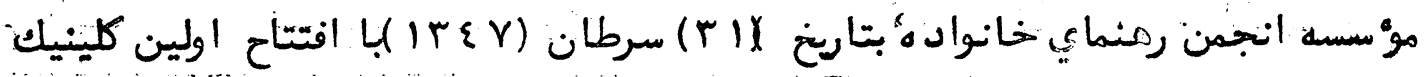
ان لدر شفاخايه زايشكاه روي امد ا فكترول نفو س- تاء مين ازدياد فوامل حمل و رمنبائى

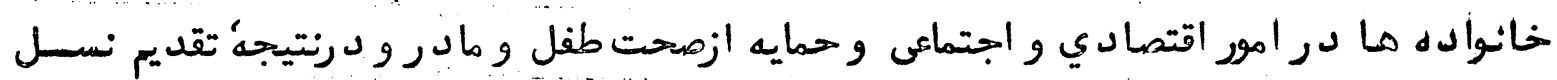

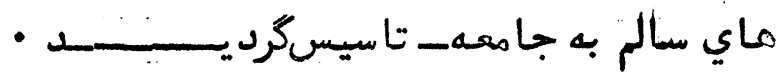

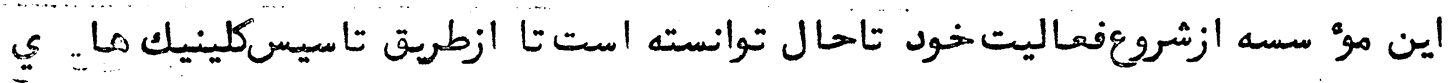

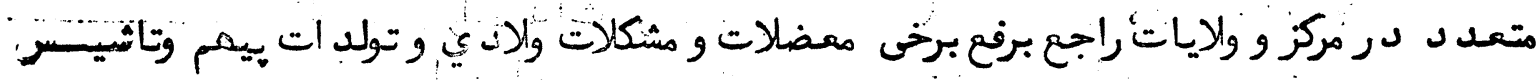

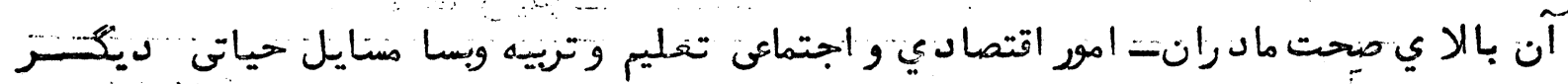

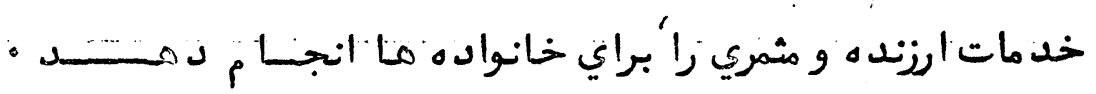

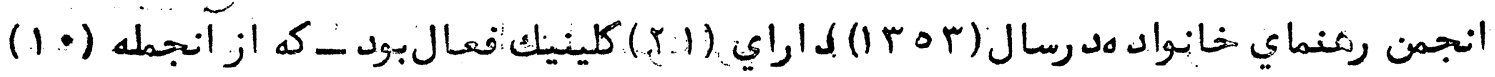

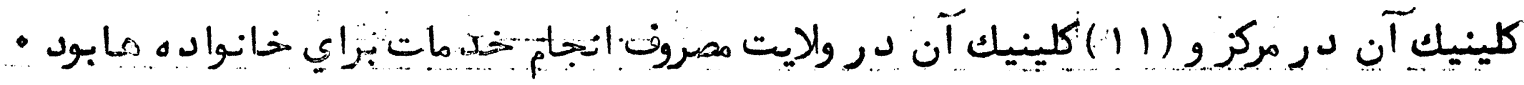

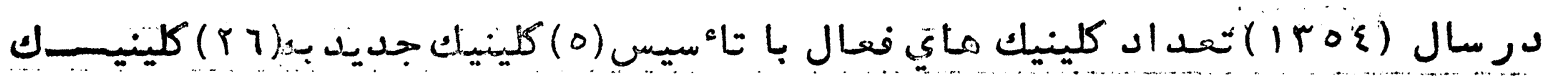

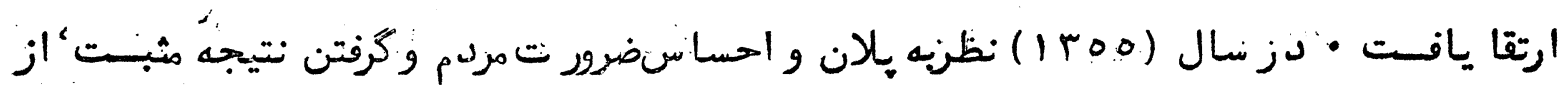

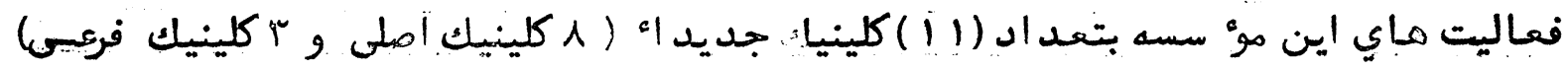

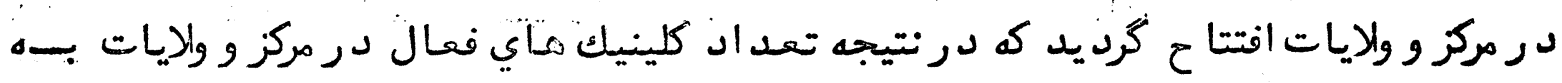
• كلينيك افزايشيافــr.Yr)

كلينيك ماي فعال إنجمن رمنمابي خانواده و سبال تاسيسآن دير مركز و ولايســات

شماره اسم كلينيك ماي. تسال تاسيس شماره اسم كلينيك ماي بال تاسيشن مسرك الم

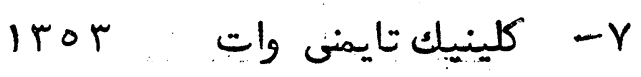

$\operatorname{lr} \varepsilon \gamma$

(r) - كلينيك كارته

iror

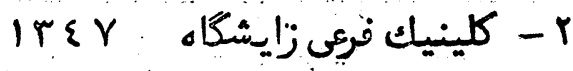

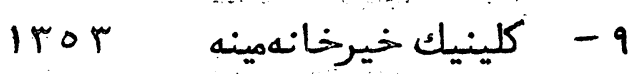

r Ir

• | - كلينيك مهاينه خانهمركزي |

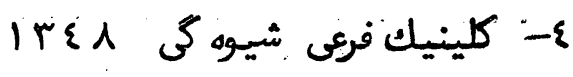

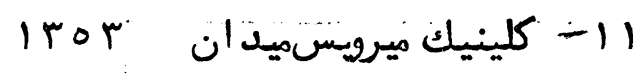

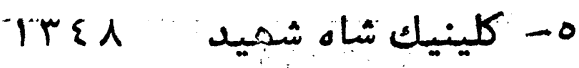

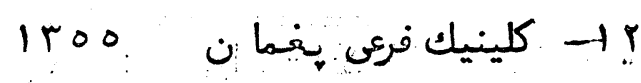

Iro. 
GL

شماره اسم كلينيك ماي ولايا ت سال تائيس شماره باسم كلينيك ماي ولايات تاسئس

\begin{tabular}{|c|c|c|c|c|c|c|}
\hline Kros & لغهـان & كلينيك & $-1 \varepsilon$ & $\operatorname{lr} \varepsilon q$ & مســـرا = & 1- كلينيك \\
\hline irot & خوســت & ע & -10 & $1 \pi \varepsilon q$ & لشكرگساه & r- : עر \\
\hline 1500 & باد غيس & עر & -17 & $1 r \varepsilon q$ & مزارشريف & $\nu-r$ \\
\hline $11 \% 00$ & جوزجان & עد & -18 & $1 r \varepsilon q$ & جلال آباد & ع- رر \\
\hline 1900 & سمنكـان & עد & -11 & $1 r \varepsilon q$ & יبـــروا ن & 0- رد \\
\hline 1500 & تخـــــار & עد & -19 & 170. & بغــــلان & ו- עر \\
\hline iroo & جغهران & ע & $-r$. & iro: & كــدوز & $\nu-\gamma$ \\
\hline 1000 & ارزكان & עد & $-r .1$ & iro. & غــزنس & ג- رر \\
\hline 1 roo & باميا ن ... & رע & - rr & $|r o|$ & كد مار & 9 \\
\hline 1700 & نيمسروز & עد & $-r r$ & $|r o|$ & لوكتــر & • \\
\hline 1000 & فرعى ميد ار & עد & $-T \xi$ & Iros & ميمنــــهـ & 11 \\
\hline \multirow{2}{*}{\multicolumn{2}{|c|}{ עر بلخمري 1roo }} & رנ & $-r_{0}$ & 1rog & نــــراه & ז'ו-رر \\
\hline & & & & Iros & بدخشان & $\nu^{-1 r}$ \\
\hline
\end{tabular}

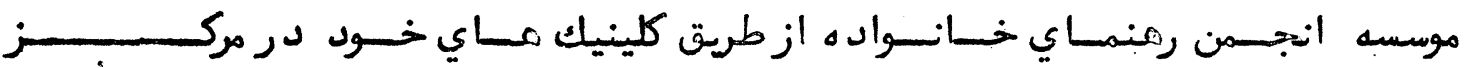

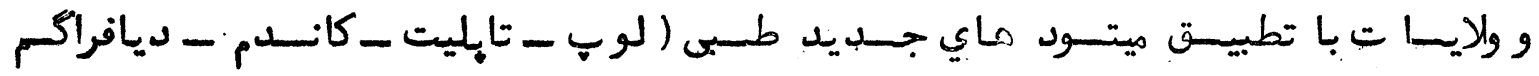

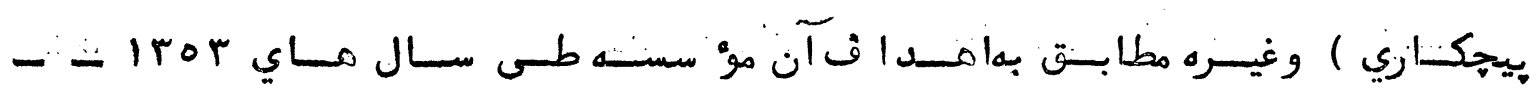

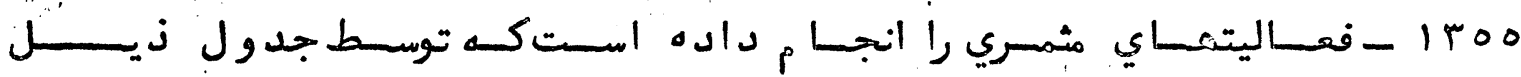

$$
\text { • مي }
$$

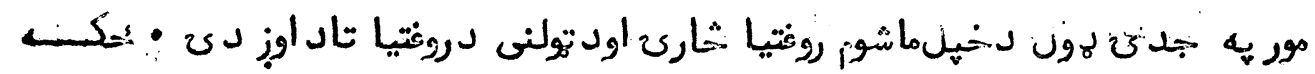

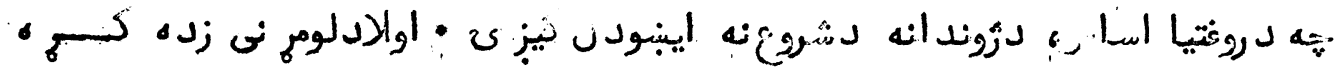

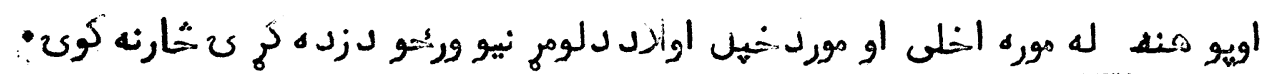

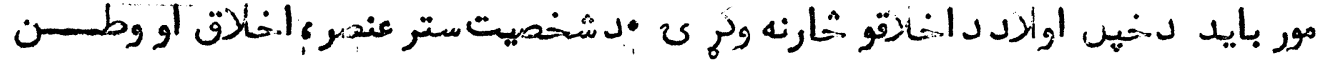

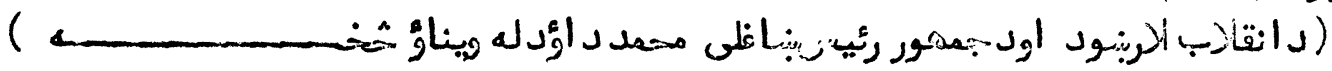




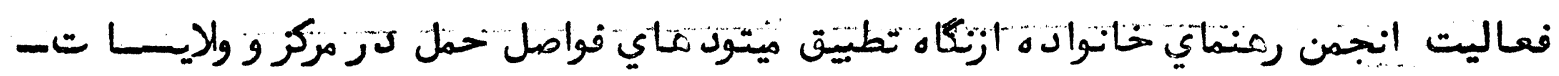
(1roo-1ror) (

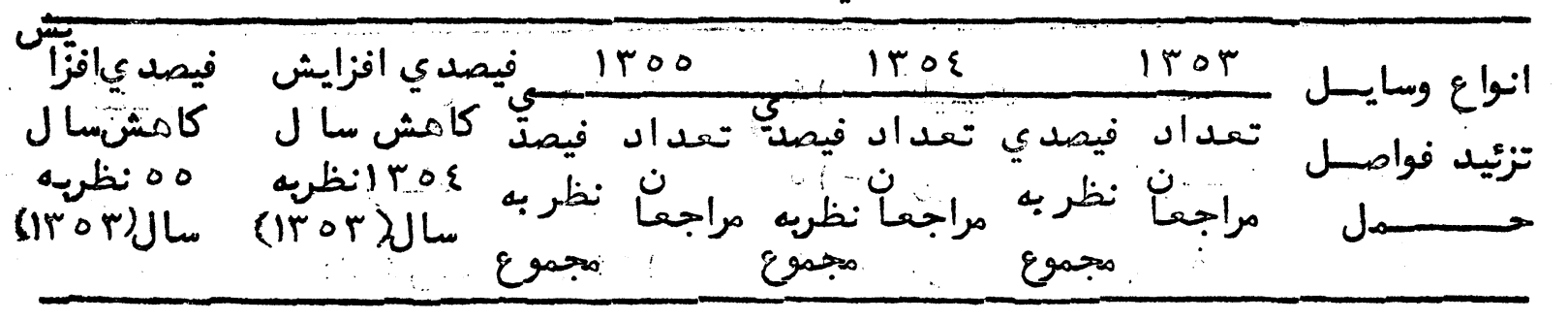

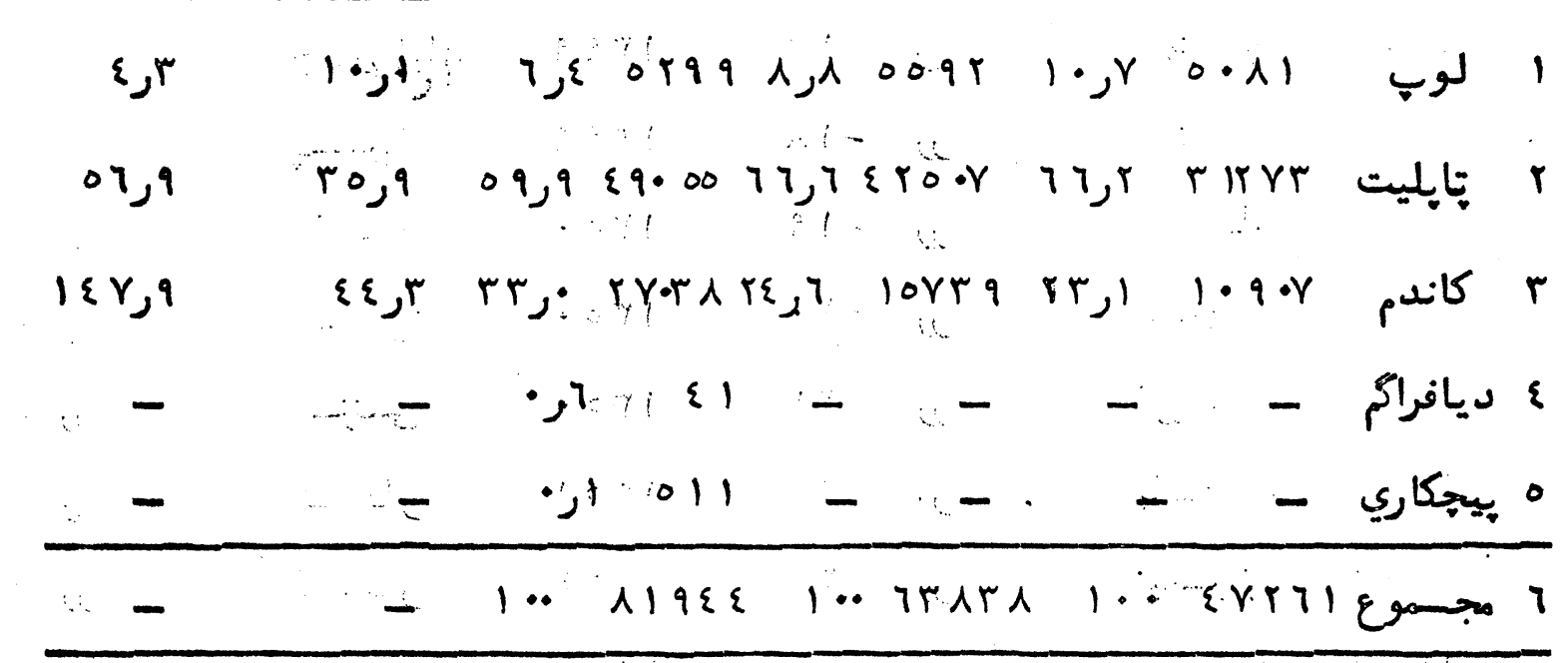

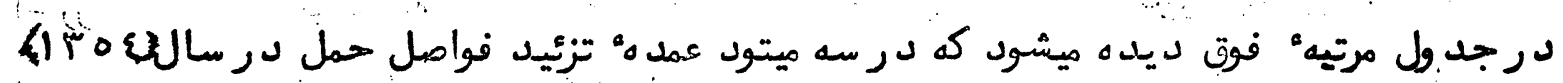

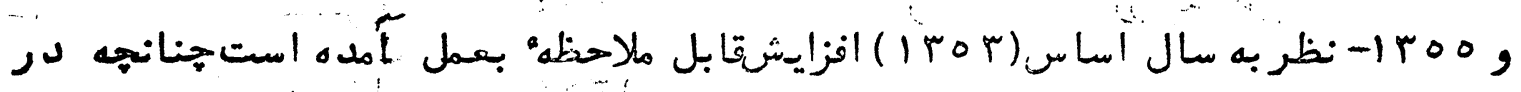

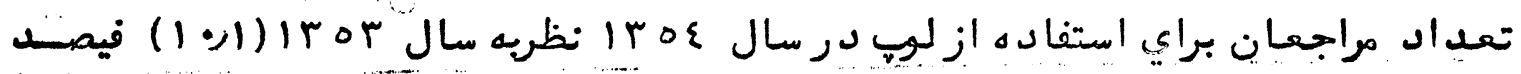
تإيليت (q ره r) فيصد وكاندم (rرع ) نيصد از دياد رخد اده است • مسمنا ن درسال

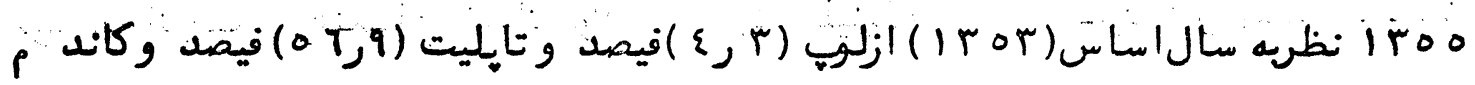

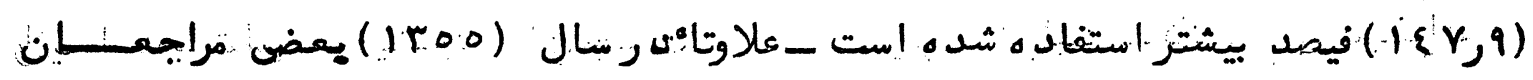

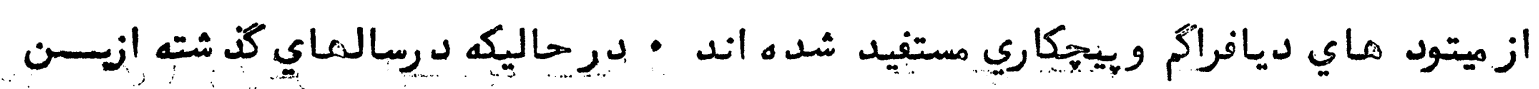

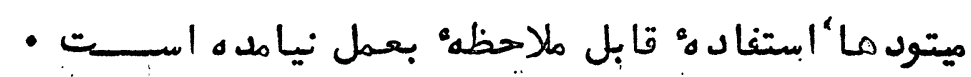

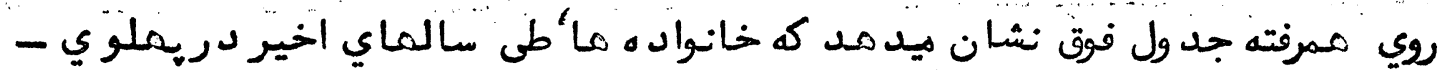

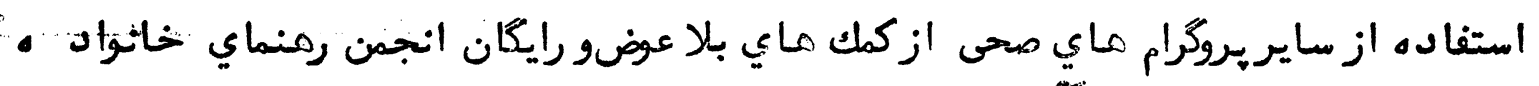

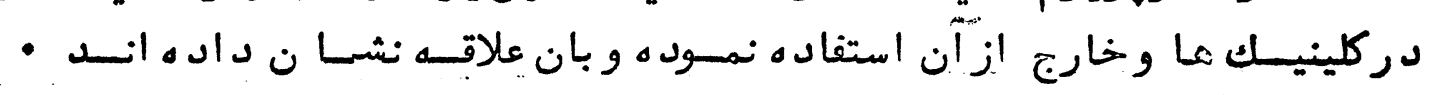

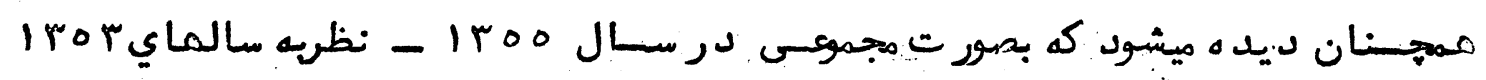

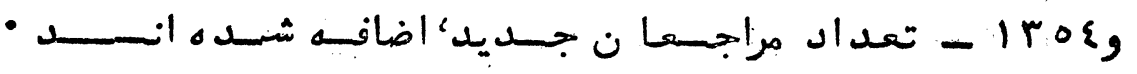




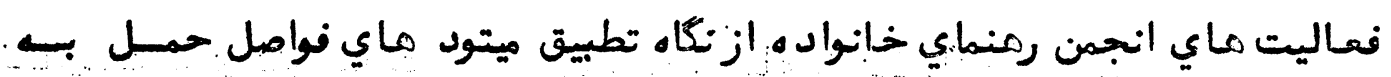

تفسريست مركز و ولايا تعلى سال (1roo )

L

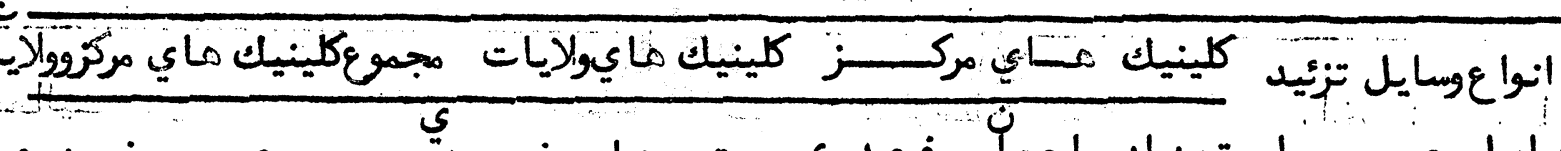

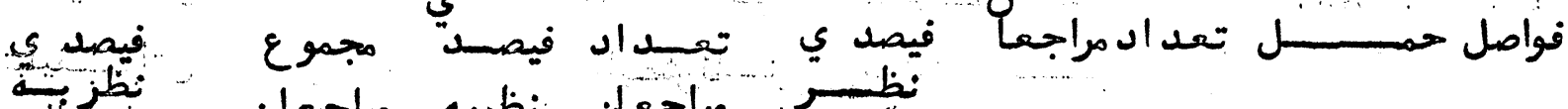

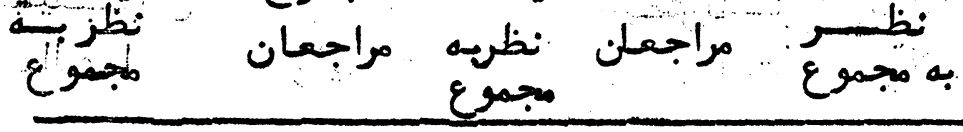

\begin{tabular}{|c|c|c|c|c|c|c|}
\hline $1, \varepsilon$ & o & r & $100 r$ & 1,9 & rrs & لبوت \\
\hline$\circ 9,9$ & $\{9 \cdot 00 ;$ & $r, r$ & rYqAY & $0 \cdot 1$ & 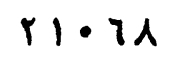 & تايليت \\
\hline •رrr. & $r Y \cdot r \Lambda$ & $r 0, q$ & 1.rrq & $r q, r$ & $17 \gamma \cdot \varepsilon$ & كـاندم \\
\hline ر & 011 & - & - & r & 011 & ع بيجكاري \\
\hline • & $\{1$ & - & - & ارن & $\{1$ & ه ديافرام م \\
\hline $1 \cdots$ & $\wedge \mid q \& \varepsilon$ & $1 \cdots$ & rqArr & $1 \cdots$ & $\{Y \cdot Y\}$ & مجــموع ع \\
\hline
\end{tabular}

بملاحظه" جد ول فوق طور مجوعى .ازتإيليت د ر مركر و ولايات تقريبا. ( . ) فيصد _كاند م .

- فيمد استفاده بعمل آمده استس (rr)

لد رقسمت تبليغنـــات

يكى از امد افعمده؛ انجمن رهنماي خانواده تنوير افكار مادر ان وخانم ما د ر زمينه ماي مختلف جون امور صحى - اجتما عى ـ اقتصادي _ تربيوي وازدياد فاصله بين ولاد تمـــــا ميباشد كه نكا ت مذكورتوسطعده؛ ازمبلنان انجمن د ركلينيك ما_ شفاخانه ما - و منازل شخصى براي ميرمنما بوجه احسن تبليغ ميكردد ـ مسجنا ن مبلفان انجمن رمنماي خانواده.

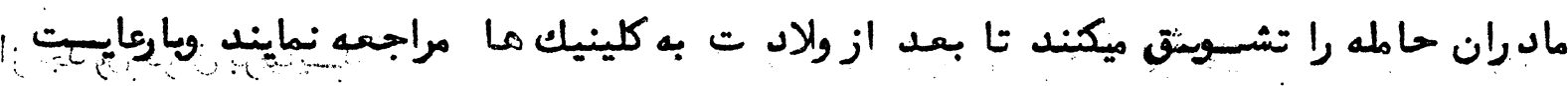
ايجاد فواصل حمل صحت و سلامست خود :وكودكان خود را ازخطر اتيكه متوجه؛ شيان ميليا:ثين. مصنو ن نكمد ارند • مم جنان اين موسيسه توسط تعليما ت بملوي بستسر نمايشفلم ما دروكزيا.

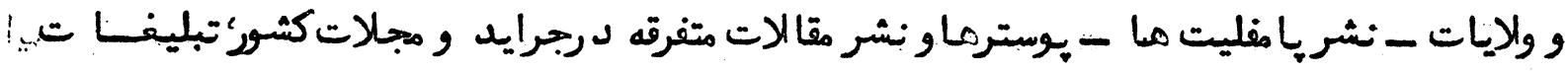

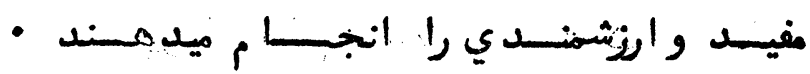

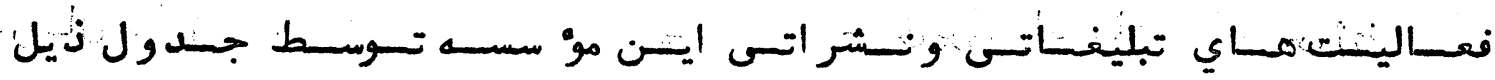

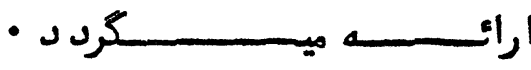




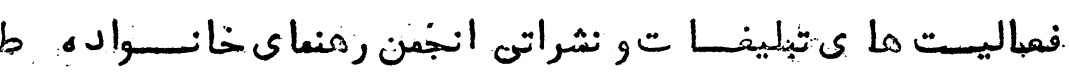

سالمناى (ror - 1roo

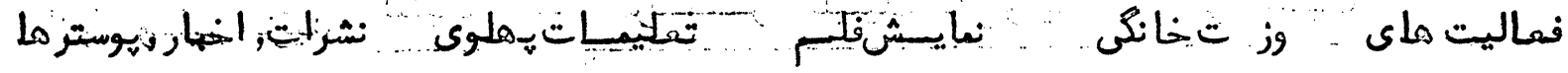

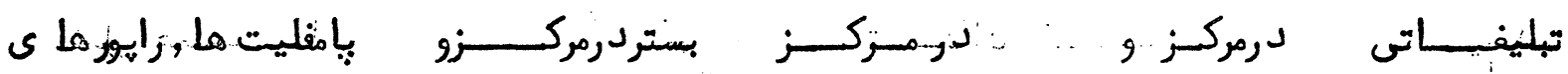

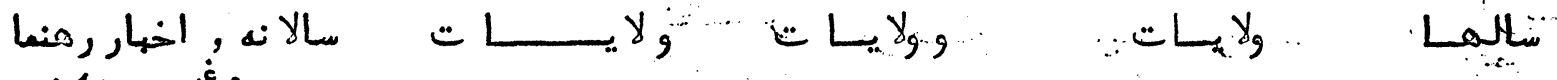

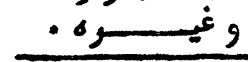

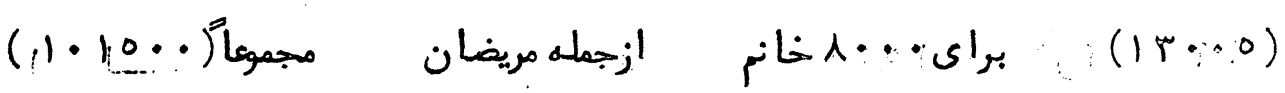

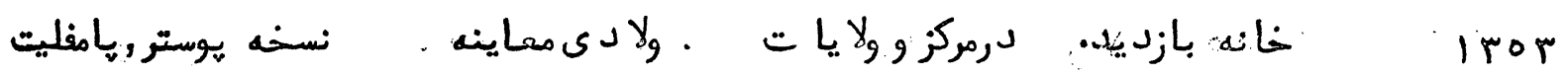

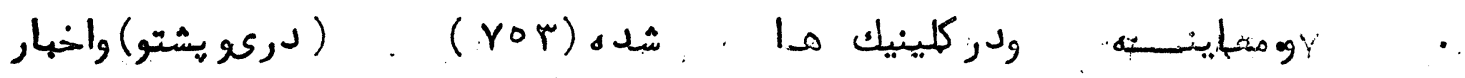

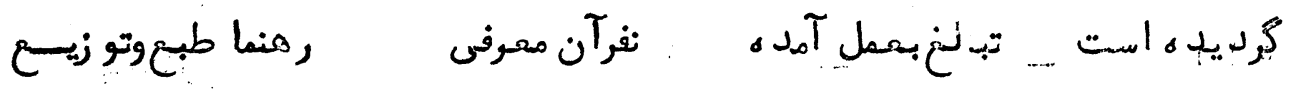

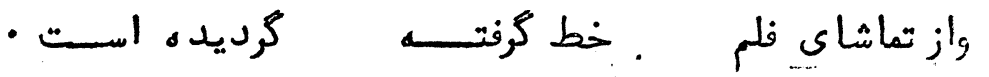

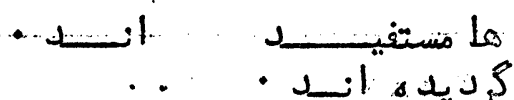

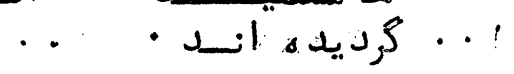

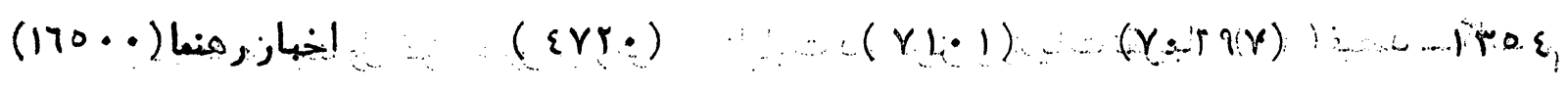
\begin{tabular}{llllll}
0 & 0 \\
\hline
\end{tabular}

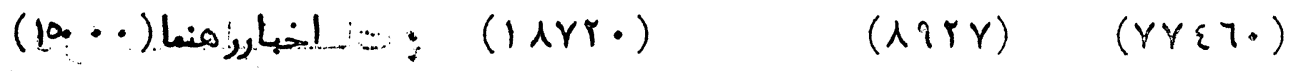

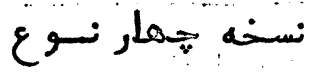
يوستر (ro..

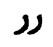
נ) 29 troo

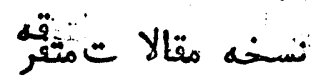
در جرايد ومجنلاع كثر

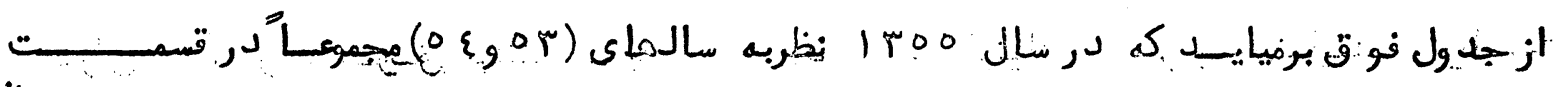

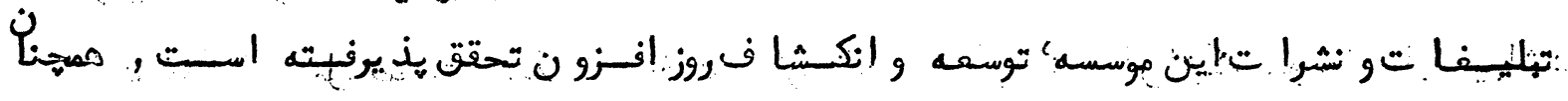

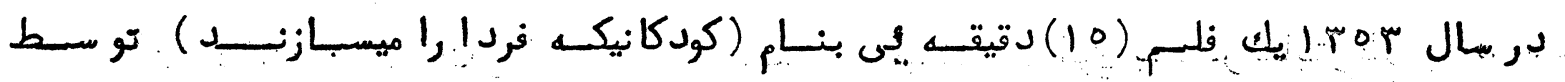

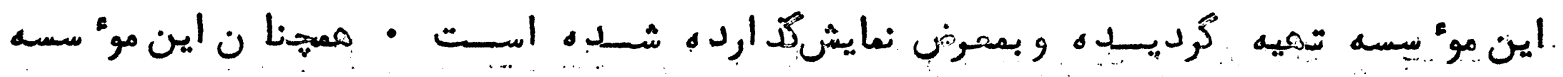

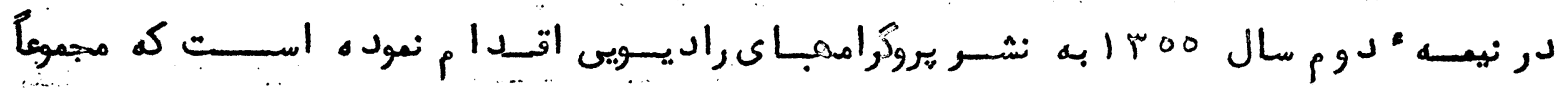

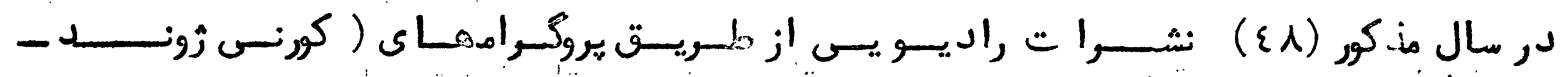

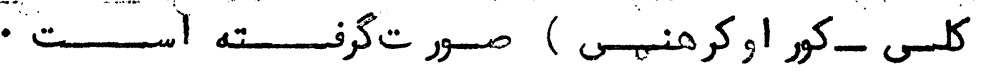

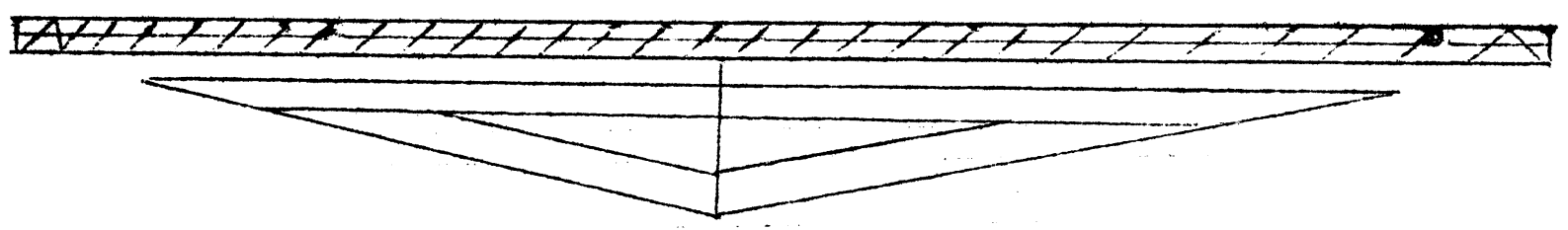




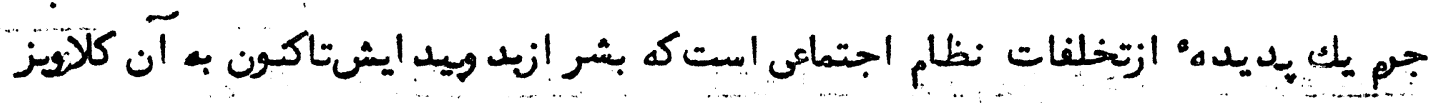

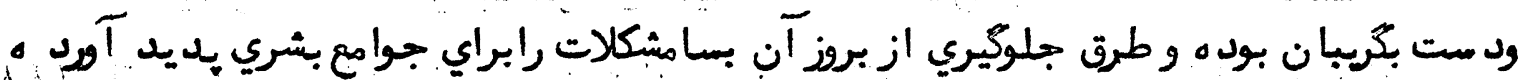
است. بطوركه همواره توجه جدي مقامات دولتى را جهت جارهجوى و اتخان تل اييروقايسـوي ومجادلوي د ربرابرآن به خود معطوف داشته ابيت -

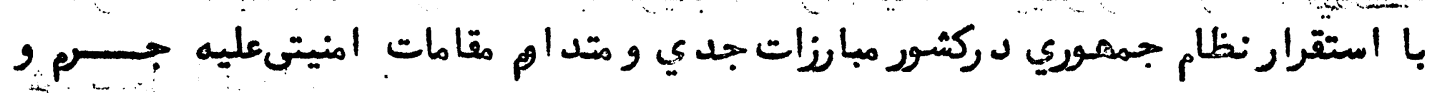
جنايات وانحرافات اخلاقى كه ازتاثيرات سوء آن همهه جوامع بشريكم ويشمتضرميشوند -

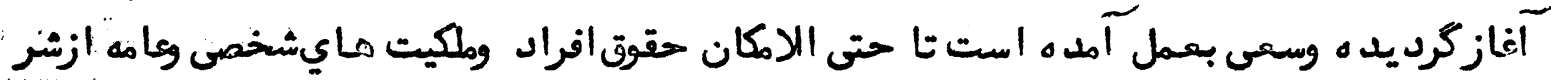

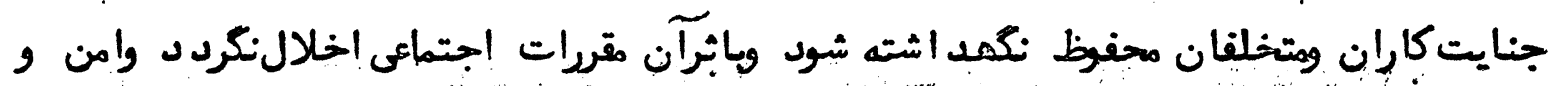

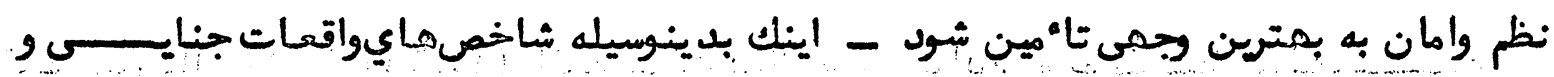

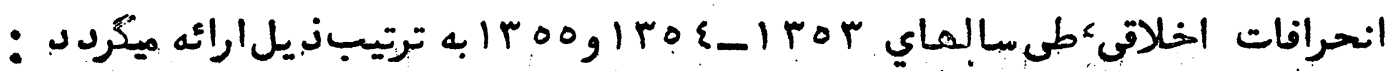
شاخصرهايواقعات جبايى طل سالهاي

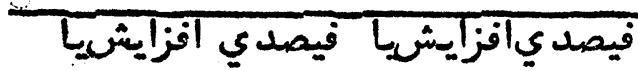

$\therefore$ :00 Iroo lrok fror

نوعواقعه

iror نظربسال

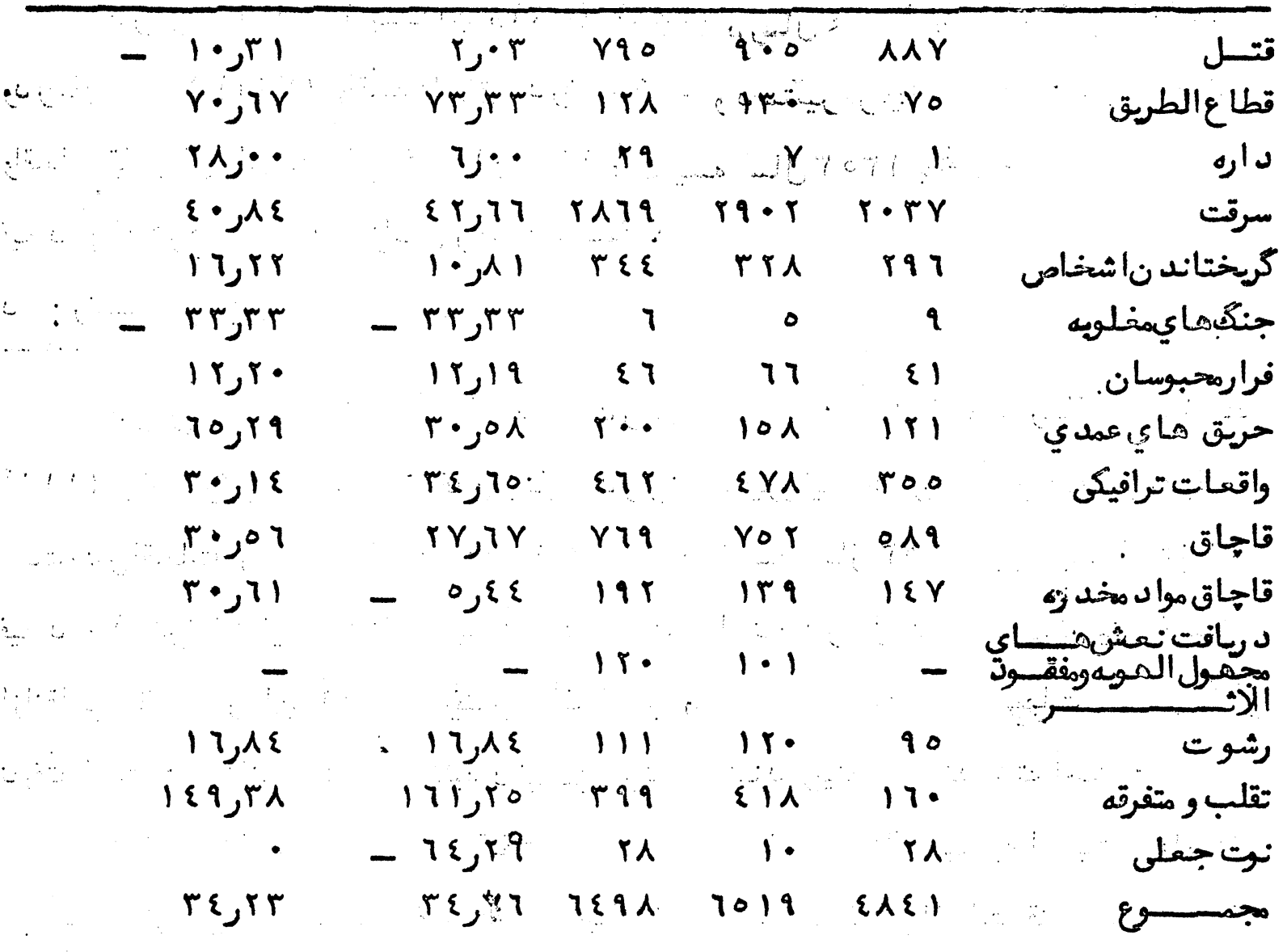




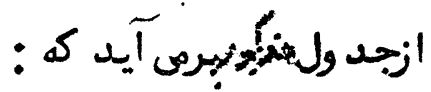

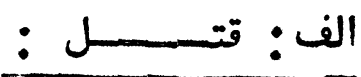

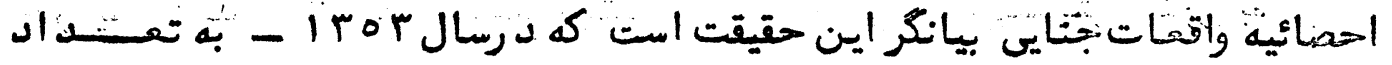

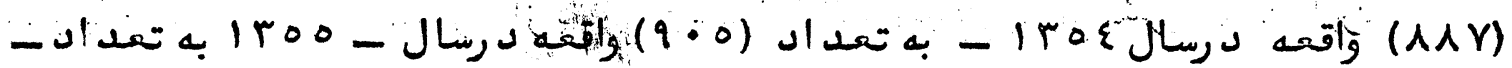

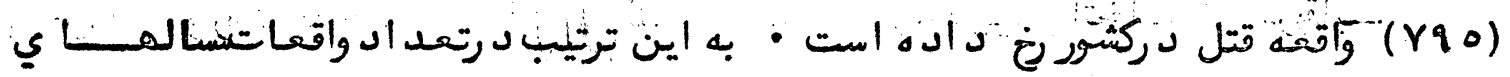

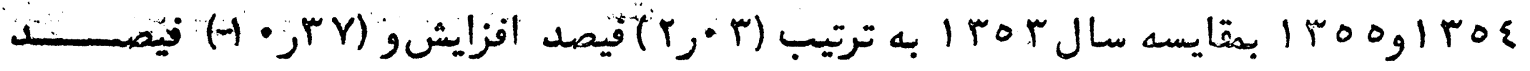

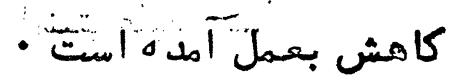

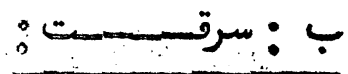

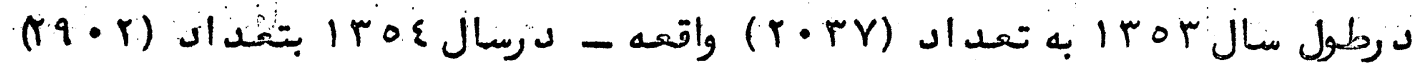

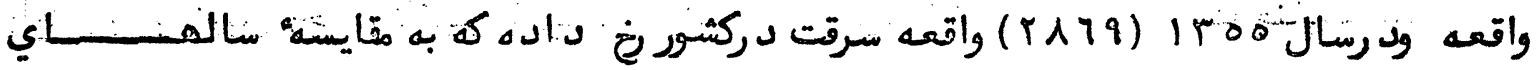

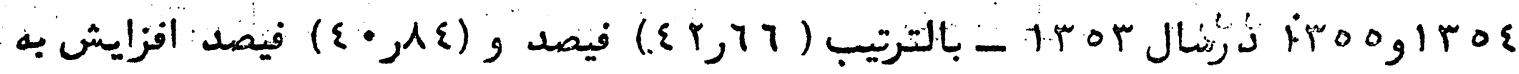

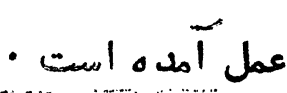

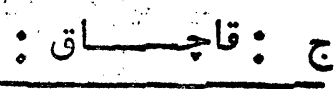

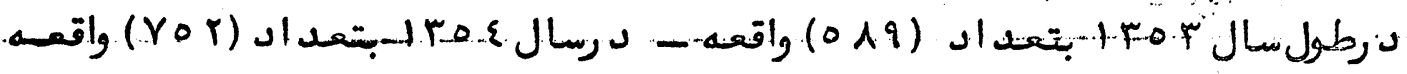

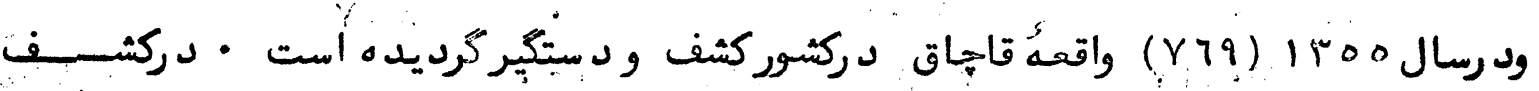

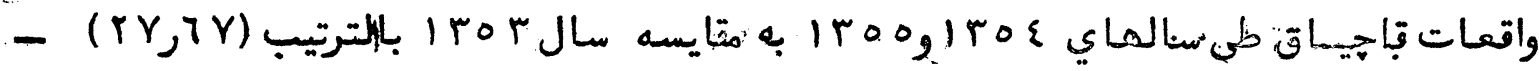

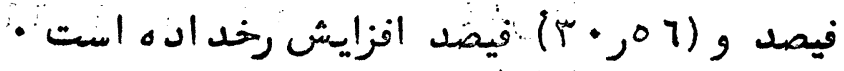

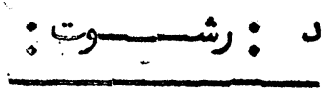

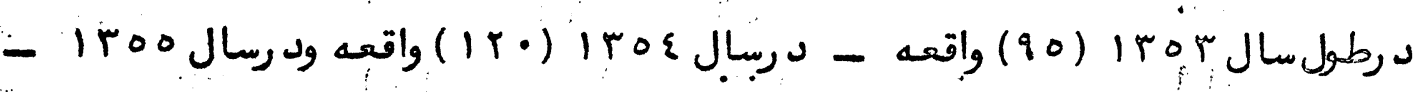

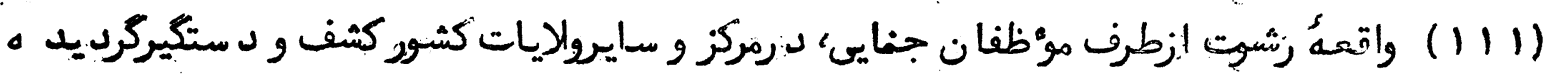

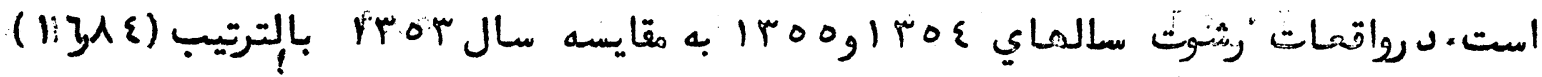

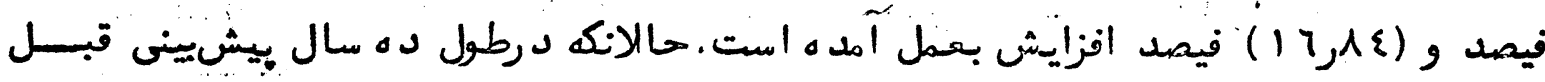

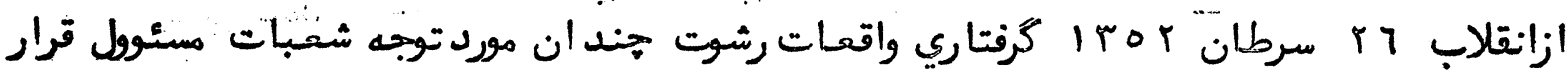

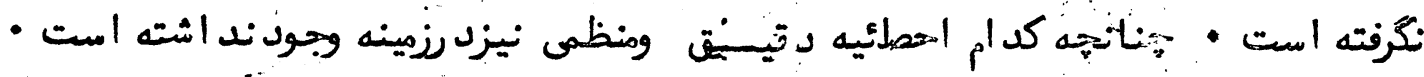

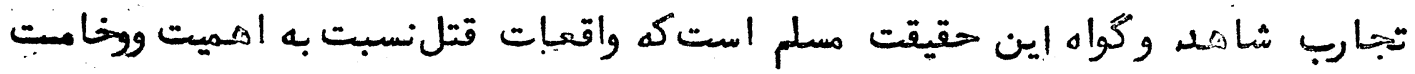

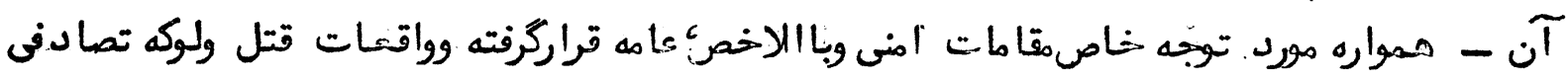

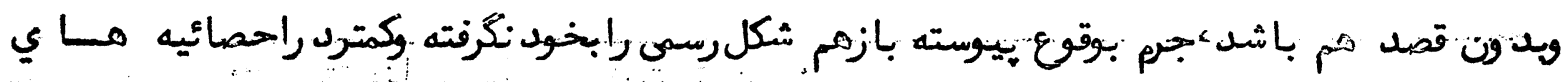




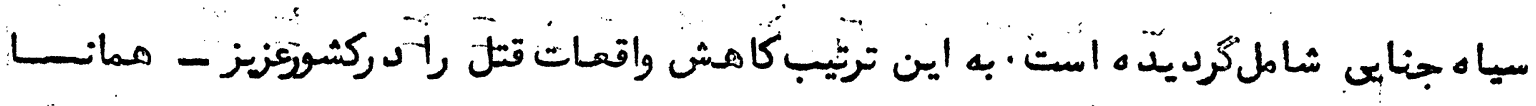

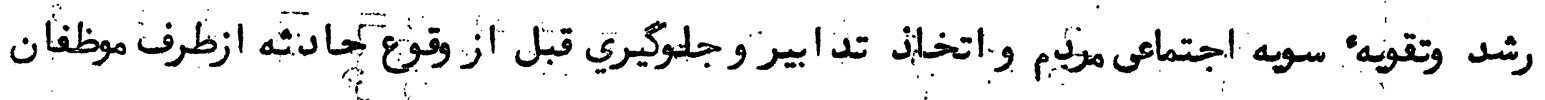

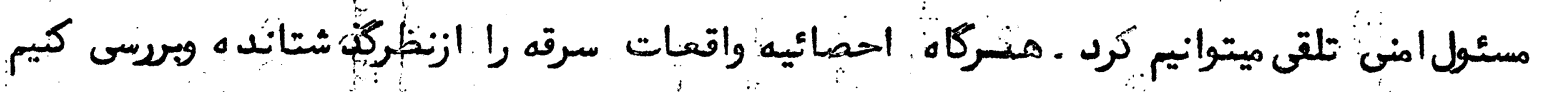

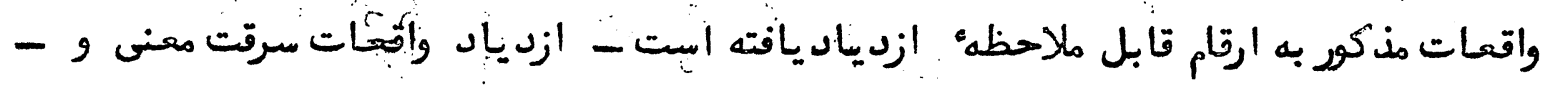

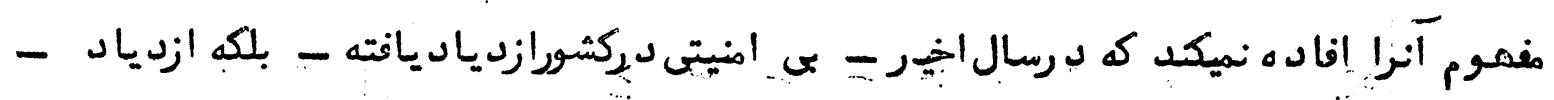

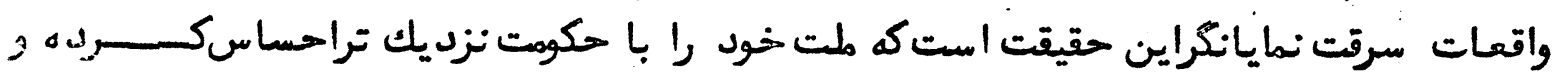

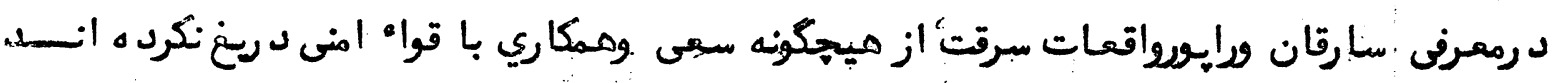

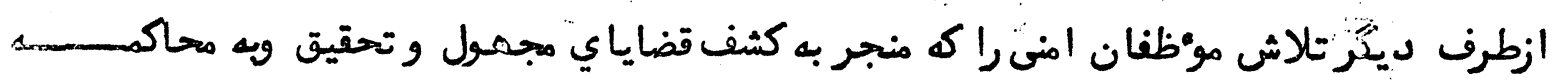

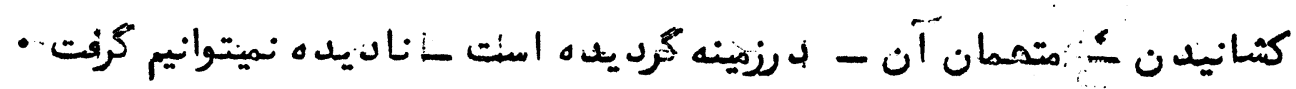

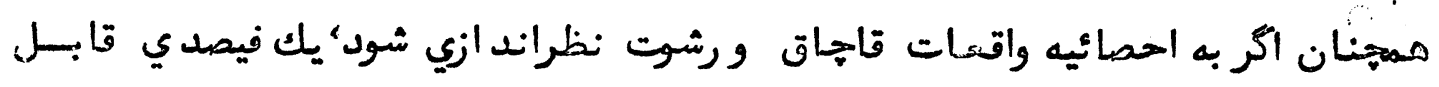

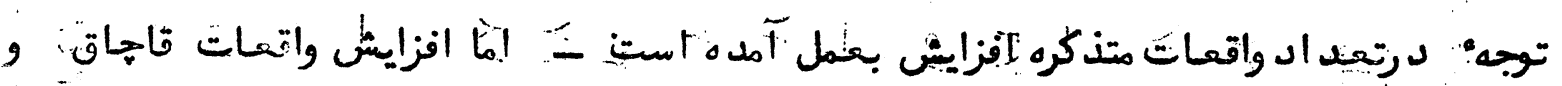

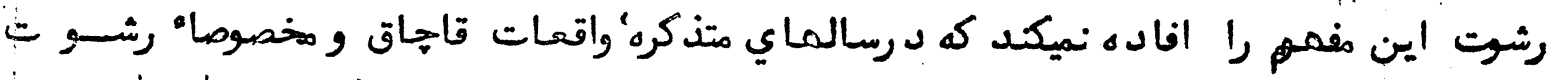

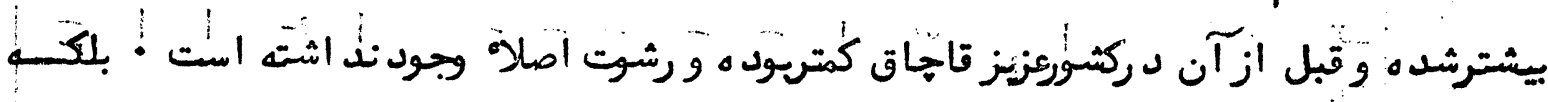

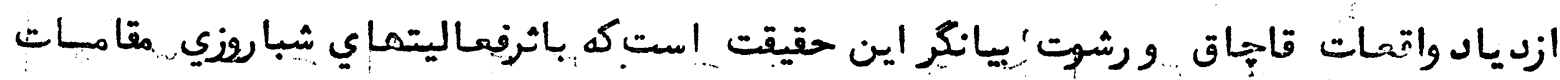

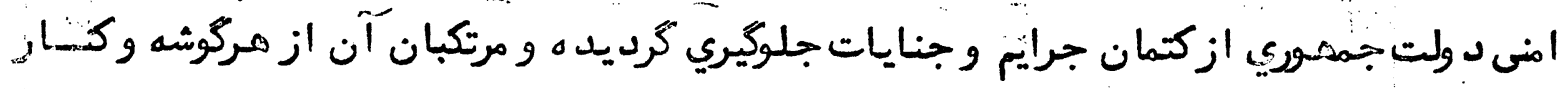

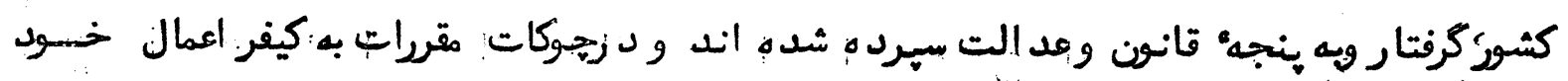




\begin{tabular}{|c|c|c|c|c|c|c|c|c|c|c|c|c|c|c|c|}
\hline تروان & يدخشان & تخار & كندز & بذلان & سمنكان & جوزجان & فارياب & بلن & بادغيس & مرات & ارزكان & كثلذ هار ر & كابل & 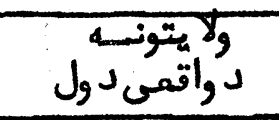 & شماره \\
\hline$Y r$ & ir: & $r \cdot$ & $\xi\rceil$ & ry & $r \varepsilon$ & $O \varepsilon$ & $r$ & $7 \cdot$ & 17 & rir & $r$ & $v_{1}$ & $1 \cdot \varepsilon$ & قتــــلـ & 1 \\
\hline 9 & - & 1 & $r$ & 1 & - & $1 \cdot$ & 1. & 1 & - & $Y$ & 1 & 18 & 。 & قطاع الطريق & $r$ \\
\hline- & - & - & - & - & - & - & - & - & - & - & - & - & - & داره & $r$ \\
\hline 99 & $1 \varepsilon$ & $1 \varepsilon r$ & $11 \varepsilon:$ & iro & 57 & ivo & $\varepsilon 1$ & r & rr & 187 & 1 & ro. & rr & سرقــت & $\varepsilon$ \\
\hline ra & $r$ & 11 & $r 1$ & $r$ & .7 & 18 & $r$ & iA & $\varepsilon$ & ro & 1 & $r Y$ & & كريختاند ناشخاه &. \\
\hline 1 & - & - & - & - & - & - & - & - & - & 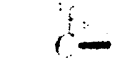 & 1 & - & 1 & جنكماى منِلوهيه & -7 \\
\hline 7 & - & $r$ & - & $\varepsilon$ & $r$ & $r$ & - & $r$ & 1 & $r$ & - & $\varepsilon$ & $r$ & فرارمحهوسين. & $Y$ \\
\hline$\varepsilon$ & 1 & $\varepsilon$ & 9. & $r$ & 1 & $r$ & 1 & 11 & 1 & $r$ & - & $\lambda$ & $\varepsilon$ & جيقماي عمالى & $\lambda$ \\
\hline rq & $r$ & $\because$ & $1 \varepsilon$ & rI & 1. & 9 & - & $r \cdot$ & 1 & $r$. & $r$ & rI & Ir & واتمات ترافيكى & 9 \\
\hline 7 & 1 & - & 1 & $r$ & - & - & $r$ & 1 & 1. & rq & 1 & $1 \varepsilon \gamma$ & Y.I & قإياق & 1.0 \\
\hline$r$ & $\varepsilon$ & 1 & r & r & $r$ & $\circ$ & - & 17 & 1 & 11 & $i$ & 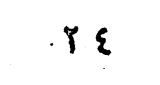 & & قاباقوموادمخدر & 1.1 \\
\hline - & - & - & - & - & - & - & - & - & - & - & - & - & -6 & 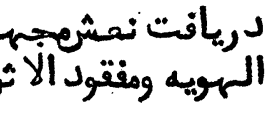 & ir \\
\hline$\varepsilon$ & 1 & - & 9 & r & - & $r$ & $r$ & r & $r$ & 0 & 1 & 0 & \&o. & اخذ رنوت & ir \\
\hline $1 \varepsilon$ & 。 & 11 & 11 & : & $r$ & 9 & 0 & ir & - & 11 & - & $1 \%$ & $r \cdot$ & تقلب و متفرقه & I \\
\hline 1 & - & - & - & $i$ & - & - & - & $\xi$ & - & 1 & - & 1 & 7 & نوت جملى : & 10 \\
\hline rYT & ₹ᄉ & Y10 & rer & YT\& & 1.0 & rAl & or & \&ro & 71 & $r \varepsilon \Lambda$ & 19 & o9r & $\varepsilon \mid r$ & مجمـــــــوع & 17 \\
\hline
\end{tabular}




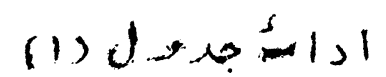

\begin{tabular}{|c|c|c|c|c|c|c|c|c|c|c|c|c|c|c|}
\hline هجموع & نيمروز & كراه & غزنى & زاليل & ميدان & غروات & باميان & هلمند & لوكس. & ككتياء & لفمان & 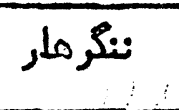 & ولا يتونه دواتِمى دول & شماره \\
\hline 11r & $r$ & $i \varepsilon$ & 10 & 11 & 19 & $\pi$ & $T r$ & $r r$ & $T$ & Ar & 11 & $9 \pi$ & قتسل & 1 \\
\hline ro & - & - & - & $r$ & - & - & - & $r$ & - & 1 & $r$ & 1 & تطاع الظريق “- & $r$ \\
\hline 1 & - & - & - & - & - & - & - & 1 & - & - & - & - & داره : : & r \\
\hline$r \cdot r Y$ & $1 \cdot$ & ri & 9 & $r \cdot$ & $r \cdot$ & - & 17 & $1 \cdot 7$ & $r \varepsilon$ & $\xi \gamma$ & $\varepsilon 1$ & 90 & سرقت & $\varepsilon$ \\
\hline 897 & $r$ & - & - & $1 \cdot$ & $r$ & - & $\varepsilon$ & Ir & 7 & ir & 11 & r & كريختاندن اشخاص & 。 \\
\hline 9 & - & - & - & 1 & - & - & - & - & - & $r$ & - & $r$ & جنك ماكب نلوهيه & $i$ \\
\hline$\varepsilon$ & 1 & 1 & 1 & $r$ & $r$ & - & - & 1 & - & - & - & $\varepsilon$ & فرإمحهوسين & r \\
\hline$|r|$ & $\cdots-$ & 0 & - & $r$ & $r$ & - & $r$ & ir & 7 & .18 & $\varepsilon$ & 11 & حهيق هاي عبدى & $\wedge$ \\
\hline ros & $r$ & 1 & $r$ & $1 \varepsilon$ & $\wedge$ & - & $r$ & 1.7 & - & .0 & $\checkmark$ & $\varepsilon \cdot$ & واتينات نتزافيكى & 9 \\
\hline $0 \wedge 9$ & - ro & $\varepsilon \gamma$ & $r$ & $\varepsilon$ & - & $=$ & - & rr. & 0 & $r r$ & $\wedge$ & $1 \varepsilon r$ & تإباق & 1. \\
\hline $1 \varepsilon \gamma$ & $\cdots r$ & 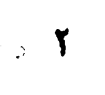 & $r$ & - & - & - & - & $\varepsilon$ & - & 1 & - & 18 & تاباق ومواد مخدره & $H$ \\
\hline & & & & & & & & & & & & \multicolumn{2}{|c|}{ دريافت نمشمجههول الهويه . '. } & ry \\
\hline- & - & - & - & - & $=$ & $=$ & - & - & - & - & - & - & ومنقود الاثرى & \\
\hline 90 & - & 1 & 1 & r & 1 & - & - & $r$ & - & 1 & 1 & $r$ & اخذ رشوت & ir \\
\hline 17. & 1 & 1 & $\lambda$ & - & $r$ & - & $r$ & ○ & 1 & $r$ & r & 1. & تقلب و متفرقه & $1 \varepsilon$ \\
\hline ru & 1 & 1 & 1 & 1 & - & - & - & $r$ & 1 & - & - & $\gamma$ & نوتجملى & 10 \\
\hline 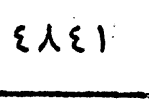 & 01 & 99 & $\{\curlywedge$ & ᄉ. & IY & ir & $\xi$. & 119 & $\circ$ & 119 & $1 \cdot 1$ & $\varepsilon 79$ & مجعـــوع & 17 \\
\hline
\end{tabular}




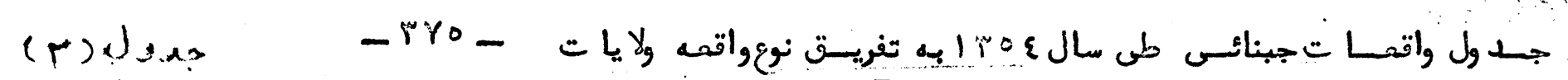

\begin{tabular}{|c|c|c|c|c|c|c|c|c|c|c|c|c|c|c|}
\hline بدخشا ن & تخـار & ن كـندز & بفــلا & سمنكا ن & جوزجان & فارياب & بلسن & بادغيس & مرات : & ارزB ن & كند ميار & كابـلن & 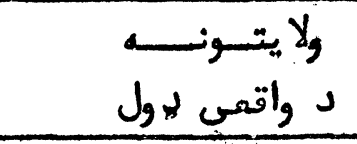 & شعاره \\
\hline$r$ & rᄉ & 07 & $\varepsilon Y$ & 11 & YT & 17 & $\xi \wedge$ & $1 \cdot$ & 19 & 10 & ro & $9 r$ & قتـــــــــــ & 1 \\
\hline$r$ & $\varepsilon$ & $r$ & - & 1 & $r$ & 1. & 0 & - & 9 & 11 & TT & r.Y & قداع الطريق & r. \\
\hline- & 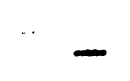 & - & - & - & . - & - & - & - & - & - & - & 1 & دار & $r$ \\
\hline rt & 111 & 579 & 181 & $\varepsilon \varepsilon$ & 1.7 & $1 \cdot 1$ & $r \varepsilon$ & $1 \varepsilon$ & lor & ra & Tr人 & $7 \varepsilon 0$ & سـرتجــت & $\xi$ \\
\hline$:-$ & 1.0 & $r .7$ & 7 & 1 & . 0. & $\cdot-$ & T.A & $\cdot \varepsilon$ & 17 & $r$ & $r \cdot$ & : Y.Y. & كريختاند ن اشخاص & o! \\
\hline - & - & $r$ & .1. & - & - & - & - & - & - & - & - & - & جنك ماي مفلو به & 7 \\
\hline 1 & r & $r$ & $\varepsilon$ & $r$ & - & 1 & :r & $r$ & 1 & 1 & $r$ & 1. & فرار محتر سيـن & $r$ \\
\hline - & $\varepsilon$ & iV & $\varepsilon$ & 1 & $r$ & $r$ & $\therefore 9$ & $\varepsilon$ & $\therefore 1$. & - & 11 & 1.. & حويق مائ عمدى & $\wedge$ \\
\hline$r$ & $\varepsilon$ & I.Y & $\varepsilon \gamma$. & 18 & 7 & r & TY & $\varepsilon$ & T.r & $\varepsilon$ & ri & qr & واقمات ترافيكس & 9 \\
\hline - & 1 & 7 & 1 & $r$ & r. & - & $\cdots$ & 1. & $r \varepsilon$ & $\uparrow$ & 1.0 & 178 & قسابت & 1. \\
\hline 7 & 1. & $\gamma$ & $r$ & - & $r$ & - & $r$ & - & $Y$ & 1 & ro. & $\therefore . r$ & قانيا ق وموادَ مخدره & $H$ \\
\hline & & & & & & & 1 & & . & & & & دريافت نمثزمجههول & 18 \\
\hline 1 & 。 & 11 & 7 & 1 & $r$ & - & 0 & - & 1. & - & 7 & 17 & و مفقود الاثر ى & $\because$ \\
\hline$r$ & $r$ & 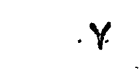 & 0 & - & r & $r$ & 1 & r &.$Y$ & $r$ & 18 & $\varepsilon \varepsilon$ & اخــن رشــو ت & ir \\
\hline$r$ & $1 \varepsilon$ & หq & 10. & $1 \pi$ & $\varepsilon$ & $?$ & $r$. & 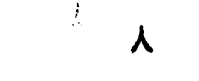 & ro & 7 & $\varepsilon r$ & 71 & تقلب و متغرتــــــ & $1 \varepsilon$ \\
\hline- & - & - & - & - & - & - & $\therefore-$ & - & . $\quad-$ & - & $r$ & $r$ & نو تجملــــــ & 10 \\
\hline$\infty 0$ & $r \cdot q$ & ETr & 179 & 90 & IVt & $1 \pi 9$ & r.1. & 0. & 410 & 10 & $71 \%$ & 1877 & مجــــــــــ & 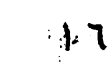 \\
\hline
\end{tabular}




\begin{tabular}{|c|c|c|c|c|c|c|c|c|c|c|c|c|c|c|c|c|}
\hline مجموغ & نهمروز & & 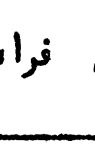 & 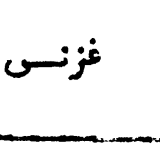 & زابـل & ميدلن & غرات & بامبــان & هلمند & لونــر & بكتياء & لفمان & نتنُر مار & هروا ن & 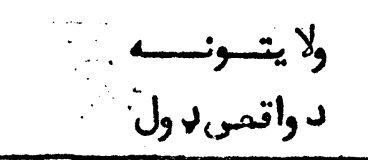 & شعـاره \\
\hline $9 \cdot 6$ & ० & r & IY & rl & 10 & $1 \varepsilon$ & $1 \varepsilon$ & $r$ & ro & ○ & ২人 & ri & $10 \varepsilon$ & oy & قتــــــ & 1 \\
\hline wr & $\bullet$ & 1. & - & 1 & 1 & $r$ & $r$ & 1 & $\circ$. & - & $\varepsilon$ & 1 & 7 & $r$. & قدلاع الطريق . & r \\
\hline$r$ & & $\cdots$ & - & - & - & - & 1 & - & - & - & $i$ & 1 & $r$. & - & دارزه & $r$ \\
\hline$r q \cdot r$ & Ir & & $r r$ & $\because \lambda$ & ri & $r \varepsilon$ & $r \varepsilon$ & 11 & $11 \cdot$ & 11 & ०q & rᄉ & 111 & 101 & سـإنـــتــــت & $\varepsilon$ \\
\hline rir & - & & $\varepsilon$ & 7 & $\lambda$ & $r$ & 1 & $r$ & $r \cdot$ & $\therefore \varepsilon$ & $1 . r$ & 1 & $\varepsilon \cdot \bullet$ & r.r. & كريختانبل ن اشـام & 。 \\
\hline$\stackrel{0}{-}$ & - & & - & 1. & - & - & - & - & - & - & - & T & - & 1 & جنك ماى مخلو به & 7 \\
\hline 17 & 1 & & $r$ & $r$ & 1 & 1 & - & 1 & \{ & 1 & $r$ & 1 & $y$ & $\circ$ & فرار مهدهوسيسـن & r. \\
\hline 10.1 & 1. & & $r$ & 10 & 1 . & $\varepsilon$ & - & $r$ & 7 & $r$ & 1. & $=$ & 17 & 1 & حريق هاي.عددى & $\wedge$ \\
\hline$\{r \lambda$ & 1 & & 9 & r. & 9 & 11 & - & $r$ & 17 & 11 & r. & rq & ro. & rY & واقمـات ترافيكس & 9 \\
\hline Yo.r. & 71. & $\cdots r$ & Тย & 10. & 0. & - & - & - & - & 7 & vr. & $a$ & $r H_{\nu}$ & $r$ & تإِـــــــــ ق & 1. \\
\hline 189 & 1 & & 1 & $r$ & 1. & - & - & - & $r$ & - & 0 & 1. & 11 & ० & تابياق و مرواد مخدره & 11 \\
\hline$\cdots$ & & & & & $\cdots$ & & . & & & & & & & 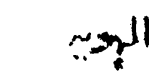 & دريانـــئيشيشمجهول & ir \\
\hline 1.1 & - & - & 1 & $r$ & 1 & o. & - & $r$ & $\Lambda$ & - & $r$ & 1 & $\varepsilon$ & 7 & ومفقود الانـــــــى & \\
\hline $1 \%$. & - & & $r$ & 1 & 1 & 1. & - & $r$ & $\Lambda$ & 1 & $r$ & - & 。 & 7 & أخسـذ رثــو ت & ir \\
\hline$\{1 \curlywedge$ & $r$ & & 1 & $\lambda$ & $\varepsilon$ & ○. & $r$ & $r$ & $\varepsilon$ & $\Lambda$. & $r r$ & $r$ & $r r$ & $\uparrow \cdot$ & تقلب و متغرقتســــ & $1 . \varepsilon$ \\
\hline 1. & - & & - & - & - & - & - & - & 1 & - & - & - & $r$ & 1 & بِنـــمو ت جملى & 1.0 \\
\hline 7019 & ir & & $\cdot 9$ & 111 & Ar & ᄉ. & ६० & rג & भIन & or & $r \cdot$. & 111 & vit & ror & هنعنـــوع & 1.7 \\
\hline
\end{tabular}




\begin{tabular}{|c|c|c|c|c|c|c|c|c|c|c|c|c|c|c|c|}
\hline بد بـشـــان & تخـــا. & كندز & بغلان & سمنكّا ن & ل & رياب جزي & & س بالهمن & بأدني & هــات & الرزBان & كند مار & كابــلـ & 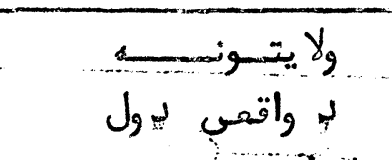 & شمــارة \\
\hline$\gamma$ & 17 & ६० & หq & ir & $r x$ & & ir & $\varepsilon r$ & $1 \varepsilon$ & rr & $r$ & $\varepsilon r$ & $\wedge \varepsilon$ & 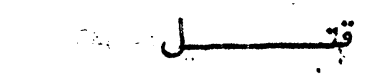 & $!$ \\
\hline - & $r$ & $Y$ & - & $r$ & i & 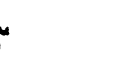 & - & ○ & $r$ & iri & 9 & $r$ & $r r$ & قداع الذزريستق & $r$ \\
\hline - & - & $r$ & - & - & - & & - & 1 & - & $r$ & $r$ & $\varepsilon$ & $\varepsilon$ & داره & $r$ \\
\hline ro & 91 & rר & Ar & er & 111 & & ro & $\forall 00$ & rr & YYQ & rr. & $r \varepsilon$. & YMT & 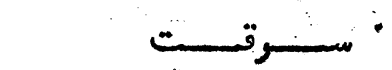 & $\varepsilon$ \\
\hline$r$ & ir & $r \varepsilon$ & $1 \varepsilon$ & 1 & $\cdots$ & & 1 & ir & $r$ & rr & o & r६ & .07 & كريختاندن اشخاص & 。 \\
\hline - & - & - & - & - & - & & - & - & - & 1 & - & - & - & جـــنى ملاى منتلوبه & 7 \\
\hline 1 & 1 & 7 & $\varepsilon$ & - & r & & r & $r$ & $\vdots$ & - & 1 & $\uparrow$ & $r$ & عرار محهوسيــــن & r. \\
\hline$r$ & $\varepsilon$ & 1. & $\lambda$ & 1 & 7 & & 1 & 10 & $\varepsilon$ & 1 & $\varepsilon$ & 10 & ir & خريق هاى عمدى & $\wedge$ \\
\hline$r$ & 11 & 11. & rY & 7 & 11 & & $\varepsilon$ & $r \varepsilon$ & $\varepsilon$ & ro. & 1 & $\xi Y$ & q. & واقتما تأترافيكسى & $q$ \\
\hline- & - & 1 & - & - & $\cdot 1$ & & - & 0 & - & rr. & 1 & 11 & 109 & 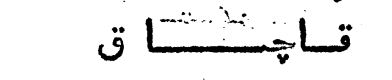 & $1:$ \\
\hline$r$ & 1 & - & $\varepsilon$ & 1 & r & & 1 & ir & 1 & $r r$ & $\ddot{-}$ & $\begin{array}{l}r v \\
\ddots\end{array}$ & 9. & 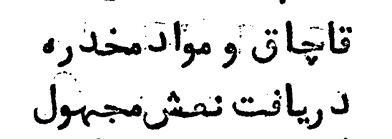 & $\begin{array}{l}H \\
1.5\end{array}$ \\
\hline - & $\circ$ & 7 & $\varepsilon$ & 1 & $r$ & & $i$ & ir & - & $\therefore$ & $\varepsilon$ & $\therefore$ & 19 & الهويه و مفقود الاثرى &. \\
\hline 1 & $r$ & $r$ & $r$ & 1 & - & & - & $r$ & 1 & :0 & - & 11 & $\varepsilon r$ & اخـــ رشــوت & ir \\
\hline$\varepsilon$ & $\varepsilon$ & IY & ir & r & $r$ & & $r$ & $r \cdot$ & 0. & $\xi १$ & r & ro. & $1 \pi$ & تقلب و.متثرتــه & 1.8 \\
\hline- & - & - & - & $\circ$ & 1 & & 1 &.- & - & $r$ & - & - & $.1 r$ & جفٍِ نو تجملى & 10 \\
\hline 01 & 101 & $\varepsilon \cdot 7$ & $r \cdot r$ & ir & 110 & & $1 \cdot Y$ & $\varepsilon !$ & 00 & $0 . \cdot$ & 91 & or. & 1870 & 身 & 17 \\
\hline
\end{tabular}




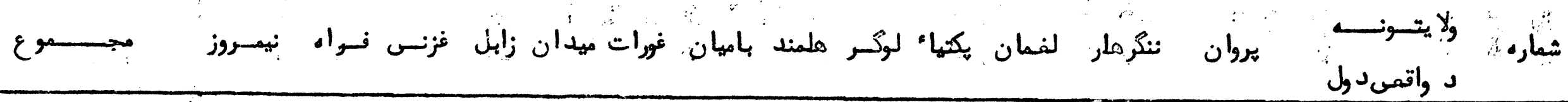

\begin{tabular}{|c|c|c|c|c|c|c|c|c|c|c|c|c|c|c|}
\hline Y90. & $r$ & 19 & 17 & 9 & 11 & 11 & $r$ & rr & $1 \varepsilon r$ & $r r$ & 119 & $\circ \varepsilon$ & 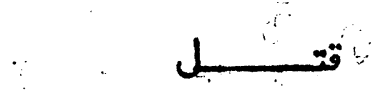 & 1 \\
\hline$M A$ & - & - & 7 & $r$ & $r$ & $r$ & 1 & 1 & 11 & - & 1. & ir & قطاع الطريستق & $r$ \\
\hline 18 & 1 & - & - & 1 & .. & - & - & $\ldots r$ & -- & - & 。 & $r$ & داره & $r$ \\
\hline 8179 & 11 & $r \cdot$ & $\varepsilon q$. & ry. & 87 & r. & $1 \varepsilon$ & 119 & $r . r q$ & $r \cdot$ & $10 Y$ & $\| r$ & 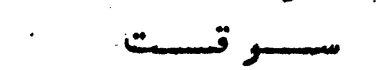 & ⿷ \\
\hline$r \varepsilon \varepsilon$ & - & $Y$ & $r$ & $\varepsilon$ & 0 & 1 & $r$ & ri. & $7 \mathrm{a}$ & ir & $\varepsilon \theta$ & 19 & كريختاند ن اشخام & 。 \\
\hline 1 & - & $\dot{-}$ & 1 & - & 1. & - & - & - & -1 & 1 & - & 1. & جسنك هاى منلهيه & 1 \\
\hline$\varepsilon\}$ & 1 & - & - & - & $r$ & 1 & $\dot{-}$ &. .1 & $1: \varepsilon$ & 1 & 9 & $r$ & نـــازر محهو سيـين & $r$ \\
\hline$r \cdot$. & - & $r$ & 11 & 0. & 1 & - & - & Ir. & $r \quad q$ & o. & ra & 9 & حريق مائعمد ى & $\curlywedge$ \\
\hline$\varepsilon \pi$ & 1 & 9 & 1.9 & 11 & $q$ & 1 & 1 & ET & Y r I. & $Y$. & $r 1$ & rY & واقمات ترانيكسي & 9 \\
\hline Y 79 & or & r. & Yr & - & - & 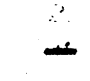 & 1. & $r$ & & 7 & PYT & $\varepsilon$ & 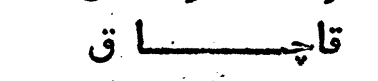 & 1. \\
\hline $19 \pi$ & $\begin{array}{r}.1 \\
-.1\end{array}$ & - & $r$ & - & - & - & - & ○ & -- & - & 18 & 1. & قاهاق و مطادمخدره & 11 \\
\hline$i r$ & $r$ & 1 & 7 & $r$ & $r$ & $r$ & 1 & 0 & $r \quad r$ & 1 & 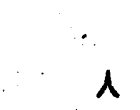 & $i$. & 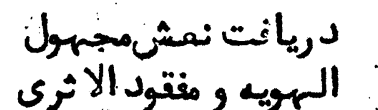 & ir. \\
\hline 1.11 & $r$ & $r$ & $r$ & 1 & - & - & $r$ & r & $-r$ & $r$ & $r$ & - & 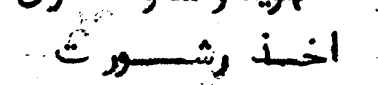 & ir \\
\hline riq & 1. & $\varepsilon$ & 11 & 0 & 7 & 1 & 1 & $1 \varepsilon$ & $r$ ir & $r$ & iq & 19 & ثلـلب ومتفرقتـ & $1 \varepsilon$ \\
\hline$r \cdot \lambda$ & - & - & - & - & - & $r$ & - & - & $r \quad-$ & - & 1 & - & نوت تجعــــلى & 1.0 \\
\hline $7 \varepsilon १ \Lambda^{\prime \prime}$ & iy & 90 & 100 & $\lambda$ & וד & $\varepsilon r$ & Tr & $\dot{r} \varepsilon$. & the rri & 9 & $r \varepsilon r$ & rro & موع ع & $r i$ \\
\hline
\end{tabular}




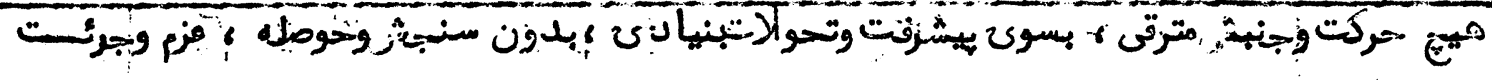

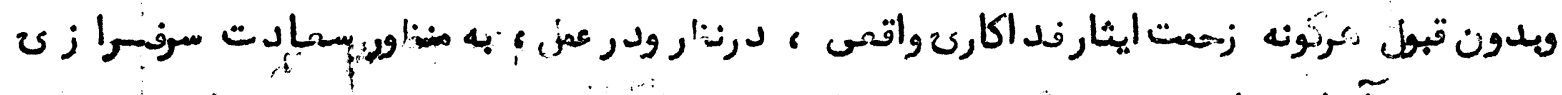

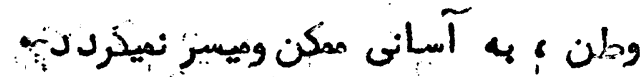
* * * * * * *

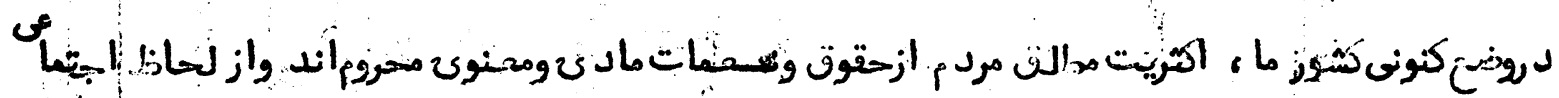

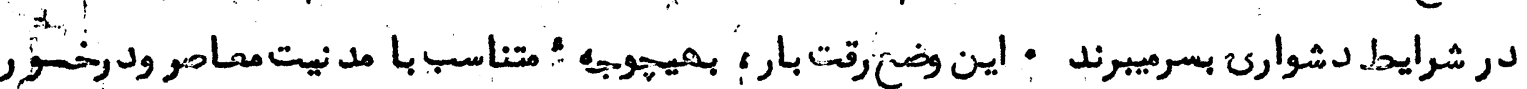

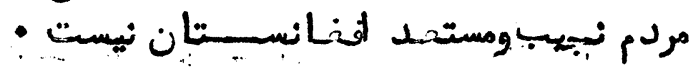

$\begin{array}{lllll}\dot{\gamma} & \dot{\gamma} & \dot{\gamma} & \phi\end{array}$

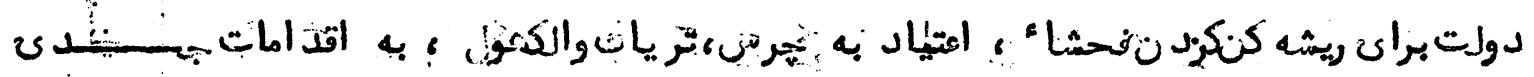

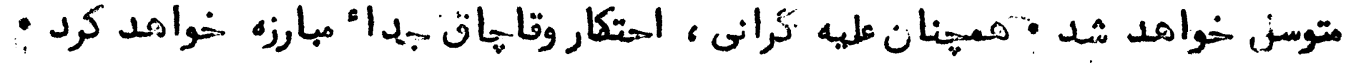

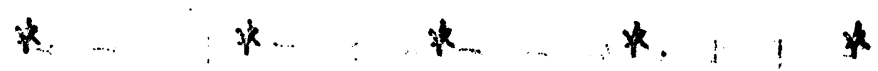

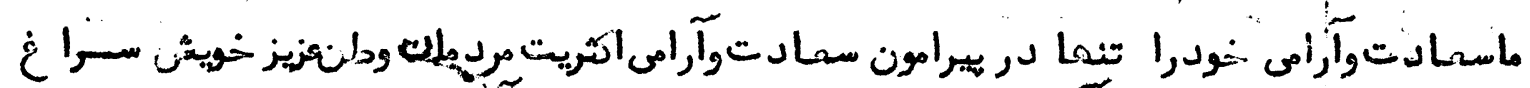

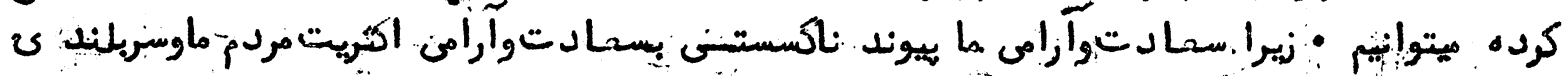

* * * * * *

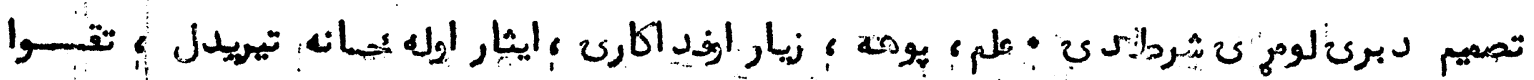

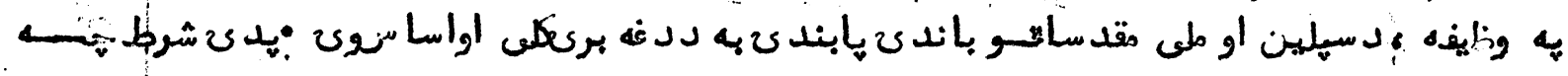

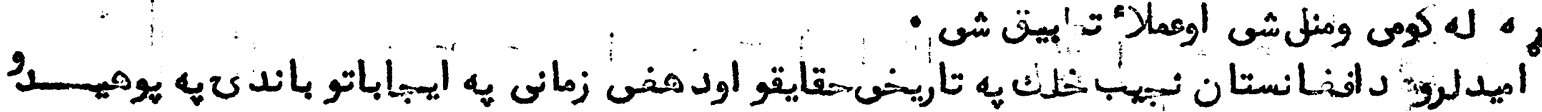

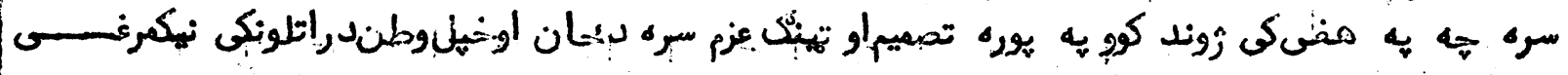

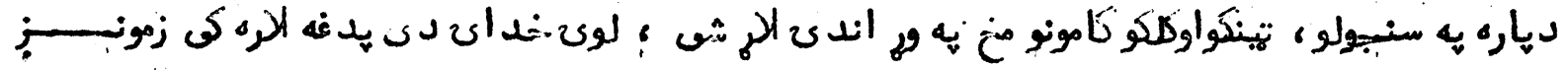

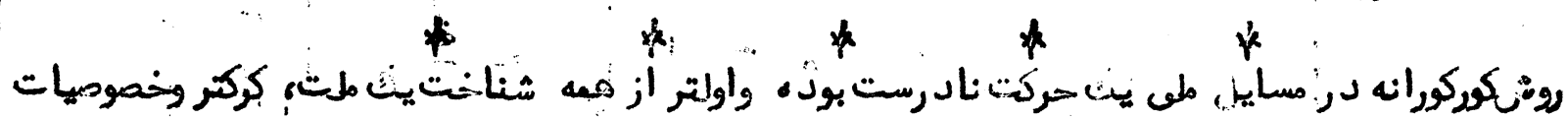

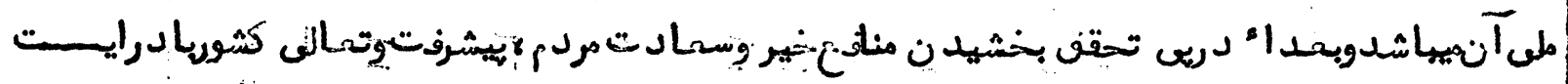

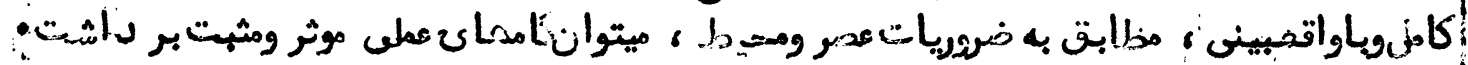

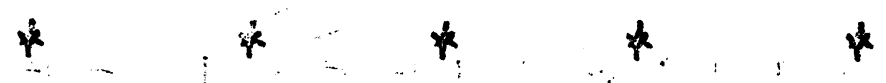

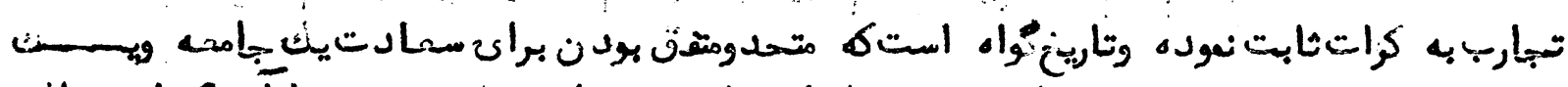

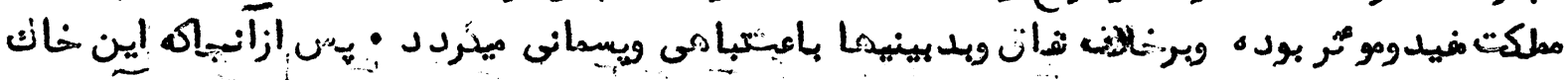

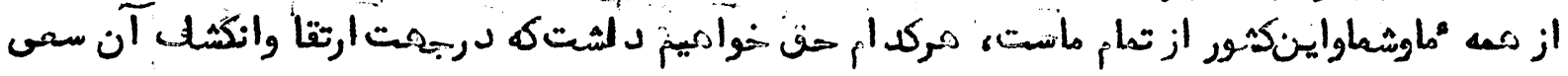

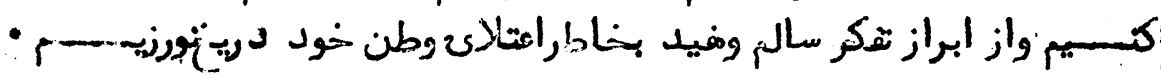

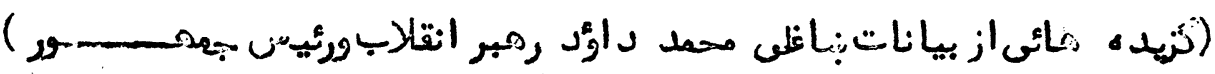




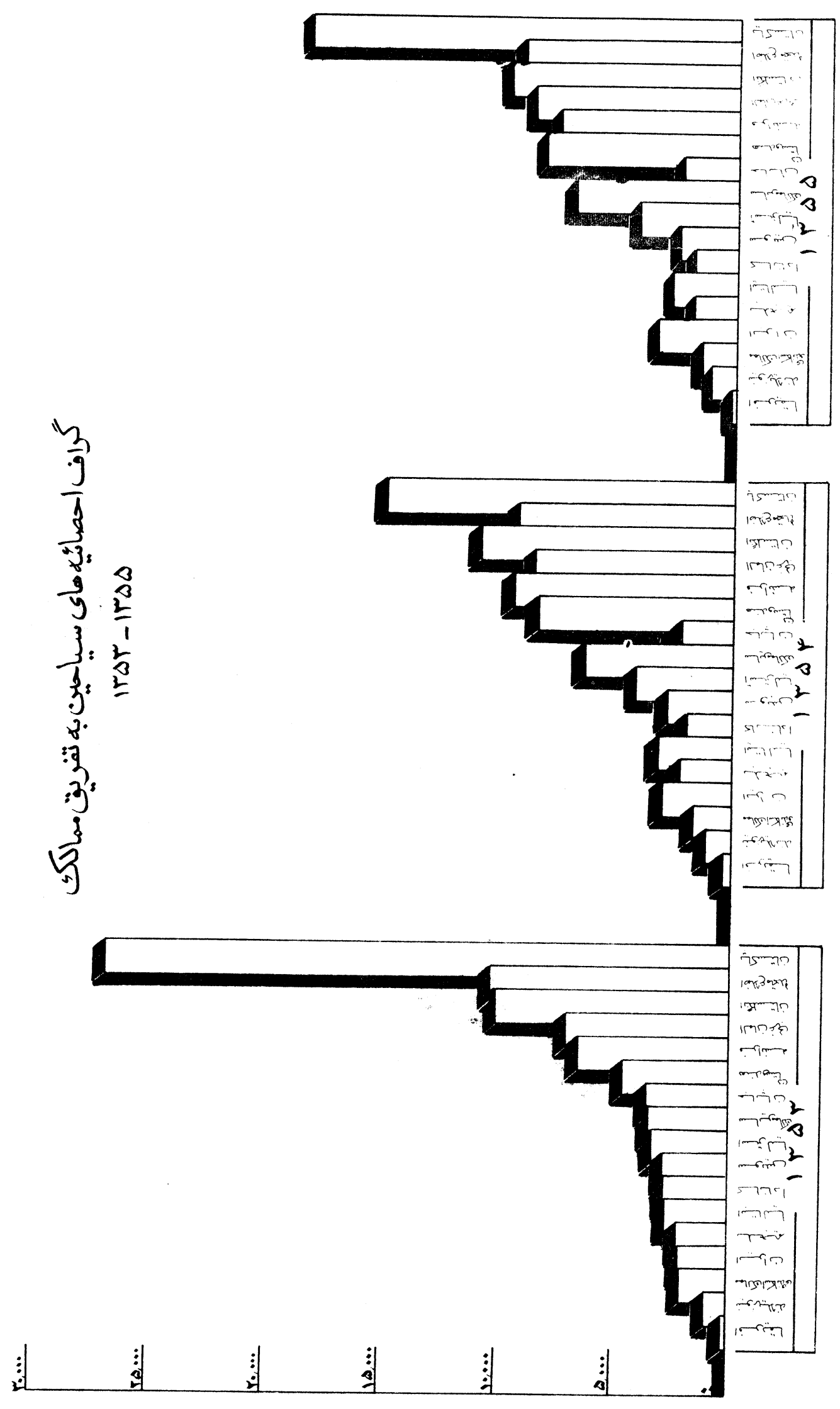




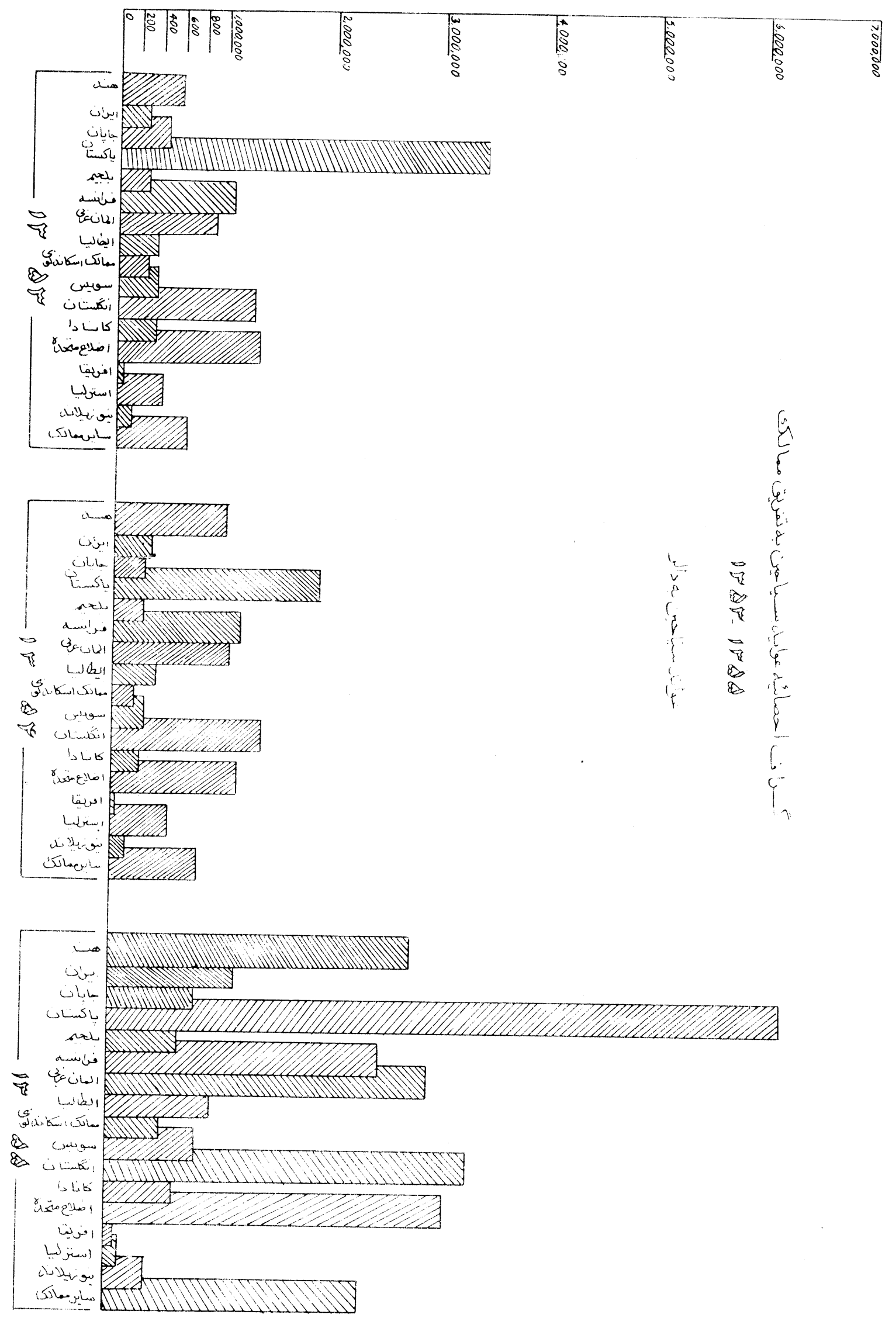




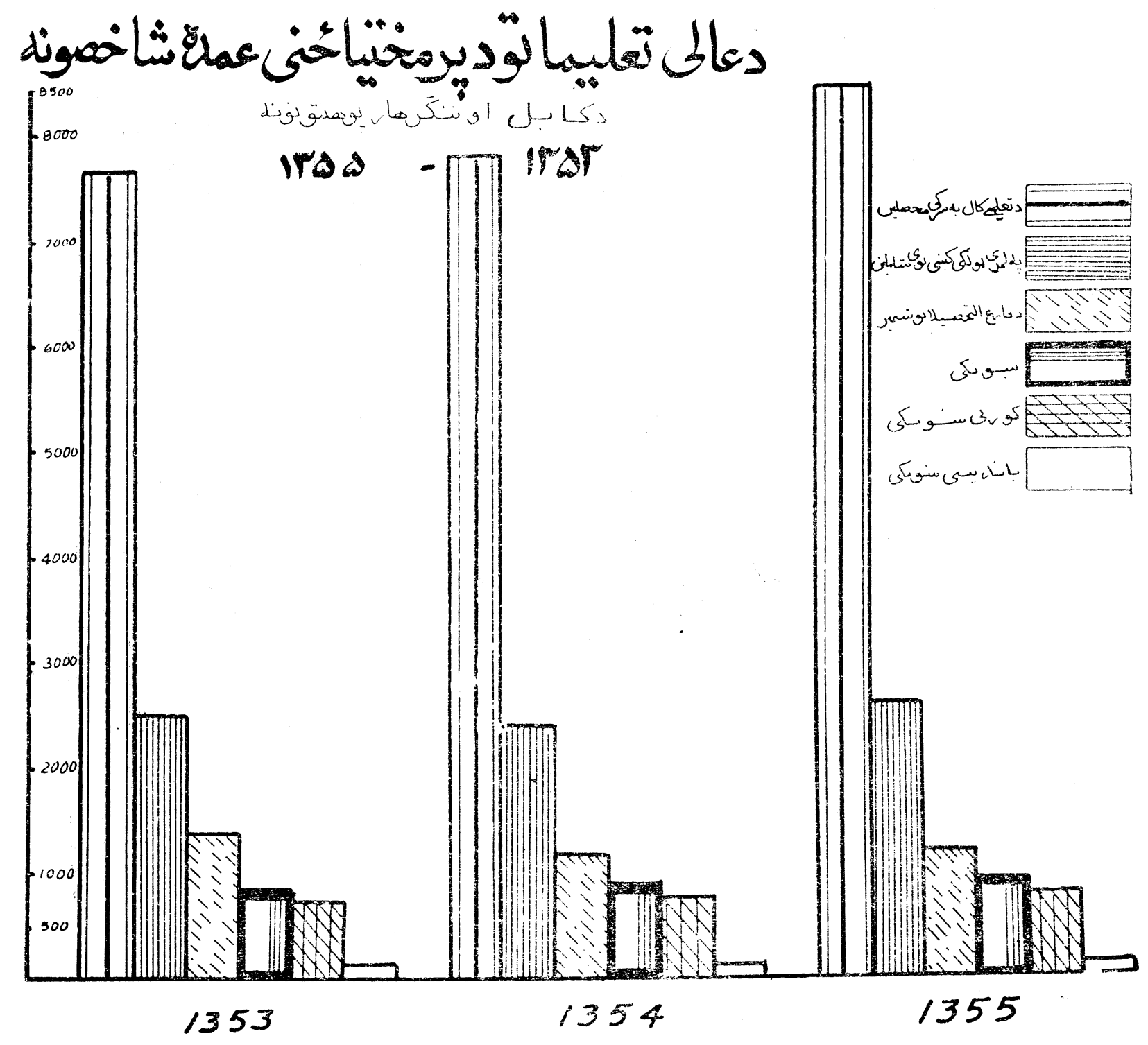




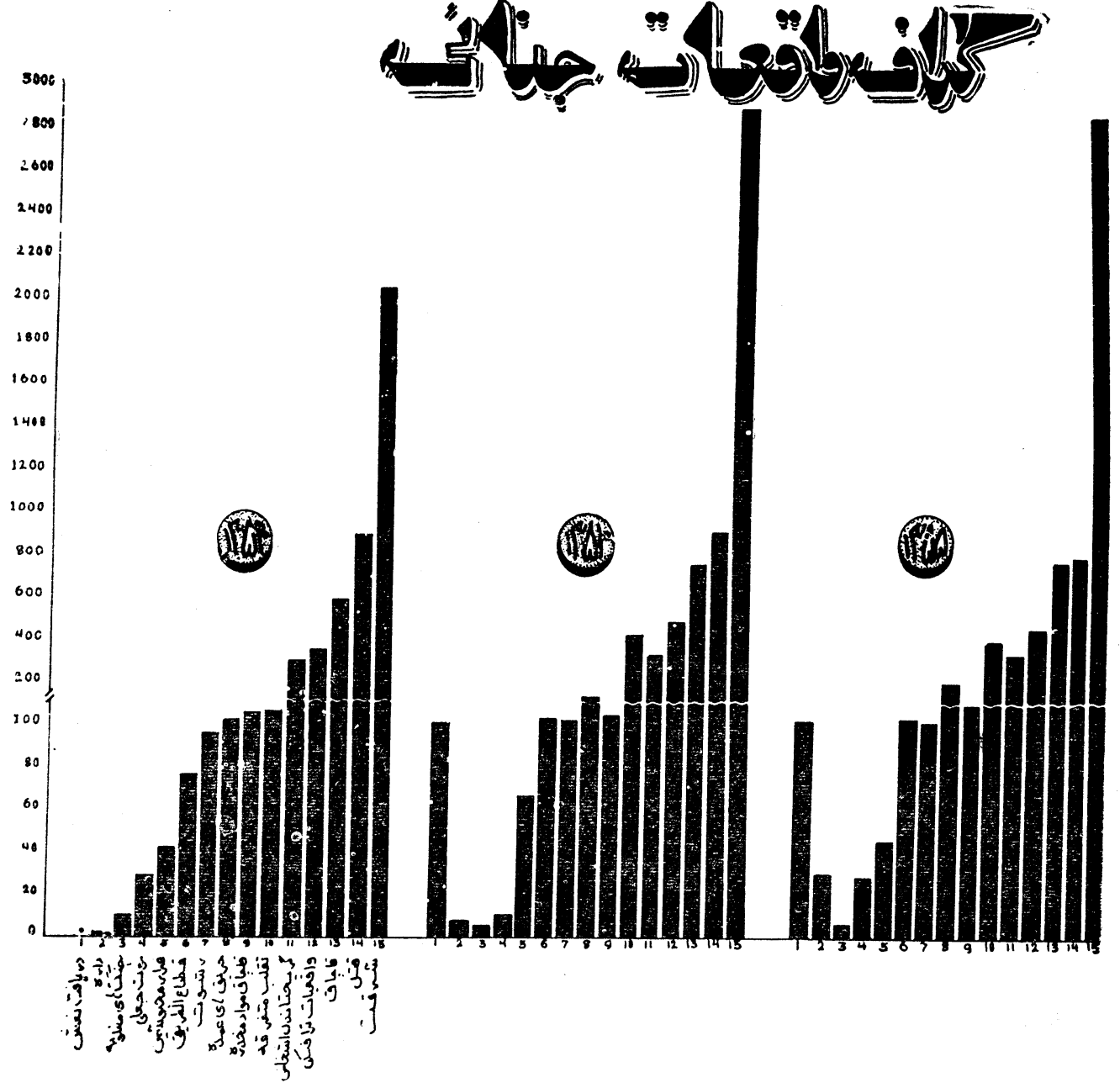




\section{فصنشتميم}

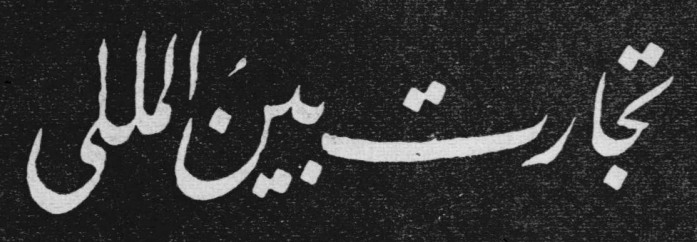

9

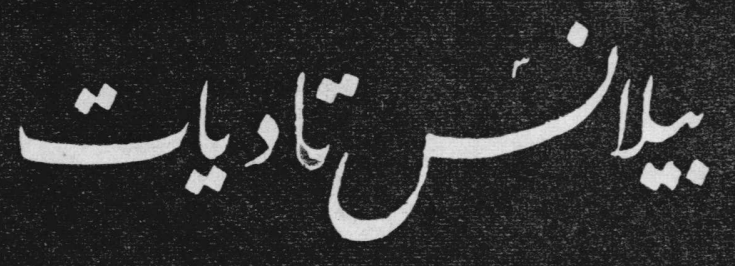

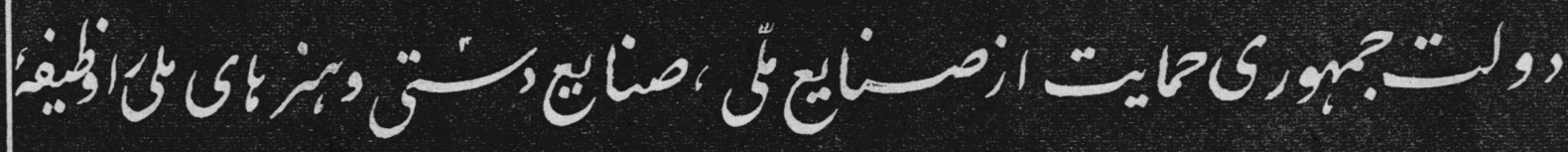
تو

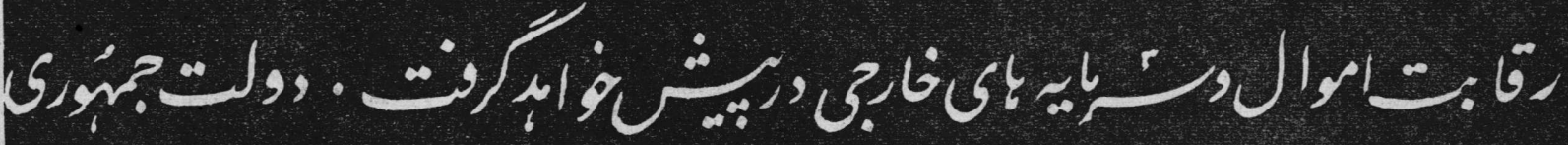

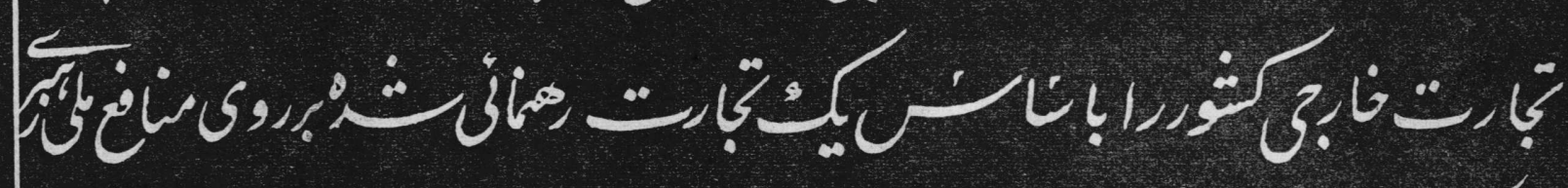
., 4 is

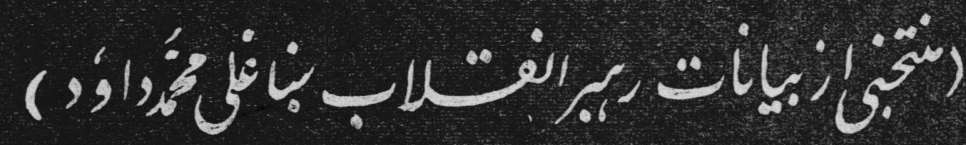

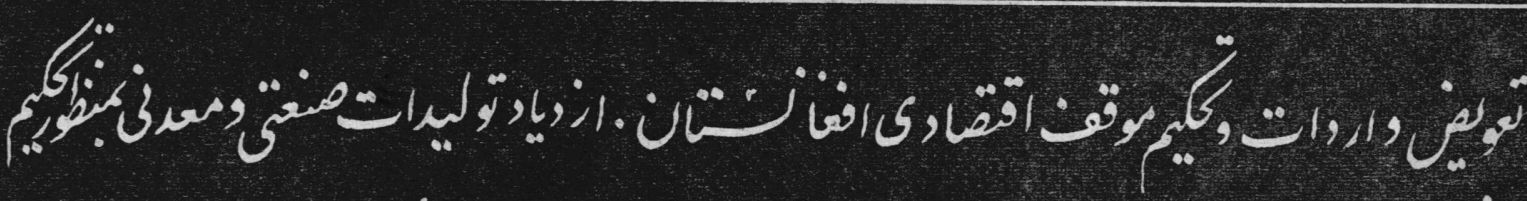

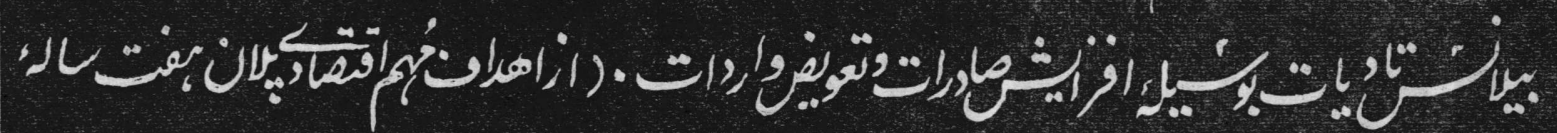




\section{فـ \\ تجارت خارجى افغانستان}

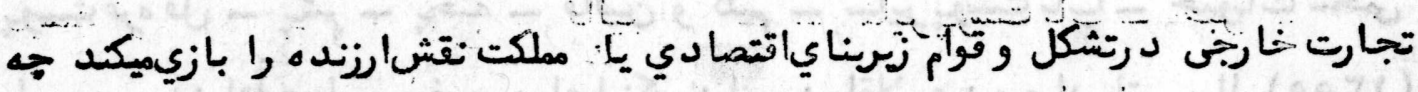

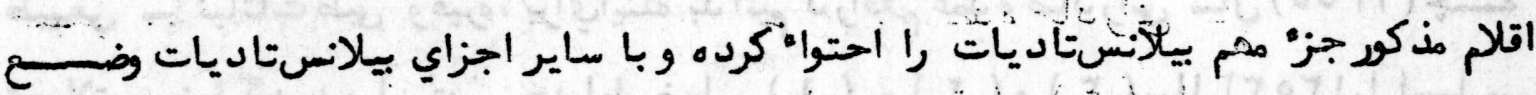

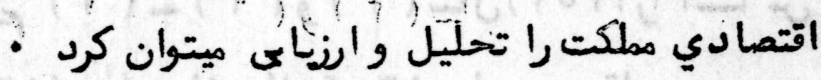

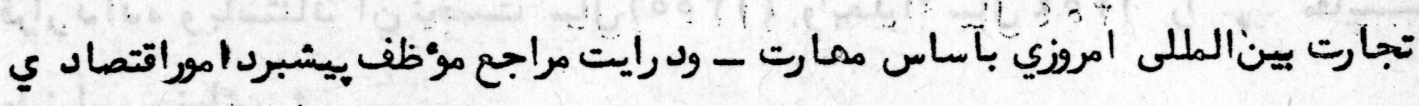

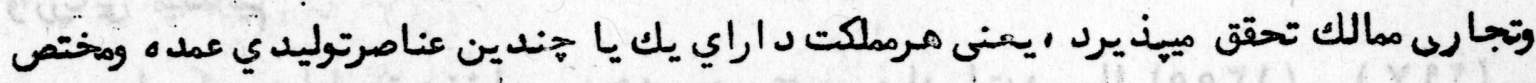

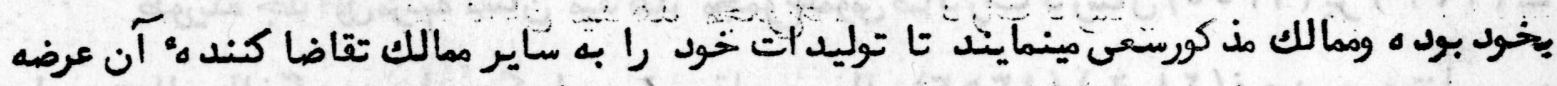

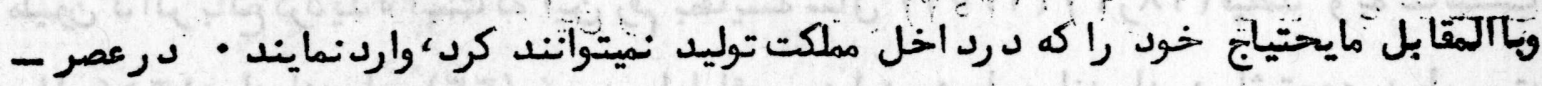

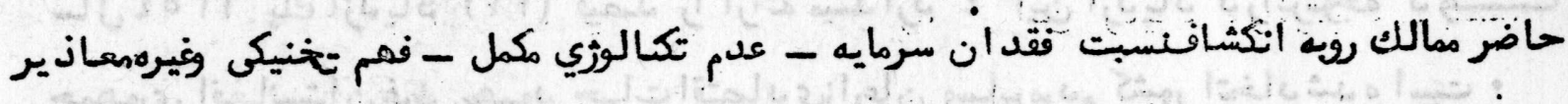

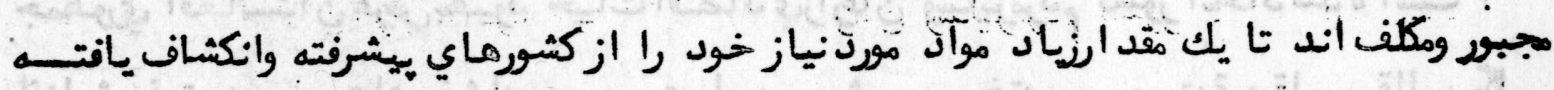

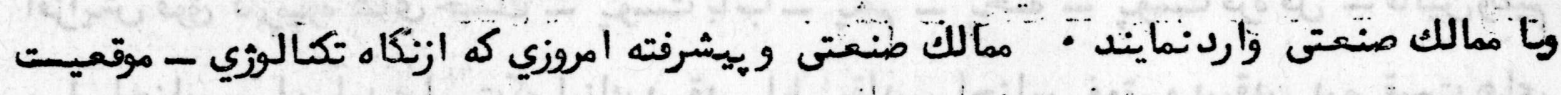

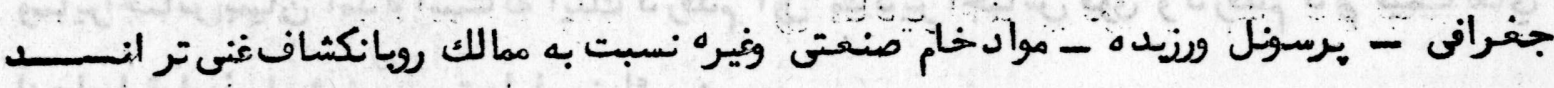

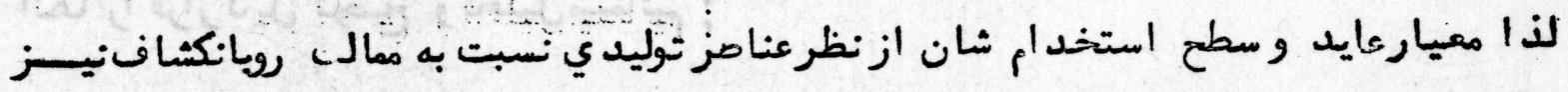

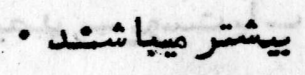

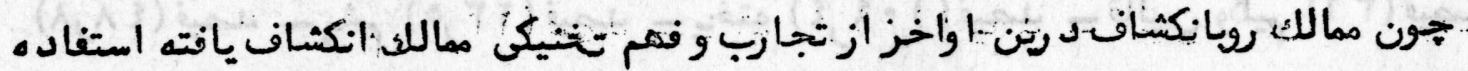

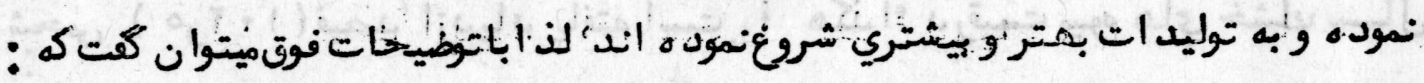

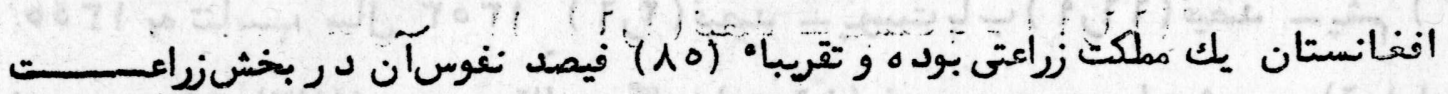

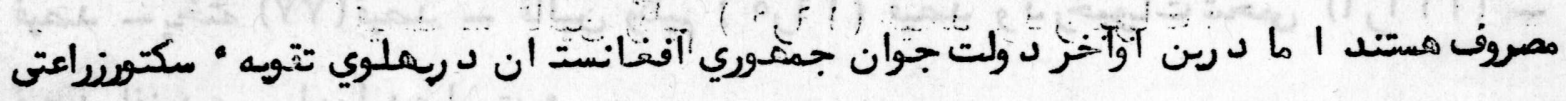

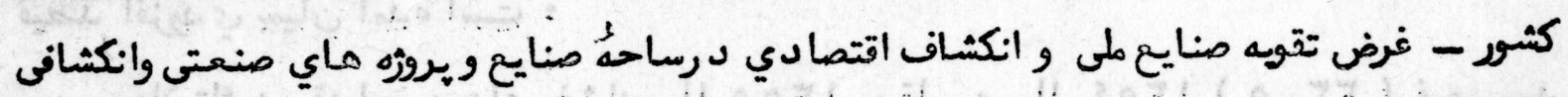

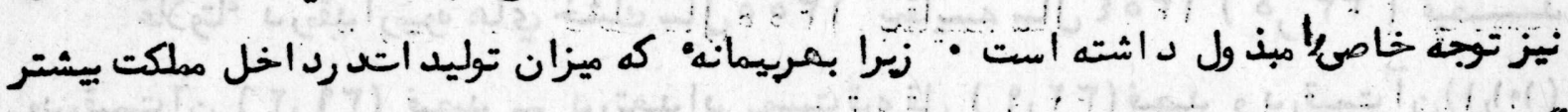

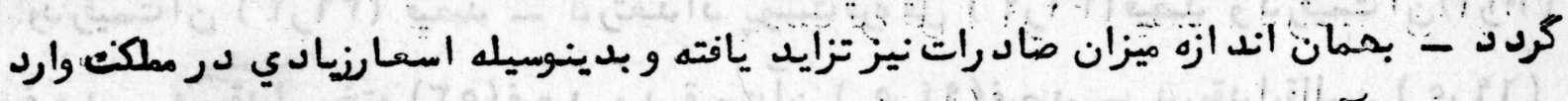

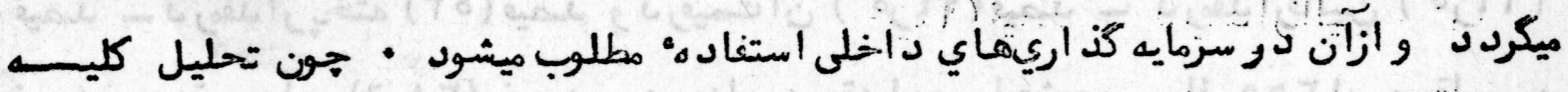

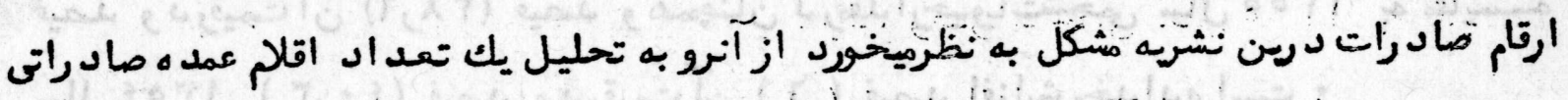

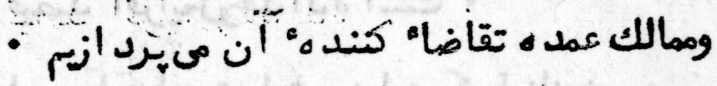




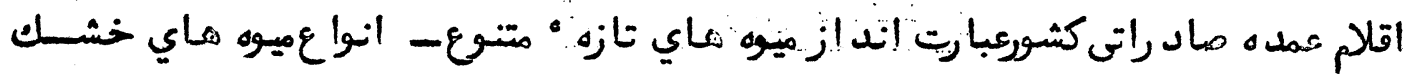
بوست قره قل - هشم - يخته - قالين و كليم - سايريوست باب - حبوات شحسى - كاز

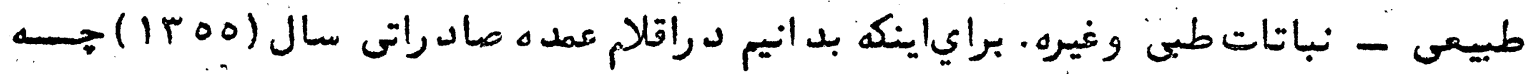

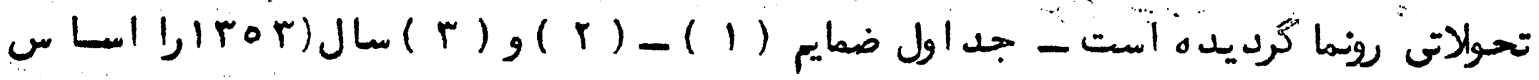

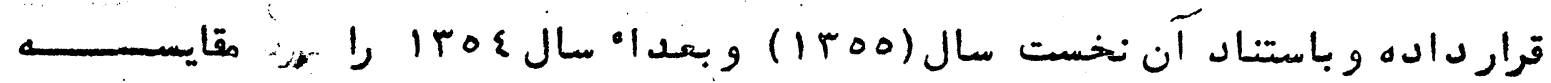

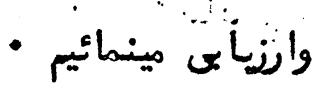

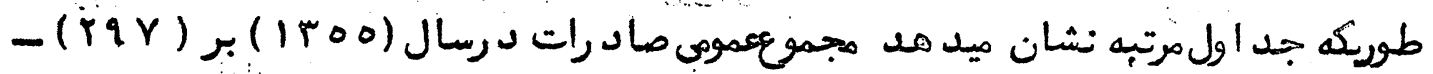

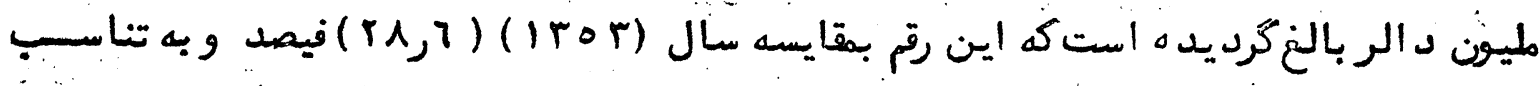

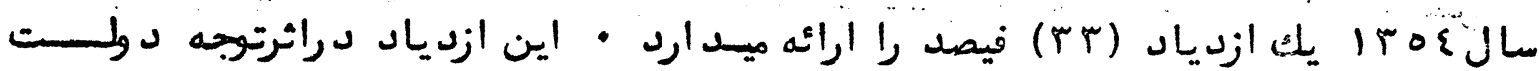

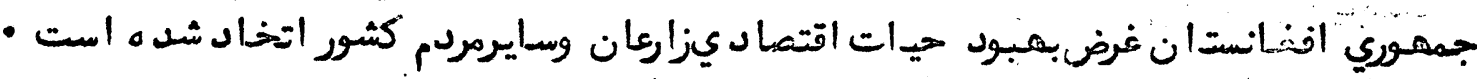

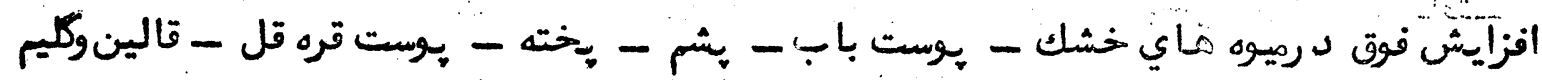

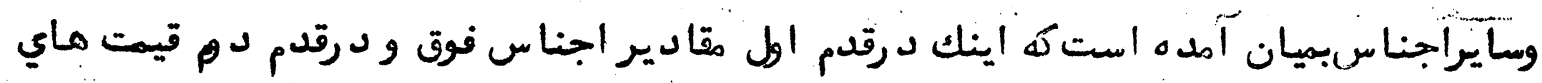
أنما رأ قرارنيل توضيح و وتحليل مينمائيم :

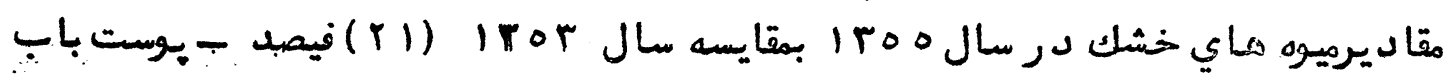

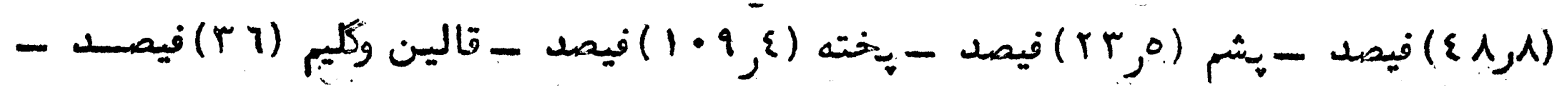

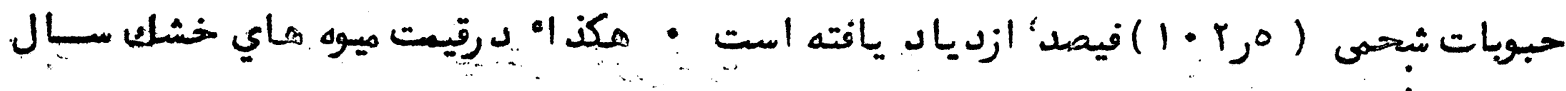

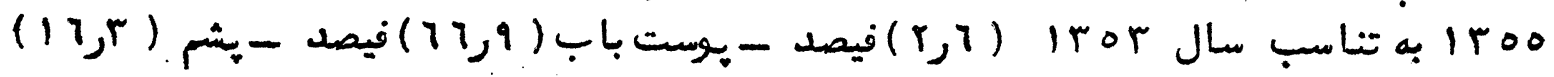

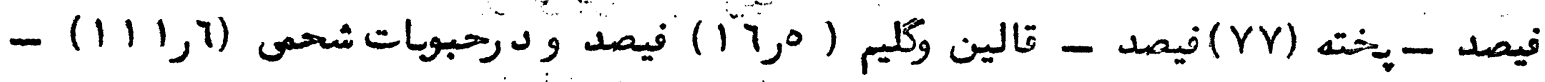
فيصد افزودي بميان آمده است فيمد

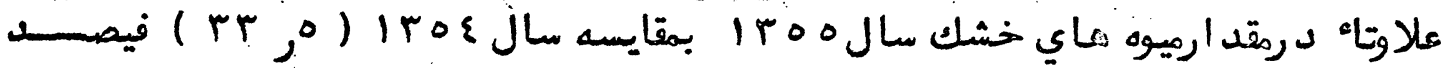

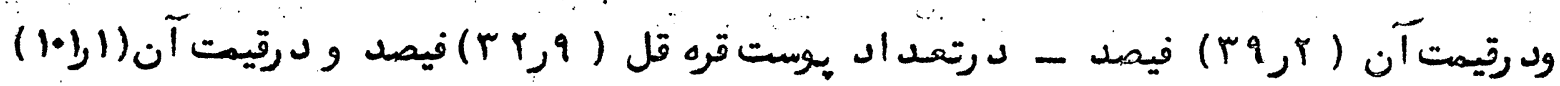

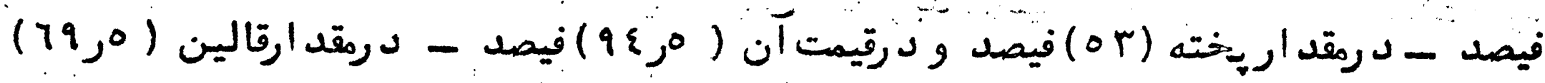

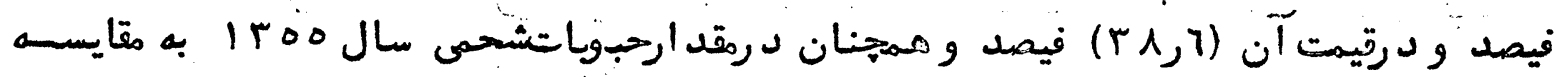

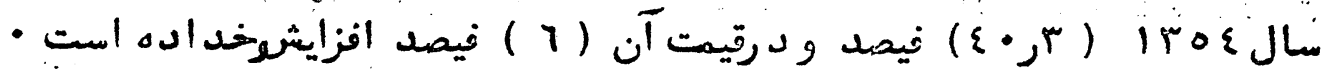

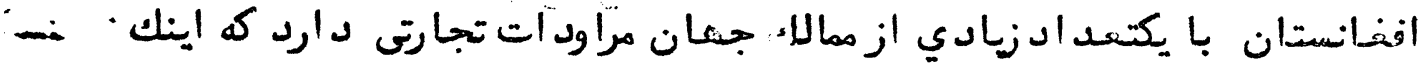

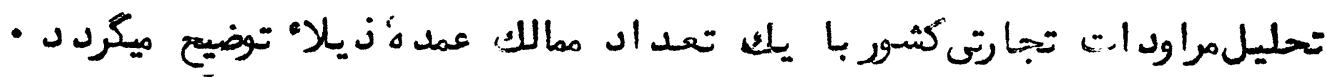

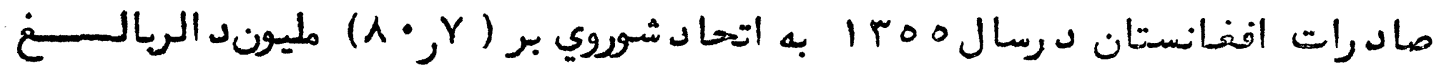

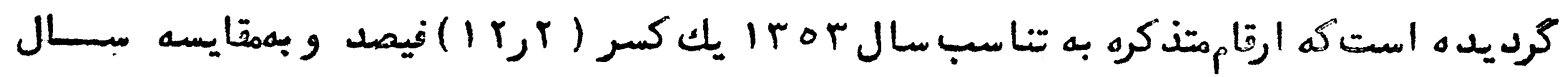




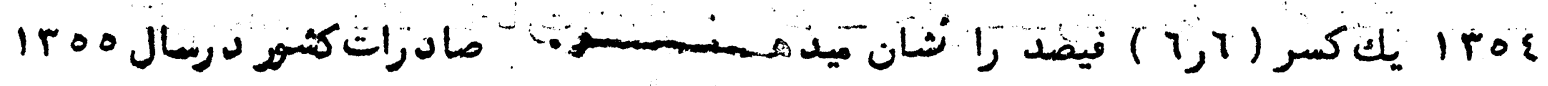

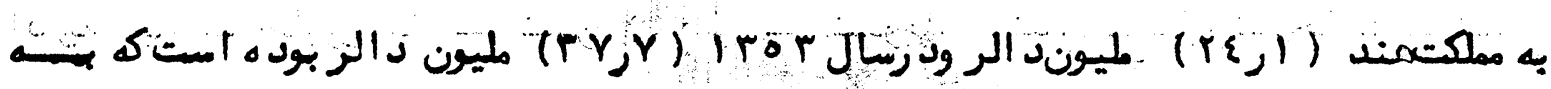

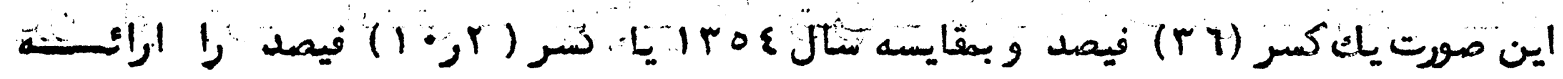
مينمايد

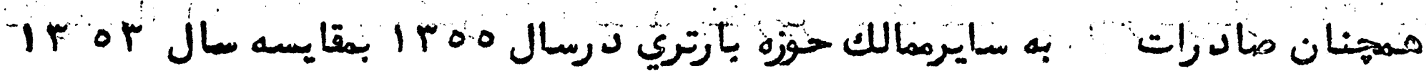

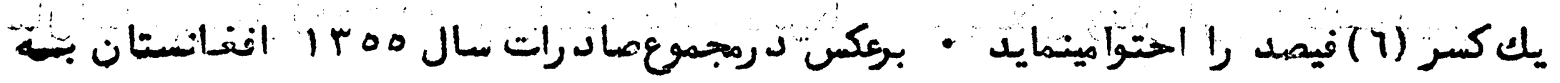

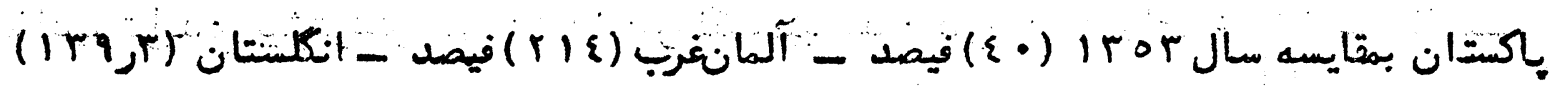

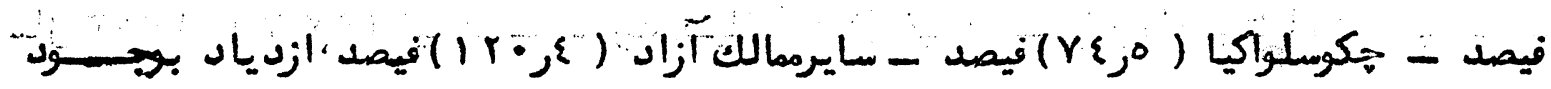

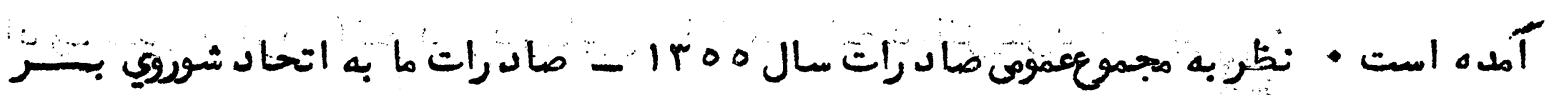

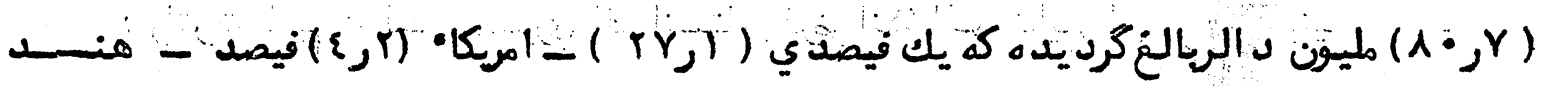

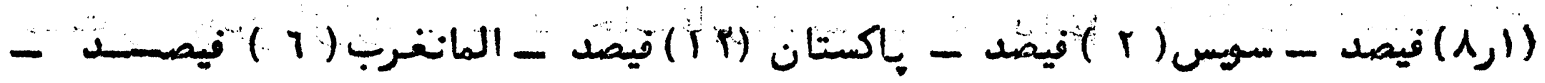

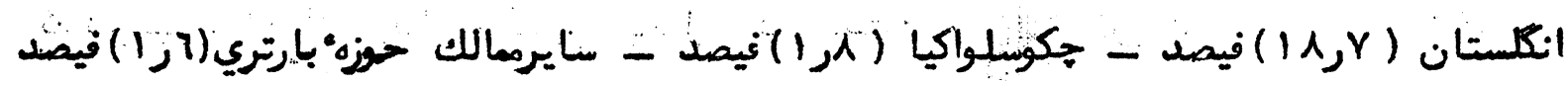

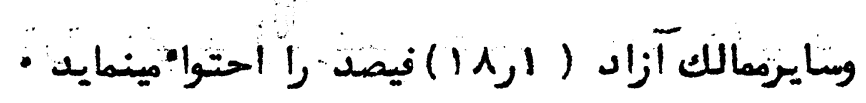
:تصنيـــــــ

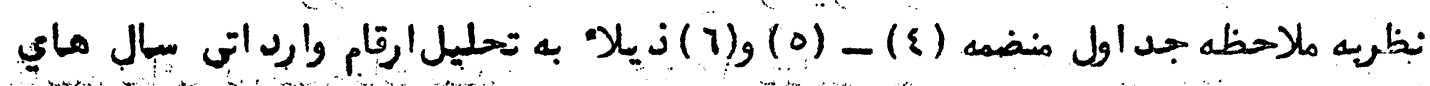
: (iroog rog_l ror)

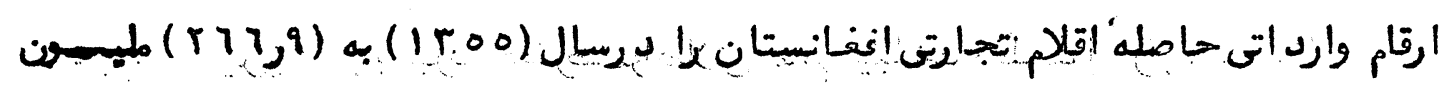

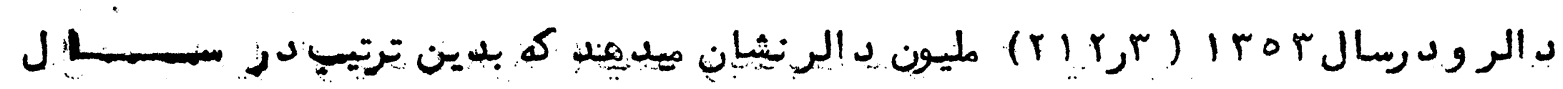

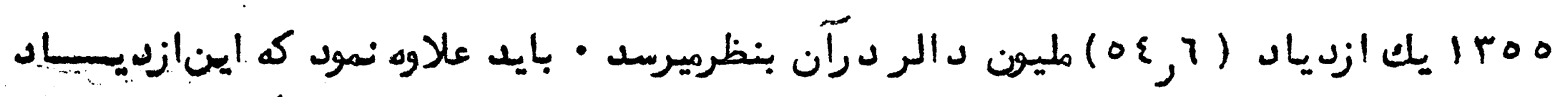

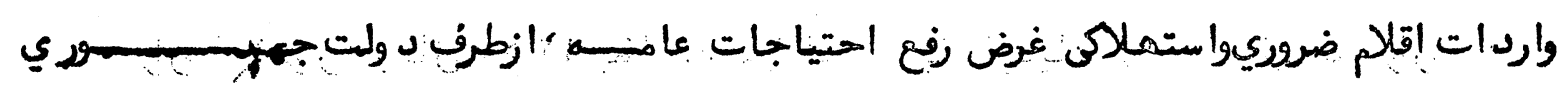

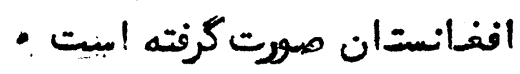

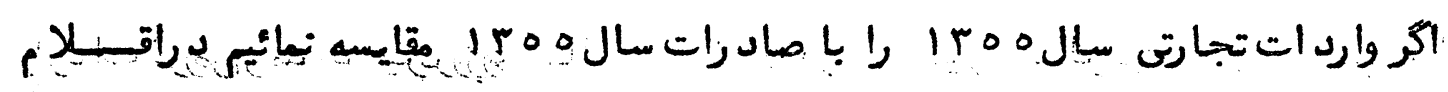

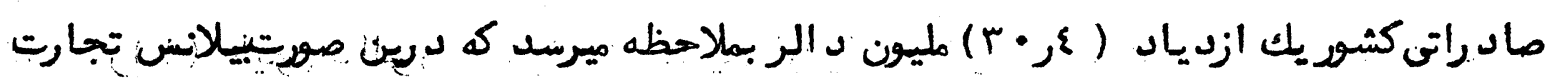

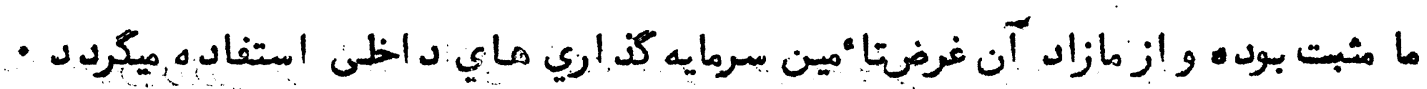

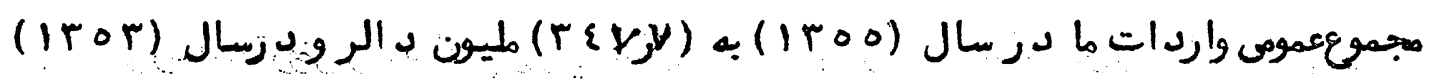

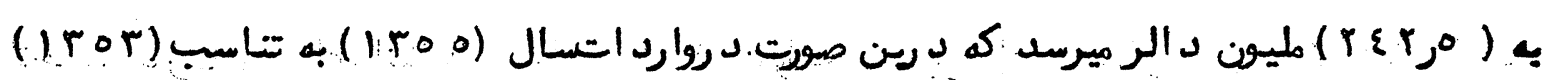

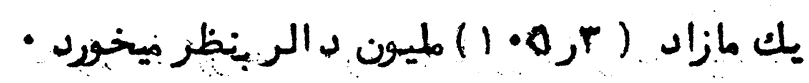

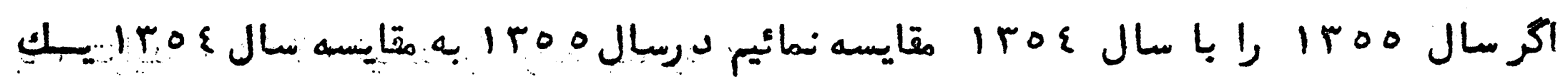
كسر ( 'رן .) مليون د الربملاحظه ميرسد - 


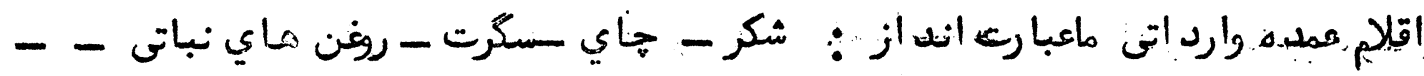

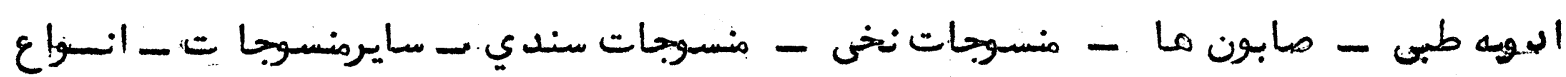

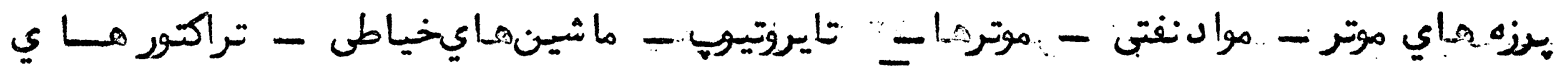

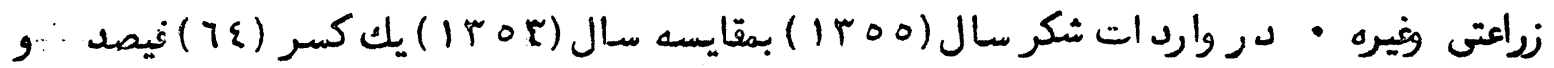

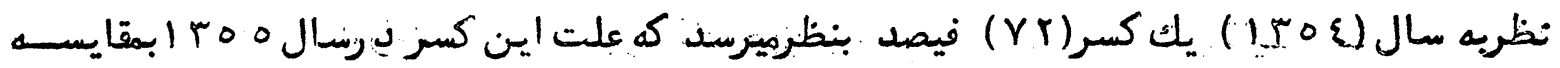

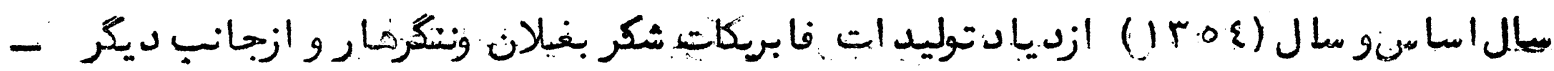

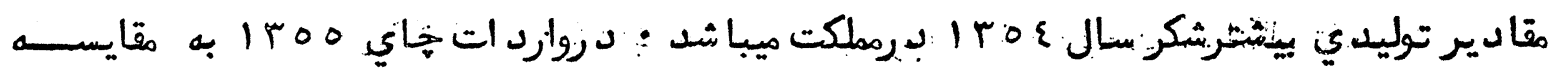

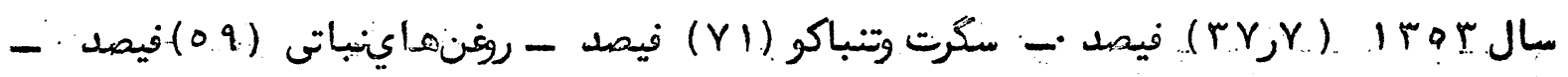

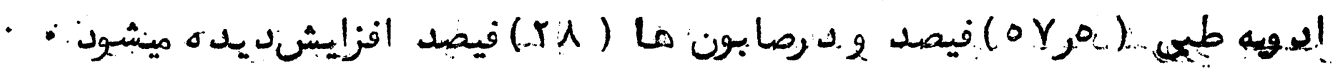

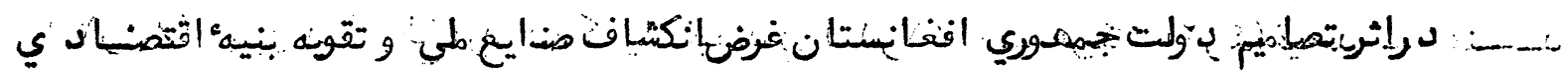

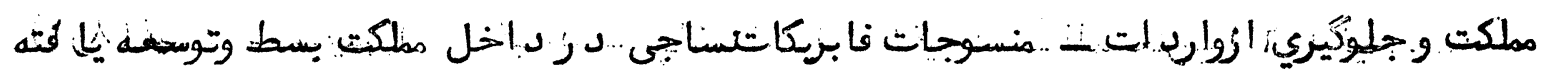

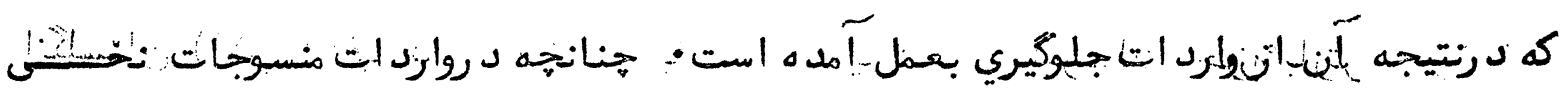

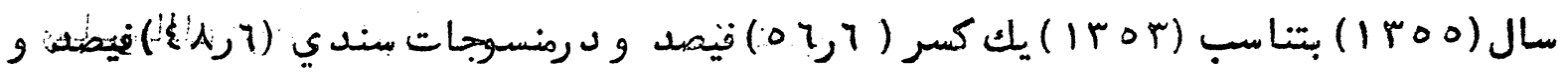

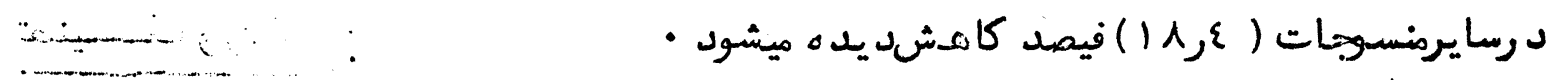

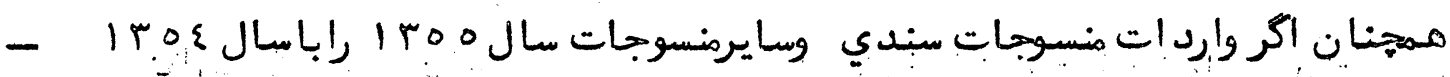

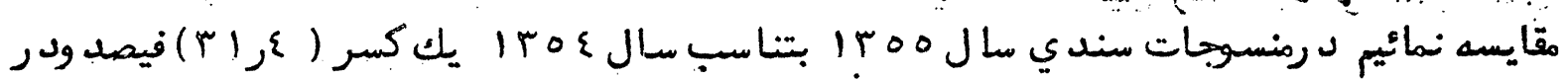

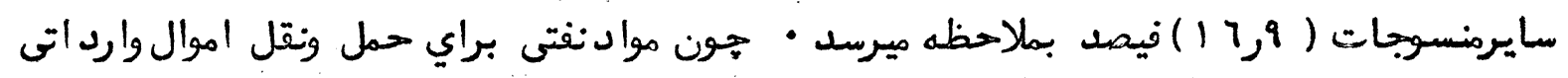

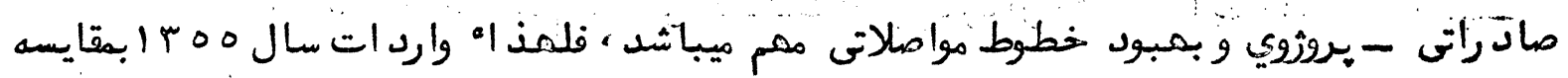

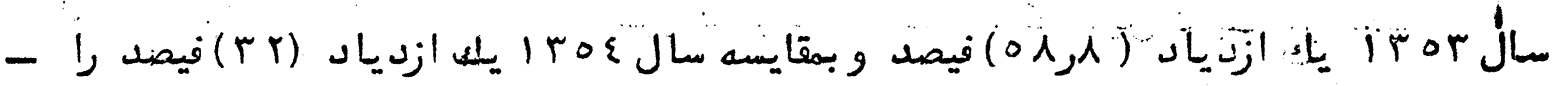
- احتوامينمايد

وارد اتَ موتر درسال وتيوب درسال مذكوريمقايسه سال اساسيك مازاد (

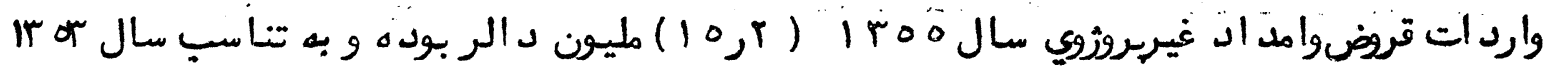

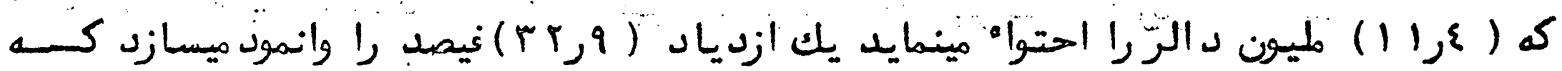

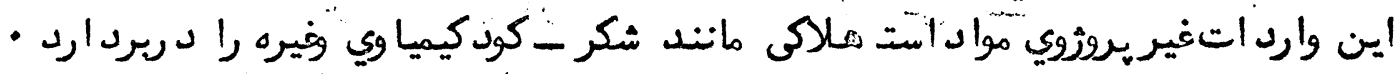

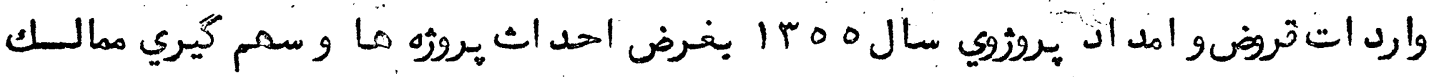

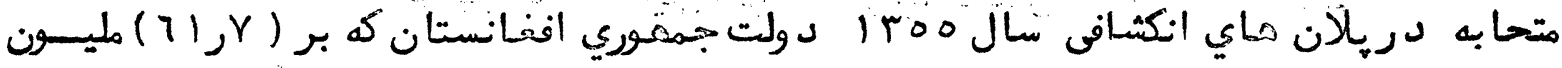

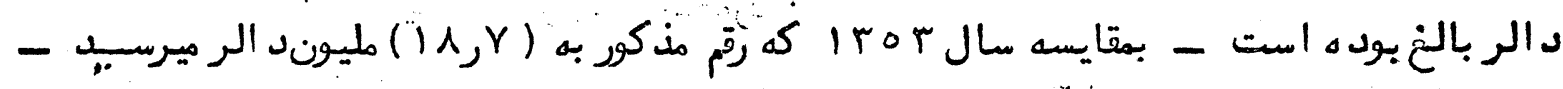

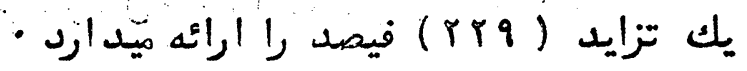




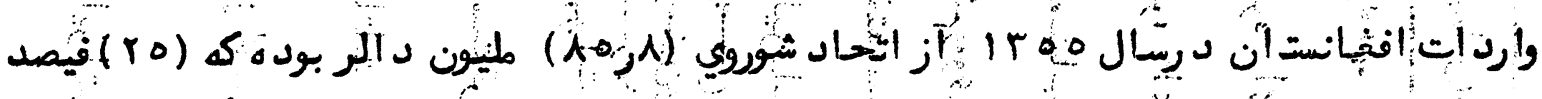

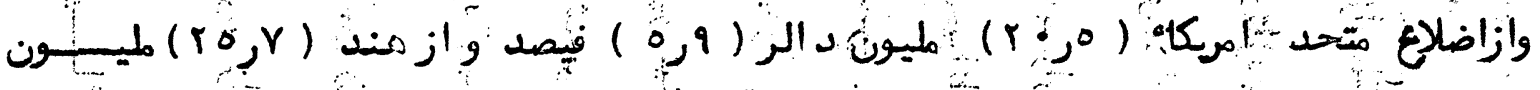

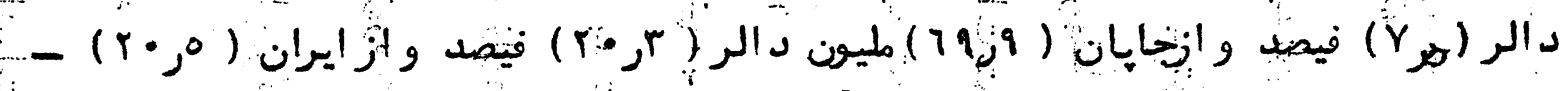

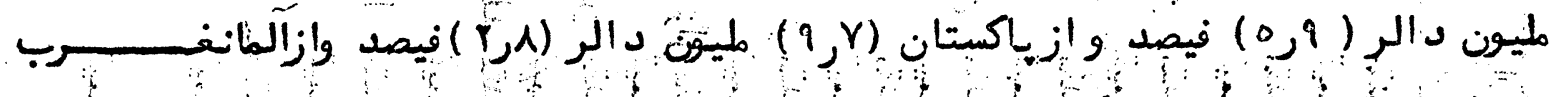

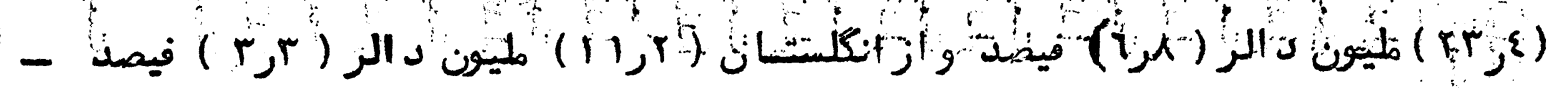
وازهكوسلواكيا ( و, ) مليون د الر ( ورr) فيمد و از سايرممالك حوزه بارتري ( 0رع ) مليسون

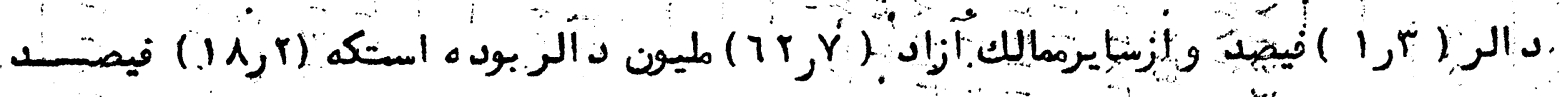

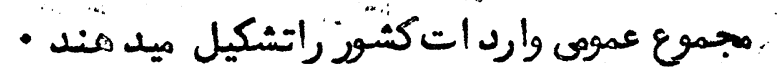

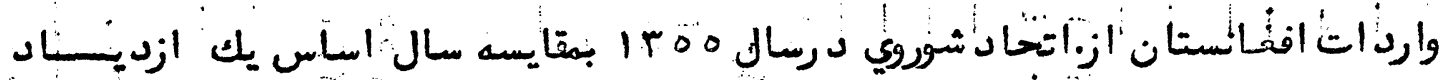

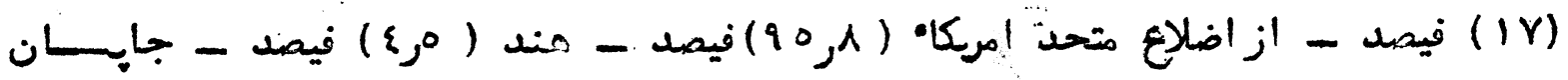

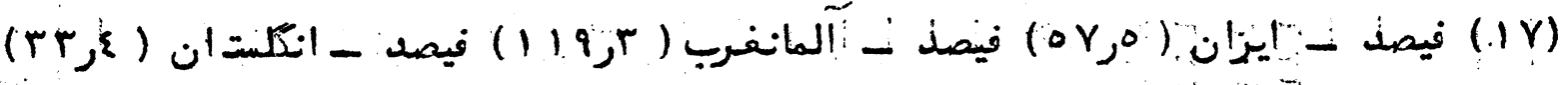
فيصد - سايرمدالك بازتري ( - مينمايند

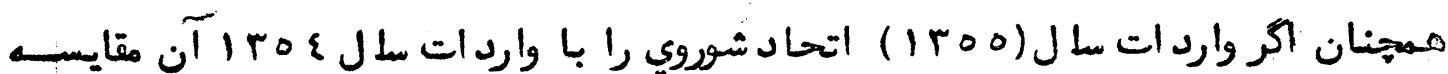

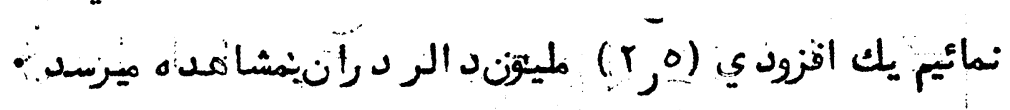

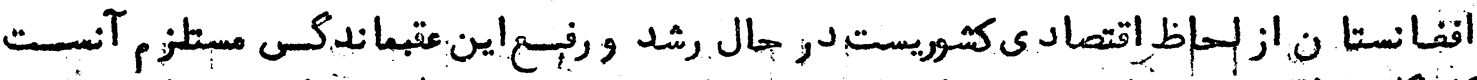

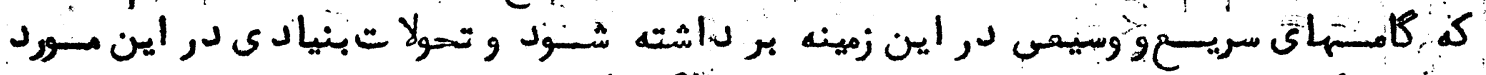

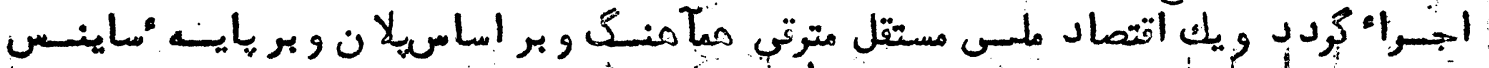

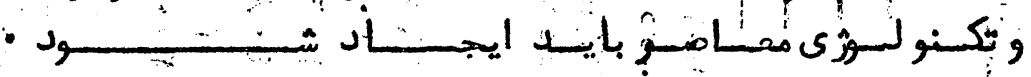

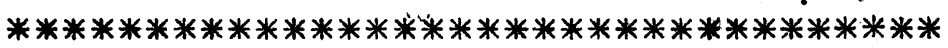

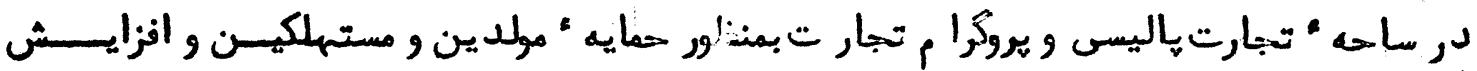

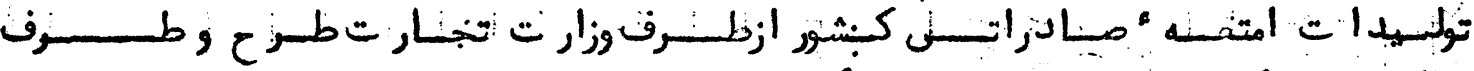

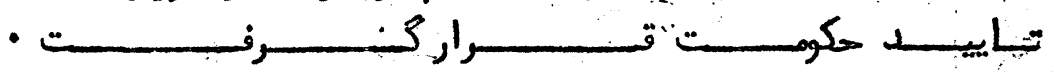

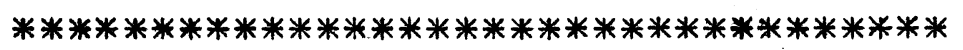

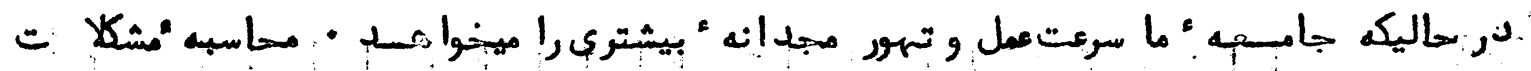

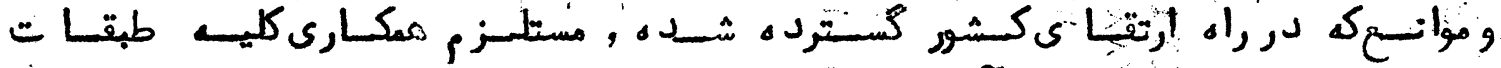

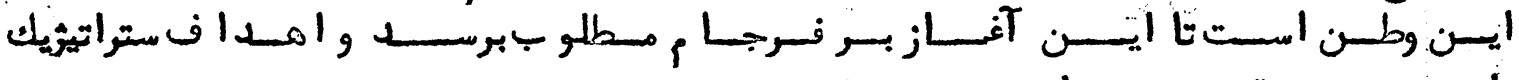
米米米米米米米米米米

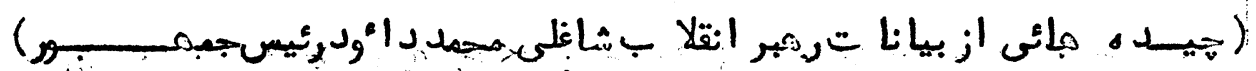




\begin{tabular}{|c|c|c|c|c|c|c|c|c|c|c|c|}
\hline جموع & 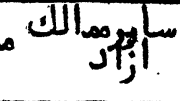 & بإبرومالك & 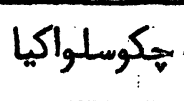 & إنكاتسان & آلمانفرب & خ بإكستان & منوجزرليند & مند & 'امريكا' & ش شورى & وآيمت مقذار \\
\hline rT\&Y & Y19. & - & rq & - & $r \varepsilon$ & - & $\therefore$ & - & - & - & مقد ار \\
\hline $1 Y 10$ & $1 Y 0 \varepsilon$ & - & 18 & - & $1 \varepsilon$ & - & - & $\because \quad-$ & - & - & قيمت \\
\hline $\begin{array}{l}\text { Irirgr } \\
\text { riol. }\end{array}$ & $\begin{array}{l}q 1 \cdot r \\
\{11 q\end{array}$ & $\overline{-}$ & $=$ & - & $=$ & $\begin{array}{l}\text { 1 } 5997 \\
10010\end{array}$ & $\overline{-}$ & $\begin{array}{l}\pi>\gamma 7 \\
1 \cdot q \cdot r\end{array}$ & $\overline{-}$ & $\begin{array}{l}\varepsilon \varepsilon \bar{Y} \\
q Y Y\end{array}$ & قيمتد \\
\hline 7.rro & $r \varepsilon \cdot r$ & 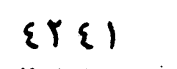 & $\varepsilon \varepsilon r$ & $01 \cdot r$ & o AY & 9011 & $\varepsilon 1$ & MrYT & - & rE7 \&. & مقد ار \\
\hline $7 \xi 1 \cdot r$ & $7 \cdot r \varepsilon$ & r $1 \wedge 0$ & $\varepsilon \mid r$ & $0, \alpha 0$ & roo & YIYT & $\varepsilon 0$ & rorry & - & I ThYO & قيمت \\
\hline $\begin{array}{l}Y \backslash 1.11 \\
Y .0 Y\end{array}$ & $\begin{array}{l}\text { Try } \\
\text { rirr }\end{array}$ & $\begin{array}{l}10 \\
\text { Or }\end{array}$ & $\begin{array}{l}r \lambda .1 \\
0.19\end{array}$ & $\begin{array}{l}18.2 \\
000\end{array}$ & 1 & $\begin{array}{l}r \varepsilon\} \\
10 r .\end{array}$ & $=$ & $\begin{array}{l}1 \\
r\end{array}$ & $\begin{array}{l}r \cdot 1 \\
1 \cdot \gamma \xi\end{array}$ & $\begin{array}{r}019 \\
119 r\end{array}$ & قيمتَ \\
\hline$\varepsilon \cdot \varepsilon \cdot$ & $i$ & - & - & - & - & $\xi \quad \xi$ & - & - & $\therefore \quad-$ & $\varepsilon \cdot r \cdot \dot{r}$ & ققد قار \\
\hline $\begin{array}{l}\text { 7)gr } \\
\text { rrygr }\end{array}$ & Yo. & irró & $14 \ldots$ & $19 \overline{0}$ & $=$ & $\begin{array}{r}Y \\
0.1\end{array}$ & $\overline{-}$ & $\overline{-}$ & $\overline{-}$ & 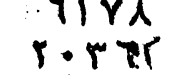 & مقدار \\
\hline r\&i人r & 9Yo & $r \cdot 10$ & $r .07$ & $r !$ & - & 10 & - & $!$ & - & rqu.r & \\
\hline O & $1 \cdot r$ & - & - & 117 & 187 & - & IAY & - & 11 & - & تر مقدار \\
\hline $199 .$. & rrqA & 1 & - & $\varepsilon \varepsilon \cdot \lambda$ & EY. & - & AIYT & - & $r: 0$ & - & قيمت \\
\hline$\lambda \lambda$ & $\{\lambda$ & - & - & $r \varepsilon$ & : 15 & - & Y & $\because$ & 1 & - & رقمدار \\
\hline ANr & $\varepsilon 0$. & - & 1 & ro. & $\operatorname{lrl}$ & 1 & $r$ & - & $\because \quad 1 r$ & - & قيمت \\
\hline 9910 & TYo. & - & - & - & .71. & $\therefore \quad \varepsilon \hat{\curlywedge} \cdot$ & $\therefore \quad-$ & $r$ & - & A广YT & مقد ار \\
\hline \&|rr & $\{\circ\}$ & - & - & - & rr & : $r \varepsilon \cdot$ & - & 10 & - & rrol. & 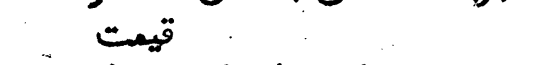 \\
\hline Arr & 11 & - & - & $1 \cdot 9$ & - & - & $\because$ & - & - & - & تـت قره قلبـمزارجلد مقد ار \\
\hline IrrYr & ror & - & - & $19 \cdot 17$ & - & - & - & - & - & - & قيمت \\
\hline$r) \cdot r \cdot$ & $Y \varepsilon \curlyvee \wedge$ & - & - & $|r|$ & $7 \varepsilon$ & $r \cdot 7 q$ & $\therefore$ & $107 r$ & NTOo & ry r & نباتإتطبن وزيوه ما \\
\hline 19^. & rir & - & - & or & $1 r$ & 1.rr & $r r$ & irgr & rrAr & रहा & قيمت \\
\hline 队人॰ $\left\{7 \varepsilon_{0}\right.$ & - & - & - & - & - & - & - & - & $-r$ & $10 \leqslant 7 \leqslant$. & كازطبيمى بـمزارمترمكمب مقدار \\
\hline rr.90: & 一 & $-?$ & - & - & - & - & - & - & - & rr. 90 & : قيمت \\
\hline 7971 & rqYr & - & - & ryt & roo & YrI & $\therefore \quad \wedge r$ & - & $71 \cdot$ & l krq & سايو اشيـــــاء \\
\hline rropos & T\&६Yr & 01 & $r \cdot Y r$ & TMTTS & 0791 & $r 719$. & Arri & $\nabla 70 \varepsilon$ & $011 \%$ & 91941 & مجموع عمومى مادرات \\
\hline
\end{tabular}


4

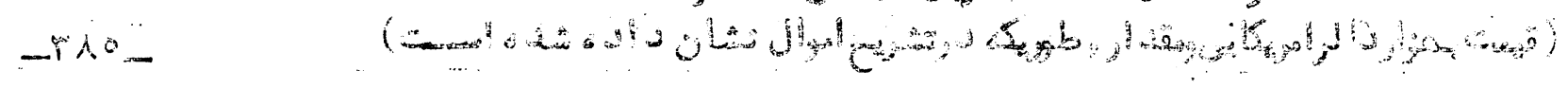

\begin{tabular}{|c|c|c|c|c|c|c|c|c|c|c|c|c|}
\hline "مجمــوع & سأيؤاد آلك & سأيوممالك & هجيوسلواكيا & إنكستان & آلمأنفركب & هاكستان & سويزرليند & 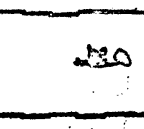 & امريكا' & شوروى & وأحد مقد & جنا من عمد ه \\
\hline ITr & 1.71 & - & I r & $=$ & 119 & $r r$ & $r \wedge \lambda$ & - & - & - & مقدار & عزارحلقه \\
\hline$|r| \xi$ & 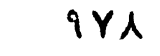 & - & $r \cdot$ & - & 10 & 9 & TIS & - & - & - & قيمت & \\
\hline $\begin{array}{l}\text { IrYYrT } \\
\text { rYI } 90\end{array}$ & $\begin{array}{l}1 \& r y \\
0 \leqslant\}\end{array}$ & $\overline{-}$ & $\overline{-}$ & $\overline{-}$ & I & $\begin{array}{l}99011 \\
\text { Irys. }\end{array}$ & I & 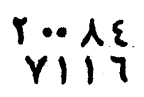 & I & $\begin{array}{l}77 r 9 \\
199 .\end{array}$ & قيمت ار & زه به تن \\
\hline o\{ $\{\lambda\}$ & $17 r \dot{r}$ & $\varepsilon \wedge \dot{\gamma}$ & $\varepsilon \cdot r$ & rq & 101 & $100 \mathrm{rl}$ & $\varepsilon Y$ & 799. & - & $\left.r \cdot \varepsilon_{0}\right)$ & مقد ار & تشك بهة تن \\
\hline$\{Y Y 7\}$ & rogr & 110. & rro & $r \cdot i r$ & ด ห & lr. \& & $r r$ & $1 \varepsilon 7$. & - & Irq99 & قيمت & \\
\hline ratq & oqr & $1 \lambda$ & \&OY & or & - & .11 & - & - & $q \cdots$ & $\mid \varepsilon\{. \mid$ & مقدار & \\
\hline||$Y \& \Lambda$ & $r\{7\}$ & YrT & $117 Y$ & $r \cdot \varepsilon$ & 7 & IrAY & - & - & $r Y \cdot T$ & $r \cdot \lambda I$ & قيمت & \\
\hline ArA & & - & - & $Y \varepsilon T$ & - & - & - & - & - & 97 & مقِد ار & \\
\hline 1.rol & 11 1 & - & $\therefore$ & 9191 & - & - & - & $=$ & - & 1109 & قيمت & \\
\hline o It & $\gamma \cdot \xi \gamma$ & - & - & - & - & - & $=$ & - & ril & orró & مقدار, & هوانأَتَ بتن \\
\hline $890^{6}$ & $1 \cdot 1$ & - & - & - & - & - & - & - & $\gamma \cdot 0$ & YIY & قيمت & \\
\hline rrort & $1 \times 9 \varepsilon$ & rYOY & or $\varepsilon$ & Ma: & $17 \cdot r^{\circ}$ & - & - & - & $\because$ & 11/ & مقذ1 & $\ldots$ \\
\hline rioox & $101 \%$ & $19 Y 1$ & $\circ \varepsilon$ & $1 \cdot 19$ & 10.rY \& & - & - & - & $\cdots$ & IISY & قيمت & \\
\hline$\{r\}$ & $1 r \varepsilon$ & 1 & - & $\varepsilon r$ & Irr & - & $|r|$ & $\ddot{-}$ & $1 \%$ & $\ldots .1$ & مقد از & $=1.0$ \\
\hline I TYrA & r.7. & ro & - & $|87|$ & 0.001 & - & D० \&. & - & IYA & ? & قيتكت & \\
\hline$r i$ & ir & - & $\therefore$ & ir & $r$ & - & 1 & - & $\therefore$ & - & ار مقذار & - a \\
\hline$r q a$ & $10 \varepsilon$ & $\therefore \varepsilon$ & $\therefore-$ & $17 r$ & $\varepsilon \varepsilon$ & - & rr & - & $r$ & . - & قيتزت & \\
\hline jo人ry & rrqu & $1 \cdot r$ & $\therefore$ & $\therefore-$ & $i \Lambda$ & ixis & - & rrr & $1 \varepsilon \cdot$ & $1.11 Y$ & مقدار & حهوبات شحمىسه تن \\
\hline Arol & rirq & YI & $\frac{-}{-}$ & - & $r \cdot$ & $1 \cdot 1 \lambda$ & - & TrI & !ई1 & 5771 & قيمت & \\
\hline PNTYYI & - & - & - & - & - & - & - & - & - & $r \lambda|7 r Y|$ & سب مقدار & 18 زطبيمىبـمزارمترمكم \\
\hline 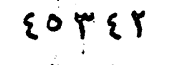 & - & - & $\div$ & - & $\because$ & $\ddot{-}$ & - & - & - & \&OY\&r. & قيمت & \\
\hline $1710 \ldots$ & ryol & - & - & 90 & Yr & rᄉl & - & $7 \varepsilon \lambda$ & $\|\wedge\|^{\circ}$ & 0. & مقد ار & نباتات طبي وزيره ما \\
\hline $1 \cdot\{r\}$ & IVEr & - & - & rᄉ & T & rle & - & $\varepsilon \varepsilon \cdot q$ & $r q \cdot r$ & $1 \cdot$ & قيمت & \\
\hline คห११ & olru & AY & - & $\varepsilon 7 Y$ & YMr & oᄉr & ir & 1 & VYY & qYr & قيمت & 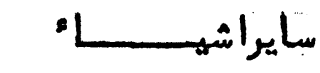 \\
\hline זרדזיו & Y & $\{\gamma \circ \varepsilon$ & $r I \cdot r$ & 101.9 & YYr人。 & $r q \circ 7 \varepsilon$ & 191 & M人々q & 947r & $\Lambda\rceil\{\mid \curlywedge$ & قيمت & ادرات \\
\hline
\end{tabular}




\section{$-r \wedge$ 工}

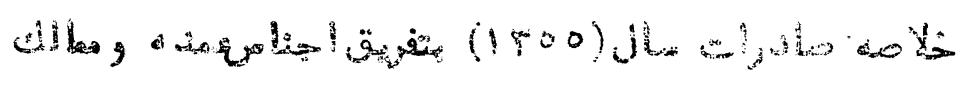

\begin{tabular}{|c|c|c|c|c|c|c|c|c|c|c|c|c|}
\hline مجمسـوع & 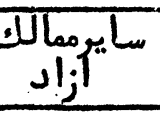 & سائمعالك & جكوسلوايا & انظستان & آلهانغرب & ياكستـان & سوينرليند & مند & امريكاء & شوروى & واريمت دقدا & اجناس عمده \\
\hline $\begin{array}{l}\text { rrit } \\
\text { ryoo }\end{array}$ & $\begin{array}{l}\{7 \hat{y} \\
r 7 \varepsilon\end{array}$ & I & $\begin{array}{l}{ }_{1} \\
\cdots\end{array}$ & - & $\begin{array}{l}11 \text { ry } \\
\text { Nyr }\end{array}$ & $\begin{array}{l}110 \\
0 .\end{array}$ & $\begin{array}{l}0\}\{ \\
\varepsilon>\varepsilon\end{array}$ & $=$ & $\overline{-}$ & $\overline{-}$ & قيمت ار & يهزار حلقه \\
\hline $\begin{array}{l}\| 1 \% \varepsilon . Y \\
r r\{\lambda \varepsilon\end{array}$ & $\begin{array}{l}r \cdot r \\
i r \lambda\end{array}$ & - & $=$ & $=$ & $=$ & $\begin{array}{l}1 \cdot r \cdot Y 9 \\
19 \lambda \cdot 1\end{array}$ & $=$ & $\begin{array}{l}\text { Irro } \\
\text { rqY. }\end{array}$ & $=$ & $\begin{array}{l}\text { rryr } \\
1.71\end{array}$ & قيمت ار & مهوه ماكتازه به تن \\
\hline $\begin{array}{l}\text { Yride } \\
\text { ToYAr }\end{array}$ & $\begin{array}{l}\text { iriY } \\
\text { list. }\end{array}$ & $\begin{array}{l}\varepsilon 190 \\
\text { r70. }\end{array}$ & $\begin{array}{l}r \cdot q \\
r \varepsilon q\end{array}$ & $\begin{array}{l}q \cdot 9 \lambda \\
0 . \lambda Y \wedge\end{array}$ & $\begin{array}{l}r r \cdot 1 \\
r r i s\end{array}$ & $\begin{array}{l}q\{\lambda \varepsilon \\
Y \xi \mid r\end{array}$ & $\begin{array}{l}1 \cdot r \\
Y \varepsilon \quad 1\end{array}$ & $\begin{array}{l}\text { III:99 } \\
\text { inrre }\end{array}$ & $\begin{array}{l}\text { rers } \\
\text { rryy }\end{array}$ & $\begin{array}{l}\text { rrileq } \\
\text { irryi }\end{array}$ & قتمت ار & كخشك به تن \\
\hline $\begin{array}{l}r i \varepsilon r \\
\text { IIrrr }\end{array}$ & $\begin{array}{l}1.19 \\
\varepsilon \cdot 19\end{array}$ & $\begin{array}{l}r \cdot \varepsilon \\
\text { ᄉri }\end{array}$ & $\begin{array}{l}\varepsilon 1 \gamma \\
1 r \cdot \varphi\end{array}$ & $\begin{array}{l}r \varepsilon \\
100\end{array}$ & $\begin{array}{rlr}r \pi \\
r \wedge r\end{array}$ & rirr & $=$ & $=$ & $\begin{array}{r}779 \\
\text { r人1? }\end{array}$ & i. & قيمت ار & ستباب تُمزارجلد \\
\hline $\begin{array}{l}111 \varepsilon \\
r \cdot \lambda r .\end{array}$ & - & - & $=$ & $\begin{array}{r}99 . \\
1.1918 \varepsilon\end{array}$ & $\begin{array}{c}Y \\
1 \varepsilon .\end{array}$ & $=$ & $\overline{-}$ & - & $=$ & $\begin{array}{l}118 \\
1791\end{array}$ & قتمدار & \\
\hline $\begin{array}{l}\{q 91 \\
Y r \cdot 1\end{array}$ & $\ddot{0}$ & $=$ & $\therefore$ & . 1. & $\therefore=$ & - & $=$ & $=$ & $\begin{array}{l}\text { ris } \\
\text { rris }\end{array}$ & $\begin{array}{l}\varepsilon 7 \varepsilon \varepsilon \varepsilon \\
7 r y-\end{array}$ & ققيتد ار & $=-1.1$. \\
\hline $\begin{array}{l}\{9117 \\
\text { TIrYA }\end{array}$ & $\begin{array}{r}1.0 q \\
\| 1 \xi r \lambda\end{array}$ & $\begin{array}{l}r .1 \\
o r\end{array}$ & $\begin{array}{l}r 1 Y 7 \\
1917\end{array}$ & $\begin{array}{l}\text { rrrre } \\
\text { riryt }\end{array}$ & $\begin{array}{c}0 \varepsilon 7 \xi \\
100 \%\end{array}$ & - & $=$ & - & $\overline{-}$ & $\begin{array}{l}1.097 \\
1 \varepsilon \cdot \varepsilon q\end{array}$ & متمد ار & طلو نه \\
\hline $\begin{array}{l}\text { Yrq } \\
\text { rTI9 }\end{array}$ & $\begin{aligned} 8 \% q \\
9010\end{aligned}$ & $=$ & $=$ & $\begin{array}{l}\text { oर } \\
\text { rrgq }\end{array}$ & $\begin{array}{l}1111 \\
00.0\end{array}$ & $\bar{I}$ & $\begin{array}{l}11 \bar{\varepsilon} \\
0 . \lambda r\end{array}$ & $\bar{T}$ & $\begin{array}{l}\overline{1} \varepsilon \\
r \varepsilon q\end{array}$ & rry & ق ققد ار & \\
\hline $\begin{aligned} \text { ro } \\
\text { Eqd }\end{aligned}$ & $r \dot{i}$ & $\overline{1}$ & $\overline{-}$ & . I & $\varepsilon r$ & $\overline{-}$ & 9 & - & $\dot{\bar{T}}$ & $=$ & قيد ارز & بوستيتونيخونتينجه به \\
\hline TYYIY & rql. & r... & $r \cdot \lambda \cdot r$ & $\therefore-$ & 10 & Yort & - & - & - & YYY \& & مقدار ر) & حهوبات شحمىبه تن \\
\hline $\begin{array}{c}\text { AY } Y Y \\
r \leqslant 10<0\end{array}$ & YrqA & 90 & $\lambda \lambda \cdot$ & $\cdots-$ & 9 & $r \wedge \varepsilon 1$ & - & - & - & : YTY & قيعت & \\
\hline 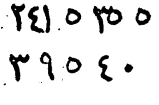 & $=$ & $\overline{-}$ & $\overline{-}$ & $\cdots$ & $\overline{-}$ & - & $z^{2}$ & $=$ & $\overline{-}$ & $\begin{array}{l}\text { Y(E) YOO } \\
\text { rq0द. }\end{array}$ & قيمتركِ & 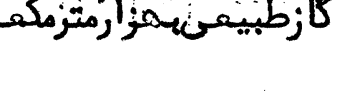 \\
\hline $\begin{array}{l}19 Y 0 \varepsilon \\
117 \% .\end{array}$ & $\begin{array}{l}\text { Vr } \varepsilon \varepsilon \\
\text { rrTr }\end{array}$ & - & $\bar{z}$ & $r_{\varphi}$ & 91 & $\begin{array}{l}r \lambda Y Y \\
r I \cdot r\end{array}$ & 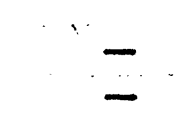 & $\begin{array}{r}9.9 \\
r r i 1 ?\end{array}$ & $\begin{array}{l}Y\{0 \wedge \\
\text { YAr }\end{array}$ & $=$ & 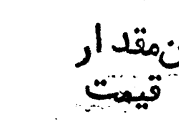 & نباتاتـطبىوزيره مابت \\
\hline rlorA & 1.099 & - & IY & $10 \varepsilon$ & $r 1 \cdots$ & rere & rr. & - & rols & rir & قيمت & سايراشيـــــــا" \\
\hline & $9 \notin 0$ & 704. & r & $0 \wedge 1$ & 19 9 & r777ג & 0199 & Ү & 1YOro & . $7 \curlywedge \varepsilon$ & قيمت & مومنهادرات \\
\hline
\end{tabular}




\begin{tabular}{|c|c|c|c|c|c|c|c|c|c|c|c|c|}
\hline كتموع & آسائيومالج & سائيم:ترك & ، خكوسلواكيا & انكستان & العلنفرب & هاكستان & ايران & جايان & منســ & 'امريكا' & شورى & اجناس عمده \\
\hline rIYYY & 1 & 1 & - & - & - & - & - & - & - & - & & شكر \\
\hline $1077 \varepsilon$ & Irry & 10. & - & 09 & - & 11 & - & $x$ & $\operatorname{mrq} \varepsilon$ & - & & st \\
\hline 1099 & $\cdots$ & - & - & $9 \gamma$ & - & 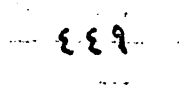 & - & - & IY & $1 \cdot 11$ & - & سكرت , تنهاكو \\
\hline 10\% & ฉ६१५ & - & - & r. & $r$ & $\ddot{-}$ & YIT & rol & - & io & rir & روغن ماكنهاتى \\
\hline iri. & royi & roo & - & $r q u$ & $17 \cdots$ & $Y \wedge$ & 1 & $r$ & $1 \varepsilon$ & $r \cdot r$ & ror & آد \\
\hline rq9o & $1 \varepsilon$ & - & - & roi & $i$ & $i \cdot 17$ & i & - & Irr & $\varepsilon$ & ג & مأهونها \\
\hline IrYYT & rะq & 101 & - & $1 \cdot r$ & $1 Y \varepsilon$ & irri & or & $790 \mathrm{r}$ & $1 \therefore 1$ & rq & 9 & تازنعا \\
\hline YAAT & 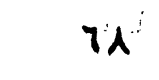 & o \{ & $|r|$ & $0 \cdots$ & $r$ & rror & $r \varepsilon$ & ilir & 10.7 & - & 1111 & متنسوجات نخى \\
\hline$\| \gamma \varepsilon r$ & $r \lambda$. & rry & - & - & - & ri & 170 & riqg & r 190 & - & $7 \varepsilon 7$ & منتسوجات شيثلدى \\
\hline ra. ir & 1ह) ₹ & - & - & \&o. & 10 & $\mathrm{ri}$ & $79 r$ & $r$ \& Gir & rir & $\varepsilon 1 \lambda$ & - & تبايونيسبوبات \\
\hline ะดห & ro & - & - & $\varepsilon 1 r$ & Irir & 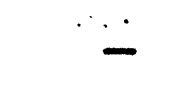 & $\varepsilon$ & rAג & Y & or. & 1791 & موتر ما: " \\
\hline qort & rir & - & - & $r \varepsilon 0 \wedge$ & ¿Yo & $O \varepsilon$ & Ar & 101 & $r q 1$ & ryr & Hor & يرزة جاتموتر \\
\hline rrol: & $Y \varepsilon:$ & $\varepsilon$ & - & 091 & ᄊ1 & 17 & $9 r 91$ & $2=$ & $\therefore$ & Irr & 11091 & \\
\hline$r \cdot \therefore \varepsilon$ & or & - & - & 9 & ६ ? & $\varepsilon$ & \{o & $r$ & 7 & - & jer. & يإِيوثماي جديد \\
\hline Arili & $7 r$ & i & 7 & $\mathrm{rr}^{-1}$ & 19 & 0 & - & 1.78 & 199 & - & rrr & تايروتيوي \\
\hline 111 & $n$ & 91 & - & 97 & 1 & ir & - & $r \varepsilon$ & rri & - & - & بطيسكل \\
\hline
\end{tabular}




\begin{tabular}{|c|c|c|c|c|c|c|c|c|c|c|c|c|}
\hline مجمِوع & سآيومأل & سايرممالك & يجوسلواكيا & انكانستان & آلمانفرب & "اكستان & ايران & جايان & مند & امريكا & شوروى & ناسعمده \\
\hline$\because V \lambda \lambda$ & $\therefore$ Ir & rY & - & - & 1 & rT & $1 r$ & rrr & $r Y=$ & - & 0 & نُخ اطن \\
\hline 777 & $: \quad-$ & - & $\varepsilon$ & - & - & $\rightarrow$ & $y$ & - & YI & - & 7ro: & كرد \\
\hline$r \varepsilon 0$. & 97. & rr & $r$ & 1 \&o & $O q_{0}$ & $1 \cdots$ & ir & ryi & ri & $\therefore$ & $r\{\}$ & انشينماكيرقىوغيربرقى \\
\hline$Y \cdot Y 7$ & isto & דוזי & - & 17. & $1+\varepsilon q$ & ใ & $1 \cdot$ & 7. & $: 1 T \lambda$ & $0 \& Y$ & 11 & موأذكيهياوى \\
\hline 11 & - & - & - & - & $\underline{-}$ & - & - & - & - & - & 110 & تراكتور ماكنراعتى \\
\hline$\{107$ & $17 \lambda^{\circ}$ & - & - & $1 \cdots$ & ri & - & - & $\varepsilon 7 \gamma$ & - & $\cdot \Delta \wedge \wedge \lambda$ & - & البَسَة مستشمل \\
\hline rirry & $001 \varepsilon$ & 1018 & ו & rq.r.q & rqYq & $\varepsilon 1, \varepsilon r$ & $r \varepsilon r$ & $Y \cdot \gamma r$ & 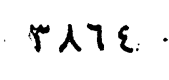 & ६०१ & $.01 r$ & أشهاء \\
\hline rirro. & r\&OYA & $r \varepsilon 7 \varepsilon$ & YYq & A\&TV & $1 \cdot \cdots 1$ & $1 \cdot r 9 r$ & $1 r \ldots o$ & oq $\vee ₹ 0$ & $r\{0 \lambda \lambda$ & $7 \cdot r \gamma$ & $0.9 r 9$ & \\
\hline $11 \varepsilon \varepsilon \varepsilon$ & rith & - & - & 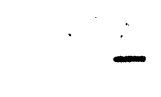 & $\therefore$ & - & - & - & - & i & ArYr & ترون وامدادغيريروزوى \\
\hline I Arri & $7 \cdot r$ & - & - & - & orr & - & - & - & - & rois & $\mid \varepsilon \cdot r q$ & زوضعامداذ يروزوى \\
\hline r\&YOYY & YYTOQ & $r \varepsilon 7 \varepsilon$ & YYq & $\begin{array}{c}\text { A\&rY } \\
\vdots \vdots\end{array}$ & 1.77 & $\begin{array}{c}\text { l. rar } \\
\text {. }\end{array}$ & 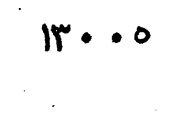 & ० १ $₹\{0$ & $r\{0 \wedge \wedge$ & $1 \cdot\{79$ & YrT\&l & عمومىوارلا ت \\
\hline
\end{tabular}




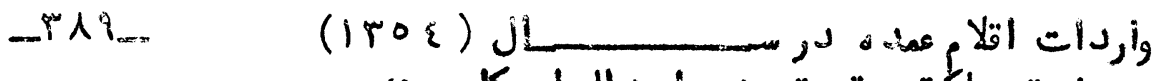

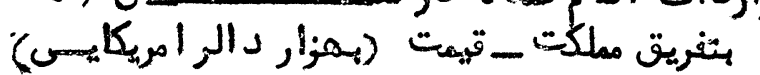

\begin{tabular}{|c|c|c|c|c|c|c|c|c|c|c|c|c|}
\hline مجمسوع & 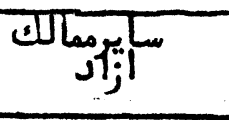 & سأيوماثلت & هكوسلواكيا & انكستان & آلمانفرب & باكستان & ايران & جايان & منـــد & امريكا" & شوروى & اجناسعمد ه \\
\hline$\pi r a 11$ & - & - & - & $r \cdot Y \cdot$ & $17 \cdot 7 Y$ & - & 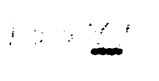 & $A=$ & $\varepsilon \pi \mid \gamma$ & - & $11 \cdot 7 r$ & شكر \\
\hline$r \cdot \varepsilon . q r$ & $\{r \mid\}$ & $\varepsilon q\}$ & - & rir. & - & $\Lambda$ & - & - & rolor & - & ros & جاى \\
\hline grr & Y & - & - & 111. & . & ror & - & tr & Yr. & 97. & 17 & سكرّزت وتنباكو \\
\hline ATIr & TrY & - & - & $\circ$ & - & - & - & $\operatorname{Trq}$ & 17 & r & $17 \varepsilon$ & روغنبهاكنباتى \\
\hline$T r \cdot r$ & $\{11\}$ & $17 \varepsilon$ & - & or. & 1711 & $1 . r$ & - & $\varepsilon$ & $i$ & 79 & or & ادويه طهى \\
\hline or $\varepsilon \cdot Y$ & I7I & $1 \cdots$ & - & $Y \varepsilon \lambda$ & $\mu$ & A. & $\varepsilon \wedge^{\circ}$ & rT & Ar & $T \varepsilon$ & rire & مابون هt \\
\hline $1 \cdot 7.71$ & m oo: & $r \varepsilon Y$ & yo. & 11.9 & rrit & $1 \cdot Y q$ & $r_{\bullet}$ & $\{\varepsilon \circ \varepsilon$ & $\lambda \varepsilon_{--}$ & 119 & ir & : تارها \\
\hline 19.79 & 70. & - & 19 & $r$ & $i$ & Dor & $r$ & $\varepsilon \wedge 9^{\circ}$ & Doy. & $\therefore$ & 1197 & مُنسوجات نخى \\
\hline AY.A. & 1.97 & rr & - & - & $r$ & 'rr & $1 \cdot r$ & 7778 & $1 \cdot\{7$ & 19. & $790^{\circ}$ & منسوجات سندى \\
\hline TYOTE & ory & 7 & - & $07 . Y$ & $\varepsilon r$ & $r r$ & o9r & rreqA & $\mid \varepsilon]$ & 971 & NoY & سايرمنسوبجات \\
\hline I Trry & $r Y \varepsilon$ & 1 & $r$ & $11 \varepsilon$ & $1.91 \ldots$ & - & rr.. & 900 & rirr & $r \varepsilon$ & 17.0 & موتر ها \\
\hline 071. & o $\{\lambda$ & $\varepsilon$ & $r \varepsilon$ & $r \varepsilon r \lambda$ & TIE & $r r$ & 91 & 91 & rrq & $r$ & $q \cdot r$ & مززه جاتموتر \\
\hline$r Y \cdot T^{-}$ & 11. & - & - & 1181 & 10 & 11 & 1901 & - & $r$ & rq. & lorir & مواد نفتى \\
\hline rYq9 & ६ภ૪ & 17 & $1 \cdot$ & o & rq & 1 & $\{1 \curlywedge$ & r & $r$ & 1 & ivig & يايوشهاكجديد \\
\hline 11041 & 107 & $1 \varepsilon$ & $r \cdot$ & 9 & 10 & Ir & - & $r \cdot \lambda r r$ & 190 & - & roo & ت ايموتيوه \\
\hline$O Y \varepsilon$ & 09 & ro & - & $1 \% 4$ & $Y$ & ir & - & 01 & T\&q & - & ro & بايسكلويرزه جاتأر. \\
\hline
\end{tabular}




$$
-r q \cdot
$$

ادامه جلدول (0) ضميمه

\begin{tabular}{|c|c|c|c|c|c|c|c|c|c|c|c|c|}
\hline مجموع & 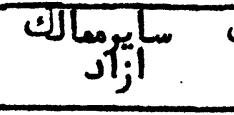 & سأيرمالك & جكوسلواكيا & انكستان & آلمانغرب & هاكتـان & ايران & جايان & منسـ & امريكاء & شوروى & اجناس عمد ه \\
\hline $010^{\circ}$ & $70^{\circ}$ & $r \varepsilon$ & - & - & $\varepsilon$ & $r$ & $r$ & 197 & $r i r$ & - & $\varepsilon$ & ماشينماكخياطى \\
\hline $100 \%$ & or & $r u^{5}$ & ro & - & - & $r$ & 1.9 & - & 194 & - & $11 \lambda x$ & Sوتـرد \\
\hline odar & $\operatorname{TrA}$ & IY: & $r r$ & $r \cdot r$ & 1000 & rAT & 10 & Irr & oyo & $\operatorname{lrl}$ & \multicolumn{2}{|c|}{ مابهنهل كرقىوغيروقى 19.} \\
\hline ryri & rri! & rog & - & IVA & $1 \cdot 89$ & $19 \%$ & 9 & or & o $\varepsilon$ & \&Y. & ri\& & مواد كيمياوى \\
\hline$r \varepsilon I$ & - & - & - & - & - & - & $\therefore$ & - & - & - & $r\{r:$ & تراكتورها كزززاغثى \\
\hline$\varepsilon \cdot \Lambda \varepsilon$ & TrT\& & - & - & 119 & rir & - & - & 177 & 2 & irrr & $\therefore-$ & البسه مستخفل \\
\hline$\varepsilon r i \cdot r$ & ᄉr $\& \curlywedge$ & 1410 & rrig & rTN & \&9TA & rur & rqur. & Tin & \&รq & rer & rare & سايراشياء \\
\hline rustir & rrory & rq7e & ז & $1877 \varepsilon$ & rurre & $r \varepsilon Y$. & Irgir & irito & \&ाนтा & ० & $\varepsilon \varepsilon \cdot 11$ & مجمــــوع \\
\hline ror AN & rrar & - & - & - & 0970 & - & - & EYo & - & $91 \mathrm{Ar}$ & trer. & قروزن وامد اد غيريروزوى \\
\hline 07.90 & $1191 \varepsilon$ & Trr & rot & - & ril & $\therefore=$ & I TrY & - & - & Arro. & $r r \cdot k t$ & قرون إهئ اديروثرى \\
\hline r\{q่นา & $\varepsilon \wedge \lambda \cdot \varepsilon$ & rogi & rAYY & KrT'ร & $\varepsilon r \varepsilon Y q$ & $Y \varepsilon \gamma \cdot$ & $10019^{\circ}$ & TYY... & E1T.7\% & TYYYY & रrEा & منجّموع عمومى وارد ات \\
\hline
\end{tabular}




\section{-rq1_

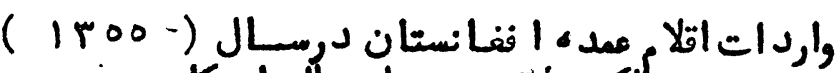

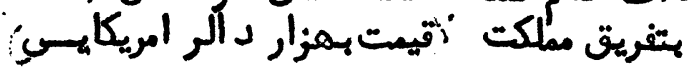

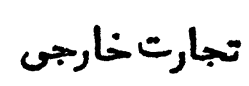
جدول (1) ضميعه

\begin{tabular}{|c|c|c|c|c|c|c|c|c|c|c|c|c|}
\hline مجمسوع & نيإبرممالك & نائرمالك & جكوبنواكيا & انكستان & آلمانغرب & ياكستان & ايران & جإن & منسـد & امريكا' & شوروى & اجنامعمده \\
\hline $9 \varepsilon 7 \varepsilon$ & - & - & - & - & P770 & - & - & - & - & - & orqq & \\
\hline rlorr & rTYo & q\& & - & 11 & - & $r \lambda$ & - & $7 \varepsilon$ & irror. & - & $1 \cdot 1$ & جاى \\
\hline rvit & 7 & - & - & $1 \xi$ & - & IYYE & - & - & $\lambda$ & $1 r \cdot A$ & - & \\
\hline i & $7 \cdot r \cdot$ & - & - & - & $\varepsilon$ & 1 & 1 & ०१Y & rrr & $r r \cdot \lambda$ & \&1 भr & هباىنباتي \\
\hline $1 \therefore \varepsilon y$ & & 199 & $r \cdot r$ & $A Y Y$ & $1,1 \leqslant 0$. & 11 & $\therefore \quad-$ & - & 11 & 191 & $|\lambda|$ & ا دي طهى \\
\hline 0110 & vir. & $\varepsilon r$ & - & $1 \cdot 9$ & ir & oIA & $Y 9 \lambda$ & $1 . \ldots$ & $\lambda$ & $r \varepsilon$ & 1811 & مابونما \\
\hline $989 \varepsilon$ & $\{\lambda \wedge\}$ & ㅅㅅ & $\varepsilon \cdot \lambda$ & $\cdots-$ & 1r & Irr. & ri & rrre. & $0 \leqslant 0$ & $1 \varepsilon$ & $\varepsilon \vartheta$ & تارمها \\
\hline rero & 0.9 & - & - & $\therefore$ & $r \varepsilon$ & $r \cdot r$ & 19 & $\{1 \cdot 0$. & $0.1 \varepsilon$ & $\because$ & $r \cdot 90^{\circ}$ & \\
\hline $7 \cdot r$ & Irr & $\varepsilon \xi$ & - & - & $r$ & $r$ & $\mathrm{YA}$ & \&Y人i & 1.09 & - & $\varepsilon r \lambda$ & منسوجات سندى \\
\hline$n q r \cdot$ & $\operatorname{rin}$ & $r \cdot$. & $r r$ & 970 & 91. & 0 & $r \cdot i$ & $r \cdot 1 / \cdot$ & $1 \varepsilon$ & YTA & $1 \cdot 1$ & رمنسيوجات \\
\hline oroq. & $r$ & - & - & rqr. & irir & - & $\therefore$ & $r \cdot r$ & - & $\checkmark i$ & $970^{\circ}$ & 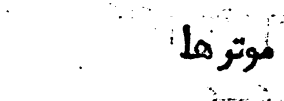 \\
\hline $017 !$ & rA.Y. & 77. & Ir & $r \varepsilon r \cdot:$ & rir & 111 & 911 & rrq & ro.: & o \& & orr & مرزه جاتموتر \\
\hline rorri & orr. & - & - & $117 r$ & $\lambda \lambda$ & 119 & $\pi \cdot i \varepsilon$ & - & - & 710 & $r-\lambda$. & \\
\hline rirt & $\operatorname{trr}$ & $\therefore-$ & - & 9 & 79 & 1 & $\varepsilon q$ & ry & - & - & 1199 & يانيونشا ىجد يد \\
\hline IAYFr & qry & $r q$ & 7 & 01 & $\varepsilon$ & $\lambda$ & - & 17917 & OD & - & 71: & تايووتيوت \\
\hline Yoq & Ire & Ir & - & 111 & - & - & - & $\{1$ & $\{07$ & - & - & بايسكل \\
\hline
\end{tabular}




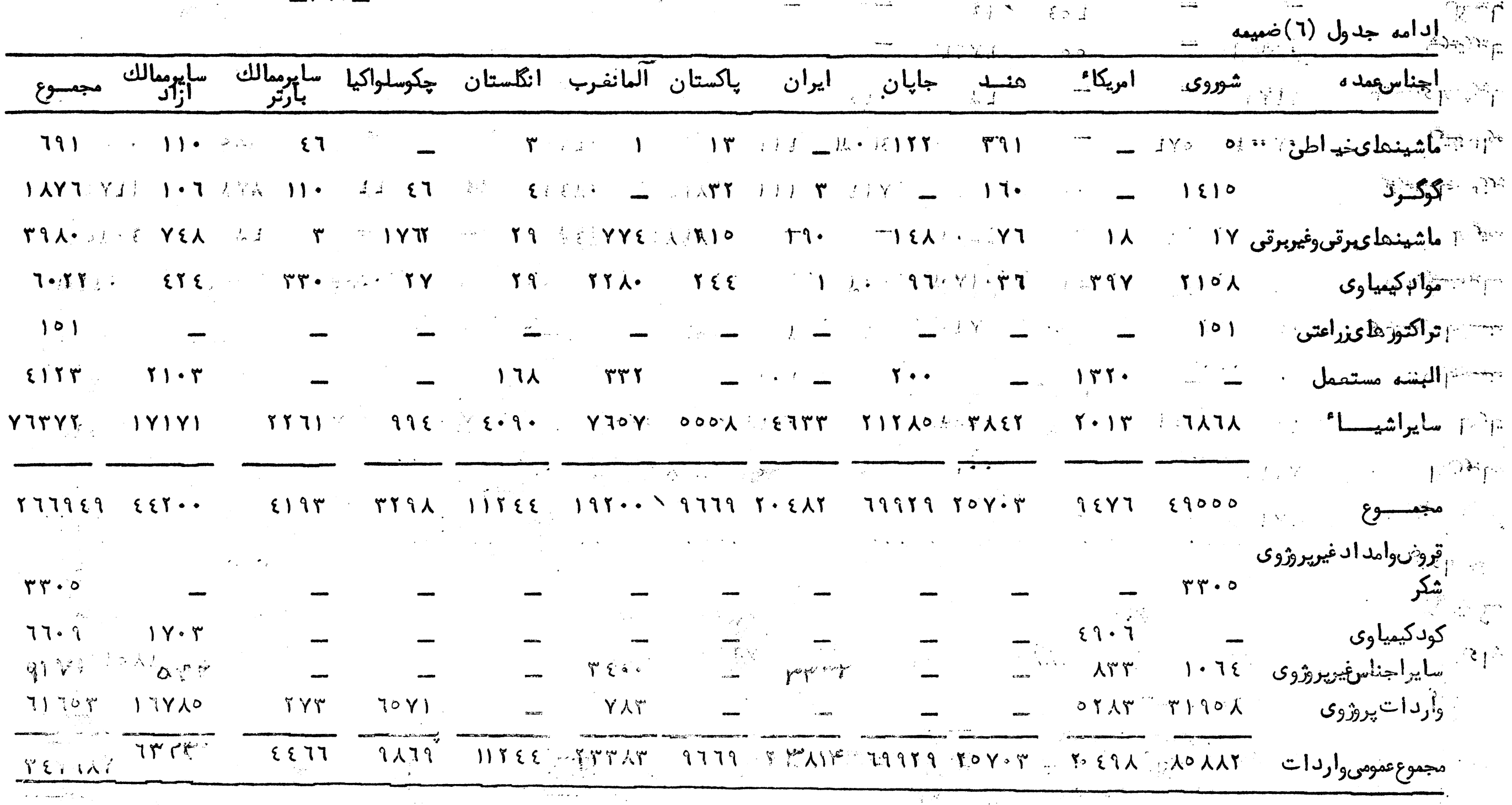




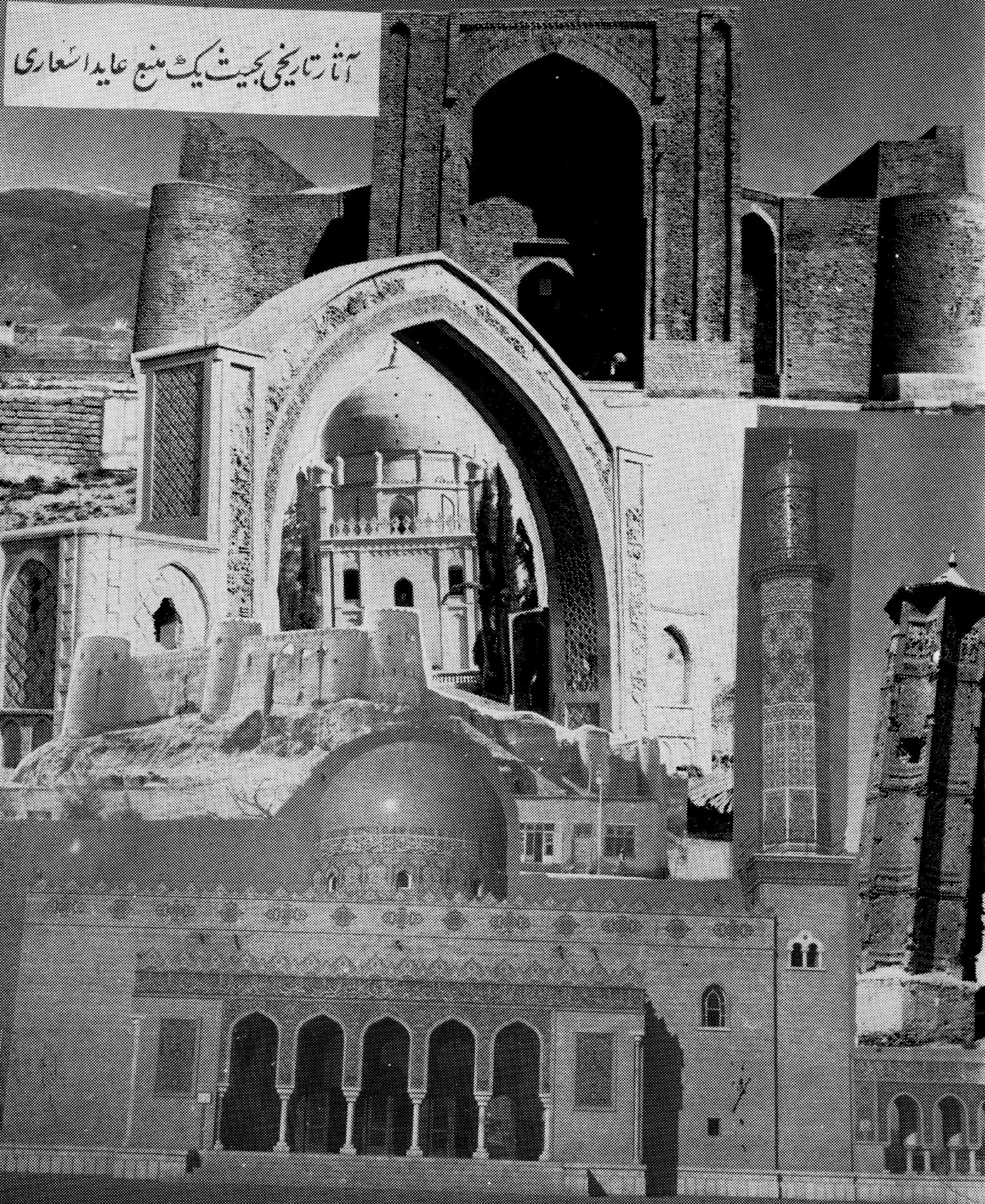



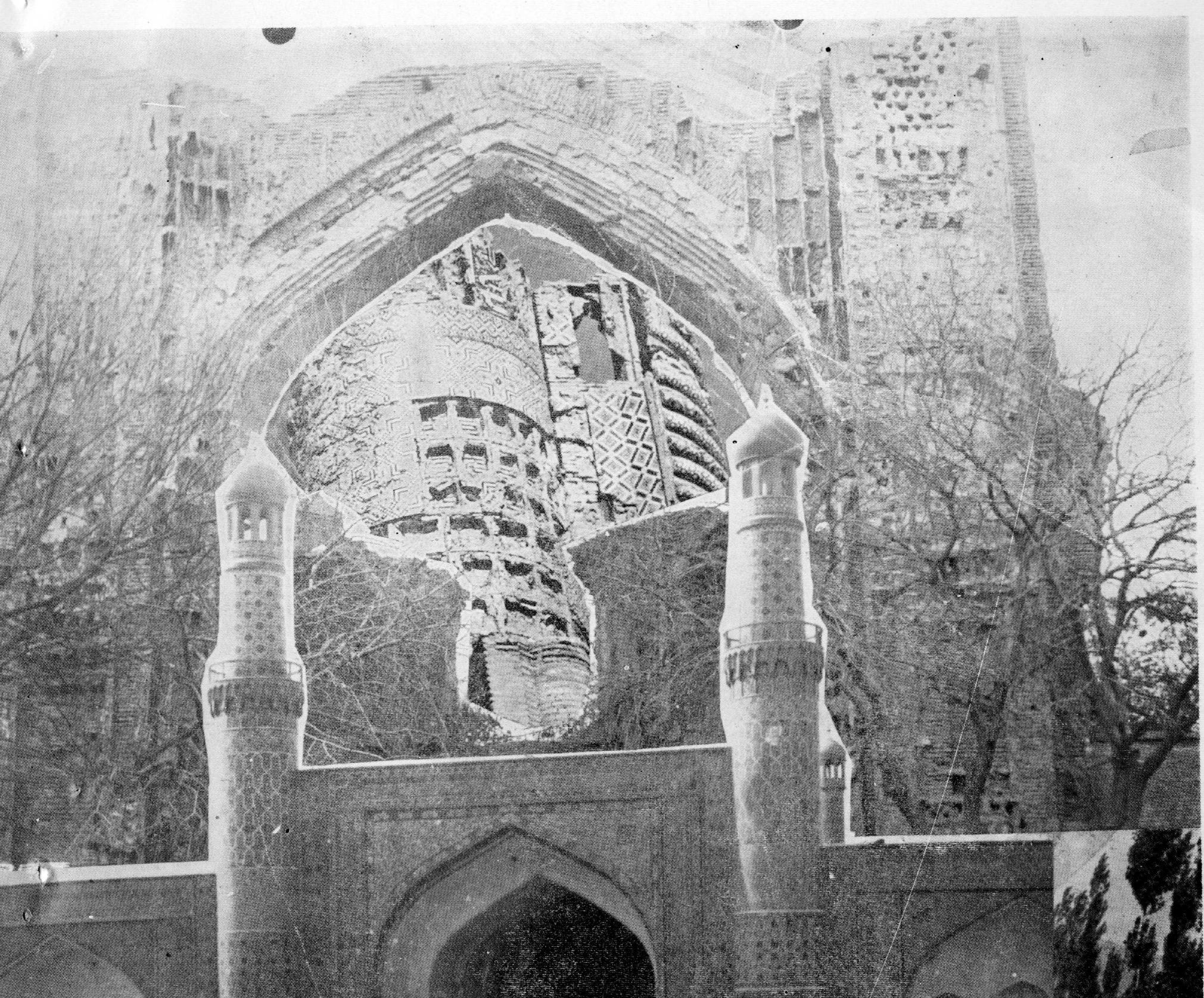

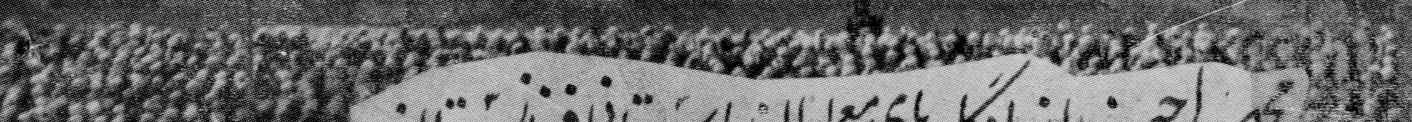

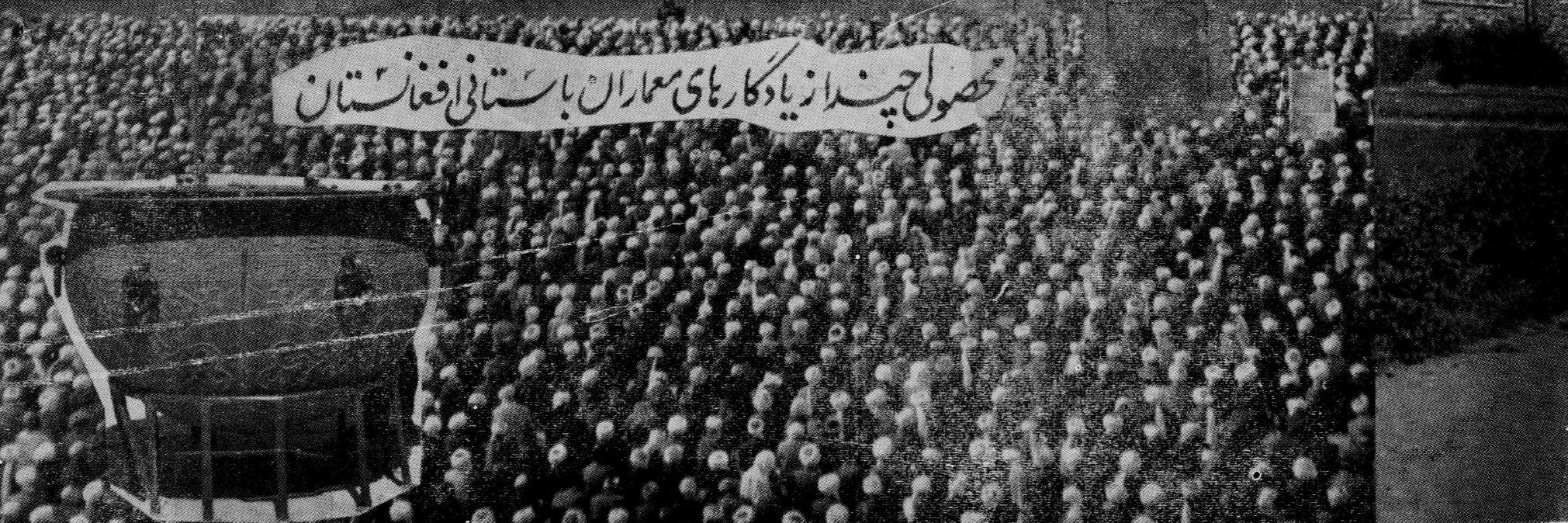

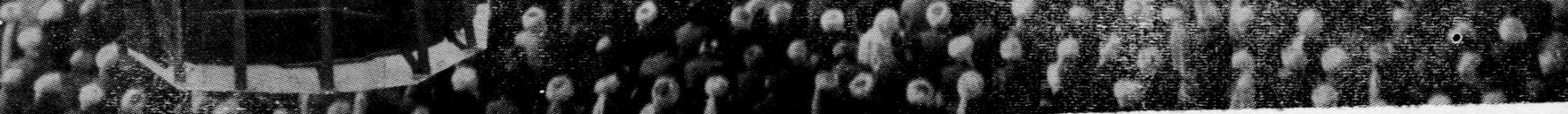




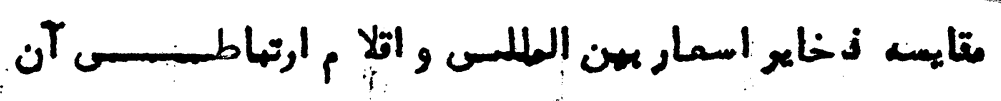

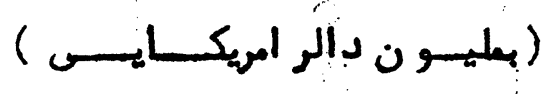

\section{تجارتخارجس جدول (Y)}

حوت ع 1roo

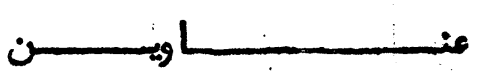

الهـف:

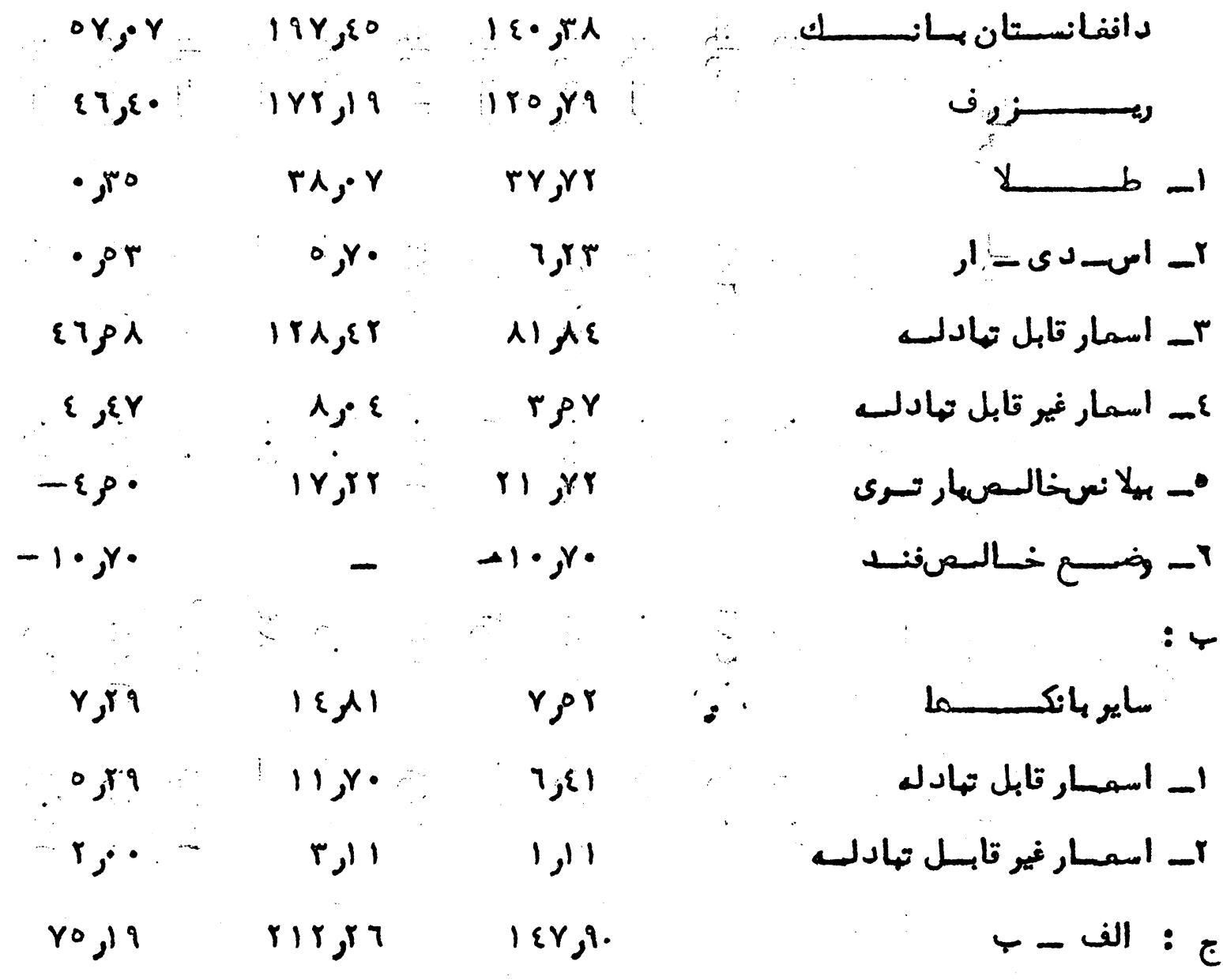

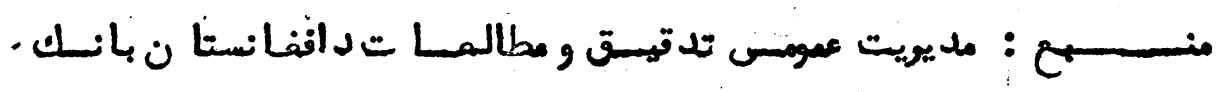

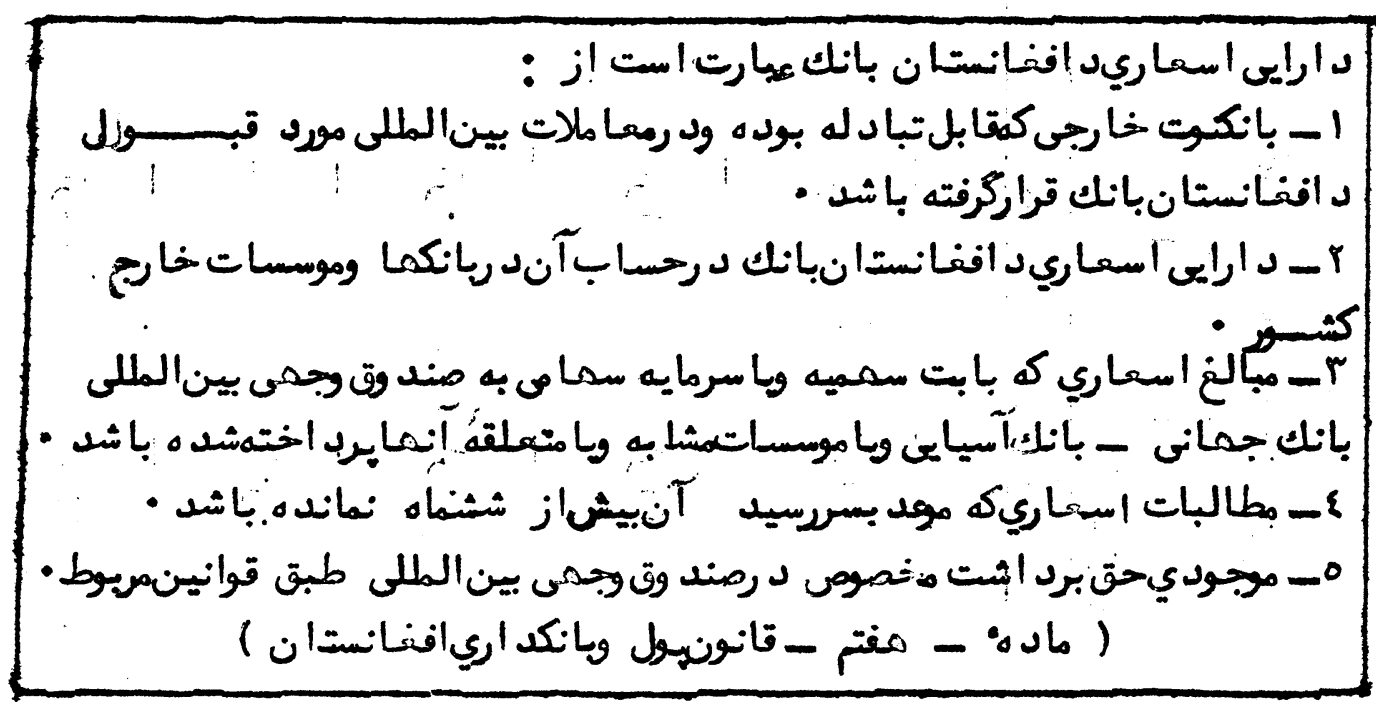




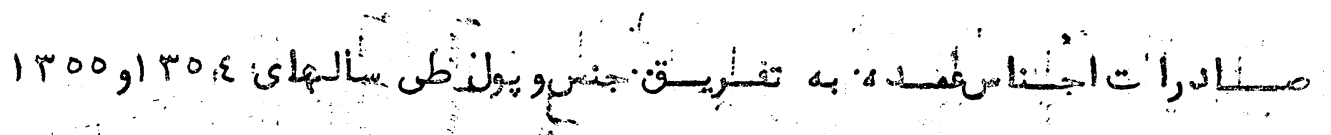

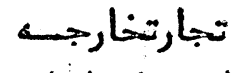

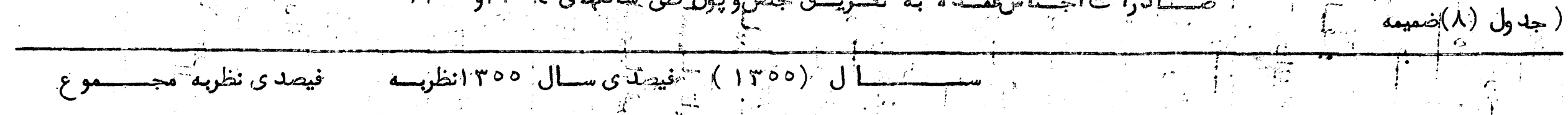

\begin{tabular}{|c|c|c|c|c|c|c|c|c|}
\hline 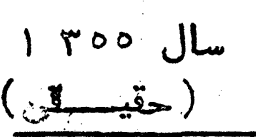 & سـالع & 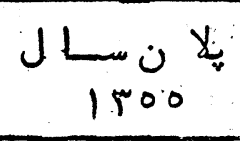 & س & حقيقسن & طبق هلا ن & سال & واحد مقي & 1 \\
\hline 9 & 1 & $r$ & 7 & 0 & $\varepsilon \quad \vdots$ & $\therefore r$ & $r$ & 1 \\
\hline- & - & 77,5 & $1 \cdot 7,9$ & 91,1 & : & $\lambda \varepsilon, r$ & مزاز تن & منسيوه تــــازه \\
\hline $7 j$ & ب & Yo, r & 1.98 & $r \cdot E A T$ & rYr.. & 11705 & مزارد الر & $\therefore$ \\
\hline - & - & $11 Y, Y$ & D & Rro & Tr & $0\{, y$ & هزار تسـن & ميسوه خشبـلك . \\
\hline r & r & 101,7 & ri & 70 YAY & $\varepsilon r \varepsilon \cdots$ & 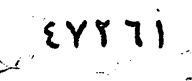 & مزْاِ د الת & \\
\hline- & - & r & $r 7, r$ & 1, & 0 & $\varepsilon, 0$ & تَفْزار تــن & سِِتــــــرو م \\
\hline • إ. & - & $r \cdot \lambda$ & $18, r$ & rry & $11 \varepsilon$ & IrrT & مزار د الر & 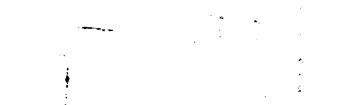 \\
\hline- & - & $r \cdot \dot{ }$ & & • & ; & & هزارتسـن & 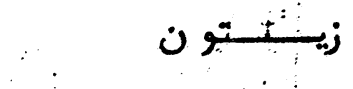 \\
\hline$\cdot r$ & - & ri & - & $\lambda \varepsilon$ & $\varepsilon \cdots$ & & مزار دالر & \\
\hline- & - & $\mid r t, \pi$ & 105,5 & $\varepsilon q, \lambda$ & $\varepsilon \cdot 1$ & rro & هزار تــن & بخته مسلو ع \\
\hline$r \cdot$, & $|\xi|$ & $\| v$ & 198 & 91 r. & orir: & M $100 \lambda$ & هزار د الر & $\therefore$ \\
\hline - & - & 1100 & $1 \varepsilon \cdot 0$ & $r r$ & ir & $10 \mu$ & هزَار تسـن & تخم حهوبات شعسى . \\
\hline$r, 9$ & rر & 118 & $1 \cdot 7$ & ᄉY\&Y & ६१५. & Arol & مزار بدالر & $\vdots$ \\
\hline
\end{tabular}




\section{-r9o-}

\begin{tabular}{|c|c|c|c|c|c|c|c|c|}
\hline 9 & $\Lambda$ & $r$ & 7 & $0 !:$ & $\varepsilon$ & $r$ & $r y$ & 1 \\
\hline- & - & $11 \cdot, 7$ & 118,9 & $\operatorname{lig}$ & $18, q$ & $17 x$ & مكارارتتسن & نباتا ث كله \\
\hline$r, q$ & $\varepsilon, \gamma$ & 1980 & $111, \varepsilon$ & 1trי" & $7 \cdot \varepsilon r$ & $1 \cdot \xi \pi T$ & موار دالر & \\
\hline- & - & - & $19, \gamma$ & $r r, r$. & - & $r q$ & مزار تــن & 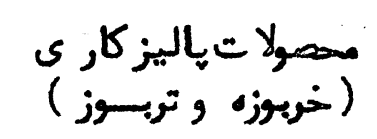 \\
\hline • & $1, \varepsilon$ & 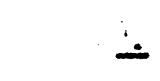 & $\lambda \varepsilon, \varepsilon$ & rTYY & - & rir| & مزار بدالر & \\
\hline- & - & $99 ;$ & Irrg. & $111 \varepsilon$ & 1190 & Ars; & مبزار جـــد & قره تــــــلـل \\
\hline$r$, & $\varepsilon, \gamma$ & Iryjz & $r \cdot i$ & $r \cdot A r:$ & | & $1 \cdot r 01$ & مزار بِالِر & \% \\
\hline - & - & $1.0, r$ & $I \varepsilon r, \gamma$ & rmit & $r r \cdot:$ & ITr. & نــزارحجلقه & رود ه \\
\hline$\cdot, 7$ & ד, & $\lambda \mu, \tau$ & T & 1roo & $194:$ & ITIE & مزار يدالر & \\
\hline- & $\ddot{-}$ & - & . & - & $\div$ & - & هزارتسن & كرشـــــــت \\
\hline- & - & - & - & - & - & - & مزار يـالر & \\
\hline 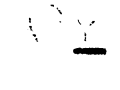 & - & $1 \cdot \xi \xi r$ & $19 ;$ & 0 : & $\varepsilon \beta$ & 0,7 & هزارتسن & ششــــ \\
\hline$r, \varepsilon$ & $r, r$ & $1.0 \mathrm{gr}$ & $9 \cdot$, & YYol & (4)!! & 1910 & مزار دي إلبر. & \\
\hline- & $\cdot-$ & $9 \cdot 5$ & $i \varepsilon \lambda$ & Pr $\{7$ & rq... & rirg & مزارجلبـد & موستست با ب \\
\hline$\varepsilon ;$ & rر & Yr, & $1 \cdots j$ & IIYYr & $101 \%$ & $11 \gamma \varepsilon i$ & هزا, يد الر & $\ldots$ \\
\hline- & - & 97,7 & $10 \mu$ & $r \varepsilon 10$ & ro.. & rAIT & مليؤن مترمكسب & كاز طلبيقتســن \\
\hline $1 \pi, \pi$ & $r$ & $91, r$ & Ar $r$ & rqo e. & $\varepsilon \cdot r_{0}$ & 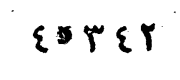 & مزار دالــــ ـ. & (n) \\
\hline
\end{tabular}




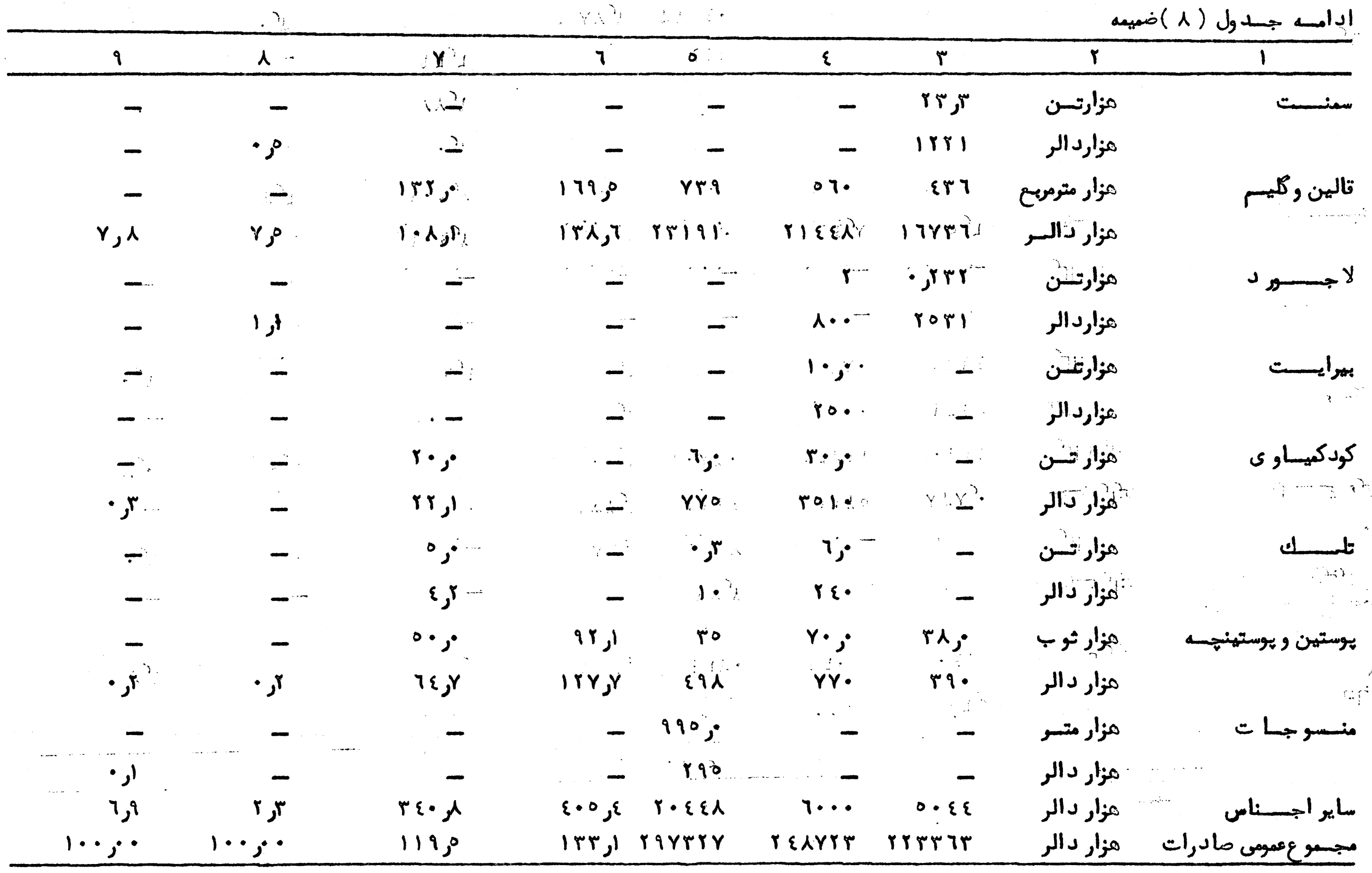




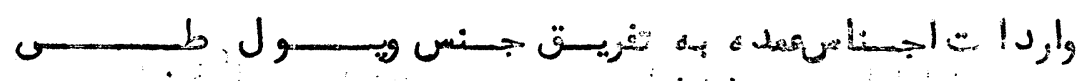

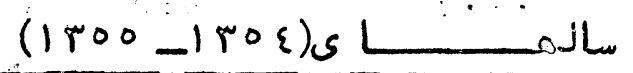

\begin{tabular}{|c|c|c|c|c|c|c|c|c|}
\hline \multicolumn{2}{|c|}{ فيصدى نظربه مجـــــــوع } & \multicolumn{4}{|c|}{ 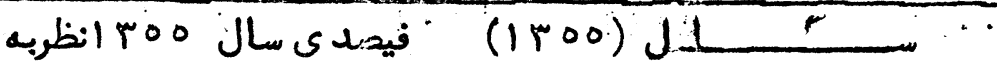 } & \multirow{2}{*}{ سال ع ro } & \multirow{2}{*}{\multicolumn{2}{|c|}{ 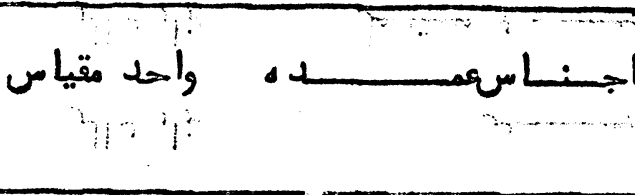 }} \\
\hline 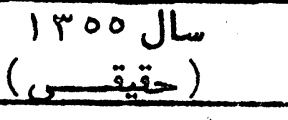 & $\begin{array}{c}J L \\
1 \text { Trog }\end{array}$ & 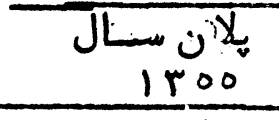 & $\begin{array}{l}J L \\
1 Y 0 \varepsilon \\
\end{array}$ & حقيقـتقن & طبق يلان & & & \\
\hline 9 & $\lambda$ & 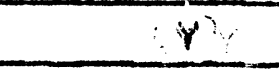 & $\pi$ & 0 & $\varepsilon$ & $r$ & 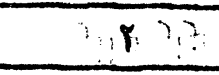 & 1 \\
\hline- & - & $00 ., y$ & $\varepsilon \wedge, q$ & rY & $\varepsilon 1$, & $\varepsilon Y$ & 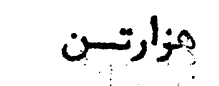 & شكsـ \\
\hline ro. & ir & $\left\{0, x^{q}\right.$ & re, & ใ६ ๆ & $r \cdot 7 \ldots$ & rThו & مزار دالر & \\
\hline- & - & 91,9 & $9 \varepsilon, \varepsilon$ & iv & 11,0 & it & مزارتسن & $s \stackrel{\longrightarrow}{\longrightarrow}$ \\
\hline ᄉ & $11, \varepsilon$ & rr & $r \cdot r$ & rioro & rq7\% & $r \cdot \varepsilon i r$ & مِّار دالر & \\
\hline$-\cdots$ & - & ro: & iro, & 9 & 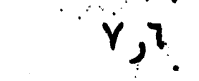 & is & 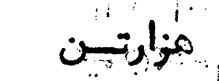 & \\
\hline r r & $r$ & $r 19, r$ & $i \varepsilon ; \gamma$ & 11118 & $01 \ldots$ & Y90\% & عِي:ار دالر & \\
\hline 1, & • & $100^{\circ} \times$ & آ & ryry & $r \ldots$ & igr & 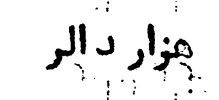 & تنباكــــو. \\
\hline 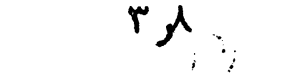 & 9,0 & 180,7 & $1 \varepsilon q, q$ & $1 \cdots \varepsilon \gamma$ & $\wedge \cdots$ & $T Y \cdot r$ & م مْإِ دَالת & ادوية طبى \\
\hline - & - & $1.0, r$ & $1.1, y$ & $r \leqslant 0$ & rrr & रहा & مغزارتسن & مواد ننتى - مجموع \\
\hline $1 T$ & . & 110,7 & irto & roYri & $r \cdot q \cdot$. & $r Y \cdot 70^{\circ}$ & فزاردألر & \\
\hline - & - & - & 1) & 21 & - & $1 \cdot r$ & 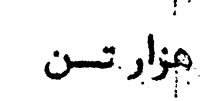 & مختِلتج \\
\hline $0, \varepsilon$ & so & - & 100, & $1 \varepsilon r O A$ & - & 9870 & مزار دالر & \\
\hline - & - & - & $1 \% 8$ & 180 & - & irr & هزارتسن & ديــــــــــــ \\
\hline $0, y$ & 0, & - & $\mid 1 \varepsilon$ & $10 \mathrm{rA}$ & - & lirgl & مزأر دالر & \\
\hline
\end{tabular}


91

1

-

1,5

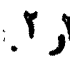

$Y$,

11,0

i 1

$\cdot$,

r

$r, \wedge$

$\cdot r$

1,0

1,5

\section{$\lambda$}

$\therefore, 7$

-

1,

1,

.1

ires

is

1 l

• $1 \cdot 1,9$

- $\lambda$

$\Lambda, \gamma$

$0, \varepsilon$

rifl

r

$+790$

1,0

Ar $r$

I

$110 \mathrm{r}$

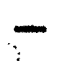

$i$

Irq, r.

- ITYs rats

$-$

$119, \quad r r \varepsilon$

RT. S T. TR

Ay, livrr

$11, \varepsilon \varepsilon$

A.; r.Yrr

$10 \%$ \& हा1.

IVT; 1.19

$r \cdot$ s. Ero

\&น, $1 \cdots r\}$

ITr rog

$1 \cdot 1,0$ हाr

N. $1 . \varepsilon$ rq०
$-$

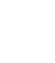

179r

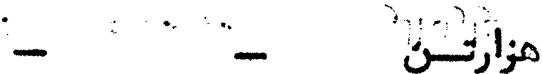

- Pزاردالر

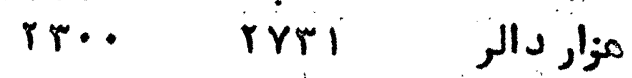

مزار دالر

مخدولا تكيميـاوى

$01 . \quad 0$

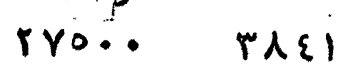

ro. ror

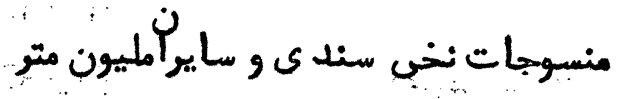

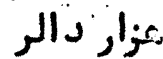

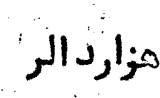

هزار دالر

A.. $\quad$ r170

هزار بالر

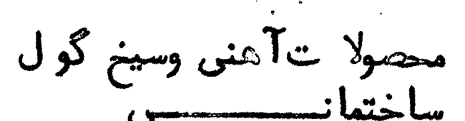

rT... rrTht

مزار دالر

$7 \cdot$

०Y $\varepsilon$

مزار دالر

ساير انواعمواد نفتى

تمل خـاك

$\varepsilon \gamma$.

r...

$\varepsilon \cdot \curlywedge \varepsilon$

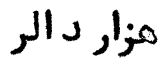

هزار دالر

البنســـــهـ مستعمل

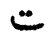

قرطاسيسية

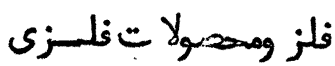

ماشين اللا - وموتر ما

بايستـل

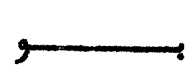


-49

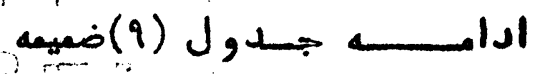

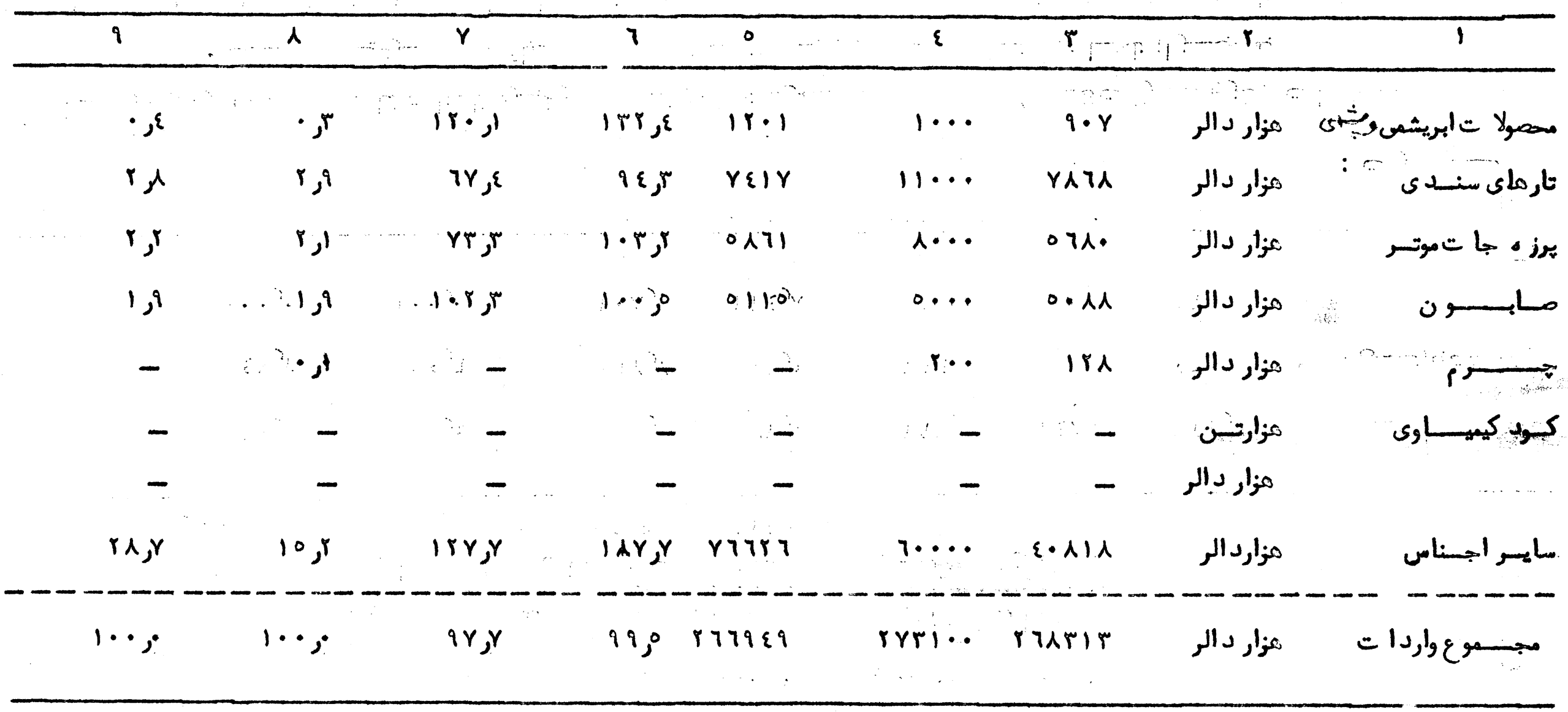




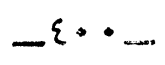

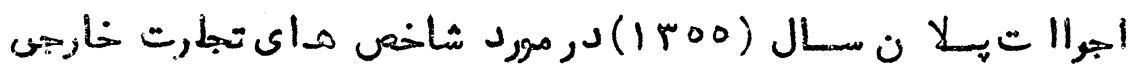

\begin{tabular}{|c|c|c|c|c|c|c|c|c|}
\hline & & & \multicolumn{4}{|c|}{ 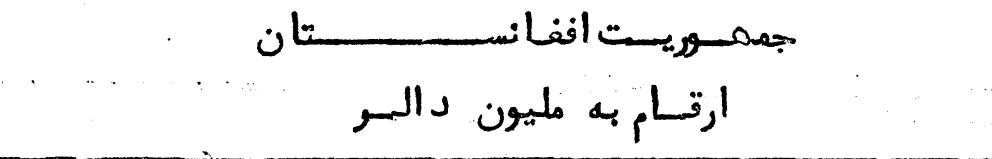 } & \multicolumn{2}{|r|}{ تجارتخارجيسى (•) ضميمه } \\
\hline \multirow{2}{*}{$i$} & \multicolumn{2}{|c|}{ فيمد ى نظظر به مجـــــــــوع } & \multicolumn{2}{|c|}{ فيصدى سان } & \multicolumn{2}{|c|}{ سـ } & \multirow{2}{*}{ 1ro\&J } & \multirow{2}{*}{$\begin{array}{c}0 \\
9 \\
9 \cdots\end{array}$} \\
\hline & 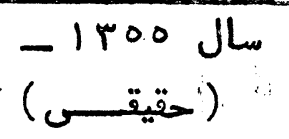 & 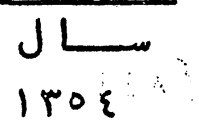 & 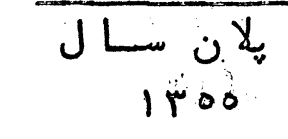 & JL & حقيقـــ : & 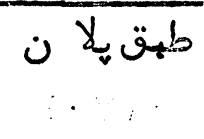 & & \\
\hline \multicolumn{9}{|c|}{-} \\
\hline & $0 Y$ ry & $\{0, \varepsilon$ & 119,0 & $|r r|$ & $r q r, r$ & $r \varepsilon \wedge, Y$ & rrrgr & مسادرا بت تجارتسى \\
\hline & $\varepsilon r$, & $0 \varepsilon, 7$ & $9 r, y$ & 19,0 & $r 77,9$ & lipl & ring, & وار دا ت تجبارتسـس \\
\hline$\because$ & $1 \cdots$, & $1 \cdot 1$ & $1 \cdot 1,1$ & $\| \varepsilon \beta$ & $07 \varepsilon$ & 0 or & $\{91,7$ & دورا ن تجســار ت \\
\hline
\end{tabular}

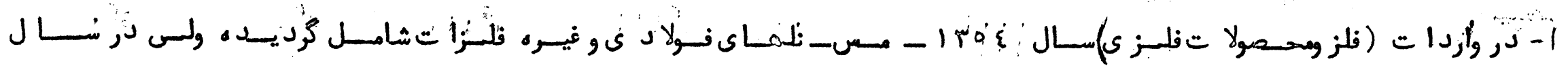

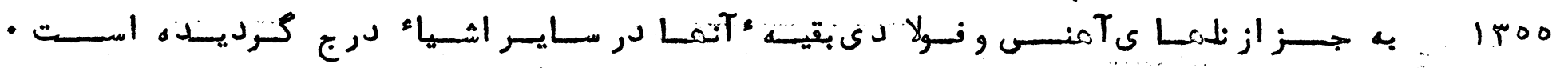

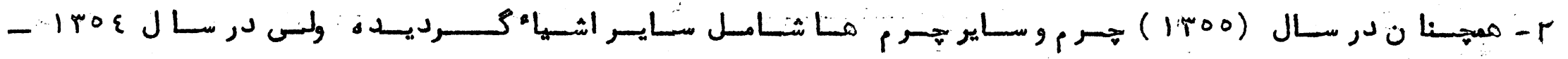

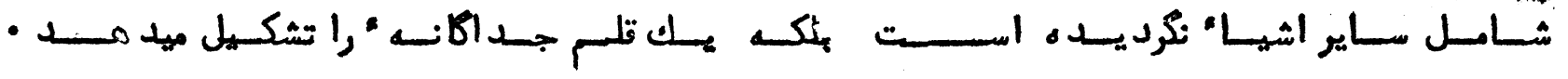




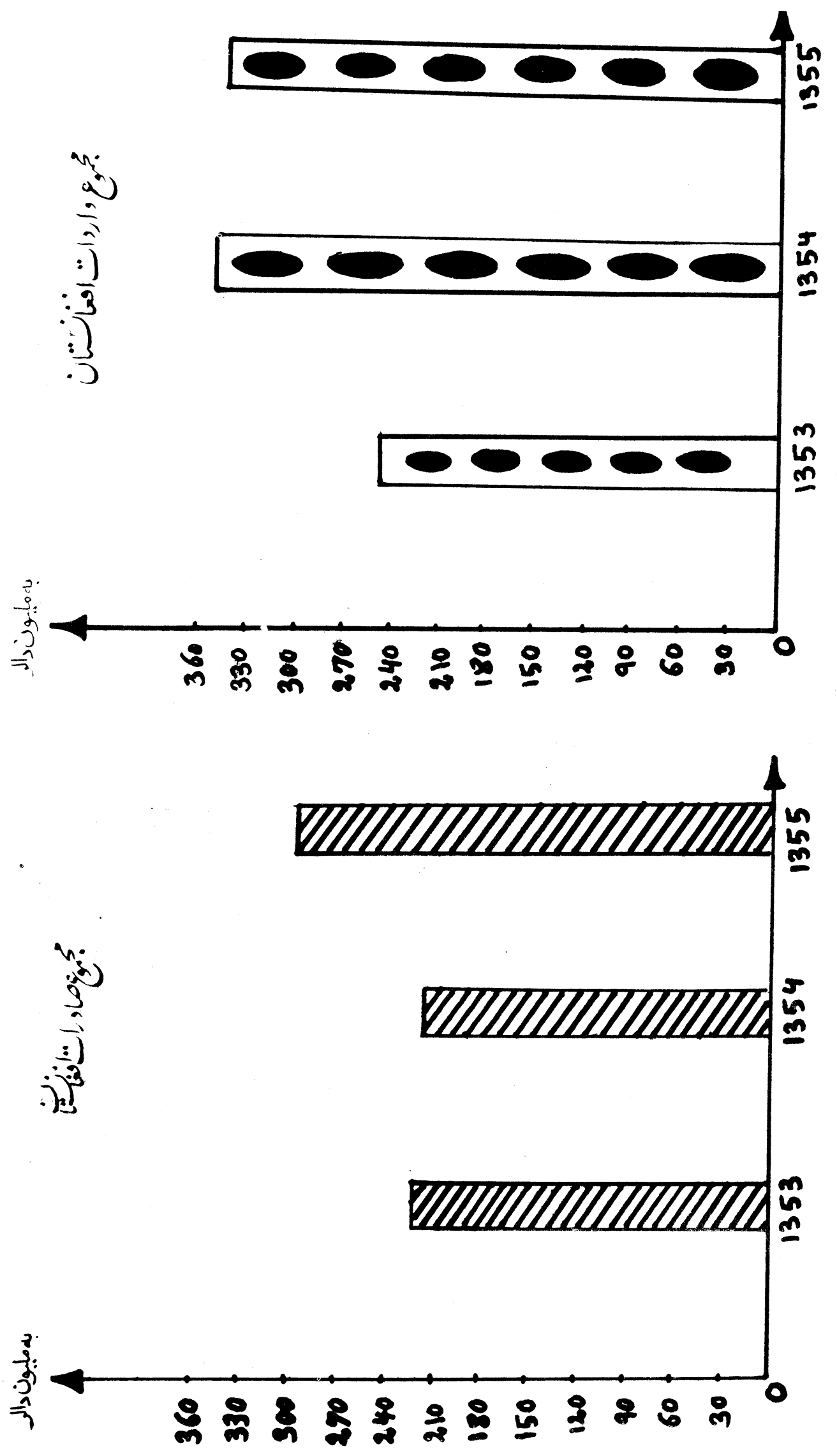



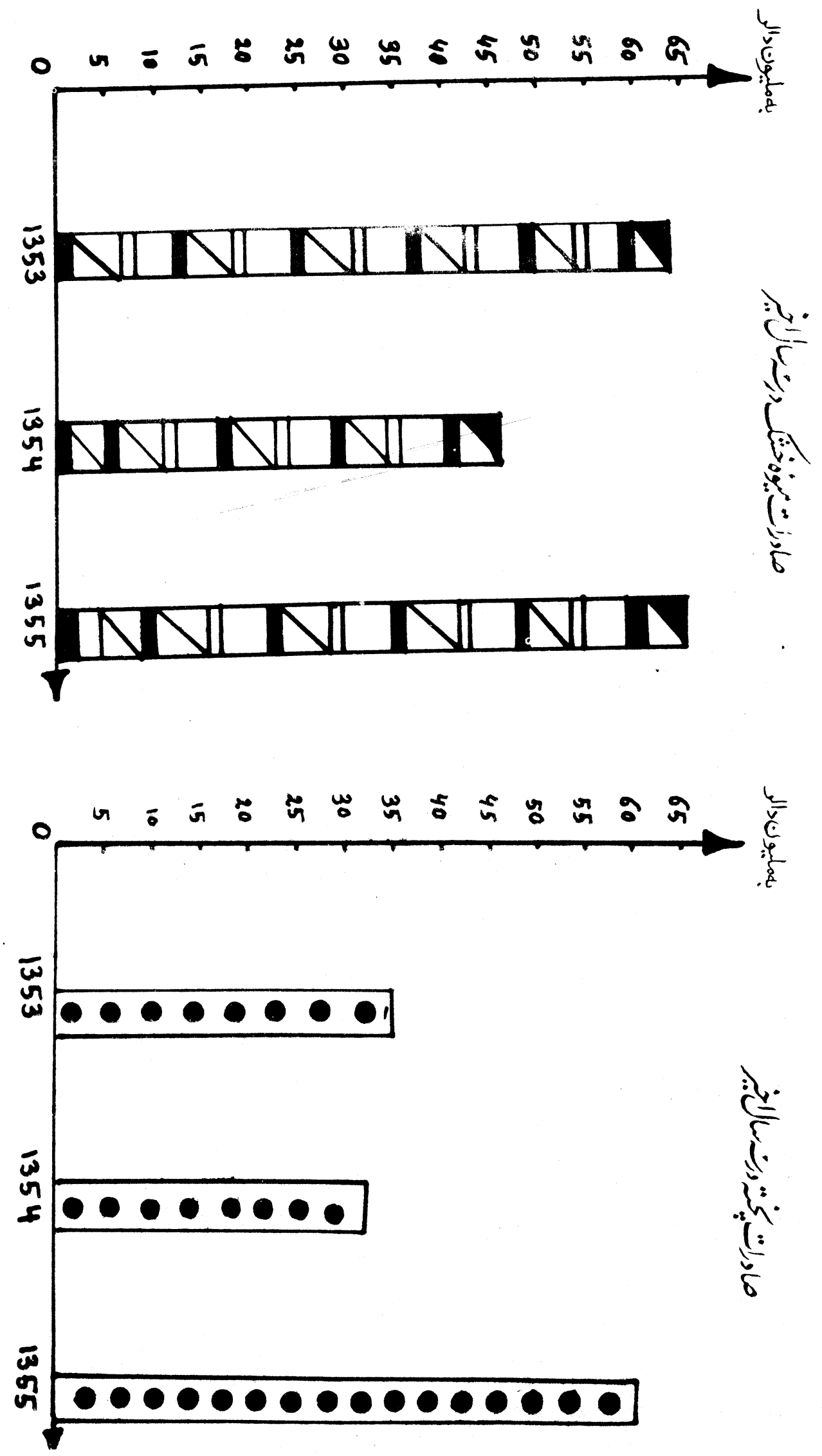


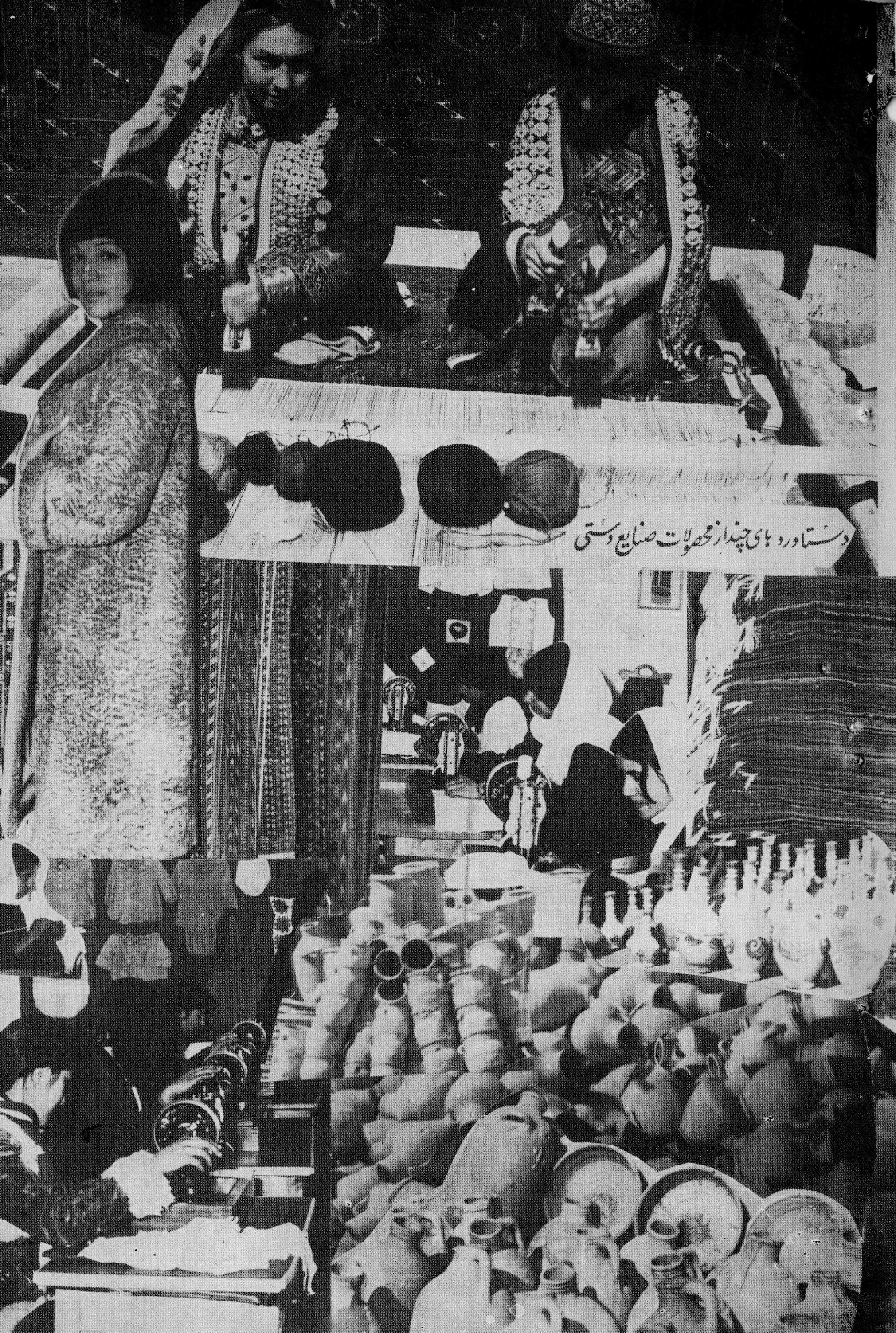




\section{A. $6.1,11$}

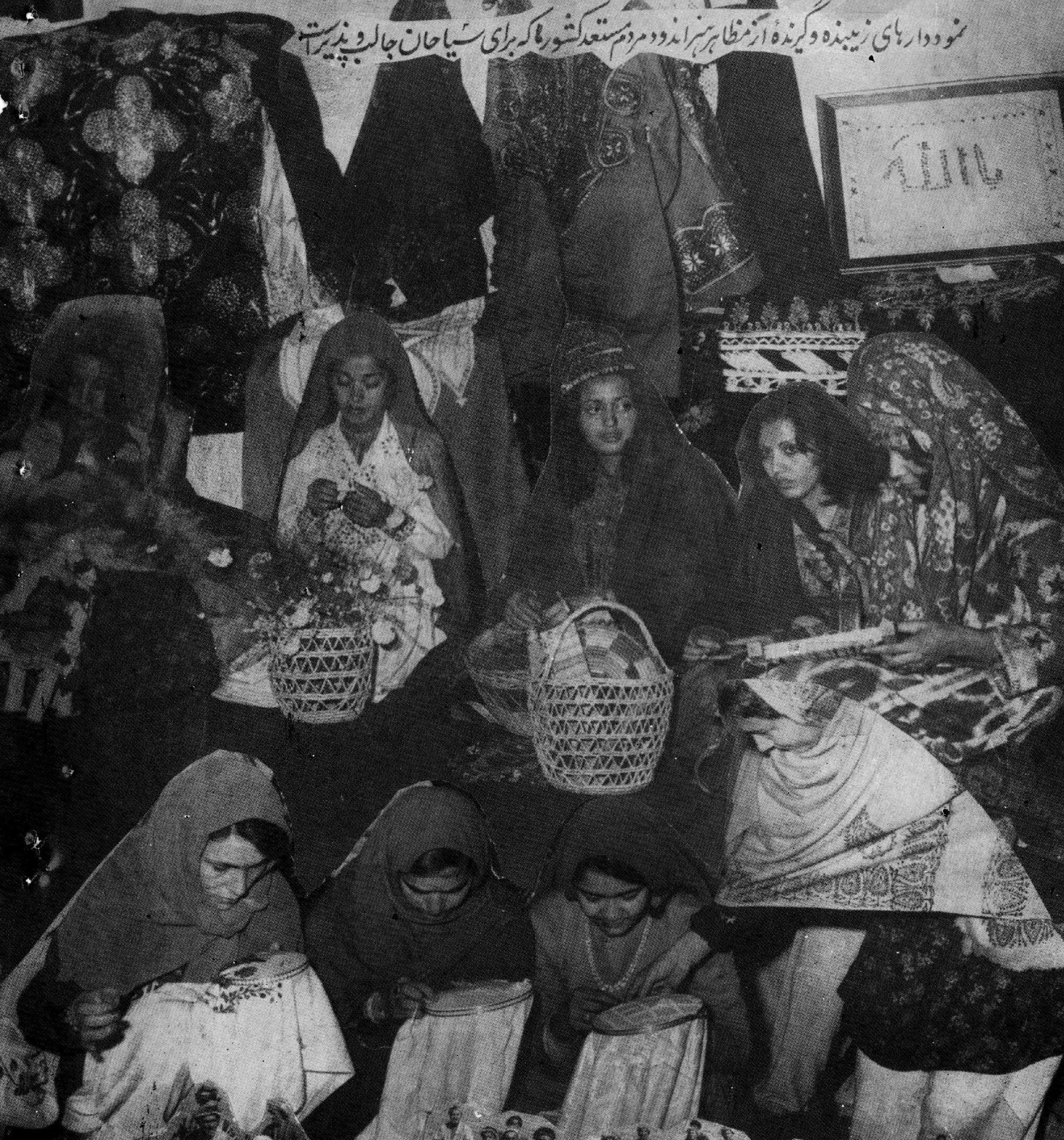

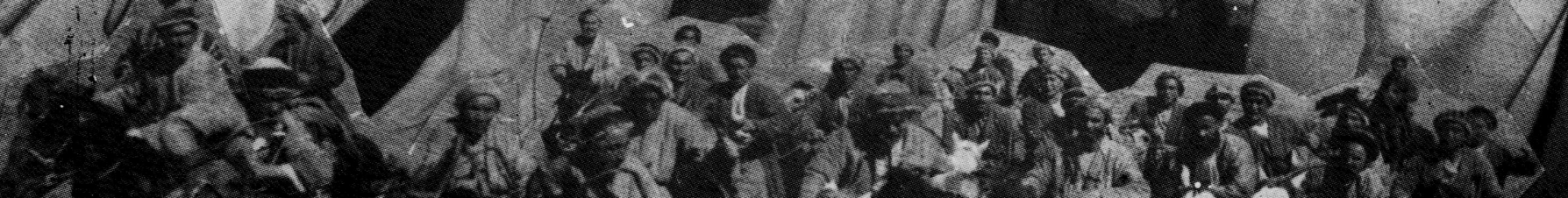

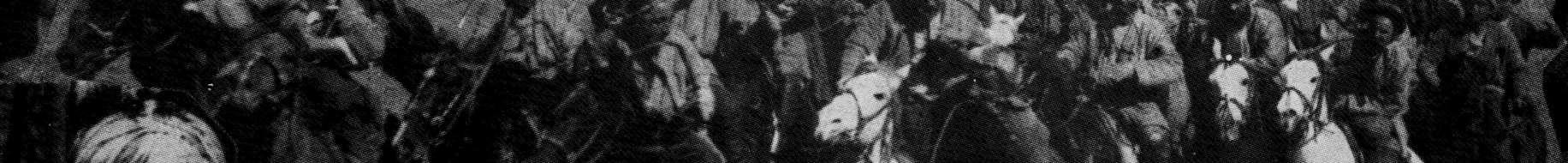

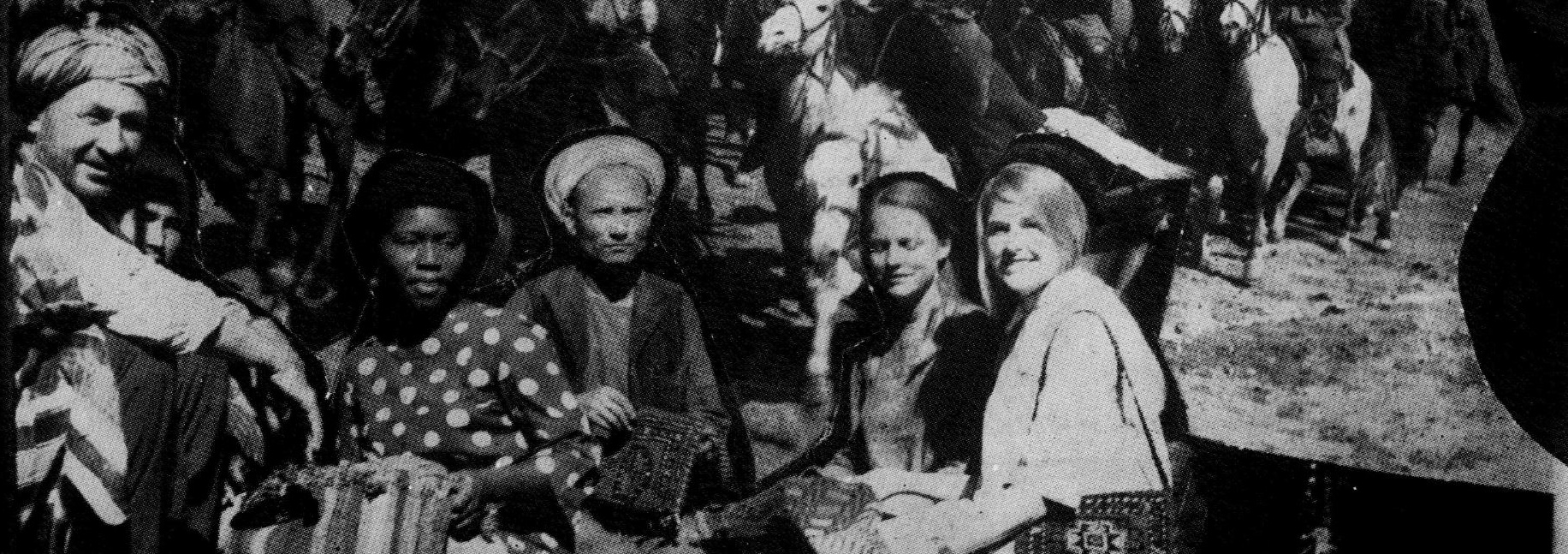


بيلا نستاد يات افنا نسـتان.

سال (1roo_lror)

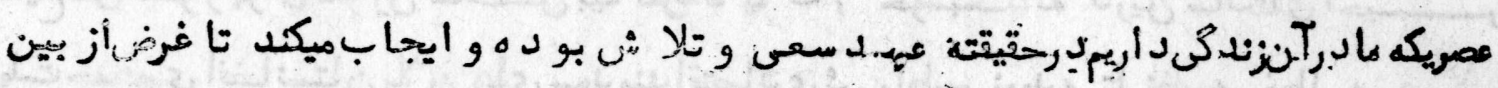

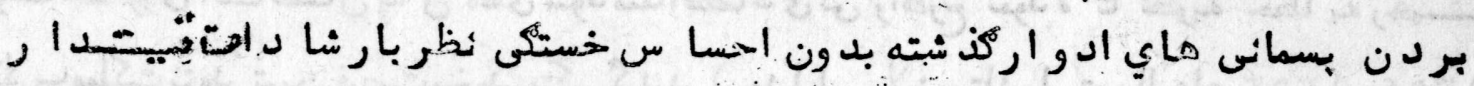

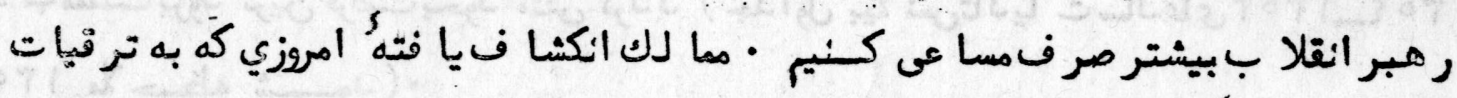

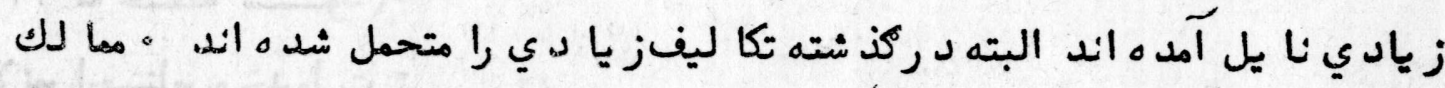

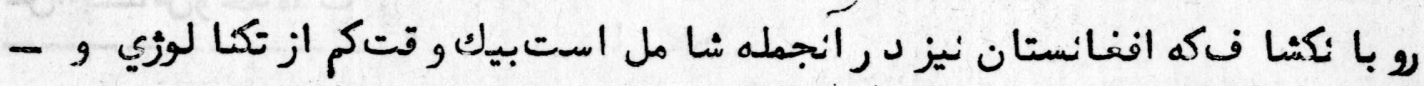

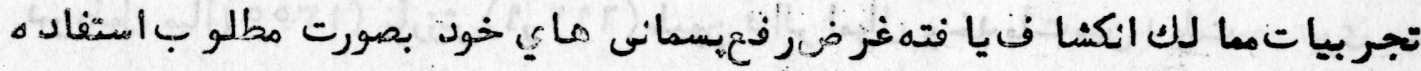

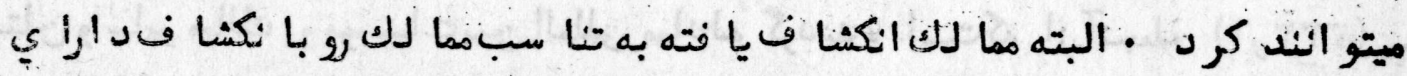

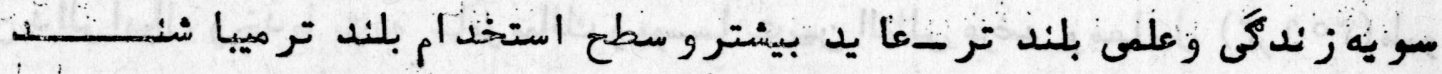

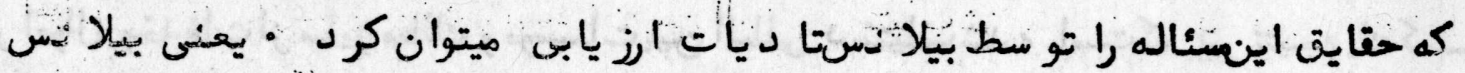

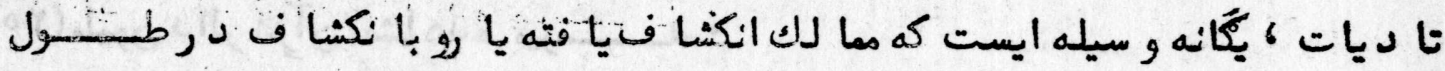

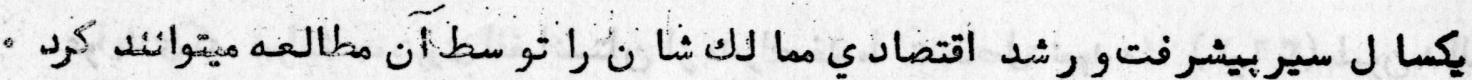

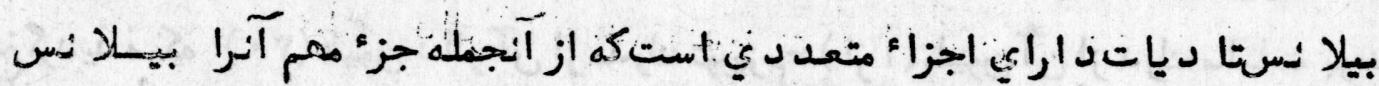

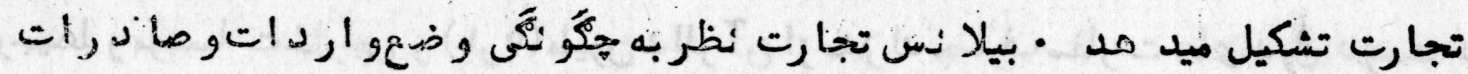

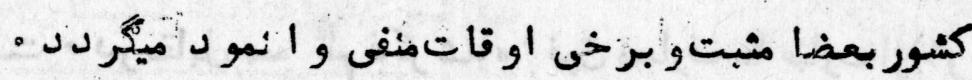

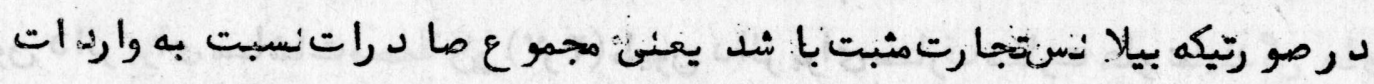

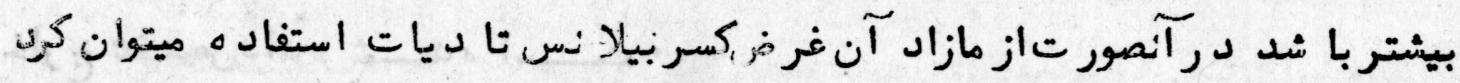

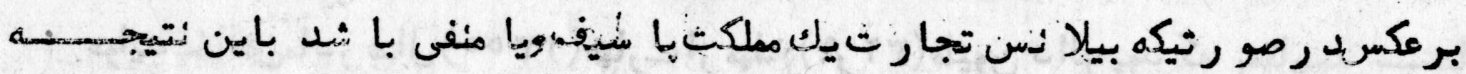

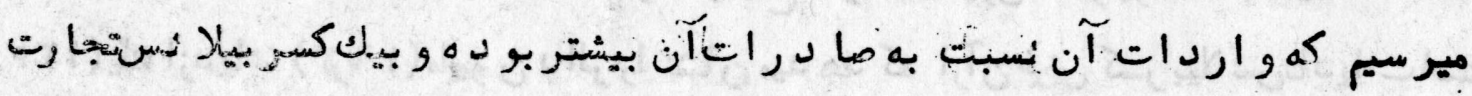
موا جه ميبا شد

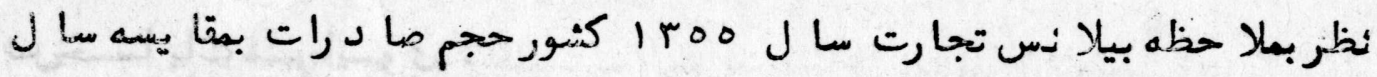

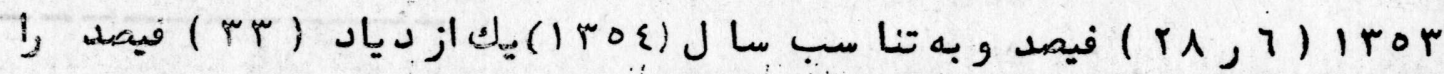

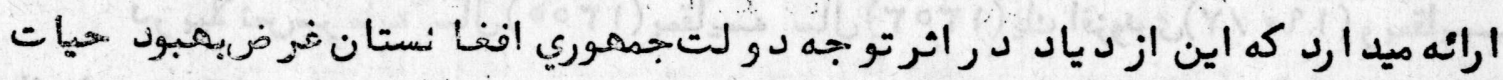

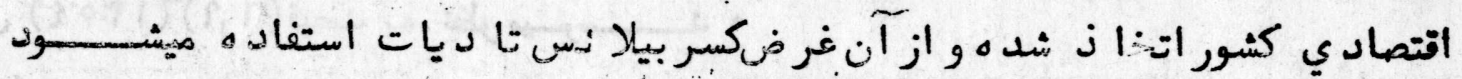

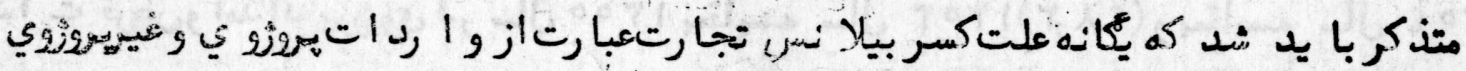

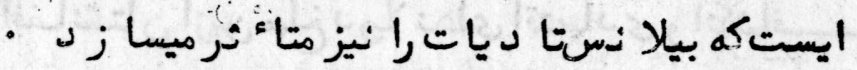

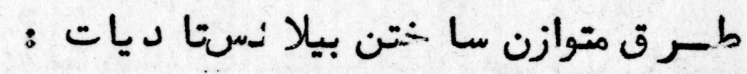

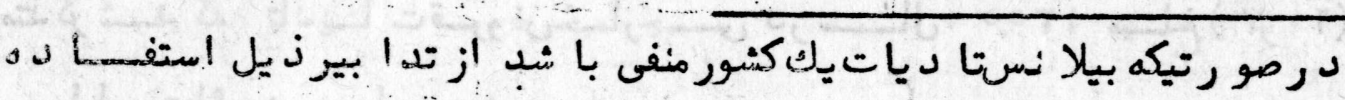
ميتوان كـرد ا-و ظيفه بانك مركزي استكه د رحا لت انفلا سيون مقد ارحبم بو ل شا مل دو ران 


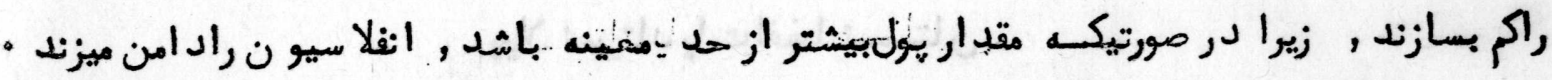

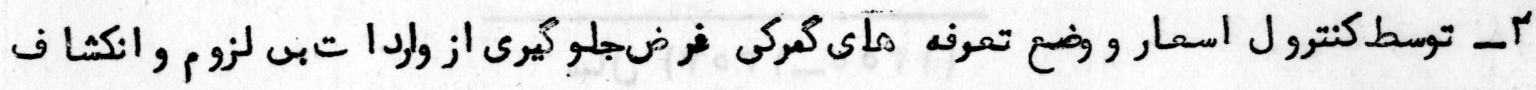

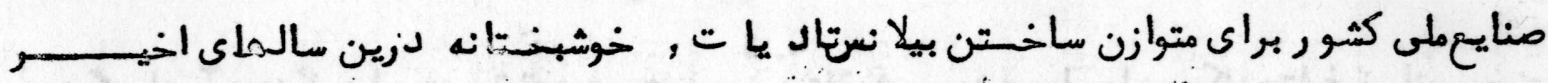

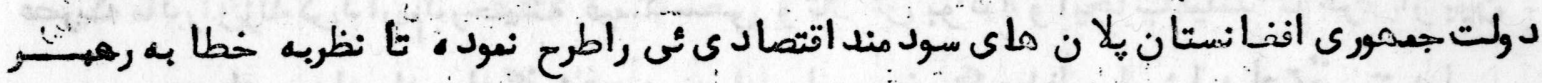

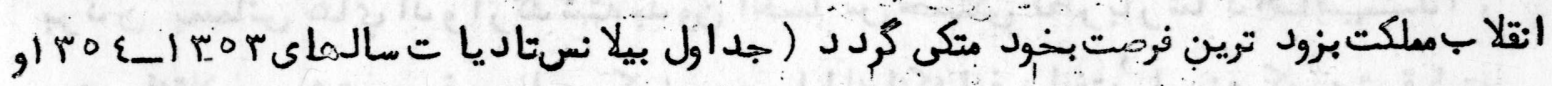
• بيسلانساجسناسوخدمات - - - - - - - -

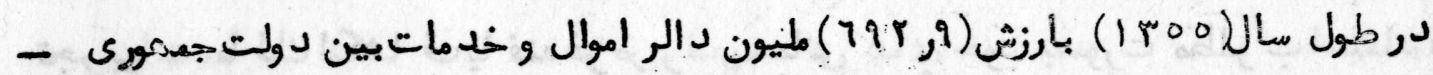

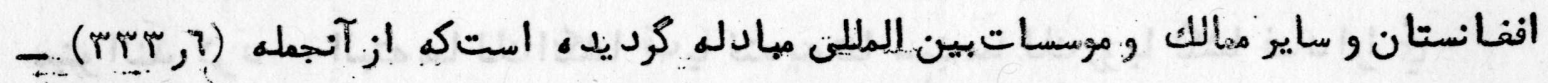

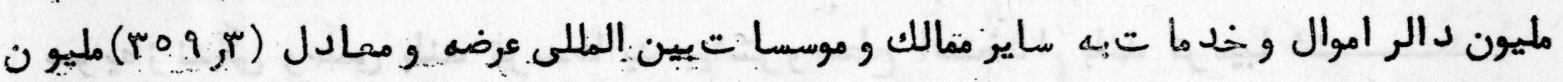

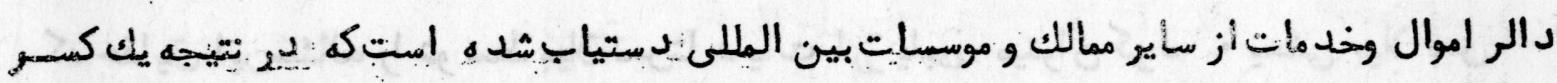

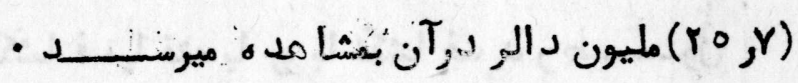

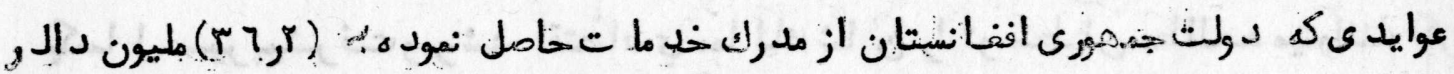

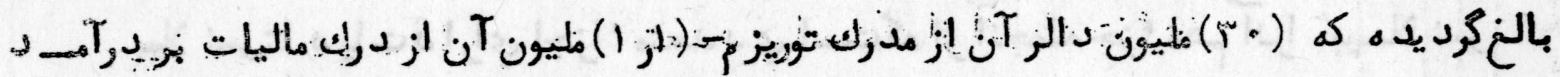

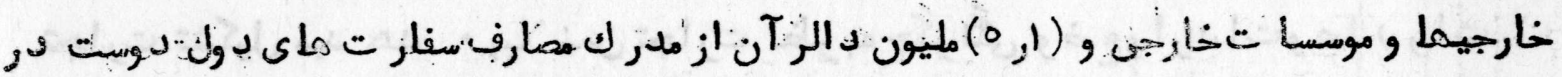

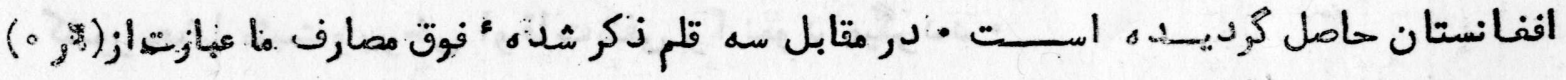

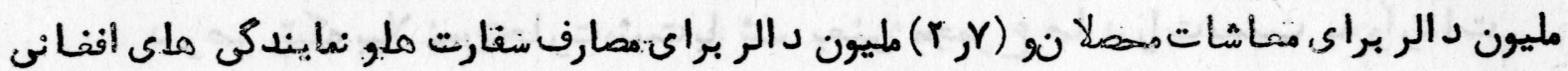

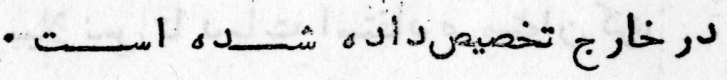

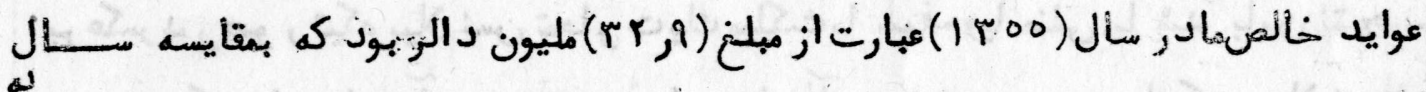

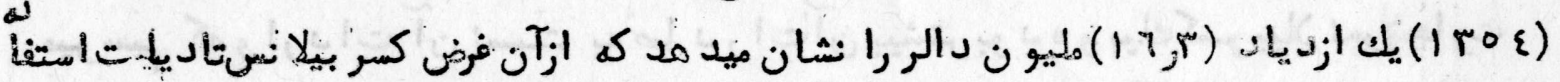

$$
\text { ميس }
$$

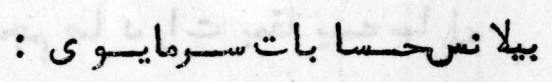

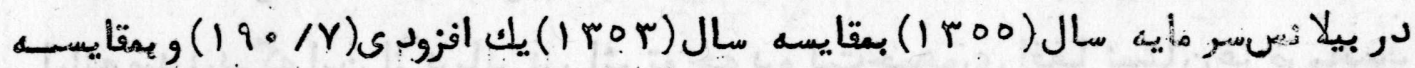

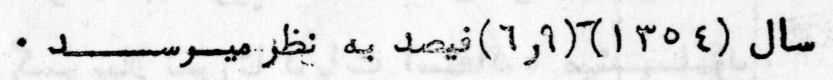

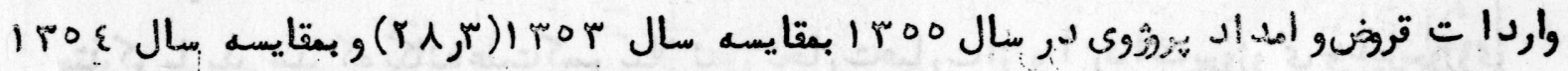

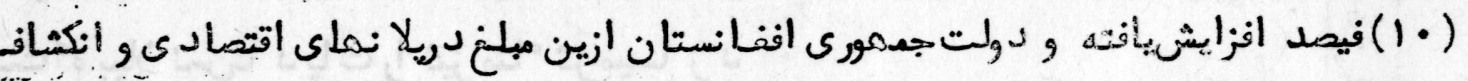

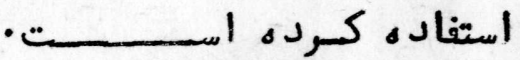

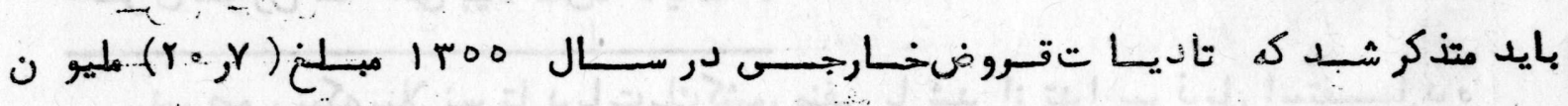




\begin{tabular}{|c|c|c|c|c|c|c|c|c|c|c|}
\hline \multicolumn{3}{|c|}{ مجموع حوزه بارتر وآز إ:د } & \multicolumn{3}{|c|}{. } & \multicolumn{3}{|c|}{ 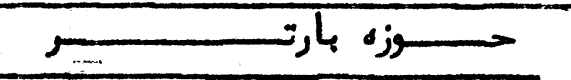 } & \multirow{2}{*}{ 1) } & \multirow[b]{2}{*}{$\cdots$} \\
\hline بيلانس & دبــ & $ت{ }^{-1}$ & بيلانس & د & كريدت & بيلانسس & د بس & كريدت & & \\
\hline$-r 0, y$ & $r \circ 9, r$ & (1 & -14 & 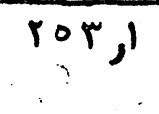 & $r \varepsilon 1$, & $-1 r, \pi$ & $1 \cdot 7,5$ & $9 r, 7$ & 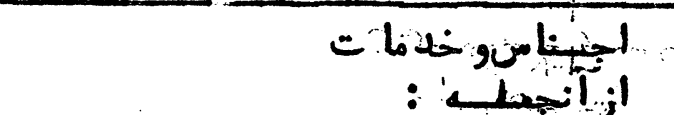 & -1 \\
\hline$+r \cdot \varepsilon$ & rir, & $\curlyvee 9 Y, \varepsilon$ & $-r$ & $r \cdot १, q$ & $r \cdot 7,7$ & $+r r, r$ & or, 1 & $9 \cdot \lambda$ & وارردات ومادراتاموال تجارتسى & \\
\hline$+r q, \varepsilon$ & $\cdot{ }^{7}$ & $r \cdot g$ & $+\varphi q, \varepsilon$ & $\cdot, 7$ & $r \cdot, \cdot$ & . $\quad-$ & $\therefore$ & - & مسافر توكرمحنــــــــــ & \\
\hline$+1,1$ & - & 1,1 & + & - & 1 & - & - & - & 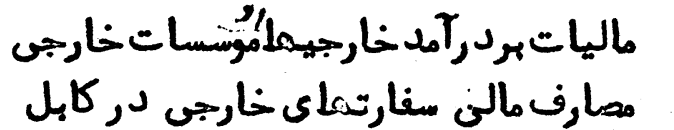 & \\
\hline$+r$, & $r, Y$ & ار & $+1, r$ & $r$ & $r$ & +1, & $\cdot y$ & $1 \mu$ & واز أفتانستا ن درمالك خارجبــن & \\
\hline$-71,7$ & 71,7 & - & 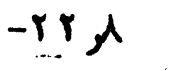 & A & - & $-r \wedge, \lambda$ & $-r \lambda, \lambda$ & - & وارداتأموال وخدها تَيروزو تَ & $\cdots$ \\
\hline-19, & 19, & - & $-1 \varepsilon, 7$ & $i \varepsilon, 1$ & - & $-\varepsilon, \varepsilon$ & $\varepsilon, \varepsilon$ & - & وارد ات امداد مواد استملاكى غير تروزوى & \\
\hline$-\Lambda, \varepsilon$ & $\Lambda, \varepsilon$ & - & $-r$ & $r$ & - & $-0, r$ & 0,0 & - & 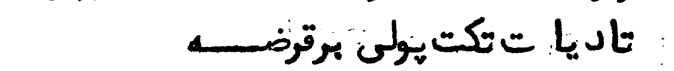 & $!$ \\
\hline$+09,9$ & $r \cdot, r$ & $\lambda \cdot y-$ & $+r \wedge, \varepsilon$ & 9 & $r r, \varepsilon$ & $+r 1 ; 0$ & in & $\varepsilon r, r$ & 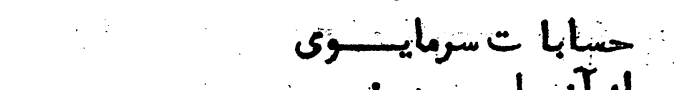 & -1 \\
\hline$+71,7$ & - & TI & +4r & - & r ג & $+r i, \lambda$ & - & $r \wedge, \lambda$ & 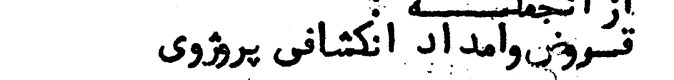 & 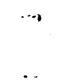 \\
\hline+19 & - & 19, & $+1 \varepsilon$ & - & $\mid \varepsilon, 7$ & $+\varepsilon, \varepsilon$ & - & $\varepsilon, \varepsilon$ & امداد مواد استملاككـ إسى & \\
\hline$-r \cdot Y$ & $r \cdot, \gamma$ & - & -9, & 9, & $\therefore-$ & $-11, y$ & $11, y$ & - & تاديات امل قروضخارجبــى & \\
\hline$r \varepsilon, r \cdot$ & $r \wedge \cdot ;$ & $\varepsilon \mid \varepsilon, \gamma-$ & $+17,5$ & $r 7 \cdot 1$ & 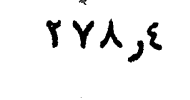 & $+1.4,9$ & $11.4,9$ & iros & = & $\vdots$ \\
\hline$+r \cdot r$ & - & - & - & - & - & - & - & - & 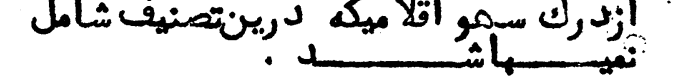 & \\
\hline$+7 \varepsilon, r y$ & - & - & - & - & - & - & - & $-c$ & تخولا ت درحسابات د ارائى شاى اسمارs & $-\varepsilon$ \\
\hline$+0, y$ & - & - & - & - & - & - & - & 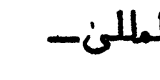 & حق برد ابتت مخصوصازصند وقوجهه بهنا & \\
\hline$I Y r, r$ & - & - & - & - & - & - & - & - & 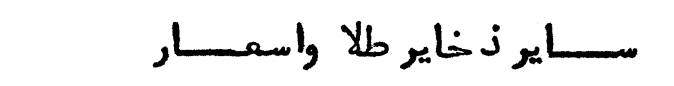 & \\
\hline
\end{tabular}




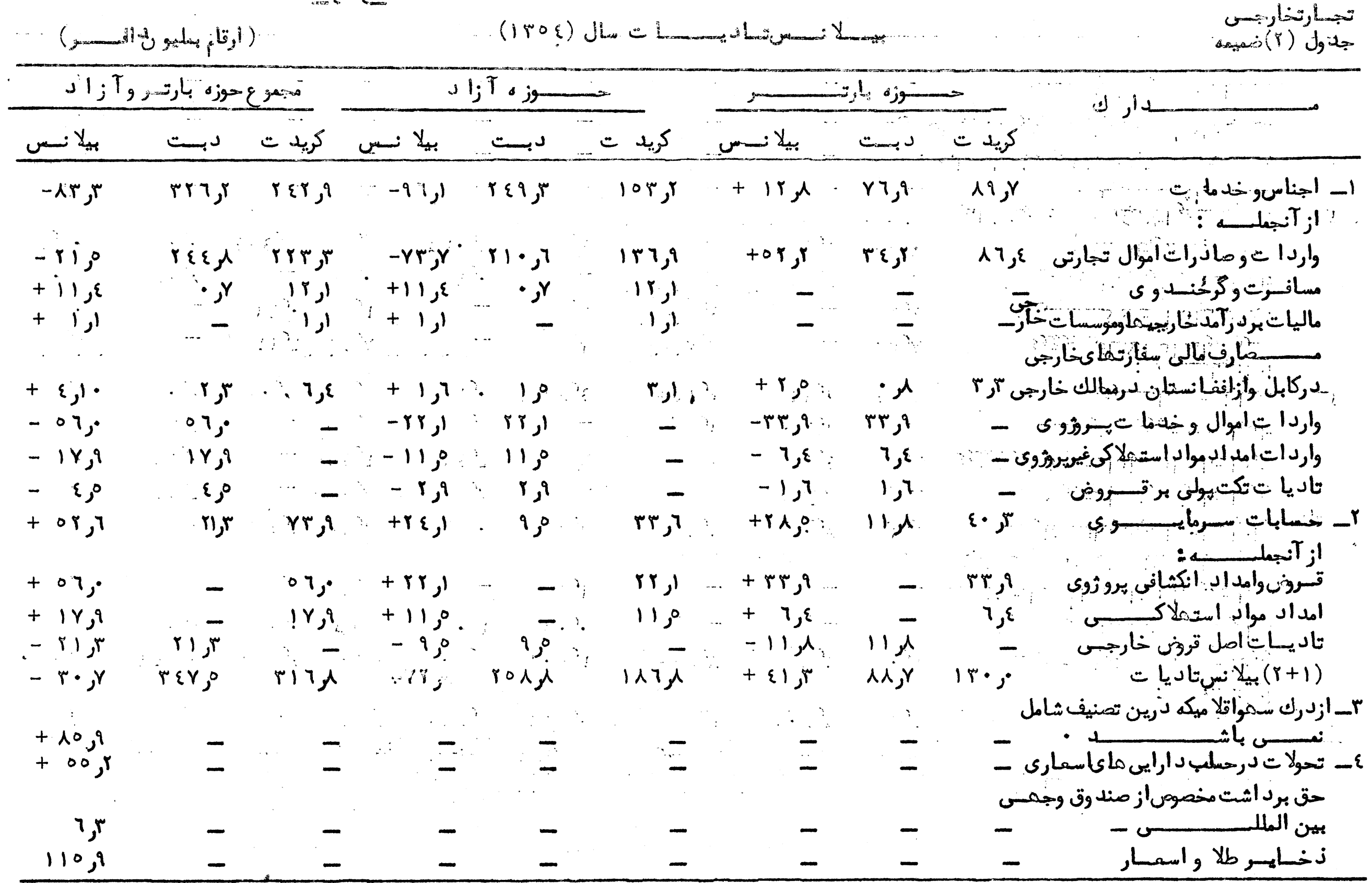




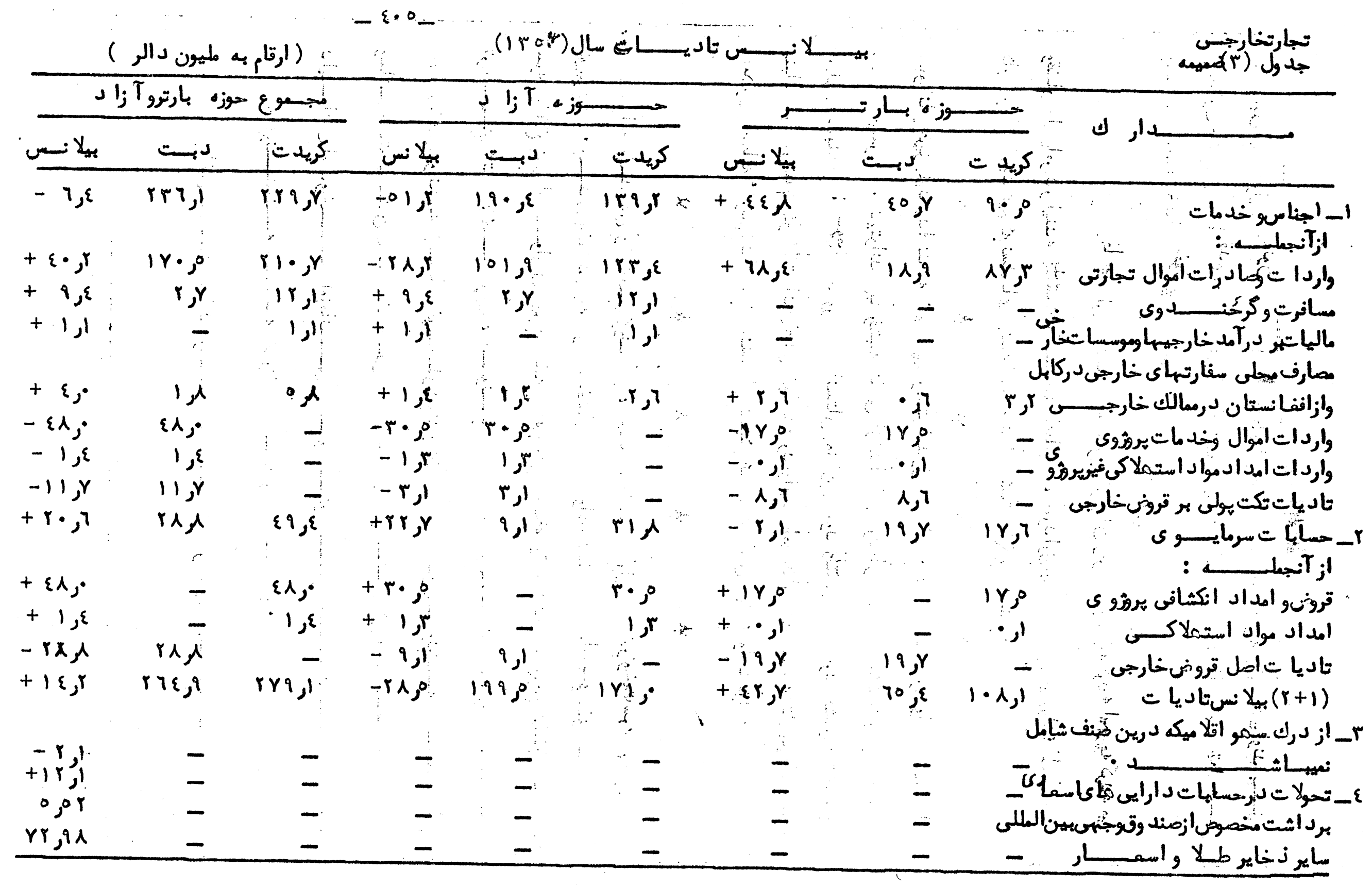




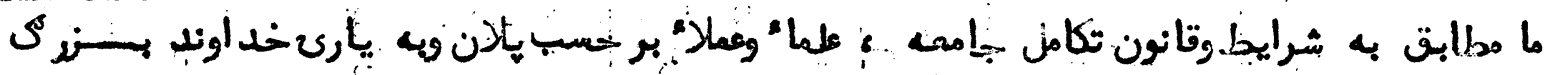

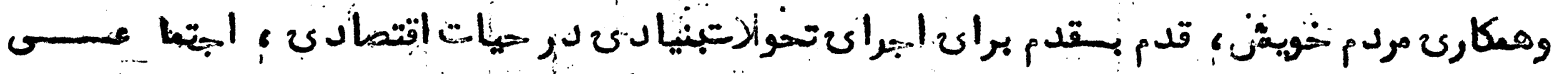

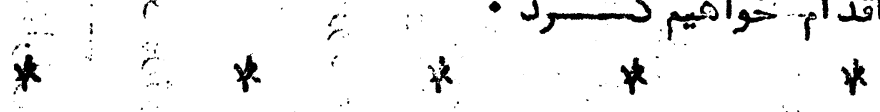

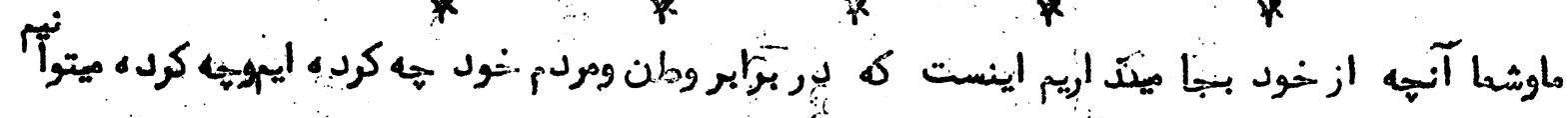

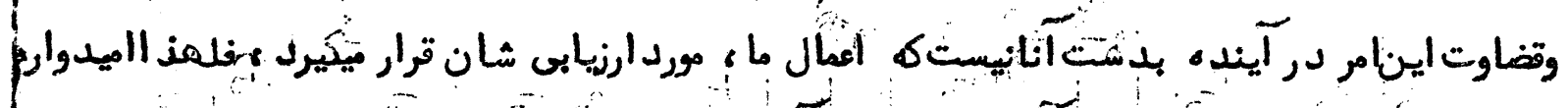

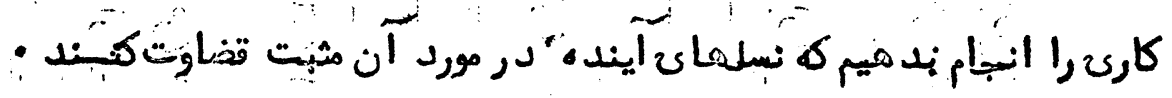
* * * * * * * * * * * * *

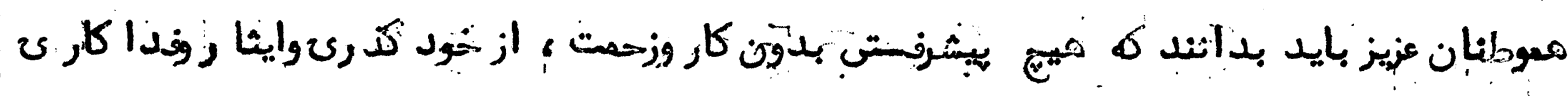

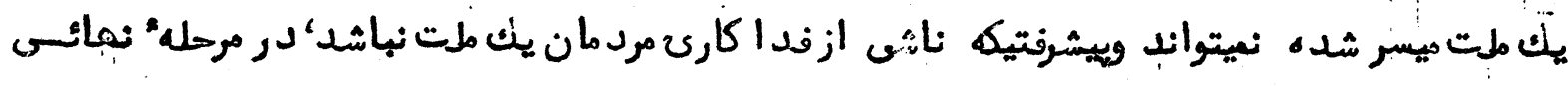

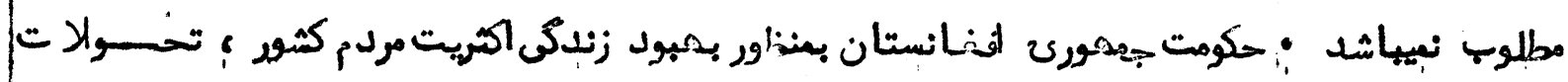

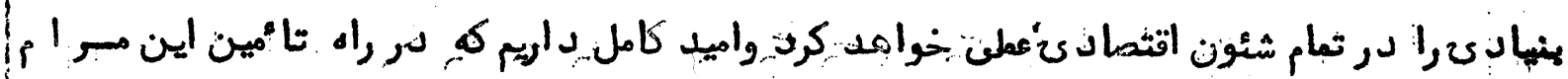

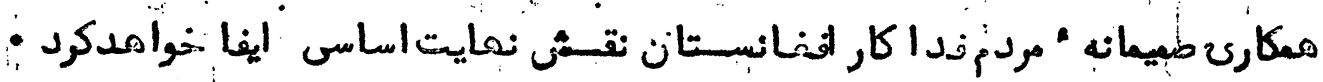

\section{$* * * * * \ldots$}

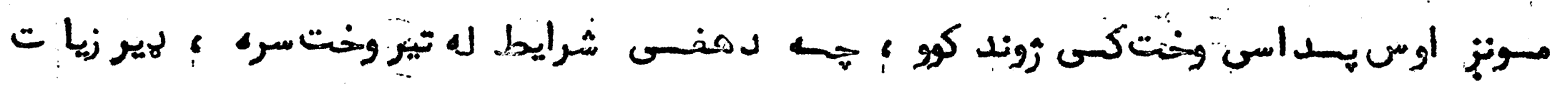

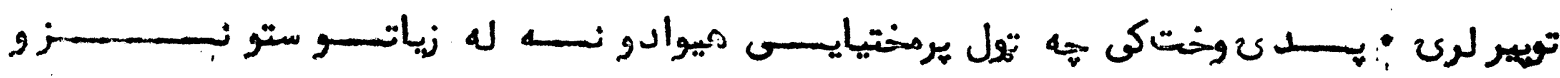

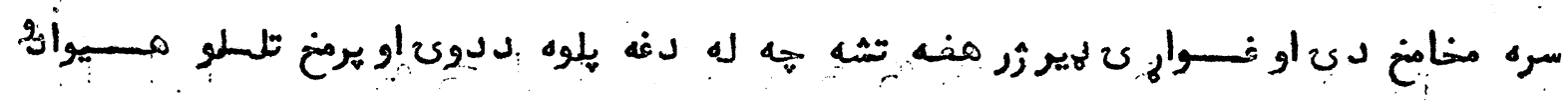

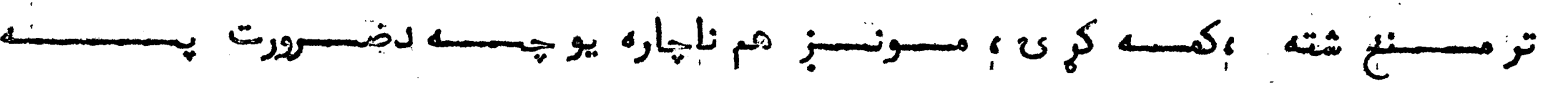

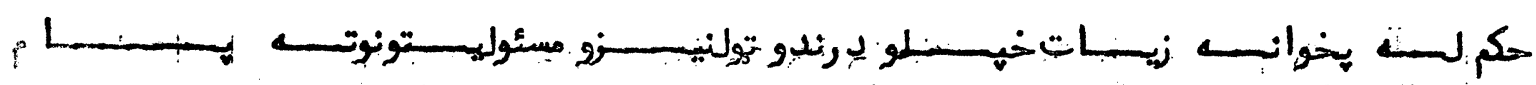

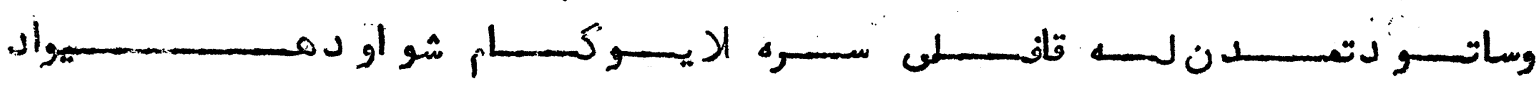

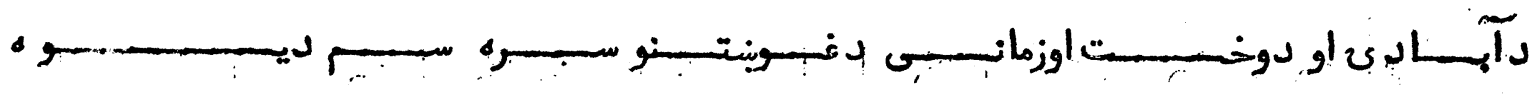

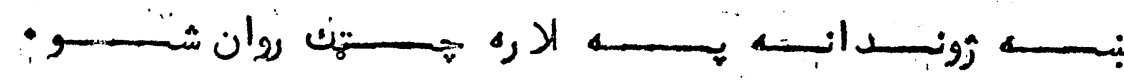

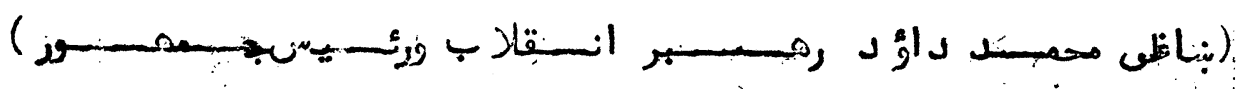


فضلهفمت

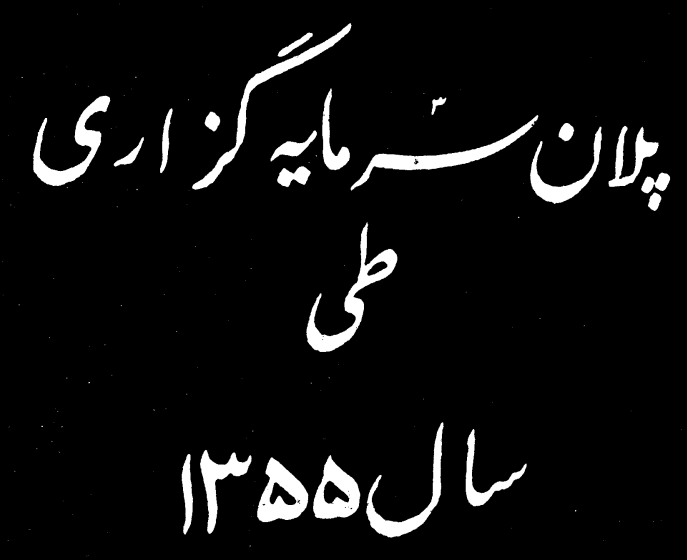

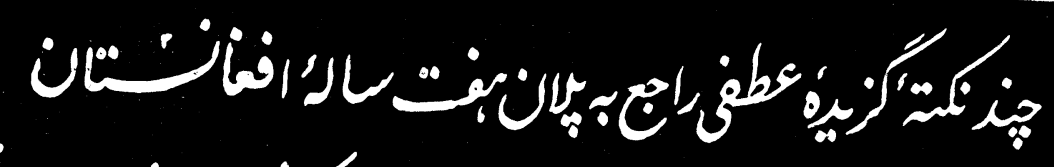

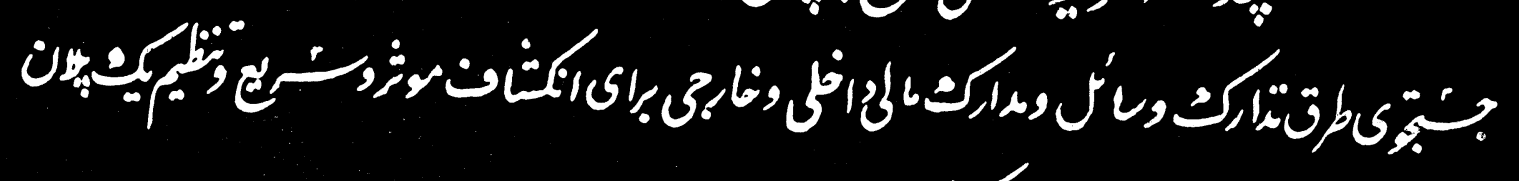

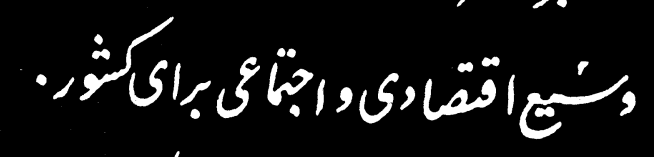

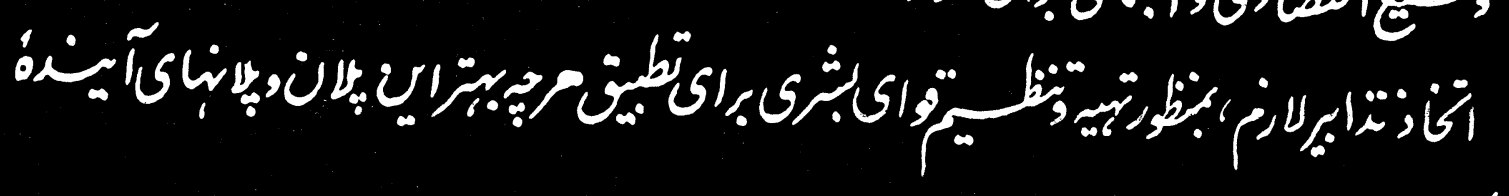
(il) 


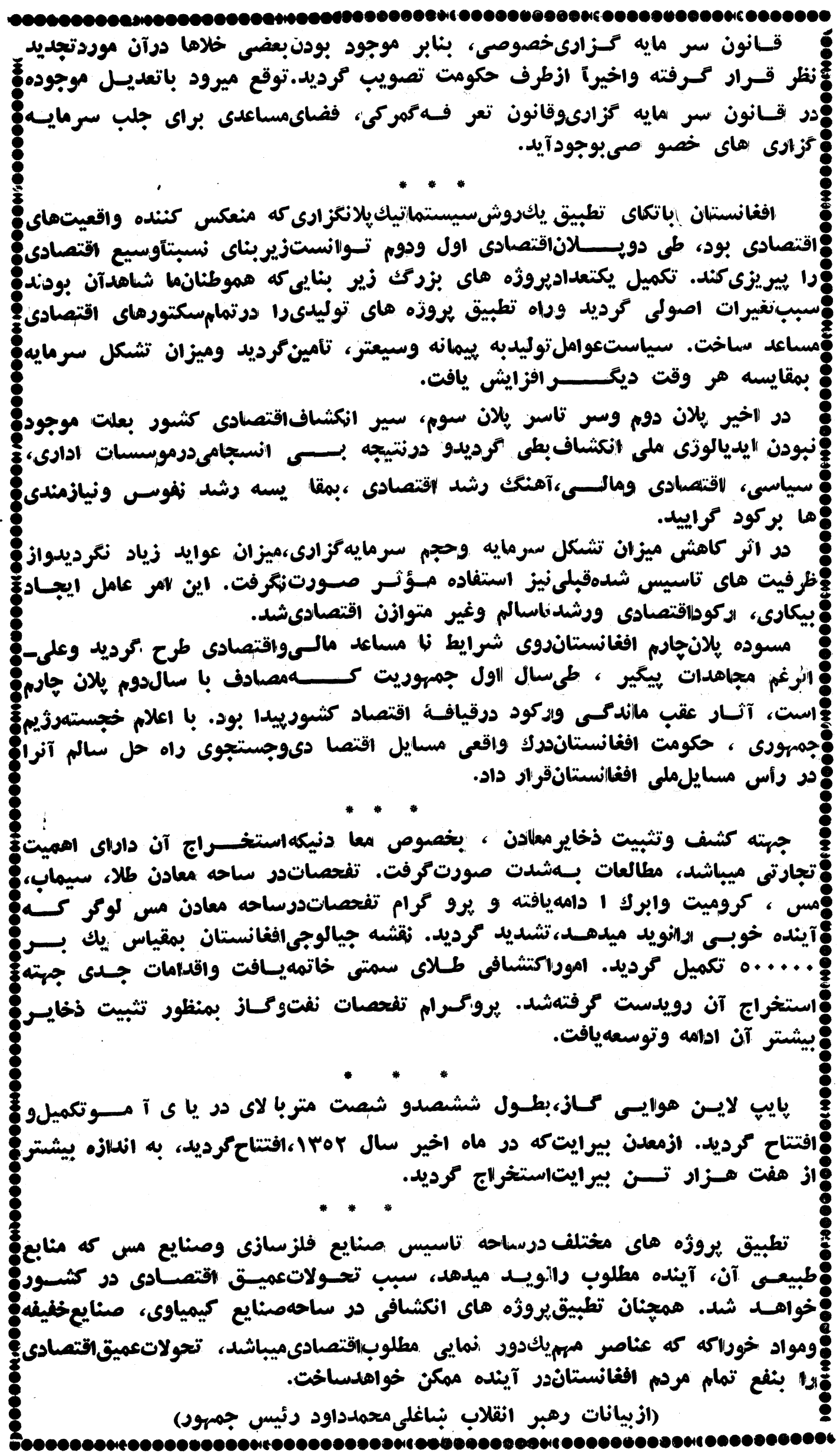




\section{فصـل هفتـم}

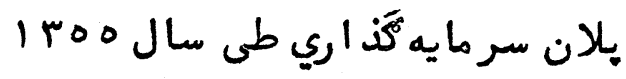

لد ريلان هفت ساله انكثا ف اقتصاد ي و اجتما عى دو لت جمهور ي افغـــا نستا ن

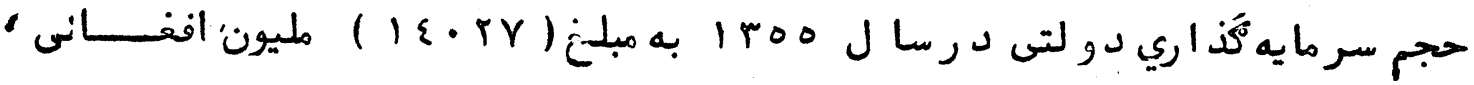

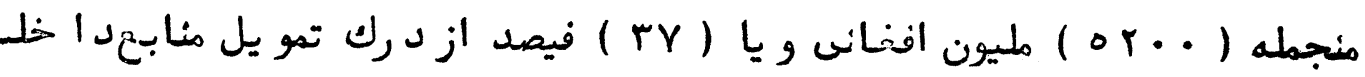

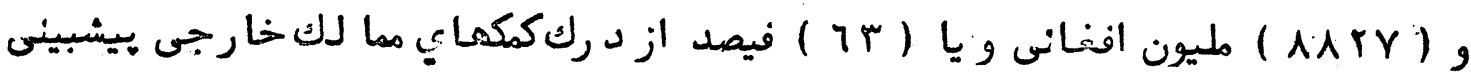
•

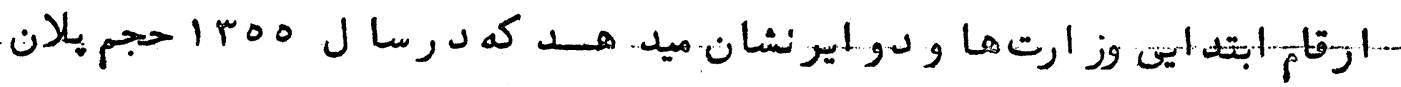

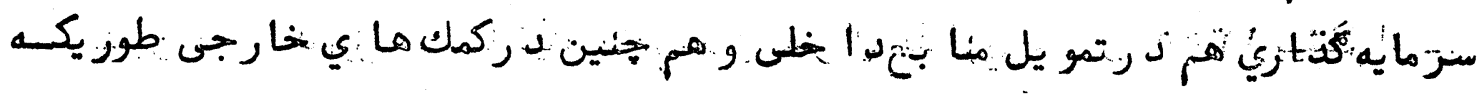

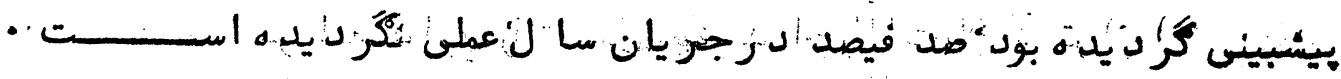

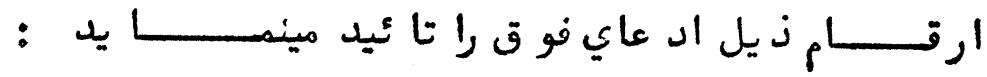

سر مايه كزذ اري اسا سى بطورعموم بتفريق منابعطى سال Iroo

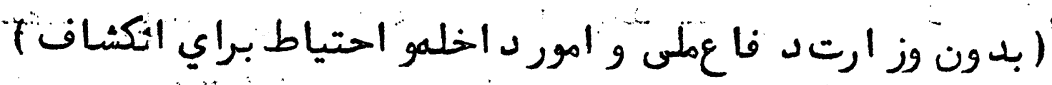

\begin{tabular}{|c|c|c|c|}
\hline فيصـلـل ئل ن & حقيقسى استفاد & يلان سال & واحد مقياس \\
\hline (*AYjᄉ & $\varepsilon r r \xi, r$ & $\varepsilon \wedge \vee q, r$ & مليون افغانى \\
\hline$(* r r, \gamma$ & $7 r$ & 19. & مليو ن ب الر \\
\hline r r & YI.9. Y, & $1 r \varepsilon 90, r$ & مليون افغانى. \\
\hline
\end{tabular}

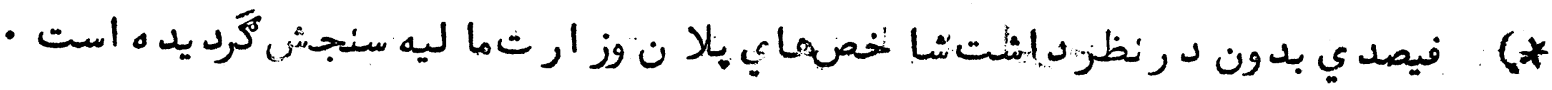

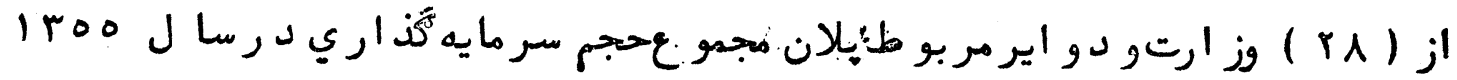

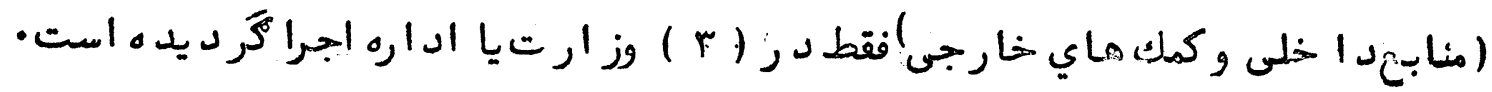

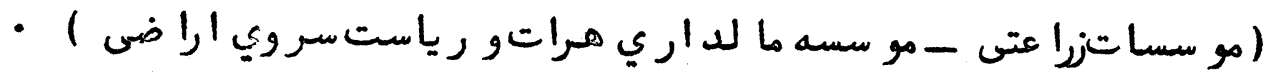
همجنين بيشتر از ( • و ) فيصد هلان ؛ تو سط وز ارتعد ليه - 9 وفيصد - وز ارت

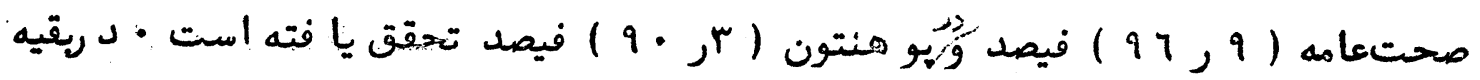

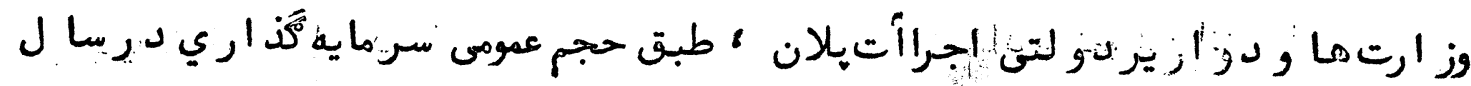

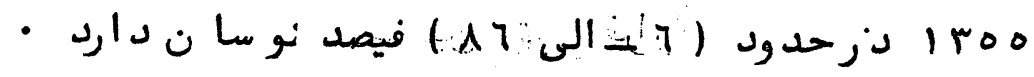

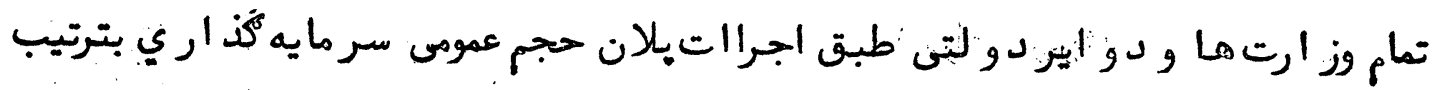
ن يل ثزو ب بندي ميشو ند 


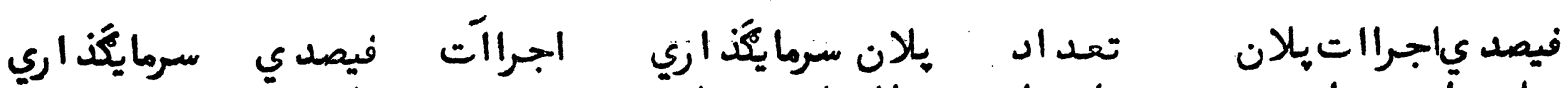

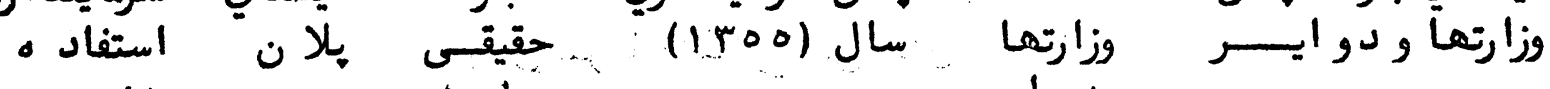

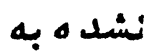
مليو ن بن بهن افغانى

|فيبيولا

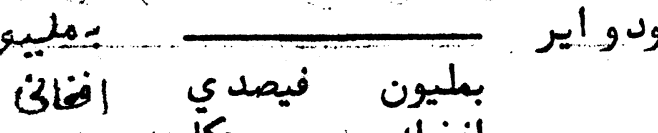

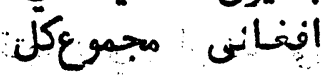

الى • الم فيصسـ

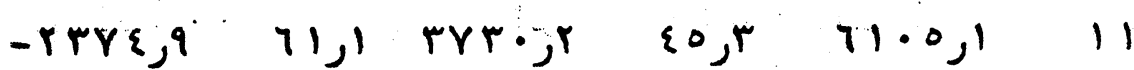

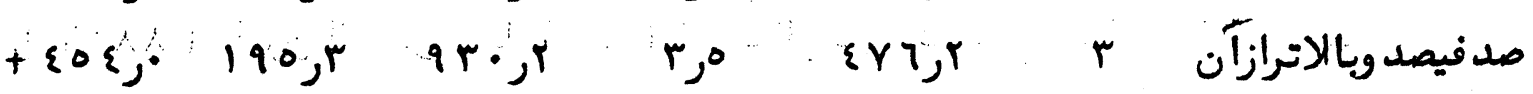
مجمسوع مد

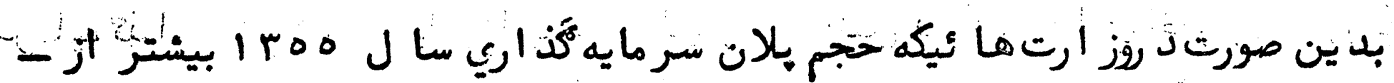

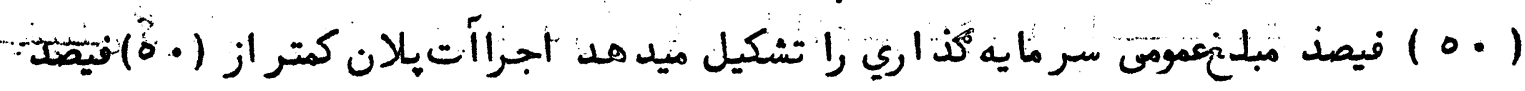

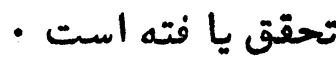

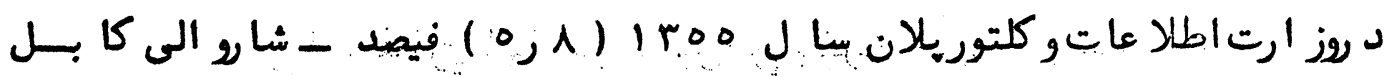

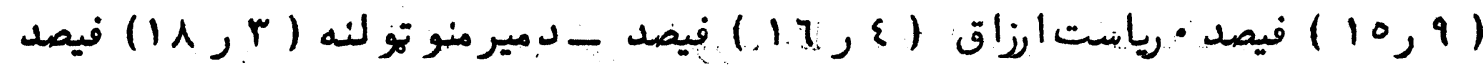

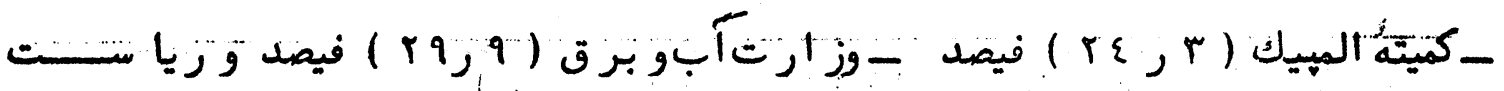

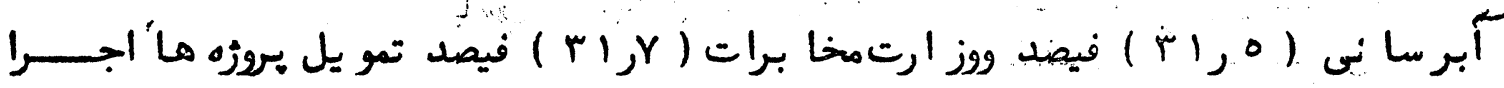

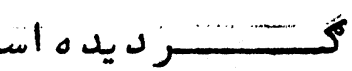

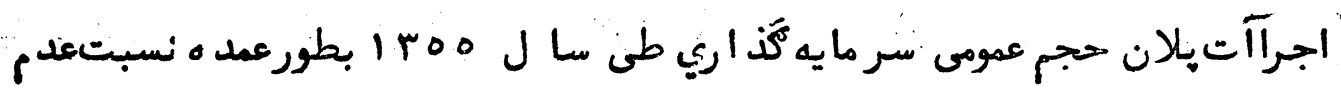

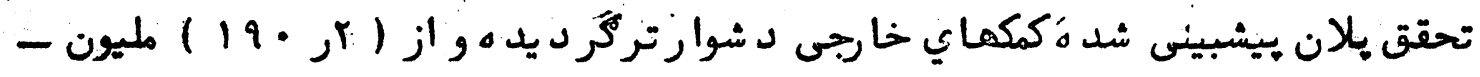

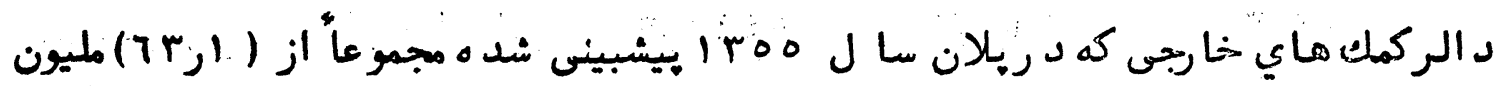

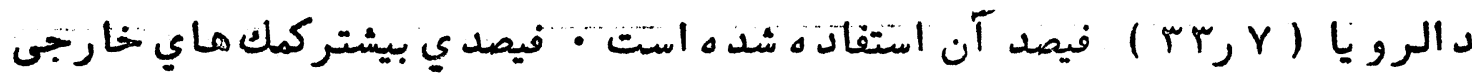

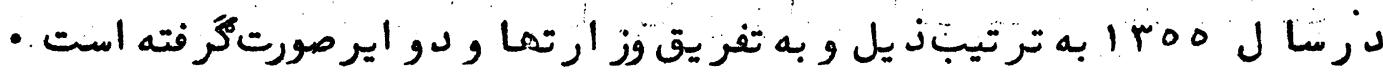

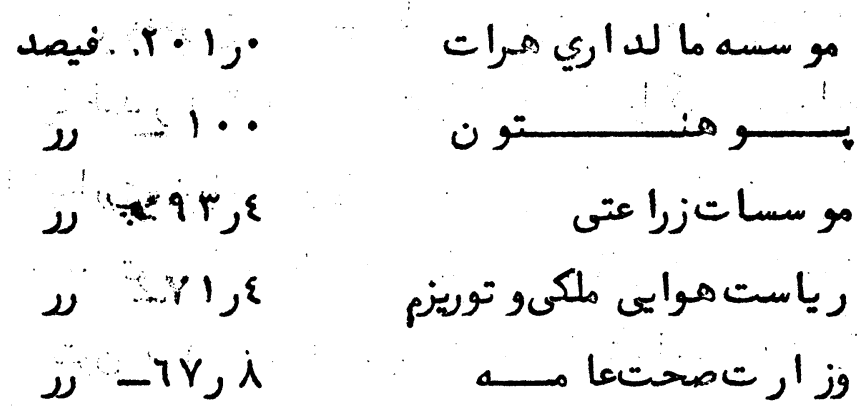

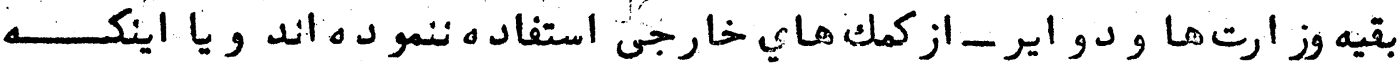

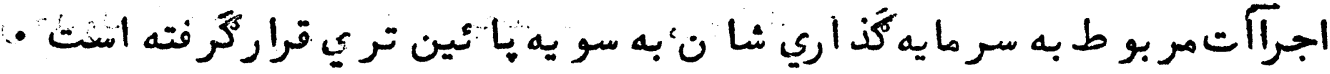

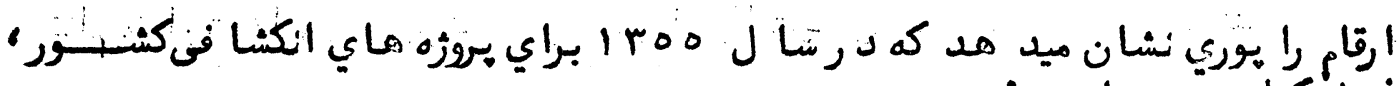
ما لك ذيل كمك نموي ده اند : 


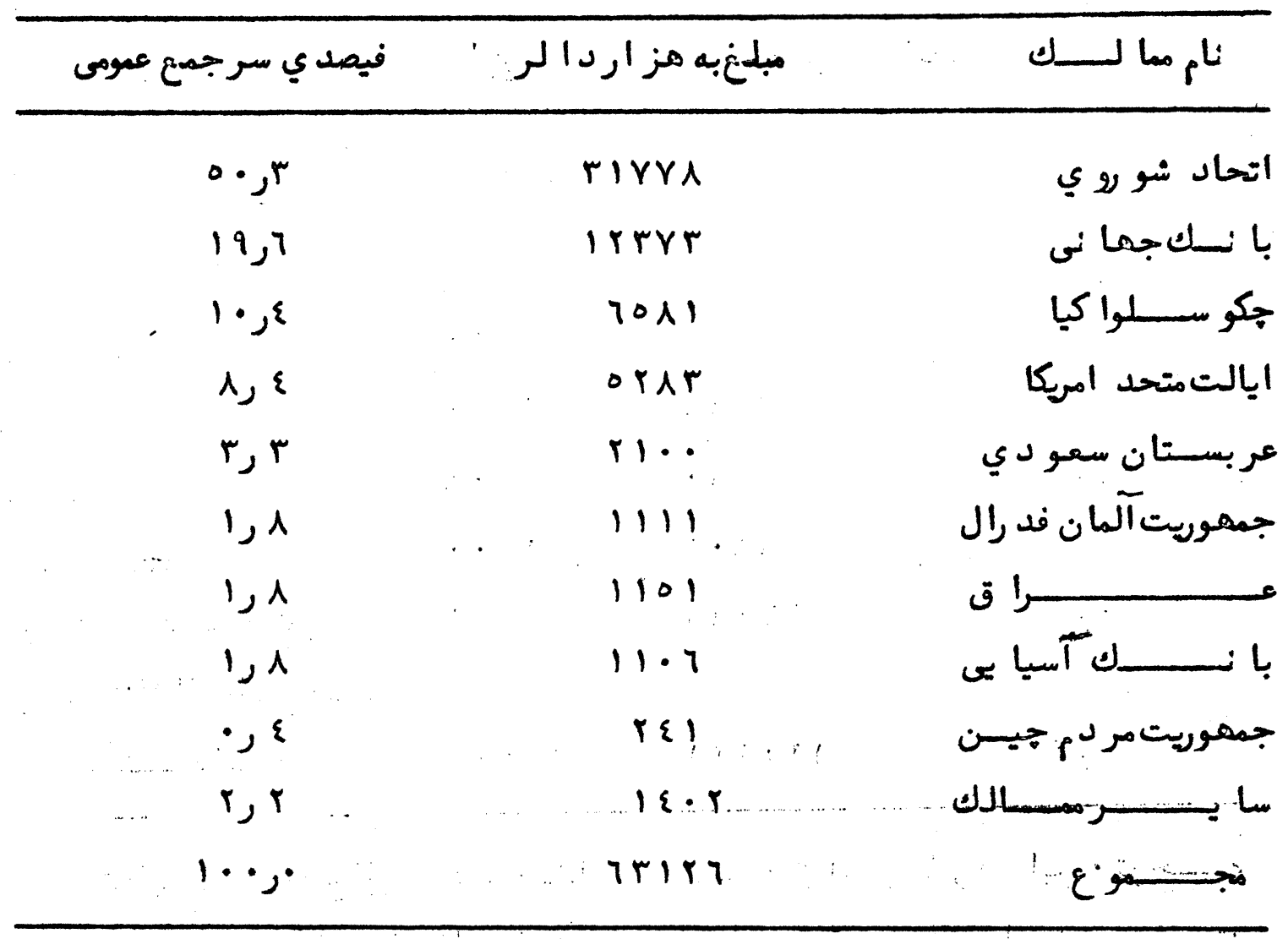

ارقامى كه د رجدول فو ق ذكرگر ديد · نشان ميد هد كه د رمبلغزمومى كمك هـاي

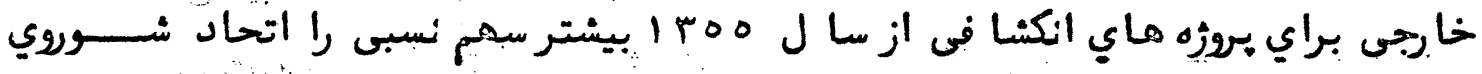

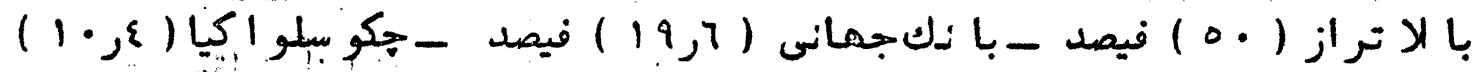

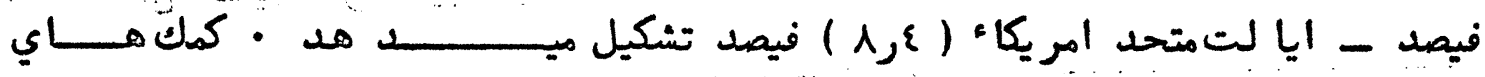
سا ير مها لك خارجى به مبلنغمومى (1)

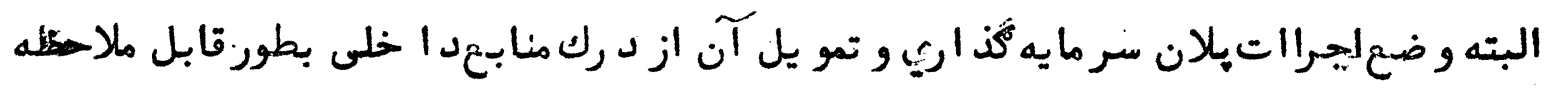

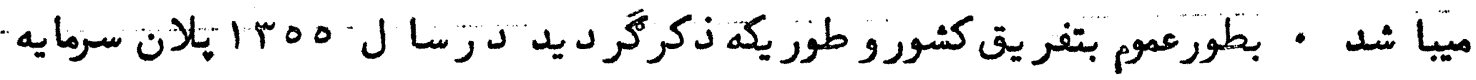

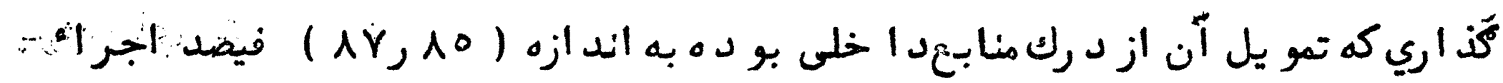

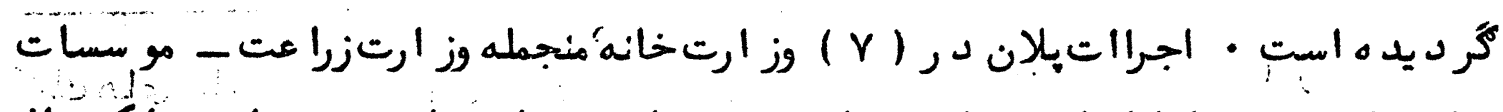

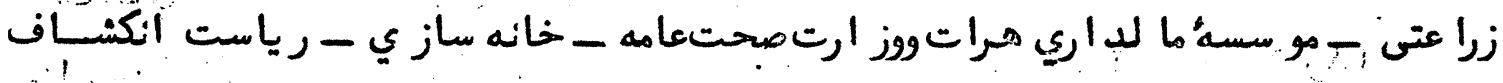

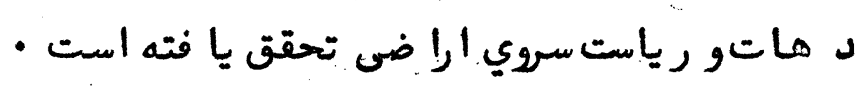

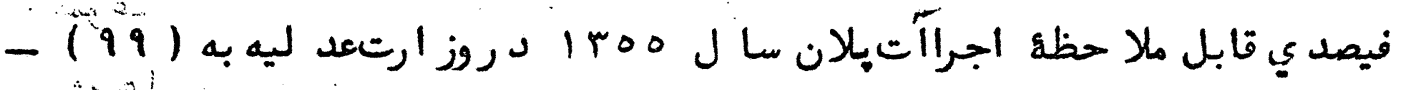

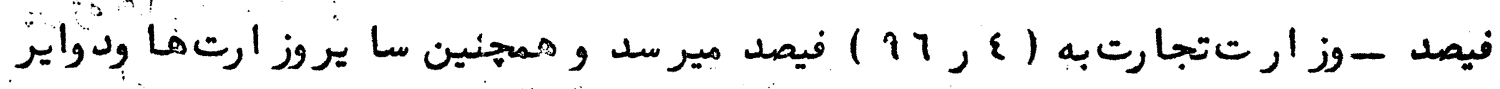

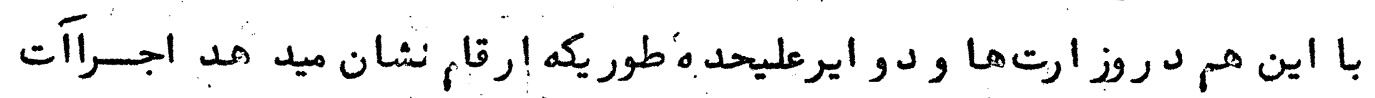

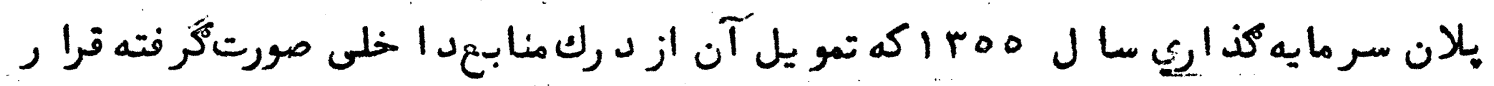




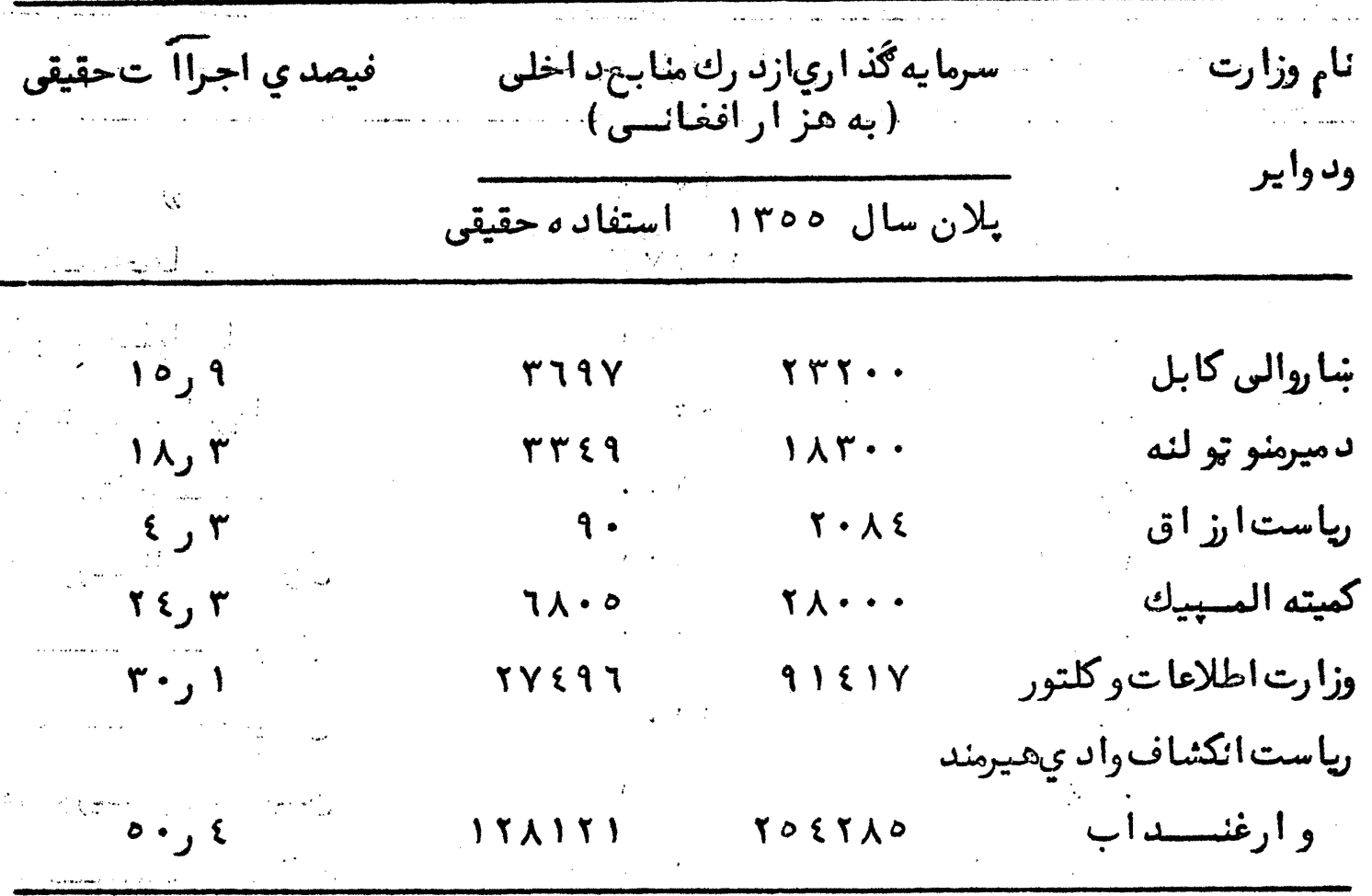

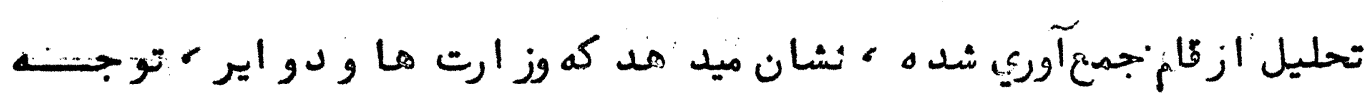

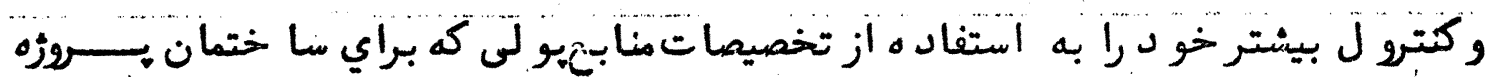
هاي انتقا لى ميبا ثد "معطو فيد ارئل د رحا ليكه يلان سا ل ل

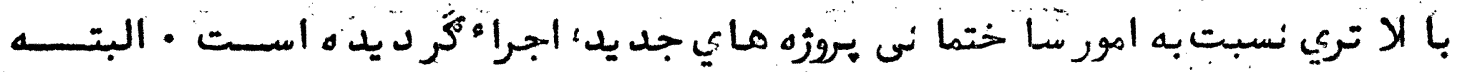

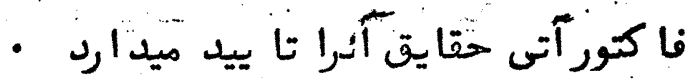

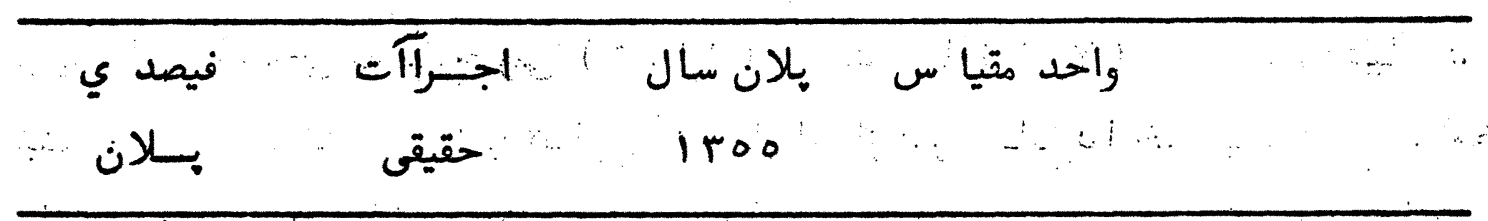

كروزه هواي انتقا لى :

\begin{tabular}{|c|c|c|c|c|}
\hline or,$q$ & o. 1 & 90,7 & مليون د الر & كمك هاي خا رجى \\
\hline 91,0 & $r \xi: q, q$ & ر & رُ افغـا نى & 1. \\
\hline$\varepsilon \varepsilon$ & or & virr & ري اففا ني & \\
\hline$i r$ & o & $q \varepsilon, 7$ & ليو ن د الر & كمك د \\
\hline$i \cdot, r$ & $\Lambda \mid \varepsilon$ & IrrAرo & لر افنـا نى & خلسى \\
\hline$\varepsilon, \gamma$ & $\mid$ rᄉ⿵, $\Lambda$ & rربr & رر افنانى & \\
\hline
\end{tabular}

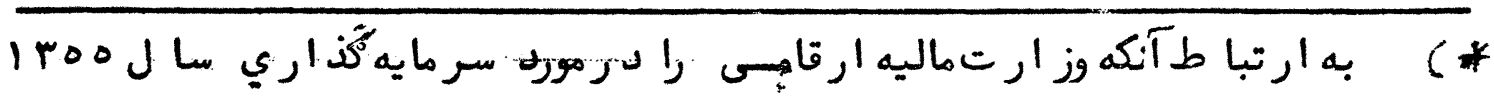




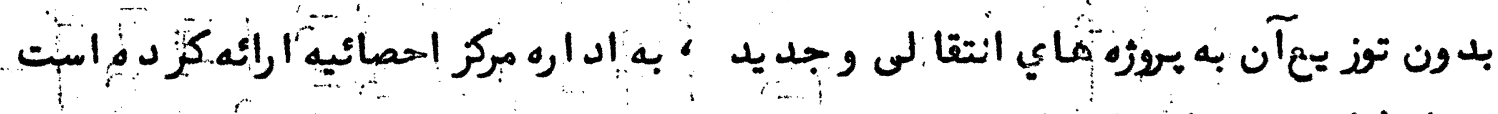

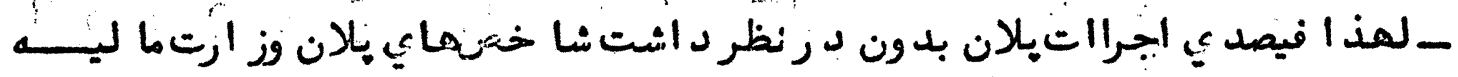

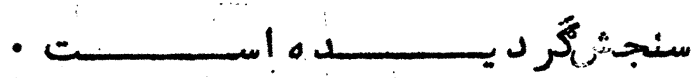

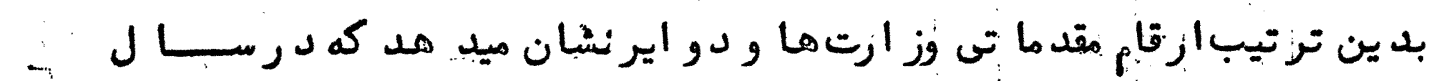

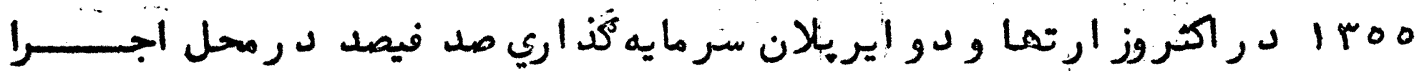

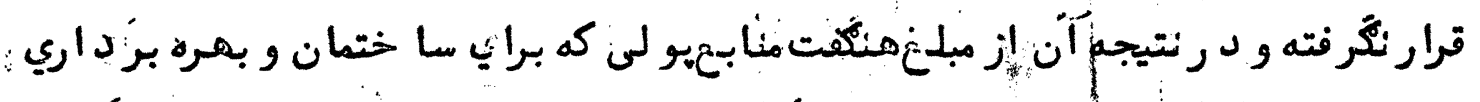

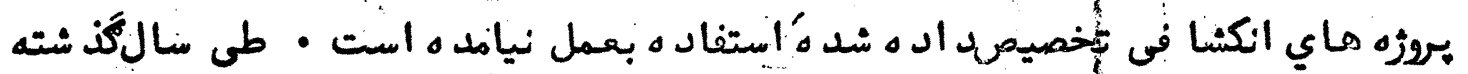

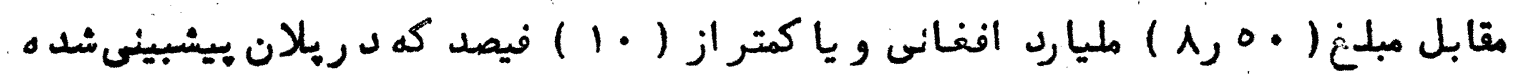

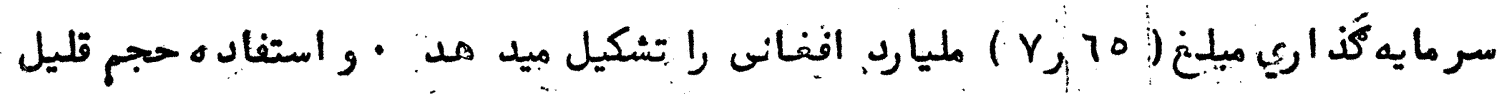

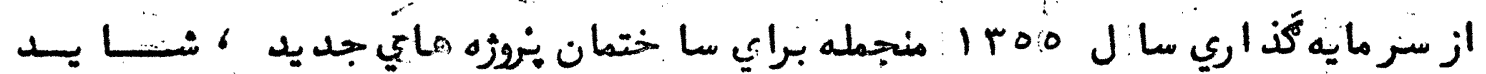

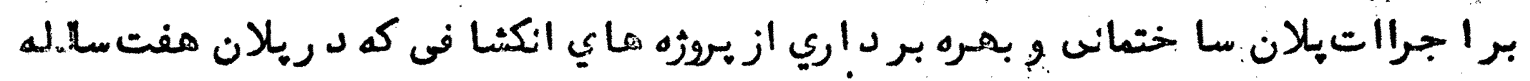

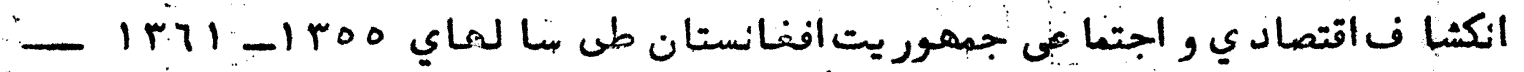

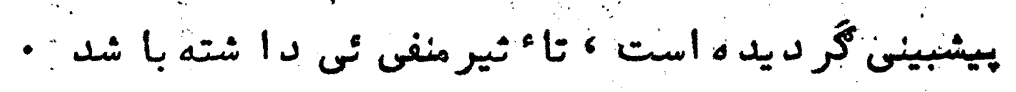

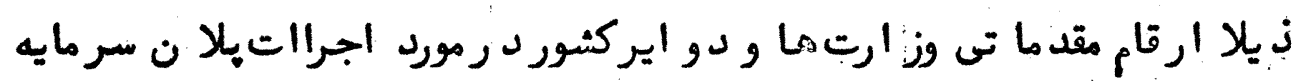

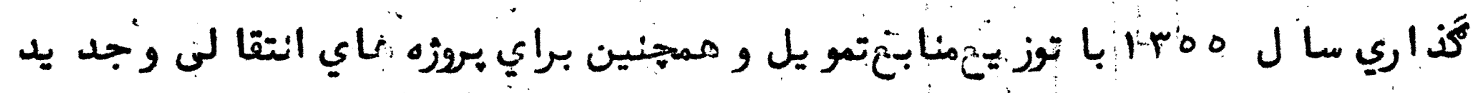

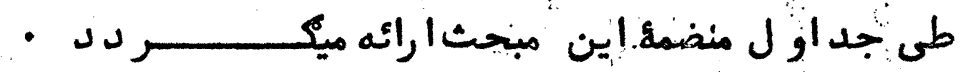




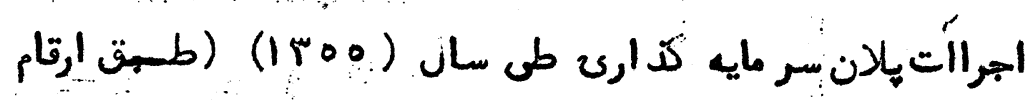

جدول ضميه (1)

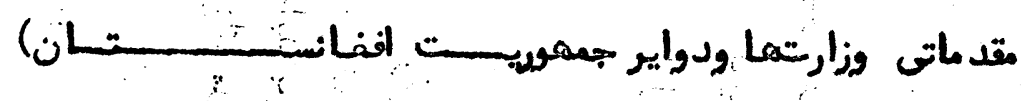

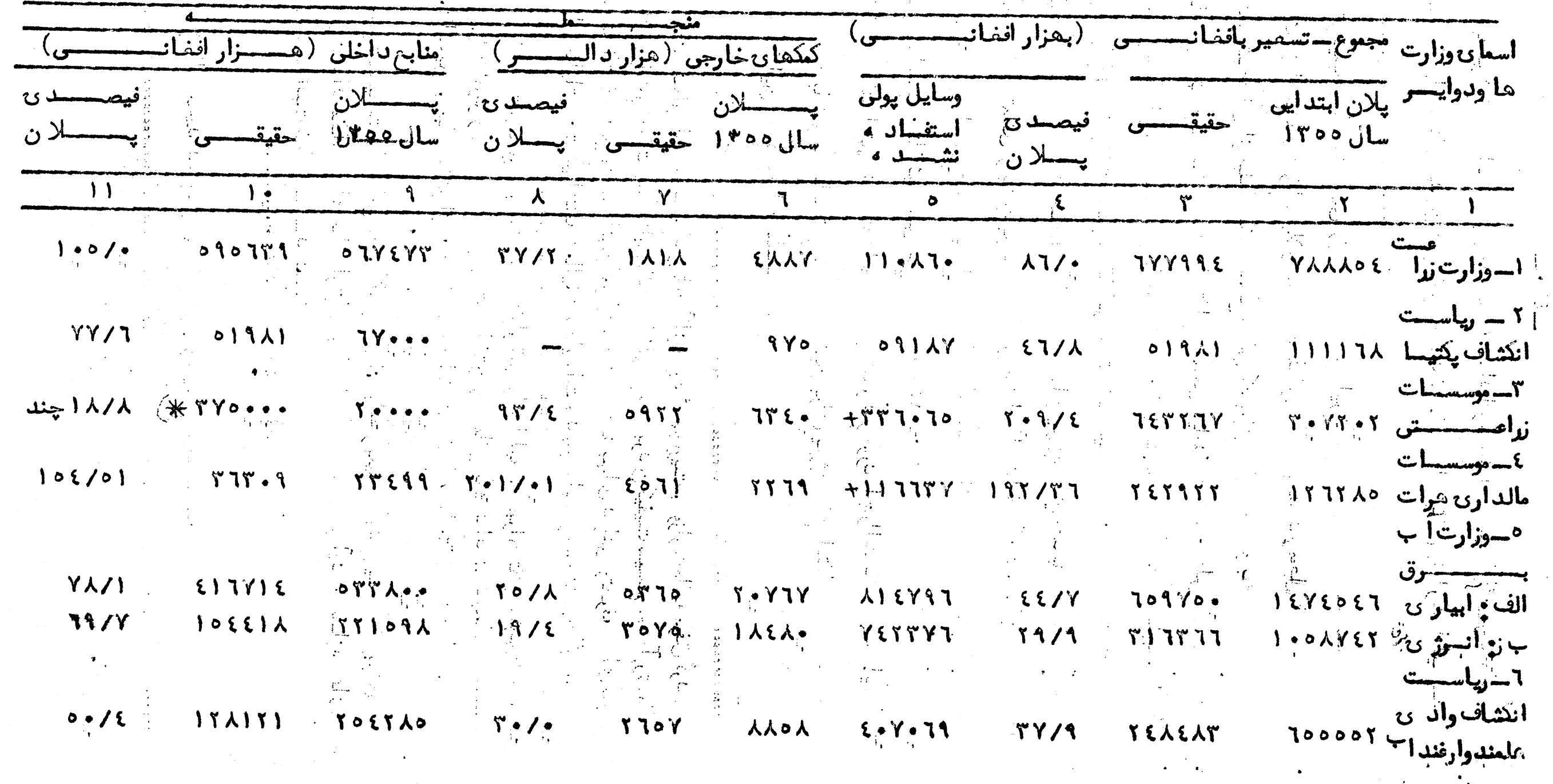




$$
\text { - } \mid r_{-}
$$

ادامه جدول ضميمه (1)

\begin{tabular}{|c|c|c|c|c|c|c|c|c|c|}
\hline 11 & 1. & 9 & $\lambda$ & $\gamma$ & 7 & $\circ$ & $\varepsilon$ & $r$ & $r$ \\
\hline ᄉr $/ \lambda$ & NVAMOT & 1.71978 & $\varepsilon r / \lambda$ & rIrqI & RIITT & r.YYYTE & or $/ 0$ & 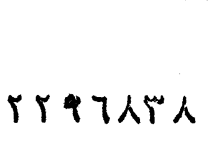 & 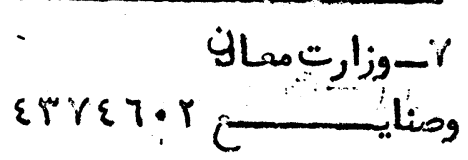 \\
\hline$\because$ & $\therefore$ & $\cdots$ & $\cdots$ & & 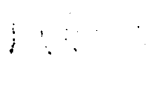 & ; & $\therefore \quad$ & $\cdots$ & 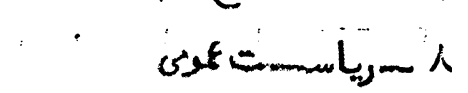 \\
\hline$\varepsilon / r$ & $9 \cdot$ & $r \cdot \wedge \varepsilon$ & $18 / 9$ & $r_{1}$ & pqr & $17 \gamma \lambda \varepsilon$ & $17 / \varepsilon$ & rr人દ & r.TA \\
\hline$\because \because$ & $\because \cdots$ & $\begin{aligned} 7 \lambda y \cdot 1 \\
\vdots\end{aligned}$ & $\because \cdots$ & $\because \because$ & $r \cdot \cdots$ & 1.197 & $0 . / 5$ & $1+170:$ & r • \\
\hline $17 / \varepsilon$ & 1rรq. & is: & - & - & iro & 7irs & $71 / 7$ & 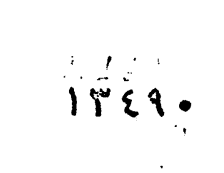 & ت: : 1977 : \\
\hline$\therefore \cdot$ & & $\therefore$. & $\cdots$ & & $\ldots$ & $\cdots$ & $\because$ & $\therefore \cdots$ & 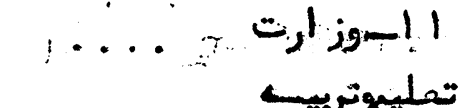 \\
\hline $81 / 1$ & $1071 \times 7$ & rlotrt & $\cdots$ & - & r & Vyilo & $i v / r$ & 10 Ykkt & 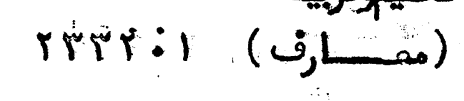 \\
\hline $19 / 7$ & ogror & 777人ᄉ & $1, \ldots 1$ & $1 \cdots$ & $1 \cdots$ & 7941 & $9: / 4$ & TErit & VIr|ג ريوهنتون \\
\hline & & . & & & $\cdots$ & & 10 & $\because:$ & 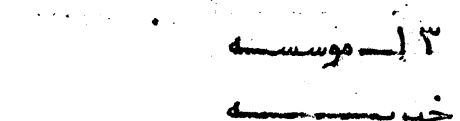 \\
\hline$\stackrel{1}{\wedge}$ & riqq & 1 人r: & $=$ & - & - & $|\varepsilon \uparrow 0|$ & $1 \wedge / \mu$ & พฺะq & 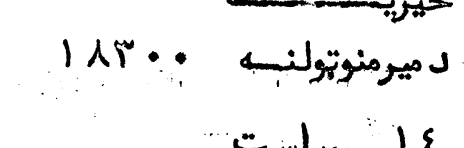 \\
\hline$r \varepsilon / r^{*}$ & $71 \cdot 0$ & $r \lambda \cdots$ & - & - & - & 11190 & $r \varepsilon / r$ & $71 \cdot 0$ & 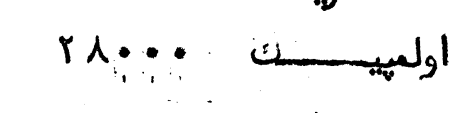 \\
\hline$r \cdot / 1$ & rマ\&q7 & $|1 \varepsilon| \vee$ & $\because / r$ & $1 \varepsilon$ & $\lambda 71 \varepsilon$ & Eoro... & $0 / 1$ & |人|r| & اطلاعاتوزكلتور \\
\hline $1 Y T / 4$ & IVTOYY & $1: 9199$ & $78 / 1$ & Tr. & FY $\{7$ & 1979 & $97 / 9$ & rr人.人! & صحت عامســ \\
\hline
\end{tabular}


EI

اد امه جدول ضميمه (1)

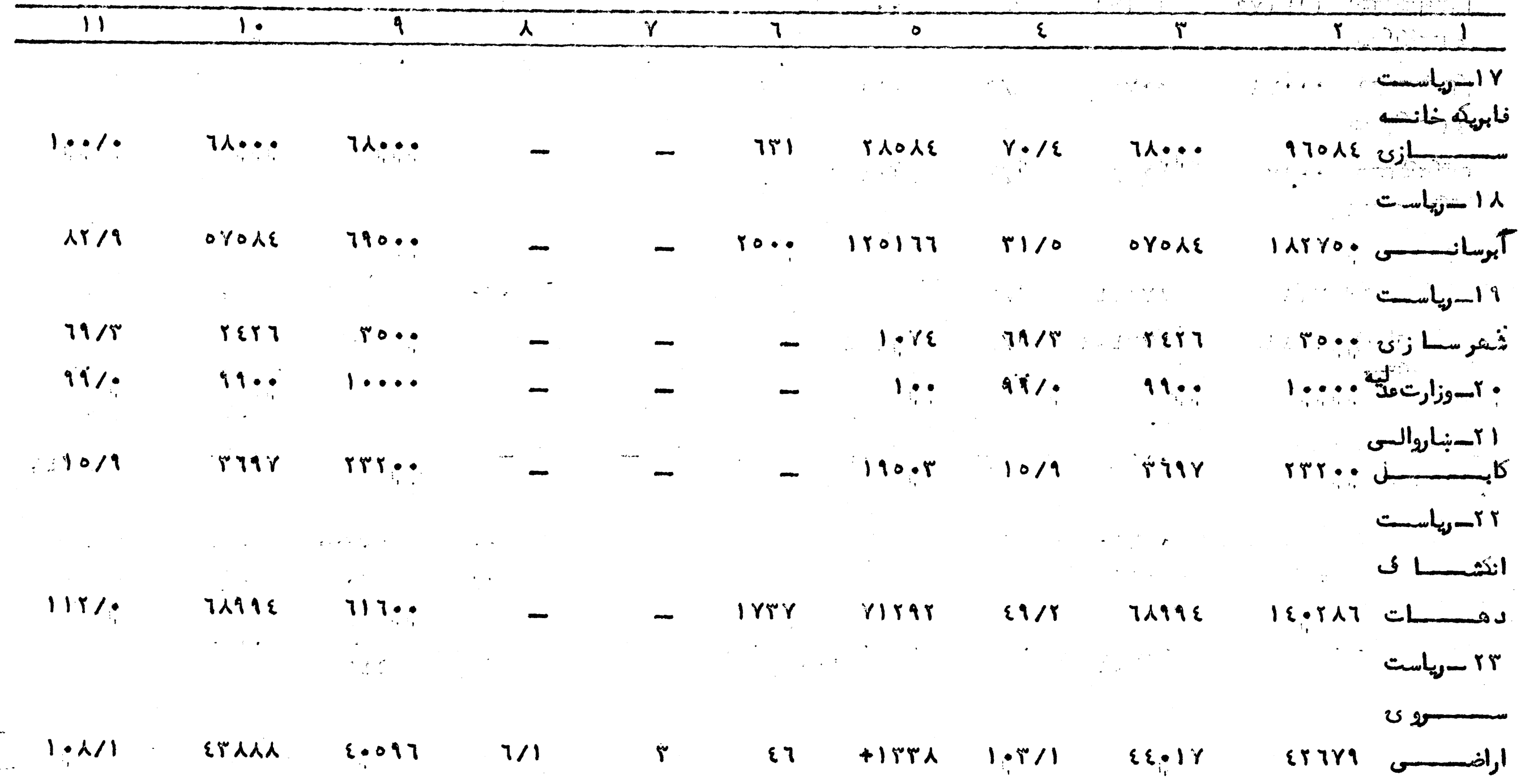


-

ادامه جدول ضميه (1)

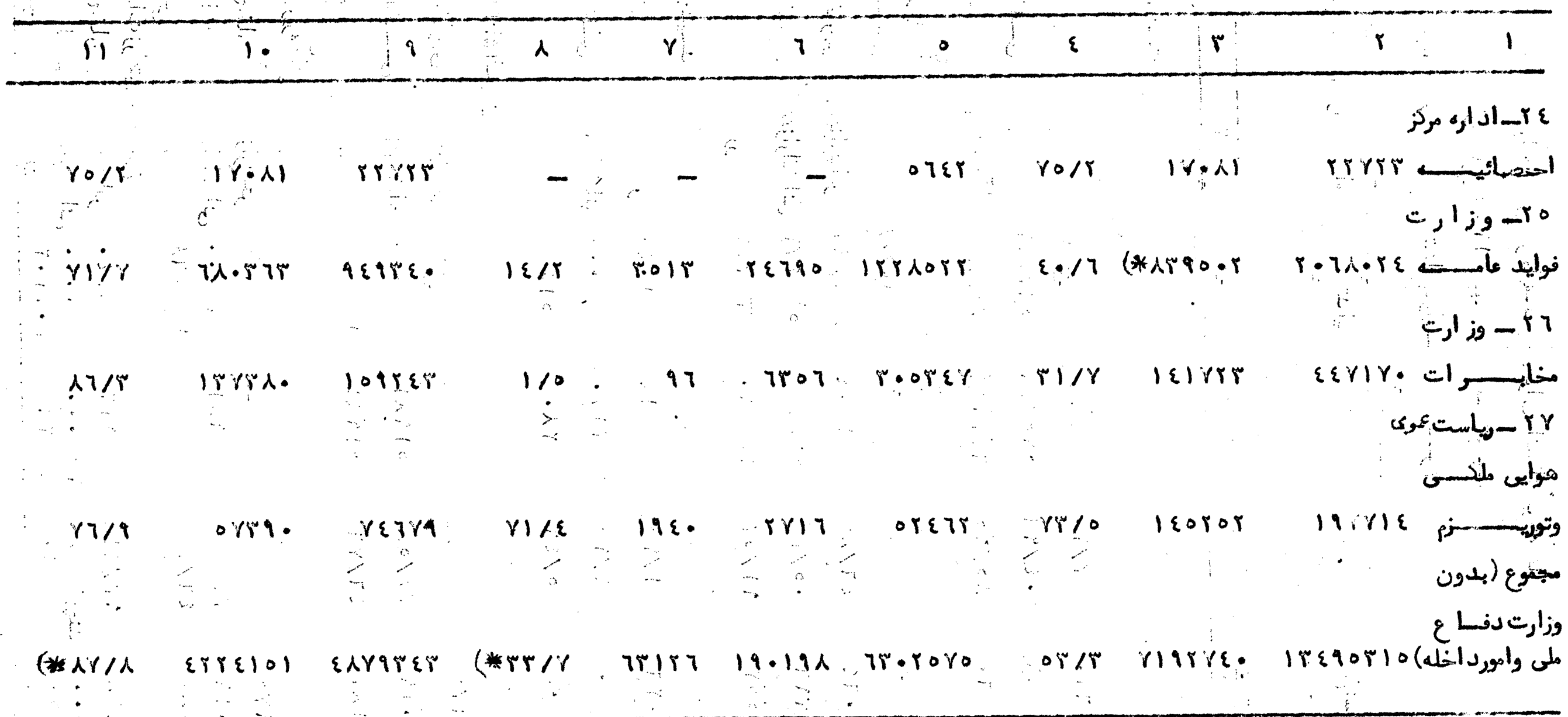




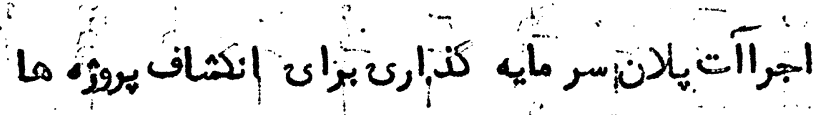

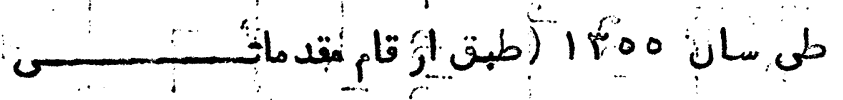

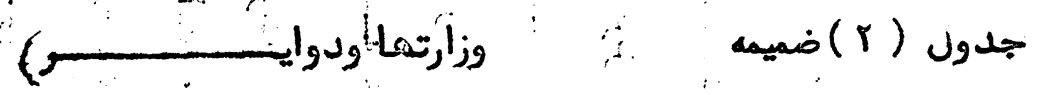

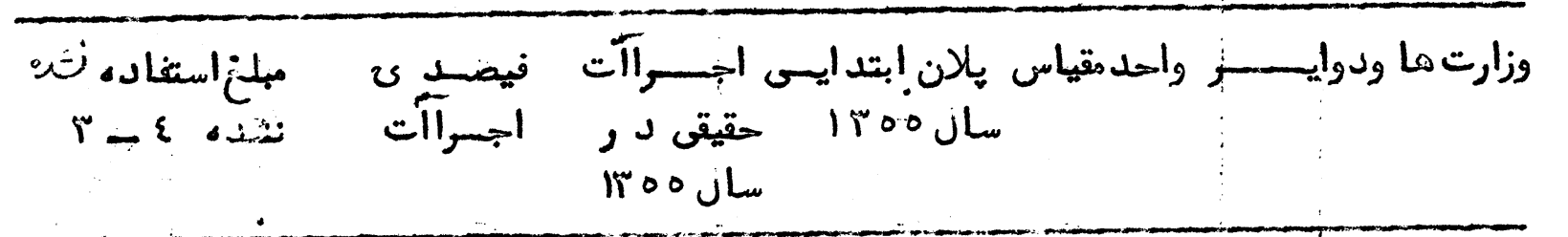

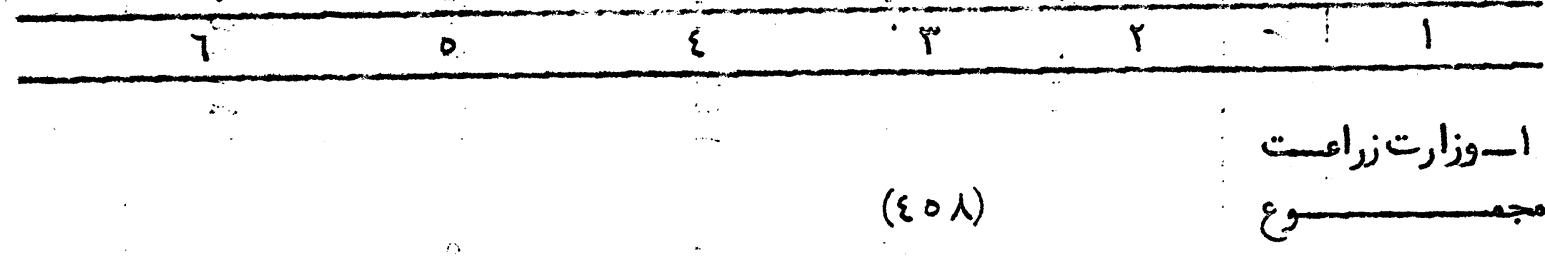

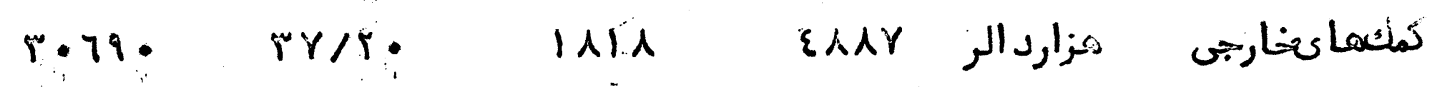

منابت داخلس

11.07. 10/90 7\%99

$(\varepsilon \circ 1)$

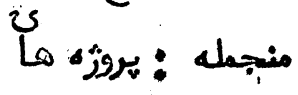

S

منابت دانلئى : هزارافناني

مiór

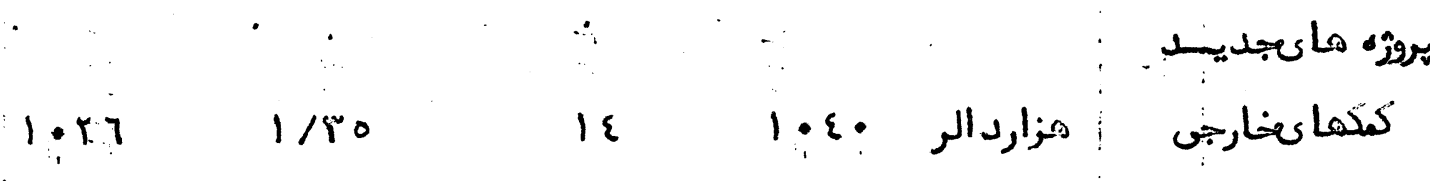

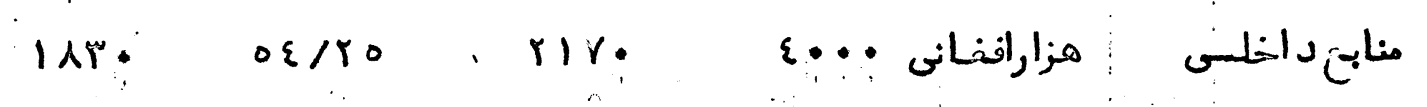

مهم-

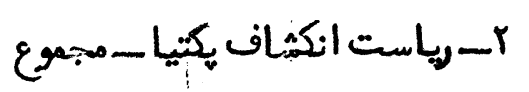

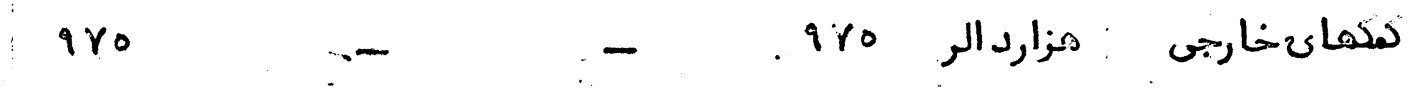

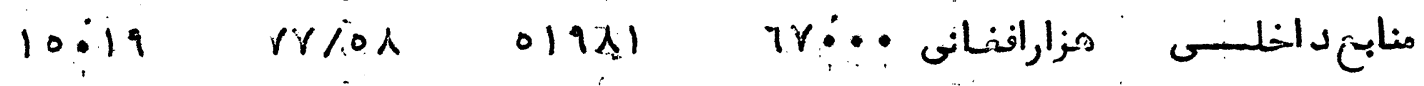

ه

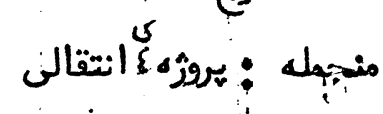

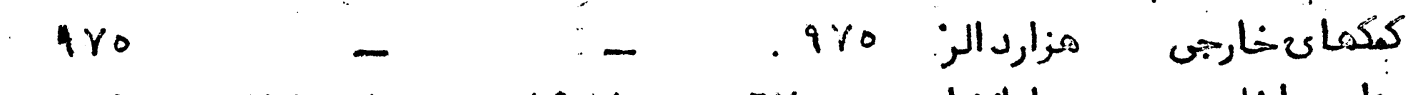

منابعداخلى

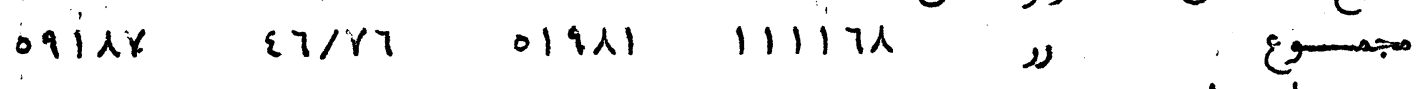

•

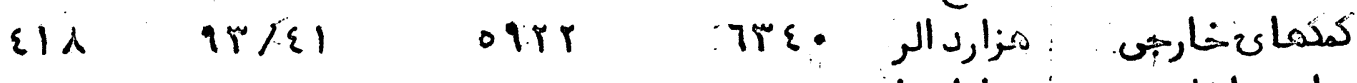

منابت دانله

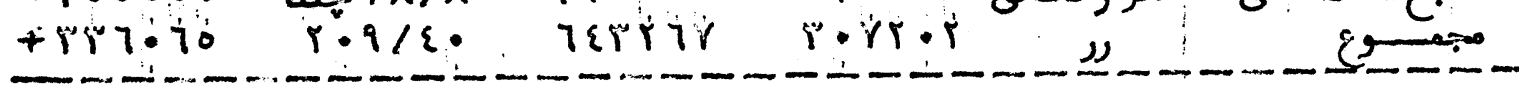


ادامه جدول (r) ضيعـــ

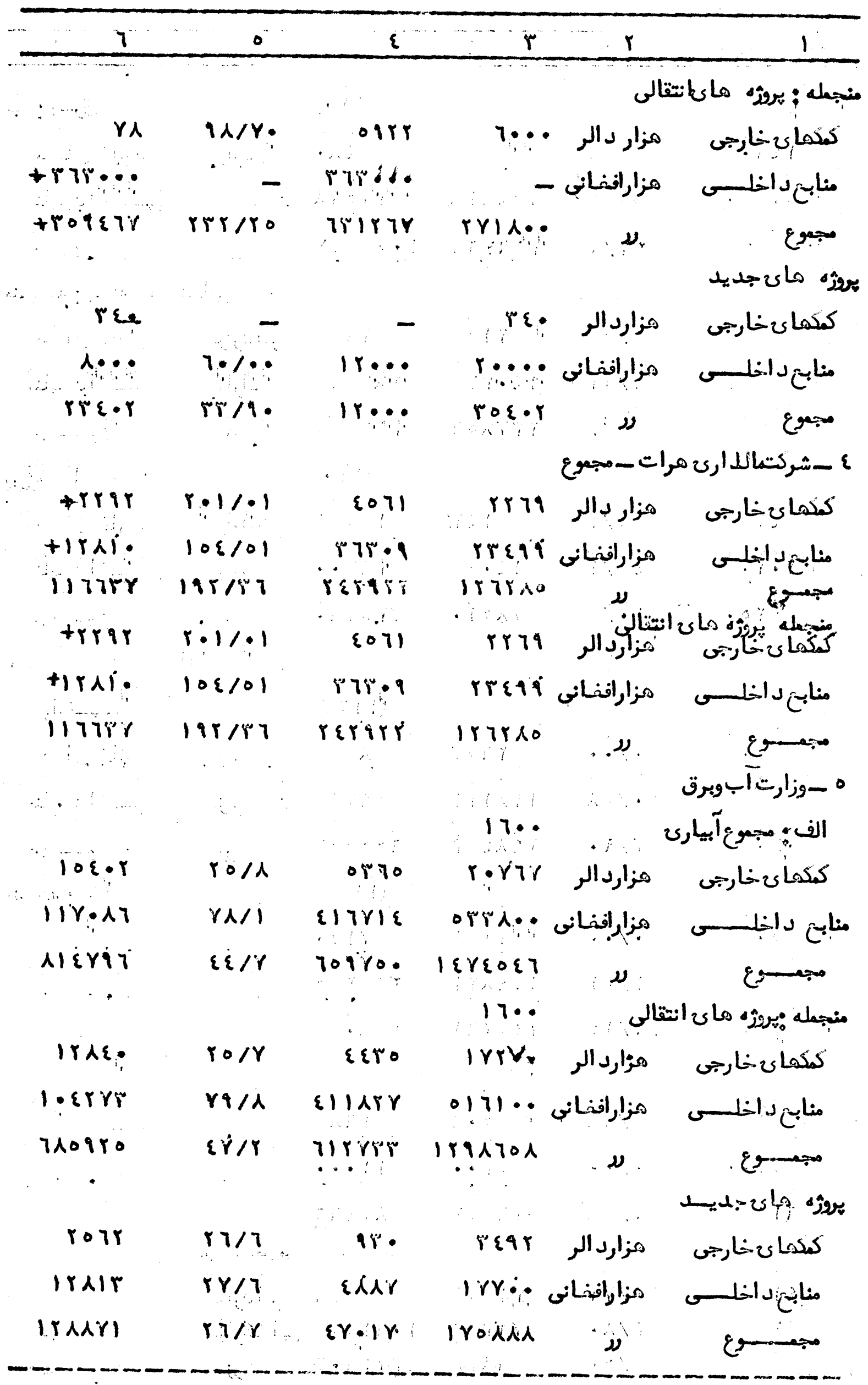


ادامه جدول ( Y ) ضيمه

\begin{tabular}{|c|c|c|c|c|c|}
\hline 7 & 0 & $\varepsilon$ & $r$ & r & 1 \\
\hline$\therefore$ & & & $(1 Y \cdot)$ & & ب : :بسرق \\
\hline 189.0 & $19: 2$ & royo & IA\&A: & هزارد الر & كذهاىخارجنى \\
\hline Trin. & $\because 71 / \mathrm{r}$ & $\mid 0\{\varepsilon \mid \lambda$ & -rrtork & هزارافنـاني & منابِ د آخلنـني \\
\hline Verryt & $19 / 9$ & . & $1.0 \wedge Y \varepsilon Y$ & נע & مجمسوبغ \\
\hline
\end{tabular}

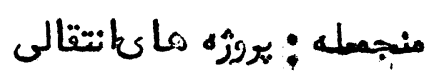

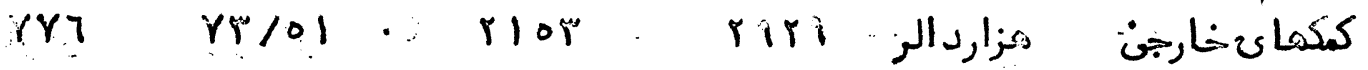

منابع داخلت

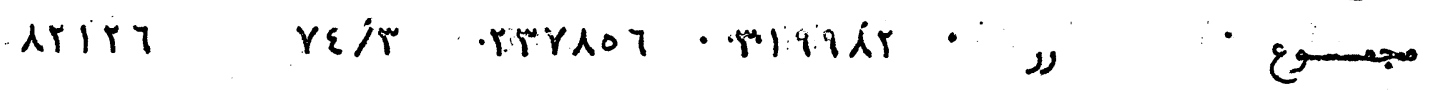

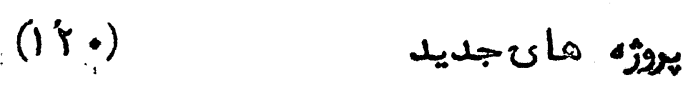

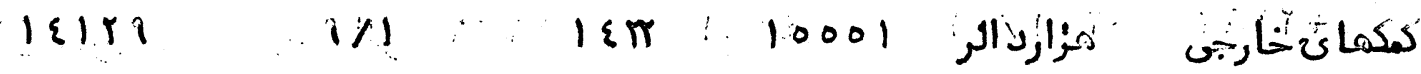

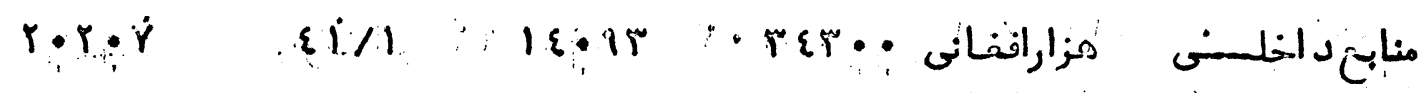

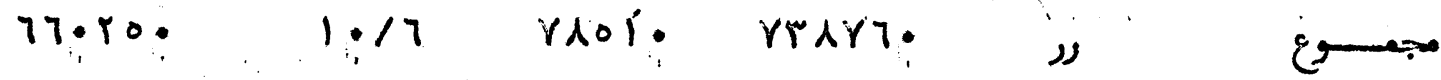

T-رياست انكشأن واد كن هلمنب

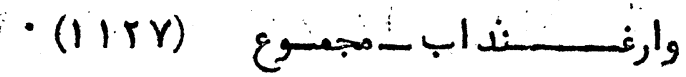

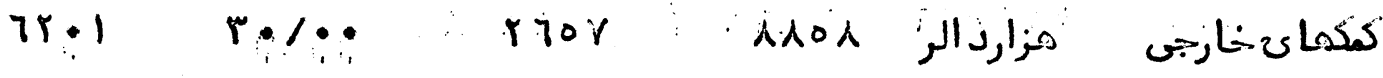

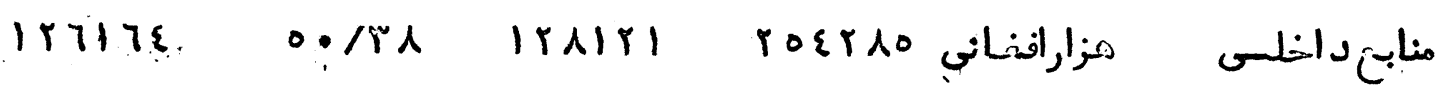

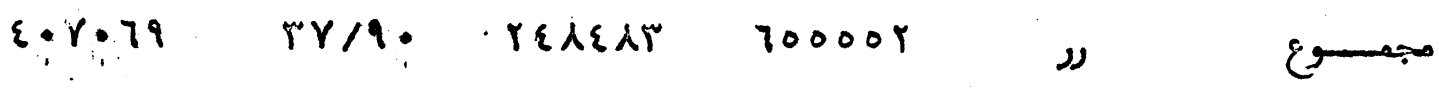

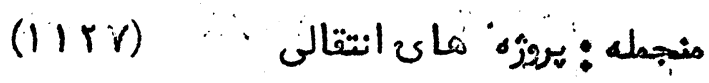

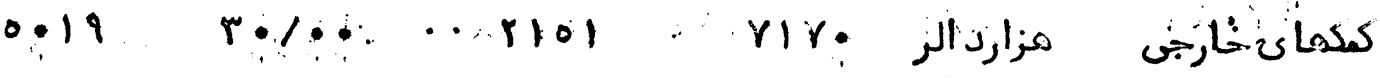

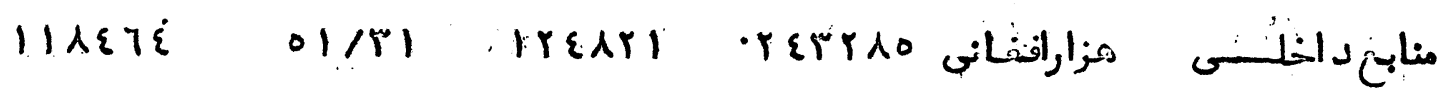

م\&okro

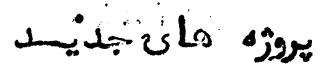

كSOاتخارجى

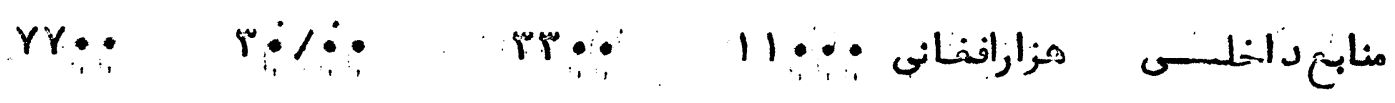

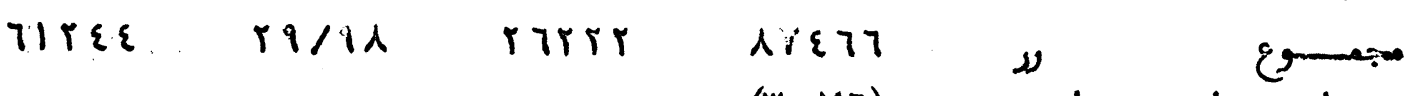

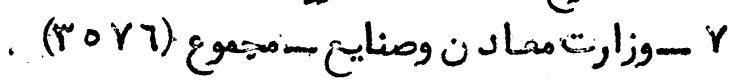

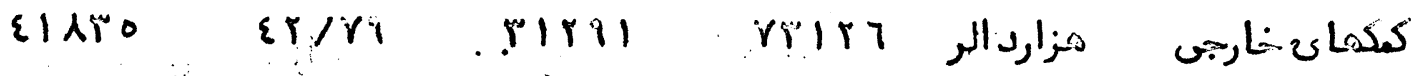

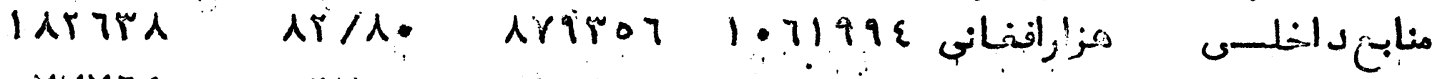

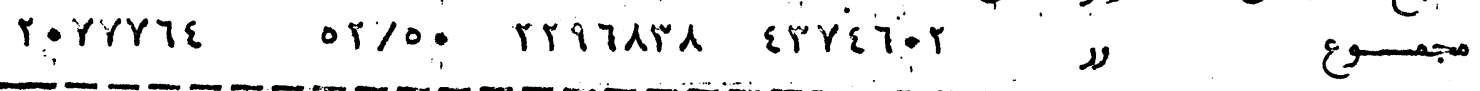




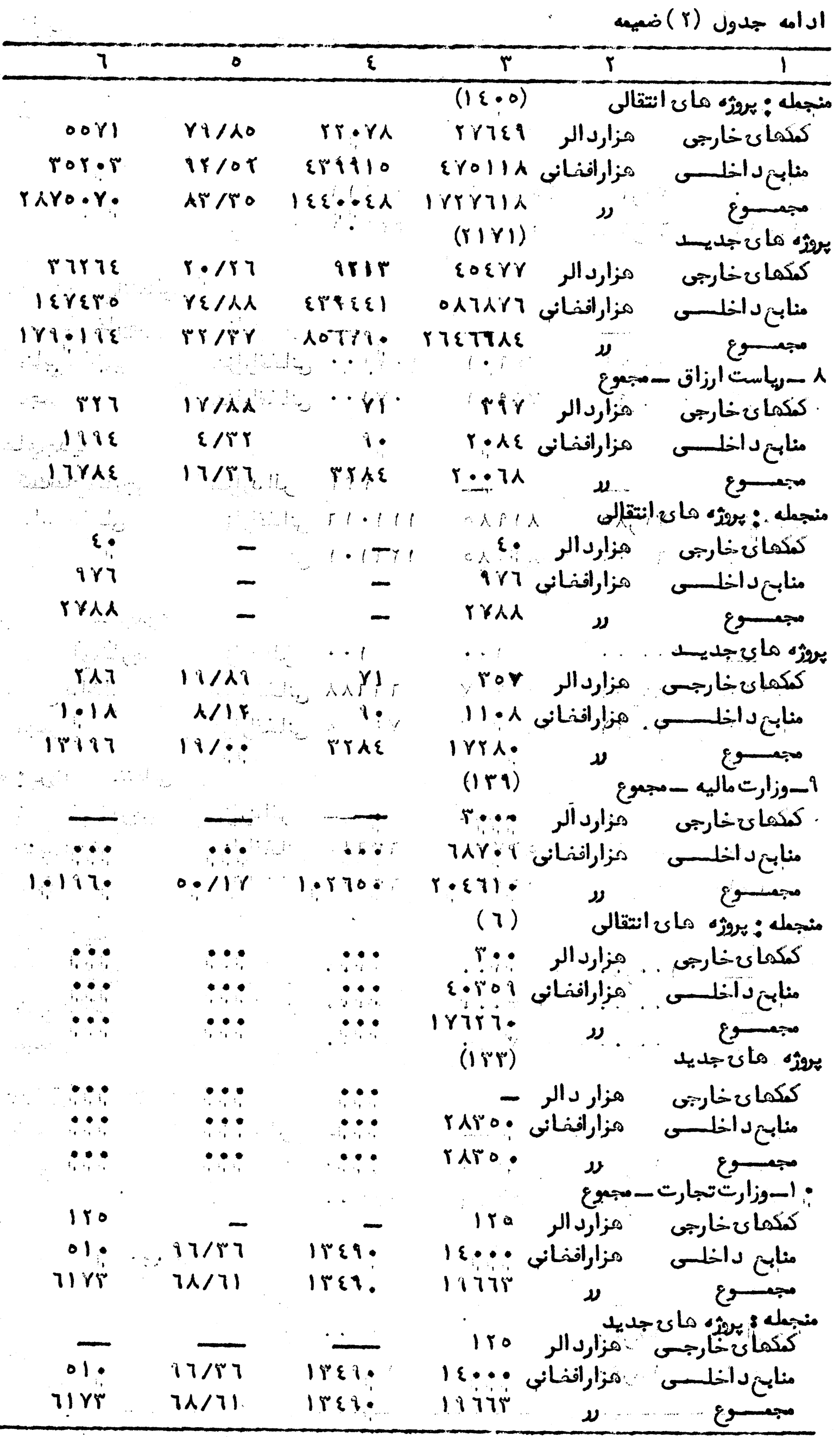




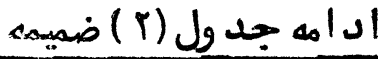

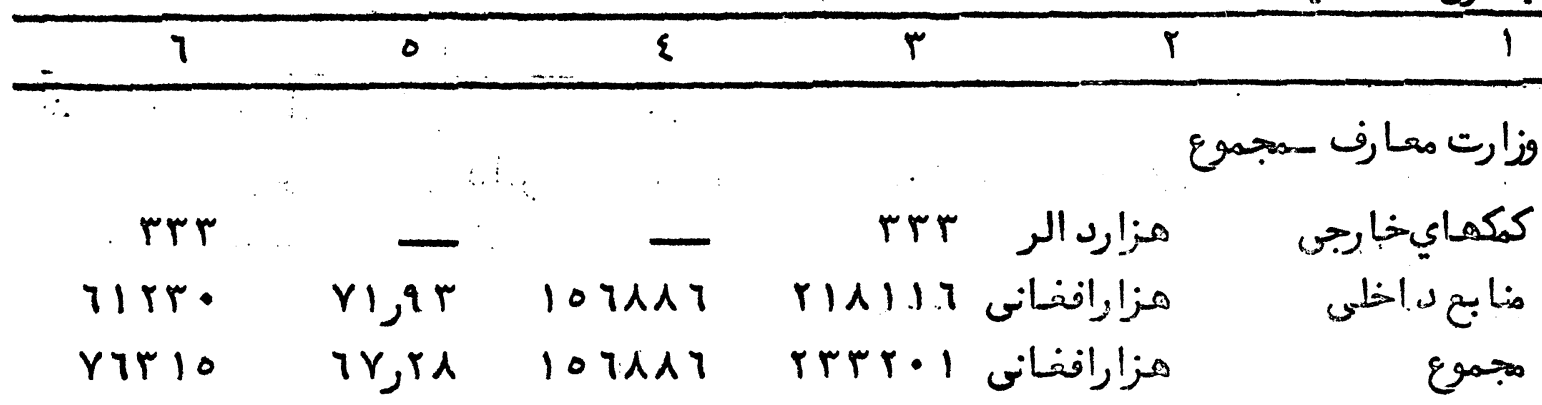

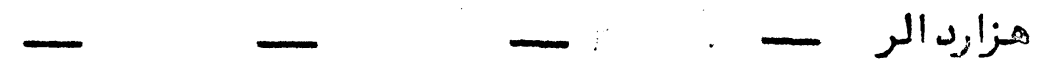

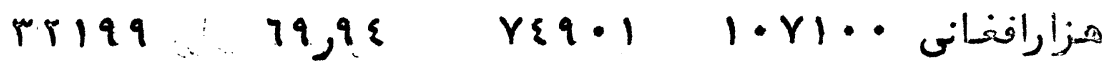

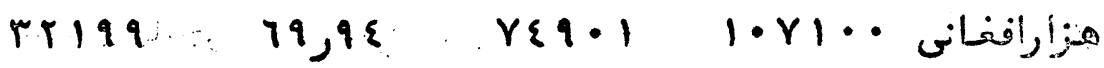

rrr

$r q \div r$

₹ะ|ा

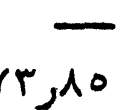

$10, \cdot r$
19190

ᄉ 191

1

०q Yor

TETAY $\begin{array}{ll}7 q r i & 19,71 \\ 7 q r 1 & q \cdot, r r\end{array}$

\section{9ri \\ 79 r.

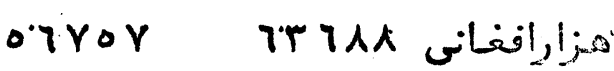

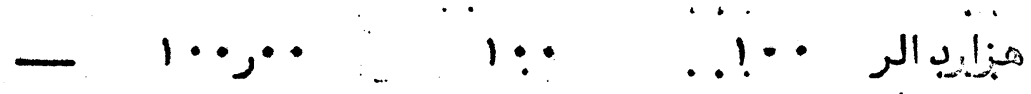

$$
\begin{aligned}
& \text { - }
\end{aligned}
$$

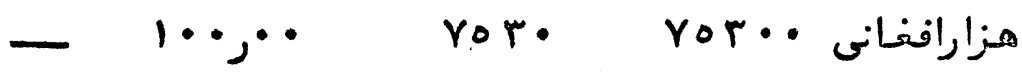

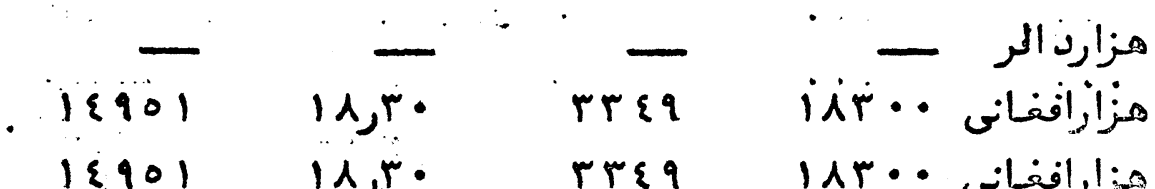 هilisq




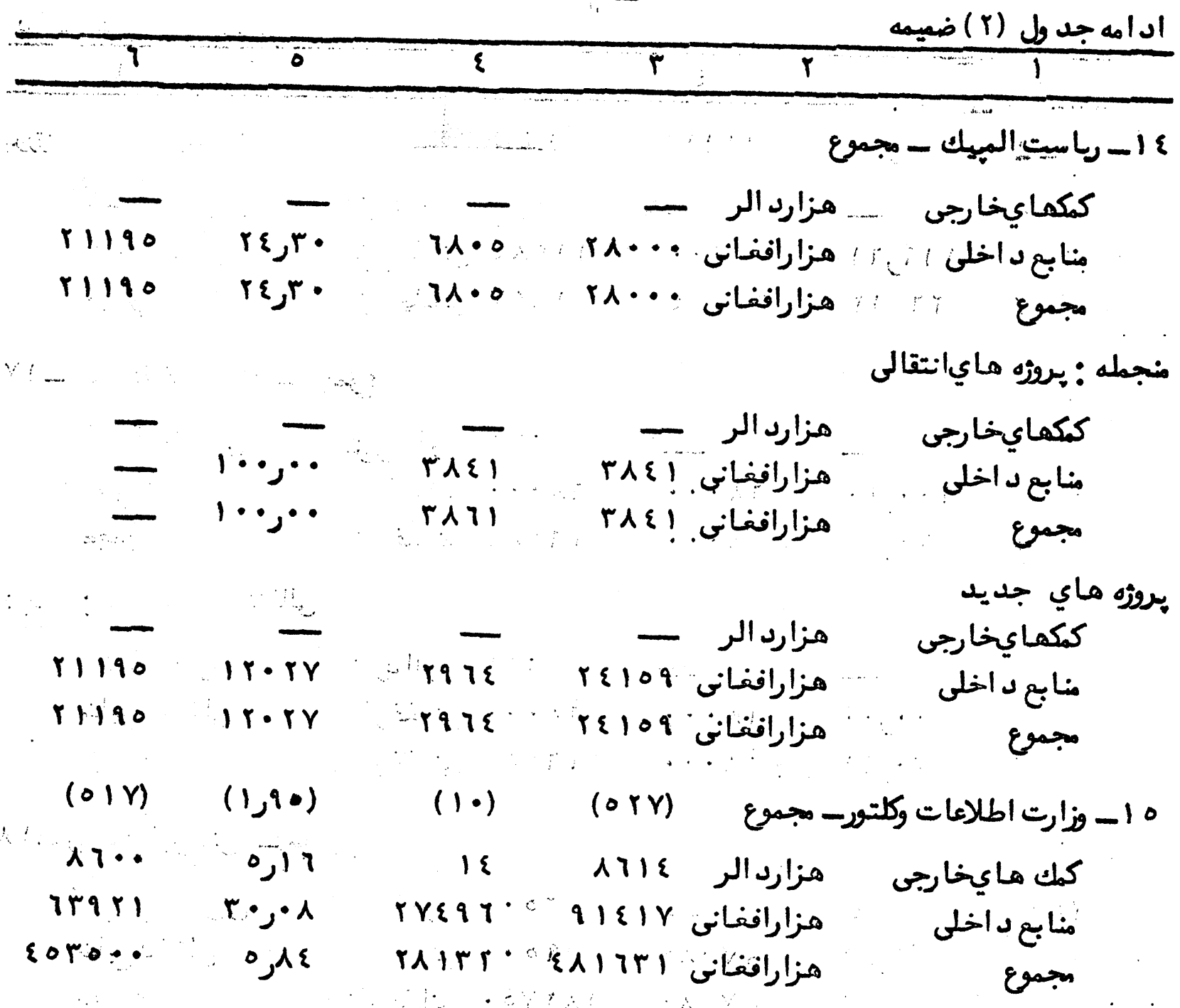

منجمله : يروزه مايانتقالى

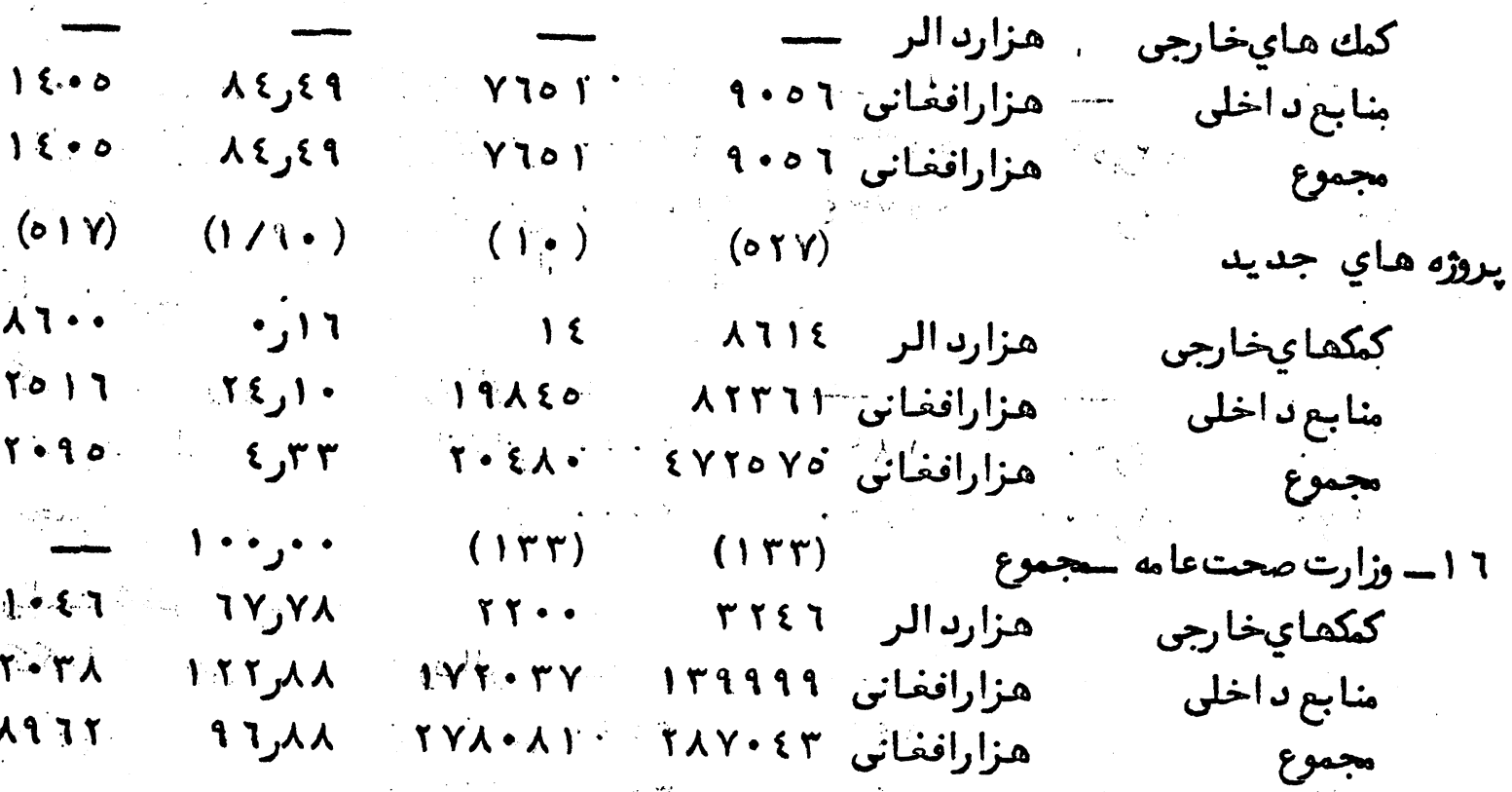

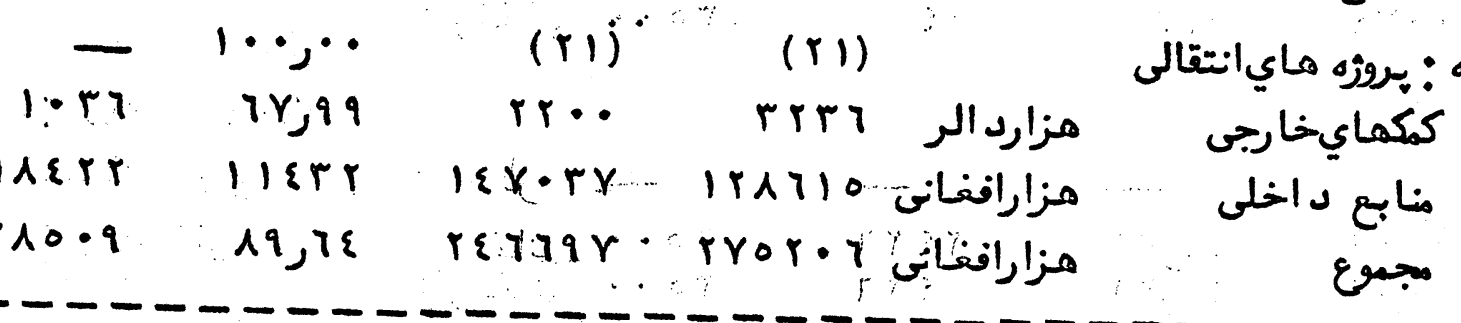




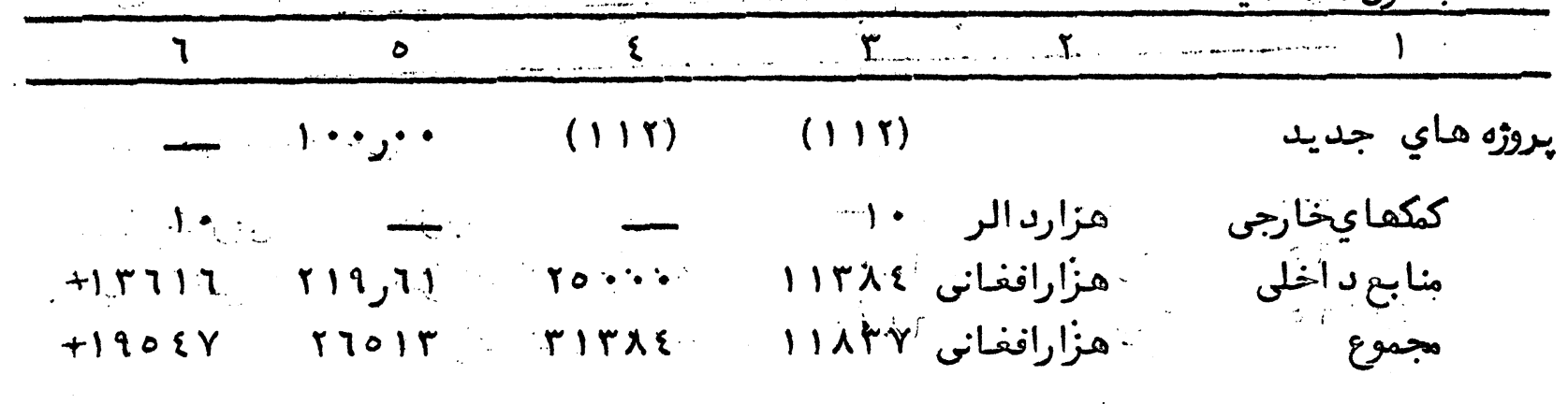

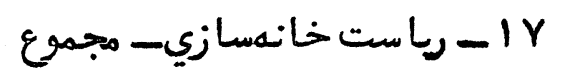

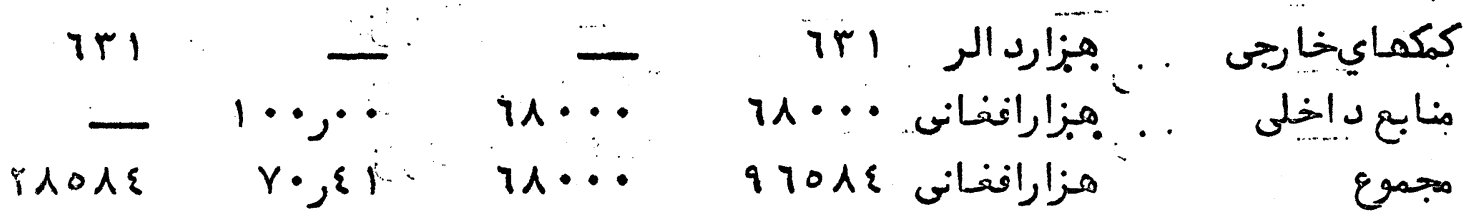
منجمله : بروره هيا ي انتقالى كمكمايخارجى

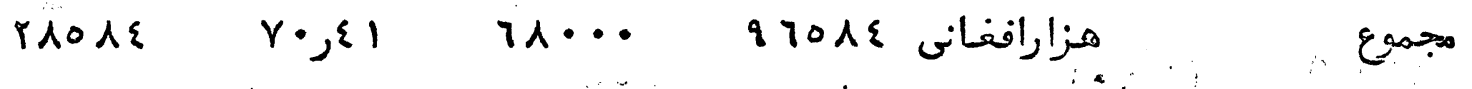

$$
\text { 11 }
$$

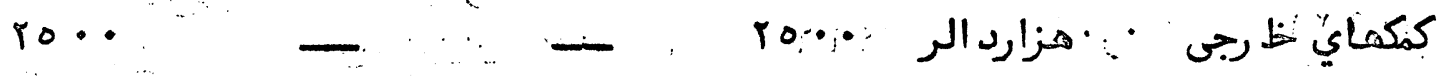

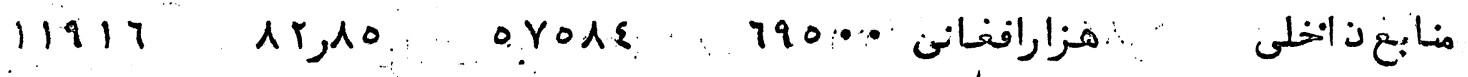

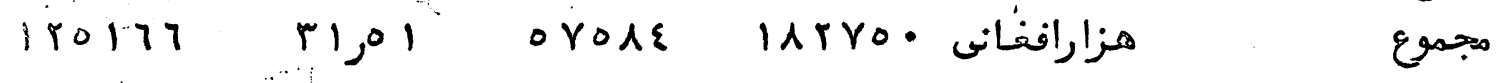

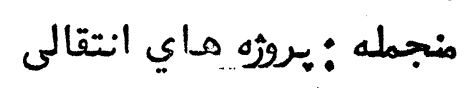

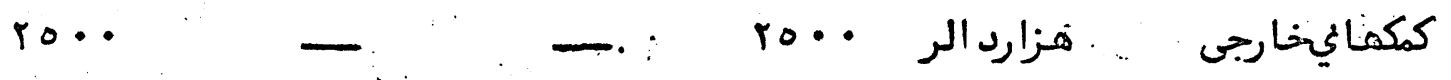

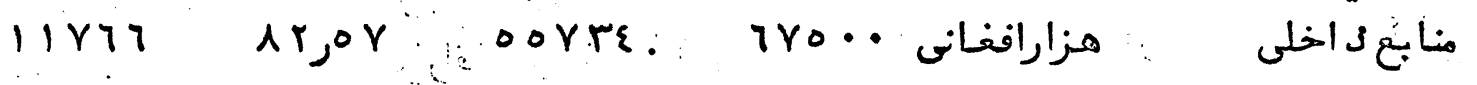
مجموع: يروزه هاي جمل يد

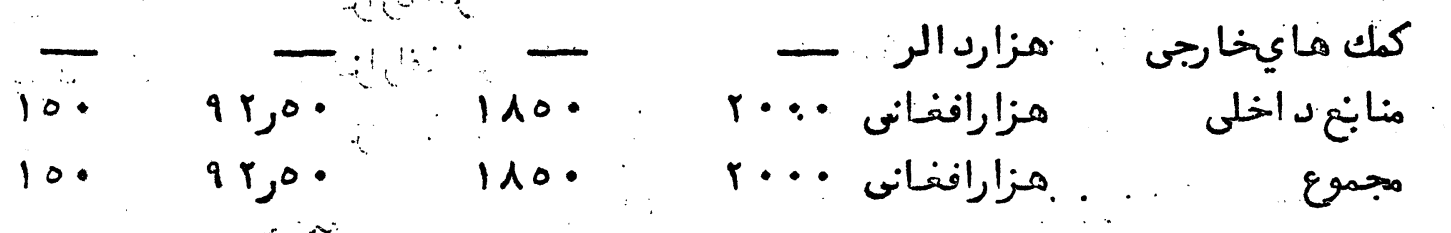

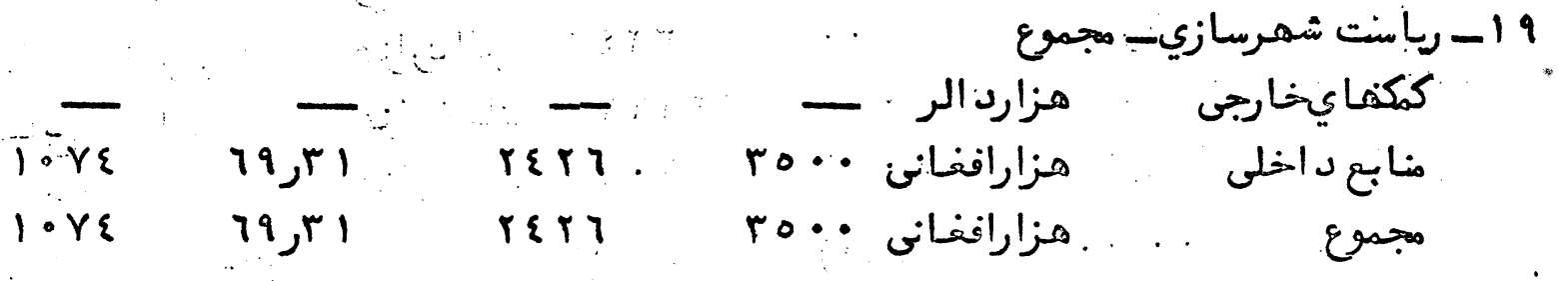

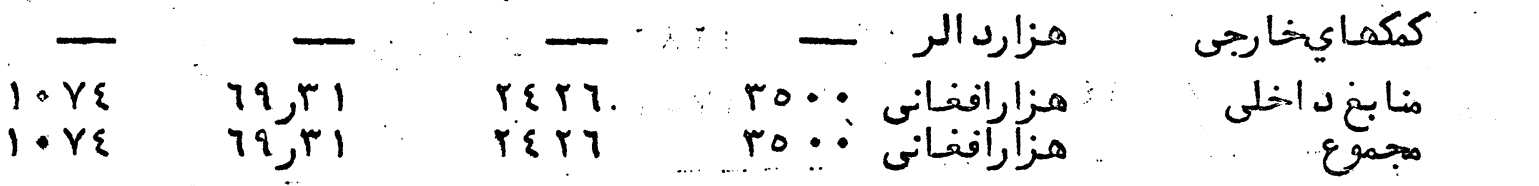




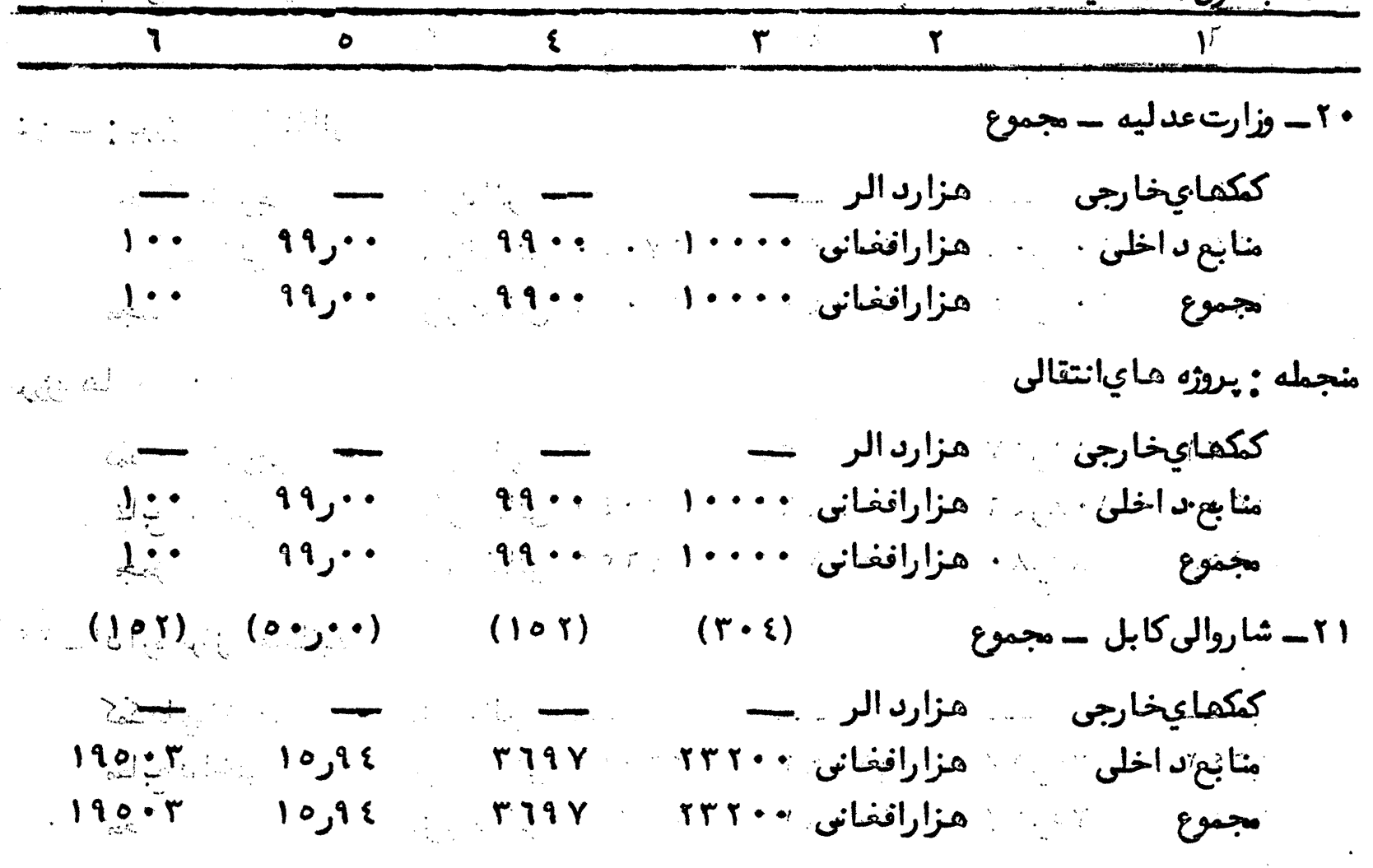

منجمله: بروزه هايانتقالى

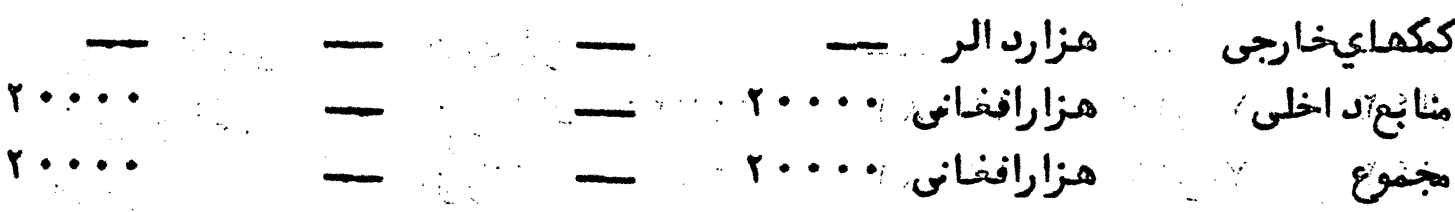
بروثة ماي جديد

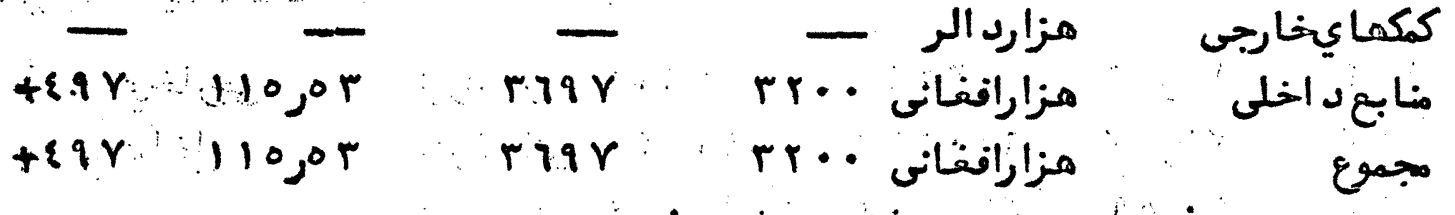

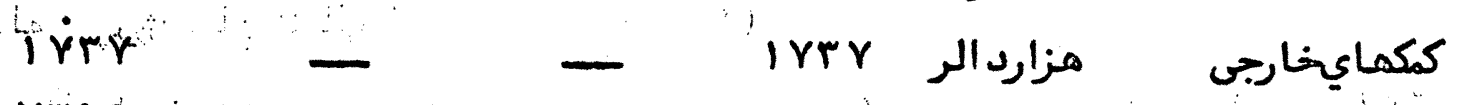

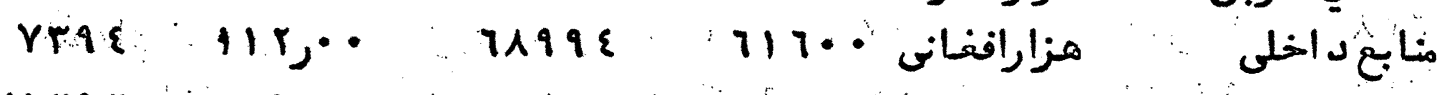

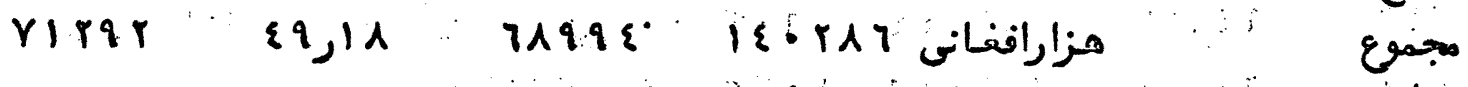

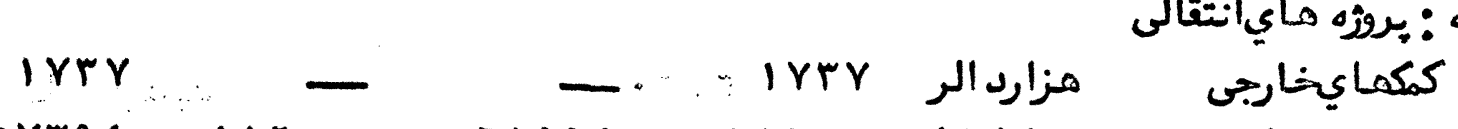

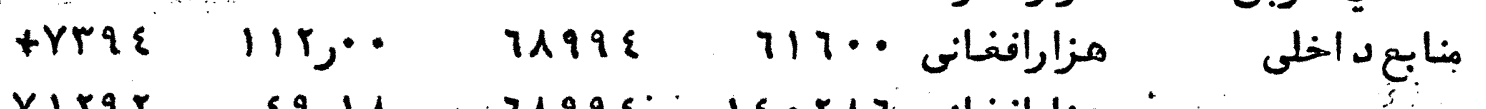

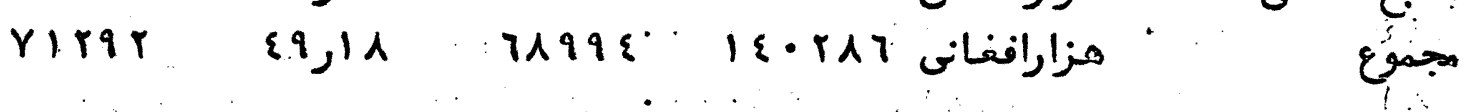

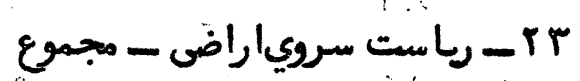

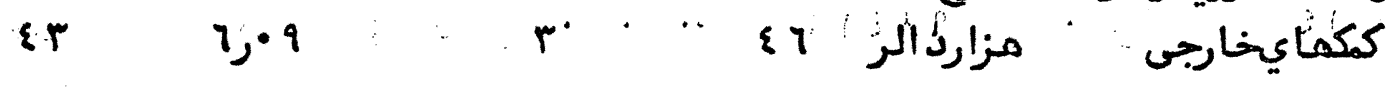
منابعداظي

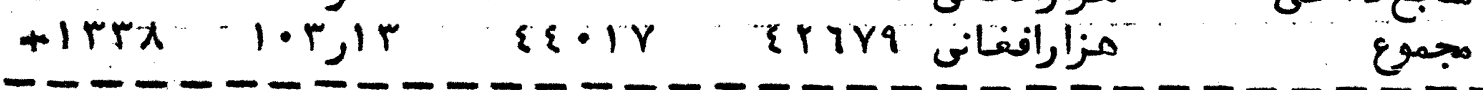


اد اهه جد ول (r) (r) ضميمه

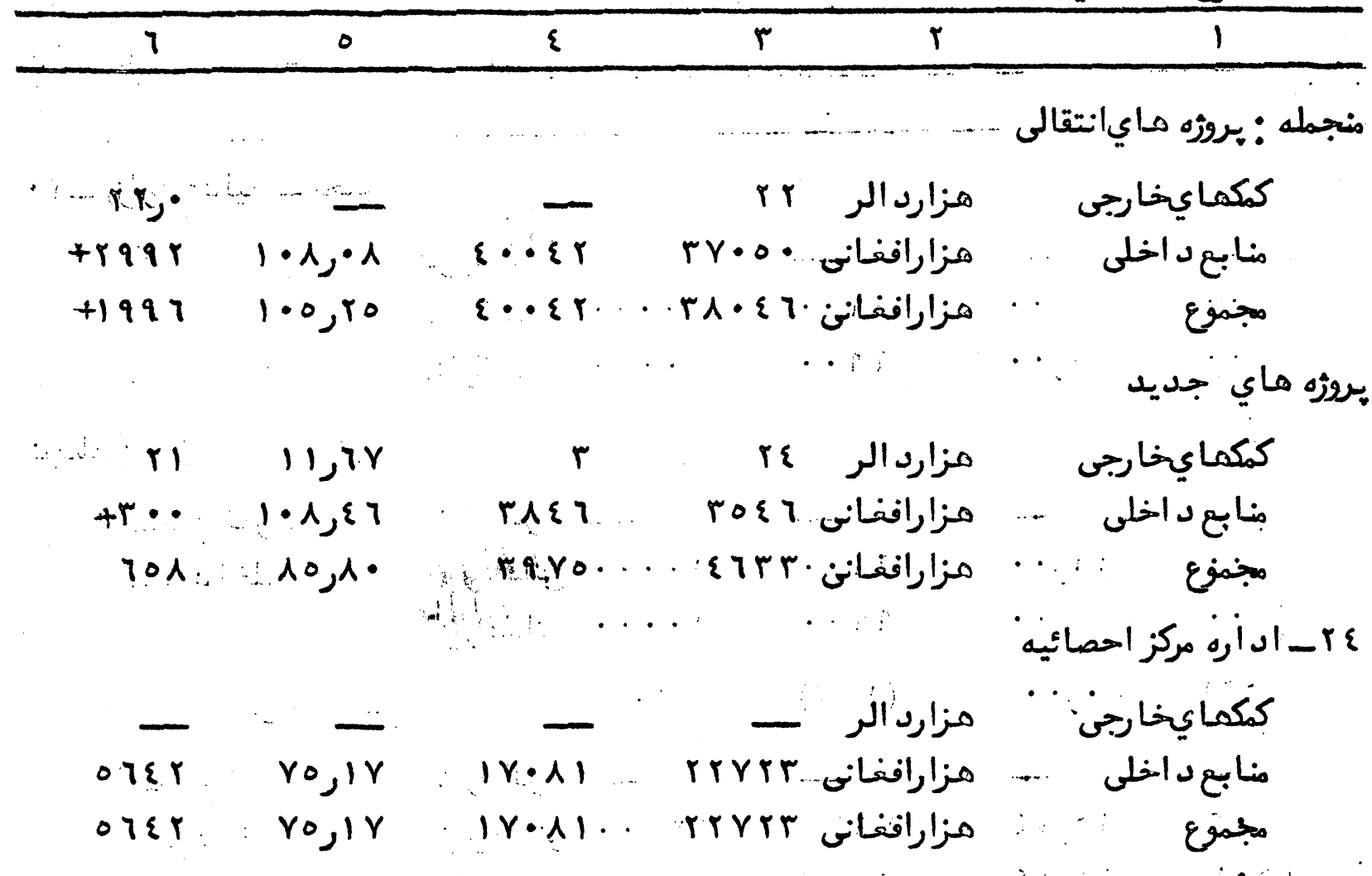

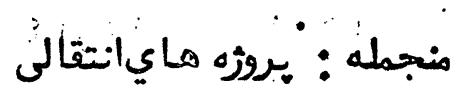

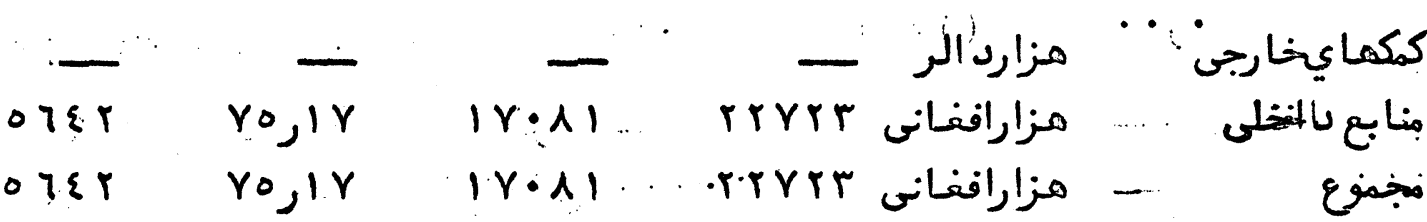

( Trro

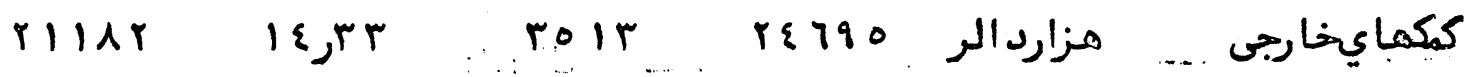

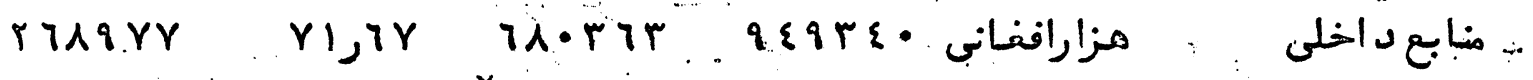

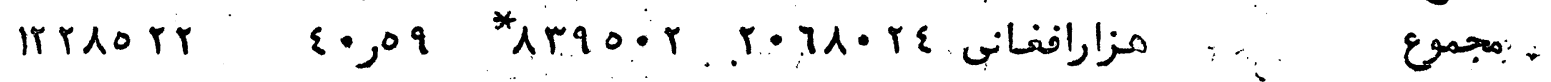

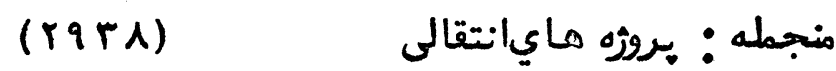

كمكايخارجى . rror roq0. 909 .

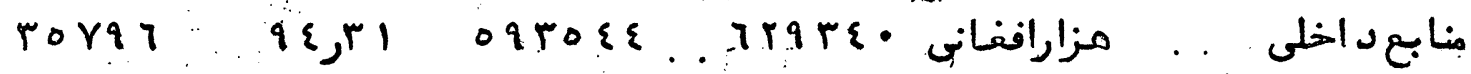

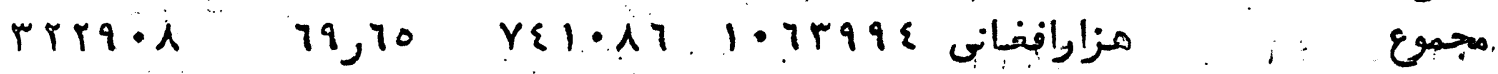

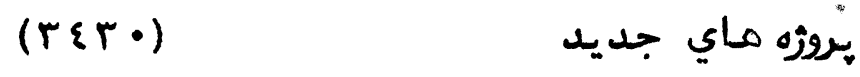

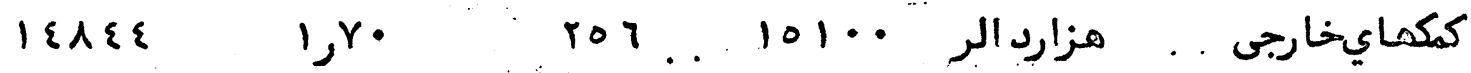

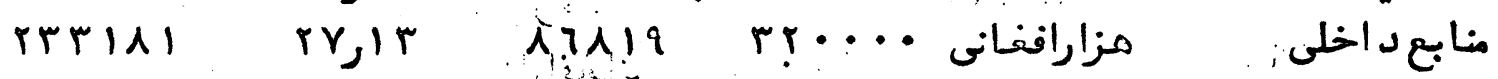
مجموع 
اد مم جد ول (T) ضميهه

7

is.

$7 r 7$

rINTr

$r \cdot 0 \leqslant \varepsilon r$

\&ค १

\&०Y

PrI. AN
1,01

A T, rV

ri, 79

rIT

trroor

Y\&r०q

$$
r, r q
$$

$\circ 7,0 \mathrm{r}$

$r 1,77$

\section{$\varepsilon$}

$r$

7 - סزارت مخابرات - مجموع

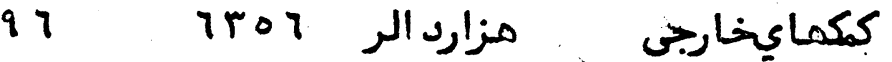

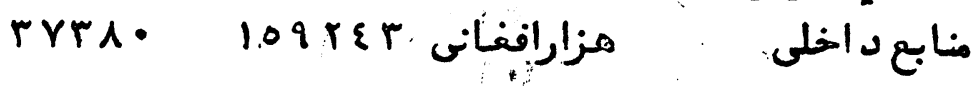

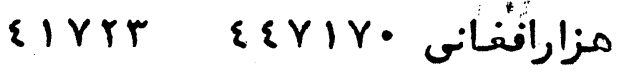

منجمله : يروزه مايانتقالى

كمك مايخارجى هزارد الر و

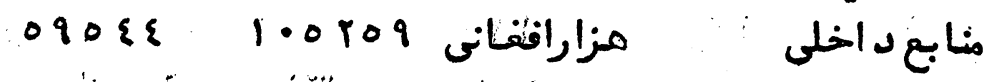

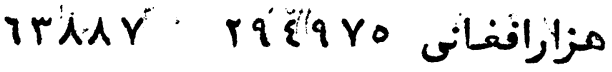

هنموع

بروثه ماي جديد

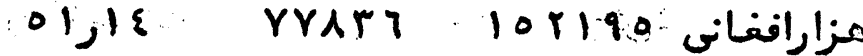

كمكايخ نمارجى

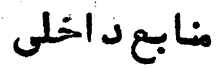

مجموع

r

STr

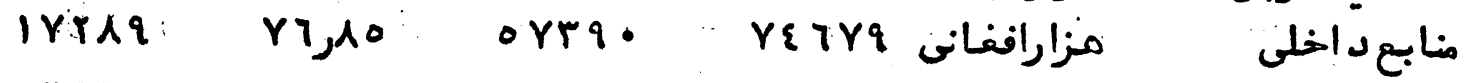

هـr

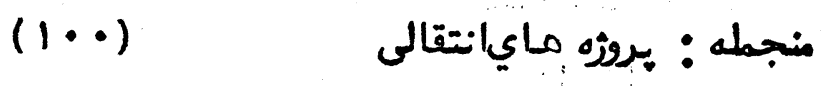

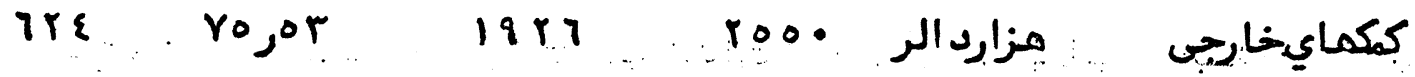

م

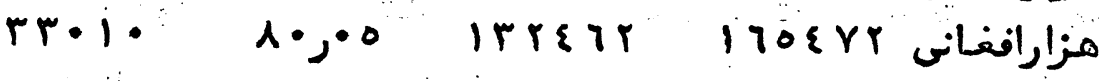

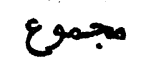

$$
(\varepsilon \cdots)
$$

بروئه ماي جديد

lor

$\wedge, \varepsilon$

$1 \varepsilon$

هزارد الر 77

كمكايخارجى

I rO\&

$\varepsilon q, r o$

IYIYT

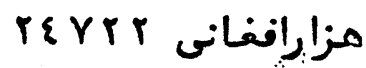

19 \&० $\mathrm{r}$

rq, $r$

irva.

مزارافنانى rrrer

$$
\text { منابع د اخلى كيماي }
$$

مجموع

$$
\begin{aligned}
& \text { مجموع سرمايكذ اري) بلد ون } \\
& \text { زارت دنا عملى وأمورد اخله) }
\end{aligned}
$$

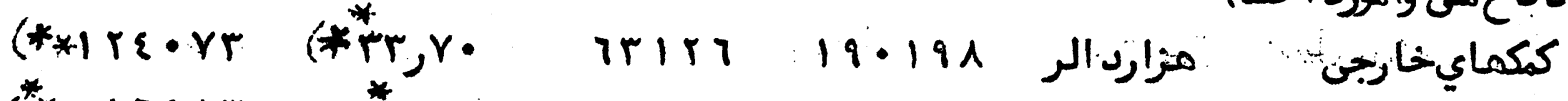

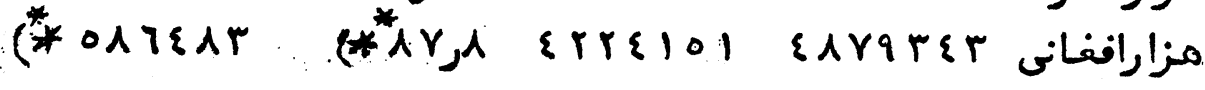

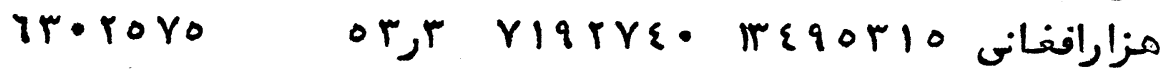
منابع د اخلئ. هجموع 
اد امه جد ول (Y) (T) إضميمه

\begin{tabular}{llllll}
\hline & 0 & $r$ & $r$ & 1
\end{tabular}

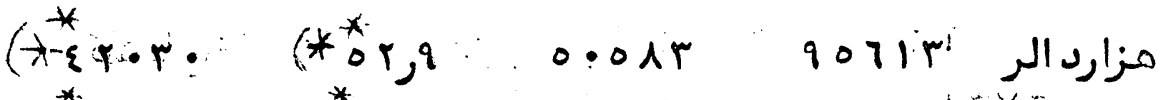
(*0.0.9) (*.人)

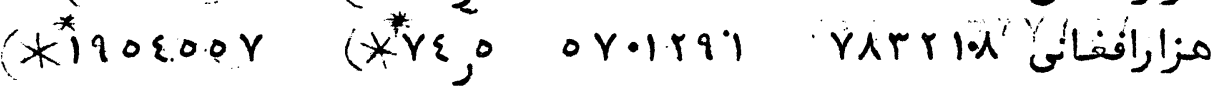
منجمله : مروزه هايانتقالى كمكمايخارجى

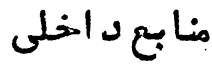
مجموع من يروزه ماي جديد كمكايخارجى " : من : * * *

مجنموع

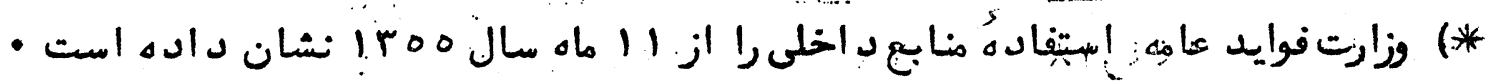

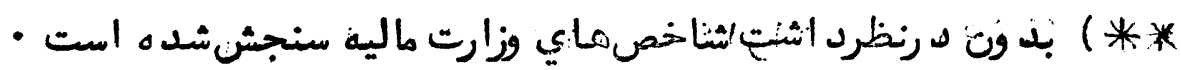

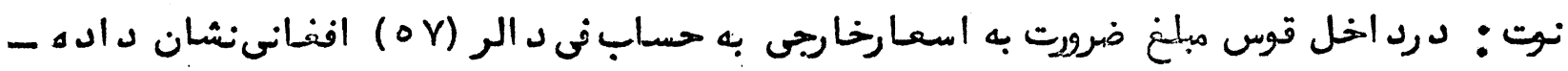

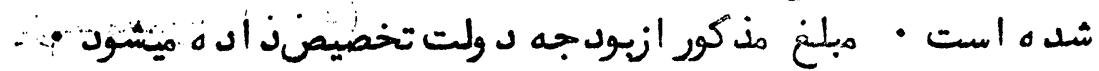

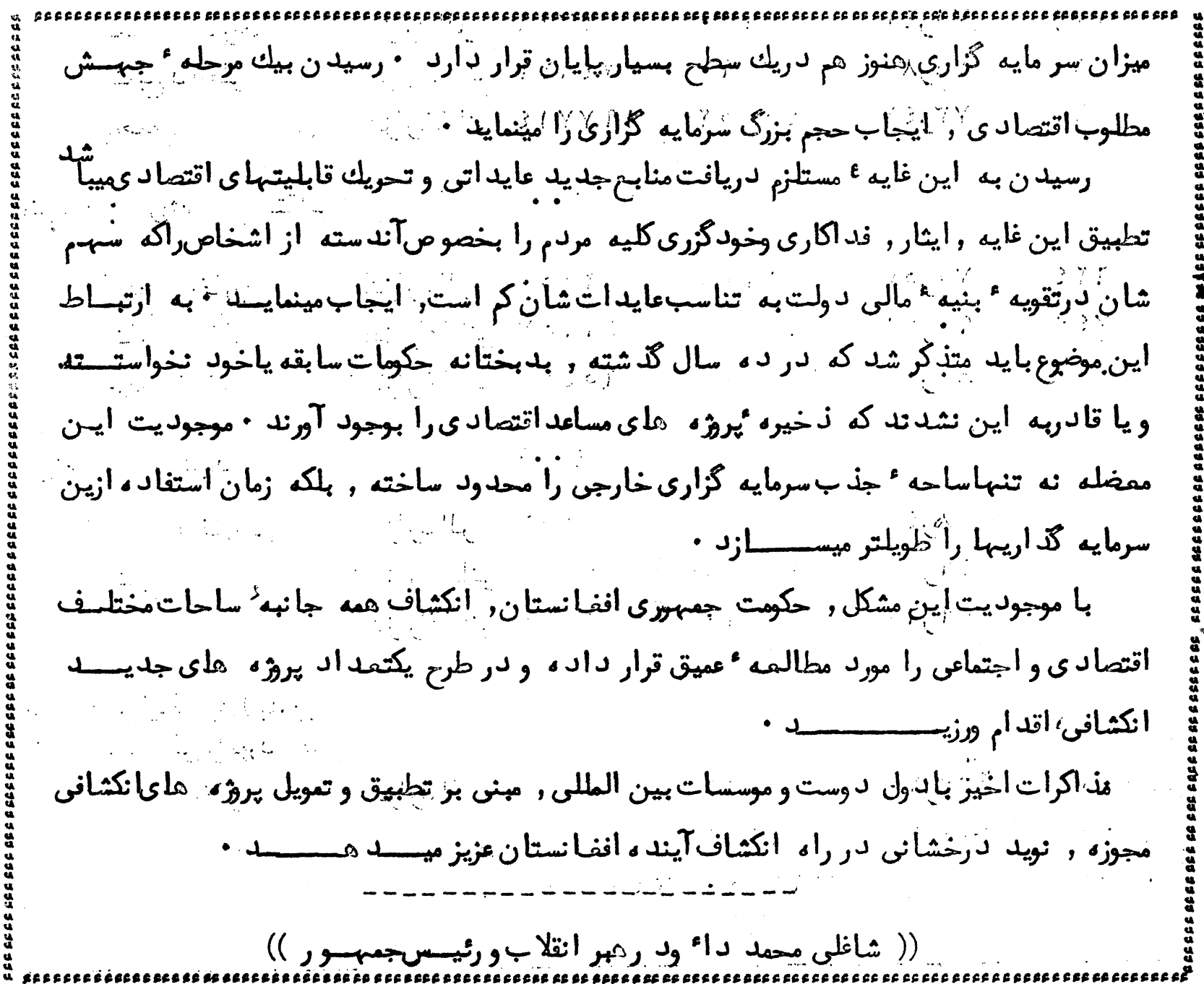




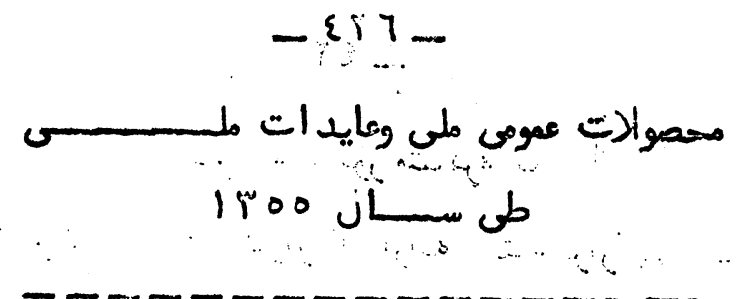

Iニニニニニニニニニッニーニーニー

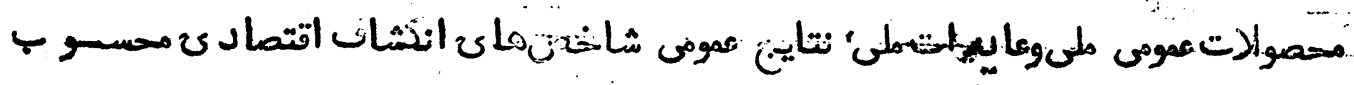

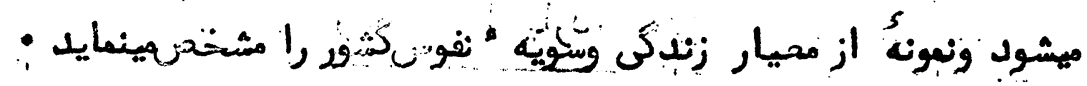

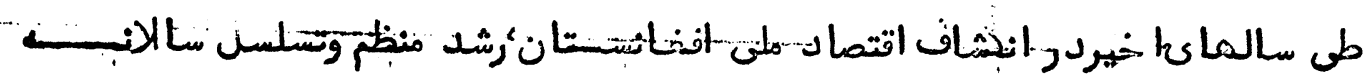

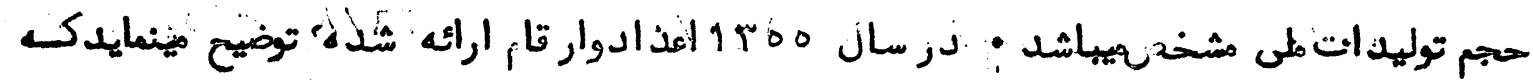

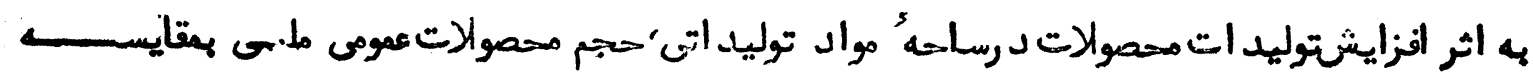

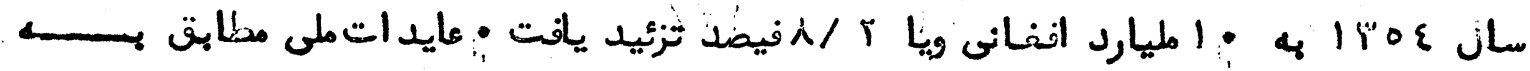

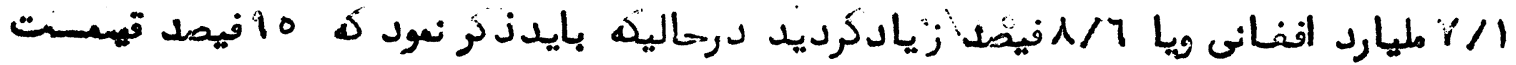

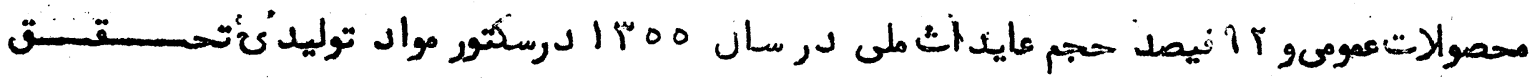

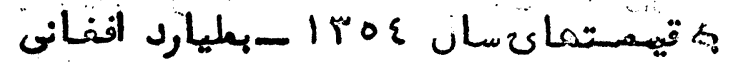
هذيرفته

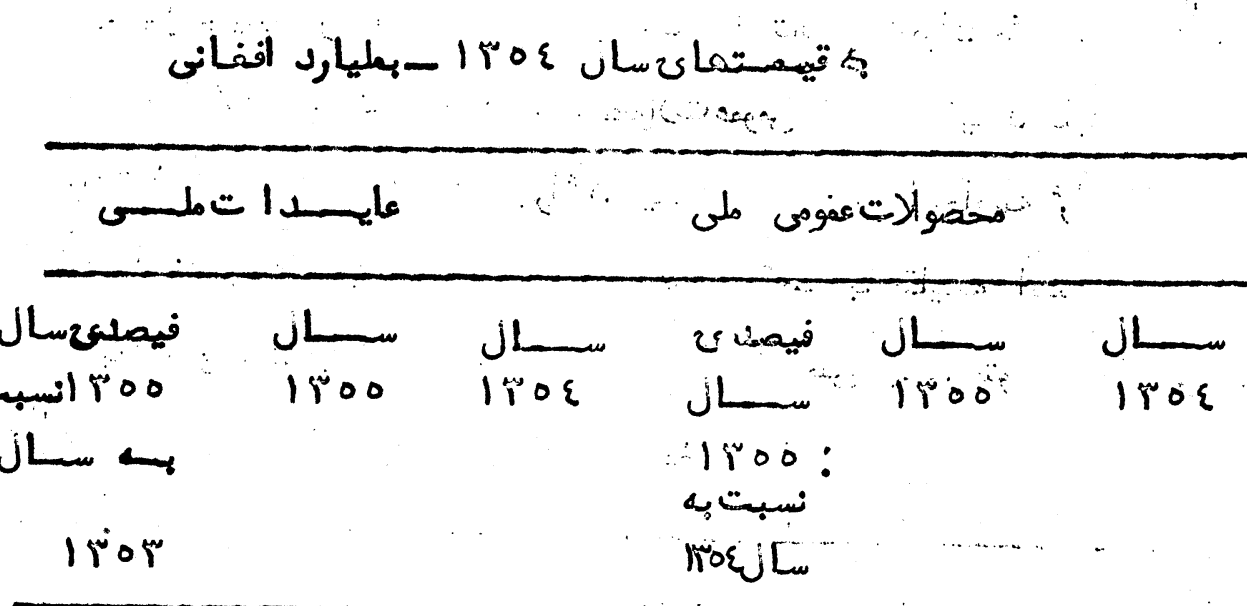

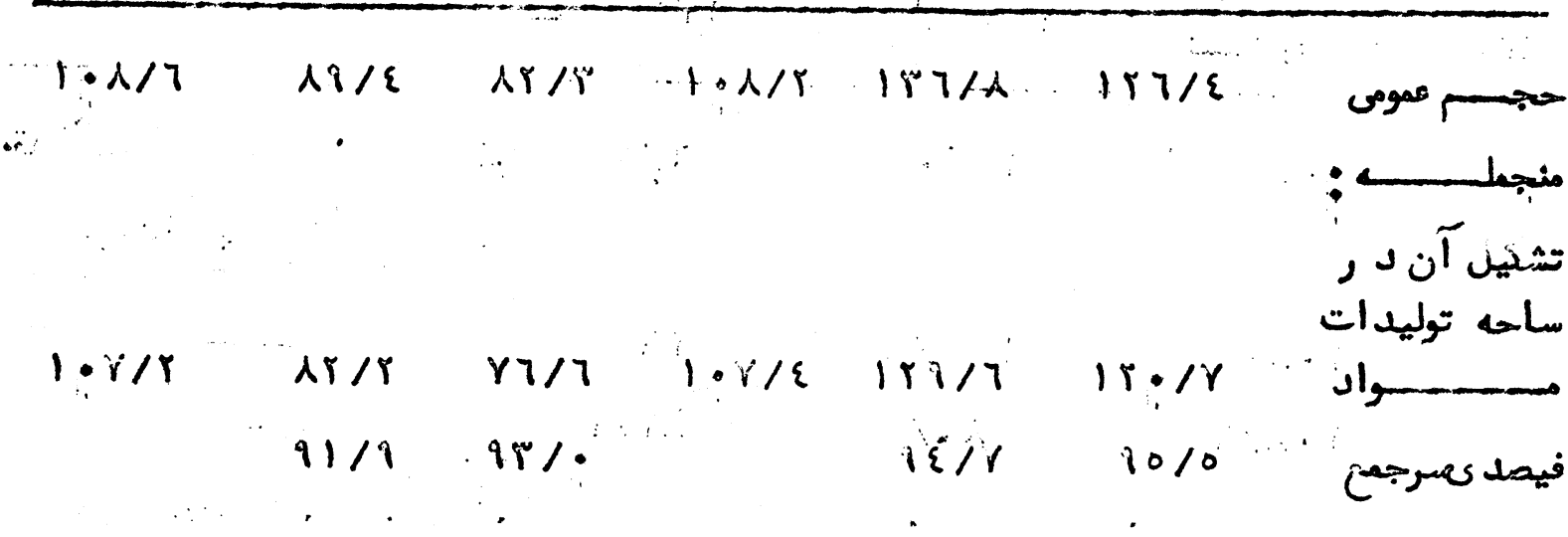

طوريكه مـ ملوم ابستصنصت -زراعتّوساختمان عمده ترين مواد توليد ح درين ساحه محسسو ب

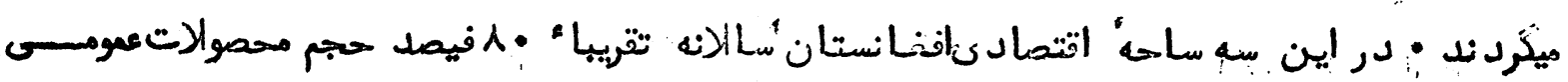

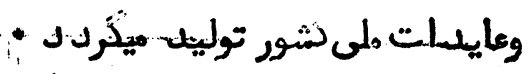




$$
-\varepsilon r Y
$$

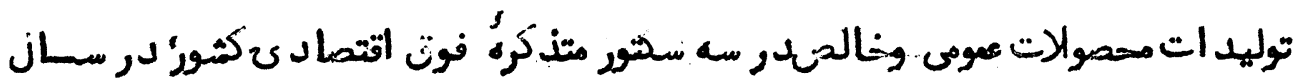

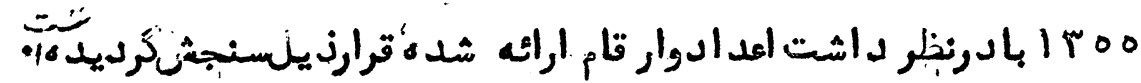

\begin{tabular}{|c|c|}
\hline عايدات ملى & محدوالات عمومى ملسى \\
\hline
\end{tabular}

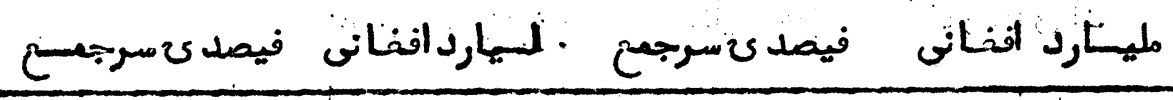

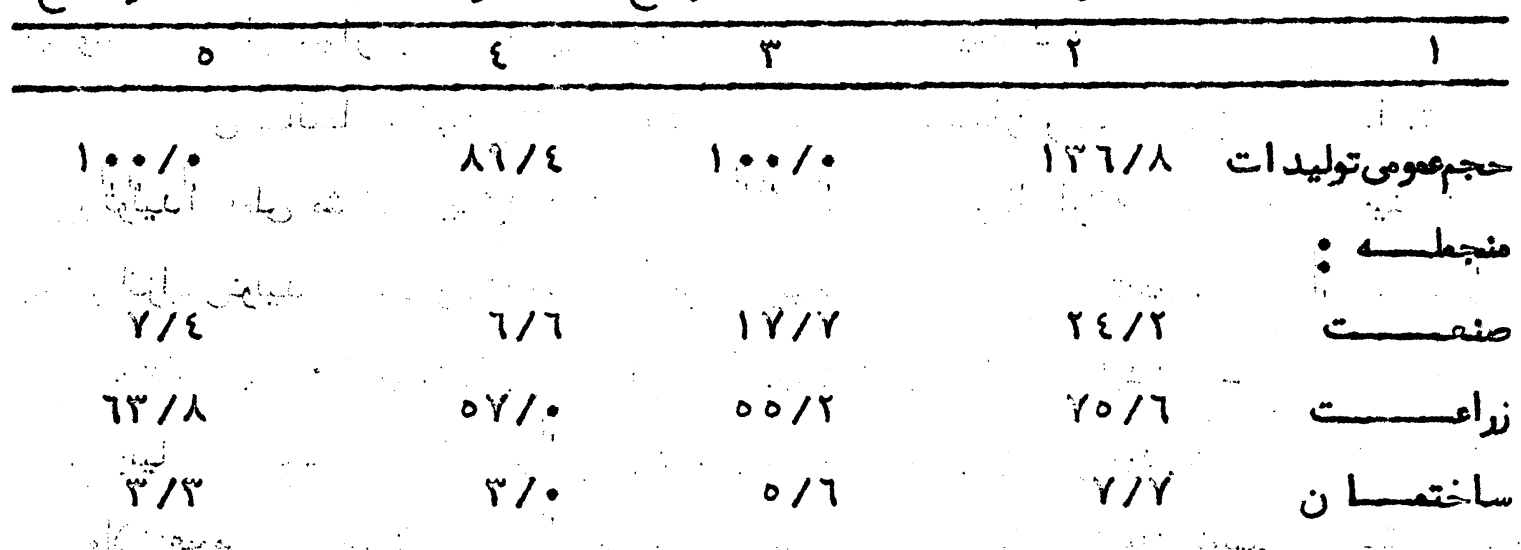

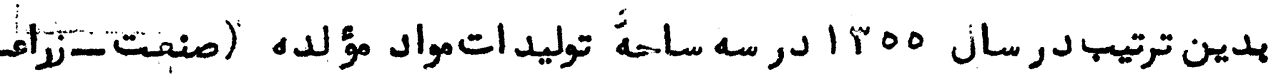

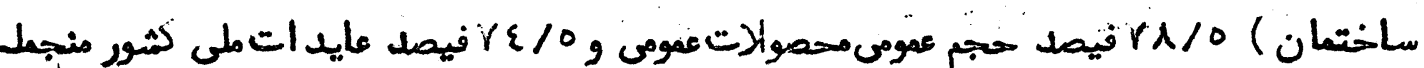

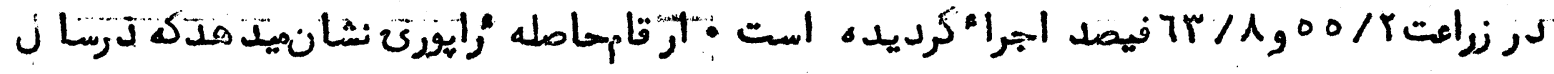

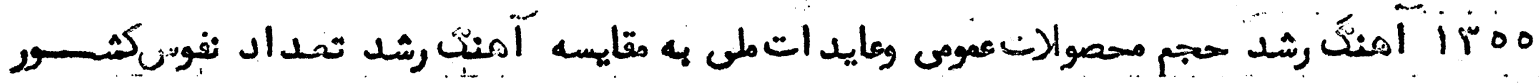

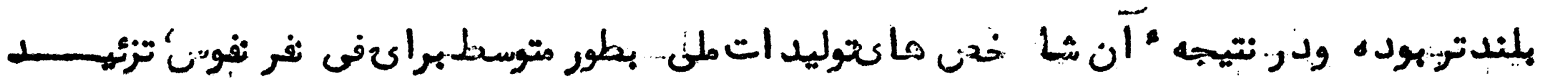

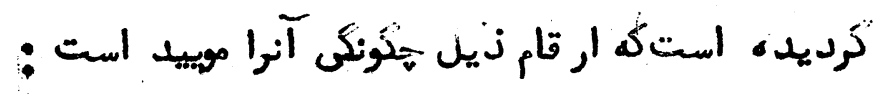
فيصل

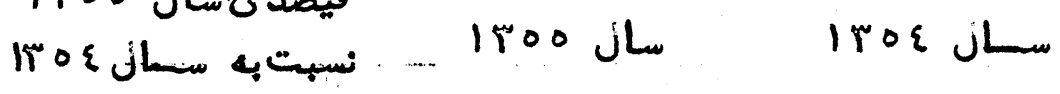

$1 \cdot T / N$

18100

|

$19 / \varepsilon$

$1 \cdot 1 / 7$

ᄉ.T

or \&

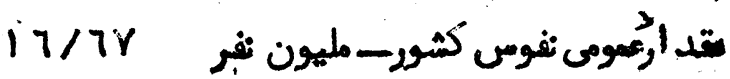
حجم توليدات به مليارد افذانسى

$1 r 7 / \varepsilon$

Ar/r

بطورمتوسط هراكنى نفرنفوسنافئن

$\supset \wedge \varepsilon$

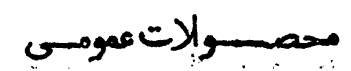

\& عايدات مل

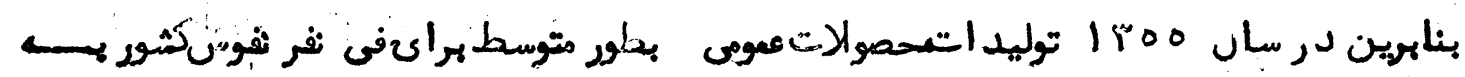

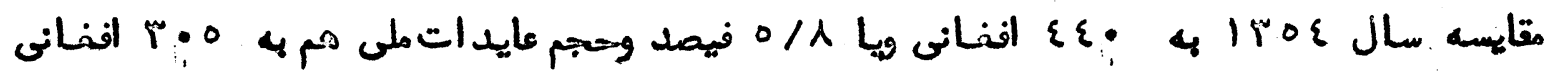




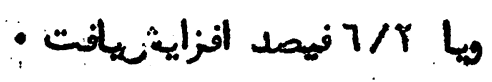

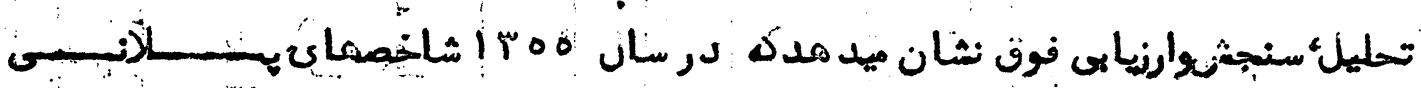

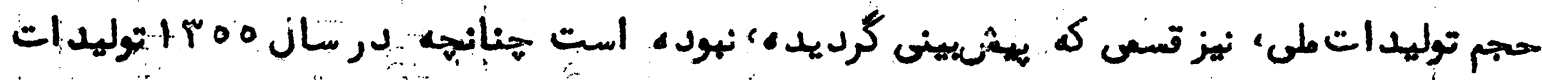

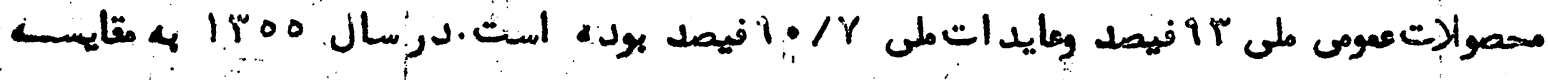

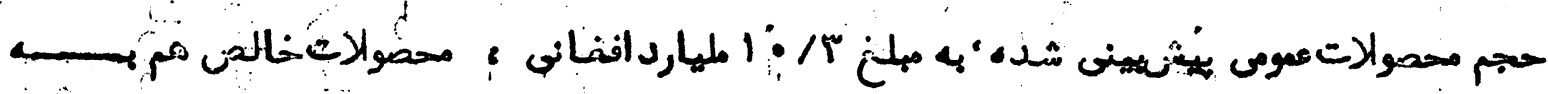

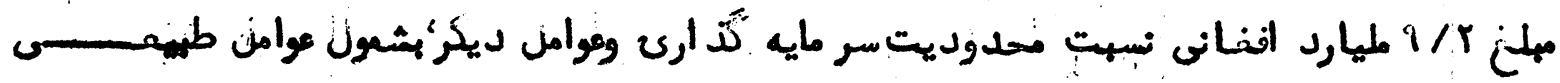

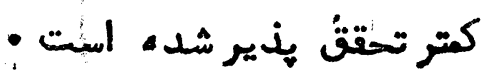

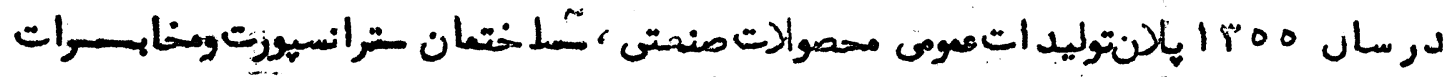

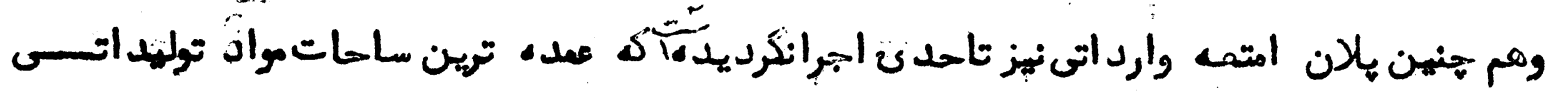

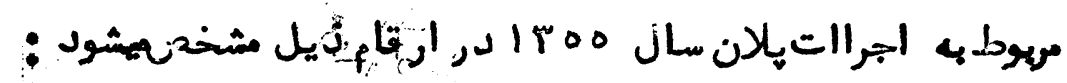

\begin{tabular}{|c|c|c|c|c|c|c|}
\hline 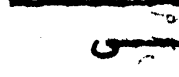 & عائليرات ملري & $\dot{r}$ & $\therefore c$ & يجمومى ملنَبر & مهم & \\
\hline فيصسل نيلان & اجسرالت & 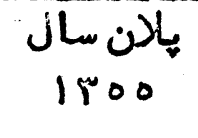 & فيسـلاند & اجرا|| & يالن سال & \\
\hline $1: 18$ & $11 / 8$ & $\therefore 9 / 7$ & $110 /$ & $\because 1 \Gamma 7 / \lambda$ & $\mid \varepsilon \gamma / 1$ & \\
\hline $89 / 8$ & 1rpr & $\approx \lambda I / \varepsilon$ & $11 \%$ & $151 / 7$ & $15: / 9$ & L \\
\hline $97 / 1$ & $7 / 01$ & $\because 7 / 10$ & $17 \%$ & $r \varepsilon \neq r \mid$ & ro/rr & 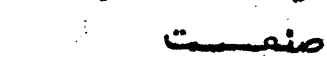 \\
\hline $1 \because / 8$ & $\circ \gamma / \bullet \varepsilon$ & $07 / 7 \varepsilon$ & $1 \cdot \because / r$ & Yo/Or & $\gamma \circ / \cdot \varepsilon$ & زراعه \\
\hline $9 \cdot 10$ & $1 / 17$ & $r / r 1$ & $9 \cdot 1$ & $8 / 70$ & $1 / 0:$ & ساختعـان \\
\hline $9 १ / 1$ & $r / Y 0$ & $\because \sim / T Y$ & $90 \%$ & $\varepsilon / . \tau$. & $\varepsilon / 1:$ & رتومخابرات \\
\hline
\end{tabular}

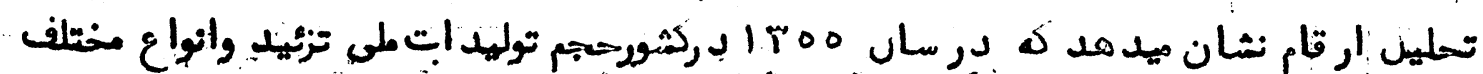

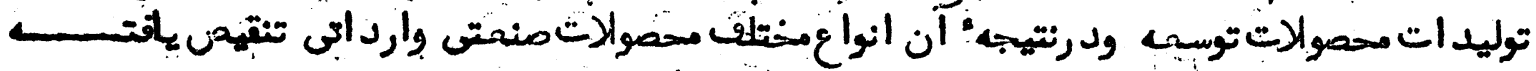

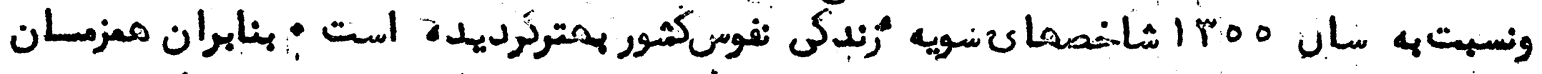

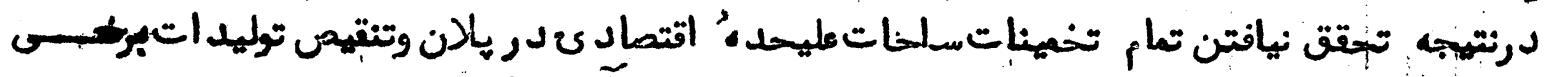

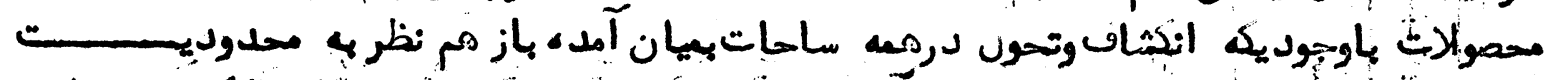

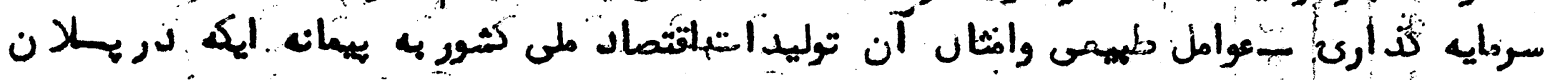

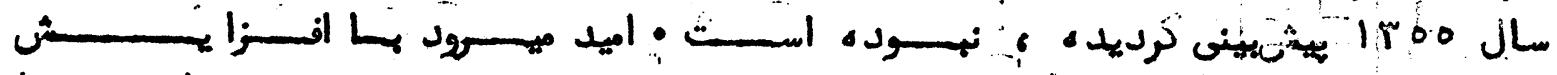

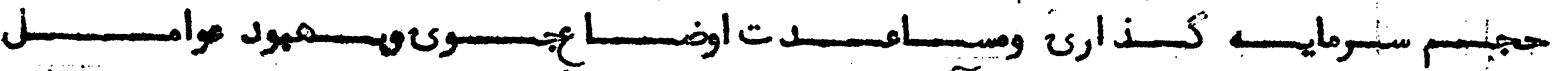

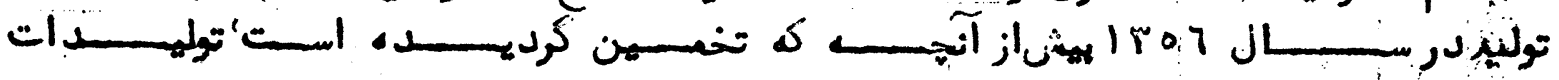

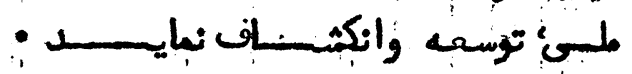




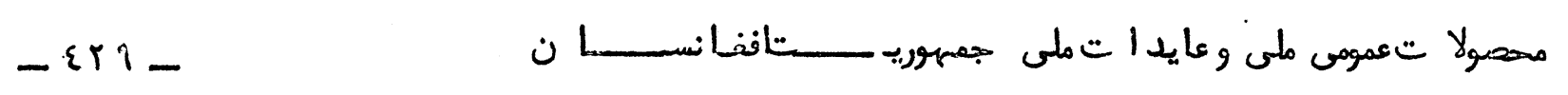

\begin{tabular}{|c|c|c|c|c|c|c|c|}
\hline فيصدى سرجــــــــــ & \multicolumn{3}{|c|}{ أفيصد سي سا ل 1.00 نسبت به سال } & \multicolumn{2}{|c|}{ 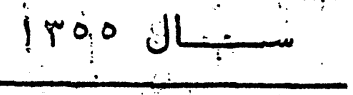 } & \multirow{2}{*}{\multicolumn{2}{|c|}{ سعـــــال }} \\
\hline مبن & Jris? & " & سL & هـقي & طبـ & & \\
\hline$\Lambda$ & $1 \cdot \gamma$ & 7 & $\circ$ & $\varepsilon$ & $r$ & $r$ & 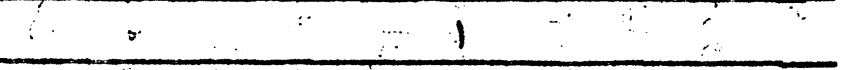 \\
\hline$\vdots$ & $\therefore$ & & & & & & 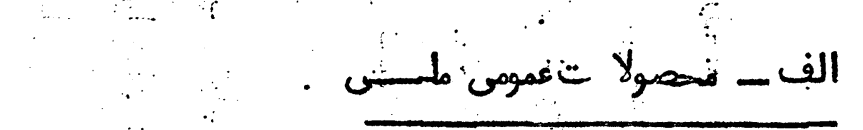 \\
\hline $1 \cdots$ & 90,0 & 95 & $\begin{array}{l}1 \cdot A, Y \\
\cdots \\
1 \cdot v, \varepsilon\end{array}$ & $\begin{array}{l}1 r 7 \mu 1 \\
1 \times 9,0 y\end{array}$ & $\left|\begin{array}{l}|\varepsilon \gamma,| r \\
|r \cdot j| \varepsilon \mid\end{array}\right|$ & $\begin{array}{l}\mid r T, \varepsilon r \\
i r \cdot, r\end{array}$ & 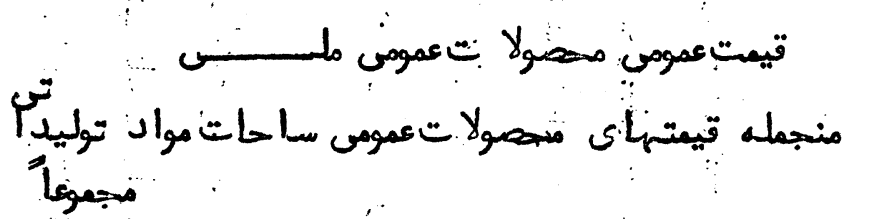 \\
\hline$I Y, Y$ & 10,9 & $9 \%$ & r.l, & $x \in$ & rojr & rrig. & 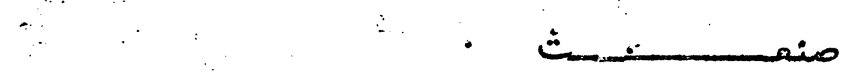 \\
\hline $00, r$ & $.0 \%$ & $1 \cdots, r$ & $1.0 \lambda$ & yo,op & Yo, $\varepsilon$ & $\gamma 1, \varepsilon \varepsilon$ & 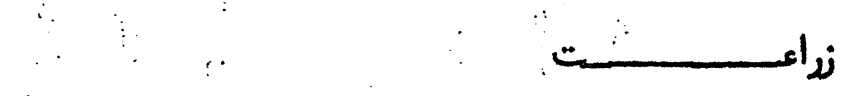 \\
\hline$r$ & $8, q$ & $=99$ & $11 \cdot 9$ & \& & $\varepsilon, 1 \cdot$ & ז & ترانسنـــــــور تـو منابــــرا ت \\
\hline 0,7 & $\varepsilon$ & $\therefore 9 \cdot 9$ & $1 \varepsilon \cdot 5$ & $Y, 70$ & 1;: & $0, \varepsilon \varepsilon$ & 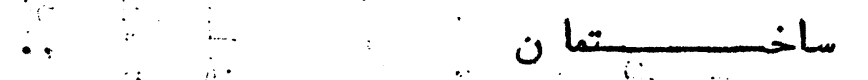 \\
\hline 118 & $\therefore 110^{0}$ & $1 \cdots$ & 111 & 17,19 & 17,9 & $\mid \varepsilon, \varepsilon \wedge$ & تهيه مواد الززاتسـب \\
\hline 1 ع & $1 ; \xi$ & 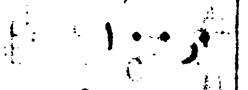 & $1: 7,5$ & 1,19 & 1.19 & $1 ; \gamma 1$ & سايو ساحات مواد توليد اتـــنِ \\
\hline 1,7 & 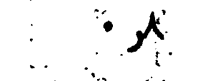 & 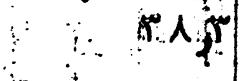 & $\operatorname{irlo}$ & 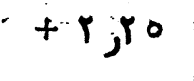 & $+0, \mu$ & $+1, r$ & تفاو تـأدرات و وارد ات طبق امتعهُ تجارتي (+-) \\
\hline$r, y$ & $\left(\begin{array}{c}r \\
\vdots \\
\vdots\end{array}\right.$ & 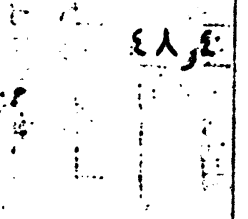 & $1 \cdot 7, \varepsilon$ & $\begin{array}{c}+\varepsilon, 99 \\
\therefore\end{array}$ & $\begin{array}{c}+1 \cdot, \operatorname{ri} \\
\vdots \\
\vdots\end{array}$ & $+\varepsilon, 7$ & 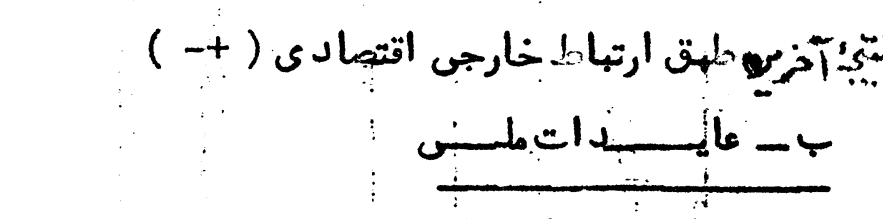 \\
\hline
\end{tabular}




0

$\varepsilon$

$r$

$r$

1

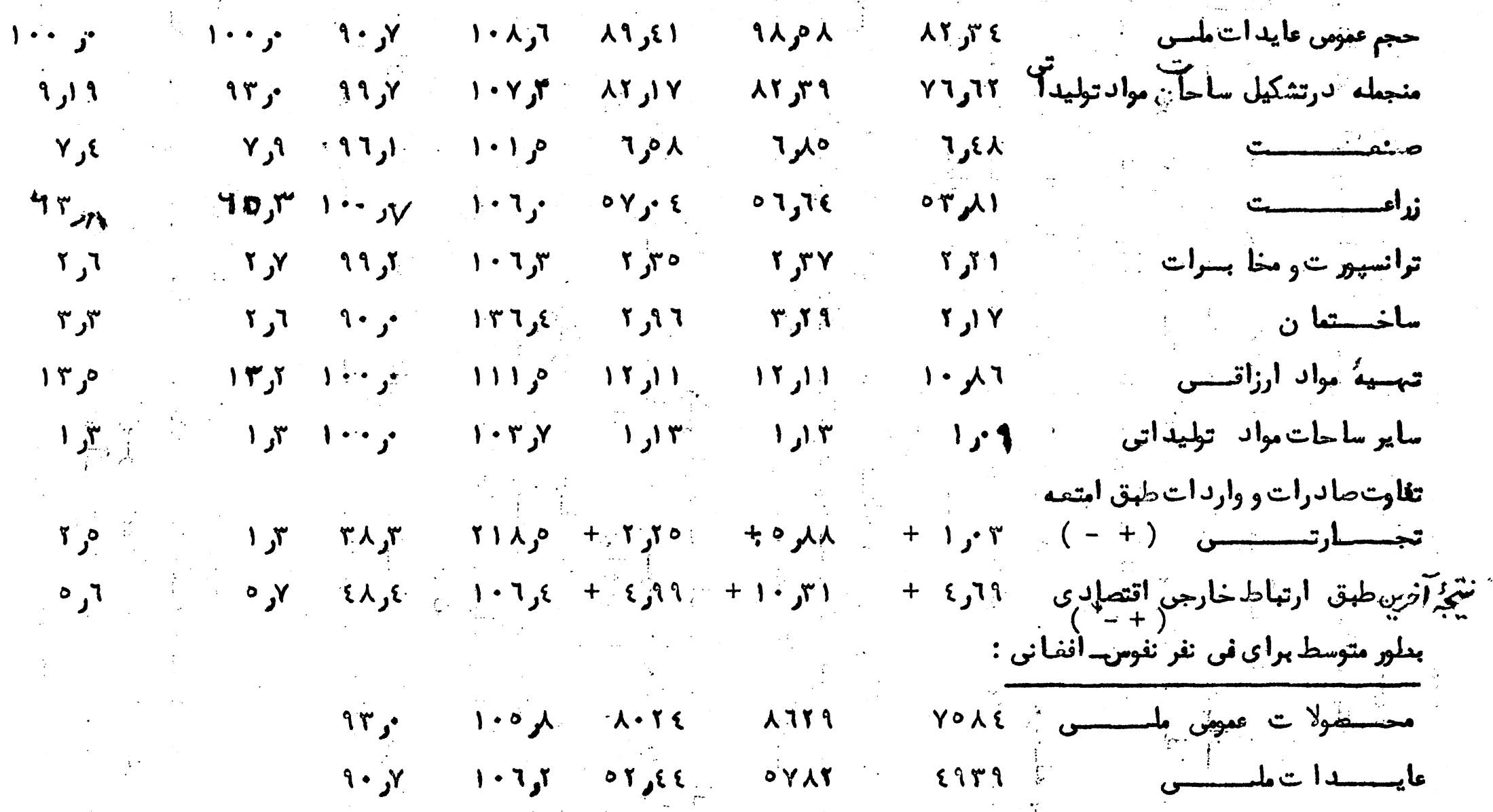




\section{:0ich $v$ |liollicilis

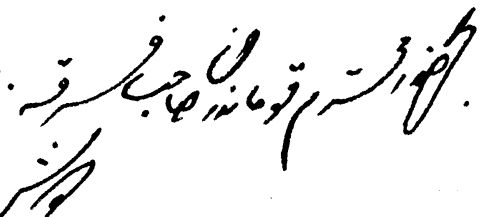

का a 1 (a)

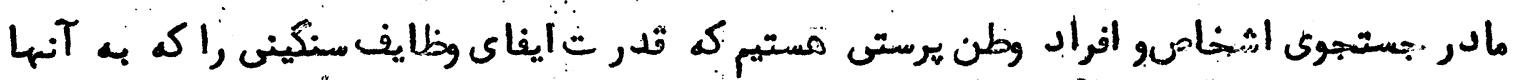

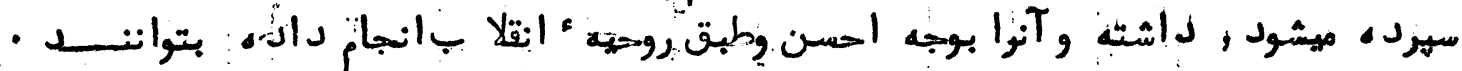
米米米米米类米米米米

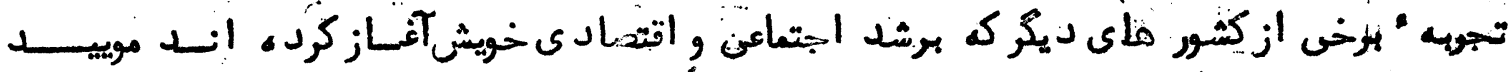

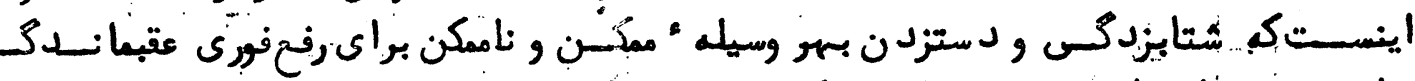

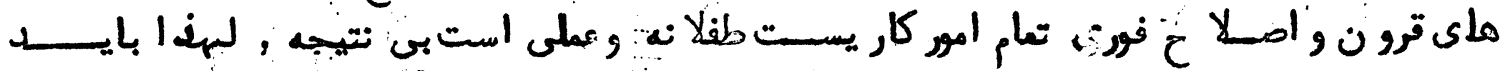

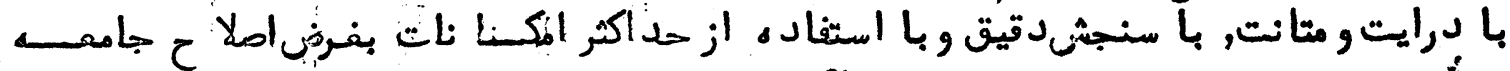

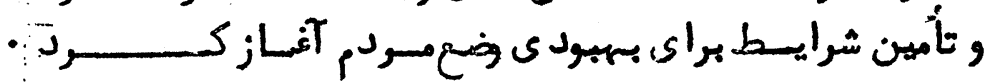

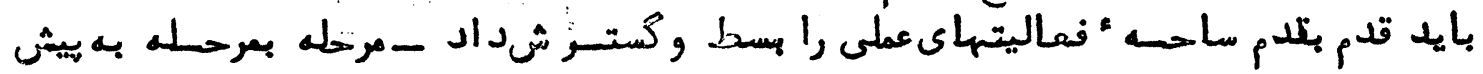

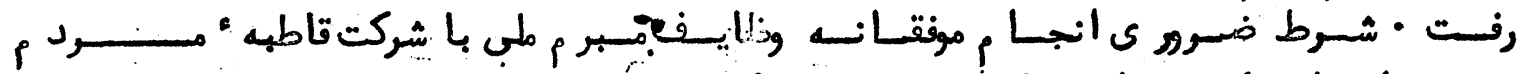

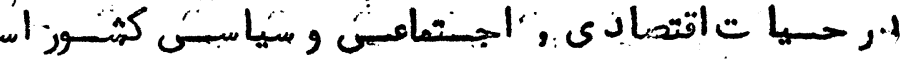
米米米米米米米米米

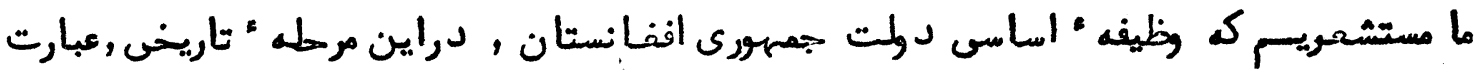

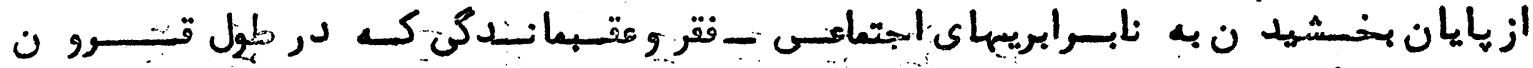

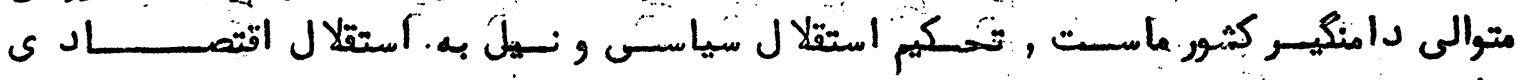

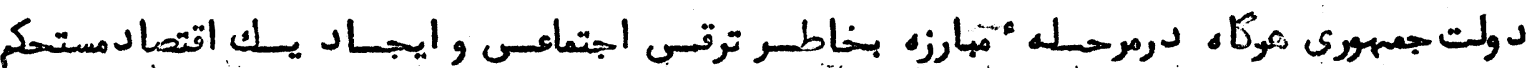

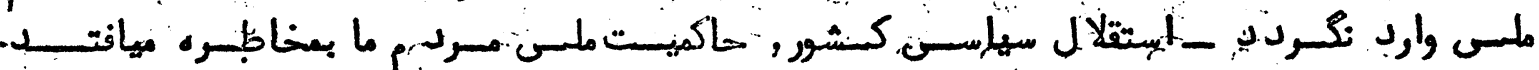

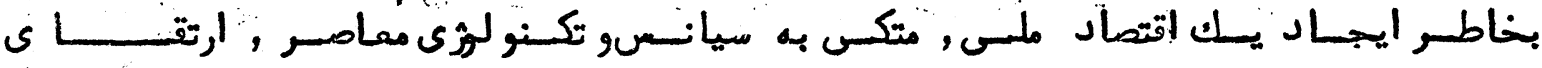

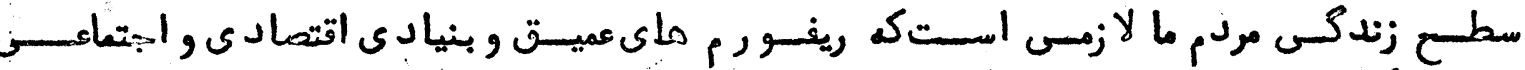

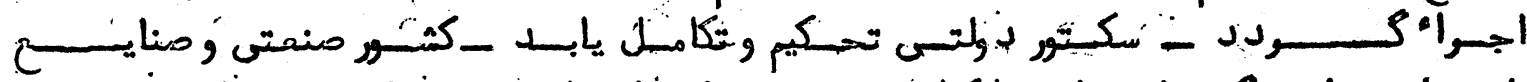

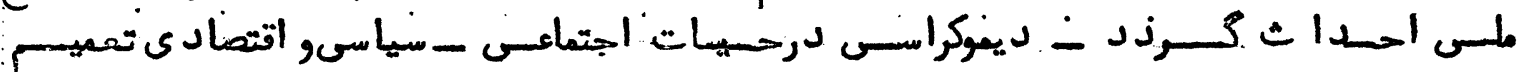
- يس

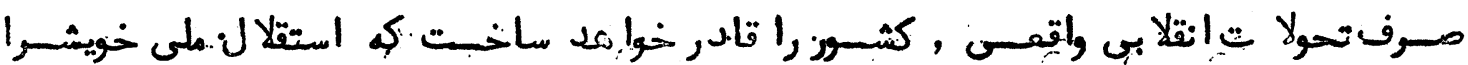

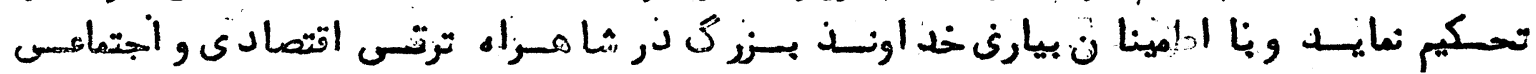

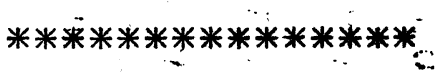

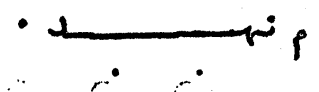

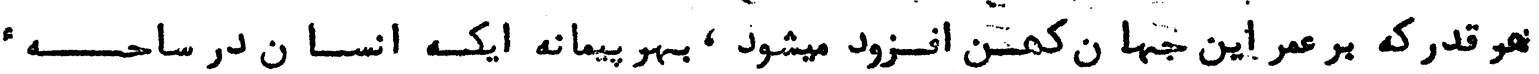

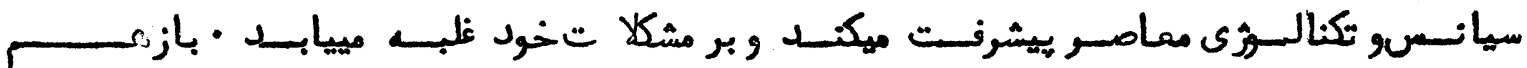

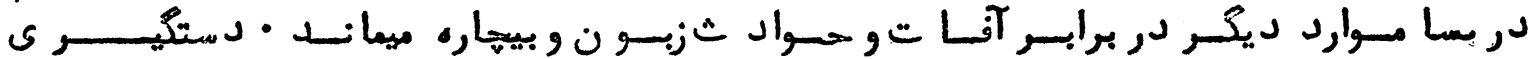

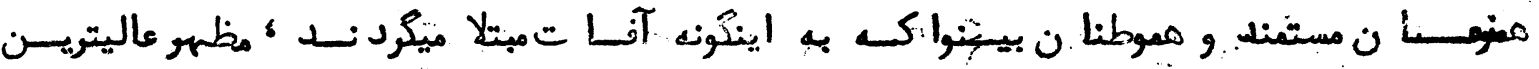

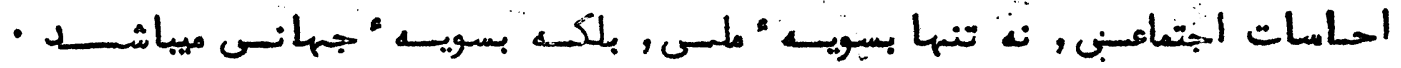

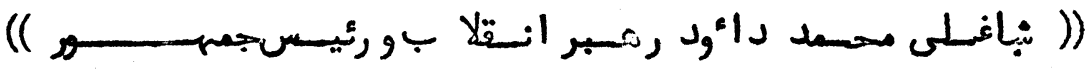


Statistical Information of Afghanistan is an anmual publication that has been issued since the 17th of July, 1974, the first anniversary of Republic Day. It is a summary of statistics relating to the social and economic activities of Afghanistan.

Article twenty-two (22) of the Statistical Law of Afghanistan .states: "Official statistics shall be the data which have been published, distributed or verified by the Central Statistics Office." Accordingly, It is this office that undertakes the preparation and distribution of $P E R$ their sources.

This edition, the fourth annual issue, represents the data accumulation of the past three years that was available as of July 13, 1977. Unless otherwise indicated, the figures are all for Afghanistan as presently constituted.

It should be reiterated that the contents of this volume were oollected from many sources. Because of a number of factors, including orrors in reporting, computation and processing, and incomplete coverage, drist data are subject to error.

The responsibility for the accuracy of the data collected directly by CSO and for selection of the material and its presentation rests with efice.

CSO welcomes all suggestions for improving the presentation of data. is of CSO publications are kindly requested to make their needs and suggestions known in writing for consideration in planning future editions.

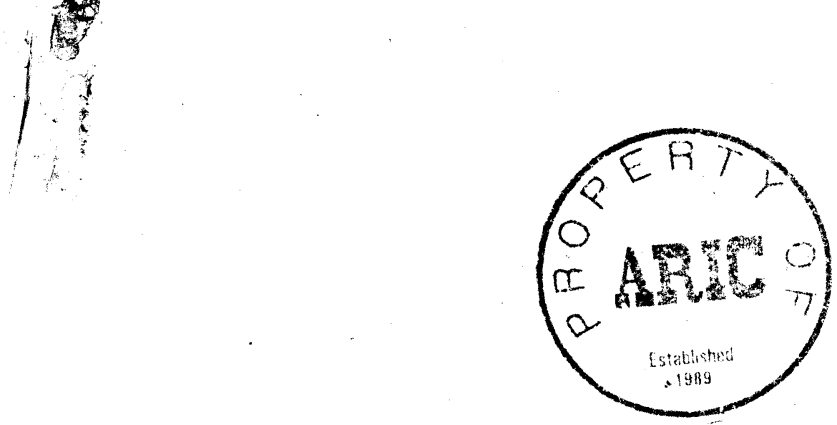

A.K. Hakimi

President General

Central Statistics Office

P.0.Box 2002

Nadir Shah Meenah

Kabul, Afghanistan 
PUBLICATION OF CENTRAL STATIST ICAL OFFICE FOR AUTHORS, WRITERS,

RESEARCH WORKERS AND CONCERNED READERS.

GET THE COPY YOU IIKE WE HAVE READY FOR SALE THE PROVISIONAL

- GAZETTEER OF AFGHANISTAN, STATISTICAL YEARBOOK OF AFGHANISTAN

' FOREIGN TRADE STATISTICS OF AFGHANISTAN.

I (TMPORT-EXXPORT), QUARTERLY REVIEW OF AFGHAN STATISTICS..AND ETC.

I YOU CAN ORDER FOR ONE OR MORE COPIES OF YOUR CHOICE FROM OUR

PUBLICATIONS OFFICE.

1

1 